\title{
Panorama de la educación 2014 INDICADORES DE LA OCDE
}

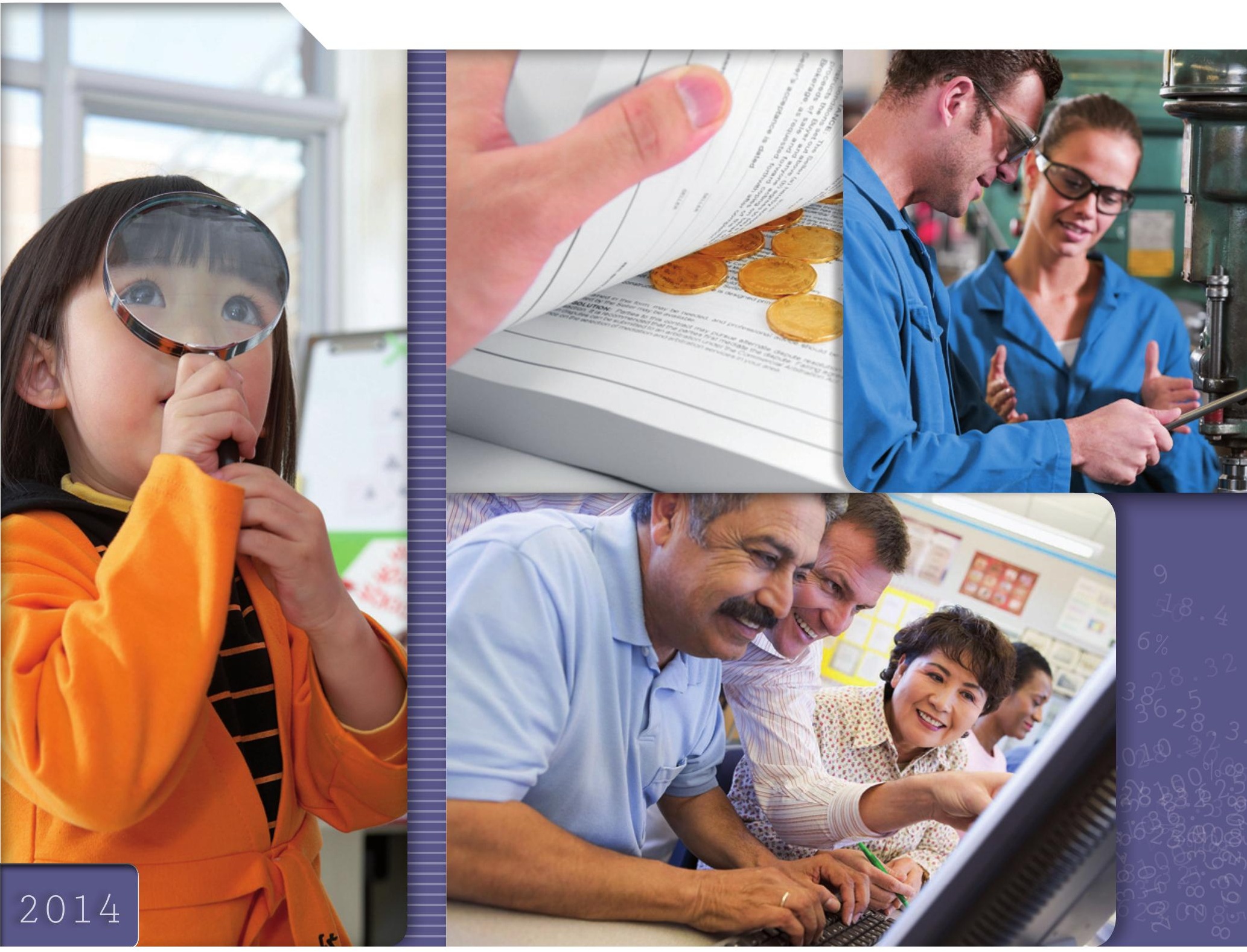




\title{
Panorama de la educación 2014
}

\author{
INDICADORES DE LA OCDE
}


Esta obra ha sido publicada originalmente en inglés y francés con los títulos:

Education at a Glance 2014: OECD Indicators.

Regards sur l'éducation 2014: Les indicateurs de l'OCDE.

(C) OCDE 2014

(C) 2014 Fundación Santillana para la edición española.

Obra publicada por acuerdo con la OCDE.

(C) Secretaría General Técnica del Ministerio de Educación, Cultura y Deporte

Subdirección General de Documentación y Publicaciones

Traducción: Ministerio de Educación, Cultura y Deporte, en colaboración con el Gabinete Lingüístico del Centro Superior de Idiomas Modernos de la Universidad Complutense de Madrid.

Edición: Alberto Martín Baró.

Los datos estadísticos para Israel fueron proporcionados por las autoridades israelíes competentes bajo su responsabilidad. El uso de estos datos por parte de la OCDE se hace sin prejuzgar la situación de los Altos del Golán, Jerusalén Oriental y las colonias israelíes en Cisjordania de acuerdo con los términos del derecho internacional.

Dirección de arte: José Crespo

Jefe de desarrollo de proyecto: Javier Tejeda

Desarrollo gráfico cubierta: José Luis García, Raúl de Andrés

Dirección técnica: Ángel García Encinar

Coordinación técnica: Marisa Valbuena

Composición, confección y montaje: Luis González Prieto

Corrección: Nuria del Peso, Juan David Latorre

\section{Créditos de las fotografías:}

Stocklib Image Bank (C) Cathy Yeulet

Fotolia.com (C) Feng Yu

Getty Images $@$ blue jean images

Printed in Spain

Impreso en España por

NIPO 030-14-272-0 en línea

NIPO 030-14-271-5 papel

Catálogo de publicaciones del Ministerio: www.mecd.gob.es

Catálogo general de publicaciones oficiales: publicacionesoficiales.boe.es 


\section{PRÓlogo}

Los gobiernos prestan cada vez más atención a los análisis comparativos internacionales sobre las oportunidades y los resultados de la educación al desarrollar políticas para mejorar las expectativas sociales y económicas de los individuos, proporcionar incentivos para una mayor eficiencia de los sistemas educativos y ayudar a movilizar recursos con que responder a las crecientes demandas. La Dirección de Educación y Competencias de la OCDE contribuye a estos esfuerzos mediante la elaboración y el análisis de indicadores cuantitativos susceptibles de comparación internacional, que se publican anualmente en Panorama de la educación. Junto con los informes de la OCDE sobre políticas nacionales, estos indicadores pueden ayudar a los gobiernos a construir sistemas de educación más efectivos y equitativos.

Panorama de la educación responde a las necesidades de una amplia gama de usuarios: desde gobiernos que buscan enseñanzas políticas a investigadores que necesitan datos para la elaboración de nuevos análisis, hasta el público general que desea seguir el progreso de su sistema educativo en la producción de estudiantes a escala mundial. Esta publicación examina la calidad de los resultados del aprendizaje, los instrumentos políticos y los factores contextuales que condicionan dichos resultados, así como los diversos beneficios individuales y sociales derivados de la inversión en educación.

Panorama de la educación es el producto de un largo esfuerzo de colaboración entre los gobiernos de los países miembros de la OCDE, los expertos y las instituciones que trabajan en el programa de análisis de Indicadores de Sistemas Educativos (INES) de la OCDE, y el Secretariado de la OCDE. La publicación ha sido preparada por el personal de la División de Innovación y Medición del Progreso de la Dirección de Educación y Competencias de la OCDE, bajo la responsabilidad de Dirk Van Damme y Corinne Heckmann, y en cooperación con Étienne Albiser, Rodrigo Castañeda Valle, Éric Charbonnier, Estelle Herbaut, Karinne Logez, Koji Miyamoto, Joris Ranchin, Cuauhtémoc Rebolledo Gómez, Gara Rojas González, Ignacio Marín, Wida Rogh, David Valenciano y Jean Yip. Han proporcionado apoyo administrativo Rhodia Diallo y Laetitia Dehelle, y consejo y apoyo analítico Camila de Moraes, Adrien Régnier-Laurent y Vaishali Zambre. El equipo de redacción ha contado con la revisión analítica de José Luis Álvarez-Galván, Francesco Avvisati, Rose Bolognini, Veronica Borg, Vanessa Denis, Alfonso Echazarra, Carlos González Sancho, Sonia Guerriero, María Huerta, Hiroko Ikesako, Marco Kools, Kelly Makowiecki, Patricia Mangeol, Simon Normandeau, Giannina Rech, Michele Rimini, Simone Stelten, William Thorn, Karine Tremblay, Sophie Vayssettes, Elisabeth Villoutreix y Juliana Zapata. Marilyn Achiron, Louise Binns, Marika Boiron, Célia Braga-Schich, Cassandra Davis y Sophie Limoges han proporcionado un valioso apoyo en los procesos de edición y producción. Los países miembros han dirigido el desarrollo de esta publicación por medio del Grupo de Trabajo INES y de las Redes INES. Al final del libro se facilita la lista con los nombres de los miembros de los diversos organismos y de los expertos individuales que han colaborado con esta publicación en particular y con el programa INES de la OCDE en general.

A pesar de que en los últimos años se han realizado grandes progresos, los países miembros y la OCDE siguen haciendo esfuerzos para fortalecer la relación entre las necesidades de las políticas y la disponibilidad de datos susceptibles de comparación internacional. Esto plantea diversos desafíos y compromisos. En primer lugar, los indicadores deben abordar cuestiones educativas prioritarias en las agendas políticas nacionales, en las que las comparaciones internacionales puedan ofrecer un valor añadido importante a los análisis y las evaluaciones de ámbito nacional. En segundo lugar, los indicadores deben respetar tanto la posibilidad de comparación internacional como la fidelidad a las peculiaridades nacionales que permitan tener en cuenta las diferencias históricas, institucionales y culturales de cada país. En tercer lugar, es necesario presentar los indicadores de la manera más sencilla posible, sin por ello perder de vista los detalles que reflejan la existencia de realidades educativas complejas. Por último, aunque se intenta limitar el conjunto de indicadores, este ha de ser lo suficientemente amplio como para que resulte útil a los responsables políticos de países que hacen frente a diferentes desafíos educativos. 
La OCDE seguirá afrontando tales desafíos con determinación y no se limitará al análisis de indicadores en áreas de fácil y prometedor acceso para la elaboración de los datos, sino que continuará avanzando precisamente en aquellas otras áreas en las que todavía se requiera una considerable inversión en el trabajo conceptual. En este sentido, los próximos esfuerzos se van a centrar en el Programa para la Evaluación Internacional de Alumnos (PISA) y en su extensión mediante el Programa para la Evaluación Internacional de las Competencias de los Adultos (PIAAC, por sus siglas en inglés), de la OCDE, así como en el Estudio Internacional sobre Enseñanza y Aprendizaje (TALIS, por sus siglas en inglés) de la OCDE. 
Editorial ……

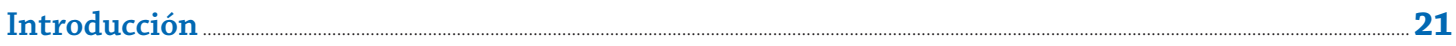

Guía del lector

Acerca de la Encuesta sobre las Competencias de los Adultos _ 31

CAPÍTULO A RESULTADOS DE LAS INSTITUCIONES EDUCATIVAS

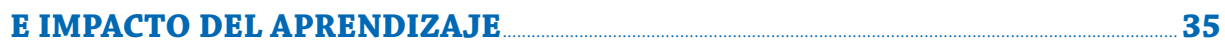

Indicador A1 ¿Hasta qué nivel han estudiado los adultos? ……............................................................

Tabla A1.1a Nivel de educación alcanzado por la población de 25 a 64 años de edad (2012)..............49

Tabla A1.2a Porcentaje de adultos que han completado al menos la educación secundaria superior, por grupo de edad (2012)

Tabla A1.3a Porcentaje de adultos que han completado la educación terciaria, por tipo de programa y grupo de edad (2012)

Tabla A1.4a Tendencias de los niveles de educación alcanzados, por grupo de edad, y tasa media de crecimiento anual (2000, 2005-2012)

Tabla A1.5a Nivel de educación alcanzado por la población de 25 a 64 años de edad, por orientación del programa y sexo (2012)

Tabla A1.6a (L) Nivel de educación alcanzado por la población de 25 a 64 años de edad, por nivel de comprensión lectora (2012)

Tabla A1.7a (L) Distribución de los niveles de comprensión lectora, por edad (2012).

Tabla A1.8 (L) Porcentaje de la población de 25 a 64 años de edad con educación secundaria superior o postsecundaria no terciaria de orientación profesional o general, por nivel de comprensión lectora y puntuación media (2012)

Tabla A1.9a (L) Puntuación media en comprensión lectora, por nivel educativo alcanzado y edad (2012).

Indicador A2 ¿Cuántos estudiantes se espera que completen la educación secundaria superior?

Tabla A2.1a Tasas de graduación en educación secundaria superior y media de edades (2012)

Tabla A2.1b. Tasas de graduación en educación secundaria superior: menores de 25 años (2012)

Tabla A2.2a Tendencias de las tasas de graduación por primera vez en el nivel de secundaria superior (1995-2012).

Tabla A2.3a Distribución de graduados en educación secundaria superior de formación profesional, por ámbito de estudio y sexo (2012)

Tabla A2.4 Finalización con éxito de programas de educación secundaria superior, por sexo y orientación del programa

Tabla A2.5

Finalización con éxito de programas de educación secundaria superior, por orientación y duración del programa 
Indicador A3 ¿Cuántos estudiantes se espera que completen la educación terciaria?

Tabla A3.1b

Tasas de graduación en educación terciaria de estudiantes menores de la edad típica de graduación (2012)

Tabla A3.2a Tendencias de las tasas de graduación en educación terciaria (1995-2012)

Indicador A4 ¿En qué medida influye la educación de los padres en la participación de los hijos en educación terciaria?

Tabla A4.1a Participación en educación terciaria de la población de 20 a 34 años, por sexo y nivel educativo de los padres (2012).

Tabla A4.1b Probabilidad de participar en educación terciaria, por nivel educativo de los padres y sexo (2012)

Tabla A4.2 Nivel educativo de la población no estudiante, por grupo de edad y nivel educativo de los padres (2012)

Tabla A4.3 (L) Nivel de comprensión lectora de la población no estudiante, por grupo de edad, sexo y nivel educativo de los padres (2012)

Tabla A4.4

Movilidad educativa de la población no estudiante, por grupo de edad y nivel educativo de los padres (2012)

Indicador A5 ¿Cómo afecta el nivel educativo alcanzado a la participación en el mercado laboral?

Tabla A5.1a

Tasas de empleo, por nivel educativo alcanzado (2012)

Tabla A5.1b

Tasas de empleo, por nivel educativo alcanzado y sexo (2012)

Tabla A5.2a

Tasas de desempleo, por nivel educativo alcanzado (2012)

Tabla A5.2b

Tasas de desempleo, por nivel educativo alcanzado y sexo (2012)

Tabla A5.3a

Tendencias de las tasas de empleo, por nivel educativo alcanzado y grupo de edad (2000, 2005-2012)

Tabla A5.4a

Tendencias de las tasas de desempleo, por nivel educativo alcanzado y grupo de edad (2000, 2005-2012).

Tabla A5.5a Distribución de adultos con educación secundaria superior o postsecundaria no terciaria, por su estatus en el mercado laboral y orientación del programa (2012)

Tabla A5.6

Proporción de asalariados a tiempo completo durante todo el año en el total de asalariados, por nivel educativo alcanzado y grupo de edad (2012)

Tabla A5.7a (L) Estatus en el mercado laboral, por nivel educativo alcanzado y nivel de comprensión lectora (2012)

Tabla A5.8 (L) Puntuación media en comprensión lectora en adultos con educación secundaria superior o postsecundaria no terciaria, por estatus en el mercado laboral y orientación del programa (2012).

Tabla A5.9a (L) Distribución de la población adulta por niveles de comprensión lectora y estatus en el mercado laboral (2012).

Tabla A5.10a (L) Distribución de los trabajadores a tiempo completo o a tiempo parcial, por nivel de comprensión lectora y por grupo de edad (2012)

Indicador A6 ¿Cuáles son las ventajas de la educación en los ingresos?

Tabla A6.1a Ingresos relativos de los trabajadores, por nivel educativo alcanzado

y grupo de edad (2012) 
Tabla A6.2a Tendencias de los ingresos relativos de los trabajadores, por nivel educativo alcanzado y sexo (2000, 2005, 2010, 2011, 2012)

Tabla A6.3a Diferencias de ingresos entre mujeres y hombres trabajadores, por nivel educativo alcanzado y grupo de edad (2012).

Tabla A6.3b

Tendencias de las diferencias de ingresos entre mujeres y hombres trabajadores, por nivel educativo alcanzado (2000, 2005, 2010, 2012).

Tabla A6.5a

Ingresos relativos de los estudiantes de 15 a 24 años con ingresos laborales, por nivel educativo alcanzado y sexo (2012).

Tabla A6.5b

Proporción de jóvenes de 15 a 29 años con ingresos laborales entre todos los jóvenes de 15 a 29 años, por grupo de edad y estatus de estudiante (2012)

Tabla A6.6a (L) Ingresos medios mensuales de los trabajadores, por nivel educativo alcanzado y nivel de comprensión lectora (2012)

Indicador A7 ¿Cuáles son los incentivos para invertir en educación?

Tabla A7.1a

Costes y beneficios privados para un hombre que alcanza la educación secundaria superior o postsecundaria no terciaria (2010)

Tabla A7.1b Costes y beneficios privados para una mujer que alcanza la educación secundaria superior o postsecundaria no terciaria (2010)

Tabla A7.2a

Costes y beneficios públicos para un hombre que alcanza la educación secundaria superior o postsecundaria no terciaria (2010)

Tabla A7.2b

Costes y beneficios públicos para una mujer que alcanza la educación secundaria superior o postsecundaria no terciaria (2010)

Tabla A7.3a Costes y beneficios privados para un hombre que alcanza la educación terciaria (2010)

Tabla A7.3b

Costes y beneficios privados para una mujer que alcanza

la educación terciaria (2010)

Tabla A7.4a Costes y beneficios públicos para un hombre que alcanza

la educación terciaria (2010)

Tabla A7.4b Costes y beneficios públicos para una mujer que alcanza

la educación terciaria (2010)

Indicador A8 ¿Cuáles son los resultados sociales de la educación?

Tabla A8.1a (L) Porcentaje de adultos que refieren tener buena salud, por nivel educativo alcanzado y comprensión lectora (2012).

Tabla A8.2a (L) Porcentaje de adultos que refieren trabajar como voluntarios al menos una vez al mes, por nivel educativo alcanzado y comprensión lectora (2012)

Tabla A8.3a (L) Porcentaje de adultos que refieren confiar en los demás, por nivel educativo alcanzado y comprensión lectora (2012).

Tabla A8.4a (L) Porcentaje de adultos que creen tener voz en el gobierno, por nivel educativo alcanzado y comprensión lectora (2012).

Indicador A9 ¿Qué relación existe entre el rendimiento de los estudiantes y la equidad en educación?

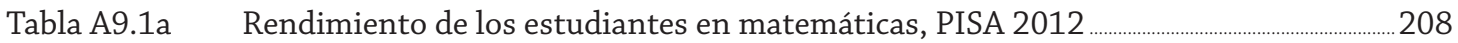

Tabla A9.1c Cambio entre 2003 y 2012 del rendimiento de los estudiantes en matemáticas ..........209

Tabla A9.2 Relación entre el rendimiento en matemáticas y el estatus socioeconómico 210 
Tabla B1.1a Gasto anual de instituciones educativas por estudiante para todos los servicios (2011)

Tabla B1.2 Gasto anual de instituciones educativas por estudiante para servicios básicos, auxiliares y de I+D (2011)

Tabla B1.3a

Gasto acumulativo de instituciones educativas por estudiante para todos los servicios a lo largo de la duración media de los estudios de educación terciaria (2011)

Tabla B1.4 Gasto anual de instituciones educativas por estudiante para todos los servicios, con relación al PIB per cápita (2011)

Tabla B1.5a

Cambio en el gasto de instituciones educativas por estudiante para todos los servicios, con relación a diferentes factores en los niveles de educación primaria, secundaria y postsecundaria no terciaria (1995, 2000, 2005, 2008, 2009, 2010, 2011)

Tabla B1.5b Cambio en el gasto de instituciones educativas por estudiante para todos los servicios, con relación a diferentes factores en el nivel de educación terciaria $(1995,2000,2005,2008,2009,2010,2011)$

Tabla B1.6

Gasto anual de instituciones educativas por estudiante para todos

los servicios, por tipo de programa (2011)

Indicador B2

¿Qué proporción de la riqueza nacional se dedica a la educación?

Tabla B2.1

Gasto en instituciones educativas como porcentaje del PIB, por nivel de educación (2011)

Tabla B2.2 Tendencias del gasto en instituciones educativas como porcentaje del PIB, por nivel de educación (1995, 2000, 2005, 2008, 2009, 2010, 2011)

Tabla B2.3 Gasto en instituciones educativas como porcentaje del PIB, por fuente de financiación y nivel de educación (2011).

Tabla B2.4

Gasto en instituciones educativas por categoría de servicios, como porcentaje del PIB (2011)

Tabla B2.5 Cambio del gasto público en instituciones educativas como porcentaje del PIB (2008, 2009, 2010, 2011)

Indicador B3 ¿Cuánta inversión pública y privada se destina a educación?

Tabla B3.1

Proporciones relativas de gasto público y privado en instituciones educativas para todos los niveles de educación (2011)

Tabla B3.2a

Tendencias de las proporciones relativas de gasto público en instituciones educativas e índice de cambio del gasto público y privado para todos los niveles de educación (1995, 2000, 2005, 2008 a 2011)

Tabla B3.2b Tendencias de las proporciones relativas de gasto público en instituciones educativas e índice de cambio del gasto público y privado en educación primaria, secundaria y postsecundaria no terciaria (1995, 2000, 2005, 2008 a 2011).

Tabla B3.2c

Tendencias de las proporciones relativas de gasto público en instituciones de educación terciaria e índice de cambio del gasto público y privado 1995, 2000, 2005, 2008 a 2011)

Tabla B3.3

Gasto público anual en instituciones educativas por estudiante,

por tipo de institución (2011) 
Indicador B4 ¿Cuál es el gasto público total en educación?

Tabla B4.1 Gasto público total en educación (2011)

Tabla B4.2 Tendencias del gasto público total en educación

(1995, 2000, 2005, 2008, 2009, 2010 y 2011)

Tabla B4.3

Fuentes de fondos públicos para educación primaria, secundaria

y postsecundaria no terciaria (2011)

Indicador B5 ¿Cuánto pagan los estudiantes de educación terciaria y qué ayudas públicas reciben?

Tabla B5.1 Tasas medias anuales de matrícula estimadas cobradas por instituciones de educación terciaria de tipo A (2011)

Tabla B5.2

Ayuda económica a estudiantes y tasas de matrícula cobradas por instituciones

de educación terciaria de tipo A (2011).

Tabla B5.3

Préstamos públicos a estudiantes en educación terciaria de tipo $\mathrm{A}$ (año académico 2010-2011)

Tabla B5.4

Ayudas públicas a familias y a otras entidades privadas para educación

terciaria (2011)

Indicador B6

¿En qué recursos y servicios se gastan los fondos destinados a educación?

Tabla B6.1

Gasto de las instituciones educativas de primaria y secundaria,

por categoría de recursos (2011)

Tabla B6.2

Gasto de las instituciones educativas, por categoría de recursos y nivel de educación (2011).

Indicador B7

¿Qué factores influyen en el nivel de gasto en educación?

Tabla B7.1

Coste salarial de los profesores por estudiante, por nivel

de educación (2012)

Tabla B7.2a

Factores utilizados para calcular el coste salarial de los profesores por estudiante, en educación primaria (2000, 2005, 2008 y 2012)

Tabla B7.2b

Factores utilizados para calcular el coste salarial de los profesores por estudiante, en educación secundaria inferior (2000, 2005, 2008 y 2012)

Tabla B7.3 Contribución de diversos factores al coste salarial de los profesores por estudiante en educación primaria (2000, 2005, 2008 y 2012).

Tabla B7.4 Contribución de diversos factores al coste salarial de profesores por estudiante en educación secundaria inferior (2000, 2005, 2008 y 2012) ﹎.._......316

Tabla B7.5 Contribución de diversos factores al coste salarial de profesores por estudiante en educación secundaria superior (2012)

Tabla C1.1a

Tasas de matriculación en educación, por grupos de edad (2012).

Tabla C1.2

Tendencias de las tasas de matriculación (1995-2012).

Tabla C1.3

Patrones de matriculación en educación secundaria superior y postsecundaria no terciaria (2012)

Tabla C1.4 Porcentaje de estudiantes en educación primaria, secundaria y terciaria, por modalidad de estudio y sexo (2012) 
Indicador C2

Tabla C2.1

Tabla C2.2

Tabla C2.3

Indicador C3

Tabla C3.1a

Tabla C3.1b

Tabla C3.2a

Tabla C3.3a

Indicador C4

Tabla C4.1

Tabla C4.2

Tabla C4.3

Tabla C4.4

Tabla C4.5

Tabla C4.6

Indicador C5

Tabla C5.2a

Tabla C5.3a

Tabla C5.4

Tabla C5.5

Indicador C6

Tabla C6.1 (L)
¿En qué se diferencian los sistemas de educación infantil del mundo?

Tasas de matriculación en educación infantil y primaria, por edad (2005, 2012)

Características de los programas de educación infantil (2011, 2012)

Características de los programas de solo educación y educación infantil integrada (2012)

¿Cuántos estudiantes se espera que accedan a la educación terciaria?

Tasas de ingreso en educación terciaria y media de edad de los nuevos ingresados, por sexo y programa (2012)

Tasas de ingreso en educación terciaria de los estudiantes por debajo de la edad típica de ingreso, por sexo y programa (2012)

Tendencias de las tasas de ingreso en educación terciaria (1995-2012)

Distribución de nuevos ingresados en educación terciaria,

por ámbito de estudio (2012)

¿Quién estudia en el extranjero y dónde?

Movilidad de estudiantes internacionales y estudiantes extranjeros en educación terciaria $(2005,2012)$

Distribución de estudiantes internacionales y extranjeros matriculados en educación terciaria, por ámbito de estudio (2012)

Distribución de estudiantes internacionales y extranjeros matriculados

en educación terciaria, por país de origen (2012)

Ciudadanos que estudian en el extranjero en educación terciaria, por país de destino (2012)

Patrones de movilidad de los estudiantes extranjeros e internacionales (2012) ...........379

Tendencias del número de estudiantes extranjeros matriculados

en educación terciaria, por región de destino y origen (2000 a 2012) 380

Transición de la educación al trabajo: ¿dónde están los jóvenes de 15 a 29 años?

Años esperados en educación y no en educación para los jóvenes de 15 a 29 años, por situación laboral (2012)

Porcentaje de jóvenes de 15 a 29 años en educación y no en educación, por grupo de edad y situación laboral (2012)

Tendencias del porcentaje de jóvenes de 15 a 29 años en educación y no en educación, empleados o no, por grupo de edad (1997-2012)

Porcentaje de jóvenes de 15 a 29 años en educación y no en educación, por nivel educativo alcanzado y situación laboral (2012)

Tendencias del porcentaje de trabajadores de 15 a 29 años a tiempo parcial y a tiempo completo en educación y no en educación (2006-2012)

¿Cuántos adultos participan en la educación y el aprendizaje?

Participación en educación formal y/o no formal, por nivel

de comprensión lectora (2012)

Tabla C6.2a (L) Participación en educación formal y/o no formal, por nivel de comprensión lectora y nivel educativo alcanzado (2012).

Participación en educación formal y/o no formal, por sexo (2012) 
Tabla C6.4 Participación en educación formal y/o no formal y deseo de participar en actividades de aprendizaje (2012)

Tabla C6.5 Motivos dados para no haber participado en más actividades de aprendizaje o en alguna, por situación de participación en actividades de educación formal y/o no formal (2012)

Indicador C7 ¿En qué se diferencian instituciones y centros escolares públicos de instituciones y centros privados?

Tabla C7.1

Estudiantes en educación infantil, primaria y secundaria, por tipo de centro escolar (2012).

Tabla C7.2

Tipo de centro escolar y rendimiento en matemáticas (2012)

Tabla C7.3

Tipo de centro escolar y rendimiento en matemáticas (2003)

Tabla C7.4

Entorno de aprendizaje, por tipo de centro escolar (2012)

Tabla C7.5

Responsabilidad del centro escolar en la asignación de recursos, currículo

y evaluación, por tipo de centro escolar y nivel de educación (2012)

Tabla C7.6

Estudiantes en educación terciaria, por tipo de institución $(2003,2012)$

\section{CAPÍTULO D EL ENTORNO DE APRENDIZAJE Y LA ORGANIZACIÓN} DE LOS CENTROS ESCOLARES

Indicador D1

¿Cuánto tiempo pasan los estudiantes en clase?

Tabla D1.1

Horas de enseñanza en educación general obligatoria (2014)

Tabla D1.2

Organización de la educación general obligatoria (2014).

Tabla D1.3a

Horas de enseñanza por materia en educación primaria (2014).

Tabla D1.3b

Horas de enseñanza por materia en educación secundaria inferior (2014)

Indicador D2

¿Cuál es la ratio alumnos-profesor y cómo es el tamaño de las clases?

Tabla D2.1

Tamaño medio de la clase, por tipo de institución y nivel de educación (2012)

Tabla D2.2

Ratio alumnos-profesor en instituciones educativas (2012).

Tabla D2.3

Ratio alumnos-profesor por tipo de institución (2012)

Indicador D3

¿Cuál es el salario de los profesores?

Tabla D3.1

Salarios reglamentarios de los profesores en diferentes momentos de su carrera (2012).

Tabla D3.2 Salarios de los profesores en relación con los ingresos de los trabajadores con educación terciaria de 25 a 64 años de edad a tiempo completo, todo el año (2012)

Tabla D3.3 Comparación de los salarios reglamentarios de los profesores (2012).................................. 493

Tabla D3.4 Salarios medios reales de los profesores (2012).

Tabla D3.5

Tendencias de los salarios de los profesores entre 2000 y 2012

Indicador D4

¿Cuánto tiempo dedican los profesores a enseñar?

Tabla D4.1

Organización del horario laboral de los profesores (2012)

Tabla D4.2

Número de horas de enseñanza al año (2000, 2005, 2010 y 2012)

507

Indicador D5

¿Quiénes componen el profesorado?.

Tabla D5.1

Distribución por edad del profesorado (2012)

Tabla D5.2

Distribución por edad del profesorado (2012, 2002) 
Indicador D6

Tabla D6.1a

Tabla D6.1b

Tabla D6.1c

Tabla D6.1d

Tabla D6.2c

Tabla D6.3c

Tabla D6.5c

Indicador D7

Tabla D7.1c

Tabla D7.2c

Tabla D7.3c

ANEXO 1

Tabla X1.1a.

Tabla X1.1b.

Tabla X1.1c.

Tabla X1.1d.

Tabla X1.2a.

Tabla X1.2b.

ANEXO 2

Tabla X2.1.

Tabla X2.2.

Tabla X2.3.

¿Qué requisitos son necesarios para ser profesor?

Formación inicial del profesorado e ingreso en la profesión docente, en educación infantil (2013)

Formación inicial del profesorado e ingreso en la profesión docente, en educación primaria (2013).

Formación inicial del profesorado e ingreso en la profesión docente, en educación secundaria inferior (2013)

Formación inicial del profesorado e ingreso en la profesión docente, en educación secundaria superior (2013)

Requisitos para ingresar y avanzar en la formación inicial del profesorado, en educación secundaria inferior (2013)

Contenidos de la formación inicial del profesorado, en educación secundaria inferior (2013)

Ingreso en la profesión docente, en educación secundaria inferior (2013)

¿Qué implantación tienen las actividades de desarrollo profesional para los profesores?

Requisitos para el desarrollo profesional de los profesores, en educación secundaria inferior (2013).

Contenido de las actividades de desarrollo profesional obligatorio

de los profesores, en educación secundaria inferior (2013)

Desarrollo profesional no obligatorio de los profesores, en educación secundaria inferior (2013).

CARACTERÍSTICAS DE LOS SISTEMAS EDUCATIVOS

Tasa de graduación en educación secundaria superior: edades típicas de graduación y método utilizado para calcular las tasas de graduación (2012)

Tasa de graduación en educación postsecundaria no terciaria:

edades típicas de graduación y método utilizado para calcular las tasas

de graduación (2012)

Tasa de graduación en educación terciaria: edades típicas de graduación y método utilizado para calcular las tasas de graduación (2012)

Tasa de ingreso en educación terciaria: edades típicas de ingreso

y método utilizado para calcular las tasas de ingreso (2012)

Año escolar y año presupuestario utilizados en los cálculos de los indicadores para los países de la OCDE.

Año escolar y año presupuestario utilizados en los cálculos de los indicadores para los países asociados

Visión general del contexto económico mediante las variables básicas (periodo de referencia: año natural 2011, precios corrientes de 2011)

Estadísticas de referencia básicas (periodo de referencia: año natural 2011, precios corrientes de 2011)

Estadísticas de referencia básicas (periodo de referencia: año natural 1995, 2000, 2005, 2008, 2009, 2010) 
Tabla X2.4a. Salarios reglamentarios de los profesores en varios momentos de su carrera (2012)

Tabla X2.4b. Tendencias en los salarios de los profesores entre 2000 y 2012

Tabla X2.4c. Estadísticas de referencia para el cálculo de los salarios de los profesores (2000, 2005-2012)

ANEXO 3

Personas que han participado en esta publicación

Publicaciones relacionadas de la OCDE

\section{Este libro tiene}

\section{《s}

StatLinks

ज्ञात

Un servicio que ofrece archivos en Excel $^{\circledR}$ a partir de las páginas impresas.

Busque los StatLinks en la parte inferior de las tablas y los gráficos de este libro. Para descargar la correspondiente hoja de Excel ${ }^{\circledR}$, teclee el vínculo

en su buscador de Internet comenzando con el prefijo http://dx.doi.org.

Si está leyendo la edición del libro en PDF y su ordenador está conectado a Internet, simplemente pulse en el vínculo. 



\section{EDITORIAL EDUCACIÓN Y COMPETENCIAS PARA UN CRECIMIENTO INCLUYENTE}

El mundo está saliendo lentamente de la peor crisis económica de nuestras vidas. Dado que la productividad, la innovación, la inversión y el comercio no funcionan todavía a pleno rendimiento, el proceso de recuperación sigue entrañando riesgos. También va siendo cada vez más obvio que el crecimiento económico no es suficiente para promover el progreso social, particularmente si los dividendos del crecimiento no se comparten de manera equitativa. Ciertamente, el coste social de la crisis sigue constituyendo una pesada carga: más de 46 millones de personas desempleadas en los países de la OCDE y pobreza relativa que afecta a millones de personas más. En muchos países, la brecha entre los más ricos y los más pobres se hace cada vez más amplia, el desempleo juvenil continúa siendo elevado y el acceso a los servicios sociales sigue siendo complicado para muchos. El mundo busca vías de estimular el crecimiento económico de una manera más incluyente. La OCDE contribuye a esta iniciativa poniendo a disposición de los responsables políticos información y herramientas que estos pueden utilizar para formular nuevas políticas que nos acerquen a ese objetivo.

Esta edición de Panorama de la educación ofrece amplias pruebas del papel crucial que la educación y las competencias juegan a la hora de promover el progreso social. Además de las fuentes de datos utilizadas habitualmente para generar los Indicadores de Educación de la OCDE, esta edición también recurre a la rica base de datos sobre competencias que proporciona la Encuesta sobre las Competencias de los Adultos 2012, un producto del Programa para la Evaluación Internacional de las Competencias de los Adultos de la OCDE (PIAAC), publicado en octubre de 2013 (OECD, 2013a). Si añadimos los datos 2012 sobre los resultados del aprendizaje de los jóvenes de 15 años de edad procedentes del Programa para la Evaluación Internacional de Alumnos de la OCDE (PISA 2012), publicado en 2013 y 2014 (OECD, 2013b y 2014a), y los datos 2013 sobre el profesorado de educación secundaria inferior procedentes del Estudio Internacional sobre Enseñanza y Aprendizaje de la OCDE (TALIS 2013), publicado en junio de 2014 (OECD, 2014b), tenemos la base de información internacional más rica sobre educación y competencias jamás recopilada. Y gracias a nuestra herramienta web para la investigación Education GPS, se puede acceder a esta información con facilidad simplemente pinchando con el ratón.

A primera vista, la información muestra que en los países de la OCDE el acceso a la educación sigue en expansión. El cambio experimentado por las sociedades en solo un par de generaciones, desde que la educación era únicamente para una escasa élite hasta hoy día, cuando tres cuartas partes de la población han completado como mínimo la educación secundaria superior, sigue generando consecuencias. Actualmente, cerca del $40 \%$ de los adultos entre los 25 y los 34 años de edad ha completado la educación terciaria, una proporción que supera en 15 puntos porcentuales la de los adultos entre los 55 y los 64 años de edad; y en muchos países esta diferencia excede los 20 puntos porcentuales. El hecho de que la crisis no haya ralentizado este proceso de expansión es de gran importancia; por el contrario, cuando los exiguos mercados laborales apenas proporcionaban alternativas, muchas personas aprovecharon los bajos costes de oportunidad para invertir en su educación con el objetivo de mejorar sus oportunidades para acceder a una vida mejor. Y en las economías emergentes, la escolarización está en expansión -partiendo de una base relativamente estrecha- a un ritmo que sobrepasa al del mundo industrializado.

Por tanto, no resulta sorprendente que el nivel de competencias de la población también haya aumentado espectacularmente. Los datos sobre competencias muestran que, en los 24 países de la OCDE o entidades subnacionales que participaron en la Encuesta sobre las Competencias de los Adultos, se da un aumento medio de 13 puntos porcentuales entre la proporción de adultos de mayor y menor edad que alcanzan las puntuaciones más elevadas de comprensión lectora; en varios países, la proporción de adultos más jóvenes con este nivel de comprensión lectora supera en 20 puntos porcentuales la proporción de los adultos de mayor edad. Sin embargo, los datos también muestran que el nivel de educación alcanzado no siempre se corresponde con el nivel de competencias. Además, no todos los países que muestran los mayores aumentos de las tasas del nivel de educación muestran también el mayor aumento de la proporción de adultos altamente cualificados. De hecho, en todos los países, los adultos con niveles de 
educación similares pueden tener niveles de competencias muy diferentes, lo cual señala la necesidad de reflexionar sobre el modo en el que se definen las cualificaciones educativas.

Aparentemente, la expansión de la educación y el aumento generalizado del nivel de competencias de la población deberían implicar una fuerza laboral creciente y mejor cualificada. Sin embargo, las divisiones económicas se hacen cada vez más profundas, porque el impacto de las competencias sobre las oportunidades de vida de las personas ha aumentado considerablemente. En el caso del empleo, una media del $80 \%$ de los adultos con educación terciaria tienen empleo, en comparación con menos del $60 \%$ de aquellos que no han completado la educación secundaria superior. La brecha de empleo entre estos dos grupos es de 30 puntos porcentuales o más en varios países. Aun así, las personas con educación terciaria, especialmente los adultos jóvenes, no son inmunes al desempleo, y muchos gobiernos están preocupados por el aumento del desempleo en los graduados universitarios. Como media en los países de la OCDE, la tasa de desempleo en adultos con educación terciaria alcanzó el 5,0\% en 2012 (ascendiendo desde un 3,3\% en 2008), pero en los adultos de 25 a 34 años de edad alcanzó el 7,4\% (ascendiendo desde un 4,6\% en 2008). En comparación, la tasa de desempleo en los adultos de 25 a 34 años de edad que no han completado la educación secundaria superior alcanzó el 19,8 \% en 2012 (y porcentajes más elevados en muchos países), ascendiendo desde un $13,6 \%$ en 2008. Nuestros datos vuelven a confirmar que los adultos jóvenes con un nivel de educación bajo son los que más han sufrido la crisis económica.

La falta de competencias aumenta el riesgo de desempleo incluso en personas con niveles de educación parecidos. Por ejemplo, como media en los países que participaron en la Encuesta sobre las Competencias de los Adultos, un $5,8 \%$ de los adultos sin educación secundaria superior, pero que alcanzaban un nivel moderado de comprensión lectora, estaban desempleados en comparación con un $8,0 \%$ de adultos con un nivel de educación similar, pero un nivel bajo de comprensión lectora. De manera similar, en los adultos que han completado la educación terciaria, un 3,9\% de aquellos cuyo nivel de comprensión lectora era bajo estaban desempleados, en comparación con un 2,5\% de aquellos cuyo nivel de competencia estaba entre los más elevados.

Los datos sobre ingresos también señalan una brecha cada vez más amplia entre "tener y no tener» un nivel educativo. En los países de la OCDE, la diferencia entre los ingresos generados por el empleo de los adultos que no cuentan con educación secundaria superior y los que cuentan con educación terciaria sigue ampliándose. Si representamos los ingresos medios de los adultos de 25 a 64 años de edad que cuentan con educación secundaria superior mediante un índice de 100, el nivel de ingresos de los adultos que no cuentan con educación secundaria superior fue de 80 en 2000 y descendió a 76 en 2012, mientras que los ingresos medios de los adultos con educación terciaria aumentaron de 151 en 2000 a 159 en 2012. Estos datos también muestran que la brecha de ingresos relativos entre los adultos con un nivel de educación medio y un nivel alto aumentó hasta duplicar la brecha existente entre los adultos con un nivel de educación medio y un nivel de educación bajo. Esto quiere decir que, en términos relativos, los ingresos de los adultos con un nivel de educación medio se acercaron a los de aquellos con niveles de educación bajos, lo cual encaja con la tesis de que las clases medias están disminuyendo.

El aumento de la desigualdad en la distribución de ingresos está cada vez más determinado por la distribución de la educación y las competencias en las sociedades. En los países de la OCDE, un 73\% de las personas que no cuentan con educación secundaria superior se encuentran como máximo en el nivel medio de ingresos, mientras que el porcentaje correspondiente en el caso de los graduados universitarios es solo de un $27 \%$. El nivel de educación alcanzado es el baremo que lleva a las personas a la pobreza o a la riqueza relativa; la distribución de las competencias en una sociedad, el que esta sea o no incluyente, se refleja en el grado de desigualdad de ingresos de la sociedad. Los países que cuentan con grandes proporciones de adultos con bajos niveles de competencias también tienen niveles altos de desigualdad de ingresos, medida con el coeficiente de Gini, igual que los países con un perfil de competencias polarizado (es decir, muchas personas con nivel de competencias bajo y muchas personas con nivel de competencias alto, la distribución de competencias suele estar relacionada con el entorno socioeconómico).

Los riesgos -y, en muchos casos, también las penalizaciones- que conlleva tener un nivel de educación y de competencias bajo no tienen que ver exclusivamente con los ingresos y el empleo, sino con muchas otras consecuencias sociales. Por ejemplo, hay una diferencia de 23 puntos porcentuales entre la proporción de adultos con niveles altos de educación y la proporción de adultos con niveles bajos de educación que declaran disfrutar de buena salud. Los niveles de confianza interpersonal, participación en actividades voluntarias y la creencia de que un individuo puede ejercer una influencia sobre el proceso político son todos factores que se relacionan estrechamente con los niveles de educación y competencias. Por lo tanto, las sociedades en las que existen grandes proporciones de personas con un nivel bajo de competencias corren el riesgo de sufrir el deterioro de la cohesión social y del bienestar. Cuando grandes cantidades de personas no comparten los beneficios a los que acceden las poblaciones con niveles 
más altos de competencias, los costes sociales a largo plazo relacionados con la sanidad, el desempleo y la seguridad, entre otros, se acumulan y se hacen abrumadores.

Ciertamente, la creciente división social entre «los que tienen» $\mathrm{y}$ «los que no tienen» en el contexto educativo, y el riesgo que conlleva excluir a estos últimos de los beneficios sociales de la expansión educativa, amenazan a las sociedades en conjunto. En el pasado, la preocupación principal de los países consistía en elevar el nivel medio de capital humano sin prestar mucha atención al modo en que la educación y las competencias estaban distribuidas entre la población. Por supuesto, es necesario mejorar el nivel general de educación y competencias de una población para conseguir crecimiento económico y progreso social. Sin embargo, según los países desarrollados avanzan hacia niveles más elevados de educación y competencias, las medidas agregadas de capital humano parecen no servir para explicar las diferencias del producto económico entre países. El análisis de los datos de la Encuesta sobre las Competencias de los Adultos muestra que, cuando las personas de todos los niveles de competencia se benefician de un mayor acceso a la educación, también mejora el crecimiento económico y la inclusión social. Los países con proporciones pequeñas de adultos con un nivel bajo de competencias y grandes proporciones de adultos con un nivel elevado de competencias, es decir, países con una distribución de competencias más incluyente, consiguen mejores resultados económicos (PIB per cápita) y mayor igualdad social (coeficiente de Gini) que los países con un nivel medio de competencias similar, pero mayores diferencias entre la población en cuanto al nivel de competencias (Van Damme, 2014).

Por este motivo, la educación y las competencias se han convertido en dimensiones cada vez más importantes de la desigualdad social; pero también son una parte indispensable de la solución a este problema. La educación puede sacar a las personas de la pobreza y la exclusión social, pero para que esto sea así el nivel de educación tiene que traducirse en movilidad social. Quizá la mayor amenaza para el crecimiento incluyente sea el riesgo de que la movilidad social pueda llegar a estancarse. La comparación de nuestros datos transversales entre grupos de edad parece confirmar que en los países de la OCDE este riesgo es real. En los países que participaron en la Encuesta sobre las Competencias de los Adultos en 2012, un $39 \%$ de los adultos de 35 a 44 años de edad, como media, contaban con una cualificación terciaria. El entorno educativo de los padres desempeñaba un papel importante en la probabilidad de que los hijos consiguieran también una cualificación terciaria: un $68 \%$ de los adultos que tenían por lo menos un progenitor con educación terciaria también habían completado la educación terciaria; mientras que solo un $24 \%$ de los adultos cuyos padres no habían completado la educación secundaria superior contaba con este nivel de educación. Sin embargo, en el grupo de menor edad (de 25 a 34 años), en el cual la proporción que había completado la educación terciaria había ascendido a un $43 \%$, el impacto del entorno educativo de los padres era igualmente fuerte: de los adultos que tenían por lo menos un progenitor con educación terciaria, un $65 \%$ contaba con este nivel de educación, mientras que en los adultos cuyos padres tenían un nivel de educación bajo esta proporción era solo de un $23 \%$. En otras palabras, los beneficios de la expansión educativa fueron compartidos por la clase media, pero no alcanzaron a las familias menos favorecidas. En términos relativos, los hijos de familias con un nivel de educación bajo sufrieron una exclusión cada vez mayor con respecto a los beneficios potenciales que la expansión educativa supuso para la mayor parte de la población. Incluso cuando el acceso a la educación fuera posible, la interacción entre su entorno desfavorecido y la calidad más baja de educación que estos estudiantes sufren de manera desproporcionada tuvo un resultado educativo que no les ayudó a ascender en la escala social.

Las sociedades incluyentes necesitan sistemas educativos que promuevan el aprendizaje y la adquisición de competencias de una manera equitativa y que apoye la meritocracia y la movilidad social. Cuando el motor de la movilidad social se ralentiza, las sociedades se hacen menos incluyentes. Incluso ahora que el acceso a la educación está en expansión, demasiadas familias se arriesgan a permanecer excluidas de las promesas de la movilidad educativa intergeneracional. Como media en los países que participaron en la Encuesta sobre las Competencias de los Adultos, la movilidad ascendente (el porcentaje de la población con un nivel de educación superior al de sus padres) se estima en un $42 \%$ en los adultos de 55 a 64 años de edad y en un $43 \%$ entre los adultos de 45 a 54 años de edad, pero desciende a un $38 \%$ en los adultos de 35 a 44 años de edad y a un $32 \%$ en los adultos de 25 a 34 años de edad. La movilidad educativa descendente aumenta desde un $9 \%$ en los adultos de 55 a 64 años de edad y un $10 \%$ en los adultos de 45 a 54 años de edad, hasta un $12 \%$ en los adultos de 35 a 44 años de edad y un $16 \%$ en los adultos de 25 a 34 años de edad. Estos datos sugieren que la expansión educativa todavía no ha dado como resultado una sociedad más incluyente, y que este desafío ha de ser afrontado con la mayor urgencia.

Las medias de la OCDE pueden resultar engañosas, ya que esconden amplias diferencias entre países. En esta edición de Panorama de la educación, los resultados más interesantes pueden no ser las medias que incluyen todos los países de la OCDE, sino el modo en el que los indicadores destacan las diferencias entre países. Estas variaciones reflejan diferentes contextos históricos y culturales, pero también demuestran el poder de las políticas. Distintas políticas 
producen diferentes resultados, y esto también es cierto en lo que se refiere a la educación y las competencias. Algunos países tienen más éxito que otros en interrumpir el ciclo de desigualdad social que desemboca en desigualdad educativa, en contener el riesgo de exclusión por medio de la educación y las competencias, y en limitar la proporción de adultos con un bajo nivel de competencias a la vez que proporcionan oportunidades al máximo número posible de adultos para que puedan mejorar este nivel.

La educación y las competencias son la clave para el bienestar futuro y tendrán una importancia crítica para restablecer el crecimiento a largo plazo, luchar contra el desempleo, promover la competitividad y nutrir sociedades más incluyentes y cohesionadas. Esta amplia recopilación de datos sobre educación y competencias ayuda a los países a compararse y establecer parámetros de referencia, contribuyendo así a identificar las políticas que funcionan.

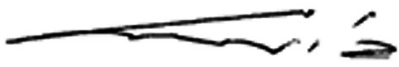

Ángel Gurría

Secretario General de la OCDE 


\section{Referencias}

Education GPS: The World of Education at your Fingertips, http://gpseducation.oecd.org.

OECD Initiative on Inclusive Growth, www.oecd.org/inclusive-growth.

$\operatorname{OECD}(2014 \mathrm{a})$ :

- PISA 2012 Results: What Students Know and Can Do (Volume I, edición revisada, febrero de 2014): Student Performance in Mathematics, Reading and Science, PISA, OECD Publishing, París, http://dx.doi.org/10.1787/9789264208780-en.

- PISA 2012 Results: Creative Problem Solving (Volume V): Students' Skills in Tackling Real-Life Problem, PISA, OECD Publishing, París, http://dx.doi.org/10.1787/9789264208070-en.

- PISA 2012 Results: Students and Money (Volume VI): Financial Literacy Skills for the 21st Century, PISA, OECD Publishing, París, http://dx.doi.org/10.1787/9789264208094-en.

OECD (2014b), TALIS 2013 Results: An International Perspective on Teaching and Learning, TALIS, OECD Publishing, París, http:// dx.doi.org/10.1787/9789264196261-en.

OECD (2013a), OECD Skills Outlook 2013: First Results from the Survey of Adult Skills, OECD Publishing, París, http://dx.doi. org/10.1787/9789264204256-en.

$\operatorname{OECD}(2013 b)$ :

- PISA 2012 Results: Excellence through Equity (Volume II): Giving Every Student the Chance to Succeed, PISA, OECD Publishing, París, http://dx.doi.org/10.1787/9789264201132-en.

- PISA 2012 Results: Ready to Learn (Volume III): Students' Engagement, Drive and Self-Beliefs, PISA, OECD Publishing, París, http://dx.doi.org/10.1787/9789264201170-en.

- PISA 2012 Results: What Makes Schools Successful? (Volume IV): Resources, Policies and Practices, PISA, OECD Publishing, París, http://dx.doi.org/10.1787/9789264201156-en.

Van Damme, D. (2014), «How closely is the distribution of skills related to countries'overall level of social inequality and economic prosperity?», EDU NAEC Paper Series, No. 1, www.oecd.org/edu/skills-beyond-school/EDUNAEC1.pdf. 



\section{INTRODUCCIÓN: LOS INDICADORES Y SU ESTRUCTURA}

\section{Estructura organizativa}

Panorama de la educación 2014: Indicadores de la OCDE ofrece un amplio abanico de indicadores actualizados y comparables que reflejan un consenso profesional sobre cómo evaluar el actual estado de la educación a escala internacional. Los indicadores aportan información sobre los recursos humanos y económicos invertidos en educación, sobre el funcionamiento y la evolución de los sistemas educativos y de aprendizaje, y sobre el rendimiento de las inversiones realizadas en educación. Los indicadores están organizados por temas y van acompañados de una serie de datos contextuales. Los indicadores de educación se presentan dentro de una estructura organizativa que:

- distingue entre los actores de los sistemas educativos: estudiantes y profesores, los marcos de la enseñanza y los entornos del aprendizaje, los proveedores de servicios educativos y el conjunto del sistema educativo;

- agrupa los indicadores dependiendo de si estos abordan los resultados educativos desde una perspectiva individual o nacional, los instrumentos políticos o las circunstancias que condicionan estos resultados, o los antecedentes o limitaciones que sitúan las decisiones políticas en su contexto; y

- determina las cuestiones políticas relacionadas con los indicadores, distinguiendo tres categorías principales: la calidad de los resultados y las oportunidades de la educación, la relación entre la equidad y los resultados y las oportunidades de la educación, y la adecuación y eficiencia de la gestión de los recursos.

La siguiente tabla describe las dos primeras dimensiones:

\begin{tabular}{|c|c|c|c|c|c|c|}
\hline & 1. & $\begin{array}{l}\text { Rendimiento } \\
\text { y resultados } \\
\text { de la educación } \\
\text { y el aprendizaje }\end{array}$ & 2. & $\begin{array}{l}\text { Instrumentos } \\
\text { políticos y } \\
\text { circunstancias } \\
\text { que configuran los } \\
\text { resultados de la } \\
\text { educación }\end{array}$ & 3. & $\begin{array}{l}\text { Antecedentes } \\
\text { y limitaciones que } \\
\text { contextualizan las } \\
\text { decisiones políticas }\end{array}$ \\
\hline $\begin{array}{l}\text { I. Personas que } \\
\text { participan en } \\
\text { la educación y } \\
\text { el aprendizaje }\end{array}$ & 1.I. & $\begin{array}{l}\text { Calidad y distribución } \\
\text { de los resultados } \\
\text { individuales de } \\
\text { la educación }\end{array}$ & 2.I. & $\begin{array}{l}\text { Actitudes, compromiso } \\
\text { y comportamientos } \\
\text { individuales con } \\
\text { respecto a la enseñanza } \\
\text { y el aprendizaje }\end{array}$ & 3.I. & $\begin{array}{l}\text { Características del } \\
\text { entorno de alumnos } \\
\text { y profesores }\end{array}$ \\
\hline $\begin{array}{l}\text { II. Marcos de la } \\
\text { enseñanza }\end{array}$ & 1.II. & $\begin{array}{l}\text { Calidad de la } \\
\text { transmisión } \\
\text { de conocimientos }\end{array}$ & 2.II. & $\begin{array}{l}\text { Pedagogía, prácticas } \\
\text { de aprendizaje } \\
\text { y ambiente en el aula }\end{array}$ & 3.II. & $\begin{array}{l}\text { Condiciones de } \\
\text { aprendizaje de los alumnos } \\
\text { y condiciones de trabajo } \\
\text { de los profesores }\end{array}$ \\
\hline $\begin{array}{l}\text { III. Proveedores } \\
\text { de servicios } \\
\text { educativos }\end{array}$ & 1.III. & $\begin{array}{l}\text { Productividad } \\
\text { y rendimiento de los } \\
\text { centros e instituciones } \\
\text { docentes }\end{array}$ & 2.III. & $\begin{array}{l}\text { Entorno y organización } \\
\text { escolar }\end{array}$ & 3.III. & $\begin{array}{l}\text { Características de los } \\
\text { proveedores de servicios } \\
\text { y de sus colectividades }\end{array}$ \\
\hline $\begin{array}{l}\text { IV. Conjunto } \\
\text { del sistema } \\
\text { educativo }\end{array}$ & 1.IV. & $\begin{array}{l}\text { Rendimiento global } \\
\text { del sistema educativo }\end{array}$ & 2.IV. & $\begin{array}{l}\text { Parámetros escolares } \\
\text { de todo el sistema, } \\
\text { asignación de recursos } \\
\text { y políticas educativas }\end{array}$ & 3.IV. & $\begin{array}{l}\text { Contextos nacionales de } \\
\text { carácter educativo, social, } \\
\text { económico y demográfico }\end{array}$ \\
\hline
\end{tabular}




\section{Los actores de los sistemas educativos}

El programa de Indicadores de los Sistemas Educativos (INES) de la OCDE pretende evaluar el rendimiento global de los sistemas nacionales de educación, más que comparar distintas instituciones u otras entidades regionales y locales. No obstante, cada vez es más evidente que muchas de las características importantes del desarrollo, del funcionamiento y del impacto de los sistemas educativos solo pueden ser evaluadas mediante un análisis de los resultados educativos y de su relación con los recursos utilizados y los procesos a un nivel individual e institucional. Con el fin de explicar todo lo anteriormente expuesto, la estructura de los indicadores distingue entre un nivel macro, dos niveles intermedios y un nivel micro de los sistemas educativos. Estos niveles se refieren a:

- el conjunto del sistema educativo;

- las instituciones educativas y los proveedores de servicios educativos;

- el marco de la enseñanza y el entorno de aprendizaje dentro de las instituciones; y

- los participantes individuales en la educación y el aprendizaje.

En cierta medida, estos niveles corresponden a las entidades de las que se han obtenido los datos, pero su importancia se centra sobre todo en el hecho de que muchas características de los sistemas educativos tienen efectos muy diferentes según el nivel del sistema de que se trate, lo cual debe tenerse en cuenta. Por ejemplo, en el nivel de los estudiantes de una clase, la relación entre los resultados de los estudiantes y el tamaño de la clase puede ser negativa en el caso de que grupos con pocos estudiantes se beneficien de un mayor contacto con los profesores. En el nivel de la clase o del centro escolar, a menudo se tiende a agrupar intencionadamente a los estudiantes de forma que aquellos que presentan más dificultades de aprendizaje estén en grupos más reducidos y reciban una atención más individualizada. A nivel del centro escolar, por tanto, es frecuente que la relación que existe entre tamaño de la clase y rendimiento de los estudiantes sea positiva, lo que sugiere que el rendimiento de los estudiantes de clases relativamente numerosas es mejor que el de los de clases más reducidas. A nivel del sistema educativo en su conjunto, la relación entre los resultados de los estudiantes y el tamaño de la clase también puede verse afectado, por ejemplo, por el entorno socioeconómico de los estudiantes del centro o por factores asociados a los hábitos de aprendizaje de los diferentes países. Por este motivo, análisis realizados en el pasado a partir de datos exclusivamente de nivel macro han conducido a veces a conclusiones erróneas.

\section{Resultados, instrumentos políticos y antecedentes}

La segunda dimensión de la estructura organizativa agrupa los indicadores en cada uno de los niveles anteriormente mencionados:

- los indicadores sobre los resultados obtenidos en los sistemas educativos, así como los relacionados con el impacto de los niveles de conocimiento y destreza en los individuos, en las sociedades y en las economías, están agrupados bajo el subtítulo de rendimiento y resultados de la educación y el aprendizaje;

- el subtítulo instrumentos políticos y circunstancias agrupa las actividades que buscan información sobre los instrumentos políticos o las circunstancias que configuran el rendimiento y los resultados en cada nivel; y

- por lo general, estos instrumentos políticos y circunstancias tienen antecedentes, es decir, factores que definen o limitan las políticas. Estos factores se presentan bajo el subtítulo de antecedentes y limitaciones. Los antecedentes o limitaciones suelen ser específicos para un determinado nivel del sistema educativo: los antecedentes a un cierto nivel pueden muy bien constituir instrumentos políticos en un nivel superior. Por ejemplo, para los profesores y los estudiantes de un centro escolar, las cualificaciones de los profesores son una limitación determinada, mientras que en el nivel del sistema educativo el perfeccionamiento profesional del cuerpo docente es un instrumento político clave.

\section{Cuestiones políticas}

Cada una de las celdas así construidas se puede utilizar para abordar una variedad de cuestiones desde diferentes perspectivas políticas. Para los propósitos de esta tabla, las perspectivas políticas se han agrupado en las tres categorías siguientes, que constituyen la tercera dimensión de la estructura definida para organizar los indicadores INES:

- calidad de los resultados y las oportunidades de la educación;

- igualdad de resultados de la educación y equidad de oportunidades educativas; y

- adecuación, efectividad y eficiencia de la gestión de los recursos. 
Además de las dimensiones ya mencionadas, la perspectiva temporal, como dimensión adicional en la estructura, también permite modelar los aspectos dinámicos de la evolución de los sistemas educativos.

Los indicadores presentados en Panorama de la educación 2014 se ajustan a esta estructura, aunque a menudo se refieren a más de una celda.

La mayor parte de los indicadores del Capítulo A titulado Resultados de las instituciones educativas e impacto del aprendizaje están relacionados con la primera columna de la tabla, que describe el rendimiento y los resultados de la educación. Además, los indicadores del Capítulo A que evalúan, por ejemplo, el nivel de formación de diferentes generaciones no se limitan a presentar los resultados de los sistemas educativos, sino que también proporcionan una explicación contextual de interés para políticas educativas actuales, como pueden ser las que se refieren al aprendizaje a lo largo de la vida.

El Capítulo B, que analiza los Recursos económicos y humanos invertidos en educación, proporciona indicadores que constituyen tanto instrumentos políticos como antecedentes de interés para las políticas o, en ocasiones, ambas cosas a la vez. Por ejemplo, el gasto por estudiante es una de las medidas políticas clave que más directamente influye en el estudiante, ya que actúa como una limitación en el entorno del aprendizaje en el centro y en las condiciones de aprendizaje del estudiante en el aula.

El Capítulo C aborda cuestiones relativas al Acceso a la educación, participación y progresión. Los indicadores de este capítulo combinan información sobre resultados, instrumentos políticos y contextos. Por ejemplo, los porcentajes de internacionalización y progresión de la educación miden los resultados de políticas y prácticas en el aula, en el centro escolar y en el sistema educativo. También pueden facilitar información contextual que permita elaborar políticas, mediante la identificación de áreas en las que es necesaria la intervención, por ejemplo, para afrontar el problema de la falta de equidad.

El Capítulo D analiza El entorno de aprendizaje y la organización de los centros escolares. En este capítulo, los indicadores sobre horas lectivas, jornada laboral y salarios de los profesores no son únicamente instrumentos políticos que pueden ser utilizados, sino que proporcionan asimismo información contextual referida, por una parte, a la calidad de la enseñanza en el marco educativo y, por otra parte, a los resultados del estudiante individual. Este capítulo también ofrece datos sobre el perfil de los profesores, los niveles de gobierno donde se toman decisiones sobre la educación y las vías y entradas para acceder a la educación secundaria y terciaria.

Hay que señalar que Panorama de la educación incluye una cantidad significativa de datos sobre países asociados (para más detalles a este respecto véase la Guía del lector). 



\section{GUÍA DEL LECTOR}

\section{Cobertura estadistica}

A pesar de que la falta de datos en muchos países todavía limita el alcance de los indicadores, la cobertura, en principio, abarca la totalidad del sistema educativo nacional (dentro del territorio nacional), independientemente del carácter público o privado de las instituciones implicadas, de sus fuentes de financiación y de los mecanismos utilizados para la prestación de servicios. Con una excepción, que se detallará más adelante, en las estadísticas se incluyen todas las categorías de alumnos y todos los grupos de edad: niños (incluidos los alumnos con necesidades especiales), adultos, ciudadanos del país, ciudadanos extranjeros y alumnos matriculados en programas de educación a distancia, programas de educación especial o programas educativos organizados por ministerios distintos al Ministerio de Educación, a condición de que el programa educativo tenga como principal objetivo ampliar o profundizar los conocimientos del individuo. Sin embargo, los niños menores de tres años solo se incluyen si participan en programas típicamente ofrecidos a niños que tienen como mínimo tres años. El gasto básico en educación y las cifras de matriculación no incluyen la formación profesional y las enseñanzas técnicas dispensadas en el lugar de trabajo, a menos que se trate de programas de formación que combinen estudios y prácticas laborales considerados explícitamente como parte del sistema educativo.

En las estadísticas se incluyen también las actividades educativas clasificadas como enseñanza 'para adultos' o 'no reglada', siempre que impliquen estudios o contenidos curriculares similares a los de la enseñanza reglada o que los programas básicos lleven a la obtención de cualificaciones similares a los de los programas de enseñanza ordinaria correspondientes.

Se han excluido los cursos para adultos que se realizan básicamente por interés general, con fines de enriquecimiento personal o como actividad de tiempo libre.

\section{Información de los países}

Este volumen incluye datos sobre educación de los 34 países miembros de la OCDE, de dos países asociados que participan en el Programa de Indicadores de los Sistemas Educativos de la OCDE (INES), a saber, Brasil y Federación Rusa, y otros países asociados que no participan en INES (Argentina, Arabia Saudí, China, Colombia, India, Indonesia, Letonia y Sudáfrica). Las fuentes de datos para estos últimos ocho países se ofrecen debajo de las tablas.

Los datos estadísticos para Israel fueron proporcionados por las autoridades israelíes competentes bajo su responsabilidad. El uso de estos datos por parte de la OCDE se hace sin prejuzgar la situación de los Altos del Golán, Jerusalén Oriental y las colonias israelíes en Cisjordania de acuerdo con los términos del derecho internacional.

\section{Cálculo de medias internacionales}

La media de la OCDE es la media no ponderada de los datos de todos los países de la OCDE para los que hay datos disponibles o que han podido ser estimados. Por consiguiente, la media de la OCDE se refiere a una media de los valores obtenidos en los sistemas educativos nacionales y se puede utilizar para comparar el valor de un indicador de un país determinado con el valor de un país tipo o país medio. La media de países no tiene en cuenta el tamaño absoluto del sistema educativo de cada país.

El total de la OCDE se calcula como la media ponderada de los datos de todos los países de la OCDE para los que hay datos disponibles o que han podido ser estimados. Esta media refleja el valor para un indicador determinado si se considera toda la OCDE en su conjunto. Este enfoque se utiliza, por ejemplo, en los gráficos sobre el gasto para comparar los datos de un país específico con los de todos los países de la zona OCDE para los que hay datos disponibles, considerando esta zona como una entidad individual. 
Tanto la media de la OCDE como el total de la OCDE pueden verse afectados de manera significativa por la falta de datos. Al tratarse de una muestra de países relativamente pequeña, no se ha utilizado ningún método estadístico para compensar esta carencia. En los casos en los que una categoría de datos no es aplicable a un país determinado (código "a») o el valor de los datos es insignificante para el cálculo correspondiente (código «n»), se ha atribuido el valor cero con el fin de calcular la media de la OCDE. En los casos en los que ni el numerador ni el denominador de una ratio es aplicable a un país determinado (código «a»), dicho país no se incluye en la media de la OCDE.

En las tablas sobre financiación que utilizan series de tendencia para el periodo 1995-2011, tanto la media de la OCDE como el total de la OCDE también han sido calculados para los países que tienen datos de todos los años de referencia, lo cual permite realizar una comparación de la media de la OCDE y el total de la OCDE para ese periodo de tiempo, evitando así distorsiones causadas por la exclusión de ciertos países en diferentes años.

Asimismo, se presenta en muchos indicadores una media UE21. Se calcula como la media no ponderada de los valores de los datos relativos a los 21 países de la OCDE que son miembros de la Unión Europea para los cuales hay datos disponibles o que se pueden estimar. Estos 21 países son Alemania, Austria, Bélgica, Dinamarca, Eslovenia, España, Estonia, Finlandia, Francia, Grecia, Hungría, Irlanda, Italia, Luxemburgo, Países Bajos, Polonia, Portugal, Reino Unido, República Checa, República Eslovaca y Suecia.

Se presenta para algunos indicadores una media G20. Se calcula como la media no ponderada de los datos de todos los países del G20 cuando se dispone de datos o se pueden estimar (Arabia Saudí, Argentina, Australia, Brasil, Canadá, China, Corea, España, Estados Unidos, Federación Rusa, Francia, India, Indonesia, Italia, Japón, México, Reino Unido, Sudáfrica y Turquía; la Unión Europea es el miembro número 20 del G20, pero no se incluye en los cálculos). No se calcula la media del G20 si no se dispone de datos de China o India.

Algunos indicadores presentan una media. Esta media se incluye en las tablas que incluyen datos de la Encuesta sobre las Competencias de los Adultos 2012, un producto del Programa para la Evaluación Internacional de las Competencias de los Adultos (PIAAC, por sus siglas en inglés) de la OCDE. Esta media se corresponde con la media aritmética de las estimaciones incluidas en la tabla o gráfico, tanto de entidades nacionales como subnacionales (incluyendo Flandes [Bélgica] e Inglaterra/Irlanda del Norte [Reino Unido]). Los países asociados no están incluidos en ninguna de las medias presentadas en las tablas o gráficos.

\section{Error estándar (E.E.)}

Las estimaciones estadísticas que se presentan en este informe se basan en grupos de muestra de adultos, y no en los valores que se podrían obtener si cada persona de la población objeto de estudio en cada país respondiera a cada pregunta. Por tanto, cada estimación conlleva un grado de incertidumbre asociado con el muestreo y con errores de medida que se puede expresar como un error estándar. El uso de intervalos de confianza permite extraer deducciones sobre las medias y las proporciones de la población reflejando la incertidumbre asociada a las estimaciones de la muestra. En este informe, los intervalos de confianza se establecen a un nivel del $95 \%$. Es decir, el resultado de la población correspondiente se encontraría dentro de un intervalo de confianza en 95 de cada 100 réplicas de la medida en distintas muestras extraídas de la misma población.

En las tablas que muestran un error estándar, una de las columnas se denomina «\%», e indica el porcentaje medio, y otra de las columnas se denomina «E.E.», e indica el error estándar. Dado el método de sondeo, los porcentajes incluyen una incertidumbre de muestreo de dos veces el error estándar (E.E.). Por ejemplo, en los valores: $\%=10$ y E.E. = 2,6, el valor $10 \%$ incluye una zona de incertidumbre de dos veces $(1,96)$ el error estándar de 2,6 , asumiendo un riesgo de error del $5 \%$. Por tanto, el verdadero porcentaje probablemente se encontraría (riesgo de error del $5 \%$ ) entre un $5 \%$ y un $15 \%$ («intervalo de confianza»). El intervalo de confianza se calcula de la siguiente manera: \% +/- 1,96* E.E., es decir, en el ejemplo anterior, $5 \%=10 \%-1,96 * 2,6$ y $15 \%=10 \%+1,96 * 2,6$.

\section{Clasificación de los niveles educativos}

La clasificación de los niveles educativos está basada en la revisión de la Clasificación Internacional Normalizada de la Educación (CINE, ISCED 1997 en inglés). ISCED 1997 es una herramienta para recopilar estadísticas 
educativas a nivel internacional; distingue entre seis niveles de educación. CINE 1997 ha sido recientemente revisada y la nueva Clasificación Internacional Normalizada de la Educación (CINE 2011) ha sido adoptada oficialmente en noviembre de 2011. Esta nueva clasificación será implementada en Panorama de la educación 2015.

\section{Término utilizado en esta publicación}

\section{Educación infantil}

Primera etapa de la enseñanza organizada, diseñada para introducir a los niños muy pequeños en la atmósfera escolar. Edad mínima de ingreso: 3 años.

\section{Educación primaria}

Diseñada para proporcionar una sólida educación básica en lectura, escritura y matemáticas, y una comprensión básica de algunas otras materias. Edad de ingreso: entre 5 y 7 años. Duración: 6 años.

\section{Educación secundaria inferior}

Completa la educación básica, por lo general con una orientación más temática y con profesores más especializados. El ingreso sigue a los 6 años de educación primaria. Duración: 3 años. En algunos países, el final de este nivel marca el final de la educación obligatoria.

\section{Educación secundaria superior}

Mayor especialización por materias que en secundaria inferior, con profesores por lo general más cualificados. Se supone que los estudiantes hayan completado 9 años de educación o escolarización de secundaria inferior antes de ingresar en secundaria superior y tienen por lo común 15 o 16 años.

\section{Educación postsecundaria no terciaria}

Este nivel, a escala internacional, es un puente entre la educación secundaria superior y la educación postsecundaria. Sin embargo, a escala nacional se le podría considerar como un nivel de secundaria superior o postsecundaria. El contenido del programa, sin ser tan avanzado como el de los programas terciarios, puede no ser mucho más avanzado que el de secundaria superior. Su duración suele equivaler a entre 6 meses y 2 años de estudio a tiempo completo. Los estudiantes suelen ser mayores que los matriculados en educación secundaria superior.

\section{Educación terciaria}

\section{Educación terciaria de tipo A}

Los programas suelen tener una base teórica y han sido concebidos para el acceso a programas de investigación avanzada y profesiones que requieren un alto grado de conocimientos y cualificaciones, como medicina, odontología o arquitectura. La duración es al menos de 3 años a tiempo completo, aunque la duración usual es de 4 o más años. Estos programas no se ofrecen exclusivamente en las universidades; y no todos los programas reconocidos a escala nacional como programas universitarios cumplen los criterios necesarios para ser clasificados como programas terciarios de tipo A. Los programas terciarios de tipo A incluyen programas de segundo grado, como el máster americano.
Clasificación CINE (y subcategorías)

CINE 0

CINE 1

CINE 2 (subcategorías: 2A prepara a los estudiantes para continuar la educación académica que conduce a $3 \mathrm{~A} ; 2 \mathrm{~B}$ tiene una orientación más profesional que conduce a $3 \mathrm{~B}$; $2 \mathrm{C}$ ofrece preparación para entrar en el mercado laboral)

CINE 3 (subcategorías: 3A prepara a los estudiantes para la educación de nivel universitario 5A; 3B para el ingreso en educación terciaria de orientación profesional $5 \mathrm{~B} ; 3 \mathrm{C}$ prepara a los estudiantes para el mercado laboral o para la educación postsecundaria no terciaria del nivel CINE 4)

CINE 4 (subcategorías: el nivel 4A puede preparar a los alumnos para el acceso a la educación terciaria, tanto a la universitaria como a la formación profesional; el 4B suele prepararlos para entrar en el mercado laboral)

CINE 5 (subcategorías: 5A y 5B; véase a continuación)

\section{CINE 5A}


Educación terciaria de tipo $B$

Los programas suelen ser más cortos que los estudios terciarios de tipo A y se centran en el desarrollo de destrezas técnicas, prácticas u ocupacionales para el acceso directo al mercado laboral, aunque puede que los programas respectivos comprendan algunas bases teóricas. Su duración mínima es equivalente a 2 años a tiempo completo en el nivel terciario.

\section{Programas de investigación avanzada}

Programas que llevan directamente a obtener una cualificación en investigación avanzada, como por ejemplo un doctorado.

En la mayoría de los países, la duración teórica de estos programas es de 3 años a tiempo completo (para un total acumulado de un equivalente al menos a 7 años a tiempo completo al nivel terciario). No obstante, el tiempo real de matriculación suele ser más largo. Los programas están dedicados a estudios avanzados e investigaciones originales.
CINE 5B

CINE 6

El glosario que aparece en la página de Internet www.oecd.org/edu/eag.htm también describe detalladamente estos niveles educativos, y el Anexo 1 muestra las edades típicas de los graduados en los principales programas educativos, por cada nivel CINE.

\section{Simbolos utilizados para los datos que faltan y abreviaturas}

En las tablas y los gráficos se utilizan estos símbolos y abreviaturas:

a Datos no aplicables porque la categoría no existe en el país.

c El número de observaciones no es suficiente para permitir cálculos fiables (es decir, en PISA hay menos de 30 estudiantes o menos de 5 centros escolares con datos válidos; en la Encuesta sobre las Competencias de los Adultos hay menos de 30 individuos). No obstante, estas estadísticas han sido incluidas en el cálculo de las medias nacionales.

EESC Índice PISA de estatus económico, social y cultural

m Datos no disponibles.

n Magnitud insignificante o igual a cero.

$r$ Los valores son inferiores a un determinado umbral de fiabilidad y deberían ser interpretados con precaución (para definiciones específicas en cada país, véase Anexo 3).

E.E. Error estándar.

w Datos retirados a petición del país en cuestión.

$\mathrm{x}$ Datos incluidos en otra categoría o en otra columna de la tabla: por ejemplo, $\mathrm{x}(2)$ significa que los datos figuran en la columna 2 de la tabla.

Media no comparable con otros niveles de educación.

\section{Otros recursos}

La página de Internet www.oecd.org/edu/eag.htm proporciona información detallada acerca de los métodos empleados para el cálculo de los indicadores, la interpretación de los mismos en los contextos nacionales respectivos y las fuentes de datos utilizadas. También facilita acceso a los datos de base de los indicadores y a un glosario en inglés y francés de los términos técnicos usados en esta publicación.

Todos los cambios introducidos después de la publicación de Panorama de la educación 2012 aparecen en la página de Internet www.oecd.org/edu/eag.htm.

Panorama de la educación utiliza el servicio StatLinks de la OCDE. Todas las tablas y gráficos de la presente

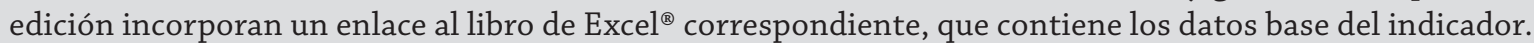
Estos enlaces son estables y permanecerán invariables. Además, los usuarios de la versión electrónica de Panorama de la educación podrán acceder directamente al libro de Excel en una ventana separada a través de estos enlaces. 


\section{Disposición de las tablas}

En todas las tablas, los números que aparecen en paréntesis en la parte superior de las columnas se utilizan simplemente como referencia. Cuando no aparece un número consecutivo, la columna solo está disponible en Internet.

\section{Códigos utilizados para las entidades territoriales}

Los siguientes códigos se emplean en algunos gráficos. El nombre del país o entidad territorial se emplea en el texto. Nótese que en todo el texto la Comunidad flamenca de Bélgica se puede denominar «Bélgica (Fl.)» y la Comunidad francófona «Bélgica (Fr.)», o «Flandes (Bélgica) y «Bélgica (Fr.)», respectivamente.

$\begin{array}{ll}\text { ARG Argentina } & \text { ISL Islandia } \\ \text { AUS Australia } & \text { ISR Israel } \\ \text { AUT Austria } & \text { ITA Italia } \\ \text { BEL Bélgica } & \text { JPN Japón } \\ \text { BFL Bélgica (comunidad flamenca) } & \text { KOR Corea } \\ \text { BFR Bélgica (comunidad francófona) } & \text { LUX Luxemburgo } \\ \text { BRA Brasil } & \text { LVA Letonia } \\ \text { CAN Canadá } & \text { MEX México } \\ \text { CHE Suiza } & \text { NLD Países Bajos } \\ \text { CHL Chile } & \text { NOR Noruega } \\ \text { CHN China } & \text { NZL Nueva Zelanda } \\ \text { CZE República Checa } & \text { POL Polonia } \\ \text { DEU Alemania } & \text { PRT Portugal } \\ \text { DNK Dinamarca } & \text { RUS Federación Rusa } \\ \text { ENG Inglaterra } & \text { SAU Arabia Saudí } \\ \text { ESP España } & \text { SCO Escocia } \\ \text { EST Estonia } & \text { SVK República Eslovaca } \\ \text { FIN Finlandia } & \text { SVN Eslovenia } \\ \text { FRA Francia } & \text { SWE Suecia } \\ \text { GRC Grecia } & \text { TUR Turquía } \\ \text { HUN Hungría } & \text { UKM Reino Unido } \\ \text { IDN Indonesia } & \text { USA Estados Unidos } \\ \text { IND India } & \text { ZAF Sudáfrica } \\ \text { IRL Irlanda } & \end{array}$





\section{ACERCA DE LA ENCUESTA SOBRE LAS COMPETENCIAS DE LOS ADULTOS}

\section{El diseño y los métodos}

La Encuesta sobre las Competencias de los Adultos, que forma parte del Programa para la Evaluación Internacional de las Competencias de los Adultos (PIAAC, por sus siglas en inglés) de la OCDE, evaluó los niveles de comprensión lectora, de competencia matemática y de resolución de problemas en ambientes informatizados de los adultos de 16 a 65 años. Estas destrezas son competencias clave para procesar información en diferentes contextos sociales y laborales y son necesarias para la plena integración y participación de los adultos en el mercado laboral y en la educación, así como en la formación y la vida social y cívica.

También se recopiló información sobre los antecedentes de los encuestados, su educación, su experiencia en el mercado laboral, su salud. Además, la encuesta recoge una amplia gama de información sobre las actividades de los encuestados relacionadas con la lectura y las matemáticas, así como información sobre el uso de tecnologías de la información y de la comunicación en el trabajo y en la vida cotidiana, y sobre una serie de competencias genéricas, como la colaboración con los demás y la organización de su propio tiempo, requeridas a las personas en su trabajo. Asimismo se les preguntó si sus competencias y cualificaciones coincidían con los requisitos de sus empleos y si gozaban de autonomía sobre aspectos clave de su trabajo.

La Encuesta sobre las Competencias de los Adultos se diseñó principalmente como una evaluación informatizada. La mayoría de los encuestados realizaron dicha evaluación en este formato, pero los participantes sin experiencia previa con ordenadores o con conocimientos de informática limitados la realizaron en formato impreso. Todos ellos completaron la evaluación en el idioma nacional de su país, en los idiomas del país de residencia o, en algunos casos, en un idioma minoritario.

Veinticuatro países ${ }^{1}$ participaron en la primera ronda de la evaluación ${ }^{2}$. En la mayoría de ellos, la recopilación de datos se llevó a cabo entre agosto de 2011 y marzo de 2012. Todos los países participantes realizaron las evaluaciones de comprensión lectora y de competencia matemática. En cuatro países (Chipre ${ }^{3}$, España, Francia e Italia) no se realizó la prueba sobre resolución de problemas en ambientes informatizados.

Los lectores deben tener en cuenta que la muestra de Federación Rusa no incluye a la población del área municipal de Moscú. Por tanto, los datos publicados no representan a toda la población de 16 a 65 años residente en Rusia, sino a la población de Rusia excluyendo la población que reside en el área municipal de Moscú. Se puede encontrar información más detallada sobre los datos de Federación Rusa así como de otros países en el Technical Report of the Survey of Adult Skills (OECD, 2013, de próxima publicación).

Para más información sobre el diseño y los métodos utilizados en la encuesta, consulte los siguientes enlaces:

OECD (2013), OECD Skills Outlook 2013: First Results from the Survey of Adult Skills, OECD Publishing, París, http: // dx.doi.org/10.1787/9789264204256-en.

OECD (2013), The Survey of Adult Skills: Reader's Companion, OECD Publishing, París, http://dx.doi.org/ 10.1787/9789264204027-en.

La Encuesta sobre las Competencias de los Adultos define la comprensión lectora, la competencia matemática y la resolución de problemas en ambientes informatizados de la siguiente manera:

\section{Comprensión lectora}

La comprensión lectora se define como «la capacidad de comprender, evaluar y utilizar la información escrita para participar en la sociedad, lograr distintas metas y desarrollar el conocimiento y el potencial de uno mismo». No se trata solo de producir y comprender el lenguaje hablado o de elaborar textos (escritura). La comprensión lectora supone la capacidad que implica la construcción de significados, la valoración y el uso de información escrita para 
lograr una serie de objetivos en distintos contextos. Por tanto, va más allá de las destrezas de decodificación o de comprensión de textos para abarcar la capacidad de responder a los textos de manera apropiada en el contexto correspondiente.

\section{Competencia matemática}

La competencia matemática se define como la capacidad de identificar, usar, interpretar y comunicar ideas e información matemática para participar y gestionar las necesidades matemáticas que surgen en determinadas situaciones a lo largo de la edad adulta. Un adulto competente en matemáticas es aquel que responde de forma adecuada a los contenidos matemáticos, a la información y a las ideas representadas de diversas maneras con el fin de gestionar situaciones y resolver problemas en la vida real. Aunque la competencia matemática depende, en parte, de la capacidad lectora y de la comprensión de un texto, implica más que la simple aplicación de las destrezas aritméticas a la información insertada en dicho texto.

\section{Resolución de problemas en ambientes informatizados}

La resolución de problemas en ambientes informatizados se define como «el uso de la tecnología digital, de las herramientas de comunicación y las redes para adquirir y evaluar información, comunicarse con otros y realizar tareas prácticas». Esta competencia se centra en «la capacidad para resolver problemas con fines personales, laborales y cívicos mediante la creación de objetivos y planes apropiados a través del acceso y del uso de la información con la ayuda de ordenadores y redes informáticas» (OCDE Skills Outlook 2013: First Results from the Survey of Adult Skills, http: //dx.doi.org/10.1787/9789264204256-en).

La resolución de problemas en ambientes informatizados representa la confluencia entre lo que a veces se describe como «competencia informática» (es decir, la capacidad de usar herramientas y aplicaciones TIC) y las destrezas cognitivas necesarias para resolver problemas. Sin embargo, el objetivo no era poner a prueba la competencia en las herramientas TIC de forma aislada, sino evaluar la capacidad de los adultos para utilizarlas con el fin de identificar, procesar, evaluar y analizar la información de manera efectiva para conseguir los objetivos marcados.

\section{Informe sobre los resultados}

En cada uno de los tres ámbitos evaluados, la competencia se considera como un proceso de capacitación continuo que implica el dominio de las tareas de procesamiento de la información de creciente complejidad. Los resultados están representados en una escala de 500 puntos.

Para facilitar la interpretación de los resultados, esta escala se ha dividido en «niveles de competencia» definidos por rangos de puntuación. Se han establecido seis niveles de competencia para la comprensión lectora y competencia numérica (Niveles del 1 al 5 y por debajo del Nivel 1) y cuatro niveles para la resolución de problemas en entornos tecnológicos (Niveles del 1 al 3 y por debajo del Nivel 1). Cada nivel de competencia se define por el tipo de tareas que los adultos pueden completar con éxito y les otorga una puntuación que les sitúa dentro del rango de puntuación que define a un nivel. A continuación se detallan las descripciones de los tipos de tareas relacionadas con cada nivel competencia.

\section{Competencia en el Nivel 5 (puntuaciones iguales o superiores a 376 puntos)}

El Nivel 5 es el nivel de competencia más alto de la escala. Los adultos que alcanzan este nivel son capaces de realizar tareas que implican la búsqueda y la integración de información a través de textos complejos y extensos, de sintetizar ideas o puntos de vista similares y opuestos, o de evaluar pruebas y argumentos. También pueden aplicar y analizar modelos lógicos y conceptuales, contrastar la fiabilidad de las fuentes y seleccionar la información clave. Son conscientes de cuál es la información retórica y sutil, y son capaces de realizar inferencias de alto nivel o utilizar conocimientos básicos específicos.

\section{Competencia en el Nivel 4 (puntuaciones entre 326 puntos y por debajo de 376 puntos)}

En el Nivel 4, los adultos pueden realizar operaciones múltiples para integrar, interpretar o sintetizar información de múltiples tipos de textos, complejos o extensos, continuos, discontinuos o mixtos que implican información condicional o irrelevante.

\section{Competencia en el Nivel 3 (puntuaciones entre 276 puntos y por debajo de 326 puntos)}

Los adultos que alcanzan el Nivel 3 pueden comprender y responder adecuadamente a los textos complejos o extensos, incluyendo textos continuos, discontinuos o mixtos. También pueden entender las estructuras del texto y los 
recursos retóricos y pueden identificar, interpretar o evaluar una o más partes de la información y, por tanto, realizar deducciones apropiadas. Pueden realizar operaciones múltiples y distinguir los datos relevantes de la información irrelevante con el fin de identificar y formular respuestas.

\title{
Competencia en el Nivel 2 (puntuaciones entre 226 puntos y por debajo de 276 puntos)
}

En el Nivel 2, los adultos pueden integrar dos o más partes de la información según un criterio determinado. También son capaces de comparar, contrastar o hacer razonamientos acerca de la información dada y hacer deducciones de bajo nivel. También pueden buscar en los textos digitales para identificar la información en diversas partes de un documento.

\section{Competencia en el Nivel 1 (puntuaciones entre 176 puntos y por debajo de 226 puntos)}

En el Nivel 1, los adultos pueden leer textos continuos relativamente cortos, tanto digitales como impresos, así como textos discontinuos o mixtos para localizar una determinada parte de la información que es idéntica o similar a la información dada en la pregunta o directriz. Estos textos contienen poca información irrelevante. Los adultos que alcanzan este nivel pueden rellenar formularios simples, comprender el vocabulario básico, determinar el significado de las oraciones y leer textos continuos con un cierto grado de fluidez.

\section{Competencia por debajo del Nivel 1 (puntuaciones por debajo de 176 puntos)}

Los individuos en este nivel pueden leer textos breves relacionados con temas familiares y localizar una parte específica de la información que se asemeja a la información de la pregunta o directriz. No es preciso que entiendan la estructura de las oraciones o párrafos y solo se requiere de ellos el conocimiento de vocabulario básico. Las tareas por debajo del Nivel 1 no emplean funciones específicas relacionadas con los textos digitales.

Para obtener más información acerca de la Encuesta sobre las Competencias de los Adultos (PIAAC), consulte el siguiente enlace: http://skills.oecd.org y http://www.oecd.org/site/piaac/

\author{
Notas \\ 1. Alemania, Australia, Austria, Bélgica (Flandes), Canadá, Corea, Chipre, Dinamarca, España, Estados Unidos, Estonia, \\ Federación Rusa, Finlandia, Francia, Irlanda, Italia, Japón, Noruega, Países Bajos, Polonia, Reino Unido (Inglaterra e Irlanda del \\ Norte), República Checa, República Eslovaca y Suecia. \\ 2. Otros 9 países aportarán datos en 2014. \\ 3. Los lectores deben tener en cuenta la información siguiente facilitada por Turquía y los Estados Miembros de la Unión Europea \\ integrados en la OCDE con respecto a la situación de Chipre:
}

Nota de las autoridades de Turquía: La información que aparece en esta publicación sobre Chipre se refiere a la zona sur de la isla. No existe ninguna autoridad en la isla que represente a la población turca y a la grecochipriota. Turquía reconoce a la República Turca del Norte de Chipre (TRNC, por sus siglas en inglés). Hasta que no se encuentre una solución perdurable y justa dentro del contexto de las Naciones Unidas, Turquía se reserva su posición en lo concerniente a la «situación de Chipre».

Nota de los Estados Miembros de la Unión Europea integrados en la OCDE y de la Unión Europea: La República de Chipre está reconocida por todos los miembros de Naciones Unidas, excepto Turquía. La información que aparece en este documento hace referencia a la zona situada bajo el control efectivo del Gobierno de la República de Chipre. 



\section{Capítulo}
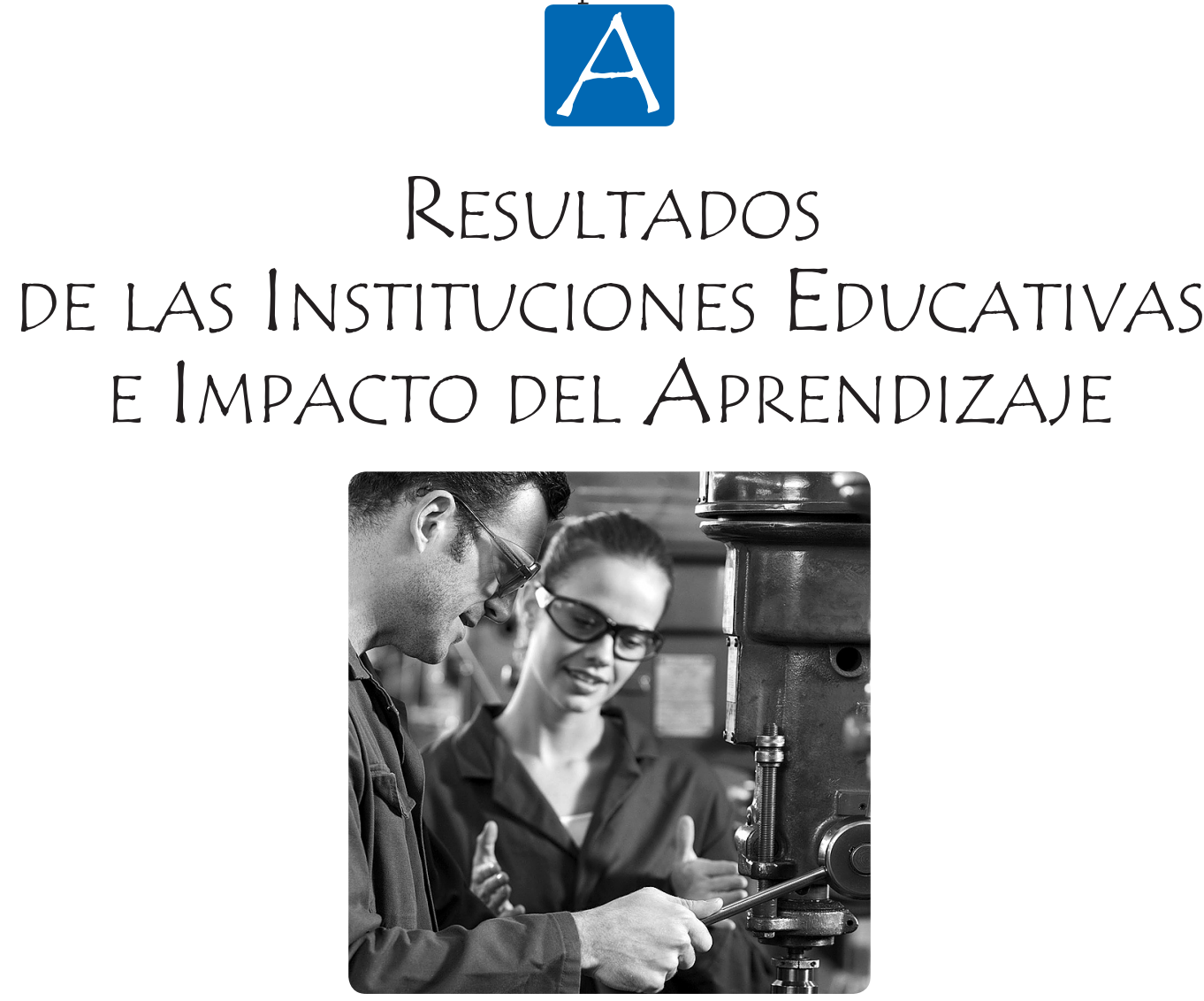

Indicador A1 ¿Hasta qué nivel han estudiado los adultos? StatLink त्ञाजा http://dx.doi.org/10.1787/888933114761

Indicador A2 ¿Cuántos estudiantes se espera que completen la educación secundaria superior?

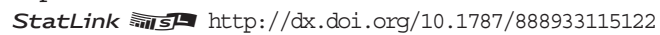

Indicador A3 ¿Cuántos estudiantes se espera que completen la educación terciaria?

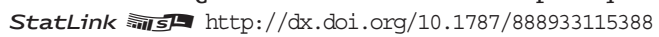

Indicador A4 ¿En qué medida influye la educación de los padres en la participación de los hijos en educación terciaria?

StatLink 部西 http://dx.doi.org/10.1787/888933115521

Indicador A5 ¿Cómo afecta el nivel educativo alcanzado a la participación en el mercado laboral?

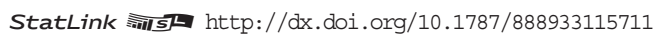

Indicador A6 ¿Cuáles son las ventajas de la educación en los ingresos?

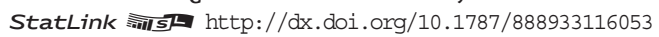

Indicador A7 ¿Cuáles son los incentivos para invertir en educación?

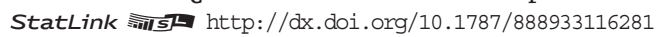

Indicador A8 ¿Cuáles son los resultados sociales de la educación?

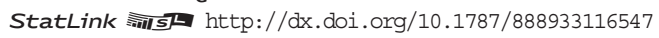

Indicador A9 ¿Qué relación existe entre el rendimiento de los estudiantes y la equidad en educación?

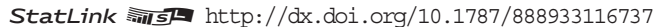




\section{¿HASTA QUÉ NIVEL HAN ESTUDIADO LOS ADULTOS?}

- En todos los países, aproximadamente un 75 \% de los adultos entre 25 y 64 años de edad han completado como mínimo la educación secundaria superior; en la franja entre los 25 y los 34 años, esta proporción es del $80 \%$.

- Como media, las mujeres entre 25 y 34 años de edad consiguen resultados superiores a los de los hombres de su misma edad, tanto en la educación secundaria superior como en la educación terciaria.

- En todos los países que participaron en la Encuesta sobre las Competencias de los Adultos (PIAAC), la proporción de adultos que alcanzan los niveles más altos en comprensión lectora es mayor entre los adultos que han completado la educación terciaria.

\section{Gráfico A1.1. Porcentaje de adultos con educación terciaria en 2000 y 2012}

\section{5-64 años}

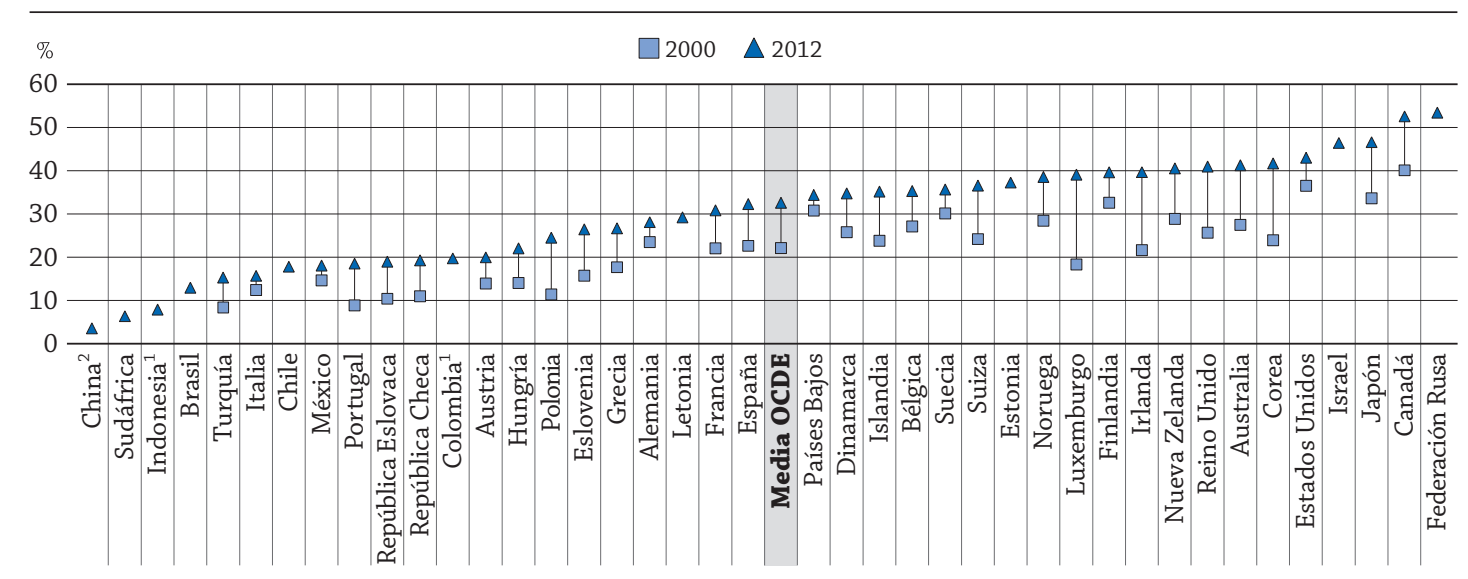

1. Año de referencia 2011.

2. Año de referencia 2010.

Los países están clasificados en orden ascendente del porcentaje de adultos de 25 a 64 años que completaron en 2012 (o el último año disponible) la educación terciaria.

Fuente: OCDE. Tabla A1.4a. Para ver notas, consulte Anexo 3 (www.oecd.org/edu/eag.htm).

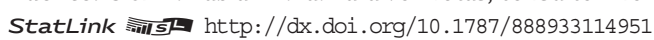

\section{Contexto}

El nivel de educación alcanzado es el porcentaje de una población que ha completado un determinado nivel de educación. Un nivel más elevado de educación se asocia con mejor salud, mayor participación social y tasas de empleo más elevadas, y se percibe como un acceso a mejores oportunidades laborales y a ingresos relativos más elevados. Las competencias básicas, como la lectura y la competencia matemática, también guardan una estrecha relación con mejores resultados en el mercado laboral y con vidas mejores y más saludables. Todo esto constituye un fuerte incentivo para que las personas deseen obtener un nivel de educación más elevado y para que los gobiernos desarrollen las competencias de la población por medio de la educación.

El nivel de educación alcanzado se utiliza frecuentemente como medida del capital humano y del nivel de competencias de un individuo, en otras palabras, es una medida de las competencias de las que dispone la población y la fuerza laboral. Las cualificaciones ofrecen información certificada sobre el tipo de conocimientos y competencias que las personas graduadas han adquirido a través de la educación formal.

La importancia de la educación y la formación reglada para el desarrollo de competencias como la comprensión lectora y la competencia matemática es hoy en día más evidente que nunca. La Encuesta sobre las Competencias de los Adultos (OECD, 2013a), producto del Programa para la Evaluación Internacional de las Competencias de los Adultos (PIAAC) de la OCDE, complementa los datos anuales sobre los niveles de formación con nuevos datos relativos a la distribución de competencias en lectura, competencia matemática y competencias para la solución de problemas en la población adulta. 
Durante las últimas décadas, casi todos los países de la OCDE han experimentado ascensos significativos en los niveles de formación alcanzados por sus poblaciones. La educación terciaria se ha expandido de manera notable y, en la mayor parte de los países de la OCDE, una gran mayoría de adultos cuenta actualmente con una cualificación de educación secundaria superior.

Este indicador incluye información sobre los niveles de educación alcanzados y, por primera vez, un panorama de las competencias de los adultos que incluye nivel y orientación de la formación, edad y sexo.

\section{Otros resultados}

- En algunos países de la OCDE, las tasas de educación terciaria de los adultos jóvenes superan las de los adultos de más edad en una media de más de 20 puntos porcentuales.

- En la mayor parte de los países de la OCDE y países asociados, más del $40 \%$ de los adultos entre 25 y 34 años han completado la educación terciaria, pero en los adultos entre 55 y 64 años esta proporción solo se alcanza en Canadá, Estados Unidos, Federación Rusa e Israel.

- En Australia, Finlandia, Japón, Países Bajos y Suecia, más del 30 \% de los adultos con educación terciaria alcanzan el Nivel 4 o 5 -los niveles más elevados- en comprensión lectora en la Encuesta sobre las Competencias de los Adultos.

\section{Tendencias}

Entre 2000 y 2012, la proporción de personas que no han completado la educación secundaria superior o postsecundaria no terciaria ha disminuido a un ritmo medio anual del $3 \%$. Mientras tanto, la educación terciaria continuó expandiéndose durante el mismo periodo, aumentando en más de un $3 \%$ cada año. Por primera vez en 2012, en los países de la OCDE uno de cada tres adultos tenía una cualificación de educación terciaria.

Las diferencias de sexo en cuanto a los niveles de educación alcanzados se han invertido a lo largo de los años. En el año 2000, las tasas de hombres adultos con educación terciaria superaban a las de las mujeres adultas. En 2012, la situación es la inversa: un 34\% de mujeres han completado la educación terciaria en comparación con un $31 \%$ de los hombres.

\section{Nota}

En esta publicación diversos indicadores muestran el nivel de educación alcanzado por las personas. El Indicador A1 muestra el nivel de formación, es decir, el porcentaje de una población que ha completado con éxito un nivel concreto de educación y la relación que existe entre el nivel de formación y la adquisición de competencias básicas. Las tasas de graduación en los Indicadores A2 y A3 miden el porcentaje estimado de adultos jóvenes que se prevé que conseguirán una graduación de un nivel concreto de educación a lo largo de sus vidas. Las tasas de graduación de los programas de educación secundaria superior del Indicador A2 estiman la proporción de estudiantes que acceden a un programa y lo completan con éxito en un determinado periodo de tiempo. 


\section{Análisis}

\section{Niveles de educación alcanzados en los paises de la OCDE}

\section{Nivel de educación secundaria superior e importancia de la formación profesional (FP)}

El nivel de educación más comúnmente alcanzado en la mayoría de los países de la OCDE es la educación secundaria superior: la proporción de adultos (entre 25 y 64 años) cuyo nivel máximo de educación alcanzado es la educación secundaria superior o postsecundaria no terciaria (niveles CINE 3 y 4; véase la sección Definiciones al final de este capítulo) es mayor que la de los adultos con otros niveles máximos de educación. Como media, la educación secundaria superior es el nivel máximo de graduación alcanzado por aproximadamente un $45 \%$ de los adultos de los países de la OCDE. En Austria, Hungría, Letonia, Polonia, República Checa y República Eslovaca, más del $60 \%$ de los adultos han completado este nivel de educación (Tabla A1.4a).

El aumento de las tasas de graduación señala que las personas están permaneciendo más tiempo en el sistema educativo y que las iniciativas políticas han tenido éxito en su tratamiento de problemas como el abandono escolar y la falta de equidad en la educación. De hecho, los resultados del último ciclo del Programa para la Evaluación Internacional de Alumnos (PISA) de la OCDE pusieron de manifiesto que la mayor parte de los países que han mejorado su rendimiento desde 2003 mantuvieron o mejoraron la equidad en la educación, promoviendo el acceso universal a un estándar mínimo de educación (OECD, 2013b).

\section{Gráfico A1.2. Población cuyo máximo nivel de educación alcanzado es la educación secundaria superior o postsecundaria no terciaria, por orientación del programa (2012)}

\section{Entre 25 y 64 años de edad}

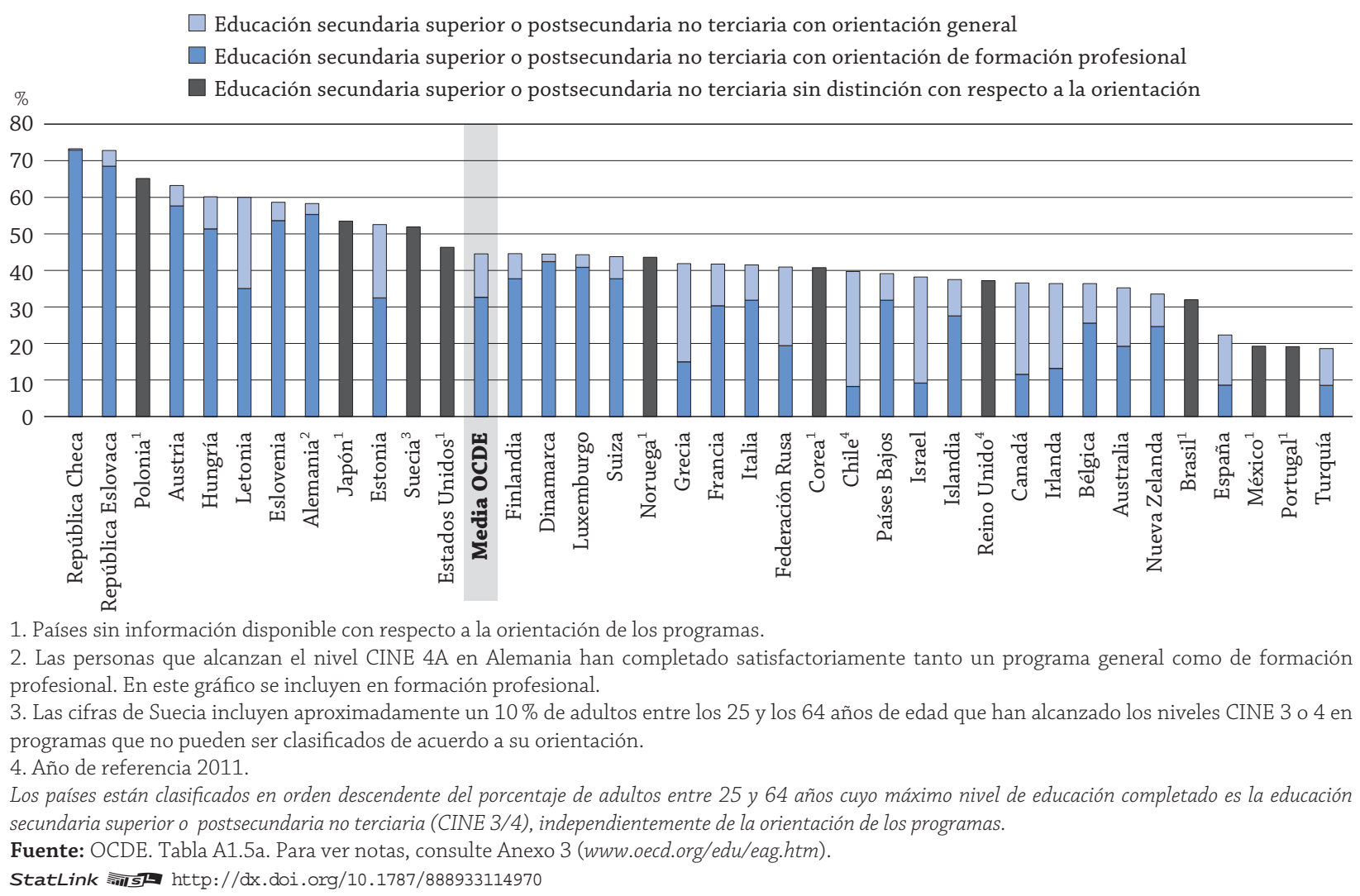

El Gráfico A1.2 muestra el porcentaje de la población cuyo nivel máximo de educación alcanzado es la educación secundaria superior o postsecundaria no terciaria y si la graduación obtenida es parte de un itinerario general o profesional. Muestra también la importancia que tiene la formación profesional en la educación secundaria superior en distintos países. Al menos uno de cada dos adultos en Alemania, Austria, Eslovenia, Hungría, República Checa y República Eslovaca cuenta con una graduación profesional de educación secundaria superior como nivel máximo de educación alcanzado, mientras que en Chile, España, Israel y Turquía esta proporción es inferior al $10 \%$. Existen 
grandes diferencias entre países, tanto en el nivel de educación alcanzado dependiendo de la orientación de los programas como en la tasa de graduaciones de educación secundaria superior en general (Tabla A1.5a).

Los países que tienen tasas de graduación secundaria superior relativamente bajas se dividen en dos categorías: o bien la mayor parte de las personas dejan la educación antes de obtener una cualificación secundaria superior (es decir, su nivel de educación es inferior a la educación secundaria superior), o bien continúan su educación más allá de este nivel hasta completar un nivel superior (es decir, completan la educación terciaria). En Australia, Canadá, Corea, España, Federación Rusa, Irlanda, Israel, Nueva Zelanda y Reino Unido, las tasas de graduación terciaria son superiores a las tasas de graduación secundaria superior. En Luxemburgo y Portugal, las tasas de graduación secundaria superior y graduación terciaria son similares (Tabla A1.4a).

La diferencia por sexo en las tasas de graduación se ha revertido entre los adultos más jóvenes. Como media, las mujeres entre 25 y 34 años muestran tasas de graduación más elevadas en educación terciaria que los hombres de la misma edad. Como media, aproximadamente un $84 \%$ de las mujeres más jóvenes han completado al menos la educación secundaria superior, mientras que en el caso de los hombres más jóvenes lo han hecho un 81 \% (Tablas A1.2b y A1.4b, disponibles en Internet).

\section{Graduaciones terciarias}

El Gráfico A1.1 muestra que, en los países de la OCDE, las graduaciones terciarias (incluyendo los programas de investigación avanzada, es decir, los niveles CINE 5A, 5B y 6) han aumentado en 10 puntos porcentuales desde el año 2000. Como media, un $34 \%$ de las mujeres adultas y un $31 \%$ de los hombres adultos han completado la educación terciaria. Los adultos más jóvenes han incentivado este aumento, y el cambio es aún mayor entre las mujeres: en todos los países de la OCDE: las mujeres más jóvenes muestran tasas de graduación terciaria que superan las de las mujeres de más edad en una media de más de 20 puntos porcentuales (Tabla A1.3b, disponible en Internet).

\section{Gráfico A1.3. Porcentaje de adultos de menor y mayor edad con educación terciaria (2012) Personas de 25 a 34 y de 55 a 64 años de edad y diferencia en puntos porcentuales entre estos dos grupos}

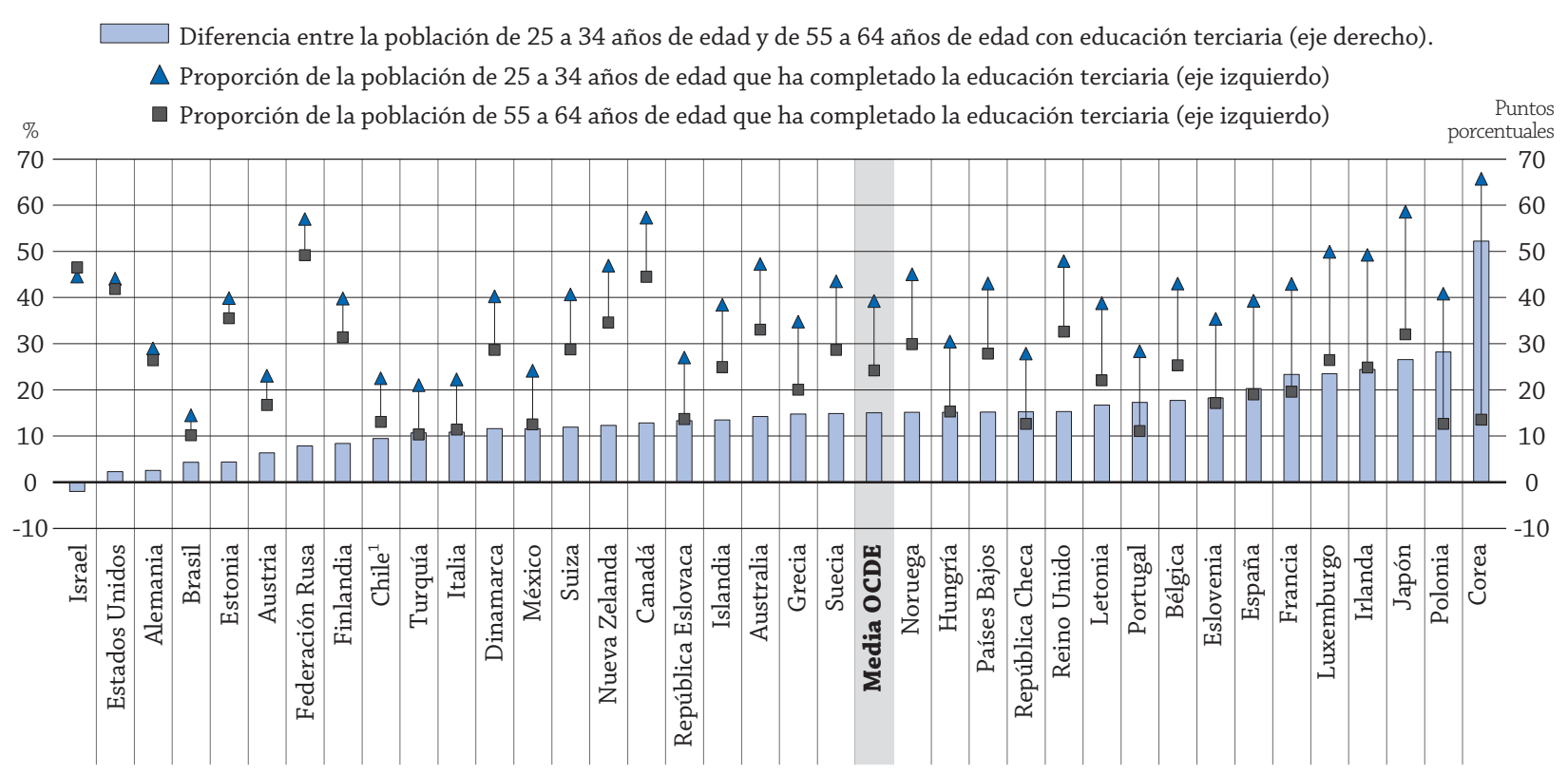

1. Año de referencia 2011.

Los países están clasificados en orden ascendente de la diferencia en puntos porcentuales entre la proporción de adultos con educación terciaria de 25 a 34 años $y$ de 55 a 64 años.

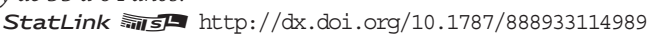

El Gráfico A1.3 muestra que, en algunos países, la diferencia entre generaciones es sustancial: de más de 20 puntos porcentuales en España, Francia, Irlanda, Japón, Luxemburgo y Polonia. En Corea hay una diferencia de 52 puntos porcentuales entre las tasas de graduación terciaria de estos dos grupos de edad. En cambio, la diferencia de las tasas de graduación terciaria entre los dos grupos de edad es inferior a los tres puntos porcentuales en Alemania, Estados Unidos e Israel (Tabla A1.3a). 


\section{Cuadro A1.1. Relevancia política de las comparaciones subnacionales}

El propósito principal de Panorama de la educación consiste en proporcionar una recopilación fiable de comparaciones internacionales clave de estadísticas educativas. A pesar de que los países muestren determinados valores en estas comparaciones, los lectores no deberían asumir que los países sean internamente homogéneos. Las medias de los países incluyen variaciones significativas entre jurisdicciones subnacionales, igual que la media de la OCDE incluye experiencias nacionales muy diversas.

En la mayor parte de los países de la OCDE, al menos algunas decisiones relativas a la política educativa son tomadas por las delegaciones gubernamentales subnacionales, mientras que las decisiones nacionales pueden afectar a las entidades subnacionales de manera diferente. En algunos países, la estructura del sistema educativo y una expansión geográfica relativamente pequeña pueden limitar la relevancia política de las comparaciones subnacionales. En países que cuentan con sistemas educativos federales, los gobiernos subnacionales son los principales responsables de gestionar programas de educación; incluso en aquellos países en los que el sistema educativo es más centralizado, las delegaciones de educación subnacionales pueden tener responsabilidades administrativas específicas. Por tanto, no es sorprendente que los valores internos registrados por grandes países federales como Alemania, Canadá y Estados Unidos, en los que son las delegaciones regionales las que controlan en gran medida la educación, puedan mostrar grandes diferencias entre sí. Sin embargo, muchos otros países con sistemas educativos centralizados, como Francia e Italia, también muestran sustanciales variaciones internas. En 2011, la proporción de adultos de 25 a 34 años con graduación terciaria en Estados Unidos oscilaba entre un mínimo del $29 \%$ en el estado de Nevada y un máximo del $71 \%$ en el distrito de Columbia (tratado por Estados Unidos como estado a efectos estadísticos). En 2010, en Canadá, la proporción de adultos de 25 a 34 años que habían completado la educación terciaria oscilaba entre un $28 \%$ en Nunavut y un $64 \%$ en Ontario. En Alemania, la proporción de adultos de 25 a 34 años con educación terciaria oscilaba entre un $20 \%$ en Sachsen-Anhalt y un 38\% en Berlín.

A pesar de que Francia cuente con un sistema educativo nacional, experimenta una variación sustancial entre regiones con respecto a las graduaciones terciarias. El porcentaje de adultos de 25 a 34 años que cuentan con una graduación terciaria oscilaba entre un mínimo del $19 \%$ en la Guayana Francesa y un máximo del $55 \%$ en Île-deFrance. En 2011, en Italia, la proporción de graduaciones terciarias en los adultos de 30 a 34 años oscilaba entre un $15 \%$ en Campania y un $27 \%$ en Apulia, basándose en datos recopilados por Eurostat para la Unión Europea. Las tasas de graduación terciaria de los adultos de 30 a 34 años en el Reino Unido oscilaban entre un $32 \%$ en Merseyside y un $69 \%$ en el centro de Londres. Los países que muestran grandes diferencias entre regiones subnacionales en las tasas de graduación terciaria (es decir, de más del doble) en los adultos de 30 a 34 años incluyen España, Grecia, Hungría, Portugal, República Eslovaca y Turquía. Los países de la OCDE en los que las diferencias son menores incluyen Austria, Eslovenia, Finlandia, Irlanda, Noruega, Polonia, Suecia y Suiza.

Otros tipos de estadísticas educativas también muestran variaciones subnacionales sustanciales, incluyendo aquellas relacionadas con el nivel de educación terciaria. En algunos países, las proporciones de jóvenes de 15 a 19 años matriculados en centros escolares de educación secundaria o en educación terciaria mostraron grandes variaciones entre unidades subnacionales en 2011. Por ejemplo, las tasas de matriculación de los adultos de 15 a 19 años en áreas subnacionales oscilaban entre un $70 \%$ y un $95 \%$ en España, entre un $58 \%$ y un $87 \%$ en Italia y un $71 \%$ y un $95 \%$ en Portugal. Aunque sigan siendo significativos, los rangos fueron menores en países como Estados Unidos (entre un $82 \%$ y un $91 \%$ ), Francia (entre un $69 \%$ y un $88 \%$ ) y Reino Unido (entre un $71 \%$ y un $88 \%$ ). Algunos países mostraron pequeñas diferencias subnacionales en las tasas de matriculación de los jóvenes de 15 a 19 años, incluyendo Noruega (entre un $84 \%$ y un $92 \%$ ) y Suecia (entre un $87 \%$ y un $88 \%$ ).

A pesar de que sea necesario obtener una información más completa para comprender el contexto geográfico de estos datos y sus implicaciones locales, por sí solos ilustran que las medias a nivel nacional a menudo enmascaran variaciones importantes a nivel subnacional que son de gran interés para los responsables políticos nacionales y locales. Además de las delimitaciones gubernamentales, puede que otros tipos de distinciones subnacionales sean también relevantes para los países, como las que tienen que ver con las fronteras geográficas o la distinción entre medios urbanos y rurales. Algunos países con medias nacionales relativamente altas pueden incluir áreas locales que estén muy por detrás de estos niveles medios. Algunos países con medias nacionales muy bajas pueden incluir algunas localidades con buenos resultados. Los datos subnacionales también pueden contribuir a mostrar el éxito con el que los países garantizan la equidad educativa entre regiones. 
La proporción de adultos entre 25 y 34 años que han completado la educación terciaria supera el $40 \%$ en la mayor parte de los países de la OCDE y países asociados (la media de la OCDE es de un 39\%), mientras que, en los adultos entre 55 y 64 años, esto solo sucede en Canadá, Estados Unidos, Federación Rusa e Israel. Los datos también muestran que en Brasil solo un $14 \%$ de los adultos entre 25 y 34 años han completado la educación terciaria y que en Brasil, Chile, Italia, México, Polonia, Portugal, República Checa y Turquía menos del $14 \%$ de los adultos entre 55 y 64 años lo han hecho.

A pesar de que en el grupo de adultos entre 55 y 64 años la proporción de hombres que tienen una graduación terciaria es superior ( $25 \%$ ) a la de las mujeres $(23 \%)$, en la mayor parte de los países de la OCDE, la proporción de mujeres -particularmente de mujeres jóvenes- que tienen una graduación terciaria supera a la proporción de hombres. Las tasas de graduación terciaria entre mujeres jóvenes (de 25 a 34 años) han aumentado de manera importante en Australia, Bélgica, Canadá, Corea, Dinamarca, Estonia, Federación Rusa, Irlanda, Israel, Japón, Letonia, Luxemburgo, Noruega, Nueva Zelanda, Polonia, Reino Unido y Suecia, donde al menos una de cada dos mujeres jóvenes ha completado la educación terciaria (Tabla A1.3b, disponible en Internet).

\section{Nivel de educación y comprensión lectora y competencia matemática}

La Encuesta sobre las Competencias de los Adultos evaluó el nivel de comprensión lectora y competencia matemática. Estas competencias se consideran básicas, al ser esenciales para emprender otros aprendizajes, por ejemplo, las personas aprenden a leer y después aprenden a través de la lectura. Dado que estas competencias se adquieren y se desarrollan sobre todo por medio de la educación reglada, evaluar el nivel de comprensión lectora y competencia matemática puede proporcionar a los gobiernos y a los responsables políticos una indicación sobre la efectividad de sus sistemas educativos.

A pesar de que estén estrechamente relacionados entre sí, la comprensión lectora y la competencia matemática y el nivel de educación alcanzado miden cosas diferentes. Las cualificaciones obtenidas a través de la educación formal no siempre reflejan el nivel que tiene una persona en lectura o competencia matemática, incluso en el momento de la vida en el que se adquieren esas cualificaciones. También representan otras competencias que la comprensión lectora y la competencia matemática no pueden reflejar, tales como el conocimiento especializado (o práctico) y competencias profesionales específicas.

El Gráfico A1.4 desvela algo de esta compleja relación y muestra la dispersión de la puntuación media de comprensión lectora en la Encuesta sobre las Competencias de los Adultos para todos los niveles de educación tomados de

\section{Gráfico A1.4. Puntuación media de comprensión lectora, por nivel educativo alcanzado (2012)} Encuesta sobre las Competencias de los Adultos, de 25 a 64 años de edad

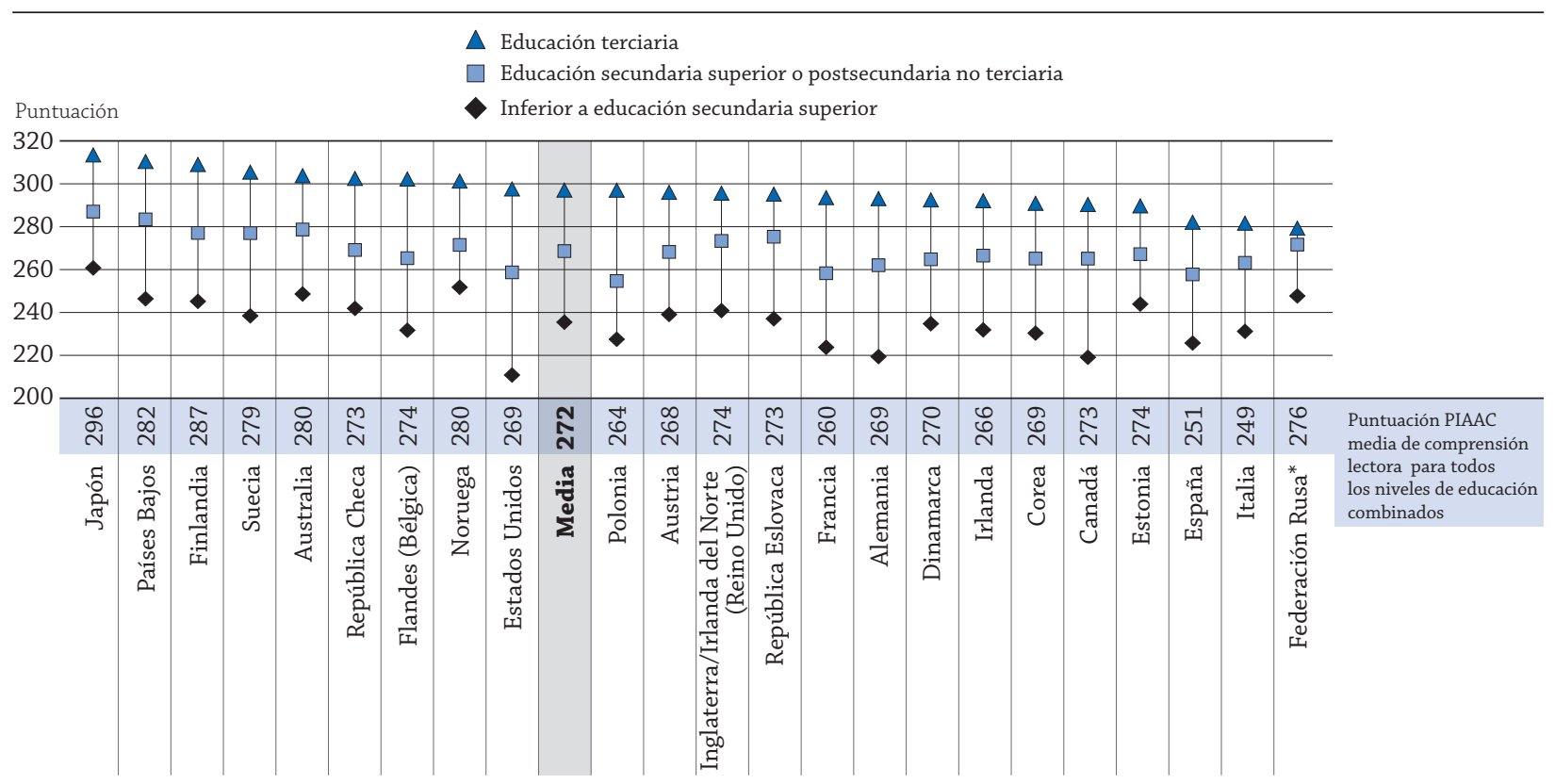

\footnotetext{
* Para los datos de Federación Rusa, véase nota en la sección de Metodología.
}

Los países están clasificados en orden descendente de la puntuación media de comprensión lectora de los adultos de 25 a 64 años con educación terciaria. Fuente: OCDE. Tabla A1.9a (L). Para ver notas, consulte Anexo 3 (www.oecd.org/edu/eag.htm).

StatLink 제피 http://dx.doi.org/10.1787/888933115008 
Gráfico A1.5. Porcentaje de adultos cuya puntuación en comprensión lectora alcanza el Nivel 4 o 5, por nivel educativo alcanzado (2012)

Encuesta sobre las Competencias de los Adultos, de 25 a 64 años de edad

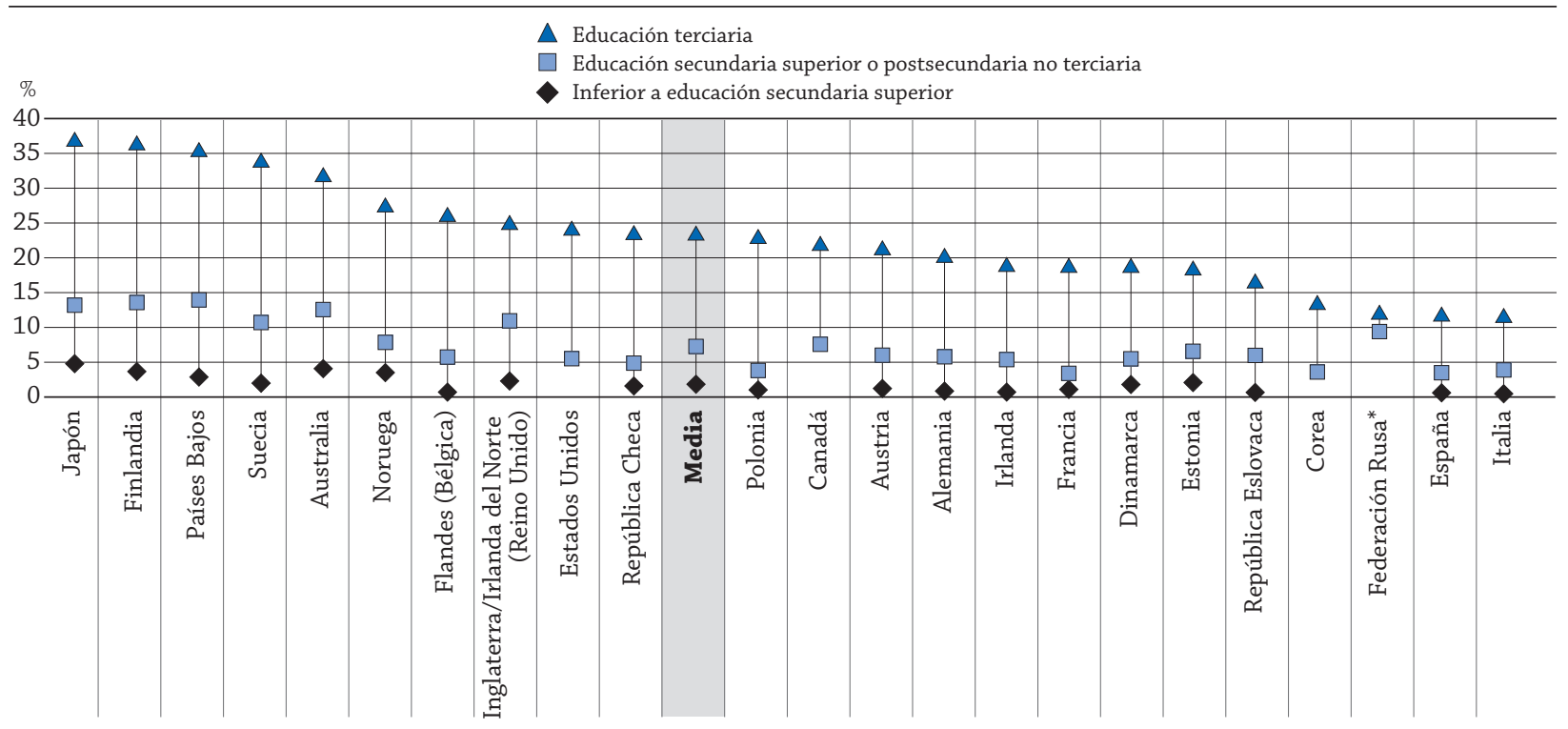

* Para los datos de Federación Rusa, véase nota en la sección de Metodología.

Los países están clasificados en orden descendente del porcentaje de adultos de 25 a 64 años de edad con educación terciaria que alcanzan el Nivel 4 o 5 de comprensión lectora.

Fuente: OCDE. Tabla A1.6a (L). Para ver notas, consulte Anexo 3 (www.oecd.org/edu/eag.htm).

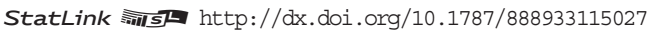

manera conjunta. La puntuación media de comprensión lectora supera los 270 puntos. En todos los países, la puntuación media más elevada es la de los adultos que han completado la educación terciaria y la más baja es la de aquellos que no han alcanzado la educación secundaria superior. En todos los países excepto en Federación Rusa, los adultos que han completado la educación terciaria consiguen una puntuación media por encima de los 280 puntos. En todos los países, la diferencia media entre la puntuación de los adultos que han completado la educación terciaria y aquellos que no han alcanzado la educación secundaria superior es de unos 60 puntos y oscila entre los 30 puntos de Federación Rusa y los 70 puntos de Alemania, Canadá, Estados Unidos y Flandes (Bélgica) (Tabla A1.9a [L]).

El Gráfico A1.5 muestra que, en todos los países, la proporción de adultos que consiguen los más altos niveles de competencia en la Encuesta sobre las Competencias de los Adultos (es decir, un Nivel 4 o 5) es mayor entre los adultos que han completado la educación terciaria. La proporción de adultos que alcanzan el Nivel 4 o 5 de competencia

\section{Cuadro A1.2. Competencias de los adultos y disposición a utilizar las tecnologías de la información y la comunicación (TIC) para resolver problemas}

Aunque, por un lado, exista la necesidad de nuevas y mejores competencias en el contexto de un mercado laboral en constante evolución, por otro lado, el rápido desarrollo de nuevas tecnologías convierte en redundantes algunas competencias. Tal como Frank Levy (2010) observó, «... la tecnología puede cambiar la naturaleza del trabajo más rápidamente de lo que las personas pueden cambiar sus competencias». Por tanto, disponer de las competencias necesarias para utilizar la tecnología y completar tareas no rutinarias para las cuales la tecnología (todavía) no puede sustituir a las personas resulta muy valioso. Para la mayor parte de los trabajadores de hoy, las competencias en TIC resultan clave para obtener un trabajo o un mejor salario; para las economías, las competencias en TIC son cruciales para mantener la competitividad en el mercado global. Los países de la OCDE anticipan que la tecnología continuará siendo uno de los motores principales de la creación de empleo y han establecido el desarrollo de competencias en TIC como la estrategia política más importante para la recuperación económica (Chinien y Boutin, 2011; OECD, 2010). 
Además de la comprensión lectora y la competencia matemática, la Encuesta sobre las Competencias de los Adultos también evaluó las competencias para la solución de problemas en entornos ricos en tecnología y estimó la frecuencia de uso de diferentes competencias, incluyendo las competencias en TIC, en el trabajo y en el hogar. La evaluación de solución de problemas en entornos ricos en tecnología se llevó a cabo por medio de ordenadores. Los participantes tenían que tener experiencia previa con ordenadores, cierta capacidad para realizar tareas con el ordenador portátil planteadas por el entrevistador y unas mínimas competencias informáticas, que se pusieron a prueba con un sencillo test de seis tareas llamado «uso básico de las TIC». En todos los países que participaron en la encuesta, un $74 \%$ de los participantes superaron el test sobre el uso básico de las TIC y realizaron la evaluación por ordenador (OECD, 2013a). La evaluación sobre solución de problemas se centraba en la competencia de la naturaleza del problema, el establecimiento de objetivos intermedios y pasos por medio de los cuales se pudiera solucionar el problema y la ejecución de los pasos necesarios para alcanzar esos objetivos intermedios. Aun así, los problemas presentados en la evaluación estaban directamente relacionados con la tecnología informática, y la solución de los problemas requería utilizar esta tecnología. Por lo tanto, los niveles más elevados de competencia en la solución de problemas en entornos ricos en tecnologías reflejan tanto competencias más elevadas en la solución de problemas como mejores competencias en el uso de tecnología digital, herramientas de comunicación y redes para adquirir y evaluar información, comunicarse con otros y realizar tareas prácticas (Grupo de Expertos PIAAC en Solución de Tareas en Entornos Ricos en Tecnología, 2009).

La información disponible a través de la Encuesta sobre las Competencias de los Adultos permitió crear un indicador que mide las competencias y la disposición a utilizar las TIC para resolver problemas. Este indicador combina la información sobre los resultados de la evaluación de solución de problemas (cuatro grupos, desde por debajo del Nivel 1 hasta el Nivel 3) y la información sobre los motivos por los que no se participó en la evaluación por ordenador y por los que no se tiene una puntuación en solución de problemas (tres grupos). La división de los grupos se validó con la declaración de los participantes con respecto a la frecuencia con la que estiman que utilizan las TIC. El uso de las TIC (la frecuencia de diferentes actividades que implican el uso del ordenador y de Internet) está relacionado con el nivel de competencias y con la disposición a utilizar las TIC para la solución de problemas (véase Gráfico A1.b más abajo). Los grupos mencionados se describen de la siguiente manera:

- Grupo 0: Ningún uso, ninguna competencia. Individuos sin experiencia informática. En los 19 países que participaron en la evaluación de solución de problemas en entornos ricos en tecnología, un $9 \%$ de los adultos entre 16 y 65 años de edad pertenece a este grupo.

- Grupo 1: Falta de disposición para utilizar nuevos dispositivos y sistemas, uso mínimo de las TIC. Este grupo optó por no participar en la evaluación por ordenador. A pesar de que los motivos por los que se optó por no participar en la evaluación puedan ser muy diversos, la frecuencia de uso del ordenador en el hogar, así como el nivel declarado de competencias informáticas necesarias para el trabajo, son menores que en el siguiente grupo; por tanto, es probable que este grupo también tenga un nivel inferior de competencias en el uso de las TIC. Aproximadamente un $10 \%$ de la población pertenece a este grupo.

- Grupo 2: Competencias mínimas en TIC, uso moderado de las TIC. Estos son individuos con un nivel bajo de competencias en TIC, pero que utilizan las TIC con confianza. Son capaces de utilizar solo «una función dentro de un interfaz genérico» (OECD, 2013c) y pueden no ser capaces de realizar incluso tareas muy básicas relacionadas con las TIC, como desplazar o destacar texto (uso básico de las TIC). Este grupo incluye a individuos con puntuaciones por debajo del Nivel 1 en la evaluación de solución de problemas en entornos ricos en tecnología y aquellos que no superan el test de uso básico de las TIC. Estos dos grupos se fusionaron en uno, ya que sus experiencias en el uso de ordenadores eran similares en todos los países: utilizan los ordenadores en el hogar más a menudo que las personas del Grupo 1, pero menos que las personas del Grupo 3. También difieren de los otros grupos en su comprensión lectora y en su competencia matemática, generalmente mejores que las de las personas del Grupo 0, pero no tan buenas como las de las personas de los Grupos 1 y 3 . Este grupo representa un $17 \%$ de la población aproximadamente.

- Grupo 3: Competencias moderadas en TIC y solución de problemas (Nivel 1). Estos individuos pueden «utilizar aplicaciones tecnológicas ampliamente disponibles y conocidas, como los programas de correo electrónico o un navegador de Internet» (OECD, 2013c). A menudo no conocen y no saben cómo utilizar herramientas y funciones específicas (por ejemplo, una función para ordenar). Las tareas que son capaces de realizar requieren poca o ninguna navegación. Aproximadamente un $29 \%$ de la población pertenece a este grupo. 
- Grupo 4: Buenas competencias en TIC y solución de problemas (Niveles 2 y 3). Estos son individuos con competencias en TIC elevadas que pueden resolver problemas complejos por medio de la tecnología. A este nivel, «las tareas suelen requerir el uso de aplicaciones tecnológicas tanto genéricas como más específicas. Resolver el problema requiere algo de navegación entre páginas y aplicaciones. El uso de herramientas (por ejemplo, una función para ordenar) facilita la solución del problema» (OECD, 2013c). Aproximadamente un $33 \%$ de la población pertenece a este grupo.

\section{Gráfico A1.a.Distribución de competencias y disposición a utilizar las tecnologías de la información y la comunicación (TIC) para resolver problemas (RP) en la población adulta De 25 a 64 años de edad}

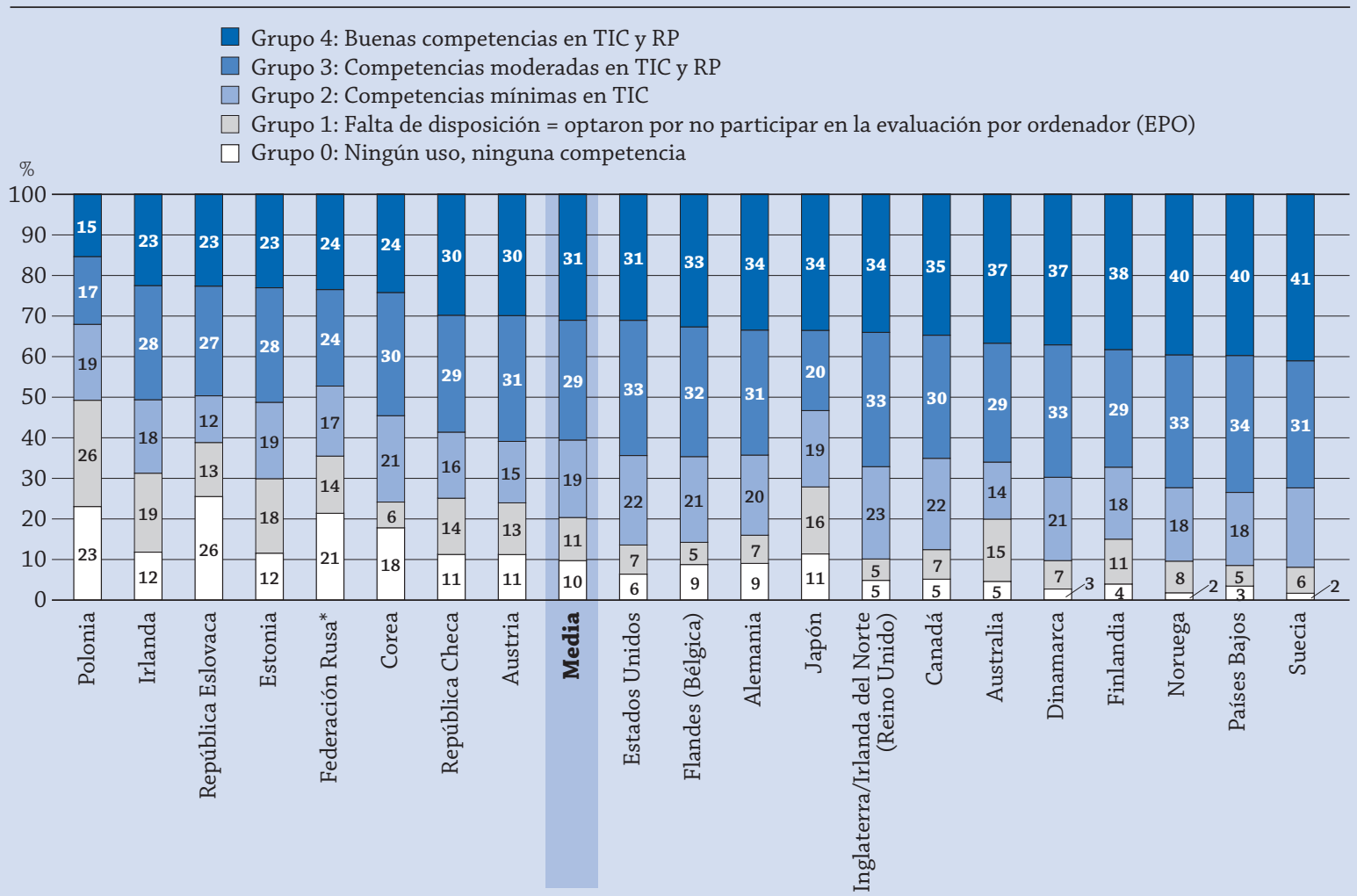

* Para los datos de Federación Rusa, véase nota en la sección de Metodología.

Los países están clasificados en orden ascendente de la proporción de población adulta que tiene buenas competencias en TIC y RP.

Fuente: OCDE. Encuesta sobre las Competencias de los Adultos (PIAAC). Para ver notas, consulte Anexo 3 (www.oecd.org/edu/eag.htm).

StatLink Aत्ता Th http://dx.doi.org/10.1787/888933115065

A pesar de que existe una clara relación entre la frecuencia de uso del ordenador en el hogar y las competencias y disposición para usar las TIC (Gráfico A1.b), se utiliza el término "grupo» en lugar de «nivel» porque estas agrupaciones tienen una naturaleza diferente a la de los niveles de comprensión lectora y competencia matemática y se basan en tipos diferentes de información. Los grupos 0 y 1 se basan en información sobre experiencia previa y en la disposición para utilizar ordenadores en una situación de test; los grupos 2-4 se basan en una evaluación de competencias en TIC y solución de problemas.

El Gráfico A1.a representa la distribución de la población de acuerdo con estos cinco grupos en cada uno de los países que participaron en la Encuesta sobre las Competencias de los Adultos.

El Gráfico A1.c muestra que el aumento de competencias y la predisposición para utilizar las TIC para la solución de problemas se asocia con diferencias significativas en los salarios de los adultos en todos los países. Otras relaciones entre competencias y disposición para utilizar las TIC en la solución de problemas serán analizados en un capítulo especial en Panorama de la educación 2015. 


\section{Gráfico A1.b. Frecuencia de uso de las TIC en el hogar (índice 1-5) en personas con diferentes competencias y disposiciones a utilizar las tecnologías de la información y la comunicación (TIC) para resolver problemas (RP) \\ 25-64 años}

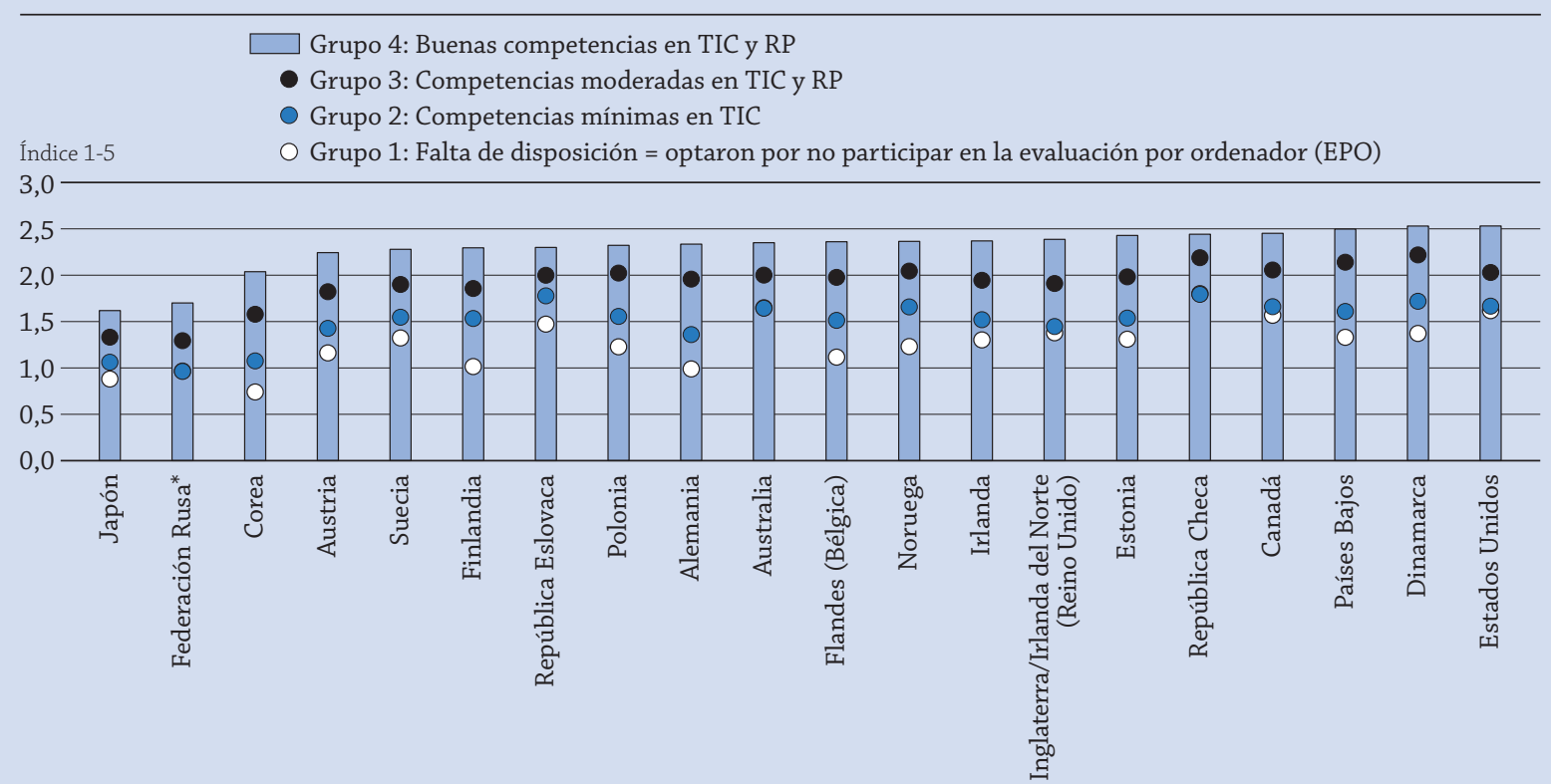

* Para los datos de Federación Rusa, véase nota en la sección de Metodología.

Los países están clasificados en orden ascendente de la frecuencia con la que la población adulta con buenas competencias en TIC y en RP utiliza las TIC en el hogar.

Fuente: OCDE. Encuesta sobre las Competencias de los Adultos (PIAAC). Para ver notas, consulte Anexo 3 (www.oecd.org/edu/eag.htm). StatLink 제개 http://dx.doi.org/10.1787/888933115084

Gráfico A1.c. Diferencia salarial (\%) en comparación con el grupo 0 (ningún uso, ninguna competencia), ajustada con respecto a edad y educación De 25 a 64 años de edad

\begin{tabular}{ll}
\hline & Grupo 4: Buenas competencias en TIC y RP \\
& Grupo 3: Competencias moderadas en TIC y RP \\
\% Grupo 2: Competencias mínimas en TIC & O Grupo 1: Falta de disposición = optaron por no participar en la evaluación por ordenador (EPO) \\
\hline
\end{tabular}

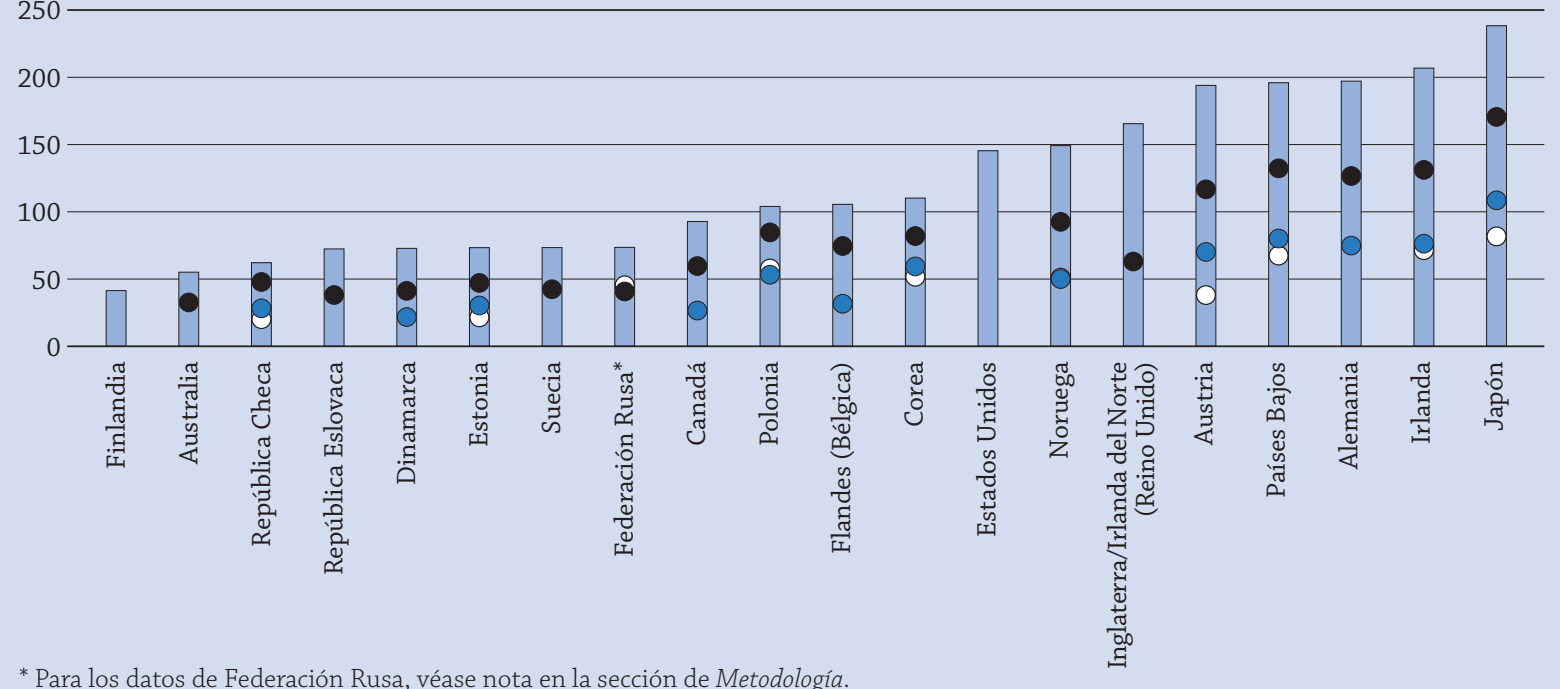

* Para los datos de Federación Rusa, véase nota en la sección de Metodología.

Nota: El gráfico solo muestra diferencias estadísticamente significativas.

Los países están clasificados en orden ascendente de la diferencia salarial (\%) en comparación con el grupo 0.

Fuente: OCDE. Encuesta sobre las Compentencias de los Adultos (PIAAC). Para ver notas, consulte Anexo 3 (www.oecd.org/edu/eag.htm). StatLink 제그 http://dx.doi.org/10.1787/888933115103 


\section{Gráfico A1.6. Porcentaje de adultos de menor y mayor edad cuya puntuación en comprensión lectora alcanza el Nivel 4 o 5 (2012) \\ Encuesta sobre las Competencias de los Adultos, de 25 a 34 y de 55 a 64 años de edad}

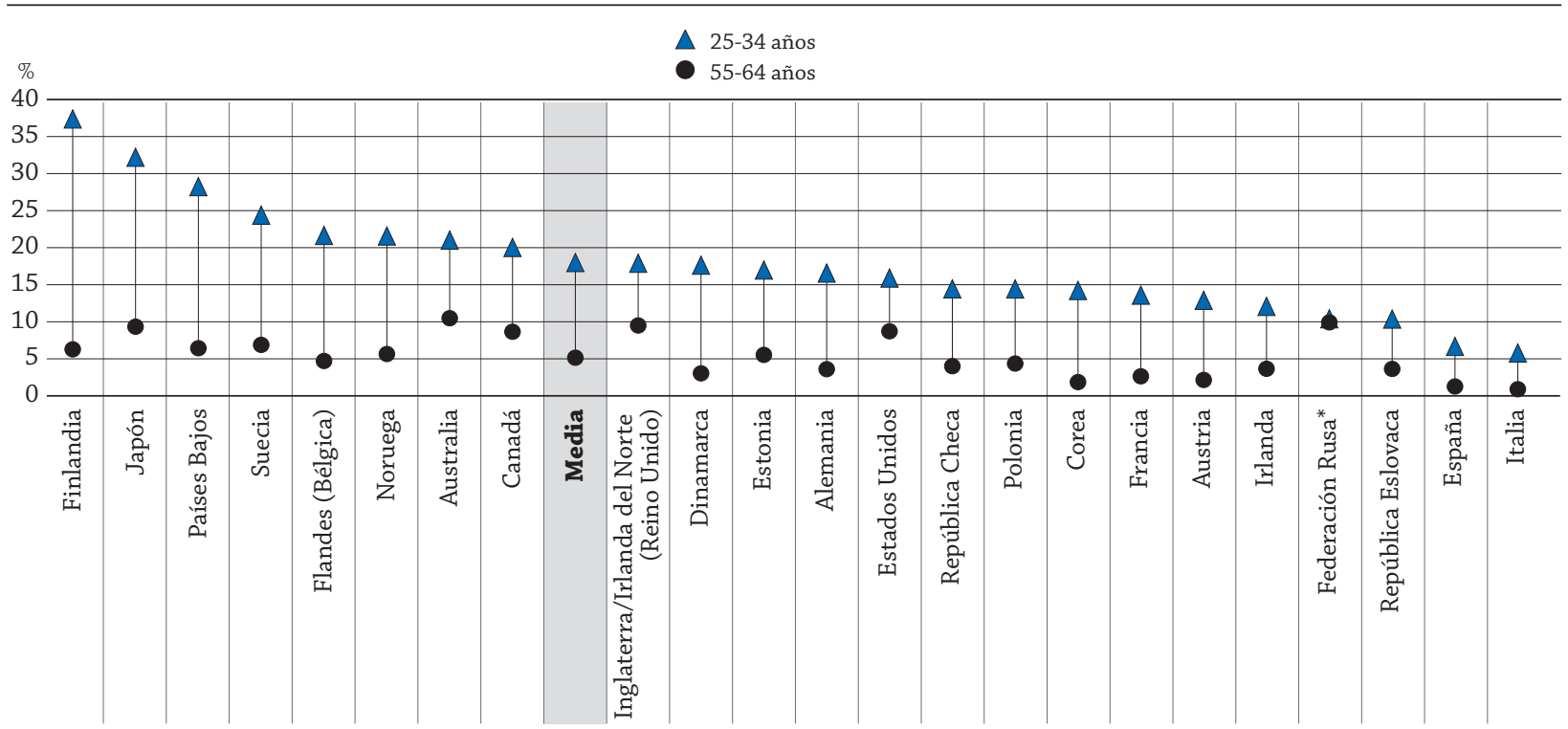

* Para los datos de Federación Rusa, véase nota en la sección de Metodología.

Los países están clasificados en orden descendente del porcentaje de adultos de 25 a 64 años con educación terciaria que alcanzan el Nivel 4 o 5 de competencia lectora.

Fuente: OCDE. Tabla A1.7a (L). Para ver notas, consulte Anexo 3 (www.oecd.org/edu/eag.htm).

StatLink 젶ㄴ http://dx.doi.org/10.1787/888933115046

en lectura alcanza las cifras más elevadas en Australia, Finlandia, Japón, Países Bajos y Suecia: más del $30 \%$ de toda la población que ha completado la educación terciaria alcanza puntuaciones en los Niveles 4 o 5 . En estos países, la diferencia de puntuaciones entre los adultos que han completado la educación terciaria y aquellos que no han alcanzado la educación secundaria superior también es la más elevada: más de 25 puntos porcentuales. Los datos también muestran que, en todos los países, la proporción de adultos que alcanzan un Nivel 4 o 5 de comprensión lectora es mayor entre adultos con un nivel de educación más elevado. La diferencia en los niveles de comprensión lectora entre adultos que han alcanzado la educación terciaria y adultos que han alcanzado la educación secundaria superior es mayor que entre adultos que han alcanzado la educación secundaria superior y adultos que no lo han hecho (Tabla A1.6a [L]).

El Gráfico A1.6 muestra que, en todos los países, la proporción de adultos que alcanzan un Nivel 4 o 5 de comprensión lectora en la Encuesta sobre las Competencias de los Adultos es superior en los adultos más jóvenes que en los adultos de más edad con una diferencia media de aproximadamente 10 puntos porcentuales. Esta diferencia es de más de 20 puntos porcentuales en Finlandia, Japón y Países Bajos. En todos los países, más del $5 \%$ de los adultos jóvenes alcanzan estos altos niveles de competencia, mientras que en Alemania, Austria, Corea, Dinamarca, España, Francia, Irlanda, Italia, Polonia, República Checa y República Eslovaca menos del 5 \% de los adultos de más edad los alcanzan (Tabla A1.7a [L]).

\section{Definiciones}

Grupos de edad: adultos se refiere a personas de 25 a 64 años; adultos jóvenes se refiere a personas de 25 a 34 años; adultos de más edad se refiere a personas de 55 a 64 años.

Niveles de educación: inferior a la educación secundaria superior se corresponde con los niveles CINE $0,1,2$ y programas $3 C$ cortos; educación secundaria superior o postsecundaria no terciaria se corresponde con los niveles CINE 3A, 3B, programas 3C largos y el nivel CINE 4; y educación terciaria se corresponde con los niveles CINE 5A, 5B y 6. Para ver una presentación de todos los niveles CINE, consulte la Guía del lector que aparece al principio de este libro. 


\section{Metodología}

Los datos sobre la población y el nivel de educación de la mayor parte de los países provienen de las bases de datos de la OCDE y Eurostat, que la Red LSO de la OCDE (Mercado Laboral y Resultados Sociales del Aprendizaje) elabora a partir de las Encuestas Nacionales de Población Activa. Los datos sobre el nivel de educación de Arabia Saudí, Argentina, China, Colombia, Indonesia y Sudáfrica proceden de la base de datos del Instituto de Estadística (UIS) de la UNESCO sobre nivel de educación de la población mayor de 25 años. Los datos sobre los niveles de competencia y las puntuaciones medias se basan en la Encuesta sobre las Competencias de los Adultos (PIAAC) (2012). PIAAC es el Programa para la Evaluación Internacional de las Competencias de los Adultos de la OCDE. Para información adicional, consulte Acerca de la Encuesta sobre las Competencias de los Adultos al comienzo de esta publicación y el Anexo 3 (www.oecd.org/edu/eag.htm).

El Cuadro A1.1 se basa en el estudio INES sobre datos subnacionales.

Los perfiles de competencia están basados en el porcentaje de la población de 25 a 64 años de edad que ha completado satisfactoriamente un nivel determinado de educación.

La mayoría de países de la OCDE incluyen en el nivel CINE 0 los datos sobre la población que no ha alcanzado ningún nivel de educación (por ejemplo, adultos analfabetos o población cuyo nivel educativo no está contemplado en las clasificaciones nacionales) y, por tanto, las medias para los niveles CINE 0/1 (por ejemplo, educación infantil y educación primaria) pueden estar influidas por este hecho.

\section{Nota sobre los datos de Israel}

Los datos estadísticos para Israel fueron proporcionados por las autoridades israelíes competentes bajo su responsabilidad. El uso de estos datos por parte de la OCDE se hace sin prejuzgar la situación de los Altos del Golán, Jerusalén Este y los asentamientos israelíes en Cisjordania de acuerdo con los términos del derecho internacional.

\section{Nota sobre los datos de Federación Rusa en la Encuesta sobre las Competencias de los Adultos (PIAAC)}

Los lectores deben tener en cuenta que la muestra de Federación Rusa no incluye la población del área municipal de Moscú. Por tanto, los datos publicados no representan a toda la población de 16 a 65 años residente en Rusia, sino a la población de Rusia excluyendo a la población que reside en el área municipal de Moscú. Para obtener información más detallada sobre los datos de Federación Rusa así como de otros países en Technical Report of the Survey of Adult Skills (OECD, de próxima publicación).

\section{Referencias}

Chinien, C. y F. Boutin (2011), Defining Essential Digital Skills in the Canadian Workplace: Final Report, WDM-Consultants.

Levy, F. (2010), «How Technology Changes Demands for Human Skills», OECD Education Working Papers, No. 45, OECD Publishing, París, http://dx.doi.org/10.1787/5kmhds6czqzq-en.

OECD (2013a), OECD Skills Outlook 2013: First Results from the Survey of Adult Skills, OECD Publishing, París, http://dx.doi. org/10.1787/9789264204256-en.

OECD (2013b), PISA 2012 Results: Excellence through Equity (Volume II): Giving Every Student the Chance to Succeed, PISA, OECD Publishing, http://dx.doi.org/10.1787/9789264201132-en.

OECD (2013c), The Survey of Adult Skills: Reader's Companion, OECD Publishing, París, http://dx.doi.org/10.1787/9789264204027-en. OECD (2010), «Highlights», en OECD Information Technology Outlook 2010, OECD Publishing, París, http://www.oecd.org/dataoecd/60/21/46444955.pdf

PIAAC Expert Group in Problem Solving in Technology-Rich Environments (2009), «PIAAC Problem Solving in Technology-Rich Environments: A Conceptual Framework», OECD Education Working Papers, No. 36, OECD Publishing, París, http://dx.doi. org/10.1787/220262483674. 


\section{Tablas del Indicador A1}

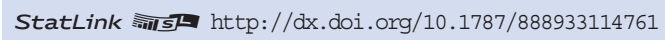

Tabla A1.1a Nivel de educación alcanzado por la población de 25 a 64 años de edad (2012)

WEB Tabla A1.1b Nivel de educación alcanzado por la población de 25 a 64 años de edad, por sexo (2012)

Tabla A1.2a Porcentaje de adultos que han completado al menos la educación secundaria superior, por grupo de edad (2012)

WEB Tabla A1.2b Porcentaje de adultos que han completado al menos la educación secundaria superior, por grupo de edad y sexo (2012

Tabla A1.3a Porcentaje de adultos que han completado la educación terciaria, por tipo de programa y grupo de edad (2012)

WEB Tabla A1.3b Porcentaje de adultos que han completado la educación terciaria, por tipo de programa, grupo de edad y sexo (2012)

Tabla A1.4a Tendencias de los niveles de educación alcanzados, por grupo de edad, y tasa media de crecimiento anual (2000, 2005-2012)

WEB Tabla A1.4b Tendencias de los niveles de educación alcanzados, por sexo y grupo de edad, y tasa media de crecimiento anual (2000, 2005-2012)

Tabla A1.5a Nivel de educación alcanzado por la población de 25 a 64 años de edad, por orientación del programa y sexo (2012)

WEB Tabla A1.5b Nivel de educación alcanzado, por orientación del programa, grupo de edad y sexo (2012)

Tabla A1.6a (L) Nivel de educación alcanzado por la población de 25 a 64 años de edad, por nivel de comprensión lectora (2012)

WEB Tabla A1.6a (N) Nivel de educación alcanzado por la población de 25 a 64 años de edad, por nivel de competencia matemática (2012)

WEB Tabla A1.6b (L) Nivel de educación alcanzado por la población de 25 a 64 años de edad, por nivel de comprensión lectora y sexo (2012)

WEB Tabla A1.6b (N) Nivel de educación alcanzado por la población de 25 a 64 años de edad, por nivel de competencia matemática y sexo (2012)

Tabla A1.7a (L) Distribución de los niveles de comprensión lectora, por edad (2012)

WEB Tabla A1.7a (N) Distribución de los niveles de competencia matemática, por edad (2012)

WEB Tabla A1.7b (L) Distribución de los niveles de comprensión lectora, por edad y sexo (2012)

WEB Tabla A1.7b (N) Distribución de los niveles PIAAC de competencia matemática, por edad y sexo (2012)

Tabla A1.8 (L) Porcentaje de la población de 25 a 64 años de edad con educación secundaria superior o postsecundaria no terciaria de orientación profesional o general, por nivel de comprensión lectora y puntuación media (2012)

WEB Tabla A1.8 (N) Porcentaje de la población de 25 a 64 años de edad con educación secundaria superior o postsecundaria no terciaria de orientación profesional o general, por nivel de competencia matemática y puntuación media (2012)

Tabla A1.9a (L) Puntuación media en comprensión lectora, por nivel educativo alcanzado y edad (2012)

WEB Tabla A1.9a (N) Puntuación media de competencia matemática, por nivel de educación y edad (2012)

WEB Tabla A1.9b (L) Distribución de la puntuación media de comprensión lectora, de 25 a 64 años de edad (2012)

WEB Tabla A1.9b (N) Distribución de la puntuación media de competencia matemática, de 25 a 64 años de edad (2012) 
Tabla A1.1a. Nivel de educación alcanzado por la población de 25 a 64 años de edad (2012)

\begin{tabular}{|c|c|c|c|c|c|c|c|c|c|c|}
\hline & \multirow[b]{2}{*}{$\begin{array}{c}\text { Educación } \\
\text { infantil } \\
\text { y primaria }\end{array}$} & \multirow[b]{2}{*}{$\begin{array}{l}\text { Educación } \\
\text { secundaria } \\
\text { inferior }\end{array}$} & \multirow[b]{2}{*}{$\begin{array}{l}\text { CINE 3C } \\
\text { (programa } \\
\text { corto) }\end{array}$} & \multicolumn{2}{|c|}{$\begin{array}{l}\text { Educación secundaria } \\
\text { superior }\end{array}$} & \multirow{2}{*}{$\begin{array}{l}\text { Educación } \\
\text { post } \\
\text { secundaria } \\
\text { no terciaria }\end{array}$} & \multicolumn{3}{|c|}{ Educación terciaria } & \multirow[b]{2}{*}{$\begin{array}{l}\text { Todos los } \\
\text { niveles de } \\
\text { educación }\end{array}$} \\
\hline & & & & $\begin{array}{c}\text { CINE 3C } \\
\text { (programa } \\
\text { largo)/3B }\end{array}$ & CINE 3A & & Tipo B & Tipo A & $\begin{array}{c}\text { Programas de } \\
\text { investigación } \\
\text { avanzada }\end{array}$ & \\
\hline & (1) & (2) & (3) & (4) & (5) & (6) & (7) & (8) & (9) & (10) \\
\hline Alemania & 3 & 10 & $\mathrm{a}$ & 47 & 3 & 8 & 11 & 16 & 1 & 100 \\
\hline Australia & 6 & 18 & a & 14 & 16 & 5 & 11 & 29 & 1 & 100 \\
\hline Austria & $\mathrm{x}(2)$ & 16 & 1 & 47 & 6 & 10 & 7 & 13 & $\mathrm{x}(8)$ & 100 \\
\hline Bélgica & 12 & 16 & a & 10 & 24 & 3 & 17 & 18 & 1 & 100 \\
\hline Canadá & 3 & 8 & a & $\mathrm{x}(5)$ & 25 & 12 & 25 & 28 & $\mathrm{x}(8)$ & 100 \\
\hline Chile $^{1}$ & 18 & 25 & $\mathrm{a}$ & $\mathrm{x}(5)$ & 40 & a & 6 & 11 & 1 & 100 \\
\hline Corea & 8 & 10 & a & $\mathrm{x}(5)$ & 41 & a & 13 & 28 & $\mathrm{x}(8)$ & 100 \\
\hline Dinamarca & 1 & 20 & 1 & 37 & 6 & c & 6 & 28 & 1 & 100 \\
\hline Eslovenia & 1 & 14 & a & 27 & 32 & a & 12 & 12 & 2 & 100 \\
\hline España & 17 & 29 & a & 9 & 14 & $\mathrm{n}$ & 10 & 22 & 1 & 100 \\
\hline Estados Unidos & 4 & 7 & $\mathrm{x}(5)$ & $\mathrm{x}(5)$ & 46 & $\mathrm{x}(5)$ & 10 & 31 & 1 & 100 \\
\hline Estonia & 1 & 10 & a & 14 & 32 & 7 & 13 & 24 & $\mathrm{n}$ & 100 \\
\hline Finlandia & 6 & 10 & a & a & 44 & 1 & 13 & 25 & 1 & 100 \\
\hline Francia & 10 & 18 & a & 30 & 11 & $\mathrm{n}$ & 12 & 18 & 1 & 100 \\
\hline Grecia & 21 & 11 & $\mathrm{x}(4)$ & 7 & 27 & 8 & 9 & 17 & $\mathrm{n}$ & 100 \\
\hline Hungría & 1 & 17 & a & 29 & 29 & 2 & 1 & 21 & 1 & 100 \\
\hline Irlanda & 10 & 14 & 1 & $\mathrm{x}(5)$ & 21 & 13 & 15 & 24 & 1 & 100 \\
\hline Islandia & 21 & 7 & 2 & 19 & 10 & 6 & 4 & 30 & 1 & 100 \\
\hline Israel & 10 & 6 & a & 7 & 31 & a & 14 & 31 & 1 & 100 \\
\hline Italia & 10 & 32 & 1 & 8 & 33 & 1 & $\mathrm{n}$ & 15 & $\mathrm{n}$ & 100 \\
\hline Japón & $\mathrm{x}(5)$ & $\mathrm{x}(5)$ & $\mathrm{x}(5)$ & $\mathrm{x}(5)$ & 53 & a & 20 & 26 & $\mathrm{x}(8)$ & 100 \\
\hline Luxemburgo & 8 & 9 & 5 & 16 & 20 & 4 & 13 & 25 & 1 & 100 \\
\hline México & 39 & 23 & a & 5 & 14 & a & 1 & 17 & $\mathrm{x}(8)$ & 100 \\
\hline Noruega & $\mathrm{n}$ & 18 & a & 27 & 13 & 4 & 2 & 36 & 1 & 100 \\
\hline Nueva Zelanda & $x(2)$ & 19 & 7 & 14 & 9 & 11 & 15 & 25 & $\mathrm{x}(8)$ & 100 \\
\hline Países Bajos & 8 & 19 & $\mathrm{x}(4)$ & 14 & 22 & 3 & 3 & 31 & 1 & 100 \\
\hline Polonia & $\mathrm{x}(2)$ & 10 & a & 31 & 31 & 4 & $\mathrm{x}(8)$ & 25 & $\mathrm{x}(8)$ & 100 \\
\hline Portugal & 42 & 21 & $\mathrm{x}(5)$ & $\mathrm{x}(5)$ & 19 & $\mathrm{n}$ & $\mathrm{x}(8)$ & 16 & 3 & 100 \\
\hline Reino Unido & $\mathrm{n}$ & 9 & 13 & 30 & 7 & a & 10 & 30 & 1 & 100 \\
\hline República Checa & $\mathrm{n}$ & 7 & a & 38 & 35 & $x(5)$ & $\mathrm{x}(8)$ & 19 & $\mathrm{x}(8)$ & 100 \\
\hline República Eslovaca & $\mathrm{n}$ & 8 & $\mathrm{x}(4)$ & 35 & 38 & $\mathrm{x}(5)$ & 1 & 17 & $\mathrm{n}$ & 100 \\
\hline Suecia & 4 & 9 & a & $\mathrm{x}(5)$ & 45 & 7 & 9 & 25 & 1 & 100 \\
\hline Suiza & 3 & 9 & 2 & 39 & 5 & 6 & 11 & 23 & 3 & 100 \\
\hline Turquía & 55 & 12 & a & 9 & 10 & a & $\mathrm{x}(8)$ & 15 & $\mathrm{x}(8)$ & 100 \\
\hline & \multicolumn{3}{|c|}{$\begin{array}{l}\text { Nivel inferior a la educación } \\
\text { secundaria superior }\end{array}$} & \multicolumn{3}{|c|}{$\begin{array}{l}\text { Nivel de educación } \\
\text { secundaria superior }\end{array}$} & \multicolumn{3}{|c|}{ Nivel de educación terciaria } & \\
\hline Media OCDE & \multicolumn{3}{|c|}{24} & \multicolumn{3}{|c|}{44} & \multirow{2}{*}{\multicolumn{3}{|c|}{33}} & \\
\hline Media UE21 & \multicolumn{3}{|c|}{23} & \multicolumn{3}{|c|}{48} & & & & \\
\hline Arabia Saudí ${ }^{4}$ & 33 & 18 & $\mathrm{a}$ & $\mathrm{x}(5)$ & 23 & 5 & $\mathrm{x}(8)$ & 21 & $\mathrm{x}(8)$ & 100 \\
\hline Argentina ${ }^{2}$ & 44 & 14 & a & $\mathrm{x}(5)$ & 28 & a & $\mathrm{x}(8)$ & 14 & $\mathrm{x}(8)$ & 100 \\
\hline Brasil & 40 & 15 & $x(5)$ & $\mathrm{x}(5)$ & 32 & a & $\mathrm{x}(8)$ & 13 & $\mathrm{x}(8)$ & 100 \\
\hline China ${ }^{3}$ & 35 & 43 & $\mathrm{~m}$ & $\mathrm{x}(5)$ & 14 & 5 & $\mathrm{x}(8)$ & 4 & $\mathrm{x}(8)$ & 100 \\
\hline Colombia ${ }^{1}$ & 44 & 14 & a & $\mathrm{x}(5)$ & 22 & a & $x(8)$ & 20 & $\mathrm{x}(8)$ & 100 \\
\hline Federación Rusa & 1 & 5 & $\mathrm{x}(4)$ & 19 & 21 & $\mathrm{x}(4)$ & 26 & 28 & $\mathrm{n}$ & 100 \\
\hline India & $\mathrm{m}$ & $\mathrm{m}$ & $\mathrm{m}$ & $\mathrm{m}$ & $\mathrm{m}$ & $\mathrm{m}$ & $\mathrm{m}$ & $\mathrm{m}$ & $\mathrm{m}$ & $\mathrm{m}$ \\
\hline Indonesia $^{1}$ & 56 & 16 & a & $\mathrm{x}(5)$ & 21 & a & $x(8)$ & 8 & $\mathrm{x}(8)$ & 100 \\
\hline Letonia & 1 & 10 & $\mathrm{~m}$ & 3 & 48 & 8 & 1 & 27 & $\mathrm{n}$ & 100 \\
\hline Sudáfrica & 26 & 14 & $\mathrm{a}$ & $\mathrm{x}(5)$ & 47 & 7 & $\mathrm{x}(8)$ & 6 & $\mathrm{x}(8)$ & 100 \\
\hline
\end{tabular}


Tabla A1.2a. Porcentaje de adultos que han completado al menos la educación secundaria superior, por grupo de edad (2012)

\begin{tabular}{|c|c|c|c|c|c|c|}
\hline & \multicolumn{6}{|c|}{ Edad } \\
\hline & $25-64$ & $30-34$ & $25-34$ & $35-44$ & $45-54$ & $55-64$ \\
\hline & (1) & (2) & (3) & (4) & (5) & (6) \\
\hline Alemania & 86 & 87 & 87 & 87 & 87 & 84 \\
\hline Australia & 76 & 86 & 87 & 81 & 71 & 64 \\
\hline Austria & 83 & 89 & 89 & 86 & 83 & 74 \\
\hline Bélgica & 72 & 82 & 82 & 79 & 69 & 56 \\
\hline Canadá & 89 & 93 & 92 & 92 & 88 & 84 \\
\hline Chile $^{1}$ & 57 & 72 & 77 & 61 & 50 & 38 \\
\hline Corea & 82 & 98 & 98 & 96 & 78 & 48 \\
\hline Dinamarca & 78 & 83 & 82 & 82 & 77 & 71 \\
\hline Eslovenia & 85 & 94 & 94 & 89 & 83 & 74 \\
\hline España & 55 & 65 & 64 & 62 & 51 & 35 \\
\hline Estados Unidos & 89 & 89 & 89 & 89 & 89 & 90 \\
\hline Estonia & 90 & 86 & 86 & 90 & 94 & 88 \\
\hline Finlandia & 85 & 91 & 90 & 90 & 87 & 74 \\
\hline Francia & 73 & 83 & 83 & 79 & 69 & 59 \\
\hline Grecia & 68 & 81 & 83 & 74 & 65 & 50 \\
\hline Hungría & 82 & 87 & 88 & 84 & 82 & 75 \\
\hline Irlanda & 75 & 86 & 86 & 80 & 70 & 55 \\
\hline Islandia & 71 & 77 & 75 & 75 & 71 & 61 \\
\hline Israel & 85 & 89 & 90 & 86 & 81 & 77 \\
\hline Italia & 57 & 70 & 72 & 62 & 53 & 42 \\
\hline Japón & $\mathrm{m}$ & $\mathrm{m}$ & $\mathrm{m}$ & $\mathrm{m}$ & $\mathrm{m}$ & $\mathrm{m}$ \\
\hline Luxemburgo & 78 & 86 & 86 & 80 & 76 & 69 \\
\hline México & 37 & 42 & 46 & 37 & 35 & 25 \\
\hline Noruega & 82 & 84 & 82 & 86 & 79 & 82 \\
\hline Nueva Zelanda & 74 & 81 & 80 & 78 & 73 & 64 \\
\hline Países Bajos & 73 & 83 & 83 & 78 & 72 & 61 \\
\hline Polonia & 90 & 94 & 94 & 92 & 90 & 81 \\
\hline Portugal & 38 & 55 & 58 & 43 & 27 & 20 \\
\hline Reino Unido & 78 & 85 & 85 & 81 & 76 & 69 \\
\hline República Checa & 92 & 93 & 94 & 95 & 93 & 87 \\
\hline República Eslovaca & 92 & 94 & 94 & 94 & 92 & 86 \\
\hline Suecia & 88 & 90 & 91 & 92 & 88 & 79 \\
\hline Suiza & 86 & 89 & 89 & 88 & 86 & 82 \\
\hline Turquía & 34 & 43 & 46 & 32 & 25 & 21 \\
\hline Media OCDE & 75 & 82 & 82 & 79 & 73 & 64 \\
\hline Media UE21 & 77 & 84 & 84 & 81 & 75 & 66 \\
\hline
\end{tabular}

\begin{tabular}{|c|c|c|c|c|c|c|}
\hline 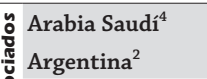 & $\begin{array}{l}49 \\
42\end{array}$ & $\begin{array}{l}\mathrm{m} \\
\mathrm{m}\end{array}$ & $\begin{array}{l}\mathrm{m} \\
\mathrm{m}\end{array}$ & $\begin{array}{l}\mathrm{m} \\
\mathrm{m}\end{array}$ & $\begin{array}{l}\mathrm{m} \\
\mathrm{m}\end{array}$ & $\begin{array}{l}\mathrm{m} \\
\mathrm{m}\end{array}$ \\
\hline ڤ̆ & 45 & 56 & 59 & 45 & 38 & 27 \\
\hline ฒّ China ${ }^{3}$ & 22 & $\mathrm{~m}$ & $\mathrm{~m}$ & $\mathrm{~m}$ & $\mathrm{~m}$ & $\mathrm{~m}$ \\
\hline Colombia $^{1}$ & 42 & $\mathrm{~m}$ & $\mathrm{~m}$ & $\mathrm{~m}$ & $\mathrm{~m}$ & $\mathrm{~m}$ \\
\hline Federación Rusa & 94 & 94 & 94 & 95 & 96 & 92 \\
\hline India & $\mathrm{m}$ & $\mathrm{m}$ & $\mathrm{m}$ & $\mathrm{m}$ & $\mathrm{m}$ & $\mathrm{m}$ \\
\hline Indonesia $^{1}$ & 29 & $\mathrm{~m}$ & $\mathrm{~m}$ & $\mathrm{~m}$ & $\mathrm{~m}$ & $\mathrm{~m}$ \\
\hline Letonia & 89 & 84 & 85 & 89 & 94 & 87 \\
\hline Sudáfrica & 61 & $\mathrm{~m}$ & $\mathrm{~m}$ & $\mathrm{~m}$ & $\mathrm{~m}$ & $\mathrm{~m}$ \\
\hline Media G20 & 61 & $\mathrm{~m}$ & $\mathrm{~m}$ & $\mathrm{~m}$ & $\mathrm{~m}$ & $\mathrm{~m}$ \\
\hline
\end{tabular}

Nota: Estos cálculos excluyen los programas CINE 3C cortos.

1. Año de referencia 2011.

2. Año de referencia 2003.

3. Año de referencia 2010.

4. Año de referencia 2013.

Fuente: OCDE. Arabia Saudí, Argentina, China, Colombia, India, Indonesia, Sudáfrica: Instituto de Estadística de la UNESCO. Letonia: Eurostat. Para ver notas, consulte Anexo 3 (www.oecd.org/edu/eag.htm).

Para obtener más información acerca de los símbolos utilizados en lugar de los datos que faltan, consulte la Guía del lector.

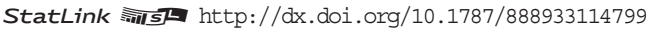


Tabla A1.3a. Porcentaje de adultos que han completado la educación terciaria, por tipo de programa y grupo de edad (2012)

\begin{tabular}{|c|c|c|c|c|c|c|c|c|c|c|c|c|c|c|c|c|c|c|c|}
\hline & \multicolumn{6}{|c|}{ Educación terciaria de tipo $B$} & \multicolumn{6}{|c|}{$\begin{array}{l}\text { Educación terciaria de tipo } \mathrm{A} \\
\text { y programas de investigación avanzada }\end{array}$} & \multicolumn{7}{|c|}{ Total educación terciaria } \\
\hline & $\begin{array}{l}\text { 'ర } \\
\text { فे }\end{array}$ & $\begin{array}{l}\text { के } \\
\text { ồ }\end{array}$ & $\begin{array}{l}\text { ले } \\
\text { மे }\end{array}$ & $\begin{array}{l}\stackrel{H}{1} \\
\text { ம் }\end{array}$ & $\begin{array}{l}\text { Ĺ } \\
\text { 乌ీ }\end{array}$ & 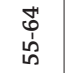 & $\begin{array}{l}\text { ठै' } \\
\text { مे }\end{array}$ & $\begin{array}{l}\text { ले } \\
\text { oे }\end{array}$ & $\begin{array}{l}\text { लै } \\
\text { மे }\end{array}$ & $\begin{array}{l}\text { 岁 } \\
\text { 岗 }\end{array}$ & $\begin{array}{l}\stackrel{H}{h} \\
\text { ம் }\end{array}$ & $\begin{array}{l}\text { 'ో } \\
\text { م⿱ }\end{array}$ & $\begin{array}{l}\text { ड़ } \\
\text { مे }\end{array}$ & $\begin{array}{l}\text { ले } \\
\text { 仓े }\end{array}$ & $\begin{array}{l}\text { 今े } \\
\text { ஸे }\end{array}$ & $\begin{array}{l}\stackrel{+}{1} \\
\text { 岗 }\end{array}$ & 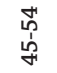 & $\begin{array}{l}\text { 今. } \\
\text { h } \\
\text { in }\end{array}$ & $\begin{array}{c}25-64 \\
\text { (en miles) }\end{array}$ \\
\hline & (1) & (2) & (3) & (4) & (5) & (6) & (7) & (8) & (9) & (10) & (11) & (12) & (13) & (14) & (15) & (16) & (17) & (18) & (19) \\
\hline Alemania & 11 & 10 & 9 & 11 & 12 & 11 & 17 & 22 & 19 & 19 & 15 & 15 & 28 & 32 & 29 & 30 & 28 & 26 & 12.612 \\
\hline Australia & 11 & 11 & 10 & 13 & 12 & 10 & 30 & 38 & 37 & 32 & 25 & 23 & 41 & 49 & 47 & 45 & 37 & 33 & 4.846 \\
\hline Austria & 7 & 6 & 5 & 7 & 8 & 8 & 13 & 20 & 18 & 14 & 10 & 8 & 20 & 26 & 23 & 22 & 19 & 17 & 934 \\
\hline Bélgica & 17 & 20 & 18 & 20 & 16 & 13 & 18 & 24 & 25 & 21 & 16 & 12 & 35 & 44 & 43 & 40 & 32 & 25 & 2.089 \\
\hline Canadá & 25 & 26 & 25 & 27 & 25 & 22 & 28 & 32 & 32 & 32 & 24 & 22 & 53 & 58 & 57 & 59 & 50 & 44 & 9.981 \\
\hline Chile $^{1}$ & 6 & 6 & 6 & 7 & 6 & 4 & 12 & 17 & 16 & 12 & 9 & 9 & 18 & 23 & 22 & 19 & 16 & 13 & 1.492 \\
\hline Corea & 13 & 25 & 26 & 17 & 6 & 2 & 28 & 40 & 40 & 36 & 23 & 11 & 42 & 66 & 66 & 52 & 29 & 14 & 12.331 \\
\hline Dinamarca & 6 & 6 & 5 & 6 & 6 & 5 & 29 & 37 & 35 & 32 & 27 & 24 & 35 & 43 & 40 & 39 & 32 & 29 & 817 \\
\hline Eslovenia & 12 & 15 & 14 & 13 & 11 & 9 & 15 & 24 & 22 & 18 & 12 & 8 & 26 & 39 & 35 & 30 & 23 & 17 & 315 \\
\hline España & 10 & 13 & 13 & 12 & 8 & 4 & 23 & 27 & 27 & 27 & 20 & 15 & 32 & 40 & 39 & 39 & 28 & 19 & 8.508 \\
\hline Estados Unidos & 10 & 11 & 10 & 11 & 10 & 11 & 33 & 35 & 34 & 35 & 31 & 31 & 43 & 45 & 44 & 46 & 41 & 42 & 70.207 \\
\hline Estonia & 13 & 12 & 13 & 12 & 13 & 12 & 25 & 27 & 27 & 24 & 24 & 23 & 37 & 39 & 40 & 36 & 37 & 35 & 272 \\
\hline Finlandia & 13 & 2 & 1 & 15 & 21 & 17 & 26 & 44 & 39 & 33 & 21 & 15 & 40 & 46 & 40 & 47 & 41 & 31 & 1.136 \\
\hline Francia & 12 & 17 & 16 & 16 & 10 & 7 & 19 & 27 & 27 & 22 & 14 & 13 & 31 & 44 & 43 & 38 & 24 & 20 & 10.049 \\
\hline Grecia & 9 & 11 & 13 & 8 & 8 & 5 & 18 & 20 & 21 & 19 & 16 & 15 & 27 & 31 & 35 & 27 & 24 & 20 & 1.641 \\
\hline Hungría & 1 & 1 & 1 & 1 & c & c & 21 & 29 & 29 & 22 & 19 & 15 & 22 & 30 & 30 & 22 & 19 & 15 & 1.225 \\
\hline Irlanda & 15 & 18 & 16 & 18 & 13 & 10 & 25 & 33 & 33 & 28 & 19 & 15 & 40 & 51 & 49 & 46 & 32 & 25 & 965 \\
\hline Islandia & 4 & c & 3 & 5 & 5 & 5 & 31 & 40 & 36 & 37 & 30 & 20 & 35 & 40 & 38 & 42 & 34 & 25 & 56 \\
\hline Israel & 14 & 13 & 12 & 14 & 14 & 16 & 33 & 38 & 33 & 36 & 30 & 30 & 46 & 51 & 44 & 50 & 45 & 47 & 1.691 \\
\hline Italia & $\mathbf{n}$ & $\mathrm{n}$ & $\mathrm{n}$ & $\mathrm{n}$ & $\mathrm{n}$ & $\mathrm{n}$ & 15 & 21 & 22 & 17 & 12 & 11 & 16 & 22 & 22 & 17 & 12 & 11 & 5.272 \\
\hline Japón & 20 & $\mathrm{~m}$ & 23 & 25 & 20 & 13 & 26 & $\mathrm{~m}$ & 35 & 27 & 26 & 19 & 47 & $\mathrm{~m}$ & 59 & 52 & 46 & 32 & 30.890 \\
\hline Luxemburgo & 13 & 12 & 14 & 15 & 12 & 10 & 26 & 38 & 36 & 30 & 20 & 17 & 39 & 50 & 50 & 45 & 32 & 26 & 114 \\
\hline México & 1 & 1 & 1 & 1 & 1 & 1 & 17 & 20 & 23 & 15 & 15 & 12 & 18 & 21 & 24 & 16 & 17 & 13 & 9.661 \\
\hline Noruega & 2 & c & $1^{r}$ & 2 & 3 & 3 & 36 & 47 & 44 & 41 & 32 & 27 & 39 & 47 & 45 & 44 & 35 & 30 & 1.017 \\
\hline Nueva Zelanda & 15 & 14 & 14 & 15 & 16 & 17 & 25 & 34 & 33 & 28 & 22 & 18 & 41 & 48 & 47 & 42 & 38 & 35 & 882 \\
\hline Países Bajos & 3 & 3 & 3 & 3 & 3 & 2 & 32 & 41 & 40 & 34 & 28 & 25 & 34 & 44 & 43 & 37 & 31 & 28 & 2.922 \\
\hline Polonia & $\mathbf{x}(7)$ & $\mathrm{x}(8)$ & $\mathrm{x}(9)$ & $\mathrm{x}(10)$ & $\mathrm{x}(11)$ & $\mathrm{x}(12)$ & 25 & 39 & 41 & 26 & 16 & 13 & 25 & 39 & 41 & 26 & 16 & 13 & 5.157 \\
\hline Portugal & $\mathbf{x}(7)$ & $\mathrm{x}(8)$ & $\mathrm{x}(9)$ & $x(10)$ & $\mathrm{x}(11)$ & $\mathrm{x}(12)$ & 19 & 27 & 28 & 20 & 14 & 11 & 19 & 27 & 28 & 20 & 14 & 11 & 1.095 \\
\hline Reino Unido & 10 & 9 & 8 & 11 & 11 & 10 & 31 & 42 & 40 & 35 & 26 & 22 & 41 & 50 & 48 & 45 & 37 & 33 & 13.508 \\
\hline República Checa & $\mathbf{x}(7)$ & $\mathrm{x}(8)$ & $\mathrm{x}(9)$ & $x(10)$ & $\mathrm{x}(11)$ & $\mathrm{x}(12)$ & 19 & 26 & 28 & 19 & 18 & 13 & 19 & 26 & 28 & 19 & 18 & 13 & 1.164 \\
\hline República Eslovaca & 1 & 1 & 1 & 1 & 1 & 1 & 18 & 22 & 26 & 16 & 15 & 12 & 19 & 24 & 27 & 17 & 16 & 14 & 598 \\
\hline Suecia & 9 & 9 & 9 & 8 & 9 & 10 & 27 & 39 & 34 & 32 & 21 & 19 & 36 & 48 & 43 & 40 & 30 & 29 & 1.736 \\
\hline Suiza & 11 & 10 & 9 & 12 & 12 & 10 & 26 & 34 & 32 & 29 & 23 & 19 & 37 & 44 & 41 & 41 & 35 & 29 & 1.619 \\
\hline Turquía & $\mathbf{x}(7)$ & $\mathrm{x}(8)$ & $\mathrm{x}(9)$ & $\mathrm{x}(10)$ & $\mathrm{x}(11)$ & $\mathrm{x}(12)$ & 15 & 19 & 21 & 15 & 10 & 10 & 15 & 19 & 21 & 15 & 10 & 10 & 5.271 \\
\hline
\end{tabular}

Media OCDE

Total OCDE

(en miles)

\begin{tabular}{l|l|l|l|l|l|l|l|l|l|l|l|l|l|l|l|l|l|}
$\mathbf{1 0}$ & 10 & 10 & 11 & 10 & 9 & $\mathbf{2 4}$ & 31 & 30 & 26 & 20 & 17 & $\mathbf{3 2}$ & 40 & 39 & 35 & 29 & 24 \\
\hline
\end{tabular}

Media UE21

\begin{tabular}{|c|c|c|c|c|c|c|c|c|c|c|c|c|c|c|c|c|c|c|c|}
\hline $\begin{array}{l}\text { Arabia Saudí }{ }^{4} \\
\text { Argentina }^{2}\end{array}$ & $\begin{array}{l}\mathbf{x}(13) \\
\mathbf{x}(13)\end{array}$ & $\begin{array}{l}\mathrm{m} \\
\mathrm{m}\end{array}$ & $\begin{array}{l}\mathrm{m} \\
\mathrm{m}\end{array}$ & $\begin{array}{l}\mathrm{m} \\
\mathrm{m}\end{array}$ & $\begin{array}{l}\mathrm{m} \\
\mathrm{m}\end{array}$ & $\begin{array}{l}\mathrm{m} \\
\mathrm{m}\end{array}$ & $\begin{array}{l}\mathbf{x}(13) \\
\mathbf{x}(13)\end{array}$ & $\begin{array}{l}\mathrm{m} \\
\mathrm{m}\end{array}$ & $\begin{array}{l}\mathrm{m} \\
\mathrm{m}\end{array}$ & $\begin{array}{l}\mathrm{m} \\
\mathrm{m}\end{array}$ & $\begin{array}{l}\mathrm{m} \\
\mathrm{m}\end{array}$ & $\begin{array}{l}\mathrm{m} \\
\mathrm{m}\end{array}$ & $\begin{array}{l}21 \\
14\end{array}$ & $\begin{array}{l}\mathrm{m} \\
\mathrm{m}\end{array}$ & $\begin{array}{l}\mathrm{m} \\
\mathrm{m}\end{array}$ & $\begin{array}{l}\mathrm{m} \\
\mathrm{m}\end{array}$ & $\begin{array}{l}\mathrm{m} \\
\mathrm{m}\end{array}$ & $\begin{array}{l}\mathrm{m} \\
\mathrm{m}\end{array}$ & $\begin{array}{l}\mathrm{m} \\
\mathrm{m}\end{array}$ \\
\hline Brasil & $\mathbf{x}(7)$ & $x(8)$ & $\mathrm{x}(9)$ & $\mathrm{x}(10)$ & $\mathrm{x}(11)$ & $\mathrm{x}(12)$ & 13 & 15 & 14 & 13 & 13 & 10 & 13 & 15 & 14 & 13 & 13 & 10 & 13.199 \\
\hline China ${ }^{3}$ & $\mathbf{x}(\mathbf{1 3})$ & $\mathrm{m}$ & $\mathrm{m}$ & $\mathrm{m}$ & $\mathrm{m}$ & $\mathrm{m}$ & $\mathbf{x}(\mathbf{1 3})$ & $\mathrm{m}$ & $\mathrm{m}$ & $\mathrm{m}$ & $\mathrm{m}$ & $\mathrm{m}$ & 4 & $\mathrm{~m}$ & $\mathrm{~m}$ & $\mathrm{~m}$ & $\mathrm{~m}$ & $\mathrm{~m}$ & $\mathrm{~m}$ \\
\hline Federación Rusa & 26 & 22 & 21 & 26 & 28 & 28 & 28 & 34 & 35 & 29 & 24 & 21 & 53 & 56 & 57 & 55 & 52 & 49 & 44.583 \\
\hline India & & $\mathrm{m}$ & $\mathrm{m}$ & $\mathrm{m}$ & $\mathrm{m}$ & $\mathrm{m}$ & $\mathbf{m}$ & $\mathrm{m}$ & $\mathrm{m}$ & $\mathrm{m}$ & $\mathrm{m}$ & $\mathrm{m}$ & $\mathbf{m}$ & $\mathrm{m}$ & $\mathrm{m}$ & $\mathrm{m}$ & $\mathrm{m}$ & $\mathrm{m}$ & $\mathrm{m}$ \\
\hline Indonesia $^{1}$ & $\mathbf{x}(\mathbf{1 3})$ & $\mathrm{m}$ & $\mathrm{m}$ & $\mathrm{m}$ & $\mathrm{m}$ & $\mathrm{m}$ & $\mathbf{x}(\mathbf{1 3})$ & $\mathrm{m}$ & $\mathrm{m}$ & $\mathrm{m}$ & $\mathrm{m}$ & $\mathrm{m}$ & 8 & $\mathrm{~m}$ & $\mathrm{~m}$ & $\mathrm{~m}$ & $\mathrm{~m}$ & $\mathrm{~m}$ & $\mathrm{~m}$ \\
\hline Sudáfrica & $\mathbf{x}(\mathbf{1 3})$ & $\mathrm{m}$ & $\mathrm{m}$ & $\mathrm{m}$ & $\mathrm{m}$ & $\mathrm{m}$ & $\mathbf{x}(\mathbf{1 3})$ & $\mathrm{m}$ & $\mathrm{m}$ & $\mathrm{m}$ & $\mathrm{m}$ & $\mathrm{m}$ & 6 & $\mathrm{~m}$ & $\mathrm{~m}$ & $\mathrm{~m}$ & $\mathrm{~m}$ & $\mathrm{~m}$ & $\mathrm{~m}$ \\
\hline
\end{tabular}

\begin{tabular}{|l|c|c|c|c|c|c|c|c|c|c|c|c|c|c|c|c|c|c|c|c|c|}
$\begin{array}{l}\text { Media G20 } \\
\begin{array}{l}\text { Total G20 } \\
\text { (en miles) }\end{array}\end{array}$ & $\mathbf{x}(\mathbf{1 3})$ & $\mathrm{m}$ & $\mathrm{m}$ & $\mathrm{m}$ & $\mathrm{m}$ & $\mathrm{m}$ & $\mathbf{x}(\mathbf{1 3})$ & $\mathrm{m}$ & $\mathrm{m}$ & $\mathrm{m}$ & $\mathrm{m}$ & $\mathrm{m}$ & $\mathbf{2 7}$ & $\mathrm{m}$ & $\mathrm{m}$ & $\mathrm{m}$ & $\mathrm{m}$ & $\mathrm{m}$ & $\mathrm{m}$ \\
\hline
\end{tabular}

1. Año de referencia 2011.

2. Año de referencia 2003.

3. Año de referencia 2010.

4. Año de referencia 2013.

Fuente: OCDE. Arabia Saudí, Argentina, China, Colombia, India, Indonesia, Sudáfrica: Instituto de Estadística de la UNESCO. Letonia: Eurostat. Para ver notas, consulte Anexo 3 (www.oecd.org/edu/eag.htm).

Para obtener más información acerca de los símbolos utilizados en lugar de los datos que faltan, consulte la Guía del lector.

StatLink 제은 http://dx.doi.org/10.1787/888933114818 
Tabla A1.4a. [1/2] Tendencias de los niveles de educación alcanzados, por grupo de edad, y tasa media de crecimiento anual (2000, 2005-2012)

\begin{tabular}{|c|c|c|c|c|c|c|c|c|c|c|c|c|c|}
\hline & \multirow[b]{3}{*}{ Nivel de educación alcanzado } & \multicolumn{4}{|c|}{ 25-64 años } & \multicolumn{4}{|c|}{ 25-34 años } & \multicolumn{4}{|c|}{$55-64$ años } \\
\hline & & 2000 & 2005 & 2010 & 2012 & 2000 & 2005 & 2010 & 2012 & 2000 & 2005 & 2010 & 2012 \\
\hline & & (1) & (2) & $(7)$ & (9) & (11) & (12) & (17) & (19) & (21) & $(22)$ & (27) & (29) \\
\hline \multirow{3}{*}{ ü Alemania } & Inferior a educación secundaria superior & 18 & 17 & 14 & 14 & 15 & 16 & 14 & 13 & 26 & 21 & 17 & 16 \\
\hline & Secundaria superior o postsecundaria no terciaria & 58 & 59 & 59 & 58 & 63 & 62 & 60 & 58 & 54 & 56 & 58 & 58 \\
\hline & Terciaria & 23 & 25 & 27 & 28 & 22 & 22 & 26 & 29 & 20 & 23 & 25 & 26 \\
\hline \multirow[t]{3}{*}{ Australia } & Inferior a educación secundaria superior & 41 & 35 & 27 & 24 & 32 & 21 & 15 & 13 & 54 & 50 & 42 & 36 \\
\hline & Secundaria superior o postsecundaria no terciaria & 31 & 33 & 36 & 35 & 37 & 41 & 40 & 39 & 27 & 26 & 29 & 30 \\
\hline & Terciaria & 27 & 32 & 38 & 41 & 31 & 38 & 44 & 47 & 19 & 24 & 30 & 33 \\
\hline Austria & Inferior a educación secundaria superior & 24 & 19 & 18 & 17 & 16 & 13 & 12 & 11 & 37 & 30 & 27 & 26 \\
\hline & Secundaria superior o postsecundaria no terciaria & 62 & 63 & 63 & 63 & 69 & 68 & 67 & 66 & 53 & 56 & 56 & 57 \\
\hline & Terciaria & 14 & 18 & 19 & 20 & 14 & 20 & 21 & 23 & 10 & 14 & 16 & 17 \\
\hline Bélgica & Inferior a educación secundaria superior & 41 & 34 & 30 & 28 & 25 & 19 & 18 & 18 & 62 & 52 & 46 & 44 \\
\hline & Secundaria superior o postsecundaria no terciaria & 31 & 35 & 36 & 36 & 39 & 40 & 38 & 39 & 22 & 26 & 29 & 31 \\
\hline & Terciaria & 27 & 31 & 35 & 35 & 36 & 41 & 44 & 43 & 17 & 22 & 26 & 25 \\
\hline Canadá & Inferior a educación secundaria superior & 19 & 15 & 12 & 11 & 12 & 9 & 8 & 8 & 36 & 25 & 18 & 16 \\
\hline & Secundaria superior o postsecundaria no terciaria & 41 & 39 & 38 & 36 & 40 & 37 & 36 & 35 & 36 & 39 & 40 & 39 \\
\hline & Terciaria & 40 & 46 & 51 & 53 & 48 & 54 & 56 & 57 & 28 & 36 & 42 & 44 \\
\hline Chile $^{1}$ & Inferior a educación secundaria superior & $\mathrm{m}$ & $\mathrm{m}$ & 29 & $\mathrm{~m}$ & $\mathrm{~m}$ & $\mathrm{~m}$ & 13 & $\mathrm{~m}$ & $\mathrm{~m}$ & $\mathrm{~m}$ & 47 & $\mathrm{~m}$ \\
\hline & Terciaria & $\mathrm{m}$ & $\mathrm{m}$ & 27 & $\mathrm{~m}$ & $\mathrm{~m}$ & $\mathrm{~m}$ & 38 & $\mathrm{~m}$ & $\mathrm{~m}$ & $\mathrm{~m}$ & 19 & $\mathrm{~m}$ \\
\hline Corea & Inferior a educación secundaria superior & 32 & 24 & 20 & 18 & 7 & 3 & 2 & 2 & 71 & 65 & 57 & 52 \\
\hline & Secundaria superior o postsecundaria no terciaria & 44 & 44 & 41 & 41 & 56 & 46 & 33 & 33 & 20 & 25 & 30 & 34 \\
\hline & Terciaria & 24 & 32 & 40 & 42 & 37 & 51 & 65 & 66 & 9 & 10 & 13 & 14 \\
\hline Dinamarca & Inferior a educación secundaria superior & 20 & 19 & 24 & 22 & 13 & 13 & 20 & 18 & 31 & 25 & 32 & 29 \\
\hline & Secundaria superior o postsecundaria no terciaria & 54 & 47 & 42 & 43 & 58 & 48 & 42 & 42 & 51 & 48 & 41 & 42 \\
\hline & Terciaria & 26 & 34 & 33 & 35 & 29 & 40 & 38 & 40 & 18 & 27 & 28 & 29 \\
\hline Eslovenia $^{2}$ & Inferior a educación secundaria superior & 25 & 20 & 17 & 15 & 15 & 9 & 7 & 6 & 39 & 31 & 28 & 26 \\
\hline & Secundaria superior o postsecundaria no terciaria & 59 & 60 & 60 & 59 & 66 & 67 & 62 & 59 & 49 & 53 & 56 & 57 \\
\hline & Terciaria & 16 & 20 & 24 & 26 & 19 & 25 & 31 & 35 & 12 & 16 & 16 & 17 \\
\hline España & Inferior a educación secundaria superior & 62 & 51 & 47 & 45 & 45 & 36 & 35 & 36 & 85 & 74 & 68 & 65 \\
\hline & Secundaria superior o postsecundaria no terciaria & 16 & 21 & 22 & 22 & 21 & 24 & 26 & 25 & 6 & 11 & 14 & 16 \\
\hline & Terciaria & 23 & 28 & 31 & 32 & 34 & 40 & 39 & 39 & 10 & 14 & 18 & 19 \\
\hline Estados Unidos & Inferior a educación secundaria superior & 13 & 12 & 11 & 11 & 12 & 13 & 12 & 11 & 18 & 14 & 10 & 10 \\
\hline & Secundaria superior o postsecundaria no terciaria & 51 & 49 & 47 & 46 & 50 & 47 & 46 & 45 & 52 & 49 & 49 & 48 \\
\hline & Terciaria & 36 & 39 & 42 & 43 & 38 & 39 & 42 & 44 & 30 & 37 & 41 & 42 \\
\hline Estonia $^{2}$ & Inferior a educación secundaria superior & 15 & 11 & 11 & 10 & 9 & 13 & 13 & 14 & 33 & 20 & 15 & 12 \\
\hline & Secundaria superior o postsecundaria no terciaria & 56 & 56 & 54 & 53 & 60 & 55 & 49 & 47 & 39 & 51 & 54 & 53 \\
\hline & Terciaria & 29 & 33 & 35 & 37 & 31 & 33 & 38 & 40 & 27 & 29 & 31 & 36 \\
\hline Finlandia & Inferior a educación secundaria superior & 27 & 21 & 17 & 15 & 14 & 11 & 9 & 10 & 50 & 39 & 30 & 26 \\
\hline & Secundaria superior o postsecundaria no terciaria & 41 & 41 & 42 & 42 & 45 & 42 & 41 & 40 & 31 & 35 & 37 & 39 \\
\hline & Terciaria & 22 & 25 & 29 & 31 & 31 & 40 & 43 & 43 & 13 & 16 & 18 & 20 \\
\hline Grecia & Inferior a educación secundaria superior & 51 & 43 & 35 & 32 & 31 & 26 & 21 & 17 & 75 & 68 & 56 & 50 \\
\hline & Secundaria superior o postsecundaria no terciaria & 32 & 36 & 41 & 42 & 45 & 49 & 48 & 48 & 17 & 20 & 27 & 30 \\
\hline & Terciaria & 18 & 21 & 25 & 27 & 24 & 26 & 31 & 35 & 8 & 12 & 17 & 20 \\
\hline Hungría & Inferior a educación secundaria superior & 31 & 24 & 19 & 18 & 19 & 15 & 14 & 12 & 60 & 39 & 26 & 25 \\
\hline & Secundaria superior o postsecundaria no terciaria & 55 & 59 & 61 & 60 & 67 & 65 & 60 & 57 & 28 & 46 & 58 & 59 \\
\hline & Terciaria & 14 & 17 & 20 & 22 & 15 & 20 & 26 & 30 & 12 & 15 & 16 & 15 \\
\hline Irlanda & Inferior a educación secundaria superior & 43 & 35 & 27 & 25 & 27 & 19 & 14 & 14 & 64 & 60 & 50 & 45 \\
\hline & Secundaria superior o postsecundaria no terciaria & 36 & 35 & 35 & 35 & 43 & 40 & 37 & 37 & 22 & 23 & 29 & 30 \\
\hline & Terciaria & 22 & 29 & 38 & 40 & 30 & 41 & 48 & 49 & 13 & 17 & 22 & 25 \\
\hline Islandia & Inferior a educación secundaria superior & 44 & 37 & 33 & 29 & 37 & 31 & 28 & 25 & 60 & 51 & 45 & 39 \\
\hline & Secundaria superior o postsecundaria no terciaria & 32 & 32 & 34 & 36 & 33 & 33 & 36 & 37 & 27 & 28 & 32 & 36 \\
\hline & Terciaria & 24 & 31 & 33 & 35 & 30 & 36 & 36 & 38 & 13 & 21 & 23 & 25 \\
\hline Israel & Inferior a educación secundaria superior & $\mathrm{m}$ & 21 & 18 & 15 & $\mathrm{~m}$ & 14 & 12 & 10 & $\mathrm{~m}$ & 31 & 26 & 23 \\
\hline & Secundaria superior o postsecundaria no terciaria & $\mathrm{m}$ & 33 & 37 & 38 & $\mathrm{~m}$ & 36 & 44 & 46 & $\mathrm{~m}$ & 26 & 29 & 31 \\
\hline & Terciaria & $\mathrm{m}$ & 46 & 46 & 46 & $\mathrm{~m}$ & 50 & 44 & 44 & $\mathrm{~m}$ & 43 & 45 & 47 \\
\hline Italia & Inferior a educación secundaria superior & 55 & 50 & 45 & 43 & 41 & 34 & 29 & 28 & 76 & 70 & 62 & 58 \\
\hline & Secundaria superior o postsecundaria no terciaria & 36 & 38 & 40 & 42 & 49 & 50 & 50 & 50 & 18 & 22 & 28 & 31 \\
\hline & Terciaria & 10 & 12 & 15 & 16 & 11 & 16 & 21 & 22 & 6 & 8 & 11 & 11 \\
\hline Japón & Inferior a educación secundaria superior & 17 & $\mathrm{~m}$ & $\mathrm{~m}$ & $\mathrm{~m}$ & 6 & $\mathrm{~m}$ & $\mathrm{~m}$ & $\mathrm{~m}$ & 37 & $\mathrm{~m}$ & $\mathrm{~m}$ & $\mathrm{~m}$ \\
\hline & Secundaria superior o postsecundaria no terciaria & 49 & 60 & 55 & 53 & 46 & 47 & 43 & 41 & 48 & 78 & 71 & 68 \\
\hline & Terciaria & 34 & 40 & 45 & 47 & 48 & 53 & 57 & 59 & 15 & 22 & 29 & 32 \\
\hline Luxemburgo & Inferior a educación secundaria superior & 39 & 34 & 22 & 22 & 32 & 23 & 16 & 14 & 51 & 45 & 31 & 31 \\
\hline & Secundaria superior o postsecundaria no terciaria & 43 & 39 & 42 & 39 & 45 & 40 & 40 & 36 & 36 & 37 & 44 & 42 \\
\hline & Terciaria & 18 & 27 & 35 & 39 & 23 & 37 & 44 & 50 & 13 & 19 & 25 & 26 \\
\hline México & Inferior a educación secundaria superior & 71 & 68 & 65 & 63 & 63 & 62 & 57 & 54 & 87 & 84 & 78 & 75 \\
\hline & Secundaria superior o postsecundaria no terciaria & 14 & 17 & 18 & 19 & 20 & 20 & 21 & 22 & 6 & 8 & 10 & 12 \\
\hline & Terciaria & 15 & 15 & 17 & 18 & 17 & 18 & 21 & 24 & 7 & 8 & 12 & 13 \\
\hline
\end{tabular}

Nota: Las columnas que muestran los datos de los años 2006, 2007, 2008, 2009, 2011 están disponibles en Internet (véase StatLink más abajo).

1. Por ruptura en la serie temporal entre 2010 y 2011, los datos de 2011 no son comparables con los de años anteriores.

2. Las cifras de Eslovenia y Estonia correspondientes a 2011 que aparecen en esta tabla pueden diferir de las cifras que aparecen en otras tablas del Indicador A5, porque la fuente de los datos es diferente. Los datos de todos los años de esta tabla proceden de EU-LFS.

3. Las cifras de 2000 no son comparables con las de años más recientes, ya que en 2000 se utilizó la clasificación antigua de niveles de educación.

Fuente: OCDE. Para ver notas, consulte Anexo 3 (www.oecd.org/edu/eag.htm).

Para obtener más información acerca de los símbolos utilizados en lugar de los datos que faltan, consulte la Guía del lector.

StatLink त्ञात http://dx.doi.org/10.1787/888933114837 
Tabla A1.4a. [2/2] Tendencias de los niveles de educación alcanzados, por grupo de edad, y tasa media de crecimiento anual (2000, 2005-2012)

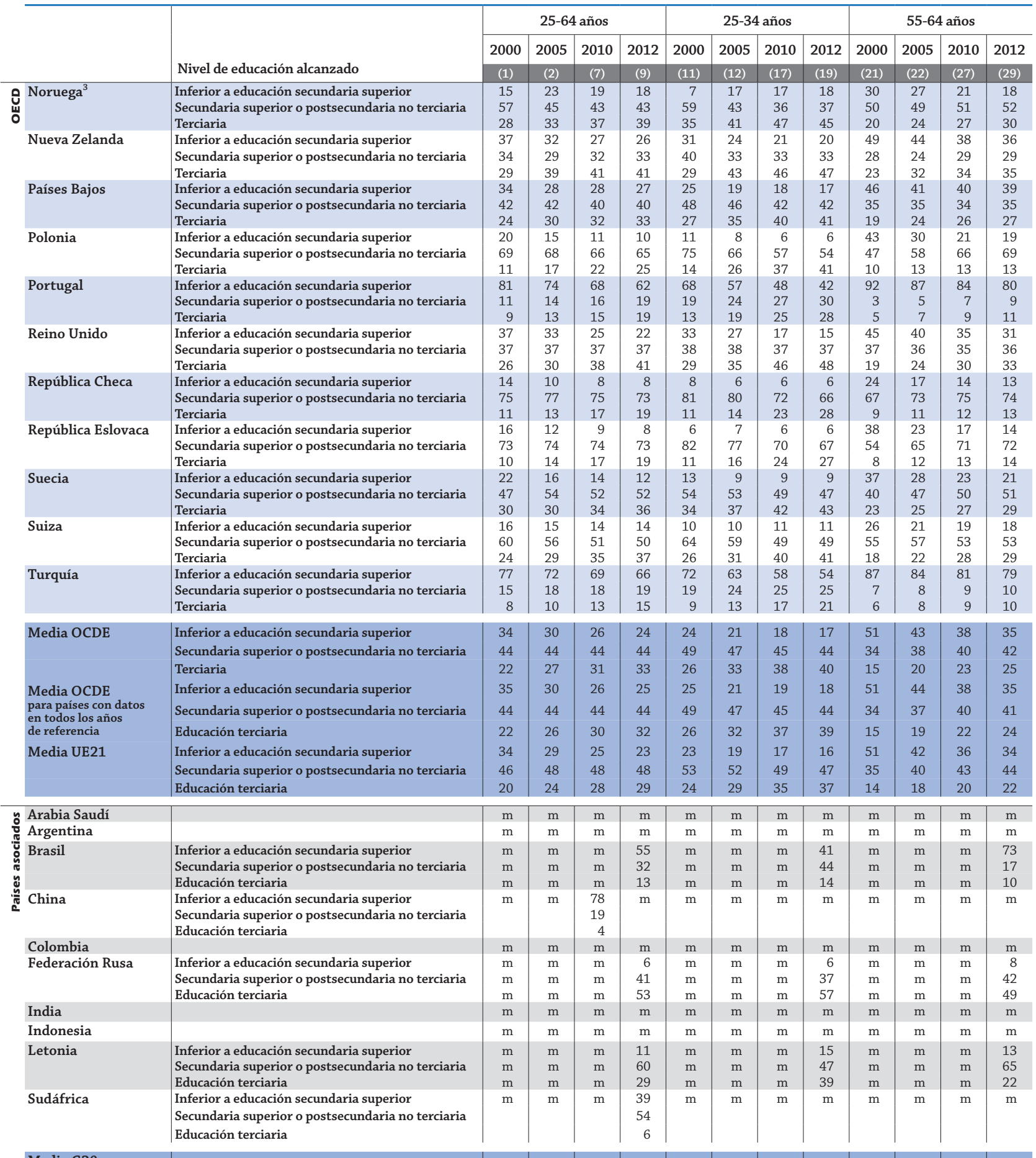


Tabla A1.5a. Nivel de educación alcanzado por la población de 25 a 64 años de edad, por orientación del programa y sexo (2012)

Educación secundaria superior o postsecundaria no terciaria, de 25 a 64 años de edad

\begin{tabular}{|c|c|c|c|c|c|c|c|c|c|}
\hline & \multicolumn{3}{|c|}{ Formación profesional } & \multicolumn{3}{|c|}{ General } & \multicolumn{3}{|c|}{ Total $^{1}$} \\
\hline & $\mathrm{H}+\mathrm{M}$ & Hombres & Mujeres & $\mathrm{H}+\mathrm{M}$ & Hombres & Mujeres & $\mathrm{H}+\mathrm{M}$ & Hombres & Mujeres \\
\hline & (1) & (2) & (3) & (4) & (5) & (6) & (7) & (8) & (9) \\
\hline Australia & 19 & 25 & 13 & 16 & 15 & 17 & 35 & 40 & 30 \\
\hline Austria & 58 & 61 & 54 & 6 & 5 & 6 & 63 & 66 & 60 \\
\hline Bélgica & 26 & 28 & 23 & 11 & 10 & 12 & 36 & 38 & 35 \\
\hline Chile $^{2}$ & 8 & 8 & 8 & 31 & 32 & 31 & 40 & 40 & 39 \\
\hline Corea & $\mathrm{x}(7)$ & $\mathrm{x}(8)$ & $\mathrm{x}(9)$ & $\mathrm{x}(7)$ & $\mathrm{x}(8)$ & $\mathrm{x}(9)$ & 41 & 41 & 41 \\
\hline Dinamarca & 42 & 47 & 38 & 2 & 2 & 2 & 43 & 48 & 38 \\
\hline Eslovenia & 54 & 61 & 46 & 5 & 4 & 6 & 59 & 65 & 52 \\
\hline España & 9 & 8 & 9 & 14 & 14 & 13 & 22 & 22 & 22 \\
\hline Estados Unidos & $\mathrm{x}(7)$ & $\mathrm{x}(8)$ & $\mathrm{x}(9)$ & $\mathrm{x}(7)$ & $\mathrm{x}(8)$ & $\mathrm{x}(9)$ & 46 & 48 & 45 \\
\hline Estonia & 32 & 38 & 28 & 20 & 21 & 19 & 53 & 59 & 47 \\
\hline Francia & 30 & 35 & 26 & 11 & 9 & 13 & 42 & 44 & 39 \\
\hline Grecia & 15 & 18 & 12 & 27 & 24 & 29 & 42 & 42 & 42 \\
\hline Hungría & 51 & 60 & 43 & 9 & 6 & 11 & 60 & 66 & 55 \\
\hline Irlanda & 13 & 14 & 12 & 23 & 23 & 23 & 35 & 36 & 34 \\
\hline Islandia & 28 & 36 & 19 & 10 & 8 & 11 & 36 & 44 & 28 \\
\hline Israel & 9 & 11 & 7 & 29 & 31 & 27 & 38 & 42 & 35 \\
\hline Italia & 32 & 36 & 28 & 10 & 6 & 13 & 42 & 42 & 41 \\
\hline Japón & $x(7)$ & $x(8)$ & $\mathrm{x}(9)$ & $x(7)$ & $x(8)$ & $\mathrm{x}(9)$ & 53 & 53 & 54 \\
\hline Luxemburgo & 41 & 40 & 42 & 3 & 3 & 4 & 39 & 38 & 40 \\
\hline México & $\mathrm{x}(7)$ & $\mathrm{x}(8)$ & $\mathrm{x}(9)$ & $\mathrm{x}(7)$ & $\mathrm{x}(8)$ & $\mathrm{x}(9)$ & 19 & 19 & 20 \\
\hline Noruega & $\mathrm{x}(7)$ & $\mathrm{x}(8)$ & $\mathrm{x}(9)$ & $\mathrm{x}(7)$ & $\mathrm{x}(8)$ & $\mathrm{x}(9)$ & 43 & 48 & 39 \\
\hline Nueva Zelanda & 25 & 31 & 19 & 9 & 8 & 9 & 33 & 39 & 28 \\
\hline Países Bajos & 32 & 32 & 32 & 7 & 7 & 7 & 40 & 41 & 40 \\
\hline Polonia & $\mathrm{x}(7)$ & $\mathrm{x}(8)$ & $\mathrm{x}(9)$ & $\mathrm{x}(7)$ & $\mathrm{x}(8)$ & $\mathrm{x}(9)$ & 65 & 69 & 61 \\
\hline República Checa & 73 & 76 & 70 & $\mathrm{n}$ & $\mathrm{n}$ & $\mathrm{n}$ & 73 & 76 & 70 \\
\hline República Eslovaca & 68 & 74 & 63 & 4 & 3 & 6 & 73 & 77 & 69 \\
\hline Suecia & 33 & 37 & 28 & 10 & 10 & 10 & 52 & 56 & 48 \\
\hline Suiza $^{4}$ & 38 & 36 & 40 & 6 & 5 & 7 & 50 & 46 & 53 \\
\hline Turquía & 9 & 10 & 6 & 10 & 11 & 9 & 19 & 21 & 15 \\
\hline Media OCDE & 33 & 36 & 29 & 12 & 11 & 12 & 44 & 46 & 41 \\
\hline Media UE21 & 39 & 42 & 36 & 10 & 9 & 10 & 48 & 50 & 45 \\
\hline
\end{tabular}

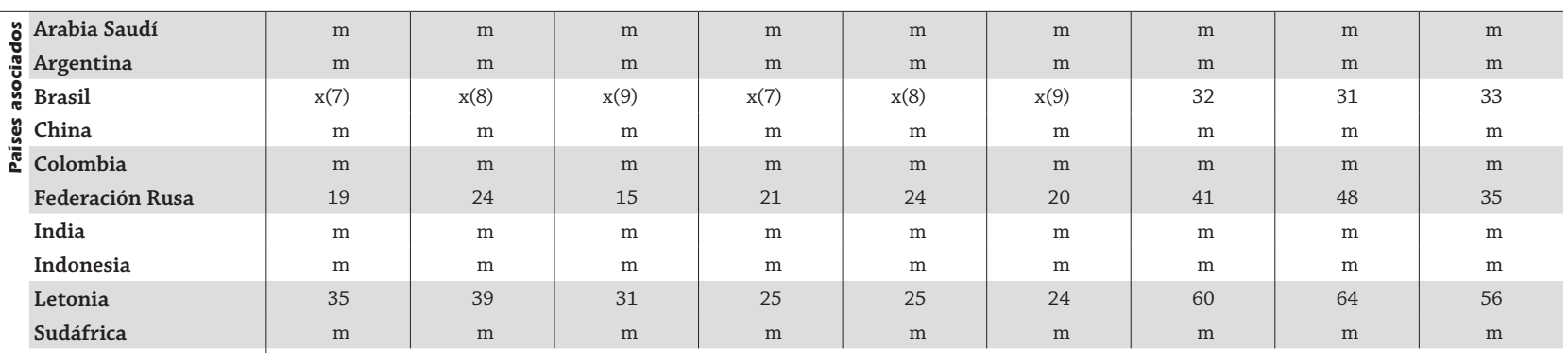

\section{Media G20}

$\mathrm{m}$

$\mathrm{m}$

$\mathrm{m}$

m

1. Las cifras representan uno de los siguientes supuestos: las proporciones combinadas de personas que han completado un programa vocacional y general; las proporciones combinadas de personas que han completado programas de ambas orientaciones y programas que no especifican su orientación; o la proporción de personas que han completado programas que no especifican su orientación. Las cifras de estas columnas son equivalentes a las de la educación secundaria superior o postsecundaria no terciaria que aparecen en las Tablas A1.4a y b.

2. Año de referencia 2011.

3. Las personas que alcanzan el nivel CINE $4 \mathrm{~A}$ en Alemania han completado satisfactoriamente tanto un programa general como de formación profesional. En esta tabla se han asignado a formación profesional.

4. Las personas que alcanzan el nivel CINE 4 en Suiza solo se incluyen en el total, dado que no es posible distinguir la orientación del programa en este nivel CINE.

Fuente: OCDE. Para ver notas, consulte Anexo 3 (www.oecd.org/edu/eag.htm).

Para obtener más información acerca de los símbolos utilizados en lugar de los datos que faltan, consulte la Guía del lector.

StatLink 차진 http://dx.doi.org/10.1787/888933114856 
Tabla A1.6a (L). [1/2] Nivel de educación alcanzado por la población de 25 a 64 años de edad, por nivel de comprensión lectora (2012)

Comprensión lectora en la Encuesta sobre las Competencias de los Adultos

\begin{tabular}{|c|c|c|c|c|c|c|c|c|c|}
\hline & \multirow{3}{*}{$\begin{array}{c}\text { Nivel de } \\
\text { competencia }\end{array}$} & \multicolumn{2}{|c|}{\begin{tabular}{|c|} 
Nivel inferior a la educación \\
secundaria superior
\end{tabular}} & \multicolumn{2}{|c|}{$\begin{array}{c}\text { Educación secundaria } \\
\text { superior o postsecundaria } \\
\text { no terciaria }\end{array}$} & \multicolumn{2}{|c|}{ Educación terciaria } & \multicolumn{2}{|c|}{$\begin{array}{c}\text { Todos los niveles } \\
\text { de educación }\end{array}$} \\
\hline & & $\%$ & E.E. & $\%$ & E.E. & $\%$ & E.E. & $\%$ & E.E. \\
\hline & & (1) & (2) & (3) & (4) & (5) & (6) & (7) & (8) \\
\hline \multicolumn{10}{|l|}{ Entidades nacionales } \\
\hline \multirow{3}{*}{ Ј Alemania } & $0 / 1$ & 55 & $(3,7)$ & 20 & $(1,1)$ & 6 & $(0,8)$ & 18 & $(0,8)$ \\
\hline & 2 & 35 & $(3,8)$ & 42 & $(1,6)$ & 25 & $(1,6)$ & 35 & $(1,1)$ \\
\hline & 3 & 9 & $(2,0)$ & 33 & $(1,3)$ & 49 & $(1,6)$ & 36 & $(1,0)$ \\
\hline \multirow[t]{4}{*}{ Australia } & $0 / 1$ & 28 & $(1,6)$ & 11 & $(1,0)$ & 5 & $(0,5)$ & 13 & $(0,6)$ \\
\hline & 2 & 40 & $(1,9)$ & 33 & $(1,7)$ & 19 & $(1,4)$ & 29 & $(0,8)$ \\
\hline & 3 & 28 & $(1,7)$ & 44 & $(1,8)$ & 45 & $(1,8)$ & 40 & $(1,1)$ \\
\hline & $4 / 5$ & 4 & $(0,7)$ & 13 & $(1,4)$ & 32 & $(1,5)$ & 18 & $(0,8)$ \\
\hline \multirow{4}{*}{ Austria } & $0 / 1$ & 35 & $(2,2)$ & 14 & $(0,8)$ & 4 & $(0,9)$ & 16 & $(0,7)$ \\
\hline & 2 & 45 & $(2,5)$ & 42 & $(1,4)$ & 24 & $(1,8)$ & 39 & $(1,0)$ \\
\hline & 3 & 19 & $(2,3)$ & 38 & $(1,4)$ & 51 & $(2,0)$ & 37 & $(1,0)$ \\
\hline & $4 / 5$ & 1 & $(0,6)$ & 6 & $(0,6)$ & 21 & $(1,5)$ & 8 & $(0,5)$ \\
\hline \multirow{3}{*}{ Canadá } & 2 & 35 & $(2,4)$ & 39 & $(1,1)$ & 26 & $(0,7)$ & 32 & $(0,7)$ \\
\hline & 3 & 12 & $(1,3)$ & 35 & $(1,1)$ & 43 & $(1,0)$ & 37 & $(0,7)$ \\
\hline & $4 / 5$ & 1 & $(0,4)$ & 8 & $(0,8)$ & 22 & $(0,9)$ & 14 & $(0,6)$ \\
\hline \multirow{4}{*}{ Corea } & $0 / 1$ & 43 & $(2,2)$ & 13 & $(0,9)$ & 3 & $(0,4)$ & 14 & $(0,6)$ \\
\hline & 2 & 44 & $(2,1)$ & 48 & $(1,7)$ & 29 & $(1,3)$ & 40 & $(0,9)$ \\
\hline & 3 & 12 & $(1,3)$ & 35 & $(1,7)$ & 55 & $(1,3)$ & 39 & $(1,0)$ \\
\hline & $4 / 5$ & c & c & 4 & $(0,5)$ & 14 & $(0,9)$ & 7 & $(0,4)$ \\
\hline \multirow[t]{4}{*}{ Dinamarca } & $0 / 1$ & 39 & $(2,3)$ & 16 & $(1,0)$ & 6 & $(0,5)$ & 16 & $(0,6)$ \\
\hline & 2 & 40 & $(2,2)$ & 42 & $(1,5)$ & 23 & $(1,2)$ & 34 & $(0,9)$ \\
\hline & 3 & 20 & $(1,9)$ & 37 & $(1,5)$ & 52 & $(1,4)$ & 40 & $(0,8)$ \\
\hline & $4 / 5$ & 2 & $(0,7)$ & 5 & $(0,7)$ & 19 & $(1,3)$ & 10 & $(0,6)$ \\
\hline España & $0 / 1$ & 47 & $(1,5)$ & 21 & $(1,4)$ & 8 & $(1,0)$ & 29 & $(0,8)$ \\
\hline & 2 & 41 & $(1,4)$ & 46 & $(2,0)$ & 32 & $(1,5)$ & 39 & $(0,9)$ \\
\hline & 3 & 12 & $(1,1)$ & 30 & $(1,8)$ & 48 & $(1,8)$ & 27 & $(0,8)$ \\
\hline & $4 / 5$ & 1 & $(0,2)$ & 3 & $(0,8)$ & 12 & $(1,1)$ & 5 & $(0,4)$ \\
\hline Estados Unidos & $0 / 1$ & 62 & $(2,8)$ & 22 & $(1,4)$ & 5 & $(0,7)$ & 19 & $(0,9)$ \\
\hline & 2 & 31 & $(2,8)$ & 42 & $(1,8)$ & 23 & $(1,3)$ & 33 & $(1,2)$ \\
\hline Estonia & $0 / 1$ & 33 & $(2,1)$ & 16 & $(1,0)$ & 7 & $(0,6)$ & 14 & $(0,6)$ \\
\hline & 2 & 42 & $(2,7)$ & 40 & $(1,1)$ & 28 & $(1,1)$ & 35 & $(0,7)$ \\
\hline & 3 & 23 & $(2,2)$ & 38 & $(1,1)$ & 47 & $(1,6)$ & 40 & $(1,0)$ \\
\hline & $4 / 5$ & 2 & $(0,8)$ & 7 & $(0,7)$ & 19 & $(1,2)$ & 11 & $(0,7)$ \\
\hline Finlandia & $0 / 1$ & 31 & $(2,5)$ & 13 & $(0,9)$ & 4 & $(0,5)$ & 11 & $(0,5)$ \\
\hline & 2 & 41 & $(2,6)$ & 33 & $(1,6)$ & 16 & $(1,1)$ & 27 & $(0,9)$ \\
\hline & 3 & 25 & $(2,3)$ & 40 & $(1,6)$ & 44 & $(1,4)$ & 40 & $(0,9)$ \\
\hline & $4 / 5$ & 4 & $(1,1)$ & 14 & $(1,0)$ & 37 & $(1,2)$ & 22 & $(0,6)$ \\
\hline Francia & $0 / 1$ & 49 & $(1,3)$ & 20 & $(1,0)$ & 5 & $(0,6)$ & 23 & $(0,6)$ \\
\hline & 2 & 37 & $(1,5)$ & 45 & $(1,1)$ & 24 & $(1,3)$ & 37 & $(0,8)$ \\
\hline & 3 & 13 & $(1,1)$ & 31 & $(1,0)$ & 52 & $(1,3)$ & 33 & $(0,7)$ \\
\hline & $4 / 5$ & 1 & $(0,3)$ & 3 & $(0,4)$ & 19 & $(1,1)$ & 7 & $(0,4)$ \\
\hline Irlanda & $0 / 1$ & 40 & $(2,3)$ & 14 & $(1,2)$ & 5 & $(0,7)$ & 18 & $(0,9)$ \\
\hline & 2 & 43 & $(2,4)$ & 42 & $(1,6)$ & 27 & $(1,5)$ & 37 & $(0,9)$ \\
\hline & 3 & 16 & $(1,5)$ & 38 & $(1,8)$ & 49 & $(1,5)$ & 36 & $(0,9)$ \\
\hline & $4 / 5$ & 1 & $(0,4)$ & 5 & $(0,9)$ & 19 & $(1,4)$ & 9 & $(0,6)$ \\
\hline Italia & $0 / 1$ & 42 & $(2,0)$ & 17 & $(1,3)$ & 9 & $(1,3)$ & 29 & $(1,2)$ \\
\hline & 2 & 44 & $(1,7)$ & 45 & $(1,6)$ & 31 & $(2,3)$ & 43 & $(1,0)$ \\
\hline & 3 & 13 & $(1,2)$ & 35 & $(1,8)$ & 48 & $(2,6)$ & 25 & $(1,0)$ \\
\hline & $4 / 5$ & $\mathrm{n}$ & $(0,3)$ & 4 & $(0,7)$ & 12 & $(1,7)$ & 3 & $(0,3)$ \\
\hline Japón & $0 / 1$ & 19 & $(2,2)$ & 6 & $(0,8)$ & 1 & $(0,3)$ & 5 & $(0,4)$ \\
\hline & 2 & 42 & $(3,1)$ & 30 & $(1,4)$ & 12 & $(0,9)$ & 23 & $(0,9)$ \\
\hline & 3 & 34 & $(2,7)$ & 51 & $(1,5)$ & 50 & $(1,5)$ & 49 & $(1,1)$ \\
\hline & $4 / 5$ & 5 & $(1,4)$ & 13 & $(1,0)$ & 37 & $(1,3)$ & 23 & $(0,8)$ \\
\hline Noruega & $0 / 1$ & 26 & $(2,0)$ & 13 & $(1,3)$ & 5 & $(0,6)$ & 12 & $(0,7)$ \\
\hline & 2 & 41 & $(2,4)$ & 37 & $(1,6)$ & 17 & $(1,1)$ & 30 & $(0,9)$ \\
\hline & 3 & 30 & $(2,0)$ & 42 & $(1,5)$ & 51 & $(1,4)$ & 43 & $(0,9)$ \\
\hline & $4 / 5$ & 4 & $(1,1)$ & 8 & $(1,0)$ & 28 & $(1,2)$ & 15 & $(0,7)$ \\
\hline
\end{tabular}

* Para los datos de Federación Rusa, véase nota en la sección de Metodología.

Nota: Las filas que muestran información combinada de todos los niveles PIAAC de comprensión lectora están disponibles en Internet (véase StatLink más abajo). Fuente: OCDE. Encuesta sobre las Competencias de los Adultos (PIAAC) (2012). PIAAC se refiere al Programa para la Evaluación Internacional de las Competencias de los Adultos de la OCDE. Para ver notas, consulte Anexo 3 (www.oecd.org/edu/eag.htm).

Para obtener más información acerca de los símbolos utilizados en lugar de los datos que faltan, consulte la Guía del lector.

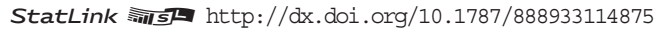


Tabla A1.6a (L). [2/2] Nivel de educación alcanzado por la población de 25 a 64 años de edad, por nivel de comprensión lectora (2012)

Comprensión lectora en la Encuesta sobre las Competencias de los Adultos

\begin{tabular}{|c|c|c|c|c|c|c|c|c|c|}
\hline & \multirow{3}{*}{$\begin{array}{c}\text { Nivel de } \\
\text { competencia }\end{array}$} & \multicolumn{2}{|c|}{$\begin{array}{c}\text { Nivel inferior } \\
\text { a la educación } \\
\text { secundaria superior }\end{array}$} & \multicolumn{2}{|c|}{$\begin{array}{l}\text { Educación secundaria } \\
\text { superior o postsecundaria } \\
\text { no terciaria }\end{array}$} & \multicolumn{2}{|c|}{ Educación terciaria } & \multicolumn{2}{|c|}{$\begin{array}{l}\text { Todos los niveles } \\
\text { de educación }\end{array}$} \\
\hline & & $\%$ & E.E. & $\%$ & E.E. & $\%$ & E.E. & $\%$ & E.E. \\
\hline & & (1) & (2) & (3) & (4) & (5) & (6) & (7) & (8) \\
\hline \multicolumn{10}{|l|}{ Entidades nacionales } \\
\hline \multirow{4}{*}{ Países Bajos } & $0 / 1$ & 32 & $(1,7)$ & 9 & $(1,0)$ & 3 & $(0,6)$ & 13 & $(0,6)$ \\
\hline & 2 & 39 & $(1,9)$ & 31 & $(1,5)$ & 14 & $(1,1)$ & 27 & $(0,8)$ \\
\hline & 3 & 26 & $(1,7)$ & 47 & $(1,6)$ & 48 & $(1,5)$ & 41 & $(0,8)$ \\
\hline & $4 / 5$ & 3 & $(0,7)$ & 14 & $(1,1)$ & 36 & $(1,5)$ & 18 & $(0,8)$ \\
\hline \multirow[t]{4}{*}{ Polonia } & $0 / 1$ & 45 & $(3,1)$ & 24 & $(1,1)$ & 4 & $(0,8)$ & 20 & $(0,7)$ \\
\hline & 2 & 39 & $(3,2)$ & 44 & $(1,4)$ & 24 & $(1,5)$ & 38 & $(1,1)$ \\
\hline & 3 & 15 & $(2,1)$ & 29 & $(1,2)$ & 48 & $(2,0)$ & 33 & $(1,1)$ \\
\hline & $4 / 5$ & 1 & $(0,7)$ & 4 & $(0,5)$ & 23 & $(1,7)$ & 9 & $(0,6)$ \\
\hline \multirow{4}{*}{ República Checa } & $0 / 1$ & 33 & $(4,6)$ & 12 & $(1,1)$ & 2 & $(0,9)$ & 12 & $(0,9)$ \\
\hline & 2 & 46 & $(6,0)$ & 43 & $(2,4)$ & 18 & $(2,9)$ & 38 & $(1,9)$ \\
\hline & 3 & 19 & $(4,4)$ & 40 & $(2,0)$ & 57 & $(3,8)$ & 41 & $(1,8)$ \\
\hline & $4 / 5$ & 2 & $(1,3)$ & 5 & $(0,7)$ & 24 & $(3,0)$ & 8 & $(0,8)$ \\
\hline \multirow[t]{4}{*}{ República Eslovaca } & $0 / 1$ & 37 & $(2,6)$ & 9 & $(0,7)$ & 3 & $(0,8)$ & 12 & $(0,7)$ \\
\hline & 2 & 44 & $(3,2)$ & 39 & $(1,6)$ & 23 & $(2,1)$ & 37 & $(1,2)$ \\
\hline & 3 & 18 & $(2,2)$ & 46 & $(1,5)$ & 57 & $(2,1)$ & 44 & $(1,1)$ \\
\hline & $4 / 5$ & 1 & $(0,5)$ & 6 & $(0,6)$ & 17 & $(1,9)$ & 7 & $(0,5)$ \\
\hline \multirow[t]{4}{*}{ Suecia } & $0 / 1$ & 34 & $(2,7)$ & 12 & $(1,0)$ & 5 & $(0,6)$ & 14 & $(0,7)$ \\
\hline & 2 & 43 & $(3,5)$ & 32 & $(1,8)$ & 15 & $(1,3)$ & 28 & $(1,2)$ \\
\hline & 3 & 21 & $(2,2)$ & 45 & $(1,9)$ & 46 & $(1,5)$ & 41 & $(1,0)$ \\
\hline & $4 / 5$ & 2 & $(0,8)$ & 11 & $(0,9)$ & 34 & $(1,6)$ & 17 & $(0,6)$ \\
\hline \multicolumn{10}{|l|}{ Entidades subnacionales } \\
\hline \multirow[t]{4}{*}{ Flandes (Bélgica) } & $0 / 1$ & 42 & $(2,3)$ & 16 & $(1,1)$ & 3 & $(0,5)$ & 16 & $(0,6)$ \\
\hline & 2 & 41 & $(2,4)$ & 41 & $(1,5)$ & 17 & $(1,3)$ & 32 & $(0,9)$ \\
\hline & 3 & 17 & $(1,8)$ & 36 & $(1,8)$ & 53 & $(1,7)$ & 40 & $(1,1)$ \\
\hline & $4 / 5$ & 1 & $(0,4)$ & 6 & $(0,7)$ & 26 & $(1,6)$ & 13 & $(0,7)$ \\
\hline \multirow[t]{4}{*}{ Inglaterra (Reino Unido) } & $0 / 1$ & 34 & $(1,7)$ & 14 & $(1,4)$ & 7 & $(0,9)$ & 16 & $(0,8)$ \\
\hline & 2 & 45 & $(2,2)$ & 35 & $(1,8)$ & 23 & $(1,4)$ & 33 & $(1,0)$ \\
\hline & 3 & 20 & $(1,6)$ & 39 & $(1,6)$ & 45 & $(1,8)$ & 37 & $(1,1)$ \\
\hline & $4 / 5$ & 2 & $(0,7)$ & 11 & $(1,1)$ & 25 & $(1,8)$ & 15 & $(0,9)$ \\
\hline \multirow{4}{*}{$\begin{array}{l}\text { Irlanda del Norte } \\
\text { (Reino Unido) }\end{array}$} & $0 / 1$ & 35 & $(2,5)$ & 14 & $(2,0)$ & 5 & $(1,0)$ & 18 & $(1,3)$ \\
\hline & 2 & 46 & $(2,6)$ & 41 & $(2,9)$ & 23 & $(2,1)$ & 37 & $(1,8)$ \\
\hline & 3 & 17 & $(2,0)$ & 38 & $(3,6)$ & 50 & $(2,1)$ & 35 & $(1,8)$ \\
\hline & $4 / 5$ & 1 & $(0,4)$ & 8 & $(1,2)$ & 22 & $(2,1)$ & 10 & $(0,8)$ \\
\hline \multirow{4}{*}{$\begin{array}{l}\text { Inglaterra/Irlanda del Norte } \\
\text { (Reino Unido) }\end{array}$} & $0 / 1$ & 34 & $(1,7)$ & 14 & $(1,3)$ & 7 & $(0,9)$ & 16 & $(0,8)$ \\
\hline & 2 & 45 & $(2,1)$ & 35 & $(1,8)$ & 23 & $(1,4)$ & 33 & $(1,0)$ \\
\hline & 3 & 19 & $(1,5)$ & 39 & $(1,6)$ & 45 & $(1,8)$ & 37 & $(1,0)$ \\
\hline & $4 / 5$ & 2 & $(0,7)$ & 11 & $(1,1)$ & 25 & $(1,7)$ & 14 & $(0,9)$ \\
\hline \multirow[t]{4}{*}{ Media } & $0 / 1$ & 39 & $(0,5)$ & 15 & $(0,2)$ & 5 & $(0,2)$ & 16 & $(0,2)$ \\
\hline & 2 & 41 & $(0,6)$ & 40 & $(0,3)$ & 22 & $(0,3)$ & 34 & $(0,2)$ \\
\hline & 3 & 19 & $(0,4)$ & 38 & $(0,3)$ & 49 & $(0,4)$ & 38 & $(0,2)$ \\
\hline & $4 / 5$ & 2 & $(0,2)$ & 7 & $(0,2)$ & 24 & $(0,3)$ & 12 & $(0,1)$ \\
\hline \multirow{4}{*}{ Federación Rusa* } & $0 / 1$ & c & c & 15 & $(2,5)$ & 11 & $(1,6)$ & 13 & $(1,7)$ \\
\hline & 2 & c & c & 36 & $(2,7)$ & 34 & $(2,5)$ & 35 & $(2,0)$ \\
\hline & 3 & c & c & 40 & $(3,8)$ & 44 & $(2,2)$ & 42 & $(2,2)$ \\
\hline & $4 / 5$ & c & c & 9 & $(2,9)$ & 12 & $(2,1)$ & 11 & $(2,0)$ \\
\hline
\end{tabular}

* Para los datos de Federación Rusa, véase nota en la sección de Metodología.

Nota: Las filas que muestran información combinada de todos los niveles PIAAC de comprensión lectora están disponibles en Internet (consulte StatLink más abajo). Fuente: OCDE. Encuesta sobre las Competencias de los Adultos (PIAAC) (2012). PIAAC se refiere al Programa para la Evaluación Internacional de las Competencias de los Adultos de la OCDE. Para ver notas, consulte Anexo 3 (www.oecd.org/edu/eag.htm).

Para obtener más información acerca de los símbolos utilizados en lugar de los datos que faltan, consulte la Guía del lector.

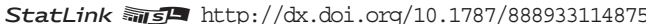


Tabla A1.7a (L). Distribución de los niveles de comprensión lectora, por edad (2012) Comprensión lectora en la Encuesta sobre las Competencias de los Adultos

\begin{tabular}{|c|c|c|c|c|c|c|c|c|c|c|c|c|c|c|c|c|c|}
\hline & & \multicolumn{8}{|c|}{ 25-34 años } & \multicolumn{8}{|c|}{ 55-64 años } \\
\hline & & \multicolumn{2}{|c|}{ Nivel 0/1 } & \multicolumn{2}{|c|}{ Nivel 2} & \multicolumn{2}{|c|}{ Nivel 3} & \multicolumn{2}{|c|}{ Nivel 4/5 } & \multicolumn{2}{|c|}{ Nivel 0/1 } & \multicolumn{2}{|c|}{ Nivel 2} & \multicolumn{2}{|c|}{ Nivel 3} & \multicolumn{2}{|c|}{ Nivel 4/5 } \\
\hline & & $\%$ & E.E. & $\%$ & E.E. & $\%$ & E.E. & $\%$ & E.E. & $\%$ & E.E. & $\%$ & E.E. & $\%$ & E.E. & $\%$ & E.E. \\
\hline & & (1) & (2) & (3) & $(4)$ & (5) & (6) & (7) & $(8)$ & (25) & (26) & (27) & (28) & (29) & (30) & (31) & (32) \\
\hline \multirow{2}{*}{ 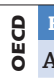 } & Entidades nacionales & & & & & & & & & & & & & & & & \\
\hline & Alemania & 14 & $(1,4)$ & 28 & $(1,7)$ & 42 & $(1,7)$ & 17 & $(1,5)$ & 23 & $(2,1)$ & 45 & $(2,4)$ & 29 & $(1,8)$ & 4 & $(0,9)$ \\
\hline & Australia & 10 & $(1,1)$ & 26 & $(1,8)$ & 43 & $(2,4)$ & 21 & $(1,7)$ & 20 & $(1,7)$ & 35 & $(2,0)$ & 35 & $(1,9)$ & 10 & $(1,2)$ \\
\hline & Austria & 11 & $(1,3)$ & 31 & $(1,9)$ & 45 & $(2,0)$ & 13 & $(1,3)$ & 24 & $(1,8)$ & 51 & $(2,6)$ & 23 & $(2,1)$ & 2 & $(0,6)$ \\
\hline & Canadá & 11 & $(0,9)$ & 29 & $(1,7)$ & 40 & $(2,1)$ & 20 & $(1,3)$ & 23 & $(1,1)$ & 37 & $(1,3)$ & 32 & $(1,1)$ & 9 & $(0,8)$ \\
\hline & Corea & 4 & $(0,6)$ & 28 & $(1,7)$ & 53 & $(1,8)$ & 14 & $(1,3)$ & 30 & $(1,7)$ & 47 & $(1,9)$ & 21 & $(1,8)$ & 2 & $(0,5)$ \\
\hline & Dinamarca & 12 & $(1,1)$ & 26 & $(2,0)$ & 44 & $(2,3)$ & 18 & $(1,8)$ & 25 & $(1,1)$ & 43 & $(1,2)$ & 29 & $(1,1)$ & 3 & $(0,5)$ \\
\hline & España & 20 & $(1,4)$ & 39 & $(1,8)$ & 34 & $(1,5)$ & 7 & $(1,0)$ & 46 & $(2,0)$ & 38 & $(2,1)$ & 15 & $(1,6)$ & 1 & $(0,5)$ \\
\hline & Estados Unidos & 17 & $(1,7)$ & 31 & $(2,2)$ & 37 & $(2,2)$ & 16 & $(1,7)$ & 22 & $(1,7)$ & 36 & $(2,4)$ & 34 & $(1,9)$ & 9 & $(1,0)$ \\
\hline & Estonia & 10 & $(1,1)$ & 28 & $(1,5)$ & 45 & $(1,8)$ & 17 & $(1,5)$ & 20 & $(1,4)$ & 41 & $(1,6)$ & 34 & $(1,6)$ & 5 & $(0,8)$ \\
\hline & Finlandia & 5 & $(0,9)$ & 15 & $(1,7)$ & 43 & $(2,1)$ & 37 & $(1,6)$ & 20 & $(1,3)$ & 41 & $(1,5)$ & 32 & $(1,4)$ & 6 & $(0,7)$ \\
\hline & Francia & 13 & $(1,1)$ & 31 & $(1,5)$ & 42 & $(1,8)$ & 14 & $(1,0)$ & 35 & $(1,4)$ & 40 & $(1,6)$ & 23 & $(1,2)$ & 3 & $(0,4)$ \\
\hline & Irlanda & 13 & $(1,1)$ & 35 & $(1,7)$ & 40 & $(1,7)$ & 12 & $(1,2)$ & 28 & $(2,1)$ & 40 & $(2,2)$ & 28 & $(1,9)$ & 4 & $(0,9)$ \\
\hline & Italia & 22 & $(2,3)$ & 38 & $(2,4)$ & 34 & $(2,3)$ & 6 & $(1,1)$ & 41 & $(2,5)$ & 42 & $(2,7)$ & 16 & $(1,9)$ & 1 & $(0,4)$ \\
\hline & Japón & 2 & $(0,6)$ & 14 & $(1,6)$ & 52 & $(1,9)$ & 32 & $(2,0)$ & 12 & $(1,2)$ & 38 & $(1,9)$ & 41 & $(2,1)$ & 9 & $(1,2)$ \\
\hline & Noruega & 11 & $(1,3)$ & 21 & $(1,7)$ & 46 & $(2,4)$ & 22 & $(1,9)$ & 19 & $(1,8)$ & 42 & $(2,4)$ & 34 & $(2,0)$ & 6 & $(0,8)$ \\
\hline & Países Bajos & 8 & $(1,2)$ & 19 & $(1,5)$ & 45 & $(2,4)$ & 28 & $(2,4)$ & 22 & $(1,5)$ & 38 & $(2,0)$ & 34 & $(1,9)$ & 6 & $(0,9)$ \\
\hline & Polonia & 14 & $(1,3)$ & 34 & $(2,0)$ & 39 & $(2,1)$ & 14 & $(1,3)$ & 28 & $(1,7)$ & 42 & $(2,0)$ & 26 & $(1,6)$ & 4 & $(1,0)$ \\
\hline & República Checa & 7 & $(1,3)$ & 29 & $(2,9)$ & 50 & $(2,9)$ & 14 & $(1,8)$ & 17 & $(2,1)$ & 43 & $(3,8)$ & 36 & $(3,5)$ & 4 & $(1,1)$ \\
\hline & República Eslovaca & 11 & $(1,1)$ & 32 & $(1,7)$ & 47 & $(1,7)$ & 10 & $(1,2)$ & 15 & $(1,6)$ & 41 & $(2,3)$ & 40 & $(2,1)$ & 4 & $(0,9)$ \\
\hline & Suecia & 11 & $(1,2)$ & 20 & $(1,7)$ & 45 & $(2,2)$ & 24 & $(1,7)$ & 19 & $(1,5)$ & 39 & $(2,2)$ & 35 & $(2,1)$ & 7 & $(1,0)$ \\
\hline \multicolumn{18}{|c|}{ Entidades subnacionales } \\
\hline & Flandes (Bélgica) & 8 & $(1,0)$ & 23 & $(1,7)$ & 47 & $(2,2)$ & 22 & $(1,9)$ & 26 & $(1,5)$ & 39 & $(2,0)$ & 31 & $(2,1)$ & 5 & $(0,9)$ \\
\hline & Inglaterra (Reino Unido) & 14 & $(1,6)$ & 29 & $(2,2)$ & 38 & $(1,9)$ & 18 & $(1,5)$ & 19 & $(1,6)$ & 38 & $(2,1)$ & 34 & $(2,3)$ & 10 & $(1,5)$ \\
\hline & Irlanda del Norte (Reino Unido) & 15 & $(2,2)$ & 31 & $(2,9)$ & 40 & $(2,8)$ & 14 & $(1,7)$ & 24 & $(2,5)$ & 43 & $(2,8)$ & 28 & $(2,8)$ & 6 & $(1,4)$ \\
\hline & $\begin{array}{l}\text { Inglaterra/Irlanda del Norte } \\
\text { (Reino Unido) }\end{array}$ & 14 & $(1,5)$ & 30 & $(2,1)$ & 38 & $(1,9)$ & 18 & $(1,4)$ & 19 & $(1,6)$ & 38 & $(2,0)$ & 33 & $(2,2)$ & 9 & $(1,5)$ \\
\hline & Media OCDE & 11 & $(0,3)$ & 28 & $(0,4)$ & 43 & $(0,4)$ & 18 & $(0,3)$ & 24 & $(0,4)$ & 41 & $(0,5)$ & 30 & $(0,4)$ & 5 & $(0,2)$ \\
\hline 氙 & Federación Rusa* & 15 & $(2,7)$ & 35 & $(3,1)$ & 40 & $(3,7)$ & 10 & $(2,2)$ & 12 & $(2,5)$ & 36 & $(4,6)$ & 42 & $(4,9)$ & 10 & $(2,2)$ \\
\hline
\end{tabular}

* Para los datos de Federación Rusa, véase nota en la sección de Metodología.

Nota: Las columnas que muestran los datos de otros grupos de edad (es decir: 35-44, 45-54 y 25-64 años de edad) están disponibles en Internet (véase StatLink más abajo).

Fuente: OCDE. Encuesta sobre las Competencias de los Adultos (PIAAC) (2012). PIAAC se refiere al Programa para la Evaluación Internacional de las Competencias de los Adultos de la OCDE. Para ver notas, consulte Anexo 3 (www.oecd.org/edu/eag.htm).

Para obtener más información acerca de los símbolos utilizados en lugar de los datos que faltan, consulte la Guía del lector.

StatLink 젝ㄴ http://dx.doi.org/10.1787/888933114894 
Tabla A1.8 (L). Porcentaje de la población de 25 a 64 años de edad con educación secundaria superior o postsecundaria no terciaria de orientación profesional o general, por nivel de comprensión lectora y puntuación media (2012)

Comprensión lectora en la Encuesta sobre las Competencias de los Adultos

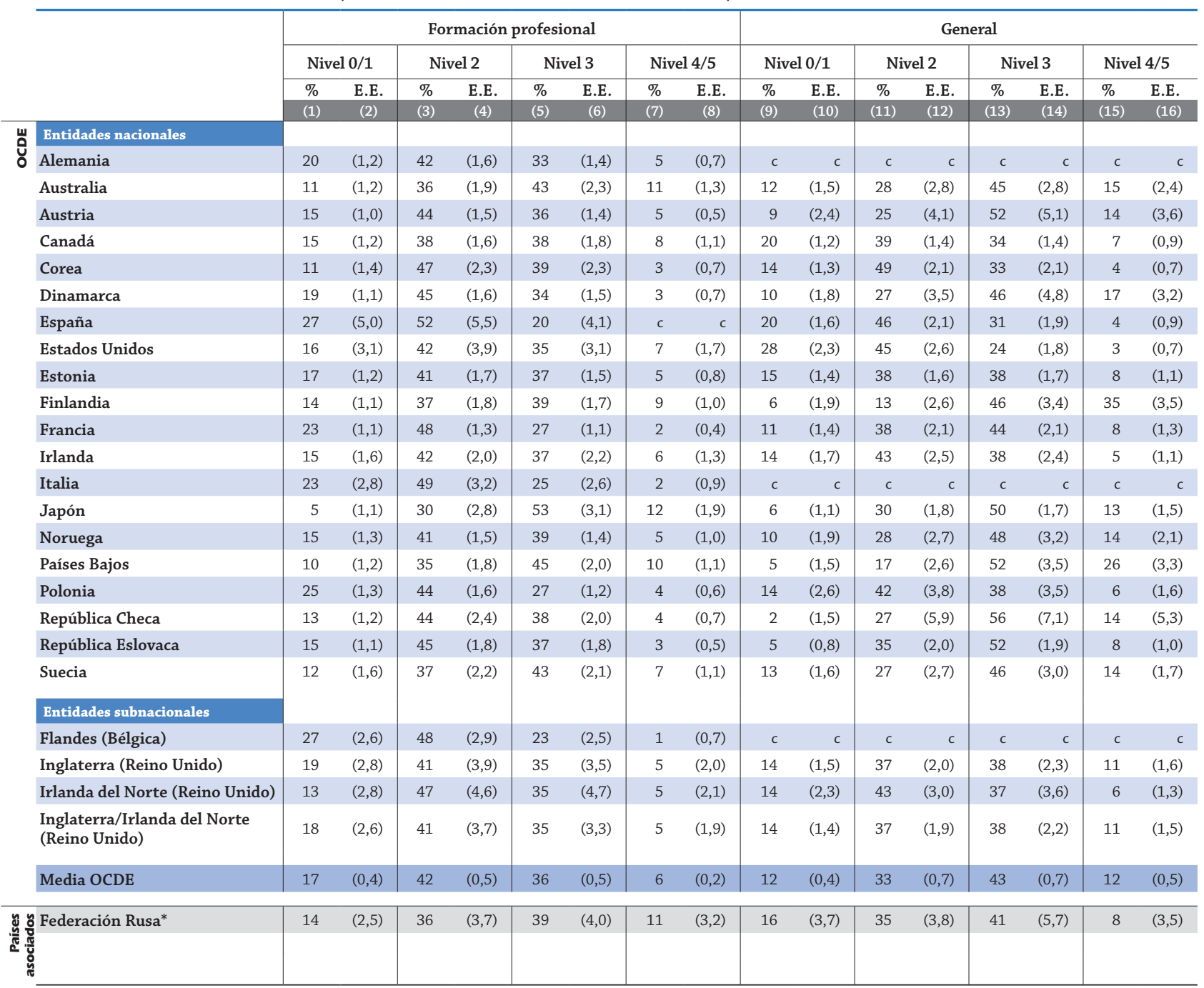

* Para los datos de Federación Rusa, véase nota en la sección de Metodología.

Nota: Las columnas que muestran los niveles de PIAAC para el total (es decir, general más formación profesional) y las puntuaciones PIAAC medias por orientación del programa están disponibles en Internet (véase StatLink más abajo).

Fuente: OCDE. Encuesta sobre las Competencias de los Adultos (PIAAC) (2012). PIAAC se refiere al Programa para la Evaluación Internacional de las Competencias de los Adultos de la OCDE. Para ver notas, consulte Anexo 3 (www.oecd.org/edu/eag.htm).

Para obtener más información acerca de los símbolos utilizados en lugar de los datos que faltan, consulte la Guía del lector.

StatLink 제매 http://dx.doi.org/10.1787/888933114913 
Tabla A1.9a (L). Puntuación media en comprensión lectora, por nivel educativo alcanzado y edad (2012) Comprensión lectora en la Encuesta sobre las Competencias de los Adultos

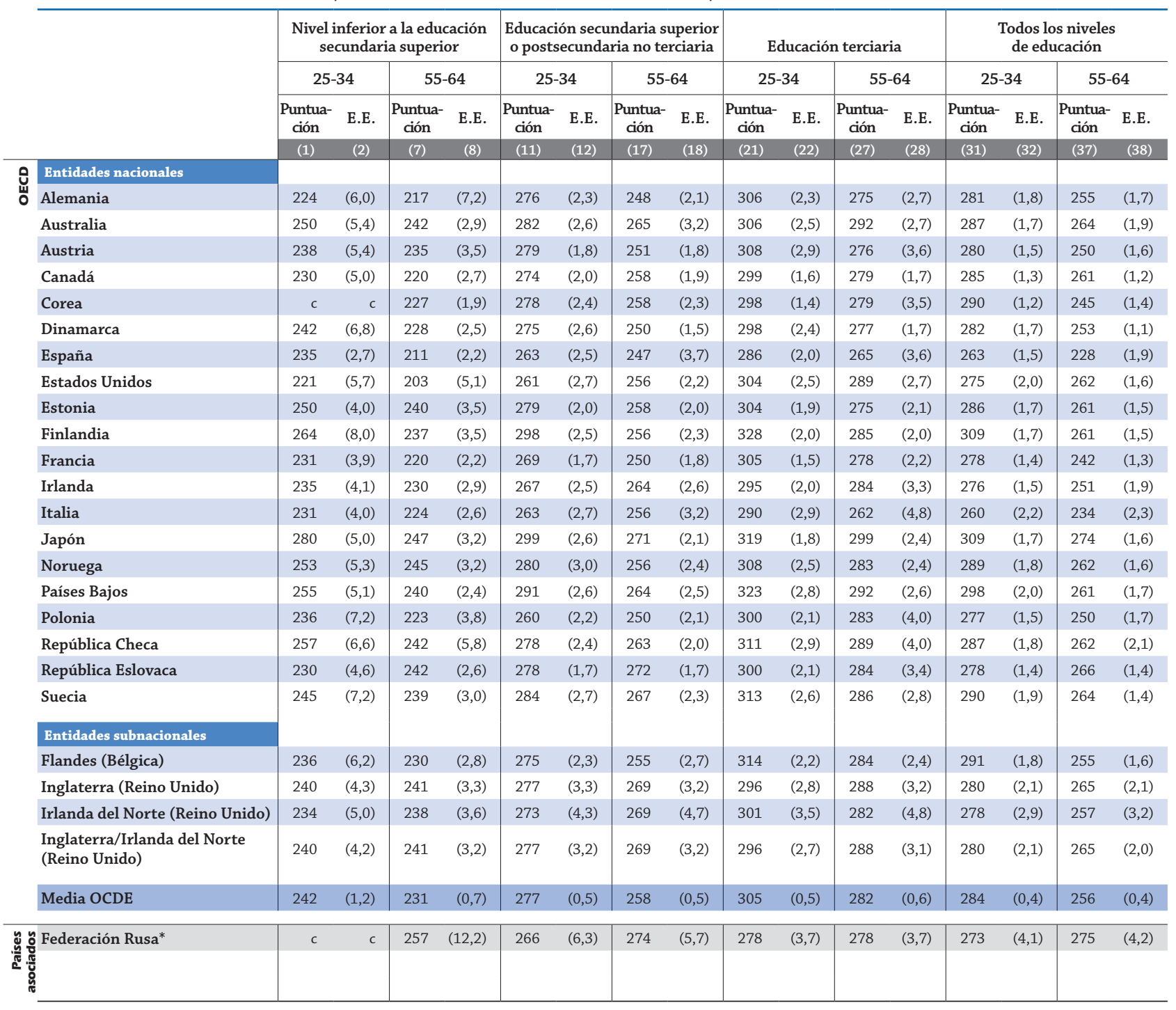

* Para los datos de Federación Rusa, véase nota en la sección de Metodología.

Nota: Las columnas que muestran los datos de otros grupos de edad (es decir, 35-44, 45-54 y 25-64 años de edad) están disponibles en Internet (véase StatLink más abajo).

Fuente: OCDE. Encuesta sobre las Competencias de los Adultos (PIAAC) (2012). PIAAC se refiere al Programa para la Evaluación Internacional de las Competencias de los Adultos de la OCDE. Para ver notas, consulte Anexo 3 (www.oecd.org/edu/eag.htm).

Para obtener más información acerca de los símbolos utilizados en lugar de los datos que faltan, consulte la Guía del lector.

StatLink 제내 http://dx.doi.org/10.1787/888933114932 


\section{¿CUÁNTOS ESTUDIANTES SE ESPERA QUE COMPLETEN LA EDUCACIÓN SECUNDARIA SUPERIOR?}

- Según los modelos actuales, se estima que una media del $84 \%$ de los jóvenes de los países de la OCDE de hoy completarán la educación secundaria superior a lo largo de sus vidas: en los países del G20, alrededor del $80 \%$ de los jóvenes así lo harán.

- Las mujeres jóvenes se graduarán con mayor probabilidad que los hombres jóvenes en los programas de secundaria superior en casi todos los países de la OCDE, lo que supone una inversión del modelo histórico.

- Más del 10\% de los graduados en secundaria superior en Dinamarca, Finlandia, Noruega y Países Bajos son mayores de 25 años, mientras que en Islandia solo lo son cerca del $20 \%$.

\section{Gráfico A2.1. Tasas de graduación en educación secundaria superior (2012)}

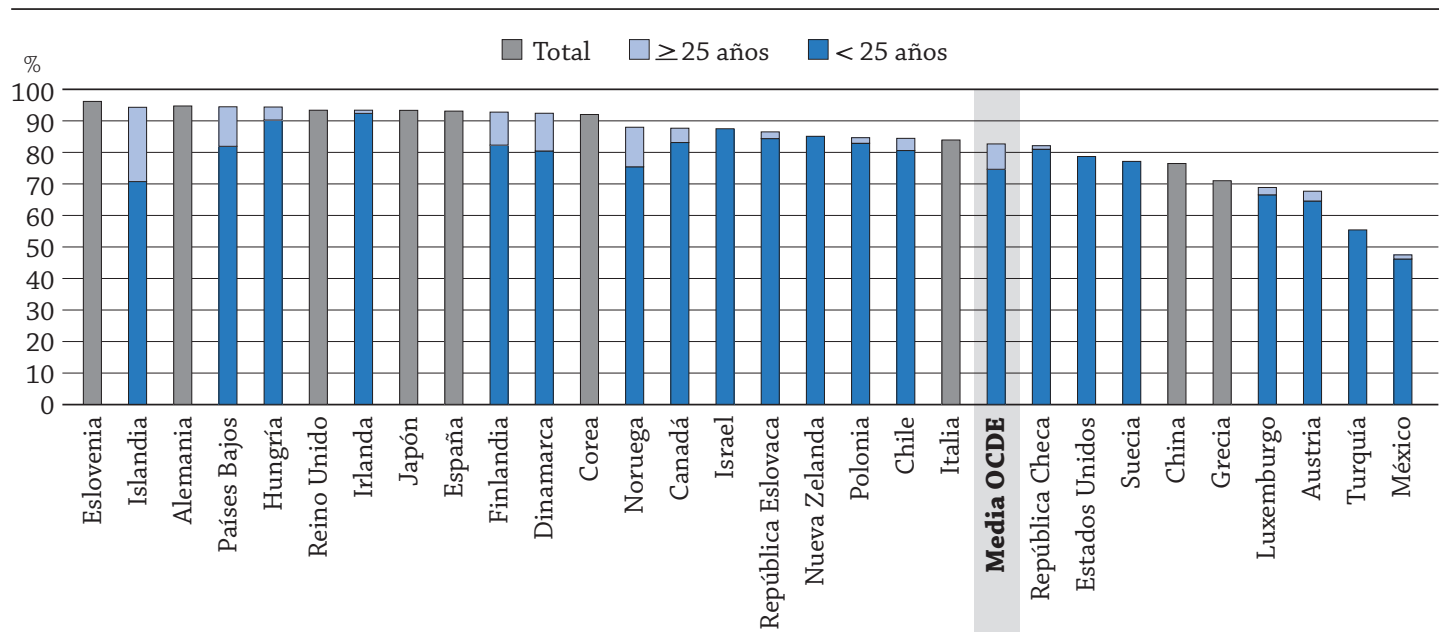

Nota: Este gráfico solo incluye los graduados por primera vez en programas de educación secundaria superior.

1. Año de referencia 2011.

2. Los programas que se extienden a lo largo de los niveles CINE 3 y 4 (Höhere berufsbildende Schule) no están incluidos.

Los países están clasificados en orden descendente de las tasas de graduación en educación secundaria superior en 2012.

Fuente: OCDE. Tablas A2.1a y A2.1b. Para ver notas, consulte Anexo 3 (www.oecd.org/edu/eag.htm).

StatLink त्ना SL http://dx.doi.org/10.1787/888933115255

\section{Contexto}

La educación secundaria superior, que consolida las competencias básicas y el conocimiento de los estudiantes a través de un itinerario académico o de formación profesional, tiene por objetivo preparar a los estudiantes para que entren en la educación terciaria o en el mercado laboral y pasen a ser ciudadanos comprometidos. En muchos países, este nivel educativo no es obligatorio y puede durar de dos a cinco años. Sin embargo, es crucial que esos dos itinerarios sean de igual calidad y que ambos aseguren que los estudiantes puedan hacer esas transiciones con éxito.

Graduarse en educación secundaria superior ha pasado a ser cada vez más importante en todos los países, dado que las competencias necesarias en el mercado laboral están basándose cada vez más en el conocimiento, y a los trabajadores se les exige progresivamente que se adapten a las incertidumbres de una economía global que cambia con rapidez. Aun cuando las tasas de graduación dan cuenta del alcance del éxito de los sistemas educativos en preparar a los estudiantes para que afronten los requisitos mínimos del mercado laboral, no indican cuál es la calidad de los resultados educativos.

Al final de la educación secundaria inferior en muchos países de la OCDE, los estudiantes pueden salir o desvincularse del sistema educativo, lo que a su vez conlleva que pueden dejar la escuela sin una cualificación de secundaria superior. Estos jóvenes suelen afrontar serias dificultades para entrar -y permanecer- en el mercado de trabajo. Dejar la escuela pronto es un problema tanto para las personas como para la sociedad. Los responsables de adopción de políticas están examinando el modo de reducir el número de jóvenes que abandonan la escuela prematuramente, y se definen como aquellos estudian- 
tes que no completan la educación secundaria superior. La comparación de medidas internacionales sobre cómo pueden completar los estudiantes los programas de secundaria superior puede ayudar en los esfuerzos que se realizan para tal fin, lo que también implica conocer cuántos estudiantes no completan estos programas.

\section{Otros resultados}

- En 25 de los 31 países con datos disponibles, las tasas de graduación por primera vez en secundaria superior igualan o superan el $\mathbf{7 5} \%$. En Alemania, Corea, Dinamarca, Eslovenia, España, Finlandia, Hungría, Irlanda, Islandia, Japón, Letonia, Países Bajos y Reino Unido, las tasas de graduación son iguales o superiores al $90 \%$.

- Como media en los países de la OCDE, los estudiantes se gradúan por vez primera en el nivel de secundaria superior con 19 años, desde los 17 años en Estados Unidos, Israel, Nueva Zelanda y Turquía a los 22 años o más en Islandia y Noruega.

- En los programas de formación profesional se están graduando más mujeres jóvenes que nunca. Sus tasas de graduación en estos programas se van aproximando a las de los hombres jóvenes.

- La mayoría de los hombres jóvenes matriculados en programas de formación profesional de secundaria superior optan por estudiar ingenierías, producción industrial y construcción, mientras que las mujeres jóvenes de dichos programas optan por ámbitos de estudio diferentes, sobre todo empresariales, derecho, ciencias sociales, salud y bienestar y servicios.

- En esta edición, es la tercera vez que se publican datos comparables de 29 países que participan en un seguimiento especial sobre la terminación con éxito de los programas de secundaria superior. Los datos muestran que el $\mathbf{7 2} \%$ de los estudiantes que comienzan la educación secundaria superior completan los programas que empezaron dentro de la duración teórica del programa. Sin embargo, hay grandes diferencias en las tasas de finalización, dependiendo del sexo y del tipo de programa.

\section{Tendencias}

Desde 2000, las tasas de graduación en secundaria superior se han incrementado en una media de 8 puntos porcentuales en los países de la OCDE con datos comparables. El mayor incremento se dio en México, que arrojó una tasa de crecimiento anual del 3\% entre 2000 y 2012.

\section{Nota}

Las tasas de graduación representan el porcentaje estimado de personas de una cohorte de edad determinada que se espera que se gradúen en algún momento de su vida. Esta estimación se basa en el número de graduados de 2012 y en la distribución de edad de este grupo. Las tasas de graduación se basan tanto en la población como en el modelo actual de graduación y, por tanto, son sensibles a cualesquiera cambios del sistema educativo, como la introducción de nuevos programas y el aumento o disminución de la duración de los mismos. Las tasas de graduación pueden ser muy elevadas -incluso por encima del $100 \%$ - en un periodo en el que un número inesperado de personas vuelven a la escuela. Esto sucedió en 2010 en Portugal, por ejemplo, cuando se lanzó el programa de «Nuevas Oportunidades» para dar una segunda oportunidad a quienes dejaron la escuela prematuramente sin un diploma de secundaria.

En este indicador, la edad se refiere generalmente a la edad de los estudiantes al principio del año natural; los estudiantes podrían ser un año mayores que la edad indicada cuando se graduaron al final del año escolar. Se consideran los 25 años como la edad superior límite para completar la educación inicial. Entre los países de la OCDE, más del $90 \%$ de quienes se graduaron por primera vez en los programas de secundaria superior en 2012 eran más jóvenes de 25 años. Las personas que se graduaron en este nivel a la edad de 25 años o más se suelen matricular en programas específicos, por ejemplo, en programas de segundas oportunidades. 


\section{Análisis}

\section{Graduación en programas de secundaria superior}

\section{Una instantánea de las tasas de graduación en secundaria superior}

Desde 2000, las tasas de primera graduación en secundaria superior se incrementaron en cerca de 8 puntos porcentuales. Las estimaciones actuales indican que el $84 \%$ de las personas completarán la educación secundaria superior a lo largo de sus vidas en los países de la OCDE (Tabla A2.1a). Se considera que lograr la educación secundaria superior es una credencial mínima para poder acceder con éxito al mercado laboral y necesaria para continuar con educación superior. Los costes de no completar este nivel educativo a tiempo -tanto los individuales como los de la sociedadpueden ser considerables (véanse Indicadores A6 y A7).

Las tasas de graduación dan una indicación sobre si las iniciativas gubernamentales han tenido éxito en incrementar el número de personas que se gradúan en educación secundaria superior. Las grandes diferencias en las tasas de graduación entre los países reflejan la variedad de sistemas y programas disponibles.

En Alemania, Corea, Dinamarca, Eslovenia, España, Finlandia, Hungría, Irlanda, Islandia, Japón, Letonia, Países Bajos y Reino Unido, se espera que se gradúen en educación secundaria superior a lo largo de su vida más del $90 \%$ de las personas; en México y Turquía, se espera que lo hagan menos del $60 \%$ de las personas (Tabla A2.1a). Sin embargo, España, México y Turquía arrojan las tasas de crecimiento anuales más altas (de 1995 o 2000 a 2012) de graduación en secundaria superior, considerablemente por encima de la media del 0,8\% de la OCDE. La tasa anual de crecimiento en España y Turquía sobrepasa el 2\%, mientras que en México el incremento anual supera el $3 \%$ (Tabla A2.2a). Algunos países hicieron del incremento del número de estudiantes con acceso a la educación secundaria superior una prioridad anterior y por ello las tasas de graduación en Corea, Japón y Noruega alcanzaron el $90 \%$ ya en 2000 y han permanecido altas desde entonces.

La formación profesional (FP) es una parte importante de la educación secundaria superior en muchos países de la OCDE (véase el Indicador A1). Entre 2005 y 2012, las tasas de graduación en programas de preformación profesional y de formación profesional estuvieron a la altura de la tónica general en las tasas de secundaria superior, incrementándose como media en cerca de 3 puntos porcentuales. Sin embargo, las tendencias varían considerablemente de unos países a otros. En Alemania, por ejemplo, las tasas de graduación en FP de secundaria superior disminuyeron 15 puntos porcentuales durante el periodo en cuestión, mientras que en Portugal se incrementaron en un 37\% (Tabla A2.2b, disponible en Internet).

Además, las tasas de graduación no implican que todos los graduados deseen continuar con un grado de terciaria o pasar al mercado laboral inmediatamente. De hecho, el número de graduados que cierran ciclo sin pasar a tener un empleo ni continuar en educación o formación (NI-NI) ha ido en aumento en todos los países de la OCDE (véase el Indicador (5). Por esta razón, es importante contar con programas de secundaria superior de calidad que proporcionen a las personas la adecuada combinación de oportunidades de orientación y educación, con el fin de asegurarse de que una vez que los estudiantes se han graduado no permanezcan en un callejón sin salida.

\section{Tasas de graduación en secundaria superior por edad}

Las tasas de graduación varían también en función de la edad de los graduados. Como se indica en la sección anterior, la edad de un estudiante en el momento de su graduación puede guardar relación con los cambios en el sistema educativo. Por ejemplo, las oportunidades disponibles para completar la educación secundaria superior en un momento de su vida posterior, o la duración de los programas generales y de formación profesional, pueden conllevar diferencias en la edad típica de los graduados.

La media de edad de quien se gradúa por primera vez en secundaria superior en los países de la OCDE es de 19 años; más del $90 \%$ de quienes se gradúan por primera vez tienen 25 años o menos. Sin embargo, la edad a la que se gradúan los estudiantes de educación secundaria varía en función de los países, y a veces significativamente. En Estados Unidos, Israel y Turquía, la media de edad de los estudiantes que se gradúan por primera vez es de 17 años, los más jóvenes entre todos los países de la OCDE. Islandia y Noruega están en el extremo opuesto, con una media de edad de 22 años o más (Tablas A2.1a y b).

Se dan variaciones en la edad de los graduados también dentro de los países. Tal como se muestra en el Gráfico A2.2, hay notables diferencias entre las edades de los estudiantes que se gradúan en programas de formación profesional y los que se gradúan en programas generales dentro de un mismo país. Como media, la edad de graduación es más alta en los estudiantes de FP (22 años) que en los graduados de programas generales (19 años). Sin embargo, en 
Bélgica, Brasil, Dinamarca, Finlandia, Irlanda, Islandia, Noruega y Países Bajos, la media de edad de los graduados en programas de FP es de 25 años y más; en Australia, alcanza los 31 años (Gráfico A2.2).

La media de edad de quienes se gradúan por primera vez también refleja contextos nacionales específicos. En algunos países, los estudiantes pueden abandonar el sistema educativo con relativa facilidad y volver a reintegrarse en él más adelante. Por esa razón, las tasas de graduación para estudiantes de 25 años o más son relativamente altas en Dinamarca, Finlandia, Noruega y Países Bajos, donde al menos el $10 \%$ de los graduados son mayores de 25, mientras que en Islandia el $20 \%$ de los graduados en secundaria superior son mayores de 25 años. Del mismo modo, el hecho de que la proporción de graduados fuera de la edad típica de graduación varíe entre los países y programas puede también relacionarse con la disponibilidad de programas de «segunda oportunidad». Este tipo de programas ayudan a mejorar las destrezas de cara al mercado laboral. En Portugal, por ejemplo, el programa de «Nuevas Oportunidades» lanzado en 2005 se introdujo para proporcionar una segunda oportunidad a personas que dejaron la escuela pronto o que se encontraban en riesgo de hacerlo, y para ayudar a quienes están ya trabajando a que adquieran más cualificación. El resultado de esta iniciativa es que las tasas de graduación subieron en más de 40 puntos porcentuales entre 2008 y 2010. En 2010, más del $40 \%$ de los estudiantes en cuestión eran mayores de 25 años.

\section{Gráfico A2.2. Media de edad ${ }^{1}$ de graduación en secundaria superior (2012)}

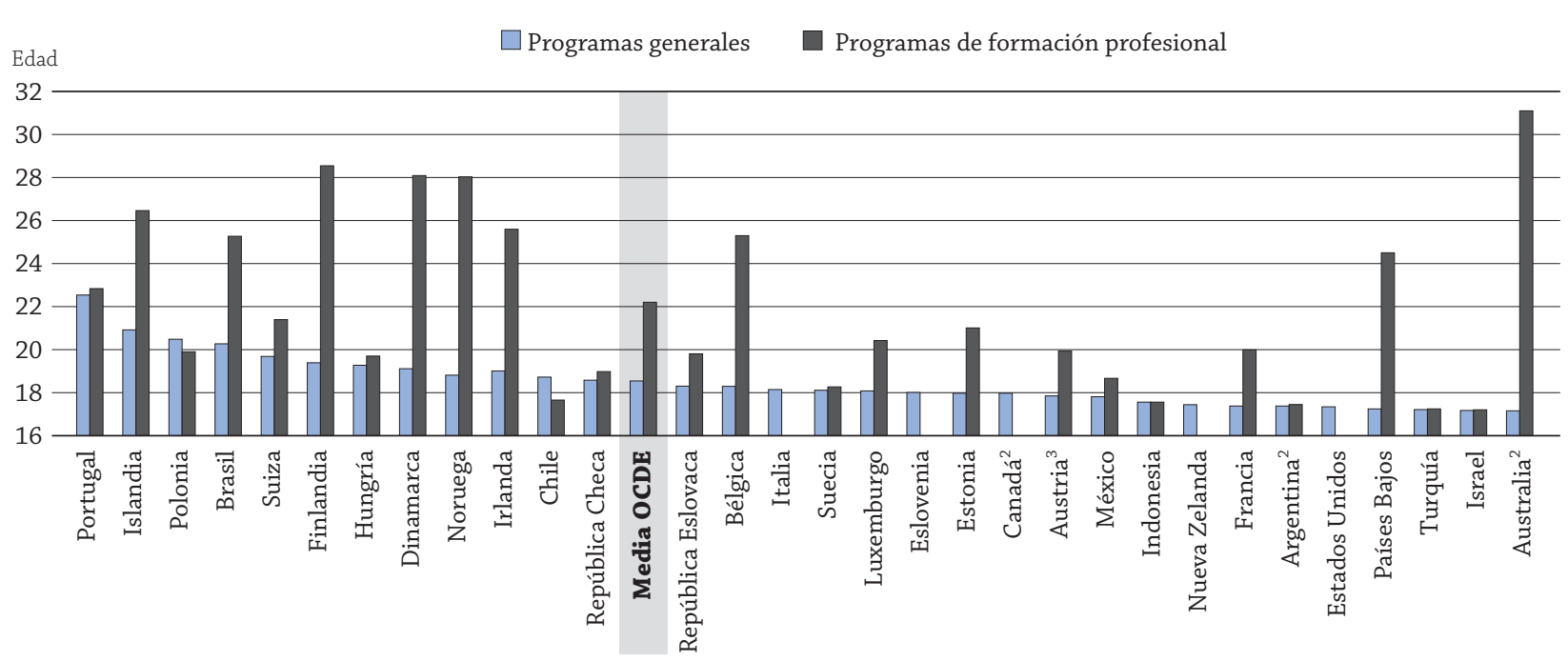

1. La media de edad se refiere en términos generales a la edad de los estudiantes al inicio del año natural; los estudiantes pueden ser un año mayores de la edad indicada cuando se gradúan al final de año escolar.

2. Año de referencia 2011.

3. Los programas que se extienden a lo largo de los niveles CINE 3 y 4 (Höhere berufsbildende Schule) no están incluidos.

Los países están clasificados en orden descendente de la media de edad de graduación en educación secundaria superior en programas generales en 2012.

Fuente: OCDE. Tabla A2.1a. Para ver notas, consulte Anexo 3 (www.oecd.org/edu/eag.htm).

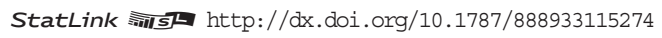

\section{Tasas de graduación en secundaria superior, por sexo}

En la mayoría de los países de la OCDE, las tasas de graduación por vez primera en secundaria superior también varían significativamente entre hombres y mujeres. Como media, las tasas de graduación de mujeres $(87 \%)$ son superiores a las de los hombres (81\%). En Dinamarca, Grecia, Islandia, Israel y Noruega, las tasas de graduación de mujeres son al menos 10 puntos porcentuales superiores a las de los hombres. Solo en Alemania y Austria la proporción de hombres graduados es ligeramente superior a la de mujeres graduadas (Tabla A2.1a).

Esta tendencia es incluso más acusada en estudiantes menores de 25 que se gradúan en programas generales. En 2012, las tasas de graduación en programas de secundaria general fueron como media del $54 \%$ para las mujeres y $43 \%$ para los hombres en los países de la OCDE. En Austria, Eslovenia, Italia, Polonia, República Checa y República Eslovaca, las mujeres sobrepasan en número de graduación a los hombres en una ratio al menos de tres a dos (Tabla A2.1b).

Hasta ahora, los hombres han tenido tasas de graduación más altas que las mujeres en los programas de preformación profesional y de formación profesional, aunque en algunos países esto no sea así. Como media, las tasas de 
graduación en estos programas son superiores en los hombres que en las mujeres en 3 puntos porcentuales (50\% y $46 \%$, respectivamente). Esta tendencia ha ido cambiando en muchos países, incluso en Bélgica, Dinamarca, España, Finlandia, Irlanda y Países Bajos, donde las tasas de graduación de mujeres son al menos 5 puntos porcentuales superiores a las de los hombres. Sin embargo, los programas de formación profesional no están disponibles en todos los países de la misma manera, con lo cual las tasas de graduación pueden diferir sustancialmente. Las tasas de preformación profesional y de formación profesional están por encima del $70 \%$ en Austria, Eslovenia, Finlandia, Francia, Irlanda, Países Bajos y Suiza; pero en Argentina, Brasil, Canadá, Corea, Estonia, Hungría, Indonesia, Japón, Letonia, México y Turquía las tasas están por debajo del 30\% (Tabla A2.1a).

\section{Graduación en secundaria superior y ámbito de estudio}

Las diferencias de sexo también son patentes en la elección del ámbito de estudio de los jóvenes cuando buscan realizar estudios de formación profesional. Estas diferencias pueden atribuirse a las percepciones tradicionales de los roles e identidades de género, así como a los valores culturales que se asocian a veces con ámbitos de estudio concretos. Como media, la mayoría de los estudiantes de formación profesional de grado superior se gradúan en programas de ingeniería, producción industrial y construcción (34\%), y en todos los países de la OCDE, la gran mayoría de los graduados en esta área son hombres (Tabla A2.3a y b, disponible en Internet). En Hungría, Noruega y República Checa, más del $70 \%$ de los graduados en este ámbito son hombres. Por el contrario, las graduadas están más dispersas entre las ciencias sociales, empresariales y derecho (24\%), salud y bienestar (19\%) y servicios (19\%) (Tabla A2.3a).

\section{Graduación en programas de postsecundaria no terciaria}

Se ofrecen distintos tipos de programas de postsecundaria no terciaria en los países de la OCDE. Estos programas están a caballo entre la educación secundaria superior y la postsecundaria, y pueden ser consideradas como programas de educación secundaria superior o de postsecundaria, dependiendo del país en cuestión. Aunque el contenido de estos programas puede que no sea significativamente más avanzado que el de los programas de secundaria superior, amplía el conocimiento de las personas que ya han alcanzado la cualificación de secundaria superior.

Los estudiantes de estos programas suelen ser mayores que aquellos que están matriculados en centros de secundaria superior. Estos programas ofrecen habitualmente títulos de formación profesional y de oficios, e incluyen formación de maestros de preescolar en Austria y formación profesional en el sistema dual para aquellos que han alcanzado cualificaciones de secundaria superior general en Alemania. Los aprendizajes diseñados para estudiantes que ya se han graduado en un programa de secundaria superior también se incluyen en estos programas (Tabla A2.1c, disponible en Internet).

Las tasas de graduación por primera vez en educación postsecundaria no terciaria son más bajas que las de los programas de secundaria superior. Como media, se estima que un $9 \%$ de los jóvenes de hoy en los países de la OCDE completarán programas de postsecundaria no terciaria a lo largo de sus vidas. La tasa de mujeres (9\%) es ligeramente superior que la de los hombres (8\%). Las tasas más elevadas de graduación en estos programas se dan en Austria (26\%), Nueva Zelanda (33\%) y República Checa (28\%); y en estos tres países las tasas de graduación son considerablemente más altas en las mujeres (32\%, $39 \%$ y $32 \%$, respectivamente) que en los hombres ( $20 \%$, $27 \%$ y $24 \%$, respectivamente). (Tabla A2.1c, disponible en Internet).

\section{Transiciones después de programas de educación secundaria superior o postsecundaria no terciaria}

La inmensa mayoría de estudiantes que se gradúan en educación secundaria superior se gradúan en programas diseñados para dar acceso a la educación terciaria (CINE 3A y 3B). Los programas que facilitan la entrada directa a la educación terciaria de tipo A (CINE 3A) son los preferidos por los estudiantes de todos los países, con la excepción de Austria, Eslovenia y Suiza, donde los sistemas educativos tienen una orientación más fuerte hacia la formación profesional y por ello los jóvenes se gradúan en educación secundaria superior que conduzca a programas de educación terciaria de tipo B. Para programas de secundaria superior largos que conduzcan al mercado laboral o a educación postsecundaria no terciaria (CINE 3C largos), las tasas de graduación en 2012 estuvieron en una media del 18\% en los países de la OCDE (Tabla A2.1a).

El Gráfico A2.3 muestra el modo en que cambian los países cuando la proporción de estudiantes que se gradúan en programas ideados como preparación para entrar en los programas de terciaria de tipo A (CINE 3A y 4A) se comparan con la proporción de estudiantes que de hecho entran en estos programas con edades por debajo de los 25 años. En Bélgica, Chile, Finlandia, Irlanda, Israel y Suecia, hay al menos una diferencia de 30 puntos porcentuales entre estos dos grupos. Ello sugiere que muchos estudiantes que alcanzan cualificaciones que les permitirían entrar en progra- 


\section{Gráfico A2.3. Acceso a la educación terciaria de tipo A de los graduados en educación secundaria superior y postsecundaria no terciaria de menos de 25 años (2012)}

$\square$ Tasas de graduación en programas de educación secundaria superior y postsecundaria no terciaria concebidos para preparar a los estudiantes menores de 25 años para el acceso a la educación terciaria de tipo A

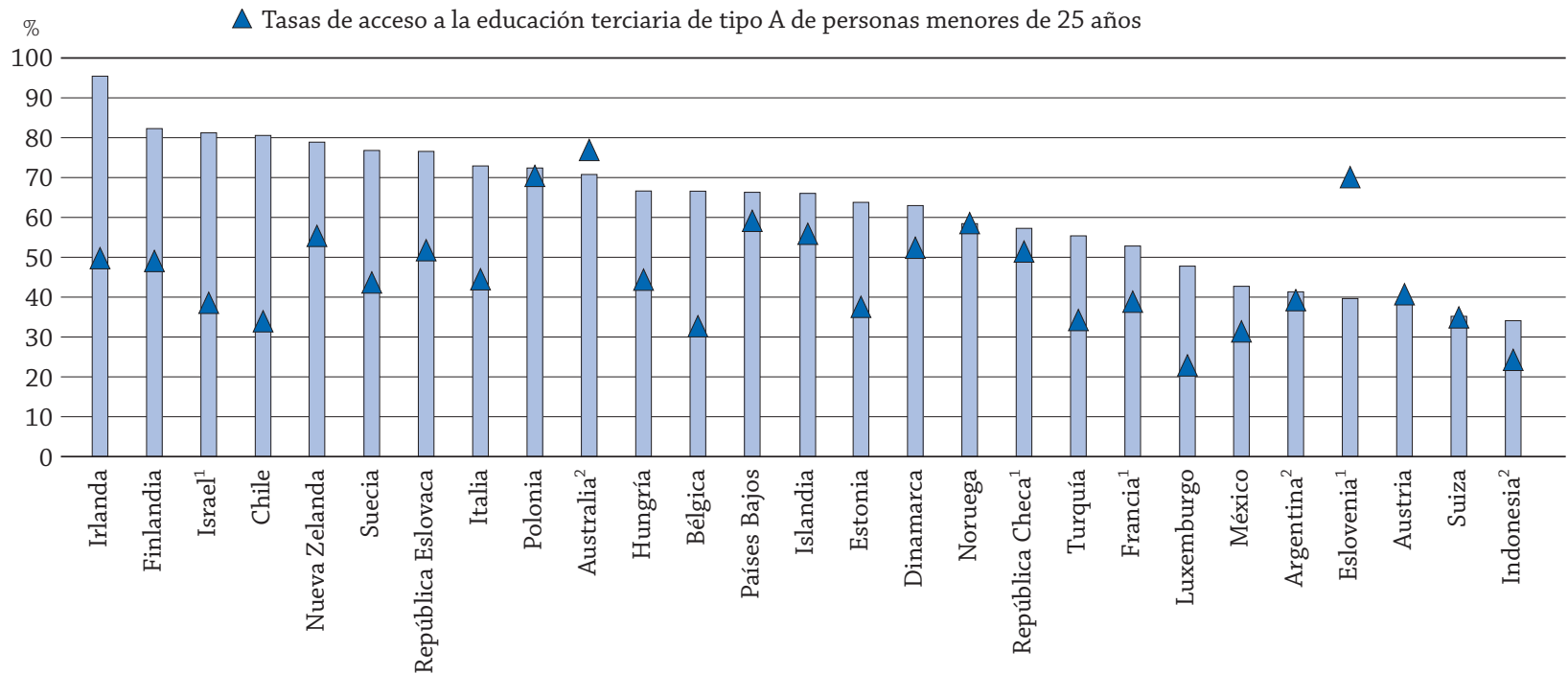

1. Faltan los datos de los graduados en educación postsecundaria no terciaria.

2. Año de referencia de las tasas de graduación 2011.

Los países están clasificados en orden descendente de las tasas de graduación en programas de educación secundaria superior concebidos para preparar a los estudiantes menores de 25 años para el acceso a la educación terciaria de tipo A en 2012.

Fuente: OCDE. Tablas A2.1b, A2.1c (disponibles en internet) y C3.1b. Para ver notas, consulte Anexo 3 (www.oecd.org/edu/eag.htm).

StatLink 제그 http://dx.doi.org/10.1787/888933115293

\section{Cuadro A2.1. Finalización y graduación: dos medidas diferentes}

¿Cómo se mide la finalización en Panorama de la educación? «La finalización con éxito» describe el porcentaje de estudiantes que pasan a un programa de secundaria superior por vez primera y que se gradúan en él en un determinado número de años tras haber accedido a esta formación. Es una medida de la eficiencia con que los estudiantes pasan por la educación secundaria superior. Representa la relación entre los graduados y quienes acceden por ver primera al mismo nivel educativo. El cálculo se realiza utilizando el periodo de tiempo que se asigna normalmente para la consecución del programa, y tras dos años más (para estudiantes que tuvieran que repetir un año o cursos individuales, que estudiasen a tiempo parcial, etc.). Este indicador también incluye el porcentaje de estudiantes que no se gradúan en un programa de secundaria superior, pero que aún siguen estudiando. Esto puede incluir a algunos estudiantes a tiempo parcial que necesitan más tiempo para completar sus estudios, y a adultos que deciden volver a la escuela, tal vez mientras están trabajando. Este indicador solo cubre los programas de educación inicial.

Esta medida no debería confundirse con las tasas de graduación en secundaria superior. Las tasas de graduación representan el porcentaje estimado de personas de una cierta cohorte de edad que se espera que se gradúen en algún momento de sus vidas. Mide la producción de los graduados en educación secundaria superior, con relación a la población del país, y representa la relación entre todos los graduados en un año determinado y una población concreta. Para cada país, para un año concreto, se detalla el número de estudiantes que se gradúan por grupos de edad. Por ejemplo, el número de graduados de 15 años se divide por el número total de individuos de 15 años del país; el número de graduados de 16 años se divide por el número total de individuos de 16 años del país, etc. La tasa de graduación es la suma de esas tasas de graduación específicas por edad.

Un tercer indicador en Panorama de la educación emplea la noción de logro educativo (véase Indicador A1). El logro mide el porcentaje de población que ha alcanzado un determinado nivel educativo, en este caso, aquellos que se graduaron en secundaria superior. Representa la relación entre todos los graduados (de un año concreto y de años precedentes) y el conjunto de la población. 
mas de terciaria de tipo A no lo hacen, aunque los programas de secundaria superior en Bélgica e Israel también preparen a estudiantes para programas terciarios de tipo B. Al igual que la decisión de continuar en la educación secundaria superior, la decisión de los estudiantes de entrar en la educación terciaria puede depender de distintos factores, como el coste de oportunidad de invertir en educación terciaria en comparación con entrar en el mercado laboral (Zapata, de próxima aparición) (véase Indicador A7).

En Finlandia, la educación secundaria superior incluye la formación profesional y muchos graduados se suman al mercado laboral tras completar este nivel, sin ningún estudio de nivel terciario. También hay un sistema de numerus clausus en la educación superior finlandesa, que implica que el número de plazas de acceso está restringido. Por ello, los graduados en educación general secundaria superior pueden tomarse un descanso de dos o tres años antes de conseguir una plaza en una universidad o institución politécnica. En Irlanda, la mayoría de los estudiantes de secundaria se presentan al examen Leaving Certificate (CINE 3A). Aunque está ideado para permitir que los estudiantes pasen a la educación terciaria, no todos los estudiantes que se presentan a este examen tienen intención de hacerlo. Hasta la aparición de la crisis económica global, quienes finalizaban estudios secundarios en Irlanda podían beneficiarse de un mercado laboral potente, y esto podría haber influido en esa diferencia.

Por el contrario, en Eslovenia, la tasa de graduación en secundaria superior y en postsecundaria no terciaria es significativamente inferior -de casi 30 puntos porcentuales- a las tasas de acceso a programas terciarios de tipo A. Aunque con toda probabilidad muchos estudiantes en Eslovenia se graduarán en programas de secundaria superior que conduzcan a programas terciarios de tipo B, algunos deciden proseguir sus estudios universitarios más adelante, y lo pueden hacer debido a la flexibilidad de itinerarios entre los dos tipos de programas terciarios del país.

\section{Finalización con éxito de los programas de secundaria superior}

Esta edición de Panorama de la educación presenta, por vez primera, un indicador que mide la finalización con éxito de los programas de secundaria superior y, por tanto, de los itinerarios entre programas. El indicador arroja luz sobre el tiempo necesario para completar estos programas y la proporción de estudiantes que sigue estudiando tras la duración teórica de los programas. Permite dar una estimación del número de estudiantes que se salen de la educación y una comparativa de las tasas de finalización por sexo y orientación del programa. Así pues, al igual que la tasa de graduación, la tasa de finalización no indica la calidad de la educación secundaria superior; sin embargo, sí que indica, hasta cierto punto, la capacidad que tiene dicho nivel educativo para conseguir que los estudiantes completen el programa de secundaria superior dentro de un periodo concreto.

La mayoría de los estudiantes que empiezan la educación secundaria superior completan los programas que inician. Se estima que el $72 \%$ de los jóvenes que empiezan un programa de secundaria superior se gradúan dentro de la du-

\section{Gráfico A2.4. Finalización con éxito de programas de educación secundaria superior}

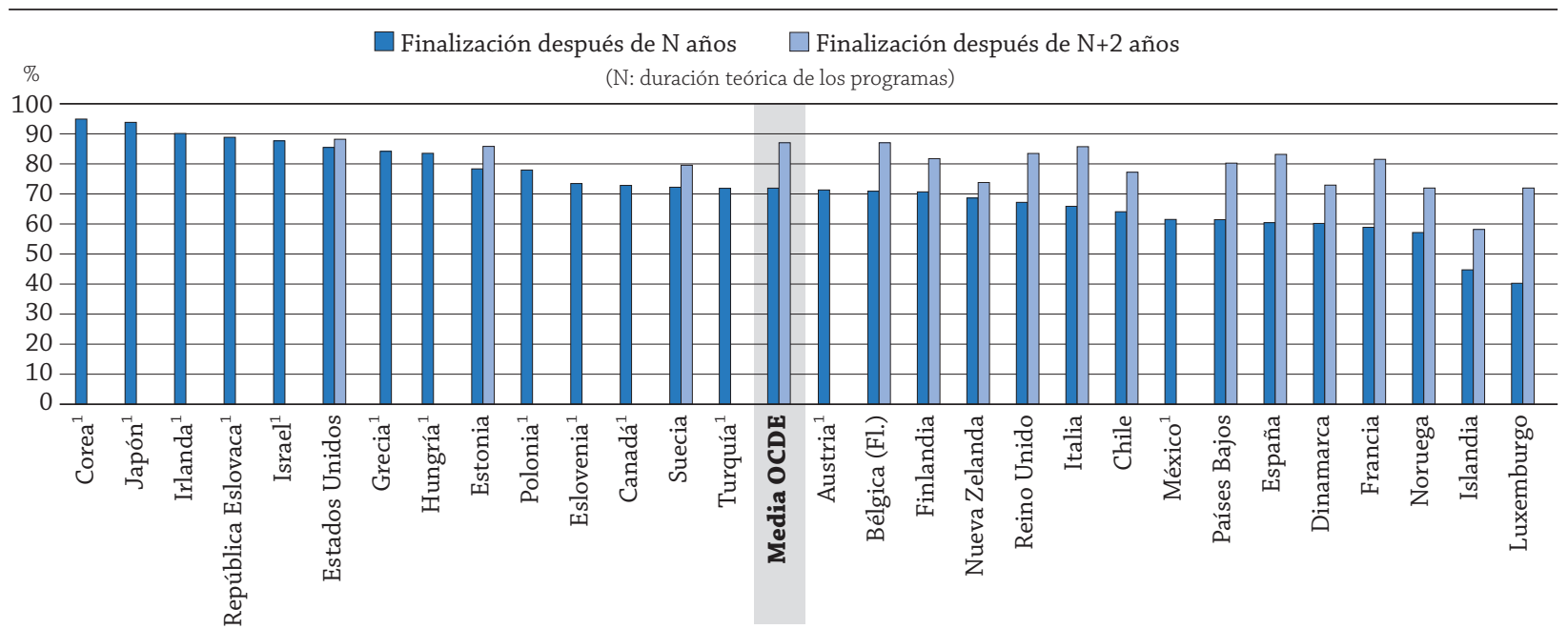

Nota: Para más información sobre este indicador, como los métodos empleados, los programas incluidos o excluidos, el año de acceso, etc., consulte Anexo 3.

1. N+2 faltan datos.

Los países están clasificados en orden descendente de la finalización con éxito de programas de educación secundaria superior.

Fuente: OCDE. Tabla A2.4. Para ver notas, consulte Anexo 3 (www.oecd.org/edu/eag2012).

StatLink त्ताजा http://dx.doi.org/10.1787/888933115312 
ración teórica del programa. Sin embargo, en algunos países, es relativamente habitual que los estudiantes y los aprendices se tomen un descanso de sus estudios y abandonen el sistema de educación por un tiempo. Algunos retoman sus estudios pronto, mientras que otros permanecen fuera de ellos durante periodos largos, lo que puede incrementar el riesgo de que el estudiante de secundaria superior no los complete. En otros países también es habitual que los estudiantes repitan un año o que cambien de programas; al hacerlo, se retrasa su graduación. Políticas educativas como la repetición de un curso pueden socavar la equidad del sistema educativo (OECD, 2012a).

La proporción de estudiantes que completan su educación en el tiempo estipulado varía considerablemente entre países: Corea arroja la contribución más alta, con un $95 \%$ y Luxemburgo la más baja, con un $40 \%$. En Corea, Estados Unidos, Grecia, Hungría, Irlanda, Israel, Japón y República Eslovaca, más del 80 \% de los estudiantes completan su educación en el tiempo estipulado. Al otorgar dos años más para que los estudiantes completen sus programas de secundaria obligatoria, una media del $87 \%$ de los estudiantes finalizan con éxito los programas dos años después del tiempo estipulado de graduación en los países de la OCDE, 15 puntos porcentuales más que la proporción de estudiantes que completan su programa dentro de la duración teórica (Tabla A2.4). Con el extra de dos años más, ocho países más superan el listón de finalización de la secundaria superior del 80 \%: España, Estonia, Finlandia, Flandes (Bélgica), Francia, Italia, Países Bajos y Reino Unido. Islandia tiene la menor proporción de estudiantes (58\%) que completan la educación secundaria superior después de dos años adicionales.

Dentro de los países, la diferencia de tasas entre finalización dentro del tiempo estipulado y dentro de dos años adicionales se debe en parte al hecho de que en la mayoría de los países de la OCDE los estudiantes pueden asistir a instituciones educativas durante años adicionales para completar su educación secundaria superior, mientras que en otros países los estudiantes mayores deben asistir a programas especiales específicamente diseñados para ellos. La diferencia de proporción de los estudiantes que completaron sus programas dentro del tiempo estipulado y la de los estudiantes que lo hicieron en los dos años adicionales es de 32 puntos porcentuales en Luxemburgo, donde es habitual que los estudiantes repitan uno o más cursos escolares. Por el contrario, en los países para los que hay datos disponibles, la diferencia en Estados Unidos y Nueva Zelanda es tan baja como tres y cinco puntos porcentuales, respectivamente (Gráfico A2.4). En Estados Unidos, es muy poco habitual que los estudiantes de más de 20 años se matriculen en un programa normal de instituto; los estudiantes que no se gradúan dentro del tiempo estipulado pueden obtener una cualificación de secundaria equivalente por haber aprobado con éxito el examen de Desarrollo Educativo General (GED).

La finalización con éxito de programas de secundaria superior también depende de lo accesibles que sean estos programas. En todos los países con datos disponibles, a excepción de México y Turquía, las tasas de acceso a secundaria superior para estudiantes de menos de 20 años están alrededor del $90 \%$. Es razonable, pues, esperar que un mayor porcentaje de estudiantes se gradúen en educación secundaria superior en los países con un acceso limitado a este nivel que en los países con un acceso casi universal. En otras palabras, los países donde los estudiantes tengan que pasar un examen o ser seleccionados por méritos académicos para entrar en programas de secundaria superior pueden hacer una mayor contribución de estudiantes brillantes que se deriven hacia esos programas, lo que puede producir una tasa de finalización elevada (Tabla A2.4). La selectividad de los programas puede obstaculizar la inequidad en la educación, dado que el acceso a los programas puede ser limitado.

\section{Finalización con éxito por sexo}

En todos los países con datos disponibles, los hombres jóvenes tienen mayor probabilidad que las mujeres jóvenes de no completar a tiempo la educación secundaria superior. Como media, el $76 \%$ de las mujeres jóvenes completan su educación secundaria superior dentro del tiempo estipulado, si se compara con el $68 \%$ de los hombres jóvenes. Solo en Corea, Finlandia, Grecia, Irlanda, Japón, República Eslovaca y Suecia la diferencia de proporciones de jóvenes, tanto de hombres como de mujeres, que no completan la educación secundaria superior está por debajo de los cinco puntos porcentuales. En Islandia, Italia, Noruega y Turquía, las mujeres jóvenes superan en número a los hombres jóvenes que completan con éxito la educación secundaria superior en más de 14 puntos porcentuales (Gráfico A2.5). Las diferencias de sexo que se aprecian en Noruega se deben con toda probabilidad al hecho de que las chicas tienden a tener mejores resultados académicos que los chicos en la escuela secundaria inferior. Al controlar los resultados de la escuela secundaria inferior, no hay diferencia de sexo, o solo una pequeña ventaja para los hombres jóvenes (Falch et al., 2010).

La diferencia por sexo disminuyó ligeramente, hasta una media de cinco puntos porcentuales, cuando la finalización se retrasó en dos años. Las diferencias en las tasas de finalización entre el tiempo estipulado y los dos años adicionales son mayores en los hombres jóvenes (16 puntos porcentuales) que en las mujeres jóvenes (13 puntos porcentuales). La disminución de la diferencia por sexo podría deberse a la alta incidencia de la repetición de curso o el cambio 


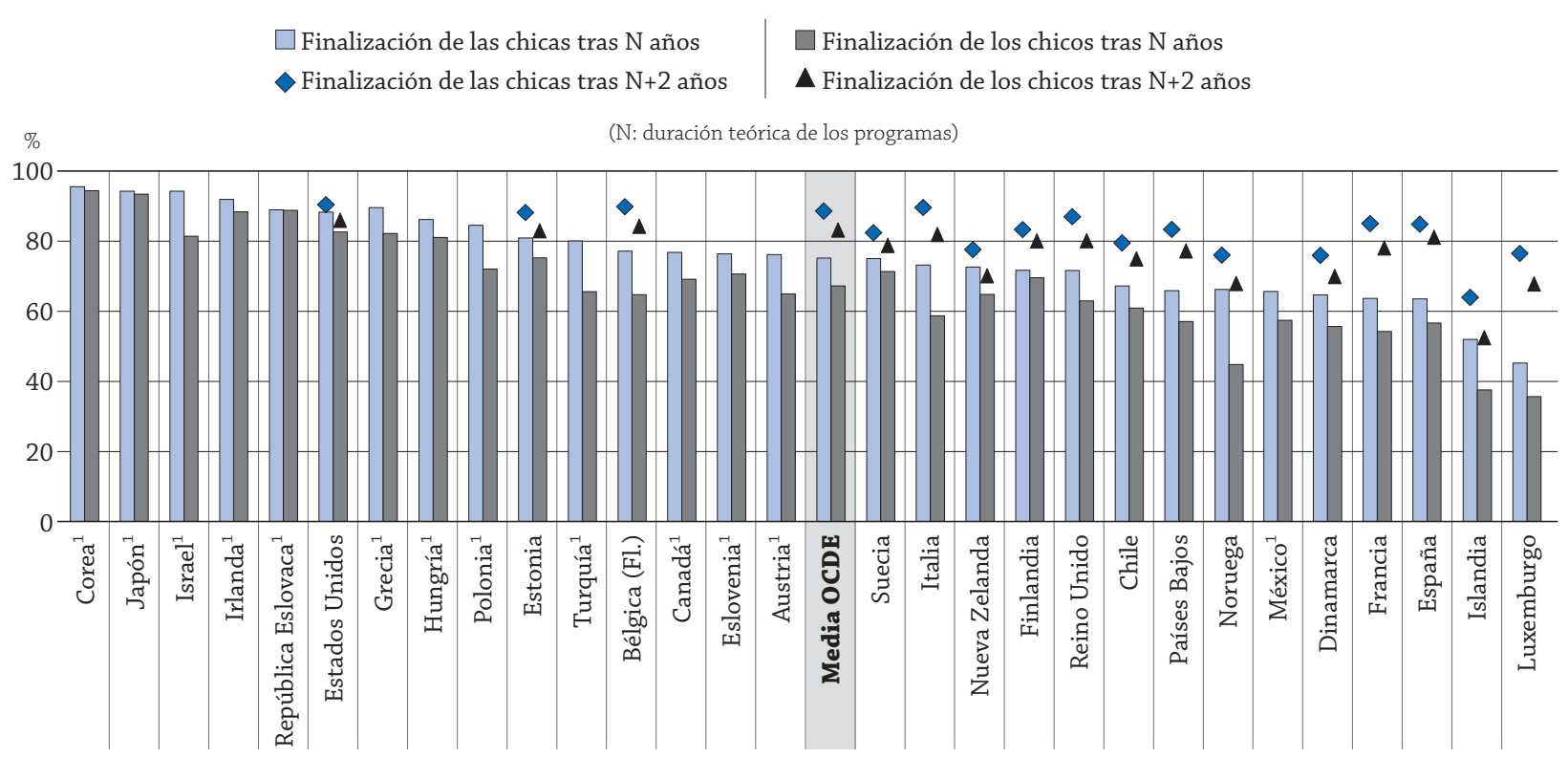

1. $\mathrm{N}+2$ faltan datos.

Los países están clasificados en orden descendente de la finalización por las chicas de programas de educación secundaria superior (tras $N$ años).

Fuente: OCDE. Tabla A2.4. Para ver notas, consulte Anexo 3 (www.oecd.org/edu/eag.htm).

StatLink 제이 http://dx.doi.org/10.1787/888933115331

a un programa diferente, o a factores socioculturales que podrían ampliar el tiempo necesario para que los hombres jóvenes completen un grado más allá de la duración estipulada del programa (OECD, 2012b).

La diferencia por sexo también varía dependiendo del programa: el $80 \%$ de las mujeres jóvenes completan los programas generales, en comparación con el $73 \%$ de los hombres jóvenes; el $67 \%$ de las mujeres jóvenes completan los programas de formación profesional, en comparación con el $61 \%$ de los varones jóvenes. En los programas de FP en Islandia, esta diferencia por sexo se amplía en más de 16 puntos porcentuales a favor de las mujeres jóvenes. En Estonia, Grecia y República Eslovaca, las mujeres jóvenes en los programas de FP no tienen tanto éxito como los hombres jóvenes en completar la educación secundaria superior dentro de la duración normal de los programas (Tabla A2.5).

Muchos estudios, incluidos los informes PISA de la OCDE, confirman que las mujeres jóvenes de los países de la OCDE tienen más probabilidad de obtener mejores resultados y menos probabilidades que los varones jóvenes de dejar los estudios escolares pronto (OECD 2012a; OECD, 2012b; OECD, 2014). Dicho lo cual, las mujeres jóvenes que dejan pronto la escuela tienden a obtener resultados inferiores a los de sus compañeros varones, pese a que tienen una formación media superior (véanse Indicadores A1 y C5). La tasa de finalización para los programas de secundaria superior y el compromiso de los estudiantes en la educación también están ligados a muchas otras cuestiones, como las presiones sociales de la familia y los amigos, las experiencias académicas previas y los cambios físicos y emocionales (OECD, 2012a; Zapata, de próxima aparición), así como a los logros educativos de los padres y al entorno inmigrante (Cuadro A2.2).

\section{Finalización con éxito por orientación del programa}

Los estudiantes acceden a programas generales o de FP en distintos estadios de sus carreras educativas en función del país. En países con un sistema integral, los estudiantes siguen un plan de estudios troncal común hasta el inicio de la educación secundaria superior a la edad de 16 años (por ejemplo, en los países nórdicos); en los países con un sistema altamente diferenciado, se puede elegir un programa en concreto o el tipo de escuela en la educación secundaria inferior a las edades de 10-13 en adelante (por ejemplo, Luxemburgo).

En varios países, los programas generales y de FP se organizan de forma separada y los estudiantes tienen que optar por una u otra. Tal es el caso de países como Alemania y Francia, donde los itinerarios de secundaria superior están claramente diferenciados. En otros países, como Suecia, en la educación secundaria superior hay poca separación entre los programas generales y de FP. A pesar de la estructura de los programas de secundaria superior, hay países 


\section{Gráfico A2.6. Finalización con éxito de programas de educación secundaria superior, por orientación y duración del programa}

\begin{tabular}{|c|c|}
\hline $\begin{array}{l}\square \text { Finalización de programas generales de } 3 \text { años } \\
\text { Finalización de programas generales de } 3 \text { años }(\mathrm{N}+2)\end{array}$ & $\begin{array}{l}\square \text { Finalización de programas de formación profesional de } 3 \text { años } \\
\text { Finalización de programas de formación profesional de } 3 \text { años }(\mathrm{N}+2)\end{array}$ \\
\hline $\begin{array}{l}\square \text { Finalización de programas generales de } 4 \text { años } \\
\triangle \text { Finalización de programas generales de } 4 \text { años }(\mathrm{N}+2)\end{array}$ & $\begin{array}{l}\text { Finalización de programas de formación profesional de } 4 \text { años } \\
\text { Finalización de programas de formación profesional de } 4 \text { años }(\mathrm{N}+2)\end{array}$ \\
\hline
\end{tabular}

$\%$ (N: duración teórica de los programas)

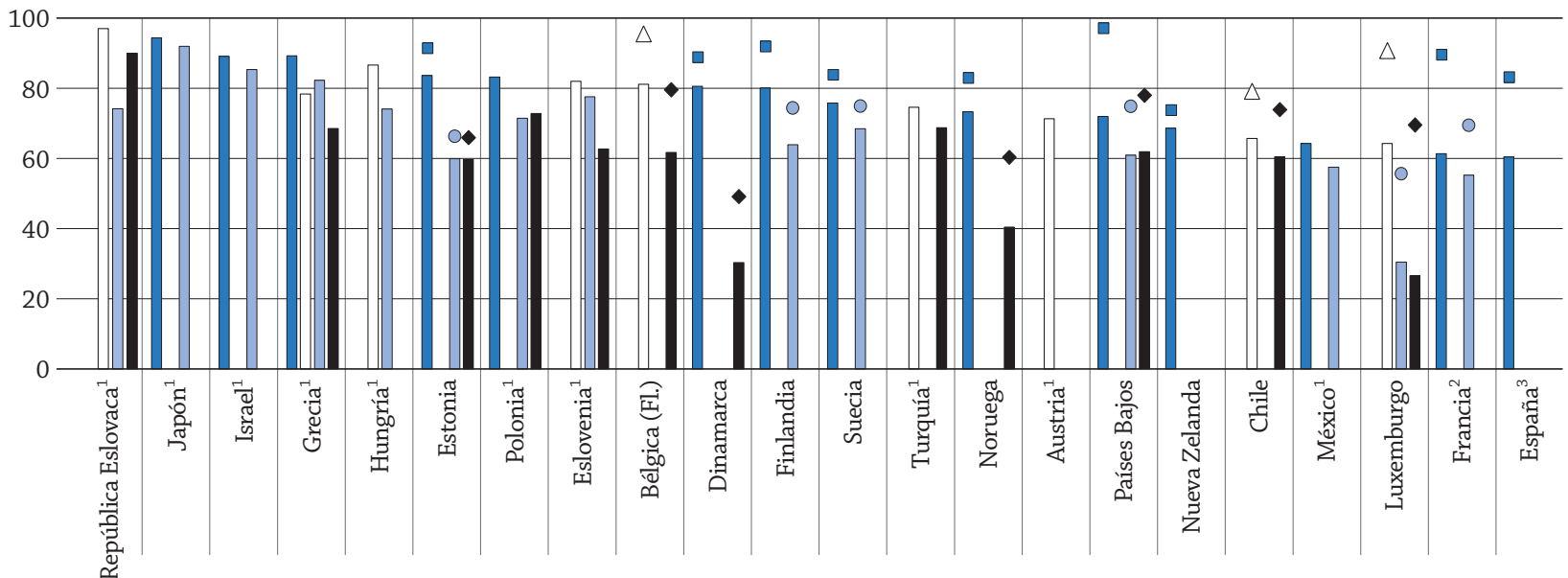

Nota: Para más información sobre este indicador, como los métodos empleados, los programas incluidos o excluidos, el año de acceso, etc., consulte Anexo 3.

1. N+2 faltan datos.

2. Programas de 2 años en lugar de 3 para los programas de formación profesional.

3. Programas de 2 años en lugar de 3 para los programas generales.

Los países están clasificados en orden descendente de la finalización de programas de educación secundaria superior general (tras $N$ años).

Fuente: OCDE. Tabla A2.5. Para ver notas, consulte Anexo 3 (www.oecd.org/edu/eag.htm).

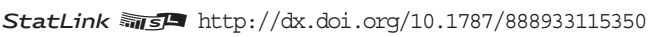

como Finlandia y Países Bajos, que ofrecen a los estudiantes oportunidades de cambiar de itinerarios. La flexibilidad entre los itinerarios de FP y generales pueden acomodarse a aquellos estudiantes que deseen cambiar de orientación y seguir un programa de secundaria superior diferente (OECD, 2012a).

Los estudiantes que entran en programas generales tienen más probabilidad de graduarse que aquellos que se matriculan en programas de FP. En los 26 países con datos disponibles, el $76 \%$ de los estudiantes completaron su programa general dentro de la duración teórica del programa, y esta proporción se incrementó en 15 puntos porcentuales en los estudiantes que completaron su programa dos años después de la duración estipulada.

Por el contrario, solo el $64 \%$ de los estudiantes completaron su programa de formación profesional dentro de la duración teórica; esa proporción se incrementó en 15 puntos porcentuales dos años después del tiempo estipulado. Mientras que la diferencia media entre las tasas de finalización para los programas de secundaria superior tanto generales como de formación profesional es de 13 puntos porcentuales, las diferencias pasan de más de 40 puntos porcentuales en Dinamarca a 5 puntos porcentuales o menos en Chile, Israel y Japón (Tabla A2.5).

La gran diferencia en las tasas de finalización entre los programas generales y de FP de la secundaria superior en los distintos países puede explicarse por el hecho de que en algunos países los estudiantes con resultados pobres pueden orientarse (o reorientarse) hacia programas de FP, mientras que los estudiantes con buenos resultados van a programas generales. Algunos estudiantes también tienen dificultad a la hora de decidir qué programa de FP se les adecúa mejor y, por tanto, tienen que repetir uno o varios cursos en este nivel de educación. Pueden también encontrar dificultades para encontrar a un empleador que les ofrezca un programa de aprendizaje, puede que tengan que esperar a que quede disponible alguna plaza en dicho programa o puede que al final dejen de intentarlo.

Los itinerarios entre estos dos tipos de educación están muy desarrollados en algunos países. En Noruega, por ejemplo, del $40 \%$ de estudiantes que entraron en un programa de FP y se graduaron dentro del tiempo estipulado, el $45 \%$ se graduó con un título de formación profesional y el $55 \%$ cambió de programa y se graduó con un diploma general. En Chile, del $66 \%$ de los estudiantes que entraron en un programa general y se graduaron dentro del tiempo estipulado, el $79 \%$ se graduó con un diploma general y el 21\% se cambió de programa y se graduó con un diploma de FP (Tabla A2.5). 


\section{Cuadro A2.2. Finalización con éxito de los programas de educación secundaria, por nivel educativo de los padres o entorno inmigrante}

Ratio de graduados en relación con nuevos matriculados, basada en cohortes

\begin{tabular}{|c|c|c|c|c|c|c|}
\hline & \multirow[b]{2}{*}{$\mathrm{N}=$ duración teórica } & \multicolumn{3}{|c|}{$\begin{array}{c}\text { CINE } 3 \text { por nivel educativo } \\
\text { de los padres }\end{array}$} & \multicolumn{2}{|c|}{$\begin{array}{l}\text { CINE } 3 \text { con un entorno inmigrante } \\
\text { (primera o segunda generación) }\end{array}$} \\
\hline & & CINE 0-2 & CINE 3 & CINE 5-6 & Primera generación & Segunda generación \\
\hline \multirow{2}{*}{ Bélgica (Fl.) } & durante $\mathrm{N}$ & 58 & 71 & 80 & $\mathrm{~m}$ & $\mathrm{~m}$ \\
\hline & 2 años después de $\mathrm{N}$ & 75 & 89 & 94 & $\mathrm{~m}$ & $\mathrm{~m}$ \\
\hline \multirow{2}{*}{ Chile } & durante $\mathrm{N}$ & 78 & 82 & 86 & $\mathrm{~m}$ & $\mathrm{~m}$ \\
\hline & 2 años después de $\mathrm{N}$ & 87 & 90 & 92 & $\mathrm{~m}$ & $\mathrm{~m}$ \\
\hline \multirow{2}{*}{ Dinamarca } & durante $\mathrm{N}$ & 44 & 56 & 73 & 46 & 50 \\
\hline & 2 años después de $\mathrm{N}$ & 54 & 72 & 84 & 57 & 64 \\
\hline \multirow{2}{*}{ Estados Unidos } & durante $\mathrm{N}$ & 68 & 83 & 91 & 80 & 84 \\
\hline & 2 años después de $\mathrm{N}$ & 74 & 86 & 92 & 85 & 89 \\
\hline \multirow{2}{*}{ Finlandia } & durante $\mathrm{N}$ & 57 & 68 & 76 & 56 & 62 \\
\hline & 2 años después de $\mathrm{N}$ & 67 & 78 & 88 & 70 & 78 \\
\hline \multirow{2}{*}{ Francia } & durante $\mathrm{N}$ & 50 & 59 & 68 & 46 & 49 \\
\hline & 2 años después de $\mathrm{N}$ & 70 & 83 & 92 & 68 & 71 \\
\hline \multirow{2}{*}{ Hungría } & durante $\mathrm{N}$ & $\mathrm{m}$ & $\mathrm{m}$ & $\mathrm{m}$ & 32 & $\mathrm{~m}$ \\
\hline & 2 años después de $\mathrm{N}$ & $\mathrm{m}$ & $\mathrm{m}$ & $\mathrm{m}$ & $\mathrm{m}$ & $\mathrm{m}$ \\
\hline \multirow{2}{*}{ Islandia } & durante $\mathrm{N}$ & $\mathrm{m}$ & $\mathrm{m}$ & $\mathrm{m}$ & 26 & 20 \\
\hline & 2 años después de $\mathrm{N}$ & $\mathrm{m}$ & $\mathrm{m}$ & $\mathrm{m}$ & 31 & 20 \\
\hline \multirow{2}{*}{ Israel } & durante $\mathrm{N}$ & 78 & 92 & 95 & 85 & $\mathrm{~m}$ \\
\hline & 2 años después de $\mathrm{N}$ & $\mathrm{m}$ & $\mathrm{m}$ & $\mathrm{m}$ & $\mathrm{m}$ & $\mathrm{m}$ \\
\hline \multirow{2}{*}{ Noruega } & durante $\mathrm{N}$ & 36 & 52 & 70 & 39 & 55 \\
\hline & 2 años después de $\mathrm{N}$ & 49 & 69 & 83 & 52 & 68 \\
\hline \multirow{2}{*}{ Países Bajos } & durante $\mathrm{N}$ & $\mathrm{m}$ & $\mathrm{m}$ & $\mathrm{m}$ & 51 & 53 \\
\hline & 2 años después de $\mathrm{N}$ & $\mathrm{m}$ & $\mathrm{m}$ & $\mathrm{m}$ & 67 & 73 \\
\hline \multirow[b]{2}{*}{ Suecia } & durante $\mathrm{N}$ & 59 & 73 & 80 & 65 & 68 \\
\hline & 2 años después de $\mathrm{N}$ & 67 & 80 & 88 & 74 & 76 \\
\hline \multirow{2}{*}{ Reino Unido } & durante $\mathrm{N}$ & 49 & 69 & 85 & $\mathrm{~m}$ & $\mathrm{~m}$ \\
\hline & 2 años después de $\mathrm{N}$ & 69 & 84 & 93 & $\mathrm{~m}$ & $\mathrm{~m}$ \\
\hline
\end{tabular}

Nota: Para más información sobre este indicador, como los métodos empleados, los programas incluidos o excluidos, el año de acceso, etc., consulte Anexo 3 (www.oecd.org/edu/eag.htm).

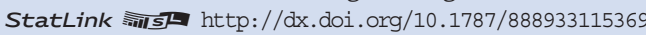

Entre los 29 países que participaron en el estudio sobre la finalización con éxito de la educación superior, 13 informaron de tasas de finalización por grupos sociales separados. Estas tasas no pueden compararse directamente con las tasas generales presentadas anteriormente, dado que las cohortes utilizadas para calcularlas no son las mismas. Se presenta una descripción detallada de la cohorte empleada para cada país en el Anexo 3. El análisis siguiente se centra solo en la comparación de la finalización con éxito de los programas de secundaria superior, asociada a la educación de los padres o a un entorno de inmigración.

Diez países informaron de tasas de finalización para estudiantes inmigrantes. Las diferencias en las tasas de finalización de estudiantes inmigrantes de primera y segunda generación arrojan menos de cinco puntos porcentuales en Dinamarca, Estados Unidos, Francia, Países Bajos y Suecia. La excepción la marca Noruega, donde las tasas de finalización de estudiantes inmigrantes de segunda generación son 17 puntos porcentuales superiores a las de estudiantes de primera generación. Se necesitarán más datos para determinar si los estudiantes inmigrantes de estos países están mejor integrados en comparación con aquellos de otros países donde las tasas de finalización son similares entre estudiantes inmigrantes de primera y segunda generación.

Diez países informaron de tasas de finalización por nivel educativo de los padres. La diferencia en las tasas de finalización de la secundaria superior entre estudiantes de familias donde los padres tienen una educación terciaria y los de familias donde los padres solo cuentan con educación secundaria inferior va desde los 7 puntos porcentuales de Chile a más de 30 puntos porcentuales de Noruega y Reino Unido. En Noruega, solo el $36 \%$ de los estudiantes de familias con niveles educativos bajos completan los programas de secundaria superior en el tiempo estipulado, en comparación con el $70 \%$ de aquellos de familias con alto nivel educativo.

Los resultados de aprendizaje de los estudiantes con un entorno inmigrante o de familias con bajo nivel educativo deberían ser el foco de atención de quienes toman decisiones en materia educativa, sobre todo en países donde estos estudiantes arrojan tasas de finalización sustancialmente más bajas que las de sus compañeros que no provienen de estos grupos sociales. 
Puede que algunos estudiantes que empiezan un programa de formación profesional abandonen el sistema educativo para entrar directamente en el mercado laboral. El atractivo de las oportunidades de empleo puede desempeñar un papel en la salida de los estudiantes del sistema educativo, en concreto aquellos de los últimos cursos de la educación secundaria superior (Stearns et al., 2006 en Zapata, de próxima aparición). El acceso al empleo para personas con un nivel formativo bajo también puede influir en las tasas de finalización con éxito y en la incidencia del abandono de estudios.

Entre los estudiantes que no completan sus programas dentro del tiempo estipulado, el $56 \%$ de aquellos que siguen un programa general permanecen en el sistema educativo, en comparación con solo el $43 \%$ de aquellos que continúan con su programa de formación profesional. Hay una gran variación por países: en Finlandia, Flandes (Bélgica), Francia y Luxemburgo, el $80 \%$ o más de los estudiantes que no se graduaron tras la duración teórica de los programas generales continúan aún en el sistema educativo, en comparación con el $10 \%$ de Israel y solo el $7 \%$ de Corea (Tabla A2.5).

El cuadro es ligeramente distinto cuando se trata de la finalización de programas de secundaria superior (tanto general como de FP) por duración del programa. La duración de los programas de secundaria superior varía por países: desde los dos años en España y Holanda para programas generales a los cinco años en Luxemburgo para programas de formación profesional (Tabla A2.5). Podría pensarse que las tasas de finalización en programas de duración mayor será menor que en los programas de duración más corta. Sin embargo, el Gráfico A2.6 muestra que esta suposición no se sostiene. Por ejemplo, la duración de los programas de secundaria superior general en España es de dos años, mientras que en otros países de la OCDE es de entre tres y cuatro años. Con una tasa de finalización con éxito del $60 \%$ tras $\mathrm{N}$ años, España cuenta con la tasa más baja de finalización (que aumenta sustancialmente después de dos años al $83 \%$ ). Por el contrario, la duración de los programas generales en Hungría es de cuatro años, y la tasa de finalización con éxito del $87 \%$ para este país es la más alta. Tal como se comentó antes, la accesibilidad de los programas y la selectividad académica del sistema educativo podría dar cuenta de las altas tasas de finalización de los programas de larga duración. El compromiso de los estudiantes y la calidad de la educación de la secundaria superior y de los entornos de aprendizaje también son factores clave para su finalización.

\section{Definiciones}

Estudiantes de primera generación son aquellos que nacieron fuera del país, al igual que sus padres.

Los graduados en el periodo de referencia pueden ser graduados por vez primera o graduados que han repetido. Alguien que se gradúa por vez primera es un estudiante que se ha graduado por vez primera en un determinado nivel educativo en el periodo de referencia. Así pues, si un estudiante se ha graduado varias veces a lo largo de los años, se cuenta como graduado para cada año, pero como graduado por vez primera solo una.

Las tasas netas de graduación representan el porcentaje estimado de un grupo de edad que completará la educación secundaria superior sobre la base de los modelos de graduación actuales.

Estudiantes de segunda generación son aquellos que nacieron en el país, pero cuyos padres nacieron fuera. Hay más detalles disponibles sobre las definiciones utilizadas por los países en el Cuadro A2.2 del Anexo 3.

La finalización con éxito de los programas generales de secundaria superior representa la proporción de nuevos ingresados en programas generales de secundaria superior que se graduaron en el nivel de secundaria superior un determinado número de años más tarde (según cohortes).

La finalización con éxito de los programas de secundaria superior representa la proporción de nuevos ingresados en programas de secundaria superior que se graduaron en el nivel de secundaria superior un determinado número de años más tarde (según cohortes).

La finalización con éxito de los programas de formación profesional de secundaria superior representa la proporción de nuevos ingresados en programas generales de secundaria superior que se graduaron en el nivel de secundaria superior un determinado número de años más tarde (según cohortes).

\section{Metodología}

Los datos se refieren al año académico 2011-2012 y se basan en los datos recogidos por la UOE sobre estadísticas educativas administradas por la OCDE en 2012 (para detalles, véase Anexo 3 en www.oecd.org/edu/eag.htm).

Los datos sobre tendencias de tasas de graduación en el nivel de la secundaria superior para los años 1995 y 2000 hasta 2004 se basan en un estudio especial realizado en enero de 2007. 
A menos que se indique lo contrario, las tasas de graduación se calculan como tasas netas de graduación (es decir, como la suma de las tasas de graduación de una edad específica). Las tasas brutas de graduación se presentan para los países que no pueden facilitar esos datos con detalle. Para calcular las tasas brutas de graduación, los países identifican la edad a la que se produce la graduación de forma generalizada (véase Anexo 1). El número de graduados, independientemente de su edad, se divide por la población en edad habitual de graduación. Sin embargo, en muchos países se hace difícil la definición de una edad habitual de graduación porque los graduados están dispersos en un amplio abanico de edades.

Los graduados de los programas CINE 3A, 3B y 3C (o 4A, 4B, 4C) no entran en el cómputo de "primera vez», con lo cual las tasas de graduación no pueden sumarse, puesto que algunas personas se gradúan en más de un programa de secundaria superior y se las contaría dos veces. Lo mismo ocurre con las tasas de graduación según la orientación del programa, es decir, si es general o de formación profesional. Además, las edades habituales de graduación no tienen por qué ser las mismas en los distintos tipos de programas (véase Anexo 1). Los programas de preformación profesional y de formación profesional incluyen tanto los programas desarrollados en el centro educativo como los que combinan formación en el centro educativo y en el centro de trabajo, y se reconocen como parte del sistema educativo. No se incluye ni la educación desarrollada completamente en el centro de trabajo ni los programas de formación que no estén supervisados por una autoridad educativa oficial.

En las Tablas A2.4, A2.5 y el Cuadro A2.2, los datos se basan en un estudio especial realizado en diciembre de 2013. La finalización con éxito de los programas de secundaria superior se calcula como la ratio del número de estudiantes que se gradúan en un programa de secundaria superior durante el año de referencia y el número de nuevos ingresados en este programa $\mathrm{N}$ años antes (o $\mathrm{N}+2$ ), siendo $\mathrm{N}$ la duración del programa. El cálculo de una finalización con éxito se define como un análisis de la cohorte en tres cuartas partes de los países listados en la Tabla A2.4 (cohorte real y estudio longitudinal). La estimación para los demás países sin un sistema de seguimiento real de la cohorte supone flujos constantes de estudiantes en el nivel de secundaria superior, debido a la necesidad de una consistencia entre la cohorte de graduados en el año de referencia y la cohorte de ingresados $\mathrm{N}$ años antes (datos de la cohorte de muestra). Esa suposición puede pecar de un exceso de simplificación. Se incluye una descripción detallada del método utilizado por cada país en el Anexo 3 (años de los nuevos ingresados, años de los graduados, programas tenidos en cuenta, etc.).

\section{Nota sobre los datos de Israel}

Los datos estadísticos para Israel fueron proporcionados por las autoridades israelíes competentes bajo su responsabilidad. El uso de estos datos por parte de la OCDE se hace sin prejuzgar la situación de los Altos del Golán, Jerusalén Este y los asentamientos israelíes en Cisjordania de acuerdo con los términos del derecho internacional.

\section{Referencias}

Falch T. et al. (2010), Completion and Dropout in Upper Secondary Education in Norway: Causes and Consequences, Centre for Economic Research at NTNU, Trondheim, octubre de 2010.

OECD (2014), PISA 2012 Results: What Students Know and Can Do (Volume I, edición revisada en febrero de 2014), PISA, OECD Publishing, París, http://dx.doi.org/10.1787/9789264208780-en.

OECD (2012a), Equity and Quality in Education: Supporting Disadvantaged Students and Schools, OECD Publishing, París, http:// dx.doi.org/10.1787/9789264130852-en.

OECD (2012b), Closing the Gender Gap: Act Now, OECD Publishing, París, http://dx.doi.org/10.1787/9789264179370-en.

OECD (2010), Learning for Jobs, OECD Reviews of Vocational Education and Training, OECD Publishing, París, http://dx.doi.org/ http://dx.doi.org/10.1787/9789264087460-en.

Zapata, J. (de próxima aparición), «Upper Secondary Education: a Literature Review on Provision», OECD Publishing, París. 
Tablas del Indicador A2

StatLink 젝ㄴ http://dx.doi.org/10.1787/888933115122

Tabla A2.1a Tasas de graduación en educación secundaria superior y media de edades (2012)

Tabla A2.1b Tasas de graduación en educación secundaria superior: menores de 25 años (2012)

WEB Tabla A2.1c Tasas de graduación en educación postsecundaria no terciaria (2012)

Tabla A2.2a Tendencias de las tasas de graduación por primera vez en el nivel de secundaria superior (1995-2012)

WEB Tabla A2.2b Tendencias de las tasas de graduación (programas generales y de formación preprofesional y profesional) en el nivel de secundaria superior (2005-2012)

Tabla A2.3a Distribución de graduados en educación secundaria superior de formación profesional, por ámbito de estudio y sexo (2012)

WEB Tabla A2.3b Distribución de graduados en educación secundaria superior de formación profesional, por ámbito de estudio (2012)

Tabla A2.4 Finalización con éxito de programas de educación secundaria superior, por sexo y orientación del programa

Tabla A2.5 Finalización con éxito de programas de educación secundaria superior, por orientación y duración del programa 
Tabla A2.1a. Tasas de graduación en educación secundaria superior y media de edades (2012)

Suma de las tasas de graduación por edades específicas, por destino y orientación del programa y por sexo

\begin{tabular}{|c|c|c|c|c|c|c|c|c|c|c|c|c|c|c|c|c|}
\hline & \multicolumn{4}{|c|}{$\begin{array}{l}\text { Total (graduados } \\
\text { por primera vez) }\end{array}$} & \multicolumn{4}{|c|}{$\begin{array}{l}\text { Programas } \\
\text { generales }\end{array}$} & \multicolumn{4}{|c|}{$\begin{array}{l}\text { Programas de formación } \\
\text { preprofesional/profesional }\end{array}$} & \multirow{2}{*}{$\begin{array}{c}\text { CINE } \\
3 \mathrm{~A}^{1} \\
\\
\\
\sum_{+} \\
+ \\
\end{array}$} & \multirow{2}{*}{$\begin{array}{c}\text { CINE } \\
3 B^{1} \\
\\
\sum \\
+ \\
\text { I }\end{array}$} & \multirow{2}{*}{ 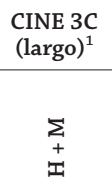 } & \multirow{2}{*}{$\begin{array}{c}\begin{array}{c}\text { CINE 3C } \\
\text { (corto) }^{1}\end{array} \\
\qquad \begin{array}{c}\sum^{1} \\
+ \\
\text { I }\end{array}\end{array}$} \\
\hline & $\begin{array}{l}\sum \\
+ \\
\pm \\
\end{array}$ & 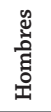 & 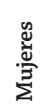 & 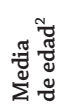 & $\begin{array}{l}\Sigma \\
+ \\
+\end{array}$ & $\begin{array}{l}\mathscr{U} \\
\text { Ğ } \\
\text { : }\end{array}$ & 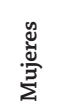 & 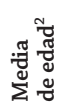 & $\begin{array}{l}\sum_{+} \\
+ \\
\text {I }\end{array}$ & 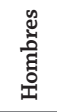 & 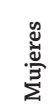 & 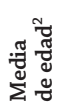 & & & & \\
\hline & (1) & (2) & (3) & (4) & (5) & (6) & (7) & (8) & (9) & (10) & (11) & (12) & (13) & (17) & (21) & (25) \\
\hline Alemania & 95 & 95 & 94 & $m$ & 49 & 44 & 54 & $m$ & 46 & 51 & 40 & $m$ & 49 & 45 & $\mathbf{a}$ & 1 \\
\hline Australia $^{3}$ & $\mathbf{m}$ & $\mathrm{m}$ & $\mathrm{m}$ & $m$ & 71 & 67 & 75 & 17 & 59 & 58 & 61 & 31 & 71 & $\mathbf{a}$ & 59 & $\mathbf{a}$ \\
\hline Austria & 68 & 71 & 64 & 18 & 18 & 14 & 22 & 18 & 76 & 87 & 65 & 20 & 18 & 55 & 1 & 20 \\
\hline Bélgica & $\mathbf{m}$ & $\mathrm{m}$ & $\mathrm{m}$ & $m$ & 35 & 31 & 40 & 18 & 66 & 61 & 72 & 25 & 59 & $\mathbf{a}$ & 19 & 23 \\
\hline Canadá ${ }^{3}$ & 88 & 85 & 91 & 19 & 84 & 81 & 88 & 18 & 4 & 4 & 3 & $m$ & 84 & a & 4 & $\mathbf{a}$ \\
\hline Chile & 84 & 81 & 88 & 18 & 55 & 52 & 58 & 19 & 30 & 30 & 30 & 18 & 84 & a & a & a \\
\hline Corea & 92 & 92 & 92 & $m$ & 71 & 70 & 72 & $m$ & 21 & 22 & 20 & $m$ & 71 & $\mathbf{a}$ & 21 & $\mathbf{a}$ \\
\hline Dinamarca & 92 & 86 & 99 & 21 & 62 & 54 & 70 & 19 & 47 & 44 & 49 & 28 & 62 & $\mathbf{a}$ & 46 & $\mathbf{n}$ \\
\hline Eslovenia & 96 & 92 & 101 & $m$ & 35 & 28 & 43 & 18 & 73 & 79 & 67 & $m$ & 39 & 46 & 21 & 2 \\
\hline España & 93 & 90 & 97 & $m$ & 52 & 46 & 59 & $m$ & 50 & 49 & 50 & $m$ & 52 & 23 & 11 & 16 \\
\hline Estados Unidos & 79 & 75 & 82 & 17 & $\mathbf{x}(\mathbf{1})$ & $x(2)$ & $\mathrm{x}(3)$ & $x(4)$ & $\mathbf{x}(\mathbf{1})$ & $\mathrm{x}(2)$ & $x(3)$ & $x(4)$ & $\mathbf{a}$ & $\mathbf{a}$ & a & $\mathbf{a}$ \\
\hline Estonia & $\mathbf{m}$ & $\mathrm{m}$ & $\mathrm{m}$ & $m$ & 65 & 55 & 76 & 18 & 22 & 27 & 17 & 21 & 65 & 20 & 2 & $\mathbf{a}$ \\
\hline Finlandia & 93 & 89 & 96 & 21 & 44 & 37 & 52 & 19 & 97 & 89 & 106 & 29 & 93 & $\mathbf{a}$ & a & a \\
\hline Francia & $\mathbf{m}$ & $\mathrm{m}$ & $\mathrm{m}$ & $m$ & 53 & 46 & 60 & 17 & 75 & 77 & 72 & 20 & 53 & 24 & 4 & 47 \\
\hline Grecia & 71 & 64 & 78 & $m$ & 71 & 64 & 78 & $m$ & 33 & 39 & 27 & $m$ & 71 & $\mathbf{a}$ & 33 & $\mathbf{x}(\mathbf{2 1})$ \\
\hline Hungría & 94 & 95 & 94 & 19 & 70 & 63 & 77 & 19 & 25 & 32 & 18 & 20 & 70 & $\mathbf{a}$ & 25 & $\mathbf{x}(21)$ \\
\hline Irlanda & 93 & 92 & 95 & 19 & 69 & 70 & 68 & 19 & 80 & 61 & 99 & 26 & 97 & a & 6 & 46 \\
\hline Islandia & 95 & 82 & 109 & 23 & 79 & 64 & 94 & 21 & 55 & 55 & 56 & 26 & 76 & 3 & 37 & 18 \\
\hline Israel & 87 & 82 & 93 & 17 & 53 & 48 & 59 & 17 & 34 & 35 & 34 & 17 & 81 & $\mathbf{a}$ & 6 & $\mathbf{a}$ \\
\hline Italia & 84 & 82 & 86 & $m$ & 36 & 27 & 46 & 18 & 64 & 72 & 56 & $m$ & 75 & 1 & $\mathbf{a}$ & 24 \\
\hline Japón & 93 & 92 & 94 & $m$ & 71 & 68 & 75 & $m$ & 22 & 24 & 20 & $m$ & 71 & 1 & 21 & $\mathbf{x}(\mathbf{2 1})$ \\
\hline Luxemburgo & 69 & 66 & 72 & 20 & 31 & 27 & 35 & 18 & 47 & 46 & 47 & 20 & 47 & 9 & 20 & 1 \\
\hline México & 47 & 45 & 50 & 18 & 44 & 41 & 46 & 18 & 4 & 4 & 4 & 19 & 44 & a & 4 & $\mathbf{a}$ \\
\hline Noruega & 88 & 83 & 94 & 22 & 59 & 48 & 71 & 19 & 34 & 41 & 27 & 28 & 59 & $\mathbf{a}$ & 34 & $\mathbf{m}$ \\
\hline Nueva Zelanda & 85 & 83 & 88 & 17 & 85 & 83 & 88 & 17 & $\mathbf{m}$ & $\mathrm{m}$ & $\mathrm{m}$ & $m$ & 74 & m & $\mathbf{m}$ & 11 \\
\hline Países Bajos & 94 & 91 & 98 & 21 & 42 & 38 & 45 & 17 & 78 & 79 & 76 & 25 & 70 & a & 49 & a \\
\hline Polonia & 85 & 80 & 89 & 20 & 52 & 40 & 65 & 20 & 39 & 47 & 31 & 20 & 77 & a & 14 & $\mathbf{a}$ \\
\hline Portugal & $\mathbf{m}$ & $\mathrm{m}$ & $\mathrm{m}$ & $m$ & 47 & 40 & 54 & 23 & 50 & 50 & 50 & 23 & a & $\mathbf{a}$ & $\mathbf{a}$ & $\mathbf{a}$ \\
\hline Reino Unido & 93 & 92 & 95 & $m$ & $\mathbf{m}$ & $\mathrm{m}$ & $\mathrm{m}$ & $m$ & $\mathbf{m}$ & $\mathrm{m}$ & $\mathrm{m}$ & $m$ & m & $\mathbf{m}$ & 81 & 12 \\
\hline República Checa & 82 & 81 & 83 & 19 & 24 & 18 & 30 & 19 & 58 & 63 & 53 & 19 & 58 & $\mathbf{n}$ & 24 & a \\
\hline República Eslovaca & 86 & 85 & 89 & 19 & 27 & 21 & 33 & 18 & 66 & 71 & 62 & 20 & 78 & $\mathbf{a}$ & 14 & $\mathbf{1}$ \\
\hline Suecia & 77 & 75 & 80 & 18 & 43 & 38 & 48 & 18 & 35 & 37 & 32 & 18 & 77 & $\mathbf{n}$ & $\mathbf{n}$ & $\mathbf{n}$ \\
\hline Suiza & $\mathbf{m}$ & $\mathrm{m}$ & $\mathrm{m}$ & $m$ & 34 & 27 & 41 & 20 & 71 & 77 & 66 & 21 & 30 & 69 & 6 & $\mathbf{x}(\mathbf{2 1})$ \\
\hline Turquía & 55 & 54 & 57 & 17 & 30 & 27 & 32 & 17 & 26 & 27 & 25 & 17 & 55 & a & a & m \\
\hline Media OCDE & 84 & 81 & 87 & 19 & 52 & 46 & 58 & 19 & 48 & 50 & 46 & 22 & 61 & 10 & 18 & 8 \\
\hline Media UE21 & 86 & 84 & 89 & 20 & 46 & 40 & 53 & 19 & 56 & 58 & 54 & 22 & 61 & 11 & 18 & 10 \\
\hline Arabia Saudí & m & $\mathrm{m}$ & $\mathrm{m}$ & $m$ & $\mathbf{m}$ & $\mathrm{m}$ & $\mathrm{m}$ & $m$ & $\mathbf{m}$ & $\mathrm{m}$ & $\mathrm{m}$ & $m$ & $\mathbf{m}$ & $\mathbf{m}$ & $\mathbf{m}$ & $\mathbf{m}$ \\
\hline Argentina ${ }^{3}$ & $\mathbf{m}$ & $\mathrm{m}$ & $\mathrm{m}$ & $m$ & 34 & 28 & 41 & 17 & 7 & 7 & 7 & 17 & 41 & $\mathbf{a}$ & a & a \\
\hline Brasil & $\mathbf{m}$ & $\mathrm{m}$ & $\mathrm{m}$ & $m$ & 63 & 51 & 75 & 20 & 12 & 10 & 14 & 25 & 64 & 12 & $\mathbf{a}$ & $\mathbf{a}$ \\
\hline China & 76 & 76 & 77 & $m$ & 42 & 41 & 44 & $m$ & 60 & 60 & 59 & $m$ & 44 & $\mathbf{x}(\mathbf{1 3})$ & 33 & 25 \\
\hline Colombia & m & $\mathrm{m}$ & $\mathrm{m}$ & m & $\mathbf{m}$ & $\mathrm{m}$ & $\mathrm{m}$ & $m$ & $\mathbf{m}$ & $\mathrm{m}$ & $\mathrm{m}$ & $m$ & $\mathbf{m}$ & $\mathbf{m}$ & $\mathbf{m}$ & $\mathbf{m}$ \\
\hline Federación Rusa & $\mathbf{m}$ & $\mathrm{m}$ & $\mathrm{m}$ & $m$ & 43 & $\mathrm{x}(5)$ & $\mathrm{x}(5)$ & $m$ & 45 & $\mathrm{x}(9)$ & $x(9)$ & $m$ & 43 & 18 & 22 & 5 \\
\hline India & $\mathbf{m}$ & $\mathrm{m}$ & $\mathrm{m}$ & $m$ & $\mathbf{m}$ & $\mathrm{m}$ & $\mathrm{m}$ & $m$ & $\mathbf{m}$ & $\mathrm{m}$ & $\mathrm{m}$ & $m$ & $\mathbf{m}$ & $\mathbf{m}$ & $\mathbf{m}$ & $\mathbf{m}$ \\
\hline Indonesia $^{3}$ & $\mathbf{m}$ & $\mathrm{m}$ & $\mathrm{m}$ & $m$ & 36 & 32 & 41 & 18 & 25 & 29 & 22 & 18 & 36 & 25 & $\mathbf{a}$ & $\mathbf{a}$ \\
\hline Letonia & 90 & 87 & 93 & 20 & 63 & 55 & 70 & 19 & 28 & 33 & 23 & 20 & 86 & $\mathbf{a}$ & 4 & a \\
\hline Sudáfrica & $\mathbf{m}$ & $\mathrm{m}$ & $\mathrm{m}$ & $m$ & $\mathbf{m}$ & $\mathrm{m}$ & $\mathrm{m}$ & $m$ & $\mathbf{m}$ & $\mathrm{m}$ & $\mathrm{m}$ & $m$ & $\mathbf{m}$ & $\mathbf{m}$ & $\mathbf{m}$ & $\mathbf{m}$ \\
\hline Media G20 & 77 & 76 & 78 & $m$ & 52 & 48 & 58 & $m$ & 34 & 34 & 31 & $m$ & 54 & 9 & 16 & 9 \\
\hline
\end{tabular}

Notas: Las columnas que muestran las tasas de graduación para hombres y mujeres y la media de edad en el nivel de secundaria superior por orientación del programa (es decir, columnas 14-16, 18-20, 22-24, 26-28) están disponibles en Internet (véase StatLink más abajo).

Para más información sobre el método empleado para calcular las tasas de graduación (tasas brutas frente a tasas netas) y las edades típicas correspondientes, consulte Anexo 1.

La falta de equivalencia entre la cobertura de los datos de población y los de graduados significa que las tasas de graduación de los países que son exportadores netos de estudiantes pueden ser subestimadas (Luxemburgo, por ejemplo) y las de los importadores netos pueden ser sobreestimadas.

1. CINE 3A (de preparación para el acceso directo a educación terciaria de tipo A).

CINE 3B (de preparación para el acceso directo a educación terciaria de tipo B).

CINE 3C (largo) de duración similar a la de los programas típicos 3A o 3B.

CINE 3C (corto) de duración más breve que los programas típicos 3A o 3B.

2. La media de edad se refiere en términos generales a la edad de los estudiantes al inicio del año natural; los estudiantes pueden ser un año mayores de la edad indicada cuando se gradúan al final del año escolar. Se refiere a una edad de media ponderada. Para saber cómo se calcula, consulte Anexo 3.

3. Año de referencia 2011.

4. Las cifras solo se refieren a la educación secundaria inferior. Para más explicaciones, consulte Anexo 3.

Fuente: OCDE. Arabia Saudí, Argentina, China, Colombia, India, Indonesia, Sudáfrica: Instituto de Estadística de la UNESCO. Letonia: Eurostat. Para ver notas, consulte Anexo 3 (www.oecd.org/edu/eag.htm)

Para obtener más información acerca de los símbolos utilizados en lugar de los datos que faltan, consulte la Guía del lector.

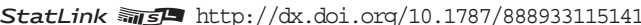


Tabla A2.1b. Tasas de graduación en educación secundaria superior: menores de 25 años (2012) Suma de las tasas de graduación por año de edad, por destino y orientación del programa y por sexo

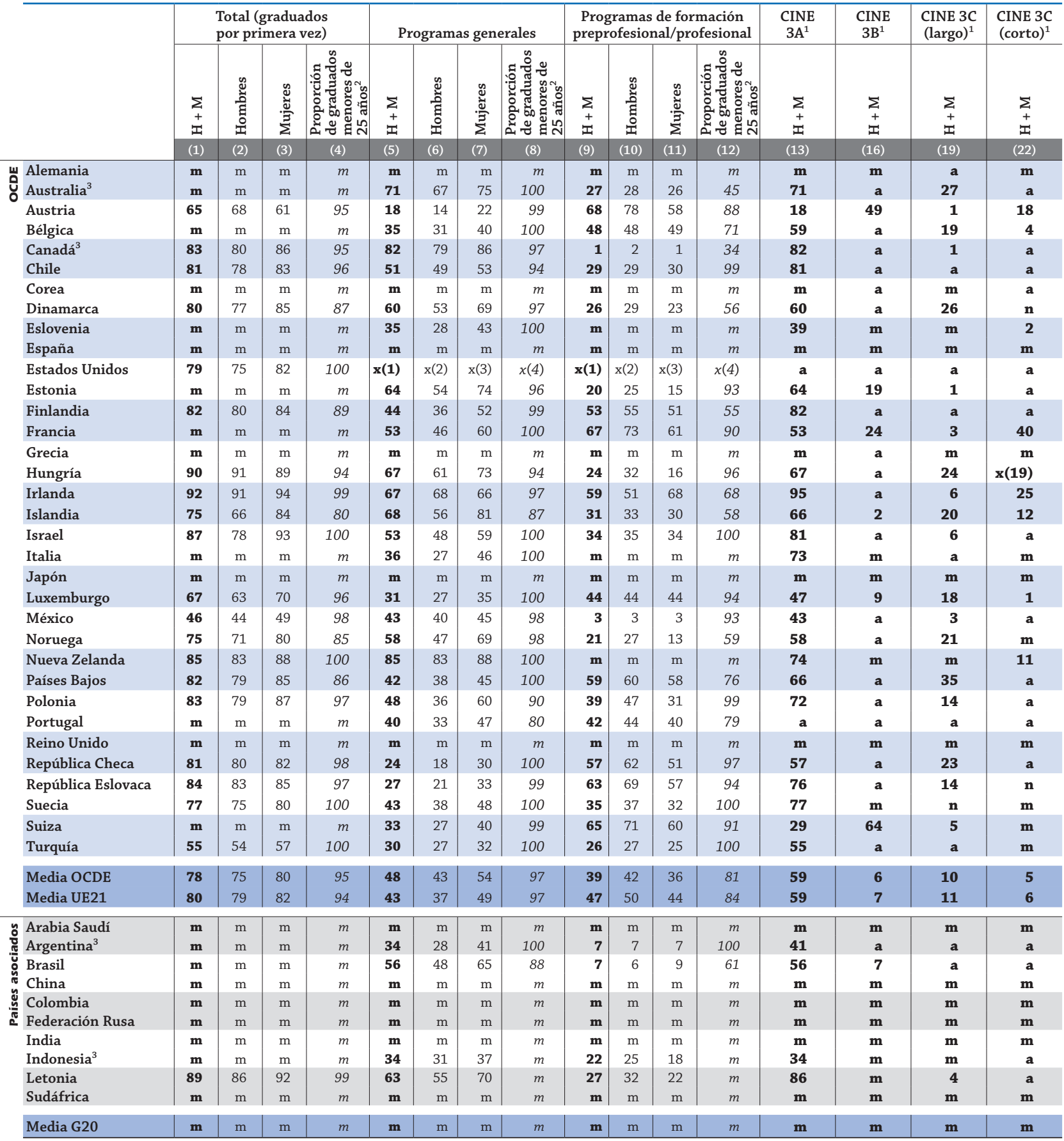

Notas: Las columnas que muestran las tasas de graduación para hombres y mujeres en el nivel de secundaria superior por orientación del programa (es decir, columnas 14-15, 17-18, 20-21, 23-24) están disponibles en Internet (véase StatLink más abajo).

Para más información sobre el método empleado para calcular las tasas de graduación (tasas brutas frente a tasas netas) y las edades típicas correspondientes, consulte Anexo 1.

La falta de equivalencia entre la cobertura de los datos de población y los de graduados significa que las tasas de graduación de los países que son exportadores netos de estudiantes pueden ser subestimadas (Luxemburgo, por ejemplo) y las de los importadores netos pueden ser sobreestimadas.

1. CINE $3 \mathrm{~A}$ (de preparación para el acceso directo a educación terciaria de tipo A).

CINE 3B (de preparación para el acceso directo a educación terciaria de tipo B).

CINE 3C (largo) de duración similar a la de los programas típicos 3A o 3B.

CINE 3C (corto) de duración más breve que los programas típicos 3A o 3B.

2. Proporción de graduados menores de 25 años en la totalidad de la población de graduados.

3. Año de referencia 2011.

Fuentes: OCDE. Arabia Saudí, Argentina, China, Colombia, India, Indonesia, Sudáfrica: Instituto de Estadística de la UNESCO. Letonia: Eurostat. Para ver notas, consulte Anexo 3 (www.oecd.org/edu/eag.htm).

Para obtener más información acerca de los símbolos utilizados en lugar de los datos que faltan, consulte la Guía del lector.

StatLink 部 St http://dx.doi.org/10.1787/888933115160 
Tabla A2.2a. Tendencias de las tasas de graduación por primera vez en el nivel de secundaria superior (1995-2012)

\begin{tabular}{|c|c|c|c|c|c|c|c|c|c|c|c|c|c|c|c|}
\hline & 1995 & 2000 & 2001 & 2002 & 2003 & 2004 & 2005 & 2006 & 2007 & 2008 & 2009 & 2010 & 2011 & 2012 & $\begin{array}{c}\text { Tasa media de } \\
\text { crecimiento anual }^{1} \\
1995-2012 \\
\end{array}$ \\
\hline Alemania $^{3}$ & 100 & 92 & 92 & 94 & 97 & 99 & 99 & 100 & 100 & 97 & 84 & 87 & 92 & 95 & $\mathrm{~m}$ \\
\hline Australia & $\mathrm{m}$ & $\mathrm{m}$ & $\mathrm{m}$ & $\mathrm{m}$ & $\mathrm{m}$ & $\mathrm{m}$ & $\mathrm{m}$ & $\mathrm{m}$ & $\mathrm{m}$ & $\mathrm{m}$ & $\mathrm{m}$ & $\mathrm{m}$ & $\mathrm{m}$ & m & $\mathrm{m}$ \\
\hline Austria $^{2}$ & $\mathrm{~m}$ & $\mathrm{~m}$ & $\mathrm{~m}$ & $\mathrm{~m}$ & $\mathrm{~m}$ & $\mathrm{~m}$ & $\mathrm{~m}$ & $\mathrm{~m}$ & $\mathrm{~m}$ & $\mathrm{~m}$ & $\mathrm{~m}$ & $\mathrm{~m}$ & 66 & 68 & $\mathrm{~m}$ \\
\hline Bélgica & $\mathrm{m}$ & $\mathrm{m}$ & $\mathrm{m}$ & $\mathrm{m}$ & $\mathrm{m}$ & $\mathrm{m}$ & $\mathrm{m}$ & $\mathrm{m}$ & $\mathrm{m}$ & $\mathrm{m}$ & $\mathrm{m}$ & $\mathrm{m}$ & $\mathrm{m}$ & $\mathbf{m}$ & $\mathrm{m}$ \\
\hline Canadá & $\mathrm{m}$ & $\mathrm{m}$ & 77 & 79 & 83 & 79 & 80 & 81 & 77 & 81 & 81 & 85 & 88 & m & $\mathrm{m}$ \\
\hline Chile & $\mathrm{m}$ & $\mathrm{m}$ & $\mathrm{m}$ & $\mathrm{m}$ & $\mathrm{m}$ & 79 & 85 & 82 & 82 & 83 & 85 & 83 & 83 & 84 & $\mathrm{~m}$ \\
\hline Corea & 88 & 96 & 100 & 99 & 92 & 94 & 94 & 93 & 91 & 93 & 89 & 94 & 93 & 92 & $0,3 \%$ \\
\hline Dinamarca & 83 & 95 & 95 & 94 & 88 & 88 & 82 & 84 & 85 & 83 & 85 & 86 & 90 & 92 & $0,7 \%$ \\
\hline Eslovenia & $\mathrm{m}$ & $\mathrm{m}$ & $\mathrm{m}$ & $\mathrm{m}$ & $\mathrm{m}$ & $\mathrm{m}$ & 85 & 97 & 91 & 85 & 96 & 94 & 99 & 96 & $\mathrm{~m}$ \\
\hline España & 62 & 60 & 66 & 66 & 67 & 66 & 72 & 72 & 74 & 73 & 74 & 80 & 88 & 93 & $2,4 \%$ \\
\hline Estados Unidos & 69 & 70 & 71 & 73 & 74 & 75 & 76 & 75 & 75 & 76 & 76 & 77 & 77 & 79 & $0,7 \%$ \\
\hline Estonia & $\mathrm{m}$ & $\mathrm{m}$ & $\mathrm{m}$ & $\mathrm{m}$ & $\mathrm{m}$ & $\mathrm{m}$ & $\mathrm{m}$ & $\mathrm{m}$ & $\mathrm{m}$ & $\mathrm{m}$ & $\mathrm{m}$ & $\mathrm{m}$ & $\mathrm{m}$ & m & $\mathrm{m}$ \\
\hline Finlandia & 91 & 91 & 85 & 84 & 90 & 95 & 94 & 94 & 97 & 93 & 95 & 93 & 96 & 93 & $0,1 \%$ \\
\hline Francia & $\mathrm{m}$ & $\mathrm{m}$ & $\mathrm{m}$ & $\mathrm{m}$ & $\mathrm{m}$ & $\mathrm{m}$ & $\mathrm{m}$ & $\mathrm{m}$ & $\mathrm{m}$ & $\mathrm{m}$ & $\mathrm{m}$ & $\mathrm{m}$ & $\mathrm{m}$ & $\mathbf{m}$ & $\mathrm{m}$ \\
\hline Grecia & 80 & 54 & 76 & 85 & 96 & 93 & 100 & 98 & 96 & 91 & $\mathrm{~m}$ & $\mathrm{~m}$ & $\mathrm{~m}$ & 71 & $-0,7 \%$ \\
\hline Hungría & $\mathrm{m}$ & $\mathrm{m}$ & 83 & 82 & 87 & 86 & 84 & 87 & 84 & 78 & 86 & 86 & 86 & 94 & $\mathrm{~m}$ \\
\hline Irlanda & $\mathrm{m}$ & 74 & 77 & 78 & 91 & 92 & 91 & 87 & 90 & 88 & 91 & 94 & 89 & 93 & $1,9 \%$ \\
\hline Islandia & 80 & 67 & 70 & 79 & 81 & 87 & 79 & 87 & 86 & 89 & 89 & 88 & 90 & 95 & $1,1 \%$ \\
\hline Israel & $\mathrm{m}$ & $\mathrm{m}$ & $\mathrm{m}$ & 90 & 89 & 93 & 90 & 90 & 92 & 90 & 89 & 92 & 85 & 87 & $\mathrm{~m}$ \\
\hline Italia & $\mathrm{m}$ & 78 & 81 & 78 & $\mathrm{~m}$ & 82 & 85 & 86 & 84 & 86 & 81 & 83 & 79 & 84 & $0,6 \%$ \\
\hline Japón & 96 & 95 & 93 & 94 & 95 & 96 & 95 & 96 & 96 & 95 & 95 & 96 & 96 & 93 & $-0,2 \%$ \\
\hline Luxemburgo & $\mathrm{m}$ & $\mathrm{m}$ & $\mathrm{m}$ & 69 & 71 & 69 & 75 & 71 & 75 & 73 & 69 & 70 & 70 & 69 & $\mathrm{~m}$ \\
\hline México & $\mathrm{m}$ & 33 & 34 & 35 & 37 & 39 & 40 & 42 & 43 & 44 & 45 & 47 & 49 & 47 & $3,1 \%$ \\
\hline Noruega & 77 & 99 & 105 & 97 & 92 & 100 & 89 & 88 & 92 & 91 & 91 & 87 & 90 & 88 & $0,8 \%$ \\
\hline Nueva Zelanda & $\mathrm{m}$ & $\mathrm{m}$ & $\mathrm{m}$ & $\mathrm{m}$ & $\mathrm{m}$ & $\mathrm{m}$ & $\mathrm{m}$ & $\mathrm{m}$ & $\mathrm{m}$ & $\mathrm{m}$ & $\mathrm{m}$ & $\mathrm{m}$ & $\mathrm{m}$ & $\mathbf{m}$ & $\mathrm{m}$ \\
\hline Países Bajos & $\mathrm{m}$ & $\mathrm{m}$ & $\mathrm{m}$ & $\mathrm{m}$ & $\mathrm{m}$ & $\mathrm{m}$ & $\mathrm{m}$ & $\mathrm{m}$ & $\mathrm{m}$ & $\mathrm{m}$ & $\mathrm{m}$ & $\mathrm{m}$ & 92 & 94 & $\mathrm{~m}$ \\
\hline Polonia & $\mathrm{m}$ & 90 & 93 & 91 & 86 & 79 & 85 & 81 & 84 & 83 & 85 & 84 & 84 & 85 & $-0,5 \%$ \\
\hline Portugal $^{4}$ & 52 & 52 & 48 & 50 & 60 & 53 & 51 & 54 & 65 & 63 & 96 & 104 & 89 & $\mathbf{m}$ & $\mathrm{m}$ \\
\hline Reino Unido & $\mathrm{m}$ & $\mathrm{m}$ & $\mathrm{m}$ & $\mathrm{m}$ & $\mathrm{m}$ & $\mathrm{m}$ & 86 & 88 & 89 & 91 & 92 & 93 & 93 & 93 & $\mathrm{~m}$ \\
\hline República Checa & 78 & $\mathrm{~m}$ & 84 & 83 & 88 & 87 & 89 & 89 & 88 & 85 & 83 & 80 & 78 & 82 & $0,3 \%$ \\
\hline República Eslovaca & 85 & 87 & 72 & 60 & 56 & 83 & 85 & 86 & 86 & 82 & 82 & 86 & 85 & 86 & $0,1 \%$ \\
\hline Suecia & $\mathrm{m}$ & 75 & 71 & 72 & 76 & 78 & 76 & 75 & 74 & 74 & 74 & 75 & 75 & 77 & $0,2 \%$ \\
\hline Suiza & 86 & 88 & 91 & 91 & 88 & 87 & 87 & 88 & 88 & 88 & 92 & 94 & $\mathrm{~m}$ & m & $\mathrm{m}$ \\
\hline Turquía & 37 & 37 & 37 & 37 & 41 & 55 & 48 & 52 & 58 & 26 & 45 & 54 & 56 & 55 & $2,4 \%$ \\
\hline
\end{tabular}

\begin{tabular}{l|c|c|c|c|c|c|c|c|c|c|c|c|c|c|c|} 
Media OCDE & 78 & 76 & 77 & 78 & 79 & 81 & 82 & 82 & 83 & 81 & 83 & 84 & 82 & $\mathbf{8 4}$ & $\mathrm{m}$ \\
$\begin{array}{l}\text { Media OCDE para } \\
\text { los países con datos } \\
\text { de 2000-2012 }\end{array}$ & & 76 & 76 & 75 & 76 & 80 & 79 & 79 & 81 & 79 & 81 & 83 & 83 & 84 & $0,8 \%$ \\
Media UE21 & 79 & 77 & 79 & 77 & 79 & 78 & 81 & 82 & 84 & 84 & 85 & 85 & 83 & $\mathbf{8 3}$ & $\mathrm{m}$ \\
\hline
\end{tabular}

\begin{tabular}{|c|c|c|c|c|c|c|c|c|c|c|c|c|c|c|c|}
\hline Arabia Saudí & $\mathrm{m}$ & $\mathrm{m}$ & $\mathrm{m}$ & $\mathrm{m}$ & $\mathrm{m}$ & $\mathrm{m}$ & $\mathrm{m}$ & $\mathrm{m}$ & $\mathrm{m}$ & $\mathrm{m}$ & $\mathrm{m}$ & $\mathrm{m}$ & $\mathrm{m}$ & m & $\mathrm{m}$ \\
\hline Argentina & $\mathrm{m}$ & $\mathrm{m}$ & $\mathrm{m}$ & $\mathrm{m}$ & $\mathrm{m}$ & $\mathrm{m}$ & $\mathrm{m}$ & $\mathrm{m}$ & $\mathrm{m}$ & $\mathrm{m}$ & $\mathrm{m}$ & $\mathrm{m}$ & $\mathrm{m}$ & $\mathbf{m}$ & $\mathrm{m}$ \\
\hline Brasil & $\mathrm{m}$ & $\mathrm{m}$ & $\mathrm{m}$ & $\mathrm{m}$ & $\mathrm{m}$ & $\mathrm{m}$ & $\mathrm{m}$ & $\mathrm{m}$ & $\mathrm{m}$ & $\mathrm{m}$ & $\mathrm{m}$ & $\mathrm{m}$ & $\mathrm{m}$ & $\mathbf{m}$ & $\mathrm{m}$ \\
\hline China & $\mathrm{m}$ & $\mathrm{m}$ & $\mathrm{m}$ & $\mathrm{m}$ & $\mathrm{m}$ & $\mathrm{m}$ & $\mathrm{m}$ & $\mathrm{m}$ & $\mathrm{m}$ & $\mathrm{m}$ & $\mathrm{m}$ & 69 & 73 & 76 & $\mathrm{~m}$ \\
\hline Colombia & $\mathrm{m}$ & $\mathrm{m}$ & $\mathrm{m}$ & $\mathrm{m}$ & $\mathrm{m}$ & $\mathrm{m}$ & $\mathrm{m}$ & $\mathrm{m}$ & $\mathrm{m}$ & $\mathrm{m}$ & $\mathrm{m}$ & $\mathrm{m}$ & $\mathrm{m}$ & m & $\mathrm{m}$ \\
\hline Federación Rusa & $\mathrm{m}$ & $\mathrm{m}$ & $\mathrm{m}$ & $\mathrm{m}$ & $\mathrm{m}$ & $\mathrm{m}$ & $\mathrm{m}$ & $\mathrm{m}$ & $\mathrm{m}$ & $\mathrm{m}$ & $\mathrm{m}$ & $\mathrm{m}$ & $\mathrm{m}$ & $\mathbf{m}$ & $\mathrm{m}$ \\
\hline India & $\mathrm{m}$ & $\mathrm{m}$ & $\mathrm{m}$ & $\mathrm{m}$ & $\mathrm{m}$ & $\mathrm{m}$ & $\mathrm{m}$ & $\mathrm{m}$ & $\mathrm{m}$ & $\mathrm{m}$ & $\mathrm{m}$ & $\mathrm{m}$ & $\mathrm{m}$ & $\mathbf{m}$ & $\mathrm{m}$ \\
\hline Indonesia & $\mathrm{m}$ & $\mathrm{m}$ & $\mathrm{m}$ & $\mathrm{m}$ & $\mathrm{m}$ & $\mathrm{m}$ & $\mathrm{m}$ & $\mathrm{m}$ & $\mathrm{m}$ & $\mathrm{m}$ & $\mathrm{m}$ & $\mathrm{m}$ & $\mathrm{m}$ & $\mathbf{m}$ & $\mathrm{m}$ \\
\hline Letonia & $\mathrm{m}$ & $\mathrm{m}$ & $\mathrm{m}$ & $\mathrm{m}$ & $\mathrm{m}$ & $\mathrm{m}$ & $\mathrm{m}$ & $\mathrm{m}$ & $\mathrm{m}$ & $\mathrm{m}$ & $\mathrm{m}$ & $\mathrm{m}$ & $\mathrm{m}$ & 90 & $\mathrm{~m}$ \\
\hline Sudáfrica & $\mathrm{m}$ & $\mathrm{m}$ & $\mathrm{m}$ & $\mathrm{m}$ & $\mathrm{m}$ & $\mathrm{m}$ & $\mathrm{m}$ & $\mathrm{m}$ & $\mathrm{m}$ & $\mathrm{m}$ & $\mathrm{m}$ & $\mathrm{m}$ & $\mathrm{m}$ & m & $\mathrm{m}$ \\
\hline Media G20 & $\mathrm{m}$ & $\mathrm{m}$ & $\mathrm{m}$ & $\mathrm{m}$ & $\mathrm{m}$ & $\mathrm{m}$ & $\mathrm{m}$ & $\mathrm{m}$ & $\mathrm{m}$ & $\mathrm{m}$ & $\mathrm{m}$ & 71 & 75 & 76 & $\mathrm{~m}$ \\
\hline
\end{tabular}

Notas: Hasta 2004, las tasas de graduación en el nivel de educación secundaria superior se calculaban sobre una base bruta. Desde 2005 y para todos los países con disponibilidad de datos, las tasas de graduación se calculan como tasas de graduación netas (es decir, como la suma de las tasas de graduación de una edad específica). Para más información sobre el método empleado para calcular las tasas de graduación (tasas brutas frente a tasas netas) y las edades típicas correspondientes, consulte Anexo 1.

1. Para los países sin datos para 1995, la tasa media de crecimiento anual de 2000-2012 se indica en cursiva.

2. Los programas que se extienden a lo largo de los niveles 3 y 4 de ISCED (Höhere berufsbildende Schule) no están incluidos.

3. Ruptura en las series entre 2008 y 2009 en Alemania debido a una reasignación parcial de los programas de formación profesional a CINE 2 y CINE 5B.

4. Año de referencia 1997 en lugar de 1995.

Fuentes: OCDE. Arabia Saudí, Argentina, China, Colombia, India, Indonesia, Sudáfrica: Instituto de Estadística de la UNESCO. Letonia: Eurostat. Para ver notas, consulte Anexo 3 (www.oecd.org/edu/eag.htm).

Para obtener más información acerca de los símbolos utilizados en lugar de los datos que faltan, consulte la Guía del lector.

StatLink 젶ㄴ http://dx.doi.org/10.1787/888933115179 
Tabla A2.3a. Distribución de graduados en educación secundaria superior de formación profesional, por ámbito de estudio y sexo (2012)

\begin{tabular}{|c|c|c|c|c|c|c|c|c|c|c|c|c|c|c|c|c|c|c|}
\hline & \multicolumn{9}{|c|}{ Hombres } & \multicolumn{9}{|c|}{ Mujeres } \\
\hline & 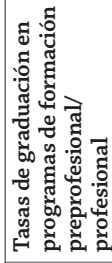 & 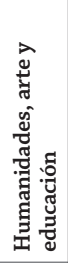 & 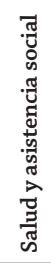 & 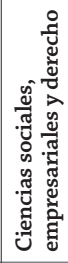 & 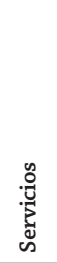 & 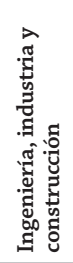 & 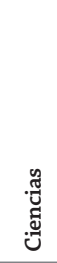 & 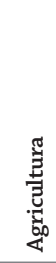 & 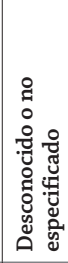 & 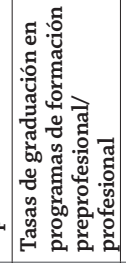 & 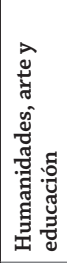 & 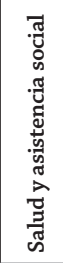 & 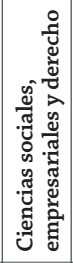 & 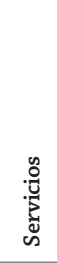 & 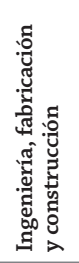 & 莺 & 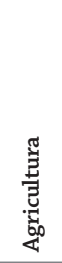 & 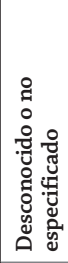 \\
\hline & (1) & (2) & (5) & (6) & $(7)$ & (8) & (9) & $(14)$ & (15) & (16) & (17) & $(20)$ & (21) & (22) & (23) & (24) & (29) & $(30)$ \\
\hline 山lemania & 51 & 2 & 3 & 27 & 9 & 53 & 4 & 3 & $\mathrm{n}$ & 40 & 3 & 16 & 54 & 17 & 7 & 1 & 1 & $\mathrm{n}$ \\
\hline Australia $^{1}$ & 58 & 2 & 5 & 13 & 12 & 59 & 2 & 6 & 1 & 61 & 6 & 37 & 30 & 16 & 5 & 1 & 2 & 4 \\
\hline Austria $^{2}$ & 87 & 1 & 1 & 11 & 8 & 46 & 2 & 8 & 23 & 65 & 2 & 9 & 35 & 21 & 7 & $\mathrm{n}$ & 8 & 19 \\
\hline Bélgica & 61 & 15 & 6 & 11 & 7 & 32 & 3 & 2 & 23 & 72 & 23 & 23 & 12 & 13 & 2 & $\mathrm{n}$ & 1 & 26 \\
\hline Canadá $^{1}$ & 4 & $\mathrm{~m}$ & $\mathrm{~m}$ & $\mathrm{~m}$ & $\mathrm{~m}$ & $\mathrm{~m}$ & $\mathrm{~m}$ & $\mathrm{~m}$ & $\mathrm{~m}$ & 3 & $\mathrm{~m}$ & $\mathrm{~m}$ & $\mathrm{~m}$ & $\mathrm{~m}$ & $\mathrm{~m}$ & $\mathrm{~m}$ & $\mathrm{~m}$ & $\mathrm{~m}$ \\
\hline Chile & 30 & 1 & 2 & 24 & 7 & 59 & $\mathrm{n}$ & 6 & $\mathrm{n}$ & 30 & 13 & 8 & 48 & 16 & 12 & $\mathrm{n}$ & 4 & $\mathrm{n}$ \\
\hline Corea & 22 & 18 & $\mathrm{n}$ & 7 & 4 & 58 & 11 & 2 & $\mathrm{n}$ & 20 & 34 & 1 & 26 & 5 & 20 & 12 & 1 & $\mathrm{n}$ \\
\hline Dinamarca & 44 & 3 & 7 & 17 & 15 & 49 & $\mathrm{n}$ & 8 & $\mathrm{n}$ & 49 & 1 & 50 & 31 & 10 & 5 & $\mathrm{n}$ & 4 & $\mathrm{n}$ \\
\hline Eslovenia & 79 & 3 & 5 & 13 & 13 & 54 & 7 & 5 & $\mathrm{n}$ & 67 & 14 & 21 & 33 & 21 & 6 & $\mathrm{n}$ & 5 & $\mathrm{n}$ \\
\hline España & 49 & 17 & 5 & 10 & 10 & 42 & 9 & 4 & 3 & 50 & 29 & 24 & 25 & 15 & 3 & 2 & 1 & 1 \\
\hline Estados Unidos & $m$ & $\mathrm{~m}$ & $\mathrm{~m}$ & $\mathrm{~m}$ & $\mathrm{~m}$ & $\mathrm{~m}$ & $\mathrm{~m}$ & $\mathrm{~m}$ & $\mathrm{~m}$ & $m$ & $\mathrm{~m}$ & $\mathrm{~m}$ & $\mathrm{~m}$ & $\mathrm{~m}$ & $\mathrm{~m}$ & $\mathrm{~m}$ & $\mathrm{~m}$ & $\mathrm{~m}$ \\
\hline Estonia & 27 & 1 & $\mathrm{n}$ & $\mathrm{n}$ & 15 & 68 & 9 & 7 & $\mathrm{n}$ & 17 & 6 & 4 & 8 & 52 & 19 & 5 & 6 & $\mathrm{n}$ \\
\hline Finlandia & 89 & 4 & 5 & 10 & 16 & 55 & 4 & 5 & $\mathrm{n}$ & 106 & 7 & 31 & 20 & 26 & 10 & 1 & 6 & $\mathrm{n}$ \\
\hline Francia & 77 & 2 & 3 & 14 & 12 & 62 & $\mathrm{n}$ & 7 & $\mathrm{n}$ & 72 & 2 & 29 & 32 & 26 & 7 & $\mathrm{n}$ & 3 & $\mathrm{n}$ \\
\hline Grecia & $m$ & $\mathrm{~m}$ & $\mathrm{~m}$ & $\mathrm{~m}$ & $\mathrm{~m}$ & $\mathrm{~m}$ & $\mathrm{~m}$ & $\mathrm{~m}$ & $\mathrm{~m}$ & $m$ & $\mathrm{~m}$ & $\mathrm{~m}$ & $\mathrm{~m}$ & $\mathrm{~m}$ & $\mathrm{~m}$ & $\mathrm{~m}$ & $\mathrm{~m}$ & $\mathrm{~m}$ \\
\hline Hungría & 32 & 1 & $\mathrm{n}$ & 4 & 21 & 73 & $\mathrm{n}$ & 2 & $\mathrm{n}$ & 18 & 3 & 8 & 23 & 52 & 11 & $\mathrm{n}$ & 3 & $\mathrm{n}$ \\
\hline Irlanda & 61 & $\mathrm{~m}$ & $\mathrm{~m}$ & $\mathrm{~m}$ & $\mathrm{~m}$ & $\mathrm{~m}$ & $\mathrm{~m}$ & $\mathrm{~m}$ & $\mathrm{~m}$ & 99 & $\mathrm{~m}$ & $\mathrm{~m}$ & $\mathrm{~m}$ & $\mathrm{~m}$ & $\mathrm{~m}$ & $\mathrm{~m}$ & $\mathrm{~m}$ & $\mathrm{~m}$ \\
\hline Islandia & 55 & 14 & 1 & 11 & 16 & 54 & 2 & 2 & $\mathrm{n}$ & 56 & 24 & 21 & 21 & 26 & 6 & $\mathrm{n}$ & $\mathrm{n}$ & 2 \\
\hline Israel & 35 & $\mathrm{~m}$ & $\mathrm{~m}$ & $\mathrm{~m}$ & $\mathrm{~m}$ & $\mathrm{~m}$ & $\mathrm{~m}$ & $\mathrm{~m}$ & $\mathrm{~m}$ & 34 & $\mathrm{~m}$ & $\mathrm{~m}$ & $\mathrm{~m}$ & $\mathrm{~m}$ & $\mathrm{~m}$ & $\mathrm{~m}$ & $\mathrm{~m}$ & $\mathrm{~m}$ \\
\hline Italia & 72 & $\mathrm{~m}$ & $\mathrm{~m}$ & $\mathrm{~m}$ & $\mathrm{~m}$ & $\mathrm{~m}$ & $\mathrm{~m}$ & $\mathrm{~m}$ & $\mathrm{~m}$ & 56 & $\mathrm{~m}$ & $\mathrm{~m}$ & $\mathrm{~m}$ & $\mathrm{~m}$ & $\mathrm{~m}$ & $\mathrm{~m}$ & $\mathrm{~m}$ & $\mathrm{~m}$ \\
\hline Japón & 24 & $\mathrm{n}$ & 1 & 17 & 2 & 56 & $\mathrm{n}$ & 11 & 12 & 20 & $\mathrm{n}$ & 10 & 40 & 12 & 8 & $\mathrm{n}$ & 12 & 17 \\
\hline Luxemburgo & 46 & $\mathrm{~m}$ & $\mathrm{~m}$ & $\mathrm{~m}$ & $\mathrm{~m}$ & $\mathrm{~m}$ & $\mathrm{~m}$ & $\mathrm{~m}$ & $\mathrm{~m}$ & 47 & $\mathrm{~m}$ & $\mathrm{~m}$ & $\mathrm{~m}$ & $\mathrm{~m}$ & $\mathrm{~m}$ & $\mathrm{~m}$ & $\mathrm{~m}$ & $\mathrm{~m}$ \\
\hline México & 4 & $\mathrm{~m}$ & $\mathrm{~m}$ & $\mathrm{~m}$ & $\mathrm{~m}$ & $\mathrm{~m}$ & $\mathrm{~m}$ & $\mathrm{~m}$ & $\mathrm{~m}$ & 4 & $\mathrm{~m}$ & $\mathrm{~m}$ & $\mathrm{~m}$ & $\mathrm{~m}$ & $\mathrm{~m}$ & $\mathrm{~m}$ & $\mathrm{~m}$ & $\mathrm{~m}$ \\
\hline Noruega & 41 & 1 & 4 & 2 & 15 & 72 & 3 & 3 & $\mathrm{n}$ & 27 & 4 & 48 & 12 & 24 & 9 & $\mathrm{n}$ & 3 & $\mathrm{n}$ \\
\hline Nueva Zelanda & $m$ & $\mathrm{~m}$ & $\mathrm{~m}$ & $\mathrm{~m}$ & $\mathrm{~m}$ & $\mathrm{~m}$ & $\mathrm{~m}$ & $\mathrm{~m}$ & $\mathrm{~m}$ & $m$ & $\mathrm{~m}$ & $\mathrm{~m}$ & $\mathrm{~m}$ & $\mathrm{~m}$ & $\mathrm{~m}$ & $\mathrm{~m}$ & $\mathrm{~m}$ & $\mathrm{~m}$ \\
\hline Países Bajos & 79 & 4 & 8 & 18 & 25 & 34 & 7 & 4 & $\mathrm{n}$ & 76 & 7 & 45 & 23 & 19 & 3 & $\mathrm{n}$ & 3 & $\mathrm{n}$ \\
\hline Polonia & 47 & 1 & $\mathrm{n}$ & 8 & 13 & 62 & 13 & 4 & $\mathrm{n}$ & 31 & 3 & $\mathrm{n}$ & 31 & 47 & 13 & 2 & 3 & $\mathrm{n}$ \\
\hline Portugal & 50 & $\mathrm{~m}$ & $\mathrm{~m}$ & $\mathrm{~m}$ & $\mathrm{~m}$ & $\mathrm{~m}$ & $\mathrm{~m}$ & $\mathrm{~m}$ & $\mathrm{~m}$ & 50 & $\mathrm{~m}$ & $\mathrm{~m}$ & $\mathrm{~m}$ & $\mathrm{~m}$ & $\mathrm{~m}$ & $\mathrm{~m}$ & $\mathrm{~m}$ & $\mathrm{~m}$ \\
\hline Reino Unido & $m$ & $\mathrm{~m}$ & $\mathrm{~m}$ & $\mathrm{~m}$ & $\mathrm{~m}$ & $\mathrm{~m}$ & $\mathrm{~m}$ & $\mathrm{~m}$ & $\mathrm{~m}$ & $m$ & $\mathrm{~m}$ & $\mathrm{~m}$ & $\mathrm{~m}$ & $\mathrm{~m}$ & $\mathrm{~m}$ & $\mathrm{~m}$ & $\mathrm{~m}$ & $\mathrm{~m}$ \\
\hline República Checa & 63 & 3 & 1 & 10 & 12 & 70 & $\mathrm{n}$ & 3 & $\mathrm{n}$ & 53 & 8 & 13 & 33 & 30 & 9 & $\mathrm{n}$ & 5 & $\mathrm{n}$ \\
\hline República Eslovaca & 71 & 4 & 2 & 11 & 19 & 61 & $\mathrm{n}$ & 3 & $\mathrm{n}$ & 62 & 8 & 13 & 35 & 33 & 8 & $\mathrm{n}$ & 3 & $\mathrm{n}$ \\
\hline Suecia & 37 & 8 & 7 & 6 & 10 & 65 & $\mathrm{n}$ & 4 & $\mathrm{n}$ & 32 & 24 & 27 & 13 & 18 & 8 & $\mathrm{n}$ & 10 & $\mathrm{n}$ \\
\hline Suiza & 77 & 2 & 2 & 24 & 6 & 54 & 4 & 6 & 2 & 66 & 4 & 23 & 48 & 12 & 9 & $\mathrm{n}$ & 3 & 1 \\
\hline Turquía & 27 & 1 & 2 & 11 & 4 & 52 & 13 & $\mathrm{n}$ & 17 & 25 & 4 & 26 & 17 & 8 & 11 & 10 & $\mathrm{n}$ & 24 \\
\hline
\end{tabular}

Media OCDE

Media UE21

\begin{tabular}{l|l|l|l|l|l|l|l|l|l|l|l|l|l|l|l|l|l|}
50 & 4 & 3 & 11 & 10 & $\mathbf{4 8}$ & 4 & 4 & 17 & 47 & 9 & 19 & $\mathbf{2 4}$ & 19 & 7 & 2 & 3 & 17
\end{tabular}

\begin{tabular}{|c|c|c|c|c|c|c|c|c|c|c|c|c|c|c|c|c|c|c|}
\hline $\begin{array}{l}\text { Arabia Saudí } \\
\text { Argentina }{ }^{1}\end{array}$ & $\begin{array}{c}m \\
7\end{array}$ & $\begin{array}{l}\mathrm{m} \\
\mathrm{m}\end{array}$ & $\begin{array}{l}\mathrm{m} \\
\mathrm{m}\end{array}$ & $\begin{array}{l}\mathrm{m} \\
\mathrm{m}\end{array}$ & $\begin{array}{l}\mathrm{m} \\
\mathrm{m}\end{array}$ & $\begin{array}{l}\mathrm{m} \\
\mathrm{m}\end{array}$ & $\begin{array}{l}\mathrm{m} \\
\mathrm{m}\end{array}$ & $\begin{array}{l}\mathrm{m} \\
\mathrm{m}\end{array}$ & $\begin{array}{l}\mathrm{m} \\
\mathrm{m}\end{array}$ & $\begin{array}{r}m \\
7\end{array}$ & $\begin{array}{l}\mathrm{m} \\
\mathrm{m}\end{array}$ & $\begin{array}{l}\mathrm{m} \\
\mathrm{m}\end{array}$ & $\begin{array}{l}\mathrm{m} \\
\mathrm{m}\end{array}$ & $\begin{array}{l}\mathrm{m} \\
\mathrm{m}\end{array}$ & $\begin{array}{l}\mathrm{m} \\
\mathrm{m}\end{array}$ & $\begin{array}{l}\mathrm{m} \\
\mathrm{m}\end{array}$ & $\begin{array}{l}\mathrm{m} \\
\mathrm{m}\end{array}$ & $\begin{array}{l}\mathrm{m} \\
\mathrm{m}\end{array}$ \\
\hline Brasil & 10 & $\mathrm{~m}$ & $\mathrm{~m}$ & $\mathrm{~m}$ & $\mathrm{~m}$ & $\mathrm{~m}$ & $\mathrm{~m}$ & $\mathrm{~m}$ & $\mathrm{~m}$ & 14 & $\mathrm{~m}$ & $\mathrm{~m}$ & $\mathrm{~m}$ & $\mathrm{~m}$ & $\mathrm{~m}$ & $\mathrm{~m}$ & $\mathrm{~m}$ & $\mathrm{~m}$ \\
\hline 乡 China & 60 & $\mathrm{~m}$ & $\mathrm{~m}$ & $\mathrm{~m}$ & $\mathrm{~m}$ & $\mathrm{~m}$ & $\mathrm{~m}$ & $\mathrm{~m}$ & $\mathrm{~m}$ & 59 & $\mathrm{~m}$ & $\mathrm{~m}$ & $\mathrm{~m}$ & $\mathrm{~m}$ & $\mathrm{~m}$ & $\mathrm{~m}$ & $\mathrm{~m}$ & $\mathrm{~m}$ \\
\hline Colombia & $m$ & $\mathrm{~m}$ & $\mathrm{~m}$ & $\mathrm{~m}$ & $\mathrm{~m}$ & $\mathrm{~m}$ & $\mathrm{~m}$ & $\mathrm{~m}$ & $\mathrm{~m}$ & 60 & $\mathrm{~m}$ & $\mathrm{~m}$ & $\mathrm{~m}$ & $\mathrm{~m}$ & $\mathrm{~m}$ & $\mathrm{~m}$ & $\mathrm{~m}$ & $\mathrm{~m}$ \\
\hline Federación Rusa & $m$ & $\mathrm{~m}$ & $\mathrm{~m}$ & $\mathrm{~m}$ & $\mathrm{~m}$ & $\mathrm{~m}$ & $\mathrm{~m}$ & $\mathrm{~m}$ & $\mathrm{~m}$ & $m$ & $\mathrm{~m}$ & $\mathrm{~m}$ & $\mathrm{~m}$ & $\mathrm{~m}$ & $\mathrm{~m}$ & $\mathrm{~m}$ & $\mathrm{~m}$ & $\mathrm{~m}$ \\
\hline India & $m$ & $\mathrm{~m}$ & $\mathrm{~m}$ & $\mathrm{~m}$ & $\mathrm{~m}$ & $\mathrm{~m}$ & $\mathrm{~m}$ & $\mathrm{~m}$ & $\mathrm{~m}$ & $m$ & $\mathrm{~m}$ & $\mathrm{~m}$ & $\mathrm{~m}$ & $\mathrm{~m}$ & $\mathrm{~m}$ & $\mathrm{~m}$ & $\mathrm{~m}$ & $\mathrm{~m}$ \\
\hline Indonesia $^{1}$ & 29 & 2 & 2 & 49 & $\mathrm{n}$ & 39 & $\mathrm{n}$ & $\mathrm{n}$ & 8 & 22 & 2 & 6 & 49 & $\mathrm{n}$ & 29 & $\mathrm{n}$ & 4 & 10 \\
\hline Letonia & 33 & 4 & $\mathrm{n}$ & 6 & 12 & 67 & 10 & 2 & $\mathrm{n}$ & 23 & 15 & 3 & 34 & 34 & 9 & 2 & 2 & $\mathrm{n}$ \\
\hline Sudáfrica & $m$ & $\mathrm{~m}$ & $\mathrm{~m}$ & $\mathrm{~m}$ & $\mathrm{~m}$ & $\mathrm{~m}$ & $\mathrm{~m}$ & $\mathrm{~m}$ & $\mathrm{~m}$ & $m$ & $\mathrm{~m}$ & $\mathrm{~m}$ & $\mathrm{~m}$ & $\mathrm{~m}$ & $\mathrm{~m}$ & $\mathrm{~m}$ & $\mathrm{~m}$ & $\mathrm{~m}$ \\
\hline
\end{tabular}

\begin{tabular}{|l|l|l|l|l|l|l|l|l|l|l|l|l|l|l|l|l|l|l|} 
Media G20 & 33 & $\mathrm{~m}$ & $\mathrm{~m}$ & $\mathrm{~m}$ & $\mathrm{~m}$ & $\mathrm{~m}$ & $\mathrm{~m}$ & $\mathrm{~m}$ & $\mathrm{~m}$ & 30 & $\mathrm{~m}$ & $\mathrm{~m}$ & $\mathrm{~m}$ & $\mathrm{~m}$ & $\mathrm{~m}$ & $\mathrm{~m}$ & $\mathrm{~m}$ & $\mathrm{~m}$ \\
\hline
\end{tabular}

Notas: Las tasas de graduación en formación preprofesional y profesional aparecen en esta tabla (columnas 1 a 16) para poner de relieve la proporción de graduados en formación preprofesional y profesional en todos los graduados de secundaria superior de cada país. Las columnas que muestran el desglose de humanidades, letras y enseñanza $(3,4,18$ y 19) y de ciencias (10-13, 25-28) están disponibles en Internet (véase StatLink más abajo). Las cifras en negrita indican los ámbitos de estudio con mayor proporción de graduados en cada país.

1. Año de referencia 2011.

2. Los programas que se extienden a lo largo de los niveles 3 y 4 de ISCED (Höhere berufsbildende Schule) no están incluidos.

Fuentes: OCDE. Arabia Saudí, Argentina, China, Colombia, India, Indonesia, Sudáfrica: Instituto de Estadística de la UNESCO. Letonia: Eurostat. Para ver notas, consulte Anexo 3 (www.oecd.org/edu/eag.htm).

Para obtener más información acerca de los símbolos utilizados en lugar de los datos que faltan, consulte la Guía del lector.

StatLink 젠ㅁ http://dx.doi.org/10.1787/888933115198 
Tabla A2.4. [1/2] Finalización con éxito de programas de educación secundaria superior, por sexo y orientación del programa

Ratio de graduados con relación a los nuevos ingresados, basada en cohortes

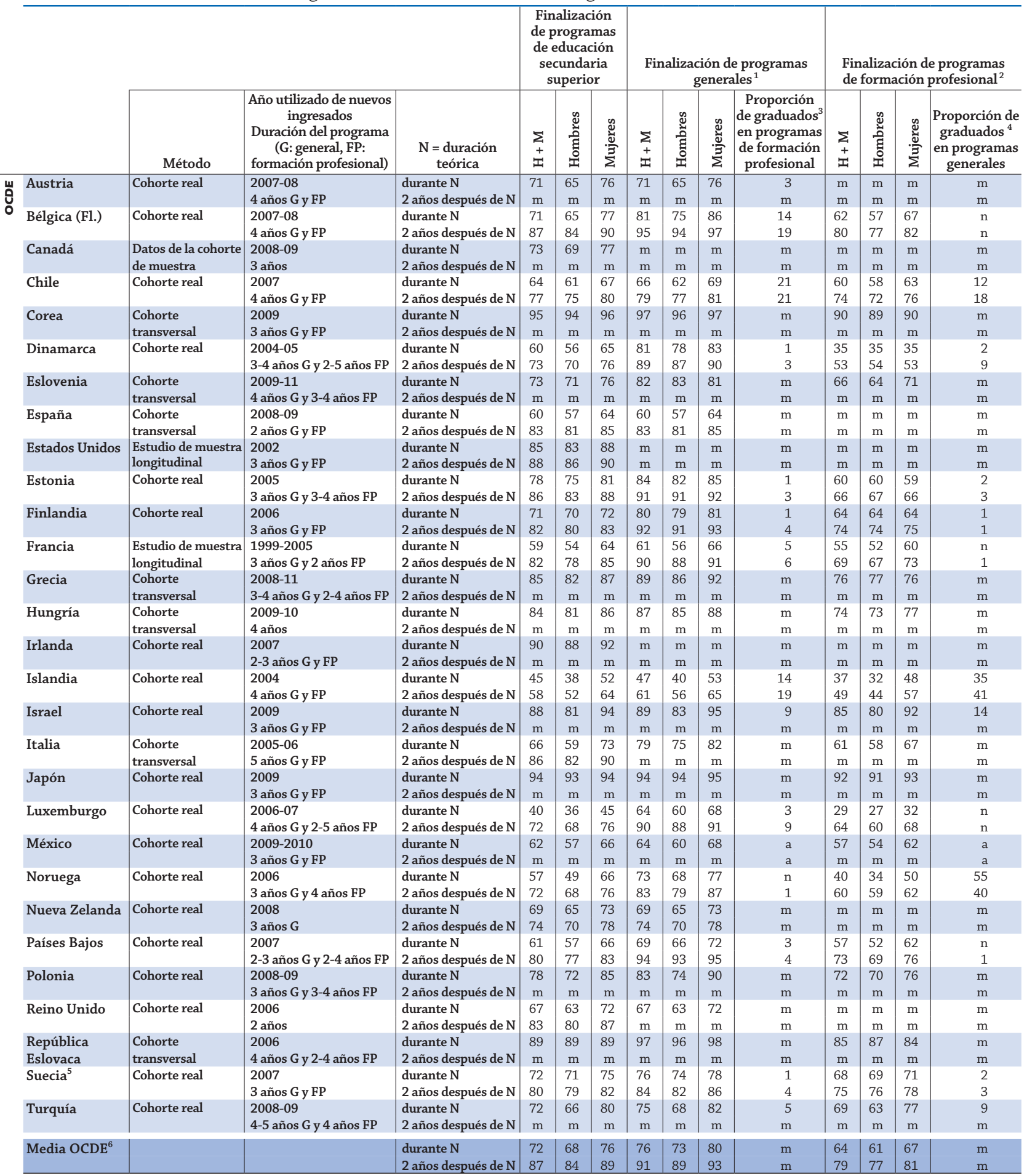

Nota: Los datos presentados en esta tabla provienen de una encuesta especial en la que 29 países participaron y solo tratan de programas de educación inicial. Para más información sobre este indicador, como los métodos empleados, los programas incluidos o excluidos, el año de acceso, etc., consulte Anexo 3.

1. Ingresados en programas generales CINE 3 que se graduaron en un programa general o de formación profesional.

2. Ingresados en programas de formación profesional CINE 3 que se graduaron en un programa general o de formación profesional.

3. Ingresados en programas generales CINE 3 que se graduaron en un programa de formación profesional.

4. Ingresados en programas de formación profesional CINE 3 que se graduaron en un programa general.

5. Excluyendo a los estudiantes que han continuado sus estudios en el sistema de educación para adultos.

6. La media OCDE para N+2 corresponde a la media OCDE para N+la diferencia (en puntos porcentuales) de la media de países con datos $\mathrm{N}$ y $\mathrm{N}+2$.

Fuente: OCDE. Para ver notas, consulte Anexo 3 (www.oecd.org/edu/eag.htm).

Para obtener más información acerca de los símbolos utilizados en lugar de los datos que faltan, consulte la Guía del lector.

StatLink 제이 http://dx.doi.org/10.1787/888933115217 
Tabla A2.4. [2/2] Finalización con éxito de programas de educación secundaria superior, por sexo y orientación del programa

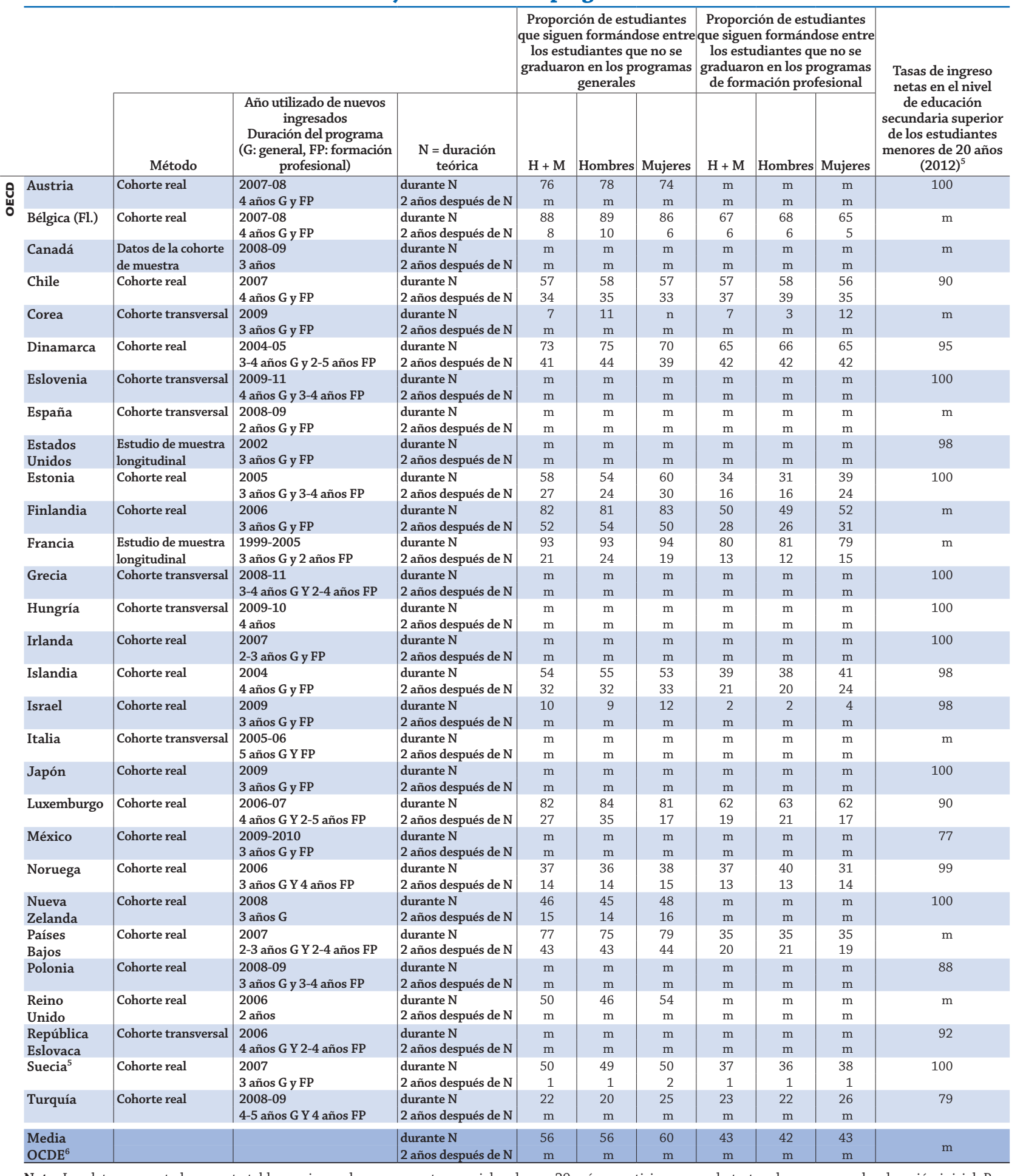

Nota: Los datos presentados en esta tabla provienen de una encuesta especial en la que 29 países participaron y solo tratan de programas de educación inicial. Para más información sobre este indicador, como los métodos empleados, los programas incluidos o excluidos, el año de acceso, etc., consulte Anexo 3.

1. Ingresados en programas generales CINE 3 que se graduaron en un programa general o de formación profesional.

2. Ingresados en programas de formación profesional CINE 3 que se graduaron en un programa general o de formación profesional.

3. Ingresados en programas generales CINE 3 que se graduaron en un programa de formación profesional.

4. Ingresados en programas de formación profesional CINE 3 que se graduaron en un programa general.

5. Excluyendo a los estudiantes que han continuado sus estudios en el sistema de educación para adultos.

6. La media OCDE para N+2 corresponde a la media OCDE para $\mathrm{N}+$ la diferencia (en puntos porcentuales) de la media de países con datos $\mathrm{N}$ y $\mathrm{N}+2$.

Fuente: OCDE. Para ver notas, consulte Anexo 3 (www.oecd.org/edu/eag.htm).

Para obtener más información acerca de los símbolos utilizados en lugar de los datos que faltan, consulte la Guía del lector.

StatLink 젶ㄴ http://dx.doi.org/10.1787/888933115217 
Tabla A2.5. Finalización con éxito de programas de educación secundaria superior, por orientación y duración del programa

Ratio de graduados con relación a los nuevos ingresados, basada en cohortes

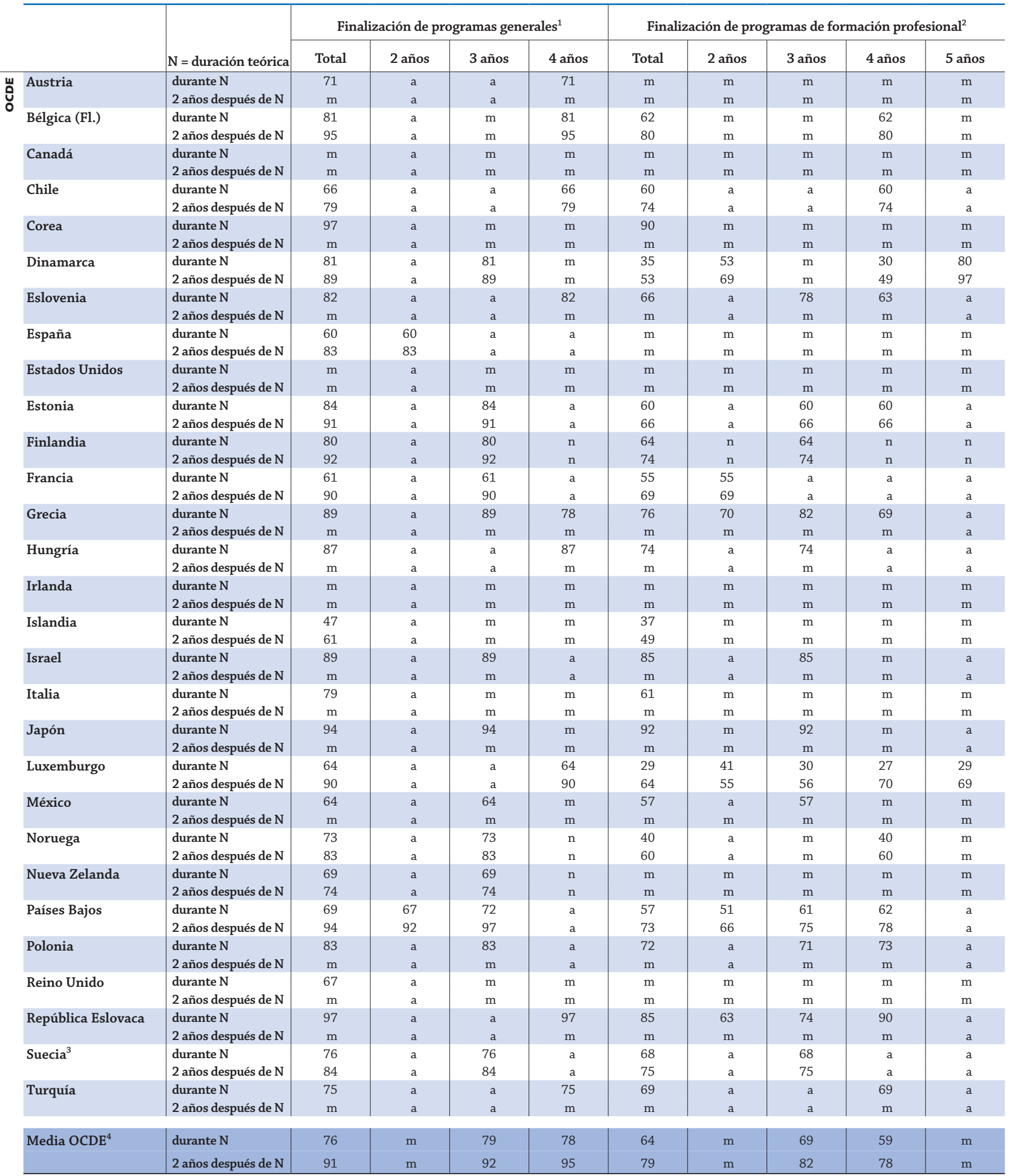

Nota: Para más información sobre este indicador, como los métodos empleados, los programas incluidos o excluidos, el año de acceso, etc., consulte Anexo 3.

1. Ingresados en programas generales CINE 3 que se graduaron en un programa general o de formación profesional.

2. Ingresados en programas de formación profesional CINE 3 que se graduaron en un programa general o de formación profesional.

3. Excluyendo a los estudiantes que han continuado sus estudios en el sistema de educación para adultos.

4. La media OCDE para N+2 corresponde a la media OCDE para N+la diferencia (en puntos porcentuales) de la media de países con datos $\mathrm{N}$ y N+2.

Fuente: OCDE. Para ver notas, consulte Anexo 3 (www.oecd.org/edu/eag.htm).

Para obtener más información acerca de los símbolos utilizados en lugar de los datos que faltan, consulte la Guía del lector.

StatLink 제프 http://dx.doi.org/10.1787/888933115236 



\section{¿CUÁNTOS ESTUDIANTES SE ESPERA QUE COMPLETEN LA EDUCACIÓN TERCIARIA?}

- Según los modelos actuales de graduación, se espera que una media del 39\% de los adultos jóvenes de hoy de los países de la OCDE completen estudios de educación terciaria de tipo A (nivel universitario) a lo largo de su vida.

- Se espera que en torno a una media del $11 \%$ de los adultos jóvenes de hoy de los países de la OCDE completen estudios de educación terciaria de tipo B (formación profesional) a lo largo de su vida.

- Como media, los estudiantes de los países de la OCDE obtienen su primera graduación universitaria con 27 años, y las edades van desde menos de 25 en Bélgica, Indonesia, Luxemburgo, México, Países Bajos y Reino Unido, hasta los 29 o más en Brasil, Finlandia, Islandia, Israel y Suecia.

\section{Gráfico A3.1. Media de edad ${ }^{1}$ de graduados en el nivel CINE 5A y distribución por edad (2012)}

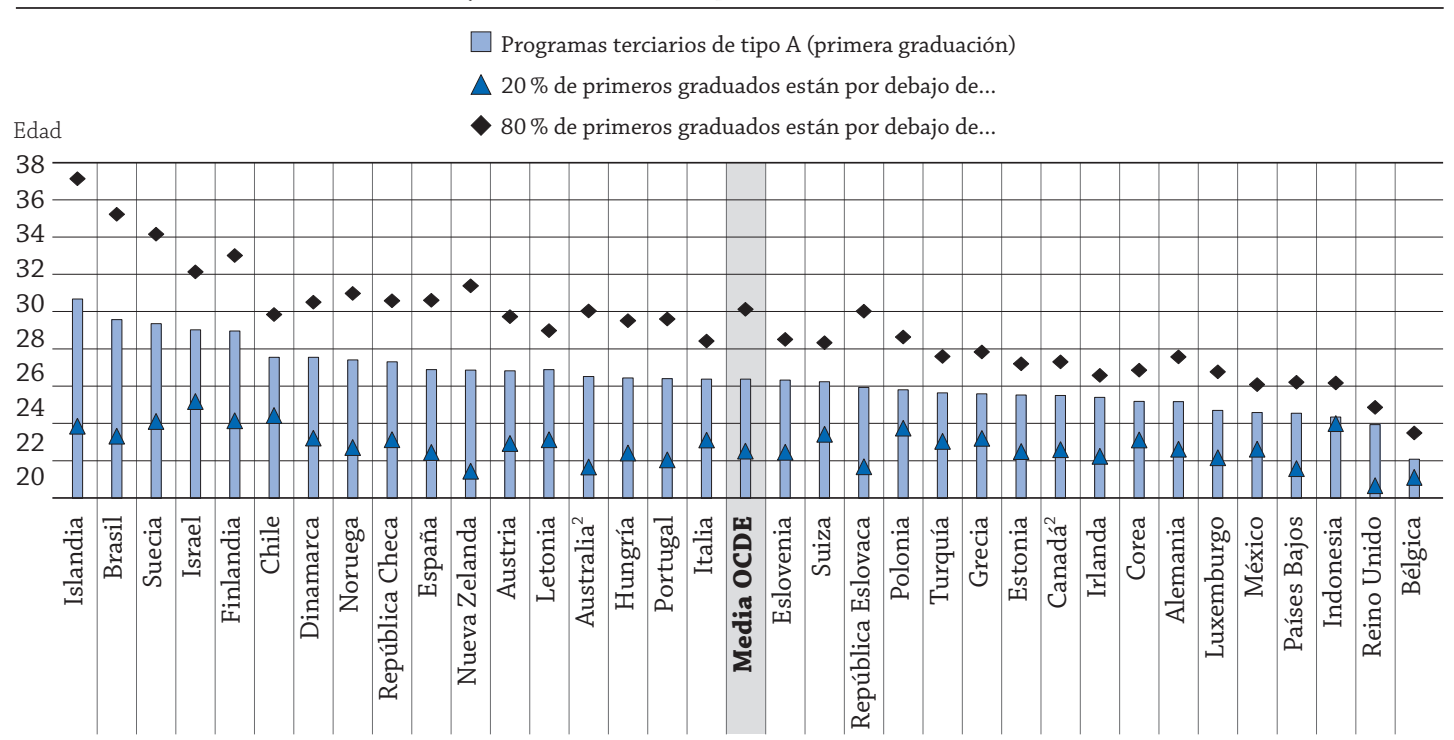

1. La media de edad se refiere a una media de edad ponderada, generalmente la edad de los estudiantes al inicio del año natural. Los estudiantes pueden tener un año más de la edad indicada cuando se gradúan al final del curso escolar. Para saber cómo se calcula la media de edad, consulte Anexo 3.

2. Año de referencia 2011.

Los países están clasificados en orden descendente de la media de edad de graduación en educación terciaria de tipo A en 2012.

Fuente: OCDE. Tabla A3.1a. Para ver notas, consulte Anexo 3 (www.oecd.org/edu/eag.htm).

StatLink त्ञाI

\section{Contexto}

Las tasas de graduación en educación terciaria ilustran la capacidad que tiene un país para dotar de conocimientos y cualificaciones especializados a sus futuros trabajadores. En los países de la OCDE, los individuos tienen fuertes incentivos para obtener una cualificación terciaria: desde salarios más elevados a mejores perspectivas de empleo (véanse Indicadores A5 y A6 para seguir leyendo sobre estos temas). La educación terciaria varía en gran medida en cuanto a estructura y alcance entre los países, y parece que las tasas de graduación se ven influidas por la facilidad de acceso y la flexibilidad para terminar estos programas, así como por la demanda de mayores cualificaciones en el mercado laboral. La ampliación del acceso y la vinculación de la enseñanza terciaria a las demandas del mercado laboral son fundamentales en economías basadas en el conocimiento; sin embargo, estos objetivos son difíciles de alcanzar cuando los presupuestos son ajustados.

En las últimas décadas, el acceso a la enseñanza terciaria se ha ampliado notablemente, implicando a nuevos tipos de instituciones que ofrecen una oferta más amplia y nuevas modalidades de prestación (OECD, 2008). En paralelo, la población estudiante se está haciendo cada vez más heterogénea, dado 
que grupos que tradicionalmente estaban excluidos participan ahora de la educación terciaria; tal es el caso de personas de más edad que buscan mejorar sus cualificaciones para tener éxito en un mercado

\section{Otros resultados}

- La mayoría de los graduados en programas de educación terciaria son mujeres, excepto en el nivel de doctorado. Según los modelos actuales de graduación, se estima que una media del $15 \%$ más de mujeres que de hombres en los países de la OCDE terminarán los estudios terciarios de tipo A a lo largo de su vida, el $47 \%$ frente al $31 \%$.

- En los países de la OCDE, se espera que una media del 1,6\% de los jóvenes termine programas de investigación avanzada.

- Los estudiantes internacionales representan un porcentaje significativo de los graduados de educación terciaria en varios países, como Australia (18\%) y Nueva Zelanda (11\%).

\section{Tendencias}

En los últimos 17 años, las tasas de graduación en educación terciaria de tipo A se han incrementado en 20 puntos porcentuales en los países de la OCDE con datos disponibles, mientras que las tasas de graduación en educación terciaria de tipo B han permanecido estables. Aunque los doctorados solo representan una proporción muy pequeña de los programas de educación terciaria, la tasa de graduación en estos programas se ha duplicado en el mismo periodo, del 0,8\% al 1,6\%.

\section{Notas}

Las tasas de graduación representan el porcentaje estimado de una cohorte de edad que se espera que se gradúe a lo largo de su vida. Este cálculo se basa en el número de graduados en 2012 y en la distribución por edades de este grupo. En consecuencia, las tasas de graduación se basan en el modelo actual de graduación y por ello son sensibles a cualquier cambio en los sistemas educativos, como la introducción de nuevos programas, o cualquier variación en la duración de estos, como las que han tenido lugar recientemente en muchos países de la UE con la aplicación del Proceso de Bolonia.

En este indicador, 30 años se considera la edad típica más alta de graduación para graduados por primera vez, tanto en programas terciarios de tipo A como de tipo B. El límite superior de la edad típica de un graduado en un programa de investigación avanzada es de 35 años.

Muchos países establecen una clara diferencia entre graduaciones universitarias de primer y de segundo grado (es decir, programas de grado y de postgrado). Sin embargo, en algunos países, los grados que se pueden comparar con un máster a nivel internacional se obtienen mediante un único programa de larga duración. Para que las comparaciones sean precisas, los datos que se presentan en este indicador se refieren a quienes se gradúan por primera vez, a menos que se indique otra cosa. 


\section{Análisis}

Según los modelos de graduación actuales, una media del 38\% de los jóvenes de los 26 países de la OCDE de los que hay datos comparables de 2012 se graduarán por vez primera en programas de educación terciaria de tipo A a lo largo de su vida. La proporción va desde menos del $25 \%$ en Chile, Hungría, Luxemburgo y México, al $50 \%$ o más en Australia, Islandia, Nueva Zelanda y Polonia (Gráfico A3.2).

Estos programas, ofertados de forma habitual por las universidades, suelen tener una base teórica y están diseñados para dotar de cualificaciones que posibiliten el acceso a programas de investigación avanzada y profesiones con altos requisitos de conocimientos y competencias.

\section{Gráfico A3.2. Tasas de graduación por primera vez en educación terciaria de tipo A y B (1995 y 2012)}

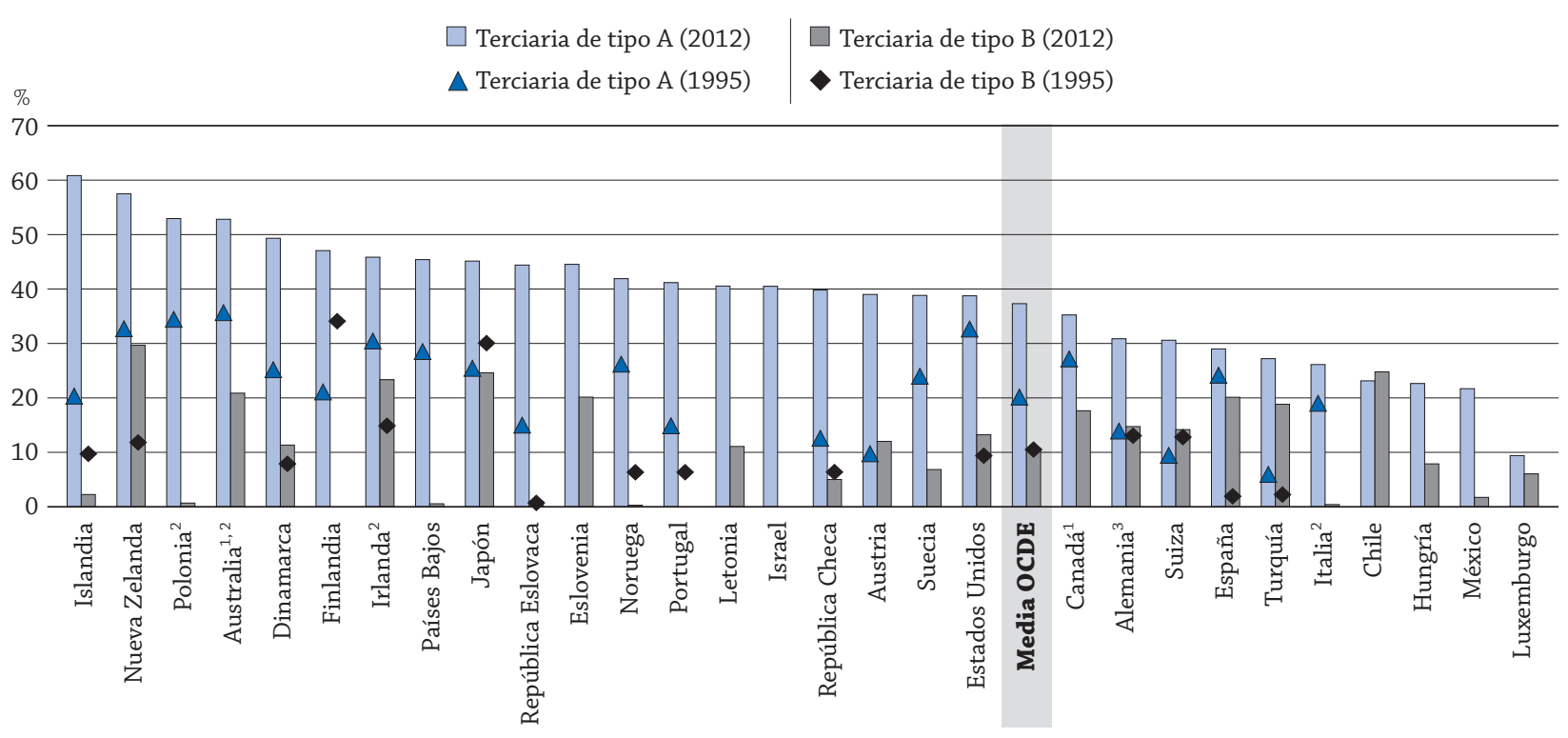

1. Año de referencia 2011 en lugar de 2012.

2. Año de referencia 2000 en lugar de 1995.

Los países están clasificados en orden descendente de las tasas de graduación por primera vez en educación terciaria de tipo A en 2012.

Fuente: OCDE. Tabla A3.2a Para ver notas, consulte Anexo 3 (www.oecd.org/edu/eag.htm).

StatLink 젬 http://dx.doi.org/10.1787/888933115483

Como media, el $39 \%$ de los jóvenes de los países de la OCDE se graduarán por primera vez en programas de educación terciaria de tipo A de primer grado (a menudo llamados grado) y el 18\% en programas de educación terciaria de tipo A de segundo grado (a menudo llamados máster). En los programas de primer grado, la tasa de graduación es igual o superior al 50 \% en Australia, Federación Rusa, Finlandia, Islandia, Nueva Zelanda y Polonia, pero es del $25 \%$ o menos en Arabia Saudí, Argentina, Bélgica, Chile, China, Estonia, Grecia, Indonesia, Luxemburgo, México y Sudáfrica. Las bajas tasas de graduación en Bélgica y China se ven compensadas por un mayor nivel de tasas de graduación en programas de formación profesional de primer grado. En China, se estima que un $15 \%$ de los jóvenes de hoy se graduarán en un programa terciario de tipo $\mathrm{A}$, y el $18 \%$ se graduarán en un programa terciario de tipo $\mathrm{B}$, de formación profesional, a lo largo de su vida. La tasa de graduación en un programa de segundo grado es igual o superior al $30 \%$ en Polonia, Portugal y República Eslovaca. Con la puesta en marcha del Proceso de Bolonia, los programas en este nivel de educación han aumentado considerablemente en muchos países de la UE (Tabla A3.1a).

La demanda de programas orientados a la formación profesional no ha aumentado tan rápidamente en los últimos años como la demanda de programas universitarios. En 2012, las tasas de graduación en programas de educación terciaria de tipo B alcanzaron una media del $11 \%$ entre los 27 países de la OCDE con datos comparables: el $12 \%$ de las mujeres y el $10 \%$ de los hombres se graduaron en dichos programas. Estos programas se clasifican en el mismo nivel académico que la mayoría de los programas de tipo teórico, pero su duración suele ser más reducida (normalmente de dos a tres años). Lo habitual es que no conduzcan a titulaciones universitarias, sino que doten al individuo de competencias que pueden utilizarse directamente en el mercado laboral, y den respuesta a las necesidades de especialización (Tabla A3.1a). 


\section{Datos sobre tendencias}

En todos los países con datos comparables disponibles, las tasas de graduación en educación terciaria de tipo A aumentaron entre 1995 y 2012. El incremento fue especialmente notable entre 1995 y 2005, del $20 \%$ al 36\%, y luego se estabilizaron. A lo largo de los cinco últimos años, las tasas de graduación en educación terciaria de tipo A han permanecido estables, en torno al 38\%. Desde 1995, el año en que hubo datos disponibles por primera vez, las expectativas sobre tasas de graduación en educación terciaria subieron 20 puntos porcentuales o más en Austria, Dinamarca, Finlandia, Polonia, Portugal, República Checa, República Eslovaca y Suiza (Tabla A3.2a).

El Proceso de Bolonia ha incrementado la armonización entre los sistemas de educación superior, apartándose de los programas más largos y favoreciendo los programas de tres años. El resultado es que algunos países han visto cómo sus tasas de graduación han aumentado, tal es el caso de República Checa entre 2004 y 2007, y Finlandia y República Eslovaca entre 2007 y 2008.

Las tendencias en la educación terciaria de tipo B entre 1995 y 2012 variaron en algunos países, aun cuando la media de la OCDE ha permanecido estable. En España, el acusado incremento de las tasas en este tipo de educación, del 2\% al $20 \%$, puede atribuirse a la introducción de nuevos programas de formación profesional de nivel avanzado; en Nueva Zelanda y Turquía, las tasas de graduación de nivel terciario de tipo B también subieron en más de 15 puntos porcentuales durante este periodo. Por el contrario, en Finlandia, dado que los programas de educación terciaria de tipo B se están suprimiendo progresivamente, las tasas de graduación universitaria han disminuido bruscamente mientras que los programas de educación terciaria con orientación académica han aumentado (Gráfico A3.2).

Los datos sobre tendencias por sexo muestran que el crecimiento de las tasas de graduación en la educación terciaria de tipo A ha sido especialmente acusado entre las mujeres en distintos países de la OCDE, como Austria, República Checa, República Eslovaca, con incrementos de más de 20 puntos porcentuales, y Eslovenia, con un aumento de casi

\section{Gráfico A3.3. Tasas de graduación "por primera vez» en educación terciaria de tipo A, incluyendo y excluyendo a los estudiantes internacionales, por edad (2012)}

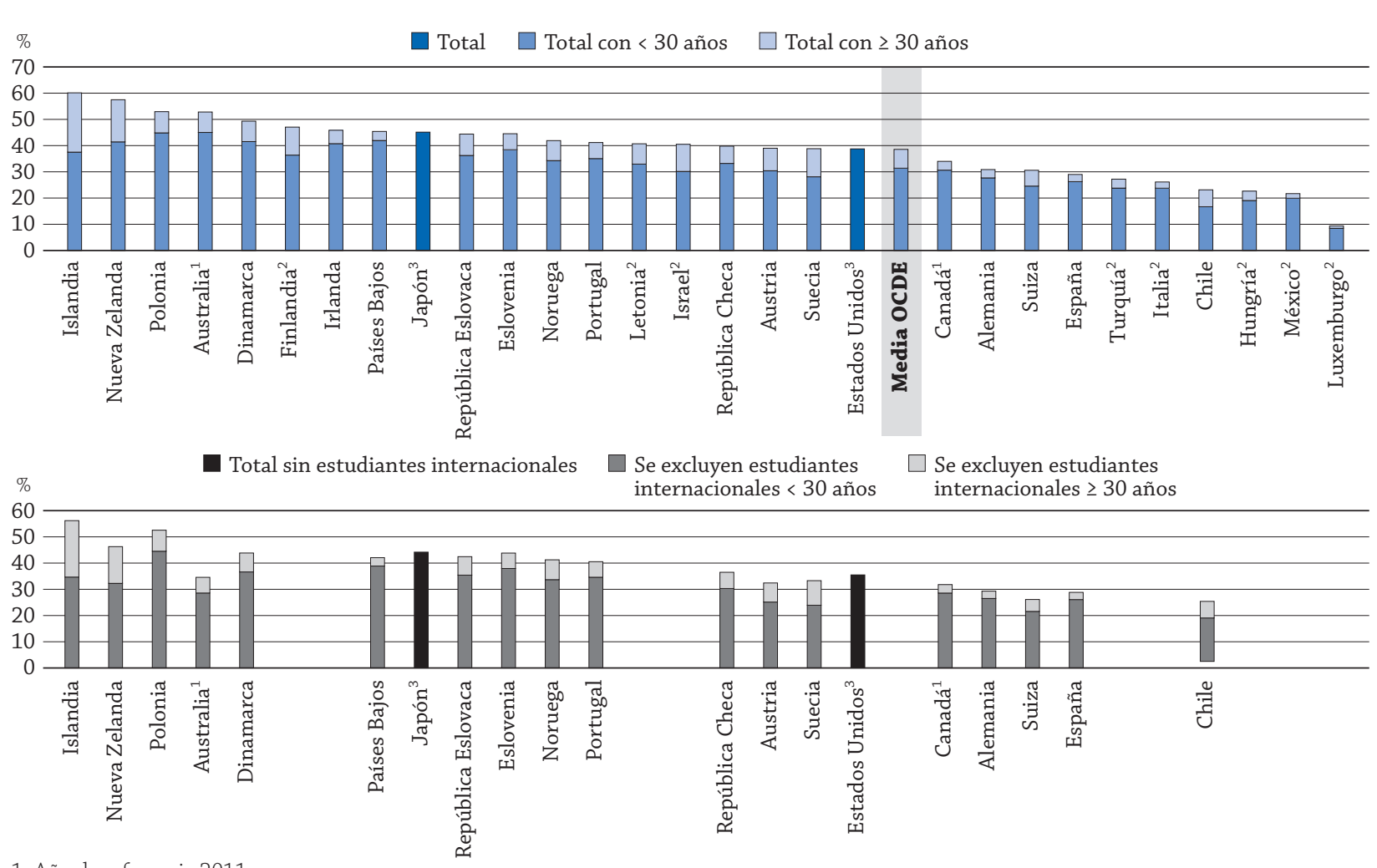

1. Año de referencia 2011.

2. No se incluyen los graduados estudiantes internacionales.

3. No se incluyen graduados por edad.

Los países se clasifican en orden descendente de las tasas totales de graduación en educación terciaria de tipo A en 2012.

Fuente: OCDE. Tablas A3.1a y A3.1b. Para ver notas, consulte Anexo 3 (www.oecd.org/edu/eag.htm).

StatLink त्ञात http://dx.doi.org/10.1787/888933115502 
40 puntos porcentuales entre 2005 y 2012. Las tasas de graduación de los hombres en estos países también crecieron, pero en mucha menor proporción (Tabla A3.2b, disponible en Internet).

\section{Tasas de graduación por debajo de la edad típica de graduación}

En los países de la OCDE, como media, un estudiante obtiene su primer grado universitario a la edad de 27 años, pero la edad de graduación varía mucho en función de los países. Los estudiantes de Bélgica, Indonesia, Luxemburgo, México, Países Bajos y Reino Unido se gradúan antes de los 25 años, mientras que los estudiantes de Brasil, Finlandia, Islandia, Israel y Suecia reciben su primer grado universitario tras alcanzar los 29 años (Cuadro A3.1).

Las diferencias de edad entre los graduados pueden vincularse a factores estructurales, como la graduación en educación secundaria superior, la longitud de los programas de educación terciaria o la obligación de realizar el servicio militar. Las diferencias de edad también pueden estar vinculadas a factores económicos, como la falta de becas y la flexibilidad para combinar trabajo y estudio, o la existencia de políticas para animar a aquellos que han adquirido experiencia en el puesto de trabajo a que se matriculen en educación terciaria con el fin de mejorar o aumentar su cualificación. En el actual contexto global de distorsión económica, algunos jóvenes han optado por alargar sus estudios de enseñanza terciaria dado que el coste de oportunidad de entrar en un mercado laboral inestable es elevado en diversos países de la OCDE. El hecho de que estos hombres y mujeres estén accediendo más tarde a la población activa tiene repercusiones económicas que los responsables de adopción de políticas deberían considerar, como un mayor gasto por estudiante y la pérdida de ingresos fiscales como resultado de que estas personas tienen vidas laborales más cortas.

Menos de un tercio de los adultos jóvenes se espera que terminen la educación terciaria de tipo A antes de los 30 años, desde un máximo superior al $40 \%$ en Australia, Dinamarca, Irlanda, Nueva Zelanda, Países Bajos y Polonia, hasta el $20 \%$ o menos en Chile, Hungría, Luxemburgo y México (Gráfico A3.3).

\section{Tasas de graduación excluyendo a los estudiantes internacionales}

El término «estudiantes internacionales» se refiere a estudiantes que han cruzado fronteras expresamente con la intención de estudiar. Por razones diversas, los estudiantes internacionales tienen una gran repercusión en las tasas de graduación estimadas. Por definición, se consideran graduados por primera vez, independientemente de su educación previa en otros países (es decir, un estudiante internacional que accede y se gradúa en un programa de segundo grado se considerará como graduado por primera vez en su país de destino). Es más, dado que han cruzado fronteras con la intención de estudiar y no necesariamente de trabajar o permanecer en el país de llegada, pueden incrementar el número absoluto de graduados dentro de la población. En los países con una alta proporción de estudiantes internacionales como Australia y Nueva Zelanda, las tasas de graduación se ven, pues, infladas artificialmente. Por ejemplo, cuando los estudiantes internacionales dejan de tenerse en cuenta, en Australia y Nueva Zelanda las tasas de graduación por primera vez en educación terciaria de tipo A disminuyen 18 y 11 puntos porcentuales, respectivamente, y las tasas de graduación por primera vez en educación terciaria de tipo B disminuyen 8 puntos porcentuales en Nueva Zelanda (Tabla A3.1a).

\section{Tasas de graduación para los programas de investigación avanzada}

Los graduados de doctorado son aquellos que han obtenido el nivel más alto de educación formal e incluyen de forma habitual a investigadores que han obtenido un doctorado. Según los modelos de graduación de 2012, una media de $1,6 \%$ de jóvenes de los países de la OCDE se graduarán en programas de investigación avanzada, en comparación con el 1,0\% de 2000. Los países con mayor incremento en las tasas de graduación en investigación avanzada son Dinamarca, Irlanda, Italia, Noruega, Nueva Zelanda, Reino Unido, República Checa y República Eslovaca, donde las tasas de graduación se incrementaron al menos un punto porcentual entre 2000 y 2012 (Tabla A3.2c, disponible en Internet).

Aunque las tasas de graduación para mujeres $(1,5 \%)$ son más bajas que las de los hombres $(1,7 \%)$ en el nivel de doctorado, se estima que la proporción de mujeres que se graduarán en un programa de investigación avanzada es mayor que la de los hombres. En Estados Unidos, Finlandia, Italia, Letonia y Portugal, las tasas de graduación de mujeres son al menos un 0,2\% mayores que las de los hombres (Tabla A3.1a).

Algunos países tratan de atraer estudiantes internacionales a los estudios de doctorado. Por ejemplo, las altas tasas de graduación en estos niveles (más del 2,5\%) observadas en Alemania, Finlandia, Suecia y Suiza se deben en parte a la gran proporción de estudiantes internacionales en el nivel de doctorado (Tabla A3.1a). Al excluir a los estudiantes internacionales de los cálculos, se reducen las tasas de graduación en estos países desde los 0,3 puntos porcentuales en Finlandia a los 1,6 puntos porcentuales de Suiza, donde aproximadamente la mitad de los graduados de doctorado son estudiantes internacionales. 
Como media en el conjunto de los países de la OCDE, los graduados de programas de investigación avanzada tienen 35 años, pero la media de edad en cuanto a graduación va desde los 32 años o más jóvenes en Alemania, Indonesia, Países Bajos y República Eslovaca, a los 38 o más en Brasil, Corea, Finlandia, Israel, Letonia, Noruega y Portugal (Tabla A3.1a).

\section{Diferencias entre sexos por ámbitos de estudio}

La distribución de graduados por ámbito de estudio viene dada por la popularidad relativa de estos ámbitos entre los estudiantes, el número relativo de puestos ofrecidos en las universidades e instituciones equivalentes, y la estructura de graduaciones en las distintas disciplinas en cada país.

Las mujeres predominan entre los graduados en la mayoría de los ámbitos de estudio, pero especialmente en los de educación y salud y asistencia social, en donde representan casi el $78 \%$ y el $75 \%$, respectivamente, de todos los estudiantes de educación terciaria (programas de educación terciaria de tipo A y de investigación avanzada) que se graduaron en estos ámbitos en 2012. Por el contrario, las mujeres solo alcanzan una pequeña fracción de las graduaciones en los ámbitos de ingeniería, industria y construcción (28\%), e informática (20\%). (Tabla A3.3, disponible en Internet). Solo en Argentina, Colombia, Estonia, Islandia, Italia, Luxemburgo y Polonia, la proporción de mujeres que se graduaron en los ámbitos de ingeniería, industria y construcción en 2012 iguala o supera la de uno de cada tres graduados.

Esta situación ha cambiado poco desde el año 2000, pese a las muchas iniciativas para promover la igualdad de género en los países de la OCDE y en la UE. Por ejemplo, en 2000, la Unión Europea estableció como objetivo incrementar el número de graduados de educación terciaria de tipo A en matemáticas, ciencias y tecnología al menos en un $15 \%$ para 2010, y reducir los desequilibrios de género en estas materias. Hasta ahora, sin embargo, los avances hacia este objetivo han sido insignificantes. Alemania, Portugal, República Checa, República Eslovaca y Suiza son los únicos cinco países en los que la proporción de mujeres en el amplio ámbito de la ciencia (que incluye biología, física, matemáticas, estadística e informática) creció al menos en 10 puntos porcentuales entre 2000 y 2012. Como resultado, estos países se encuentran ahora más cerca o incluso por encima de la media de la OCDE en este sentido. En los países de la OCDE, la proporción de mujeres en estos ámbitos ha crecido levemente, del $40 \%$ en 2000 al $41 \%$ en 2012, aun cuando la proporción de mujeres en el conjunto de los ámbitos aumentó del $54 \%$ al $58 \%$ durante ese periodo. Aunque la proporción de mujeres en ingeniería, industria y construcción es pequeña, aumentó también ligeramente, del $23 \%$ al $28 \%$, a lo largo de la última década (Tabla A3.3, disponible en Internet).

\section{Definiciones}

Un programa de primer grado de educación terciaria de tipo A tiene una duración acumulada teórica de tres años, en equivalente a tiempo completo. Estas graduaciones son, por ejemplo, el bachelor's degree (título de grado en España) en muchos países de habla inglesa, el Diplom en muchos países de habla alemana y la Licence en muchos países de habla francesa.

Un graduado por primera vez es un estudiante que se ha graduado por vez primera en un determinado nivel educativo o, en el caso del CINE 5, en un programa de tipo 5A o 5B durante el periodo de referencia. Así pues, si un estudiante se ha graduado varias veces a lo largo de los años, dicho estudiante se cuenta como graduado cada año, pero solo una vez como graduado por primera vez.

Estudiantes internacionales son aquellos que dejaron su país de origen y se mudaron a otro país con el fin de estudiar. Por definición, se consideran graduados por primera vez, independientemente de su educación previa en otros países.

Las tasas netas de graduación representan el porcentaje estimado de personas de una cohorte de edad concreta que completarán un programa de educación terciaria a lo largo de su vida, según los modelos actuales de graduación.

Los programas de segundo grado y programas más avanzados de base teórica (por ejemplo, el máster en muchos países) se clasifican dentro de los programas terciarios de tipo $\mathrm{A}$, aparte de los de investigación avanzada, que tienen su propia clasificación en CINE 6.

Graduados en educación terciaria son los que obtienen un grado universitario, una graduación en formación profesional o titulación en investigación avanzada de nivel de doctorado. 


\section{Metodología}

Los datos se refieren al curso académico 2011-2012 y se basan en la recopilación de estadísticas educativas UOE gestionada por la OCDE en 2012 (para detalles, véase Anexo 3 en www.oecd.org/edu/eag.htm).

Los datos sobre el impacto de los estudiantes internacionales en las tasas de graduación en educación terciaria se basan en un estudio especial realizado por la OCDE en diciembre de 2012.

Los datos sobre tendencias en las tasas de graduación de nivel terciario para los años 1995 y 2000 hasta 2004 se basan en un estudio especial realizado en enero de 2007.

Para permitir comparaciones con independencia de las diferencias en las estructuras de graduaciones nacionales, los títulos de nivel universitario se subdividen en función de la teórica duración total del periodo de estudio: dicho de otro modo, el número estándar de años, establecidos por ley o por reglamentos, en los cuales un estudiante puede completar el programa. Las graduaciones alcanzadas en programas de menos de tres años de duración no se consideran equivalentes para completar ese nivel educativo y no se incluyen en este indicador. Los programas de segundo grado se clasifican en función de la duración acumulada de los programas de primer y segundo grado. Las personas con un primer grado universitario no se incluyen en el recuento de graduados por primera vez.

A menos que se especifique lo contrario, las tasas de graduación se calculan como tasas netas de graduación (es decir, como la suma de tasas de graduación para cada edad específica). Se presentan las tasas brutas de graduación para los países que no pueden proporcionar dichos datos detallados. Con el fin de calcular las tasas de graduación brutas, los países identifican la edad típica de graduación (véase Anexo I). El número de graduados, independientemente de su edad, se divide por la población en la edad típica de graduación. Sin embargo, en muchos países es difícil definir la edad típica de graduación, porque los graduados están repartidos en un amplio abanico de edades.

\section{Nota sobre los datos de Israel}

Los datos estadísticos para Israel fueron proporcionados por las autoridades israelíes competentes bajo su responsabilidad. El uso de estos datos por parte de la OCDE se hace sin prejuzgar la situación de los Altos del Golán, Jerusalén Este y los asentamientos israelíes en Cisjordania de acuerdo con los términos del derecho internacional.

\section{Tablas del Indicador A3}

\section{StatLink त्माज्ञा $\mathrm{http}: / / \mathrm{dx} . \mathrm{doi} .0 \mathrm{gg} / 10.1787 / 888933115388$}

Tabla A3.1a Tasas de graduación en educación terciaria y media de edad de graduación (2012)

Tabla A3.1b Tasas de graduación en educación terciaria de estudiantes menores de la edad típica de graduación (2012)

Tabla A3.2a Tendencias de las tasas de graduación en educación terciaria (1995-2012)

Tabla A3.2b Tendencias de las tasas de graduación en educación terciaria, por sexo (2005-2012)

Tabla A3.2c Tendencias de las tasas netas de graduación en el nivel de investigación avanzada (1995-2012) 
Tabla A3.1a. Tasas de graduación en educación terciaria y media de edad de graduación (2012)

Suma de las tasas de graduación por edad específica, por sexo y destino del programa

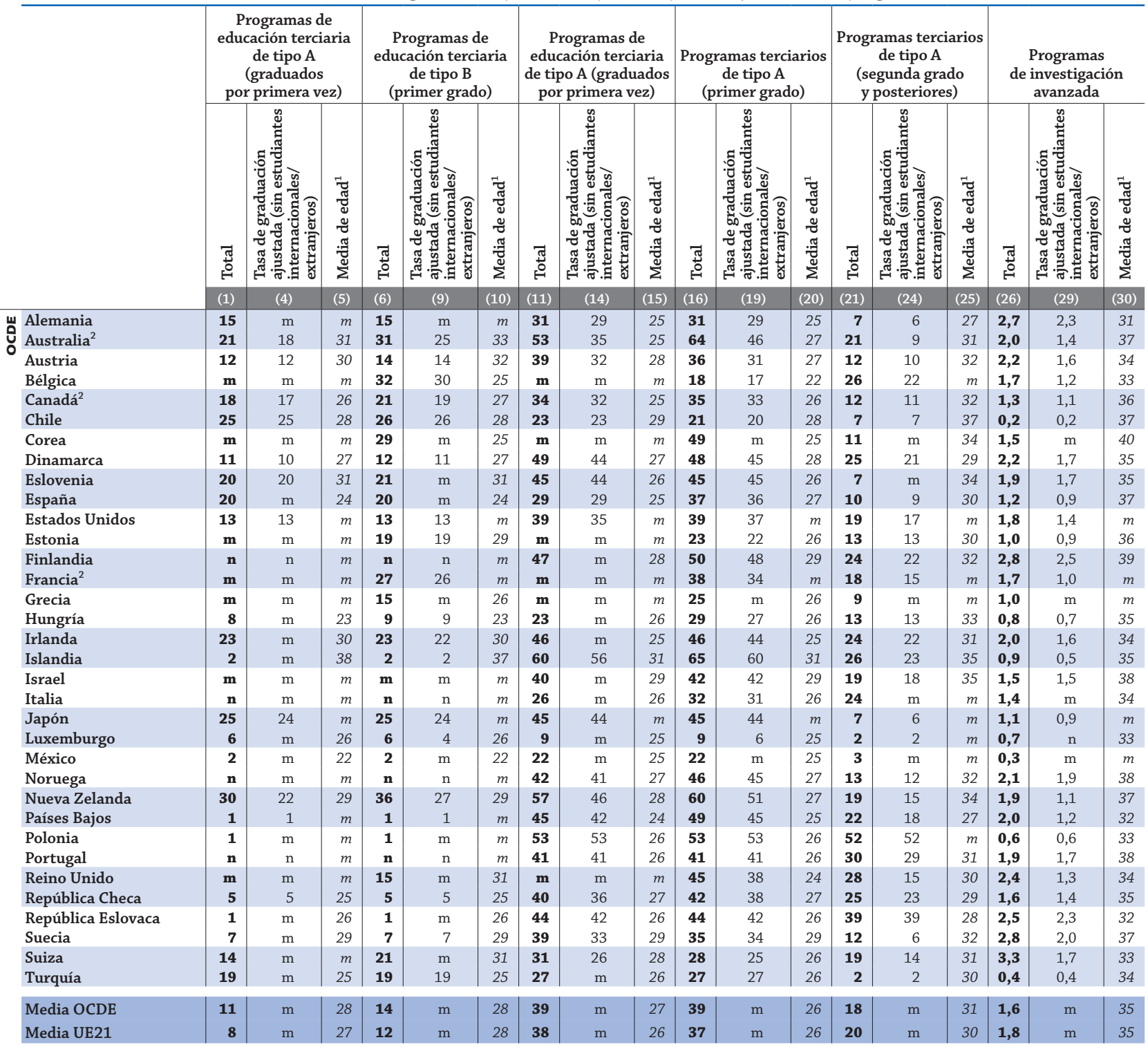

\begin{tabular}{|c|c|c|c|c|c|c|c|c|c|c|c|c|c|c|c|c|c|c|}
\hline $\begin{array}{l}\text { Arabia Saudí } \\
\text { Argentina }\end{array}$ & $\begin{array}{l}\mathbf{m} \\
\mathbf{m}\end{array}$ & $\begin{array}{l}\mathrm{m} \\
\mathrm{m}\end{array}$ & $\begin{array}{l}m \\
m\end{array}$ & $\begin{array}{r}8 \\
15\end{array}$ & $\begin{array}{l}\mathrm{m} \\
\mathrm{m}\end{array}$ & $\begin{array}{l}m \\
m\end{array}$ & $\begin{array}{l}\mathbf{m} \\
\mathbf{m}\end{array}$ & $\begin{array}{l}\mathrm{m} \\
\mathrm{m}\end{array}$ & $\begin{array}{l}m \\
m\end{array}$ & $\begin{array}{l}19 \\
12\end{array}$ & $\begin{array}{l}\mathrm{m} \\
\mathrm{m}\end{array}$ & $\begin{array}{l}m \\
m\end{array}$ & $\begin{array}{l}2 \\
1\end{array}$ & $\begin{array}{l}\mathrm{m} \\
\mathrm{m}\end{array}$ & $\begin{array}{l}m \\
m\end{array}$ & $\begin{array}{l}0,1 \\
0,3\end{array}$ & $\begin{array}{l}\mathrm{m} \\
\mathrm{m}\end{array}$ & $\begin{array}{l}m \\
m\end{array}$ \\
\hline Brasil & $\mathbf{m}$ & $\mathrm{m}$ & $m$ & 6 & 6 & 32 & $\mathbf{m}$ & $\mathrm{m}$ & $m$ & 28 & 28 & 30 & 2 & 2 & 33 & 0,5 & 0,5 & 38 \\
\hline China & $\mathbf{m}$ & $\mathrm{m}$ & $m$ & 18 & $\mathrm{~m}$ & $m$ & $\mathbf{m}$ & $\mathrm{m}$ & $m$ & 15 & $\mathrm{~m}$ & $m$ & $\mathbf{n}$ & $\mathrm{m}$ & $m$ & m & $\mathrm{m}$ & $m$ \\
\hline Colombia & $\mathbf{m}$ & $\mathrm{m}$ & $m$ & $\mathrm{~m}$ & $\mathrm{~m}$ & $m$ & $\mathbf{m}$ & $\mathrm{m}$ & $m$ & $\mathbf{m}$ & $\mathrm{m}$ & $m$ & $\mathbf{m}$ & $\mathrm{m}$ & $m$ & $\mathbf{m}$ & $\mathrm{m}$ & $m$ \\
\hline Federación Rusa & $\mathbf{m}$ & $\mathrm{m}$ & $m$ & 26 & 26 & $m$ & $\mathbf{m}$ & $\mathrm{m}$ & $m$ & 60 & 59 & $m$ & 2 & $\mathrm{~m}$ & $m$ & m & $\mathrm{m}$ & $m$ \\
\hline India & $\mathbf{m}$ & $\mathrm{m}$ & $m$ & $\mathbf{m}$ & $\mathrm{m}$ & $m$ & $\mathbf{m}$ & $\mathrm{m}$ & $m$ & $\mathbf{m}$ & $\mathrm{m}$ & $m$ & $\mathbf{m}$ & $\mathrm{m}$ & $m$ & $\mathbf{m}$ & $\mathrm{m}$ & $m$ \\
\hline Indonesia & $\mathbf{m}$ & $\mathrm{m}$ & $m$ & 5 & $\mathrm{~m}$ & $m$ & $\mathbf{m}$ & $\mathrm{m}$ & $m$ & 15 & $\mathrm{~m}$ & $m$ & 1 & $\mathrm{~m}$ & $m$ & $\mathbf{0 , 1}$ & $\mathrm{m}$ & $m$ \\
\hline Letonia & 12 & $\mathrm{~m}$ & 28 & 12 & $\mathrm{~m}$ & 28 & 43 & $\mathrm{~m}$ & 27 & 43 & $\mathrm{~m}$ & 27 & 17 & $\mathrm{~m}$ & 30 & 1,0 & $\mathrm{~m}$ & 38 \\
\hline Sudáfrica & $\mathbf{m}$ & $\mathrm{m}$ & $m$ & 5 & $\mathrm{~m}$ & $m$ & $\mathbf{m}$ & $\mathrm{m}$ & $m$ & 6 & $\mathrm{~m}$ & $m$ & 4 & $\mathrm{~m}$ & $m$ & 0,2 & $\mathrm{~m}$ & $m$ \\
\hline
\end{tabular}

\section{\begin{tabular}{|l|l|l|l|l|l|l|l|l|l|l|l|l|l|l|l|l|l|l|} 
Media G20 & $\mathbf{m}$ & $\mathrm{m}$ & $\mathrm{m}$ & $\mathbf{1 5}$ & $\mathrm{m}$ & $\mathrm{m}$ & $\mathbf{m}$ & $\mathrm{m}$ & $\mathrm{m}$ & $\mathbf{3 0}$ & $\mathrm{m}$ & $\mathrm{m}$ & $\mathbf{1 1}$ & $\mathrm{m}$ & $\mathrm{m}$ & $\mathbf{1 , 0}$ & $\mathrm{m}$ & $\mathrm{m}$ \\
\hline
\end{tabular}}

Notas: Las columnas que muestran las tasas de graduación para hombres y mujeres (es decir, columnas 2, 3, 7, 8, 12, 13, 17, 18, 22, 23, 27, 28) están disponibles en Internet (véase StatLink más abajo).

Para más información sobre el método empleado para calcular las tasas de graduación (tasas brutas frente a tasas netas) y las edades típicas correspondientes, consulte Anexo 1. La falta de equivalencia entre la cobertura de los datos de población y los de graduados significa que las tasas de graduación de los países que son exportadores netos de estudiantes pueden estar subestimadas, y las de los que son importadores netos pueden estar sobreestimadas. Las tasas de graduación ajustadas de las Tablas A3.1a y A3.1b tratan de compensar este desfase.

1. La media de edad se refiere a una media de edad ponderada, generalmente la edad de los estudiantes al inicio del año natural. Los estudiantes pueden tener un año más de la edad indicada cuando se gradúan al final del curso escolar. Para saber cómo se calcula la media de edad, consulte Anexo 3.

2. Año de referencia 2011.

Fuentes: OCDE. Arabia Saudí, Argentina, China, Colombia, India, Indonesia, Sudáfrica: Instituto de Estadística de la UNESCO. Letonia: Eurostat. Para ver notas, consulte Anexo 3 (www.oecd.org/edu/eag.htm).

Para obtener más información acerca de los símbolos utilizados en lugar de los datos que faltan, consulte la Guía del lector.

StatLink : iाls http://dx.doi.org/10.1787/888933115407 
Tabla A3.1b. Tasas de graduación en educación terciaria de estudiantes menores de la edad típica de graduación (2012)

Suma de las tasas de graduación por edad específica hasta los 30 años para educación terciaria de tipo A y B, y hasta los 35 años para programas de investigación avanzada, por sexo y destino del programa

\begin{tabular}{|c|c|c|c|c|c|c|c|c|c|c|c|c|c|}
\hline & & \multicolumn{2}{|c|}{$\begin{array}{c}\text { Programas de } \\
\text { educación terciaria } \\
\text { de tipo B (graduados } \\
\text { por primera vez) }\end{array}$} & \multicolumn{2}{|c|}{$\begin{array}{c}\text { Programas de } \\
\text { educación terciaria } \\
\text { de tipo B } \\
\text { (primer grado) }\end{array}$} & \multicolumn{2}{|c|}{\begin{tabular}{|c|} 
Programas de \\
educación terciaria \\
de tipo A (graduados \\
por primera vez)
\end{tabular}} & \multicolumn{2}{|c|}{$\begin{array}{c}\text { Programas de } \\
\text { educación terciaria } \\
\text { de tipo A } \\
\text { (primer grado) }\end{array}$} & \multicolumn{2}{|c|}{$\begin{array}{c}\text { Programas de } \\
\text { educación terciaria } \\
\text { de tipo A (segundo } \\
\text { grado y posteriores) }\end{array}$} & \multicolumn{2}{|c|}{$\begin{array}{c}\text { Programas } \\
\text { de investigación } \\
\text { avanzada }\end{array}$} \\
\hline & & 퓸 & 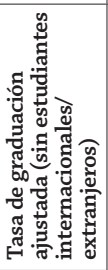 & సีّ & 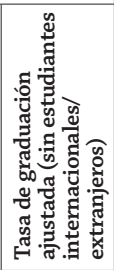 & శึี兀 & 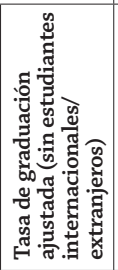 & సี & 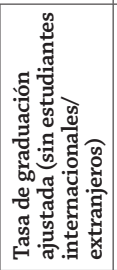 & हేँ & 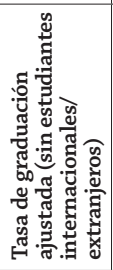 & సีّ & 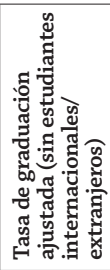 \\
\hline & & (1) & (4) & (5) & $(8)$ & (9) & (12) & (13) & (16) & (17) & (20) & (21) & (24) \\
\hline \multirow{33}{*}{ 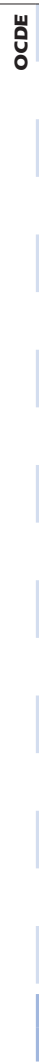 } & Alemania & $\mathbf{m}$ & $\mathrm{m}$ & $\mathbf{m}$ & $\mathrm{m}$ & 28 & 26 & 28 & 26 & 6 & 5 & 2,3 & 2,0 \\
\hline & Australia $^{1}$ & 12 & 9 & 16 & 11 & 45 & 29 & 51 & 34 & 13 & 4 & 1,1 & 0,7 \\
\hline & Austria & 8 & 7 & 8 & 8 & 30 & 25 & 29 & 25 & 7 & 6 & 1,6 & 1,2 \\
\hline & Bélgica & $\mathbf{m}$ & $\mathrm{m}$ & 28 & $\mathrm{~m}$ & m & $\mathrm{m}$ & 18 & $\mathrm{~m}$ & 24 & $\mathrm{~m}$ & 1,3 & $\mathrm{~m}$ \\
\hline & Chile & 17 & 17 & 18 & 18 & 17 & 17 & 16 & 16 & 2 & 2 & 0,2 & 0,2 \\
\hline & Corea & $\mathbf{m}$ & $\mathrm{m}$ & 25 & $\mathrm{~m}$ & m & $\mathrm{m}$ & 47 & $\mathrm{~m}$ & 5 & $\mathrm{~m}$ & 0,6 & $\mathrm{~m}$ \\
\hline & Dinamarca & 9 & 7 & 9 & 8 & 42 & 37 & 39 & 36 & 18 & 16 & 1,5 & 1,1 \\
\hline & Eslovenia & 12 & 12 & 12 & $\mathrm{~m}$ & 38 & 38 & 39 & 39 & 3 & $\mathrm{~m}$ & 1,2 & 1,1 \\
\hline & España & 18 & $\mathrm{~m}$ & 18 & $\mathrm{~m}$ & 26 & 26 & 31 & 31 & 7 & 6 & 0,7 & $\mathrm{~m}$ \\
\hline & Estados Unidos & $\mathbf{m}$ & $\mathrm{m}$ & $\mathbf{m}$ & $\mathrm{m}$ & $\mathbf{m}$ & $\mathrm{m}$ & $\mathbf{m}$ & $\mathrm{m}$ & $\mathbf{m}$ & $\mathrm{m}$ & m & $\mathrm{m}$ \\
\hline & Estonia & $\mathbf{m}$ & $\mathrm{m}$ & 13 & $\mathrm{~m}$ & $\mathbf{m}$ & $\mathrm{m}$ & 19 & $\mathrm{~m}$ & 9 & $\mathrm{~m}$ & 0,6 & $\mathrm{~m}$ \\
\hline & Finlandia & $\mathbf{n}$ & $\mathrm{n}$ & $\mathbf{n}$ & $\mathrm{n}$ & 36 & $\mathrm{~m}$ & 37 & 35 & 14 & 13 & 1,1 & 0,9 \\
\hline & Francia $^{1}$ & $\mathbf{m}$ & $\mathrm{m}$ & $\mathbf{m}$ & $\mathrm{m}$ & m & $\mathrm{m}$ & $\mathbf{m}$ & $\mathrm{m}$ & $\mathbf{m}$ & $\mathrm{m}$ & $\mathbf{m}$ & $\mathrm{m}$ \\
\hline & Grecia & m & $\mathrm{m}$ & 13 & $\mathrm{~m}$ & $\mathbf{m}$ & $\mathrm{m}$ & 23 & $\mathrm{~m}$ & $\mathbf{m}$ & $\mathrm{m}$ & $\mathbf{m}$ & $\mathrm{m}$ \\
\hline & Hungría & 7 & $\mathrm{~m}$ & 8 & $\mathrm{~m}$ & 19 & $\mathrm{~m}$ & 24 & $\mathrm{~m}$ & 7 & $\mathrm{~m}$ & 0,5 & $\mathrm{~m}$ \\
\hline & Irlanda & 15 & $\mathrm{~m}$ & 15 & 15 & 41 & $\mathrm{~m}$ & 41 & 39 & 15 & 13 & 1,4 & 1,1 \\
\hline & Islandia $^{1}$ & 1 & $\mathrm{~m}$ & 1 & 1 & 37 & 35 & 39 & 38 & 10 & 8 & 0,7 & 0,4 \\
\hline & Israel & $\mathbf{m}$ & $\mathrm{m}$ & $\mathbf{m}$ & $\mathrm{m}$ & 30 & $\mathrm{~m}$ & 31 & $\mathrm{~m}$ & 6 & $\mathrm{~m}$ & 0,6 & $\mathrm{~m}$ \\
\hline & Italia & m & $\mathrm{m}$ & $\mathbf{m}$ & $\mathrm{m}$ & 24 & $\mathrm{~m}$ & 28 & $\mathrm{~m}$ & $\mathbf{m}$ & $\mathrm{m}$ & 1,1 & $\mathrm{~m}$ \\
\hline & Japón & m & $\mathrm{m}$ & $\mathbf{m}$ & $\mathrm{m}$ & $\mathbf{m}$ & $\mathrm{m}$ & $\mathbf{m}$ & $\mathrm{m}$ & $\mathbf{m}$ & $\mathrm{m}$ & $\mathbf{m}$ & $\mathrm{m}$ \\
\hline & Luxemburgo & 5 & $\mathrm{~m}$ & m & $\mathrm{m}$ & 8 & $\mathrm{~m}$ & 8 & $\mathrm{~m}$ & 2 & $\mathrm{~m}$ & 0,6 & $\mathrm{~m}$ \\
\hline & México & 2 & $\mathrm{~m}$ & 2 & $\mathrm{~m}$ & 20 & $\mathrm{~m}$ & 20 & $\mathrm{~m}$ & $\mathbf{m}$ & $\mathrm{m}$ & $\mathbf{m}$ & $\mathrm{m}$ \\
\hline & Países Bajos & $\mathbf{n}$ & $\mathrm{n}$ & $\mathbf{n}$ & $\mathrm{m}$ & 42 & 39 & 44 & 41 & 18 & 15 & 1,7 & 1,1 \\
\hline & Polonia & 1 & $\mathrm{~m}$ & 1 & $\mathrm{~m}$ & 45 & 45 & 45 & 45 & $\mathbf{m}$ & $\mathrm{m}$ & 0,5 & $\mathrm{~m}$ \\
\hline & Portugal & $\mathbf{n}$ & $\mathrm{n}$ & $\mathbf{n}$ & $\mathrm{n}$ & 35 & 35 & 35 & 35 & 20 & 20 & 1,0 & 0,9 \\
\hline & Reino Unido & m & $\mathrm{m}$ & 8 & 7 & $\mathbf{m}$ & $\mathrm{m}$ & 40 & 33 & 18 & 8 & 1,6 & 0,9 \\
\hline & República Checa & 4 & 4 & 4 & 4 & 33 & 30 & 35 & 32 & 20 & 19 & 0,8 & 0,6 \\
\hline & República Eslovaca & 1 & $\mathrm{~m}$ & 1 & $\mathrm{~m}$ & 36 & 35 & 36 & 35 & 30 & 29 & 1,9 & 1,9 \\
\hline & Suecia & 5 & $\mathrm{~m}$ & 5 & 5 & 28 & 24 & 24 & 24 & 7 & 3 & 1,7 & 1,1 \\
\hline & Suiza & $\mathbf{m}$ & $\mathrm{m}$ & 13 & $\mathrm{~m}$ & 25 & 22 & 24 & 22 & 12 & 9 & 2,6 & 1,3 \\
\hline & Turquía & 16 & $\mathrm{~m}$ & 16 & $\mathrm{~m}$ & 24 & $\mathrm{~m}$ & 24 & $\mathrm{~m}$ & 1 & $\mathrm{~m}$ & 0,2 & $\mathrm{~m}$ \\
\hline & Media OCDE & 8 & $\mathrm{~m}$ & 10 & $\mathrm{~m}$ & 31 & $\mathrm{~m}$ & 32 & $\mathrm{~m}$ & 11 & $\mathrm{~m}$ & 1,1 & $\mathrm{~m}$ \\
\hline & Media UE21 & 6 & $\mathrm{~m}$ & 9 & $\mathrm{~m}$ & 32 & $\mathrm{~m}$ & 31 & $\mathrm{~m}$ & 13 & $\mathrm{~m}$ & 1,2 & $\mathrm{~m}$ \\
\hline \multirow{11}{*}{ 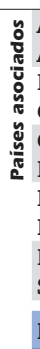 } & Arabia Saudí & $\mathbf{m}$ & $\mathrm{m}$ & $\mathbf{m}$ & $\mathrm{m}$ & $\mathbf{m}$ & $\mathrm{m}$ & $\mathbf{m}$ & $\mathrm{m}$ & $\mathbf{m}$ & $\mathrm{m}$ & $\mathbf{m}$ & $\mathrm{m}$ \\
\hline & Argentina $^{1}$ & $\mathbf{m}$ & $\mathrm{m}$ & $\mathbf{m}$ & $\mathrm{m}$ & $\mathbf{m}$ & $\mathrm{m}$ & $\mathbf{m}$ & $\mathrm{m}$ & $\mathbf{m}$ & $\mathrm{m}$ & $\mathbf{m}$ & $\mathrm{m}$ \\
\hline & Brasil & $\mathbf{m}$ & $\mathrm{m}$ & 3 & $\mathrm{~m}$ & $\mathbf{m}$ & $\mathrm{m}$ & 18 & $\mathrm{~m}$ & 1 & $\mathrm{~m}$ & 0,2 & $\mathrm{~m}$ \\
\hline & China & $\mathbf{m}$ & $\mathrm{m}$ & $\mathbf{m}$ & $\mathrm{m}$ & $\mathbf{m}$ & $\mathrm{m}$ & $\mathbf{m}$ & $\mathrm{m}$ & $\mathbf{m}$ & $\mathrm{m}$ & m & $\mathrm{m}$ \\
\hline & Colombia & m & $\mathrm{m}$ & $\mathrm{m}$ & $\mathrm{m}$ & $\mathbf{m}$ & $\mathrm{m}$ & $\mathbf{m}$ & $\mathrm{m}$ & $\mathbf{m}$ & $\mathrm{m}$ & $\mathbf{m}$ & $\mathrm{m}$ \\
\hline & Federación Rusa & $\mathbf{m}$ & $\mathrm{m}$ & $\mathbf{m}$ & $\mathrm{m}$ & $\mathbf{m}$ & $\mathrm{m}$ & $\mathbf{m}$ & $\mathrm{m}$ & $\mathbf{m}$ & $\mathrm{m}$ & $\mathbf{m}$ & $\mathrm{m}$ \\
\hline & India & $\mathbf{m}$ & $\mathrm{m}$ & $\mathbf{m}$ & $\mathrm{m}$ & $\mathbf{m}$ & $\mathrm{m}$ & $\mathbf{m}$ & $\mathrm{m}$ & $\mathbf{m}$ & $\mathrm{m}$ & $\mathbf{m}$ & $\mathrm{m}$ \\
\hline & Indonesia & $\mathbf{m}$ & $\mathrm{m}$ & 1 & $\mathrm{~m}$ & $\mathbf{m}$ & $\mathrm{m}$ & 13 & $\mathrm{~m}$ & 1 & $\mathrm{~m}$ & 0,1 & $\mathrm{~m}$ \\
\hline & Letonia & 9 & $\mathrm{~m}$ & 9 & $\mathrm{~m}$ & 35 & $\mathrm{~m}$ & 35 & $\mathrm{~m}$ & 11 & $\mathrm{~m}$ & 0,5 & $\mathrm{~m}$ \\
\hline & Sudáfrica & $\mathbf{m}$ & $\mathrm{m}$ & $\mathbf{m}$ & $\mathrm{m}$ & m & $\mathrm{m}$ & m & $\mathrm{m}$ & $\mathbf{m}$ & $\mathrm{m}$ & m & $\mathrm{m}$ \\
\hline & Media G20 & m & $\mathrm{m}$ & $\mathbf{m}$ & $\mathrm{m}$ & m & $\mathrm{m}$ & $\mathbf{m}$ & $\mathrm{m}$ & $\mathbf{m}$ & $\mathrm{m}$ & $\mathbf{m}$ & $\mathrm{m}$ \\
\hline
\end{tabular}

Notas: Las columnas que muestran las tasas de graduación para hombres y mujeres (es decir, columnas 2, 3, 6, 7, 10, 11, 14, 15, 18, 19, 22, 23) están disponibles en Internet (véase StatLink más abajo).

Para más información sobre el método empleado para calcular las tasas de graduación (tasas brutas frente a tasas netas) y las edades típicas correspondientes, consulte Anexo 1. La falta de equivalencia entre la cobertura de los datos de población y los de graduados significa que las tasas de graduación de los países que son exportadores netos de estudiantes pueden estar subestimadas, y las de los que son importadores netos pueden estar sobreestimadas. Las tasas de graduación ajustadas de las Tablas A3.1a y A3.1b tratan de compensar este desfase.

Las medias se han ajustado al $100 \%$ y no se corresponden exactamente con la media de cada columna.

1. Año de referencia 2011.

Fuentes: OCDE. Arabia Saudí, Argentina, China, Colombia, India, Indonesia, Sudáfrica: Instituto de Estadística de la UNESCO. Letonia: Eurostat. Para ver notas, consulte Anexo 3 (www.oecd.org/edu/eag.htm).

Para obtener más información acerca de los símbolos utilizados en lugar de los datos que faltan, consulte la Guía del lector.

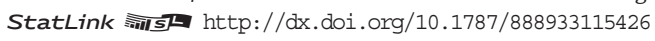


Tabla A3.2a. Tendencias de las tasas de graduación en educación terciaria (1995-2012) Suma de las tasas de graduación por edad específica, por destino del programa

\begin{tabular}{|c|c|c|c|c|c|c|c|c|c|c|c|c|}
\hline & \multicolumn{6}{|c|}{ Educación terciaria de tipo $5 \mathrm{~A}$ (graduados por primera vez) } & \multicolumn{6}{|c|}{ Educación terciaria de tipo $5 \mathrm{~B}$ (graduados por primera vez) } \\
\hline & 1995 & 2000 & 2005 & 2010 & 2011 & 2012 & 1995 & 2000 & 2005 & 2010 & 2011 & 2012 \\
\hline & (1) & (2) & (7) & (12) & (13) & (14) & (15) & (16) & (21) & (26) & (27) & (28) \\
\hline Alemania $^{1}$ & 14 & 18 & 20 & 30 & 31 & 31 & 13 & 11 & 11 & 14 & 14 & 15 \\
\hline Australia & $\mathrm{m}$ & 36 & 50 & 50 & 53 & $\mathbf{m}$ & $\mathrm{m}$ & $\mathrm{m}$ & $\mathrm{m}$ & 17 & 21 & $\mathbf{m}$ \\
\hline Austria & 10 & 15 & 20 & 30 & 35 & 39 & $\mathrm{~m}$ & $\mathrm{~m}$ & 8 & 12 & 12 & 12 \\
\hline Bélgica & $\mathrm{m}$ & $\mathrm{m}$ & $\mathrm{m}$ & $\mathrm{m}$ & $\mathrm{m}$ & $\mathbf{m}$ & $\mathrm{m}$ & $\mathrm{m}$ & $\mathrm{m}$ & $\mathrm{m}$ & $\mathrm{m}$ & $\mathbf{m}$ \\
\hline Canadá & 27 & 27 & 32 & 35 & 35 & $\mathbf{m}$ & $\mathrm{m}$ & $\mathrm{m}$ & 20 & 21 & 18 & $\mathbf{m}$ \\
\hline Chile & $\mathrm{m}$ & $\mathrm{m}$ & $\mathrm{m}$ & $\mathrm{m}$ & $\mathrm{m}$ & 23 & $\mathrm{~m}$ & $\mathrm{~m}$ & $\mathrm{~m}$ & $\mathrm{~m}$ & $\mathrm{~m}$ & 25 \\
\hline Corea & $\mathrm{m}$ & $\mathrm{m}$ & $\mathrm{m}$ & $\mathrm{m}$ & $\mathrm{m}$ & $\mathbf{m}$ & $\mathrm{m}$ & $\mathrm{m}$ & $\mathrm{m}$ & $\mathrm{m}$ & $\mathrm{m}$ & $\mathbf{m}$ \\
\hline Dinamarca & 25 & 37 & 46 & 50 & 50 & 49 & 8 & 10 & 10 & 9 & 11 & 11 \\
\hline Eslovenia & $\mathrm{m}$ & $\mathrm{m}$ & 18 & 29 & 37 & 45 & $\mathrm{~m}$ & $\mathrm{~m}$ & 24 & 26 & 27 & 20 \\
\hline España $^{2}$ & 24 & 29 & 30 & 30 & 32 & 29 & 2 & 8 & 15 & 16 & 18 & 20 \\
\hline Estados Unidos & 33 & 34 & 34 & 38 & 39 & 39 & 9 & 8 & 10 & 11 & 12 & 13 \\
\hline Estonia & $\mathrm{m}$ & $\mathrm{m}$ & $\mathrm{m}$ & $\mathrm{m}$ & $\mathrm{m}$ & $\mathbf{m}$ & $\mathrm{m}$ & $\mathrm{m}$ & $\mathrm{m}$ & $\mathrm{m}$ & $\mathrm{m}$ & $\mathbf{m}$ \\
\hline Finlandia & 21 & 40 & 47 & 49 & 47 & 47 & 34 & 7 & $\mathrm{n}$ & $\mathrm{n}$ & $\mathrm{n}$ & $\mathbf{n}$ \\
\hline Francia & $\mathrm{m}$ & $\mathrm{m}$ & $\mathrm{m}$ & $\mathrm{m}$ & $\mathrm{m}$ & $\mathbf{m}$ & $\mathrm{m}$ & $\mathrm{m}$ & $\mathrm{m}$ & $\mathrm{m}$ & $\mathrm{m}$ & $\mathbf{m}$ \\
\hline Grecia & 14 & 15 & 25 & $\mathrm{~m}$ & $\mathrm{~m}$ & $\mathbf{m}$ & 5 & 6 & 11 & $\mathrm{~m}$ & $\mathrm{~m}$ & $\mathbf{m}$ \\
\hline Hungría & $\mathrm{m}$ & $\mathrm{m}$ & 33 & 31 & 27 & 23 & $\mathrm{~m}$ & $\mathrm{~m}$ & 4 & 6 & 7 & 8 \\
\hline Irlanda & $\mathrm{m}$ & 30 & 38 & 47 & 43 & 46 & $\mathrm{~m}$ & 15 & 24 & 26 & 24 & 23 \\
\hline Islandia & 20 & 33 & 56 & 60 & 61 & 60 & 10 & 5 & 4 & 2 & 2 & 2 \\
\hline Israel & $\mathrm{m}$ & $\mathrm{m}$ & 35 & 37 & 40 & 40 & $\mathrm{~m}$ & $\mathrm{~m}$ & $\mathrm{~m}$ & $\mathrm{~m}$ & $\mathrm{~m}$ & $\mathbf{m}$ \\
\hline Italia & $\mathrm{m}$ & 19 & 41 & 32 & 32 & 26 & $\mathrm{~m}$ & $\mathrm{n}$ & 1 & 1 & $\mathrm{~m}$ & $\mathbf{m}$ \\
\hline Japón & 25 & 29 & 37 & 40 & 40 & 45 & 30 & 30 & 28 & 25 & 25 & 25 \\
\hline Luxemburgo & $\mathrm{m}$ & $\mathrm{m}$ & $\mathrm{m}$ & $\mathrm{m}$ & $\mathrm{m}$ & 9 & $\mathrm{~m}$ & $\mathrm{~m}$ & $\mathrm{~m}$ & $\mathrm{~m}$ & $\mathrm{~m}$ & 6 \\
\hline México & $\mathrm{m}$ & $\mathrm{m}$ & 17 & 20 & 21 & 22 & $\mathrm{~m}$ & $\mathrm{~m}$ & 1 & 1 & 2 & 2 \\
\hline Noruega & 26 & 37 & 41 & 42 & 43 & 42 & 6 & 6 & 2 & $\mathrm{n}$ & $\mathrm{n}$ & $\mathbf{n}$ \\
\hline Nueva Zelanda & 33 & 50 & 51 & 49 & 53 & 57 & 12 & 17 & 23 & 27 & 30 & 30 \\
\hline Países Bajos & 29 & 35 & 42 & 42 & 42 & 45 & $\mathrm{~m}$ & $\mathrm{~m}$ & $\mathrm{n}$ & $\mathrm{n}$ & $\mathrm{n}$ & 1 \\
\hline Polonia & $\mathrm{m}$ & 34 & 47 & 55 & 58 & 53 & $\mathrm{~m}$ & $\mathrm{~m}$ & $\mathrm{n}$ & 1 & 1 & 1 \\
\hline Portugal & 15 & 23 & 32 & 40 & 39 & 41 & 6 & 8 & 9 & $\mathrm{n}$ & $\mathrm{n}$ & $\mathbf{n}$ \\
\hline Reino Unido & $\mathrm{m}$ & 42 & 48 & 50 & 54 & $\mathbf{m}$ & $\mathrm{m}$ & 7 & 11 & 12 & 13 & $\mathbf{m}$ \\
\hline República Checa & 13 & 14 & 23 & 38 & 41 & 40 & 6 & 5 & 6 & 5 & 5 & 5 \\
\hline República Eslovaca & 15 & $\mathrm{~m}$ & 30 & 49 & 46 & 44 & 1 & 2 & 2 & 1 & 1 & 1 \\
\hline Suecia & 24 & 28 & 38 & 37 & 41 & 39 & $\mathrm{~m}$ & 4 & 5 & 6 & 7 & 7 \\
\hline Suiza & 9 & 12 & 27 & 31 & 32 & 31 & 13 & 14 & 8 & 16 & 15 & 14 \\
\hline Turquía & 6 & 9 & 12 & 23 & 23 & 27 & 2 & $\mathrm{~m}$ & $\mathrm{~m}$ & 19 & 17 & 19 \\
\hline Media OCDE & 20 & 28 & 36 & 39 & 41 & 38 & 11 & 9 & 9 & 11 & 11 & 10 \\
\hline $\begin{array}{l}\text { Media OCDE para } \\
\text { países con datos } \\
\text { de } 1995,2005 \text { y } 2012\end{array}$ & 20 & & 35 & & & 42 & 11 & & & & & 11 \\
\hline Media UE21 & 18 & 27 & 34 & 40 & 41 & 38 & 9 & 7 & 8 & 8 & 9 & 8 \\
\hline Arabia Saudí & $\mathrm{m}$ & 13 & 18 & 20 & 20 & $\mathbf{m}$ & $\mathrm{n}$ & 3 & 5 & 8 & 8 & m \\
\hline Argentina & $\mathrm{m}$ & $\mathrm{m}$ & $\mathrm{m}$ & $\mathrm{m}$ & $\mathrm{m}$ & $\mathbf{m}$ & $\mathrm{m}$ & $\mathrm{m}$ & $\mathrm{m}$ & $\mathrm{m}$ & $\mathrm{m}$ & m \\
\hline Brasil & $\mathrm{m}$ & 10 & $\mathrm{~m}$ & $\mathrm{~m}$ & $\mathrm{~m}$ & $\mathbf{m}$ & $\mathrm{m}$ & $\mathrm{m}$ & $\mathrm{m}$ & $\mathrm{m}$ & $\mathrm{m}$ & $\mathbf{m}$ \\
\hline China & $\mathrm{m}$ & $\mathrm{m}$ & $\mathrm{m}$ & $\mathrm{m}$ & $\mathrm{m}$ & $\mathbf{m}$ & $\mathrm{m}$ & $\mathrm{m}$ & $\mathrm{m}$ & $\mathrm{m}$ & $\mathrm{m}$ & $\mathbf{m}$ \\
\hline Colombia & $\mathrm{m}$ & $\mathrm{m}$ & $\mathrm{m}$ & $\mathrm{m}$ & $\mathrm{m}$ & $\mathbf{m}$ & $\mathrm{m}$ & $\mathrm{m}$ & $\mathrm{m}$ & $\mathrm{m}$ & $\mathrm{m}$ & m \\
\hline Federación Rusa & $\mathrm{m}$ & $\mathrm{m}$ & $\mathrm{m}$ & $\mathrm{m}$ & $\mathrm{m}$ & $\mathbf{m}$ & $\mathrm{m}$ & $\mathrm{m}$ & $\mathrm{m}$ & $\mathrm{m}$ & $\mathrm{m}$ & $\mathbf{m}$ \\
\hline India & $\mathrm{m}$ & $\mathrm{m}$ & $\mathrm{m}$ & $\mathrm{m}$ & $\mathrm{m}$ & $\mathbf{m}$ & $\mathrm{m}$ & $\mathrm{m}$ & $\mathrm{m}$ & $\mathrm{m}$ & $\mathrm{m}$ & $\mathbf{m}$ \\
\hline Indonesia & $\mathrm{m}$ & $\mathrm{m}$ & $\mathrm{m}$ & $\mathrm{m}$ & $\mathrm{m}$ & $\mathbf{m}$ & $\mathrm{m}$ & $\mathrm{m}$ & $\mathrm{m}$ & $\mathrm{m}$ & $\mathrm{m}$ & $\mathbf{m}$ \\
\hline Letonia & $\mathrm{m}$ & $\mathrm{m}$ & $\mathrm{m}$ & $\mathrm{m}$ & $\mathrm{m}$ & 43 & $\mathrm{~m}$ & $\mathrm{~m}$ & $\mathrm{~m}$ & $\mathrm{~m}$ & $\mathrm{~m}$ & 12 \\
\hline Sudáfrica & $\mathrm{m}$ & $\mathrm{m}$ & $\mathrm{m}$ & $\mathrm{m}$ & $\mathrm{m}$ & $\mathbf{m}$ & $\mathrm{m}$ & $\mathrm{m}$ & $\mathrm{m}$ & $\mathrm{m}$ & $\mathrm{m}$ & $\mathbf{m}$ \\
\hline Media G20 & $\mathrm{m}$ & $\mathrm{m}$ & $\mathrm{m}$ & $\mathrm{m}$ & $\mathrm{m}$ & $\mathbf{m}$ & $\mathrm{m}$ & $\mathrm{m}$ & $\mathrm{m}$ & $\mathrm{m}$ & $\mathrm{m}$ & m \\
\hline
\end{tabular}

Nota: Se pueden consultar en Internet los años 2001, 2002, 2003, 2004, 2006 y 2007 (véase Statlink más abajo).

Hasta 2004, las tasas de graduación en los niveles de educación terciaria de tipo A o B se calculaban sobre una base bruta. Desde 2005, y para todos los países con datos disponibles, las tasas de graduación se calculan como tasas de graduación netas (es decir, como la suma de las tasas de graduación de una edad específica). Para más información sobre el método empleado para calcular las tasas de graduación (tasas brutas frente a tasas netas) y las edades típicas correspondientes, consulte Anexo 1.

1. Ruptura en las series entre 2008 y 2009 debido a una reasignación parcial de los programas de formación profesional a CINE 2 y CINE 5B.

2. Ruptura en la serie temporal tras un cambio metodológico en 2008 para CINE 5A.

Fuentes: OCDE. Arabia Saudí, Argentina, China, Colombia, India, Indonesia, Sudáfrica: Instituto de Estadística de la UNESCO. Letonia: Eurostat. Para ver notas, consulte Anexo 3 (www.oecd.org/edu/eag.htm).

Para obtener más información acerca de los símbolos utilizados en lugar de los datos que faltan, consulte la Guía del lector.

StatLink 젝ㄴ http://dx.doi.org/10.1787/888933115445 


\section{INDICADOR A4}

\section{¿EN QUÉ MEDIDA INFLUYE LA EDUCACIÓN DE LOS PADRES EN LA PARTICIPACIÓN DE LOS HIJOS EN EDUCACIÓN TERCIARIA?}

- En todos los países, aproximadamente un $40 \%$ de los adultos (entre 25 y 64 años) que no son estudiantes cuentan con un nivel de educación superior al de sus progenitores. Corea, Federación Rusa, Finlandia y Flandes (Bélgica), muestran el nivel más elevado de movilidad educativa intergeneracional: en estos países más del $55 \%$ de las personas que no son estudiantes han completado un nivel de educación superior al de sus padres.

- Más del 30\% de los adultos que no son estudiantes cuyos padres no han completado la educación secundaria superior también finalizaron su escolarización antes de completar este nivel. Sin embargo, más del $45 \%$ de estos adultos sí han completado la educación secundaria superior o postsecundaria no terciaria y aproximadamente un $20 \%$ han completado la educación terciaria.

- En todos los países participantes, un $25 \%$ de los adultos cuyos padres no han alcanzado la educación secundaria superior no superan el Nivel 1 de comprensión lectora, el nivel más bajo de la Encuesta sobre las Competencias de los Adultos (PIAAC), mientras que solo aproximadamente un $5 \%$ alcanzan un Nivel 4 o 5 . Entre aquellos adultos cuyos padres cuentan con educación terciaria, más del $20 \%$ alcanzan el Nivel 4 o 5 .

\section{Gráfico A4.1. Porcentaje de estudiantes de 20 a 34 años en educación terciaria, por nivel educativo de los padres (2012)}

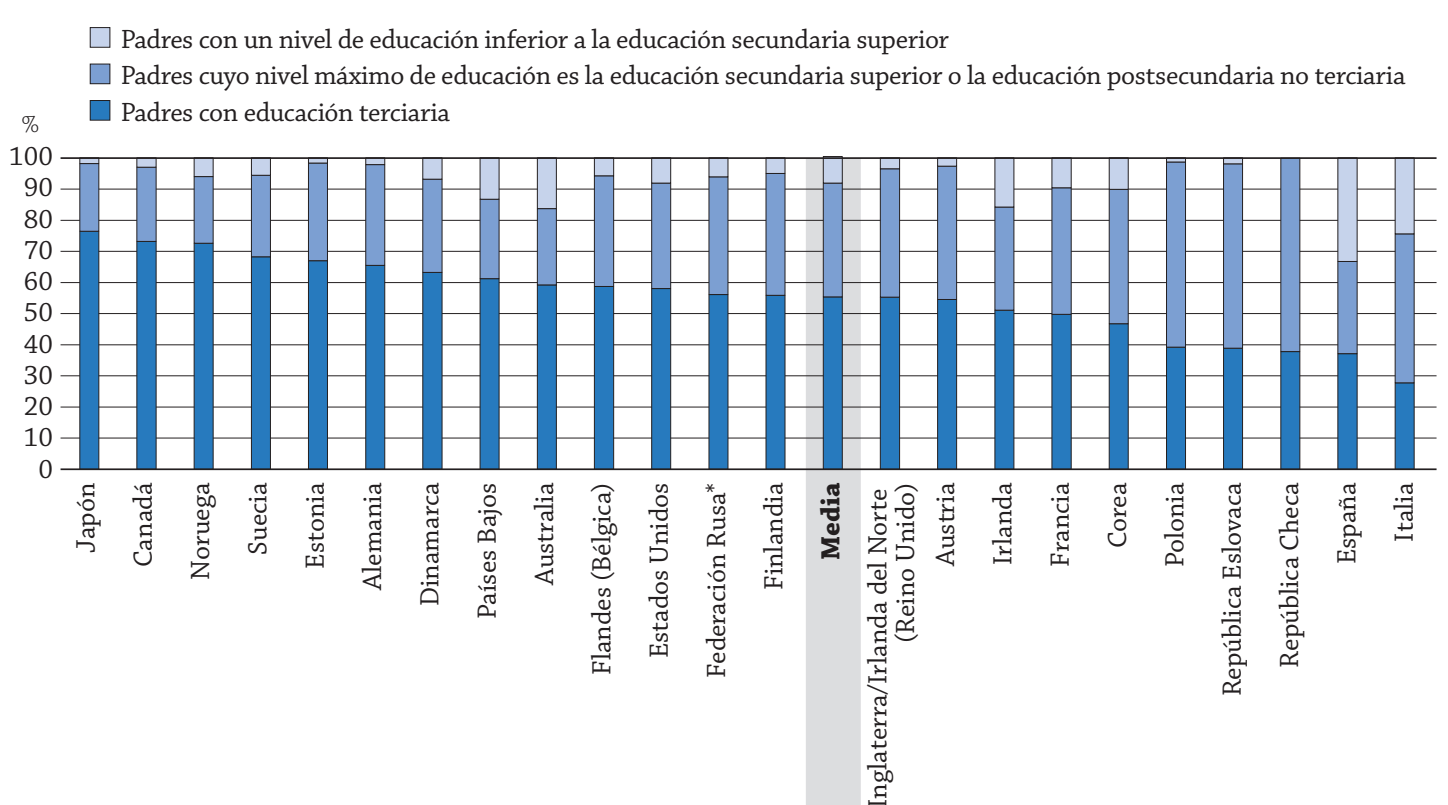

* Para los datos de Federación Rusa, véase nota en la sección de Metodología.

Los países están clasificados en orden descendente de la participación en educación terciaria de estudiantes de 20 a 34 años cuyos padres han alcanzado la educación terciaria.

Fuente: OCDE. Tabla A4.1a. Para ver notas, consulte Anexo 3 (www.oecd.org/edu/eag.htm).

StatLink 제대 http://dx.doi.org/10.1787/888933115635

\section{Contexto}

La educación guarda una estrecha relación con los ingresos, el empleo, las posibilidades económicas en general y el bienestar de las personas y, por tanto, puede reducir la desigualdad social, pero también puede perpetuarla. Brindar a todos los jóvenes la oportunidad de obtener una educación de calidad es algo justo y parte fundamental del contrato social. Es fundamental enfrentarse a la desigualdad en las oportunidades educativas para mantener la movilidad social y ampliar el número de candidatos que pueden acceder a la educación superior y a puestos de trabajo altamente cualificados. Por primera vez, este indicador se basa en la Encuesta sobre las Competencias de los Adultos, que forma parte del Pro- 
grama para la Evaluación Internacional de las Competencias de los Adultos (PIAAC) de la OCDE, para analizar cómo influye la educación de los padres en la participación de los hijos en la educación terciaria.

Para un país que pretenda promover el crecimiento futuro, es de crucial importancia contar con una población activa educada y cualificada. En los mercados laborales altamente cambiantes de hoy, la diferencia entre el rendimiento de los trabajadores poco cualificados y el de los altamente cualificados es cada vez más amplia. Como media, los adultos con niveles de educación inferiores muestran los niveles de desempleo e inactividad más elevados y los sueldos más bajos, que además descienden con mayor rapidez a lo largo de su vida activa (véanse Indicadores A5 y A6). Una población numerosa de trabajadores poco cualificados puede suponer una carga social más gravosa y una agudización de las desigualdades, y ambas cosas resultan complicadas y costosas de abordar una vez que las personas han dejado la educación inicial.

Los resultados de PISA 2012 muestran que, en varios países que diseñaron e implementaron políticas haciendo mayor hincapié en la equidad, los estudiantes de entornos desfavorecidos mejoraron su rendimiento. Un número significativo de países cuyos resultados no alcanzaron la media en 2003 mejoraron notablemente sus puntuaciones en el programa PISA 2012. En varios de estos países, la mejora se debió principalmente a que un mayor número de estudiantes recibieron una educación de mayor calidad (OECD, 2013).

Por tanto, es importante proporcionar igualdad de condiciones en la educación a todos los jóvenes, incluyendo aquellos de entornos con bajos entornos educativos. Diversas opciones en el desarrollo de políticas, como mantener el coste de la educación superior a un nivel razonable y financiar los sistemas de apoyo a los estudiantes, pueden ayudar a los estudiantes desfavorecidos. Es importante garantizar el acceso y el éxito en la educación terciaria de manera universal, pero también lo es abordar las desigualdades en las primeras etapas de escolarización.

\section{Otros resultados}

- En Alemania, Austria, España, Estados Unidos, Italia, Polonia, República Checa y República Eslovaca, más del $50 \%$ de los adultos que no son estudiantes han completado el mismo nivel de educación que sus padres.

- En todos los países, al menos un $35 \%$ de la población entre 20 y 34 años de edad que cursa educación terciaria tiene por lo menos un progenitor que ha completado este nivel de educación. En Alemania, Canadá, Estonia, Noruega y Suecia, este porcentaje es al menos de un $65 \%$.

- Como media, un $\mathbf{1 2}$ \% de los adultos que no son estudiantes han completado un nivel de educación inferior al de sus padres. En Alemania, Austria, Dinamarca, Estados Unidos, Estonia, Noruega y Suecia este porcentaje supera el $15 \%$.

\section{Tendencias}

La expansión de los sistemas educativos en muchos países de la OCDE, tanto en los niveles de educación secundaria superior o postsecundaria no terciaria y de educación terciaria, ha brindado a los jóvenes (entre 25 y 34 años) la oportunidad de alcanzar un nivel de educación superior al de sus padres. Como media en los países de la OCDE que participaron en la Encuesta sobre las Competencias de los Adultos, un $32 \%$ de los jóvenes han alcanzado un nivel educativo superior al de sus padres, mientras que solo un $16 \%$ no han alcanzado el mismo nivel educativo que sus padres. En todos los países exceptuando Alemania, Estonia, Noruega y Suecia, la movilidad educativa absoluta tiende a ser ascendente más que descendente, lo cual refleja la expansión de los sistemas educativos en la mayor parte de los países de la OCDE. Esta expansión ha sido particularmente notable en Corea, España, Federación Rusa, Francia, Irlanda e Italia, donde la diferencia entre la movilidad ascendente y descendente es de 30 puntos porcentuales o más. 


\section{Análisis}

\section{Indicadores de movilidad y terminología}

La bibliografía sobre movilidad generalmente distingue entre medidas de movilidad absolutas y relativas. En lo que respecta a la educación, la movilidad absoluta se refiere a la proporción de personas cuyo nivel de educación es diferente al de sus progenitores: Es mayor en el caso de la movilidad ascendente y menor en el caso de la descendente en todas las generaciones. Las medidas de movilidad absoluta son sensibles al número de niveles de educación que se seleccionen para las comparaciones intergeneracionales (cuanto mayor es el número de categorías, mayor suele ser la movilidad que se observa) y, de manera más esencial, a cambios en la estructura del sistema educativo, especialmente a su expansión en niveles concretos. Los patrones de movilidad se pueden desagregar aún más en movilidad de corto alcance (que se refiere a movimientos entre categorías adyacentes) y movilidad de largo alcance (que se refiere a movimientos entre categorías más distantes), ya que estas pueden tener implicaciones muy diferentes para las personas. En cambio, la inmovilidad educativa significa que los hijos alcanzan el mismo nivel de educación que sus padres.

El análisis de movilidad educativa también incluye medidas de movilidad relativa, que evalúan la diferencia entre las probabilidades de alcanzar determinado nivel de educación que tienen personas cuyos padres han alcanzado diferentes niveles de educación. Un ejemplo extremo de movilidad relativa sería que no existiera diferencia en las probabilidades de alcanzar un determinado nivel de educación u otro entre personas de diferentes entornos educativos.

Las medidas de movilidad absoluta y relativa tienden a guardar relación entre sí, pero reflejan información diferente. El hecho de que un país muestre mayor o menor movilidad absoluta que otro no significa necesariamente que las oportunidades de acceso a un nivel determinado de educación para personas de distintos entornos sean mayores o menores que en otro país.

Este indicador examina las posibilidades de acceder a la educación terciaria en lugar de abandonar el sistema educativo habiendo completado un nivel inferior entre aquellas personas cuyos padres alcanzaron diferentes niveles de educación. Por tanto, este indicador proporciona información sobre las ventajas y desventajas asociadas a tener padres con distintos niveles de logro educativo.

\section{Desigualdades entre países en cuanto a la participación en educación terciaria}

Para algunos jóvenes, no es factible aspirar a una educación superior. Algunos adultos jóvenes pueden verse obligados a incorporarse al mercado laboral antes que otros para poder mantenerse y mantener a sus familias. Crecer en una familia desfavorecida en la que el nivel de educación de los progenitores es bajo conlleva a menudo un menor apoyo económico para poder continuar estudiando. Esta situación se ve acentuada si el sistema educativo no apoya a los estudiantes de entornos desfavorecidos. A corto plazo, seguir estudiando puede implicar renunciar a ingresos generados por el trabajo. En estos casos, no resulta sorprendente que el nivel de educación alcanzado por los padres y el entorno socioeconómico afecten de tal manera el nivel de educación alcanzado por los estudiantes.

Más de la mitad de los estudiantes de educación terciaria de 20 a 34 años de edad tienen por lo menos un progenitor que ha alcanzado ese mismo nivel de educación (56\%), y un poco más de un tercio (36\%) tienen por lo menos un progenitor cuyo máximo nivel de educación completado es la educación secundaria superior. En cambio, la proporción de estudiantes de educación terciaria de 20 a 34 años de edad cuyos progenitores no han completado la educación secundaria superior es pequeña: aproximadamente uno de cada diez estudiantes de educación terciaria tiene progenitores cuyo nivel de educación es inferior a la educación secundaria superior (9\%).

Tal como muestra el gráfico introductorio (Gráfico A4.1), en todos los países, en torno al $35 \%$ de los estudiantes de educación terciaria de 20 a 34 años tienen por lo menos un progenitor que ha completado ese nivel de educación. En Alemania, Canadá, Estonia, Noruega y Suecia esto es así en un $65 \%$ o más de esos estudiantes. Los datos se refieren a estudiantes matriculados, por ello se debe tener en cuenta que en algunos países, entre ellos Suecia, los estudiantes (por ejemplo que proceden de un entorno familiar académico) son más propensos a cursar programas universitarios más largos, de manera que suponen un aumento de las cifras de matriculación. En todos los países con datos disponibles, exceptuando España, la proporción de estudiantes de educación terciaria cuyos padres han completado la educación secundaria superior es mayor que la proporción de estudiantes de educación terciaria con padres cuyo nivel educativo es inferior a la educación secundaria superior.

Evaluar las desigualdades en el acceso a la educación superior es un primer paso crucial para diseñar políticas destinadas a reducirlas. La medida básica de movilidad relativa es la ratio de probabilidades (consulte la sección Definiciones más abajo). En todos los países que disponen de datos comparables, la probabilidad de que un estudiante participe en la educación terciaria, dependiendo del nivel educativo que haya alcanzado su padre o su madre, es dos veces 
mayor si al menos uno de los dos progenitores completó la educación secundaria superior o postsecundaria no terciaria, en comparación con un estudiante cuyos padres completaron un nivel educativo inferior a la educación secundaria superior, y la probabilidad es 4,5 veces mayor si los padres alcanzaron la educación terciaria (Tabla A4.1b).

Como media, un $9 \%$ de todos los estudiantes de educación terciaria tienen padres con niveles educativos bajos, mientras que un $19 \%$ del total de progenitores (es decir, padres de estudiantes y no estudiantes) tienen un nivel educativo bajo. Las proporciones mayores de estudiantes de educación terciaria de 20 a 34 años cuyos padres han alcanzado un nivel de educación inferior a la educación secundaria superior (en los países que disponen de datos) se encuentran en Australia, España, Irlanda, Italia y Países Bajos (más del $10 \%$ ). Sin embargo, estos países se encuentran entre los que también hay una mayor proporción de padres cuyo nivel educativo está por debajo de la educación secundaria superior con respecto al total de los padres (más del 20\%) (Gráfico A4.2).

\section{Gráfico A4.2. Participación en educación terciaria de estudiantes de 20 a 34 años cuyos padres tienen nivel educativo inferior a la secundaria superior (2012)}

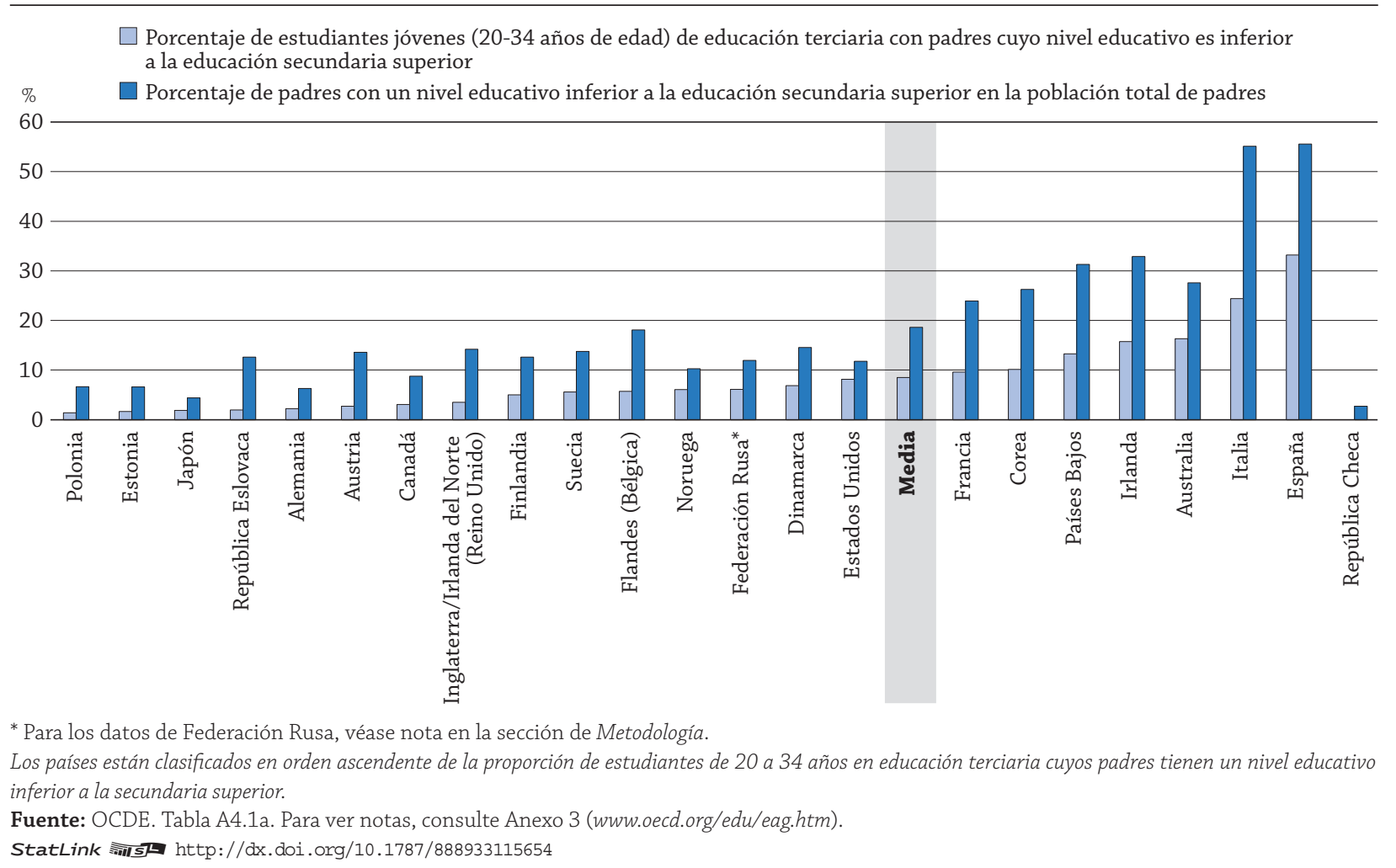

\section{Movilidad intergeneracional en la educación}

Tal y como muestra el Indicador A1, como media, las tasas de graduación terciaria han ido aumentando en los últimos años, particularmente entre las generaciones más jóvenes. De hecho, tanto las tasas más altas de graduación terciaria ( $40 \%$ ) como las proporciones más bajas de personas que no han completado por lo menos la educación secundaria superior (menos del $20 \%$ ) se encuentran entre la población de 25 a 34 años. Además, la proporción de adultos mayores (de 55 a 64 años) con educación terciaria alcanzó un máximo histórico de un $25 \%$ en 2012 (desde el año 2000). Entre los años 2000 y 2012, el crecimiento anual medio de las tasas de graduación terciaria en la población de 55 a 64 años -4\%- fue el más elevado entre todas las generaciones (Indicador A1, Tabla A1.4a).

Esto sugiere que en la mayor parte de los países con información disponible el acceso a la educación ha experimentado una expansión positiva. Como media, aproximadamente un $40 \%$ de la población de 25 a 64 años ha alcanzado un nivel de educación más elevado que el de sus padres (movilidad ascendente). Sin embargo, en la mayor parte de los países, entre un $40 \%$ y un $50 \%$ de los adultos que no estudian han alcanzado el mismo nivel de educación que sus padres (statu quo). Esta proporción es aún mayor en Alemania, Austria, España, Estados Unidos, Italia, República Checa y República Eslovaca (Tabla A4.4). 
El Gráfico A4.3 muestra que en todos los países aproximadamente la mitad de los adultos alcanzan el mismo nivel de educación que sus padres, y la otra mitad alcanzan un nivel de educación superior o inferior al de sus padres. En todos los países, la movilidad ascendente (es decir, adultos cuyo nivel de educación supera el de sus padres) es considerablemente más común que la movilidad descendente. La movilidad intergeneracional en la educación tiene una incidencia particularmente alta en Corea, Federación Rusa, Finlandia y Flandes (Bélgica): en estos países más del $55 \%$ de los adultos han superado o no alcanzado el nivel de educación de sus progenitores. En estos países más del $45 \%$ de los adultos alcanzaron un nivel de educación que supera el de sus padres (movilidad ascendente absoluta), la proporción mayor entre todos los países. Sin embargo, en Finlandia y Flandes (Bélgica), una proporción relativamente amplia de adultos -aproximadamente un $8 \%$ - alcanzaron un nivel de educación inferior al de sus progenitores (movilidad descendente).

En Alemania, Austria, Italia, República Checa y República Eslovaca, más del 55\% de los adultos alcanzaron el mismo nivel de educación que sus padres. En España e Italia, más del $40 \%$ de los adultos cuyo nivel educativo es inferior a la educación secundaria superior tienen padres que sí alcanzaron ese nivel educativo. En Alemania, Austria, Repú-

Gráfico A4.3. Movilidad educativa absoluta (2012)

Porcentaje de población no estudiante de 25 a 64 años cuyo nivel educativo es superior (movilidad ascendente), inferior (movilidad descendente) o igual (statu quo) al de sus padres

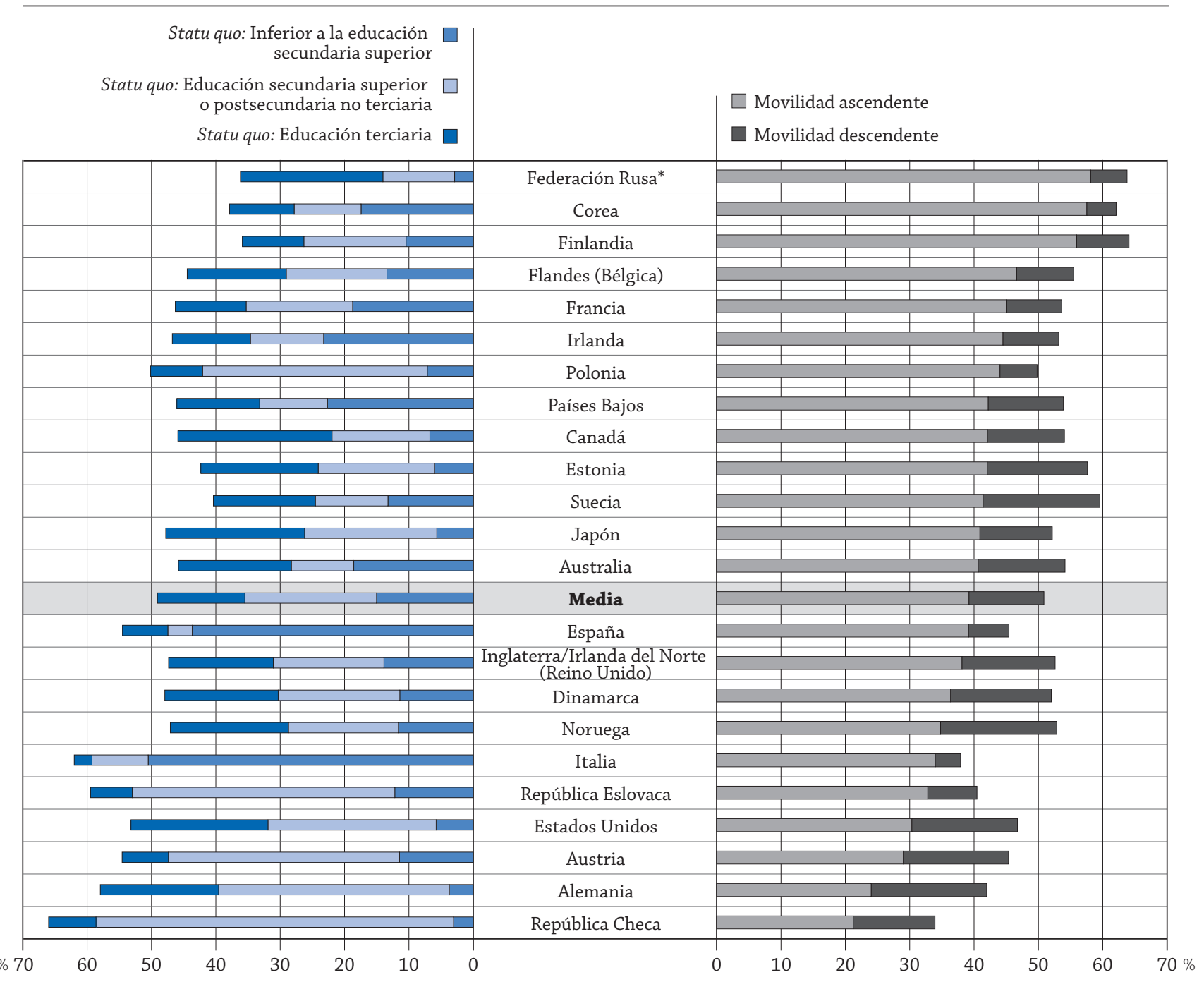

* Para los datos de Federación Rusa, véase nota en la sección de Metodología.

Los países están clasificados en orden descendente de la proporción de adultos con movilidad ascendente en relación con el nivel educativo de sus padres.

Fuente: OCDE. Tabla A4.4. Para ver notas, consulte Anexo 3 (www.oecd.org/edu/eag.htm).

StatLink 젶ㄴ http://dx.doi.org/10.1787/888933115673 
blica Checa y República Eslovaca, más del 35\% de los adultos que completaron la educación secundaria superior o postsecundaria no terciaria tienen padres que también alcanzaron ese mismo nivel educativo. Estos países, junto con Eslovenia, Hungría y Polonia, son los países de la OCDE con las mayores proporciones de adultos que cuentan con este nivel educativo (más del $55 \%$ en cada país; Tabla A1.5a en el Indicador A1). En Canadá, Estados Unidos, Federación Rusa y Japón más del $20 \%$ de los adultos cuyos padres han alcanzado educación terciaria también alcanzan ese nivel educativo (Tabla A4.4).

Como media, la movilidad ascendente absoluta es más común entre mujeres ( $40 \%$ ) que entre hombres (38\%). Sin embargo, en algunos países, la movilidad educativa ascendente de los hombres es considerablemente mayor que la de las mujeres: Alemania ( $21 \%$ en mujeres y $27 \%$ en hombres), Austria ( $25 \%$ y $33 \%$, respectivamente), Corea ( $53 \%$ y $62 \%$, respectivamente) y Países Bajos ( $40 \%$ y $45 \%$, respectivamente) (Tabla A4.4).

La movilidad intergeneracional varía dependiendo del nivel de educación y del contexto. Más del $30 \%$ de los adultos que no son estudiantes y cuyos padres no completaron la educación secundaria superior también finalizaron su escolarización antes de completar este nivel educativo. Sin embargo, más del $45 \%$ de estos adultos han alcanzado la educación secundaria superior o postsecundaria no terciaria y aproximadamente un $20 \%$ tienen educación terciaria. En Canadá, Federación Rusa y Finlandia, más del $30 \%$ de este grupo de adultos han alcanzado la educación terciaria. En cambio, en Alemania, Austria, Estados Unidos, Italia, Polonia, República Checa y República Eslovaca, un máximo del $15 \%$ de los adultos que no son estudiantes y cuyos padres cuentan con un nivel de educación inferior a la educación secundaria superior han alcanzado una educación terciaria (Tabla A4.2).

De manera similar, en todos los países, más del $65 \%$ de los adultos que no son estudiantes y cuyos padres cuentan con educación terciaria han alcanzado el mismo nivel educativo; aproximadamente el $30 \%$ han completado la educación secundaria superior o postsecundaria no terciaria como nivel máximo y solo un $5 \%$ han finalizado su escolarización antes de completar la educación secundaria superior. En todos los países excepto Austria, que tiene una de las proporciones más elevadas de adultos con educación secundaria superior o postsecundaria no terciaria, más del $50 \%$ de los adultos cuyos padres han alcanzado una educación terciaria también han alcanzado este nivel educativo (Tabla A4.2).

El acceso a la educación terciaria también se ve afectado por las desigualdades en etapas más tempranas de la escolarización. Una de las condiciones necesarias para alcanzar niveles superiores de educación es haber adquirido las competencias y los conocimientos necesarios para continuar estudiando. La movilidad intergeneracional en la educación puede verse muy afectada por las primeras etapas de escolarización de un estudiante, ya que los centros escolares pueden reforzar tanto las ventajas como las desventajas socioeconómicas. Desde el primer ciclo de PISA, los resultados han mostrado que, en muchos países, el entorno socioeconómico de los estudiantes está relacionado con su rendimiento escolar. Muy a menudo, los estudiantes que vienen de entornos desfavorecidos tienen un acceso limitado a una educación de calidad. Como media, un estudiante de un entorno socioeconómico más favorable supera en una prueba de matemáticas a otro de un entorno desfavorecido en 39 puntos. Esta diferencia representa el equivalente de casi un año de escolarización (OECD, 2013). Proporcionar acceso a una educación infantil, primaria y secundaria de calidad es algo esencial para que todos los estudiantes tengan la posibilidad de acceder a la educación terciaria, independientemente del nivel educativo alcanzado por sus padres, su ocupación o estatus en el mercado laboral.

\section{Competencias de los adultos en relación con el nivel educativo de los padres}

La educación de los padres también parece influir sobre los resultados que obtiene una persona en pruebas de comprensión lectora y competencia matemática. Como media, de acuerdo con la Encuesta sobre las Competencias de los Adultos, producto del Programa para la Evaluación Internacional de las Competencias de los Adultos (PIAAC) de la OCDE, la mayor parte de las personas que obtienen puntuaciones elevadas en comprensión lectora pertenecen a familias en las que por lo menos uno de los progenitores ha alcanzado una educación terciaria. De manera similar, la mayor parte de los adultos que se encuentran dentro de los niveles más bajos de comprensión lectora tienen padres cuyo nivel más alto ha sido el nivel inferior a la educación secundaria superior (Tabla A4.3 [L]).

El Gráfico A4.4 muestra la comprensión lectora de los adultos en relación con el nivel educativo alcanzado por sus padres. En todos los países participantes, un $25 \%$ de los adultos cuyos padres cuentan con un nivel educativo inferior a la educación secundaria superior alcanzan el Nivel 1 o quedan por debajo de este, un $40 \%$ alcanzan el Nivel 2, menos del 30\% alcanzan el Nivel 3, y solo en torno a un 5\% alcanzan el Nivel 4 o 5 . En Alemania, España, Estados Unidos, Francia, Italia y Polonia, más del $30 \%$ de estos adultos alcanzan el Nivel 1 o quedan por debajo de este en cuanto a comprensión lectora, mientras que un máximo del $3 \%$ alcanzan el Nivel 4 o 5 . De manera similar, aparecen pequeñas proporciones de adultos con niveles de competencia elevados en Austria, República Checa y República Eslovaca. 
Esta imagen cambia de manera significativa cuando se tiene en cuenta a los adultos cuyos padres han completado la educación terciaria. En todos los países, un $7 \%$ de estos adultos alcanzan el Nivel 1 o quedan por debajo de este en comprensión lectora en la Encuesta sobre las Competencias de los Adultos, menos del $25 \%$ alcanzan el Nivel 2, más del $45 \%$ alcanzan el Nivel 3 y más del $20 \%$ alcanzan el Nivel 4 o 5. En la mayor parte de los países, más del $20 \%$ de los adultos cuyos padres tienen educación terciaria alcanzan el Nivel 4 o 5 en comprensión lectora, y en Australia, Finlandia, Japón y Países Bajos este porcentaje es de un $30 \%$ o más.

Entre los adultos cuyos padres no completaron la educación secundaria superior, aproximadamente uno de cada tres tampoco lo ha hecho, mientras que el resto ha completado como mínimo la educación secundaria superior. Uno de cada cuatro de estos adultos alcanza el Nivel 1 o queda por debajo de este en comprensión lectora (Tablas A4.2 y A4.3 [L]).

Flexibilizar la movilidad intergeneracional requiere un enfoque múltiple. Las estrategias a largo plazo, incluyendo la distribución de recursos y oportunidades de manera igualitaria en todo el sistema escolar y la adscripción del mejor profesorado y personal de dirección a centros escolares con resultados por debajo de la media, han dado buenos resultados en algunos países en los que el rendimiento es alto y la equidad supera la media, particularmente en Canadá, Corea, Finlandia y Japón (OECD, 2012). En síntesis, todos los estudiantes, independientemente del entorno socioeconómico del que provengan, deberían tener las mismas oportunidades de alcanzar el éxito.

\section{Gráfico A4.4. Niveles de comprensión lectora y nivel educativo de los padres (2012) Encuesta sobre las Competencias de los Adultos, porcentaje de población no estudiante de 25 a 64 años con un determinado nivel de comprensión lectora}

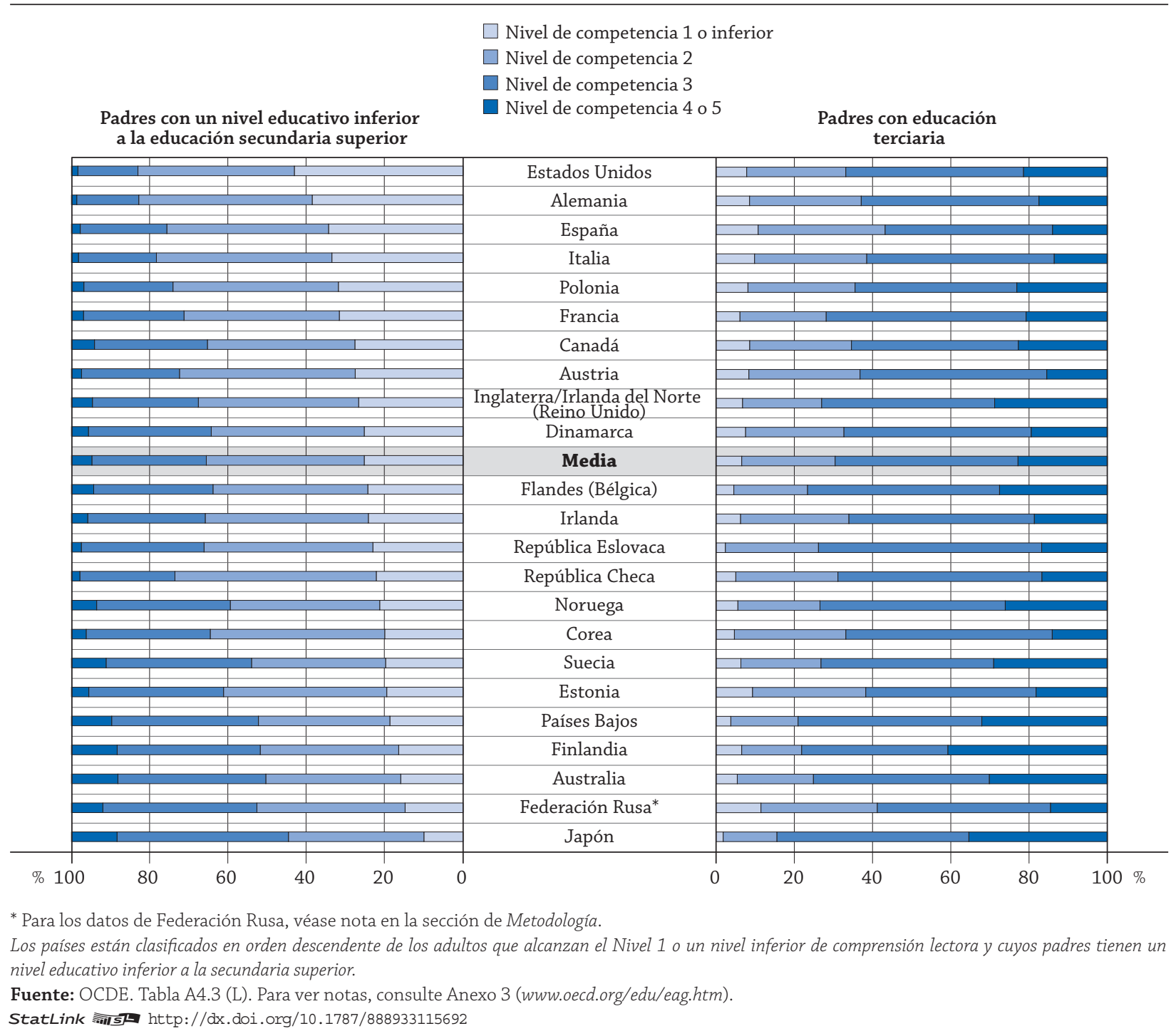




\section{Definiciones}

Adultos se refiere a personas de 25 a 64 años de edad.

Niveles de educación: inferior a educación secundaria superior se corresponde con los niveles CINE 0, 1, 2 y programas $3 C$ cortos; educación secundaria superior o postsecundaria no terciaria se corresponde con los niveles CINE 3A, 3B, programas 3C largos y el nivel CINE 4; y educación terciaria se corresponde con los niveles CINE 5A, 5B y 6. Para ver una presentación de todos los niveles CINE, consulte la Guía del lector que aparece al principio de este libro.

Ratio de probabilidades se refiere a la probabilidad relativa de que ocurra un evento dentro de un grupo concreto en relación con un grupo de referencia. Una ratio de probabilidades de 1 representa una probabilidad igual de que un evento ocurra dentro de un grupo concreto en relación con el grupo de referencia. Los coeficientes inferiores a 1 indican que la probabilidad de que ocurra un evento dentro de un grupo concreto es menor en comparación con el grupo de referencia, y los coeficientes superiores a 1 representan una mayor probabilidad.

Nivel de educación completado: inferior a educación secundaria superior significa que ambos progenitores han completado un nivel CINE 0, 1, 2 o programas 3 C cortos; educación secundaria superior o postsecundaria no terciaria significa que al menos uno de los progenitores (madre o padre) ha completado un nivel CINE 3A, 3B, programas $3 C$ largos, o un nivel CINE 4; y educación terciaria significa que al menos uno de los progenitores (madre o padre) ha completado un nivel CINE 5A, 5B o 6. Para ver una presentación de todos los niveles CINE, consulte la Guía del lector que aparece al principio de este libro.

\section{Metodología}

Todos los datos se basan en la Encuesta sobre las Competencias de los Adultos (PIAAC) (2012). PIAAC es el Programa para la Evaluación Internacional de las Competencias de los Adultos de la OCDE. Para ver información adicional, consulte Acerca de la Encuesta sobre las Competencias de los Adultos al principio de esta publicación y el Anexo 3 (www.oecd.org/edu/eag.htm).

\section{Nota sobre los datos correspondientes a Federación Rusa en la Encuesta sobre las Competencias de los Adultos (PIAAC)}

Los lectores deben tener en cuenta que la muestra correspondiente a Federación Rusa no incluye a la población de la zona municipal de Moscú. Por tanto, los datos publicados no representan a toda la población de 16 a 65 años residente en Rusia, sino a la población de Rusia, excluyendo la población que reside en el área municipal de Moscú. Se puede encontrar información más detallada sobre los datos de Federación Rusa así como de otros países en el Technical Report of the Survey of Adult Skills (OECD, de próxima publicación).

\section{Referencias}

OECD (2013), PISA 2012 Results: Excellence through Equity (Volume II): Giving Every Student the Chance to Succeed, PISA, OECD Publishing, http://dx.doi.org/10.1787/9789264201132-en.

OECD (2012), «How pronounced is income inequality around the world - and how can education help reduce it?», Education Indicadors in Focus, OECD Publishing, París, http://www.oecd.org/edu/50204168.pdf.

\section{Tablas del Indicador A4}

StatLink त्नाIs http://dx.doi.org/10.1787/888933115521

Tabla A4.1a Participación en educación terciaria de la población de 20 a 34 años, por sexo y nivel educativo de los padres (2012)

Tabla A4.1b Probabilidad de participar en educación terciaria, por nivel educativo de los padres y sexo (2012)

Tabla A4.2 Nivel educativo de la población no estudiante, por grupo de edad y nivel educativo de los padres (2012)

Tabla A4.3 (L) Nivel de comprensión lectora de la población no estudiante, por grupo de edad, sexo y nivel educativo de los padres (2012)

WEB Tabla A4.3 (N) Nivel de competencia matemática de la población no estudiante, por grupo de edad, sexo y nivel educativo de los padres (2012)

Tabla A4.4 Movilidad educativa de la población no estudiante, por grupo de edad y nivel educativo de los padres (2012) 
Tabla A4.1a. Participación en educación terciaria de la población de 20 a 34 años, por sexo y nivel educativo de los padres (2012)

Porcentaje de jóvenes de 20 a 34 años en educación terciaria, por nivel educativo de los padres, y nivel educativo de los padres de la población de jóvenes de 20 a 34 años (estudiantes y no estudiantes), por sexo

Lectura de la segunda fila, primera columna de esta tabla: en Australia, un 16\% de la población de 20 a 34 años de edad con progenitores cuyo nivel educativo es inferior a la educación secundaria superior está matriculado en educación terciaria. Debido al método de sondeo, los porcentajes (\%) incluyen una incertidumbre asociada al muestreo de dos veces el error estándar (E.E.). Para obtener más información, consulte la Guía del lector.

\begin{tabular}{|c|c|c|c|c|c|c|c|c|c|c|c|c|c|c|c|}
\hline & & \multicolumn{7}{|c|}{$\begin{array}{l}\text { Porcentaje de estudiantes en educación terciaria } \\
\text { por nivel educativo de los padres }\end{array}$} & \multicolumn{7}{|c|}{$\begin{array}{l}\text { Nivel educativo de los padres en la población total } \\
\text { (estudiantes y no estudiantes) }\end{array}$} \\
\hline & & \multicolumn{2}{|c|}{$\begin{array}{l}\text { Inferior a la } \\
\text { educación } \\
\text { secundaria } \\
\text { superior }\end{array}$} & \multicolumn{2}{|c|}{$\begin{array}{c}\text { Educación } \\
\text { secundaria } \\
\text { superior o } \\
\text { postsecundaria } \\
\text { no terciaria }\end{array}$} & \multicolumn{2}{|c|}{$\begin{array}{c}\text { Educación } \\
\text { terciaria }\end{array}$} & \multirow{2}{*}{$\begin{array}{c}\text { Total } \\
\%\end{array}$} & \multicolumn{2}{|c|}{$\begin{array}{l}\text { Inferior a la } \\
\text { educación } \\
\text { secundaria } \\
\text { superior }\end{array}$} & \multicolumn{2}{|c|}{$\begin{array}{c}\text { Educación } \\
\text { secundaria } \\
\text { superior o } \\
\text { postsecundaria } \\
\text { no terciaria }\end{array}$} & \multicolumn{2}{|c|}{$\begin{array}{c}\text { Educación } \\
\text { terciaria }\end{array}$} & \multirow{2}{*}{$\begin{array}{c}\text { Total } \\
\%\end{array}$} \\
\hline & & $\%$ & E.E. & $\%$ & E.E. & $\%$ & E.E. & & $\%$ & E.E. & $\%$ & E.E. & $\%$ & E.E. & \\
\hline & & (1) & & (3) & $(4)$ & (5) & (6) & (7) & (8) & (9) & (10) & (11) & (12) & (13) & (14) \\
\hline \multicolumn{16}{|c|}{ س Entidades nacionales } \\
\hline & Alemania & 2 & $(0,9)$ & 32 & $(2,8)$ & 65 & $(2,8)$ & 100 & 6 & $(0,8)$ & 48 & $(1,7)$ & 46 & $(1,7)$ & 100 \\
\hline & Australia & 16 & $(2,7)$ & 24 & $(3,7)$ & 59 & $(3,6)$ & 100 & 28 & $(1,4)$ & 30 & $(1,5)$ & 42 & $(1,4)$ & 100 \\
\hline & Austria & 3 & $(1,1)$ & 43 & $(2,8)$ & 55 & $(3,0)$ & 100 & 14 & $(0,9)$ & 59 & $(1,4)$ & 28 & $(1,2)$ & 100 \\
\hline & Canadá & 3 & $(0,6)$ & 24 & $(1,7)$ & 73 & $(1,7)$ & 100 & 9 & $(0,5)$ & 35 & $(1,0)$ & 56 & $(1,1)$ & 100 \\
\hline & Corea & 10 & $(1,7)$ & 43 & $(3,3)$ & 47 & $(3,6)$ & 100 & 26 & $(1,0)$ & 46 & $(1,4)$ & 28 & $(1,2)$ & 100 \\
\hline & Dinamarca & 7 & $(1,3)$ & 30 & $(2,4)$ & 63 & $(2,5)$ & 100 & 15 & $(0,9)$ & 38 & $(1,3)$ & 47 & $(1,4)$ & 100 \\
\hline & España & 33 & $(3,0)$ & 30 & $(3,1)$ & 37 & $(2,8)$ & 100 & 56 & $(1,3)$ & 25 & $(1,2)$ & 19 & $(1,0)$ & 100 \\
\hline & Estados Unidos & 8 & $(1,9)$ & 34 & $(3,0)$ & 58 & $(3,1)$ & 100 & 12 & $(0,9)$ & 40 & $(1,4)$ & 48 & $(1,5)$ & 100 \\
\hline & Estonia & 2 & $(0,6)$ & 31 & $(2,3)$ & 67 & $(2,3)$ & 100 & 7 & $(0,5)$ & 44 & $(0,9)$ & 50 & $(0,9)$ & 100 \\
\hline & Finlandia & 5 & $(1,1)$ & 39 & $(2,4)$ & 56 & $(2,5)$ & 100 & 13 & $(0,9)$ & 51 & $(1,2)$ & 36 & $(1,2)$ & 100 \\
\hline & Francia & 10 & $(1,8)$ & 41 & $(2,7)$ & 50 & $(2,5)$ & 100 & 24 & $(1,0)$ & 48 & $(1,4)$ & 28 & $(1,1)$ & 100 \\
\hline & Irlanda & 16 & $(2,6)$ & 33 & $(3,5)$ & 51 & $(3,7)$ & 100 & 33 & $(1,3)$ & 35 & $(1,4)$ & 32 & $(1,2)$ & 100 \\
\hline & Italia & 24 & $(3,7)$ & 48 & $(4,3)$ & 28 & $(3,6)$ & 100 & 55 & $(1,8)$ & 35 & $(1,7)$ & 10 & $(1,0)$ & 100 \\
\hline & Japón & 2 & $(1,1)$ & 22 & $(3,1)$ & 76 & $(3,2)$ & 100 & 4 & $(0,7)$ & 44 & $(1,6)$ & 51 & $(1,5)$ & 100 \\
\hline & Noruega & 6 & $(1,2)$ & 21 & $(2,3)$ & 73 & $(2,4)$ & 100 & 10 & $(0,9)$ & 38 & $(1,4)$ & 51 & $(1,4)$ & 100 \\
\hline & Países Bajos & 13 & $(2,0)$ & 25 & $(2,3)$ & 61 & $(2,7)$ & 100 & 31 & $(1,4)$ & 31 & $(1,3)$ & 38 & $(1,6)$ & 100 \\
\hline & Polonia & 1 & $(0,3)$ & 59 & $(1,7)$ & 39 & $(1,7)$ & 100 & 7 & $(0,7)$ & 72 & $(0,9)$ & 21 & $(0,8)$ & 100 \\
\hline & República Checa & c & c & 62 & $(2,7)$ & 38 & $(2,6)$ & 100 & 3 & $(0,5)$ & 75 & $(1,4)$ & 22 & $(1,4)$ & 100 \\
\hline & República Eslovaca & 2 & $(1,0)$ & 59 & $(2,5)$ & 39 & $(2,6)$ & 100 & 13 & $(1,0)$ & 69 & $(1,2)$ & 19 & $(1,1)$ & 100 \\
\hline & Suecia & 6 & $(1,4)$ & 26 & $(3,0)$ & 68 & $(3,2)$ & 100 & 14 & $(0,9)$ & 34 & $(1,5)$ & 53 & $(1,7)$ & 100 \\
\hline \multicolumn{16}{|c|}{ Entidades subnacionales } \\
\hline & Flandes (Bélgica) & 6 & $(1,4)$ & 36 & $(2,9)$ & 59 & $(3,0)$ & 100 & 18 & $(1,0)$ & 42 & $(1,3)$ & 40 & $(1,2)$ & 100 \\
\hline & Inglaterra (Reino Unido) & 3 & $(1,6)$ & 41 & $(5,0)$ & 56 & $(5,0)$ & 100 & 14 & $(1,2)$ & 49 & $(1,7)$ & 37 & $(1,8)$ & 100 \\
\hline & $\begin{array}{l}\text { Inglaterra/Irlanda del Norte } \\
\text { (Reino Unido) }\end{array}$ & 4 & $(1,5)$ & 41 & $(4,9)$ & 55 & $(4,9)$ & 100 & 14 & $(1,2)$ & 49 & $(1,6)$ & 37 & $(1,7)$ & 100 \\
\hline & Irlanda del Norte (Reino Unido) & 13 & $(3,4)$ & 42 & $(5,3)$ & 46 & $(5,0)$ & 100 & 22 & $(1,4)$ & 52 & $(1,8)$ & 26 & $(1,7)$ & 100 \\
\hline & Media & 9 & $(0,4)$ & 37 & $(0,6)$ & 55 & $(0,6)$ & 100 & 19 & $(0,2)$ & 45 & $(0,3)$ & 36 & $(0,3)$ & 100 \\
\hline पू. & Federación Rusa* & 6 & $(1,7)$ & 38 & $(3,3)$ & 56 & $(2,9)$ & 100 & 12 & $(2,5)$ & 44 & $(2,3)$ & 44 & $(2,8)$ & 100 \\
\hline
\end{tabular}

* Para los datos de Federación Rusa, véase nota en la sección de Metodología.

Nota: Las filas que muestran los datos de hombres y mujeres por separado están disponibles en Internet (véase StatLink más abajo).

Fuente: OCDE. Encuesta sobre las Competencias de los Adultos (PIAAC) (2012). PIAAC se refiere al Programa para la Evaluación Internacional de las Competencias de los Adultos de la OCDE. Para ver notas, consulte Anexo 3 (www.oecd.org/edu/eag.htm).

Para obtener más información acerca de los símbolos utilizados en lugar de los datos que faltan, consulte la Guía del lector.

StatLink 제패 http://dx.doi.org/10.1787/888933115540 
Tabla A4.1b. Probabilidad de participar en educación terciaria, por nivel educativo de los padres y sexo (2012)

De 20 a 34 años; ratio de probabilidades

La 'ratio de probabilidades' refleja la probabilidad relativa de participar en educación terciaria de las personas cuyos padres tienen un nivel de educación secundaria superior o educación terciaria en comparación con la de las personas cuyos padres tienen un nivel de educación inferior a la educación secundaria superior. Este último grupo se toma como categoría de referencia para interpretar la probabilidad relativa, de manera que su ratio de probabilidades sea 1 . Las diferencias entre los grupos son estadísticamente significativas al alcanzar el $95 \%$ si el «valor p» asociado con la ratio de probabilidades es inferior a 0,5 .

Lectura de la segunda fila: En Australia, una persona cuyos padres tengan como nivel educativo máximo la educación secundaria superior tiene casi dos veces más probabilidades $(1,8)$ de participar en educación terciaria que otra cuyos padres tengan solo un nivel educativo inferior a la educación secundaria superior. Una persona cuyos padres tengan educación terciaria tiene aproximadamente cuatro veces $(4,3)$ más probabilidades de participar en educación terciaria que otra cuyos padres tengan un nivel educativo inferior a la educación secundaria superior.

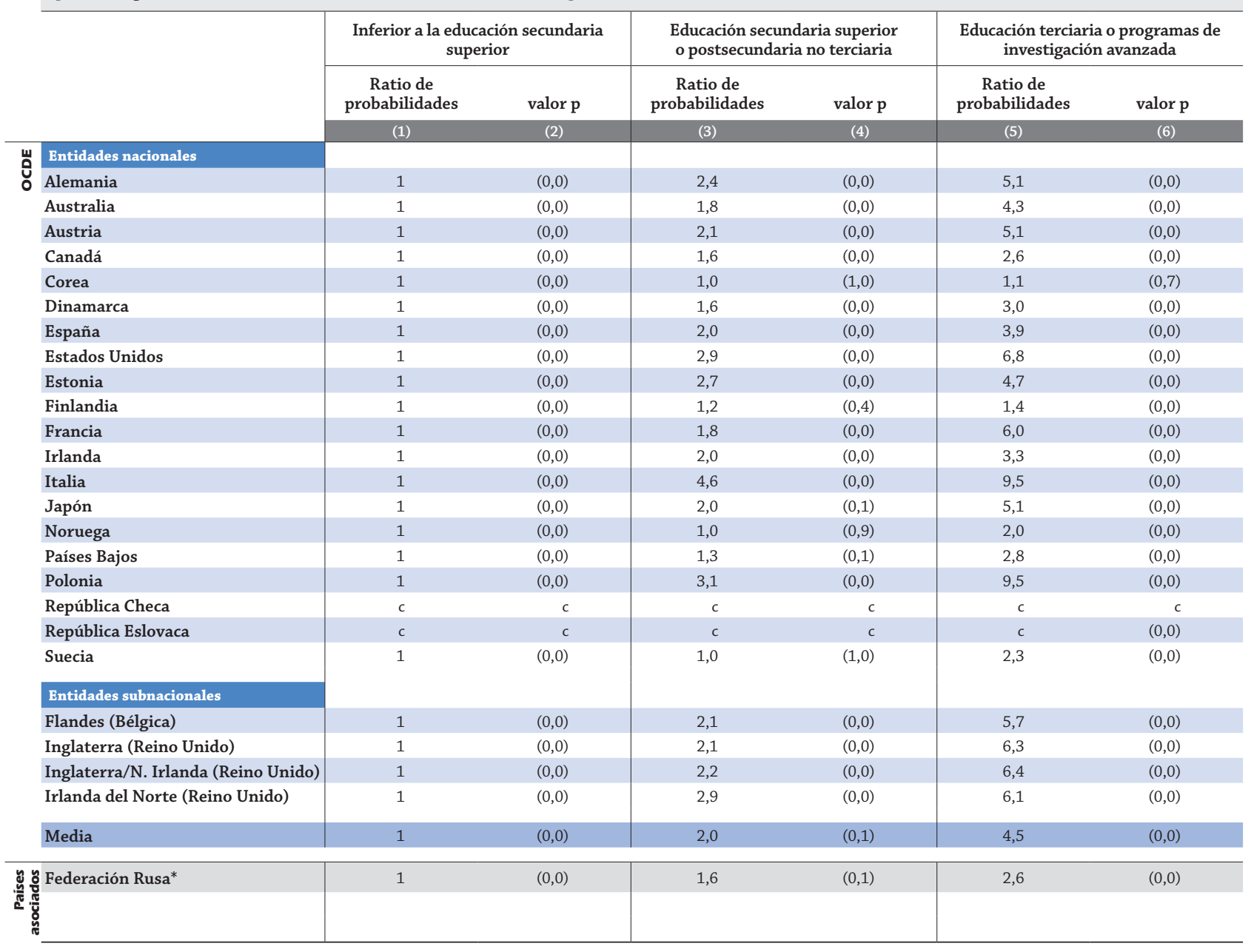

* Para los datos de Federación Rusa, véase nota en la sección de Metodología.

Nota: Las filas que muestran los datos de hombres y mujeres por separado están disponibles en Internet (véase StatLink más abajo).

Fuente: OCDE. Encuesta sobre las Competencias de los Adultos (PIAAC) (2012). PIAAC se refiere al Programa para la Evaluación Internacional de las Competencias de los Adultos de la OCDE. Para ver notas, consulte Anexo 3 (www.oecd.org/edu/eag.htm).

Para obtener más información acerca de los símbolos utilizados en lugar de los datos que faltan, consulte la Guía del lector.

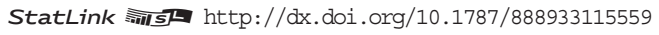


Tabla A4.2. [1/4] Nivel educativo de la población no estudiante, por grupo de edad y nivel educativo de los padres (2012)

\section{5-34 años}

\begin{tabular}{|c|c|c|c|c|c|c|c|c|c|c|c|c|c|}
\hline \multicolumn{14}{|c|}{$\begin{array}{l}\text { Esta tabla muestra, para cada país, la cualificación más alta alcanzada por los no estudiantes de } 25 \text { a } 34 \text { años de edad } \\
\text { sus padres. Por ejemplo, entre las mujeres canadienses de } 25 \text { a } 34 \text { años de edad que tienen al menos un progenitor qu } \\
3 \% \text { tienen una educación inferior a la secundaria superior, un } 25 \% \text { tienen educación secundaria superior o postsecund } \\
\text { también la educación terciaria. }\end{array}$} \\
\hline & \multirow[t]{3}{*}{ (1) } & \multicolumn{6}{|c|}{$\begin{array}{l}\text { Padres con un nivel educativo inferior } \\
\text { a educación secundaria superior }\end{array}$} & \multicolumn{6}{|c|}{$\begin{array}{l}\text { Padres cuyo nivel educativo máximo } \\
\text { es educación secundaria superior } \\
\text { o postsecundaria no terciaria }\end{array}$} \\
\hline & & \multicolumn{2}{|c|}{ Hombres } & \multicolumn{2}{|c|}{ Mujeres } & \multicolumn{2}{|c|}{$\mathrm{H}+\mathrm{M}$} & \multicolumn{2}{|c|}{ Hombres } & \multicolumn{2}{|c|}{ Mujeres } & & $\mathrm{M}$ \\
\hline & & $\%$ & E.E. & $\%$ & E.E. & $\%$ & E.E. & $\%$ & E.E. & $\%$ & E.E. & $\%$ & E.E. \\
\hline Entidades nacionales & & & & & & & & & & & & & \\
\hline Alemania & Inferior a educación secundaria superior & c & & c & c & c & c & 7 & $(2,0)$ & 10 & $(2,4)$ & 8 & $(1,6)$ \\
\hline & Secundaria superior o postsecundaria no terciaria & $c$ & & c & & $c$ & $c$ & 66 & $(4,3)$ & 65 & $(3,7)$ & 66 & $(2,9)$ \\
\hline & Terciaria & c & c & c & c & $c$ & $c$ & 27 & $(3,9)$ & 25 & $(3,1)$ & 26 & $(2,6)$ \\
\hline Australia & Inferior a educación secundaria superior & 27 & $(4,8)$ & 20 & $(3,6)$ & 23 & $(2,8)$ & 17 & $(4,1)$ & 14 & $(3,9)$ & 16 & $(2,8)$ \\
\hline & Secundaria superior o postsecundaria no terciaria & 52 & $(5,7)$ & 47 & $(5,8)$ & 50 & $(3,8)$ & 55 & $(4,6)$ & 38 & $(5,0)$ & 47 & $(3,3)$ \\
\hline & Terciaria & 21 & $(3,5)$ & 33 & $(5,3)$ & 27 & $(2,8)$ & 28 & $(4,3)$ & 48 & $(5,4)$ & 38 & $(3,4)$ \\
\hline Austria & Inferior a educación secundaria superior & c & & c & c & 34 & $(3,5)$ & 9 & $(1,6)$ & 11 & $(2,0)$ & 10 & $(1,3)$ \\
\hline & Secundaria superior o postsecundaria no terciaria & c & & c & c & 58 & $(3,9)$ & 75 & $(2,4)$ & 73 & $(2,5)$ & 74 & $(1,8)$ \\
\hline & Terciaria & c & c & c & c & 8 & $(2,2)$ & 16 & $(2,0)$ & 16 & $(1,8)$ & 16 & $(1,4)$ \\
\hline Canadá & Inferior a educación secundaria superior & 21 & $(5,0)$ & 26 & $(4,7)$ & 24 & $(3,3)$ & 12 & $(2,3)$ & 5 & $(1,1)$ & 9 & $(1,3)$ \\
\hline & Secundaria superior o postsecundaria no terciaria & 48 & $(6,5)$ & 34 & $(4,9)$ & 40 & $(3,9)$ & 46 & $(3,6)$ & 39 & $(2,9)$ & 43 & $(2,4)$ \\
\hline & Terciaria & 31 & $(5,8)$ & 40 & $(5,3)$ & 36 & $(3,9)$ & 42 & $(3,3)$ & 56 & $(2,8)$ & 49 & $(2,2)$ \\
\hline Corea & Inferior a educación secundaria superior & 6 & $(1,7)$ & 6 & $(1,9)$ & 6 & $(1,2)$ & 1 & $(0,8)$ & c & c & 1 & $(0,5)$ \\
\hline & Secundaria superior o postsecundaria no terciaria & 42 & $(3,0)$ & 40 & $(3,7)$ & 41 & $(2,1)$ & 40 & $(3,0)$ & 31 & $(2,8)$ & 35 & $(1,9)$ \\
\hline & Terciaria & 52 & $(3,2)$ & 54 & $(3,4)$ & 53 & $(2,0)$ & 59 & $(2,9)$ & 68 & $(2,9)$ & 64 & $(1,9)$ \\
\hline Dinamarca & Inferior a educación secundaria superior & c & c & c & c & 33 & $(4,6)$ & 12 & $(3,1)$ & 12 & $(3,0)$ & 12 & $(2,3)$ \\
\hline & Secundaria superior o postsecundaria no terciaria & c & & c & c & 43 & $(4,7)$ & 59 & $(4,6)$ & 33 & $(3,7)$ & 48 & $(3,1)$ \\
\hline & Terciaria & c & c & c & c & 25 & $(3,7)$ & 30 & $(3,5)$ & 56 & $(4,1)$ & 41 & $(2,5)$ \\
\hline España & Inferior a educación secundaria superior & 56 & $(3,1)$ & 45 & $(3,2)$ & 51 & $(2,2)$ & 30 & $(4,5)$ & 14 & $(3,1)$ & 22 & $(2,9)$ \\
\hline & Secundaria superior o postsecundaria no terciaria & 25 & $(2,6)$ & 23 & $(2,8)$ & 24 & $(1,7)$ & 37 & $(5,3)$ & 28 & $(4,7)$ & 32 & $(3,7)$ \\
\hline & Terciaria & 19 & $(2,2)$ & 32 & $(2,9)$ & 25 & $(1,9)$ & 33 & $(4,2)$ & 58 & $(5,1)$ & 46 & $(3,6)$ \\
\hline Estados Unidos & Inferior a educación secundaria superior & c & c & c & c & 35 & $(4,6)$ & 11 & $(2,7)$ & 5 & $(1,5)$ & 8 & $(1,7)$ \\
\hline & Secundaria superior o postsecundaria no terciaria & c & c & c & c & 61 & $(4.7)$ & 59 & $(4.2)$ & 52 & $(3.7)$ & 56 & $(2.7)$ \\
\hline & Terciaria & c & c & c & c & 5 & $(1.4)$ & 30 & $(4.1)$ & 43 & $(3.5)$ & 36 & $(2.9)$ \\
\hline Estonia & Inferior a educación secundaria superior & c & c & c & c & 38 & $(5,8)$ & 19 & $(2,5)$ & 12 & $(2,2)$ & 15 & $(1,7)$ \\
\hline & Secundaria superior o postsecundaria no terciaria & c & c & c & c & 44 & $(4,8)$ & 52 & $(3,4)$ & 39 & $(3,0)$ & 46 & $(2,2)$ \\
\hline & Terciaria & c & c & c & c & 18 & $(4,0)$ & 29 & $(3,0)$ & 49 & $(2,7)$ & 39 & $(2,1)$ \\
\hline Finlandia & Inferior a educación secundaria superior & c & c & c & c & 7 & $(2,8)$ & 12 & $(2,7)$ & 7 & $(1,9)$ & 9 & $(1,6)$ \\
\hline & Secundaria superior o postsecundaria no terciaria & c & & $c$ & c & 58 & $(4,4)$ & 56 & $(3,4)$ & 38 & $(3,2)$ & 47 & $(2,2)$ \\
\hline & Terciaria & c & $c$ & c & c & 34 & $(4,5)$ & 32 & $(3,1)$ & 55 & $(3,2)$ & 43 & $(2,2)$ \\
\hline Francia & Inferior a educación secundaria superior & 28 & $(3,7)$ & 25 & $(3,3)$ & 26 & $(2,4)$ & 12 & $(2,2)$ & 6 & $(1,5)$ & 9 & $(1,3)$ \\
\hline & Secundaria superior o postsecundaria no terciaria & 48 & $(3,9)$ & 49 & $(4,2)$ & 48 & $(2,5)$ & 55 & $(3,4)$ & 45 & $(3,2)$ & 50 & $(2,2)$ \\
\hline & Terciaria & 24 & $(3,8)$ & 26 & $(3,5)$ & 25 & $(2,3)$ & 33 & $(3,3)$ & 48 & $(3,3)$ & 41 & $(2,2)$ \\
\hline Irlanda & Inferior a educación secundaria superior & 25 & $(3,0)$ & 22 & $(2,7)$ & 24 & $(1,9)$ & 11 & $(2,3)$ & 5 & $(1,4)$ & 8 & $(1,3)$ \\
\hline & Secundaria superior o postsecundaria no terciaria & 44 & $(3,7)$ & 48 & $(3,0)$ & 46 & $(2,1)$ & 51 & $(4,6)$ & 41 & $(3,7)$ & 46 & $(2,7)$ \\
\hline & Terciaria & 31 & $(3,3)$ & 29 & $(2,5)$ & 30 & $(1,7)$ & 38 & $(4,5)$ & 54 & $(3,7)$ & 46 & $(2,8)$ \\
\hline Italia & Inferior a educación secundaria superior & 49 & $(3,9)$ & 40 & $(3,7)$ & 45 & $(2,6)$ & c & c & 6 & $(2,6)$ & 10 & $(2,7)$ \\
\hline & Secundaria superior o postsecundaria no terciaria & 44 & $(4,0)$ & 49 & $(3,7)$ & 46 & $(2,7)$ & c & c & 52 & $(5,4)$ & 54 & $(3,5)$ \\
\hline & Terciaria & 8 & $(2,1)$ & 11 & $(2,1)$ & 9 & $(1,5)$ & c & c & 42 & $(4,8)$ & 36 & $(3,3)$ \\
\hline Japón & Inferior a educación secundaria superior & c & c & c & c & c & c & 9 & $(2,2)$ & 9 & $(2,8)$ & 9 & $(1,6)$ \\
\hline & Secundaria superior o postsecundaria no terciaria & c & c & c & c & c & c & 47 & $(3,4)$ & 43 & $(3,6)$ & 45 & $(2,4)$ \\
\hline & Terciaria & c & c & c & c & c & $c$ & 44 & $(3,7)$ & 47 & $(3,5)$ & 45 & $(2,6)$ \\
\hline Noruega & Inferior a educación secundaria superior & c & c & c & c & c & c & 24 & $(3,5)$ & 17 & $(3,1)$ & 21 & $(2,4)$ \\
\hline & Secundaria superior o postsecundaria no terciaria & c & & c & c & $c$ & $c$ & 50 & $(3,7)$ & 40 & $(4,8)$ & 45 & $(2,8)$ \\
\hline & Terciaria & c & c & c & c & c & c & 26 & $(3,5)$ & 43 & $(4,1)$ & 34 & $(2,6)$ \\
\hline Países Bajos & Inferior a educación secundaria superior & 36 & $(5,3)$ & 19 & $(3,3)$ & 27 & $(3,2)$ & 15 & $(2,6)$ & 14 & $(3,3)$ & 14 & $(2,0)$ \\
\hline & Secundaria superior o postsecundaria no terciaria & 41 & $(5,1)$ & 47 & $(4,4)$ & 44 & $(3,3)$ & 49 & $(5,3)$ & 47 & $(4,8)$ & 48 & $(3,2)$ \\
\hline & Terciaria & 23 & $(4,7)$ & 34 & $(4,1)$ & 29 & $(3,0)$ & 36 & $(5,7)$ & 39 & $(4,4)$ & 37 & $(3,3)$ \\
\hline Polonia & Inferior a educación secundaria superior & c & c & c & $\mathrm{c}$ & 18 & $(4,3)$ & 6 & $(1,3)$ & 4 & $(1,2)$ & 5 & $(0,9)$ \\
\hline & Secundaria superior o postsecundaria no terciaria & c & & c & c & 67 & $(5,2)$ & 63 & $(2,6)$ & 49 & $(2,7)$ & 56 & $(2,0)$ \\
\hline & Terciaria & c & c & c & c & 16 & $(4,7)$ & 32 & $(2,6)$ & 47 & $(2,8)$ & 39 & $(1,9)$ \\
\hline República Checa & Inferior a educación secundaria superior & c & c & c & c & c & c & 8 & $(1,7)$ & 6 & $(1,8)$ & 7 & $(1,2)$ \\
\hline & Secundaria superior o postsecundaria no terciaria & c & & c & c & c & c & 80 & $(2,2)$ & 65 & $(3,0)$ & 73 & $(1,8)$ \\
\hline & Terciaria & $c$ & $c$ & c & c & c & $c$ & 12 & $(1,7)$ & 28 & $(2,4)$ & 19 & $(1,3)$ \\
\hline República Eslovaca & Inferior a educación secundaria superior & 60 & $(5,8)$ & 57 & $(5,8)$ & 58 & $(4,6)$ & 7 & $(1,2)$ & 5 & $(0,9)$ & 6 & $(0,7)$ \\
\hline & Secundaria superior o postsecundaria no terciaria & 40 & $(5,8)$ & 39 & $(5,7)$ & 40 & $(4,4)$ & 73 & $(2,5)$ & 67 & $(2,9)$ & 70 & $(2,1)$ \\
\hline & Terciaria & c & $\mathrm{c}$ & 4 & $(2,3)$ & 2 & $(1,2)$ & 20 & $(2,6)$ & 28 & $(2,7)$ & 24 & $(2,0)$ \\
\hline Suecia & Inferior a educación secundaria superior & c & c & c & c & 25 & $(4,5)$ & 19 & $(4,4)$ & 11 & $(3,2)$ & 15 & $(2,8)$ \\
\hline & Secundaria superior o postsecundaria no terciaria & c & & $c$ & c & 48 & $(4,2)$ & 57 & $(5,4)$ & 51 & $(4,8)$ & 54 & $(3,9)$ \\
\hline & Terciaria & $c$ & c & $c$ & $c$ & 27 & $(3,7)$ & 23 & $(3,7)$ & 38 & $(4,6)$ & 31 & $(3,2)$ \\
\hline
\end{tabular}

* Para los datos de Federación Rusa, véase nota en la sección de Metodología.

Nota: Las columnas que muestran los datos de otros desgloses por edad y de todos los niveles educativos de los padres de manera conjunta están disponibles en Internet (véase StatLink más abajo).

Fuente: OCDE. Encuesta sobre las Competencias de los Adultos (PIAAC) (2012). PIAAC se refiere al Programa para la Evaluación Internacional de las Competencias de los Adultos de la OCDE. Para ver notas, consulte Anexo 3 (www.oecd.org/edu/eag.htm).

Para obtener más información acerca de los símbolos utilizados en lugar de los datos que faltan, consulte la Guía del lector.

StatLink ज्ञाs http://dx.doi.org/10.1787/888933115578 
Tabla A4.2. [2/4] Nivel educativo de la población no estudiante, por grupo de edad y nivel educativo de los padres (2012)

\section{5-34 años}

Esta tabla muestra, para cada país, la cualificación más alta alcanzada por los no estudiantes de 25 a 34 años de edad en comparación con el nivel educativo de sus padres. Por ejemplo, entre las mujeres canadienses de 25 a 34 años de edad que tienen al menos un progenitor que ha alcanzado la educación terciaria, un $3 \%$ tienen una educación inferior a la secundaria superior, un $25 \%$ tienen educación secundaria superior o postsecundaria no terciaria y un $73 \%$ han alcanzado también la educación terciaria.

\begin{tabular}{|c|c|c|c|c|c|c|c|c|c|c|c|c|c|c|}
\hline & & \multirow[b]{3}{*}{ Nivel educativo alcanzado } & \multicolumn{6}{|c|}{$\begin{array}{l}\text { Padres con un nivel educativo inferior } \\
\text { a educación secundaria superior }\end{array}$} & \multicolumn{6}{|c|}{$\begin{array}{l}\text { Padres cuyo nivel educativo máximo } \\
\text { es educación secundaria superior } \\
\text { o postsecundaria no terciaria }\end{array}$} \\
\hline & & & \multicolumn{2}{|c|}{ Hombres } & \multicolumn{2}{|c|}{ Mujeres } & \multicolumn{2}{|c|}{$\mathrm{H}+\mathrm{M}$} & \multicolumn{2}{|c|}{ Hombres } & \multicolumn{2}{|c|}{ Mujeres } & \multicolumn{2}{|c|}{$\mathrm{H}+\mathrm{M}$} \\
\hline & & & (25) & (26) & (27) & $(28)$ & (29) & $(30)$ & (31) & $(32)$ & (33) & $(34)$ & (35) & $(36)$ \\
\hline \multirow{3}{*}{ :ّ } & Entidades subnacionales & & & & & & & & & & & & & \\
\hline & Flandes (Bélgica) & Inferior a educación secundaria superior & c & c & 17 & $(4,0)$ & 17 & $(3,3)$ & 8 & $(2,1)$ & 6 & $(2,0)$ & 7 & $(1,4)$ \\
\hline & & Terciaria & c & c & 29 & $(4,9)$ & 22 & $(3,6)$ & 33 & $(3,5)$ & 47 & $(3,7)$ & 40 & $(2,3)$ \\
\hline & Inglaterra (Reino Unido) & Inferior a educación secundaria superior & c & c & c & c & 36 & $(4,6)$ & 16 & $(3,1)$ & 12 & $(2,4)$ & 14 & $(1,8)$ \\
\hline & & Secundaria superior o postsecundaria no terciaria & c & c & c & c & 40 & $(4,9)$ & 39 & $(4,7)$ & 41 & $(3,6)$ & 40 & $(3,1)$ \\
\hline & & Terciaria & c & c & c & c & 24 & $(4,8)$ & 45 & $(4,2)$ & 47 & $(3,5)$ & 46 & $(2,7)$ \\
\hline & $\begin{array}{l}\text { Inglaterra/Irlanda } \\
\text { del Norte (Reino Unido) }\end{array}$ & & 37 & & 36 & & 36 & $(4,3)$ & 16 & $(3,0)$ & 12 & $(2,3)$ & 14 & $(1,7)$ \\
\hline & & Secundaria superior o postsecundaria no terciaria & 38 & $(6,7)$ & 41 & $(5,8)$ & 40 & $(4,6)$ & 39 & $(4,5)$ & 41 & $(3,4)$ & 40 & $(2,9)$ \\
\hline \multirow{3}{*}{\multicolumn{2}{|c|}{$\begin{array}{l}\text { Irlanda del Norte } \\
\text { (Reino Unido) }\end{array}$}} & & c & c & 40 & $(6,8)$ & 44 & $(4,6)$ & 17 & $(4,4)$ & 12 & $(3,0)$ & 15 & $(2,6)$ \\
\hline & & Secundaria superior o postsecundaria no terciaria & c & c & 34 & $(5,1)$ & 36 & $(4,2)$ & 42 & $(4,6)$ & 45 & $(3,9)$ & 44 & $(2,8)$ \\
\hline & & Terciaria & c & c & 26 & $(5,0)$ & 20 & $(3,2)$ & 40 & $(5,4)$ & 43 & $(4,3)$ & 42 & $(2,8)$ \\
\hline \multirow{3}{*}{\multicolumn{2}{|c|}{ Media }} & Inferior a educación secundaria superior & 35 & $(1,5)$ & 29 & $(1,2)$ & 29 & $(0,9)$ & 13 & $(0,6)$ & 9 & $(0,5)$ & 11 & $(0,4)$ \\
\hline & & Secundaria superior o postsecundaria no terciaria & 42 & $(1,5)$ & 43 & $(1,4)$ & 48 & $(0,9)$ & 56 & $(0,9)$ & 47 & $(0,8)$ & 51 & $(0,6)$ \\
\hline & & Terciaria & 26 & $(1,4)$ & 29 & $(1,2)$ & 23 & $(0,7)$ & 32 & $(0,8)$ & 45 & $(0,8)$ & 38 & $(0,5)$ \\
\hline \multirow{3}{*}{ 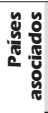 } & \multirow{3}{*}{ Federación Rusa* } & Inferior a educación secundaria superior & c & c & c & c & c & c & 14 & $(3,2)$ & 2 & $(1,2)$ & 8 & $(1,5)$ \\
\hline & & Secundaria superior o postsecundaria no terciaria & c & c & c & c & c & c & 22 & $(4,2)$ & 32 & $(2,6)$ & 27 & $(2,9)$ \\
\hline & & Terciaria & c & c & c & c & c & c & 64 & $(5,2)$ & 65 & $(3,0)$ & 65 & $(2,9)$ \\
\hline
\end{tabular}

* Para los datos de Federación Rusa, véase nota en la sección de Metodología.

Nota: Las columnas que muestran los datos de otros desgloses por edad y de todos los niveles educativos de los padres de manera conjunta están disponibles en Internet (véase StatLink más abajo).

Fuente: OCDE. Encuesta sobre las Competencias de los Adultos (PIAAC) (2012). PIAAC se refiere al Programa para la Evaluación Internacional de las Competencias de los Adultos de la OCDE. Para ver notas, consulte Anexo 3 (www.oecd.org/edu/eag.htm).

Para obtener más información acerca de los símbolos utilizados en lugar de los datos que faltan, consulte la Guía del lector.

StatLink 제내 http://dx.doi.org/10.1787/888933115578 
Tabla A4.2. [3/4] Nivel educativo de la población no estudiante, por grupo de edad y nivel educativo de los padres (2012)

25-34 años

\begin{tabular}{|c|c|c|c|c|c|c|c|c|c|c|c|c|c|}
\hline \multicolumn{14}{|c|}{$\begin{array}{l}\text { Esta tabla muestra, para cada país, la cualificación más alta alcanzada por los no estudiantes de } 25 \text { a } 34 \text { años de edad en comparación con el nivel educativo de } \\
\text { sus padres. Por ejemplo, entre las mujeres canadienses de } 25 \text { a } 34 \text { años de edad que tienen al menos un progenitor que ha alcanzado la educación terciaria, un } \\
3 \% \text { tienen una educación inferior a la secundaria superior, un } 25 \% \text { tienen educación secundaria superior o postsecundaria no terciaria y un } 73 \% \text { han alcanzado } \\
\text { también la educación terciaria. }\end{array}$} \\
\hline & \multirow[b]{4}{*}{ Nivel educativo alcanzado } & \multicolumn{6}{|c|}{ Padres con Educación terciaria } & \multicolumn{6}{|c|}{$\begin{array}{c}\text { Todos los niveles de educación } \\
\text { de los padres }\end{array}$} \\
\hline & & \multicolumn{2}{|c|}{ Hombres } & \multicolumn{2}{|c|}{ Mujeres } & \multicolumn{2}{|c|}{$\mathrm{H}+\mathrm{M}$} & \multicolumn{2}{|c|}{ Hombres } & \multicolumn{2}{|c|}{\begin{tabular}{|l|} 
Mujeres \\
\end{tabular}} & & $+\mathrm{M}$ \\
\hline & & $\%$ & E.E. & $\%$ & E.E. & $\%$ & E.E. & $\%$ & E.E. & $\%$ & E.E. & $\%$ & E.E. \\
\hline & & $(37)$ & $(38)$ & (39) & $(40)$ & (41) & $(42)$ & $(43)$ & $(44)$ & $(45)$ & $(46)$ & $(47)$ & $(48)$ \\
\hline Entidades nacionales & & & & & & & & & & & & & \\
\hline Alemania & Inferior a educación secundaria superior & 8 & $(2,8)$ & 8 & $(3,5)$ & 8 & $(2,2)$ & 9 & $(1,8)$ & 10 & $(2,0)$ & 10 & $(1,3)$ \\
\hline & Secundaria superior o postsecundaria no terciaria & & $(4,4)$ & 34 & $(4,3)$ & 41 & $(3,1)$ & 58 & $(3,2)$ & 52 & $(2,9)$ & 55 & $(2,1)$ \\
\hline & Terciaria & 44 & $(3,8)$ & 59 & $(4,4)$ & 51 & $(3,0)$ & 33 & $(2,7)$ & 38 & $(2,6)$ & 35 & $(1,9)$ \\
\hline Australia & Inferior a educación secundaria superior & 4 & $(1,3)$ & 5 & $(1,7)$ & 4 & $(1,1)$ & 15 & $(1,9)$ & 12 & $(1,4)$ & 14 & $(1,1)$ \\
\hline & Secundaria superior o postsecundaria no terciaria & 36 & $(3,9)$ & 16 & $(2,5)$ & 26 & $(2,4)$ & 47 & $(2,6)$ & 32 & $(2,8)$ & 40 & $(1,7)$ \\
\hline & Terciaria & 60 & $(4,1)$ & 79 & $(2,8)$ & 70 & $(2,6)$ & 38 & $(2,3)$ & 56 & $(2,7)$ & 47 & $(1,6)$ \\
\hline Austria & Inferior a educación secundaria superior & 4 & $(2,6)$ & 8 & $(3,1)$ & 6 & $(2,2)$ & 11 & $(0,9)$ & 15 & $(1,2)$ & 13 & $(0,8)$ \\
\hline & Secundaria superior o postsecundaria no terciaria & 66 & $(4,5)$ & 55 & $(4,5)$ & 60 & $(3,4)$ & 71 & $(1,5)$ & 65 & $(1,4)$ & 68 & $(1,0)$ \\
\hline & Terciaria & 29 & $(3,9)$ & 37 & $(3,6)$ & 34 & $(2,7)$ & 18 & $(1,2)$ & 19 & $(1,0)$ & 19 & $(0,8)$ \\
\hline Canadá & Inferior a educación secundaria superior & 3 & $(1,0)$ & 3 & $(0,8)$ & 3 & $(0,6)$ & 9 & $(1,2)$ & 7 & $(0,8)$ & 8 & $(0,7)$ \\
\hline & Secundaria superior o postsecundaria no terciaria & 29 & $(2,6)$ & 25 & $(2,5)$ & 27 & $(1,8)$ & 38 & $(2,1)$ & 31 & $(1,4)$ & 35 & $(1,3)$ \\
\hline & Terciaria & 67 & $(2,6)$ & 73 & $(2,5)$ & 70 & $(1,9)$ & 53 & $(1,8)$ & 62 & $(1,5)$ & 58 & $(1,1)$ \\
\hline Corea & Inferior a educación secundaria superior & c & c & c & c & c & c & 3 & $(0,6)$ & 2 & $(0,7)$ & 3 & $(0,5)$ \\
\hline & Secundaria superior o postsecundaria no terciaria & 17 & $(4,1)$ & 12 & $(3,3)$ & 15 & $(2,6)$ & 36 & $(1,5)$ & 30 & $(1,9)$ & 33 & $(0,8)$ \\
\hline & Terciaria & 83 & $(4,1)$ & 87 & $(3,5)$ & 85 & $(2,6)$ & 61 & $(1,5)$ & 68 & $(1,9)$ & 64 & $(0,7)$ \\
\hline Dinamarca & Inferior a educación secundaria superior & 8 & $(2,5)$ & 9 & $(3,4)$ & 9 & $(2,0)$ & 14 & $(2,1)$ & 14 & $(2,1)$ & 14 & $(1,5)$ \\
\hline & Secundaria superior o postsecundaria no terciaria & 31 & $(4,4)$ & 14 & $(3,1)$ & 22 & $(2,5)$ & 46 & $(3,0)$ & 26 & $(2,4)$ & 36 & $(1,9)$ \\
\hline & Terciaria & 61 & $(4,3)$ & 76 & $(3,9)$ & 69 & $(2,7)$ & 40 & $(2,7)$ & 60 & $(2,6)$ & 50 & $(1,7)$ \\
\hline España & Inferior a educación secundaria superior & c & c & c & c & 11 & $(2,3)$ & 43 & $(2,2)$ & 32 & $(2,1)$ & 38 & $(1,5)$ \\
\hline & Secundaria superior o postsecundaria no terciaria & c & & c & c & 22 & $(3,4)$ & 27 & $(2,3)$ & 25 & $(2,0)$ & 26 & $(1,4)$ \\
\hline & Terciaria & c & c & c & c & 67 & $(3,6)$ & 30 & $(1,8)$ & 43 & $(2,1)$ & 36 & $(1,2)$ \\
\hline Estados Unidos & Inferior a educación secundaria superior & 8 & $(2,7)$ & 2 & $(0,9)$ & 5 & $(1,4)$ & 12 & $(2,1)$ & 8 & $(1,2)$ & 10 & $(1,1)$ \\
\hline & Secundaria superior o postsecundaria no terciaria & 45 & $(3,1)$ & 31 & $(4,6)$ & 38 & $(2,8)$ & 53 & $(2,4)$ & 44 & $(2,5)$ & 48 & $(1,5)$ \\
\hline & Terciaria & 47 & $(3,7)$ & 67 & $(4,7)$ & 57 & $(3,1)$ & 35 & $(2,3)$ & 48 & $(2,3)$ & 42 & $(1,6)$ \\
\hline Estonia & Inferior a educación secundaria superior & 10 & $(2,0)$ & 6 & $(1,6)$ & 8 & $(1,2)$ & 16 & $(1,6)$ & 11 & $(1,5)$ & 14 & $(1,1)$ \\
\hline & Secundaria superior o postsecundaria no terciaria & 46 & $(3,1)$ & 25 & $(2,9)$ & 36 & $(2,2)$ & 48 & $(2,3)$ & 34 & $(2,2)$ & 41 & $(1,5)$ \\
\hline & Terciaria & 44 & $(3,5)$ & 70 & $(3,2)$ & 56 & $(2,4)$ & 35 & $(2,1)$ & 55 & $(2,1)$ & 45 & $(1,6)$ \\
\hline Finlandia & Inferior a educación secundaria superior & 5 & $(2,3)$ & 4 & $(2,2)$ & 4 & $(1,6)$ & 10 & $(1,9)$ & 5 & $(1,3)$ & 8 & $(1,1)$ \\
\hline & Secundaria superior o postsecundaria no terciaria & 44 & $(4,8)$ & 18 & $(3,6)$ & 31 & $(2,9)$ & 55 & $(2,4)$ & 34 & $(2,4)$ & 44 & $(1,6)$ \\
\hline & Terciaria & 51 & $(4,9)$ & 79 & $(4,1)$ & 65 & $(3,2)$ & 35 & $(2,3)$ & 61 & $(2,4)$ & 48 & $(1,6)$ \\
\hline Francia & Inferior a educación secundaria superior & 4 & $(1,5)$ & 4 & $(2,2)$ & 4 & $(1,3)$ & 14 & $(1,4)$ & 12 & $(1,5)$ & 13 & $(1,1)$ \\
\hline & Secundaria superior o postsecundaria no terciaria & 26 & $(4,0)$ & 13 & $(2,5)$ & 20 & $(2,5)$ & 45 & $(2,0)$ & 39 & $(2,4)$ & 42 & $(1,4)$ \\
\hline & Terciaria & 70 & $(4,2)$ & 83 & $(3,2)$ & 76 & $(2,7)$ & 41 & $(2,2)$ & 49 & $(2,3)$ & 45 & $(1,3)$ \\
\hline Irlanda & Inferior a educación secundaria superior & 6 & $(1,9)$ & 2 & $(1,4)$ & 4 & $(1,2)$ & 15 & $(1,0)$ & 11 & $(1,1)$ & 13 & $(0,5)$ \\
\hline & Secundaria superior o postsecundaria no terciaria & 33 & $(3,9)$ & 24 & $(4,0)$ & 28 & $(2,7)$ & 44 & $(2,2)$ & 39 & $(1,8)$ & 41 & $(1,2)$ \\
\hline & Terciaria & 61 & $(3,9)$ & 74 & $(4,1)$ & 68 & $(2,8)$ & 41 & $(2,2)$ & 51 & $(1,8)$ & 46 & $(1,1)$ \\
\hline Italia & Inferior a educación secundaria superior & c & $\mathrm{c}$ & c & $\mathrm{c}$ & c & $\mathrm{C}$ & 36 & $(3,3)$ & 26 & $(2,7)$ & 31 & $(2,0)$ \\
\hline & Secundaria superior o postsecundaria no terciaria & c & & c & c & c & c & 46 & $(3,2)$ & 48 & $(2,8)$ & 47 & $(1,9)$ \\
\hline & Terciaria & c & c & c & c & $c$ & c & 17 & $(2,1)$ & 26 & $(2,2)$ & 22 & $(1,4)$ \\
\hline Japón & Inferior a educación secundaria superior & 4 & $(1,7)$ & 4 & $(1,5)$ & 4 & $(1,1)$ & 8 & $(1,5)$ & 7 & $(1,6)$ & 8 & $(1,0)$ \\
\hline & Secundaria superior o postsecundaria no terciaria & 26 & $(3,4)$ & 21 & $(3,2)$ & 23 & $(2,3)$ & 37 & $(2,2)$ & 32 & $(2,4)$ & 35 & $(1,8)$ \\
\hline & Terciaria & 70 & $(3,7)$ & 75 & $(3,3)$ & 73 & $(2,4)$ & 55 & $(2,2)$ & 60 & $(2,2)$ & 58 & $(1,7)$ \\
\hline Noruega & Inferior a educación secundaria superior & 14 & $(3,3)$ & 4 & $(1,7)$ & 9 & $(1,9)$ & 20 & $(2,2)$ & 13 & $(1,7)$ & 17 & $(1,4)$ \\
\hline & Secundaria superior o postsecundaria no terciaria & 36 & $(3,9)$ & 25 & $(3,6)$ & 30 & $(3,0)$ & 43 & $(2,5)$ & 31 & $(2,5)$ & 37 & $(1,8)$ \\
\hline & Terciaria & 50 & $(4,3)$ & 71 & $(3,7)$ & 61 & $(3,1)$ & 37 & $(2,4)$ & 55 & $(2,2)$ & 46 & $(1,6)$ \\
\hline Países Bajos & Inferior a educación secundaria superior & 12 & $(3,5)$ & 11 & $(3,4)$ & 12 & $(2,3)$ & 21 & $(2,4)$ & 15 & $(2,1)$ & 18 & $(1,5)$ \\
\hline & Secundaria superior o postsecundaria no terciaria & 28 & $(4,7)$ & 25 & $(4,3)$ & 27 & $(3,1)$ & 39 & $(2,8)$ & 40 & $(2,9)$ & 40 & $(2,0)$ \\
\hline & Terciaria & 60 & $(4,8)$ & 64 & $(5,1)$ & 62 & $(3,4)$ & 40 & $(3,1)$ & 45 & $(2,8)$ & 42 & $(1,9)$ \\
\hline Polonia & Inferior a educación secundaria superior & 2 & $(1,5)$ & c & c & 1 & $(0,8)$ & 7 & $(1,3)$ & 4 & $(1,0)$ & 5 & $(0,8)$ \\
\hline & Secundaria superior o postsecundaria no terciaria & 19 & $(3,8)$ & 16 & $(4,6)$ & 18 & $(3,3)$ & 54 & $(2,0)$ & 46 & $(2,4)$ & 50 & $(1,7)$ \\
\hline & Terciaria & 79 & $(4,0)$ & 83 & $(4,6)$ & 81 & $(3,3)$ & 39 & $(2,2)$ & 51 & $(2,5)$ & 45 & $(1,7)$ \\
\hline República Checa & Inferior a educación secundaria superior & c & & c & c & 3 & $(0,9)$ & 8 & $(1,4)$ & 5 & $(1,5)$ & 7 & $(1,0)$ \\
\hline & Secundaria superior o postsecundaria no terciaria & 35 & $(6,5)$ & 22 & $(7,0)$ & 29 & $(4,2)$ & 71 & $(2,2)$ & 58 & $(2,5)$ & 65 & $(1,7)$ \\
\hline & Terciaria & 60 & $(6,7)$ & 78 & $(7,0)$ & 69 & $(4,1)$ & 21 & $(1,9)$ & 37 & $(2,1)$ & 28 & $(1,2)$ \\
\hline República Eslovaca & Inferior a educación secundaria superior & c & c & c & c & c & c & 13 & $(1,2)$ & 12 & $(1,5)$ & 13 & $(1,0)$ \\
\hline & Secundaria superior o postsecundaria no terciaria & c & & c & c & 37 & $(3,7)$ & 64 & $(2,0)$ & 57 & $(2,3)$ & 60 & $(1,6)$ \\
\hline & Terciaria & c & c & c & c & 63 & $(3,7)$ & 23 & $(1,8)$ & 31 & $(2,2)$ & 27 & $(1,6)$ \\
\hline Suecia & Inferior a educación secundaria superior & 10 & $(2,8)$ & 4 & $(1,9)$ & 7 & $(1,7)$ & 15 & $(2,2)$ & 12 & $(2,1)$ & 13 & $(1,5)$ \\
\hline & Secundaria superior o postsecundaria no terciaria & 48 & $(3,5)$ & 33 & $(3,8)$ & 41 & $(2,5)$ & 51 & $(2,6)$ & 42 & $(2,3)$ & 47 & $(1,6)$ \\
\hline & Terciaria & 42 & $(2,7)$ & 63 & $(3,9)$ & 51 & $(2,4)$ & 34 & $(1,7)$ & 46 & $(2,2)$ & 40 & $(1,4)$ \\
\hline
\end{tabular}

* Para los datos de Federación Rusa, véase nota en la sección de Metodología.

Nota: Las columnas que muestran los datos de otros desgloses por edad y de todos los niveles educativos de los padres de manera conjunta están disponibles en Internet (véase StatLink más abajo).

Fuente: OCDE. Encuesta sobre las Competencias de los Adultos (PIAAC) (2012). PIAAC se refiere al Programa para la Evaluación Internacional de las Competencias de los Adultos de la OCDE. Para ver notas, consulte Anexo 3 (www.oecd.org/edu/eag.htm).

Para obtener más información acerca de los símbolos utilizados en lugar de los datos que faltan, consulte la Guía del lector.

StatLink 젶ㄴ http://dx.doi.org/10.1787/888933115578 
Tabla A4.2. [4/4] Nivel educativo de la población no estudiante, por grupo de edad y nivel educativo de los padres (2012)

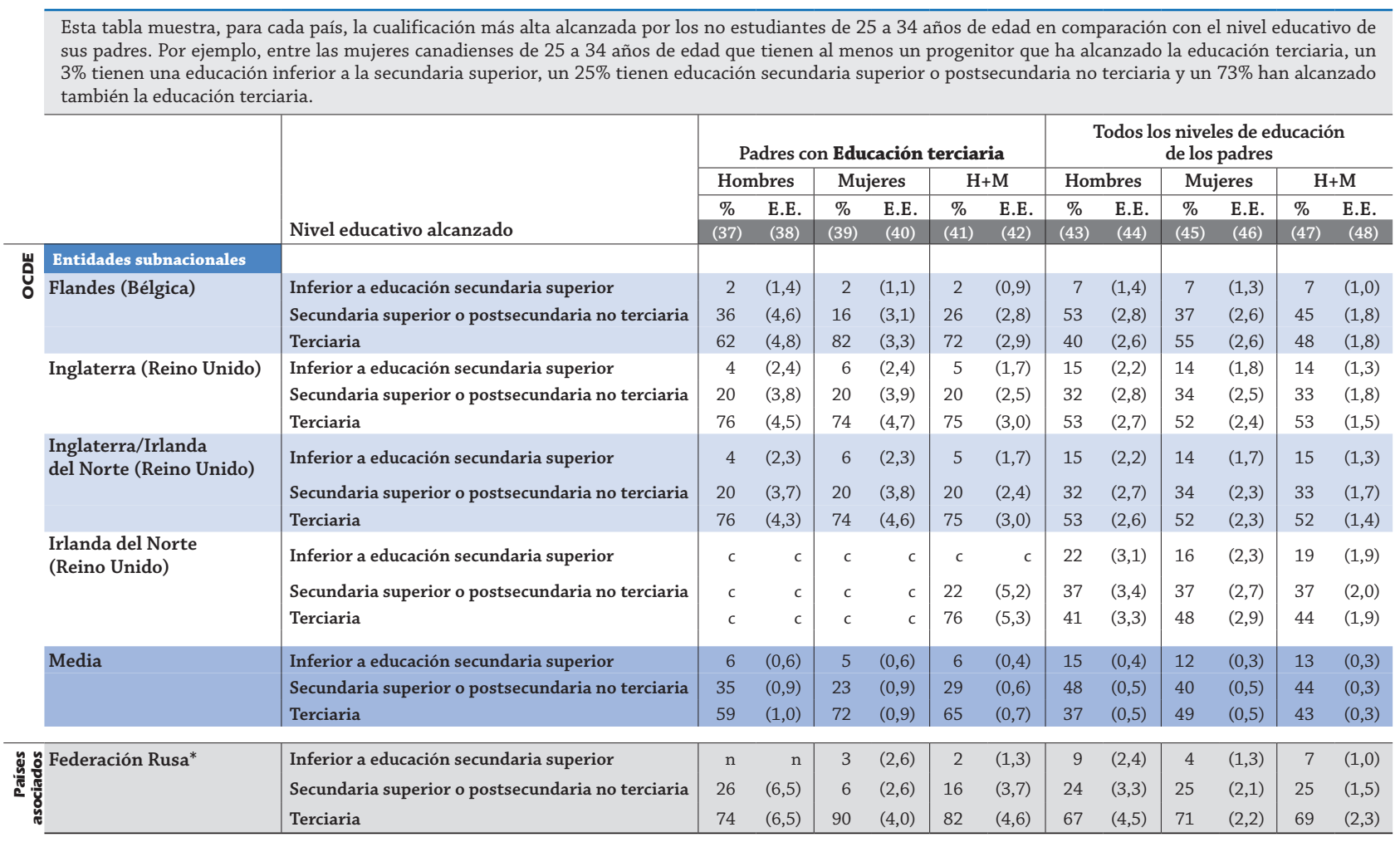

* Para los datos de Federación Rusa, véase nota en la sección de Metodología.

Nota: Las columnas que muestran los datos de otros desgloses por edad y de todos los niveles educativos de los padres de manera conjunta están disponibles en Internet (véase StatLink más abajo).

Fuente: OCDE. Encuesta sobre las Competencias de los Adultos (PIAAC) (2012). PIAAC se refiere al Programa para la Evaluación Internacional de las Competencias de los Adultos de la OCDE. Para ver notas, consulte Anexo 3 (www.oecd.org/edu/eag.htm).

Para obtener más información acerca de los símbolos utilizados en lugar de los datos que faltan, consulte la Guía del lector.

StatLink Aत्नाs http://dx.doi.org/10.1787/888933115578 
Tabla A4.3 (L). [1/2] Nivel de comprensión lectora de la población no estudiante, por grupo de edad, sexo y nivel educativo de los padres (2012)

Comprensión lectora en la Encuesta sobre las Competencias de los Adultos, de 25 a 34 años de edad

\begin{tabular}{|c|c|c|c|c|c|c|c|c|c|c|c|c|c|c|c|c|}
\hline & \multirow{4}{*}{$\begin{array}{c}\text { Nivel } \\
\text { PIAAC de } \\
\text { competencia }\end{array}$} & \multicolumn{3}{|c|}{$\begin{array}{c}\text { Padres con un nivel } \\
\text { educativo Inferior a la } \\
\text { educación secundaria } \\
\text { superior }\end{array}$} & \multicolumn{6}{|c|}{$\begin{array}{l}\text { Padres cuyo nivel educativo } \\
\text { máximo es educación } \\
\text { secundaria superior o } \\
\text { postsecundaria no terciaria }\end{array}$} & \multicolumn{3}{|c|}{$\begin{array}{c}\text { Padres con } \\
\text { Educación terciaria }\end{array}$} & \multicolumn{3}{|c|}{$\begin{array}{c}\text { Todos los niveles educativos } \\
\text { de los padres }\end{array}$} \\
\hline & & Hombres & Mujeres & $\mathrm{H}+\mathrm{M}$ & \multicolumn{2}{|c|}{ Hombres } & \multicolumn{2}{|c|}{ Mujeres } & & I+M & Hombres & Mujeres & $\mathrm{H}+\mathrm{M}$ & Hombres & Mujeres & $\mathrm{H}+\mathrm{M}$ \\
\hline & & $\%$ E.E. & $\%$ E.E. & $\%$ E.E. & $\%$ & E.E. & $\%$ & E.E. & $\%$ & E.E. & $\%$ E.E. & $\%$ E.E. & $\%$ E.E. & $\%$ E.E. & $\%$ E.E. & $\%$ E.E. \\
\hline & & (25) (26) & (27) (28) & (29) $(30)$ & $(31)$ & $(32)$ & $(33)$ & $(34)$ & $(35)$ & $(36)$ & (37) (38) & (39) (40) & (41) (42) & (43) (44) & (45) (46) & (47) (48) \\
\hline Entidades nacionales & & & & & & & & & & & & & & & & \\
\hline & 2 & c & c & c & 32 & $(4,9)$ & & $(4,8)$ & & $(3,5)$ & $24(4,3)$ & $20(3,9)$ & $22(2,7)$ & $30(2,9)$ & $28(2,8)$ & $29(2,0)$ \\
\hline & 3 & c & c & c & 42 & $(5,1)$ & & $(4,7)$ & 42 & $(3,3)$ & $45(5,3)$ & $51(5,3)$ & $48(3,5)$ & $41(3,7)$ & $44(3,3)$ & $42(2,3)$ \\
\hline & $4 / 5$ & c & c & c & 12 & $(3,3)$ & 9 & $(2,9)$ & 11 & $(1,9)$ & $23(4,6)$ & $22(4,2)$ & $23(3,2)$ & $16(2,7)$ & $14(2,3)$ & $15(1,7)$ \\
\hline Australia & $0 / 1$ & $18(4,8)$ & $14(3,9)$ & $16(3,0)$ & 11 & $(3,0)$ & & $(4,2)$ & 11 & $(2,7)$ & $3(1,9)$ & $4(1,8)$ & $4(1,3)$ & $10(1,8)$ & $9(1,7)$ & $10(1,2)$ \\
\hline & 2 & $32(5,6)$ & $35(5,9)$ & $34(4,2)$ & 28 & $(5,0)$ & 24 & $(5,5)$ & 26 & $(3,9)$ & $19(4,5)$ & $18(3,7)$ & $18(2,8)$ & $26(2,8)$ & $25(2,9)$ & $26(2,2)$ \\
\hline & 3 & $39(5,9)$ & $37(6,2)$ & $38(4,6)$ & 44 & $(5,8)$ & 47 & $(6,5)$ & 45 & $(4,7)$ & $48(5,9)$ & $43(4,0)$ & $45(3,4)$ & $44(3,7)$ & $42(3,5)$ & $43(2,8)$ \\
\hline & $4 / 5$ & $10(2,8)$ & $14(3,5)$ & $12(2,2)$ & 17 & $(4,6)$ & 18 & $(5,7)$ & 18 & $(4,1)$ & $29(4,4)$ & $35(3,9)$ & $32(2,9)$ & $19(2,3)$ & $23(2,7)$ & $21(1,9)$ \\
\hline Austria & $0 / 1$ & $\begin{array}{ll}\text { c } & c\end{array}$ & $\begin{array}{ll}c & c\end{array}$ & $29(4,5)$ & 8 & $(2,8)$ & 9 & $(2,6)$ & 9 & $(2,1)$ & c & c & $7(2,7)$ & $11(2,4)$ & $12(2,1)$ & $12(1,5)$ \\
\hline & 3 & & c & $23(5,1)$ & 46 & $(4,0)$ & 46 & $(4,5)$ & 46 & $(3,0)$ & c & c & $54(5,2)$ & $44(3,2)$ & $44(3,1)$ & $44(2,2)$ \\
\hline & $4 / 5$ & c & c & $4(2,0)$ & 10 & $(2,2)$ & 9 & $(2,2)$ & 9 & $(1,6)$ & c & c & $20(3,4)$ & $12(1,8)$ & $10(1,7)$ & $11(1,2)$ \\
\hline Canadá & $0 / 1$ & $24(4,5)$ & $28(5,6)$ & $26(3,7)$ & 14 & $(2,9)$ & 14 & $(2,4)$ & 14 & $(1,8)$ & $7(1,8)$ & $6(1,3)$ & $7(1,1)$ & $12(1,5)$ & $12(1,4)$ & $12(1,0)$ \\
\hline & 2 & $40(7,0)$ & $31(6,2)$ & $35(4,8)$ & 33 & $(4,5)$ & 31 & $(3,5)$ & 32 & $(2,9)$ & $24(3,3)$ & $27(3,3)$ & $26(2,3)$ & $29(2,3)$ & $29(2,5)$ & $29(1,8)$ \\
\hline & 3 & $32(7,9)$ & $32(6,4)$ & $32(5,0)$ & 36 & $(4,7)$ & 40 & $(3,3)$ & 38 & $(3,1)$ & $42(3,5)$ & $43(4,2)$ & $42(3,1)$ & $39(3,0)$ & $40(2,7)$ & $39(2,3)$ \\
\hline & $4 / 5$ & $4(4,0)$ & $9(3,5)$ & $7(2,6)$ & 17 & $(3,1)$ & 15 & $(2,4)$ & 16 & $(2,0)$ & $27(3,4)$ & $24(2,7)$ & $25(2,3)$ & $20(2,2)$ & $19(1,6)$ & $20(1,5)$ \\
\hline Corea & $0 / 1$ & $9(2,6)$ & $7(2,3)$ & $8(1,7)$ & 3 & $(1,5)$ & 3 & $(1,2)$ & 3 & $(0,9)$ & c $\quad c$ & & $\begin{array}{ll}c & c\end{array}$ & $5(1,2)$ & $4(0,9)$ & $4(0,7)$ \\
\hline & 2 & $35(4,8)$ & $36(5,4)$ & $36(3,4)$ & 28 & $(3,9)$ & 29 & $(4,6)$ & 29 & $(2,8)$ & c & $19(3,9)$ & $17(2,7)$ & $28(2,5)$ & $29(3,0)$ & $29(1,8)$ \\
\hline & 3 & $48(5,2)$ & $50(5,5)$ & $49(3,8)$ & 53 & $(4,6)$ & 55 & $(4,3)$ & 54 & $(3,1)$ & c & $62(5,6)$ & $60(4,3)$ & $52(2,9)$ & $55(3,0)$ & $53(1,9)$ \\
\hline & $4 / 5$ & $8(2,8)$ & $7(2,3)$ & $7(1,9)$ & 16 & $(3,0)$ & 13 & $(2,7)$ & 14 & $=(2,2)$ & c & $17(4,4)$ & $22(3,6)$ & $15(1,9)$ & $12(1,7)$ & $13(1,4)$ \\
\hline Dinamarca & $0 / 1$ & c & c & $29(4,8)$ & 12 & $(3,3)$ & 11 & $(3,0)$ & 12 & $(2,3)$ & $8(2,3)$ & $7(2,3)$ & $8(1,7)$ & $14(2,1)$ & $13(2,0)$ & $13(1,4)$ \\
\hline & 2 & c & c & $37(6,2)$ & 30 & $(4,5)$ & 32 & $(6,0)$ & 31 & $(3,9)$ & $19(3,8)$ & $23(4,6)$ & $21(3,1)$ & $26(2,8)$ & $29(3,6)$ & $28(2,3)$ \\
\hline & 3 & c & c & $27(4,9)$ & 47 & $(5,0)$ & 47 & $(6,6)$ & 47 & $(4,2)$ & $47(4,7)$ & $47(4,9)$ & $47(3,5)$ & $43(3,3)$ & $44(3,5)$ & $43(2,5)$ \\
\hline & $4 / 5$ & c & c & $7(2,7)$ & 11 & $(3,1)$ & 10 & $(3,8)$ & 11 & $(2,5)$ & $27(4,4)$ & $22(4,2)$ & $24(2,9)$ & $17(2,3)$ & $15(2,8)$ & $16(1,9)$ \\
\hline España & $0 / 1$ & $26(3,0)$ & $29(3,5)$ & $28(2,4)$ & c & & 14 & $(4,4)$ & 14 & $=(3,3)$ & c & & $9(3,3)$ & $21(2,3)$ & $22(2,6)$ & $22(1,8)$ \\
\hline & 2 & $47(3,9)$ & $44(4,1)$ & $46(2,9)$ & c & & 44 & $(6,6)$ & 43 & $(4,3)$ & c & c & $34(5,7)$ & $43(3,1)$ & $43(3,6)$ & $43(2,2)$ \\
\hline Estados Unidos & $0 / 1$ & c & c & c & & $(5,1)$ & 11 & $(3,7)$ & 17 & $(3,0)$ & $10(3,5)$ & $4(1,9)$ & $7(2,0)$ & $21(2,9)$ & $13(2,3)$ & $17(1,8)$ \\
\hline & 2 & c & c & c & 36 & $(5,3)$ & 41 & $(5,9)$ & 38 & $(3,7)$ & $26(5,3)$ & $26(3,7)$ & $26(3,4)$ & $30(3,5)$ & $34(3,1)$ & $32(2,3)$ \\
\hline & 3 & c & c & c & 33 & $(4,8)$ & 35 & $(6,0)$ & 34 & $(3,6)$ & $41(5,7)$ & $49(4,7)$ & $45(3,7)$ & $35(2,9)$ & $38(3,1)$ & $37(2,2)$ \\
\hline & $4 / 5$ & c & c & c & 10 & $(3,2)$ & 13 & $(3,2)$ & 11 & $(2,5)$ & $23(4,3)$ & $21(4,1)$ & $22(2,9)$ & $15(2,2)$ & $14(2,2)$ & $15(1,6)$ \\
\hline Estonia & $0 / 1$ & c & c & c & 10 & $(2,3)$ & 12 & $(2,4)$ & 11 & $(1,7)$ & $8(2,4)$ & $7(2,0)$ & $8(1,5)$ & $10(1,7)$ & $10(1,5)$ & $10(1,2)$ \\
\hline & 2 & c & c & c & 35 & $(3,8)$ & 33 & $(4,3)$ & 34 & $(3,0)$ & $26(3,2)$ & $20(3,8)$ & $24(2,4)$ & $31(2,5)$ & $29(2,9)$ & $30(1,8)$ \\
\hline & 3 & c & c & c & 46 & $(3,7)$ & 46 & $(4,5)$ & 46 & $(2,9)$ & $43(4,0)$ & $48(4,7)$ & $45(3,2)$ & $44(2,5)$ & $46(3,3)$ & $45(2,1)$ \\
\hline & $4 / 5$ & c & c & c & 10 & $(2,7)$ & 9 & $(3,1)$ & 10 & $(2,3)$ & $23(3,0)$ & $24(3,3)$ & $23(2,4)$ & $15(2,1)$ & $15(2,2)$ & $15(1,7)$ \\
\hline Finlandia & $0 / 1$ & c & c & $9(3,3)$ & 5 & $(2,1)$ & 2 & $(1,1)$ & 3 & $(1,2)$ & c & c & $4(1,9)$ & $7(1,8)$ & $2(1,1)$ & $5(1,1)$ \\
\hline & 2 & c & c & $21(5,1)$ & 24 & $(3,6)$ & 14 & $(3,2)$ & 19 & $(2,6)$ & c & & $9(2,8)$ & $20(2,7)$ & $13(2,6)$ & $17(2,0)$ \\
\hline & 3 & $c$ & c & $44(5,3)$ & 43 & $(4,5)$ & & $(4,6)$ & 46 & $(3,4)$ & c & c & $38(4,4)$ & $40(3,0)$ & $47(3,3)$ & $43(2,3)$ \\
\hline & $4 / 5$ & c & c & $26(4,7)$ & 27 & $(3,7)$ & 35 & $(4,2)$ & 31 & $(3,0)$ & c & c & $49(4,0)$ & $33(2,6)$ & $37(2,9)$ & $35(2,0)$ \\
\hline Francia & $0 / 1$ & c & $21(3,6)$ & $21(2,5)$ & 10 & $(2,3)$ & 6 & $(1,7)$ & 8 & $(1,5)$ & $5(1,9)$ & c & $5(1,6)$ & $11(1,6)$ & $11(1,6)$ & $11(1,2)$ \\
\hline & 2 & $c$ & $39(4,3)$ & $39(3,8)$ & 34 & $(3,9)$ & 33 & $(3,8)$ & 34 & $=(2,9)$ & $14(3,7)$ & c & $15(2,9)$ & $30(2,5)$ & $31(2,2)$ & $30(1,8)$ \\
\hline & 3 & c & $34(4,2)$ & $34(4,3)$ & 44 & $(4,2)$ & 48 & $(4,0)$ & 46 & $(2,8)$ & $50(5,2)$ & c & $52(3,9)$ & $43(3,3)$ & $45(2,6)$ & $44(2,2)$ \\
\hline & $4 / 5$ & c & $5(2,0)$ & $6(1,8)$ & 12 & $(3,1)$ & 12 & $(2,6)$ & 12 & $(1,7)$ & $32(4,7)$ & c & $28(3,5)$ & $16(2,1)$ & $13(1,8)$ & $14(1,2)$ \\
\hline Irlanda & $0 / 1$ & $20(3,8)$ & $17(2,8)$ & $18(2,5)$ & 10 & $(3,5)$ & 10 & $(2,4)$ & 10 & $(2,2)$ & $8(3,0)$ & $6(2,9)$ & $7(2,1)$ & $13(2,0)$ & $11(1,5)$ & $12(1,3)$ \\
\hline & 2 & $36(4,5)$ & $46(4,7)$ & $41(3,3)$ & 35 & $(5,2)$ & & $(4,9)$ & 37 & $(3,4)$ & $29(5,1)$ & $30(4,3)$ & $29(3,1)$ & $34(2,6)$ & $39(2,4)$ & $36(1,7)$ \\
\hline & 3 & $35(4,6)$ & $33(5,2)$ & $34(3,2)$ & 39 & $(4,8)$ & 41 & $(4,3)$ & 40 & $(3,0)$ & $44(5,3)$ & $47(5,4)$ & $46(3,8)$ & $39(3,0)$ & $40(3,0)$ & $39(2,0)$ \\
\hline & $4 / 5$ & $10(3,3)$ & $4(1,7)$ & $7(1,5)$ & 15 & $(3,6)$ & 10 & $(3,0)$ & 13 & $(2,6)$ & $19(4,6)$ & $17(4,2)$ & $18(3,3)$ & $14(2,5)$ & $10(2,0)$ & $12(1,5)$ \\
\hline Italia & $0 / 1$ & $30(3,8)$ & $30(4,6)$ & $30(3,1)$ & c & & c & & 16 & $(3,4)$ & c & c & c & $25(2,9)$ & $24(3,7)$ & $24(2,5)$ \\
\hline & 2 & $45(4,9)$ & $40(4,9)$ & $42(3,4)$ & c & & c & & 35 & $(4,2)$ & c & c & c & $38(3,5)$ & $40(3,6)$ & $39(2,6)$ \\
\hline & 3 & $22(4,2)$ & $27(4,1)$ & $24(3,1)$ & c & & c & & 42 & $(4,5)$ & c & c & c & $31(3,5)$ & $33(3,4)$ & $32(2,5)$ \\
\hline & $4 / 5$ & $3(1,5)$ & $3(1,7)$ & $3(1,1)$ & c & c & c & & 7 & $(3,1)$ & c & c & c & $6(2,1)$ & $4(1,5)$ & $5(1,2)$ \\
\hline Japón & $0 / 1$ & c & c & c & 3 & $(1,4)$ & & $(1,5)$ & 3 & $(1,0)$ & c & c & $1(0,6)$ & $2(0,9)$ & $2(0,8)$ & $2(0,6)$ \\
\hline & 2 & c & c & c & 13 & $(3,1)$ & & $(3,4)$ & 15 & $(2,5)$ & $10(2,7)$ & $11(2,6)$ & $10(1,9)$ & $12(1,9)$ & $14(2,3)$ & $13(1,7)$ \\
\hline & 3 & c & c & c & 55 & $(4,9)$ & & $(4,7)$ & 54 & $(3,3)$ & $48(5,0)$ & $52(4,2)$ & $50(3,2)$ & $52(3,0)$ & $52(3,3)$ & $52(1,9)$ \\
\hline & $4 / 5$ & c & c & c & 29 & $(4,2)$ & 28 & $(4,5)$ & 29 & $(2,9)$ & $40(5,0)$ & $36(3,8)$ & $38(3,3)$ & $33(3,1)$ & $32(3,2)$ & $33(1,9)$ \\
\hline
\end{tabular}

* Para los datos de Federación Rusa, véase nota en la sección de Metodología.

Nota: Las columnas que muestran datos de otros desgloses por edad están disponibles en Internet (véase StatLink más abajo).

Fuente: OCDE. Encuesta sobre las Competencias de los Adultos (PIAAC) (2012). PIAAC se refiere al Programa para la Evaluación Internacional de las Competencias de los Adultos de la OCDE. Para ver notas, consulte el Anexo 3 (www.oecd.org/edu/eag.htm).

Para obtener más información acerca de los símbolos utilizados en lugar de los datos que faltan, consulte la Guía del lector.

StatLink 젶ㄴ http://dx.doi.org/10.1787/888933115597 
Tabla A4.3 (L). [2/2] Nivel de comprensión lectora de la población no estudiante, por grupo de edad, sexo y nivel educativo de los padres (2012)

Comprensión lectora en la Encuesta sobre las Competencias de los Adultos, de 25 a 34 años de edad

\begin{tabular}{|c|c|c|c|c|c|c|c|c|c|c|c|c|c|c|c|c|c|c|}
\hline & & \multirow{4}{*}{$\begin{array}{c}\text { Nivel } \\
\text { PIAAC de } \\
\text { competencia }\end{array}$} & \multicolumn{5}{|c|}{$\begin{array}{c}\text { Padres con un nivel } \\
\text { educativo Inferior a la } \\
\text { educación secundaria } \\
\text { superior }\end{array}$} & \multicolumn{5}{|c|}{$\begin{array}{c}\text { Padres cuyo nivel educativo } \\
\text { máximo es educación } \\
\text { secundaria superior } \\
\text { o postsecundaria no } \\
\text { terciaria }\end{array}$} & \multicolumn{3}{|c|}{$\begin{array}{c}\text { Padres con } \\
\text { Educación terciaria }\end{array}$} & \multicolumn{3}{|c|}{$\begin{array}{l}\text { Todos los niveles } \\
\text { educativos de los padres }\end{array}$} \\
\hline & & & \multicolumn{2}{|c|}{ Hombres } & \multicolumn{2}{|c|}{ Mujeres } & $\mathrm{H}+\mathrm{M}$ & Hombres & \multicolumn{2}{|c|}{ Mujeres } & \multicolumn{2}{|c|}{$\mathrm{H}+\mathrm{M}$} & Hombres & Mujeres & $\mathrm{H}+\mathrm{M}$ & Hombres & Mujeres & $\mathrm{H}+\mathrm{M}$ \\
\hline & & & $\%$ & E.E. & & E.E. & $\%$ E.E. & $\%$ E.E. & & E.E. & $\%$ & E.E. & $\%$ E.E. & \% E.E. & $\%$ E.E. & \% & $\begin{array}{|ll|}\% & \text { E.E. } \\
\end{array}$ & $\%$ E.E. \\
\hline & & & $(25)$ & & & (28) & (29) (30) & (31) (32) & & ) (34) & (35) & (36) & (37) (38) & (39) $(40)$ & (41) (42) & (43) (44) & (45) (46) & (47) (48) \\
\hline & Entidades nacionales & & & & & & & & & & & & & & & & & \\
\hline & Noruega & $0 / 1$ & c & & c & & c & $10(2,9)$ & & $1(3,2)$ & & $(2,2)$ & $7(2,3)$ & $5(2,0)$ & $6(1,5)$ & $13(1,8)$ & $10(2,0)$ & $11(1,4)$ \\
\hline & & 2 & c & & c & & c & $25(4,5)$ & & $8(4,3)$ & 27 & $(3,0)$ & $17(3,5)$ & $16(3,3)$ & $17(2,4)$ & $21(2,6)$ & $22(2,6)$ & $22(1,9)$ \\
\hline & & 3 & c & & c & & c & $47(5,3)$ & & $9(4,9)$ & 48 & $(3,6)$ & $45(4,8)$ & $51(5,2)$ & $48(3,9)$ & $44(3,3)$ & $48(3,4)$ & $46(2,6)$ \\
\hline & & $4 / 5$ & c & c & c & & & $19(4,0)$ & & $2(3,1)$ & 15 & $(2,7)$ & $31(4,1)$ & $28(3,8)$ & $29(2,9)$ & $23(2,8)$ & $20(2,5)$ & $21(2,0)$ \\
\hline & Países Bajos & $0 / 1$ & c & c & & $(4,0)$ & $16(3,3)$ & c & & c & & $(1,7)$ & c & $c$ & $4(1,8)$ & $8(2,0)$ & $8(1,9)$ & $8(1,4)$ \\
\hline & & 2 & c & & & $(5,3)$ & $24(3,4)$ & c & & c & & $(3,2)$ & c & c & $12(2,8)$ & $19(2,8)$ & $21(3,1)$ & $20(1,7)$ \\
\hline & & 3 & c & & & $(5,7)$ & $44(4,2)$ & c & c & $c$ & & $(4,6)$ & c & c & $47(4,6)$ & $45(3,4)$ & $46(3,8)$ & $45(2,5)$ \\
\hline & & $4 / 5$ & c & c & & $(4,0)$ & $16(3,0)$ & c & & c & 27 & $(3,7)$ & c & c & $37(4,5)$ & $28(3,1)$ & $25(3,2)$ & $26(2,3)$ \\
\hline & Polonia & $0 / 1$ & c & c & c & & c & $17(2,4)$ & & $\beta(2,4)$ & 15 & $(1,8)$ & $3(1,9)$ & $7(4,3)$ & $5(2,2)$ & $15(2,0)$ & $13(1,9)$ & $14(1,5)$ \\
\hline & & 2 & c & & c & & c & $39(3,9)$ & & $4(3,2)$ & 37 & $(2,6)$ & $21(5,1)$ & $24(6,7)$ & $22(3,9)$ & $37(3,6)$ & $33(2,3)$ & $35(2,2)$ \\
\hline & & 3 & c & & c & & c & $37(3,8)$ & & $9(3,2)$ & & $(2,6)$ & $45(7,3)$ & $44(6,2)$ & $44(4,8)$ & $37(3,3)$ & $39(2,7)$ & $38(2,2)$ \\
\hline & & $4 / 5$ & c & c & c & & c & $7(2,0)$ & & $4(2,4)$ & 11 & $(1,5)$ & $32(6,8)$ & $25(5,9)$ & $29(4,4)$ & $12(1,9)$ & $15(2,1)$ & $13(1,4)$ \\
\hline & República Checa & $0 / 1$ & c & c & c & & c & $9(2,8)$ & & $B(2,3)$ & & $(1,8)$ & c & & $2(1,9)$ & $8(2,2)$ & $7(1,8)$ & $7(1,4)$ \\
\hline & & 2 & c & & c & & c & $33(4,3)$ & & $1(4,4)$ & & $(3,4)$ & c & $13(7,3)$ & $16(5,2)$ & $30(3,8)$ & $29(3,6)$ & $30(3,0)$ \\
\hline & & 3 & c & & c & & c & $47(4,3)$ & & $9(5,2)$ & 48 & $(3,3)$ & c & $56(9,9)$ & $57(6,6)$ & $49(4,1)$ & $49(4,5)$ & $49(3,0)$ \\
\hline & & $4 / 5$ & c & c & c & & c & $11(2,7)$ & & $2(3,1)$ & & $(2,1)$ & c & $29(9,4)$ & $26(5,7)$ & $13(2,5)$ & $15(3,0)$ & $14(1,8)$ \\
\hline & República Eslovaca & $0 / 1$ & c & c & c & & $40(5,0)$ & $7(1,7)$ & & $B(1,7)$ & & $(1,2)$ & c & c & c & $12(1,4)$ & $11(1,8)$ & $11(1,2)$ \\
\hline & & 2 & c & & c & & $40(4,7)$ & $35(3,4)$ & & $2(2,6)$ & & $(2,1)$ & c & c & $20(4,7)$ & $34(2,6)$ & $31(2,2)$ & $33(1,7)$ \\
\hline & & 3 & c & & c & & $18(3,2)$ & $49(3,6)$ & & $(2,9)$ & & $(2,4)$ & c & c & $59(5,6)$ & $44(2,6)$ & $48(2,5)$ & $46(1,8)$ \\
\hline & & $4 / 5$ & c & c & c & c & c & $9(2,2)$ & & $(1,9)$ & & $(1,5)$ & c & c & $19(4,3)$ & $10(1,7)$ & $10(1,8)$ & $10(1,2)$ \\
\hline & Suecia & $0 / 1$ & c & c & c & & c & c & & $c$ & & $(2,3)$ & $6(2,0)$ & $5(2,1)$ & $6(1,5)$ & $8(1,8)$ & $12(1,9)$ & $10(1,3)$ \\
\hline & & 2 & c & & c & & c & c & & c & & $(3,7)$ & $17(4,0)$ & $17(4,0)$ & $17(2,7)$ & $20(2,9)$ & $19(3,1)$ & $20(2,0)$ \\
\hline & & 3 & c & c & c & & c & c & & $c$ & 48 & $(3,9)$ & $46(4,9)$ & $46(5,3)$ & $46(3,6)$ & $46(3,7)$ & $45(3,3)$ & $46(2,4)$ \\
\hline & & $4 / 5$ & c & c & c & & c & c & c & c & 22 & $(3,3)$ & $32(4,5)$ & $32(4,7)$ & $32(3,3)$ & $26(2,7)$ & $24(2,8)$ & $25(2,0)$ \\
\hline & Entidade & & & & & & & & & & & & & & & & & \\
\hline & Flandes (Bélgica) & $0 / 1$ & c & & c & & $22(3,9)$ & $4(1,6)$ & & $6(1,9)$ & & $(1,3)$ & $4(1,9)$ & $3(1,8)$ & $3(1,3)$ & $8(1,7)$ & $8(1,5)$ & $8(1,1)$ \\
\hline & & 2 & c & & c & & $36(5,1)$ & $28(4,3)$ & & $7(4,6)$ & & $(2,8)$ & $12(3,9)$ & $13(3,9)$ & $13(2,4)$ & $24(2,9)$ & $23(3,3)$ & $24(1,9)$ \\
\hline & & 3 & c & & c & & $32(5,5)$ & $49(5,1)$ & & $3(4,6)$ & 51 & $(3,4)$ & $48(7,0)$ & $53(6,6)$ & $51(4,1)$ & $44(4,1)$ & $50(3,5)$ & $47(2,5)$ \\
\hline & & $4 / 5$ & c & c & c & c & $11(3,7)$ & $19(3,8)$ & & $4(3,7)$ & 17 & $(2,6)$ & $36(5,9)$ & $31(5,8)$ & $33(4,2)$ & $24(2,9)$ & $20(2,9)$ & $22(2,1)$ \\
\hline & Inglaterra (Reino Unido) & $0 / 1$ & c & c & c & & $34(5,9)$ & $10(3,0)$ & & $(2,7)$ & 10 & $(2,2)$ & c & $6(2,8)$ & $6(2,3)$ & $12(2,5)$ & $13(2,3)$ & $13(1,7)$ \\
\hline & & 2 & c & & c & & $42(8,2)$ & $32(4,9)$ & & $5(4,0)$ & 28 & $(3,3)$ & c & $21(5,0)$ & $19(3,6)$ & $28(3,6)$ & $27(2,8)$ & $27(2,4)$ \\
\hline & & 3 & c & c & c & & $21(5,1)$ & $42(5,4)$ & & $6(4,9)$ & & $(3,8)$ & c & $48(5,6)$ & $44(4,1)$ & $39(3,6)$ & $42(3,4)$ & $40(2,4)$ \\
\hline & & $4 / 5$ & c & c & c & & $3(2,0)$ & $16(4,1)$ & & $9(3,6)$ & 18 & $(2,8)$ & c & $25(5,3)$ & $31(3,6)$ & $21(3,0)$ & $18(2,7)$ & $20(1,9)$ \\
\hline & In & $0 / 1$ & c & c & & $(6,6)$ & $34(5,6)$ & $10(2,9)$ & & $(2,6)$ & 10 & $(2,1)$ & $6(3,3)$ & $6(2,8)$ & $6(2,3)$ & $12(2,4)$ & $13(2,2)$ & $13(1,7)$ \\
\hline & del Norte ( & 2 & c & c & & $(6,5)$ & $41(7,7)$ & $31(4,7)$ & & $5(3,9)$ & 28 & $(3,2)$ & $17(5,0)$ & $21(4,8)$ & $19(3,6)$ & $28(3,5)$ & $27(2,7)$ & $27(2,3)$ \\
\hline & & 3 & c & c & & $(5,6)$ & $22(4,8)$ & $42(5,2)$ & & $6(4,7)$ & & $(3,7)$ & $41(7,0)$ & $48(5,5)$ & $44(4,0)$ & $39(3,5)$ & $42(3,3)$ & $40(2,4)$ \\
\hline & & $4 / 5$ & c & c & & $(2,4)$ & $3(1,9)$ & $16(4,0)$ & & $9(3,4)$ & & $(2,7)$ & $36(5,8)$ & $25(5,2)$ & $31(3,6)$ & $21(2,9)$ & $18(2,6)$ & $20(1,9)$ \\
\hline & Irland & $0 / 1$ & c & & c & & $32(5,5)$ & c & & $2(3,6)$ & & $(2,9)$ & c & c & $4(3,4)$ & $13(3,4)$ & $15(2,8)$ & $14(2,2)$ \\
\hline & (Rein & 2 & c & & c & & $35(6,0)$ & c & & $4(4,9)$ & & $(4,5)$ & c & c & $24(6,6)$ & $29(5,1)$ & $32(3,5)$ & $31(3,0)$ \\
\hline & & 3 & c & & c & & $27(5,8)$ & c & & $2(5,2)$ & & $(4,4)$ & $c$ & c & $50(6,7)$ & $41(5,1)$ & $40(3,5)$ & $41(3,4)$ \\
\hline & & $4 / 5$ & c & c & c & & $5(3,3)$ & c & & $2(3,3)$ & & $(3,0)$ & c & c & $21(4,2)$ & $16(3,6)$ & $12(2,1)$ & $14(2,0)$ \\
\hline & Media & $0 / 1$ & c & c & c & & $23(1,0)$ & $10(0,7)$ & & $(0,6)$ & & $(0,5)$ & $6(0,7)$ & $6(0,7)$ & $5(0,4)$ & $12(0,4)$ & $11(0,4)$ & $11(0,3)$ \\
\hline & & ? & c & & c & & $37(1,3)$ & $31(1,0)$ & & $1(1,0)$ & & $(0,7)$ & $20(1,1)$ & $20(1,1)$ & $19(0,7)$ & $28(0,6)$ & $28(0,6)$ & $28(0,4)$ \\
\hline & & 3 & c & c & c & & $32(1,2)$ & $44(1,1)$ & & $6(1,1)$ & & $(0,8)$ & $45(1,5)$ & $49(1,5)$ & $48(0,9)$ & $42(0,7)$ & $44(0,7)$ & $43(0,5)$ \\
\hline & & $4 / 5$ & c & c| & c & & $8(0,7)$ & $15(0,8)$ & & $4(0,8)$ & & $(0,5)$ & $29(1,3)$ & $26(1,3)$ & $27(0,8)$ & $18(0,5)$ & $|17(0,5)|$ & $17(0,4)$ \\
\hline & Federación Rusa* & $0 / 1$ & c & & c & & c & c & & $4(5,3)$ & & $(4,8)$ & c & $10(2,7)$ & $11(2,4)$ & $19(3,8)$ & $\mid 11(3,1)$ & $15(2,7)$ \\
\hline & & ת & c & & c & & c & c & & $7(5,6)$ & & $(4,0)$ & c & $27(5,3)$ & $32(4,6)$ & $36(4,5)$ & $34(3,8)$ & $35(3,3)$ \\
\hline & & 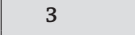 & c & & c & & c & c & & $8(6,8)$ & & $(6,1)$ & c & $48(4,8)$ & $43(4,3)$ & $36(5,2)$ & $42(4,1)$ & $39(3,9)$ \\
\hline & & $4 / 5$ & C & c| & c & c & c & c & & $1(3,6)$ & & $(2,6)$ & c & $15(3,7)$ & $14(4,0)$ & $9(3,1)$ & $12(2,5)$ & $11(2,3)$ \\
\hline
\end{tabular}

* Para los datos de Federación Rusa, véase nota en la sección de Metodología.

Nota: Las columnas que muestran datos de otros desgloses por edad están disponibles en Internet (véase StatLink más abajo).

Fuente: OCDE. Encuesta sobre las Competencias de los Adultos (PIAAC) (2012). PIAAC se refiere al Programa para la Evaluación Internacional de las Competencias de los Adultos de la OCDE. Para ver notas, consulte Anexo 3 (www.oecd.org/edu/eag.htm).

Para obtener más información acerca de los símbolos utilizados en lugar de los datos que faltan, consulte la Guía del lector.

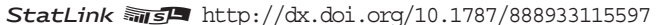


Tabla A4.4. Movilidad educativa de la población no estudiante, por grupo de edad y nivel educativo de los padres (2012)

Población no estudiante de 25 a 34 años de edad cuyo nivel educativo es inferior (movilidad descendente), superior (movilidad ascendente) o igual (statu quo) al de los padres

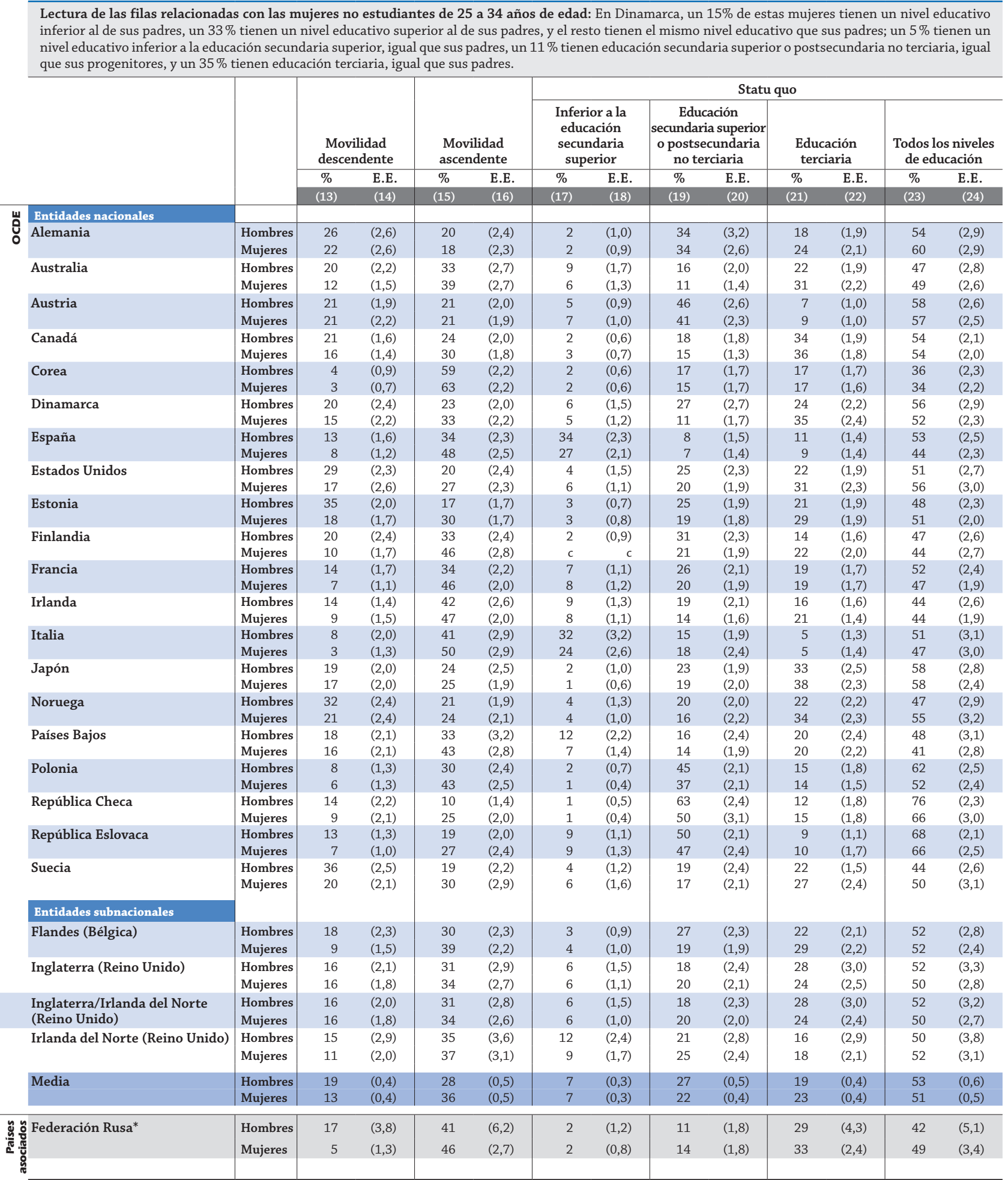

* Para los datos de Federación Rusa, véase nota en la sección de Metodología.

Nota: Las filas que muestran los datos conjuntos de ambos sexos (es decir, hombres más mujeres) y las columnas que muestran otros desgloses por edad están disponibles en Internet (véase StatLink más abajo).

Fuente: OCDE. Encuesta sobre las Competencias de los Adultos (PIAAC) (2012). PIAAC se refiere al Programa para la Evaluación Internacional de las Competencias de los Adultos de la OCDE. Para ver notas, consulte Anexo 3 (www.oecd.org/edu/eag.htm).

Para obtener más información acerca de los símbolos utilizados en lugar de los datos que faltan, consulte la Guía del lector.

StatLink 젝ㄴ $h$ htp://dx.doi.org/10.1787/888933115616 



\section{INDICADOR A5 ¿CÓMO AFECTA EL NIVEL EDUCATIVO ALCANZADO A LA PARTICIPACIÓN EN EL MERCADO LABORAL?}

- Como media, más del $80 \%$ de las personas con educación terciaria están empleadas, frente al $70 \%$ con educación secundaria superior o postsecundaria no terciaria y a menos del $60 \%$ de aquellas con formación inferior a educación secundaria superior.

- Los adultos jóvenes con educación terciaria tienen una tasa de desempleo superior a la de los adultos mayores con ese mismo nivel educativo, en torno al $7 \%$ y al $4 \%$, respectivamente.

- Entre los adultos empleados, el $74 \%$ con estudios terciarios trabaja a tiempo completo en comparación con el $71 \%$ de quienes tienen educación secundaria superior. Aproximadamente el $64 \%$ de los adultos que no tienen educación secundaria superior trabajan a tiempo completo.

\section{Gráfico A5.1. Tasas de empleo de las personas de 25 a 64 años, por nivel educativo alcanzado (2012)}

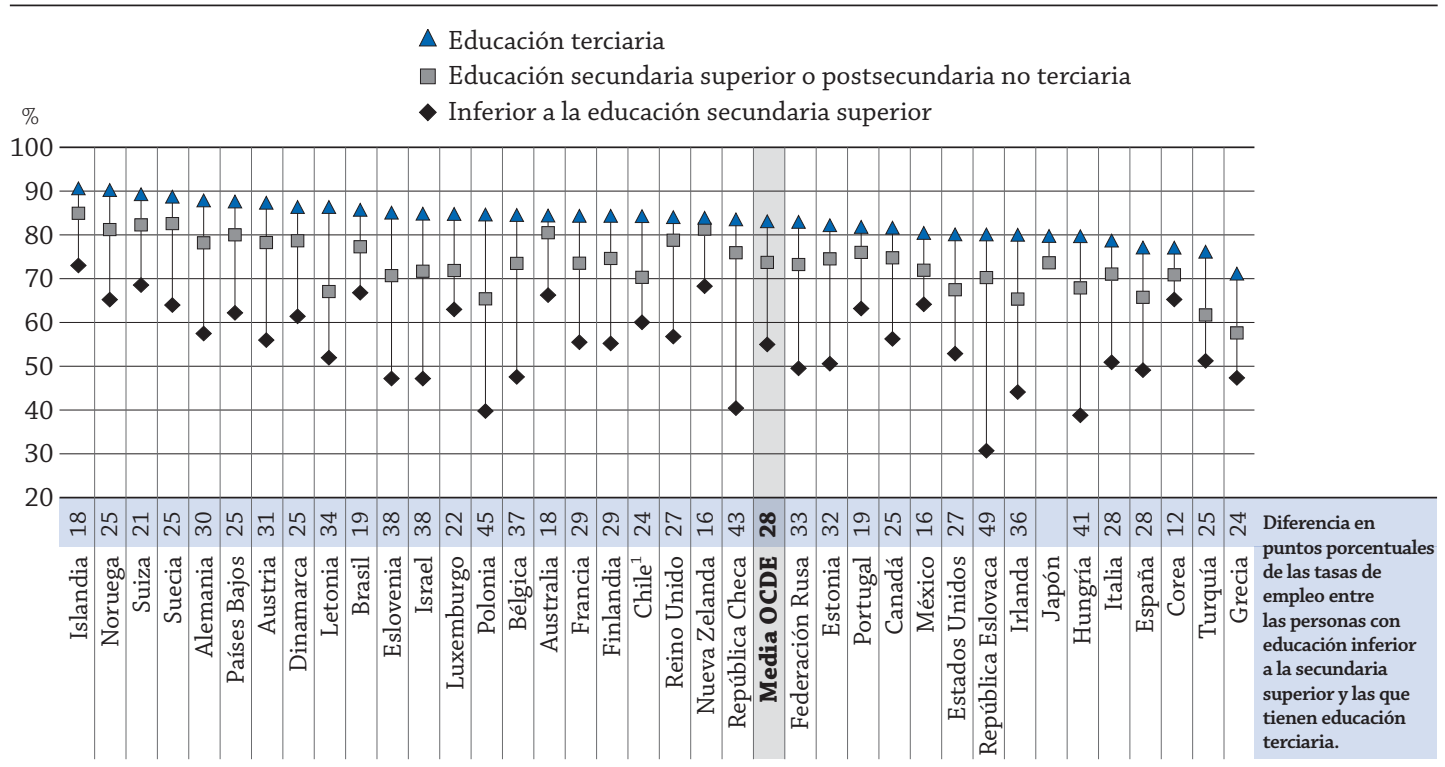

1. Año de referencia 2011 .

Los países están clasificados en orden descendente de las tasas de empleo de las personas de 25 a 64 años con educación terciaria. Fuente: OCDE. Tabla A5.3a. Para ver notas, consulte Anexo 3 (www.oecd.org/edu/eag.htm).

StatLink 제내 http://dx.doi.org/10.1787/888933115958

\section{Contexto}

Las economías de los países de la OCDE dependen de la incorporación de trabajadores altamente cualificados. Las cualificaciones académicas se utilizan con frecuencia para medir el capital humano y el nivel de competencias de una persona. En la mayoría de los países de la OCDE, las personas altamente cualificadas tienen las tasas de empleo más elevadas, mientras que aquellas con estudios inferiores se encuentran en mayor riesgo de desempleo. Teniendo en cuenta los avances tecnológicos que han transformado las necesidades del mercado laboral mundial, las personas con más competencias o con una mayor especialización son las más solicitadas.

Este indicador muestra por primera vez cómo las personas con determinadas cualificaciones educativas y competencias básicas se ajustan a la demanda del mercado laboral basándose, por un lado, en la Encuesta sobre las Competencias de los Adultos, un producto del Programa para la Evaluación Internacional de las Competencias de los Adultos de la OCDE (PIAAC) y, por otro lado, en los datos de la OCDE. Mientras que las cualificaciones se utilizan como muestra para medir determinadas capacidades que los trabajadores deben tener, su competencia en los conocimientos básicos, como comprensión lectora y competencia matemática, se han medido por separado. 
Aunque estas competencias básicas se adquieren durante la escolarización, no se desarrollan solamente a través de la educación formal ya que, aunque el desarrollo de las competncias comienza con la educación, se desarrollan y se conservan si se utilizan a lo largo de la vida, especialmente en el puesto de trabajo.

Aun así, la escolarización influye significativamente en el perfeccionamiento de las competencias básicas, como se muestra en el Indicador A1: según los datos de la Encuesta sobre las Competencias de los Adultos, las personas con bajos niveles educativos tienen puntuaciones más bajas en lectura o matemáticas que aquellas con niveles superiores de educación. Por tanto, las cualificaciones educativas y la competencia en determinadas capacidades se examinan conjuntamente a la hora de analizar los resultados del mercado laboral.

\section{Otros resultados}

- En los países de la OCDE, un promedio del $87 \%$ de las personas que lograron los niveles más altos -Nivel 4 o 5- en comprensión lectora en la Encuesta sobre las Competencias de los Adultos tienen empleo, mientras que el 3,5\% están desempleadas y el 10\% están inactivas en el mercado laboral. En Alemania, Estonia, Flandes (Bélgica), Noruega, Países Bajos y Suecia, el $90 \%$ o más de los individuos altamente cualificados están empleados.

- En Alemania, Austria, Bélgica, Eslovenia, Estonia, Federación Rusa, Hungría, Irlanda, Israel, Polonia, República Checa y República Eslovaca, las tasas de empleo de los adultos con educación terciaria son al menos un $30 \%$ mayores que las tasas de empleo de aquellos con educación inferior a secundaria superior.

- Las tasas de desempleo son generalmente inferiores en las personas con formación profesional superior o con titulación postsecundaria no terciaria (un $8 \%$ ) a las de adultos con educación secundaria superior (un $9 \%$ ).

\section{Tendencias}

Los datos obtenidos a lo largo de los años sobre las tasas de empleo y de desempleo proporcionan una base que permite evaluar las tendencias a largo plazo y las variaciones en los riesgos que plantea el mercado laboral a hombres y mujeres con diferentes niveles educativos y diferentes edades. En los últimos 15 años, las tasas de empleo de las personas con educación terciaria de los países de la OCDE han sido superiores a las de aquellas que no tienen ese nivel educativo. Por otro lado, las tasas de desempleo entre los hombres y las mujeres con estudios inferiores son mayores a las de aquellos que cuentan con una educación terciaria. En general, los adultos más jóvenes son los que más se preparan y las tasas de desempleo son superiores entre aquellos que solo tienen una formación inferior a educación secundaria superior; en 2012, en los países de la OCDE, alrededor del $20 \%$ de los adultos jóvenes estaban desempleados, lo que supone la tasa más alta registrada en más de una década. 


\section{Anălisis}

\section{Resultados en el mercado laboral, por nivel educativo, grupo de edad y sexo}

\section{Empleo, por nivel educativo y grupo de edad}

Las competencias son uno de los principales motores del crecimiento económico y, por ello, los mercados laborales recompensan a los individuos altamente cualificados (véase Indicador A6). De este modo, tener una educación terciaria aumenta la probabilidad de estar empleado. Como se muestra en el Gráfico A5.1, esto se cumple en todos los países de la OCDE y del G-20 con datos disponibles. Un promedio de más del $80 \%$ de las personas con educación terciaria están empleadas, frente al $70 \%$ de los que tienen educación secundaria superior o postsecundaria no terciaria y al $60 \%$ de aquellas con formación inferior a educación secundaria superior. En algunos países hay una gran diferencia en las tasas de empleo de las personas que tienen una educación terciaria y aquellas cuya formación es inferior a educación secundaria superior. Por ejemplo, en Alemania, Austria, Bélgica, Eslovenia, Estonia, Federación Rusa, Hungría, Irlanda, Israel, Polonia, República Checa y República Eslovaca, se da una diferencia del $30 \%$ en las tasas de empleo de estos dos grupos (Tabla A5.3a).

También se dan diferencias significativas en las tasas de empleo de los adultos jóvenes y los adultos mayores. No solo son los adultos más jóvenes los que alcanzan niveles superiores de educación con respecto a los adultos de más edad (véase el Indicador A1), también tienen más probabilidades de conseguir un empleo. La proporción de individuos de 25 a 34 años con educación secundaria superior o postsecundaria no terciaria que están empleados es una media de 20 puntos porcentuales mayor que la de las personas de 55 a 64 años con el mismo nivel educativo (el $75 \%$ y el $55 \%$, respectivamente). Alrededor del $60 \%$ de los adultos jóvenes con una formación inferior a educación secundaria superior están empleados frente a solo un $40 \%$ de los adultos mayores con el mismo nivel educativo, mientras que entre los adultos con educación terciaria más del $80 \%$ de los adultos jóvenes están empleados, en comparación con menos del $70 \%$ de los adultos mayores (Tabla A5.3a).

La mayor diferencia entre los grupos de edad y el nivel de estudios se da en Austria, Eslovenia, Federación Rusa Luxemburgo y Turquía. En Eslovenia, por ejemplo, el $80 \%$ de los adultos jóvenes con educación secundaria superior o postsecundaria no terciaria están empleados frente al $30 \%$ de los adultos de más edad con el mismo nivel educativo (Tabla A5.3a).

\section{Empleo, por sexo}

En todos los países de la OCDE y en todos los niveles de educación sigue habiendo diferencias por sexo en lo que respecta al empleo. Solo el $65 \%$ de las mujeres tienen un empleo frente al $80 \%$ de los hombres. La diferencia por sexo en las tasas de empleo es mayor entre los adultos con menos educación y alcanza los 20 puntos porcentuales entre hombres y mujeres con educación secundaria inferior (el $68 \%$ y el $48 \%$, respectivamente). Entre aquellos con educación secundaria superior la diferencia en la tasa de empleo es de 15 puntos porcentuales (el $80 \%$ para los hombres, el $64 \%$ para las mujeres con nivel educativo CINE 3C programa largo y CINE 3B; el $80 \%$ para los hombres, el $65 \%$ para las mujeres con nivel educativo CINE 3A). Con respecto a la educación terciaria, la variación entre hombres y mujeres es de 10 puntos porcentuales ( $86 \%$ de los hombres están empleados frente al $76 \%$ de las mujeres con nivel educativo CINE 5B; en el nivel educativo CINE 5A / 6, el porcentaje es del $89 \%$ de los hombres y el $80 \%$ de las mujeres). Aunque la diferencia entre hombres y mujeres con respecto a las tasas de empleo se reduce a medida que aumenta el nivel educativo, en los países de la OCDE la tasa de empleo de las mujeres con educación terciaria es sustancialmente inferior a la de los hombres, a pesar de que en 2012 hubo un porcentaje mayor de mujeres que de hombres con educación terciaria (un $34 \%$ y un $31 \%$, respectivamente) (Tabla A5.1b y véase Tabla A1.1b, disponible en Internet).

La diferencia de las tasas de empleo entre hombres y mujeres con cualificación terciaria de tipo A o de programas de investigación avanzada es mayor en Corea, Japón, México, República Checa y Turquía, donde supera los 15 puntos porcentuales. En Islandia, Noruega, Portugal y Suecia, la diferencia de las tasas de empleo entre sexos es inferior a 3 puntos porcentuales (Tabla A5.1b).

\section{Desempleo, por nivel educativo y grupo de edad}

El riesgo de desempleo también está relacionado con el nivel educativo: aquellos que tienen un nivel educativo superior tienen menos probabilidades de estar desempleados. Como se muestra en el Gráfico A5.2, una media del $14 \%$ de los adultos con un nivel educativo inferior a secundaria superior estaban desempleados en 2012 en los países de la OCDE. Esta proporción se mantuvo prácticamente sin cambios entre 2005 y 2012 (un $11 \%$ y un 14\%, respectivamente). Sin embargo, en algunos países se dieron cambios significativos. En España, Grecia, Hungría e Irlanda, las tasas de desempleo en las personas con niveles educativos bajos aumentaron considerablemente en más de 10 pun- 
Gráfico A5.2. Tasas de desempleo de las personas de 25 a 64 años, por nivel educativo alcanzado $(2005,2010$ y 2012)

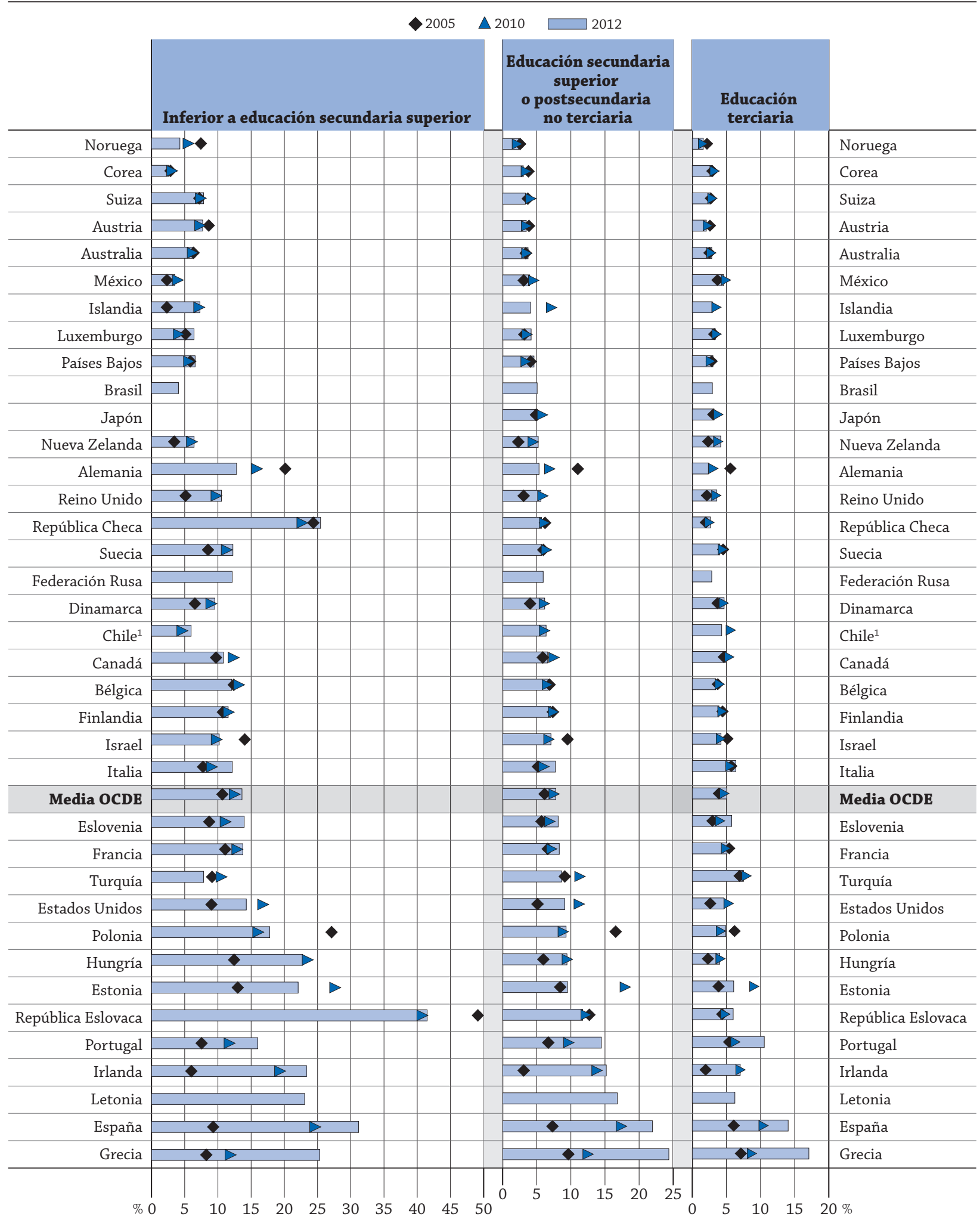

1. Año de referencia 2011.

Los países se clasifican en orden ascendente de las tasas de desempleo en 2012 de personas de 25 a 64 años con educación secundaria superior o postsecundaria no terciaria.

Fuente: OCDE. Tabla A5.4a. Para ver notas, consulte Anexo 3 (www.oecd.org/edu/eag.htm).

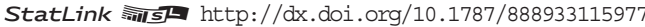


tos porcentuales durante este periodo. Entre 2010 y 2012, las tasas de desempleo disminuyeron significativamente en Alemania, Canadá, Estados Unidos, Estonia y Turquía (Tabla A5.4a).

En 2012, alrededor del $8 \%$ de los adultos con educación secundaria superior o postsecundaria no terciaria estaban desempleados en los países de la OCDE. Las tasas de desempleo entre adultos con este nivel de educación varían considerablemente y oscilan desde el $2 \%$ en Noruega hasta en torno al $24 \%$ en Grecia. Por otro lado, en los países de la OCDE, el $5 \%$ de los adultos con educación terciaria estaban desempleados; solo en España, Grecia y Portugal las tasas de desempleo de los adultos con educación terciaria superaron el 10\% (Gráfico A5.2).

En algunos países, la diferencia de las tasas de desempleo entre adultos con niveles altos y bajos de educación es muy estrecha o, incluso, se invierte. Por ejemplo, en Brasil, Corea, México y Turquía, las tasas de desempleo de las personas con educación secundaria superior o postsecundaria no terciaria fueron superiores a las de aquellas con educación inferior a secundaria superior. En México, las tasas de desempleo de adultos con educación secundaria superior o postsecundaria no terciaria fueron inferiores a las de aquellos con educación terciaria (Tabla A5.4a).

El desempleo golpea con más fuerza a las nuevas generaciones. En todos los niveles educativos, las tasas de desempleo son más altas en los adultos jóvenes que en los adultos mayores. En los países de la OCDE, un promedio del $10 \%$ de los adultos mayores sin educación secundaria superior están desempleados en comparación con el $20 \%$ de los adultos jóvenes con un nivel educativo similar. Igualmente, el $10 \%$ de los adultos más jóvenes con educación secundaria superior o postsecundaria no terciaria están sin empleo, frente al $7 \%$ de los adultos de más edad con nivel de educación similar. La diferencia entre los dos grupos de edad es menor entre los adultos con educación terciaria: el $7 \%$ de los adultos jóvenes carecen de empleo frente al $4 \%$ de los adultos mayores. Esto indica lo importante que es contar con una titulación terciaria. El hecho de que los adultos jóvenes tengan las tasas más altas de empleo y desempleo con respecto a los adultos de más edad evidencia una estrecha relación con el aumento de las tasas de inactividad entre los adultos mayores (Tabla A5.4a).

\section{Desempleo, por sexo}

Las diferencias entre sexos en las tasas de desempleo son, como media, menores que en las tasas de empleo. En los adultos con una educación inferior a secundaria superior, las tasas de desempleo son similares para mujeres y hombres (un $13 \%$ para las mujeres y un $14 \%$ para los hombres). En los adultos que tienen educación secundaria superior o postsecundaria no terciaria, las tasas de desempleo son superiores en las mujeres que en los hombres (un $9 \%$ y un $7 \%$, respectivamente). También se da la misma tendencia entre los adultos con educación terciaria, donde la tasa de desempleo es del $5 \%$ para ambos sexos (Tablas A5.4b y c, disponibles en Internet).

En Grecia y Turquía, las diferencias entre sexos en las tasas de desempleo aumentan. En 2012, por ejemplo, el 11\% de las mujeres con educación terciaria en Turquía carecían de empleo en comparación con el $6 \%$ de los hombres (en Grecia, el porcentaje es del $20 \%$ y del $14 \%$, respectivamente). Estas diferencias aumentan en los adultos con educación secundaria superior: el 17\% de las mujeres no tenían un empleo frente al $7 \%$ de los hombres (en Grecia es así para el $30 \%$ de las mujeres y para el $21 \%$ de los hombres) (Tablas A5.4b y c, disponibles en Internet).

\section{Desempleo, por ámbito de estudio en el nivel terciario}

Aunque los trabajadores con educación terciaria tienen tasas de desempleo más bajas si se comparan con las tasas de los trabajadores con menor formación, esto no significa que todas las personas con educación terciaria disfruten de esta ventaja o que las tasas de desempleo de los graduados de todo tipo de programas de educación terciaria sean las más bajas. Estados Unidos y otros países arrojan resultados dispares en relación con el empleo de trabajadores con graduación terciaria de tipo A. Por ejemplo, en Estados Unidos, los datos de los salarios de las personas de 25 a 29 años muestran que los graduados en ingeniería e informática tienen salarios más altos que los graduados en educación y servicios sociales.

No obstante, los datos acerca de las tasas de desempleo de Estados Unidos no muestran cifras que permitan relacionarlas con ámbitos de estudio con gran demanda e ingresos altos. Por ejemplo, la tasa de desempleo de los graduados altamente remunerados en el campo de la informática y los sistemas de información fue del $5 \%$, más alta que la tasa de desempleo del $2 \%$ de los graduados en programas de enseñanza secundaria, cuyos ingresos son inferiores y cuya tasa de desempleo es la más baja de los programas educativos. Por otro lado, un estudio llevado a cabo en Canadá en 2007 revela que la tasa de desempleo de las personas que obtuvieron una titulación terciaria de tipo A en 2005 oscilaba entre el $3 \%$ para los graduados en agricultura, medicina e ingeniería y el $8 \%$ para los graduados en educación. Estos hallazgos ilustran la complejidad y la diversidad de los resultados para los graduados en educación terciaria que se incorporan al mercado laboral (véase el Cuadro A5.1 en OECD, 2013a). 


\section{Situación de la población activa, por orientación del programa (formación profesional o general)}

La Clasificación Internacional Normalizada de la Educación (CINE-97) define la formación profesional (FP) como «la educación destinada principalmente a que los individuos adquieran las destrezas prácticas, los conocimientos técnicos y la comprensión necesaria para tener un empleo en una ocupación concreta o en una clase de ocupaciones u oficios determinados. La finalización de estos programas implica una cualificación profesional dentro del mercado laboral reconocida por las autoridades competentes del país en el que se obtenga» (UNESCO, 1997).

La formación profesional se orienta generalmante a los estudiantes con educación secundaria superior o postsecundaria no terciaria. En algunos países, las reformas facilitan a los graduados en formación profesional el acceso a una educación terciaria; en otros, dichos programas se imparten también en el nivel terciario.

En algunos sistemas educativos, el aprendizaje impartido en la escuela se combina con prácticas en el trabajo. Ejemplos de este «sistema dual» se encuentran en Alemania, Austria, Luxemburgo, Países Bajos y Suiza. Una de las principales ventajas de este sistema es la colaboración entre el sector público y el privado, donde los interlocutores sociales y los empresarios se involucran en el desarrollo de programas de formación profesional, incluyendo a menudo la definición de los marcos curriculares. En muchos de estos sistemas, los empresarios invierten en los programas de formación profesional mediante la financiación de las prácticas y de los gastos de instructores, materiales y equipos.

Entre otros efectos positivos, la combinación de la formación en el aula y las prácticas en el lugar de trabajo dentro de un entorno educativo formal integrado ayuda a la incorporación de los estudiantes de formación profesional al mercado laboral. Las investigaciones demuestran que la formación profesional puede tener un buen retorno de la inversión pública. En algunos países con sistemas de formación profesional sólidos, como Alemania, contribuyen además a luchar contra el problema del desempleo juvenil (CEDEFOP, 2011).

En los países de la OCDE de los que se dispone de datos, el $75 \%$ de las personas con formación profesional superior o postsecundaria no terciaria tienen empleo, una tasa que es 5 puntos porcentuales superior a la de aquellas personas cuya máxima cualificación es la educación secundaria superior de orientación general.

Las tasas de desempleo son generalmente menores entre las personas con formación profesional superior o postsecundaria no terciaria: un $8 \%$ frente al $9 \%$ de los adultos con educación secundaria superior. En Dinamarca y Eslovenia, las tasas de desempleo de quienes tienen formación profesional superior o postsecundaria no terciaria son al menos 3 puntos porcentuales menores que las de personas con educación secundaria superior. El patrón opuesto ocurre en Grecia e Irlanda (Tabla A5.5a).

Un posible inconveniente es que las competencias que los individuos adquieren a través de la formación profesional pueden estar limitadas en un mercado laboral en continuo cambio. Asimismo, los graduados en formación profesional se enfrentan a otras desventajas. Como se muestra en el Indicador A1, las personas con formación profesional superior tienen niveles inferiores de competencia lectora, según los datos de la Encuesta sobre las Competencias de los Adultos, a los de aquellas con educación secundaria superior general. Este resultado no es anómalo, dado que la encuesta mide las competencias que más se desarrollan en los programas generales, mientras que las destrezas específicas de formación profesional no se miden. Sin embargo, este hallazgo señala la importancia de fomentar las competencias para el procesamiento de la información, como la competencia lectora y matemática, con el fin de aumentar la adaptación de los graduados en formación profesional al mercado laboral (OECD, 2013b).

\section{Asalariados a tiempo completo entre los adultos con educación terciaria}

No solo la probabilidad de estar empleado aumenta con el nivel de educación, también lo hace la posibilidad de estar contratado a tiempo completo. En los países de la OCDE, el $70 \%$ de los asalariados de todos los niveles educativos trabajan a tiempo completo y, entre los adultos empleados, el $71 \%$ de los asalariados con educación secundaria superior lo hacen a tiempo completo, frente al $74 \%$ de los asalariados con educación terciaria. Aproximadamente el $64 \%$ de los asalariados con una educación inferior a secundaria superior trabajan a tiempo completo (Tabla A5.6). La definición de trabajo a tiempo completo varía según los países: en algunos, el término lo define el encuestado; en otros, hay un número mínimo oficial de horas. El número mínimo de horas varía desde las 30 horas semanales en Grecia, Nueva Zelanda y República Checa a las 44 horas semanales en Chile. Para más información, consulte la sección Definiciones en el Indicador A6 y el Anexo 3 (www.oecd.org / edu / eag.htm).

En la mayoría de los países de la OCDE, la proporción de hombres adultos de 35 a 44 años que trabajan a tiempo completo es considerablemente mayor que la proporción de hombres de 55 a 64 años que lo hacen. Entre las mujeres no se observa el mismo patrón. De hecho, en cada nivel educativo, la proporción de mujeres de 55 a 64 años que trabajan a tiempo completo es similar a la de mujeres de 35 a 44 años con el mismo nivel de educación (Tabla A5.6). 
Gráfico A5.3. Trabajadores con educación terciaria, por sexo y grupo de edad (2012) Porcentaje de asalariados a tiempo completo y durante todo el año

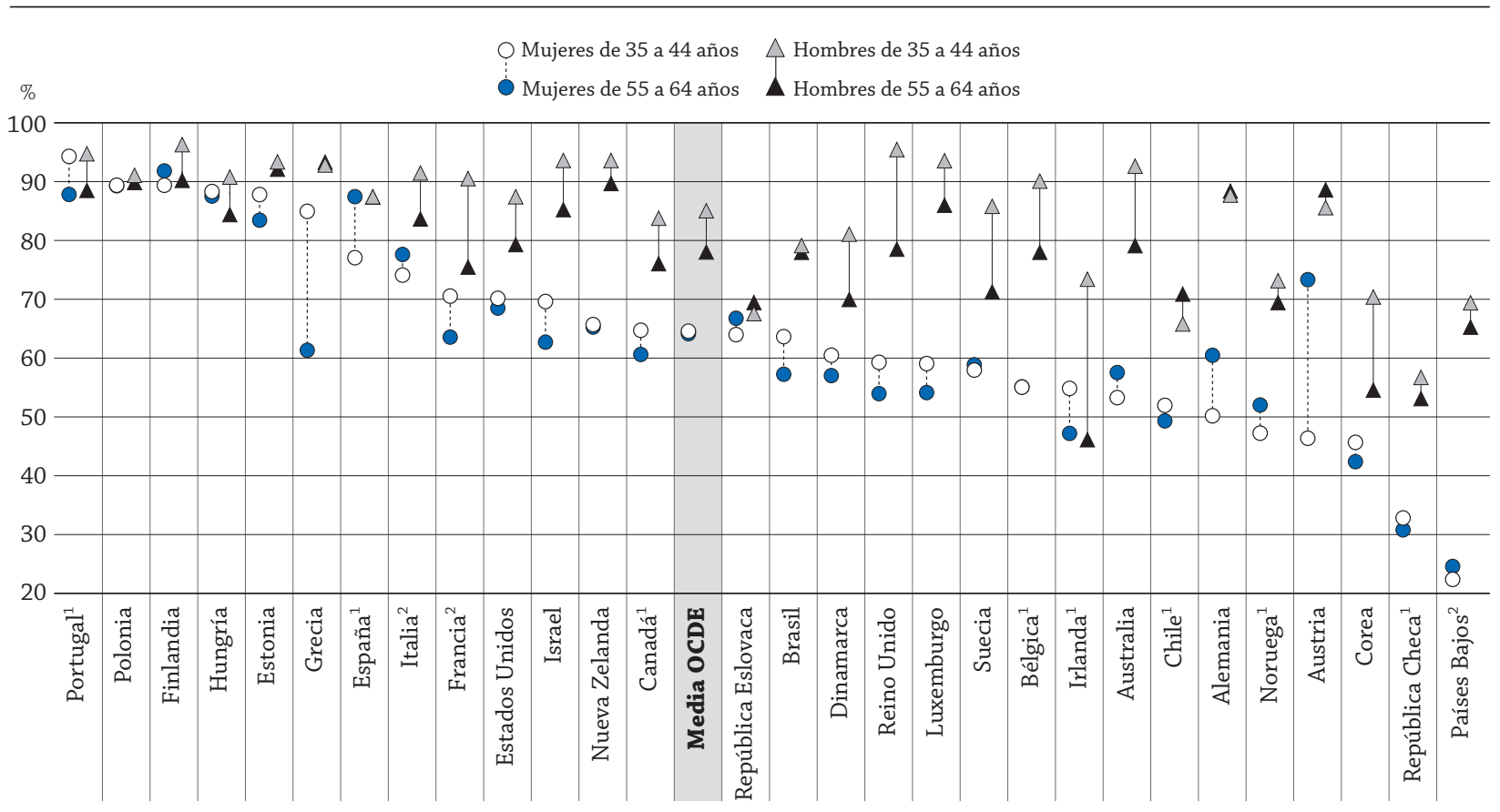

1. Año de referencia 2011.

2. Año de referencia 2010.

Los países se clasifican en orden descendente del porcentaje de mujeres de 35 a 44 años asalariadas a tiempo completo.

Fuente: OCDE. Tabla A5.6. Para ver notas, consulte Anexo 3 (www.oecd.org/edu/eag.htm).

StatLink 제매 http://dx.doi.org/10.1787/888933115996

El Gráfico A5.3 muestra la proporción de trabajadores a tiempo completo de ambos sexos con educación terciaria de 35 a 44 años y de 55 a 64 años. La longitud de las líneas continuas indica la diferencia en la proporción de hombres de ambos grupos de edad que trabajan a tiempo completo; la longitud de las líneas de puntos indica la diferencia en la proporción de mujeres de ambos grupos de edad que trabajan a tiempo completo.

Muchas mujeres con edades comprendidas entre los 35 y los 44 años tienen hijos pequeños y trabajan a tiempo parcial. Por ejemplo, en Alemania, Austria y España, la proporción de mujeres de más edad con educación terciaria que trabajan a tiempo completo es sustancialmente mayor que la proporción de mujeres más jóvenes con el mismo nivel educativo. En otros países como Francia, Grecia, Irlanda, Israel, Luxemburgo, Portugal y Reino Unido, la proporción de mujeres que trabajan a tiempo completo es mayor entre las mujeres más jóvenes que entre las mujeres de mayor edad. En Bélgica, Estados Unidos, Finlandia, Hungría, Nueva Zelanda, Países Bajos, Polonia, República Checa y Suecia, la diferencia entre las mujeres de ambos grupos de edad que trabajan a tiempo completo es mínima. Aun así, la proporción de mujeres con educación terciaria que trabajan a tiempo completo es considerablemente menor, en los países de la OCDE, que la proporción de hombres con el mismo nivel educativo que lo hacen, aunque en Estonia y Finlandia más del $80 \%$ de las mujeres y los hombres con educación terciaria y de ambos grupos de edad trabajan a tiempo completo (Tabla A5.6).

Por otro lado, los estudiantes y los padres con niños pequeños tienen que elegir entre trabajar a tiempo parcial o no trabajar. Como muestra el Indicador A6, un promedio del $10 \%$ de los adultos con educación terciaria (educación terciaria de tipo A o programas de investigación avanzada) no son asalariados y esta proporción es mayor entre las mujeres (un 12\%) que entre los hombres (un 7\%) (véanse el Indicador A6 y la Tabla A6.4, disponible en Internet).

\section{Los resultados en el mercado laboral y las competencias lectora y matemática}

Evaluar la relación entre las competencias de las personas y su demanda en el mercado laboral es un objetivo importante de la Encuesta sobre las Competencias de los Adultos (OECD, 2013c). Sin embargo, aun cuando las competencias en lectura, en matemáticas y en solución de problemas -las analizadas en dicho Estudio- son importantes entre las competencias generales de una persona, solo representan algunas de las capacidades que los trabajadores aportan a su puesto de trabajo (OECD, 2013b). 

Gráfico A5.4. Empleados adultos con Nivel 2 o 4/5 de comprensión lectora,
por nivel educativo alcanzado (2012)

Encuesta sobre las Competencias de los Adultos, porcentaje para empleados de 25 a 64 años de edad

Nivel 2 de comprensión lectora

4 Nivel 4/5 de comprensión lectora

Educación secundaria superior

Educación terciaria

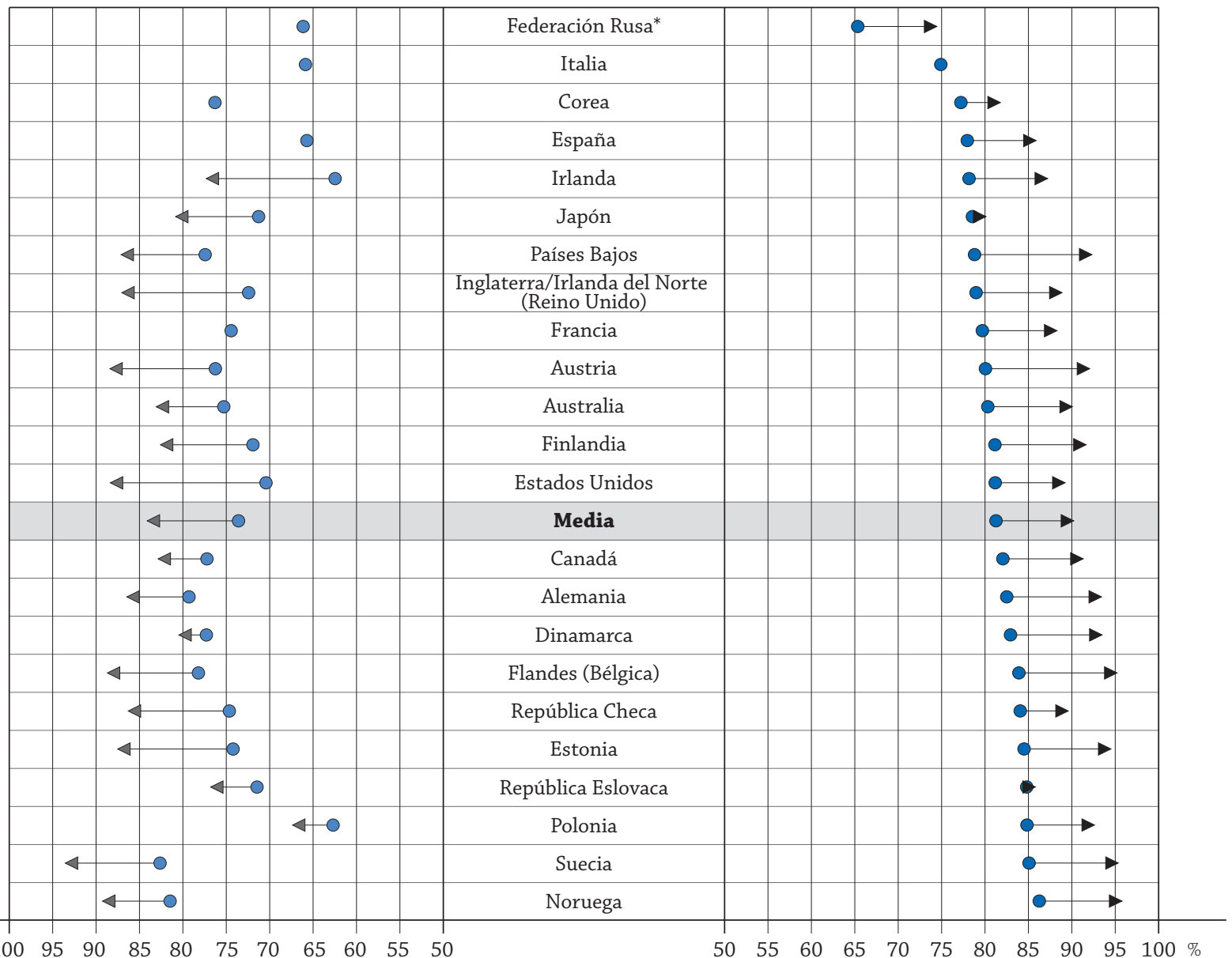

* Para los datos de Federación Rusa, véase nota en la sección de Metodología.

Los países están clasificados en orden ascendente de la proporción de adultos empleados con educación terciaria y Nivel 2 de comprensión lectora.

Fuente: OCDE. TablaA5.7a (L). Para ver notas, consulte Anexo 3 (www.oecd.org/edu/eag.htm).

StatLink 젬ㄴ http://dx.doi.org/10.1787/888933116015

En los países de la OCDE, el $87 \%$ de las personas que obtuvieron el Nivel 4 o 5 en comprensión lectora, los niveles más altos medidos en la Encuesta sobre las Competencias de los Adultos, están empleadas, mientras que el 3,5\% están desempleadas y el $10 \%$ están inactivas en el mercado laboral. En Alemania, Estonia, Flandes (Bélgica), Noruega, Países Bajos y Suecia, el $90 \%$ o más de los individuos altamente cualificados están empleados.

\section{Empleo y comprensión lectora}

Como se muestra en el Gráfico A5.4, los niveles más altos de competencia (marcados con triángulos) se asocian con mayores tasas de empleo en casi todos los países con datos disponibles. Esto es así tanto para las personas con educación terciaria como para aquellas con educación secundaria superior (Tabla A5.7a [L]).

Como se muestra en el Indicador A1, la proporción de personas con educación secundaria superior que obtuvieron un Nivel 4 o 5 en la Encuesta sobre las Competencias de los Adultos es muy baja (por debajo del $5 \%$ en Corea, España, Francia, Italia y Polonia). Entre los adultos con educación terciaria, estas proporciones superan el $10 \%$ (véase Indicador A1).

Este análisis indica que el mercado laboral recompensa a quienes tienen niveles altos de comprensión lectora, lo que generalmente se asocia con mayores niveles de educación formal, incluso en países como Australia, Finlandia, Japón, 
Países Bajos y Suecia, donde aproximadamente uno de cada tres adultos con educación terciaria alcanza el Nivel 4 o 5 en comprensión lectora (véase Tabla A1.6a [L]).

El Gráfico A5.4 muestra también que en Austria, Finlandia, Flandes (Bélgica) y Suecia, las tasas de empleo son 10 puntos porcentuales superiores para las personas que alcanzaron el Nivel 4 o 5 en la Encuesta sobre las Competencias de los Adultos a las de aquellos que alcanzaron el Nivel 2, independientemente de su nivel de educación. Sin embargo, los mercados laborales de diversos países dan una importancia distinta a las cualificaciones y a las competencias. En algunos contextos, la titulación académica tiene más peso para conseguir un empleo que el nivel de las competencias. Por ejemplo, entre los adultos con educación terciaria en Corea, Japón y República Eslovaca, o entre los adultos con educación secundaria superior o postsecundaria no terciaria (incluidas las cualificaciones de FP) en Dinamarca y República Eslovaca, la diferencia de las tasas de empleo relacionadas con los niveles de comprensión lectora es muy pequeña (Tabla A5.7a [L]).

\section{Desempleo e inactividad, y comprensión lectora}

En general, existe un gran número de personas capacitadas que están desempleadas o inactivas y esto se debe a diversos motivos. Aunque algunas personas desempleadas obtienen en las competencias lectora y matemática y en solución de problemas en ambientes tecnológicos puntuaciones similares a las de las personas empleadas, las desempleadas pueden carecer de otras competencias clave necesarias para conseguir un trabajo, tales como las competencias específicas o genéricas solicitadas para ese puesto de trabajo. Alguna situación de inactividad puede ser voluntaria o temporal, como en el caso de los jóvenes que se están formando a tiempo completo o las personas que cuidan de sus familiares. Asimismo, aunque la comprensión lectora sirva para obtener un conjunto más completo de competencias, existe un gran número de desempleados con buenas puntuaciones y este dato sí es importante para las políticas relacionadas con el mercado laboral. Las discordancias entre las competencias de las personas y los requisitos para optar a un puesto de trabajo, además de algunas limitaciones institucionales, es probable que impidan que personas cualificadas se incorporen a un puesto de trabajo o que lo busquen (OECD, 2013b).

En el año 2012, el $20 \%$ de los adultos de los países de la OCDE con educación secundaria superior o postsecundaria no terciaria, independientemente de la orientación del programa, estaban inactivos y en torno a un $8 \%$ de estos adul-

\section{Gráfico A5.5. Adultos inactivos con nivel de educación inferior a educación terciaria, por nivel de comprensión lectora (2012)}

Encuesta sobre las Competencias de los Adultos, porcentaje de personas inactivas de 25 a 64 años con educación secundaria superior o postsecundaria no terciaria como nivel educativo más alto alcanzado

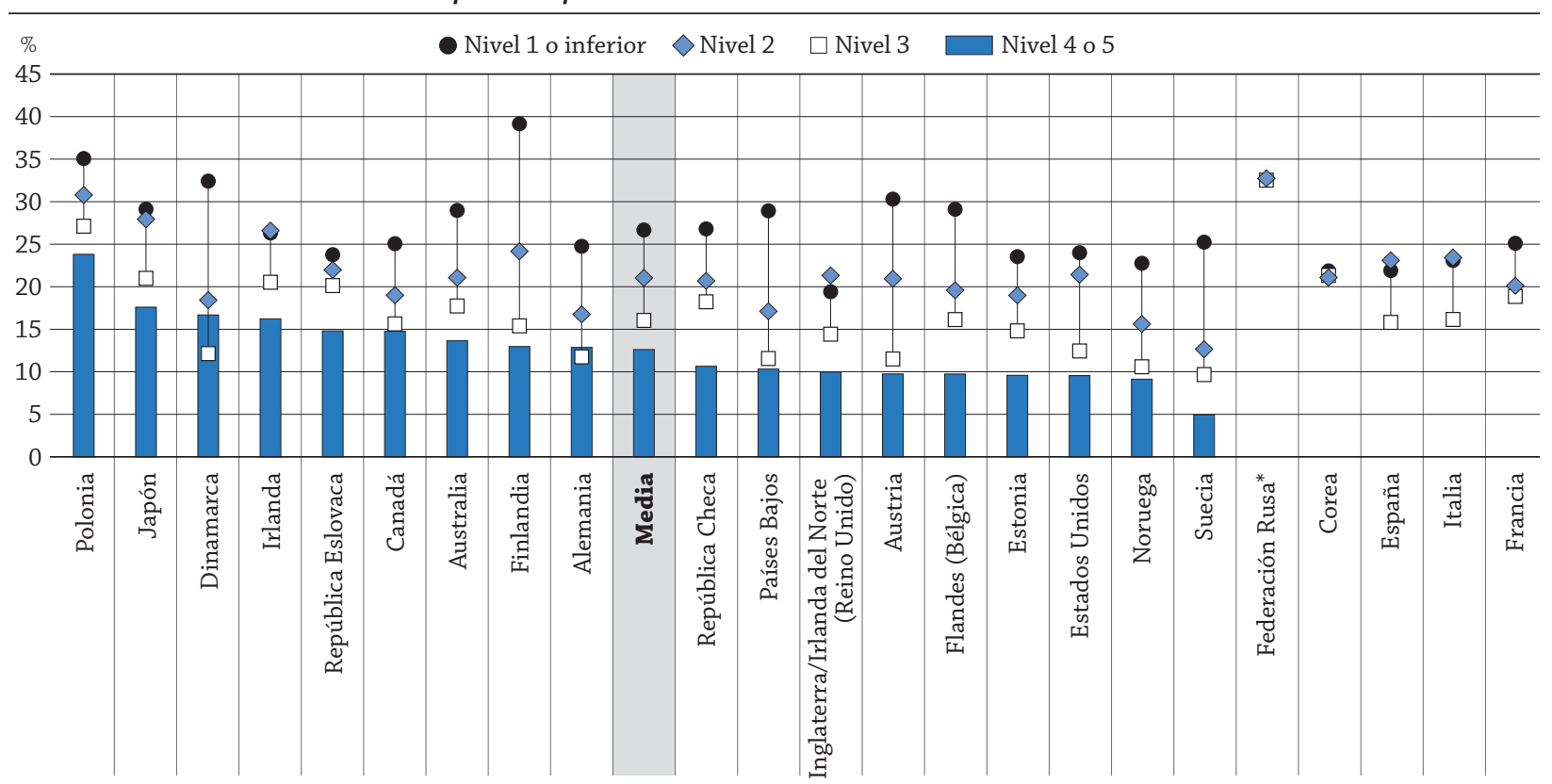

* Para los datos de Federación Rusa, véase nota en la sección de Metodología.

Los países están clasificados en orden descendente del porcentaje de adultos inactivos con educación secundaria superior que obtuvieron el Nivel 4 o 5 de comprensión lectora.

Fuente: OCDE. TablaA5.7a (L). Para ver notas, consulte Anexo 3 (www.oecd.org/edu/eag.htm).

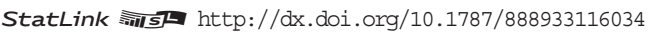


tos estaban desempleados (Tabla A5.5a). Los datos muestran que cuanto más bajo es el nivel de competencias, más altas son las tasas de desempleo e inactividad. Sin embargo, según muestra el Gráfico A5.5, en la mayoría de los países existe un gran número de adultos cualificados cuyas capacidades no se están aprovechando. Esto se puede ver en la proporción de personas inactivas con altos niveles de competencia, en particular aquellas con educación secundaria superior o postsecundaria no terciaria. En Dinamarca, Irlanda, Japón y Polonia, están inactivos más del 15\% de los adultos con educación secundaria superior que alcanzaron el Nivel 4 o 5 en competencia lectora (Tabla A5.7a [L]).

\section{Definiciones}

La población activa (fuerza de trabajo) es el número total de personas empleadas y desempleadas, según la definición de la Encuesta de Población Activa.

Grupos de edad: el término adultos se refiere a personas de 25 a 64 años; el término adultos jóvenes se refiere a personas de 25 a 34 años; el término adultos mayores hace referencia a personas de 55 a 64 años. La población en edad de trabajar es la población total de personas de 25 a 64 años.

Personas empleadas son aquellas que durante la semana de referencia del estudio: 1) tenían un trabajo remunerado (estaban empleadas) u obtuvieron un beneficio (autónomos y trabajadores familiares no remunerados) durante al menos una hora; o 2) tenían un trabajo, pero se ausentaron temporalmente (por lesión, enfermedad, vacaciones, huelga o cierre patronal, estudios o formación, maternidad o paternidad, etc.).

La tasa de empleo se refiere al número de personas con empleo dentro del porcentaje de la población en edad de trabajar (el número de personas empleadas se divide por el número de todas las personas en edad de trabajar). Las tasas de empleo por sexo, edad, nivel educativo, programas de orientación y grupos de edad, se calculan dentro de cada categoría; por ejemplo, la tasa de empleo de las mujeres se calcula dividiendo el número de mujeres empleadas por el número total de mujeres en edad de trabajar.

A tiempo completo se aplica a aquellas personas que han trabajado durante todo el año al menos 30 horas semanales. La duración del período de referencia varía desde una semana a un año. Los trabajadores autónomos están excluidos en algunos países. Los datos de la Tabla A5.10 provienen de la Encuesta sobre las Competencias de los Adultos. Se considera que una persona trabaja a tiempo completo si sus horas de trabajo semanales son más de 30. Para las definiciones nacionales de empleo a tiempo completo, consulte Definiciones del Indicador A6 y el Anexo 3 (www.oecd.org/edu/eag.htm).

Personas inactivas son aquellas que durante la semana de referencia del estudio no estaban empleadas ni desempleadas, es decir, que no estaban buscando un empleo de manera activa. El número de personas inactivas se calcula restando el número de personas activas (fuerza de trabajo) del total de todas las personas en edad de trabajar.

La tasa de inactividad se refiere a las personas inactivas como porcentaje de la población (es decir, el número de personas inactivas dividido por el número total de las personas en edad de trabajar). Las tasas de empleo por sexo, edad, nivel educativo, programas de orientación y grupos de edad, se calculan dentro de cada categoría; por ejemplo, la tasa de inactividad de las personas con un título de educación terciaria se calcula dividiendo el número de personas inactivas con educación terciaria por el número total de personas con educación terciaria en edad de trabajar.

Niveles de educación: Inferior a la educación secundaria superior se corresponde con los niveles educativos CINE 0, 1, 2 y 3 C de programas cortos. Educación secundaria superior o postsecundaria no terciaria se corresponde con los niveles educativos CINE 3 C de programas largos y los niveles 3B, 3A y 4. Educación terciaria se corresponde con los niveles educativos CINE 5B, 5A y 6. Para ver la presentación de todos los niveles CINE, consulte la Guía del lector al principio de este libro.

La tasa de desempleo se refiere a las personas desempleadas como porcentaje de la población activa (es decir, el número de desempleados se divide por la suma de personas empleadas y desempleadas). Las tasas de desempleo por sexo, edad, nivel educativo, programas de orientación y grupos de edad, se calculan dentro de cada categoría; por ejemplo, la tasa de desempleo de las mujeres se calcula dividiendo el número de mujeres desempleadas por el número total de mujeres que están en activo dentro de la fuerza laboral.

Personas desempleadas son aquellas que durante la semana de referencia del estudio estaban sin trabajo (es decir, ni tenían un puesto de trabajo ni estaban en el trabajo durante una hora o más como asalariadas o por cuenta propia), buscaban activamente un empleo (es decir, durante las cuatro semanas previas a la semana de referencia aportaron pruebas de una búsqueda activa de trabajo como asalariadas o por cuenta propia) y aquellas que estaban disponibles para comenzar a trabajar (es decir, disponibles para un trabajo remunerado o por cuenta propia antes de finalizar las dos semanas posteriores a la semana de referencia). 


\section{Metodología}

Los datos sobre la población, el nivel educativo y la demanda del mercado laboral de la mayoría de los países se toman de las bases de datos de la OCDE y Eurostat, que se extraen de las Encuestas Nacionales de Población Activa por la Red LSO (siglas en inglés de Mercado Laboral y Resultados Sociales del Aprendizaje) de la OCDE. Los datos sobre el nivel educativo de Arabia Saudí, Argentina, China, Colombia, Indonesia y Sudáfrica provienen del Instituto de Estadística (UIS) de la UNESCO, que es una base de datos sobre el nivel educativo de la población de 25 años en adelante. Los datos sobre los ingresos proceden de una recopilación de datos especial llevada a cabo por la Red LSO de la OCDE sobre los ingresos de las personas que trabajan a tiempo completo y el año completo. Para las definiciones nacionales de empleo a tiempo completo, consulte la sección Definiciones en el Indicador A6. Los datos sobre los niveles de competencia y puntuaciones medias se basan en la Encuesta sobre las Competencias de los Adultos (PIAAC) (2012). PIAAC es el Programa de la OCDE para la Evaluación Internacional de las Competencias de los Adultos. Para obtener información adicional, consulte Acerca de la Encuesta sobre las Competencias de los Adultos al comienzo de esta publicación y en el Anexo 3 (www.oecd.org/edu/eag.htm).

\section{Nota sobre los datos de Israel}

Los datos estadísticos para Israel fueron proporcionados por las autoridades israelíes competentes bajo su responsabilidad. El uso de estos datos por parte de la OCDE se hace sin prejuzgar la situación de los Altos del Golán, Jerusalén Este y los asentamientos israelíes en Cisjordania de acuerdo con los términos del derecho internacional.

Nota sobre los datos de Federación Rusa en la Encuesta sobre las Competencias de los Adultos (PIAAC)

Los lectores deben tener en cuenta que la muestra de Federación Rusa no incluye a la población del área municipal de Moscú. Por tanto, los datos publicados no representan a toda la población de 16 a 65 años residente en Rusia, sino a la población de Rusia excluyendo la población que reside en el área municipal de Moscú. Se puede encontrar información más detallada sobre los datos de Federación Rusa así como de otros países en Technical Report of the Survey of Adult Skills (OECD, de próxima publicación).

\section{Referencias}

Centro Europeo para el Desarrollo de la Formación Profesional (CEDEFOP) (2011), The Benefits of Vocational Education and Training, Publications Office of the European Union, Luxembourg.

OECD (2013a), Education at a Glance 2013: OECD Indicators, OECD Publishing, París, http://dx.doi.org/10.1787/eag-2013-en.

Versión española: Panorama de la educación, 2013: indicadores de la OCDE, Ministerio de Educación, Cultura y Deporte, Santillana, Madrid.

OECD (2013b), OECD Skills Outlook 2013: First Results from the Survey of Adult Skills, OECD Publishing, París, http://dx.doi. org/10.1787/9789264204256-en.

OECD (2013c), The Survey of Adult Skills: Reader's Companion, OECD Publishing, París, http://dx.doi.org/10.1787/9789264204027-en. UNESCO (1997), «Clasificación Internacional. Normalizada de Educación: (CINE) 1997», www.unesco.org/education/information/ nfsunesco/doc/isced_1997.htm.

\section{Tablas del Indicador A5}

StatLink त्नाजा http://dx.doi.org/10.1787/888933115711

Tabla A5.1a Tasas de empleo, por nivel educativo alcanzado (2012).

Tabla A5.1b Tasas de empleo, por nivel educativo alcanzado y sexo (2012)

Tabla A5.2a Tasas de desempleo, por nivel educativo alcanzado (2012)

Tabla A5.2b Tasas de desempleo, por nivel educativo alcanzado y sexo (2012)

Tabla A5.3a Tendencias de las tasas de desempleo, por nivel educativo alcanzado y grupo de edad (2000, 2005-2012)

WEB Tabla A5.3b

Tendencias de las tasas de empleo entre hombres, por nivel educativo alcanzado y grupo de edad $(2000,2005-2012)$ 
Tabla A5.4a Tendencias de las tasas de desempleo, por nivel educativo alcanzado y grupo de edad (2000, 2005-2012)

WEB Tabla A5.4b

Tendencias de las tasas de desempleo en hombres, por nivel educativo alcanzado y grupo de edad (2000, 2005-2012)

WEB Tabla A5.4c

Tendencias en las tasas de desempleo entre mujeres, por nivel educativo alcanzado y grupo de edad (2000, 2005-2012)

Tabla A5.5a

Distribución de adultos con educación secundaria superior o postsecundaria no terciaria, por su estatus en el mercado laboral y orientación del programa (2012)

WEB Tabla A5.5b

Distribución de adultos por su estatus en el mercado laboral, nivel educativo alcanzado, orientación del programa y sexo (2012)

WEB Tabla A5.5c

Distribución de adultos por su estatus en el mercado laboral, nivel educativo alcanzado, orientación del programa y edad (2012)

Tabla A5.6 Porcentaje de asalariados a tiempo completo durante todo el año en el total de asalariados, por nivel educativo alcanzado y grupo de $\operatorname{edad}^{1}$ (2012)

Tabla A5.7a (L) Estatus en el mercado laboral, por nivel educativo alcanzado y nivel de comprensión lectora (2012)

WEB Tabla A5.7a (N) Estatus en el mercado laboral, por nivel educativo alcanzado y nivel de competencia matemática (2012)

WEB Tabla A5.7b (L) Estatus en el mercado laboral, por nivel educativo alcanzado, nivel de comprensión lectora y sexo (2012)

WEB Tabla A5.7b (N) Estatus en el mercado laboral, por nivel educativo alcanzado, nivel de competencia matemática y sexo (2012).

WEB Tabla A5.7c (L) Estatus en el mercado laboral, por nivel educativo alcanzado, comprensión lectora y grupo de edad (2012)

WEB Tabla A5.7c (N) Estatus en el mercado laboral, por nivel educativo alcanzado, competencia matemática y grupo de edad (2012)

Tabla A5.8 (L) Puntuación media en comprensión lectora en adultos con educación secundaria superior o postsecundaria no terciaria, por estatus en el mercado laboral y orientación del programa (2012)

WEB Tabla A5.8 (N) Puntuación media en competencia matemática en adultos con educación secundaria superior o postsecundaria no terciaria, por estatus en el mercado laboral y orientación del programa (2012)

Tabla A5.9a (L) Distribución de la población adulta por niveles de comprensión lectora y estatus en el mercado laboral (2012)

WEB Tabla A5.9a (N) Distribución de la población adulta por niveles de competencia matemática y estatus en el mercado laboral (2012)

WEB Tabla A5.9b (L) Puntuación media en comprensión lectora, por nivel educativo y estatus en el mercado laboral (2012)

WEB Tabla A5.9b (N) Puntuación media en nivel de competencia matemática, por nivel educativo y estatus en el mercado laboral (2012)

Tabla A5.10a (L) Distribución de los trabajadores a tiempo completo o a tiempo parcial, por nivel de comprensión lectora y por grupo de edad (2012)

WEB Tabla A5.10a (N) Distribución de trabajadores a tiempo completo o a tiempo parcial, por nivel de competencia matemática y grupo de edad (2012)

WEB Tabla A5.10b (L) Distribución de trabajadores a tiempo completo o a tiempo parcial, por comprensión lectora, grupo de edad y sexo (2012)

WEB Tabla A5.10b (N) Distribución de trabajadores a tiempo completo o a tiempo parcial, por competencia matemática, grupo de edad y sexo (2012) 
Tabla A5.1a. Tasas de empleo, por nivel educativo alcanzado (2012)

Porcentaje de personas empleadas de 25 a 64 años del total de la población de 25 a 64 años

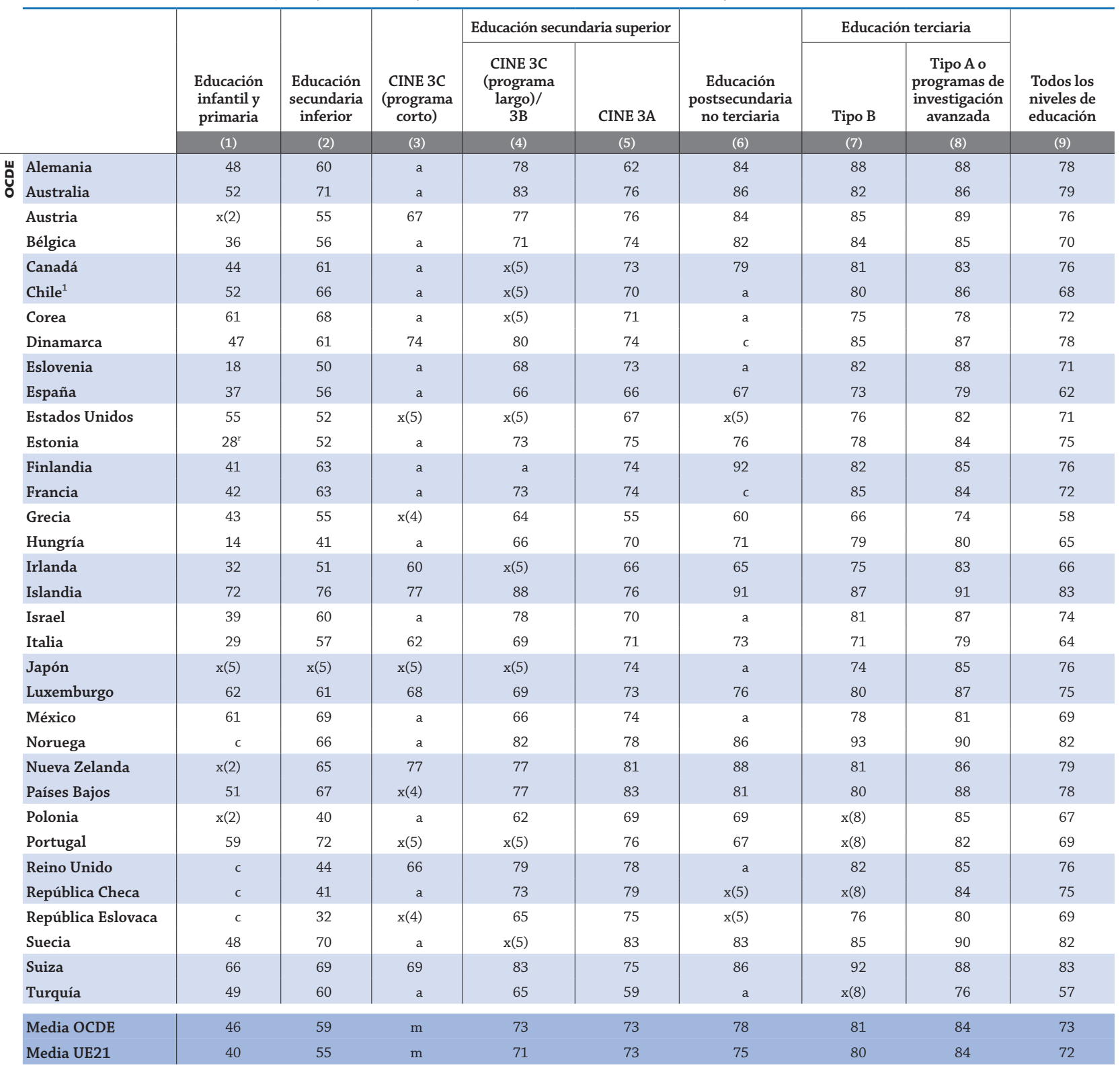

\begin{tabular}{|c|c|c|c|c|c|c|c|c|c|}
\hline $\begin{array}{l}\text { Arabia Saudí } \\
\text { Argentina }\end{array}$ & $\begin{array}{l}\mathrm{m} \\
\mathrm{m}\end{array}$ & $\begin{array}{l}\mathrm{m} \\
\mathrm{m}\end{array}$ & $\begin{array}{l}\mathrm{m} \\
\mathrm{m}\end{array}$ & $\begin{array}{l}\mathrm{m} \\
\mathrm{m}\end{array}$ & $\begin{array}{l}\mathrm{m} \\
\mathrm{m}\end{array}$ & $\begin{array}{l}\mathrm{m} \\
\mathrm{m}\end{array}$ & $\begin{array}{l}\mathrm{m} \\
\mathrm{m}\end{array}$ & $\begin{array}{l}\mathrm{m} \\
\mathrm{m}\end{array}$ & $\begin{array}{l}\mathrm{m} \\
\mathrm{m}\end{array}$ \\
\hline $\begin{array}{l}\text { Brasil } \\
\text { China }\end{array}$ & $\begin{array}{l}65 \\
\mathrm{~m}\end{array}$ & $\begin{array}{l}72 \\
\mathrm{~m}\end{array}$ & $\begin{array}{r}\mathrm{x}(5) \\
\mathrm{m}\end{array}$ & $\begin{array}{r}\mathrm{x}(5) \\
\mathrm{m}\end{array}$ & $\begin{array}{l}77 \\
\mathrm{~m}\end{array}$ & $\begin{array}{l}\mathrm{a} \\
\mathrm{m}\end{array}$ & $\begin{array}{r}\mathrm{x}(8) \\
\mathrm{m}\end{array}$ & $\begin{array}{l}86 \\
\mathrm{~m}\end{array}$ & $\begin{array}{l}73 \\
\mathrm{~m}\end{array}$ \\
\hline $\begin{array}{l}\text { Colombia } \\
\text { Federación Rusa }\end{array}$ & $\begin{array}{r}\mathrm{m} \\
26\end{array}$ & $\begin{array}{r}\mathrm{m} \\
53\end{array}$ & $\begin{array}{r}\mathrm{m} \\
\mathrm{x}(4)\end{array}$ & $\begin{array}{r}\mathrm{m} \\
78\end{array}$ & $\begin{array}{l}\mathrm{m} \\
69\end{array}$ & $\begin{array}{r}m \\
\mathrm{x}(4)\end{array}$ & $\begin{array}{r}\mathrm{m} \\
79\end{array}$ & $\begin{array}{l}\mathrm{m} \\
87\end{array}$ & $\begin{array}{r}\mathrm{m} \\
77\end{array}$ \\
\hline $\begin{array}{l}\text { India } \\
\text { Indonesia }\end{array}$ & $\begin{array}{l}\mathrm{m} \\
\mathrm{m}\end{array}$ & $\begin{array}{l}\mathrm{m} \\
\mathrm{m}\end{array}$ & $\begin{array}{l}\mathrm{m} \\
\mathrm{m}\end{array}$ & $\begin{array}{l}\mathrm{m} \\
\mathrm{m}\end{array}$ & $\begin{array}{l}\mathrm{m} \\
\mathrm{m}\end{array}$ & $\begin{array}{l}\mathrm{m} \\
\mathrm{m}\end{array}$ & $\begin{array}{l}\mathrm{m} \\
\mathrm{m}\end{array}$ & $\begin{array}{l}\mathrm{m} \\
\mathrm{m}\end{array}$ & $\begin{array}{l}\mathrm{m} \\
\mathrm{m}\end{array}$ \\
\hline $\begin{array}{l}\text { Letonia } \\
\text { Sudáfrica }\end{array}$ & $\begin{array}{l}24 \\
\mathrm{~m}\end{array}$ & $\begin{array}{l}53 \\
\mathrm{~m}\end{array}$ & $\begin{array}{r}\mathrm{x}(4) \\
\mathrm{m}\end{array}$ & $\begin{array}{l}66 \\
\mathrm{~m}\end{array}$ & $\begin{array}{l}66 \\
\mathrm{~m}\end{array}$ & $\begin{array}{r}\mathrm{x}(4) \\
\mathrm{m}\end{array}$ & $\begin{array}{r}92 \\
\mathrm{~m}\end{array}$ & $\begin{array}{r}86 \\
\mathrm{~m}\end{array}$ & $\begin{array}{r}71 \\
\mathrm{~m}\end{array}$ \\
\hline Media G20 & $\mathrm{m}$ & $\mathrm{m}$ & $\mathrm{m}$ & $\mathrm{m}$ & $\mathrm{m}$ & $\mathrm{m}$ & $\mathrm{m}$ & $\mathrm{m}$ & $\mathrm{m}$ \\
\hline
\end{tabular}

1. Año de referencia 2011

Fuente: OCDE. Arabia Saudí, Argentina, China, Colombia, India, Indonesia, Sudáfrica: Instituto de Estadística de la UNESCO. Letonia: Eurostat. Para ver notas, consulte Anexo 3 (www.oecd.org/edu/eag.htm).

Para obtener más información acerca de los símbolos utilizados en lugar de los datos que faltan, consulte la Guía del lector.

StatLink 젠 http://dx.doi.org/10.1787/888933115730 
Tabla A5.1b. [1/2] Tasas de empleo, por nivel educativo alcanzado y sexo (2012)

Porcentaje de personas empleadas de 25 a 64 años del total de la población de 25 a 64 años

\begin{tabular}{|c|c|c|c|c|c|c|c|c|c|c|}
\hline & & \multirow[b]{2}{*}{$\begin{array}{c}\text { Educación } \\
\text { infantily } \\
\text { primaria }\end{array}$} & \multirow[b]{2}{*}{$\begin{array}{l}\text { Educación } \\
\text { secundaria } \\
\text { inferior }\end{array}$} & \multirow[b]{2}{*}{$\begin{array}{c}\text { CINE } 3 C \\
\text { (programa } \\
\text { corto) }\end{array}$} & \multicolumn{2}{|c|}{ Educación secundaria superior } & \multirow[b]{2}{*}{$\begin{array}{c}\text { Educación } \\
\text { postsecundaria } \\
\text { no terciaria }\end{array}$} & \multicolumn{2}{|c|}{ Educación terciaria } & \multirow[b]{2}{*}{$\begin{array}{l}\text { Todos los } \\
\text { niveles de } \\
\text { educación }\end{array}$} \\
\hline & & & & & $\begin{array}{c}\text { CINE 3C } \\
\text { (programa } \\
\text { largo)/ } \\
\text { 3B }\end{array}$ & CINE 3A & & Tipo B & $\begin{array}{c}\text { Tipo A o } \\
\text { programas de } \\
\text { investigación } \\
\text { avanzada }\end{array}$ & \\
\hline & & (1) & (2) & (3) & (4) & (5) & (6) & (7) & (8) & (9) \\
\hline \multirow[t]{2}{*}{ Alemania } & Hombres & 60 & 70 & a & 83 & 67 & 87 & 91 & 92 & 84 \\
\hline & Mujeres & 38 & 54 & a & 73 & 56 & 82 & 84 & 84 & 73 \\
\hline \multirow[t]{2}{*}{ Australia } & Hombres & 67 & 81 & a & 88 & 86 & 92 & 90 & 91 & 87 \\
\hline & Mujeres & 39 & 62 & $\mathrm{a}$ & 71 & 68 & 80 & 76 & 81 & 71 \\
\hline \multirow[t]{2}{*}{ Austria } & Hombres & $\mathrm{x}(2)$ & 63 & 86 & 81 & 81 & 88 & 88 & 92 & 82 \\
\hline & Mujeres & $\mathrm{x}(2)$ & 50 & 60 & 72 & 72 & 81 & 81 & 85 & 71 \\
\hline \multirow[t]{2}{*}{ Bélgica } & Hombres & 46 & 65 & a & 78 & 80 & 88 & 86 & 88 & 76 \\
\hline & Mujeres & 27 & 46 & a & 64 & 67 & 74 & 82 & 83 & 64 \\
\hline \multirow[t]{2}{*}{ Canadá } & Hombres & 54 & 68 & a & $\mathrm{x}(5)$ & 79 & 82 & 84 & 86 & 80 \\
\hline & Mujeres & 34 & 50 & $\mathrm{a}$ & $\mathrm{x}(5)$ & 67 & 73 & 78 & 80 & 72 \\
\hline \multirow[t]{2}{*}{ Chile $^{1}$} & Hombres & 77 & 88 & $\mathrm{a}$ & $\mathrm{x}(5)$ & 86 & $\mathrm{a}$ & 90 & 92 & 86 \\
\hline & Mujeres & 33 & 45 & a & $\mathrm{x}(5)$ & 56 & a & 72 & 81 & 53 \\
\hline \multirow[t]{2}{*}{ Corea } & Hombres & 71 & 81 & a & $\mathrm{x}(5)$ & 84 & a & 91 & 90 & 86 \\
\hline & Mujeres & 56 & 59 & a & $\mathrm{x}(5)$ & 57 & a & 60 & 62 & 59 \\
\hline \multirow{2}{*}{ Dinamarca } & Hombres & $51^{r}$ & 67 & 74 & 82 & 78 & c & 88 & 90 & 81 \\
\hline & Mujeres & 45 & 54 & 74 & 76 & 69 & c & 81 & 85 & 74 \\
\hline \multirow[t]{2}{*}{ Eslovenia } & Hombres & 22 & 59 & a & 72 & 77 & $\mathrm{a}$ & 84 & 90 & 75 \\
\hline & Mujeres & 14 & 41 & a & 61 & 69 & a & 80 & 86 & 67 \\
\hline \multirow[t]{2}{*}{ España } & Hombres & 45 & 63 & a & 72 & 71 & c & 78 & 82 & 68 \\
\hline & Mujeres & 29 & 48 & a & 60 & 60 & c & 67 & 76 & 56 \\
\hline \multirow{2}{*}{ Estados Unidos } & Hombres & 68 & 60 & $\mathrm{x}(5)$ & $\mathrm{x}(5)$ & 73 & $x(5)$ & 79 & 87 & 77 \\
\hline & Mujeres & 40 & 42 & $\mathrm{x}(5)$ & $\mathrm{x}(5)$ & 62 & $x(5)$ & 73 & 77 & 66 \\
\hline \multirow{2}{*}{ Estonia } & Hombres & c & 57 & a & 76 & 81 & 83 & 79 & 90 & 78 \\
\hline & Mujeres & c & 45 & a & 67 & 69 & 72 & 78 & 81 & 72 \\
\hline Finlandia & Hombres & 43 & 68 & a & a & 77 & 92 & 81 & 89 & 77 \\
\hline & Mujeres & 40 & 56 & a & a & 71 & 91 & 83 & 82 & 74 \\
\hline Francia & Hombres & 49 & 71 & a & 77 & 79 & c & 89 & 87 & 77 \\
\hline & Mujeres & 36 & 56 & a & 68 & 71 & c & 82 & 81 & 67 \\
\hline Grecia & Hombres & 56 & 68 & $\mathrm{x}(4)$ & 70 & 69 & 71 & 71 & 78 & 68 \\
\hline & Mujeres & 31 & 40 & $\mathrm{x}(4)$ & 47 & 44 & 51 & 60 & 69 & 47 \\
\hline Hungría & Hombres & 22 & 50 & a & 70 & 77 & 80 & 90 & 86 & 72 \\
\hline & Mujeres & c & 34 & a & 57 & 65 & 61 & 75 & 75 & 59 \\
\hline Irlanda & Hombres & 39 & 61 & 66 & $\mathrm{x}(5)$ & 73 & 71 & 81 & 86 & 71 \\
\hline & Mujeres & 25 & 38 & 55 & $\mathrm{x}(5)$ & 58 & 59 & 71 & 80 & 61 \\
\hline Islandia & Hombres & 77 & 80 & c & 90 & 80 & 91 & 91 & 92 & 87 \\
\hline & Mujeres & 67 & 73 & 66 & 82 & 74 & 91 & 86 & 90 & 80 \\
\hline Israel & Hombres & 56 & 72 & $\mathrm{a}$ & 84 & 75 & $\mathrm{a}$ & 88 & 90 & 80 \\
\hline & Mujeres & 24 & 42 & a & 68 & 65 & a & 75 & 84 & 69 \\
\hline Italia & Hombres & 47 & 71 & 76 & 80 & 80 & 82 & 81 & 84 & 75 \\
\hline & Mujeres & 16 & 41 & 55 & 58 & 62 & 68 & 64 & 75 & 53 \\
\hline Japón & Hombres & $\mathrm{x}(5)$ & $\mathrm{x}(5)$ & $\mathrm{x}(5)$ & $\mathrm{x}(5)$ & 85 & a & 92 & 92 & 88 \\
\hline & Mujeres & $\mathrm{x}(5)$ & $\mathrm{x}(5)$ & $\mathrm{x}(5)$ & $\mathrm{x}(5)$ & 62 & a & 67 & 69 & 64 \\
\hline Luxemburgo & Hombres & 68 & 76 & 77 & 79 & 80 & 78 & 87 & 91 & 83 \\
\hline & Mujeres & 57 & 49 & 60 & 58 & 68 & 74 & 74 & 82 & 67 \\
\hline México & Hombres & 87 & 91 & a & 90 & 91 & a & 89 & 88 & 89 \\
\hline & Mujeres & 41 & 49 & a & 58 & 55 & a & 73 & 72 & 51 \\
\hline
\end{tabular}

1. Año de referencia 2011.

Fuentes: OCDE. Arabia Saudí, Argentina, China, Colombia, India, Indonesia, Sudáfrica: Instituto de Estadística de la UNESCO. Letonia: Eurostat. Para ver notas, consulte Anexo 3 (www.oecd.org/edu/eag.htm).

Para obtener más información acerca de los símbolos utilizados en lugar de los datos que faltan, consulte la Guía del lector.

StatLink 제개 http://dx.doi.org/10.1787/888933115749 
Tabla A5.1b. [2/2] Tasas de empleo, por nivel educativo alcanzado y sexo (2012)

Porcentaje de personas empleadas de 25 a 64 años del total de la población de 25 a 64 años

\begin{tabular}{|c|c|c|c|c|c|c|c|c|c|c|}
\hline & & \multirow[b]{2}{*}{$\begin{array}{l}\text { Educación } \\
\text { infantil } \\
\text { y primaria }\end{array}$} & \multirow[b]{2}{*}{$\begin{array}{l}\text { Educación } \\
\text { secundaria } \\
\text { inferior }\end{array}$} & \multirow[b]{2}{*}{$\begin{array}{l}\text { CINE 3C } \\
\text { (programa } \\
\text { corto) }\end{array}$} & \multicolumn{2}{|c|}{$\begin{array}{l}\text { Educación secundaria } \\
\text { superior }\end{array}$} & \multirow[b]{2}{*}{$\begin{array}{c}\text { Educación } \\
\text { postsecundaria } \\
\text { no terciaria }\end{array}$} & \multicolumn{2}{|c|}{ Educación terciaria } & \multirow[b]{2}{*}{$\begin{array}{l}\text { Todos los } \\
\text { niveles de } \\
\text { educación }\end{array}$} \\
\hline & & & & & $\begin{array}{l}\text { CINE } 3 \text { C } \\
\text { (programa } \\
\text { largo) } / 3 \mathrm{~B}\end{array}$ & CINE 3A & & Tipo B & $\begin{array}{c}\text { Tipo A o } \\
\text { programas de } \\
\text { investigación } \\
\text { avanzada }\end{array}$ & \\
\hline & & (1) & (2) & (3) & (4) & (5) & (6) & (7) & (8) & (9) \\
\hline \multirow[t]{2}{*}{ Noruega } & Hombres & c & 70 & a & 86 & 83 & 88 & 94 & 91 & 85 \\
\hline & Mujeres & c & 61 & a & 77 & 73 & 82 & 91 & 89 & 79 \\
\hline \multirow[t]{2}{*}{ Nueva Zelanda } & Hombres & $\mathrm{x}(2)$ & 74 & 86 & 84 & 88 & 91 & 88 & 90 & 86 \\
\hline & Mujeres & $\mathrm{x}(2)$ & 56 & 71 & 71 & 75 & 74 & 76 & 82 & 73 \\
\hline \multirow[t]{2}{*}{ Países Bajos } & Hombres & 64 & 78 & $\mathrm{x}(4)$ & 82 & 87 & 85 & 84 & 90 & 84 \\
\hline & Mujeres & 40 & 56 & $\mathrm{x}(4)$ & 72 & 79 & 76 & 76 & 86 & 72 \\
\hline \multirow[t]{2}{*}{ Polonia } & Hombres & $\mathrm{x}(2)$ & 50 & a & 70 & 80 & 81 & $\mathrm{x}(8)$ & 89 & 75 \\
\hline & Mujeres & $\mathrm{x}(2)$ & 30 & $\mathrm{a}$ & 50 & 58 & 64 & $\mathrm{x}(8)$ & 82 & 60 \\
\hline \multirow[t]{2}{*}{ Portugal } & Hombres & 66 & 76 & $\mathrm{x}(5)$ & $\mathrm{x}(5)$ & 78 & 67 & $\mathrm{x}(8)$ & 82 & 73 \\
\hline & Mujeres & 51 & 68 & $x(5)$ & $\mathrm{x}(5)$ & 74 & 68 & $\mathrm{x}(8)$ & 82 & 66 \\
\hline \multirow[t]{2}{*}{ Reino Unido } & Hombres & c & 54 & 76 & 84 & 83 & $\mathrm{a}$ & 88 & 89 & 82 \\
\hline & Mujeres & c & 35 & 59 & 73 & 73 & a & 76 & 80 & 70 \\
\hline \multirow[t]{2}{*}{ República Checa } & Hombres & c & 51 & a & 81 & 89 & $\mathrm{x}(5)$ & $\mathrm{x}(8)$ & 91 & 84 \\
\hline & Mujeres & c & 36 & a & 62 & 71 & $x(5)$ & $\mathrm{x}(8)$ & 76 & 66 \\
\hline \multirow[t]{2}{*}{ República Eslovaca } & Hombres & c & 38 & $\mathrm{x}(4)$ & 73 & 85 & $\mathrm{x}(5)$ & 79 & 86 & 77 \\
\hline & Mujeres & c & 28 & $\mathrm{x}(4)$ & 54 & 67 & $\mathrm{x}(5)$ & 75 & 76 & 61 \\
\hline \multirow[t]{2}{*}{ Suecia } & Hombres & 58 & 77 & a & $\mathrm{x}(5)$ & 86 & 86 & 86 & 91 & 85 \\
\hline & Mujeres & 38 & 60 & a & $\mathrm{x}(5)$ & 79 & 78 & 83 & 90 & 80 \\
\hline \multirow[t]{2}{*}{ Suiza } & Hombres & 76 & 78 & 77 & 90 & 78 & 90 & 95 & 93 & 90 \\
\hline & Mujeres & 58 & 62 & 67 & 76 & 73 & 83 & 87 & 82 & 76 \\
\hline \multirow[t]{2}{*}{ Turquía } & Hombres & 74 & 79 & a & 83 & 79 & a & $\mathrm{x}(8)$ & 84 & 78 \\
\hline & Mujeres & 27 & 25 & a & 32 & 30 & a & $\mathrm{x}(8)$ & 65 & 33 \\
\hline \multirow[t]{2}{*}{ Media OCDE } & Hombres & 58 & 68 & $\mathrm{~m}$ & 80 & 80 & 84 & 86 & 89 & 80 \\
\hline & Mujeres & 38 & 48 & $\mathrm{~m}$ & 64 & 65 & 74 & 76 & 80 & 65 \\
\hline \multirow[t]{2}{*}{ Media UE21 } & Hombres & 51 & 64 & $\mathrm{~m}$ & 78 & 79 & 82 & 85 & 88 & 78 \\
\hline & Mujeres & 36 & 47 & $\mathrm{~m}$ & 64 & 67 & 72 & 77 & 81 & 66 \\
\hline \multirow{2}{*}{$\begin{array}{l}\text { Arabia Saudí } \\
\text { Argentina }\end{array}$} & & $\mathrm{m}$ & $\mathrm{m}$ & $\mathrm{m}$ & $\mathrm{m}$ & $\mathrm{m}$ & $\mathrm{m}$ & $\mathrm{m}$ & $\mathrm{m}$ & $\mathrm{m}$ \\
\hline & & $\mathrm{m}$ & $\mathrm{m}$ & $\mathrm{m}$ & $\mathrm{m}$ & $\mathrm{m}$ & $\mathrm{m}$ & $\mathrm{m}$ & $\mathrm{m}$ & $\mathrm{m}$ \\
\hline Brasil & Hombres & 82 & 87 & $\mathrm{x}(5)$ & $\mathrm{x}(5)$ & 89 & a & $\mathrm{x}(8)$ & 92 & 86 \\
\hline & Mujeres & 48 & 57 & $\mathrm{x}(5)$ & $\mathrm{x}(5)$ & 67 & a & $x(8)$ & 81 & 60 \\
\hline China & & $\mathrm{m}$ & $\mathrm{m}$ & $\mathrm{m}$ & $\mathrm{m}$ & $\mathrm{m}$ & $\mathrm{m}$ & $\mathrm{m}$ & $\mathrm{m}$ & $\mathrm{m}$ \\
\hline Colombia & & $\mathrm{m}$ & $\mathrm{m}$ & $\mathrm{m}$ & $\mathrm{m}$ & $\mathrm{m}$ & $\mathrm{m}$ & $\mathrm{m}$ & $\mathrm{m}$ & $\mathrm{m}$ \\
\hline Federación Rusa & Hombres & c & 61 & $\mathrm{x}(4)$ & 83 & 77 & $\mathrm{x}(4)$ & 86 & 91 & 83 \\
\hline & Mujeres & c & 43 & $\mathrm{x}(4)$ & 71 & 60 & $\mathrm{x}(4)$ & 75 & 83 & 72 \\
\hline India & & $\mathrm{m}$ & $\mathrm{m}$ & $\mathrm{m}$ & $\mathrm{m}$ & $\mathrm{m}$ & $\mathrm{m}$ & $\mathrm{m}$ & $\mathrm{m}$ & $\mathrm{m}$ \\
\hline Indonesia & & $\mathrm{m}$ & $\mathrm{m}$ & $\mathrm{m}$ & $\mathrm{m}$ & $\mathrm{m}$ & $\mathrm{m}$ & $\mathrm{m}$ & $\mathrm{m}$ & $\mathrm{m}$ \\
\hline Letonia & Hombres & 34 & 60 & $\mathrm{x}(4)$ & 63 & 71 & $\mathrm{x}(4)$ & 94 & 87 & 73 \\
\hline & Mujeres & c & 42 & $\mathrm{x}(4)$ & 72 & 61 & $\mathrm{x}(4)$ & 91 & 85 & 69 \\
\hline Sudáfrica & & $\mathrm{m}$ & $\mathrm{m}$ & $\mathrm{m}$ & $\mathrm{m}$ & $\mathrm{m}$ & $\mathrm{m}$ & $\mathrm{m}$ & $\mathrm{m}$ & $\mathrm{m}$ \\
\hline Media G20 & & $\mathrm{m}$ & $\mathrm{m}$ & $\mathrm{m}$ & $\mathrm{m}$ & $\mathrm{m}$ & $\mathrm{m}$ & $\mathrm{m}$ & $\mathrm{m}$ & $\mathrm{m}$ \\
\hline
\end{tabular}

1. Año de referencia 2011.

Fuentes: OCDE. Arabia Saudí, Argentina, China, Colombia, India, Indonesia, Sudáfrica: Instituto de Estadística de la UNESCO. Letonia: Eurostat. Para ver notas, consulte Anexo 3 (www.oecd.org/edu/eag.htm).

Para obtener más información acerca de los símbolos utilizados en lugar de los datos que faltan, consulte la Guía del lector.

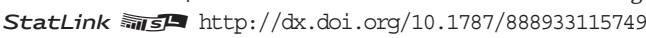


Tabla A5.2a. Tasas de desempleo, por nivel educativo alcanzado (2012)

Porcentaje de personas desempleadas de 25 a 64 años del total de la población de 25 a 64 años de la población activa

\begin{tabular}{|c|c|c|c|c|c|c|c|c|c|}
\hline & \multirow[b]{2}{*}{$\begin{array}{l}\text { Educación } \\
\text { infantil y } \\
\text { primaria }\end{array}$} & \multirow[b]{2}{*}{$\begin{array}{l}\text { Educación } \\
\text { secundaria } \\
\text { inferior }\end{array}$} & \multirow[b]{2}{*}{$\begin{array}{c}\text { CINE 3C } \\
\text { (programa } \\
\text { breve) }\end{array}$} & \multicolumn{2}{|c|}{ Educación secundaria superior } & \multirow[b]{2}{*}{$\begin{array}{c}\text { Educación } \\
\text { postsecun- } \\
\text { daria no } \\
\text { terciaria }\end{array}$} & \multicolumn{2}{|c|}{ Educación terciaria } & \multirow[b]{2}{*}{$\begin{array}{l}\text { Todos los } \\
\text { niveles de } \\
\text { educación }\end{array}$} \\
\hline & & & & $\begin{array}{c}\text { CINE 3C } \\
\text { (programa } \\
\text { largo)/3B }\end{array}$ & CINE 3A & & Tipo B & $\begin{array}{c}\text { Tipo A o } \\
\text { Programas de } \\
\text { investigación } \\
\text { avanzada }\end{array}$ & \\
\hline & (1) & (2) & (3) & (4) & (5) & (6) & (7) & (8) & (9) \\
\hline Alemania & 16,7 & 11,8 & $\mathrm{a}$ & 5,5 & 7,0 & 3,7 & 2,0 & 2,6 & 5,2 \\
\hline Australia & 8,5 & 5,7 & a & 3,7 & 3,9 & 3,3 & 3,3 & 2,7 & 3,9 \\
\hline Austria & $x(2)$ & 8,2 & c & 3,4 & 4,7 & 3,1 & c & 2,6 & 3,7 \\
\hline Bélgica & 14,6 & 10,8 & a & 7,7 & 6,4 & $5,7^{x}$ & 3,0 & 3,8 & 6,5 \\
\hline Canadá & 12,6 & 10,4 & a & $\mathrm{x}(5)$ & 6,7 & 6,3 & 5,2 & 4,8 & 6,1 \\
\hline Chile $^{1}$ & 5,9 & 6,0 & $\mathrm{a}$ & $\mathrm{x}(5)$ & 6,4 & $\mathrm{a}$ & 4,6 & 4,2 & 5,8 \\
\hline Corea & 2,4 & 2,7 & $\mathrm{a}$ & $\mathrm{x}(5)$ & 3,0 & $\mathrm{a}$ & 3,2 & 2,7 & 2,9 \\
\hline Dinamarca & c & 9,8 & c & 5,8 & 8,4 & c & 5,1 & 4,6 & 6,2 \\
\hline Eslovenia & $30,5^{x}$ & 13,4 & a & 8,5 & 7,9 & a & 6,4 & 5,3 & 8,1 \\
\hline España & 35,8 & 29,3 & $\mathrm{a}$ & 22,8 & 21,5 & c & 17,6 & 12,5 & 22,8 \\
\hline Estados Unidos & 11,2 & 16,2 & $\mathrm{x}(5)$ & $\mathrm{x}(5)$ & 9,1 & $\mathrm{x}(5)$ & 6,5 & 4,1 & 7,4 \\
\hline Estonia & c & 21,6 & $\mathrm{a}$ & 11,9 & 8,6 & 8,9 & 8,6 & 4,8 & 9,1 \\
\hline Finlandia & 10,9 & 11,8 & a & a & 7,2 & c & 3,8 & 4,0 & 6,2 \\
\hline Francia & 14,6 & 13,4 & a & 8,3 & 8,2 & c & 4,8 & 5,2 & 8,4 \\
\hline Grecia & 24,9 & 26,0 & $\mathrm{x}(4)$ & 25,9 & 23,0 & 26,9 & 21,1 & 15,1 & 22,4 \\
\hline Hungría & 44,5 & 21,9 & a & 11,3 & 7,6 & 9,6 & c & 3,9 & 9,7 \\
\hline Irlanda & 26,4 & 22,4 & 19,1 & $\mathrm{x}(5)$ & 13,5 & 17,8 & 9,1 & 5,8 & 13,1 \\
\hline Islandia & 8,0 & c & c & 4,4 & c & c & c & 2,9 & 4,5 \\
\hline Israel & 11,0 & 9,3 & a & 6,6 & 7,2 & a & 4,9 & 3,9 & 5,9 \\
\hline Italia & 16,2 & 11,5 & 14,4 & 7,6 & 7,7 & 10,9 & 9,2 & 6,3 & 9,0 \\
\hline Japón & $\mathrm{x}(5)$ & $\mathrm{x}(5)$ & $\mathrm{x}(5)$ & $\mathrm{x}(5)$ & 5,1 & a & 3,7 & 2,8 & 4,2 \\
\hline Luxemburgo & $7,5^{x}$ & $4,9^{x}$ & $7,1^{\mathrm{r}}$ & 5,1 & 3,8 & c & $3,4^{x}$ & 3,4 & 4,2 \\
\hline México & 3,3 & 3,8 & a & 2,8 & 4,4 & a & 3,7 & 4,6 & 3,8 \\
\hline Noruega & c & 4,1 & a & 2,0 & 2,9 & c & c & 1,7 & 2,3 \\
\hline Nueva Zelanda & $\mathrm{m}$ & 7,2 & 4,5 & 7,6 & 4,3 & 3,2 & 6,0 & 3,1 & 5,0 \\
\hline Países Bajos & 7,7 & 6,2 & $\mathrm{x}(4)$ & 4,8 & 4,3 & 3,7 & 5,0 & 2,9 & 4,4 \\
\hline Polonia & $\mathrm{m}$ & 17,8 & $\mathrm{a}$ & 10,9 & 7,8 & 9,5 & $\mathrm{x}(8)$ & 4,9 & 8,6 \\
\hline Portugal & 16,1 & 15,8 & $\mathrm{x}(5)$ & $\mathrm{x}(5)$ & 14,2 & 24,4 & $\mathrm{x}(8)$ & 10,5 & 14,5 \\
\hline Reino Unido & c & 13,7 & 8,9 & 5,7 & 5,1 & a & 3,6 & 3,6 & 5,6 \\
\hline República Checa & c & 25,5 & a & 7,3 & 4,0 & $\mathrm{x}(5)$ & $\mathrm{x}(8)$ & 2,6 & 6,1 \\
\hline República Eslovaca & 2,0 & 40,9 & $\mathrm{x}(4)$ & 15,2 & 8,8 & a & c & 6,1 & 12,2 \\
\hline Suecia & 19,8 & 10,0 & a & $\mathrm{m}$ & 5,6 & 6,3 & 5,0 & 3,7 & 5,8 \\
\hline Suiza & 7,2 & 8,1 & $7,5^{x}$ & 3,2 & 5,4 & 2,7 & 2,0 & 3,0 & 3,6 \\
\hline Turquía & 7,3 & 9,8 & a & 7,6 & 9,6 & a & $\mathrm{x}(8)$ & 7,5 & 7,9 \\
\hline Media OCDE & 14,6 & 13,4 & $\mathrm{~m}$ & 8,2 & 7,7 & 9,1 & 6,0 & 4,8 & 7,5 \\
\hline Media UE21 & 19,2 & 16,5 & $\mathrm{~m}$ & 9,9 & 8,8 & 10,9 & 7,2 & 5,4 & 9,1 \\
\hline Arabia Saudí & $\mathrm{m}$ & $\mathrm{m}$ & $\mathrm{m}$ & $\mathrm{m}$ & $\mathrm{m}$ & $\mathrm{m}$ & $\mathrm{m}$ & $\mathrm{m}$ & $\mathrm{m}$ \\
\hline Argentina & $\mathrm{m}$ & $\mathrm{m}$ & $\mathrm{m}$ & $\mathrm{m}$ & $\mathrm{m}$ & $\mathrm{m}$ & $\mathrm{m}$ & $\mathrm{m}$ & $\mathrm{m}$ \\
\hline Brasil & 3,7 & 4,9 & $x(5)$ & $\mathrm{x}(5)$ & 5,1 & a & $\mathrm{x}(8)$ & 2,9 & 4,2 \\
\hline China & $\mathrm{m}$ & $\mathrm{m}$ & $\mathrm{m}$ & $\mathrm{m}$ & $\mathrm{m}$ & $\mathrm{m}$ & $\mathrm{m}$ & $\mathrm{m}$ & $\mathrm{m}$ \\
\hline Colombia & $\mathrm{m}$ & $\mathrm{m}$ & $\mathrm{m}$ & $\mathrm{m}$ & $\mathrm{m}$ & $\mathrm{m}$ & $\mathrm{m}$ & $\mathrm{m}$ & $\mathrm{m}$ \\
\hline Federación Rusa & c & 11,7 & $\mathrm{x}(4)$ & 5,1 & 6,8 & $\mathrm{x}(4)$ & 3,4 & 2,3 & 4,4 \\
\hline India & $\mathrm{m}$ & $\mathrm{m}$ & $\mathrm{m}$ & $\mathrm{m}$ & $\mathrm{m}$ & $\mathrm{m}$ & $\mathrm{m}$ & $\mathrm{m}$ & $\mathrm{m}$ \\
\hline Indonesia & $\mathrm{m}$ & $\mathrm{m}$ & $\mathrm{m}$ & $\mathrm{m}$ & $\mathrm{m}$ & $\mathrm{m}$ & $\mathrm{m}$ & $\mathrm{m}$ & $\mathrm{m}$ \\
\hline Letonia & 42,1 & 22,2 & $\mathrm{x}(4)$ & 14,9 & 17,5 & $\mathrm{x}(4)$ & c & 6,4 & 13,9 \\
\hline Sudáfrica & $\mathrm{m}$ & $\mathrm{m}$ & $\mathrm{m}$ & $\mathrm{m}$ & $\mathrm{m}$ & $\mathrm{m}$ & $\mathrm{m}$ & $\mathrm{m}$ & $\mathrm{m}$ \\
\hline Media G20 & $\mathrm{m}$ & $\mathrm{m}$ & $\mathrm{m}$ & $\mathrm{m}$ & $\mathrm{m}$ & $\mathrm{m}$ & $\mathrm{m}$ & $\mathrm{m}$ & $\mathrm{m}$ \\
\hline
\end{tabular}

1. Año de referencia 2011.

Fuentes: OCDE. Arabia Saudí, Argentina, China, Colombia, India, Indonesia, Sudáfrica: Instituto de Estadística de la UNESCO. Letonia: Eurostat. Para ver notas, consulte Anexo 3 (www.oecd.org/edu/eag.htm).

Para obtener más información acerca de los símbolos utilizados en lugar de los datos que faltan, consulte la Guía del lector.

StatLink 제그 http://dx.doi.org/10.1787/888933115768 
Tabla A5.2b. [1/2] Tasas de desempleo, por nivel educativo alcanzado y sexo (2012) Porcentaje depersonas desempleadas de 25 a 64 años del total de la población de 25 a 64 años de la población activa

\begin{tabular}{|c|c|c|c|c|c|c|c|c|c|c|}
\hline & & \multirow[b]{2}{*}{$\begin{array}{l}\text { Educación } \\
\text { infantil y } \\
\text { primaria }\end{array}$} & \multirow[b]{2}{*}{$\begin{array}{l}\text { Educación } \\
\text { secundaria } \\
\text { inferior }\end{array}$} & \multirow[b]{2}{*}{$\begin{array}{c}\text { CINE 3C } \\
\text { (programa } \\
\text { corto) }\end{array}$} & \multicolumn{2}{|c|}{$\begin{array}{l}\text { Educación secundaria } \\
\text { superior }\end{array}$} & \multirow[b]{2}{*}{$\begin{array}{c}\text { Educación } \\
\text { postsecun- } \\
\text { daria no } \\
\text { terciaria }\end{array}$} & \multicolumn{2}{|c|}{ Educación terciaria } & \multirow[b]{2}{*}{$\begin{array}{l}\text { Todos los } \\
\text { niveles de } \\
\text { educación }\end{array}$} \\
\hline & & & & & $\begin{array}{c}\text { CINE } 3 C \\
\text { (programa } \\
\text { largo) } 3 B\end{array}$ & CINE $3 \mathrm{~A}$ & & Tipo B & $\begin{array}{c}\text { Tipo A o } \\
\text { Programas de } \\
\text { investigación } \\
\text { avanzada }\end{array}$ & \\
\hline & & (1) & (2) & (3) & (4) & (5) & (6) & (7) & (8) & (9) \\
\hline \multirow{2}{*}{ Alemania } & Hombres & 17,8 & 13,4 & a & 5,8 & 7,2 & 4,3 & 1,8 & 2,4 & 5,4 \\
\hline & Mujeres & 15,0 & 10,4 & a & 5,3 & 6,7 & 3,1 & 2,1 & 2,9 & 5,0 \\
\hline \multirow[t]{2}{*}{ Australia } & Hombres & 7,7 & 5,8 & $\mathrm{a}$ & 3,5 & 3,3 & $2,0^{x}$ & 2,7 & 2,4 & 3,5 \\
\hline & Mujeres & 9,8 & 5,6 & $\mathrm{a}$ & 4,3 & 4,6 & 4,7 & 3,9 & 3,0 & 4,2 \\
\hline \multirow[t]{2}{*}{ Austria } & Hombres & $\mathrm{x}(2)$ & 10,0 & c & 3,5 & $4,3^{r}$ & 3,5 & c & 2,3 & 3,7 \\
\hline & Mujeres & $\mathrm{x}(2)$ & 6,8 & c & 3,4 & $5,0^{x}$ & 2,7 & c & 3,0 & 3,7 \\
\hline \multirow[t]{2}{*}{ Bélgica } & Hombres & 15,0 & 10,3 & $\mathrm{a}$ & 7,6 & 5,5 & c & 3,1 & 3,9 & 6,5 \\
\hline & Mujeres & 13,8 & 11,7 & $\mathrm{a}$ & 7,9 & 7,6 & c & 3,0 & 3,7 & 6,4 \\
\hline \multirow[t]{2}{*}{ Canadá } & Hombres & 12,0 & 10,4 & a & $\mathrm{x}(5)$ & 6,9 & 6,3 & 5,4 & 4,9 & 6,3 \\
\hline & Mujeres & 13,4 & 10,2 & a & $\mathrm{x}(5)$ & 6,5 & 6,4 & 5,0 & 4,7 & 5,8 \\
\hline \multirow[t]{2}{*}{ Chile $^{1}$} & Hombres & 4,9 & 4,5 & a & $\mathrm{x}(5)$ & 4,8 & a & 4,7 & 4,2 & 4,7 \\
\hline & Mujeres & 7,8 & 8,5 & a & $\mathrm{x}(5)$ & 8,4 & a & 4,4 & 4,1 & 7,3 \\
\hline \multirow{2}{*}{ Corea } & Hombres & 3,8 & 3,3 & a & $\mathrm{x}(5)$ & 3,4 & a & 3,2 & 2,7 & 3,2 \\
\hline & Mujeres & 1,3 & 2,1 & a & $\mathrm{x}(5)$ & 2,5 & a & 3,1 & 2,7 & 2,5 \\
\hline \multirow[t]{2}{*}{ Dinamarca } & Hombres & c & 10,0 & c & 5,8 & 7,6 & c & $4,0^{x}$ & 4,3 & 6,3 \\
\hline & Mujeres & c & 9,6 & c & 5,8 & 9,4 & $\mathrm{n}$ & 6,5 & 4,7 & 6,1 \\
\hline \multirow[t]{2}{*}{ Eslovenia } & Hombres & 32,6 & 13,1 & a & 7,5 & 7,5 & a & 5,1 & 3,9 & 7,5 \\
\hline & Mujeres & 26,4 & 13,8 & a & 10,8 & 8,3 & a & 7,3 & 6,3 & 8,7 \\
\hline \multirow[t]{2}{*}{ España } & Hombres & 36,0 & 28,4 & a & 21,4 & 20,2 & c & 15,3 & 11,2 & 22,5 \\
\hline & Mujeres & 35,7 & 30,5 & a & 24,2 & 23,0 & c & 20,9 & 13,5 & 23,2 \\
\hline \multirow[t]{2}{*}{ Estados Unidos } & Hombres & 10,2 & 15,8 & $\mathrm{x}(5)$ & $\mathrm{x}(5)$ & 9,7 & $\mathrm{x}(5)$ & 6,9 & 4,3 & 8,0 \\
\hline & Mujeres & 12,9 & 16,7 & $\mathrm{x}(5)$ & $\mathrm{x}(5)$ & 8,4 & $\mathrm{x}(5)$ & 6,1 & 3,8 & 6,8 \\
\hline \multirow[t]{2}{*}{ Estonia } & Hombres & c & 23,3 & a & 11,2 & 8,3 & $8,7^{x}$ & 9,5 & 4,0 & 9,7 \\
\hline & Mujeres & c & 18,2 & a & 13,2 & 9,0 & $9,0^{x}$ & 8,0 & 5,4 & 8,6 \\
\hline Finlandia & Hombres & 10,4 & 10,9 & a & a & 7,6 & c & 5,7 & 4,0 & 6,9 \\
\hline & Mujeres & $11,5^{x}$ & 13,4 & a & a & 6,5 & c & 2,6 & 3,9 & 5,5 \\
\hline Francia & Hombres & 14,6 & 13,1 & a & 7,6 & 8,0 & c & 4,8 & 5,1 & 8,2 \\
\hline & Mujeres & 14,7 & 13,8 & $\mathrm{a}$ & 9,3 & 8,3 & c & 4,9 & 5,3 & 8,6 \\
\hline Grecia & Hombres & 25,3 & 22,9 & $\mathrm{x}(4)$ & 22,1 & 19,5 & 21,9 & 17,7 & 12,5 & 19,9 \\
\hline & Mujeres & 24,2 & 31,8 & $\mathrm{x}(4)$ & 39,0 & 27,3 & 31,9 & 25,1 & 17,9 & 25,7 \\
\hline Hungría & Hombres & c & 21,9 & $\mathrm{a}$ & 11,0 & 7,9 & c & c & 3,9 & 10,0 \\
\hline & Mujeres & c & 22,0 & a & 11,9 & 7,3 & 13,5 & c & 3,9 & 9,4 \\
\hline Irlanda & Hombres & 31,6 & 25,2 & 23,1 & $\mathrm{x}(5)$ & 16,1 & 20,1 & 10,2 & 6,3 & 16,0 \\
\hline & Mujeres & 14,4 & 15,8 & c & $\mathrm{x}(5)$ & 10,0 & 14,5 & 8,2 & 5,4 & 9,4 \\
\hline Islandia & Hombres & 7,7 & c & $\mathrm{n}$ & c & c & c & c & 3,8 & 4,7 \\
\hline & Mujeres & c & c & c & c & c & c & c & 2,2 & 4,3 \\
\hline Israel & Hombres & 11,5 & 8,9 & $\mathrm{a}$ & 6,0 & 6,9 & a & 4,2 & 3,8 & 5,9 \\
\hline & Mujeres & 10,1 & 10,2 & a & 7,9 & 7,6 & a & 5,6 & 4,0 & 5,9 \\
\hline Italia & Hombres & 16,0 & 10,3 & 13,2 & 6,3 & 6,7 & 8,8 & 8,9 & 5,2 & 8,3 \\
\hline & Mujeres & 16,8 & 13,8 & 15,2 & 9,1 & 9,0 & 12,4 & 9,5 & 7,2 & 10,1 \\
\hline Japón & Hombres & $\mathrm{x}(5)$ & $\mathrm{x}(5)$ & $\mathrm{x}(5)$ & $\mathrm{x}(5)$ & 5,5 & a & 4,2 & 2,9 & 4,4 \\
\hline & Mujeres & $\mathrm{x}(5)$ & $\mathrm{x}(5)$ & $x(5)$ & $\mathrm{x}(5)$ & 4,5 & a & 3,4 & 2,7 & 3,9 \\
\hline Luxemburgo & Hombres & $8,3^{r}$ & c & c & $3,1^{r}$ & $3,4^{x}$ & c & $3,3^{r}$ & $2,8^{r}$ & 3,6 \\
\hline & Mujeres & $6,6^{r}$ & $8,1^{r}$ & c & $8,2^{x}$ & $4,2^{x}$ & c & $3,4^{x}$ & $4,2^{r}$ & 5,0 \\
\hline México & Hombres & 3,5 & 3,4 & a & 2,4 & 4,2 & a & 3,7 & 4,6 & 3,8 \\
\hline & Mujeres & 3,0 & 4,4 & a & 3,0 & 4,7 & a & 3,7 & 4,7 & 3,9 \\
\hline
\end{tabular}

1. Año de referencia 2011.

Fuentes: OCDE. Arabia Saudí, Argentina, China, Colombia, India, Indonesia, Sudáfrica: Instituto de Estadística de la UNESCO. Letonia: Eurostat. Para ver notas, consulte Anexo 3 (www.oecd.org/edu/eag.htm).

Para obtener más información acerca de los símbolos utilizados en lugar de los datos que faltan, consulte la Guía del lector.

StatLink 제이 http://dx.doi.org/10.1787/888933115787 
Tabla A5.2b. [2/2] Tasas de desempleo, por nivel educativo alcanzado y sexo (2012)

Porcentaje depersonas desempleadas de 25 a 64 años del total de la población de 25 a 64 años de la población activa

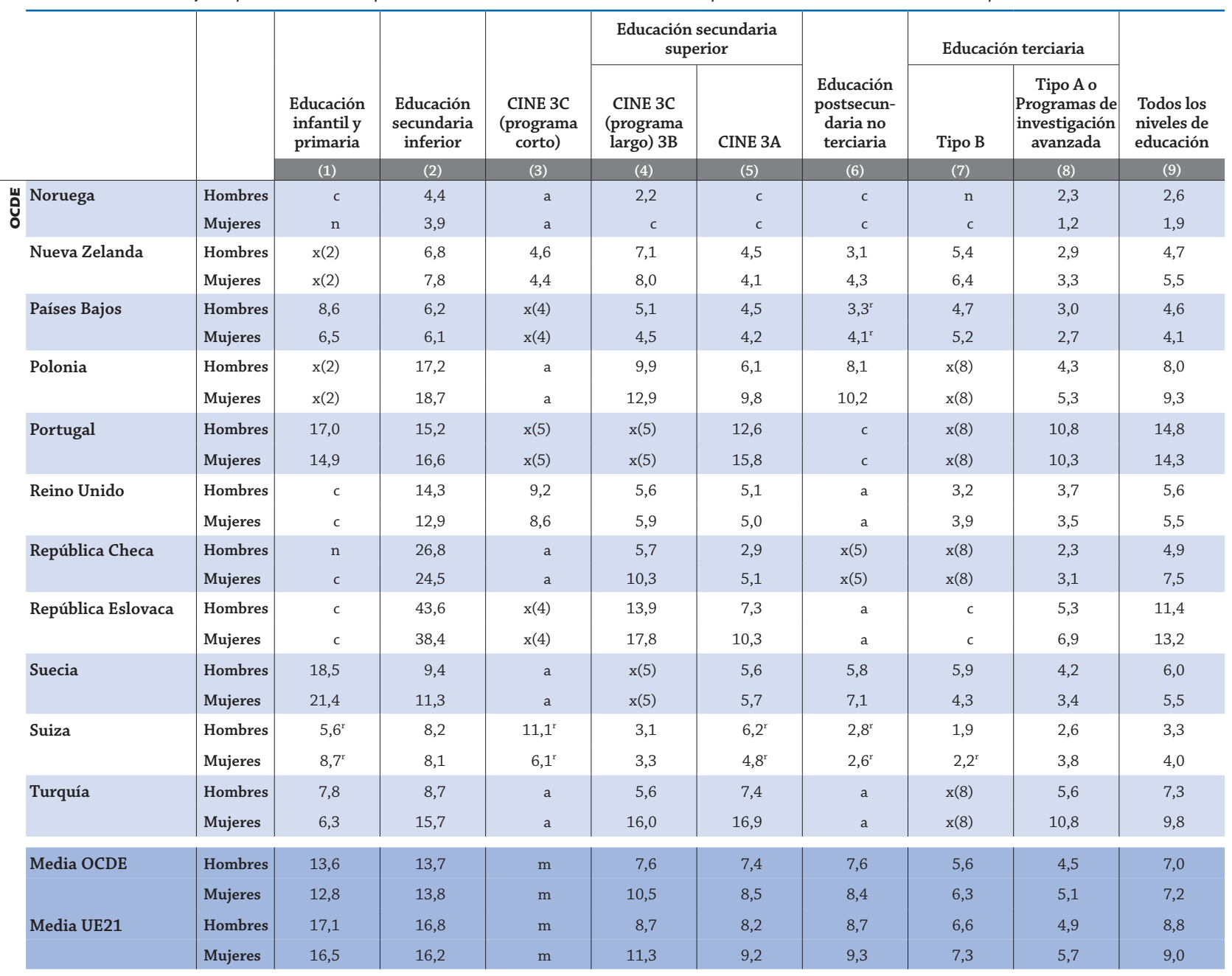

\begin{tabular}{|c|c|c|c|c|c|c|c|c|c|c|}
\hline $\begin{array}{l}\text { Arabia Saudí } \\
\text { Argentina }\end{array}$ & & $\begin{array}{l}\mathrm{m} \\
\mathrm{m}\end{array}$ & $\begin{array}{l}\mathrm{m} \\
\mathrm{m}\end{array}$ & $\begin{array}{l}\mathrm{m} \\
\mathrm{m}\end{array}$ & $\begin{array}{l}\mathrm{m} \\
\mathrm{m}\end{array}$ & $\begin{array}{l}\mathrm{m} \\
\mathrm{m}\end{array}$ & $\begin{array}{l}\mathrm{m} \\
\mathrm{m}\end{array}$ & $\begin{array}{l}\mathrm{m} \\
\mathrm{m}\end{array}$ & $\begin{array}{l}\mathrm{m} \\
\mathrm{m}\end{array}$ & $\begin{array}{l}\mathrm{m} \\
\mathrm{m}\end{array}$ \\
\hline \multirow[t]{2}{*}{ Brasil } & Hombres & 2,8 & 3,4 & $x(5)$ & $\mathrm{x}(5)$ & 3,4 & $\mathrm{a}$ & $\mathrm{x}(8)$ & 2,2 & 3,0 \\
\hline & Mujeres & 5,3 & 7,1 & $x(5)$ & $\mathrm{x}(5)$ & 7,0 & a & $\mathrm{x}(8)$ & 3,5 & 5,8 \\
\hline China & & $\mathrm{m}$ & $\mathrm{m}$ & $\mathrm{m}$ & $\mathrm{m}$ & $\mathrm{m}$ & $\mathrm{m}$ & $\mathrm{m}$ & $\mathrm{m}$ & $\mathrm{m}$ \\
\hline Colombia & & $\mathrm{m}$ & $\mathrm{m}$ & $\mathrm{m}$ & $\mathrm{m}$ & $\mathrm{m}$ & $\mathrm{m}$ & $\mathrm{m}$ & $\mathrm{m}$ & $\mathrm{m}$ \\
\hline Federación Rusa & Mujeres & c & 11,0 & $\mathrm{x}(4)$ & 5,2 & 7,1 & $\mathrm{x}(4)$ & 3,3 & 2,3 & 4,1 \\
\hline India & & $\mathrm{m}$ & $\mathrm{m}$ & $\mathrm{m}$ & $\mathrm{m}$ & $\mathrm{m}$ & $\mathrm{m}$ & $\mathrm{m}$ & $\mathrm{m}$ & $\mathrm{m}$ \\
\hline Indonesia & & $\mathrm{m}$ & $\mathrm{m}$ & $\mathrm{m}$ & $\mathrm{m}$ & $\mathrm{m}$ & $\mathrm{m}$ & $\mathrm{m}$ & $\mathrm{m}$ & $\mathrm{m}$ \\
\hline \multirow[t]{2}{*}{ Letonia } & Hombres & c & 19,2 & $\mathrm{x}(4)$ & 17,9 & 17,4 & $\mathrm{x}(4)$ & c & 7,4 & 15,0 \\
\hline & Mujeres & c & 28,6 & $\mathrm{x}(4)$ & c & 17,6 & $\mathrm{x}(4)$ & c & 5,8 & 12,8 \\
\hline Sudáfrica & & $\mathrm{m}$ & $\mathrm{m}$ & $\mathrm{m}$ & $\mathrm{m}$ & $\mathrm{m}$ & $\mathrm{m}$ & $\mathrm{m}$ & $\mathrm{m}$ & $\mathrm{m}$ \\
\hline Media G20 & & $\mathrm{m}$ & $\mathrm{m}$ & $\mathrm{m}$ & $\mathrm{m}$ & $\mathrm{m}$ & $\mathrm{m}$ & $\mathrm{m}$ & $\mathrm{m}$ & $\mathrm{m}$ \\
\hline
\end{tabular}

1. Año de referencia 2011.

Fuentes: OCDE. Arabia Saudí, Argentina, China, Colombia, India, Indonesia, Sudáfrica: Instituto de Estadística de la UNESCO. Letonia: Eurostat. Para ver notas, consulte Anexo 3 (www.oecd.org/edu/eag.htm).

Para obtener más información acerca de los símbolos utilizados en lugar de los datos que faltan, consulte la Guía del lector.

StatLink त्ञाIs http://dx.doi.org/10.1787/888933115787 
Tabla A5.3a. [1/2] Tendencias de las tasas de empleo, por nivel educativo alcanzado y grupo de edad (2000, 2005-2012)

Porcentaje de personas empleadas de 25 a 64 años, de 25 a 34 años y de 55 a 64 años del total de la población de 25 a 64 años, de 25 a 34 años y de 55 a 64 años.

\begin{tabular}{|c|c|c|c|c|c|c|c|c|c|c|c|c|c|}
\hline & \multirow[b]{3}{*}{ Nivel educativo alcanzado } & \multicolumn{4}{|c|}{$\begin{array}{c}\text { Tasas de empleo de las } \\
\text { personas de } 25 \text { a } 64 \text { años }\end{array}$} & \multicolumn{4}{|c|}{$\begin{array}{c}\text { Tasas de empleo de las } \\
\text { personas de } 25 \text { a } 34 \text { años }\end{array}$} & \multicolumn{4}{|c|}{$\begin{array}{c}\text { Tasas de empleo de las } \\
\text { personas de } 55 \text { a } 64 \text { años }\end{array}$} \\
\hline & & 2000 & 2005 & 2010 & 2012 & 2000 & 2005 & 2010 & 2012 & 2000 & 2005 & 2010 & 2012 \\
\hline & & (1) & $(2)$ & (7) & (9) & (11) & $(12)$ & (17) & $(19)$ & $(41)$ & $(42)$ & $(47)$ & $(49)$ \\
\hline \multirow{2}{*}{ Alemania } & Secundaria superior o postsecundaria no terciaria & 70 & 71 & 76 & 78 & 79 & 74 & 78 & 81 & 37 & 43 & 56 & 60 \\
\hline & Terciaria & 83 & 83 & 87 & 88 & 89 & 85 & 88 & 89 & 58 & 63 & 73 & 75 \\
\hline \multirow[t]{2}{*}{ Australia } & Inferior a educación secundaria superior & 61 & 63 & 65 & 66 & 64 & 64 & 61 & 62 & 39 & 46 & 53 & 56 \\
\hline & Secundaria superior o postsecundaria no terciaria & 77 & 80 & 80 & 80 & 80 & 81 & 78 & 81 & 53 & 62 & 71 & 72 \\
\hline \multirow[t]{3}{*}{ Austria } & Inferior a educación secundaria superior & 54 & 53 & 56 & 56 & 70 & 61 & 61 & 65 & 19 & 24 & 31 & 30 \\
\hline & Secundaria superior o postsecundaria no terciaria & 75 & 74 & 78 & 78 & 84 & 84 & 84 & 86 & 29 & 31 & 41 & 42 \\
\hline & Terciaria & 87 & 85 & 86 & 87 & 92 & 87 & 87 & 89 & 59 & 54 & 64 & 67 \\
\hline \multirow[t]{3}{*}{ Bélgica } & Inferior a educación secundaria superior & 51 & 49 & 49 & 48 & 64 & 57 & 56 & 54 & 19 & 21 & 26 & 26 \\
\hline & Secundaria superior o postsecundaria no terciaria & 75 & 74 & 74 & 73 & 84 & 81 & 80 & 78 & 31 & 38 & 41 & 44 \\
\hline & Terciaria & 85 & 84 & 84 & 85 & 92 & 90 & 89 & 89 & 46 & 49 & 53 & 57 \\
\hline Canadá & Inferior a educación secundaria superior & 55 & 56 & 55 & 56 & 60 & 62 & 58 & 59 & 37 & 41 & 43 & 44 \\
\hline & Secundaria superior o postsecundaria no terciaria & 76 & 76 & 74 & 75 & 79 & 80 & 77 & 79 & 52 & 57 & 58 & 60 \\
\hline & Terciaria & 83 & 82 & 81 & 82 & 86 & 85 & 84 & 84 & 57 & 62 & 65 & 65 \\
\hline & Secundaria superior o postsecundaria no terciaria & $\mathrm{m}$ & $\mathrm{m}$ & 72 & $\mathbf{m}$ & $\mathrm{m}$ & $\mathrm{m}$ & 74 & $\mathbf{m}$ & $\mathrm{m}$ & $\mathrm{m}$ & 59 & $\mathbf{m}$ \\
\hline & Terciaria & $\mathrm{m}$ & $\mathrm{m}$ & 79 & $\mathbf{m}$ & $\mathrm{m}$ & $\mathrm{m}$ & 75 & $\mathbf{m}$ & $\mathrm{m}$ & $\mathrm{m}$ & 74 & $\mathbf{m}$ \\
\hline Corea & Inferior a educación secundaria superior & 68 & 66 & 65 & 65 & 65 & 62 & 57 & 59 & 59 & 58 & 59 & 61 \\
\hline & Secundaria superior o postsecundaria no terciaria & 69 & 70 & 71 & 71 & 64 & 64 & 64 & 63 & 53 & 59 & 62 & 64 \\
\hline & Terciaria & 75 & 77 & 76 & 77 & 74 & 74 & 74 & 75 & 57 & 61 & 64 & 68 \\
\hline Dinamarca & Inferior a educación secundaria superior & 62 & 62 & 63 & 61 & 70 & 64 & 65 & 62 & 41 & 42 & 46 & 47 \\
\hline & Secundaria superior o postsecundaria no terciaria & 81 & 80 & 79 & 79 & 85 & 83 & 82 & 79 & 57 & 61 & 59 & 63 \\
\hline & Terciaria & 88 & 86 & 86 & 86 & 88 & 87 & 86 & 85 & 73 & 73 & 71 & 73 \\
\hline Eslovenia $^{1}$ & Inferior a educación secundaria superior & 53 & 56 & 51 & 47 & 75 & 70 & 60 & 52 & 20 & 27 & 28 & 25 \\
\hline & Secundaria superior o postsecundaria no terciaria & 74 & 75 & 73 & 71 & 86 & 84 & 81 & 80 & 18 & 27 & 32 & 30 \\
\hline & Terciaria & 86 & 87 & 87 & 85 & 92 & 91 & 88 & 84 & 48 & 51 & 57 & 55 \\
\hline España & Inferior a educación secundaria superior & 54 & 59 & 53 & 49 & 65 & 71 & 58 & 53 & 33 & 38 & 36 & 36 \\
\hline & Secundaria superior o postsecundaria no terciaria & 72 & 75 & 69 & 66 & 73 & 77 & 68 & 63 & 51 & 51 & 53 & 53 \\
\hline & Terciaria & 80 & 82 & 80 & 77 & 75 & 81 & 78 & 73 & 64 & 65 & 64 & 65 \\
\hline Estados Unidos & Inferior a educación secundaria superior & 58 & 57 & 52 & 53 & 64 & 62 & 55 & 56 & 40 & 39 & 40 & 39 \\
\hline & Secundaria superior o postsecundaria no terciaria & 77 & 73 & 68 & 67 & 80 & 74 & 68 & 68 & 58 & 58 & 57 & 57 \\
\hline & Terciaria & 85 & 82 & 80 & 80 & 87 & 83 & 82 & 82 & 70 & 72 & 70 & 71 \\
\hline Estonia $^{1}$ & Inferior a educación secundaria superior & 42 & 50 & 45 & 51 & 53 & 60 & 51 & 57 & 24 & 36 & 30 & 34 \\
\hline & Secundaria superior o postsecundaria no terciaria & 70 & 74 & 69 & 75 & 74 & 77 & 70 & 77 & 46 & 53 & 54 & 58 \\
\hline & $\begin{array}{l}\text { Terciaria } \\
\end{array}$ & 84 & 84 & 84 & 84 & 84 & 86 & 84 & 83 & 60 & 66 & 70 & 70 \\
\hline Francia & Inferior a educación secundaria superior & 56 & 59 & 55 & 55 & 61 & 63 & 57 & 56 & 24 & 32 & 32 & 36 \\
\hline & Secundaria superior o postsecundaria no terciaria & 75 & 76 & 74 & 74 & 80 & 80 & 79 & 77 & 31 & 40 & 41 & 45 \\
\hline & Terciaria & 83 & 83 & 84 & 84 & 85 & 86 & 87 & 86 & 50 & 56 & 55 & 61 \\
\hline Grecia & Inferior a educación secundaria superior & 58 & 59 & 57 & 47 & 67 & 72 & 64 & 51 & 39 & 39 & 40 & 33 \\
\hline & Secundaria superior o postsecundaria no terciaria & 65 & 69 & 67 & 58 & 69 & 73 & 71 & 58 & 31 & 38 & 37 & 33 \\
\hline & Terciaria & 81 & 82 & 80 & 71 & 79 & 79 & 77 & 65 & 50 & 59 & 57 & 50 \\
\hline Hungría & Inferior a educación secundaria superior & 36 & 38 & 38 & 39 & 50 & 49 & 40 & 43 & 12 & 16 & 20 & 21 \\
\hline & Secundaria superior o postsecundaria no terciaria & 72 & 70 & 66 & 68 & 75 & 75 & 71 & 72 & 29 & 39 & 35 & 38 \\
\hline & Terciaria & 82 & 83 & 79 & 80 & 83 & 83 & 79 & 79 & 52 & 60 & 54 & 57 \\
\hline Irlanda & Inferior a educación secundaria superior & 56 & 58 & 48 & 44 & 68 & 64 & 44 & 40 & 39 & 45 & 41 & 38 \\
\hline & Secundaria superior o postsecundaria no terciaria & 77 & 77 & 66 & 65 & 85 & 83 & 67 & 65 & 48 & 56 & 55 & 56 \\
\hline & Terciaria & 88 & 87 & 81 & 80 & 91 & 89 & 83 & 83 & 67 & 70 & 66 & 61 \\
\hline Islandia & Inferior a educación secundaria superior & 89 & 83 & 76 & 73 & 89 & 81 & 68 & 72 & 83 & 82 & 75 & 70 \\
\hline & Secundaria superior o postsecundaria no terciaria & 89 & 88 & 82 & 85 & 82 & 81 & 71 & 77 & 89 & 86 & 82 & 84 \\
\hline & Terciaria & 97 & 92 & 89 & 91 & 96 & 92 & 86 & 87 & 92 & 89 & 88 & 89 \\
\hline Israel & Inferior a educación secundaria superior & $\mathrm{m}$ & 41 & 45 & 47 & $\mathrm{~m}$ & 43 & 45 & $\mathbf{5 0}$ & $\mathrm{m}$ & 32 & 38 & 41 \\
\hline & Secundaria superior o postsecundaria no terciaria & $\mathrm{m}$ & 67 & 70 & 72 & $\mathrm{~m}$ & 65 & 68 & 70 & $\mathrm{~m}$ & 52 & 62 & 65 \\
\hline & Terciaria & $\mathrm{m}$ & 80 & 82 & 85 & $\mathrm{~m}$ & 80 & 82 & 86 & $\mathrm{~m}$ & 68 & 71 & 73 \\
\hline Italia & Inferior a educación secundaria superior & 49 & 52 & 50 & 51 & 60 & 65 & 57 & 56 & 23 & 24 & 26 & 29 \\
\hline & Secundaria superior o postsecundaria no terciaria & 71 & 74 & 73 & 71 & 68 & 72 & 69 & 67 & 40 & 44 & 48 & 51 \\
\hline & Terciaria & 82 & 80 & 78 & 79 & 73 & 69 & 67 & 67 & 58 & 67 & 67 & 70 \\
\hline Japón & Inferior a educación secundaria superior & 67 & $\mathrm{~m}$ & $\mathrm{~m}$ & $\mathbf{m}$ & 70 & $\mathrm{~m}$ & $\mathrm{~m}$ & $\mathbf{m}$ & 59 & $\mathrm{~m}$ & $\mathrm{~m}$ & $\mathbf{m}$ \\
\hline & Secundaria superior o postsecundaria no terciaria & 74 & 72 & 73 & 74 & 74 & 76 & 76 & 76 & 61 & 62 & 64 & 63 \\
\hline & Terciaria & 79 & 79 & 80 & 80 & 78 & 78 & 81 & 81 & 72 & 72 & 70 & 70 \\
\hline Luxemburgo & Inferior a educación secundaria superior & 58 & 62 & 62 & 63 & 78 & 79 & 78 & 78 & 15 & 22 & 25 & 29 \\
\hline & Secundaria superior o postsecundaria no terciaria & 73 & 72 & 72 & 72 & 85 & 82 & 83 & 80 & 32 & 30 & 35 & 35 \\
\hline & Terciaria & 84 & 84 & 85 & 85 & 83 & 87 & 87 & 87 & 65 & 60 & 67 & 65 \\
\hline
\end{tabular}

Nota: Las columnas que muestran años y grupos de edad adicionales están disponibles en Internet (véase StatLink más abajo).

1. Las cifras del año 2011 para Eslovenia y Estonia que aparecen en esta tabla pueden diferir de otras tablas del Indicador A5 pues provienen de fuentes diferentes. Los datos de todos los años de esta tabla proceden de EU-LFS.

2. Las cifras de 2000 no son comparables con las de años más recientes, ya que en 2000 se utilizó la clasificación antigua de niveles de educación.

Fuentes: OCDE. Arabia Saudí, Argentina, China, Colombia, India, Indonesia, Sudáfrica: Instituto de Estadística de la UNESCO. Letonia: Eurostat. Para ver notas, consulte Anexo 3 (www.oecd.org/edu/eag.htm).

Para obtener más información acerca de los símbolos utilizados en lugar de los datos que faltan, consulte la Guía del lector.

StatLink 젶ㄴ http://dx.doi.org/10.1787/888933115806 
Tabla A5.3a. [2/2] Tendencias de las tasas de empleo, por nivel educativo alcanzado y grupo de edad (2000, 2005-2012)

Porcentaje de personas empleadas de 25 a 64 años, de 25 a 34 años y de 55 a 64 años del total de la población de 25 a 64 años, de 25 a 34 años y de 55 a 64 años.

\begin{tabular}{|c|c|c|c|c|c|c|c|c|c|c|c|c|c|}
\hline & \multirow[b]{3}{*}{ Nivel educativo alcanzado } & \multicolumn{4}{|c|}{$\begin{array}{l}\text { Tasas de empleo de las } \\
\text { personas de } 25 \text { a } 64 \text { años }\end{array}$} & \multicolumn{4}{|c|}{$\begin{array}{l}\text { Tasas de empleo de las } \\
\text { personas de } 25 \text { a } 34 \text { años }\end{array}$} & \multicolumn{4}{|c|}{$\begin{array}{l}\text { Tasas de empleo de las } \\
\text { personas de } 55 \text { a } 64 \text { años }\end{array}$} \\
\hline & & 2000 & 2005 & 2010 & 2012 & 2000 & 2005 & 2010 & 2012 & 2000 & 2005 & 2010 & 2012 \\
\hline & & (1) & (2) & (7) & (9) & (11) & (12) & (17) & (19) & (41) & (42) & (47) & $(49)$ \\
\hline \multirow[t]{3}{*}{ México } & Inferior a educación secundaria superior & 61 & 62 & 63 & 64 & 63 & 63 & 63 & 65 & 51 & 52 & 53 & 54 \\
\hline & Secundaria superior o postsecundaria no terciaria & 71 & 71 & 72 & 72 & 71 & 71 & 73 & 72 & 48 & 46 & 50 & 53 \\
\hline & Terciaria & 82 & 82 & 81 & 80 & 80 & 79 & 80 & 79 & 69 & 68 & 67 & 66 \\
\hline \multirow[t]{3}{*}{ Noruega $^{2}$} & Inferior a educación secundaria superior & 65 & 64 & 64 & 65 & 67 & 66 & 64 & 67 & 53 & 48 & 51 & 53 \\
\hline & Secundaria superior o postsecundaria no terciaria & 83 & 82 & 82 & 81 & 84 & 84 & 85 & 82 & 68 & 70 & 68 & 69 \\
\hline & Terciaria & 90 & 89 & 90 & 90 & 87 & 86 & 89 & 89 & 86 & 85 & 84 & 85 \\
\hline \multirow[t]{3}{*}{ Nueva Zelanda } & Inferior a educación secundaria superior & 65 & 70 & 68 & 68 & 63 & 68 & 64 & 63 & 49 & 61 & 64 & 65 \\
\hline & Secundaria superior o postsecundaria no terciaria & 80 & 84 & 82 & 81 & 78 & 82 & 77 & 77 & 65 & 75 & 78 & 80 \\
\hline & Terciaria & 82 & 84 & 84 & 84 & 82 & 81 & 81 & 82 & 67 & 78 & 82 & 81 \\
\hline \multirow[t]{3}{*}{ Países Bajos } & Inferior a educación secundaria superior & 58 & 60 & 61 & 62 & 73 & 70 & 70 & 69 & 27 & 35 & 42 & 47 \\
\hline & Secundaria superior o postsecundaria no terciaria & 79 & 78 & 80 & 80 & 88 & 86 & 87 & 85 & 43 & 49 & 57 & 60 \\
\hline & Terciaria & 86 & 86 & 87 & 88 & 94 & 92 & 92 & 91 & 54 & 62 & 68 & 73 \\
\hline \multirow[t]{3}{*}{ Polonia } & Inferior a educación secundaria superior & 43 & 38 & 40 & 40 & 50 & 45 & 49 & 47 & 24 & 21 & 22 & 24 \\
\hline & Secundaria superior o postsecundaria no terciaria & 67 & 62 & 65 & 65 & 71 & 68 & 74 & 73 & 28 & 28 & 34 & 38 \\
\hline & Terciaria & 85 & 83 & 85 & 85 & 87 & 83 & 86 & 84 & 51 & 55 & 56 & 62 \\
\hline \multirow[t]{3}{*}{ Portugal } & Inferior a educación secundaria superior & 73 & 71 & 68 & 63 & 83 & 81 & 75 & 71 & 50 & 50 & 48 & 44 \\
\hline & Secundaria superior o postsecundaria no terciaria & 83 & 79 & 80 & 76 & 83 & 78 & 80 & 75 & 51 & 48 & 51 & 52 \\
\hline & Terciaria & 91 & 87 & 85 & 82 & 91 & 87 & 85 & 78 & 69 & 61 & 58 & 62 \\
\hline Reino Unido & Inferior a educación secundaria superior & 65 & 65 & 56 & 57 & 66 & 64 & 56 & 56 & 51 & 56 & 44 & 44 \\
\hline & Secundaria superior o postsecundaria no terciaria & 81 & 82 & 78 & 79 & 83 & 81 & 79 & 80 & 65 & 69 & 63 & 65 \\
\hline & Terciaria & 88 & 88 & 84 & 84 & 91 & 90 & 87 & 86 & 66 & 72 & 65 & 66 \\
\hline República Checa & Inferior a educación secundaria superior & 47 & 41 & 43 & 40 & 51 & 43 & 47 & 43 & 17 & 20 & 26 & 27 \\
\hline & Secundaria superior o postsecundaria no terciaria & 76 & 75 & 74 & 76 & 77 & 78 & 76 & 77 & 39 & 47 & 46 & 49 \\
\hline & Terciaria & 87 & 86 & 83 & 84 & 83 & 81 & 77 & 75 & 66 & 69 & 71 & 76 \\
\hline República Eslovaca & Inferior a educación secundaria superior & 31 & 26 & 30 & 31 & 29 & 16 & 21 & 30 & 7 & 9 & 21 & 20 \\
\hline & Secundaria superior o postsecundaria no terciaria & 71 & 71 & 70 & 70 & 72 & 73 & 72 & 72 & 27 & 34 & 41 & 43 \\
\hline & Terciaria & 86 & 84 & 82 & 80 & 83 & 84 & 78 & 75 & 54 & 54 & 66 & 65 \\
\hline Suecia & Inferior a educación secundaria superior & 68 & 66 & 63 & 64 & 67 & 65 & 60 & 59 & 56 & 59 & 60 & 61 \\
\hline & Secundaria superior o postsecundaria no terciaria & 82 & 81 & 81 & 83 & 83 & 81 & 80 & 80 & 66 & 69 & 70 & 73 \\
\hline & Terciaria & 87 & 87 & 88 & 89 & 82 & 84 & 85 & 86 & 79 & 83 & 81 & 83 \\
\hline Suiza & Inferior a educación secundaria superior & 64 & 65 & 69 & 69 & 68 & 68 & 70 & 69 & 47 & 51 & 54 & 54 \\
\hline & Secundaria superior o postsecundaria no terciaria & 81 & 80 & 81 & 82 & 84 & 83 & 84 & 84 & 66 & 65 & 67 & 70 \\
\hline & Terciaria & 90 & 90 & 88 & 89 & 91 & 91 & 87 & 89 & 78 & 79 & 79 & 81 \\
\hline Turquía & Inferior a educación secundaria superior & 53 & 47 & 49 & 51 & 55 & 49 & 51 & 54 & 38 & 30 & 31 & 34 \\
\hline & Secundaria superior o postsecundaria no terciaria & 64 & 62 & 60 & 62 & 67 & 64 & 64 & 65 & 20 & 24 & 24 & 27 \\
\hline & Terciaria & 78 & 75 & 76 & 76 & 83 & 79 & 77 & 77 & 37 & 34 & 38 & 40 \\
\hline Media OCDE & Inferior a educación secundaria superior & 57 & 57 & 56 & 55 & 64 & 61 & 58 & 57 & 36 & 38 & 41 & 41 \\
\hline & Secundaria superior o postsecundaria no terciaria & 75 & 75 & 74 & 74 & 78 & 77 & 75 & 75 & 46 & 50 & 53 & 55 \\
\hline & Terciaria & 85 & 84 & 83 & 83 & 85 & 84 & 83 & 82 & 63 & 66 & 67 & 68 \\
\hline & Inferior a educación secundaria superior & 57 & 57 & 56 & 55 & 64 & 62 & 58 & 57 & 35 & 39 & 40 & 41 \\
\hline $\begin{array}{l}\text { con datos de todos } \\
\text { coses }\end{array}$ & Secundaria superior o postsecundaria no terciaria & 75 & 75 & 74 & 74 & 78 & 78 & 76 & 75 & 46 & 50 & 52 & 54 \\
\hline los años de referencia & Educación terciaria & 85 & 84 & 83 & 83 & 86 & 85 & 83 & 82 & 62 & 65 & 67 & 68 \\
\hline Media UE21 & Inferior a educación secundaria & 53 & 54 & 52 & 51 & 63 & 61 & 56 & 55 & 29 & 33 & 35 & 35 \\
\hline & Secundaria superior o postsecundaria no terciaria & 74 & 74 & 73 & 73 & 79 & 78 & 77 & 75 & 40 & 45 & 48 & 50 \\
\hline & Educación terciaria & 85 & 85 & 84 & 83 & 86 & 85 & 83 & 82 & 60 & 63 & 64 & 66 \\
\hline An Arabia Saudí & & $\mathrm{m}$ & $\mathrm{m}$ & $\mathrm{m}$ & $\mathbf{m}$ & $\mathrm{m}$ & $\mathrm{m}$ & $\mathrm{m}$ & $\mathbf{m}$ & $\mathrm{m}$ & $\mathrm{m}$ & $\mathrm{m}$ & $\mathbf{m}$ \\
\hline Argentina & & $\mathrm{m}$ & $\mathrm{m}$ & $\mathrm{m}$ & $\mathbf{m}$ & $\mathrm{m}$ & $\mathrm{m}$ & $\mathrm{m}$ & $\mathbf{m}$ & $\mathrm{m}$ & $\mathrm{m}$ & $\mathrm{m}$ & $\mathbf{m}$ \\
\hline Brasil & Inferior a educación secundaria superior & $\mathrm{m}$ & $\mathrm{m}$ & $\mathrm{m}$ & 67 & $\mathrm{~m}$ & $\mathrm{~m}$ & $\mathrm{~m}$ & 71 & $\mathrm{~m}$ & $\mathrm{~m}$ & $\mathrm{~m}$ & 50 \\
\hline & Secundaria superior o postsecundaria no terciaria & $\mathrm{m}$ & $\mathrm{m}$ & $\mathrm{m}$ & 77 & $\mathrm{~m}$ & $\mathrm{~m}$ & $\mathrm{~m}$ & 79 & $\mathrm{~m}$ & $\mathrm{~m}$ & $\mathrm{~m}$ & 55 \\
\hline & Educación terciaria & $\mathrm{m}$ & $\mathrm{m}$ & $\mathrm{m}$ & 86 & $\mathrm{~m}$ & $\mathrm{~m}$ & $\mathrm{~m}$ & 89 & $\mathrm{~m}$ & $\mathrm{~m}$ & $\mathrm{~m}$ & 65 \\
\hline China & & $\mathrm{m}$ & $\mathrm{m}$ & $\mathrm{m}$ & $\mathbf{m}$ & $\mathrm{m}$ & $\mathrm{m}$ & $\mathrm{m}$ & $\mathbf{m}$ & $\mathrm{m}$ & $\mathrm{m}$ & $\mathrm{m}$ & $\mathbf{m}$ \\
\hline Colombia & & $\mathrm{m}$ & $\mathrm{m}$ & $\mathrm{m}$ & $\mathbf{m}$ & $\mathrm{m}$ & $\mathrm{m}$ & $\mathrm{m}$ & $\mathbf{m}$ & $\mathrm{m}$ & $\mathrm{m}$ & $\mathrm{m}$ & $\mathbf{m}$ \\
\hline Federación Rusa & Inferior a educación secundaria superior & $\mathrm{m}$ & $\mathrm{m}$ & $\mathrm{m}$ & 50 & $\mathrm{~m}$ & $\mathrm{~m}$ & $\mathrm{~m}$ & 59 & $\mathrm{~m}$ & $\mathrm{~m}$ & $\mathrm{~m}$ & 28 \\
\hline & Secundaria superior o postsecundaria no terciaria & $\mathrm{m}$ & $\mathrm{m}$ & $\mathrm{m}$ & 73 & $\mathrm{~m}$ & $\mathrm{~m}$ & $\mathrm{~m}$ & 80 & $\mathrm{~m}$ & $\mathrm{~m}$ & $\mathrm{~m}$ & 44 \\
\hline & Educación terciaria & $\mathrm{m}$ & $\mathrm{m}$ & $\mathrm{m}$ & 83 & $\mathrm{~m}$ & $\mathrm{~m}$ & $\mathrm{~m}$ & 89 & $\mathrm{~m}$ & $\mathrm{~m}$ & $\mathrm{~m}$ & 53 \\
\hline India & & $\mathrm{m}$ & $\mathrm{m}$ & $\mathrm{m}$ & $\mathbf{m}$ & $\mathrm{m}$ & $\mathrm{m}$ & $\mathrm{m}$ & $\mathbf{m}$ & $\mathrm{m}$ & $\mathrm{m}$ & $\mathrm{m}$ & $\mathbf{m}$ \\
\hline Indonesia & & $\mathrm{m}$ & $\mathrm{m}$ & $\mathrm{m}$ & $\mathbf{m}$ & $\mathrm{m}$ & $\mathrm{m}$ & $\mathrm{m}$ & $\mathbf{m}$ & $\mathrm{m}$ & $\mathrm{m}$ & $\mathrm{m}$ & $\mathbf{m}$ \\
\hline Letonia & Inferior a educación secundaria superior & $\mathrm{m}$ & $\mathrm{m}$ & $\mathrm{m}$ & 52 & $\mathrm{~m}$ & $\mathrm{~m}$ & $\mathrm{~m}$ & 56 & $\mathrm{~m}$ & $\mathrm{~m}$ & $\mathrm{~m}$ & 33 \\
\hline & Secundaria superior o postsecundaria no terciaria & $\mathrm{m}$ & $\mathrm{m}$ & $\mathrm{m}$ & 67 & $\mathrm{~m}$ & $\mathrm{~m}$ & $\mathrm{~m}$ & 72 & $\mathrm{~m}$ & $\mathrm{~m}$ & $\mathrm{~m}$ & 50 \\
\hline & Educación terciaria & $\mathrm{m}$ & $\mathrm{m}$ & $\mathrm{m}$ & 86 & $\mathrm{~m}$ & $\mathrm{~m}$ & $\mathrm{~m}$ & 87 & $\mathrm{~m}$ & $\mathrm{~m}$ & $\mathrm{~m}$ & 73 \\
\hline Sudáfrica & & $\mathrm{m}$ & $\mathrm{m}$ & $\mathrm{m}$ & $\mathbf{m}$ & $\mathrm{m}$ & $\mathrm{m}$ & $\mathrm{m}$ & $\mathbf{m}$ & $\mathrm{m}$ & $\mathrm{m}$ & $\mathrm{m}$ & $\mathbf{m}$ \\
\hline Media G20 & Inferior a educación secundaria superior & $\mathrm{m}$ & $\mathrm{m}$ & $\mathrm{m}$ & $\mathbf{m}$ & $\mathrm{m}$ & $\mathrm{m}$ & $\mathrm{m}$ & $\mathbf{m}$ & $\mathrm{m}$ & $\mathrm{m}$ & $\mathrm{m}$ & $\mathbf{m}$ \\
\hline
\end{tabular}

Nota: Las columnas que muestran años y grupos de edad adicionales están disponibles en Internet (véase StatLink más abajo).

1. Las cifras del año 2011 para Eslovenia y Estonia que aparecen en esta tabla pueden diferir de otras tablas del Indicador A5 pues provienen de fuentes diferentes. Los datos de todos los años de esta tabla proceden de EU-LFS.

2. Las cifras de 2000 no son comparables con las de años más recientes, ya que en 2000 se utilizó la clasificación antigua de niveles de educación.

Fuentes: OCDE. Arabia Saudí, Argentina, China, Colombia, India, Indonesia, Sudáfrica: Instituto de Estadística de la UNESCO. Letonia: Eurostat. Para ver notas, consulte Anexo 3 (www.oecd.org/edu/eag.htm).

Para obtener más información acerca de los símbolos utilizados en lugar de los datos que faltan, consulte la Guía del lector.

StatLink 部 
Tabla A5.4a. [1/2] Tendencias de las tasas de desempleo, por nivel educativo alcanzado y grupo de edad (2000, 2005-2012)

Porcentaje de personas desempleadas de 25 a 64 años, de 25 a 34 años y de 55 a 64 años del total de la población activa de 25 a 64 años, de 25 a 34 años y de 55 a 64 años

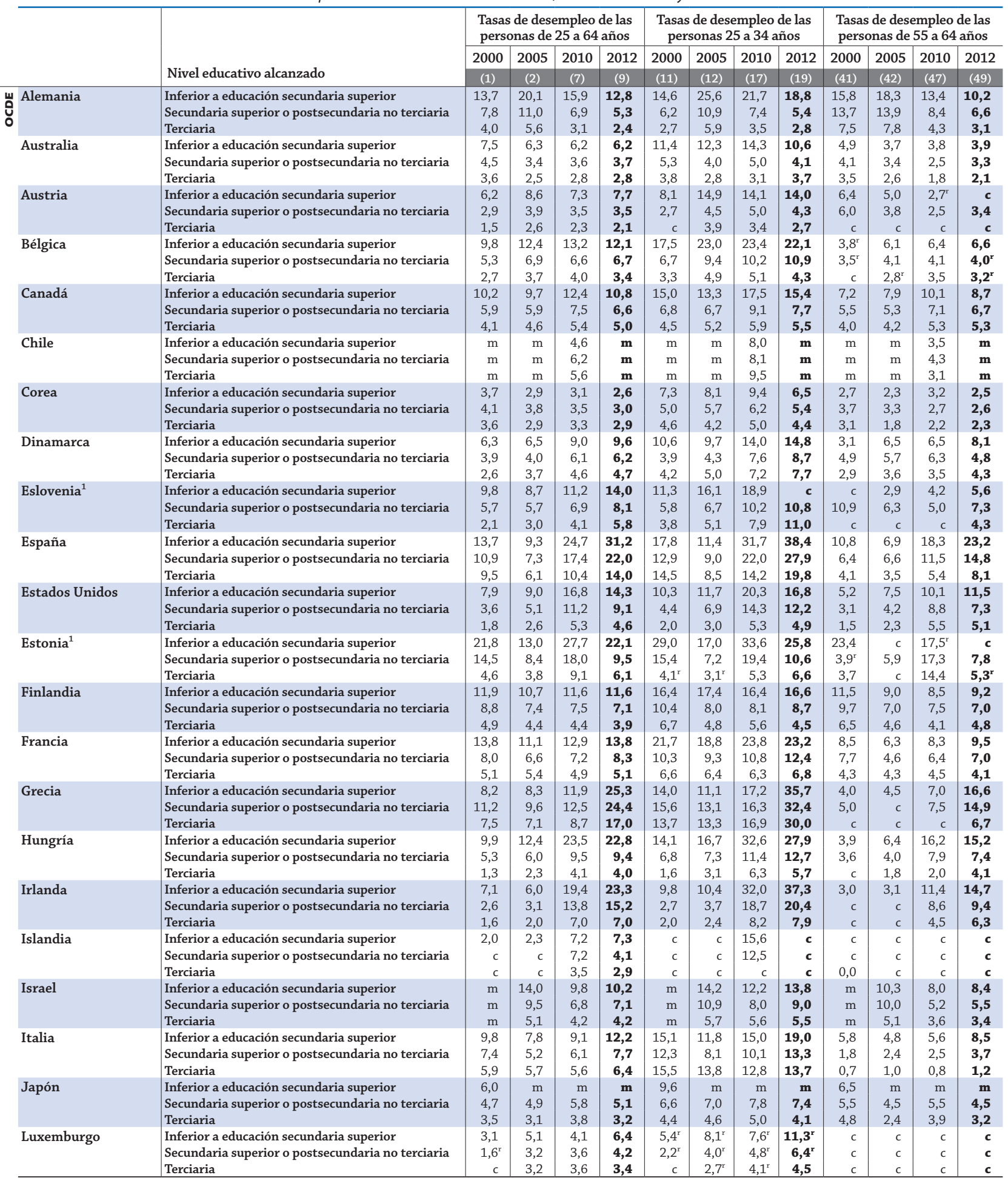

Nota: Las columnas que muestran años y grupos de edad adicionales están disponibles en Internet (véase StatLink más abajo).

1. Las cifras del año 2011 para Eslovenia y Estonia que aparecen en esta tabla pueden diferir de otras tablas del Indicador A5 pues provienen de fuentes diferentes. Los datos de todos los años de esta tabla proceden de EU-LFS.

2. Las cifras de 2000 no son comparables con las de años más recientes, ya que en 2000 se utilizó la clasificación antigua de niveles de educación.

Fuentes: OCDE. Arabia Saudí, Argentina, China, Colombia, India, Indonesia, Sudáfrica: Instituto de Estadística de la UNESCO. Letonia: Eurostat. Para ver notas, consulte Anexo 3 (www.oecd.org/edu/eag.htm)

Para obtener más información acerca de los símbolos utilizados en lugar de los datos que faltan, consulte la Guía del lector

StatLink 젶ㄴ http://dx.doi.org/10.1787/888933115825 
Tabla A5.4a. [2/2] Tendencias de las tasas de desempleo, por nivel educativo alcanzado y grupo de edad (2000, 2005-2012)

Porcentaje de personas desempleadas de 25 a 64 años, de 25 a 34 años y de 55 a 64 años del total de la población activa de 25 a 64 años, de 25 a 34 años y de 55 a 64 años

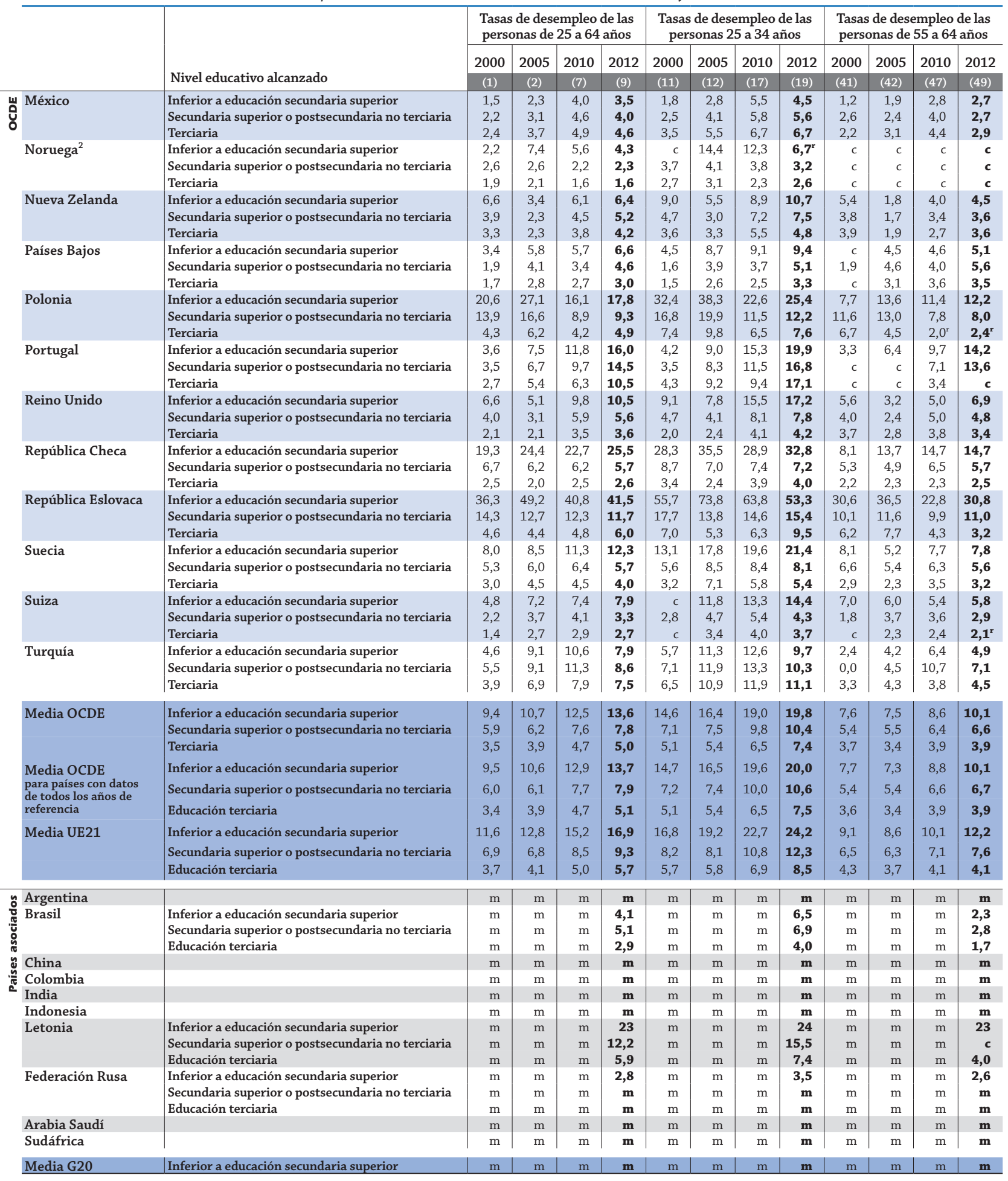

Nota: Las columnas que muestran años y grupos de edad adicionales están disponibles en Internet (véase StatLink más abajo).

1. Las cifras del año 2011 para Eslovenia y Estonia que aparecen en esta tabla pueden diferir de otras tablas del Indicador A5 pues provienen de fuentes diferentes. Los datos de todos los años de esta tabla proceden de EU-LFS.

2. Las cifras de 2000 no son comparables con las de años más recientes, ya que en 2000 se utilizó la clasificación antigua de niveles de educación.

Fuentes: OCDE. Arabia Saudí, Argentina, China, Colombia, India, Indonesia, Sudáfrica: Instituto de Estadística de la UNESCO. Letonia: Eurostat. Para ver notas, consulte Anexo 3 (www.oecd.org/edu/eag.htm).

Para obtener más información acerca de los símbolos utilizados en lugar de los datos que faltan, consulte la Guía del lector.

StatLink त्ञाज http://dx.doi.org/10.1787/888933115825 
Tabla A5.5a. Distribución de adultos con educación secundaria superior o postsecundaria no terciaria, por su estatus en el mercado laboral y orientación del programa (2012)

Personas de 25 a 64 años con educación secundaria superior o postsecundaria no terciaria como máximo nivel educativo alcanzado

\begin{tabular}{|c|c|c|c|c|c|c|c|c|c|}
\hline & \multicolumn{3}{|c|}{ Tasa de empleo, \% } & \multicolumn{3}{|c|}{ Tasa de desempleo, \% } & \multicolumn{3}{|c|}{ Tasa de inactividad, \% } \\
\hline & $\begin{array}{l}\text { Formación } \\
\text { profesional }\end{array}$ & General & Total $^{1}$ & $\begin{array}{l}\text { Formación } \\
\text { profesional }\end{array}$ & General & Total $^{1}$ & $\begin{array}{l}\text { Formación } \\
\text { profesional }\end{array}$ & General & Total $^{1}$ \\
\hline & (1) & (2) & (3) & (4) & (5) & (6) & (7) & (8) & (9) \\
\hline Alemania & 79 & 62 & 78 & 5,3 & 7,0 & 5,3 & 17 & 34 & 17 \\
\hline Australia & 84 & 76 & 80 & 3,6 & 3,9 & 3,7 & 13 & 20 & 16 \\
\hline Austria & 78 & 76 & 78 & 3,4 & 4,7 & 3,5 & 19 & 20 & 19 \\
\hline Canadá & 79 & 73 & 75 & 6,3 & 6,7 & 6,6 & 16 & 22 & 20 \\
\hline Chile $^{2}$ & 74 & 69 & 70 & 6,9 & 6,2 & 6,4 & 20 & 26 & 25 \\
\hline Corea & $x(3)$ & $x(3)$ & 71 & $x(6)$ & $x(6)$ & 3,0 & $\mathrm{x}(9)$ & $\mathrm{x}(9)$ & 27 \\
\hline Dinamarca & 79 & 61 & 79 & 5,9 & 12,5 & 6,2 & 16 & 30 & 16 \\
\hline Eslovenia & 71 & 66 & 71 & 7,9 & 11,0 & 8,1 & 23 & 25 & 23 \\
\hline España & 66 & 66 & 66 & 22,8 & 21,5 & 22,0 & 15 & 16 & 16 \\
\hline Estados Unidos & $x(3)$ & $x(3)$ & 67 & $x(6)$ & $x(6)$ & 9,1 & $\mathrm{x}(9)$ & $\mathrm{x}(9)$ & 26 \\
\hline Finlandia & 75 & 73 & 75 & 6,8 & 8,2 & 7,1 & 20 & 21 & 20 \\
\hline Francia & 73 & 74 & 74 & 8,3 & 8,3 & 8,3 & 20 & 19 & 20 \\
\hline Grecia & 62 & 55 & 58 & 26,4 & 23,0 & 24,4 & 16 & 28 & 24 \\
\hline Hungría & 69 & 63 & 68 & 9,4 & 9,4 & 9,4 & 24 & 30 & 25 \\
\hline Irlanda & 66 & 65 & 65 & 17,8 & 13,9 & 15,2 & 20 & 25 & 23 \\
\hline Islandia & 88 & 76 & 85 & 3,7 & c & 4,1 & 9 & 19 & 11 \\
\hline Israel & 79 & 69 & 72 & 6,2 & 7,4 & 7,1 & 16 & 25 & 23 \\
\hline Italia & 74 & 63 & 71 & 7,4 & 8,9 & 7,7 & 21 & 31 & 23 \\
\hline Japón & $\mathrm{x}(3)$ & $\mathrm{x}(3)$ & 74 & $\mathrm{x}(6)$ & $\mathrm{x}(6)$ & 5,1 & $\mathrm{x}(9)$ & $\mathrm{x}(9)$ & 22 \\
\hline Luxemburgo & 72 & 67 & 72 & 4,5 & c & 4,2 & 25 & 30 & 25 \\
\hline México & $\mathrm{x}(3)$ & $\mathrm{x}(3)$ & 72 & $\mathrm{x}(6)$ & $\mathrm{x}(6)$ & 4,0 & $\mathrm{x}(9)$ & $\mathrm{x}(9)$ & 25 \\
\hline Noruega & $\mathrm{x}(3)$ & $\mathrm{x}(3)$ & 81 & $\mathrm{x}(6)$ & $\mathrm{x}(6)$ & 2,3 & $\mathrm{x}(9)$ & $\mathrm{x}(9)$ & 17 \\
\hline Nueva Zelanda & 82 & 81 & 81 & 5,5 & 4,3 & 5,2 & 14 & 16 & 14 \\
\hline Países Bajos & 81 & 77 & 80 & 4,3 & 5,3 & 4,6 & 15 & 18 & 16 \\
\hline Reino Unido & $x(3)$ & $\mathrm{x}(3)$ & 79 & $x(6)$ & $\mathrm{x}(6)$ & 5,6 & $\mathrm{x}(9)$ & $\mathrm{x}(9)$ & 17 \\
\hline República Checa & 76 & 72 & 76 & 5,7 & c & 5,7 & 19 & c & 19 \\
\hline República Eslovaca & 71 & 66 & 70 & 11,6 & 13,9 & 11,7 & 20 & 24 & 20 \\
\hline Suecia & 84 & 87 & 83 & 5,1 & 3,5 & 5,7 & 11 & 9 & 12 \\
\hline Suiza & 83 & 76 & 82 & 3,2 & 5,1 & 3,3 & 15 & 20 & 15 \\
\hline Turquía & 65 & 59 & 62 & 7,6 & 9,6 & 8,6 & 29 & 35 & 32 \\
\hline Media OCDE & 75 & 70 & 74 & 8,1 & 9,3 & 7,7 & 18 & 24 & 20 \\
\hline Media UE21 & 76 & 70 & 74 & 8,8 & 10,0 & 8,7 & 17 & 23 & 19 \\
\hline
\end{tabular}

\begin{tabular}{|c|c|c|c|c|c|c|c|c|c|}
\hline $\begin{array}{l}\text { Arabia Saudí } \\
\text { Argentina }\end{array}$ & $\begin{array}{l}\mathrm{m} \\
\mathrm{m}\end{array}$ & $\begin{array}{l}\mathrm{m} \\
\mathrm{m}\end{array}$ & $\begin{array}{l}\mathrm{m} \\
\mathrm{m}\end{array}$ & $\begin{array}{l}\mathrm{m} \\
\mathrm{m}\end{array}$ & $\begin{array}{l}\mathrm{m} \\
\mathrm{m}\end{array}$ & $\begin{array}{l}\mathrm{m} \\
\mathrm{m}\end{array}$ & $\begin{array}{l}\mathrm{m} \\
\mathrm{m}\end{array}$ & $\begin{array}{l}\mathrm{m} \\
\mathrm{m}\end{array}$ & $\begin{array}{l}\mathrm{m} \\
\mathrm{m}\end{array}$ \\
\hline ڤ̊ำ Brasil & $\mathrm{x}(3)$ & $\mathrm{x}(3)$ & 77 & $\mathrm{x}(6)$ & $x(6)$ & 5,1 & $\mathrm{x}(9)$ & $\mathrm{x}(9)$ & 19 \\
\hline y̆ China & $\mathrm{m}$ & $\mathrm{m}$ & $\mathrm{m}$ & $\mathrm{m}$ & $\mathrm{m}$ & $\mathrm{m}$ & $\mathrm{m}$ & $\mathrm{m}$ & $\mathrm{m}$ \\
\hline ¿ Colombia & $\mathrm{m}$ & $\mathrm{m}$ & $\mathrm{m}$ & $\mathrm{m}$ & $\mathrm{m}$ & $\mathrm{m}$ & $\mathrm{m}$ & $\mathrm{m}$ & $\mathrm{m}$ \\
\hline Federación Rusa & 78 & 69 & 73 & 5,1 & 6,8 & 5,9 & 18 & 26 & 22 \\
\hline India & $\mathrm{m}$ & $\mathrm{m}$ & $\mathrm{m}$ & $\mathrm{m}$ & $\mathrm{m}$ & $\mathrm{m}$ & $\mathrm{m}$ & $\mathrm{m}$ & $\mathrm{m}$ \\
\hline Indonesia & $\mathrm{m}$ & $\mathrm{m}$ & $\mathrm{m}$ & $\mathrm{m}$ & $\mathrm{m}$ & $\mathrm{m}$ & $\mathrm{m}$ & $\mathrm{m}$ & $\mathrm{m}$ \\
\hline Letonia & 69 & 64 & 67 & 15,0 & 19,3 & 16,7 & 19 & 21 & 20 \\
\hline Sudáfrica & $\mathrm{m}$ & $\mathrm{m}$ & $\mathrm{m}$ & $\mathrm{m}$ & $\mathrm{m}$ & $\mathrm{m}$ & $\mathrm{m}$ & $\mathrm{m}$ & $\mathrm{m}$ \\
\hline
\end{tabular}

Media G20

1. «Total» se refiere a la media ponderada de las tasas de empleo, desempleo e inactividad de las personas con nivel educativo CINE $3 / 4$.

2. Año de referencia 2011.

Fuente: OCDE. Para ver notas, consulte Anexo 3 (www.oecd.org/edu/eag.htm).

Para obtener más información acerca de los símbolos utilizados en lugar de los datos que faltan, consulte la Guía del lector.

StatLink त्गाज् http://dx.doi.org/10.1787/888933115844 
Tabla A5.6. [1/2] Porcentaje de asalariados a tiempo completo durante todo el año en el total de asalariados, por nivel educativo alcanzado y grupo de edad ${ }^{1}$ (2012)

\begin{tabular}{|c|c|c|c|c|c|c|c|c|c|c|c|c|c|c|}
\hline \multicolumn{15}{|c|}{$\begin{array}{l}\text { Cómo leer esta tabla: En Australia, el } 86 \% \text { de los hombres de } 25 \text { a } 64 \text { años con formación inferior a educación secundaria superior que tienen ingresos del } \\
\text { empleo trabajan a tiempo completo. Entre las mujeres de } 25 \text { a } 64 \text { años de edad, el } 46 \% \text { de las que tienen ingresos del empleo trabajan a tiempo completo. }\end{array}$} \\
\hline & & & \multicolumn{3}{|c|}{$\begin{array}{l}\text { Nivel inferior a la educación } \\
\text { secundaria superior }\end{array}$} & \multicolumn{3}{|c|}{$\begin{array}{l}\text { Educación secundaria } \\
\text { superior o postsecundaria } \\
\text { no terciaria }\end{array}$} & \multicolumn{3}{|c|}{ Educación terciaria } & \multicolumn{3}{|c|}{$\begin{array}{l}\text { Todos los niveles } \\
\text { de educación }\end{array}$} \\
\hline & & & $25-64$ & $35-44$ & $55-64$ & $25-64$ & $35-44$ & $55-64$ & $25-64$ & $35-44$ & $55-64$ & $25-64$ & $35-44$ & $55-64$ \\
\hline & & & (1) & (2) & (3) & (4) & (5) & (6) & (7) & (8) & (9) & (10) & (11) & (12) \\
\hline \multirow[t]{3}{*}{ Alemania } & \multirow[t]{3}{*}{2012} & Hombres & 85 & 90 & 90 & 84 & 89 & 82 & 86 & 88 & 88 & 84 & 88 & 85 \\
\hline & & Mujeres & 38 & 30 & 35 & 44 & 40 & 41 & 56 & 50 & 60 & 47 & 42 & 46 \\
\hline & & $\mathrm{H}+\mathrm{M}$ & 61 & 61 & 59 & 64 & 64 & 61 & 72 & 70 & 77 & 66 & 65 & 66 \\
\hline \multirow[t]{3}{*}{ Australia } & \multirow[t]{3}{*}{2012} & Hombres & 86 & 90 & 78 & 90 & 93 & 84 & 89 & 93 & 79 & 89 & 92 & 81 \\
\hline & & Mujeres & 46 & 42 & 44 & 52 & 45 & 48 & 61 & 53 & 58 & 56 & 49 & 51 \\
\hline & & $\mathrm{H}+\mathrm{M}$ & 68 & 68 & 62 & 76 & 74 & 72 & 74 & 72 & 68 & 74 & 72 & 67 \\
\hline \multirow[t]{3}{*}{ Austria } & \multirow[t]{3}{*}{2012} & Hombres & 62 & 60 & 69 & 76 & 77 & 80 & 83 & 86 & 89 & 76 & 77 & 81 \\
\hline & & Mujeres & 36 & 33 & 41 & 41 & 35 & 47 & 54 & 46 & 73 & 43 & 37 & 52 \\
\hline & & $\mathrm{H}+\mathrm{M}$ & 47 & 44 & 53 & 60 & 56 & 68 & 69 & 68 & 82 & 60 & 57 & 69 \\
\hline Bélgica & 2011 & Hombres & 77 & $\mathrm{~m}$ & 69 & 64 & 64 & 60 & 86 & 90 & 78 & 83 & 88 & 73 \\
\hline & & Mujeres & 32 & $\mathrm{~m}$ & $\mathrm{~m}$ & 57 & 55 & 55 & 58 & 55 & 55 & 49 & 45 & 46 \\
\hline & & $\mathrm{H}+\mathrm{M}$ & 59 & 66 & 55 & 65 & 65 & 60 & 72 & 72 & 69 & 67 & 68 & 62 \\
\hline Canadá & 2011 & Hombres & 74 & 70 & 68 & 78 & 79 & 75 & 71 & 84 & 76 & 74 & 80 & 74 \\
\hline & & Mujeres & 69 & 50 & 50 & 53 & 60 & 55 & 61 & 65 & 61 & 59 & 62 & 58 \\
\hline & & $\mathrm{H}+\mathrm{M}$ & 73 & 63 & 61 & 68 & 71 & 66 & 66 & 74 & 68 & 67 & 72 & 67 \\
\hline Chile & 2011 & Hombres & 55 & 52 & 60 & 64 & 69 & 70 & 65 & 66 & 71 & 61 & 62 & 65 \\
\hline & & Mujeres & 38 & 34 & 43 & 51 & 49 & 53 & 53 & 52 & 49 & 47 & 45 & 48 \\
\hline & & $\mathrm{H}+\mathrm{M}$ & 49 & 46 & 55 & 58 & 60 & 63 & 59 & 59 & 62 & 55 & 55 & 59 \\
\hline Corea & 2012 & Hombres & 74 & 77 & 70 & 79 & 81 & 75 & 68 & 70 & 55 & 73 & 74 & 68 \\
\hline & & Mujeres & 64 & 66 & 62 & 63 & 63 & 58 & 50 & 46 & 42 & 58 & 55 & 60 \\
\hline & & $\mathrm{H}+\mathrm{M}$ & 68 & 71 & 65 & 72 & 73 & 70 & 62 & 62 & 53 & 67 & 67 & 65 \\
\hline Dinamarca & 2012 & Hombres & 50 & 50 & 51 & 58 & 62 & 55 & 74 & 81 & 70 & 61 & 66 & 58 \\
\hline & & Mujeres & 43 & 41 & 45 & 51 & 52 & 46 & 58 & 60 & 57 & 52 & 54 & 50 \\
\hline & & $\mathrm{H}+\mathrm{M}$ & 47 & 47 & 48 & 55 & 57 & 51 & 65 & 69 & 63 & 57 & 60 & 54 \\
\hline Eslovenia & & & $\mathbf{m}$ & $\mathrm{m}$ & $\mathrm{m}$ & $\mathbf{m}$ & $\mathrm{m}$ & $\mathrm{m}$ & $\mathbf{m}$ & $\mathrm{m}$ & $\mathrm{m}$ & m & $\mathrm{m}$ & $\mathrm{m}$ \\
\hline España & 2011 & Hombres & 75 & 73 & 77 & 78 & 77 & 83 & 84 & 87 & 87 & 79 & 79 & 81 \\
\hline & & Mujeres & 51 & 43 & 61 & 63 & 64 & 76 & 75 & 77 & 87 & 65 & 64 & 72 \\
\hline & & $\mathrm{H}+\mathrm{M}$ & 66 & 62 & 71 & 72 & 71 & 80 & 79 & 82 & 87 & 72 & 73 & 78 \\
\hline Estados Unidos & 2012 & Hombres & 66 & 68 & 66 & 76 & 78 & 75 & 84 & 87 & 79 & 79 & 81 & 76 \\
\hline & & Mujeres & 52 & 55 & 55 & 64 & 65 & 65 & 70 & 70 & 68 & 66 & 67 & 66 \\
\hline & & $\mathrm{H}+\mathrm{M}$ & 61 & 64 & 61 & 71 & 73 & 70 & 77 & 79 & 74 & 73 & 75 & 71 \\
\hline Estonia & 2012 & Hombres & 98 & 95 & 98 & 98 & 99 & 95 & 94 & 93 & 92 & 97 & 97 & 95 \\
\hline & & Mujeres & 84 & 79 & 69 & 89 & 90 & 83 & 88 & 88 & 83 & 88 & 88 & 82 \\
\hline & & $\mathrm{H}+\mathrm{M}$ & 93 & 89 & 85 & 93 & 94 & 88 & 90 & 90 & 86 & 92 & 92 & 87 \\
\hline Finlandia & 2012 & Hombres & 92 & 94 & 90 & 93 & 95 & 91 & 95 & 96 & 90 & 94 & 96 & 91 \\
\hline & & Mujeres & 88 & 88 & 90 & 92 & 93 & 93 & 91 & 89 & 92 & 91 & 90 & 92 \\
\hline & & $\mathrm{H}+\mathrm{M}$ & 90 & 92 & 90 & 93 & 94 & 92 & 93 & 92 & 91 & 93 & 93 & 91 \\
\hline Francia & 2010 & Hombres & 72 & 78 & 59 & 81 & 86 & 62 & 87 & 90 & 75 & 81 & 86 & 64 \\
\hline & & Mujeres & 46 & 49 & 39 & 59 & 60 & 59 & 69 & 71 & 64 & 61 & 63 & 53 \\
\hline & & $\mathrm{H}+\mathrm{M}$ & 59 & 64 & 48 & 71 & 74 & 60 & 77 & 80 & 70 & 71 & 75 & 59 \\
\hline Grecia & 2012 & Hombres & 74 & 68 & 75 & 81 & 86 & 76 & 91 & 93 & 93 & 82 & 84 & 80 \\
\hline & & Mujeres & 59 & 52 & 67 & 70 & 72 & 68 & 80 & 85 & 61 & 72 & 75 & 66 \\
\hline & & $\mathrm{H}+\mathrm{M}$ & 69 & 63 & 72 & 77 & 81 & 72 & 86 & 89 & 84 & 78 & 80 & 75 \\
\hline Hungría & 2012 & Hombres & 76 & 78 & 73 & 84 & 85 & 81 & 89 & 91 & 84 & 84 & 86 & 81 \\
\hline & & Mujeres & 75 & 78 & 66 & 79 & 79 & 75 & 89 & 88 & 88 & 81 & 82 & 77 \\
\hline & & $\mathrm{H}+\mathrm{M}$ & 76 & 78 & 69 & 82 & 83 & 79 & 89 & 89 & 86 & 83 & 84 & 79 \\
\hline Irlanda & 2011 & Hombres & 41 & 44 & 32 & 50 & 54 & 43 & 67 & 73 & 46 & 55 & 63 & 39 \\
\hline & & Mujeres & 24 & 31 & 21 & 38 & 35 & 38 & 58 & 55 & 47 & 46 & 46 & 36 \\
\hline & & $\mathrm{H}+\mathrm{M}$ & 35 & 39 & 29 & 44 & 45 & 40 & 63 & 64 & 47 & 51 & 55 & 37 \\
\hline Islandia & & & $\mathbf{m}$ & $\mathrm{m}$ & $\mathrm{m}$ & $\mathbf{m}$ & $\mathrm{m}$ & $\mathrm{m}$ & $\mathbf{m}$ & $\mathrm{m}$ & $\mathrm{m}$ & $\mathbf{m}$ & $\mathrm{m}$ & $\mathrm{m}$ \\
\hline Israel & 2012 & Hombres & 86 & 88 & 81 & 90 & 91 & 88 & 87 & 94 & 85 & 88 & 92 & 85 \\
\hline & & Mujeres & 46 & 50 & 41 & 65 & 70 & 55 & 66 & 70 & 63 & 66 & 70 & 59 \\
\hline & & $\mathrm{H}+\mathrm{M}$ & 74 & 80 & 67 & 80 & 82 & 74 & 77 & 82 & 74 & 78 & 82 & 73 \\
\hline Italia & 2010 & Hombres & 78 & 82 & 67 & 85 & 89 & 78 & 88 & 91 & 84 & 82 & 86 & 74 \\
\hline & & Mujeres & 48 & 45 & 46 & 62 & 58 & 72 & 72 & 74 & 78 & 60 & 58 & 62 \\
\hline & & $\mathrm{H}+\mathrm{M}$ & 67 & 69 & 59 & 75 & 75 & 75 & 80 & 82 & 81 & 73 & 74 & 69 \\
\hline Japón & & & $\mathbf{m}$ & $\mathrm{m}$ & $\mathrm{m}$ & $\mathbf{m}$ & $\mathrm{m}$ & $\mathrm{m}$ & m & $\mathrm{m}$ & $\mathrm{m}$ & m & $\mathrm{m}$ & $\mathrm{m}$ \\
\hline
\end{tabular}

Nota: La duración del periodo de referencia varía desde una semana a un año. En algunos países se excluye a los trabajadores autónomos.

1. El término a tiempo completo se refiere a las personas que trabajan un mínimo de 30 horas semanales durante todo el año. Para ver más detalles, consulte el Indicador A6 y el Anexo 3.

Fuente: OCDE. Para ver notas, consulte Anexo 3 (www.oecd.org/edu/eag.htm).

Para obtener más información acerca de los símbolos utilizados en lugar de los datos que faltan, consulte la Guía del lector.

StatLink 젶ㄴ http://dx.doi.org/10.1787/888933115863 
Tabla A5.6. [2/2] Porcentaje de asalariados a tiempo completo durante todo el año en el total de asalariados, por nivel educativo alcanzado y grupo de edad ${ }^{1}$ (2012)

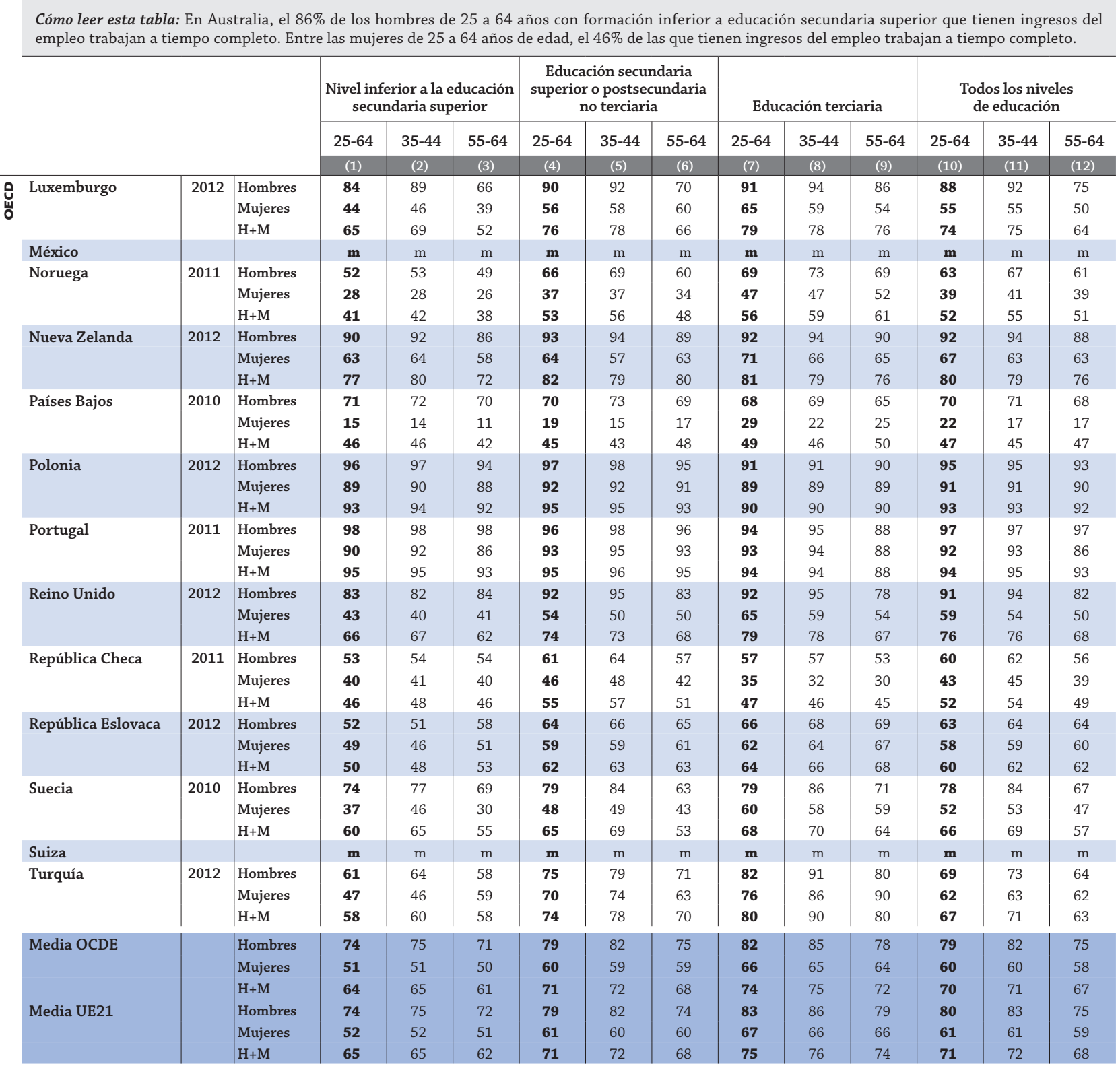

\begin{tabular}{|c|c|c|c|c|c|c|c|c|c|c|c|c|c|c|}
\hline Argentina & & & $\mathbf{m}$ & $\mathrm{m}$ & $\mathrm{m}$ & $\mathbf{m}$ & $\mathrm{m}$ & $\mathrm{m}$ & $\mathbf{m}$ & $\mathrm{m}$ & $\mathrm{m}$ & $\mathbf{m}$ & $\mathrm{m}$ & $\mathrm{m}$ \\
\hline Brasil & 2012 & Hombres & 73 & 75 & 74 & 79 & 82 & 80 & 78 & 79 & 78 & 76 & 77 & 76 \\
\hline 品 & & Mujeres & 48 & 50 & 44 & 64 & 65 & 60 & 63 & 64 & 57 & 57 & 58 & 49 \\
\hline$\ddot{\omega}$ & & $\mathrm{H}+\mathrm{M}$ & 64 & 65 & 63 & 72 & 74 & 72 & 70 & 70 & 68 & 67 & 69 & 65 \\
\hline China & & & $\mathbf{m}$ & $\mathrm{m}$ & $\mathrm{m}$ & $\mathbf{m}$ & $\mathrm{m}$ & $\mathrm{m}$ & $\mathbf{m}$ & $\mathrm{m}$ & $\mathrm{m}$ & $\mathbf{m}$ & $\mathrm{m}$ & $\mathrm{m}$ \\
\hline Colombia & & & $\mathbf{m}$ & $\mathrm{m}$ & $\mathrm{m}$ & $\mathbf{m}$ & $\mathrm{m}$ & $\mathrm{m}$ & $\mathbf{m}$ & $\mathrm{m}$ & $\mathrm{m}$ & $\mathbf{m}$ & $\mathrm{m}$ & $\mathrm{m}$ \\
\hline India & & & $\mathbf{m}$ & $\mathrm{m}$ & $\mathrm{m}$ & $\mathbf{m}$ & $\mathrm{m}$ & $\mathrm{m}$ & $\mathbf{m}$ & $\mathrm{m}$ & $\mathrm{m}$ & $\mathbf{m}$ & $\mathrm{m}$ & $\mathrm{m}$ \\
\hline Indonesia & & & $\mathbf{m}$ & $\mathrm{m}$ & $\mathrm{m}$ & $\mathbf{m}$ & $\mathrm{m}$ & $\mathrm{m}$ & $\mathbf{m}$ & $\mathrm{m}$ & $\mathrm{m}$ & $\mathbf{m}$ & $\mathrm{m}$ & $\mathrm{m}$ \\
\hline Letonia & & & $\mathbf{m}$ & $\mathrm{m}$ & $\mathrm{m}$ & $\mathbf{m}$ & $\mathrm{m}$ & $\mathrm{m}$ & m & $\mathrm{m}$ & $\mathrm{m}$ & $\mathbf{m}$ & $\mathrm{m}$ & $\mathrm{m}$ \\
\hline Federación Rusa & & & $\mathbf{m}$ & $\mathrm{m}$ & $\mathrm{m}$ & $\mathbf{m}$ & $\mathrm{m}$ & $\mathrm{m}$ & $\mathbf{m}$ & $\mathrm{m}$ & $\mathrm{m}$ & $\mathbf{m}$ & $\mathrm{m}$ & $\mathrm{m}$ \\
\hline Arabia Saudí & & & $\mathbf{m}$ & $\mathrm{m}$ & $\mathrm{m}$ & $\mathbf{m}$ & $\mathrm{m}$ & $\mathrm{m}$ & $\mathbf{m}$ & $\mathrm{m}$ & $\mathrm{m}$ & $\mathbf{m}$ & $\mathrm{m}$ & $\mathrm{m}$ \\
\hline Sudáfrica & & & $\mathbf{m}$ & $\mathrm{m}$ & $\mathrm{m}$ & $\mathbf{m}$ & $\mathrm{m}$ & $\mathrm{m}$ & $\mathbf{m}$ & $\mathrm{m}$ & $\mathrm{m}$ & $\mathbf{m}$ & $\mathrm{m}$ & $\mathrm{m}$ \\
\hline Media G20 & & & m & $\mathrm{m}$ & $\mathrm{m}$ & $\mathbf{m}$ & $\mathrm{m}$ & $\mathrm{m}$ & $\mathbf{m}$ & $\mathrm{m}$ & $\mathrm{m}$ & $\mathbf{m}$ & $\mathrm{m}$ & $\mathrm{m}$ \\
\hline
\end{tabular}

Nota: La duración del periodo de referencia varía desde una semana a un año. En algunos países se excluye a los trabajadores autónomos.

1. El término a tiempo completo se refiere a las personas que trabajan un mínimo de 30 horas semanales durante todo el año. Para ver más detalles, consulte el Indicador A6 y el Anexo 3.

Fuente: OCDE. Para ver notas, consulte Anexo 3 (www.oecd.org/edu/eag.htm).

Para obtener más información acerca de los símbolos utilizados en lugar de los datos que faltan, consulte la Guía del lector.

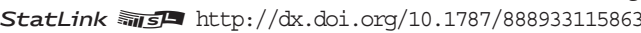


Tabla A5.7a (L). [1/2] Estatus en el mercado laboral, por nivel educativo alcanzado y nivel de comprensión lectora (2012)

Comprensión lectora en la Encuesta sobre las Competencias de los Adultos, porcentaje de las personas de 25 a 64 años

\begin{tabular}{|c|c|c|c|c|c|c|c|c|c|c|c|c|c|c|c|c|c|c|c|}
\hline & \multirow{4}{*}{$\begin{array}{c}\text { Nivel de } \\
\text { competencia }\end{array}$} & \multicolumn{6}{|c|}{ Empleado } & \multicolumn{6}{|c|}{ Desempleado } & \multicolumn{6}{|c|}{ Inactivo } \\
\hline & & \multicolumn{2}{|c|}{\begin{tabular}{|c|}
$\begin{array}{c}\text { Inferior a } \\
\text { educación } \\
\text { secundaria } \\
\text { superior }\end{array}$ \\
\end{tabular}} & \multicolumn{2}{|c|}{\begin{tabular}{|c|} 
Educación \\
secundaria \\
superior o \\
postsecundaria \\
no terciaria
\end{tabular}} & \multicolumn{2}{|c|}{$\begin{array}{c}\text { Educación } \\
\text { terciaria }\end{array}$} & \multicolumn{2}{|c|}{$\begin{array}{c}\begin{array}{c}\text { Inferior a } \\
\text { educación } \\
\text { secundaria } \\
\text { superior }\end{array} \\
\end{array}$} & \multicolumn{2}{|c|}{\begin{tabular}{|c|} 
Educación \\
secundaria \\
superior o \\
postsecundaria \\
no terciaria
\end{tabular}} & $\begin{array}{l}\text { Educ } \\
\text { terc }\end{array}$ & $\begin{array}{l}\text { ación } \\
\text { iaria }\end{array}$ & $\begin{array}{r}\mathrm{N} \\
\text { infer } \\
\text { educ } \\
\text { secur } \\
\text { sup } \\
\end{array}$ & $\begin{array}{l}\text { vel } \\
\text { lor a la } \\
\text { ación } \\
\text { adaria } \\
\text { erior }\end{array}$ & $\begin{array}{r}\text { Educ } \\
\text { secu } \\
\text { supe } \\
\text { postsec } \\
\text { no te }\end{array}$ & $\begin{array}{l}\text { ción } \\
\text { daria } \\
\text { ior o } \\
\text { indaria } \\
\text { ciaria }\end{array}$ & $\begin{array}{c}\text { Educ } \\
\text { terc }\end{array}$ & $\begin{array}{l}\text { cación } \\
\text { ciaria }\end{array}$ \\
\hline & & $\%$ & E.E. & $\%$ & E.E. & $\%$ & E.E. & $\%$ & E.E. & $\%$ & E.E. & $\%$ & E.E. & $\%$ & E.E. & $\%$ & E.E. & $\%$ & E.E. \\
\hline & & & & (3) & $(4)$ & (5) & (6) & (9) & (10) & $(11)$ & $(12)$ & $(13)$ & $(14)$ & $(17)$ & (18) & (19) & $(20)$ & $(21)$ & (22) \\
\hline Entidades nacion & & & & & & & & & & & & & & & & & & & \\
\hline & 2 & 60 & $(5,4)$ & 79 & $(1,7)$ & 83 & $(2,4)$ & 8,3 & $(3,7)$ & 4,0 & $(0,9)$ & 3,0 & $(1,1)$ & 32 & $(5,0)$ & 17 & $(1,6)$ & 15 & $(2,3)$ \\
\hline & 3 & c & c & 84 & $(1,7)$ & 91 & $(1,4)$ & c & c & 4,3 & $(1,0)$ & 2,1 & $(0,6)$ & c & c & 12 & $(1,5)$ & 7 & $(1,2)$ \\
\hline & $4 / 5$ & c & c & 86 & $(3,4)$ & 93 & $(2,1)$ & c & c & c & c & 1,7 & $(0,8)$ & c & c & 13 & $(3,2)$ & 6 & $(1,9)$ \\
\hline Australia & $0 / 1$ & 50 & $(3,4)$ & 66 & $(3,7)$ & 70 & $(5,7)$ & 3,4 & $(1,3)$ & 5,3 & $(2,3)$ & 5,2 & $(3,7)$ & 47 & $(3,5)$ & 29 & $(3,9)$ & 25 & $(5,2)$ \\
\hline & 2 & 65 & $(3,0)$ & 75 & $(2,2)$ & 80 & $(2,5)$ & 3,6 & $(1,2)$ & 3,7 & $(1,0)$ & 4,2 & $(1,6)$ & 32 & $(2,9)$ & 21 & $(2,0)$ & 16 & $(2,5)$ \\
\hline & 3 & 73 & $(2,8)$ & 79 & $(1,8)$ & 85 & $(1,5)$ & 3,2 & $(1,7)$ & 3,3 & $(0,9)$ & 3,0 & $(0,8)$ & 24 & $(2,5)$ & 18 & $(1,8)$ & 12 & $(1,3)$ \\
\hline & $4 / 5$ & c & c & 82 & $(4,1)$ & 89 & $(1,5)$ & c & c & 3,9 & $(2,4)$ & 2,2 & $(0,8)$ & c & c & 14 & $(3,7)$ & 8 & $(1,4)$ \\
\hline Austria & $0 / 1$ & 54 & $(3,5)$ & 67 & $(2,9)$ & c & c & 6,9 & $(1,9)$ & 3,1 & $(1,1)$ & c & c & 39 & $(3,4)$ & 30 & $(2,7)$ & c & c \\
\hline & 3 & 68 & $(4,6)$ & 86 & $(1,4)$ & 89 & $(1,9)$ & 2,6 & $(1,6)$ & 2,6 & $(0,7)$ & 2,0 & $(0,9)$ & 29 & $(4,8)$ & 11 & $(1,3)$ & 9 & $(1,7)$ \\
\hline & $4 / 5$ & c & c & 88 & $(3,4)$ & 91 & $(2,4)$ & c & c & 2,5 & $(1,6)$ & c & c & c & c & 10 & $(2,8)$ & 7 & $(2,3)$ \\
\hline Canadá & $0 / 1$ & 54 & $(2,3)$ & 70 & $(2,0)$ & 75 & $(2,9)$ & 4,5 & $(1,1)$ & 4,7 & $(1,1)$ & 4,3 & $(1,4)$ & 42 & $(2,4)$ & 25 & $(1,8)$ & 21 & $(2,6)$ \\
\hline & 2 & 61 & $(3,3)$ & 77 & $(1,4)$ & 82 & $(1,5)$ & 4,7 & $(1,5)$ & 3,8 & $(0,7)$ & 3,3 & $(0,7)$ & 35 & $(3,0)$ & 19 & $(1,3)$ & 15 & $(1,4)$ \\
\hline & 3 & 68 & $(5,1)$ & 81 & $(1,4)$ & 87 & $(0,9)$ & 5,1 & $(3,1)$ & 2,9 & $(0,6)$ & 2,7 & $(0,5)$ & 26 & $(4,6)$ & 16 & $(1,2)$ & 10 & $(0,8)$ \\
\hline & $4 / 5$ & c & c & 82 & $(3,8)$ & 91 & $(1,1)$ & c & c & 3,0 & $(2,0)$ & 2,3 & $(0,6)$ & c & c & 15 & $(3,5)$ & 7 & $(1,0)$ \\
\hline Corea & $0 / 1$ & 61 & $(2,6)$ & 76 & $(3,4)$ & c & c & 2,1 & $(0,9)$ & 1,9 & $(1,0)$ & c & c & 37 & $(2,7)$ & 22 & $(3,4)$ & c & c \\
\hline & 2 & 65 & $(2,4)$ & 76 & $(1,4)$ & 77 & $(1,7)$ & 1,7 & $(0,8)$ & 2,6 & $(0,6)$ & 2,3 & $(0,7)$ & 33 & $(2,4)$ & 21 & $(1,5)$ & 21 & $(1,6)$ \\
\hline & 3 & 69 & $(5,5)$ & 76 & $(2,0)$ & 80 & $(1,2)$ & 2,9 & $(1,7)$ & 3,1 & $(0,8)$ & 2,3 & $(0,6)$ & 28 & $(5,7)$ & 21 & $(1,9)$ & 18 & $(1,3)$ \\
\hline & $4 / 5$ & c & c & c & c & 81 & $(2,6)$ & c & c & c & c & 4,2 & $(1,7)$ & c & c & c & c & 15 & $(2,6)$ \\
\hline Dinamarca & $0 / 1$ & 52 & $(2,8)$ & 62 & $(2,9)$ & 69 & $(4,0)$ & 7,1 & $(1,5)$ & 5,4 & $(1,7)$ & 4,5 & $(1,8)$ & 41 & $(2,6)$ & 32 & $(2,6)$ & 26 & $(3,7)$ \\
\hline & 2 & 65 & $(3,4)$ & 77 & $(1,7)$ & 83 & $(1,8)$ & 5,7 & $(1,7)$ & 4,3 & $(0,8)$ & 3,8 & $(1,1)$ & 29 & $(3,1)$ & 18 & $(1,6)$ & 13 & $(1,5)$ \\
\hline & 3 & 76 & $(5,0)$ & 82 & $(1,7)$ & 89 & $(1,0)$ & 7,1 & $(2,5)$ & 5,4 & $(1,0)$ & 3,3 & $(0,7)$ & 17 & $(4,2)$ & 12 & $(1,3)$ & 8 & $(0,8)$ \\
\hline & $4 / 5$ & c & c & 80 & $(5,4)$ & 93 & $(1,7)$ & c & c & 3,5 & $(3,0)$ & 3,0 & $(1,2)$ & c & c & 17 & $(5,0)$ & 4 & $(1,2)$ \\
\hline España & $0 / 1$ & 43 & $(1,4)$ & 66 & $(4,5)$ & 73 & $(4,5)$ & 18,4 & $(1,3)$ & 12,1 & $(2,9)$ & 8,3 & $(2,7)$ & 38 & $(1,6)$ & 22 & $(3,4)$ & 19 & $(4,0)$ \\
\hline & 2 & 54 & $(1,7)$ & 66 & $(2,8)$ & 78 & $(2,3)$ & 16,8 & $(1,6)$ & 11,2 & $(1,9)$ & 9,5 & $(1,5)$ & 29 & $(1,9)$ & 23 & $(2,5)$ & 13 & $(1,8)$ \\
\hline & 3 & 63 & $(3,7)$ & 72 & $(3,4)$ & 81 & $(1,7)$ & 14,4 & $(2,7)$ & 12,5 & $(2,4)$ & 8,8 & $(1,1)$ & 23 & $(3,2)$ & 16 & $(2,8)$ & 10 & $(1,3)$ \\
\hline & 2 & 63 & $(6,0)$ & 70 & $(2,0)$ & 81 & $(2,3)$ & 9,2 & $(3,5)$ & 8,2 & $(1,1)$ & 5,0 & $(1,4)$ & 28 & $(5,0)$ & 21 & $(1,9)$ & 14 & $(2,0)$ \\
\hline & 3 & c & c & 81 & $(1,7)$ & 86 & $(1,2)$ & c & c & 6,2 & $(1,2)$ & 4,8 & $(0,8)$ & c & c & 12 & $(1,5)$ & 9 & $(1,1)$ \\
\hline & $4 / 5$ & c & c & 88 & $(3,7)$ & 88 & $(1,9)$ & c & c & 2,7 & $(1,9)$ & 2,6 & $(0,7)$ & c & c & 10 & $(3,6)$ & 9 & $(1,8)$ \\
\hline Estonia & $0 / 1$ & 49 & $(3,4)$ & 68 & $(2,7)$ & 79 & $(4,2)$ & 8,7 & $(2,3)$ & 8,1 & $(1,5)$ & 5,7 & $(1,9)$ & 42 & $(3,6)$ & 24 & $(2,5)$ & 15 & $(3,7)$ \\
\hline & 2 & 56 & $(3,2)$ & 74 & $(1,5)$ & 85 & $(1,6)$ & 11,3 & $(2,0)$ & 6,8 & $(0,8)$ & 3,9 & $(0,8)$ & 32 & $(3,2)$ & 19 & $(1,3)$ & 12 & $(1,4)$ \\
\hline & 3 & 65 & $(4,4)$ & 80 & $(1,5)$ & 88 & $(1,0)$ & 6,5 & $(2,2)$ & 5,6 & $(0,8)$ & 3,9 & $(0,6)$ & 28 & $(4,5)$ & 15 & $(1,3)$ & 8 & $(0,9)$ \\
\hline & $4 / 5$ & c & c & 87 & $(3,0)$ & 94 & $(1,3)$ & c & c & 3,5 & $(1,8)$ & 1,9 & $(0,7)$ & c & c & 10 & $(2,7)$ & 4 & $(1,2)$ \\
\hline Finlandia & $0 / 1$ & 39 & $(4,4)$ & 55 & $(3,9)$ & c & c & 3,1 & $(1,7)$ & 6,1 & $(1,9)$ & c & c & 58 & $(4,6)$ & 39 & $(3,9)$ & c & c \\
\hline & 2 & 57 & $(3,9)$ & 72 & $(2,0)$ & 81 & $(2,3)$ & 3,9 & $(1,4)$ & 3,9 & $(1,1)$ & 2,6 & $(1,0)$ & 39 & $(3,7)$ & 24 & $(2,1)$ & 16 & $(2,0)$ \\
\hline & 3 & 68 & $(6,0)$ & 80 & $(1,6)$ & 89 & $(1,3)$ & 5,3 & $(2,3)$ & 4,7 & $(1,0)$ & 2,4 & $(0,6)$ & 27 & $(5,2)$ & 15 & $(1,6)$ & 9 & $(1,1)$ \\
\hline & $4 / 5$ & c & c & 82 & $(2,6)$ & 91 & $(1,2)$ & c & c & 5,1 & $(1,6)$ & 3,0 & $(0,6)$ & c & c & 13 & $(2,3)$ & 6 & $(1,0)$ \\
\hline Francia & $0 / 1$ & 50 & $(1,8)$ & 68 & $(2,5)$ & 65 & $(4,6)$ & 6,5 & $(1,1)$ & 7,3 & $(1,1)$ & 8,1 & $(2,9)$ & 44 & $(1,8)$ & 25 & $(2,2)$ & 27 & $(4,2)$ \\
\hline & 2 & 57 & $(2,2)$ & 74 & $(1,5)$ & 80 & $(2,0)$ & 6,4 & $(1,1)$ & 5,5 & $(0,7)$ & 4,1 & $(1,0)$ & 37 & $(2,1)$ & 20 & $(1,4)$ & 16 & $(1,8)$ \\
\hline & 3 & 61 & $(3,8)$ & 75 & $(1,7)$ & 87 & $(1,0)$ & 7,1 & $(2,2)$ & 6,3 & $(0,9)$ & 3,0 & $(0,6)$ & 32 & $(3,8)$ & 19 & $(1,6)$ & 10 & $(1,0)$ \\
\hline & $4 / 5$ & c & c & c & c & 88 & $(2,3)$ & c & c & c & c & 4,6 & $(1,4)$ & c & c & c & c & 8 & $(1,9)$ \\
\hline Irlanda & $0 / 1$ & 41 & $(3,2)$ & 60 & $(4,4)$ & 72 & $(5,9)$ & 9,1 & $(1,7)$ & 13,4 & $(2,6)$ & 5,0 & $(2,6)$ & 50 & $(3,6)$ & 26 & $(3,8)$ & 23 & $(5,7)$ \\
\hline & 2 & 52 & $(2,9)$ & 62 & $(1,8)$ & 78 & $(2,2)$ & 11,2 & $(2,0)$ & 11,0 & $(1,2)$ & 5,9 & $(1,2)$ & 36 & $(2,9)$ & 27 & $(1,8)$ & 16 & $(2,0)$ \\
\hline & 3 & 56 & $(4,9)$ & 70 & $(2,2)$ & 82 & $(1,6)$ & 6,4 & $(2,7)$ & 9,4 & $(1,5)$ & 4,1 & $(0,8)$ & 38 & $(4,7)$ & 21 & $(1,6)$ & 14 & $(1,3)$ \\
\hline & $4 / 5$ & c & c & 77 & $(5,7)$ & 86 & $(2,9)$ & c & c & 7,1 & $(3,7)$ & 2,4 & $(1,2)$ & c & c & 16 & $(4,6)$ & 11 & $(2,3)$ \\
\hline Italia & $0 / 1$ & 50 & $(2,4)$ & 69 & $(4,3)$ & c & c & 11,2 & $(1,5)$ & 8,2 & $(2,2)$ & c & c & 39 & $(2,2)$ & 23 & $(3,4)$ & c & c \\
\hline & 2 & 54 & $(2,3)$ & 66 & $(2,5)$ & 75 & $(3,8)$ & 7,6 & $(1,5)$ & 10,7 & $(1,7)$ & 9,2 & $(3,0)$ & 38 & $(2,1)$ & 23 & $(2,1)$ & 16 & $(3,1)$ \\
\hline & 3 & 63 & $(4,6)$ & 75 & $(2,7)$ & 83 & $(2,8)$ & 7,8 & $(2,5)$ & 8,6 & $(1,7)$ & 5,1 & $(2,2)$ & 30 & $(4,0)$ & 16 & $(2,1)$ & 11 & $(2,4)$ \\
\hline & $4 / 5$ & c & c & c & c & c & c & c & c & c & c & c & c & c & c & c & c & c & c \\
\hline Japón & $0 / 1$ & 65 & $(5,9)$ & 71 & $(6,6)$ & c & c & c & c & c & c & c & c & 33 & $(5,7)$ & 29 & $(6,6)$ & $c$ & c \\
\hline & 2 & 66 & $(4,0)$ & 71 & $(2,4)$ & 79 & $(3,1)$ & c & c & c & c & c & c & 34 & $(4,0)$ & 28 & $(2,4)$ & 21 & $(3,0)$ \\
\hline & 3 & 77 & $(5,1)$ & 76 & $(1,5)$ & 80 & $(1,4)$ & c & c & 2,5 & $(0,7)$ & 1,4 & $(0,5)$ & 20 & $(4,8)$ & 21 & $(1,6)$ & 19 & $(1,3)$ \\
\hline & $4 / 5$ & c & c & 80 & $(3,8)$ & 79 & $(1,6)$ & c & c & 2,2 & $(1,8)$ & 3,0 & $(0,7)$ & c & c & 18 & $(4,0)$ & 18 & $(1,6)$ \\
\hline
\end{tabular}

* Para los datos de Federación Rusa, véase nota en la sección de Metodología.

Nota: Las columnas que muestran los datos referentes a todos los niveles educativos están disponibles en Internet (véase StatLink más abajo).

Fuente: OCDE. Encuesta sobre las Competencias de los Adultos (PIAAC) (2012). PIAAC se refiere al Programa para la Evaluación Internacional de las Competencias de los Adultos de la OCDE. Para ver notas, consulte Anexo 3 (www.oecd.org/edu/eag.htm).

Para obtener más información acerca de los símbolos utilizados en lugar de los datos que faltan, consulte la Guía del lector.

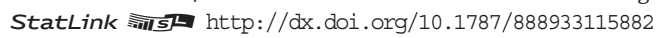


Tabla A5.7a (L). [2/2] Estatus en el mercado laboral, por nivel educativo alcanzado y nivel de comprensión lectora (2012)

Comprensión lectora en la Encuesta sobre las Competencias de los Adultos, porcentaje de las personas de 25 a 64 años

\begin{tabular}{|c|c|c|c|c|c|c|c|c|c|c|c|c|c|c|c|c|c|c|c|}
\hline & \multirow{4}{*}{$\begin{array}{c}\text { Nivel de } \\
\text { competencia }\end{array}$} & \multicolumn{6}{|c|}{ Empleado } & \multicolumn{6}{|c|}{ Desempleado } & \multicolumn{6}{|c|}{ Inactivo } \\
\hline & & \multicolumn{2}{|c|}{$\begin{array}{c}\text { Inferior a } \\
\text { educación } \\
\text { secundaria } \\
\text { superior }\end{array}$} & \multicolumn{2}{|c|}{\begin{tabular}{|c|} 
Educación \\
secundaria \\
superior o \\
postsecundaria \\
no terciaria
\end{tabular}} & \multicolumn{2}{|c|}{$\begin{array}{c}\text { Educación } \\
\text { terciaria }\end{array}$} & \multicolumn{2}{|c|}{$\begin{array}{c}\text { Inferior a } \\
\text { educación } \\
\text { secundaria } \\
\text { superior }\end{array}$} & \multicolumn{2}{|c|}{$\begin{array}{c}\text { Educación } \\
\text { secundaria } \\
\text { superior o } \\
\text { postsecundaria } \\
\text { no terciaria }\end{array}$} & \multicolumn{2}{|c|}{$\begin{array}{c}\text { Educación } \\
\text { terciaria }\end{array}$} & \multicolumn{2}{|c|}{\begin{tabular}{|c|} 
Nivel \\
inferior a la \\
educación \\
secundaria \\
superior
\end{tabular}} & \multicolumn{2}{|c|}{\begin{tabular}{|c|} 
Educación \\
secundaria \\
superior o \\
postsecundaria \\
no terciaria \\
\end{tabular}} & \multicolumn{2}{|c|}{$\begin{array}{c}\text { Educación } \\
\text { terciaria }\end{array}$} \\
\hline & & $\%$ & E.E. & $\%$ & E.E. & $\%$ & E.E. & $\%$ & E.E. & $\%$ & E.E. & $\%$ & E.E. & $\%$ & E.E. & $\%$ & E.E. & $\%$ & E.E. \\
\hline & & (1) & (2) & (3) & (4) & (5) & (6) & (9) & (10) & (11) & (12) & (13) & (14) & (17) & (18) & (19) & (20) & (21) & (22) \\
\hline \multirow{5}{*}{$\begin{array}{l}\text { Entidades } \\
\text { Noruega }\end{array}$} & & & & & & & & & & & & & & & & & & & \\
\hline & $0 / 1$ & 57 & $(4,5)$ & 72 & $(3,6)$ & c & c & 4,2 & $(1,7)$ & 4,8 & $(2,0)$ & c & c & 39 & $(4,1)$ & 23 & $(3,6)$ & c & c \\
\hline & 2 & 72 & $(3,3)$ & 81 & $(2,0)$ & 86 & $(2,3)$ & 2,8 & $(1,3)$ & 2,9 & $(0,9)$ & 2,2 & $(1,0)$ & 26 & $(3,1)$ & 16 & $(1,8)$ & 12 & $(2,3)$ \\
\hline & 3 & 78 & $(3,6)$ & 87 & $(1,7)$ & 93 & $(0,9)$ & 3,0 & $(1,3)$ & 2,8 & $(0,8)$ & 1,6 & $(0,4)$ & 19 & $(3,3)$ & 11 & $(1,6)$ & 5 & $(0,8)$ \\
\hline & $4 / 5$ & c & c & 89 & $(3,4)$ & 95 & $(1,0)$ & c & c & c & c & 0,7 & $(0,4)$ & c & ${ }^{c}$ & 9 & $(3,4)$ & 4 & $(0,9)$ \\
\hline Países Bajos & $0 / 1$ & 54 & $(3,3)$ & 68 & $(5,6)$ & c & c & 6,8 & $(1,8)$ & 3,5 & $(2,1)$ & c & c & 39 & $(3,4)$ & 29 & $(5,0)$ & c & c \\
\hline & 2 & 64 & $(2,8)$ & 77 & $(2,1)$ & 79 & $(3,7)$ & 3,6 & $(1,2)$ & 5,5 & $(1,3)$ & c & c & 33 & $(2,7)$ & 17 & $(2,0)$ & 19 & $(3,5)$ \\
\hline & 3 & 76 & $(3,3)$ & 85 & $(1,4)$ & 90 & $(1,5)$ & 1,8 & $(1,0)$ & 3,1 & $(0,7)$ & 2,5 & $(0,8)$ & 22 & $(3,0)$ & 12 & $(1,4)$ & 8 & $(1,2)$ \\
\hline & $4 / 5$ & c & c & 86 & $(3,7)$ & 92 & $(1,5)$ & c & c & 3,2 & $(1,6)$ & 3,0 & $(1,0)$ & c & c & 10 & $(3,1)$ & 5 & $(1,2)$ \\
\hline Polonia & $0 / 1$ & 37 & $(4,1)$ & 57 & $(2,7)$ & c & c & 9,5 & $(2,5)$ & 7,5 & $(1,5)$ & c & c & 53 & $(4,2)$ & 35 & $(2,4)$ & c & c \\
\hline & 2 & 45 & $(4,7)$ & 63 & $(2,0)$ & 85 & $(2,6)$ & 13,2 & $(3,6)$ & 6,5 & $(1,0)$ & 3,1 & $(1,2)$ & 41 & $(4,6)$ & 31 & $(2,1)$ & 12 & $(2,2)$ \\
\hline & 3 & c & c & 67 & $(2,1)$ & 87 & $(1,5)$ & c & c & 5,5 & $(1,1)$ & 3,5 & $(0,8)$ & c & c & 27 & $(2,2)$ & 9 & $(1,4)$ \\
\hline & $4 / 5$ & c & c & 67 & $(6,4)$ & 92 & $(2,0)$ & c & c & 9,5 & $(4,3)$ & 2,0 & $(0,9)$ & c & c & 24 & $(5,0)$ & 6 & $(1,7)$ \\
\hline República Checa & $0 / 1$ & 39 & $(7,0)$ & 70 & $(4,1)$ & c & c & 13,8 & $(5,6)$ & 2,8 & $(0,9)$ & c & c & 48 & $(6,8)$ & 27 & $(4,1)$ & c & c \\
\hline & 2 & 47 & $(5,8)$ & 75 & $(1,8)$ & 84 & $(4,3)$ & 15,0 & $(3,7)$ & 4,7 & $(1,0)$ & 2,4 & $(1,8)$ & 38 & $(5,9)$ & 21 & $(1,7)$ & 14 & $(4,0)$ \\
\hline & 3 & c & c & 78 & $(1,9)$ & 83 & $(3,4)$ & c & c & 3,3 & $(1,0)$ & 3,3 & $(1,6)$ & c & c & 18 & $(1,7)$ & 14 & $(3,0)$ \\
\hline & $4 / 5$ & c & c & 86 & $(5,3)$ & 89 & $(4,1)$ & c & c & 3,7 & $(2,4)$ & 0,7 & $(0,5)$ & c & c & 11 & $(4,6)$ & 10 & $(4,0)$ \\
\hline República Eslovaca & $0 / 1$ & 25 & $(3,4)$ & 65 & $(3,9)$ & c & c & 13,6 & $(2,2)$ & 11,3 & $(2,3)$ & c & c & c & c & 24 & $(3,4)$ & c & c \\
\hline & 2 & 36 & $(3,2)$ & 71 & $(1,6)$ & 85 & $(2,9)$ & 12,1 & $(1,9)$ & 6,6 & $(0,9)$ & 2,1 & $(1,1)$ & 51 & $(3,1)$ & 22 & $(1,4)$ & 13 & $(2,8)$ \\
\hline & 3 & 43 & $(5,3)$ & 73 & $(1,6)$ & 88 & $(1,9)$ & 10,1 & $(3,1)$ & 6,7 & $(0,9)$ & 3,9 & $(1,0)$ & 46 & $(5,4)$ & 20 & $(1,4)$ & 9 & $(1,6)$ \\
\hline & $4 / 5$ & c & c & 76 & $(4,5)$ & 85 & $(4,4)$ & c & c & 9,0 & $(3,1)$ & 2,3 & $(1,4)$ & c & c & 15 & $(3,5)$ & 13 & $(4,0)$ \\
\hline Suecia & $0 / 1$ & 50 & $(4,3)$ & 67 & $(4,0)$ & c & c & 11,7 & $(2,8)$ & 7,6 & $(1,9)$ & c & c & 38 & $(4,1)$ & 25 & $(3,7)$ & c & c \\
\hline & 2 & 69 & $(3,3)$ & 83 & $(2,1)$ & 85 & $(3,0)$ & 6,7 & $(2,4)$ & 4,7 & $(1,1)$ & 3,3 & $(1,5)$ & 24 & $(2,8)$ & 13 & $(1,8)$ & 12 & $(2,6)$ \\
\hline & 3 & 79 & $(5,6)$ & 87 & $(1,4)$ & 92 & $(1,2)$ & 7,5 & $(3,6)$ & 3,0 & $(0,8)$ & 2,8 & $(0,8)$ & 14 & $(4,3)$ & 10 & $(1,2)$ & 6 & $(1,0)$ \\
\hline & $4 / 5$ & c & c & 93 & $(2,8)$ & 95 & $(1,3)$ & c & c & 2,2 & $(1,4)$ & 1,2 & $(0,7)$ & c & c & 5 & $(2,3)$ & 4 & $(1,1)$ \\
\hline Entidades subnacionales & & & & & & & & & & & & & & & & & & & \\
\hline Flandes (Bélgica) & $0 / 1$ & 45 & $(3,3)$ & 69 & $(2,8)$ & c & c & 2,0 & $(0,8)$ & 2,4 & $(1,0)$ & c & c & 53 & $(3,4)$ & 29 & $(2,8)$ & c & c \\
\hline & 2 & 57 & $(3,6)$ & 78 & $(1,7)$ & 84 & $(2,6)$ & 2,3 & $(0,9)$ & 2,2 & $(0,6)$ & 1,4 & $(0,8)$ & 41 & $(3,6)$ & 20 & $(1,7)$ & 15 & $(2,6)$ \\
\hline & 3 & 63 & $(6,3)$ & 83 & $(1,7)$ & 89 & $(1,2)$ & c & c & 1,0 & $(0,5)$ & 1,4 & $(0,4)$ & 36 & $(6,4)$ & 16 & $(1,7)$ & 9 & $(1,1)$ \\
\hline & $4 / 5$ & c & c & 88 & $(3,3)$ & 94 & $(1,3)$ & c & c & c & c & 0,8 & $(0,5)$ & c & c & 10 & $(3,5)$ & 5 & $(1,2)$ \\
\hline Inglater & $0 / 1$ & 51 & $(2,9)$ & 72 & $(4,5)$ & 73 & $(7,0)$ & 9,8 & $(1,9)$ & 9,0 & $(2,5)$ & 5,3 & $(2,4)$ & 40 & $(2,7)$ & 19 & $(3,9)$ & 22 & $(6,3)$ \\
\hline (Reino L & 2 & 65 & $(2,6)$ & 72 & $(2,2)$ & 79 & $(2,7)$ & 7,2 & $(1,5)$ & 6,3 & $(1,4)$ & 4,0 & $(1,4)$ & 28 & $(2,4)$ & 21 & $(2,1)$ & 17 & $(2,4)$ \\
\hline & 3 & 68 & $(4,1)$ & 81 & $(1,8)$ & 86 & $(1,3)$ & 2,4 & $(1,6)$ & 4,3 & $(1,0)$ & 2,6 & $(0,6)$ & 30 & $(3,9)$ & 14 & $(1,7)$ & 12 & $(1,2)$ \\
\hline & $4 / 5$ & c & c & 86 & $(3,2)$ & 88 & $(1,8)$ & c & c & 3,7 & $(1,9)$ & 1,9 & $(0,7)$ & c & c & 10 & $(2,6)$ & 10 & $(1,6)$ \\
\hline Ingla & $0 / 1$ & 50 & $(2,8)$ & 72 & $(4,3)$ & 73 & $(6,8)$ & 9,5 & $(1,8)$ & 9,0 & $(2,4)$ & 5,4 & $(2,3)$ & 40 & $(2,6)$ & 19 & $(3,8)$ & 22 & $(6,1)$ \\
\hline Norte (Reino Unido) & 2 & 64 & $(2,5)$ & 72 & $(2,1)$ & 79 & $(2,6)$ & 7,0 & $(1,4)$ & 6,3 & $(1,3)$ & 3,9 & $(1,3)$ & 29 & $(2,3)$ & 21 & $(2,0)$ & 17 & $(2,3)$ \\
\hline & 3 & 67 & $(3,9)$ & 81 & $(1,8)$ & 86 & $(1,2)$ & 2,5 & $(1,5)$ & 4,3 & $(1,0)$ & 2,6 & $(0,5)$ & 30 & $(3,7)$ & 14 & $(1,6)$ & 12 & $(1,2)$ \\
\hline & $4 / 5$ & c & c & 86 & $(3,1)$ & 88 & $(1,7)$ & c & c & 3,6 & $(1,9)$ & 2,0 & $(0,7)$ & c & c & 10 & $(2,6)$ & 10 & $(1,6)$ \\
\hline Irlanda del Norte & $0 / 1$ & 47 & $(3,5)$ & 63 & $(4,9)$ & c & c & 3,7 & $(1,0)$ & 9,2 & $(3,4)$ & c & c & 49 & $(3,4)$ & 28 & $(4,8)$ & c & c \\
\hline (Reino Unido) & 2 & 58 & $(2,9)$ & 71 & $(2,9)$ & 78 & $(3,4)$ & 2,9 & $(1,1)$ & 5,7 & $(1,6)$ & 3,4 & $(1,4)$ & 39 & $(2,8)$ & 23 & $(2,7)$ & 18 & $(3,1)$ \\
\hline & 3 & 60 & $(4,8)$ & 78 & $(2,9)$ & 87 & $(1,7)$ & 4,4 & $(2,1)$ & 4,1 & $(1,8)$ & 2,5 & $(1,0)$ & 36 & $(4,9)$ & 18 & $(2,5)$ & 11 & $(1,5)$ \\
\hline & $4 / 5$ & c & & c & & 90 & $(3,5)$ & c & c & c & c & 3,9 & $(2,6)$ & c & & c & c & 6 & $(2,3)$ \\
\hline Media & $0 / 1$ & 49 & $(0,8)$ & 67 & $(0,8)$ & 72 & $(1,8)$ & 8,0 & $(0,5)$ & 6,6 & $(0,4)$ & 5,8 & $(0,9)$ & 42 & $(0,8)$ & 27 & $(0,8)$ & 22 & $(1,6)$ \\
\hline & 2 & 59 & $(0,8)$ & 74 & $(0,4)$ & 81 & $(0,6)$ & 7,5 & $(0,5)$ & 5,6 & $(0,2)$ & 3,9 & $(0,3)$ & 34 & $(0,7)$ & 21 & $(0,4)$ & 15 & $(0,5)$ \\
\hline & 3 & 67 & $(1,1)$ & 79 & $(0,4)$ & 87 & $(0,3)$ & 5,8 & $(0,6)$ & 4,9 & $(0,2)$ & 3,2 & $(0,2)$ & 27 & $(1,0)$ & 16 & $(0,4)$ & 10 & $(0,3)$ \\
\hline & $4 / 5$ & c & c & 83 & $(1,0)$ & 89 & $(0,5)$ & $c$ & c & 4,3 & $(0,6)$ & 2,5 & $(0,2)$ & c & c & 13 & $(0,9)$ & 8 & $(0,4)$ \\
\hline
\end{tabular}

\begin{tabular}{|c|c|c|c|c|c|c|c|c|c|c|c|c|c|c|c|c|c|c|c|}
\hline \multirow[t]{4}{*}{ 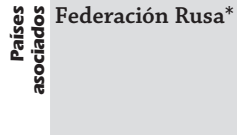 } & $0 / 1$ & c & c & c & c & 53 & $(4,7)$ & c & c & c & c & 2,5 & $(1,8)$ & c & c & c & c & 44 & $(4,5)$ \\
\hline & 2 & c & c & 66 & $(4,1)$ & 65 & $(2,5)$ & c & c & c & c & 2,4 & $(1,1)$ & c & c & 33 & $(4,5)$ & 32 & $(2,2)$ \\
\hline & 3 & c & c & 63 & $(6,4)$ & 72 & $(2,3)$ & c & c & 4,1 & $(2,2)$ & 2,6 & $(0,9)$ & c & c & 33 & $(5,5)$ & 25 & $(2,3)$ \\
\hline & $4 / 5$ & c & c & c & c & 74 & $(4,2)$ & c & c & c & c & 4,3 & $(2,0)$ & c & c & c & $c$ & 22 & $(4,8)$ \\
\hline
\end{tabular}

* Para los datos de Federación Rusa, véase nota en la sección de Metodología.

Nota: Las columnas que muestran los datos referentes a todos los niveles educativos están disponibles en Internet (véase StatLink más abajo).

Fuente: OCDE. Encuesta sobre las Competencias de los Adultos (PIAAC) (2012). PIAAC se refiere al Programa para la Evaluación Internacional de las Competencias de los Adultos de la OCDE. Para ver notas, consulte Anexo 3 (www.oecd.org/edu/eag.htm).

Para obtener más información acerca de los símbolos utilizados en lugar de los datos que faltan, consulte la Guía del lector.

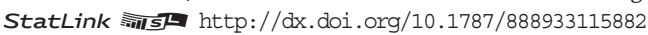


Tabla A5.8 (L). Puntuación media en comprensión lectora en adultos con educación secundaria superior o postsecundaria no terciaria, por estatus en el mercado laboral y orientación del programa (2012)

Comprensión lectora en la Encuesta sobre las Competencias de los Adultos, porcentaje de las personas de 25 a 64 años

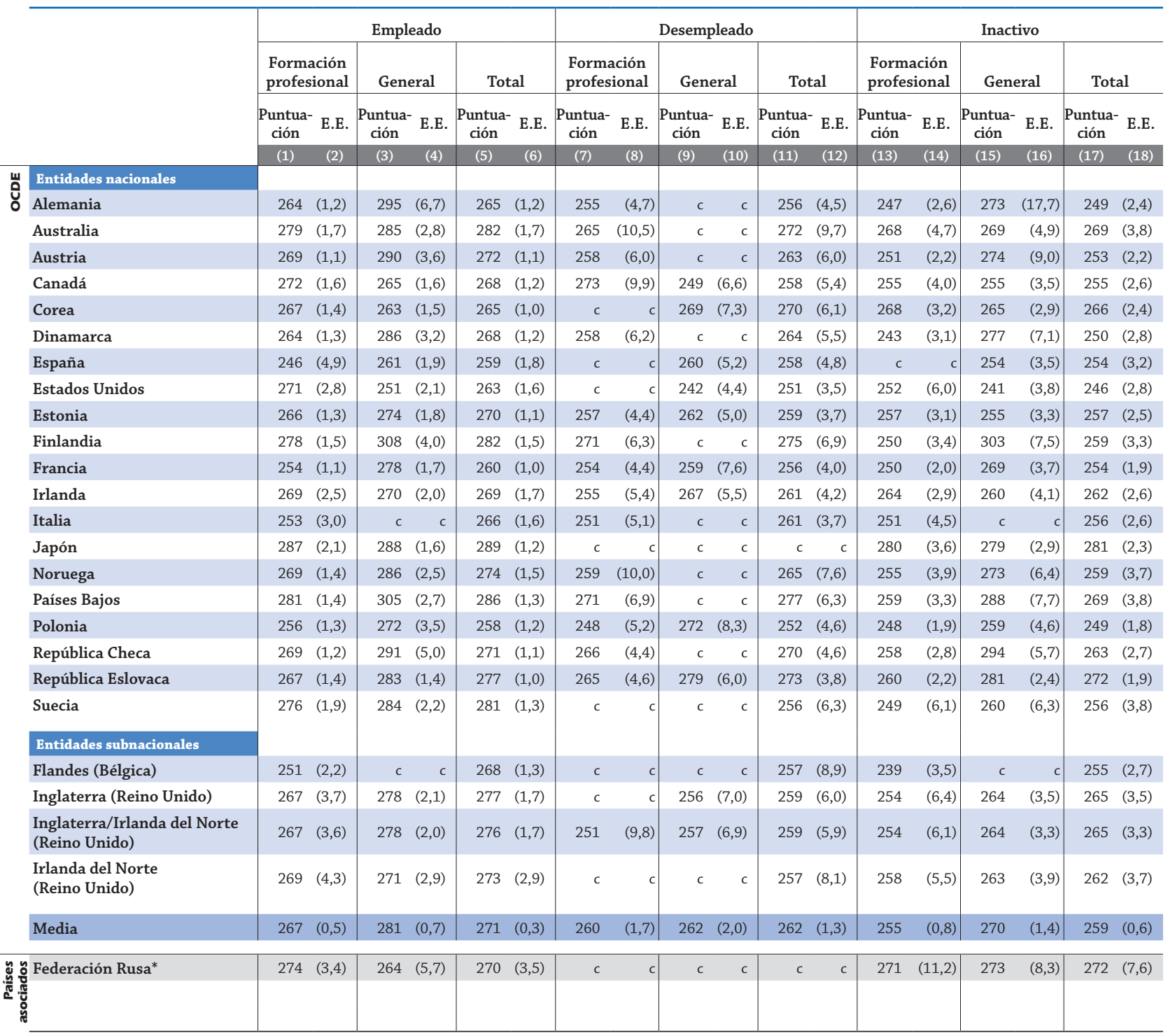

* Para los datos de Federación Rusa, véase nota en la sección de Metodología.

Fuente: OCDE. Encuesta sobre las Competencias de los Adultos (PIAAC) (2012). PIAAC se refiere al Programa para la Evaluación Internacional de las Competencias de los Adultos de la OCDE. Para ver notas, consulte Anexo 3 (www.oecd.org/edu/eag.htm).

Para obtener más información acerca de los símbolos utilizados en lugar de los datos que faltan, consulte la Guía del lector.

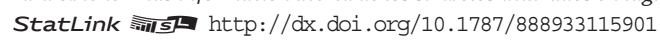


Tabla A5.9a (L). Distribución de la población adulta por niveles de comprensión lectora y estatus en el mercado laboral (2012)

Comprensión lectora en la Encuesta sobre las Competencias de los Adultos, porcentaje de las personas de 25 a 64 años

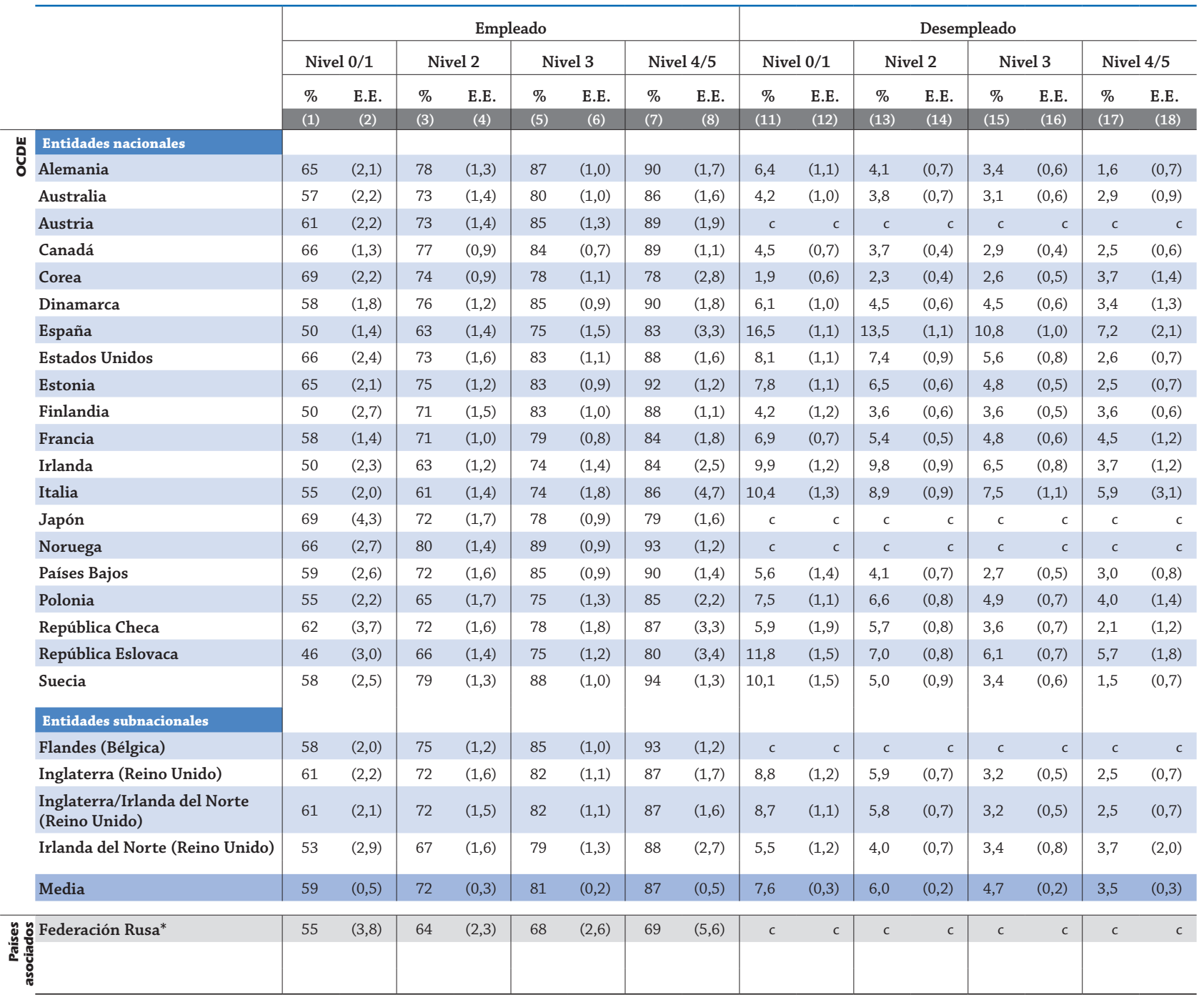

* Para los datos de Federación Rusa, véase nota en la sección de Metodología.

Nota: Las columnas que muestran los datos de todos los niveles combinados de competencia en comprensión lectora y las que muestran las tasas de inactividad por niveles de comprensión lectora están disponibles en Internet (véase StatLink más abajo).

Fuente: OCDE. Encuesta sobre las Competencias de los Adultos (PIAAC) (2012). PIAAC se refiere al Programa para la Evaluación Internacional de las Competencias de los Adultos de la OCDE. Para ver notas, consulte Anexo 3 (www.oecd.org/edu/eag.htm).

Para obtener más información acerca de los símbolos utilizados en lugar de los datos que faltan, consulte la Guía del lector.

StatLink 젝ㄴ http://dx.doi.org/10.1787/888933115920 
Tabla A5.10a (L). Distribución de los trabajadores a tiempo completo o a tiempo parcial, por nivel de comprensión lectora y por grupo de edad (2012)

Comprensión lectora en la Encuesta sobre las Competencias de los Adultos

\begin{tabular}{|c|c|c|c|c|c|c|c|c|c|c|c|c|c|c|c|c|c|}
\hline & \multirow{3}{*}{$\begin{array}{l}\text { Intensidad del } \\
\text { trabajo }\end{array}$} & \multicolumn{8}{|c|}{ 25-34 años } & \multicolumn{8}{|c|}{ 55-64 años } \\
\hline & & \multicolumn{2}{|c|}{ Nivel 0/1 } & \multicolumn{2}{|c|}{ Nivel 2} & \multicolumn{2}{|c|}{ Nivel 3} & \multicolumn{2}{|c|}{ Nivel $4 / 5$} & \multicolumn{2}{|c|}{ Nivel 0/1 } & \multicolumn{2}{|c|}{ Nivel 2} & \multicolumn{2}{|c|}{ Nivel 3} & \multicolumn{2}{|c|}{ Nivel $4 / 5$} \\
\hline & & $\%$ & E.E. & $\%$ & E.E. & $\%$ & E.E. & $\%$ & E.E. & $\%$ & E.E. & $\%$ & E.E. & $\%$ & E.E. & $\%$ & E.E. \\
\hline \multirow{3}{*}{$\begin{array}{l}\text { Entidades nacionales } \\
\text { Alemania }\end{array}$} & & & & & & & & & & & & & & & & & \\
\hline & A tiempo parcial & 12 & $(3,5)$ & 25 & $(3,9)$ & 44 & $(6,2)$ & 20 & $(4,8)$ & 23 & $(4,6)$ & 45 & $(6,8)$ & 29 & $(4,8)$ & 3 & $(1,7)$ \\
\hline & A tiempo completo & 12 & $(1,8)$ & 29 & $(2,3)$ & 43 & $(2,5)$ & 16 & $(1,8)$ & 16 & $(2,9)$ & 44 & $(3,5)$ & 35 & $(2,8)$ & 5 & $(1,4)$ \\
\hline \multirow[t]{2}{*}{ Australia } & A tiempo parcial & 13 & $(3,1)$ & 26 & $(4,0)$ & 39 & $(4,4)$ & 23 & $(3,7)$ & 16 & $(3,1)$ & 35 & $(4,1)$ & 40 & $(4,5)$ & 9 & $(2,1)$ \\
\hline & A tiempo completo & 7 & $(1,3)$ & 23 & $(1,8)$ & 45 & $(3,0)$ & 24 & $(2,3)$ & 15 & $(1,8)$ & 33 & $(3,0)$ & 39 & $(2,7)$ & 13 & $(2,2)$ \\
\hline \multirow[t]{2}{*}{ Austria } & A tiempo parcial & 13 & $(3,8)$ & 28 & $(5,0)$ & 46 & $(5,8)$ & 13 & $(3,7)$ & $c$ & c & c & c & c & c & c & c \\
\hline & A tiempo completo & 8 & $(1,6)$ & 31 & $(2,6)$ & 47 & $(2,8)$ & 14 & $(1,8)$ & 17 & $(2,8)$ & 50 & $(4,1)$ & 30 & $(3,4)$ & 4 & $(1,4)$ \\
\hline Canadá & A tiempo parcial & 7 & $(2,2)$ & 29 & $(4,0)$ & 41 & $(4,4)$ & 23 & $(3,4)$ & 15 & $(2,5)$ & 39 & $(3,7)$ & 35 & $(3,5)$ & 10 & $(2,4)$ \\
\hline & A tiempo completo & 9 & $(1,1)$ & 27 & $(2,0)$ & 42 & $(2,6)$ & 22 & $(1,6)$ & 21 & $(1,4)$ & 35 & $(1,7)$ & 33 & $(1,6)$ & 10 & $(1,1)$ \\
\hline Corea & A tiempo parcial & c & & c & c & c & c & c & c & 36 & $(4,5)$ & 45 & $(5,5)$ & 18 & $(4,3)$ & c & c \\
\hline & A tiempo completo & 4 & $(0,9)$ & 28 & $(2,2)$ & 54 & $(2,3)$ & 14 & $(1,7)$ & 28 & $(2,3)$ & 47 & $(2,9)$ & 23 & $(2,6)$ & 2 & $(0,9)$ \\
\hline Dinamarca & A tiempo parcial & c & c & c & c & c & c & c & c & 25 & $(3,5)$ & 45 & $(4,5)$ & 27 & $(3,6)$ & 3 & $(1,2)$ \\
\hline & A tiempo completo & 9 & $(1,2)$ & 27 & $(2,5)$ & 46 & $(2,8)$ & 18 & $(2,2)$ & 17 & $(1,3)$ & 43 & $(1,7)$ & 36 & $(1,8)$ & 4 & $(0,8)$ \\
\hline España & A tiempo parcial & 12 & $(3,4)$ & 33 & $(4,7)$ & 45 & $(4,9)$ & 10 & $(3,8)$ & c & c & c & c & c & c & c & c \\
\hline & A tiempo completo & 18 & $(2,1)$ & 42 & $(2,6)$ & 34 & $(2,2)$ & 7 & $(1,3)$ & 39 & $(3,0)$ & 38 & $(3,1)$ & 21 & $(3,0)$ & 2 & $(1,1)$ \\
\hline Estados Unidos & A tiempo parcial & c & c & c & c & c & c & c & c & c & c & c & c & c & c & c & c \\
\hline & A tiempo completo & 16 & $(1,8)$ & 29 & $(2,8)$ & 37 & $(2,5)$ & 18 & $(2,2)$ & 18 & $(2,4)$ & 34 & $(3,0)$ & 38 & $(2,6)$ & 10 & $(1,4)$ \\
\hline Estonia & A tiempo parcial & c & c & c & c & c & c & c & c & c & c & c & c & c & c & c & c \\
\hline & A tiempo completo & 8 & $(1,2)$ & 28 & $(1,7)$ & 46 & $(2,0)$ & 18 & $(1,8)$ & 15 & $(1,5)$ & 40 & $(2,3)$ & 37 & $(2,3)$ & 7 & $(1,2)$ \\
\hline Finlandia & A tiempo parcial & c & c & c & c & c & c & c & c & 9 & $(3,3)$ & 51 & $(6,3)$ & 32 & $(5,8)$ & 8 & $(3,2)$ \\
\hline & A tiempo completo & 4 & $(1,0)$ & 15 & $(2,1)$ & 42 & $(2,3)$ & 39 & $(1,9)$ & 14 & $(1,6)$ & 38 & $(2,2)$ & 40 & $(2,1)$ & 8 & $(1,1)$ \\
\hline Francia & A tiempo parcial & c & & c & c & c & c & c & $c$ & 36 & $(4,0)$ & 38 & $(4,5)$ & 25 & $(3,9)$ & 2 & $(1,1)$ \\
\hline & A tiempo completo & 9 & $(1,2)$ & 31 & $(1,9)$ & 45 & $(2,3)$ & 15 & $(1,2)$ & 30 & $(1,9)$ & 42 & $(2,1)$ & 25 & $(1,7)$ & 3 & $(0,8)$ \\
\hline Irlanda & A tiempo parcial & 12 & $(3,3)$ & 41 & $(4,6)$ & 38 & $(4,5)$ & 9 & $(3,0)$ & 22 & $(3,9)$ & 43 & $(5,2)$ & 31 & $(5,1)$ & 3 & $(1,5)$ \\
\hline & A tiempo completo & 8 & $(1,2)$ & 31 & $(2,2)$ & 45 & $(2,4)$ & 16 & $(2,1)$ & 24 & $(3,6)$ & 41 & $(4,3)$ & 31 & $(3,1)$ & 4 & $(1,9)$ \\
\hline Italia & A tiempo parcial & c & c & c & c & c & c & c & c & c & c & c & c & c & c & c & c \\
\hline & A tiempo completo & 20 & $(2,8)$ & 35 & $(3,3)$ & 38 & $(3,3)$ & 7 & $(1,6)$ & 35 & $(4,8)$ & 43 & $(5,3)$ & 21 & $(3,8)$ & 2 & $(1,1)$ \\
\hline Japón & A tiempo parcial & c & c & c & c & c & c & c & c & 15 & $(3,1)$ & 36 & $(4,0)$ & 40 & $(4,2)$ & 9 & $(2,3)$ \\
\hline & A tiempo completo & 2 & $(0,7)$ & 12 & $(1,7)$ & 53 & $(2,3)$ & 33 & $(2,4)$ & 11 & $(1,7)$ & 36 & $(2,8)$ & 43 & $(2,8)$ & 10 & $(1,7)$ \\
\hline Noruega & A tiempo parcial & 18 & $(4,2)$ & 20 & $(4,7)$ & 43 & $(5,6)$ & 19 & $(4,1)$ & 24 & $(4,7)$ & 46 & $(5,4)$ & 27 & $(5,2)$ & 3 & $(2,0)$ \\
\hline & A tiempo completo & 9 & $(1,3)$ & 20 & $(2,0)$ & 48 & $(2,6)$ & 24 & $(2,1)$ & 12 & $(1,9)$ & 40 & $(3,1)$ & 41 & $(2,7)$ & 7 & $(1,4)$ \\
\hline Países Bajos & A tiempo parcial & 8 & $(2,4)$ & 21 & $(3,8)$ & 46 & $(4,8)$ & 25 & $(3,6)$ & 19 & $(2,9)$ & 39 & $(3,8)$ & 36 & $(4,0)$ & 5 & $(2,0)$ \\
\hline & A tiempo completo & 5 & $(1,2)$ & 17 & $(2,0)$ & 47 & $(3,1)$ & 32 & $(3,3)$ & 16 & $(2,7)$ & 34 & $(3,6)$ & 40 & $(3,0)$ & 10 & $(2,1)$ \\
\hline Polonia & A tiempo parcial & 6 & $(3,5)$ & 30 & $(5,7)$ & 48 & $(7,5)$ & 16 & $(5,3)$ & c & c & c & c & c & c & c & c \\
\hline & A tiempo completo & 12 & $(1,5)$ & 33 & $(2,8)$ & 38 & $(2,7)$ & 16 & $(1,6)$ & 20 & $(2,5)$ & 42 & $(3,9)$ & 32 & $(3,5)$ & 6 & $(2,1)$ \\
\hline República Checa & $\begin{array}{l}\text { A tiempo parcial } \\
\text { A tiempo complet }\end{array}$ & $\begin{array}{l}c \\
6\end{array}$ & $\begin{array}{r}c \\
(14)\end{array}$ & $\begin{array}{r}c \\
26\end{array}$ & c & $\begin{array}{c}c \\
51\end{array}$ & c & $\begin{array}{c}c \\
16\end{array}$ & $\begin{array}{cc}c \\
0\end{array}$ & $c^{c}$ & $\begin{array}{r}c \\
(27)\end{array}$ & c & $\begin{array}{r}c \\
(53)\end{array}$ & $\begin{array}{c}c \\
37\end{array}$ & c & $\begin{array}{l}c \\
6\end{array}$ & c \\
\hline República Eslovaca & A tiempo parcial & c & c & c & c & c & c & c & c & 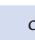 & c & c & c & c & c & c & c \\
\hline & A tiempo completo & 6 & $(1,1)$ & 30 & $(2,1)$ & 52 & $(2,3)$ & 12 & $(1,7)$ & 11 & $(2,1)$ & 41 & $(3,4)$ & 44 & $(2,9)$ & 4 & $(1,2)$ \\
\hline Suecia & $\begin{array}{l}\text { A tiempo parcial } \\
\text { A tiempo completo }\end{array}$ & $\begin{array}{l}\text { c } \\
6\end{array}$ & $\begin{array}{r}{ }^{c} \\
(1,2)\end{array}$ & $\begin{array}{r}c \\
20\end{array}$ & $\begin{array}{r}c \\
(2,1)\end{array}$ & $\begin{array}{r}c \\
45\end{array}$ & $\begin{array}{r}{ }^{c} \\
(2,6)\end{array}$ & $\begin{array}{r}c \\
28\end{array}$ & $\begin{array}{r}{ }^{c} \\
(2,2)\end{array}$ & $\begin{array}{r}c \\
13\end{array}$ & $\begin{array}{r}c \\
(1,5)\end{array}$ & $\begin{array}{r}c \\
36\end{array}$ & $\begin{array}{r}c \\
(2,8)\end{array}$ & $\begin{array}{r}c \\
41\end{array}$ & $\begin{array}{r}{ }^{c} \\
(2,9)\end{array}$ & $\begin{array}{l}\text { c } \\
9\end{array}$ & $\begin{array}{r}c \\
(1,5)\end{array}$ \\
\hline Entidades subnacionales & & & & & & & & & & & & & & & & & \\
\hline Flandes (Bélgica) & A tiempo parcial & c & c & c & c & c & c & c & c & 20 & $(4,7)$ & 46 & $(6,3)$ & 28 & $(5,4)$ & 5 & $(3,2)$ \\
\hline & A tiempo com & 5 & $(1,0)$ & 22 & $(2,1)$ & 49 & $(2,8)$ & 24 & $(2,3)$ & 18 & $(2,7)$ & 37 & $(3,4)$ & 37 & $(3,6)$ & 8 & $(1,9)$ \\
\hline Inglaterra (Reino Unido) & A tiempo parcial & 17 & $(4,3)$ & 29 & $(4,7)$ & 38 & $(5,0)$ & 16 & $(4,2)$ & 16 & $(3,6)$ & 36 & $(5,9)$ & 39 & $(4,8)$ & 9 & $(3,4)$ \\
\hline & A tiempo completo & 8 & $(1,6)$ & 28 & $(2,4)$ & 42 & $(2,7)$ & 21 & $(2,1)$ & 17 & $(3,2)$ & 38 & $(3,4)$ & 33 & $(3,6)$ & 12 & $(2,4)$ \\
\hline Inglaterra/Irlanda del & A tiempo parcial & 17 & $(4,1)$ & 29 & $(4,7)$ & 38 & $(4,9)$ & 16 & $(4,1)$ & 16 & $(3,5)$ & 37 & $(5,8)$ & 39 & $(4,7)$ & 9 & $(3,4)$ \\
\hline Norte (Reino Unido) & A tiempo completo & 8 & $(1,5)$ & 28 & $(2,4)$ & 43 & $(2,6)$ & 21 & $(2,1)$ & 17 & $(3,2)$ & 38 & $(3,3)$ & 33 & $(3,5)$ & 12 & $(2,3)$ \\
\hline Irla & A tiempo parcial & c & & c & c & c & c & c & & $\mathrm{c}$ & & c & & c & c & c & c \\
\hline (Reino Unido) & A tiempo completo & 9 & $(2,5)$ & 28 & $(3,8)$ & 46 & $(3,7)$ & 17 & $(2,2)$ & 20 & $(4,7)$ & 38 & $(5,0)$ & 32 & $(4,5)$ & 9 & $(2,7)$ \\
\hline Media & A tiempo parcial & 12 & $(1,1)$ & 28 & $(1,4)$ & 43 & $(1,7)$ & 17 & $(1,3)$ & 21 & $(1,1)$ & 42 & $(1,5)$ & 32 & $(1,3)$ & 6 & $(0,7)$ \\
\hline & A tiempo completo & 9 & $(0,3)$ & 26 & $(0,5)$ & 45 & $(0,6)$ & 20 & $(0,4)$ & 19 & $(0,5)$ & 40 & $(0,7)$ & 34 & $(0,6)$ & 7 & $(0,3)$ \\
\hline
\end{tabular}

\begin{tabular}{|c|c|c|c|c|c|c|c|c|c|c|c|c|c|c|c|c|c|}
\hline 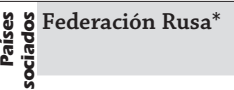 & \begin{tabular}{|l|} 
A tiempo parcial \\
A tiempo completo
\end{tabular} & $\begin{array}{r}c \\
12\end{array}$ & $\begin{array}{r}c \\
(2,2)\end{array}$ & $\begin{array}{r}c \\
34\end{array}$ & $\begin{array}{r} \\
c \\
(3,9)\end{array}$ & $\begin{array}{r}c \\
44\end{array}$ & $\begin{array}{r} \\
(3,8)\end{array}$ & $\begin{array}{r}{ }^{c} \\
10\end{array}$ & $\begin{array}{r}c \\
(2,4)\end{array}$ & $\begin{array}{l}c \\
8\end{array}$ & $\begin{array}{r}{ }^{c} \\
(3,2)\end{array}$ & $\begin{array}{r}{ }^{c} \\
34\end{array}$ & $\begin{array}{r}c \\
(6,8)\end{array}$ & $\begin{array}{r}c \\
44\end{array}$ & $\begin{array}{r}c \\
(7,2)\end{array}$ & $\begin{array}{r}c \\
13\end{array}$ & $\begin{array}{r}c \\
(4,1)\end{array}$ \\
\hline
\end{tabular}

* Para los datos de Federación Rusa, véase nota en la sección de Metodología.

Nota: Las columnas que muestran datos referentes a los grupos de edad de 35 a 44 años, de 45 a 54 años y de 25 a 65 años están disponibles en Internet (véase StatLink más abajo).

Fuente: OCDE. Encuesta sobre las Competencias de los Adultos (PIAAC) (2012). PIAAC se refiere al Programa para la Evaluación Internacional de las Competencias de los Adultos de la OCDE. Para ver notas, consulte Anexo 3 (www.oecd.org/edu/eag.htm).

Para obtener más información acerca de los símbolos utilizados en lugar de los datos que faltan, consulte la Guía del lector.

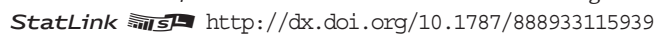




\section{¿CUÁLES SON LAS VENTAJAS DE LA EDUCACIÓN EN LOS INGRESOS?}

- En todos los países de la OCDE, los adultos con educación terciaria ganan más que los adultos con educación secundaria superior o postsecundaria no terciaria, y estos, a su vez, ganan más que los adultos sin educación secundaria superior.

- En los países de la OCDE, en comparación con los adultos que tienen educación secundaria superior e ingresos laborales, aquellos sin esta cualificación ganan alrededor del $20 \%$ menos, los que tienen educación postsecundaria no terciaria alrededor del $10 \%$ más, los que tienen educación terciaria de tipo B (orientación profesional) un $30 \%$ más y los que tienen educación terciaria de tipo A (orientación académica) o investigación avanzada ganan un $70 \%$ más.

- En los países de la OCDE, una mujer con educación terciaria gana alrededor del $75 \%$ de lo que gana un hombre con un nivel educativo similar. Solo en Bélgica, Eslovenia, España y Turquía los ingresos de las mujeres con educación terciaria representan el $80 \%$ o más de los ingresos de los hombres. En Brasil, Chile y Hungría, las mujeres con una titulación terciaria ganan un $65 \%$ o menos de lo que ganan los hombres con el mismo nivel educativo.

- Como media, un graduado en educación terciaria con un rendimiento de Nivel 4 o 5 en comprensión lectora, según la Encuesta sobre las Competencias de los Adultos (PIAAC), gana un $45 \%$ más que un adulto con un nivel similar de educación con un rendimiento de Nivel 1 o inferior en comprensión lectora; en los adultos con educación secundaria superior, hay una diferencia de ingresos de alrededor del $30 \%$ entre aquellos con una competencia lectora elevada y aquellos con una competencia baja.

\section{Gráfico A6.1. Ingresos relativos de los trabajadores, por nivel educativo alcanzado y sexo (2012)}

Personas de 25 a 65 años con ingresos laborales; educación secundaria superior = 100

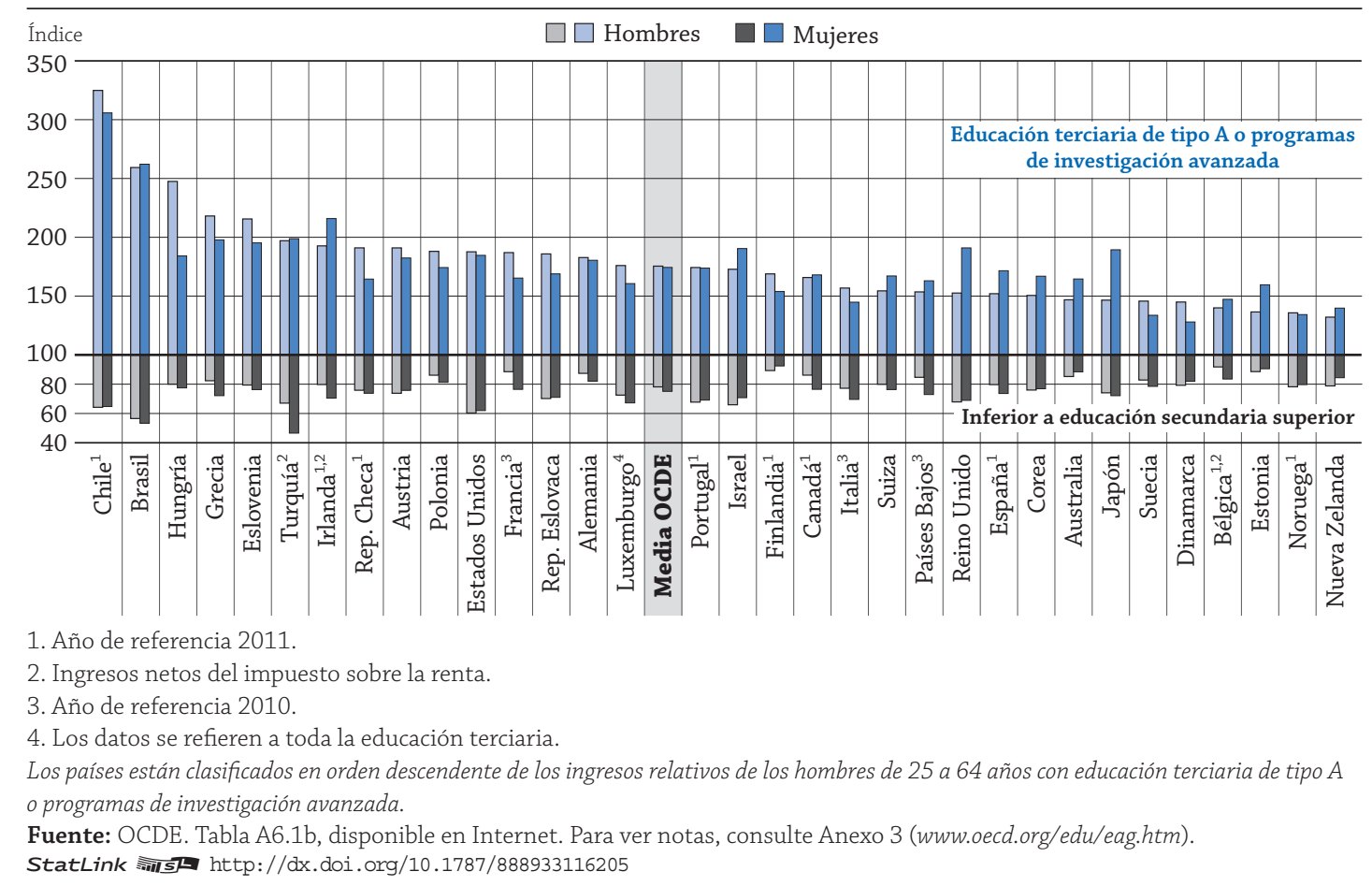

\section{Contexto}

Aun cuando tener un mejor empleo es solo uno de los muchos resultados sociales e individuales positivos de alcanzar una cualificación superior, los datos indican que un nivel superior de educación suele traducirse en una mayor probabilidad de empleo (véase Indicador A5) e ingresos más elevados. De hecho, en todos los países de la OCDE de los que se dispone de información, cuanto mayor es el nivel de educación, mayores son los ingresos relativos. Esto también es cierto para los niveles de competencias: según la Encuesta sobre las Competencias de los Adultos, un producto del Programa para la Evaluación Interna- 
cional de las Competencias de los Adultos (PIAAC) de la OCDE, las personas con una elevada comprensión lectora manifiestan contar con los salarios más altos, mientras que aquellas con un bajo dominio en competencias generalmente declaran ingresos más bajos.

El potencial de obtener mayores ingresos y que dichos ingresos aumenten con el tiempo, junto con otros beneficios sociales, es un incentivo para que las personas decidan continuar con su educación y formación; esto es así aunque varíen las recompensas económicas, según el ámbito de estudio elegido (véase Cuadro A6.1 de Panorama de la educación 2013, OECD [2013]). Mientras que los ingresos de las personas con un nivel educativo mayor tienden a incrementarse con la edad, los ingresos relativos de las personas con una educación inferior a la secundaria superior tienden a disminuir. «Los ingresos relativos» son los porcentajes de los ingresos de los adultos con niveles educativos distintos a la educación secundaria superior en relación con los ingresos de aquellos con educación secundaria superior.

Las variaciones de los ingresos relativos entre países reflejan diversos factores, incluyendo la demanda de competencias en el mercado laboral, la oferta de trabajadores con diversos niveles educativos, la legislación sobre el salario mínimo, el poder de los sindicatos, la cobertura de los convenios colectivos, la incidencia relativa del trabajo a tiempo parcial o estacional y la composición de edad de la población activa.

La información de este indicador muestra que las ventajas en cuanto a ingresos aumentan o disminuyen según la educación, edad, sexo y dominio de competencias. Cada uno de estos factores parece influir, en distinta medida, en las ventajas en cuanto a ingresos de las personas. Cuanto mayor es la cualificación obtenida, mejor posicionadas están las personas para ganar un salario más elevado y conseguir aumentos salariales con el tiempo. Además, un elevado dominio de competencias parece recompensar en el mercado laboral, no solo respecto a la tasa de empleo, sino también a los ingresos medios. Sin embargo, en muchos países persisten las diferencias de ingresos por sexo, con independencia del nivel de educación o competencias.

\section{Otros resultados}

- Solo el 10\% de las personas con educación terciaria están en la categoría de ingresos bajos y, en general, las personas con educación terciaria tienen considerablemente más probabilidades de ganar el doble que un trabajador medio. Alrededor del $30 \%$ de los trabajadores con educación terciaria ganan el doble que un trabajador medio y tienen unas probabilidades considerablemente menores de estar en la categoría de bajos ingresos que aquellos con una educación inferior a la secundaria superior (el 3\% gana más del doble de la mediana y el 30\% gana igual o menos de la mitad de la mediana).

- En Brasil, Estados Unidos y Turquía, los adultos sin educación secundaria superior son los más penalizados en sus salarios, ya que ganan, en el mejor caso, un $35 \%$ menos que las personas con dicha cualificación. En Brasil, Chile y Hungría, quienes tienen educación terciaria son, comparativamente, los mejor retribuidos, ganando más del doble que una persona con educación secundaria superior.

- Alrededor del $65 \%$ de los no estudiantes de 15 a 24 años tienen ingresos laborales, mientras que menos de la mitad de los estudiantes los tienen (aproximadamente un 40\%). En los países de la OCDE, alrededor del $50 \%$ de los jóvenes de 15 a 24 años cuentan con ingresos laborales.

- Las mujeres con educación terciaria o inferior a educación secundaria superior de 55 a 64 años pueden esperar ganar alrededor de un $75 \%$ de lo que ganan los hombres de edades y niveles educativos similares, mientras que las mujeres de esa edad con educación secundaria superior pueden esperar ganar alrededor de un $80 \%$ de lo que ganan los hombres de esa misma edad y nivel educativo.

\section{Tendencias}

En todos los países de la OCDE, los adultos con educación terciaria ganan considerablemente más que los adultos con una educación inferior a secundaria superior. Entre 2005 y 2012, en los países con datos disponibles para ambos años, los ingresos relativos de los adultos sin educación secundaria superior permanecieron estables o disminuyeron en algún grado, en comparación con los ingresos de los adultos con educación secundaria superior. Además, en la mayoría de estos países, los ingresos de los adultos con educación terciaria en comparación con los ingresos de los adultos con educación secundaria superior aumentaron o permanecieron estables durante ese mismo periodo; las únicas excepciones son Estados Unidos y Hungría.

Estas diferencias sugieren que la demanda de competencias de mayor nivel y actualizadas ha crecido, y que las personas con un bajo nivel de cualificación son incluso más vulnerables en la actualidad. 


\section{Anălisis}

\section{Nivel educativo alcanzado e ingresos relativos}

Cuanto mayor es el nivel de educación, mayores son los ingresos relativos. Los «ingresos relativos» se refieren a los ingresos de los adultos con rentas laborales que han alcanzado un nivel educativo distinto al de educación secundaria superior, en relación con los ingresos de quienes tienen una educación secundaria superior.

En todos los países de la OCDE, los adultos con educación terciaria ganan más que los adultos con educación secundaria superior, quienes a su vez ganan más que los adultos con una educación inferior a secundaria superior. En muchos países, la educación secundaria superior es el nivel a partir del cual más estudios y formación suponen ingresos relativos elevados. Por tanto, la educación secundaria superior puede considerarse la referencia con la cual se pueden medir los ingresos relacionados con el nivel educativo alcanzado. Dado que los costes de la inversión privada en los niveles posteriores a la educación secundaria superior aumentan considerablemente en la mayoría de los países, una ventaja de ingresos elevados es un incentivo importante para que las personas inviertan tiempo y dinero en educación superior (Tabla A6.1a).

La diferencia de ingresos entre los adultos con educación terciaria y los que tienen solo secundaria superior es generalmente más pronunciada que la diferencia entre las personas con secundaria superior y las que no han alcanzado ese nivel. En todos los países de la OCDE, en comparación con los adultos que tienen ingresos laborales y educación secundaria superior, aquellos sin esta cualificación ganan un $20 \%$ menos, aquellos con educación postsecundaria no terciaria un $10 \%$ más, aquellos con educación terciaria de tipo B un $30 \%$ más y aquellos con educación terciaria de tipo A o un programa de investigación avanzada ganan un $70 \%$ más.

Brasil, Chile, Estados Unidos, Hungría y Turquía muestran las mayores diferencias en ingresos según el nivel educativo. En Brasil, Estados Unidos y Turquía, quienes no han alcanzado la educación secundaria superior son los más penalizados, ya que ganan como mínimo un 35\% menos que las personas con esta cualificación. En Brasil, Chile y Hungría, las personas con educación terciaria obtienen las mayores recompensas, en comparación con las personas con un menor nivel educativo, ya que ganan más del doble que una persona con educación secundaria superior (Tabla A6.1a).

\section{Ingresos relativos, por sexo}

En los países de la OCDE, los ingresos relativos se ven afectados en distinta medida por el nivel educativo alcanzado. El Gráfico A6.1 muestra que, como media en los países de la OCDE, no existen grandes diferencias entre hombres y mujeres en los ingresos relativos procedentes de rentas laborales según el nivel educativo. Un hombre o una mujer con educación terciaria (incluyendo solo los niveles CINE 5A o 6 en el Gráfico A6.1) gana alrededor de un 70\% más que una persona del mismo sexo con educación secundaria superior. No obstante, existen grandes diferencias entre los países. En Brasil y Chile (tanto hombres como mujeres), Eslovenia (hombres), Grecia, Hungría e Irlanda (mujeres), los adultos con educación terciaria ganan más del doble que aquellos con solo educación secundaria superior (Tabla A6.1b, disponible en Internet).

En los adultos con educación terciaria, las diferencias de los ingresos relativos (es decir, en comparación con los ingresos de los adultos con educación secundaria superior) entre hombres y mujeres varían entre los países. En Australia, Corea, España, Estonia, Irlanda, Israel, Japón, Reino Unido y Suiza, los ingresos relativos de las mujeres son más de 10 puntos porcentuales mayores que los de los hombres, mientras que en Chile, Dinamarca, Eslovenia, Finlandia, Francia, Grecia, Hungría, Italia, Luxemburgo, Polonia, República Checa, República Eslovaca y Suecia, los ingresos de los hombres son más de 10 puntos porcentuales mayores que los de las mujeres. En ambos casos, las diferencias son relativas a los ingresos de personas del mismo sexo con educación secundaria superior que cuentan con rentas laborales. En las comparaciones por sexo, hay que tener en cuenta que puede haber grandes diferencias entre ambos en la proporción de personas con ingresos laborales (Tabla A6.1b, disponible en Internet).

\section{Ingresos relativos, por edad}

Un mayor nivel educativo está asociado a unos ingresos más elevados a lo largo de la vida laboral. Como media en los países de la OCDE, los ingresos aumentan con el nivel de educación alcanzado, pero este incremento es especialmente notable en los trabajadores mayores. Las personas con un nivel mayor de educación tienen más probabilidades de estar empleadas y de seguir empleadas, así como de ampliar su experiencia laboral.

En el Gráfico A6.2, la diferencia de los ingresos relativos de los trabajadores mayores (de 55 a 64 años) se resta de la diferencia de los ingresos relativos de los trabajadores más jóvenes (de 25 a 34 años). En ambos casos, las diferencias son en relación con los ingresos de los miembros del mismo grupo de edad con educación secundaria superior e ingresos laborales. El resultado es la diferencia porcentual de los ingresos relativos entre los dos grupos de edad. To- 
mando la media de la OCDE como ejemplo, los adultos jóvenes con un nivel de educación inferior a la secundaria superior ganan alrededor de un $80 \%$ de lo que ganan los adultos jóvenes con educación secundaria superior. Esta proporción es del $70 \%$ para los adultos mayores (Tabla A6.1a). En el Gráfico A6.2 se muestra la diferencia entre estos dos grupos de edad, que es de unos 10 puntos porcentuales. Para los trabajadores con educación terciaria de tipo A o una cualificación de investigación avanzada (nivel CINE 5A o 6), la diferencia de los ingresos relativos entre los dos grupos de edad se calcula de la misma manera, con un promedio de alrededor de 35 puntos porcentuales.

Los ingresos relativos de los adultos mayores con educación terciaria son más elevados que los de los adultos más jóvenes en la mayoría de los países de la OCDE y el G20, con excepción de Irlanda. Como media, la diferencia entre los dos grupos es de hasta 35 puntos porcentuales. Para quienes tienen solo un nivel educativo inferior a secundaria superior, la desventaja de los ingresos relativos aumenta para los trabajadores mayores en todos los países salvo Alemania, Dinamarca, Finlandia, Noruega, Reino Unido, República Eslovaca y Suecia. El aumento de esta desventaja no es tan marcado como el aumento de la ventaja de ingresos para quienes tienen educación terciaria, lo que indica que la educación terciaria es clave para la obtención de unos ingresos más elevados a una edad más avanzada (Tabla A6.1a).

\section{Gráfico A6.2. Diferencia de los ingresos relativos entre trabajadores mayores y más jóvenes, por nivel educativo alcanzado (2012)}

Personas de 55 a 64 años y de 25 a 34 años con ingresos laborales; diferencia porcentual, ingresos relativos a trabajadores con educación secundaria superior

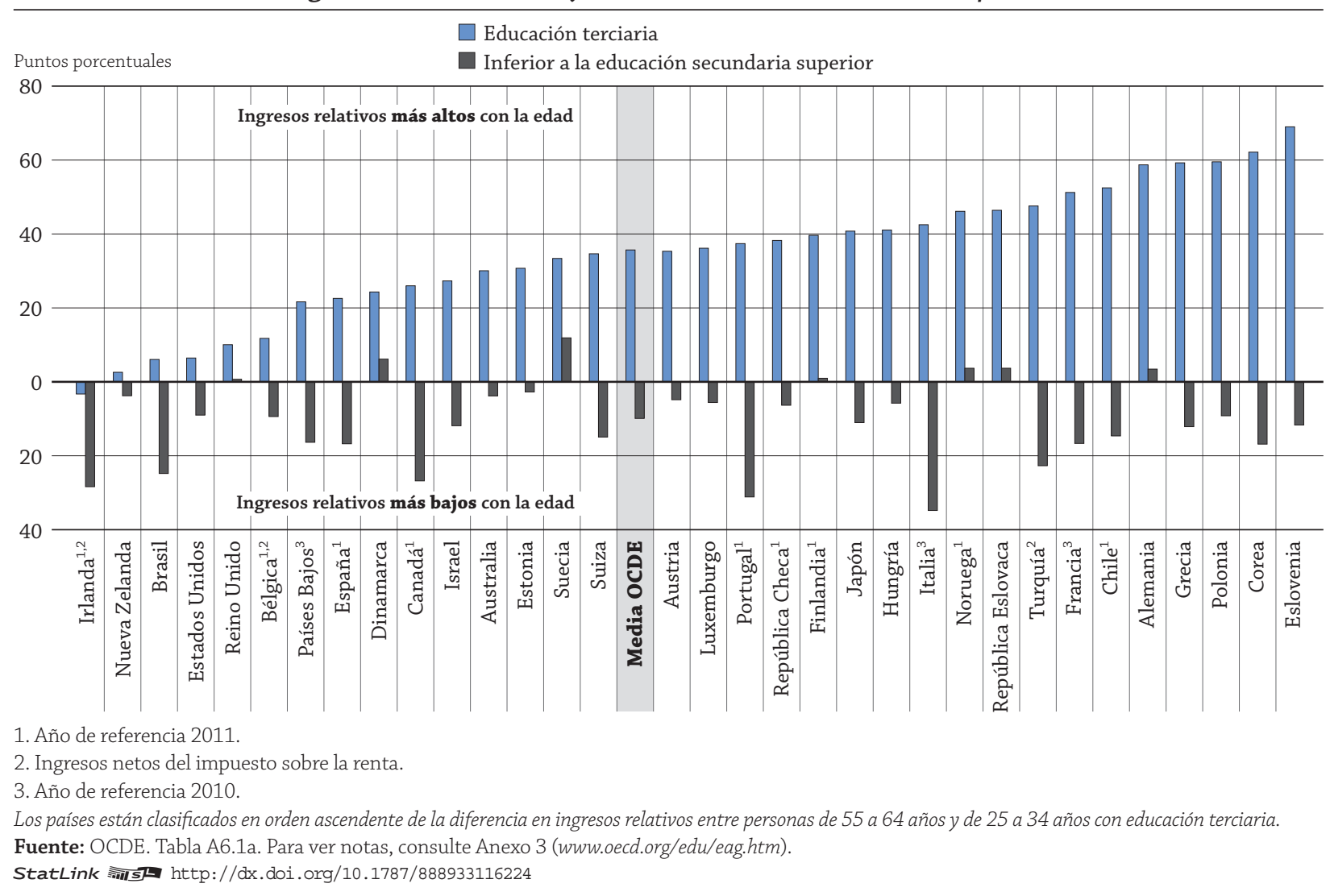

\section{Tendencias de los ingresos relativos, por nivel de educación alcanzado}

Entre 2005 y 2012, en los países con datos disponibles para ambos años, los ingresos relativos de los adultos con un nivel de educación inferior a la secundaria superior y con ingresos laborales han permanecido estables o han disminuido en cierta medida, en comparación con los ingresos de los adultos con educación secundaria superior. En la mayoría de los países, salvo Estados Unidos y Hungría, los ingresos relativos de adultos con educación terciaria aumentaron entre 2005 y 2012. No obstante, los ingresos relativos han experimentado grandes fluctuaciones en varios países. Además, los datos sobre las tendencias de los ingresos dependen en cada país de los cambios de los ingresos de las personas con cualificaciones de educación secundaria superior. Por este motivo es difícil evaluar la evolución media de los ingresos relativos en los distintos niveles de educación a lo largo de los años (véase la sección de Metodología para más información) (Tabla A6.2a). 


\section{Gráfico A6.3. Diferencias en los ingresos relativos de los trabajadores, por nivel educativo alcanzado (2012) \\ Personas de 25 a 64 años con ingresos laborales}

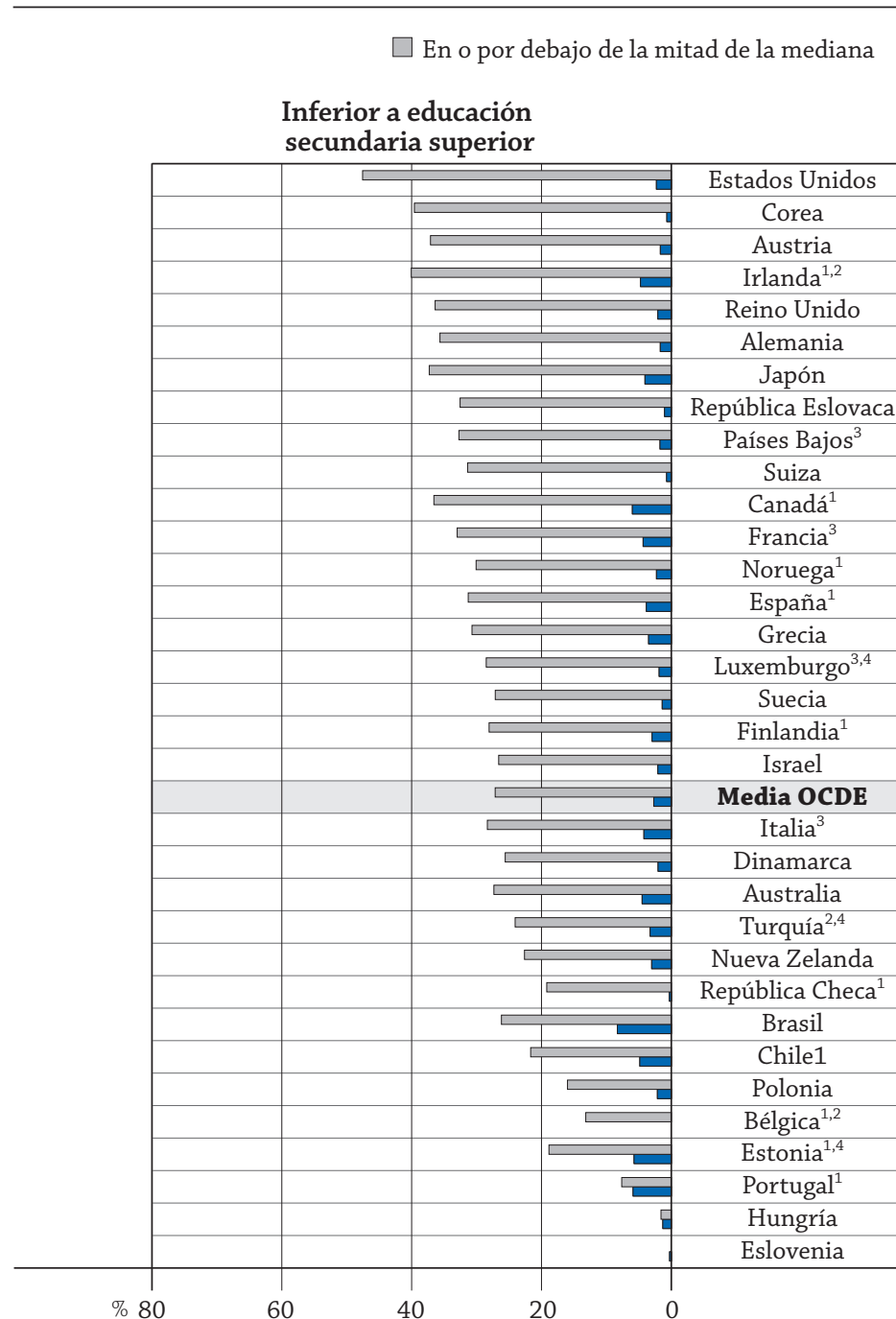

Más de dos veces la mediana

Educación terciaria de tipo A o programas de investigación avanzada secundaria superior

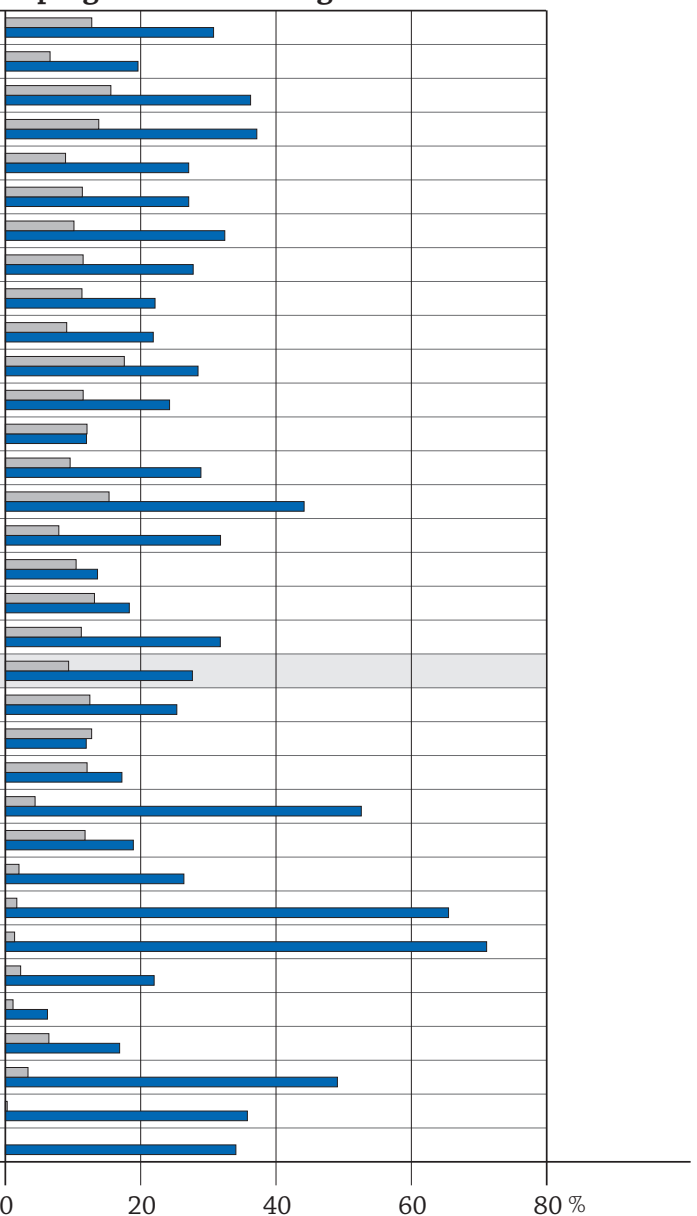

1. Año de referencia 2011.

2. Ingresos netos del impuesto sobre la renta.

3. Año de referencia 2010.

4. Los datos se refieren a toda la educación terciaria.

Los países están clasificados en orden descendente de la diferencia en la proporción de personas de 25 a 64 años en o por debajo de la mitad de la mediana y la proporción de la población que gana más de dos veces la mediana, con una educación inferior a la secundaria superior.

Fuente: OCDE. Tabla A6.4, disponible en Internet. Para ver notas, consulte Anexo 3 (www.oecd.org/edu/eag.htm).

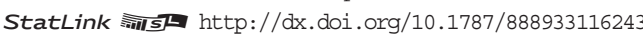

\section{Diferencias de ingresos entre hombres y mujeres, por nivel de educación alcanzado}

Con independencia del nivel de educación, la diferencia de ingresos por sexo persiste. Los datos disponibles sobre trabajadores a tiempo completo y año completo, muestran que la mayor brecha entre los sexos en los ingresos se encuentra en los trabajadores con educación terciaria. En los países de la OCDE, una mujer con educación terciaria gana un $75 \%$ de lo que gana un hombre con educación terciaria. Solo en Bélgica, Eslovenia, España y Turquía los ingresos de las mujeres con educación terciaria representan el $80 \%$ o más de los ingresos de los hombres. En Brasil, Chile y Hungría, las mujeres con una titulación terciaria ganan un $65 \%$ o menos de lo que ganan los hombres con el mismo nivel educativo (Tabla A6.3a).

Como media, solo las mujeres con educación secundaria superior o postsecundaria no terciaria que trabajan a tiempo completo aumentan con la edad sus ingresos en comparación con los de los hombres. Las mujeres con educación 
terciaria y las mujeres con un nivel inferior al de educación secundaria superior no registran con la edad un aumento de ingresos, en relación con los de los hombres. Las mujeres con educación terciaria o las mujeres con un nivel inferior al de secundaria de 55 a 64 años pueden esperar ganar alrededor de un $75 \%$ de lo que ganan los hombres de edad y nivel educativo similar, mientras que las mujeres de esa edad con una educación secundaria superior pueden esperar ganar alrededor de un $80 \%$ de lo que ganan los hombres de esa misma edad y nivel educativo (Tabla A6.3a).

\section{Distribución de ingresos según el nivel de educación alcanzado}

Los datos sobre la distribución de los ingresos en los grupos con distintos niveles de educación pueden mostrar cuánto se acercan los ingresos a la mediana del país. Además de ofrecer información sobre la equidad de los ingresos, estos datos indican los riesgos asociados a la inversión en educación, ya que el riesgo normalmente se mide por la variación de los resultados. Los datos sobre la distribución de los ingresos (Tabla A6.4, disponible en Internet) incluyen ingresos de todos los individuos empleados, y esto limita el análisis, ya que las horas trabajadas afectan a los ingresos, en general, y a su distribución, en particular (véase la sección de Metodología para más información).

Para las personas con rentas laborales, las cinco categorías de ingresos referidas oscilan entre «igual o inferior a la mitad de la mediana» $\mathrm{y}$ «más del doble de la mediana», mientras que la proporción de personas sin ingresos laborales se muestra en una columna distinta. En el Gráfico A6.3 se contrastan los resultados de las personas que no tienen educación secundaria superior con los de las personas que han completado la educación terciaria de tipo A o programas de investigación avanzada (CINE 5A o 6), comparando la proporción de perceptores de ingresos en o por debajo de la mitad de la mediana con los que ganan más del doble de la mediana. Como es de esperar, existe una gran diferencia entre estas dos categorías educativas; como media, las personas con educación terciaria tienen considerablemente más probabilidades de ganar el doble que el trabajador medio (alrededor de un $30 \%$ ) y sustancialmente menos probabilidades de estar en la categoría de bajos ingresos (alrededor del 10\%) que aquellas que no han completado la educación secundaria superior (el $3 \%$ ganan más del doble de la mediana y aproximadamente el $30 \%$ ganan igual o menos de la mitad de la mediana) (Tabla A6.4, disponible en Internet).

Existen, no obstante, algunas diferencias notables en los resultados de las personas con educación terciaria según el país. En Brasil y Chile, el $65 \%$ o más de las personas con educación terciaria de tipo A o un programa de investigación avanzada ganan el doble que el trabajador medio; en Austria, Canadá y Grecia, el 15\% o más de las personas con este grado se encuentran en la categoría de los ingresos más bajos (en o por debajo de la mitad de la mediana); y en Dinamarca y Noruega, una persona con este grado tiene aproximadamente las mismas probabilidades de estar en la categoría de ingresos mínimos o máximos (Gráfico A6.3).

En todos los países, las personas que permanecen con una baja cualificación toda su vida laboral (inferior a educación secundaria superior) suelen enfrentarse a grandes desventajas de ingresos. Como media en los países de la OCDE, menos del $5 \%$ de aquellos con un nivel de educación inferior a la secundaria superior ganan el doble de la mediana nacional. Solo en Brasil, Canadá, Estonia y Portugal esta proporción es superior al $5 \%$. Como media, más del 25\% de las personas que no han completado la educación secundaria superior ganan menos de la mitad de la mediana nacional; en Estados Unidos, más del 45\% de este grupo lo hace (Gráfico A6.3).

\section{Ingresos relativos de los estudiantes}

En los países de la OCDE, alrededor del $50 \%$ de los jóvenes de 15 a 24 años cuentan con ingresos laborales. En este grupo de edad, una mayoría de no estudiantes (alrededor del $65 \%$ ) tienen ingresos laborales, mientras que menos de la mitad de los estudiantes tienen tales ingresos (alrededor del 40\%). En Bélgica, Chile, España, Grecia e Italia, menos del 10\% de los estudiantes de 15 a 24 años tienen ingresos laborales. Es importante considerar que en algunos países, como Suiza, una proporción de estudiantes matriculados en educación secundaria superior cuentan con ingresos debido a contratos de aprendizaje, pero estos estudiantes no se han incluido en los cálculos. Los datos sobre los ingresos de los estudiantes muestran que las mujeres de esta edad tienen una probabilidad de 5 puntos porcentuales mayor de trabajar que sus compañeros masculinos (Tabla A6.5b y Tabla A6.5c, disponible en Internet).

Como media, entre los estudiantes con ingresos laborales, aquellos que han completado la educación secundaria superior o postsecundaria no terciaria tienen unos ingresos mayores que los estudiantes con un nivel inferior a la secundaria superior con ingresos laborales, en comparación con los no estudiantes (Tabla A6.5a).

Estos resultados apoyan la idea generalizada de que los estudios posteriores a la educación obligatoria suponen una pérdida de ingresos, incluso cuando se combinan estudios y trabajo. Esta pérdida de ingresos, junto con las tasas de matrícula y la necesidad de devolver los préstamos, podría desalentar a algunas personas de estudiar mientras están activos en el mercado laboral. 


\section{Ingresos mensuales medios y niveles de comprensión lectora en la Encuesta sobre las Competencias de los Adultos}

Cuanto mayor sea la comprensión lectora, mayores son los ingresos mensuales, según la Encuesta sobre las Competencias de los Adultos. En cambio, las personas con una baja comprensión lectora tienen en general los ingresos mensuales más bajos. El Gráfico A6.4 muestra que en todos los países, los ingresos mensuales medios en dólares estadounidenses son superiores a medida que aumenta tanto el nivel de educación alcanzado como el nivel de comprensión lectora (lado derecho del gráfico). En todos los países con datos disponibles, los ingresos mensuales medios son menores para las personas con un rendimiento igual o inferior al Nivel 1 en comprensión lectora y más altos para las personas con un rendimiento de Nivel 4 o 5 (lado izquierdo del gráfico). Como media en los países, una persona con un nivel de comprensión lectora de 4 o 5 gana un $65 \%$ más que una persona con un Nivel 1 o inferior.

No obstante, la diferencia en los ingresos mensuales medios entre las personas de cada nivel de comprensión lectora de PIAAC varía mucho de un país a otro. A medida que aumenta el nivel de competencia, las diferencias en los retornos oscilan entre menos del $50 \%$ en Dinamarca, Federación Rusa, Finlandia, Italia y Suecia, y más del 100\% en Estados Unidos.

Además, en la sección derecha del gráfico se muestra el impacto medio de las competencias y el nivel educativo alcanzado sobre los ingresos mensuales medios. En todos los niveles de educación combinados, las ventajas de ingresos son mayores en los niveles superiores de competencia. Como media, un graduado de terciaria con un rendimiento de Nivel 4 o 5 en comprensión lectora, según la Encuesta sobre las Competencias de los Adultos, gana un $45 \%$ más

\section{Gráfico A6.4. Ingresos medios mensuales, por nivel de comprensión lectora (2012) Encuesta sobre las Competencias de los Adultos, personas de 25 a 64 años con ingresos laborales} que trabajan a tiempo completo (es decir, 30 horas o más a la semana)

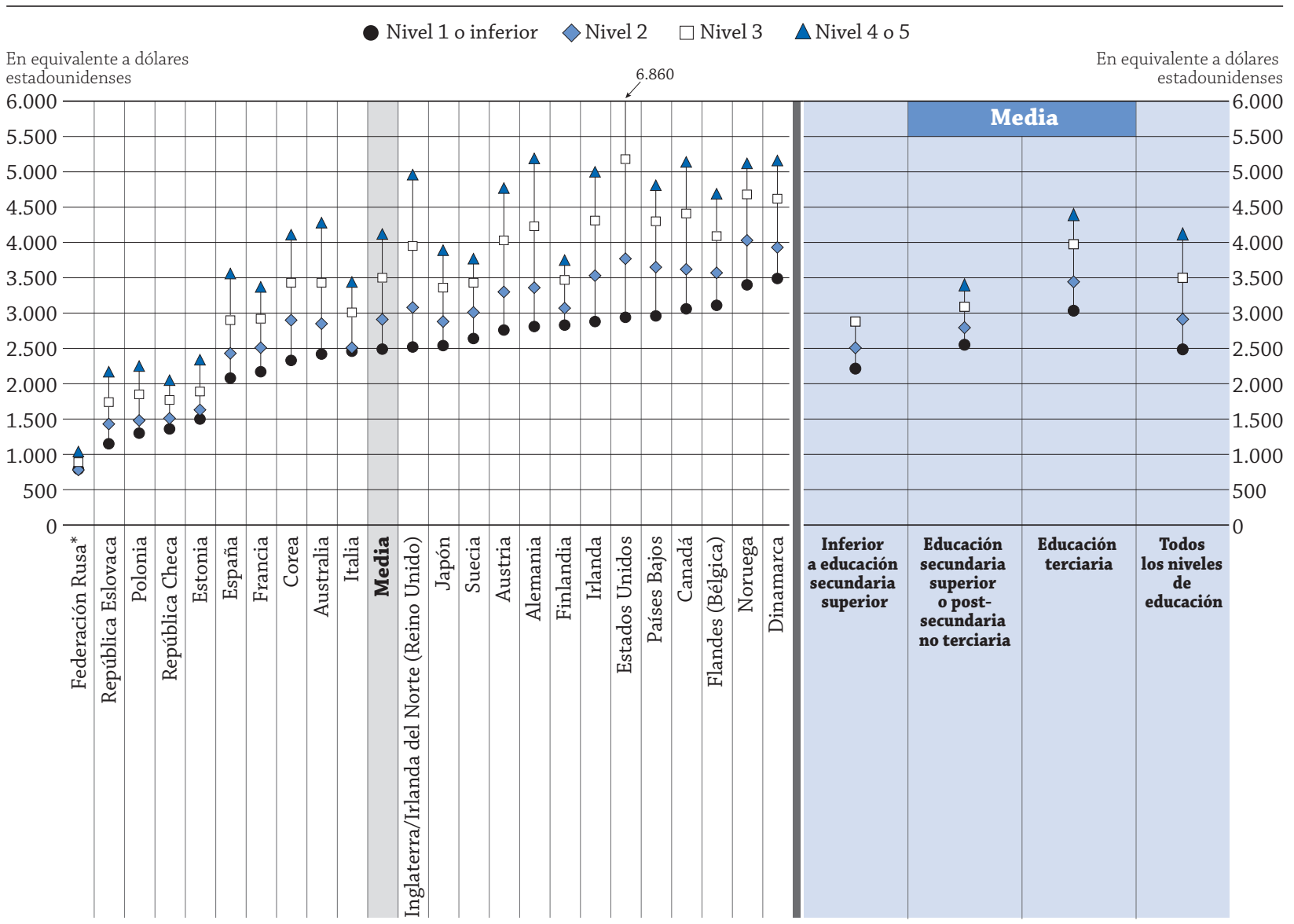

* Para los datos de Federación Rusa, véase nota en la sección de Metodología.

Los países están clasificados en orden ascendente de los ingresos medios mensuales por Nivel 0/1 de comprensión lectora.

Fuente: OCDE. Tabla A6.6a (L). Para ver notas, consulte Anexo 3 (www.oecd.org/edu/eag.htm).

StatLink 젶ㄴ http://dx.doi.org/10.1787/888933116262 
que un adulto con un nivel educativo similar y con un rendimiento de Nivel 1 en comprensión lectora; entre los adultos con educación secundaria superior, la diferencia de ingresos es del $30 \%$ entre los que tienen una elevada competencia lectora y aquellos con una competencia baja.

\section{Definiciones}

Grupos de edad: adultos se refiere a las personas de 25 a 64 años; adultos jóvenes se refiere a las personas de 25 a 34 años; adultos mayores se refiere a las personas de 55 a 64 años. La población en edad laboral es el total de la población de 25 a 64 años.

Niveles de educación: inferior a secundaria superior corresponde a los niveles CINE 0, 1, 2 y $3 C$ programas cortos; secundaria superior o postsecundaria no terciaria corresponde a niveles CINE 3A, 3B, 3C programas largos, y nivel CINE 4; y terciaria corresponde a niveles CINE 5A, 5B y 6. Para una presentación de todos los niveles CINE, véase la Guía del lector al inicio de este libro.

\section{Metodología}

El indicador se basa en dos recopilaciones de datos distintas. Una es la recopilación de datos periódica de la red LSO (siglas en inglés de Mercado Laboral y Resultados Sociales del Aprendizaje) de la OCDE que tiene en cuenta los ingresos de todas las personas con renta laboral durante el periodo de referencia, aunque hayan trabajado a tiempo parcial o parte del año; esta base de datos contiene datos sobre ingresos de estudiantes en comparación con los de no estudiantes. También recoge información sobre los ingresos de las personas que trabajan a tiempo completo y todo el año, para la Tabla A6.3a. La segunda recopilación de datos es la Encuesta sobre las Competencias de los Adultos, para las Tablas A6.6a, b y c y A6.7. Los datos sobre los niveles de destreza en PIAAC se basan en la Encuesta sobre las Competencias de los Adultos (PIAAC) (2012). PIAAC es el Programa para la Evaluación Internacional de las Competencias de los Adultos de la OCDE. Véase Acerca de la Encuesta sobre las Competencias de los Adultos al inicio de esta publicación y Anexo 3 (www.oecd.org/edu/eag.htm) para más información.

\section{Recopilación de datos sobre ingresos regulares}

La recopilación de datos sobre ingresos regulares (utilizada en todas las tablas salvo las Tablas A6.6 y A6.7) ofrece información basada en periodos de referencia anuales, mensuales o semanales, dependiendo del país. La duración del periodo de referencia también varía. Australia, Nueva Zelanda y Reino Unido registran datos sobre los ingresos semanales; Bélgica, Brasil, Chile, Corea, Estonia, Finlandia, Israel (tres meses), Portugal y Suiza registran datos mensuales; y todos los demás países registran datos anuales. Francia registra datos anuales a partir de 2008 y datos mensuales hasta 2007. Los datos sobre los ingresos son antes de impuestos, excepto en Bélgica, Corea y Turquía, donde los ingresos referidos son netos, después del impuesto sobre la renta. Los datos sobre los ingresos de las personas que trabajan a tiempo parcial están excluidos de la recopilación de datos regulares en Eslovenia, Hungría, Portugal y República Checa; y se excluyen los datos sobre ingresos de parte del año en Hungría, Portugal y República Checa. Los ingresos de los trabajadores autónomos se excluyen en muchos países y, en general, no existe un método sencillo y comparable para separar los ingresos del empleo de los retornos del capital invertido en un negocio.

Puesto que los datos de ingresos difieren entre los países de diversas maneras, los resultados deberán interpretarse con cautela. Por ejemplo, en los países que registran ingresos anuales, las diferencias en la incidencia de trabajo estacional entre las personas con distintos niveles de educación tendrán un efecto sobre los ingresos relativos que no se refleja de igual manera en los datos de los países que registran ingresos semanales o mensuales. Además, los datos disponibles en las Tablas A6.2a y b se refieren a los ingresos relativos y, por tanto, deben utilizarse con cautela para evaluar la evolución de los ingresos relativos en los distintos niveles de educación. Para las Tablas A6.5a y b, las diferencias entre los países podrían ser el resultado de diferencias entre las fuentes de datos y la longitud del periodo de referencia. Para más detalles, véase Anexo 3.

La media total (hombres más mujeres, es decir, $\mathrm{H}+\mathrm{M}$ ) de ingresos no es el promedio simple de las cifras de ingresos de hombres y mujeres, sino la media basada en los ingresos de la población total. Esta media global pondera la cifra de ingresos medios por separado para hombres y mujeres según la proporción de hombres y mujeres con los distintos niveles educativos alcanzados.

\section{Recopilación de datos de trabajo a tiempo completo y año completo}

La recopilación de datos de trabajo a tiempo completo y año completo proporciona información para la Tabla A6.3a (diferencias por sexo en los ingresos del trabajo a tiempo completo) y la Tabla A5.6 (diferencias en los ingresos del trabajo a tiempo completo por nivel de educación alcanzado). 
Para la definición de ingresos a tiempo completo (en las Tablas A5.6 y A6.3a), se preguntó a los países si habían aplicado un criterio subjetivo de tiempo completo o un valor umbral del número normal de horas trabajadas a la semana. Bélgica, España, Francia, Italia, Luxemburgo, Portugal, Reino Unido y Suecia informaron que habían aplicado criterios subjetivos de tiempo completo; los demás países definieron la condición de tiempo completo según el número de horas trabajadas a la semana. El umbral fue de 44/45 horas a la semana en Chile, 37 horas a la semana en República Eslovaca, 36 horas en Eslovenia y Hungría, 35 horas en Alemania, Australia, Canadá, Corea, Estados Unidos, Estonia, Israel y Noruega, y 30 horas en Grecia, Nueva Zelanda y República Checa. Los demás países participantes no aplicaron un número mínimo normal de horas de trabajo a tiempo completo. En algunos países, los datos sobre ingresos a tiempo completo durante todo el año se basan en la Encuesta Europea sobre Ingresos y Condiciones de Vida (EU-SILC, por sus siglas en inglés), que utiliza un enfoque subjetivo para establecer el criterio de tiempo completo.

\title{
Encuesta sobre las Competencias de los Adultos
}

Los datos para las Tablas A6.6 y A6.7 proceden de la Encuesta sobre las Competencias de los Adultos, un producto del Programa para la Evaluación Internacional de las Competencias de los Adultos de la OCDE (PIAAC).

«Ingresos mensuales» incluye bonificaciones para los asalariados y trabajadores autónomos, en dólares estadounidenses ajustados por PPA. La distribución salarial se recortó para eliminar los percentiles $1^{\circ}$ y $99^{\circ}$.

Solo se ha tenido en cuenta a las personas que trabajan a tiempo completo; se considera que una persona trabaja a tiempo completo si las horas laborales semanales son iguales a 30 o más.

Nota sobre los datos de Israel

Los datos estadísticos para Israel fueron proporcionados por las autoridades israelíes competentes bajo su responsabilidad. El uso de estos datos por parte de la OCDE se hace sin prejuzgar la situación de los Altos del Golán, Jerusalén Este y los asentamientos israelíes en Cisjordania de acuerdo con los términos del derecho internacional.

Nota sobre los datos de Federación Rusa en la Encuesta sobre las Competencias de los Adultos (PIAAC)

Los lectores deben tener en cuenta que la muestra de Federación Rusa no incluye a la población del área municipal de Moscú. Por tanto, los datos publicados no representan a toda la población de 16 a 65 años residente en Rusia, sino a la población de Rusia excluyendo la población que reside en el área municipal de Moscú. Se puede encontrar información más detallada sobre los datos de la Federación Rusa así como de otros países en el Informe técnico de la Encuesta de las Competencias de los Adultos (OCDE, de próxima publicación).

\section{Referencia}

OECD (2013), Education at a Glance 2013: OECD Indicators, OECD Publishing, París, http://dx.doi.org/10.1787/eag-2013-en. Versión española: Panorama de la educación 2013: Indicadores de la OCDE, Ministerio de Educación, Cultura y Deporte, Santillana, Madrid.

\section{Tablas del Indicador A6}

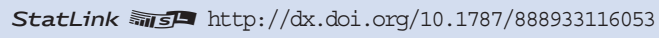

Tabla A6.1a Ingresos relativos de los trabajadores, por nivel educativo alcanzado y grupo de edad (2012)

WEB Tabla A6.1b Ingresos relativos de los trabajadores, por nivel educativo alcanzado, grupo de edad y sexo (2012)

Tabla A6.2a Tendencias de los ingresos relativos de los trabajadores, por nivel educativo alcanzado y sexo $(2000,2005,2010,2011,2012)$

WEB Tabla A6.2b Tendencias de los ingresos relativos de los trabajadores, por nivel educativo alcanzado y sexo (2000-12)

Tabla A6.3a Diferencias de ingresos entre mujeres y hombres trabajadores, por nivel educativo alcanzado y grupo de edad (2012)

Tabla A6.3b Tendencias de las diferencias de ingresos entre mujeres y hombres trabajadores, por nivel educativo alcanzado $(2000,2005,2010,2012)$

WEB Tabla A6.3c

Tendencias de las diferencias de ingresos entre mujeres y hombres trabajadores, por nivel educativo alcanzado (2000-12) 
WEB Tabla A6.4 Distribución de las personas de 25 a 64 años, por sexo, nivel educativo alcanzado y nivel de ingresos relativos a los ingresos medios (2012)

Tabla A6.5a Ingresos relativos de los estudiantes de 15 a 24 años con ingresos laborales, por nivel educativo alcanzado y sexo (2012)

Tabla A6.5b Porcentaje de jóvenes de 15 a 29 años con ingresos laborales entre todos los jóvenes de 15 a 29 años, por grupo de edad y estatus de estudiante (2012)

WEB Tabla A6.5c Porcentaje de jóvenes de 15 a 29 años con ingresos laborales entre todos los jóvenes de 15 a 29 años, por grupo de edad, estatus de estudiante y sexo (2012)

Tabla A6.6a (L) Ingresos medios mensuales de los trabajadores, por nivel educativo alcanzado y nivel de comprensión lectora

WEB Tabla A6.6a (N) Ingresos medios mensuales de los trabajadores, por nivel educativo alcanzado y nivel de competencia matemática (2012)

WEB Tabla A6.6b (L) Ingresos medios mensuales de los trabajadores, por nivel educativo alcanzado, nivel de comprensión lectora y sexo (2012)

WEB Tabla A6.6b (N) Ingresos medios mensuales de los trabajadores, por nivel educativo alcanzado, nivel de competencia matemática y sexo (2012)

WEB Tabla A6.6c (L) Ingresos medios mensuales de los trabajadores, por nivel educativo alcanzado, nivel de comprensión lectora y edad (2012)

WEB Tabla A6.6c (N) Ingresos medios mensuales de los trabajadores, por nivel educativo alcanzado, nivel de competencia matemática y edad (2012)

WEB Tabla A6.7 (L) Ingresos mensuales medios de los trabajadores, por nivel educativo alcanzado, comprensión lectora y años desde la graduación más reciente (2012)

WEB Tabla A6.7 (N) Ingresos mensuales medios de los trabajadores, por nivel educativo alcanzado, competencia matemática y años desde la graduación más reciente (2012) 
Tabla A6.1a. Ingresos relativos de los trabajadores, por nivel educativo alcanzado y grupo de edad (2012) Adultos con ingresos laborales; educación secundaria superior $=100$

\begin{tabular}{|c|c|c|c|c|c|c|c|c|c|c|c|c|c|c|c|c|}
\hline & \multirow[b]{3}{*}{ Año } & \multicolumn{3}{|c|}{$\begin{array}{l}\text { Inferior a educación } \\
\text { secundaria superior }\end{array}$} & \multicolumn{3}{|c|}{$\begin{array}{c}\text { Educación } \\
\text { postsecundaria } \\
\text { no terciaria }\end{array}$} & \multicolumn{3}{|c|}{$\begin{array}{l}\text { Educación terciaria } \\
\text { de tipo B }\end{array}$} & \multicolumn{3}{|c|}{$\begin{array}{c}\text { Educación terciaria } \\
\text { de tipo A o programas de } \\
\text { investigación avanzada }\end{array}$} & \multicolumn{3}{|c|}{$\begin{array}{c}\text { Toda la educación } \\
\text { terciaria }\end{array}$} \\
\hline & & $25-64$ & $25-34$ & $55-64$ & $25-64$ & $25-34$ & $55-64$ & $25-64$ & $25-34$ & $55-64$ & $25-64$ & $25-34$ & $55-64$ & $25-64$ & $25-34$ & $55-64$ \\
\hline & & (1) & (2) & (3) & (4) & (5) & (6) & (7) & (8) & (9) & (10) & (11) & (12) & (13) & (14) & (15) \\
\hline Alemania & 2012 & 84 & 84 & 87 & 114 & 118 & 114 & 146 & 145 & 141 & 183 & 149 & 227 & 174 & 148 & 207 \\
\hline Australia & 2012 & 83 & 88 & 84 & 99 & 95 & 108 & 114 & 111 & 129 & 142 & 121 & 159 & 134 & 119 & 149 \\
\hline Austria & 2012 & 70 & 70 & 66 & 127 & 112 & 162 & 143 & 120 & 144 & 185 & 143 & 194 & 171 & 138 & 173 \\
\hline Bélgica $^{1}$ & 2011 & 90 & 92 & 83 & 95 & 101 & 89 & 116 & 113 & 117 & 142 & 132 & 153 & 128 & 123 & 135 \\
\hline Canadá & 2011 & 87 & 103 & 76 & 111 & 125 & 105 & 113 & 110 & 111 & 163 & 133 & 185 & 139 & 123 & 149 \\
\hline Chile & 2011 & 66 & 70 & 56 & $\mathrm{~m}$ & $\mathrm{~m}$ & $\mathrm{~m}$ & 151 & 133 & 143 & 309 & 261 & 323 & 260 & 227 & 279 \\
\hline Corea & 2012 & 71 & 82 & 65 & $\mathrm{~m}$ & $\mathrm{~m}$ & $\mathrm{~m}$ & 116 & 113 & 144 & 161 & 133 & 196 & 147 & 126 & 188 \\
\hline Dinamarca & 2012 & 81 & 78 & 84 & 61 & 42 & 104 & 117 & 116 & 113 & 130 & 112 & 142 & 128 & 112 & 137 \\
\hline Eslovenia & 2012 & 78 & 85 & 73 & $\mathrm{~m}$ & $\mathrm{~m}$ & $\mathrm{~m}$ & 152 & 130 & 165 & 200 & 150 & 240 & 180 & 142 & 211 \\
\hline España & 2011 & 80 & 87 & 70 & c & c & c & 106 & 105 & 103 & 156 & 139 & 160 & 141 & 127 & 150 \\
\hline Estados Unidos & 2012 & 63 & 70 & 61 & $\mathrm{~m}$ & $\mathrm{~m}$ & $\mathrm{~m}$ & 109 & 112 & 100 & 182 & 170 & 180 & 174 & 165 & 172 \\
\hline Estonia & 2012 & 94 & 93 & 91 & $\mathrm{~m}$ & $\mathrm{~m}$ & $\mathrm{~m}$ & $\mathrm{~m}$ & $\mathrm{~m}$ & $\mathrm{~m}$ & 134 & 116 & 147 & 134 & 116 & 147 \\
\hline Finlandia & 2011 & 92 & 92 & 93 & $\mathrm{~m}$ & $\mathrm{~m}$ & $\mathrm{~m}$ & 128 & 118 & 127 & 157 & 127 & 205 & 147 & 126 & 166 \\
\hline Francia & 2010 & 82 & 89 & 72 & $\mathrm{~m}$ & $\mathrm{~m}$ & $\mathrm{~m}$ & 127 & 126 & 136 & 170 & 145 & 212 & 154 & 138 & 189 \\
\hline Grecia & 2012 & 79 & 94 & 82 & 99 & 111 & 77 & 151 & 127 & 185 & 198 & 140 & 267 & 152 & 127 & 187 \\
\hline Hungría & 2012 & 78 & 81 & 76 & 122 & 116 & 127 & 127 & 121 & 157 & 209 & 182 & 223 & 208 & 181 & 222 \\
\hline Irlanda $^{1}$ & 2011 & 84 & 104 & 76 & 99 & 99 & 108 & 131 & 123 & 109 & 201 & 186 & 185 & 175 & 165 & 162 \\
\hline Islandia & & $\mathrm{m}$ & $\mathrm{m}$ & $\mathrm{m}$ & $\mathrm{m}$ & $\mathrm{m}$ & $\mathrm{m}$ & $\mathrm{m}$ & $\mathrm{m}$ & $\mathrm{m}$ & $\mathrm{m}$ & $\mathrm{m}$ & $\mathrm{m}$ & $\mathrm{m}$ & $\mathrm{m}$ & $\mathrm{m}$ \\
\hline Israel & 2012 & 71 & 76 & 64 & 109 & 91 & 94 & 112 & 96 & 109 & 170 & 133 & 174 & 152 & 123 & 151 \\
\hline Italia & 2010 & 77 & 94 & 59 & $\mathrm{~m}$ & $\mathrm{~m}$ & $\mathrm{~m}$ & $\mathrm{~m}$ & $\mathrm{~m}$ & $\mathrm{~m}$ & 147 & 125 & 167 & 147 & 125 & 167 \\
\hline Japón & 2012 & 78 & 87 & 76 & $\mathrm{~m}$ & $\mathrm{~m}$ & $\mathrm{~m}$ & 91 & 99 & 99 & 172 & 144 & 203 & 152 & 136 & 177 \\
\hline Luxemburgo & 2012 & 70 & 68 & 63 & 119 & 86 & 71 & $\mathrm{~m}$ & $\mathrm{~m}$ & $\mathrm{~m}$ & $\mathrm{~m}$ & $\mathrm{~m}$ & $\mathrm{~m}$ & 168 & 148 & 184 \\
\hline México & & $\mathrm{m}$ & $\mathrm{m}$ & $\mathrm{m}$ & $\mathrm{m}$ & $\mathrm{m}$ & $\mathrm{m}$ & $\mathrm{m}$ & $\mathrm{m}$ & $\mathrm{m}$ & $\mathrm{m}$ & $\mathrm{m}$ & $\mathrm{m}$ & $\mathrm{m}$ & $\mathrm{m}$ & $\mathrm{m}$ \\
\hline Noruega & 2011 & 78 & 76 & 80 & 128 & 125 & 137 & 155 & 136 & 169 & 128 & 107 & 152 & 130 & 108 & 154 \\
\hline Nueva Zelanda & 2012 & 82 & 85 & 82 & 110 & 115 & 101 & 105 & 107 & 100 & 134 & 126 & 146 & 123 & 121 & 123 \\
\hline Países Bajos & 2010 & 83 & 90 & 74 & $\mathrm{~m}$ & $\mathrm{~m}$ & $\mathrm{~m}$ & 145 & 134 & 145 & 157 & 137 & 160 & 156 & 137 & 159 \\
\hline Polonia & 2012 & 85 & 89 & 80 & 107 & 99 & 112 & $\mathrm{~m}$ & $\mathrm{~m}$ & $\mathrm{~m}$ & 172 & 146 & 205 & 172 & 146 & 205 \\
\hline Portugal & 2011 & 70 & 82 & 51 & 104 & 109 & 96 & 161 & 141 & 154 & 171 & 157 & 204 & 170 & 156 & 193 \\
\hline Reino Unido & 2012 & 70 & 68 & 69 & $\mathrm{~m}$ & $\mathrm{~m}$ & $\mathrm{~m}$ & 130 & 127 & 136 & 164 & 153 & 170 & 156 & 149 & 159 \\
\hline República Checa & 2011 & 73 & 78 & 71 & $\mathrm{~m}$ & $\mathrm{~m}$ & $\mathrm{~m}$ & 117 & 114 & 118 & 181 & 154 & 190 & 176 & 149 & 187 \\
\hline República Eslovaca & 2012 & 67 & 66 & 70 & $\mathrm{~m}$ & $\mathrm{~m}$ & $\mathrm{~m}$ & 126 & 116 & 134 & 175 & 145 & 193 & 173 & 144 & 190 \\
\hline Suecia & 2012 & 82 & 76 & 88 & 121 & 79 & 138 & 107 & 92 & 115 & 135 & 115 & 158 & 128 & 110 & 143 \\
\hline Suiza & 2012 & 77 & 84 & 70 & 107 & 102 & 117 & 141 & 131 & 143 & 165 & 135 & 182 & 158 & 134 & 169 \\
\hline Turquía $^{1}$ & 2012 & 63 & 68 & 46 & a & a & a & $\mathrm{m}$ & $\mathrm{m}$ & $\mathrm{m}$ & 191 & 186 & 234 & 191 & 186 & 234 \\
\hline
\end{tabular}

\begin{tabular}{|l|l|l|l|l|l|l|l|l|l|l|l|l|l|l|l|l|} 
Media OCDE & 78 & 83 & 73 & 108 & 102 & 110 & 127 & 119 & 131 & 170 & 145 & 191 & 159 & 140 & 176 \\
\hline
\end{tabular} Media UE21

\begin{tabular}{l|l|l|l|l|l|l|l|l|l|l|l|l|l|l|}
79 & 84 & 75 & 106 & 98 & 109 & 131 & 122 & 135 & 168 & 143 & 190 & 159 & 138 & 175 \\
\hline
\end{tabular}

\begin{tabular}{|c|c|c|c|c|c|c|c|c|c|c|c|c|c|c|c|c|}
\hline $\begin{array}{l}\text { Arabia Saudí } \\
\text { Argentina }\end{array}$ & & $\begin{array}{l}\mathrm{m} \\
\mathrm{m}\end{array}$ & $\begin{array}{l}\mathrm{m} \\
\mathrm{m}\end{array}$ & $\begin{array}{l}\mathrm{m} \\
\mathrm{m}\end{array}$ & $\begin{array}{l}\mathrm{m} \\
\mathrm{m}\end{array}$ & $\begin{array}{l}\mathrm{m} \\
\mathrm{m}\end{array}$ & $\begin{array}{l}\mathrm{m} \\
\mathrm{m}\end{array}$ & $\begin{array}{l}\mathrm{m} \\
\mathrm{m}\end{array}$ & $\begin{array}{l}\mathrm{m} \\
\mathrm{m}\end{array}$ & $\begin{array}{l}\mathrm{m} \\
\mathrm{m}\end{array}$ & $\begin{array}{l}\mathrm{m} \\
\mathrm{m}\end{array}$ & $\begin{array}{l}\mathrm{m} \\
\mathrm{m}\end{array}$ & $\begin{array}{l}\mathrm{m} \\
\mathrm{m}\end{array}$ & $\begin{array}{l}\mathrm{m} \\
\mathrm{m}\end{array}$ & $\begin{array}{l}\mathrm{m} \\
\mathrm{m}\end{array}$ & $\begin{array}{l}\mathrm{m} \\
\mathrm{m}\end{array}$ \\
\hline Brasil & 2012 & 58 & 65 & 41 & $\mathrm{~m}$ & $\mathrm{~m}$ & $\mathrm{~m}$ & $\mathrm{~m}$ & $\mathrm{~m}$ & $\mathrm{~m}$ & 247 & 235 & 241 & 247 & 235 & 241 \\
\hline China & & $\mathrm{m}$ & $\mathrm{m}$ & $\mathrm{m}$ & $\mathrm{m}$ & $\mathrm{m}$ & $\mathrm{m}$ & $\mathrm{m}$ & $\mathrm{m}$ & $\mathrm{m}$ & $\mathrm{m}$ & $\mathrm{m}$ & $\mathrm{m}$ & $\mathrm{m}$ & $\mathrm{m}$ & $\mathrm{m}$ \\
\hline Colombia & & $\mathrm{m}$ & $\mathrm{m}$ & $\mathrm{m}$ & $\mathrm{m}$ & $\mathrm{m}$ & $\mathrm{m}$ & $\mathrm{m}$ & $\mathrm{m}$ & $\mathrm{m}$ & $\mathrm{m}$ & $\mathrm{m}$ & $\mathrm{m}$ & $\mathrm{m}$ & $\mathrm{m}$ & $\mathrm{m}$ \\
\hline Federación Rusa & & $\mathrm{m}$ & $\mathrm{m}$ & $\mathrm{m}$ & $\mathrm{m}$ & $\mathrm{m}$ & $\mathrm{m}$ & $\mathrm{m}$ & $\mathrm{m}$ & $\mathrm{m}$ & $\mathrm{m}$ & $\mathrm{m}$ & $\mathrm{m}$ & $\mathrm{m}$ & $\mathrm{m}$ & $\mathrm{m}$ \\
\hline India & & $\mathrm{m}$ & $\mathrm{m}$ & $\mathrm{m}$ & $\mathrm{m}$ & $\mathrm{m}$ & $\mathrm{m}$ & $\mathrm{m}$ & $\mathrm{m}$ & $\mathrm{m}$ & $\mathrm{m}$ & $\mathrm{m}$ & $\mathrm{m}$ & $\mathrm{m}$ & $\mathrm{m}$ & $\mathrm{m}$ \\
\hline Letonia & & $\mathrm{m}$ & $\mathrm{m}$ & $\mathrm{m}$ & $\mathrm{m}$ & $\mathrm{m}$ & $\mathrm{m}$ & $\mathrm{m}$ & $\mathrm{m}$ & $\mathrm{m}$ & $\mathrm{m}$ & $\mathrm{m}$ & $\mathrm{m}$ & $\mathrm{m}$ & $\mathrm{m}$ & $\mathrm{m}$ \\
\hline Sudáfrica & & $\mathrm{m}$ & $\mathrm{m}$ & $\mathrm{m}$ & $\mathrm{m}$ & $\mathrm{m}$ & $\mathrm{m}$ & $\mathrm{m}$ & $\mathrm{m}$ & $\mathrm{m}$ & $\mathrm{m}$ & $\mathrm{m}$ & $\mathrm{m}$ & $\mathrm{m}$ & $\mathrm{m}$ & $\mathrm{m}$ \\
\hline Media G20 & & $\mathrm{m}$ & $\mathrm{m}$ & $\mathrm{m}$ & $\mathrm{m}$ & $\mathrm{m}$ & $\mathrm{m}$ & $\mathrm{m}$ & $\mathrm{m}$ & $\mathrm{m}$ & $\mathrm{m}$ & $\mathrm{m}$ & $\mathrm{m}$ & $\mathrm{m}$ & $\mathrm{m}$ & $\mathrm{m}$ \\
\hline
\end{tabular}

1. Ingresos netos del impuesto sobre la renta.

Fuente: OCDE. Para ver notas, consulte Anexo 3 (www.oecd.org/edu/eag.htm).

Para obtener más información acerca de los símbolos utilizados en lugar de los datos que faltan, consulte la Guía del lector.

StatLink 제피 http://dx.doi.org/10.1787/888933116072 
Tabla A6.2a. [1/2] Tendencias de los ingresos relativos de los trabajadores, por nivel educativo alcanzado y sexo $(2000,2005,2010,2011,2012)$

Personas de 25 a 65 años con ingresos laborales; educación secundaria superior $=100$

\begin{tabular}{|c|c|c|c|c|c|c|c|c|c|c|c|c|c|c|c|c|}
\hline & \multirow[b]{3}{*}{ Nivel educativo alcanzado } & \multicolumn{3}{|c|}{2000} & \multicolumn{3}{|c|}{2005} & \multicolumn{3}{|c|}{2010} & \multicolumn{3}{|c|}{2011} & \multicolumn{3}{|c|}{2012} \\
\hline & & $\begin{array}{c}\text { Hom- } \\
\text { bres }\end{array}$ & $\begin{array}{c}\text { Muje- } \\
\text { res }\end{array}$ & $\mathrm{H}+\mathrm{M}$ & $\begin{array}{c}\text { Hom- } \\
\text { bres }\end{array}$ & $\begin{array}{c}\text { Muje- } \\
\text { res }\end{array}$ & $\mathrm{H}+\mathrm{M}$ & $\begin{array}{c}\text { Hom- } \\
\text { bres }\end{array}$ & $\begin{array}{c}\text { Muje- } \\
\text { res }\end{array}$ & $\mathrm{H}+\mathrm{M}$ & $\begin{array}{c}\text { Hom- } \\
\text { bres }\end{array}$ & $\begin{array}{c}\text { Muje- } \\
\text { res }\end{array}$ & $\mathrm{H}+\mathrm{M}$ & $\begin{array}{c}\text { Hom- } \\
\text { bres }\end{array}$ & $\begin{array}{c}\text { Muje- } \\
\text { res }\end{array}$ & $\mathrm{H}+\mathrm{M}$ \\
\hline & & (1) & (2) & (3) & $(4)$ & (5) & (6) & (7) & $(8)$ & (9) & (10) & $(11)$ & (12) & (13) & (14) & (15) \\
\hline \multirow{3}{*}{ 岂 $\mathrm{A}$} & Inferior a educación secundaria superior & 81 & 74 & 76 & 95 & 80 & 89 & 97 & 77 & 88 & 91 & 85 & 88 & 87 & 82 & 84 \\
\hline & Terciaria & 143 & 141 & 145 & 153 & 156 & 159 & 176 & 159 & 172 & 166 & 163 & 169 & 171 & 172 & 174 \\
\hline & Inferior a educación secundaria superior & $\mathrm{m}$ & $\mathrm{m}$ & $\mathrm{m}$ & 88 & 88 & 81 & $\mathrm{~m}$ & $\mathrm{~m}$ & $\mathrm{~m}$ & $\mathrm{~m}$ & $\mathrm{~m}$ & $\mathrm{~m}$ & 85 & 88 & 83 \\
\hline \multirow[t]{2}{*}{ Austria } & Inferior a educación secundaria superior & $\mathrm{m}$ & $\mathrm{m}$ & $\mathrm{m}$ & 80 & 78 & 74 & 73 & 75 & 69 & 71 & 78 & 69 & 74 & 76 & 70 \\
\hline & Terciaria & $\mathrm{m}$ & $\mathrm{m}$ & $\mathrm{m}$ & 157 & 165 & 158 & 163 & 173 & 165 & 164 & 174 & 166 & 171 & 174 & 171 \\
\hline \multirow[t]{2}{*}{ Bélgica $^{1}$} & Inferior a educación secundaria superior & 93 & 83 & 92 & 91 & 82 & 89 & 92 & 86 & 91 & 92 & 84 & 90 & $\mathrm{~m}$ & $\mathrm{~m}$ & $\mathrm{~m}$ \\
\hline & Terciaria & 128 & 133 & 128 & 137 & 134 & 133 & 132 & 135 & 131 & 129 & 134 & 128 & $\mathrm{~m}$ & $\mathrm{~m}$ & $\mathrm{~m}$ \\
\hline \multirow[t]{2}{*}{ Canadá } & Inferior a educación secundaria superior & 84 & 72 & 83 & 80 & 70 & 80 & 81 & 79 & 83 & 86 & 77 & 87 & $\mathrm{~m}$ & $\mathrm{~m}$ & $\mathrm{~m}$ \\
\hline & Terciaria & 149 & 139 & 143 & 140 & 140 & 138 & 146 & 154 & 145 & 144 & 142 & 139 & $\mathrm{~m}$ & $\mathrm{~m}$ & $\mathrm{~m}$ \\
\hline Chile & Inferior a educación secundaria superior & $\mathrm{m}$ & $\mathrm{m}$ & $\mathrm{m}$ & $\mathrm{m}$ & $\mathrm{m}$ & $\mathrm{m}$ & $\mathrm{m}$ & $\mathrm{m}$ & $\mathrm{m}$ & 64 & 65 & 66 & $\mathrm{~m}$ & $\mathrm{~m}$ & $\mathrm{~m}$ \\
\hline \multirow[t]{2}{*}{ Corea } & Inferior a educación secundaria superior & $\mathrm{m}$ & $\mathrm{m}$ & $\mathrm{m}$ & 73 & 76 & 68 & 71 & 77 & 69 & 72 & 78 & 71 & 76 & 77 & 71 \\
\hline & Terciaria & $\mathrm{m}$ & $\mathrm{m}$ & $\mathrm{m}$ & 139 & 160 & 149 & 143 & 155 & 151 & 137 & 153 & 147 & 140 & 152 & 147 \\
\hline \multirow[t]{2}{*}{ Dinamarca } & Inferior a educación secundaria superior & $\mathrm{m}$ & $\mathrm{m}$ & $\mathrm{m}$ & 82 & 84 & 82 & 80 & 83 & 81 & 79 & 83 & 81 & 79 & 82 & 81 \\
\hline & Terciaria & $\mathrm{m}$ & $\mathrm{m}$ & $\mathrm{m}$ & 133 & 126 & 125 & 141 & 126 & 129 & 138 & 126 & 128 & 138 & 126 & 128 \\
\hline \multirow[t]{2}{*}{ Eslovenia } & Inferior a educación secundaria superior & $\mathrm{m}$ & $\mathrm{m}$ & $\mathrm{m}$ & $\mathrm{m}$ & $\mathrm{m}$ & $\mathrm{m}$ & 75 & 74 & 75 & 77 & 76 & 76 & 79 & 76 & 78 \\
\hline & Terciaria & $\mathrm{m}$ & $\mathrm{m}$ & $\mathrm{m}$ & $\mathrm{m}$ & $\mathrm{m}$ & $\mathrm{m}$ & 201 & 181 & 186 & 197 & 180 & 183 & 192 & 177 & 180 \\
\hline \multirow[t]{2}{*}{ España } & Inferior a educación secundaria superior & $\mathrm{m}$ & $\mathrm{m}$ & $\mathrm{m}$ & 79 & 72 & 80 & 81 & 74 & 80 & 80 & 74 & 80 & $\mathrm{~m}$ & $\mathrm{~m}$ & $\mathrm{~m}$ \\
\hline & Terciaria & $\mathrm{m}$ & $\mathrm{m}$ & $\mathrm{m}$ & 132 & 155 & 137 & 134 & 157 & 140 & 136 & 155 & 141 & $\mathrm{~m}$ & $\mathrm{~m}$ & $\mathrm{~m}$ \\
\hline Estados Unidos & Inferior a educación secundaria superior & 65 & 66 & 68 & 69 & 67 & 71 & 64 & 61 & 66 & 64 & 58 & 64 & 60 & 62 & 63 \\
\hline & Terciaria & 181 & 169 & 176 & 196 & 178 & 186 & 184 & 175 & 177 & 182 & 181 & 177 & 180 & 177 & 174 \\
\hline Estonia & Inferior a educación secundaria superior & $\mathrm{m}$ & $\mathrm{m}$ & $\mathrm{m}$ & $\mathrm{m}$ & $\mathrm{m}$ & $\mathrm{m}$ & $\mathrm{m}$ & $\mathrm{m}$ & $\mathrm{m}$ & 81 & 81 & 87 & 89 & 91 & 94 \\
\hline & Terciaria & $\mathrm{m}$ & $\mathrm{m}$ & $\mathrm{m}$ & $\mathrm{m}$ & $\mathrm{m}$ & $\mathrm{m}$ & $\mathrm{m}$ & $\mathrm{m}$ & $\mathrm{m}$ & 146 & 148 & 135 & 137 & 160 & 134 \\
\hline Francia $^{2}$ & Inferior a educación secundaria superior & $\mathrm{m}$ & $\mathrm{m}$ & $\mathrm{m}$ & 90 & 81 & 86 & 89 & 76 & 82 & $\mathrm{~m}$ & $\mathrm{~m}$ & $\mathrm{~m}$ & $\mathrm{~m}$ & $\mathrm{~m}$ & $\mathrm{~m}$ \\
\hline & Terciaria & $\mathrm{m}$ & $\mathrm{m}$ & $\mathrm{m}$ & 152 & 142 & 144 & 162 & 155 & 154 & $\mathrm{~m}$ & $\mathrm{~m}$ & $\mathrm{~m}$ & $\mathrm{~m}$ & $\mathrm{~m}$ & $\mathrm{~m}$ \\
\hline Grecia & Inferior a educación secundaria superior & $\mathrm{m}$ & $\mathrm{m}$ & $\mathrm{m}$ & $\mathrm{m}$ & $\mathrm{m}$ & $\mathrm{m}$ & $\mathrm{m}$ & $\mathrm{m}$ & $\mathrm{m}$ & 69 & 52 & 62 & 82 & 72 & 79 \\
\hline & Terciaria & $\mathrm{m}$ & $\mathrm{m}$ & $\mathrm{m}$ & $\mathrm{m}$ & $\mathrm{m}$ & $\mathrm{m}$ & $\mathrm{m}$ & $\mathrm{m}$ & $\mathrm{m}$ & 151 & 231 & 171 & 169 & 140 & 152 \\
\hline Hungría & Inferior a educación secundaria superior & 81 & 77 & 77 & 80 & 77 & 78 & 80 & 75 & 77 & 79 & 75 & 76 & 80 & 77 & 78 \\
\hline & Terciaria & 252 & 179 & 210 & 269 & 202 & 229 & 259 & 198 & 221 & 256 & 193 & 217 & 246 & 184 & 208 \\
\hline Irlanda ${ }^{1}$ & Inferior a educación secundaria superior & 82 & 64 & 87 & 83 & 67 & 84 & 76 & 78 & 81 & 80 & 70 & 84 & $\mathrm{~m}$ & $\mathrm{~m}$ & $\mathrm{~m}$ \\
\hline & Terciaria & 135 & 161 & 149 & 187 & 190 & 192 & 168 & 177 & 165 & 169 & 190 & 175 & $\mathrm{~m}$ & $\mathrm{~m}$ & $\mathrm{~m}$ \\
\hline Islandia & & $\mathrm{m}$ & $\mathrm{m}$ & $\mathrm{m}$ & $\mathrm{m}$ & $\mathrm{m}$ & $\mathrm{m}$ & $\mathrm{m}$ & $\mathrm{m}$ & $\mathrm{m}$ & $\mathrm{m}$ & $\mathrm{m}$ & $\mathrm{m}$ & $\mathrm{m}$ & $\mathrm{m}$ & $\mathrm{m}$ \\
\hline Israel & Inferior a educación secundaria superior & $\mathrm{m}$ & $\mathrm{m}$ & $\mathrm{m}$ & 74 & 72 & 79 & 68 & 63 & 72 & 69 & 66 & 72 & 66 & 71 & 71 \\
\hline & Terciaria & $\mathrm{m}$ & $\mathrm{m}$ & $\mathrm{m}$ & 160 & 158 & 151 & 164 & 150 & 152 & 159 & 152 & 151 & 153 & 171 & 152 \\
\hline Italia & Inferior a educación secundaria superior & 71 & 84 & 78 & $\mathrm{~m}$ & $\mathrm{~m}$ & $\mathrm{~m}$ & 77 & 70 & 77 & $\mathrm{~m}$ & $\mathrm{~m}$ & $\mathrm{~m}$ & $\mathrm{~m}$ & $\mathrm{~m}$ & $\mathrm{~m}$ \\
\hline & Terciaria & 143 & 137 & 138 & $\mathrm{~m}$ & $\mathrm{~m}$ & $\mathrm{~m}$ & 157 & 145 & 147 & $\mathrm{~m}$ & $\mathrm{~m}$ & $\mathrm{~m}$ & $\mathrm{~m}$ & $\mathrm{~m}$ & $\mathrm{~m}$ \\
\hline Japón & Inferior a educación secundaria superior & $\mathrm{m}$ & $\mathrm{m}$ & $\mathrm{m}$ & $\mathrm{m}$ & $\mathrm{m}$ & $\mathrm{m}$ & $\mathrm{m}$ & $\mathrm{m}$ & $\mathrm{m}$ & $\mathrm{m}$ & $\mathrm{m}$ & $\mathrm{m}$ & 74 & 72 & 78 \\
\hline & Terciaria & $\mathrm{m}$ & $\mathrm{m}$ & $\mathrm{m}$ & $\mathrm{m}$ & $\mathrm{m}$ & $\mathrm{m}$ & $\mathrm{m}$ & $\mathrm{m}$ & $\mathrm{m}$ & $\mathrm{m}$ & $\mathrm{m}$ & $\mathrm{m}$ & 144 & 160 & 152 \\
\hline Luxemburgo & Inferior a educación secundaria superior & $\mathrm{m}$ & $\mathrm{m}$ & $\mathrm{m}$ & $\mathrm{m}$ & $\mathrm{m}$ & $\mathrm{m}$ & 69 & 68 & 67 & $\mathrm{~m}$ & $\mathrm{~m}$ & $\mathrm{~m}$ & 73 & 67 & 70 \\
\hline & Terciaria & $\mathrm{m}$ & $\mathrm{m}$ & $\mathrm{m}$ & $\mathrm{m}$ & $\mathrm{m}$ & $\mathrm{m}$ & 166 & 166 & 161 & $\mathrm{~m}$ & $\mathrm{~m}$ & $\mathrm{~m}$ & 176 & 161 & 168 \\
\hline México & & $\mathrm{m}$ & $\mathrm{m}$ & $\mathrm{m}$ & $\mathrm{m}$ & $\mathrm{m}$ & $\mathrm{m}$ & $\mathrm{m}$ & $\mathrm{m}$ & $\mathrm{m}$ & $\mathrm{m}$ & $\mathrm{m}$ & $\mathrm{m}$ & $\mathrm{m}$ & $\mathrm{m}$ & $\mathrm{m}$ \\
\hline Noruega & Inferior a educación secundaria superior & 81 & 82 & 80 & 79 & 81 & 79 & 78 & 79 & 78 & 78 & 80 & 78 & $\mathrm{~m}$ & $\mathrm{~m}$ & $\mathrm{~m}$ \\
\hline & Terciaria & 134 & 134 & 131 & 136 & 136 & 131 & 137 & 136 & 131 & 137 & 135 & 130 & $\mathrm{~m}$ & $\mathrm{~m}$ & $\mathrm{~m}$ \\
\hline Nueva Zelanda & Inferior a educación secundaria superior & 79 & 86 & 82 & 79 & 78 & 81 & 81 & 83 & 83 & 80 & 85 & 83 & 79 & 84 & 82 \\
\hline & Terciaria & 128 & 126 & 127 & 122 & 121 & 125 & 130 & 132 & 131 & 124 & 129 & 125 & 122 & 127 & 123 \\
\hline
\end{tabular}

1. Ingresos netos del impuesto sobre la renta.

2. Interrupción en la serie entre 2007 y 2008 , cambio en la fuente de datos.

3. Las medias no pueden compararse a lo largo de los años, ya que el número de países utilizados para calcular dichas medias es diferente cada año.

Fuente: OCDE. Para ver notas, consulte Anexo 3 (www.oecd.org/edu/eag.htm).

Para obtener más información acerca de los símbolos utilizados en lugar de los datos que faltan, consulte la Guía del lector.

StatLink त्ञाज ht htp://dx.doi.org/10.1787/888933116091 
Tabla A6.2a. [2/2] Tendencias de los ingresos relativos de los trabajadores, por nivel educativo alcanzado y sexo $(2000,2005,2010,2011,2012)$

Personas de 25 a 65 años con ingresos laborales; educación secundaria superior $=100$

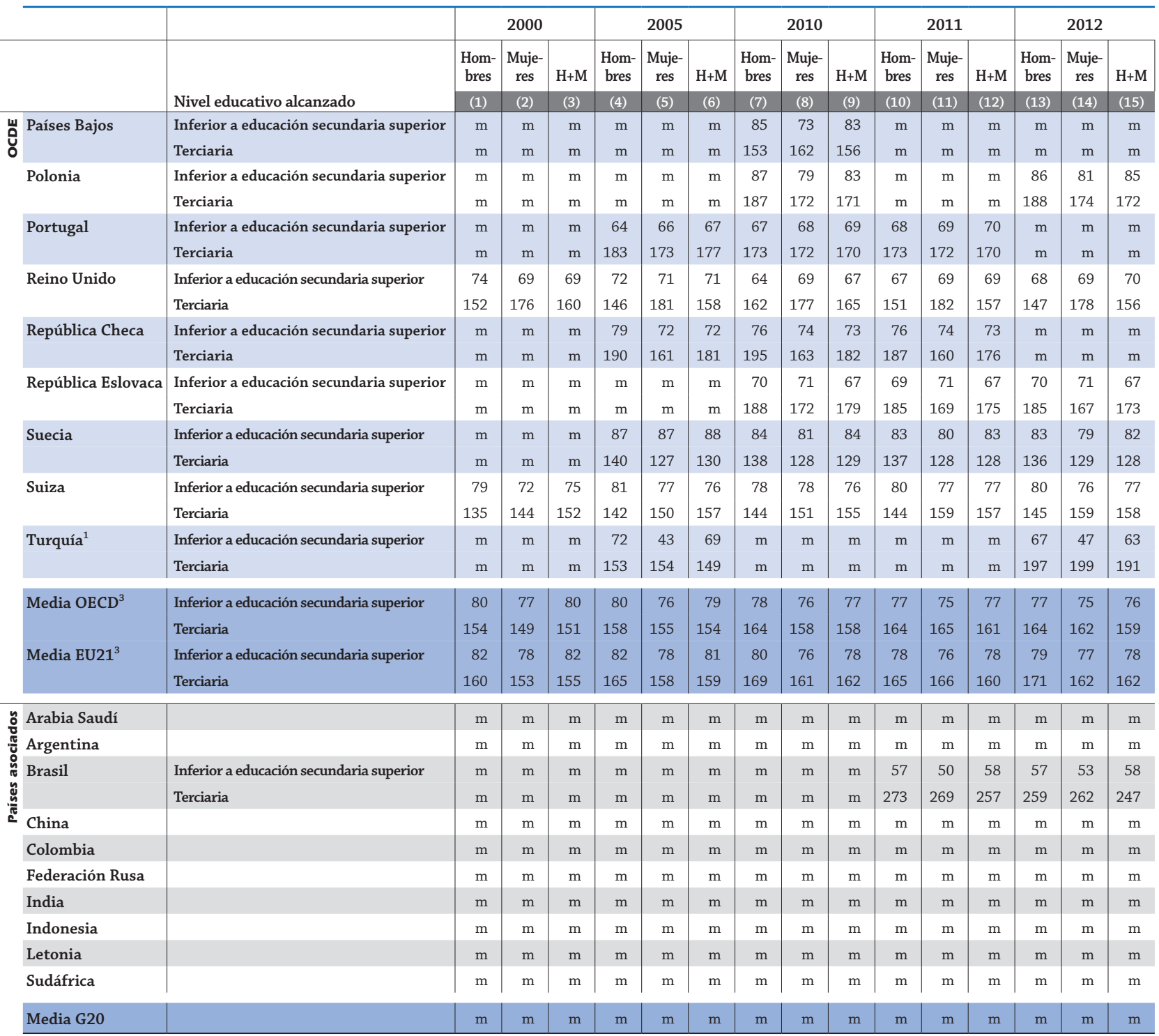

1. Ingresos netos del impuesto sobre la renta.

2. Interrupción en la serie entre 2007 y 2008 , cambio en la fuente de datos.

3. Las medias no pueden compararse a lo largo de los años, ya que el número de países utilizados para calcular dichas medias es diferente cada año.

Fuente: OCDE. Para ver notas, consulte Anexo 3 (www.oecd.org/edu/eag.htm).

Para obtener más información acerca de los símbolos utilizados en lugar de los datos que faltan, consulte la Guía del lector.

StatLink 젶ㄴ http://dx.doi.org/10.1787/888933116091 
Tabla A6.3a. Diferencias de ingresos entre mujeres y hombres trabajadores, por nivel educativo alcanzado y grupo de edad (2012)

Adultos con ingresos laborales; ingresos anuales medios de trabajo a tiempo completo, todo el año, de las mujeres como porcentaje de los ingresos de los hombres

\begin{tabular}{|c|c|c|c|c|c|c|c|c|c|c|}
\hline & \multirow[b]{3}{*}{ Año } & \multicolumn{3}{|c|}{ Inferior a educación secundaria superior } & \multicolumn{3}{|c|}{$\begin{array}{l}\text { Educación secundaria superior } \\
\text { o postsecundaria no terciaria }\end{array}$} & \multicolumn{3}{|c|}{ Educación terciaria } \\
\hline & & $25-64$ & $35-44$ & $55-64$ & $25-64$ & $35-44$ & $55-64$ & $25-64$ & $35-44$ & $55-64$ \\
\hline & & (1) & (2) & (3) & (4) & (5) & (6) & (7) & (8) & (9) \\
\hline Alemania & 2012 & 82 & 79 & 92 & 82 & 83 & 86 & 72 & 73 & 73 \\
\hline Australia & 2012 & 79 & 80 & 81 & 75 & 74 & 78 & 75 & 75 & 69 \\
\hline Austria & 2012 & 76 & 74 & 77 & 76 & 76 & 80 & 76 & 80 & 79 \\
\hline Bélgica $^{1}$ & 2011 & 80 & $\mathrm{~m}$ & $\mathrm{~m}$ & 98 & 96 & 99 & 86 & 86 & 81 \\
\hline Canadá & 2011 & 65 & 70 & 73 & 70 & 71 & 70 & 69 & 68 & 70 \\
\hline Chile & 2011 & 76 & 79 & 70 & 69 & 68 & 71 & 62 & 70 & 53 \\
\hline Corea & 2012 & 65 & 67 & 63 & 64 & 62 & 67 & 68 & 67 & 69 \\
\hline Dinamarca & 2012 & 83 & 80 & 82 & 80 & 78 & 83 & 75 & 76 & 73 \\
\hline Eslovenia & 2012 & 85 & 84 & 85 & 88 & 84 & 99 & 82 & 80 & 87 \\
\hline España & 2011 & 78 & 86 & 75 & 79 & 78 & 90 & 86 & 83 & 92 \\
\hline Estados Unidos & 2012 & 75 & 90 & 72 & 70 & 69 & 67 & 69 & 70 & 69 \\
\hline Estonia & 2012 & 64 & 60 & 88 & 59 & 59 & 66 & 68 & 64 & 69 \\
\hline Finlandia & 2012 & 79 & 75 & 79 & 79 & 76 & 79 & 76 & 75 & 74 \\
\hline Francia & 2010 & 74 & 69 & 76 & 79 & 75 & 75 & 73 & 77 & 70 \\
\hline Grecia & 2012 & 76 & 75 & 65 & 84 & 86 & 69 & 70 & 75 & 66 \\
\hline Hungría & 2012 & 81 & 81 & 78 & 84 & 81 & 90 & 63 & 57 & 70 \\
\hline Irlanda $^{1}$ & 2011 & 73 & 84 & 71 & 77 & 76 & 75 & 76 & 86 & 80 \\
\hline Islandia & & $\mathrm{m}$ & $\mathrm{m}$ & $\mathrm{m}$ & $\mathrm{m}$ & $\mathrm{m}$ & $\mathrm{m}$ & $\mathrm{m}$ & $\mathrm{m}$ & $\mathrm{m}$ \\
\hline Israel & 2012 & 77 & 57 & 87 & 66 & 68 & 60 & 72 & 70 & 80 \\
\hline Italia & 2010 & 78 & 79 & 72 & 78 & 78 & 77 & 69 & 77 & 68 \\
\hline Japón & 2012 & $\mathrm{~m}$ & $\mathrm{~m}$ & $\mathrm{~m}$ & $\mathrm{~m}$ & $\mathrm{~m}$ & $\mathrm{~m}$ & $\mathrm{~m}$ & $\mathrm{~m}$ & $\mathrm{~m}$ \\
\hline Luxemburgo & 2012 & 82 & 85 & 71 & 83 & 88 & 66 & 72 & 89 & 65 \\
\hline México & & $\mathrm{m}$ & $\mathrm{m}$ & $\mathrm{m}$ & $\mathrm{m}$ & $\mathrm{m}$ & $\mathrm{m}$ & $\mathrm{m}$ & $\mathrm{m}$ & $\mathrm{m}$ \\
\hline Noruega & 2011 & 82 & 80 & 82 & 79 & 78 & 78 & 74 & 75 & 72 \\
\hline Nueva Zelanda & 2012 & 84 & 90 & 78 & 83 & 85 & 83 & 79 & 76 & 80 \\
\hline Países Bajos & 2010 & 77 & 79 & 76 & 79 & 85 & 79 & 74 & 83 & 74 \\
\hline Polonia & 2012 & 73 & 69 & 74 & 79 & 72 & 89 & 71 & 66 & 76 \\
\hline Portugal & 2011 & 75 & 75 & 74 & 72 & 72 & 69 & 70 & 74 & 68 \\
\hline Reino Unido & 2012 & 75 & 73 & 79 & 72 & 71 & 66 & 80 & 82 & 76 \\
\hline República Checa & 2011 & 79 & 78 & 80 & 80 & 74 & 87 & 70 & 64 & 85 \\
\hline República Eslovaca & 2012 & 73 & 74 & 72 & 75 & 71 & 83 & 67 & 59 & 73 \\
\hline Suecia & & $\mathrm{m}$ & $\mathrm{m}$ & $\mathrm{m}$ & $\mathrm{m}$ & $\mathrm{m}$ & $\mathrm{m}$ & $\mathrm{m}$ & $\mathrm{m}$ & $\mathrm{m}$ \\
\hline Suiza & & $\mathrm{m}$ & $\mathrm{m}$ & $\mathrm{m}$ & $\mathrm{m}$ & $\mathrm{m}$ & $\mathrm{m}$ & $\mathrm{m}$ & $\mathrm{m}$ & $\mathrm{m}$ \\
\hline Turquía $^{1}$ & 2012 & 67 & 64 & 59 & 83 & 74 & 148 & 82 & 85 & 69 \\
\hline Media OCDE & & 76 & 76 & 76 & 77 & 76 & 80 & 73 & 75 & 73 \\
\hline Media UE21 & & 77 & 77 & 77 & 79 & 78 & 80 & 74 & 75 & 75 \\
\hline ¿̆ Arabia Saudí & & $\mathrm{m}$ & $\mathrm{m}$ & $\mathrm{m}$ & $\mathrm{m}$ & $\mathrm{m}$ & $\mathrm{m}$ & $\mathrm{m}$ & $\mathrm{m}$ & $\mathrm{m}$ \\
\hline Argentina & & $\mathrm{m}$ & $\mathrm{m}$ & $\mathrm{m}$ & $\mathrm{m}$ & $\mathrm{m}$ & $\mathrm{m}$ & $\mathrm{m}$ & $\mathrm{m}$ & $\mathrm{m}$ \\
\hline 递 Brasil & 2012 & 68 & 69 & 64 & 62 & 60 & 58 & 63 & 63 & 66 \\
\hline 递 China & & $\mathrm{m}$ & $\mathrm{m}$ & $\mathrm{m}$ & $\mathrm{m}$ & $\mathrm{m}$ & $\mathrm{m}$ & $\mathrm{m}$ & $\mathrm{m}$ & $\mathrm{m}$ \\
\hline Colombia & & $\mathrm{m}$ & $\mathrm{m}$ & $\mathrm{m}$ & $\mathrm{m}$ & $\mathrm{m}$ & $\mathrm{m}$ & $\mathrm{m}$ & $\mathrm{m}$ & $\mathrm{m}$ \\
\hline Federación Rusa & & $\mathrm{m}$ & $\mathrm{m}$ & $\mathrm{m}$ & $\mathrm{m}$ & $\mathrm{m}$ & $\mathrm{m}$ & $\mathrm{m}$ & $\mathrm{m}$ & $\mathrm{m}$ \\
\hline India & & $\mathrm{m}$ & $\mathrm{m}$ & $\mathrm{m}$ & $\mathrm{m}$ & $\mathrm{m}$ & $\mathrm{m}$ & $\mathrm{m}$ & $\mathrm{m}$ & $\mathrm{m}$ \\
\hline Indonesia & & $\mathrm{m}$ & $\mathrm{m}$ & $\mathrm{m}$ & $\mathrm{m}$ & $\mathrm{m}$ & $\mathrm{m}$ & $\mathrm{m}$ & $\mathrm{m}$ & $\mathrm{m}$ \\
\hline Letonia & & $\mathrm{m}$ & $\mathrm{m}$ & $\mathrm{m}$ & $\mathrm{m}$ & $\mathrm{m}$ & $\mathrm{m}$ & $\mathrm{m}$ & $\mathrm{m}$ & $\mathrm{m}$ \\
\hline Sudáfrica & & $\mathrm{m}$ & $\mathrm{m}$ & $\mathrm{m}$ & $\mathrm{m}$ & $\mathrm{m}$ & $\mathrm{m}$ & $\mathrm{m}$ & $\mathrm{m}$ & $\mathrm{m}$ \\
\hline Media G20 & & $\mathrm{m}$ & $\mathrm{m}$ & $\mathrm{m}$ & $\mathrm{m}$ & $\mathrm{m}$ & $\mathrm{m}$ & $\mathrm{m}$ & $\mathrm{m}$ & $\mathrm{m}$ \\
\hline
\end{tabular}

Nota: Las columnas que muestran los ingresos relativos de todos los niveles de educación combinados están disponibles en Internet (véase StatLink más abajo).

1. Ingresos netos del impuesto sobre la renta.

Fuente: OCDE. Para ver notas, consulte Anexo 3 (www.oecd.org/edw/eag.htm).

Para obtener más información acerca de los símbolos utilizados en lugar de los datos que faltan, consulte la Guía del lector.

StatLink 게네 $\mathrm{http}: / / \mathrm{dx}$.doi.org/10.1787/888933116110 
Tabla A6.3b. Tendencias de las diferencias de ingresos entre mujeres y hombres trabajadores, por nivel educativo alcanzado $(2000,2005,2010,2011,2012)$

Personas de 25 a 64 años con ingresos laborales; ingresos anuales medios de las mujeres como porcentaje de los ingresos de los hombres

\begin{tabular}{|c|c|c|c|c|c|c|c|c|c|c|c|c|c|c|c|}
\hline & \multicolumn{5}{|c|}{ Inferior a educación secundaria superior } & \multicolumn{5}{|c|}{$\begin{array}{l}\text { Educación secundaria superior } \\
\text { o postsecundaria no terciaria }\end{array}$} & \multicolumn{5}{|c|}{ Educación terciaria } \\
\hline & 2000 & 2005 & 2010 & 2011 & 2012 & 2000 & 2005 & 2010 & 2011 & 2012 & 2000 & 2005 & 2010 & 2011 & 2012 \\
\hline & (1) & (2) & (3) & (4) & (5) & (6) & (7) & (8) & (9) & (10) & (11) & (12) & (13) & (14) & (15) \\
\hline Alemania & 56 & 52 & 49 & 56 & 56 & 63 & 62 & 62 & 61 & 62 & 61 & 62 & 56 & 59 & 60 \\
\hline Australia & $\mathrm{m}$ & 61 & $\mathrm{~m}$ & $\mathrm{~m}$ & 62 & $\mathrm{~m}$ & 61 & $\mathrm{~m}$ & $\mathrm{~m}$ & 61 & $\mathrm{~m}$ & 64 & $\mathrm{~m}$ & $\mathrm{~m}$ & 65 \\
\hline Austria & $\mathrm{m}$ & 57 & 61 & 65 & 62 & $\mathrm{~m}$ & 60 & 60 & 59 & 60 & $\mathrm{~m}$ & 62 & 63 & 63 & 62 \\
\hline Bélgica $^{1}$ & 64 & 67 & 72 & 70 & $\mathrm{~m}$ & 72 & 75 & 77 & 77 & $\mathrm{~m}$ & 74 & 73 & 79 & 80 & $\mathrm{~m}$ \\
\hline Canadá & 53 & 55 & 61 & 57 & $\mathrm{~m}$ & 61 & 61 & 62 & 61 & $\mathrm{~m}$ & 57 & 62 & 67 & 64 & $\mathrm{~m}$ \\
\hline Chile & $\mathrm{m}$ & $\mathrm{m}$ & $\mathrm{m}$ & 66 & $\mathrm{~m}$ & $\mathrm{~m}$ & $\mathrm{~m}$ & $\mathrm{~m}$ & 65 & $\mathrm{~m}$ & $\mathrm{~m}$ & $\mathrm{~m}$ & $\mathrm{~m}$ & 63 & $\mathrm{~m}$ \\
\hline Corea & $\mathrm{m}$ & 61 & 64 & 63 & 60 & $\mathrm{~m}$ & 59 & 59 & 58 & 60 & $\mathrm{~m}$ & 67 & 64 & 65 & 65 \\
\hline Dinamarca & $\mathrm{m}$ & 73 & 80 & 78 & 77 & $\mathrm{~m}$ & 71 & 76 & 75 & 74 & $\mathrm{~m}$ & 67 & 68 & 68 & 68 \\
\hline Eslovenia & $\mathrm{m}$ & $\mathrm{m}$ & 85 & 85 & 85 & $\mathrm{~m}$ & $\mathrm{~m}$ & 87 & 86 & 88 & $\mathrm{~m}$ & $\mathrm{~m}$ & 79 & 79 & 82 \\
\hline España & $\mathrm{m}$ & 58 & 66 & 67 & $\mathrm{~m}$ & $\mathrm{~m}$ & 64 & 71 & 72 & $\mathrm{~m}$ & $\mathrm{~m}$ & 75 & 84 & 82 & $\mathrm{~m}$ \\
\hline Estados Unidos & 60 & 63 & 63 & 58 & 66 & 60 & 65 & 66 & 64 & 64 & 56 & 59 & 63 & 63 & 63 \\
\hline Estonia & $\mathrm{m}$ & $\mathrm{m}$ & 59 & 62 & 58 & $\mathrm{~m}$ & $\mathrm{~m}$ & 60 & 62 & 56 & $\mathrm{~m}$ & $\mathrm{~m}$ & 62 & 63 & 66 \\
\hline Finlandia & 76 & 78 & 77 & 76 & $\mathrm{~m}$ & 71 & 73 & 74 & 74 & $\mathrm{~m}$ & 61 & 65 & 68 & 68 & $\mathrm{~m}$ \\
\hline Francia $^{2}$ & $\mathrm{~m}$ & 68 & 61 & $\mathrm{~m}$ & $\mathrm{~m}$ & $\mathrm{~m}$ & 75 & 71 & $\mathrm{~m}$ & $\mathrm{~m}$ & $\mathrm{~m}$ & 70 & 68 & $\mathrm{~m}$ & $\mathrm{~m}$ \\
\hline Grecia & $\mathrm{m}$ & $\mathrm{m}$ & $\mathrm{m}$ & 32 & 70 & $\mathrm{~m}$ & $\mathrm{~m}$ & $\mathrm{~m}$ & 44 & 79 & $\mathrm{~m}$ & $\mathrm{~m}$ & $\mathrm{~m}$ & 65 & 66 \\
\hline Hungría & 83 & 88 & 83 & 84 & 84 & 88 & 93 & 89 & 88 & 85 & 62 & 69 & 68 & 67 & 64 \\
\hline Irlanda $^{1}$ & 46 & 49 & 60 & 56 & $\mathrm{~m}$ & 60 & 63 & 64 & 65 & $\mathrm{~m}$ & 71 & 62 & 63 & 71 & $\mathrm{~m}$ \\
\hline Islandia & $\mathrm{m}$ & $\mathrm{m}$ & $\mathrm{m}$ & $\mathrm{m}$ & $\mathrm{m}$ & $\mathrm{m}$ & $\mathrm{m}$ & $\mathrm{m}$ & $\mathrm{m}$ & $\mathrm{m}$ & $\mathrm{m}$ & $\mathrm{m}$ & $\mathrm{m}$ & $\mathrm{m}$ & $\mathrm{m}$ \\
\hline Israel & $\mathrm{m}$ & 57 & 60 & 62 & 61 & $\mathrm{~m}$ & 59 & 65 & 66 & 58 & $\mathrm{~m}$ & 58 & 60 & 63 & 63 \\
\hline Italia & 76 & $\mathrm{~m}$ & 62 & $\mathrm{~m}$ & $\mathrm{~m}$ & 65 & $\mathrm{~m}$ & 69 & $\mathrm{~m}$ & $\mathrm{~m}$ & 62 & $\mathrm{~m}$ & 64 & $\mathrm{~m}$ & $\mathrm{~m}$ \\
\hline Japón & $\mathrm{m}$ & $\mathrm{m}$ & $\mathrm{m}$ & $\mathrm{m}$ & 42 & $\mathrm{~m}$ & $\mathrm{~m}$ & $\mathrm{~m}$ & $\mathrm{~m}$ & 43 & $\mathrm{~m}$ & $\mathrm{~m}$ & $\mathrm{~m}$ & $\mathrm{~m}$ & 48 \\
\hline Luxemburgo & $\mathrm{m}$ & $\mathrm{m}$ & 63 & $\mathrm{~m}$ & 66 & $\mathrm{~m}$ & $\mathrm{~m}$ & 64 & $\mathrm{~m}$ & 71 & $\mathrm{~m}$ & $\mathrm{~m}$ & 64 & $\mathrm{~m}$ & 65 \\
\hline México & $\mathrm{m}$ & $\mathrm{m}$ & $\mathrm{m}$ & $\mathrm{m}$ & $\mathrm{m}$ & $\mathrm{m}$ & $\mathrm{m}$ & $\mathrm{m}$ & $\mathrm{m}$ & $\mathrm{m}$ & $\mathrm{m}$ & $\mathrm{m}$ & $\mathrm{m}$ & $\mathrm{m}$ & $\mathrm{m}$ \\
\hline Noruega & 63 & 65 & 68 & 68 & $\mathrm{~m}$ & 62 & 63 & 66 & 66 & $\mathrm{~m}$ & 62 & 63 & 65 & 66 & $\mathrm{~m}$ \\
\hline Nueva Zelanda & 67 & 61 & 69 & 70 & 70 & 64 & 64 & 65 & 64 & 67 & 61 & 61 & 68 & 68 & 69 \\
\hline Países Bajos & $\mathrm{m}$ & $\mathrm{m}$ & 49 & $\mathrm{~m}$ & $\mathrm{~m}$ & $\mathrm{~m}$ & $\mathrm{~m}$ & 57 & $\mathrm{~m}$ & $\mathrm{~m}$ & $\mathrm{~m}$ & $\mathrm{~m}$ & 60 & $\mathrm{~m}$ & $\mathrm{~m}$ \\
\hline Polonia & $\mathrm{m}$ & $\mathrm{m}$ & 72 & $\mathrm{~m}$ & 73 & $\mathrm{~m}$ & $\mathrm{~m}$ & 81 & $\mathrm{~m}$ & 79 & $\mathrm{~m}$ & $\mathrm{~m}$ & 72 & $\mathrm{~m}$ & 72 \\
\hline Portugal & $\mathrm{m}$ & 73 & 71 & 72 & $\mathrm{~m}$ & $\mathrm{~m}$ & 71 & 71 & 71 & $\mathrm{~m}$ & $\mathrm{~m}$ & 67 & 70 & 70 & $\mathrm{~m}$ \\
\hline Reino Unido & 50 & 55 & 70 & 50 & 58 & 54 & 56 & 65 & 48 & 57 & 63 & 69 & 71 & 58 & 69 \\
\hline República Checa & $\mathrm{m}$ & 74 & 79 & 79 & $\mathrm{~m}$ & $\mathrm{~m}$ & 80 & 82 & 81 & $\mathrm{~m}$ & $\mathrm{~m}$ & 68 & 68 & 69 & $\mathrm{~m}$ \\
\hline República Eslovaca & $\mathrm{m}$ & $\mathrm{m}$ & 73 & 75 & 73 & $\mathrm{~m}$ & $\mathrm{~m}$ & 73 & 72 & 72 & $\mathrm{~m}$ & $\mathrm{~m}$ & 67 & 66 & 65 \\
\hline Suecia & $\mathrm{m}$ & 74 & 73 & 72 & 72 & $\mathrm{~m}$ & 73 & 74 & 74 & 75 & $\mathrm{~m}$ & 68 & 71 & 71 & 72 \\
\hline Suiza & 53 & 54 & 58 & 55 & 55 & 58 & 57 & 59 & 58 & 58 & 62 & 60 & 61 & 63 & 63 \\
\hline Turquía $^{1}$ & $\mathrm{~m}$ & 47 & $\mathrm{~m}$ & $\mathrm{~m}$ & 55 & $\mathrm{~m}$ & 78 & $\mathrm{~m}$ & $\mathrm{~m}$ & 79 & $\mathrm{~m}$ & 78 & $\mathrm{~m}$ & $\mathrm{~m}$ & 80 \\
\hline
\end{tabular}

\begin{tabular}{|l|l|l|l|l|l|l|l|l|l|l|l|l|l|l|l|} 
Media OCDE $^{3}$ & 62 & 63 & 67 & 65 & 65 & 65 & 67 & 69 & 67 & 67 & 63 & 66 & 67 & 67 & 66 \\
Media UE21 $^{3}$ & 65 & 67 & 68 & 67 & 69 & 68 & 70 & 71 & 69 & 72 & 65 & 68 & 68 & 69 & 68 \\
\hline
\end{tabular}

\begin{tabular}{|c|c|c|c|c|c|c|c|c|c|c|c|c|c|c|c|}
\hline $\begin{array}{l}\text { Arabia Saudí } \\
\text { ". Argentina }\end{array}$ & $\begin{array}{l}\mathrm{m} \\
\mathrm{m}\end{array}$ & $\begin{array}{l}\mathrm{m} \\
\mathrm{m}\end{array}$ & $\begin{array}{l}\mathrm{m} \\
\mathrm{m}\end{array}$ & $\begin{array}{l}\mathrm{m} \\
\mathrm{m}\end{array}$ & $\begin{array}{l}\mathrm{m} \\
\mathrm{m}\end{array}$ & $\begin{array}{l}\mathrm{m} \\
\mathrm{m}\end{array}$ & $\begin{array}{l}\mathrm{m} \\
\mathrm{m}\end{array}$ & $\begin{array}{l}\mathrm{m} \\
\mathrm{m}\end{array}$ & $\begin{array}{l}\mathrm{m} \\
\mathrm{m}\end{array}$ & $\begin{array}{l}\mathrm{m} \\
\mathrm{m}\end{array}$ & $\begin{array}{l}\mathrm{m} \\
\mathrm{m}\end{array}$ & $\begin{array}{l}\mathrm{m} \\
\mathrm{m}\end{array}$ & $\begin{array}{l}\mathrm{m} \\
\mathrm{m}\end{array}$ & $\begin{array}{l}\mathrm{m} \\
\mathrm{m}\end{array}$ & $\begin{array}{l}\mathrm{m} \\
\mathrm{m}\end{array}$ \\
\hline Bürasil & $\mathrm{m}$ & $\mathrm{m}$ & $\mathrm{m}$ & 51 & 55 & $\mathrm{~m}$ & $\mathrm{~m}$ & $\mathrm{~m}$ & 59 & 58 & $\mathrm{~m}$ & $\mathrm{~m}$ & $\mathrm{~m}$ & 58 & 59 \\
\hline 乡ै China & $\mathrm{m}$ & $\mathrm{m}$ & $\mathrm{m}$ & $\mathrm{m}$ & $\mathrm{m}$ & $\mathrm{m}$ & $\mathrm{m}$ & $\mathrm{m}$ & $\mathrm{m}$ & $\mathrm{m}$ & $\mathrm{m}$ & $\mathrm{m}$ & $\mathrm{m}$ & $\mathrm{m}$ & $\mathrm{m}$ \\
\hline Colombia & $\mathrm{m}$ & $\mathrm{m}$ & $\mathrm{m}$ & $\mathrm{m}$ & $\mathrm{m}$ & $\mathrm{m}$ & $\mathrm{m}$ & $\mathrm{m}$ & $\mathrm{m}$ & $\mathrm{m}$ & $\mathrm{m}$ & $\mathrm{m}$ & $\mathrm{m}$ & $\mathrm{m}$ & $\mathrm{m}$ \\
\hline Federación Rusa & $\mathrm{m}$ & $\mathrm{m}$ & $\mathrm{m}$ & $\mathrm{m}$ & $\mathrm{m}$ & $\mathrm{m}$ & $\mathrm{m}$ & $\mathrm{m}$ & $\mathrm{m}$ & $\mathrm{m}$ & $\mathrm{m}$ & $\mathrm{m}$ & $\mathrm{m}$ & $\mathrm{m}$ & $\mathrm{m}$ \\
\hline India & $\mathrm{m}$ & $\mathrm{m}$ & $\mathrm{m}$ & $\mathrm{m}$ & $\mathrm{m}$ & $\mathrm{m}$ & $\mathrm{m}$ & $\mathrm{m}$ & $\mathrm{m}$ & $\mathrm{m}$ & $\mathrm{m}$ & $\mathrm{m}$ & $\mathrm{m}$ & $\mathrm{m}$ & $\mathrm{m}$ \\
\hline Indonesia & $\mathrm{m}$ & $\mathrm{m}$ & $\mathrm{m}$ & $\mathrm{m}$ & $\mathrm{m}$ & $\mathrm{m}$ & $\mathrm{m}$ & $\mathrm{m}$ & $\mathrm{m}$ & $\mathrm{m}$ & $\mathrm{m}$ & $\mathrm{m}$ & $\mathrm{m}$ & $\mathrm{m}$ & $\mathrm{m}$ \\
\hline Letonia & $\mathrm{m}$ & $\mathrm{m}$ & $\mathrm{m}$ & $\mathrm{m}$ & $\mathrm{m}$ & $\mathrm{m}$ & $\mathrm{m}$ & $\mathrm{m}$ & $\mathrm{m}$ & $\mathrm{m}$ & $\mathrm{m}$ & $\mathrm{m}$ & $\mathrm{m}$ & $\mathrm{m}$ & $\mathrm{m}$ \\
\hline Sudáfrica & $\mathrm{m}$ & $\mathrm{m}$ & $\mathrm{m}$ & $\mathrm{m}$ & $\mathrm{m}$ & $\mathrm{m}$ & $\mathrm{m}$ & $\mathrm{m}$ & $\mathrm{m}$ & $\mathrm{m}$ & $\mathrm{m}$ & $\mathrm{m}$ & $\mathrm{m}$ & $\mathrm{m}$ & $\mathrm{m}$ \\
\hline
\end{tabular}

\begin{tabular}{c|c|c|c|c|c|c|c|c|c|c|c|c|c|c|c} 
Media G20 & $\mathrm{m}$ & $\mathrm{m}$ & $\mathrm{m}$ & $\mathrm{m}$ & $\mathrm{m}$ & $\mathrm{m}$ & $\mathrm{m}$ & $\mathrm{m}$ & $\mathrm{m}$ & $\mathrm{m}$ & $\mathrm{m}$ & $\mathrm{m}$ & $\mathrm{m}$ & $\mathrm{m}$ & $\mathrm{m}$ \\
\hline
\end{tabular}

1. Ingresos netos del impuesto sobre la renta.

2. Interrupción en la serie entre 2007 y 2008 , cambio en la fuente de datos.

3. Las medias no pueden compararse a lo largo de los años, ya que el número de países utilizados para calcular dichas medias es diferente cada año.

Fuente: OCDE. Para ver notas, consulte Anexo 3 (www.oecd.org/edu/eag.htm).

Para obtener más información acerca de los símbolos utilizados en lugar de los datos que faltan, consulte la Guía del lector.

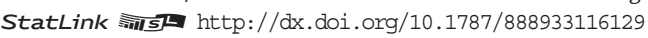


Tabla A6.5a. Ingresos relativos de los estudiantes de 15 a 24 años con ingresos laborales, por nivel educativo alcanzado y sexo (2012) ${ }^{1}$

Ingresos de los estudiantes de 15 a 24 años con renta laboral en comparación con los ingresos de los jóvenes de 15 a 24 años no estudiantes con renta laboral; no estudiantes con renta laboral $=100$

\begin{tabular}{|c|c|c|c|c|c|c|c|c|c|c|}
\hline & \multirow[b]{3}{*}{ Año } & \multicolumn{3}{|c|}{ Inferior a educación secundaria superior } & \multicolumn{3}{|c|}{$\begin{array}{l}\text { Educación secundaria superior } \\
\text { o postsecundaria no terciaria }\end{array}$} & \multicolumn{3}{|c|}{ Educación terciaria } \\
\hline & & Hombres & Mujeres & $\mathrm{H}+\mathrm{M}$ & Hombres & Mujeres & $\mathrm{H}+\mathrm{M}$ & Hombres & Mujeres & $\mathrm{H}+\mathrm{M}$ \\
\hline & & (1) & (2) & (3) & (4) & (5) & (6) & (7) & (8) & (9) \\
\hline Alemania & 2012 & 38 & 48 & 41 & 34 & 48 & 40 & c & c & c \\
\hline Australia & 2012 & c & c & 29 & 51 & 57 & 52 & c & c & 68 \\
\hline Austria & 2012 & 57 & 54 & 55 & 37 & 32 & 33 & c & c & c \\
\hline Bélgica & 2010 & 56 & 57 & 54 & 78 & 63 & 67 & 79 & 83 & 82 \\
\hline Canadá & 2011 & 34 & 47 & 37 & 47 & 57 & 49 & 51 & 55 & 53 \\
\hline Chile & 2011 & 123 & 78 & 112 & 121 & 93 & 111 & c & c & c \\
\hline Corea & 2012 & 41 & 40 & 40 & 64 & 53 & 57 & c & c & c \\
\hline Dinamarca & 2012 & 45 & 46 & 44 & 42 & 55 & 47 & c & c & c \\
\hline Eslovenia & & $\mathrm{m}$ & $\mathrm{m}$ & $\mathrm{m}$ & $\mathrm{m}$ & $\mathrm{m}$ & $\mathrm{m}$ & $\mathrm{m}$ & $\mathrm{m}$ & $\mathrm{m}$ \\
\hline España & 2011 & 49 & 71 & 56 & 45 & 32 & 39 & c & c & c \\
\hline Estados Unidos & 2012 & 24 & 34 & 26 & 50 & 66 & 56 & 64 & 73 & 68 \\
\hline Estonia & 2012 & c & c & c & c & c & c & c & c & c \\
\hline Finlandia & 2011 & 33 & 48 & c & 55 & 58 & c & c & c & c \\
\hline Francia & 2010 & 53 & 46 & 50 & 46 & 47 & 45 & c & c & c \\
\hline Grecia & 2012 & c & c & c & 58 & 121 & 92 & c & c & c \\
\hline Hungría & & $\mathrm{m}$ & $\mathrm{m}$ & $\mathrm{m}$ & $\mathrm{m}$ & $\mathrm{m}$ & $\mathrm{m}$ & $\mathrm{m}$ & $\mathrm{m}$ & $\mathrm{m}$ \\
\hline Irlanda & 2011 & 21 & c & 17 & 57 & 60 & 57 & c & c & c \\
\hline Islandia & & $\mathrm{m}$ & $\mathrm{m}$ & $\mathrm{m}$ & $\mathrm{m}$ & $\mathrm{m}$ & $\mathrm{m}$ & $\mathrm{m}$ & $\mathrm{m}$ & $\mathrm{m}$ \\
\hline Israel & 2012 & c & c & c & 63 & 22 & 44 & c & c & c \\
\hline Italia & 2010 & 45 & 45 & 43 & 45 & 79 & 59 & c & c & c \\
\hline Japón & & $\mathrm{m}$ & $\mathrm{m}$ & $\mathrm{m}$ & $\mathrm{m}$ & $\mathrm{m}$ & $\mathrm{m}$ & $\mathrm{m}$ & $\mathrm{m}$ & $\mathrm{m}$ \\
\hline Luxemburgo & & $\mathrm{m}$ & $\mathrm{m}$ & $\mathrm{m}$ & $\mathrm{m}$ & $\mathrm{m}$ & $\mathrm{m}$ & $\mathrm{m}$ & $\mathrm{m}$ & $\mathrm{m}$ \\
\hline México & & $\mathrm{m}$ & $\mathrm{m}$ & $\mathrm{m}$ & $\mathrm{m}$ & $\mathrm{m}$ & $\mathrm{m}$ & $\mathrm{m}$ & $\mathrm{m}$ & $\mathrm{m}$ \\
\hline Noruega & 2011 & 38 & 34 & 36 & 38 & 46 & 40 & c & c & c \\
\hline Nueva Zelanda & 2010 & 42 & 29 & 35 & 62 & 47 & 53 & c & c & c \\
\hline Países Bajos & & $\mathrm{m}$ & $\mathrm{m}$ & $\mathrm{m}$ & $\mathrm{m}$ & $\mathrm{m}$ & $\mathrm{m}$ & $\mathrm{m}$ & $\mathrm{m}$ & $\mathrm{m}$ \\
\hline Polonia & & $\mathrm{m}$ & $\mathrm{m}$ & $\mathrm{m}$ & $\mathrm{m}$ & $\mathrm{m}$ & $\mathrm{m}$ & $\mathrm{m}$ & $\mathrm{m}$ & $\mathrm{m}$ \\
\hline Portugal & & $\mathrm{m}$ & $\mathrm{m}$ & $\mathrm{m}$ & $\mathrm{m}$ & $\mathrm{m}$ & $\mathrm{m}$ & $\mathrm{m}$ & $\mathrm{m}$ & $\mathrm{m}$ \\
\hline Reino Unido & 2012 & 31 & 57 & 48 & 51 & 51 & 49 & 79 & 76 & 78 \\
\hline República Checa & & $\mathrm{m}$ & $\mathrm{m}$ & $\mathrm{m}$ & $\mathrm{m}$ & $\mathrm{m}$ & $\mathrm{m}$ & $\mathrm{m}$ & $\mathrm{m}$ & $\mathrm{m}$ \\
\hline República Eslovaca & & $\mathrm{m}$ & $\mathrm{m}$ & $\mathrm{m}$ & $\mathrm{m}$ & $\mathrm{m}$ & $\mathrm{m}$ & $\mathrm{m}$ & $\mathrm{m}$ & $\mathrm{m}$ \\
\hline Suecia & 2009 & 11 & 12 & 11 & 46 & 58 & 50 & 30 & 44 & 38 \\
\hline Suiza & 2012 & 36 & 47 & 43 & 63 & 50 & 56 & c & c & c \\
\hline Turquía & 2012 & 81 & 99 & 83 & 100 & 64 & 84 & c & c & c \\
\hline Media OCDE & & 45 & 50 & 45 & 57 & 57 & 56 & c & c & c \\
\hline Media UE21 & & 40 & 48 & 42 & 49 & 59 & 53 & c & c & c \\
\hline Arabia Saudí & & $\mathrm{m}$ & $\mathrm{m}$ & $\mathrm{m}$ & $\mathrm{m}$ & $\mathrm{m}$ & $\mathrm{m}$ & $\mathrm{m}$ & $\mathrm{m}$ & $\mathrm{m}$ \\
\hline Argentina & & $\mathrm{m}$ & $\mathrm{m}$ & $\mathrm{m}$ & $\mathrm{m}$ & $\mathrm{m}$ & $\mathrm{m}$ & $\mathrm{m}$ & $\mathrm{m}$ & $\mathrm{m}$ \\
\hline Brasil & 2012 & 59 & 74 & 62 & 114 & 115 & 112 & $\mathrm{~m}$ & $\mathrm{~m}$ & $\mathrm{~m}$ \\
\hline China & & $\mathrm{m}$ & $\mathrm{m}$ & $\mathrm{m}$ & $\mathrm{m}$ & $\mathrm{m}$ & $\mathrm{m}$ & $\mathrm{m}$ & $\mathrm{m}$ & $\mathrm{m}$ \\
\hline Colombia & & $\mathrm{m}$ & $\mathrm{m}$ & $\mathrm{m}$ & $\mathrm{m}$ & $\mathrm{m}$ & $\mathrm{m}$ & $\mathrm{m}$ & $\mathrm{m}$ & $\mathrm{m}$ \\
\hline Federación Rusa & & $\mathrm{m}$ & $\mathrm{m}$ & $\mathrm{m}$ & $\mathrm{m}$ & $\mathrm{m}$ & $\mathrm{m}$ & $\mathrm{m}$ & $\mathrm{m}$ & $\mathrm{m}$ \\
\hline India & & $\mathrm{m}$ & $\mathrm{m}$ & $\mathrm{m}$ & $\mathrm{m}$ & $\mathrm{m}$ & $\mathrm{m}$ & $\mathrm{m}$ & $\mathrm{m}$ & $\mathrm{m}$ \\
\hline Indonesia & & $\mathrm{m}$ & $\mathrm{m}$ & $\mathrm{m}$ & $\mathrm{m}$ & $\mathrm{m}$ & $\mathrm{m}$ & $\mathrm{m}$ & $\mathrm{m}$ & $\mathrm{m}$ \\
\hline Letonia & & $\mathrm{m}$ & $\mathrm{m}$ & $\mathrm{m}$ & $\mathrm{m}$ & $\mathrm{m}$ & $\mathrm{m}$ & $\mathrm{m}$ & $\mathrm{m}$ & $\mathrm{m}$ \\
\hline Sudáfrica & & $\mathrm{m}$ & $\mathrm{m}$ & $\mathrm{m}$ & $\mathrm{m}$ & $\mathrm{m}$ & $\mathrm{m}$ & $\mathrm{m}$ & $\mathrm{m}$ & $\mathrm{m}$ \\
\hline Media G20 & & $\mathrm{m}$ & $\mathrm{m}$ & $\mathrm{m}$ & $\mathrm{m}$ & $\mathrm{m}$ & $\mathrm{m}$ & $\mathrm{m}$ & $\mathrm{m}$ & $\mathrm{m}$ \\
\hline
\end{tabular}

Nota: Las columnas que muestran los ingresos relativos de todos los niveles de educación combinados están disponibles en Internet (véase StatLink más abajo).

1. Para algunos países de esta tabla el desglose de edades es de los 16 a los 24 años.

Fuente: OCDE. Para ver notas, consulte Anexo 3 (www.oecd.org/edw/eag.htm).

Para obtener más información acerca de los símbolos utilizados en lugar de los datos que faltan, consulte la Guía del lector.

StatLink 게네 $\mathrm{http}: / / \mathrm{dx}$.doi.org/10.1787/888933116148 
Tabla A6.5b. Porcentaje de jóvenes de 15 a 29 años con ingresos laborales entre todos los jóvenes de 15 a 29 años, por grupo de edad y estatus de estudiante (2012)

\begin{tabular}{|c|c|c|c|c|c|c|c|}
\hline & \multirow[b]{3}{*}{ Año } & \multicolumn{3}{|c|}{ De 15 a 24 años $^{1}$} & \multicolumn{3}{|c|}{ De 25 a 29 años } \\
\hline & & No estudiantes & Estudiantes & Total & No estudiantes & Estudiantes & Total \\
\hline & & (1) & (2) & (3) & (4) & (5) & (6) \\
\hline Alemania & 2012 & 66 & 37 & 46 & 70 & 62 & 68 \\
\hline Australia & 2012 & 70 & 47 & 56 & 79 & 71 & 77 \\
\hline Austria & 2012 & 87 & 64 & 73 & 91 & 81 & 89 \\
\hline Bélgica & 2010 & 60 & 6 & 24 & 73 & 41 & 71 \\
\hline Canadá & 2011 & 86 & 68 & 75 & 89 & 77 & 87 \\
\hline Chile & 2011 & 50 & 10 & 27 & 70 & 45 & 66 \\
\hline Corea & 2012 & 54 & 10 & 24 & 71 & 32 & 68 \\
\hline Dinamarca & 2012 & 71 & 71 & 71 & 81 & 82 & 82 \\
\hline Eslovenia & & $\mathrm{m}$ & $\mathrm{m}$ & $\mathrm{m}$ & $\mathrm{m}$ & $\mathrm{m}$ & $\mathrm{m}$ \\
\hline España & 2011 & 53 & 10 & 26 & 73 & 54 & 70 \\
\hline Estados Unidos & 2012 & 72 & 41 & 54 & c & c & c \\
\hline Estonia & 2012 & c & 13 & 22 & c & c & 49 \\
\hline Finlandia & 2011 & c & c & c & c & c & c \\
\hline Francia & 2010 & 78 & 35 & 56 & 91 & 79 & 90 \\
\hline Grecia & 2012 & 32 & 5 & 15 & 58 & 30 & 55 \\
\hline Hungría & & $\mathrm{m}$ & $\mathrm{m}$ & $\mathrm{m}$ & $\mathrm{m}$ & $\mathrm{m}$ & $\mathrm{m}$ \\
\hline Irlanda & 2011 & 35 & 26 & 30 & 69 & 36 & 65 \\
\hline Islandia & & $\mathrm{m}$ & $\mathrm{m}$ & $\mathrm{m}$ & $\mathrm{m}$ & $\mathrm{m}$ & $\mathrm{m}$ \\
\hline Israel & 2012 & 63 & 18 & 42 & 76 & 68 & 74 \\
\hline Italia & 2010 & 56 & 12 & 33 & 79 & 38 & 74 \\
\hline Japón & & $\mathrm{m}$ & $\mathrm{m}$ & $\mathrm{m}$ & $\mathrm{m}$ & $\mathrm{m}$ & $\mathrm{m}$ \\
\hline Luxemburgo & & $\mathrm{m}$ & $\mathrm{m}$ & $\mathrm{m}$ & $\mathrm{m}$ & $\mathrm{m}$ & $\mathrm{m}$ \\
\hline México & & $\mathrm{m}$ & $\mathrm{m}$ & $\mathrm{m}$ & $\mathrm{m}$ & $\mathrm{m}$ & $\mathrm{m}$ \\
\hline Noruega & 2011 & 71 & 76 & 74 & 89 & 90 & 90 \\
\hline Nueva Zelanda & 2010 & 69 & 33 & 48 & 75 & 61 & 73 \\
\hline Países Bajos & & $\mathrm{m}$ & $\mathrm{m}$ & $\mathrm{m}$ & $\mathrm{m}$ & $\mathrm{m}$ & $\mathrm{m}$ \\
\hline Polonia & & $\mathrm{m}$ & $\mathrm{m}$ & $\mathrm{m}$ & $\mathrm{m}$ & $\mathrm{m}$ & $\mathrm{m}$ \\
\hline Portugal & & $\mathrm{m}$ & $\mathrm{m}$ & $\mathrm{m}$ & $\mathrm{m}$ & $\mathrm{m}$ & $\mathrm{m}$ \\
\hline Reino Unido & 2012 & 65 & 33 & 51 & 79 & 62 & 77 \\
\hline República Checa & & $\mathrm{m}$ & $\mathrm{m}$ & $\mathrm{m}$ & $\mathrm{m}$ & $\mathrm{m}$ & $\mathrm{m}$ \\
\hline República Eslovaca & & $\mathrm{m}$ & $\mathrm{m}$ & $\mathrm{m}$ & $\mathrm{m}$ & $\mathrm{m}$ & $\mathrm{m}$ \\
\hline Suecia & 2009 & 100 & 100 & 100 & 99 & 100 & 99 \\
\hline Suiza & 2012 & 70 & 17 & 36 & 82 & 60 & 78 \\
\hline Turquía & 2012 & 76 & 77 & 76 & 86 & 88 & 86 \\
\hline Media OCDE & & 66 & 37 & 48 & 79 & 63 & 76 \\
\hline Media UE21 & & 64 & 34 & 46 & 79 & 60 & 74 \\
\hline Arabia Saudí & & $\mathrm{m}$ & $\mathrm{m}$ & $\mathrm{m}$ & $\mathrm{m}$ & $\mathrm{m}$ & $\mathrm{m}$ \\
\hline Argentina & & $\mathrm{m}$ & $\mathrm{m}$ & $\mathrm{m}$ & $\mathrm{m}$ & $\mathrm{m}$ & $\mathrm{m}$ \\
\hline Brasil & 2012 & 64 & 34 & 50 & 76 & 73 & 75 \\
\hline China & & $\mathrm{m}$ & $\mathrm{m}$ & $\mathrm{m}$ & $\mathrm{m}$ & $\mathrm{m}$ & $\mathrm{m}$ \\
\hline Colombia & & $\mathrm{m}$ & $\mathrm{m}$ & $\mathrm{m}$ & $\mathrm{m}$ & $\mathrm{m}$ & $\mathrm{m}$ \\
\hline Federación Rusa & & $\mathrm{m}$ & $\mathrm{m}$ & $\mathrm{m}$ & $\mathrm{m}$ & $\mathrm{m}$ & $\mathrm{m}$ \\
\hline India & & $\mathrm{m}$ & $\mathrm{m}$ & $\mathrm{m}$ & $\mathrm{m}$ & $\mathrm{m}$ & $\mathrm{m}$ \\
\hline Indonesia & & $\mathrm{m}$ & $\mathrm{m}$ & $\mathrm{m}$ & $\mathrm{m}$ & $\mathrm{m}$ & $\mathrm{m}$ \\
\hline Letonia & & $\mathrm{m}$ & $\mathrm{m}$ & $\mathrm{m}$ & $\mathrm{m}$ & $\mathrm{m}$ & $\mathrm{m}$ \\
\hline Sudáfrica & & $\mathrm{m}$ & $\mathrm{m}$ & $\mathrm{m}$ & $\mathrm{m}$ & $\mathrm{m}$ & $\mathrm{m}$ \\
\hline Media G20 & & $\mathrm{m}$ & $\mathrm{m}$ & $\mathrm{m}$ & $\mathrm{m}$ & $\mathrm{m}$ & $\mathrm{m}$ \\
\hline
\end{tabular}

1. Para algunos países de esta tabla el desglose de edades es de los 16 a los 24 años.

Fuente: OCDE. Para ver notas, consulte Anexo 3 (www.oecd.org/edu/eag.htm).

Para obtener más información acerca de los símbolos utilizados en lugar de los datos que faltan, consulte la Guía del lector.

StatLink 젬ㄴ http://dx.doi.org/10.1787/888933116167 
Tabla A6.6a (L). [1/2] Ingresos medios mensuales de los trabajadores, por nivel educativo alcanzado y nivel de comprensión lectora (2012)

Comprensión lectora en la Encuesta sobre las Competencias de los Adultos, personas de 25 a 64 años con ingresos laborales que trabajan a tiempo completo (es decir, 30 horas o más a la semana); en equivalente a dólares estadounidenses convertidos mediante PPA para el consumo privado

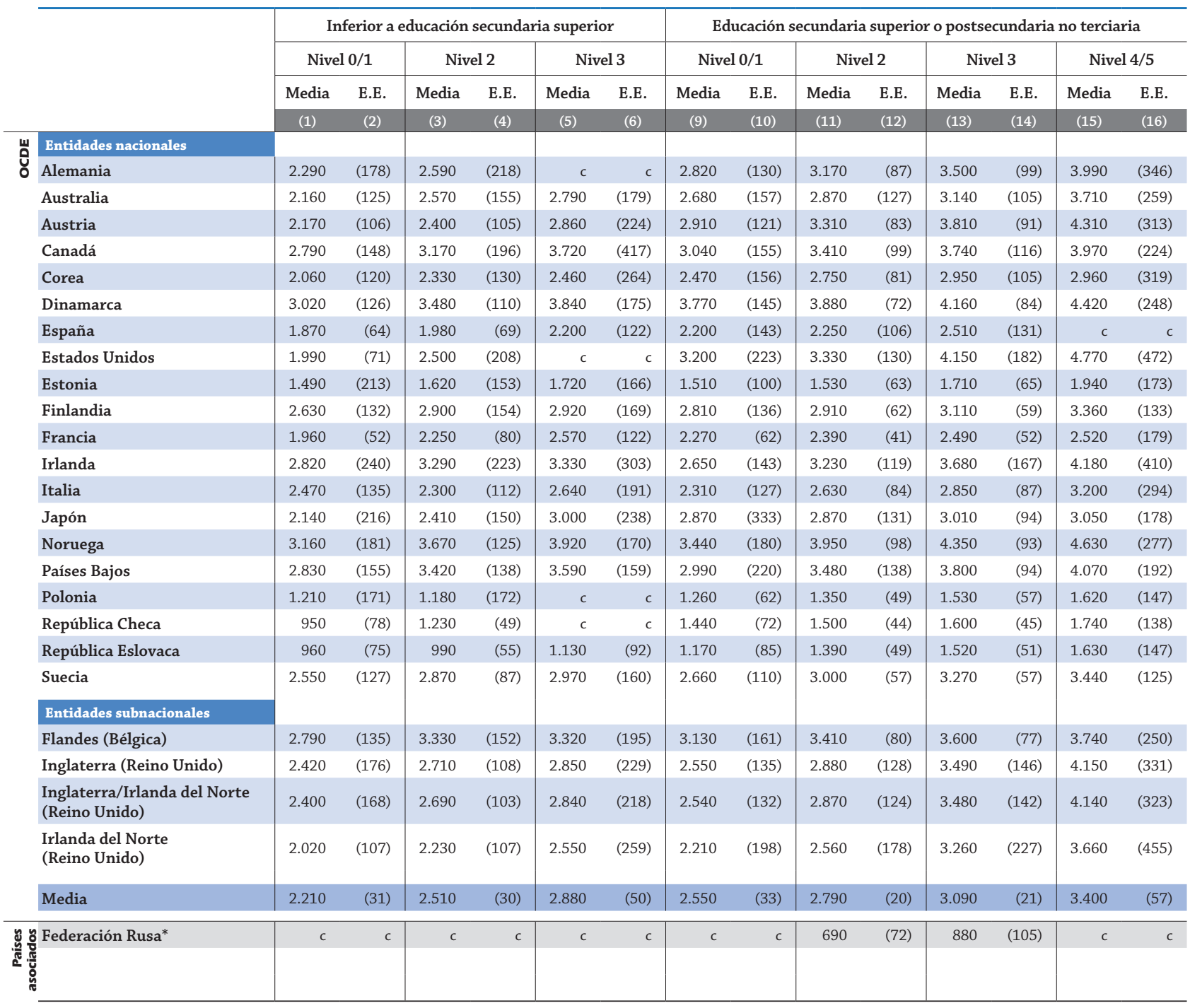

* Para los datos de Federación Rusa, véase nota en la sección de Metodología.

Notas: Para el nivel inferior a la educación secundaria superior, el nivel de comprensión lectora 4 o 5 está disponible solo en Internet, ya que en muchos países existen demasiado pocas observaciones para ofrecer una estimación fiable. Los valores de las medias de esta tabla se han redondeado a la decena más próxima. Los valores no redondeados están disponibles en Internet.

Fuente: OCDE. Encuesta sobre las Competencias de los Adultos (PIAAC) (2012). PIAAC se refiere al Programa para la Evaluación Internacional de las Competencias de los Adultos de la OCDE. Para ver notas, consulte Anexo 3 (www.oecd.org/edu/eag.htm).

Para obtener más información acerca de los símbolos utilizados en lugar de los datos que faltan, consulte la Guía del lector.

StatLink त्नाज् http://dx.doi.org/10.1787/888933116186 
Tabla A6.6a (L). [2/2] Ingresos medios mensuales de los trabajadores, por nivel educativo alcanzado y nivel de comprensión lectora (2012)

Comprensión lectora en la Encuesta sobre las Competencias de los Adultos, personas de 25 a 64 años con ingresos laborales que trabajan a tiempo completo (es decir, 30 horas o más a la semana); en equivalente a dólares estadounidenses convertidos mediante PPA para el consumo privado

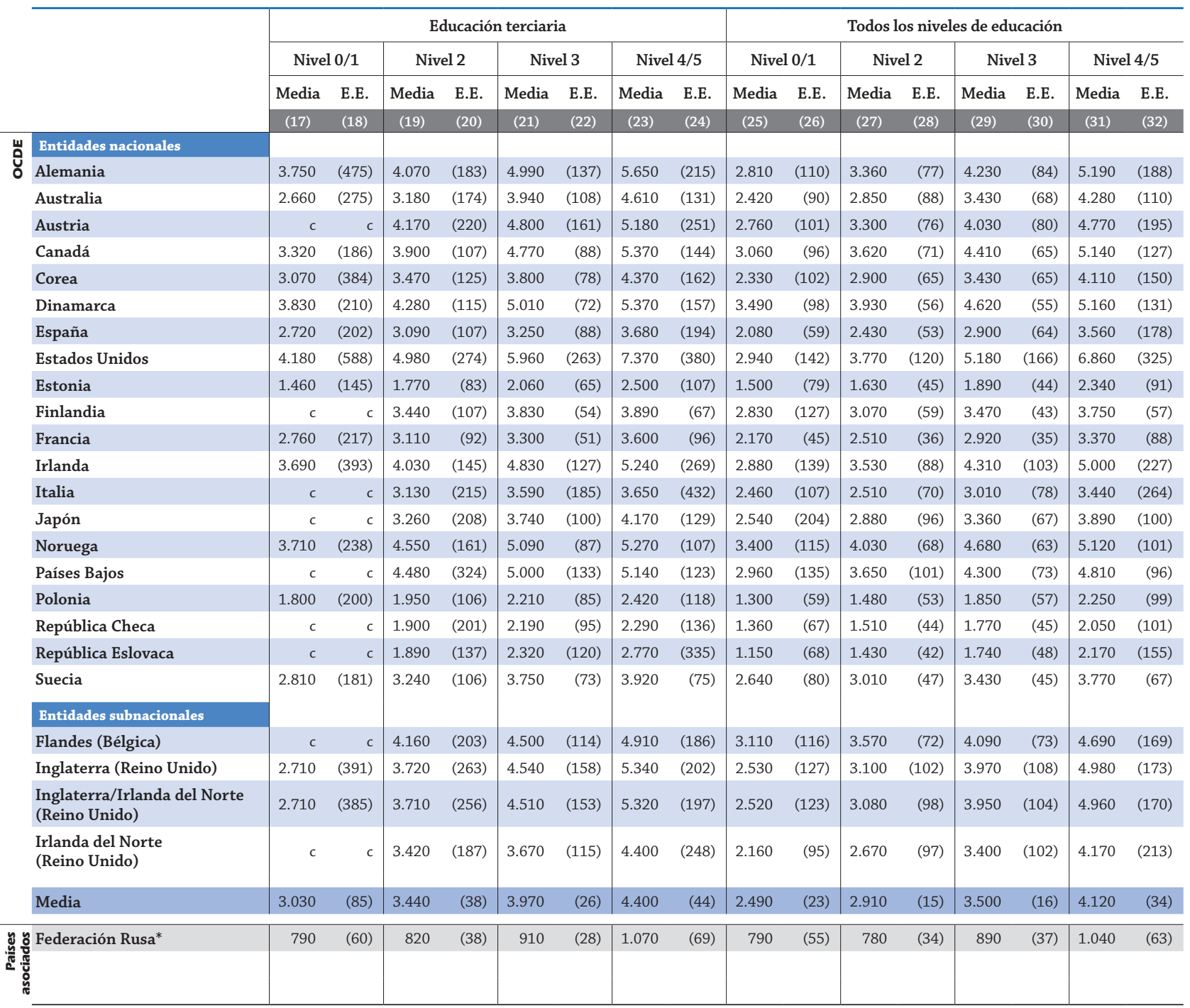

* Para los datos de Federación Rusa, véase nota en la sección de Metodología.

Notas: Para el nivel inferior a la educación secundaria superior, el nivel de comprensión lectora 4 o 5 está disponible solo en Internet, ya que en muchos países existen demasiado pocas observaciones para ofrecer una estimación fiable. Los valores de las medias de esta tabla se han redondeado a la decena más próxima. Los valores no redondeados están disponibles en Internet.

Fuente: OCDE. Encuesta sobre las Competencias de los Adultos (PIAAC) (2012). PIAAC se refiere al Programa para la Evaluación Internacional de las Competencias de los Adultos de la OCDE. Para ver notas, consulte Anexo 3 (www.oecd.org/edu/eag.htm).

Para obtener más información acerca de los símbolos utilizados en lugar de los datos que faltan, consulte la Guía del lector.

StatLink 제이 http://dx.doi.org/10.1787/888933116186 



\section{¿CUÁLES SON LOS INCENTIVOS PARA INVERTIR EN EDUCACIÓN?}

- Las personas que completan la educación terciaria se benefician de un retorno considerable de la inversión: tienen más probabilidades de obtener un empleo y de ganar más que las personas sin educación terciaria.

- Por término medio en los países de la OCDE, el retorno económico para las personas con educación terciaria es alrededor del doble que para aquellas con educación secundaria superior o postsecundaria no terciaria.

- Pero la educación no solamente favorece a los individuos, sino que la población en general también se beneficia de una mayor proporción de personas con educación terciaria a través de una mayor recaudación fiscal y cotizaciones sociales.

- El retorno público neto de una inversión en educación terciaria para un varón es de más de 105.000 dólares estadounidenses en todos los países de la OCDE, casi tres veces el importe de la inversión pública en su educación. Para una mujer, el retorno público es de más de 60.000 dólares estadounidenses, casi dos veces el importe de la inversión pública en su educación.

\section{Gráfico A7.1. Retornos privados y públicos netos asociados a un hombre que alcanza la educación terciaria (2010)}

En comparación con los retornos de la educación secundaria superior o postsecundaria no terciaria

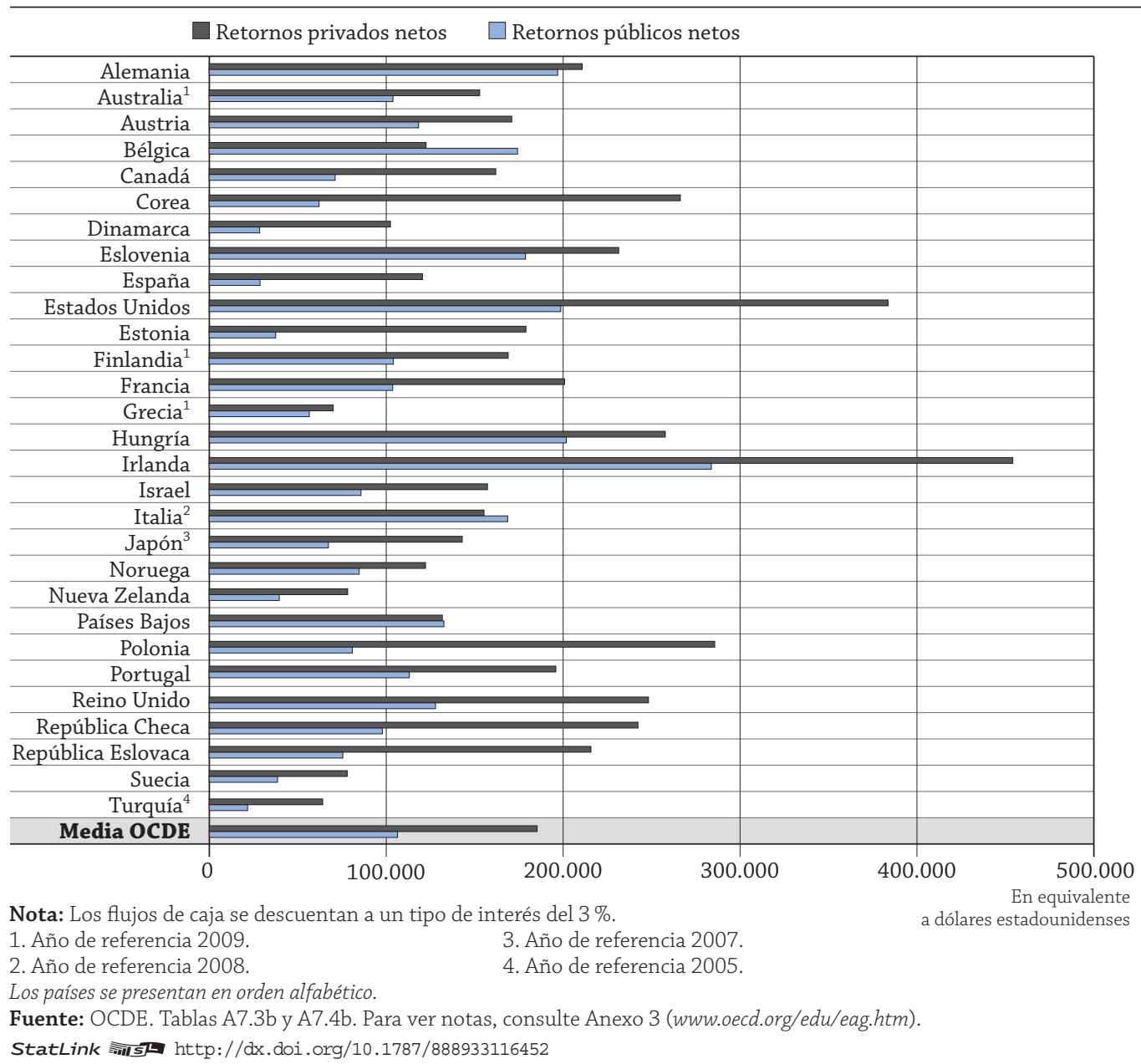

\section{Contexto}

Alcanzar un nivel de educación superior beneficia tanto a los individuos como a la sociedad, no solo económicamente, sino por el bienestar al que se asocia, con mejores resultados para la salud y mayor participación cívica. Para los individuos, contar con estudios superiores mejora sus probabilidades de empleo y 
reduce el riesgo de desempleo. Mejores oportunidades en el mercado laboral (véase Indicador A5) y mayores expectativas de beneficios económicos (véase Indicador A6) son incentivos fuertes para que las personas inviertan en educación y pospongan el consumo y los ingresos actuales por una recompensa futura. La sociedad, a su vez, se beneficia a través de un menor gasto público en programas de bienestar social y de la recaudación de los impuestos pagados por los individuos una vez que acceden al mercado laboral.

Para los responsables políticos es crucial conocer los incentivos económicos que representa para los individuos la inversión en educación. Por ejemplo, un incremento significativo en la demanda de trabajadores con mayor-nivel educativo por parte del mercado laboral puede aumentar los ingresos y los retornos antes de que se estabilice la oferta. Esto indicaría una necesidad de invertir más en educación. En los países con legislaciones y estructuras laborales rígidas que tienden a limitar las diferencias salariales de manera generalizada, esta señal sería más débil.

Tener en cuenta el retorno de la educación también es relevante para las políticas sobre el acceso a la educación, la fiscalidad y los costes de la educación superior para las personas. Por tanto, es importante considerar el equilibrio entre los retornos públicos y los privados junto con la información de los demás indicadores de esta publicación. No basta con considerar solo la tasa de retorno público para determinar el importe óptimo que deberían invertir los gobiernos en la educación (véase Cuadro A7.1 de Panorama de la educación 2013 [OECD, 2013a]).

En países con programas de educación terciaria largos e ingresos relativamente altos tras la educación secundaria superior o la postsecundaria no terciaria, el efecto de los ingresos no percibidos es considerable (véase Indicador B1). La magnitud de este efecto depende también de los niveles salariales esperados y de la probabilidad de encontrar trabajo con o sin una graduación terciaria. A medida que empeora el mercado laboral para los jóvenes (véase Indicador C5), el efecto de los ingresos no percibidos se reduce y la inversión en educación terciaria resulta menos costosa. Puesto que las personas con nivel de educación más alto se mueven mejor en el mercado laboral en tiempos difíciles (véase Indicador A5), el beneficio es aún mayor para el individuo y para la sociedad. Los datos de 2010 (utilizados en este volumen), cuando los efectos de la crisis económica global ya eran muy marcados, demuestran que tanto los retornos privados como los públicos son mayores para las personas con educación terciaria en comparación con aquellas con educación secundaria superior y postsecundaria no terciaria.

Hay que recordar que diversos factores educativos y contextuales no reflejados en este indicador afectan al retorno de la educación. Por ejemplo, el ámbito de estudio, la situación económica específica de cada país, el contexto del mercado laboral y el marco institucional, así como factores sociales y culturales.

\section{Otros resultados}

- Los beneficios de los ingresos brutos de la educación terciaria, en comparación con la renta de una persona con educación secundaria superior o postsecundaria no terciaria, son de 350.000 dólares estadounidenses para los hombres y de $\mathbf{2 5 0 . 0 0 0 ~ d o ́ l a r e s ~ e s t a d o u n i d e n s e s ~ p a r a ~ l a s ~ m u j e r e s ~}$ en todos los países de la OCDE.

- Los beneficios de los ingresos brutos para una persona que obtenga una graduación de educación secundaria superior o postsecundaria no terciaria, en comparación con los beneficios para una persona que no haya alcanzado este nivel de educación, son especialmente elevados en Austria, Estados Unidos y Noruega. En estos países, representan al menos 260.000 dólares estadounidenses para los hombres y 160.000 dólares estadounidenses para las mujeres.

- Por término medio en los 28 países de la OCDE de los que se dispone de datos, el retorno público (valor actual neto) para un hombre que haya completado la educación secundaria superior o postsecundaria no terciaria es de alrededor de 39.000 dólares estadounidenses en comparación con un hombre que no haya alcanzado ese nivel de educación. Para una mujer, el retorno público es de $\mathbf{2 4 . 0 0 0 ~ d o ́ l a r e s ~ e s t a d o u n i d e n s e s . ~}$

- Salvo pocas excepciones, los retornos privados netos relacionados con la obtención de una educación terciaria superan aquellos relacionados con alcanzar una educación secundaria superior o postsecundaria no terciaria. Solo en Noruega y Suecia, la educación secundaria superior o postsecundaria no terciaria aporta más retorno a los hombres.

- En los países de la OCDE, una persona invierte, como media, alrededor de 50.000 dólares estadounidenses en obtener una titulación terciaria. En Japón y Países Bajos, la inversión media supera los 100.000 dólares estadounidenses cuando se tienen en cuenta los costes directos y los indirectos. 


\section{Análisis}

\section{Retornos económicos de la inversión en educación}

Este indicador ofrece información sobre los costes y beneficios de la educación y los incentivos para invertir en educación. Evalúa los beneficios económicos de la educación para un individuo estimando la ventaja de ingresos de los niveles superiores de educación, considerando los costes directos e indirectos y los beneficios de alcanzar esos niveles de educación. Además de obtener ingresos mayores en comparación con las personas con niveles educativos inferiores, también es un beneficio la mayor probabilidad de encontrar empleo, expresada en términos monetarios por la variable denominada «efecto del desempleo» (véase la sección Definiciones más adelante).

Los costes incluyen costes directos, principalmente matrículas, y costes indirectos, debido a impuestos sobre la renta más elevados, cotizaciones sociales, pérdida salarial causada por retraso en la entrada al mercado laboral y menos derecho a prestaciones sociales, como ayudas para la vivienda, ayudas familiares u otras prestaciones sociales adicionales. Además, las cotizaciones sociales y los impuestos sobre la renta suponen cierto porcentaje de los ingresos y tienden a ser mayores para las personas con una educación superior, ya que tienden a ganar más.

Los beneficios económicos y los costes de la educación terciaria se comparan con los de la educación secundaria superior o postsecundaria no terciaria; para la educación secundaria superior o postsecundaria no terciaria, la referencia es la educación inferior a la secundaria superior. En el cálculo, se comparan mujeres con mujeres, y hombres con hombres. Los cálculos se han realizado por separado entre hombres y mujeres, y no se ha computado ninguna media para explicar las diferencias por sexo en la diferencia de ingresos y las tasas de desempleo.

Proporcionar información sobre los costes y beneficios de la educación y los incentivos para invertir en educación es una labor difícil que conlleva ciertas consideraciones metodológicas y analíticas. Invertir en educación, tanto por parte de los individuos como de los gobiernos, implica una interacción compleja de factores y efectos que van más allá de los que aquí se han tenido en cuenta. Por tanto, este indicador debe interpretarse en el contexto de otros indicadores de este volumen (y de Panorama de la educación 2013 [OECD, 2013a]) para comprender mejor los resultados. Las limitaciones de los cálculos, y los conceptos y supuestos subyacentes, se presentan en la sección Metodología al final del capítulo.

\section{Incentivos de los individuos para invertir en educación}

\section{Educación secundaria superior o postsecundaria no terciaria}

En todos los países de la OCDE, un hombre que invierta en educación secundaria superior o postsecundaria no terciaria puede esperar una ganancia neta de alrededor de 100.000 dólares estadounidenses durante su vida laboral en comparación con un hombre que haya alcanzado un nivel de educación inferior al de secundaria superior. Sin embargo, el importe varía significativamente de un país a otro: en Estados Unidos, Irlanda y República Eslovaca, este nivel educativo genera 160.000 dólares estadounidenses o más a lo largo de la vida laboral (Tabla A7.1a).

Los beneficios para un individuo se basan generalmente en los ingresos brutos y en el menor riesgo de desempleo. En todos los países, los hombres con una educación secundaria superior o postsecundaria no terciaria disfrutan de una ventaja de ingresos significativa en comparación con aquellos que no han alcanzado ese nivel educativo. El valor de un menor riesgo de desempleo también puede ser considerable. En Alemania, Bélgica, Irlanda, República Checa y República Eslovaca, las mejores perspectivas en el mercado laboral para un hombre con este nivel de educación se valoran en 80.000 dólares estadounidenses o más (Tabla A7.1a).

Los costes directos, ingresos no percibidos, efectos del impuesto sobre la renta, efectos sobre las prestaciones y cotizaciones sociales (véase sección de Definiciones más adelante) son parte de los costes de la educación. Los costes directos de la educación son iguales para un hombre que para una mujer. Los costes directos de la inversión de una persona en educación secundaria superior o postsecundaria no terciaria son insignificantes en todos los países (representando, por término medio, menos del $2 \%$ y como máximo el $6 \%$ de los beneficios). Por tanto, los ingresos no percibidos representan el principal coste de la inversión -lo que un estudiante podría potencialmente ganar si no estuviera estudiando-. Los ingresos no percibidos varían sustancialmente entre los países, dependiendo de la duración de la educación, los niveles de ingresos y la diferencia de ingresos entre las personas con educación secundaria superior o postsecundaria no terciaria y aquellos sin ella (Tablas A7.1a y A7.1b).

Las buenas perspectivas en el mercado laboral tanto para hombres como para mujeres que no han completado la educación secundaria superior o postsecundaria no terciaria aumentan los costes de las inversiones posteriores en educación; al igual que lo hacen las pequeñas diferencias de ingresos y los programas más largos de educación secundaria superior o postsecundaria no terciaria. En España, Estonia, Hungría, República Eslovaca y Turquía, los ingresos no percibidos se estiman por debajo de los 13.000 dólares estadounidenses para un individuo (tanto hom- 


\section{Gráfico A7.2. Costes y beneficios privados para un hombre y una mujer que alcanzan la educación secundaria superior o postsecundaria no terciaria (2010) \\ En comparación con los costes y beneficios del nivel de educación inferior a secundaria superior}

Coste directo $\square$ Pérdida de ingresos $\square$ Efecto del impuesto sobre la renta $\mathbb{N}$ Efecto de las cotizaciones sociales

$\square$ Efecto de las prestaciones $\square$ Beneficios de los ingresos brutos $\square$ Efecto del desempleo

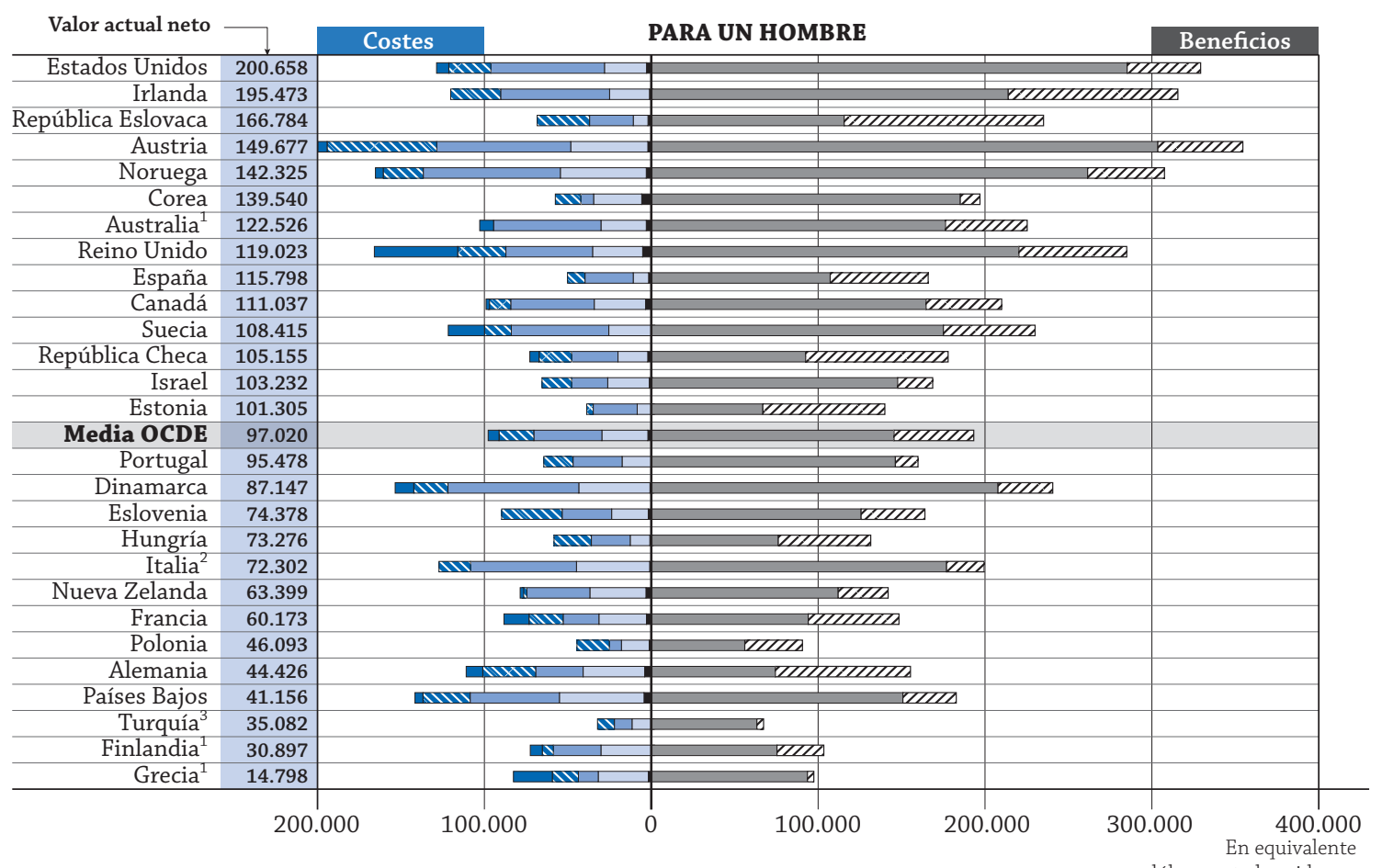

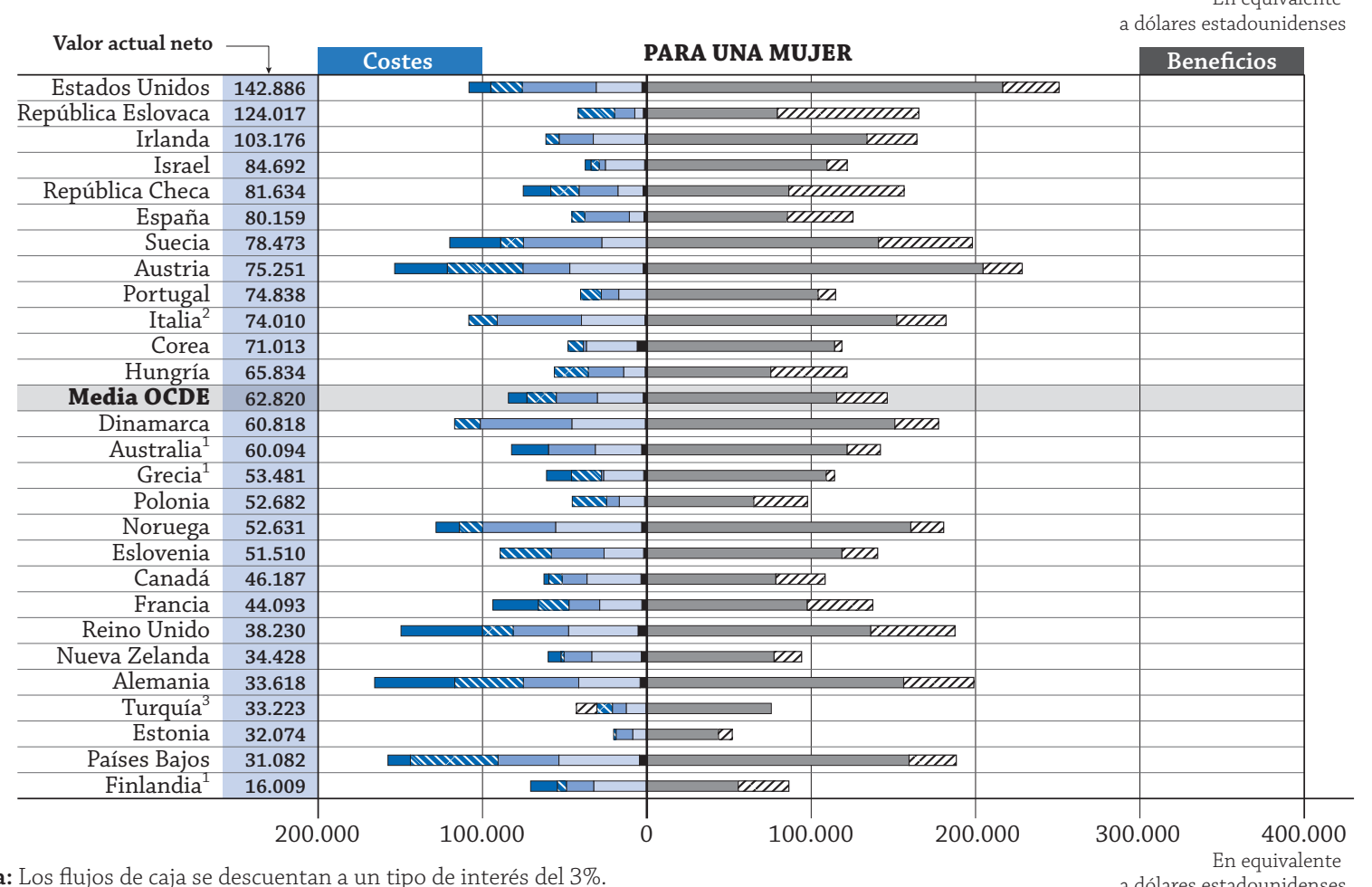

1. Año de referencia 2009

2. Año de referencia 2008.

3. Año de referencia 2005.

Los países están clasificados en orden descendente del valor actual neto privado.

Fuente: OCDE. Tablas A7.1a y A7.1b. Para ver notas, consulte Anexo 3 (www.oecd.org/edu/eag.htm).

StatLink 部 SD http://dx.doi.org/10.1787/888933116471 
bre como mujer), mientras que en Austria, Dinamarca, Noruega y Países Bajos superan los 42.000 dólares estadounidenses por persona (hombre o mujer) (Tablas A7.1a y b).

Los datos sobre los varones que alcanzan la educación secundaria superior o postsecundaria no terciaria indican que los países con efectos del impuesto sobre la renta relativamente altos (estimados en más de 65.000 dólares estadounidenses) son Austria, Dinamarca, Estados Unidos, Irlanda y Noruega. En Estonia, también, el impacto de los impuestos representa casi el $40 \%$ de la ventaja de ingresos para un hombre que haya completado la educación secundaria superior o postsecundaria no terciaria. El efecto del impuesto sobre la renta es menos significativo (estimado en menos de 20.000 dólares estadounidenses) en Corea, Grecia, Polonia y Turquía. Alemania, Austria, Eslovenia, Países Bajos y República Eslovaca son los países con las mayores proporciones de cotizaciones sociales (importe estimado en más de 22.000 dólares estadounidenses tanto para hombres como para mujeres) (Tablas A7.1a y b). En Dinamarca, Francia, Grecia, Reino Unido y Suecia los costes indirectos debido a menores derechos a asistencia y otras prestaciones sociales suman más 10.000 dólares estadounidenses para un hombre (Tabla A7.1a).

En general, los hombres disfrutan de mayores retornos económicos de su educación secundaria superior o postsecundaria no terciaria que las mujeres, excepto en Grecia, Italia y Polonia. En estos países, el valor actual neto privado para una mujer que complete un nivel de educación secundaria superior o postsecundaria es mayor que para los hombres. Por término medio en todos los países de la OCDE, una mujer puede esperar una ganancia neta de 63.000 dólares estadounidenses a lo largo de su vida laboral, alrededor de 34.000 dólares estadounidenses menos que un hombre. La diferencia por sexo en el retorno neto privado es especialmente pronunciada en Austria, Corea, Estonia, Irlanda, Noruega y Reino Unido. La diferencia es mayor en Irlanda, donde los beneficios de los ingresos brutos para un hombre que haya alcanzado la educación secundaria superior o postsecundaria no terciaria rondan los 195.000 dólares estadounidenses, pero solo alrededor de la mitad de esta cifra, 103.000 dólares estadounidenses, para una mujer. Los principales motivos de esa diferencia en el retorno privado radican en las diferencias en el efecto del desempleo por sexo que, por término medio, beneficia más a los hombres que a las mujeres. Esto significa que tener una educación secundaria superior o postsecundaria no terciaria en comparación con no tenerla, aumenta las probabilidades de empleo para los hombres más que para las mujeres (Gráfico A7.2).

\section{Educación terciaria}

Las personas que obtienen una graduación terciaria pueden esperar un retorno neto aún mayor que las que han invertido solo hasta el nivel educativo de secundaria superior. Por término medio en los países de la OCDE, el retorno para las personas con educación terciaria es de 185.000 dólares estadounidenses para los hombres y de 130.000 dólares estadounidenses para las mujeres en comparación con las personaes que solo cuentan con educación secundaria superior o postsecundaria no terciaria. Salvo pocas excepciones, el retorno neto privado relacionado con la educación terciaria supera al de la educación secundaria superior o postsecundaria no terciaria.

El retorno privado neto de invertir en educación terciaria es normalmente mayor para los hombres que para las mujeres. En España, Grecia, Nueva Zelanda y Turquía, el retorno es mayor para las mujeres (Tablas A7.3a y b).

El valor de los beneficios de los ingresos brutos para hombres y mujeres con educación terciaria es considerable: por término medio, 350.000 dólares estadounidenses para los hombres y 250.000 dólares estadounidenses para las mujeres. Sin embargo, existen también variaciones significativas entre países.

Eslovenia, Hungría, Polonia y República Checa están entre los países donde la ventaja en los ingresos está por encima de la media de la OCDE a pesar de unos costes globales y unos niveles de renta inferiores en comparación con otros países de la OCDE. Esto se puede explicar por la baja tasa de graduados en educación terciaria en la población en edad de trabajar, lo cual indica a su vez una oferta baja de personas con educación superior. Estas circunstancias, con el paso del tiempo, pueden haber conducido a un aumento de los ingresos y a una desigualdad salarial entre personas con educación terciaria y las que no han alcanzado este nivel de educación.

Por término medio en los países de la OCDE, en comparación con la educación secundaria superior o postsecundaria no terciaria, el impacto de las prestaciones por desempleo es menos pronunciado que la diferencia de ingresos; pero los efectos de los impuestos, las cotizaciones y prestaciones sociales, y los costes directos de la educación, son más sustanciales. En particular, las personas con educación terciaria permanecen más tiempo estudiando y, por tanto, pierden una cantidad considerable de ingresos (ingresos no percibidos) que podrían haber recibido si se hubieran incorporado antes al mercado laboral.

Los costes de la inversión privada en educación terciaria, incluyendo costes directos e indirectos, son muy elevados en algunos países. En los países de la OCDE, las personas invierten alrededor de 50.000 dólares estadounidenses en 
obtener una graduación terciaria. En Japón, la inversión media supera los 100.000 dólares estadounidenses para un hombre y en Países Bajos para ambos sexos. Por término medio en los países de la OCDE, los costes directos como las matrículas, constituyen una quinta parte de la inversión total realizada por un graduado en educación terciaria (estimada en 10.000 dólares estadounidenses para ambos sexos) (Tablas A7.3a y b).

Una manera de mitigar un retorno débil en el mercado laboral es ofrecer estudios superiores a un coste menor para las personas. Aparte de subvencionar los costes directos de la educación, varios países ofrecen también a los estudiantes préstamos y becas para mejorar los incentivos y el acceso a la educación. Mientras que las becas son transferencias en metálico o en especie y que no requieren ser devueltas, los préstamos son ayudas que sí hay que devolver. Este indicador solo tiene en cuenta las becas; no informa sobre los préstamos (véase Cuadro A7.1 sobre el impacto de los préstamos en un número limitado de países).

Las becas son especialmente importantes en Dinamarca y Estados Unidos, donde cubren alrededor del $35 \%$ (o 29.000 dólares estadounidenses) y el 26\% (o 27.000 dólares estadounidenses), respectivamente, del coste total de la educación terciaria. En Austria, Finlandia, Países Bajos y Suecia, las becas se estiman en 8.000 dólares estadounidenses o más, alrededor del $15 \%$ del coste total (Tablas A7.3a y b).

Sin embargo, los datos indican que los países con los costes directos más elevados en educación terciaria, concretamente Australia, Canadá, Estados Unidos y Reino Unido, ofrecen pequeñas cantidades de becas en comparación con los costes directos. En Australia y Canadá, las becas cubren menos del $5 \%$ de los costes directos de la educación terciaria. En Corea y Japón, los costes directos de la educación terciaria están también entre los más altos, pero no hay información sobre becas. No obstante, muchos países, incluyendo aquellos que ofrecen solo pequeñas becas, proporcionan préstamos a los estudiantes, que deben devolverse una vez graduados. La normativa sobre préstamos varía mucho entre los países, en concreto acerca del momento en que los graduados tienen que empezar a devolver los préstamos (por ejemplo, cuando empiecen a ganar por encima de cierto umbral, justo después de su graduación, etc.) y el tipo de interés aplicable. Sin embargo, para la mayoría de los préstamos a los estudiantes, el importe total que debe devolverse y la cantidad a abonar en cada periodo depende de su situación laboral y de los ingresos reales percibidos después de la graduación. La disponibilidad de préstamos para los estudiantes, junto con una información y orientación adecuada sobre su funcionamiento, pueden animar a los estudiantes, sobre todo a aquellos de un entorno socioeconómico desfavorecido, a continuar sus estudios. Pero puesto que los préstamos deben ser devueltos tras la graduación -y, por tanto, restados de los beneficios de los ingresos- reducen los beneficios económicos de la educación.

\section{Tasa de retorno público de la inversión en educación}

\section{Educación secundaria superior o postsecundaria no terciaria}

Como se ha mencionado anteriormente, los niveles educativos más altos se traducen por término medio en mayores ingresos (véase Indicador A6). En este sentido, la inversión en educación genera retornos públicos, puesto que las personas con educación terciaria pagan más impuestos sobre la renta y más contribuciones a la seguridad social, y requieren menos prestaciones sociales. Los retornos públicos de la inversión en la educación secundaria superior o postsecundaria no terciaria de hombres y mujeres son positivos en la mayoría de los países. Por término medio, en todos los países de la OCDE, este nivel de educación genera un retorno público neto de 39.000 dólares estadounidenses para los varones y de 24.000 dólares estadounidenses para las mujeres (Tablas A7.2a y b).

Por término medio, los beneficios públicos duplican los costes públicos globales de la educación secundaria superior o postsecundaria no terciaria, tanto para hombres como para mujeres. En Reino Unido, los beneficios públicos son diez veces superiores a los costes públicos para los hombres y para las mujeres con este nivel de educación (Tablas A7.2a y b).

\section{Educación terciaria}

Por término medio en los países de la OCDE, la inversión pública en la educación terciaria de una persona es 38.000 dólares estadounidenses mayor que la inversión en educación secundaria superior o postsecundaria (teniendo en cuenta el gasto público directo y los costes indirectos). La inversión pública más elevada en la educación terciaria de una persona (más de 50.000 dólares estadounidenses mayor que para los individuos en un nivel educativo inferior) se da en Alemania, Austria, Dinamarca, Finlandia, Países Bajos y Suecia (Gráfico A7.3).

En la mayoría de los países, el retorno público de la educación terciaria es sustancialmente mayor que el de la educación secundaria superior o postsecundaria no terciaria. Esto se debe fundamentalmente a los impuestos más altos y las contribuciones sociales más elevadas que provienen de sueldos más altos de las personas con educación terciaria. Por término medio, en los países de la OCDE, el retorno público neto de una inversión en educación terciaria es superior a los 105.000 dólares estadounidenses para un hombre y más de 60.000 dólares estadounidenses para una 
mujer. Teniendo en cuenta los costes directos, ingresos no percibidos y ayudas públicas, los beneficios públicos derivados de un hombre con educación terciaria son cuatro veces superiores a los costes públicos, y los de una mujer con la misma educación, 2,5 veces mayores (Tablas A7.4a y b).

En general, las diferencias salariales son la fuente de las desigualdades en el retorno tanto para los individuos como para el sector público. Cuando las diferencias salariales son menores, el retorno de la educación superior es menor. Esto es así especialmente en Dinamarca, Noruega, Nueva Zelanda y Suecia. Los países nórdicos han compensado, por lo general, los efectos de esta débil estructura de incentivos proporcionando un sistema de educación superior prácticamente gratuito y ofreciendo un generoso sistema de ayudas a los estudiantes (véase Indicador B5).

Puesto que la ventaja en los ingresos varía considerablemente en los países de la OCDE, el pago de impuestos y los beneficios para el sector público también varían de manera algo distinta a lo que se podría esperar. Debido a las menores ventajas de los ingresos en los países nórdicos, los ingresos medios para graduados en educación terciaria están normalmente por debajo del nivel de ingresos al que se aplican elevados impuestos marginales. Las mayores ganancias públicas en impuestos y cotizaciones a la seguridad social de la educación superior suelen darse en los países con grandes diferenciales de ingresos o donde los niveles medios de ingresos alcanzan elevados niveles del impuesto sobre la renta. En Alemania, Austria, Bélgica, Dinamarca, Eslovenia, Estados Unidos, Hungría, Irlanda, Italia y Países Bajos, las personas con educación terciaria pagan considerablemente más impuestos y cotizaciones sociales. En estos países, la ventaja de ingresos está por encima de la media de la OCDE y, por tanto, las cotizaciones sociales también son mayores.

\section{Gráfico A7.3. Costes y beneficios públicos para una mujer que alcanza la educación terciaria (2010)}

En comparación con los retornos de la educación secundaria superior o postsecundaria no terciaria

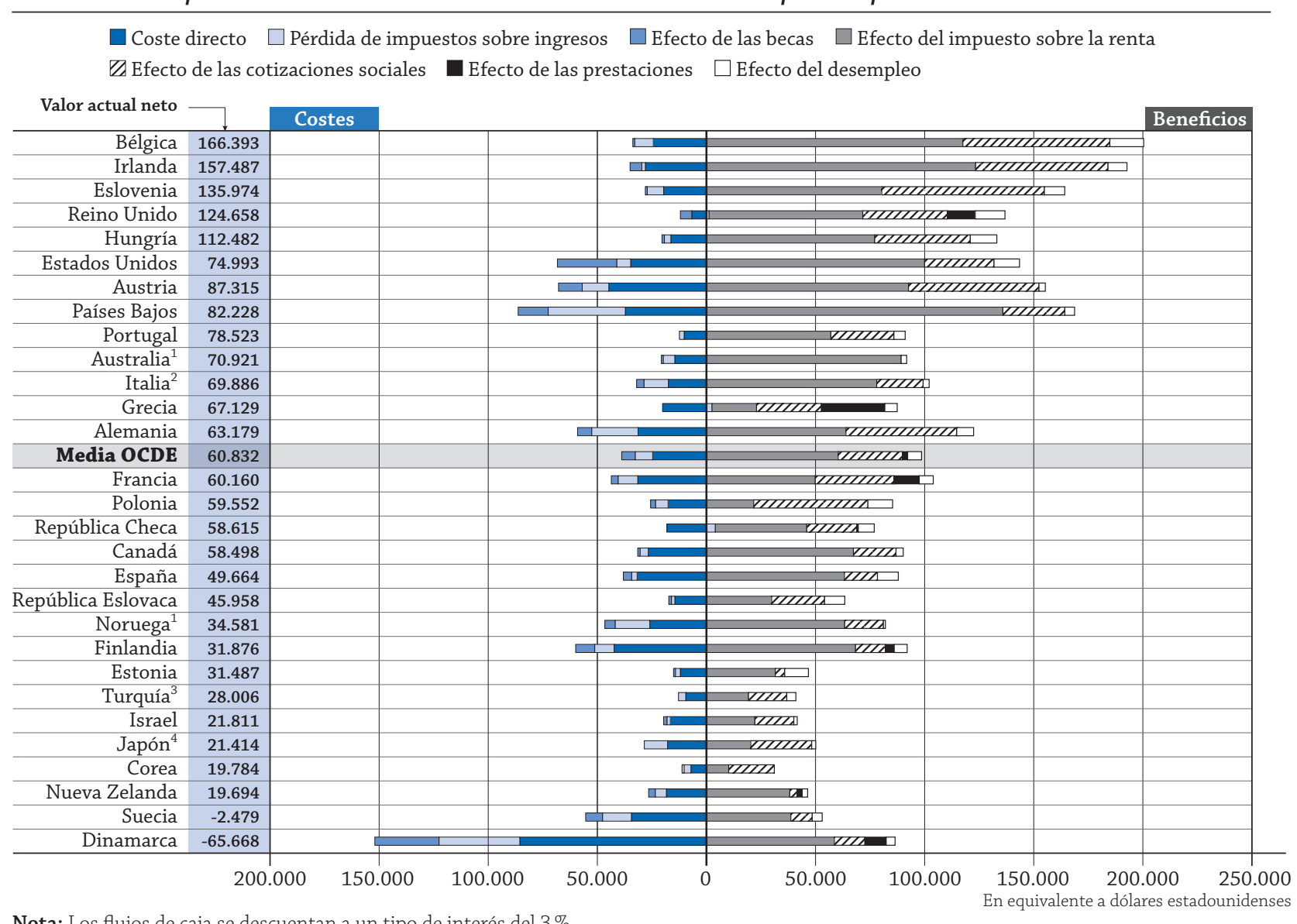

Nota: Los flujos de caja se descuentan a un tipo de interés del $3 \%$.

1. Año de referencia 2009.

2. Año de referencia 2008.

3. Año de referencia 2005.

4. Año de referencia 2007.

Los países están clasificados en orden descendente del valor actual neto público.

Fuente: OCDE. Tabla A7.4b. Para ver notas, consulte Anexo 3 (www.oecd.org/edu/eag.htm).

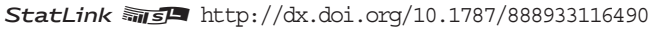


Varios países cuentan con políticas fiscales que, de manera efectiva, reducen los impuestos reales pagados por los individuos, sobre todo en los niveles de rentas altas. Muchos países de la OCDE han introducido desgravaciones fiscales por el pago de intereses sobre hipotecas para fomentar la compra de viviendas. Estos planes básicamente favorecen a las personas con una educación superior y elevados impuestos marginales. Los incentivos fiscales para la vivienda son especialmente grandes en Dinamarca, Estados Unidos, Finlandia, Grecia, Noruega, Países Bajos, República Checa y Suecia (véase Andrews et al., 2011).

\section{La distribución de los costes de la educación entre el sector público y los individuos}

Los costes directos de la educación son soportados en gran medida por el sector público. Como media, en los países de la OCDE, los individuos soportan alrededor del $30 \%$ del total de los costes directos de la inversión pública y privada en educación terciaria. Solo en unos cuantos países, especialmente en Australia, Corea, Estados Unidos, Japón y Reino Unido, los costes directos privados, como las tasas de matriculación, representan más del $55 \%$ de los costes globales directos de la inversión pública y privada en educación terciaria. Algunos países ofrecen becas y préstamos a los estudiantes, para aliviar la carga económica de la educación terciaria. Estas becas se conceden con diferentes criterios, como el rendimiento escolar o el entorno socioeconómico del estudiante, para animar a los jóvenes de entornos menos favorecidos a que prosigan su educación. Los países nórdicos ofrecen becas de una cuantía considerable, Dinamarca (29.000 dólares estadounidenses), Finlandia (9.000 dólares estadounidenses) y Suecia (8.000 dólares estadounidenses), así como Austria (11.000 dólares estadounidenses), Países Bajos (14.000 dólares estadounidenses) y Estados Unidos

\section{Gráfico A7.4. Costes públicos frente a privados para un hombre que alcanza la educación terciaria (2010)}

En comparación con los retornos de la educación secundaria superior o postsecundaria no terciaria

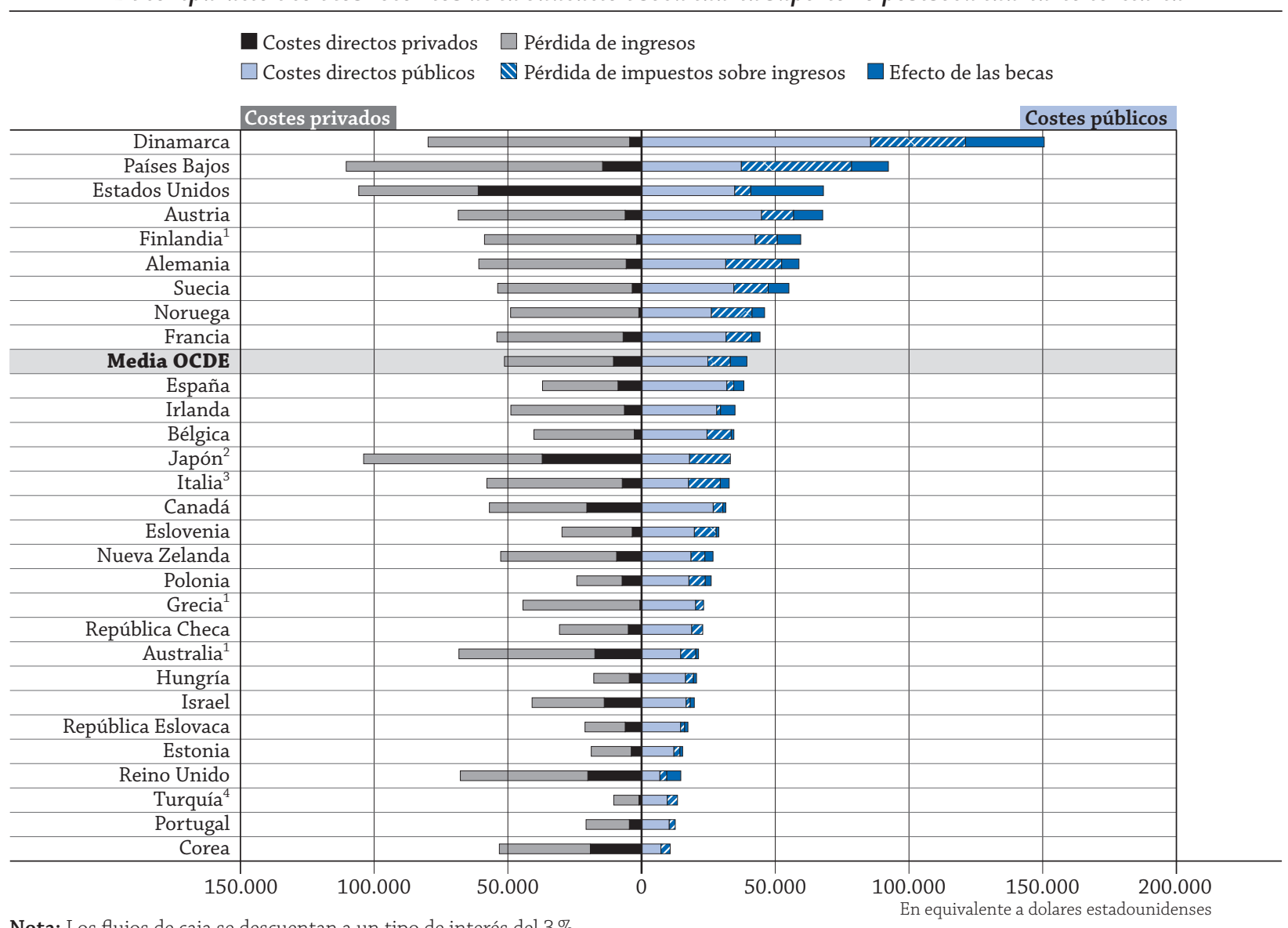

Nota: Los flujos de caja se descuentan a un tipo de interés del $3 \%$.

1. Año de referencia 2009.

2. Año de referencia 2007.

3. Año de referencia 2008.

4. Año de referencia 2005.

Los países están clasificados en orden descendente de los costes públicos totales.

Fuente: OCDE. Tablas A7.3a y A7.4a. Para ver notas, consulte Anexo 3 (www.oecd.org/edu/eag.htm).

StatLink 部 SD http://dx.doi.org/10.1787/888933116509 


\section{Cuadro A7.1. Un paso más en la estimación de los retornos de la educación}

Aparte de las diferencias de ingresos, relacionadas con las condiciones del mercado laboral, los principales componentes de los retornos de la educación están relacionados con las decisiones políticas sobre el acceso a la educación, los impuestos y los costes de la educación para las personas. El análisis del valor actual neto puede ampliarse de diversas formas, según la disponibilidad de datos. Por ejemplo, el análisis de este capítulo tiene en cuenta los sistemas de becas para los estudiantes y excluye los sistemas de préstamos.

En este cuadro se ha dado un paso más y se presenta el primer intento de cuantificar el impacto en los retornos de la educación de los préstamos a los estudiantes para programas de educación terciaria, basándose en la información sobre préstamos que se recabó a través de una encuesta ad hoc de la Red de Resultados Laborales y Sociales de la Educación (Labour and Social Outcomes of Education, LSO, por sus siglas en inglés) de la OCDE en los 14 países mostrados en el gráfico siguiente (tablas disponibles en Internet).

En este análisis, el impacto de los préstamos a los estudiantes de educación terciaria abarca los siguientes aspectos:

- Acceso a préstamos o porcentaje de estudiantes que reciben préstamos.

- Importe medio del préstamo habitual a estudiantes.

- El coste o tipo de interés cobrado.

- La remisión/condonación, es decir, la proporción global esperada de un préstamo medio cancelada por incobrable/irrecuperable.

Hay dos amplios tipos de préstamos a los estudiantes: préstamos con devolución fija (al estilo de las hipotecas) y préstamos supeditados a los ingresos. Ambos sistemas implican ciertos costes para el gobierno que garantiza la devolución del préstamo o subvenciona los tipos de interés. En teoría, el predominio de los sistemas supeditados a los ingresos o de devolución fija afectará a los retornos netos de la educación, en cuanto que el porcentaje de remisión es mayor en los sistemas supeditados a los ingresos (implicando mayores costes para el gobierno y mayores beneficios para los estudiantes) (véase Cuadro B5.1).

De acuerdo con el planteamiento para estimar el retorno económico de la educación, sobre la base de la teoría de inversión de la bibliografía financiera, se ha tenido en cuenta tanto el préstamo medio por estudiante por año

\section{Gráfico A7.a. Contribución de las becas y los préstamos al valor actual neto privado para un hombre que alcanza la educación terciaria (2010)}

En comparación con un hombre que ha alcanzado la educación secundaria superior o postsecundaria no terciaria, en equivalente a miles de dólares estadounidenses convertidos mediante PPA para el PIB

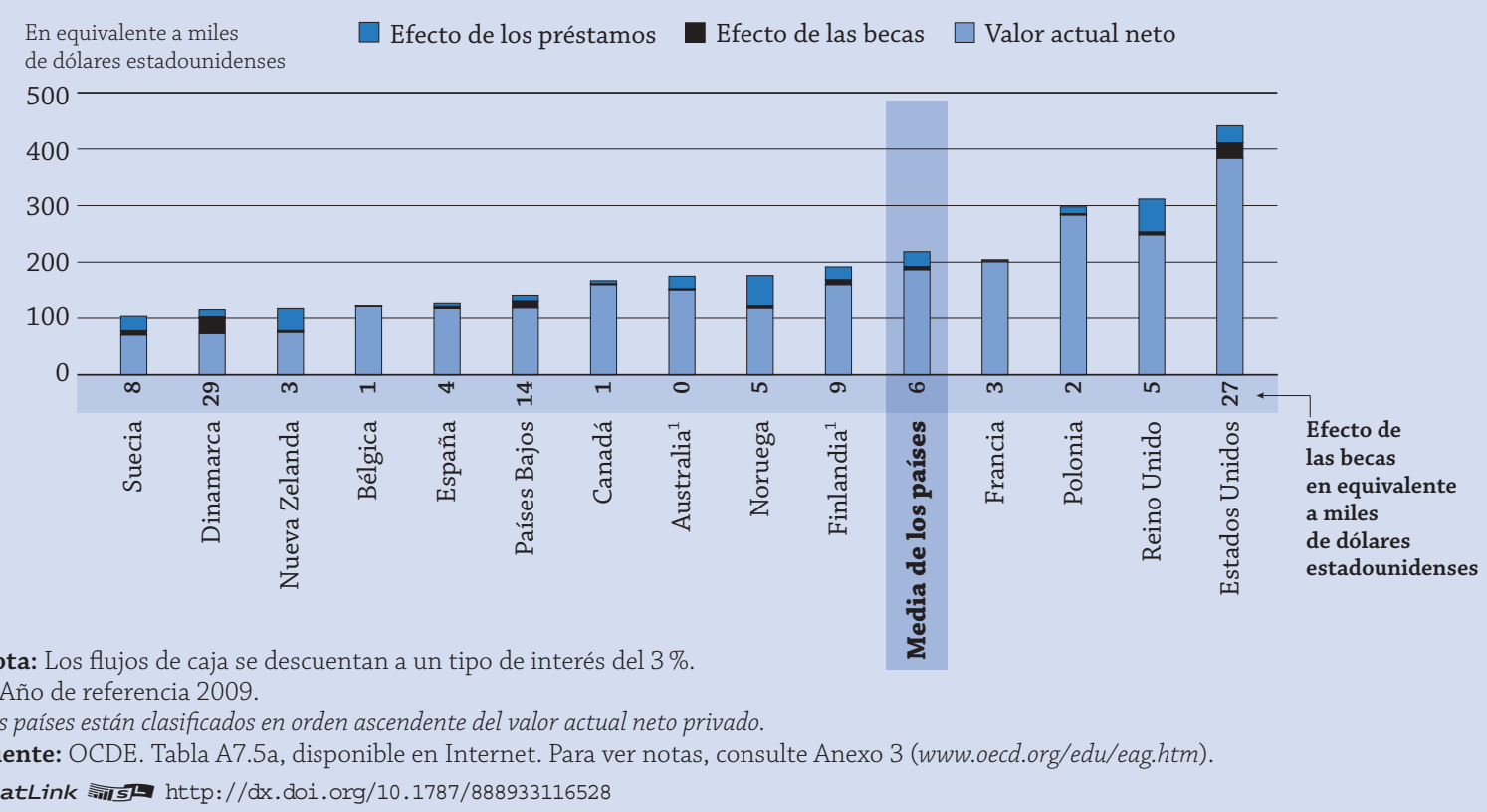

StatLink 젝ㄴ http://dx.doi.org/10.1787/888933116528 
(basado en el porcentaje de estudiantes que reciben un préstamo y el importe medio de dichos préstamos) y el tipo de interés medio de estos préstamos. La base para integrar el tipo de interés de los préstamos es considerar que hay más de una fuente de financiación y que el peso de cada elemento es proporcional a su valor de mercado. El resultado es el coste medio ponderado de capital (CMPC), una combinación ponderada del tipo de interés del préstamo y de la tasa de descuento (es decir, el tipo de interés al que pueden tomar prestados los bancos fondos del banco central). El CMPC permite calcular un valor actual neto expresando las ganancias en unidades monetarias. La remisión/condonación por completar los estudios en plazo u otro incentivo basado en el rendimiento, o los pagos fallidos de préstamos garantizados por el gobierno, se han integrado en los cálculos del impacto de los préstamos sobre los valores actuales netos, con un efecto positivo sobre el valor actual neto. El efecto de los préstamos presentado en este cuadro es, por tanto, una combinación de estos componentes.

Los resultados del análisis muestran que, en los 14 países con datos disponibles, el impacto de los préstamos sobre el indicador del valor actual neto es mayor en Estados Unidos, Noruega, Nueva Zelanda, Reino Unido y Suecia que en Canadá y Países Bajos, aunque todos estos países cuentan con sistemas bien desarrollados de apoyo a los estudiantes.

El gráfico también muestra que existen grandes diferencias entre los países en las tasas de matriculación cobradas por las instituciones de educación terciaria de tipo A a los estudiantes nacionales a tiempo completo en los programas de primer grado y en la ayuda económica a estos estudiantes. Australia, Canadá, Estados Unidos, Nueva Zelanda, Países Bajos y Reino Unido son países con niveles comparativamente altos de tasas de matrícula y sistemas bien desarrollados de apoyo a los estudiantes. Dinamarca, Finlandia, Noruega y Suecia son países con niveles comparativamente bajos de tasas de matrículas y sistemas bien desarrollados de apoyo a los estudiantes (véase Indicador B5).

En Países Bajos, las ayudas o becas tienen un mayor impacto sobre el valor actual neto privado que los préstamos, porque las becas son más accesibles que los préstamos -más de dos de cada tres estudiantes reciben una beca (en comparación con uno de cada tres estudiantes que aprovechan los préstamos)-y porque el importe medio de una beca es mayor que el importe medio de un préstamo. El coste medio de los préstamos en Países Bajos es más elevado que en otros países, pero esta estimación no tiene en cuenta reglas financieras específicas, como la desgravación fiscal de ciertos costes educativos, etc.

En Canadá, los estudiantes se benefician de unas tasas de remisión relativamente altas, es decir, se espera que una gran proporción del préstamo medio se cancele si se completan los estudios. El coste medio relativamente elevado de los préstamos contrarresta, no obstante, su beneficio global (el elevado tipo de interés que se cobra por el préstamo una vez completados los estudios).

No sorprende entonces que el impacto de los préstamos sea insignificante en Bélgica, España y Francia, ya que estos países tienen unas tasas de matrícula comparativamente bajas y sistemas de apoyo a los estudiantes menos desarrollados.

(27.000 dólares estadounidenses). Curiosamente, los datos disponibles no muestran ninguna relación entre costes directos y becas. Los países donde las becas son mayores no siempre tienen los costes directos privados más elevados. En cambio, de los cinco países donde los costes directos son más elevados, solo Reino Unido ofrece becas sustanciales a sus estudiantes (5.000 dólares estadounidenses). Pero existen otros planes financiados por los gobiernos además de las becas, que incluyen préstamos subvencionados para estudiantes (véase Cuadro A7.1) y descuentos en las matrículas para estudiantes menos favorecidos económicamente, que pueden ayudar a reducir el coste privado de acceder a la educación terciaria (Tablas A7.3a y A7.4a).

\section{Definiciones}

Adultos se refiere a las personas de 25 a 64 años.

Costes directos son un reflejo de la cantidad que, procedente de todas las fuentes (públicas, privadas y hogares), se gasta en los estudiantes en un año. Los costes directos dependen de la duración de la educación.

Los ingresos no percibidos mientras se estudia dependen del nivel de los ingresos que una persona que no estudia puede percibir y de la duración de los estudios. Los ingresos no percibidos de un individuo son netos de impuestos, cotizaciones sociales y prestaciones sociales. 
Los impuestos no percibidos sobre la renta incluyen los impuestos, las cotizaciones sociales y las prestaciones sociales no percibidas por el sector público.

Beneficios de los ingresos brutos son estimaciones de los ingresos que recibirá un individuo cuando esté en el mercado laboral.

El efecto del impuesto sobre la renta es el importe estimado recibido por el sector público a través de los impuestos. Normalmente es la fuente principal de ingresos públicos para las inversiones en educación. Es más pronunciado en el nivel terciario de la educación debido a los impuestos progresivos sobre la renta.

La tasa interna de retorno indica a qué tipo de interés real se alcanza el punto de equilibrio de la inversión.

Niveles de educación: inferior a secundaria superior corresponde a los niveles CINE 0, 1, 2 y programas cortos 3C; secundaria superior o postsecundaria no terciaria corresponde a los niveles CINE 3A, 3B, programas largos $3 \mathrm{C}$ y nivel CINE 4; y terciaria corresponde a los niveles CINE 5A, 5B y 6. Para una presentación de todos los niveles CINE, véase la Guía del lector al inicio de este libro.

El valor actual neto es la diferencia entre los beneficios descontados y los costes de inversión descontados, y representa el valor añadido que genera la educación por encima del $3 \%$ de interés real que se cobra por estos flujos de caja.

El efecto de las cotizaciones sociales en los cálculos solo afecta a aquellas pagadas por los trabajadores y no las abonadas por los empleadores. Estas últimas son una fuente adicional de ingresos públicos. En la mayoría de los países de la OCDE, las personas pagan cotizaciones sociales a una cuota fija y, por tanto, las diferencias entre los niveles de educación son menores y proporcionales al nivel de renta.

El efecto de las prestaciones se refiere a las prestaciones sociales vinculadas a un cierto nivel de renta.

El efecto del desempleo se traduce en ventajas monetarias utilizando el nivel de ingresos para cada categoría de educación durante la vida laboral.

\section{Metodología}

Este indicador se basa en la información recogida en otros capítulos de Panorama de la educación 2013 (OECD, 2013a), con una excepción: para poder calcular los retornos públicos y examinar los beneficios netos para las personas, se ha utilizado información de la base de datos sobre impuestos salariales de la OCDE (Taxing Wages). Los datos sobre ingresos provienen de la base de datos recopilada por la Red LSO (siglas en inglés de Resultados Laborales y Sociales de la Educación) (disponibles como ingresos relativos en Panorama de la educación 2013, Indicador A6). Los datos sobre los costes directos de la educación se toman de los Indicadores B1 y B3. Los datos sobre la probabilidad de encontrar un empleo (tasa de desempleo de distintas categorías de educación y grupos de edad) se toman del Indicador A5. El salario mínimo se utiliza como aproximación de lo que un estudiante podría potencialmente ganar si no estuviera estudiando, calculando los ingresos no percibidos en el nivel de la educación secundaria superior o postsecundaria no terciaria. Véase Anexo 3 (www.oecd.org/edu/eag.htm) para más información.

Para calcular los retornos de la educación, el planteamiento que se ha adoptado es el del valor actual neto (VAN) de la inversión. Dentro de este marco, los costes y los beneficios a lo largo de toda la vida se trasladan al inicio de la inversión. Esto se hace descontando todos los flujos de caja hasta el inicio de la inversión con un tipo de interés fijo (tasa de descuento). Elegir el tipo de interés es difícil, ya que debe reflejar no solo el horizonte temporal global de la inversión, sino también el coste del endeudamiento o el riesgo percibido de la inversión. Con el fin de simplificar, y para que la interpretación de los resultados sea más fácil, se aplica la misma tasa de descuento en todos los países de la OCDE.

Para llegar a una tasa de descuento razonable, se han empleado como referente bonos del estado a largo plazo. El tipo de interés medio a largo plazo en los países de la OCDE fue de aproximadamente 4,4\% en 2010 (Base de Datos Financiera de la OCDE [OECD, 2013b]). Asumiendo que los bancos centrales de los países hayan logrado anclar las expectativas de inflación en o por debajo del $2 \%$ al año, esto implica un tipo de interés real del $2 \%$ al $3 \%$. La tasa de descuento real del $3 \%$ utilizada en este indicador refleja el hecho de que los cálculos se han hecho en precios constantes. El cambio de la tasa de descuento tiene un impacto sustancial sobre el valor actual neto de la educación.

Descontar los costes y beneficios al valor actual con este tipo de interés hace que los retornos económicos sobre la inversión global y los valores de los distintos componentes sean comparables a lo largo del tiempo y entre los países. Utilizar la misma unidad de análisis tiene también la ventaja de hacer posible añadir o restar componentes en los 
diferentes niveles educativos o entre el sector público y el privado para comprender cómo interactúan los distintos factores.

Los cálculos del VAN se basan en el mismo método que los cálculos de la tasa interna de retorno (TIR). La principal diferencia entre los dos métodos radica en cómo se fija el tipo de interés. Para los cálculos desarrollados dentro del marco de la TIR, el tipo de interés se aumenta al nivel al cual los beneficios económicos equivalen al coste de la inversión y establece la tasa de descuento en la cual la inversión alcanza el punto de equilibrio.

Para calcular el VAN privado, los costes de inversión privada incluyen la pérdida de ingresos después de impuestos y ajustados según la probabilidad de encontrar empleo (tasa de desempleo) y el gasto privado directo en educación. Estas dos corrientes de inversión tienen en cuenta la duración de los estudios. En el lado de los beneficios, se emplean perfiles de ingresos por edad para calcular el diferencial de ingresos entre distintos niveles educativos. Estos diferenciales de ingresos brutos se ajustan según las diferencias de los impuestos sobre la renta, las cotizaciones sociales y las prestaciones sociales, incluyendo prestaciones para la vivienda y asistencia social relacionada con el nivel de ingresos, para llegar a los diferenciales de ingresos netos. Los flujos de caja se ajustan aún más según la probabilidad de encontrar empleo. Los cálculos se realizan por separado en hombres y mujeres para tener en cuenta las diferencias de los diferenciales de ingresos y de las tasas de desempleo.

Al calcular el VAN público, los costes públicos incluyen pérdida de impuestos recaudados durante los años de estudios (impuesto sobre la renta y cotizaciones sociales) y gasto público, teniendo en cuenta la duración de los estudios. La pérdida de impuestos recaudados es baja en algunos países, porque los jóvenes tienen un nivel de ingresos bajo. El gasto público en educación incluye gastos directos, como el pago de los salarios de los profesores o la construcción de edificios escolares, la compra de libros de texto, etc., y transferencias públicas y privadas, como subvenciones a familias para becas y demás ayudas, y a otras entidades privadas que ofrecen formación en el lugar de trabajo, etc. Los beneficios del sector público son una recaudación adicional de impuestos y cotizaciones sociales asociada a unos ingresos más elevados y el ahorro de prestaciones, por ejemplo, prestaciones para la vivienda y ayuda social que el sector público no necesita abonar dados los elevados niveles de ingresos.

Es importante considerar algunas de las amplias limitaciones conceptuales de la estimación de los retornos económicos aquí realizada. Por ejemplo:

- Para calcular los retornos a lo largo de toda la vida, se utilizan los 64 años como el límite superior de edad en todos los países. Sin embargo, la edad a la que se tiene derecho a una pensión varía mucho entre los países. Unos pocos años más o menos en el mercado laboral pueden suponer una diferencia sustancial en los retornos de la educación tanto públicos como privados. Por tanto, es probable que, en los países donde la edad de jubilación se desvíe mucho de los 64 años, las tasas de retorno estén sobrevaloradas o infravaloradas.

- Dado que los ingresos generalmente aumentan con el nivel de educación alcanzado, los individuos con niveles de educación más elevados normalmente consumen más bienes y servicios, y por tanto pagan más impuestos sobre el valor añadido (IVA). De manera que los retornos públicos están infravalorados en este indicador.

- Las personas con rentas más altas también tienden a contribuir más a sus pensiones y, una vez que abandonan el mercado laboral, tendrán una mayor ventaja de ingresos que no se tiene en cuenta en estos cálculos. Las personas con mayor nivel de educación suelen vivir más años, lo que implica costes públicos adicionales que no se han tenido en cuenta aquí. Además, en los países en los que una parte sustancial del sistema de pensiones está financiado por las empresas a través de cotizaciones añadidas a los salarios, los retornos de la educación superior normalmente están infraestimados en comparación con los países en los que las pensiones son pagadas por los individuos.

- Muchos gobiernos cuentan con programas que proporcionan préstamos a los estudiantes a bajos tipos de interés. Los préstamos pueden ser un fuerte incentivo para que las personas continúen sus estudios y reduzcan el coste de obtener una educación superior. Sin embargo, puesto que los préstamos han de ser devueltos más adelante, también reducen los beneficios de la educación. Estas subvenciones pueden a menudo suponer una diferencia sustancial en los retornos de la educación para los individuos, pero no se han incluido aquí.

- En algunos países, la prestación por desempleo es bastante generosa, mientras que en otros las personas desempleadas deben depender de la asistencia social.

- Los costes directos son principalmente las tasas de matrícula, pero también los costes del material escolar y los gastos corrientes asociados al cambio de residencia requerido para cursar determinados estudios. Estos costes no se han tenido en cuenta aquí. 
- Los datos incluidos son solo valores contables. Los resultados difieren, sin duda, de las estimaciones econométricas que utilicen los mismos datos a nivel micro (es decir, datos sobre encuestas de los hogares o los individuos) en lugar de un flujo durante toda la vida de ingresos derivados de los ingresos medios.

- Para la educación secundaria superior o postsecundaria no terciaria, hace falta cautela al interpretar los ingresos no percibidos, ya que el salario mínimo se utiliza como una aproximación.

Considerando estos factores, los retornos de la educación en los distintos países deben evaluarse con cautela.

El planteamiento utilizado aquí estima los ingresos futuros de los individuos con distintos niveles de educación, basándose en el conocimiento de cómo varían los actuales ingresos brutos medios con el nivel educativo y la edad. Sin embargo, la relación entre los distintos niveles de educación alcanzados y los ingresos puede variar en el futuro, ya que cambios tecnológicos, económicos y sociales pueden alterar la relación entre los niveles salariales y los educativos.

Las diferencias de los retornos entre los países reflejan en parte las distintas condiciones institucionales y no de mercado que afectan a los ingresos, como condiciones institucionales que limitan la flexibilidad de los ingresos relativos.

$\mathrm{Al}$ estimar los beneficios, se ha tenido en cuenta el efecto de la educación sobre el incremento de la probabilidad de encontrar empleo cuando se desea trabajar. Sin embargo, esto también hace que la estimación sea sensible a la etapa del ciclo económico en la cual se recopilaron los datos. Puesto que los individuos con un mayor nivel de educación tienen normalmente un vínculo más fuerte con el mercado de trabajo, el valor de la educación en general aumenta en épocas de poco crecimiento económico.

Los cálculos incluyen también diversos supuestos restrictivos necesarios para una comparación internacional. Para calcular la inversión en educación, la pérdida de ingresos se ha normalizado al nivel del salario mínimo legal o su equivalente en aquellos países donde los datos de ingresos incluyen trabajo a tiempo parcial. En los casos en los que no se disponía de un salario mínimo nacional, se seleccionó el salario fijado en los convenios colectivos. Este supuesto parece contrarrestar los ingresos tan bajos registrados en el grupo de 15 a 24 años, que condujeron a estimaciones excesivamente elevadas en anteriores ediciones del Panorama de la educación. En Hungría, Japón, Países Bajos, Portugal, Reino Unido y República Checa se utilizaron ingresos reales para el cálculo de la pérdida de ingresos, ya que el trabajo a tiempo parcial se excluye de estas recopilaciones de datos sobre ingresos.

Los costes y beneficios de la educación secundaria superior o postsecundaria no terciaria no pudieron calcularse para Bélgica, porque la educación secundaria superior o postsecundaria no terciaria es obligatoria en este país. El hecho de que la educación secundaria superior sea obligatoria impide una aplicación consistente de la metodología para este indicador, puesto que utiliza un planteamiento de inversión. Este planteamiento asume que las personas pueden elegir invertir en un nivel de educación para obtener ciertos beneficios. En los países en los que un determinado nivel educativo es obligatorio, las personas no pueden elegir y, por tanto, esta metodología no es aplicable en tales casos.

Para más información sobre la metodología, véase OECD, 2011, y Anexo 3 en www.oecd.org/edu/eag.htm.

\section{Nota sobre los datos de Israel}

Los datos estadísticos para Israel fueron proporcionados por las autoridades israelíes competentes bajo su responsabilidad. El uso de estos datos por parte de la OCDE se hace sin prejuzgar la situación de los Altos del Golán, Jerusalén Este y los asentamientos israelíes en Cisjordania de acuerdo con los términos del derecho internacional.

\section{Referencias}

Andrews, D., A. Caldera Sánchez y Å. Johansson (2011), «Housing Markets and Structural Policies in OECD Countries», OECD Economics Department Working Papers, No. 836, OECD Publishing, París, http://dx.doi.org/10.1787/5kgk8t2k9vf3-en.

OECD (2013a), Education at a Glance 2013: OECD Indicators, OECD Publishing, París, http://dx.doi.org/10.1787/eag-2013-en.

Versión española: Panorama de la educación, 2013: Indicadores de la OCDE, Ministerio de Educación, Cultura y Deporte, Santillana, Madrid.

OECD (2013b), «Exchange Rates (USD monthly averages)», Monthly Monetary and Financial Statistics (MEI) (database), http:// stats.oecd.org/Index.aspx?QueryId=169.

OECD (2011), «Guía del usuario para el Indicador A9: Incentivos para invertir en educación», en Panorama de la educación 2011: Indicadores de la OCDE. OECD Publishing, París (disponible en Internet: http://dx.doi.org/10.1787/eag-2011-en). 
Tablas del Indicador A7

StatLink 젬ㄴ http://dx.doi.org/10.1787/888933116281

Tabla A7.1a Costes y beneficios privados para un hombre que alcanza la educación secundaria superior o postsecundaria no terciaria (2010)

Tabla A7.1b Costes y beneficios privados para una mujer que alcanza la educación secundaria superior o postsecundaria no terciaria (2010)

Tabla A7.2a Costes y beneficios públicos para un hombre que alcanza la educación secundaria superior o postsecundaria no terciaria (2010)

Tabla A7.2b Costes y beneficios públicos para una mujer que alcanza la educación secundaria superior o postsecundaria no terciaria (2010)

Tabla A7.3a Costes y beneficios privados para un hombre que alcanza la educación terciaria (2010)

Tabla A7.3b Costes y beneficios privados para una mujer que alcanza la educación terciaria (2010)

Tabla A7.4a Costes y beneficios públicos para un hombre que alcanza la educación terciaria (2010)

Tabla A7.4b Costes y beneficios públicos para una mujer que alcanza la educación terciaria (2010)

WEB Tabla A7.5a Valor actual neto privado incluyendo becas y préstamos para un hombre que alcanza la educación terciaria (2010)

WEB Tabla A7.5b Valor actual neto privado incluyendo becas y préstamos para una mujer que alcanza la educación terciaria (2010)

WEB Tabla A7.6a Valor actual neto público incluyendo becas y préstamos para un hombre que alcanza la educación terciaria (2010)

WEB Tabla A7.6b Valor actual neto público incluyendo becas y préstamos para una mujer que alcanza la educación terciaria (2010) 
Tabla A7.1a. Costes y beneficios privados para un hombre que alcanza la educación secundaria superior o postsecundaria no terciaria (2010)

En comparación con un hombre que tiene educación secundaria inferior, en equivalente a dólares estadounidenses convertidos mediante PPA para el PIB

\begin{tabular}{|c|c|c|c|c|c|c|c|c|c|c|c|c|}
\hline & & $\begin{array}{c}\text { Costes } \\
\text { directos }\end{array}$ & $\begin{array}{c}\text { Pérdida de } \\
\text { ingresos }\end{array}$ & $\begin{array}{l}\text { Costes } \\
\text { totales }\end{array}$ & $\begin{array}{c}\text { Beneficios } \\
\text { de los } \\
\text { ingresos } \\
\text { brutos }\end{array}$ & $\begin{array}{c}\text { Efecto del } \\
\text { impuesto } \\
\text { sobre la } \\
\text { renta }\end{array}$ & $\begin{array}{l}\text { Efecto de las } \\
\text { cotizaciones } \\
\text { sociales }\end{array}$ & $\begin{array}{l}\text { Efecto de las } \\
\text { prestaciones }\end{array}$ & $\begin{array}{l}\text { Efecto del } \\
\text { desempleo }\end{array}$ & $\begin{array}{c}\text { Beneficios } \\
\text { totales }\end{array}$ & $\begin{array}{l}\text { Valor } \\
\text { actual } \\
\text { neto }\end{array}$ & $\begin{array}{c}\text { Tasa } \\
\text { interna } \\
\text { de retorno }\end{array}$ \\
\hline & Año & (1) & $(2)$ & (3) & $(4)$ & $(5)$ & (6) & $(7)$ & $(8)$ & (9) & $(10)$ & (11) \\
\hline \multirow{2}{*}{$\begin{array}{l}\text { Alemania } \\
\text { Australia }\end{array}$} & 2010 & -3.973 & -36.901 & -40.874 & 74.406 & -28.450 & -31.726 & -9.942 & 81.012 & 85.299 & 44.426 & $7,5 \%$ \\
\hline & 2009 & -3.019 & -27.156 & $\mathbf{- 3 0 . 1 7 5}$ & 176.400 & -64.407 & 0 & -8.303 & 49.011 & 152.701 & 122.526 & $19,9 \%$ \\
\hline Austria & 2010 & -2.084 & -46.210 & -48.294 & 303.737 & -80.357 & -65.732 & -10.652 & 50.975 & 197.971 & 149.677 & $12,1 \%$ \\
\hline Bélgica $^{1}$ & & $\mathrm{~m}$ & $\mathrm{~m}$ & $\mathbf{m}$ & $\mathrm{m}$ & $\mathrm{m}$ & $\mathrm{m}$ & $\mathrm{m}$ & $\mathrm{m}$ & & & $\mathrm{m}$ \\
\hline Canadá & 2010 & -3.424 & -30.793 & -34.217 & 164.771 & -50.060 & -13.432 & -1.362 & 45.338 & 145.254 & 111.037 & $13,3 \%$ \\
\hline Chile & & $\mathrm{m}$ & $\mathrm{m}$ & $\mathbf{m}$ & $\mathrm{m}$ & $\mathrm{m}$ & $\mathrm{m}$ & $\mathrm{m}$ & $\mathrm{m}$ & & & \\
\hline Corea & 2010 & -5.756 & -28.830 & -34.587 & 185.305 & -7.688 & -15.277 & 0 & 11.785 & 174.126 & 139.540 & $13,1 \%$ \\
\hline Dinamarca & 2010 & -797 & -42.671 & -43.468 & 207.899 & -78.437 & -20.515 & -11.164 & 32.831 & 130.615 & 87.147 & $11,7 \%$ \\
\hline Eslovenia & 2010 & -1.833 & -21.943 & -23.776 & 125.817 & -29.689 & -36.241 & 0 & 38.266 & 98.153 & 74.378 & $12,8 \%$ \\
\hline España & 2010 & -1.613 & -9.225 & -10.838 & 107.297 & -28.928 & -10.463 & 0 & 58.730 & 126.636 & 115.798 & $35,3 \%$ \\
\hline Estados Unidos & 2010 & -2.853 & -25.225 & -28.078 & 285.333 & -68.131 & -25.197 & -7.344 & 44.074 & 228.736 & 200.658 & $19,4 \%$ \\
\hline Estonia & 2010 & -249 & -8.196 & -8.445 & 66.894 & -26.383 & -3.919 & 0 & 73.157 & 109.750 & 101.305 & $39,5 \%$ \\
\hline Finlandia & 2009 & -178 & -30.022 & -30.201 & 75.381 & -28.532 & -6.632 & -7.202 & 28.082 & 61.097 & 30.897 & $7,8 \%$ \\
\hline Francia & 2010 & -2.904 & -28.503 & -31.407 & 94.133 & -21.451 & -20.444 & -15.050 & 54.391 & 91.579 & 60.173 & $10,6 \%$ \\
\hline Grecia & 2009 & -1.780 & -30.044 & -31.824 & 93.624 & -11.870 & -15.658 & -23.320 & 3.845 & 46.622 & 14.798 & $4,1 \%$ \\
\hline Hungría & 2010 & -878 & -11.766 & -12.644 & 76.171 & -23.298 & -22.368 & 0 & 55.414 & 85.919 & 73.276 & $19,3 \%$ \\
\hline Irlanda & 2010 & -1.084 & -23.927 & -25.011 & 214.036 & -65.316 & -29.965 & 0 & 101.729 & 220.484 & 195.473 & $30,3 \%$ \\
\hline Islandia & & $\mathrm{m}$ & $\mathrm{m}$ & m & $\mathrm{m}$ & $\mathrm{m}$ & m & $\mathrm{m}$ & $\mathrm{m}$ & $\mathbf{m}$ & m & $\mathrm{m}$ \\
\hline Israel & 2010 & -1.215 & -24.905 & -26.120 & 147.712 & -21.659 & -17.721 & 0 & 21.021 & 129.352 & 103.232 & $12,6 \%$ \\
\hline Italia & 2008 & -986 & -43.886 & -44.872 & 177.073 & -63.514 & -18.903 & 0 & 22.519 & 117.174 & 72.302 & $8,1 \%$ \\
\hline Japón ${ }^{2}$ & & $\mathrm{~m}$ & $\mathrm{~m}$ & $\mathbf{m}$ & $\mathrm{m}$ & $\mathrm{m}$ & $\mathrm{m}$ & $\mathrm{m}$ & $\mathrm{m}$ & $\mathbf{m}$ & $\mathbf{m}$ & $\mathrm{m}$ \\
\hline Luxemburgo & & $\mathrm{m}$ & $\mathrm{m}$ & $\mathbf{m}$ & $\mathrm{m}$ & $\mathrm{m}$ & $\mathrm{m}$ & $\mathrm{m}$ & $\mathrm{m}$ & $\mathbf{m}$ & $\mathbf{m}$ & $\mathrm{m}$ \\
\hline México & & $\mathrm{m}$ & $\mathrm{m}$ & $\mathbf{m}$ & $\mathrm{m}$ & $\mathrm{m}$ & $\mathrm{m}$ & $\mathrm{m}$ & $\mathrm{m}$ & $\mathbf{m}$ & $\mathbf{m}$ & $\mathrm{m}$ \\
\hline Noruega & 2010 & -3.023 & -51.519 & -54.543 & 261.645 & -82.184 & -23.995 & -4.680 & 46.082 & 196.868 & 142.325 & $13,0 \%$ \\
\hline Nueva Zelanda & 2010 & -3.213 & -33.613 & -36.827 & 112.064 & -37.790 & -2.839 & -1.172 & 29.961 & 100.226 & 63.399 & $8,7 \%$ \\
\hline Países Bajos & 2010 & -4.358 & -50.747 & -55.105 & 150.870 & -53.510 & -28.296 & -4.801 & 31.999 & 96.261 & 41.156 & $5,7 \%$ \\
\hline Polonia & 2010 & -1.276 & -16.640 & $-\mathbf{1 7 . 9 1 6}$ & 56.062 & -7.234 & -19.415 & 0 & 34.594 & 64.008 & 46.093 & $11,6 \%$ \\
\hline Portugal & 2010 & 0 & -17.510 & -17.510 & 146.361 & -29.407 & -17.538 & 0 & 13.572 & 112.987 & 95.478 & $12,0 \%$ \\
\hline Reino Unido & 2010 & -5.195 & -30.014 & -35.209 & 220.438 & -51.976 & -28.912 & -49.957 & 64.640 & 154.232 & 119.023 & $18,2 \%$ \\
\hline República Checa & 2010 & -2.130 & -17.846 & -19.976 & 92.549 & -27.793 & -19.496 & -5.574 & 85.445 & 125.131 & 105.155 & $18,2 \%$ \\
\hline República Eslovaca & 2010 & -2.007 & -8.802 & -10.809 & 115.675 & -26.205 & -31.402 & 0 & 119.524 & 177.592 & 166.784 & $35,1 \%$ \\
\hline Suecia & 2010 & -16 & -25.456 & -25.473 & 175.142 & -58.469 & -16.085 & -21.705 & 55.004 & 133.887 & 108.415 & $16,5 \%$ \\
\hline Suiza & & $\mathrm{m}$ & $\mathrm{m}$ & & & & $\mathrm{m}$ & $\mathrm{m}$ & $\mathrm{m}$ & $\mathbf{m}$ & $\mathbf{m}$ & $\mathrm{m}$ \\
\hline Turquía & 2005 & -336 & -11.218 & -11.554 & 63.318 & -10.584 & -10.115 & 0 & 4.017 & 46.637 & 35.082 & $9,5 \%$ \\
\hline Media OCDE & & -2.081 & -27.169 & -29.250 & 147.041 & -40.123 & -20.455 & -6.749 & 46.556 & 126.270 & 97.020 & $15,8 \%$ \\
\hline Media UE21 & & -1.755 & -26.332 & -28.087 & 135.451 & -38.990 & -23.353 & -8.388 & 52.933 & 117.653 & 89.566 & $16,7 \%$ \\
\hline
\end{tabular}

\begin{tabular}{|c|c|c|c|c|c|c|c|c|c|c|c|}
\hline $\begin{array}{l}\text { Arabia Saudí } \\
\text { Argentina }\end{array}$ & $\begin{array}{l}\mathrm{m} \\
\mathrm{m}\end{array}$ & $\begin{array}{l}\mathrm{m} \\
\mathrm{m}\end{array}$ & $\begin{array}{l}\mathbf{m} \\
\mathbf{m}\end{array}$ & $\begin{array}{l}\mathrm{m} \\
\mathrm{m}\end{array}$ & $\begin{array}{l}\mathrm{m} \\
\mathrm{m}\end{array}$ & $\begin{array}{l}\mathrm{m} \\
\mathrm{m}\end{array}$ & $\begin{array}{l}\mathrm{m} \\
\mathrm{m}\end{array}$ & $\begin{array}{l}\mathrm{m} \\
\mathrm{m}\end{array}$ & $\begin{array}{l}\mathbf{m} \\
\mathbf{m}\end{array}$ & $\begin{array}{l}\mathbf{m} \\
\mathbf{m}\end{array}$ & $\begin{array}{l}\mathrm{m} \\
\mathrm{m}\end{array}$ \\
\hline $\begin{array}{l}\text { Brasil } \\
\text { China }\end{array}$ & $\begin{array}{l}\mathrm{m} \\
\mathrm{m}\end{array}$ & $\begin{array}{l}\mathrm{m} \\
\mathrm{m}\end{array}$ & $\begin{array}{l}\mathbf{m} \\
\mathbf{m}\end{array}$ & $\begin{array}{l}\mathrm{m} \\
\mathrm{m}\end{array}$ & $\begin{array}{l}\mathrm{m} \\
\mathrm{m}\end{array}$ & $\begin{array}{l}\mathrm{m} \\
\mathrm{m}\end{array}$ & $\begin{array}{l}\mathrm{m} \\
\mathrm{m}\end{array}$ & $\begin{array}{l}\mathrm{m} \\
\mathrm{m}\end{array}$ & $\begin{array}{l}\mathbf{m} \\
\mathbf{m}\end{array}$ & $\begin{array}{l}\mathbf{m} \\
\mathbf{m}\end{array}$ & $\begin{array}{l}\mathrm{m} \\
\mathrm{m}\end{array}$ \\
\hline $\begin{array}{l}\text { Colombia } \\
\text { Federación Rusa }\end{array}$ & $\begin{array}{l}\mathrm{m} \\
\mathrm{m}\end{array}$ & $\begin{array}{l}\mathrm{m} \\
\mathrm{m}\end{array}$ & $\begin{array}{l}\mathbf{m} \\
\mathbf{m}\end{array}$ & $\begin{array}{l}\mathrm{m} \\
\mathrm{m}\end{array}$ & $\begin{array}{l}\mathrm{m} \\
\mathrm{m}\end{array}$ & $\begin{array}{l}\mathrm{m} \\
\mathrm{m}\end{array}$ & $\begin{array}{l}\mathrm{m} \\
\mathrm{m}\end{array}$ & $\begin{array}{l}\mathrm{m} \\
\mathrm{m}\end{array}$ & $\begin{array}{l}\mathbf{m} \\
\mathbf{m}\end{array}$ & $\begin{array}{l}\mathbf{m} \\
\mathbf{m}\end{array}$ & $\begin{array}{l}\mathrm{m} \\
\mathrm{m}\end{array}$ \\
\hline $\begin{array}{l}\text { India } \\
\text { Indonesia }\end{array}$ & $\begin{array}{l}\mathrm{m} \\
\mathrm{m}\end{array}$ & $\begin{array}{l}\mathrm{m} \\
\mathrm{m}\end{array}$ & $\begin{array}{l}\mathbf{m} \\
\mathbf{m}\end{array}$ & $\begin{array}{l}\mathrm{m} \\
\mathrm{m}\end{array}$ & $\begin{array}{l}\mathrm{m} \\
\mathrm{m}\end{array}$ & $\begin{array}{l}\mathrm{m} \\
\mathrm{m}\end{array}$ & $\begin{array}{l}\mathrm{m} \\
\mathrm{m}\end{array}$ & $\begin{array}{l}\mathrm{m} \\
\mathrm{m}\end{array}$ & $\begin{array}{l}\mathbf{m} \\
\mathbf{m}\end{array}$ & $\begin{array}{l}\mathbf{m} \\
\mathbf{m}\end{array}$ & $\begin{array}{l}\mathrm{m} \\
\mathrm{m}\end{array}$ \\
\hline $\begin{array}{l}\text { Letonia } \\
\text { Sudáfrica }\end{array}$ & $\begin{array}{l}\mathrm{m} \\
\mathrm{m}\end{array}$ & $\begin{array}{l}\mathrm{m} \\
\mathrm{m}\end{array}$ & $\begin{array}{l}\mathbf{m} \\
\mathbf{m}\end{array}$ & $\begin{array}{l}\mathrm{m} \\
\mathrm{m}\end{array}$ & $\begin{array}{l}\mathrm{m} \\
\mathrm{m}\end{array}$ & $\begin{array}{l}\mathrm{m} \\
\mathrm{m}\end{array}$ & $\begin{array}{l}\mathrm{m} \\
\mathrm{m}\end{array}$ & $\begin{array}{l}\mathrm{m} \\
\mathrm{m}\end{array}$ & $\begin{array}{l}\mathbf{m} \\
\mathbf{m}\end{array}$ & $\begin{array}{l}\mathbf{m} \\
\mathbf{m}\end{array}$ & $\begin{array}{l}\mathrm{m} \\
\mathrm{m}\end{array}$ \\
\hline
\end{tabular}

Nota: Los valores se basan en la diferencia entre los hombres que han completado educación secundaria superior o postsecundaria no terciaria y aquellos que no lo han hecho.

1. Los datos de Bélgica no se incluyen en la tabla, porque la educación secundaria superior es obligatoria.

2. Los datos de educación secundaria inferior y superior no se desglosan.

Fuente: OCDE. Para ver notas, consulte Anexo 3 (www.oecd.org/edu/eag.htm).

Para obtener más información acerca de los símbolos utilizados en lugar de los datos que faltan, consulte la Guía del lector.

StatLink 제개 http://dx.doi.org/10.1787/888933116300 
Tabla A7.1b. Costes y beneficios privados para una mujer que alcanza la educación secundaria superior o postsecundaria no terciaria (2010)

En comparación con una mujer que tiene educación secundaria inferior, en equivalente a dólares estadounidenses convertidos mediante PPA para el PIB

\begin{tabular}{|c|c|c|c|c|c|c|c|c|c|c|c|c|}
\hline & & $\begin{array}{c}\text { Costes } \\
\text { directos }\end{array}$ & $\begin{array}{c}\text { Pérdida de } \\
\text { ingresos }\end{array}$ & $\begin{array}{l}\text { Costes } \\
\text { totales }\end{array}$ & $\begin{array}{c}\text { Beneficios } \\
\text { de los } \\
\text { ingresos } \\
\text { brutos }\end{array}$ & $\begin{array}{l}\text { Efecto del } \\
\text { impuesto } \\
\text { sobre la } \\
\text { renta }\end{array}$ & $\begin{array}{c}\text { Efecto de las } \\
\text { cotizaciones } \\
\text { sociales }\end{array}$ & $\begin{array}{l}\text { Efecto de las } \\
\text { prestaciones }\end{array}$ & $\begin{array}{l}\text { Efecto del } \\
\text { desempleo }\end{array}$ & $\begin{array}{c}\text { Beneficios } \\
\text { totales }\end{array}$ & $\begin{array}{c}\text { Valor } \\
\text { actual } \\
\text { neto }\end{array}$ & $\begin{array}{c}\text { Tasa } \\
\text { interna } \\
\text { de retorno }\end{array}$ \\
\hline & Año & (1) & (2) & (3) & (4) & (5) & (6) & (7) & (8) & (9) & (10) & (11) \\
\hline Alemania & 2010 & -3.973 & -37.300 & -41.272 & 156.387 & -33.692 & -41.680 & -48.767 & 42.644 & 74.891 & 33.618 & $6,4 \%$ \\
\hline Australia & 2009 & -3.019 & -28.198 & -31.217 & 122.044 & -28.457 & 0 & -22.467 & 20.190 & 91.311 & 60.094 & $12,7 \%$ \\
\hline Austria & 2010 & -2.084 & -44.642 & -46.726 & 204.709 & -28.457 & -46.030 & -32.029 & 23.784 & 121.977 & 75.251 & $9,0 \%$ \\
\hline Bélgica $^{1}$ & & $\mathrm{~m}$ & $\mathrm{~m}$ & $\mathbf{m}$ & $\mathrm{m}$ & $\mathrm{m}$ & $\mathrm{m}$ & $\mathrm{m}$ & $\mathrm{m}$ & $\mathbf{m}$ & $\mathbf{m}$ & $\mathrm{m}$ \\
\hline Canadá & 2010 & -3.424 & -32.817 & -36.241 & 78.654 & -15.117 & -8.057 & -3.002 & 29.950 & 82.428 & 46.187 & $7,1 \%$ \\
\hline Chile & & $\mathrm{m}$ & $\mathrm{m}$ & $\mathbf{m}$ & $\mathrm{m}$ & $\mathrm{m}$ & $\mathrm{m}$ & $\mathrm{m}$ & $\mathrm{m}$ & $\mathbf{m}$ & $\mathbf{m}$ & $\mathrm{m}$ \\
\hline Corea & 2010 & -5.756 & -30.875 & -36.631 & 114.418 & -1.830 & -9.342 & 0 & 4.399 & 107.644 & 71.013 & $11,3 \%$ \\
\hline Dinamarca & 2010 & -797 & -44.663 & -45.460 & 151.000 & -55.719 & -15.607 & 0 & 26.604 & 106.278 & 60.818 & $9,1 \%$ \\
\hline Eslovenia & 2010 & -1.833 & -24.045 & -25.877 & 118.868 & -32.045 & -31.131 & 0 & 21.694 & 77.387 & 51.510 & $8,8 \%$ \\
\hline España & 2010 & -1.613 & -8.881 & -10.494 & 85.625 & -27.101 & -7.802 & 0 & 39.931 & 90.653 & 80.159 & $16,5 \%$ \\
\hline Estados Unidos & 2010 & -2.853 & -27.807 & -30.659 & 216.685 & -44.957 & -19.154 & -13.250 & 34.220 & 173.546 & 142.886 & $16,7 \%$ \\
\hline Estonia & 2010 & -249 & -8.187 & -8.436 & 43.751 & -10.151 & -1.455 & 0 & 8.365 & 40.510 & 32.074 & $31,6 \%$ \\
\hline Finlandia & 2009 & -178 & -31.990 & -32.168 & 55.774 & -16.608 & -5.546 & -16.226 & 30.783 & 48.177 & 16.009 & $5,5 \%$ \\
\hline Francia & 2010 & -2.904 & -25.642 & -28.546 & 97.781 & -18.674 & -18.682 & -27.615 & 39.828 & 72.639 & 44.093 & $8,1 \%$ \\
\hline Grecia & 2009 & -1.780 & -24.381 & -26.160 & 109.244 & -1.304 & -18.230 & -15.164 & 5.096 & 79.641 & 53.481 & $7,8 \%$ \\
\hline Hungría & 2010 & -878 & -13.082 & -13.960 & 75.548 & -21.486 & -20.637 & 0 & 46.369 & 79.794 & 65.834 & $15,8 \%$ \\
\hline Irlanda & 2010 & -1.084 & -31.344 & -32.428 & 134.069 & -20.768 & -8.056 & 0 & 30.359 & 135.604 & 103.176 & $15,0 \%$ \\
\hline Islandia & & $\mathrm{m}$ & $\mathrm{m}$ & $\mathbf{m}$ & $\mathrm{m}$ & $\mathrm{m}$ & $\mathrm{m}$ & $\mathrm{m}$ & $\mathrm{m}$ & $\mathbf{m}$ & $\mathbf{m}$ & $\mathrm{m}$ \\
\hline Israel & 2010 & -1.215 & -23.860 & -25.076 & 109.731 & -3.747 & -5.003 & -3.505 & 12.291 & 109.768 & 84.692 & $13,0 \%$ \\
\hline Italia & 2008 & -986 & -38.624 & -39.610 & 152.167 & -51.238 & -17.293 & 0 & 29.983 & 113.620 & 74.010 & $8,4 \%$ \\
\hline Japón $^{2}$ & & $\mathrm{~m}$ & $\mathrm{~m}$ & $\mathbf{m}$ & $\mathrm{m}$ & $\mathrm{m}$ & $\mathrm{m}$ & $\mathrm{m}$ & $\mathrm{m}$ & $\mathbf{m}$ & $\mathbf{m}$ & $\mathrm{m}$ \\
\hline Luxemburgo & & $\mathrm{m}$ & $\mathrm{m}$ & $\mathbf{m}$ & $\mathrm{m}$ & $\mathrm{m}$ & $\mathrm{m}$ & $\mathrm{m}$ & $\mathrm{m}$ & $\mathbf{m}$ & $\mathbf{m}$ & $\mathrm{m}$ \\
\hline México & & $\mathrm{m}$ & $\mathrm{m}$ & $\mathbf{m}$ & $\mathrm{m}$ & $\mathrm{m}$ & $\mathrm{m}$ & $\mathrm{m}$ & $\mathrm{m}$ & $\mathbf{m}$ & $\mathbf{m}$ & $\mathrm{m}$ \\
\hline Noruega & 2010 & -3.023 & -52.322 & -55.345 & 160.744 & -44.395 & -14.122 & -14.220 & 19.969 & 107.976 & 52.631 & $6,9 \%$ \\
\hline Nueva Zelanda & 2010 & -3.213 & -30.148 & -33.362 & 77.579 & -16.827 & -1.872 & -7.825 & 16.735 & 67.790 & 34.428 & $7,7 \%$ \\
\hline Países Bajos & 2010 & -4.358 & -48.974 & -53.332 & 159.683 & -36.998 & -53.343 & -13.638 & 28.711 & 84.414 & 31.082 & $5,1 \%$ \\
\hline Polonia & 2010 & -1.276 & -15.341 & -16.618 & 65.215 & -7.681 & -20.906 & 0 & 32.672 & 69.299 & 52.682 & $11,7 \%$ \\
\hline Portugal & 2010 & 0 & -16.952 & -16.952 & 104.322 & -10.554 & -12.633 & 0 & 10.654 & 91.790 & 74.838 & $11,3 \%$ \\
\hline Reino Unido & 2010 & -5.195 & -42.268 & -47.464 & 136.400 & -33.662 & -18.761 & -49.494 & 51.211 & 85.693 & 38.230 & $6,7 \%$ \\
\hline República Checa & 2010 & -2.130 & -15.299 & -17.429 & 86.525 & -23.652 & -17.196 & -16.740 & 70.127 & 99.064 & 81.634 & $19,3 \%$ \\
\hline República Eslovaca & 2010 & -2.007 & -5.179 & -7.187 & 79.613 & -12.302 & -22.099 & 0 & 85.991 & 131.204 & 124.017 & $43,8 \%$ \\
\hline Suecia & 2010 & -16 & -27.231 & -27.247 & 141.055 & -47.672 & -13.857 & -30.949 & 57.144 & 105.720 & 78.473 & $11,5 \%$ \\
\hline Suiza & & $\mathrm{m}$ & & & & $\mathrm{m}$ & $\mathrm{m}$ & $\mathrm{m}$ & $\mathrm{m}$ & $\mathbf{m}$ & $\mathbf{m}$ & $\mathrm{m}$ \\
\hline Turquía & 2005 & -336 & -12.058 & -12.394 & 75.879 & -8.395 & -9.432 & 0 & -12.434 & 45.618 & 33.223 & $9,2 \%$ \\
\hline Media OCDE & & -2.081 & -27.486 & -29.566 & 115.314 & -24.203 & -16.960 & -11.663 & 29.899 & 92.386 & 62.820 & $12,5 \%$ \\
\hline Media UE21 & & -1.755 & -26.528 & -28.282 & 113.565 & -25.777 & -20.576 & -13.191 & 35.892 & 89.913 & 61.631 & $13,2 \%$ \\
\hline
\end{tabular}

\begin{tabular}{|c|c|c|c|c|c|c|c|c|c|c|c|}
\hline $\begin{array}{l}\text { Arabia Saudí } \\
\frac{\pi}{0} \text { Argentina }\end{array}$ & $\begin{array}{l}\mathrm{m} \\
\mathrm{m}\end{array}$ & $\begin{array}{l}\mathrm{m} \\
\mathrm{m}\end{array}$ & $\begin{array}{l}\mathbf{m} \\
\mathbf{m}\end{array}$ & $\begin{array}{l}\mathrm{m} \\
\mathrm{m}\end{array}$ & $\begin{array}{l}\mathrm{m} \\
\mathrm{m}\end{array}$ & $\begin{array}{l}\mathrm{m} \\
\mathrm{m}\end{array}$ & $\begin{array}{l}\mathrm{m} \\
\mathrm{m}\end{array}$ & $\begin{array}{l}\mathrm{m} \\
\mathrm{m}\end{array}$ & $\begin{array}{l}\mathbf{m} \\
\mathbf{m}\end{array}$ & $\begin{array}{l}\mathbf{m} \\
\mathbf{m}\end{array}$ & $\begin{array}{l}\mathrm{m} \\
\mathrm{m}\end{array}$ \\
\hline Brasil & $\mathrm{m}$ & $\mathrm{m}$ & $\mathbf{m}$ & $\mathrm{m}$ & $\mathrm{m}$ & $\mathrm{m}$ & $\mathrm{m}$ & $\mathrm{m}$ & $\mathbf{m}$ & $\mathbf{m}$ & $\mathrm{m}$ \\
\hline China & $\mathrm{m}$ & $\mathrm{m}$ & $\mathbf{m}$ & $\mathrm{m}$ & $\mathrm{m}$ & $\mathrm{m}$ & $\mathrm{m}$ & $\mathrm{m}$ & $\mathbf{m}$ & $\mathbf{m}$ & $\mathrm{m}$ \\
\hline $\begin{array}{l}\text { Colombia } \\
\text { Federación Rusa }\end{array}$ & $\begin{array}{l}\mathrm{m} \\
\mathrm{m}\end{array}$ & $\begin{array}{l}\mathrm{m} \\
\mathrm{m}\end{array}$ & $\begin{array}{l}\mathbf{m} \\
\mathbf{m}\end{array}$ & $\begin{array}{l}\mathrm{m} \\
\mathrm{m}\end{array}$ & $\begin{array}{l}\mathrm{m} \\
\mathrm{m}\end{array}$ & $\begin{array}{l}\mathrm{m} \\
\mathrm{m}\end{array}$ & $\begin{array}{l}\mathrm{m} \\
\mathrm{m}\end{array}$ & $\begin{array}{l}\mathrm{m} \\
\mathrm{m}\end{array}$ & $\begin{array}{l}\mathbf{m} \\
\mathbf{m}\end{array}$ & $\begin{array}{l}\mathbf{m} \\
\mathbf{m}\end{array}$ & $\begin{array}{l}\mathrm{m} \\
\mathrm{m}\end{array}$ \\
\hline India & $\mathrm{m}$ & $\mathrm{m}$ & $\mathbf{m}$ & $\mathrm{m}$ & $\mathrm{m}$ & $\mathrm{m}$ & $\mathrm{m}$ & $\mathrm{m}$ & $\mathbf{m}$ & $\mathbf{m}$ & $\mathrm{m}$ \\
\hline Indonesia & $\mathrm{m}$ & $\mathrm{m}$ & $\mathbf{m}$ & $\mathrm{m}$ & $\mathrm{m}$ & $\mathrm{m}$ & $\mathrm{m}$ & $\mathrm{m}$ & $\mathbf{m}$ & $\mathbf{m}$ & $\mathrm{m}$ \\
\hline Letonia & $\mathrm{m}$ & $\mathrm{m}$ & $\mathbf{m}$ & $\mathrm{m}$ & $\mathrm{m}$ & $\mathrm{m}$ & $\mathrm{m}$ & $\mathrm{m}$ & $\mathbf{m}$ & $\mathbf{m}$ & $\mathrm{m}$ \\
\hline Sudáfrica & $\mathrm{m}$ & $\mathrm{m}$ & $\mathbf{m}$ & $\mathrm{m}$ & $\mathrm{m}$ & $\mathrm{m}$ & $\mathrm{m}$ & $\mathrm{m}$ & $\mathbf{m}$ & $\mathbf{m}$ & $\mathrm{m}$ \\
\hline
\end{tabular}

\begin{tabular}{l|l|l|l|l|l|l|l|l|l|l|l|l|} 
Media G20 & & $\mathrm{m}$ & $\mathrm{m}$ & $\mathbf{m}$ & $\mathrm{m}$ & $\mathrm{m}$ & $\mathrm{m}$ & $\mathrm{m}$ & $\mathrm{m}$ & $\mathbf{m}$ & $\mathbf{m}$ & $\mathrm{m}$
\end{tabular}

Nota: Los valores se basan en la diferencia entre los hombres que han completado educación secundaria superior o postsecundaria no terciaria y aquellos que no lo han hecho.

1. Los datos de Bélgica no se incluyen en la tabla, porque la educación secundaria superior es obligatoria.

2. Los datos de educación secundaria inferior y superior no se desglosan.

Fuente: OCDE. Para ver notas, consulte Anexo 3 (www.oecd.org/edu/eag.htm).

Para obtener más información acerca de los símbolos utilizados en lugar de los datos que faltan, consulte la Guía del lector.

StatLink 게 जी http://dx.doi.org/10.1787/888933116300 
Tabla A7.2a. Costes y beneficios públicos para un hombre que alcanza la educación secundaria superior o postsecundaria no terciaria (2010)

En comparación con un hombre que tiene educación secundaria inferior, en equivalente a dólares estadounidenses convertidos mediante PPA para el PIB

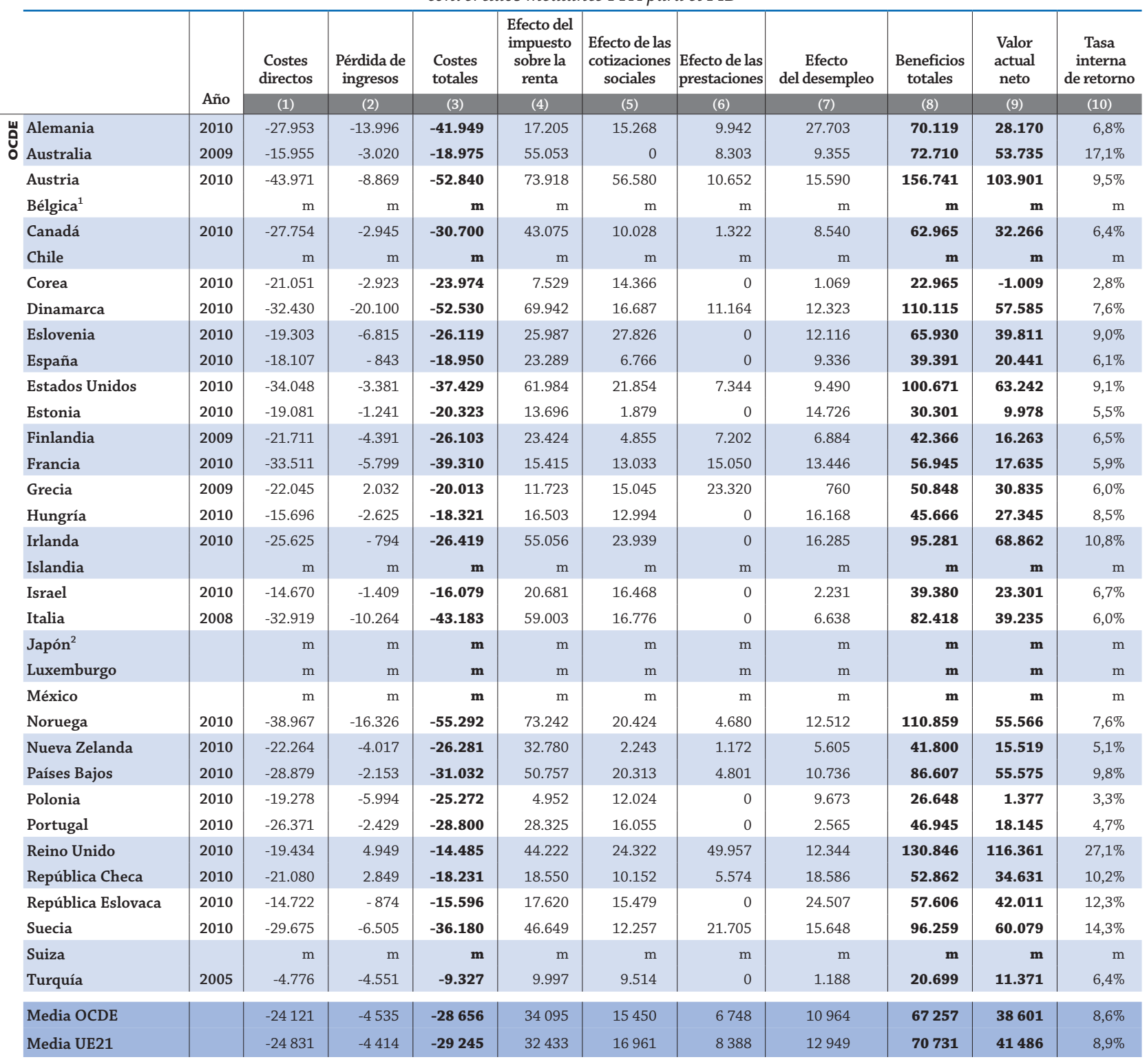

\begin{tabular}{|c|c|c|c|c|c|c|c|c|c|c|}
\hline $\begin{array}{l}\text { Arabia Saudí } \\
\frac{\pi}{\tilde{c}} \text { Argentina }\end{array}$ & $\begin{array}{l}\mathrm{m} \\
\mathrm{m}\end{array}$ & $\begin{array}{l}\mathrm{m} \\
\mathrm{m}\end{array}$ & $\begin{array}{l}\mathbf{m} \\
\mathbf{m}\end{array}$ & $\begin{array}{l}\mathrm{m} \\
\mathrm{m}\end{array}$ & $\begin{array}{l}\mathrm{m} \\
\mathrm{m}\end{array}$ & $\begin{array}{l}\mathrm{m} \\
\mathrm{m}\end{array}$ & $\begin{array}{l}\mathrm{m} \\
\mathrm{m}\end{array}$ & $\begin{array}{l}\mathbf{m} \\
\mathbf{m}\end{array}$ & $\begin{array}{l}\mathbf{m} \\
\mathbf{m}\end{array}$ & $\begin{array}{l}\mathrm{m} \\
\mathrm{m}\end{array}$ \\
\hline 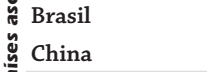 & $\begin{array}{l}\mathrm{m} \\
\mathrm{m}\end{array}$ & $\begin{array}{l}\mathrm{m} \\
\mathrm{m}\end{array}$ & $\begin{array}{l}\mathbf{m} \\
\mathbf{m}\end{array}$ & $\begin{array}{l}\mathrm{m} \\
\mathrm{m}\end{array}$ & $\begin{array}{l}\mathrm{m} \\
\mathrm{m}\end{array}$ & $\begin{array}{l}\mathrm{m} \\
\mathrm{m}\end{array}$ & $\begin{array}{l}\mathrm{m} \\
\mathrm{m}\end{array}$ & $\begin{array}{l}\mathbf{m} \\
\mathbf{m}\end{array}$ & $\begin{array}{l}\mathbf{m} \\
\mathbf{m}\end{array}$ & $\begin{array}{l}\mathrm{m} \\
\mathrm{m}\end{array}$ \\
\hline $\begin{array}{l}\text { Colombia } \\
\text { Federación Rusa }\end{array}$ & $\begin{array}{l}\mathrm{m} \\
\mathrm{m}\end{array}$ & $\begin{array}{l}\mathrm{m} \\
\mathrm{m}\end{array}$ & $\begin{array}{l}\mathbf{m} \\
\mathbf{m}\end{array}$ & $\begin{array}{l}\mathrm{m} \\
\mathrm{m}\end{array}$ & $\begin{array}{l}\mathrm{m} \\
\mathrm{m}\end{array}$ & $\begin{array}{l}\mathrm{m} \\
\mathrm{m}\end{array}$ & $\begin{array}{l}\mathrm{m} \\
\mathrm{m}\end{array}$ & $\begin{array}{l}\mathbf{m} \\
\mathbf{m}\end{array}$ & $\begin{array}{l}\mathbf{m} \\
\mathbf{m}\end{array}$ & $\begin{array}{l}\mathrm{m} \\
\mathrm{m}\end{array}$ \\
\hline $\begin{array}{l}\text { India } \\
\text { Indonesia }\end{array}$ & $\begin{array}{l}\mathrm{m} \\
\mathrm{m}\end{array}$ & $\begin{array}{l}\mathrm{m} \\
\mathrm{m}\end{array}$ & $\begin{array}{l}\mathbf{m} \\
\mathbf{m}\end{array}$ & $\begin{array}{l}\mathrm{m} \\
\mathrm{m}\end{array}$ & $\begin{array}{l}\mathrm{m} \\
\mathrm{m}\end{array}$ & $\begin{array}{l}\mathrm{m} \\
\mathrm{m}\end{array}$ & $\begin{array}{l}\mathrm{m} \\
\mathrm{m}\end{array}$ & $\begin{array}{l}\mathbf{m} \\
\mathbf{m}\end{array}$ & $\begin{array}{l}\mathbf{m} \\
\mathbf{m}\end{array}$ & $\begin{array}{l}\mathrm{m} \\
\mathrm{m}\end{array}$ \\
\hline $\begin{array}{l}\text { Letonia } \\
\text { Sudáfrica }\end{array}$ & $\begin{array}{l}\mathrm{m} \\
\mathrm{m}\end{array}$ & $\begin{array}{l}\mathrm{m} \\
\mathrm{m}\end{array}$ & $\begin{array}{l}\mathbf{m} \\
\mathbf{m}\end{array}$ & $\begin{array}{l}\mathrm{m} \\
\mathrm{m}\end{array}$ & $\begin{array}{l}\mathrm{m} \\
\mathrm{m}\end{array}$ & $\begin{array}{l}\mathrm{m} \\
\mathrm{m}\end{array}$ & $\begin{array}{l}\mathrm{m} \\
\mathrm{m}\end{array}$ & $\begin{array}{l}\mathbf{m} \\
\mathbf{m}\end{array}$ & $\begin{array}{l}\mathbf{m} \\
\mathbf{m}\end{array}$ & $\begin{array}{l}\mathrm{m} \\
\mathrm{m}\end{array}$ \\
\hline Media G20 & $\mathrm{m}$ & $\mathrm{m}$ & m & $\mathrm{m}$ & $\mathrm{m}$ & $\mathrm{m}$ & $\mathrm{m}$ & $\mathbf{m}$ & $\mathbf{m}$ & $\mathrm{m}$ \\
\hline
\end{tabular}

Nota: Los valores se basan en la diferencia entre los hombres que han completado educación secundaria superior o postsecundaria no terciaria y aquellos que no lo han hecho.

1. Los datos de Bélgica no se incluyen en la tabla, porque la educación secundaria superior es obligatoria.

2. Los datos de educación secundaria inferior y superior no se desglosan.

Fuente: OCDE. Para ver notas, consulte Anexo 3 (www.oecd.org/edu/eag.htm).

Para obtener más información acerca de los símbolos utilizados en lugar de los datos que faltan, consulte la Guía del lector.

StatLink 젝ㄴ http://dx.doi.org/10.1787/888933116338 
Tabla A7.2b. Costes y beneficios públicos para una mujer que alcanza la educación secundaria superior o postsecundaria no terciaria (2010)

En comparación con una mujer que tiene educación secundaria inferior, en equivalente a dólares estadounidenses convertidos mediante PPA para el PIB

\begin{tabular}{|c|c|c|c|c|c|c|c|c|c|c|c|}
\hline & & $\begin{array}{l}\text { Costes } \\
\text { directos }\end{array}$ & $\begin{array}{l}\text { Pérdida de } \\
\text { ingresos }\end{array}$ & $\begin{array}{l}\text { Costes } \\
\text { totales }\end{array}$ & $\begin{array}{l}\text { Efecto del } \\
\text { impuesto } \\
\text { sobre la } \\
\text { renta }\end{array}$ & $\begin{array}{c}\text { Efecto de las } \\
\text { cotizaciones } \\
\text { sociales }\end{array}$ & $\begin{array}{l}\text { Efecto de las } \\
\text { prestaciones }\end{array}$ & $\begin{array}{l}\text { Efecto del } \\
\text { desempleo }\end{array}$ & $\begin{array}{c}\text { Beneficios } \\
\text { totales }\end{array}$ & $\begin{array}{c}\text { Valor } \\
\text { actual } \\
\text { neto }\end{array}$ & $\begin{array}{c}\text { Tasa } \\
\text { interna } \\
\text { de retorno }\end{array}$ \\
\hline & Año & (1) & (2) & (3) & (4) & (5) & (6) & (7) & (8) & (9) & (10) \\
\hline Alemania & 2010 & -27.953 & -14.147 & -42.100 & 30.323 & 33.057 & 48.767 & 11.993 & 124.140 & 82.040 & $13,7 \%$ \\
\hline Australia & 2009 & -15.955 & -3.136 & -19.091 & 26.218 & 0 & 22.467 & 2.239 & 50.924 & 31.833 & $18,4 \%$ \\
\hline Austria & 2010 & -43.971 & -8.568 & -52.539 & 28.045 & 41.879 & 32.029 & 4.562 & 106.516 & 53.977 & $8,2 \%$ \\
\hline Bélgica $^{1}$ & & $\mathrm{~m}$ & $\mathrm{~m}$ & m & $\mathrm{m}$ & $\mathrm{m}$ & $\mathrm{m}$ & $\mathrm{m}$ & $\mathbf{m}$ & m & $\mathrm{m}$ \\
\hline Canadá & 2010 & -28.587 & -3.233 & -31.820 & 13.613 & 6.115 & 3.002 & 3.447 & 26.176 & -5.644 & $2,3 \%$ \\
\hline Chile & & $\mathrm{m}$ & $\mathrm{m}$ & m & $\mathrm{m}$ & $\mathrm{m}$ & $\mathrm{m}$ & $\mathrm{m}$ & $\mathbf{m}$ & m & $\mathrm{m}$ \\
\hline Corea & 2010 & -21.051 & -3.130 & -24.181 & 1.797 & 9.001 & 0 & 374 & 11.172 & -13.009 & $-1,0 \%$ \\
\hline Dinamarca & 2010 & -32.430 & -21.038 & -53.468 & 49.505 & 12.177 & 0 & 9.644 & 71.326 & 17.858 & $4,8 \%$ \\
\hline Eslovenia & 2010 & -19.303 & -7.468 & -26.771 & 30.404 & 26.364 & 0 & 6.407 & 63.175 & 36.404 & $7,4 \%$ \\
\hline España & 2010 & -18.107 & -811 & -18.919 & 25.096 & 5.301 & 0 & 4.506 & 34.904 & 15.985 & $5,2 \%$ \\
\hline Estados Unidos & 2010 & -34.048 & -3.727 & -37.775 & 41.313 & 16.564 & 13.250 & 6.233 & 77.360 & 39.585 & $7,5 \%$ \\
\hline Estonia & 2010 & -19.081 & -1.240 & -20.321 & 8.914 & 1.223 & 0 & 1.469 & 11.606 & -8.715 & $0,2 \%$ \\
\hline Finlandia & 2009 & -21.711 & -4.679 & -26.390 & 12.075 & 3.607 & 16.226 & 6.472 & 38.380 & 11.989 & $6,6 \%$ \\
\hline Francia & 2010 & -33.511 & -5.217 & -38.728 & 15.257 & 13.296 & 27.615 & 8.802 & 64.970 & 26.243 & $5,6 \%$ \\
\hline Grecia & 2009 & -22.045 & 1.649 & -20.396 & 1.347 & 17.423 & 15.164 & 764 & 34.699 & 14.303 & $4,8 \%$ \\
\hline Hungría & 2010 & -15.696 & -2.918 & -18.614 & 16.259 & 12.802 & 0 & 13.062 & 42.123 & 23.509 & $7,5 \%$ \\
\hline Irlanda & 2010 & -25.625 & -1.040 & -26.665 & 19.850 & 7.690 & 0 & 1.284 & 28.824 & 2.159 & $3,3 \%$ \\
\hline Islandia & & $\mathrm{m}$ & $\mathrm{m}$ & m & $\mathrm{m}$ & $\mathrm{m}$ & $\mathrm{m}$ & $\mathrm{m}$ & $\mathbf{m}$ & m & $\mathrm{m}$ \\
\hline Israel & 2010 & -14.670 & -1.350 & -16.020 & 3.668 & 4.543 & 3.505 & 539 & 12.254 & -3.766 & $1,8 \%$ \\
\hline Italia & 2008 & -32.919 & -9.033 & -41.952 & 47.153 & 14.467 & 0 & 6.910 & 68.530 & 26.578 & $5,2 \%$ \\
\hline Japón $^{2}$ & & $\mathrm{~m}$ & $\mathrm{~m}$ & m & $\mathrm{m}$ & $\mathrm{m}$ & $\mathrm{m}$ & $\mathrm{m}$ & $\mathbf{m}$ & m & $\mathrm{m}$ \\
\hline Luxemburgo & & $\mathrm{m}$ & $\mathrm{m}$ & $\mathbf{m}$ & $\mathrm{m}$ & $\mathrm{m}$ & $\mathrm{m}$ & $\mathrm{m}$ & $\mathbf{m}$ & $\mathbf{m}$ & $\mathrm{m}$ \\
\hline México & & $\mathrm{m}$ & $\mathrm{m}$ & $\mathbf{m}$ & $\mathrm{m}$ & $\mathrm{m}$ & $\mathrm{m}$ & $\mathrm{m}$ & $\mathbf{m}$ & $\mathbf{m}$ & $\mathrm{m}$ \\
\hline Noruega & 2010 & -38.967 & -16.580 & -55.547 & 41.576 & 12.582 & 14.220 & 4.360 & 72.737 & 17.190 & $4,8 \%$ \\
\hline Nueva Zelanda & 2010 & -22.264 & -3.603 & -25.867 & 14.529 & 1.540 & 7.825 & 2.630 & 26.524 & 657 & $3,1 \%$ \\
\hline Países Bajos & 2010 & -28.879 & 1.113 & -27.766 & 35.228 & 46.047 & 13.638 & 9.066 & $\mathbf{m}$ & 76.213 & $14,6 \%$ \\
\hline Polonia & 2010 & -19.278 & -5.526 & -24.804 & 5.740 & 13.937 & 0 & 8.910 & 28.588 & 3.784 & $3,6 \%$ \\
\hline Portugal & 2010 & -26.371 & -2.352 & -28.722 & 10.290 & 11.473 & 0 & 1.424 & 23.187 & -5.536 & $2,3 \%$ \\
\hline Reino Unido & 2010 & -19.434 & 8.961 & -10.473 & 27.379 & 15.059 & 49.494 & 9.985 & 101.917 & 91.444 & $19,3 \%$ \\
\hline República Checa & 2010 & -21.080 & 2.442 & -18.638 & 17.417 & 9.532 & 16.740 & 13.901 & 57.589 & 38.951 & $10,5 \%$ \\
\hline República Eslovaca & 2010 & -14.722 & -514 & -15.236 & 9.428 & 10.668 & 0 & 14.305 & 34.401 & 19.165 & $7,8 \%$ \\
\hline Suecia & 2010 & -29.675 & -6.959 & -36.633 & 36.329 & 9.895 & 30.949 & 15.306 & 92.478 & 55.845 & $13,6 \%$ \\
\hline Suiza & & $\mathrm{m}$ & $\mathrm{m}$ & $\mathbf{m}$ & $\mathrm{m}$ & $\mathrm{m}$ & $\mathrm{m}$ & $\mathrm{m}$ & $\mathbf{m}$ & $\mathbf{m}$ & $\mathrm{m}$ \\
\hline Turquía & 2005 & -4.776 & -4.892 & -9.668 & 10.025 & 11.264 & 0 & -3.463 & 17.827 & 8.159 & $5,8 \%$ \\
\hline Media OCDE & & -24.152 & -4.333 & -28.485 & 21.436 & 13.611 & 11.663 & 6.116 & 50.859 & 24.341 & $6,9 \%$ \\
\hline Media UE21 & & -24.831 & -4.071 & -28.902 & 22.423 & 16.100 & 13.191 & 7.830 & 57.075 & 30.642 & $7,6 \%$ \\
\hline
\end{tabular}

\begin{tabular}{|c|c|c|c|c|c|c|c|c|c|c|}
\hline 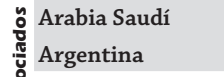 & $\begin{array}{l}\mathrm{m} \\
\mathrm{m}\end{array}$ & $\begin{array}{l}\mathrm{m} \\
\mathrm{m}\end{array}$ & $\begin{array}{l}\mathbf{m} \\
\mathbf{m}\end{array}$ & $\begin{array}{l}\mathrm{m} \\
\mathrm{m}\end{array}$ & $\begin{array}{l}\mathrm{m} \\
\mathrm{m}\end{array}$ & $\begin{array}{l}\mathrm{m} \\
\mathrm{m}\end{array}$ & $\begin{array}{l}\mathrm{m} \\
\mathrm{m}\end{array}$ & $\begin{array}{l}\mathbf{m} \\
\mathbf{m}\end{array}$ & $\begin{array}{l}\mathbf{m} \\
\mathbf{m}\end{array}$ & $\begin{array}{l}\mathrm{m} \\
\mathrm{m}\end{array}$ \\
\hline 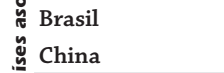 & $\begin{array}{l}\mathrm{m} \\
\mathrm{m}\end{array}$ & $\begin{array}{l}\mathrm{m} \\
\mathrm{m}\end{array}$ & $\begin{array}{l}\mathbf{m} \\
\mathbf{m}\end{array}$ & $\begin{array}{l}\mathrm{m} \\
\mathrm{m}\end{array}$ & $\begin{array}{l}\mathrm{m} \\
\mathrm{m}\end{array}$ & $\begin{array}{l}\mathrm{m} \\
\mathrm{m}\end{array}$ & $\begin{array}{l}\mathrm{m} \\
\mathrm{m}\end{array}$ & $\begin{array}{l}\mathbf{m} \\
\mathbf{m}\end{array}$ & $\begin{array}{l}\mathbf{m} \\
\mathbf{m}\end{array}$ & $\begin{array}{l}\mathrm{m} \\
\mathrm{m}\end{array}$ \\
\hline $\begin{array}{l}\text { Federación Rusa } \\
\text { Folombia }\end{array}$ & $\begin{array}{l}\mathrm{m} \\
\mathrm{m}\end{array}$ & $\begin{array}{l}\mathrm{m} \\
\mathrm{m}\end{array}$ & $\begin{array}{l}\mathbf{m} \\
\mathbf{m}\end{array}$ & $\begin{array}{l}\mathrm{m} \\
\mathrm{m}\end{array}$ & $\begin{array}{l}\mathrm{m} \\
\mathrm{m}\end{array}$ & $\begin{array}{l}\mathrm{m} \\
\mathrm{m}\end{array}$ & $\begin{array}{l}\mathrm{m} \\
\mathrm{m}\end{array}$ & $\begin{array}{l}\mathbf{m} \\
\mathbf{m}\end{array}$ & $\begin{array}{l}\mathbf{m} \\
\mathbf{m}\end{array}$ & $\begin{array}{l}\mathrm{m} \\
\mathrm{m}\end{array}$ \\
\hline $\begin{array}{l}\text { India } \\
\text { Indonesia }\end{array}$ & $\begin{array}{l}\mathrm{m} \\
\mathrm{m}\end{array}$ & $\begin{array}{l}\mathrm{m} \\
\mathrm{m}\end{array}$ & $\begin{array}{l}\mathbf{m} \\
\mathbf{m}\end{array}$ & $\begin{array}{l}\mathrm{m} \\
\mathrm{m}\end{array}$ & $\begin{array}{l}\mathrm{m} \\
\mathrm{m}\end{array}$ & $\begin{array}{l}\mathrm{m} \\
\mathrm{m}\end{array}$ & $\begin{array}{l}\mathrm{m} \\
\mathrm{m}\end{array}$ & $\begin{array}{l}\mathbf{m} \\
\mathbf{m}\end{array}$ & $\begin{array}{l}\mathbf{m} \\
\mathbf{m}\end{array}$ & $\begin{array}{l}\mathrm{m} \\
\mathrm{m}\end{array}$ \\
\hline $\begin{array}{l}\text { Letonia } \\
\text { Sudáfrica }\end{array}$ & $\begin{array}{l}\mathrm{m} \\
\mathrm{m}\end{array}$ & $\begin{array}{l}\mathrm{m} \\
\mathrm{m}\end{array}$ & $\begin{array}{l}\mathbf{m} \\
\mathbf{m}\end{array}$ & $\begin{array}{l}\mathrm{m} \\
\mathrm{m}\end{array}$ & $\begin{array}{l}\mathrm{m} \\
\mathrm{m}\end{array}$ & $\begin{array}{l}\mathrm{m} \\
\mathrm{m}\end{array}$ & $\begin{array}{l}\mathrm{m} \\
\mathrm{m}\end{array}$ & $\begin{array}{l}\mathbf{m} \\
\mathbf{m}\end{array}$ & $\begin{array}{l}\mathbf{m} \\
\mathbf{m}\end{array}$ & $\begin{array}{l}\mathrm{m} \\
\mathrm{m}\end{array}$ \\
\hline
\end{tabular}

\section{Media G20}

\begin{tabular}{l|l|l|l}
$\mathrm{m}$ & $\mathrm{m}$ & $\mathbf{m}$
\end{tabular}

$\mathrm{m}$

\begin{tabular}{l|l|l|l|}
$\mathrm{m}$ & $\mathrm{m}$ & $\mathrm{m}$ & $\mathbf{m}$
\end{tabular}

m $\quad$ m

Nota: Los valores se basan en la diferencia entre las mujeres que han completado educación secundaria superior o postsecundaria no terciaria y aquellas que no lo han hecho.

1. Los datos de Bélgica no se incluyen en la tabla, porque la educación secundaria superior es obligatoria.

2. Los datos de educación secundaria inferior y superior no se desglosan.

Fuente: OCDE. Para ver notas, consulte Anexo 3 (www.oecd.org/edu/eag.htm).

Para obtener más información acerca de los símbolos utilizados en lugar de los datos que faltan, consulte la Guía del lector.

StatLink 제대 http://dx.doi.org/10.1787/888933116357 
Tabla A7.3a. Costes y beneficios privados para un hombre que alcanza la educación terciaria (2010) En comparación con un hombre que tiene educación secundaria superior o postsecundaria no terciaria, en equivalente a dólares estadounidenses convertidos mediante PPA para el PIB

\begin{tabular}{|c|c|c|c|c|c|c|c|c|c|c|c|c|c|}
\hline & & $\begin{array}{c}\text { Costes } \\
\text { directos }\end{array}$ & $\begin{array}{c}\text { Pérdida de } \\
\text { ingresos }\end{array}$ & $\begin{array}{l}\text { Costes } \\
\text { totales }\end{array}$ & $\begin{array}{c}\text { Beneficios } \\
\text { de los } \\
\text { ingresos } \\
\text { brutos }\end{array}$ & $\begin{array}{c}\text { Efecto del } \\
\text { impuesto } \\
\text { sobre la } \\
\text { renta }\end{array}$ & $\begin{array}{c}\text { Efecto de las } \\
\text { cotizaciones } \\
\text { sociales }\end{array}$ & $\begin{array}{c}\text { Efecto } \\
\text { de las } \\
\text { prestaciones }\end{array}$ & $\begin{array}{l}\text { Efecto del } \\
\text { desempleo }\end{array}$ & $\begin{array}{l}\text { Efecto } \\
\text { de las } \\
\text { becas }\end{array}$ & $\begin{array}{c}\text { Beneficios } \\
\text { totales }\end{array}$ & $\begin{array}{c}\text { Valor } \\
\text { actual } \\
\text { neto }\end{array}$ & $\begin{array}{c}\text { Tasa } \\
\text { interna } \\
\text { de } \\
\text { retorno }\end{array}$ \\
\hline & Año & (1) & (2) & (3) & (4) & (5) & (6) & (7) & (8) & (9) & (10) & (11) & (12) \\
\hline Alemania & 2010 & -5.813 & -55.093 & -60.906 & 462.289 & -166.502 & -89.273 & 0 & 58.741 & 6.472 & 271.727 & 210.821 & $13,4 \%$ \\
\hline Australia & 2009 & -17.528 & -50.814 & -68.342 & 339.977 & -124.441 & 0 & 0 & 5.363 & 335 & 221.234 & 152.892 & $9,0 \%$ \\
\hline Austria & 2010 & -6.199 & -62.401 & -68.600 & 396.272 & -132.408 & -53.634 & 0 & 18.521 & 10.877 & 239.629 & 171.029 & $10,1 \%$ \\
\hline Bélgica & 2010 & -2.780 & -37.528 & -40.307 & 348.982 & -155.156 & -53.464 & 0 & 21.666 & 862 & 162.891 & 122.584 & $11,9 \%$ \\
\hline Canadá & 2010 & -20.529 & -36.423 & -56.952 & 293.058 & -96.272 & -6.355 & 0 & 27.401 & 1.103 & 218.935 & 161.982 & $10,2 \%$ \\
\hline Chile & & $\mathrm{m}$ & $\mathrm{m}$ & $\mathbf{m}$ & $\mathrm{m}$ & $\mathrm{m}$ & $\mathrm{m}$ & $\mathrm{m}$ & $\mathrm{m}$ & $\mathrm{m}$ & $\mathbf{m}$ & $\mathbf{m}$ & $\mathrm{m}$ \\
\hline Corea & 2010 & -19.211 & -34.019 & -53.231 & 379.884 & -47.160 & -25.602 & 0 & 12.407 & $\mathrm{~m}$ & 319.528 & 266.298 & $12,8 \%$ \\
\hline Dinamarca & 2010 & -4.509 & -75.357 & -79.866 & 314.158 & -143.348 & -26.897 & -8.763 & 17.765 & 29.411 & 182.326 & 102.460 & $8,4 \%$ \\
\hline Eslovenia & 2010 & -3.564 & -26.242 & -29.806 & 447.946 & -110.866 & -96.037 & 0 & 19.992 & 259 & 261.294 & 231.488 & $17,1 \%$ \\
\hline España & 2010 & -8.864 & -28.219 & -37.083 & 178.900 & -52.903 & -14.033 & 0 & 41.874 & 3.791 & 157.629 & 120.546 & $11,2 \%$ \\
\hline Estados Unidos & 2010 & $\mid-61.135$ & -44.678 & -105.813 & 628.922 & -210.898 & -55.768 & 0 & 100.046 & 27.162 & 489.463 & 383.649 & $15,4 \%$ \\
\hline Estonia & 2010 & -3.924 & -14.951 & -18.875 & 207.579 & -46.145 & -6.453 & 0 & 42.224 & 730 & 197.934 & 179.059 & $20,6 \%$ \\
\hline Finlandia & 2009 & -1.873 & -56.911 & -58.784 & 343.119 & -138.956 & -24.568 & 0 & 39.479 & 8.730 & 227.803 & 169.020 & $11,9 \%$ \\
\hline Francia & 2010 & -6.963 & -47.182 & -54.145 & 380.704 & -95.841 & -51.427 & -691 & 19.109 & 3.103 & 254.957 & 200.812 & $11,4 \%$ \\
\hline Grecia & 2009 & -690 & -43.715 & -44.405 & 182.193 & -35.679 & -29.437 & -8.700 & 6.156 & $\mathrm{~m}$ & 114.533 & 70.128 & $7,5 \%$ \\
\hline Hungría & 2010 & -4.664 & -13.268 & -17.932 & 459.159 & -147.118 & -75.232 & 0 & 37.773 & 1.135 & 275.718 & 257.785 & $28,5 \%$ \\
\hline Irlanda & 2010 & -6.478 & -42.453 & -48.931 & 684.820 & -259.751 & -58.952 & 0 & 131.625 & 5.412 & 503.154 & 454.224 & $29,9 \%$ \\
\hline Islandia & & $\mathrm{m}$ & $\mathrm{m}$ & $\mathbf{m}$ & $\mathrm{m}$ & $\mathrm{m}$ & $\mathrm{m}$ & $\mathrm{m}$ & $\mathrm{m}$ & $\mathrm{m}$ & m & $\mathbf{m}$ & $\mathrm{m}$ \\
\hline Israel & 2010 & -14.023 & -26.963 & -40.987 & 285.448 & -69.772 & -35.702 & 0 & 16.788 & 1.528 & 198.291 & 157.304 & $11,8 \%$ \\
\hline Italia & 2008 & -7.285 & -50.608 & -57.893 & 408.011 & -159.562 & -41.835 & 0 & 3.295 & 3.330 & 213.239 & 155.346 & $8,1 \%$ \\
\hline Japón & 2007 & $\mid-37.215$ & -66.750 & $-103.965 \mid$ & 326.614 & -64.523 & -36.039 & 0 & 20.931 & $\mathrm{~m}$ & 246.983 & 143.018 & $7,4 \%$ \\
\hline Luxemburgo & & $\mathrm{m}$ & $\mathrm{m}$ & $\mathbf{m}$ & $\mathrm{m}$ & $\mathrm{m}$ & $\mathrm{m}$ & $\mathrm{m}$ & $\mathrm{m}$ & $\mathrm{m}$ & $\mathbf{m}$ & $\mathbf{m}$ & $\mathrm{m}$ \\
\hline México & & $\mathrm{m}$ & $\mathrm{m}$ & $\mathbf{m}$ & $\mathrm{m}$ & $\mathrm{m}$ & $\mathrm{m}$ & $\mathrm{m}$ & $\mathrm{m}$ & $\mathrm{m}$ & $\mathbf{m}$ & $\mathbf{m}$ & $\mathrm{m}$ \\
\hline Noruega & 2010 & -1.086 & -47.946 & -49.032 & 274.357 & -107.528 & -23.197 & 0 & 23.000 & 4.690 & 171.321 & 122.289 & $8,2 \%$ \\
\hline Nueva Zelanda & 2010 & -9.384 & -43.347 & -52.731 & 193.910 & -62.325 & -3.875 & -86 & 358 & 3.039 & 131.021 & 78.290 & $7,3 \%$ \\
\hline Países Bajos & 2010 & -14.646 & -95.834 & -110.480 & 442.661 & -197.999 & -26.901 & 0 & 10.736 & 13.770 & 242.267 & 131.787 & $7,2 \%$ \\
\hline Polonia & 2010 & -7.343 & -16.928 & -24.270 & 376.155 & -30.873 & -75.986 & 0 & 38.492 & 2.228 & 310.015 & 285.745 & $24,6 \%$ \\
\hline Portugal & 2010 & -4.627 & -16.181 & -20.808 & 324.887 & -89.461 & -36.243 & 0 & 17.564 & $\mathrm{~m}$ & 216.746 & 195.937 & $18,3 \%$ \\
\hline Reino Unido & 2010 & -20.162 & -47.655 & -67.817 & 413.163 & -89.124 & -49.107 & -4.303 & 40.284 & 5.225 & 316.138 & 248.322 & $14,3 \%$ \\
\hline República Checa & 2010 & -5.029 & -25.719 & -30.748 & 365.437 & -70.726 & -41.771 & 0 & 20.181 & $\mathrm{~m}$ & 273.121 & 242.373 & $18,6 \%$ \\
\hline República Eslovaca & 2010 & -6.183 & -15.019 & -21.202 & 290.121 & -51.866 & -40.961 & 0 & 38.465 & 1.226 & 236.985 & 215.783 & $21,4 \%$ \\
\hline Suecia & 2010 & -3.560 & -50.291 & -53.851 & 209.467 & -84.430 & -9.281 & 0 & 8.454 & 7.735 & 131.945 & 78.094 & $7,4 \%$ \\
\hline Suiza & & & $\mathrm{m}$ & $\mathbf{m}$ & & $\mathrm{m}$ & $\mathrm{m}$ & $\mathrm{m}$ & $\mathrm{m}$ & $\mathrm{m}$ & $\mathbf{m}$ & $\mathbf{m}$ & $\mathrm{m}$ \\
\hline Turquía & 2005 & -1.061 & -9.402 & -10.463 & 106.985 & -18.682 & -16.424 & 0 & 2.761 & $\mathrm{~m}$ & $\mathbf{7 4 . 6 4 0}$ & 64.177 & $19,3 \%$ \\
\hline Media OCDE & & -10.563 & -40.755 & -51.318 & 347.075 & -105.528 & -38.085 & -777 & 29.016 & 6.181 & 236.602 & 185.284 & $13,9 \%$ \\
\hline Media UE21 & & -6.258 & -41.078 & -47.335 & 361.801 & -112.936 & -45.075 & -1.123 & 31.620 & 6.135 & 239.503 & 192.167 & $15,1 \%$ \\
\hline
\end{tabular}

\begin{tabular}{|c|c|c|c|c|c|c|c|c|c|c|c|c|}
\hline $\begin{array}{l}\text { Arabia Saudí } \\
\text { : Argentina }\end{array}$ & $\begin{array}{l}\mathrm{m} \\
\mathrm{m}\end{array}$ & $\begin{array}{l}\mathrm{m} \\
\mathrm{m}\end{array}$ & $\begin{array}{l}\mathbf{m} \\
\mathbf{m}\end{array}$ & $\begin{array}{l}\mathrm{m} \\
\mathrm{m}\end{array}$ & $\begin{array}{l}\mathrm{m} \\
\mathrm{m}\end{array}$ & $\begin{array}{l}\mathrm{m} \\
\mathrm{m}\end{array}$ & $\begin{array}{l}\mathrm{m} \\
\mathrm{m}\end{array}$ & $\begin{array}{l}\mathrm{m} \\
\mathrm{m}\end{array}$ & $\begin{array}{l}\mathrm{m} \\
\mathrm{m}\end{array}$ & $\begin{array}{l}\mathbf{m} \\
\mathbf{m}\end{array}$ & $\begin{array}{l}\mathbf{m} \\
\mathbf{m}\end{array}$ & $\begin{array}{l}\mathrm{m} \\
\mathrm{m}\end{array}$ \\
\hline $\begin{array}{l}\text { L Brasil } \\
\tilde{y} \text { China }\end{array}$ & $\begin{array}{l}\mathrm{m} \\
\mathrm{m}\end{array}$ & $\begin{array}{l}\mathrm{m} \\
\mathrm{m}\end{array}$ & $\begin{array}{l}\mathbf{m} \\
\mathbf{m}\end{array}$ & $\begin{array}{l}\mathrm{m} \\
\mathrm{m}\end{array}$ & $\begin{array}{l}\mathrm{m} \\
\mathrm{m}\end{array}$ & $\begin{array}{l}\mathrm{m} \\
\mathrm{m}\end{array}$ & $\begin{array}{l}\mathrm{m} \\
\mathrm{m}\end{array}$ & $\begin{array}{l}\mathrm{m} \\
\mathrm{m}\end{array}$ & $\begin{array}{l}\mathrm{m} \\
\mathrm{m}\end{array}$ & $\begin{array}{l}\mathbf{m} \\
\mathbf{m}\end{array}$ & $\begin{array}{l}\mathbf{m} \\
\mathbf{m}\end{array}$ & $\begin{array}{l}\mathrm{m} \\
\mathrm{m}\end{array}$ \\
\hline $\begin{array}{l}\Sigma^{\sigma} \text { Colombia } \\
\text { Federación Rusa }\end{array}$ & $\begin{array}{l}\mathrm{m} \\
\mathrm{m}\end{array}$ & $\begin{array}{l}\mathrm{m} \\
\mathrm{m}\end{array}$ & $\begin{array}{l}\mathbf{m} \\
\mathbf{m}\end{array}$ & $\begin{array}{l}\mathrm{m} \\
\mathrm{m}\end{array}$ & $\begin{array}{l}\mathrm{m} \\
\mathrm{m}\end{array}$ & $\begin{array}{l}\mathrm{m} \\
\mathrm{m}\end{array}$ & $\begin{array}{l}\mathrm{m} \\
\mathrm{m}\end{array}$ & $\begin{array}{l}\mathrm{m} \\
\mathrm{m}\end{array}$ & $\begin{array}{l}\mathrm{m} \\
\mathrm{m}\end{array}$ & $\begin{array}{l}\mathbf{m} \\
\mathbf{m}\end{array}$ & $\begin{array}{l}\mathbf{m} \\
\mathbf{m}\end{array}$ & $\begin{array}{l}\mathrm{m} \\
\mathrm{m}\end{array}$ \\
\hline $\begin{array}{l}\text { India } \\
\text { Indonesia }\end{array}$ & $\begin{array}{l}\mathrm{m} \\
\mathrm{m}\end{array}$ & $\begin{array}{l}\mathrm{m} \\
\mathrm{m}\end{array}$ & $\begin{array}{l}\mathbf{m} \\
\mathbf{m}\end{array}$ & $\begin{array}{c}\mathrm{m} \\
\mathrm{m}\end{array}$ & $\begin{array}{l}\mathrm{m} \\
\mathrm{m}\end{array}$ & $\begin{array}{l}\mathrm{m} \\
\mathrm{m}\end{array}$ & $\begin{array}{l}\mathrm{m} \\
\mathrm{m}\end{array}$ & $\begin{array}{l}\mathrm{m} \\
\mathrm{m}\end{array}$ & $\begin{array}{l}\mathrm{m} \\
\mathrm{m}\end{array}$ & $\begin{array}{l}\mathbf{m} \\
\mathbf{m}\end{array}$ & $\begin{array}{l}\mathbf{m} \\
\mathbf{m}\end{array}$ & $\begin{array}{l}\mathrm{m} \\
\mathrm{m}\end{array}$ \\
\hline $\begin{array}{l}\text { Letonia } \\
\text { Sudáfrica }\end{array}$ & $\begin{array}{l}\mathrm{m} \\
\mathrm{m}\end{array}$ & $\begin{array}{l}\mathrm{m} \\
\mathrm{m}\end{array}$ & $\begin{array}{l}\mathbf{m} \\
\mathbf{m}\end{array}$ & $\begin{array}{l}\mathrm{m} \\
\mathrm{m}\end{array}$ & $\begin{array}{l}\mathrm{m} \\
\mathrm{m}\end{array}$ & $\begin{array}{l}\mathrm{m} \\
\mathrm{m}\end{array}$ & $\begin{array}{l}\mathrm{m} \\
\mathrm{m}\end{array}$ & $\begin{array}{l}\mathrm{m} \\
\mathrm{m}\end{array}$ & $\begin{array}{l}\mathrm{m} \\
\mathrm{m}\end{array}$ & $\begin{array}{l}\mathbf{m} \\
\mathbf{m}\end{array}$ & $\begin{array}{l}\mathbf{m} \\
\mathbf{m}\end{array}$ & $\begin{array}{l}\mathrm{m} \\
\mathrm{m}\end{array}$ \\
\hline
\end{tabular}

\section{Media G20}

Nota: Los valores se basan en la diferencia entre los hombres que han completado educación terciaria y aquellos que han completado educación secundaria superior o postsecundaria no terciaria.

Fuente: OCDE. Para ver notas, consulte Anexo 3 (www.oecd.org/edu/eag.htm).

Para obtener más información acerca de los símbolos utilizados en lugar de los datos que faltan, consulte la Guía del lector.

StatLink 젶ㄴ $h$ ttp://dx.doi.org/10.1787/888933116376 
Tabla A7.3b. Costes y beneficios privados para una mujer que alcanza la educación terciaria (2010)

En comparación con una mujer que tiene educación secundaria superior o postsecundaria no terciaria, en equivalente a dólares estadounidenses convertidos mediante PPA para el PIB

\begin{tabular}{|c|c|c|c|c|c|c|c|c|c|c|c|c|c|}
\hline & & $\begin{array}{c}\text { Costes } \\
\text { directos }\end{array}$ & $\begin{array}{c}\text { Pérdida de } \\
\text { ingresos }\end{array}$ & $\begin{array}{l}\text { Costes } \\
\text { totales }\end{array}$ & $\begin{array}{c}\text { Beneficios } \\
\text { de los } \\
\text { ingresos } \\
\text { brutos }\end{array}$ & $\begin{array}{c}\text { Efecto del } \\
\text { impuesto } \\
\text { sobre la } \\
\text { renta }\end{array}$ & $\begin{array}{c}\text { Efecto de las } \\
\text { cotizaciones } \\
\text { sociales }\end{array}$ & $\begin{array}{c}\text { Efecto } \\
\text { de las } \\
\text { prestaciones }\end{array}$ & $\begin{array}{l}\text { Efecto del } \\
\text { desempleo }\end{array}$ & $\begin{array}{l}\text { Efecto } \\
\text { de las } \\
\text { becas }\end{array}$ & $\begin{array}{c}\text { Beneficios } \\
\text { totales }\end{array}$ & $\begin{array}{c}\text { Valor } \\
\text { actual } \\
\text { neto }\end{array}$ & $\begin{array}{c}\text { Tasa } \\
\text { interna } \\
\text { de } \\
\text { retorno }\end{array}$ \\
\hline & Año & (1) & (2) & (3) & (4) & (5) & (6) & (7) & (8) & (9) & (10) & (11) & (12) \\
\hline Alemania & 2010 & -5.813 & -55.984 & -61.797 & 247.459 & -67.041 & -55.248 & -17 & 22.124 & 6.472 & 153.749 & 91.952 & $8,5 \%$ \\
\hline Australia & 2009 & -17.528 & -52.120 & -69.648 & 253.308 & -91.641 & 0 & 0 & 13.021 & 335 & 175.023 & 105.374 & $8,9 \%$ \\
\hline Austria & 2010 & -6.199 & -63.316 & -69.515 & 331.700 & -93.938 & -61.225 & 0 & 8.104 & 10.877 & 195.518 & 126.003 & $9,0 \%$ \\
\hline Bélgica & 2010 & -2.780 & -35.428 & -38.207 & 310.555 & -127.305 & -72.908 & 0 & 40.296 & 862 & 151.500 & 113.293 & $13,7 \%$ \\
\hline Canadá & 2010 & -20.529 & -37.837 & -58.366 & 261.335 & -69.368 & -20.695 & 0 & 16.627 & 1.103 & 189.002 & 130.636 & $11,4 \%$ \\
\hline Chile & & $\mathrm{m}$ & $\mathrm{m}$ & $\mathbf{m}$ & $\mathrm{m}$ & $\mathrm{m}$ & $\mathrm{m}$ & $\mathrm{m}$ & $\mathrm{m}$ & $\mathrm{m}$ & $\mathbf{m}$ & $\mathbf{m}$ & $\mathrm{m}$ \\
\hline Corea & 2010 & -19.211 & -35.087 & -54.298 & 268.211 & -10.077 & -20.463 & 0 & -5.570 & $\mathrm{~m}$ & 232.101 & 177.802 & $11,0 \%$ \\
\hline Dinamarca & 2010 & -4.509 & -78.578 & -83.087 & 175.082 & -61.404 & -15.158 & -9.772 & 10.710 & 29.411 & 128.869 & 45.782 & $6,5 \%$ \\
\hline Eslovenia & 2010 & -3.564 & -26.170 & -29.734 & 343.115 & -84.277 & -79.783 & 0 & 24.076 & 259 & 203.390 & 173.657 & $15,3 \%$ \\
\hline España & 2010 & -8.864 & -27.626 & -36.490 & 237.736 & -69.735 & -18.075 & 0 & 46.399 & 3.791 & 200.115 & 163.625 & $14,5 \%$ \\
\hline Estados Unidos & 2010 & -61.135 & -47.732 & -108.867 & 416.147 & -107.923 & -35.416 & 0 & 47.389 & 27.162 & 347.358 & 238.491 & $12,9 \%$ \\
\hline Estonia & 2010 & -3.924 & -15.754 & -19.678 & 153.829 & -40.802 & -5.839 & 0 & 54.649 & 730 & 162.567 & 142.889 & $29,7 \%$ \\
\hline Finlandia & 2009 & -1.873 & -60.589 & -62.461 & 211.875 & -72.749 & -15.039 & -4.079 & 21.742 & 8.730 & 150.480 & 88.019 & $8,8 \%$ \\
\hline Francia & 2010 & -6.963 & -44.369 & -51.332 & 263.248 & -52.801 & -39.383 & -11.640 & 24.882 & 3.103 & 187.409 & 136.077 & $10,9 \%$ \\
\hline Grecia & 2009 & -690 & -36.674 & -37.363 & 186.037 & -21.786 & -33.976 & -29.066 & 26.865 & $\mathrm{~m}$ & 128.074 & 90.710 & $9,6 \%$ \\
\hline Hungría & 2010 & -4.664 & -13.164 & -17.828 & 257.527 & -83.602 & -49.345 & 0 & 32.818 & 1.135 & 158.533 & 140.705 & $24,6 \%$ \\
\hline Irlanda & 2010 & -6.478 & -48.135 & -54.612 & 456.714 & -129.055 & -63.508 & 0 & 39.212 & 5.412 & 308.775 & 254.163 & $21,0 \%$ \\
\hline Islandia & & $\mathrm{m}$ & $\mathrm{m}$ & $\mathbf{m}$ & $\mathrm{m}$ & $\mathrm{m}$ & $\mathrm{m}$ & $\mathrm{m}$ & $\mathrm{m}$ & $\mathrm{m}$ & $\mathbf{m}$ & $\mathbf{m}$ & $\mathrm{m}$ \\
\hline Israel & 2010 & -14.023 & -27.428 & -41.451 & 151.423 & -22.840 & -18.663 & 0 & 12.245 & 1.528 & 123.692 & 82.240 & $8,6 \%$ \\
\hline Italia & 2008 & -7.285 & -47.826 & -55.111 & 223.811 & -79.954 & -21.986 & 0 & 7.563 & 3.330 & 132.764 & 77.652 & $6,9 \%$ \\
\hline Japón & 2007 & -37.215 & -49.265 & -86.481 & 231.306 & -20.848 & -29.117 & 0 & 9.951 & $\mathrm{~m}$ & 191.293 & 104.812 & $7,8 \%$ \\
\hline Luxemburgo & & $\mathrm{m}$ & $\mathrm{m}$ & $\mathbf{m}$ & $\mathrm{m}$ & $\mathrm{m}$ & $\mathrm{m}$ & $\mathrm{m}$ & $\mathrm{m}$ & $\mathrm{m}$ & $\mathbf{m}$ & $\mathbf{m}$ & $\mathrm{m}$ \\
\hline México & & $\mathrm{m}$ & $\mathrm{m}$ & $\mathbf{m}$ & $\mathrm{m}$ & $\mathrm{m}$ & $\mathrm{m}$ & $\mathrm{m}$ & $\mathrm{m}$ & $\mathrm{m}$ & $\mathbf{m}$ & $\mathbf{m}$ & $\mathrm{m}$ \\
\hline Noruega & 2010 & -1.086 & -50.062 & -51.148 & 227.688 & -63.403 & -17.791 & 0 & 785 & 4.690 & 151.970 & 100.822 & $9,6 \%$ \\
\hline Nueva Zelanda & 2010 & -9.384 & -42.595 & -51.980 & 167.699 & -40.316 & -3.622 & -2.329 & 13.769 & 3.039 & 138.239 & 86.260 & $10,3 \%$ \\
\hline Países Bajos & 2010 & -14.646 & -90.283 & -104.929 & 353.759 & -137.587 & -30.982 & 0 & 11.955 & 13.770 & 210.915 & 105.985 & $7,0 \%$ \\
\hline Polonia & 2010 & -7.343 & -16.014 & -23.356 & 243.941 & -24.419 & -60.782 & 0 & 39.454 & 2.228 & 200.423 & 177.066 & $21,6 \%$ \\
\hline Portugal & 2010 & -4.627 & -15.481 & -20.108 & 262.280 & -59.602 & -31.363 & 0 & 22.688 & $\mathrm{~m}$ & 194.001 & 173.893 & $22,0 \%$ \\
\hline Reino Unido & 2010 & -20.162 & -47.080 & -67.241 & 351.526 & -79.076 & -43.645 & -12.831 & 55.550 & 5.225 & 276.748 & 209.506 & $12,3 \%$ \\
\hline República Checa & 2010 & -4.882 & -24.979 & -29.862 & 208.439 & -45.919 & -26.193 & -688 & 29.891 & $\mathrm{~m}$ & 165.530 & 135.668 & $15,3 \%$ \\
\hline República Eslovaca & 2010 & -6.183 & -15.551 & -21.734 & 181.063 & -33.609 & -29.678 & 0 & 40.616 & 1.226 & 159.618 & 137.884 & $18,5 \%$ \\
\hline Suecia & 2010 & -3.560 & -51.796 & -55.356 & 140.237 & -42.057 & -10.883 & 0 & 15.631 & 7.735 & 110.663 & 55.306 & $7,1 \%$ \\
\hline Suiza & & $\mathrm{m}$ & $\mathrm{m}$ & $\mathbf{m}$ & $\mathrm{m}$ & $\mathrm{m}$ & $\mathrm{m}$ & $\mathrm{m}$ & $\mathrm{m}$ & $\mathrm{m}$ & $\mathbf{m}$ & $\mathbf{m}$ & $\mathrm{m}$ \\
\hline Turquía & 2005 & -1.061 & -8.185 & -9.246 & 116.530 & -21.267 & -19 & 0 & 14.075 & $\mathrm{~m}$ & 89.711 & 80.466 & $19,2 \%$ \\
\hline Media OCDE & & -10.558 & -40.176 & -50.734 & 249.434 & -63.945 & -32.082 & -2.428 & 24.052 & 6.181 & 179.932 & 129.198 & $13,2 \%$ \\
\hline Media UE21 & & -6.250 & -40.740 & -46.990 & 256.997 & -70.336 & -38.250 & -3.405 & 28.761 & 6.135 & 178.982 & 131.992 & $14,1 \%$ \\
\hline
\end{tabular}

\begin{tabular}{|c|c|c|c|c|c|c|c|c|c|c|c|c|}
\hline $\begin{array}{l}\text { Arabia Saudí } \\
\text { ỡ Argentina }\end{array}$ & $\begin{array}{l}\mathrm{m} \\
\mathrm{m}\end{array}$ & $\begin{array}{l}\mathrm{m} \\
\mathrm{m}\end{array}$ & $\begin{array}{l}\mathbf{m} \\
\mathbf{m}\end{array}$ & $\begin{array}{l}\mathrm{m} \\
\mathrm{m}\end{array}$ & $\begin{array}{l}\mathrm{m} \\
\mathrm{m}\end{array}$ & $\begin{array}{l}\mathrm{m} \\
\mathrm{m}\end{array}$ & $\begin{array}{l}\mathrm{m} \\
\mathrm{m}\end{array}$ & $\begin{array}{l}\mathrm{m} \\
\mathrm{m}\end{array}$ & $\begin{array}{l}\mathrm{m} \\
\mathrm{m}\end{array}$ & $\begin{array}{l}\mathbf{m} \\
\mathbf{m}\end{array}$ & $\begin{array}{l}\mathbf{m} \\
\mathbf{m}\end{array}$ & $\begin{array}{l}\mathrm{m} \\
\mathrm{m}\end{array}$ \\
\hline Brasil & $\mathrm{m}$ & $\mathrm{m}$ & $\mathbf{m}$ & $\mathrm{m}$ & $\mathrm{m}$ & $\mathrm{m}$ & $\mathrm{m}$ & $\mathrm{m}$ & $\mathrm{m}$ & $\mathbf{m}$ & $\mathbf{m}$ & $\mathrm{m}$ \\
\hline China & $\mathrm{m}$ & $\mathrm{m}$ & $\mathbf{m}$ & $\mathrm{m}$ & $\mathrm{m}$ & $\mathrm{m}$ & $\mathrm{m}$ & $\mathrm{m}$ & $\mathrm{m}$ & $\mathbf{m}$ & $\mathbf{m}$ & $\mathrm{m}$ \\
\hline Colombia & $\mathrm{m}$ & $\mathrm{m}$ & $\mathbf{m}$ & $\mathrm{m}$ & $\mathrm{m}$ & $\mathrm{m}$ & $\mathrm{m}$ & $\mathrm{m}$ & $\mathrm{m}$ & $\mathbf{m}$ & $\mathbf{m}$ & $\mathrm{m}$ \\
\hline Federación Rusa & $\mathrm{m}$ & $\mathrm{m}$ & $\mathbf{m}$ & $\mathrm{m}$ & $\mathrm{m}$ & $\mathrm{m}$ & $\mathrm{m}$ & $\mathrm{m}$ & $\mathrm{m}$ & $\mathbf{m}$ & $\mathbf{m}$ & $\mathrm{m}$ \\
\hline India & $\mathrm{m}$ & $\mathrm{m}$ & $\mathbf{m}$ & $\mathrm{m}$ & $\mathrm{m}$ & $\mathrm{m}$ & $\mathrm{m}$ & $\mathrm{m}$ & $\mathrm{m}$ & $\mathbf{m}$ & $\mathbf{m}$ & $\mathrm{m}$ \\
\hline Indonesia & $\mathrm{m}$ & $\mathrm{m}$ & $\mathbf{m}$ & $\mathrm{m}$ & $\mathrm{m}$ & $\mathrm{m}$ & $\mathrm{m}$ & $\mathrm{m}$ & $\mathrm{m}$ & $\mathbf{m}$ & $\mathbf{m}$ & $\mathrm{m}$ \\
\hline Letonia & $\mathrm{m}$ & $\mathrm{m}$ & $\mathbf{m}$ & $\mathrm{m}$ & $\mathrm{m}$ & $\mathrm{m}$ & $\mathrm{m}$ & $\mathrm{m}$ & $\mathrm{m}$ & $\mathbf{m}$ & $\mathbf{m}$ & $\mathrm{m}$ \\
\hline Sudáfrica & $\mathrm{m}$ & $\mathrm{m}$ & $\mathbf{m}$ & $\mathrm{m}$ & $\mathrm{m}$ & $\mathrm{m}$ & $\mathrm{m}$ & $\mathrm{m}$ & $\mathrm{m}$ & $\mathbf{m}$ & $\mathbf{m}$ & $\mathrm{m}$ \\
\hline
\end{tabular}

\begin{tabular}{|l|l|l|l|l|l|l|l|l|l|l|l|l|l|l|} 
Media G20 & & $\mathrm{m}$ & $\mathrm{m}$ & $\mathbf{m}$ & $\mathrm{m}$ & $\mathrm{m}$ & $\mathrm{m}$ & $\mathrm{m}$ & $\mathrm{m}$ & $\mathrm{m}$ & $\mathbf{m}$ & $\mathbf{m}$ & $\mathrm{m}$ \\
\hline
\end{tabular}

Nota: Los valores se basan en la diferencia entre las mujeres que han completado educación terciaria y aquellas que han completado educación secundaria superior o postsecundaria no terciaria.

Fuente: OCDE. Para ver notas, consulte Anexo 3 (www.oecd.org/edu/eag.htm).

Para obtener más información acerca de los símbolos utilizados en lugar de los datos que faltan, consulte la Guía del lector.

StatLink 세개 http://dx.doi.org/10.1787/888933116395 
Tabla A7.4a. Costes y beneficios públicos para un hombre que alcanza la educación terciaria (2010) En comparación con un hombre que tiene educación secundaria superior o postsecundaria no terciaria, en equivalente a dólares estadounidenses convertidos mediante PPA para el PIB

\begin{tabular}{|c|c|c|c|c|c|c|c|c|c|c|c|c|}
\hline & & $\begin{array}{c}\text { Costes } \\
\text { directos }\end{array}$ & $\begin{array}{c}\text { Pérdida de } \\
\text { ingresos }\end{array}$ & $\begin{array}{l}\text { Efecto de } \\
\text { las becas }\end{array}$ & $\begin{array}{l}\text { Costes } \\
\text { totales }\end{array}$ & $\begin{array}{c}\text { Efecto del } \\
\text { impuesto } \\
\text { sobre la } \\
\text { renta }\end{array}$ & $\begin{array}{c}\text { Efecto de las } \\
\text { cotizaciones } \\
\text { sociales }\end{array}$ & $\begin{array}{c}\text { Efecto } \\
\text { de las } \\
\text { prestaciones }\end{array}$ & $\begin{array}{l}\text { Efecto del } \\
\text { desempleo }\end{array}$ & $\begin{array}{c}\text { Beneficios } \\
\text { totales }\end{array}$ & $\begin{array}{c}\text { Valor } \\
\text { actual } \\
\text { neto }\end{array}$ & $\begin{array}{c}\text { Tasa } \\
\text { interna } \\
\text { de retorno }\end{array}$ \\
\hline & Año & (1) & (2) & (3) & (4) & (5) & (6) & (7) & (8) & (9) & (10) & (11) \\
\hline Alemania & 2010 & -31.421 & -20.896 & -6.472 & -58.789 & 153.573 & 78.113 & 0 & 24.090 & 255.776 & 196.987 & $11,9 \%$ \\
\hline Australia & 2009 & -14.588 & -5.652 & -335 & -20.575 & 123.233 & 0 & 0 & 1.208 & 124.441 & 103.866 & $12,9 \%$ \\
\hline Austria & 2010 & -44.819 & -11.977 & -10.877 & -67.673 & 128.843 & 50.561 & 0 & 6.637 & 186.041 & 118.368 & $8,0 \%$ \\
\hline Bélgica & 2010 & -24.413 & -9.051 & -862 & -34.326 & 149.431 & 50.456 & 0 & 8.733 & 208.619 & 174.293 & $15,1 \%$ \\
\hline Canadá & 2010 & -26.735 & -3.589 & -1.103 & -31.427 & 91.254 & 4.772 & 0 & 6.602 & 102.627 & 71.201 & $8,9 \%$ \\
\hline Chile & & $\mathrm{m}$ & $\mathrm{m}$ & $\mathrm{m}$ & $\mathbf{m}$ & $\mathrm{m}$ & $\mathrm{m}$ & $\mathrm{m}$ & $\mathrm{m}$ & $\mathbf{m}$ & $\mathbf{m}$ & $\mathrm{m}$ \\
\hline Corea & 2010 & -7.198 & -3.449 & $\mathrm{~m}$ & -10.648 & 46.494 & 24.687 & 0 & 1.581 & 72.762 & 62.115 & $12,3 \%$ \\
\hline Dinamarca & 2010 & -85.578 & -35.496 & -29.411 & -150.485 & 137.397 & 25.140 & 8.763 & 7.708 & 179.007 & 28.522 & $3,8 \%$ \\
\hline Eslovenia & 2010 & -19.698 & -8.151 & -259 & -28.108 & 107.113 & 91.799 & 0 & 7.991 & 206.903 & 178.795 & $15,4 \%$ \\
\hline España & 2010 & -31.833 & -2.577 & -3.791 & -38.201 & 46.168 & 11.387 & 0 & 9.381 & 66.936 & 28.735 & $5,6 \%$ \\
\hline Estados Unidos & 2010 & -34.787 & -5.989 & -27.162 & -67.937 & 189.603 & 48.143 & 0 & 28.922 & 266.667 & 198.730 & $10,8 \%$ \\
\hline Estonia & 2010 & -12.037 & -2.264 & -730 & -15.032 & 38.729 & 5.313 & 0 & 8.557 & 52.599 & 37.567 & $10,5 \%$ \\
\hline Finlandia & 2009 & -42.400 & -8.324 & -8.730 & -59.454 & 128.733 & 22.053 & 0 & 12.738 & 163.525 & 104.071 & $8,3 \%$ \\
\hline Francia & 2010 & -31.533 & -9.599 & -3.103 & -44.236 & 92.737 & 48.871 & 691 & 5.660 & 147.960 & 103.724 & $8,7 \%$ \\
\hline Grecia & 2009 & -20.179 & 2.956 & $\mathrm{~m}$ & -17.223 & 34.885 & 28.464 & 8.700 & 1.766 & 73.816 & 56.593 & $11,6 \%$ \\
\hline Hungría & 2010 & -16.393 & -2.960 & -1.135 & -20.489 & 138.343 & 69.279 & 0 & 14.727 & 222.349 & 201.861 & $23,0 \%$ \\
\hline Irlanda & 2010 & -28.066 & -1.409 & -5.412 & -34.887 & 231.031 & 49.600 & 0 & 38.072 & 318.703 & 283.816 & $26,9 \%$ \\
\hline Islandia & & $\mathrm{m}$ & $\mathrm{m}$ & $\mathrm{m}$ & $\mathbf{m}$ & $\mathrm{m}$ & $\mathrm{m}$ & $\mathrm{m}$ & $\mathrm{m}$ & $\mathbf{m}$ & $\mathbf{m}$ & $\mathrm{m}$ \\
\hline Israel & 2010 & -16.613 & -1.526 & -1.528 & -19.666 & 67.496 & 34.209 & 0 & 3.768 & 105.474 & 85.807 & $11,4 \%$ \\
\hline Italia & 2008 & -17.538 & -11.836 & -3.330 & -32.704 & 157.696 & 41.484 & 0 & 2.217 & 201.397 & 168.693 & $10,1 \%$ \\
\hline Japón & 2007 & -17.897 & -15.254 & $\mathrm{~m}$ & -33.151 & 62.285 & 33.612 & 0 & 4.665 & 100.562 & 67.411 & $8,4 \%$ \\
\hline Luxemburgo & & $\mathrm{m}$ & $\mathrm{m}$ & $\mathrm{m}$ & $\mathbf{m}$ & $\mathrm{m}$ & $\mathrm{m}$ & $\mathrm{m}$ & $\mathrm{m}$ & $\mathbf{m}$ & $\mathbf{m}$ & $\mathrm{m}$ \\
\hline México & & $\mathrm{m}$ & $\mathrm{m}$ & $\mathrm{m}$ & $\mathbf{m}$ & $\mathrm{m}$ & $\mathrm{m}$ & $\mathrm{m}$ & $\mathrm{m}$ & $\mathbf{m}$ & $\mathbf{m}$ & $\mathrm{m}$ \\
\hline Noruega & 2010 & -26.059 & -15.194 & -4.690 & -45.942 & 102.100 & 21.412 & 0 & 7.213 & 130.725 & 84.783 & $7,1 \%$ \\
\hline Nueva Zelanda & 2010 & -18.444 & -5.180 & -3.039 & -26.663 & 61.879 & 3.868 & 86 & 453 & 66.286 & 39.623 & $7,0 \%$ \\
\hline Países Bajos & 2010 & -37.254 & -41.204 & -13.770 & -92.227 & 195.349 & 25.117 & 0 & 4.433 & 224.900 & 132.673 & $7,2 \%$ \\
\hline Polonia & 2010 & -17.653 & -6.097 & -2.228 & -25.978 & 28.162 & 68.381 & 0 & 10.316 & 106.860 & 80.882 & $12,4 \%$ \\
\hline Portugal & 2010 & -10.295 & -2.245 & $\mathrm{~m}$ & -12.540 & 85.300 & 34.368 & 0 & 6.036 & 125.705 & 113.164 & $16,1 \%$ \\
\hline Reino Unido & 2010 & -6.798 & -2.591 & -5.225 & -14.615 & 82.483 & 45.366 & 4.303 & 10.381 & 142.534 & 127.919 & $26,1 \%$ \\
\hline República Checa & 2010 & -18.717 & 4.105 & $\mathrm{~m}$ & -14.612 & 67.727 & 39.580 & 0 & 5.191 & 112.497 & $\mathbf{9 7 . 8 8 5}$ & $17,6 \%$ \\
\hline República Eslovaca & 2010 & -14.559 & -1.492 & -1.226 & -17.276 & 47.313 & 36.008 & 0 & 9.505 & 92.826 & 75.550 & $13,8 \%$ \\
\hline Suecia & 2010 & -34.448 & -12.852 & -7.735 & -55.035 & 82.130 & 8.756 & 0 & 2.826 & 93.711 & 38.676 & $5,2 \%$ \\
\hline Suiza & & $\mathrm{m}$ & $\mathrm{m}$ & $\mathrm{m}$ & $\mathbf{m}$ & $\mathrm{m}$ & $\mathrm{m}$ & $\mathrm{m}$ & $\mathrm{m}$ & $\mathbf{m}$ & $\mathbf{m}$ & $\mathrm{m}$ \\
\hline Turquía & 2005 & -9.567 & -3.814 & $\mathrm{~m}$ & -13.381 & 18.209 & 16.010 & 0 & 886 & 35.106 & 21.724 & $9,3 \%$ \\
\hline Media OCDE & & -24.742 & -8.400 & -6.181 & -38.044 & 99.852 & 35.062 & 777 & 8.699 & 144.390 & 106.346 & $11,9 \%$ \\
\hline Media UE21 & & -27.282 & -9.198 & -6.135 & -41.694 & 106.657 & 41.505 & 1.123 & 9.848 & 159.133 & 117.439 & $12,9 \%$ \\
\hline
\end{tabular}

\begin{tabular}{|c|c|c|c|c|c|c|c|c|c|c|c|}
\hline $\begin{array}{l}\text { Arabia Saudí } \\
\text { : Argentina }\end{array}$ & $\begin{array}{l}\mathrm{m} \\
\mathrm{m}\end{array}$ & $\begin{array}{l}\mathrm{m} \\
\mathrm{m}\end{array}$ & $\begin{array}{l}\mathrm{m} \\
\mathrm{m}\end{array}$ & $\begin{array}{l}\mathbf{m} \\
\mathbf{m}\end{array}$ & $\begin{array}{l}\mathrm{m} \\
\mathrm{m}\end{array}$ & $\begin{array}{l}\mathrm{m} \\
\mathrm{m}\end{array}$ & $\begin{array}{l}\mathrm{m} \\
\mathrm{m}\end{array}$ & $\begin{array}{l}\mathrm{m} \\
\mathrm{m}\end{array}$ & $\begin{array}{l}\mathbf{m} \\
\mathbf{m}\end{array}$ & $\begin{array}{l}\mathbf{m} \\
\mathbf{m}\end{array}$ & $\begin{array}{l}\mathrm{m} \\
\mathrm{m}\end{array}$ \\
\hline 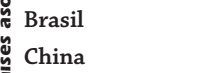 & $\begin{array}{l}\mathrm{m} \\
\mathrm{m}\end{array}$ & $\begin{array}{l}\mathrm{m} \\
\mathrm{m}\end{array}$ & $\begin{array}{l}\mathrm{m} \\
\mathrm{m}\end{array}$ & $\begin{array}{l}\mathbf{m} \\
\mathbf{m}\end{array}$ & $\begin{array}{l}\mathrm{m} \\
\mathrm{m}\end{array}$ & $\begin{array}{l}\mathrm{m} \\
\mathrm{m}\end{array}$ & $\begin{array}{l}\mathrm{m} \\
\mathrm{m}\end{array}$ & $\begin{array}{l}\mathrm{m} \\
\mathrm{m}\end{array}$ & $\begin{array}{l}\mathbf{m} \\
\mathbf{m}\end{array}$ & $\begin{array}{l}\mathbf{m} \\
\mathbf{m}\end{array}$ & $\begin{array}{l}\mathrm{m} \\
\mathrm{m}\end{array}$ \\
\hline $\begin{array}{l}\text { Colombia } \\
\text { Federación Rusa }\end{array}$ & $\begin{array}{l}\mathrm{m} \\
\mathrm{m}\end{array}$ & $\begin{array}{l}\mathrm{m} \\
\mathrm{m}\end{array}$ & $\begin{array}{l}\mathrm{m} \\
\mathrm{m}\end{array}$ & $\begin{array}{l}\mathbf{m} \\
\mathbf{m}\end{array}$ & $\begin{array}{l}\mathrm{m} \\
\mathrm{m}\end{array}$ & $\begin{array}{l}\mathrm{m} \\
\mathrm{m}\end{array}$ & $\begin{array}{l}\mathrm{m} \\
\mathrm{m}\end{array}$ & $\begin{array}{l}\mathrm{m} \\
\mathrm{m}\end{array}$ & $\begin{array}{l}\mathbf{m} \\
\mathbf{m}\end{array}$ & $\begin{array}{l}\mathbf{m} \\
\mathbf{m}\end{array}$ & $\begin{array}{l}\mathrm{m} \\
\mathrm{m}\end{array}$ \\
\hline $\begin{array}{l}\text { India } \\
\text { Indonesia }\end{array}$ & $\begin{array}{l}\mathrm{m} \\
\mathrm{m}\end{array}$ & $\begin{array}{l}\mathrm{m} \\
\mathrm{m}\end{array}$ & $\begin{array}{l}\mathrm{m} \\
\mathrm{m}\end{array}$ & $\begin{array}{l}\mathbf{m} \\
\mathbf{m}\end{array}$ & $\begin{array}{l}\mathrm{m} \\
\mathrm{m}\end{array}$ & $\begin{array}{l}\mathrm{m} \\
\mathrm{m}\end{array}$ & $\begin{array}{l}\mathrm{m} \\
\mathrm{m}\end{array}$ & $\begin{array}{l}\mathrm{m} \\
\mathrm{m}\end{array}$ & $\begin{array}{l}\mathbf{m} \\
\mathbf{m}\end{array}$ & $\begin{array}{l}\mathbf{m} \\
\mathbf{m}\end{array}$ & $\begin{array}{l}\mathrm{m} \\
\mathrm{m}\end{array}$ \\
\hline $\begin{array}{l}\text { Letonia } \\
\text { Sudáfrica }\end{array}$ & $\begin{array}{l}\mathrm{m} \\
\mathrm{m}\end{array}$ & $\begin{array}{l}\mathrm{m} \\
\mathrm{m}\end{array}$ & $\begin{array}{l}\mathrm{m} \\
\mathrm{m}\end{array}$ & $\begin{array}{l}\mathbf{m} \\
\mathbf{m}\end{array}$ & $\begin{array}{l}\mathrm{m} \\
\mathrm{m}\end{array}$ & $\begin{array}{l}\mathrm{m} \\
\mathrm{m}\end{array}$ & $\begin{array}{l}\mathrm{m} \\
\mathrm{m}\end{array}$ & $\begin{array}{l}\mathrm{m} \\
\mathrm{m}\end{array}$ & $\begin{array}{l}\mathbf{m} \\
\mathbf{m}\end{array}$ & $\begin{array}{l}\mathbf{m} \\
\mathbf{m}\end{array}$ & $\begin{array}{l}\mathrm{m} \\
\mathrm{m}\end{array}$ \\
\hline
\end{tabular}

\section{Media G20}

Nota: Los valores se basan en la diferencia entre los hombres que han completado educación terciaria y aquellos que han completado educación secundaria superior o postsecundaria no terciaria.

Fuente: OCDE. Para ver notas, consulte Anexo 3 (www.oecd.org/edu/eag.htm).

Para obtener más información acerca de los símbolos utilizados en lugar de los datos que faltan, consulte la Guía del lector.

StatLink 제대 http://dx.doi.org/10.1787/888933116414 
Tabla A7.4b. Costes y beneficios públicos para una mujer que alcanza la educación terciaria (2010)

En comparación con una mujer que tiene educación secundaria superior o postsecundaria no terciaria, en equivalente a dólares estadounidenses convertidos mediante PPA para el PIB

\begin{tabular}{|c|c|c|c|c|c|c|c|c|c|c|c|c|}
\hline & & $\begin{array}{c}\text { Costes } \\
\text { directos }\end{array}$ & $\begin{array}{c}\text { Pérdida de } \\
\text { ingresos }\end{array}$ & $\begin{array}{l}\text { Efecto de } \\
\text { las becas }\end{array}$ & $\begin{array}{l}\text { Costes } \\
\text { totales }\end{array}$ & $\begin{array}{c}\text { Efecto del } \\
\text { impuesto } \\
\text { sobre la } \\
\text { renta }\end{array}$ & $\begin{array}{c}\text { Efecto de las } \\
\text { cotizaciones } \\
\text { sociales }\end{array}$ & $\begin{array}{c}\text { Efecto } \\
\text { de las } \\
\text { prestaciones }\end{array}$ & $\begin{array}{l}\text { Efecto del } \\
\text { desempleo }\end{array}$ & $\begin{array}{c}\text { Beneficios } \\
\text { totales }\end{array}$ & $\begin{array}{c}\text { Valor } \\
\text { actual } \\
\text { neto }\end{array}$ & $\begin{array}{c}\text { Tasa } \\
\text { interna } \\
\text { de retorno }\end{array}$ \\
\hline & Año & (1) & (2) & (3) & (4) & (5) & (6) & (7) & (8) & (9) & (10) & (11) \\
\hline Alemania & 2010 & -31.421 & -21.234 & -6.472 & -59.127 & 63.819 & 50.751 & 17 & 7.718 & 122.306 & 63.179 & $6,9 \%$ \\
\hline Australia & 2009 & -14.588 & -5.797 & -335 & -20.720 & 89.111 & 0 & 0 & 2.530 & 91.641 & 70.921 & $13,5 \%$ \\
\hline Austria & 2010 & -44.819 & -12.152 & -10.877 & -67.849 & 92.488 & 59.772 & 0 & 2.903 & 155.164 & 87.315 & $7,0 \%$ \\
\hline Bélgica & 2010 & -24.413 & -8.544 & -862 & -33.820 & 117.399 & 67.323 & 0 & 15.490 & 200.212 & 166.393 & $19,0 \%$ \\
\hline Canadá & 2010 & -26.735 & -3.728 & -1.103 & -31.566 & 67.254 & 19.517 & 0 & 3.293 & 90.064 & 58.498 & $9,5 \%$ \\
\hline Chile & & $\mathrm{m}$ & $\mathrm{m}$ & $\mathrm{m}$ & $\mathbf{m}$ & $\mathrm{m}$ & $\mathrm{m}$ & $\mathrm{m}$ & $\mathrm{m}$ & $\mathbf{m}$ & $\mathbf{m}$ & $\mathrm{m}$ \\
\hline Corea & 2010 & -7.198 & -3.557 & $\mathrm{~m}$ & -10.756 & 10.123 & 20.892 & 0 & -474 & 30.540 & 19.784 & $8,0 \%$ \\
\hline Dinamarca & 2010 & -85.578 & -37.013 & -29.411 & -152.002 & 58.528 & 13.964 & 9.772 & 4.069 & 86.334 & -65.668 & $0,4 \%$ \\
\hline Eslovenia & 2010 & -19.698 & -8.128 & -259 & -28.085 & 80.209 & 74.531 & 0 & 9.320 & 164.060 & 135.974 & $13,1 \%$ \\
\hline España & 2010 & -31.833 & -2.523 & -3.791 & -38.147 & 63.118 & 15.146 & 0 & 9.546 & 87.811 & 49.664 & $7,5 \%$ \\
\hline Estados Unidos & 2010 & -34.787 & -6.398 & -27.162 & -68.347 & 99.860 & 31.811 & 0 & 11.668 & 143.339 & 74.993 & $7,4 \%$ \\
\hline Estonia & 2010 & -12.037 & -2.386 & -730 & -15.153 & 31.454 & 4.315 & 0 & 10.872 & 46.641 & 31.487 & $12,9 \%$ \\
\hline Finlandia & 2009 & -42.400 & -8.862 & -8.730 & -59.992 & 68.219 & 13.657 & 4.079 & 5.912 & 91.868 & 31.876 & $5,2 \%$ \\
\hline Francia & 2010 & -31.533 & -9.027 & -3.103 & -43.664 & 49.775 & 35.999 & 11.640 & 6.409 & 103.824 & 60.160 & $8,4 \%$ \\
\hline Grecia & 2009 & -20.179 & 2.480 & $\mathrm{~m}$ & -17.699 & 20.386 & 29.703 & 29.066 & 5.673 & 84.828 & 67.129 & $11,7 \%$ \\
\hline Hungría & 2010 & -16.393 & -2.937 & -1.135 & -20.465 & 77.014 & 43.784 & 0 & 12.149 & 132.947 & 112.482 & $17,3 \%$ \\
\hline Irlanda & 2010 & -28.066 & -1.598 & -5.412 & -35.076 & 123.230 & 60.647 & 0 & 8.686 & 192.563 & 157.487 & $17,5 \%$ \\
\hline Islandia & & $\mathrm{m}$ & $\mathrm{m}$ & $\mathrm{m}$ & $\mathbf{m}$ & $\mathrm{m}$ & $\mathrm{m}$ & $\mathrm{m}$ & $\mathrm{m}$ & $\mathbf{m}$ & m & $\mathrm{m}$ \\
\hline Israel & 2010 & -16.613 & -1.552 & -1.528 & -19.692 & 22.108 & 17.839 & 0 & 1.557 & 41.503 & 21.811 & $6,4 \%$ \\
\hline Italia & 2008 & -17.538 & -11.185 & -3.330 & -32.053 & 77.919 & 21.270 & 0 & 2.750 & 101.940 & 69.886 & $8,0 \%$ \\
\hline Japón & 2007 & -17.897 & -10.654 & $\mathrm{~m}$ & -28.551 & 20.218 & 27.924 & 0 & 1.822 & 49.965 & 21.414 & $6,2 \%$ \\
\hline Luxemburgo & & $\mathrm{m}$ & $\mathrm{m}$ & $\mathrm{m}$ & $\mathbf{m}$ & $\mathrm{m}$ & $\mathrm{m}$ & $\mathrm{m}$ & $\mathrm{m}$ & $\mathbf{m}$ & $\mathbf{m}$ & $\mathrm{m}$ \\
\hline México & & $\mathrm{m}$ & $\mathrm{m}$ & $\mathrm{m}$ & $\mathbf{m}$ & $\mathrm{m}$ & $\mathrm{m}$ & $\mathrm{m}$ & $\mathrm{m}$ & $\mathbf{m}$ & $\mathbf{m}$ & $\mathrm{m}$ \\
\hline Noruega & 2010 & -26.059 & -15.864 & -4.690 & -46.613 & 63.264 & 17.730 & 0 & 199 & 81.193 & 34.581 & $5,8 \%$ \\
\hline Nueva Zelanda & 2010 & -18.444 & -5.090 & -3.039 & -26.573 & 38.104 & 3.348 & 2.329 & 2.486 & 46.267 & 19.694 & $6,5 \%$ \\
\hline Países Bajos & 2010 & -37.254 & -35.318 & -13.770 & -86.341 & 135.724 & 28.393 & 0 & 4.453 & 168.569 & 82.228 & $6,5 \%$ \\
\hline Polonia & 2010 & -17.653 & -5.768 & -2.228 & -25.648 & 21.556 & 52.341 & 0 & 11.304 & 85.200 & 59.552 & $10,5 \%$ \\
\hline Portugal & 2010 & -10.295 & -2.148 & $\mathrm{~m}$ & -12.443 & 56.914 & 28.879 & 0 & 5.172 & 90.966 & 78.523 & $14,9 \%$ \\
\hline Reino Unido & 2010 & -6.798 & 1.128 & -5.225 & -10.895 & 70.396 & 38.718 & 12.831 & 13.607 & 135.553 & 124.658 & $36,4 \%$ \\
\hline República Checa & 2010 & -18.172 & 3.987 & $\mathrm{~m}$ & -14.185 & 41.879 & 22.919 & 688 & 7.315 & 72.800 & 58.615 & $14,6 \%$ \\
\hline República Eslovaca & 2010 & -14.559 & -1.544 & -1.226 & -17.329 & 29.789 & 24.260 & 0 & 9.238 & 63.287 & 45.958 & $11,1 \%$ \\
\hline Suecia & 2010 & -34.448 & -13.236 & -7.735 & -55.420 & 38.592 & 9.798 & 0 & 4.551 & 52.940 & -2.479 & $2,8 \%$ \\
\hline $\begin{array}{l}\text { Suiza } \\
\text { Turquía }\end{array}$ & 2005 & $\begin{array}{r}\mathrm{m} \\
-9.567\end{array}$ & $\begin{array}{r}\mathrm{m} \\
-3.320\end{array}$ & $\begin{array}{l}\mathrm{m} \\
\mathrm{m}\end{array}$ & $\begin{array}{r}m \\
-12.887\end{array}$ & $\begin{array}{r}\mathrm{m} \\
19.194\end{array}$ & $\begin{array}{r}\mathrm{m} \\
17.528\end{array}$ & $\begin{array}{l}\mathrm{m} \\
0\end{array}$ & $\begin{array}{r}\mathrm{m} \\
4.171\end{array}$ & $\begin{array}{r}m \\
40.894\end{array}$ & $\begin{array}{r}m \\
28.006\end{array}$ & $\begin{array}{r}m \\
9,1 \%\end{array}$ \\
\hline Media OCDE & & -24.723 & -7.999 & -6.181 & -37.624 & 60.264 & 29.405 & 2.428 & 6.358 & 98.456 & 60.832 & $10,5 \%$ \\
\hline Media UE21 & & -27.254 & -8.800 & -6.135 & -41.270 & 65.920 & 34.809 & 3.405 & 7.857 & 111.991 & 70.721 & $11,6 \%$ \\
\hline
\end{tabular}

\begin{tabular}{|c|c|c|c|c|c|c|c|c|c|c|c|}
\hline $\begin{array}{l}\text { Arabia Saudí } \\
\text { đ̃ } \\
\text { Argentina }\end{array}$ & $\begin{array}{l}\mathrm{m} \\
\mathrm{m}\end{array}$ & $\begin{array}{l}\mathrm{m} \\
\mathrm{m}\end{array}$ & $\begin{array}{l}\mathrm{m} \\
\mathrm{m}\end{array}$ & $\begin{array}{l}\mathbf{m} \\
\mathbf{m}\end{array}$ & $\begin{array}{l}\mathrm{m} \\
\mathrm{m}\end{array}$ & $\begin{array}{l}\mathrm{m} \\
\mathrm{m}\end{array}$ & $\begin{array}{l}\mathrm{m} \\
\mathrm{m}\end{array}$ & $\begin{array}{l}\mathrm{m} \\
\mathrm{m}\end{array}$ & $\begin{array}{l}\mathbf{m} \\
\mathbf{m}\end{array}$ & $\begin{array}{l}\mathbf{m} \\
\mathbf{m}\end{array}$ & $\begin{array}{l}\mathrm{m} \\
\mathrm{m}\end{array}$ \\
\hline 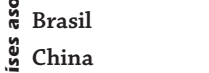 & $\begin{array}{l}\mathrm{m} \\
\mathrm{m}\end{array}$ & $\begin{array}{l}\mathrm{m} \\
\mathrm{m}\end{array}$ & $\begin{array}{l}\mathrm{m} \\
\mathrm{m}\end{array}$ & $\begin{array}{l}\mathbf{m} \\
\mathbf{m}\end{array}$ & $\begin{array}{l}\mathrm{m} \\
\mathrm{m}\end{array}$ & $\begin{array}{l}\mathrm{m} \\
\mathrm{m}\end{array}$ & $\begin{array}{l}\mathrm{m} \\
\mathrm{m}\end{array}$ & $\begin{array}{l}\mathrm{m} \\
\mathrm{m}\end{array}$ & $\begin{array}{l}\mathbf{m} \\
\mathbf{m}\end{array}$ & $\begin{array}{l}\mathbf{m} \\
\mathbf{m}\end{array}$ & $\begin{array}{l}\mathrm{m} \\
\mathrm{m}\end{array}$ \\
\hline $\begin{array}{l}\Sigma^{\pi} \text { Colombia } \\
\text { Federación Rusa }\end{array}$ & $\begin{array}{l}\mathrm{m} \\
\mathrm{m}\end{array}$ & $\begin{array}{l}\mathrm{m} \\
\mathrm{m}\end{array}$ & $\begin{array}{l}\mathrm{m} \\
\mathrm{m}\end{array}$ & $\begin{array}{l}\mathbf{m} \\
\mathbf{m}\end{array}$ & $\begin{array}{l}\mathrm{m} \\
\mathrm{m}\end{array}$ & $\begin{array}{l}\mathrm{m} \\
\mathrm{m}\end{array}$ & $\begin{array}{l}\mathrm{m} \\
\mathrm{m}\end{array}$ & $\begin{array}{l}\mathrm{m} \\
\mathrm{m}\end{array}$ & $\begin{array}{l}\mathbf{m} \\
\mathbf{m}\end{array}$ & $\begin{array}{l}\mathbf{m} \\
\mathbf{m}\end{array}$ & $\begin{array}{l}\mathrm{m} \\
\mathrm{m}\end{array}$ \\
\hline $\begin{array}{l}\text { India } \\
\text { Indonesia }\end{array}$ & $\begin{array}{l}\mathrm{m} \\
\mathrm{m}\end{array}$ & $\begin{array}{l}\mathrm{m} \\
\mathrm{m}\end{array}$ & $\begin{array}{l}\mathrm{m} \\
\mathrm{m}\end{array}$ & $\begin{array}{l}\mathbf{m} \\
\mathbf{m}\end{array}$ & $\begin{array}{l}\mathrm{m} \\
\mathrm{m}\end{array}$ & $\begin{array}{l}\mathrm{m} \\
\mathrm{m}\end{array}$ & $\begin{array}{l}\mathrm{m} \\
\mathrm{m}\end{array}$ & $\begin{array}{l}\mathrm{m} \\
\mathrm{m}\end{array}$ & $\begin{array}{l}\mathbf{m} \\
\mathbf{m}\end{array}$ & $\begin{array}{l}\mathbf{m} \\
\mathbf{m}\end{array}$ & $\begin{array}{l}\mathrm{m} \\
\mathrm{m}\end{array}$ \\
\hline $\begin{array}{l}\text { Letonia } \\
\text { Sudáfrica }\end{array}$ & $\begin{array}{l}\mathrm{m} \\
\mathrm{m}\end{array}$ & $\begin{array}{l}\mathrm{m} \\
\mathrm{m}\end{array}$ & $\begin{array}{l}\mathrm{m} \\
\mathrm{m}\end{array}$ & $\begin{array}{l}\mathbf{m} \\
\mathbf{m}\end{array}$ & $\begin{array}{l}\mathrm{m} \\
\mathrm{m}\end{array}$ & $\begin{array}{l}\mathrm{m} \\
\mathrm{m}\end{array}$ & $\begin{array}{l}\mathrm{m} \\
\mathrm{m}\end{array}$ & $\begin{array}{l}\mathrm{m} \\
\mathrm{m}\end{array}$ & $\begin{array}{l}\mathbf{m} \\
\mathbf{m}\end{array}$ & $\begin{array}{l}\mathbf{m} \\
\mathbf{m}\end{array}$ & $\begin{array}{l}\mathrm{m} \\
\mathrm{m}\end{array}$ \\
\hline
\end{tabular}

\section{Media G20}

$\mathrm{m}$

$\mathbf{m}$

$\mathrm{m}$

\begin{tabular}{l|l|l|}
$\mathbf{m}$ & $\mathbf{m}$ & $\mathrm{m}$
\end{tabular}

Nota: Los valores se basan en la diferencia entre las mujeres que han completado educación terciaria y aquellas que han completado educación secundaria superior o postsecundaria no terciaria.

Fuente: OCDE. Para ver notas, consulte Anexo 3 (www.oecd.org/edu/eag.htm).

Para obtener más información acerca de los símbolos utilizados en lugar de los datos que faltan, consulte la Guía del lector.

StatLink 제으 http://dx.doi.org/10.1787/888933116433 


\section{¿CUÁLES SON LOS RESULTADOS SOCIALES DE LA EDUCACIÓN?}

- Tanto el nivel de educación alcanzado como la comprensión lectora están fuertemente asociados a elevados niveles de resultados sociales, incluyendo la percepción subjetiva del estado de salud, el voluntariado, la confianza interpersonal y la eficacia política. Entre las personas con el mismo nivel educativo, aquellas con niveles superiores de comprensión lectora tienen mejores resultados sociales.

- Existe una relación especialmente estrecha entre comprensión lectora y eficacia política en los graduados de educación terciaria. Como media, en 20 países de la OCDE, en los adultos graduados en educación terciaria que creen tener voz en el gobierno, la diferencia es de 21 puntos porcentuales entre los que obtienen el nivel máximo y el mínimo en comprensión lectora.

- Existe una fuerte relación entre comprensión lectora y voluntariado en aquellas personas que no han completado la educación secundaria superior. Como media, en 21 países de la OCDE, la diferencia en la proporción de adultos que indican que ejercen el voluntariado al menos una vez al mes entre los adultos con bajo nivel de estudios y el nivel máximo y mínimo en comprensión lectora es de 8 puntos porcentuales.

\section{Gráfico A8.1. Resultados sociales del aprendizaje en los países de la OCDE (2012)} Encuesta sobre las Competencias de los Adultos, media para personas de 25 a 64 años
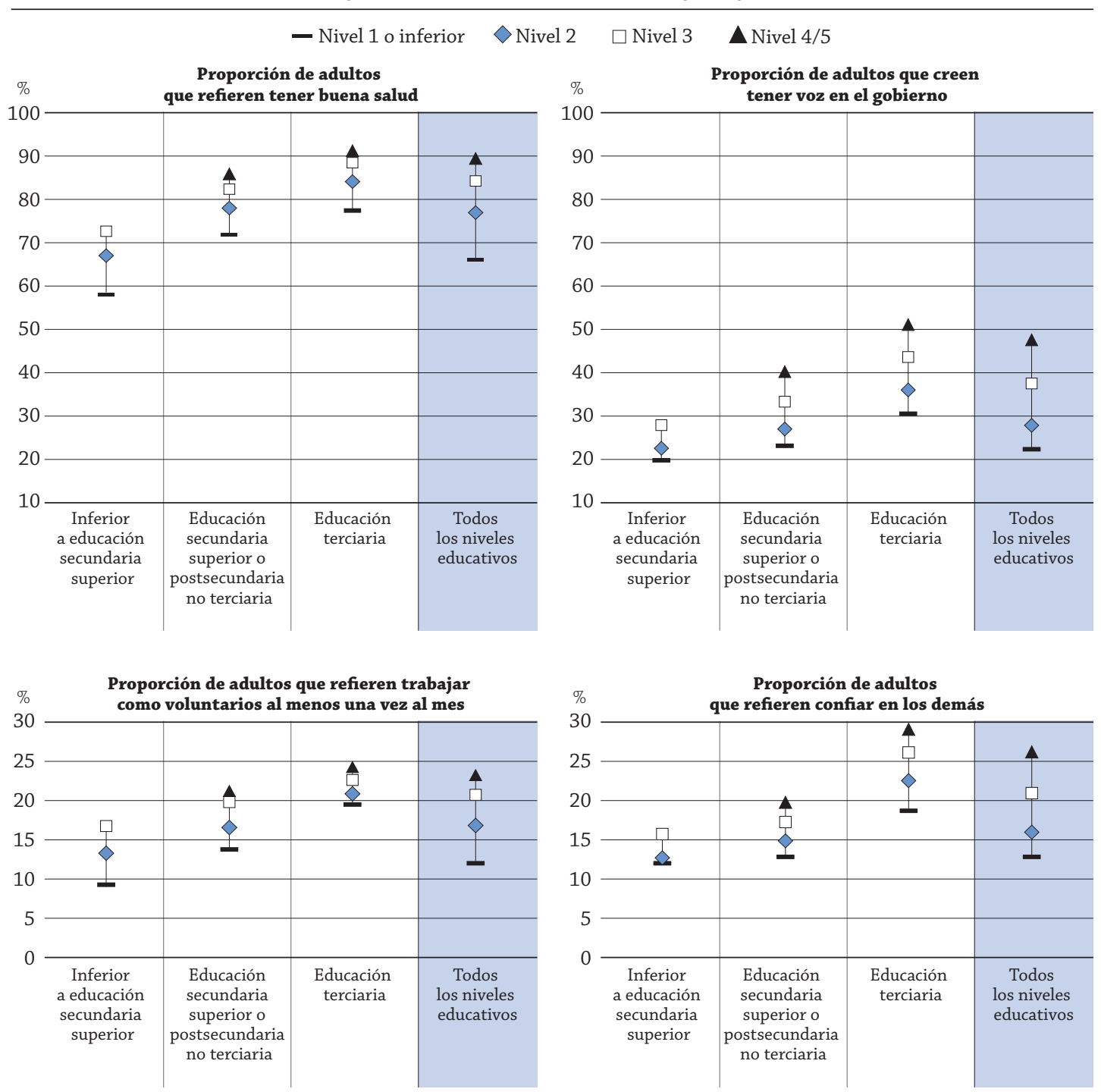

Fuente: OCDE. Tablas A8.1a (L), A8.2c (L), A8.3a (L) y A8.4a (L). Para ver notas, consulte Anexo 3 (www.oecd.org/edu/eag.htm).

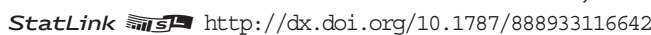




\section{Contexto}

Mejorar la salud es un objetivo clave de las políticas de todos los países de la OCDE. Esto se refleja en el elevado gasto público en salud, que en 2009 supuso el 6,9\% del PIB en los países de la OCDE (OECD, 2011a). Este importe es mucho mayor que el gasto público en educación del 5,0\% ese mismo año (OECD, 2011b). Aunque los considerables recursos dedicados a la sanidad han ayudado a las personas en general a vivir más tiempo, la naturaleza de los problemas de salud ha cambiado, incrementándose recientemente las dolencias crónicas debilitantes como las enfermedades cardiovasculares, la diabetes y la depresión. Los esfuerzos para combatir estas tendencias dependen en parte de alterar el estilo de vida de las personas, que puede mejorarse mediante las competencias cognitivas y socioemocionales desarrolladas mediante la educación (OECD, 2013a).

La cohesión social, a menudo reflejada en el nivel de participación cívica y social, también preocupa mucho en los países de la OCDE. Los países generalmente perciben que los niveles de participación cívica, eficacia política y confianza son inadecuados y, por tanto, suponen un reto para el mantenimiento del buen funcionamiento de las instituciones democráticas y de los procesos políticos. La educación puede desempeñar un papel importante para garantizar la cohesión social, fomentando las competencias cognitivas, la autoeficacia y la flexibilidad sobre las que se basa la interacción social y política.

\section{Otros resultados}

- Las diferencias de los resultados sociales entre aquellos adultos con el máximo y el mínimo nivel de comprensión lectora son generalmente comparables a las diferencias de los resultados sociales entre quienes no han alcanzado la educación secundaria superior y quienes han completado la educación terciaria. Por ejemplo, entre los adultos que dicen gozar de buena salud y tienen un nivel educativo elevado y los que tienen un nivel educativo bajo la diferencia es de 23 puntos porcentuales. La diferencia de los que dicen tener buena salud entre los adultos con la máxima y la mínima comprensión lectora es también de 23 puntos porcentuales.

- Las mujeres parecen beneficiarse más de mejorar las competencias en cuanto a indicar que tienen mejor salud y más confianza en los demás. Por ejemplo, en las mujeres que dicen confiar en los demás, la diferencia entre aquellas con la máxima y la mínima comprensión lectora es de 19 puntos porcentuales. Una cifra similar para los hombres es de 15 puntos porcentuales. 


\section{Análisis}

El indicador de este año sobre los resultados sociales de la educación (y las competencias) incluye parámetros sobre percepción subjetiva de la salud, voluntariado, confianza interpersonal y eficacia política, medidos en la Encuesta sobre las Competencias de los Adultos, un producto del Programa para la Evaluación Internacional de las Competencias de los Adultos (PIAAC) de la OCDE. Estos cuatro parámetros de los resultados sociales se incluyen entre los indicadores clave del bienestar individual y nacional (OECD, 2013a).

Tanto el nivel educativo alcanzado como la comprensión lectora están asociados de forma positiva a estos parámetros de resultados sociales (Gráficos A8.2, A8.3, A8.4 y A8.5, Tablas A8.1, A8.2, A8.3 y A8.4). Las diferencias de los resultados entre aquellos con distintos niveles de comprensión lectora o logro educativo son a veces sustanciales. Aunque los modelos específicos de cada país pueden variar, los resultados globales y la fuerza de las relaciones son similares cuando se utilizan escalas numéricas (Tabla A8.1a[N], Tabla A8.2a[N], Tabla A8.3a[N] y Tabla A8.4a[N]).

\section{Percepción subjetiva de la salud}

Como media en 22 países de la OCDE, la diferencia de la proporción de adultos que considera que tiene «buena salud» entre aquellos con un nivel educatico elevado (es decir, terciario) y un nivel bajo (es decir, inferior a secundaria superior) es de 23 puntos porcentuales (Gráfico A8.2, Tabla A8.1a[L]). En particular, las mayores diferencias se observaron en Polonia (38 puntos porcentuales) y República Eslovaca (37 puntos porcentuales). Igualmente, la diferencia de la percepción subjetiva de salud entre aquellos con la máxima y la mínima comprensión lectora, según la Encuesta sobre las Competencias de los Adultos, es de 23 puntos porcentuales, como media en estos países (Gráfico A8.2 y Tabla A8.1a[L]). Estonia registró las mayores diferencias con 34 puntos porcentuales.

\section{Gráfico A8.2. Porcentaje de adultos que refieren tener buena salud, por nivel educativo alcanzado y comprensión lectora (2012) Encuesta sobre las Competencias de los Adultos, personas de 25 a 64 años}

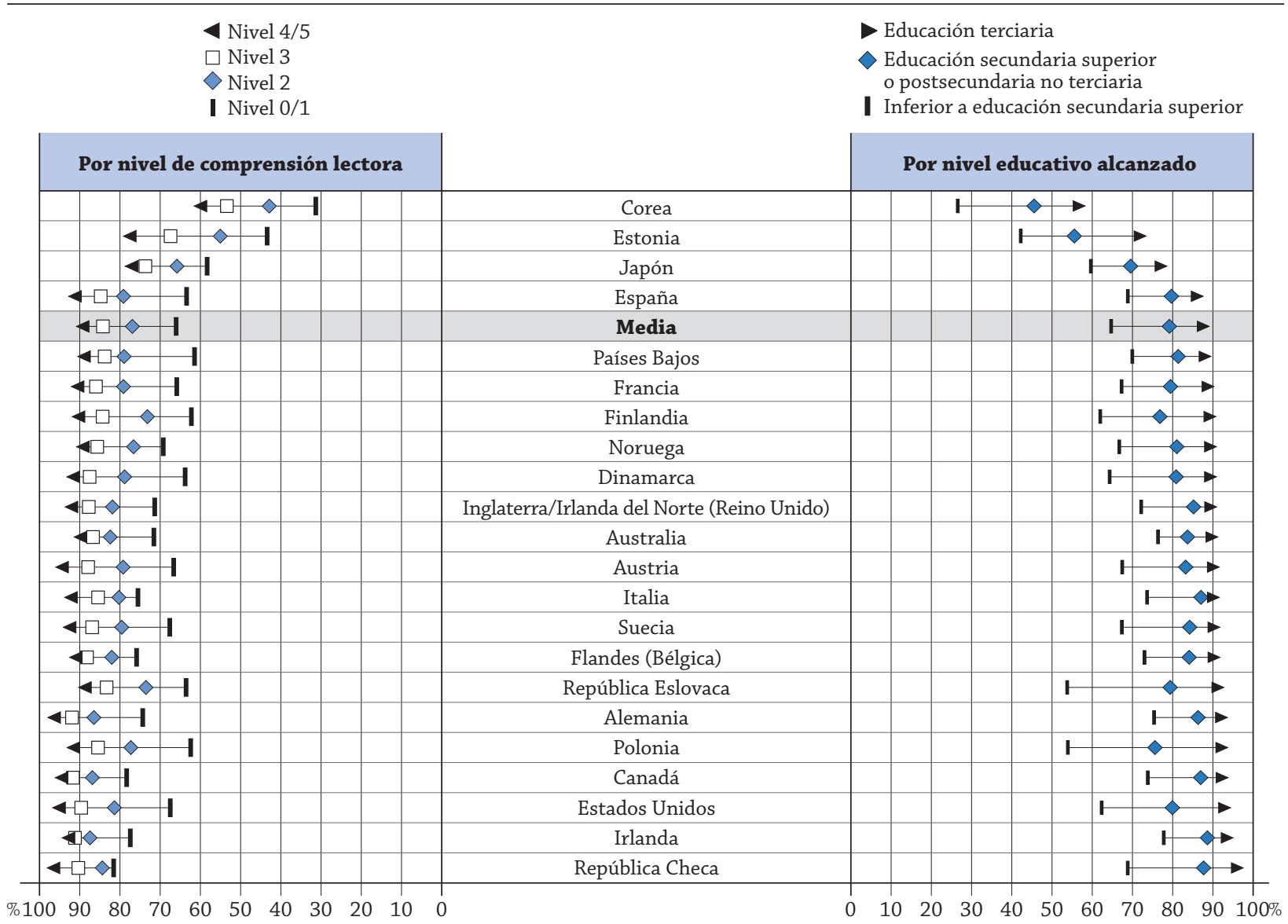

Los países están clasificados en orden ascendente de la proporción de personas con educación terciaria que refieren tener buena salud. Fuente: OCDE. Tabla A8.1a (L). Para ver notas, consulte Anexo 3 (www.oecd.org/edu/eag.htm).

StatLink 젬ㄴ http://dx.doi.org/10.1787/888933116661 


\section{Voluntariado}

La diferencia de la proporción de adultos que dicen participar en actividades de voluntariado entre aquellos con un nivel de educación alto y un nivel bajo es de 10 puntos porcentuales, como media en 21 países de la OCDE (Gráfico A8.3 y Tabla A8.2a[L]). Se observan diferencias particularmente grandes en Estados Unidos (26 puntos porcentuales) y en Alemania (17 puntos porcentuales). Igualmente, las diferencias de la participación personal en actividades de voluntariado entre aquellos con la máxima y la mínima comprensión lectora es de 11 puntos porcentuales, como media en estos países (Gráfico A8.3 y Tabla A8.2a[L]). Se observan diferencias particularmente elevadas en Estados Unidos (21 puntos porcentuales) y en Canadá (20 puntos porcentuales).

\section{Gráfico A8.3. Porcentaje de adultos que refieren trabajar como voluntarios al menos una vez al mes, por nivel educativo alcanzado y comprensión lectora (2012) Encuesta sobre las Competencias de los Adultos, personas de 25 a 64 años}

\begin{tabular}{|c|c|c|c|c|c|c|c|}
\hline \multicolumn{3}{|c|}{$\begin{array}{l}4 \text { Nivel 4/5 } \\
\square \text { Nivel } 3 \\
\diamond \text { Nivel } 2 \\
\text { I Nivel 0/1 }\end{array}$} & & \multicolumn{4}{|c|}{$\begin{array}{l}\text { Educación terciaria } \\
\diamond \text { Educación secundaria superior } \\
\text { o postsecundaria no terciaria } \\
\text { I Inferior a educación secundaria superior }\end{array}$} \\
\hline \multicolumn{3}{|c|}{ Por nivel de comprensión lector } & & \multicolumn{4}{|c|}{ Por nivel educativo alcanzado } \\
\hline & & 3 & Japón & & $\rightarrow$ & & \\
\hline & & $4-\square$ & Estonia & $1-$ & $\rightarrow$ & & \\
\hline & & $4-\square+1$ & Corea & & $\mathbf{r}$ & & \\
\hline & & $4 \square$ & Polonia & $1<$ & $\rightarrow$ & & \\
\hline & & $\pi$ & República Checa & $1-1$ & $\rightarrow$ & & \\
\hline & & K & República Eslovaca & $1 \diamond$ & $\rightarrow$ & & \\
\hline & & $4-\square-1$ & España & \begin{tabular}{l|l}
1 \\
\end{tabular} & $\rightarrow$ & & \\
\hline & & $\square \triangleleft \diamond \mid$ & Italia & & $1 \diamond$ & $\rightarrow$ & \\
\hline & $4 \square$ & $8 \quad 1$ & Suecia & & 1 & $\rightarrow$ & \\
\hline & 4 & $\diamond \quad 1$ & Media & & $1 \curvearrowright$ & $\rightarrow$ & \\
\hline & $4-5$ & $>>1$ & Inglaterra/Irlanda del Norte (Reino Unido) & & $1>$ & $\rightarrow$ & \\
\hline & $4-\square-$ & $\sqrt{1}$ & Irlanda & & 1 & $\longrightarrow$ & \\
\hline & $4-\square$ & $\diamond-1$ & Australia & & 1 & 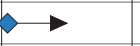 & \\
\hline & $4 \square$ & $\begin{array}{ll}1 & 1\end{array}$ & Flandes (Bélgica) & & $1 \diamond$ & $\longrightarrow$ & \\
\hline & $4 \square$ & $\Delta$ & Finlandia & & 18 & $\longrightarrow$ & \\
\hline & $\square \triangleleft$ & I & Dinamarca & & 1 & $\longrightarrow$ & \\
\hline & $4-\square \curvearrowright$ & I & Alemania & & 1 & $\diamond$ & \\
\hline & $\square \triangleleft \diamond$ & | & Austria & & 1 & $\diamond$ & \\
\hline 4 & $\square \diamond$ & I & Canadá & & 1 & $\longrightarrow$ & \\
\hline & 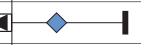 & & Países Bajos & & & $1 \diamond$ & $\rightarrow$ \\
\hline 4 & $\diamond$ & I & Noruega & & & 1 & $\infty$ \\
\hline $4 \quad \square$ & $\diamond$ & I & Estados Unidos & & I & $\diamond$ & $\longrightarrow$ \\
\hline 40 & 30 & 10 & 0 & 10 & 0 & 20 & 30 \\
\hline
\end{tabular}

Los países están clasificados en orden ascendente de la proporción de personas con educación terciaria que refieren trabajar como voluntarios al menos una vez al mes. Fuente: OCDE. Tabla A8.2a (L). Para ver notas, consulte Anexo 3 (www.oecd.org/edu/eag.htm).

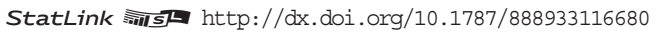

\section{Confianza interpersonal}

La diferencia de la proporción de adultos que declaran «poder confiar en los demás» entre aquellos con un nivel de educación alto y un nivel bajo es de 16 puntos porcentuales, como media en 22 países de la OCDE (Gráfico A8.4 y Tabla A8.3c[L]). Se observan diferencias particularmente grandes en Dinamarca (31 puntos porcentuales) y Países Bajos (25 puntos porcentuales). Asimismo, las diferencias en la confianza interpersonal entre aquellos con la máxima y la mínima comprensión lectora es de 17 puntos porcentuales, como media en estos países (Gráfico A8.4 y Tabla A8.3c[L]). Se observan diferencias particularmente elevadas en Dinamarca (33 puntos porcentuales) y Noruega (29 puntos porcentuales). 


\section{Gráfico A8.4. Porcentaje de adultos que refieren confiar en los demás, por nivel educativo alcanzado y comprensión lectora (2012) \\ Encuesta sobre las Competencias de los Adultos, personas de 25 a 64 años}

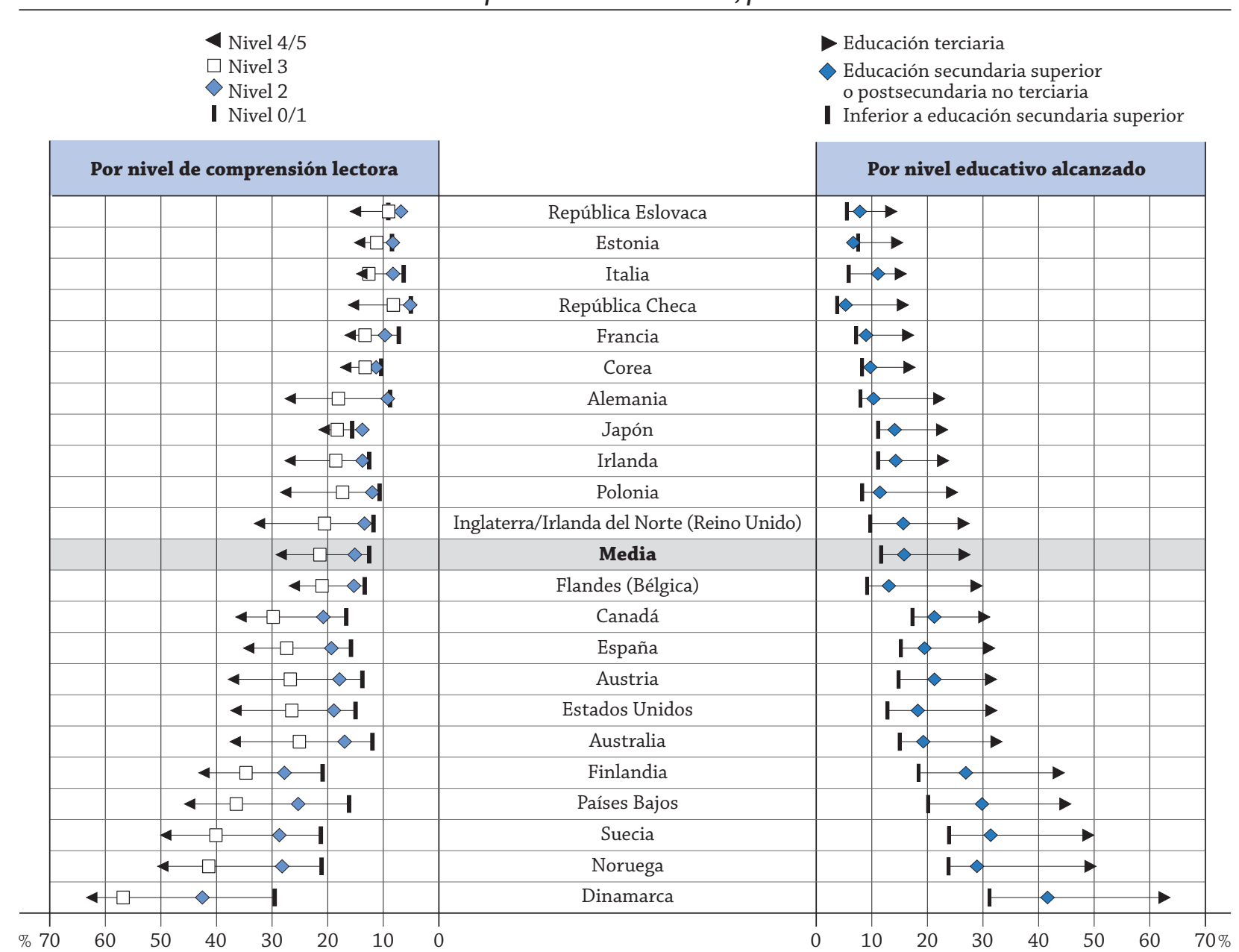

Los países están clasificados en orden ascendente de la proporción de personas con educación terciaria que refieren confiar en los demás.

Fuente: OCDE. Tabla A8.2a (L). Para ver notas, consulte Anexo 3 (www.oecd.org/edu/eag.htm).

StatLink त्ञाI $\mathrm{http}: / / \mathrm{dx}$.doi.org/10.1787/888933116699

\section{Eficacia política}

Como media en 20 países de la OCDE, la diferencia de la proporción de adultos que dicen «creer que tienen voz en el gobierno» entre aquellos con un nivel de educación alto y un nivel bajo es de 20 puntos porcentuales (Gráfico A8.5 y Tabla A8.4a[L]). Se observan diferencias particularmente grandes en Noruega (33 puntos porcentuales) y Países Bajos (27 puntos porcentuales). En todos estos países, la diferencia de la eficacia política personal entre los adultos con la máxima y la mínima comprensión lectora es de 25 puntos porcentuales como media (Gráfico A8.5 y Tabla A8.4a[L]). Se observa una diferencia particularmente grande de 43 puntos porcentuales en Noruega.

Las diferencias de los resultados sociales entre aquellos con la máxima y la mínima comprensión lectora son generalmente comparables a las diferencias de los resultados sociales entre aquellos que no han completado la educación secundaria superior y aquellos que han alcanzado la educación terciaria (Gráficos A8.1, A8.2, A8.3 y A8.4 y A8.5 y Tablas A8.1, A8.2, A8.3 y A8.4). Nótese que el porcentaje de adultos con la mínima y la máxima puntuación en comprensión lectora es del $12 \%$ y el $16 \%$, respectivamente (OECD, 2013b). En cambio, los adultos que no han completado la educación secundaria superior y aquellos que han alcanzado la educación terciaria son el $24 \%$ y el $33 \%$, respectivamente. Esto podría implicar que la relación entre nivel educativo alcanzado y resultados sociales es más fuerte que la relación entre comprensión lectora y resultados sociales. De manera similar, la OCDE (2013b, pp 232) sugiere que la relación entre comprensión lectora y salarios es mucho más fuerte que la relación entre años en educación y salarios. 
Gráfico A8.5. Porcentaje de adultos que creen tener voz en el gobierno, por nivel educativo alcanzado y comprensión lectora (2012)

Encuesta sobre las Competencias de los Adultos, personas de 25 a 64 años

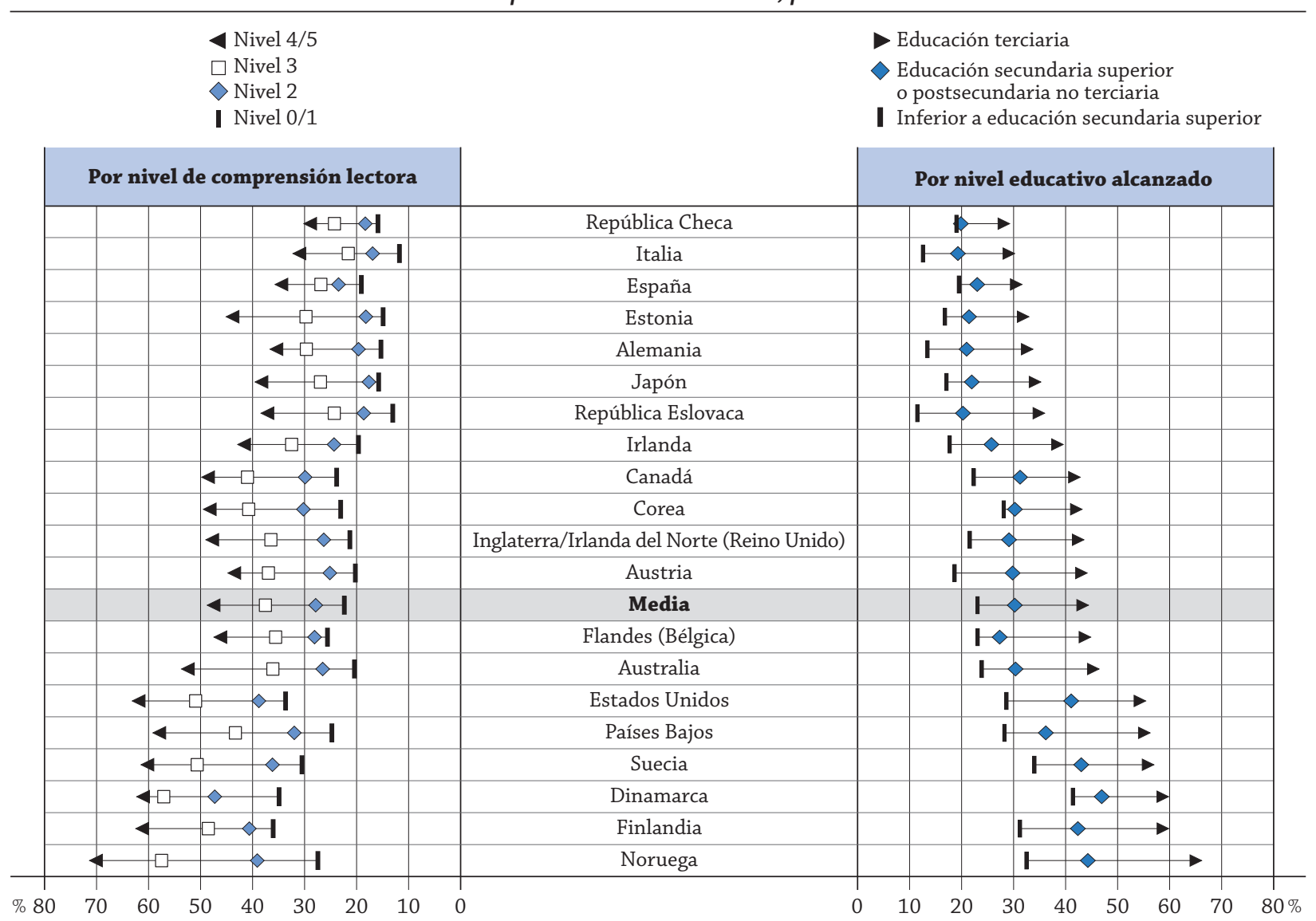

Los países están clasificados en orden ascendente de la proporción de personas con educación terciaria que refieren creer que tienen voz en el gobierno.

Fuente: OCDE. Tabla A8.2a (L). Para ver notas, consulte Anexo 3 (www.oecd.org/edu/eag.htm).

StatLink 제이 http://dx.doi.org/10.1787/888933116718

\section{Efectos causales}

Otros estudios que utilizan datos longitudinales sugieren que las asociaciones presentadas en los Gráficos A8.1, A8.2, A8.3, A8.4 y A8.5 pueden reflejar efectos causales de la educación y las competencias sobre los resultados sociales. Por ejemplo, Conti, Heckman y Urzua (2010), utilizando el Estudio Británico de Cohortes (BCS) (1970), muestran que una proporción considerable de la relación entre el nivel educativo alcanzado y la percepción de salud refleja efectos causales. Heckman et al. (2014) también demuestran, utilizando el Estudio Nacional Longitudinal de la Juventud (NLSY), que las competencias cognitivas y socioemocionales muestran efectos causales en diversos resultados del mercado laboral y sociales. Asimismo, Heckman y Kautz (2013), utilizando pruebas de estudios experimentales, muestran que diversos programas infantiles y escolares tienen un impacto sobre los resultados educativos, laborales y sociales al reforzar las competencias cognitivas y socioemocionales.

\section{Relación entre comprensión lectora y resultados sociales, por nivel educativo alcanzado}

En el Gráfico A8.1 se indica la relación entre comprensión lectora y cuatro parámetros de resultados sociales por separado para tres niveles de educación, concretamente inferior a secundaria superior, secundaria superior o postsecundaria no terciaria y terciaria. Este gráfico sugiere que la fuerza de la relación varía según los niveles educativos. Por ejemplo, existe una fuerte relación entre comprensión lectora y eficacia política, sobre todo en los graduados de educación terciaria. La educación terciaria puede dar a los estudiantes un mayor acceso a la toma de decisiones públicas y a la política, y la comprensión lectora puede mejorar la capacidad de una persona de contribuir a dicho proceso. El poder de la comprensión lectora aumenta a medida que los individuos reciben mayores oportunidades de demostrar dicha competencia. Además, existe una fuerte relación entre comprensión lectora y voluntariado, sobre todo entre aquellos que no han alcanzado la educación secundaria superior. Las personas con un nivel 
de educación más bajo pueden tener un acceso relativamente limitado a las actividades de voluntariado, pero los datos son consistentes con el argumento de que una mayor comprensión lectora puede compensarlo ampliamente, mejorando su capacidad de comprender los beneficios de las actividades de voluntariado tanto para uno mismo como para la sociedad y poder acceder a las más apropiadas. Este análisis también sugiere que la educación puede tener un efecto directo (o independiente) en los resultados sociales por encima de los efectos indirectos al elevar la comprensión lectora.

\section{El papel del sexo}

Las mujeres parecen beneficiarse más de mejorar el nivel alcanzado de educación y las competencias en cuanto a tener una mejor salud y mayor confianza en los demás. Como media en 22 países de la OCDE, las diferencias entre las mujeres con un nivel de educación alto y uno bajo que declaran tener «buena salud» es de 25 puntos porcentuales (Tabla A8.1b). Al comparar a los hombres con una educación similar, la diferencia es de 22 puntos porcentuales. Más aún, la diferencia entre las mujeres con el máximo y el mínimo nivel de competencias que declaran «poder confiar en los demás» es de 19 puntos porcentuales. Al comparar a los hombres con una educación similar, la diferencia es de 15 puntos porcentuales. En cambio, es menos probable que las mujeres se beneficien más que los hombres de una mejora de su nivel educativo en cuanto a referir que tienen mejor estado de salud, que llevan a cabo acciones de voluntariado y que creen que tienen voz en el gobierno.

\section{Definiciones}

Grupos de edad: adultos se refiere a las personas de 25 a 64 años.

La confianza interpersonal, es decir, poder confiar en los demás, se define como la actitud de aquellos que están muy en desacuerdo o en desacuerdo con que solo hay unas pocas personas en las que se puede confiar plenamente.

Niveles de educación: inferior a secundaria superior corresponde a los niveles CINE 0, 1, 2 y 3 C programas cortos; secundaria superior o postsecundaria no terciaria corresponde a los niveles CINE 3A, 3B, 3C programas largos, y nivel CINE 4; y terciaria corresponde a los niveles CINE 5A, 5B y 6. Para una presentación de todos los niveles CINE, consulte la Guía del lector al inicio de este libro.

La eficacia política, es decir, creer que tienen voz en el gobierno, se define como la actitud de aquellos que están muy en desacuerdo o en desacuerdo con la afirmación «La gente como yo no tiene voz sobre lo que haga el gobierno».

Percepción subjetiva de la salud, es decir, de buena salud, se define como la actitud de aquellos que refieren tener una salud excelente, muy buena o buena.

Voluntariado se define como la actitud de aquellos que declaran realizar algún trabajo de voluntariado al menos una vez al mes.

\section{Metodología}

Todos los datos se basan en la Encuesta sobre las Competencias de los Adultos (PIAAC) (2012). PIAAC es el Programa para la Evaluación Internacional de las Competencias de los Adultos de la OCDE. Véase Acerca de la Encuesta sobre las Competencias de los Adultos al inicio de esta publicación y Anexo 3 (www.oecd.org/edu/eag.htm) para más información.

Nota sobre los datos de Federación Rusa en la Encuesta sobre las Competencias de los Adultos (PIAAC)

Los lectores deben tener en cuenta que la muestra de Federación Rusa no incluye a la población del área municipal de Moscú. Por tanto los datos publicados no representan a toda la población residente de 16 a 65 años en Rusia sino a la población de Rusia excluyendo a la población que reside en el área municipal de Moscú. Se ofrece información más detallada sobre los datos de la Federación Rusa así como de otros países en el Informe técnico de la evaluación de las competencias de los adultos (OCDE, de próxima publicación).

\section{Referencias}

Conti, G., J.J. Heckman y S. Urzua (2010), «The education-health gradient», American Economic Review: Papers \& Proceedings 100, mayo de 2010, pp. 234-248.

Heckman, J.J., J.E. Humphries, G. Veramendi y S. Urzua (2014), «Education, health and wages», NBER Working Paper, No. 19971, National Bureau of Economic Research, marzo de 2014.

Heckman, J.J. y T. Kautz (2013), «Fostering and measuring skills: Interventions that improve character and cognition», NBER Working Paper, No. 19656, National Bureau of Economic Research, noviembre de 2013. 
OECD (2013a), How's Life? 2013: Measuring Well-being, OECD Publishing, París, http://dx.doi.org/10.1787/9789264201392-en. OECD (2013b), OECD Skills Outlook 2013: First Results from the Survey of Adult Skills, OECD Publishing, París, http://dx.doi. org/10.1787/9789264204256-en.

OECD (2011a), Health at a Glance 2011, OECD Publishing, París, http://dx.doi.org/10.1787/health_glance-2013-en.

OECD (2013), Education at a Glance 2011: OECD Indicators, OECD Publishing, París, http://dx.doi.org/10.1787/eag-2013-en. Versión española: Panorama de la educación 2011: Indicadores de la OCDE, Ministerio de Educación, Cultura y Deporte, Santillana, Madrid.

OECD (2010), Improving Health and Social Cohesion through Education, OECD Publishing, París. http://dx.doi.org/10.1787/ 9789264086319-en.

\section{Tablas del Indicador A8}

\section{StatLink त्नांडा http://dx.doi.org/10.1787/888933116547}

Tabla A8.1a (L) Porcentaje de adultos que refieren tener buena salud, por nivel educativo alcanzado y comprensión lectora (2012)

WEB Tabla A8.1a (N) Porcenteje de adultos que refieren tener buena salud, por nivel educativo alcanzado y competencia matemática (2012)

WEB Tabla A8.1b (L) Porcentaje de adultos que refieren tener buena salud, por nivel educativo alcanzado, comprensión lectora y sexo (2012)

WEB Tabla A8.1b (N) Porcenteje de adultos que refieren tener buena salud, por nivel educativo alcanzado, competencia matemática y sexo (2012)

Tabla A8.2a (L) Porcentaje de adultos que refieren trabajar como voluntarios al menos una vez al mes, por nivel educativo alcanzado y comprensión lectora (2012)

WEB Tabla A8.2a (N) Porcentaje de adultos que refieren trabajar como voluntarios al menos una vez al mes, por nivel educativo alcanzado y competencia matemática (2012)

WEB Tabla A8.2b (L) Porcentaje de adultos que refieren trabajar como voluntarios al menos una vez al mes, por nivel educativo alcanzado, comprensión lectora y sexo (2012)

WEB Tabla A8.2b (N) Porcentaje de adultos que refieren trabajar como voluntarios al menos una vez al mes, por nivel educativo alcanzado, competencia matemática y sexo (2012)

Tabla A8.3a (L) Porcentaje de adultos que refieren confiar en los demás, por nivel educativo alcanzado y comprensión lectora (2012)

WEB Tabla A8.3a (N) Porcentaje de adultos que refieren confiar en los demás, por nivel educativo alcanzado y competencia matemática (2012)

WEB Tabla A8.3b (L) Porcenteje de adultos que refieren confiar en los demás, por nivel educativo alcanzado, comprensión lectora y sexo (2012)

WEB Tabla A8.3b (N) Porcentaje de adultos que refieren confiar en los demás, por nivel educativo alcanzado, competencia matemática y sexo (2012)

WEB Tabla A8.3c (L) Porcentaje de adultos que refieren que los demás no se aprovechan de ellos, por nivel educativo alcanzado y comprensión lectora (2012)

WEB Tabla A8.3c (N) Porcentaje de adultos que refieren que los demás no se aprovechan de ellos, por nivel educativo alcanzado y competencia matemática (2012)

WEB Tabla A8.3d (L) Porcentaje de adultos que refieren que los demás no se aprovechan de ellos, por nivel educativo alcanzado, comprensión lectora y sexo (2012)

WEB Tabla A8.3d (N) Porcentaje de adultos que refieren que los demás no se aprovechan de ellos, por nivel educativo alcanzado, competencia matemática y sexo (2012)

Tabla A8.4a (L) Porcentaje de adultos que creen tener voz en el gobierno, por nivel educativo alcanzado y comprensión lectora (2012)

WEB Tabla A8.4a (N) Porcentaje de adultos que creen tener voz en el gobierno, por nivel educativo alcanzado y competencia matemática (2012)

WEB Tabla A8.4b (L) Porcentaje de adultos que creen tener voz en el gobierno, por nivel educativo alcanzado, comprensión lectora y sexo (2012)

WEB Tabla A8.4b (N) Porcentaje de adultos que creen tener voz en el gobierno, por nivel educativo alcanzado, competencia matemática y sexo (2012) 
Tabla A8.1a (L). [1/2] Porcentaje de adultos que refieren tener buena salud, por nivel educativo alcanzado y comprensión lectora (2012)

Nivel de comprensión lectora en la Encuesta sobre las Competencias de los Adultos, personas de 25 a 64 años

\begin{tabular}{|c|c|c|c|c|c|c|c|c|c|c|c|c|c|c|c|c|c|c|}
\hline & \multicolumn{8}{|c|}{ Inferior a educación secundaria superior } & \multicolumn{10}{|c|}{ Educación secundaria superior o postsecundaria no terciaria } \\
\hline & \multicolumn{2}{|c|}{ Nivel 0/1 } & \multicolumn{2}{|c|}{ Nivel 2} & \multicolumn{2}{|c|}{ Nivel 3} & \multicolumn{2}{|c|}{ Total } & \multicolumn{2}{|c|}{ Nivel 0/1 } & \multicolumn{2}{|c|}{ Nivel 2} & \multicolumn{2}{|c|}{ Nivel 3} & \multicolumn{2}{|c|}{ Nivel 4/5 } & \multicolumn{2}{|c|}{ Total } \\
\hline & $\%$ & E.E. & $\%$ & E.E. & $\%$ & E.E. & $\%$ & E.E. & $\%$ & E.E. & $\%$ & E.E. & $\%$ & E.E. & $\%$ & E.E. & $\%$ & E.E. \\
\hline & (1) & $(2)$ & (3) & $(4)$ & $(5)$ & $(6)$ & (9) & (10) & (11) & (12) & (13) & (14) & (15) & $(16)$ & $(17)$ & (18) & (19) & $(20)$ \\
\hline Entidades nacionales & & & & & & & & & & & & & & & & & & \\
\hline Alemania & 71 & $(4,3)$ & 80 & $(4,7)$ & 82 & $(8,2)$ & 75 & $(2,5)$ & 76 & $(2,3)$ & 87 & $(1,4)$ & 90 & $(1,4)$ & 96 & $(2,6)$ & 86 & $(0,8)$ \\
\hline Australia & 67 & $(3,2)$ & 79 & $(2,7)$ & 82 & $(3,0)$ & 76 & $(1,2)$ & 77 & $(3,5)$ & 82 & $(1,9)$ & 86 & $(1,6)$ & 85 & $(2,5)$ & 84 & $(1,1)$ \\
\hline Austria & 60 & $(3,5)$ & 69 & $(3,2)$ & 75 & $(5,3)$ & 68 & $(1,7)$ & 71 & $(2,8)$ & 81 & $(1,4)$ & 88 & $(1,2)$ & 93 & $(2,8)$ & 83 & $(0,6)$ \\
\hline Canadá & 69 & $(2,2)$ & 76 & $(2,6)$ & 87 & $(3,6)$ & 74 & $(1,7)$ & 82 & $(1,8)$ & 87 & $(1,2)$ & 89 & $(1,1)$ & 91 & $(3,3)$ & 87 & $(0,6)$ \\
\hline Corea & 22 & $(2,6)$ & 28 & $(2,7)$ & 35 & $(5,2)$ & 27 & $(1,4)$ & 41 & $(3,8)$ & 44 & $(2,0)$ & 49 & $(2,5)$ & 52 & $(9,5)$ & 46 & $(1,3)$ \\
\hline Dinamarca & 54 & $(2,9)$ & 68 & $(3,1)$ & 78 & $(3,9)$ & 64 & $(1,5)$ & 69 & $(3,0)$ & 80 & $(1,8)$ & 85 & $(1,7)$ & 89 & $(4,7)$ & 81 & $(0,9)$ \\
\hline España & 60 & $(1,7)$ & 76 & $(1,7)$ & 81 & $(3,3)$ & 69 & $(1,2)$ & 73 & $(3,9)$ & 81 & $(2,6)$ & 81 & $(3,1)$ & 92 & $(6,1)$ & 80 & $(1,4)$ \\
\hline Estados Unidos & 57 & $(4,2)$ & 70 & $(6,3)$ & 78 & $(10,1)$ & 62 & $(2,7)$ & 71 & $(2,6)$ & 79 & $(2,1)$ & 85 & $(2,1)$ & 90 & $(4,2)$ & 80 & $(1,4)$ \\
\hline Estonia & 37 & $(3,6)$ & 42 & $(3,4)$ & 47 & $(5,3)$ & 42 & $(1,8)$ & 43 & $(3,3)$ & 52 & $(1,7)$ & 62 & $(1,8)$ & 69 & $(4,7)$ & 56 & $(0,9)$ \\
\hline Finlandia & 58 & $(4,2)$ & 60 & $(4,2)$ & 70 & $(5,6)$ & 62 & $(1,8)$ & 62 & $(4,5)$ & 74 & $(2,1)$ & 81 & $(1,5)$ & 84 & $(3,2)$ & 77 & $(1,0)$ \\
\hline Francia & 61 & $(2,1)$ & 72 & $(2,2)$ & 78 & $(3,9)$ & 67 & $(1,0)$ & 71 & $(2,7)$ & 80 & $(1,5)$ & 83 & $(1,9)$ & 85 & $(4,7)$ & 80 & $(0,8)$ \\
\hline Irlanda & 71 & $(2,4)$ & 82 & $(2,4)$ & 85 & $(4,0)$ & 78 & $(1,3)$ & 88 & $(2,7)$ & 89 & $(1,5)$ & 89 & $(1,6)$ & 88 & $(5,3)$ & 89 & $(0,8)$ \\
\hline Italia & 72 & $(2,2)$ & 75 & $(2,2)$ & 75 & $(4,1)$ & 74 & $(1,3)$ & 87 & $(2,7)$ & 86 & $(1,8)$ & 88 & $(1,9)$ & 91 & $(5,0)$ & 87 & $(1,1)$ \\
\hline Japón & 53 & $(6,2)$ & 55 & $(4,8)$ & 68 & $(5,4)$ & 60 & $(2,5)$ & 63 & $(6,2)$ & 67 & $(2,5)$ & 72 & $(1,9)$ & 70 & $(4,5)$ & 70 & $(1,3)$ \\
\hline Noruega & 61 & $(4,4)$ & 65 & $(3,4)$ & 75 & $(3,3)$ & 67 & $(1,9)$ & 73 & $(4,1)$ & 79 & $(2,2)$ & 84 & $(1,8)$ & 88 & $(4,0)$ & 81 & $(1,0)$ \\
\hline Países Bajos & 59 & $(3,2)$ & 77 & $(2,6)$ & 72 & $(3,4)$ & 70 & $(1,3)$ & 64 & $(5,6)$ & 81 & $(2,0)$ & 84 & $(1,6)$ & 85 & $(3,5)$ & 81 & $(1,0)$ \\
\hline Polonia & 45 & $(4,1)$ & 59 & $(4,1)$ & 66 & $(7,9)$ & 54 & $(2,3)$ & 66 & $(2,4)$ & 76 & $(1,5)$ & 82 & $(2,1)$ & 86 & $(6,0)$ & 76 & $(0,9)$ \\
\hline República Checa & 73 & $(7,0)$ & 66 & $(6,7)$ & 68 & $(9,3)$ & 69 & $(3,6)$ & 84 & $(3,5)$ & 86 & $(1,9)$ & 90 & $(1,9)$ & 95 & $(3,7)$ & 88 & $(0,9)$ \\
\hline República Eslovaca & 51 & $(3,6)$ & 52 & $(4,1)$ & 62 & $(5,9)$ & 54 & $(2,2)$ & 75 & $(3,5)$ & 77 & $(1,5)$ & 82 & $(1,2)$ & 86 & $(4,2)$ & 79 & $(0,7)$ \\
\hline Suecia & 59 & $(4,1)$ & 71 & $(3,9)$ & 75 & $(5,9)$ & 67 & $(2,3)$ & 75 & $(3,9)$ & 82 & $(2,3)$ & 86 & $(1,5)$ & 92 & $(2,6)$ & 84 & $(0,9)$ \\
\hline Entidades subnacionales & & & & & & & & & & & & & & & & & & \\
\hline Flandes (Bélgica) & 68 & $(2,6)$ & 77 & $(2,5)$ & 76 & $(4,6)$ & 73 & $(1,6)$ & 83 & $(2,5)$ & 82 & $(1,6)$ & 87 & $(1,8)$ & 90 & $(4,1)$ & 84 & $(0,8)$ \\
\hline Inglaterra (Reino Unido) & 60 & $(2,8)$ & 76 & $(2,5)$ & 83 & $(3,9)$ & 72 & $(1,4)$ & 82 & $(3,4)$ & 83 & $(2,0)$ & 87 & $(1,8)$ & 92 & $(2,7)$ & 85 & $(1,0)$ \\
\hline $\begin{array}{l}\text { Inglaterra/Irlanda del Norte } \\
\text { (Reino Unido) }\end{array}$ & 60 & $(2,7)$ & 76 & $(2,4)$ & 83 & $(3,8)$ & 72 & $(1,3)$ & 82 & $(3,3)$ & 83 & $(2,0)$ & 87 & $(1,8)$ & 92 & $(2,7)$ & 85 & $(1,0)$ \\
\hline Irlanda del Norte (Reino Unido) & 62 & $(3,5)$ & 70 & $(3,0)$ & 73 & $(4,4)$ & 68 & $(1,8)$ & 77 & $(4,4)$ & 82 & $(2,6)$ & 85 & $(2,5)$ & 89 & $(5,1)$ & 83 & $(1,4)$ \\
\hline Media OCDE & 59 & $(0,8)$ & 67 & $(0,8)$ & 73 & $(1,2)$ & 65 & $(0,4)$ & 72 & $(0,8)$ & 78 & $(0,4)$ & 82 & $(0,4)$ & 86 & $(1,0)$ & 79 & $(0,2)$ \\
\hline Federación Rusa* & w & w & w & w & w & w & w & w & w & w & $\mathrm{w}$ & w & $\mathrm{w}$ & $\mathrm{w}$ & w & w & w & w \\
\hline
\end{tabular}

* Para los datos de Federación Rusa, véase nota en la sección de Metodología.

Nota: Las columnas que muestran datos de los Niveles 4 y 5 de comprensión lectora y del nivel inferior a educación secundaria superior están disponibles en Internet (véase StatLink más abajo).

Fuente: OCDE. Encuesta sobre las Competencias de los Adultos (PIAAC) (2012). PIAAC se refiere al Programa para la Evaluación Internacional de las Competencias de los Adultos de la OCDE. Para ver notas, consulte Anexo 3 (www.oecd.org/edu/eag.htm).

Para obtener más información acerca de los símbolos utilizados en lugar de los datos que faltan, consulte la Guía del lector.

StatLink 젶ㄴ http://dx.doi.org/10.1787/888933116566 
Tabla A8.1a (L). [2/2] Porcentaje de adultos que refieren tener buena salud, por nivel educativo alcanzado y comprensión lectora (2012)

Nivel de comprensión lectora en la Encuesta sobre las Competencias de los Adultos, personas de 25 a 64 años

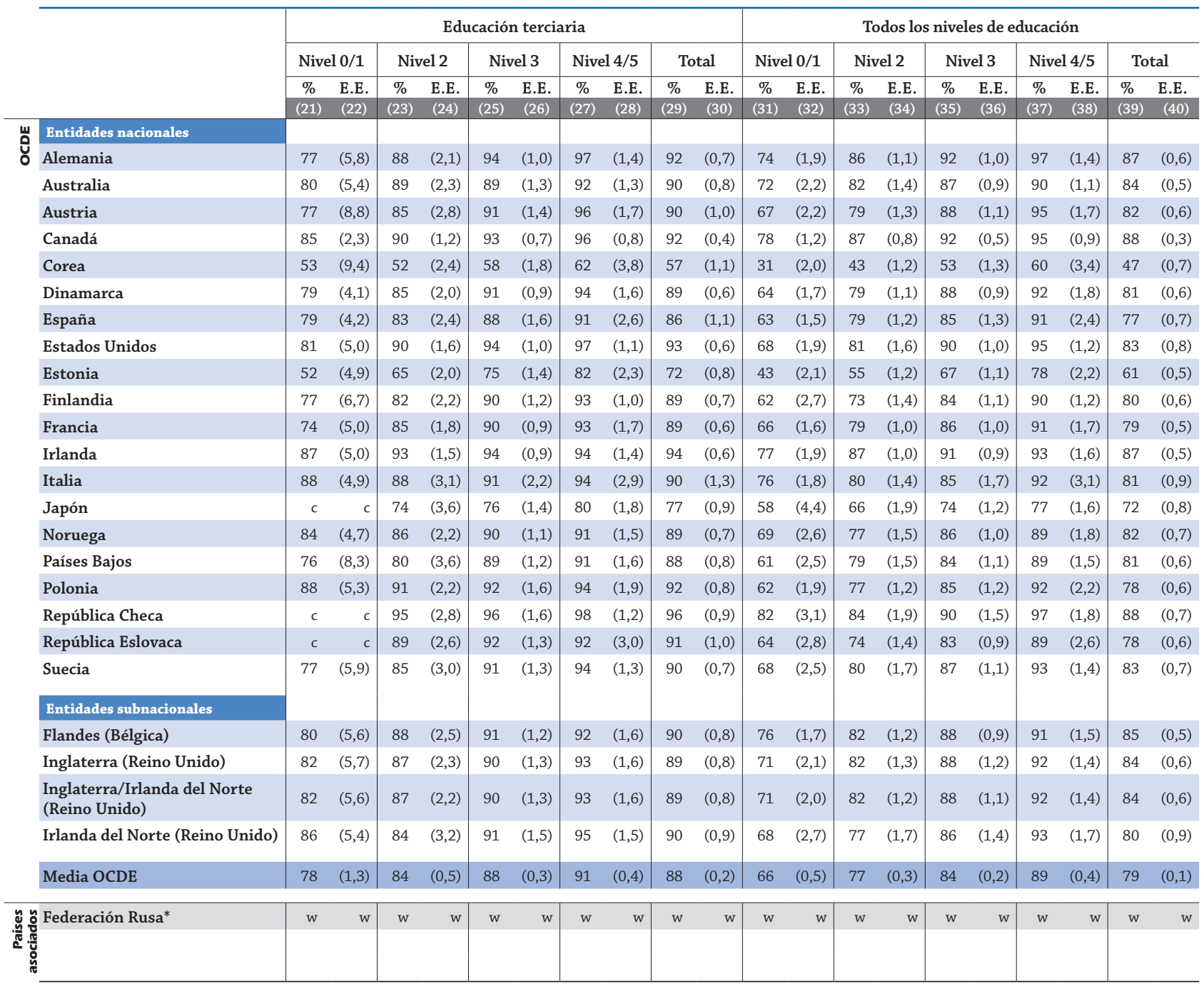

* Para los datos de Federación Rusa, véase nota en la sección de Metodología.

Nota: Las columnas que muestran datos de los Niveles 4 y 5 de comprensión lectora y del nivel inferior a educación secundaria superior están disponibles en Internet (véase StatLink más abajo).

Fuente: OCDE. Encuesta sobre las Competencias de los Adultos (PIAAC) (2012). PIAAC se refiere al Programa para la Evaluación Internacional de las Competencias de los Adultos de la OCDE. Para ver notas, consulte Anexo 3 (www.oecd.org/edu/eag.htm).

Para obtener más información acerca de los símbolos utilizados en lugar de los datos que faltan, consulte la Guía del lector.

StatLink 제이 http://dx.doi.org/10.1787/888933116566 
Tabla A8.2a (L). [1/2] Porcentaje de adultos que refieren trabajar como voluntarios al menos una vez al mes, por nivel educativo alcanzado y comprensión lectora (2012)

Nivel de comprensión lectora en la Encuesta sobre las Competencias de los Adultos, personas de 25 a 64 años

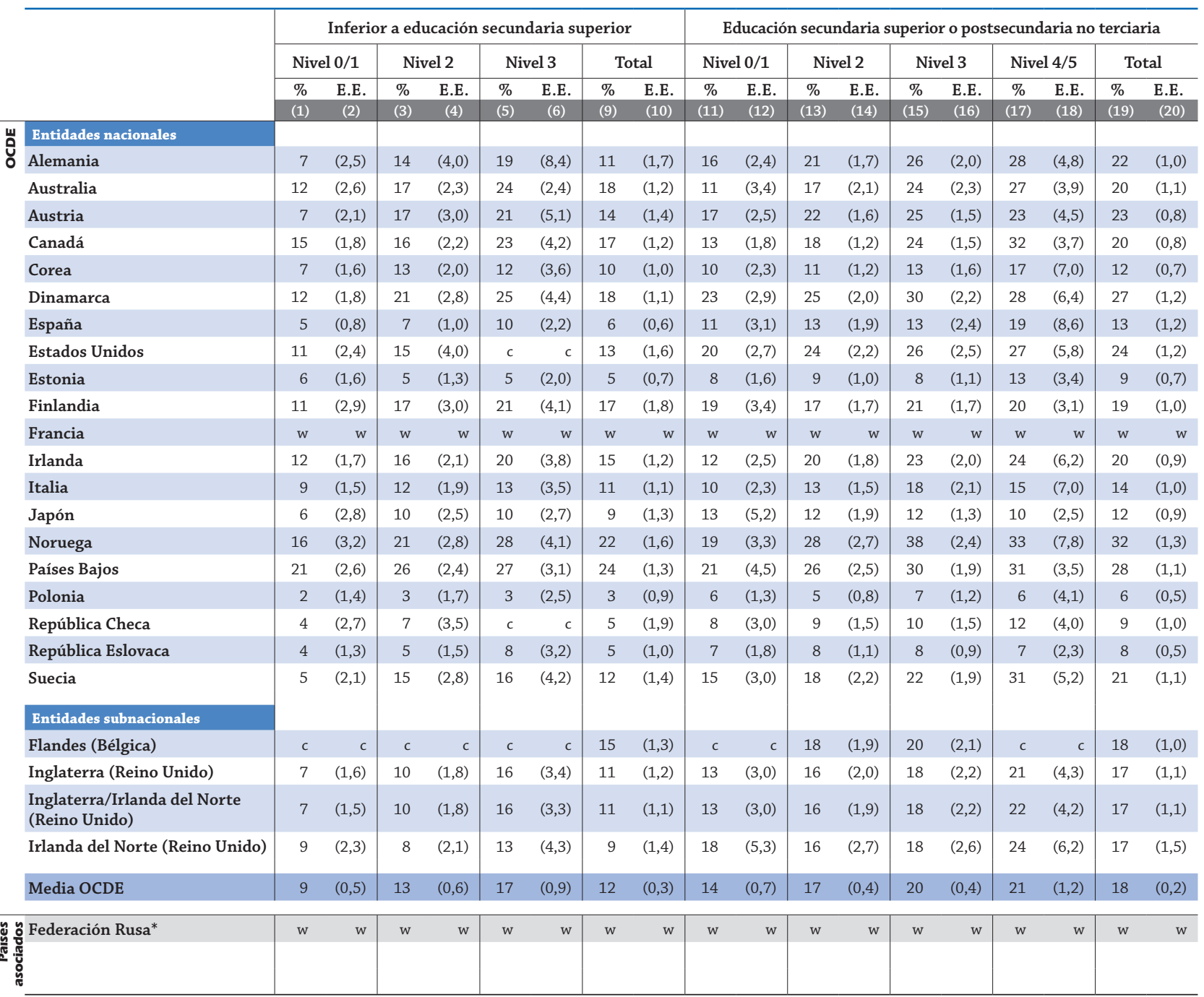

* Para los datos de Federación Rusa, véase nota en la sección de Metodología.

Nota: Las columnas que muestran datos de los Niveles 4 y 5 de comprensión lectora y del nivel inferior a educación secundaria superior están disponibles en Internet (véase StatLink más abajo).

Fuente: OCDE. Encuesta sobre las Competencias de los Adultos (PIAAC) (2012). PIAAC se refiere al Programa para la Evaluación Internacional de las Competencias de los Adultos de la OCDE. Para ver notas, consulte Anexo 3 (www.oecd.org/edu/eag.htm).

Para obtener más información acerca de los símbolos utilizados en lugar de los datos que faltan, consulte la Guía del lector.

StatLink 제내 http://dx.doi.org/10.1787/888933116585 
Tabla A8.2a (L). [2/2] Porcentaje de adultos que refieren trabajar como voluntarios al menos una vez al mes, por nivel educativo alcanzado y comprensión lectora (2012)

Nivel de comprensión lectora en la Encuesta sobre las Competencias de los Adultos, personas de 25 a 64 años

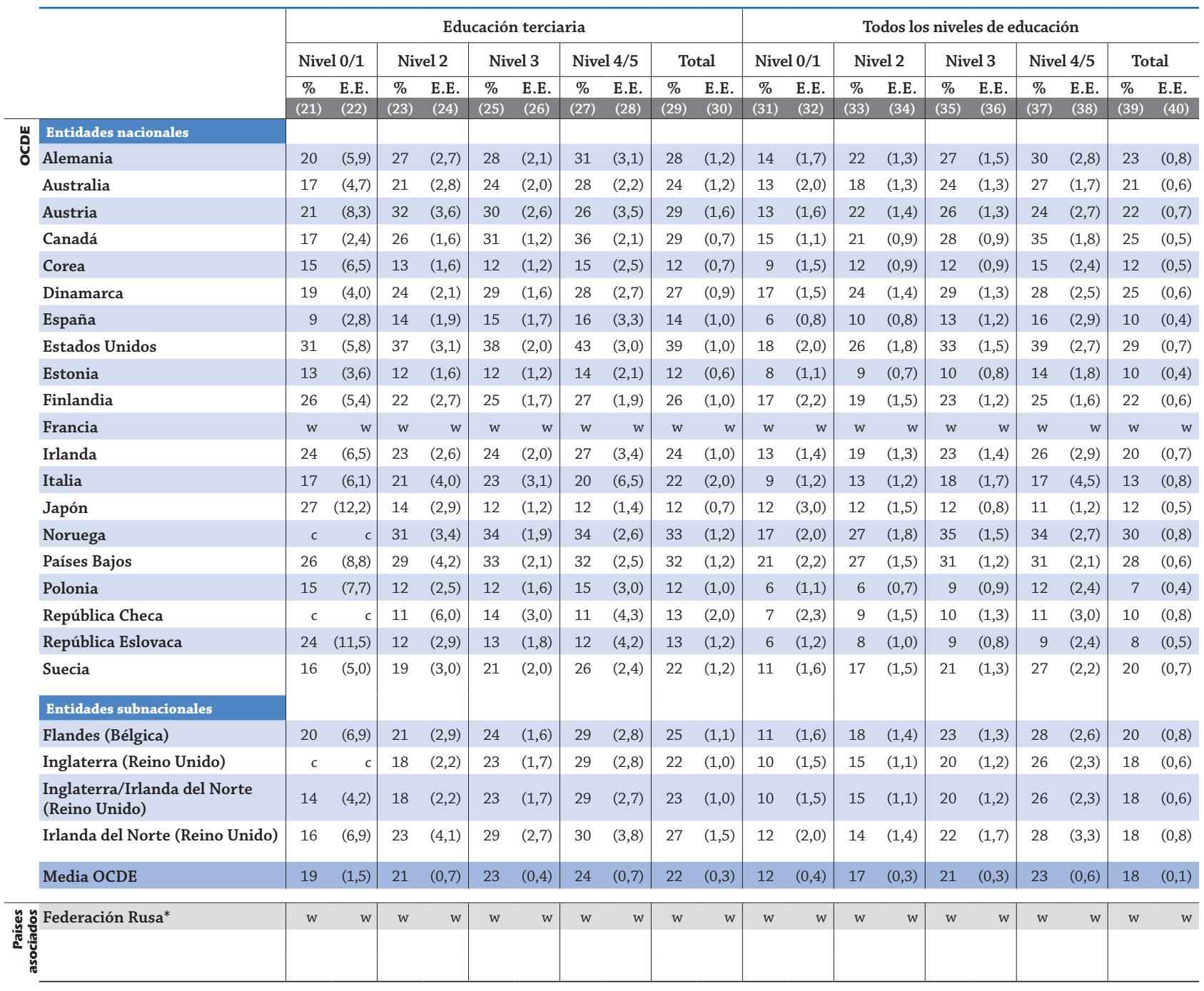

* Para los datos de Federación Rusa, véase nota en la sección de Metodología.

Nota: Las columnas que muestran datos de los Niveles 4 y 5 de comprensión lectora y del nivel inferior a educación secundaria superior están disponibles en Internet (véase StatLink más abajo).

Fuente: OCDE. Encuesta sobre las Competencias de los Adultos (PIAAC) (2012). PIAAC se refiere al Programa para la Evaluación Internacional de las Competencias de los Adultos de la OCDE. Para ver notas, consulte Anexo 3 (www.oecd.org/edu/eag.htm).

Para obtener más información acerca de los símbolos utilizados en lugar de los datos que faltan, consulte la Guía del lector.

StatLink 젬ㄴ http://dx.doi.org/10.1787/888933116585 
Tabla A8.3a (L). [1/2] Porcentaje de adultos que refieren confiar en los demás, por nivel educativo alcanzado y comprensión lectora (2012)

Nivel de comprensión lectora en la Encuesta sobre las Competencias de los Adultos, personas de 25 a 64 años

\begin{tabular}{|c|c|c|c|c|c|c|c|c|c|c|c|c|c|c|c|c|c|c|}
\hline & \multicolumn{8}{|c|}{ Inferior a educación secundaria superior } & \multicolumn{10}{|c|}{ Educación secundaria superior o postsecundaria no terciaria } \\
\hline & \multicolumn{2}{|c|}{ Nivel 0/1 } & \multicolumn{2}{|c|}{ Nivel 2} & \multicolumn{2}{|c|}{ Nivel 3} & \multicolumn{2}{|c|}{ Total } & \multicolumn{2}{|c|}{ Nivel 0/1 } & \multicolumn{2}{|c|}{ Nivel 2} & \multicolumn{2}{|c|}{ Nivel 3} & \multicolumn{2}{|c|}{ Nivel 4/5 } & \multicolumn{2}{|c|}{ Total } \\
\hline & $\%$ & E.E. & $\%$ & E.E. & $\%$ & E.E. & $\%$ & E.E. & $\%$ & E.E. & $\%$ & E.E. & $\%$ & E.E. & $\%$ & E.E. & $\%$ & E.E. \\
\hline & (1) & (2) & (3) & (4) & (5) & (6) & (9) & (10) & (11) & (12) & (13) & (14) & (15) & (16) & (17) & (18) & (19) & (20) \\
\hline Entidades nacionales & & & & & & & & & & & & & & & & & & \\
\hline Alemania & 9 & $(2,6)$ & 8 & $(2,7)$ & c & c & 8 & $(1,6)$ & 7 & $(1,6)$ & 7 & $(1,1)$ & 14 & $(1,5)$ & 21 & $(4,2)$ & 10 & $(0,7)$ \\
\hline Australia & 10 & $(1,7)$ & 14 & $(1,9)$ & 20 & $(2,1)$ & 15 & $(0,9)$ & 14 & $(3,1)$ & 15 & $(1,8)$ & 21 & $(2,1)$ & 30 & $(4,6)$ & 19 & $(1,1)$ \\
\hline Austria & 13 & $(2,7)$ & 15 & $(2,4)$ & 17 & $(3,8)$ & 15 & $(1,3)$ & 14 & $(2,5)$ & 18 & $(1,4)$ & 25 & $(1,4)$ & 34 & $(4,6)$ & 21 & $(0,9)$ \\
\hline Canadá & 14 & $(1,8)$ & 18 & $(2,5)$ & 26 & $(6,4)$ & 17 & $(1,3)$ & 18 & $(1,7)$ & 18 & $(1,3)$ & 25 & $(1,8)$ & 28 & $(4,8)$ & 21 & $(0,7)$ \\
\hline Corea & 9 & $(1,8)$ & 8 & $(1,5)$ & 7 & $(2,8)$ & 8 & $(1,0)$ & 11 & $(2,2)$ & 9 & $(1,0)$ & 10 & $(1,2)$ & 13 & $(5,4)$ & 10 & $(0,6)$ \\
\hline Dinamarca & 22 & $(2,2)$ & 31 & $(3,1)$ & 49 & $(4,8)$ & 31 & $(1,5)$ & 33 & $(3,0)$ & 39 & $(2,0)$ & 47 & $(2,2)$ & 48 & $(6,3)$ & 42 & $(1,3)$ \\
\hline España & 14 & $(1,2)$ & 16 & $(1,4)$ & 17 & $(3,1)$ & 15 & $(0,7)$ & 21 & $(3,5)$ & 17 & $(2,3)$ & 20 & $(3,0)$ & 29 & $(10,3)$ & 19 & $(1,5)$ \\
\hline Estados Unidos & 13 & $(3,1)$ & 12 & $(3,8)$ & 14 & $(8,7)$ & 13 & $(2,2)$ & 15 & $(2,0)$ & 17 & $(1,9)$ & 21 & $(2,3)$ & 28 & $(5,4)$ & 18 & $(1,1)$ \\
\hline Estonia & 9 & $(1,9)$ & 8 & $(1,9)$ & 5 & $(2,5)$ & 8 & $(0,9)$ & 7 & $(1,4)$ & 6 & $(0,8)$ & 7 & $(1,0)$ & 9 & $(2,5)$ & 7 & $(0,5)$ \\
\hline Finlandia & 12 & $(3,0)$ & 21 & $(3,6)$ & 22 & $(4,4)$ & 18 & $(1,9)$ & 23 & $(3,4)$ & 26 & $(2,0)$ & 28 & $(1,8)$ & 30 & $(3,6)$ & 27 & $(1,0)$ \\
\hline Francia & 7 & $(1,0)$ & 7 & $(1,2)$ & 7 & $(2,3)$ & 7 & $(0,6)$ & 7 & $(1,2)$ & 9 & $(0,9)$ & 9 & $(1,2)$ & 11 & $(4,5)$ & 9 & $(0,6)$ \\
\hline Irlanda & 11 & $(2,0)$ & 10 & $(1,7)$ & 12 & $(3,2)$ & 11 & $(1,0)$ & 14 & $(3,2)$ & 14 & $(1,7)$ & 15 & $(1,9)$ & 15 & $(5,6)$ & 14 & $(0,9)$ \\
\hline Italia & 5 & $(1,1)$ & 6 & $(1,2)$ & 7 & $(2,9)$ & 6 & $(0,7)$ & 9 & $(2,2)$ & 11 & $(1,8)$ & 12 & $(2,0)$ & 12 & $(4,2)$ & 11 & $(1,1)$ \\
\hline Japón & 13 & $(4,0)$ & 10 & $(2,7)$ & 11 & $(3,2)$ & 11 & $(1,5)$ & 18 & $(5,1)$ & 13 & $(1,9)$ & 14 & $(1,5)$ & 13 & $(3,4)$ & 14 & $(0,9)$ \\
\hline Noruega & 21 & $(3,6)$ & 20 & $(2,9)$ & 29 & $(4,0)$ & 24 & $(1,7)$ & 18 & $(3,6)$ & 26 & $(2,5)$ & 33 & $(2,0)$ & 35 & $(5,0)$ & 29 & $(1,1)$ \\
\hline Países Bajos & 14 & $(1,9)$ & 18 & $(2,1)$ & 29 & $(3,0)$ & 20 & $(1,2)$ & 21 & $(3,9)$ & 28 & $(2,7)$ & 32 & $(2,1)$ & 34 & $(4,1)$ & 30 & $(1,0)$ \\
\hline Polonia & 10 & $(2,5)$ & 7 & $(2,6)$ & 4 & $(2,9)$ & 8 & $(1,2)$ & 10 & $(1,5)$ & 10 & $(1,4)$ & 13 & $(1,8)$ & 20 & $(5,6)$ & 11 & $(0,8)$ \\
\hline República Checa & 4 & $(1,8)$ & c & c & c & c & 4 & $(1,1)$ & 6 & $(2,3)$ & 5 & $(1,3)$ & 5 & $(1,1)$ & 6 & $(2,6)$ & 5 & $(0,6)$ \\
\hline República Eslovaca & 9 & $(2,0)$ & 4 & $(1,3)$ & 3 & $(1,9)$ & 6 & $(0,9)$ & 8 & $(2,0)$ & 7 & $(0,9)$ & 8 & $(0,9)$ & 12 & $(3,7)$ & 8 & $(0,5)$ \\
\hline Suecia & 20 & $(3,7)$ & 23 & $(3,4)$ & 31 & $(5,1)$ & 24 & $(1,8)$ & 23 & $(3,6)$ & 27 & $(2,2)$ & 35 & $(2,1)$ & 38 & $(4,9)$ & 31 & $(1,2)$ \\
\hline Entidades subnacionales & & & & & & & & & & & & & & & & & & \\
\hline Flandes (Bélgica) & 10 & $(2,1)$ & 10 & $(2,2)$ & 6 & $(2,6)$ & 9 & $(1,2)$ & 14 & $(2,3)$ & 12 & $(1,5)$ & 13 & $(1,6)$ & 15 & $(5,5)$ & 13 & $(0,8)$ \\
\hline Inglaterra (Reino Unido) & 10 & $(2,1)$ & 8 & $(1,6)$ & 13 & $(2,9)$ & 10 & $(1,0)$ & 10 & $(2,5)$ & 12 & $(2,0)$ & 17 & $(2,2)$ & 27 & $(5,4)$ & 16 & $(1,1)$ \\
\hline $\begin{array}{l}\text { Inglaterra/Irlanda del Norte } \\
\text { (Reino Unido) }\end{array}$ & 10 & $(2,0)$ & 8 & $(1,6)$ & 12 & $(2,8)$ & 10 & $(0,9)$ & 10 & $(2,4)$ & 12 & $(1,9)$ & 17 & $(2,2)$ & 27 & $(5,2)$ & 16 & $(1,0)$ \\
\hline Irlanda del Norte (Reino Unido) & 10 & $(1,9)$ & 8 & $(1,7)$ & 10 & $(3,0)$ & 9 & $(1,1)$ & 16 & $(5,1)$ & 17 & $(2,4)$ & 17 & $(3,1)$ & 18 & $(7,9)$ & 17 & $(1,4)$ \\
\hline Media OCDE & 12 & $(0,5)$ & 13 & $(0,5)$ & 16 & $(0,9)$ & 13 & $(0,3)$ & 14 & $(0,6)$ & 16 & $(0,4)$ & 19 & $(0,4)$ & 23 & $(1,1)$ & 18 & $(0,2)$ \\
\hline Federación Rusa* & w & $\mathrm{w}$ & w & $\mathrm{w}$ & w & $\mathrm{w}$ & $\mathrm{w}$ & w & $\mathrm{w}$ & $\mathrm{w}$ & $\mathrm{w}$ & $\mathrm{w}$ & $\mathrm{w}$ & $\mathrm{w}$ & w & w & $\mathrm{w}$ & w \\
\hline
\end{tabular}

* Para los datos de Federación Rusa, véase nota en la sección de Metodología.

Nota: Las columnas que muestran datos de los Niveles 4 y 5 de comprensión lectora y del nivel inferior a educación secundaria superior están disponibles en Internet (véase StatLink más abajo).

Fuente: OCDE. Encuesta sobre las Competencias de los Adultos (PIAAC) (2012). PIAAC se refiere al Programa para la Evaluación Internacional de las Competencias de los Adultos de la OCDE. Para ver notas, consulte Anexo 3 (www.oecd.org/edu/eag.htm).

Para obtener más información acerca de los símbolos utilizados en lugar de los datos que faltan, consulte la Guía del lector.

StatLink 제피 http://dx.doi.org/10.1787/888933116604 
Tabla A8.3a (L). [2/2] Porcentaje de adultos que refieren confiar en los demás, por nivel educativo alcanzado y comprensión lectora (2012)

Nivel de comprensión lectora en la Encuesta sobre las Competencias de los Adultos, personas de 25 a 64 años

\begin{tabular}{|c|c|c|c|c|c|c|c|c|c|c|c|c|c|c|c|c|c|c|c|c|c|}
\hline & & \multicolumn{10}{|c|}{ Educación terciaria } & \multicolumn{10}{|c|}{ Todos los niveles de educación } \\
\hline & & \multicolumn{2}{|c|}{ Nivel 0/1 } & \multicolumn{2}{|c|}{ Nivel 2} & \multicolumn{2}{|c|}{ Nivel 3} & \multicolumn{2}{|c|}{ Nivel 4/5 } & \multicolumn{2}{|c|}{ Total } & \multicolumn{2}{|c|}{ Nivel 0/1 } & \multicolumn{2}{|c|}{ Nivel 2} & \multicolumn{2}{|c|}{ Nivel 3} & \multicolumn{2}{|c|}{ Nivel 4/5 } & \multicolumn{2}{|c|}{ Total } \\
\hline & & $\%$ & E.E. & $\%$ & E.E. & $\%$ & E.E. & $\%$ & E.E. & $\%$ & E.E. & $\%$ & E.E. & $\%$ & E.E. & $\%$ & E.E. & $\%$ & E.E. & $\%$ & E.E. \\
\hline & & (21) & (22) & $(23)$ & $(24)$ & $(25)$ & (26) & $(27)$ & $(28)$ & (29) & $(30)$ & $(31)$ & (32) & (33) & $(34)$ & $(35)$ & $(36)$ & $(37)$ & $(38)$ & (39) & $(40)$ \\
\hline \multirow{2}{*}{ 岁 } & Entidades nacionales & & & & & & & & & & & & & & & & & & & & \\
\hline & Alemania & 18 & $(5,5)$ & 14 & $(2,3)$ & 23 & $(1,9)$ & 30 & $(2,7)$ & 22 & $(1,0)$ & 9 & $(1,4)$ & 9 & $(1,0)$ & 18 & $(1,2)$ & 27 & $(2,3)$ & 14 & $(0,6)$ \\
\hline & Australia & 17 & $(5,3)$ & 23 & $(2,8)$ & 32 & $(2,0)$ & 41 & $(2,1)$ & 32 & $(1,0)$ & 12 & $(1,5)$ & 17 & $(1,2)$ & 25 & $(1,3)$ & 37 & $(1,8)$ & 23 & $(0,7)$ \\
\hline & Austria & 18 & $(7,3)$ & 21 & $(3,3)$ & 34 & $(2,9)$ & 40 & $(4,5)$ & 31 & $(1,6)$ & 14 & $(1,7)$ & 18 & $(1,1)$ & 27 & $(1,3)$ & 37 & $(3,5)$ & 22 & $(0,7)$ \\
\hline & Canadá & 18 & $(2,5)$ & 24 & $(1,4)$ & 33 & $(1,2)$ & 37 & $(2,1)$ & 30 & $(0,7)$ & 17 & $(1,1)$ & 21 & $(0,9)$ & 30 & $(1,0)$ & 36 & $(2,1)$ & 26 & $(0,5)$ \\
\hline & Corea & 21 & $(6,6)$ & 17 & $(1,6)$ & 16 & $(1,1)$ & 18 & $(2,9)$ & 17 & $(0,7)$ & 10 & $(1,3)$ & 11 & $(0,7)$ & 13 & $(0,8)$ & 17 & $(2,6)$ & 12 & $(0,4)$ \\
\hline & Dinamarca & 46 & $(4,5)$ & 58 & $(2,3)$ & 65 & $(1,5)$ & 67 & $(2,9)$ & 63 & $(1,0)$ & 30 & $(1,7)$ & 43 & $(1,2)$ & 57 & $(1,2)$ & 63 & $(2,6)$ & 48 & $(0,7)$ \\
\hline & España & 23 & $(4,8)$ & 27 & $(2,3)$ & 34 & $(2,0)$ & 36 & $(4,6)$ & 31 & $(1,2)$ & 16 & $(1,2)$ & 19 & $(1,1)$ & 27 & $(1,5)$ & 34 & $(4,2)$ & 21 & $(0,6)$ \\
\hline & Estados Unidos & 20 & $(6,4)$ & 26 & $(2,8)$ & 32 & $(1,7)$ & 39 & $(2,9)$ & 31 & $(1,2)$ & 15 & $(2,1)$ & 19 & $(1,5)$ & 26 & $(1,5)$ & 37 & $(2,7)$ & 23 & $(0,8)$ \\
\hline & Estonia & 11 & $(2,7)$ & 12 & $(1,6)$ & 16 & $(1,4)$ & 17 & $(2,1)$ & 15 & $(0,7)$ & 8 & $(1,1)$ & 8 & $(0,7)$ & 11 & $(0,8)$ & 14 & $(1,5)$ & 10 & $(0,4)$ \\
\hline & Finlandia & 40 & $(7,6)$ & 37 & $(3,0)$ & 43 & $(1,8)$ & 47 & $(2,1)$ & 44 & $(1,1)$ & 21 & $(2,3)$ & 28 & $(1,5)$ & 35 & $(1,3)$ & 42 & $(1,9)$ & 33 & $(0,7)$ \\
\hline & Francia & 7 & $(2,6)$ & 14 & $(1,8)$ & 18 & $(1,3)$ & 18 & $(2,2)$ & 17 & $(0,8)$ & 7 & $(0,7)$ & 10 & $(0,7)$ & 13 & $(0,8)$ & 16 & $(1,9)$ & 11 & $(0,4)$ \\
\hline & Irlanda & 18 & $(5,5)$ & 18 & $(2,1)$ & 23 & $(1,7)$ & 30 & $(2,7)$ & 23 & $(1,0)$ & 13 & $(1,7)$ & 14 & $(0,9)$ & 19 & $(1,1)$ & 27 & $(2,6)$ & 16 & $(0,6)$ \\
\hline & Italia & 13 & $(5,5)$ & 12 & $(3,2)$ & 18 & $(2,6)$ & 16 & $(5,6)$ & 15 & $(1,4)$ & 6 & $(0,9)$ & 8 & $(0,9)$ & 13 & $(1,3)$ & 14 & $(3,7)$ & 9 & $(0,6)$ \\
\hline & Japón & c & c & 17 & $(2,8)$ & 23 & $(1,4)$ & 24 & $(1,7)$ & 23 & $(0,9)$ & 16 & $(3,1)$ & 14 & $(1,4)$ & 18 & $(1,0)$ & 21 & $(1,4)$ & 18 & $(0,6)$ \\
\hline & Noruega & 28 & $(5,6)$ & 42 & $(3,8)$ & 51 & $(2,0)$ & 54 & $(2,7)$ & 49 & $(1,2)$ & 21 & $(2,3)$ & 28 & $(1,9)$ & 41 & $(1,3)$ & 50 & $(2,4)$ & 36 & $(0,8)$ \\
\hline & Países Bajos & 19 & $(8,8)$ & 38 & $(4,1)$ & 45 & $(2,2)$ & 50 & $(2,6)$ & 45 & $(1,3)$ & 16 & $(1,7)$ & 25 & $(1,7)$ & 36 & $(1,3)$ & 45 & $(2,2)$ & 32 & $(0,6)$ \\
\hline & Polonia & 17 & $(6,3)$ & 21 & $(3,3)$ & 24 & $(2,4)$ & 30 & $(3,6)$ & 24 & $(1,3)$ & 11 & $(1,3)$ & 12 & $(1,1)$ & 17 & $(1,3)$ & 28 & $(3,1)$ & 15 & $(0,6)$ \\
\hline & República Checa & c & c & 7 & $(4,4)$ & 16 & $(3,6)$ & 22 & $(5,1)$ & 16 & $(2,2)$ & 5 & $(1,6)$ & 5 & $(1,1)$ & 8 & $(1,4)$ & 15 & $(3,7)$ & 7 & $(0,7)$ \\
\hline & República Eslovaca & $c$ & c & 11 & $(2,7)$ & 12 & $(1,5)$ & 19 & $(4,1)$ & 13 & $(1,1)$ & 9 & $(1,6)$ & 7 & $(0,8)$ & 9 & $(0,8)$ & 15 & $(3,0)$ & 9 & $(0,4)$ \\
\hline & Suecia & 22 & $(5,6)$ & 41 & $(4,1)$ & 50 & $(2,1)$ & 55 & $(2,4)$ & 49 & $(1,3)$ & 21 & $(2,3)$ & 29 & $(1,6)$ & 40 & $(1,5)$ & 49 & $(2,3)$ & 36 & $(0,8)$ \\
\hline \multicolumn{22}{|c|}{ Entidades subnacionales } \\
\hline & Flandes (Bélgica) & 30 & $(7,9)$ & 29 & $(4,2)$ & 29 & $(2,1)$ & 29 & $(2,7)$ & 29 & $(1,2)$ & 13 & $(1,7)$ & 15 & $(1,3)$ & 21 & $(1,2)$ & 26 & $(2,5)$ & 19 & $(0,6)$ \\
\hline & Inglaterra (Reino Unido) & 21 & $(5,6)$ & 21 & $(2,8)$ & 25 & $(2,0)$ & 36 & $(3,1)$ & 27 & $(1,2)$ & 12 & $(1,6)$ & 13 & $(1,3)$ & 21 & $(1,4)$ & 32 & $(2,8)$ & 19 & $(0,7)$ \\
\hline & $\begin{array}{l}\text { Inglaterra/Irlanda del Norte } \\
\text { (Reino Unido) }\end{array}$ & 20 & $(5,5)$ & 21 & $(2,7)$ & 25 & $(1,9)$ & 36 & $(3,1)$ & 26 & $(1,2)$ & 12 & $(1,6)$ & 13 & $(1,3)$ & 21 & $(1,4)$ & 32 & $(2,8)$ & 18 & $(0,7)$ \\
\hline & Irlanda del Norte (Reino Unido) & 10 & $(6,3)$ & 18 & $(3,4)$ & 24 & $(2,4)$ & 30 & $(4,1)$ & 23 & $(1,6)$ & 11 & $(1,9)$ & 14 & $(1,5)$ & 19 & $(1,8)$ & 26 & $(4,0)$ & 16 & $(0,8)$ \\
\hline & Media OCDE & 21 & $(1,3)$ & 24 & $(0,6)$ & 30 & $(0,4)$ & 34 & $(0,7)$ & 29 & $(0,3)$ & 14 & $(0,4)$ & 17 & $(0,3)$ & 24 & $(0,3)$ & 31 & $(0,6)$ & 21 & $(0,1)$ \\
\hline 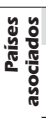 & Federación Rusa* & $w$ & $\mathrm{w}$ & w & $w$ & $\mathrm{w}$ & $\mathrm{w}$ & w & $\mathrm{w}$ & $\mathrm{w}$ & $\mathrm{w}$ & $\mathrm{w}$ & $\mathrm{w}$ & $\mathrm{w}$ & $\mathrm{w}$ & $\mathrm{w}$ & $\mathrm{w}$ & w & $\mathrm{w}$ & w & W \\
\hline
\end{tabular}

* Para los datos de Federación Rusa, véase nota en la sección de Metodología.

Nota: Las columnas que muestran datos de los Niveles 4 y 5 de comprensión lectora y del nivel inferior a educación secundaria superior están disponibles en Internet (véase StatLink más abajo)

Fuente: OCDE. Encuesta sobre las Competencias de los Adultos (PIAAC) (2012). PIAAC se refiere al Programa para la Evaluación Internacional de las Competencias de los Adultos de la OCDE. Para ver notas, consulte Anexo 3 (www.oecd.org/edu/eag.htm).

Para obtener más información acerca de los símbolos utilizados en lugar de los datos que faltan, consulte la Guía del lector.

StatLink 젠ㅁ http://dx.doi.org/10.1787/888933116604 
Tabla A8.4a (L). [1/2] Porcentaje de adultos que creen tener voz en el gobierno, por nivel educativo alcanzado y comprensión lectora (2012)

Nivel de comprensión lectora en la Encuesta sobre las Competencias de los Adultos, personas de 25 a 64 años

\begin{tabular}{|c|c|c|c|c|c|c|c|c|c|c|c|c|c|c|c|c|c|c|}
\hline & \multicolumn{8}{|c|}{ Inferior a educación secundaria superior } & \multicolumn{10}{|c|}{ Educación secundaria superior o postsecundaria no terciaria } \\
\hline & \multicolumn{2}{|c|}{ Nivel 0/1 } & \multicolumn{2}{|c|}{ Nivel 2} & \multicolumn{2}{|c|}{ Nivel 3} & \multicolumn{2}{|c|}{ Total } & \multicolumn{2}{|c|}{ Nivel 0/1 } & \multicolumn{2}{|c|}{ Nivel 2} & \multicolumn{2}{|c|}{ Nivel 3} & \multicolumn{2}{|c|}{ Nivel 4/5 } & \multicolumn{2}{|c|}{ Total } \\
\hline & $\%$ & E.E. & $\%$ & E.E. & $\%$ & E.E. & $\%$ & E.E. & $\%$ & E.E. & $\%$ & E.E. & $\%$ & E.E. & $\%$ & E.E. & $\%$ & E.E. \\
\hline & (1) & (2) & (3) & (4) & (5) & (6) & (9) & (10) & (11) & (12) & (13) & (14) & (15) & (16) & (17) & (18) & (19) & (20) \\
\hline Entidades nacionales & & & & & & & & & & & & & & & & & & \\
\hline Alemania & 12 & $(2,9)$ & 15 & $(3,9)$ & 13 & $(8,2)$ & 13 & $(2,1)$ & 17 & $(2,3)$ & 18 & $(1,5)$ & 26 & $(1,9)$ & 31 & $(5,0)$ & 21 & $(0,8)$ \\
\hline Australia & 18 & $(2,6)$ & 21 & $(2,3)$ & 30 & $(3,1)$ & 24 & $(1,3)$ & 23 & $(3,5)$ & 26 & $(2,3)$ & 32 & $(2,3)$ & 43 & $(4,3)$ & 30 & $(1,1)$ \\
\hline Austria & 15 & $(3,0)$ & 18 & $(2,5)$ & 25 & $(4,2)$ & 19 & $(1,6)$ & 23 & $(2,6)$ & 26 & $(1,6)$ & 35 & $(1,9)$ & 40 & $(4,9)$ & 30 & $(1,0)$ \\
\hline Canadá & 20 & $(2,1)$ & 21 & $(2,5)$ & 35 & $(6,0)$ & 22 & $(1,4)$ & 24 & $(2,1)$ & 28 & $(1,5)$ & 37 & $(1,7)$ & 37 & $(4,9)$ & 31 & $(0,9)$ \\
\hline Corea & 21 & $(2,4)$ & 31 & $(2,7)$ & 39 & $(5,6)$ & 28 & $(1,5)$ & 24 & $(3,4)$ & 27 & $(1,7)$ & 35 & $(2,1)$ & 40 & $(7,8)$ & 30 & $(1,2)$ \\
\hline Dinamarca & 33 & $(3,1)$ & 42 & $(3,3)$ & 55 & $(4,9)$ & 41 & $(1,6)$ & 37 & $(2,8)$ & 46 & $(2,3)$ & 51 & $(2,8)$ & 54 & $(8,0)$ & 47 & $(1,2)$ \\
\hline España & 18 & $(1,6)$ & 21 & $(1,8)$ & 20 & $(2,7)$ & 19 & $(0,9)$ & 21 & $(3,8)$ & 23 & $(2,7)$ & 23 & $(2,8)$ & 29 & $(12,2)$ & 23 & $(1,4)$ \\
\hline Estados Unidos & 29 & $(3,2)$ & 28 & $(6,6)$ & 28 & $(12,7)$ & 29 & $(2,4)$ & 37 & $(2,5)$ & 37 & $(2,1)$ & 47 & $(2,9)$ & 58 & $(6,1)$ & 41 & $(1,2)$ \\
\hline Estonia & 17 & $(2,4)$ & 16 & $(2,2)$ & 17 & $(3,0)$ & 17 & $(1,2)$ & 12 & $(1,8)$ & 17 & $(1,2)$ & 27 & $(1,6)$ & 38 & $(4,0)$ & 21 & $(0,8)$ \\
\hline Finlandia & 27 & $(4,4)$ & 32 & $(3,6)$ & 33 & $(4,9)$ & 31 & $(2,4)$ & 42 & $(3,8)$ & 39 & $(2,7)$ & 42 & $(2,3)$ & 51 & $(4,3)$ & 42 & $(1,2)$ \\
\hline Francia & $\mathrm{w}$ & w & w & w & w & w & $\mathrm{w}$ & w & $\mathrm{w}$ & $\mathrm{w}$ & $\mathrm{w}$ & $\mathrm{w}$ & $\mathrm{w}$ & w & $\mathrm{w}$ & w & w & $\mathrm{w}$ \\
\hline Irlanda & 18 & $(2,3)$ & 16 & $(2,3)$ & 19 & $(4,3)$ & 18 & $(1,4)$ & 16 & $(2,9)$ & 25 & $(1,8)$ & 28 & $(2,2)$ & 37 & $(7,0)$ & 26 & $(1,2)$ \\
\hline Italia & 11 & $(1,7)$ & 13 & $(2,0)$ & 16 & $(4,0)$ & 12 & $(1,3)$ & 13 & $(2,5)$ & 19 & $(1,8)$ & 22 & $(2,2)$ & 26 & $(7,1)$ & 19 & $(1,1)$ \\
\hline Japón & 14 & $(4,2)$ & 14 & $(3,4)$ & 22 & $(4,0)$ & 17 & $(1,8)$ & 14 & $(4,4)$ & 16 & $(1,9)$ & 23 & $(1,6)$ & 34 & $(3,7)$ & 22 & $(1,0)$ \\
\hline Noruega & 24 & $(4,0)$ & 28 & $(3,1)$ & 43 & $(4,2)$ & 32 & $(1,8)$ & 29 & $(4,0)$ & 39 & $(2,8)$ & 50 & $(2,6)$ & 59 & $(5,9)$ & 44 & $(1,6)$ \\
\hline Países Bajos & 22 & $(2,6)$ & 28 & $(2,2)$ & 35 & $(3,0)$ & 28 & $(1,5)$ & 33 & $(4,6)$ & 30 & $(2,4)$ & 36 & $(2,2)$ & 50 & $(4,3)$ & 36 & $(1,3)$ \\
\hline Polonia & $\mathrm{w}$ & $\mathrm{w}$ & w & w & $\mathrm{w}$ & $\mathrm{w}$ & w & $\mathrm{w}$ & $\mathrm{w}$ & $\mathrm{w}$ & $\mathrm{w}$ & $\mathrm{w}$ & $\mathrm{w}$ & $\mathrm{w}$ & $\mathrm{w}$ & $\mathrm{w}$ & $\mathrm{w}$ & w \\
\hline República Checa & 19 & $(6,3)$ & 19 & $(5,3)$ & 17 & $(6,9)$ & 19 & $(3,0)$ & 15 & $(3,8)$ & 17 & $(2,0)$ & 24 & $(2,4)$ & 22 & $(7,6)$ & 20 & $(1,2)$ \\
\hline República Eslovaca & 9 & $(2,1)$ & 12 & $(2,3)$ & 14 & $(3,6)$ & 11 & $(1,1)$ & 16 & $(2,8)$ & 20 & $(1,5)$ & 20 & $(1,5)$ & 27 & $(4,5)$ & 20 & $(0,8)$ \\
\hline Suecia & 27 & $(4,0)$ & 34 & $(4,2)$ & 41 & $(5,7)$ & 34 & $(2,5)$ & 30 & $(4,7)$ & 34 & $(2,4)$ & 49 & $(2,2)$ & 56 & $(4,8)$ & 43 & $(1,2)$ \\
\hline Entidades subnacionales & & & & & & & & & & & & & & & & & & \\
\hline Flandes (Bélgica) & 22 & $(2,7)$ & 22 & $(2,6)$ & 27 & $(4,4)$ & 23 & $(1,4)$ & 28 & $(3,2)$ & 26 & $(2,0)$ & 27 & $(2,2)$ & 32 & $(5,8)$ & 27 & $(1,0)$ \\
\hline Inglaterra (Reino Unido) & 18 & $(2,8)$ & 20 & $(2,5)$ & 29 & $(4,3)$ & 22 & $(1,5)$ & 21 & $(3,9)$ & 27 & $(2,6)$ & 31 & $(2,4)$ & 41 & $(5,3)$ & 29 & $(1,4)$ \\
\hline $\begin{array}{l}\text { Inglaterra/Irlanda del Norte } \\
\text { (Reino Unido) }\end{array}$ & 18 & $(2,6)$ & 20 & $(2,4)$ & 29 & $(4,1)$ & 21 & $(1,5)$ & 20 & $(3,8)$ & 27 & $(2,6)$ & 31 & $(2,3)$ & 40 & $(5,2)$ & 29 & $(1,3)$ \\
\hline Irlanda del Norte (Reino Unido) & 14 & $(2,1)$ & 15 & $(2,1)$ & 14 & $(3,8)$ & 15 & $(1,0)$ & 17 & $(4,8)$ & 19 & $(2,7)$ & 23 & $(3,0)$ & 32 & $(7,0)$ & 21 & $(1,5)$ \\
\hline Media OCDE & 20 & $(0,7)$ & 23 & $(0,7)$ & 28 & $(1,2)$ & 23 & $(0,4)$ & 24 & $(0,8)$ & 27 & $(0,5)$ & 33 & $(0,5)$ & 40 & $(1,4)$ & 30 & $(0,3)$ \\
\hline Federación Rusa* & $\mathrm{w}$ & $\mathrm{w}$ & w & w & w & w & w & $\mathrm{w}$ & w & w & w & w & w & $\mathrm{w}$ & w & w & $\mathrm{w}$ & w \\
\hline
\end{tabular}

* Para los datos de Federación Rusa, véase nota en la sección de Metodología.

Nota: Las columnas que muestran datos de los Niveles 4 y 5 de comprensión lectora y del nivel inferior a educación secundaria superior están disponibles en Internet (véase StatLink más abajo).

Fuente: OCDE. Encuesta sobre las Competencias de los Adultos (PIAAC) (2012). PIAAC se refiere al Programa para la Evaluación Internacional de las Competencias de los Adultos de la OCDE. Para ver notas, consulte Anexo 3 (www.oecd.org/edu/eag.htm).

Para obtener más información acerca de los símbolos utilizados en lugar de los datos que faltan, consulte la Guía del lector.

StatLink 젶ㄴ http://dx.doi.org/10.1787/888933116623 
Tabla A8.4a (L). [2/2] Porcentaje de adultos que creen tener voz en el gobierno, por nivel educativo alcanzado y comprensión lectora (2012)

Nivel de comprensión lectora en la Encuesta sobre las Competencias de los Adultos, personas de 25 a 64 años

\begin{tabular}{|c|c|c|c|c|c|c|c|c|c|c|c|c|c|c|c|c|c|c|c|c|c|}
\hline & & \multicolumn{10}{|c|}{ Educación terciaria } & \multicolumn{10}{|c|}{ Todos los niveles de educación } \\
\hline & & \multicolumn{2}{|c|}{ Nivel 0/1 } & \multicolumn{2}{|c|}{ Nivel 2} & \multicolumn{2}{|c|}{ Nivel 3} & \multicolumn{2}{|c|}{ Nivel 4/5 } & \multicolumn{2}{|c|}{ Total } & \multicolumn{2}{|c|}{ Nivel 0/1 } & \multicolumn{2}{|c|}{ Nivel 2} & \multicolumn{2}{|c|}{ Nivel 3} & \multicolumn{2}{|c|}{ Nivel 4/5 } & \multicolumn{2}{|c|}{ Total } \\
\hline & & $\%$ & E.E. & $\%$ & E.E. & $\%$ & E.E. & $\%$ & E.E. & $\%$ & E.E. & $\%$ & E.E. & $\%$ & E.E. & $\%$ & E.E. & $\%$ & E.E. & $\%$ & E.E. \\
\hline & & (21) & (22) & $(23)$ & (24) & $(25)$ & (26) & $(27)$ & (28) & (29) & (30) & $(31)$ & (32) & (33) & (34) & (35) & $(36)$ & $(37)$ & (38) & (39) & $(40)$ \\
\hline \multirow{2}{*}{ 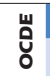 } & Entidades nacionales & & & & & & & & & & & & & & & & & & & & \\
\hline & Alemania & 17 & $(5,1)$ & 27 & $(2,9)$ & 35 & $(2,0)$ & 38 & $(3,1)$ & 33 & $(1,3)$ & 15 & $(1,8)$ & 20 & $(1,2)$ & 30 & $(1,3)$ & 35 & $(2,5)$ & 24 & $(0,7)$ \\
\hline & Australia & 24 & $(6,9)$ & 36 & $(2,9)$ & 43 & $(2,2)$ & 57 & $(2,6)$ & 45 & $(1,2)$ & 20 & $(1,9)$ & 27 & $(1,5)$ & 36 & $(1,4)$ & 53 & $(2,0)$ & 34 & $(0,6)$ \\
\hline & Austria & 32 & $(10,4)$ & 35 & $(3,9)$ & 46 & $(2,6)$ & 47 & $(4,4)$ & 43 & $(1,6)$ & 20 & $(2,0)$ & 25 & $(1,3)$ & 37 & $(1,5)$ & 44 & $(2,9)$ & 30 & $(0,8)$ \\
\hline & Canadá & 29 & $(2,6)$ & 35 & $(1,7)$ & 43 & $(1,4)$ & 51 & $(2,1)$ & 42 & $(0,8)$ & 24 & $(1,3)$ & 30 & $(1,0)$ & 41 & $(1,1)$ & 49 & $(1,9)$ & 36 & $(0,5)$ \\
\hline & Corea & 30 & $(8,0)$ & 34 & $(2,2)$ & 44 & $(1,8)$ & 51 & $(3,9)$ & 42 & $(1,3)$ & 23 & $(2,0)$ & 30 & $(1,2)$ & 41 & $(1,4)$ & 48 & $(3,6)$ & 35 & $(0,8)$ \\
\hline & Dinamarca & 36 & $(4,8)$ & 54 & $(2,6)$ & 61 & $(1,8)$ & 63 & $(3,1)$ & 59 & $(1,1)$ & 35 & $(1,9)$ & 47 & $(1,5)$ & 57 & $(1,6)$ & 61 & $(3,1)$ & 51 & $(0,8)$ \\
\hline & España & 24 & $(5,3)$ & 28 & $(2,7)$ & 31 & $(2,2)$ & 37 & $(4,3)$ & 30 & $(1,2)$ & 19 & $(1,6)$ & 23 & $(1,2)$ & 27 & $(1,6)$ & 35 & $(3,9)$ & 24 & $(0,6)$ \\
\hline & Estados Unidos & 32 & $(6,3)$ & 47 & $(2,8)$ & 55 & $(2,0)$ & 63 & $(3,2)$ & 54 & $(1,5)$ & 34 & $(1,8)$ & 39 & $(1,7)$ & 51 & $(1,7)$ & 62 & $(3,0)$ & 45 & $(1,0)$ \\
\hline & Estonia & 18 & $(3,5)$ & 21 & $(1,9)$ & 34 & $(1,6)$ & 47 & $(2,8)$ & 32 & $(1,0)$ & 15 & $(1,4)$ & 18 & $(1,0)$ & 30 & $(1,0)$ & 44 & $(2,4)$ & 25 & $(0,5)$ \\
\hline & Finlandia & 41 & $(7,4)$ & 51 & $(3,6)$ & 57 & $(2,2)$ & 66 & $(2,0)$ & 59 & $(1,1)$ & 36 & $(2,8)$ & 41 & $(1,9)$ & 49 & $(1,5)$ & 61 & $(2,0)$ & 48 & $(0,8)$ \\
\hline & Francia & w & $\mathrm{w}$ & w & $\mathrm{w}$ & w & $\mathrm{w}$ & w & $\mathrm{w}$ & w & w & w & w & w & $\mathrm{w}$ & w & w & w & $\mathrm{w}$ & w & w \\
\hline & Irlanda & 35 & $(6,6)$ & 34 & $(2,9)$ & 39 & $(1,9)$ & 44 & $(3,5)$ & 38 & $(1,2)$ & 20 & $(1,8)$ & 24 & $(1,2)$ & 32 & $(1,4)$ & 42 & $(3,3)$ & 28 & $(0,7)$ \\
\hline & Italia & 26 & $(7,4)$ & 31 & $(4,5)$ & 26 & $(3,3)$ & 37 & $(8,3)$ & 29 & $(2,2)$ & 12 & $(1,4)$ & 17 & $(1,4)$ & 22 & $(1,8)$ & 31 & $(5,4)$ & 17 & $(0,9)$ \\
\hline & Japón & c & c & 24 & $(3,3)$ & 32 & $(1,5)$ & 41 & $(2,0)$ & 34 & $(1,0)$ & 16 & $(3,2)$ & 18 & $(1,6)$ & 27 & $(1,1)$ & 38 & $(1,8)$ & 27 & $(0,6)$ \\
\hline & Noruega & 36 & $(5,6)$ & 52 & $(3,5)$ & 67 & $(2,0)$ & 74 & $(2,5)$ & 65 & $(1,1)$ & 27 & $(2,5)$ & 39 & $(1,8)$ & 57 & $(1,5)$ & 70 & $(2,3)$ & 50 & $(0,8)$ \\
\hline & Países Bajos & 28 & $(10,0)$ & 46 & $(4,5)$ & 54 & $(2,2)$ & 62 & $(2,6)$ & 55 & $(1,5)$ & 25 & $(2,4)$ & 32 & $(1,6)$ & 43 & $(1,5)$ & 58 & $(2,3)$ & 41 & $(0,9)$ \\
\hline & Polonia & w & $\mathrm{w}$ & w & $\mathrm{w}$ & w & $\mathrm{w}$ & $\mathrm{w}$ & w & w & w & $\mathrm{w}$ & w & $\mathrm{w}$ & $\mathrm{w}$ & w & w & w & $\mathrm{w}$ & $\mathrm{w}$ & w \\
\hline & República Checa & c & c & 25 & $(6,4)$ & 27 & $(4,0)$ & 34 & $(4,9)$ & 28 & $(2,4)$ & 16 & $(3,2)$ & 18 & $(2,0)$ & 24 & $(2,2)$ & 29 & $(3,9)$ & 21 & $(1,1)$ \\
\hline & República Eslovaca & $c$ & c & 23 & $(3,8)$ & 36 & $(2,8)$ & 48 & $(6,4)$ & 35 & $(2,0)$ & 13 & $(2,0)$ & 19 & $(1,2)$ & 24 & $(1,4)$ & 37 & $(3,6)$ & 22 & $(0,7)$ \\
\hline & Suecia & 44 & $(6,5)$ & 45 & $(4,2)$ & 56 & $(2,3)$ & 62 & $(2,4)$ & 56 & $(1,4)$ & 30 & $(2,9)$ & 36 & $(1,8)$ & 51 & $(1,5)$ & 60 & $(2,1)$ & 46 & $(0,9)$ \\
\hline \multicolumn{22}{|c|}{ Entidades subnacionales } \\
\hline & Flandes (Bélgica) & 33 & $(9,3)$ & 39 & $(3,9)$ & 43 & $(2,1)$ & 50 & $(2,8)$ & 44 & $(1,3)$ & 26 & $(1,9)$ & 28 & $(1,4)$ & 36 & $(1,4)$ & 46 & $(2,5)$ & 33 & $(0,8)$ \\
\hline & Inglaterra (Reino Unido) & 33 & $(6,7)$ & 33 & $(3,2)$ & 43 & $(2,4)$ & 52 & $(3,2)$ & 42 & $(1,4)$ & 21 & $(2,3)$ & 27 & $(1,8)$ & 37 & $(1,6)$ & 48 & $(2,7)$ & 33 & $(0,9)$ \\
\hline & $\begin{array}{l}\text { Inglaterra/Irlanda del Norte } \\
\text { (Reino Unido) }\end{array}$ & 33 & $(6,6)$ & 33 & $(3,1)$ & 43 & $(2,3)$ & 52 & $(3,1)$ & 42 & $(1,4)$ & 21 & $(2,2)$ & 26 & $(1,7)$ & 36 & $(1,5)$ & 48 & $(2,6)$ & 32 & $(0,9)$ \\
\hline & Irlanda del Norte (Reino Unido) & 23 & $(8,2)$ & 31 & $(4,6)$ & 35 & $(2,9)$ & 47 & $(4,5)$ & 36 & $(1,9)$ & 16 & $(2,0)$ & 20 & $(1,8)$ & 27 & $(1,8)$ & 42 & $(3,8)$ & 24 & $(0,8)$ \\
\hline & Media OCDE & 30 & $(1,7)$ & 36 & $(0,8)$ & 44 & $(0,5)$ & 51 & $(0,9)$ & 43 & $(0,3)$ & 22 & $(0,5)$ & 28 & $(0,3)$ & 38 & $(0,3)$ & 48 & $(0,7)$ & 33 & $(0,2)$ \\
\hline 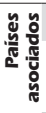 & Federación Rusa* & $\mathrm{w}$ & & $\mathrm{w}$ & $\mathrm{w}$ & $\mathrm{w}$ & $\mathrm{w}$ & $\mathrm{w}$ & $\mathrm{w}$ & $\mathrm{w}$ & $\mathrm{w}$ & $\mathrm{w}$ & $\mathrm{w}$ & $\mathrm{w}$ & $\mathrm{w}$ & $\mathrm{w}$ & $\mathrm{w}$ & $\mathrm{w}$ & $\mathrm{w}$ & $w$ & w \\
\hline
\end{tabular}

* Para los datos de Federación Rusa, véase nota en la sección de Metodología.

Nota: Las columnas que muestran datos de los Niveles 4 y 5 de comprensión lectora y del nivel inferior a educación secundaria superior están disponibles en Internet (véase StatLink más abajo).

Fuente: OCDE. Encuesta sobre las Competencias de los Adultos (PIAAC) (2012). PIAAC se refiere al Programa para la Evaluación Internacional de las Competencias de los Adultos de la OCDE. Para ver notas, consulte Anexo 3 (www.oecd.org/edu/eag.htm).

Para obtener más información acerca de los símbolos utilizados en lugar de los datos que faltan, consulte la Guía del lector.

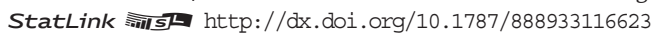




\section{¿QUÉ RELACIÓN EXISTE ENTRE EL RENDIMIENTO DE LOS ESTUDIANTES Y LA EQUIDAD EN EDUCACIÓN?}

- Shanghái-China tiene el rendimiento más alto en matemáticas de todos los países y economías que participaron en PISA 2012, con una puntuación media de 613 puntos, 119 puntos, o el equivalente al progreso de casi tres cursos escolares, por encima de la media de la OCDE. Singapur, Hong Kong-China, Taiwán, Corea, Macao-China, Japón, Liechtenstein, Suiza y Países Bajos, en orden descendente según sus puntuaciones, completan la lista de los diez países con mejor rendimiento en matemáticas.

- Los chicos tienen un rendimiento mejor que el de las chicas en matemáticas en 37 de los 64 países que participaron en PISA 2012 y las chicas obtienen mejores resultados en cinco países.

- Australia, Canadá, Corea, Estonia, Finlandia, Hong Kong-China, Japón, Liechtenstein, MacaoChina y Países Bajos se caracterizan por altos niveles de rendimiento y por la equidad en las oportunidades educativas, según la evaluación PISA 2012.

\section{Gráfico A9.1. Rendimiento de los estudiantes en matemáticas, por sexos, PISA 2012}

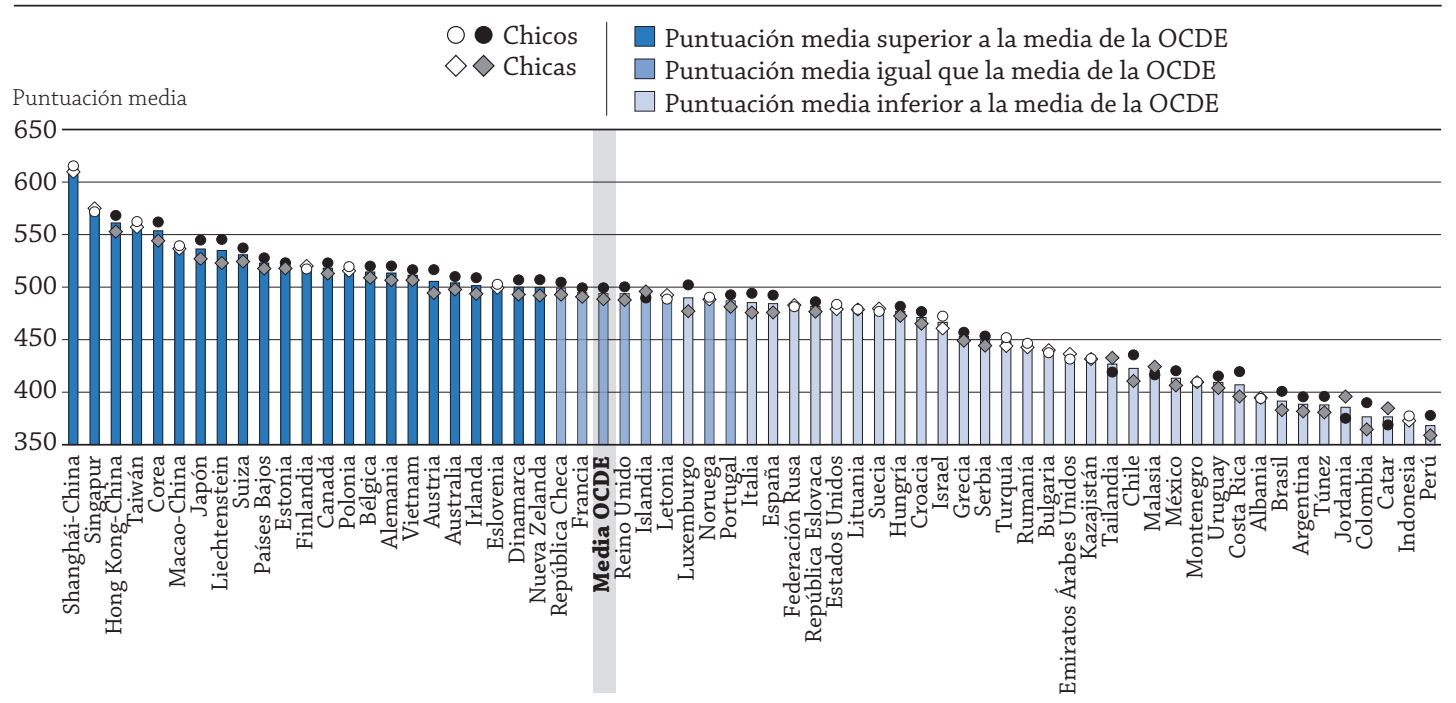

Nota: Las diferencias por sexo estadísticamente significativas están marcadas en un tono más oscuro.

Los países están clasificados en orden descendente de su puntuación media en matemáticas.

Fuente: OCDE. Tabla A9.1a. Para ver notas, consulte Anexo 3 (www.oecd.org/edu/eag.htm).

StatLink 形IS http://dx.doi.org/10.1787/888933116813

\section{Contexto}

Centrado principalmente en las matemáticas, el Programa para la Evaluación Internacional de Alumnos (PISA) 2012 midió la capacidad de los estudiantes de quince años para razonar matemáticamente y utilizar conceptos, procedimientos, datos y herramientas matemáticos para describir, explicar y predecir fenómenos. Esta encuesta trienal, que evalúa el rendimiento de los estudiantes en lectura, matemáticas, ciencias y solución de problemas, no solamente determina si los estudiantes son capaces de reproducir aquello que han aprendido, sino que también examina cómo lo extrapolan y cómo aplican ese conocimiento en situaciones nuevas, tanto dentro del centro escolar como fuera de él. Este enfoque es reflejo del hecho de que en las sociedades modernas se recompensa a los individuos no por lo que saben, sino por lo que pueden hacer con aquello que saben.

Los resultados de PISA revelan lo que es posible lograr en educación al mostrar qué son capaces de hacer los estudiantes de aquellos sistemas educativos con mayor rendimiento y con el ritmo de mejora más rápido. Los resultados permiten a los responsables de la adopción de políticas educativas de todo el mundo valorar el conocimiento y las competencias de los estudiantes de sus respectivos países en comparación con los de otros, establecer objetivos para sus políticas a partir de metas mensurables alcanzadas por otros sistemas educativos y aprender de las medidas políticas y de las prácticas adoptadas en otros países. 
Al analizar los resultados de la evaluación PISA en el contexto de varias características demográficas y sociales de los estudiantes y de los centros escolares, tales como el sexo, el estatus socioeconómico y el entorno inmigrante, PISA muestra asimismo con qué nivel de equidad están proporcionando oportunidades educativas y logrando resultados educativos los países participantes, lo que es indicativo del nivel de equidad en la sociedad en general.

\section{Otros resultados}

- Por término medio en los países de la OCDE, el $13 \%$ de los estudiantes tienen un rendimiento alto en matemáticas (Niveles 5 o 6). Al mismo tiempo, el 23\% de los estudiantes de los países de la OCDE y el $32 \%$ de los estudiantes de todos los países participantes tienen un rendimiento bajo en matemáticas (esto es, no alcanzaron el Nivel 2 de competencia básica).

- Solamente en seis países la diferencia de las puntuaciones en matemáticas entre chicos y chicas -a favor de los chicos- es superior al equivalente al progreso de medio curso de escolarización formal.

- En los países de la OCDE, el 15\% de la diferencia del rendimiento entre estudiantes se explica por diferencias de su estatus socioeconómico. En los países donde esta vinculación es fuerte, los estudiantes de familias desfavorecidas tienen menos posibilidades de superar estas estadísticas y de alcanzar altos niveles de rendimiento. Y lo que es más revelador, aproximadamente 39 puntos -lo que equivale a alrededor de un curso de escolarización formal- separan el rendimiento en matemáticas de aquellos estudiantes considerados socioeconómicamente favorecidos del de aquellos cuyo estatus socioeconómico se aproxima a la media de la OCDE.

\section{Tendencias}

- De los 64 países y economías de los que se dispone de datos de tendencias entre 2003 y 2012, 25 mejoraron su rendimiento en matemáticas, 25 no mostraron cambios y 14 empeoraron.

- De los países que mostraron cierta mejoría entre 2003 y 2012, Italia, Polonia y Portugal redujeron la proporción de estudiantes con bajo rendimiento e incrementaron la proporción de estudiantes con alto rendimiento.

- De los 39 países y economías que participaron tanto en PISA 2003 como en PISA 2012, Alemania, México y Turquía mejoraron su rendimiento en matemáticas y sus niveles de equidad en la educación durante dicho periodo. 


\section{Análisis}

\section{Resultados de PISA 2012}

Los países y economías participantes en PISA pueden dividirse en tres grandes grupos, como se muestra en el Gráfico A9.1: los que obtienen puntuaciones medias estadísticamente similares a la media de la OCDE (marcados en azul intermedio), los que obtienen puntuaciones medias superiores a la media de la OCDE (marcados en azul oscuro) y los que obtienen puntuaciones medias inferiores a la media de la OCDE (marcados en azul claro).La puntuación media en matemáticas de todos los países de la OCDE en PISA 2012 es de 494 puntos.

De los 64 países y economías que participaron en PISA 2012, 23 obtienen resultados superiores a la media de la OCDE, siete obtienen resultados similares a la media de la OCDE y 34 obtienen puntuaciones inferiores a esta media.

La diferencia entre la economía con la puntuación más alta y el país con la puntuación más baja es de 245 puntos. En los países de la OCDE esta diferencia es de 140 puntos. Para medir la magnitud de estas diferencias en las puntuaciones, 41 puntos equivalen al progreso de un curso de escolarización formal (véase Tabla A1.2 en el Volumen I de PISA 2012 Results).

\section{Diferencias entre sexos del rendimiento en matemáticas}

Como media en los países de la OCDE, los chicos mejoran los resultados de las chicas en 11 puntos. Pese al estereotipo según el cual los chicos son mejores que las chicas en matemáticas, los chicos muestran ventaja solamente en 37 de los 64 países y economías que participaron en PISA 2012, y en solo seis países la diferencia entre sexos -a favor de los chicos- es mayor que el equivalente a medio curso escolar.

La mayor diferencia en las puntuaciones entre chicos y chicas se observa en Chile, Colombia y Luxemburgo: una diferencia de alrededor de 25 puntos. En Austria, Costa Rica y Liechtenstein esta diferencia está entre los 22 y los 24 puntos.

En cambio, solo en cinco países las chicas obtienen mejores resultados que los chicos en matemáticas. La mayor diferencia se registra en Jordania, donde las chicas obtienen una puntuación aproximadamente 21 puntos por encima de la de los chicos. Las chicas obtienen mejores resultados que los chicos en Catar, Irlanda, Malasia y Tailandia.

\section{Tendencias del rendimiento medio en matemáticas}

Las tendencias del rendimiento medio indican si los sistemas escolares están mejorando y cómo. Los 64 países y economías que participaron en PISA 2012 tienen disponibles datos de tendencias. Treinta y ocho de ellos disponen de datos del rendimiento en matemáticas de 2012 y de los tres informes PISA anteriores (2003, 2006 y 2009); 17 tienen datos de 2012 y dos evaluaciones anteriores y nueve tienen datos de 2012 y una evaluación previa. Para comprender mejor las tendencias de cada país o economía y utilizar el máximo número de países posibles para hacer comparaciones, este indicador se centra en el cambio anual del rendimiento de los estudiantes (véanse las secciones Definiciones y Metodología al final de este indicador). Para los países y economías que han participado en las cuatro evaluaciones PISA el cambio anualizado tiene en cuenta los cuatro años en que se realizó el estudio; para los países que disponen de datos válidos de menos evaluaciones, solamente se tiene en cuenta la información válida y disponible.

Como se observa en el Gráfico A9.2, el rendimiento ha permanecido generalmente sin cambios, pero más países han mejorado que empeorado en su rendimiento en matemáticas. De los 64 países y economías de los que se tienen datos de tendencias hasta 2012, 25 han mejorado su media anual de rendimiento en matemáticas, mientras que 14 muestran un deterioro medio del rendimiento entre 2003 y 2012. Para los restantes 25 países y economías no hay cambios del rendimiento en matemáticas durante este periodo. Albania, Catar, Emiratos Árabes Unidos, salvo Dubái, Kazajistán y Malasia muestran una mejora media del rendimiento en matemáticas de más de 5 puntos por año. En los países de la OCDE se observan mejoras en el rendimiento en matemáticas en Israel (con una mejora media de más de cuatro puntos por año), México y Turquía (más de tres puntos por año), Italia, Polonia y Portugal (más de dos puntos por año) y Alemania, Chile y Grecia (más de un punto por año). De los países que han participado en todas las evaluaciones desde 2003, Brasil, Italia, México, Polonia, Portugal, Túnez y Turquía muestran una mejora media del rendimiento en matemáticas de más de 2,5 puntos por año (véase Tabla A9.1c).

\section{Estudiantes con el mejor y el peor rendimiento en matemáticas en PISA 2012}

Los resultados de la evaluación PISA 2012 muestran que fomentar el alto rendimiento y luchar contra el bajo rendimiento no se excluyen. Algunos países con altos rendimientos en PISA 2012 como Estonia y Finlandia ofrecen también pocas variaciones en las puntuaciones de los estudiantes. 


\section{Gráfico A9.2. Cambio anualizado del rendimiento en matemáticas a lo largo de la participación en PISA \\ Diferencia de la puntuación en matemáticas asociada a un año natural}

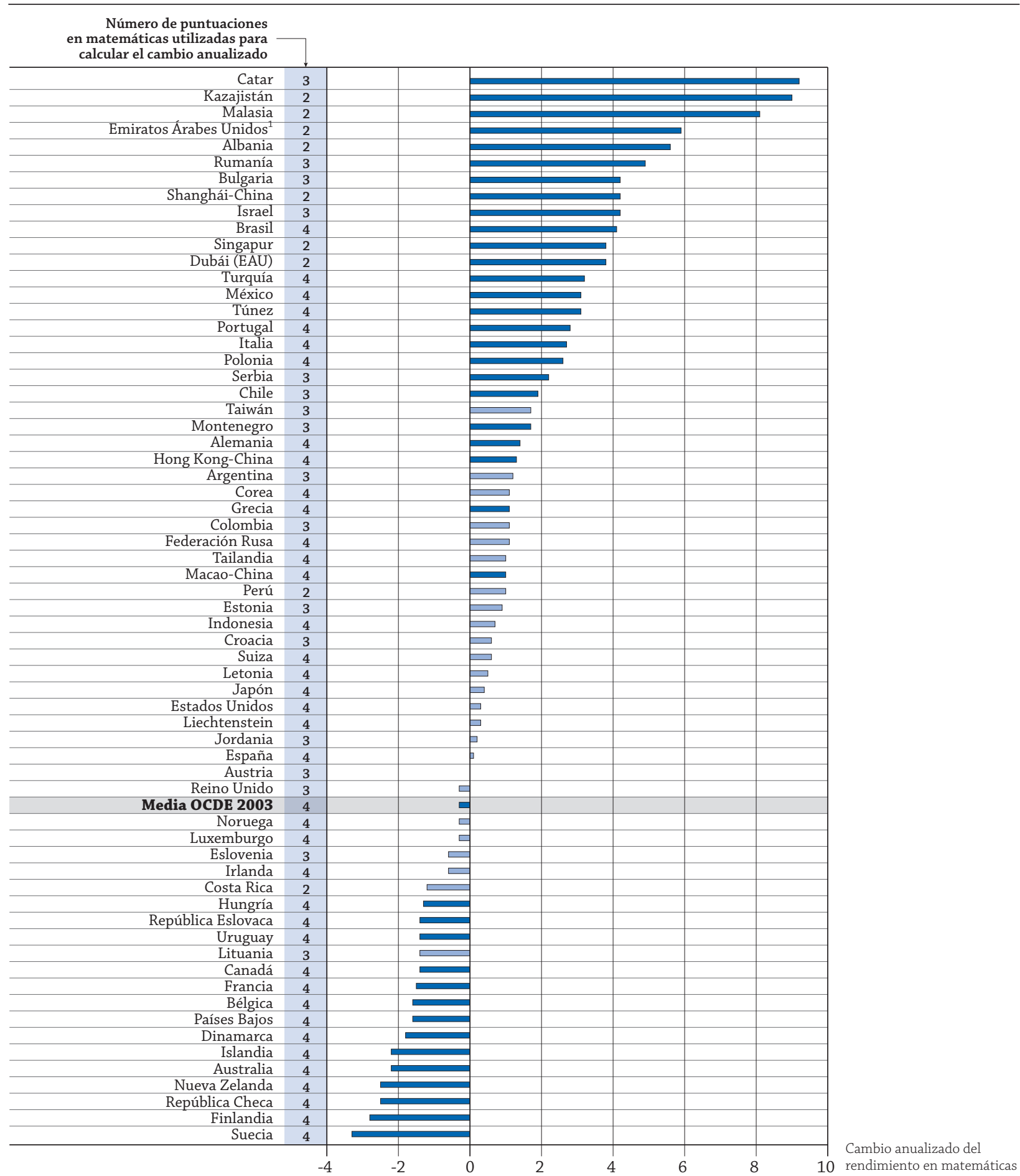

Notas: Los cambios de puntuación estadísticamente significativos están marcados en un tono más oscuro.

El cambio anualizado es el cambio medio anual en puntuaciones PISA desde la primera participación de un país o economía en PISA hasta PISA 2012. Se calcula teniendo en cuenta la participación completa del país o economía en PISA.

La media de la OCDE de 2003 solo compara países de la OCDE con puntuaciones en matemáticas aptas para la comparación desde 2003.

1. Excluido Dubái. En Emiratos Árabes Unidos, Dubái realizó la evaluación PISA 2009 en 2009 y el resto de los Emiratos Árabes Unidos lo hizo en 2010 como parte de PISA 2009+. Por tanto, los resultados se ofrecen por separado.

Los países están clasificados en orden descendente de su cambio anualizado en el rendimiento en matemáticas.

Fuente: OCDE. Tabla A9.1c. Para ver notas, consulte Anexo 3 (www.oecd.org/edu/eag.htm)

StatLink 세이 http://dx.doi.org/10.1787/888933116832 
Prácticamente uno de cada tres estudiantes coreanos tiene un alto rendimiento en matemáticas, lo que significa que puntúa en los Niveles 5 o 6 de la evaluación (véanse las secciones Definiciones y Metodología al final de este indicador para una descripción de los niveles de competencia alcanzados por los estudiantes con los mejores y los peores resultados). Aproximadamente el $31 \%$ de los estudiantes de Corea obtienen un alto rendimiento, lo que supone la mayor proporción entre todos los países de la OCDE. Aunque esta proporción es mucho mayor que la media del $13 \%$ de la OCDE, es, no obstante, inferior a la de Shanghái-China, donde más del $50 \%$ de los estudiantes tienen un alto rendimiento (véase Tabla A9.1a).

Entre los países con puntuaciones medias similares en PISA hay diferencias notables del porcentaje de estudiantes con un alto rendimiento. Por ejemplo, Dinamarca tiene una puntuación media de 500 puntos en matemáticas en PISA 2012 y un $10 \%$ de los estudiantes con un alto rendimiento, una proporción inferior a la media de la OCDE, de alrededor del $13 \%$. Nueva Zelanda tiene una puntuación media en matemáticas de 500 puntos y el $15 \%$ de los estudiantes alcanzan los niveles superiores de competencia.

Más del $40 \%$ de estudiantes de 21 países y economías, incluidos los países de la OCDE Chile y México, no alcanzan el nivel básico de competencia en matemáticas (Nivel 2). En el mejor de los casos, estos estudiantes son capaces de extraer información relevante de una única fuente y utilizar algoritmos, fórmulas, procedimientos o convenciones básicas para resolver problemas con números enteros. La proporción de estudiantes de 15 años en

\section{Gráfico A9.3. Porcentaje de estudiantes con alto y bajo rendimiento en matemáticas, PISA 2003 y 2012}

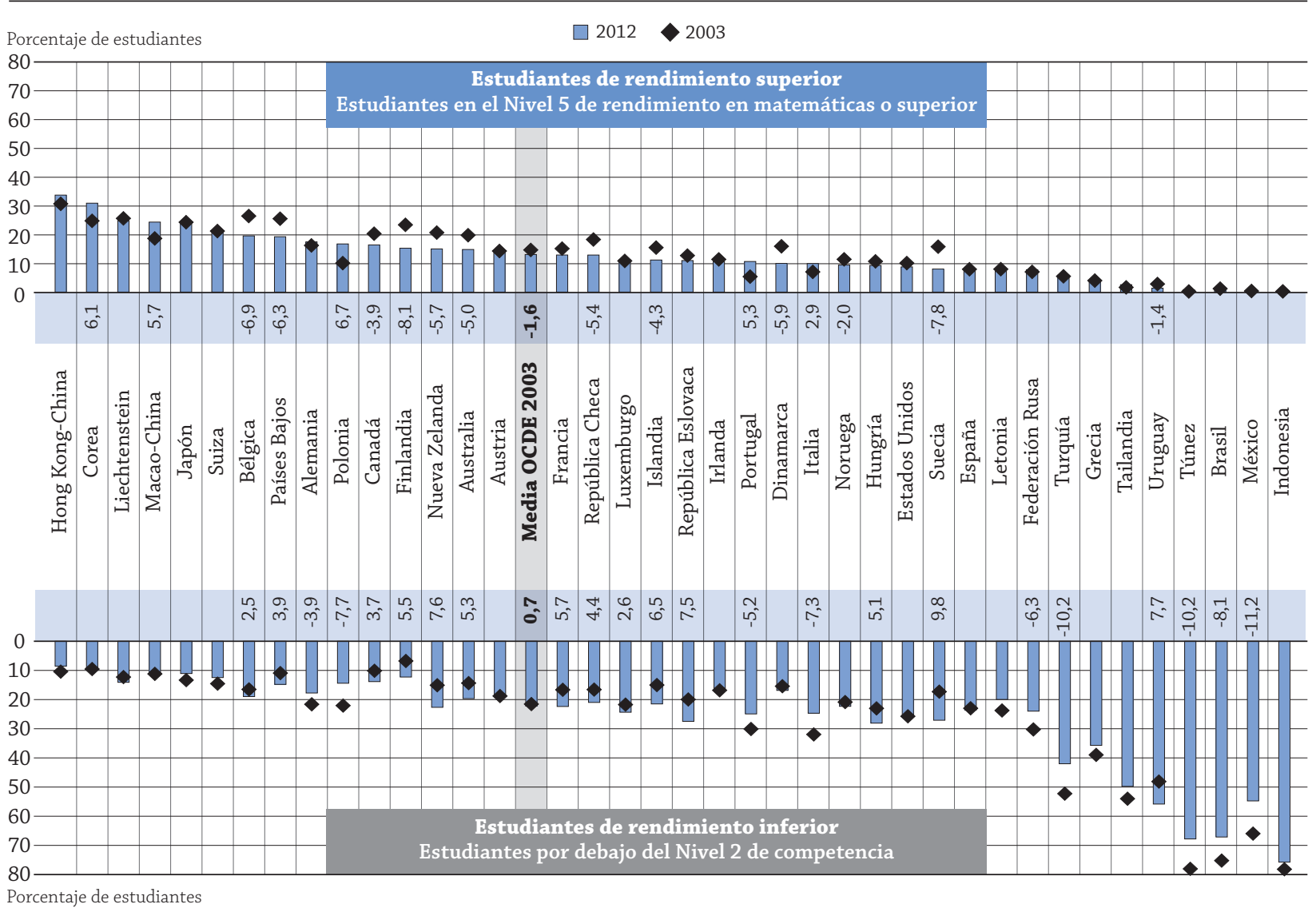

Notas: El gráfico solo muestra países y economías que participaron tanto en la evaluación PISA 2003 como en la de PISA 2012.

El cambio entre PISA 2003 y PISA 2012 en la proporción de estudiantes con un rendimiento por debajo del Nivel 2 en matemáticas se muestra bajo el nombre del país o economía. El cambio entre PISA 2003 y PISA 2012 en la proporción de estudiantes con un rendimiento en el Nivel 5 o superior en matemáticas se muestra encima del nombre del país o economía. Solo se muestran cambios estadísticamente significativos.

La media de la OCDE de 2003 solo compara países de la OCDE con puntuaciones aptas para la comparación desde 2003.

Los países están clasificados en orden descendente del porcentaje de estudiantes en el Nivel 5 o superior del rendimiento en matemáticos en 2012.

Fuente: OCDE. Tablas A9.1a, A9.1b y A9.1c. Para ver notas, consulte Anexo 3 (www.oecd.org/edu/eag.htm).

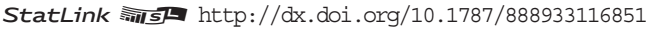


este nivel varía mucho entre países, desde menos de uno de cada diez en cuatro países y economías, hasta la mayoría de los estudiantes en 15 países. La mayor parte de los estudiantes que puntúan por debajo del Nivel 2 en matemáticas tienen pocas probabilidades de continuar en el sistema educativo más allá de la educación obligatoria y, por tanto, corren el riesgo de encontrarse con dificultades al utilizar conceptos matemáticos a lo largo de su vida.

Para aumentar la proporción de estudiantes con un alto rendimiento, los países y economías han de prestar atención a las barreras que para el éxito suponen el entorno socioeconómico (examinado en el Volumen II de Resultados de PISA 2012), la relación entre el rendimiento y las actitudes de los estudiantes ante el aprendizaje (examinadas en el Volumen III de Resultados de PISA 2012) y la organización, recursos y entorno de aprendizaje de los centros escolares (examinados en el Volumen IV de Resultados de PISA 2012).

\section{Tendencias de la proporción de estudiantes con mejor y peor rendimiento}

Al considerar los cambios de la proporción de estudiantes con los mejores y peores rendimientos entre PISA 2003 y PISA 2012 se evidencian algunas pautas. Los países o economías pueden, pues, ser clasificados de acuerdo a cómo han evolucionado estos dos grupos durante ese periodo.

- Mejora general: reducción de la proporción de estudiantes con bajo rendimiento e incremento de la de estudiantes con alto rendimiento

Los países que han reducido la proporción de estudiantes que puntúan por debajo del Nivel 2 y han incrementado la proporción de quienes puntúan por encima del Nivel 5 son los que han logrado extender las mejoras de sus sistemas educativos a todos los niveles de rendimiento. Entre 2003 y 2012 esto se ha observado en Italia, Polonia y Portugal (véase Gráfico A9.3).

- Disminución del bajo rendimiento: reducciones de la proporción de estudiantes con bajo rendimiento, pero sin cambios en la de estudiantes con alto rendimiento

Otros países han concentrado el cambio en los estudiantes que no alcanzaron el nivel básico de competencia. Estos países han registrado mejoras significativas del rendimiento de sus estudiantes con el nivel más bajo, que ahora tienen las capacidades básicas para participar plenamente en la sociedad. Entre 2003 y 2012 Alemania, Brasil, Federación Rusa, México, Túnez y Turquía vieron reducida la proporción de estudiantes que puntúan por debajo del Nivel 2 de competencia en matemáticas (véase Gráfico A9.3).

- Fomento del alto rendimiento: incremento de la proporción de estudiantes con alto rendimiento, pero sin cambios en la de estudiantes con bajo rendimiento

Algunos países incrementaron la proporción de estudiantes con un rendimiento en el Nivel 5 o superior. Se trata de estudiantes que pueden manejar contenidos y procesos matemáticos complejos. Entre 2003 y 2012 MacaoChina y Corea aumentaron en alrededor de seis puntos porcentuales la proporción de estudiantes con un rendimiento a este nivel (véase Gráfico A9.3).

- Incremento de la proporción del estudiantes con bajo rendimiento o disminución de la de estudiantes con alto rendimiento

En 16 países, la proporción de estudiantes que no alcanzan el nivel de competencia básico aumentó, o la proporción de estudiantes que alcanzan los niveles de competencia más altos disminuyó entre PISA 2003 y PISA 2012 (véase Gráfico A9.3).

\section{Rendimiento y equidad}

La equidad en educación significa proporcionar a todos los estudiantes, independientemente de su estatus socioeconómico, oportunidades para que se beneficien de la educación. Así definida, la equidad no implica que todos obtengan los mismos resultados de la educación. Pero sí que el estatus socioeconómico de los estudiantes no tenga influencia o tenga una influencia escasa en su rendimiento y que todos los estudiantes, sea cual sea su entorno, tengan acceso a recursos educativos de calidad y oportunidades de aprendizaje.

Aunque el bajo rendimiento escolar no tiene su origen directamente en las desventajas socioeconómicas, el entorno socioeconómico de los estudiantes y de los centros escolares sí parece tener una poderosa influencia en los resultados del aprendizaje. Ya sea porque las familias favorecidas tienen una mayor capacidad para reforzar y enriquecer el efecto de los centros escolares, porque los estudiantes de familias favorecidas acuden a centros escolares de mayor calidad o porque los centros escolares están sencillamente mejor equipados para apoyar y desarrollar a los jóvenes de entornos favorecidos, en muchos países los centros educativos tienden a reproducir pautas existentes de 


\section{Gráfico A9.4. Rendimiento de los estudiantes y equidad}

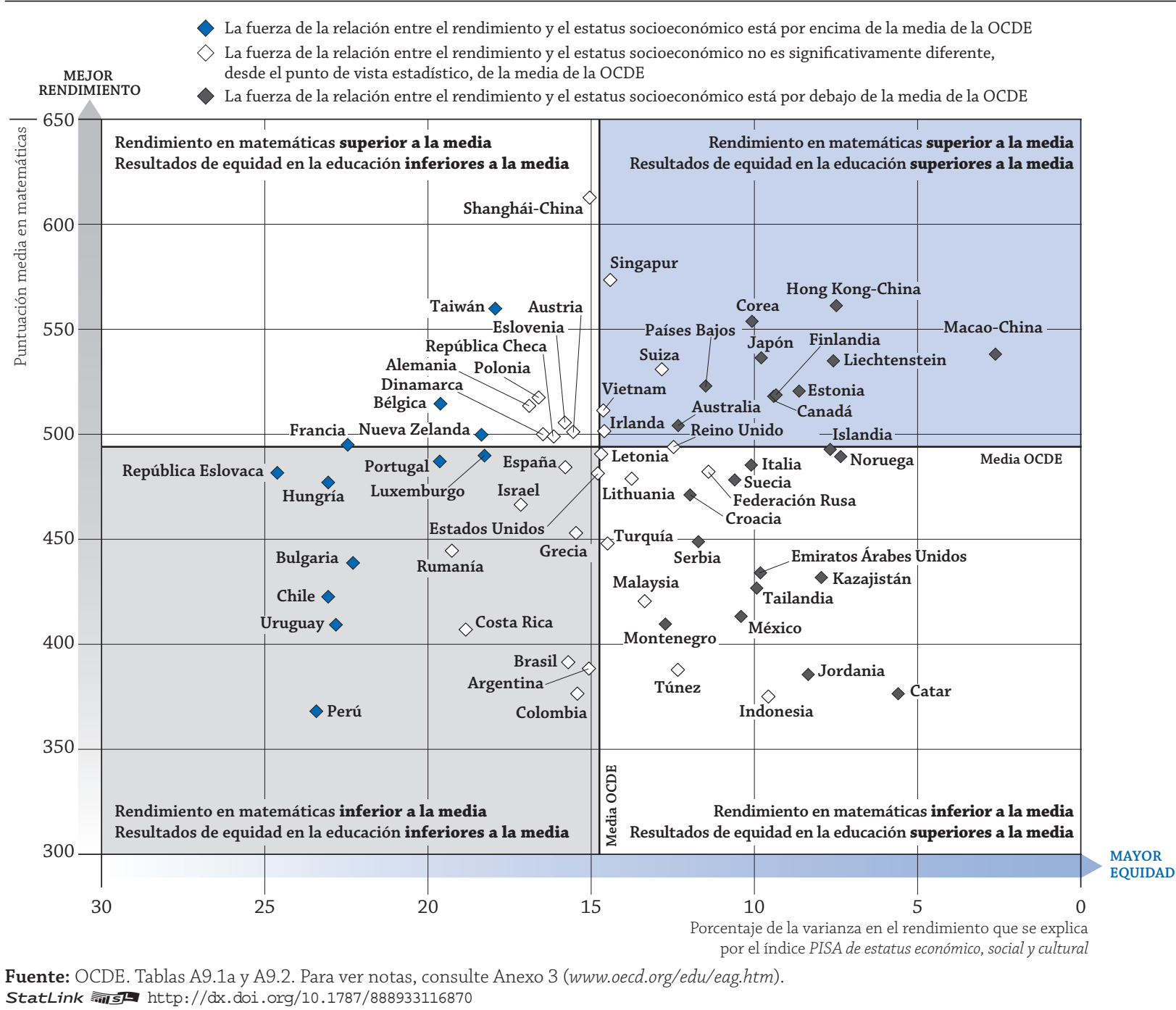

privilegio socioeconómico en lugar de crear una distribución más equitativa de las oportunidades y resultados del aprendizaje.

El entorno socioeconómico de los estudiantes se mide con el Índice PISA de estatus económico, social y cultural, que está basado en la información proporcionada por los estudiantes acerca de la formación y ocupación de sus padres y de sus recursos familiares, como una mesa de estudio o la cantidad de libros que hay en su casa (véanse las secciones Definiciones y Metodología al final de este indicador).

PISA identifica dos formas principales de medir la equidad de los resultados educativos: la proporción de la variación del rendimiento atribuida al estatus socioeconómico (la fuerza del gradiente socioeconómico) y la magnitud media de las diferencias del rendimiento entre grupos socioeconómicos (la pendiente del gradiente socioeconómico).

La proporción de la variación del rendimiento que se explica por el estatus socioeconómico, junto con las diferencias del rendimiento a través de la distribución socioeconómica, son indicadores útiles para determinar si los esfuerzos para mejorar el rendimiento de los estudiantes deberían dirigirse especialmente a aquellos estudiantes que obtienen resultados bajos o a aquellos que provienen de entornos socioeconómicos desfavorecidos. Por tanto, existe una distinción importante entre la fuerza del gradiente social, vinculada con la proximidad entre el rendimiento obtenido por los estudiantes y las previsiones acerca de su rendimiento basadas en su estatus socioeconómico, y la pendiente del gradiente social, que se refiere al tamaño medio de la diferencia del rendimiento vinculada con una diferencia dada del estatus socioeconómico. 


\section{Estatus socioeconómico de los estudiantes}

En los países de la OCDE, el 15\% de la variación del rendimiento de los estudiantes en matemáticas se atribuye a diferencias en su estatus socioeconómico. En los países y economías con alto rendimiento esta proporción varía desde el $3 \%$ en Macao-China hasta el $20 \%$ en Bélgica. Por el contrario, en Bulgaria, Chile, Francia, Hungría, Perú, República Eslovaca y Uruguay, más del $20 \%$ de la diferencia del rendimiento de los estudiantes se puede atribuir a su estatus socioeconómico. En los países donde esta proporción es amplia, los estudiantes de familias desfavorecidas tienen menos probabilidades de alcanzar altos niveles de rendimiento.

Como se observa en el Gráfico A9.4, de los 23 sistemas escolares que puntuaron por encima de la media de la OCDE en PISA 2012, la relación entre rendimiento y estatus socioeconómico es inferior a la media en 10 países y economías: Australia, Canadá, Corea, Estonia, Finlandia, Hong Kong-China, Japón, Liechtenstein, Macao-China y Países Bajos. En otros 10 (Alemania, Austria, Dinamarca, Eslovenia, Irlanda, Polonia, Shanghái-China, Singapur, Suiza y Vietnam), esta relación es similar a la media. Solamente en tres países y economías con alto rendimiento: Bélgica, Nueva Zelanda y Taiwán, la relación entre el rendimiento y el estatus socioeconómico es superior a la media.

Como media en los países de la OCDE, la pendiente del gradiente socioeconómico es de 39 puntos, lo que significa que un cambio de una unidad en el Índice PISA de estatus económico, social y cultural está vinculado con una diferencia de 39 puntos en matemáticas. Se prevé que los estudiantes favorecidos (aquellos que tienen un valor 1 en el índice) obtengan una puntuación media 39 puntos superior a la de un estudiante con un estatus socioeconómico medio (es decir, aquellos que tienen un valor 0 en el índice), y 78 puntos superior a un estudiante desfavorecido (aquellos con un valor de -1 en el índice).

En los 23 países y economías con el rendimiento más alto, las diferencias del rendimiento relacionadas con el estatus socioeconómico son inferiores a la media en Canadá, Estonia, Finlandia, Hong Kong-China, Macao-China y Vietnam, alrededor de la media en 12 países y economías y superiores a la media en cinco.

En los países con gradientes poco pronunciados, es decir, en los que las diferencias del rendimiento relacionadas con el estatus socioeconómico son pequeñas, las medidas políticas dirigidas específicamente a los estudiantes procedentes de entornos desfavorecidos no lograrían, por sí solas, abordar las necesidades de muchos de sus estudiantes con bajo rendimiento. En este caso, orientar las medidas hacia los estudiantes con un rendimiento bajo podría ser más eficaz que dirigirlas a los estudiantes desfavorecidos.

\section{Tendencias de la equidad entre PISA 2003 y PISA 2012}

$\mathrm{Al}$ analizar los datos de diferentes evaluaciones PISA es posible identificar a aquellos países que han avanzado hacia sistemas escolares más equitativos.

Entre 2003 y 2012, la diferencia media del rendimiento en matemáticas relacionada con un cambio de una unidad en el Índice PISA de estatus económico, social y cultural continuó siendo de 39 puntos, pero el grado en el cual el estatus socioeconómico de los estudiantes pronosticaba el rendimiento en matemáticas disminuyó del $17 \%$ al $15 \%$. Dicho de otro modo, en 2012 era algo más fácil que en 2003 que los estudiantes no se ajustaran a las previsiones sobre su rendimiento basadas en su estatus socioeconómico.

México y Turquía avanzaron hacia una mayor equidad reduciendo tanto la pendiente como la fuerza del gradiente socioeconómico, a la vez que mejoraban el rendimiento de forma global. Esto significa que en estos dos países fue más sencillo en 2012 que en 2003 que los estudiantes no se ajustaran a las previsiones sobre su rendimiento dado su estatus socioeconómico y que la diferencia media del rendimiento entre los estudiantes favorecidos y los desfavorecidos se redujera. En Alemania, la diferencia del rendimiento entre los estudiantes socioeconómicamente favorecidos y desfavorecidos permaneció sin cambios. Sin embargo, una mayor proporción de estudiantes obtuvo un rendimiento superior al previsible según su estatus socioeconómico. Lo que es más importante, en estos tres países la mejora de la equidad se combinó con una mejora del rendimiento en matemáticas (Gráfico A9.5 y Tabla A9.2).

Otros países y economías que mejoraron su rendimiento en matemáticas (Brasil, Grecia, Hong Kong-China, Italia, Macao-China, Polonia y Túnez) mantuvieron sus niveles de equidad; solamente en Portugal hubo mejoras del rendimiento acompañadas de una reducción de la equidad. Estos resultados ponen de manifiesto cómo, para la mayoría de los países y economías, las mejoras del rendimiento no se producen a expensas de la equidad (véase Volumen II de Resultados de PISA 2012). 


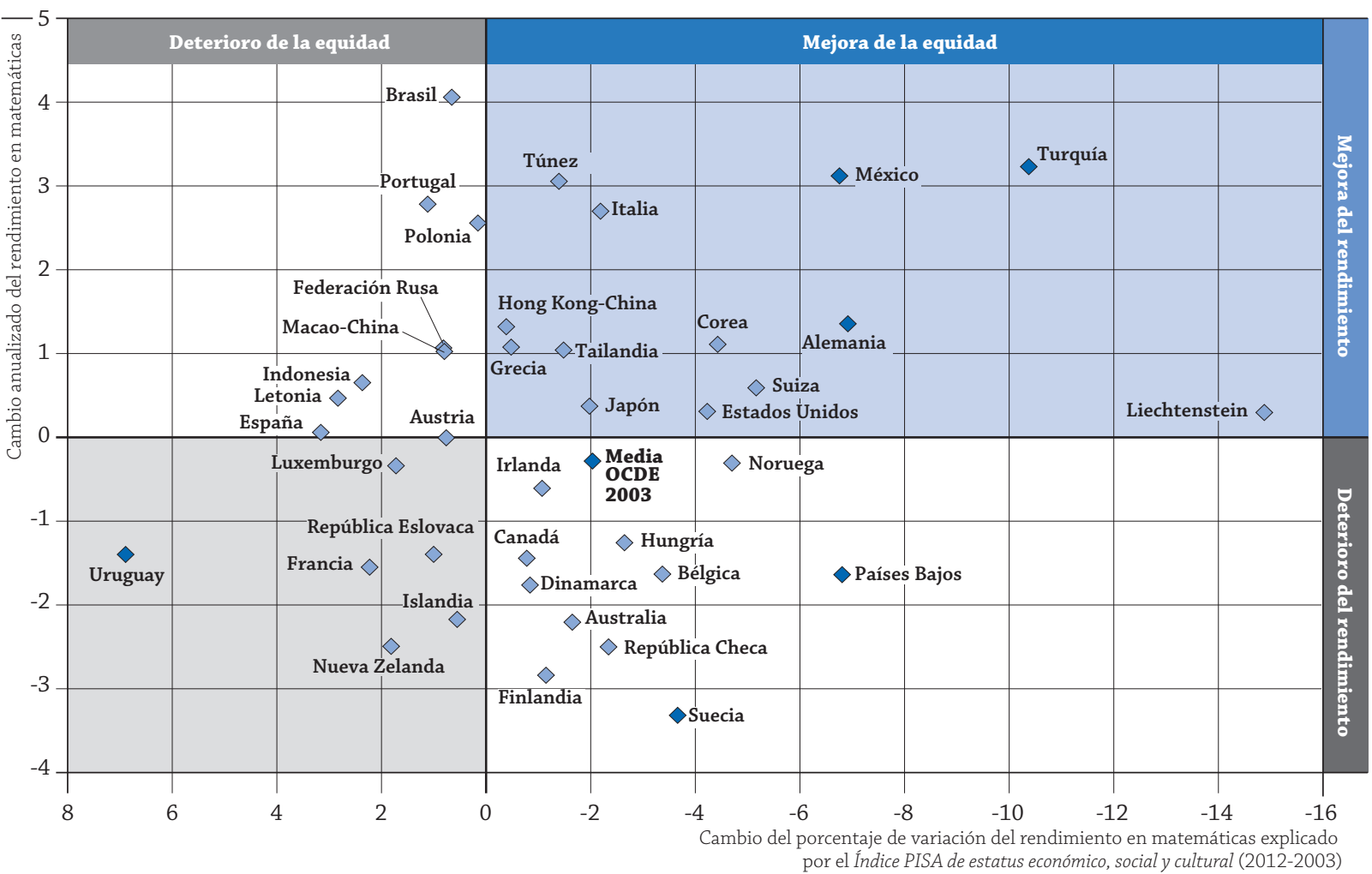

Notas: Los cambios tanto en equidad como en rendimiento entre 2003 y 2012 que son estadísticamente significativos están marcados en un tono más oscuro.

El cambio anualizado es el cambio medio anual en puntuaciones PISA desde la primera participación de un país o economía en PISA hasta PISA 2012. Se calcula teniendo en cuenta la participación completa del país o economía en PISA.

Solo se muestran los países o economías con datos aptos para la comparación de PISA 2003 y PISA 2012

Para asegurar la comparabilidad en el tiempo, los valores de PISA 2003 en el Índice PISA de estatus económico, social y cultural se han adaptado a la escala de PISA 2012 de este índice. Así, los resultados mostrados en este gráfico pueden diferir de los presentados en Aprender para el mundo de mañana: Primeros resultados de PISA 2003 (OECD, 2004).

La media de la OCDE de 2003 solo considera países con puntuaciones en matemáticas y valores del Índice PISA de estatus económico, social y cultural desde PISA 2003.

Fuente: OCDE. Tablas A9.1c y A9.2. Para ver notas, consulte Anexo 3 (www.oecd.org/edu/eag.htm).

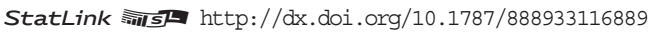

\section{Definiciones}

Cambio anualizado es la tasa media de cambio a la que han variado las puntuaciones medias en matemáticas de un país o economía a lo largo de su participación en las evaluaciones PISA. Por tanto, un cambio anualizado positivo de $\mathrm{x}$ puntos indica que el país o economía ha mejorado su rendimiento en $\mathrm{x}$ puntos al año desde sus primeros resultados en PISA válidos para la comparación. Para los países que han participado en solo dos evaluaciones, el cambio anualizado es igual a la diferencia entre las dos evaluaciones dividida entre el número de años que han pasado entre las evaluaciones.

Estudiantes con bajo rendimiento en matemáticas son aquellos que no alcanzan el Nivel básico 2 en la evaluación PISA. En el Nivel 2 los estudiantes saben interpretar y reconocer situaciones en contextos que solo requieren una inferencia directa; extraer información relevante de una sola fuente y utilizar un único modelo de representación; emplear algoritmos, fórmulas, procedimientos o convenciones elementales para resolver problemas con números enteros, y realizar interpretaciones literales de los resultados.

Estudiantes con alto rendimiento en matemáticas son aquellos que puntúan en el Nivel 5 o 6 de la evaluación PISA. Saben desarrollar y trabajar con modelos para situaciones complejas, identificando los condicionantes y especificando los supuestos; pueden seleccionar, comparar y evaluar estrategias adecuadas de solución de problemas para abor- 
dar problemas complejos relativos a estos modelos; pueden trabajar estratégicamente utilizando competencias amplias y bien desarrolladas de pensamiento y razonamiento, representaciones relacionadas de forma adecuada, caracterizaciones simbólicas y formales, así como intuiciones relativas a estas situaciones; pueden reflexionar sobre su trabajo y formular y comunicar sus interpretaciones y razonamientos.

\section{Metodología}

El cambio anualizado es una medida consistente del progreso de un país en los resultados educativos, ya que está basada en información disponible de todas las evaluaciones. Por tanto, es menos sensible a mediciones anormales que pudieran alterar las tendencias de un país en PISA si los resultados se compararan solo entre dos evaluaciones. El cambio anualizado se calcula como la línea que mejor se ajusta a lo largo de las participaciones de un país en PISA. El año que cada estudiante participó en PISA se representa en una regresión lineal con sus puntuaciones en PISA, obteniendo el cambio anualizado. El cambio anualizado también tiene en cuenta el hecho de que, para algunos países, el periodo entre las evaluaciones PISA es inferior a tres años (para más información véase el Volumen I de Resultados de PISA 2012).

El Índice PISA de estatus económico, social y cultural (ESCS, por sus siglas en inglés) se derivó de los tres índices siguientes: el máximo nivel ocupacional de los padres (HISEI, por sus siglas en inglés), el máximo nivel educativo de los padres en años de escolarización según la CINE (PARED, por sus siglas en inglés), y el índice de posesiones en el hogar (HOMEPOS, por sus siglas en inglés). En PISA 2012, los estudiantes contestaron sobre la disponibilidad de 14 artículos en sus hogares. Además, cada país añadió tres artículos indicativos de la riqueza familiar en el contexto de dicho país. El índice de posesiones en el hogar (HOMEPOS) se derivó de estos artículos e incluyó asimismo la variable que indica el número de libros en el hogar. Sin embargo, la escala de posesiones familiares para PISA 2012 se computó de forma diferente que en los ciclos anteriores con el fin de posibilitar un estudio de tendencias. Para más detalles, véase la sección de tendencias en el ESCS, en PISA 2012 Technical Report (OECD, de próxima publicación).

Las puntuaciones del ESCS se obtuvieron como puntuaciones de componentes para el primer componente principal, siendo cero la puntuación de un estudiante medio de la OCDE y uno la desviación estándar entre países de la OCDE con la misma ponderación. Para los países asociados las puntuaciones en el ESEC se obtuvieron así:

$$
E S C S=\frac{\beta_{1} H_{I S E I^{\prime}+\beta_{2}} \text { PARED'+ } \beta_{3} \text { HOMEPOS }^{\prime}}{\varepsilon_{f}}
$$

donde $\beta_{1}, \beta_{2}$ y $\beta_{3}$ son las cargas factoriales de la OCDE, HISEI', PARED' y HOMEPOS' las variables estandarizadas de la $\mathrm{OCDE}$ y $\varepsilon_{f}$ es el valor propio del primer componente principal. Para más información sobre el ESCS, véase PISA 2012 Technical Report (OECD, de próxima publicación).

\section{Nota sobre los datos de Israel}

Los datos estadísticos para Israel fueron proporcionados por las autoridades israelíes competentes bajo su responsabilidad. El uso de estos datos por parte de la OCDE se hace sin prejuzgar la situación de los Altos del Golán, Jerusalén Este y los asentamientos israelíes en Cisjordania de acuerdo con los términos del derecho internacional.

\section{Referencias}

OECD (2014), PISA 2012 Results: What Students Know and Can Do (Volume I, edición revisada, febrero, 2014), PISA, OECD Publishing, París. http://dx.doi.org/10.1797/9789264201118-en

OECD (2013), PISA 2012 Results: Excellence Through Equity: Giving Every Student the Chance to Succeed (Volume II), PISA, OECD Publishing, París. http://dx.doi.org/10.1797/9789264201132-en

\section{Tablas del Indicador A9}

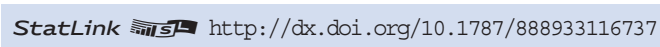

Tabla A9.1a Rendimiento de los estudiantes en matemáticas, PISA 2012

WEB Tabla A9.1b Rendimiento de los estudiantes en matemáticas, PISA 2003

Tabla A9.1c Cambio entre 2003 y 2012 del rendimiento de los estudiantes en matemáticas

Tabla A9.2 Relación entre el rendimiento en matemáticas y el estatus socioeconómico 
Tabla A9.1a. Rendimiento de los estudiantes en matemáticas, PISA 2012

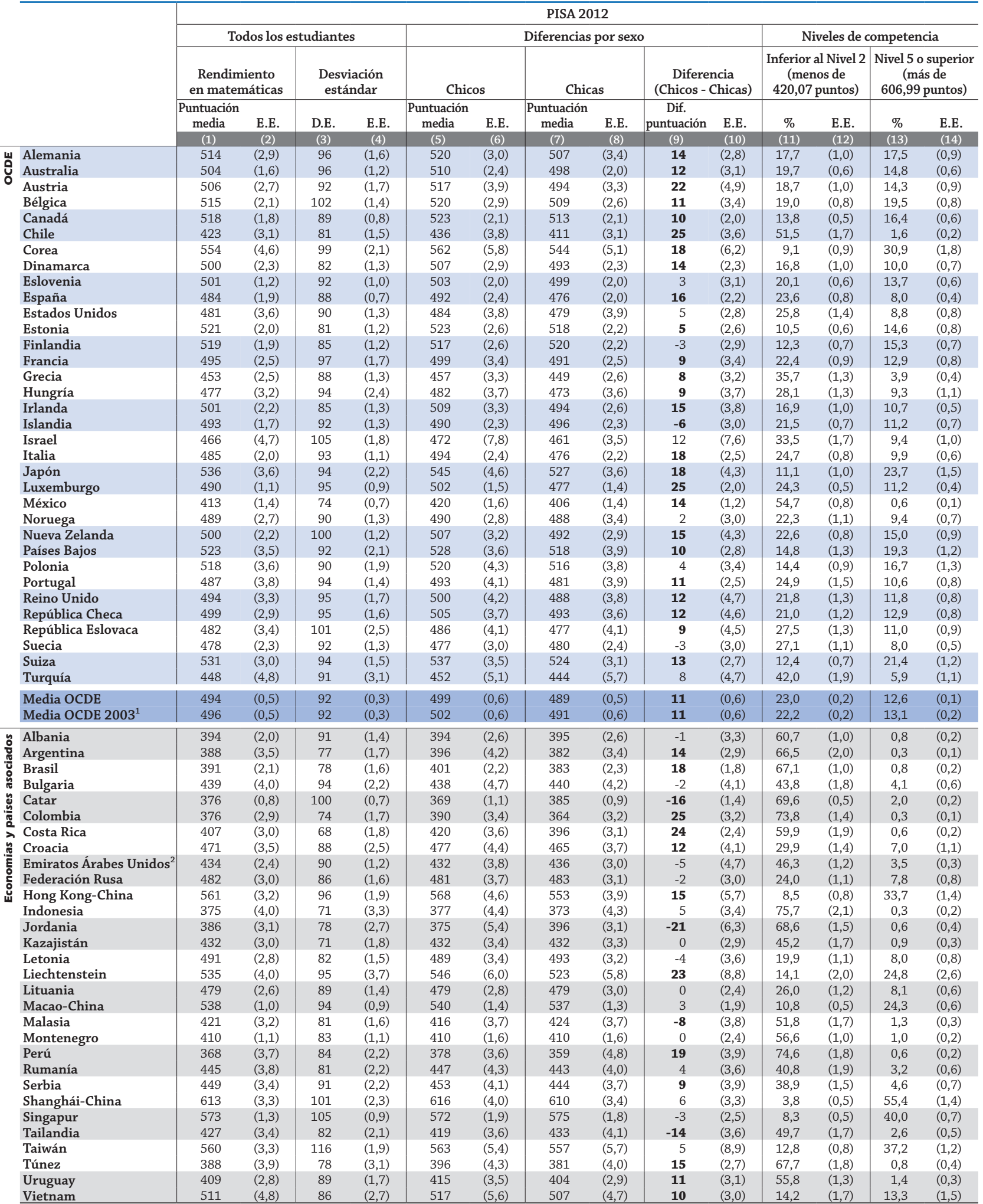

Nota: Los valores estadísticamente significativos se indican en negrita.

1. La media de la OCDE de 2003 solo compara países de la OCDE con puntuaciones en matemáticas aptas para la comparación desde 2003.

2. En Emiratos Árabes Unidos, Dubái realizó la evaluación PISA 2009 en 2009 y el resto de los Emiratos Árabes Unidos lo hizo en 2010 como parte de PISA $2009+$. Por tanto, los resultados se ofrecen por separado. Los rendimientos en matemáticas en 2012 para Dubái y el resto de los Emiratos Árabes Unidos son, respectivamente, $464(1,2)$ y $423(3,2)$.

Para obtener más información acerca de los símbolos utilizados en lugar de los datos que faltan, consulte la Guía del lector.

Fuente: OCDE, Base de datos PISA 2012.

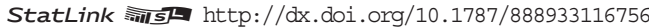


Tabla A9.1c. Cambio entre 2003 y 2012 del rendimiento de los estudiantes en matemáticas

\begin{tabular}{|c|c|c|c|c|c|c|c|c|c|c|c|c|c|c|}
\hline & \multicolumn{14}{|c|}{ Cambio entre 2003 y 2012 (PISA 2012 - PISA 2003) } \\
\hline & \multirow{2}{*}{\multicolumn{2}{|c|}{\begin{tabular}{|c|} 
Todos los estudiantes \\
Rendimiento \\
en matemáticas
\end{tabular}}} & \multirow{2}{*}{\multicolumn{2}{|c|}{\begin{tabular}{|c|} 
Cambio anualizado \\
en matemáticas \\
entre todas \\
las evaluaciones \\
PISA $^{1}$ \\
\end{tabular}}} & \multicolumn{6}{|c|}{ Diferencias de sexo } & \multicolumn{4}{|c|}{ Niveles de competencia } \\
\hline & & & & & \multicolumn{2}{|c|}{ Chicos } & Chica & & $\begin{array}{r}\text { Diferen } \\
\text { (Chicos - C }\end{array}$ & $\begin{array}{l}\text { cia } \\
\text { Chicas) }\end{array}$ & $\begin{array}{r}\text { Inferior al } \\
\text { (menos } \\
420,07 \mathrm{pu}\end{array}$ & $\begin{array}{l}\text { Nivel } 2 \\
\text { s de } \\
\text { untos) }\end{array}$ & $\begin{array}{r}\text { Nivel } 5 \text { o su } \\
\text { (más } \\
606,99 \text { pu }\end{array}$ & $\begin{array}{l}\text { uperior } \\
\text { de } \\
\text { antos) }\end{array}$ \\
\hline & $\begin{array}{c}\text { Dif. de } \\
\text { puntuación }\end{array}$ & E.E. & $\begin{array}{c}\text { Cambio } \\
\text { anual }\end{array}$ & E.E. & $\begin{array}{c}\text { Dif. de } \\
\text { puntuación }\end{array}$ & E.E. & $\begin{array}{c}\text { Dif. de } \\
\text { puntuación }\end{array}$ & E.E. & $\begin{array}{c}\text { Dif. de } \\
\text { puntuación }\end{array}$ & E.E. & \begin{tabular}{|c} 
Diferencia \\
de \%
\end{tabular} & E.E. & \begin{tabular}{|c} 
Diferencia \\
de $\%$
\end{tabular} & E.E. \\
\hline & (1) & (2) & (3) & (4) & (5) & (6) & (7) & (8) & (9) & (10) & (11) & (12) & (13) & (14) \\
\hline Alemania & 11 & $(4,8)$ & 1,4 & $(0,5)$ & 12 & $(5,4)$ & 8 & $(5,5)$ & 5 & $(5,3)$ & $-3,9$ & $(1,6)$ & 1,2 & $(1,4)$ \\
\hline Australia & -20 & $(3,3)$ & $-2,2$ & $(0,3)$ & -17 & $(4,3)$ & -24 & $(3,9)$ & 7 & $(4,9)$ & 5,3 & $(1,1)$ & $-5,0$ & $(1,1)$ \\
\hline Austria & 0 & $(4,6)$ & 0,0 & $(0,5)$ & 7 & $(5,9)$ & -7 & $(5,5)$ & 15 & $(7,3)$ & $-0,1$ & $(1,6)$ & 0,0 & $(1,4)$ \\
\hline Bélgica & -15 & $(3,7)$ & $-1,6$ & $(0,4)$ & -13 & $(4,9)$ & -16 & $(4,6)$ & 4 & $(5,7)$ & 2,5 & $(1,2)$ & $-6,9$ & $(1,3)$ \\
\hline Canadá & -14 & $(3,2)$ & $-1,4$ & $(0,3)$ & -18 & $(3,5)$ & -17 & $(3,4)$ & -1 & $(3,0)$ & 3,7 & $(0,9)$ & $-3,9$ & $(1,1)$ \\
\hline Chile & $\mathrm{m}$ & $\mathrm{m}$ & 1,9 & $(0,9)$ & $\mathrm{m}$ & $\mathrm{m}$ & $\mathrm{m}$ & $\mathrm{m}$ & $\mathrm{m}$ & $\mathrm{m}$ & $\mathrm{m}$ & $\mathrm{m}$ & $\mathrm{m}$ & $\mathrm{m}$ \\
\hline Corea & 12 & $(5,9)$ & 1,1 & $(0,6)$ & 10 & $(7,5)$ & 16 & $(7,7)$ & -5 & $(9,4)$ & $-0,4$ & $(1,3)$ & 6,1 & $(2,4)$ \\
\hline Dinamarca & -14 & $(4,1)$ & $-1,8$ & $(0,4)$ & -16 & $(4,8)$ & -13 & $(4,2)$ & -3 & $(4,4)$ & 1,4 & $(1,4)$ & $-5,9$ & $(1,2)$ \\
\hline Eslovenia & $\mathrm{m}$ & $\mathrm{m}$ & $-0,6$ & $(0,4)$ & $\mathrm{m}$ & $\mathrm{m}$ & $\mathrm{m}$ & $\mathrm{m}$ & $\mathrm{m}$ & $\mathrm{m}$ & $\mathrm{m}$ & $\mathrm{m}$ & $\mathrm{m}$ & $\mathrm{m}$ \\
\hline España & -1 & $(3,6)$ & 0,1 & $(0,4)$ & 3 & $(4,6)$ & -5 & $(3,5)$ & 8 & $(3,8)$ & 0,6 & $(1,4)$ & 0,1 & $(0,9)$ \\
\hline Estados Unidos & -2 & $(5,0)$ & 0,3 & $(0,6)$ & -2 & $(5,4)$ & -1 & $(5,4)$ & -2 & $(3,9)$ & 0,1 & $(2,0)$ & $-1,3$ & $(1,1)$ \\
\hline Estonia & $\mathrm{m}$ & $\mathrm{m}$ & 0,9 & $(0,7)$ & $\mathrm{m}$ & $\mathrm{m}$ & $\mathrm{m}$ & $\mathrm{m}$ & $\mathrm{m}$ & $\mathrm{m}$ & $\mathrm{m}$ & $\mathrm{m}$ & $\mathrm{m}$ & $\mathrm{m}$ \\
\hline Finlandia & -26 & $(3,3)$ & $-2,8$ & $(0,3)$ & -31 & $(4,1)$ & -20 & $(3,6)$ & -10 & $(4,0)$ & 5,5 & $(0,9)$ & $-8,1$ & $(1,2)$ \\
\hline Francia & -16 & $(4,0)$ & $-1,5$ & $(0,4)$ & -16 & $(5,3)$ & -16 & $(4,3)$ & 0 & $(5,6)$ & 5,7 & $(1,5)$ & $-2,2$ & $(1,3)$ \\
\hline Grecia & 8 & $(5,0)$ & $\mathbf{1 , 1}$ & $(0,5)$ & 2 & $(6,1)$ & 13 & $(5,0)$ & -11 & $(4,9)$ & $-3,3$ & $(2,5)$ & $-0,1$ & $(0,7)$ \\
\hline Hungría & -13 & $(4,7)$ & $-1,3$ & $(0,5)$ & -12 & $(5,4)$ & -13 & $(5,3)$ & 1 & $(5,1)$ & 5,1 & $(1,8)$ & $-1,4$ & $(1,5)$ \\
\hline Irlanda & -1 & $(3,8)$ & $-0,6$ & $(0,4)$ & -1 & $(4,8)$ & -2 & $(4,7)$ & 1 & $(5,7)$ & 0,1 & $(1,5)$ & $-0,7$ & $(1,0)$ \\
\hline Islandia & -22 & $(2,9)$ & $-2,2$ & $(0,3)$ & -18 & $(3,8)$ & -27 & $(3,7)$ & 9 & $(4,4)$ & 6,5 & $(1,1)$ & $-4,3$ & $(1,0)$ \\
\hline Israel & $\mathrm{m}$ & $\mathrm{m}$ & 4,2 & $(1,1)$ & $\mathrm{m}$ & $\mathrm{m}$ & $\mathrm{m}$ & $\mathrm{m}$ & $\mathrm{m}$ & $\mathrm{m}$ & $\mathrm{m}$ & $\mathrm{m}$ & $\mathrm{m}$ & $\mathrm{m}$ \\
\hline Italia & 20 & $(4,2)$ & 2,7 & $(0,4)$ & 19 & $(5,5)$ & 19 & $(4,8)$ & 1 & $(6,7)$ & $-7,3$ & $(1,8)$ & 2,9 & $(0,8)$ \\
\hline Japón & 2 & $(5,7)$ & 0,4 & $(0,6)$ & 6 & $(7,7)$ & -3 & $(5,7)$ & 9 & $(7,3)$ & $-2,3$ & $(1,6)$ & $-0,6$ & $(2,2)$ \\
\hline Luxemburgo & -3 & $(2,4)$ & $-0,3$ & $(0,3)$ & 0 & $(3,1)$ & -8 & $(2,8)$ & 8 & $(3,3)$ & 2,6 & $(1,0)$ & 0,4 & $(0,8)$ \\
\hline México & 28 & $(4,3)$ & $\mathbf{3 , 1}$ & $(0,5)$ & 30 & $(4,9)$ & 26 & $(4,7)$ & 3 & $(4,2)$ & $-11,2$ & $(2,2)$ & 0,3 & $(0,1)$ \\
\hline Noruega & -6 & $(4,1)$ & $-0,3$ & $(0,5)$ & -8 & $(4,4)$ & -4 & $(4,9)$ & -4 & $(4,4)$ & 1,5 & $(1,6)$ & $-2,0$ & $(1,0)$ \\
\hline Nueva Zelanda & -24 & $(3,7)$ & $-2,5$ & $(0,4)$ & -24 & $(4,7)$ & -24 & $(4,7)$ & 1 & $(6,2)$ & 7,6 & $(1,3)$ & $-5,7$ & $(1,2)$ \\
\hline Países Bajos & -15 & $(5,1)$ & $-1,6$ & $(0,6)$ & -12 & $(5,7)$ & -17 & $(5,6)$ & 5 & $(5,6)$ & 3,9 & $(1,8)$ & $-6,3$ & $(1,9)$ \\
\hline Polonia & 27 & $(4,8)$ & 2,6 & $(0,5)$ & 27 & $(5,5)$ & 28 & $(5,1)$ & -2 & $(4,4)$ & $-7,7$ & $(1,5)$ & 6,7 & $(1,6)$ \\
\hline Portugal & 21 & $(5,5)$ & 2,8 & $(0,6)$ & 20 & $(6,2)$ & 21 & $(5,6)$ & -1 & $(4,4)$ & $-5,2$ & $(2,4)$ & 5,3 & $(1,0)$ \\
\hline Reino Unido & $\mathrm{m}$ & $\mathrm{m}$ & $-0,3$ & $(0,6)$ & $\mathrm{m}$ & $\mathrm{m}$ & $\mathrm{m}$ & $\mathrm{m}$ & $\mathrm{m}$ & $\mathrm{m}$ & $\mathrm{m}$ & $\mathrm{m}$ & $\mathrm{m}$ & $\mathrm{m}$ \\
\hline República Checa & -17 & $(4,9)$ & $-2,5$ & $(0,5)$ & -19 & $(6,0)$ & -16 & $(6,0)$ & -3 & $(6,7)$ & 4,4 & $(1,8)$ & $-5,4$ & $(1,5)$ \\
\hline República Eslovaca & -17 & $(5,2)$ & $-1,4$ & $(0,5)$ & -21 & $(6,0)$ & -12 & $(5,7)$ & -9 & $(5,3)$ & 7,5 & $(2,0)$ & $-1,7$ & $(1,3)$ \\
\hline Suecia & -31 & $(3,9)$ & $-3,3$ & $(0,4)$ & -35 & $(4,6)$ & -26 & $(4,4)$ & -9 & $(3,9)$ & $\mathbf{9 , 8}$ & $(1,6)$ & $-7,8$ & $(1,0)$ \\
\hline Suiza & 4 & $(4,9)$ & 0,6 & $(0,5)$ & 3 & $(6,2)$ & 7 & $(5,2)$ & -4 & $(5,2)$ & $-2,1$ & $(1,2)$ & 0,2 & $(2,0)$ \\
\hline Turquía & 25 & $(8,5)$ & 3,2 & $(0,8)$ & 22 & $(9,6)$ & 29 & $(9,0)$ & -7 & $(8,0)$ & $-10,2$ & $(3,4)$ & 0,4 & $(1,9)$ \\
\hline Media OCDE $2003^{2}$ & -3 & $(0,9)$ & $-0,3$ & $(0,1)$ & -3 & $(1,0)$ & -4 & $(1,0)$ & 0 & $(1,0)$ & 0,7 & $(0,3)$ & $-1,6$ & $(0,3)$ \\
\hline Albania & $\mathrm{m}$ & $\mathrm{m}$ & 5,6 & $(1,7)$ & $\mathrm{m}$ & $\mathrm{m}$ & $\mathrm{m}$ & $\mathrm{m}$ & $\mathrm{m}$ & $\mathrm{m}$ & $\mathrm{m}$ & $\mathrm{m}$ & $\mathrm{m}$ & $\mathrm{m}$ \\
\hline Argentina & $\mathrm{m}$ & $\mathrm{m}$ & 1,2 & $(1,3)$ & $\mathrm{m}$ & $\mathrm{m}$ & $\mathrm{m}$ & $\mathrm{m}$ & $\mathrm{m}$ & $\mathrm{m}$ & $\mathrm{m}$ & $\mathrm{m}$ & $\mathrm{m}$ & $\mathrm{m}$ \\
\hline Brasil & 35 & $(5,6)$ & $\mathbf{4 , 1}$ & $(0,6)$ & 36 & $(6,7)$ & 34 & $(5,3)$ & 2 & $(4,8)$ & $-8,1$ & $(2,2)$ & $-0,4$ & $(0,5)$ \\
\hline Bulgaria & $\mathrm{m}$ & $\mathrm{m}$ & 4,2 & $(1,3)$ & $\mathrm{m}$ & $\mathrm{m}$ & $\mathrm{m}$ & $\mathrm{m}$ & $\mathrm{m}$ & $\mathrm{m}$ & $\mathrm{m}$ & $\mathrm{m}$ & $\mathrm{m}$ & $\mathrm{m}$ \\
\hline Catar & $\mathrm{m}$ & $\mathrm{m}$ & $\mathbf{9 , 2}$ & $(0,4)$ & $\mathrm{m}$ & $\mathrm{m}$ & $\mathrm{m}$ & $\mathrm{m}$ & $\mathrm{m}$ & $\mathrm{m}$ & $\mathrm{m}$ & $\mathrm{m}$ & $\mathrm{m}$ & $\mathrm{m}$ \\
\hline Colombia & $\mathrm{m}$ & $\mathrm{m}$ & 1,1 & $(0,9)$ & $\mathrm{m}$ & $\mathrm{m}$ & $\mathrm{m}$ & $\mathrm{m}$ & $\mathrm{m}$ & $\mathrm{m}$ & $\mathrm{m}$ & $\mathrm{m}$ & $\mathrm{m}$ & $\mathrm{m}$ \\
\hline Costa Rica & $\mathrm{m}$ & $\mathrm{m}$ & $-1,2$ & $(2,3)$ & $\mathrm{m}$ & $\mathrm{m}$ & $\mathrm{m}$ & $\mathrm{m}$ & $\mathrm{m}$ & $\mathrm{m}$ & $\mathrm{m}$ & $\mathrm{m}$ & $\mathrm{m}$ & $\mathrm{m}$ \\
\hline Croacia & $\mathrm{m}$ & $\mathrm{m}$ & 0,6 & $(0,8)$ & $\mathrm{m}$ & $\mathrm{m}$ & $\mathrm{m}$ & $\mathrm{m}$ & $\mathrm{m}$ & $\mathrm{m}$ & $\mathrm{m}$ & $\mathrm{m}$ & $\mathrm{m}$ & $\mathrm{m}$ \\
\hline Emiratos Árabes Unidos ${ }^{3}$ & $\mathrm{~m}$ & $\mathrm{~m}$ & $\mathrm{~m}$ & $\mathrm{~m}$ & $\mathrm{~m}$ & $\mathrm{~m}$ & $\mathrm{~m}$ & $\mathrm{~m}$ & $\mathrm{~m}$ & $\mathrm{~m}$ & $\mathrm{~m}$ & $\mathrm{~m}$ & $\mathrm{~m}$ & $\mathrm{~m}$ \\
\hline Federación Rusa & 14 & $(5,5)$ & 1,1 & $(0,6)$ & 8 & $(6,7)$ & 20 & $(5,5)$ & -12 & $(5,3)$ & $-6,3$ & $(2,3)$ & 0,8 & $(1,2)$ \\
\hline Hong Kong-China & 11 & $(5,9)$ & 1,3 & $(0,6)$ & 16 & $(8,2)$ & 5 & $(6,3)$ & 11 & $(8,6)$ & $-1,9$ & $(1,4)$ & 3,0 & $(2,2)$ \\
\hline Indonesia & 15 & $(5,9)$ & 0,7 & $(0,6)$ & 16 & $(6,2)$ & 14 & $(6,6)$ & 1 & $(4,3)$ & $-2,4$ & $(2,8)$ & 0,0 & $(0,2)$ \\
\hline Jordania & $\mathrm{m}$ & $\mathrm{m}$ & 0,2 & $(0,8)$ & $\mathrm{m}$ & $\mathrm{m}$ & $\mathrm{m}$ & $\mathrm{m}$ & $\mathrm{m}$ & $\mathrm{m}$ & $\mathrm{m}$ & $\mathrm{m}$ & $\mathrm{m}$ & $\mathrm{m}$ \\
\hline Kazajistán & $\mathrm{m}$ & $\mathrm{m}$ & 9,0 & $(1,5)$ & $\mathrm{m}$ & $\mathrm{m}$ & $\mathrm{m}$ & $\mathrm{m}$ & $\mathrm{m}$ & $\mathrm{m}$ & $\mathrm{m}$ & $\mathrm{m}$ & $\mathrm{m}$ & $\mathrm{m}$ \\
\hline Letonia & 7 & $(5,0)$ & 0,5 & $(0,5)$ & 4 & $(6,2)$ & 10 & $(5,1)$ & -7 & $(4,7)$ & $-3,8$ & $(1,9)$ & 0,0 & $(1,2)$ \\
\hline Liechtenstein & -1 & $(6,0)$ & 0,3 & $(0,6)$ & -4 & $(9,6)$ & 2 & $(8,7)$ & -6 & $(13,9)$ & 1,8 & $(2,7)$ & $-0,8$ & $(4,4)$ \\
\hline Lituania & $\mathrm{m}$ & $\mathrm{m}$ & $-1,4$ & $(0,8)$ & $\mathrm{m}$ & $\mathrm{m}$ & $\mathrm{m}$ & $\mathrm{m}$ & $\mathrm{m}$ & $\mathrm{m}$ & $\mathrm{m}$ & $\mathrm{m}$ & $\mathrm{m}$ & $\mathrm{m}$ \\
\hline Macao-China & 11 & $(3,6)$ & 1,0 & $(0,4)$ & 1 & $(5,4)$ & 20 & $(4,0)$ & -18 & $(6,4)$ & $-0,4$ & $(1,3)$ & 5,7 & $(1,7)$ \\
\hline Malasia & $\mathrm{m}$ & $\mathrm{m}$ & 8,1 & $(2,1)$ & $\mathrm{m}$ & $\mathrm{m}$ & $\mathrm{m}$ & $\mathrm{m}$ & $\mathrm{m}$ & $\mathrm{m}$ & $\mathrm{m}$ & $\mathrm{m}$ & $\mathrm{m}$ & $\mathrm{m}$ \\
\hline Montenegro & $\mathrm{m}$ & $\mathrm{m}$ & 1,7 & $(0,5)$ & $\mathrm{m}$ & $\mathrm{m}$ & $\mathrm{m}$ & $\mathrm{m}$ & $\mathrm{m}$ & $\mathrm{m}$ & $\mathrm{m}$ & $\mathrm{m}$ & $\mathrm{m}$ & $\mathrm{m}$ \\
\hline Perú & $\mathrm{m}$ & $\mathrm{m}$ & 1,0 & $(2,1)$ & $\mathrm{m}$ & $\mathrm{m}$ & $\mathrm{m}$ & $\mathrm{m}$ & $\mathrm{m}$ & $\mathrm{m}$ & $\mathrm{m}$ & $\mathrm{m}$ & $\mathrm{m}$ & $\mathrm{m}$ \\
\hline Rumanía & $\mathrm{m}$ & $\mathrm{m}$ & 4,9 & $(1,0)$ & $\mathrm{m}$ & $\mathrm{m}$ & $\mathrm{m}$ & $\mathrm{m}$ & $\mathrm{m}$ & $\mathrm{m}$ & $\mathrm{m}$ & $\mathrm{m}$ & $\mathrm{m}$ & $\mathrm{m}$ \\
\hline Serbia & $\mathrm{m}$ & $\mathrm{m}$ & 2,2 & $(0,9)$ & $\mathrm{m}$ & $\mathrm{m}$ & $\mathrm{m}$ & $\mathrm{m}$ & $\mathrm{m}$ & $\mathrm{m}$ & $\mathrm{m}$ & $\mathrm{m}$ & $\mathrm{m}$ & $\mathrm{m}$ \\
\hline Shanghái-China & $\mathrm{m}$ & $\mathrm{m}$ & 4,2 & $(1,7)$ & $\mathrm{m}$ & $\mathrm{m}$ & $\mathrm{m}$ & $\mathrm{m}$ & $\mathrm{m}$ & $\mathrm{m}$ & $\mathrm{m}$ & $\mathrm{m}$ & $\mathrm{m}$ & $\mathrm{m}$ \\
\hline Singapur & $\mathrm{m}$ & $\mathrm{m}$ & $\mathbf{3 , 8}$ & $(1,0)$ & $\mathrm{m}$ & $\mathrm{m}$ & $\mathrm{m}$ & $\mathrm{m}$ & $\mathrm{m}$ & $\mathrm{m}$ & $\mathrm{m}$ & $\mathrm{m}$ & $\mathrm{m}$ & $\mathrm{m}$ \\
\hline Tailandia & 10 & $(5,0)$ & 1,0 & $(0,6)$ & 4 & $(5,7)$ & 14 & $(5,6)$ & -10 & $(5,4)$ & $-4,2$ & $(2,6)$ & 0,9 & $(0,6)$ \\
\hline Taiwán & $\mathrm{m}$ & $\mathrm{m}$ & 1,7 & $(0,9)$ & $\mathrm{m}$ & $\mathrm{m}$ & $\mathrm{m}$ & $\mathrm{m}$ & $\mathrm{m}$ & $\mathrm{m}$ & $\mathrm{m}$ & $\mathrm{m}$ & $\mathrm{m}$ & $\mathrm{m}$ \\
\hline Túnez & 29 & $(5,0)$ & 3,1 & $(0,5)$ & 31 & $(5,5)$ & 28 & $(5,4)$ & 3 & $(3,7)$ & $-10,2$ & $(2,3)$ & 0,6 & $(0,4)$ \\
\hline Uruguay & -13 & $(4,7)$ & $-1,4$ & $(0,5)$ & -13 & $(5,6)$ & -12 & $(5,2)$ & -1 & $(4,9)$ & 7,7 & $(2,2)$ & $-1,4$ & $(0,5)$ \\
\hline Vietnam & $\mathrm{m}$ & $\mathrm{m}$ & $\mathrm{m}$ & $\mathrm{m}$ & $\mathrm{m}$ & $\mathrm{m}$ & $\mathrm{m}$ & $\mathrm{m}$ & $\mathrm{m}$ & $\mathrm{m}$ & $\mathrm{m}$ & $\mathrm{m}$ & $\mathrm{m}$ & $\mathrm{m}$ \\
\hline
\end{tabular}

Nota: Los valores estadísticamente significativos se indican en negrita.

1. El cambio anualizado es el cambio medio anual en puntuaciones PISA desde la primera participación de un país o economía en PISA hasta PISA 2012. Para los países con más de una medida disponible, se calcula el cambio anualizado con un modelo de regresión lineal. Este modelo considera que Costa Rica, Emiratos Árabes Unidos (excepto Dubái) y Malasia implementaron la evaluación PISA 2009 en 2010 como parte de PISA 2009+.

2. La media de la OCDE de 2003 solo compara países de la OCDE con puntuaciones en matemáticas aptas para la comparación desde 2003.

3. En Emiratos Árabes Unidos, Dubái realizó la evaluación PISA 2009 en 2009 y el resto de los Emiratos Árabes Unidos lo hizo en 2010 como parte de PISA $2009+$. Por tanto, los resultados se ofrecen por separado. Los cambios anualizados para Dubái y el resto de los Emiratos Árabes Unidos son significativos y son, respectivamente, $3,8(0,9)$ y $5,9(2,6)$.

Para obtener más información acerca de los símbolos utilizados en lugar de los datos que faltan, consulte la Guía del lector.

Fuente: OCDE, Base de datos PISA 2012.

StatLink त्नाIS http://dx.doi.org/10.1787/888933116775 
Tabla A9.2. Relación entre el rendimiento en matemáticas y el estatus socioeconómico Resultados basados en los informes de los estudiantes sobre sí mismos

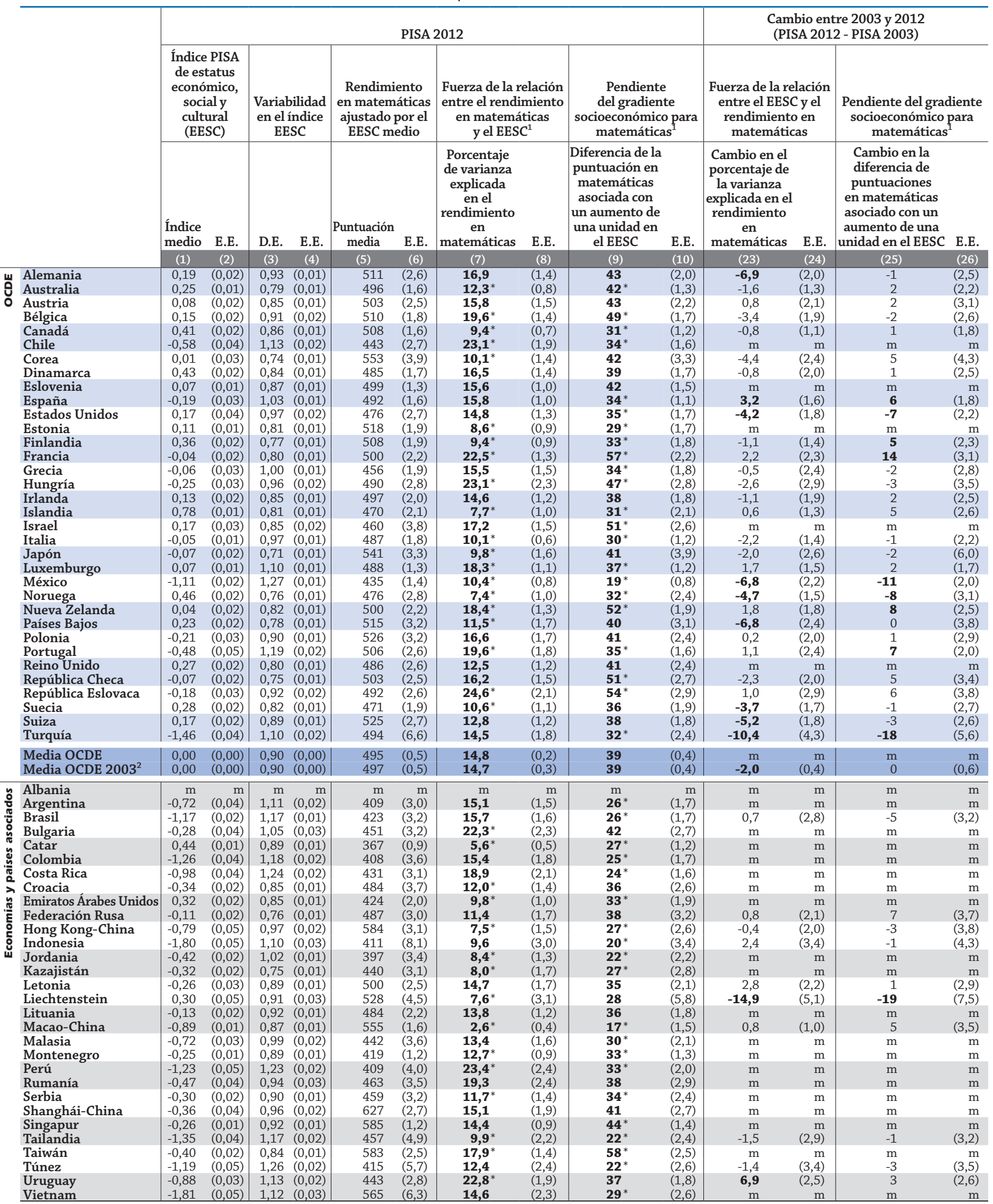

Notas: Los valores y cambios estadísticamente significativos se indican en negrita. Los valores que son significativamente diferentes desde el punto de vista estadístico de la media de la OCDE se indican con un asterisco.

Las columnas 11 a 22 están disponibles en Internet (véase StatLink más abajo).

1. Regresión bivariante de nivel único del rendimiento en el EESC. La pendiente es el coeficiente de regresión del EESC y la fuerza es $\mathrm{r}$ al cuadrado $\mathrm{x} 100$. 2. La media de la OCDE 2003 solo compara países de la OCDE con datos comparables desde PISA 2003.

Para obtener más información acerca de los símbolos utilizados en lugar de los datos que faltan, consulte la Guía del lector.

Fuente: OCDE, Base de datos PISA 2012.

StatLink 젝ㅁ http://dx.doi.org/10.1787/888933116794 


\section{Capítulo}

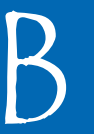

\section{RECURSOS ECONÓMICOS Y HUMANOS INVERTIDOS EN EDUCACIÓN}

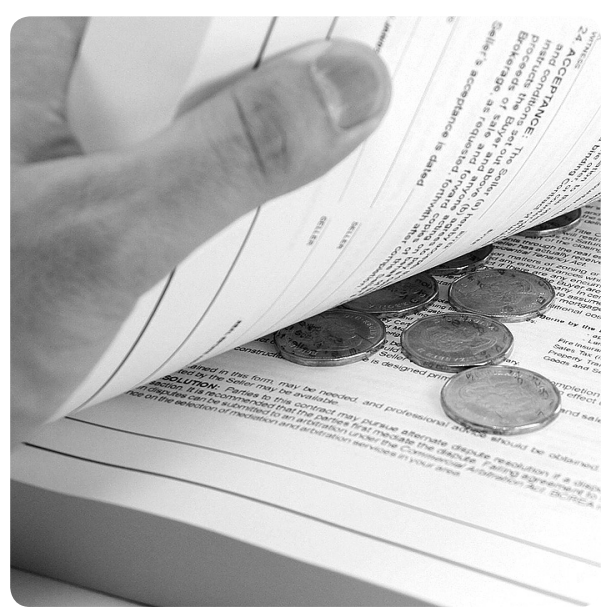

Indicador B1 ¿Cuál es el gasto en educación por estudiante? StatLink 形

Indicador B2 ¿Qué proporción de la riqueza nacional se dedica a la educación? StatLink 解 http://dx.doi.org/10.1787/888933117174

Indicador B3 ¿Cuánta inversión pública y privada se destina a educación? StatLink Ants http://dx.doi.org/10.1787/888933117364

Indicador B4 ¿Cuál es el gasto público total en educación?

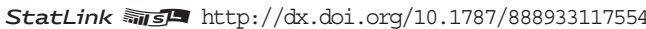

Indicador B5 ¿Cuánto pagan los estudiantes de educación terciaria y qué ayudas públicas reciben?

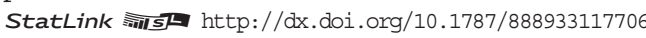

Indicador B6 ¿En qué recursos y servicios se gastan los fondos destinados a educación? StatLink 䨛 Sl http://dx.doi.org/10.1787/888933117858

Indicador B7 ¿Qué factores influyen en el nivel de gasto en educación? StatLink AnIs http://dx.doi.org/10.1787/888933117953 


\section{Clasificación de los gastos en educación}

Los gastos en educación se clasifican en este capítulo según las tres dimensiones siguientes:

- La primera dimensión -representada en el diagrama de abajo por el eje horizontal- define el destino de los gastos. Los recursos destinados a los centros escolares y a las universidades, a los ministerios de Educación y otros organismos directamente implicados en impartir y apoyar la enseñanza constituyen uno de los componentes de esta dimensión. Otro componente son los gastos en educación fuera de las instituciones educativas.

- La segunda dimensión -representada en el diagrama de abajo por el eje vertical-clasifica los bienes y servicios adquiridos. No todos los gastos efectuados en instituciones educativas pueden clasificarse como gastos directos en educación o en enseñanza. En numerosos países de la OCDE, las instituciones educativas ofrecen no solo servicios en materia educativa, sino también diversos tipos de servicios auxiliares -tales como comida, transporte, alojamiento, etc.- destinados a ayudar a los estudiantes y a sus familias. En la educación terciaria, los recursos destinados a las actividades de investigación y desarrollo pueden ser importantes. No todos los gastos en bienes y servicios de educación se verifican dentro de las instituciones educativas. Por ejemplo, las familias pueden comprar material y manuales escolares por su cuenta o pagar clases particulares a sus hijos.

- La tercera dimensión -representada en el diagrama de abajo por distintos colores- distingue las fuentes de los fondos, que comprenden los recursos del sector público y de organismos internacionales (indicados en azul claro) y los de las economías domésticas y otras entidades privadas (indicadas en azul intermedio). En el caso en que los gastos de carácter privado estén subvencionados por fondos públicos, las celdas de la tabla están coloreadas en gris.

\begin{tabular}{|c|c|c|}
\hline & Fondos de fuentes públicas & Fondos privados subvencionados \\
\hline & $\begin{array}{l}\text { Gastos en instituciones educativas } \\
\text { (por ejemplo, colegios, universidades, } \\
\text { administración y servicios de ayuda } \\
\text { a los estudiantes) }\end{array}$ & $\begin{array}{l}\text { Gastos en educación fuera } \\
\text { de las instituciones educativas } \\
\text { (por ejemplo, compras privadas de bienes } \\
\text { y servicios, incluidas clases particulares) }\end{array}$ \\
\hline \multirow{3}{*}{$\begin{array}{r}\text { Gastos } \\
\text { en servicios } \\
\text { educativos } \\
\text { básicos }\end{array}$} & $\begin{array}{l}\text { Por ejemplo, gastos públicos en servicios de } \\
\text { enseñanza en las instituciones educativas }\end{array}$ & $\begin{array}{l}\text { Por ejemplo, gastos privados } \\
\text { subvencionados en la compra de libros }\end{array}$ \\
\hline & $\begin{array}{l}\text { Por ejemplo, gastos privados } \\
\text { subvencionados en servicios de enseñanza } \\
\text { en las instituciones educativas }\end{array}$ & \multirow[t]{2}{*}{$\begin{array}{l}\text { Por ejemplo, gastos privados en la compra } \\
\text { de libros y otro material escolar, o en clases } \\
\text { particulares }\end{array}$} \\
\hline & $\begin{array}{l}\text { Por ejemplo, gastos privados en tasas } \\
\text { de matrícula }\end{array}$ & \\
\hline \multirow{2}{*}{$\begin{array}{r}\text { Gastos } \\
\text { en investigación } \\
\text { y desarrollo }\end{array}$} & $\begin{array}{l}\text { Por ejemplo, gastos públicos } \\
\text { en investigación en la universidad }\end{array}$ & \\
\hline & $\begin{array}{l}\text { Por ejemplo, fondos de la industria privada } \\
\text { para investigación y desarrollo en } \\
\text { instituciones educativas }\end{array}$ & \\
\hline \multirow[t]{2}{*}{$\begin{array}{r}\text { Gastos } \\
\text { en servicios } \\
\text { educativos aparte } \\
\text { de la enseñanza }\end{array}$} & $\begin{array}{l}\text { Por ejemplo, gastos públicos en servicios } \\
\text { auxiliares tales como comida, transporte } \\
\text { escolar o alojamiento en los campus }\end{array}$ & $\begin{array}{l}\text { Por ejemplo, gastos privados } \\
\text { subvencionados en subsistencia } \\
\text { del estudiante o precios reducidos del } \\
\text { transporte }\end{array}$ \\
\hline & $\begin{array}{l}\text { Por ejemplo, gastos privados en tasas por } \\
\text { servicios auxiliares }\end{array}$ & $\begin{array}{l}\text { Por ejemplo, gastos privados en } \\
\text { subsistencia del estudiante o en transporte }\end{array}$ \\
\hline
\end{tabular}




\section{Diagramas de cobertura}

Para los Indicadores B1, B2, B3 у B6

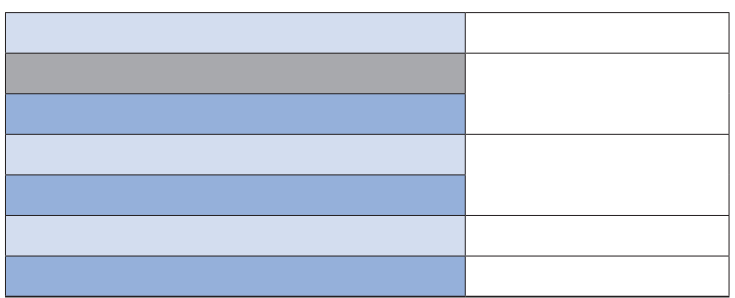

\section{CAPÍTULO B}

Para los Indicadores B4 y B5

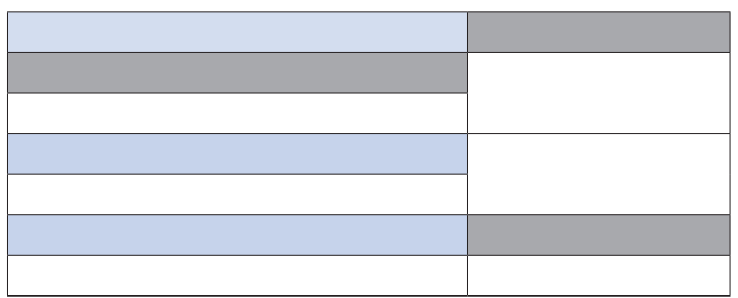




\section{¿CUÁL ES EL GASTO EN EDUCACIÓN POR ESTUDIANTE?}

- Por término medio, los países de la OCDE gastan 9.487 dólares estadounidenses por estudiante desde la educación primaria a la terciaria: 8.296 dólares estadounidenses por estudiante de primaria, 9.280 dólares estadounidenses por estudiante de secundaria y 13.958 dólares estadounidenses por estudiante de educación terciaria.

- En la educación primaria, secundaria y postsecundaria no terciaria, el $94 \%$ del total del gasto por estudiante va dedicado a servicios educativos básicos. Las mayores diferencias se aprecian en el nivel terciario, en parte porque el gasto en I+D representa una media del $32 \%$ del gasto total por estudiante.

- De 2005 a 2011, el gasto por estudiante en las instituciones educativas de educación primaria, secundaria y postsecundaria no terciaria aumentó una media de 17 puntos porcentuales en los países de la OCDE; pero entre 2009 y 2011 la inversión en educación disminuyó en aproximadamente un tercio de los países de la OCDE como resultado de la crisis económica.

\section{Gráfico B1.1. Gasto anual de instituciones educativas por estudiante, por tipo de servicio (2011)}

En equivalente a dólares estadounidenses convertidos mediante PPA, sobre la base de equivalentes a tiempo completo, desde la educación primaria a la terciaria

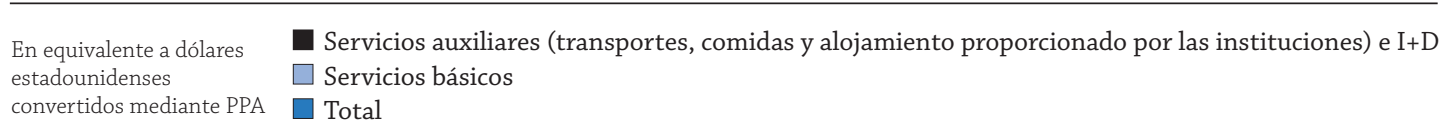
convertidos mediante PPA $\square$ Total

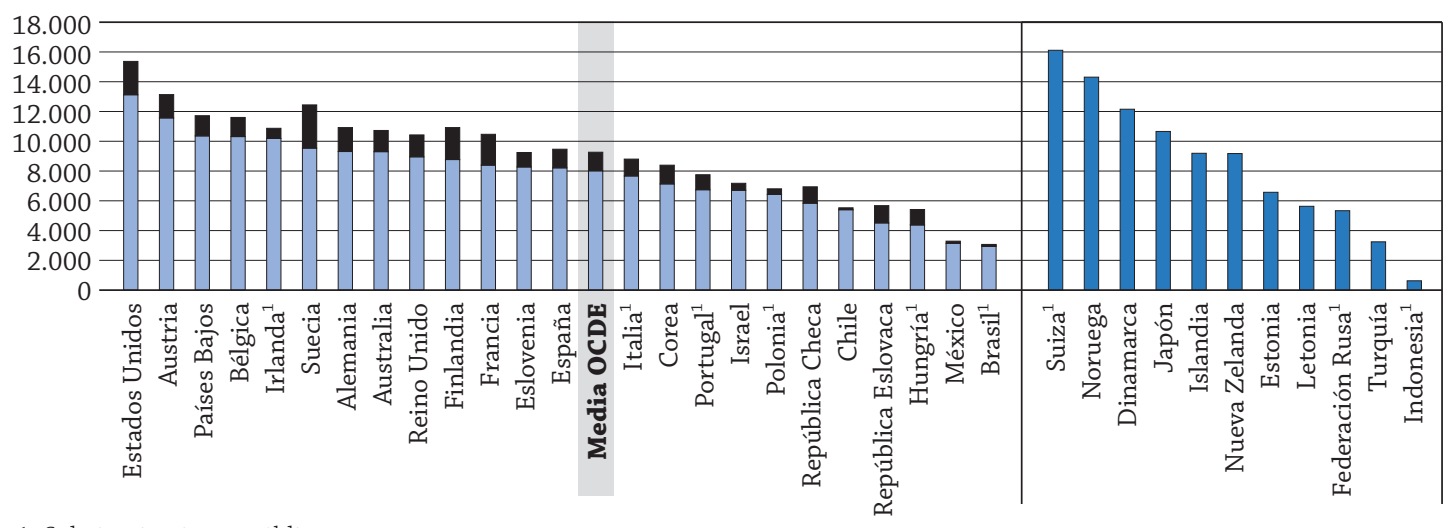

1. Solo instituciones públicas.

Los países están clasificados en orden descendente del gasto de instituciones educativas por estudiante para servicios básicos.

Fuente: OCDE. Tabla B1.2. Para ver notas, consulte Anexo 3 (www.oecd.org/edu/eag.htm).

StatLink ज्ञाज http://dx.doi.org/10.1787/888933117060

\section{Contexto}

La demanda de una educación de alta calidad, que puede traducirse en costes más elevados por estudiante, ha de equilibrarse con otras exigencias en el gasto público y la carga fiscal total. Los responsables políticos deben también mantener un equilibrio entre la importancia de mejorar la calidad de los servicios educativos y la conveniencia de ampliar el acceso a las oportunidades educativas, sobre todo en el nivel terciario. Un estudio comparativo de las tendencias del gasto de las instituciones educativas por estudiante muestra que, en muchos países de la OCDE, el gasto no ha aumentado al mismo nivel que las matrículas. Además, algunos países de la OCDE hacen hincapié en un mayor acceso a la educación superior, mientras que otros invierten en una educación casi universal para niños a partir de los tres o cuatro años. Tanto la inversión en educación como el número de estudiantes matriculados pueden verse afectados por las crisis financieras. Así pues, la reciente crisis económica global es probable que haya afectado al nivel de gasto por estudiante. Sin embargo, dado que la crisis empezó a finales de 2008, los datos disponibles hasta 2011 aún no muestran el alcance total de este impacto.

El gasto por estudiante en instituciones educativas se ve muy influido por los salarios de los profesores (véanse Indicadores B6 y D3), los sistemas de pensiones, las horas lectivas y de enseñanza (véase Indi- 
cador B7), el coste de los materiales pedagógicos y las instalaciones, el programa ofertado (por ejemplo, general o de formación profesional) y el número de estudiantes matriculados en el sistema educativo (véase Indicador $\mathrm{C} 1$ ). Las políticas para atraer a nuevos profesores, para reducir el tamaño medio de las clases o para cambiar los modelos de dotación de personal (véase Indicador D2) han implicado también cambios en el gasto de las instituciones educativas por estudiante a lo largo del tiempo. Los servicios auxiliares y de I+D también pueden influir en el nivel de gasto por estudiante.

\section{Otros resultados}

- Entre los diez países con mayor gasto por estudiante en instituciones educativas de secundaria, los elevados salarios de los profesores y las bajas ratios alumnos-profesor son a menudo los principales factores que explican el nivel de gasto.

- En los niveles de primaria y secundaria hay una relación fuerte y positiva entre el gasto de las instituciones educativas por estudiante y el PIB per cápita. La relación se debilita en el nivel de educación terciaria, principalmente porque los mecanismos de financiación y los modelos de matriculación se diferencian más en este nivel.

- Si se excluyen las actividades periféricas de la formación (investigación y desarrollo y servicios auxiliares, como los servicios de asistencia social a los estudiantes), los países de la OCDE gastan por año una media de 8.002 dólares estadounidenses desde la educación primaria hasta la terciaria. Si se compara con el gasto total medio, esta cantidad inferior se explica por el gasto mucho menor por estudiante en el nivel terciario cuando se excluyen las actividades periféricas de la formación.

- Por término medio, los países de la OCDE gastan casi el doble por estudiante de educación terciaria que por uno de educación primaria. Sin embargo, las actividades de I+D o servicios auxiliares pueden explicar una proporción significativa del gasto en el nivel terciario. Cuando se excluyen estos servicios, el gasto por estudiante en servicios educativos básicos en el nivel terciario sigue siendo como media un $11 \%$ mayor que en los niveles de educación primaria, secundaria y postsecundaria no terciaria.

- La orientación de los programas de educación secundaria influye en el nivel de gasto por estudiante en la mayoría de los países. Entre los 19 países de la OCDE con datos desagregados sobre el gasto en programas generales y de formación profesional en el nivel de educación secundaria superior, se gastó una media de 694 dólares estadounidenses más por estudiante en programas de formación profesional que por uno en el programa general.

\section{Tendencias}

Entre 1995 y 2011, un periodo relativamente estable de matriculación de estudiantes en los niveles de educación primaria, secundaria y postsecundaria no terciaria en la mayoría de los países, el gasto de las instituciones educativas por estudiante se incrementó en promedio más del $60 \%$ en cada país con datos disponibles, excepto Italia. En los países de la OCDE, el incremento medio fue relativamente mayor a lo largo del periodo 1995-2005 que en el periodo 2005-2011. El mayor incremento del gasto por estudiante entre 2005 y 2011 se dio en los países que en 2011 todavía contaban con el nivel más bajo de gasto por estudiante. Desde el principio de la crisis económica en 2008, el gasto por estudiante de educación primaria, secundaria y postsecundaria no terciaria ha seguido aumentando, excepto en Dinamarca, España, Estonia, Federación Rusa, Hungría, Islandia e Italia.

En el nivel de educación terciaria, el gasto por estudiante aumentó entre 1995 y 2011 en la mayoría de los países, excepto en Australia, Brasil, Hungría, Israel, República Checa y Suiza. En los países de la OCDE, la media de gasto por estudiante de educación terciaria se mantuvo constante entre 1995 y 2000 y luego aumentó a un ritmo similar entre 2000 y 2005, y entre 2005 y 2011. Desde el inicio de la crisis económica en 2008, el gasto por estudiante de terciaria ha disminuido en más de un tercio de los países, principalmente porque la matriculación subió más deprisa que el gasto. En Irlanda, Islandia, Federación Rusa y Polonia, sin embargo, ha habido un descenso real del gasto. 


\section{Análisis}

\section{Gasto de instituciones educativas por estudiante}

El gasto por estudiante desde la educación primaria hasta la terciaria en 2011 oscilaba entre 4.000 dólares estadounidenses o menos en Brasil, Indonesia, México y Turquía, más de 10.000 dólares estadounidenses por estudiante en Alemania, Australia, Austria, Bélgica, Dinamarca, Finlandia, Francia, Irlanda, Japón, Noruega, Países Bajos, Reino Unido y Suecia, y más de 15.000 dólares estadounidenses en Estados Unidos y Suiza. En más del 25\% de los países con datos disponibles (9 de 35), el gasto por estudiante oscilaba entre 10.000 dólares estadounidenses y menos de 12.000 dólares estadounidenses por estudiante desde la educación primaria hasta la educación terciaria (Gráfico B1.1 y Tabla B1.1a).

Los países tienen distintas prioridades para asignar sus recursos (véase Indicador B7). Por ejemplo, entre los diez países con el mayor gasto de instituciones educativas por estudiante en la educación secundaria inferior (véase Indicador B1), Dinamarca, Estados Unidos, Irlanda, Luxemburgo, Países Bajos y Suiza están entre los países con los salarios más altos de los profesores tras 15 años de experiencia en la educación secundaria; y Austria, Finlandia, Luxemburgo y Noruega están entre los países con ratios profesor-estudiante más bajas en dicho nivel (véase Tabla B7.2b).

Aun cuando el gasto por estudiante desde la primaria hasta la terciaria es similar en algunos países de la OCDE, el modo en que se distribuyen los recursos entre los distintos niveles de educación varía en gran medida. El gasto de instituciones educativas por estudiante en un país tipo de la OCDE (representado por la media simple de todos los países de la OCDE) asciende a 8.296 dólares estadounidenses en el nivel de primaria, 9.280 dólares estadounidenses en el nivel de secundaria y 13.958 dólares estadounidenses en el de terciaria (Tabla B1.1a y Gráfico B1.2). El gasto medio por estudiante de educación terciaria se ve afectado por el alto gasto -más de 20.000 dólares estadounidenses- en algunos países de la OCDE, sobre todo, Canadá, Dinamarca, Estados Unidos, Suecia y Suiza.

Estas medias enmascaran una amplia escala del gasto de instituciones educativas por estudiante en todos los países de la OCDE, variando en un factor de 11 en el nivel de primaria y en un factor de 6 en el nivel de secundaria. En el nivel de primaria, la escala de gasto va desde los 2.700 dólares estadounidenses o menos por estudiante en Argentina, Brasil, Colombia, Indonesia, México y Turquía hasta más de 23.000 dólares estadounidenses en Luxemburgo. En el nivel de secundaria, el gasto va de 3.000 dólares estadounidenses o menos por estudiante en Brasil, Colombia, Indonesia, México y Turquía hasta más de 16.000 dólares estadounidenses en Luxemburgo (Tabla B1.1a y Gráfico B1.2).

Estas comparaciones se basan en la paridad de poder adquisitivo (PPA) para el PIB, y no en los tipos de cambio de mercado; por tanto, reflejan la cantidad de moneda nacional que se necesita para producir en un determinado país la misma cesta de bienes y servicios que produce Estados Unidos en dólares estadounidenses.

\section{Gasto por estudiante en los servicios educativos básicos}

En los países de la OCDE, la media del gasto en servicios educativos básicos representa el $84 \%$ del total del gasto por estudiante, desde la educación primaria a la terciaria, y pasa del 94\% en Brasil, Chile, México y Polonia. En 2 de los 24 países con datos disponibles -República Eslovaca y Suecia- los servicios educativos básicos representan menos del $80 \%$ del gasto total por estudiante. El gasto anual en I+D y en servicios auxiliares influye en la clasificación de países para todos los servicios combinados. Sin embargo, esta imagen de conjunto enmascara las grandes variaciones que hay entre los niveles educativos (Tabla B1.2).

En los niveles de primaria y de secundaria, el nivel de gasto está dominado por la inversión en servicios educativos básicos. Como media, los países de la OCDE con datos disponibles gastan el 94\% del gasto total (o sea 8.297 dólares estadounidenses) de instituciones de educación primaria, secundaria y postsecundaria no terciaria por estudiante en servicios educativos básicos. En 10 de los 25 países con datos disponibles, los servicios auxiliares facilitados por estas instituciones representan menos del $5 \%$ del gasto total por estudiante. La proporción del gasto total por estudiante dedicado a servicios auxiliares sobrepasa el 10\% en Corea, Finlandia, Francia, Hungría, República Eslovaca y Suecia (Tabla B1.2).

Se constatan mayores diferencias en el nivel de educación terciaria, en parte porque el gasto de I+D da cuenta de una gran proporción del gasto en educación. Los países de la OCDE en los que la I+D se realiza mayoritariamente en instituciones de educación terciaria (por ejemplo, en Portugal, Suecia y Suiza) tienden a mostrar un mayor gasto de instituciones educativas por estudiante que aquellos en que una gran proporción de I+D se lleva a cabo en otras instituciones públicas o en la industria.

Dejando a un lado las actividades de I+D y los servicios auxiliares (servicios periféricos, como los servicios de asistencia social a estudiantes), el gasto de instituciones terciarias en servicios educativos básicos es, como media, de 9.262 dólares estadounidenses por estudiante. Oscila desde los 5.000 dólares estadounidenses o menos en Estonia hasta más de 10.000 dólares estadounidenses en Austria, Brasil, Canadá, Finlandia, Irlanda, Israel, Noruega, Países Bajos y Suiza, y más de 19.000 dólares estadounidenses en Estados Unidos (Tabla B1.2). 
Gráfico B1.2a. Gasto anual de instituciones educativas por estudiante para todos los servicios, por nivel de educación (2011)

En equivalente a dólares estadounidenses convertidos mediante PPA, sobre la base de equivalentes a tiempo completo

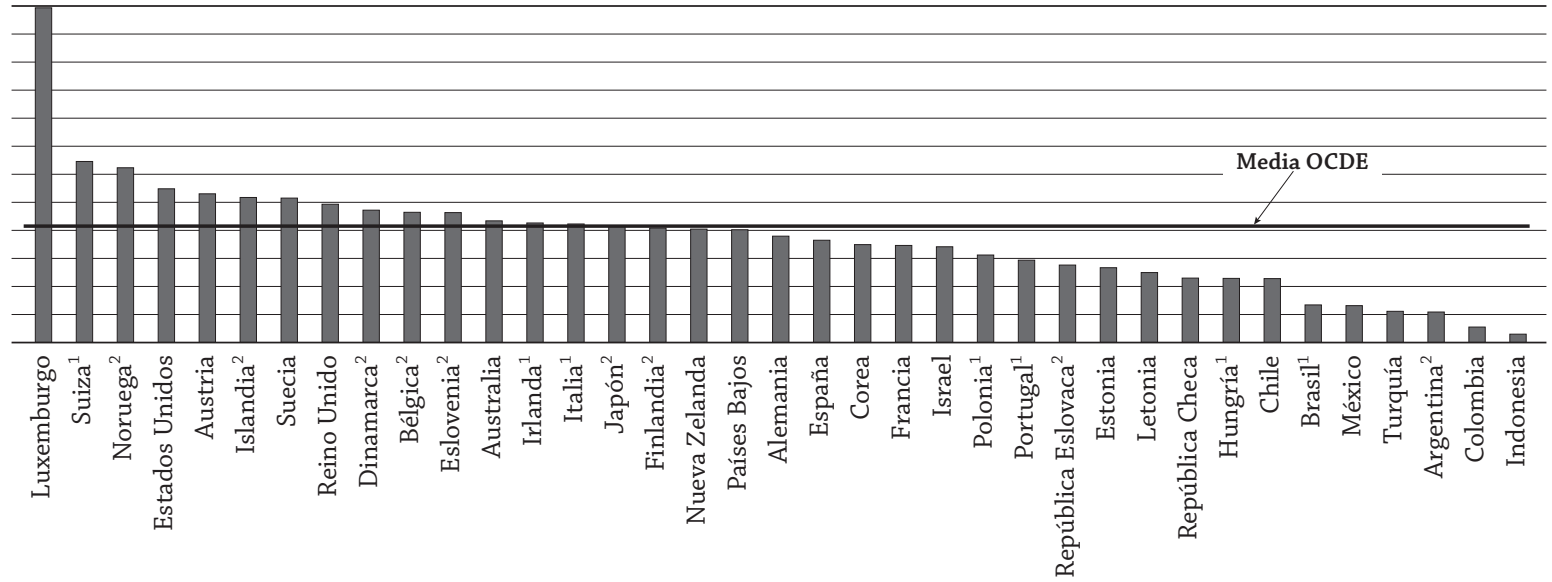

En equivalente a dólares estadounidenses convertidos mediante PPA

Educación secundaria

20.000

18.000

16.000

14.000

12.000

10.000

8.000

4.000

2.000

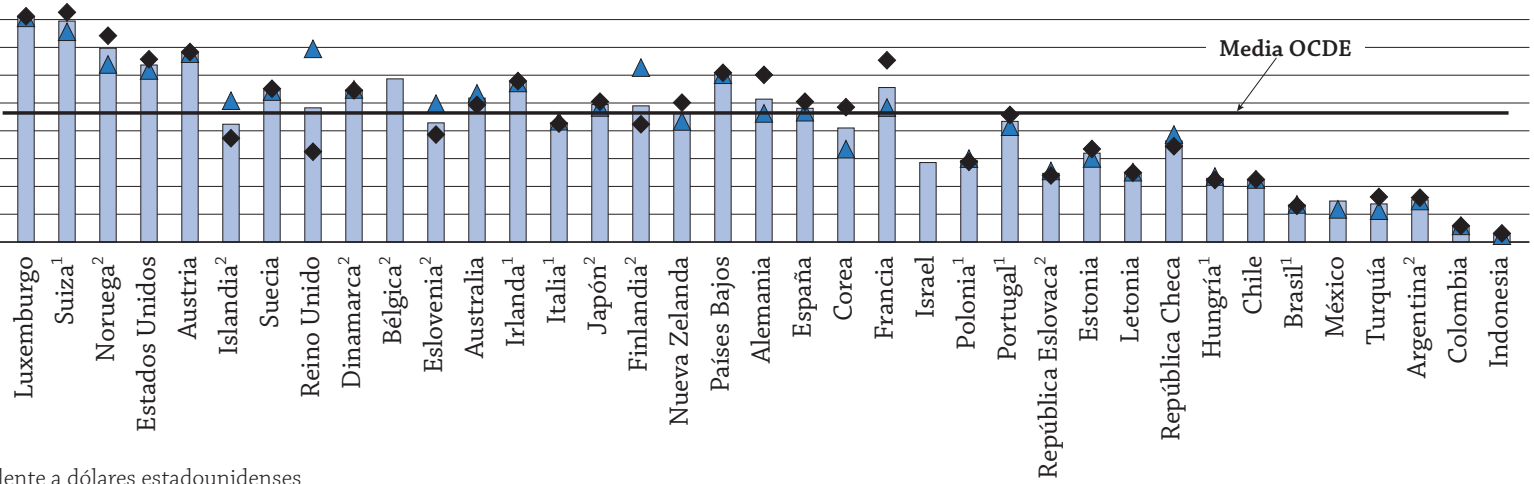

En equivalente a dólares estadounidenses

convertidos mediante PPA

Educación terciaria

28.000

26.000

24.000

20.000

18.000

16.000

14.000

12.000

10.000

8.000

6.000

4.000

2.000

$\square$ Educación secundaria $\Delta$ Educación secundaria inferior $\diamond$ Educación secundaria superior

$$
0
$$

$+$

( 
Como media en los países de la OCDE, el gasto en I+D y en servicios auxiliares en educación terciaria representa un $32 \%$ y un $4 \%$, respectivamente, de todo el gasto por estudiante en instituciones terciarias. En 6 de los 28 países de la OCDE con datos disponibles de I+D y servicios auxiliares de forma desagregada del gasto total -Alemania, Australia, Noruega, Portugal, Suecia y Suiza-, el gasto en I+D y servicios auxiliares representa al menos el $40 \%$ del gasto total en educación terciaria por estudiante en instituciones educativas. Esto puede traducirse en cantidades significativas: en Alemania, Australia, Noruega, Suecia y Suiza, el gasto en I+D y servicios auxiliares asciende a más de 6.000 dólares estadounidenses por estudiante, y este es también el caso en Canadá, Estados Unidos, Finlandia y Países Bajos (Tabla B1.2).

\section{Gasto de instituciones educativas por estudiante en distintos niveles de educación}

El gasto de instituciones educativas por estudiante aumenta con el nivel de educación en casi todos los países, pero el tamaño de los diferenciales cambia notablemente (Tabla B1.1a y Gráfico B1.3). El gasto en educación secundaria es, como media, 1,1 veces mayor que el gasto en educación primaria. Esta ratio supera el 1,5 en Francia, Países Bajos y República Checa, en gran medida por el aumento simultáneo del número de horas de enseñanza para los alumnos y el descenso significativo del número de horas lectivas de los profesores entre la educación primaria y secundaria, si se compara con la media de la OCDE. En estos países, los salarios del profesorado también son más bajos en la educación primaria, si se comparan con la educación secundaria inferior (véanse Indicadores B7, D1 y D4).

Las instituciones educativas de los países de la OCDE gastan una media de 1,7 veces más por estudiante de educación terciaria que por uno de primaria, pero los modelos de gasto cambian mucho, principalmente porque las políticas educativas varían más en el nivel terciario (véase Indicador B5). Por ejemplo, Austria, Corea, Eslovenia, Estonia, Islandia, Italia, Nueva Zelanda, Reino Unido y República Eslovaca gastan menos de 1,5 veces más en un estudiante de educación terciaria que en uno de primaria, pero México y Turquía gastan el triple, y Brasil cuatro veces más (Tabla B1.1a y Gráfico B1.3).

\section{Gráfico B1.3. Gasto de instituciones educativas por estudiante para todos los servicios, en distintos niveles de educación en relación con la educación primaria (2011) Educación primaria $=100$}

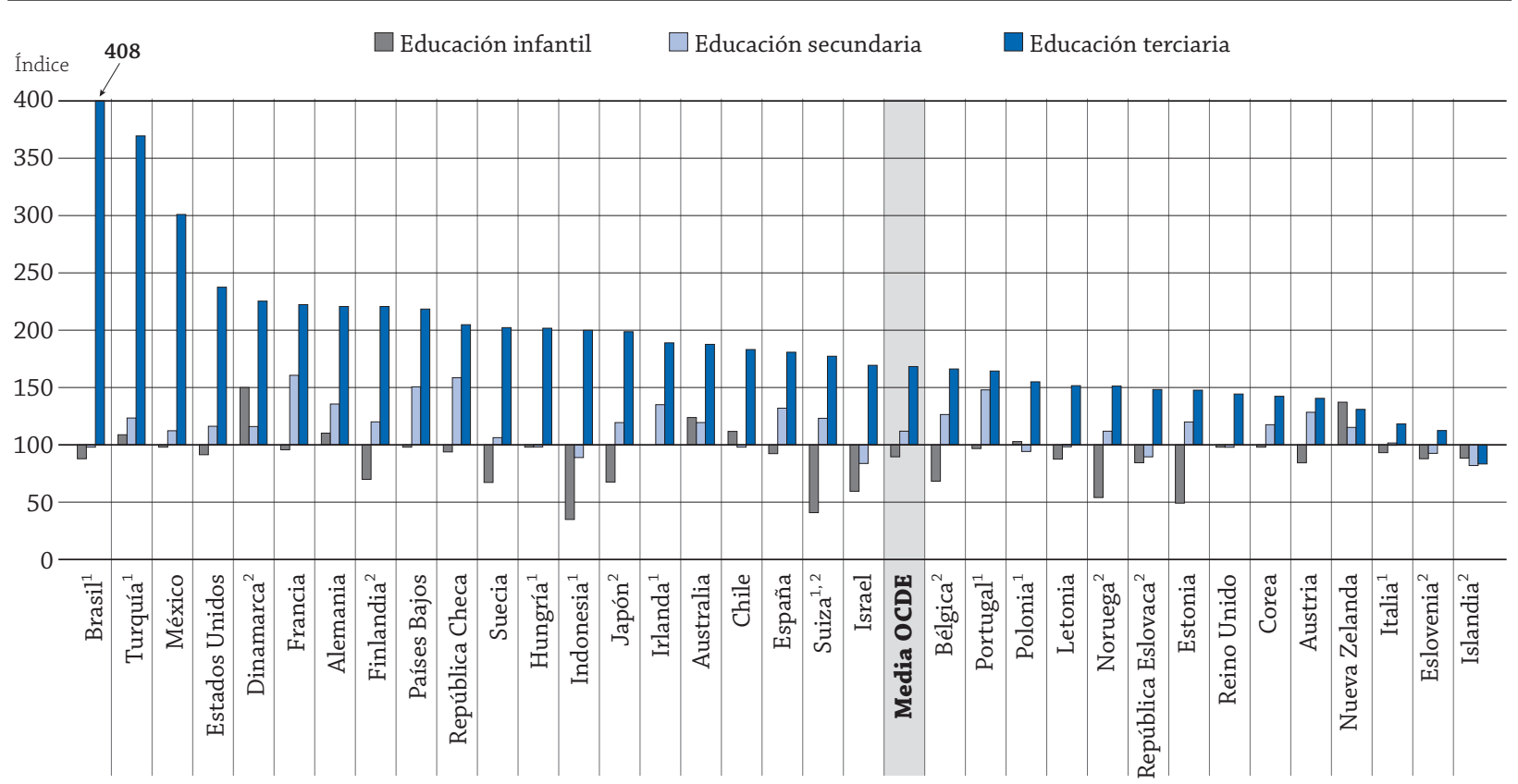

Nota: Una ratio de 300 para educación terciaria significa que el gasto de instituciones educativas por estudiante de terciaria es tres veces mayor que el gasto de instituciones educativas por estudiante de primaria.

Una ratio de 50 en la educación infantil significa que el gasto de las instituciones educativas por estudiante de educación infantil es la mitad del gasto de las instituciones educativas por estudiante de primaria.

1. Solo instituciones públicas.

2. Algunos niveles educativos están incluidos junto con otros. Véase el código «X» en la Tabla B1.1a para obtener más detalles.

Los países están clasificados en orden descendente del gasto de instituciones educativas por estudiante en educación terciaria en relación con la educación primaria. Fuente: OCDE. Tabla B1.1a. Para ver notas, consulte Anexo 3 (www.oecd.org/edu/eag.htm).

StatLink त्गाज् http://dx.doi.org/10.1787/888933117098 


\section{Diferencias del gasto por estudiante entre los programas de educación general y de formación profesional}

En los 19 países de la OCDE con datos disponibles, se gasta una media de 694 dólares estadounidenses más por estudiante de formación profesional de educación secundaria superior que en uno de un programa general. Los países con mayor matriculación en programas para aprendices de formación profesional dual en el nivel de secundaria superior (por ejemplo, Alemania, Austria, Finlandia, Francia, Hungría, Luxemburgo, Países Bajos y Suiza) suelen ser aquellos con mayores diferencias entre el gasto por estudiante en programas generales y de formación profesional, si se compara con la media de la OCDE. Por ejemplo, Finlandia gasta 1.480 dólares estadounidenses más por estudiante de FP que de programas generales; Alemania gasta 4.020 dólares estadounidenses más; Países Bajos gasta 3.139 dólares estadounidenses más; Nueva Zelanda gasta 1.286 dólares estadounidenses más. Francia (852 dólares estadounidenses más), República Checa (1.397 dólares estadounidenses más) y República Eslovaca (1.442 dólares estadounidenses más) también gastan más por estudiante en programas de FP de lo que gastan por un estudiante de programas generales, aunque las diferencias sean menores. Las excepciones a este modelo son Australia y Hungría, donde el gasto por estudiante matriculado en un programa general es ligeramente más alto que el de un estudiante de un programa para aprendices. La infravaloración del gasto realizado por empresas privadas en programas de FP dual puede explicar en parte las pequeñas diferencias entre Austria, Francia y Hungría (Tabla B1.6, y véanse Tabla C1.3 del Indicador C1 y Cuadro B3.1 de Panorama de la educación 2011).

\section{Gasto de instituciones educativas por estudiante a lo largo de la duración media de los estudios terciarios}

Dado que la duración y la intensidad de la educación terciaria varían de país en país, las diferencias del gasto anual en servicios educativos por estudiante (Gráfico B1.2) no reflejan necesariamente las diferencias del coste total de formación de un estudiante típico de terciaria. Por ejemplo, si la duración típica de los estudios de educación terciaria es larga, un gasto anual comparativamente bajo de instituciones educativas por estudiante puede resultar en gastos generales relativamente altos en la educación terciaria. El Gráfico B1.4 muestra el gasto medio por estudiante a lo largo de sus estudios de educación terciaria. Las cifras tienen en cuenta todos los estudiantes para los que se haya incurrido en gastos, incluidos aquellos que no terminan sus estudios. Aunque los cálculos se basan en un número simplificado de supuestos y, por tanto, deben tratarse con cautela (véase Anexo 3 en www.oecd.org/edu/eag.htm), hay algunas diferencias notables entre el gasto anual y el agregado en la clasificación de los países.

Por ejemplo, el gasto anual por estudiante de educación terciaria en Japón viene a ser aproximadamente el mismo que el de Irlanda, 16.446 dólares estadounidenses y 16.095 dólares estadounidenses, respectivamente (Tabla B1.1a). Sin embargo, la duración media de los estudios terciarios es más de un año más larga en Japón que en Irlanda (4,5 y 3,2 años, respectivamente). Por consiguiente, el gasto acumulativo para cada estudiante de terciaria es de 20.000 dólares estadounidenses menos en Irlanda (52.148 dólares estadounidenses) que en Japón (73.364 dólares estadounidenses) (Gráfico B1.4 y Tabla B1.3a).

El coste total de la educación terciaria de tipo A en Suiza (132.433 dólares estadounidenses) es más del doble del que declaran dos terceras partes de los países, a excepción de Alemania, Austria, España, Finlandia, Francia, Japón, Países Bajos y Suecia (Tabla B1.3a). Estas cifras han de interpretarse teniendo en cuenta las diferencias entre las estructuras de las graduaciones de educación terciaria nacionales y las posibles diferencias en las cualificaciones que obtienen los estudiantes tras completar sus estudios. Los programas terciarios de tipo B (más cortos y con orientación profesional) tienden a ser menos costosos que los programas terciarios de tipo A, esencialmente porque su duración es más reducida.

\section{Gasto de instituciones educativas por estudiante con relación al PIB per capita}

Dado que el acceso a la educación es universal (y habitualmente obligatoria) en los niveles inferiores de la escolaridad en la mayoría de los países de la OCDE, el gasto de instituciones educativas por estudiante en esos niveles con relación al PIB per capita se puede interpretar como los recursos gastados en la población en edad escolar con relación a la capacidad de pago del país. En niveles educativos superiores, esta medida es más difícil de interpretar, porque los niveles de matriculación del alumnado varían radicalmente entre países. En el nivel terciario, por ejemplo, los países de la OCDE pueden alcanzar un rango relativamente alto en esta medida si una amplia franja de su riqueza se gasta en educar a un número relativamente pequeño de estudiantes.

En los países de la OCDE, el gasto de instituciones educativas por estudiante está en una media del $23 \%$ del PIB per capita en el nivel de primaria, del $26 \%$ en educación secundaria y del $41 \%$ para la terciaria. En general, desde la 


\section{Gráfico B1.4. Gasto acumulativo de instituciones educativas por estudiante a lo largo de la duración media de los estudios de educación terciaria (2011)}

Gasto anual de instituciones educativas por estudiante, multiplicado por la duración media de los estudios, en equivalente a dólares estadounidenses convertidos mediante PPA.

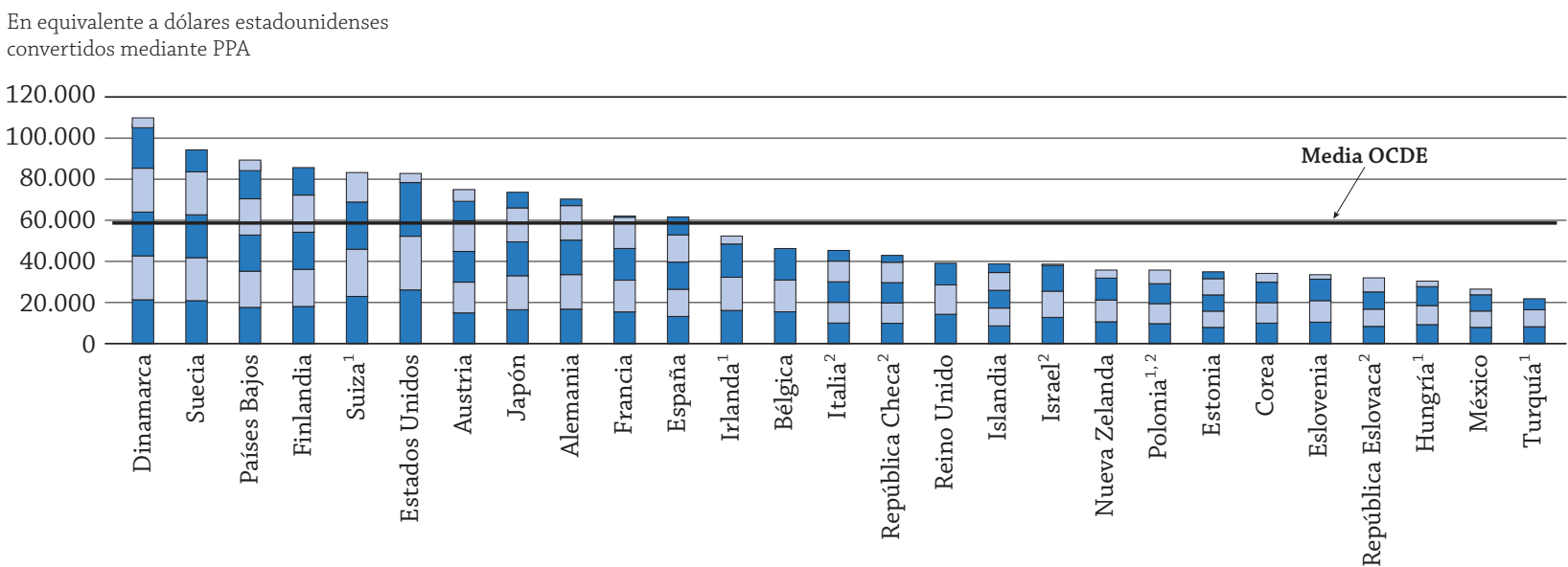

Nota: Cada segmento de la barra representa el gasto anual de instituciones educativas por estudiante. El número de segmentos representa el número medio de cursos que permanece un estudiante en educación terciaria.

1. Solo instituciones públicas.

2. Solo programas de educación terciaria de tipo A y de investigación avanzada.

Los países están clasificados en orden descendente del gasto de instituciones educativas por estudiante a lo largo de la duración media de los estudios de educación terciaria.

Fuente: OCDE. Tabla B1.3a. Para ver notas, consulte Anexo 3 (www.oecd.org/edu/eag.htm)

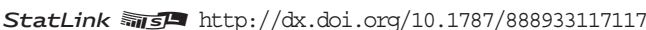

educación primaria a la terciaria, el gasto medio por estudiante está en una media del $27 \%$ del PIB per capita en los países de la OCDE (Tabla B1.4). Los países con niveles bajos de gasto pueden, sin embargo, mostrar distribuciones de inversión con relación al PIB per capita similares a las de los países con un alto nivel de gasto por estudiante. Por ejemplo, Corea y Portugal -países con un nivel de gasto de instituciones educativas por estudiante por debajo de la media de la OCDE en el nivel de secundaria y por debajo de la media en el PIB per cápita de la OCDE- gastan más por estudiante con relación al PIB per capita que la media de la OCDE.

Es difícil de interpretar la relación entre el PIB per cápita y el gasto de instituciones educativas por estudiante. Sin embargo, hay una relación clara y positiva entre los dos, tanto en el nivel educativo de primaria como en el de secundaria; en otras palabras, los países más pobres tienden a gastar menos por estudiante que los más ricos. Aunque la relación es generalmente positiva en estos niveles, se dan variaciones incluso entre países con niveles similares del PIB per cápita, y especialmente en aquellos en que el PIB per cápita supera los 30.000 dólares estadounidenses. Israel y Nueva Zelanda, por ejemplo, tienen niveles similares de PIB per cápita (véase Tabla X2.1 del Anexo 2), pero gastan muy distintas proporciones del mismo en la educación primaria y la secundaria. En Israel, las proporciones son del $23 \%$ en el nivel de primaria, y del $19 \%$ en el nivel de secundaria (en o por debajo de las medias de la OCDE del $23 \%$ y del $26 \%$, respectivamente), mientras que en Nueva Zelanda las proporciones están entre las más altas, $26 \%$ y $30 \%$ respectivamente (Tabla B1.4 y Gráfico B1.2b, disponible en Internet).

Hay más variación en los niveles de gasto en educación terciaria, y la relación entre la riqueza relativa de los países y sus niveles de gasto varía también. Canadá, Dinamarca, Estados Unidos y Suecia gastan más del $49 \%$ del PIB per cápita en cada estudiante de educación terciaria, una de las proporciones más altas tras Brasil (Tabla B1.4 y Gráfico B1.5). Brasil gasta el equivalente al $93 \%$ del PIB per cápita por cada estudiante de terciaria; sin embargo, los estudiantes de educación terciaria solo representan el $4 \%$ de los matriculados en todos los niveles de educación en conjunto (Tabla B1.7, disponible en Internet).

\section{Cambio en el gasto de las instituciones educativas por estudiante entre 1995 y 2011}

Los cambios en el gasto de instituciones educativas reflejan en gran medida los cambios en el tamaño de la población en edad escolar y en los salarios de los profesores. Estos gastos tienden a aumentar a lo largo del tiempo en términos 


\section{Gráfico B1.5. Relación entre el gasto anual por estudiante en 2011 y el cambio del gasto por estudiante entre 2005 y 2011}

En equivalente a dólares estadounidenses convertidos mediante PPA, sobre la base de equivalentes a tiempo completo

Gasto anual por estudiante

(2011, en dólares

Educación primaria, secundaria y postsecundaria no terciaria

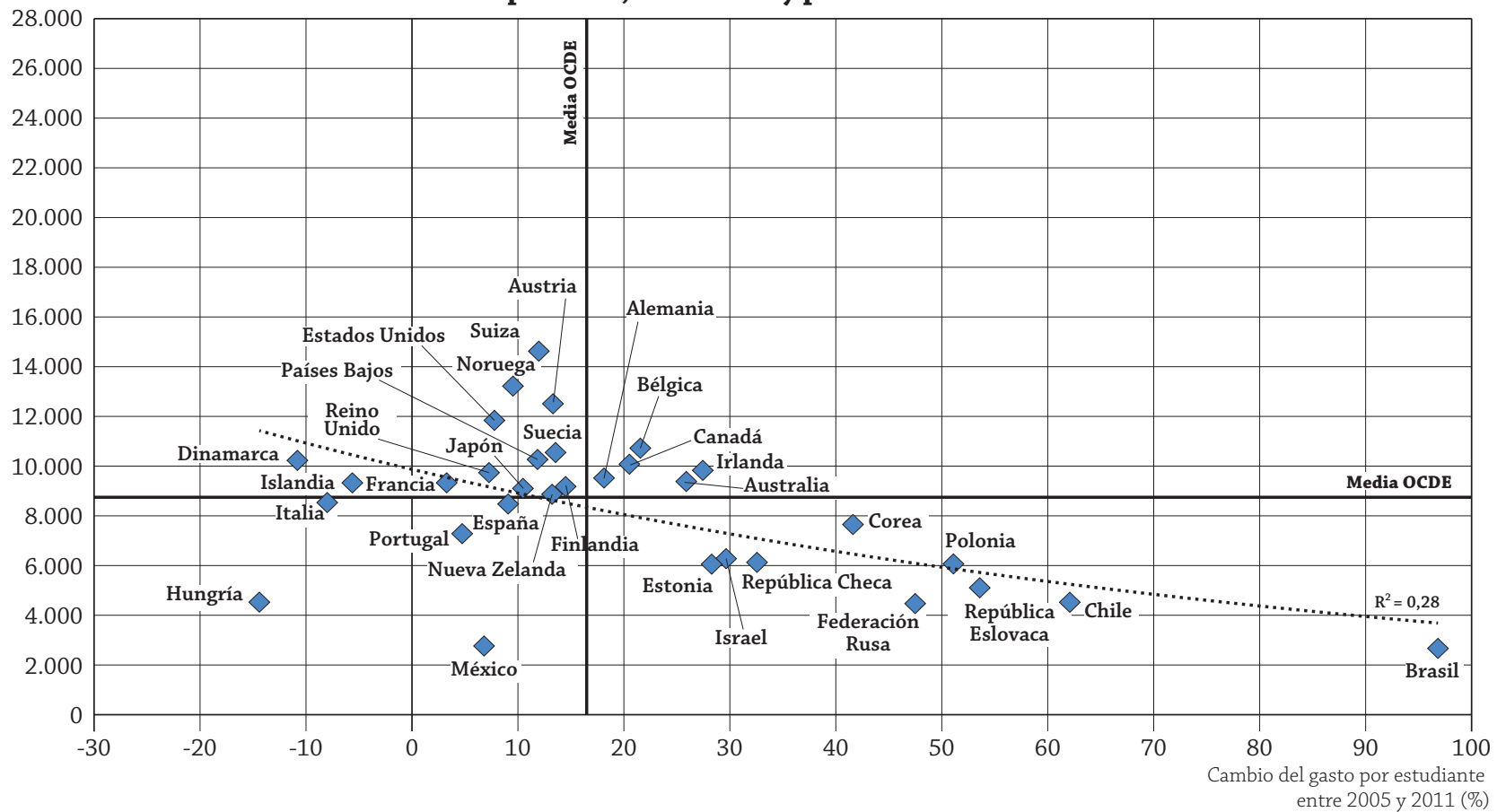

Gasto anual por estudiante

(2011, en dólares estadounidenses)

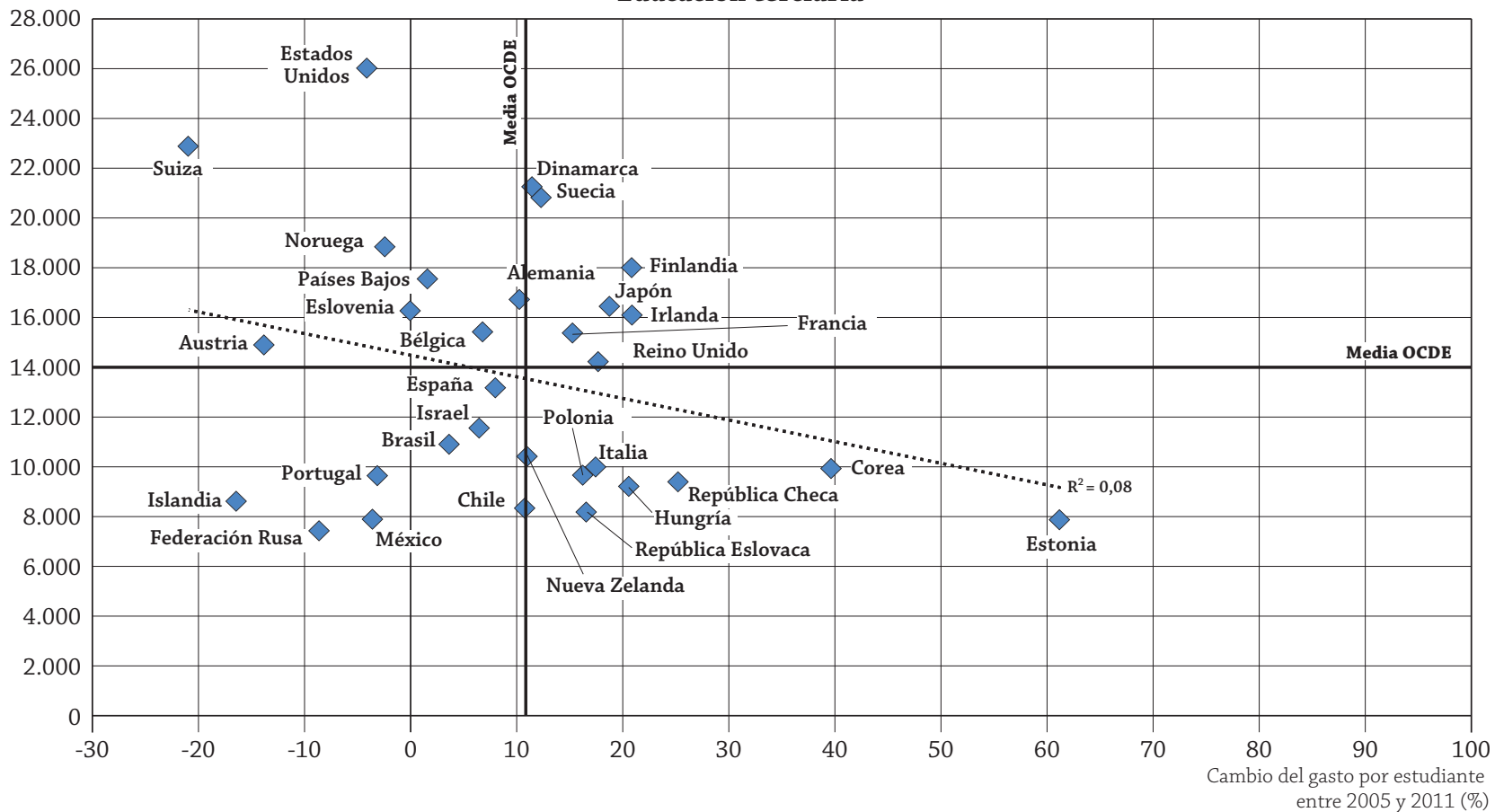

Fuente: OCDE. Tablas B1.2, B1.5a y B1.5b. Para ver notas, consulte Anexo 3 (www.oecd.org/edu/eag.htm).

StatLink 쳎ㄴ http://dx.doi.org/10.1787/888933117136 
reales: los salarios de los profesores, el componente principal de los costes, han crecido en la mayoría de los países en la última década (véase Indicador D3). El tamaño de la población en edad escolar-influye tanto en los niveles de matriculación como en la cantidad de recursos y el esfuerzo organizativo que un país debe invertir en su sistema educativo. Cuanta más población en edad escolar haya, mayor será la demanda potencial de servicios educativos. El cambio en el gasto por estudiante a lo largo de los años también puede variar entre los niveles educativos dentro de los países, dado que tanto la matriculación como el gasto pueden seguir distintas tendencias en distintos niveles educativos. En educación terciaria, en comparación con otros niveles educativos, el gasto por estudiante decreció en muchos países entre 2005 y 2011 (Tablas B1.5a y B1.5b, y Gráfico B1.5).

El gasto de instituciones educativas por estudiante de primaria, secundaria y postsecundaria no terciaria se incrementó en cada país en una media de más del 60 \% entre 1995 y 2011, tiempo en el que la matriculación en estos niveles fue relativamente estable. En la mayoría de los países, el incremento fue relativamente mayor a lo largo del periodo 1995-2005 que en el periodo 2005-2011, como resultado de un mayor incremento del gasto en el primer periodo que en el segundo.

Entre 2005 y 2011, en 23 de los 34 países con datos disponibles, el gasto de instituciones educativas por estudiante de educación primaria, secundaria y postsecundaria no terciaria se incrementó al menos en un $10 \%$. El incremento superó el $50 \%$ en Brasil, Chile, Polonia y República Eslovaca. Por el contrario, en Francia y Portugal este gasto se incrementó en sólo $5 \%$ o menos. Solo Dinamarca, Hungría, Islandia e Italia mostraron un descenso en el gasto por estudiante de educación primaria, secundaria y postsecundaria no terciaria durante este periodo (Tabla B1.5.a).

En Brasil, Chile, Federación Rusa, Polonia y República Eslovaca, los incrementos del gasto por estudiante a lo largo de 2005-2011 están entre los mayores, pero estos países en 2011 se encontraban aún entre aquellos con menor gasto por estudiante. La correlación entre el nivel de gasto por estudiante y sus variaciones a lo largo del tiempo es débil. Por ejemplo, Hungría y México, con niveles similares de gasto por estudiante en 2011, no incrementaron su gasto por estudiante de forma similar. El gasto por estudiante disminuyó en Hungría a lo largo del periodo como resultado de una disminución tanto del gasto como de la matriculación. En Hungría, las disminuciones de matriculación no parecen haber sido el factor principal que está detrás de los cambios en el gasto por estudiante (Tabla B1.5a y Gráfico B1.5).

Desde el comienzo de la crisis económica en 2008, sin embargo, el gasto por estudiante de educación primaria, secundaria y postsecundaria no terciaria disminuyó en unos pocos países, principalmente en Dinamarca, España, Estonia, Federación Rusa, Hungría, Islandia e Italia. Si excluimos España, este descenso resulta de la disminución del gasto (además de un gran aumento de matriculaciones en Dinamarca). En la mayoría de los países, el gasto siguió aumentando incluso cuando las matrículas disminuyeron (excepto en Australia e Israel), lo que significó un mayor gasto por estudiante. Esto demuestra que, en la mayoría de los países, la crisis económica global no había afectado aún a las inversiones generales en educación (Gráfico B1.6).

El modelo es diferente en el nivel de educación terciaria. El gasto por estudiante aumentó entre 1995 y 2011 en la mayoría de los países, a excepción de Australia, Brasil, Hungría, Israel, República Checa y Suiza, donde el gasto no se correspondió con las crecientes matriculaciones. Como media en los países de la OCDE, el gasto de instituciones educativas por estudiante de educación terciaria permaneció estable entre 1995 y 2000, pero luego se incrementó en proporciones similares (del 5\% al 10\%) entre el 2000 y el 2005, y entre 2005 y 2011.

Entre 2005 y 2011, el gasto por estudiante de educación terciaria aumentó en la mayoría de los países, y en un $10 \%$ como media en los países de la OCDE con datos disponibles. Este incremento alcanzó el $40 \%$ o más en Corea y Estonia, tras un gran aumento del gasto junto con una matriculación constante. Por el contrario, a lo largo de este periodo, el gasto por estudiante descendió en cerca de una cuarta parte de los países (8 de los 32 países con datos disponibles), especialmente en Austria, Islandia y Suiza (en un $14 \%$ o más). En todos estos países, la disminución se debió al rápido incremento del número de estudiantes de terciaria (Tabla B1.5b y Gráfico B1.5).

Desde el comienzo de la crisis económica en 2008, el gasto de instituciones de educación terciaria ha disminuido en 4 de los 32 países con datos disponibles: Federación Rusa, Irlanda, Islandia y Polonia. Esto condujo a una disminución del gasto por estudiante en esos países a excepción de Federación Rusa y Polonia, donde la matriculación disminuyó incluso más deprisa. De forma global, el gasto por estudiante disminuyó en más de un tercio de los países entre 2008 y 2011, principalmente debido a que la matriculación creció más deprisa que el gasto (Gráfico B1.6).

\section{Definiciones}

Los servicios auxiliares se definen como los servicios proporcionados por instituciones educativas no relacionados con la misión educativa principal. El componente principal de estos servicios auxiliares son los servicios de asistencia 


\section{Gráfico B1.6. Cambios en el gasto de instituciones educativas por estudiante, por nivel de educación $(2008,2011)$ \\ Índice de cambio entre 2008 y 2011 (2008 =100, 2011 precios constantes)}

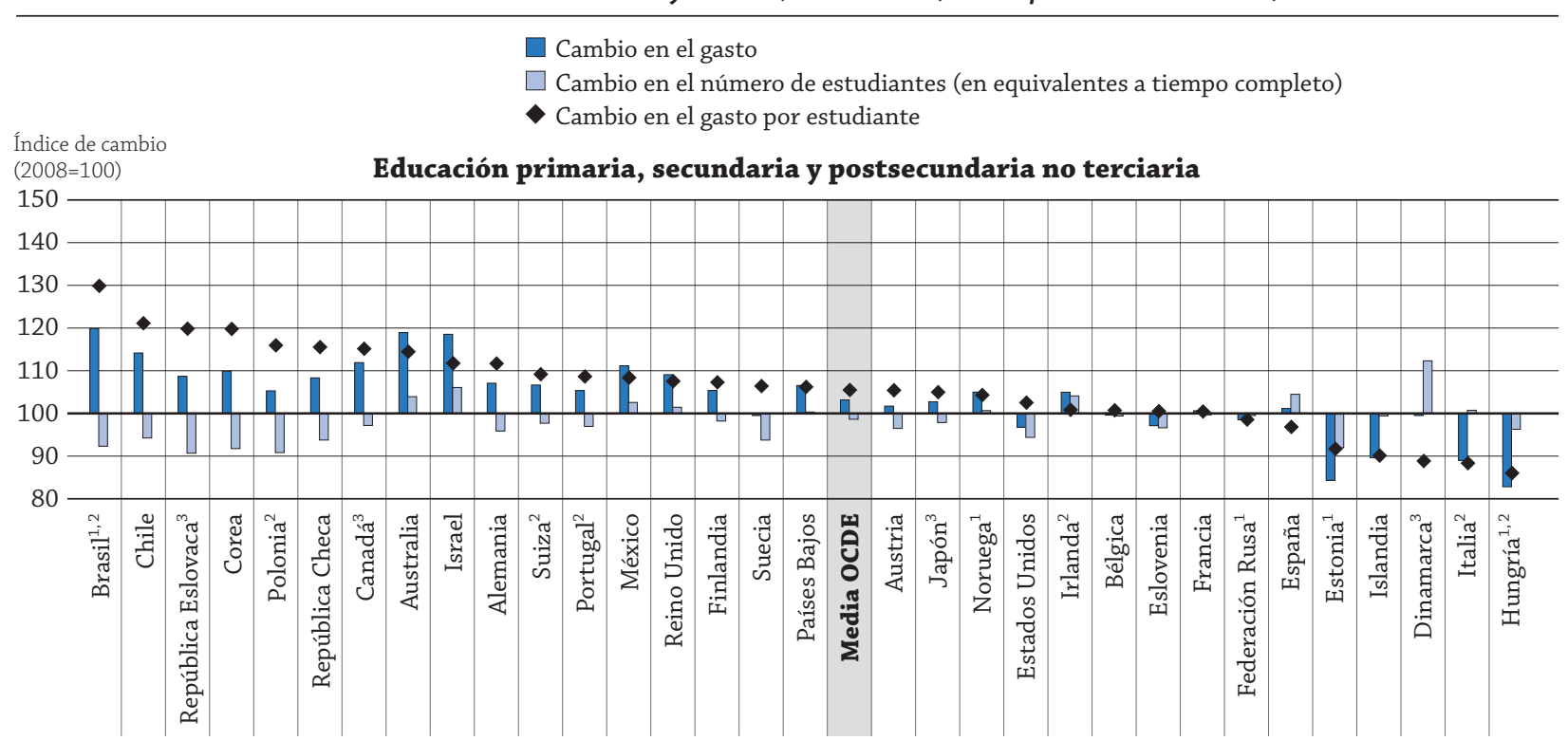

Índice de cambio

$(2008=100)$

Educación terciaria

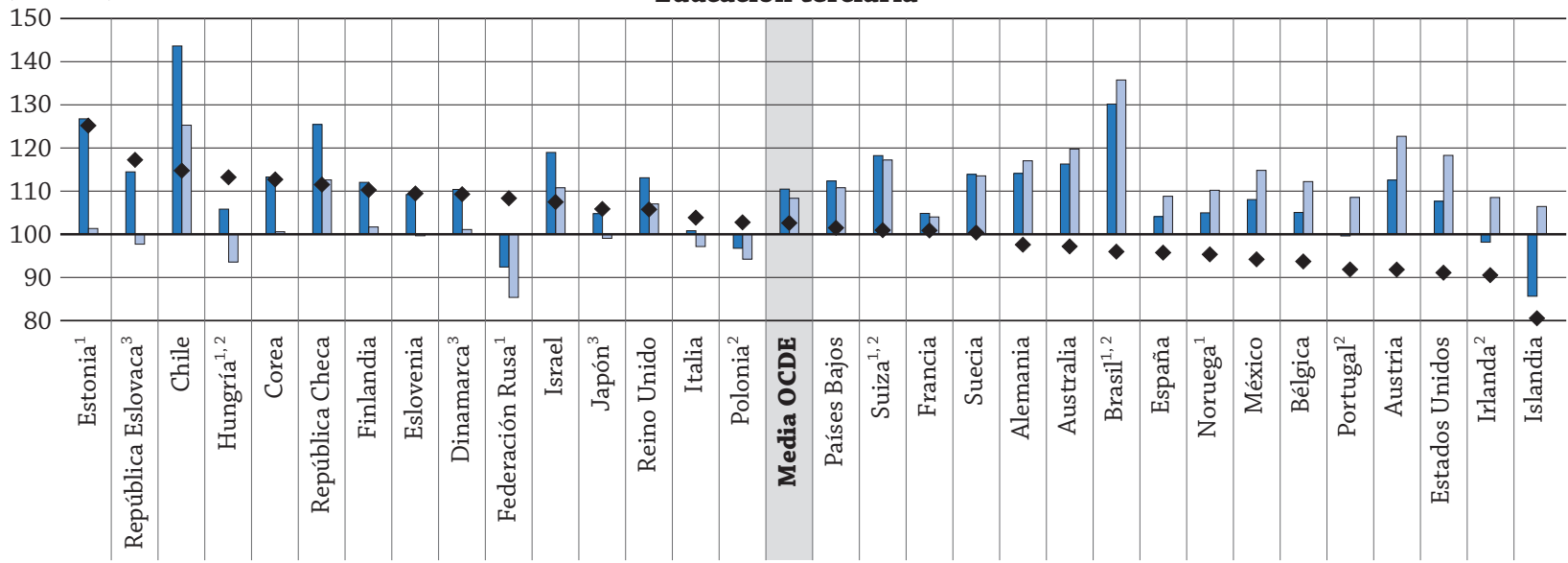

1. Solo gasto público.

2. Solo instituciones públicas.

3. Algunos niveles educativos están incluidos junto con otros. Véase el código «X» en la Tabla B1.1a para obtener más detalles.

Los países están clasificados en orden descendente del cambio en el gasto de instituciones educativas por estudiante.

Fuente: OCDE. Tablas B1.5a y B1.5b. Para ver notas, consulte Anexo 3 (www.oecd.org/edu/eag.htm).

StatLink 제이 http://dx.doi.org/10.1787/888933117155

social a los estudiantes. En la educación primaria, secundaria y postsecundaria no terciaria, los servicios de asistencia social al estudiante incluyen elementos como comida, servicios sanitarios escolares y transporte desde y hasta el centro educativo. En el nivel terciario se incluyen las residencias (dormitorios), comedores universitarios y servicios de atención sanitaria.

Los servicios educativos básicos están directamente relacionados con la educación en instituciones educativas, lo que incluye los salarios de los profesores, la construcción y el mantenimiento de los edificios escolares, el material escolar, los libros y la administración de los centros escolares.

Investigación y desarrollo (I+D) incluye la investigación realizada en universidades y otras instituciones de educación terciaria, independientemente de si la investigación se financia con fondos de instituciones generales, mediante subvenciones independientes o contratos de patrocinadores públicos o privados. 


\section{Metodología}

Los datos se refieren al año financiero 2011 y se basan en la recopilación de estadísticas educativas de la UOE gestionadas por la OCDE en 2013 (para detalles, véase Anexo 3 en www.oecd.org/edu/eag.htm).

Las Tablas B1.5a y B1.5b muestran los cambios en el gasto de instituciones educativas por estudiante entre los años financieros de 1995, 2000, 2005, 2008, 2009, 2010 y 2011. Se pidió a los países de la OCDE que recabasen datos de 1995, 2000, 2005, 2008, 2009 y 2010 según las definiciones y coberturas de la recopilación de datos de la UOE. Todos los datos sobre gasto e información sobre el PIB de 1995, 2000 y 2005, 2008, 2009 y 2010 están adaptados a los precios de 2011 utilizando el deflactor de precios del PIB.

El indicador muestra el gasto público y privado directo de instituciones educativas con relación al número de estudiantes matriculados en equivalentes a tiempo completo. Los subsidios públicos para los gastos de manutención de los estudiantes fuera de las instituciones educativas se han excluido para asegurar la comparabilidad internacional.

Los servicios educativos básicos se estiman como una cantidad residual de todos los gastos, es decir, el gasto total en instituciones educativas una vez descontados los gastos en I+D y servicios auxiliares. La clasificación del gasto en I+D se basa en los datos recabados de las instituciones que desarrollan la I+D más que en las fuentes de financiación.

El gasto de instituciones educativas por estudiante en un nivel concreto de educación se calcula dividiendo el gasto total de las instituciones educativas en ese nivel por la correspondiente matriculación equivalente a tiempo completo. Solo se tienen en cuenta las instituciones y programas educativos para los que hay datos disponibles tanto de matriculación como de gasto. El gasto en moneda nacional se convierte a su equivalente en dólares estadounidenses, dividiendo la cifra de la moneda nacional por el índice de la paridad de poder adquisitivo (PPA) para el PIB. Se usa el índice de PPA porque el tipo de cambio del mercado se ve afectado por muchos factores (tipos de interés, políticas comerciales, expectativas de crecimiento económico, etc.) que poco tienen que ver con el poder adquisitivo relativo actual de los distintos países de la OCDE (véase Anexo 2 para más detalles).

Los datos de gasto para los estudiantes de instituciones educativas privadas no están disponibles en ciertos países, y algunos proporcionan datos incompletos sobre instituciones privadas independientes. Cuando ese es el caso, solo se ha tenido en cuenta el gasto en instituciones públicas y privadas dependientes del gobierno.

El gasto de instituciones educativas por estudiante con relación al PIB per cápita se calcula haciendo constar el gasto de las instituciones educativas por estudiante en unidades de la moneda nacional como porcentaje del PIB per cápita, también en moneda nacional. En casos en que los datos del gasto educativo y los datos del PIB pertenecen a distintos periodos de referencia, los datos del gasto se ajustan al mismo periodo de referencia que los datos del PIB, utilizando las tasas de inflación para el país de la OCDE en cuestión (véase Anexo 2).

El gasto acumulativo a lo largo del transcurso medio de los estudios de educación terciaria (Tabla B1.3a) se calcula multiplicando el gasto corriente anual por la duración habitual de los estudios de educación terciaria. La metodología empleada para estimar la duración típica de los estudios de educación terciaria se describe en el Anexo 3 (www.oecd.org/edu/eag.htm). Para estimaciones sobre la duración de la educación terciaria, los datos se basan en un estudio realizado en los países de la OCDE en 2013.

Equivalente a un estudiante a tiempo completo: La clasificación de los países de la OCDE por gasto anual en servicios educativos por estudiante se ve afectada por las diferencias en lo que los países definen como a tiempo completo, a tiempo parcial y el equivalente de matriculación a tiempo completo. Algunos países de la OCDE cuentan cada participante en el nivel de educación terciaria como un estudiante a tiempo completo, mientras que otros determinan la intensidad de participación de un estudiante por los créditos que ha obtenido en la consecución de las asignaturas durante un periodo de referencia específico. Los países de la OCDE que pueden dar cuenta de matriculación a tiempo parcial de forma precisa tienen un gasto aparente más elevado de instituciones educativas por estudiante a tiempo completo que los países de la OCDE que no pueden diferenciar los distintos tipos de asistencia estudiantil.

Nota sobre los datos de Israel

Los datos estadísticos para Israel fueron proporcionados por las autoridades israelíes competentes bajo su responsabilidad. El uso de estos datos por parte de la OCDE se hace sin prejuzgar la situación de los Altos del Golán, Jerusalén Este y los asentamientos israelíes en Cisjordania de acuerdo con los términos del derecho internacional. 
Tablas del Indicador B1

StatLink 제그 http://dx.doi.org/10.1787/888933116908

Tabla B1.1a Gasto anual de instituciones educativas por estudiante para todos los servicios (2011)

WEB Tabla B1.1b Gasto anual de instituciones educativas por estudiante para servicios básicos (2011)

Tabla B1.2 Gasto anual de instituciones educativas por estudiante para servicios básicos, auxiliares y de I+D (2011)

Tabla B1.3a Gasto acumulativo de instituciones educativas por estudiante para todos los servicios a lo largo de la duración media de los estudios de educación terciaria (2011)

WEB Tabla B1.3b Gasto acumulativo de instituciones educativas por estudiante para todos los servicios a lo largo de la duración teórica de los estudios de educación primaria y secundaria (2011)

Tabla B1.4 Gasto anual de instituciones educativas por estudiante para todos los servicios, con relación al PIB per cápita (2011)

Tabla B1.5a Cambio en el gasto de instituciones educativas por estudiante para todos los servicios, con relación a diferentes factores en los niveles de educación primaria, secundaria y postsecundaria no terciaria $(1995,2000,2005,2008,2009,2010,2011)$

Tabla B1.5b Cambio en el gasto de instituciones educativas por estudiante para todos los servicios, con relación a diferentes factores en el nivel de educación terciaria $(1995,2000,2005,2008,2009,2010,2011)$

Tabla B1.6 Gasto anual de instituciones educativas por estudiante para todos los servicios, por tipo de programa (2011)

WEB Tabla B1.7 Porcentaje de gasto de instituciones educativas en comparación con la proporción de estudiantes matriculados en cada nivel de educación (2011) 
Tabla B1.1a. Gasto anual de instituciones educativas por estudiante para todos los servicios (2011)

En equivalente a dólares estadounidenses convertidos mediante PPA para el PIB, por nivel educativo, sobre la base de equivalentes a tiempo completo

\begin{tabular}{|c|c|c|c|c|c|c|c|c|c|c|c|}
\hline & \multirow[b]{2}{*}{$\begin{array}{c}\text { Educación } \\
\text { infantil } \\
\text { (para niños } \\
\text { de } 3 \text { años } \\
\text { en adelante) }\end{array}$} & \multirow[b]{2}{*}{$\begin{array}{c}\text { Educación } \\
\text { primaria }\end{array}$} & \multicolumn{3}{|c|}{ Educación secundaria } & \multirow[b]{2}{*}{$\begin{array}{c}\text { Educación } \\
\text { post- } \\
\text { secundaria } \\
\text { no terciaria }\end{array}$} & \multicolumn{3}{|c|}{$\begin{array}{c}\text { Educación terciaria } \\
\text { (incluyendo actividades de I+D) }\end{array}$} & \multirow[b]{2}{*}{$\begin{array}{c}\text { Toda la } \\
\text { educación } \\
\text { terciaria } \\
\text { (excluyendo } \\
\text { actividades } \\
\text { de I+D) }\end{array}$} & \multirow{2}{*}{$\begin{array}{c}\text { De } \\
\text { educación } \\
\text { primaria } \\
\text { a terciaria } \\
\text { (incluyendo } \\
\text { actividades } \\
\text { de I+D) }\end{array}$} \\
\hline & & & $\begin{array}{c}\text { Educación } \\
\text { secundaria } \\
\text { inferior }\end{array}$ & $\begin{array}{c}\text { Educación } \\
\text { secundaria } \\
\text { superior }\end{array}$ & $\begin{array}{c}\text { Toda la } \\
\text { educación } \\
\text { secundaria }\end{array}$ & & $\begin{array}{c}\text { Educación } \\
\text { terciaria } \\
\text { de tipo B }\end{array}$ & $\begin{array}{c}\text { Educación } \\
\text { terciaria de tipo } \\
\text { A y programas } \\
\text { de investigación } \\
\text { avanzada }\end{array}$ & $\begin{array}{c}\text { Toda la } \\
\text { educación } \\
\text { terciaria }\end{array}$ & & \\
\hline & (1) & (2) & (3) & (4) & $(5)$ & (6) & (7) & (8) & (9) & (10) & (11) \\
\hline Alemania & 8.351 & 7.579 & 9.247 & 12.022 & 10.275 & 9.694 & 8.891 & 18.348 & 16.723 & 10.164 & 10.904 \\
\hline Australia & 10.734 & 8.671 & 10.689 & 9.859 & 10.354 & 6.728 & 8.495 & 18.038 & 16.267 & 10.068 & 10.711 \\
\hline Austria & 8.933 & 10.600 & 13.547 & 13.666 & 13.607 & 5.917 & 6.944 & 14.967 & 14.895 & 10.487 & 13.116 \\
\hline Bélgica & 6.333 & 9.281 & $x(5)$ & $\mathrm{x}(5)$ & 11.732 & $x(5)$ & $\mathrm{x}(9)$ & $\mathrm{x}(9)$ & 15.420 & 10.075 & 11.585 \\
\hline Canadá $^{1,2}$ & $x(2)$ & 9.232 & $x(2)$ & 11.607 & $\mathrm{~m}$ & $\mathrm{~m}$ & 15.729 & 27.373 & 23.226 & 17.006 & $\mathbf{m}$ \\
\hline Chile $^{3}$ & 5.083 & 4.551 & 4.494 & 4.496 & 4.495 & a & 5.045 & 11.082 & 8.333 & 7.897 & 5.522 \\
\hline Corea & 6.861 & 6.976 & 6.674 & 9.698 & 8.199 & a & 5.692 & 11.230 & 9.927 & 8.168 & 8.382 \\
\hline Dinamarca & 14.148 & 9.434 & 10.971 & 10.908 & 10.937 & $\mathrm{x}(4,9)$ & $\mathrm{x}(9)$ & $\mathrm{x}(9)$ & 21.254 & 4.827 & 12.136 \\
\hline Eslovenia & 8.136 & 9.260 & 9.947 & 7.724 & 8.568 & $x(4)$ & $\mathrm{x}(9)$ & $\mathrm{x}(9)$ & 10.413 & 8.279 & 9.233 \\
\hline Estados Unidos & 10.010 & 10.958 & 12.338 & 13.143 & 12.731 & $\mathrm{~m}$ & $\mathrm{x}(9)$ & $\mathrm{x}(9)$ & 26.021 & 23.094 & 15.345 \\
\hline Estonia & 2.618 & 5.328 & 6.009 & 6.688 & 6.389 & 8.333 & 6.628 & 8.450 & 7.868 & 4.827 & 6.563 \\
\hline Finlandia & 5.700 & 8.159 & 12.545 & 8.467 & 9.792 & $x(5)$ & $\mathrm{n}$ & 18.002 & 18.002 & 10.973 & 10.905 \\
\hline Francia & 6.615 & 6.917 & 9.668 & 13.071 & 11.109 & $\mathrm{~m}$ & 12.554 & 16.328 & 15.375 & 10.470 & 10.454 \\
\hline Grecia & $\mathrm{m}$ & $\mathrm{m}$ & $\mathrm{m}$ & $\mathrm{m}$ & $\mathrm{m}$ & $\mathrm{m}$ & $\mathrm{m}$ & $\mathrm{m}$ & $\mathrm{m}$ & $\mathrm{m}$ & $\mathbf{m}$ \\
\hline Hungría $^{2}$ & 4.564 & 4.566 & 4.709 & 4.455 & 4.574 & 3.165 & 5.213 & 9.521 & 9.210 & 7.153 & 5.410 \\
\hline Irlanda $^{2}$ & $\mathrm{~m}$ & 8.520 & 11.442 & 11.576 & 11.502 & 11.636 & $x(9)$ & $\mathrm{x}(9)$ & 16.095 & 11.938 & 10.857 \\
\hline Islandia & 9.138 & 10.339 & 10.160 & 7.461 & 8.470 & $x(5)$ & $x(9)$ & $\mathrm{x}(9)$ & 8.612 & $\mathrm{~m}$ & 9.180 \\
\hline Israel & 4.058 & 6.823 & $x(5)$ & $x(5)$ & 5.712 & 2.834 & 6.474 & 12.711 & 11.554 & $\mathrm{~m}$ & 7.167 \\
\hline Italia $^{2}$ & 7.868 & 8.448 & 8.686 & 8.519 & 8.585 & $\mathrm{~m}$ & 9.134 & 9.993 & 9.990 & 6.482 & 8.790 \\
\hline Japón & 5.591 & 8.280 & 9.677 & 10.093 & 9.886 & $x(4,9)$ & 10.181 & 18.110 & 16.446 & $\mathrm{~m}$ & 10.646 \\
\hline Luxemburgo $^{4}$ & 25.074 & 23.871 & 16.125 & 16.238 & 16.182 & $\mathrm{~m}$ & $\mathrm{~m}$ & $\mathrm{~m}$ & $\mathrm{~m}$ & $\mathrm{~m}$ & $\mathbf{m}$ \\
\hline México & 2.568 & 2.622 & 2.344 & 4.034 & 2.943 & a & $\mathrm{x}(9)$ & $\mathrm{x}(9)$ & 7.889 & 6.476 & 3.286 \\
\hline Noruega & 6.730 & 12.459 & 12.769 & 14.838 & 13.939 & $x(5)$ & $\mathrm{x}(9)$ & $x(9)$ & 18.840 & 11.036 & 14.288 \\
\hline Polonia $^{2}$ & 6.409 & 6.233 & 5.995 & 5.764 & 5.870 & 10.620 & 6.851 & 9.686 & 9.659 & 7.916 & 6.796 \\
\hline Portugal $^{2}$ & 5.674 & 5.865 & 8.294 & 9.139 & 8.676 & $\mathrm{~m}$ & $\mathrm{x}(9)$ & $x(9)$ & 9.640 & 5.219 & 7.741 \\
\hline Reino Unido & 9.692 & 9.857 & 13.894 & 6.491 & 9.649 & a & $x(9)$ & $x(9)$ & 14.223 & 10.570 & 10.412 \\
\hline República Checa & 4.302 & 4.587 & 7.730 & 6.886 & 7.270 & 2.205 & 3.350 & 9.856 & 9.392 & 6.320 & 6.931 \\
\hline República Eslovaca & 4.653 & 5.517 & 5.109 & 4.783 & 4.938 & $x(4)$ & $x(4)$ & 8.177 & 8.177 & 6.436 & 5.667 \\
\hline Suecia & 6.915 & 10.295 & 10.823 & 11.022 & 10.938 & 4.029 & 6.604 & 22.090 & 20.818 & 9.922 & 12.426 \\
\hline Suiza $^{2}$ & 5.267 & 12.907 & 15.124 & 16.521 & 15.891 & $\mathrm{x}(4)$ & 6.371 & 24.287 & 22.882 & 10.017 & 16.090 \\
\hline Turquía & 2.412 & 2.218 & 2.250 & 3.239 & 2.736 & a & $\mathrm{x}(9)$ & $\mathrm{x}(9)$ & 8.193 & $\mathrm{~m}$ & 3.240 \\
\hline Media OCDE & 7.428 & 8.296 & 9.377 & 9.506 & 9.280 & 4.811 & $\sim$ & $\sim$ & 13.958 & 9.635 & 9.487 \\
\hline Total OCDE & 7.044 & 7.900 & 9.111 & 9.953 & 9.505 & $\sim$ & $\sim$ & & 17.929 & 14.596 & 10.561 \\
\hline Media UE21 & 7.933 & 8.482 & 9.795 & 9.457 & 9.615 & 6.103 & $\sim$ & $\sim$ & 13.572 & 8.741 & 9.531 \\
\hline Arabia Saudí & $\mathrm{m}$ & $\mathrm{m}$ & $\mathrm{m}$ & $\mathrm{m}$ & $\mathrm{m}$ & $\mathrm{m}$ & $\mathrm{m}$ & $\mathrm{m}$ & $\mathrm{m}$ & $\mathrm{m}$ & $\mathbf{m}$ \\
\hline Argentina $^{2}$ & 1.979 & 2.167 & 2.947 & 3.184 & 3.034 & a & 2.255 & $\mathrm{~m}$ & $\mathrm{~m}$ & $\mathrm{~m}$ & $\mathbf{m}$ \\
\hline Brasil $^{2}$ & 2.349 & 2.673 & 2.700 & 2.605 & 2.662 & a & $x(9)$ & $x(9)$ & 10.902 & 10.140 & 3.066 \\
\hline China & $\mathrm{m}$ & $\mathrm{m}$ & $\mathrm{m}$ & $\mathrm{m}$ & $\mathrm{m}$ & $\mathrm{m}$ & $\mathrm{m}$ & $\mathrm{m}$ & $\mathrm{m}$ & $\mathrm{m}$ & $\mathbf{m}$ \\
\hline Colombia $^{3}$ & 1.301 & 1.094 & 1.159 & 1.163 & 1.160 & a & 2.906 & $\mathrm{~m}$ & $\mathrm{~m}$ & $\mathrm{~m}$ & $\mathbf{m}$ \\
\hline Federación Rusa & $\mathrm{m}$ & $\mathrm{x}(5)$ & $x(5)$ & $x(5)$ & 4.470 & $x(5)$ & 4.446 & 8.095 & 7.424 & 6.898 & 5.328 \\
\hline India & $\mathrm{m}$ & $\mathrm{m}$ & $\mathrm{m}$ & $\mathrm{m}$ & $\mathrm{m}$ & $\mathrm{m}$ & $\mathrm{m}$ & $\mathrm{m}$ & $\mathrm{m}$ & $\mathrm{m}$ & $\mathbf{m}$ \\
\hline Indonesia $^{3}$ & 205 & 587 & 449 & 617 & 522 & a & 1.888 & 1.012 & 1.173 & $\mathrm{~m}$ & 625 \\
\hline Letonia & 4.359 & 4.982 & 5.019 & 4.983 & 4.998 & 5.452 & 7.389 & 7.578 & 7.552 & 5.832 & 5.624 \\
\hline Sudáfrica & $\mathrm{m}$ & $\mathrm{m}$ & $\mathrm{m}$ & $\mathrm{m}$ & $\mathrm{m}$ & $\mathrm{m}$ & $\mathrm{m}$ & $\mathrm{m}$ & $\mathrm{m}$ & $\mathrm{m}$ & $\mathbf{m}$ \\
\hline Media G20 & $\mathrm{m}$ & $\mathrm{m}$ & $\mathrm{m}$ & $\mathrm{m}$ & $\mathrm{m}$ & $\mathrm{m}$ & $\mathrm{m}$ & $\mathrm{m}$ & $\mathrm{m}$ & $\mathrm{m}$ & $\mathbf{m}$ \\
\hline
\end{tabular}

1. Año de referencia 2010.

2. Solo instituciones públicas (para Canadá, solo en educación terciaria; para Italia, excepto en educación terciaria).

3. Año de referencia 2012.

4. La educación infantil y primaria incluye los reembolsos por parte de las autoridades locales de años anteriores.

Fuentes: OCDE. Arabia Saudí, Argentina, China, Colombia, India, Indonesia, Sudáfrica: Instituto de Estadística de la UNESCO. Letonia: Eurostat. Para ver notas, consulte Anexo 3 (www.oecd.org/edu/eag.htm).

Para obtener más información acerca de los símbolos utilizados en lugar de los datos que faltan, consulte la Guía del lector.

StatLink 제내 http://dx.doi.org/10.1787/888933116927 
Tabla B1.2. Gasto anual de instituciones educativas por estudiante para servicios básicos, auxiliares y de I+D (2011)

En equivalente a dólares estadounidenses convertidos mediante PPA para el PIB, por nivel educativo y tipo de servicio, sobre la base de equivalentes a tiempo completo

\begin{tabular}{|c|c|c|c|c|c|c|c|c|c|c|}
\hline & \multicolumn{3}{|c|}{$\begin{array}{l}\text { Educación primaria, secundaria } \\
\text { y postsecundaria no terciaria }\end{array}$} & \multicolumn{4}{|c|}{ Educación terciaria } & \multicolumn{3}{|c|}{ De educación primaria a terciaria } \\
\hline & $\begin{array}{l}\text { Servicios } \\
\text { educativos } \\
\text { básicos }\end{array}$ & $\begin{array}{c}\text { Servicios } \\
\text { auxiliares } \\
\text { (transporte, } \\
\text { comidas, } \\
\text { alojamiento } \\
\text { proporcionado } \\
\text { por las } \\
\text { instituciones) }\end{array}$ & Total & $\begin{array}{l}\text { Servicios } \\
\text { educativos } \\
\text { básicos }\end{array}$ & $\begin{array}{c}\text { Servicios } \\
\text { auxiliares } \\
\text { (transporte, } \\
\text { comidas, } \\
\text { alojamiento } \\
\text { proporcionado } \\
\text { por las } \\
\text { instituciones) }\end{array}$ & $\mathrm{I}+\mathrm{D}$ & Total & $\begin{array}{l}\text { Servicios } \\
\text { educativos } \\
\text { básicos }\end{array}$ & $\begin{array}{c}\text { Servicios } \\
\text { auxiliares } \\
\text { (transporte, } \\
\text { comidas, } \\
\text { alojamiento } \\
\text { proporcionado } \\
\text { por las } \\
\text { instituciones) } \\
\text { e I+D }\end{array}$ & Total \\
\hline & (1) & (2) & (3) & (4) & (5) & (6) & (7) & (8) & (9) & (10) \\
\hline Alemania & 9.260 & 260 & 9.521 & 9.457 & 707 & 6.559 & 16.723 & 9.298 & 1.606 & 10.904 \\
\hline Australia & 9.221 & 162 & 9.383 & 9.571 & 496 & 6.200 & 16.267 & 9.288 & 1.422 & 10.711 \\
\hline Austria & 11.956 & 552 & 12.509 & 10.368 & 119 & 4.408 & 14.895 & 11.552 & 1.565 & 13.116 \\
\hline Bélgica & 10.430 & 293 & 10.722 & 9.726 & 350 & 5.345 & 15.420 & 10.300 & 1.284 & 11.585 \\
\hline Canadá $^{1,2,3}$ & 9.586 & 492 & 10.078 & 17.006 & 1.187 & 6.219 & 23.226 & $\mathrm{~m}$ & $\mathrm{~m}$ & $\mathbf{m}$ \\
\hline Chile $^{4}$ & 4.522 & a & 4.522 & 7.897 & $\mathrm{x}(4)$ & 436 & 8.333 & 5.407 & 114 & 5.522 \\
\hline Corea & 6.668 & 984 & 7.652 & 8.093 & 75 & 1.758 & 9.927 & 7.125 & 1.257 & 8.382 \\
\hline Dinamarca $^{1}$ & 10.230 & $\mathrm{a}$ & 10.230 & $x(7)$ & a & $\mathrm{x}(7)$ & 21.254 & $\mathrm{x}(10)$ & $\mathrm{x}(10)$ & 12.136 \\
\hline Eslovenia & 8.267 & 600 & 8.867 & 8.248 & 31 & 2.134 & 10.413 & 8.262 & 971 & 9.233 \\
\hline España & 8.010 & 466 & 8.476 & 8.939 & 496 & 3.737 & 13.173 & 8.203 & 1.250 & 9.454 \\
\hline Estados Unidos & 10.879 & 961 & 11.841 & 19.896 & 3.198 & 2.928 & 26.021 & 13.107 & 2.237 & 15.345 \\
\hline Estonia & $x(3)$ & $\mathrm{x}(3)$ & 6.055 & 4.827 & $\mathrm{x}(4)$ & 3.041 & 7.868 & $\mathrm{x}(10)$ & $x(10)$ & 6.563 \\
\hline Finlandia & 8.222 & 958 & 9.180 & 10.973 & $\mathrm{n}$ & 7.029 & 18.002 & 8.759 & 2.145 & 10.905 \\
\hline Francia & 8.091 & 1.238 & 9.329 & 9.662 & 808 & 4.905 & 15.375 & 8.384 & 2.071 & 10.454 \\
\hline Grecia & $\mathrm{m}$ & $\mathrm{m}$ & $\mathbf{m}$ & $\mathrm{m}$ & $\mathrm{m}$ & $\mathrm{m}$ & $\mathbf{m}$ & $\mathrm{m}$ & $\mathrm{m}$ & $\mathbf{m}$ \\
\hline Hungría $^{3}$ & 4.002 & 525 & 4.527 & 5.959 & 1.194 & 2.056 & 9.210 & 4.371 & 1.039 & 5.410 \\
\hline Irlanda $^{3}$ & 9.830 & $\mathrm{~m}$ & 9.830 & 11.938 & $\mathrm{~m}$ & 4.157 & 16.095 & 10.175 & 681 & 10.857 \\
\hline Islandia & $x(3)$ & $x(3)$ & 9.326 & $\mathrm{x}(7)$ & $\mathrm{x}(7)$ & $\mathrm{x}(7)$ & 8.612 & $\mathrm{x}(10)$ & $\mathrm{x}(10)$ & 9.180 \\
\hline Israel & 5.969 & 308 & 6.277 & 10.296 & 1.258 & $\mathrm{~m}$ & 11.554 & 6.699 & 468 & 7.167 \\
\hline Italia $^{3,5}$ & 8.133 & 401 & 8.534 & 6.114 & 368 & 3.509 & 9.990 & 7.659 & 1.131 & 8.790 \\
\hline Japón $^{1}$ & $\mathrm{x}(3)$ & $\mathrm{x}(3)$ & 9.102 & $\mathrm{x}(7)$ & $\mathrm{x}(7)$ & $\mathrm{x}(7)$ & 16.446 & $\mathrm{x}(10)$ & $\mathrm{x}(10)$ & 10.646 \\
\hline Luxemburgo & 18.160 & 1.237 & 19.600 & $\mathrm{~m}$ & $\mathrm{~m}$ & $\mathrm{~m}$ & m & $\mathrm{m}$ & $\mathrm{m}$ & m \\
\hline México & $\mathrm{x}(3)$ & $\mathrm{x}(3)$ & 2.765 & 6.476 & $\mathrm{~m}$ & 1.413 & 7.889 & 3.142 & 144 & 3.286 \\
\hline Noruega & $x(3)$ & $x(3)$ & 13.219 & 10.850 & 187 & 7.804 & 18.840 & $\mathrm{x}(10)$ & $\mathrm{x}(10)$ & 14.288 \\
\hline Nueva Zelanda & $\mathrm{x}(3)$ & $\mathrm{x}(3)$ & 8.831 & 9.039 & $\mathrm{x}(4)$ & 1.543 & 10.582 & $x(10)$ & $\mathrm{x}(10)$ & 9.163 \\
\hline Países Bajos & 10.268 & $\mathrm{n}$ & 10.268 & 10.665 & $\mathrm{n}$ & 6.884 & 17.549 & 10.346 & 1.355 & 11.701 \\
\hline Polonia $^{3}$ & 6.038 & 28 & 6.066 & 7.916 & $\mathrm{n}$ & 1.743 & 9.659 & 6.420 & 376 & 6.796 \\
\hline Portugal $^{3}$ & 7.102 & 180 & 7.282 & 5.219 & $\mathrm{x}(4)$ & 4.421 & 9.640 & 6.735 & 1.006 & 7.741 \\
\hline Reino Unido & 8.938 & 800 & 9.738 & 8.975 & 1.595 & 3.653 & 14.223 & 8.944 & 1.469 & 10.412 \\
\hline República Checa & 5.699 & 430 & 6.128 & 6.241 & 79 & 3.072 & 9.392 & 5.832 & 1.099 & 6.931 \\
\hline República Eslovaca $^{1}$ & 4.390 & 715 & 5.105 & 5.036 & 1.401 & 1.741 & 8.177 & 4.508 & 1.159 & 5.667 \\
\hline Suecia & 9.435 & 1.113 & 10.548 & 9.922 & $\mathrm{n}$ & 10.896 & 20.818 & 9.524 & 2.902 & 12.426 \\
\hline Suiza $^{3}$ & $\mathrm{x}(3)$ & $\mathrm{x}(3)$ & 14.623 & 10.017 & $\mathrm{x}(4)$ & 12.864 & 22.882 & $\mathrm{x}(10)$ & $\mathrm{x}(10)$ & 16.090 \\
\hline Turquía & 2.423 & 78 & 2.501 & $\mathrm{x}(7)$ & $x(7)$ & $\mathrm{m}$ & 8.193 & $\mathrm{x}(10)$ & $\mathrm{x}(10)$ & 3.240 \\
\hline Media OCDE & 8.297 & 511 & 8.868 & 9.262 & 616 & 4.461 & 13.958 & 8.002 & 1.250 & 9.487 \\
\hline Media UE21 & 8.761 & 544 & 9.126 & 8.344 & 447 & 4.405 & 13.572 & 8.193 & 1.359 & 9.531 \\
\hline $\begin{array}{l}\text { Arabia Saudí } \\
\text { Argentina }^{3}\end{array}$ & $\begin{array}{r}m \\
x(3)\end{array}$ & $\begin{array}{r}\mathrm{m} \\
\mathrm{x}(3)\end{array}$ & $\begin{array}{r}\mathrm{m} \\
2.578\end{array}$ & $\begin{array}{r}m \\
x(7)\end{array}$ & $\begin{array}{r}\mathrm{m} \\
\mathrm{x}(7)\end{array}$ & $\begin{array}{r}\mathrm{m} \\
\mathrm{x}(7)\end{array}$ & $\begin{array}{l}\mathbf{m} \\
\mathbf{m}\end{array}$ & $\begin{array}{r}m \\
\mathrm{x}(10)\end{array}$ & $\begin{array}{r}m \\
x(10)\end{array}$ & $\begin{array}{l}\mathbf{m} \\
\mathbf{m}\end{array}$ \\
\hline $\mathrm{Brasil}^{3}$ & $\mathrm{x}(3)$ & $\mathrm{x}(3)$ & 2.667 & 10.140 & $\mathrm{x}(4)$ & 762 & 10.902 & 3.029 & 37 & 3.066 \\
\hline China & $\mathrm{m}$ & $\mathrm{m}$ & $\mathbf{m}$ & $\mathrm{m}$ & $\mathrm{m}$ & $\mathrm{m}$ & $\mathbf{m}$ & $\mathrm{m}$ & $\mathrm{m}$ & $\mathbf{m}$ \\
\hline Colombia $^{4}$ & $\mathrm{x}(3)$ & $\mathrm{x}(3)$ & 1.126 & $\mathrm{~m}$ & $\mathrm{~m}$ & $\mathrm{~m}$ & $\mathbf{m}$ & $\mathrm{m}$ & $\mathrm{m}$ & m \\
\hline Federación Rusa & $\mathrm{x}(3)$ & $x(3)$ & 4.470 & $x(7)$ & $\mathrm{x}(7)$ & 526 & 7.424 & $x(10)$ & $\mathrm{x}(10)$ & 5.328 \\
\hline India & $\mathrm{m}$ & $\mathrm{m}$ & $\mathbf{m}$ & $\mathrm{m}$ & $\mathrm{m}$ & $\mathrm{m}$ & $\mathbf{m}$ & $\mathrm{m}$ & $\mathrm{m}$ & $\mathbf{m}$ \\
\hline Indonesia & $\mathrm{x}(3)$ & $x(3)$ & 560 & $\mathrm{x}(7)$ & $\mathrm{x}(7)$ & $\mathrm{x}(7)$ & 1.173 & $x(10)$ & $x(10)$ & 625 \\
\hline Letonia & $\mathrm{x}(3)$ & $\mathrm{x}(3)$ & 4.995 & 5.832 & $\mathrm{x}(4)$ & 1.720 & 7.552 & $\mathrm{x}(10)$ & $\mathrm{x}(10)$ & 5.624 \\
\hline Sudáfrica & $\mathrm{m}$ & $\mathrm{m}$ & $\mathbf{m}$ & $\mathrm{m}$ & $\mathrm{m}$ & $\mathrm{m}$ & m & $\mathrm{m}$ & $\mathrm{m}$ & m \\
\hline Media G20 & $\mathrm{m}$ & $\mathrm{m}$ & $\mathbf{m}$ & $\mathrm{m}$ & $\mathrm{m}$ & $\mathrm{m}$ & m & $\mathrm{m}$ & $\mathrm{m}$ & m \\
\hline
\end{tabular}

1. Algunos niveles educativos están incluidos junto con otros. Véase el código «X» en la Tabla B1.1a para obtener más detalles.

2. Año de referencia 2010.

3. Solo instituciones públicas (para Canadá, solo en educación terciaria; para Italia, excepto en educación terciaria).

4. Año de referencia 2012.

5. Excluye la educación postsecundaria no terciaria.

Fuentes: OCDE. Arabia Saudí, Argentina, China, Colombia, India, Indonesia, Sudáfrica: Instituto de Estadística de la UNESCO. Letonia: Eurostat. Para ver notas, consulte Anexo 3 (www.oecd.org/edu/eag.htm).

Para obtener más información acerca de los símbolos utilizados en lugar de los datos que faltan, consulte la Guía del lector.

StatLink त्ताs http://dx.doi.org/10.1787/888933116946 
Tabla B1.3a. Gasto acumulativo de instituciones educativas por estudiante para todos los servicios a lo largo de la duración media de los estudios de educación terciaria (2011)

En equivalente a dólares estadounidenses convertidos mediante PPA para el PIB, por tipo de programa

\begin{tabular}{|c|c|c|c|c|c|c|c|}
\hline & \multirow[b]{3}{*}{ Método $^{1}$} & \multicolumn{3}{|c|}{$\begin{array}{l}\text { Duración media de los estudios de educación terciaria } \\
\text { en } 2011 \text { (en años) }\end{array}$} & \multicolumn{3}{|c|}{\begin{tabular}{|c} 
Gasto acumulativo por estudiante \\
a lo largo de la duración media de los estudios de educación \\
terciaria (en dólares estadounidenses)
\end{tabular}} \\
\hline & & $\begin{array}{l}\text { Educación } \\
\text { terciaria } \\
\text { de tipo B }\end{array}$ & $\begin{array}{c}\text { Educación } \\
\text { terciaria de tipo A } \\
\text { y programas de } \\
\text { investigación } \\
\text { avanzada }\end{array}$ & $\begin{array}{l}\text { Educación } \\
\text { terciaria } \\
\text { de tipo B }\end{array}$ & $\begin{array}{c}\text { Educación terciaria } \\
\text { de tipo B }\end{array}$ & $\begin{array}{c}\text { Educación } \\
\text { terciaria de tipo A } \\
\text { y programas de } \\
\text { investigación } \\
\text { avanzada }\end{array}$ & $\begin{array}{c}\text { Toda la educación } \\
\text { terciaria }\end{array}$ \\
\hline & & (1) & (2) & (3) & (4) & (5) & (6) \\
\hline $\begin{array}{l}\text { Alemania } \\
\text { Australia }\end{array}$ & MC & $\begin{array}{r}2,41 \\
\mathrm{~m}\end{array}$ & $\begin{array}{r}4,95 \\
\mathrm{~m}\end{array}$ & $\begin{array}{r}4,19 \\
m\end{array}$ & $\begin{array}{r}21.427 \\
\mathrm{~m}\end{array}$ & $\begin{array}{r}90.821 \\
\mathrm{~m}\end{array}$ & $\begin{array}{r}70.069 \\
\mathrm{~m}\end{array}$ \\
\hline Austria & MC & 2,34 & 6,10 & 5,34 & 16.248 & 91.300 & 79.539 \\
\hline Bélgica $^{2}$ & MC & 2,41 & 3,67 & 2,99 & $\mathrm{x}(6)$ & $\mathrm{x}(6)$ & 46.107 \\
\hline Canadá & & $\mathrm{m}$ & $\mathrm{m}$ & $\mathbf{m}$ & $\mathrm{m}$ & $\mathrm{m}$ & $\mathbf{m}$ \\
\hline Chile & & $\mathrm{m}$ & $\mathrm{m}$ & $\mathbf{m}$ & $\mathrm{m}$ & $\mathrm{m}$ & $\mathbf{m}$ \\
\hline Corea & MC & 2,07 & 4,22 & 3,43 & 11.782 & 47.392 & 34.048 \\
\hline Dinamarca & FA & 2,74 & 5,49 & 5,20 & $\mathrm{x}(6)$ & $\mathrm{x}(6)$ & 110.520 \\
\hline Eslovenia & FA & 2,63 & 3,64 & 3,21 & $\mathrm{x}(6)$ & $\mathrm{x}(6)$ & 33.409 \\
\hline España & MC & 2,15 & 5,54 & 4,66 & 21.590 & 77.190 & 61.386 \\
\hline Estados Unidos & FA & $\mathrm{x}(3)$ & $\mathrm{x}(3)$ & 3,17 & $\mathrm{x}(6)$ & $\mathrm{x}(6)$ & 82.488 \\
\hline Estonia & MC & 3,29 & 4,97 & 4,42 & 21.808 & 41.978 & 34.810 \\
\hline Finlandia & MC & $\mathrm{a}$ & 4,74 & 4,74 & a & 85.328 & 85.328 \\
\hline Francia $^{3}$ & MC & 3,00 & 4,74 & 4,02 & 37.662 & 77.397 & 61.807 \\
\hline Grecia & & $\mathrm{m}$ & $\mathrm{m}$ & $\mathbf{m}$ & $\mathrm{m}$ & $\mathrm{m}$ & $\mathbf{m}$ \\
\hline Hungría $^{4}$ & FA & 1,85 & 3,71 & 3,29 & 9.664 & 35.335 & 30.292 \\
\hline Irlanda $^{4}$ & MC & 2,21 & 4,02 & 3,24 & $\mathrm{x}(6)$ & $\mathrm{x}(6)$ & 52.148 \\
\hline Islandia & MC & $\mathrm{x}(3)$ & $\mathrm{x}(3)$ & 4,49 & $\mathrm{x}(6)$ & $\mathrm{x}(6)$ & 38.668 \\
\hline Israel & MC & $\mathrm{m}$ & 3,03 & $\mathbf{m}$ & $\mathrm{m}$ & 38.513 & $\mathbf{m}$ \\
\hline Italia & FA & $\mathrm{m}$ & 4,52 & $\mathbf{m}$ & $\mathrm{m}$ & 45.168 & $\mathbf{m}$ \\
\hline Japón & MC & 2,09 & 4,63 & 4,46 & 21.312 & 83.893 & 73.364 \\
\hline Luxemburgo & & $\mathrm{m}$ & $\mathrm{m}$ & $\mathbf{m}$ & $\mathrm{m}$ & $\mathrm{m}$ & $\mathbf{m}$ \\
\hline México & FA & 1,72 & 3,49 & 3,35 & $\mathrm{x}(6)$ & $\mathrm{x}(6)$ & 26.428 \\
\hline Noruega & & $\mathrm{m}$ & $\mathrm{m}$ & $\mathbf{m}$ & $\mathrm{m}$ & $\mathrm{m}$ & $\mathbf{m}$ \\
\hline Nueva Zelanda & MC & 1,93 & 4,06 & 3,37 & 17.137 & 44.584 & 35.655 \\
\hline Países Bajos & MC & $\mathrm{m}$ & 5,26 & 5,26 & $\mathrm{~m}$ & 92.373 & 92.310 \\
\hline Polonia $^{4}$ & MC & $\mathrm{m}$ & 3,68 & $\mathbf{m}$ & $\mathrm{m}$ & 35.644 & $\mathbf{m}$ \\
\hline Portugal & & $\mathrm{m}$ & $\mathrm{m}$ & $\mathbf{m}$ & $\mathrm{m}$ & $\mathrm{m}$ & $\mathbf{m}$ \\
\hline Reino Unido ${ }^{3}$ & MC & $\mathrm{x}(3)$ & $\mathrm{x}(3)$ & 2,74 & $\mathrm{x}(6)$ & $x(6)$ & 38.971 \\
\hline República Checa ${ }^{3}$ & MC & 2,36 & 4,34 & 4,10 & $\mathrm{~m}$ & 42.777 & $\mathbf{m}$ \\
\hline República Eslovaca & FA & 2,47 & 3,90 & $\mathbf{3 , 8 2}$ & $\mathrm{m}$ & 31.892 & $\mathbf{m}$ \\
\hline Suecia & MC & 2,44 & 4,70 & 4,51 & 16.095 & 103.827 & 93.890 \\
\hline Suiza $^{4}$ & MC & 2,19 & 5,45 & 3,62 & 13.932 & 132.433 & 82.929 \\
\hline Turquía & MC & 1,94 & 2,73 & 2,65 & $\mathrm{x}(6)$ & $\mathrm{x}(6)$ & 21.746 \\
\hline Media OCDE & & 2,21 & 4,40 & 3,93 & $\sim$ & $\sim$ & $\mathbf{5 8 . 4 5 0}$ \\
\hline Media UE21 & & 2,31 & 4,59 & 4,11 & $\sim$ & $\sim$ & 63.613 \\
\hline
\end{tabular}

\begin{tabular}{|c|c|c|c|c|c|c|}
\hline $\begin{array}{l}\text { Arabia Saudí } \\
\text { Argentina }\end{array}$ & $\begin{array}{l}\mathrm{m} \\
\mathrm{m}\end{array}$ & $\begin{array}{l}\mathrm{m} \\
\mathrm{m}\end{array}$ & $\begin{array}{l}\mathbf{m} \\
\mathbf{m}\end{array}$ & $\begin{array}{l}\mathrm{m} \\
\mathrm{m}\end{array}$ & $\begin{array}{l}\mathrm{m} \\
\mathrm{m}\end{array}$ & $\begin{array}{l}\mathbf{m} \\
\mathbf{m}\end{array}$ \\
\hline Brasil & $\mathrm{m}$ & $\mathrm{m}$ & $\mathbf{m}$ & $\mathrm{m}$ & $\mathrm{m}$ & $\mathbf{m}$ \\
\hline yू China & $\mathrm{m}$ & $\mathrm{m}$ & $\mathbf{m}$ & $\mathrm{m}$ & $\mathrm{m}$ & $\mathbf{m}$ \\
\hline $\begin{array}{l}\text { Colombia } \\
\text { Federación Rusa }\end{array}$ & $\begin{array}{l}\mathrm{m} \\
\mathrm{m}\end{array}$ & $\begin{array}{l}\mathrm{m} \\
\mathrm{m}\end{array}$ & $\begin{array}{l}\mathbf{m} \\
\mathbf{m}\end{array}$ & $\begin{array}{l}\mathrm{m} \\
\mathrm{m}\end{array}$ & $\begin{array}{l}\mathrm{m} \\
\mathrm{m}\end{array}$ & $\begin{array}{l}\mathbf{m} \\
\mathbf{m}\end{array}$ \\
\hline $\begin{array}{l}\text { India } \\
\text { Indonesia }\end{array}$ & $\begin{array}{l}\mathrm{m} \\
\mathrm{m}\end{array}$ & $\begin{array}{l}\mathrm{m} \\
\mathrm{m}\end{array}$ & $\begin{array}{l}\mathbf{m} \\
\mathbf{m}\end{array}$ & $\begin{array}{l}\mathrm{m} \\
\mathrm{m}\end{array}$ & $\begin{array}{l}\mathrm{m} \\
\mathrm{m}\end{array}$ & $\begin{array}{l}\mathbf{m} \\
\mathbf{m}\end{array}$ \\
\hline $\begin{array}{l}\text { Letonia } \\
\text { Sudáfrica }\end{array}$ & $\begin{array}{l}\mathrm{m} \\
\mathrm{m}\end{array}$ & $\begin{array}{l}\mathrm{m} \\
\mathrm{m}\end{array}$ & $\begin{array}{l}\mathbf{m} \\
\mathbf{m}\end{array}$ & $\begin{array}{l}\mathrm{m} \\
\mathrm{m}\end{array}$ & $\begin{array}{l}\mathrm{m} \\
\mathrm{m}\end{array}$ & $\begin{array}{l}\mathbf{m} \\
\mathbf{m}\end{array}$ \\
\hline Media G20 & $\mathrm{m}$ & $\mathrm{m}$ & m & $\mathrm{m}$ & $\mathrm{m}$ & $\mathbf{m}$ \\
\hline
\end{tabular}

1. Se ha utilizado el Método Cadena (MC) o una Fórmula de Aproximación (FA) para calcular la duración de los estudios de educación terciaria.

2. Año de referencia 2008.

3. La duración media de los estudios de educación terciaria se calcula basándose en datos nacionales.

4. Solo instituciones públicas (para Hungría, duración media para instituciones públicas y privadas).

Fuentes: OCDE. Arabia Saudí, Argentina, China, Colombia, India, Indonesia, Sudáfrica: Instituto de Estadística de la UNESCO. Letonia: Eurostat. Para ver notas, consulte Anexo 3 (www.oecd.org/edu/eag.htm).

Para obtener más información acerca de los símbolos utilizados en lugar de los datos que faltan, consulte la Guía del lector.

StatLink 젠 http://dx.doi.org/10.1787/888933116965 
Tabla B1.4. Gasto anual de instituciones educativas por estudiante para todos los servicios, con relación al PIB per cápita (2011)

Por nivel de educación, sobre la base de equivalentes de tiempo completo

\begin{tabular}{|c|c|c|c|c|c|c|c|c|c|c|c|}
\hline & \multirow[b]{2}{*}{$\begin{array}{c}\text { Educación } \\
\text { infantil } \\
\text { (para niños } \\
\text { de } 3 \text { años } \\
\text { en adelante) }\end{array}$} & \multirow[b]{2}{*}{$\begin{array}{c}\text { Educación } \\
\text { primaria }\end{array}$} & \multicolumn{3}{|c|}{ Educación secundaria } & \multirow[b]{2}{*}{$\begin{array}{c}\text { Educación } \\
\text { post- } \\
\text { secundaria } \\
\text { no terciaria }\end{array}$} & \multicolumn{3}{|c|}{$\begin{array}{c}\text { Educación terciaria } \\
\text { (incluyendo actividades de I+D) }\end{array}$} & \multirow[b]{2}{*}{\begin{tabular}{|c|} 
Toda la \\
educación \\
terciaria \\
(excluyendo \\
actividades \\
de I+D)
\end{tabular}} & \multirow[b]{2}{*}{\begin{tabular}{|c} 
De \\
educación \\
primaria \\
a terciaria \\
(incluyendo \\
actividades \\
de I+D)
\end{tabular}} \\
\hline & & & $\begin{array}{c}\text { Educación } \\
\text { secundaria } \\
\text { inferior }\end{array}$ & $\begin{array}{c}\text { Educación } \\
\text { secundaria } \\
\text { superior }\end{array}$ & $\begin{array}{c}\text { Toda la } \\
\text { educación } \\
\text { secundaria }\end{array}$ & & $\begin{array}{c}\text { Educación } \\
\text { terciaria } \\
\text { de tipo B }\end{array}$ & $\begin{array}{c}\text { Educación } \\
\text { terciaria } \\
\text { de tipo Ay } \\
\text { programas de } \\
\text { investigación } \\
\text { avanzada }\end{array}$ & $\begin{array}{c}\text { Toda la } \\
\text { educación } \\
\text { terciaria }\end{array}$ & & \\
\hline & (1) & (2) & (3) & (4) & (5) & (6) & (7) & (8) & (9) & (10) & (11) \\
\hline Alemania & 20 & 18 & 23 & 29 & 25 & 24 & 22 & 45 & 41 & 25 & 27 \\
\hline Australia & 25 & 20 & 25 & 23 & 24 & 16 & 20 & 42 & 38 & 23 & 25 \\
\hline Austria & 21 & 25 & 32 & 32 & 32 & 14 & 16 & 35 & 35 & 24 & 31 \\
\hline Bélgica & 16 & 23 & $\mathrm{x}(5)$ & $\mathrm{x}(5)$ & 29 & $\mathrm{x}(5)$ & $\mathrm{x}(9)$ & $\mathrm{x}(9)$ & 38 & 25 & 29 \\
\hline Canadá $^{1,2}$ & $x(2)$ & 25 & $\mathrm{x}(2)$ & 31 & $\mathrm{~m}$ & $\mathrm{~m}$ & 42 & 73 & 62 & 45 & $\mathbf{m}$ \\
\hline Chile $^{3}$ & 24 & 21 & 21 & 21 & 21 & a & 23 & 52 & 39 & 37 & 26 \\
\hline Corea & 24 & 24 & 23 & 33 & 28 & $\mathrm{a}$ & 20 & 39 & 34 & 28 & 29 \\
\hline Dinamarca & 34 & 23 & 26 & 26 & 26 & $x(4,9)$ & $\mathrm{x}(9)$ & $\mathrm{x}(9)$ & 51 & $\mathrm{~m}$ & 29 \\
\hline Eslovenia & 29 & 33 & 35 & 27 & 30 & $\mathrm{x}(4)$ & $\mathrm{x}(9)$ & $\mathrm{x}(9)$ & 37 & 29 & 33 \\
\hline España & 21 & 23 & 29 & 31 & 30 & a & 31 & 43 & 41 & 29 & 29 \\
\hline Estados Unidos & 20 & 22 & 25 & 27 & 26 & $\mathrm{~m}$ & $\mathrm{x}(9)$ & $\mathrm{x}(9)$ & 53 & 47 & 31 \\
\hline Estonia & 11 & 23 & 26 & 29 & 28 & 36 & 29 & 37 & 34 & 21 & 28 \\
\hline Finlandia & 15 & 21 & 32 & 22 & 25 & $\mathrm{x}(5)$ & $\mathrm{n}$ & 47 & 47 & 28 & 28 \\
\hline Francia & 18 & 19 & 27 & 36 & 31 & $\mathrm{~m}$ & 34 & 45 & 42 & 29 & 29 \\
\hline Grecia & $\mathrm{m}$ & $\mathrm{m}$ & $\mathrm{m}$ & $\mathrm{m}$ & $\mathrm{m}$ & $\mathrm{m}$ & $\mathrm{m}$ & $\mathrm{m}$ & $\mathrm{m}$ & $\mathrm{m}$ & $\mathbf{m}$ \\
\hline Hungría $^{2}$ & 20 & 20 & 21 & 20 & 20 & 14 & 23 & 42 & 41 & 32 & 24 \\
\hline Irlanda $^{2}$ & $\mathrm{~m}$ & 20 & 27 & 27 & 27 & 27 & $\mathrm{x}(9)$ & $\mathrm{x}(9)$ & 37 & 28 & 25 \\
\hline Islandia & 24 & 27 & 27 & 20 & 22 & $\mathrm{x}(5)$ & $\mathrm{x}(9)$ & $\mathrm{x}(9)$ & 23 & $\mathrm{~m}$ & 24 \\
\hline Israel & 13 & 23 & $\mathrm{x}(5)$ & $\mathrm{x}(5)$ & 19 & 9 & 21 & 42 & 38 & $\mathrm{~m}$ & 24 \\
\hline Italia $^{2}$ & 23 & 25 & 26 & 25 & 25 & $\mathrm{~m}$ & 27 & 30 & 29 & 19 & 26 \\
\hline Japón & 16 & 24 & 28 & 29 & 29 & $\mathrm{x}(4,9)$ & 29 & 52 & 48 & $\mathrm{~m}$ & 31 \\
\hline Luxemburgo & 28 & 27 & 18 & 18 & 18 & $\mathrm{~m}$ & $\mathrm{~m}$ & $\mathrm{~m}$ & $\mathrm{~m}$ & $\mathrm{~m}$ & $\mathbf{m}$ \\
\hline México & 15 & 15 & 14 & 24 & 17 & a & $\mathrm{x}(9)$ & $\mathrm{x}(9)$ & 46 & 38 & 19 \\
\hline Noruega & 14 & 27 & 27 & 32 & 30 & $\mathrm{x}(5)$ & $\mathrm{x}(9)$ & $\mathrm{x}(9)$ & 40 & 24 & 31 \\
\hline Nueva Zelanda & 35 & 26 & 28 & 32 & 30 & 31 & 28 & 35 & 34 & 29 & 29 \\
\hline Países Bajos & 19 & 19 & 28 & 28 & 28 & 27 & 24 & 41 & 41 & 25 & 27 \\
\hline Polonia $^{2}$ & 29 & 29 & 28 & 26 & 27 & 49 & 31 & 45 & 44 & 36 & 31 \\
\hline Portugal $^{2}$ & 22 & 23 & 32 & 36 & 34 & $\mathrm{~m}$ & $\mathrm{x}(9)$ & $\mathrm{x}(9)$ & 38 & 20 & 30 \\
\hline Reino Unido & 29 & 29 & 41 & 19 & 28 & a & $\mathrm{x}(9)$ & $\mathrm{x}(9)$ & 42 & 31 & 31 \\
\hline República Checa & 16 & 17 & 29 & 25 & 27 & 8 & 12 & 36 & 35 & 23 & 26 \\
\hline República Eslovaca & 19 & 22 & 20 & 19 & 20 & $\mathrm{x}(4)$ & $\mathrm{x}(4)$ & 33 & 33 & 26 & 23 \\
\hline Suecia & 17 & 25 & 26 & 26 & 26 & 10 & 16 & 53 & 50 & 24 & 30 \\
\hline Suiza $^{2}$ & 10 & 25 & 29 & 32 & 31 & $\mathrm{x}(4)$ & 12 & 47 & 44 & 19 & 31 \\
\hline Turquía & 14 & 12 & 13 & 18 & 15 & a & $\mathrm{x}(9)$ & $\mathrm{x}(9)$ & 46 & $\mathrm{~m}$ & 18 \\
\hline Media OCDE & 21 & 23 & 26 & 27 & 26 & 15 & 23 & 43 & 41 & 28 & 27 \\
\hline Media UE21 & 20 & 22 & 26 & 27 & 26 & 13 & 22 & 41 & 39 & 28 & 27 \\
\hline Arabia Saudí & $\mathrm{m}$ & $\mathrm{m}$ & $\mathrm{m}$ & $\mathrm{m}$ & $\mathrm{m}$ & $\mathrm{m}$ & $\mathrm{m}$ & $\mathrm{m}$ & $\mathrm{m}$ & $\mathrm{m}$ & $\mathbf{m}$ \\
\hline Argentina ${ }^{2}$ & 18 & 20 & 27 & 29 & 28 & $\mathrm{a}$ & 21 & $\mathrm{~m}$ & $\mathrm{~m}$ & $\mathrm{~m}$ & $\mathbf{m}$ \\
\hline Brasil ${ }^{2}$ & 20 & 23 & 23 & 22 & 23 & a & $\mathrm{x}(9)$ & $\mathrm{x}(9)$ & 93 & 86 & 26 \\
\hline y China & $\mathrm{m}$ & $\mathrm{m}$ & $\mathrm{m}$ & $\mathrm{m}$ & $\mathrm{m}$ & $\mathrm{m}$ & $\mathrm{m}$ & $\mathrm{m}$ & $\mathrm{m}$ & $\mathrm{m}$ & $\mathbf{m}$ \\
\hline Colombia ${ }^{3}$ & 13 & 11 & 11 & 11 & 11 & a & 28 & $\mathrm{~m}$ & $\mathrm{~m}$ & $\mathrm{~m}$ & $\mathbf{m}$ \\
\hline Federación Rusa & $\mathrm{m}$ & $\mathrm{x}(5)$ & $x(5)$ & $\mathrm{x}(5)$ & 20 & a & 20 & 36 & 33 & 31 & 24 \\
\hline India & $\mathrm{m}$ & $\mathrm{m}$ & $\mathrm{m}$ & $\mathrm{m}$ & $\mathrm{m}$ & $\mathrm{m}$ & $\mathrm{m}$ & $\mathrm{m}$ & $\mathrm{m}$ & $\mathrm{m}$ & $\mathbf{m}$ \\
\hline Indonesia & $\mathrm{m}$ & $\mathrm{m}$ & $\mathrm{m}$ & $\mathrm{m}$ & $\mathrm{m}$ & $\mathrm{m}$ & $\mathrm{m}$ & $\mathrm{m}$ & $\mathrm{m}$ & $\mathrm{m}$ & $\mathbf{m}$ \\
\hline Letonia & 22 & 25 & 25 & 25 & 25 & 27 & 37 & 38 & 38 & 29 & 28 \\
\hline Sudáfrica & $\mathrm{m}$ & $\mathrm{m}$ & $\mathrm{m}$ & $\mathrm{m}$ & $\mathrm{m}$ & $\mathrm{m}$ & $\mathrm{m}$ & $\mathrm{m}$ & $\mathrm{m}$ & $\mathrm{m}$ & $\mathbf{m}$ \\
\hline Media G20 & $\mathrm{m}$ & $\mathrm{m}$ & $\mathrm{m}$ & $\mathrm{m}$ & $\mathrm{m}$ & $\mathrm{m}$ & $\mathrm{m}$ & $\mathrm{m}$ & $\mathrm{m}$ & $\mathrm{m}$ & m \\
\hline
\end{tabular}

1. Año de referencia 2010.

2. Solo instituciones públicas (para Canadá, solo en educación terciaria; para Italia, excepto en educación terciaria).

3. Año de referencia 2012.

Fuentes: OCDE. Arabia Saudí, Argentina, China, Colombia, India, Indonesia, Sudáfrica: Instituto de Estadística de la UNESCO. Letonia: Eurostat. Para ver notas, consulte Anexo 3 (www.oecd.org/edu/eag.htm).

Para obtener más información acerca de los símbolos utilizados en lugar de los datos que faltan, consulte la Guía del lector.

StatLink 게그 http://dx.doi.org/10.1787/888933116984 
Tabla B1.5a. Cambio en el gasto de instituciones educativas por estudiante para todos los servicios, con relación a diferentes factores en los niveles de educación primaria, secundaria y postsecundaria no terciaria $(1995,2000,2005,2008,2009,2010,2011)$

Índice de cambio (deflactor del PIB $2005=100$, precios constantes)

\begin{tabular}{|c|c|c|c|c|c|c|c|c|c|c|c|c|}
\hline & \multicolumn{12}{|c|}{ Educación primaria, secundaria y postsecundaria no terciaria } \\
\hline & \multicolumn{4}{|c|}{$\begin{array}{l}\text { Cambio en el gasto } \\
(2005=100)\end{array}$} & \multicolumn{4}{|c|}{$\begin{array}{l}\text { Cambio en el número de estudiantes } \\
(2005=100)\end{array}$} & \multicolumn{4}{|c|}{$\begin{array}{l}\text { Cambio en el gasto por estudiante } \\
(2005=100)\end{array}$} \\
\hline & 2000 & 2008 & 2010 & 2011 & 2000 & 2008 & 2010 & 2011 & 2000 & 2008 & 2010 & 2011 \\
\hline & (2) & (3) & (5) & (6) & (8) & (9) & (11) & (12) & (14) & (15) & (17) & (18) \\
\hline Alemania & 100 & 101 & 109 & 108 & 102 & 95 & 93 & 91 & 97 & 106 & 117 & 118 \\
\hline Australia & 83 & 110 & 133 & 130 & 93 & 100 & 101 & 103 & 89 & 110 & 131 & 126 \\
\hline Austria & 97 & 105 & 105 & 107 & 101 & 98 & 95 & 94 & 95 & 107 & 110 & 113 \\
\hline Bélgica & 94 & 116 & 115 & 116 & 91 & 96 & 95 & 96 & 103 & 121 & 121 & 122 \\
\hline Canadá $^{1,2}$ & 86 & 104 & 117 & 117 & 99 & 100 & 98 & 97 & 87 & 105 & 119 & 121 \\
\hline Chile $^{3}$ & 96 & 129 & 126 & 147 & 99 & 96 & 93 & 91 & 97 & 134 & 135 & 162 \\
\hline Corea & 69 & 116 & 126 & 127 & 102 & 98 & 93 & 90 & 68 & 118 & 135 & 142 \\
\hline Dinamarca $^{1}$ & 86 & 99 & 107 & 99 & 95 & 99 & 105 & 111 & 91 & 100 & 102 & 89 \\
\hline Eslovenia & $\mathrm{m}$ & 104 & 104 & 101 & $\mathrm{~m}$ & 93 & 90 & 90 & m & 113 & 115 & 113 \\
\hline España & 93 & 115 & 119 & 116 & 107 & 102 & 105 & 107 & 87 & 113 & 113 & 109 \\
\hline Estados Unidos & 86 & 111 & 113 & 107 & 98 & 106 & 100 & 100 & 88 & 105 & 114 & 108 \\
\hline Estonia $^{4}$ & 80 & 126 & 112 & 107 & 121 & 90 & 85 & 83 & 66 & 140 & 132 & 128 \\
\hline Finlandia & 81 & 107 & 112 & 113 & 95 & 101 & 100 & 99 & 85 & 107 & 112 & 114 \\
\hline Francia & 100 & 102 & 105 & 103 & 102 & 100 & 100 & 100 & 98 & 103 & 105 & 103 \\
\hline Grecia $^{1}$ & 78 & $\mathrm{~m}$ & $\mathrm{~m}$ & $\mathrm{~m}$ & 101 & $\mathrm{~m}$ & $\mathrm{~m}$ & $\mathrm{~m}$ & 77 & $\mathbf{m}$ & $\mathbf{m}$ & $\mathbf{m}$ \\
\hline Hungría $^{4}$ & 69 & 95 & 84 & 79 & 104 & 96 & 94 & 92 & 66 & 99 & 90 & 86 \\
\hline Irlanda $^{5}$ & 68 & 132 & 140 & 138 & 97 & 104 & 108 & 109 & 70 & 126 & 130 & 127 \\
\hline Islandia & 72 & 106 & 92 & 95 & 94 & 101 & 101 & 101 & 77 & 105 & 91 & 94 \\
\hline Israel & 95 & 121 & 130 & 144 & 94 & 104 & 108 & 111 & 101 & 116 & 120 & 130 \\
\hline Italia ${ }^{5,6}$ & 96 & 104 & 97 & 93 & 99 & 100 & 100 & 101 & 97 & 104 & 97 & 92 \\
\hline Japón $^{1}$ & 99 & 102 & 105 & 105 & 109 & 97 & 96 & 95 & 90 & 105 & 109 & 110 \\
\hline Luxemburgo & $\mathrm{m}$ & $\mathrm{m}$ & $\mathrm{m}$ & $\mathrm{m}$ & $\mathrm{m}$ & $\mathrm{m}$ & $\mathrm{m}$ & $\mathrm{m}$ & $\mathbf{m}$ & $\mathbf{m}$ & $\mathbf{m}$ & $\mathbf{m}$ \\
\hline México & 80 & 102 & 110 & 113 & 95 & 103 & 105 & 106 & 85 & 99 & 104 & 107 \\
\hline Noruega $^{4}$ & 87 & 107 & 113 & 112 & 95 & 102 & 102 & 102 & 92 & 105 & 111 & 110 \\
\hline Nueva Zelanda & $\mathrm{m}$ & $\mathrm{m}$ & $\mathrm{m}$ & $\mathrm{m}$ & $\mathrm{m}$ & 100 & 100 & 99 & $\mathbf{m}$ & $\mathbf{m}$ & m & $\mathbf{m}$ \\
\hline Países Bajos & 83 & 107 & 116 & 114 & 97 & 101 & 102 & 102 & 86 & 105 & 114 & 112 \\
\hline Polonia & 89 & 115 & 123 & 121 & 110 & 88 & 83 & 80 & 81 & 130 & 149 & 151 \\
\hline Portugal $^{5}$ & 98 & 96 & 109 & 101 & 111 & 100 & 99 & 97 & 88 & 96 & 110 & 105 \\
\hline Reino Unido & 70 & 100 & 107 & 109 & 113 & 100 & 100 & 102 & 62 & 100 & 108 & 107 \\
\hline República Checa & 76 & 106 & 111 & 115 & 107 & 93 & 89 & 87 & 71 & 115 & 125 & 133 \\
\hline República Eslovaca $^{1}$ & 73 & 115 & 135 & 125 & 108 & 90 & 84 & 82 & 68 & 128 & 159 & 154 \\
\hline Suecia & 88 & 103 & 103 & 103 & 98 & 97 & 91 & 91 & 90 & 107 & 113 & 114 \\
\hline Suiza $^{5}$ & 88 & 101 & 106 & 108 & 98 & 99 & 98 & 97 & 89 & 103 & 109 & 112 \\
\hline Turquía & $\mathrm{m}$ & $\mathrm{m}$ & $\mathrm{m}$ & $\mathrm{m}$ & $\mathrm{m}$ & $\mathrm{m}$ & $\mathrm{m}$ & $\mathrm{m}$ & $\mathbf{m}$ & $\mathbf{m}$ & $\mathbf{m}$ & $\mathbf{m}$ \\
\hline
\end{tabular}

\begin{tabular}{|c|}
\hline Media OCDF \\
\hline
\end{tabular}
Media UE21

\begin{tabular}{|c|c|c|c|c|c|c|c|c|c|c|c|c|}
\hline $\begin{array}{l}\text { Arabia Saudí } \\
\text { Argentina }\end{array}$ & $\begin{array}{l}\mathrm{m} \\
\mathrm{m}\end{array}$ & $\begin{array}{l}\mathrm{m} \\
\mathrm{m}\end{array}$ & $\begin{array}{l}\mathrm{m} \\
\mathrm{m}\end{array}$ & $\begin{array}{l}\mathrm{m} \\
\mathrm{m}\end{array}$ & $\begin{array}{l}\mathrm{m} \\
\mathrm{m}\end{array}$ & $\begin{array}{l}\mathrm{m} \\
\mathrm{m}\end{array}$ & $\begin{array}{l}\mathrm{m} \\
\mathrm{m}\end{array}$ & $\begin{array}{l}\mathrm{m} \\
\mathrm{m}\end{array}$ & $\begin{array}{l}\mathbf{m} \\
\mathbf{m}\end{array}$ & $\begin{array}{l}\mathbf{m} \\
\mathbf{m}\end{array}$ & $\begin{array}{l}\mathbf{m} \\
\mathbf{m}\end{array}$ & $\begin{array}{l}\mathbf{m} \\
\mathbf{m}\end{array}$ \\
\hline Brasil $^{4,5}$ & 66 & 146 & 170 & 175 & 98 & 96 & 91 & 89 & 67 & 152 & 187 & 197 \\
\hline China & $\mathrm{m}$ & $\mathrm{m}$ & $\mathrm{m}$ & $\mathrm{m}$ & $\mathrm{m}$ & $\mathrm{m}$ & $\mathrm{m}$ & $\mathrm{m}$ & $\mathbf{m}$ & $\mathbf{m}$ & $\mathbf{m}$ & $\mathbf{m}$ \\
\hline Colombia & $\mathrm{m}$ & $\mathrm{m}$ & $\mathrm{m}$ & $\mathrm{m}$ & $\mathrm{m}$ & $\mathrm{m}$ & $\mathrm{m}$ & $\mathrm{m}$ & $\mathbf{m}$ & $\mathbf{m}$ & $\mathbf{m}$ & $\mathbf{m}$ \\
\hline Federación Rusa & 66 & 132 & 126 & 130 & $\mathrm{~m}$ & 88 & 87 & 88 & $\mathbf{m}$ & 150 & 144 & 147 \\
\hline India & $\mathrm{m}$ & $\mathrm{m}$ & $\mathrm{m}$ & $\mathrm{m}$ & $\mathrm{m}$ & $\mathrm{m}$ & $\mathrm{m}$ & $\mathrm{m}$ & $\mathbf{m}$ & $\mathbf{m}$ & $\mathbf{m}$ & $\mathbf{m}$ \\
\hline Indonesia & $\mathrm{m}$ & $\mathrm{m}$ & $\mathrm{m}$ & $\mathrm{m}$ & $\mathrm{m}$ & $\mathrm{m}$ & $\mathrm{m}$ & $\mathrm{m}$ & $\mathbf{m}$ & $\mathbf{m}$ & $\mathbf{m}$ & $\mathbf{m}$ \\
\hline Letonia & $\mathrm{m}$ & $\mathrm{m}$ & $\mathrm{m}$ & $\mathrm{m}$ & $\mathrm{m}$ & $\mathrm{m}$ & $\mathrm{m}$ & $\mathrm{m}$ & m & m & m & m \\
\hline Sudáfrica & $\mathrm{m}$ & $\mathrm{m}$ & $\mathrm{m}$ & $\mathrm{m}$ & $\mathrm{m}$ & $\mathrm{m}$ & $\mathrm{m}$ & $\mathrm{m}$ & $\mathbf{m}$ & m & m & $\mathbf{m}$ \\
\hline Media G20 & $\mathrm{m}$ & $\mathrm{m}$ & $\mathrm{m}$ & $\mathrm{m}$ & $\mathrm{m}$ & $\mathrm{m}$ & $\mathrm{m}$ & $\mathrm{m}$ & $\mathbf{m}$ & m & m & $\mathbf{m}$ \\
\hline
\end{tabular}

Notas: Los años 1995 y 2009 (columnas 1, 4, 7, 10, 13 y 16) están disponibles en Internet (véase Statlink más abajo).

1. Algunos niveles educativos están incluidos junto con otros. Véase el código «X» en la Tabla B1.1a para obtener más detalles.

2. Año de referencia 2010 en lugar de 2011.

3. Año de referencia 2012 en lugar de 2011. Año de referencia 2006 en lugar de 2005.

4. Solo gasto público.

5. Solo instituciones públicas.

6. Excluyendo la educación postsecundaria no terciaria.

Fuentes: OCDE. Arabia Saudí, Argentina, China, Colombia, India, Indonesia, Sudáfrica: Instituto de Estadística de la UNESCO. Letonia: Eurostat. Para ver notas, consulte Anexo 3 (www.oecd.org/edu/eag.htm).

Para obtener más información acerca de los símbolos utilizados en lugar de los datos que faltan, consulte la Guía del lector.

StatLink 젶ㄴ http://dx.doi.org/10.1787/888933117003 
Tabla B1.5b. Cambio en el gasto de instituciones educativas por estudiante para todos los servicios, con relación a diferentes factores en el nivel de educación terciaria

$(1995,2000,2005,2008,2009,2010,2011)$

Indice de cambio (deflactor del PIB $2005=100$, precios constantes)

\begin{tabular}{|c|c|c|c|c|c|c|c|c|c|c|c|c|}
\hline & \multicolumn{12}{|c|}{ Educación terciaria } \\
\hline & \multicolumn{4}{|c|}{$\begin{array}{l}\text { Cambio en el gasto } \\
(2005=100)\end{array}$} & \multicolumn{4}{|c|}{$\begin{array}{l}\text { Cambio en el número de estudiantes } \\
(2005=100)\end{array}$} & \multicolumn{4}{|c|}{$\begin{array}{l}\text { Cambio en el gasto por estudiante } \\
(2005=100)\end{array}$} \\
\hline & 2000 & 2008 & 2010 & 2011 & 2000 & 2008 & 2010 & 2011 & 2000 & 2008 & 2010 & 2011 \\
\hline & (2) & (3) & (5) & (6) & (8) & (9) & (11) & (12) & (14) & (15) & (17) & (18) \\
\hline Alemania & 94 & 115 & 126 & 131 & 93 & 102 & 113 & 119 & 101 & 113 & 111 & 110 \\
\hline Australia & 84 & 111 & 126 & 129 & $\mathrm{~m}$ & 108 & 125 & 129 & $\mathbf{m}$ & 103 & 101 & 100 \\
\hline Austria & 75 & 111 & 126 & 125 & 103 & 118 & 139 & 145 & 73 & 94 & 90 & 86 \\
\hline Bélgica & 98 & 118 & 124 & 124 & 94 & 103 & 112 & 116 & 104 & 114 & 110 & 107 \\
\hline Canadá $^{1,2,3}$ & 86 & 108 & 117 & 116 & $\mathrm{~m}$ & $\mathrm{~m}$ & $\mathrm{~m}$ & $\mathrm{~m}$ & $\mathbf{m}$ & $\mathbf{m}$ & $\mathbf{m}$ & $\mathbf{m}$ \\
\hline Chile $^{4}$ & 84 & 128 & 170 & 184 & 73 & 133 & 161 & 166 & 115 & 97 & 106 & 111 \\
\hline Corea & 79 & 127 & 138 & 144 & 93 & 103 & 102 & 103 & 84 & 124 & 135 & 140 \\
\hline Dinamarca $^{1}$ & 86 & 102 & 110 & 113 & 98 & 100 & 108 & 101 & 88 & 102 & 102 & 111 \\
\hline Eslovenia & $\mathrm{m}$ & 103 & 108 & 113 & $\mathrm{~m}$ & 102 & 104 & 102 & $\mathbf{m}$ & 101 & 105 & 111 \\
\hline España & 88 & 119 & 127 & 124 & 107 & 105 & 111 & 114 & 82 & 113 & 114 & 108 \\
\hline Estados Unidos & 78 & 112 & 118 & 120 & 89 & 106 & 123 & 126 & 88 & 105 & 96 & 96 \\
\hline Estonia $^{5}$ & 92 & 128 & 140 & 162 & 85 & 99 & 100 & 101 & 108 & 129 & 139 & 161 \\
\hline Finlandia & 86 & 108 & 116 & 120 & 95 & 98 & 99 & 100 & 91 & 110 & 118 & 121 \\
\hline Francia & 93 & 113 & 117 & 118 & 95 & 99 & 102 & 103 & 98 & 114 & 115 & 115 \\
\hline Grecia $^{1}$ & 42 & $\mathrm{~m}$ & $\mathrm{~m}$ & $\mathrm{~m}$ & 68 & $\mathrm{~m}$ & $\mathrm{~m}$ & $\mathrm{~m}$ & 63 & $\mathbf{m}$ & $\mathbf{m}$ & $\mathbf{m}$ \\
\hline Hungría $^{3,5}$ & 81 & 105 & 96 & 112 & 66 & 99 & 86 & 93 & 122 & 107 & 111 & 121 \\
\hline Irlanda $^{3}$ & 101 & 135 & 136 & 132 & 85 & 101 & 109 & 109 & 118 & 134 & 125 & 121 \\
\hline Islandia & 69 & 114 & 101 & 98 & 68 & 110 & 117 & 117 & 103 & 104 & 86 & 84 \\
\hline Israel & 90 & 100 & 107 & 118 & 82 & 101 & 108 & 111 & 110 & 99 & 99 & 106 \\
\hline Italia & 93 & 113 & 112 & 114 & 90 & 100 & 98 & 97 & 103 & 113 & 114 & 117 \\
\hline Japón ${ }^{1}$ & 94 & 109 & 110 & 115 & 99 & 98 & 96 & 97 & 95 & 112 & 114 & 119 \\
\hline Luxemburgo & $\mathrm{m}$ & $\mathrm{m}$ & $\mathrm{m}$ & $\mathrm{m}$ & $\mathrm{m}$ & $\mathrm{m}$ & $\mathrm{m}$ & $\mathrm{m}$ & $\mathbf{m}$ & $\mathbf{m}$ & $\mathbf{m}$ & $\mathbf{m}$ \\
\hline México & 73 & 113 & 127 & 122 & 83 & 110 & 120 & 126 & 88 & 102 & 105 & 96 \\
\hline Noruega $^{5}$ & 83 & 102 & 105 & 107 & 88 & 99 & 106 & 109 & 95 & 102 & 100 & 98 \\
\hline Nueva Zelanda & $\mathrm{m}$ & $\mathrm{m}$ & $\mathrm{m}$ & $\mathrm{m}$ & $\mathrm{m}$ & 126 & 133 & 133 & $\mathbf{m}$ & $\mathbf{m}$ & $\mathbf{m}$ & $\mathbf{m}$ \\
\hline Países Bajos & 86 & 110 & 121 & 124 & 85 & 110 & 119 & 122 & 100 & 100 & 102 & 102 \\
\hline Polonia & 57 & 112 & 120 & 108 & 60 & 99 & 95 & 93 & 96 & 113 & 126 & 116 \\
\hline Portugal $^{3}$ & 70 & 107 & 114 & 107 & 90 & 101 & 107 & 110 & 78 & 106 & 107 & 97 \\
\hline Reino Unido & 66 & 115 & 105 & 130 & 93 & 103 & 110 & 110 & 70 & 111 & 95 & 118 \\
\hline República Checa & 65 & 133 & 141 & 167 & 72 & 118 & 132 & 133 & 90 & 112 & 107 & 125 \\
\hline República Eslovaca $^{1}$ & 67 & 123 & 128 & 141 & 71 & 124 & 124 & 121 & 94 & 99 & 103 & 117 \\
\hline Suecia & 86 & 105 & 117 & 120 & 82 & 94 & 103 & 106 & 105 & 112 & 114 & 112 \\
\hline Suiza $^{3,5}$ & 77 & 90 & 102 & 107 & 79 & 115 & 128 & 135 & 98 & 78 & 79 & 79 \\
\hline Turquía & $\mathrm{m}$ & $\mathrm{m}$ & $\mathrm{m}$ & $\mathrm{m}$ & $\mathrm{m}$ & $\mathrm{m}$ & $\mathrm{m}$ & $\mathrm{m}$ & $\mathbf{m}$ & $\mathbf{m}$ & $\mathbf{m}$ & $\mathbf{m}$ \\
\hline Media OCDE & 81 & 113 & 120 & 125 & 85 & 106 & 113 & 115 & 95 & 108 & 108 & 110 \\
\hline Media UE21 & 80 & 115 & 120 & 125 & 86 & 104 & 109 & 110 & 94 & 110 & 111 & 115 \\
\hline
\end{tabular}

\begin{tabular}{|c|c|c|c|c|c|c|c|c|c|c|c|c|}
\hline $\begin{array}{l}\text { Arabia Saudí } \\
\text { Argentina }\end{array}$ & $\begin{array}{l}\mathrm{m} \\
\mathrm{m}\end{array}$ & $\begin{array}{l}\mathrm{m} \\
\mathrm{m}\end{array}$ & $\begin{array}{l}\mathrm{m} \\
\mathrm{m}\end{array}$ & $\begin{array}{l}\mathrm{m} \\
\mathrm{m}\end{array}$ & $\begin{array}{l}\mathrm{m} \\
\mathrm{m}\end{array}$ & $\begin{array}{l}\mathrm{m} \\
\mathrm{m}\end{array}$ & $\begin{array}{l}\mathrm{m} \\
\mathrm{m}\end{array}$ & $\begin{array}{l}\mathrm{m} \\
\mathrm{m}\end{array}$ & $\begin{array}{l}\mathbf{m} \\
\mathbf{m}\end{array}$ & $\begin{array}{l}\mathbf{m} \\
\mathbf{m}\end{array}$ & $\begin{array}{l}\mathbf{m} \\
\mathbf{m}\end{array}$ & $\begin{array}{l}\mathbf{m} \\
\mathbf{m}\end{array}$ \\
\hline Brasil $^{3,5}$ & 79 & 119 & 148 & 155 & 70 & 110 & 125 & 150 & 112 & 108 & 119 & 104 \\
\hline China & $\mathrm{m}$ & $\mathrm{m}$ & $\mathrm{m}$ & $\mathrm{m}$ & $\mathrm{m}$ & $\mathrm{m}$ & $\mathrm{m}$ & $\mathrm{m}$ & $\mathbf{m}$ & $\mathbf{m}$ & $\mathbf{m}$ & $\mathbf{m}$ \\
\hline Colombia & $\mathrm{m}$ & $\mathrm{m}$ & $\mathrm{m}$ & $\mathrm{m}$ & $\mathrm{m}$ & $\mathrm{m}$ & $\mathrm{m}$ & $\mathrm{m}$ & $\mathbf{m}$ & $\mathbf{m}$ & $\mathbf{m}$ & $\mathbf{m}$ \\
\hline Federación Rusa & 44 & 147 & 145 & 136 & $\mathrm{~m}$ & 175 & 156 & 149 & $\mathbf{m}$ & 84 & 93 & 91 \\
\hline India & $\mathrm{m}$ & $\mathrm{m}$ & $\mathrm{m}$ & $\mathrm{m}$ & $\mathrm{m}$ & $\mathrm{m}$ & $\mathrm{m}$ & $\mathrm{m}$ & $\mathbf{m}$ & $\mathbf{m}$ & $\mathbf{m}$ & $\mathbf{m}$ \\
\hline Indonesia & $\mathrm{m}$ & $\mathrm{m}$ & $\mathrm{m}$ & $\mathrm{m}$ & $\mathrm{m}$ & $\mathrm{m}$ & $\mathrm{m}$ & $\mathrm{m}$ & $\mathbf{m}$ & $\mathbf{m}$ & $\mathbf{m}$ & $\mathbf{m}$ \\
\hline Sudáfrica & $\mathrm{m}$ & $\mathrm{m}$ & $\mathrm{m}$ & $\mathrm{m}$ & $\mathrm{m}$ & $\mathrm{m}$ & $\mathrm{m}$ & $\mathrm{m}$ & $\mathbf{m}$ & $\mathbf{m}$ & $\mathbf{m}$ & m \\
\hline
\end{tabular}

Notas: Los años 1995 y 2009 (columnas 1, 4, 7, 10, 13 y 16) están disponibles en Internet (véase Statlink más abajo).

1. Algunos niveles educativos están incluidos junto con otros. Véase el código «X» en la Tabla B1.1a para obtener más detalles.

2. Año de referencia 2010 en lugar de 2011.

3. Solo instituciones públicas.

4. Año de referencia 2012 en lugar de 2011. Año de referencia 2006 en lugar de 2005.

5. Solo gasto público.

Fuentes: OCDE. Arabia Saudí, Argentina, China, Colombia, India, Indonesia, Sudáfrica: Instituto de Estadística de la UNESCO. Letonia: Eurostat. Para ver notas, consulte Anexo 3 (www.oecd.org/edu/eag.htm).

Para obtener más información acerca de los símbolos utilizados en lugar de los datos que faltan, consulte la Guía del lector.

StatLink त्नाIS http://dx.doi.org/10.1787/888933117022 
Tabla B1.6. Gasto anual de instituciones educativas por estudiante para todos los servicios,
por tipo de programa (2011)

En equivalente a dólares estadounidenses convertidos mediante PPA para el PIB, por nivel educativo, sobre la base de equivalentes a tiempo completo

\begin{tabular}{|c|c|c|c|c|c|c|c|c|c|}
\hline & \multicolumn{9}{|c|}{ Educación secundaria } \\
\hline & \multicolumn{3}{|c|}{ Educación secundaria inferior } & \multicolumn{3}{|c|}{ Educación secundaria superior } & \multicolumn{3}{|c|}{ Toda la educación secundaria } \\
\hline & $\begin{array}{l}\text { Todos los } \\
\text { programas }\end{array}$ & $\begin{array}{l}\text { Programas } \\
\text { generales }\end{array}$ & $\begin{array}{c}\text { Programas } \\
\text { de formación } \\
\text { profesional / } \\
\text { preprofesional }\end{array}$ & $\begin{array}{c}\text { Todos los } \\
\text { programas }\end{array}$ & $\begin{array}{l}\text { Programas } \\
\text { generales }\end{array}$ & $\begin{array}{l}\text { Programas } \\
\text { de formación } \\
\text { profesional / } \\
\text { preprofesional }\end{array}$ & $\begin{array}{c}\text { Todos los } \\
\text { programas }\end{array}$ & $\begin{array}{l}\text { Programas } \\
\text { generales }\end{array}$ & $\begin{array}{c}\text { Programas } \\
\text { de formación } \\
\text { profesional / } \\
\text { preprofesional }\end{array}$ \\
\hline & (1) & (2) & (3) & (4) & (5) & (6) & (7) & (8) & (9) \\
\hline 山̆ Alemania & 9.247 & 9.247 & a & 12.022 & 9.975 & 13.995 & 10.275 & 9.410 & 13.995 \\
\hline Australia & 10.689 & 11.068 & 6.728 & 9.859 & 11.337 & 6.727 & 10.354 & 11.158 & 6.727 \\
\hline Austria & 13.547 & 13.547 & a & 13.666 & 12.668 & 14.022 & 13.607 & 13.362 & 14.022 \\
\hline Bélgica $^{1}$ & $\mathbf{x}(7)$ & $\mathrm{x}(7)$ & $\mathrm{x}(7)$ & $\mathbf{x}(7)$ & $\mathrm{x}(7)$ & $\mathrm{x}(7)$ & 11.732 & $\mathrm{x}(7)$ & $\mathrm{x}(7)$ \\
\hline Canadá ${ }^{1,2}$ & $\mathbf{m}$ & $\mathrm{m}$ & $\mathrm{m}$ & 11.607 & $\mathrm{x}(4)$ & $\mathrm{x}(4)$ & $\mathbf{m}$ & $\mathrm{m}$ & $\mathrm{m}$ \\
\hline Chile $^{3}$ & 4.494 & 4.494 & a & 4.496 & 3.840 & 5.900 & 4.495 & 4.113 & 5.900 \\
\hline Corea & 6.674 & 6.674 & a & 9.698 & $\mathrm{x}(4)$ & $\mathrm{x}(4)$ & 8.199 & $\mathrm{x}(7)$ & $\mathrm{x}(7)$ \\
\hline Dinamarca & 10.971 & 10.971 & $\mathrm{a}$ & 10.908 & $\mathrm{x}(4)$ & $\mathrm{x}(4)$ & 10.937 & $\mathrm{x}(7)$ & $x(7)$ \\
\hline Eslovenia $^{1}$ & 9.947 & 9.947 & a & 7.724 & $\mathrm{x}(4)$ & $\mathrm{x}(4)$ & 8.568 & $\mathrm{x}(7)$ & $\mathrm{x}(7)$ \\
\hline España & 9.335 & $\mathrm{x}(1)$ & $\mathrm{x}(1)$ & 10.090 & $\mathrm{x}(4)$ & $\mathrm{x}(4)$ & 9.615 & $x(7)$ & $x(7)$ \\
\hline Estados Unidos & 12.338 & 12.338 & $\mathrm{a}$ & 13.143 & 13.143 & a & 12.731 & 12.731 & a \\
\hline Estonia & 6.009 & $\mathrm{x}(1)$ & $\mathrm{x}(1)$ & 6.688 & 6.153 & 7.651 & 6.389 & 6.074 & 7.651 \\
\hline Finlandia $^{1}$ & 12.545 & 12.545 & a & 8.467 & 7.407 & 8.887 & 9.792 & 10.639 & 8.887 \\
\hline Francia & 9.668 & 9.668 & a & 13.071 & 12.735 & 13.587 & 11.109 & 10.612 & 13.587 \\
\hline Grecia & $\mathbf{m}$ & $\mathrm{m}$ & $\mathrm{m}$ & $\mathbf{m}$ & $\mathrm{m}$ & $\mathrm{m}$ & $\mathbf{m}$ & $\mathrm{m}$ & $\mathrm{m}$ \\
\hline Hungría $^{4}$ & 4.709 & 4.733 & 1.931 & 4.455 & 4.989 & 3.094 & 4.574 & 4.848 & 3.064 \\
\hline Irlanda $^{4}$ & 11.442 & $\mathrm{x}(1)$ & $\mathrm{x}(1)$ & 11.576 & $\mathrm{x}(4)$ & $\mathrm{x}(4)$ & 11.502 & $\mathrm{x}(7)$ & $\mathrm{x}(7)$ \\
\hline Islandia $^{1}$ & 10.160 & 10.160 & a & 7.461 & $\mathrm{x}(4)$ & $\mathrm{x}(4)$ & 8.470 & $\mathrm{x}(7)$ & $x(7)$ \\
\hline Israel & $x(7)$ & $\mathrm{x}(8)$ & $\mathrm{x}(9)$ & $\mathbf{x}(7)$ & $\mathrm{x}(8)$ & $\mathrm{x}(9)$ & 5.712 & 4.128 & 13.905 \\
\hline Italia $^{4}$ & 8.686 & 8.681 & 9.646 & 8.519 & $\mathrm{x}(4)$ & $\mathrm{x}(4)$ & 8.585 & $\mathrm{x}(7)$ & $x(7)$ \\
\hline Japón $^{1}$ & 9.677 & 9.677 & a & 10.093 & $\mathrm{x}(4)$ & $\mathrm{x}(4)$ & 9.886 & $x(7)$ & $x(7)$ \\
\hline Luxemburgo & 16.125 & 16.125 & a & 16.238 & 16.701 & 15.942 & 16.182 & 16.289 & 15.942 \\
\hline México & 2.344 & 2.805 & 516 & 4.034 & 3.986 & 4.522 & 2.943 & 3.260 & 1.302 \\
\hline Noruega $^{1}$ & 12.769 & 12.769 & a & 14.838 & $x(4)$ & $x(4)$ & 13.939 & $x(7)$ & $x(7)$ \\
\hline Nueva Zelanda & 8.670 & 8.670 & a & 10.023 & 9.747 & 11.033 & 9.312 & 9.117 & 11.033 \\
\hline Países Bajos & 12.031 & 10.646 & 15.632 & 12.171 & 10.028 & 13.167 & 12.100 & 10.460 & 13.890 \\
\hline Polonia $^{4}$ & 5.995 & $\mathrm{x}(1)$ & $\mathrm{x}(1)$ & 5.764 & 5.709 & 5.376 & 5.870 & $\mathrm{x}(7)$ & $x(7)$ \\
\hline Portugal $^{4}$ & 8.294 & $\mathrm{x}(1)$ & $\mathrm{x}(1)$ & 9.139 & $\mathrm{x}(4)$ & $\mathrm{x}(4)$ & 8.676 & $\mathrm{x}(7)$ & $\mathrm{x}(7)$ \\
\hline Reino Unido $^{1}$ & $x(7)$ & $\mathrm{x}(7)$ & $\mathrm{x}(7)$ & $x(7)$ & $\mathrm{x}(7)$ & $\mathrm{x}(7)$ & 9.649 & $\mathrm{x}(7)$ & $x(7)$ \\
\hline República Checa & 7.730 & 7.699 & $\mathrm{x}(1)$ & 6.886 & 5.867 & 7.264 & 7.270 & 7.249 & 7.302 \\
\hline República Eslovaca ${ }^{1}$ & 5.109 & 5.109 & $\mathrm{x}(6)$ & 4.783 & 3.803 & 5.245 & 4.938 & 4.769 & 5.245 \\
\hline Suecia & 10.823 & 10.894 & $\mathrm{~m}$ & 11.022 & 10.771 & 11.208 & 10.938 & 10.848 & 11.208 \\
\hline Suiza $^{1,4}$ & 15.124 & 15.124 & a & 16.521 & 16.035 & 16.730 & 15.891 & 15.368 & 16.730 \\
\hline Turquía & 2.250 & $\mathrm{x}(1)$ & a & 3.239 & 3.292 & 3.181 & 2.736 & 2.599 & 3.181 \\
\hline Media OCDE & 9.377 & $\sim$ & $\sim$ & 9.506 & 8.613 & 9.307 & 9.280 & 8.572 & 9.643 \\
\hline Media UE21 & 9.568 & $\sim$ & $\sim$ & 9.622 & 8.900 & 9.953 & 9.615 & 9.506 & 10.436 \\
\hline 气 Arabia Saudí & $\mathbf{m}$ & $\mathrm{m}$ & $\mathrm{m}$ & $\mathbf{m}$ & $\mathrm{m}$ & $\mathrm{m}$ & $\mathbf{m}$ & $\mathrm{m}$ & $\mathrm{m}$ \\
\hline Argentina ${ }^{4}$ & 2.947 & 2.947 & a & 3.184 & $\mathrm{x}(4)$ & $\mathrm{x}(4)$ & 3.034 & $\mathrm{x}(7)$ & $\mathrm{x}(7)$ \\
\hline Brasil ${ }^{4}$ & 2.700 & 2.700 & a & 2.605 & $\mathrm{x}(4)$ & $\mathrm{x}(4)$ & 2.662 & $\mathrm{x}(7)$ & $x(7)$ \\
\hline 气̆ China & $\mathbf{m}$ & $\mathrm{m}$ & $\mathrm{m}$ & $\mathbf{m}$ & $\mathrm{m}$ & $\mathrm{m}$ & $\mathbf{m}$ & $\mathrm{m}$ & $\mathrm{m}$ \\
\hline Colombia ${ }^{3}$ & 1.159 & $\mathrm{x}(1)$ & $\mathrm{x}(1)$ & 1.163 & $x(4)$ & $\mathrm{x}(4)$ & 1.160 & $\mathrm{x}(7)$ & $x(7)$ \\
\hline Federación Rusa ${ }^{1}$ & $x(7)$ & $\mathrm{x}(8)$ & $\mathrm{a}$ & $x(7)$ & $\mathrm{x}(8)$ & $\mathrm{x}(9)$ & 4.470 & 4.492 & 4.299 \\
\hline India & $\mathbf{m}$ & $\mathrm{m}$ & $\mathrm{m}$ & $\mathbf{m}$ & $\mathrm{m}$ & $\mathrm{m}$ & $\mathbf{m}$ & $\mathrm{m}$ & $\mathrm{m}$ \\
\hline Indonesia $^{3}$ & 449 & 449 & a & 617 & 853 & 307 & 522 & 571 & 307 \\
\hline Letonia & 5.019 & 5.025 & 4.226 & 4.983 & 5.241 & 4.599 & 4.998 & 5.123 & 4.594 \\
\hline Sudáfrica & $\mathbf{m}$ & $\mathrm{m}$ & $\mathrm{m}$ & m & $\mathrm{m}$ & $\mathrm{m}$ & $\mathbf{m}$ & $\mathrm{m}$ & $\mathrm{m}$ \\
\hline Media G20 & $\mathbf{m}$ & $\mathrm{m}$ & $\mathrm{m}$ & m & $\mathrm{m}$ & $\mathrm{m}$ & m & $\mathrm{m}$ & $\mathrm{m}$ \\
\hline
\end{tabular}

1. Algunos niveles educativos están incluidos junto con otros. Véase el código «X» en la Tabla B1.1a para obtener más detalles.

2. Año de referencia 2010 .

3. Año de referencia 2012

4. Solo instituciones públicas.

Fuentes: OCDE. Arabia Saudí, Argentina, China, Colombia, India, Indonesia, Sudáfrica: Instituto de Estadística de la UNESCO. Letonia: Eurostat. Para ver notas, consulte Anexo 3 (www.oecd.org/edu/eag.htm)

Para obtener más información acerca de los símbolos utilizados en lugar de los datos que faltan, consulte la Guía del lector.

StatLink त्ञाज ht htp://dx.doi.org/10.1787/888933117041 



\section{¿QUÉ PROPORCIÓN DE LA RIQUEZA NACIONAL SE DEDICA A LA EDUCACIÓN?}

- En 2011, los países de la OCDE gastaron una media del 6,1\% de su PIB en instituciones educativas; siete países (Argentina, Corea, Dinamarca, Islandia, Israel, Noruega y Nueva Zelanda) gastaron más del $7 \%$.

- Entre 2000 y 2011, el gasto en todos los niveles educativos considerados de forma conjunta aumentó a un ritmo más rápido que el crecimiento del PIB en casi todos los países con datos disponibles.

- Desde el comienzo de la crisis económica en 2008 y hasta 2011, el PIB creció en términos reales en la mitad de los países con datos disponibles, mientras que el gasto público en instituciones educativas disminuyó en solo seis países. En el periodo más breve de 2009 a 2011, el PIB creció en términos reales en la mayoría de los países y el gasto público en instituciones educativas disminuyó en un tercio de los países de la OCDE, probablemente como consecuencia de las políticas de consolidación fiscal.

\section{Gráfico B2.1. Gasto en instituciones educativas como porcentaje del PIB para todos los niveles de educación (2000, 2008 y 2011)}

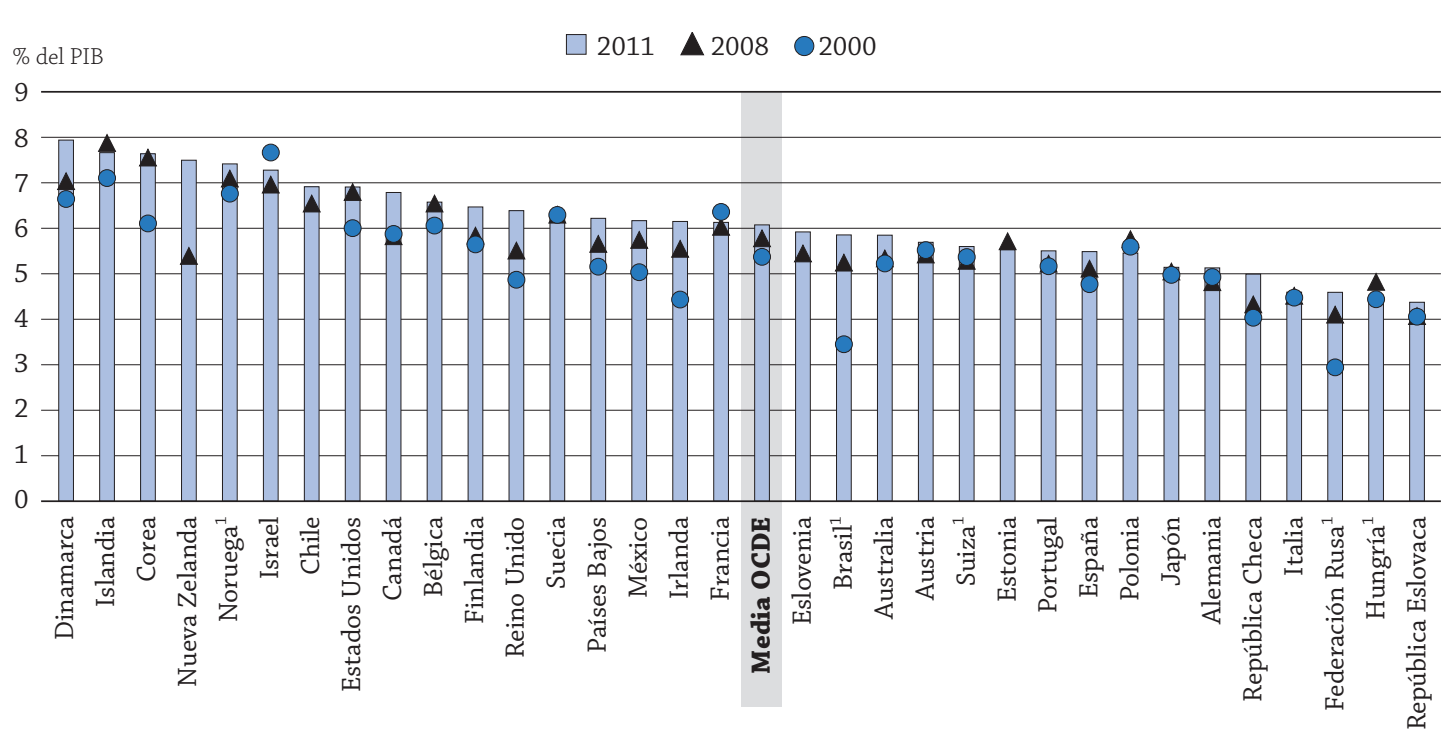

1. Solo gasto público (para Suiza, solo en educación terciaria; para Noruega, solo en educación primaria, secundaria y postsecundaria no terciaria; para Estonia y Federación Rusa, solo para 2000).

Los países están clasificados en orden descendente del gasto procedente de fuentes tanto públicas como privadas en instituciones educativas en 2011.

Fuente: OCDE. Tabla B2.2. Para ver notas, consulte Anexo 3 (www.oecd.org/edu/eag.htm).

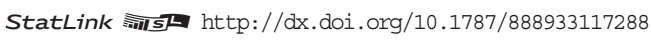

\section{Contexto}

Este indicador presenta una medida del gasto en instituciones educativas en relación con la riqueza de un país. La riqueza nacional se calcula basándose en el PIB, y el gasto en educación incluye los gastos de los gobiernos, las empresas y los estudiantes y sus familias.

Los países invierten en instituciones educativas para ayudar a fomentar el crecimiento económico, mejorar la productividad, contribuir al desarrollo personal y social, y reducir las desigualdades sociales, entre otros motivos. La proporción del gasto en educación en relación con el PIB depende de las diversas preferencias de varios actores públicos y privados. No obstante, el gasto educativo procede mayoritariamente de los presupuestos públicos y está controlado muy de cerca por los gobiernos. En tiempos de crisis económica, incluso sectores clave como la educación pueden ser objeto de recortes presupuestarios. 
El nivel de gasto en instituciones educativas depende del tamaño de la población de estudiantes de un país, de las tasas de matriculación, del nivel de los salarios de los profesores y de la organización e impartición de la enseñanza. En los niveles de educación primaria y secundaria inferior (que se corresponden aproximadamente con la población de 5 a 14 años), las tasas de matriculación son de cerca del $100 \%$ en los países de la OCDE y los cambios del número de estudiantes están muy relacionados con los cambios demográficos. Este no es tanto el caso en la educación secundaria superior y terciaria, porque parte de la población afectada ha dejado el sistema educativo (véase Indicador $\mathrm{C} 1$ ).

\section{Otros resultados}

- El gasto en educación infantil representa casi una décima parte del gasto en instituciones educativas, o el 0,6\% del PIB, como media en los países de la OCDE. Las diferencias entre países son significativas. Por ejemplo, mientras que el gasto en educación infantil es inferior al 0,2\% del PIB en Australia y Suiza, es de alrededor del 1\% o más en Dinamarca e Islandia.

- La educación primaria, secundaria y postsecundaria no terciaria suponen casi dos tercios del gasto en instituciones educativas, o el 3,8\% del PIB, como media en los países de la OCDE. Argentina y Nueva Zelanda son los que más gastan de todos los países de la OCDE y países asociados, con un $5 \%$ o más del PIB destinado a estos niveles educativos, mientras que Federación Rusa, Hungría, Japón, Letonia, República Checa, República Eslovaca y Turquía destinan el $3 \%$ o menos de su PIB a estos niveles.

- La educación terciaria supone una cuarta parte del gasto en instituciones educativas, o el 1,6\% del PIB, como media en los países de la OCDE. Canadá, Chile, Corea y Estados Unidos destinan entre el 2,4\% y el 2,8\% de su PIB a las instituciones terciarias.

- El gasto privado en instituciones educativas como porcentaje del PIB es mayor en la educación terciaria, como media en los países de la OCDE. Esta proporción es mayor en Chile, Corea y Estados Unidos, donde oscila entre el 1,7\% y el 1,9\% del PIB.

\section{Tendencias}

Para todos los niveles educativos en conjunto, la inversión pública en educación aumentó en una media del $7 \%$ en los países de la OCDE entre 2008 y 2011. No obstante, el crecimiento anual del gasto público en instituciones educativas se ralentizó durante dicho periodo, desde el $4 \%$ en 2008-2009 hasta el $1 \%$ en 2009-2010 y 2010-2011, como media en los países de la OCDE.

A lo largo de todo el periodo 2008-2011, solo Estados Unidos, Estonia, Federación Rusa, Hungría. Islandia e Italia recortaron (en términos reales) el gasto público en instituciones educativas; pero el gasto público solo disminuyó en cinco países en el periodo 2008-2009, y en diez países entre 2009 y 2011. En Federación Rusa, Hungría. Islandia, Italia y Portugal, el gasto público disminuyó un $5 \%$ o más entre 2009 y 2011. 


\section{Análisis}

\section{Gasto global en relación con el PIB}

La proporción de la riqueza nacional que se destina a las instituciones educativas es sustancial en todos los países de la OCDE y países asociados con datos disponibles. En 2011, los países de la OCDE gastaron una media del 6,1\% de su PIB en instituciones educativas; los países de la OCDE en total también gastaron el 6,1\% de su PIB conjunto en instituciones educativas, incluyendo fuentes de financiación públicas y privadas.

En 2011, el gasto en instituciones educativas (todos los niveles en conjunto) en relación con el PIB fue superior al $6 \%$ en la mitad de los países de la OCDE y asociados de los que se dispone de datos, e incluso superior al $7 \%$ en siete de ellos: Argentina, Corea, Dinamarca, Islandia, Israel, Noruega y Nueva Zelanda. En el otro extremo del espectro, Federación Rusa, Hungría, Italia, República Eslovaca y Turquía destinaron menos del $5 \%$ de su PIB a educación (Tabla B2.1).

Gráfico B2.2. Gasto en instituciones educativas como porcentaje del PIB (2011) Procedente de fuentes de financiación públicas y privadas, por nivel de educación y fuente de financiación
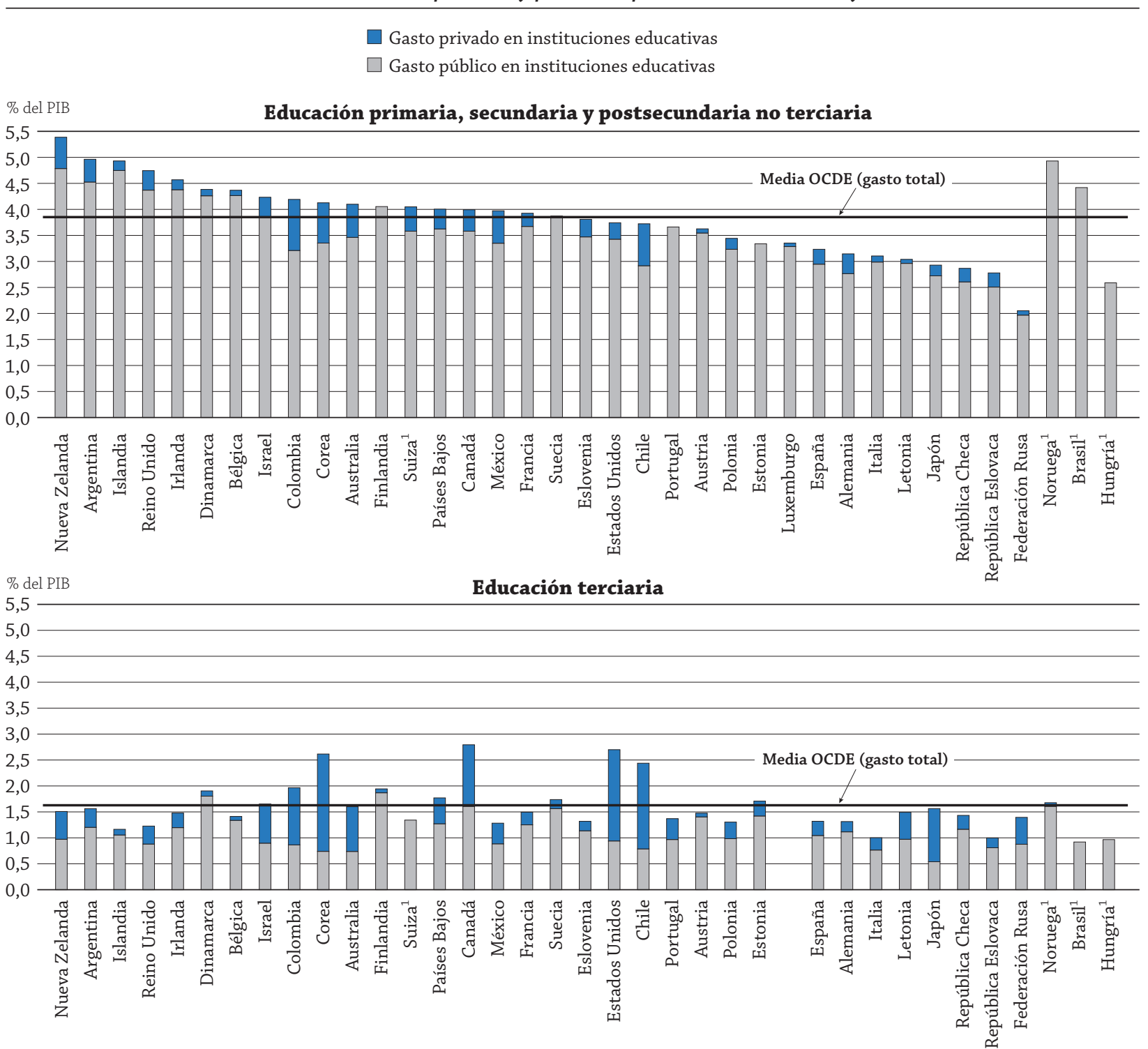

1. Gasto público (para Suiza, solo en educación terciaria; para Noruega, solo en educación primaria, secundaria y postsecundaria no terciaria).

Los países están clasificados en orden descendente del gasto procedente de fuentes tanto públicas como privadas en instituciones educativas en educación primaria, secundaria y postsecundaria no terciaria.

Fuente: OCDE. Tabla B2.3. Para ver notas, consulte Anexo 3 (www.oecd.org/edu/eag.htm).

StatLink त्ञाई 


\section{Gasto en instituciones educativas por nivel de educación}

Una media de casi dos tercios del gasto en educación de todos los países de la OCDE se destina a la educación primaria, secundaria y postsecundaria no terciaria, mientras que un cuarto se destina a la educación terciaria y casi una décima parte a la educación infantil. La educación primaria y la secundaria inferior reciben como media el $42 \%$ del gasto en educación en los países de la OCDE. El gasto en instituciones educativas depende de la edad de la población. En la mayoría de los casos, los países con un gasto en instituciones educativas en relación con el PIB superior a la media son normalmente aquellos con una proporción superior a la media de personas cuya edad corresponde a los niveles de educación primaria y secundaria inferior (Tabla B2.2 y véase Indicador C1).

En todos los países de la OCDE y países asociados con datos disponibles, el nivel de recursos nacionales que se destinan a la educación primaria, secundaria y postsecundaria no terciaria en conjunto es la mayor proporción del gasto total en instituciones educativas (comparada con la proporción del gasto destinado a la educación infantil y a la terciaria). Esta proporción es superior al $50 \%$ en casi todos los países, excepto Federación Rusa (45\%). Para la educación primaria, secundaria y postsecundaria no terciaria el gasto como porcentaje del PIB oscila desde el $3 \%$ o menos en Federación Rusa, Hungría, Japón, Letonia, República Checa, República Eslovaca y Turquía al $5 \%$ o más en Argentina y Nueva Zelanda.

El gasto en educación primaria y secundaria inferior supone el 1,5\% o más del PIB en todos los países y alcanza el $3 \%$ o más en Argentina, Australia, Brasil, Colombia, Dinamarca, Irlanda, Islandia, México, Noruega, Nueva Zelanda y Reino Unido (Tabla B2.1).

Todos los países, excepto Dinamarca e Islandia, dedican menos del 1\% de su PIB a la educación infantil. Sin embargo, los datos sobre la educación infantil deben ser analizados con cautela, ya que hay grandes diferencias entre países en las tasas de matriculación, la edad a la que comienza la educación infantil y el grado hasta el cual las estadísticas miden la educación infantil privada (véase Indicador C1).

El gasto en educación terciaria supone al menos el 1,5\% del PIB en más de la mitad de los países y supera el 2,4\% en Canadá, Chile, Corea y Estados Unidos. Hay cuatro países que destinan el 1\% o menos de su PIB a la educación terciaria: Brasil, Hungría, Italia y República Eslovaca (Tabla B2.1 y Gráfico B2.2).

\section{Cambios del gasto global en instituciones educativas entre 2000 y 2011}

El aumento del número de estudiantes matriculados en educación secundaria superior y educación terciaria entre 2000 y 2011 estuvo acompañado en la mayoría de los países de un aumento del gasto en estos niveles.

Durante el periodo 2000-2011, en aquellos países con datos comparables, tanto el gasto en instituciones educativas (todos los niveles educativos en conjunto) como el PIB aumentaron (véase Tabla X2.3, Anexo 2). En Francia, Israel y Polonia, el gasto en educación aumentó menos que el PIB, lo que lleva a una disminución del gasto como proporción del PIB de hasta 0,4 puntos porcentuales. En todos los demás países con datos comparables, el gasto en instituciones educativas (todos los niveles educativos en conjunto) aumentó a un ritmo superior que el PIB, lo que da como resultado un aumento del gasto en instituciones educativas como porcentaje del PIB (Gráfico B2.1). El aumento fue de más de un punto porcentual en Brasil (del 3,5\% al 5,9\%), Corea (del 6,1\% al 7,6\%), Dinamarca (del 6,6\% al 7,9\%), Federación Rusa (del 2,9\% al 4,6\%), Irlanda (del 4,4\% al 6,2\%), México (del 5,0\% al 6,2\%), Países Bajos (del 5,2\% al 6,2\%), Reino Unido (del 4,9\% al 6,4\%) y Turquía (del 2,5\% al 4,2\%) (Tabla B2.2).

Hubo cambios similares del gasto en educación primaria, secundaria y postsecundaria no terciaria consideradas en conjunto, así como en educación terciaria.

\section{Efecto de la crisis económica en el gasto público en instituciones educativas entre 2008 y 2011}

La crisis económica global que comenzó en 2008 tuvo -y sigue teniendo- grandes efectos negativos en los diferentes sectores de la economía. Al contar solamente con datos de 2008 a 2011, el impacto total de la crisis en la financiación de las instituciones educativas no se puede evaluar, pero sus primeros efectos en la economía en un sentido más amplio ya pueden observarse.

Entre 2008 y 2011 el PIB (expresado en precios constantes) disminuyó en más de un tercio de los países con datos disponibles (en 15 de 36 ) y en un $5 \%$ o más en cuatro países: Eslovenia, Grecia, Irlanda e Islandia. Como más de tres cuartas partes del gasto educativo proceden de fuentes de financiación públicas en la mayoría de los países, ¿cómo afectó la caída del PIB al gasto público en educación? Las cifras disponibles muestran que el sector de la educación quedó relativamente intacto con los primeros recortes de los presupuestos. 
Gráfico B2.3. Impacto de la crisis económica en el gasto público en educación Índice de cambio entre 2008 y 2011 del gasto en instituciones educativas como porcentaje del PIB, en todos los niveles de educación ( $2008=100,2011$ precios constantes)

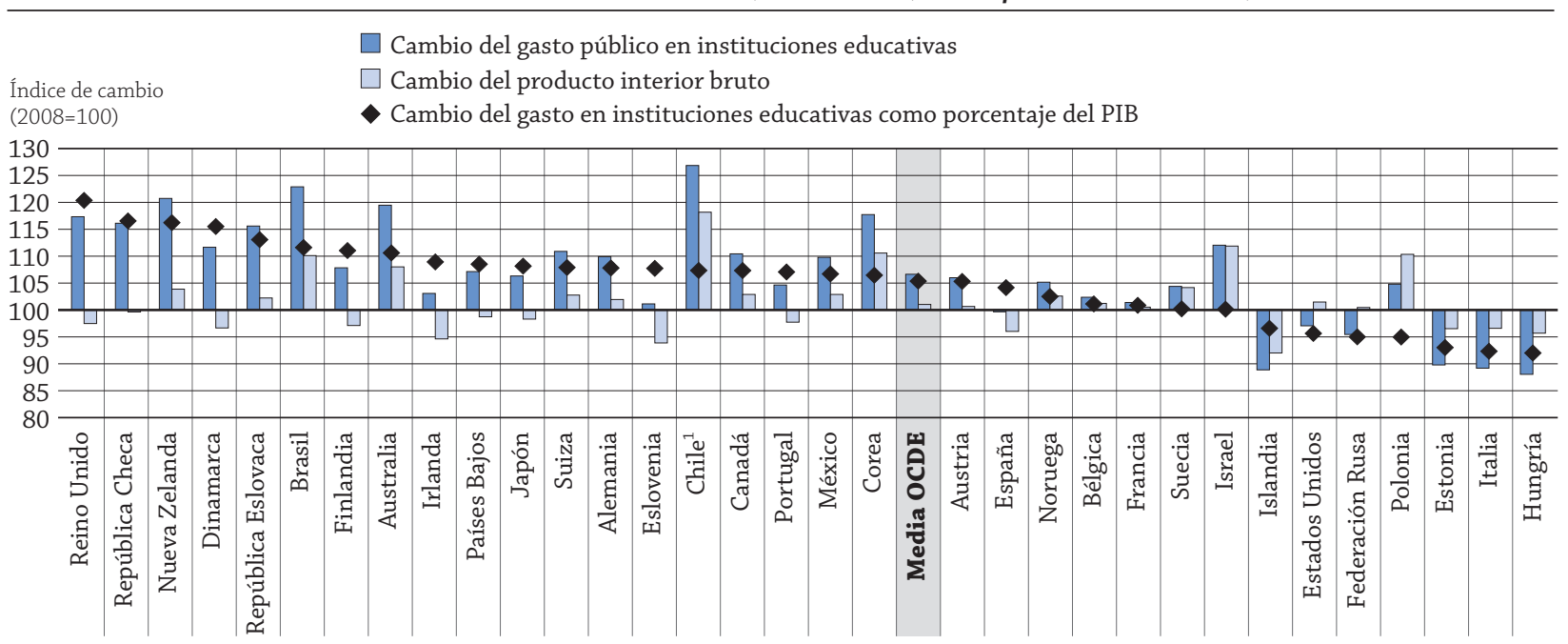

Índice de cambio del gasto público en instituciones educativas

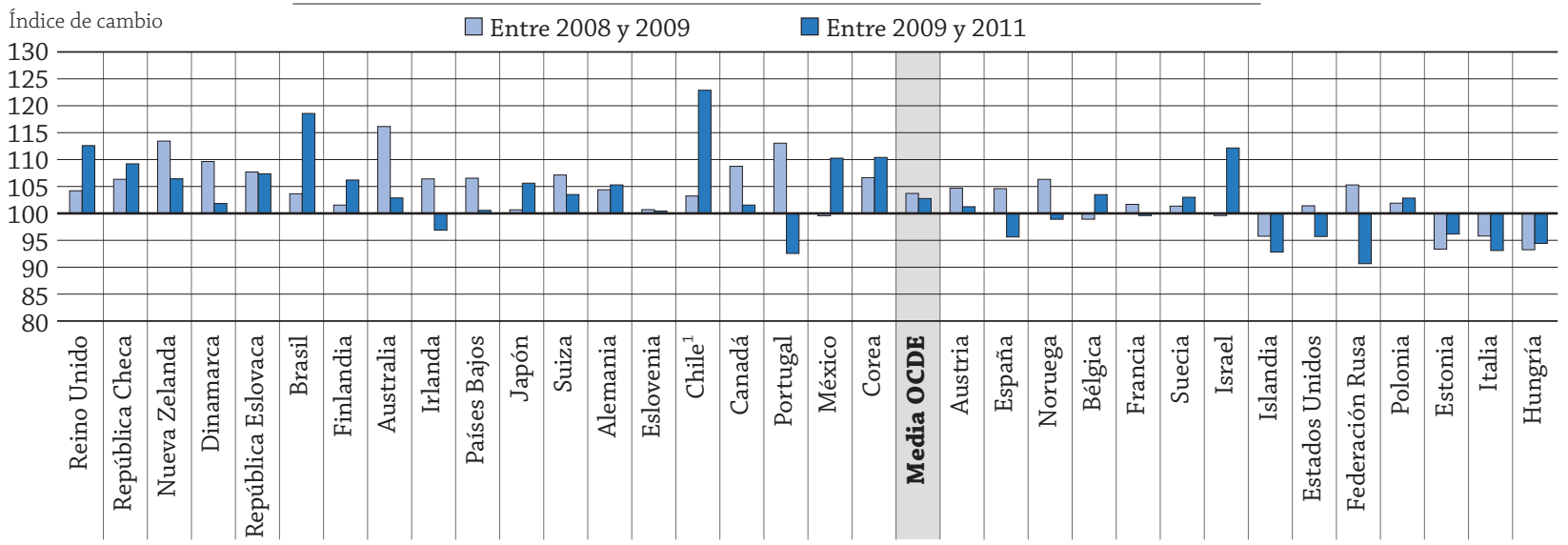

Índice de cambio del producto interior bruto

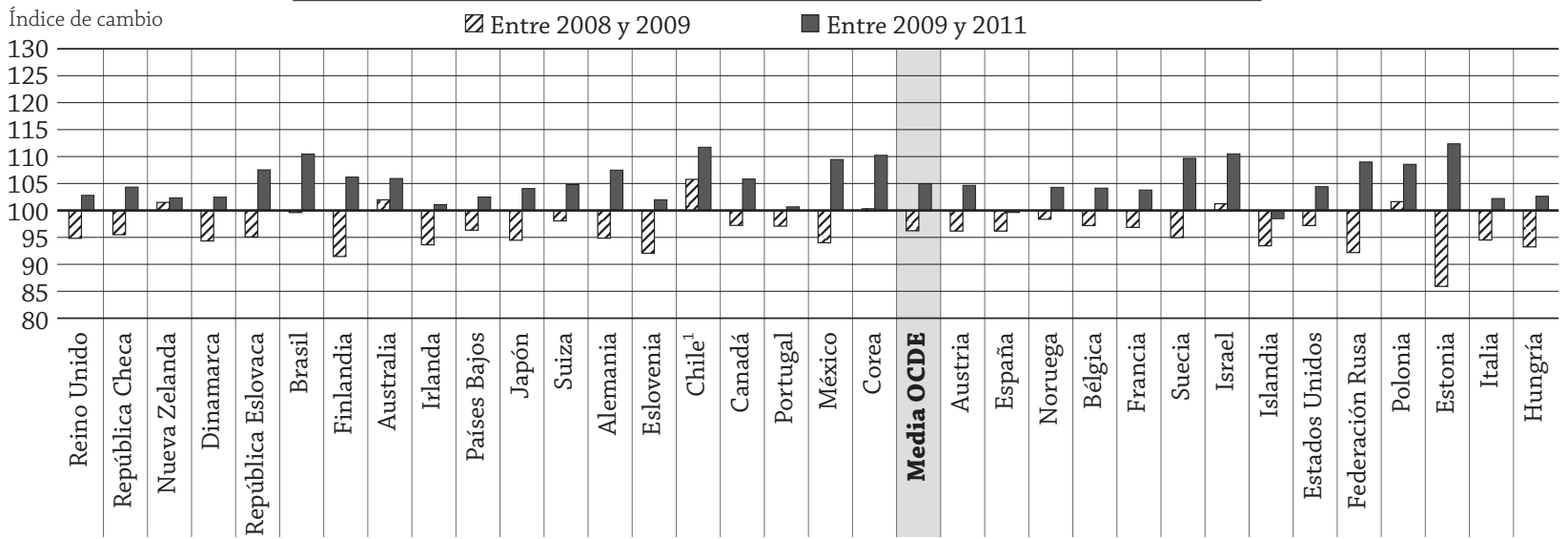

1. Los datos se refieren a 2009-2012 en lugar de 2008-2011.

Los países están clasificados en orden descendente del cambio en el gasto en instituciones educativas como porcentaje del PIB.

Fuente: OCDE. Tabla B2.5. Para ver notas, consulte Anexo 3 (www.oecd.org/edu/eag.htm).

StatLink त्ञाI $\mathrm{s}$ http://dx.doi.org/10.1787/888933117326

Cómo leer este gráfico

El gráfico muestra el cambio del gasto público en educación, y en la proporción de la renta nacional, entre 2008 y 2011, el cambio resultante del gasto público en las instituciones educativas como porcentaje del PIB, y los cambios del gasto público en las instituciones educativas y del PIB entre 2008-2009 y 2009-2011. 
Puesto que los presupuestos públicos de la mayoría de los países se aprueban muchos meses antes de que se produzca el gasto en sí, hay ciertas rigideces inherentes a la financiación de la educación. Además, la mayoría de los gobiernos tratan de proteger la educación de las reducciones drásticas de la inversión pública.

De los 34 países con datos disponibles para el periodo 2008-2011, solo seis recortaron (en términos reales) el gasto público en instituciones educativas: Estados Unidos (un $3 \%$ ), Estonia (un $10 \%$ ), Federación Rusa (un $5 \%$ ), Hungría (un $12 \%$ ), Islandia (un $11 \%$ ) e Italia (un 11\%). En estos países, esto se tradujo en una disminución del gasto en instituciones educativas como porcentaje del PIB (al ser la disminución del gasto mayor que la disminución del PIB, o al aumentar el PIB al mismo tiempo). En todos los demás países, el gasto público en instituciones educativas aumentó, mientras que el PIB disminuyó en algunos de ellos. Como resultado, la proporción del PIB destinada a la educación siguió creciendo entre 2008 y 2011. Una excepción a esta tendencia es Polonia, donde el PIB creció a un ritmo más rápido que el gasto público en instituciones educativas, lo que ha dado lugar a una disminución del gasto público en instituciones educativas como porcentaje del PIB (Gráfico B2.3).

Los cambios globales durante el periodo de tres años de 2008-2011 ocultan diferentes pautas de variaciones cuando se analizan los periodos 2008-2009 y 2009-2011 por separado.

Mientras que el PIB disminuyó entre 2008 y 2009 en la mayoría de los 30 países con datos disponibles (excepto Australia, Chile, Corea, Israel, Nueva Zelanda y Polonia), aumentó de nuevo en 2010 o en 2011 en la mayoría de los países, lo que llevó a un aumento global del PIB entre 2009 y 2011 en todos los países salvo en dos: Grecia, donde el PIB disminuyó en ambos años y un 12\% entre 2009 y 2011; e Islandia, donde el aumento del PIB entre 2010 y 2011 no compensó su disminución entre 2009 y 2010 (una disminución del $2 \%$ entre 2009 y 2011).

Mientras tanto, el gasto público en instituciones educativas siguió unas pautas diferentes y comenzó a disminuir con cierto retraso comparado con el PIB, como resultado de la necesaria diferencia temporal entre el comienzo de la crisis y los ajustes de los presupuestos públicos. Mientras que el PIB disminuyó en la mayoría de los países entre 2008 y 2009, el gasto público en instituciones educativas aumentó en la mayoría de los países durante ese periodo, en un $4 \%$ como media en los países de la OCDE. No obstante, el gasto público disminuyó un $4 \%$ o más en Estonia, Hungría, Islandia e Italia. Como el PIB disminuyó aún más en dichos países, el gasto público como porcentaje del PIB aumentó en la mayoría de los países. Esta proporción solo disminuyó ligeramente (menos del 2\%) en Chile e Israel.

Durante el periodo 2009-2011, el gasto público disminuyó entre 2009 y 2010, o entre 2010 y 2011, o de forma continuada a lo largo del periodo de dos años en más países que entre 2008 y 2009. Durante todo el periodo 2009-2011 el gasto público descendió en 10 países (más del $5 \%$ en Federación Rusa, Hungría, Islandia, Italia y Portugal), mientras que el PIB aumentó en la mayoría de los países. Unido al aumento del PIB, esto llevó a un descenso del gasto público en educación como porcentaje del PIB en todos estos países, de forma especialmente significativa en Estonia (un 14\%) y Federación Rusa (un 17\%). No obstante, en otros 12 países el aumento del gasto público en educación entre 2009 y 2011 no siguió el ritmo del crecimiento del PIB, por lo que el gasto público en educación como porcentaje del PIB también se redujo, en un $5 \%$ o más en Polonia y Suecia.

\section{Gasto en enseñanza, investigación y desarrollo, y servicios auxiliares}

Como media en los países de la OCDE, el $90 \%$ del gasto conjunto en educación primaria, secundaria y postsecundaria no terciaria se destina a servicios básicos. Esta proporción es significativamente menor en el nivel terciario (con una media del $70 \%$ en la OCDE), porque otros servicios, en concreto los relacionados con la investigación y el desarrollo (I+D), pueden representar una gran proporción del gasto total en educación.

En el nivel terciario, la proporción del gasto en I+D como porcentaje del PIB oscila desde menos del 0,2\% en Brasil y Chile hasta más del 0,6\% en Australia, Canadá, Estonia, Finlandia, Noruega, Países Bajos y Suiza, y más del 0,9\% en Suecia. Estas diferencias ayudan a explicar las variaciones entre países del gasto global por cada estudiante del nivel terciario (Tabla B2.4 y Gráfico B2.4). Por ejemplo, los altos niveles de gasto en I+D en los países mencionados anteriormente implican que el gasto de instituciones educativas por estudiante sería considerablemente inferior en estos países si se excluyera el componente de I+D (véase Tabla B1.2).

En muchos países de la OCDE, los centros escolares y las universidades proporcionan servicios de asistencia a los estudiantes y, en algunos casos, servicios para la población en general. Este gasto en servicios auxiliares es sufragado por el sector público y por tasas que pagan los estudiantes y sus familias. Como media en los países de la OCDE, alrededor del 0,22\% del PIB se destina a servicios auxiliares en los niveles de enseñanza primaria, secundaria y postsecundaria no terciaria en su conjunto (Tabla B2.4). Esta proporción es de más del 0,4\% en Corea, Finlandia, Francia y Suecia. 
Los servicios auxiliares son sufragados por usuarios privados con más frecuencia en el nivel terciario que en ningún otro nivel. En los países de la OCDE, se destina una media del 0,06 \% del PIB a servicios auxiliares en el nivel terciario. Esta proporción es de más del 0,1\% en Canadá, Hungría, Israel y República Eslovaca y alcanza el 0,33\% en Estados Unidos.

\section{Gráfico B2.4. Gasto en instituciones educativas para servicios educativos básicos, I+D y servicios auxiliares como porcentaje del PIB, en el nivel de educación terciaria (2011)}

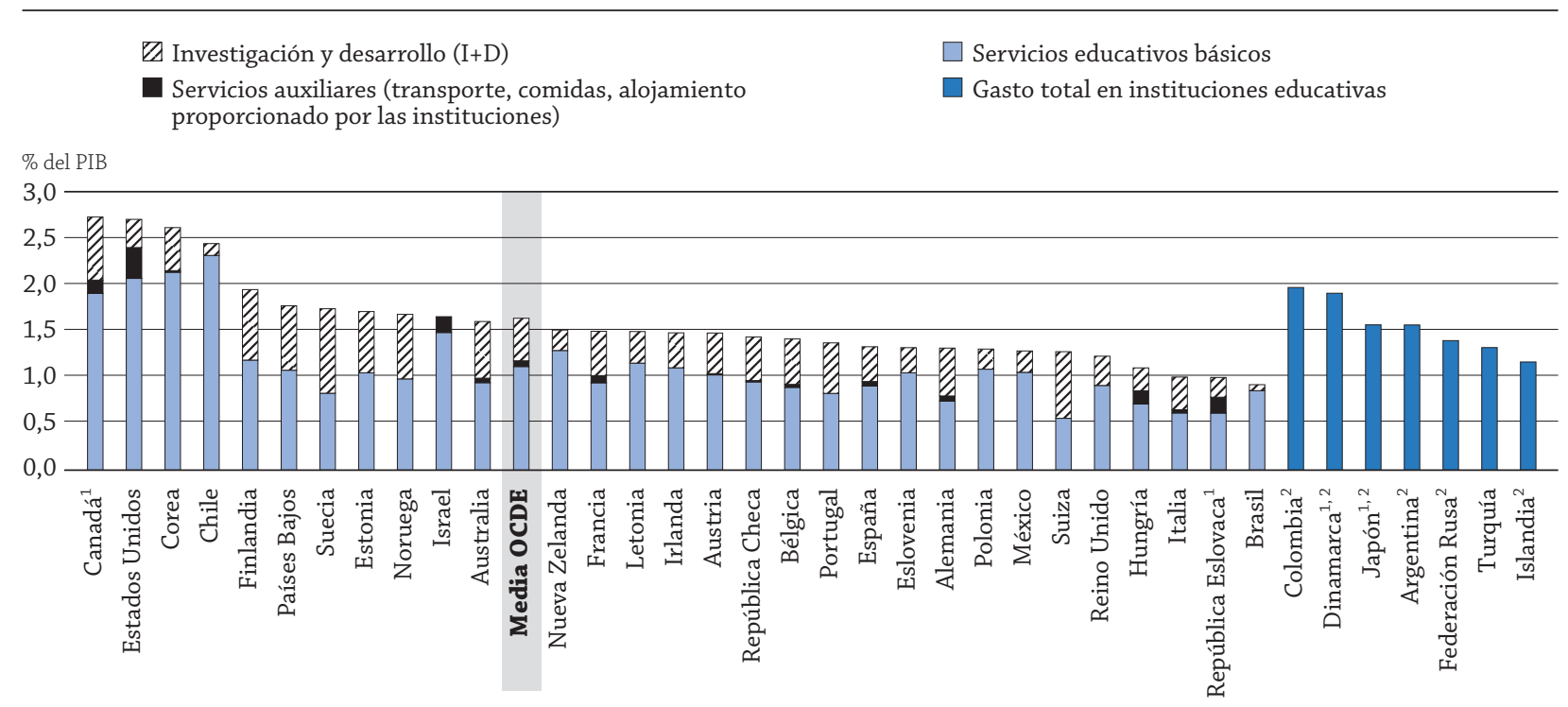

1. Algunos niveles educativos están incluidos junto con otros. Véase el código «X» en la Tabla B1.1a para obtener más detalles.

2. El gasto total en educación terciaria incluyendo el gasto en investigación y desarrollo (I+D).

Los países están clasificados en orden descendente del gasto total en instituciones de educación terciaria.

Fuente: OCDE. Tabla B2.4. Para ver notas, consulte Anexo 3 (www.oecd.org/edu/eag.htm).

StatLink 제이 http://dx.doi.org/10.1787/888933117345

\section{Gasto en instituciones educativas según fuentes de financiación}

La educación se financia con fuentes tanto públicas como privadas. El aumento del gasto en instituciones educativas como respuesta al aumento de matriculaciones y otros factores implica una mayor carga económica para la sociedad en su conjunto. Sin embargo, esta carga no recae enteramente en la financiación pública (véase Indicador A7). Como media, del 6,1\% del PIB conjunto en el área de la OCDE destinado a la educación, tres cuartas partes (el 5,3\% del PIB conjunto) provienen de fuentes de financiación públicas para todos los niveles educativos en su conjunto (Tabla B2.3). Los fondos públicos son la mayor fuente de financiación de la educación en todos los países y suponen al menos el $62 \%$ (en Chile) y hasta casi el 98\% (en Finlandia) del gasto total. Sin embargo, el desglose del gasto en educación por fuente de financiación y por nivel educativo muestra grandes diferencias entre países (véase Indicador B3).

\section{Definiciones}

Los servicios auxiliares son servicios proporcionados por las instituciones educativas que son adicionales a la misión docente principal. El componente principal de los servicios auxiliares son los servicios de asistencia a los estudiantes. En educación primaria, secundaria y postsecundaria no terciaria, los servicios de asistencia a los estudiantes incluyen aspectos como comedor, servicios sanitarios escolares y transporte escolar. En el nivel terciario incluyen residencias para estudiantes, comedores y asistencia sanitaria.

Los servicios educativos básicos incluyen todos los servicios relacionados directamente con la enseñanza en las instituciones educativas, tales como profesorado, instalaciones escolares, material didáctico, libros y administración de los centros educativos.

El gasto en I+D incluye el gasto total en investigación llevada a cabo en universidades y otras instituciones educativas terciarias, independientemente de si se financia mediante el presupuesto general institucional o mediante otras ayudas o contratos con patrocinadores públicos o privados. La clasificación del gasto se basa en datos recogidos en las instituciones que llevan a cabo $\mathrm{I}+\mathrm{D}$, y no en las fuentes de financiación. 
Los pagos privados para bienes y servicios educativos adquiridos fuera de las instituciones educativas incluyen los bienes y servicios educativos realizados fuera de las instituciones educativas. Por ejemplo, las familias pueden comprar libros de texto y materiales ellas mismas o buscar clases particulares para sus hijos.

\section{Metodología}

Los datos se refieren al año financiero de 2011 y se basan en la recopilación de datos UOE sobre estadísticas educativas gestionada por la OCDE en 2013 (para más detalles véase Anexo 3 en www.oecd.org/edu/eag.htm).

\section{Nota sobre los datos de Israel}

Los datos estadísticos para Israel fueron proporcionados por las autoridades israelíes competentes bajo su responsabilidad. El uso de estos datos por parte de la OCDE se hace sin prejuzgar la situación de los Altos del Golán, Jerusalén Este y los asentamientos israelíes en Cisjordania de acuerdo con los términos del derecho internacional.

\section{Tablas del Indicador B2}

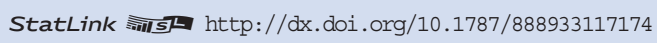

Tabla B2.1 Gasto en instituciones educativas como porcentaje del PIB, por nivel de educación (2011)

Tabla B2.2 Tendencias del gasto en instituciones educativas como porcentaje del PIB, por nivel de educación $(1995,2000,2005,2008,2009,2010,2011)$

Tabla B2.3 Gasto en instituciones educativas como porcentaje del PIB, por fuente de financiación y nivel de educación (2011)

Tabla B2.4 Gasto en instituciones educativas por categoría de servicios, como porcentaje del PIB (2011)

Tabla B2.5 Cambio del gasto público en instituciones educativas como porcentaje del PIB $(2008,2009,2010,2011)$ 
Tabla B2.1. Gasto en instituciones educativas como porcentaje del PIB, por nivel de educación (2011) Procedente de fuentes de financiación públicas y privadas ${ }^{1}$

\begin{tabular}{|c|c|c|c|c|c|c|c|c|c|}
\hline & \multirow[b]{2}{*}{$\begin{array}{c}\text { Educación } \\
\text { infantil } \\
\text { (para niños de } \\
3 \text { años o más) }\end{array}$} & \multicolumn{4}{|c|}{$\begin{array}{l}\text { Educación primaria, secundaria } \\
\text { y postsecundaria no terciaria }\end{array}$} & \multicolumn{3}{|c|}{ Educación terciaria } & \multirow[b]{2}{*}{\begin{tabular}{|c|} 
Todos los \\
niveles de \\
educación \\
combinados \\
(incluyendo \\
los programas \\
no asignados)
\end{tabular}} \\
\hline & & $\begin{array}{c}\text { Toda la } \\
\text { educación } \\
\text { primaria, } \\
\text { secundaria y } \\
\text { postsecundaria } \\
\text { no terciaria }\end{array}$ & $\begin{array}{l}\text { Educación } \\
\text { primaria } \\
\text { y educación } \\
\text { secundaria } \\
\text { inferior }\end{array}$ & $\begin{array}{l}\text { Educación } \\
\text { secundaria } \\
\text { superior }\end{array}$ & $\begin{array}{c}\text { Educación } \\
\text { postsecundaria } \\
\text { no terciaria }\end{array}$ & $\begin{array}{l}\text { Toda la } \\
\text { educación } \\
\text { terciaria }\end{array}$ & $\begin{array}{c}\text { Educación } \\
\text { terciaria } \\
\text { de tipo B }\end{array}$ & \begin{tabular}{|c|} 
Educación \\
terciaria \\
de tipo Ay \\
programas de \\
investigación \\
avanzada
\end{tabular} & \\
\hline & (1) & (2) & (3) & (4) & (5) & (6) & (7) & (8) & (9) \\
\hline U Alemania & 0,6 & 3,1 & 2,0 & 1,0 & 0,2 & 1,3 & 0,1 & 1,2 & 5,1 \\
\hline ठ Australia & 0,1 & 4,1 & 3,2 & 0,8 & 0,1 & 1,6 & 0,2 & 1,4 & 5,8 \\
\hline Austria & 0,6 & 3,6 & 2,3 & 1,3 & $\mathrm{n}$ & 1,5 & $\mathrm{n}$ & 1,5 & 5,7 \\
\hline Bélgica $^{2}$ & 0,6 & 4,4 & 1,6 & 2,8 & $\mathrm{x}(4)$ & 1,4 & $\mathrm{x}(6)$ & $\mathrm{x}(6)$ & 6,6 \\
\hline Canadá ${ }^{3}$ & $x(3)$ & 4,0 & 2,4 & 1,6 & $x(7)$ & 2,8 & 0,9 & 1,9 & 6,8 \\
\hline Chile $^{4}$ & 0,8 & 3,7 & 2,5 & 1,3 & a & 2,4 & 0,7 & 1,8 & 6,9 \\
\hline Corea & 0,3 & 4,1 & 2,7 & 1,5 & a & 2,6 & 0,3 & 2,3 & 7,6 \\
\hline Dinamarca & 1,4 & 4,4 & 3,1 & 1,3 & $\mathrm{x}(4,6)$ & 1,9 & $\mathrm{x}(6)$ & $\mathrm{x}(6)$ & 7,9 \\
\hline Eslovenia & 0,8 & 3,8 & 2,7 & 1,1 & $\mathrm{x}(4)$ & 1,3 & $\mathrm{x}(6)$ & $\mathrm{x}(6)$ & 5,9 \\
\hline España & 0,9 & 3,2 & 2,5 & 0,7 & a & 1,3 & 0,2 & 1,1 & 5,5 \\
\hline Estados Unidos & 0,5 & 3,7 & 2,7 & 1,0 & $\mathrm{~m}$ & 2,7 & $\mathrm{x}(6)$ & $\mathrm{x}(6)$ & 6,9 \\
\hline Estonia & 0,4 & 3,4 & 2,0 & 1,1 & 0,3 & 1,7 & 0,5 & 1,2 & 5,5 \\
\hline Finlandia & 0,4 & 4,1 & 2,5 & 1,6 & $\mathrm{x}(4)$ & 1,9 & $\mathrm{n}$ & 1,9 & 6,5 \\
\hline Francia & 0,7 & 3,9 & 2,6 & 1,3 & $\mathrm{n}$ & 1,5 & 0,3 & 1,2 & 6,1 \\
\hline Grecia & $\mathrm{m}$ & $\mathrm{m}$ & $\mathrm{m}$ & $\mathrm{m}$ & $\mathrm{m}$ & $\mathrm{m}$ & $\mathrm{m}$ & $\mathrm{m}$ & $\mathbf{m}$ \\
\hline Hungría $^{5}$ & 0,6 & 2,6 & 1,5 & 1,0 & 0,1 & 1,0 & $\mathrm{n}$ & 0,9 & 4,4 \\
\hline Irlanda & $\mathrm{x}(9)$ & 4,6 & 3,3 & 0,9 & 0,4 & 1,5 & $\mathrm{x}(6)$ & $\mathrm{x}(6)$ & 6,2 \\
\hline Islandia & 1,0 & 4,9 & 3,6 & 1,3 & $\mathrm{x}(4)$ & 1,2 & $\mathrm{x}(6)$ & 1,2 & 7,7 \\
\hline Israel & 0,7 & 4,2 & 2,4 & 1,8 & $\mathrm{n}$ & 1,7 & 0,3 & 1,4 & 7,3 \\
\hline Italia & 0,5 & 3,1 & 1,9 & 1,2 & 0,1 & 1,0 & $\mathrm{n}$ & 1,0 & 4,6 \\
\hline Japón & 0,2 & 2,9 & 2,1 & 0,9 & $x(4,6)$ & 1,6 & 0,2 & 1,3 & 5,1 \\
\hline Luxemburgo & 0,8 & 3,4 & 2,5 & 0,8 & $\mathrm{n}$ & $\mathrm{m}$ & $\mathrm{m}$ & $\mathrm{m}$ & $\mathbf{m}$ \\
\hline México & 0,6 & 4,0 & 3,1 & 0,9 & a & 1,3 & $\mathrm{x}(6)$ & $\mathrm{x}(6)$ & 6,2 \\
\hline Noruega $^{5}$ & 0,5 & 4,9 & 3,3 & 1,6 & $\mathrm{x}(4)$ & 1,7 & $\mathrm{x}(6)$ & $\mathrm{x}(6)$ & 7,4 \\
\hline Nueva Zelanda & 0,6 & 5,4 & 3,6 & 1,6 & 0,2 & 1,5 & 0,2 & 1,3 & 7,5 \\
\hline Países Bajos & 0,4 & 4,0 & 2,7 & 1,3 & $\mathrm{n}$ & 1,8 & $\mathrm{n}$ & 1,8 & 6,2 \\
\hline Polonia & 0,7 & 3,4 & 2,4 & 1,0 & $\mathrm{n}$ & 1,3 & $\mathrm{n}$ & 1,3 & 5,5 \\
\hline Portugal & 0,4 & 3,7 & 2,6 & 1,1 & $\mathrm{~m}$ & 1,4 & $\mathrm{x}(6)$ & $\mathrm{x}(6)$ & 5,5 \\
\hline Reino Unido & 0,4 & 4,7 & 3,7 & 1,0 & a & 1,2 & $\mathrm{x}(6)$ & $\mathrm{x}(6)$ & 6,4 \\
\hline República Checa & 0,5 & 2,9 & 1,8 & 1,1 & $\mathrm{n}$ & 1,4 & $\mathrm{n}$ & 1,4 & 5,0 \\
\hline República Eslovaca & 0,5 & 2,8 & 1,8 & 1,0 & $\mathrm{x}(4)$ & 1,0 & $\mathrm{x}(4)$ & 1,0 & $\mathbf{4 , 4}$ \\
\hline Suecia & 0,7 & 3,9 & 2,6 & 1,3 & $\mathrm{n}$ & 1,7 & $\mathrm{x}(6)$ & $\mathrm{x}(6)$ & 6,3 \\
\hline Suiza $^{5}$ & 0,2 & 4,0 & 2,6 & 1,4 & $\mathrm{x}(4)$ & 1,3 & $\mathrm{n}$ & 1,2 & 5,6 \\
\hline Turquía $^{5}$ & 0,2 & 2,7 & 1,8 & 0,9 & a & 1,3 & $\mathrm{x}(6)$ & $\mathrm{x}(6)$ & 4,2 \\
\hline Media OCDE & 0,6 & 3,8 & 2,5 & 1,2 & $\mathrm{n}$ & 1,6 & 0,2 & 1,4 & 6,1 \\
\hline Total OCDE & 0,5 & 3,6 & 2,5 & 1,1 & $\mathrm{n}$ & 1,9 & 0,2 & 1,4 & 6,1 \\
\hline Media UE21 & 0,6 & 3,6 & 2,4 & 1,2 & $\mathrm{n}$ & 1,4 & 0,1 & 1,3 & 5,8 \\
\hline Arabia Saudí & $\mathrm{m}$ & $\mathrm{m}$ & $\mathrm{m}$ & $\mathrm{m}$ & $\mathrm{m}$ & $\mathrm{m}$ & $\mathrm{m}$ & $\mathrm{m}$ & $\mathbf{m}$ \\
\hline Argentina & 0,7 & 5,0 & 3,8 & 1,1 & a & 1,6 & 0,5 & 1,1 & 7,2 \\
\hline $\mathrm{Brasil}^{5}$ & 0,5 & 4,4 & 3,4 & 1,0 & $\mathrm{a}$ & 0,9 & $\mathrm{x}(6)$ & $\mathrm{x}(6)$ & 5,9 \\
\hline China & $\mathrm{m}$ & $\mathrm{m}$ & $\mathrm{m}$ & $\mathrm{m}$ & $\mathrm{m}$ & $\mathrm{m}$ & $\mathrm{m}$ & $\mathrm{m}$ & $\mathbf{m}$ \\
\hline Colombia $^{4}$ & 0,5 & 4,2 & 3,6 & 0,6 & a & 2,0 & $\mathrm{x}(6)$ & $\mathrm{x}(6)$ & 6,7 \\
\hline Federación Rusa & 0,8 & 2,1 & $x(2)$ & $x(2)$ & $\mathrm{x}(2)$ & 1,4 & 0,2 & 1,2 & 4,6 \\
\hline India & $\mathrm{m}$ & $\mathrm{m}$ & $\mathrm{m}$ & $\mathrm{m}$ & $\mathrm{m}$ & $\mathrm{m}$ & $\mathrm{m}$ & $\mathrm{m}$ & $\mathbf{m}$ \\
\hline Indonesia & $\mathrm{m}$ & $\mathrm{m}$ & $\mathrm{m}$ & $\mathrm{m}$ & $\mathrm{m}$ & $\mathrm{m}$ & $\mathrm{m}$ & $\mathrm{m}$ & $\mathbf{m}$ \\
\hline Letonia & 0,8 & 3,0 & 2,1 & 0,9 & $\mathrm{n}$ & 1,5 & 0,2 & 1,3 & 5,4 \\
\hline Sudáfrica & $\mathrm{m}$ & $\mathrm{m}$ & $\mathrm{m}$ & $\mathrm{m}$ & $\mathrm{m}$ & $\mathrm{m}$ & $\mathrm{m}$ & $\mathrm{m}$ & $\mathbf{m}$ \\
\hline
\end{tabular}

\begin{tabular}{|l|l|l|l|l|l|l|l|l|l|} 
Media G20 & $\mathrm{m}$ & $\mathrm{m}$ & $\mathrm{m}$ & $\mathrm{m}$ & $\mathrm{m}$ & $\mathrm{m}$ & $\mathrm{m}$ & $\mathrm{m}$ & $\mathbf{m}$ \\
\hline
\end{tabular}

1. Incluye fuentes internacionales.

2. La columna 3 solo se refiere a la educación primaria y la columna 4 se refiere a toda la educación secundaria.

3. Año de referencia 2010.

4. Año de referencia 2012

5. Solo gasto público (para Suiza, solo en educación terciaria; para Noruega, solo en educación primaria, secundaria y postsecundaria no terciaria).

Fuentes: OCDE. Arabia Saudí, Argentina, China, Colombia, India, Indonesia, Sudáfrica: Instituto de Estadística de la UNESCO. Letonia: Eurostat. Para ver notas, consulte Anexo 3 (www.oecd.org/edu/eag.htm).

Para obtener más información acerca de los símbolos utilizados en lugar de los datos que faltan, consulte la Guía del lector.

StatLink 제개 http://dx.doi.org/10.1787/888933117193 
Tabla B2.2. Tendencias del gasto en instituciones educativas como porcentaje del PIB, por nivel de educación $(1995,2000,2005,2008,2009,2010,2011)$

Procedente de fuentes de financiación públicas y privadas, por año

\begin{tabular}{|c|c|c|c|c|c|c|c|c|c|c|c|c|c|c|c|}
\hline & \multicolumn{5}{|c|}{$\begin{array}{l}\text { Educación primaria, secundaria } \\
\text { y postsecundaria no terciaria }\end{array}$} & \multicolumn{5}{|c|}{ Educación terciaria } & \multicolumn{5}{|c|}{$\begin{array}{c}\text { Total para todos los niveles de } \\
\text { educación }\end{array}$} \\
\hline & 2000 & 2005 & 2008 & 2010 & 2011 & 2000 & 2005 & 2008 & 2010 & 2011 & 2000 & 2005 & 2008 & 2010 & 2011 \\
\hline & (2) & (3) & (4) & (6) & (7) & (9) & (10) & (11) & (13) & (14) & (16) & (17) & (18) & $(20)$ & (21) \\
\hline Alemania & 3,3 & 3,2 & 3,0 & 3,3 & 3,1 & 1,1 & 1,1 & 1,2 & 1,3 & 1,3 & 4,9 & 5,0 & 4,8 & 5,3 & 5,1 \\
\hline Australia & 3,6 & 3,7 & 3,7 & 4,3 & 4,1 & 1,4 & 1,5 & 1,5 & 1,6 & 1,6 & 5,2 & 5,3 & 5,3 & 6,1 & 5,8 \\
\hline Austria & 3,9 & 3,7 & 3,6 & 3,7 & 3,6 & 1,1 & 1,3 & 1,3 & 1,5 & 1,5 & 5,5 & 5,5 & 5,4 & 5,8 & 5,7 \\
\hline Bélgica & 4,1 & 4,1 & 4,4 & 4,4 & 4,4 & 1,3 & 1,2 & 1,4 & 1,4 & 1,4 & 6,1 & 6,0 & 6,5 & 6,6 & 6,6 \\
\hline Canadá $^{1,2}$ & 3,3 & 3,4 & 3,4 & 3,7 & 4,0 & 2,3 & 2,4 & 2,5 & 2,6 & 2,8 & 5,9 & 5,8 & 5,8 & 6,4 & 6,8 \\
\hline Chile $^{3}$ & 4,2 & 3,2 & 3,9 & 3,4 & 3,7 & 2,0 & 1,7 & 2,0 & 2,4 & 2,4 & 6,5 & 5,4 & 6,5 & 6,4 & 6,9 \\
\hline Corea & 3,5 & 4,1 & 4,2 & 4,2 & 4,1 & 2,2 & 2,3 & 2,6 & 2,6 & 2,6 & 6,1 & 6,7 & 7,6 & 7,6 & 7,6 \\
\hline Dinamarca $^{2}$ & 4,1 & 4,5 & 4,2 & 4,8 & 4,4 & 1,6 & 1,7 & 1,7 & 1,9 & 1,9 & 6,6 & 7,4 & $\mathbf{7 , 0}$ & 8,0 & 7,9 \\
\hline Eslovenia & $\mathrm{m}$ & 4,1 & 3,7 & 3,9 & 3,8 & $\mathrm{~m}$ & 1,3 & 1,1 & 1,3 & 1,3 & $\mathbf{m}$ & 6,0 & 5,4 & 5,9 & 5,9 \\
\hline España & 3,2 & 2,9 & 3,1 & 3,3 & 3,2 & 1,1 & 1,1 & 1,2 & 1,4 & 1,3 & 4,8 & 4,6 & 5,1 & 5,6 & 5,5 \\
\hline Estados Unidos & 3,6 & 3,6 & 3,9 & 4,0 & 3,7 & 2,1 & 2,3 & 2,5 & 2,7 & 2,7 & 6,0 & 6,4 & 6,8 & 7,0 & 6,9 \\
\hline Estonia & $\mathrm{m}$ & 3,5 & 3,9 & 3,9 & 3,4 & $\mathrm{~m}$ & 1,2 & 1,3 & 1,6 & 1,7 & $\mathbf{m}$ & 5,0 & 5,7 & 6,0 & 5,5 \\
\hline Finlandia & 3,6 & 3,9 & 3,8 & 4,1 & 4,1 & 1,7 & 1,7 & 1,7 & 1,9 & 1,9 & 5,6 & 6,0 & 5,8 & 6,5 & 6,5 \\
\hline Francia & 4,3 & 4,0 & 3,9 & 4,1 & 3,9 & 1,3 & 1,3 & 1,4 & 1,5 & 1,5 & 6,4 & 6,0 & 6,0 & 6,3 & 6,1 \\
\hline Grecia $^{2}$ & 2,7 & 2,8 & $\mathrm{~m}$ & $\mathrm{~m}$ & $\mathrm{~m}$ & 0,8 & 1,5 & $\mathrm{~m}$ & $\mathrm{~m}$ & $\mathrm{~m}$ & 3,6 & 4,3 & $\mathbf{m}$ & $\mathbf{m}$ & $\mathbf{m}$ \\
\hline Hungría $^{4}$ & 2,8 & 3,3 & 3,0 & 2,8 & 2,6 & 0,9 & 0,9 & 0,9 & 0,8 & 1,0 & 4,4 & 5,1 & 4,8 & 4,6 & 4,4 \\
\hline Irlanda & 2,9 & 3,4 & 4,1 & 4,7 & 4,6 & 1,5 & 1,1 & 1,4 & 1,6 & 1,5 & 4,4 & 4,5 & 5,5 & 6,4 & 6,2 \\
\hline Islandia & 4,8 & 5,4 & 5,1 & 4,9 & 4,9 & 1,1 & 1,2 & 1,3 & 1,2 & 1,2 & 7,1 & 8,0 & 7,9 & 7,8 & 7,7 \\
\hline Israel & 4,3 & 4,1 & 4,0 & 4,0 & 4,2 & 1,9 & 1,9 & 1,5 & 1,6 & 1,7 & 7,7 & 7,5 & $\mathbf{7 , 0}$ & 7,0 & 7,3 \\
\hline Italia & 3,1 & 3,1 & 3,2 & 3,1 & 3,1 & 0,9 & 0,9 & 1,0 & 1,0 & 1,0 & 4,5 & $\mathbf{4 , 4}$ & 4,5 & 4,4 & 4,6 \\
\hline Japón ${ }^{2}$ & 3,0 & 2,9 & 2,8 & 2,9 & 2,9 & 1,4 & 1,4 & 1,5 & 1,5 & 1,6 & 5,0 & 4,9 & 5,0 & 5,1 & 5,1 \\
\hline Luxemburgo & $\mathrm{m}$ & 3,7 & $\mathrm{~m}$ & 3,6 & 3,4 & $\mathrm{~m}$ & $\mathrm{~m}$ & $\mathrm{~m}$ & $\mathrm{~m}$ & $\mathrm{~m}$ & $\mathbf{m}$ & $\mathbf{m}$ & $\mathbf{m}$ & $\mathbf{m}$ & $\mathbf{m}$ \\
\hline México & 3,5 & 4,0 & 3,7 & 4,0 & 4,0 & 1,0 & 1,2 & 1,2 & 1,4 & 1,3 & 5,0 & 5,9 & 5,7 & 6,2 & 6,2 \\
\hline Noruega $^{4}$ & 5,0 & 5,1 & 4,8 & 5,1 & 4,9 & 1,6 & 1,7 & 1,6 & 1,6 & 1,7 & 6,8 & 7,5 & 7,1 & 7,4 & 7,4 \\
\hline Nueva Zelanda & $\mathrm{m}$ & 3,9 & 3,8 & 4,4 & 5,4 & $\mathrm{~m}$ & 0,9 & 1,1 & 1,0 & 1,5 & $\mathbf{m}$ & 5,1 & 5,4 & 5,9 & 7,5 \\
\hline Países Bajos & 3,4 & 3,8 & 3,7 & 4,1 & 4,0 & 1,4 & 1,5 & 1,6 & 1,7 & 1,8 & 5,2 & 5,8 & 5,7 & 6,3 & 6,2 \\
\hline Polonia & 3,9 & 3,7 & 3,6 & 3,7 & 3,4 & 1,1 & 1,6 & 1,5 & 1,5 & 1,3 & 5,6 & 5,9 & 5,8 & 5,8 & 5,5 \\
\hline Portugal & 3,7 & 3,7 & 3,4 & 3,9 & 3,7 & 1,0 & 1,3 & 1,3 & 1,5 & 1,4 & 5,2 & 5,5 & 5,2 & 5,8 & 5,5 \\
\hline Reino Unido & 3,5 & 4,3 & 4,1 & 4,5 & 4,7 & 1,0 & 1,3 & 1,4 & 1,3 & 1,2 & 4,9 & 5,9 & 5,5 & 6,2 & 6,4 \\
\hline República Checa & 2,7 & 2,9 & 2,6 & 2,8 & 2,9 & 0,8 & 1,0 & 1,1 & 1,2 & 1,4 & 4,0 & 4,5 & 4,3 & 4,7 & 5,0 \\
\hline República Eslovaca ${ }^{2}$ & 2,7 & 2,9 & 2,6 & 3,1 & 2,8 & 0,8 & 0,9 & 0,9 & 0,9 & 1,0 & 4,1 & $\mathbf{4 , 4}$ & 4,1 & 4,6 & 4,4 \\
\hline Suecia & 4,2 & 4,2 & 4,0 & 4,0 & 3,9 & 1,6 & 1,6 & 1,6 & 1,8 & 1,7 & 6,3 & 6,4 & 6,3 & 6,5 & 6,3 \\
\hline Suiza $^{4}$ & 4,0 & 4,2 & 3,9 & 4,0 & 4,0 & 1,1 & 1,4 & 1,1 & 1,2 & 1,3 & 5,4 & 5,9 & 5,3 & 5,6 & 5,6 \\
\hline Turquía $^{4}$ & 1,8 & $\mathrm{~m}$ & $\mathrm{~m}$ & 2,5 & 2,7 & 0,7 & $\mathrm{~m}$ & $\mathrm{~m}$ & $\mathrm{~m}$ & 1,3 & 2,5 & $\mathbf{m}$ & $\mathbf{m}$ & $\mathbf{m}$ & 4,2 \\
\hline Media OCDE & 3,6 & 3,7 & 3,7 & 3,9 & 3,8 & 1,3 & 1,4 & 1,5 & 1,6 & 1,6 & 5,4 & 5,7 & 5,8 & 6,1 & 6,1 \\
\hline Total OCDE & 3,5 & 3,6 & 3,6 & 3,7 & 3,6 & 1,6 & 1,7 & 1,8 & 1,9 & 1,9 & 5,5 & 5,8 & 6,0 & 6,2 & 6,1 \\
\hline Media UE21 & 3,5 & 3,6 & 3,6 & 3,8 & 3,6 & 1,1 & 1,3 & 1,3 & 1,4 & 1,4 & 5,1 & 5,4 & 5,5 & 5,9 & 5,8 \\
\hline $\begin{array}{l}\text { Media OCDE para los } 25 \text { países } \\
\text { con datos en todos los años } \\
\text { de referencia }\end{array}$ & 3,6 & 3,7 & 3,6 & 3,8 & 3,7 & 1,3 & 1,4 & 1,5 & 1,6 & 1,6 & 5,4 & 5,7 & 5,6 & 6,0 & 6,0 \\
\hline Arabia Saudí & $\mathrm{m}$ & $\mathrm{m}$ & $\mathrm{m}$ & $\mathrm{m}$ & $\mathrm{m}$ & $\mathrm{m}$ & $\mathrm{m}$ & $\mathrm{m}$ & $\mathrm{m}$ & $\mathrm{m}$ & $\mathbf{m}$ & $\mathbf{m}$ & $\mathbf{m}$ & $\mathbf{m}$ & $\mathbf{m}$ \\
\hline Argentina & $\mathrm{m}$ & $\mathrm{m}$ & $\mathrm{m}$ & $\mathrm{m}$ & 5,0 & $\mathrm{~m}$ & $\mathrm{~m}$ & $\mathrm{~m}$ & $\mathrm{~m}$ & 1,6 & $\mathbf{m}$ & $\mathbf{m}$ & $\mathbf{m}$ & m & 7,2 \\
\hline Brasil $^{4}$ & 2,4 & 3,2 & 4,1 & 4,3 & 4,4 & 0,7 & 0,8 & 0,8 & 0,9 & 0,9 & 3,5 & $\mathbf{4 , 4}$ & 5,2 & 5,6 & 5,9 \\
\hline China & $\mathrm{m}$ & $\mathrm{m}$ & $\mathrm{m}$ & $\mathrm{m}$ & $\mathrm{m}$ & $\mathrm{m}$ & $\mathrm{m}$ & $\mathrm{m}$ & $\mathrm{m}$ & $\mathrm{m}$ & $\mathbf{m}$ & $\mathbf{m}$ & $\mathbf{m}$ & $\mathbf{m}$ & $\mathbf{m}$ \\
\hline Colombia $^{3}$ & $\mathrm{~m}$ & $\mathrm{~m}$ & $\mathrm{~m}$ & $\mathrm{~m}$ & 4,2 & $\mathrm{~m}$ & $\mathrm{~m}$ & $\mathrm{~m}$ & $\mathrm{~m}$ & 2,0 & $\mathbf{m}$ & $\mathbf{m}$ & $\mathbf{m}$ & $\mathbf{m}$ & 6,7 \\
\hline Federación Rusa ${ }^{4}$ & 1,7 & 1,9 & 2,0 & 2,0 & 2,1 & 0,5 & 0,8 & 0,9 & 1,0 & 1,4 & 2,9 & 3,8 & 4,1 & 4,0 & 4,6 \\
\hline India & $\mathrm{m}$ & $\mathrm{m}$ & $\mathrm{m}$ & $\mathrm{m}$ & $\mathrm{m}$ & $\mathrm{m}$ & $\mathrm{m}$ & $\mathrm{m}$ & $\mathrm{m}$ & $\mathrm{m}$ & $\mathbf{m}$ & $\mathbf{m}$ & $\mathbf{m}$ & $\mathbf{m}$ & $\mathbf{m}$ \\
\hline Indonesia & $\mathrm{m}$ & $\mathrm{m}$ & $\mathrm{m}$ & $\mathrm{m}$ & $\mathrm{m}$ & $\mathrm{m}$ & $\mathrm{m}$ & $\mathrm{m}$ & $\mathrm{m}$ & $\mathrm{m}$ & $\mathbf{m}$ & $\mathbf{m}$ & $\mathbf{m}$ & $\mathbf{m}$ & $\mathbf{m}$ \\
\hline Letonia & $\mathrm{m}$ & $\mathrm{m}$ & $\mathrm{m}$ & $\mathrm{m}$ & 3,0 & $\mathrm{~m}$ & $\mathrm{~m}$ & $\mathrm{~m}$ & $\mathrm{~m}$ & 1,5 & $\mathbf{m}$ & $\mathbf{m}$ & $\mathbf{m}$ & $\mathbf{m}$ & 5,4 \\
\hline Sudáfrica & $\mathrm{m}$ & $\mathrm{m}$ & $\mathrm{m}$ & $\mathrm{m}$ & $\mathrm{m}$ & $\mathrm{m}$ & $\mathrm{m}$ & $\mathrm{m}$ & $\mathrm{m}$ & $\mathrm{m}$ & $\mathbf{m}$ & $\mathbf{m}$ & $\mathbf{m}$ & $\mathbf{m}$ & $\mathbf{m}$ \\
\hline Media G20 & $\mathrm{m}$ & $\mathrm{m}$ & $\mathrm{m}$ & $\mathrm{m}$ & $\mathrm{m}$ & $\mathrm{m}$ & $\mathrm{m}$ & $\mathrm{m}$ & $\mathrm{m}$ & $\mathrm{m}$ & $\mathbf{m}$ & $\mathbf{m}$ & $\mathbf{m}$ & $\mathbf{m}$ & $\mathbf{m}$ \\
\hline
\end{tabular}

Notas: Los años 1995 y 2009 (columnas 1, 5, 8, 12, 15 y 19) están disponibles en Internet (véase Statlink más abajo). Las columnas «Total para todos los niveles de educación» incluyen la educación infantil que no se muestra en columnas separadas en esta tabla.

1. Año de referencia 2010 en lugar de 2011.

2. Algunos niveles educativos están incluidos junto con otros. Véase el código «X» en la Tabla B1.1a para obtener más detalles.

3. Año de referencia 2011 en lugar de 2010. Año de referencia 2006 en lugar de 2005.

4. Solo gasto público (para Suiza, solo en educación terciaria; para Noruega, solo en educación primaria, secundaria y postsecundaria no terciaria; Federación Rusa, datos disponibles solo para 1995 y 2000).

Fuentes: OCDE. Arabia Saudí, Argentina, China, Colombia, India, Indonesia, Sudáfrica: Instituto de Estadística de la UNESCO. Letonia: Eurostat. Para ver notas, consulte Anexo 3 (www.oecd.org/edu/eag.htm).

Para obtener más información acerca de los símbolos utilizados en lugar de los datos que faltan, consulte la Guía del lector.

StatLink त्गाI http://dx.doi.org/10.1787/888933117212 
Tabla B2.3. Gasto en instituciones educativas como porcentaje del PIB, por fuente de financiación y nivel de educación (2011)

Procedente de fuentes de financiación públicas y privadas

\begin{tabular}{|c|c|c|c|c|c|c|c|c|c|c|c|c|}
\hline & \multicolumn{3}{|c|}{ Educación infantil } & \multicolumn{3}{|c|}{$\begin{array}{l}\text { Educación primaria, secundaria } \\
\text { y postsecundaria no terciaria }\end{array}$} & \multicolumn{3}{|c|}{ Educación terciaria } & \multicolumn{3}{|c|}{ Todos los niveles de educación } \\
\hline & Pública $^{1}$ & Privada $^{2}$ & Total & Pública $^{1}$ & Privada $^{2}$ & Total & Pública $^{1}$ & Privada $^{2}$ & Total & Pública $^{1}$ & Privada $^{2}$ & Total \\
\hline & (1) & (2) & (3) & (4) & (5) & (6) & (7) & (8) & (9) & (10) & (11) & (12) \\
\hline Alemania & 0,47 & 0,12 & 0,59 & 2,8 & 0,4 & 3,1 & 1,1 & 0,2 & 1,3 & 4,4 & 0,7 & 5,1 \\
\hline Australia & 0,11 & 0,04 & 0,15 & 3,5 & 0,6 & 4,1 & 0,7 & 0,9 & 1,6 & 4,3 & 1,5 & 5,8 \\
\hline Austria & 0,59 & $\mathrm{n}$ & 0,59 & 3,5 & 0,1 & 3,6 & 1,4 & 0,1 & 1,5 & 5,5 & 0,2 & 5,7 \\
\hline Bélgica & 0,63 & 0,02 & 0,64 & 4,3 & 0,1 & 4,4 & 1,3 & 0,1 & 1,4 & 6,4 & 0,2 & 6,6 \\
\hline Canadá ${ }^{3,4}$ & $\mathrm{x}(4)$ & $\mathrm{x}(5)$ & $\mathbf{x}(6)$ & 3,6 & 0,4 & 4,0 & 1,6 & 1,2 & 2,8 & 5,2 & 1,6 & 6,8 \\
\hline Chile $^{5}$ & 0,63 & 0,12 & 0,75 & 2,9 & 0,8 & 3,7 & 0,8 & 1,7 & 2,4 & 4,3 & 2,6 & 6,9 \\
\hline Corea & 0,16 & 0,13 & 0,29 & 3,4 & 0,8 & 4,1 & 0,7 & 1,9 & 2,6 & 4,9 & 2,8 & 7,6 \\
\hline Dinamarca $^{4}$ & 1,30 & 0,11 & 1,41 & 4,3 & 0,1 & 4,4 & 1,8 & 0,1 & 1,9 & 7,5 & 0,4 & 7,9 \\
\hline Eslovenia & 0,64 & 0,15 & 0,79 & 3,5 & 0,3 & 3,8 & 1,1 & 0,2 & 1,3 & 5,3 & 0,7 & 5,9 \\
\hline España & 0,67 & 0,27 & 0,93 & 2,9 & 0,3 & 3,2 & 1,0 & 0,3 & 1,3 & 4,7 & 0,8 & 5,5 \\
\hline Estados Unidos & 0,33 & 0,14 & 0,47 & 3,4 & 0,3 & 3,7 & 0,9 & 1,8 & 2,7 & 4,7 & 2,2 & 6,9 \\
\hline Estonia & 0,42 & 0,01 & 0,42 & 3,3 & $\mathrm{n}$ & 3,4 & 1,4 & 0,3 & 1,7 & 5,2 & 0,3 & 5,5 \\
\hline Finlandia & 0,40 & 0,04 & 0,45 & 4,1 & $\mathrm{n}$ & 4,1 & 1,9 & 0,1 & 1,9 & 6,3 & 0,1 & 6,5 \\
\hline Francia & 0,66 & 0,04 & 0,71 & 3,7 & 0,3 & 3,9 & 1,3 & 0,2 & 1,5 & 5,6 & 0,5 & 6,1 \\
\hline Grecia & $\mathrm{m}$ & $\mathrm{m}$ & $\mathbf{m}$ & $\mathrm{m}$ & $\mathrm{m}$ & $\mathbf{m}$ & $\mathrm{m}$ & $\mathrm{m}$ & $\mathbf{m}$ & $\mathrm{m}$ & $\mathrm{m}$ & $\mathbf{m}$ \\
\hline Hungría & 0,63 & $\mathrm{~m}$ & $\mathbf{m}$ & 2,6 & $\mathrm{~m}$ & $\mathbf{m}$ & 1,0 & $\mathrm{~m}$ & $\mathbf{m}$ & 4,4 & $\mathrm{~m}$ & $\mathbf{m}$ \\
\hline Irlanda & $\mathrm{m}$ & $\mathrm{m}$ & $\mathbf{m}$ & 4,4 & 0,2 & 4,6 & 1,2 & 0,3 & 1,5 & 5,7 & 0,5 & 6,2 \\
\hline Islandia & 0,73 & 0,23 & 0,96 & 4,7 & 0,2 & 4,9 & 1,1 & 0,1 & 1,2 & 6,9 & 0,7 & 7,7 \\
\hline Israel & 0,60 & 0,11 & 0,71 & 3,8 & 0,4 & 4,2 & 0,9 & 0,8 & 1,7 & 5,6 & 1,7 & 7,3 \\
\hline Italia & 0,44 & 0,05 & 0,49 & 3,0 & 0,1 & 3,1 & 0,8 & 0,2 & 1,0 & 4,2 & 0,4 & 4,6 \\
\hline Japón ${ }^{4}$ & 0,10 & 0,12 & 0,22 & 2,7 & 0,2 & 2,9 & 0,5 & 1,0 & 1,6 & 3,6 & 1,6 & 5,1 \\
\hline Luxemburgo & 0,76 & 0,01 & 0,76 & 3,3 & 0,1 & 3,4 & $\mathrm{~m}$ & $\mathrm{~m}$ & $\mathbf{m}$ & $\mathrm{m}$ & $\mathrm{m}$ & $\mathbf{m}$ \\
\hline México & 0,54 & 0,10 & 0,64 & 3,3 & 0,6 & 4,0 & 0,9 & 0,4 & 1,3 & 5,0 & 1,1 & 6,2 \\
\hline Noruega & 0,48 & 0,03 & 0,51 & 4,9 & $\mathrm{~m}$ & $\mathbf{m}$ & 1,6 & 0,1 & 1,7 & 7,3 & $\mathrm{~m}$ & $\mathbf{m}$ \\
\hline Nueva Zelanda & 0,51 & 0,09 & 0,60 & 4,8 & 0,6 & 5,4 & 1,0 & 0,5 & 1,5 & 6,3 & 1,2 & 7,5 \\
\hline Países Bajos & 0,41 & 0,03 & 0,44 & 3,6 & 0,4 & 4,0 & 1,3 & 0,5 & 1,8 & 5,3 & 0,9 & 6,2 \\
\hline Polonia & 0,54 & 0,17 & 0,71 & 3,2 & 0,2 & 3,4 & 1,0 & 0,3 & 1,3 & 4,8 & 0,7 & 5,5 \\
\hline Portugal & 0,39 & $\mathrm{n}$ & 0,39 & 3,7 & $\mathrm{n}$ & 3,7 & 1,0 & 0,4 & 1,4 & 5,1 & 0,4 & 5,5 \\
\hline Reino Unido & 0,34 & 0,08 & 0,42 & 4,4 & 0,4 & 4,7 & 0,9 & 0,3 & 1,2 & 5,6 & 0,8 & 6,4 \\
\hline República Checa & 0,47 & 0,04 & 0,51 & 2,6 & 0,3 & 2,9 & 1,2 & 0,3 & 1,4 & 4,4 & 0,6 & 5,0 \\
\hline República Eslovaca ${ }^{4}$ & 0,41 & 0,08 & 0,49 & 2,5 & 0,3 & 2,8 & 0,8 & 0,2 & 1,0 & 3,8 & 0,5 & 4,4 \\
\hline Suecia & 0,72 & $\mathrm{n}$ & 0,72 & 3,9 & $\mathrm{n}$ & 3,9 & 1,6 & 0,2 & 1,7 & 6,2 & 0,2 & 6,3 \\
\hline Suiza & 0,19 & $\mathrm{~m}$ & $\mathbf{m}$ & 3,6 & 0,5 & 4,0 & 1,3 & $\mathrm{~m}$ & $\mathbf{m}$ & 5,2 & 0,4 & 5,6 \\
\hline Turquía & $\mathrm{m}$ & $\mathrm{m}$ & $\mathbf{m}$ & $\mathrm{m}$ & $\mathrm{m}$ & $\mathbf{m}$ & $\mathrm{m}$ & $\mathrm{m}$ & m & $\mathrm{m}$ & $\mathrm{m}$ & $\mathbf{m}$ \\
\hline Media OCDE & 0,51 & 0,08 & 0,60 & 3,6 & 0,3 & 3,9 & 1,1 & 0,5 & 1,6 & 5,3 & 0,9 & 6,1 \\
\hline Total OCDE & 0,38 & 0,11 & 0,49 & 3,3 & 0,3 & 3,7 & 1,0 & 1,0 & 2,0 & 4,8 & 1,5 & 6,2 \\
\hline Media UE21 & 0,57 & 0,07 & 0,64 & 3,5 & 0,2 & 3,7 & 1,2 & 0,2 & 1,5 & 5,3 & 0,5 & 5,8 \\
\hline Arabia Saudí & $\mathrm{m}$ & $\mathrm{m}$ & $\mathbf{m}$ & $\mathrm{m}$ & $\mathrm{m}$ & $\mathbf{m}$ & $\mathrm{m}$ & $\mathrm{m}$ & $\mathbf{m}$ & $\mathrm{m}$ & $\mathrm{m}$ & $\mathbf{m}$ \\
\hline Argentina & 0,51 & 0,18 & 0,68 & 4,5 & 0,4 & 5,0 & 1,2 & 0,4 & 1,6 & 6,2 & 1,0 & 7,2 \\
\hline Brasil & 0,52 & $\mathrm{~m}$ & $\mathbf{m}$ & 4,4 & $\mathrm{~m}$ & $\mathbf{m}$ & 0,9 & $\mathrm{~m}$ & $\mathbf{m}$ & 5,9 & $\mathrm{~m}$ & $\mathbf{m}$ \\
\hline China & $\mathrm{m}$ & $\mathrm{m}$ & $\mathbf{m}$ & $\mathrm{m}$ & $\mathrm{m}$ & $\mathbf{m}$ & $\mathrm{m}$ & $\mathrm{m}$ & $\mathbf{m}$ & $\mathrm{m}$ & $\mathrm{m}$ & $\mathbf{m}$ \\
\hline Colombia ${ }^{5}$ & 0,27 & 0,23 & $\mathbf{0 , 5 0}$ & 3,2 & 1,0 & 4,2 & 0,9 & 1,1 & 2,0 & 4,3 & 2,3 & 6,7 \\
\hline Federación Rusa & 0,71 & 0,09 & 0,80 & 2,0 & 0,1 & 2,1 & 0,9 & 0,5 & 1,4 & 3,9 & 0,7 & 4,6 \\
\hline India & $\mathrm{m}$ & $\mathrm{m}$ & $\mathbf{m}$ & $\mathrm{m}$ & $\mathrm{m}$ & $\mathbf{m}$ & $\mathrm{m}$ & $\mathrm{m}$ & $\mathbf{m}$ & $\mathrm{m}$ & $\mathrm{m}$ & $\mathbf{m}$ \\
\hline Indonesia & $\mathrm{m}$ & $\mathrm{m}$ & $\mathbf{m}$ & $\mathrm{m}$ & $\mathrm{m}$ & $\mathbf{m}$ & $\mathrm{m}$ & $\mathrm{m}$ & $\mathbf{m}$ & $\mathrm{m}$ & $\mathrm{m}$ & $\mathbf{m}$ \\
\hline Letonia & 0,81 & 0,02 & 0,83 & 3,0 & 0,1 & 3,0 & 1,0 & 0,5 & 1,5 & 4,7 & 0,6 & 5,4 \\
\hline Sudáfrica & $\mathrm{m}$ & $\mathrm{m}$ & m & $\mathrm{m}$ & $\mathrm{m}$ & $\mathbf{m}$ & $\mathrm{m}$ & $\mathrm{m}$ & $\mathbf{m}$ & $\mathrm{m}$ & $\mathrm{m}$ & $\mathbf{m}$ \\
\hline
\end{tabular}

Media G20

m $\quad m$ m

$\mathbf{m}$

1. Incluye subsidios públicos para los hogares atribuibles a las instituciones educativas y el gasto directo de las instituciones educativas procedente de fuentes internacionales.

2. Subsidios públicos netos atribuibles a las instituciones educativas.

3. Año de referencia 2010 .

4. Algunos niveles educativos están incluidos junto con otros. Véase el código «X» en la Tabla B1.1a para obtener más detalles.

5. Año de referencia 2012.

Fuentes: OCDE. Arabia Saudí, Argentina, China, Colombia, India, Indonesia, Sudáfrica: Instituto de Estadística de la UNESCO. Letonia: Eurostat. Para ver notas, consulte Anexo 3 (www.oecd.org/edu/eag.htm).

Para obtener más información acerca de los símbolos utilizados en lugar de los datos que faltan, consulte la Guía del lector.

StatLink 겍ㄴ http://dx.doi.org/10.1787/888933117231 
Tabla B2.4. Gasto en instituciones educativas por categoría de servicios, como porcentaje del PIB (2011)

Gasto en enseñanza, I+D y servicios auxiliares en instituciones educativas y gasto privado para la adquisición de bienes educativos adquiridos fuera de las instituciones educativas

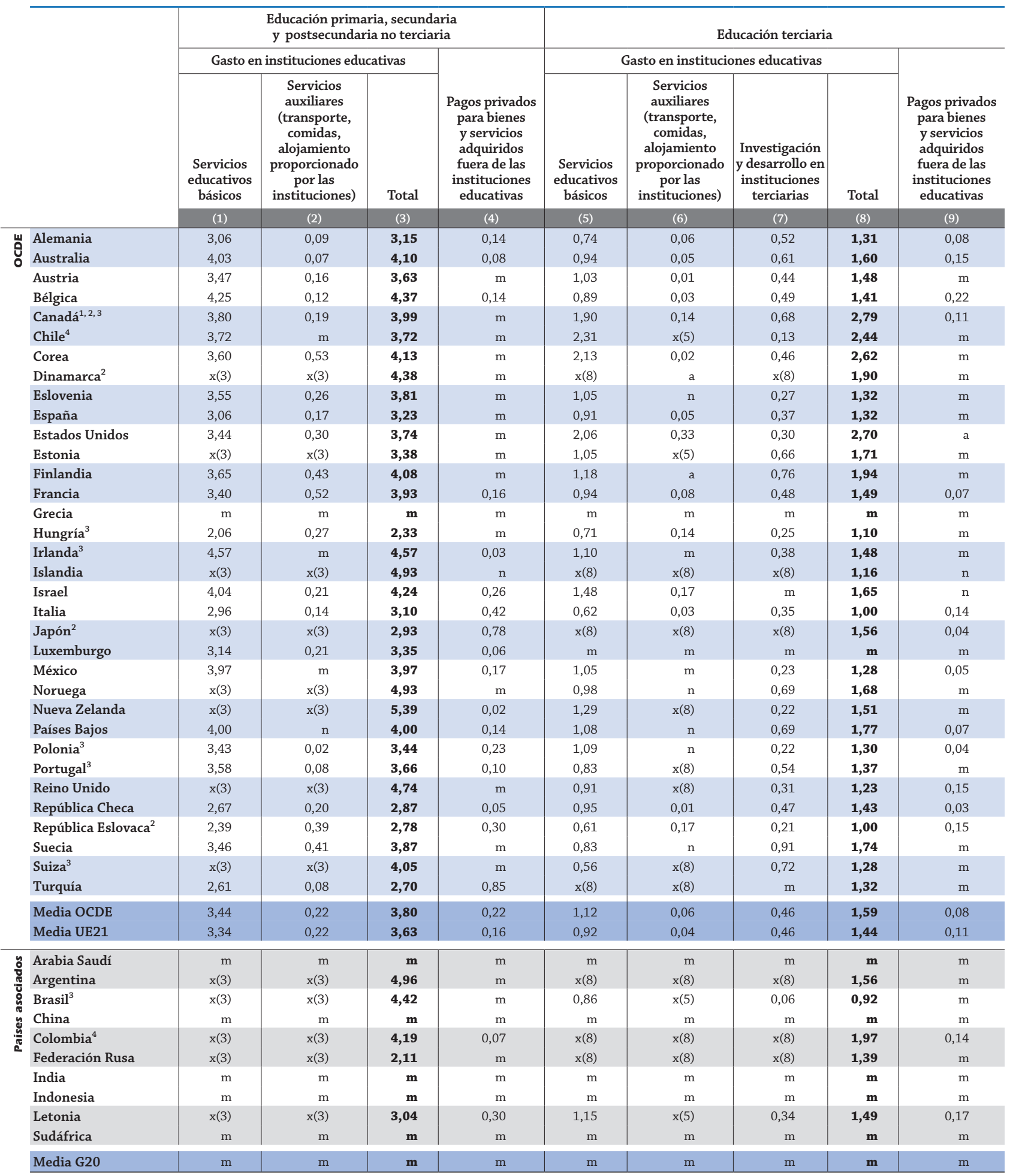

1. Año de referencia 2010.

2. Algunos niveles educativos están incluidos junto con otros. Véase el código «ญ» en la Tabla B1.1a para obtener más detalles.

3. Solo instituciones públicas (para Canadá, solo en educación terciaria; para Italia, excepto en educación terciaria).

4. Año de referencia 2012.

Fuentes: OCDE. Arabia Saudí, Argentina, China, Colombia, India, Indonesia, Sudáfrica: Instituto de Estadística de la UNESCO. Letonia: Eurostat. Para ver notas, consulte Anexo 3 (www.oecd.org/edu/eag.htm).

Para obtener más información acerca de los símbolos utilizados en lugar de los datos que faltan, consulte la Guía del lector.

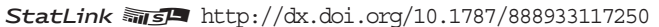


Tabla B2.5. Cambio del gasto público en instituciones educativas como porcentaje del PIB $(2008,2009,2010,2011)$

Índice de cambio entre 2008 y 2011 del gasto público en instituciones educativas como porcentaje del PIB, para todos los niveles de educación (precios constantes 2011)

\begin{tabular}{|c|c|c|c|c|c|c|c|c|c|c|c|c|c|c|c|}
\hline & \multicolumn{5}{|c|}{$\begin{array}{l}\text { Cambio del gasto público }{ }^{1} \text { en instituciones } \\
\text { educativas para todos los niveles de educación }\end{array}$} & \multicolumn{5}{|c|}{ Cambio del producto interior bruto } & \multicolumn{5}{|c|}{$\begin{array}{l}\text { Cambio del gasto público en instituciones } \\
\text { educativas como porcentaje del PIB }\end{array}$} \\
\hline & \multirow[b]{2}{*}{ 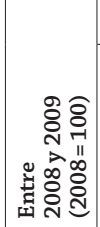 } & \multicolumn{3}{|c|}{ Entre 2009 y 2011} & \multirow[b]{2}{*}{ 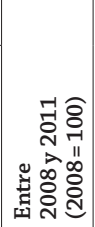 } & \multirow[b]{2}{*}{ 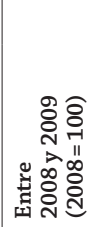 } & \multicolumn{3}{|c|}{ Entre 2009 y 2011} & \multirow[b]{2}{*}{ 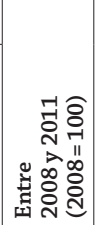 } & \multirow[b]{2}{*}{ 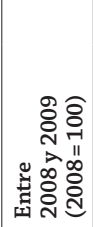 } & \multicolumn{3}{|c|}{ Entre 2009 y 2011} & \multirow[b]{2}{*}{ 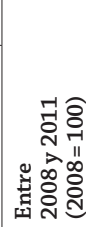 } \\
\hline & & 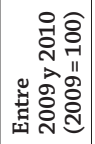 & 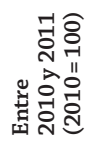 & 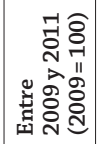 & & & 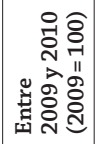 & 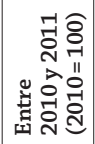 & 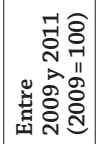 & & & 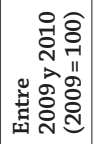 & 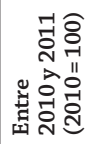 & 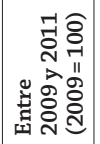 & \\
\hline & (1) & (2) & (3) & (4) & $(5)$ & (6) & (7) & (8) & (9) & (10) & (11) & (12) & (13) & (14) & (15) \\
\hline Alemania & 104 & 104 & 101 & 105 & 110 & 95 & 104 & 103 & 107 & 102 & 110 & 100 & 98 & 98 & 108 \\
\hline Australia & 116 & 106 & 97 & 103 & 119 & 102 & 102 & 104 & 106 & 108 & 114 & 104 & 93 & 97 & 111 \\
\hline Austria & 105 & 100 & 101 & 101 & 106 & 96 & 102 & 103 & 105 & 101 & 109 & 98 & 98 & 97 & 105 \\
\hline Bélgica & 99 & 102 & 101 & 103 & 102 & 97 & 102 & 102 & 104 & 101 & 102 & 100 & 99 & 99 & 101 \\
\hline Canadá & 109 & 101 & 101 & 102 & 110 & 97 & 103 & 103 & 106 & 103 & 112 & 98 & 98 & 96 & 107 \\
\hline Chile $^{2}$ & 103 & 104 & 119 & 123 & 127 & 106 & 106 & 106 & 112 & 118 & 98 & 98 & 112 & 110 & 107 \\
\hline Dinamarca & 110 & 102 & 100 & 102 & 112 & 94 & 101 & 101 & 102 & 97 & 116 & 100 & 99 & 99 & 116 \\
\hline Eslovenia & 101 & 101 & 100 & 100 & 101 & 92 & 101 & 101 & 102 & 94 & 109 & 99 & 99 & 98 & 108 \\
\hline España & 105 & 99 & 97 & 96 & 100 & 96 & 100 & 100 & 100 & 96 & 109 & 99 & 97 & 96 & 104 \\
\hline Estados Unidos & 101 & 98 & 98 & 96 & 97 & 97 & 103 & 102 & 104 & 101 & 104 & 96 & 96 & 92 & 96 \\
\hline Estonia & 93 & 96 & 101 & 96 & 90 & 86 & 103 & 110 & 112 & 97 & 109 & 93 & 92 & 86 & 93 \\
\hline Finlandia & 102 & 104 & 102 & 106 & 108 & 91 & 103 & 103 & 106 & 97 & 111 & 101 & 99 & 100 & 111 \\
\hline Francia & 102 & 101 & 99 & 100 & 101 & 97 & 102 & 102 & 104 & 101 & 105 & 99 & 97 & 96 & 101 \\
\hline Grecia & $\mathrm{m}$ & $\mathrm{m}$ & $\mathrm{m}$ & $\mathbf{m}$ & $\mathbf{m}$ & 97 & 95 & 93 & 88 & 86 & $\mathrm{~m}$ & $\mathrm{~m}$ & $\mathrm{~m}$ & $\mathbf{m}$ & $\mathbf{m}$ \\
\hline Hungría & 93 & 97 & 98 & 94 & 88 & 93 & 101 & 102 & 103 & 96 & 100 & 96 & 96 & 92 & 92 \\
\hline Irlanda & 106 & 99 & 98 & 97 & 103 & 94 & 99 & 102 & 101 & 95 & 114 & 100 & 96 & 96 & 109 \\
\hline Islandia & 96 & 92 & 101 & 93 & 89 & 93 & 96 & 103 & 98 & 92 & 102 & 95 & 99 & 94 & 97 \\
\hline Israel & 100 & 107 & 105 & 112 & 112 & 101 & 106 & 105 & 110 & 112 & 99 & 101 & 100 & 102 & 100 \\
\hline Italia & 96 & 97 & 96 & 93 & 89 & 95 & 102 & 100 & 102 & 97 & 101 & 95 & 96 & 91 & 92 \\
\hline Japón & 101 & 104 & 101 & 106 & 106 & 94 & 105 & 99 & 104 & 98 & 107 & 100 & 102 & 101 & 108 \\
\hline Luxemburgo & $\mathrm{m}$ & $\mathrm{m}$ & $\mathrm{m}$ & $\mathbf{m}$ & $\mathbf{m}$ & 94 & 103 & 102 & 105 & 99 & $\mathrm{~m}$ & $\mathrm{~m}$ & $\mathrm{~m}$ & $\mathbf{m}$ & $\mathbf{m}$ \\
\hline Nueva Zelanda & 113 & 99 & 108 & 106 & 121 & 101 & 100 & 102 & 102 & 104 & 112 & 99 & 105 & 104 & 116 \\
\hline Países Bajos & 107 & 102 & 99 & 101 & 107 & 96 & 102 & 101 & 102 & 99 & 111 & 100 & 98 & 98 & 109 \\
\hline Polonia & 102 & 103 & 100 & 103 & 105 & 102 & 104 & 105 & 109 & 110 & 100 & 99 & 96 & 95 & 95 \\
\hline Portugal & 113 & 100 & 93 & 93 & 105 & 97 & 102 & 99 & 101 & 98 & 116 & 98 & 94 & 92 & 107 \\
\hline Reino Unido & 104 & 102 & 110 & 113 & 117 & 95 & 102 & 101 & 103 & 97 & 110 & 100 & 109 & 110 & 120 \\
\hline República Checa & 106 & 101 & 109 & 109 & 116 & 95 & 102 & 102 & 104 & 100 & 111 & 98 & 107 & 105 & 117 \\
\hline República Eslovaca & 108 & 108 & 99 & 107 & 116 & 95 & 104 & 103 & 108 & 102 & 113 & 104 & 96 & 100 & 113 \\
\hline Suecia & 101 & 102 & 101 & 103 & 104 & 95 & 107 & 103 & 110 & 104 & 107 & 96 & 98 & 94 & 100 \\
\hline Suiza & 107 & 101 & 102 & 104 & 111 & 98 & 103 & 102 & 105 & 103 & 109 & 98 & 101 & 99 & 108 \\
\hline Turquía & $\mathrm{m}$ & $\mathrm{m}$ & $\mathrm{m}$ & $\mathbf{m}$ & $\mathbf{m}$ & 95 & 109 & 109 & 119 & 113 & $\mathrm{~m}$ & $\mathrm{~m}$ & $\mathrm{~m}$ & $\mathbf{m}$ & $\mathbf{m}$ \\
\hline Media OCDE & 104 & 101 & 101 & 103 & 107 & 96 & 103 & 102 & 105 & 101 & 108 & 99 & 99 & 98 & 105 \\
\hline Media UE21 & 103 & 101 & 100 & 101 & 104 & 95 & 102 & 102 & 104 & 98 & 109 & 99 & 98 & 97 & 105 \\
\hline
\end{tabular}

\begin{tabular}{|c|c|c|c|c|c|c|c|c|c|c|c|c|c|c|c|}
\hline $\begin{array}{l}\text { Arabia Saudí } \\
\text { Argentina }\end{array}$ & $\begin{array}{l}\mathrm{m} \\
\mathrm{m}\end{array}$ & $\begin{array}{l}\mathrm{m} \\
\mathrm{m}\end{array}$ & $\begin{array}{l}\mathrm{m} \\
\mathrm{m}\end{array}$ & $\begin{array}{l}\mathbf{m} \\
\mathbf{m}\end{array}$ & $\begin{array}{l}\mathbf{m} \\
\mathbf{m}\end{array}$ & $\begin{array}{l}\mathrm{m} \\
\mathrm{m}\end{array}$ & $\begin{array}{l}\mathrm{m} \\
\mathrm{m}\end{array}$ & $\begin{array}{l}\mathrm{m} \\
\mathrm{m}\end{array}$ & $\begin{array}{l}\mathbf{m} \\
\mathbf{m}\end{array}$ & $\begin{array}{l}\mathbf{m} \\
\mathbf{m}\end{array}$ & $\begin{array}{l}\mathrm{m} \\
\mathrm{m}\end{array}$ & $\begin{array}{l}\mathrm{m} \\
\mathrm{m}\end{array}$ & $\begin{array}{l}\mathrm{m} \\
\mathrm{m}\end{array}$ & $\begin{array}{l}\mathbf{m} \\
\mathbf{m}\end{array}$ & $\begin{array}{l}\mathbf{m} \\
\mathbf{m}\end{array}$ \\
\hline Brasil & 104 & 114 & 104 & 119 & 123 & 100 & 110 & 101 & 110 & 110 & 104 & 104 & 104 & 107 & 112 \\
\hline China & $\mathrm{m}$ & $\mathrm{m}$ & $\mathrm{m}$ & $\mathbf{m}$ & $\mathbf{m}$ & $\mathrm{m}$ & $\mathrm{m}$ & $\mathrm{m}$ & $\mathbf{m}$ & $\mathbf{m}$ & $\mathrm{m}$ & $\mathrm{m}$ & $\mathrm{m}$ & $\mathbf{m}$ & $\mathbf{m}$ \\
\hline Colombia & $\mathrm{m}$ & $\mathrm{m}$ & $\mathrm{m}$ & $\mathbf{m}$ & $\mathbf{m}$ & $\mathrm{m}$ & $\mathrm{m}$ & $\mathrm{m}$ & m & $\mathbf{m}$ & $\mathrm{m}$ & $\mathrm{m}$ & $\mathrm{m}$ & $\mathbf{m}$ & $\mathbf{m}$ \\
\hline Federación Rusa & 105 & 89 & 102 & 91 & 95 & 92 & 105 & 104 & 109 & 100 & 114 & 85 & 98 & 83 & 95 \\
\hline India & $\mathrm{m}$ & $\mathrm{m}$ & $\mathrm{m}$ & $\mathbf{m}$ & $\mathbf{m}$ & $\mathrm{m}$ & $\mathrm{m}$ & $\mathrm{m}$ & $\mathbf{m}$ & $\mathbf{m}$ & $\mathrm{m}$ & $\mathrm{m}$ & $\mathrm{m}$ & $\mathbf{m}$ & $\mathbf{m}$ \\
\hline Indonesia & $\mathrm{m}$ & $\mathrm{m}$ & $\mathrm{m}$ & $\mathbf{m}$ & $\mathbf{m}$ & $\mathrm{m}$ & $\mathrm{m}$ & $\mathrm{m}$ & $\mathbf{m}$ & $\mathbf{m}$ & $\mathrm{m}$ & $\mathrm{m}$ & $\mathrm{m}$ & $\mathbf{m}$ & $\mathbf{m}$ \\
\hline Letonia & $\mathrm{m}$ & $\mathrm{m}$ & $\mathrm{m}$ & $\mathbf{m}$ & $\mathbf{m}$ & $\mathrm{m}$ & $\mathrm{m}$ & $\mathrm{m}$ & $\mathbf{m}$ & $\mathbf{m}$ & $\mathrm{m}$ & $\mathrm{m}$ & $\mathrm{m}$ & $\mathbf{m}$ & $\mathbf{m}$ \\
\hline Sudáfrica & $\mathrm{m}$ & $\mathrm{m}$ & $\mathrm{m}$ & $\mathbf{m}$ & $\mathbf{m}$ & $\mathrm{m}$ & $\mathrm{m}$ & $\mathrm{m}$ & $\mathbf{m}$ & $\mathbf{m}$ & $\mathrm{m}$ & $\mathrm{m}$ & $\mathrm{m}$ & $\mathbf{m}$ & m \\
\hline
\end{tabular}

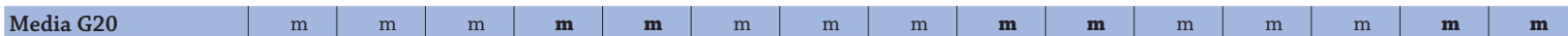

1. Excluidos los subsidios atribuibles a pagos a instituciones educativas recibidos de fuentes de financiación públicas.

2. Los datos se refieren a 2009-2012 en lugar de 2008-2011.

Fuentes: OCDE. Arabia Saudí, Argentina, China, Colombia, India, Indonesia, Sudáfrica: Instituto de Estadística de la UNESCO. Letonia: Eurostat. Para ver notas, consulte Anexo 3 (www.oecd.org/edu/eag.htm).

Para obtener más información acerca de los símbolos utilizados en lugar de los datos que faltan, consulte la Guía del lector.

StatLink 젬 http://dx.doi.org/10.1787/888933117269 



\section{¿CUÁNTA INVERSIÓN PÚBLICA Y PRIVADA SE DESTINA A EDUCACIÓN?}

- Como media en los países de la OCDE, el $84 \%$ de todos los fondos de las instituciones educativas proviene directamente de fuentes públicas.

- Como media en los países de la OCDE, casi el 92\% de los fondos de instituciones de educación primaria, secundaria y postsecundaria no terciaria proviene de fuentes públicas; solo en Chile y Colombia este porcentaje es inferior al $80 \%$.

- Las instituciones de educación terciaria, y en menor medida las de educación infantil, son las que reciben la mayor proporción de financiación privada, con un $31 \%$ y un $19 \%$, respectivamente. En todos los países (excepto Italia) con datos comparables, para todos los niveles de educación en su conjunto la financiación pública de las instituciones educativas aumentó entre 2000 y 2011. Sin embargo, como consecuencia de una mayor participación de las familias en los costes de la educación, la proporción de financiación privada se incrementó en un porcentaje aún mayor en más de tres cuartas partes de los países.

\section{Gráfico B3.1. Proporción del gasto privado en instituciones educativas (2011)}

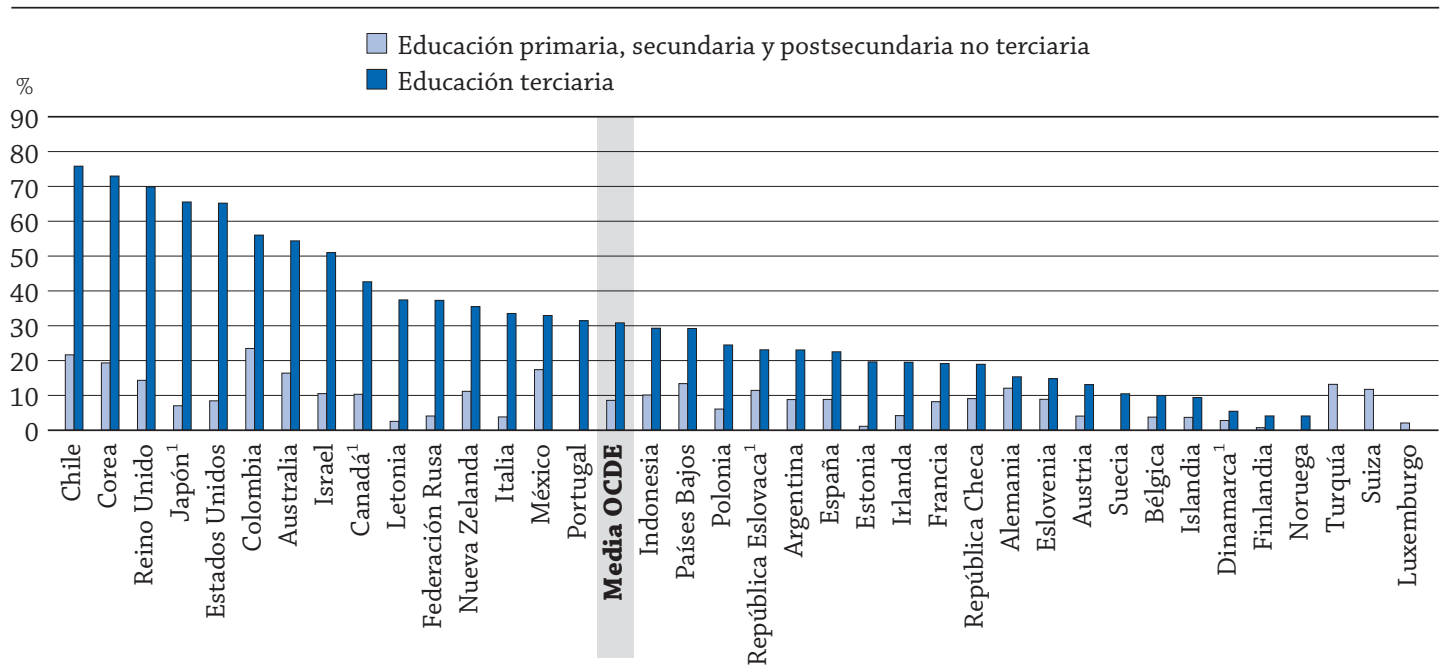

1. Algunos niveles educativos están incluidos junto con otros. Véase el código «X» en la Tabla B1.1a para obtener más detalles.

Los países están clasificados en orden descendente de la proporción de gasto privado en instituciones educativas de educación terciaria.

Fuente: OCDE. Tabla B3.1. Para ver notas, consulte Anexo 3 (www.oecd.org/edu/eag.htm).

StatLink 霜S http://dx.doi.org/10.1787/888933117478

\section{Cómo leer este gráfico}

El gráfico muestra el gasto privado en instituciones educativas como porcentaje del gasto total en instituciones educativas. Incluye todo el dinero transferido a tales instituciones procedente de fuentes privadas, incluyendo financiación pública mediante subvenciones a las familias, tasas privadas de servicios educativos u otro gasto privado (por ejemplo, alojamiento y comida) que pase por las instituciones educativas.

\section{Contexto}

Hoy día, un número mayor de personas se benefician de un abanico más amplio de programas educativos ofrecidos por un número creciente de proveedores. Por ello, se está volviendo cada vez más importante responder a la pregunta de quién debe financiar el esfuerzo de las personas para recibir más educación, los gobiernos o los propios individuos. En la situación económica actual, muchos gobiernos se encuentran con dificultades a la hora de facilitar los recursos necesarios para financiar la creciente demanda de educación en sus países utilizando solo fondos públicos. Además, algunos responsables de la adopción de políticas afirman que quienes más se benefician de la educación, los individuos que la reciben, deben hacerse cargo al menos de parte de los costes. Así, aunque los recursos públicos siguen suponiendo una parte muy significativa de la inversión en educación de los países, el papel de la financiación privada es cada vez más destacado. 
El equilibrio entre financiación pública y privada de la educación es una cuestión muy importante para la adopción de políticas en muchos países de la OCDE. Es una cuestión especialmente relevante para la educación infantil y terciaria, donde es menos frecuente una financiación pública completa o casi completa. En estos niveles, la financiación privada procede sobre todo de las familias, lo que da lugar a controversias sobre la igualdad en el acceso a la educación. El debate es especialmente intenso en lo que se refiere al pago de la educación terciaria. Algunos partícipes manifiestan su temor a que el equilibrio entre financiación pública y privada se altere hasta el extremo de disuadir a los estudiantes potenciales de educación terciaria. Otros consideran que los países deben aumentar considerablemente la ayuda pública a los estudiantes, mientras que otros son partidarios de un mayor esfuerzo para aumentar los fondos para la educación terciaria procedente de empresas privadas. Por el contrario, la educación primaria, secundaria y postsecundaria no terciaria, que es en su mayor parte obligatoria, suele concebirse como un bien público y, por tanto, se financia mayoritariamente con fondos públicos.

\section{Otros resultados}

- El gasto público se destina principalmente a financiar instituciones públicas, pero también, en diferentes porcentajes, a instituciones privadas. Para todos los niveles educativos en conjunto, el gasto público en instituciones públicas por estudiante es casi el doble del gasto público en instituciones privadas, como media en los países de la OCDE. Sin embargo, esta proporción varía desde menos del doble en educación primaria, secundaria y postsecundaria no terciaria $(1,8)$, y en educación infantil $(1,8)$, hasta casi el triple $(2,9)$ en educación terciaria.

- Los países con menor gasto público por estudiante, tanto en instituciones públicas como privadas de educación terciaria, son también los que presentan menor número de estudiantes matriculados en instituciones públicas de educación terciaria, con excepción de Colombia, México y Polonia.

- En la mayoría de los países con datos disponibles, las familias asumen la mayor parte del gasto privado en educación terciaria, con la excepción de Argentina, Austria, Bélgica, Canadá, República Checa y Suecia, donde la financiación privada procedente de entidades distintas de las familias (por ejemplo, empresas privadas y organizaciones sin ánimo de lucro) es más significativa que la aportada por las familias, sobre todo porque las tasas de matrícula que cobran las instituciones terciarias en estos países son bajas o de escasa consideración (con excepción de Canadá).

\section{Tendencias}

Durante el periodo comprendido entre 2000 y 2011, la proporción media de financiación pública de las instituciones terciarias disminuyó de un 73,7\% en 2000 a un 69,1\% en 2005 y luego ligeramente a un $68,3 \%$ en 2011 (como media en los 20 países de la OCDE con datos comparables sobre tendencias para esos años) (Tabla B3.2c). Esta tendencia se debe en gran medida a la influencia de algunos países europeos, donde se han producido cambios significativos en las tasas de matrícula y donde las empresas participan de forma más activa al ofrecer ayuda económica a instituciones terciarias.

Entre 2000 y 2011, se observa un aumento de la proporción de financiación privada en la educación terciaria en más de tres cuartas partes de los países con datos comparables (21 de los 26 países). Esta proporción aumentó, por término medio en los países de la OCDE, en seis puntos porcentuales y en más de nueve puntos porcentuales en Austria, Israel, Italia, México, Portugal, Reino Unido y República Eslovaca (Tabla B3.2c). En estos países, excepto en Italia, la proporción de financiación privada aumentó más entre 2000 y 2008 como consecuencia de un aumento mucho mayor de la financiación privada que de la pública.

Entre 2000 y 2011, la proporción de financiación privada aumentó también en educación primaria, secundaria y postsecundaria no terciaria y en todos los niveles educativos en conjunto, como media en los países de la OCDE, y de forma más significativa en Reino Unido (en todos los niveles educativos en conjunto) y República Eslovaca (Tablas B3.2a y B3.2b). 


\section{Análisis}

\section{Gasto público y privado en instituciones educativas}

La financiación de las instituciones educativas en los países de la OCDE sigue siendo principalmente pública, aunque existe una parte sustancial -y creciente- de financiación privada en la educación terciaria. Como media en los países de la OCDE, el $84 \%$ de todos los fondos de las instituciones educativas proviene directamente de fuentes públicas y el $16 \%$ de fuentes privadas (Tabla B3.1).

Sin embargo, esta proporción de fondos públicos y privados varía considerablemente entre países. Comparando el gasto en todos los niveles educativos, la proporción de fondos privados supera el 19\% en Canadá, Israel y México, el $25 \%$ en Australia, Colombia, Estados Unidos, Japón y Reino Unido, y el $35 \%$ en Chile y Corea. En cambio, en Finlandia y Suecia menos del $3 \%$ del gasto en educación procede de fuentes privadas (Tabla B3.1).

El gasto privado en educación para todos los niveles educativos en conjunto aumentó entre 2000 y 2011, como media en los países de la OCDE con datos disponibles para esos años; y en la mayoría de los países, el gasto privado como porcentaje del gasto total en instituciones educativas también aumentó. Como resultado, la proporción de financiación pública en las instituciones educativas disminuyó al menos 3 puntos porcentuales en casi una cuarta parte de los países de la OCDE (Canadá, Estados Unidos, Israel, Italia, México y Portugal) y más de diez puntos porcentuales en Reino Unido y República Eslovaca. Estas disminuciones se deben principalmente a un aumento significativo del nivel de gasto privado durante ese mismo periodo. Por ejemplo, en Portugal y Reino Unido, las tasas de matrícula cobradas por las instituciones educativas terciarias aumentaron considerablemente (Tablas B3.2a y B3.2c).

Sin embargo, las reducciones de la proporción del gasto público en relación con el gasto total en instituciones educativas (y, por consiguiente, el aumento de la proporción del gasto privado) no han ido de la mano de recortes (en términos reales) del gasto público en educación, dado que solo en Italia se produjo una disminución del gasto público entre los años 2000 y 2011 (Tabla B3.2a). De hecho, muchos países de la OCDE con el mayor crecimiento del gasto privado han registrado también el mayor aumento de la financiación pública de la educación. Esto indica que un aumento del gasto privado no tiende a reemplazar a la inversión pública, sino que la complementa. Sin embargo, en la mayoría de los países ha habido un aumento mucho mayor de la financiación privada que de la pública entre 2000 y 2005 que entre 2005 y 2011. Como consecuencia de ello, la proporción media de la financiación pública en los países con datos disponibles para esos años disminuyó de un 86,0\% en 2000 a un 83,5\% en 2005 y luego se mantuvo estable en un 83,2\% hasta 2011.

No obstante, las proporciones de gasto público y gasto privado en instituciones educativas varían según los países y el nivel de educación.

\section{Gasto público y privado en instituciones educativas de educación primaria, secundaria y postsecundaria no terciaria}

En todos los países, la financiación de la educación primaria, secundaria y postsecundaria no terciaria es esencialmente pública. La financiación privada en estos niveles es inferior al 10\%, excepto en Alemania, Australia, Canadá, Chile, Colombia, Corea, Indonesia, Israel, México, Nueva Zelanda, Países Bajos, Reino Unido, República Eslovaca, Suiza y Turquía (Tabla B3.2b y Gráfico B3.2). En la mayoría de los países en estos niveles, la proporción más alta de gasto privado procede de las familias y comprende principalmente gastos de matrícula. Sin embargo, en Países Bajos y Suiza, la mayor parte del gasto privado procede de contribuciones de empresas, en el marco del sistema dual de formación de aprendices en la educación secundaria superior y postsecundaria no terciaria (véase Cuadro B3.1 en Panorama de la educación 2011).

Entre 2000 y 2011, en 20 de los países con datos comparables se produjo una ligera disminución de la proporción de financiación pública en la educación primaria, secundaria y postsecundaria no terciaria (de un 91,6\% en 2000 a un $91,0 \%$ en 2011). Esta proporción disminuyó en dos puntos porcentuales o más en Canadá, Israel, México y Reino Unido, alcanzando hasta nueve puntos porcentuales en República Eslovaca. En los demás países, el cambio se produjo en la dirección opuesta, es decir, hacia una mayor financiación pública, y superó los tres puntos porcentuales entre 2000 y 2011 en Chile (de 68,4 \% a 78,3 \%) y en Japón (de 89,8\% a 93,0 \%) (Tabla B3.2b).

\section{Gasto público y privado en instituciones educativas de educación terciaria}

En educación terciaria, los altos retornos privados (véase Indicador A7) sugieren que se podría justificar una mayor contribución de los individuos y de otras entidades privadas a los costes de este nivel educativo, siempre y cuando los gobiernos aseguren el acceso de los estudiantes a la financiación con independencia de su situación económica 
Gráfico B3.2. Distribución del gasto público y privado en instituciones educativas (2011) Por nivel de educación
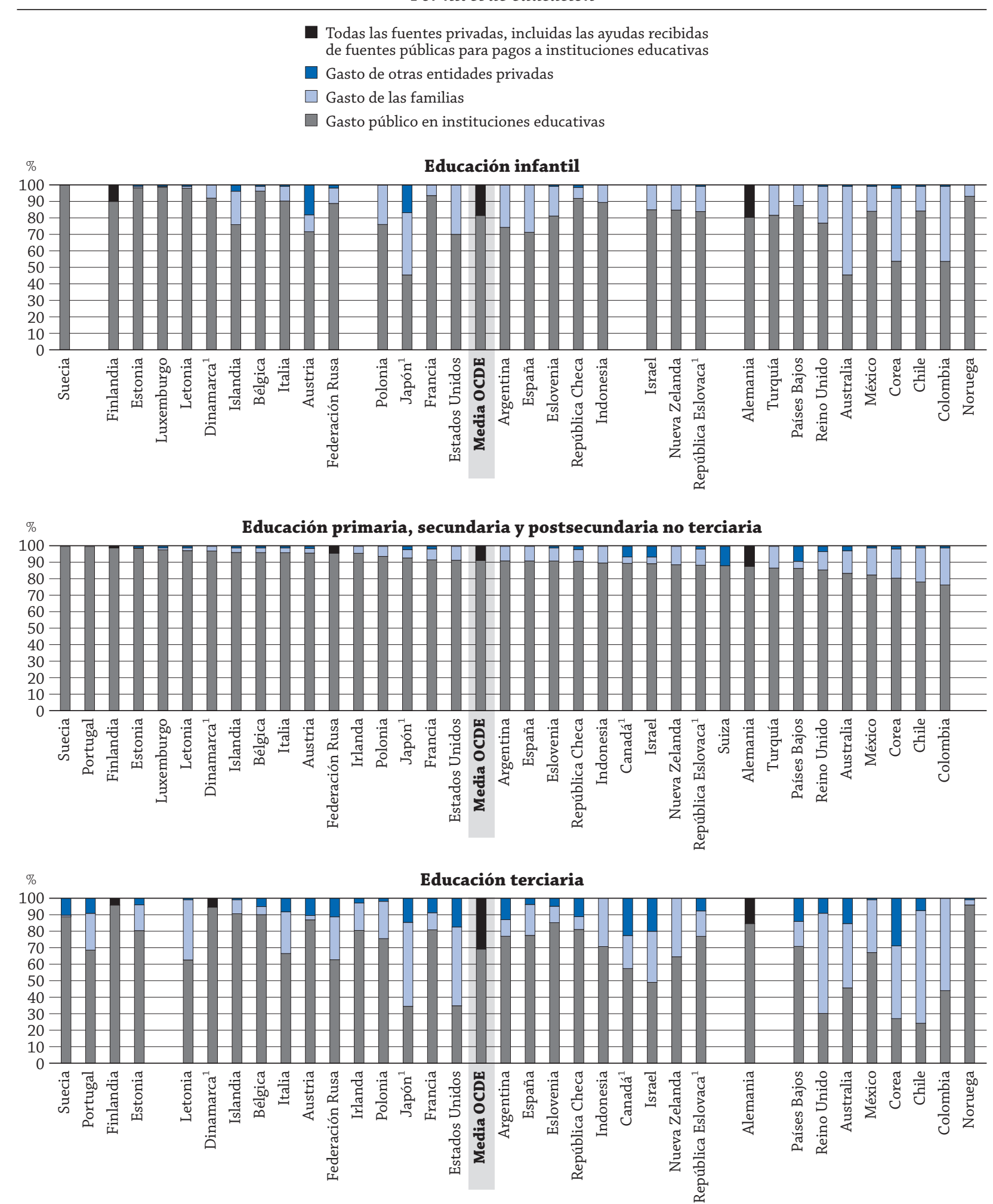

1. Algunos niveles educativos están incluidos junto con otros. Véase el código «X» en la Tabla B1.1a para obtener más detalles.

Los países están clasificados en orden descendente de la proporción de gasto público en instituciones educativas en primaria, secundaria y postsecundaria no terciaria.

Fuente: OCDE. Tabla B3.1. Para ver notas, consulte Anexo 3 (www.oecd.org/edu/eag.htm).

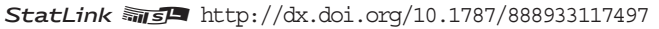


(véase Indicador B5). En todos los países, la proporción de gasto privado en educación es mucho mayor en el nivel terciario que en educación primaria, secundaria y postsecundaria no terciaria, y representa como media el $31 \%$ del gasto total en este nivel educativo (Tabla B3.1).

La proporción de gasto en instituciones terciarias cubierta por individuos, empresas y otras fuentes privadas, incluyendo pagos privados subvencionados, varía desde menos del $6 \%$ en Dinamarca, Finlandia y Noruega (países en los que las tasas de matrícula son bajas o de escasa importancia), a más del $40 \%$ en Australia, Canadá, Colombia, Estados Unidos, Israel y Japón, y a casi el 70 \% o más en Chile, Corea y Reino Unido (Gráfico B3.2 y Tabla B3.1). De estos países, en Corea y Reino Unido, la mayoría de los estudiantes están matriculados en centros privados (alrededor del $80 \%$ en universidades privadas en Corea, y el $100 \%$ en centros privados dependientes del gobierno en Reino Unido). En Corea, más del $40 \%$ del presupuesto educativo se cubre con las tasas de matrícula, mientras que en Reino Unido la educación terciaria se financia con una combinación de tasas de matrícula, pagadas por los estudiantes directamente a las instituciones, y becas del gobierno central, pagadas de forma indirecta a través de una agencia para la financiación de la educación superior (véanse Indicadores B5 y C7).

La contribución de entidades privadas distintas de las familias a la financiación de las instituciones educativas es, como media, mayor en la educación terciaria que en los demás niveles educativos en todos los países de la OCDE. En más de un tercio de los países de la OCDE con datos disponibles (Australia, Austria, Canadá, Corea, Estados Unidos, Israel, Japón, Países Bajos, República Checa y Suecia) y en Argentina y Federación Rusa, la proporción del gasto en instituciones terciarias cubierta por entidades privadas distintas de las familias representa el 10 \% o más. En Suecia, estas contribuciones se destinan en buena parte a patrocinar investigación y desarrollo.

En muchos países de la OCDE, el crecimiento de la participación en la educación terciaria (véase Indicador C1) es una respuesta a la fuerte demanda tanto individual como social. El aumento de la matrícula se ha visto acompañado de incrementos en el nivel de inversión tanto pública como privada, y de variaciones en la proporción del gasto público y privado. Como media en los 20 países de la OCDE con datos disponibles sobre tendencias para todos los años de referencia, la proporción de financiación pública en instituciones terciarias disminuyó de un 73,7\% en 2000 a un 69,1\% en 2005, y luego ligeramente durante los años siguientes hasta un 68,3 \% en 2011. Esta tendencia es más notable en algunos países, sobre todo en países europeos, donde se han producido mayores aumentos de la financiación privada, a través de las tasas de matrícula o de una participación más activa de las empresas, fundamentalmente mediante ayudas a las instituciones terciarias. En la mayoría de los países con datos disponibles para estos años, el cambio en la proporción de financiación pública y privada ha sido menor a partir de 2008. En algunos países, sobre todo en Austria, Chile, Portugal, República Checa y República Eslovaca, la proporción de financiación pública disminuyó entre 2000 y 2008, y luego aumentó entre 2008 y 2011 (Tabla B3.2c, Gráfico B3.3 y véase Indicador B5).

En 21 de los 26 países con datos comparables de 2000 y 2011, la proporción privada del gasto educativo en educación terciaria aumentó. Este aumento supera los 9 puntos porcentuales en Austria, Israel, Italia, México, Portugal y República Eslovaca, y los 37 puntos porcentuales en Reino Unido. En Australia, se produjo un aumento notable entre 1995 y 2000, debido a los cambios del Higher Education Contribution Scheme/Higher Education Loan Programme (HECS/HELP) (Plan de Contribución a Estudios Superiores/Programa de Préstamos para Estudios Superiores) que tuvieron lugar en 1997. Por otra parte, el enorme aumento de la financiación privada en Reino Unido se debe a las sucesivas subidas de las tasas de matrícula durante esa misma década (para más detalles véanse Indicador B5 y Anexo 3). Por el contrario, Chile, Corea, España, Irlanda y Polonia muestran una disminución significativa de la proporción privada asignada a instituciones educativas terciarias entre 2000 y 2011. En Irlanda, la principal razón para esta disminución es la supresión de las tasas de matrícula en los programas de educación terciaria de primer grado que se ha implantado de forma gradual en la última década.

En algunos países, las tendencias de los cambios en la proporción de financiación pública y privada se mueven en direcciones opuestas tanto antes como después de 2008. En España, Estados Unidos e Irlanda, por ejemplo, la proporción de financiación privada disminuyó entre 2000 y 2008 y luego aumentó entre 2008 y 2011 en menor medida, excepto en Estados Unidos. Por el contrario, en Australia, Austria, Corea, Chile, Japón, Portugal, República Checa y República Eslovaca (y en menor medida en Bélgica, Finlandia y Suecia), la proporción de financiación privada aumentó entre 2000 y 2008, para disminuir luego entre 2008 y 2011, pero en conjunto la proporción de financiación privada aumentó entre 2000 y 2011 en todos los países excepto Corea y Chile. Polonia es el único país en el que la proporción de financiación privada disminuyó en ambos periodos, de 2000 a 2008 y de 2008 a 2011 (Gráfico B3.3). 


\section{Gráfico B3.3. Proporción del gasto privado en instituciones de educación terciaria (2000, 2008, y 2011) y cambio en puntos porcentuales de la proporción del gasto privado entre 2000 y 2011}

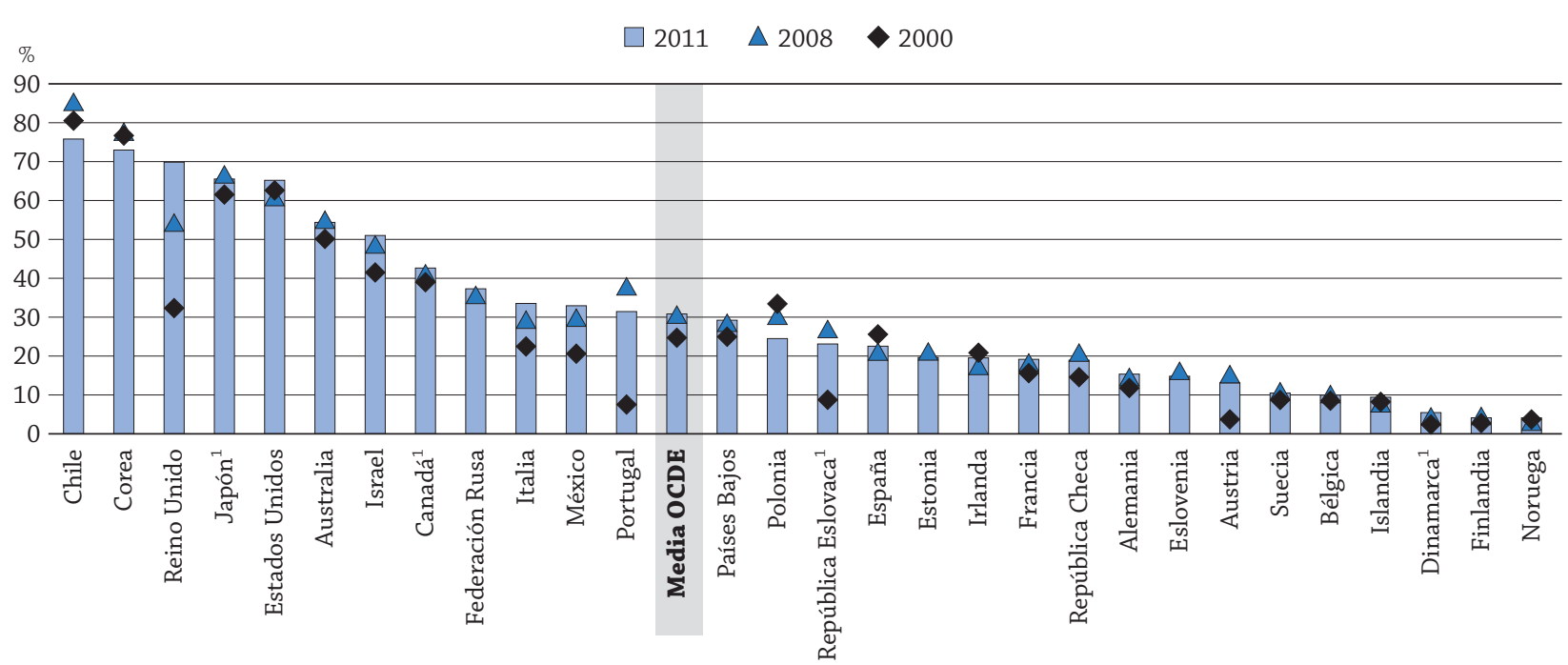

Cambio (en puntos porcentuales) de la proporción de gasto privado entre 2000 y 2011

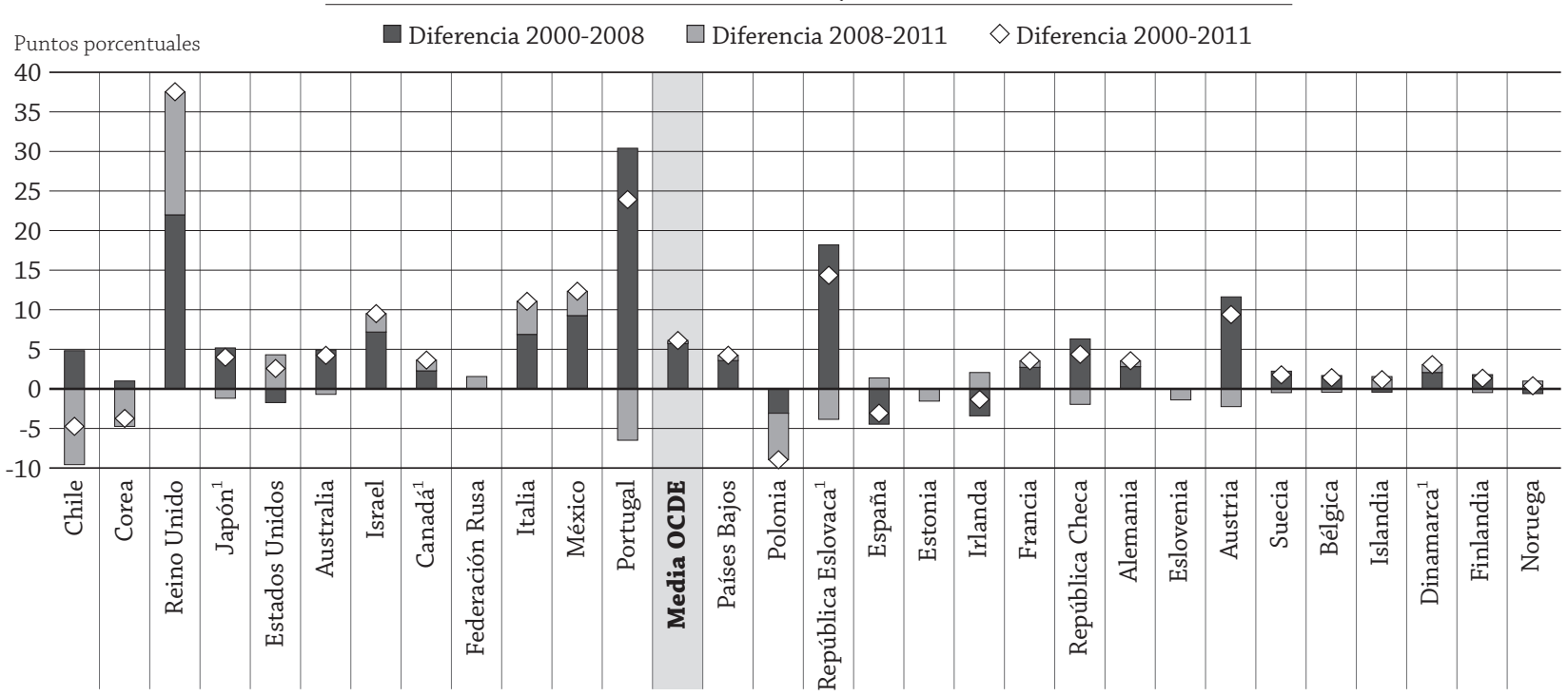

1. Algunos niveles educativos están incluidos junto con otros. Véase el código «X» en la Tabla B1.1a para obtener más detalles.

Los países están clasificados en orden descendente de la proporción de gasto privado en instituciones educativas en 2011.

Fuente: OCDE. Tabla B3.2c. Para ver notas, consulte Anexo 3 (www.oecd.org/edu/eag.htm).

StatLink 제개 http://dx.doi.org/10.1787/888933117516

El gasto privado en instituciones educativas ha aumentado en general más rápidamente que el gasto público entre 2000 y 2011. Sin embargo, la inversión pública en educación terciaria también aumentó en todos los países con datos disponibles de 2000 y 2011, independientemente de los cambios en el gasto privado. Cuatro de los diez países con mayores aumentos en el gasto privado durante este periodo (Austria, Chile, República Checa y República Eslovaca) figuran también entre los diez países con mayores aumentos del gasto público (Tabla B3.2c).

\section{Gasto público en instituciones educativas por estudiante y tipo de institución}

El nivel de gasto público muestra en parte el valor que los gobiernos conceden a la educación (véanse Indicadores B2 y B4). Lógicamente, los fondos públicos van a las instituciones públicas, pero en algunos casos una parte significativa del presupuesto público se destina a instituciones educativas privadas. 
La Tabla B3.3 muestra la inversión pública en instituciones educativas en relación con el tamaño del sistema educativo, centrándose en el gasto público en instituciones educativas públicas y privadas por estudiante (los fondos privados se han excluido de la Tabla B3.3, aunque en algunos países representan una proporción importante de los recursos de que disponen las instituciones educativas, especialmente las de nivel terciario). Puede considerarse, por tanto, un dato complementario al gasto público en relación con la riqueza nacional (véase Indicador B2).

Como media en los países de la OCDE, en todos los niveles de educación en conjunto, el gasto público por estudiante en instituciones públicas es casi el doble del que se destina a instituciones privadas por estudiante (8.952 y 4.614 dólares estadounidenses, respectivamente). Sin embargo, esta diferencia varía según el nivel de educación. En educación infantil, el gasto público por estudiante en instituciones públicas es alrededor de 1,8 veces mayor que en instituciones privadas (6.502 y 3.618 dólares estadounidenses, respectivamente), al igual que en los niveles de primaria, secundaria y postsecundaria no terciaria (8.762 y 4.918 dólares estadounidenses, respectivamente). En la educación terciaria, el gasto público por estudiante en instituciones públicas es casi el triple que en instituciones privadas (11.877 y 4.061 dólares estadounidenses, respectivamente).

En educación infantil, el gasto público por estudiante, tanto en instituciones públicas como privadas, se sitúa por termino medio en 6.043 dólares estadounidenses en los países de la OCDE, pero varía desde menos de 2.000 dólares en Turquía y el país asociado Colombia hasta más de 22.000 dólares en Luxemburgo. El gasto público por estudiante suele ser mayor en instituciones públicas que en privadas, pero las instituciones privadas matriculan en general a menos estudiantes que las públicas. Por ejemplo, en México, el gasto público por estudiante en instituciones privadas es insignificante, y la proporción de estudiantes matriculados en instituciones privadas es relativamente pequeña. Por el contrario, casi la totalidad de los estudiantes están matriculados en centros privados en Nueva Zelanda y el gasto público por estudiante en instituciones privadas es superior a la media (9.526 dólares estadounidenses) (Tabla B3.3 y véase Tabla C2.2).

En educación primaria, secundaria y postsecundaria no terciaria (los niveles con mayor proporción de financiación pública, Tabla B3.2b), el gasto público por estudiante, tanto en instituciones públicas como privadas, alcanza un promedio en los países de la OCDE de 7.996 dólares estadounidenses, pero varía desde menos de 2.300 dólares estadounidenses en México, Turquía y el país asociado Colombia hasta más de 10.000 en Austria, Bélgica, Estados Unidos, Luxemburgo, Noruega y Suecia. En este nivel, la mayoría de los estudiantes están matriculados en instituciones públicas y el gasto público por estudiante suele ser más alto en instituciones públicas que en privadas, excepto en Colombia, Finlandia, Israel y Noruega (Tabla B3.3). En estos tres países de la OCDE, entre un $7 \%$ y un $25 \%$ de los estudiantes se matriculan en instituciones privadas. En México y Países Bajos, el gasto público por estudiante en instituciones privadas es bajo o insignificante, ya que el sector privado es mínimo y no recibe o apenas recibe fondos públicos (véase Tabla C1.4).

En educación terciaria, el gasto público por estudiante, tanto en instituciones públicas como privadas, alcanza en los países de la OCDE un promedio de 9.221 dólares estadounidenses, pero varía desde aproximadamente 2.000 dólares en Chile a más de 17.000 en Dinamarca, Finlandia, Noruega y Suecia, cuatro países en los que el nivel de gasto privado es bajo o insignificante en este nivel educativo. En todos los países con datos disponibles, excepto en Hungría y Letonia, el gasto público por estudiante es más elevado en las instituciones públicas que en las privadas (Tabla B3.3 y Gráfico B3.4).

En este nivel educativo, los modelos de asignación de fondos públicos a instituciones públicas y privadas varían entre países. En Dinamarca y Países Bajos, al menos el $90 \%$ de los estudiantes de educación terciaria están matriculados en instituciones públicas y la mayoría del gasto público se destina a estas instituciones. El gasto público en instituciones públicas por estudiante es más elevado que la media de la OCDE y el gasto público en instituciones privadas por estudiante es insignificante. En estos países, la financiación privada complementa a la pública en diferente grado: el gasto privado es inferior al $6 \%$ del gasto total en instituciones públicas y privadas en Dinamarca y superior al $28 \%$ en Países Bajos (Gráfico B3.4 y Tabla B3.1).

En Bélgica, Estonia, Finlandia, Hungría, Islandia y Suecia, el gasto público se destina tanto a instituciones públicas como privadas, y el gasto público en instituciones privadas por estudiante representa al menos el $58 \%$-y hasta más del 100\%- del gasto público en instituciones públicas de educación terciaria por estudiante (Tabla B3.4). Sin embargo, estos países presentan modelos diferentes. En Hungría, Islandia y Suecia, al menos el $80 \%$ de los estudiantes están matriculados en instituciones públicas, mientras que en Bélgica y Estonia los estudiantes de educación terciaria están matriculados mayoritariamente en instituciones privadas dependientes del gobierno. En todos estos países, el gasto privado en instituciones terciarias es inferior a la media de la OCDE. En el resto de países, el gasto público se destina principalmente a instituciones públicas (Gráfico B3.4 y Tabla B3.4). 


\section{Gráfico B3.4. Gasto público anual en instituciones educativas por estudiante en educación terciaria, por tipo de institución (2011)}

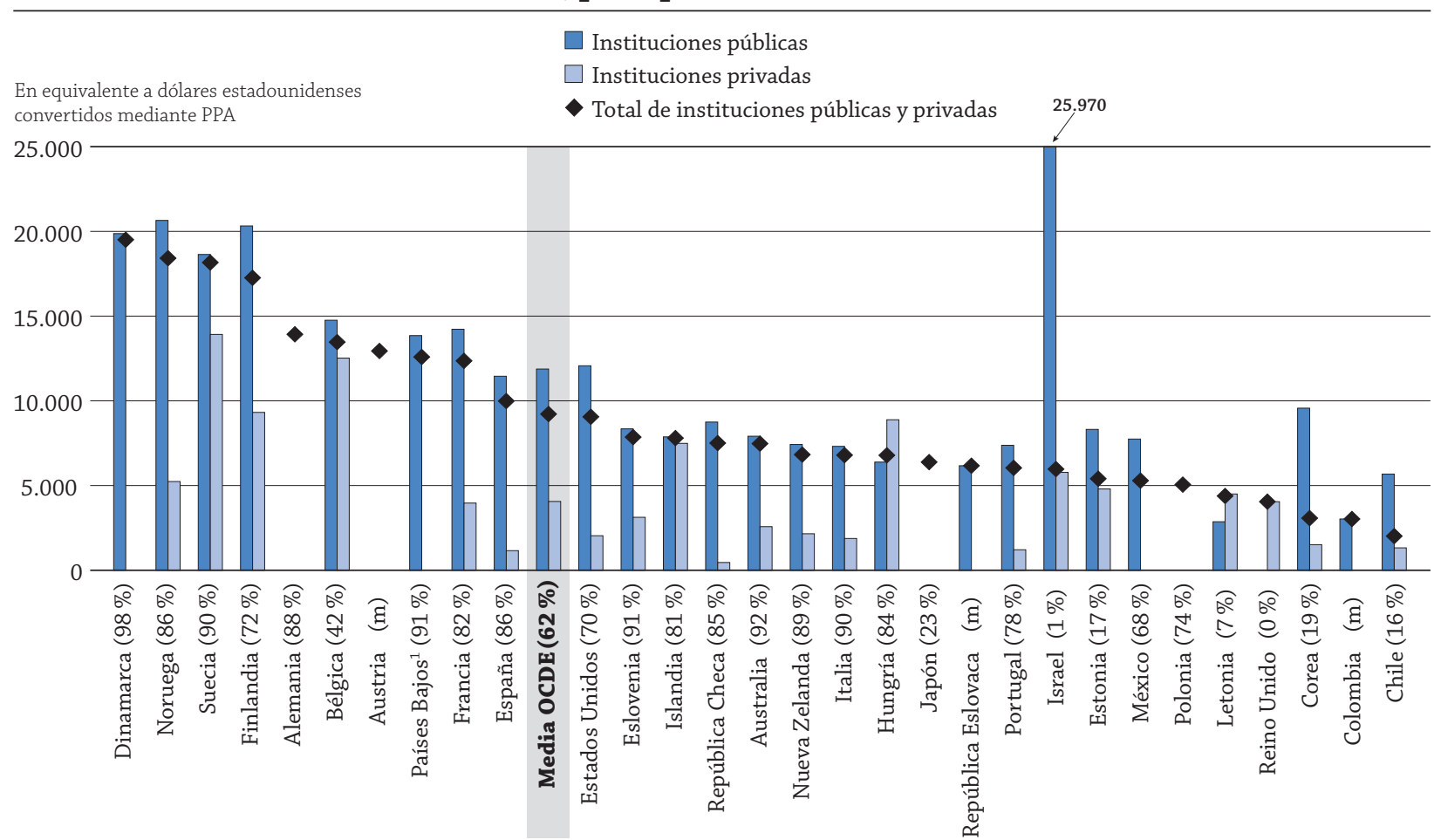

Nota: Las cifras entre paréntesis representan el porcentaje de estudiantes matriculados en instituciones públicas terciarias, sobre la base de equivalentes a tiempo completo.

1. Las instituciones privadas dependientes del gobierno están incluidas en instituciones públicas.

Los países están clasificados en orden descendente de la proporción de gasto privado en instituciones educativas publicas y privadas por estudiante.

Fuente: OCDE. Tabla B3.3. Para ver notas, consulte Anexo 3 (www.oecd.org/edu/eag.htm).

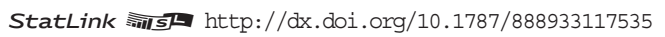

\section{Definiciones}

Por otras entidades privadas se entiende las empresas privadas y organizaciones sin ánimo de lucro, incluyendo asociaciones religiosas, benéficas y organizaciones empresariales y sindicales.

El gasto privado incluye todo el gasto directo en instituciones educativas, parcialmente cubierto o no por subvenciones públicas. También se incluye el gasto de las empresas privadas en programas de prácticas laborales y de aprendices llevados a cabo por los centros de formación. Las ayudas públicas destinadas a familias, y que están incluidas en el gasto privado, aparecen por separado.

La proporción pública y privada del gasto en instituciones educativas se refiere a los porcentajes del gasto total originado, o generado, en los sectores respectivos.

El gasto público se pone en relación con el total de estudiantes en instituciones públicas y privadas, reciban o no financiación pública.

\section{Metodología}

Los datos se refieren al año financiero de 2011 y proceden de la recopilación UOE de datos estadísticos sobre educación, gestionada por la OCDE en 2013 (para más detalles, véase Anexo 3 en www.oecd.org/edu/eag.htm).

No todos los gastos en bienes y servicios educativos se producen dentro de las instituciones educativas. Por ejemplo, las familias pueden adquirir libros de texto y material escolar o pagar clases particulares para sus hijos fuera de dichas instituciones. En educación terciaria, los gastos de manutención de los estudiantes y los ingresos no generados pueden suponer también una proporción importante de los costes educativos. Todos los gastos realizados fuera de las instituciones educativas, aunque se paguen con subvenciones públicas, están excluidos de este indicador. Las subvenciones o ayudas públicas para gastos educativos fuera de las instituciones se analizan en los Indicadores B4 y B5. 
Una parte de los presupuestos de las instituciones educativas está relacionada con los servicios auxiliares ofrecidos a los estudiantes, incluyendo servicios asistenciales (manutención, alojamiento y transporte). Parte del coste de estos servicios se cubre mediante tasas pagadas por los estudiantes, que también están incluidas en el indicador.

Los datos del gasto de 1995 y 2000 proceden de un estudio especial actualizado en 2012, en el que se han ajustado dichos gastos de 1995 y 2000 a los métodos y definiciones empleados en la recopilación actual de datos UOE.

\section{Nota sobre los datos de Israel}

Los datos estadísticos para Israel fueron proporcionados por las autoridades israelíes competentes bajo su responsabilidad. El uso de estos datos por parte de la OCDE se hace sin prejuzgar la situación de los Altos del Golán, Jerusalén Este y los asentamientos israelíes en Cisjordania de acuerdo con los términos del derecho internacional.

\section{Tablas del Indicador B3}

StatLink 감 http://dx.doi.org/10.1787/888933117364

Tabla B3.1 Proporciones relativas de gasto público y privado en instituciones educativas para todos los niveles de educación (2011)

Tabla B3.2a Tendencias de las proporciones relativas de gasto público en instituciones educativas e índice de cambio del gasto público y privado para todos los niveles de educación (1995, 2000, 2005, 2008 a 2011)

Tabla B3.2b Tendencias de las proporciones relativas de gasto público en instituciones educativas e índice de cambio del gasto público y privado en educación primaria, secundaria y postsecundaria no terciaria (1995, 2000, 2005, 2008 a 2011)

Tabla B3.2c Tendencias de las proporciones relativas de gasto público en instituciones de educación terciaria e índice de cambio del gasto público y privado (1995, 2000, 2005, 2008 a 2011)

Tabla B3.3 Gasto público anual en instituciones educativas por estudiante, por tipo de institución (2011) 
Tabla B3.1. Proporciones relativas de gasto público y privado en instituciones educativas para todos los niveles de educación (2011)

Distribución de fuentes de financiación pública y privada de las instituciones educativas después de transferencias de fuentes públicas

\begin{tabular}{|c|c|c|c|c|c|c|c|c|c|c|c|c|c|c|c|}
\hline & \multicolumn{5}{|c|}{$\begin{array}{l}\text { Educación primaria, secundaria } \\
\text { y postsecundaria no terciaria }\end{array}$} & \multicolumn{5}{|c|}{ Educación terciaria } & \multicolumn{5}{|c|}{ Todos los niveles } \\
\hline & \multirow[b]{2}{*}{ 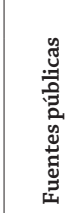 } & \multicolumn{3}{|c|}{ Fuentes privadas } & \multirow[b]{2}{*}{ 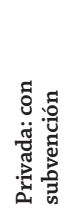 } & \multirow[b]{2}{*}{ 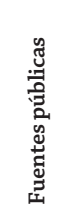 } & \multicolumn{3}{|c|}{ Fuentes privadas } & \multirow[b]{2}{*}{ 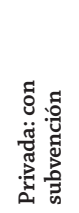 } & \multirow[b]{2}{*}{ 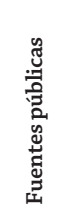 } & \multicolumn{3}{|c|}{ Fuentes privadas } & \multirow[b]{2}{*}{ 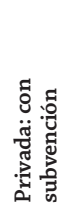 } \\
\hline & & 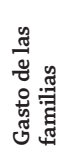 & 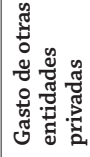 & 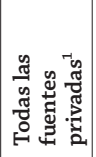 & & & 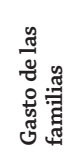 & 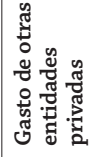 & 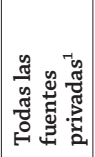 & & & 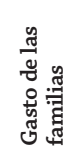 & 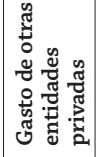 & 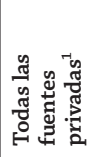 & \\
\hline & (6) & (7) & (8) & (9) & $(10)$ & (11) & (12) & (13) & (14) & (15) & $(16)$ & (17) & (18) & (19) & (20) \\
\hline 山 Alemania & 87,9 & $\mathrm{x}(9)$ & $\mathrm{x}(9)$ & 12,1 & $\mathrm{~m}$ & 84,7 & $\mathrm{x}(14)$ & $\mathrm{x}(14)$ & 15,3 & $\mathrm{~m}$ & 86,4 & $\mathrm{x}(19)$ & $\mathrm{x}(19)$ & 13,6 & $\mathrm{~m}$ \\
\hline $\bar{\Xi}$ Australia & 83,6 & 13,8 & 2,6 & 16,4 & 0,9 & 45,6 & 39,0 & 15,4 & 54,4 & 0,5 & 72,2 & 21,7 & 6,1 & 27,8 & 1,4 \\
\hline Austria & 95,9 & 2,8 & 1,3 & 4,1 & 1,8 & 86,9 & 2,7 & 10,5 & 13,1 & 8,2 & 91,1 & 3,5 & 5,4 & 8,9 & 6,2 \\
\hline Bélgica & 96,2 & 3,7 & 0,1 & 3,8 & 1,4 & 90,1 & 4,9 & 5,1 & 9,9 & 4,5 & 95,0 & 3,8 & 1,1 & 5,0 & 2,0 \\
\hline Canadá ${ }^{2,3}$ & 89,7 & 3,9 & 6,4 & 10,3 & $\mathrm{x}(6)$ & 57,4 & 20,0 & 22,6 & 42,6 & 1,1 & 76,4 & 10,5 & 13,1 & 23,6 & 0,5 \\
\hline Chile $^{4}$ & 78,3 & 20,8 & 0,9 & 21,7 & $\mathrm{a}$ & 24,2 & 68,3 & 7,5 & 75,8 & 8,1 & 59,9 & 36,9 & 3,2 & 40,1 & 2,8 \\
\hline Corea & 80,7 & 17,8 & 1,5 & 19,3 & 0,6 & 27,0 & 44,1 & 28,9 & 73,0 & 1,2 & 62,8 & 26,4 & 10,9 & 37,2 & 1,1 \\
\hline Dinamarca $^{3}$ & 97,2 & 2,8 & $\mathrm{n}$ & 2,8 & $\mathrm{n}$ & 94,5 & $\mathrm{x}(14)$ & $\mathrm{x}(14)$ & 5,5 & $\mathrm{n}$ & 94,5 & 4,2 & 1,2 & 5,5 & $\mathrm{~m}$ \\
\hline Eslovenia & 91,1 & 8,2 & 0,7 & 8,9 & $\mathrm{n}$ & 85,2 & 9,9 & 4,9 & 14,8 & $\mathrm{n}$ & 88,5 & 10,0 & 1,5 & 11,5 & $\mathrm{n}$ \\
\hline España & 91,1 & 8,9 & a & 8,9 & a & 77,5 & 18,7 & 3,8 & 22,5 & 1,7 & 84,5 & 14,6 & 0,9 & 15,5 & 0,4 \\
\hline Estados Unidos & 91,6 & 8,4 & $\mathrm{~m}$ & 8,4 & $\mathrm{~m}$ & 34,8 & 47,8 & 17,4 & 65,2 & $\mathrm{~m}$ & 67,9 & 25,3 & 6,8 & 32,1 & $\mathrm{~m}$ \\
\hline Estonia & 98,9 & 0,9 & 0,2 & 1,1 & $\mathrm{~m}$ & 80,4 & 15,6 & 4,0 & 19,6 & $\mathrm{~m}$ & 93,7 & 5,0 & 1,3 & 6,3 & $\mathrm{~m}$ \\
\hline Finlandia & 99,3 & $\mathrm{x}(9)$ & $\mathrm{x}(9)$ & 0,7 & $\mathrm{n}$ & 95,9 & $\mathrm{x}(14)$ & $\mathrm{x}(14)$ & 4,1 & 0,2 & 97,6 & $\mathrm{x}(19)$ & $\mathrm{x}(19)$ & 2,4 & $\mathrm{n}$ \\
\hline Francia & 91,8 & 6,7 & 1,5 & 8,2 & 1,7 & 80,8 & 10,4 & 8,8 & 19,2 & 2,6 & 89,4 & 7,5 & 3,1 & 10,6 & $\mathrm{~m}$ \\
\hline Grecia & $\mathbf{m}$ & $\mathrm{m}$ & $\mathrm{m}$ & $\mathbf{m}$ & $\mathrm{m}$ & $\mathbf{m}$ & $\mathrm{m}$ & $\mathrm{m}$ & $\mathbf{m}$ & $\mathrm{m}$ & $\mathbf{m}$ & $\mathrm{m}$ & $\mathrm{m}$ & $\mathbf{m}$ & $\mathrm{m}$ \\
\hline Hungría & $\mathbf{m}$ & $\mathrm{m}$ & $\mathrm{m}$ & $\mathbf{m}$ & $\mathrm{n}$ & $\mathbf{m}$ & $\mathrm{m}$ & $\mathrm{m}$ & $\mathbf{m}$ & $\mathrm{n}$ & $\mathbf{m}$ & $\mathrm{m}$ & $\mathrm{m}$ & $\mathbf{m}$ & $\mathrm{m}$ \\
\hline Irlanda & 95,8 & 4,2 & $\mathrm{~m}$ & 4,2 & $\mathrm{n}$ & 80,5 & 16,6 & 2,9 & 19,5 & $\mathrm{n}$ & 92,3 & 7,1 & 0,7 & 7,7 & $\mathrm{n}$ \\
\hline Islandia & 96,3 & 3,5 & 0,2 & 3,7 & a & 90,6 & 8,7 & 0,7 & $\mathbf{9 , 4}$ & a & 90,3 & 8,4 & 1,3 & 9,7 & $\mathrm{a}$ \\
\hline Israel & 89,5 & 4,0 & 6,5 & 10,5 & 1,2 & 49,0 & 30,9 & 20,1 & 51,0 & 5,3 & 75,1 & 15,7 & 9,2 & 24,9 & 2,0 \\
\hline Italia & 96,2 & 3,6 & 0,2 & 3,8 & $\mathrm{n}$ & 66,5 & 25,3 & 8,2 & 33,5 & 9,1 & 89,2 & 8,9 & 1,9 & 10,8 & 2,0 \\
\hline Japón $^{3}$ & 93,0 & 5,1 & 2,0 & 7,0 & $\mathrm{~m}$ & 34,5 & 50,9 & 14,6 & 65,5 & $\mathrm{~m}$ & 69,5 & 20,5 & 9,9 & 30,5 & $\mathrm{~m}$ \\
\hline Luxemburgo & 97,9 & 1,8 & 0,3 & 2,1 & $\mathrm{n}$ & $\mathbf{m}$ & $\mathrm{m}$ & $\mathrm{m}$ & m & $\mathrm{m}$ & $\mathbf{m}$ & $\mathrm{m}$ & $\mathrm{m}$ & $\mathbf{m}$ & $\mathrm{m}$ \\
\hline México & 82,6 & 17,3 & 0,1 & 17,4 & 1,7 & 67,1 & 32,6 & 0,4 & 32,9 & 1,9 & 80,3 & 19,6 & 0,2 & 19,7 & 1,5 \\
\hline Noruega & $\mathbf{m}$ & $\mathrm{m}$ & $\mathrm{m}$ & $\mathbf{m}$ & $\mathrm{m}$ & 95,9 & 3,4 & 0,7 & 4,1 & $\mathrm{~m}$ & $\mathbf{m}$ & $\mathrm{m}$ & $\mathrm{m}$ & $\mathbf{m}$ & $\mathrm{m}$ \\
\hline Nueva Zelanda & 88,8 & 11,2 & $\mathrm{x}(7)$ & 11,2 & $\mathrm{~m}$ & 64,5 & 35,5 & $\mathrm{x}(12)$ & 35,5 & $\mathrm{~m}$ & 83,6 & 16,4 & $\mathrm{x}(17)$ & 16,4 & $\mathrm{~m}$ \\
\hline Países Bajos & 86,6 & 4,3 & 9,1 & 13,4 & 3,9 & 70,8 & 15,2 & 14,1 & 29,2 & 0,3 & 82,3 & 7,9 & 9,8 & 17,7 & 3,0 \\
\hline Polonia & 93,9 & 6,1 & $\mathrm{~m}$ & 6,1 & $\mathrm{~m}$ & 75,5 & 22,6 & 1,9 & 24,5 & $\mathrm{n}$ & 87,2 & $\mathrm{x}(19)$ & $\mathrm{x}(19)$ & 12,8 & $\mathrm{~m}$ \\
\hline Portugal & 99,9 & $\mathrm{n}$ & $\mathrm{m}$ & $\mathbf{n}$ & $\mathrm{m}$ & 68,6 & 22,3 & 9,2 & 31,4 & $\mathrm{~m}$ & 92,5 & 5,3 & 2,2 & 7,5 & $\mathrm{~m}$ \\
\hline Reino Unido & 85,7 & 11,2 & 3,2 & 14,3 & 6,4 & 30,2 & 60,7 & 9,1 & 69,8 & 39,9 & 74,9 & 21,0 & 4,1 & 25,1 & 12,4 \\
\hline República Checa & 90,9 & 7,2 & 1,9 & 9,1 & $\mathrm{n}$ & 81,1 & 7,8 & 11,2 & 18,9 & $\mathrm{n}$ & 88,1 & 7,5 & 4,5 & 11,9 & $\mathrm{n}$ \\
\hline República Eslovaca ${ }^{3}$ & 88,6 & 9,8 & 1,6 & 11,4 & 1,7 & 76,9 & 15,4 & 7,7 & 23,1 & 3,8 & 85,7 & 11,5 & 2,8 & 14,3 & 2,1 \\
\hline Suecia & 100,0 & $\mathrm{n}$ & $\mathrm{a}$ & $\mathbf{n}$ & $\mathrm{a}$ & 89,5 & 0,2 & 10,3 & 10,5 & $\mathrm{n}$ & 97,2 & $\mathrm{n}$ & 2,7 & 2,8 & $\mathrm{n}$ \\
\hline Suiza & 88,3 & $\mathrm{n}$ & 11,7 & 11,7 & 0,2 & $\mathbf{m}$ & $\mathrm{m}$ & $\mathrm{m}$ & m & $\mathrm{m}$ & $\mathbf{m}$ & $\mathrm{m}$ & $\mathrm{m}$ & $\mathbf{m}$ & $\mathrm{m}$ \\
\hline Turquía & 86,8 & 13,2 & a & 13,2 & a & m & $\mathrm{m}$ & $\mathrm{m}$ & m & $\mathrm{m}$ & m & $\mathrm{m}$ & $\mathrm{m}$ & $\mathbf{m}$ & $\mathrm{m}$ \\
\hline Media OCDE & 91,4 & $\sim$ & $\sim$ & 8,6 & 0,9 & 69,2 & $\sim$ & $\sim$ & 30,8 & 3,8 & 83,9 & & $\sim$ & 16,1 & 2,0 \\
\hline Media UE21 & 93,9 & $\sim$ & $\sim$ & 6,1 & 1,1 & 78,6 & $\sim$ & $\sim$ & 21,4 & 4,4 & 89,4 & $\sim$ & $\sim$ & 10,6 & 2,3 \\
\hline Arabia Saudí & m & $\mathrm{m}$ & $\mathrm{m}$ & $\mathrm{m}$ & $\mathrm{m}$ & $\begin{array}{r}\mathrm{m} \\
76.9\end{array}$ & $\mathrm{~m}$ & $\mathrm{~m}$ & m & $\mathrm{m}$ & $\begin{array}{r}m \\
86.5\end{array}$ & $\mathrm{~m}$ & $\mathrm{~m}$ & m & $\mathrm{m}$ \\
\hline $\begin{array}{l}\text { Argentina } \\
\text { Brasil }\end{array}$ & $\begin{array}{r}91,2 \\
\mathrm{~m}\end{array}$ & $\begin{array}{r}8,8 \\
\mathrm{~m}\end{array}$ & m & $\begin{array}{r}8,8 \\
\text { m }\end{array}$ & $\mathrm{m}$ & $\begin{array}{r}76,9 \\
\mathrm{~m}\end{array}$ & $\begin{array}{l}10,0 \\
\mathrm{~m}\end{array}$ & m & m & $\begin{array}{l}\mathrm{m} \\
\mathrm{m}\end{array}$ & $\begin{array}{r}86,5 \\
\mathrm{~m}\end{array}$ & $\begin{array}{r}10,7 \\
\mathrm{~m}\end{array}$ & $\begin{array}{r}2,8 \\
\mathrm{~m}\end{array}$ & $\begin{array}{r}13,5 \\
\mathrm{~m}\end{array}$ & $\begin{array}{c}\mathrm{n} \\
\mathrm{m}\end{array}$ \\
\hline ז China & $\mathbf{m}$ & $\mathrm{m}$ & $\mathrm{m}$ & $\mathbf{m}$ & $\mathrm{m}$ & $\mathbf{m}$ & $\mathrm{m}$ & $\mathrm{m}$ & $\mathbf{m}$ & $\mathrm{m}$ & m & $\mathrm{m}$ & $\mathrm{m}$ & $\mathbf{m}$ & $\mathrm{m}$ \\
\hline$\frac{\hat{n}}{\pi}$ Colombia $^{4}$ & 76,5 & 23,3 & 0,2 & 23,5 & $\mathrm{~m}$ & 44,0 & 56,0 & $\mathrm{n}$ & 56,0 & $\mathrm{~m}$ & 65,1 & 34,7 & 0,2 & 34,9 & $\mathrm{~m}$ \\
\hline Federación Rusa & 95,9 & $\mathrm{x}(9)$ & $\mathrm{x}(9)$ & 4,1 & a & 62,7 & 26,0 & 11,3 & 37,3 & a & 84,9 & $\mathrm{x}(19)$ & $\mathrm{x}(19)$ & 15,1 & $\mathrm{a}$ \\
\hline India & $\mathbf{m}$ & $\mathrm{m}$ & $\mathrm{m}$ & $\mathbf{m}$ & $\mathrm{m}$ & $\mathbf{m}$ & $\mathrm{m}$ & $\mathrm{m}$ & $\mathbf{m}$ & $\mathrm{m}$ & $\mathbf{m}$ & $\mathrm{m}$ & $\mathrm{m}$ & $\mathbf{m}$ & $\mathrm{m}$ \\
\hline Indonesia $^{4}$ & 89,9 & 10,1 & a & 10,1 & $\mathrm{~m}$ & 70,7 & 29,3 & $\mathrm{~m}$ & 29,3 & $\mathrm{~m}$ & 87,0 & 13,0 & $\mathrm{~m}$ & 13,0 & $\mathrm{~m}$ \\
\hline Letonia & 97,4 & 2,4 & 0,2 & 2,6 & $\mathrm{~m}$ & 62,6 & 37,2 & 0,2 & 37,4 & $\mathrm{~m}$ & 88,3 & 11,5 & 0,2 & 11,7 & $\mathrm{~m}$ \\
\hline Sudáfrica & $\mathbf{m}$ & $\mathrm{m}$ & $\mathrm{m}$ & $\mathbf{m}$ & $\mathrm{m}$ & $\mathbf{m}$ & $\mathrm{m}$ & $\mathrm{m}$ & $\mathbf{m}$ & $\mathrm{m}$ & $\mathbf{m}$ & $\mathrm{m}$ & $\mathrm{m}$ & $\mathbf{m}$ & $\mathrm{m}$ \\
\hline
\end{tabular}

Notas: Educación infantil (columnas 1, 2, 3, 4 y 5) está disponible en Internet (véase Statlink más abajo).

1. Incluidas las ayudas atribuibles a pagos a las instituciones educativas recibidos de fondos públicos.

2. Año de referencia 2010 en lugar de 2011.

3. Algunos niveles educativos están incluidos junto con otros. Véase el código «X» en la Tabla B1.1a para obtener más detalles.

4. Año de referencia 2012 en lugar de 2011.

Fuentes: OCDE. Arabia Saudí, Argentina, China, Colombia, India, Indonesia, Sudáfrica: Instituto de Estadística de la UNESCO. Letonia: Eurostat. Para ver notas, consulte Anexo 3 (www.oecd.org/edu/eag.htm).

Para obtener más información acerca de los símbolos utilizados en lugar de los datos que faltan, consulte la Guía del lector.

StatLink त्ञाज्ञ http://dx.doi.org/10.1787/888933117383 


\section{Tabla B3.2a. Tendencias de las proporciones relativas de gasto público en instituciones educativas e índice de cambio del gasto público y privado para todos los niveles de educación $(1995,2000,2005,2008$ a 2011)}

Índice de cambio de fuentes públicas de financiación en instituciones educativas después de transferencias de fuentes públicas, por año

\begin{tabular}{|c|c|c|c|c|c|c|c|c|c|c|c|c|c|}
\hline & \multirow{2}{*}{\multicolumn{5}{|c|}{$\begin{array}{l}\text { Proporción de gasto público en instituciones } \\
\text { educativas (\%) }\end{array}$}} & \multicolumn{8}{|c|}{$\begin{array}{l}\text { Índice de cambio entre } 1995 \text { y } 2011 \text { del gasto en instituciones educativas } \\
\qquad(2005=100 \text {, precios constantes })\end{array}$} \\
\hline & & & & & & \multicolumn{4}{|c|}{ Fuentes públicas } & \multicolumn{4}{|c|}{ Fuentes privadas ${ }^{2}$} \\
\hline & 2000 & 2005 & 2008 & 2010 & 2011 & 2000 & 2008 & 2010 & 2011 & 2000 & 2008 & 2010 & 2011 \\
\hline & $(2)$ & (3) & (4) & (6) & (7) & (9) & $(10)$ & (12) & (13) & (15) & (16) & (18) & (19) \\
\hline Alemania & 86,1 & 85,7 & 85,4 & 85,9 & 86,4 & 97 & 105 & 114 & 115 & 94 & 107 & 112 & 108 \\
\hline Australia & 74,1 & 72,7 & 71,6 & 74,1 & 72,2 & 85 & 109 & 134 & 130 & 79 & 115 & 125 & 133 \\
\hline Austria & 94,0 & 91,4 & 90,8 & 91,0 & 91,1 & 95 & 107 & 112 & 113 & 64 & 116 & 118 & 118 \\
\hline Bélgica & 94,3 & 94,2 & 94,3 & 94,8 & 95,0 & 93 & 116 & 118 & 119 & 92 & 113 & 104 & 100 \\
\hline Canadá $^{3}$ & 79,9 & 75,5 & 76,0 & 75,8 & 76,4 & 94 & 107 & 117 & 118 & 73 & 104 & 115 & 112 \\
\hline Chile $^{4}$ & 55,2 & 52,8 & 58,9 & 57,9 & 59,9 & 92 & 146 & 157 & 186 & 83 & 114 & 127 & 139 \\
\hline Corea & 59,2 & 58,9 & 59,6 & 61,6 & 62,8 & 73 & 128 & 143 & 151 & 72 & 125 & 128 & 128 \\
\hline Dinamarca & 96,0 & 92,3 & 92,2 & 94,5 & 94,5 & 88 & 98 & 109 & 110 & 44 & 100 & 76 & 76 \\
\hline Eslovenia & $\mathrm{m}$ & 87,0 & 88,4 & 88,4 & 88,5 & $\mathrm{~m}$ & 108 & 109 & 109 & $\mathrm{~m}$ & 94 & 96 & 94 \\
\hline España & 87,4 & 88,6 & 87,1 & 85,4 & 84,5 & 87 & 118 & 122 & 118 & 97 & 136 & 161 & 168 \\
\hline Estados Unidos & 72,0 & 71,8 & 71,5 & 69,4 & 67,9 & 83 & 111 & 110 & 108 & 83 & 112 & 124 & 129 \\
\hline Finlandia & 98,0 & 97,8 & 97,4 & 97,6 & 97,6 & 83 & 107 & 114 & 116 & 76 & 126 & 121 & 124 \\
\hline Francia & 91,2 & 90,8 & 90,0 & 89,8 & 89,4 & 98 & 104 & 107 & 105 & 94 & 115 & 120 & 124 \\
\hline Grecia & 93,8 & 94,0 & $\mathrm{~m}$ & $\mathrm{~m}$ & $\mathrm{~m}$ & 68 & $\mathrm{~m}$ & $\mathrm{~m}$ & $\mathrm{~m}$ & 70 & $\mathrm{~m}$ & $\mathrm{~m}$ & $\mathrm{~m}$ \\
\hline Hungría & 88,3 & 91,3 & $\mathrm{~m}$ & $\mathrm{~m}$ & $\mathrm{~m}$ & 71 & 99 & 89 & 87 & 99 & $\mathrm{~m}$ & $\mathrm{~m}$ & $\mathrm{~m}$ \\
\hline Irlanda & 90,5 & 93,7 & 93,8 & 92,5 & 92,3 & 74 & 133 & 139 & 137 & 115 & 129 & 167 & 170 \\
\hline Islandia & 90,0 & 89,6 & 90,9 & 90,4 & 90,3 & 72 & 112 & 98 & 99 & 69 & 96 & 90 & 92 \\
\hline Israel & 79,8 & 74,9 & 78,0 & 77,6 & 75,1 & 98 & 120 & 128 & 134 & 74 & 101 & 110 & 133 \\
\hline Italia & 94,3 & 91,4 & 91,4 & 90,1 & 89,2 & 98 & 106 & 98 & 95 & 63 & 106 & 115 & 123 \\
\hline Japón & 71,0 & 68,6 & 66,4 & 70,2 & 69,5 & 99 & 103 & 108 & 109 & 89 & 114 & 100 & 105 \\
\hline Luxemburgo & $\mathrm{m}$ & $\mathrm{m}$ & $\mathrm{m}$ & $\mathrm{m}$ & $\mathrm{m}$ & $\mathrm{m}$ & $\mathrm{m}$ & $\mathrm{m}$ & $\mathrm{m}$ & $\mathrm{m}$ & $\mathrm{m}$ & $\mathrm{m}$ & $\mathrm{m}$ \\
\hline México & 85,3 & 80,3 & 80,8 & 80,5 & 80,3 & 82 & 107 & 114 & 118 & 57 & 104 & 113 & 118 \\
\hline Noruega & 95,0 & $\mathrm{~m}$ & 98,2 & 98,1 & $\mathrm{~m}$ & 79 & 106 & 111 & 111 & $\mathrm{~m}$ & $\mathrm{~m}$ & $\mathrm{~m}$ & $\mathrm{~m}$ \\
\hline Nueva Zelanda & $\mathrm{m}$ & 78,4 & 82,4 & 82,6 & 83,6 & 89 & 110 & 123 & 133 & $\mathrm{~m}$ & 85 & 94 & 94 \\
\hline Países Bajos & 84,0 & 84,3 & 83,3 & 83,3 & 82,3 & 83 & 106 & 115 & 113 & 85 & 113 & 123 & 131 \\
\hline Polonia & 89,0 & 90,7 & 87,1 & 86,2 & 87,2 & 80 & 111 & 117 & 116 & 96 & 160 & 182 & 167 \\
\hline Portugal & 98,6 & 92,6 & 90,5 & 92,6 & 92,5 & 96 & 96 & 108 & 100 & 18 & 126 & 108 & 101 \\
\hline República Eslovaca & 96,4 & 83,9 & 82,5 & 84,2 & 85,7 & 84 & 114 & 133 & 132 & 16 & 126 & 129 & 114 \\
\hline Suecia & 97,0 & 97,0 & 97,3 & 97,5 & 97,2 & 87 & 106 & 110 & 111 & 89 & 97 & 93 & 104 \\
\hline Suiza & $\mathrm{m}$ & $\mathrm{m}$ & $\mathrm{m}$ & $\mathrm{m}$ & $\mathrm{m}$ & 86 & 98 & 106 & 108 & 74 & 107 & 97 & 97 \\
\hline Turquía & 98,6 & $\mathrm{~m}$ & $\mathrm{~m}$ & $\mathrm{~m}$ & $\mathrm{~m}$ & $\mathrm{~m}$ & $\mathrm{~m}$ & $\mathrm{~m}$ & $\mathrm{~m}$ & $\mathrm{~m}$ & $\mathrm{~m}$ & $\mathrm{~m}$ & $\mathrm{~m}$ \\
\hline
\end{tabular}

Media OCDE

Media OCDE para

los 21 países con datos

en todos los años

de referencia

Media UE21

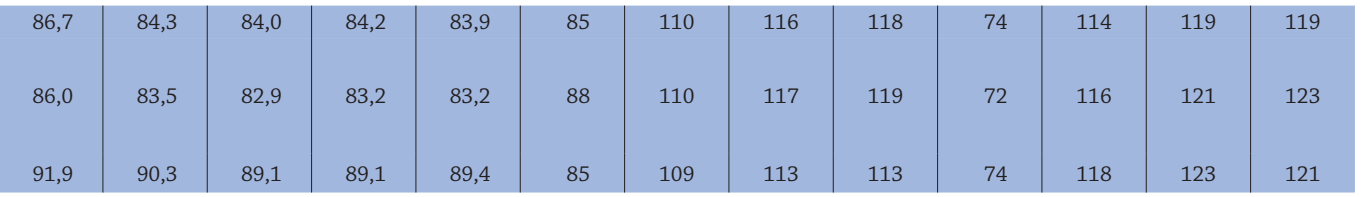

\begin{tabular}{|c|c|c|c|c|c|c|c|c|c|c|c|c|c|}
\hline Arabia Saudí & $\mathrm{m}$ & $\mathrm{m}$ & $\mathrm{m}$ & $\mathrm{m}$ & $\mathrm{m}$ & $\mathrm{m}$ & $\mathrm{m}$ & $\mathrm{m}$ & $\mathrm{m}$ & $\mathrm{m}$ & $\mathrm{m}$ & $\mathrm{m}$ & $\mathrm{m}$ \\
\hline Argentina & $\mathrm{m}$ & $\mathrm{m}$ & $\mathrm{m}$ & $\mathrm{m}$ & 86,5 & $\mathrm{~m}$ & $\mathrm{~m}$ & $\mathrm{~m}$ & $\mathrm{~m}$ & $\mathrm{~m}$ & $\mathrm{~m}$ & $\mathrm{~m}$ & $\mathrm{~m}$ \\
\hline Brasil & $\mathrm{m}$ & $\mathrm{m}$ & $\mathrm{m}$ & $\mathrm{m}$ & $\mathrm{m}$ & 69 & 140 & 165 & 172 & $\mathrm{~m}$ & $\mathrm{~m}$ & $\mathrm{~m}$ & $\mathrm{~m}$ \\
\hline China & $\mathrm{m}$ & $\mathrm{m}$ & $\mathrm{m}$ & $\mathrm{m}$ & $\mathrm{m}$ & $\mathrm{m}$ & $\mathrm{m}$ & $\mathrm{m}$ & $\mathrm{m}$ & $\mathrm{m}$ & $\mathrm{m}$ & $\mathrm{m}$ & $\mathrm{m}$ \\
\hline Federación Rusa & $\mathrm{m}$ & $\mathrm{m}$ & 85,8 & 84,2 & 84,9 & 58 & 134 & 126 & 128 & $\mathrm{~m}$ & $\mathrm{~m}$ & $\mathrm{~m}$ & $\mathrm{~m}$ \\
\hline India & $\mathrm{m}$ & $\mathrm{m}$ & $\mathrm{m}$ & $\mathrm{m}$ & $\mathrm{m}$ & $\mathrm{m}$ & $\mathrm{m}$ & $\mathrm{m}$ & $\mathrm{m}$ & $\mathrm{m}$ & $\mathrm{m}$ & $\mathrm{m}$ & $\mathrm{m}$ \\
\hline Indonesia $^{4}$ & $\mathrm{~m}$ & $\mathrm{~m}$ & $\mathrm{~m}$ & $\mathrm{~m}$ & 87,0 & $\mathrm{~m}$ & $\mathrm{~m}$ & $\mathrm{~m}$ & $\mathrm{~m}$ & $\mathrm{~m}$ & $\mathrm{~m}$ & $\mathrm{~m}$ & $\mathrm{~m}$ \\
\hline Sudáfrica & $\mathrm{m}$ & $\mathrm{m}$ & $\mathrm{m}$ & $\mathrm{m}$ & $\mathrm{m}$ & $\mathrm{m}$ & $\mathrm{m}$ & $\mathrm{m}$ & $\mathrm{m}$ & $\mathrm{m}$ & $\mathrm{m}$ & $\mathrm{m}$ & $\mathrm{m}$ \\
\hline Media G20 & $\mathrm{m}$ & $\mathrm{m}$ & $\mathrm{m}$ & $\mathrm{m}$ & $\mathrm{m}$ & $\mathrm{m}$ & $\mathrm{m}$ & $\mathrm{m}$ & $\mathrm{m}$ & $\mathrm{m}$ & $\mathrm{m}$ & $\mathrm{m}$ & $\mathrm{m}$ \\
\hline
\end{tabular}

Notas: Los años 1995 y 2009 (columnas 1, 5, 8, 11, 14 y 17) están disponibles en Internet (véase StatLink más abajo).

1. Excluidos los fondos no nacionales del gasto público y total en instituciones educativas.

2. Incluidas ayudas atribuibles a pagos a las instituciones educativas recibidas de fuentes públicas.

3. Año de referencia 2010 en lugar de 2011.

4. Año de referencia 2012 en lugar de 2011.

Fuentes: OCDE. Arabia Saudí, Argentina, China, Colombia, India, Indonesia, Sudáfrica: Instituto de Estadística de la UNESCO. Letonia: Eurostat. Para ver notas, consulte Anexo 3 (www.oecd.org/edu/eag.htm).

Para obtener más información acerca de los símbolos utilizados en lugar de los datos que faltan, consulte la Guía del lector.

StatLink 젶ㄴ http://dx.doi.org/10.1787/888933117402 
Tabla B3.2b. Tendencias de las proporciones relativas de gasto público en instituciones educativas e índice de cambio del gasto público y privado en educación primaria, secundaria y postsecundaria no terciaria (1995, 2000, 2005, 2008 a 2011)

Índice de cambio de fuentes públicas de financiación en instituciones educativas después de transferencias de fuentes públicas, por año

\begin{tabular}{|c|c|c|c|c|c|c|c|c|c|c|c|c|c|}
\hline & \multirow{2}{*}{\multicolumn{5}{|c|}{$\begin{array}{c}\text { Proporción de gasto público en institucion } \\
\text { es educativas (\%) }\end{array}$}} & \multicolumn{8}{|c|}{$\begin{array}{l}\text { Índice de cambio entre } 1995 \text { y } 2011 \text { del gasto en instituciones educativas } \\
(2005=100 \text {, precios constantes })\end{array}$} \\
\hline & & & & & & \multicolumn{4}{|c|}{ Fuentes públicas } & \multicolumn{4}{|c|}{ Fuentes privadas ${ }^{2}$} \\
\hline & 2000 & 2005 & 2008 & 2010 & 2011 & 2000 & 2008 & 2010 & 2011 & 2000 & 2008 & 2010 & 2011 \\
\hline & (2) & (3) & (4) & (6) & (7) & (9) & (10) & (12) & (13) & (15) & (16) & (18) & (19) \\
\hline 山् Alemania & 87,1 & 87,5 & 87,1 & 87,8 & 87,9 & 99 & 100 & 109 & 108 & 103 & 104 & 106 & 104 \\
\hline Australia & 83,7 & 83,5 & 82,5 & 84,7 & 83,6 & 83 & 108 & 135 & 130 & 82 & 116 & 123 & 129 \\
\hline Austria & 95,8 & 94,3 & 95,9 & 95,5 & 95,9 & 98 & 107 & 106 & 109 & 71 & 75 & 83 & 76 \\
\hline Bélgica & 94,7 & 94,7 & 95,2 & 96,0 & 96,2 & 94 & 117 & 117 & 118 & 94 & 106 & 88 & 83 \\
\hline Canadá, & 92,4 & 89,9 & 88,6 & 89,3 & 89,7 & 88 & 103 & 116 & 116 & 65 & 117 & 123 & 119 \\
\hline Chile $^{5}$ & 68,4 & 69,8 & 78,4 & 78,6 & 78,3 & 94 & 145 & 141 & 165 & 100 & 92 & 89 & 105 \\
\hline Corea & 80,8 & 77,0 & 77,8 & 78,5 & 80,7 & 72 & 117 & 128 & 133 & 58 & 112 & 118 & 107 \\
\hline Dinamarca $^{3}$ & 97,8 & 97,9 & 97,6 & 97,6 & 97,2 & 86 & 99 & 107 & 98 & 89 & 112 & 123 & 133 \\
\hline Eslovenia & $\mathrm{m}$ & 91,9 & 91,7 & 91,3 & 91,1 & $\mathrm{~m}$ & 104 & 103 & 101 & $\mathrm{~m}$ & 107 & 111 & 111 \\
\hline España & 93,0 & 93,5 & 93,1 & 91,8 & 91,1 & 93 & 114 & 117 & 113 & 100 & 121 & 149 & 158 \\
\hline Estados Unidos & 91,7 & 91,8 & 91,8 & 92,5 & 91,6 & 86 & 111 & 114 & 107 & 87 & 111 & 103 & 110 \\
\hline Estonia & $\mathrm{m}$ & 98,9 & 99,0 & 98,7 & 98,9 & 80 & 126 & 112 & 107 & 0 & 121 & 133 & 111 \\
\hline Finlandia & 99,3 & 99,2 & 99,0 & 99,2 & 99,3 & 82 & 107 & 112 & 113 & 65 & 126 & 105 & 98 \\
\hline Francia & 92,6 & 92,5 & 92,3 & 92,0 & 91,8 & 100 & 102 & 104 & 102 & 98 & 105 & 111 & 112 \\
\hline Grecia & 91,7 & 92,5 & $\mathrm{~m}$ & $\mathrm{~m}$ & $\mathrm{~m}$ & 77 & $\mathrm{~m}$ & $\mathrm{~m}$ & $\mathrm{~m}$ & 86 & $\mathrm{~m}$ & $\mathrm{~m}$ & $\mathrm{~m}$ \\
\hline Hungría & 92,7 & 95,5 & $\mathrm{~m}$ & $\mathrm{~m}$ & $\mathrm{~m}$ & 69 & 95 & 84 & 79 & 114 & $\mathrm{~m}$ & $\mathrm{~m}$ & $\mathrm{~m}$ \\
\hline Irlanda & 96,0 & 96,8 & 97,7 & 95,9 & 95,8 & 67 & 133 & 138 & 137 & 86 & 97 & 179 & 183 \\
\hline Islandia & 96,4 & 96,2 & 96,4 & 96,2 & 96,3 & 73 & 106 & 92 & 95 & 69 & 102 & 93 & 93 \\
\hline Israel & 94,1 & 93,0 & 93,0 & 92,4 & 89,5 & 96 & 121 & 129 & 138 & 79 & 121 & 142 & 216 \\
\hline Italia & 97,8 & 96,3 & 97,1 & 96,6 & 96,2 & 94 & 105 & 98 & 93 & 55 & 81 & 89 & 96 \\
\hline Japón ${ }^{3}$ & 89,8 & 90,1 & 90,0 & 93,0 & 93,0 & 98 & 102 & 108 & 108 & 101 & 103 & 73 & 74 \\
\hline Luxemburgo & $\mathrm{m}$ & $\mathrm{m}$ & $\mathrm{m}$ & 97,9 & 97,9 & $\mathrm{~m}$ & $\mathrm{~m}$ & 104 & 100 & $\mathrm{~m}$ & $\mathrm{~m}$ & $\mathrm{~m}$ & $\mathrm{~m}$ \\
\hline México & 86,1 & 82,9 & 82,9 & 82,7 & 82,6 & 83 & 102 & 109 & 113 & 65 & 102 & 111 & 115 \\
\hline Noruega & 99,0 & $\mathrm{~m}$ & $\mathrm{~m}$ & $\mathrm{~m}$ & $\mathrm{~m}$ & 87 & 107 & 113 & 112 & $\mathrm{~m}$ & $\mathrm{~m}$ & $\mathrm{~m}$ & $\mathrm{~m}$ \\
\hline Nueva Zelanda & $\mathrm{m}$ & 84,9 & 85,7 & 87,4 & 88,8 & 91 & 102 & 118 & 132 & $\mathrm{~m}$ & 96 & 96 & 93 \\
\hline Países Bajos & 86,1 & 87,1 & 86,6 & 86,9 & 86,6 & 82 & 106 & 115 & 113 & 90 & 111 & 118 & 118 \\
\hline Polonia & 95,4 & 98,2 & 94,7 & 93,8 & 93,9 & 87 & 111 & 118 & 116 & 225 & 339 & 422 & 407 \\
\hline Portugal & 99,9 & 99,9 & 99,9 & 100,0 & 99,9 & 98 & 96 & 109 & 101 & 99 & 90 & 87 & 89 \\
\hline Reino Unido & 88,7 & 83,0 & 77,9 & 78,9 & 85,7 & 75 & 94 & 102 & 113 & 47 & 130 & 133 & 92 \\
\hline República Checa & 91,7 & 89,9 & 90,4 & 90,8 & 90,9 & 78 & 107 & 112 & 116 & 63 & 101 & 101 & 104 \\
\hline República Eslovaca ${ }^{3}$ & 97,6 & 86,2 & 84,8 & 88,0 & 88,6 & 84 & 113 & 138 & 129 & 13 & 126 & 117 & 104 \\
\hline Suecia & 99,9 & 99,9 & 99,9 & 99,9 & 100,0 & 88 & 103 & 103 & 103 & 106 & 90 & 66 & $\mathrm{~m}$ \\
\hline Suiza & 88,9 & 86,9 & 86,3 & 88,1 & 88,3 & 90 & 101 & 108 & 110 & 74 & 107 & 97 & 97 \\
\hline Turquía & $\mathrm{m}$ & $\mathrm{m}$ & $\mathrm{m}$ & $\mathrm{m}$ & 86,8 & $\mathrm{~m}$ & $\mathrm{~m}$ & $\mathrm{~m}$ & $\mathrm{~m}$ & $\mathrm{~m}$ & $\mathrm{~m}$ & $\mathrm{~m}$ & $\mathrm{~m}$ \\
\hline Media OCDE & 92,1 & 91,0 & 90,8 & 91,4 & 91,4 & 86 & 109 & 113 & 113 & 85 & 115 & 120 & 123 \\
\hline $\begin{array}{l}\text { Media OCDE para } \\
\text { los } 21 \text { países con datos } \\
\text { en todos los años } \\
\text { de referencia }\end{array}$ & 91,6 & 90,4 & 90,5 & 90,9 & 91,0 & 88 & 109 & 116 & 117 & 80 & 108 & 112 & 118 \\
\hline Media UE21 & 94,3 & 93,8 & 93,3 & 93,6 & 93,9 & 86 & 107 & 110 & 108 & 84 & 119 & 129 & 128 \\
\hline
\end{tabular}

\begin{tabular}{|c|c|c|c|c|c|c|c|c|c|c|c|c|c|}
\hline $\begin{array}{l}\text { Arabia Saudí } \\
\text { Argentina }\end{array}$ & $\begin{array}{l}\mathrm{m} \\
\mathrm{m}\end{array}$ & $\begin{array}{l}\mathrm{m} \\
\mathrm{m}\end{array}$ & $\begin{array}{l}\mathrm{m} \\
\mathrm{m}\end{array}$ & $\begin{array}{l}\mathrm{m} \\
\mathrm{m}\end{array}$ & $\begin{array}{r}m \\
91,2\end{array}$ & $\begin{array}{l}\mathrm{m} \\
\mathrm{m}\end{array}$ & $\begin{array}{l}\mathrm{m} \\
\mathrm{m}\end{array}$ & $\begin{array}{l}\mathrm{m} \\
\mathrm{m}\end{array}$ & $\begin{array}{l}\mathrm{m} \\
\mathrm{m}\end{array}$ & $\begin{array}{l}\mathrm{m} \\
\mathrm{m}\end{array}$ & $\begin{array}{l}\mathrm{m} \\
\mathrm{m}\end{array}$ & $\begin{array}{l}\mathrm{m} \\
\mathrm{m}\end{array}$ & $\begin{array}{l}\mathrm{m} \\
\mathrm{m}\end{array}$ \\
\hline Brasil & $\mathrm{m}$ & $\mathrm{m}$ & $\mathrm{m}$ & $\mathrm{m}$ & $\mathrm{m}$ & 66 & 146 & 170 & 175 & $\mathrm{~m}$ & $\mathrm{~m}$ & $\mathrm{~m}$ & $\mathrm{~m}$ \\
\hline China & $\mathrm{m}$ & $\mathrm{m}$ & $\mathrm{m}$ & $\mathrm{m}$ & $\mathrm{m}$ & $\mathrm{m}$ & $\mathrm{m}$ & $\mathrm{m}$ & $\mathrm{m}$ & $\mathrm{m}$ & $\mathrm{m}$ & $\mathrm{m}$ & $\mathrm{m}$ \\
\hline Colombia $^{5}$ & $\mathrm{~m}$ & $\mathrm{~m}$ & $\mathrm{~m}$ & $\mathrm{~m}$ & 76,5 & $\mathrm{~m}$ & $\mathrm{~m}$ & $\mathrm{~m}$ & $\mathrm{~m}$ & $\mathrm{~m}$ & $\mathrm{~m}$ & $\mathrm{~m}$ & $\mathrm{~m}$ \\
\hline Federación Rusa & $\mathrm{m}$ & $\mathrm{m}$ & 96,8 & 96,9 & 95,9 & 66 & 132 & 126 & 130 & $\mathrm{~m}$ & $\mathrm{~m}$ & $\mathrm{~m}$ & $\mathrm{~m}$ \\
\hline India & $\mathrm{m}$ & $\mathrm{m}$ & $\mathrm{m}$ & $\mathrm{m}$ & $\mathrm{m}$ & $\mathrm{m}$ & $\mathrm{m}$ & $\mathrm{m}$ & $\mathrm{m}$ & $\mathrm{m}$ & $\mathrm{m}$ & $\mathrm{m}$ & $\mathrm{m}$ \\
\hline Indonesia $^{5}$ & $\mathrm{~m}$ & $\mathrm{~m}$ & $\mathrm{~m}$ & $\mathrm{~m}$ & 89,9 & $\mathrm{~m}$ & $\mathrm{~m}$ & $\mathrm{~m}$ & $\mathrm{~m}$ & $\mathrm{~m}$ & $\mathrm{~m}$ & $\mathrm{~m}$ & $\mathrm{~m}$ \\
\hline Letonia & $\mathrm{m}$ & $\mathrm{m}$ & $\mathrm{m}$ & $\mathrm{m}$ & 97,4 & $\mathrm{~m}$ & $\mathrm{~m}$ & $\mathrm{~m}$ & $\mathrm{~m}$ & $\mathrm{~m}$ & $\mathrm{~m}$ & $\mathrm{~m}$ & $\mathrm{~m}$ \\
\hline Sudáfrica & $\mathrm{m}$ & $\mathrm{m}$ & $\mathrm{m}$ & $\mathrm{m}$ & $\mathrm{m}$ & $\mathrm{m}$ & $\mathrm{m}$ & $\mathrm{m}$ & $\mathrm{m}$ & $\mathrm{m}$ & $\mathrm{m}$ & $\mathrm{m}$ & $\mathrm{m}$ \\
\hline
\end{tabular}

\section{Media G20}

Notas: Los años 1995 y 2009 (columnas 1, 5, 8, 11, 14 y 17) están disponibles en Internet (véase StatLink más abajo).

1. Excluidos los fondos no nacionales del gasto público y total en instituciones educativas.

2. Incluidas ayudas atribuibles a pagos a las instituciones educativas recibidas de fuentes públicas.

3. Algunos niveles educativos están incluidos junto con otros. Véase el código «X» en la Tabla B1.1a para obtener más detalles.

4. Año de referencia 2010 en lugar de 2011.

5. Año de referencia 2012 en lugar de 2011.

Fuentes: OCDE. Arabia Saudí, Argentina, China, Colombia, India, Indonesia, Sudáfrica: Instituto de Estadística de la UNESCO. Letonia: Eurostat. Para ver notas, consulte Anexo 3 (www.oecd.org/edu/eag.htm).

Para obtener más información acerca de los símbolos utilizados en lugar de los datos que faltan, consulte la Guía del lector.

StatLink त्ञाज http://dx.doi.org/10.1787/888933117421 
Tabla B3.2c. Tendencias de las proporciones relativas de gasto público en instituciones de educación terciaria e índice de cambio del gasto público y privado (1995, 2000, 2005, 2008 a 2011)

Índice de cambio de fuentes públicas de financiación en instituciones educativas después de transferencias de fuentes públicas, por año

\begin{tabular}{|c|c|c|c|c|c|c|c|c|c|c|c|c|c|}
\hline & \multirow{2}{*}{\multicolumn{5}{|c|}{$\begin{array}{l}\text { Proporción de gasto público } \\
\text { en instituciones educativas } \\
\text { (\%) }\end{array}$}} & \multicolumn{8}{|c|}{$\begin{array}{l}\text { Índice de cambio entre } 1995 \text { y } 2011 \text { del gasto en instituciones educativas } \\
\qquad(2005=100 \text {, a precios constantes })\end{array}$} \\
\hline & & & & & & \multicolumn{4}{|c|}{ Fuentes públicas } & \multicolumn{4}{|c|}{ Fuentes privadas ${ }^{2}$} \\
\hline & 2000 & 2005 & 2008 & 2010 & 2011 & 2000 & 2008 & 2010 & 2011 & 2000 & 2008 & 2010 & 2011 \\
\hline & (2) & (3) & (4) & (6) & (7) & (9) & (10) & (12) & (13) & (15) & (16) & (18) & (19) \\
\hline Alemania & 88,2 & 85,3 & 85,4 & 84,4 & 84,7 & 98 & 115 & 124 & 130 & 76 & 114 & 134 & 137 \\
\hline Australia & 49,9 & 45,4 & 44,9 & 46,5 & 45,6 & 92 & 110 & 129 & 130 & 77 & 112 & 124 & 129 \\
\hline Austria & 96,3 & 92,9 & 84,7 & 87,8 & 86,9 & 77 & 101 & 119 & 117 & 39 & 240 & 215 & 231 \\
\hline Bélgica & 91,5 & 90,6 & 89,8 & 89,8 & 90,1 & 99 & 116 & 123 & 122 & 89 & 128 & 134 & 130 \\
\hline Canadá $^{3,4}$ & 61,0 & 55,1 & 58,7 & 56,6 & 57,4 & 95 & 115 & 120 & 121 & 74 & 99 & 113 & 110 \\
\hline Chile $^{5}$ & 19,5 & 15,9 & 14,6 & 22,1 & 24,2 & 103 & 118 & 237 & 279 & 81 & 130 & 158 & 166 \\
\hline Corea & 23,3 & 24,3 & 22,3 & 27,3 & 27,0 & 76 & 117 & 154 & 160 & 80 & 131 & 132 & 139 \\
\hline Dinamarca $^{3}$ & 97,6 & 96,7 & 95,5 & 95,0 & 94,5 & 87 & 99 & 105 & 107 & 62 & 135 & 163 & 181 \\
\hline Eslovenia & $\mathrm{m}$ & 76,5 & 83,8 & 84,7 & 85,2 & 0 & 114 & 120 & 121 & $\mathrm{~m}$ & 72 & 71 & 69 \\
\hline España & 74,4 & 77,9 & 78,9 & 78,2 & 77,5 & 84 & 120 & 127 & 123 & 102 & 114 & 125 & 126 \\
\hline Estados Unidos & 37,4 & 39,7 & 39,1 & 36,3 & 34,8 & 74 & 110 & 108 & 105 & 81 & 113 & 125 & 130 \\
\hline Francia & 84,4 & 83,6 & 81,7 & 81,9 & 80,8 & 94 & 110 & 115 & 114 & 89 & 125 & 129 & 137 \\
\hline Grecia & 99,7 & 96,7 & $\mathrm{~m}$ & $\mathrm{~m}$ & $\mathrm{~m}$ & 44 & $\mathrm{~m}$ & $\mathrm{~m}$ & $\mathrm{~m}$ & 3 & $\mathrm{~m}$ & $\mathrm{~m}$ & $\mathrm{~m}$ \\
\hline Hungría & 76,7 & 78,5 & $\mathrm{~m}$ & $\mathrm{~m}$ & $\mathrm{~m}$ & 81 & 105 & 96 & 112 & 90 & $\mathrm{~m}$ & $\mathrm{~m}$ & $\mathrm{~m}$ \\
\hline Irlanda & 79,2 & 84,0 & 82,6 & 81,2 & 80,5 & 95 & 133 & 132 & 127 & 131 & 147 & 160 & 161 \\
\hline Islandia & 91,8 & 90,5 & 92,2 & 91,2 & 90,6 & 70 & 116 & 101 & 98 & 60 & 94 & 94 & 97 \\
\hline Israel & 58,5 & 46,5 & 51,3 & 54,2 & 49,0 & 113 & 110 & 125 & 125 & 69 & 91 & 92 & 113 \\
\hline Italia & 77,5 & 73,2 & 70,7 & 67,6 & 66,5 & 99 & 108 & 102 & 101 & 78 & 123 & 134 & 140 \\
\hline Japón ${ }^{3}$ & 38,5 & 33,7 & 33,3 & 34,4 & 34,5 & 107 & 108 & 112 & 117 & 87 & 110 & 109 & 113 \\
\hline Luxemburgo & $\mathrm{m}$ & $\mathrm{m}$ & $\mathrm{m}$ & $\mathrm{m}$ & $\mathrm{m}$ & $\mathrm{m}$ & $\mathrm{m}$ & $\mathrm{m}$ & $\mathrm{m}$ & $\mathrm{m}$ & $\mathrm{m}$ & $\mathrm{m}$ & $\mathrm{m}$ \\
\hline México & 79,4 & 69,0 & 70,1 & 69,9 & 67,1 & 84 & 115 & 128 & 118 & 49 & 109 & 123 & 129 \\
\hline Noruega & 96,3 & $\mathrm{~m}$ & 96,9 & 96,0 & 95,9 & 83 & 102 & 105 & 107 & $\mathrm{~m}$ & $\mathrm{~m}$ & $\mathrm{~m}$ & $\mathrm{~m}$ \\
\hline Nueva Zelanda & $\mathrm{m}$ & 59,7 & 70,4 & 66,3 & 64,5 & 84 & 133 & 126 & 121 & $\mathrm{~m}$ & 83 & 95 & 98 \\
\hline Países Bajos & 75,0 & 73,0 & 71,5 & 71,8 & 70,8 & 88 & 107 & 118 & 119 & 80 & 116 & 125 & 133 \\
\hline Polonia & 66,6 & 74,0 & 69,6 & 70,6 & 75,5 & 52 & 105 & 111 & 111 & 74 & 130 & 132 & 102 \\
\hline Portugal & 92,5 & 68,1 & 62,1 & 69,0 & 68,6 & 98 & 97 & 113 & 104 & 17 & 127 & 108 & 101 \\
\hline Reino Unido & 67,7 & $\mathrm{~m}$ & 45,7 & 37,1 & 30,2 & $\mathrm{~m}$ & $\mathrm{~m}$ & $\mathrm{~m}$ & $\mathrm{~m}$ & 64 & 182 & 227 & 192 \\
\hline Suecia & 91,3 & 88,2 & 89,1 & 90,6 & 89,5 & 90 & 106 & 120 & 121 & 65 & 97 & 93 & 106 \\
\hline Suiza & $\mathrm{m}$ & $\mathrm{m}$ & $\mathrm{m}$ & $\mathrm{m}$ & $\mathrm{m}$ & 77 & 90 & 102 & 107 & $\mathrm{~m}$ & $\mathrm{~m}$ & $\mathrm{~m}$ & $\mathrm{~m}$ \\
\hline Turquía & 95,4 & $\mathrm{~m}$ & $\mathrm{~m}$ & $\mathrm{~m}$ & $\mathrm{~m}$ & $\mathrm{~m}$ & $\mathrm{~m}$ & $\mathrm{~m}$ & $\mathrm{~m}$ & $\mathrm{~m}$ & $\mathrm{~m}$ & $\mathrm{~m}$ & $\mathrm{~m}$ \\
\hline Media OCDE & 75,3 & 70,5 & 69,4 & 69,3 & 69,2 & 86 & 112 & 122 & 127 & 69 & 122 & 131 & 132 \\
\hline $\begin{array}{l}\text { Media OCDE para } \\
\text { los } 21 \text { países con datos } \\
\text { en todos los años } \\
\text { de referencia }\end{array}$ & 73,7 & 69,1 & 68,1 & 68,6 & 68,3 & 91 & 112 & 125 & 129 & 70 & 126 & 134 & 139 \\
\hline Media UE21 & 85,1 & 82,3 & 78,7 & 78,3 & 78,6 & 80 & 112 & 118 & 123 & 66 & 131 & 139 & 138 \\
\hline
\end{tabular}

\begin{tabular}{|c|c|c|c|c|c|c|c|c|c|c|c|c|c|}
\hline Arabia Saudí & $\mathrm{m}$ & $\mathrm{m}$ & $\mathrm{m}$ & $\mathrm{m}$ & $\mathrm{m}$ & $\mathrm{m}$ & $\mathrm{m}$ & $\mathrm{m}$ & $\mathrm{m}$ & $\mathrm{m}$ & $\mathrm{m}$ & $\mathrm{m}$ & $\mathrm{m}$ \\
\hline Argentina & $\mathrm{m}$ & $\mathrm{m}$ & $\mathrm{m}$ & $\mathrm{m}$ & 76,9 & $\mathrm{~m}$ & $\mathrm{~m}$ & $\mathrm{~m}$ & $\mathrm{~m}$ & $\mathrm{~m}$ & $\mathrm{~m}$ & $\mathrm{~m}$ & $\mathrm{~m}$ \\
\hline Brasil & $\mathrm{m}$ & $\mathrm{m}$ & $\mathrm{m}$ & $\mathrm{m}$ & $\mathrm{m}$ & 79 & 119 & 148 & 155 & $\mathrm{~m}$ & $\mathrm{~m}$ & $\mathrm{~m}$ & $\mathrm{~m}$ \\
\hline China & $\mathrm{m}$ & $\mathrm{m}$ & $\mathrm{m}$ & $\mathrm{m}$ & $\mathrm{m}$ & $\mathrm{m}$ & $\mathrm{m}$ & $\mathrm{m}$ & $\mathrm{m}$ & $\mathrm{m}$ & $\mathrm{m}$ & $\mathrm{m}$ & $\mathrm{m}$ \\
\hline Federación Rusa & $\mathrm{m}$ & $\mathrm{m}$ & 64,3 & 62,2 & 62,7 & 44 & 147 & 145 & 136 & $\mathrm{~m}$ & $\mathrm{~m}$ & $\mathrm{~m}$ & $\mathrm{~m}$ \\
\hline India & $\mathrm{m}$ & $\mathrm{m}$ & $\mathrm{m}$ & $\mathrm{m}$ & $\mathrm{m}$ & $\mathrm{m}$ & $\mathrm{m}$ & $\mathrm{m}$ & $\mathrm{m}$ & $\mathrm{m}$ & $\mathrm{m}$ & $\mathrm{m}$ & $\mathrm{m}$ \\
\hline Indonesia $^{5}$ & $\mathrm{~m}$ & $\mathrm{~m}$ & $\mathrm{~m}$ & $\mathrm{~m}$ & 70,7 & $\mathrm{~m}$ & $\mathrm{~m}$ & $\mathrm{~m}$ & $\mathrm{~m}$ & $\mathrm{~m}$ & $\mathrm{~m}$ & $\mathrm{~m}$ & $\mathrm{~m}$ \\
\hline Sudáfrica & $\mathrm{m}$ & $\mathrm{m}$ & $\mathrm{m}$ & $\mathrm{m}$ & $\mathrm{m}$ & $\mathrm{m}$ & $\mathrm{m}$ & $\mathrm{m}$ & $\mathrm{m}$ & $\mathrm{m}$ & $\mathrm{m}$ & $\mathrm{m}$ & $\mathrm{m}$ \\
\hline
\end{tabular}

Media G20

Notas: Los años 1995 y 2009 (columnas 1, 5, 8, 11, 14 y 17) están disponibles en Internet (véase StatLink más abajo).

1. Excluidos los fondos no nacionales del gasto público y total en instituciones educativas.

2. Incluidas ayudas atribuibles a pagos a las instituciones educativas recibidas de fuentes públicas.

3. Algunos niveles educativos están incluidos junto con otros. Véase el código «X» en la Tabla B1.1a para obtener más detalles.

4. Año de referencia 2010 en lugar de 2011.

5. Año de referencia 2012 en lugar de 2011.

Fuentes: OCDE. Arabia Saudí, Argentina, China, Colombia, India, Indonesia, Sudáfrica: Instituto de Estadística de la UNESCO. Letonia: Eurostat. Para ver notas, consulte Anexo 3 (www.oecd.org/edu/eag.htm).

Para obtener más información acerca de los símbolos utilizados en lugar de los datos que faltan, consulte la Guía del lector.

StatLink 게이 http://dx.doi.org/10.1787/888933117440 
Tabla B3.3. Gasto público anual en instituciones educativas por estudiante, por tipo de institución (2011)

En equivalente a dólares estadounidenses convertidos mediante PPA para el PIB, por nivel de educación y tipo de institución

\begin{tabular}{|c|c|c|c|c|c|c|c|c|c|c|c|c|c|}
\hline & \multicolumn{3}{|c|}{ Educación infantil } & \multicolumn{3}{|c|}{$\begin{array}{c}\text { Educación primaria, } \\
\text { secundaria y postsecundaria } \\
\text { no terciaria }\end{array}$} & \multicolumn{4}{|c|}{ Educación terciaria } & \multicolumn{3}{|c|}{$\begin{array}{c}\text { Total para todos los niveles } \\
\text { de educación }\end{array}$} \\
\hline & 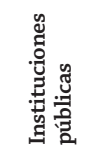 & 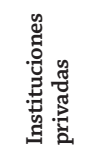 & 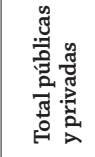 & 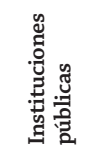 & 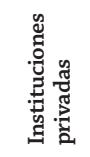 & 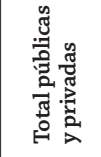 & 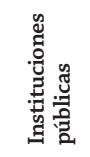 & 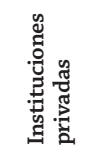 & 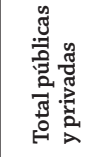 & 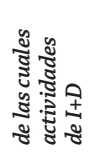 & 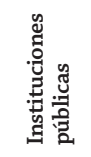 & 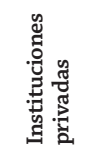 & 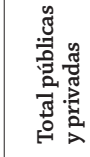 \\
\hline & (1) & (2) & (3) & (4) & (5) & (6) & (7) & (8) & (9) & (10) & (11) & (12) & (13) \\
\hline Australia & $\mathrm{x}(3)$ & $\mathrm{x}(3)$ & 4.880 & 9.188 & 6.817 & 8.387 & 7.912 & 2.575 & 7.475 & 5.718 & $\mathrm{x}(13)$ & $\mathrm{x}(13)$ & 8.122 \\
\hline Austria & $\mathrm{x}(3)$ & $\mathrm{x}(3)$ & 6.406 & $\mathrm{x}(6)$ & $\mathrm{x}(6)$ & 11.999 & $\mathrm{x}(9)$ & $\mathrm{x}(9)$ & 12.942 & 4.408 & $\mathrm{x}(13)$ & $\mathrm{x}(13)$ & 11.395 \\
\hline Bélgica & 6.672 & 5.595 & 6.103 & 11.395 & 9.576 & 10.315 & 14.758 & 12.521 & 13.468 & 4.149 & 11.517 & 9.478 & 10.335 \\
\hline Canadá $^{1}$ & $\mathrm{x}(4)$ & $\mathrm{m}$ & $\mathbf{m}$ & 9.522 & $\mathrm{~m}$ & $\mathbf{m}$ & 14.312 & $\mathrm{~m}$ & $\mathbf{m}$ & $m$ & 10.629 & $\mathrm{~m}$ & $\mathbf{m}$ \\
\hline Chile $^{2}$ & 5.864 & 3.490 & 4.285 & 4.970 & 2.591 & 3.543 & 5.675 & 1.324 & 2.016 & 398 & 5.152 & 2.324 & 3.276 \\
\hline República Checa & 3.984 & 2.550 & 3.957 & 5.710 & 3.714 & 5.572 & 8.747 & 460 & 7.507 & 2.999 & 6.222 & 2.403 & 5.926 \\
\hline Dinamarca & $\mathrm{x}(3)$ & $\mathrm{x}(3)$ & 13.031 & 10.513 & 6.393 & 9.943 & 19.868 & a & 19.509 & $x(9)$ & 12.903 & 5.436 & 12.061 \\
\hline Estonia & 2.587 & 2.131 & 2.573 & 6.033 & 4.533 & 5.974 & 8.314 & 4.801 & 5.405 & 2.358 & 5.442 & 4.711 & 5.281 \\
\hline Finlandia & 5.247 & 3.945 & 5.135 & 9.096 & 9.281 & 9.113 & 20.321 & 9.319 & 17.260 & 5.713 & 10.179 & 8.832 & 10.013 \\
\hline Francia & 6.683 & 2.759 & 6.199 & 9.315 & 5.491 & 8.558 & 14.225 & 3.967 & 12.360 & 4.578 & 9.588 & 4.941 & 8.739 \\
\hline Alemania & $\mathrm{x}(3)$ & $\mathrm{x}(3)$ & 6.717 & $\mathrm{x}(6)$ & $\mathrm{x}(6)$ & 8.371 & $\mathrm{x}(9)$ & $\mathrm{x}(9)$ & 13.927 & $x(9)$ & $\mathrm{x}(13)$ & $\mathrm{x}(13)$ & 9.202 \\
\hline Grecia & $\mathrm{m}$ & $\mathrm{m}$ & $\mathbf{m}$ & $\mathrm{m}$ & $\mathrm{m}$ & $\mathbf{m}$ & $\mathrm{m}$ & $\mathrm{m}$ & $\mathbf{m}$ & m & $\mathrm{m}$ & $\mathrm{m}$ & $\mathbf{m}$ \\
\hline Hungría & $\mathrm{x}(3)$ & $x(3)$ & 4.127 & $\mathrm{x}(6)$ & $\mathrm{x}(6)$ & 4.270 & 6.385 & 8.883 & 6.786 & 1.377 & $\mathrm{x}(13)$ & $\mathrm{x}(13)$ & 4.928 \\
\hline Islandia & 7.285 & 4.426 & 6.947 & 9.207 & 6.204 & 8.980 & 7.873 & 7.491 & 7.802 & $x(9)$ & 9.291 & 6.335 & 8.994 \\
\hline Irlanda & $\mathrm{x}(3)$ & $\mathrm{x}(3)$ & 5.405 & 9.492 & $\mathrm{~m}$ & m & 12.826 & $\mathrm{~m}$ & $\mathbf{m}$ & 4.157 & 10.037 & $\mathrm{~m}$ & m \\
\hline Israel & 3.830 & 1.876 & 3.211 & 5.589 & 6.001 & 5.682 & 25.970 & 5.779 & 5.971 & $m$ & 5.613 & 5.025 & 5.400 \\
\hline Italia $^{3}$ & 7.259 & 444 & 5.216 & 8.192 & 1.423 & 7.682 & 7.314 & 1.876 & 6.795 & 3.226 & 7.926 & 1.098 & 7.158 \\
\hline Japón & $\mathrm{x}(3)$ & $\mathrm{x}(3)$ & 2.849 & $\mathrm{x}(6)$ & $\mathrm{x}(6)$ & 8.579 & $\mathrm{x}(9)$ & $\mathrm{x}(9)$ & 6.384 & $x(9)$ & $\mathrm{x}(13)$ & $\mathrm{x}(13)$ & 8.106 \\
\hline Corea & 8.365 & 2.652 & 3.929 & 7.090 & 5.798 & 6.856 & 9.567 & 1.511 & 3.076 & 1.281 & 8.686 & 2.888 & 6.354 \\
\hline Luxemburgo & 23.958 & 3.757 & 22.144 & 20.606 & 6.722 & 18.598 & $\mathrm{~m}$ & $\mathrm{~m}$ & $\mathbf{m}$ & $m$ & $\mathrm{~m}$ & $\mathrm{~m}$ & m \\
\hline México & 2.509 & 2 & 2.160 & 2.552 & 6 & 2.284 & 7.745 & $a$ & 5.291 & 1.413 & 3.072 & 4 & 2.677 \\
\hline Países Bajos ${ }^{4}$ & 7.321 & 3.095 & 6.983 & 8.950 & $\mathrm{n}$ & 8.753 & 13.850 & $\mathrm{n}$ & 12.590 & 5.355 & 9.612 & 626 & 9.252 \\
\hline Nueva Zelanda & 2.450 & 9.526 & 9.409 & 8.219 & 2.537 & 7.844 & 7.425 & 2.156 & 6.826 & 1.543 & 8.067 & 5.877 & 7.769 \\
\hline Noruega & 7.228 & 5.462 & 6.422 & 13.244 & 13.630 & 13.263 & 20.647 & 5.238 & 18.417 & 7.047 & 14.099 & 10.922 & 13.714 \\
\hline Polonia & $\mathrm{x}(3)$ & $x(3)$ & 4.146 & $\mathrm{x}(6)$ & $\mathrm{x}(6)$ & \begin{tabular}{|l|}
5.308 \\
\end{tabular} & $\mathrm{x}(9)$ & $\mathrm{x}(9)$ & 5.056 & 996 & $\mathrm{x}(13)$ & $\mathrm{x}(13)$ & 5.093 \\
\hline Portugal & 5.674 & $\mathrm{~m}$ & $\mathbf{m}$ & 7.278 & $\mathrm{~m}$ & $\mathbf{m}$ & 7.377 & 1.211 & 6.043 & 3.003 & 7.265 & $\mathrm{~m}$ & m \\
\hline República Eslovaca & 3.941 & 3.011 & 3.906 & 4.536 & 4.356 & 4.520 & 6.170 & $\mathrm{~m}$ & 6.170 & 1.652 & 4.883 & 4.256 & 4.840 \\
\hline Eslovenia & 6.697 & 2.134 & 6.567 & 8.060 & 5.684 & 8.027 & 8.346 & 3.127 & 7.858 & 1.596 & 7.919 & 3.715 & 7.784 \\
\hline España & 6.956 & 2.083 & 5.232 & 9.291 & 3.689 & 7.569 & 11.452 & 1.158 & 9.987 & 2.687 & 9.285 & 3.080 & 7.488 \\
\hline Suecia & 6.992 & 6.528 & 6.915 & 10.634 & 10.028 & 10.548 & 18.638 & 13.920 & 18.163 & 8.359 & 11.219 & 9.668 & 11.000 \\
\hline Suiza & 5.267 & $\mathrm{~m}$ & $\mathbf{m}$ & 12.724 & $\mathrm{~m}$ & $\mathbf{m}$ & 22.882 & $\mathrm{~m}$ & $\mathbf{m}$ & $m$ & 13.799 & $\mathrm{~m}$ & $\mathbf{m}$ \\
\hline Turquía & 2.102 & $\mathrm{n}$ & 1.971 & 2.233 & $\mathrm{a}$ & 2.233 & $\mathrm{~m}$ & $\mathrm{~m}$ & $\mathbf{m}$ & $m$ & $\mathrm{~m}$ & $\mathrm{~m}$ & $\mathbf{m}$ \\
\hline Reino Unido & 6.213 & 12.217 & 7.457 & 9.936 & 2.559 & 8.336 & a & 4.049 & 4.049 & 1.667 & 9.631 & 3.627 & 7.675 \\
\hline Estados Unidos & 10.975 & 1.909 & 7.019 & 11.753 & 1.009 & 10.840 & 12.069 & 2.039 & 9.057 & $x(9)$ & 11.760 & 1.652 & 10.062 \\
\hline Media OCDE & 6.502 & 3.618 & 6.043 & 8.762 & 4.918 & 7.996 & 11.877 & 4.061 & 9.221 & 3.290 & 8.952 & 4.614 & 7.876 \\
\hline Media UE21 & 7.156 & 3.865 & 6.748 & 9.315 & 5.246 & 8.525 & 11.162 & 4.664 & 10.326 & 3.428 & 8.909 & 4.759 & 8.128 \\
\hline Argentina & 1.979 & $\mathrm{~m}$ & $\mathbf{m}$ & 2.578 & $\mathrm{~m}$ & $\mathbf{m}$ & $\mathrm{m}$ & $\mathrm{m}$ & $\mathbf{m}$ & $m$ & $\mathrm{~m}$ & $\mathrm{~m}$ & $\mathbf{m}$ \\
\hline Brasil & 2.349 & $\mathrm{~m}$ & $\mathbf{m}$ & 2.667 & $\mathrm{~m}$ & $\mathbf{m}$ & 10.902 & $\mathrm{~m}$ & $\mathbf{m}$ & 762 & 2.985 & $\mathrm{~m}$ & m \\
\hline China & $\mathrm{m}$ & $\mathrm{m}$ & $\mathbf{m}$ & $\mathrm{m}$ & $\mathrm{m}$ & $\mathbf{m}$ & $\mathrm{m}$ & $\mathrm{m}$ & $\mathbf{m}$ & m & $\mathrm{m}$ & $\mathrm{m}$ & $\mathbf{m}$ \\
\hline Colombia $^{2}$ & 1.857 & 2.111 & 1.871 & 1.608 & 1.818 & 1.619 & 3.027 & $\mathrm{~m}$ & 3.027 & $m$ & 1.063 & 1.838 & 1.084 \\
\hline India & $\mathrm{m}$ & $\mathrm{m}$ & m & $\mathrm{m}$ & $\mathrm{m}$ & $\mathbf{m}$ & $\mathrm{m}$ & $\mathrm{m}$ & $\mathbf{m}$ & m & $\mathrm{m}$ & $\mathrm{m}$ & m \\
\hline Indonesia & $\mathrm{m}$ & $\mathrm{m}$ & $\mathbf{m}$ & $\mathrm{m}$ & $\mathrm{m}$ & $\mathbf{m}$ & $\mathrm{m}$ & $\mathrm{m}$ & $\mathbf{m}$ & m & $\mathrm{m}$ & $\mathrm{m}$ & m \\
\hline Letonia & 4.407 & 1.704 & 4.269 & 4.901 & 1.885 & 4.860 & 2.865 & 4.503 & 4.384 & 1.531 & 4.752 & 4.263 & 4.653 \\
\hline Federación Rusa & $\mathrm{m}$ & $\mathrm{m}$ & $\mathbf{m}$ & 4.322 & $\mathrm{~m}$ & $\mathbf{m}$ & 5.221 & $\mathrm{~m}$ & $\mathbf{m}$ & m & $\mathrm{m}$ & $\mathrm{m}$ & $\mathbf{m}$ \\
\hline Arabia Saudí & $\mathrm{m}$ & $\mathrm{m}$ & $\mathbf{m}$ & $\mathrm{m}$ & $\mathrm{m}$ & $\mathbf{m}$ & $\mathrm{m}$ & $\mathrm{m}$ & $\mathbf{m}$ & $m$ & $\mathrm{~m}$ & $\mathrm{~m}$ & m \\
\hline Sudáfrica & $\mathrm{m}$ & $\mathrm{m}$ & $\mathbf{m}$ & $\mathrm{m}$ & $\mathrm{m}$ & m & $\mathrm{m}$ & $\mathrm{m}$ & $\mathbf{m}$ & $m$ & $\mathrm{~m}$ & $\mathrm{~m}$ & m \\
\hline Media G20 & $\mathrm{m}$ & $\mathrm{m}$ & $\mathbf{m}$ & $\mathrm{m}$ & $\mathrm{m}$ & m & $\mathrm{m}$ & $\mathrm{m}$ & $\mathbf{m}$ & m & $\mathrm{m}$ & $\mathrm{m}$ & m \\
\hline
\end{tabular}

1. Año de referencia 2010.

2. Año de referencia 2012.

3. Excluyendo la educación postsecundaria no terciaria.

4. Las instituciones privadas dependientes del gobierno están incluidas en instituciones públicas.

Fuentes: OCDE. Arabia Saudí, Argentina, China, Colombia, India, Indonesia, Sudáfrica: Instituto de Estadística de la UNESCO. Letonia: Eurostat. Para ver notas, consulte Anexo 3 (www.oecd.org/edu/eag.htm).

Para obtener más información acerca de los símbolos utilizados en lugar de los datos que faltan, consulte la Guía del lector.

StatLink 제인 $\mathrm{http}: / / \mathrm{dx}$.doi.org/10.1787/888933117459 


\section{¿CUÁL ES EL GASTO PÚBLICO TOTAL EN EDUCACIÓN?}

- Por término medio en los países de la OCDE, la educación representa el 12,9 \% del gasto público total, pero los valores de cada uno de los países varían desde menos del $10 \%$ en Hungría, Italia y Japón hasta más del $20 \%$ en Indonesia, México y Nueva Zelanda.

- La proporción de gasto público en educación aumentó entre 1995 y 2005 en la mayoría de los países con datos disponibles para esos dos años. Solo Canadá, Francia, Israel, Japón, Nueva Zelanda y Portugal muestran un patrón diferente.

- Mientras que la proporción de gasto público dedicado a educación disminuyó en dos tercios de los países entre 2005 y 2011, durante el periodo más corto de 2008 a 2011-el de mayor crisis económica-, el gasto público en educación creció en mayor porcentaje (o disminuyó en menor porcentaje) que el gasto público en todos los demás servicios en 16 de 31 países con datos disponibles.

\section{Gráfico B4.1. Gasto público total en educación como porcentaje del gasto público total $(1995,2005,2011)$}

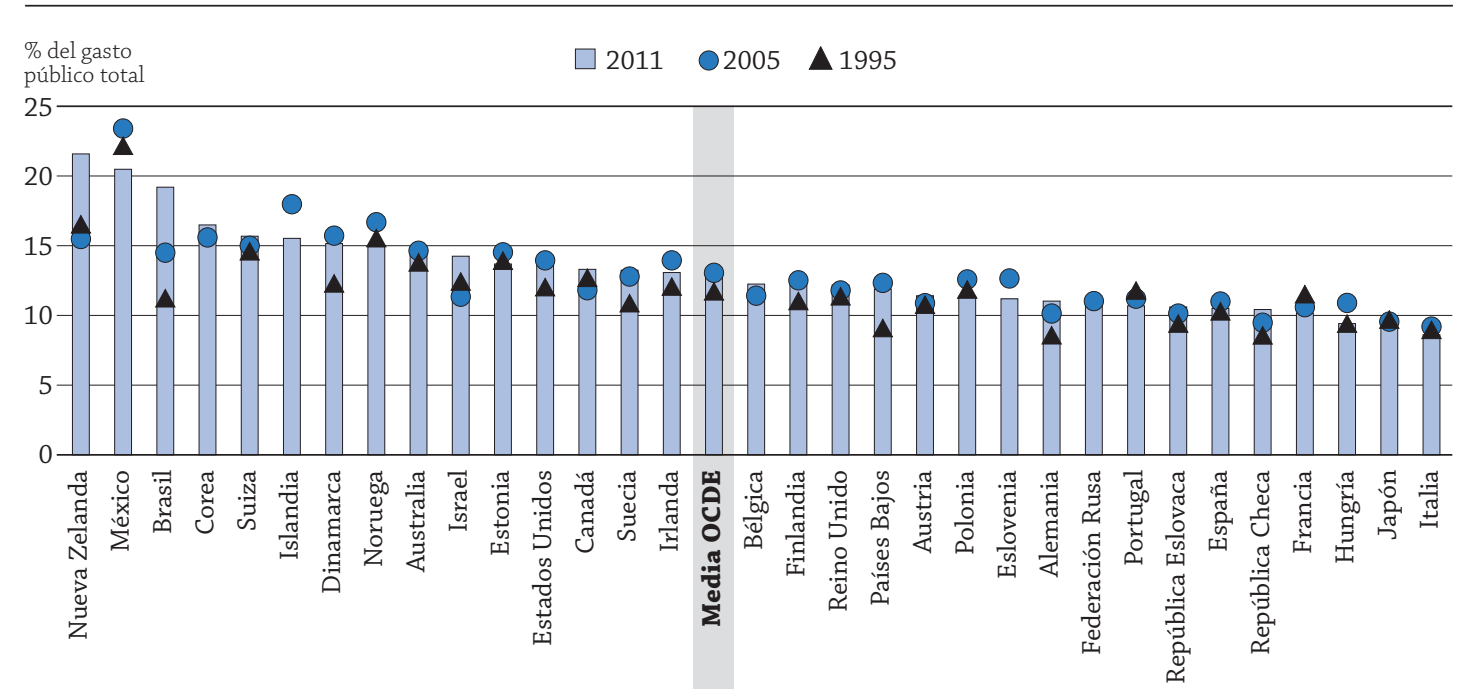

Los países están clasificados en orden descendente del gasto público total en educación en todos los niveles educativos como porcentaje del gasto público total en 2011.

Fuente: OCDE. Tabla B4.2. Para ver notas, consulte Anexo 3 (www.oecd.org/edu/eag.htm).

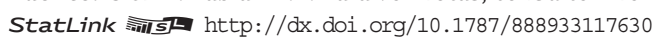

\section{Contexto}

Las decisiones de los países en la asignación del presupuesto a los diversos sectores, incluidas la educación, la sanidad, la seguridad social o la defensa, dependen no solo de sus prioridades, sino también de si los mercados por sí solos pueden ofrecer esos servicios de forma adecuada, especialmente en el nivel de educación terciaria. Si los beneficios públicos de un determinado servicio son mayores que sus beneficios privados, puede que los mercados no logren suministrar ese servicio, así la financiación por parte de los gobiernos puede ayudar a aumentar el acceso a la educación terciaria.

Sin embargo, la crisis económica ha aumentado la presión sobre los presupuestos públicos, limitando los recursos que pueden asignarse a la educación. Esto puede afectar, a su vez, tanto al acceso a la educación como a los resultados y la calidad de la educación. Por otro lado, la demanda de educación y formación por parte de quienes no tienen un empleo puede aumentar, requiriendo a su vez un mayor gasto educativo. No obstante, un mayor gasto educativo no se asocia necesariamente con mejores resultados ni con la calidad de la educación. Además, los niveles de gasto se ven afectados por muchos factores (véase Indicador B7) que han de tenerse en cuenta al comparar los países.

Este indicador presenta el gasto público en educación, tanto como porcentaje del gasto público total de los países, como en relación con su producto interior bruto, para reflejar el volumen relativo de los 
presupuestos públicos. Además, el indicador incluye datos sobre las diferentes fuentes de los fondos públicos invertidos en educación (gobierno central, regional y local) y sobre las transferencias de fondos entre estos niveles de gobierno.

\section{INDICADOR B 4}

\section{Otros resultados}

- En la mayoría de los países de la OCDE y países asociados (32 de los 37 países con datos disponibles), el gasto público en educación primaria, secundaria y postsecundaria no terciaria es más del doble que en educación terciaria.

- El gasto público está más descentralizado en primaria, secundaria y postsecundaria no terciaria que en educación terciaria. Como media en los países de la OCDE, más del $50 \%$ de los fondos públicos iniciales para estos niveles de educación proceden del gobierno central, mientras que más de un $85 \%$ de los fondos públicos iniciales para educación terciaria tienen este origen.

- En educación primaria, secundaria y postsecundaria no terciaria, solo Nueva Zelanda tiene un sistema de financiación pública completamente centralizado, mientras que, para la educación terciaria, nueve países (Chile, Estonia, Islandia, Irlanda Letonia, Noruega, Nueva Zelanda, Países Bajos y República Eslovaca) cuentan con un sistema de financiación completamente centralizado.

\section{Tendencias}

Entre 1995 y 2011, el porcentaje del gasto público total dedicado a educación (considerando todos los niveles de educación en conjunto) se incrementó ligeramente en dos tercios de los países con datos disponibles. Pero este incremento no fue continuo en todo el periodo: entre 2005 y 2011, el gasto público en educación como porcentaje del gasto público total disminuyó en más de la mitad de los países con datos disponibles. Esta disminución fue especialmente importante (1 punto porcentual o más) en Eslovenia, Hungría, Islandia, México, Noruega y Polonia (Tabla B4.2).

Durante el periodo 1995-2011 se produjeron cambios similares del gasto público en educación como porcentaje del PIB. Sin embargo, una vez más, esta evolución fue muy diferente entre 2005 y 2011. Mientras que el porcentaje del gasto público dedicado a educación disminuyó en la mayoría de los países entre 2005 y 2011, el gasto en educación como porcentaje del PIB disminuyó en menos de un tercio de los países durante este periodo. Como media en los países de la OCDE con datos disponibles para ambos años, este porcentaje aumentó ligeramente.

Entre 2008 y 2011, en todos los países excepto en Estados Unidos, Estonia, Hungría, Islandia, Italia y Reino Unido, aumentó tanto el gasto público destinado a educación como el destinado a los demás servicios. Sin embargo, en 13 de 31 países, el gasto público en el conjunto de los servicios aumentó más rápidamente o disminuyó más despacio que el gasto público destinado a educación (Tabla B4.2). 


\section{Análisis}

\section{Nivel general de recursos públicos invertidos en educación}

En 2011, el gasto público total en educación como porcentaje del gasto público total se situó por termino medio en un 12,9\% en los países de la OCDE, oscilando desde menos de un $10 \%$ en Hungría (9,4\%), Italia (8,6\%) y Japón $(9,1 \%)$ hasta un $20 \%$ o más en Indonesia (20,5\%), México (20,5\%) y Nueva Zelanda (21,6\%) (Gráfico B4.1 y Tabla B4.1).

En la mayoría de los países, en torno a dos tercios del gasto público total en educación como porcentaje del gasto público total se dedican a la educación primaria, secundaria y postsecundaria no terciaria. Esto se explica fundamentalmente por las tasas de matriculación casi universales en estos niveles educativos (véase Indicador C1) y la estructura demográfica de la población.

El gasto público dedicado a educación terciaria supone casi la cuarta parte $(24,5 \%)$ del gasto público total en educación, como media en los países de la OCDE. En la OCDE y países asociados, los porcentajes oscilan desde menos del $16 \%$ en Corea (15,6\%) a más del $30 \%$ en Canadá (35,6\%), Finlandia (32,0\%) y Turquía (37,8\%).

Si se examina el gasto público en educación como porcentaje del gasto público total, es necesario tener en cuenta la cuantía relativa de los presupuestos públicos. De hecho, el panorama es diferente cuando se observa el gasto público total en educación como porcentaje del producto interior bruto para todos los niveles de educación en conjunto, en comparación con el panorama descrito anteriormente del gasto público total en educación como porcentaje del gasto público total. Presentan las menores tasas de gasto público en educación en relación con el PIB en 2011 algunos países de la OCDE como Italia (4,3\%), Japón (3,8\%), República Eslovaca (4,1\%) y Turquía (4,1\%), y el país asociado Federación Rusa (3,9\%). En el otro extremo del abanico, solo Dinamarca y Noruega gastan más del $8 \%$ de su PIB en educación (8,7\% ambos), porcentaje muy superior a la media de la OCDE, situada en el 5,6\% (Tabla B4.1).

En contra de lo que podría pensarse, los cinco países con un gasto público total en educación más elevado como porcentaje del gasto público total en 2011-concretamente Brasil, Corea, México, Nueva Zelanda y Suiza (Gráfico B4.1) - se sitúan en los puestos inferiores en términos de gasto público total en todos los servicios como porcentaje del PIB (Gráfico B4.2). Dinamarca y Noruega son la excepción, con porcentajes elevados en ambos conceptos.

Cuando se observa el gasto público total en todos los servicios (incluyendo sanidad, seguridad social y medio ambiente), y no simplemente el gasto público en educación, como proporción del PIB, los porcentajes varían considerablemente entre países. En 2011, casi un tercio de los países con datos disponibles presentaron una proporción del gasto público total en todos los servicios en relación con el PIB por encima del $50 \%$, y en cuatro de ellos el porcentaje superó el 55 \% (57,7\% en Dinamarca, 55,3\% en Finlandia, 55,9\% en Francia y 59,1\% en Noruega). En el extremo opuesto, en Corea y México, el gasto público total en todos los servicios representó el 30,2\% y el 25,5\% del PIB, respectivamente (Gráfico B4.2 y véase Anexo 2).

\section{Gráfico B4.2. Gasto público total en todos los servicios como porcentaje del PIB (2000, 2011)}

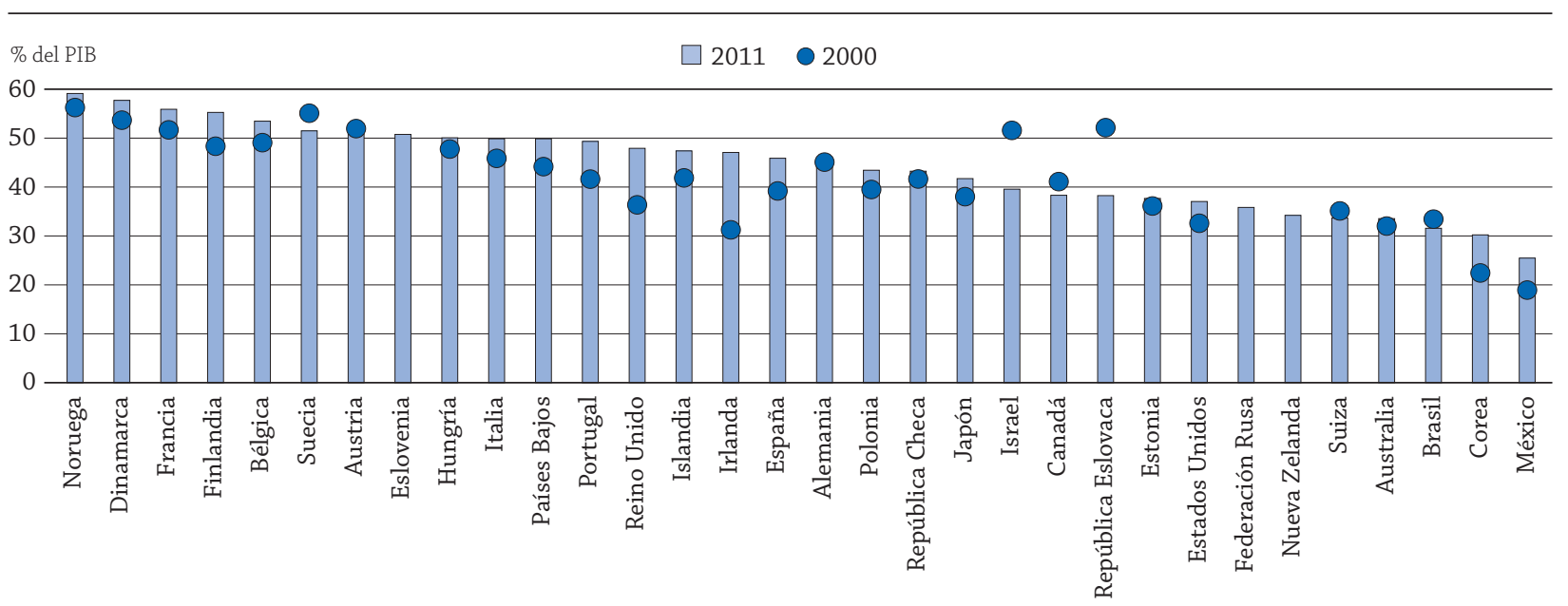

Nota: Este gráfico representa el gasto público en todos los servicios y no solamente el gasto público en educación.

Los países están clasificados en orden descendente del gasto público total como porcentaje del PIB en 2011.

Fuente: OCDE. Anexo 2. Para ver notas, consulte Anexo 3 (www.oecd.org/edu/eag.htm).

StatLink 체으 http://dx.doi.org/10.1787/888933117649 


\section{Cambios del gasto público total en educación como porcentaje del gasto público total entre 1995 y 2011}

Durante el periodo de 1995 a 2005 se observó un aumento significativo...

Durante un periodo de 10 años (1995-2005), el gasto público en educación (en todos los niveles en conjunto) como porcentaje del gasto público total aumentó en 21 de los 27 países de la OCDE con datos disponibles para los años 1995 y 2005 (como media, en 0,9 puntos porcentuales en estos 27 países). Solo Canadá, Francia, Israel, Japón, Nueva Zelanda y Portugal muestran patrones diferentes.

Entre 1995 y 2005, la evolución del gasto público en educación como porcentaje del producto interior bruto aumentó menos que la del gasto público en educación como porcentaje del gasto público total. Por termino medio, el gasto público en educación como porcentaje del producto interior bruto aumentó en 0,1 puntos porcentuales entre 1995 y 2005, mientras que el gasto público en educación como porcentaje del gasto público total aumentó en 1,4 puntos durante el mismo periodo. En relación con el PIB, el gasto público en educación aumentó en un punto porcentual en Dinamarca, mientras que disminuyó en más de un punto porcentual en Canadá (Tabla B4.2).

\section{...pero se observó una disminución a partir de 2005, coincidiendo con la crisis económica de 2008}

Los modelos de gasto cambiaron considerablemente entre 2005 y 2011. Durante este periodo de seis años, el gasto público en educación como porcentaje del gasto público total disminuyó en más de la mitad de los países con datos disponibles (18 de 32 países) en una media de 0,2 puntos porcentuales (de un 13,1\% en 2005 a un 12,9\% en 2011). Las mayores reducciones se observaron en Islandia y México (-2,4 y -2,9 puntos porcentuales, respectivamente) y fueron asimismo importantes en Eslovenia, Hungría, Noruega y Polonia (-1,0 puntos porcentuales o más). En cambio, Canadá, Israel y Nueva Zelanda no siguieron esta tendencia, presentando todos ellos un aumento (entre 1,5 y 6,1 puntos porcentuales) del gasto en educación como porcentaje del gasto público total entre 2005 y 2011 , tras una disminución (entre 0,9 y 1,1 puntos porcentuales) entre 1995 y 2005.

Si se compara 2011 con 2005, los datos muestran una tendencia diferente, dado que el PIB se vio afectado también por la crisis económica. Como consecuencia de ello, el gasto público en educación como porcentaje del PIB aumentó o se mantuvo estable en la mayoría de los países excepto en Hungría, Islandia, Noruega, Polonia y Suiza, donde disminuyó en 0,2 puntos porcentuales o más entre esos dos años. Como media en los países de la OCDE con datos disponibles para todos los años, el aumento se situó en 0,3 puntos porcentuales. (Tabla B4.2 y véase Cuadro B2.1 en Indicador B2).

\section{Gráfico B4.3. Índice de cambio entre 2008 y 2011 del gasto público total en educación como porcentaje del gasto público total para todos los servicios}

(2008=100, 2011 precios constantes)

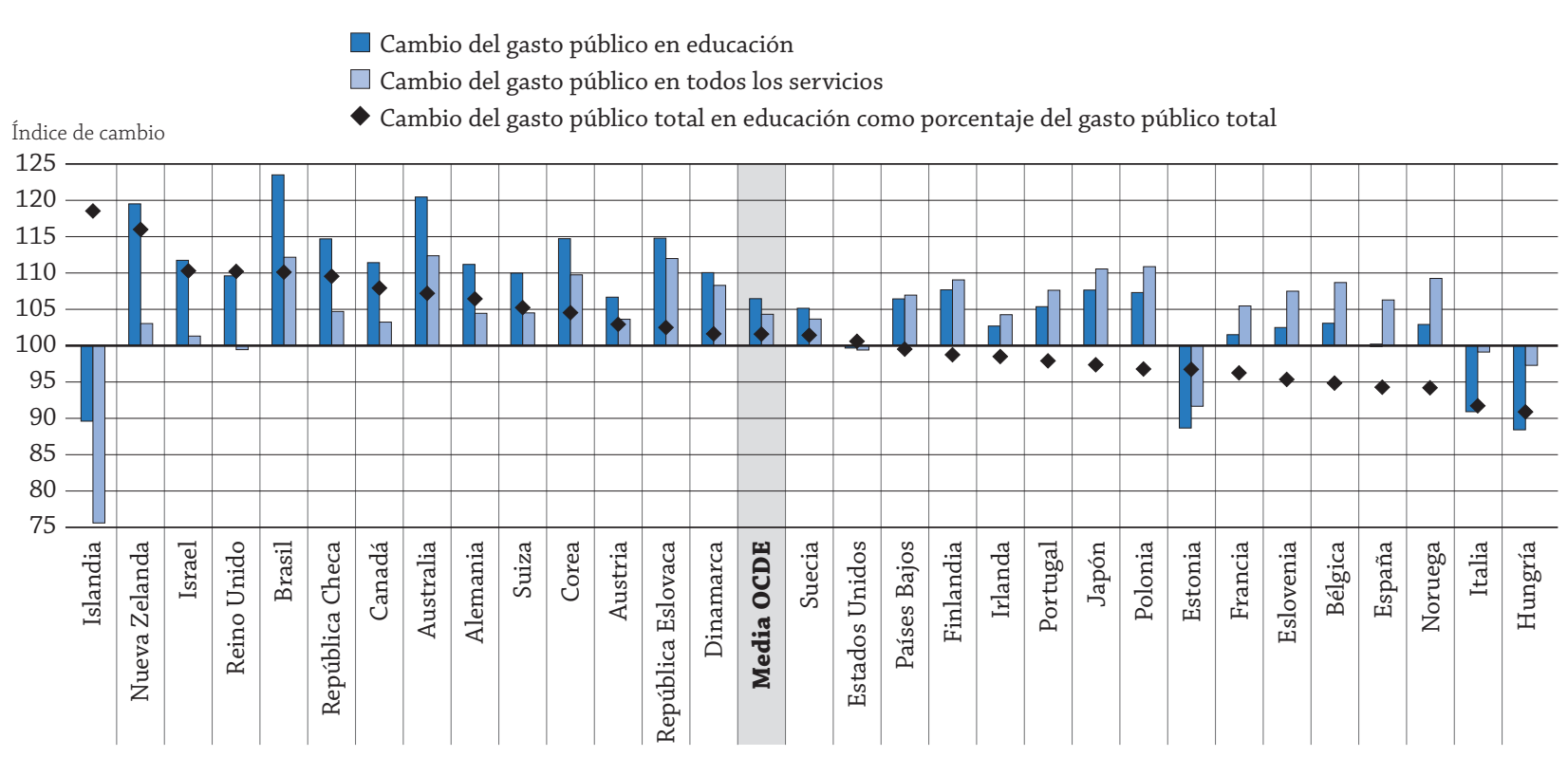

Los países están clasificados en orden descendente del cambio del gasto público total en educación como porcentaje del gasto público total.

Fuente: OCDE. Tabla B4.2. Para ver notas, consulte Anexo 3 (www.oecd.org/edu/eag.htm).

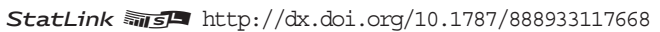




\section{Primer efecto de la crisis económica: el gasto público en educación varió en menor proporción que el gasto público en todos los servicios en la mitad de los países}

Las variaciones observadas entre 2008 y 2011 están vinculadas probablemente a los primeros efectos de la crisis económica global, que comenzó en 2008. La crisis añadió mayor presión a los presupuestos públicos generales, obligando a los gobiernos a priorizar asignaciones dentro de la educación y de otros sectores públicos clave, como la sanidad y la seguridad social (Tabla B4.2 y Gráfico B4.3)

Entre 2008 y 2011, no existe una tendencia global clara en lo que se refiere a la evolución del gasto público en educación como porcentaje del gasto público total, como ocurrió durante el periodo 1995-2005. No obstante, en 25 de 31 países, tanto el gasto público en educación como el gasto público total en todos los servicios aumentó entre 2008 y 2011. En 12 de estos 25 países, el gasto público en todos los servicios creció más rápidamente que el gasto público en educación (Tabla B4.2 y Gráfico B4.3). Las diferencias más notables se observan en Bélgica, Eslovenia y Noruega. En los otros 13 países, el gasto público en educación creció más rápidamente que el gasto público en todos los servicios. El aumento del gasto público en todos los servicios osciló entre el $1 \%$ de Israel y el $12 \%$ de Australia, Brasil y República Eslovaca.

En los restantes seis países, Estados Unidos, Estonia, Hungría, Islandia, Italia y Reino Unido, el gasto público en todos los servicios disminuyó entre 2008 y 2011. En Islandia, donde el gasto público en todos los servicios se redujo en nada menos que un $24 \%$, el gasto público en educación también disminuyó, pero no de una forma tan brusca. En Estados Unidos y Reino Unido, el gasto público en todos los servicios disminuyó solo ligeramente, mientras que el gasto público en educación aumentó (Reino Unido) o se mantuvo estable (Estados Unidos). En Estonia, Hungría e Italia, el gasto público en educación se redujo de forma más brusca que el gasto público en todos los servicios (Tabla B4.2 y Gráfico B4.3).

\section{Fuentes de los fondos públicos invertidos en educación}

Todas las fuentes públicas, aparte de las internacionales, del gasto en educación se clasifican en tres niveles diferentes de gobierno: central, regional y local. En algunos países, la financiación de la educación está centralizada, mientras que en otros la financiación puede estar descentralizada después de transferencias entre los diferentes niveles de gobierno.

En los últimos años, muchos centros escolares se han vuelto más autónomos y descentralizados, aumentando su obligación de rendir cuentas ante los estudiantes, padres y público en general por sus resultados. Los resultados del informe PISA de la OCDE sugieren que, cuando se combinan de forma inteligente la autonomía y la obligación de rendir cuentas, suelen obtenerse mejores rendimientos educativos.

La financiación pública está más centralizada en educación terciaria que en los niveles educativos inferiores. En 2011, el 50,3 \% de los fondos públicos para educación primaria, secundaria y postsecundaria no terciaria en su conjunto antes de transferencias procedían del gobierno central, como media en los países de la OCDE, en comparación con el 85,1\% para educación terciaria (Tabla B4.3 y Tabla B4.4, disponible en Internet).

En educación primaria, secundaria y postsecundaria no terciaria en su conjunto, la proporción de fondos públicos iniciales desde el gobierno central difiere en gran medida de unos países a otros. Tres países informaron de una proporción inferior al $10 \%$, a saber Canadá (3,2\%), Polonia (3,4\%) y Suiza (3,3\%). En Canadá, la financiación de la educación primaria y secundaria se verifica a nivel provincial o territorial con la excepción de una pequeña cantidad de financiación federal para algunas escuelas de Primeras Naciones o Aborígenes. En el otro extremo, los fondos públicos provienen casi exclusivamente del gobierno central en Irlanda, Nueva Zelanda y Turquía, y más del $90 \%$ de los fondos públicos iniciales provinieron del gobierno central en Chile (95,1\%), Eslovenia (90,4\%), Israel (90,8\%) y Países Bajos (90,4\%).

No obstante, este cuadro cambia cuando se tienen en cuenta las transferencias entre distintos niveles de gobierno. Después de estas transferencias, menos del $5 \%$ de los fondos públicos provinieron de fuentes del gobierno central en Argentina (3,7\%), Australia (4,5\%), Canadá (2,7\%), Corea (0,8\%), Estados Unidos (0,5\%), Japón (1,8\%), Polonia $(2,4 \%)$ y Suiza $(0,2 \%)$. Solo Nueva Zelanda tenía un sistema de financiación enteramente centralizado aun después de tener en cuenta las transferencias (Gráfico B4.4 y Tabla B4.3).

Las transferencias de fondos desde el gobierno central a los niveles regionales y locales en educación primaria, secundaria y postsecundaria no terciaria en su conjunto son mayores que en educación terciaria, como media en los países de la OCDE, ampliando el alcance de la descentralización en esos niveles educativos. Como media en los países de la OCDE, el $43,4 \%$ de los fondos públicos para educación primaria, secundaria y postsecundaria no terciaria en 


\section{Gráfico B4.4. Distribución de fuentes iniciales de fondos educativos públicos por nivel de gobierno, en educación primaria, secundaria y postsecundaria no terciaria (2011)} En porcentaje

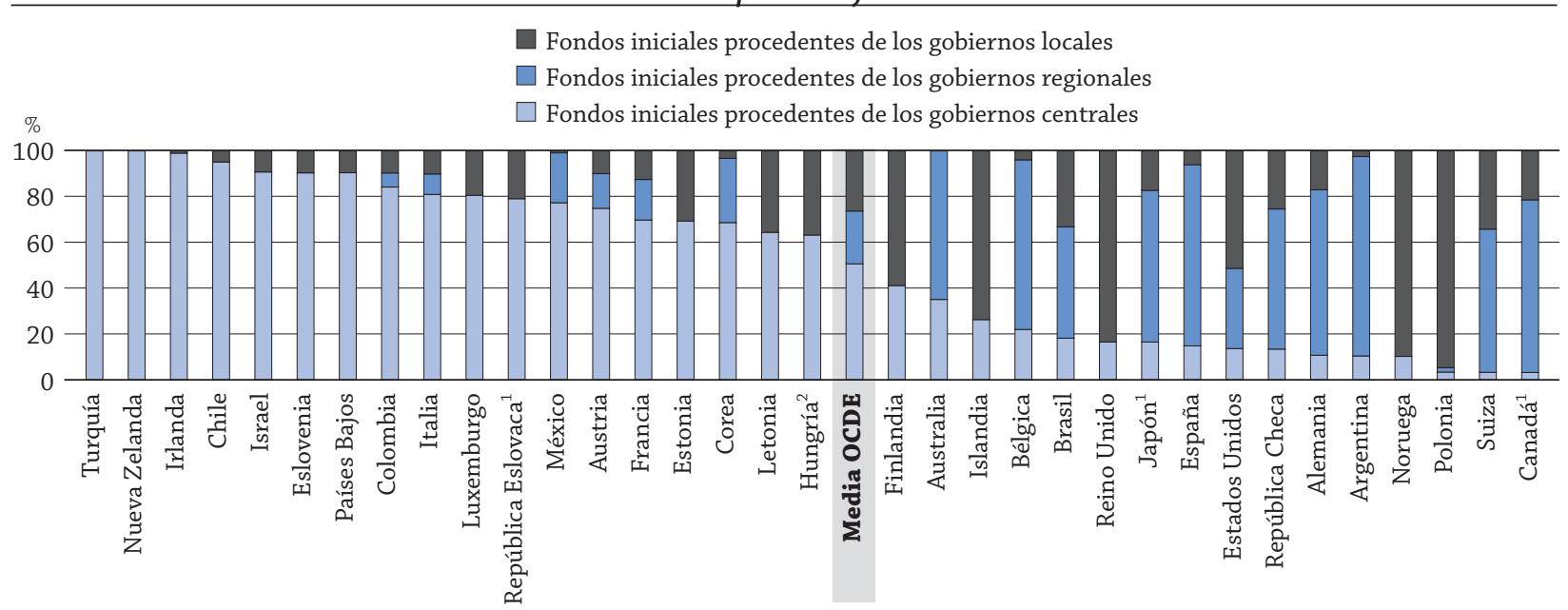

Variación de la proporción de fondos para educación recibidos de los diferentes niveles de gobierno entre compradores iniciales y finales de recursos educativos, en primaria, secundaria y postsecundaria no terciaria (2011) En puntos porcentuales

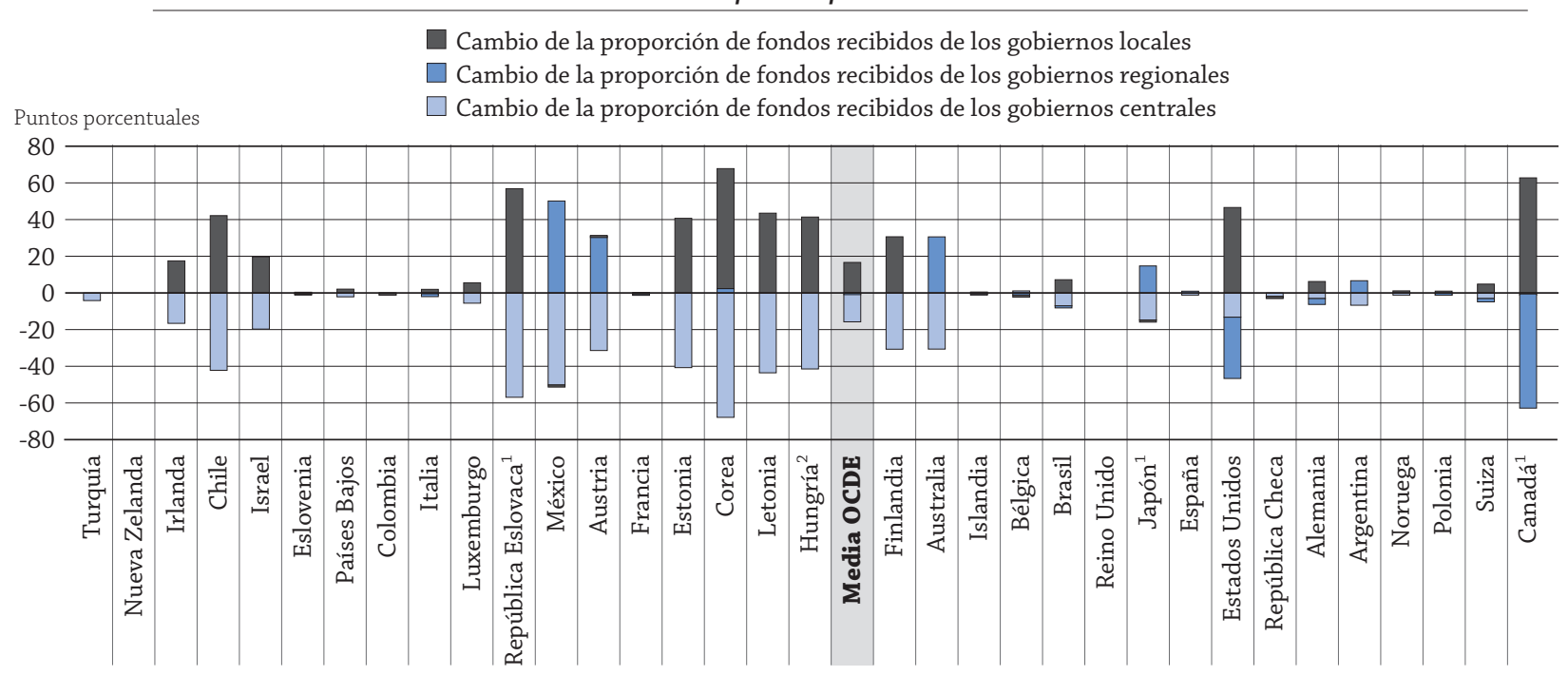

1. Algunos niveles educativos están incluidos junto con otros. Véase el código «X» en la Tabla B1.1a para obtener más detalles.

2. Los fondos de nivel local incluyen los fondos de nivel regional.

Los países están clasificados en orden descendente de la proporción de fuentes iniciales de fondos procedentes del gobierno central.

Fuente: OCDE. Tabla B4.3. Para ver notas, consulte Anexo 3 (www.oecd.org/edu/eag.htm).

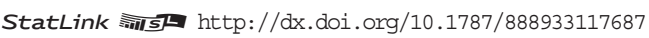

su conjunto provinieron de fuentes locales después de transferencias, en comparación con el 27,0\% antes de transferencias. En educación terciaria, los fondos públicos de fuentes locales representaron menos del $3 \%$ de los fondos antes y después de transferencias, como media en los países de la OCDE (Tabla B4.3 y Tabla B4.4, disponible en Internet).

En educación primaria, secundaria y postsecundaria no terciaria en su conjunto, el grado de las transferencias de fondos públicos desde el gobierno central a niveles inferiores de gobierno varía considerablemente entre países. La diferencia después de las transferencias desde el gobierno central a niveles inferiores supone más de 40 puntos porcentuales en Chile, Corea, Estonia, Hungría, Letonia, México y República Eslovaca. En Canadá y Estados Unidos, la diferencia después de las transferencias de fondos públicos regionales a fuentes locales supera los 30 puntos porcentuales (Gráfico B4.4). 
En educación terciaria, los porcentajes de fondos públicos procedentes del gobierno central son relativamente elevados, tanto antes como después de transferencias entre niveles de gobierno. Los porcentajes más bajos de fondos públicos del gobierno central se registran en Alemania (26,8\% y 20,4\%, antes y después de transferencias, respectivamente), Bélgica (27,9\% y 26,6 \%) y España (17,8 \% y 17,6 \%). En el extremo opuesto, en 11 países (Chile, Estonia, Hungría, Islandia, Letonia, Noruega, Nueva Zelanda, Países Bajos, Portugal, Reino Unido y República Eslovaca) estos porcentajes alcanzan casi el $100 \%$ tanto antes como después de transferencias (Tabla B4.4, disponible en Internet).

\section{Definiciones}

El gasto público en educación incluye el gasto público directo en instituciones educativas y las ayudas para gastos de alojamiento y manutención de los estudiantes y para otros gastos privados fuera de las instituciones. Incluye los gastos realizados por todas las entidades públicas, incluidos ministerios distintos del de educación, y gobiernos locales y regionales, así como otros organismos públicos. Los países de la OCDE difieren en la forma de utilizar el dinero público en educación. Los fondos públicos pueden entregarse directamente a las instituciones o pueden canalizarse hasta las instituciones a través de programas estatales o a través de las familias, y pueden limitarse a la adquisición de servicios educativos o utilizarse además para cubrir los gastos de alojamiento y manutención de los estudiantes.

Todas las fuentes gubernamentales, aparte de las internacionales, para el gasto en educación pueden clasificarse en tres niveles: gobierno central (nacional), gobierno regional (provincia, estado, territorio, etc.) y gobierno local (municipio, distrito, ayuntamiento, etc.). Los términos «regional» $\mathrm{y}$ «local» se aplican a gobiernos cuya responsabilidad se limita a una determinada subdivisión geográfica de un país. No son válidos para instituciones gubernamentales cuyas funciones no estén limitadas geográficamente, sino en términos de responsabilidad de un servicio, función o categoría de estudiantes concreta.

El gasto público total se refiere al gasto corriente y de capital no reembolsable de todos los niveles de gobierno: central, regional y local. Incluye el gasto público directo en instituciones educativas, así como las ayudas públicas a las familias (por ejemplo, becas y préstamos a estudiantes para gastos de matrícula y gastos de alojamiento y manutención) y a otras entidades privadas para gastos educativos (por ejemplo, ayudas a empresas u organizaciones sindicales que imparten programas para aprendices).

\section{Metodología}

Los datos se refieren al año financiero y proceden de la recopilación UOE de datos estadísticos sobre educación, gestionada por la OCDE en 2013 (para más detalles, véase Anexo 3 en www.oecd.org/edu/eag.htm).

Las cifras de gasto público total se han tomado de la Base de Datos de Cuentas Nacionales de la OCDE (OECD National Accounts Database) (véase Anexo 2) y utilizan el Sistema Nacional de Cuentas 1993.

El gasto en educación se expresa como porcentaje del gasto total del sector público y como porcentaje del PIB de cada país.

Aunque los gastos de servicio de la deuda (como los pagos de intereses) se incluyen en el gasto público total, se han excluido del gasto público en educación. La razón es que algunos países no pueden separar los pagos de intereses relacionados con la educación de los de otros servicios. Esto supone que el gasto público en educación como porcentaje del gasto público total puede subestimarse en aquellos países en que los pagos de intereses constituyen un porcentaje elevado del gasto público total en todos los servicios.

Nota sobre los datos de Israel

Los datos estadísticos para Israel fueron proporcionados por las autoridades israelíes competentes bajo su responsabilidad. El uso de estos datos por parte de la OCDE se hace sin prejuzgar la situación de los Altos del Golán, Jerusalén Este y los asentamientos israelíes en Cisjordania de acuerdo con los términos del derecho internacional.

\section{Referencia}

OECD (2013), PISA 2012 Results: What Makes Schools Successful? (Volume IV): Resources, Policies and Practices, PISA, OECD Publishing. París, http: //dx.doi.org/10.1787/9789264201156-en. 
Tablas of Indicador B4

StatLink त्नाजा http://dx.doi.org/10.1787/888933117554

Tabla B4.1 Gasto público total en educación (2011)

Tabla B4.2 Tendencias del gasto público total en educación (1995, 2000, 2005, 2008, 2009, 2010 y 2011)

Tabla B4.3 Fuentes de fondos públicos para educación primaria, secundaria y postsecundaria no terciaria (2011)

WEB Tabla B4.4 Fuentes de fondos públicos para educación terciaria, antes y después de transferencias, por nivel de gobierno (2011)

WEB Tabla B4.5 Distribución del gasto público total en educación (2011)

WEB Tabla B4.6 Gasto público en educación, por nivel educativo (2011) 
Tabla B4.1. Gasto público total en educación (2011)

Gasto público directo en instituciones educativas más ayudas públicas a las familias ${ }^{1}$ y otras entidades privadas, como porcentaje del PIB y del gasto público total, por nivel de educación

\begin{tabular}{|c|c|c|c|c|c|c|c|c|}
\hline & \multicolumn{4}{|c|}{$\begin{array}{l}\text { Gasto público }{ }^{1} \text { en educación } \\
\text { como porcentaje del gasto público total }\end{array}$} & \multicolumn{4}{|c|}{$\begin{array}{l}\text { Gasto público }{ }^{1} \text { en educación } \\
\text { como porcentaje del PIB }\end{array}$} \\
\hline & $\begin{array}{l}\text { Educación } \\
\text { infantil }\end{array}$ & $\begin{array}{c}\text { Educación } \\
\text { primaria, } \\
\text { secundaria y } \\
\text { postsecundaria } \\
\text { no terciaria }\end{array}$ & $\begin{array}{l}\text { Educación } \\
\text { terciaria }\end{array}$ & $\begin{array}{c}\text { Todos } \\
\text { los niveles } \\
\text { de educación } \\
\text { en conjunto }\end{array}$ & $\begin{array}{c}\text { Educación } \\
\text { infantil }\end{array}$ & $\begin{array}{c}\text { Educación } \\
\text { primaria, } \\
\text { secundaria y } \\
\text { postsecundaria } \\
\text { no terciaria }\end{array}$ & $\begin{array}{l}\text { Educación } \\
\text { terciaria }\end{array}$ & $\begin{array}{c}\text { Todos } \\
\text { los niveles } \\
\text { de educación } \\
\text { en conjunto }\end{array}$ \\
\hline & (1) & (2) & (3) & (4) & (5) & (6) & (7) & (8) \\
\hline Alemania & 1,0 & 6,7 & 3,1 & 11,0 & 0,5 & 3,0 & 1,4 & 5,0 \\
\hline Australia & 0,3 & 10,8 & 3,3 & 14,4 & 0,1 & 3,6 & 1,1 & 4,8 \\
\hline Austria & 1,2 & 7,2 & 3,1 & 11,4 & 0,6 & 3,6 & 1,6 & 5,8 \\
\hline Bélgica & 1,2 & 8,1 & 2,7 & 12,2 & 0,6 & 4,3 & 1,4 & 6,5 \\
\hline Canadá $^{2,3}$ & $x(2)$ & 8,6 & 4,7 & 13,3 & $\mathrm{x}(6)$ & 3,6 & 2,0 & 5,6 \\
\hline Chile $^{4}$ & $\mathrm{~m}$ & $\mathrm{~m}$ & $\mathrm{~m}$ & $\mathbf{m}$ & 0,6 & 2,9 & 1,0 & 4,5 \\
\hline Corea & 0,5 & 11,2 & 2,6 & 16,5 & 0,2 & 3,4 & 0,8 & 5,0 \\
\hline Dinamarca $^{3}$ & 2,4 & 8,1 & 4,2 & 15,2 & 1,4 & 4,7 & 2,4 & 8,7 \\
\hline Eslovenia & 1,3 & 7,2 & 2,7 & 11,2 & 0,6 & 3,7 & 1,4 & 5,7 \\
\hline España & 1,5 & 6,6 & 2,5 & 10,5 & 0,7 & 3,0 & 1,1 & 4,8 \\
\hline Estados Unidos & 0,9 & 9,2 & 3,5 & 13,6 & 0,3 & 3,4 & 1,3 & 5,1 \\
\hline Estonia & 1,1 & 9,1 & 3,4 & 13,7 & 0,4 & 3,4 & 1,3 & 5,2 \\
\hline Finlandia & 0,7 & 7,6 & 3,9 & 12,2 & 0,4 & 4,2 & 2,2 & 6,8 \\
\hline Francia & 1,2 & 6,6 & 2,3 & 10,2 & 0,7 & 3,7 & 1,3 & 5,7 \\
\hline Grecia & $\mathrm{m}$ & $\mathrm{m}$ & $\mathrm{m}$ & $\mathbf{m}$ & $\mathrm{m}$ & $\mathrm{m}$ & $\mathrm{m}$ & $\mathbf{m}$ \\
\hline Hungría & 1,3 & 5,4 & 2,2 & 9,4 & 0,6 & 2,7 & 1,1 & 4,7 \\
\hline Irlanda & 0,2 & 10,0 & 2,8 & 13,1 & 0,1 & 4,7 & 1,3 & 6,2 \\
\hline Islandia & 1,5 & 10,2 & 3,0 & 15,5 & 0,7 & 4,8 & 1,4 & 7,4 \\
\hline Israel & 1,5 & 9,7 & 2,3 & 14,2 & 0,6 & 3,8 & 0,9 & 5,6 \\
\hline Italia & 0,9 & 6,1 & 1,7 & 8,6 & 0,4 & 3,0 & 0,8 & 4,3 \\
\hline Japón $^{3}$ & 0,2 & 6,5 & 1,8 & 9,1 & 0,1 & 2,7 & 0,8 & 3,8 \\
\hline Luxemburgo & 1,8 & 7,6 & $\mathrm{~m}$ & $\mathbf{m}$ & 0,8 & 3,2 & $\mathrm{~m}$ & $\mathbf{m}$ \\
\hline México & 2,1 & 13,6 & 3,7 & 20,5 & 0,5 & 3,5 & 0,9 & 5,2 \\
\hline Noruega & 0,8 & 9,1 & 4,5 & 14,9 & 0,5 & 5,3 & 2,6 & 8,7 \\
\hline Nueva Zelanda & 1,5 & 14,6 & 5,5 & 21,6 & 0,5 & 5,0 & 1,9 & 7,4 \\
\hline Países Bajos & 0,8 & 7,6 & 3,5 & 11,9 & 0,4 & 3,8 & 1,7 & 5,9 \\
\hline Polonia & 1,2 & 7,5 & 2,6 & 11,4 & 0,5 & 3,3 & 1,1 & 4,9 \\
\hline Portugal & 0,8 & 7,6 & 2,1 & 10,7 & 0,4 & 3,8 & 1,0 & 5,3 \\
\hline Reino Unido & 0,7 & 8,8 & 2,7 & 12,2 & 0,3 & 4,4 & 1,3 & 6,0 \\
\hline República Checa & 1,1 & 6,2 & 2,7 & 10,4 & 0,5 & 2,7 & 1,2 & 4,5 \\
\hline República Eslovaca $^{3}$ & 1,1 & 6,8 & 2,5 & 10,6 & 0,4 & 2,6 & 0,9 & 4,1 \\
\hline Suecia & 1,4 & 8,0 & 3,9 & 13,2 & 0,7 & 4,1 & 2,0 & 6,8 \\
\hline Suiza & 0,6 & 10,8 & 4,1 & 15,7 & 0,2 & 3,6 & 1,4 & 5,3 \\
\hline Turquía & 0,4 & 6,3 & 4,1 & 10,9 & 0,2 & 2,4 & 1,5 & 4,1 \\
\hline Media OCDE & 1,1 & 8,4 & 3,2 & 12,9 & 0,6 & 3,6 & 1,4 & 5,6 \\
\hline Media UE21 & 1,1 & 7,4 & 2,9 & 11,5 & 0,6 & 3,6 & 1,4 & 5,6 \\
\hline
\end{tabular}

\begin{tabular}{|c|c|c|c|c|c|c|c|c|}
\hline $\begin{array}{l}\text { Arabia Saudí } \\
\text { đorgentina }\end{array}$ & $\begin{array}{l}\mathrm{m} \\
\mathrm{m}\end{array}$ & $\begin{array}{l}\mathrm{m} \\
\mathrm{m}\end{array}$ & $\begin{array}{l}\mathrm{m} \\
\mathrm{m}\end{array}$ & $\begin{array}{l}\mathbf{m} \\
\mathbf{m}\end{array}$ & $\begin{array}{r}\mathrm{m} \\
0,5\end{array}$ & $\begin{array}{r}\mathrm{m} \\
4,5\end{array}$ & $\begin{array}{r}\mathrm{m} \\
1,2\end{array}$ & $\begin{array}{r}\mathrm{m} \\
6,3\end{array}$ \\
\hline Brasil & 1,7 & 14,3 & 3,2 & 19,2 & 0,5 & 4,5 & 1,0 & 6,1 \\
\hline China & $\mathrm{m}$ & $\mathrm{m}$ & $\mathrm{m}$ & $\mathbf{m}$ & $\mathrm{m}$ & $\mathrm{m}$ & $\mathrm{m}$ & $\mathbf{m}$ \\
\hline Colombia $^{4}$ & $\mathrm{~m}$ & $\mathrm{~m}$ & $\mathrm{~m}$ & $\mathbf{m}$ & 0,3 & 3,3 & 1,0 & 4,5 \\
\hline Federación Rusa & 2,0 & 5,5 & 2,4 & 10,9 & 0,7 & 2,0 & 0,9 & 3,9 \\
\hline India & $\mathrm{m}$ & $\mathrm{m}$ & $\mathrm{m}$ & $\mathbf{m}$ & $\mathrm{m}$ & $\mathrm{m}$ & $\mathrm{m}$ & $\mathbf{m}$ \\
\hline Indonesia $^{4}$ & $\mathrm{x}(4)$ & $\mathrm{x}(4)$ & $\mathrm{x}(4)$ & 20,5 & $\mathrm{~m}$ & $\mathrm{~m}$ & $\mathrm{~m}$ & $\mathbf{m}$ \\
\hline Letonia & $\mathrm{m}$ & $\mathrm{m}$ & $\mathrm{m}$ & $\mathbf{m}$ & 0,8 & 3,1 & 1,0 & 4,9 \\
\hline Sudáfrica & $\mathrm{m}$ & $\mathrm{m}$ & $\mathrm{m}$ & $\mathbf{m}$ & $\mathrm{n}$ & $\mathrm{m}$ & $\mathrm{m}$ & $\mathbf{m}$ \\
\hline Media G20 & $\mathrm{m}$ & $\mathrm{m}$ & $\mathrm{m}$ & $\mathbf{m}$ & $\mathrm{m}$ & $\mathrm{m}$ & $\mathrm{m}$ & m \\
\hline
\end{tabular}

1. El gasto público presentado en esta tabla incluye las ayudas públicas a las familias para gastos de subsistencia (becas y otras ayudas a estudiantes y familias, y préstamos a estudiantes), que no se gastan en instituciones educativas. Por tanto, las cifras que se muestran aquí son superiores a las del gasto público en instituciones que aparecen en la Tabla B2.4.

2. Año de referencia 2010 en lugar de 2011.

3. Algunos niveles educativos están incluidos junto con otros. Véase el código «X» en la Tabla B1.1a para obtener más detalles.

4. Año de referencia 2012 en lugar de 2011.

Fuentes: OCDE. Arabia Saudí, Argentina, China, Colombia, India, Indonesia, Sudáfrica: Instituto de Estadística de la UNESCO. Letonia: Eurostat. Para ver notas, consulte Anexo 3 (www.oecd.org/edu/eag.htm).

Para obtener más información acerca de los símbolos utilizados en lugar de los datos que faltan, consulte la Guía del lector.

StatLink 需宁L http://dx.doi.org/10.1787/888933117573 
Tabla B4.2. Tendencias del gasto público total en educación $(1995,2000,2005,2008,2009,2010$ y 2011)

Gasto público directo en instituciones educativas más ayudas públicas a las familias ${ }^{1}$ y otras entidades privadas, como porcentaje del PIB y del gasto público total, para todos los niveles de educación combinados por año

\begin{tabular}{|c|c|c|c|c|c|c|c|c|c|c|c|c|c|}
\hline & \multirow{2}{*}{\multicolumn{5}{|c|}{$\begin{array}{l}\text { Gasto público }{ }^{1} \text { en educación como } \\
\text { porcentaje del gasto público total }\end{array}$}} & \multirow{2}{*}{\multicolumn{5}{|c|}{$\begin{array}{l}\text { Gasto público }{ }^{1} \text { en educación como } \\
\text { porcentaje del PIB }\end{array}$}} & \multicolumn{3}{|c|}{$\begin{array}{l}\text { Índice de cambio entre } 2008 \text { y } 2011 \\
(2008=100,2011 \text { precios constantes })\end{array}$} \\
\hline & & & & & & & & & & & \multirow{2}{*}{$\begin{array}{l}\text { Gasto } \\
\text { público en } \\
\text { educación }\end{array}$} & \multirow{2}{*}{$\begin{array}{l}\text { Gasto } \\
\text { público en } \\
\text { todos los } \\
\text { servicios }\end{array}$} & \multirow{2}{*}{$\begin{array}{c}\text { Gasto público total } \\
\text { en educación como } \\
\text { porcentaje del gasto } \\
\text { público total }\end{array}$} \\
\hline & 2000 & 2005 & 2008 & 2010 & 2011 & 2000 & 2005 & 2008 & 2010 & 2011 & & & \\
\hline & (2) & (3) & (4) & (6) & (7) & (9) & (10) & (11) & (13) & (14) & (15) & (16) & (17) \\
\hline Alemania & 10,2 & 10,1 & 10,4 & 10,6 & 11,0 & 4,6 & 4,8 & 4,6 & 5,1 & 5,0 & 111 & 104 & 106 \\
\hline Australia & 14,3 & 14,6 & 13,5 & 15,2 & 14,4 & 4,6 & 4,5 & 4,3 & 5,1 & 4,8 & 120 & 112 & 107 \\
\hline Austria & 10,7 & 10,9 & 11,1 & 11,2 & 11,4 & 5,6 & 5,4 & 5,5 & 5,9 & 5,8 & 107 & 104 & 103 \\
\hline Bélgica & 12,0 & 11,4 & 12,9 & 12,5 & 12,2 & 5,9 & 5,9 & 6,4 & 6,6 & 6,5 & 103 & 109 & 95 \\
\hline Canadá ${ }^{2,3}$ & 12,4 & 11,8 & 12,3 & 13,2 & 13,3 & 5,1 & 4,6 & 4,7 & 5,2 & 5,1 & 111 & 103 & 108 \\
\hline Chile $^{4}$ & 15,0 & 16,2 & 17,2 & 17,7 & $\mathrm{~m}$ & 3,8 & 3,0 & 4,2 & 4,1 & 4,5 & 126 & $\mathrm{~m}$ & $\mathrm{~m}$ \\
\hline Corea & 16,6 & 15,6 & 15,8 & 16,2 & 16,5 & 3,7 & 4,1 & 4,8 & 4,9 & 5,0 & 115 & 110 & 105 \\
\hline Dinamarca $^{3}$ & 15,4 & 15,7 & 14,9 & 15,3 & 15,2 & 8,3 & 8,3 & 7,7 & 8,8 & 8,7 & 110 & 108 & 102 \\
\hline Eslovenia & $\mathrm{m}$ & 12,7 & 11,7 & 11,3 & 11,2 & $\mathrm{~m}$ & 5,7 & 5,2 & 5,7 & 5,7 & 102 & 107 & 95 \\
\hline España & 10,9 & 11,0 & 11,1 & 10,7 & 10,5 & 4,3 & 4,2 & 4,6 & 5,0 & 4,8 & 100 & 106 & $\mathrm{~m}$ \\
\hline Estados Unidos & 13,8 & 13,9 & 13,5 & 12,7 & 13,6 & 4,5 & 4,9 & 5,1 & 5,2 & 5,0 & 100 & 99 & 101 \\
\hline Estonia & 14,9 & 14,5 & 14,2 & 14,0 & 13,7 & 5,4 & 4,9 & 5,6 & 5,7 & 5,2 & 89 & 92 & 97 \\
\hline Finlandia & 12,5 & 12,5 & 12,4 & 12,3 & 12,2 & 6,0 & 6,3 & 6,1 & 6,8 & 6,8 & 108 & 109 & 99 \\
\hline Francia & 11,6 & 10,6 & 10,5 & 10,4 & 10,2 & 6,0 & 5,7 & 5,6 & 5,9 & 5,7 & 102 & 105 & 96 \\
\hline Grecia & 7,2 & $\mathrm{~m}$ & $\mathrm{~m}$ & $\mathrm{~m}$ & $\mathrm{~m}$ & 3,4 & $\mathrm{~m}$ & $\mathrm{~m}$ & $\mathrm{~m}$ & $\mathrm{~m}$ & $\mathrm{~m}$ & 88 & $\mathrm{~m}$ \\
\hline Hungría & 10,4 & 10,9 & 10,4 & 9,8 & 9,4 & 5,0 & 5,5 & 5,1 & 4,9 & 4,7 & 88 & 97 & 91 \\
\hline Irlanda & 13,6 & 13,9 & 13,3 & 9,8 & 13,1 & 4,2 & 4,7 & 5,7 & 6,4 & 6,2 & 103 & 104 & 99 \\
\hline Islandia & 15,9 & 18,0 & 13,1 & 14,7 & 15,5 & 6,7 & 7,6 & 7,6 & 7,6 & 7,4 & 90 & 76 & 119 \\
\hline Israel & 12,3 & 11,3 & 12,9 & 13,2 & 14,2 & 6,3 & 5,6 & 5,6 & 5,6 & 5,6 & 112 & 101 & 110 \\
\hline Italia & 9,9 & 9,2 & 9,4 & 8,9 & 8,6 & 4,5 & 4,4 & 4,6 & 4,5 & 4,3 & 91 & 99 & 92 \\
\hline Japón ${ }^{3}$ & 9,5 & 9,6 & 9,4 & 9,3 & 9,1 & 3,6 & 3,5 & 3,5 & 3,8 & 3,8 & 108 & 111 & 97 \\
\hline Luxemburgo & $\mathrm{m}$ & $\mathrm{m}$ & $\mathrm{m}$ & $\mathrm{m}$ & $\mathrm{m}$ & $\mathrm{m}$ & $\mathrm{m}$ & $\mathrm{m}$ & $\mathrm{m}$ & $\mathrm{m}$ & $\mathrm{m}$ & 109 & $\mathrm{~m}$ \\
\hline México & 23,4 & 23,4 & 20,6 & 20,6 & 20,5 & 4,4 & 5,0 & 4,9 & 5,3 & 5,2 & 110 & 110 & 100 \\
\hline Noruega & 14,0 & 16,7 & 16,1 & 15,2 & 15,2 & 7,8 & 9,3 & 8,8 & 8,8 & 8,8 & 103 & 109 & 94 \\
\hline Nueva Zelanda & $\mathrm{m}$ & 15,5 & 18,6 & 20,0 & 21,6 & 6,6 & 6,0 & 6,4 & 7,1 & 7,4 & 120 & 103 & 116 \\
\hline Países Bajos & 11,3 & 12,3 & 11,9 & 11,6 & 11,9 & 5,0 & 5,5 & 5,5 & 6,0 & 5,9 & 106 & 107 & 100 \\
\hline Polonia & 12,7 & 12,6 & 11,8 & 11,4 & 11,4 & 5,0 & 5,5 & 5,1 & 5,2 & 4,9 & 107 & 111 & 97 \\
\hline Portugal & 12,5 & 11,2 & 10,9 & 10,9 & 10,7 & 5,2 & 5,2 & 4,9 & 5,6 & 5,3 & 105 & 108 & 98 \\
\hline Reino Unido & 11,7 & 11,8 & 11,0 & 11,9 & 12,2 & 4,2 & 5,1 & 5,2 & 5,9 & 5,8 & 110 & 99 & 110 \\
\hline República Checa & 9,2 & 9,5 & 9,5 & 9,7 & 10,4 & 3,8 & 4,1 & 3,9 & 4,2 & 4,5 & 115 & 105 & 110 \\
\hline República Eslovaca ${ }^{3}$ & 7,5 & 10,1 & 10,3 & 10,6 & 10,6 & 3,9 & 3,8 & 3,6 & 4,2 & 4,1 & 115 & 112 & 102 \\
\hline Suecia & 13,0 & 12,8 & 13,1 & 13,3 & 13,2 & 7,2 & 6,9 & 6,8 & 7,0 & 6,8 & 105 & 104 & 101 \\
\hline Suiza & 14,4 & 15,0 & 14,9 & 15,8 & 15,7 & 5,1 & 5,5 & 4,9 & 5,2 & 5,3 & 110 & 105 & 105 \\
\hline Turquía & $\mathrm{m}$ & $\mathrm{m}$ & $\mathrm{m}$ & $\mathrm{m}$ & 10,9 & $\mathrm{~m}$ & $\mathrm{~m}$ & $\mathrm{~m}$ & $\mathrm{~m}$ & 3,8 & $\mathrm{~m}$ & 116 & $\mathrm{~m}$ \\
\hline Media OCDE & 12,6 & 13,1 & 12,9 & 12,9 & 12,9 & 5,2 & 5,3 & 5,4 & 5,7 & 5,6 & 106 & 104 & 102 \\
\hline Media UE21 & 11,4 & 11,8 & 11,6 & 11,4 & 11,5 & 5,1 & 5,4 & 5,3 & 5,8 & 5,6 & 104 & 104 & 99 \\
\hline $\begin{array}{l}\text { Media OCDE } \\
\text { (países con datos } \\
\text { para todos los años) }\end{array}$ & 12,5 & 12,6 & 12,4 & 12,3 & 12,5 & 5,2 & 5,3 & 5,3 & 5,6 & 5,6 & $\sim$ & $\sim$ & $\sim$ \\
\hline ¿ Arabia Saudí & $\mathrm{m}$ & $\mathrm{m}$ & $\mathrm{m}$ & $\mathrm{m}$ & $\mathrm{m}$ & $\mathrm{m}$ & $\mathrm{m}$ & $\mathrm{m}$ & $\mathrm{m}$ & $\mathrm{m}$ & $\mathrm{m}$ & $\mathrm{m}$ & $\mathrm{m}$ \\
\hline Argentina & $\mathrm{m}$ & $\mathrm{m}$ & $\mathrm{m}$ & $\mathrm{m}$ & $\mathrm{m}$ & $\mathrm{m}$ & $\mathrm{m}$ & $\mathrm{m}$ & $\mathrm{m}$ & 6,3 & $\mathrm{~m}$ & $\mathrm{~m}$ & $\mathrm{~m}$ \\
\hline Brasil & 10,5 & 14,5 & 17,4 & 18,1 & 19,2 & 3,5 & 4,5 & 5,4 & 5,8 & 6,1 & 123 & 112 & 110 \\
\hline Thina & $\mathrm{m}$ & $\mathrm{m}$ & $\mathrm{m}$ & $\mathrm{m}$ & $\mathrm{m}$ & $\mathrm{m}$ & $\mathrm{m}$ & $\mathrm{m}$ & $\mathrm{m}$ & $\mathrm{m}$ & $\mathrm{m}$ & $\mathrm{m}$ & $\mathrm{m}$ \\
\hline "Colombia ${ }^{4}$ & $\mathrm{~m}$ & $\mathrm{~m}$ & $\mathrm{~m}$ & $\mathrm{~m}$ & $\mathrm{~m}$ & $\mathrm{~m}$ & $\mathrm{~m}$ & $\mathrm{~m}$ & $\mathrm{~m}$ & 4,5 & $\mathrm{~m}$ & $\mathrm{~m}$ & $\mathrm{~m}$ \\
\hline Federación Rusa & 10,6 & 11,0 & $\mathrm{~m}$ & $\mathrm{~m}$ & 10,9 & 2,9 & 3,8 & 4,1 & 4,0 & 3,9 & $\mathrm{~m}$ & $\mathrm{~m}$ & $\mathrm{~m}$ \\
\hline India & $\mathrm{m}$ & $\mathrm{m}$ & $\mathrm{m}$ & $\mathrm{m}$ & $\mathrm{m}$ & $\mathrm{m}$ & $\mathrm{m}$ & $\mathrm{m}$ & $\mathrm{m}$ & $\mathrm{m}$ & $\mathrm{m}$ & $\mathrm{m}$ & $\mathrm{m}$ \\
\hline Indonesia & $\mathrm{m}$ & $\mathrm{m}$ & $\mathrm{m}$ & $\mathrm{m}$ & 20,5 & $\mathrm{~m}$ & $\mathrm{~m}$ & $\mathrm{~m}$ & $\mathrm{~m}$ & $\mathrm{~m}$ & $\mathrm{~m}$ & $\mathrm{~m}$ & $\mathrm{~m}$ \\
\hline Letonia & $\mathrm{m}$ & $\mathrm{m}$ & $\mathrm{m}$ & $\mathrm{m}$ & $\mathrm{m}$ & $\mathrm{m}$ & $\mathrm{m}$ & $\mathrm{m}$ & $\mathrm{m}$ & 4,9 & $\mathrm{~m}$ & $\mathrm{~m}$ & $\mathrm{~m}$ \\
\hline Sudáfrica & $\mathrm{m}$ & $\mathrm{m}$ & $\mathrm{m}$ & $\mathrm{m}$ & $\mathrm{m}$ & $\mathrm{m}$ & $\mathrm{m}$ & $\mathrm{m}$ & $\mathrm{m}$ & $\mathrm{m}$ & $\mathrm{m}$ & $\mathrm{m}$ & $\mathrm{m}$ \\
\hline Media G20 & $\mathrm{m}$ & $\mathrm{m}$ & $\mathrm{m}$ & $\mathrm{m}$ & $\mathrm{m}$ & $\mathrm{m}$ & $\mathrm{m}$ & $\mathrm{m}$ & $\mathrm{m}$ & $\mathrm{m}$ & $\mathrm{m}$ & $\mathrm{m}$ & $\mathrm{m}$ \\
\hline
\end{tabular}

Notas: Los años 1995 y 2009 (columnas 1, 5, 8 y 12 ) están disponibles en Internet (véase StatLink más abajo).

1. El gasto público presentado en esta tabla incluye las ayudas públicas a las familias para gastos de subsistencia (becas y otras ayudas a estudiantes y familias, y préstamos a estudiantes), que no se gastan en instituciones educativas. Así pues, las cifras que aparecen aquí son más elevadas que las cifras del gasto público en instituciones que aparecen en la Tabla B2.4.

2. Año de referencia 2010 en lugar de 2011.

3. Algunos niveles educativos están incluidos junto con otros. Véase el código «x» en la Tabla B1.1a para obtener más detalles.

4. Año de referencia 2012 en lugar de 2011. Los datos se refieren a 2009-2012 en lugar de 2008-2011.

Fuentes: OCDE. Arabia Saudí, Argentina, China, Colombia, India, Indonesia, Sudáfrica: Instituto de Estadística de la UNESCO. Letonia: Eurostat. Para ver notas, consulte Anexo 3 (www.oecd.org/edu/eag.htm).

Para obtener más información acerca de los símbolos utilizados en lugar de los datos que faltan, consulte la Guía del lector.

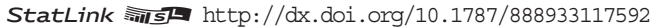


Tabla B4.3 Fuentes de fondos públicos para educación primaria, secundaria y postsecundaria no terciaria (2011)

Antes y después de transferencias

\begin{tabular}{|c|c|c|c|c|c|c|c|c|}
\hline & \multicolumn{4}{|c|}{$\begin{array}{c}\text { Fondos iniciales } \\
\text { (antes de transferencias entre niveles de gobierno) }\end{array}$} & \multicolumn{4}{|c|}{$\begin{array}{c}\text { Fondos finales } \\
\text { (después de transferencias entre niveles de gobierno) }\end{array}$} \\
\hline & Central & Regional & Local & Total & Central & Regional & Local & Total \\
\hline & (1) & (2) & (3) & (4) & (5) & (6) & (7) & (8) \\
\hline Alemania & 10,7 & 72,3 & 17,0 & 100 & 7,7 & 69,1 & 23,2 & 100 \\
\hline Australia & 35,1 & 64,9 & $\mathrm{~m}$ & 100 & 4,5 & 95,5 & $\mathrm{~m}$ & 100 \\
\hline Austria & 74,9 & 15,2 & 9,9 & 100 & 43,5 & 46,2 & 10,3 & 100 \\
\hline Bélgica & 22,0 & 74,1 & 3,9 & 100 & 23,1 & 73,0 & 3,9 & 100 \\
\hline Chile $^{3}$ & 95,1 & a & 4,9 & 100 & 53,0 & a & 47,0 & 100 \\
\hline Corea & 68,7 & 28,1 & 3,2 & 100 & 0,8 & 30,5 & 68,7 & 100 \\
\hline Dinamarca $^{2}$ & $\mathrm{~m}$ & $\mathrm{~m}$ & $\mathrm{~m}$ & 100 & 44,0 & $n$ & 56,0 & 100 \\
\hline Eslovenia & 90,4 & a & 9,6 & 100 & 90,0 & $a$ & 10,0 & 100 \\
\hline España & 14,8 & 79,2 & 6,0 & 100 & 13,9 & 80,1 & 6,0 & 100 \\
\hline Estados Unidos & 13,7 & 35,0 & 51,3 & 100 & 0,5 & 1,6 & 97,9 & 100 \\
\hline Estonia & 69,4 & a & 30,6 & 100 & 28,7 & $\mathrm{a}$ & 71,3 & 100 \\
\hline Finlandia & 41,2 & $a$ & 58,8 & 100 & 10,5 & $\mathrm{a}$ & 89,5 & 100 \\
\hline Grecia & $\mathrm{m}$ & $\mathrm{m}$ & $\mathrm{m}$ & $\mathrm{m}$ & $\mathrm{m}$ & $\mathrm{m}$ & $\mathrm{m}$ & $\mathrm{m}$ \\
\hline Hungría & 63,3 & $x(3)$ & 36,7 & 100 & 21,8 & $x(7)$ & 78,2 & 100 \\
\hline Irlanda & 99,0 & a & 1,0 & 100 & 82,5 & a & 17,5 & 100 \\
\hline Islandia & 26,3 & a & 73,7 & 100 & 25,8 & a & 74,2 & 100 \\
\hline Israel & 90,8 & $\mathrm{a}$ & 9,2 & 100 & 71,1 & $\mathrm{a}$ & 28,9 & 100 \\
\hline Italia & 81,0 & 8,9 & 10,0 & 100 & 80,5 & 7,4 & 12,0 & 100 \\
\hline Japón ${ }^{2}$ & 16,5 & 66,2 & 17,2 & 100 & 1,8 & 81,0 & 17,2 & 100 \\
\hline Luxemburgo & 80,6 & a & 19,4 & 100 & 75,1 & a & 24,9 & 100 \\
\hline México & 77,4 & 22,4 & 0,2 & 100 & 27,2 & 72,6 & 0,2 & 100 \\
\hline Noruega & 10,2 & $\mathrm{n}$ & 89,8 & 100 & 9,1 & $\mathrm{n}$ & 90,9 & 100 \\
\hline Nueva Zelanda & 100,0 & $\mathrm{n}$ & $\mathrm{n}$ & 100 & 100,0 & $\mathrm{n}$ & $\mathrm{n}$ & 100 \\
\hline Países Bajos & 90,4 & $\mathrm{n}$ & 9,5 & 100 & 88,3 & $\mathrm{n}$ & 11,6 & 100 \\
\hline Polonia & 3,4 & 1,9 & 94,7 & 100 & 2,4 & 2,0 & 95,7 & 100 \\
\hline Portugal & $\mathrm{m}$ & $\mathrm{m}$ & $\mathrm{m}$ & $\mathrm{m}$ & $\mathrm{m}$ & $\mathrm{m}$ & $\mathrm{m}$ & $\mathrm{m}$ \\
\hline Reino Unido & 16,5 & a & 83,5 & 100 & 16,5 & $a$ & 83,5 & 100 \\
\hline Suecia & $\mathrm{m}$ & $\mathrm{m}$ & $\mathrm{m}$ & $\mathrm{m}$ & $\mathrm{m}$ & $\mathrm{m}$ & $\mathrm{m}$ & $\mathrm{m}$ \\
\hline Suiza & 3,3 & 62,6 & 34,2 & 100 & 0,2 & 60,8 & 39,0 & 100 \\
\hline Turquía & 100,0 & a & $\mathrm{m}$ & 100 & 96 & 4 & $\mathrm{~m}$ & 100 \\
\hline Media OCDE & 52,0 & 23,7 & 27,0 & 100 & 36,3 & 23,9 & 43,4 & 100 \\
\hline Media UE21 & 54,1 & 20,7 & 26,5 & 100 & 40,7 & 21,0 & 39,4 & 100 \\
\hline Arabia Saudí & $\mathrm{m}$ & $\mathrm{m}$ & $\mathrm{m}$ & $\mathrm{m}$ & $\mathrm{m}$ & $\mathrm{m}$ & $\mathrm{m}$ & $\mathrm{m}$ \\
\hline Argentina & 10,4 & 87,1 & 2,4 & 100 & 3,7 & 93,8 & 2,4 & 100 \\
\hline Brasil & 18,2 & 48,7 & 33,1 & 100 & 11,2 & 48,4 & 40,4 & 100 \\
\hline China & $\mathrm{m}$ & $\mathrm{m}$ & $\mathrm{m}$ & $\mathrm{m}$ & $\mathrm{m}$ & $\mathrm{m}$ & $\mathrm{m}$ & $\mathrm{m}$ \\
\hline Colombia $^{3}$ & 84,2 & 6,2 & 9,6 & 100 & 84,2 & 6,2 & 9,6 & 100 \\
\hline Federación Rusa & $\mathrm{m}$ & $\mathrm{m}$ & $\mathrm{m}$ & $\mathrm{m}$ & 6,7 & 93,3 & $\mathrm{n}$ & 100 \\
\hline India & $\mathrm{m}$ & $\mathrm{m}$ & $\mathrm{m}$ & $\mathrm{m}$ & $\mathrm{m}$ & $\mathrm{m}$ & $\mathrm{m}$ & $\mathrm{m}$ \\
\hline Indonesia & $\mathrm{m}$ & $\mathrm{m}$ & $\mathrm{m}$ & $\mathrm{m}$ & $\mathrm{m}$ & $\mathrm{m}$ & $\mathrm{m}$ & $\mathrm{m}$ \\
\hline Letonia & 64,5 & $\mathrm{a}$ & 35,5 & 100 & 20,9 & $\mathrm{a}$ & 79,1 & 100 \\
\hline Sudáfrica & $\mathrm{m}$ & $\mathrm{m}$ & $\mathrm{m}$ & $\mathrm{m}$ & $\mathrm{m}$ & $\mathrm{m}$ & $\mathrm{m}$ & $\mathrm{m}$ \\
\hline Media G20 & $\mathrm{m}$ & $\mathrm{m}$ & $\mathrm{m}$ & $\mathrm{m}$ & $\mathrm{m}$ & $\mathrm{m}$ & $\mathrm{m}$ & $\mathrm{m}$ \\
\hline
\end{tabular}

1 Año de referencia 2010

2. Algunos niveles educativos están incluidos junto con otros. Véase el código «X» en la Tabla B1.1a para obtener más detalles.

3. Año de referencia 2012.

Fuentes: OCDE. Arabia Saudí, Argentina, China, Colombia, India, Indonesia, Sudáfrica: Instituto de Estadística de la UNESCO. Letonia: Eurostat. Para ver notas, consulte Anexo 3 (www.oecd.org/edu/eag.htm).

Para obtener más información acerca de los símbolos utilizados en lugar de los datos que faltan, consulte la Guía del lector

StatLink त्ञाज http://dx.doi.org/10.1787/888933117611 



\section{¿CUÁNTO PAGAN LOS ESTUDIANTES DE EDUCACIÓN TERCIARIA Y QUÉ AYUDAS PÚBLICAS RECIBEN?}

- Los países de la OCDE difieren significativamente en el importe de las tasas de matrícula que cobran sus instituciones de educación terciaria. En ocho países de la OCDE, las instituciones públicas no cobran tasas de matrícula, mientras que en un tercio de los 26 países de la OCDE con datos disponibles las tasas de matrícula anuales cobradas por las instituciones públicas a los estudiantes nacionales superan los 1.500 dólares estadounidenses.

- Un número creciente de países de la OCDE cobran tasas de matrícula más elevadas a los estudiantes internacionales que a los nacionales.

- Los países con tasas de matrícula elevadas suelen ser también aquellos donde las entidades privadas (por ejemplo, las empresas) más contribuyen a la financiación de las instituciones terciarias.

- Por término medio, cerca de un $22 \%$ del gasto público en educación terciaria se destina a ayudar a los estudiantes, a las familias y a otras entidades privadas.

Gráfico B5.1. Relación entre las tasas de matrícula medias cobradas por las instituciones públicas y la proporción de estudiantes que se benefician de préstamos públicos y/o becas o ayudas en educación terciaria de tipo A (2011) Para estudiantes nacionales a tiempo completo en equivalente a dólares estadounidenses convertidos mediante PPA para el PIB, año académico 2010-2011.

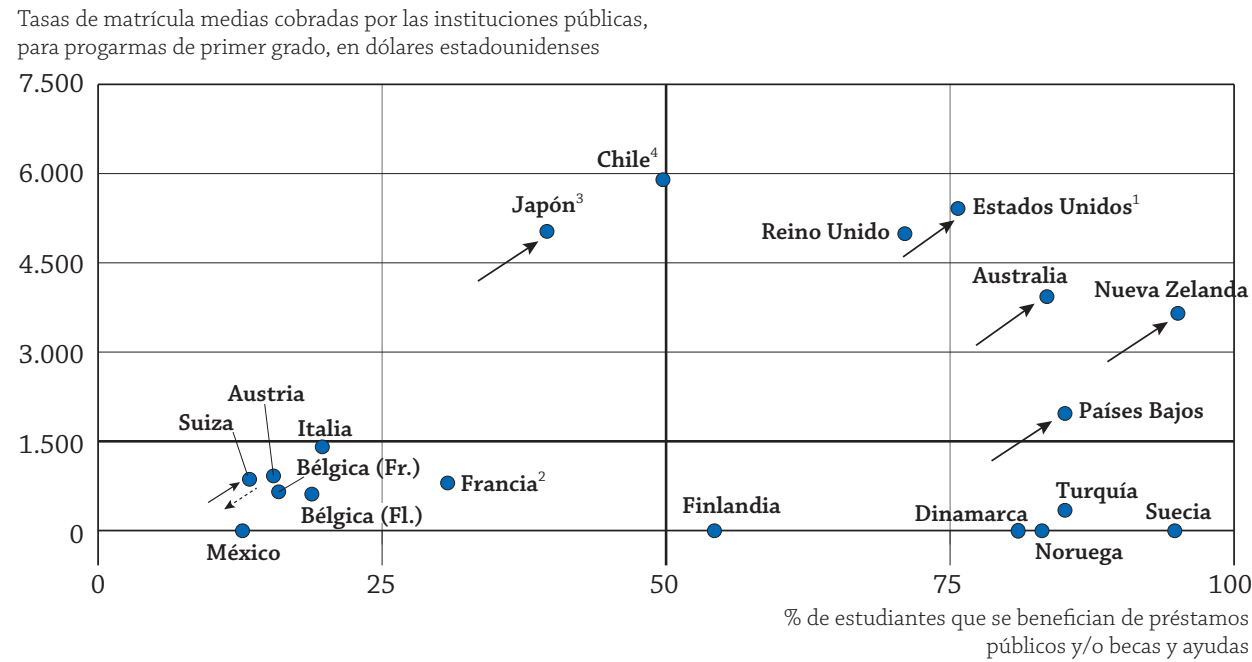

1. Las cifras incluyen a todos los estudiantes (nacionales a tiempo completo y no nacionales o extranjeros a tiempo completo).

2. Tasas medias de matrícula entre 200 y 1.402 dólares estadounidenses para programas universitarios dependientes del Ministerio de Educación.

3. Las tasas de matrícula se refieren a instituciones públicas, pero más de dos tercios de los estudiantes están matriculados en instituciones privadas.

4. Si solo son tenidas en cuenta las instituciones públicas, la proporción de estudiantes que se benefician de préstamos públicos y/o becas o ayudas debe ser $68 \%$.

Fuente: OCDE. Tablas B5.1 y B5.2. Para ver notas, consulte Anexo 3 (www.oecd.org/edu/eag.htm).

StatLink त्ञाज http://dx.doi.org/10.1787/888933117801

Cómo leer este gráfico

Este gráfico muestra las relaciones entre las tasas anuales de matrícula cobradas por las instituciones educativas en la educación terciaria de tipo A y las ayudas públicas a las familias para costes de alojamiento y manutención de los estudiantes. Las flechas muestran cómo han cambiado desde 1995 las tasas medias de matrícula y la proporción de estudiantes que se benefician de ayudas públicas tras las reformas.

\section{Contexto}

Las decisiones políticas sobre los importes de las tasas de matrícula afectan tanto al coste de los estudios terciarios para los estudiantes como a los recursos disponibles para las instituciones de educación terciaria. Las ayudas públicas a los estudiantes y sus familias actúan también como un instrumento político que los gobiernos pueden utilizar para estimular la participación en la educación, particular- 
mente entre los estudiantes de familias con bajo nivel de ingresos, cubriendo parte de los costes de la educación, así como otros gastos relacionados con los mismos. De este modo, los gobiernos pueden abordar cuestiones tales como el acceso a los estudios terciarios y la igualdad de oportunidades. Por consiguiente, se deberá juzgar el éxito de estas ayudas, al menos en parte, mediante el análisis de los indicadores de participación, permanencia y finalización de los estudios de educación terciaria.

Las ayudas públicas a los estudiantes también financian indirectamente a las instituciones de educación terciaria. Canalizar la financiación de las instituciones a través de los estudiantes puede ayudar también a aumentar la competencia entre las instituciones y a responder mejor a las necesidades de los estudiantes. Dado que las ayudas para los costes de subsistencia de los estudiantes pueden servir como sustituto de los ingresos laborales, las ayudas públicas pueden mejorar los resultados académicos al permitir que los estudiantes trabajen menos. Estas ayudas adoptan diversas formas: subsidios basados en ingresos, asignaciones familiares para los estudiantes, deducciones fiscales para estudiantes o sus padres, $\mathrm{u}$ otras transferencias a las familias. Los gobiernos deben encontrar el equilibrio adecuado entre los diferentes tipos de ayudas, especialmente en un periodo de crisis económica. Partiendo de un determinado fondo para subsidios, las ayudas públicas tales como desgravaciones fiscales o asignaciones familiares pueden ser un estímulo menos eficaz para los estudiantes con bajo nivel de ingresos que las ayudas en función de los ingresos, dado que las primeras no están destinadas específicamente a apoyar a los estudiantes con bajos ingresos. No obstante, pueden contribuir a atenuar los desequilibrios económicos existentes entre las familias con y sin hijos estudiando.

\section{Otros resultados}

- En los países de la OCDE, las tasas de matrícula para estudios de segundo grado y posteriores no son en general mucho más elevadas que las de estudios de primer grado en instituciones públicas o instituciones privadas dependientes del gobierno. Excepciones a este patrón se observan en Australia, Chile y Reino Unido.

- La elevada proporción de estudiantes matriculados en educación terciaria en algunos países que no cobran tasas de matrícula se debe probablemente a sistemas muy desarrollados de ayudas económicas a los estudiantes de estos países, y no solo a la ausencia de tasas de matrícula.

- Los países de la OCDE en los que los estudiantes deben abonar tasas de matrícula, pero pueden beneficiarse de ayudas públicas especialmente elevadas, no muestran niveles inferiores de acceso a la educación terciaria de tipo $\mathrm{A}$.

- Los sistemas de ayudas económicas a estudiantes que ofrecen préstamos con devolución supeditada a los ingresos para todos los estudiantes junto con ayudas basadas en los ingresos pueden fomentar el acceso a los estudios y la igualdad de oportunidades, a la vez que se comparten los costes de la educación superior entre el estado y los estudiantes.

\section{Tendencias}

Como se informó en Panorama de la educación 2013, a partir de 199514 de los 25 países con datos comparables han emprendido reformas en las tasas de matrícula. En estos 14 países excepto en Islandia y República Eslovaca, las reformas estuvieron acompañadas de cambios en las ayudas públicas a disposición de los estudiantes.

A partir de 2009 se han introducido nuevos cambios en las tasas de matrícula y sistemas de ayudas públicas en varios países. Por ejemplo, en Reino Unido, las tasas de matrícula se duplicaron o casi triplicaron en algunas universidades en 2012, como parte de un plan del gobierno para estabilizar las finanzas universitarias. Sin embargo, los datos que se presentan aquí y que corresponden al periodo 2010-2011 no reflejan esos cambios posteriores. Igualmente, en 2011 Corea puso en marcha reformas para aumentar el nivel de ayudas públicas a disposición de los estudiantes de educación superior, con el objetivo de reforzar el acceso a los estudios y la igualdad de oportunidades en educación terciaria de tipo $\mathrm{A}$. 


\section{Análisis}

\section{Tasas de matrícula anuales cobradas por instituciones de educación terciaria de tipo A a estudiantes nacionales}

El coste de la educación superior y la mejor forma de ayudar a los estudiantes a pagarla figuran actualmente entre los temas más candentes del debate sobre políticas públicas en educación. El nivel de las tasas de matrícula que cobran las instituciones de educación terciaria -así como el nivel y tipo de ayuda económica que los países ofrecen mediante sus sistemas de apoyo a los estudiantes- pueden influir de modo notable en el acceso a los estudios y en la igualdad de oportunidades en educación terciaria.

Es un reto conseguir el equilibrio adecuado entre la oferta de ayudas suficientes a las instituciones mediante las tasas de matrícula y el mantenimiento de las posibilidades de acceso a los estudios y de la igualdad de oportunidades. Por un lado, unas tasas de matrícula elevadas aumentan los recursos de que disponen las instituciones educativas, estimulan sus esfuerzos para mantener programas académicos de calidad y desarrollar otros nuevos, y ayudan a las instituciones a adaptarse a los aumentos de los índices de matriculación. Por tanto, varios factores influyen en el nivel de las tasas de matrícula, como el salario de los profesores, en la competencia por contratar a los mejores dentro de un mercado académico global, el desarrollo de servicios no docentes (servicios de empleo o relaciones con las empresas), el aumento del aprendizaje digital y las inversiones de apoyo a la internacionalización.

Sin embargo, las tasas de matrícula también pueden limitar el acceso a la educación de los estudiantes, especialmente de los que proceden de familias con bajos ingresos, sobre todo en ausencia de un sistema consistente de ayudas públicas que les ayuden a pagar o devolver el coste de sus estudios. Además, unas tasas de matrícula elevadas pueden dificultar que algunos estudiantes opten por campos que requieran periodos de estudio más extensos, sobre todo si las oportunidades laborales en estos campos son insuficientes.

Por el contrario, unas tasas de matrícula más bajas pueden facilitar el acceso a los estudios y la igualdad de oportunidades en educación superior, especialmente en los sectores de población con bajo nivel de ingresos. Sin embargo, también pueden limitar la capacidad de las instituciones terciarias para mantener una adecuada calidad educativa, especialmente a la vista de la expansión masiva de la educación terciaria en todos los países de la OCDE en los últimos años. Además, las presiones presupuestarias derivadas de la crisis económica mundial pueden dificultar aún más que los países con tasas académicas reducidas puedan mantener este modelo en el futuro.

El establecimiento de tasas de matrícula diferenciadas, ya sea por nivel educativo, campo de estudio, posibilidades económicas de los estudiantes o forma de pago, es un modo de que los países ajusten sus tasas de matrícula para tener en cuenta la igualdad de oportunidades en el acceso a la educación terciaria, los costes de la enseñanza y las oportunidades del mercado laboral.

Se observan grandes diferencias entre países en las tasas medias de matrícula cobradas por las instituciones públicas de educación terciaria de tipo A a estudiantes nacionales en programas de primer grado. En los cinco países nórdicos de la OCDE (Dinamarca, Finlandia, Islandia, Noruega y Suecia) y en Eslovenia, México y Polonia, las instituciones públicas no cobran tasas de matrícula. Por el contrario, en un tercio de los países con datos disponibles, las tasas de matrícula anuales cobradas por las instituciones públicas a los estudiantes nacionales superan los 1.500 dólares estadounidenses y llegan hasta los 5.000 dólares o más en Chile, Corea, Estados Unidos y Japón. En Austria, Bélgica, España, Francia, Italia, Suiza y Turquía, los estudiantes pagan tasas de matrícula reducidas en educación terciaria de tipo A. Entre los 21 países de la UE con datos disponibles, solo Países Bajos, Reino Unido y República Eslovaca aplican tasas de matrícula anuales superiores a los 1.500 dólares estadounidenses por estudiante nacional a tiempo completo (Tabla B5.1 y Gráfico B5.2).

Las tasas de matrícula pagadas por estudiantes nacionales en programas de segundo grado y posteriores no son en general mucho más elevadas que las que se pagan en programas de primer grado. En la mayoría de los países con datos disponibles, las tasas son estables o ligeramente superiores a las de programas de primer grado. Hay excepciones a este patrón en Australia, Chile, Irlanda y Reino Unido. Así, en las instituciones públicas en Australia, el importe cobrado aumenta un 55\% de un tipo a otro de graduación, de 3.924 a 6.099 dólares estadounidenses, mientras que disminuye ligeramente en las instituciones privadas independientes. Además, Australia, Chile y Reino Unido diferencian también las tasas por ámbito de estudio en los programas de primer grado. En cambio, Turquía es el único país donde las tasas de los programas de segundo grado y posteriores en instituciones públicas son inferiores (Tablas B5.1 y B5.3).

\section{Tasas de matrícula para estudiantes no nacionales}

Las políticas nacionales relativas a las tasas de matrícula y a las ayudas económicas a los estudiantes abarcan, en términos generales, a todos los estudiantes que estudian en las instituciones académicas del país. Las políticas de los 


\section{Gráfico B5.2. Tasas medias anuales de matrícula cobradas por instituciones terciarias de tipo $\mathrm{A}$ a estudiantes nacionales a tiempo completo (2011)}

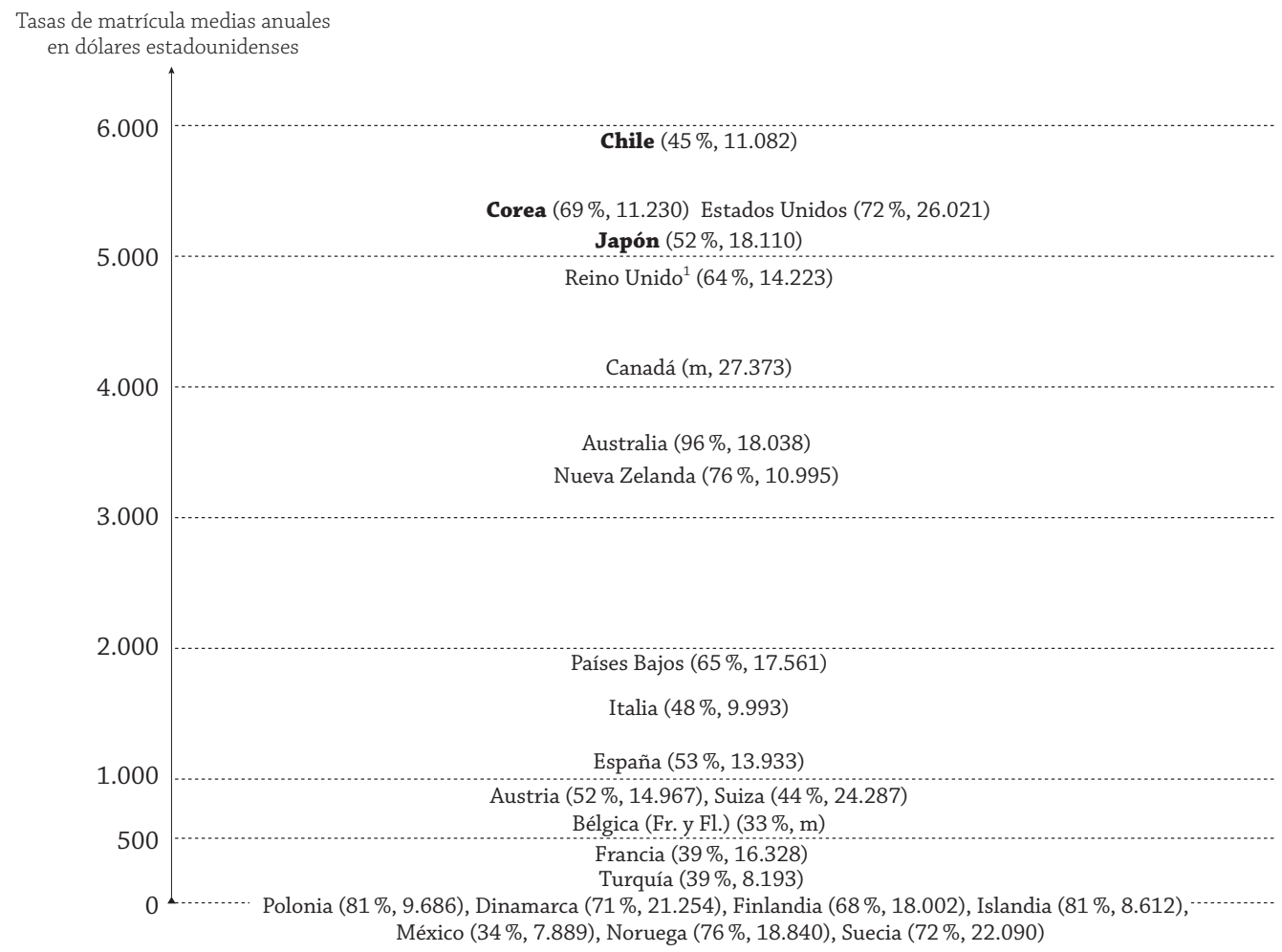

\footnotetext{
Nota: El gráfico muestra las tasas de matrícula anuales en equivalente a dólares estadounidenses convertidos mediante PPA. Los países en negrita indican que las tasas de matrícula se refieren a instituciones públicas, aunque más de dos tercios de los estudiantes están matriculados en instituciones privadas. Se añade junto a los nombres de los países la tasa neta de ingreso y el gasto por estudiante (en dólares estadounidenses) en los programas de educación terciaria de tipo A.

Este gráfico no tiene en cuenta becas, subsidios o préstamos que compensan total o parcialmente las tasas de matrícula del estudiante.

1. Las instituciones públicas no existen en este nivel de educación y casi todos los estudiantes están matriculados en instituciones dependientes del gobierno.

Fuente: OCDE. Tablas B1.1a, B5.1 e Indicador C3. Para ver notas, consulte Anexo 3 (www.oecd.org/edu/eag.htm).

Para obtener más información acerca de los símbolos utilizados en lugar de los datos que faltan, consulte la Guía del lector.

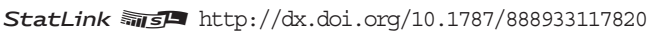

países también tienen en cuenta a los estudiantes internacionales. Las diferencias entre los estudiantes nacionales y no nacionales en el importe de las tasas que los estudiantes deben abonar o en las ayudas económicas que pueden percibir del país en el que estudian, influyen, junto con otros factores, en el flujo de estudiantes internacionales. Por un lado, el importe de las tasas puede atraer a estudiantes a algunos países o, por el contrario, puede ser un impedimento para que los estudiantes estudien en otros países (véase Indicador C4), especialmente en el contexto actual en el que los países de la OCDE están cobrando tasas de matrícula más elevadas a los estudiantes internacionales.

En la mayoría de los países con datos disponibles, las tasas de matrícula cobradas por las instituciones educativas públicas pueden diferir para los estudiantes nacionales y los internacionales inscritos en el mismo programa. En Austria, por ejemplo, la tasa media de matrícula cobrada por las instituciones públicas a los estudiantes que no son nacionales de un Estado miembro de la UE o del Espacio Económico Europeo (EEE) es el doble que la tasa cobrada a los estudiantes nacionales de estos países. Este tipo de diferenciación también se da en Canadá, Dinamarca (desde el curso académico 2006-2007), Eslovenia, Estados Unidos, Irlanda, Nueva Zelanda (excepto para estudiantes de doctorado extranjeros), Países Bajos, Polonia, Reino Unido, República Eslovaca, Suecia (desde 2011), Suiza y Turquía. En estos países, el importe de las tasas de matrícula varía según la nacionalidad o la residencia (véanse Indicador C4 y Cuadro C4.3). En Australia, los estudiantes internacionales no pueden optar a las ayudas disponibles para los estudiantes nacionales. 


\section{Gráfico B5.3. Ayudas públicas para la educación terciaria (2011)}

Ayudas públicas para educación a familias y otras entidades privadas como porcentaje del gasto público total en educación terciaria, por tipo de ayuda

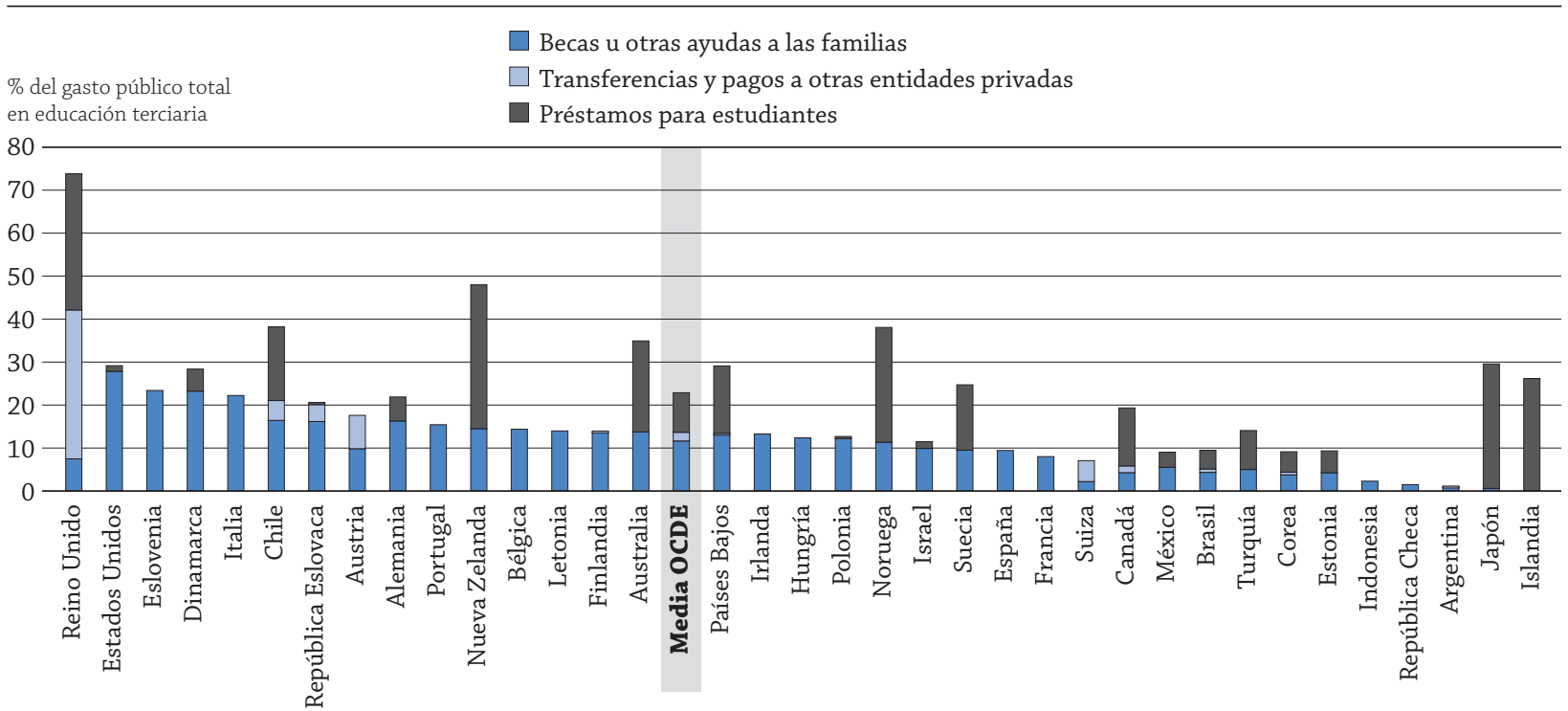

Los países están clasificados en orden descendente de la proporción de becas o ayudas a las familias y transferencias o pagos a otras entidades privadas en el gasto público total en educación terciaria.

Fuente: OCDE. Tabla B5.4. Para ver notas, consulte Anexo 3 (www.oecd.org/edu/eag.htm).

StatLink 제이 http://dx.doi.org/10.1787/888933117839

\section{Becas y préstamos a estudiantes}

Los estudios de la OCDE (OECD, 2008) sugieren que es importante contar con un sistema sólido de ayudas económicas para garantizar los buenos resultados de los estudiantes de educación superior, y que la elección del tipo de ayuda es también esencial. Una cuestión clave en muchos países de la OCDE es si la ayuda económica a las familias para la educación terciaria de tipo A debe concederse fundamentalmente en forma de becas o de préstamos. Los gobiernos subvencionan los costes de subsistencia o costes educativos de los estudiantes mediante diversas combinaciones de becas y préstamos. Las deducciones y desgravaciones fiscales no se incluyen en este indicador. Los partidarios de los préstamos a los estudiantes sostienen que el dinero empleado en tal concepto es más rentable: si el importe invertido en becas se usara en su lugar para garantizar o subvencionar préstamos, el total de ayudas disponibles para los estudiantes sería mayor y se incrementarían en términos generales las posibilidades de acceso a los estudios.

Además, los préstamos dirigen una parte del coste de la educación precisamente hacia quienes más se benefician de la inversión en educación, los estudiantes individuales, reflejando los altos retornos privados de la educación terciaria (véase Indicador A7). Los detractores de los préstamos sostienen que estos son menos eficaces que las becas para estimular a los estudiantes de bajo nivel económico a continuar sus estudios. Asimismo sostienen que los préstamos pueden ser menos rentables de lo previsto, debido a las diversas ayudas que reciben los prestatarios y las entidades crediticias, por una parte, y a los gastos de gestión que generan, por otra. Por último, un nivel elevado de deuda por parte de los estudiantes puede tener efectos adversos para los gobiernos y los propios estudiantes, si un gran número de estudiantes no logran devolver sus préstamos (véase Cuadro B5.1).

Los países de la OCDE invierten como media en torno al $22 \%$ de sus presupuestos públicos para educación terciaria en ayudas a familias y a otras entidades privadas (Gráfico B5.3). En Australia, Chile, Dinamarca, Estados Unidos, Islandia, Japón, Noruega, Nueva Zelanda, Países Bajos y Reino Unido, las ayudas públicas representan más de un $25 \%$ del gasto público en educación terciaria. Solo Argentina, Indonesia y República Checa invierten menos del $7 \%$ del total de su gasto público en educación terciaria en ayudas. No obstante, en República Checa, los fondos para ayudas a los estudiantes se envían directamente a las instituciones, que son las encargadas de su distribución entre los estudiantes (Tabla B5.4).

Un tercio de los 36 países con datos disponibles depende exclusivamente de becas o asignaciones y transferencias o pagos a otras entidades privadas. Islandia solo concede préstamos a los estudiantes, mientras que el resto de los países ponen a disposición de los estudiantes una combinación de ayudas y préstamos. Ambos tipos de apoyos están especialmente desarrollados en Australia, Chile, Estados Unidos, Noruega, Nueva Zelanda, Países Bajos, Reino Unido y Suecia. 
En general, los países que ofrecen préstamos a los estudiantes son también aquellos en los que las ayudas públicas a las familias representan la mayor proporción de todo el gasto público en educación terciaria. En la mayoría de los casos, estos países gastan solo en ayudas y becas un porcentaje superior a la media de sus presupuestos para educación terciaria (Gráfico B5.3 y Tabla B5.4).

\section{Diferencias de enfoque entre paises en la financiación de la educación terciaria}

Muchos países tienen objetivos similares en lo que respecta a la educación terciaria, como reforzar la economía del conocimiento, aumentar las posibilidades de acceso de los estudiantes, estimular tasas elevadas de finalización de los estudios y asegurar la estabilidad económica de sus sistemas de educación superior. Sin embargo, los países de la OCDE difieren drásticamente en la forma de compartir el coste de la educación superior entre los gobiernos, los estudiantes y sus familias y otras entidades privadas, así como en la ayuda económica que ofrecen a los estudiantes.

Como se ha mencionado anteriormente, los costes de la educación superior y el tipo de ayudas disponibles para los estudiantes presentan variaciones considerables entre los países de la OCDE. Esta sección ofrece una taxonomía de los diferentes modelos de financiación de la educación terciaria en los países para los que se dispone de datos, y analiza la repercusión de estos modelos en el acceso a la educación terciaria. Los países han sido agrupados en cuatro modelos según dos parámetros: el nivel de las tasas de matrícula y las ayudas económicas disponibles dentro del sistema de apoyo a los estudiantes de educación terciaria de cada país.

No existe un único modelo en los países de la OCDE para la financiación de las instituciones de educación terciaria de tipo A. Algunos países en los que se cobran tasas de matrícula similares por las instituciones de educación de tipo A pueden presentar diferencias en el porcentaje de estudiantes que se benefician de las ayudas públicas o en el importe medio de dichas ayudas (Tablas B5.1, B5.2, B5.3, B5.4 y Tabla B5.5 disponible en Internet, y Gráfico B5.1). Dado que las disposiciones relativas a las tasas de matrícula cobradas por las instituciones de educación terciaria han sido objeto de reformas en muchos países de la OCDE desde 1995, algunos países han cambiado de un modelo a otro durante este periodo (véase Gráfico B5.1 y Cuadro B5.1 en Panorama de la educación 2012).

\section{Modelo 1. Países sin tasas de matrícula o con tasas de matrícula bajas y con importantes sistemas de ayuda a los estudiantes}

Este grupo incluye a los países nórdicos: Dinamarca, Finlandia, Islandia, Noruega y Suecia, con sistemas impositivos más progresivos (OECD, 2011) y donde los estudiantes no pagan tasas de matrícula, a la vez que se benefician de generosas ayudas públicas en la educación superior. Sin embargo, los individuos han de hacer frente a elevados impuestos sobre la renta en estos países. El porcentaje medio de acceso a los estudios terciarios de tipo A correspondiente a este grupo, el $74 \%$, se sitúa muy por encima de la media de la OCDE, que es del $59 \%$ (véanse Indicador C3 y Tabla C3.2a). Los altos índices de matriculación en estos países pueden deberse también al atractivo de los sistemas avanzados de ayudas económicas a estudiantes, y no solo a la ausencia de tasas de matrícula. Por ejemplo, en estos países, más del $55 \%$ de los estudiantes de este grupo puede beneficiarse de becas y asignaciones o préstamos públicos, o de una combinación de ambos (Tablas B5.1 y B5.2 y Gráfico B5.1).

Esta forma de financiación de la educación terciaria refleja el gran arraigo de valores sociales en estos países, como la igualdad de oportunidades y la equidad social. La idea de que el gobierno debe proporcionar a sus ciudadanos educación terciaria gratuita es un rasgo destacado de la cultura educativa existente en estos países: la financiación tanto de las instituciones como de los estudiantes se basa en el principio de que el acceso a la educación terciaria es un derecho, no un privilegio. Sin embargo, Dinamarca y Suecia (a partir de 2011) decidieron introducir tasas de matrícula para los estudiantes no nacionales a fin de aumentar los recursos disponibles en sus instituciones de educación terciaria. Esta posibilidad se contempló también en Islandia. El riesgo de este modelo es que podría desanimar a algunos estudiantes internacionales de estudiar en estos países. Suecia ha experimentado una reducción del número de estudiantes de otros países desde que introdujo esta reforma: entre el otoño de 2010 y el otoño de 2011 el número de estudiantes procedentes de fuera del Espacio Económico Europeo o Suiza que no formaban parte de un programa de intercambio disminuyó en casi un $80 \%$ (Agencia Nacional Sueca de Educación Superior, 2013).

\section{Modelo 2. Países con tasas de matrícula elevadas y con sistemas bien desarrollados de ayuda a los estu- diantes \\ Un segundo grupo lo integran Australia, Canadá, Estados Unidos, Nueva Zelanda, Países Bajos y Reino Unido, en los que existen barreras potencialmente elevadas para el acceso a los estudios terciarios de tipo A, pero en los que tam- bién se conceden importantes ayudas públicas a los estudiantes de este nivel. Es de destacar que el porcentaje medio de acceso a los estudios terciarios de tipo A correspondiente a este grupo de países, $75 \%$, está muy por encima de la media de la OCDE y por encima de la mayoría de los países (excepto los países nórdicos) con tasas de matrícula bajas.}


Los países incluidos en el Modelo 2 suelen ser aquellos cuyas entidades privadas (como empresas y organizaciones sin ánimo de lucro) contribuyen en mayor grado a la financiación de las instituciones terciarias; en otras palabras, en los países del Modelo 2, el coste de la educación se comparte entre el gobierno, las familias y las empresas privadas (Gráfico B3.2 y Tabla B3.2b).

Las tasas de matrícula que se cobran en las instituciones de estudios terciarios de tipo A superan los 1.500 dólares estadounidenses en todos estos países, pero más del $75 \%$ de los estudiantes de educación terciaria de tipo A reciben ayudas públicas (en Australia, Estados Unidos, Nueva Zelanda, Países Bajos y Reino Unido, los cinco países de los que se dispone de información; véanse Tablas B5.1 y B5.2). Los sistemas de ayuda a los estudiantes están bien desarrollados y, en términos generales, cubren las necesidades de toda la población estudiantil. El porcentaje del gasto público en educación terciaria destinado a ayudas públicas es superior a la media de la OCDE (22\%) en cinco de los seis países: Australia (35\%), Estados Unidos (29\%), Nueva Zelanda (48\%), Países Bajos (29\%) y Reino Unido (74\%), y cercano a la media en Canadá (19\%) (Tabla B5.4).

El acceso a la educación terciaria de tipo A en este grupo de países es superior a la media de la OCDE. Por ejemplo, Australia y Nueva Zelanda tienen dos de los índices más elevados de acceso a la educación terciaria de tipo A (96\% y $79 \%$, respectivamente), debido en gran parte al alto porcentaje de estudiantes internacionales matriculados en educación terciaria de tipo A. Las tasas de ingreso en educación terciaria de tipo A estaban por encima de la media de la OCDE (59\%) en Estados Unidos (72\%), Países Bajos (65\%) y Reino Unido (64\%) en 2011. Estos países invierten más por estudiante de educación terciaria en servicios básicos (servicios directamente relacionados con la enseñanza) que la media de la OCDE y tienen una recaudación por imposición fiscal sobre la renta en términos de porcentaje del PIB relativamente elevada en comparación con la media de la OCDE. El caso de Países Bajos es una excepción, dado que su nivel de imposición fiscal sobre la renta está por debajo de la media de la OCDE (véase Tabla B1.1b, disponible en Internet, y Tabla C3.1).

Los estudios de la OCDE (OECD, 2008) sugieren que, en general, este modelo puede ser una forma efectiva de que los países mejoren las posibilidades de acceso a la educación superior. Sin embargo, en periodos de crisis económica, unas tasas de matrícula elevadas pueden suponer una carga financiera considerable para los estudiantes y sus familias y pueden desanimar a algunos de cursar educación terciaria, aun cuando dispongan de niveles relativamente elevados de ayudas. Esta cuestión es muy debatida en Canadá, Estados Unidos y Reino Unido.

\section{Modelo 3. Países con tasas de matrícula elevadas y sistemas poco desarrollados de ayuda a los estudiantes}

En Chile, Corea y Japón, la mayoría de los estudiantes pagan tasas de matrícula elevadas (como media, más de 4.500 dólares estadounidenses en instituciones de educación terciaria de tipo A), pero los sistemas de ayuda a los estudiantes están algo menos desarrollados que en los Modelos 1 y 2, lo que supone potencialmente una carga económica considerable para los estudiantes y sus familias. Los índices de ingreso en instituciones terciarias de tipo $\mathrm{A}$ se sitúan por debajo de la media de la OCDE, en Chile (45\%) y en Japón (52\%), pero significativamente por encima de la media en Corea (69\%). En Japón y Corea, algunos estudiantes que obtienen resultados académicos destacados en sus estudios, pero que tienen dificultades para financiarlos, pueden beneficiarse de unas tasas de ingreso o de matrícula inferiores o quedar exentos del pago de las mismas en su totalidad.

Japón y Corea se sitúan entre los países de menor nivel de gasto público en porcentaje del PIB asignado a la educación terciaria (véase Tabla B4.1). Este hecho explica en parte el bajo porcentaje de estudiantes que pueden beneficiarse de los préstamos públicos. No obstante, ambos países han puesto en marcha reformas recientes para mejorar el sistema de apoyo a los estudiantes.

\section{Modelo 4. Países con tasas de matrícula bajas y sistemas poco desarrollados de ayuda a los estudiantes}

El cuarto y último grupo incluye a todos los demás países europeos de los que se dispone de datos (Austria, Bélgica, España, Francia, Irlanda, Italia, Polonia, Portugal, República Checa y Suiza) y a México. Todos estos países cobran tasas de matrícula moderadas en comparación con las de los Modelos 2 y 3, aunque desde 1995 en algunos de estos países se han introducido reformas, sobre todo en Austria e Italia, para aumentar las tasas de matrícula que cobran las instituciones públicas (Gráfico B5.1 y Cuadro B5.1). En los países del Modelo 4 existen barreras económicas relativamente bajas en las tasas de matrícula para el acceso a la educación terciaria (o no tienen tasas de matrícula, como en el caso de Irlanda y México), junto con unas ayudas relativamente bajas a los estudiantes, destinadas principalmente a grupos específicos. Las tasas de matrícula que se cobran en las instituciones públicas en los países de este modelo nunca superan los 1.300 dólares estadounidenses y el porcentaje de estudiantes que se benefician de las ayudas públicas se sitúa por debajo del $40 \%$ en los países de los que se dispone de datos (Tablas B5.1 y B5.2). 
En los países del Modelo 4, el nivel de dependencia de los recursos públicos para la financiación de la educación terciaria es alto y los niveles de participación están habitualmente por debajo de la media de la OCDE. Es de destacar que el índice medio de acceso a la educación terciaria de tipo A en este grupo de países, un 56 \%, es relativamente bajo, aunque en el caso de Bélgica se contrarresta con altos índices de acceso a la educación terciaria de tipo B. De igual modo, el gasto por estudiante en la educación terciaria de tipo A es también comparativamente bajo en este grupo de países (Gráfico B5.2 y véase Indicador B1). Estos datos indican que, aunque unas tasas de matrícula elevadas pueden suponer barreras a la participación de los estudiantes, unas tasas de matrícula bajas, que generalmente se asocian con mayor accesibilidad a la educación, no son en sí mismas condición suficiente para garantizar mayor acceso ni mayor calidad en la educación terciaria de tipo A.

En estos países, los estudiantes y sus familias pueden beneficiarse de ayudas facilitadas por entidades ajenas al Ministerio de Educación (por ejemplo, asignaciones para alojamiento, desgravaciones o deducciones fiscales para la educación) que no forman parte del presente análisis. Por ejemplo, en Francia las asignaciones para alojamiento pueden representar un importe total equivalente al $90 \%$ de las becas o ayudas, y en torno a un tercio de los estudiantes se benefician de estas asignaciones. En Polonia, un rasgo digno de mención lo constituye el hecho de que algunos estudiantes tienen sus estudios costeados completamente con cargo a las finanzas públicas, mientras que los estudiantes a tiempo parcial tienen que costearse ellos solos el total de sus estudios.

Los países del Modelo 4 no disponen de sistemas de préstamos (préstamos públicos o préstamos garantizados por el Estado) o estos solo están a disposición de un reducido porcentaje de estudiantes (Tabla B5.2). Además, el nivel de gasto público y de recaudación por imposición fiscal sobre la renta en términos de porcentaje sobre el PIB presenta una variación significativamente mayor entre los países incluidos en este grupo con respecto a los otros grupos.

\section{Sistemas de préstamos públicos y montante de los préstamos públicos}

Los sistemas de préstamos públicos (véase Cuadro B5.1 sobre tipos de préstamos a estudiantes) están especialmente bien desarrollados en Australia, Estados Unidos, Noruega y Reino Unido, donde en torno a un $70 \%$ o más de los estudiantes se benefician de préstamos públicos durante su educación terciaria de tipo A. Los sistemas de préstamos públicos están muy desarrollados también en Nueva Zelanda (64\%) y en Islandia y Suecia (donde un $63 \%$ y un $40 \%$ de los estudiantes, respectivamente, disfrutan de un préstamo), dos países donde, junto con Noruega, las instituciones educativas no cobran tasas de matrícula a los estudiantes nacionales. Al mismo tiempo, en Estados Unidos, que está entre los países con tasas de matrícula más elevadas en educación terciaria de tipo A, un $84 \%$ de los estudiantes a tiempo y año completo se benefician de un préstamo público cada año.

La ayuda económica que los estudiantes reciben de préstamos públicos durante sus estudios no puede analizarse únicamente a partir de la proporción de estudiantes que tienen préstamos. La ayuda a los estudiantes depende también del montante que pueden recibir mediante préstamos públicos. En los países con datos comparables, el montante bruto anual de préstamos públicos disponible para cada estudiante supera los 4.000 dólares estadounidenses en aproximadamente la mitad de los países y varía de menos de 3.000 dólares estadounidenses en Bélgica (Comunidad francófona), Finlandia (préstamos garantizados por el gobierno en lugar de préstamos públicos), Países Bajos y Turquía, a más de 9.000 dólares estadounidenses en España, Estados Unidos, Islandia, México, Noruega y Reino Unido (Tabla B5.3, año de referencia 2010-2011).

\section{Cuadro B5.1. Préstamos a estudiantes: sistemas de devolución supeditada a los ingresos frente a devolución fija}

La inversión en educación terciaria suele facilitar que los individuos tengan mejores perspectivas en el mercado laboral, reduce el riesgo de desempleo y puede dar lugar a mayores retornos públicos y privados (véanse Indicadores A5, A6 y A7).

Los préstamos a estudiantes, que complementan las ayudas y becas, están destinados a ayudar a los estudiantes a pagar el coste de su educación terciaria (tasas de matrícula y costes de alojamiento y manutención). Los sistemas de préstamos públicos se han desarrollado de forma relativamente reciente, sobre todo durante las décadas de 1960 y 1980, durante un periodo de aumento generalizado de la matriculación en educación terciaria, a la vez que se incrementaban las tasas de matrícula. 
Sin embargo, la carga de la deuda que los estudiantes han de acumular es un factor que puede influir en su decisión de invertir en educación terciaria. El volumen de la carga de la deuda depende del nivel de las tasas de matrícula y de los costes de alojamiento y manutención, así como de los intereses a pagar por el préstamo (que pueden estar subvencionados o no).

Para quienes viven en países sin tasas de matrícula o con tasas de matrícula bajas en educación terciaria (Modelos 1 y 4 , véase arriba), la deuda contraída en el momento de la graduación será normalmente inferior que la de los estudiantes que estudian en países con tasas de matrícula elevadas, dado que los préstamos a estudiantes se utilizan fundamentalmente para cubrir sus costes de alojamiento y manutención. Sin embargo, los países nórdicos, donde no hay tasas de matrícula o son muy bajas, el nivel de deuda de los estudiantes en el momento de la graduación puede ser elevado, puesto que los costes de alojamiento y manutención son altos en esos países. Para los individuos que estudian en países donde la educación terciaria supone tasas de matrícula elevadas (Modelos 2 y 3), el nivel de deuda en el momento de la graduación puede ser más alto y los incentivos y riesgos de la inversión en educación terciaria pueden variar en función del tipo de préstamo que reciban.

En sentido amplio, existen dos tipos de prestamos a estudiantes: préstamos de devolución fija (también conocidos como préstamos tipo hipoteca) y préstamos de devolución supeditada a los ingresos. En un sistema de préstamos de devolución fija, los estudiantes tienen la obligación de devolver el préstamo dentro de un periodo de tiempo fijo, sea cual sea su situación económica una vez acabados sus estudios. Esto puede suponer una pesada carga económica sobre los graduados (o quienes no hayan conseguido graduarse) si tienen un nivel de ingresos bajo, como se comprobó recientemente durante la crisis económica, cuando la deuda de los estudiantes en Estados Unidos alcanzó 1,1 billones de dólares estadounidenses en 2013. En los sistemas de préstamos con devolución supeditada a los ingresos, la devolución está condicionada a que los ingresos del prestatario alcancen un cierto umbral, y prevén la condonación de la deuda pasado un cierto periodo de tiempo. Este tipo de acuerdo de devolución tiene en cuenta la capacidad del estudiante graduado para devolver el préstamo.

Ambos sistemas implican algún coste para el gobierno que garantiza la devolución del préstamo o subvenciona las tasas de interés. La devolución de préstamos públicos puede constituir una fuente sustancial de ingresos para los gobiernos (gracias al pago de intereses, ya que la devolución del capital es solo una transacción en el balance) y puede reducir significativamente los costes de los programas de préstamos. Sin embargo, la carga financiera potencial para los gobiernos es más incierta si se conceden préstamos con devolución supeditada a los ingresos, dado que el reembolso de los mismos está condicionado a las posibilidades de encontrar trabajo y alcanzar un nivel de ingresos por encima del umbral mínimo establecido para el reembolso del préstamo. Este tipo de préstamo a estudiantes se ha introducido en varios países en los últimos años. Por ejemplo, Reino Unido sustituyó en 1999 el sistema de préstamos tipo hipoteca por un sistema de préstamos con devolución supeditada a los ingresos. Aunque la mayoría de los estudiantes en instituciones terciarias de tipo A en Reino Unido tienen un préstamo, este sistema tuvo que apoyarse en una ayuda adicional del gobierno cifrada en seis mil millones de libras esterlinas en 2011 (más del $30 \%$ del gasto público total en educación terciaria; véase Tabla B5.4), aunque el gasto final del gobierno es inferior al indicado cuando se tiene en cuenta la devolución de los préstamos. Con el aumento de las deuda de los estudiantes, Estados Unidos introdujo también sistemas de préstamos con devolución supeditada a los ingresos: un programa de devolución según ingresos en 2009 y el plan denominado «Pay-As-You-Earn» (PAYE) en 2012.

Cuando se considera la educación como una inversión, los prestamos a estudiantes tienen repercusión visible en los retornos netos de la educación (véase Indicador A7). Los retornos privados (para los estudiantes) de la educación dependen de los costes de los tipos de interés asociados a los préstamos y de los beneficios resultantes de su remisión (además de la posibilidad de acceso a la educación y sus beneficios asociados). Los retornos públicos netos (para los gobiernos) disminuyen en relación con los costes derivados de subvencionar tasas de interés más bajas para los préstamos a estudiantes y los costes asociados a la remisión de los préstamos.

El predominio de los sistemas de devolución supeditada a los ingresos o de los de devolución fija afecta a los retornos netos de la educación, dado que la tasa de remisión es mayor con los sistemas de devolución supeditada a los ingresos (que suponen mayores costes para los gobiernos, pero mayores beneficios para los estudiantes). Entre los países de los que se dispone de datos, Canadá y Reino Unido son los que informan de una mayor condonación de deudas y están asimismo entre los países con tasas de interés más elevadas en los préstamos (Tabal B5.3). 
La comparación entre tasas medias de matrícula e importe medio de los préstamos debe interpretarse con cautela dado que, en un programa de educación determinado, el importe del préstamo puede variar mucho de unos estudiantes a otros, incluso si las tasas de matrícula del programa coinciden. No obstante, este dato permite saber si los estudiantes reciben préstamos para cubrir las tasas de matrícula y los costes de alojamiento y manutención. Cuanto más elevadas sean las tasas de matrícula que cobran las instituciones, mayor será la necesidad de ayuda económica a los estudiantes mediante préstamos públicos. La presión financiera sobre los gobiernos de la ayuda a los estudiantes aumenta a medida que se elevan las tasas de matrícula. En los países de la OCDE con datos disponibles sobre el volumen bruto anual de préstamos públicos a estudiantes, el importe medio de los préstamos es superior a las tasas de matrícula medias cobradas por las instituciones públicas, excepto en Australia. Ello sugiere que los préstamos públicos se utilizan también para los costes de alojamiento y manutención de los estudiantes durante sus estudios.

Entre los países con tasas de matrícula medias por encima de los 1.500 dólares estadounidenses en instituciones públicas de educación terciaria de tipo A, el importe medio de los préstamos a estudiantes en Estados Unidos y en Reino Unido (instituciones privadas dependientes del gobierno) es al menos el doble de las tasas medias de matrícula. La mayor diferencia entre las tasas medias de matrícula y el importe medio de los préstamos se observa en los países nórdicos, en los que las instituciones no cobran tasas de matrícula y un gran número de estudiantes se benefician de préstamos públicos de un importe medio que oscila entre unos 4.200 dólares estadounidenses en Dinamarca y unos 9.400 en Noruega, alcanzando los 10.400 dólares estadounidenses en Islandia (Tabla B5.1a y Tabla B5.3).

Los sistemas de préstamos públicos ofrecen también ayuda económica a los estudiantes mediante las tasas de interés que los estudiantes tendrían que pagar, los sistemas de devolución e incluso los mecanismos de remisión o condonación de la deuda (Tabla B5.3).

\section{Ayuda económica mediante tipos de interés}

La ayuda económica en forma de tipos de interés reducidos en préstamos públicos o privados tiene dos vertientes: los tipos de interés pagados por los estudiantes durante y después de sus estudios pueden ser distintos. Es difícil comparar los tipos de interés entre países, ya que no se conoce la estructura de los tipos de interés, ya sean públicos o privados, y puede variar de forma significativa entre países, de manera que un determinado tipo de interés se considere alto en un país y bajo en otro. Sin embargo, la diferencia de los tipos durante y después de la educación terciaria está destinada a reducir la carga financiera de los estudiantes durante su periodo de estudio. Por ejemplo, en Canadá, Islandia, Japón, Noruega y Nueva Zelanda, no se aplica ningún tipo de interés nominal sobre los préstamos públicos durante este periodo, pero tras los estudios puede aplicarse a los estudiantes o graduados un tipo de interés en relación con los costes monetarios pagados por el gobierno o incluso mayor. Por ejemplo, Nueva Zelanda, que aprobó préstamos libres de intereses para los prestatarios mientras residieran en el país en 2006-2007, cobra intereses a aquellos estudiantes que estén en otros países. En cambio, Bélgica, Estados Unidos, Estonia, Hungría, Países Bajos, Polonia, Reino Unido y Suecia no diferencian entre el tipo de interés aplicado a los estudiantes durante y después de los estudios. En Australia, no se aplica interés a los préstamos, pero la parte del préstamo que no se ha devuelto pasados 11 meses o más se revaloriza para asegurar que se mantiene su valor en términos reales (Tabla B5.3).

\section{Devolución de los préstamos}

Los informes actuales sobre los gastos de los hogares en educación como parte del gasto privado (véase Indicador B3) no tienen en cuenta la devolución de los préstamos públicos por los prestatarios anteriores. Como se ve en la Tabla B5.3, el periodo de devolución varía según países, oscilando desde menos de 10 años en Australia, Bélgica (Comunidad francófona), España, Finlandia, Nueva Zelanda y Turquía, a 20 años o más en Islandia y Suecia. Entre los 17 países de la OCDE de los que se dispone de datos sobre sistemas de devolución, cuatro países de habla inglesa (Australia, Nueva Zelanda, Reino Unido y en determinadas circunstancias Estados Unidos) junto con Hungría, Islandia, Países Bajos y Suecia establecen la devolución de los préstamos dependiendo del nivel de ingresos de los graduados (con un periodo máximo de devolución de hasta 15 años en el caso de Países Bajos). En los países con sistemas de devolución supeditada a los ingresos, el umbral mínimo anual por encima del cual los prestatarios han de reembolsar el préstamo varía ampliamente entre países: mientras que es especialmente bajo en Suecia (menos de 7.000 dólares estadounidenses), varía desde unos 13.000 dólares estadounidenses en Nueva Zelanda a más de 29.000 dólares en Australia.

Los países de habla inglesa son también países en los que las tasas medias de matrícula cobradas por las instituciones superan los 1.500 dólares estadounidenses y el importe medio de los préstamos figura entre los más altos de los países con un sistema público de préstamos (Tabla B5.3). 


\section{Deuda en el momento de la graduación}

En momentos de crisis económica que supone dificultades potenciales a la hora de encontrar trabajo para los jóvenes graduados, el nivel de deuda en el momento de la graduación es fuente de preocupación. Cuando disminuyen las oportunidades que ofrece el mercado laboral, muchos graduados tienden a volver a los estudios, lo cual a su vez hace que sus deudas aumenten.

En varios países, la mayoría de los estudiantes se encuentran endeudados en el momento de la graduación. Los países cuyas instituciones de educación terciaria cobran tasas de matrícula elevadas son también aquellos en los que los estudiantes acumulan mayores deudas en la graduación. Por el contrario, en los países con una proporción relativamente reducida de estudiantes endeudados, la carga de la deuda es también más ligera. Por ejemplo, en Turquía, uno de cada cinco estudiantes está endeudado en el momento de la graduación por un importe medio de unos 5.200 dólares estadounidenses, mientras que en Estados Unidos dos de cada tres graduados tienen deudas derivadas de préstamos por un importe medio de 25.400 dólares estadounidenses.

Los países que no cobran tasas de matrícula a los estudiantes nacionales muestran también un nivel alto de deudas. Este es el caso de los estudiantes en Suecia, que se gradúan con una deuda media de 20.000 dólares estadounidenses. En Noruega, la deuda del estudiante medio alcanza los 25.000 dólares estadounidenses. A diferencia de lo que ocurre en países con tasas de matrícula elevadas, los préstamos en estos países se destinan a cubrir todo tipo de gastos de los estudiantes. Además, en estos países los ingresos son en general menores tras la graduación, a lo que se añade un nivel elevado de impuestos (véase el Modelo 1).

\section{Definiciones}

Las tasas medias de matrícula cobradas por las instituciones públicas y privadas de educación terciaria de tipo A no distinguen las tasas de matrícula por el tipo de programa. Este indicador presenta una visión general de las tasas de matrícula en educación terciaria de tipo A según la clase de institución y el porcentaje de estudiantes que recibe o no becas o asignaciones para cubrir dichas tasas de matrícula total o parcialmente. Las cantidades de las tasas de matrícula y el correspondiente porcentaje de estudiantes deben interpretarse con cautela, ya que son el resultado de la media ponderada de los principales programas de educación terciaria de tipo A y no abarcan todas las instituciones educativas.

Dentro del gasto público transferido a los estudiantes, familias y otras entidades privadas se incluyen los fondos que pueden ir indirectamente a las instituciones educativas, como las ayudas que se emplean para cubrir las tasas de matrícula, y otras ayudas que no llegan, ni siquiera indirectamente, a las instituciones educativas, como las destinadas a cubrir los costes de alojamiento y manutención de los estudiantes.

Las ayudas públicas a las familias incluyen las asignaciones o becas (ayudas no reembolsables), los préstamos públicos a estudiantes (que deben reembolsarse), las asignaciones familiares o por hijos supeditadas a la situación del estudiante, las ayudas públicas en metálico o en especie, expresamente destinadas a alojamiento, transporte, gastos médicos, libros y materiales, actividades sociales y recreativas y otros fines, y las ayudas en forma de préstamos de bajo interés de entidades crediticias privadas.

Sin embargo, la ayuda pública no distingue entre los diversos tipos de ayudas o préstamos, tales como becas, asignaciones familiares y pagos en especie. Los gobiernos también pueden apoyar a los estudiantes y sus familias mediante asignaciones para gastos de alojamiento, desgravaciones y bonificaciones fiscales para la educación. Estas ayudas no se consideran en este indicador y, por consiguiente, puede darse el caso de que las ayudas económicas estén sustancialmente subestimadas en algunos países.

Es también práctica habitual que los gobiernos avalen la devolución de los préstamos concedidos a los estudiantes por las instituciones privadas. En algunos países de la OCDE, esta forma de ayuda pública indirecta es tan importante o más que la ayuda económica directa a los estudiantes. En todo caso, y por razones comparativas, el indicador solo tiene en cuenta los importes relativos a las transferencias públicas a entidades privadas para préstamos privados, no el valor total de los préstamos generados. No obstante, en algunas de las tablas se ofrece información cualitativa que puede arrojar alguna luz sobre esta clase de ayuda pública.

Los préstamos a estudiantes se refieren al volumen total de los préstamos a estudiantes con el fin de ofrecer información sobre el nivel de ayuda que reciben los estudiantes actuales. El montante bruto de los préstamos es una variable aceptable para evaluar las ayudas económicas que se conceden a los beneficiarios actuales de la educación. El pago de intereses y la devolución del principal por los prestatarios deben tenerse en cuenta al efecto de evaluar el coste neto de los préstamos concedidos a los estudiantes por entidades públicas y privadas. No obstante, por lo ge- 
neral, dichos pagos no son efectuados por los estudiantes actuales, sino por los antiguos estudiantes y no están cubiertos en este indicador. Además, en la mayoría de los países, la devolución de los préstamos no revierte en las autoridades educativas, por lo que estas no pueden disponer de los mismos para financiar otros gastos de educación. Los indicadores de la OCDE tienen en cuenta el importe íntegro (bruto) de las becas y préstamos en los debates sobre la ayuda económica a los estudiantes actuales. Algunos países de la OCDE también tienen dificultades para cuantificar el importe de los préstamos concedidos a los estudiantes. Por tanto, los datos sobre préstamos a los estudiantes deben interpretarse con cautela.

\section{Metodología}

Los datos se refieren al año financiero 2011 y proceden de la recopilación UOE de datos estadísticos sobre educación, realizada por la OCDE en 2012 (para más detalles, véase Anexo 3 en www.oecd.org/edu/eag.htm).

Los datos sobre las tasas de matrícula cobradas por las instituciones educativas y las ayudas financieras a los estudiantes aplicadas desde 1995 fueron recabados mediante una encuesta especial llevada a cabo en 2012 y se refieren al curso académico 2010-2011.

Los importes de las tasas de matrícula y de los préstamos en divisa nacional se muestran en equivalente a dólares estadounidenses obtenido dividiendo la cantidad expresada en la divisa nacional por el coeficiente de PPA (paridad de poder adquisitivo) para el PIB. Los importes de las tasas de matrícula y los correspondientes porcentajes de estudiantes deben interpretarse con cautela, ya que representan la media ponderada de los principales programas de educación terciaria de tipo A y no cubren todas las instituciones educativas.

Los costes públicos destinados a préstamos privados garantizados por el Estado se incluyen en concepto de ayudas a otras entidades privadas. A diferencia de los préstamos públicos, solo se incluye el coste neto de estos préstamos.

No se incluye el valor de las deducciones o desgravaciones fiscales a familias y estudiantes.

\section{Nota sobre los datos de Israel}

Los datos estadísticos para Israel fueron proporcionados por las autoridades israelíes competentes bajo su responsabilidad. El uso de estos datos por parte de la OCDE se hace sin prejuzgar la situación de los Altos del Golán, Jerusalén Este y los asentamientos israelíes en Cisjordania de acuerdo con los términos del derecho internacional.

\section{Referencias}

OECD (2008), Tertiary Education for the Knowledge Society: Volume 1 and Volume 2, OECD Publishing, París, http:// dx.doi.org/10.1787/9789264046535-en.

OECD (2011), Revenue Statistics 2011, OECD Publishing, París, http://dx.doi.org/10.1787/ctpa-rev-data-en.

Swedish National Agency for Higher Education (2012), «Fewer Students from Asia after the Tuition Reform», Statistical Analysis, Estocolmo.

\section{Tablas del Indicador B5}

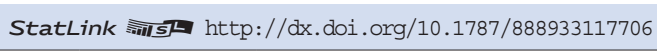

Tabla B5.1 Tasas medias anuales de matrícula estimadas cobradas por instituciones de educación terciaria de tipo A (2011)

Tabla B5.2 Ayuda económica a estudiantes y tasas de matrícula cobradas por instituciones de educación terciaria de tipo A (2011)

Tabla B5.3 Préstamos públicos a estudiantes en educación terciaria de tipo A (año académico 2010-2011)

Tabla B5.4 Ayudas públicas a familias y a otras entidades privadas para educación terciaria (2011)

WEB Tabla B5.5 Ayudas públicas a familias y a otras entidades privadas para educación primaria, secundaria y postsecundaria no terciaria (2011) 
Tabla B5.1. [1/2] Tasas medias anuales de matrícula estimadas cobradas por instituciones de educación terciaria de tipo $\mathbf{A}^{\mathbf{1}}$ (2011)

Estudiantes nacionales, en equivalente a dólares estadounidenses convertidos mediante PPA, por tipo de institución y estructura del grado, sobre la base de estudiantes a tiempo completo, año académico 2010-2011

Nota: Las tasas de matrícula y las proporciones asociadas de estudiantes deben interpretarse con cautela, ya que son el resultado dela media ponderada de los principales programas terciarios de tipo A y no cubren todas las instituciones educativas. No obstante, las cifras presentadas pueden considerarse buenas aproximaciones y muestran la diferencia entre países de las tasas de matrícula cobradas por las principales instituciones educativas y para la mayoría de los estudiantes.

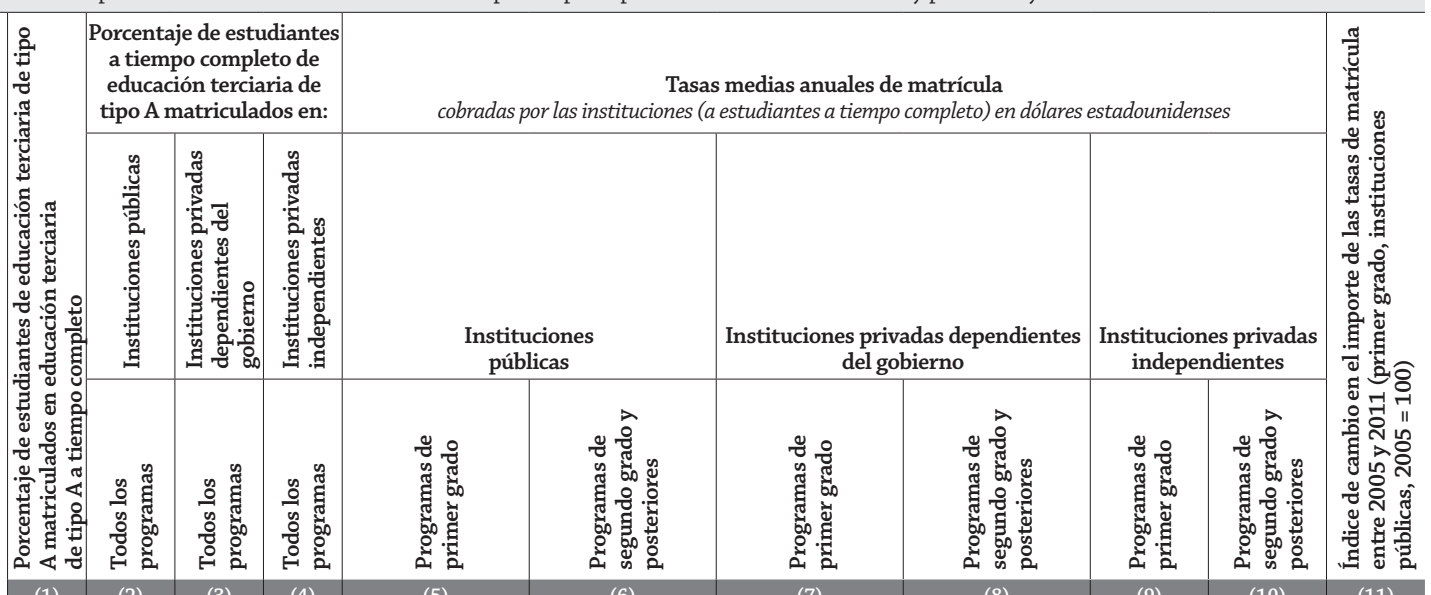

\begin{tabular}{|c|c|c|c|c|c|c|c|c|c|c|c|c|}
\hline \multirow{4}{*}{ 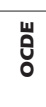 } & & (1) & (2) & (3) & (4) & (5) & (6) & (7) & (8) & (9) & (10) & (11) \\
\hline & Alemania & 94 & 96 & 4 & $\mathrm{x}(3)$ & $\mathrm{m}$ & $\mathrm{m}$ & $\mathrm{m}$ & $\mathrm{m}$ & $\mathrm{m}$ & $\mathrm{m}$ & $\mathrm{m}$ \\
\hline & Australia & 71 & 96 & a & 4 & 3.924 & 6.099 & a & a & 10.110 & 9.635 & 128 \\
\hline & Austria $^{2}$ & $\mathrm{~m}$ & 84 & 13 & 3 & 860 & 860 & 860 & 860 & Hasta 11.735 & Hasta 11.735 & $\mathrm{~m}$ \\
\hline & Bélgica (Fl.) & 75 & 52 & 48 & $\mathrm{~m}$ & 576 a 653 & 576 a 653 & 576 a 653 & 576 a 653 & $\mathrm{~m}$ & $\mathrm{~m}$ & $\mathrm{~m}$ \\
\hline & Bélgica (Fr.) & 84 & 33 & 67 & $\mathrm{~m}$ & 653 & 696 & 754 & 785 & $\mathrm{~m}$ & $\mathrm{~m}$ & $\mathrm{~m}$ \\
\hline & Canadá & 82 & $\mathrm{~m}$ & $\mathrm{~m}$ & $\mathrm{~m}$ & 4.288 & $\mathrm{~m}$ & $x(4)$ & $\mathrm{m}$ & $x(4)$ & $\mathrm{m}$ & 124 \\
\hline & Chile & $\mathrm{m}$ & 23 & 18 & 59 & 5.885 & 6.345 & 6.924 & 8.757 & 6.230 & 8.357 & $\mathrm{~m}$ \\
\hline & Corea & $\mathrm{m}$ & 23 & a & 77 & 5.395 & $\mathrm{~m}$ & a & a & 9.383 & $\mathrm{~m}$ & $\mathrm{~m}$ \\
\hline & Dinamarca $^{3}$ & 90 & $\mathrm{~m}$ & $\mathrm{~m}$ & $\mathrm{~m}$ & Sin tasas de matrícula & Sin tasas de matrícula & $\mathrm{m}$ & $\mathrm{m}$ & a & a & $\mathrm{m}$ \\
\hline & Eslovenia & 75 & 94 & 6 & 1 & $\mathrm{n}$ & $\mathrm{n}$ & $\mathrm{n}$ & $\mathrm{n}$ & 11.040 & 12.144 & $\mathrm{~m}$ \\
\hline & España & 76 & 88 & a & 12 & 1.129 & $\mathrm{~m}$ & a & a & $\mathrm{m}$ & $\mathrm{m}$ & $\mathrm{m}$ \\
\hline & Estados Unidos & 66 & 70 & a & 30 & 5.402 & $\mathrm{~m}$ & a & a & 17.163 & $\mathrm{~m}$ & 116 \\
\hline & Estonia & 87 & $\mathrm{~m}$ & 93 & 7 & $\mathrm{~m}$ & $\mathrm{~m}$ & 3.527 & 3.786 & 5.322 & 6.699 & $\mathrm{~m}$ \\
\hline & Finlandia & 56 & 74 & 26 & $\mathrm{a}$ & Sin tasas de matrícula & Sin tasas de matrícula & Sin tasas de matrícula & Sin tasas de matrícula & a & a & $\mathrm{m}$ \\
\hline & Francia & $\mathrm{m}$ & 86 & 5 & 9 & 200 a 1.402 & 273 a 1.402 & 1.138 a 8.290 & $x(6)$ & $\mathrm{m}$ & $\mathrm{m}$ & 116 \\
\hline & Grecia & 100 & $\mathrm{~m}$ & $\mathrm{~m}$ & $\mathrm{~m}$ & $\mathrm{~m}$ & $\mathrm{~m}$ & $\mathrm{~m}$ & $\mathrm{~m}$ & $\mathrm{~m}$ & $\mathrm{~m}$ & $\mathrm{~m}$ \\
\hline & Irlanda & 87 & $\mathrm{~m}$ & $\mathrm{a}$ & $\mathrm{m}$ & 6.450 & 7.036 & a & a & $\mathrm{m}$ & $\mathrm{m}$ & 136 \\
\hline & Islandia & 71 & $\mathrm{~m}$ & $\mathrm{~m}$ & $\mathrm{~m}$ & $\mathrm{~m}$ & $\mathrm{~m}$ & $\mathrm{~m}$ & $\mathrm{~m}$ & $\mathrm{~m}$ & $\mathrm{~m}$ & $\mathrm{~m}$ \\
\hline & Israel & 82 & $\mathrm{~m}$ & $\mathrm{~m}$ & $\mathrm{~m}$ & $\mathrm{~m}$ & $\mathrm{~m}$ & $\mathrm{~m}$ & $\mathrm{~m}$ & $\mathrm{~m}$ & $\mathrm{~m}$ & $\mathrm{~m}$ \\
\hline & Italia & 100 & 90 & a & 10 & 1.407 & $\mathrm{x}(5)$ & a & a & 4.406 & $\mathrm{x}(9)$ & $\mathrm{m}$ \\
\hline & Japón & 91 & 25 & a & 75 & 5.019 & 5.106 & a & a & 8.039 & 7.423 & 109 \\
\hline & Luxemburgo & 95 & $\mathrm{~m}$ & $\mathrm{~m}$ & $\mathrm{~m}$ & $\mathrm{~m}$ & $\mathrm{~m}$ & $\mathrm{~m}$ & $\mathrm{~m}$ & $\mathrm{~m}$ & $\mathrm{~m}$ & $\mathrm{~m}$ \\
\hline & México & 95 & 67 & $\mathrm{a}$ & 33 & Sin tasas de matrícula & Sin tasas de matrícula & a & a & 5.684 & $\mathrm{x}(9)$ & $\mathrm{m}$ \\
\hline & Noruega & 71 & 85 & 5 & 10 & Sin tasas de matrícula & Sin tasas de matrícula & $\mathrm{m}$ & $\mathrm{m}$ & 5.868 & 7.296 & $\mathrm{~m}$ \\
\hline & Nueva Zelanda & 60 & $\mathrm{~m}$ & $\mathrm{~m}$ & $\mathrm{~m}$ & 3.645 & $\mathrm{x}(4)$ & $\mathrm{m}$ & $\mathrm{m}$ & $\mathrm{m}$ & $\mathrm{m}$ & 135 \\
\hline & Países Bajos & 86 & $\mathrm{~m}$ & a & $\mathrm{m}$ & 1.966 & $\mathrm{x}(4)$ & a & a & $\mathrm{m}$ & $\mathrm{m}$ & 113 \\
\hline & Polonia & 45 & 90 & a & 10 & $\mathrm{n}$ & $\mathrm{n}$ & a & a & 1.242 & 1.335 & $\mathrm{~m}$ \\
\hline & Portugal $^{3}$ & $\mathrm{~m}$ & $\mathrm{~m}$ & $\mathrm{~m}$ & $\mathrm{~m}$ & $\mathrm{~m}$ & $\mathrm{~m}$ & $\mathrm{~m}$ & $\mathrm{~m}$ & $\mathrm{~m}$ & $\mathrm{~m}$ & $\mathrm{~m}$ \\
\hline & Reino Unido & 76 & a & 100 & $\mathrm{n}$ & a & a & 4.980 & 7.814 & $\mathrm{~m}$ & $\mathrm{~m}$ & $\mathrm{~m}$ \\
\hline & República Checa & 97 & $\mathrm{~m}$ & $\mathrm{~m}$ & $\mathrm{~m}$ & $\mathrm{~m}$ & $\mathrm{~m}$ & $\mathrm{~m}$ & $\mathrm{~m}$ & $\mathrm{~m}$ & $\mathrm{~m}$ & $\mathrm{~m}$ \\
\hline & República Eslovaca & 64 & 93 & $\mathrm{a}$ & 7 & Máximo 2.916 & $\mathrm{x}(4)$ & $\mathrm{a}$ & a & $\mathrm{m}$ & $\mathrm{m}$ & $\mathrm{m}$ \\
\hline & Turquía & 100 & 94 & a & 6 & 332 & 270 & a & a & $\mathrm{m}$ & $\mathrm{m}$ & 136 \\
\hline 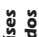 & Brasil & $\mathrm{m}$ & $\mathrm{m}$ & $\mathrm{m}$ & $\mathrm{m}$ & $\mathrm{m}$ & $\mathrm{m}$ & $\mathrm{m}$ & $\mathrm{m}$ & $\mathrm{m}$ & $\mathrm{m}$ & $\mathrm{m}$ \\
\hline c & Federación Rusa & 49 & $\mathrm{~m}$ & $\mathrm{~m}$ & $\mathrm{~m}$ & $\mathrm{~m}$ & $\mathrm{~m}$ & $\mathrm{~m}$ & $\mathrm{~m}$ & $\mathrm{~m}$ & $\mathrm{~m}$ & $\mathrm{~m}$ \\
\hline
\end{tabular}

1. No se tienen en cuenta las becas o asignaciones que los estudiantes puedan recibir.

2. Incluye estudiantes en programas de investigación avanzada.

3. Tasas de matrícula en toda la educación terciaria.

Fuente: OCDE. Tabla B5.1 en Panorama de la educación 2013. Para ver notas, consulte Anexo 3 (www.oecd.org/edu/eag.htm)

Para obtener más información acerca de los símbolos utilizados en lugar de los datos que faltan, consulte la Guía del lector.

StatLink 部实 http://dx.doi.org/10.1787/888933117725 


\title{
Tabla B5.1. [2/2] Tasas medias anuales de matrícula estimadas cobradas por instituciones de educación terciaria de tipo $A^{1}$ (2011)
}

Estudiantes nacionales, en equivalente a dólares estadounidenses convertidos mediante PPA, por tipo de institución y estructura del grado, sobre la base de estudiantes a tiempo completo, año académico 2010-2011

\begin{abstract}
Nota: Las tasas de matrícula y las proporciones asociadas de estudiantes deben interpretarse con cautela, ya que son el resultado de la media ponderada de los principales programas terciarios de tipo A y no cubren todas las instituciones educativas. No obstante, las cifras presentadas pueden considerarse buenas aproximaciones y muestran la diferencia entre países de las tasas de matrícula cobradas por las principales instituciones educativas y para la mayoría de los estudiantes.
\end{abstract}

\begin{tabular}{|c|c|c|}
\hline \multirow{2}{*}{\multicolumn{2}{|c|}{ (2) }} & \multirow{2}{*}{ Comentario } \\
\hline & & \\
\hline 㟒 & Alemania & \\
\hline Uू & Australia & $\begin{array}{l}\text { El 93\% de los estudiantes nacionales en instituciones públicas estudian en centros subvencionados y pagan una media de } 3.817 \text { dólares estadounidenses } \\
\text { en concepto de tasas de matrícula, incluyendo las ayudas HECS/HELP. Se produjo un aumento significativo ( 50\%) de las becas para estudiantes } \\
\text { nacionales entre } 2007 \text { y } 2009 \text { como consecuencia de las reformas llevadas a cabo por el gobierno destinadas a doblar el número de becas a estudiantes de la } \\
\text { Commonwealth en } 2012 \text {. Las nuevas becas se destinaron fundamentalmente a estudiantes que estudian programas con prioridad nacional, estudiantes que } \\
\text { necesitaban cambiar de lugar para estudiar programas especializados y estudiantes nativos. }\end{array}$ \\
\hline & Austria $^{2}$ & $\begin{array}{l}\text { A partir del verano de } 2009 \text {, los estudiantes nacionales y los procedentes de UE/EEE tienen que pagar las tasas de matrícula si sobrepasan la duración teórica } \\
\text { del programa de estudios en dos semestres, así como los estudiantes no procedentes de países de UE/EEE (excepto estudiantes de países subdesarrollados). }\end{array}$ \\
\hline & Bélgica (Fl.) & $\begin{array}{l}\text { Las tasas de matrícula se refieren a la cantidad mínima y máxima que las instituciones cobran de acuerdo con el grado (cifras de índices). Las tasas de } \\
\text { matrícula se refieren a estudiantes matriculados en programas de primer grado (título de grado) y segundo grado (máster). La información no se refiere a } \\
\text { otros programas ulteriores (por ejemplo, máster tras máster). Esta información se refiere a estudiantes sin beca (los estudiantes con beca se benefician de } \\
\text { tasas de matrícula más bajas; véase Anexo } 3 \text { para obtener información más detallada). }\end{array}$ \\
\hline & Bélgica (Fr.) & $\begin{array}{l}\text { Las tasas de matrícula cobradas por los programas son las mismas en las instituciones públicas y en las privadas, pero la distribución de los estudiantes } \\
\text { difiere entre ambas instituciones; por tanto, la media ponderada no es la misma. }\end{array}$ \\
\hline & \multicolumn{2}{|r|}{ ( } \\
\hline \multicolumn{3}{|c|}{ Chile } \\
\hline \multicolumn{3}{|c|}{ Corea } \\
\hline & Eslovenia & $\begin{array}{l}\text { En instituciones públicas y privadas dependientes del gobierno: los estudiantes a tiempo completo de primer y segundo nivel no pagan tasas de } \\
\text { matrícula. Pero los estudiantes de segundo ciclo que ya tienen una cualificación o grado equivalente al segundo ciclo sí han de pagarlas. }\end{array}$ \\
\hline \multicolumn{3}{|r|}{ ( } \\
\hline & Estados Unidos & Las cifras incluyen a todos los estudiantes (nacionales a tiempo completo y no nacionales o extranjeros a tiempo completo) \\
\hline & Estonia & $\begin{array}{l}\text { En Estonia existe un sistema dual de matrícula. Los estudiantes que son admitidos en plazas de financiación pública no pagan matrícula. Las universidades pueden } \\
\text { cobrar tasas de matrícula a los estudiantes admitidos en las plazas adicionales no pagadas por el gobierno. En este caso, las universidades deciden tanto el importe de } \\
\text { la matrícula como el número de estudiantes a quienes cobrarla. En los programas de investigación avanzada, por ejemplo, las universidades crean la mayoría de las } \\
\text { plazas adicionales sin tasas de matrícula. En cierta medida, lo mismo ocurre en los programas de segundo grado y posteriores. }\end{array}$ \\
\hline & Finlandia & No se incluyen las cuotas obligatorias de socio para las asociaciones de estudiantes. \\
\hline & Francia & $\begin{array}{l}\text { Tasas de matrícula en instituciones públicas hacen referencia a programas universitarios dependientes del Ministerio de Educación Superior en el nivel } \\
\text { más bajo de tasas de matrícula y al diploma estatal de Psicomotricista }(1.218 €) \text { en el nivel más alto de tasas de matrícula en instituciones públicas. Para } \\
\text { las instituciones privadas dependientes del gobierno, los niveles más bajos de tasas de matrícula mencionados en la tabla hacen referencia a la Universidad } \\
\text { Católica y los niveles más altos a las escuelas de artes plásticas. }\end{array}$ \\
\hline \multicolumn{3}{|r|}{ m } \\
\hline \multicolumn{3}{|c|}{ Hungría } \\
\hline & Irlanda & $\begin{array}{l}\text { Las tasas de matrícula exigidas por las instituciones públicas las paga directamente el gobierno en el caso de estudiantes de primer grado a tiempo } \\
\text { completo procedentes de la Unión Europea, exclusivamente. Aproximadamente un tercio de todas las tasas de matrícula proceden de las familias (sobre } \\
\text { todo para estudiantes a tiempo parcial, estudiantes de posgrado y estudiantes no procedentes de la UE). Esto significa que en el curso } 2010-2011 \text { los } \\
\text { estudiantes solo pagaron } 1.500 € \text { del nivel de tasas anterior. }\end{array}$ \\
\hline \multicolumn{3}{|c|}{ Israel } \\
\hline & Italia & $\begin{array}{l}\text { Cada institución fija escalas de tasas de matrícula que dependen de las circunstancias económicas de la familia del estudiante, de acuerdo con criterios de equidad } \\
\text { y solidaridad que se basan en normas generales establecidas a nivel nacional. Las tasas de matrícula medias anuales se calculan sobre la base de las tasas de } \\
\text { matrícula reales que paga cada estudiante. Los estudiantes completamente exentos de pagar tasas no se incluyen en el cálculo de la media. }\end{array}$ \\
\hline & Japón & Las tasas de matrícula medias anuales no incluyen las tasas de admisión cobradas por los centros escolares el primer año \\
\hline \multicolumn{3}{|c|}{ Luxemburgo } \\
\hline \multicolumn{3}{|c|}{ México } \\
\hline & Noruega & Las tasas de estudiantes son representativas de la institución privada CINE 5 dominante en Noruega. \\
\hline \multicolumn{3}{|c|}{ Nueva Zelanda } \\
\hline \multicolumn{3}{|c|}{ Países Bajos } \\
\hline \multicolumn{3}{|c|}{ Polonia } \\
\hline \multicolumn{3}{|c|}{ Portugal $^{3}$} \\
\hline \multicolumn{3}{|c|}{ Reino Unido } \\
\hline \multicolumn{3}{|c|}{ República Checa } \\
\hline & $\begin{array}{l}\text { República } \\
\text { Eslovaca }\end{array}$ & $\begin{array}{l}\text { Generalmente, los estudiantes a tiempo completo no pagan tasas de matrícula, pero los estudiantes que están matriculados simultáneamente en el mismo año } \\
\text { académico en dos o más programas de estudio ofrecidos por una universidad pública en el mismo nivel han de pagar tasas de matrícula anuales por el segundo } \\
\text { y siguientes programas de estudio durante el mismo año académico. Además, los estudiantes que permanecen estudiando más tiempo que el normalmente } \\
\text { necesario para finalizar los estudios han de pagar una matrícula anual por cada año adicional de estudio. }\end{array}$ \\
\hline & Suecia & En el otoño de 2011 se introdujeron tasas de matrícula para los estudiantes de fuera del EEE y Suiza. \\
\hline \multicolumn{3}{|c|}{ Suiza } \\
\hline \multicolumn{3}{|c|}{ Turquía } \\
\hline & Brasil & \\
\hline & Federación Rusa & \\
\hline
\end{tabular}

1. No se tienen en cuenta las becas o asignaciones que los estudiantes puedan recibir.

2. Incluye estudiantes en programas de investigación avanzada.

3. Tasas de matrícula en toda la educación terciaria.

Fuente: OCDE. Tabla B5.1 en Panorama de la educación 2013. Para ver notas, consulte Anexo 3 (www.oecd.org/edu/eag.htm).

Para obtener más información acerca de los símbolos utilizados en lugar de los datos que faltan, consulte la Guía del lector.

StatLink 제개 http://dx.doi.org/10.1787/888933117725 
Tabla B5.2. Ayuda económica a estudiantes y tasas de matrícula cobradas por instituciones de educación terciaria de tipo A (2011)

Estudiantes nacionales y programas de primer grado, sobre la base de estudiantes a tiempo completo, año académico 2010-2011

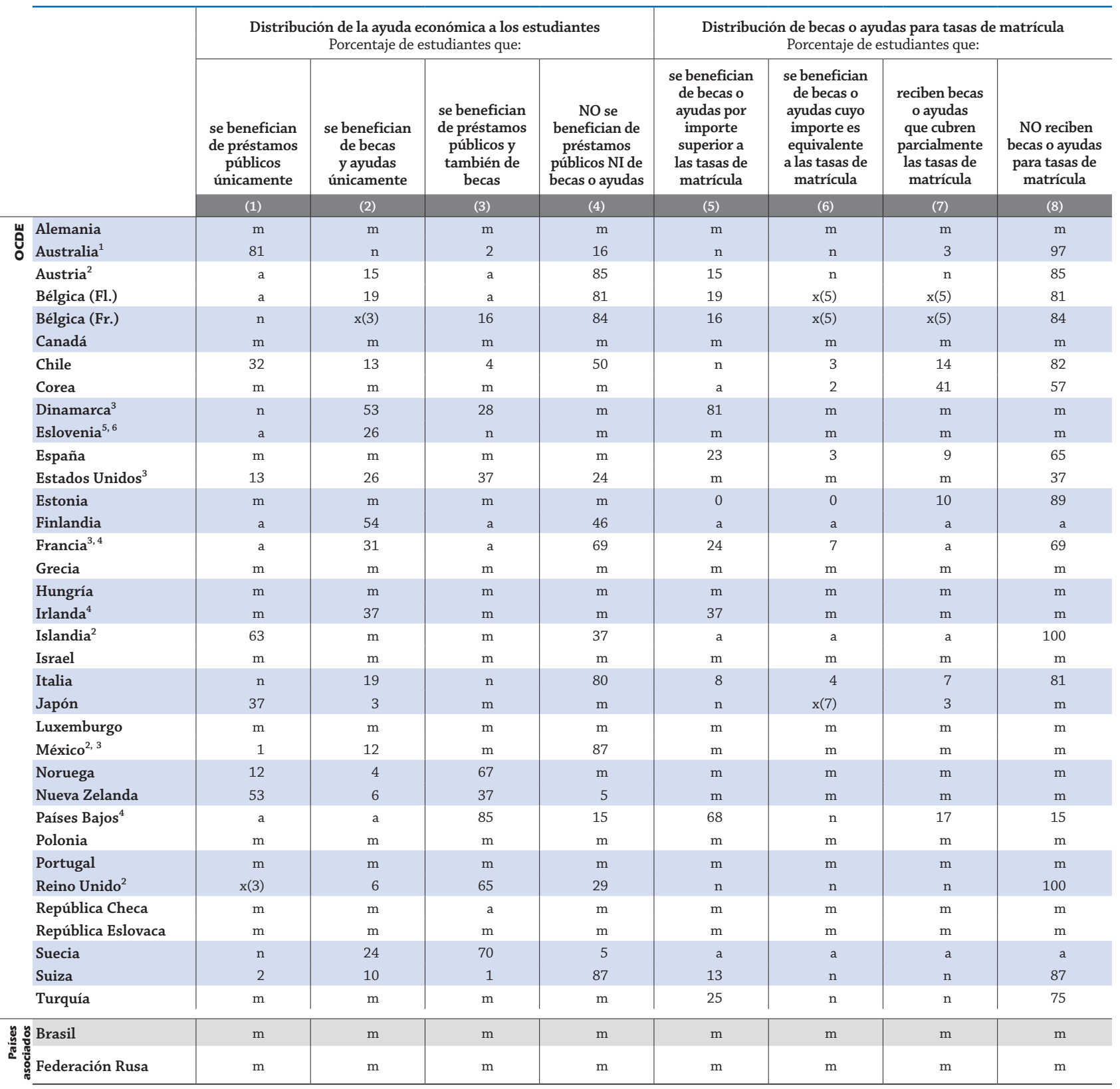

1. Excluye estudiantes extranjeros.

2. Los datos se refieren al año académico 2008-2009.

3. Distribución de estudiantes en toda la educación terciaria (solo universidad pública, incluida la educación terciaria de tipo B en Francia).

4. Solo instituciones públicas.

5. La columna 2 incluye solo becas.

6. Los datos se refieren al año académico 2009-2010.

Fuente: OCDE. Tabla B5.2 en Panorama de la educación 2013. Para ver notas, consulte Anexo 3 (www.oecd.org/edu/eag.htm).

Para obtener más información acerca de los símbolos utilizados en lugar de los datos que faltan, consulte la Guía del lector.

StatLink 제피 http://dx.doi.org/10.1787/888933117744 


\section{Tabla B5.3. [1/2] Préstamos públicos a estudiantes en educación terciaria de tipo A (año académico 2010-2011)}

Estudiantes nacionales, en equivalente a dólares estadounidenses convertidos mediante PPA

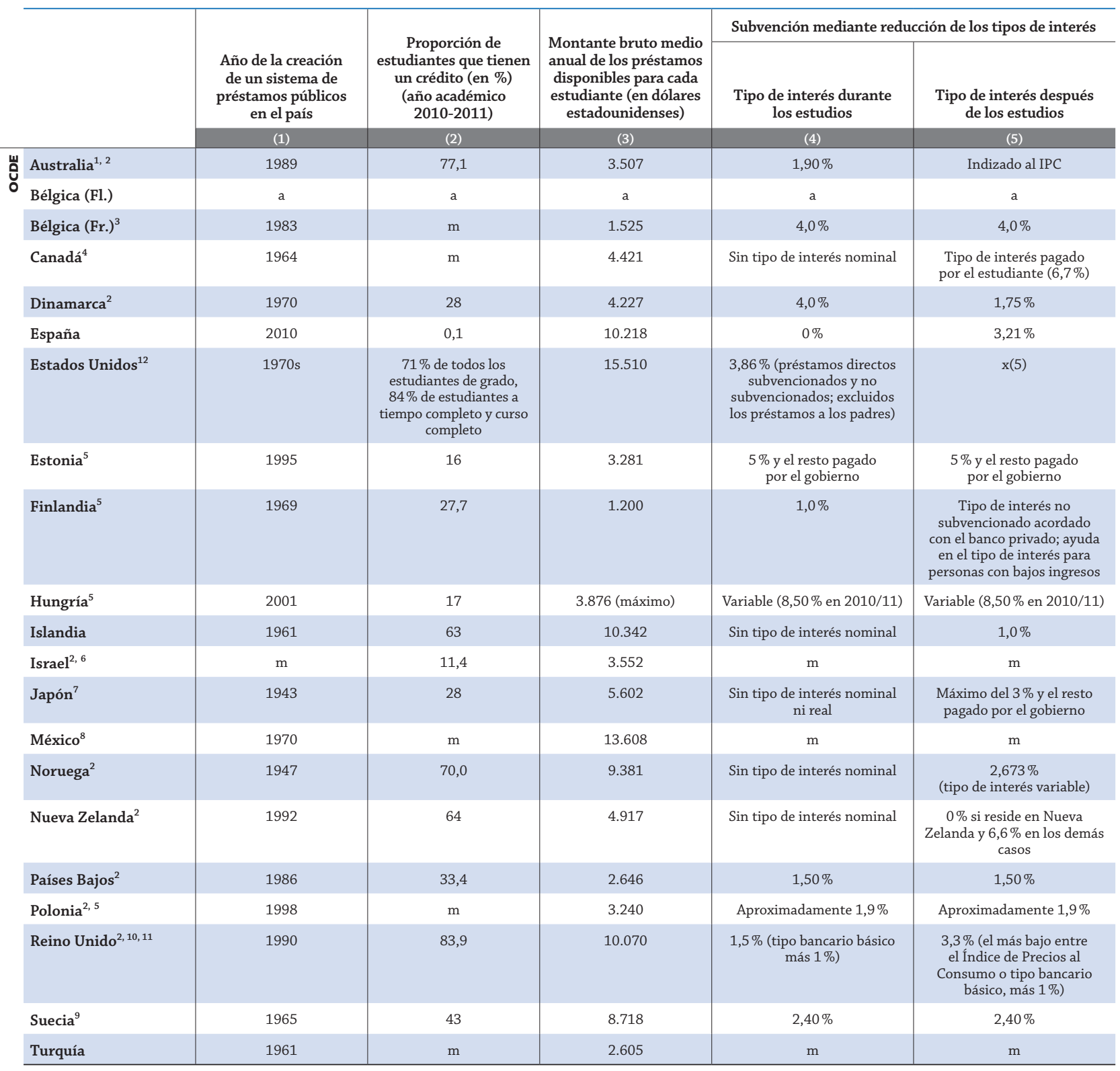

1. Incluidos países de la Commonwealth.

2. Todos los estudiantes de educación terciaria.

3. Préstamo concedido a los padres del estudiante y que han de devolver los propios padres.

4. Préstamo fuera de Quebec. En Quebec, solo hay préstamos privados garantizados por el gobierno.

5. Préstamo garantizado por el estado en lugar de préstamo público.

6. El montante anual de préstamos se refiere tanto a los préstamos públicos como privados.

7. Año de referencia 2006-2007. Montante medio de los préstamos a estudiantes en el primer programa de cualificación CINE 5A.

8. Montante medio de préstamos para estudiantes de educación terciaria.

9. Montante medio anual de devoluciones en educación terciaria.

10. El montante bruto anual de préstamos se refiere a los estudiantes de Inglaterra.

11. Año de referencia 2009-2011.

12. Solo estudiantes de primer grado en el nivel 5 de CINE. Incluye préstamos del programa PLUS (Préstamos a Padres para Estudiantes de Grado) y otros préstamos concedidos directamente a los padres. El total prestado no incluye los préstamos de familiares y amigos. El montante bruto anual medio de préstamos disponibles para cada estudiante se refiere a estudiantes a tiempo completo y curso completo. Año académico 2011-2012, excepto en la columna 4, que se refiere a 2013-2014.

Fuente: OCDE. Para ver notas, consulte Anexo 3 (www.oecd.org/edu/eag.htm).

Para obtener más información acerca de los símbolos utilizados en lugar de los datos que faltan, consulte la Guía del lector.

StatLink 젝ㄴ http://dx.doi.org/10.1787/888933117763 
Tabla B5.3. [2/2] Préstamos públicos a estudiantes en educación terciaria de tipo A (año académico 2010-2011)

Estudiantes nacionales, en equivalente a dólares estadounidenses convertidos mediante PPA

\begin{tabular}{|c|c|c|c|c|c|c|}
\hline & \multicolumn{4}{|c|}{ Devolución } & \multicolumn{2}{|c|}{ Deuda en el momento de la graduación } \\
\hline & $\begin{array}{l}\text { Sistema de } \\
\text { devolución }\end{array}$ & $\begin{array}{l}\text { Umbral mínimo } \\
\text { anual de ingresos } \\
\text { (en dólares } \\
\text { estadounidenses) }\end{array}$ & $\begin{array}{l}\text { Duración del } \\
\text { periodo típico } \\
\text { de amortización } \\
\text { (en años) }\end{array}$ & $\begin{array}{c}\text { Montante } \\
\text { anual medio de } \\
\text { devoluciones } \\
\text { (en dólares } \\
\text { estadounidenses) }\end{array}$ & $\begin{array}{l}\text { Porcentaje de } \\
\text { graduados con } \\
\text { deudas (en \%) }\end{array}$ & $\begin{array}{l}\text { Deuda media en } \\
\text { el momento de } \\
\text { la graduación } \\
\text { (en dólares } \\
\text { estadounidenses) }\end{array}$ \\
\hline & $(6)$ & (7) & (8) & (9) & (10) & (11) \\
\hline Australia $^{1,2}$ & $\begin{array}{l}\text { Dependiendo } \\
\text { de los ingresos }\end{array}$ & 29.355 & 7,9 & $\mathrm{~m}$ & $\begin{array}{c}55 \% \\
\text { (graduados domésticos) }\end{array}$ & $\mathrm{m}$ \\
\hline Bélgica (Fl.) & a & a & a & a & a & a \\
\hline Bélgica $(\mathrm{Fr} .)^{3}$ & Tipo hipoteca & - & 5 & 276 & a & a \\
\hline Canadá ${ }^{4}$ & Tipo hipoteca & - & 10 & 1.058 & $\mathrm{~m}$ & $\mathrm{~m}$ \\
\hline Dinamarca $^{2}$ & Tipo hipoteca & - & 7 to 15 & 1.975 & 45 & 19.800 \\
\hline España & Tipo hipoteca & $\mathrm{m}$ & 4,43 & 4.392 & $\mathrm{~m}$ & 18.918 \\
\hline Estados Unidos ${ }^{12}$ & $\begin{array}{c}\text { Tipo hipoteca y } \\
\text { Dependiendo de los } \\
\text { ingresos }\end{array}$ & - & 10 to 25 & $\mathrm{~m}$ & 67,7 & 25.400 \\
\hline Estonia $^{5}$ & Tipo hipoteca & a & $\mathrm{m}$ & $\mathrm{m}$ & $\mathrm{m}$ & $\mathrm{m}$ \\
\hline Finlandia ${ }^{5}$ & Tipo hipoteca & - & $\begin{array}{c}\text { De } 5 \text { a } 10 \text { años. } \\
\text { Estimados en función } \\
\text { de la duración de los } \\
\text { estudios y el montante } \\
\text { medio de los préstamos } \\
\text { de estudio }\end{array}$ & 1.353 & 38,5 & 7.990 \\
\hline Hungría $^{5}$ & $\begin{array}{l}\text { Dependiendo de los } \\
\text { ingresos }\end{array}$ & Ninguno & $\begin{array}{l}\text { Expectativa } \\
\text { de 10-15 años }\end{array}$ & 1.039 & 27,6 & 9.263 \\
\hline Islandia & $\begin{array}{l}\text { Una parte fija y otra } \\
\text { dependiendo de los } \\
\text { ingresos }\end{array}$ & - & 22 & $3,75 \%$ de los ingresos & $\mathrm{m}$ & $\mathrm{m}$ \\
\hline Israel $^{2,6}$ & $\mathrm{~m}$ & $\mathrm{~m}$ & $\mathrm{~m}$ & $\mathrm{~m}$ & $\mathrm{~m}$ & $\mathrm{~m}$ \\
\hline Japón ${ }^{7}$ & Tipo hipoteca & - & 15 & 1.196 & $\mathrm{~m}$ & $\mathrm{~m}$ \\
\hline México $^{8}$ & $\mathrm{~m}$ & $\mathrm{~m}$ & $\mathrm{~m}$ & $\mathrm{~m}$ & $\mathrm{~m}$ & $\mathrm{~m}$ \\
\hline Noruega $^{2}$ & $\begin{array}{l}\text { Tipo hipoteca } \\
\text { (con excepciones) }\end{array}$ & - & 16,4 & 1.987 & $\mathrm{~m}$ & 25.188 \\
\hline Países Bajos ${ }^{2}$ & $\begin{array}{l}\text { Dependiendo } \\
\text { de los ingresos }\end{array}$ & 18.685 & 15 & $\mathrm{~m}$ & $\mathrm{~m}$ & 13.108 \\
\hline Polonia $^{2,5}$ & Tipo hipoteca & - & $\begin{array}{c}\mathrm{m} \text { (dos veces la } \\
\text { duración del préstamo) }\end{array}$ & $\mathrm{m}$ & 11 & $3.720-22.330$ \\
\hline Reino Unido $^{2,10,11}$ & $\begin{array}{l}\text { Dependiendo de los } \\
\text { ingresos }\end{array}$ & 25.341 & $14-15$ & $\begin{array}{l}9 \% \text { del montante } \\
\text { de los ingresos que } \\
\text { supere el umbral }\end{array}$ & $\begin{array}{c}79 \% \text { de los estudiantes } \\
\text { elegibles }\end{array}$ & 18.507 \\
\hline Suecia $^{9}$ & $\begin{array}{c}\text { Tipo hipoteca } \\
\text { (con excepciones) }\end{array}$ & 6.735 & 25 & 1.131 & $\mathrm{~m}$ & 20.238 \\
\hline Turquía & Tipo hipoteca & - & $1-2$ & 2.576 & 20 & 5.152 \\
\hline
\end{tabular}

1. Incluidos países de la Commonwealth.

2. Todos los estudiantes de educación terciaria.

3. Préstamo concedido a los padres del estudiante y que han de devolver los propios padres.

4. Préstamo fuera de Quebec. En Quebec, solo hay préstamos privados garantizados por el gobierno.

5. Préstamo garantizado por el estado en lugar de préstamo público.

6. El montante anual de préstamos se refiere tanto a los préstamos públicos como privados.

7. Año de referencia 2006-2007. Montante medio de los préstamos a estudiantes en el primer programa de cualificación CINE 5A.

8. Montante medio de préstamos para estudiantes de educación terciaria.

9. Montante medio anual de devoluciones en educación terciaria.

10. El montante bruto anual de préstamos se refiere a los estudiantes de Inglaterra.

11. Año de referencia 2009-2011.

12. Solo estudiantes de primer grado en el nivel 5 de CINE. Incluye préstamos del programa PLUS (Préstamos a Padres para Estudiantes de Grado) y otros préstamos concedidos directamente a los padres. El total prestado no incluye los préstamos de familiares y amigos. El montante bruto anual medio de préstamos disponibles para cada estudiante se refiere a estudiantes a tiempo completo y curso completo. Año académico 2011-2012, excepto en la columna 4, que se refiere a 2013-2014.

Fuente: OCDE. Para ver notas, consulte Anexo 3 (www.oecd.org/edu/eag.htm).

Para obtener más información acerca de los símbolos utilizados en lugar de los datos que faltan, consulte la Guía del lector.

StatLink 젶ㄴ http://dx.doi.org/10.1787/888933117763 
Tabla B5.4. Ayudas públicas a familias y a otras entidades privadas para educación terciaria (2011) En porcentaje del gasto público total en educación y PIB

\begin{tabular}{|c|c|c|c|c|c|c|c|c|}
\hline & \multirow[b]{3}{*}{$\begin{array}{l}\text { Gasto público } \\
\text { directo para las } \\
\text { instituciones }\end{array}$} & \multicolumn{6}{|c|}{ Ayudas públicas para educación a entidades privadas } & \multirow[b]{3}{*}{$\begin{array}{l}\text { Ayudas públicas } \\
\text { para educación } \\
\text { a entidades } \\
\text { privadas como } \\
\text { porcentaje } \\
\text { del PIB }\end{array}$} \\
\hline & & \multicolumn{5}{|c|}{ Ayuda económica a los estudiantes } & \multirow[b]{2}{*}{ Total } & \\
\hline & & $\begin{array}{l}\text { Becas u otras } \\
\text { ayudas a las } \\
\text { familias }\end{array}$ & $\begin{array}{c}\text { Préstamos para } \\
\text { estudiantes }\end{array}$ & Total & $\begin{array}{c}\text { Becas u otras } \\
\text { ayudas a } \\
\text { las familias } \\
\text { imputables a las } \\
\text { instituciones } \\
\text { educativas }\end{array}$ & $\begin{array}{c}\text { Transferencias } \\
\text { y pagos a otras } \\
\text { entidades } \\
\text { privadas }\end{array}$ & & \\
\hline & (1) & (2) & (3) & (4) & (5) & (6) & (7) & (8) \\
\hline Alemania & 78,1 & 16,3 & 5,6 & 21,9 & $\mathrm{~m}$ & $\mathrm{n}$ & 21,9 & 0,31 \\
\hline Australia & 65,0 & 13,7 & 21,2 & 34,9 & 0,7 & $\mathrm{n}$ & 35,0 & 0,39 \\
\hline Austria & 82,4 & 9,8 & a & 9,8 & $\mathrm{~m}$ & 7,8 & 17,6 & 0,27 \\
\hline Bélgica & 85,6 & 14,4 & $\mathrm{n}$ & 14,4 & 4,2 & $\mathrm{n}$ & 14,4 & 0,21 \\
\hline Canadá ${ }^{1}$ & 80,7 & 4,3 & 13,5 & 17,8 & $\mathrm{~m}$ & 1,6 & 19,3 & 0,38 \\
\hline Chile $^{2}$ & 61,8 & 16,4 & 17,2 & 33,6 & 16,0 & 4,6 & 38,2 & 0,36 \\
\hline Corea & 90,9 & 3,8 & 4,8 & 8,5 & 3,5 & 0,6 & $\mathbf{9 , 1}$ & 0,07 \\
\hline Dinamarca $^{3}$ & 71,6 & 23,2 & 5,1 & 28,4 & $\mathrm{n}$ & $\mathrm{n}$ & 28,4 & 0,69 \\
\hline Eslovenia & 76,6 & 23,4 & $\mathrm{n}$ & 23,4 & $\mathrm{~m}$ & $\mathrm{n}$ & 23,4 & 0,32 \\
\hline España & 90,6 & 9,4 & $\mathrm{n}$ & 9,4 & 2,0 & $\mathrm{n}$ & $\mathbf{9 , 4}$ & 0,11 \\
\hline Estados Unidos & 70,8 & 27,9 & 1,3 & 29,2 & $\mathrm{~m}$ & $\mathrm{~m}$ & 29,2 & 0,39 \\
\hline Estonia & 90,7 & 4,3 & 5,1 & 9,3 & $\mathrm{~m}$ & $\mathrm{n}$ & 9,3 & 0,12 \\
\hline Finlandia & 86,0 & 13,7 & $\mathrm{n}$ & 13,7 & $\mathrm{n}$ & 0,2 & 14,0 & 0,30 \\
\hline Francia & 92,0 & 8,0 & $\mathrm{~m}$ & 8,0 & $\mathrm{~m}$ & a & 8,0 & 0,10 \\
\hline Grecia & $\mathbf{m}$ & $\mathrm{m}$ & $\mathrm{m}$ & $\mathrm{m}$ & $\mathrm{m}$ & $\mathrm{m}$ & $\mathbf{m}$ & $\mathrm{m}$ \\
\hline Hungría & 87,6 & 12,4 & $\mathrm{~m}$ & 12,4 & $\mathrm{n}$ & $\mathrm{n}$ & 12,4 & 0,14 \\
\hline Irlanda & 86,7 & 13,3 & $\mathrm{n}$ & 13,3 & $\mathrm{n}$ & $\mathrm{n}$ & 13,3 & 0,18 \\
\hline Islandia & 73,8 & $\mathrm{~m}$ & 26,2 & 26,2 & a & $\mathrm{n}$ & 26,2 & 0,37 \\
\hline Israel & 88,5 & 9,9 & 1,6 & 11,5 & 9,6 & $\mathrm{n}$ & 11,5 & 0,11 \\
\hline Italia & 77,8 & 22,2 & $\mathrm{n}$ & 22,2 & 10,6 & $\mathrm{n}$ & 22,2 & 0,18 \\
\hline Japón $^{3}$ & 70,4 & 0,6 & 29,0 & 29,6 & $\mathrm{~m}$ & $\mathrm{n}$ & 29,6 & 0,23 \\
\hline Luxemburgo & $\mathbf{m}$ & $\mathrm{m}$ & $\mathrm{m}$ & $\mathrm{m}$ & $\mathrm{m}$ & $\mathrm{m}$ & $\mathbf{m}$ & $\mathrm{m}$ \\
\hline México & 91,0 & 5,5 & 3,5 & 9,0 & 2,5 & a & 9,0 & 0,09 \\
\hline Noruega & 61,9 & 11,4 & 26,7 & 38,1 & $\mathrm{~m}$ & $\mathrm{n}$ & 38,1 & 0,99 \\
\hline Nueva Zelanda & 52,0 & 14,5 & 33,5 & 48,0 & $\mathrm{~m}$ & $\mathrm{n}$ & 48,0 & 0,90 \\
\hline Países Bajos & 70,9 & 13,2 & 15,7 & 28,8 & $\mathrm{n}$ & 0,3 & 29,1 & 0,50 \\
\hline Polonia & 87,3 & 12,2 & 0,5 & 12,7 & $\mathrm{~m}$ & $\mathrm{n}$ & 12,7 & 0,14 \\
\hline Portugal & 84,6 & 15,4 & $\mathrm{~m}$ & 15,4 & $\mathrm{~m}$ & $\mathrm{~m}$ & 15,4 & 0,16 \\
\hline Reino Unido & 26,2 & 7,5 & 31,7 & 39,2 & $\mathrm{x}(4)$ & 34,7 & 73,8 & 0,99 \\
\hline República Checa & 98,5 & 1,5 & a & 1,5 & $\mathrm{~m}$ & $\mathrm{n}$ & 1,5 & 0,02 \\
\hline República Eslovaca $^{3}$ & 79,4 & 16,2 & 0,5 & 16,7 & $\mathrm{~m}$ & 3,9 & 20,6 & 0,20 \\
\hline Suecia & 75,3 & 9,5 & 15,2 & 24,7 & a & a & 24,7 & 0,49 \\
\hline Suiza & 92,9 & 2,2 & $\mathrm{n}$ & 2,2 & $\mathrm{~m}$ & 4,9 & 7,1 & 0,10 \\
\hline Turquía & 85,9 & 5,0 & 9,1 & 14,1 & $\mathrm{n}$ & $\mathrm{m}$ & 14,1 & 0,22 \\
\hline Media OCDE & 78,5 & 11,6 & 9,2 & 19,6 & 3,1 & 2,0 & 21,5 & 0,31 \\
\hline Arabia Saudí & $\mathbf{m}$ & $\mathrm{m}$ & $\mathrm{m}$ & $\mathrm{m}$ & $\mathrm{m}$ & $\mathrm{m}$ & $\mathbf{m}$ & $\mathrm{m}$ \\
\hline Argentina & 98,9 & 1,1 & $\mathrm{n}$ & 1,1 & $\mathrm{~m}$ & 0,1 & 1,1 & 0,01 \\
\hline Brasil & 90,5 & 4,3 & 4,4 & 8,7 & $x(2)$ & 0,8 & 9,5 & 0,10 \\
\hline China & $\mathbf{m}$ & $\mathrm{m}$ & $\mathrm{m}$ & $\mathrm{m}$ & $\mathrm{m}$ & $\mathrm{m}$ & $\mathbf{m}$ & $\mathrm{m}$ \\
\hline Colombia $^{2}$ & 86,5 & $\mathrm{x}(4)$ & $\mathrm{x}(4)$ & 13,5 & $\mathrm{x}(4)$ & $\mathrm{n}$ & 13,5 & 0,14 \\
\hline Federación Rusa & $\mathbf{m}$ & $\mathrm{m}$ & a & $\mathrm{m}$ & a & $\mathrm{m}$ & $\mathbf{m}$ & $\mathrm{m}$ \\
\hline India & $\mathbf{m}$ & $\mathrm{m}$ & $\mathrm{m}$ & $\mathrm{m}$ & $\mathrm{m}$ & $\mathrm{m}$ & $\mathbf{m}$ & $\mathrm{m}$ \\
\hline Indonesia $^{2}$ & 97,7 & 2,3 & $\mathrm{~m}$ & 2,3 & $\mathrm{~m}$ & $\mathrm{~m}$ & 2,3 & $\mathrm{~m}$ \\
\hline Letonia & 86,0 & 14,0 & $\mathrm{n}$ & 14,0 & $x(2)$ & $\mathrm{n}$ & 14,0 & 0,14 \\
\hline Sudáfrica & $\mathbf{m}$ & $\mathrm{m}$ & $\mathrm{m}$ & $\mathrm{m}$ & $\mathrm{m}$ & $\mathrm{m}$ & $\mathbf{m}$ & $\mathrm{m}$ \\
\hline Media G20 & m & $\mathrm{m}$ & $\mathrm{m}$ & $\mathrm{m}$ & $\mathrm{m}$ & $\mathrm{m}$ & m & $\mathrm{m}$ \\
\hline
\end{tabular}

1. Año de referencia 2010.

2. Año de referencia 2012.

3. Algunos niveles educativos están incluidos junto con otros. Véase el código «X» en la Tabla B1.1a para obtener más detalles.

Fuentes: OCDE. Arabia Saudí, Argentina, China, Colombia, India, Indonesia, Sudáfrica: Instituto de Estadística de la UNESCO. Letonia: Eurostat. Para ver notas, consulte Anexo 3 (www.oecd.org/edu/eag.htm).

Para obtener más información acerca de los símbolos utilizados en lugar de los datos que faltan, consulte la Guía del lector.

StatLink 제피 http://dx.doi.org/10.1787/888933117782 


\section{¿EN QUÉ RECURSOS Y SERVICIOS SE GASTAN LOS FONDOS DESTINADOS A EDUCACIÓN?}

- Como media en los países de la OCDE, alrededor del $90 \%$ o más del gasto total en educación se destina al gasto corriente, y en la mayoría de los países de la OCDE, tanto en los niveles de educación primaria, secundaria y postsecundaria no terciaria en conjunto como en el nivel de educación terciaria.

- En 25 de los 33 países de la OCDE y países asociados con datos disponibles, la proporción del gasto total destinado al gasto de capital en educación terciaria es mayor que en el conjunto de los niveles de educación primaria, secundaria y postsecundaria no terciaria. Esto podría estar relacionado con la expansión de la educación terciaria en los últimos años y la consecuente necesidad de construir nuevos edificios.

- En la OCDE y los países asociados con datos disponibles, la mayor parte del gasto corriente se destina a la retribución del personal docente (profesores y otros).

- El gasto corriente destinado a partidas distintas de la retribución del personal es el mayor en el nivel de educación terciaria, donde alcanza el $33 \%$ de todo el gasto corriente como media en los países de la OCDE. En ocho países de la OCDE y asociados, esta proporción es superior al $40 \%$. Esto podría deberse al coste más alto de las instalaciones y del equipamiento en educación terciaria, en comparación con otros niveles educativos.

\section{Gráfico B6.1. Distribución del gasto corriente de instituciones educativas para educación primaria, secundaria y postsecundaria no terciaria (2011)}

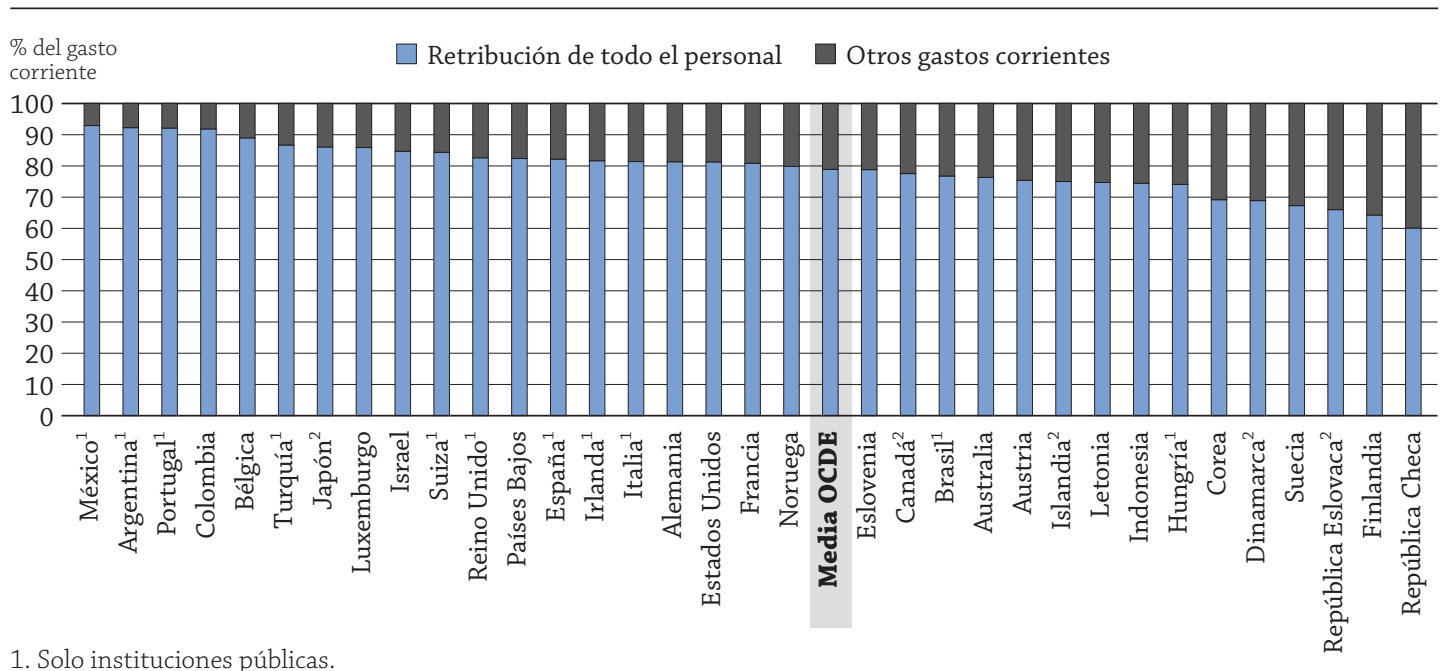

1. Solo instituciones públicas.

2. Algunos niveles educativos están incluidos junto con otros. Véase el código «X» en la Tabla B1.1a para obtener más detalles.

Los países están ordenados en orden descendente del porcentaje de retribución de todo el personal educativo en educación primaria, secundaria y postsecundaria no terciaria.

Fuente: OCDE. Tabla B6.2. Para ver notas, consulte Anexo 3 (www.oecd.org/edu/eag.htm).

StatLink 제매 http://dx.doi.org/10.1787/888933117915

\section{Contexto}

Las decisiones sobre la asignación de recursos afectan a las condiciones materiales en las que tiene lugar la enseñanza y pueden influir también en la naturaleza de esta.

Aunque se puede ahorrar recortando el gasto de capital (por ejemplo, no construyendo nuevos centros educativos) y algunos gastos corrientes (no comprando ciertos materiales didácticos), al aumentar la presión sobre los presupuestos para educación, son los cambios del gasto en personal los que tienen el mayor impacto en el gasto total. Ahorrar dinero recortando salarios y beneficios o reduciendo el número de profesores y otros tipos de personal resulta impopular desde el punto de vista político y seguramente sea contraproducente, ya que disuade a buenos profesores de querer entrar o permanecer en la profesión. Por ello, además de manejar los recursos materiales de modo más eficiente, es esencial 
mejorar la gestión de los recursos humanos para aumentar la calidad de los sistemas educativos. Asimismo, aplazar gastos como la contratación de nuevos profesores o los aumentos salariales son otras medidas temporales para enfrentarse a la presión sobre los presupuestos públicos.

Este indicador describe los recursos y servicios en los que se gastan los fondos para educación. Muestra la diferencia entre el gasto corriente y el de capital. El gasto de capital puede verse afectado por el número creciente de matriculaciones, que a menudo llevan a la construcción de nuevos edificios. Este indicador presenta asimismo detalles acerca de en qué se emplea el gasto corriente, si en la retribución del personal educativo o en otras partidas. El gasto corriente se ve afectado principalmente por los salarios de los profesores (véase Indicador D3), pero también por los sistemas de pensiones, la distribución por edad de los profesores y la cantidad de personal no docente empleado en educación. Además, las instituciones educativas no solo proporcionan enseñanza, sino también otros servicios, como los de comedor, transporte, alojamiento o actividades de investigación. Todos estos gastos se tratan en este indicador.

\section{Otros resultados}

- Los países de la OCDE gastan por término medio el $21 \%$ del gasto corriente para la educación primaria, secundaria y postsecundaria no terciaria en partidas distintas a la retribución del personal educativo. Apenas hay diferencias entre la educación primaria y la secundaria en términos de la proporción del gasto corriente que se destina a partidas distintas a la retribución. La diferencia es superior a 5 puntos porcentuales solamente en Brasil, Francia, Indonesia, Irlanda y Luxemburgo y alcanza los 20 puntos porcentuales en Dinamarca.

- En casi todos los países, excepto en Indonesia y República Checa, en el nivel de educación terciaria, la mayor parte del gasto corriente está relacionada con la retribución del personal. En educación terciaria, solamente Brasil, Colombia e Islandia destinan más del $80 \%$ del gasto corriente a la retribución del personal; en el conjunto de los niveles de educación primaria, secundaria y postsecundaria no terciaria lo hacen 18 países.

- La proporción del gasto corriente destinada a fines distintos a la retribución del personal es mayor en el nivel terciario que en el conjunto de los niveles de educación primaria, secundaria y postsecundaria no terciaria en casi todos los países, excepto en Brasil, Colombia, Dinamarca e Islandia. 


\section{Análisis}

\section{Gasto corriente y de capital de las instituciones educativas}

El gasto educativo incluye tanto gasto corriente como gasto de capital. El gasto corriente de las instituciones educativas comprende el gasto en recursos escolares necesarios anualmente para las actividades que realizan los centros educativos. Incluye, por ejemplo, la retribución de los profesores y otros empleados, el mantenimiento de edificios, el servicio de comedor o el alquiler de edificios y otras instalaciones. El gasto de capital de las instituciones educativas se refiere al gasto en bienes que duran más de un año. Incluye, por ejemplo, gastos en construcción, obras y reparaciones importantes de edificios.

La mayor proporción de gasto corresponde al gasto corriente, dada la gran cantidad de personal que requiere la enseñanza. En 2011, por término medio aproximadamente el $90 \%$ o más del gasto total de los países de la OCDE se destinó a gasto corriente en el conjunto de los niveles de educación primaria, secundaria y postsecundaria no terciaria $(92,6 \%)$ y en el nivel terciario $(89,5 \%)$. El gasto corriente supone más del $79 \%$ del gasto total en cada nivel de educación en todos los países de la OCDE y en los países asociados, excepto en la educación terciaria en Colombia e Indonesia. La proporción varía desde el $81 \%$ (Australia) hasta casi el 99\% (Portugal) en la educación primaria; desde el 86\% (Corea) hasta casi el 99\% (Portugal) en la educación secundaria; y desde el 50\% (Colombia) hasta el 98\% (Dinamarca) en la educación terciaria. La media de la OCDE presenta valores similares para los niveles de educación primaria y secundaria, y una diferencia de 3 puntos porcentuales entre el conjunto de la educación primaria, secundaria y postsecundaria no terciaria (92,6 \%) y la educación terciaria (89,5\%) (Tablas B6.1 y B6.2 y Gráfico B6.2).

No obstante, las diferencias entre el gasto corriente en la educación primaria, secundaria y postsecundaria no terciaria y en la educación terciaria pueden ser relativamente grandes. En la mayoría de los países, la proporción de gasto corriente en los niveles educativos anteriores a la educación terciaria es mayor que en este último nivel. Las tres principales excepciones son Dinamarca, Finlandia y Noruega, donde la proporción de gasto corriente en la educación terciaria es superior entre cuatro y seis puntos porcentuales a la del conjunto de los niveles de educación primaria, secundaria y postsecundaria no terciaria. En cambio, la proporción de gasto corriente en el conjunto de los niveles de educación primaria, secundaria y postsecundaria no terciaria supera la proporción en el nivel terciario en diez puntos porcentuales o más en Colombia, España, Indonesia, Polonia, República Checa, República Eslovaca y Turquía.

Las diferencias entre países probablemente reflejen cómo están organizados los diferentes niveles educativos en cada país, así como hasta qué punto el aumento del número de matriculaciones requiere la construcción de nuevos edificios, especialmente en el nivel terciario. El gasto de capital en el nivel terciario es superior al $15 \%$ en Colombia (49,6 \%), España (17,6\%), Indonesia (28,1\%), Letonia (17,0\%), Polonia (20,2\%), República Checa (19,4\%) y República Eslovaca (19,4\%). Las maneras en que los países describen el gasto de capital relacionado con los edificios universitarios pueden explicar también las diferencias de la proporción de gasto corriente y de capital en el nivel de educación terciaria. Por ejemplo, los edificios y terrenos utilizados para la educación pueden ser propiedad de las instituciones, ser utilizados gratuitamente por ellas o alquilados, y la cantidad de gasto corriente y de capital depende en parte del tipo de gestión inmobiliaria de cada país (véase Cuadro B6.1 en Panorama de la educación 2012 [OECD, 2012]).

\section{Distribución del gasto corriente}

El gasto corriente de las instituciones educativas puede subdividirse además en tres amplias categorías funcionales: retribución de los profesores, retribución de otro personal y otros gastos corrientes, que incluyen materiales y suministros didácticos, mantenimiento de edificios, servicio de comedor y alquiler de instalaciones escolares. El importe asignado a cada una de estas categorías depende en parte de los cambios actuales y previstos de las matriculaciones, de las retribuciones del personal educativo y de los gastos de mantenimiento y construcción de instalaciones educativas. A pesar de que las proporciones de estas categorías no experimentan grandes cambios cada año, las decisiones de los países pueden afectar no solo a los importes, sino también a estas proporciones.

Como media en los países de la OCDE, en los niveles de educación primaria, secundaria y postsecundaria no terciaria más del $62 \%$ del gasto corriente se destina a la retribución de los profesores, el $15 \%$ a la retribución de otro personal y el $21 \%$ a gastos distintos a la retribución. En educación terciaria, como media en los países de la OCDE el $42 \%$ del gasto corriente se destina a la retribución de los profesores, ya que se destinan proporciones mayores a la retribución de otro personal (casi el $25 \%$ ) y a otros gastos corrientes (alrededor del $33 \%$ ).

Hay diferencias relativamente grandes en la distribución del gasto corriente entre el conjunto de los niveles de educación primaria, secundaria y postsecundaria no terciaria y el nivel de educación terciaria. Por ejemplo, en todos los países, la proporción destinada a la retribución de los profesores es mayor en el conjunto de los niveles de educación 
primaria, secundaria y postsecundaria no terciaria que en el nivel de terciaria. La única excepción es Colombia, donde la proporción en educación terciaria es superior en nueve puntos porcentuales a la proporción en el conjunto de los niveles inferiores. La proporción para otros gastos corrientes solamente es superior al $30 \%$ en el conjunto de los niveles de educación primaria, secundaria y postsecundaria no terciaria en seis países: Corea (30,9\%), Dinamarca (31,2\%), Finlandia (35,8\%), República Checa (39,9\%), República Eslovaca (34,0\%) y Suecia (32,8\%). En cambio, en el nivel terciario esta proporción es de más del $30 \%$ en casi la mitad de los países de la OCDE y menos del $20 \%$ solo en tres países: Brasil (16,1\%), Colombia (7,5\%) e Islandia (12,9\%).

\section{Gráfico B6.2. Distribución del gasto corriente y del gasto de capital en instituciones educativas (2011)}

Por categoría de recursos y nivel de educación

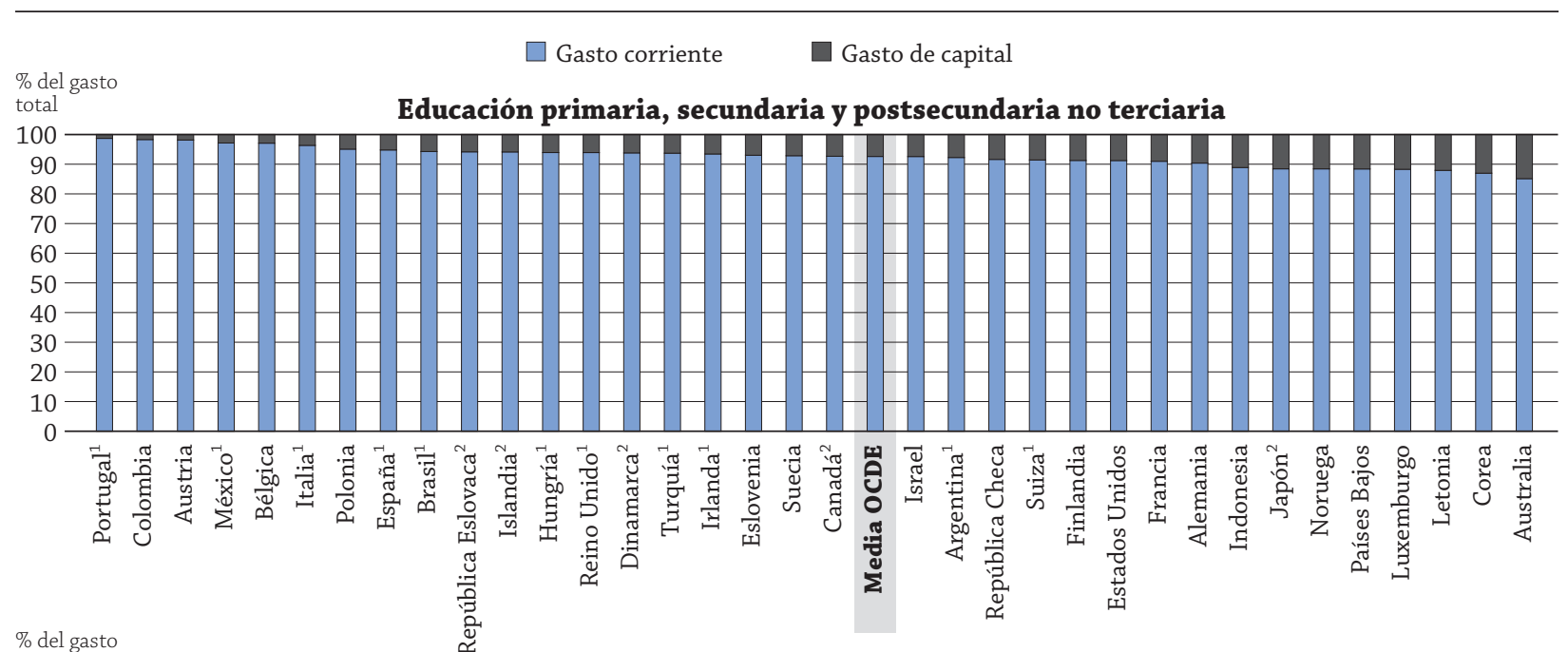

$\%$ del gasto
total

Educación terciaria

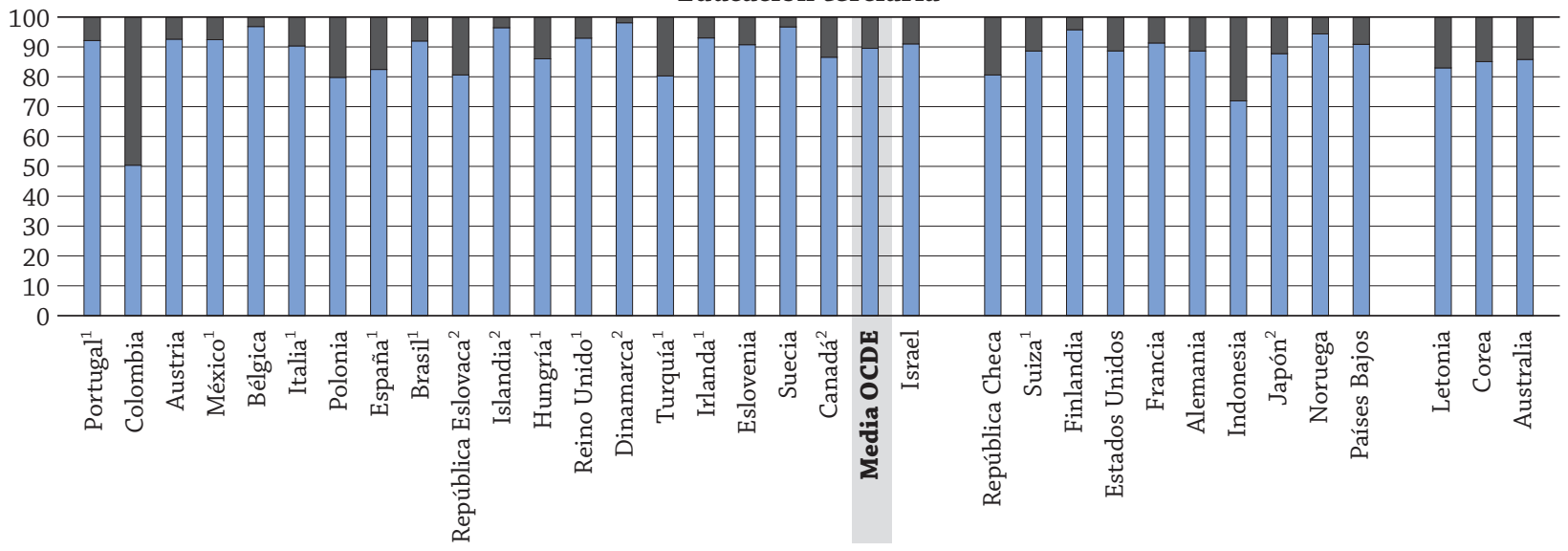

1. Solo instituciones públicas (para Italia y Reino Unido, excepto en educación terciaria).

2. Algunos niveles educativos están incluidos junto con otros. Véase el código «X» en la Tabla B1.1a para obtener más detalles.

Los países están clasificados en orden descendente del porcentaje de gasto corriente en educación primaria, secundaria y postsecundaria no terciaria.

Fuente: OCDE. Tabla B6.2. Para ver notas, consulte Anexo 3 (www.oecd.org/edu/eag.htm).

StatLink 需西 http://dx.doi.org/10.1787/888933117934

La variación del gasto corriente que no se destina a la retribución del personal entre niveles educativos ilustra la diferencia de tamaño de los sistemas administrativos (por ejemplo, la cantidad de empleados o el equipamiento del que dispone el personal administrativo) entre esos niveles. Se supone que el coste de las instalaciones y del equipamiento será mayor en educación terciaria que en otros niveles educativos. Asimismo, las diferencias entre países en la retribución de otro personal probablemente sea reflejo de hasta qué punto se ha incluido en la categoría "personal no docente» a personal educativo como directores de estudios, tutores, conductores de autobús, enfermeros, conserjes y personal de mantenimiento (véase Indicador D2). La retribución del personal que trabaja en investigación y 
desarrollo en el nivel de educación terciaria puede explicar igualmente parte de las diferencias entre países y entre niveles educativos en la proporción del gasto corriente que se destina a la retribución de otro personal.

\section{B6 Definiciones}

El gasto de capital se refiere a los gastos en activos que duran más de un año, incluyendo el gasto en construcción, obras y reparaciones importantes de edificios, y en equipamiento nuevo o de reemplazo. El gasto de capital al que se refiere el indicador representa el valor del capital educativo adquirido o creado durante el año considerado, es decir, el valor del capital generado con independencia de si dicho gasto ha sido financiado mediante ingresos corrientes o a través de préstamos. Ni el gasto corriente ni el de capital incluyen la amortización de la deuda.

El gasto corriente se refiere a los gastos en bienes y servicios consumidos en el año en curso que deben efectuarse de manera periódica con el fin de asegurar la prestación de los servicios educativos. El gasto corriente de las instituciones educativas sin contar la retribución del personal educativo se invierte en servicios subcontratados como servicios de apoyo (por ejemplo, mantenimiento de edificios escolares), en servicios complementarios (por ejemplo, servicio de comedor para los estudiantes) y en el alquiler de edificios escolares y de otras instalaciones. Estos servicios los proporcionan proveedores externos, a diferencia de los servicios que ofrecen las autoridades e instituciones educativas mediante su propio personal.

\section{Metodología}

Los datos se refieren al año financiero de 2011 y se basan en la recopilación de datos UOE sobre estadísticas educativas gestionada por la OCDE en 2013 (para más detalles véase Anexo 3 en www.oecd.org/edu/eag.htm).

Los cálculos cubren el gasto de las instituciones públicas o, donde se disponía de esta información, de las instituciones públicas y privadas.

\section{Nota sobre los datos de Israel}

Los datos estadísticos para Israel fueron proporcionados por las autoridades israelíes competentes bajo su responsabilidad. El uso de estos datos por parte de la OCDE se hace sin prejuzgar la situación de los Altos del Golán, Jerusalén Este y los asentamientos israelíes en Cisjordania de acuerdo con los términos del derecho internacional.

\section{Referencia}

OECD (2012), Education at a Glance 2012: OECD Indicators, OECD Publishing, París. http://dx.doi.org/10.1787/eag2012-en. Versión española: Panorama de la educación 2012: Indicadores de la OCDE, Ministerio de Educación, Cultura y Deporte, Santillana, Madrid.

\section{Tablas del Indicador B6}

\section{StatLink त्नांst http://dx.doi.org/10.1787/888933117858}

Tabla B6.1 Gasto de las instituciones educativas de primaria y secundaria, por categoría de recursos (2011)

Tabla B6.2 Gasto de las instituciones educativas, por categoría de recursos y nivel de educación (2011) 
Tabla B6.1. Gasto de las instituciones educativas de primaria y secundaria, por categoría de recursos (2011)

Distribución del gasto total y corriente de las instituciones educativas procedente de fuentes públicas y privadas

\begin{tabular}{|c|c|c|c|c|c|c|c|c|c|c|c|c|}
\hline & \multicolumn{6}{|c|}{ Educación primaria } & \multicolumn{6}{|c|}{ Educación secundaria } \\
\hline & \multicolumn{2}{|c|}{$\begin{array}{c}\text { Porcentaje } \\
\text { del gasto total }\end{array}$} & \multicolumn{4}{|c|}{$\begin{array}{c}\text { Porcentaje } \\
\text { del gasto corriente }\end{array}$} & \multicolumn{2}{|c|}{$\begin{array}{c}\text { Porcentaje } \\
\text { del gasto total }\end{array}$} & \multicolumn{4}{|c|}{$\begin{array}{c}\text { Porcentaje } \\
\text { del gasto corriente }\end{array}$} \\
\hline & 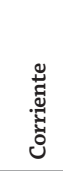 & 丞 & 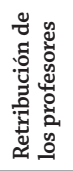 & 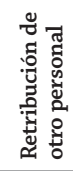 & 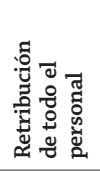 & 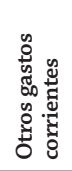 & 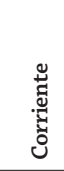 & 䒕 & 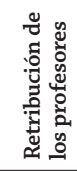 & 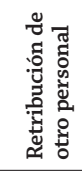 & 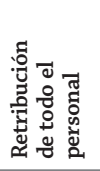 & 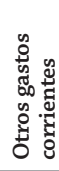 \\
\hline & (1) & (2) & (3) & $(4)$ & (5) & (6) & (7) & $(8)$ & (9) & (10) & (11) & (12) \\
\hline Alemania & 90,8 & 9,2 & $\mathrm{x}(5)$ & $\mathrm{x}(5)$ & 82,1 & 17,9 & 90,2 & 9,8 & $\mathrm{x}(11)$ & $\mathrm{x}(11)$ & 81,5 & 18,5 \\
\hline Australia & 81,3 & 18,7 & 62,9 & 15,1 & 78,0 & 22,0 & 88,3 & 11,7 & 59,2 & 16,2 & 75,4 & 24,6 \\
\hline Austria & 98,1 & 1,9 & 60,7 & 12,6 & 73,3 & 26,7 & 98,2 & 1,8 & 68,0 & 8,6 & 76,5 & 23,5 \\
\hline Bélgica $^{1}$ & 96,2 & 3,8 & 69,7 & 19,3 & 89,0 & 11,0 & 97,5 & 2,5 & 72,4 & 16,5 & 88,9 & 11,1 \\
\hline Canadá $^{1,2}$ & 92,6 & 7,4 & 62,6 & 15,0 & 77,5 & 22,5 & 92,6 & 7,4 & 62,6 & 15,0 & 77,5 & 22,5 \\
\hline Chile & $\mathbf{m}$ & $\mathbf{m}$ & $\mathrm{m}$ & $\mathrm{m}$ & $\mathrm{m}$ & $\mathrm{m}$ & $\mathbf{m}$ & $\mathbf{m}$ & $\mathrm{m}$ & $\mathrm{m}$ & $\mathrm{m}$ & $\mathrm{m}$ \\
\hline Dinamarca $^{1}$ & 94,7 & 5,3 & 63,4 & 17,0 & 80,5 & 19,5 & 93,0 & 7,0 & 39,0 & 20,7 & 59,8 & 40,2 \\
\hline Eslovenia $^{1}$ & 92,4 & 7,6 & $\mathrm{x}(5)$ & $\mathrm{x}(5)$ & 81,2 & 18,8 & 93,5 & 6,5 & $\mathrm{x}(11)$ & $\mathrm{x}(11)$ & 76,8 & 23,2 \\
\hline España $^{3}$ & 94,9 & 5,1 & 71,0 & 9,7 & 80,7 & 19,3 & 94,7 & 5,3 & 74,9 & 8,3 & 83,1 & 16,9 \\
\hline Estados Unidos & 91,2 & 8,8 & 54,6 & 26,6 & 81,3 & 18,7 & 91,2 & 8,8 & 54,6 & 26,6 & 81,2 & 18,8 \\
\hline Estonia & $\mathbf{m}$ & m & $\mathrm{m}$ & $\mathrm{m}$ & $\mathrm{m}$ & $\mathrm{m}$ & m & $\mathbf{m}$ & $\mathrm{m}$ & $\mathrm{m}$ & $\mathrm{m}$ & $\mathrm{m}$ \\
\hline Finlandia $^{1}$ & 91,7 & 8,3 & 55,6 & 9,5 & 65,1 & 34,9 & 91,0 & 9,0 & 51,1 & 12,7 & 63,8 & 36,2 \\
\hline Francia & 91,6 & 8,4 & 56,8 & 20,4 & 77,2 & 22,8 & 90,6 & 9,4 & 58,4 & 24,0 & 82,5 & 17,5 \\
\hline Grecia & $\mathbf{m}$ & m & $\mathrm{m}$ & $\mathrm{m}$ & $\mathrm{m}$ & $\mathrm{m}$ & $\mathbf{m}$ & $\mathbf{m}$ & $\mathrm{m}$ & $\mathrm{m}$ & $\mathrm{m}$ & $\mathrm{m}$ \\
\hline Hungría $^{3}$ & 94,1 & 5,9 & $\mathrm{x}(5)$ & $\mathrm{x}(5)$ & 72,8 & 27,2 & 93,8 & 6,2 & $\mathrm{x}(11)$ & $\mathrm{x}(11)$ & 74,7 & 25,3 \\
\hline Irlanda $^{3}$ & 92,0 & 8,0 & 76,5 & 12,4 & 89,0 & 11,0 & 94,5 & 5,5 & 70,2 & 8,9 & 79,1 & 20,9 \\
\hline Islandia $^{1}$ & 93,0 & 7,0 & $\mathrm{x}(5)$ & $x(5)$ & 74,5 & 25,5 & 95,2 & 4,8 & $x(11)$ & $\mathrm{x}(11)$ & 75,4 & 24,6 \\
\hline Israel & 91,5 & 8,5 & $\mathrm{x}(5)$ & $\mathrm{x}(5)$ & 85,2 & 14,8 & 94,0 & 6,1 & $\mathrm{x}(11)$ & $\mathrm{x}(11)$ & 83,9 & 16,1 \\
\hline Italia $^{3}$ & 96,6 & 3,4 & 62,4 & 19,0 & 81,3 & 18,7 & 97,2 & 2,8 & 64,7 & 18,7 & 83,4 & 16,6 \\
\hline Japón $^{1}$ & 88,1 & 11,9 & $\mathrm{x}(5)$ & $\mathrm{x}(5)$ & 85,8 & 14,2 & 88,6 & 11,4 & $\mathrm{x}(11)$ & $\mathrm{x}(11)$ & 86,2 & 13,8 \\
\hline Luxemburgo & 85,8 & 14,2 & 78,4 & 3,7 & 82,1 & 17,9 & 91,1 & 8,9 & 77,0 & 12,9 & 89,9 & 10,1 \\
\hline México $^{3}$ & 97,4 & 2,6 & 86,4 & 8,2 & 94,6 & 5,4 & 96,8 & 3,2 & 78,8 & 12,0 & 90,8 & 9,2 \\
\hline Países Bajos & 88,0 & 12,0 & $\mathrm{x}(5)$ & $\mathrm{x}(5)$ & 83,6 & 16,4 & 88,6 & 11,4 & $\mathrm{x}(11)$ & $\mathrm{x}(11)$ & 81,6 & 18,4 \\
\hline Polonia & 94,1 & 5,9 & $\mathrm{x}(1)$ & $\mathrm{x}(1)$ & $\mathrm{x}(1)$ & $\mathrm{x}(1)$ & 95,9 & 4,1 & $\mathrm{x}(7)$ & $\mathrm{x}(7)$ & $\mathrm{x}(7)$ & $\mathrm{x}(7)$ \\
\hline Portugal $^{3}$ & 98,7 & 1,3 & 80,0 & 13,9 & 93,9 & 6,1 & 98,7 & 1,3 & 80,7 & 10,2 & 90,9 & 9,1 \\
\hline Reino Unido ${ }^{3}$ & 93,7 & 6,3 & 54,4 & 29,0 & 83,4 & 16,6 & 94,0 & 6,0 & 59,8 & 22,0 & 81,8 & 18,2 \\
\hline República Checa & 90,1 & 9,9 & 46,1 & 16,5 & 62,6 & 37,4 & 92,1 & 7,9 & 46,8 & 12,4 & 59,2 & 40,8 \\
\hline República Eslovaca $^{1}$ & 92,6 & 7,4 & 51,1 & 13,8 & 64,9 & 35,1 & 94,8 & 5,2 & 52,4 & 14,0 & 66,4 & 33,6 \\
\hline Suecia & 93,5 & 6,5 & 52,7 & 16,7 & 69,4 & 30,6 & 92,3 & 7,7 & 50,7 & 14,9 & 65,6 & 34,4 \\
\hline Suiza $^{1,3}$ & 90,5 & 9,5 & 66,6 & 16,6 & 83,2 & 16,8 & 92,0 & 8,0 & 73,0 & 12,2 & 85,2 & 14,8 \\
\hline Turquía $^{3}$ & 96,3 & 3,7 & $\mathrm{x}(5)$ & $x(5)$ & 89,3 & 10,7 & 91,9 & 8,1 & $x(11)$ & $\mathrm{x}(11)$ & 84,8 & 15,2 \\
\hline Media OCDE & 92,3 & 7,7 & 63,3 & 15,5 & 79,7 & 20,3 & 92,9 & 7,1 & 62,5 & 15,0 & 78,4 & 21,6 \\
\hline Media UE21 & 93,1 & 6,9 & 62,8 & 15,3 & 78,5 & 21,5 & 93,8 & 6,2 & 61,9 & 14,6 & 77,0 & 23,0 \\
\hline Arabia Saudí & $\mathbf{m}$ & m & $\mathrm{m}$ & $\mathrm{m}$ & $\mathrm{m}$ & $\mathrm{m}$ & $\mathbf{m}$ & $\mathbf{m}$ & $\mathrm{m}$ & $\mathrm{m}$ & $\mathrm{m}$ & $\mathrm{m}$ \\
\hline Argentina $^{3}$ & 94,7 & 5,3 & 70,7 & 20,6 & 91,3 & 8,7 & 90,2 & 9,8 & 68,2 & 24,7 & 92,9 & 7,1 \\
\hline Brasil $^{2}$ & 94,3 & 5,7 & $\mathrm{x}(5)$ & $\mathrm{x}(5)$ & 72,0 & 28,0 & 94,2 & 5,8 & $\mathrm{x}(11)$ & $\mathrm{x}(11)$ & 79,8 & 20,2 \\
\hline China & $\mathbf{m}$ & $\mathbf{m}$ & $\mathrm{m}$ & $\mathrm{m}$ & $\mathrm{m}$ & $\mathrm{m}$ & $\mathbf{m}$ & $\mathbf{m}$ & $\mathrm{m}$ & $\mathrm{m}$ & $\mathrm{m}$ & $\mathrm{m}$ \\
\hline Colombia $^{4}$ & 98,3 & 1,7 & 82,8 & 9,0 & 91,8 & 8,2 & 98,3 & 1,7 & 82,8 & 9,0 & 91,8 & 8,2 \\
\hline Federación Rusa & $\mathbf{m}$ & m & $\mathrm{m}$ & $\mathrm{m}$ & $\mathrm{m}$ & $\mathrm{m}$ & $\mathbf{m}$ & $\mathbf{m}$ & $\mathrm{m}$ & $\mathrm{m}$ & $\mathrm{m}$ & $\mathrm{m}$ \\
\hline India & $\mathbf{m}$ & $\mathbf{m}$ & $\mathrm{m}$ & $\mathrm{m}$ & $\mathrm{m}$ & $\mathrm{m}$ & $\mathbf{m}$ & $\mathbf{m}$ & $\mathrm{m}$ & $\mathrm{m}$ & $\mathrm{m}$ & $\mathrm{m}$ \\
\hline Indonesia $^{4}$ & 86,5 & 13,5 & $\mathrm{x}(5)$ & $\mathrm{x}(5)$ & 81,2 & 18,8 & 92,6 & 7,4 & $\mathrm{x}(11)$ & $\mathrm{x}(11)$ & 64,2 & 35,8 \\
\hline Letonia & 87,7 & 12,3 & $\mathrm{x}(5)$ & $x(5)$ & 75,4 & 24,6 & 88,0 & 12,0 & $\mathrm{x}(11)$ & $\mathrm{x}(11)$ & 74,2 & 25,8 \\
\hline Sudáfrica & $\mathbf{m}$ & m & $\mathrm{m}$ & $\mathrm{m}$ & $\mathrm{m}$ & m & m & m & m & $\mathrm{m}$ & $\mathrm{m}$ & $\mathrm{m}$ \\
\hline Media G20 & $\mathbf{m}$ & m & $\mathrm{m}$ & $\mathrm{m}$ & $\mathrm{m}$ & $\mathrm{m}$ & $\mathbf{m}$ & m & $\mathrm{m}$ & $\mathrm{m}$ & $\mathrm{m}$ & $\mathrm{m}$ \\
\hline
\end{tabular}

1. Algunos niveles educativos están incluidos junto con otros. Véase el código «X» en la Tabla B1.1a para obtener más detalles.

2. Año de referencia 2010.

3. Solo instituciones públicas.

4. Año de referencia 2012.

Fuentes: OCDE. Arabia Saudí, Argentina, China, Colombia, India, Indonesia, Sudáfrica: Instituto de Estadística de la UNESCO. Letonia: Eurostat. Para ver notas, consulte Anexo 3 (www.oecd.org/edu/eag.htm).

Para obtener más información acerca de los símbolos utilizados en lugar de los datos que faltan, consulte la Guía del lector.

StatLink 젝ㄴ http://dx.doi.org/10.1787/888933117877 
Tabla B6.2. Gasto de las instituciones educativas, por categoría de recursos y nivel de educación (2011) Distribución del gasto total y corriente de las instituciones educativas procedente de fuentes públicas y privadas

\begin{tabular}{|c|c|c|c|c|c|c|c|c|c|c|c|c|}
\hline & \multicolumn{6}{|c|}{$\begin{array}{l}\text { Educación primaria, secundaria } \\
\text { y postsecundaria no terciaria }\end{array}$} & \multicolumn{6}{|c|}{ Educación terciaria } \\
\hline & \multicolumn{2}{|c|}{$\begin{array}{c}\text { Porcentaje } \\
\text { del gasto total }\end{array}$} & \multicolumn{4}{|c|}{$\begin{array}{c}\text { Porcentaje } \\
\text { del gasto corriente }\end{array}$} & \multicolumn{2}{|c|}{$\begin{array}{c}\text { Porcentaje } \\
\text { del gasto total }\end{array}$} & \multicolumn{4}{|c|}{$\begin{array}{c}\text { Porcentaje } \\
\text { del gasto corriente }\end{array}$} \\
\hline & نัّ & $\begin{array}{l}\text { ज्ञ } \\
\text { ड़ }\end{array}$ & 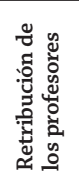 & 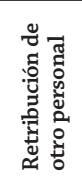 & 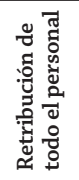 & 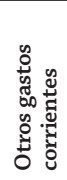 & 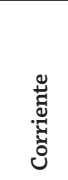 & $\begin{array}{l}\text { Jేّ } \\
\text { తే: }\end{array}$ & 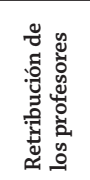 & 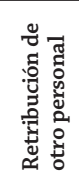 & 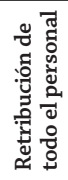 & 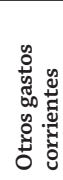 \\
\hline & (1) & (2) & (3) & (4) & (5) & (6) & (7) & (8) & (9) & (10) & (11) & (12) \\
\hline Alemania & 90,3 & 9,7 & $\mathrm{x}(5)$ & $\mathrm{x}(5)$ & 81,3 & 18,7 & 88,6 & 11,4 & $\mathrm{x}(11)$ & $\mathrm{x}(11)$ & 66,7 & 33,3 \\
\hline Australia & 85,1 & 14,9 & 60,4 & 15,9 & 76,3 & 23,7 & 85,8 & 14,2 & 33,6 & 28,6 & 62,2 & 37,8 \\
\hline Austria & 98,1 & 1,9 & 65,7 & 9,7 & 75,4 & 24,6 & 92,6 & 7,4 & 57,2 & 6,0 & 63,2 & 36,9 \\
\hline Bélgica & 97,0 & 3,0 & 71,5 & 17,5 & 88,9 & 11,1 & 96,8 & 3,2 & 50,7 & 28,4 & 79,1 & 20,9 \\
\hline Canadá $\hat{a}^{1,2}$ & 92,6 & 7,4 & 62,6 & 15,0 & 77,5 & 22,5 & 86,6 & 13,4 & 37,7 & 27,5 & 65,2 & 34,8 \\
\hline Chile & $\mathbf{m}$ & $\mathbf{m}$ & $\mathrm{m}$ & $\mathrm{m}$ & $\mathrm{m}$ & $\mathrm{m}$ & $\mathbf{m}$ & $\mathbf{m}$ & $\mathrm{m}$ & $\mathrm{m}$ & $\mathrm{m}$ & $\mathrm{m}$ \\
\hline Corea & 86,9 & 13,1 & 55,7 & 13,4 & 69,1 & 30,9 & 85,1 & 14,9 & 33,4 & 18,6 & 52,0 & 48,0 \\
\hline Dinamarca $^{2}$ & 93,8 & 6,2 & 49,7 & 19,1 & 68,8 & 31,2 & 98,1 & 1,9 & 45,6 & 32,4 & 78,0 & 22,0 \\
\hline Eslovenia & 93,0 & 7,0 & $\mathrm{x}(5)$ & $\mathrm{x}(5)$ & 78,8 & 21,2 & 90,7 & 9,3 & $\mathrm{x}(11)$ & $\mathrm{x}(11)$ & 67,2 & 32,8 \\
\hline España $^{3}$ & 94,8 & 5,2 & 73,3 & 8,8 & 82,1 & 17,9 & 82,4 & 17,6 & 56,3 & 20,8 & 77,2 & 22,8 \\
\hline Estados Unidos & 91,2 & 8,8 & 54,6 & 26,6 & 81,3 & 18,7 & 88,6 & 11,4 & 29,6 & 35,5 & 65,1 & 34,9 \\
\hline Estonia & $\mathbf{m}$ & $\mathbf{m}$ & $\mathrm{m}$ & $\mathrm{m}$ & $\mathrm{m}$ & $\mathrm{m}$ & $\mathbf{m}$ & $\mathbf{m}$ & $\mathrm{m}$ & $\mathrm{m}$ & $\mathrm{m}$ & $\mathrm{m}$ \\
\hline Finlandia & 91,2 & 8,8 & 52,6 & 11,6 & 64,2 & 35,8 & 95,7 & 4,3 & 34,6 & 29,6 & 64,2 & 35,8 \\
\hline Francia & 90,9 & $\mathbf{9 , 1}$ & 57,9 & 22,9 & 80,8 & 19,2 & 91,3 & 8,7 & 48,9 & 30,3 & 79,2 & 20,8 \\
\hline Grecia & $\mathbf{m}$ & $\mathbf{m}$ & $\mathrm{m}$ & $\mathrm{m}$ & $\mathrm{m}$ & $\mathrm{m}$ & $\mathbf{m}$ & $\mathbf{m}$ & $\mathrm{m}$ & $\mathrm{m}$ & $\mathrm{m}$ & $\mathrm{m}$ \\
\hline Hungría $^{3}$ & 93,9 & 6,1 & $\mathrm{x}(5)$ & $\mathrm{x}(5)$ & 74,1 & 25,9 & 86,0 & 14,0 & $\mathrm{x}(11)$ & $\mathrm{x}(11)$ & 56,1 & 43,9 \\
\hline Irlanda $^{3}$ & 93,4 & 6,6 & 70,9 & 10,7 & 81,6 & 18,4 & 93,0 & 7,0 & 43,5 & 27,0 & 70,5 & 29,5 \\
\hline Islandia $^{2}$ & 94,1 & 5,9 & $\mathrm{x}(5)$ & $\mathrm{x}(5)$ & 75,0 & 25,0 & 96,4 & 3,6 & $\mathrm{x}(11)$ & $\mathrm{x}(11)$ & 87,1 & 12,9 \\
\hline Israel & 92,5 & 7,5 & $\mathrm{x}(5)$ & $\mathrm{x}(5)$ & 84,6 & 15,4 & 91,0 & 9,0 & $\mathrm{x}(11)$ & $\mathrm{x}(11)$ & 77,4 & 22,6 \\
\hline Italia $^{3}$ & 96,3 & 3,7 & 62,4 & 18,9 & 81,4 & 18,6 & 90,3 & 9,7 & 33,9 & 28,9 & 62,8 & 37,2 \\
\hline Japón ${ }^{2}$ & 88,4 & 11,6 & $\mathrm{x}(5)$ & $\mathrm{x}(5)$ & 86,0 & 14,0 & 87,7 & 12,3 & $\mathrm{x}(11)$ & $\mathrm{x}(11)$ & 59,9 & 40,1 \\
\hline Luxemburgo & 88,3 & 11,7 & 77,8 & 8,1 & 85,8 & 14,2 & $\mathbf{m}$ & $\mathbf{m}$ & $\mathrm{m}$ & $\mathrm{m}$ & $\mathrm{m}$ & $\mathrm{m}$ \\
\hline México $^{3}$ & 97,1 & 2,9 & 82,9 & 10,0 & 92,9 & 7,1 & 92,4 & 7,6 & 61,7 & 15,3 & 77,0 & 23,0 \\
\hline Noruega & 88,4 & 11,6 & $x(5)$ & $\mathrm{x}(5)$ & 79,8 & 20,2 & 94,3 & 5,7 & $\mathrm{x}(11)$ & $\mathrm{x}(11)$ & 67,1 & 32,9 \\
\hline Nueva Zelanda & $\mathbf{m}$ & $\mathbf{m}$ & $\mathrm{m}$ & $\mathrm{m}$ & $\mathrm{m}$ & $\mathrm{m}$ & $\mathbf{m}$ & $\mathbf{m}$ & $\mathrm{m}$ & $\mathrm{m}$ & $\mathrm{m}$ & $\mathrm{m}$ \\
\hline Países Bajos & 88,4 & 11,6 & $x(5)$ & $\mathrm{x}(5)$ & 82,3 & 17,7 & 90,9 & 9,1 & $\mathrm{x}(11)$ & $\mathrm{x}(11)$ & 71,6 & 28,4 \\
\hline Polonia & 95,0 & 5,0 & $\mathrm{x}(1)$ & $\mathrm{x}(1)$ & $\mathrm{x}(1)$ & $\mathrm{x}(1)$ & 79,8 & 20,2 & $\mathrm{x}(11)$ & $\mathrm{x}(11)$ & 74,7 & 25,3 \\
\hline Portugal $^{3}$ & 98,7 & 1,3 & 80,4 & 11,7 & 92,1 & 7,9 & 92,1 & 7,9 & $\mathrm{x}(11)$ & $\mathrm{x}(11)$ & 74,4 & 25,6 \\
\hline Reino Unido ${ }^{3}$ & 93,9 & 6,1 & 57,2 & 25,4 & 82,6 & 17,4 & 92,9 & 7,1 & 35,0 & 25,4 & 60,4 & 39,6 \\
\hline República Checa & 91,6 & 8,4 & 46,6 & 13,5 & 60,1 & 39,9 & 80,6 & 19,4 & 30,1 & 18,5 & 48,6 & 51,4 \\
\hline República Eslovaca² & 94,1 & 5,9 & 52,0 & 13,9 & 66,0 & 34,0 & 80,6 & 19,4 & 33,7 & 23,4 & 57,1 & 42,9 \\
\hline Suecia & 92,8 & 7,2 & 51,2 & 15,6 & 67,2 & 32,8 & 96,7 & 3,3 & $\mathrm{x}(11)$ & $\mathrm{x}(11)$ & 64,0 & 36,0 \\
\hline Suiza $^{3}$ & 91,4 & 8,6 & 70,2 & 14,1 & 84,3 & 15,7 & 88,6 & 11,4 & 48,5 & 27,2 & 75,8 & 24,2 \\
\hline Turquía $^{3}$ & 93,7 & 6,3 & $\mathrm{x}(5)$ & $\mathrm{x}(5)$ & 86,7 & 13,3 & 80,3 & 19,7 & $\mathrm{x}(11)$ & $\mathrm{x}(11)$ & 52,9 & 47,1 \\
\hline Media OCDE & 92,6 & 7,4 & 62,8 & 15,1 & 78,9 & 21,1 & 89,5 & 10,5 & 42,0 & 24,9 & 67,5 & 32,5 \\
\hline Media UE21 & 93,4 & 6,6 & 62,1 & 14,8 & 77,4 & 22,6 & 90,0 & 10,0 & 42,7 & 24,6 & 67,5 & 32,5 \\
\hline Arabia Saudí & $\mathbf{m}$ & $\mathbf{m}$ & $\mathrm{m}$ & $\mathrm{m}$ & $\mathrm{m}$ & $\mathrm{m}$ & $\mathbf{m}$ & $\mathbf{m}$ & $\mathrm{m}$ & $\mathrm{m}$ & $\mathrm{m}$ & $\mathrm{m}$ \\
\hline Argentina ${ }^{3}$ & 92,2 & 7,8 & 69,4 & 22,9 & 92,2 & 7,8 & $\mathbf{m}$ & $\mathbf{m}$ & $\mathrm{m}$ & $\mathrm{m}$ & $\mathrm{m}$ & $\mathrm{m}$ \\
\hline Brasil $^{3}$ & 94,2 & 5,8 & $\mathrm{x}(5)$ & $\mathrm{x}(5)$ & 76,7 & 23,3 & 92,0 & 8,0 & $\mathrm{x}(11)$ & $\mathrm{x}(11)$ & 83,9 & 16,1 \\
\hline y China & $\mathbf{m}$ & $\mathbf{m}$ & $\mathrm{m}$ & $\mathrm{m}$ & $\mathrm{m}$ & $\mathrm{m}$ & $\mathbf{m}$ & $\mathbf{m}$ & $\mathrm{m}$ & $\mathrm{m}$ & $\mathrm{m}$ & $\mathrm{m}$ \\
\hline Colombia ${ }^{4}$ & 98,3 & 1,7 & 82,8 & 9,0 & 91,8 & 8,2 & 50,4 & 49,6 & 92,5 & $\mathrm{~m}$ & 92,5 & 7,5 \\
\hline Federación Rusa & $\mathbf{m}$ & $\mathbf{m}$ & $\mathrm{m}$ & $\mathrm{m}$ & $\mathrm{m}$ & $\mathrm{m}$ & $\mathbf{m}$ & $\mathbf{m}$ & $\mathrm{m}$ & $\mathrm{m}$ & $\mathrm{m}$ & $\mathrm{m}$ \\
\hline India & $\mathbf{m}$ & $\mathbf{m}$ & $\mathrm{m}$ & $\mathrm{m}$ & $\mathrm{m}$ & $\mathrm{m}$ & $\mathbf{m}$ & $\mathbf{m}$ & $\mathrm{m}$ & $\mathrm{m}$ & $\mathrm{m}$ & $\mathrm{m}$ \\
\hline Indonesia $^{4}$ & 88,8 & 11,2 & $x(5)$ & $\mathrm{x}(5)$ & 74,4 & 25,6 & 71,9 & 28,1 & $\mathrm{x}(11)$ & $\mathrm{x}(11)$ & 31,5 & 68,5 \\
\hline Letonia & 87,9 & 12,1 & $\mathrm{x}(5)$ & $\mathrm{x}(5)$ & 74,7 & 25,3 & 83,0 & 17,0 & $\mathrm{x}(11)$ & $\mathrm{x}(11)$ & 59,7 & 40,3 \\
\hline Sudáfrica & $\mathbf{m}$ & $\mathbf{m}$ & $\mathrm{m}$ & $\mathrm{m}$ & $\mathrm{m}$ & $\mathrm{m}$ & $\mathbf{m}$ & $\mathbf{m}$ & $\mathrm{m}$ & $\mathrm{m}$ & $\mathrm{m}$ & $\mathrm{m}$ \\
\hline Media G20 & m & $\mathbf{m}$ & $\mathrm{m}$ & $\mathrm{m}$ & $\mathrm{m}$ & $\mathrm{m}$ & $\mathbf{m}$ & m & $\mathrm{m}$ & $\mathrm{m}$ & $\mathrm{m}$ & $\mathrm{m}$ \\
\hline
\end{tabular}

1. Año de referencia 2010 .

2. Algunos niveles educativos están incluidos junto con otros. Véase el código «X» en la Tabla B1.1a para obtener más detalles.

3. Solo instituciones públicas (para Italia y Reino Unido, excepto en educación terciaria).

4. Año de referencia 2012.

Fuentes: OCDE. Arabia Saudí, Argentina, China, Colombia, India, Indonesia, Sudáfrica: Instituto de Estadística de la UNESCO. Letonia: Eurostat. Para ver notas, consulte Anexo 3 (www.oecd.org/edu/eag.htm).

Para obtener más información acerca de los símbolos utilizados en lugar de los datos que faltan, consulte la Guía del lector.

StatLink 젶ㄴ http://dx.doi.org/10.1787/888933117896 



\section{¿QUÉ FACTORES INFLUYEN EN EL NIVEL DE GASTO EN EDUCACIÓN?}

- Cuatro factores influyen en el nivel de gasto en educación relacionado con el coste salarial de los profesores por estudiante: las horas de enseñanza de los estudiantes, las horas lectivas de los profesores, los salarios de los profesores y el tamaño estimado de las clases. Por tanto, un nivel determinado de coste salarial de los profesores por estudiante puede ser el resultado de distintas combinaciones entre estos cuatro factores.

- Se dan grandes diferencias entre los costes salariales de los profesores por estudiante de distintos países; en la mayor parte de los países, el coste salarial de los profesores por estudiante aumenta con el nivel de educación.

- Entre 2008 y 2012, el coste salarial de los profesores por estudiante aumentó aproximadamente en dos tercios de los países en educación primaria y en más de la mitad de los países en educación secundaria inferior. Como media, aumentó un $7 \%$ (de 2.454 a 2.633 dólares estadounidenses) en educación primaria y en $4 \%$ (de 3.217 a 3.355 dólares estadounidenses) en educación secundaria inferior.

\section{Gráfico B7.1. Coste salarial de los profesores (en dólares estadounidenses) por estudiante, por nivel de educación (2012)}

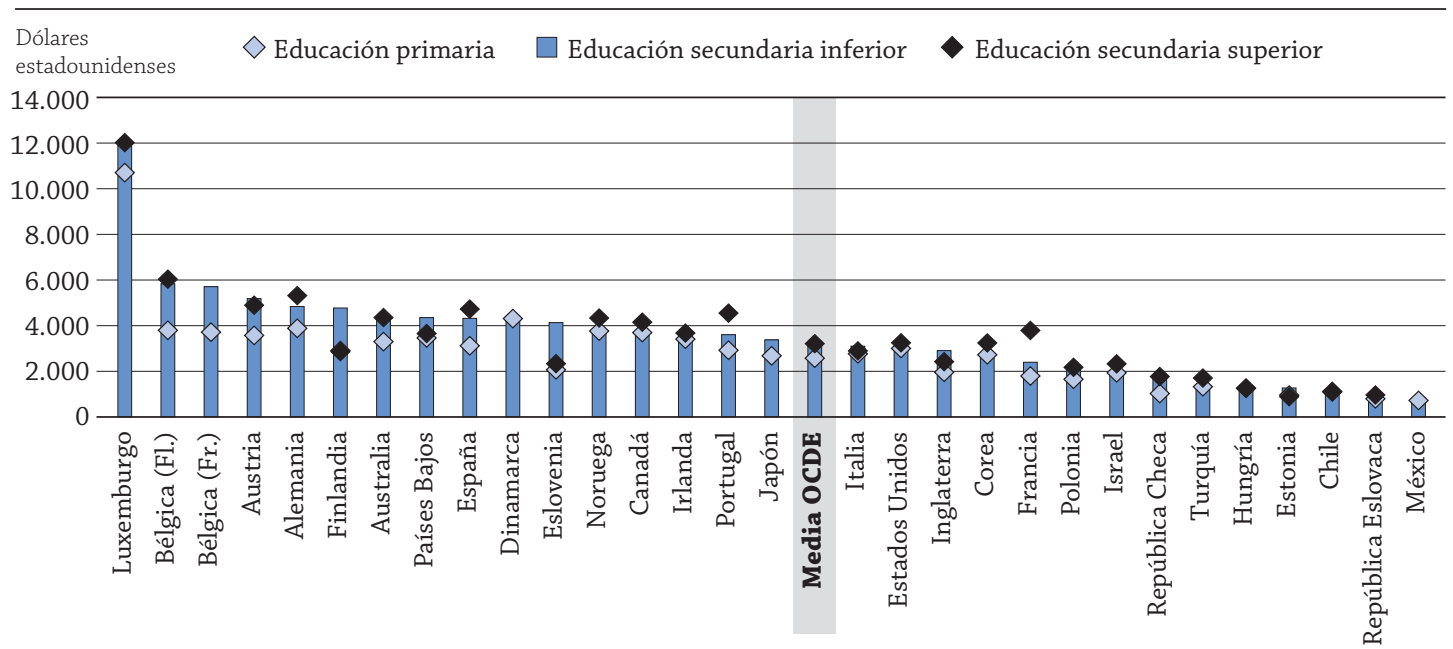

Los países están clasificados en orden descendente del coste salarial de los profesores por estudiante en educación secundaria inferior. Fuente: OCDE. Tabla B7.1. Para ver notas, consulte Anexo 3 (www.oecd.org/edu/eag.htm).

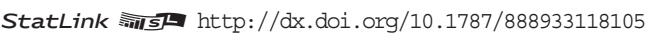

\section{Contexto}

Los gobiernos han ido prestando cada vez más atención a la relación que existe entre la cantidad de recursos que se dedica a la educación y los resultados del aprendizaje de los estudiantes. Los gobiernos buscan proporcionar más y mejor educación a sus poblaciones y, al mismo tiempo, garantizar que los fondos públicos se utilicen de manera eficiente, en especial cuando los presupuestos públicos son sometidos a ajustes. La retribución de los profesores generalmente representa la mayor parte del gasto en educación y, por tanto, del gasto por estudiante. Es una función de las horas de enseñanza de los estudiantes, las horas lectivas de los profesores, los salarios de los profesores y el número de docentes necesarios para enseñar a los estudiantes, que depende del tamaño estimado de las clases (Cuadro B7.1).

Las diferencias entre países en estos cuatro factores pueden explicar diferencias en el nivel de gasto por estudiante. De manera similar, un nivel determinado de gasto puede ser el resultado de combinaciones diferentes de estos factores. Este indicador examina las opciones elegidas por los distintos países al invertir sus recursos en educación primaria y secundaria, y explora cómo los cambios de las políticas entre 2000, 2005, 2008 y 2012 en relación con estos cuatro factores afectaron al coste salarial de los 
profesores. Sin embargo, algunas de estas opciones no necesariamente reflejan decisiones políticas, sino más bien cambios demográficos, tales como un número decreciente de estudiantes. Así, por ejemplo, en países en los que las matriculaciones han disminuido en años recientes, el tamaño de las clases también disminuiría, a menos que simultáneamente decreciera el número de docentes.

\section{INDICADOR $\mathrm{B}_{7}$}

\section{Otros resultados}

- Unos niveles similares de gasto entre países pueden enmascarar una variedad de opciones políticas. Esto contribuye a explicar por qué no hay una relación simple entre el gasto general en educación y el nivel de rendimiento de los estudiantes. Por ejemplo, en el nivel de educación secundaria superior, Francia e Irlanda tenían niveles parecidos de costes salariales de los profesores por estudiante en 2012, ambos por encima de la media. En Francia, esto se debió principalmente al efecto combinado de un valor inferior a la media en el nivel salarial de los docentes y el tamaño de las clases y un valor superior a la media en las horas de enseñanza. En cambio, en Irlanda se debió principalmente a un nivel salarial superior a la media, cuyo efecto se veía compensado por un número de horas de enseñanza inferior a la media.

- Los salarios de los profesores son generalmente el factor principal que diferencia el coste salarial medio de los profesores en los distintos niveles de educación; el tamaño estimado de las clases es el segundo factor más importante.

- Al tener en cuenta las diferencias de la riqueza económica entre países, los salarios de los profesores son un factor menos determinante de las diferencias en el coste salarial medio de los profesores por estudiante.

\section{Tendencias}

El aumento del coste salarial de los profesores por estudiante entre 2008 y 2012 resultó principalmente de cambios en dos factores: los salarios de los profesores y el tamaño estimado de las clases. Entre 2008 y 2012, en los países que disponen de datos para ambos años, los salarios de los profesores aumentaron como media un 3,0\% en educación primaria y casi un 1,5\% en educación secundaria inferior, mientras que el tamaño estimado de las clases disminuyó un 2,6 \% como media en educación primaria y aumentó un $6,1 \%$ como media en educación secundaria inferior. Las variaciones de los otros dos factores, las horas de enseñanza de los estudiantes y las horas lectivas de los profesores, son generalmente menores en la mayor parte de los países: el número de horas de enseñanza en el nivel de educación secundaria inferior fue el factor que más varió durante este periodo y aumentó como media un $3,7 \%$ en los países que disponen de datos para ambos años.

En los niveles de educación primaria y secundaria inferior, en la mayor parte de los países se incrementó el salario de los profesores o se redujo el tamaño estimado de las clases, o ambas cosas, entre 2008 y 2012. Estos cambios resultaron en un aumento del coste salarial por estudiante. Sin embargo, el coste salarial por estudiante disminuyó en algunos países durante este mismo periodo, las disminuciones más significativas ( $14 \%$ o más) se dieron en Hungría e Italia tanto en educación primaria como en educación secundaria, en República Checa en educación primaria y en Portugal en educación secundaria inferior. Algunos países introdujeron reformas que, desde 2005, han afectado al coste salarial de los profesores por estudiante. Por ejemplo, en Hungría, el número de horas lectivas de los profesores aumentó en educación secundaria en 2006, haciendo disminuir el número de docentes necesarios en este nivel. Esto, a su vez, hizo decrecer el gasto dedicado al salario de los profesores. Italia implementó reformas respecto al tamaño de las clases para aumentar ligeramente el número de estudiantes por clase. Esto redujo el coste salarial de los profesores por estudiante (véase Tabla B7.5 en Panorama de la educación 2012 [OECD, 2012]). 


\title{
Análisis
}

\section{Variación del coste salarial de los profesores por estudiante por nivel de educación}

El gasto por estudiante refleja los factores estructurales e institucionales relacionados con la organización de los centros escolares y el currículo. El gasto se puede desglosar en retribución de los profesores y otros gastos (definidos como el gasto que no está destinado a la retribución de los profesores). La retribución de los profesores constituye generalmente la mayor proporción del gasto en educación. Por este motivo, el nivel de retribución de los profesores, dividido entre el número de estudiantes (designado aquí «coste salarial de los profesores por estudiante»), constituye la principal proporción del gasto por estudiante.

\section{Cuadro B7.1. Relación entre el coste salarial de los profesores por estudiante y las horas de enseñanza de los estudiantes, horas lectivas de los profesores, salarios de los profesores y tamaño de las clases}

Una manera de analizar los factores que tienen un impacto en el gasto por estudiante y de medir sus efectos consiste en comparar las diferencias entre las cifras nacionales y la media de la OCDE. Este análisis calcula las diferencias entre el gasto por estudiante de los países y la media de la OCDE, y después calcula cómo contribuyen estos distintos factores a la variación con respecto a la media de la OCDE.

Este ejercicio se basa en una relación matemática entre los distintos factores y sigue el método presentado en la publicación canadiense Education Statistics Bulletin/Boletín de Estadísticas Educativas (2005) (para ver explicaciones, consulte Anexo 3). El gasto educativo está matemáticamente relacionado con factores relativos al contexto de los centros escolares de un país (número de horas de enseñanza de los estudiantes, número de horas lectivas de los profesores, estimación del tamaño de las clases) y con un factor relativo a los profesores (salario reglamentario).

El gasto se desglosa en retribución de los profesores y otros gastos (definidos como el gasto que no está destinado a la retribución de los profesores). La retribución de los profesores dividida entre el número de estudiantes, o el «coste salarial de los profesores por estudiante» (CSE), se calcula por medio de la siguiente fórmula:

$$
\text { CSE }=S A L \times \text { Hens } \times \frac{1}{\text { Hprof }} \times \frac{1}{\text { TamClase }}=\frac{S A L}{\text { Ratioalum/profesor }}
$$

\author{
SAL: salarios de los profesores (los salarios reglamentarios tras 15 años de experiencia) \\ Hens: horas de enseñanza de los estudiantes (calculadas como el número anual de horas de enseñanza de los estudiantes) \\ Hprof: horas lectivas de los profesores (calculadas como el número anual de horas lectivas de los profesores) \\ Tamclase: tamaño estimado de la clase \\ Ratioalum/profesor: ratio de alumnos por profesor
}

Con la excepción del tamaño de la clase (que no se calcula en el nivel de educación secundaria superior, ya que en este nivel el tamaño de la clase es difícil de definir y comparar, debido a que los estudiantes pueden asistir a distintas clases dependiendo de la materia), los valores de las distintas variables se pueden obtener a partir de los indicadores publicados en Panorama de la educación (Capítulo D). Sin embargo, para el propósito de este análisis, se calcula un tamaño de clase «estimado» basado en la ratio de estudiantes por profesor y el número de horas lectivas de los profesores y de enseñanza de los estudiantes (véase Cuadro D2.1). Como valor estimado, este tamaño de clase debe ser interpretado con precaución.

Utilizando esta relación matemática y comparando los valores de un país en cada uno de los cuatro factores con las medias de la OCDE es posible medir tanto las contribuciones directas como indirectas de cada uno de estos cuatro factores a la variación del coste salarial por estudiante que existe entre ese país y la media de la OCDE (para más detalles, consulte Anexo 3). Por ejemplo, en el caso de que solo interactúen dos factores, si un trabajador recibe un aumento del $10 \%$ en su salario por hora y aumenta el número de horas de trabajo en un $20 \%$, sus ingresos aumentarán en un $32 \%$ como resultado de la contribución directa de cada una de estas variaciones $(0,1+0,2)$ y la contribución indirecta de estas variaciones debido a la combinación de los dos factores $(0,1 * 0,2)$. 
Para explicar las diferencias del nivel de riqueza económica de cada país al comparar los costes salariales por estudiante, estos costes, así como los salarios de los profesores, se pueden dividir entre el PIB per cápita (asumiendo que el PIB per cápita es una estimación del nivel de riqueza económica de los países). Esto posibilita comparar el coste salarial «relativo» por estudiante (véase Panorama de la educación 2014, tablas disponibles en Internet).

La retribución de los profesores se basa en las horas de enseñanza de los estudiantes, las horas lectivas de los profesores, los salarios de los profesores y el número de docentes necesarios para enseñar a los estudiantes, que depende del tamaño estimado de las clases (Cuadro B7.1). Como consecuencia, las diferencias entre países en estos cuatro factores pueden explicar las diferencias del nivel de gasto. Del mismo modo, un nivel determinado de gasto puede ser el resultado de una combinación diferente de estos factores.

Los costes salariales de los profesores por estudiante muestran un patrón común en los países de la OCDE: generalmente ascienden de manera acusada con el nivel de educación. Sin embargo, en algunos países (particularmente en Eslovenia, Finlandia y Países Bajos) son más bajos en el nivel de educación secundaria superior que en el nivel de educación secundaria inferior. En general, en los países de la OCDE con datos disponibles para cada uno de estos niveles en 2012, el coste salarial medio de los profesores por estudiante es de 2.701 dólares estadounidenses por estudiante de educación primaria, 3.358 dólares estadounidenses por estudiante de educación secundaria inferior y 3.359 dólares estadounidenses por estudiante de educación secundaria superior (Gráfico B7.1).

\section{Disparidades en el coste salarial de los profesores entre paises de la OCDE}

La variación entre países del coste salarial de los profesores por estudiante entre niveles de educación es significativa. En 2012, la diferencia fue de menos de 50 dólares estadounidenses en Chile y Hungría entre estos tres niveles de educación, pero superó los 1.800 dólares en Bélgica (Comunidad francófona), Finlandia y Francia, y superó los 2.000 dólares estadounidenses en Bélgica (Comunidad flamenca) y Eslovenia (Tabla B7.1 y Gráfico B7.1).

Este aumento del coste salarial de los profesores por estudiante que se da según asciende el nivel de educación es en parte el resultado de incrementos en los salarios de los profesores y en el número de horas de enseñanza de los estudiantes en niveles de educación superiores. En 2012, los salarios medios en la OCDE oscilaban entre 39.642 dólares estadounidenses en educación primaria, 41.382 dólares estadounidenses en educación secundaria inferior y 43.949 dólares estadounidenses en educación secundaria superior. La media de horas de enseñanza anuales de la OCDE varía entre 805 horas en educación primaria, 920 horas en educación secundaria inferior y 947 horas en educación secundaria superior. El aumento también está relacionado con el hecho de que las horas lectivas de los profesores generalmente disminuyen según asciende el nivel de educación, lo cual implica que son necesarios más docentes para dar clase a un determinado número de estudiantes (la media de horas lectivas anuales en 2012 desciende de 782 horas en educación primaria a 691 horas en educación secundaria inferior, a 655 horas en educación secundaria superior). Sin embargo, en los niveles superiores de educación, las clases más numerosas tienden a reducir el coste salarial por estudiante (el tamaño medio estimado de las clases en la OCDE aumenta entre educación primaria, secundaria inferior y secundaria superior, de 15,7 estudiantes a 17,8 estudiantes y a 19,6 estudiantes, respectivamente) (Tablas B7.2a y B7.2b, y Tabla B7.2c, disponible en Internet).

\section{Variaciones en los costes salariales de los profesores por estudiante entre 2008 y 2012}

El coste salarial de los profesores por estudiante también varía a lo largo del tiempo en un determinado nivel de educación. Estos cambios solo se analizan en los niveles de educación primaria y secundaria inferior, porque no hay datos de tendencias disponibles en el nivel de educación secundaria superior. Este análisis también se limita a países que disponen de datos para los años 2008 y 2012 (27 y 25 países, respectivamente, para educación primaria y secundaria inferior), ya que son menos los países que disponen de datos comparables que abarquen un periodo de tiempo más largo (2000, 2005, 2008 y 2012).

El coste salarial de los profesores por estudiante aumentó tanto en educación primaria como en educación secundaria inferior entre 2008 y 2012, pero de manera diferente: un 7\% en educación primaria (de 2.454 dólares estadounidenses a 2.633 dólares estadounidenses) y un $4 \%$ en educación secundaria inferior (de 3.217 dólares estadounidenses a 3.355 dólares estadounidenses), como media en los países que disponen de datos para ambos años (Gráfico B7.2).

En la mayor parte de los países, el coste salarial de los profesores por estudiante en estos dos niveles de educación aumentó entre 2008 y 2012. El aumento alcanzó o superó el $25 \%$ en educación primaria en Corea, Israel y Turquía, 
y superó el $45 \%$ en educación primaria en Luxemburgo y en educación secundaria inferior en Estonia y Polonia (Gráfico B7.3).

Sin embargo, el coste salarial de los profesores por estudiante también disminuyó entre 2008 y 2012 en un número significativo de países y de manera especialmente notable en Hungría (un $23 \%$ en educación primaria y un $20 \%$ en educación secundaria inferior) y en Italia (un $15 \%$ en educación primaria y un $20 \%$ en educación secundaria inferior). También se observaron disminuciones similares del coste salarial de los profesores por estudiante en educación primaria en República Checa (un 15\%) y en educación secundaria inferior en Portugal (un 19\%). Se dio un descenso del 8\%-11\% en educación primaria en España, Estados Unidos, Inglaterra y Portugal, y un descenso de una magnitud similar en educación secundaria inferior en España e Irlanda (Gráfico B7.2).

\section{Impacto de los salarios de los profesores y del tamaño de las clases en el coste salarial de los profesores por estudiante}

De los cuatro factores que determinan el nivel del coste salarial de los profesores, dos son los principales responsables de las amplias variaciones que se dan en este coste: los salarios de los profesores y el tamaño de las clases. Entre 2008 y 2012, en países que disponen de datos para este periodo, el salario medio de los profesores (expresado en precios constantes) aumentó un 3,0\% en educación primaria y un 1,5\% en educación secundaria inferior, mientras

\section{Gráfico B7.2. Cambio del coste salarial (en dólares estadounidenses) de los profesores por estudiante, por nivel de educación $(2005,2008,2012)$}

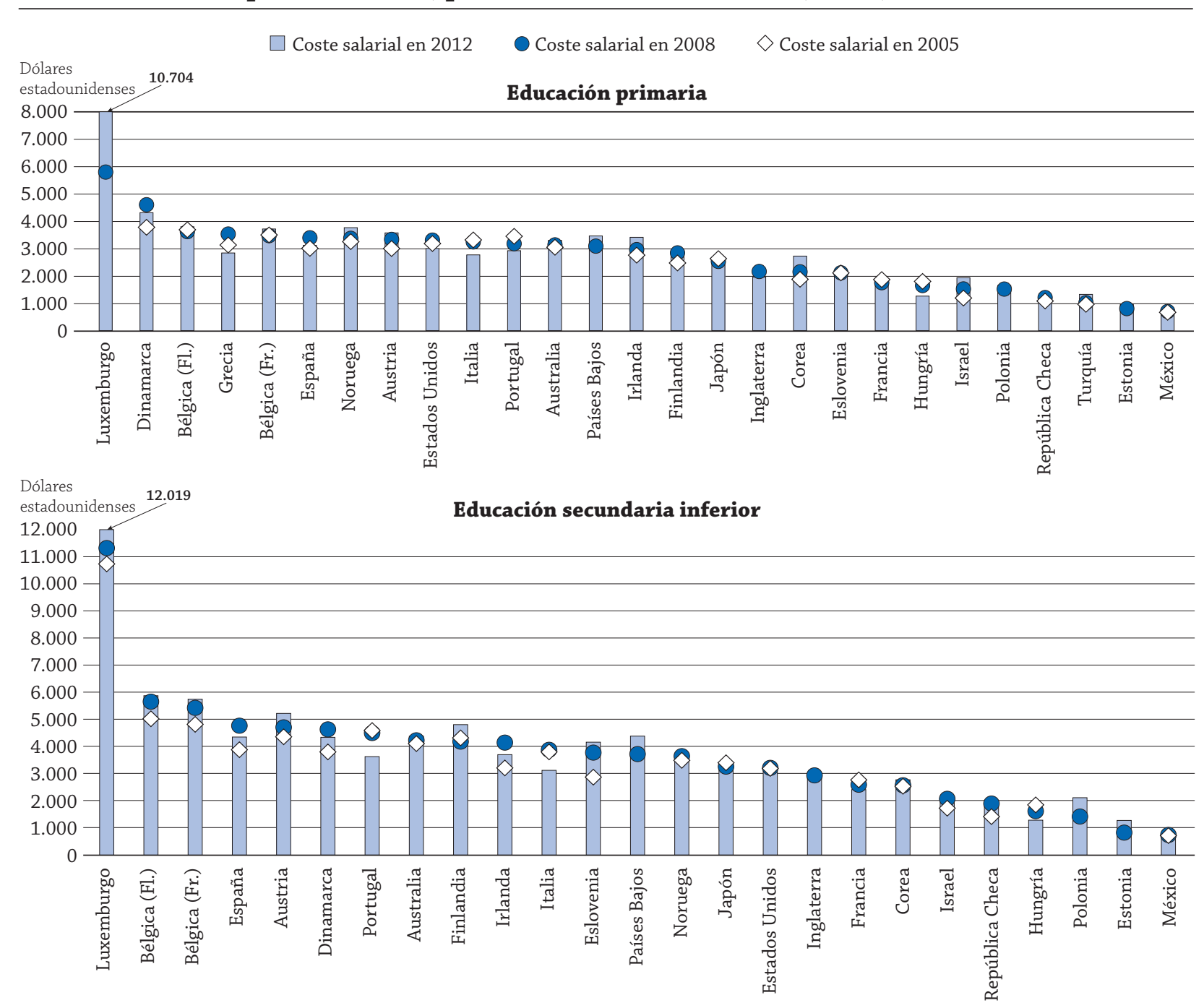

Los países están clasificados en orden descendente del coste salarial de los profesores por estudiante en 2008.

Fuente: OCDE. Tablas B7.3 y B7.4. Para ver notas, consulte Anexo 3 (www.oecd.org/edu/eag.htm).

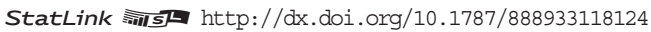


que el tamaño estimado de las clases disminuyó como media aproximadamente un 2,6\% en educación primaria y aumentó un 6,1\% en educación secundaria inferior (Tablas B7.2a y B7.2b).

Como media en los países de la OCDE con datos comparables para 2008 y 2012, los salarios de los profesores aumentaron en términos reales, pero disminuyeron en la mayor parte de los países durante este periodo. En el nivel de educación primaria, esto reflejó el gran aumento salarial de los profesores de Luxemburgo (de un $41 \%$ ) que contrarrestó las disminuciones salariales de otros países. En educación secundaria inferior, disminuciones y aumentos en un número similar de países resultaron en un ligero aumento de la media. Los salarios de los profesores disminuyeron en algunos países, de manera más notable en Grecia y Hungría (más de un $22 \%$ tanto en educación primaria como secundaria inferior), y esto puede explicar la mayor parte de la disminución del coste salarial de los profesores por estudiante en estos países (Gráfico B7.3).

\section{Gráfico B7.3. Cambio del coste salarial de los profesores por estudiante, salarios de los profesores y tamaño estimado de la clase en educación primaria y secundaria inferior $(2008,2012)$}

Cambio, en porcentaje, entre 2008 y 2012
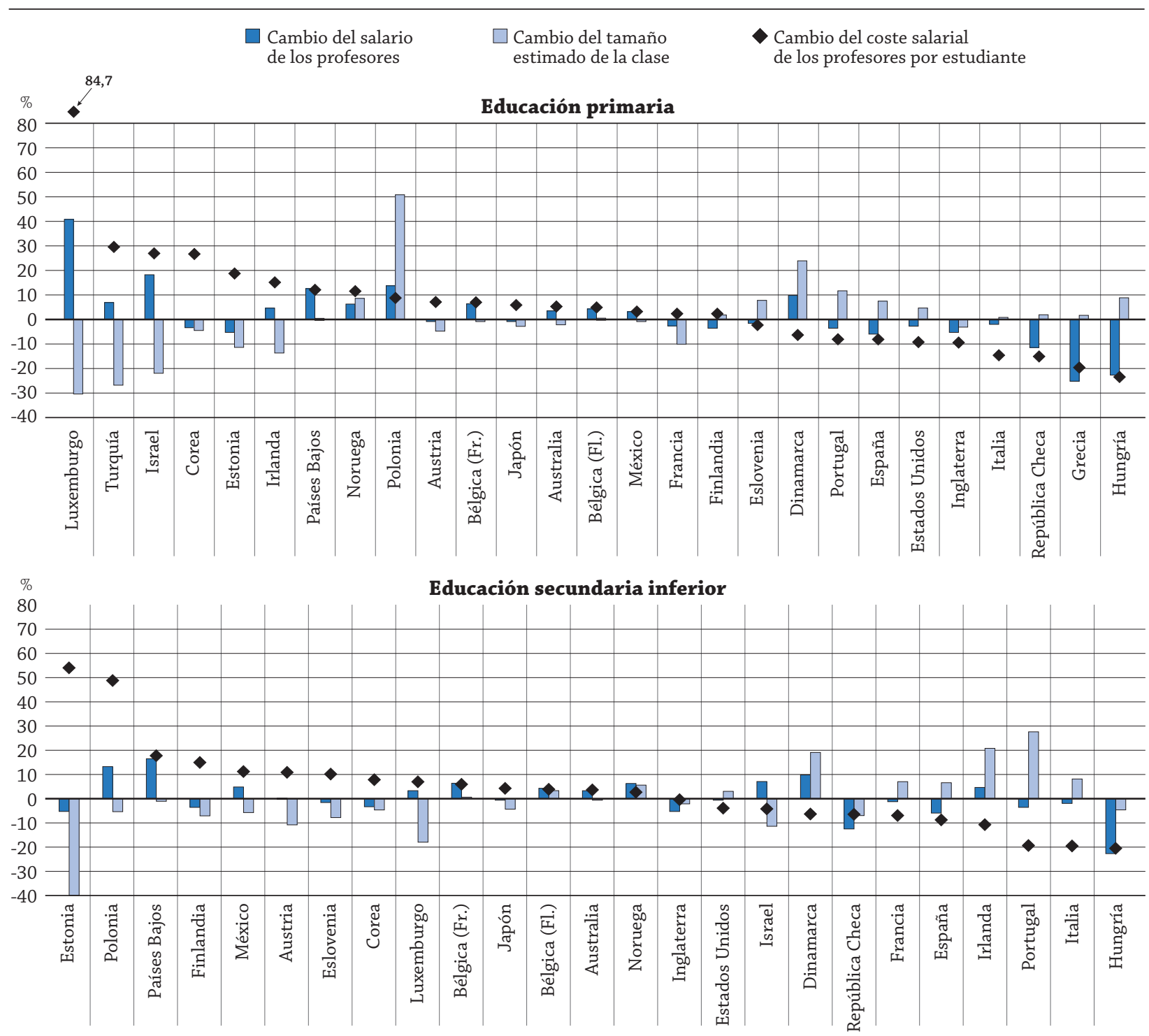

Los países están clasificados en orden descendente del cambio del coste salarial de los profesores por estudiante entre 2008 y 2012.

Fuente: OCDE. Tablas B7.2a, B7.2b, B7.3 y B7.4. Para ver notas, consulte Anexo 3 (www.oecd.org/edu/eag.htm).

StatLink 제내 http://dx.doi.org/10.1787/888933118143 


\section{Gráfico B7.4. Contribución (en dólares estadounidenses) de diversos factores al coste salarial de los profesores por estudiante, en educación secundaria superior (2012)}

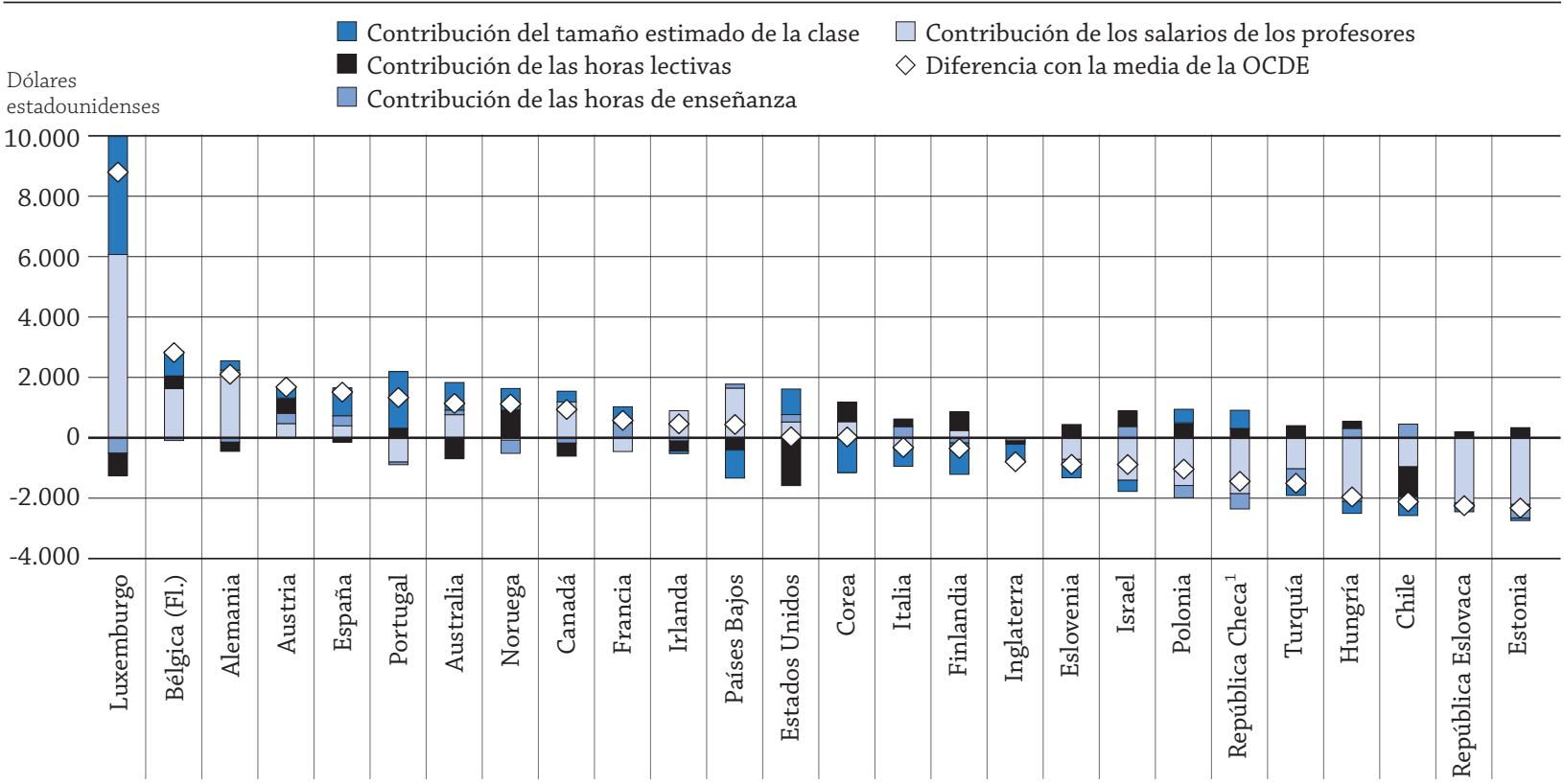

Nota: Las contribuciones expresadas en porcentaje del PIB per cápita están disponibles en Internet.

1. La contribución de las horas de enseñanza se calcula sobre horas mínimas de enseñanza.

Los países están clasificados en orden descendente de la diferencia entre el coste salarial de los profesores por estudiante y la media de la OCDE.

Fuente: OCDE. Tabla B7.5. Para ver notas, consulte Anexo 3 (www.oecd.org/edu/eag.htm).

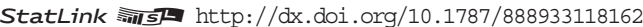

En cambio, en los países con datos relativos a 2008 y 2012, el tamaño estimado de las clases tendió a disminuir en menos de la mitad de ellos en educación primaria y en más de la mitad de ellos en educación secundaria inferior, generando un aumento del coste salarial de los profesores. En educación primaria y secundaria inferior, las mayores reducciones se observaron en países en los que el tamaño estimado de las clases era relativamente grande en 2008 (Israel y Turquía en educación primaria, Estonia en educación secundaria inferior) y también en países en los que el tamaño estimado de las clases estaba por debajo de la media en 2008 (Luxemburgo, tanto en educación primaria como en educación secundaria inferior). Sin embargo, el tamaño estimado de las clases aumentó de manera significativa en algunos países, contribuyendo a una disminución del coste salarial por estudiante. Esto sucedió de manera más notable en Dinamarca (de 10,9 a 13,6 estudiantes) y Polonia (de 8,1 a 12,2 estudiantes) en educación primaria, y en Portugal en educación secundaria inferior (de 9,7 a 12,4 estudiantes).

Los cambios del número de horas de enseñanza y horas lectivas, los otros dos factores que influyen sobre el coste salarial de los profesores, oscilaron como media entre un $-2,5 \%$ y un 3,7\% tanto en educación primaria como en educación secundaria inferior (en países con datos disponibles para ambos años) durante el mismo periodo. Esto puede reflejar la sensibilidad política de implementar reformas en estas áreas (Tabla B7.5 en Panorama de la educación 2012).

Sin embargo, en un pequeño número de países, el número de horas de enseñanza de los estudiantes y/o las horas lectivas de los profesores sí cambió de manera significativa. Por ejemplo, en Noruega, Polonia y Portugal se introdujeron reformas recientemente para aumentar el número de horas de enseñanza de los estudiantes en lectura y matemáticas. Entre 2008 y 2012, el número de horas lectivas de los profesores cambió de manera más significativa (más de 100 horas) en Corea (un descenso de 840 horas a 694 horas en educación primaria), Israel (un aumento de 731 horas a 838 horas en educación primaria) y Luxemburgo (un aumento de 634 horas a 739 horas en educación secundaria inferior). El número de horas de enseñanza aumentó más de 100 horas entre 2008 y 2012 en Islandia y Polonia en educación primaria y educación secundaria inferior y disminuyó más de 100 horas en Israel en educación secundaria inferior. La disminución del número de horas de enseñanza de los estudiantes en Italia (una reducción de casi 100 horas entre 2008 y 2012, tanto en educación primaria como en educación secundaria inferior) constituye uno de los motivos principales por los que el coste salarial de los profesores por estudiante ha disminuido en ese país (Tablas B7.2a y b). 


\section{Relación entre gasto en educación y opciones políticas}

Los niveles más elevados de gasto en educación no equivalen automáticamente a un mejor rendimiento de los sistemas educativos. Esto no resulta sorprendente, ya que puede haber países que gasten cantidades similares en educación, pero cuyas políticas y prácticas educativas no sean necesariamente similares. Por ejemplo, en 2012, el coste salarial de los profesores por estudiante en educación secundaria superior era muy similar en España y en Portugal (4.727 dólares estadounidenses y 4.550 dólares estadounidenses, respectivamente), superando la media de la OCDE en ambos casos. En Portugal, esto se debía a que el tamaño estimado de las clases era menor que la media, mientras que en España se debía a un tamaño estimado de las clases menor que la media en combinación con salario de los profesores superior a la media y un número de horas de enseñanza superior a la media. El coste salarial de los profesores por estudiante en Israel y Polonia también era similar. Aunque los salarios de los profesores fueran similares en ambos países, los otros tres factores influían en el coste salarial de los profesores de manera diferente en cada país (Tabla B7.5 y Gráfico B7.4a).

Además, a pesar de que algunos países puedan decantarse por opciones políticas similares, estas opciones pueden generar diferentes costes salariales de los profesores por estudiante. Por ejemplo, en Canadá, Estados Unidos e Irlanda, el coste salarial de los profesores por estudiante en educación secundaria superior es el punto de equilibrio entre dos efectos opuestos: un número de horas lectivas de los profesores que supera la media reduce el coste salarial de los profesores por estudiante en relación con la media de la OCDE, y unas clases relativamente pequeñas y un salario de los profesores relativamente elevado aumentan el coste salarial de los profesores por estudiante en relación con a la media de la OCDE. El coste salarial de los profesores por estudiante que resulta de esta combinación supera la media de la OCDE en estos tres países, pero varía entre menos de 100 dólares estadounidenses más en Estados Unidos y aproximadamente 1.000 dólares estadounidenses más en Canadá (Tabla B7.5 y Gráfico B7.4).

\section{Principales factores determinantes del coste salarial de los profesores por estudiante, por nivel de educación}

La comparación del coste salarial de los profesores por estudiante con la media de la OCDE y la contribución de los cuatro factores a esta diferencia permiten analizar el grado de impacto que tiene cada factor en las diferencias del coste salarial de los profesores por estudiante. En cada nivel de educación, los salarios de los profesores son casi siempre el principal factor que influye en la diferencia del coste salarial medio de los profesores por estudiante. En los países con datos disponibles para 2012, constituye el factor principal en 21 de 31 países en educación primaria, en 15 de 30 países en educación secundaria inferior y en 14 de 26 países en educación secundaria superior. Esto es así tanto en los países que tienen los valores más altos como en los que tienen los valores más bajos de coste salarial de los profesores por estudiante.

Por ejemplo, en educación secundaria superior, los salarios por encima de la media de los profesores constituye el factor principal que genera la diferencia en el país con el coste salarial más elevado (Luxemburgo), así como en ocho de los nueve países con los niveles más bajos del coste salarial de los profesores por estudiante (Eslovenia, Estonia, Hungría, Israel, Polonia, República Checa, República Eslovaca y Turquía) (Gráfico B7.4).

El tamaño estimado de las clases es el segundo factor que más contribuye a la diferencia en cada nivel de educación (en 6 países en educación primaria, en 13 países en educación secundaria inferior y en 7 países en educación secundaria superior). En educación secundaria superior, un tamaño estimado de las clases inferior a la media constituye el principal factor responsable de las variaciones del coste salarial de los profesores por estudiante en dos de los seis países con el coste salarial de los profesores por estudiante más elevado: España y Portugal (Cuadro B7.2).

\section{Principales factores determinantes del coste salarial de los profesores por estudiante, teniendo en cuenta la riqueza económica de los países}

Sin embargo, el nivel de los salarios de los profesores y, a su vez, el nivel del coste salarial de los profesores por estudiante dependen de la riqueza económica relativa del país. Para tener en cuenta las diferencias en riqueza económica de los países, se analizaron los niveles salariales de los profesores (y el coste salarial por estudiante) en relación con el PIB per cápita. Al comparar el coste salarial relativo de los profesores por estudiante utilizando este análisis, la clasificación de los países cambia (Gráfico B7.4 continuación, disponible en Internet). Sin embargo, en comparación con el análisis en dólares estadounidenses, solo un pequeño número de países experimenta un cambio de posición significativo. En educación secundaria superior, Luxemburgo tiene el coste salarial de los profesores por estudiante en dólares estadounidenses más elevado, principalmente debido a un alto nivel salarial en dólares estadounidenses, pero no como proporción del PIB per cápita, incluso aunque siga estando por encima de la media de la OCDE, debido a que el tamaño estimado de la clase es inferior a la media. En consecuencia, los salarios de los profesores como 


\section{Cuadro B7.2. Principales factores determinantes del coste salarial de los profesores por estudiante, por nivel de educación (2012)}

\begin{tabular}{|c|c|c|c|}
\hline & Educación primaria & Educación secundaria inferior & $\begin{array}{c}\text { Educación secundaria } \\
\text { superior }\end{array}$ \\
\hline Salario & $\begin{array}{c}21 \text { países } \\
\text { AUS(+), BFL(+), BFR(+), CAN(+), } \\
\text { CHL(-), CZE(-), DNK(+), EST(-), } \\
\text { DEU(+), GRC(-), HUN(-), IRL(+), } \\
\text { ISR(-), ITA(-), JPN(+), KOR(+), } \\
\text { LUX(+), MEX(-), NLD(+), POL(-), } \\
\text { SVK(-), }\end{array}$ & $\begin{array}{c}15 \text { países } \\
\text { AUS(+), CAN(+), CHL(-), CZE(-), } \\
\text { DNK(+), EST(-), DEU(+), HUN(-), } \\
\text { IRL(+), ISR(-), ITA(-), LUX(+), } \\
\text { NLD(+), POL(-), SVK(-), }\end{array}$ & $\begin{array}{c}14 \text { países } \\
\text { BFL(+), CAN(+), CZE(-), } \\
\text { EST(-), DEU(+), HUN(-), } \\
\text { IRL(+), ISR(-), LUX(+), } \\
\text { NLD(+), POL(-), SVK(-), } \\
\text { SVN(-), TUR(-), }\end{array}$ \\
\hline $\begin{array}{l}\text { Horas de } \\
\text { enseñanza }\end{array}$ & $\begin{array}{l}1 \text { país } \\
\text { FIN (-) }\end{array}$ & $\begin{array}{l}1 \text { país } \\
\operatorname{ESP}(+)\end{array}$ & $\begin{array}{l}1 \text { país } \\
\text { FRA (+) }\end{array}$ \\
\hline Horas lectivas & $\begin{array}{c}3 \text { países } \\
\text { FRA (-), SVN (+), USA (-) }\end{array}$ & $\begin{array}{l}1 \text { país } \\
\text { USA (-) }\end{array}$ & $\begin{array}{c}4 \text { países } \\
\text { AUT (+), CHL (-), NOR (+), } \\
\text { USA (-) }\end{array}$ \\
\hline $\begin{array}{l}\text { Tamaño } \\
\text { estimado } \\
\text { de clase }\end{array}$ & $\begin{array}{c}6 \text { países } \\
\text { AUT (+), ENG (-), NOR (+), } \\
\text { PRT (+), ESP (+), TUR (-) }\end{array}$ & $\begin{array}{c}13 \text { países } \\
\text { AUT (+), BFL (+), BFR (+), } \\
\text { ENG (-), FIN (+), FRA (-), JPN (-), } \\
\text { KOR (-), MEX (-), NOR (+), } \\
\text { PRT }(+), \text { SVN }(+), \text { TUR }(-)\end{array}$ & $\begin{array}{c}7 \text { países } \\
\text { AUS (+), ENG (-), FIN (-), } \\
\text { ITA }(-), \text { KOR }(-), \\
\text { PRT }(+), \operatorname{ESP}(+)\end{array}$ \\
\hline
\end{tabular}

Nota: Los signos positivos o negativos indican si el factor aumenta o disminuye el coste salarial de los profesores por estudiante. Fuente: OCDE. Tablas B7.3, B7.4 y B7.5. Para ver notas, consulte Anexo 3 (www.oecd.org/edu/eag.htm).

Consulte la Guía del lector para ver la lista de códigos de los países utilizados en esta tabla.

StatLink 젶ㄴ http://dx.doi.org/10.1787/888933118086

porcentaje del PIB per cápita no elevan el coste salarial de los profesores por estudiante (Tablas B7.3 continuación, B7.4 continuación, B7.5 continuación y Gráfico B7.5 continuación, disponibles en Internet).

Incluso después de tener en cuenta las diferencias de riqueza económica entre países, la salarios de los profesores como porcentaje del PIB per cápita y el tamaño estimado de la clase siguen siendo los principales factores determinantes de las variaciones del coste salarial medio de los profesores por estudiante en cada nivel de educación (Cuadro 7.2 continuación, disponible en Internet).

\section{Metodología}

Los datos que se refieren al año académico 2012 proceden de la recopilación UOE de datos sobre estadísticas educativas, así como del Estudio sobre Profesores y Currículo, ambos llevados a cabo por la OCDE en 2013. Los datos que se refieren a los años académicos 2000 y 2008 proceden de la recopilación UOE de datos, así como del Estudio sobre Profesores y Currículo, ambos llevados a cabo por la OCDE y publicados en la edición 2013 (datos de tendencias sobre horas lectivas y salarios de los profesores) y en las ediciones de 2002, 2007 y 2010 (ratio alumnos-profesor y horas de enseñanza) de Panorama de la educación. Se ha validado la coherencia de los datos relativos a los años 2000, 2005, 2008 y 2012 (para ver detalles, consulte Anexo 3 en www.oecd.org/edu/eag.htm).

El coste salarial de los profesores por estudiante se calcula a partir de los salarios de los profesores, el número de horas de enseñanza para los estudiantes, el número de horas lectivas de los profesores y el tamaño estimado de la clase (un valor figurado; véase Cuadro D2.1). En la mayor parte de los casos, los valores de estas variables proceden de Panorama de la educación 2013 y se refieren a los años académicos 2011-2012, 2007-2008, 2004/05 y 1999-2000. Siempre que no estén disponibles en la edición actual, los datos relativos a los años académicos 1999-2000, 20042005 y 2007-2008 proceden de las ediciones 2002, 2007 y 2010, respectivamente, de Panorama de la educación. Los datos relativos a los años 2000, 2005 y 2008 han sido comprobados para garantizar su coherencia con los datos del año 2012. Los salarios de los profesores en las divisas nacionales se han convertido a su equivalente en dólares estadounidenses dividiendo la cantidad en divisa nacional por el índice de paridad de poder adquisitivo (PPA) para el 
consumo privado, aplicando la metodología utilizada en el Indicador D3 sobre los salarios de los profesores, que da como resultado el coste salarial por estudiante expresado en su equivalente a dólares estadounidenses. Para obtener más detalles sobre el análisis de estos factores, consulte Anexo 3 en www.oecd.org/edu/eag.htm.

Nota sobre los datos de Israel

Los datos estadísticos para Israel fueron proporcionados por las autoridades israelíes competentes bajo su responsabilidad. El uso de estos datos por parte de la OCDE se hace sin prejuzgar la situación de los Altos del Golán, Jerusalén Este y los asentamientos israelíes en Cisjordania de acuerdo con los términos del derecho internacional.

\section{Referencia}

OECD (2012), Education at a Glance 2012: OECD Indicators, OECD Publishing, París, http://dx.doi.org/10.1787/eag2012-en. Versión española: Panorama de la educación 2012: Indicadores de la OCDE, Ministerio de Educación, Cultura y Deporte, Santillana, Madrid

\section{Tablas del Indicador B7}

\begin{tabular}{|c|c|c|}
\hline & Tabla B7.1 & Coste salarial de los profesores por estudiante, por nivel de educación (2012) \\
\hline & Tabla B7.2a & $\begin{array}{l}\text { Factores utilizados para calcular el coste salarial de los profesores por estudiante, } \\
\text { en educación primaria }(2000,2005,2008 \text { y 2012) }\end{array}$ \\
\hline & Tabla B7.2b & $\begin{array}{l}\text { Factores utilizados para calcular el coste salarial de los profesores por estudiante, } \\
\text { en educación secundaria inferior }(2000,2005,2008 \text { y 2012) }\end{array}$ \\
\hline WEB & Tabla B7.2c & $\begin{array}{l}\text { Factores utilizados para calcular el coste salarial de los profesores por estudiante, } \\
\text { en educación secundaria superior (2012) }\end{array}$ \\
\hline & Tabla B7.3 & $\begin{array}{l}\text { Contribución de diversos factores al coste salarial de los profesores por estudiante } \\
\text { en educación primaria }(2000,2005,2008 \text { y 2012) }\end{array}$ \\
\hline WEB & Tabla B7.3 (continuación) & $\begin{array}{l}\text { Contribución de diversos factores al coste salarial de los profesores por estudiante } \\
\text { en educación primaria (2012) }\end{array}$ \\
\hline & Tabla B7.4 & $\begin{array}{l}\text { Contribución de diversos factores al coste salarial de los profesores por estudiante } \\
\text { en educación secundaria inferior }(2000,2005,2008 \text { y 2012) }\end{array}$ \\
\hline WEB & Tabla B7.4 (continuación) & $\begin{array}{l}\text { Contribución de diversos factores al coste salarial de los profesores por estudiante } \\
\text { en educación secundaria inferior (2012) }\end{array}$ \\
\hline & Tabla B7.5 & $\begin{array}{l}\text { Contribución de diversos factores al coste salarial de los profesores por estudiante } \\
\text { en educación secundaria superior (2012) }\end{array}$ \\
\hline$W E B$ & Tabla B7.5 (continuación) & $\begin{array}{l}\text { Contribución de diversos factores al coste salarial de los profesores por estudiante } \\
\text { en educación secundaria superior (2012) }\end{array}$ \\
\hline
\end{tabular}


Tabla B7.1. Coste salarial de los profesores por estudiante, por nivel de educación (2012) En equivalente a dólares estadounidenses convertidos mediante PPA para el consumo privado, y como porcentaje del PIB per cápita

\begin{tabular}{|c|c|c|c|c|c|c|}
\hline & \multicolumn{3}{|c|}{$\begin{array}{l}\text { Coste salarial de los profesores por estudiante } \\
\text { (en dólares estadounidenses) }\end{array}$} & \multicolumn{3}{|c|}{$\begin{array}{l}\text { Coste salarial de los profesores por estudiante } \\
\text { (en porcentaje del PIB per cápita) }\end{array}$} \\
\hline & Educación primaria & $\begin{array}{c}\text { Educación } \\
\text { secundaria inferior }\end{array}$ & $\begin{array}{c}\text { Educación } \\
\text { secundaria superior }\end{array}$ & Educación primaria & $\begin{array}{l}\text { Educación } \\
\text { secundaria inferior }\end{array}$ & $\begin{array}{c}\text { Educación } \\
\text { secundaria superior }\end{array}$ \\
\hline & (1) & (2) & (3) & (4) & (5) & (6) \\
\hline Alemania & 3.884 & 4.840 & 5.318 & 9,8 & 12,2 & 13,4 \\
\hline Australia & 3.301 & 4.355 & 4.355 & 7,7 & 10,1 & 10,1 \\
\hline Austria & 3.572 & 5.185 & 4.897 & 8,4 & 12,1 & 11,5 \\
\hline Bélgica (Fl.) & 3.797 & 5.833 & 6.037 & 10,2 & 15,6 & 16,2 \\
\hline Bélgica (Fr.) & 3.716 & 5.708 & $\mathrm{~m}$ & 10,0 & 15,3 & $\mathrm{~m}$ \\
\hline Canadá & 3.696 & 3.696 & 4.152 & 9,1 & 9,1 & 10,2 \\
\hline Chile & 1.117 & 1.102 & 1.093 & 5,6 & 5,5 & 5,5 \\
\hline Corea & 2.725 & 2.757 & 3.243 & 9,8 & 9,9 & 11,6 \\
\hline Dinamarca & 4.310 & 4.310 & $\mathrm{~m}$ & 11,2 & 11,2 & $\mathrm{~m}$ \\
\hline Escocia & $\mathrm{m}$ & $\mathrm{m}$ & $\mathrm{m}$ & $\mathrm{m}$ & $\mathrm{m}$ & $\mathrm{m}$ \\
\hline Eslovenia & 2.066 & 4.133 & 2.334 & 8,2 & 16,3 & 9,2 \\
\hline España & 3.118 & 4.321 & 4.727 & 10,8 & 15,0 & 16,4 \\
\hline Estados Unidos & 3.003 & 3.068 & 3.249 & 5,8 & 5,9 & 6,3 \\
\hline Estonia & 957 & 1.270 & 886 & 4,5 & 6,0 & 4,2 \\
\hline Finlandia & 2.909 & 4.775 & 2.863 & 8,1 & 13,2 & 7,9 \\
\hline Francia & 1.795 & 2.398 & 3.790 & 5,1 & 6,8 & 10,7 \\
\hline Grecia & 2.839 & $\mathrm{~m}$ & $\mathrm{~m}$ & 12,5 & $\mathrm{~m}$ & $\mathrm{~m}$ \\
\hline Hungría & 1.263 & 1.279 & 1.255 & 6,2 & 6,3 & 6,2 \\
\hline Inglaterra & 1.959 & 2.907 & 2.421 & 5,7 & 8,4 & 7,0 \\
\hline Irlanda & 3.410 & 3.676 & 3.676 & 9,1 & 9,8 & 9,8 \\
\hline Islandia & $\mathrm{m}$ & $\mathrm{m}$ & $\mathrm{m}$ & $\mathrm{m}$ & $\mathrm{m}$ & $\mathrm{m}$ \\
\hline Israel & 1.935 & 1.974 & 2.327 & 6,6 & 6,7 & 7,9 \\
\hline Italia & 2.769 & 3.102 & 2.895 & 8,9 & 10,0 & 9,3 \\
\hline Japón & 2.680 & 3.377 & $\mathrm{~m}$ & 8,3 & 10,4 & $\mathrm{~m}$ \\
\hline Luxemburgo & 10.704 & 12.019 & 12.019 & 13,1 & 14,8 & 14,8 \\
\hline México & 724 & 822 & $\mathrm{~m}$ & 4,9 & 5,6 & $\mathrm{~m}$ \\
\hline Noruega & 3.763 & 3.719 & 4.335 & 6,3 & 6,2 & 7,3 \\
\hline Nueva Zelanda & $\mathrm{m}$ & $\mathrm{m}$ & $\mathrm{m}$ & $\mathrm{m}$ & $\mathrm{m}$ & $\mathrm{m}$ \\
\hline Países Bajos & 3.463 & 4.354 & 3.656 & 8,4 & 10,6 & 8,9 \\
\hline Polonia & 1.653 & 2.101 & 2.175 & 7,7 & 9,8 & 10,2 \\
\hline Portugal & 2.923 & 3.605 & 4.550 & 13,1 & 16,2 & 20,4 \\
\hline República Checa & 1.027 & 1.766 & 1.771 & 4,2 & 7,2 & 7,2 \\
\hline República Eslovaca & 797 & 1.044 & 964 & 3,5 & 4,5 & 4,2 \\
\hline Suecia & $\mathrm{m}$ & $\mathrm{m}$ & $\mathrm{m}$ & $\mathrm{m}$ & $\mathrm{m}$ & $\mathrm{m}$ \\
\hline Suiza & $\mathrm{m}$ & $\mathrm{m}$ & $\mathrm{m}$ & $\mathrm{m}$ & $\mathrm{m}$ & $\mathrm{m}$ \\
\hline Turquía & 1.325 & 1.376 & 1.706 & 8,4 & 8,8 & 10,9 \\
\hline Media OCDE & 2.575 & 3.129 & 3.212 & 7,7 & 9,2 & 9,4 \\
\hline
\end{tabular}

Fuente: OCDE. Para ver notas, consulte Anexo 3 (www.oecd.org/edu/eag.htm).

Para obtener más información acerca de los símbolos utilizados en lugar de los datos que faltan, consulte la Guía del lector.

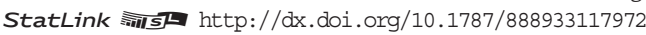


Tabla B7.2a. [1/2] Factores utilizados para calcular el coste salarial de los profesores por estudiante, en educación primaria $(2000,2005,2008$ y 2012)

\begin{tabular}{|c|c|c|c|c|c|c|c|c|c|c|c|c|}
\hline & \multicolumn{4}{|c|}{$\begin{array}{l}\text { Salario de los profesores } \\
\text { (anual, en dólares estadounidenses, } 2012 \\
\text { precios constantes) }\end{array}$} & \multicolumn{4}{|c|}{$\begin{array}{c}\text { Horas de enseñanza } \\
\text { (de los estudiantes, horas anuales) }\end{array}$} & \multicolumn{4}{|c|}{$\begin{array}{c}\text { Horas lectivas } \\
\text { (de los profesores, horas anuales) }\end{array}$} \\
\hline & 2005 & 2008 & 2012 & $\begin{array}{l}\text { Variación } \\
2008-2012 \\
(\%)\end{array}$ & 2005 & 2008 & 2012 & $\begin{array}{l}\text { Variación } \\
2008-2012 \\
(\%)\end{array}$ & 2005 & 2008 & 2012 & $\begin{array}{c}\text { Variación } \\
2008-2012 \\
(\%)\end{array}$ \\
\hline & (2) & (3) & (4) & (5) & (7) & (8) & (9) & (10) & (12) & (13) & (14) & (15) \\
\hline Alemania & $\mathrm{m}$ & $\mathrm{m}$ & 62.195 & $\mathbf{m}$ & 777 & 635 & 702 & 10,6 & 808 & 805 & 804 & $-0,1$ \\
\hline Australia $^{1}$ & 49.407 & 49.544 & 51.289 & 3,5 & 979 & 959 & 953 & $-0,6$ & 888 & 873 & 871 & $-0,1$ \\
\hline Austria $^{1}$ & 42.404 & 42.993 & 42.994 & 0,0 & 812 & 735 & 750 & 2,0 & 774 & 779 & 779 & 0,0 \\
\hline Bélgica $(\mathrm{Fl} .)^{1}$ & 47.136 & 45.664 & 47.635 & 4,3 & 835 & 840 & 831 & $-1,1$ & 761 & 765 & 748 & $-2,2$ \\
\hline Bélgica $(\mathrm{Fr} .)^{1}$ & 44.715 & 43.816 & 46.616 & 6,4 & 930 & 930 & 930 & 0,0 & 722 & 724 & 721 & $-0,4$ \\
\hline Canadá & $\mathrm{m}$ & $\mathrm{m}$ & 58.495 & $\mathbf{m}$ & $\mathrm{m}$ & $\mathrm{m}$ & 919 & $\mathbf{m}$ & $\mathrm{m}$ & $\mathrm{m}$ & 802 & $\mathbf{m}$ \\
\hline Chile & $\mathrm{m}$ & $\mathrm{m}$ & 24.725 & $\mathbf{m}$ & $\mathrm{m}$ & 1.089 & 1.007 & $-7,5$ & 1.128 & 1.101 & 1.103 & 0,2 \\
\hline Corea $^{1}$ & 52.522 & 51.879 & 50.145 & $-3,3$ & 703 & 612 & 632 & 3,3 & 883 & 840 & 694 & $-17,5$ \\
\hline Dinamarca $^{1}$ & 44.963 & 46.551 & 51.122 & 9,8 & 763 & 701 & 754 & 7,5 & 640 & 648 & 659 & 1,7 \\
\hline Escocia & 48.021 & 47.593 & 44.867 & $-5,7$ & a & $\mathrm{a}$ & a & $\mathbf{m}$ & 893 & 855 & 855 & 0,0 \\
\hline Eslovenia $^{1}$ & 31.673 & 33.345 & 32.819 & $-1,6$ & 721 & 621 & 664 & 7,0 & 627 & 627 & 627 & 0,0 \\
\hline España $^{1}$ & 43.035 & 44.513 & 41.862 & $-6,0$ & 794 & 833 & 875 & 5,0 & 880 & 880 & 880 & 0,0 \\
\hline Estados Unidos ${ }^{1}$ & 47.441 & 47.290 & 45.998 & $-2,7$ & 952 & 960 & 967 & 0,7 & 1.080 & 1.097 & 1.131 & 3,1 \\
\hline Estonia $^{1}$ & 9.587 & 13.220 & 12.525 & $-5,3$ & 910 & 595 & 650 & 9,2 & 630 & 630 & 619 & $-1,7$ \\
\hline Finlandia $^{1}$ & 39.317 & 40.907 & 39.445 & $-3,6$ & 673 & 608 & 654 & 7,5 & 677 & 677 & 673 & $-0,5$ \\
\hline Francia $^{1}$ & 36.113 & 34.912 & 33.994 & $-2,6$ & 894 & 926 & 864 & $-6,7$ & 936 & 936 & 924 & $-1,3$ \\
\hline Grecia $^{1}$ & 34.627 & 35.573 & 26.617 & $-25,2$ & 928 & 720 & 756 & 5,0 & 604 & 593 & 569 & $-3,9$ \\
\hline Hungría $^{1}$ & 19.090 & 17.486 & 13.520 & $-22,7$ & 718 & 614 & 655 & 6,6 & 583 & 611 & 604 & $-1,1$ \\
\hline Inglaterra $^{1}$ & 43.668 & 43.695 & 41.393 & $-5,3$ & 900 & 893 & 861 & $-3,5$ & $\mathrm{~m}$ & 654 & 680 & 4,1 \\
\hline Irlanda $^{1}$ & 49.451 & 52.696 & 55.148 & 4,7 & 941 & 915 & 869 & $-5,0$ & 915 & 915 & 915 & 0,0 \\
\hline Islandia & 29.811 & 31.135 & 28.742 & $-7,7$ & 792 & 720 & 857 & 19,0 & 671 & 671 & $\mathrm{~m}$ & $\mathbf{m}$ \\
\hline Israel $^{1}$ & 20.576 & 24.873 & 29.413 & 18,3 & 990 & 996 & 956 & $-3,9$ & 731 & 731 & 838 & 14,6 \\
\hline Italia $^{1}$ & 35.157 & 34.252 & 33.570 & $-2,0$ & 1.023 & 990 & 891 & $-10,0$ & 739 & 735 & 752 & 2,4 \\
\hline Japón ${ }^{1}$ & 50.982 & 47.604 & 47.561 & $-0,1$ & 774 & 709 & 754 & 6,3 & 578 & 709 & 731 & 3,2 \\
\hline Luxemburgo ${ }^{1}$ & 73.324 & 70.145 & 98.788 & 40,8 & 847 & 924 & 924 & 0,0 & 774 & 739 & 810 & 9,5 \\
\hline México $^{1}$ & 18.952 & 19.666 & 20.296 & 3,2 & 800 & 800 & 800 & 0,0 & 800 & 800 & 800 & 0,0 \\
\hline Noruega $^{1}$ & 35.497 & 36.475 & 38.773 & 6,3 & 713 & 656 & 748 & 14,0 & 741 & 741 & 741 & 0,0 \\
\hline Nueva Zelanda & 41.198 & 42.312 & 43.050 & 1,7 & 985 & 985 & $\mathrm{~m}$ & $\mathbf{m}$ & $\mathrm{m}$ & 945 & $\mathrm{~m}$ & $\mathbf{m}$ \\
\hline Países Bajos ${ }^{1}$ & $\mathrm{~m}$ & 48.720 & 54.865 & 12,6 & 1.000 & 940 & 940 & 0,0 & 930 & 930 & 930 & 0,0 \\
\hline Polonia $^{1}$ & 14.793 & 15.963 & 18.160 & 13,8 & $\mathrm{~m}$ & 486 & 703 & 44,6 & $\mathrm{~m}$ & 632 & 633 & 0,2 \\
\hline Portugal $^{1}$ & 37.224 & 35.980 & 34.694 & $-3,6$ & 861 & 776 & 812 & 4,6 & 855 & 770 & 756 & $-1,8$ \\
\hline República Checa ${ }^{1,2}$ & 18.981 & 21.863 & 19.363 & $-11,4$ & 774 & 627 & 597 & $-4,8$ & 813 & 849 & 827 & $-2,6$ \\
\hline República Eslovaca & $\mathrm{m}$ & $\mathrm{m}$ & 13.365 & $\mathbf{m}$ & $\mathrm{m}$ & 662 & 698 & 5,4 & $\mathrm{~m}$ & $\mathrm{~m}$ & 819 & $\mathbf{m}$ \\
\hline Suecia & 34.533 & $\mathrm{~m}$ & 35.115 & $\mathbf{m}$ & 741 & 741 & 741 & 0,0 & $\mathrm{~m}$ & $\mathrm{~m}$ & $\mathrm{~m}$ & $\mathbf{m}$ \\
\hline Suiza & 60.706 & 59.196 & 61.279 & 3,5 & $\mathrm{~m}$ & 713 & $\mathrm{~m}$ & $\mathbf{m}$ & $\mathrm{m}$ & $\mathrm{m}$ & $\mathrm{m}$ & $\mathbf{m}$ \\
\hline Turquía $^{1}$ & 24.834 & 24.951 & 26.678 & 6,9 & 864 & 864 & 864 & 0,0 & 639 & 639 & 720 & 12,7 \\
\hline Media OCDE & 38.056 & 38.865 & 39.642 & 0,9 & 846 & 787 & 805 & 3,6 & 783 & 778 & 782 & 0,6 \\
\hline $\begin{array}{l}\text { Media de } 27 \text { países } \\
\text { con todos los datos } \\
\text { para } 2008 \text { y } 2012\end{array}$ & & 37.947 & 39.085 & 3,0 & & 786 & 802 & 2,0 & & 760 & 764 & 0,5 \\
\hline
\end{tabular}

Nota: El año de referencia 2000 (columnas 1, 6, 11, 16, 21) está disponible en Internet (véase StatLink más abajo). Los datos de esta tabla provienen del capítulo D (datos sobre los salarios y horas lectivas de los profesores correspondientes a 2000, 2005, 2008 y 2012, datos sobre la ratio estudiantes-profesor correspondientes a 2012) o de las ediciones de Panorama de la educación correspondientes a 2002 o 2007 y 2010 (datos sobre la ratio estudiantes-profesor y horas lectivas de los estudiantes). Los datos sobre las horas de enseñanza de los estudiantes en 2012 se refieren a los datos de 2011 correspondientes a la edición 2013 de Panorama de la educación (para Estados Unidos, los datos se refieren a 2012 y han sido revisados para los años anteriores). Se han revisado algunos datos de 2000 para garantizar la coherencia con los datos de 2012.

1. Países con todos los datos disponibles tanto de 2008 como de 2012

2. Horas de enseñanza actuales de los estudiantes en 2000 y 2005, horas de enseñanza mínimas en 2012.

Fuente: OCDE. Para ver notas, consulte Anexo 3 (www.oecd.org/edu/eag.htm).

Para obtener más información acerca de los símbolos utilizados en lugar de los datos que faltan, consulte la Guía del lector.

StatLink : inls $h$ htp://dx.doi.org/10.1787/888933117991 
Tabla B7.2a. [2/2] Factores utilizados para calcular el coste salarial de los profesores por estudiante, en educación primaria $(2000,2005,2008$ y 2012)

\begin{tabular}{|c|c|c|c|c|c|c|c|c|}
\hline & \multicolumn{4}{|c|}{$\begin{array}{l}\text { Ratio alumnos-personal docente } \\
\text { (número de alumnos por profesor) }\end{array}$} & \multicolumn{4}{|c|}{$\begin{array}{l}\text { Tamaño estimado de la clase } \\
\text { (número de alumnos por clase) }\end{array}$} \\
\hline & 2005 & 2008 & 2012 & $\begin{array}{c}\text { Variación } \\
2008-2012 \\
(\%)\end{array}$ & 2005 & 2008 & 2012 & $\begin{array}{c}\text { Variación } \\
2008-2012 \\
\text { (\%) }\end{array}$ \\
\hline & (17) & (18) & (19) & (20) & $(22)=(17)^{*}(7) /(12)$ & $(23)=(18)^{*}(8) /(13)$ & $(24)=(19)^{*}(9) /(14)$ & (25) \\
\hline Alemania & 18,8 & 18,0 & 16,0 & $-10,8$ & 18,1 & 14,2 & 14,0 & $-1,4$ \\
\hline Australia $^{1}$ & 16,2 & 15,8 & 15,5 & $-1,7$ & 17,9 & 17,4 & 17,0 & $-2,2$ \\
\hline Austria $^{1}$ & 14,1 & 12,9 & 12,0 & $-6,7$ & 14,8 & 12,2 & 11,6 & $-4,8$ \\
\hline Bélgica $(\mathrm{Fl},)^{1}$ & 12,8 & 12,6 & 12,5 & $-0,6$ & 14,0 & 13,9 & 13,9 & 0,5 \\
\hline Bélgica $(\mathrm{Fr},)^{1}$ & 12,8 & 12,6 & 12,5 & $-0,6$ & 16,5 & 16,2 & 16,2 & $-0,2$ \\
\hline Canadá & $\mathrm{m}$ & 16,3 & 15,8 & $-3,1$ & $\mathrm{~m}$ & $\mathrm{~m}$ & 18,1 & $\mathbf{m}$ \\
\hline Chile & 25,9 & 24,1 & 22,1 & $-8,3$ & $\mathrm{~m}$ & 23,9 & 20,2 & $-15,3$ \\
\hline Corea $^{1}$ & 28,0 & 24,1 & 18,4 & $-23,7$ & 22,3 & 17,6 & 16,8 & $-4,5$ \\
\hline Dinamarca $^{1}$ & 11,9 & 10,1 & 11,9 & 17,2 & 14,2 & 10,9 & 13,6 & 23,9 \\
\hline Escocia & 14,9 & 20,2 & 21,1 & 4,6 & $\mathrm{~m}$ & $\mathrm{~m}$ & $\mathrm{~m}$ & $\mathbf{m}$ \\
\hline Eslovenia $^{1}$ & 15,0 & 15,8 & 15,9 & 0,7 & 17,3 & 15,6 & 16,8 & 7,8 \\
\hline España $^{1}$ & 14,3 & 13,1 & 13,4 & 2,3 & 12,9 & 12,4 & 13,3 & 7,5 \\
\hline Estados Unidos $^{1}$ & 14,9 & 14,3 & 15,3 & 7,1 & 13,1 & 12,5 & 13,1 & 4,7 \\
\hline Estonia $^{1}$ & $\mathrm{~m}$ & 16,4 & 13,1 & $-20,2$ & $\mathrm{~m}$ & 15,5 & 13,7 & $-11,4$ \\
\hline Finlandia $^{1}$ & 15,9 & 14,4 & 13,6 & $-5,8$ & 15,8 & 12,9 & 13,2 & 1,8 \\
\hline Francia $^{1}$ & 19,4 & 19,9 & 18,9 & $-4,9$ & 18,5 & 19,7 & 17,7 & $-10,1$ \\
\hline Grecia $^{1}$ & 11,1 & 10,1 & 9,4 & $-6,9$ & 17,0 & 12,2 & 12,4 & 1,7 \\
\hline Hungría $^{1}$ & 10,6 & 10,6 & 10,7 & 1,0 & 13,1 & 10,7 & 11,6 & 8,9 \\
\hline Inglaterra $^{1}$ & 14,9 & 20,2 & 21,1 & 4,6 & $\mathrm{~m}$ & 27,6 & 26,7 & $-3,1$ \\
\hline Irlanda $^{1}$ & 17,9 & 17,8 & 16,2 & $-9,1$ & 18,4 & 17,8 & 15,4 & $-13,7$ \\
\hline Islandia & 11,3 & 10,0 & 10,2 & 2,7 & 13,4 & 10,7 & $\mathrm{~m}$ & $\mathbf{m}$ \\
\hline Israel $^{1}$ & 17,3 & 16,3 & 15,2 & $-6,9$ & 23,4 & 22,2 & 17,4 & $-21,9$ \\
\hline Italia $^{1}$ & 10,6 & 10,6 & 12,1 & 14,7 & 14,7 & 14,2 & 14,4 & 0,9 \\
\hline Japón $^{1}$ & 19,4 & 18,8 & 17,7 & $-5,6$ & 25,9 & 18,8 & 18,3 & $-2,8$ \\
\hline Luxemburgo $^{1}$ & $\mathrm{~m}$ & 12,1 & 9,2 & $-23,8$ & $\mathrm{~m}$ & 15,1 & 10,5 & $-30,4$ \\
\hline México $^{1}$ & 28,3 & 28,0 & 28,0 & 0,0 & 28,3 & 28,0 & 28,0 & 0,0 \\
\hline Noruega $^{1}$ & 10,9 & 10,8 & 10,3 & $-4,7$ & 10,5 & 9,6 & 10,4 & 8,6 \\
\hline Nueva Zelanda & 18,1 & 17,1 & 16,4 & $-4,2$ & $\mathrm{~m}$ & 17,8 & $\mathrm{~m}$ & $\mathbf{m}$ \\
\hline Países Bajos ${ }^{1}$ & 15,9 & 15,8 & 15,8 & 0,5 & 17,1 & 15,9 & 16,0 & 0,5 \\
\hline Polonia $^{1}$ & 11,7 & 10,5 & 11,0 & 4,6 & $\mathrm{~m}$ & 8,1 & 12,2 & 50,9 \\
\hline Portugal $^{1}$ & 10,8 & 11,3 & 11,9 & 4,9 & 10,9 & 11,4 & 12,7 & 11,7 \\
\hline República Checa ${ }^{1,2}$ & 17,5 & 18,1 & 18,9 & 4,3 & 16,7 & 13,3 & 13,6 & 1,9 \\
\hline República Eslovaca & 18,9 & 18,6 & 16,8 & $-9,8$ & $\mathrm{~m}$ & $\mathrm{~m}$ & 14,3 & $\mathbf{m}$ \\
\hline Suecia & 12,2 & 12,2 & 11,8 & $-3,2$ & $\mathrm{~m}$ & $\mathrm{~m}$ & $\mathrm{~m}$ & m \\
\hline Suiza & 14,6 & 15,4 & $\mathrm{~m}$ & $\mathbf{m}$ & $\mathrm{m}$ & $\mathrm{m}$ & $\mathrm{m}$ & $\mathbf{m}$ \\
\hline Turquía $^{1}$ & 25,8 & 24,4 & 20,1 & $-17,5$ & 34,9 & 33,0 & 24,2 & $-26,8$ \\
\hline Media OCDE & 16,1 & 15,8 & 15,2 & $-3,1$ & 17,6 & 16,2 & 15,7 & $-0,6$ \\
\hline $\begin{array}{l}\text { Media de } 27 \text { países } \\
\text { con todos los datos } \\
\text { para } 2008 \text { y } 2012\end{array}$ & & 15,5 & 15,5 & 0,5 & 19,8 & 16,0 & 15,6 & $-2,6$ \\
\hline
\end{tabular}

Nota: El año de referencia 2000 (columnas 1, 6, 11, 16, 21) está disponible en Internet (véase StatLink más abajo). Los datos de esta tabla provienen del capítulo D (datos sobre los salarios y horas lectivas de los profesores correspondientes a 2000, 2005, 2008 y 2012, datos sobre la ratio estudiantes-profesor correspondientes a 2012) o de las ediciones de Panorama de la educación correspondientes a 2002 o 2007 y 2010 (datos sobre la ratio estudiantes-profesor y horas lectivas de los estudiantes). Los datos sobre las horas de enseñanza de los estudiantes en 2012 se refieren a los datos de 2011 correspondientes a la edición 2013 de Panorama de la educación (para Estados Unidos, los datos se refieren a 2012 y han sido revisados para los años anteriores). Se han revisado algunos datos de 2000 para garantizar la coherencia con los datos de 2012

1. Países con todos los datos disponibles tanto de 2008 como de 2012.

2. Horas de enseñanza actuales de los estudiantes en 2000 y 2005, horas de enseñanza mínimas en 2012.

Fuente: OCDE. Para ver notas, consulte Anexo 3 (www.oecd.org/edu/eag.htm).

Para obtener más información acerca de los símbolos utilizados en lugar de los datos que faltan, consulte la Guía del lector.

StatLink 제이 http://dx.doi.org/10.1787/888933117991 
Tabla B7.2b. [1/2] Factores utilizados para calcular el coste salarial de los profesores por estudiante, en educación secundaria inferior $(2000,2005,2008$ y 2012)

\begin{tabular}{|c|c|c|c|c|c|c|c|c|c|c|c|c|}
\hline & \multicolumn{4}{|c|}{$\begin{array}{l}\text { Salario de los profesores } \\
\text { (anual, en dólares estadounidenses, } 2012 \\
\text { precios constantes) }\end{array}$} & \multicolumn{4}{|c|}{$\begin{array}{c}\text { Horas de enseñanza } \\
\text { (de los estudiantes, horas anuales) }\end{array}$} & \multicolumn{4}{|c|}{$\begin{array}{c}\text { Horas lectivas } \\
\text { (de los profesores, horas anuales) }\end{array}$} \\
\hline & 2005 & 2008 & 2012 & $\begin{array}{l}\text { Variación } \\
2008-2012 \\
(\%)\end{array}$ & 2005 & 2008 & 2012 & $\begin{array}{l}\text { Variación } \\
\text { 2008-2012 } \\
\text { (\%) }\end{array}$ & 2005 & 2008 & 2012 & $\begin{array}{l}\text { Variación } \\
\text { 2008-2012 } \\
\quad(\%)\end{array}$ \\
\hline & (2) & (3) & (4) & (5) & (7) & (8) & (9) & (10) & (12) & (13) & (14) & (15) \\
\hline Alemania & $\mathrm{m}$ & $\mathrm{m}$ & 67.736 & m & 872 & 887 & 890 & 0,3 & 758 & 756 & 755 & $-0,1$ \\
\hline $\bar{\circlearrowright}$ Australia ${ }^{1}$ & 49.521 & 50.416 & 52.082 & 3,3 & 1.014 & 1.011 & 1.009 & $-0,3$ & 810 & 812 & 809 & $-0,4$ \\
\hline Austria $^{1}$ & 45.935 & 46.484 & 46.625 & 0,3 & 958 & 958 & 945 & $-1,4$ & 607 & 607 & 607 & 0,0 \\
\hline Bélgica $(\mathrm{Fl} .)^{1}$ & 47.136 & 45.664 & 47.635 & 4,3 & 960 & 965 & 955 & $-1,1$ & 690 & 679 & 652 & $-3,9$ \\
\hline Bélgica $(\mathrm{Fr} .)^{1}$ & 45.215 & 43.816 & 46.616 & 6,4 & 1.020 & 1.020 & 1.020 & 0,0 & 724 & 662 & 661 & $-0,2$ \\
\hline Canadá & $\mathrm{m}$ & $\mathrm{m}$ & 58.495 & $\mathbf{m}$ & $\mathrm{m}$ & $\mathrm{m}$ & 923 & $\mathbf{m}$ & $\mathrm{m}$ & $\mathrm{m}$ & 747 & m \\
\hline Chile & $\mathrm{m}$ & $\mathrm{m}$ & 24.725 & $\mathbf{m}$ & $\mathrm{m}$ & 1.089 & 1.083 & $-0,5$ & 1.128 & 1.101 & 1.103 & 0,2 \\
\hline Corea $^{1}$ & 52.395 & 51.760 & 50.040 & $-3,3$ & 867 & 867 & 850 & $-2,0$ & 621 & 616 & 568 & $-7,8$ \\
\hline Dinamarca $^{1}$ & 44.963 & 46.551 & 51.122 & 9,8 & 880 & 900 & 930 & 3,3 & 640 & 648 & 659 & 1,7 \\
\hline Escocia & 48.021 & 47.593 & 44.867 & $-5,7$ & $\mathrm{a}$ & a & a & $\mathbf{a}$ & 893 & 855 & 855 & 0,0 \\
\hline Eslovenia $^{1}$ & 31.673 & 33.345 & 32.819 & $-1,6$ & 791 & 791 & 817 & 3,2 & 627 & 627 & 627 & 0,0 \\
\hline España $^{1}$ & 48.298 & 48.671 & 45.783 & $-5,9$ & 956 & 1.015 & 1.050 & 3,4 & 713 & 713 & 713 & 0,0 \\
\hline Estados Unidos ${ }^{1}$ & 47.856 & 47.105 & 47.046 & $-0,1$ & 996 & 1.003 & 1.011 & 0,8 & 1.080 & 1.068 & 1.085 & 1,7 \\
\hline Estonia $^{1}$ & 9.587 & 13.220 & 12.525 & $-5,3$ & 1.073 & 802 & 770 & $-4,0$ & 630 & 630 & 619 & $-1,7$ \\
\hline Finlandia $^{1}$ & 42.799 & 44.180 & 42.601 & $-3,6$ & 815 & 829 & 913 & 10,2 & 592 & 592 & 589 & $-0,5$ \\
\hline Francia $^{1}$ & 39.002 & 37.524 & 37.065 & $-1,2$ & 1.053 & 1.072 & 1.081 & 0,8 & 648 & 648 & 648 & 0,0 \\
\hline Grecia & 34.627 & 35.573 & 26.617 & $-25,2$ & 998 & 821 & 796 & $-3,1$ & 434 & 429 & 415 & $-3,2$ \\
\hline Hungría $^{1}$ & 19.090 & 17.486 & 13.520 & $-22,7$ & 921 & 885 & 859 & $-3,0$ & 555 & 611 & 604 & $-1,1$ \\
\hline Inglaterra $^{1}$ & 43.668 & 43.695 & 41.393 & $-5,3$ & 933 & 925 & 912 & $-1,4$ & $\mathrm{~m}$ & 722 & 692 & $-4,2$ \\
\hline Irlanda $^{1}$ & 49.451 & 52.696 & 55.148 & 4,7 & 907 & 907 & 935 & 3,1 & 735 & 735 & 735 & 0,0 \\
\hline Islandia & 29.811 & 31.135 & 28.742 & $-7,7$ & 872 & 872 & 987 & 13,1 & 671 & 671 & $\mathrm{~m}$ & m \\
\hline Israel $^{1}$ & 22.965 & 25.129 & 26.912 & 7,1 & 971 & 1.139 & 981 & $-13,9$ & 579 & 579 & 629 & 8,7 \\
\hline Italia $^{1}$ & 38.295 & 37.306 & 36.577 & $-2,0$ & 1.082 & 1.089 & 990 & $-9,1$ & 605 & 601 & 616 & 2,4 \\
\hline Japón $^{1}$ & 50.982 & 47.604 & 47.561 & $-0,1$ & 869 & 868 & 866 & $-0,2$ & 505 & 603 & 602 & $-0,1$ \\
\hline Luxemburgo $^{1}$ & 95.884 & 102.386 & 105.780 & 3,3 & 782 & 908 & 900 & $-0,9$ & 642 & 634 & 739 & 16,7 \\
\hline México $^{1}$ & 24.104 & 25.016 & 26.229 & 4,8 & 1.167 & 1.167 & 1.167 & 0,0 & 1.047 & 1.047 & 1.047 & 0,0 \\
\hline Noruega $^{1}$ & 35.497 & 36.475 & 38.773 & 6,3 & 827 & 826 & 855 & 3,5 & 656 & 654 & 663 & 1,5 \\
\hline Nueva Zelanda & 41.198 & 42.312 & 44.710 & 5,7 & 962 & 985 & $\mathrm{~m}$ & m & $\mathrm{m}$ & 853 & $\mathrm{~m}$ & $\mathbf{m}$ \\
\hline Países Bajos ${ }^{1}$ & $\mathrm{~m}$ & 58.421 & 68.064 & 16,5 & 1.067 & 1.000 & 1.000 & 0,0 & 750 & 750 & 750 & 0,0 \\
\hline Polonia $^{1}$ & 17.080 & 18.277 & 20.700 & 13,3 & $\mathrm{~m}$ & 644 & 800 & 24,1 & $\mathrm{~m}$ & 562 & 561 & $-0,2$ \\
\hline Portugal $^{1}$ & 37.224 & 35.980 & 34.694 & $-3,6$ & 905 & 755 & 792 & 4,9 & 564 & 627 & 616 & $-1,8$ \\
\hline República Checa ${ }^{1,2}$ & 18.981 & 22.299 & 19.515 & $-12,5$ & 902 & 876 & 848 & $-3,1$ & 647 & 637 & 620 & $-2,6$ \\
\hline República Eslovaca & $\mathrm{m}$ & $\mathrm{m}$ & 13.365 & $\mathbf{m}$ & $\mathrm{m}$ & 883 & 832 & $-5,8$ & $\mathrm{~m}$ & $\mathrm{~m}$ & 635 & m \\
\hline Suecia & 35.411 & $\mathrm{~m}$ & 36.247 & $\mathbf{m}$ & 741 & 741 & 741 & 0,0 & $\mathrm{~m}$ & $\mathrm{~m}$ & $\mathrm{~m}$ & m \\
\hline Suiza & 69.129 & 67.669 & 69.816 & 3,2 & $\mathrm{~m}$ & 912 & $\mathrm{~m}$ & $\mathbf{m}$ & $\mathrm{m}$ & $\mathrm{m}$ & $\mathrm{m}$ & m \\
\hline Turquía & a & a & 27.607 & $\mathbf{m}$ & a & a & 864 & $\mathbf{m}$ & $\mathrm{a}$ & a & 504 & m \\
\hline Media OCDE & 40.527 & 41.860 & 41.382 & $-0,6$ & 937 & 922 & 920 & 0,7 & 698 & 701 & 691 & 0,2 \\
\hline $\begin{array}{l}\text { Media de } 25 \text { países } \\
\text { con todos los datos } \\
\text { para } 2008 \text { y } 2012\end{array}$ & & 41.260 & 41.873 & 1,5 & & 929 & 930 & 0,1 & & 682 & 708 & 3,7 \\
\hline
\end{tabular}

Nota: El año de referencia 2000 (columnas 1, 6, 11, 16, 21) está disponible en Internet (véase StatLink más abajo). Los datos de esta tabla provienen del capítulo D (datos sobre los salarios y horas lectivas de los profesores correspondientes a 2000, 2005, 2008 y 2012, datos sobre la ratio estudiantes-profesor correspondientes a 2012) o de las ediciones de Panorama de la educación correspondientes a 2002 o 2007 y 2010 (datos sobre la ratio estudiantes-profesor y horas de enseñanza de los estudiantes). Los datos sobre las horas de enseñanza de los estudiantes en 2012 se refieren a los datos de 2011 correspondientes a la edición 2013 de Panorama de la educación (para Estados Unidos, los datos se refieren a 2012 y han sido revisados para los años anteriores). Se han revisado algunos datos de 2000 para garantizar la coherencia con los datos de 2012.

1. Países con todos los datos disponibles tanto de 2005 como de 2011

2. Horas de enseñanza actuales de los estudiantes en 2000 y 2005, horas de enseñanza mínimas en 2011.

Fuente: OCDE. Para ver notas, consulte Anexo 3 (www.oecd.org/edu/eag.htm).

Para obtener más información acerca de los símbolos utilizados en lugar de los datos que faltan, consulte la Guía del lector.

StatLink गता St http://dx.doi.org/10.1787/888933118010 
Tabla B7.2b. [2/2] Factores utilizados para calcular el coste salarial de los profesores por estudiante, en educación secundaria inferior $(2000,2005,2008$ y 2012)

\begin{tabular}{|c|c|c|c|c|c|c|c|c|}
\hline & \multicolumn{4}{|c|}{$\begin{array}{l}\text { Ratio alumnos-personal docente } \\
\text { (número de alumnos por profesor) }\end{array}$} & \multicolumn{4}{|c|}{$\begin{array}{l}\text { Tamaño estimado de la clase } \\
\text { (número de alumnos por clase) }\end{array}$} \\
\hline & 2005 & 2008 & 2012 & $\begin{array}{c}\text { Variación } \\
\text { 2008-2012 } \\
(\%)\end{array}$ & 2005 & 2008 & 2012 & $\begin{array}{c}\text { Variación } \\
2008-2012 \\
(\%)\end{array}$ \\
\hline & (17) & (18) & (19) & (20) & $(22)=(17)^{*}(7) /(12)$ & $(23)=(18)^{*}(8) /(13)$ & $(24)=(19)^{*}(9) /(14)$ & (25) \\
\hline Alemania & 15,5 & 15,0 & 14,0 & $-6,9$ & 17,9 & 17,6 & 16,5 & $-6,4$ \\
\hline Australia $^{1}$ & 12,1 & 12,0 & 12,0 & $-0,3$ & 15,2 & 15,0 & 14,9 & $-0,2$ \\
\hline Austria $^{1}$ & 10,6 & 9,9 & 9,0 & $-9,5$ & 16,8 & 15,7 & 14,0 & $-10,8$ \\
\hline Bélgica $(\mathrm{Fl},)^{1}$ & 9,4 & 8,1 & 8,2 & 0,4 & 13,1 & 11,6 & 12,0 & 3,3 \\
\hline Bélgica $(\mathrm{Fr},)^{1}$ & 9,4 & 8,1 & 8,2 & 0,4 & 13,3 & 12,5 & 12,6 & 0,6 \\
\hline Canadá & $\mathrm{m}$ & 16,3 & 15,8 & $-3,1$ & $\mathrm{~m}$ & $\mathrm{~m}$ & 19,6 & $\mathbf{m}$ \\
\hline Chile & 25,9 & 24,1 & 22,4 & $-7,0$ & $\mathrm{~m}$ & 23,9 & 22,0 & $-7,6$ \\
\hline Corea $^{1}$ & 20,8 & 20,2 & 18,1 & $-10,4$ & 29,0 & 28,5 & 27,2 & $-4,6$ \\
\hline Dinamarca $^{1}$ & 11,9 & 10,1 & 11,9 & 17,2 & 16,4 & 14,1 & 16,7 & 19,1 \\
\hline Escocia & 15,1 & 15,0 & 14,2 & $-4,9$ & $\mathrm{~m}$ & $\mathrm{~m}$ & $\mathrm{~m}$ & $\mathbf{m}$ \\
\hline Eslovenia $^{1}$ & 11,1 & 8,9 & 7,9 & $-10,7$ & 14,0 & 11,2 & 10,3 & $-7,8$ \\
\hline España $^{1}$ & 12,5 & 10,3 & 10,6 & 3,1 & 16,8 & 14,6 & 15,6 & 6,6 \\
\hline Estados Unidos ${ }^{1}$ & 15,1 & 14,8 & 15,3 & 3,9 & 13,9 & 13,9 & 14,3 & 3,0 \\
\hline Estonia $^{1}$ & $\mathrm{~m}$ & 16,0 & 9,9 & $-38,5$ & $\mathrm{~m}$ & 20,4 & 12,3 & $-39,9$ \\
\hline Finlandia $^{1}$ & 10,0 & 10,6 & 8,9 & $-16,1$ & 13,7 & 14,9 & 13,8 & $-7,1$ \\
\hline Francia $^{1}$ & 14,2 & 14,6 & 15,5 & 6,1 & 23,0 & 24,1 & 25,8 & 7,0 \\
\hline Grecia & 7,9 & 7,7 & $\mathrm{~m}$ & $\mathbf{m}$ & 18,1 & 14,7 & $\mathrm{~m}$ & $\mathbf{m}$ \\
\hline Hungría $^{1}$ & 10,4 & 10,9 & 10,6 & $-2,8$ & 17,2 & 15,8 & 15,0 & $-4,6$ \\
\hline Inglaterra $^{1}$ & 15,1 & 15,0 & 14,2 & $-4,9$ & $\mathrm{~m}$ & 19,2 & 18,8 & $-2,1$ \\
\hline Irlanda $^{1}$ & 15,5 & 12,8 & 15,0 & 17,2 & 19,1 & 15,8 & 19,1 & 20,8 \\
\hline Islandia & 11,3 & 10,0 & 10,6 & 6,3 & 14,7 & 13,0 & $\mathrm{~m}$ & $\mathbf{m}$ \\
\hline Israel $^{1}$ & 13,4 & 12,2 & 13,6 & 11,8 & 22,4 & 24,0 & 21,3 & $-11,4$ \\
\hline Italia $^{1}$ & 10,1 & 9,7 & 11,8 & 21,8 & 18,1 & 17,5 & 19,0 & 8,1 \\
\hline Japón ${ }^{1}$ & 15,1 & 14,7 & 14,1 & $-4,2$ & 26,0 & 21,2 & 20,2 & $-4,3$ \\
\hline Luxemburgo $^{1}$ & 9,0 & 9,1 & 8,8 & $-3,4$ & 11,0 & 13,1 & 10,7 & $-18,0$ \\
\hline México $^{1}$ & 33,7 & 33,9 & 31,9 & $-5,7$ & 37,6 & 37,7 & 35,6 & $-5,7$ \\
\hline Noruega $^{1}$ & 10,2 & 10,1 & 10,4 & 3,5 & 12,9 & 12,7 & 13,4 & 5,6 \\
\hline Nueva Zelanda & 16,8 & 16,2 & 16,4 & 1,3 & $\mathrm{~m}$ & 18,7 & $\mathrm{~m}$ & $\mathbf{m}$ \\
\hline Países Bajos ${ }^{1}$ & 16,2 & 15,8 & 15,6 & $-1,1$ & 23,1 & 21,1 & 20,8 & $-1,1$ \\
\hline Polonia $^{1}$ & 12,7 & 12,9 & 9,9 & $-23,9$ & $\mathrm{~m}$ & 14,8 & 14,1 & $-5,4$ \\
\hline Portugal $^{1}$ & 8,2 & 8,1 & 9,6 & 19,5 & 13,1 & 9,7 & 12,4 & 27,6 \\
\hline República Checa ${ }^{1,2}$ & 13,5 & 11,8 & 11,1 & $-6,5$ & 18,8 & 16,2 & 15,1 & $-7,0$ \\
\hline República Eslovaca & 14,1 & 14,5 & 12,8 & $-11,5$ & $\mathrm{~m}$ & $\mathrm{~m}$ & 16,8 & $\mathbf{m}$ \\
\hline Suecia & 12,0 & 11,4 & 11,3 & $-1,3$ & $\mathrm{~m}$ & $\mathrm{~m}$ & $\mathrm{~m}$ & $\mathbf{m}$ \\
\hline Suiza & 11,7 & 12,1 & $\mathrm{~m}$ & $\mathbf{m}$ & $\mathrm{m}$ & $\mathrm{m}$ & $\mathrm{m}$ & $\mathbf{m}$ \\
\hline Turquía & a & $\mathrm{a}$ & 20,1 & $\mathbf{m}$ & a & a & 34,4 & $\mathbf{m}$ \\
\hline Media OCDE & 13,7 & 13,2 & 13,2 & $-1,8$ & 18,2 & 17,4 & 17,8 & $-1,6$ \\
\hline $\begin{array}{l}\text { Media de } 25 \text { países } \\
\text { con todos los datos } \\
\text { para } 2008 \text { y } 2012\end{array}$ & & 12,8 & 12,5 & $-2,7$ & & 16,0 & 17,0 & 6,1 \\
\hline
\end{tabular}

Nota: El año de referencia 2000 (columnas 1, 6, 11, 16, 21) está disponible en Internet (véase StatLink más abajo). Los datos de esta tabla provienen del capítulo D (datos sobre los salarios y horas lectivas de los profesores correspondientes a 2000, 2005, 2008 y 2012, datos sobre la ratio estudiantes-profesor correspondientes a 2012) o de las ediciones de Panorama de la educación correspondientes a 2002 o 2007 y 2010 (datos sobre la ratio estudiantes-profesor y horas de enseñanza de los estudiantes). Los datos sobre las horas de enseñanza de los estudiantes en 2012 se refieren a los datos de 2011 correspondientes a la edición 2013 de Panorama de la educación (para Estados Unidos, los datos se refieren a 2012 y han sido revisados para los años anteriores). Se han revisado algunos datos de 2000 para garantizar la coherencia con los datos de 2012.

1. Países con todos los datos disponibles tanto de 2005 como de 2011.

2. Horas de enseñanza actuales de los estudiantes en 2000 y 2005, horas de enseñanza mínimas en 2011.

Fuente: OCDE. Para ver notas, consulte Anexo 3 (www.oecd.org/edu/eag.htm).

Para obtener más información acerca de los símbolos utilizados en lugar de los datos que faltan, consulte la Guía del lector.

StatLink 需正 http://dx.doi.org/10.1787/888933118010 
Tabla B7.3. Contribución de diversos factores al coste salarial de los profesores por estudiante en educación primaria (2000, 2005, 2008 y 2012)

En equivalente a dólares estadounidenses convertidos mediante PPA para el consumo privado

\begin{tabular}{|c|c|c|c|c|c|c|c|c|}
\hline & & & & \multirow{3}{*}{ 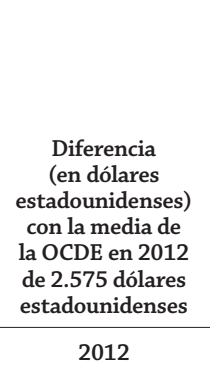 } & \multicolumn{4}{|c|}{ Contribución de los factores subyacentes a la diferencia con la media de la OCDE } \\
\hline & \multicolumn{3}{|c|}{$\begin{array}{l}\text { Coste salarial } \\
\text { de los profesores } \\
\text { por estudiante }\end{array}$} & & $\begin{array}{c}\text { Efecto (en dólares } \\
\text { estadounidenses) } \\
\text { del salario de } \\
\text { los profesores } \\
\text { por debajo o por } \\
\text { encima de la media } \\
\text { de la OCDE } \\
\text { en } 2012 \\
\text { de } 39.163 \text { dólares } \\
\text { estadounidenses }\end{array}$ & $\begin{array}{c}\text { Efecto (en dólares } \\
\text { estadounidenses) } \\
\text { de las horas de } \\
\text { enseñanza de } \\
\text { los estudiantes } \\
\text { por debajo o por } \\
\text { encima de la } \\
\text { media de la OCDE } \\
\text { en } 2012 \\
\text { de } 806 \text { horas }\end{array}$ & $\begin{array}{c}\text { Efecto (en dólares } \\
\text { estadounidenses) } \\
\text { de las horas } \\
\text { lectivas (de los } \\
\text { profesores) por } \\
\text { debajo o por } \\
\text { encima de la } \\
\text { media de la OCDE } \\
\text { en } 2012 \text { de } 779 \\
\text { horas }\end{array}$ & $\begin{array}{c}\text { Efecto (en dólares } \\
\text { estadounidenses) } \\
\text { del tamaño } \\
\text { estimado de la } \\
\text { clase por debajo } \\
\text { o por encima } \\
\text { la media } \\
\text { de la OCDE en } \\
2012 \text { de } 15,7 \\
\text { alumnos por clase }\end{array}$ \\
\hline & 2005 & 2008 & 2012 & & 2012 & 2012 & 2012 & 2012 \\
\hline & (2) & (3) & (4) & $(5)=(6)+(7)+(8)+(9)$ & (6) & (7) & (8) & (9) \\
\hline Alemania & $\mathrm{m}$ & $\mathrm{m}$ & 3.884 & 1.309 & 1.480 & -452 & -102 & 384 \\
\hline Australia & 3.047 & 3.135 & 3.301 & 726 & 792 & 495 & -330 & -231 \\
\hline Austria & 2.999 & 3.334 & 3.572 & 998 & 286 & -221 & 0 & 932 \\
\hline Bélgica (Fl.) & 3.687 & 3.619 & 3.797 & 1.223 & 615 & 96 & 130 & 381 \\
\hline Bélgica (Fr.) & 3.498 & 3.472 & 3.716 & 1.141 & 542 & 446 & 242 & -89 \\
\hline Canadá & $\mathrm{m}$ & $\mathrm{m}$ & 3.696 & 1.122 & 1.250 & 412 & -90 & -450 \\
\hline Chile & $\mathrm{m}$ & $\mathrm{m}$ & 1.117 & -1.457 & -807 & 410 & -614 & -446 \\
\hline Corea & 1.875 & 2.150 & 2.725 & 150 & 662 & -650 & 313 & -174 \\
\hline Dinamarca & 3.777 & 4.601 & 4.310 & 1.736 & 897 & -227 & 567 & 499 \\
\hline Escocia & $\mathrm{m}$ & $\mathrm{m}$ & $\mathrm{m}$ & $\mathbf{m}$ & $\mathrm{m}$ & $\mathrm{m}$ & $\mathrm{m}$ & $\mathrm{m}$ \\
\hline Eslovenia & 2.110 & 2.114 & 2.066 & -509 & -411 & -449 & 510 & -158 \\
\hline España & 3.006 & 3.394 & 3.118 & 544 & 190 & 235 & -347 & 466 \\
\hline Estados Unidos & 3.183 & 3.308 & 3.003 & 429 & 455 & 516 & -1.061 & 518 \\
\hline Estonia & $\mathrm{m}$ & 806 & 957 & -1.617 & -1.908 & -387 & 428 & 250 \\
\hline Finlandia & 2.473 & 2.842 & 2.909 & 334 & 20 & -576 & 404 & 487 \\
\hline Francia & 1.866 & 1.753 & 1.795 & -780 & -306 & 152 & -368 & -257 \\
\hline Grecia & 3.129 & 3.530 & 2.839 & 264 & -1.075 & -177 & 869 & 647 \\
\hline Hungría & 1.799 & 1.650 & 1.263 & -1.312 & -2.054 & -421 & 530 & 633 \\
\hline Inglaterra & $\mathrm{m}$ & 2.162 & 1.959 & -616 & 128 & 154 & 315 & -1.213 \\
\hline Irlanda & 2.759 & 2.962 & 3.410 & 836 & 1.022 & 228 & -484 & 71 \\
\hline Islandia & 2.634 & 3.122 & $\mathrm{~m}$ & $\mathbf{m}$ & $\mathrm{m}$ & $\mathrm{m}$ & $\mathrm{m}$ & $\mathrm{m}$ \\
\hline Israel & 1.192 & 1.524 & 1.935 & -640 & -644 & 389 & -163 & -222 \\
\hline Italia & 3.316 & 3.242 & 2.769 & 195 & -413 & 269 & 95 & 244 \\
\hline Japón & 2.632 & 2.531 & 2.680 & 105 & 513 & -177 & 168 & -399 \\
\hline Luxemburgo & $\mathrm{m}$ & 5.795 & 10.704 & 8.130 & 5.161 & 834 & -236 & 2.371 \\
\hline México & 669 & 702 & 724 & -1.850 & -954 & -11 & -40 & -845 \\
\hline Noruega & 3.253 & 3.374 & 3.763 & 1.189 & -32 & -238 & 160 & 1.299 \\
\hline Nueva Zelanda & $\mathrm{m}$ & 2.473 & $\mathrm{~m}$ & $\mathbf{m}$ & $\mathrm{m}$ & $\mathrm{m}$ & $\mathrm{m}$ & $\mathrm{m}$ \\
\hline Países Bajos & $\mathrm{m}$ & 3.089 & 3.463 & 888 & 1.016 & 466 & -539 & -55 \\
\hline Polonia & $\mathrm{m}$ & 1.520 & 1.653 & -921 & -1.649 & -301 & 463 & 566 \\
\hline Portugal & 3.448 & 3.179 & 2.923 & 348 & -335 & 21 & 84 & 578 \\
\hline República Checa & 1.083 & 1.209 & 1.027 & -1.548 & -1.183 & -520 & -105 & 260 \\
\hline República Eslovaca & $\mathrm{m}$ & $\mathrm{m}$ & 797 & -1.778 & -1.620 & -235 & -82 & 159 \\
\hline Suecia & $\mathrm{m}$ & $\mathrm{m}$ & $\mathrm{m}$ & $\mathbf{m}$ & $\mathrm{m}$ & $\mathrm{m}$ & $\mathrm{m}$ & $\mathrm{m}$ \\
\hline Suiza & $\mathrm{m}$ & $\mathrm{m}$ & $\mathrm{m}$ & $\mathbf{m}$ & $\mathrm{m}$ & $\mathrm{m}$ & $\mathrm{m}$ & $\mathrm{m}$ \\
\hline Turquía & 962 & 1.022 & 1.325 & -1.249 & -727 & 135 & 154 & -811 \\
\hline $\begin{array}{l}\text { Media OCDE de } \\
\text { los países con datos } \\
\text { para } 2008 \text { y } 2012\end{array}$ & & 2.454 & 2.633 & $\sim$ & $\sim$ & $\sim$ & $\sim$ & $\sim$ \\
\hline
\end{tabular}

Nota: El año de referencia 2000 (columna 1) está disponible en Internet (véase StatLink más abajo).

Fuente: OCDE. Para ver notas, consulte Anexo 3 (www.oecd.org/edu/eag.htm).

Para obtener más información acerca de los símbolos utilizados en lugar de los datos que faltan, consulte la Guía del lector.

StatLink הता St http://dx.doi.org/10.1787/888933118029 
Tabla B7.4. Contribución de diversos factores al coste salarial de los profesores por estudiante en educación secundaria inferior (2000, 2005, 2008 y 2012)

En equivalente a dólares estadounidenses convertidos mediante PPA para el consumo privado

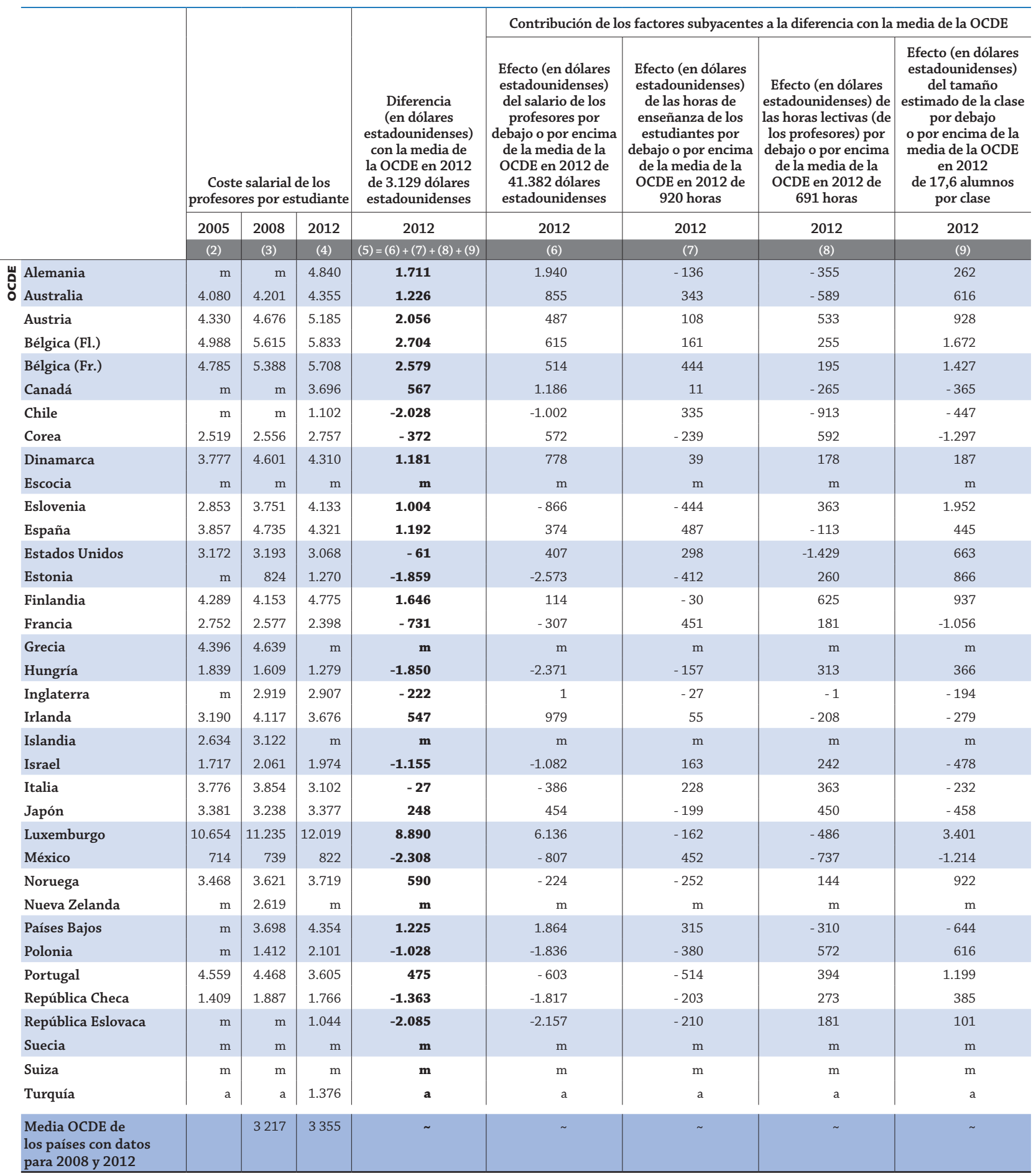

Nota: El año de referencia 2000 (columna 1) está disponible en Internet (véase StatLink más abajo).

Fuente: OCDE. Para ver notas, consulte Anexo 3 (www.oecd.org/edu/eag.htm).

Para obtener más información acerca de los símbolos utilizados en lugar de los datos que faltan, consulte la Guía del lector.

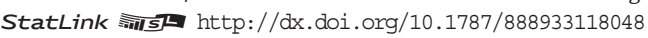


Tabla B7.5. Contribución de diversos factores al coste salarial de los profesores por estudiante en educación secundaria superior (2012)

En equivalente a dólares estadounidenses convertidos mediante PPA para el consumo privado

\begin{tabular}{|c|c|c|c|c|c|c|}
\hline & \multirow[b]{2}{*}{$\begin{array}{c}\text { Coste salarial } \\
\text { de los profesores } \\
\text { por estudiante }\end{array}$} & \multirow[b]{2}{*}{$\begin{array}{c}\text { Diferencia } \\
\text { con la media } \\
\text { de la OCDE de } \\
3.212 \text { dólares } \\
\text { estadounidenses }\end{array}$} & \multicolumn{4}{|c|}{ Contribución de los factores subyacentes a la diferencia con la media de la OCDE } \\
\hline & & & \begin{tabular}{|c|} 
Efecto (en dólares \\
estadounidenses) \\
del salario de \\
los profesores \\
por debajo o por \\
encima de la media de \\
la OCDE \\
de 42.486 dólares \\
estadounidenses
\end{tabular} & $\begin{array}{l}\text { Efecto (en dólares } \\
\text { estadounidenses) } \\
\text { de las horas de } \\
\text { enseñanza } \\
\text { de los estudiantes } \\
\text { por debajo o por } \\
\text { encima de la media } \\
\text { de la OCDE } \\
\text { de } 964 \text { horas }\end{array}$ & $\begin{array}{l}\text { Efecto (en dólares } \\
\text { estadounidenses) } \\
\text { de las horas lectivas } \\
\text { (de los profesores) } \\
\text { por debajo o por } \\
\text { encima de la media } \\
\text { de la OCDE } \\
\text { de } 668 \text { horas }\end{array}$ & $\begin{array}{c}\text { Efecto (en dólares } \\
\text { estadounidenses) } \\
\text { del tamaño } \\
\text { estimado de la clase } \\
\text { por debajo o por } \\
\text { encima de la media } \\
\text { de la OCDE } \\
\text { de } 19,1 \text { alumnos } \\
\text { por clase }\end{array}$ \\
\hline & (1) & $(2)=(3)+(4)+(5)+(6)$ & (3) & (4) & (5) & (6) \\
\hline Alemania & 5.318 & 2.106 & 2.245 & -142 & -305 & 307 \\
\hline Australia & 4.355 & 1.143 & 769 & 152 & -692 & 913 \\
\hline Austria & 4.897 & 1.685 & 474 & 340 & 507 & 363 \\
\hline Bélgica (Fl.) & 6.037 & 2.826 & 1.631 & -46 & 421 & 820 \\
\hline Bélgica (Fr.) & $\mathrm{m}$ & $\mathbf{m}$ & $\mathrm{m}$ & $\mathrm{m}$ & $\mathrm{m}$ & $\mathrm{m}$ \\
\hline Canadá & 4.152 & 941 & 1.190 & -174 & -432 & 356 \\
\hline Chile & 1.093 & -2.119 & -959 & 455 & -993 & -622 \\
\hline Corea & 3.243 & 32 & 536 & -3 & 644 & -1.145 \\
\hline Dinamarca & $\mathrm{m}$ & $\mathbf{m}$ & $\mathrm{m}$ & $\mathrm{m}$ & $\mathrm{m}$ & $\mathrm{m}$ \\
\hline Escocia & $\mathrm{m}$ & $\mathbf{m}$ & $\mathrm{m}$ & $\mathrm{m}$ & $\mathrm{m}$ & $\mathrm{m}$ \\
\hline Eslovenia & 2.334 & -877 & -712 & -168 & 444 & -441 \\
\hline España & 4.727 & 1.516 & 399 & 335 & -140 & 922 \\
\hline Estados Unidos & 3.249 & 37 & 528 & 244 & -1.582 & 846 \\
\hline Estonia & 886 & -2.325 & -2.206 & -449 & 338 & -9 \\
\hline Finlandia & 2.863 & -349 & 244 & -167 & 617 & -1.042 \\
\hline Francia & 3.790 & 579 & -452 & 486 & 108 & 436 \\
\hline Grecia & $\mathrm{m}$ & $\mathbf{m}$ & $\mathrm{m}$ & $\mathrm{m}$ & $\mathrm{m}$ & $\mathrm{m}$ \\
\hline Hungría & 1.255 & -1.957 & -2.104 & 314 & 231 & -399 \\
\hline Inglaterra & 2.421 & -790 & -73 & -42 & -97 & -579 \\
\hline Irlanda & 3.676 & 464 & 900 & -106 & -328 & -2 \\
\hline Islandia & $\mathrm{m}$ & $\mathbf{m}$ & $\mathrm{m}$ & $\mathrm{m}$ & $\mathrm{m}$ & $\mathrm{m}$ \\
\hline Israel & 2.327 & -885 & -1.406 & 376 & 513 & -368 \\
\hline Italia & 2.895 & -317 & -374 & 373 & 252 & -569 \\
\hline Japón & $\mathrm{m}$ & $\mathbf{m}$ & $\mathrm{m}$ & $\mathrm{m}$ & $\mathrm{m}$ & $\mathrm{m}$ \\
\hline Luxemburgo & 12.019 & 8.807 & 6.078 & -509 & -745 & 3.983 \\
\hline México & $\mathrm{m}$ & m & $\mathrm{m}$ & $\mathrm{m}$ & $\mathrm{m}$ & $\mathrm{m}$ \\
\hline Noruega & 4.335 & 1.123 & -75 & -438 & 925 & 712 \\
\hline Nueva Zelanda & $\mathrm{m}$ & $\mathbf{m}$ & $\mathrm{m}$ & $\mathrm{m}$ & $\mathrm{m}$ & $\mathrm{m}$ \\
\hline Países Bajos & 3.656 & 444 & 1.649 & 128 & -406 & -927 \\
\hline Polonia & 2.175 & -1.036 & -1.579 & -405 & 500 & 448 \\
\hline Portugal & 4.550 & 1.338 & -801 & -57 & 320 & 1.877 \\
\hline República Checa & 1.771 & -1.441 & -1.850 & -506 & 311 & 604 \\
\hline República Eslovaca & 964 & -2.248 & -2.154 & -52 & 201 & -243 \\
\hline Suecia & $\mathrm{m}$ & $\mathbf{m}$ & $\mathrm{m}$ & $\mathrm{m}$ & $\mathrm{m}$ & $\mathrm{m}$ \\
\hline Suiza & $\mathrm{m}$ & $\mathbf{m}$ & $\mathrm{m}$ & $\mathrm{m}$ & $\mathrm{m}$ & $\mathrm{m}$ \\
\hline Turquía & 1.706 & -1.506 & -1.027 & -421 & 404 & -462 \\
\hline
\end{tabular}

Fuente: OCDE. Para ver notas, consulte Anexo 3 (www.oecd.org/edu/eag.htm)

Para obtener más información acerca de los símbolos utilizados en lugar de los datos que faltan, consulte la Guía del lector.

StatLink 젶ㄴ http://dx.doi.org/10.1787/888933118067 



\section{Capítulo}

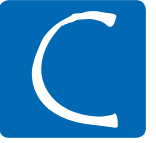

\section{ACCESO A LA EDUCACIÓN, PARTICIPACIÓN Y PROGRESIÓN}

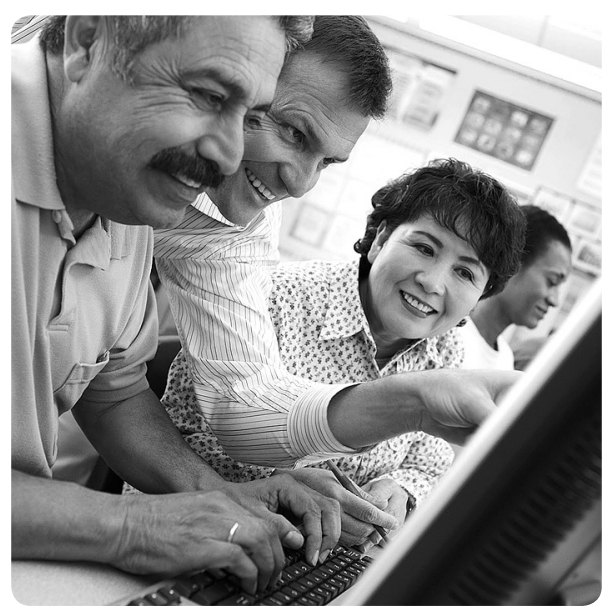

Indicador C1 ¿Quién participa en la educación?

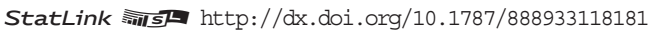

Indicador C2 ¿En qué se diferencian los sistemas de educación infantil del mundo? StatLink 게제 http://dx.doi.org/10.1787/888933118333

Indicador C3 ¿Cuántos estudiantes se espera que accedan a la educación terciaria?

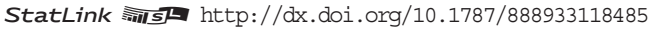

Indicador C4 ¿Quién estudia en el extranjero y dónde? StatLink ज्ञाइ http://dx.doi.org/10.1787/888933118656

Indicador C5 Transición de la educación al trabajo: ¿dónde están los jóvenes de 15 a 29 años?

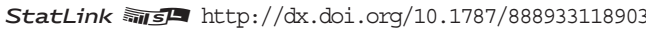

Indicador C6 ¿Cuántos adultos participan en la educación y el aprendizaje? StatLink Anा J $\mathrm{http}: / / \mathrm{dx}$.doi.org/10.1787/888933119093

Indicador $\mathrm{C} 7$ ¿En qué se diferencian instituciones y centros escolares públicos de instituciones y centros privados?

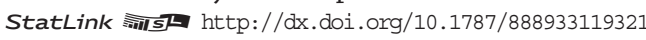




\section{¿QUIÉN PARTICIPA EN LA EDUCACIÓN?}

- El acceso a la educación entre las edades de 5 a 14 años es universal en todos los países de la OCDE y en la mayoría de los países asociados de los que se dispone de datos.

- En 2012, las tasas de matriculación de los estudiantes de 15 a 19 años fueron superiores al $75 \%$ en 34 de los 40 países de la OCDE y países asociados de los que se dispone de datos.

- Más del $20 \%$ de los jóvenes de 20 a 29 años en todos los países de la OCDE, excepto Luxemburgo, México y Reino Unido, participaron en la educación en 2012.

- De 1995 a 2012, las tasas de matriculación de los jóvenes de 20 a 29 años aumentaron 10 puntos porcentuales por término medio en los países de la OCDE con datos disponibles.

\section{Gráfico C1.1. Tasas de matriculación de los estudiantes de 20 a 29 años (1995, 2000, 2005 y 2012) \\ Estudiantes a tiempo completo y a tiempo parcial en instituciones públicas y privadas}

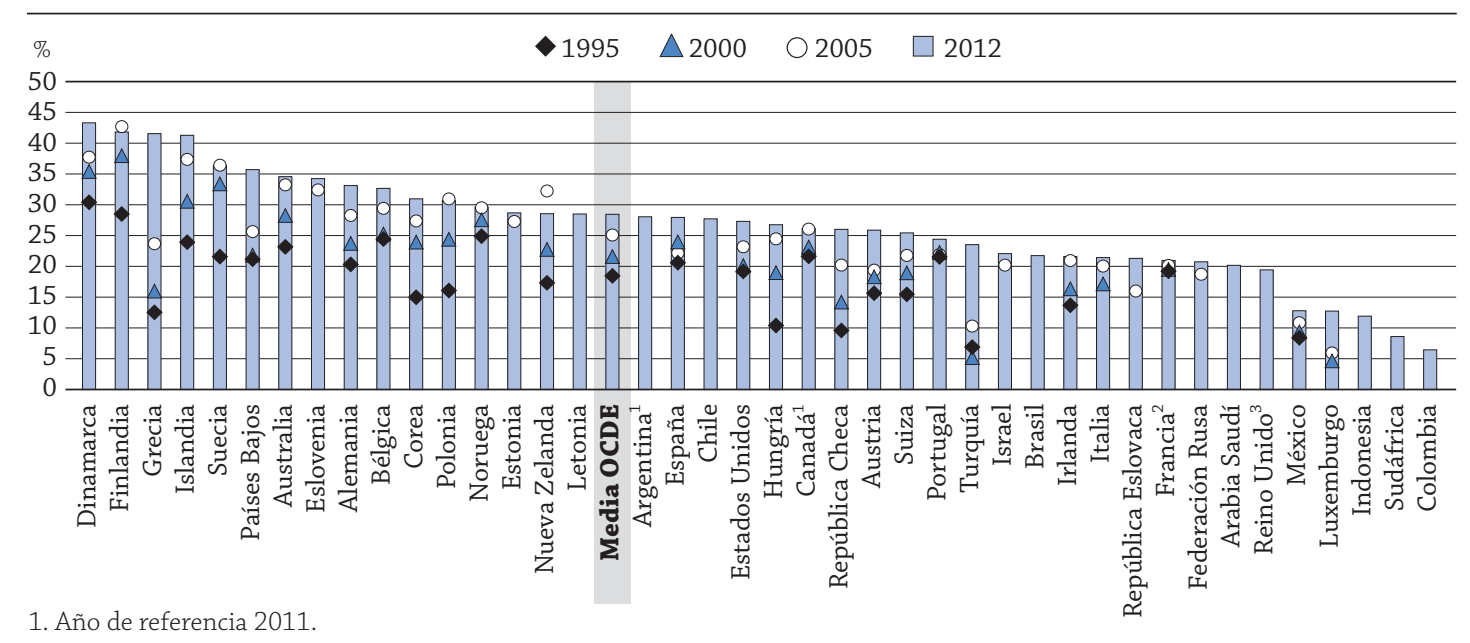

2. Excluye departamentos de ultramar en 1995.

3. Ruptura de la serie temporal tras un cambio metodológico a partir de 2006.

Los países están clasificados en orden descendente de las tasas de matriculación de los jóvenes de 20 a 29 años en 2012.

Fuente: OCDE. Tabla C1.2. Para ver notas, consulte Anexo 3 (www.oecd.org/edu/eag.htm).

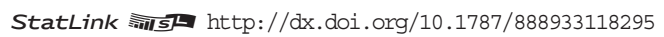

\section{Contexto}

En épocas de dificultades económicas, la ventaja de la educación para las perspectivas del mercado laboral es aún más evidente. Los sistemas de educación en la OCDE y en la mayoría de los países del G20 proporcionan actualmente acceso universal a la educación básica, de manera que tanto la educación infantil como la secundaria superior se están convirtiendo en universales en la mayoría de los países (véase también Indicador C2). La expansión de la educación secundaria superior se ha visto impulsada tanto por el aumento de la demanda como por los cambios de políticas que oscilan entre un currículo más flexible, una reorganización de la formación profesional y esfuerzos por ampliar el acceso a la educación a toda la población. Aunque se han hecho cambios similares en la educación terciaria, las tasas de participación en este nivel más elevado de la educación son significativamente menores.

La educación secundaria superior se ha convertido en la cualificación mínima para poder acceder con éxito al mercado laboral, y disminuir el riesgo de desempleo (véase Indicador A5). Completar con éxito un programa de educación secundaria superior es fundamental para abordar los problemas de equidad (OECD, 2010a; OECD, 2011), pero las tasas de finalización varían mucho entre los países de la OCDE (véase Indicador A2). Los esfuerzos por ampliar este nivel de educación aún más y ayudar a garantizar buenos retornos para todas las personas requerirá que los sistemas educativos proporcionen a los estudiantes las competencias que necesitan para ser empleables a corto plazo, y las competencias y 
conocimientos genéricos que les permitan participar en el aprendizaje permanente a lo largo de toda su vida laboral (OECD, 2010b). Los profundos cambios estructurales que han tenido lugar en el mercado laboral internacional en las últimas décadas sugieren que las personas con un mayor nivel educativo seguirán teniendo una ventaja a medida que el mercado laboral se base cada vez más en el conocimiento.

\section{INDICADOR $\mathrm{C}_{1}$}

\section{Otros resultados}

- Bajo las condiciones de matriculación de 2012, un estudiante de 5 años de un país de la OCDE puede esperar participar como media más de 17 años en educación a tiempo completo y a tiempo parcial antes de cumplir los 40 años. La duración esperada en educación oscila entre más de 13 años en India e Indonesia y más de 19 años en Australia, Dinamarca, Finlandia, Islandia y Suecia.

- En los países de la OCDE en 2012, al menos el $90 \%$ de la población en edad escolar participó como media 13 años en educación formal. Veintiséis de los 44 países con datos disponibles superaban esta media, mientras que 18 países estaban por debajo.

\section{Tendencias}

Entre 1995 y 2012, las tasas de matriculación de los jóvenes de 15 a 19 años en los países de la OCDE aumentaron de manera constante alrededor de 10 puntos porcentuales como media, del $74 \%$ al $84 \%$. Mientras que las tasas aumentaron cerca de 30 puntos porcentuales durante este periodo en Turquía y más de 20 puntos porcentuales en Grecia, Hungría y República Checa, permanecieron prácticamente sin cambios en Bélgica, donde las tasas de matriculación para este grupo de edad son de aproximadamente el 94\%, y en Alemania, donde son de aproximadamente el 90\%. En Francia, la tasa de matriculación para este grupo de edad disminuyó del $89 \%$ al $84 \%$ durante este periodo (Tabla C1.2 y Gráfico C1.2). En 2012, las tasas de matriculación de los jóvenes de 15 a 19 años seguían por debajo del $70 \%$ en China, Colombia, Israel, México y Turquía. 


\section{Análisis}

En 19 de los 44 países de la OCDE y países asociados con datos disponibles en 2012, la matriculación completa en la educación (definida aquí como una tasa de matriculación superior al $90 \%$ del grupo de población de ese rango de edad que abarque un cierto nivel de estudios) empieza entre las edades de 3 y 4 años; en los otros 25 países, la matriculación plena empieza entre los 5 y 6 años de edad, excepto en Colombia y Federación Rusa, donde empieza a los 7 años; Arabia Saudí, donde comienza a los 9 años, y China y Sudáfrica, donde empieza a los 13 y a los 10 años, respectivamente. En la mitad de los países de la OCDE y países asociados, al menos el $75 \%$ de los niños de 3 a 4 años están matriculados en programas de educación infantil o de primaria (Tabla C1.1a e Indicador C2). En Bélgica, Dinamarca, España, Francia, Islandia, Noruega y Reino Unido, la escolarización de niños de 3 a 4 años alcanzó al menos el $95 \%$ en 2012.

\section{Cuadro C1.1. Años esperados en educación}

Los niños que acceden a la educación pueden esperar pasar un año más por cada año de edad en el que existe matriculación plena en el país en el que estudian. La estimación de años esperados en educación comprende la matriculación en todo tipo de educación formal, incluyendo la participación no continua e incompleta. Por tanto, sobre la base de los patrones de matriculación de 2012, un niño de 5 años de un país de la OCDE puede esperar participar en la educación durante más de 17 años como media antes de alcanzar los 40 años de edad. Más concretamente, esta persona puede esperar estar matriculada en educación a tiempo completo durante 17 años: 9,4 años en educación primaria y secundaria inferior, 3,4 años en educación secundaria superior, 0,2 años en educación postsecundaria no terciaria y 2,7 años en educación terciaria. Este mismo estudiante puede esperar también participar en 1,2 años adicionales de estudios a tiempo parcial, principalmente de nivel terciario. Las mujeres pueden esperar estar matriculadas en educación a tiempo completo durante 17 años, mientras que los hombres pueden esperar estarlo durante 16 años, como media.

En los países con datos disponibles, el número esperado de años en educación oscila de 13,4 años en India a más de 19 años en Australia, Dinamarca y Suecia, y casi 20 años en Finlandia e Islandia (Tabla C1.6).

La matriculación en un programa educativo no se limita a un rango de edad concreto. Sobre la base de los datos de 2012, Australia, Bélgica, Finlandia, Islandia, Nueva Zelanda y Suecia cuentan con una proporción significativa de su población adulta -sobre todo adultos de 40 años y mayores- que participa en la educación. Esto se explica por la mayor tasa de matriculacion a tiempo parcial y por los programas de aprendizaje a lo largo de la vida de esos países. Por ejemplo, los sistemas basados en créditos de Suecia permiten a los adultos participar en la educación formal como vía para incrementar sus competencias.

Los años esperados en educación son solo una estimación del número potencial de años que una persona puede esperar estar en educación. Esta estimación no es comparable al nivel educativo alcanzado y puede variar también de las proyecciones de logros futuros, porque el tiempo dedicado a un programa concreto puede cambiar dentro de la población.

\section{Participación en la educación obligatoria}

La educación obligatoria varía entre países. En 2012, la edad típica de comienzo de la educación obligatoria oscilaba entre los 4 años en Luxemburgo y México y los 7 en Estonia, Federación Rusa, Finlandia, Sudáfrica y Suecia. En Estados Unidos y Reino Unido, la edad típica de comienzo oscilaba entre los 4 y 6 años y los 4 y 5 años, respectivamente; en Suiza el rango de edad era de 5 a 7 años. La educación obligatoria incluye los programas de primaria y secundaria inferior en todos los países de la OCDE, y la educación secundaria superior en la mayoría de ellos. Las tasas de matriculación de niños de 5 a 14 años superaron el $90 \%$, es decir, existe cobertura universal de la educación básica en todos los países de la OCDE y países asociados, excepto Arabia Saudí, China, India, Indonesia y Sudáfrica. En 2012, las tasas de matriculación en 35 de los 44 países con datos disponibles estuvieron en torno al $95 \%$ o fueron superiores (Tabla C1.1a).

\section{Participación en educación secundaria superior}

En los últimos años, los países han incrementado la diversidad de sus programas de educación secundaria superior. Esta diversificación se ha visto impulsada por la creciente demanda de educación secundaria superior y una evolución del currículo de conocimientos generales impartidos en programas generales y competencias prácticas 
reservadas para la formación profesional, a programas más integrales que incluyen ambos tipos de aprendizaje, lo cual conduce a vías más flexibles hacia la educación superior o el mercado laboral.

Sobre la base de los datos de 2012, las tasas de matriculación de los estudiantes de 15 a 19 años, es decir, los que habitualmente están en programas de educación secundaria superior o en transición hacia niveles superiores, alcanzaron al menos el $80 \%$ en 29 de los 42 países de la OCDE y países asociados con datos disponibles, y fueron superiores al 90\% en Alemania, Bélgica, Eslovenia, Hungría, Irlanda, Letonia, Países Bajos, Polonia y República Checa (Tabla C1.1a). En cambio, la proporción de personas en este grupo de edad que no estaban matriculadas en educación superó el $20 \%$ en Argentina, Austria, Brasil, Chile, Indonesia, Luxemburgo, Reino Unido y Sudáfrica. En Israel, esta proporción fue de más del $30 \%$, debido al servicio militar obligatorio, mientras que en México y Turquía esta proporción superó el $40 \%$. En China y Colombia la proporción alcanzó el 66 \% y el 57\%, respectivamente (Tabla C1.1a y Gráfico C1.2).

Las tasas de matriculación de los jóvenes de 15 a 19 años en los países de la OCDE aumentaron 10 puntos porcentuales como media entre 1995 y 2012. Esto se debe principalmente a la convergencia de las tasas de matriculación en los países de la OCDE en los últimos 17 años. Mientras que las tasas han aumentado más de 20 puntos porcentuales en este periodo en Grecia, Hungría, República Checa y Turquía, y 17 puntos porcentuales o más en México y Portugal, no han experimentado prácticamente ningún cambio en Alemania, Bélgica y Canadá (datos solo hasta 2011) (Tabla C1.2 y Gráfico C1.2). En cambio, se observa una disminución de la tasa de matriculación de más de 5 puntos porcentuales en Francia durante ese mismo periodo.

En 2012, al menos el $85 \%$ de los jóvenes de 15 y 16 años en 38 de los 44 países con datos disponibles estaban matriculados en educación secundaria (excepto en Federación Rusa e Indonesia, donde la tasa de matriculación para los jóvenes de 16 años era del $80 \%$ y del $69 \%$, respectivamente). Las tasas de matriculación en esas edades variaron más en otros países. Por ejemplo, en Colombia, Sudáfrica y Turquía, casi el $80 \%$ de los jóvenes de 15 años estaban matriculados, mientras que en los jóvenes de 16 años las tasas de matriculación eran del $67 \%$, del $83 \%$ y del $72 \%$, respectivamente. En China y México, el $57 \%$ y el $66 \%$ de los jóvenes de 15 años, y el $44 \%$ y el $62 \%$ de los jóvenes de 16 años, respectivamente, estaban matriculados (Tabla C1.1b, disponible en Internet).

La variación de las tasas de matriculación en educación secundaria superior refleja los distintos requisitos para su finalización o límites de edad. Por ejemplo, Alemania, Bélgica y Portugal permiten a los estudiantes mayores acabar la educación secundaria superior a tiempo parcial. En Países Bajos, los estudiantes mayores de 20 años pueden participar en programas de formación profesional de educación secundaria superior. Estas políticas, junto con otros

\section{Gráfico C1.2. Tasas de matriculación de los jóvenes de 15 a 19 años (1995, 2000, 2005 y 2012)} Estudiantes a tiempo completo y a tiempo parcial en instituciones públicas y privadas

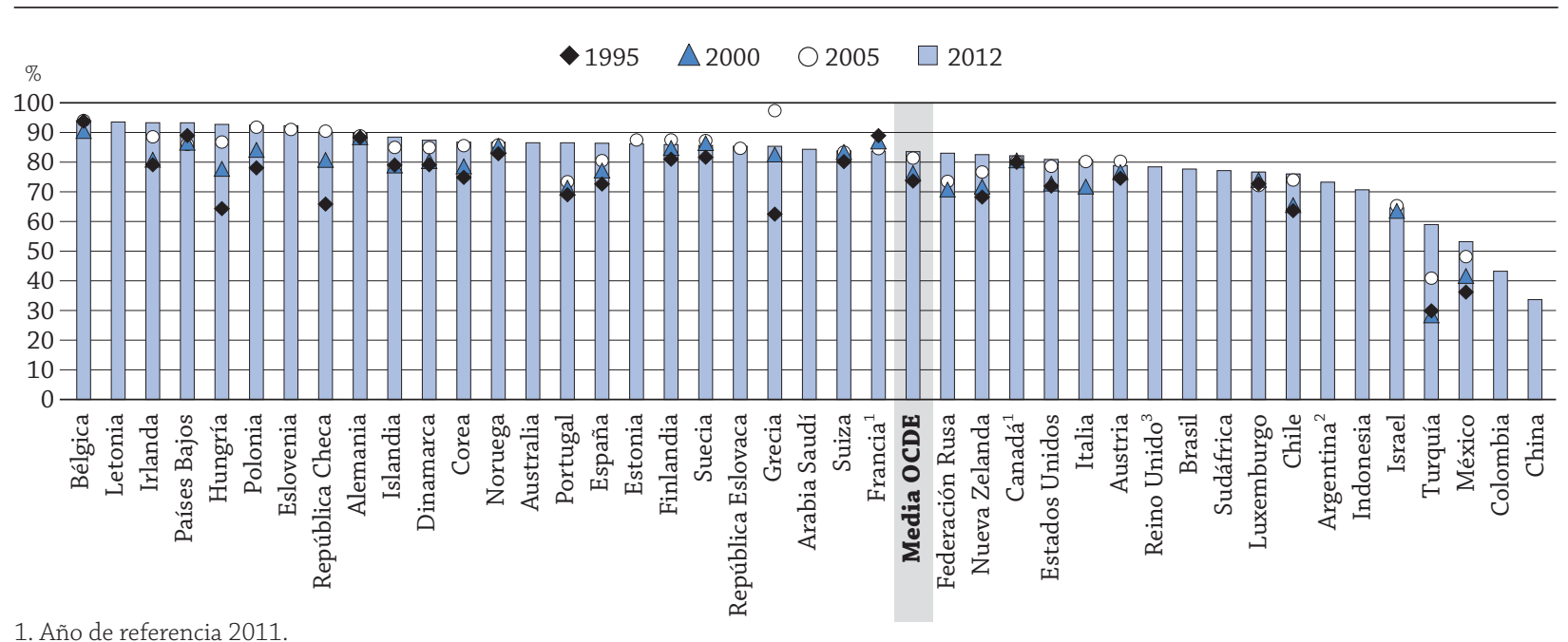

1. Año de referencia 2011.

2. Excluye departamentos de ultramar en 1995.

3. Ruptura de la serie temporal tras un cambio metodológico a partir de 2006.

Los países están clasificados en orden descendente de las tasas de matriculación de los jóvenes de 15 a 19 años en 2012.

Fuente: OCDE. Tabla C1.2. Para ver notas, consulte Anexo 3 (www.oecd.org/edu/eag.htm).

StatLink 세에 $h$ htp://dx.doi.org/10.1787/888933118314 
factores, como programas más largos, la repetición de cursos y el acceso tardío al mercado laboral o la participación en educación a la vez que se trabaja, entre otros, han derivado en una participación en la educación secundaria superior de más estudiantes mayores (véase Indicador A2). Por consiguiente, en algunos países de la OCDE, aproximadamente uno de cada cuatro jóvenes de 20 años sigue matriculado en educación secundaria superior. Este es el caso de Alemania (24\%), Dinamarca (33\%), Islandia (37\%), Luxemburgo (27\%), Países Bajos (30\%) y Suiza (23\%) (Tabla C1.1b, disponible en Internet).

\section{Programas de formación profesional (FP)}

Muchos países han renovado recientemente su interés por los programas de formación profesional, ya que se consideran eficaces para desarrollar competencias en aquellas personas que de lo contrario carecerían de cualificaciones para garantizar una transición con éxito al mercado laboral (OECD, 2010a). Los países con programas de formación profesional consolidados han sido más eficaces en controlar el desempleo juvenil (véase Indicador C5). A su vez, algunos consideran la formación profesional como una opción menos atractiva que la formación académica; y algunos estudios sugieren que la participación en la formación profesional aumenta el riesgo de desempleo en edades más avanzadas. (Hanushek et al., 2011).

En la mayoría de los países, un estudiante que completa satisfactoriamente un programa de formación de aprendices suele obtener una cualificación de educación secundaria superior o postsecundaria. En algunos países, es posible obtener una cualificación superior, como el Diploma Avanzado concedido en Australia. Los programas de formación profesional de los países de la OCDE ofrecen distintas combinaciones de formación profesional o preprofesional junto con programas de formación de aprendices. Los estudiantes de educación secundaria superior de muchos sistemas educativos pueden matricularse en programas de formación profesional, pero algunos países de la OCDE retrasan la formación profesional hasta que los estudiantes se gradúen en educación secundaria superior. Por ejemplo, mientras que los programas de formación profesional se ofrecen como educación secundaria superior avanzada en Austria, España y Hungría, programas similares se ofrecen habitualmente como educación postsecundaria en Canadá (véase Indicador A2).

En más de un tercio de los países con datos disponibles de 2012, el porcentaje de estudiantes que participaron en programas de formación preprofesional o profesional superó el $50 \%$ de todos los estudiantes matriculados en educación secundaria superior, y esta proporción fue al menos del 70 \% en Austria, Bélgica, Finlandia, Países Bajos, República Checa y República Eslovaca. En los otros dos tercios de los países, más del $50 \%$ de los estudiantes de secundaria superior estaban matriculados en programas generales en vez de en formación profesional. Esta proporción es superior al $80 \%$ en Argentina, Brasil, Canadá, Corea, México y Sudáfrica. Solo una quinta parte de los países ofrecen también cursos preprofesionales en el nivel de secundaria superior. Entre ellos, Colombia (24\%), Federación Rusa (24\%) e Irlanda (31\%) tienen una proporción significativa de estudiantes matriculados en este nivel (Tabla C1.3).

Más del 50\% de los jóvenes de 15 a 19 años en República Checa están matriculados en programas de formación profesional del nivel de secundaria superior, mientras que en Austria, Bélgica, Eslovenia, Italia y República Eslovaca la matriculación es superior al $40 \%$ para este grupo de edad.

En la mayoría de los países, la formación profesional en el nivel de secundaria superior se ofrece solo en los centros escolares. Sin embargo, en varios países se ofrecen también programas que combinan tanto el centro escolar como el lugar de trabajo. En torno al $60 \%$ de todos los estudiantes de educación secundaria superior en Suiza están matriculados en estos programas combinados de formación profesional, al igual que lo están más del $30 \%$ de todos los estudiantes de educación secundaria superior en Alemania, Austria, Dinamarca, República Checa y República Eslovaca (Tabla C1.3).

\section{Participación de los adultos jóvenes en educación}

En 2012, una media del $28 \%$ de los jóvenes de 20 a 29 años en los países de la OCDE estaban matriculados en algún tipo de educación. Las mayores proporciones de matrícula en educación en este grupo de edad (más del $40 \%$ ) se registraban en Dinamarca, Finlandia, Grecia e Islandia. En Alemania, Australia, Bélgica, Corea, Eslovenia, Países Bajos, Polonia y Suecia, la proporción superó el $30 \%$. En cambio, en Colombia, Indonesia, Luxemburgo, México y Sudáfrica, menos del $15 \%$ de los jóvenes de este grupo de edad estaban matriculados (Tabla C1.1a y Gráfico C1.1).

De 1995 a 2012, la tasa de matriculación en este segmento de la población ha crecido 10 puntos porcentuales por término medio en los países de la OCDE. En Corea, Grecia, Hungría, Islandia, República Checa y Turquía, estas tasas 
han aumentado más de 15 puntos porcentuales en ese periodo, mientras que han crecido cinco puntos porcentuales o menos en Canadá (datos solo hasta 2011), Francia, México, Noruega y Portugal (Tabla C1.2 y Gráfico C1.1).

En la mayoría de los países analizados, los jóvenes de 20 años están habitualmente matriculados en educación terciaria. En 2012, casi el 38\% de los jóvenes de 20 años de los países de la OCDE estaban matriculados en educación terciaria, como media. En Corea, siete de cada diez jóvenes de 20 años estaban matriculados en este nivel de educación, mientras que en Bélgica, Eslovenia, Estados Unidos, la Federación Rusa, Grecia e Irlanda al menos una de cada dos personas de esta edad estaba matriculada. En cambio, el $20 \%$ o menos de los jóvenes de 20 años en Brasil, Israel, Luxemburgo, Sudáfrica y Suiza estaban matriculados en educación terciaria (Tabla C1.1b, disponible en Internet).

Reanudar los estudios o continuar con ellos es una opción para los adultos que desean mejorar y diversificar sus competencias y estar más adaptados a la demanda cambiante del mercado laboral. En el actual contexto de elevado desempleo y cambios en las competencias necesarias en el mercado laboral, algunos países, como Chile, han establecido políticas concretas para animar a los adultos a cursar estudios terciarios de tipo B.

\section{Diferencias por sexo}

Estudios recientes han recalcado la importancia de contar con un enfoque más equilibrado por sexo, teniendo en cuenta que la mitad del crecimiento económico en los países de la OCDE en los últimos 50 años puede atribuirse a un nivel educativo más elevado, lo cual a su vez se ha conseguido principalmente porque más niñas y mujeres participan en todos los niveles de la educación (OECD, 2012c).

En 2012, una media del 82\% de los varones entre 15 y 19 años y el $85 \%$ de las mujeres de esa misma edad en todos los países de la OCDE estaban matriculados en educación. En la mayoría de los países de la OCDE y países asociados, las tasas de matriculación fueron superiores para las mujeres que para los varones en este grupo de edad. La mayor diferencia por sexo a esta edad se registró en Argentina, donde el $80 \%$ de las jóvenes y solo el $67 \%$ de los varones estaban matriculados en educación. Irlanda, Israel y Nueva Zelanda muestran una diferencia en la tasa de matriculación de más de cinco puntos porcentuales a favor de las mujeres. Diferencias por sexo superiores a 2 puntos porcentuales en las tasas de matriculación a favor de los varones se observan en Arabia Saudí, Suiza y Turquía. En Colombia, Dinamarca, Finlandia, Hungría, México y Suecia, hay poca o ninguna diferencia por sexo en este grupo de edad.

Entre los jóvenes de 20 a 29 años, la diferencia de edad en las tasas de matriculación es más amplia. Como media, el $30 \%$ de las mujeres y el $27 \%$ de los hombres de esta edad participan en la educación en los países de la OCDE. Al igual que con el grupo de 15 a 19 años, la tasa de matriculación entre las mujeres es más alta que entre los hombres en la mayoría de los países de la OCDE y países asociados, pero en menos países que los observados para la cohorte más joven. También existen mayores diferencias entre los países. En Argentina, por ejemplo, el 34 \% de las mujeres están matriculadas, mientras que solo el $22 \%$ de los varones lo están. En Argentina, Eslovenia y Suecia, la tasa de matriculación de las mujeres es al menos 11 puntos porcentuales mayor que la de los hombres. En Corea, la diferencia de 15 puntos porcentuales a favor de las tasas de matriculación de los hombres en comparación con las de las mujeres en 2012 está ligada al aplazamiento de la graduación en los hombres que cumplen el servicio militar obligatorio.

En la mayoría de los países, la tasa de matriculaciones en el grupo de 30 a 39 años es también más alta entre las mujeres que entre los hombres. Australia, Finlandia, Islandia, Nueva Zelanda y Suecia tienen las tasas más altas de mujeres de esta edad que participan en educación, e Islandia y Suecia muestran la mayor diferencia por sexo (al menos seis puntos porcentuales) (Tabla C1.1a).

\section{Estudios a tiempo parcial}

Los estudiantes de educación terciaria tienen más probabilidades de matricularse a tiempo completo que a tiempo parcial, con independencia del programa elegido (educación terciaria de tipo A o B). Los estudiantes pueden optar por estudios a tiempo parcial, porque participen también a la vez en el mercado laboral, debido a obligaciones familiares (sobre todo para las mujeres), debido a preferencias por diversos ámbitos de estudio o por otros motivos. En 2012, el 74\% de los estudiantes matriculados en educación terciaria de tipo B estaban matriculados a tiempo completo, mientras que solo el $26 \%$ lo estaban a tiempo parcial por término medio en los países de la OCDE. En la educación terciaria de tipo A y programas de investigación avanzada, el $79 \%$ de los estudiantes estaban matriculados a tiempo completo, mientras que el $21 \%$ lo estaban a tiempo parcial (Tabla C1.4). 
Las matriculaciones a tiempo parcial en programas de educación terciaria de tipo B superaron a las de tiempo completo en algunos países. En Australia, Estados Unidos y Nueva Zelanda, más del $50 \%$ de los estudiantes de este nivel eligieron matricularse a tiempo parcial; en Reino Unido y Suiza, lo hicieron más del $70 \%$.

A su vez, más del $50 \%$ de los estudiantes en educación terciaria de tipo A y programas avanzados en Federación Rusa, Polonia y Suecia escogieron matricularse a tiempo parcial, muchos más que la media de la OCDE del 21\%. En Argentina, España, Estados Unidos, Finlandia, Hungría, Nueva Zelanda y República Eslovaca, más del 30 \% de los estudiantes en estos niveles educativos también eligieron matricularse a tiempo parcial.

\section{Tamaño relativo de los sectores público y privado}

(Véase también el nuevo Indicador C7 para una información más detallada.)

En la mayoría de los países, las instituciones públicas proporcionan la mayor parte de la educación, desde el nivel de primaria hasta el de terciaria. Por término medio en los países de la OCDE en 2012, alrededor del $89 \%$ de los estudiantes de primaria, el $85 \%$ de los estudiantes de secundaria inferior y el $80 \%$ de los estudiantes de secundaria superior estaban matriculados en centros públicos. El $97 \%$ de los estudiantes de educación secundaria inferior y el $95 \%$ de los de educación secundaria superior asistían a una institución pública o bien a una institución privada dependiente del gobierno.

La matriculación de estudiantes en instituciones educativas privadas independientes aumenta en los niveles superiores de educación. Por ejemplo, alrededor del $3 \%$ de los estudiantes de primaria y secundaria inferior están matriculados en instituciones totalmente privadas, mientras que el porcentaje es ligeramente superior al $5 \%$ entre los estudiantes de secundaria superior. Las proporciones de estudiantes matriculados en instituciones privadas independientes en el nivel de educación terciaria son considerablemente mayores. Como media, un $19 \%$ de los estudiantes matriculados en programas de educación terciaria de tipo B y el $14 \%$ de los estudiantes matriculados en educación terciaria de tipo A y programas de investigación avanzada están matriculados en instituciones totalmente privadas. Si se consideran las instituciones totalmente privadas y las privadas dependientes del gobierno conjuntamente, alrededor del $42 \%$ de los estudiantes están matriculados en programas de tipo B y al menos el $30 \%$ de los estudiantes están matriculados en programas de tipo A y de investigación avanzada (Tabla C1.5, disponible en Internet).

El Reino Unido es el único país donde el $100 \%$ de los estudiantes en programas terciarios de tipo B y en programas terciarios de tipo A y de investigación avanzada están matriculados en instituciones privadas dependientes del gobierno (Tabla C1.5, disponible en Internet).

\section{Definiciones}

Los programas de secundaria pueden subdividirse en tres categorías, dependiendo del grado en el que estén orientados a una clase específica de profesiones u oficios y conduzcan a una cualificación relevante para el mercado laboral:

En programas mixtos impartidos en el centro educativo y en el lugar de trabajo, menos del $75 \%$ del plan de estudios se imparte en el entorno escolar o mediante educación a distancia. Estos programas pueden organizarse en colaboración con las autoridades o instituciones educativas e incluyen programas para aprendices que conllevan formación al mismo tiempo en el centro educativo y en el lugar de trabajo, y programas que conllevan intervalos alternos de asistencia a instituciones educativas y participación en formación en el trabajo (a veces se denominan programas «sándwich»).

Los programas de educación general no han sido diseñados explícitamente para preparar a los participantes para una profesión u oficio específico, ni para acceder a programas de formación profesional o técnica (menos del $25 \%$ del contenido del programa es profesional o técnico).

Los programas de formación preprofesional o pretécnica han sido diseñados principalmente para introducir a los participantes en el mundo laboral y prepararles para acceder a programas de formación profesional o técnica superior. Completar estos programas no conduce a una cualificación profesional o técnica que sea directamente relevante para el mercado laboral (al menos el $25 \%$ del contenido del programa es profesional o técnico).

El tipo de orientación del programa, ya sea profesional o general, no determina necesariamente si los participantes tienen acceso o no a la educación terciaria. En varios países de la OCDE, los programas de orientación profesional han sido diseñados para preparar a los estudiantes para continuar los estudios de nivel terciario, y en algunos países los programas generales no siempre ofrecen acceso directo a estudios superiores. 
En los programas impartidos en el centro educativo, la enseñanza tiene lugar (parcial o totalmente) en instituciones educativas. Estas incluyen centros de formación especiales dirigidos por autoridades públicas o privadas, o centros de formación especiales de empresas, si están habilitados como instituciones educativas. Estos programas pueden incluir un componente de formación que conlleve alguna experiencia práctica en el lugar de trabajo. Los programas se clasifican como impartidos en el centro educativo si al menos el $75 \%$ del plan de estudios de los mismos se imparte en el entorno del centro educativo, que puede incluir formación a distancia.

Los programas de formación profesional y preprofesional se dividen además en dos categorías: impartidos en el centro educativo y programas mixtos impartidos en el centro educativo y en el lugar de trabajo, sobre la base de la cantidad de formación proporcionada en el centro educativo frente a la impartida en el lugar de trabajo.

Los programas de formación profesional o técnica preparan a los participantes para el acceso directo a profesiones específicas sin más formación. Al finalizar estos programas se obtiene una cualificación profesional o técnica relevante para el mercado laboral.

Muchos países clasifican el modo de participación del alumno en la educación como a tiempo completo o a tiempo parcial, dependiendo de la cantidad de carga lectiva del alumno, por ejemplo a través del valor o progreso académico, tiempo en el aula y tiempo de estudio. De acuerdo con el tiempo de estudio, se diferencia entre:

Estudiante de tiempo completo es aquel cuyo tiempo de estudio (dentro y fuera del centro educativo) representa el $75 \%$ o más de la semana escolar, ya que se aplica de forma local en ese nivel de educación y normalmente se espera que permanezca en el programa un curso escolar completo.

Estudiante a tiempo parcial es aquel cuyo tiempo de estudio es menor del $75 \%$ de la semana escolar o un estudiante que permanece en un porgrama menos de un año escolar.

\section{Metodología}

Los datos de matriculación son del curso escolar 2011-2012 y proceden de la recopilación UOE de datos sobre sistemas educativos que gestiona anualmente la OCDE. Excepto cuando se especifica lo contrario, las cifras se basan en el número de personas, es decir, no se hace distinción entre estudios a tiempo completo y a tiempo parcial, ya que el concepto de estudios a tiempo parcial no está reconocido por algunos países. En algunos países de la OCDE, la educación a tiempo parcial solo está cubierta parcialmente en los datos proporcionados. Las tasas netas de matriculación expresadas como porcentajes en la Tabla C1.1a y la Tabla C1.2 se calculan dividiendo el número de estudiantes de un grupo de edad concreto matriculado en todos los niveles de educación por el tamaño de la población de dicho grupo. En la Tabla C1.1b, disponible en Internet, la tasa neta de matriculación se calcula para los estudiantes de un nivel concreto de educación.

En la Tabla C1.2, los datos sobre la evolución de las tasas de matriculación en los años 1995, 2000, 2001, 2002, 2003 y 2004 se basan en una encuesta especial realizada en enero de 2007 en los países de la OCDE y cuatro de los seis países asociados en ese momento (Brasil, Chile, Federación Rusa e Israel).

Los años esperados en educación se han calculado como la proporción de la población matriculada en edades específicas sumadas en un rango de edad. El supuesto principal es que cada año de matriculación completa corresponde a un año completo de educación esperado para un individuo menor de esa edad.

\section{Nota sobre los datos de Israel}

Los datos estadísticos para Israel fueron proporcionados por las autoridades israelíes competentes bajo su responsabilidad. El uso de estos datos por parte de la OCDE se hace sin prejuzgar la situación de los Altos del Golán, Jerusalén Este y los asentamientos israelíes en Cisjordania de acuerdo con los términos del derecho internacional.

\section{Referencias}

Hanushek, E., L. Woessmann y L. Zhang (2011), «General Education, Vocational Education, and Labor-Market Outcomes over the Life-Cycle», IZA Discussion Paper, No. 6083, Institute for the Study of Labor (IZA), Bonn, octubre de 2011.

OECD (2013), Trends Shaping Education 2013, OECD Publishing, París. http://dx.doi.org/10.1787/trends_edu-2013-en

OECD (2012a), «How Has the Global Economic Crisis Affected People with Different Levels of Education?» Education Indicators in Focus, No. 1, OECD Publishing, París. http://dx.doi.org/10.1787/5k9fgpwlc6s0-en 
OECD (2012b), «How Well Are Countries Educating Young People to the Level Needed for a Job and a Living Wage?» Education Indicators in Focus, No. 7, OECD Publishing, París. http://dx.doi.org/10.1787/5k91d4fsqjOw-en

OECD (2012c), Closing the Gender Gap: Act Now, OECD Publishing, París. http://dx.doi.org/10.1787/9789264179370-en

OECD (2011), Equity and Quality in Education: Supporting Disadvantaged Students and Schools, OECD Publishing, París. http:// dx.doi.org/10.1787/9789264130852-en

OECD (2010a), PISA 2009 Results: Overcoming Social Background: Equity in Learning Opportunities and Outcomes, (Volume II), PISA, OECD Publishing, París. http://dx.doi.org/10.1787/9789264091504-en

OECD (2010b), Learning for Jobs, OECD Reviews of Vocational Education and Training, OECD Publishing, París. http://dx.doi. org/10.1787/9789264087460-en

\section{Tablas del Indicador C1}

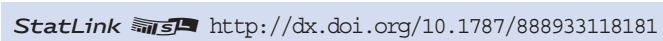

Tabla C1.1a Tasas de matriculación en educación, por grupos de edad (2012)

WEB Tabla C1.1b Características de la transición de los 15 a los 20 años, por nivel de educación (2012)

Tabla C1.2 Tendencias de las tasas de matriculación (1995-2012)

Tabla C1.3 Patrones de matriculación en educación secundaria superior y postsecundaria no terciaria (2012)

Tabla C1.4 Porcentaje de estudiantes en educación primaria, secundaria y terciaria, por modalidad de estudio y sexo (2012)

WEB Tabla C1.5 Estudiantes en educación primaria, secundaria y terciaria, por porcentaje en cada tipo de institución (2012)

Tabla C1.6 Años esperados en educación de los 5 a los 39 años de edad (2012) 
Tabla C1.1a. Tasas de matriculación en educación, por grupos de edad (2012)

Estudiantes a tiempo completo y a tiempo parcial en instituciones públicas y privadas

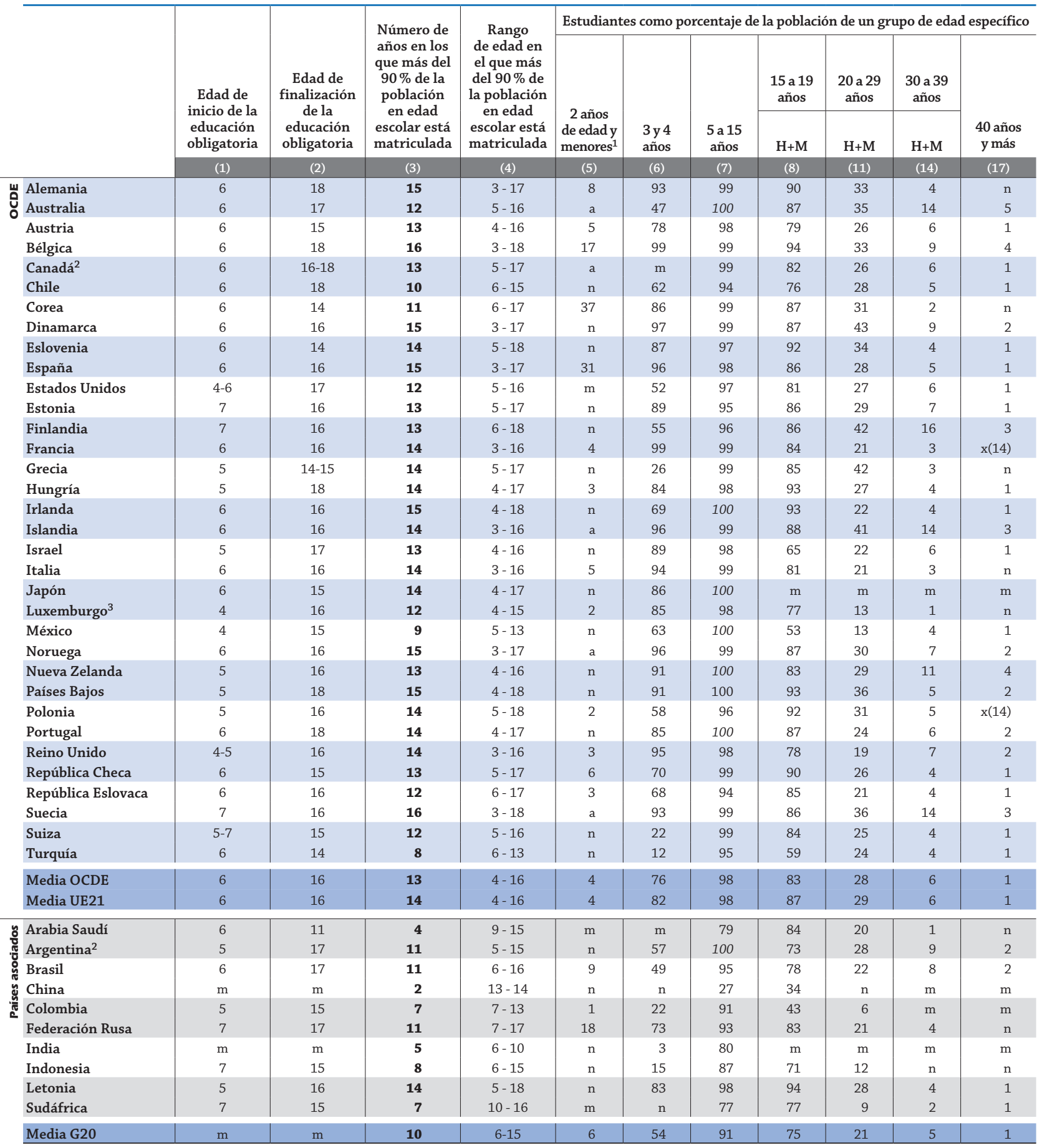

Nota: La edad de finalización de la educación obligatoria es la edad a la que finaliza la educación obligatoria. Por ejemplo, una edad de finalización de 18 años indica que todos los estudiantes menores de 18 están obligados por ley a participar en la educación. La falta de coincidencia entre la cobertura de los datos de la población y los datos de matriculación significa que las tasas de participación pueden estar subestimadas en países como Luxemburgo que son exportadores netos de estudiantes y sobreestimadas en aquellos países que son importadores netos. Tasas por encima de $100 \%$ se indican en cursiva. Tasas de matriculación por sexo para los grupos de edad de 15-19, 20-29 y 30-39 años están disponibles en Internet (véase StatLink más abajo).

1. Incluye solo programas de educación infantil en instituciones. No son la única forma de educación infantil efectiva disponible para los menores de 3 años, por tanto las deducciones sobre el acceso y la calidad de la educación infantil y las guarderías deben realizarse con cautela. En los países en los que existe un sistema integrado de educación infantil y guarderías la tasa de matriculación se anota como no aplicable para los niños menores de 2 años.

2. Año de referencia 2011.

3. Subestimado, porque muchos estudiantes residentes acuden a centros escolares en los países vecinos.

Fuentes: OCDE. Arabia Saudí, Argentina, China, Colombia, India, Indonesia y Sudáfrica: Instituto de Estadística de la UNESCO. Letonia: Eurostat. Para ver notas, consulte Anexo 3 (www.oecd.org/edu/eag.htm).

Para obtener más información acerca de los símbolos utilizados en lugar de los datos que faltan, consulte la Guía del lector.

StatLink 제고 http://dx.doi.org/10.1787/888933118200 
Tabla C1.2. Tendencias de las tasas de matriculación (1995-2012)

Estudiantes a tiempo completo y a tiempo parcial en instituciones públicas y privadas

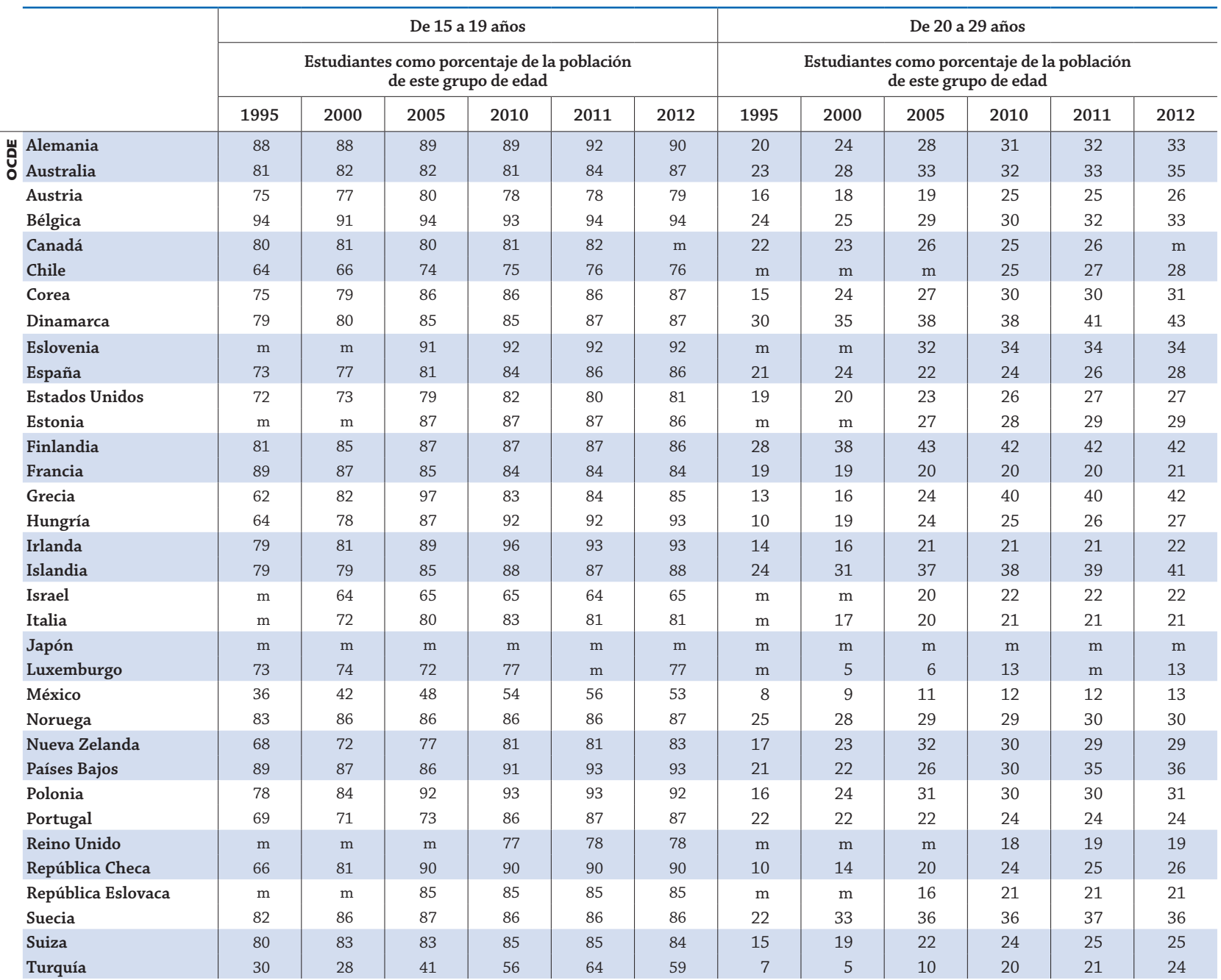

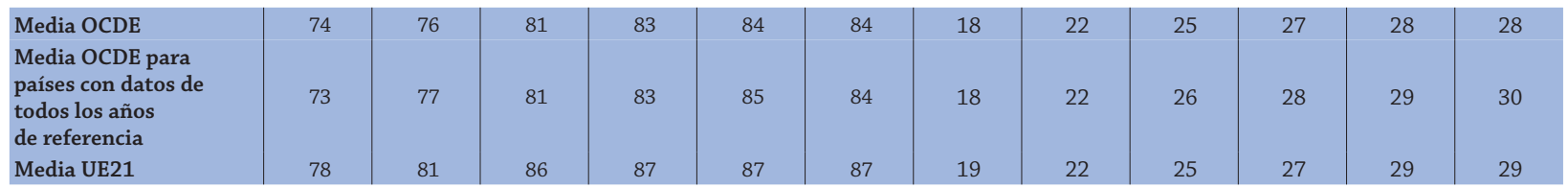

\begin{tabular}{|c|c|c|c|c|c|c|c|c|c|c|c|c|}
\hline $\begin{array}{l}\text { Arabia Saudí } \\
\text { Argentina }\end{array}$ & $\begin{array}{l}\mathrm{m} \\
\mathrm{m}\end{array}$ & $\begin{array}{l}\mathrm{m} \\
\mathrm{m}\end{array}$ & $\begin{array}{l}\mathrm{m} \\
\mathrm{m}\end{array}$ & $\begin{array}{l}87 \\
73\end{array}$ & $\begin{array}{l}\mathrm{m} \\
73\end{array}$ & $\begin{array}{r}84 \\
\mathrm{~m}\end{array}$ & $\begin{array}{l}\mathrm{m} \\
\mathrm{m}\end{array}$ & $\begin{array}{l}\mathrm{m} \\
\mathrm{m}\end{array}$ & $\begin{array}{l}\mathrm{m} \\
\mathrm{m}\end{array}$ & $\begin{array}{l}19 \\
28\end{array}$ & $\begin{array}{l}\mathrm{m} \\
28\end{array}$ & $\begin{array}{r}20 \\
\mathrm{~m}\end{array}$ \\
\hline Brasil & $\mathrm{m}$ & $\mathrm{m}$ & $\mathrm{m}$ & 76 & 77 & 78 & $\mathrm{~m}$ & $\mathrm{~m}$ & $\mathrm{~m}$ & 20 & 21 & 22 \\
\hline y China & $\mathrm{m}$ & $\mathrm{m}$ & $\mathrm{m}$ & 33 & 34 & 34 & $\mathrm{~m}$ & $\mathrm{~m}$ & $\mathrm{~m}$ & $\mathrm{~m}$ & $\mathrm{~m}$ & $\mathrm{~m}$ \\
\hline Colombia & $\mathrm{m}$ & $\mathrm{m}$ & $\mathrm{m}$ & $\mathrm{m}$ & $\mathrm{m}$ & 43 & $\mathrm{~m}$ & $\mathrm{~m}$ & $\mathrm{~m}$ & $\mathrm{~m}$ & $\mathrm{~m}$ & 6 \\
\hline Federación Rusa & $\mathrm{m}$ & 71 & 74 & $\mathrm{~m}$ & 78 & 83 & $\mathrm{~m}$ & $\mathrm{~m}$ & 19 & $\mathrm{~m}$ & 22 & 21 \\
\hline India & $\mathrm{m}$ & $\mathrm{m}$ & $\mathrm{m}$ & $\mathrm{m}$ & $\mathrm{m}$ & $\mathrm{m}$ & $\mathrm{m}$ & $\mathrm{m}$ & $\mathrm{m}$ & $\mathrm{m}$ & $\mathrm{m}$ & $\mathrm{m}$ \\
\hline Indonesia & $\mathrm{m}$ & $\mathrm{m}$ & $\mathrm{m}$ & 60 & 67 & 71 & $\mathrm{~m}$ & $\mathrm{~m}$ & $\mathrm{~m}$ & $\mathrm{~m}$ & 10 & 12 \\
\hline Letonia & $\mathrm{m}$ & $\mathrm{m}$ & $\mathrm{m}$ & $\mathrm{m}$ & $\mathrm{m}$ & 94 & $\mathrm{~m}$ & $\mathrm{~m}$ & $\mathrm{~m}$ & $\mathrm{~m}$ & $\mathrm{~m}$ & 28 \\
\hline Sudáfrica & $\mathrm{m}$ & $\mathrm{m}$ & $\mathrm{m}$ & $\mathrm{m}$ & $\mathrm{m}$ & 77 & $\mathrm{~m}$ & $\mathrm{~m}$ & $\mathrm{~m}$ & $\mathrm{~m}$ & $\mathrm{~m}$ & 9 \\
\hline
\end{tabular}

\section{Media G20}

Nota: Las columnas que muestran los años 2001, 2002, 2003, 2004, 2006, 2007, 2008 y 2009 están disponibles en Internet (véase StatLink más abajo).

Fuentes: OCDE. Arabia Saudí, Argentina, China, Colombia, India, Indonesia y Sudáfrica: Instituto de Estadística de la UNESCO. Letonia: Eurostat. Para ver notas, consulte Anexo 3 (www.oecd.org/edu/eag.htm).

Para obtener más información acerca de los símbolos utilizados en lugar de los datos que faltan, consulte la Guía del lector.

StatLink 젶ㄴ http://dx.doi.org/10.1787/888933118219 
Tabla C1.3. Patrones de matriculación en educación secundaria superior y postsecundaria no terciaria (2012)

Tasas de matriculación en instituciones públicas y privadas, por orientación del programa, grupo de edad e intensidad

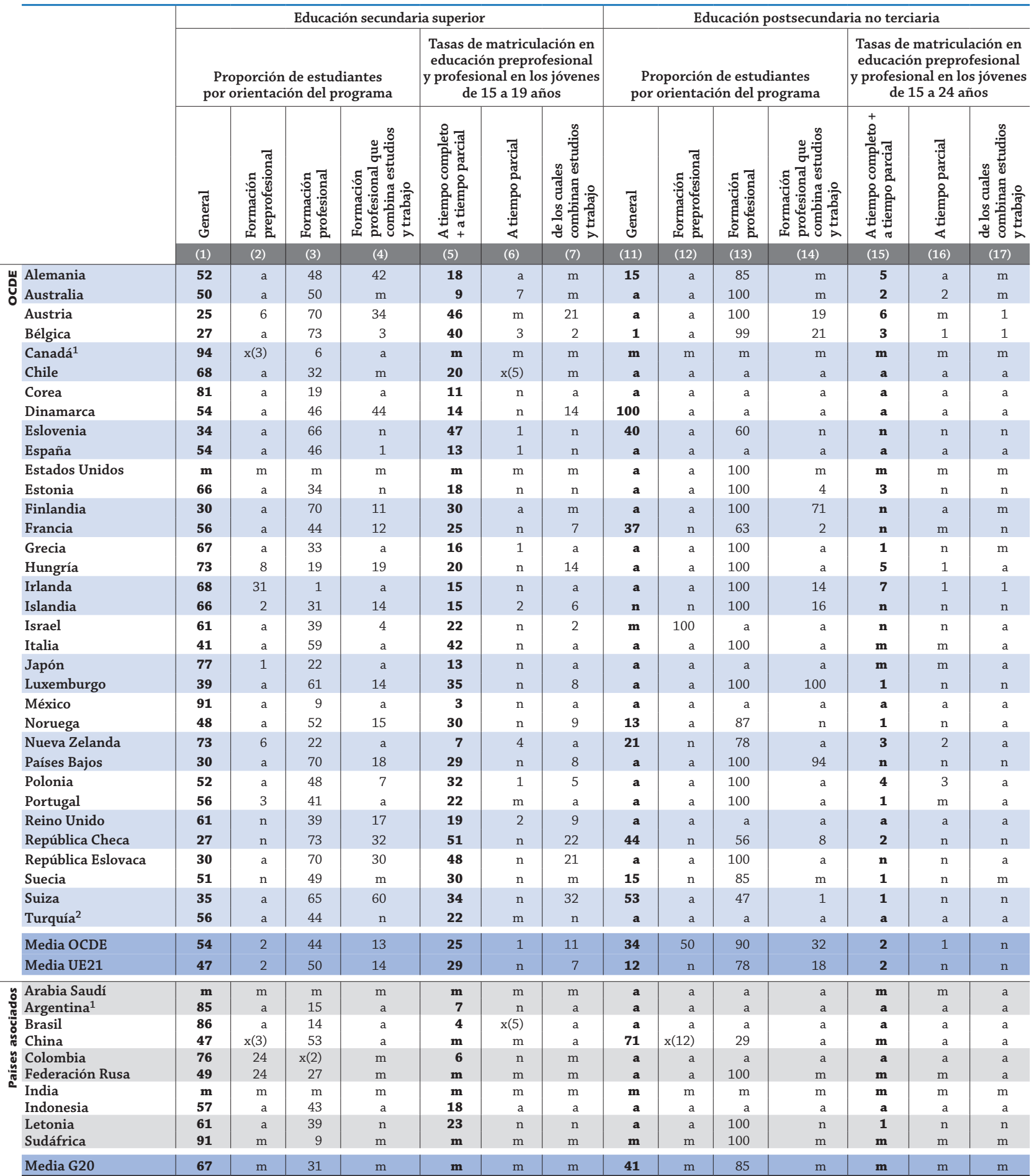

Nota: Se ha de tener en cuenta la distinta duración de los programas de secundaria superior en los países al comparar las tasas de matriculación en este nivel de educación. Las columnas que muestran las tasas de matriculación en programas de formación profesional de educación secundaria superior para estudiantes de 20 a 24 años y en programas de formación profesional postsecundaria no terciaria para estudiantes de 25 a 29 años están disponibles en Internet (véase StatLink más abajo). Las columnas 7, 10, 17 y 20 se basan en números estimados de estudiantes en programas mixtos de estudios y trabajo para los grupos de edad de referencia.

1. Año de referencia 2011.

2. Excluye CINE 3C.

Fuentes: OCDE. Arabia Saudí, Argentina, China, Colombia, India, Indonesia y Sudáfrica: Instituto de Estadística de la UNESCO. Letonia: Eurostat. Para ver notas, consulte Anexo 3 (www.oecd.org/edu/eag.htm).

Para obtener más información acerca de los símbolos utilizados en lugar de los datos que faltan, consulte la Guía del lector.

StatLink क्ना SL http://dx.doi.org/10.1787/888933118238 
Tabla C1.4. Porcentaje de estudiantes en educación primaria, secundaria y terciaria, por modalidad de estudio y sexo (2012)

\begin{tabular}{|c|c|c|c|c|c|c|c|c|c|c|}
\hline & \multicolumn{2}{|c|}{ Primaria y secundaria } & \multicolumn{4}{|c|}{ Educación terciaria de tipo B } & \multicolumn{4}{|c|}{$\begin{array}{c}\text { Educación terciaria de tipo A } \\
\text { y programas de investigación avanzada }\end{array}$} \\
\hline & $\begin{array}{l}\text { A tiempo } \\
\text { completo }\end{array}$ & $\begin{array}{c}\text { A tiempo } \\
\text { parcial }\end{array}$ & \multirow{2}{*}{$\begin{array}{c}\text { A tiempo } \\
\text { completo } \\
\mathrm{H}+\mathrm{M}\end{array}$} & \multicolumn{3}{|c|}{ A tiempo parcial } & \multirow{2}{*}{$\begin{array}{c}\text { A tiempo } \\
\text { completo } \\
\mathrm{H}+\mathrm{M}\end{array}$} & \multicolumn{3}{|c|}{ A tiempo parcial } \\
\hline & \multicolumn{2}{|c|}{$\mathrm{H}+\mathrm{M}$} & & $\mathrm{H}+\mathrm{M}$ & Hombres & Mujeres & & $\mathrm{H}+\mathrm{M}$ & Hombres & Mujeres \\
\hline & (1) & (2) & (3) & (4) & (5) & (6) & (7) & (8) & (9) & (10) \\
\hline Alemania & 100 & $\mathrm{n}$ & 87 & 13 & 23 & 7 & 86 & 14 & 15 & 12 \\
\hline Australia & 83 & 17 & 44 & 56 & 54 & 57 & 71 & 29 & 28 & 31 \\
\hline Austria & 100 & $\mathrm{n}$ & $\mathbf{m}$ & $\mathrm{m}$ & $\mathrm{m}$ & $\mathrm{m}$ & $\mathbf{m}$ & $\mathrm{m}$ & $\mathrm{m}$ & $\mathrm{m}$ \\
\hline Bélgica & 80 & 20 & 62 & 38 & 41 & 36 & 81 & 19 & 20 & 17 \\
\hline Canadá $^{1}$ & 100 & a & 88 & 12 & 11 & 13 & 77 & 23 & 21 & 24 \\
\hline Chile & 100 & $\mathrm{~m}$ & $\mathbf{m}$ & $\mathrm{m}$ & $\mathrm{m}$ & $\mathrm{m}$ & $\mathbf{m}$ & $\mathrm{m}$ & $\mathrm{m}$ & $\mathrm{m}$ \\
\hline Corea & 100 & a & $\mathbf{m}$ & $\mathrm{m}$ & $\mathrm{m}$ & $\mathrm{m}$ & $\mathbf{m}$ & $\mathrm{m}$ & $\mathrm{m}$ & $\mathrm{m}$ \\
\hline Dinamarca & 97 & 3 & 69 & 31 & 27 & 36 & 90 & 10 & 9 & 11 \\
\hline Eslovenia & 94 & 6 & 58 & 42 & 43 & 40 & 80 & 20 & 19 & 20 \\
\hline España & 91 & 9 & 93 & 7 & 5 & 9 & 69 & 31 & 33 & 29 \\
\hline Estados Unidos & 100 & a & 48 & 52 & 52 & 53 & 66 & 34 & 32 & 36 \\
\hline Estonia & 96 & 4 & 89 & 11 & 13 & 9 & 85 & 15 & 18 & 13 \\
\hline Finlandia & 100 & a & 100 & $\mathrm{a}$ & a & a & 56 & 44 & 49 & 41 \\
\hline Francia & 100 & $\mathrm{~m}$ & $\mathbf{m}$ & $\mathrm{m}$ & $\mathrm{m}$ & $\mathrm{m}$ & $\mathbf{m}$ & $\mathrm{m}$ & $\mathrm{m}$ & $\mathrm{m}$ \\
\hline Grecia & 98 & 2 & 100 & $\mathrm{a}$ & a & a & 100 & $\mathrm{a}$ & $\mathrm{a}$ & $\mathrm{a}$ \\
\hline Hungría & 95 & 5 & 75 & 25 & 22 & 27 & 66 & 34 & 30 & 37 \\
\hline Irlanda & 100 & $\mathrm{n}$ & 73 & 27 & 23 & 32 & 88 & 12 & 11 & 12 \\
\hline Islandia & 90 & 10 & 54 & 46 & 61 & 23 & 72 & 28 & 25 & 31 \\
\hline Israel & 100 & a & 100 & a & a & a & 83 & 17 & 16 & 17 \\
\hline Italia & 99 & 1 & 100 & $\mathrm{a}$ & a & a & 100 & $\mathrm{a}$ & $\mathrm{a}$ & a \\
\hline Japón & 99 & 1 & 97 & 3 & 2 & 3 & 91 & 9 & 7 & 11 \\
\hline Luxemburgo & 100 & $\mathrm{n}$ & 75 & 25 & 31 & 20 & 94 & 6 & $\mathrm{~m}$ & $\mathrm{~m}$ \\
\hline México & 100 & a & 100 & a & a & a & 100 & $\mathrm{a}$ & $\mathrm{a}$ & $\mathrm{a}$ \\
\hline Noruega & 99 & 1 & 50 & 50 & 33 & 60 & 72 & 28 & 26 & 29 \\
\hline Nueva Zelanda & 91 & 9 & 39 & 61 & 58 & 65 & 61 & 39 & 37 & 40 \\
\hline Países Bajos & 97 & 3 & 50 & 50 & 49 & 52 & 82 & 18 & 17 & 18 \\
\hline Polonia & 94 & 6 & 69 & 31 & 31 & 32 & 50 & 50 & 47 & 52 \\
\hline Portugal & 100 & $\mathrm{~m}$ & $\mathbf{m}$ & $\mathrm{m}$ & $\mathrm{m}$ & $\mathrm{m}$ & $\mathbf{m}$ & $\mathrm{m}$ & $\mathrm{m}$ & $\mathrm{m}$ \\
\hline Reino Unido & 96 & 4 & 28 & 72 & 71 & 73 & 77 & 23 & 21 & 24 \\
\hline República Checa & 100 & $\mathrm{n}$ & 90 & 10 & 10 & 9 & 98 & 2 & 2 & 3 \\
\hline República Eslovaca & 99 & 1 & 80 & 20 & 16 & 22 & 67 & 33 & 29 & 37 \\
\hline Suecia & 83 & 17 & 91 & 9 & 11 & 8 & 49 & 51 & 48 & 53 \\
\hline Suiza & 100 & $\mathrm{n}$ & 30 & 70 & 77 & 62 & 88 & 12 & 14 & 10 \\
\hline Turquía & 100 & $\mathrm{~m}$ & 100 & $\mathrm{n}$ & $\mathrm{n}$ & $\mathrm{n}$ & 100 & $\mathrm{n}$ & $\mathrm{n}$ & $\mathrm{n}$ \\
\hline Media OCDE & 97 & 4 & 74 & 26 & 26 & 26 & 79 & 21 & 20 & 22 \\
\hline Media UE21 & 96 & 4 & 77 & 23 & 23 & 23 & 79 & 21 & 22 & 22 \\
\hline Arabia Saudí & 100 & $\mathrm{n}$ & 100 & $\mathrm{n}$ & $\mathrm{n}$ & $\mathrm{n}$ & 74 & 26 & 33 & 19 \\
\hline Argentina $^{1}$ & 100 & $\mathrm{n}$ & 94 & 6 & 8 & 5 & 53 & 47 & 48 & 47 \\
\hline Brasil & 100 & $\mathrm{~m}$ & $\mathbf{m}$ & $\mathrm{m}$ & $\mathrm{m}$ & $\mathrm{m}$ & $\mathbf{m}$ & $\mathrm{m}$ & $\mathrm{m}$ & $\mathrm{m}$ \\
\hline China & 97 & 3 & 71 & 29 & 30 & 27 & 79 & 21 & 21 & 20 \\
\hline Colombia & 100 & $\mathrm{a}$ & 100 & a & a & a & 100 & a & a & a \\
\hline Federación Rusa & 100 & $\mathrm{n}$ & 67 & 33 & 37 & 30 & 48 & 52 & 49 & 54 \\
\hline India & $\mathbf{m}$ & $\mathrm{m}$ & $\mathbf{m}$ & $\mathrm{m}$ & $\mathrm{m}$ & $\mathrm{m}$ & $\mathbf{m}$ & $\mathrm{m}$ & $\mathrm{m}$ & $\mathrm{m}$ \\
\hline Indonesia & 100 & a & 100 & $\mathrm{a}$ & a & a & 100 & $\mathrm{a}$ & a & a \\
\hline Letonia & 95 & 5 & 52 & 48 & 50 & 46 & 75 & 25 & 23 & 26 \\
\hline Sudáfrica $^{2}$ & 59 & 41 & 100 & $\mathrm{n}$ & $\mathrm{n}$ & $\mathrm{n}$ & 100 & $\mathrm{n}$ & $\mathrm{n}$ & $\mathrm{n}$ \\
\hline
\end{tabular}

\begin{tabular}{|l|l|l|l|l|l|l|l|l|l|l|}
\hline Media G20 & $\mathbf{9 6}$ & 4 & $\mathbf{8 2}$ & 18 & 19 & 18 & $\mathbf{8 2}$ & 18 & 18 & 18
\end{tabular}

1. Año de referencia 2011.

2. Año de referencia 2011 para la educación terciaria.

Fuentes: OCDE. Arabia Saudí, Argentina, China, Colombia, India, Indonesia y Sudáfrica: Instituto de Estadística de la UNESCO. Letonia: Eurostat. Para ver notas, consulte Anexo 3 (www.oecd.org/edu/eag.htm).

Para obtener más información acerca de los símbolos utilizados en lugar de los datos que faltan, consulte la Guía del lector.

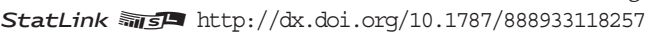


Tabla C1.6. Años esperados en educación de los 5 a los 39 años de edad (2012)

Años esperados en educación en los sistemas educativos actuales de los países (excluyendo educación de niños menores de cinco años y personas mayores de 40), por sexo y modalidad de estudio

\begin{tabular}{|c|c|c|c|c|c|c|c|c|c|c|c|c|c|c|c|}
\hline & \multicolumn{7}{|c|}{ A tiempo completo } & \multicolumn{7}{|c|}{ A tiempo parcial $^{1}$} & $\begin{array}{c}\text { A tiempo } \\
\text { completo } \\
+\quad \text { a tiempo } \\
\text { parcial }^{1}\end{array}$ \\
\hline & \multicolumn{3}{|c|}{$\begin{array}{l}\text { Todos los niveles de } \\
\text { educación conjuntos }\end{array}$} & 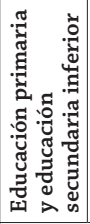 & 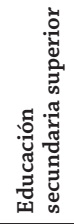 & 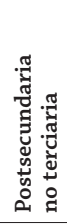 & 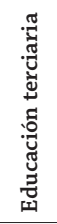 & \multicolumn{3}{|c|}{$\begin{array}{l}\text { Todos los niveles de } \\
\text { educación conjuntos }\end{array}$} & 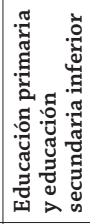 & 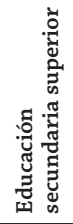 & 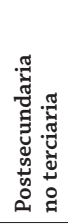 & 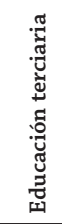 & \multirow{2}{*}{$\begin{array}{c}\begin{array}{c}\text { Todos los } \\
\text { niveles de } \\
\text { educación } \\
\text { conjuntos }\end{array} \\
\mathrm{H}+\mathrm{M}\end{array}$} \\
\hline & $\mathrm{H}+\mathrm{M}$ & Hombres & Mujeres & \multicolumn{4}{|c|}{ Hombres +Mujeres } & $\mathrm{H}+\mathrm{M}$ & Hombres & Mujeres & \multicolumn{4}{|c|}{ Hombres +Mujeres } & \\
\hline & (1) & (2) & (3) & (4) & (5) & (6) & (7) & (8) & (9) & (10) & (11) & (12) & (13) & (14) & (15) \\
\hline Alemania & 18 & 18 & 18 & 10,1 & 3,1 & 0,6 & 2,6 & 0,4 & 0,5 & 0,4 & $\mathrm{n}$ & $\mathrm{n}$ & $\mathrm{n}$ & 0,4 & 18,2 \\
\hline Australia & 16 & 16 & 16 & 11,1 & 1,9 & 0,1 & 2,7 & 3,5 & 3,5 & 3,2 & 0,6 & 1,2 & 0,4 & 1,0 & 19,4 \\
\hline Austria & 17 & 17 & 17 & 8,0 & 3,8 & 0,6 & 3,1 & $\mathbf{n}$ & $\mathrm{n}$ & $\mathrm{n}$ & $\mathrm{n}$ & $\mathrm{n}$ & $\mathrm{n}$ & $\mathrm{n}$ & 17,0 \\
\hline Bélgica & 16 & 16 & 17 & 8,4 & 4,1 & 0,3 & 2,5 & 2,6 & 2,2 & 2,9 & 0,3 & 1,3 & 0,1 & 0,9 & 18,9 \\
\hline Canadá ${ }^{2}$ & 16 & 15 & 16 & 12,5 & $\mathrm{x}(4)$ & $\mathrm{m}$ & 2,4 & 1,7 & 1,6 & 1,8 & $\mathrm{x}(4)$ & $\mathrm{x}(4)$ & $\mathrm{m}$ & 0,5 & 17,2 \\
\hline Chile $^{3}$ & 17 & 16 & 17 & 8,0 & 3,8 & a & 3,8 & n & $\mathrm{n}$ & $\mathrm{n}$ & $\mathrm{n}$ & $\mathrm{n}$ & $\mathrm{a}$ & $\mathrm{n}$ & 16,5 \\
\hline Corea $^{3}$ & 18 & 18 & 17 & 9,0 & 2,9 & $\mathrm{a}$ & 4,7 & $\mathbf{x}(\mathbf{1})$ & $\mathrm{x}(2)$ & $x(3)$ & $\mathrm{x}(4)$ & $\mathrm{x}(5)$ & $\mathrm{a}$ & $\mathrm{x}(7)$ & 17,5 \\
\hline Dinamarca & 19 & 19 & 19 & 10,6 & 3,8 & $\mathrm{n}$ & 3,4 & 0,6 & 0,5 & 0,7 & $\mathrm{n}$ & 0,3 & $\mathrm{n}$ & 0,3 & 19,4 \\
\hline Eslovenia & 17 & 16 & 18 & 8,8 & 3,9 & $\mathrm{n}$ & 3,2 & 1,4 & 1,3 & 1,5 & $\mathrm{n}$ & 0,6 & $\mathrm{n}$ & 0,8 & 18,4 \\
\hline España & 16 & 16 & 16 & 10,2 & 2,3 & $\mathrm{a}$ & 2,7 & 1,4 & 1,4 & 1,5 & 0,4 & 0,3 & $\mathrm{a}$ & 0,7 & 17,6 \\
\hline Estados Unidos & 15 & 15 & 16 & 8,9 & 2,8 & $\mathrm{~m}$ & 2,8 & 1,9 & 1,6 & 2,2 & $\mathrm{n}$ & $\mathrm{n}$ & $\mathrm{m}$ & 1,5 & 17,2 \\
\hline Estonia & 17 & 16 & 17 & 8,8 & 2,9 & 0,5 & 2,8 & 0,8 & 0,7 & 0,9 & 0,1 & 0,3 & $\mathrm{n}$ & 0,4 & 17,5 \\
\hline Finlandia & 18 & 18 & 19 & 9,0 & 4,8 & 0,2 & 2,4 & 1,6 & 1,7 & 1,6 & $\mathrm{n}$ & $\mathrm{n}$ & $\mathrm{n}$ & 1,6 & 19,7 \\
\hline Francia $^{3}$ & 16 & 16 & 17 & 9,2 & 3,3 & 0,1 & 2,9 & $\mathbf{m}$ & $\mathrm{m}$ & $\mathrm{m}$ & $\mathrm{m}$ & $\mathrm{m}$ & $\mathrm{m}$ & $\mathrm{m}$ & 16,4 \\
\hline Grecia & 18 & 18 & 19 & 9,1 & 3,2 & 0,1 & 5,0 & 0,3 & 0,4 & 0,2 & 0,1 & 0,2 & $\mathrm{n}$ & $\mathrm{n}$ & 18,6 \\
\hline Hungría & 16 & 16 & 16 & 8,0 & 4,2 & 0,4 & 2,0 & 1,2 & 1,0 & 1,4 & $\mathrm{n}$ & 0,4 & 0,1 & 0,7 & 17,6 \\
\hline Irlanda & 17 & 17 & 17 & 10,9 & 2,7 & 1,0 & 3,9 & 0,5 & 0,6 & 0,5 & $\mathrm{n}$ & $\mathrm{n}$ & 0,3 & 0,2 & 17,6 \\
\hline Islandia & 18 & 17 & 18 & 9,9 & 4,1 & 0,1 & 2,7 & 2,1 & 1,8 & 2,3 & $\mathrm{n}$ & 1,2 & 0,1 & 0,8 & 19,8 \\
\hline Israel & 15 & 15 & 16 & 8,8 & 2,8 & $\mathrm{n}$ & 2,7 & 0,4 & 0,3 & 0,4 & $\mathrm{n}$ & $\mathrm{n}$ & $\mathrm{n}$ & 0,4 & 15,8 \\
\hline Italia & 17 & 16 & 17 & 8,1 & 4,8 & $\mathrm{n}$ & 2,9 & 0,1 & 0,1 & 0,1 & 0,1 & $\mathrm{n}$ & $\mathrm{n}$ & $\mathrm{n}$ & 16,8 \\
\hline Japón & 16 & 15 & 15 & 9,2 & 2,9 & $\mathrm{n}$ & $\mathrm{m}$ & 0,4 & 0,4 & 0,4 & $\mathrm{n}$ & 0,1 & $\mathrm{n}$ & $\mathrm{m}$ & 16,3 \\
\hline Luxemburgo ${ }^{4}$ & 15 & 15 & 15 & 9,4 & 3,8 & 0,1 & 0,8 & 0,1 & 0,1 & 0,1 & $\mathrm{n}$ & $\mathrm{n}$ & $\mathrm{n}$ & 0,1 & 15,1 \\
\hline México $^{3}$ & 14 & 14 & 14 & 10,1 & 2,0 & $\mathrm{a}$ & 1,5 & $\mathbf{x}(\mathbf{1})$ & $\mathrm{x}(2)$ & $\mathrm{x}(3)$ & $\mathrm{x}(4)$ & $\mathrm{x}(5)$ & $\mathrm{a}$ & $\mathrm{x}(7)$ & 14,4 \\
\hline Noruega & 17 & 17 & 17 & 10,0 & 3,6 & 0,1 & 2,3 & 1,0 & 0,8 & 1,2 & $\mathrm{n}$ & 0,1 & 0,1 & 0,8 & 17,9 \\
\hline Nueva Zelanda & 15 & 15 & 16 & 10,2 & 2,9 & 0,2 & 2,1 & 2,7 & 2,5 & 2,9 & $\mathrm{n}$ & 0,9 & 0,4 & 1,4 & 18,1 \\
\hline Países Bajos & 18 & 18 & 18 & 10,4 & 3,5 & $\mathrm{n}$ & 3,1 & 0,7 & 0,7 & 0,7 & $\mathrm{n}$ & 0,2 & $\mathrm{n}$ & 0,4 & 18,7 \\
\hline Polonia & 16 & 15 & 16 & 8,9 & 3,0 & 0,1 & 1,9 & 2,8 & 2,3 & 3,4 & $\mathrm{n}$ & 0,5 & 0,5 & 1,7 & 18,4 \\
\hline Portugal $^{3}$ & 18 & 18 & 18 & 10,2 & 3,4 & 0,1 & 2,9 & $\mathbf{x}(\mathbf{1})$ & $\mathrm{x}(2)$ & $\mathrm{x}(3)$ & $\mathrm{x}(4)$ & $\mathrm{x}(5)$ & $x(6)$ & $\mathrm{x}(7)$ & 17,6 \\
\hline Reino Unido & 15 & 15 & 16 & 9,2 & 4,2 & $\mathrm{a}$ & 2,0 & 1,0 & 0,9 & 1,1 & 0,2 & 0,2 & $\mathrm{a}$ & 0,6 & 16,4 \\
\hline República Checa & 18 & 17 & 18 & 9,1 & 3,8 & 0,2 & 2,9 & 0,5 & 0,4 & 0,7 & $\mathrm{n}$ & $\mathrm{n}$ & 0,3 & 0,1 & 18,1 \\
\hline República Eslovaca & 15 & 15 & 16 & 8,7 & 3,7 & $\mathrm{n}$ & 1,9 & 0,8 & 0,6 & 1,1 & $\mathrm{n}$ & 0,1 & $\mathrm{n}$ & 0,7 & 16,3 \\
\hline Suecia & 16 & 16 & 17 & 9,1 & 3,2 & 0,2 & 1,8 & 3,0 & 2,4 & 3,7 & 0,7 & 1,0 & $\mathrm{n}$ & 1,3 & 19,3 \\
\hline Suiza & 17 & 17 & 17 & 9,5 & 3,5 & 0,1 & 1,9 & 0,6 & 0,7 & 0,5 & $\mathrm{n}$ & $\mathrm{n}$ & $\mathrm{n}$ & 0,5 & 17,3 \\
\hline Turquía $^{3}$ & 16 & 17 & 16 & 8,7 & 3,7 & $\mathrm{a}$ & 3,4 & m & $\mathrm{m}$ & $\mathrm{m}$ & $\mathrm{m}$ & $\mathrm{m}$ & a & $\mathrm{m}$ & 16,4 \\
\hline Media OCDE & 17 & 16 & 17 & 9,4 & 3,4 & 0,2 & 2,7 & 1,2 & 1,1 & 1,3 & 0,1 & 0,3 & 0,1 & 0,7 & 17,6 \\
\hline Media UE21 & 17 & 17 & 17 & 9,3 & 3,6 & 0,2 & 2,7 & 1,0 & 0,9 & 1,2 & 0,1 & 0,3 & 0,1 & 0,6 & 17,8 \\
\hline ¿ Arabia Saudí & 14 & 14 & 14 & 9,0 & 3,0 & $\mathrm{a}$ & 1,9 & 0,6 & 0,7 & 0,4 & $\mathrm{~m}$ & $\mathrm{n}$ & $\mathrm{a}$ & 0,6 & $\mathbf{m}$ \\
\hline Argentina ${ }^{2}$ & 16 & 15 & 16 & 11,0 & 2,4 & a & $\mathrm{m}$ & 2,6 & 2,2 & 3,0 & $\mathrm{n}$ & $\mathrm{n}$ & $\mathrm{a}$ & $\mathrm{m}$ & 18,2 \\
\hline Brasil $^{3}$ & 16 & 16 & 17 & 9,8 & 3,1 & a & 2,1 & $\mathbf{n}$ & $\mathrm{n}$ & $\mathrm{n}$ & $\mathrm{n}$ & $\mathrm{n}$ & a & $\mathrm{n}$ & 16,3 \\
\hline China & 14 & 14 & 14 & 9,4 & 2,4 & $\mathrm{~m}$ & 1,1 & 1,8 & 1,7 & 1,9 & $\mathrm{n}$ & 0,3 & $\mathrm{~m}$ & $\mathrm{~m}$ & 16,0 \\
\hline Colombia & 14 & 13 & 14 & 9,3 & 1,4 & $\mathrm{~m}$ & $\mathrm{~m}$ & $\mathbf{a}$ & $\mathrm{a}$ & $\mathrm{a}$ & a & a & $\mathrm{a}$ & $\mathrm{a}$ & 13,5 \\
\hline Federación Rusa ${ }^{5}$ & 13 & 13 & 13 & 8,5 & 2,1 & $x(5)$ & 2,7 & 3,3 & 3,1 & 3,5 & a & $\mathrm{m}$ & $\mathrm{m}$ & 1,7 & m \\
\hline India & $\mathbf{m}$ & $\mathrm{m}$ & $\mathrm{m}$ & $\mathrm{m}$ & $\mathrm{m}$ & $\mathrm{m}$ & $\mathrm{m}$ & m & $\mathrm{m}$ & $\mathrm{m}$ & $\mathrm{m}$ & $\mathrm{m}$ & $\mathrm{m}$ & $\mathrm{m}$ & 13,4 \\
\hline Indonesia & 13 & 13 & 14 & 9,1 & 2,2 & a & 1,5 & $\mathbf{n}$ & $\mathrm{n}$ & $\mathrm{n}$ & $\mathrm{n}$ & $\mathrm{n}$ & $\mathrm{a}$ & $\mathrm{n}$ & 13,5 \\
\hline Letonia & 17 & 16 & 17 & 9,2 & 3,0 & 0,1 & 2,3 & 1,3 & 1,2 & 1,5 & 0,1 & 0,4 & $\mathrm{n}$ & 0,8 & 17,8 \\
\hline Sudáfrica & $\mathbf{m}$ & $\mathrm{m}$ & $\mathrm{m}$ & $\mathrm{m}$ & $\mathrm{m}$ & $\mathrm{m}$ & $\mathrm{m}$ & m & $\mathrm{m}$ & $\mathrm{m}$ & $\mathrm{m}$ & $\mathrm{m}$ & $\mathrm{m}$ & $\mathrm{m}$ & m \\
\hline Media G20 & 15 & 15 & 16 & 9,6 & 2,9 & $\mathrm{~m}$ & 2,5 & 1,3 & 1,2 & 1,4 & $\mathrm{~m}$ & 0,2 & $\mathrm{~m}$ & $\mathrm{~m}$ & 16,5 \\
\hline
\end{tabular}

1. La expectativa de años en educación a tiempo parcial debe interpretarse con cautela, puesto que puede reflejar variaciones debidas a la diferente intensidad de la participación de los países, niveles y personas de distintas edades.

2. Año de referencia 2011.

3. A tiempo completo + a tiempo parcial.

4. Altos niveles de matriculación en el extranjero e inmigración pueden afectar a la expectativa de años en educación.

5. Las matriculaciones en CINE 3B se incluyen en los indicadores de educación terciaria.

Fuentes: OCDE. Arabia Saudí, Argentina, China, Colombia, India, Indonesia y Sudáfrica: Instituto de Estadística de la UNESCO. Letonia: Eurostat. Para ver notas, consulte Anexo 3 (www.oecd.org/edu/eag.htm).

Para obtener más información acerca de los símbolos utilizados en lugar de los datos que faltan, consulte la Guía del lector.

StatLink 젝ㄴ http://dx.doi.org/10.1787/888933118276 


\section{¿EN QUÉ SE DIFERENCIAN LOS SISTEMAS DE EDUCACIÓN INFANTIL DEL MUNDO?}

- En muchos países de la OCDE, los servicios de educación infantil se han expandido paralelamente al cambio de la participación de las mujeres en el mundo laboral. Pero mejorar el acceso sin mejorar a la vez la calidad de estos servicios no garantiza unos buenos resultados ni a nivel individual ni social.

- La educación infantil se asocia con un mejor rendimiento escolar posterior. Los estudiantes de quince años que han participado en educación infantil durante al menos un año tienen un rendimiento mejor en la encuesta del Programa para la Evaluación Internacional de Alumnos (PISA) de la OCDE que aquellos que no lo hicieron, incluso después de tener en consideración sus entornos socioeconómicos.

- En la mayoría de los países de la OCDE, la educación comienza ahora para la mayor parte de los niños mucho antes de cumplir los 5 años. Más de tres cuartas partes de los niños de 4 años (el 84\%) de los países de la OCDE están escolarizados en educación infantil y en educación primaria; en los países de la OCDE que pertenecen a la Unión Europea lo están el $89 \%$ de los niños de 4 años.

- En Alemania, Bélgica, Dinamarca, España, Francia, Islandia, Italia, Noruega, Reino Unido y Suecia, más del $90 \%$ de los niños de 3 años están escolarizados en educación infantil.

\section{Gráfico C2.1. Tasas de matriculación en educación infantil de los niños de 3 años $(2005,2012)$}

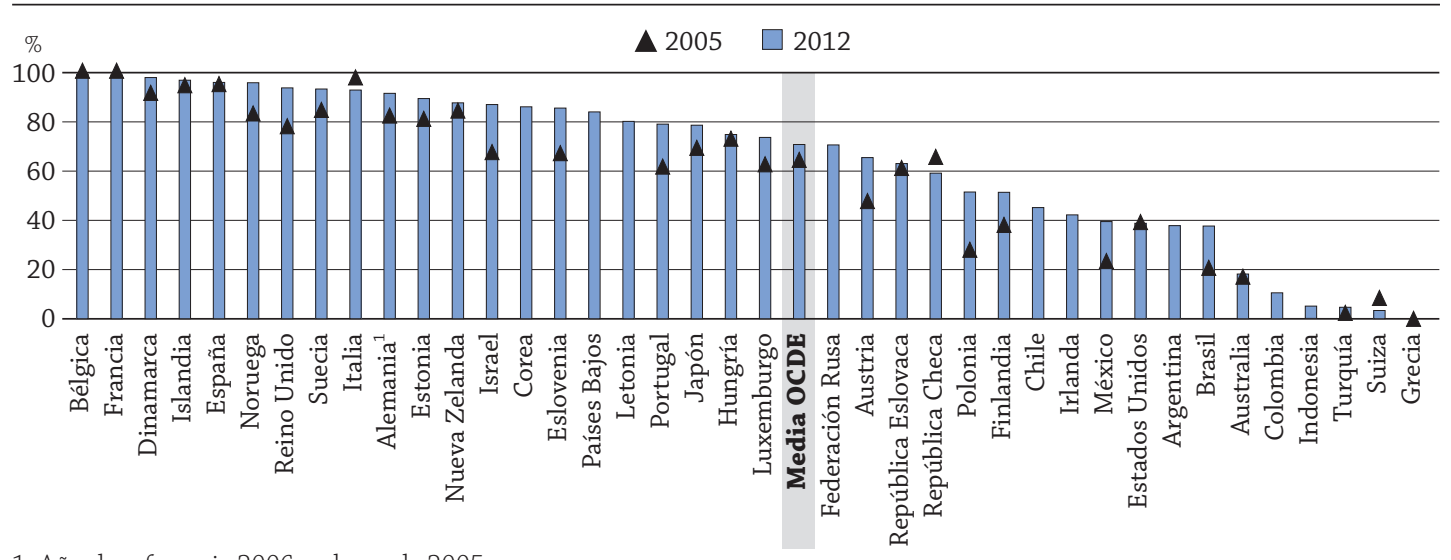

1. Año de referencia 2006 en lugar de 2005 .

Los países están clasificados en orden descendente de las tasas de matriculación de niños de 3 años en 2012.

Fuente: OCDE. Tabla C2.1. Para ver notas, consulte Anexo 3 (www.oecd.org/edu/eag.htm).

StatLink त्ञाs http://dx.doi.org/10.1787/888933118409

\section{Contexto}

Al cambiar las estructuras familiares, también lo hacen las edades de los padres. Más mujeres y hombres esperan hasta más tarde en la vida para formar sus familias. Lo hacen por varios motivos, por ejemplo la planificación de un futuro económico más seguro y una mayor madurez emocional, la toma de más tiempo hasta encontrar una relación estable y un mayor compromiso con sus carreras profesionales, antes de poner toda la atención en tener hijos. Como los padres y madres son también quienes tienen más probabilidades de estar dentro de la población activa, hay una necesidad cada vez mayor de cuidado infantil. Asimismo, cada vez se reconoce más el papel clave que desempeña la educación infantil en el desarrollo cognitivo y emocional de los niños. Por tanto, garantizar la calidad de la educación infantil se ha convertido en una prioridad política en muchos países.

Escolarizar a los niños en educación infantil también puede mitigar las desigualdades sociales y fomentar mejores resultados de los estudiantes en general. Muchas de las desigualdades que se encuentran en los sistemas educativos ya son evidentes cuando los estudiantes acceden a la escolarización formal y persisten a medida que van avanzando en el sistema educativo (Downey et al., 2004). Como las desi- 
gualdades tienden a crecer cuando la escolarización no es obligatoria, una entrada más temprana en el sistema escolar puede reducir esas desigualdades. Además, la educación preescolar contribuye a preparar a los estudiantes para acceder a la escolarización formal y tener éxito en ella (Heckman, 2000).

A medida que los países continúan expandiendo sus programas de educación infantil, será importante considerar las necesidades y expectativas de los padres respecto a la accesibilidad, el coste, el programa y la calidad y responsabilidad del personal. Si no se satisfacen las necesidades de los padres respecto a la calidad, accesibilidad o responsabilidad, algunos de ellos pueden estar más dispuestos a enviar a sus hijos a instituciones preescolares privadas, guarderías o actividades extraescolares. Esto puede ocasionar pesadas cargas económicas para los padres, incluso si se conceden subvenciones gubernamentales (Shin et al., 2009).

Existen muchos sistemas y estructuras de educación infantil y de guarderías en los países de la OCDE. En consecuencia, hay también diferentes enfoques al identificar los límites entre la educación infantil y las guarderías (véanse Cuadro C2.1 y la sección Definiciones). Estas diferencias deberían ser tenidas en cuenta al sacar conclusiones de las comparaciones entre países.

\section{Otros resultados}

- La educación infantil financiada por el sector público tiende a estar más fuertemente desarrollada en los países europeos que en los países no europeos de la OCDE. El gasto privado varía ampliamente entre países, desde el $5 \%$ o menos en Bélgica, Estonia, Letonia, Luxemburgo y Suecia hasta el $25 \%$ o más en Argentina, Australia, Austria, Colombia, Corea, España, Estados Unidos y Japón.

- Como porcentaje del PIB, el gasto en educación infantil supone una media del 0,6\% del PIB. Las diferencias entre países son significativas. Por ejemplo, mientras que se destina un $0,1 \%$ del PIB a la educación infantil en Australia, se destina alrededor del 0,8\% o más en Chile, Dinamarca, Eslovenia, España, Federación Rusa, Islandia, Letonia y Luxemburgo.

- La ratio alumnos-personal docente es también un indicador importante de los recursos que se destinan a la educación infantil. La ratio alumnos-profesor, excluyendo al personal no docente (por ejemplo, los asistentes educativos) oscila desde más de 20 alumnos por profesor en Chile, Francia, Indonesia, Israel, México y Turquía hasta menos de diez en Eslovenia, Estonia, Islandia, Nueva Zelanda y Suecia.

- Algunos países hacen un gran uso de asistentes educativos en la educación infantil. Trece países refirieron ratios menores alumnos-personal de contacto que alumnos-personal docente. Como resultado, las ratios alumnos-personal de contacto son sustancialmente inferiores que las ratios alumnos-personal docente (al menos dos alumnos menos) en Alemania, Austria, Brasil, Chile, China, Francia, Indonesia, Israel y Reino Unido.

\section{Tendencias}

A lo largo de la última década, muchos países han expandido sus programas de educación preescolar. Esta mayor atención a la educación infantil ha tenido como resultado en algunos países la extensión de la educación obligatoria a edades inferiores, la educación infantil gratuita, el suministro universal de educación infantil y guarderías, y la creación de programas que integran las guarderías en la educación infantil formal.

Como media en los países de la OCDE con datos para 2005 y 2012, la escolarización en programas de educación infantil creció desde el 64\% de los niños de 3 años en 2005 hasta el $71 \%$ en 2012, y de modo similar desde el 79\% de los niños de 4 años en 2005 hasta el 84\% en 2012. Las tasas de escolarización de los niños de 4 años en programas de educación infantil se incrementaron en 20 puntos porcentuales o más en Australia, Brasil y Polonia entre 2005 y 2012. 


\section{Análisis}

En la mayoría de los países de la OCDE, las medidas políticas respecto a la educación y el cuidado de la primera infancia (ECEC, por sus siglas en inglés) han ido paralelas a la evolución de la participación de la mujer en el mundo laboral. Desde los años setenta, cada vez más mujeres son empleadas asalariadas, tras la expansión de las economías basadas en los servicios y en el conocimiento. Como la prosperidad económica depende de la manutención de una ratio alta de empleo por población, para animar a más mujeres a ingresar en el mercado laboral los gobiernos se han interesado cada vez más en expandir los servicios de educación infantil y guarderías. En los años setenta y ochenta, los gobiernos europeos en especial llevaron a cabo medidas políticas para familias y niños con el fin de promover la natalidad y garantizar que sea viable para las mujeres combinar las responsabilidades del trabajo y de la familia (OECD, 2013c; 2011a).

La media de la edad a la que las madres tienen su primer hijo ha aumentado en todos los países de la OCDE, excepto México, en los últimos cuarenta años. En 1970, Islandia tenía la media inferior de edad a la que las mujeres tenían su primer hijo: un poco más de 21 años. Pero Islandia no era un caso aislado: de los 23 países de los que se dispone de datos, cinco países más tenían una media de edad para tener el primer hijo inferior a 23 años, y la media de edad de todos los países era de poco más de 24 años. En 1995, la edad había aumentado a más de 26 años como media entre los países de la OCDE, y en 2012 había aumentado otra vez hasta 28. A pesar de esta tendencia sigue habiendo grandes variaciones entre países. En 2012, España, Reino Unido y Suiza registraban la media de edad más elevada para tener el primer hijo, más de 30 años. En cambio, México presentaba la media de edad inferior, poco más de 21 años (Gráfico C2.2).

\section{Gráfico C2.2. Tendencias de la edad de las mujeres que son madres por primera vez (1970, 1995, 2012) \\ Media de edad a la que las madres tienen su primer hijo}

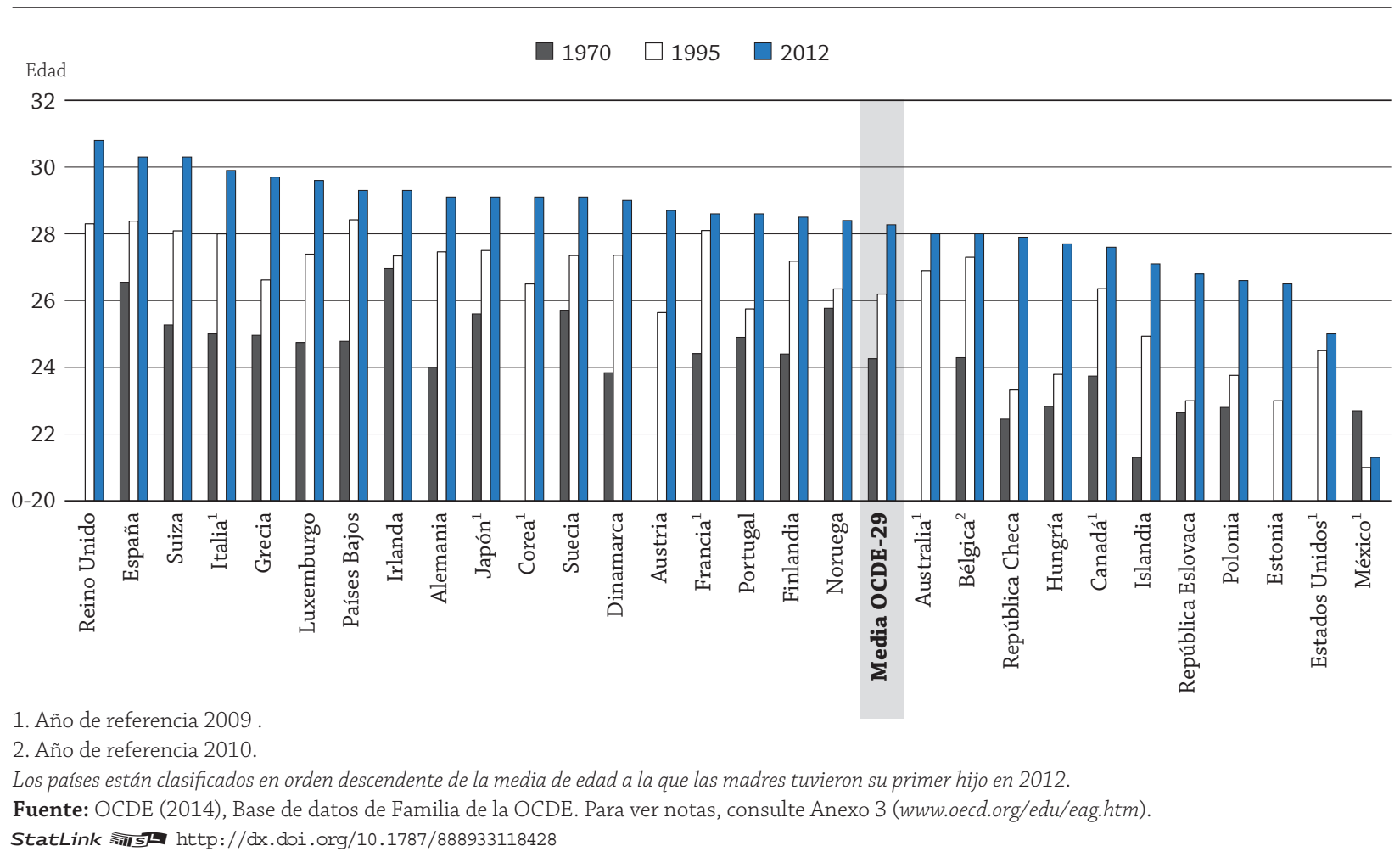

\section{Escolarización en la educación infantil}

La educación infantil es la fase inicial de la enseñanza organizada para muchos niños y puede desempeñar un papel significativo en su desarrollo. Mientras que las pautas de escolarización en educación primaria y en secundaria inferior son relativamente similares en los países de la OCDE, hay variaciones significativas en cuanto a los programas de educación infantil entre los países de la OCDE y otros países del G20, en aspectos como los niveles globales de participación en los programas, la edad típica de comienzo de los niños, la financiación y la duración de los programas. 
En la mayoría de los países de la OCDE, la educación comienza para los niños mucho antes de cumplir los cinco años. Más de tres cuartas partes (el 84\%) de los niños de 4 años de los países de la OCDE tomados en conjunto están escolarizados en programas de educación infantil y educación primaria, porcentaje que asciende al $89 \%$ como media en los países de la OCDE que pertenecen a la Unión Europea. Las tasas de escolarización en educación infantil y primaria en esa edad varían desde más del 95\% en Alemania, Bélgica, Dinamarca, España, Francia, Irlanda, Islandia, Italia, Luxemburgo, Noruega, Países Bajos y Reino Unido a menos del $60 \%$ en Finlandia, Indonesia y Turquía. También Grecia y Suiza se encuentran en este último grupo, pero como estos países no indican las tasas de escolarización en programas integrados, no se puede calcular la tasa de escolarización real, que probablemente es más alta que la que se indica aquí. En estos dos países, las tasas de escolarización más altas en programas de educación infantil son las de los niños de cinco años (Tabla C2.1).

Como media en los países de la OCDE el $74 \%$ de los estudiantes de 15 años evaluados en la encuesta del Programa para la Evaluación Internacional de Alumnos (PISA) refirieron que habían participado más de un año en educación infantil. Según las respuestas de los estudiantes, la escolarización más de un año en educación infantil era prácticamente universal hace aproximadamente diez años en Bélgica, Francia, Hungría, Islandia, Japón y Países Bajos, donde más del $90 \%$ de los jóvenes de 15 años refirieron haber participado en educación infantil durante más de un año. La educación infantil no está generalizada en Turquía, donde menos del 30\% de los jóvenes de 15 años habían participado en ella durante algún periodo de tiempo. Es poco común asistir más de un año a educación infantil en Australia, Chile, Irlanda y Polonia, donde menos del $52 \%$ de los estudiantes había participado en educación infantil durante tal cantidad de tiempo (véase OECD, 2013a, Tabla IV.3.33).

\section{Cuadro C2.1. El límite entre la educación infantil y el cuidado de la primera infancia}

Hay muchos sistemas y estructuras de educación infantil y cuidado de la primera infancia (ECEC, por sus siglas en inglés) en los países de la OCDE. En consecuencia, también hay una gran variedad de enfoques al identificar el límite entre educación infantil y guarderías. Como las propiedades educativas de los programas CINE 0 pueden ser difíciles de evaluar directamente, se utilizan diferentes medidas de muestra para llegar a una definición técnica. Estas incluyen si el programa es impartido por personal cualificado, si tiene lugar en un entorno institucional y la edad meta de los niños.

Con el fin de ayudar a los lectores de Panorama de la educación a interpretar los resultados de la educación infantil, se proporcionan a continuación una serie de ejemplos de cómo definen los países, en teoría, y refuerzan, en la práctica, el límite entre la educación infantil (ECE, por sus siglas en inglés) y el cuidado de la primera infancia en los datos referidos a la OCDE.

Para aquellos países con programas de educación infantil que tienen lugar en entornos institucionales distintos de los que proporcionan servicios de guardería, es fácil implementar una estructura válida para la información. En Bélgica, por ejemplo, los distintos entornos institucionales están financiados por distintos ministerios, lo que hace innecesarias las estimaciones, aunque la validez de la comparación internacional en cuanto a cómo se define la educación sigue sin estar clara (véase Figura 1).

Para los países con programas que combinan un programa educativo con guardería (programas «integrados»), el límite entre educación infantil y guardería es más difícil de establecer. Los países de la OCDE con programas ECEC integrados tienen a menudo también programas independientes que son puramente educativos. Más de la mitad de los países de la OCDE son incapaces, en la práctica, de distinguir entre educación infantil y guarderías en los programas integrados. De estos, la mayoría, entre los que se encuentran Dinamarca, Estados Unidos e Italia, deciden referir toda la información como CINE 0. Una minoría de países no incluyen los programas integrados en CINE 0 al informar sobre el personal (Australia, Noruega), el gasto (Corea) o toda la información en general (Grecia, Suiza). Estas diferencias deben tenerse en cuenta al sacar conclusiones sobre las comparaciones internacionales.

Para aquellos países con programas integrados que sí intentan aislar el componente educativo, se utilizan varios métodos de cálculo para aislar matriculaciones, gasto y personal. Algunos países, como Noruega, Países Bajos y Suecia prefieren aplicar un cálculo simple de 50/50, en el que la mitad de todas las matriculaciones, personal y gasto se consideran educativos. Otros países recurren a los datos de la encuesta, asignan una división diferente entre educación y guardería, o aplican un método de cálculo más complicado. Finlandia, por 
ejemplo, pondera el gasto en programas integrados según la edad del niño, mientras que Estonia utiliza una proporción estimada de gasto del $30 \%$.

La Figura 1 ofrece un diagrama de los sistemas de educación infantil y los enfoques para referir sobre ellos en los países de la OCDE y asociados. La información específica de cada país se puede encontrar en el Anexo 3 de esta publicación.

\section{Figura 1. Representación diagramática de los sistemas CINE 0 e información aportada por los países de la OCDE}

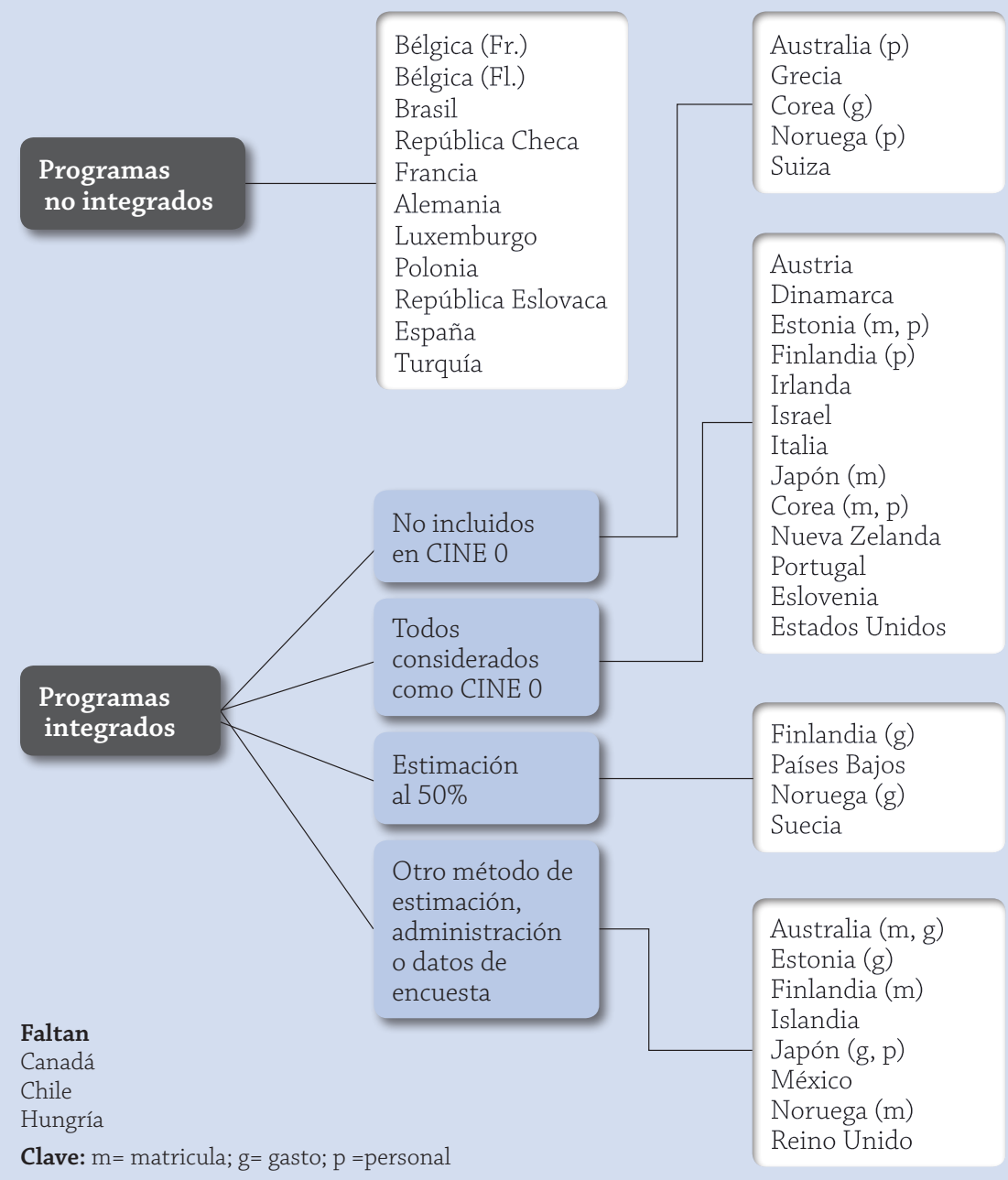

Cabe destacar que los análisis de PISA también encuentran que en la mayoría de los países los estudiantes que han asistido al menos un año a educación preescolar tienden a tener un rendimiento superior al de aquellos que no lo han hecho, incluso después de tener en cuenta su entorno socioeconómico. Las investigaciones de PISA también muestran que la relación entre la asistencia a la educación infantil y el rendimiento tiende a ser más fuerte en sistemas escolares con una mayor duración de la educación infantil, ratios alumnos-profesor inferiores en educación infantil y un mayor gasto público por niño en el nivel preescolar (OECD, 2013a, Tabla II.4.12).

Los programas educativos infantiles para niños de edades inferiores no están tan generalizados. En algunos países, la demanda de educación infantil para niños de 3 años o menos es mucho mayor que la oferta, incluso en países que financian largos permisos de maternidad y paternidad. Las tasas más altas de escolarización de niños de 3 años en educación infantil se encuentran en Bélgica, Dinamarca, España, Francia, Islandia, Italia, Noruega, Reino Unido y Suecia. En países donde la financiación pública para los permisos de maternidad y paternidad es limitada, muchos padres trabajadores tienen que buscar en el mercado privado, donde su capacidad para pagar influye significativa- 
mente en el acceso a servicios de calidad, o recurrir a acuerdos informales con la familia, amigos y vecinos (Tabla C2.1 y Starting Strong III [OECD, 2011b]).

Algunos países han hecho del acceso a la educación infantil algo prácticamente universal para los niños de tres años. La disponibilidad de la educación infantil está creciendo con rapidez en la mayoría de los países. Como media en los países de la OCDE con datos de 2005 y 2012, la escolarización creció desde el 64\% de los niños de 3 años en 2005 al $71 \%$ en 2012, y del 79\% de los niños de 4 años en 2005 al 84\% en 2012. En Brasil y Polonia, las tasas de escolarización de los niños de 4 años aumentaron en 20 puntos porcentuales o más durante ese periodo (Tabla C2.1).

\section{Financiación de la educación infantil}

Una financiación pública sostenida es imprescindible para apoyar el crecimiento y la calidad de los programas de educación infantil. Una financiación apropiada contribuye a garantizar la contratación de personal profesional cualificado para apoyar el desarrollo cognitivo, social y emocional de los niños. Invertir en instalaciones y materiales para la educación infantil ayuda también a promover el desarrollo de ambientes de aprendizaje centrados en los niños. En aquellos países que no proporcionan suficiente financiación pública para cubrir tanto la calidad como la cantidad de la educación infantil, los padres pueden tender a enviar a sus hijos a servicios de educación o guarderías privados, lo que implica grandes cargas económicas (OECD, 2011b); otros pueden preferir dejar a los niños en casa, lo que puede dificultar la participación de las mujeres en el mundo laboral (OECD, 2011a).

El gasto público para educación preescolar se destina principalmente a apoyar a las instituciones públicas, pero en algunos países también financia a instituciones privadas en diferentes niveles. Como media en los países de la OCDE, el nivel de gasto público en instituciones infantiles públicas por estudiante es de alrededor del doble que el nivel de gasto público en instituciones infantiles privadas (6.460 dólares estadounidenses y 3.618 dólares estadounidenses respectivamente) (véase la Tabla B3.4). En el nivel preescolar, el gasto anual (tanto de fuentes de financiación públicas como privadas) por alumno tanto para instituciones públicas como privadas es como media de 7.446 dólares estadounidenses en los países de la OCDE. Sin embargo, el gasto varía desde 2.500 dólares estadounidenses o menos en Argentina, Brasil, Indonesia y Turquía hasta más de 10.000 dólares estadounidenses en Australia, Dinamarca, Estados Unidos, Luxemburgo y Nueva Zelanda (Tabla C2.2, y véase Tabla B3.3 en el Indicador B3).

El gasto en educación infantil supone una media del 0,6\% del PIB colectivo. Las diferencias entre países son significativas. Por ejemplo, mientras que se destina el 0,1\% o menos del PIB a educación infantil en Australia, se destina el 0,8\% o más en Chile, Dinamarca, Eslovenia, España, Federación Rusa, Islandia, Letonia y Luxemburgo (Tabla C2.2 y Gráfico C2.3). Estas diferencias se explican en gran parte por las tasas de escolarización, las disposiciones legales y los costes, así como las diferentes edades de comienzo de la educación primaria; también influye hasta qué punto este indicador cubre la educación infantil privada. En Países Bajos y Suiza, la ausencia de datos sobre los programas

\section{Gráfico C2.3. Gasto en instituciones de educación infantil (2011) Como porcentaje del PIB, por fuente de financiación}

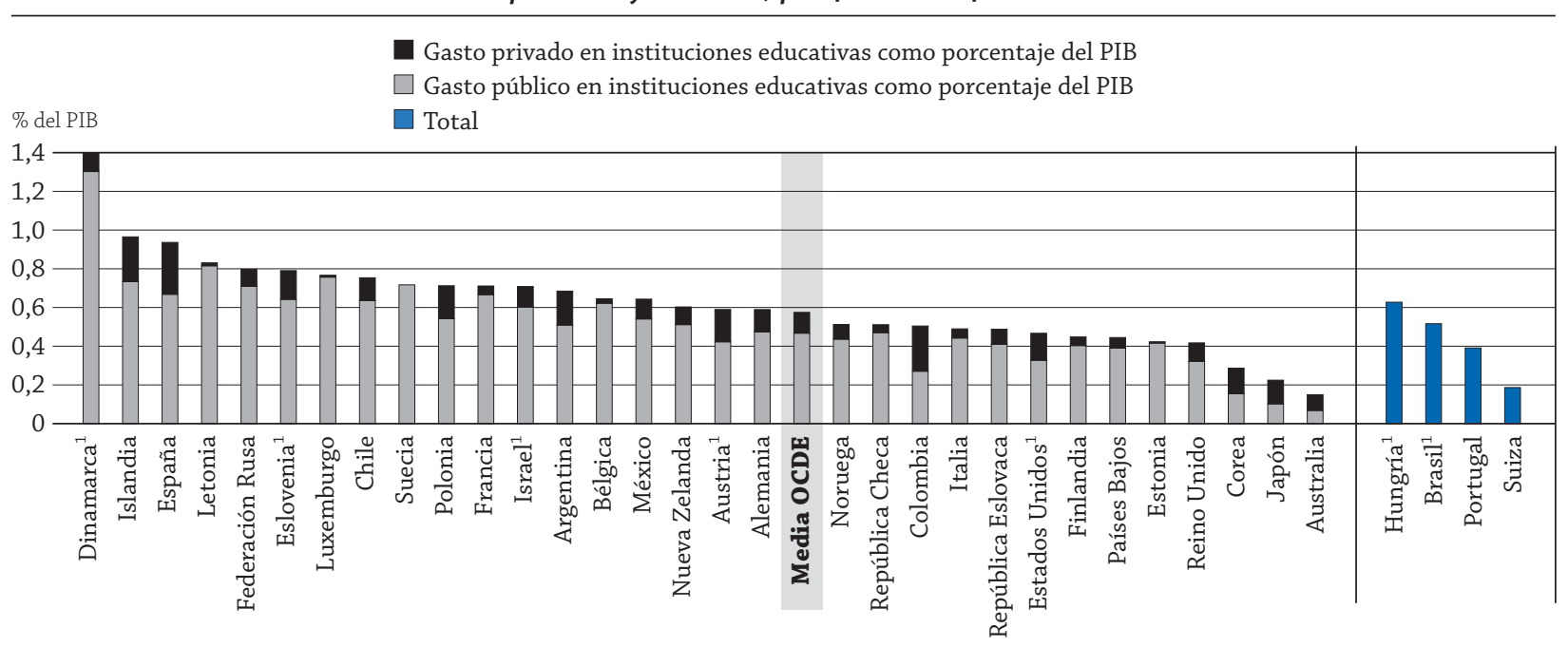

1. Incluye algo de gasto en guarderías.

Los países están clasificados en orden descendente del gasto público y privado en instituciones educativas.

Fuente: OCDE. Tabla C2.2. Para ver notas, consulte Anexo 3 (www.oecd.org/edu/eag.htm).

StatLink 케피 http://dx.doi.org/10.1787/888933118447 
integrados también puede subestimar el nivel verdadero de gasto y de escolarizaciones en los programas de educación infantil (ver más detalles en el Cuadro B2.1), y puede afectar a la comparabilidad de estos datos con los de otros países. Las inferencias sobre el acceso y la calidad de la educación y las guarderías han de realizarse, por tanto, con cautela (Tabla C2.2 y Cuadro C2.1).

La educación infantil de financiación pública tiende a estar más desarrollada en los países europeos que en los no europeos de la OCDE. En Europa, el concepto de acceso universal a la educación para niños de 3 a 6 años está generalmente aceptado. La mayoría de los países de esta zona proporcionan a todos los niños al menos dos años de educación infantil gratuita de financiación pública en los centros escolares antes de comenzar la educación primaria. A excepción de Irlanda y Países Bajos, este acceso es generalmente un derecho estatutario a partir de los 3 años, y en algunos países incluso antes de esa edad. En comparación con la educación primaria, secundaria y postsecundaria no terciaria, las instituciones preescolares obtienen la mayor proporción de fondos (19\%) de fuentes privadas. No obstante, esta proporción varía mucho, desde el $5 \%$ o menos en Bélgica, Estonia, Letonia, Luxemburgo y Suecia hasta el $25 \%$ o más en Argentina, Australia, Austria, Colombia, Corea, España, Estados Unidos y Japón (Tabla C2.2 y Starting Strong II [OECD, 2006]).

\section{La ratio alumnos-profesor varía considerablemente entre los países de la OCDE}

Las investigaciones demuestran que profesionales mejor cualificados fomentan entornos enriquecidos y estimulantes y una pedagogía de gran calidad, y que una mejor interacción entre los niños y el personal facilita mejores resultados de aprendizaje (Heckman, 2000; Shin et al., 2009). Aunque la cualificación es uno de los pronosticadores más poderosos de la calidad del personal, el nivel de cualificación solo supone una parte de la realidad. Las cualificaciones indican cuánta especialización y formación práctica se incluye en la educación inicial del personal, de qué tipos de desarrollo profesional y de formación dispone y participa el personal y cuántos años de experiencia ha acumulado. Además, las condiciones laborales pueden influir en la satisfacción profesional, lo que puede afectar a la habilidad y disposición de los profesionales para construir relaciones e interactuar atentamente con los niños (Shin et al., 2009). Unos niveles altos de reemplazos perturban la continuidad de los cuidados, debilitan los esfuerzos de desarrollo profesional, reducen la calidad global y afectan de forma negativa a los resultados de los niños.

La ratio alumnos-personal docente es también un indicador importante de los recursos que se destinan a la educación. Esta ratio se obtiene dividiendo el número de alumnos en equivalentes a tiempo completo en un nivel educativo

\section{Gráfico C2.4. Ratio alumnos-personal docente en educación infantil (2012) \\ Instituciones públicas y privadas, cálculos basados en equivalentes a tiempo completo}

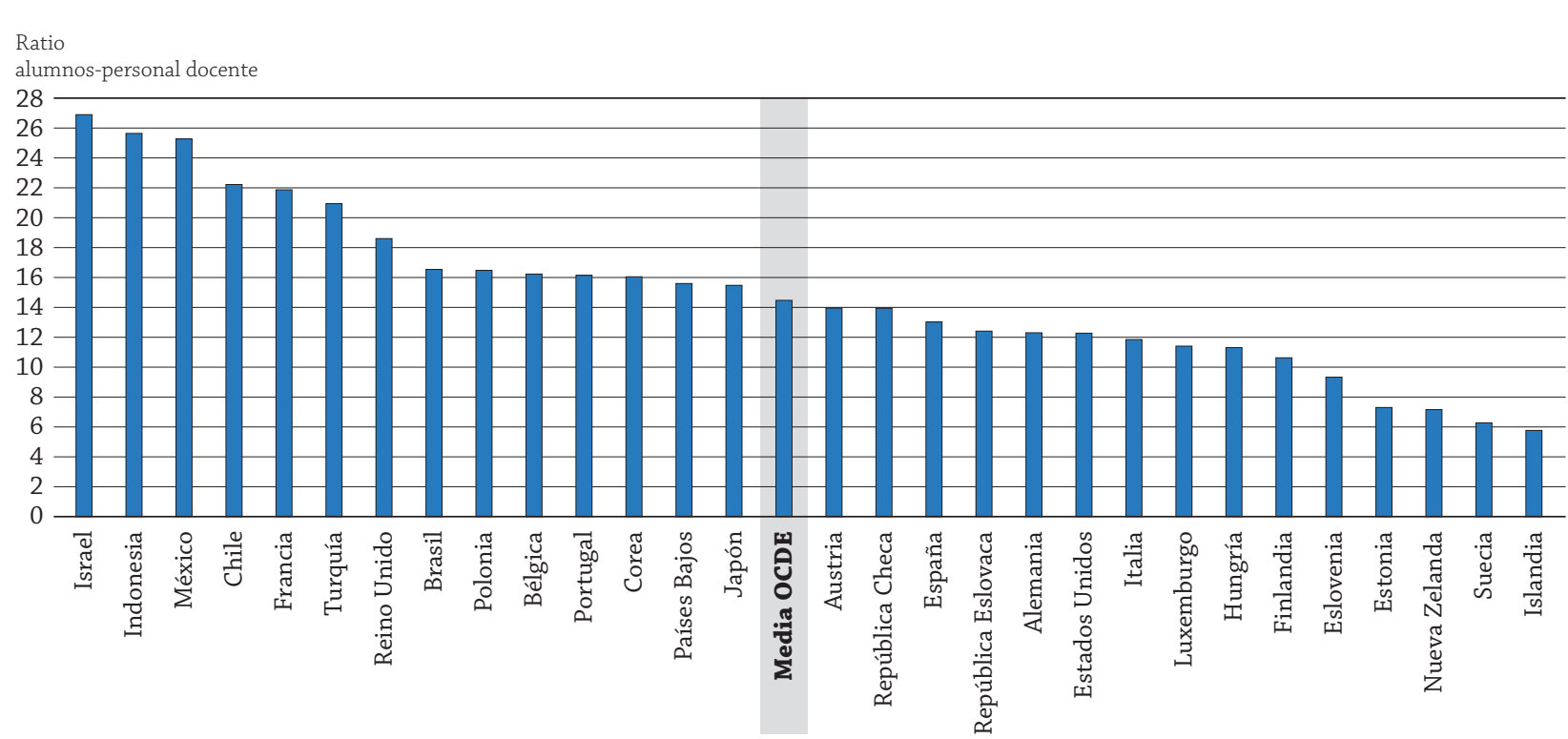

Nota: Las cifras deben interpretarse con cautela, ya que el indicador compara las ratios alumnos-profesor en países con programas «solo educación» y programas integrados «educación y guardería». En algunos países, los requisitos para el personal de estos dos tipos de programa son muy diferentes.

Los países están clasificados en orden descendente de la ratio alumnos-personal docente en educación infantil.

Fuente: OCDE. Tabla C2.2. Para ver notas, consulte Anexo 3 (www.oecd.org/edu/eag.htm).

StatLink 제그 http://dx.doi.org/10.1787/888933118466 
dado entre el número de profesores en equivalentes a tiempo completo en ese nivel y en tipos de instituciones similares. Sin embargo, esta ratio no tiene en cuenta el tiempo de enseñanza en comparación con la duración de la jornada laboral del profesor, ni cuánto tiempo pasan enseñando los profesores. Por tanto, no se puede interpretar en términos del tamaño de la clase. El número de alumnos por clase resume diferentes factores, pero distinguir entre ellos contribuye a identificar diferencias en la calidad de los sistemas educativos (véase Indicador D2).

La Tabla C2.2 muestra la ratio alumnos-personal docente, así como la ratio alumnos-personal de contacto (por ejemplo, profesores y personal no profesional [asistentes educativos]) en educación infantil. Algunos países hacen gran uso de asistentes educativos en el nivel preescolar. Doce países de la OCDE y del G20 refirieron ratios inferiores alumnos-personal de contacto (columna 4 de la Tabla C2.2) que de alumnos-personal docente. Las ratios alumnospersonal de contacto son sustancialmente inferiores en Alemania, Austria, Brasil, Chile, China, Estados Unidos, Francia, Indonesia, Israel y Reino Unido. Como media en los países de la OCDE, hay 15 alumnos por cada profesor en educación infantil. La ratio alumnos-profesor, excluyendo a los asistentes educativos, varía desde más de 20 alumnos por profesor en Chile, Francia, Indonesia, Israel, México y Turquía a menos de 10 en Eslovenia, Estonia, Islandia, Nueva Zelanda y Suecia (Tabla C2.2 y Gráfico C2.4).

\section{Definiciones}

La educación infantil o preescolar (CINE 0) se define como la primera etapa de la enseñanza organizada, diseñada principalmente para introducir a niños muy pequeños en un entorno de tipo escolar.

La distinción entre los programas clasificados como CINE 0 y los que se encuentran fuera del ámbito de CINE 0 se basa sobre todo en las propiedades educativas del programa. Como es difícil evaluar las propiedades de estos programas directamente, se utilizan varias medidas de muestra. Los programas CINE 0:

Incluyen programas de educación infantil que:

- Tienen lugar en un centro escolar o están basados en un entorno escolar.

- Están diseñados para satisfacer las necesidades educativas y de desarrollo de los niños.

- Están diseñados típicamente para niños como mínimo de 3 años de edad y no mayores de 6.

- Tienen personal formado de forma adecuada (esto es, cualificado) para proporcionar un programa educativo a los niños.

Excluyen programas de educación infantil que no cumplen estos criterios.

Los programas de solo educación de educación infantil son aquellos que ofrecen principalmente servicios educativos durante un breve periodo del día. Los padres que trabajan normalmente tienen que utilizar servicios de guardería adicionales por la mañana y/o por la tarde.

Los programas integrados de educación infantil son los que proporcionan tanto educación infantil como servicio de guardería en el mismo programa.

\section{Metodología}

En Panorama de la educación se utilizan dos métodos para clasificar a los alumnos en estudiantes a tiempo completo o a tiempo parcial:

1. Basándose en las definiciones nacionales de los programas de educación infantil.

2. Un método indirecto, derivado de la duración del primer curso de educación primaria (CINE 1).

Aunque el método de clasificación utilizado por los países difiere, esto no afecta a las tasas de escolarización (Tabla (2.1), ya que estas se basan en el número total de niños escolarizados como proporción de la población, independientemente de si los estudiantes lo son a tiempo completo o a tiempo parcial. Las diferencias de los métodos de clasificación pueden tener algún efecto en el gasto por estudiante y en la ratio alumnos-profesor, pues estos datos se basan en cifras de alumnos en equivalentes a tiempo completo.

En Panorama de la educación se excluye el componente de guardería de los programas integrados en las informaciones sobre el gasto, ya que CINE 0 se centra en los aspectos educativos del programa. Los países que no pueden desglosar el gasto de guarderías de los datos que refieren a Panorama de la educación se citan en las notas al pie de la Tabla C2.2. 
La cantidad de gasto en guarderías probablemente varía entre países y es necesario tener cautela al interpretar estos resultados (más detalles en el Cuadro C2.1).

No se pueden presentar algunas variaciones a nivel nacional y en algunos casos se ha simplificado la información acerca de las «características de los programas». Por ejemplo, en algunos países la edad de comienzo de los programas de educación infantil difiere entre jurisdicciones o regiones. En estos casos, se refiere la información más común o típica.

\section{Nota sobre los datos de Israel}

Los datos estadísticos para Israel fueron proporcionados por las autoridades israelíes competentes bajo su responsabilidad. El uso de estos datos por parte de la OCDE se hace sin prejuzgar la situación de los Altos del Golán, Jerusalén Este y los asentamientos israelíes en Cisjordania de acuerdo con los términos del derecho internacional.

\section{Referencias}

Downey, D. B., P. T. von Hippel y B. A. Broh (2004), «Are schools the great equalizer? Cognitive inequality during the summer months and the school year», American Sociological Review, Vol. 69, No. 5, pp. 613-635.

Heckman, J.J. (2000), «The Case for Investing in Disadvantaged Young Children», CESifo DICE Report, Ifo Institute for Economic Research at the University of Munich, Vol. 6, No. 2, pp. 3-8, 07.

OECD (2013a), PISA 2012 Results: What Makes Schools Successful?(Volume IV), PISA, OECD Publishing, París, http://dx.doi. org/10.1787/9789264201156-en

OECD (2013b), Trends Shaping Education 2013, OECD Publishing, París, http://dx.doi.org/10.1787/trends_edu-2013-en

OECD (2013c), «How do early childhood education and care (ECEC) policies, systems and quality vary across OECD countries?» Education Indicators in Focus, febrero, http://dx.doi.org/10.1787/5k49czkz4bq2-en

OECD (2011a), How's Life?, OECD Publishing, París, http://dx.doi.org/10.1787/9789264121164-en

OECD (2011b), Starting Strong III: A Quality Toolbox for Early Childhood Education and Care, OECD Publishing, París, http://dx.doi. org/10.1787/9789264123564-en

OECD (2010), Improving Health and Social Cohesion through Education, Educational Research and Innovation, OECD Publishing, París, http://dx.doi.org/10.1787/9789264086319-en

OECD (2006), Starting Strong II: Early Childhood Education and Care, OECD Publishing, París, http://dx.doi.org/10.1787/ 9789264035461-en

Shin, E., M. Jung y E. Park, E. (2009), «A Survey on the Development of the Pre-school Free Service Model», Research Report of the Korean Educational Development Institute, Seúl.

\section{Tablas del Indicador C2}

StatLink त्राजा http://dx.doi.org/10.1787/888933118333

Tabla C2.1 Tasas de matriculación en educación infantil y primaria, por edad $(2005,2012)$

Tabla C2.2 Características de los programas de educación infantil $(2011,2012)$

Tabla C2.3 Características de los programas de solo educación y educación infantil integrada (2012) 
Tabla C2.1 Tasas de matriculación en educación infantil y primaria, por edad ( 2005, 2012)

\begin{tabular}{|c|c|c|c|c|c|c|c|c|c|c|c|c|c|c|c|c|c|c|c|c|}
\hline & \multicolumn{10}{|c|}{ Tasas de matriculación (2012) } & \multicolumn{10}{|c|}{ Tasas de matriculación (2005) } \\
\hline & \multirow{2}{*}{\begin{tabular}{|c|}
3 años \\
0 \\
至 \\
\end{tabular}} & \multicolumn{3}{|c|}{4 años } & \multicolumn{3}{|c|}{5 años } & \multicolumn{3}{|c|}{6 años } & \multirow{2}{*}{\begin{tabular}{|c|}
3 años \\
0 \\
四 \\
y
\end{tabular}} & \multicolumn{3}{|c|}{4 años } & \multicolumn{3}{|c|}{5 años } & \multicolumn{3}{|c|}{6 años } \\
\hline & & 옳 & 寽 & సٓ & 엄 & 坖 & 胥 & 옴 & 秥 & 胥 & & 엄 & 壬 & సّٓ & 옳 & 式 & 宕 & 옳 & 秥 & సّٓ \\
\hline & (1) & (2) & (3) & (4) & (5) & (6) & (7) & (8) & (9) & (10) & (11) & (12) & $(13)$ & $(14)$ & (15) & (16) & (17) & (18) & (19) & (20) \\
\hline Alemania ${ }^{2}$ & 91 & 96 & $\mathrm{n}$ & 96 & 97 & $\mathrm{n}$ & 97 & 33 & 64 & 98 & 82 & 93 & $\mathrm{n}$ & 93 & 93 & $\mathrm{n}$ & 93 & 38 & 58 & 96 \\
\hline Australia & 18 & 74 & 1 & 76 & 16 & 86 & 100 & $\mathrm{n}$ & 100 & 100 & 17 & 51 & 2 & 53 & 18 & 72 & 91 & $\mathrm{n}$ & 100 & 100 \\
\hline Austria & 65 & 91 & $\mathrm{n}$ & 91 & 96 & $\mathrm{n}$ & 96 & 38 & 59 & 97 & 47 & 82 & $\mathrm{n}$ & 82 & 93 & $\mathrm{n}$ & 93 & 39 & 57 & 96 \\
\hline Bélgica & 98 & 99 & $\mathrm{n}$ & 99 & 98 & 1 & 99 & 5 & 94 & 98 & 100 & 100 & $\mathrm{n}$ & 100 & 99 & 1 & 100 & 6 & 94 & 100 \\
\hline Canadá & $\mathrm{m}$ & $\mathrm{m}$ & $\mathrm{m}$ & $\mathrm{m}$ & $\mathrm{m}$ & $\mathrm{m}$ & $\mathrm{m}$ & $\mathrm{m}$ & $\mathrm{m}$ & $\mathrm{m}$ & $\mathrm{m}$ & $\mathrm{m}$ & $\mathrm{m}$ & $\mathrm{m}$ & $\mathrm{m}$ & $\mathrm{m}$ & $\mathrm{m}$ & $\mathrm{m}$ & $\mathrm{m}$ & $\mathrm{m}$ \\
\hline Chile & 45 & 79 & $\mathrm{n}$ & 79 & 88 & 2 & 90 & 11 & 80 & 91 & $\mathrm{~m}$ & $\mathrm{~m}$ & $\mathrm{~m}$ & $\mathrm{~m}$ & $\mathrm{~m}$ & $\mathrm{~m}$ & $\mathrm{~m}$ & $\mathrm{~m}$ & $\mathrm{~m}$ & $\mathrm{~m}$ \\
\hline Corea & 85 & 87 & $\mathrm{n}$ & 87 & 88 & 1 & 88 & 1 & 94 & 95 & $\mathrm{~m}$ & $\mathrm{~m}$ & $\mathrm{~m}$ & $\mathrm{~m}$ & $\mathrm{~m}$ & $\mathrm{~m}$ & $\mathrm{~m}$ & $\mathrm{~m}$ & $\mathrm{~m}$ & $\mathrm{~m}$ \\
\hline Dinamarca $^{1}$ & 97 & 98 & $\mathrm{n}$ & 98 & 96 & 2 & 98 & 8 & 91 & 99 & 91 & 93 & $\mathrm{n}$ & 93 & 84 & $\mathrm{n}$ & 84 & 95 & 3 & 98 \\
\hline Eslovenia & 85 & 89 & $\mathrm{n}$ & 89 & 92 & $\mathrm{x}(9)$ & 92 & 6 & 93 & 99 & 67 & 76 & $\mathrm{n}$ & 76 & 84 & $\mathrm{n}$ & 84 & 4 & 96 & 100 \\
\hline España & 95 & 97 & $\mathrm{n}$ & 97 & 98 & $\mathrm{n}$ & 98 & 1 & 97 & 97 & 95 & 99 & $\mathrm{n}$ & 99 & 100 & $\mathrm{n}$ & 100 & 1 & 99 & 100 \\
\hline Estados Unidos & 38 & 66 & $\mathrm{n}$ & 66 & 87 & 5 & 93 & 21 & 77 & 98 & 39 & 68 & $\mathrm{n}$ & 68 & 87 & 6 & 93 & 18 & 80 & 98 \\
\hline Estonia & 89 & 89 & $\mathrm{n}$ & 89 & 91 & $\mathrm{n}$ & 91 & 78 & 14 & 91 & 81 & 84 & $\mathrm{n}$ & 84 & 88 & $\mathrm{n}$ & 88 & 100 & 12 & 100 \\
\hline Finlandia & 51 & 59 & $\mathrm{n}$ & 59 & 68 & $\mathrm{n}$ & 68 & 98 & 1 & 98 & 38 & 47 & $\mathrm{n}$ & 47 & 56 & $\mathrm{n}$ & 56 & 98 & 1 & 99 \\
\hline Francia & 98 & 100 & $\mathrm{n}$ & 100 & 100 & 1 & 100 & 1 & 98 & 100 & 100 & 100 & $\mathrm{n}$ & 100 & 99 & 1 & 100 & 2 & 94 & 96 \\
\hline Grecia & a & 53 & a & 53 & 94 & $\mathrm{a}$ & 94 & 2 & 96 & 98 & a & 58 & a & 58 & 83 & 2 & 84 & $\mathrm{n}$ & 100 & 100 \\
\hline Hungría & 74 & 93 & $\mathrm{n}$ & 93 & 96 & $\mathrm{n}$ & 96 & 71 & 23 & 94 & 73 & 91 & $\mathrm{n}$ & 91 & 97 & $\mathrm{n}$ & 97 & 74 & 25 & 99 \\
\hline Irlanda & 42 & 58 & 39 & 97 & 1 & 99 & 100 & $\mathrm{n}$ & 100 & 100 & $\mathrm{~m}$ & $\mathrm{~m}$ & $\mathrm{~m}$ & $\mathrm{~m}$ & $\mathrm{~m}$ & $\mathrm{~m}$ & $\mathrm{~m}$ & $\mathrm{~m}$ & $\mathrm{~m}$ & $\mathrm{~m}$ \\
\hline Islandia & 96 & 96 & $\mathrm{n}$ & 96 & 98 & $\mathrm{n}$ & 98 & $\mathrm{n}$ & 98 & 98 & 94 & 95 & $\mathrm{n}$ & 95 & 96 & $\mathrm{n}$ & 96 & $\mathrm{n}$ & 98 & 98 \\
\hline Israel & 86 & 92 & $\mathrm{n}$ & 92 & 96 & $\mathrm{n}$ & 97 & 13 & 84 & 97 & 67 & 84 & $\mathrm{n}$ & 84 & 93 & $\mathrm{n}$ & 94 & 13 & 81 & 95 \\
\hline Italia & 92 & 96 & a & 96 & 89 & 8 & 97 & 1 & 97 & 98 & 97 & 100 & $\mathrm{a}$ & 100 & 94 & 7 & 100 & 1 & 100 & 100 \\
\hline Japón & 78 & 94 & a & 94 & 95 & $a$ & 95 & a & 100 & 100 & 69 & 95 & a & 95 & 99 & a & 99 & a & 100 & 100 \\
\hline Luxemburgo $^{3}$ & 73 & 98 & $\mathrm{n}$ & 98 & 93 & 5 & 98 & 5 & 93 & 98 & 62 & 96 & $\mathrm{n}$ & 96 & 92 & 3 & 95 & 3 & 97 & 100 \\
\hline México & 39 & 87 & $\mathrm{n}$ & 87 & 83 & 28 & 100 & 1 & 100 & 100 & 23 & 70 & a & 70 & 88 & 10 & 98 & 1 & 100 & 100 \\
\hline Noruega & 95 & 97 & $\mathrm{n}$ & 97 & 97 & $\mathrm{n}$ & 97 & 1 & 100 & 100 & 83 & 89 & $\mathrm{n}$ & 89 & 91 & $\mathrm{n}$ & 91 & 1 & 99 & 100 \\
\hline Nueva Zelanda & 87 & 94 & $\mathrm{n}$ & 94 & 3 & 96 & 99 & $\mathrm{n}$ & 100 & 100 & 84 & 94 & $\mathrm{n}$ & 94 & 3 & 97 & 100 & $\mathrm{n}$ & 100 & 100 \\
\hline Países Bajos & 83 & 100 & $\mathrm{a}$ & 100 & 100 & $\mathrm{a}$ & 100 & $\mathrm{a}$ & 100 & 100 & $\mathrm{~m}$ & $\mathrm{~m}$ & $\mathrm{~m}$ & $\mathrm{~m}$ & $\mathrm{~m}$ & $\mathrm{~m}$ & $\mathrm{~m}$ & $\mathrm{~m}$ & $\mathrm{~m}$ & $\mathrm{~m}$ \\
\hline Polonia & 51 & 65 & $\mathrm{a}$ & 65 & 94 & $\mathrm{x}(9)$ & 94 & 76 & 19 & 95 & 28 & 38 & $\mathrm{a}$ & 38 & 48 & $\mathrm{~m}$ & 48 & 98 & 1 & 99 \\
\hline Portugal & 78 & 92 & $\mathrm{n}$ & 92 & 98 & $\mathrm{n}$ & 98 & 5 & 96 & 100 & 61 & 84 & $\mathrm{n}$ & 84 & 87 & 3 & 90 & 3 & 100 & 100 \\
\hline Reino Unido & 93 & 61 & 37 & 98 & 1 & 97 & 98 & $\mathrm{n}$ & 98 & 98 & 78 & 60 & 32 & 92 & $\mathrm{n}$ & 100 & 100 & $\mathrm{n}$ & 100 & 100 \\
\hline República Checa & 59 & 82 & $\mathrm{n}$ & 82 & 90 & $\mathrm{n}$ & 90 & 51 & 48 & 99 & 65 & 91 & $\mathrm{n}$ & 91 & 97 & $\mathrm{n}$ & 97 & 49 & 51 & 100 \\
\hline República Eslovaca & 63 & 73 & $\mathrm{n}$ & 73 & 81 & $\mathrm{n}$ & 81 & 40 & 50 & 91 & 61 & 74 & $\mathrm{n}$ & 74 & 85 & $\mathrm{n}$ & 85 & 40 & 54 & 94 \\
\hline Suecia & 93 & 94 & $\mathrm{n}$ & 94 & 95 & $\mathrm{n}$ & 95 & 97 & 1 & 98 & 84 & 89 & $\mathrm{n}$ & 89 & 90 & $\mathrm{n}$ & 90 & 96 & 3 & 99 \\
\hline Suiza & 3 & 40 & $\mathrm{n}$ & 40 & 94 & 1 & 96 & 54 & 44 & 99 & 8 & 38 & $\mathrm{n}$ & 39 & 90 & 1 & 91 & 60 & 40 & 100 \\
\hline Turquía & 5 & 19 & $\mathrm{n}$ & 19 & 70 & $\mathrm{n}$ & 70 & $\mathrm{n}$ & 96 & 96 & 2 & 5 & $\mathrm{n}$ & 5 & 23 & 8 & 32 & $\mathrm{n}$ & 83 & 83 \\
\hline Media OCDE & 70 & 82 & 2 & 84 & 81 & 13 & 94 & 22 & 76 & 98 & 64 & 77 & 1 & 79 & 77 & 11 & 88 & 29 & 70 & 99 \\
\hline $\begin{array}{l}\text { Media OCDE para } \\
\text { países con datos } \\
\text { en } 2005 \text { y } 2012\end{array}$ & 71 & 82 & 1 & 84 & 83 & 11 & 94 & 24 & 74 & 98 & 64 & 77 & 1 & 79 & 77 & 11 & 88 & 29 & 70 & 99 \\
\hline Media UE21 & 79 & 85 & 4 & 89 & 84 & 10 & 94 & 29 & 68 & 97 & 73 & 82 & 2 & 84 & 83 & 6 & 89 & 39 & 61 & 100 \\
\hline Arabia Saudí & $\mathrm{m}$ & $\mathrm{m}$ & $\mathrm{m}$ & $\mathrm{m}$ & $\mathrm{m}$ & $\mathrm{m}$ & $\mathrm{m}$ & $\mathrm{m}$ & $\mathrm{m}$ & $\mathrm{m}$ & $\mathrm{m}$ & $\mathrm{m}$ & $\mathrm{m}$ & $\mathrm{m}$ & $\mathrm{m}$ & $\mathrm{m}$ & $\mathrm{m}$ & $\mathrm{m}$ & $\mathrm{m}$ & $\mathrm{m}$ \\
\hline Argentina & 38 & 77 & $\mathrm{n}$ & 77 & 100 & $\mathrm{n}$ & 100 & $\mathrm{n}$ & 100 & 100 & $\mathrm{~m}$ & $\mathrm{~m}$ & $\mathrm{~m}$ & $\mathrm{~m}$ & $\mathrm{~m}$ & $\mathrm{~m}$ & $\mathrm{~m}$ & $\mathrm{~m}$ & $\mathrm{~m}$ & $\mathrm{~m}$ \\
\hline Brasil & 37 & 61 & $\mathrm{n}$ & 61 & 82 & $\mathrm{n}$ & 83 & 54 & 37 & 91 & 21 & 37 & $\mathrm{n}$ & 37 & 62 & 1 & 63 & 63 & 21 & 83 \\
\hline China & $\mathrm{m}$ & $\mathrm{m}$ & $\mathrm{n}$ & $\mathrm{m}$ & $\mathrm{m}$ & $\mathrm{n}$ & $\mathrm{m}$ & $\mathrm{n}$ & $\mathrm{m}$ & $\mathrm{m}$ & $\mathrm{m}$ & $\mathrm{m}$ & $\mathrm{m}$ & $\mathrm{m}$ & $\mathrm{m}$ & $\mathrm{m}$ & $\mathrm{m}$ & $\mathrm{m}$ & $\mathrm{m}$ & $\mathrm{m}$ \\
\hline Colombia & 10 & 32 & 1 & 33 & 65 & 15 & 80 & 8 & 79 & 87 & $\mathrm{~m}$ & $\mathrm{~m}$ & $\mathrm{~m}$ & $\mathrm{~m}$ & $\mathrm{~m}$ & $\mathrm{~m}$ & $\mathrm{~m}$ & $\mathrm{~m}$ & $\mathrm{~m}$ & $\mathrm{~m}$ \\
\hline Federación Rusa & 70 & 77 & $\mathrm{a}$ & 77 & 80 & $\mathrm{n}$ & 80 & 72 & 12 & 84 & $\mathrm{~m}$ & $\mathrm{~m}$ & a & $\mathrm{m}$ & $\mathrm{m}$ & $\mathrm{n}$ & $\mathrm{m}$ & $\mathrm{m}$ & 23 & $\mathrm{~m}$ \\
\hline India & $\mathrm{m}$ & $\mathrm{m}$ & $\mathrm{m}$ & $\mathrm{m}$ & $\mathrm{m}$ & $\mathrm{m}$ & $\mathrm{m}$ & $\mathrm{m}$ & $\mathrm{m}$ & $\mathrm{m}$ & $\mathrm{m}$ & $\mathrm{m}$ & $\mathrm{m}$ & $\mathrm{m}$ & $\mathrm{m}$ & $\mathrm{m}$ & $\mathrm{m}$ & $\mathrm{m}$ & $\mathrm{m}$ & $\mathrm{m}$ \\
\hline Indonesia & 5 & 25 & $\mathrm{n}$ & 25 & 41 & 4 & 46 & 24 & 72 & 97 & $\mathrm{~m}$ & $\mathrm{~m}$ & $\mathrm{~m}$ & $\mathrm{~m}$ & $\mathrm{~m}$ & $\mathrm{~m}$ & $\mathrm{~m}$ & $\mathrm{~m}$ & $\mathrm{~m}$ & $\mathrm{~m}$ \\
\hline Letonia & 80 & 87 & $\mathrm{n}$ & 87 & 96 & $\mathrm{n}$ & 96 & 92 & 5 & 97 & $\mathrm{~m}$ & $\mathrm{~m}$ & $\mathrm{~m}$ & $\mathrm{~m}$ & $\mathrm{~m}$ & $\mathrm{~m}$ & $\mathrm{~m}$ & $\mathrm{~m}$ & $\mathrm{~m}$ & $\mathrm{~m}$ \\
\hline Sudáfrica & $\mathrm{m}$ & $\mathrm{m}$ & $\mathrm{m}$ & $\mathrm{m}$ & $\mathrm{m}$ & $\mathrm{m}$ & $\mathrm{m}$ & $\mathrm{m}$ & $\mathrm{m}$ & $\mathrm{m}$ & $\mathrm{m}$ & $\mathrm{m}$ & $\mathrm{m}$ & $\mathrm{m}$ & $\mathrm{m}$ & $\mathrm{m}$ & $\mathrm{m}$ & $\mathrm{m}$ & $\mathrm{m}$ & $\mathrm{m}$ \\
\hline
\end{tabular}

Nota: Las tasas de matriculación a edades tempranas han de interpretarse con cautela; la falta de coincidencia entre la cobertura de los datos de población y los datos de matriculación significa que las tasas de participación se han podido subestimar para países como Luxemburgo, que son exportadores netos de estudiantes, y se han podido sobreestimar para los países que no importan estudiantes.

1. Se han incluido las clases obligatorias en CINE 1 a partir de 2011.

2. Año de referencia 2006 en lugar de 2005.

3. Subestimado porque muchos estudiantes residentes acuden a centros escolares en los países vecinos.

Fuentes: OCDE. Arabia Saudí, Argentina, China, Colombia, India, Indonesia, Sudáfrica: Instituto de Estadística de la UNESCO. Letonia: Eurostat. Para ver notas, consulte Anexo 3 (www.oecd.org/edu/eag.htm).

Para obtener más información acerca de los símbolos utilizados en lugar de los datos que faltan, consulte la Guía del lector.

StatLink 제기 http://dx.doi.org/10.1787/888933118352 
Tabla C2.2. Características de los programas de educación infantil $(2011,2012)$

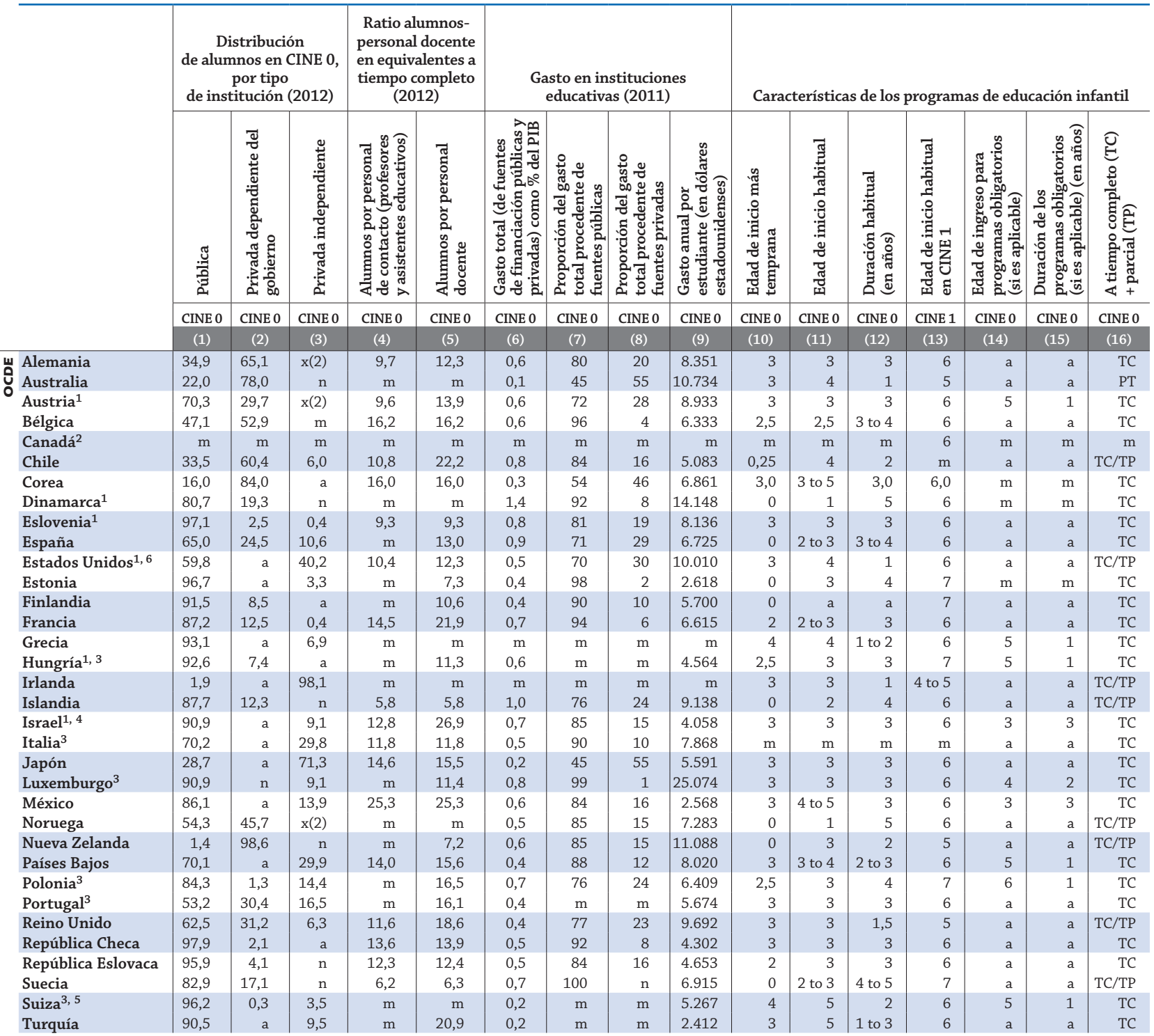

Media OCDE

Total OCDE

Media UE21

\begin{tabular}{|c|c|c|c|c|c|c|c|c|c|c|c|c|c|c|c|c|}
\hline $\begin{array}{l}\text { Arabia Saudí } \\
\text { đargentina }\end{array}$ & $\begin{array}{l}59,3 \\
68,1\end{array}$ & $\begin{array}{l}40,7 \\
24,7\end{array}$ & $\begin{array}{r}x(2) \\
7,2\end{array}$ & $\begin{array}{l}\mathrm{m} \\
\mathrm{m}\end{array}$ & $\begin{array}{l}\mathrm{m} \\
\mathrm{m}\end{array}$ & $\begin{array}{r}\mathrm{m} \\
0,7\end{array}$ & $\begin{array}{r}\mathrm{m} \\
74\end{array}$ & $\begin{array}{l}\mathrm{m} \\
26\end{array}$ & $\begin{array}{r}\mathrm{m} \\
1.979\end{array}$ & $\begin{array}{l}\mathrm{m} \\
\mathrm{m}\end{array}$ & $\begin{array}{l}\mathrm{m} \\
\mathrm{m}\end{array}$ & $\begin{array}{l}\mathrm{m} \\
\mathrm{m}\end{array}$ & $\begin{array}{l}\mathrm{m} \\
\mathrm{m}\end{array}$ & $\begin{array}{l}\mathrm{m} \\
\mathrm{m}\end{array}$ & $\begin{array}{l}\mathrm{m} \\
\mathrm{m}\end{array}$ & $\begin{array}{l}\mathrm{m} \\
\mathrm{TC}\end{array}$ \\
\hline Brasil ${ }^{1}$ & 71,0 & a & 29,0 & 12,2 & 16,5 & 0,5 & $\mathrm{~m}$ & $\mathrm{~m}$ & 2.349 & 0 & 1 & 5 & 6 & 4 & 2 & TC \\
\hline China & 50,5 & 49,5 & $x(2)$ & $\mathrm{m}$ & $\mathrm{m}$ & $\mathrm{m}$ & $\mathrm{m}$ & $\mathrm{m}$ & $\mathrm{m}$ & $\mathrm{m}$ & $\mathrm{m}$ & $\mathrm{m}$ & $\mathrm{m}$ & $\mathrm{m}$ & $\mathrm{m}$ & $\mathrm{TC}$ \\
\hline Colombia & 64,3 & a & 35,7 & $\mathrm{~m}$ & $\mathrm{~m}$ & 0,5 & 54 & 46 & 1.301 & $\mathrm{~m}$ & $\mathrm{~m}$ & $\mathrm{~m}$ & $\mathrm{~m}$ & $\mathrm{~m}$ & $\mathrm{~m}$ & $\mathrm{~m}$ \\
\hline ¿ Federación Rusa & 99,1 & a & 0,9 & $\mathrm{~m}$ & $\mathrm{~m}$ & 0,8 & 89 & 11 & $\mathrm{~m}$ & $\mathrm{~m}$ & $\mathrm{~m}$ & $\mathrm{~m}$ & $\mathrm{~m}$ & $\mathrm{~m}$ & $\mathrm{~m}$ & $\mathrm{~m}$ \\
\hline India & $\mathrm{m}$ & $\mathrm{m}$ & $\mathrm{m}$ & $\mathrm{m}$ & $\mathrm{m}$ & $\mathrm{m}$ & $\mathrm{m}$ & $\mathrm{m}$ & $\mathrm{m}$ & $\mathrm{m}$ & $\mathrm{m}$ & $\mathrm{m}$ & $\mathrm{m}$ & $\mathrm{m}$ & $\mathrm{m}$ & $\mathrm{m}$ \\
\hline Indonesia & 2,8 & a & 97,2 & 23,0 & 25,6 & $\mathrm{~m}$ & 90 & 10 & 205 & $\mathrm{~m}$ & $\mathrm{~m}$ & $\mathrm{~m}$ & $\mathrm{~m}$ & $\mathrm{~m}$ & $\mathrm{~m}$ & $\mathrm{TC}$ \\
\hline Letonia & 94,9 & a & 5,1 & $\mathrm{~m}$ & $\mathrm{~m}$ & 0,8 & 98 & 2 & 4.359 & $\mathrm{~m}$ & $\mathrm{~m}$ & $\mathrm{~m}$ & $\mathrm{~m}$ & $\mathrm{~m}$ & $\mathrm{~m}$ & $\mathrm{~m}$ \\
\hline Sudáfrica & 93,9 & 6,1 & $x(2)$ & $\mathrm{m}$ & $\mathrm{m}$ & $\mathrm{m}$ & $\mathrm{m}$ & $\mathrm{m}$ & $\mathrm{m}$ & $\mathrm{m}$ & $\mathrm{m}$ & $\mathrm{m}$ & $\mathrm{m}$ & $\mathrm{m}$ & $\mathrm{m}$ & $\mathrm{m}$ \\
\hline Media G20 & 59,3 & 23,1 & 17,6 & 14,4 & 17,0 & 0,5 & 74 & 26 & 5.854 & $\mathrm{~m}$ & $\mathrm{~m}$ & $\mathrm{~m}$ & $\mathrm{~m}$ & $\mathrm{~m}$ & $\mathrm{~m}$ & $\mathrm{~m}$ \\
\hline
\end{tabular}

1. Incluye algo de gasto en guarderías.

2. Los programas CINE 0 están disponibles en las 13 jurisdicciones y son obligatorios para los estudiantes en dos jurisdicciones. La edad de inicio más temprana, la edad de inicio habitual y la duración de los programas CINE 0 varían dependiendo de la jurisdicción.

3. Los datos sobre gastos se refieren solo a las instituciones públicas.

4. Según una ley recientemente promulgada, los programas CINE 0 son obligatorios y gratuitos en todo el país. Su aplicación empezará gradualmente a partir de 2013. 5. Los programas CINE 0 son obligatorios por dos años en algunas jurisdicciones y por solo un año en otras.

6. Los programas CINE 0 son obligatorios en alrededor de un tercio de los estados.

Fuentes: OCDE. Arabia Saudí, Argentina, China, Colombia, India, Indonesia, Sudáfrica: Instituto de Estadística de la UNESCO. Letonia: Eurostat. Para ver notas, consulte Anexo 3 (www.oecd.org/edu/eag.htm).

Para obtener más información acerca de los símbolos utilizados en lugar de los datos que faltan, consulte la Guía del lector.

StatLink 젶ㄴ http://dx.doi.org/10.1787/888933118371 
Tabla C2.3 Características de los programas de solo educación y educación infantil integrada (2012)

Existencia y características de los programas de solo educación y de educación infantil integrada

Proporción de matriculaciones en Panorama de la educación de los programas de solo educación y de educación infantil integrada

\begin{tabular}{|c|c|c|c|c|c|c|c|c|c|}
\hline & \multicolumn{3}{|c|}{ Programas de solo educación } & \multicolumn{3}{|c|}{$\begin{array}{c}\text { Programas integrados } \\
\text { (incluyen educación y guardería) }\end{array}$} & \multicolumn{3}{|c|}{$\begin{array}{l}\text { Proporción relativa de matriculaciones } \\
\text { comunicadas en Panorama de la educación }\end{array}$} \\
\hline & $\begin{array}{c}\text { Existen } \\
\text { a nivel } \\
\text { nacional }\end{array}$ & $\begin{array}{l}\text { Impartidos } \\
\text { por } \\
\text { profesores } \\
\text { cualificados }\end{array}$ & $\begin{array}{l}\text { Tienen un } \\
\text { currículo } \\
\text { oficial }\end{array}$ & $\begin{array}{c}\text { Existen } \\
\text { a nivel } \\
\text { nacional }\end{array}$ & $\begin{array}{l}\text { Impartidos } \\
\text { por } \\
\text { profesores } \\
\text { cualificados }\end{array}$ & $\begin{array}{c}\text { Tienen } \\
\text { un currículo } \\
\text { oficial }\end{array}$ & $\begin{array}{c}\text { Programas } \\
\text { de solo } \\
\text { educación }\end{array}$ & $\begin{array}{l}\text { Programas } \\
\text { integrados }\end{array}$ & Total \\
\hline & (1) & (2) & (3) & (4) & (5) & (6) & (7) & (8) & (9) \\
\hline Alemania & Sí & Sí & Sí & No & $\mathrm{a}$ & $\mathrm{a}$ & 100 & $\mathrm{a}$ & 100 \\
\hline Australia & Sí & Sí & Sí & Sí & Sí & Sí & $\mathrm{x}(9)$ & $\mathrm{x}(9)$ & 100 \\
\hline Austria & Sí & Sí & Sí & Sí & Sí & No & 3 & 97 & 100 \\
\hline Bélgica & Sí & Sí & Sí & No & $\mathrm{a}$ & a & 100 & a & 100 \\
\hline Canadá & Sí & Sí & Sí & Sí & Sí & Sí & $\mathrm{m}$ & $\mathrm{m}$ & $\mathrm{m}$ \\
\hline Chile & Sí & Sí & Sí & Sí & Sí & Sí & $\mathrm{x}(9)$ & $\mathrm{x}(9)$ & 100 \\
\hline Corea & Sí & Sí & Sí & Sí & Sí & Sí & $\mathrm{x}(9)$ & $\mathrm{x}(9)$ & 100 \\
\hline Dinamarca & No & a & a & Sí & Sí & Sí & $\mathrm{a}$ & 100 & 100 \\
\hline Eslovenia & No & a & a & Sí & Sí & Sí & a & 100 & 100 \\
\hline España & Sí & Sí & Sí & No & a & a & 100 & a & 100 \\
\hline Estados Unidos & Sí & Varía & Varía & Sí & Varía & Varía & $\mathrm{x}(9)$ & $\mathrm{x}(9)$ & 100 \\
\hline Estonia & No & $\mathrm{a}$ & $\mathrm{a}$ & Sí & Sí & Sí & a & 100 & 100 \\
\hline Finlandia & Sí & Sí & Sí & Sí & Sí & Sí & 37 & 63 & 100 \\
\hline Francia & Sí & Sí & Sí & No & $\mathrm{a}$ & a & 100 & $\mathrm{a}$ & 100 \\
\hline Grecia & Sí & Sí & Sí & Sí & $\mathrm{m}$ & $\mathrm{m}$ & 100 & $\mathrm{~m}$ & 100 \\
\hline Hungría & No & a & a & Sí & Sí & Sí & $\mathrm{a}$ & 100 & 100 \\
\hline Irlanda & No & $\mathrm{a}$ & $\mathrm{a}$ & Sí & a & a & a & 100 & 100 \\
\hline Islandia & Sí & Sí & Sí & Sí & Sí & Sí & 1 & 99 & 100 \\
\hline Israel & Sí & Sí & Sí & Sí & Sí & Sí & 98 & 2 & 100 \\
\hline Italia $^{3}$ & No & $\mathrm{a}$ & $\mathrm{a}$ & Sí & $\mathrm{m}$ & $\mathrm{m}$ & $\mathrm{a}$ & 100 & $\mathrm{~m}$ \\
\hline Japón & Sí & Sí & Sí & Sí & Varía & Varía & $\mathrm{x}(9)$ & $\mathrm{x}(9)$ & 100 \\
\hline Luxemburgo & Sí & Sí & Sí & No & $\mathrm{a}$ & a & 100 & a & 100 \\
\hline México & Sí & Sí & Sí & Sí & Sí & Sí & 99 & 1 & 100 \\
\hline Noruega & No & $\mathrm{a}$ & $\mathrm{a}$ & Sí & Sí & Sí & a & 100 & 100 \\
\hline Nueva Zelanda & No & a & $\mathrm{a}$ & Sí & Sí & Sí & a & 100 & 100 \\
\hline Países Bajos & Sí & Sí & Sí & Sí & No & Varía & 70 & 30 & 100 \\
\hline Polonia & Sí & Sí & Sí & No & a & $\mathrm{a}$ & 100 & $\mathrm{a}$ & 100 \\
\hline Portugal & No & a & a & Sí & Sí & Sí & $\mathrm{a}$ & 100 & 100 \\
\hline Reino Unido & Sí & Sí & Sí & Sí & Varía & Sí & $\mathrm{x}(9)$ & $\mathrm{x}(9)$ & 100 \\
\hline República Checa & Sí & Sí & Sí & No & a & a & 100 & a & 100 \\
\hline República Eslovaca & Sí & Sí & Sí & No & a & a & 100 & $\mathrm{a}$ & 100 \\
\hline Suecia & Sí & Sí & Sí & Sí & Sí & Sí & 25 & 75 & 100 \\
\hline Suiza & Sí & Sí & Sí & Sí & Sí & $\mathrm{m}$ & 100 & $\mathrm{~m}$ & 100 \\
\hline Turquía & Sí & Sí & Sí & No & a & a & 100 & a & 100 \\
\hline \multicolumn{10}{|l|}{$\begin{array}{l}\text { Media OCDE } \\
\text { Total OCDE } \\
\text { Media UE21 }\end{array}$} \\
\hline Arabia Saudí & $\mathrm{m}$ & $\mathrm{m}$ & $\mathrm{m}$ & $\mathrm{m}$ & $\mathrm{m}$ & $\mathrm{m}$ & $\mathrm{m}$ & $\mathrm{m}$ & $\mathrm{m}$ \\
\hline Argentina & $\mathrm{m}$ & $\mathrm{m}$ & $\mathrm{m}$ & $\mathrm{m}$ & $\mathrm{m}$ & $\mathrm{m}$ & $\mathrm{m}$ & $\mathrm{m}$ & $\mathrm{m}$ \\
\hline Brasil & Sí & Sí & No & Sí & Sí & No & $\mathrm{x}(9)$ & $\mathrm{x}(9)$ & 100 \\
\hline China & $\mathrm{m}$ & $\mathrm{m}$ & $\mathrm{m}$ & $\mathrm{m}$ & $\mathrm{m}$ & $\mathrm{m}$ & $\mathrm{m}$ & $\mathrm{m}$ & $\mathrm{m}$ \\
\hline Colombia & $\mathrm{m}$ & $\mathrm{m}$ & $\mathrm{m}$ & $\mathrm{m}$ & $\mathrm{m}$ & $\mathrm{m}$ & $\mathrm{m}$ & $\mathrm{m}$ & $\mathrm{m}$ \\
\hline Federación Rusa & $\mathrm{m}$ & $\mathrm{m}$ & $\mathrm{m}$ & $\mathrm{m}$ & $\mathrm{m}$ & $\mathrm{m}$ & $\mathrm{m}$ & $\mathrm{m}$ & $\mathrm{m}$ \\
\hline India & $\mathrm{m}$ & $\mathrm{m}$ & $\mathrm{m}$ & $\mathrm{m}$ & $\mathrm{m}$ & $\mathrm{m}$ & $\mathrm{m}$ & $\mathrm{m}$ & $\mathrm{m}$ \\
\hline Indonesia & $\mathrm{m}$ & $\mathrm{m}$ & $\mathrm{m}$ & $\mathrm{m}$ & $\mathrm{m}$ & $\mathrm{m}$ & $\mathrm{m}$ & $\mathrm{m}$ & $\mathrm{m}$ \\
\hline Letonia & $\mathrm{m}$ & $\mathrm{m}$ & $\mathrm{m}$ & $\mathrm{m}$ & $\mathrm{m}$ & $\mathrm{m}$ & $\mathrm{m}$ & $\mathrm{m}$ & $\mathrm{m}$ \\
\hline Sudáfrica & $\mathrm{m}$ & $\mathrm{m}$ & $\mathrm{m}$ & $\mathrm{m}$ & $\mathrm{m}$ & $\mathrm{m}$ & $\mathrm{m}$ & $\mathrm{m}$ & $\mathrm{m}$ \\
\hline
\end{tabular}

Fuentes: OCDE, Grupo de trabajo INES, recopilación de datos especial de programas educativos de educación infantil. Para ver notas, consulte Anexo 3 (www.oecd. org/edu/eag.htm).

Para obtener más información acerca de los símbolos utilizados en lugar de los datos que faltan, consulte la Guía del lector.

StatLink त्ञाता http://dx.doi.org/10.1787/888933118390 


\section{¿CUÁNTOS ESTUDIANTES SE ESPERA QUE ACCEDAN A LA EDUCACIÓN TERCIARIA?}

- Aunque se estima que el $58 \%$ de los adultos jóvenes de los países de la OCDE accederán a programas de educación terciaria de tipo A (principalmente de base teórica) a lo largo de su vida, menos del $3 \%$ accederán a programas de investigación avanzada.

- Los ámbitos de estudio más populares elegidos por los estudiantes que acceden por primera vez a programas de educación terciaria son ciencias sociales, administración de empresas y derecho en todos los países de la OCDE, excepto Arabia Saudí (humanidades, artes y educación), Corea (humanidades, artes y educación) y Finlandia (ingeniería, industria y construcción)

- Las tasas de ingreso en los programas de educación terciaria de tipo A siguen siendo mayores para las mujeres $(65 \%)$ que para los hombres $(52 \%)$ como media en los países de la OCDE. Pero cuanto mayor es el nivel de educación, menor es esta diferencia; y en los programas de investigación avanzada, la brecha casi desaparece.

\section{Gráfico C3.1. Tasas de ingreso en educación terciaria de tipo A (2012)}
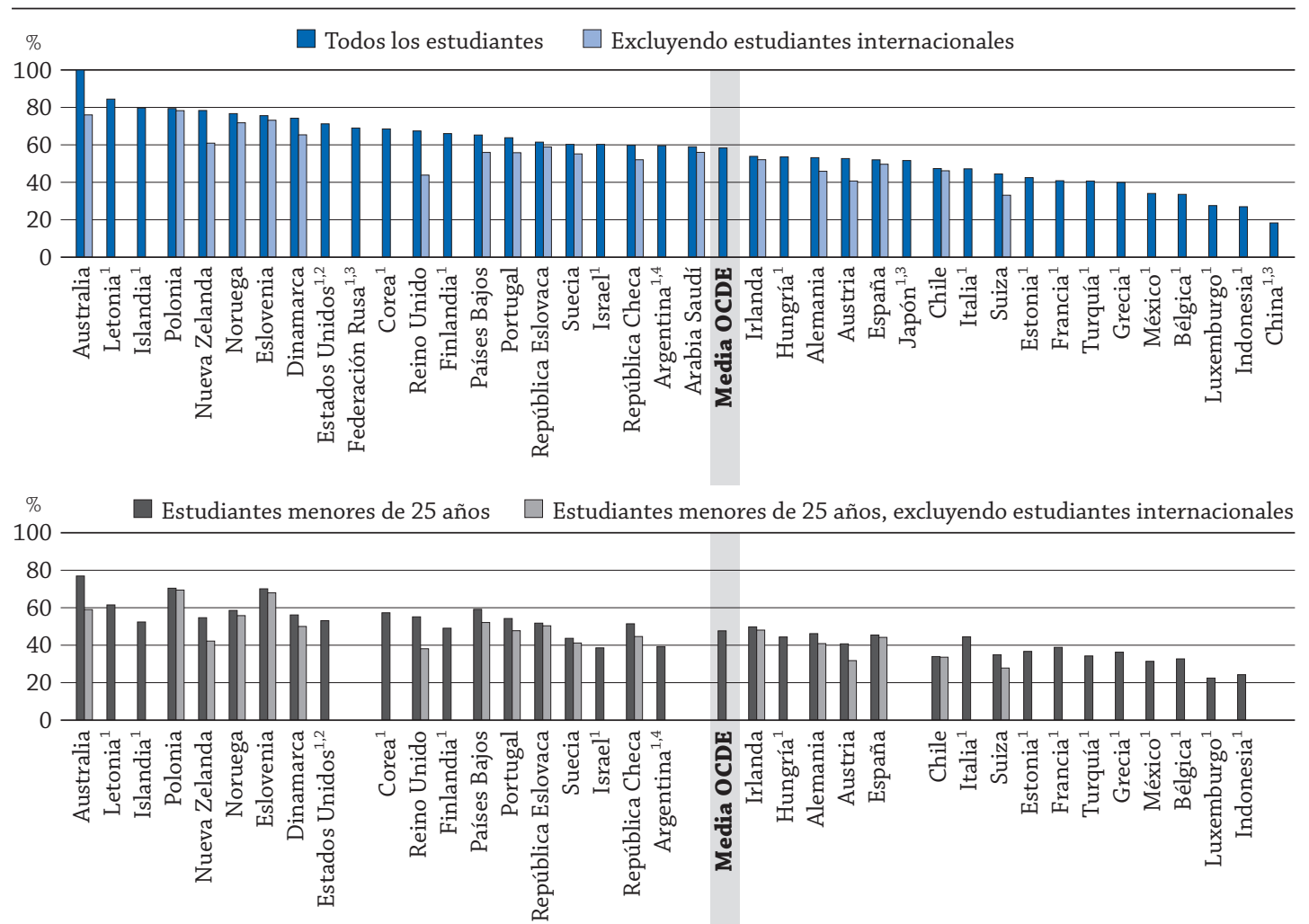

1. Faltan los datos de los nuevos ingresos de estudiantes internacionales.

2. Las tasas de ingreso en educación terciaria de tipo A incluyen las tasas de ingreso en educación terciaria de tipo B.

3. Faltan los datos de nuevos ingresados por edad.

4. Año de referencia 2011.

Los países están clasificados en orden descendente de las tasas de ingreso en educación terciaria de tipo A en 2012.

Fuente: OCDE. Tablas C3.1a y C3.1b. Para ver notas, consulte Anexo 3 (www.oecd.org/edu/eag.htm).

StatLink 제피 http://dx.doi.org/10.1787/888933118580

\section{Contexto}

Las tasas de ingreso estiman la proporción de personas que se espera que accedan a un tipo específico de programa de educación terciaria durante su vida. También ofrecen alguna indicación sobre la accesibilidad de la educación terciaria, el valor percibido de asistir a programas de educación terciaria y el grado en el que la población adquiere las competencias y conocimientos de alto nivel que pueden crear e impulsar economías basadas en el conocimiento. Unas elevadas tasas de ingreso y de participación en educación terciaria implican que se está desarrollando y manteniendo una población activa muy cualificada. 
En los países de la OCDE, la convicción de que las competencias adquiridas en la educación superior se valoran más que las competencias de las personas con un nivel educativo inferior se deriva de la percepción, tanto real como temida, de que los empleos «rutinarios» pueden exportarse a países de bajos salarios o mecanizarse, así como de la creciente conciencia de que el conocimiento y la innovación son clave para sostener el crecimiento económico. Las instituciones terciarias deben no solo satisfacer la creciente demanda ampliando el número de plazas ofrecidas, sino también adaptar los programas y métodos de enseñanza para cubrir la diversidad de necesidades de la nueva generación de estudiantes.

\section{Otros resultados}

- Aunque se espera que uno de cada 20 estudiantes acceda a programas de investigación avanzada a lo largo de su vida en Alemania y Suiza, solo uno de cada 100 estudiantes lo hará en Japón, y aún menos en Argentina, Chile, Indonesia, Luxemburgo y México.

- Sobre la base de los patrones actuales, se estima que una media del $18 \%$ de los adultos jóvenes de hoy ( $20 \%$ de mujeres y $17 \%$ de hombres) accederán a programas de educación terciaria de tipo B (más cortos y principalmente profesionales) a lo largo de su vida.

- Cuando se excluyen los estudiantes internacionales del cálculo, Eslovenia y Polonia son los dos únicos países (de los 17 países con datos disponibles) donde alrededor de siete de cada 10 jóvenes accederán a educación terciaria de tipo $\mathrm{A}$ antes de cumplir los $\mathbf{2 5}$ años.

- El aprendizaje a lo largo de la vida aún no es una realidad en todos los países de la OCDE. En Australia, Chile, Finlandia, Islandia, Israel, Nueva Zelanda y Suecia, más de 1 de cada 4 nuevos ingresados accederán a programas de educación terciaria de tipo A a partir de los 25 años. En el extremo opuesto, en Bélgica y Francia menos de 1 de cada 20 nuevos ingresados será mayor de 25 años.

\section{Tendencias}

Entre 1995 y 2012, las tasas de ingreso en programas de educación terciaria de tipo A aumentaron en casi 20 puntos porcentuales, como media en los países de la OCDE, aunque este año nuevos datos han revelado una marcada disminución de cuatro puntos porcentuales desde 2010, probablemente causada por la crisis económica. No obstante, el gran incremento previo fue el resultado de una mayor accesibilidad a la educación terciaria en muchos países y debido a los cambios estructurales de los sistemas educativos en algunos países, como la creación de nuevos programas (para cubrir las necesidades del mercado laboral) o programas más cortos (derivados de la implantación del Proceso de Bolonia). Las tasas de ingreso en los programas de educación terciaria también han aumentado debido a la expansión del acceso a dichos programas para una mayor parte de la población, incluyendo estudiantes internacionales (véase el Indicador C4) y estudiantes mayores.

Mientras tanto, las tasas de ingreso en programas de educación terciaria de tipo B permanecieron estables entre 1995 y 2012, sin ninguna variación significativa en los últimos tres años relacionada con la crisis económica.

\section{Nota}

Las tasas de ingreso representan el porcentaje estimado de una cohorte de edad que se prevé que acceda a un programa terciario a lo largo de su vida. Dicha estimación se basa en el número de nuevos ingresados en 2012 y la distribución por edad de este grupo. Por tanto, las tasas de ingreso se basan en un supuesto de "cohorte sintética», según el cual el patrón actual de ingreso constituye la mejor estimación del comportamiento del ciclo de vida de los jóvenes de hoy. Estas tasas de ingreso son sensibles a cambios en el sistema educativo, como la introducción de nuevos programas (por ejemplo la implantación del Proceso de Bolonia) o una variación del número de estudiantes internacionales. Las tasas de ingreso pueden ser muy elevadas, e incluso superiores al $100 \%$ (lo que indica claramente que el supuesto de la cohorte sintética es poco probable), durante un periodo en el que haya ingresos inesperados. En Australia, por ejemplo, la tasa de ingresos en programas de educación terciaria de tipo A se reduce más de 25 puntos porcentuales cuando se excluye a los estudiantes internacionales. En Portugal, un gran número de mujeres mayores de 25 años decidió cursar estudios universitarios, de manera que las tasas de ingreso de las mujeres aumentaron 40 puntos porcentuales de 2007 a 2011. 


\section{Análisis}

\section{Acceso global a la educación terciaria}

Se estima que el $58 \%$ de los adultos jóvenes en los países de la OCDE ingresarán en programas de educación terciaria de tipo A a lo largo de su vida si continúan los actuales patrones de ingreso. En varios países, se espera que al menos el $70 \%$ de los adultos jóvenes ingresen en este tipo de programas, mientras que se espera que lo hagan menos del $35 \%$ en Bélgica, China, Indonesia, Luxemburgo y México (Gráfico C3.1).

La proporción de estudiantes que ingresan en programas de educación terciaria de tipo B es generalmente más reducida, principalmente porque estos programas están menos desarrollados en la mayoría de los países de la OCDE. Las proporciones oscilan entre menos del $5 \%$ en Indonesia, Islandia, México, Polonia y República Eslovaca, más del $35 \%$ en Bélgica, Corea y Nueva Zelanda, y más del 50 \% en Argentina y Chile (Tabla C3.1a).

Por el contrario, en Bélgica, Chile y China, la proporción esperada de estudiantes que ingresarán en programas de educación terciaria de tipo $B$ es mayor que la de estudiantes que se espera que ingresen en programas de educación terciaria de tipo A. En estos países, un amplio acceso a programas de educación terciaria de tipo B contrarresta las tasas de ingreso relativamente bajas en programas de educación terciaria académicos (Gráfico C3.2). Otros países, notablemente Argentina, Corea e Israel, tienen tasas de ingreso cercanas a la media de la OCDE para programas de educación terciaria de tipo A y tasas de ingreso comparativamente altas en programas de educación terciaria de tipo B. En Nueva Zelanda, las tasas de ingreso en ambos tipos de programas están entre las más altas de los países de la OCDE. Sin embargo, estas tasas de ingreso se ven infladas por una mayor incidencia del acceso de estudiantes a edades más tardías y una mayor proporción de estudiantes internacionales (Tabla C3.1a).

En algunos países, las elevadas tasas de ingreso pueden reflejar un fenómeno temporal, como reformas universitarias derivadas de la implantación del Proceso de Bolonia, los efectos de la crisis económica o un repunte en el número de estudiantes internacionales.

Por término medio en los países de la OCDE con datos comparables, la proporción de adultos jóvenes que ingresaron en programas de educación terciaria de tipo A aumentó 10 puntos porcentuales de 2000 a 2012 y casi 20 puntos porcentuales de 1995 a 2012 (Tabla C3.2a). Las tasas de ingreso en estos programas aumentaron más de 20 puntos porcentuales de 2000 a 2012 en Alemania, Australia, Corea, Dinamarca, Irlanda, República Checa y República Eslovaca. En Corea, el incremento de 2007 a 2008 se vio influido por una reclasificación de programas de educación terciaria de tipo B a programas de educación terciaria de tipo A. En cambio, Finlandia, Hungría, Nueva Zelanda y Suecia son los únicos países de la OCDE que muestran una disminución de las tasas de ingreso en estos

\section{Gráfico C3.2. Tasas de ingreso en educación terciaria de tipo A y tipo B $(2000,2012)$}

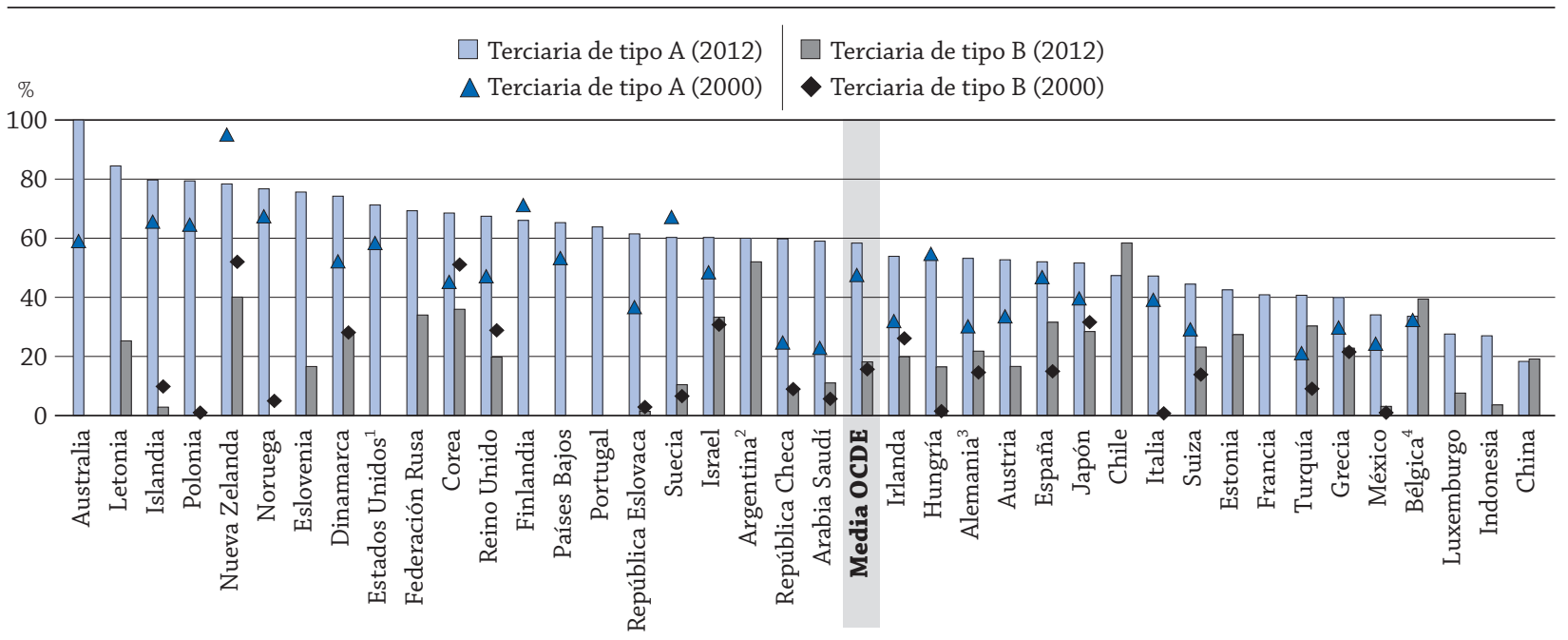

1. Las tasas de ingreso en educación terciaria de tipo A incluyen las tasas de ingreso en educación terciaria de tipo B.

2. Año de referencia 2011 en lugar de 2012.

3. Ruptura de la serie temporal entre 2008 y 2009 debido a una reasignación parcial de los programas de formación profesional a CINE 2 y CINE 5B.

4. Año de referencia 2001 en lugar de 2000

Los países están clasificados en orden descendente de las tasas de ingreso en educación terciaria de tipo A en 2012.

Fuente: OCDE. Tabla C3.2a. Para ver notas, consulte Anexo 3 (www.oecd.org/edu/eag.htm).

StatLink त्ञाIs http://dx.doi.org/10.1787/888933118599 
programas. Sin embargo, en Hungría, esta disminución se ve contrarrestada por un incremento significativo en las tasas de ingreso en los programas de educación terciaria de tipo B en ese mismo periodo. En Nueva Zelanda, el auge y la disminución de las tasas de ingreso de 2000 a 2012 refleja el número de estudiantes internacionales en ese mismo periodo (Gráfico C3.2).

En los países de la OCDE, las tasas netas globales de ingreso en programas de educación terciaria de tipo B han permanecido relativamente estables entre 2000 y 2012, excepto en España, Hungría y Turquía, donde han aumentado más de 10 puntos porcentuales, y en Corea y Nueva Zelanda, donde han disminuido más de 10 puntos porcentuales (Gráfico C3.2).

Se prevé que aproximadamente el $3 \%$ de los adultos jóvenes de hoy en los países de la OCDE ingresarán en programas de investigación avanzada a lo largo de su vida, si los patrones actuales permanecen estables. Entre los países de los que se dispone de datos, las proporciones oscilan entre el $1 \%$ o menos en Argentina, Chile, Indonesia, Japón, Luxemburgo y México, y alrededor del $5 \%$ en Alemania y Suiza (Tabla C3.1a).

\section{Edad de los nuevos ingresados en educación terciaria}

Por término medio en los países de la OCDE, el $82 \%$ de todos los nuevos ingresados en programas de educación terciaria de tipo A y el $58 \%$ de los nuevos ingresados en programas de educación terciaria de tipo B en 2012 tenían menos de 25 años. Además, el $57 \%$ de los estudiantes que ingresaron en programas de investigación avanzada en 2012 eran menores de 30 años (Tabla C3.1b).

La edad de los nuevos ingresados en educación terciaria varía en los países de la OCDE debido a las diferencias en la edad habitual de graduación en educación secundaria superior (véanse Tablas X1.1a y X1.1b), las plazas disponibles en las instituciones (admisiones con numerus clausus, uno de los muchos métodos utilizados para limitar el número de estudiantes que pueden estudiar en una institución de educación terciaria), el coste de oportunidad de incorporarse al mercado laboral antes de matricularse en educación terciaria y las expectativas culturales.

Durante la reciente crisis económica, algunos jóvenes han aplazado su acceso al mercado laboral y han seguido estudiando. Algunos gobiernos también han desarrollado programas de segunda oportunidad, dirigidos a las personas que abandonaron los estudios de manera temprana, para mejorar el nivel de capacidades de la población activa y aumentar las oportunidades de obtener una educación y competencias prácticas. No obstante, ingresar en educación terciaria en una etapa más tardía también es más costoso tanto desde el punto de vista público como individual. Significa que durante un periodo de tiempo, el potencial productivo de una persona no se aprovecha. Por consiguiente, los impuestos recaudados son menores y el gasto público puede ser más elevado. Los estudiantes mayores pueden tener más dificultades para combinar los estudios con el trabajo y, por tanto, no ser capaces de finalizar los programas a tiempo. Al comprender que un retraso en la finalización de los estudios aumenta su coste, los gobiernos están introduciendo medidas para fomentar su finalización en plazo. Sin embargo, un inicio más tardío de la educación terciaria podría indicar también que los estudiantes están más seguros de lo que quieren estudiar y están más motivados.

Tradicionalmente, los estudiantes ingresan en programas de educación terciaria inmediatamente después de completar la educación secundaria superior, y esto sigue siendo así en muchos países. Por ejemplo, en Bélgica, Francia e Indonesia, el $95 \%$ o más de todos los estudiantes que ingresan por primera vez en programas de educación terciaria de tipo A o B tienen menos de 25 años. En otros países de la OCDE, la transición de la educación secundaria superior a la terciaria puede ocurrir a una edad más tardía debido al tiempo dedicado al mercado laboral o al servicio militar. Por ejemplo, en Israel solo dos tercios de los que ingresan por primera vez en programas de educación terciaria de tipo A son menores de 25 años. En estos casos, los nuevos ingresados en programas de educación terciaria de tipo A o B representan normalmente un rango de edad mucho más amplio (Tabla C3.1b).

La proporción de nuevos ingresados mayores en estos programas de educación terciaria de tipo A y B podría reflejar la flexibilidad de los mismos y su idoneidad para los estudiantes que están fuera del grupo típico de edad. También podría reflejar el valor que se otorga a la experiencia laboral antes de acceder a la educación superior, que es característico de los países nórdicos y es frecuente también en Australia, Austria, Chile, Estados Unidos, Hungría y Nueva Zelanda, donde una proporción considerable de nuevos ingresados son mucho mayores de la edad habitual de ingreso. Los motivos difieren sustancialmente de un país a otro. Por ejemplo, en Australia, tomarse un año de transición antes de ingresar en educación terciaria se ha convertido en una tendencia: en 2009-2010 casi uno de cada cuatro estudiantes lo hizo y el $51 \%$ declaró que el «trabajo» había sido el motivo principal para dejar de estudiar un año (Lumsden y Stanwick, 2012). Algunos países exigen que los jóvenes realicen el servicio militar, posponiendo el ingreso en educación terciaria. Este es el caso de Israel, que cuenta con un servicio militar obligatorio para los hombres de 18 a 21 años y las mujeres de 18 a 20 años. 


\section{Impacto de los estudiantes internacionales en las tasas de ingreso en los programas de educación terciaria de tipo A}

Por definición, todos los estudiantes internacionales que se matriculan en un país por primera vez se cuentan como nuevos ingresados, con independencia de su educación previa en otros países. Para resaltar el impacto de los estudiantes internacionales en las tasas de ingreso en programas de educación terciaria de tipo A, las tasas de ingreso tanto no ajustadas como ajustadas (es decir, la tasa de ingreso cuando se excluye a los estudiantes internacionales) se muestran en las Tablas C3.1a y b.

En Australia, la diferencia entre las tasas de ingreso ajustadas y no ajustadas es de 26 puntos porcentuales, la más elevada entre todos los países con datos comparables. También es muy elevada en Reino Unido, con una diferencia de 24 puntos porcentuales. En Austria, Islandia, Nueva Zelanda y Suiza, la presencia de estudiantes internacionales también afecta mucho a las tasas de ingreso, con diferencias que oscilan entre los 11 y los 17 puntos porcentuales (Tabla C3.1a).

El porcentaje esperado de nuevos ingresados en educación terciaria de tipo A cambia drásticamente cuando no se incluye a los estudiantes mayores o internacionales. Estos dos grupos son importantes componentes de la población estudiantil de los países, pero pueden inflar artificialmente la proporción esperada de los jóvenes de hoy que ingresarán en educación terciaria. Cuando no se tienen en cuenta los estudiantes internacionales y mayores, Eslovenia y Polonia son los dos países con la mayor proporción de personas que se espera que ingresen en educación terciaria de tipo A con menos de 25 años. La gran proporción en Polonia está relacionada con el mayor número de estudiantes que se graduaron en programas de educación secundaria superior como resultado de las reformas educativas de 1999 en ese país, dirigidas a aumentar la calidad de sus sistemas de educación secundaria y superior e incrementar la igualdad de oportunidades educativas. Eslovenia y Polonia son también dos de los seis países con mayor porcentaje de personas de 25 a 34 años que han alcanzado al menos la educación secundaria superior (véase Indicador A1).

\section{Vías entre programas académicos y profesionales}

En algunos países, se ofrecen programas de educación terciaria de tipo A y B en distintos tipos de instituciones. Sin embargo, cada vez es más frecuente que las universidades u otras instituciones ofrezcan ambos tipos de programas, y son cada vez más parecidos en términos de currículo, orientación y resultados de aprendizaje.

En algunos países, los graduados en programas de educación terciaria de tipo B a menudo pueden ingresar en programas de educación terciaria de tipo A, normalmente en el segundo o tercer año, o incluso a un programa de máster. Sumar las tasas de ingreso en estos dos tipos de programas para obtener las tasas globales de ingreso en educación terciaria daría como resultado una sobrecontabilización. El ingreso suele estar sujeto a ciertas condiciones, como aprobar un examen especial, los logros personales o profesionales anteriores y/o la realización de un programa «puente», dependiendo del país o del programa. En algunos casos, los estudiantes que abandonan un programa académico sin haberse graduado antes pueden reorientarse con éxito hacia programas profesionales.

\section{Tasas de ingreso en programas de educación terciaria, por ámbito de estudio (educación terciaria de tipo A y B)}

En casi todos los países, una gran proporción de estudiantes cursan programas de educación terciaria en las áreas de ciencias sociales, administración de empresas y derecho. En 2012, estos ámbitos recibieron la mayor cuota de nuevos ingresados en todos los países, excepto Arabia Saudí, Corea y Finlandia. En Finlandia, la proporción de nuevos ingresados fue mayor en ingeniería, industria y construcción, mientras que en Arabia Saudí y Corea la proporción fue mayor en humanidades, artes y educación (Gráfico C3.3).

Los ámbitos relacionados con las ciencias, que comprenden ciencias e ingenierías, industria y construcción, son menos populares. Por término medio, solo una cuarta parte de los estudiantes ingresan en estos campos (Tabla C3.3a). Este bajo nivel de participación se debe en parte a la infrarrepresentación de las mujeres: como media en 2012, solo el $14 \%$ de las mujeres que ingresan en educación terciaria eligieron estos ámbitos, en comparación con el $39 \%$ de los nuevos ingresados varones. En la población de nuevos ingresados, la proporción de mujeres que eligieron campos relacionados con las ciencias oscila entre el 5\%-6\% en Bélgica, Japón y Países Bajos y el 19\%-20\% en Federación Rusa, Grecia, Italia y México, mientras que en la población de varones la proporción en estos campos oscila entre el 17\% en Argentina y el 58\% en Finlandia (Tabla C3.3b, disponible en Internet).

La distribución de ingresados en los programas de investigación avanzada por ámbito de estudio es muy distinta a la de la educación terciaria en su conjunto. Aunque ciencias sociales, administración de empresas y derecho fueron los campos de estudio más populares entre los estudiantes de educación terciaria en 2012, los estudiantes de docto- 


\section{Gráfico C3.3. Distribución de nuevos ingresados en educación terciaria, por ámbito de estudio (2012)}

En el gráfico inferior solo se muestran aquellos ámbitos en los que más de un $20 \%$ de los estudiantes ingresaron en un programa de educación terciaria en 2012

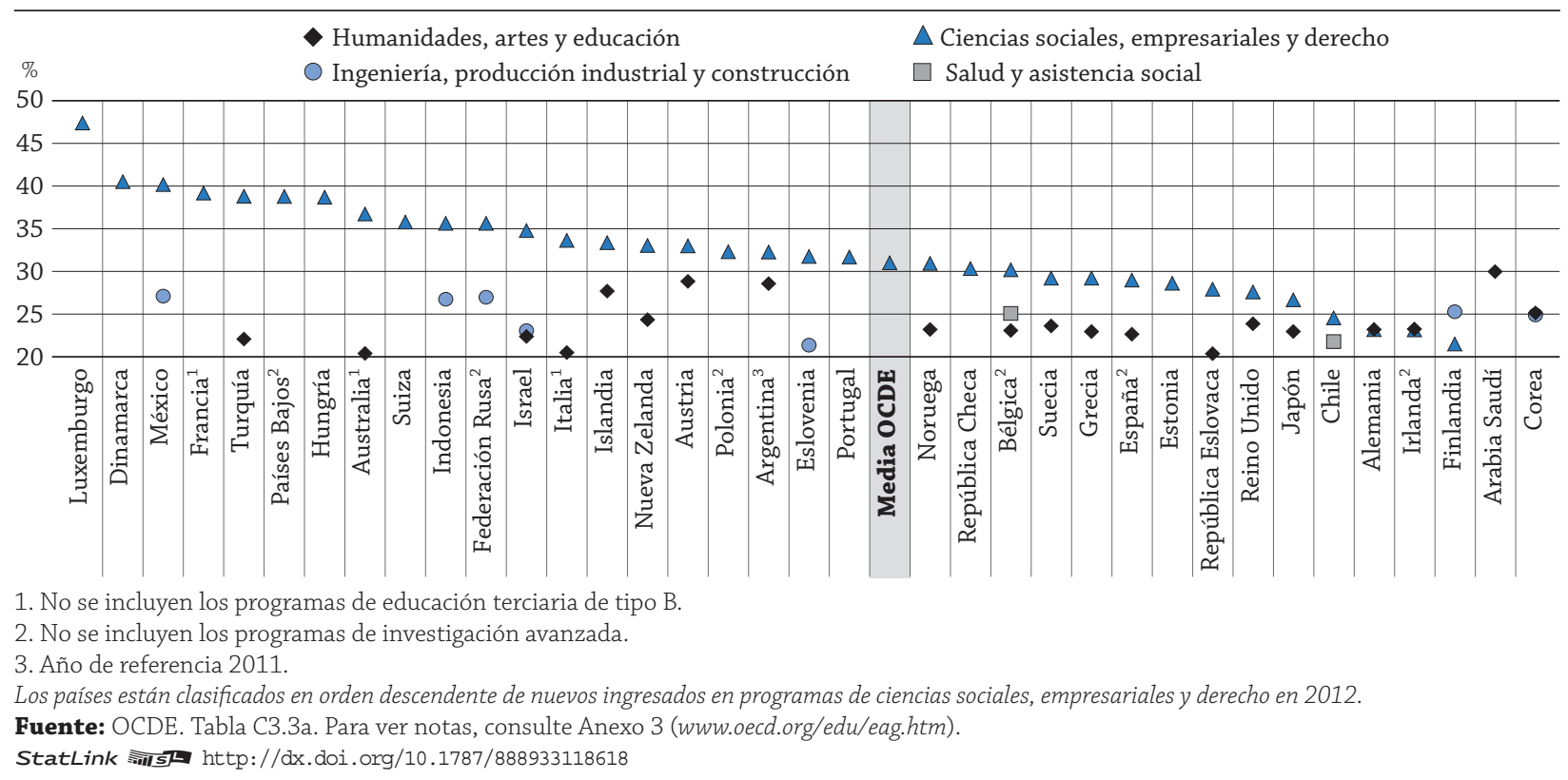

rados prefirieron los campos de ciencias algo más que ciencias sociales, administración de empresas y derecho. Casi 1 de cada 4 nuevos estudiantes de doctorado cursó estudios de ciencias (24\%), más del doble de la proporción de nuevos ingresados en educación terciaria que eligieron este campo (10 \%). En Francia, Israel y Luxemburgo, más del $35 \%$ de los estudiantes de investigación avanzada eligieron ciencias.

\section{Programas de investigación avanzada: la fábrica de conocimiento para la sociedad}

La investigación a nivel de doctorado desempeña un papel fundamental para impulsar la innovación y el desarrollo económico, y contribuye de manera significativa a la base de conocimiento nacional e internacional. Las empresas se sienten atraídas por los países donde este nivel de investigación es fácilmente accesible (Halse y Mowbray, 2011; Smith, 2010), mientras que las personas que alcanzan este nivel de educación se benefician de salarios más altos y una mayor tasa de empleo (véanse Indicadores A5 y A6).

Muchos países de la OCDE invierten grandes cantidades para proporcionar educación de nivel de doctorado. En el Gráfico C3.4 se muestra el porcentaje de estudiantes que cursarán estudios hasta el máximo nivel académico en todos los países de la OCDE. En Alemania, Austria, Eslovenia y Suiza, se prevé que alrededor de uno de cada 20 estudiantes ingrese en un programa de investigación avanzada. En cambio, en Argentina, Chile, Indonesia, Luxemburgo y México, se espera que menos de uno de cada 100 estudiantes inicien estudios de doctorado a lo largo de su vida, si continúan los patrones actuales (Tabla C3.1a). Sin embargo, las tasas de ingreso de estos países podrían estar infraestimadas, puesto que es frecuente que los estudiantes de Latinoamérica obtengan sus doctorados en Estados Unidos. Lo mismo ocurre con los indonesios en Australia y los luxemburgueses en otros países europeos.

Varios países están desarrollando programas de doctorado para atraer a estudiantes internacionales, es decir, estudiantes que se trasladan de su país de origen para estudiar en otro lugar. Atraer a los mejores estudiantes de todo el mundo ayuda a garantizar que un país desempeñe un papel primordial en la investigación y la innovación (Smith, 2010). Por ejemplo, más de la mitad de los nuevos ingresados en programas de doctorado en Suiza son estudiantes internacionales (Gráfico C3.4). Además, como muestra el indicador C4, en 2012 una proporción elevada de estudiantes matriculados en programas de doctorado internacionales en Nueva Zelanda (41\%), Reino Unido (41\%) y Suiza (51\%) eran estudiantes internacionales, es decir, ciudadanos de un país distinto a aquel donde se recopilaron los datos.

Aunque casi el $60 \%$ de los nuevos estudiantes en programas de investigación avanzada en los países de la OCDE ingresaron antes de los 30 años, existen diferencias significativas entre los países. En Alemania, Indonesia, Países 


\section{Gráfico C3.4. Tasas de ingreso en programas de investigación avanzada y media de edad de los nuevos ingresados (2012)}

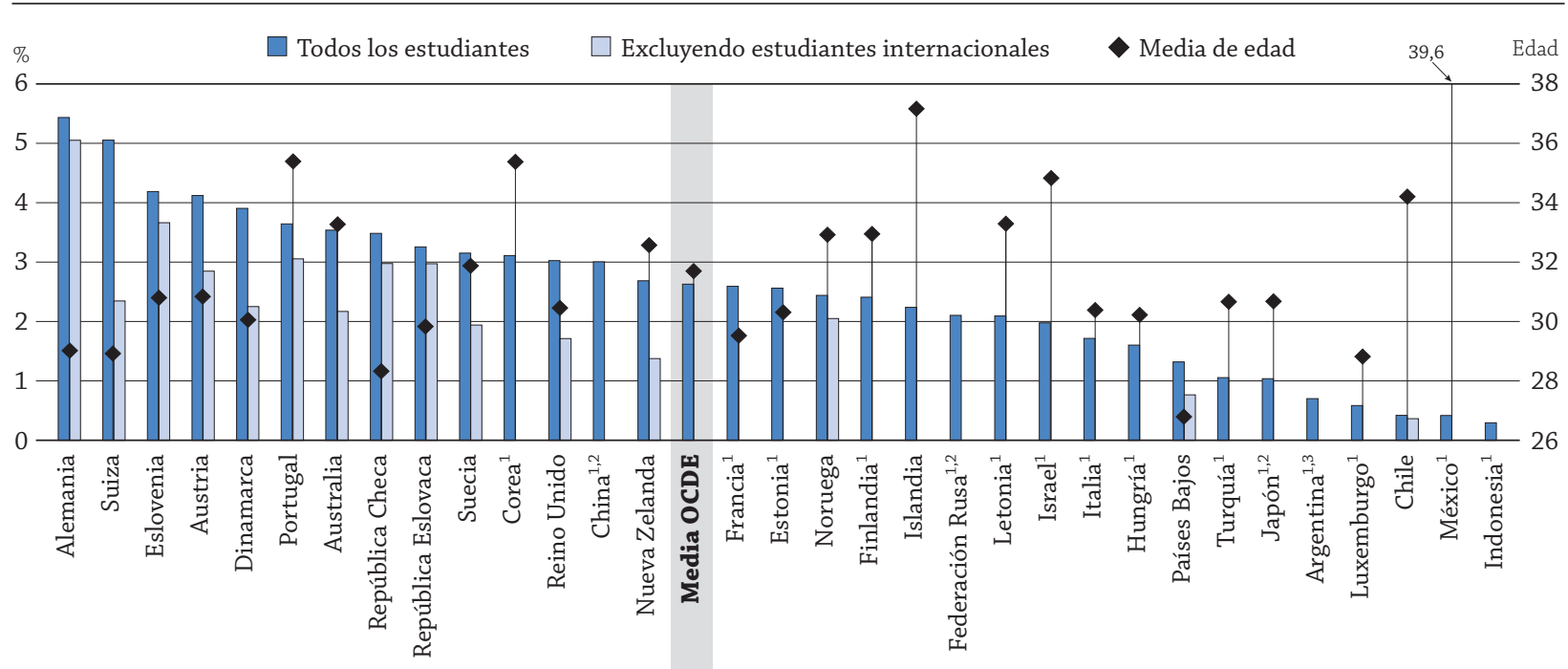

Nota: La media de edad se refiere a la edad media ponderada, generalmente la edad de los estudiantes al inicio del año natural. Los estudiantes pueden tener un año más de la edad indicada cuando se gradúan al final del curso escolar. Para saber cómo se calcula la media de edad, consulte Anexo 3.

1. Faltan los datos de los nuevos ingresos de estudiantes internacionales.

2. Faltan los datos de nuevos ingresados por edad.

3. Año de referencia 2011.

Los países están clasificados en orden descendente de los nuevos ingresados en programas de investigación avanzada en 2012.

Fuente: OCDE. Tabla C3.1a. Para ver notas, consulte Anexo 3 (www.oecd.org/edu/eag.htm).

StatLink त्ञाज http://dx.doi.org/10.1787/888933118637

Bajos y República Checa, más del $75 \%$ de los estudiantes son menores de 30 años cuando ingresan en este nivel de educación, mientras que en Corea, Islandia, Israel, México y Portugal la media de la edad de ingreso es de 35 años o más (Tabla C3.1a y b).

Estas diferencias pueden deberse a varios factores. Podrían reflejar una menor tasa de abandono y un mayor énfasis en adquirir competencias especializadas en el nivel de primer grado de educación terciaria. Algunos países ofrecen incentivos, como ayudas, becas, programas de movilidad internacional, empleos a tiempo parcial y formación a distancia, para animar a los estudiantes a cursar estudios avanzados inmediatamente después de completar su primer grado de educación terciaria. En cambio, un ingreso tardío en programas de doctorado podría estar relacionado con diferencias de las tasas de matrícula, la disponibilidad de becas y/o las expectativas culturales, como tener que acceder al mercado laboral a cierta edad u obtener experiencia profesional antes de ingresar en un programa de doctorado.

El nivel de doctorado en la educación es el único que se aproxima a la paridad por sexo. Mientras que hay proporcionalmente más mujeres que hombres en todos los demás niveles educativos, este es el único en el que la proporción de nuevos ingresados (y, por consiguiente, la proporción de graduados) es ligeramente mayor entre los hombres que las mujeres. Como media en los países de la OCDE, el 2,7\% de los hombres y el 2,6\% de las mujeres ingresan en un programa de doctorado (Tabla C3.1a).

\section{Definiciones}

Estudiantes internacionales son aquellos que se han marchado de su país de origen y se han trasladado a otro país con el fin de estudiar. Los estudiantes internacionales que se matriculan por primera vez en un programa se consideran nuevos ingresados.

Los nuevos ingresados son los estudiantes que se matriculan por primera vez en el nivel de educación correspondiente.

La tasa de ingreso en el nivel de educación terciaria es una probabilidad estimada, basada en los actuales patrones de ingreso, de que un joven ingrese en educación terciaria a lo largo de su vida. 


\section{Metodología}

Los datos se refieren al curso académico 2011-2012 y se basan en la recopilación de datos UOE sobre estadísticas educativas gestionada por la OCDE en 2013 (para más detalles véase Anexo 3 en www.oecd.org/edu/eag.htm). Los ámbitos de estudio utilizados en los instrumentos de recopilación de datos de UOE siguen la clasificación revisada CINE 97 por ámbito de estudio. Se utiliza la misma clasificación en todos los niveles educativos.

Los datos sobre las tendencias de las tasas de ingreso (Tabla C3.2a) de los años 1995, 2000, 2001, 2002, 2003 y 2004 se basan en un estudio especial llevado a cabo en los países de la OCDE en enero de 2007.

Los datos sobre el impacto de los estudiantes internacionales en las tasas de ingreso en educación terciaria se basan en un estudio especial realizado por la OCDE en diciembre de 2013.

Las Tablas C3.1a y b, C.3.2a y b muestran la suma de las tasas de ingreso netas en todas las edades.

La tasa neta de ingreso para una edad específica se obtiene dividiendo el número de nuevos ingresados de esa edad en cada tipo de educación terciaria por la población total en el grupo de edad correspondiente. La tasa neta de ingreso de un grupo de edad se calcula sumando las tasas de cada año de edad. El resultado representa una estimación de la probabilidad de que una persona joven ingrese en educación terciaria a lo largo de su vida si continúan las actuales tasas de ingreso para esa edad concreta.

La media de edad ponderada de ingreso se calcula asignando mayor peso a aquellas edades en las que el número de estudiantes que ingresan en un nuevo nivel es mayor. Esta variable ofrece al lector una idea precisa de la edad media de ingreso. Esta variable aparece por primera vez en esta edición de Panorama de la educación con la intención de mejorar la comprensión de este indicador. Véase Anexo 3 para más detalles.

No todos los países pueden distinguir entre los estudiantes que ingresan en un programa de educación terciaria por primera vez y aquellos que pasan de un nivel a otro de la educación terciaria o repiten o vuelven a entrar en un nivel tras una ausencia. Por tanto, las tasas de ingreso por primera vez en programas de educación terciaria de tipo A y de tipo B no pueden sumarse para formar una tasa de ingreso total en el nivel terciario, porque significaría contar dos veces a algunos ingresados.

\section{Nota sobre los datos de Israel}

Los datos estadísticos para Israel fueron proporcionados por las autoridades israelíes competentes bajo su responsabilidad. El uso de estos datos por parte de la OCDE se hace sin prejuzgar la situación de los Altos del Golán, Jerusalén Este y los asentamientos israelíes en Cisjordania de acuerdo con los términos del derecho internacional.

\section{Referencias}

Halse C. y S. Mowbray (2011), «The Impact of the Doctorate», Studies in Higher Education, Vol. 5, N. ${ }^{\circ}$ 36, pp. 513-525, www.tandfonline.com/doi/abs/10.1080/03075079.2011.594590.

Lumsden, M. y J. Stanwick (2012), «Who Takes A Gap Year And Why?» Longitudinal Surveys Of Australian Youth, Briefing Paper 28, National Centre for Vocational Education Research (NCVER), Adelaida, Australia.

OECD (2012), Education at a Glance 2012: OECD Indicators, OECD Publishing, París. http://www.oecd-ilibrary.org/education/education-at-a-glance-2012_eag-2012-en Versión española: Panorama de la educación 2021: Indicadores de la OCDE, Ministerio de Educación, Cultura y Deporte, Santillana, Madrid.

Smith, A. (2010), «One Step Beyond: Making The Most Of Postgraduate Education», Report for UK Department for Business, Innovation and Skills. 


\section{Tablas del Indicador C3}

StatLink 젶ㄴ http://dx.doi.org/10.1787/888933118485

Tabla C3.1a Tasas de ingreso en educación terciaria y media de edad de los nuevos ingresados, por sexo y programa (2012)

Tabla C3.1b Tasas de ingreso en educación terciaria de los estudiantes por debajo de la edad típica de ingreso, por sexo y programa (2012)

Tabla C3.2a Tendencias de las tasas de ingreso en educación terciaria (1995-2012)

WEB Tabla C3.2b Tendencias de las tasas de ingreso en educación terciaria, por sexo (2005-2012)

Tabla C3.3a Distribución de nuevos ingresados en educación terciaria, por ámbito de estudio (2012)

WEB Tabla C3.3b Distribución de nuevos ingresados en educación terciaria, por ámbito de estudio y por sexo (2012)

WEB Tabla C3.3c Distribución de nuevos ingresados en programas de investigación avanzada, por ámbito de estudio (2012) 
Tabla C3.1a. Tasas de ingreso en educación terciaria y media de edad de los nuevos ingresados, por sexo y programa (2012)

Suma de las tasas de ingreso por edad específica, por sexo y orientación del programa

\begin{tabular}{|c|c|c|c|c|c|c|c|c|c|c|c|c|c|c|c|}
\hline & \multicolumn{5}{|c|}{ Programas terciarios de tipo B } & \multicolumn{5}{|c|}{ Programas terciarios de tipo A } & \multicolumn{5}{|c|}{ Programas de investigación avanzada } \\
\hline & $\underset{+}{\sum_{ \pm}}$ & 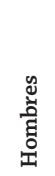 & 岕 & 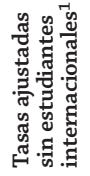 & 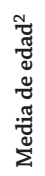 & $\underset{+}{\sum_{+}}$ & 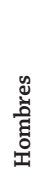 & 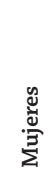 & 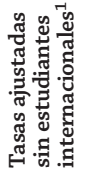 & 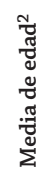 & $\begin{array}{l}\sum_{+} \\
\text {江 }\end{array}$ & 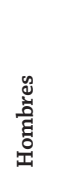 & 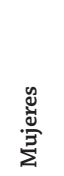 & 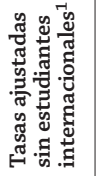 & 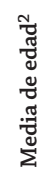 \\
\hline & (1) & (2) & (3) & (4) & $(5)$ & (6) & (7) & (8) & (9) & (10) & (11) & (12) & $(13)$ & (14) & (15) \\
\hline Australia & $\mathbf{m}$ & $\mathrm{m}$ & $\mathrm{m}$ & $\mathrm{m}$ & $m$ & 102 & 88 & 116 & 76 & 23 & 3,5 & 3,4 & 3,6 & 2,2 & 33 \\
\hline Austria & 17 & 15 & 18 & 16 & 30 & 53 & 48 & 58 & 41 & 24 & 4,1 & 4,2 & 4,0 & 2,8 & 31 \\
\hline Bélgica & 39 & 32 & 47 & $\mathrm{~m}$ & 20 & 34 & 32 & 35 & $\mathrm{~m}$ & 19 & $\mathbf{m}$ & $\mathrm{m}$ & $\mathrm{m}$ & $\mathrm{m}$ & $m$ \\
\hline Canadá & $\mathbf{m}$ & $\mathrm{m}$ & $\mathrm{m}$ & $\mathrm{m}$ & $m$ & $\mathbf{m}$ & $\mathrm{m}$ & $\mathrm{m}$ & $\mathrm{m}$ & $m$ & $\mathbf{m}$ & $\mathrm{m}$ & $\mathrm{m}$ & $\mathrm{m}$ & $m$ \\
\hline Chile & 58 & 56 & 60 & 58 & 24 & 47 & 43 & 52 & 46 & 23 & 0,4 & 0,5 & 0,4 & 0,4 & 34 \\
\hline Corea & 36 & 33 & 39 & $\mathrm{~m}$ & 21 & 69 & 68 & 69 & $\mathrm{~m}$ & 21 & 3,1 & 3,6 & 2,5 & $\mathrm{~m}$ & 35 \\
\hline Dinamarca & 28 & 27 & 28 & 25 & 30 & 74 & 64 & 85 & 65 & 24 & 3,9 & 4,1 & 3,7 & 2,2 & 30 \\
\hline España & 32 & 31 & 32 & $\mathrm{~m}$ & 23 & 52 & 44 & 60 & 50 & 22 & $\mathbf{m}$ & $\mathrm{m}$ & $\mathrm{m}$ & $\mathrm{m}$ & $m$ \\
\hline Estados Unidos & $\mathbf{x}(6)$ & $\mathrm{x}(7)$ & $\mathrm{x}(8)$ & $\mathrm{m}$ & $m$ & 71 & 64 & 79 & $\mathrm{~m}$ & 23 & $\mathbf{m}$ & $\mathrm{m}$ & $\mathrm{m}$ & $\mathrm{m}$ & $m$ \\
\hline Estonia & 27 & 23 & 32 & $\mathrm{~m}$ & 24 & 43 & 38 & 47 & $\mathrm{~m}$ & 22 & 2,6 & 2,4 & 2,7 & $\mathrm{~m}$ & 30 \\
\hline Finlandia & $\mathbf{a}$ & $\mathrm{a}$ & $\mathrm{a}$ & a & $a$ & 66 & 60 & 73 & $\mathrm{~m}$ & 24 & 2,4 & 2,2 & 2,7 & $\mathrm{~m}$ & 33 \\
\hline Francia & $\mathbf{m}$ & $\mathrm{m}$ & $\mathrm{m}$ & $\mathrm{m}$ & $m$ & 41 & 37 & 45 & $\mathrm{~m}$ & 20 & 2,6 & 2,8 & 2,4 & $\mathrm{~m}$ & 30 \\
\hline Grecia & 23 & 22 & 23 & $\mathrm{~m}$ & 20 & 40 & 32 & 48 & $\mathrm{~m}$ & 20 & $\mathbf{m}$ & $\mathrm{m}$ & $\mathrm{m}$ & $\mathrm{m}$ & $m$ \\
\hline Hungría & 16 & 12 & 21 & $\mathrm{~m}$ & 23 & 54 & 50 & 58 & $\mathrm{~m}$ & 23 & 1,6 & 1,5 & 1,7 & $\mathrm{~m}$ & 30 \\
\hline Irlanda & 20 & 24 & 15 & 19 & 22 & 54 & 49 & 59 & 52 & 20 & m & $\mathrm{m}$ & $\mathrm{m}$ & $\mathrm{m}$ & $m$ \\
\hline Islandia & 3 & 4 & 2 & $\mathrm{~m}$ & 34 & 80 & 65 & 95 & $\mathrm{~m}$ & 26 & 2,2 & 1,8 & 2,7 & $\mathrm{~m}$ & 37 \\
\hline Israel & 33 & 34 & 33 & $\mathrm{~m}$ & 25 & 60 & 54 & 67 & $\mathrm{~m}$ & 25 & 2,0 & 1,9 & 2,1 & $\mathrm{~m}$ & 35 \\
\hline Italia & $\mathbf{n}$ & $\mathrm{n}$ & $\mathrm{n}$ & $\mathrm{m}$ & $m$ & 47 & 40 & 55 & $\mathrm{~m}$ & 20 & 1,7 & 1,6 & 1,8 & $\mathrm{~m}$ & 30 \\
\hline Japón & 28 & 22 & 36 & $\mathrm{~m}$ & 18 & 52 & 56 & 47 & $\mathrm{~m}$ & 18 & 1,0 & 1,4 & 0,7 & $\mathrm{~m}$ & 31 \\
\hline Luxemburgo & 8 & 6 & 9 & $\mathrm{~m}$ & 25 & 28 & 25 & 30 & $\mathrm{~m}$ & 23 & 0,6 & 0,7 & 0,5 & $\mathrm{~m}$ & 29 \\
\hline México & 3 & 4 & 2 & $\mathrm{~m}$ & 20 & 34 & 35 & 34 & $\mathrm{~m}$ & 20 & 0,4 & 0,5 & 0,4 & $\mathrm{~m}$ & 40 \\
\hline Noruega & $\mathbf{n}$ & $\mathrm{n}$ & $\mathrm{n}$ & $\mathrm{n}$ & 31 & 77 & 63 & 91 & 72 & 24 & 2,4 & 2,4 & 2,5 & 2,0 & 33 \\
\hline Nueva Zelanda & 40 & 37 & 43 & 31 & 28 & 78 & 63 & 94 & 61 & 24 & 2,7 & 2,7 & 2,6 & 1,4 & 33 \\
\hline Portugal & $\mathbf{n}$ & $\mathrm{n}$ & $\mathrm{n}$ & $\mathrm{n}$ & $m$ & 64 & 57 & 71 & 56 & 22 & 3,6 & 3,6 & 3,7 & 3,1 & 35 \\
\hline Reino Unido & 20 & 15 & 25 & 18 & 33 & 67 & 59 & 76 & 44 & 22 & 3,0 & 3,2 & 2,8 & 1,7 & 30 \\
\hline República Checa & 9 & 5 & 13 & 9 & 23 & 60 & 52 & 68 & 52 & 23 & 3,5 & 3,7 & 3,2 & 3,0 & 28 \\
\hline República Eslovaca & $\mathbf{1}$ & 1 & 2 & $\mathrm{~m}$ & 23 & 61 & 52 & 71 & 59 & 22 & 3,3 & 3,3 & 3,2 & 3,0 & 30 \\
\hline Suecia & 10 & 10 & 11 & 10 & 27 & 60 & 49 & 72 & 55 & 24 & 3,1 & 3,3 & 3,0 & 1,9 & 32 \\
\hline Suiza & 23 & 25 & 21 & $\mathrm{~m}$ & 28 & 44 & 42 & 47 & 33 & 24 & 5,0 & 5,4 & 4,7 & 2,3 & 29 \\
\hline Turquía & 30 & 33 & 28 & $\mathrm{~m}$ & 21 & 41 & 40 & 41 & $\mathrm{~m}$ & 21 & 1,1 & 1,2 & 0,9 & $\mathrm{~m}$ & 31 \\
\hline
\end{tabular}

\begin{tabular}{|c|c|c|c|c|c|c|c|c|c|c|c|c|c|c|c|}
\hline Media OCDE & 18 & 17 & 20 & $\mathrm{~m}$ & 25 & 58 & 52 & 65 & $\mathrm{~m}$ & 22 & 2,6 & 2,7 & 2,6 & $\mathrm{~m}$ & 32 \\
\hline Media UE21 & 14 & 13 & 16 & $\mathrm{~m}$ & 25 & 56 & 49 & 62 & $\mathrm{~m}$ & 22 & 2,9 & 3,0 & 2,9 & $\mathrm{~m}$ & 30 \\
\hline Arabia Saudí & 11 & 17 & 5 & 11 & $m$ & 59 & 59 & 58 & 56 & $m$ & $\mathbf{0}$ & 0 & 0 & 0 & 0 \\
\hline Argentina $^{3}$ & 52 & 37 & 68 & $\mathrm{~m}$ & $m$ & 60 & 50 & 69 & $\mathrm{~m}$ & $m$ & 0,7 & 0,8 & 0,7 & $\mathrm{~m}$ & $m$ \\
\hline Brasil & $\mathbf{m}$ & $\mathrm{m}$ & $\mathrm{m}$ & $\mathrm{m}$ & $m$ & $\mathbf{m}$ & $\mathrm{m}$ & $\mathrm{m}$ & $\mathrm{m}$ & $m$ & $\mathbf{m}$ & $\mathrm{m}$ & $\mathrm{m}$ & $\mathrm{m}$ & $m$ \\
\hline China & 19 & 19 & 19 & $\mathrm{~m}$ & $m$ & 18 & 16 & 21 & $\mathrm{~m}$ & $m$ & 3,0 & 3,0 & 2,9 & $\mathrm{~m}$ & $m$ \\
\hline Colombia & $\mathbf{m}$ & $\mathrm{m}$ & $\mathrm{m}$ & $\mathrm{m}$ & $m$ & $\mathbf{m}$ & $\mathrm{m}$ & $\mathrm{m}$ & $\mathrm{m}$ & $m$ & m & $\mathrm{m}$ & $\mathrm{m}$ & $\mathrm{m}$ & $m$ \\
\hline Federación Rusa & 34 & $\mathrm{x}(1)$ & $\mathrm{x}(1)$ & $\mathrm{m}$ & $m$ & 69 & $\mathrm{x}(6)$ & $\mathrm{x}(6)$ & $\mathrm{m}$ & $m$ & 2,1 & $\mathrm{x}(11)$ & $\mathrm{x}(11)$ & $\mathrm{m}$ & $m$ \\
\hline India & $\mathbf{m}$ & $\mathrm{m}$ & $\mathrm{m}$ & $\mathrm{m}$ & $m$ & $\mathbf{m}$ & $\mathrm{m}$ & $\mathrm{m}$ & $\mathrm{m}$ & $m$ & $\mathbf{m}$ & $\mathrm{m}$ & $\mathrm{m}$ & $\mathrm{m}$ & $m$ \\
\hline Indonesia & 4 & 3 & 4 & $\mathrm{~m}$ & $m$ & 27 & 27 & 27 & $\mathrm{~m}$ & $m$ & 0,3 & 0,3 & 0,2 & $\mathrm{~m}$ & $m$ \\
\hline Letonia & 25 & 20 & 31 & $\mathrm{~m}$ & 25 & 84 & 72 & 98 & $\mathrm{~m}$ & 24 & 2,1 & 1,9 & 2,3 & $\mathrm{~m}$ & 33 \\
\hline Sudáfrica & m & $\mathrm{m}$ & $\mathrm{m}$ & $\mathrm{m}$ & $m$ & $\mathbf{m}$ & $\mathrm{m}$ & $\mathrm{m}$ & $\mathrm{m}$ & $m$ & $\mathbf{m}$ & $\mathrm{m}$ & $\mathrm{m}$ & $\mathrm{m}$ & $m$ \\
\hline
\end{tabular}

\section{Media G20}

Notas: La falta de coincidencia entre la cobertura de los datos de población y los datos de nuevos ingresados significa que las tasas de ingreso pueden estar subestimadas en países que son exportadores netos de estudiantes y sobreestimadas en aquellos países que son importadores netos. Las tasas de ingreso ajustadas pretenden compensar este desajuste. Consulte Anexo 3 para obtener información específica por países.

Consulte Anexo 1 para más información sobre el método utilizado para calcular las tasas de ingreso (tasas brutas frente a tasas netas) y la correspondiente edad de ingreso. 1. Las tasas de ingreso ajustadas corresponden a la tasa de ingreso cuando se excluye a los estudiantes internacionales.

2. La media de edad se refiere a la edad media ponderada, generalmente la edad de los estudiantes al inicio del año natural. Los estudiantes pueden tener un año más de la edad indicada cuando se gradúan al final del curso escolar. Para saber cómo se calcula la media de edad, consulte Anexo 3.

3. Año de referencia 2011.

Fuentes: OCDE. Arabia Saudí, Argentina, China, Colombia, India, Indonesia, Sudáfrica: Instituto de Estadística de la UNESCO. Letonia: Eurostat. Para ver notas, consulte Anexo 3 for notes (www.oecd.org/edu/eag.htm).

Para obtener más información acerca de los símbolos utilizados en lugar de los datos que faltan, consulte la Guía del lector.

StatLink 젶ㄴ http://dx.doi.org/10.1787/888933118504 
Tabla C3.1b. Tasas de ingreso en educación terciaria de los estudiantes por debajo de la edad típica de ingreso, por sexo y programa (2012)

Suma de las tasas netas de ingreso para cada año de edad hasta los 25 años para la educación terciaria de tipo A o B, y hasta los 30 para los programas de investigación avanzada

\begin{tabular}{|c|c|c|c|c|c|c|c|c|c|c|c|c|c|c|c|}
\hline & \multicolumn{5}{|c|}{ Programas terciarios de tipo $\mathrm{B}$} & \multicolumn{5}{|c|}{ Programas terciarios de tipo $\mathrm{A}$} & \multicolumn{5}{|c|}{ Programas de investigación avanzada } \\
\hline & $\underset{+}{\sum_{+}}$ & 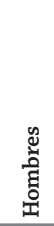 & 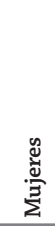 & 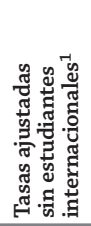 & 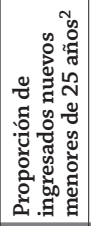 & $\underset{⿱ 土 土}{\text { 声 }}$ & 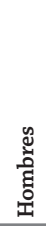 & 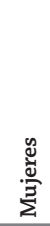 & 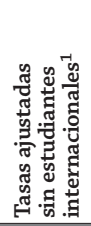 & 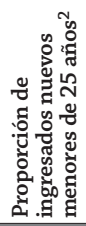 & 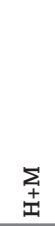 & 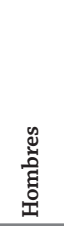 & 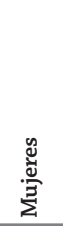 & 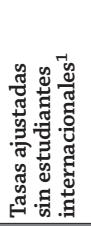 & 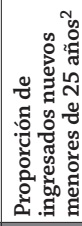 \\
\hline Alemania & 16 & 9 & 24 & $\mathrm{~m}$ & 73 & 46 & 47 & 45 & 41 & 86 & 4,0 & 4,6 & 3,5 & 3,7 & 75 \\
\hline Australia & $\mathbf{m}$ & $\mathrm{m}$ & $\mathrm{m}$ & $\mathrm{m}$ & $m$ & 77 & 67 & 88 & 59 & 74 & 1,7 & 1,7 & 1,7 & 0,9 & 49 \\
\hline Austria & 8 & 7 & 8 & 8 & 44 & 41 & 35 & 47 & 32 & 76 & 2,6 & 2,6 & 2,6 & 1,8 & 63 \\
\hline Bélgica & 38 & 31 & 44 & $\mathrm{~m}$ & 95 & 33 & 31 & 34 & $\mathrm{~m}$ & 97 & $\mathbf{m}$ & $\mathrm{m}$ & $\mathrm{m}$ & $\mathrm{m}$ & $m$ \\
\hline Canadá & $\mathbf{m}$ & $\mathrm{m}$ & $\mathrm{m}$ & $\mathrm{m}$ & $m$ & $\mathbf{m}$ & $\mathrm{m}$ & $\mathrm{m}$ & $\mathrm{m}$ & $m$ & $\mathbf{m}$ & $\mathrm{m}$ & $\mathrm{m}$ & $\mathrm{m}$ & $m$ \\
\hline Chile & 39 & 38 & 39 & 38 & 69 & 34 & 30 & 38 & 34 & 75 & 0,2 & 0,2 & 0,2 & 0,2 & 45 \\
\hline Corea & 32 & 30 & 35 & $\mathrm{~m}$ & 89 & 57 & 56 & 59 & $\mathrm{~m}$ & 83 & 1,3 & 1,4 & 1,1 & $\mathrm{~m}$ & 38 \\
\hline Dinamarca & 12 & 13 & 12 & 10 & 45 & 56 & 47 & 66 & 50 & 76 & 2,5 & 2,8 & 2,1 & 1,0 & 61 \\
\hline España & 25 & 25 & 25 & $\mathrm{~m}$ & 73 & 45 & 38 & 53 & 44 & 82 & $\mathbf{m}$ & $\mathrm{m}$ & $\mathrm{m}$ & $\mathrm{m}$ & $m$ \\
\hline Estados Unidos & $\mathbf{x}(6)$ & $\mathrm{x}(7)$ & $\mathrm{x}(8)$ & $\mathrm{m}$ & $m$ & 53 & 51 & 56 & $\mathrm{~m}$ & 76 & $\mathbf{m}$ & $\mathrm{m}$ & $\mathrm{m}$ & $\mathrm{m}$ & $m$ \\
\hline Estonia & 20 & 17 & 22 & $\mathrm{~m}$ & 71 & 37 & 33 & 41 & $\mathrm{~m}$ & 85 & 1,6 & 1,4 & 1,7 & $\mathrm{~m}$ & 65 \\
\hline Finlandia & $\mathbf{a}$ & $a$ & a & $\mathrm{a}$ & $a$ & 49 & 45 & 53 & $\mathrm{~m}$ & 75 & 1,1 & 1,1 & 1,2 & $\mathrm{~m}$ & 49 \\
\hline Francia & $\mathbf{m}$ & $\mathrm{m}$ & $\mathrm{m}$ & $\mathrm{m}$ & $m$ & 39 & 35 & 43 & $\mathrm{~m}$ & 95 & 1,8 & 1,9 & 1,7 & $\mathrm{~m}$ & 69 \\
\hline Grecia & 21 & 20 & 21 & $\mathrm{~m}$ & 88 & 36 & 29 & 44 & $\mathrm{~m}$ & 87 & $\mathbf{m}$ & $\mathrm{m}$ & $\mathrm{m}$ & $\mathrm{m}$ & $m$ \\
\hline Hungría & 14 & 10 & 18 & $\mathrm{~m}$ & 82 & 44 & 41 & 48 & $\mathrm{~m}$ & 80 & $\mathbf{1 , 1}$ & 1,0 & 1,2 & $\mathrm{~m}$ & 66 \\
\hline Irlanda & 17 & 21 & 13 & 17 & 83 & 50 & 45 & 55 & 48 & 90 & $\mathbf{m}$ & $\mathrm{m}$ & $\mathrm{m}$ & $\mathrm{m}$ & $m$ \\
\hline Islandia & 1 & 1 & 1 & $\mathrm{~m}$ & 18 & 52 & 45 & 60 & $\mathrm{~m}$ & 66 & 1,1 & 1,1 & 1,1 & $\mathrm{~m}$ & 33 \\
\hline Israel & 20 & 16 & 25 & $\mathrm{~m}$ & 62 & 39 & 29 & 48 & $\mathrm{~m}$ & 65 & 0,7 & 0,6 & 0,8 & $\mathrm{~m}$ & 35 \\
\hline Italia & $\mathbf{n}$ & $\mathrm{n}$ & $\mathrm{n}$ & $\mathrm{m}$ & $n$ & 44 & 37 & 52 & $\mathrm{~m}$ & 94 & 1,2 & 1,1 & 1,3 & $\mathrm{~m}$ & 64 \\
\hline Japón & m & $\mathrm{m}$ & $\mathrm{m}$ & $\mathrm{m}$ & $m$ & $\mathbf{m}$ & $\mathrm{m}$ & $\mathrm{m}$ & $\mathrm{m}$ & $m$ & m & $\mathrm{m}$ & $\mathrm{m}$ & $\mathrm{m}$ & $m$ \\
\hline Luxemburgo & 5 & 3 & 6 & $\mathrm{~m}$ & 57 & 22 & 21 & 24 & $\mathrm{~m}$ & 79 & 0,4 & 0,3 & 0,4 & $\mathrm{~m}$ & 63 \\
\hline México & 3 & 3 & 2 & $\mathrm{~m}$ & 93 & 31 & 32 & 31 & $\mathrm{~m}$ & 93 & $\mathbf{0 , 1}$ & 0,1 & 0,1 & $\mathrm{~m}$ & 26 \\
\hline Noruega & $\mathbf{n}$ & $\mathrm{n}$ & $\mathrm{n}$ & $\mathrm{n}$ & 38 & 59 & 48 & 70 & 56 & 76 & 1,2 & 1,3 & 1,2 & 1,0 & 49 \\
\hline Nueva Zelanda & 21 & 21 & 20 & 15 & 55 & 55 & 46 & 64 & 42 & 72 & 1,3 & 1,4 & 1,3 & 0,6 & 52 \\
\hline Portugal & $\mathbf{n}$ & $\mathrm{n}$ & $\mathrm{n}$ & $\mathrm{n}$ & $n$ & 54 & 46 & 62 & 48 & 82 & 1,6 & 1,4 & 1,7 & 1,3 & 37 \\
\hline Reino Unido & 7 & 6 & 7 & 5 & 34 & 55 & 50 & 61 & 38 & 82 & 1,8 & 1,9 & 1,7 & 1,0 & 62 \\
\hline República Checa & 7 & 4 & 10 & 7 & 80 & 51 & 46 & 57 & 45 & 83 & 2,9 & 3,0 & 2,7 & 2,5 & 79 \\
\hline República Eslovaca & $\mathbf{1}$ & 1 & 2 & $\mathrm{~m}$ & 83 & 52 & 44 & 59 & 50 & 82 & 2,3 & 2,2 & 2,4 & 2,2 & 69 \\
\hline Suecia & 5 & 5 & 5 & 5 & 52 & 44 & 37 & 51 & 41 & 74 & 1,8 & 2,0 & 1,5 & 0,9 & 57 \\
\hline Suiza & 11 & 11 & 11 & $\mathrm{~m}$ & 45 & 35 & 32 & 38 & 28 & 77 & 3,8 & 4,0 & 3,5 & 1,8 & 73 \\
\hline Turquía & 25 & 27 & 23 & $\mathrm{~m}$ & 83 & 34 & 33 & 36 & $\mathrm{~m}$ & 84 & 0,6 & 0,7 & 0,6 & $\mathrm{~m}$ & 60 \\
\hline Media OCDE & 12 & 12 & 13 & $\mathrm{~m}$ & 58 & 48 & 42 & 53 & $\mathrm{~m}$ & 82 & 1,6 & 1,7 & 1,6 & $\mathrm{~m}$ & 57 \\
\hline Media UE21 & 10 & 9 & 11 & $\mathrm{~m}$ & 57 & 48 & 42 & 53 & $\mathrm{~m}$ & 84 & 1,9 & 1,9 & 1,9 & $\mathrm{~m}$ & 64 \\
\hline Arabia Saudí & $\mathbf{m}$ & $\mathrm{m}$ & $\mathrm{m}$ & $\mathrm{m}$ & $m$ & $\mathbf{m}$ & $\mathrm{m}$ & $\mathrm{m}$ & $\mathrm{m}$ & $m$ & $\mathbf{m}$ & $\mathrm{m}$ & $\mathrm{m}$ & $\mathrm{m}$ & $m$ \\
\hline Argentina $^{3}$ & 31 & 24 & 38 & $\mathrm{~m}$ & 60 & 39 & 34 & 45 & $\mathrm{~m}$ & 68 & $\mathbf{m}$ & $\mathrm{m}$ & $\mathrm{m}$ & $\mathrm{m}$ & $m$ \\
\hline Brasil & $\mathbf{m}$ & $\mathrm{m}$ & $\mathrm{m}$ & $\mathrm{m}$ & $m$ & $\mathbf{m}$ & $\mathrm{m}$ & $\mathrm{m}$ & $\mathrm{m}$ & $m$ & $\mathbf{m}$ & $\mathrm{m}$ & $\mathrm{m}$ & $\mathrm{m}$ & $m$ \\
\hline China & $\mathbf{m}$ & $\mathrm{m}$ & $\mathrm{m}$ & $\mathrm{m}$ & $m$ & $\mathbf{m}$ & $\mathrm{m}$ & $\mathrm{m}$ & $\mathrm{m}$ & $m$ & $\mathbf{m}$ & $\mathrm{m}$ & $\mathrm{m}$ & $\mathrm{m}$ & $m$ \\
\hline Colombia & $\mathbf{m}$ & $\mathrm{m}$ & $\mathrm{m}$ & $\mathrm{m}$ & $m$ & $\mathbf{m}$ & $\mathrm{m}$ & $\mathrm{m}$ & $\mathrm{m}$ & $m$ & $\mathbf{m}$ & $\mathrm{m}$ & $\mathrm{m}$ & $\mathrm{m}$ & $m$ \\
\hline Federación Rusa & $\mathbf{m}$ & $\mathrm{m}$ & $\mathrm{m}$ & $\mathrm{m}$ & $m$ & $\mathbf{m}$ & $\mathrm{m}$ & $\mathrm{m}$ & $\mathrm{m}$ & $m$ & $\mathbf{m}$ & $\mathrm{m}$ & $\mathrm{m}$ & $\mathrm{m}$ & $m$ \\
\hline India & $\mathbf{m}$ & $\mathrm{m}$ & $\mathrm{m}$ & $\mathrm{m}$ & $m$ & $\mathbf{m}$ & $\mathrm{m}$ & $\mathrm{m}$ & $\mathrm{m}$ & $m$ & $\mathbf{m}$ & $\mathrm{m}$ & $\mathrm{m}$ & $\mathrm{m}$ & $m$ \\
\hline Indonesia & 4 & 3 & 4 & $\mathrm{~m}$ & 100 & 24 & 25 & 24 & $\mathrm{~m}$ & 100 & 0,3 & 0,3 & 0,2 & $\mathrm{~m}$ & 92 \\
\hline Letonia & 17 & 14 & 20 & $\mathrm{~m}$ & 67 & 62 & 54 & 70 & $\mathrm{~m}$ & 73 & 0,9 & 0,8 & 1,1 & $\mathrm{~m}$ & 47 \\
\hline Sudáfrica & $\mathbf{m}$ & $\mathrm{m}$ & $\mathrm{m}$ & $\mathrm{m}$ & $m$ & $\mathbf{m}$ & $\mathrm{m}$ & $\mathrm{m}$ & $\mathrm{m}$ & $m$ & m & $\mathrm{m}$ & $\mathrm{m}$ & $\mathrm{m}$ & $m$ \\
\hline
\end{tabular}

Media G20

Notas: La falta de coincidencia entre la cobertura de los datos de población y los datos de nuevos ingresados significa que las tasas de ingreso pueden estar subestimadas en países que son exportadores netos de estudiantes y sobreestimadas en aquellos países que son importadores netos. Las tasas de ingreso ajustadas pretenden compensar este desajuste. Consulte Anexo 3 para obtener información específica por países.

ConsulteAnexo 1 para más información sobre el método utilizado para calcular las tasas de ingreso (tasas brutas frente a tasas netas) y la correspondiente edad de ingreso.

1. Las tasas de ingreso ajustadas corresponden a la tasa de ingreso cuando se excluye a los estudiantes internacionales.

2. Proporción de estudiantes menores de 25 años en la población total de nuevos ingresados.

3. Año de referencia 2011.

Fuentes: OCDE. Arabia Saudí, Argentina, China, Colombia, India, Indonesia, Sudáfrica: Instituto de Estadística de la UNESCO. Letonia: Eurostat. Para ver notas, consulte Anexo 3 (www.oecd.org/edu/eag.htm)

Para obtener más información acerca de los símbolos utilizados en lugar de los datos que faltan, consulte la Guía del lector.

StatLink 젝ㄴ http://dx.doi.org/10.1787/888933118523 
Tabla C3.2a. Tendencias de las tasas de ingreso en educación terciaria (1995-2012)

\begin{tabular}{|c|c|c|c|c|c|c|c|c|c|c|c|c|}
\hline & \multicolumn{6}{|c|}{ Terciaria de tipo $5 \mathrm{~A}^{1}$} & \multicolumn{6}{|c|}{ Terciaria de tipo 5B } \\
\hline & 1995 & 2000 & 2005 & 2010 & 2011 & 2012 & 1995 & 2000 & 2005 & 2010 & 2011 & 2012 \\
\hline & (1) & (2) & (7) & (12) & (13) & (14) & (15) & $(16)$ & (21) & (26) & $(27)$ & $(28)$ \\
\hline \multirow{2}{*}{$\begin{array}{l}\text { Ŭ } \text { Alemania }^{2} \\
\text { Oustralia }\end{array}$} & 26 & 30 & 36 & 42 & 46 & 53 & 15 & 15 & 14 & 21 & 21 & 22 \\
\hline & $\mathrm{m}$ & 59 & 82 & 96 & 96 & 102 & $\mathrm{~m}$ & $\mathrm{~m}$ & $\mathrm{~m}$ & $\mathrm{~m}$ & $\mathrm{~m}$ & $\mathbf{m}$ \\
\hline Austria & 27 & 34 & 37 & 53 & 52 & 53 & $\mathrm{~m}$ & $\mathrm{~m}$ & 9 & 16 & 16 & 17 \\
\hline Bélgica & $\mathrm{m}$ & $\mathrm{m}$ & 33 & 33 & 33 & 34 & $\mathrm{~m}$ & $\mathrm{~m}$ & 34 & 38 & 38 & 39 \\
\hline Chile & $\mathrm{m}$ & $\mathrm{m}$ & 46 & 47 & 45 & 47 & $\mathrm{~m}$ & $\mathrm{~m}$ & 35 & 58 & 59 & 58 \\
\hline Corea & 41 & 45 & 51 & 71 & 69 & 69 & 27 & 51 & 48 & 36 & 37 & 36 \\
\hline Dinamarca & 40 & 52 & 57 & 65 & 71 & 74 & 33 & 28 & 23 & 25 & 26 & 28 \\
\hline Eslovenia & $\mathrm{m}$ & $\mathrm{m}$ & 40 & 77 & 75 & 76 & $\mathrm{~m}$ & $\mathrm{~m}$ & 49 & 19 & 18 & 17 \\
\hline España & $\mathrm{m}$ & 47 & 43 & 52 & 53 & 52 & 3 & 15 & 22 & 26 & 28 & 32 \\
\hline Estados Unidos & 57 & 58 & 64 & 74 & 72 & 71 & $\mathrm{x}(1)$ & $x(2)$ & $\mathrm{x}(7)$ & $\mathrm{x}(12)$ & $\mathrm{x}(13)$ & $\mathbf{x}(\mathbf{1 4})$ \\
\hline Estonia & $\mathrm{m}$ & $\mathrm{m}$ & 55 & 43 & 43 & 43 & $\mathrm{~m}$ & $\mathrm{~m}$ & 33 & 29 & 28 & 27 \\
\hline Francia & $\mathrm{m}$ & $\mathrm{m}$ & $\mathrm{m}$ & $\mathrm{m}$ & 39 & 41 & $\mathrm{~m}$ & $\mathrm{~m}$ & $\mathrm{~m}$ & $\mathrm{~m}$ & $\mathrm{~m}$ & $\mathbf{m}$ \\
\hline Grecia & 15 & 30 & 43 & $\mathrm{~m}$ & 40 & 40 & 5 & 21 & 13 & $\mathrm{~m}$ & 31 & 23 \\
\hline Hungría & $\mathrm{m}$ & 55 & 68 & 54 & 52 & 54 & $\mathrm{~m}$ & 1 & 11 & 16 & 17 & 16 \\
\hline Irlanda & $\mathrm{m}$ & 32 & 45 & 56 & 51 & 54 & $\mathrm{~m}$ & 26 & 14 & 28 & 24 & 20 \\
\hline Islandia & $\mathrm{m}$ & 66 & 74 & 93 & 81 & 80 & $\mathrm{~m}$ & 10 & 7 & 4 & 4 & 3 \\
\hline Israel & $\mathrm{m}$ & 48 & 55 & 60 & 60 & 60 & $\mathrm{~m}$ & 31 & 25 & 29 & 27 & 33 \\
\hline Italia & $\mathrm{m}$ & 39 & 56 & 49 & 48 & 47 & $\mathrm{~m}$ & 1 & $\mathrm{n}$ & $\mathrm{n}$ & $\mathrm{n}$ & $\mathbf{n}$ \\
\hline Japón & 31 & 40 & 44 & 51 & 52 & 52 & 33 & 32 & 31 & 27 & 29 & 28 \\
\hline Luxemburgo & $\mathrm{m}$ & $\mathrm{m}$ & $\mathrm{m}$ & $\mathrm{m}$ & 27 & 28 & $\mathrm{~m}$ & $\mathrm{~m}$ & $\mathrm{~m}$ & $\mathrm{~m}$ & 10 & 8 \\
\hline México & $\mathrm{m}$ & 24 & 27 & 33 & 34 & 34 & $\mathrm{~m}$ & 1 & 2 & 3 & 3 & 3 \\
\hline Noruega & 59 & 67 & 73 & 76 & 76 & 77 & 5 & 5 & $\mathrm{n}$ & $\mathrm{n}$ & $\mathrm{n}$ & $\mathbf{n}$ \\
\hline Nueva Zelanda & 83 & 95 & 76 & 79 & 76 & 78 & 44 & 52 & 50 & 47 & 44 & 40 \\
\hline Países Bajos & 44 & 53 & 59 & 65 & 65 & 65 & a & a & $\mathrm{a}$ & $\mathrm{n}$ & $\mathrm{n}$ & $\mathbf{n}$ \\
\hline Reino Unido & $\mathrm{m}$ & 47 & 51 & 63 & 64 & 67 & $\mathrm{~m}$ & 29 & 28 & 26 & 23 & 20 \\
\hline República Checa & $\mathrm{m}$ & 25 & 41 & 60 & 60 & 60 & $\mathrm{~m}$ & 9 & 8 & 9 & 9 & 9 \\
\hline República Eslovaca & 28 & 37 & 59 & 65 & 61 & 61 & 1 & 3 & $\mathrm{~m}$ & 1 & 1 & 1 \\
\hline Suecia & 57 & 67 & 76 & 76 & 72 & 60 & $\mathrm{~m}$ & 7 & 7 & 12 & 11 & 10 \\
\hline Suiza & 17 & 29 & 37 & 44 & 44 & 44 & 29 & 14 & 16 & 23 & 22 & 23 \\
\hline Turquía & 18 & 21 & 27 & 40 & 39 & 41 & 9 & 9 & 19 & 28 & 27 & 30 \\
\hline
\end{tabular}

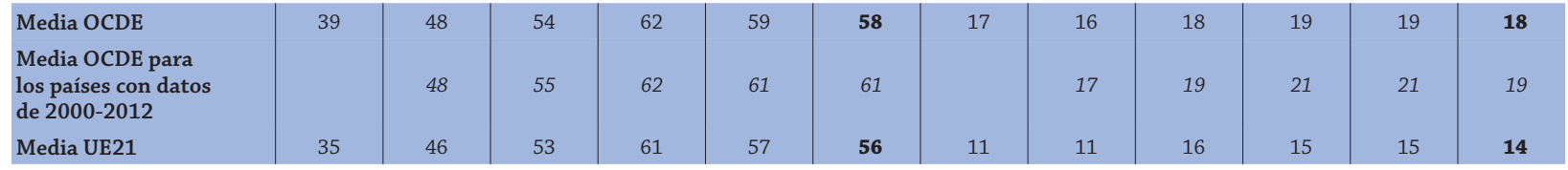

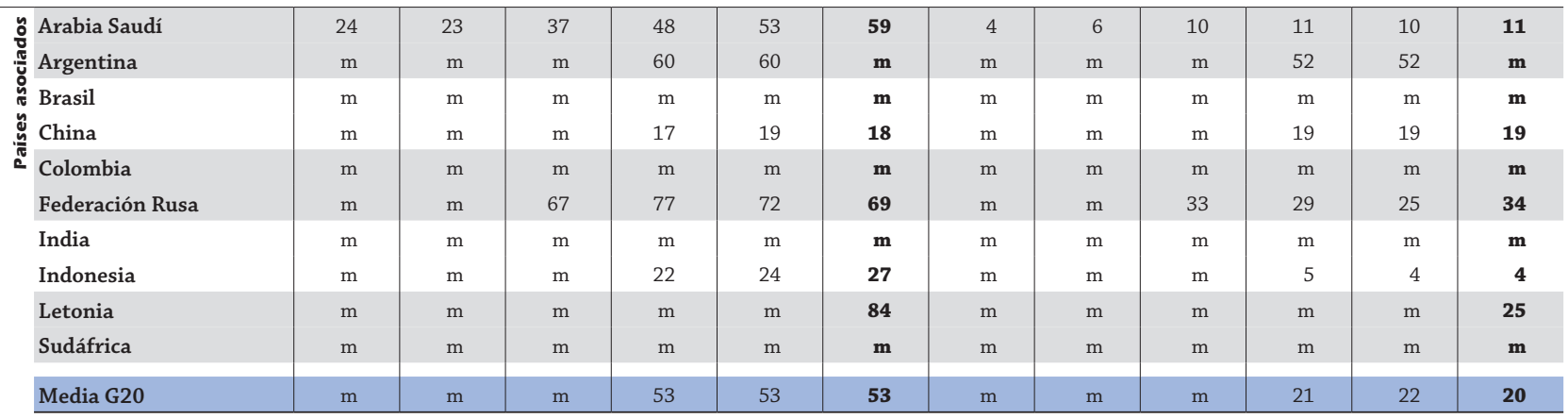

Notas: Las columnas que muestran las tasas de ingreso de los años 2001 a 2004, 2006 a 2009 (es decir, las columnas 3-6, 8-11, 17-20, 22-25) están disponibles en Internet (véase StatLink más abajo).

Consulte Anexo 1 para más información sobre el método utilizado para calcular las tasas de ingreso (tasas brutas frente a tasas netas) y la correspondiente edad de ingreso.

1. Las tasas de ingreso en educación terciaria de tipo A incluyen programas de investigación avanzada de 1995, $2000-2003$ (excepto en Alemania y Bélgica).

2. Ruptura de la serie temporal entre 2008 y 2009 debido a una reasignación parcial de los programas de formación profesional a CINE 2 y CINE $5 B$.

Fuentes: OCDE. Arabia Saudí, Argentina, China, Colombia, India, Indonesia, Sudáfrica: Instituto de Estadística de la UNESCO. Letonia: Eurostat. Para ver notas, consulte Anexo 3 (www.oecd.org/edu/eag.htm)

Para obtener más información acerca de los símbolos utilizados en lugar de los datos que faltan, consulte la Guía del lector.

StatLink 제기 http://dx.doi.org/10.1787/888933118542 
Tabla C3.3a. Distribución de nuevos ingresados en educación terciaria, por ámbito de estudio (2012)

\begin{tabular}{|c|c|c|c|c|c|c|c|c|}
\hline & $\begin{array}{c}\text { Humanidades, } \\
\text { artes } \\
\text { y educación }\end{array}$ & $\begin{array}{c}\text { Salud } \\
\text { y asistencia } \\
\text { social }\end{array}$ & $\begin{array}{c}\text { Ciencias sociales, } \\
\text { empresariales } \\
\text { y derecho }\end{array}$ & Servicios & $\begin{array}{l}\text { Ingeniería, } \\
\text { industria y } \\
\text { construcción }\end{array}$ & Ciencias & Agricultura & $\begin{array}{c}\text { Desconocido } \\
\text { o no especificado }\end{array}$ \\
\hline & (1) & (4) & (5) & (6) & (7) & (8) & (13) & (14) \\
\hline Alemania & 23 & 19 & 23 & 3 & 17 & 13 & 1 & $\mathrm{n}$ \\
\hline Australia $^{1}$ & 20 & 17 & 37 & 4 & 9 & 12 & 1 & $\mathrm{n}$ \\
\hline Austria & 29 & 7 & 33 & 3 & 16 & 10 & 1 & $\mathrm{n}$ \\
\hline Bélgica $^{2}$ & 23 & 25 & 30 & 2 & 10 & 5 & 3 & 1 \\
\hline Canadá & $\mathrm{m}$ & $\mathrm{m}$ & $\mathbf{m}$ & $\mathrm{m}$ & $\mathrm{m}$ & $\mathrm{m}$ & $\mathrm{m}$ & $\mathrm{m}$ \\
\hline Chile & 16 & 22 & 25 & 12 & 18 & 6 & 2 & $\mathrm{n}$ \\
\hline Corea & 25 & 14 & 20 & 7 & 25 & 7 & 1 & $\mathrm{n}$ \\
\hline Dinamarca & 16 & 19 & 41 & 2 & 12 & 8 & 2 & $\mathrm{n}$ \\
\hline Eslovenia & 14 & 10 & 32 & 10 & 21 & 9 & 3 & $\mathrm{n}$ \\
\hline España $^{2}$ & 23 & 13 & 29 & 8 & 16 & 9 & 1 & $\mathrm{n}$ \\
\hline Estados Unidos & $\mathrm{m}$ & $\mathrm{m}$ & $\mathbf{m}$ & $\mathrm{m}$ & $\mathrm{m}$ & $\mathrm{m}$ & $\mathrm{m}$ & $\mathrm{m}$ \\
\hline Estonia & 18 & 12 & 29 & 9 & 16 & 14 & 2 & $\mathrm{n}$ \\
\hline Finlandia & 14 & 19 & 22 & 8 & 25 & 9 & 2 & $\mathrm{n}$ \\
\hline Francia $^{1}$ & 19 & 10 & 39 & 4 & 9 & 18 & $\mathrm{n}$ & $\mathrm{n}$ \\
\hline Grecia & 23 & 11 & 29 & 2 & 17 & 15 & 3 & $\mathrm{n}$ \\
\hline Hungría & 14 & 10 & 39 & 12 & 14 & 9 & 2 & $\mathrm{n}$ \\
\hline Irlanda $^{2}$ & 23 & 14 & 23 & 7 & 11 & 17 & 2 & 2 \\
\hline Islandia & 28 & 11 & 33 & 3 & 10 & 13 & 1 & $\mathrm{n}$ \\
\hline Israel & 22 & 7 & 35 & $\mathrm{n}$ & 23 & 8 & $\mathrm{n}$ & 4 \\
\hline Italia $^{1}$ & 21 & 12 & 34 & 4 & 16 & 10 & 3 & $\mathrm{n}$ \\
\hline Japón & 23 & 16 & 27 & 9 & 14 & 2 & 2 & 7 \\
\hline Luxemburgo & $\mathrm{m}$ & 12 & 47 & $\mathrm{n}$ & 8 & 9 & $\mathrm{n}$ & $\mathrm{n}$ \\
\hline México & 14 & 9 & 40 & 1 & 27 & 6 & 2 & $\mathrm{n}$ \\
\hline Noruega & 23 & 17 & 31 & 7 & 9 & 9 & 1 & 2 \\
\hline Nueva Zelanda & 24 & 12 & 33 & 6 & 7 & 17 & 1 & $\mathrm{n}$ \\
\hline Países Bajos ${ }^{2}$ & 17 & 19 & 39 & 7 & 9 & 7 & 1 & 1 \\
\hline Polonia $^{2}$ & 19 & 9 & 32 & 10 & 18 & 10 & 2 & $\mathrm{n}$ \\
\hline Portugal & 16 & 16 & 32 & 8 & 19 & 8 & 2 & $\mathrm{n}$ \\
\hline Reino Unido & 24 & 17 & 28 & 2 & 8 & 15 & 1 & 6 \\
\hline República Checa & 17 & 13 & 30 & 6 & 15 & 13 & 4 & 2 \\
\hline República Eslovaca & 20 & 18 & 28 & 6 & 15 & 10 & 3 & $\mathrm{n}$ \\
\hline Suecia & 24 & 14 & 29 & 3 & 18 & 11 & 1 & $\mathrm{n}$ \\
\hline Suiza & 16 & 13 & 36 & 8 & 16 & 9 & 1 & 1 \\
\hline Turquía & 22 & 6 & 39 & 5 & 16 & 9 & 3 & $\mathrm{n}$ \\
\hline Media OCDE & 20 & 13 & 31 & 5 & 15 & 10 & 2 & 4 \\
\hline Media UE21 & 20 & 14 & 32 & 5 & 15 & 11 & 2 & 1 \\
\hline Arabia Saudí & 30 & 5 & 19 & 1 & 5 & 11 & 1 & 28 \\
\hline Argentina ${ }^{3}$ & 29 & 13 & 32 & 5 & 8 & 9 & 2 & 1 \\
\hline Brasil & $\mathrm{m}$ & $\mathrm{m}$ & $\mathbf{m}$ & $\mathrm{m}$ & $\mathrm{m}$ & $\mathrm{m}$ & $\mathrm{m}$ & $\mathrm{m}$ \\
\hline China & $\mathrm{m}$ & $\mathrm{m}$ & $\mathbf{m}$ & $\mathrm{m}$ & $\mathrm{m}$ & $\mathrm{m}$ & $\mathrm{m}$ & $\mathrm{m}$ \\
\hline Colombia & $\mathrm{m}$ & $\mathrm{m}$ & $\mathbf{m}$ & $\mathrm{m}$ & $\mathrm{m}$ & $\mathrm{m}$ & $\mathrm{m}$ & $\mathrm{m}$ \\
\hline Federación Rusa ${ }^{2}$ & 12 & 7 & 36 & 7 & 27 & 8 & 2 & 3 \\
\hline India & $\mathrm{m}$ & $\mathrm{m}$ & $\mathbf{m}$ & $\mathrm{m}$ & $\mathrm{m}$ & $\mathrm{m}$ & $\mathrm{m}$ & $\mathrm{m}$ \\
\hline Indonesia & 12 & 7 & 36 & 7 & 27 & 8 & 2 & 3 \\
\hline Letonia & $\mathrm{m}$ & $\mathrm{m}$ & $\mathbf{m}$ & $\mathrm{m}$ & $\mathrm{m}$ & $\mathrm{m}$ & $\mathrm{m}$ & $\mathrm{m}$ \\
\hline Sudáfrica & $\mathrm{m}$ & $\mathrm{m}$ & $\mathbf{m}$ & $\mathrm{m}$ & $\mathrm{m}$ & $\mathrm{m}$ & $\mathrm{m}$ & $\mathrm{m}$ \\
\hline Media G20 & $\mathrm{m}$ & $\mathrm{m}$ & $\mathbf{m}$ & $\mathrm{m}$ & $\mathrm{m}$ & $\mathrm{m}$ & $\mathrm{m}$ & $\mathrm{m}$ \\
\hline
\end{tabular}

Nota: Las columnas que muestran el desglose de humanidades, artes y educación (2 y 3) y ciencias (9-12) están disponibles en Internet (véase StatLink más abajo).

1. No se incluyen los programas de educación terciaria de tipo B.

2. No se incluyen los programas de investigación avanzada.

3. Año de referencia 2011.

Fuentes: OCDE. Arabia Saudí, Argentina, China, Colombia, India, Indonesia, Sudáfrica: Instituto de Estadística de la UNESCO. Letonia: Eurostat. Para ver notas, consulte Anexo 3 (www.oecd.org/edu/eag.htm)

Para obtener más información acerca de los símbolos utilizados en lugar de los datos que faltan, consulte la Guía del lector.

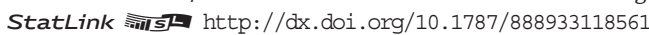





\section{¿QUIÉN ESTUDIA EN EL EXTRANJERO Y DÓNDE?}

- En 2012, más de 4,5 millones de estudiantes se matricularon en educación terciaria fuera de su país de ciudadanía. Australia, Austria, Luxemburgo, Nueva Zelanda, Reino Unido y Suiza tienen los porcentajes más altos de estudiantes internacionales en sus matriculaciones de educación terciaria.

- Los estudiantes asiáticos representan el 53\% de los estudiantes extranjeros matriculados en todo el mundo. El mayor número de estudiantes extranjeros proceden de China, Corea e India.

- En 2012, el número de estudiantes extranjeros matriculados en educación terciaria en los países de la OCDE era como media tres veces superior al de estudiantes de países de la OCDE que estudiaban en el extranjero. En los 21 países europeos que son miembros de la OCDE había una media de tres estudiantes extranjeros por cada ciudadano europeo matriculado en el extranjero.

- Alrededor del $82 \%$ de todos los estudiantes extranjeros están matriculados en países del G20, mientras que el $75 \%$ de todos los estudiantes extranjeros están matriculados en países de la OCDE. Estas proporciones han permanecido estables durante la última década.

\section{Gráfico C4.1. Evolución del número de estudiantes matriculados fuera de su país de ciudadanía, por región de destino (2000 a 2012)}

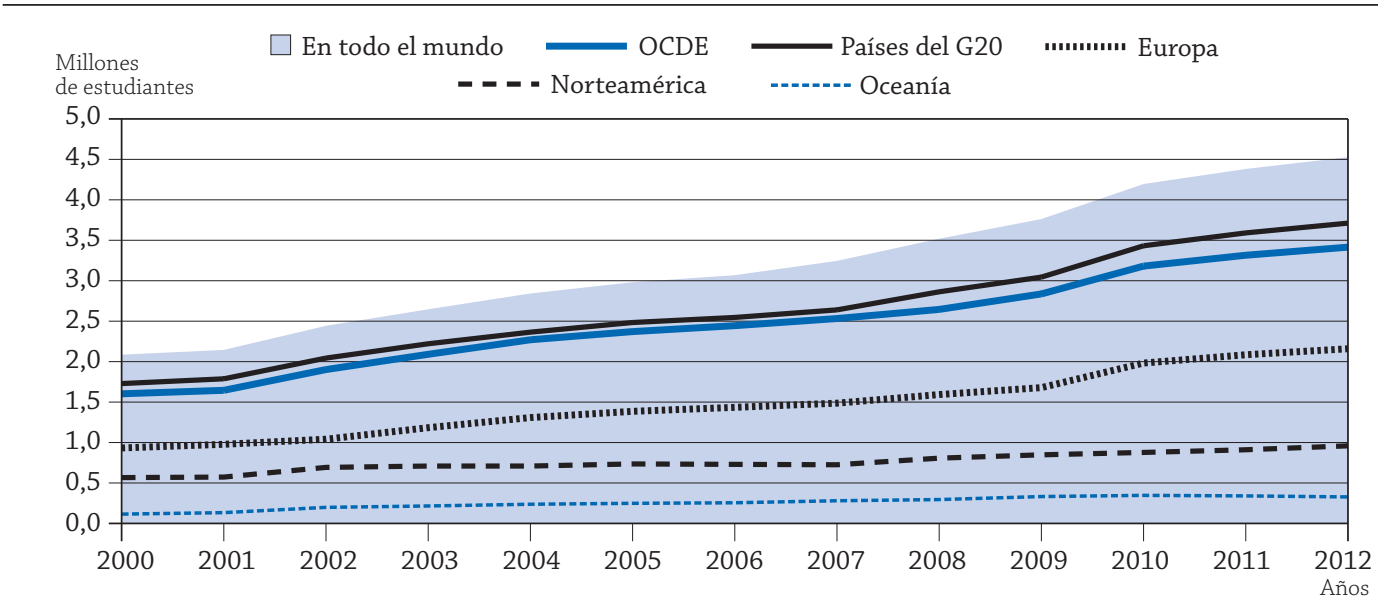

Fuente: OCDE. Tabla C4.6. Para ver notas, consulte Anexo 3 (www.oecd.org/edu/eag.htm).

StatLink iㅔㄴㅐ http://dx.doi.org/10.1787/888933118789

\section{Contexto}

A medida que las economías nacionales están cada vez más interconectadas y que crece la participación en la educación, los gobiernos y los ciudadanos conceden cada vez más importancia a la educación superior para ampliar los horizontes de los estudiantes y ayudarles a comprender mejor las lenguas, culturas y prácticas empresariales del mundo. Una de las formas que tienen los estudiantes de ampliar su conocimiento de otras sociedades y lenguas, mejorando así sus perspectivas en sectores globalizados del mercado laboral como son las corporaciones multinacionales o la investigación, es estudiar en instituciones de educación terciaria en países distintos del suyo propio.

Los factores que llevan al aumento general de la movilidad estudiantil van desde la demanda cada vez mayor de educación superior en todo el mundo y el valor percibido de estudiar en prestigiosas instituciones de educación postsecundaria en el extranjero, a políticas específicas para fomentar la movilidad estudiantil dentro de una región geográfica (como es el caso de Europa), así como a esfuerzos de los gobiernos para apoyar a los estudiantes que se dediquen a determinados ámbitos de estudio que están creciendo rápidamente en sus países de origen. Además, algunos países e instituciones realizan grandes esfuerzos de marketing para atraer a estudiantes de fuera de sus fronteras.

El aumento de la movilidad estudiantil en educación terciaria puede también proporcionar a los sistemas educativos de acogida pequeños o menos desarrollados la oportunidad de mejorar la eficiencia de 
los costes de sus sistemas educativos. Por ejemplo, puede ayudar a los países a centrar recursos limitados en programas educativos con potenciales economías de escala o a extender la participación en educación terciaria sin tener que expandir el sistema terciario dentro del país mismo. Para los países de acogida, matricular a estudiantes extranjeros no solo puede ayudar a aumentar los ingresos procedentes de la educación superior, sino también puede formar parte de una estrategia más amplia para atraer a inmigrantes altamente cualificados.

Una proporción significativa de estudiantes procedentes de países del G20 que no son parte de la OCDE incluye a estudiantes con mejor rendimiento, candidatos naturales para recibir financiación pública o privada o para tener un entorno socioeconómico relativamente alto. Esto implica que la movilidad estudiantil no solo puede aportar prestigio a los programas académicos de las instituciones de educación terciaria, sino también beneficios económicos a los sistemas educativos de acogida.

En el contexto económico actual, la disminución de ayudas para becas y subvenciones que apoyan la movilidad estudiantil, así como los presupuestos cada vez más ajustados de los ciudadanos, pueden disminuir el ritmo de la movilidad estudiantil. Por otra parte, las limitadas oportunidades del mercado laboral de los países de origen de los estudiantes pueden aumentar el atractivo de estudiar en el extranjero como forma de adquirir una ventaja competitiva, incrementando así la movilidad estudiantil.

Los estudiantes internacionales tienden a elegir programas de estudio diferentes en comparación con los estudiantes locales (véase Indicador A4 en Panorama de la educación 2012), lo que indica un cierto grado de especialización de los países en los programas que ofrecen, o falta de programas en los países de origen, o mejores oportunidades de empleo asociadas a ámbitos específicos de estudio.

En este indicador, los términos «estudiantes internacionales» o «estudiantes móviles» se refieren a estudiantes que se han trasladado desde su país de origen con el fin de estudiar. El término «estudiantes extranjeros» hace referencia a estudiantes que no son ciudadanos del país en el que están matriculados, pero pueden ser residentes de larga duración o haber nacido en dicho país. En general, los estudiantes internacionales son un subgrupo de los estudiantes extranjeros (ver sección de Definiciones al final de este indicador).

\section{Otros resultados}

- Alemania, Australia, Canadá, Estados Unidos, Francia y Reino Unido en conjunto reciben a más del $50 \%$ de todos los estudiantes extranjeros del mundo.

- Los estudiantes internacionales de los países de la OCDE proceden principalmente de Alemania, Canadá, Corea, Estados Unidos, Francia e Italia.

- Los estudiantes internacionales representan el $10 \%$ o más de las matriculaciones en educación terciaria en Australia, Austria, Luxemburgo, Nueva Zelanda, Reino Unido y Suiza. También suponen más del $30 \%$ de las matriculaciones en programas de investigación avanzada en Australia, Bélgica, Luxemburgo, Nueva Zelanda, Países Bajos, Reino Unido y Suiza.

\section{Tendencias}

Durante el periodo 2000-2012, el número de estudiantes extranjeros de nivel terciario matriculados en todo el mundo aumentó en más del doble, con una tasa media de crecimiento anual de casi el $7 \%$. En los países de la OCDE, el número de estudiantes extranjeros matriculados en el nivel terciario es un reflejo de la tendencia global.

Europa es el principal destino para los estudiantes matriculados en educación terciaria fuera de su país de origen, con un $48 \%$ de estos estudiantes, seguida por Norteamérica, que recibe al $21 \%$ de todos los estudiantes internacionales, y Asia, con el 18\%. El número de estudiantes internacionales en Oceanía se ha triplicado desde el año 2000, pero esta región recibe menos del $10 \%$ de todos los estudiantes extranjeros. En otras regiones, como África y América Latina y Caribe, también está creciendo el número de estudiantes internacionales, lo que viene a reflejar la internacionalización de las universidades en un número cada vez mayor de países (Tabla C4.6 y Gráfico C4.1). 


\section{Análisis}

En las últimas tres décadas, el número de estudiantes matriculados fuera de su país de ciudadanía ha crecido enormemente, desde 0,8 millones en todo el mundo en 1975 hasta 4,5 millones en 2012, lo que supone un aumento de más de cinco veces (Cuadro C4.1). Esta notable expansión tiene su origen en varios factores, desde el interés por promover los lazos académicos, culturales, sociales y políticos entre países, especialmente mientras iba tomando forma la Unión Europea, a un incremento sustancial en el acceso global a la educación terciaria, así como a la reducción de los costes del transporte. La internacionalización de los mercados laborales para ciudadanos altamente cualificados también ha proporcionado un incentivo a los estudiantes para adquirir experiencia internacional como parte de sus estudios.

La mayoría de los nuevos estudiantes extranjeros en educación terciaria proceden de países de fuera del área de la OCDE y es probable que contribuyan a una expansión gradual de la proporción de estudiantes extranjeros en programas de investigación avanzada en los países de la OCDE y otros países del G20 en los próximos años.

\section{Cuadro C4.1. Aumentos a largo plazo del número de estudiantes matriculados fuera de su país de ciudadanía}

\section{Crecimiento en la internacionalización de la educación terciaria (1975-2012, en millones)}

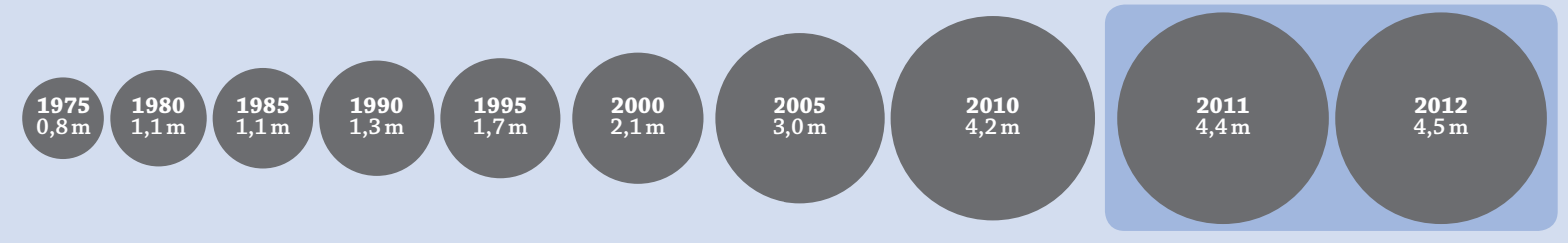

Fuentes: OCDE e Instituto de Estadística de la UNESCO.

Los datos de matrículas de estudiantes extranjeros en todo el mundo provienen de la OCDE y del Instituto de Estadística de la UNESCO (UIS). El UIS proporcionó los datos de todos los países de 1975-1995 y de la mayor parte de los países de fuera de la OCDE en 2000, 2005, 2010, 2011 y 2012. La OCDE proporcionó los datos de los países de la OCDE y las demás economías de fuera de la OCDE en 2000 y 2012. Ambas fuentes utilizan definiciones similares, de modo que se pueden combinar. Los datos que faltaban se obtuvieron de los informes con los datos más afines para garantizar que las interrupciones en la cobertura de los datos no provocaran interrupciones en las series temporales.

Los datos de la sección sombreada corresponden a una escala de tiempo diferente que el resto de la serie, pero se incluyen como información, porque son de los dos últimos años disponibles y 2012 es el año de referencia.

StatLink 젝ㄴ http://dx.doi.org/10.1787/888933118884

La movilidad estudiantil global refleja en gran medida las pautas de migración interregional e intrarregional. El crecimiento de la internacionalización de las matriculaciones terciarias en los países de la OCDE, así como la alta proporción de movilidad estudiantil intrarregional, muestran la creciente importancia de la movilidad regional sobre la movilidad global. Además, los flujos de estudiantes en los países europeos y en el este de Asia y Oceanía tienden a reflejar la evolución de las áreas geopolíticas, como son los estrechos lazos entre los países de la zona Asia-Pacífico y la mayor cooperación entre los países europeos más allá de la Unión Europea (UNESCO, 2009).

\section{Principales destinos de los estudiantes extranjeros}

Los países del G20 atraen al $82 \%$ de los estudiantes extranjeros en todo el mundo, mientras que alrededor del $75 \%$ de los estudiantes extranjeros están matriculados en educación terciaria en un país de la OCDE. En el área de la OCDE, los países de la UE21 reciben la mayor proporción (39\%) de estudiantes extranjeros. Estos 21 países también reciben el $98 \%$ de los estudiantes extranjeros matriculados en países de la UE. Aproximadamente el $74 \%$ de los estudiantes extranjeros matriculados en países de la UE21 proceden de otro país de la UE21, lo que demuestra el efecto de las políticas de movilidad de la UE. Norteamérica es la segunda región más atractiva para los estudiantes extranjeros, con un $21 \%$ del total. El perfil de los estudiantes internacionales en esta región es más diverso que el que se observa en la Unión Europea. Por ejemplo, aunque el $53 \%$ de los canadienses que estudian en el extranjero se encuentran en Estados Unidos, suponen solo el $4 \%$ de estos estudiantes internacionales. De modo similar, el 14\% de los estadounidenses que estudian en el extranjero eligen Canadá, pero solo suponen el $6 \%$ de todos los estudiantes extranjeros matriculados en educación terciaria en Canadá (Tablas C4.3, C4.4 y C4.6). 


\section{Gráfico C4.2. Distribución de estudiantes extranjeros en educación terciaria, por región de destino (2012)}

Porcentaje de estudiantes extranjeros terciarios sobre los que se refirió a la OCDE que están matriculados en cada país de destino

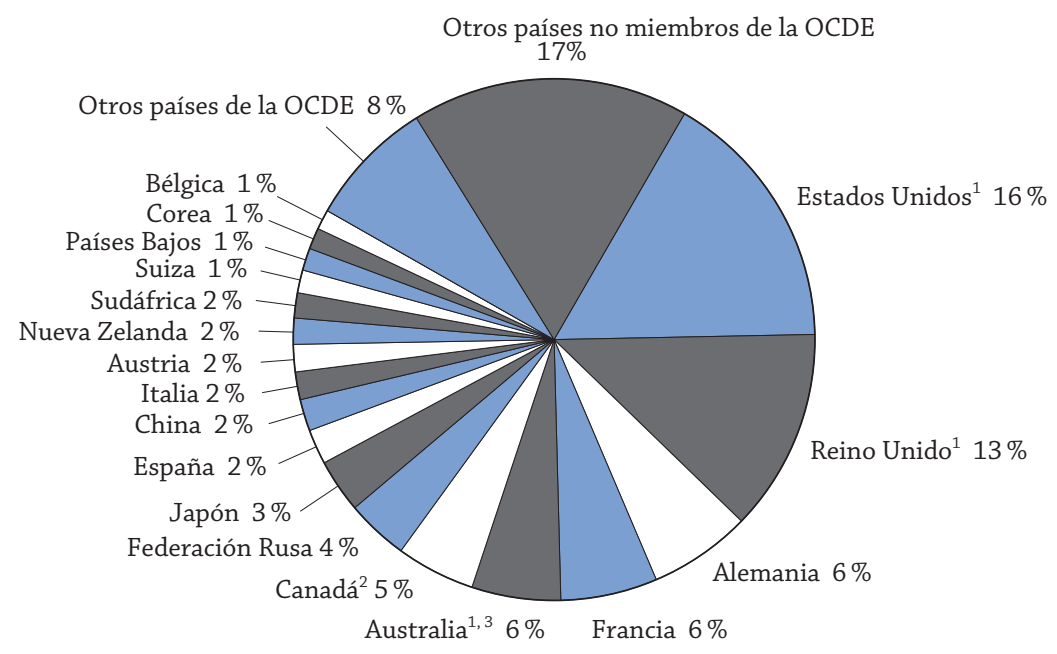

1. Los datos que se refieren a los estudiantes internacionales se definen sobre la base de su país de residencia.

2. Año de referencia 2011.

3. Las cifras de estudiantes provienen de diferentes fuentes y, por tanto, los resultados son meramente indicativos.

Fuente: OCDE. Tabla C4.4 y Tabla C4.7, disponible en Internet. Para ver notas, consulte Anexo 3 (www.oecd.org/edu/eag.htm).

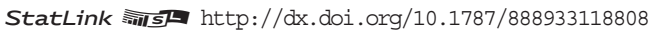

En 2012, más de uno de cada dos estudiantes extranjeros de educación terciaria estaban matriculados en Alemania, Australia, Canadá, Estados Unidos, Francia o Reino Unido. En términos absolutos, Estados Unidos recibió a la mayoría de estos estudiantes, con un $16 \%$ de todos los estudiantes extranjeros, seguido de Reino Unido (13\%), Australia (6\%), Alemania (6\%), Francia (6\%) y Canadá (5\%). Aunque estos destinos dan cuenta de más de la mitad de todos los estudiantes terciarios que llevan a cabo sus estudios en el extranjero, han surgido algunos actores nuevos en el mercado de la educación internacional en los últimos años (Gráfico C4.2 y Tabla C4.7, disponible en Internet). Junto con los seis principales destinos, en 2012 se matriculó un número significativo de estudiantes extranjeros en Federación Rusa (4\%), Japón (3\%), Austria (2\%), Italia (2\%), España (2\%) y Nueva Zelanda (2\%). Las cifras para Australia y Estados Unidos se refieren a estudiantes internacionales (Tabla C4.4).

\section{Nuevos actores en el mercado de la educación internacional}

La proporción de estudiantes internacionales que eligieron Estados Unidos como destino para estudiar programas de educación terciaria disminuyó desde el $23 \%$ en el año 2000 hasta el 16\% en 2012, y la proporción de estudiantes internacionales que eligieron Alemania disminuyó casi tres puntos porcentuales durante dicho periodo. En cambio, las proporciones de estudiantes internacionales que eligieron Corea o Nueva Zelanda como destinos aumentó al menos un punto porcentual, mientras que la proporción de estudiantes que eligieron Reino Unido o Federación Rusa se incrementó alrededor de dos puntos porcentuales (Gráfico C4.3). Algunos de estos cambios reflejan las diferencias en los enfoques de los diferentes países respecto a la internacionalización, que van desde políticas activas de marketing en la región Asia-Pacífico a un enfoque más local y promovido por las universidades en Estados Unidos.

\section{Factores subyacentes en la elección de los estudiantes de un país donde realizar sus estudios Lengua de la enseñanza}

La lengua hablada y utilizada en la enseñanza determina a veces el país en el que decide estudiar un estudiante. Los países cuya lengua de enseñanza hablan y leen muchas personas, como los países de habla inglesa, francesa, alemana, rusa y española lideran, por tanto, los destinos de los estudiantes extranjeros, tanto en términos absolutos como relativos. Japón es una excepción notable: pese a que su lengua de enseñanza no es una lengua muy extendida, acoge a un gran número de estudiantes, de los que el $94 \%$ proceden de Asia (Tabla C4.3 y Gráfico C4.2). 


\section{Gráfico C4.3. Tendencias de las cuotas del mercado internacional de la educación $(2000,2012)$}

Porcentaje de todos los estudiantes extranjeros matriculados en educación terciaria, por destino

\begin{tabular}{|c|c|c|c|c|}
\hline & Países & $\square 2000$ & Otros países del G20 & $\square 2000$ \\
\hline Cuota de mercado (\%) & de la OCDE & $\square 2012$ & y no miembros de la OCDE & $\square 2012$ \\
\hline
\end{tabular}

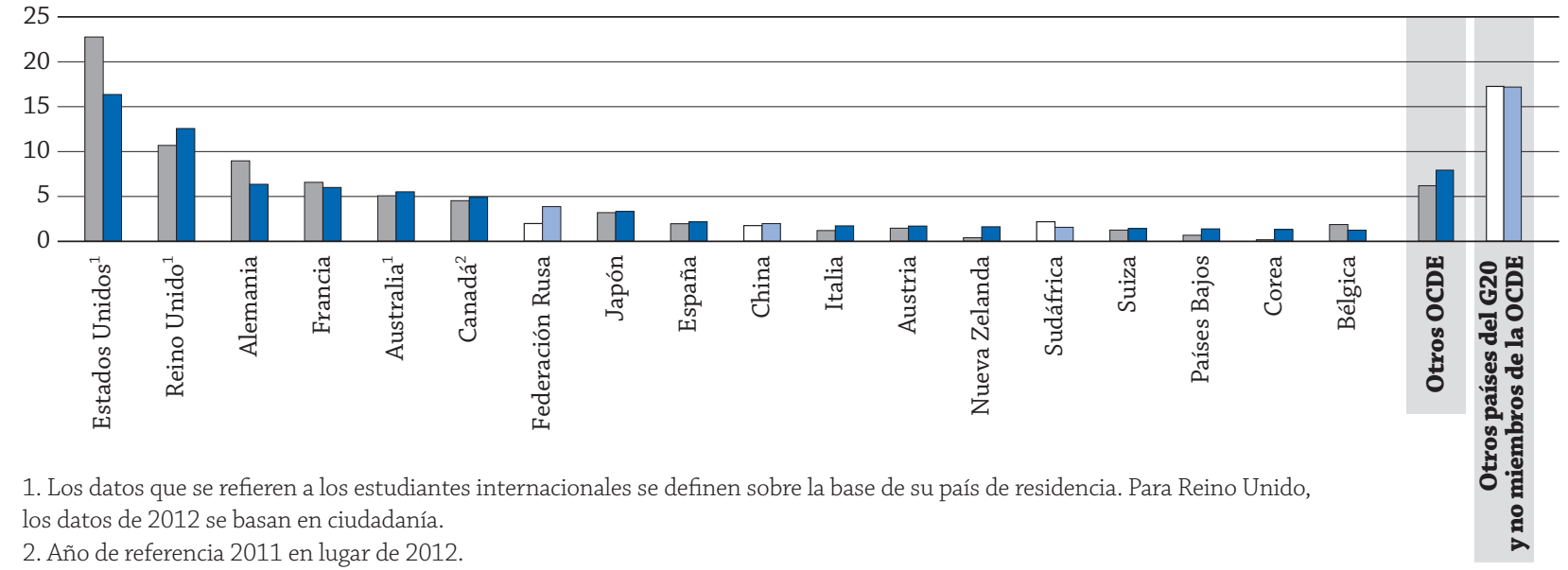

2. Año de referencia 2011 en lugar de 2012.

Los países están clasificados en orden descendente de la cuota de mercado en 2012.

Fuente: OCDE. Tabla C4.7, disponible en Internet. Para ver notas, consulte Anexo 3 (www.oecd.org/edu/eag.htm).

StatLink 젝ㄴ http://dx.doi.org/10.1787/888933118827

La prevalencia de los destinos de habla predominantemente inglesa, como Australia, Canadá, Estados Unidos, Nueva Zelanda y Reino Unido, muestra la progresiva adopción del inglés como lengua global. También puede reflejar el hecho de que los estudiantes que quieren estudiar en el extranjero probablemente hayan aprendido inglés en su país de origen o deseen mejorar sus competencias lingüísticas en inglés por medio de la inmersión en un contexto nativo de habla inglesa.

Por ello, alrededor del $41 \%$ del aumento global de las matriculaciones de estudiantes extranjeros en educación terciaria en todo el mundo entre el año 2000 y 2012 se puede atribuir a aumentos de estas matriculaciones en Austra-

\section{Cuadro C4.2. Países de la OCDE y países asociados que ofrecen programas de educación terciaria en inglés (2012)}

\begin{tabular}{l|l} 
Uso del inglés en la enseñanza \\
$\begin{array}{l}\text { Todos o casi todos los programas } \\
\text { se ofrecen en inglés }\end{array}$ & Australia, Canadá ${ }^{1}$, Estados Unidos, Irlanda, Nueva Zelanda, Reino Unido \\
\hline $\begin{array}{l}\text { Muchos programas se ofrecen } \\
\text { en inglés }\end{array}$ & Dinamarca, Finlandia, Países Bajos, Suecia \\
\hline $\begin{array}{l}\text { Algunos programas se ofrecen } \\
\text { en inglés }\end{array}$ & $\begin{array}{l}\text { Alemania, Bélgica (Fl.) })^{2}, \text { Corea, España, Francia, Hungría, Islandia, Japón, } \\
\text { Noruega, Polonia, Portugal, República Checa, República Eslovaca, Suiza }\end{array}$, Turquía \\
\hline $\begin{array}{l}\text { Ninguno o casi ningún programa } \\
\text { se ofrece en inglés }\end{array}$ & $\begin{array}{l}\text { Austria, Bélgica (Fr.), Brasil, Chile, Federación Rusa, Grecia, Israel, Italia, } \\
\text { Luxemburgo, México }\end{array}$ \\
\hline
\end{tabular}

Nota: Al evaluar hasta qué punto un país ofrece pocos o muchos programas en inglés se ha tenido en cuenta la población de dicho país. Por tanto, Alemania y Francia se encuentran entre los países con comparativamente pocos programas en inglés, a pesar de contar con más programas en inglés que Suecia en términos absolutos.

1. En Canadá, las instituciones terciarias emplean el francés (sobre todo en Quebec) o el inglés.

2. Programas de máster.

3. A discreción de las instituciones de educación terciaria.

Fuentes: OCDE, recopilación de folletos para potenciales estudiantes internacionales de DAAD (Alemania), OAD (Austria), NIIED (Corea), Cirius (Dinamarca), CIMO (Finlandia), Campus France (Francia), Campus Hungary (Hungría), Universidad de Islandia (Islandia), JPSS (Japón), SIU (Noruega), NUFFIC (Países Bajos), CRASP (Polonia), CHES y NARIC (República Checa), Instituto Sueco (Suecia) y Universidad Técnica de Oriente Medio (Turquía). 
lia, Canadá, Estados Unidos, Irlanda, Nueva Zelanda, Reino Unido y Sudáfrica (Tabla C4.7, disponible en Internet). El elevado número de países que utilizan el inglés como lengua oficial o como lengua franca refuerza este patrón. Hay grandes proporciones de estudiantes extranjeros de países de habla inglesa matriculados en educación terciaria en otros países de habla inglesa, como Australia (18\%), Canadá (más del $30 \%$ ), Estados Unidos (25\%), Irlanda (más del $40 \%$ ), Nueva Zelanda (más del 40\%), Reino Unido (más del 30\%) y Sudáfrica (más del 80\%). Como media en los países de la OCDE en 2012, alrededor de uno de cada cuatro estudiantes extranjeros procedía de un país con la misma lengua oficial o ampliamente hablada que el país de destino (Tabla C4.5).

Teniendo en cuenta este patrón, un número cada vez mayor de instituciones de países de habla no inglesa ofrecen ahora cursos en inglés. Esta tendencia se observa especialmente en países donde el uso del inglés está extendido, como los países nórdicos (Cuadro C4.2).

\section{Calidad de los programas}

Los estudiantes internacionales seleccionan cada vez más sus destinos para realizar estudios basándose en la calidad de la educación que ofrecen, tal como la perciben a partir de una amplia selección de información, así como de tablas clasificatorias de los programas de educación superior de las que se dispone hoy día tanto impresas como en Internet. Por ejemplo, la gran proporción de instituciones educativas en puestos altos de las clasificaciones que se encuentran entre los destinos principales, así como la aparición en estas clasificaciones de instituciones situadas en destinos que cada vez acogen a más estudiantes, ponen de relieve la creciente importancia de la percepción de la calidad, aun resultando muy difícil de establecer la correlación entre pautas de movilidad estudiantil y juicios sobre la calidad de determinadas instituciones.

\section{Tasas de matrícula}

En la mayoría de los países de la UE, incluyendo Alemania, Austria, Bélgica (Comunidad flamenca), Dinamarca, España, Estonia, Finlandia, Francia, Italia, Países Bajos, Polonia, Reino Unido, República Checa, República Eslovaca y Suecia, los estudiantes internacionales de otros países de la UE son tratados igual que los estudiantes nacionales en lo que se refiere a las tasas de matrícula. Esto también sucede en Irlanda, pero solo si el estudiante de la UE ha vivido en la EU, el Espacio Económico Europeo (EEE) o Suiza durante tres de los últimos cinco años. Si se cumple esta condición, el estudiante de la UE puede optar a una matrícula gratuita en un año académico concreto. En Alemania, Finlandia e Italia, esto mismo se aplica también a estudiantes de fuera de la UE.

Mientras que en Finlandia, Islandia y Noruega no se cobran tasas de matrícula, en Alemania se cobran en todas las instituciones privadas dependientes de la administración, y en algunos Bundesländer también se han introducido tasas de matrícula en instituciones terciarias públicas. En Dinamarca, los estudiantes de Noruega, Islandia y los países de la UE son tratados igual que los estudiantes nacionales y, por tanto, no pagan tasas de matrícula, ya que su formación está totalmente subvencionada. Sin embargo, la mayoría de los estudiantes internacionales de fuera de la UE y del Espacio Económico Europeo (EEE) deben pagar la totalidad de las tasas de matrícula, aunque una cantidad limitada de estudiantes aventajados de fuera de la UE/EEE pueden obtener becas que cubran la totalidad o parte de las tasas de matrícula (Cuadro C4.3).

En algunos países de fuera de la UE, como Corea, Estados Unidos, Islandia, Japón y Noruega, el tratamiento es el mismo para los estudiantes nacionales e internacionales. En Noruega, las tasas de matrícula son las mismas tanto para los estudiantes nacionales como para los internacionales: no se pagan tasas en las instituciones públicas, pero sí se pagan en algunas instituciones privadas. En Islandia, todos los estudiantes tienen que pagar unas tasas anuales de inscripción y los estudiantes de instituciones privadas además tienen que pagar tasas de matrícula. En Japón, los estudiantes nacionales y los internacionales generalmente tienen que pagar las mismas tasas de matrícula, aunque los estudiantes internacionales con becas del gobierno japonés no tienen que pagarlas y hay muchas becas disponibles para estudiantes internacionales con financiación privada. En Estados Unidos, en las instituciones públicas, los estudiantes internacionales pagan las mismas tasas que los estudiantes nacionales de fuera del estado. Sin embargo, como la mayoría de los estudiantes nacionales están matriculados en su estado, en la práctica los estudiantes internacionales pagan tasas de matrícula más altas que la mayoría de los estudiantes nacionales. En las universidades privadas, las tasas son las mismas para los estudiantes nacionales e internacionales.

En Corea, las tasas de matrícula y las ayudas para estudiantes internacionales varían dependiendo del convenio entre su institución de origen y la institución a la que acuden en Corea. En general, la mayor parte de los estudiantes internacionales en Corea pagan tasas de matrícula algo inferiores a las pagadas por los estudiantes nacionales. En Nueva Zelanda, los estudiantes internacionales, excepto los que están matriculados en programas de investigación avanzada, generalmente pagan tasas de matrícula más altas; sin embargo, los estudiantes internacionales que pro- 
ceden de Australia reciben las mismas ayudas que los estudiantes nacionales. En Australia (con las excepciones señaladas en el Cuadro C4.3) y en Canadá, todos los estudiantes internacionales pagan tasas de matrícula más elevadas que los estudiantes nacionales. También es así en Federación Rusa, a no ser que los estudiantes estén becados por el gobierno ruso.

El hecho de que Finlandia, Islandia y Noruega no tengan tasas de matrícula para los estudiantes internacionales, unido a que ofrecen programas impartidos en inglés, explica probablemente parte del fuerte crecimiento de la cantidad de estudiantes extranjeros matriculados en algunos de estos países entre los años 2005 y 2012 (Tabla C4.1). Sin embargo, dada la ausencia de tasas de matrícula y los altos costes unitarios de la educación terciaria, los estudiantes internacionales pueden suponer una pesada carga económica a sus países de destino (véase Tabla B1.1a). Por este motivo, Dinamarca, país que anteriormente no tenía tasas de matrícula, adoptó estas para estudiantes internacionales de fuera de la UE y del EEE a partir de 2006-2007. Se están debatiendo y probando opciones similares en Finlandia y se han adoptado en Suecia, que introdujo tasas de matrícula compensadas con becas para los estudiantes de fuera del área UE-EEE desde el curso académico 2011-2012. Esto se tratará en futuros análisis.

Los países que cobran a los estudiantes internacionales el coste total de su educación obtienen beneficios económicos significativos. Varios países de la región Asia-Pacífico han convertido de hecho la educación internacional en parte explícita de su estrategia de desarrollo socioeconómico y han iniciado políticas para atraer a estudiantes internacionales sobre la base de obtener beneficios o, al menos, cubrir gastos. Australia y Nueva Zelanda han adoptado con éxito las tasas de matrícula diferenciadas para los estudiantes internacionales y esto no ha obstaculizado uno de los mayores crecimientos del número de estudiantes extranjeros en los últimos años (Tabla C4.1). Esto muestra que los costes de matriculación no necesariamente desaniman a los futuros estudiantes internacionales, siempre que la calidad de la educación que se proporciona y sus posibles resultados hagan que la inversión merezca la pena.

\section{Cuadro C4.3. Estructura de las tasas de matrícula}

\begin{tabular}{|c|c|}
\hline Estructura de las tasas de matrícula & Países de la OCDE y otros países del G20 \\
\hline $\begin{array}{l}\text { Tasas de matrícula más altas para } \\
\text { los estudiantes internacionales } \\
\text { que para los nacionales }\end{array}$ & $\begin{array}{l}\text { Australia }{ }^{1} \text {, Austria }{ }^{2}, \text { Bélgica }^{2,3}, \text { Canadá, Dinamarca }{ }^{2,4}, \text { Estados Unidos }{ }^{7} \text {, } \\
\text { Estonia }^{2} \text {, Federación Rusa, Irlanda }{ }^{4}, \text { Nueva Zelanda }^{5} \text {, Países Bajos }{ }^{2} \text {, } \\
\text { Polonia }^{2} \text {, Reino Unido }{ }^{2}, \text { República } \text { Checa }^{2,4}, \text { Suecia }^{6} \text {, Turquía }\end{array}$ \\
\hline $\begin{array}{l}\text { Tasas de matrícula iguales para } \\
\text { los estudiantes internacionales y nacionales }\end{array}$ & Alemania, Corea, España, Francia, Italia, Japón, México ${ }^{8}$, Suiza $^{9}$ \\
\hline $\begin{array}{l}\text { Sin tasas de matrícula para estudiantes } \\
\text { internacionales y nacionales }\end{array}$ & Finlandia, Islandia, Noruega \\
\hline
\end{tabular}

1. Los estudiantes internacionales (excepto los de Nueva Zelanda) no pueden optar a plazas subvencionadas por el gobierno en Australia y por ello pagan las tasas de matrícula completas. Aunque esto se traduce normalmente en que los estudiantes internacionales pagan tasas más elevadas que los estudiantes nacionales (que por lo general ocupan plazas subvencionadas), hay que notar que algunos estudiantes nacionales en las universidades públicas y todos los estudiantes en las universidades privadas independientes pagan las tasas de matrícula completas como los estudiantes internacionales.

2. Para estudiantes que no pertenecen a la Unión Europea ni al Espacio Económico Europeo.

3. En Bélgica (Comunidad flamenca) solo se permiten tasas diferentes si las instituciones alcanzan un $2 \%$ de estudiantes de fuera del área del EEE.

4. Sin tasas de matrícula para los estudiantes nacionales a tiempo completo en instituciones públicas.

5. Excepto estudiantes en programas de investigación avanzada o estudiantes de Australia.

6. Para estudiantes de fuera del EEE y de Suiza.

7. En las instituciones públicas, los estudiantes internacionales pagan las mismas tasas que los estudiantes nacionales de otro estado. Sin embargo, como la mayor parte de los estudiantes nacionales se matriculan en su estado, los estudiantes internacionales pagan en la práctica tasas de matrícula más altas que la mayoría de los estudiantes nacionales. En las universidades privadas, las tasas son las mismas para los estudiantes nacionales e internacionales.

8. Algunas instituciones cobran tasas de matrícula más altas a los estudiantes internacionales.

9. Hay una diferencia insignificante entre las tasas medias anuales de matrícula que se cobran a los estudiantes nacionales y a los internacionales.

Fuente: OCDE. Indicador B5. Para ver notas, consulte Anexo 3 (www.oecd.org/edu/eag.htm). 
No obstante, al elegir entre oportunidades educativas similares, las consideraciones de tipo económico son importantes. En este sentido, el deterioro de la cuota de mercado de Estados Unidos puede atribuirse a las altas tasas de matrícula que se cobran a los estudiantes internacionales, en comparación con las que se cobran en otros destinos, sobre todo de habla inglesa, y que ofrecen oportunidades educativas similares a un precio inferior (Gráfico C4.3). Los programas de investigación avanzada en Nueva Zelanda, por ejemplo, se han vuelto más atractivos desde 2005, cuando se redujeron las tasas de matrícula para estudiantes internacionales, equiparándolas a las abonadas por los estudiantes nacionales (Cuadro C4.3).

La financiación pública «transferible» entre fronteras o el apoyo a los estudiantes para cursar educación terciaria pueden aliviar el coste de estudiar en el extranjero, como se evidencia en Chile, Finlandia, Islandia, Países Bajos, Noruega y Suecia.

\section{Políticas de inmigración}

En los últimos años, varios países de la OCDE han suavizado sus políticas de inmigración para fomentar la inmigración temporal o permanente de estudiantes internacionales (OECD, 2008). Esto convierte a estos países en más atractivos para los estudiantes y fortalece la población activa del país. Por consiguiente, las consideraciones relativas a la inmigración, así como a las tasas de matrícula, pueden afectar a las decisiones de algunos estudiantes acerca de dónde estudiar en el extranjero (OECD, 2011).

\section{Otros factores}

Los estudiantes también toman decisiones acerca de dónde estudiar teniendo en cuenta factores como: la reputación académica de instituciones o programas determinados; la flexibilidad de los programas respecto al tiempo que es necesario pasar en el extranjero para conseguir un grado; el reconocimiento de grados extranjeros; las limitaciones de la educación terciaria en el país de origen; las políticas restrictivas de admisión en la universidad del país de origen; los lazos geográficos, comerciales o históricos entre países; las futuras oportunidades de trabajo; aspiraciones culturales; y las políticas gubernamentales para facilitar la transferencia de créditos entre las instituciones de origen y de acogida.

\section{Alcance de la movilidad internacional de estudiantes en la educación terciaria}

En los países de los que se dispone de datos sobre movilidad internacional de estudiantes, Australia, Austria, Luxemburgo, Nueva Zelanda, Reino Unido y Suiza muestran los niveles más altos de movilidad de estudiantes entrantes, medida como la proporción de estudiantes internacionales en el número total de matriculaciones terciarias. En

\section{Gráfico C4.4. Movilidad estudiantil en educación terciaria (2012) Matriculaciones de estudiantes internacionales o extranjeros como porcentaje de las matriculaciones totales en educación terciaria}

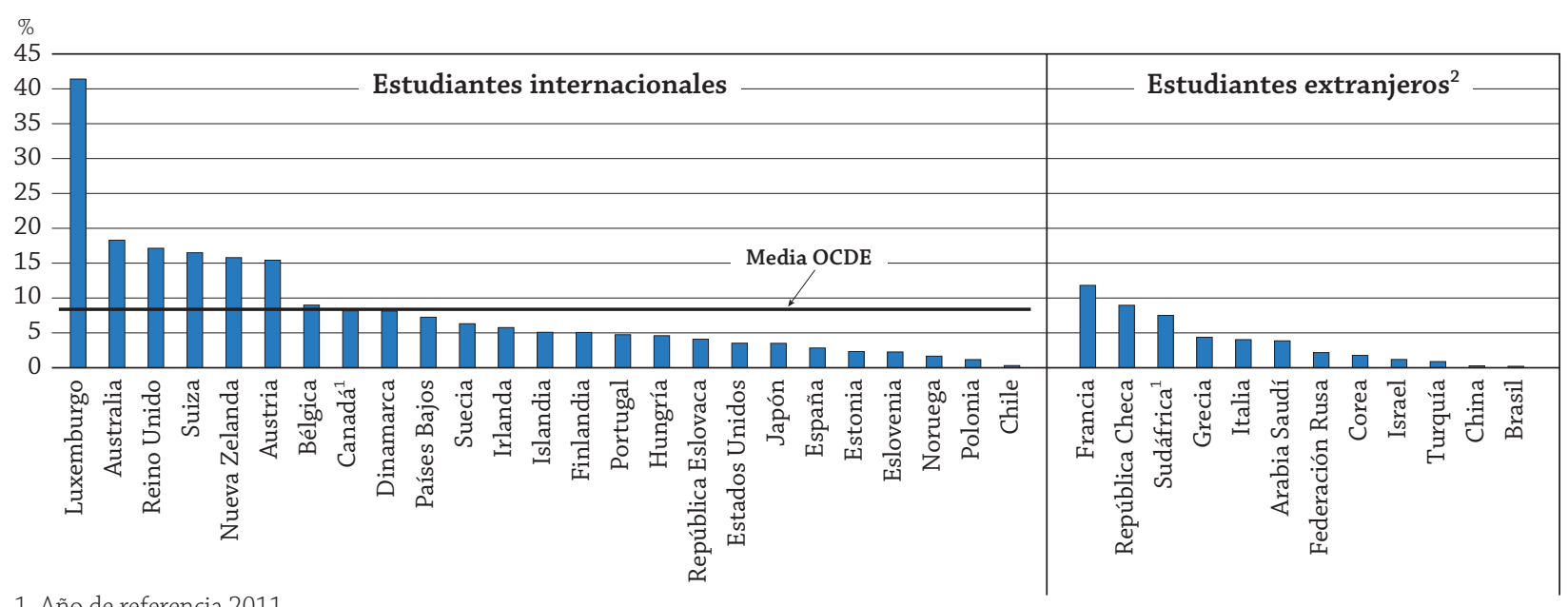

1. Año de referencia 2011.

2. Se define a los estudiantes extranjeros sobre la base de su país de ciudadanía; estos datos no se pueden comparar con los datos sobre estudiantes internacionales y, por tanto, se presentan por separado en el gráfico.

Los países están clasificados en orden descendente del porcentaje de estudiantes internacionales o extranjeros en educación terciaria.

Fuente: OCDE. Tabla C4.1. Para ver notas, consulte Anexo 3 (www.oecd.org/edu/eag.htm).

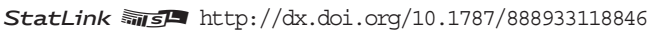


Australia, el $18 \%$ de los estudiantes matriculados en educación terciaria proceden de otro país. De modo similar, los estudiantes internacionales representan el $15 \%$ de las matriculaciones totales en educación terciaria en Austria, el $16 \%$ en Nueva Zelanda, el $16 \%$ en Suiza y el $17 \%$ en Reino Unido.

En cambio, los estudiantes internacionales suponen el $3 \%$ o menos de las matriculaciones totales en educación terciaria en Chile, Eslovenia, España, Estonia, Noruega y Polonia (Tabla C4.1 y Gráfico C4.4).

Entre los países que utilizan la definición de estudiantes internacionales basándose en el país de ciudadanía, Francia tiene la mayor proporción de estudiantes extranjeros (12\%) del total de matriculaciones en el nivel terciario. En cambio, los matriculados extranjeros representan menos del $1 \%$ del total de matriculaciones en el nivel terciario en Brasil, China y Turquía (Tabla C4.1).

\section{Proporción de estudiantes internacionales en los diferentes niveles y tipos de educación terciaria}

La proporción de estudiantes internacionales en los distintos tipos de educación terciaria en cada país de destino revela también patrones de movilidad estudiantil. En 2012, como media en los países de la OCDE, los estudiantes internacionales representaban el $6 \%$ de las matriculaciones en programas de educación terciaria de tipo B (normalmente más breves y orientados a la formación profesional). La mayor proporción de estudiantes internacionales en estos programas se encuentra en Luxemburgo (49\%), seguido de Nueva Zelanda (21\%).

En cambio, los estudiantes internacionales matriculados en programas de educación terciaria de tipo A (generalmente teóricos) suponen en la OCDE una media del $8 \%$ de las matriculaciones totales en este nivel en 2012. Luxemburgo es el país con la mayor proporción de estudiantes internacionales en este nivel, con un $34 \%$ del total, seguido de Australia con un $19 \%$, Reino Unido con un $18 \%$ y Suiza con un $17 \%$ (Tabla C4.1).

Todos los países que han facilitado información, excepto Alemania, tienen una proporción mayor de estudiantes internacionales matriculados en programas de investigación avanzada que en ningún otro programa de nivel terciario. En Luxemburgo, por ejemplo, aproximadamente cuatro de cada cinco estudiantes matriculados en programas de investigación avanzada son estudiantes internacionales. En 13 de los 26 países que han facilitado datos sobre estudiantes internacionales, más del $20 \%$ de todos los estudiantes matriculados en programas de investigación avanzada son estudiantes internacionales. En Suiza, más del $50 \%$ de todos los estudiantes matriculados en este tipo de programas son estudiantes internacionales, y en Nueva Zelanda y Reino Unido lo son más del $40 \%$.

Según el criterio de la ciudadanía, Francia tiene la mayor proporción (más del $40 \%$ ) de estudiantes extranjeros en este nivel de educación (Tabla C4.1). Estas grandes proporciones de estudiantes internacionales o extranjeros pueden ser reflejo del atractivo de los programas de investigación avanzada en estos países, o bien una preferencia por atraer a estudiantes internacionales en los niveles educativos más altos por su posible contribución a la investigación y el desarrollo nacionales, o previendo su posterior incorporación laboral como inmigrantes altamente cualificados.

Dentro de los países de acogida, la distribución de los estudiantes internacionales y extranjeros por nivel y tipo de educación terciaria revela los programas que ofrecen los países. En algunos países, una gran proporción de estudiantes internacionales están matriculados en programas de educación terciaria de tipo B. Este es el caso de España, donde el $35 \%$ de los estudiantes internacionales eligió estos programas, Grecia (34\% de estudiantes extranjeros), Nueva Zelanda (31\%), Luxemburgo (27\%), Chile (23\%), Bélgica (22\%) y Japón (20\%) (Tabla C4.1).

En otros países, una gran proporción de estudiantes internacionales se matriculan en programas de investigación avanzada. Esto se cumple sobre todo en Suiza, donde el $25 \%$ de todos los estudiantes internacionales elige estos programas. Esta preferencia también se observa en Suecia, donde el $22 \%$ de los estudiantes internacionales se matriculan en programas de investigación avanzada, así como en Estados Unidos (19\%), Irlanda (18\%) y Eslovenia (17\%).

En aquellos países que solo han referido información sobre estudiantes extranjeros, como Federación Rusa, Israel, Italia, Letonia y República Checa, al menos nueve de cada diez estudiantes extranjeros están matriculados en programas de educación terciaria de tipo A (generalmente teóricos). En China, el 27\% de todos los estudiantes extranjeros están matriculados en programas de investigación avanzada, al igual que el $11 \%$ en Francia y en Brasil (Tabla C4.1). Todos estos países tienen probabilidades de beneficiarse de la contribución de estos estudiantes internacionales de alto nivel a la investigación y el desarrollo nacionales.

\section{Perfil de la entrada de estudiantes internacionales en los diferentes destinos}

\section{Balance global de la movilidad estudiantil en los países de la OCDE}

Los países de la OCDE reciben a más estudiantes internacionales que los que envían a cursar la educación terciaria en el extranjero. En 2012, los países de la OCDE recibieron a tres estudiantes extranjeros por cada ciudadano que 
estaba estudiando fuera de su país de origen. En términos absolutos, esto representa 3,4 millones de estudiantes extranjeros en los países de la OCDE frente a más de un millón de estudiantes que estudiaban fuera de su país de ciudadanía de la OCDE. Como el $91 \%$ de los ciudadanos de la OCDE estudian en otro país de la OCDE, más de dos de cada tres estudiantes extranjeros del área de la OCDE proceden de un país que no es miembro de la OCDE (Tablas C4.4 y C4.5).

A nivel de países, el balance cambia mucho. Mientras que en Australia hay 18 estudiantes extranjeros por cada estudiante australiano que está en el extranjero, la ratio es de menos de 0,1 por 1 en México. Otros países que tienen una ratio alta de estudiantes extranjeros por estudiante nacional que estudia en el extranjero son Reino Unido (13:1), Nueva Zelanda (12:1) y Estados Unidos (11:1). Argentina, Brasil, Corea, Estonia, Islandia, Israel, Letonia, Luxemburgo, México, República Eslovaca y Turquía refieren menos de un estudiante extranjero por cada estudiante nacional que estudia en el extranjero (Tabla C4.5).

\section{Principales regiones de origen}

Los estudiantes de Asia forman el mayor grupo de estudiantes internacionales matriculados en los países que han facilitado datos a la OCDE o al instituto de Estadística de la UNESCO: el 53\% del total en todos los destinos que han ofrecido información. Las proporciones de estudiantes asiáticos entre todos los estudiantes de educación terciaria internacionales y extranjeros son especialmente grandes en Japón (94\%), Corea (93\%), Australia (82\%), Estados Unidos (73\%) y Nueva Zelanda (70\%). De todos los estudiantes internacionales y extranjeros de los países de la OCDE, el $26 \%$ proceden de países europeos (o el 17\% si se toman en consideración solo los países de la UE21), el $9 \%$ proceden de África, el $6 \%$ proceden de América Latina y el Caribe, y el $3 \%$ proceden de Norteamérica. En total, el $30 \%$ de los estudiantes internacionales matriculados en países de la OCDE son originarios de otro país de la OCDE (Tabla C4.3).

\section{Principales países de origen}

En 2012, los estudiantes de China suponían el 22\% de todos los estudiantes internacionales matriculados en educación terciaria en el área de la OCDE, la mayor proporción de todos los países que facilitaron información (Tabla C4.3). Alrededor del $28 \%$ de todos los estudiantes chinos que estudian en el extranjero están matriculados en Estados Unidos, mientras que el $11 \%$ eligen Australia, el $6 \%$ Corea, el $13 \%$ Japón y el $11 \%$ estudian en Reino Unido (Tabla C4.4). La segunda mayor proporción de estudiantes internacionales en los países de la OCDE proceden de India (5,8\%). Aproximadamente el $45 \%$ de los estudiantes indios que estudian en el extranjero están matriculados en Estados Unidos; el 17\% lo están en Reino Unido; el $6 \%$ en Canadá y el $5 \%$ en Australia (Tabla C4.4).

El predominio de los estudiantes de Asia y de Europa se observa también a nivel de países en los países de la OCDE. Los estudiantes de Francia (2,1\%), Alemania (4,2\%) y Corea (4,2\%) constituyen los mayores grupos de estudiantes internacionales de la OCDE matriculados en países de la OCDE, seguidos de los estudiantes de Estados Unidos (1,6\%), Italia (1,6\%), Canadá (1,5\%), República Eslovaca (1,2\%), Japón (1,1\%) y Turquía (1,1\%) (Tabla C4.3).

\section{Gráfico C4.5. Distribución de estudiantes extranjeros en educación terciaria, por región de origen (2012)}

Porcentaje de estudiantes extranjeros de educación terciaria matriculados en todo el mundo

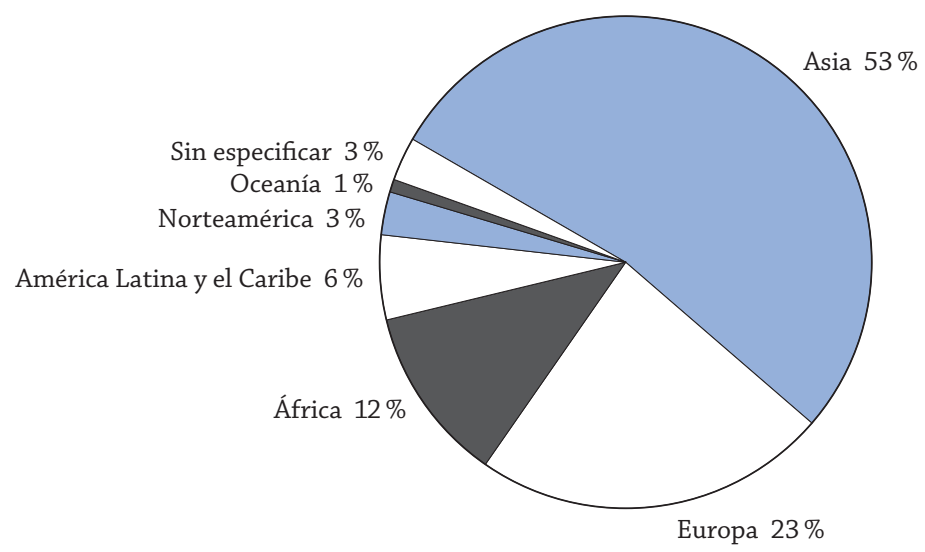

Fuente: OCDE. Tabla C4.3. Para ver notas, consulte Anexo 3 (www.oecd.org/edu/eag.htm).

StatLink 세대 http://dx.doi.org/10.1787/888933118865 
Una gran proporción de estudiantes extranjeros en los países de la OCDE proceden de países vecinos. En todos los países de la OCDE en 2012, una media del $21 \%$ de todos los estudiantes extranjeros provenían de países que comparten fronteras terrestres o marítimas con el país de destino. Los altos niveles de movilidad transfronteriza no solo revelan una situación geográfica central concreta, como es el caso de República Checa, sino que también pueden ser consecuencia de las ventajas en el coste, la calidad o la matriculación, que son más evidentes para los estudiantes de países vecinos. Se observan mayores proporciones de estudiantes extranjeros procedentes de países más allá de las fronteras inmediatas en países que tienen las mayores cuotas de mercado en educación internacional, así como en países como Portugal y España, que tienen estrechos lazos históricos y culturales con otros países más alejados de sus fronteras (Tabla C4.5 y Tabla C4.7, disponible en Internet).

En los países de la OCDE, las mayores proporciones de estudiantes procedentes de países vecinos se encuentran en Japón (81\%), Grecia (76\%), Corea (75\%), Estonia (70\%), Federación Rusa (68\%) y República Checa (65\%). Los estudiantes extranjeros de países vecinos también tienen una representación muy fuerte en Austria, Bélgica, Polonia, República Eslovaca y Sudáfrica. En cambio, solo el $4 \%$ de los estudiantes extranjeros en Canadá procede de Estados Unidos, y solo el $6 \%$ de los estudiantes en Estados Unidos procede de Bahamas, Canadá o México (Tabla C4.5 y Tabla C4.7, disponible en Internet).

El idioma es la principal atracción para los estudiantes que llegan a Portugal a estudiar: el $55 \%$ de los estudiantes extranjeros en Portugal proceden de Angola, Brasil, Cabo Verde, Guinea-Bissau, Mozambique, Santo Tomé y Príncipe o Timor Oriental, todos ellos países donde el portugués es lengua oficial (Tabla C4.5 y Tabla C4.7, disponible en Internet).

Las consideraciones lingüísticas y culturales, la proximidad geográfica y la semejanza de los sistemas educativos son factores que sopesan los estudiantes para decidir dónde estudiarán. Las consideraciones geográficas y las diferencias de los requisitos de admisión (como el numerus clausus o una mayor selectividad para algunos programas) son posibles explicaciones de la concentración de estudiantes de Alemania en Austria, de Bélgica en Francia y Países Bajos, de Francia en Bélgica, de Canadá en Estados Unidos, de Nueva Zelanda en Australia, etc. Las tradiciones lingüísticas y académicas también explican la propensión de los estudiantes de habla inglesa a concentrarse en otros países de la Commonwealth o en Estados Unidos, incluso de aquellos que están geográficamente lejos. Esto también se cumple en otras áreas geopolíticas históricas, como la antigua Unión Soviética, la Francophonie y América Latina. Las redes migratorias también influyen, como ilustra la concentración de estudiantes de ciudadanía portuguesa en Francia, de estudiantes de Turquía en Alemania o de México en Estados Unidos.

\section{Definiciones}

El país donde se ha cursado la educación anterior se define como el país donde los estudiantes obtuvieron el grado necesario para matricularse en su actual nivel educativo, es decir, el país donde los estudiantes internacionales matriculados en programas terciarios profesionales o académicos obtuvieron su formación secundaria superior o postsecundaria orientada a la formación profesional, y el país donde obtuvieron su formación terciaria más académica los estudiantes internacionales matriculados en programas de investigación avanzada. Las definiciones operacionales de los estudiantes internacionales para cada país en concreto están indicadas en las tablas y en el Anexo 3 (www.oecd.org/edu/eag.htm).

Estudiantes extranjeros son aquellos que no son ciudadanos del país en el que se recogen los datos. Aun siendo pragmática y operacional, esta clasificación es inapropiada para calcular la movilidad de los estudiantes, debido a las diferentes políticas nacionales de regularización de los inmigrantes. Por ejemplo, Australia tiene una propensión mayor que Suiza a conceder la residencia permanente a su población inmigrante. Esto implica que, aunque la proporción de estudiantes extranjeros en la matriculación terciaria es similar en ambos países, la proporción de estudiantes internacionales matriculados en educación terciaria es menor en Suiza que en Australia. Por ello, las interpretaciones de datos basados en el concepto de estudiantes extranjeros en términos de movilidad estudiantil y las comparaciones bilaterales han de realizarse con precaución.

Estudiantes internacionales o «móviles» son aquellos que abandonaron su país de origen y se trasladaron a otro país con el fin de estudiar. Dependiendo de la legislación de cada país sobre inmigración, de los convenios de movilidad, como la libre circulación de personas en la UE y el EEE, y de la disponibilidad de datos, se puede definir a los estudiantes internacionales como estudiantes que no son residentes permanentes o habituales en el país donde cursan sus estudios o, de forma alternativa, como estudiantes que obtuvieron su educación anterior en un país diferente, incluyendo otro país de la UE. 
La residencia permanente o habitual en el país que proporciona los datos se define de acuerdo con la legislación nacional. En la práctica, esto significa que el estudiante posee un visado o permiso de estudiante, o que se ha domiciliado en el país extranjero el año anterior a ingresar en el sistema educativo del país que presenta los datos.

\section{Metodología}

Los datos sobre estudiantes internacionales y extranjeros se refieren al curso académico 2011-2012, a menos que se indique lo contrario, y están basados en la recopilación de estadísticas educativas UOE gestionada por la OCDE en 2012. Los ámbitos de estudio utilizados en los instrumentos de la recopilación UOE siguen la clasificación revisada de CINE. La misma clasificación se utiliza para todos los niveles de educación (para más detalles, consulte Anexo 3 en www.oecd.org/edu/eag.htm). También se incluyen datos adicionales del Instituto de Estadística de la UNESCO.

Los datos sobre los estudiantes internacionales y extranjeros proceden de las matriculaciones en los países de destino. Por tanto, el método de obtención de datos sobre estudiantes internacionales y extranjeros es el mismo que el utilizado para la recopilación de datos sobre matriculaciones globales, es decir, se utilizan los registros de estudiantes matriculados formalmente en un programa educativo.

Se suele contabilizar a los estudiantes nacionales y a los internacionales en una fecha o periodo específico del año. Este procedimiento hace posible calcular la proporción de estudiantes internacionales en un sistema educativo. Sin embargo, el número real de individuos implicados puede ser mucho mayor, ya que son muchos los que estudian en el extranjero por un período inferior a un curso académico completo o participan en programas de intercambio que no requieren matriculación, por ejemplo, intercambios entre universidades o programas de investigación avanzada a corto plazo. Por otro lado, el conjunto de estudiantes internacionales incluye estudiantes en programas de educación a distancia que no son, estrictamente hablando, estudiantes internacionales. Esta pauta de matriculación a distancia es bastante común en las instituciones de educación terciaria de Australia, Estados Unidos y Reino Unido (OECD, 2004).

Puesto que los datos sobre estudiantes internacionales y extranjeros proceden de las matriculaciones en educación terciaria en su país de destino, la información se refiere a los estudiantes que llegan a un país más que a los estudiantes que se van al extranjero. Los países de destino cubiertos por este indicador incluyen todos los países de la OCDE y otros países del G20, excepto México, así como países que proporcionan datos similares al Instituto de Estadística de la UNESCO. Estos datos se utilizan para calcular estadísticas globales y examinar los destinos de los estudiantes y las tendencias de las cuotas de mercado.

Tanto los datos sobre los estudiantes matriculados en el extranjero como los análisis de tendencias no están basados en el número de estudiantes internacionales, sino en el número de ciudadanos extranjeros sobre los que se dispone fácilmente de datos consistentes entre países y en el tiempo. Los datos no incluyen a los estudiantes matriculados en países que no han proporcionado datos sobre estudiantes extranjeros ni a la OCDE ni al Instituto de Estadística de la UNESCO. Así pues, todas las observaciones sobre estudiantes matriculados en el extranjero pueden subestimar el número real de los ciudadanos que estudian en el extranjero (Tabla C4.3), especialmente en casos donde un número elevado de ciudadanos estudian en países que no informan a la OCDE ni al Instituto de Estadística de la UNESCO sobre sus estudiantes extranjeros, como China e India.

La proporción relativa de estudiantes internacionales en el sistema educativo afecta a las tasas de matriculación y graduación en educación terciaria, y puede incrementarlas de forma artificial en algunos ámbitos o niveles de la educación (véanse Indicadores A2 y A3). También puede afectar a la combinación documentada anteriormente de gasto público y privado (véase Indicador B3).

En países donde se aplican tasas de matrícula diferenciadas a los estudiantes internacionales, la movilidad estudiantil puede aumentar los recursos financieros de las instituciones de educación terciaria y contribuir a la financiación del sistema educativo.

Los estudiantes internacionales pueden representar una carga financiera considerable para países donde las tasas de matrícula en educación terciaria son bajas o inexistentes, debido al alto coste unitario de la educación terciaria (véase Indicador B5).

Los estudiantes matriculados en un país diferente al suyo constituyen solo un aspecto de la internacionalización de la educación terciaria. En la última década han surgido nuevas formas de educación internacional que incluyen la movilidad de programas e instituciones educativos de unos países a otros. Sin embargo, la internacionalización de la educación terciaria ha evolucionado de una manera distinta, y en respuesta a diversos factores, en las diferentes regiones del mundo. Para un análisis detallado de estas cuestiones, así como de las implicaciones comerciales y políticas de la internacionalización de la educación terciaria, véase OECD (2004). 


\section{Nota sobre los datos de Israel}

Los datos estadísticos para Israel fueron proporcionados por las autoridades israelíes competentes bajo su responsabilidad. El uso de estos datos por parte de la OCDE se hace sin prejuzgar la situación de los Altos del Golán, Jerusalén Este y los asentamientos israelíes en Cisjordania de acuerdo con los términos del derecho internacional.

\section{Referencias}

Kelo, M., U. Teichler y B. Wachter (eds.) (2005), EURODATA: Student Mobility in European Higher Education, Verlags und Mediengesellschaft, Bonn.

OECD (2011), International Migration Outlook 2011, OECD Publishing, París. http://dx.doi.org/10.1787/migr_outlook-2011-en

OECD (2008), OECD Review of Tertiary Education: Tertiary Education for the Knowledge Society, OECD Publishing, París. http:// dx.doi.org/10.1787/9789264046535-en

OECD (2004), Internationalisation and Trade in Higher Education: Opportunities and Challenges, OECD Publishing, París. http:// dx.doi.org/10.1787/9789264015067-en

UNESCO (2009), Global Education Digest 2009, UNESCO Institute for Statistics, Montreal.

UNESCO Institute for Statistics (2012), Education Database, www.uis.unesco.org, consultada el 1 de julio de 2012.

Varghese, N.V. (2009), Globalization, Economic Crisis and National Strategies for Higher Education Development, IIEP, UNESCO, París.

\section{Tablas del Indicador C4}

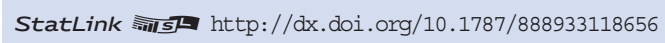

Tabla C4.1 Movilidad de estudiantes internacionales y estudiantes extranjeros en educación terciaria (2005, 2012)

Tabla C4.2 Distribución de estudiantes internacionales y extranjeros matriculados en educación terciaria, por ámbito de estudio (2012)

Tabla C4.3 Distribución de estudiantes internacionales y extranjeros matriculados en educación terciaria, por país de origen (2012)

Tabla C4.4 Ciudadanos que estudian en el extranjero en educación terciaria, por país de destino (2012)

Tabla C4.5 Patrones de movilidad de los estudiantes extranjeros e internacionales (2012)

Tabla C4.6 Tendencias del número de estudiantes extranjeros matriculados en educación terciaria, por región de destino y origen (2000 a 2012)

WEB Tabla C4.7 Número de estudiantes extranjeros en educación terciaria, por país de origen y destino (2012), y cuotas de mercado de la educación internacional $(2000,2012)$ 


\section{Tabla C4.1 Movilidad de estudiantes internacionales y estudiantes extranjeros en educación terciaria $(2005,2012)$}

Estudiantes internacionales y extranjeros matriculados como porcentaje de todos los estudiantes (internacionales y nacionales) y distribución de la movilidad internacional por nivel y tipo de educación terciaria

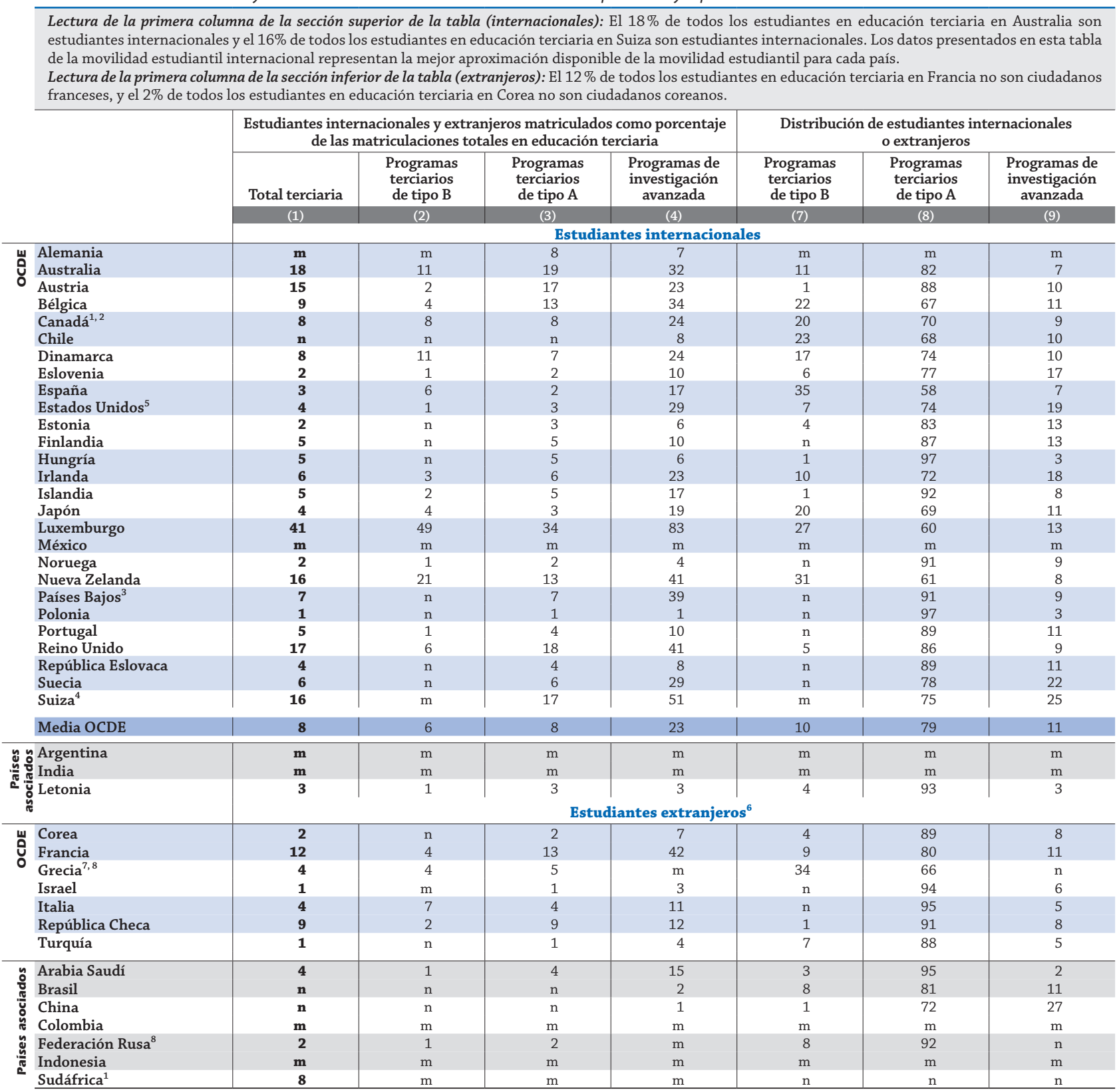

Nota: Las columnas que muestran el índice de cambio del porcentaje de estudiantes internacionales y extranjeros en el total de educación terciaria (2005 = 100) y el índice de cambio del número de estudiantes extranjeros en el total de educación terciaria (2005 = 100) están disponibles en Internet (véase Statlink más abajo).

1. Año de referencia 2011.

2. Índice de cambio basado en $2004=100$ en lugar de 2005 y año de referencia 2011

3. El denominador en el porcentaje de estudiantes internacionales incluye a todos los estudiantes en programas terciarios privados independientes. El país donde han realizado la formación anterior o de residencia de estos estudiantes es desconocido, lo que significa que no es posible determinar si estos estudiantes son internacionales o no.

4. No incluye a los estudiantes internacionales en programas terciarios de tipo B. El denominador en el porcentaje de estudiantes internacionales incluye a todos los estudiantes matriculados en educación terciaria, pero las matriculaciones de estudiantes internacionales en programas terciarios de tipo B son desconocidas, así que no se incluyen en los cálculos, por lo que los porcentajes presentados en la tabla están estimados a la baja.

5. Estudiantes internacionales en columna 6.

6. Se define a los estudiantes extranjeros sobre la base de su país de ciudadanía; estos datos no se pueden comparar con los datos sobre estudiantes internacionales y, por tanto, se presentan por separado en la tabla.

7. No incluye instituciones privadas.

8. Excluye programas de investigación avanzada.

Sources: OECD. Argentina, China, Colombia, India, Indonesia, Arabia Saudí, Sudáfrica: UNESCO Institute for Statistics. Letonia: Eurostat. Para ver notas, consulte Anexo 3 (www.oecd.org/edu/eag.htm).

Para obtener más información acerca de los símbolos utilizados en lugar de los datos que faltan, consulte la Guía del lector.

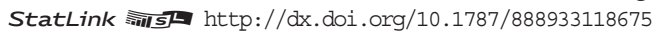


Tabla C4.2. Distribución de estudiantes internacionales y extranjeros matriculados en educación terciaria, por ámbito de estudio (2012)

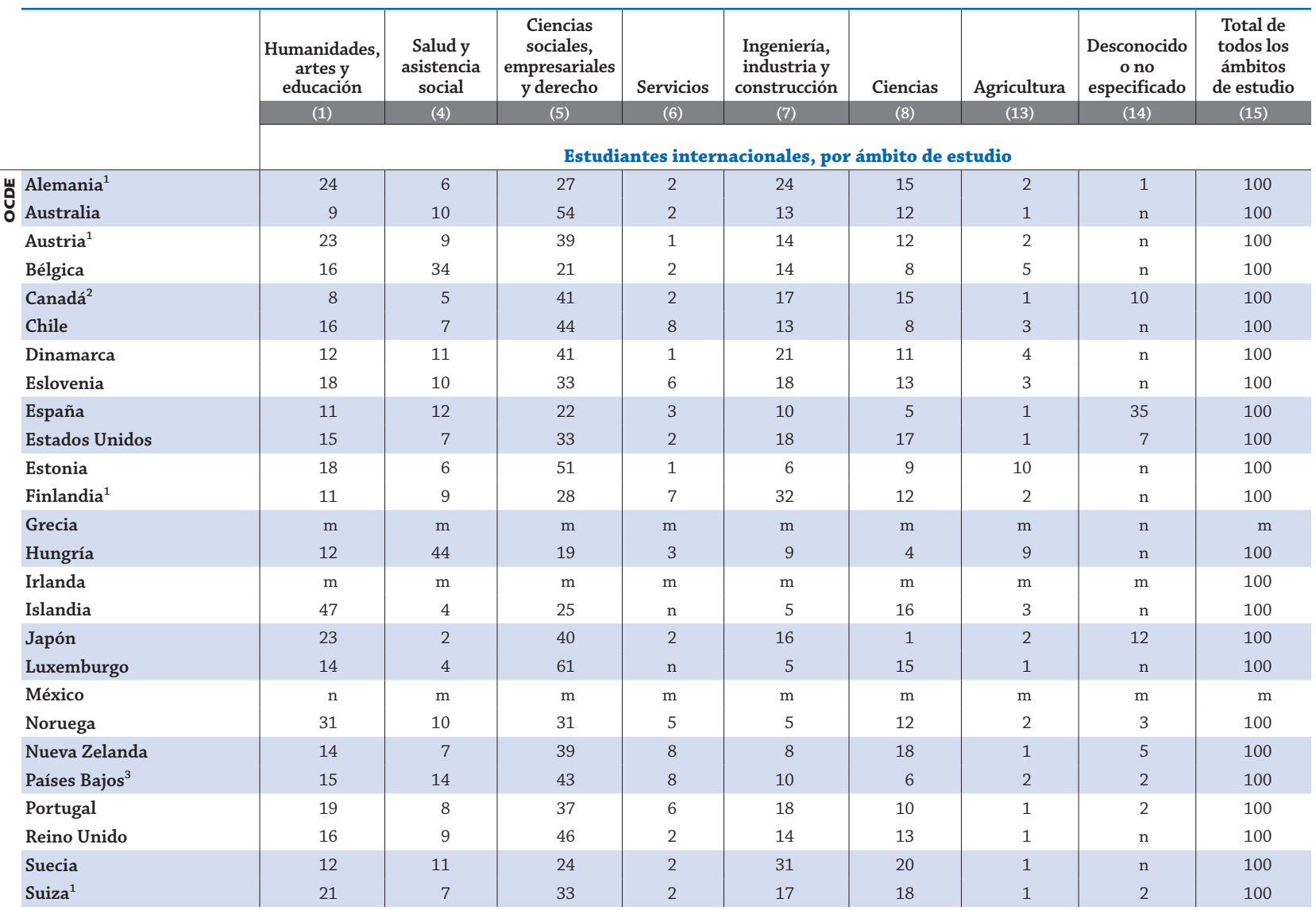

\begin{tabular}{|c|c|c|c|c|c|c|c|c|c|}
\hline 气 Arabia Saudí & $\mathrm{m}$ & $\mathrm{m}$ & $\mathrm{m}$ & $\mathrm{m}$ & $\mathrm{m}$ & $\mathrm{m}$ & $\mathrm{m}$ & $\mathrm{m}$ & $\mathrm{m}$ \\
\hline$\frac{\pi}{0}$ Argentina & $\mathrm{m}$ & $\mathrm{m}$ & $\mathrm{m}$ & $\mathrm{m}$ & $\mathrm{m}$ & $\mathrm{m}$ & $\mathrm{m}$ & $\mathrm{m}$ & $\mathrm{m}$ \\
\hline प्रे Brasil & $\mathrm{m}$ & $\mathrm{m}$ & $\mathrm{m}$ & $\mathrm{m}$ & $\mathrm{m}$ & $\mathrm{m}$ & $\mathrm{m}$ & $\mathrm{m}$ & $\mathrm{m}$ \\
\hline y China & $\mathrm{m}$ & $\mathrm{m}$ & $\mathrm{m}$ & $\mathrm{m}$ & $\mathrm{m}$ & $\mathrm{m}$ & $\mathrm{m}$ & $\mathrm{m}$ & $\mathrm{m}$ \\
\hline Colombia & $\mathrm{m}$ & $\mathrm{m}$ & $\mathrm{m}$ & $\mathrm{m}$ & $\mathrm{m}$ & $\mathrm{m}$ & $\mathrm{m}$ & $\mathrm{m}$ & $\mathrm{m}$ \\
\hline Federación Rusa & $\mathrm{m}$ & $\mathrm{m}$ & $\mathrm{m}$ & $\mathrm{m}$ & $\mathrm{m}$ & $\mathrm{m}$ & $\mathrm{m}$ & $\mathrm{m}$ & $\mathrm{m}$ \\
\hline India & $\mathrm{m}$ & $\mathrm{m}$ & $\mathrm{m}$ & $\mathrm{m}$ & $\mathrm{m}$ & $\mathrm{m}$ & $\mathrm{m}$ & $\mathrm{m}$ & $\mathrm{m}$ \\
\hline Indonesia & $\mathrm{m}$ & $\mathrm{m}$ & $\mathrm{m}$ & $\mathrm{m}$ & $\mathrm{m}$ & $\mathrm{m}$ & $\mathrm{m}$ & $\mathrm{m}$ & $\mathrm{m}$ \\
\hline Letonia & 8 & 25 & 47 & 12 & 5 & 3 & $\mathrm{n}$ & $\mathrm{n}$ & 100 \\
\hline Sudáfrica & $\mathrm{m}$ & $\mathrm{m}$ & $\mathrm{m}$ & $\mathrm{m}$ & $\mathrm{m}$ & $\mathrm{m}$ & $\mathrm{m}$ & $\mathrm{m}$ & $\mathrm{m}$ \\
\hline
\end{tabular}

\begin{tabular}{|c|c|c|c|c|c|c|c|c|c|}
\hline \multirow{3}{*}{$\begin{array}{l}\text { Corea } \\
\text { Francia }\end{array}$} & \multicolumn{9}{|c|}{ Estudiantes extranjeros, por ámbito de estudio ${ }^{4}$} \\
\hline & 25 & 4 & 45 & 4 & 16 & 5 & 1 & $\mathrm{n}$ & 100 \\
\hline & 20 & 7 & 41 & 2 & 13 & 17 & $\mathrm{n}$ & $\mathrm{n}$ & 100 \\
\hline Israel & 23 & 15 & 30 & $\mathrm{n}$ & 8 & 23 & 1 & $\mathrm{n}$ & 100 \\
\hline Italia & 21 & 16 & 32 & 2 & 21 & 6 & 2 & $\mathrm{n}$ & 100 \\
\hline Polonia & 15 & 24 & 40 & 6 & 7 & 6 & 1 & $\mathrm{n}$ & 100 \\
\hline República Checa & 13 & 16 & 39 & 3 & 11 & 15 & 2 & $\mathrm{n}$ & 100 \\
\hline Turquía & 21 & 14 & 34 & 4 & 16 & 9 & 2 & $\mathrm{n}$ & 100 \\
\hline
\end{tabular}

Nota: Las columnas que muestran el desglose de humanidades, artes y educación (2 y 3) y ciencias (9-12) están disponibles en Internet (véase StatLink más abajo).

1. No incluye programas terciarios de tipo B.

2. Año de referencia 2011.

3. No incluye programas de la educación privada.

4. Se define a los estudiantes extranjeros sobre la base de su país de ciudadanía; estos datos no se pueden comparar con los datos sobre estudiantes internacionales y, por tanto, se presentan de forma separada en la tabla y en el gráfico.

Fuentes: OCDE. Arabia Saudí, Argentina, China, Colombia, India, Indonesia y Sudáfrica: Instituto de Estadística de la UNESCO. Letonia: Eurostat. Para ver notas, consulte Anexo 3 (www.oecd.org/edu/eag.htm).

Para obtener más información acerca de los símbolos utilizados en lugar de los datos que faltan, consulte la Guía del lector.

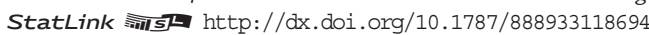


Tabla C4.3. [1/2] Distribución de estudiantes internacionales y extranjeros matriculados en educación terciaria, por país de origen (2012)

Número de estudiantes internacionales y extranjeros matriculados en educación terciaria de un país de origen como porcentaje de todos los estudiantes internacionales o extranjeros en el país de destino, basado en recuentos

La tabla muestra para cada país la proporción de estudiantes internacionales en educación terciaria que son residentes o recibieron su formación anterior en un país de origen
dado. Cuando no se dispone de datos sobre movilidad estudiantil, la tabla muestra la proporción de estudiantes extranjeros en educación terciaria que tienen la ciudadanía de un
país de origen dado.
Lectura de la tercera columna: El 15,7\% de los estudiantes terciarios internacionales en Bélgica proceden de Francia, el 9,9\% de los estudiantes terciarios internacionales en Bélgica
proceden de Países Bajos, etc.
Lectura de la décima columna: El 48,2\% de los estudiantes terciarios internacionales en Estonia proceden de Finlandia, el 1,4\% de los estudiantes terciarios internacionales en Estonia
proceden de Italia, etc.
Lectura de la columna 21: El 40,5\% de los estudiantes terciarios extranjeros en Austria son ciudadanos alemanes, el 2,4\% de los estudiantes terciarios extranjeros en Austria son
ciudadanos húngaros, etc.

Lectura de la columna 21 :
ciudadanos húngaros, etc.

Países de destino de la OCDE

\begin{tabular}{|c|c|c|c|c|c|c|c|c|c|c|c|c|c|c|c|c|c|c|c|}
\hline & \multicolumn{19}{|c|}{ Países de destino de la OCDE } \\
\hline & \multicolumn{19}{|c|}{ Estudiantes internacionales } \\
\hline 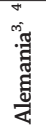 & 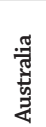 & $\frac{\Im}{6}$ & 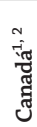 & 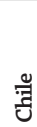 & 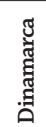 & 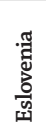 & 㱒 & 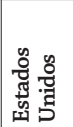 & . & 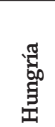 & 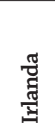 & 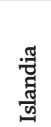 & 宽 & 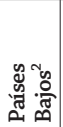 & 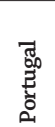 & 올 율 & 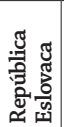 & . & 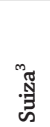 \\
\hline (1) & (2) & (3) & (4) & (5) & (6) & (7) & (8) & (9) & (10) & (11) & (12) & (13) & (14) & (15) & (16) & (17) & (18) & (19) & (20) \\
\hline a & 0,6 & 1 , & 0 & 0 & 10,6 & 10 & 25 & 1,2 & 1,9 & 12,9 & 4,3 & 13,0 & 1,6 & 43,1 & 3,0 & 3,7 & 5,1 & 4,8 & 27,1 \\
\hline
\end{tabular}

Países de origen

ulemania

ช Australia

Bélgica

Canadá

Chile

Dinamarca

Eslovenia

España

Estados Unidos

Estonia

Finlandia

Francia

Grecia

Hungría

Irlanda

Islandia

Israel

Japón

Luxemburgo

México

Noruega

Países Bajos

Polonia

Portugal

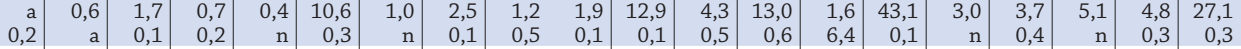

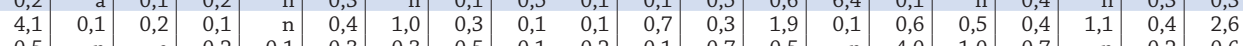

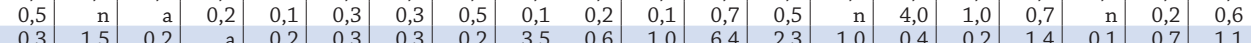
\begin{tabular}{rr|r|r|r|r|r|r|rr|r|r|r|r|r|r|r|r|r|r|}
0,3 & 1,5 & 0,2 & $\mathrm{a}$ & 0,2 & 0,3 & 0,3 & 0,2 & 3,5 & 0,6 & 1,0 & 6,4 & 2,3 & 1,0 & 0,4 & 0,2 & 1,4 & 0,1 & 0,7 & 1,1 \\
0,3 & 0,2 & 0,1 & 0,1 & $\mathrm{a}$ & 0,1 & $\mathrm{n}$ & 2,6 & 0,3 & 0,1 & $\mathrm{n}$ & 0,1 & 0,2 & 0,3 & 0,1 & 0,1 & 0,2 & $\mathrm{n}$ & 0,1 & 0,3
\end{tabular}

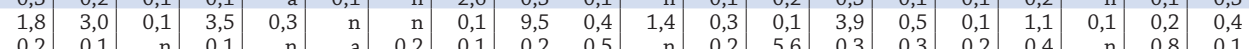
\begin{tabular}{rrrrrrrrrrrr|rr|r|r|r|r|r|r|r|r|}
0,2 & 0,1 & $\mathrm{n}$ & 0,1 & $\mathrm{n}$ & $\mathrm{a}$ & 0,2 & 0,1 & 0,2 & 0,5 & $\mathrm{n}$ & 0,2 & 5,6 & 0,3 & 0,3 & 0,2 & 0,4 & $\mathrm{n}$ & 0,8 & 0,1
\end{tabular}

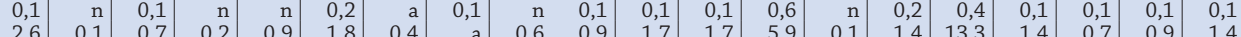

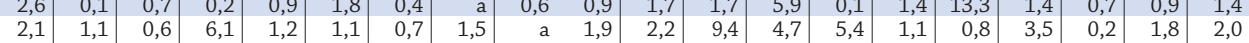

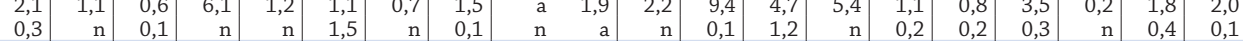

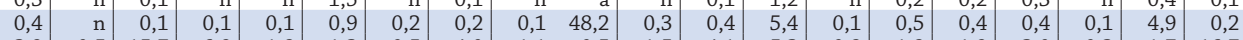

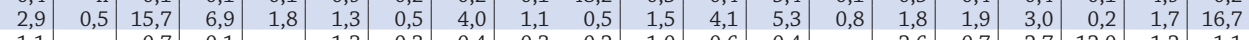

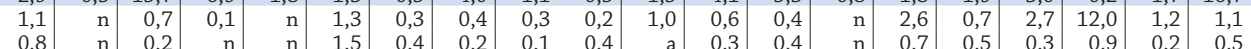

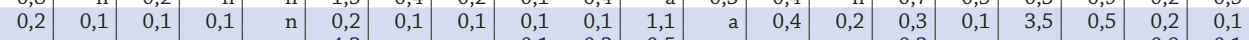

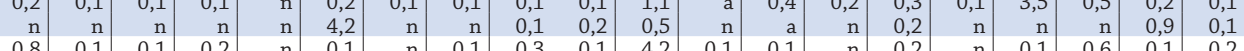

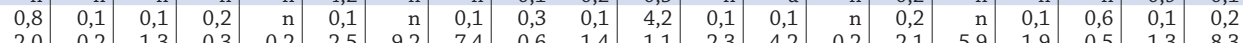

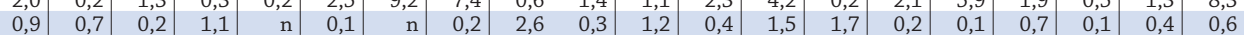

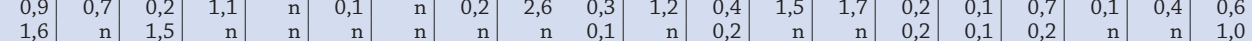
\begin{tabular}{rrrrrrrrrrrr|r|r|r|r|r|r|r|r|r|r}
1,6 & $\mathrm{n}$ & 1,5 & $\mathrm{n}$ & $\mathrm{n}$ & $\mathrm{n}$ & $\mathrm{n}$ & $\mathrm{n}$ & $\mathrm{n}$ & 0,1 & $\mathrm{n}$ & 0,2 & $\mathrm{n}$ & $\mathrm{n}$ & 0,2 & 0,1 & 0,2 & $\mathrm{n}$ & $\mathrm{n}$ & 1,0 \\
0,9 & 0,2 & 0,3 & 0,9 & 2,5 & 0,3 & 0,2 & 4,6 & 1,8 & 0,2 & 0,2 & 0,3 & 0,9 & 0,2 & 0,5 & 0,3 & 0,4 & 0,1 & 0,6 & 0,7
\end{tabular}

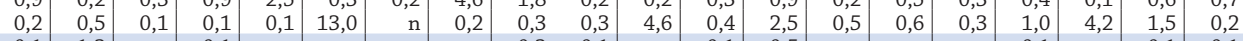

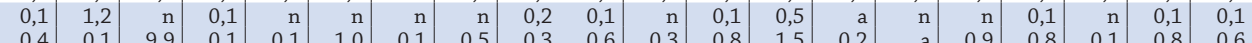

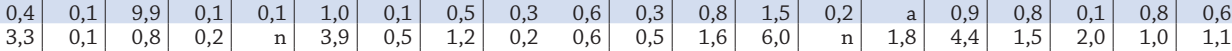

Reino Unido

República Checa

República Eslovaca

Suecia

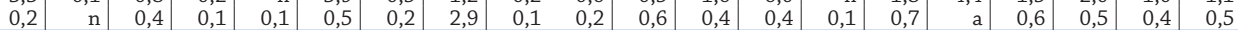

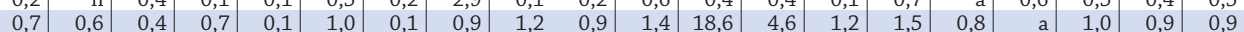

Suiza

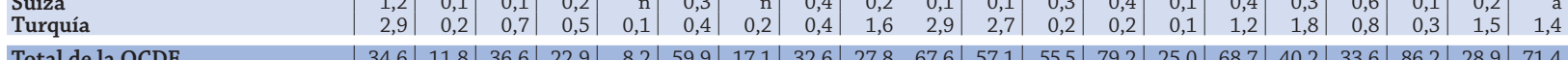

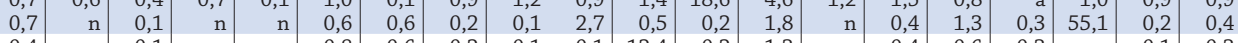

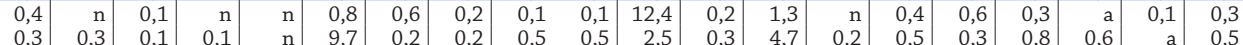

\begin{tabular}{|c|c|c|c|c|c|c|c|c|c|c|c|c|c|c|c|c|c|c|c|c|}
\hline $\begin{array}{l}\text { ¿ Arabia Saudí } \\
\text { Argentina }\end{array}$ & $\begin{array}{r}0,1 \\
0,2\end{array}$ & $\begin{array}{r}2,2 \\
n\end{array}$ & $\begin{array}{r}\mathrm{n} \\
0,1\end{array}$ & $\begin{array}{l}2,6 \\
0,1\end{array}$ & $\begin{array}{r}n \\
3,4\end{array}$ & $\begin{array}{r}\mathrm{n} \\
0,1\end{array}$ & $\begin{array}{r}\mathrm{n} \\
0,3\end{array}$ & $\begin{array}{l}0,1 \\
3,8\end{array}$ & $\begin{array}{r}4,5 \\
0,2\end{array}$ & $\begin{array}{l}\mathrm{n} \\
\mathrm{n}\end{array}$ & $\begin{array}{r}1,2 \\
n\end{array}$ & $\begin{array}{r}2,0 \\
n\end{array}$ & $\begin{array}{r}\mathrm{n} \\
0,2\end{array}$ & $\begin{array}{l}2,4 \\
0,1\end{array}$ & $\begin{array}{l}0,1 \\
0,1\end{array}$ & $\begin{array}{r}\mathrm{n} \\
0.2\end{array}$ & $\begin{array}{r}2,3 \\
n\end{array}$ & $\begin{array}{r}0,9 \\
n\end{array}$ & $\begin{array}{l}0,1 \\
0,1\end{array}$ & $\begin{array}{l}0,1 \\
0,4\end{array}$ \\
\hline$\frac{\pi}{4}$ Brasil & 1,1 & 0,3 & 0,3 & 0,3 & 2,2 & 0,3 & 0,8 & 2,8 & 1,2 & 0,6 & 0,1 & 0,3 & 0,2 & 0,4 & 0,4 & 27,9 & 0,3 & 0,1 & 0,4 & 1,2 \\
\hline China & 9,9 & 35,1 & 2,6 & 21,7 & 0,2 & 4,1 & 0,9 & 2,7 & 28,4 & 5,1 & 1,4 & 13,3 & 3,2 & 27,7 & 8,1 & 1,0 & 18,0 & $\mathrm{n}$ & 11,3 & 2,5 \\
\hline Colombia & 0,7 & 0,5 & 0,3 & 0,4 & 22,3 & 0,1 & $\mathrm{n}$ & 10,5 & 0,8 & 0,5 & $\mathrm{n}$ & 0,1 & 0,3 & 0,2 & 0,4 & 0,2 & 0,2 & $\mathrm{n}$ & 0,4 & 0,8 \\
\hline Federación Rusa & 4,9 & 0,4 & 0,6 & 0,5 & 0,1 & 0,5 & 1,6 & 1,3 & 0,6 & 8,6 & 0,5 & 0,5 & 2,3 & 0,8 & 1,0 & 0,6 & 0,8 & 0,3 & 1,8 & 2,0 \\
\hline India & 2,3 & 4,7 & 1,3 & 6,7 & 0,1 & 0,9 & 0,6 & 0,4 & 13,1 & 1,1 & 0,2 & 3,2 & 1,8 & 17,7 & 1,4 & 0,3 & 6,9 & 0,1 & 5,4 & 1,4 \\
\hline Indonesia & 0,7 & 3,8 & 0,3 & 0,5 & $\mathrm{n}$ & 0,1 & $\mathrm{n}$ & 0,1 & 0,9 & 0,3 & 0,1 & 0,1 & 0,1 & 0,9 & 1,6 & 0,1 & 0,3 & $\mathrm{n}$ & 0,2 & 0,1 \\
\hline Letonia & 0,3 & $\mathrm{n}$ & 0,1 & $\mathrm{n}$ & $\mathrm{n}$ & 3,3 & $\mathrm{n}$ & 0,1 & $\mathrm{n}$ & $\mathrm{n}$ & $\mathrm{n}$ & 0,2 & 1,4 & $\mathrm{n}$ & 0,7 & 0,3 & 0,5 & $\mathrm{n}$ & 0,4 & 0,1 \\
\hline 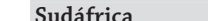 & 0,1 & 0,3 & 0,2 & 0,1 & & & & & 0,2 & 0,1 & & 0,3 & 0,1 & 0,3 & 0,2 & 0,1 & 0,3 & & 0,1 & 0.2 \\
\hline
\end{tabular}

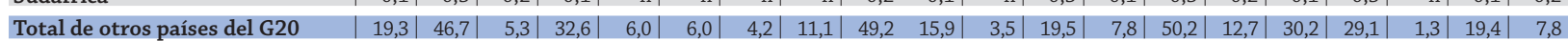

Regiones geográficas principales

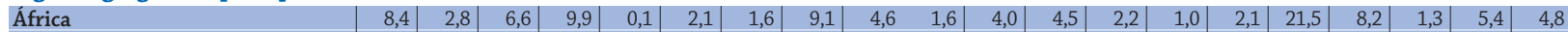

Asia

Europa

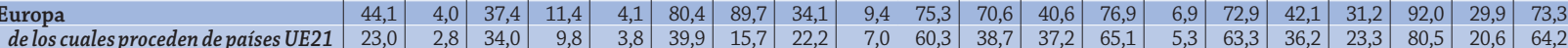

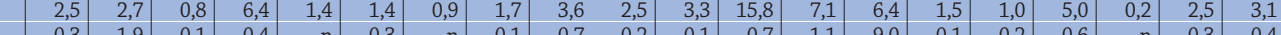

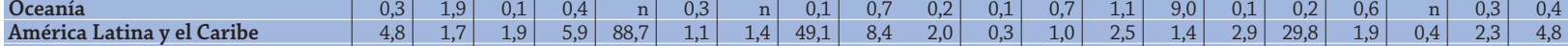

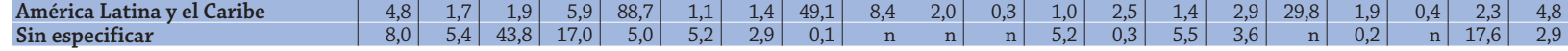
\begin{tabular}{l|c|c|c|c|c|c|c|c|c|c|c|c|c|c|c|c|c|c|c|c|c|} 
Total de todos los países & 100,0 & 100,0 & 100,0 & 100,0 & 100,0 & 100,0 & 100,0 & 100,0 & 100,0 & 100,0 & 100,0 & 100,0 & 100,0 & 100,0 & 100,0 & 100,0 & 100,0 & 100,0 & 100,0 & 100,0 \\
\hline
\end{tabular}

1. Año de referencia 2011.

2. No incluye instituciones privadas.

3. No incluye programas terciarios de tipo B.

4. No incluye programas de investigación avanzada (para Alemania, se incluyen los programas de investigación avanzada solo en regiones geográficas agregadas).

5. Los estudiantes cuyo origen no se especifica proceden mayoritariamente de los países nórdicos.

6. Se define a los estudiantes extranjeros sobre la base de su país de ciudadanía; estos datos no se pueden comparar con los datos sobre estudiantes internacionales $y$, por tanto, se presentan por separado en la tabla.

Fuentes: OCDE y el Instituto de Estadística de la UNESCO para la mayor parte de los datos de los países que no son miembros de la OCDE. Letonia: Eurostat. Para ver notas, consulte Anexo 3 (www.oecd.org/edu/eag.htm).

Para obtener más información acerca de los símbolos utilizados en lugar de los datos que faltan, consulte la Guía del lector.

StatLink 部实 http://dx.doi.org/10.1787/888933118713 
Tabla C4.3. [2/2] Distribución de estudiantes internacionales y extranjeros matriculados en educación terciaria, por país de origen (2012)

Número de estudiantes internacionales y extranjeros matriculados en educación terciaria de un país de origen como porcentaje de todos los estudiantes internacionales o extranjeros en el país de destino, basado en recuentos

La tabla muestra para cada país la proporción de estudiantes internacionales en educación terciaria que son residentes o recibieron su formación anterior en un país de origen
dado. Cuando no se dispone de datos sobre movilidad estudiantil, la tabla muestra la proporción de estudiantes extranjeros en educación terciaria que tienen la ciudadanía de un
país de origen dado.
Lectura dela tercera columna: El 15,7\% de los estudiantes terciarios internacionales en Bélgica proceden de Francia, el 9,9\% de los estudiantes terciarios internacionales en Bélgica
proceden de Países Bajos, etc.
Lectura de la décima columna: El $48,2 \%$ de los estudiantes terciarios internacionales en Estonia proceden de Finlandia, el 1,4\% de los estudiantes terciarios internacionales
en Estonia proceden de Italia, etc.
Lectura de la columna 21: El $40,5 \%$ de los estudiantes terciarios extranjeros en Austria son ciudadanos alemanes, el $2,4 \%$ de los estudiantes terciarios extranjeros en Austria son
ciudadanos húngaros, etc.

ciudadanos húngaros, etc.

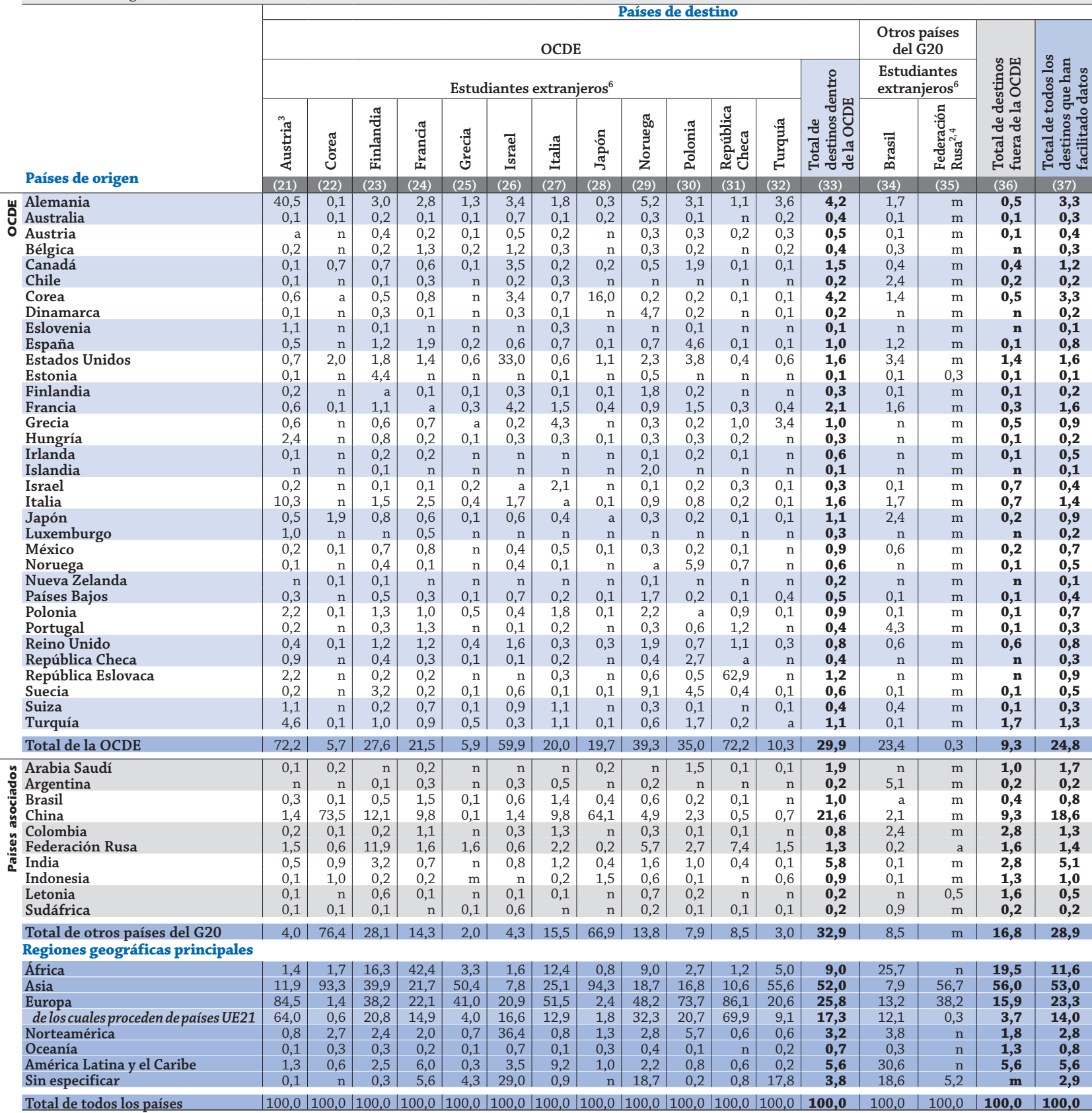

1. Año de referencia 2011

2. No incluye instituciones privadas.

3. No incluye programas terciarios de tipo B.

4. No incluye programas de investigación avanzada (para Alemania, se incluyen los programas de investigación avanzada solo en regiones geográficas agregadas).

5. Los estudiantes cuyo origen no se especifica proceden mayoritariamente de los países nórdicos.

6 . Se define a los estudiantes extranjeros sobre la base de su país de ciudadanía; estos datos no se pueden comparar con los datos sobre estudiantes internacionales y, por tanto, se presentan por separado en la tabla.

Fuentes: OCDE y el Instituto de Estadística de la UNESCO para la mayor parte de los datos de los países que no son miembros de la OCDE. Letonia: Eurostat. Para ver notas, consulte Anexo 3 (www.oecd.org/edu/eag.htm).

Para obtener más información acerca de los símbolos utilizados en lugar de los datos que faltan, consulte la Guía del lector.

StatLink 需正田 http://dx.doi.org/10.1787/888933118713 
Tabla C4.4. [1/2] Ciudadanos que estudian en el extranjero en educación terciaria, por país de destino (2012) Número de estudiantes extranjeros matriculados en educación terciaria en un país de destino dado como porcentaje de todos los estudiantes matriculados en el extranjero en los destinos notificados, basado en recuentos

\footnotetext{
La tabla muestra para cada país la proporción de estudiantes que estudian en el extranjero en educación terciaria en un país de destino dado.

Lectura de la tercera columna: El 4,5\% de los ciudadanos checos matriculados en educación terciaria en el extranjero estudian en Austria, el 10,8\% de los ciudadanos italianos matriculados en educación terciaria en el extranjero estudian en Austria, etc.

Lectura de la segunda fila: El 2,5\% de los ciudadanos de Australia matriculados en educación terciaria en el extranjero estudian en Francia, el 19,7\% de los ciudadanos de Australia matriculados en educación terciaria en el extranjero estudian en Nueva Zelanda, etc.
}

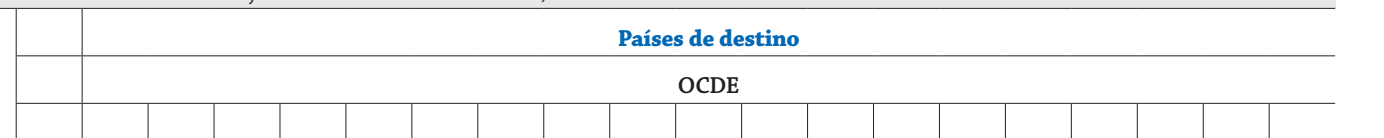

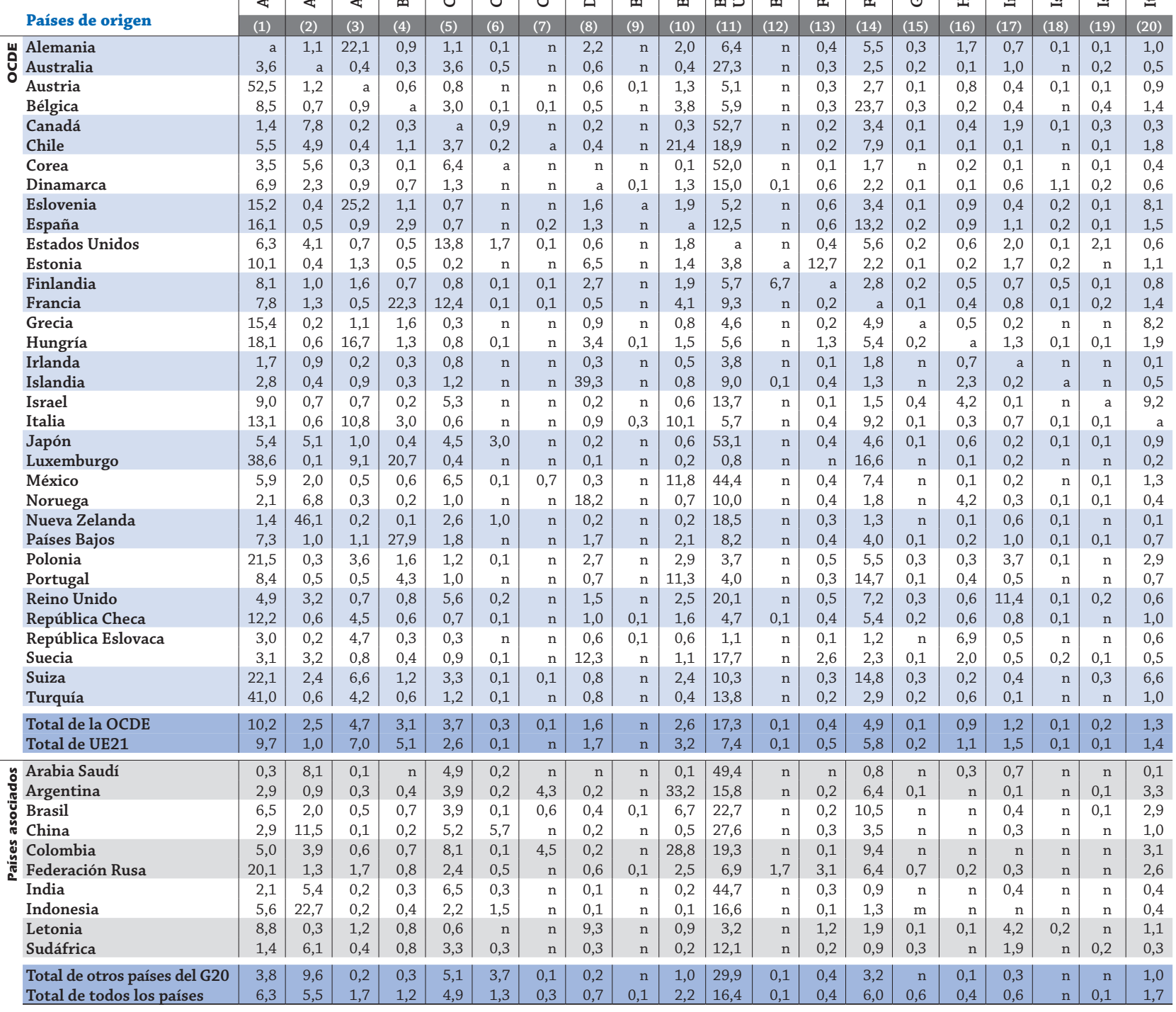

Nota: La proporción de estudiantes en el extranjero se basa solamente en el total de estudiantes matriculados en países que refieren datos a la OCDE y al Instituto de Estadística de la UNESCO.

1. Los datos remiten a estudiantes internacionales.

2. No incluye programas terciarios de tipo B.

3. Año de referencia 2011.

4. No incluye instituciones privadas.

5. No incluye programas de investigación avanzada (para Alemania, se incluyen los programas de investigación avanzada solo en las principales regiones geográficas).

6. Total basado en el cálculo realizado por el Instituto de Estadística de la UNESCO.

7. No incluye estudiantes a tiempo parcial.

Fuentes: OCDE y el Instituto de Estadística de la UNESCO para la mayor parte de los datos de los países que no son miembros de la OCDE. Letonia: Eurostat. Para ver notas, consulte Anexo 3 (www.oecd.org/edu/eag.htm).

Para obtener más información acerca de los símbolos utilizados en lugar de los datos que faltan, consulte la Guía del lector.

StatLink 제그 http://dx.doi.org/10.1787/888933118732 
Tabla C4.4. [2/2] Ciudadanos que estudian en el extranjero en educación terciaria, por país de destino (2012)

Número de estudiantes extranjeros matriculados en educación terciaria en un país de destino dado como porcentaje de todos los estudiantes matriculados en el extranjero en los destinos notificados, basado en recuentos

La tabla muestra para cada país la proporción de estudiantes que estudian en el extranjero en educación terciaria en un país de destino dado.

Lectura de la segunda columna: El 4,5\% de los ciudadanos checos matriculados en educación terciaria en el extranjero estudian en Austria, el 10,8\% de los ciudadanos italianos matriculados en educación terciaria en el extranjero estudian en Austria, etc.

Lectura de la segunda fila: El 2,5\% de los ciudadanos de Australia matriculados en educación terciaria en el extranjero estudian en Francia, el 19,7\% de los ciudadanos de Australia matriculados en educación terciaria en el extranjero estudian en Nueva Zelanda, etc.

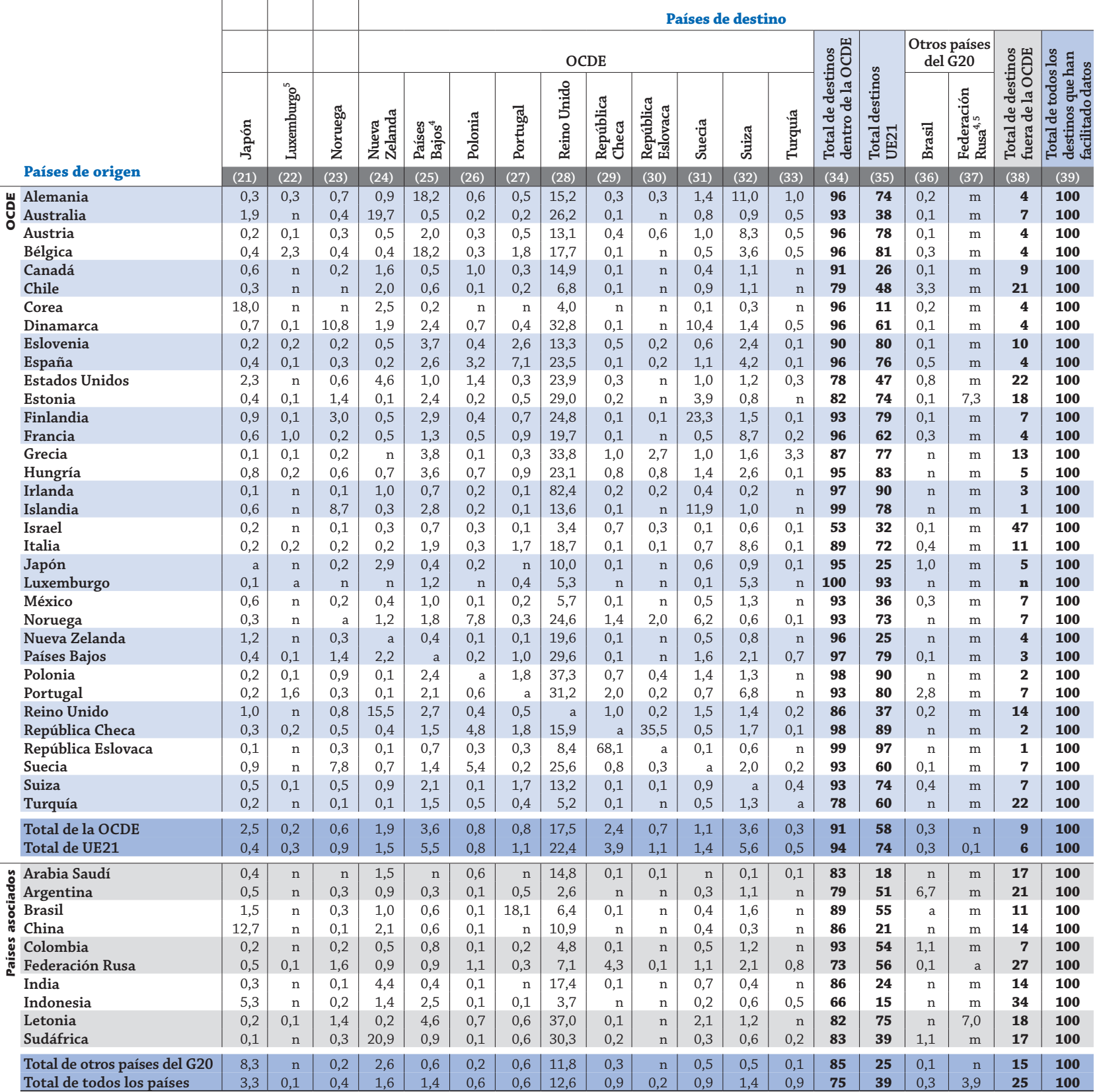

Nota: La proporción de estudiantes en el extranjero se basa solamente en el total de estudiantes matriculados en países que refieren datos a la OCDE y al Instituto de Estadística de la UNESCO.

1. Los datos remiten a estudiantes internacionales.

2. No incluye programas terciarios de tipo B.

3. Año de referencia 2011.

4. No incluye instituciones privadas.

5. No incluye programas de investigación avanzada (para Alemania, se incluyen los programas de investigación avanzada solo en las principales regiones geográficas). 6. Total basado en el cálculo realizado por el Instituto de Estadística de la UNESCO.

7. No incluye estudiantes a tiempo parcial.

Fuentes: OCDE y el Instituto de Estadística de la UNESCO para la mayor parte de los datos de los países que no son miembros de la OCDE. Letonia: Eurostat. Para ver notas, consulte Anexo 3 (www.oecd.org/edu/eag.htm).

Para obtener más información acerca de los símbolos utilizados en lugar de los datos que faltan, consulte la Guía del lector.

StatLink 젶ㄴ http://dx.doi.org/10.1787/888933118732 
Tabla C4.5. Patrones de movilidad de los estudiantes extranjeros e internacionales (2012) Movilidad regional y transfronteriza, equilibrio de movilidad y uso de la lengua oficial del país anfitrión en los países de origen

\begin{tabular}{|c|c|c|c|c|}
\hline & $\begin{array}{l}\text { Porcentaje de estudiantes } \\
\text { nacionales de educación } \\
\text { terciaria matriculados } \\
\text { en el extranjero }\end{array}$ & $\begin{array}{l}\text { Número de estudiantes } \\
\text { extranjeros por cada } \\
\text { estudiante nacional } \\
\text { en el extranjero }\end{array}$ & $\begin{array}{l}\text { Porcentaje de estudiantes } \\
\text { extranjeros procedentes } \\
\text { de países vecinos }{ }^{1}\end{array}$ & $\begin{array}{l}\text { Porcentaje de estudiantes } \\
\text { procedentes de países con } \\
\text { la misma lengua oficial }\end{array}$ \\
\hline \multirow{2}{*}{$\begin{array}{l}\text { Alemania } \\
\text { Australia }\end{array}$} & 5 & 2 & 14 & 9 \\
\hline & 1 & 18 & 40 & 18 \\
\hline $\begin{array}{l}\text { Austria } \\
\text { Bélgica }\end{array}$ & 6 & 4 & 59 & 53 \\
\hline \multirow{2}{*}{$\begin{array}{l}\text { Canadá }^{2} \\
\text { Chile }\end{array}$} & 3 & 4 & 4 & 33 \\
\hline & 1 & 1 & 33 & 59 \\
\hline Corea $^{3}$ & 4 & $\mathrm{n}$ & 75 & $\mathrm{n}$ \\
\hline Dinamarca & 3 & 4 & 36 & $\mathrm{n}$ \\
\hline \multirow{2}{*}{$\begin{array}{l}\text { Eslovenia } \\
\text { España }\end{array}$} & 3 & 1 & 31 & 6 \\
\hline & 2 & 3 & 22 & 40 \\
\hline $\begin{array}{l}\text { Estados Unidos } \\
\text { Estonia }\end{array}$ & 8 & $\mathrm{n}$ & 70 & $\mathrm{n}$ \\
\hline \multirow{2}{*}{$\begin{array}{l}\text { Finlandia } \\
\text { Francia }^{3}\end{array}$} & 4 & 2 & 20 & 3 \\
\hline & 4 & 3 & 15 & 29 \\
\hline Grecia $^{3}$ & 6 & 1 & 76 & 44 \\
\hline Hungría & 3 & 2 & 42 & $\mathrm{n}$ \\
\hline \multirow{2}{*}{$\begin{array}{l}\text { Irlanda } \\
\text { Islandia }\end{array}$} & 13 & 1 & 18 & 44 \\
\hline & 19 & $\mathrm{n}$ & 10 & $\mathrm{n}$ \\
\hline \multirow{2}{*}{$\begin{array}{l}\text { Israel }^{3} \\
\text { Italia }^{3}\end{array}$} & 4 & $\mathrm{n}$ & $\mathrm{n}$ & $\mathrm{n}$ \\
\hline & 4 & 1 & 28 & 5 \\
\hline \multirow{2}{*}{$\begin{array}{l}\text { Japón } \\
\text { Luxemburgo }\end{array}$} & 1 & 4 & 81 & $\mathrm{n}$ \\
\hline & 70 & $\mathrm{n}$ & $\mathrm{m}$ & 29 \\
\hline México & 1 & $\mathrm{n}$ & $\mathrm{m}$ & $\mathrm{m}$ \\
\hline Noruega & 8 & 1 & 25 & $\mathrm{n}$ \\
\hline $\begin{array}{l}\text { Nueva Zelanda } \\
\text { Países Bajos }\end{array}$ & 3 & 12 & 11 & 46 \\
\hline Polonia & 2 & 1 & 56 & $\mathrm{n}$ \\
\hline Portugal & 6 & 1 & 9 & 55 \\
\hline \multirow{2}{*}{$\begin{array}{l}\text { Reino Unido } \\
\text { República Checa }\end{array}$} & 2 & 13 & 14 & 32 \\
\hline & 3 & 3 & 65 & $\mathrm{n}$ \\
\hline \multirow{2}{*}{$\begin{array}{l}\text { República Eslovaca } \\
\text { Suecia }\end{array}$} & 15 & $\mathrm{n}$ & 60 & $\mathrm{n}$ \\
\hline & 5 & 2 & 20 & 6 \\
\hline Suiza & 5 & 5 & 49 & 53 \\
\hline Turquía $^{3}$ & 2 & $\mathrm{n}$ & 28 & 11 \\
\hline Total OCDE & 2 & 3 & 21 & 24 \\
\hline Total UE21 & 4 & 3 & 24 & 26 \\
\hline Arabia Saudí ${ }^{3}$ & 5 & 1 & 27 & 37 \\
\hline Argentina & $\mathrm{n}$ & $\mathrm{n}$ & $\mathrm{m}$ & 92 \\
\hline Brasil $^{3}$ & 1 & $\mathrm{n}$ & 25 & 27 \\
\hline China $^{3}$ & 2 & $\mathrm{~m}$ & $\mathrm{~m}$ & $\mathrm{~m}$ \\
\hline Colombia & 2 & $\mathrm{~m}$ & $\mathrm{~m}$ & $\mathrm{~m}$ \\
\hline Federación Rusa ${ }^{3,4}$ & 1 & 3 & 68 & 37 \\
\hline India & 1 & $\mathrm{~m}$ & $\mathrm{~m}$ & $\mathrm{~m}$ \\
\hline Indonesia $^{3}$ & 1 & $\mathrm{~m}$ & $\mathrm{~m}$ & $\mathrm{~m}$ \\
\hline Letonia & 9 & $\mathrm{n}$ & $\mathrm{m}$ & $\mathrm{m}$ \\
\hline Sudáfrica $^{3}$ & 1 & 5 & 60 & 81 \\
\hline
\end{tabular}

1. Los países vecinos son los que tienen una frontera terrestre o marítima con el país anfitrión.

2. Año de referencia 2011.

3. Los estudiantes nacionales de educación terciaria se calculan con el total de matriculaciones menos los estudiantes extranjeros, en lugar del total de matriculaciones menos los estudiantes internacionales.

4. El porcentaje de estudiantes extranjeros procedentes de países vecinos incluye a aquellos de países de la antigua Unión Soviética, sobre todo de Asia central.

Fuentes: OCDE y el Instituto de Estadística de la UNESCO para la mayor parte de los datos de los países que no son miembros de la OCDE. Letonia: Eurostat. Para las lenguas oficiales mundiales, CIA World Factbook 2012. Para ver notas, consulte Anexo 3 (www.oecd.org/edu/eag.htm).

Para obtener más información acerca de los símbolos utilizados en lugar de los datos que faltan, consulte la Guía del lector.

StatLink 제개 http://dx.doi.org/10.1787/888933118751 
Tabla C4.6. Tendencias del número de estudiantes extranjeros matriculados en educación terciaria, por región de destino y origen (2000 a 2012)

Número de estudiantes extranjeros matriculados en educación terciaria fuera de su país de origen, basado en recuentos

\begin{tabular}{|c|c|c|c|c|c|c|c|c|c|c|}
\hline \multirow{2}{*}{$\begin{array}{l}\text { Estudiantes extranjeros } \\
\text { matriculados en los siguientes } \\
\text { destinos }\end{array}$} & \multicolumn{5}{|c|}{ Número de estudiantes extranjeros } & \multicolumn{4}{|c|}{ Índice de cambio (2011) } & \multirow{2}{*}{\begin{tabular}{|c} 
Estudiantes \\
extranjeros \\
matriculados en \\
países de la OCDE \\
procedentes de las \\
siguientes regiones \\
de origen (2012)
\end{tabular}} \\
\hline & 2012 & 2011 & 2010 & 2005 & 2000 & $2011=100$ & $2010=100$ & $2005=100$ & $2000=100$ & \\
\hline África & 196.568 & 191.037 & 178.716 & 108.765 & 100.031 & 103 & 110 & 181 & 197 & 346.511 \\
\hline Asia & 806.281 & 772.410 & 726.054 & 458.377 & 334.562 & 104 & 111 & 176 & 241 & 1.662 .788 \\
\hline Europa & 2.160 .874 & 2.086 .980 & 1.984 .442 & 1.388 .027 & 935.879 & 104 & 109 & 156 & 231 & 969.377 \\
\hline Norteamérica & 961.967 & 913.480 & 880.427 & 738.401 & 569.640 & 105 & 109 & 130 & 169 & 101.100 \\
\hline América Latina y el Caribe & 71.468 & 74.267 & 76.041 & 37.114 & 28.945 & 96 & 94 & 193 & 247 & 204.874 \\
\hline Oceanía & 330.886 & 343.466 & 350.165 & 251.904 & 118.646 & 96 & 94 & 131 & 279 & 26.617 \\
\hline En todo el mundo & 4.528.044 & 4.381 .639 & 4.195 .845 & 2.982.588 & 2.087.702 & 103 & 108 & 152 & 217 & 3.415 .975 \\
\hline OCDE & 3.415 .975 & 3.316 .209 & 3.181 .939 & 2.373.011 & 1.604 .601 & 103 & 107 & 144 & 213 & 1.085 .398 \\
\hline Países de la UE & 1.822 .330 & 1.769 .450 & 1.686 .734 & 1.201 .503 & 822.025 & 103 & 108 & 152 & 222 & 779.936 \\
\hline de los cuales en los países UE21 & 1.779 .998 & 1.728 .586 & 1.647 .730 & 1.174.107 & 792.411 & 103 & 108 & 152 & 225 & 657.911 \\
\hline Países del G20 & 3.712 .641 & 3.591 .996 & 3.432 .928 & 2.485 .330 & 1.730 .913 & 103 & 108 & 149 & 214 & 1.721 .226 \\
\hline
\end{tabular}

Nota: Las cifras están basadas en el número de estudiantes extranjeros matriculados en países de la OCDE y de fuera de la OCDE que aportan datos a la OCDE y al Instituto de Estadística de la UNESCO, con el fin de ofrecer una visión global de los estudiantes extranjeros en todo el mundo. La cobertura de estos países ha evolucionado a lo largo del tiempo, por lo que los datos que faltan se han imputado donde era necesario para garantizar la comparabilidad de series temporales a lo largo del tiempo. Dada la inclusión de datos de la UNESCO para países de fuera de la OCDE y la imputación de datos que faltan, los cálculos del número de estudiantes extranjeros pueden diferir de aquellos publicados en ediciones previas de Panorama de la educación. Los totales de los años 2006 a 2009 y 2001 a 2004 están disponibles en Internet (véase Statlink más abajo).

Fuentes: OCDE y el Instituto de Estadística de la UNESCO para la mayor parte de los datos de los países que no son miembros de la OCDE. Para ver notas, consulte Anexo 3 (www.oecd.org/edu/eag.htm).

Para obtener más información acerca de los símbolos utilizados en lugar de los datos que faltan, consulte la Guía del lector.

StatLink 제그 http://dx.doi.org/10.1787/888933118770 



\section{TRANSICIÓN DE LA EDUCACIÓN AL TRABAJO: ¿DÓNDE ESTÁN LOS JÓVENES DE 15 A 29 AÑOS?}

- Durante el punto álgido de la crisis económica, la proporción de jóvenes de 15 a 29 años empleados que ya no estudiaban disminuyó del $41 \%$ en 2008 al 36\% en 2012 como media en los países de la OCDE.

- En 2012, el $15 \%$ de las personas de 15 a 29 años no estaban ni empleadas ni en educación o formación (la población «NI-NI»), como media en los países de la OCDE.

- Por término medio en los países de la OCDE, alrededor del $40 \%$ de los jóvenes de 15 a 29 años que trabajaban a tiempo parcial en 2012 querrían trabajar más horas.

Gráfico C5.1. Población NI-NI de 15 a 29 años (2012) y cambio de 2011 a 2012 Población NI-NI: personas ni empleadas ni en educación o formación

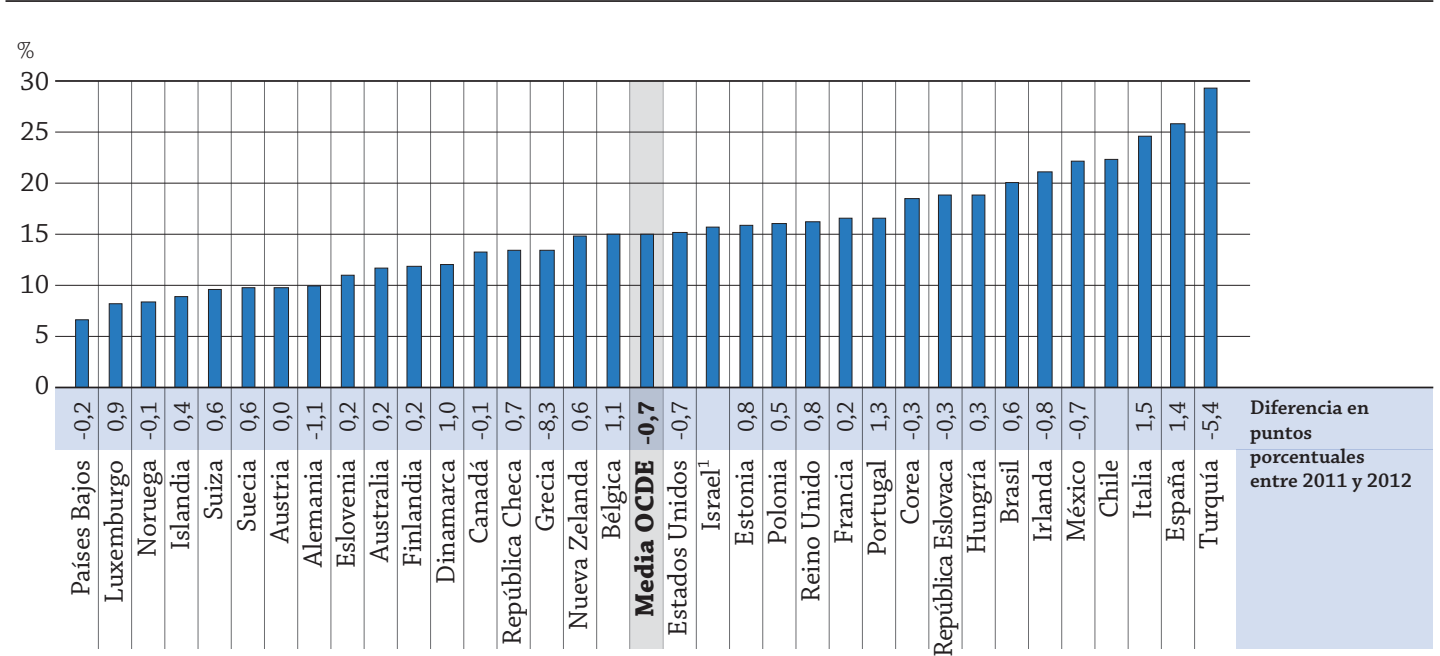

1. Los datos de 2011 y 2012 no son comparables. Véase sección de Metodología más adelante.

2. Año de referencia 2011.

Los países están clasificados en orden ascendente del porcentaje en 2012 de población NI-NI entre los jóvenes de 15 a 29 años con educación secundaria superior o postsecundaria no terciaria.

Fuente: OCDE. Tabla C5.3d, disponible en Internet. Para ver notas, consulte Anexo 3 (www.oecd.org/edu/eag.htm).

StatLink : ज्ञाज http://dx.doi.org/10.1787/888933119017

\section{Contexto}

La duración y la calidad de la enseñanza que reciben los individuos tienen un impacto sobre la transición de los estudiantes de la educación al trabajo; asimismo influyen las condiciones del mercado laboral, el entorno económico y la demografía. Las tradiciones nacionales también desempeñan un papel importante. Por ejemplo, en algunos países, los jóvenes tradicionalmente terminan los estudios antes de buscar trabajo; en otros, la educación y el empleo son simultáneos. En algunos países, hay poca diferencia en cómo experimentan la transición de la educación al trabajo las mujeres y los hombres jóvenes, mientras que en otros una proporción significativa de mujeres jóvenes se dedican exclusivamente a atender a su familia una vez que salen del sistema educativo y no acceden al mercado laboral.

El envejecimiento de la población en los países de la OCDE debería favorecer el empleo de los adultos jóvenes, ya que en teoría, cuando los mayores abandonan el mercado laboral, sus empleos están a disposición de los jóvenes. Sin embargo, durante los periodos de recesión, un menor número de ofertas de empleo hace que la transición de la educación al trabajo sea sustancialmente más difícil para la población más joven, ya que las personas con más experiencia laboral tienen una ventaja frente a las que acceden al mercado laboral por primera vez. Cuando las condiciones del mercado laboral son desfavorables, los más jóvenes tienden a permanecer más tiempo estudiando, porque las tasas de desempleo elevadas bajan los costes de oportunidad de la educación. Al mismo tiempo, la mayoría de los países están adoptando políticas para elevar la edad de la jubilación. Retrasar la jubilación ralentiza la rota- 
ción de empleos, lo cual tiende a disminuir el número de ofertas de empleo. Esto podría explicar la diferencia entre el número de jóvenes (nuevos ingresados) y personas mayores (que dejan de trabajar) en el mercado laboral.

Para mejorar la transición de los jóvenes de la educación al trabajo en cualquier clima económico, los sistemas educativos deben asegurarse de que las personas cuenten con las competencias demandadas por el mercado laboral. Durante una recesión, la inversión pública en educación puede ser una manera sensata de contrarrestar el desempleo e invertir en el crecimiento económico futuro generando esas competencias requeridas. Además, la inversión pública podría dirigirse hacia los empleadores potenciales en forma de incentivos para la contratación de jóvenes.

\section{Otros resultados}

- Por término medio en los países de la OCDE en 2012, el 49\% de los jóvenes de 15 a 29 años estaban en educación. Del $51 \%$ restante, $36 \%$ tenían un empleo, $7 \%$ estaban desempleados y el $8 \%$ estaban fuera de la población activa.

- En 2012, un joven típico de 15 años de un país de la OCDE podía esperar dedicar unos 7 años más a la educación formal durante los próximos 15 años. Además, antes de cumplir los 30 años, podía esperar tener un empleo durante unos seis años, estar desempleado casi un año y estar fuera de la población activa -es decir, ni en educación ni buscando empleo- durante más de un año.

- Las mujeres de 15 a 29 años tienen el doble de probabilidades que los hombres de ese grupo de edad de estar inactivas. Durante ese periodo, pueden esperar estar totalmente fuera de la población activa durante 1,7 años, en comparación con 0,8 años para los hombres.

\section{Tendencias}

Los esfuerzos de los gobiernos para aumentar el nivel educativo de la población han llevado a cambios significativos de la participación en la educación a lo largo de los años. En 2000, por término medio el $41 \%$ de los jóvenes de 15 a 29 años en los países de la OCDE estaban en educación; en 2012, esa proporción había crecido al $49 \%$ (Tabla C5.3a).

Durante ese mismo periodo, la proporción de jóvenes de 15 a 29 años que no estaban en educación, pero sí contaban con un empleo, disminuyó del $44 \%$ al $36 \%$. Mientras que el porcentaje de personas en educación aumentó de forma constante entre 2000 y 2012, las tendencias del empleo juvenil han estado marcadas por dos periodos de grandes disminuciones, de 2000 a 2003 (-3,3 puntos porcentuales) y de 2008 a 2012 (-4,4 puntos porcentuales). Estas disminuciones del empleo juvenil coincidieron con el declive de las actividades económicas a principios de los 2000 y la recesión desencadenada por la crisis económica global en 2008. La proporción de jóvenes de 15 a 29 años ni en educación ni empleadas (NI-NI) permaneció alrededor del 15\% entre 2000 y 2012 (Tabla C5.3a). 


\section{Análisis}

\section{Jóvenes en educación o no, y su situación en el mercado laboral}

Aunque la educación superior mejora las oportunidades económicas de los jóvenes, el declive de la economía global en los últimos años les ha hecho más difícil encontrar trabajo.

En el Gráfico C5.2 se muestra que, en los países de la OCDE, alrededor de la mitad de los jóvenes de 15 a 29 años están estudiando, y la situación es similar en todos los países, variando de menos del $40 \%$ en Brasil y México a más del $60 \%$ en Eslovenia, Grecia y Japón. Las diferencias entre los países son mayores al analizar la situación laboral de esta población. Más de la mitad de los estudiantes en Australia, Dinamarca, Islandia, Países Bajos y Suiza trabajan al menos a tiempo parcial mientras estudian. En todos los demás países, la proporción de estos adultos jóvenes que trabajan y estudian simultáneamente es menor; es inferior al $10 \%$ en Bélgica, España, Hungría e Italia. Para los adultos jóvenes que ya no están estudiando, las diferencias entre los países también son considerables, pero en todos los países la mayoría de estos adultos jóvenes están empleados.

\section{Gráfico C5.2. Porcentaje de jóvenes de 15 a 29 años en educación y no en educación, por situación laboral (2012)}

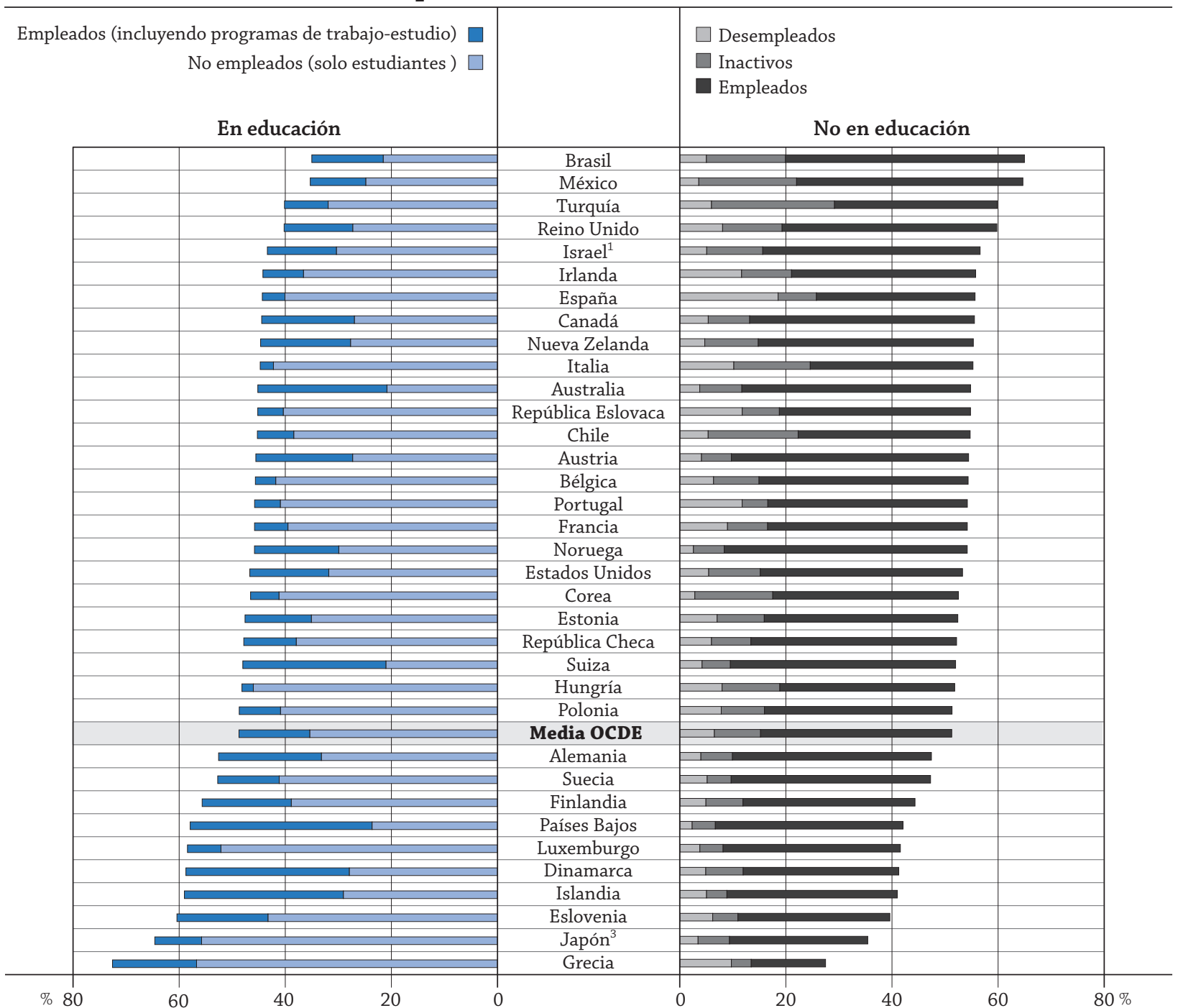

1. La baja proporción de población en educación a esta edad se debe al servicio militar obligatorio para los jóvenes de 18 a 21 años.

2. Año de referencia 2011

3. Los datos se refieren a la población de 15 a 24 años.

Los países están clasificados en orden descendente del porcentaje de jóvenes de 15 a 29 años no en educación.

Fuente: OCDE. Tabla C5.2a. Para ver notas, consulte Anexo 3 (www.oecd.org/edu/eag.htm)

StatLink 젶ㄴ http://dx.doi.org/10.1787/888933119036 
Las tasas de empleo y desempleo son indicadores útiles de cómo participan las personas en el mercado laboral, pero los jóvenes tienen una probabilidad especialmente mayor de retrasar su acceso al mismo o de abandonar la población activa (es decir, no estar ni empleados ni buscando activamente trabajo; véase la sección de Definiciones más adelante). Mientras que cada vez más jóvenes tienden a seguir estudiando más allá de la educación obligatoria y se cuentan como personas inactivas también, no sería correcto considerar a estos jóvenes como un grupo de alto riesgo. Por consiguiente, la proporción de jóvenes ni trabajando ni en educación o formación (NI-NI) es una manera mejor de medir las dificultades que tienen los adultos jóvenes para encontrar un empleo, ya que incluye no solo a aquellos que no consiguen acceder a la población activa, sino también a aquellos que no continúan estudiando.

\section{Jóvenes que no están ni empleados ni en educación o formación (NI-NI)}

Los adultos jóvenes que dejan los estudios y acceden a un mercado laboral difícil pueden estar desempleados durante largos periodos o salir de la población activa por completo, es decir, convertirse en inactivos. La proporción de jóvenes que no están empleados ni en educación o formación (NI-NI) es un mejor indicador de la dificultad a la que se enfrentan los jóvenes para encontrar un empleo que la tasa de desempleo, ya que incluye no solo a aquellos que no consiguen un empleo (desempleados), sino también a aquellos que están desalentados y no buscan activamente empleo (inactivos).

Una gran población NI-NI es a menudo el resultado de una situación económica en declive. Puede indicar también una ruptura en el camino de la educación al trabajo o una falta de coincidencia entre las competencias de los jóvenes y las competencias demandadas por el mercado laboral.

Los integrantes de la población NI-NI inactivos y desempleados de largo plazo pueden perder competencias valiosas y experimentar secuelas a largo plazo que afecten a su futuro laboral y perspectivas de ingresos, lo cual también deriva en una pérdida de capital humano y de impuestos no recaudados para las economías nacionales. Además, muchos estudios confirman la asociación entre el desempleo y una mala salud mental, incluyendo la depresión, lo cual también puede generar costes sociales adicionales para la sociedad (OECD, 2008).

El Gráfico C5.1 muestra que, en los países de la OCDE de 2011 a 2012, el porcentaje de jóvenes de 15 a 29 años que no estaban ni empleados ni en educación o formación disminuyó ligeramente 0,5 puntos porcentuales. Sin embargo, en muchos países, no ha habido esta mejoría. En Italia, por ejemplo, hubo un incremento de 2,5 puntos porcentuales en esta población durante ese periodo, mientras que el incremento en Portugal y Reino Unido fue de unos 4,0 puntos porcentuales (Tabla C5.3d, disponible en Internet).

\section{Los jóvenes de 15 a 19 años (cohorte más joven) no en educación o formación}

Dado que el acceso a la educación secundaria superior ha aumentado en los últimos años, menos jóvenes de 15 a 19 años están fuera del sistema educativo. Entre estos jóvenes, los que no están ni empleados ni en educación o formación (la población NI-NI) están especialmente en riesgo.

Cuando el mercado laboral se deteriora, los más jóvenes (de 15 a 19 años) que realizan la transición de la educación al trabajo son a menudo los primeros en tener dificultades. Estos jóvenes pueden tener una menor cualificación, mientras que las empresas tienden a preferir trabajadores más experimentados para los pocos empleos disponibles. El Gráfico C5.3 muestra que algunos países son más capaces que otros de ofrecer empleo a los jóvenes de 15 a 19 años (que aparecen en el gráfico como «no en educación, empleados»). En los países de la OCDE, uno de cada dos jóvenes de 15 a 19 años que no está en educación está trabajando; pero en Eslovenia, España Grecia e Italia, menos de uno de cada cinco adultos jóvenes que ya no estudian están empleados.

En torno a un $5 \%$ de los jóvenes de 15 a 19 años en los países de la OCDE son NI-NI y están inactivos, y se consideran en riesgo de exclusión por haber renunciado tanto a seguir estudiando como a buscar trabajo. En Brasil, Chile, México y Turquía, más del 15\% de los jóvenes de 15 a 19 años se encuentran en esta situación de no estar estudiando ni buscando trabajo (Tabla C5.2a).

\section{Población NI-NI desempleada o inactiva}

La proporción de jóvenes que ni están empleados ni en educación o formación (NI-NI) incluye a aquellos que están desempleados o inactivos. Este último grupo es especialmente importante, ya que incluye a los jóvenes desanimados que han renunciado a buscar un empleo.

Para todo el conjunto de los niveles de educación, en Chile, España, Irlanda, Italia, México y Turquía, más del 20\% de los jóvenes de 15 a 29 años son NI-NI. En España, el 19\% de los jóvenes NI-NI están desempleados, mientras que el $7 \%$ están inactivos. En Brasil, Chile, México y Turquía se observa el patrón inverso: alrededor del 15\% de los jóve- 


\section{Gráfico C5.3. Porcentaje de jóvenes de 15 a 19 años no en educación, por situación laboral (2012)}

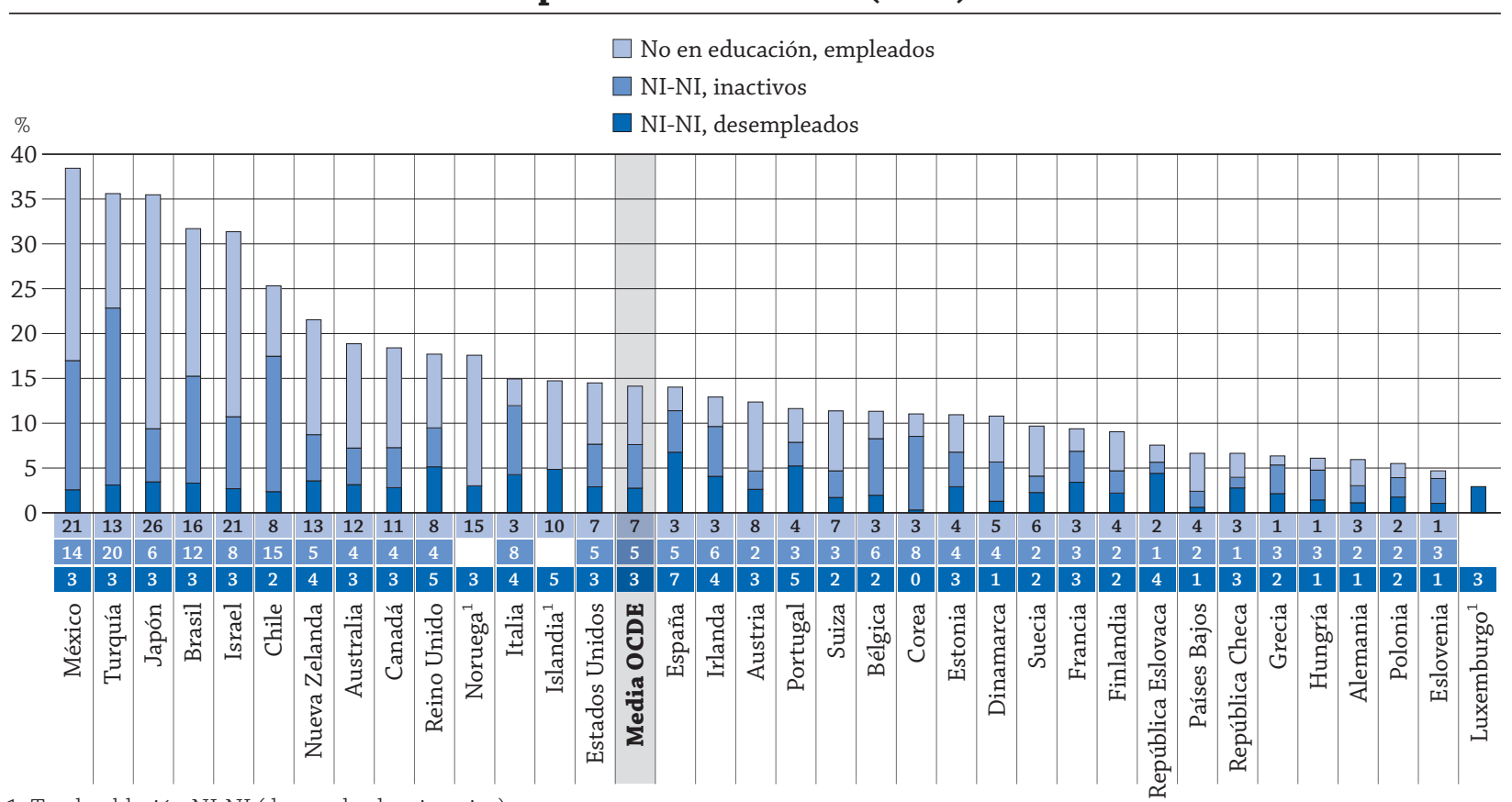

1. Total población NI-NI (desempleada + inactiva).

Los países están clasificados en orden descendente del porcentaje de jóvenes de 15 a 19 años no en educación.

Fuente: OCDE. Tabla C5.2a. Para ver notas, consulte Anexo 3 (www.oecd.org/edu/eag.htm).

StatLink त्ताs] http://dx.doi.org/10.1787/888933119055

nes NI-NI están inactivos, mientras que el $6 \%$ o menos están desempleados. En Alemania, Austria, Islandia, Luxemburgo, Noruega, Países Bajos, Suecia y Suiza, menos del $10 \%$ de los jóvenes de 15 a 29 años no estaban en educación ni empleados (Tabla C5.2a).

Como media en los países de la OCDE en 2012, el 17\% de la mujeres de 15 a 29 años eran NI-NI (6\% desempleadas y $12 \%$ inactivas), así como el $13 \%$ de los hombres de 15 a 29 años (7\% desempleados y 5\% inactivos) (Tablas C5.2b y c, disponibles en Internet).

\section{Empleo a tiempo parcial y a tiempo completo para los que están en educación y los que no}

Alrededor de uno de cada dos jóvenes de 15 a 29 años en los países de la OCDE está empleado. El $8 \%$ de estos jóvenes trabajan a tiempo parcial mientras estudian; el $5 \%$ trabajan a tiempo parcial, pero ya no estudian; el $6 \%$ trabajan a tiempo completo mientras continúan estudiando; y el $30 \%$ trabajan a tiempo completo y ya no estudian. Considerando solo este grupo de edad, alrededor de una de cada cuatro personas trabaja a tiempo parcial (el $14 \%$ de este $50 \%$ de jóvenes), y, de estos trabajadores a tiempo parcial, a más del $40 \%$ les gustaría trabajar más, es decir, desempeñan un trabajo a tiempo parcial involuntariamente (Tabla C5.5).

En el Gráfico C5.4 se muestra que la prevalencia de trabajo a tiempo parcial en los jóvenes difiere significativamente entre los países. La proporción media en la OCDE de jóvenes de 15 a 29 años que trabajan a tiempo parcial es de uno de cada cuatro, pero oscila entre uno de cada 20 en República Checa y República Eslovaca, y uno de cada dos en Dinamarca. Este gráfico muestra también que la proporción de jóvenes que trabajan a tiempo parcial o a tiempo completo mientras estudian ha aumentado en los países de la OCDE, mientras que en aquellos que ya no estudian ha habido una disminución del empleo a tiempo completo que se ha visto compensada solo en parte por un incremento del empleo a tiempo parcial.

A los trabajadores a tiempo parcial a menudo les gustaría poder trabajar más horas, si tuvieran la oportunidad de hacerlo. El trabajo a tiempo parcial se considera positivo solo cuando es voluntario. Como media en los 19 países de la OCDE con datos comparables, menos de uno de cada dos jóvenes no estudiantes que trabajan a tiempo parcial lo hacen voluntariamente (Tabla C5.4). Una gran proporción de trabajo a tiempo parcial involuntario significa que las personas están teniendo dificultades para encontrar empleos a tiempo completo y sugiere que su empleo es precario. Un trabajador a tiempo parcial avanza más lentamente por las escalas salariales y de experiencia que un traba- 


\section{Gráfico C5.4. Empleo a tiempo parcial y a tiempo completo en los jóvenes de 15 a 29 años (2006-2012)}

Media de la OCDE de la proporción de jóvenes de 15 a 29 años empleados a tiempo parcial o a tiempo completo, en educación o no (2006-2012)
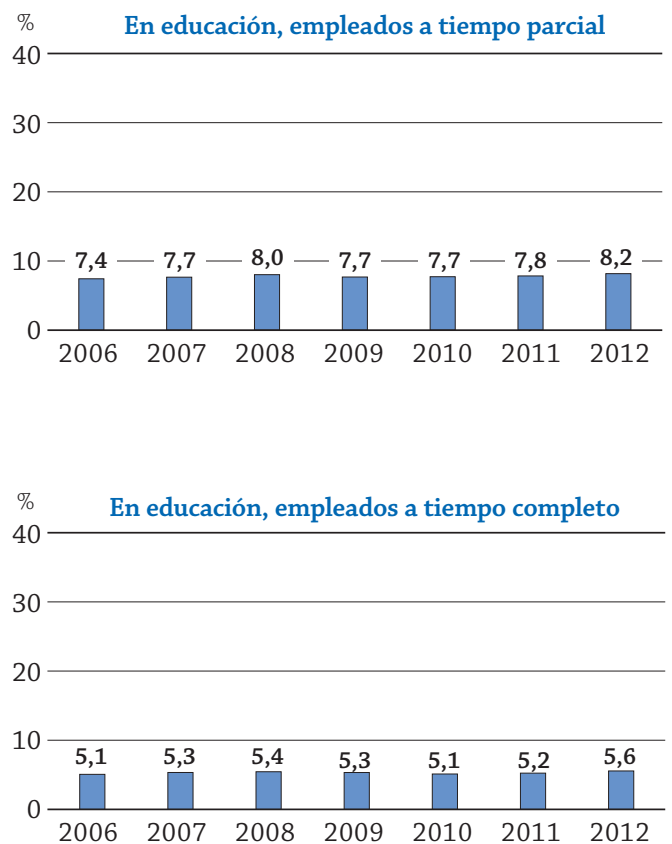

$\% \quad$ No en educación, empleados a tiempo parcial

30

20
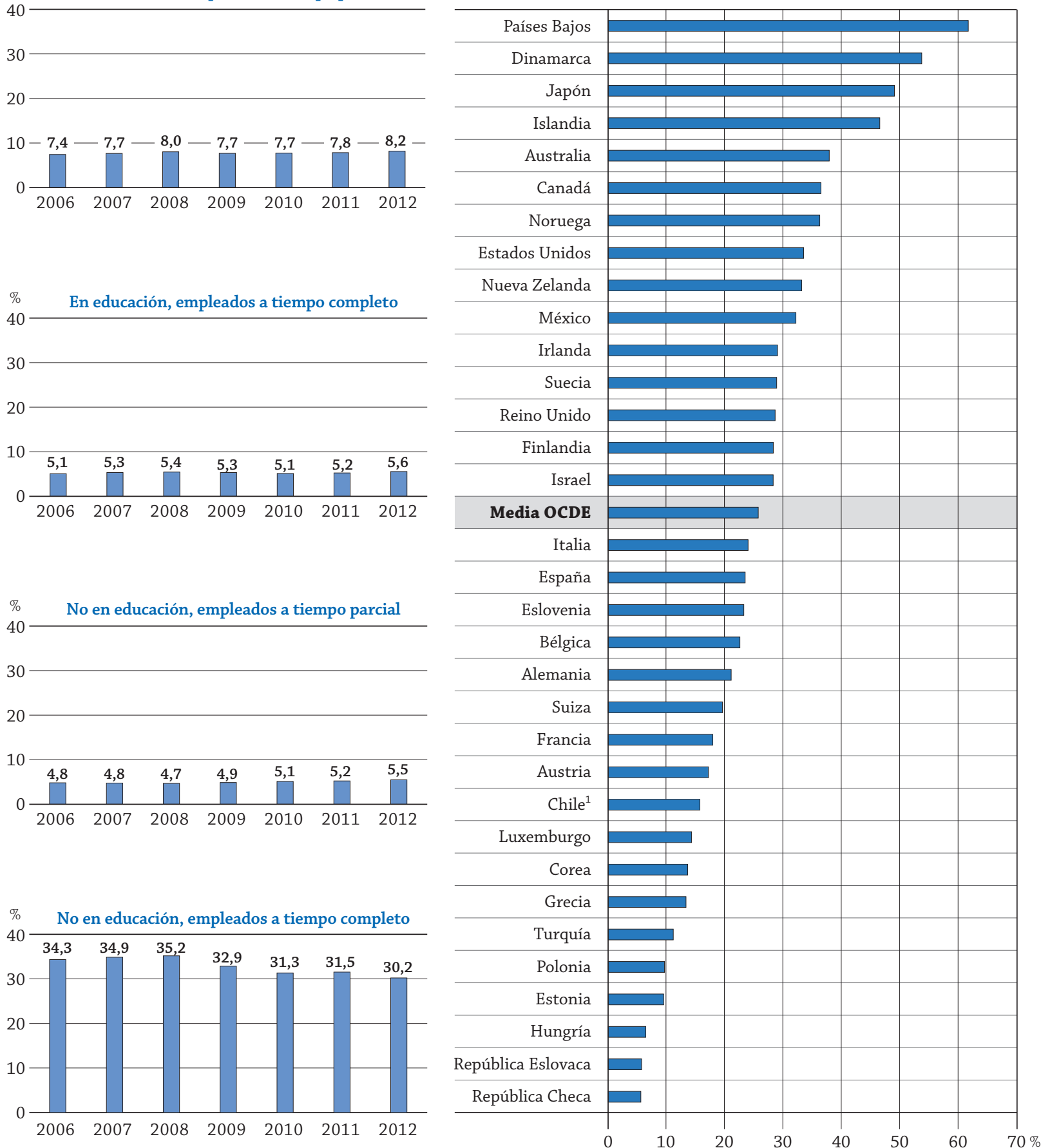

1. Año de referencia 2011.

Los países están clasificados en orden descendente del porcentaje de jóvenes de 15 a 29 años empleados a tiempo parcial del total de empleados.

Fuente: OCDE. Tabla C5.5. Para ver notas, consulte Anexo 3 (www.oecd.org/edu/eag.htm).

StatLink ज्ञाs http://dx.doi.org/10.1787/888933119074 
jador a tiempo completo, lo cual potencialmente dificulta más que una persona alcance, en remuneración o estatus laboral, a sus compañeros que trabajan a tiempo completo (OECD, 2010).

En los jóvenes de 15 a 29 años que han completado la educación inicial, el nivel educativo alcanzado está asociado de manera más positiva a las tasas de empleo. Tanto el trabajo a tiempo parcial como a tiempo completo es más frecuente entre los trabajadores más cualificados, pero la proporción de trabajadores a tiempo parcial en los empleados disminuye con el nivel de educación alcanzado, así como la proporción de trabajo a tiempo parcial involuntario (como porcentaje del empleo total). En 2012, el 13\% de los empleados jóvenes de 15 a 29 años con educación terciaria que ya no estaban en educación trabajaban a tiempo parcial (el 7,9\% del 61,5\% no en educación y empleados a tiempo parcial), mientras que el $21 \%$ de los empleados jóvenes de 15 a 29 años con una educación inferior a secundaria superior que ya no estaban en educación trabajaban a tiempo parcial (3,2\% del 15,5\% total).

La proporción relativa de empleo a tiempo parcial voluntario también disminuye a medida que aumenta el nivel de educación: el $7 \%$ de los empleados jóvenes de 15 a 29 años con educación terciaria que ya no están en educación trabajan a tiempo parcial voluntariamente (4,2\% del $61,5 \%$ total), mientras que el $12 \%$ de los empleados jóvenes de 15 a 29 años con una educación secundaria superior que ya no están en educación trabajan a tiempo parcial voluntariamente (1,8\% del $15,5 \%$ total) (Tabla C5.4)

La diferencia por sexo en el empleo a tiempo parcial de los jóvenes que ya no están estudiando es significativa. Como media en los países de la OCDE, en 2012 las mujeres de 15 a 29 años tenían el doble de probabilidades (7,2 \%) que los hombres $(3,8 \%)$ de esa edad de trabajar a tiempo parcial cuando ya no estudiaban. En los 17 países que refirieron información sobre trabajo a tiempo parcial involuntario, la proporción de mujeres jóvenes que trabajaban a tiempo parcial involuntariamente era mayor que la de hombres (3,5\% frente a 2,0\%); pero como proporción del empleo a tiempo parcial total, por sexo, la proporción de trabajo a tiempo parcial involuntario era mayor entre los hombres que entre las mujeres. Los hombres tienen menos probabilidades de trabajar a tiempo parcial; pero cuando lo hacen, es menos probable que sea por elección propia (Tablas C5.2b y c, disponibles en Internet).

\section{Años esperados en educación}

Como media en los países de la OCDE, entre los 15 y los 29 años, las personas pasan 7 años en educación (estudiando a tiempo completo o parcial) y casi 8 años no en educación (empleados, desempleados o inactivos, es decir, fuera del mercado laboral). Como media, durante casi seis de esos ocho años no en educación los jóvenes están empleados, durante casi un año están desempleados y durante un año están inactivos. Sin embargo, existen grandes diferencias entre los países: en Brasil y México, esos jóvenes pasan una media de cinco años en educación, en Dinamarca, Eslovenia, Islandia, Luxemburgo y Países Bajos pasan una media de nueve años, y en Grecia, están una media de 11 años en educación (Tabla C5.1a).

En la mayoría de los países, los estudiantes de 15 años están a punto de terminar la educación obligatoria y en la última década se han hecho esfuerzos por fomentar su participación en la educación más allá de este nivel. Como resultado, el número medio de años de educación formal esperada después de la escolarización obligatoria ha aumentado considerablemente. Como media en los países de la OCDE, desde 2000, se ha añadido un año a la duración de la educación formal; en Luxemburgo, Países Bajos, República Checa, República Eslovaca y Turquía, se han añadido dos años, mientras que en Grecia se han añadido 5 años en este periodo (Tabla C5.1c, disponible en Internet).

En la mayoría de los países, los años dedicados a la educación normalmente no se combinan con el trabajo; las únicas excepciones son Islandia, Países Bajos y Suiza, donde los jóvenes dedican una media de más de cuatro años a trabajar (incluyendo los programas de trabajo-estudio) mientras estudian. Como media en los países de la OCDE, los estudiantes dedican dos de cada siete años que están en educación a trabajar mientras estudian (Tabla C5.1a).

No existen grandes diferencias por sexo en los años esperados en educación, pero hay grandes diferencias en algunos países en la experiencia laboral de quienes han abandonado los estudios. En Brasil, México, Polonia, República Checa, República Eslovaca y Turquía, los hombres trabajan unos dos años más que las mujeres (Tabla C5.1b, disponible en Internet).

\section{Definiciones}

Empleados se refiere a personas que tenían un empleo o trabajaban durante una hora o más en un empleo remunerado o como autónomos (según la definición de la OIT). La definición seguida en este indicador excluye a aquellos que cursan programas de trabajo-estudio. Consulte el Indicador A5 y el Anexo 3 para más detalles. 
Trabajadores a tiempo completo son los que trabajan normalmente 30 horas o más en su trabajo principal. Un umbral que oscila entre 30 y 36 horas laborales se aplica en varios países, mientras que otros aplican un criterio subjetivo de tiempo completo. Consulte el Indicador A6 y el Anexo 3 para más detalles.

Inactivos son los individuos que no están en la población activa, es decir, que ni están trabajando ni buscando trabajo (desempleados). Consulte el Indicador A5 y el Anexo 3 para más detalles.

Niveles de educación: inferior a secundaria superior corresponde a los niveles CINE 0, 1, 2 y $3 C$ programas cortos; secundaria superior o postsecundaria no terciaria corresponde a los niveles CINE 3A, 3B, 3C programas largos, y nivel CINE 4; y terciaria corresponde a los niveles CINE 5A, 5B y 6. Para una presentación de todos los niveles CINE, consulte la Guía del lector al inicio de este libro.

NI-NI: Ni empleados ni en educación o formación.

El trabajo a tiempo parcial se divide en voluntario, involuntario y desconocido. El trabajo a tiempo parcial involuntario comprende las siguientes tres categorías, según las encuestas de la población activa: personas que normalmente trabajan a tiempo completo, pero que durante la semana de referencia trabajaron menos horas de lo habitual en su trabajo por motivos económicos, independientemente del número de horas menos, o que trabajaron a tiempo parcial por motivos económicos; personas que normalmente trabajan a tiempo parcial, porque no pueden encontrar un empleo a tiempo completo; y personas que normalmente trabajan a tiempo parcial por motivos distintos a su imposibilidad para encontrar un empleo a tiempo completo y que trabajaron menos horas de lo habitual en su empleo durante la semana de referencia por motivos económicos. El trabajo a tiempo parcial involuntario incluye a todas las personas que quieren trabajar más horas, no necesariamente a tiempo completo.

Personas desempleadas son aquellas que, durante la semana de referencia del estudio, no tenían un empleo (es decir, ni estaban empleadas durante una hora o más en un empleo remunerado o como autónomas), buscaban activamente un empleo (habían tomado medidas concretas durante las cuatro semanas anteriores a la semana de referencia para buscar dicho empleo por cuenta ajena o propia), y estaban disponibles actualmente para empezar a trabajar (estaban disponibles para un trabajo remunerado por cuenta ajena o propia antes del final de las dos semanas posteriores a la semana de referencia). Consulte el Indicador A5 y el Anexo 3 para más detalles.

\section{Metodología}

Los datos sobre población, nivel de educación alcanzado y estado laboral de la mayoría de los países proceden de las bases de datos de la OCDE y Eurostat, recopiladas de las Encuestas Nacionales de Población Activa de la red LSO (Mercado Laboral y Resultados Sociales del Aprendizaje) de la OCDE, y suelen referirse al primer trimestre, o a la media de los tres primeros meses del año natural. Véase Anexo 3 (www.oecd.org/edu/eag.htm) para más información.

Existen ciertas discrepancias sobre los datos recopilados. Algunos países pueden referirse a todos los empleos en vez de al principal, o tiempo parcial puede referirse a menos de 35 horas a la semana en vez de 30 horas. Los detalles sobre la cobertura del trabajo a tiempo parcial involuntario están disponibles en el Anexo 3.

Para Israel, la proporción de NI-NI en 2012 no es comparable con la de 2011. Los reclutas militares ahora se consideran empleados, a diferencia del año anterior, cuando fueron computados como fuera de la población activa.

\section{Nota sobre los datos de Israel}

Los datos estadísticos para Israel fueron proporcionados por las autoridades israelíes competentes bajo su responsabilidad. El uso de estos datos por parte de la OCDE se hace sin prejuzgar la situación de los Altos del Golán, Jerusalén Este y los asentamientos israelíes en Cisjordania de acuerdo con los términos del derecho internacional.

\section{Referencias}

OECD (2010), «How Good is Part/Time Work?», in OECD Employment Outlook 2010: Moving beyond the Jobs Crisis, OECD Publishing, París, http://dx.doi.org/10.1787/empl_outlook-2010-en.

OECD (2008), «Mental Health in OECD Countries», OECD Policy Brief, noviembre de 2008, www.oecd.org/el s/health-systems/ mental-health-systems.htm. 


\section{Tablas del Indicador C5}

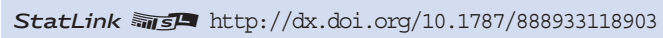

Tabla C5.1a Años esperados en educación y no en educación para los jóvenes de 15 a 29 años, por situación laboral (2012)

WEB Tabla C5.1b Años esperados en educación y no en educación para los jóvenes de 15 a 29 años, por situación laboral y sexo (2012)

WEB Tabla C5.1c Tendencias de los años esperados en educación y no en educación para los jóvenes de 15 a 29 años, por sexo (1999-2012)

Tabla C5.2a Porcentaje de jóvenes de 15 a 29 años en educación y no en educación, por grupo de edad y situación laboral (2012)

WEB Tabla C5.2b Porcentaje de hombres de 15 a 29 años en educación y no en educación, por grupo de edad y situación laboral (2012)

WEB Tabla C5.2c Porcentaje de mujeres de 15 a 29 años en educación y no en educación, por grupo de edad y situación laboral (2012)

Tabla C5.3a Tendencias del porcentaje de jóvenes de 15 a 29 años en educación y no en educación, empleados o no, por grupo de edad (1997-2012)

WEB Tabla C5.3b Tendencias del porcentaje de hombres de 15 a 29 años en educación y no en educación, empleados o no, por grupo de edad (1997-2012)

WEB Tabla C5.3c Tendencias del porcentaje de mujeres de 15 a 29 años en educación y no en educación, empleados o no, por grupo de edad (1997-2012)

WEB Tabla C5.3d Tendencias del porcentaje de jóvenes de 15 a 29 años en educación y no en educación, empleados o no, por nivel de educación alcanzado (2006-2012)

Tabla C5.4 Porcentaje de jóvenes de 15 a 29 años en educación y no en educación, por nivel educativo alcanzado y situación laboral (2012)

Tabla C5.5 Tendencias del porcentaje de trabajadores de 15 a 29 años a tiempo parcial y a tiempo completo en educación y no en educación (2006-2012) 
Tabla C5.1a. Años esperados en educación y no en educación para los jóvenes de 15 a 29 años, por situación laboral (2012)

\begin{tabular}{|c|c|c|c|c|c|c|c|}
\hline & \multicolumn{3}{|c|}{ Años esperados en educación } & \multicolumn{4}{|c|}{ Años esperados no en educación } \\
\hline & No empleados & $\begin{array}{c}\text { Empleados } \\
\text { (incluyendo } \\
\text { programas } \\
\text { de trabajo-estudio) }^{1}\end{array}$ & Subtotal & Empleados & Desempleados & Inactivos & Subtotal \\
\hline & (1) & (2) & (3) & (4) & (5) & (6) & (7) \\
\hline Alemania & 5,0 & 2,9 & 7,9 & 5,6 & 0,6 & 0,9 & 7,1 \\
\hline Australia & 3,1 & 3,6 & 6,8 & 6,5 & 0,6 & 1,2 & 8,2 \\
\hline Austria & 4,1 & 2,7 & 6,8 & 6,7 & 0,6 & 0,8 & 8,2 \\
\hline Bélgica & 6,3 & 0,6 & 6,8 & 5,9 & 1,0 & 1,3 & 8,2 \\
\hline Canadá & 4,0 & 2,6 & 6,7 & 6,4 & 0,8 & 1,2 & 8,3 \\
\hline Chile $^{2}$ & 5,8 & 1,0 & 6,8 & 4,9 & 0,8 & 2,5 & 8,2 \\
\hline Corea & 6,2 & 0,8 & 7,0 & 5,3 & 0,4 & 2,3 & 8,0 \\
\hline Dinamarca & 4,2 & 4,6 & 8,8 & 4,4 & 0,7 & 1,1 & 6,2 \\
\hline Eslovenia & 6,5 & 2,6 & 9,1 & 4,3 & 0,9 & 0,7 & 5,9 \\
\hline España & 6,0 & 0,6 & 6,6 & 4,5 & 2,8 & 1,1 & 8,4 \\
\hline Estados Unidos & 4,8 & 2,2 & 7,0 & 5,7 & 0,8 & 1,5 & 8,0 \\
\hline Estonia & 5,3 & 1,9 & 7,1 & 5,5 & 1,1 & 1,3 & 7,9 \\
\hline Finlandia & 5,8 & 2,5 & 8,3 & 4,9 & 0,7 & 1,0 & 6,7 \\
\hline Francia & 5,9 & 0,9 & 6,9 & 5,7 & 1,4 & 1,1 & 8,1 \\
\hline Grecia & 8,5 & 2,4 & 10,9 & 2,1 & 1,5 & 0,6 & 4,1 \\
\hline Hungría & 6,9 & 0,3 & 7,2 & 4,9 & 1,2 & 1,6 & 7,8 \\
\hline Irlanda & 5,5 & 1,1 & 6,6 & 5,2 & 1,7 & 1,4 & 8,4 \\
\hline Islandia & 4,4 & 4,5 & 8,8 & 4,8 & 0,8 & 0,6 & 6,2 \\
\hline Israel & 4,6 & 1,9 & 6,5 & 6,2 & 0,8 & 1,6 & 8,5 \\
\hline Italia & 6,3 & 0,4 & 6,7 & 4,6 & 1,5 & 2,2 & 8,3 \\
\hline Japón ${ }^{3}$ & 5,6 & 0,9 & 6,5 & 2,6 & 0,3 & 0,6 & 3,5 \\
\hline Luxemburgo & 7,8 & 0,9 & 8,8 & 5,0 & 0,6 & 0,7 & 6,2 \\
\hline México & 3,7 & 1,6 & 5,3 & 6,4 & 0,5 & 2,8 & 9,7 \\
\hline Noruega & 4,5 & 2,4 & 6,9 & 6,9 & 0,4 & 0,9 & 8,1 \\
\hline Nueva Zelanda & 4,2 & 2,5 & 6,7 & 6,1 & 0,7 & 1,5 & 8,3 \\
\hline Países Bajos & 3,5 & 5,1 & 8,7 & 5,3 & 0,4 & 0,7 & 6,3 \\
\hline Polonia & 6,1 & 1,2 & 7,3 & 5,3 & 1,2 & 1,2 & 7,7 \\
\hline Portugal & 6,1 & 0,7 & 6,9 & 5,6 & 1,8 & 0,7 & 8,1 \\
\hline Reino Unido & 4,2 & 2,0 & 6,2 & 6,3 & 1,1 & 1,3 & 8,8 \\
\hline República Checa & 5,7 & 1,5 & 7,2 & 5,8 & 0,9 & 1,1 & 7,8 \\
\hline República Eslovaca & 6,1 & 0,7 & 6,8 & 5,4 & 1,8 & 1,1 & 8,2 \\
\hline Suecia & 6,2 & 1,7 & 7,9 & 5,6 & 0,8 & 0,7 & 7,1 \\
\hline Suiza & 3,2 & 4,0 & 7,2 & 6,4 & 0,6 & 0,8 & 7,8 \\
\hline Turquía & 4,8 & 1,2 & 6,0 & 4,6 & 0,9 & 3,5 & 9,0 \\
\hline $\begin{array}{l}\text { Media OCDE } \\
\text { (excluyendo Chile y Japón) }\end{array}$ & 5,3 & 2,0 & 7,3 & 5,4 & 1,0 & 1,3 & 7,7 \\
\hline Media UE21 & 5,8 & 1,8 & 7,6 & 5,2 & 1,1 & 1,1 & 7,4 \\
\hline
\end{tabular}

\begin{tabular}{|c|c|c|c|c|c|c|c|}
\hline $\begin{array}{l}\text { Arabia Saudí } \\
\text { Argentina }\end{array}$ & $\begin{array}{l}\mathrm{m} \\
\mathrm{m}\end{array}$ & $\begin{array}{l}\mathrm{m} \\
\mathrm{m}\end{array}$ & $\begin{array}{l}\mathrm{m} \\
\mathrm{m}\end{array}$ & $\begin{array}{l}\mathrm{m} \\
\mathrm{m}\end{array}$ & $\begin{array}{l}\mathrm{m} \\
\mathrm{m}\end{array}$ & $\begin{array}{l}\mathrm{m} \\
\mathrm{m}\end{array}$ & $\begin{array}{l}\mathrm{m} \\
\mathrm{m}\end{array}$ \\
\hline Brasil & 3,2 & 2,0 & 5,2 & 6,8 & 0,8 & 2,2 & 9,8 \\
\hline China & $\mathrm{m}$ & $\mathrm{m}$ & $\mathrm{m}$ & $\mathrm{m}$ & $\mathrm{m}$ & $\mathrm{m}$ & $\mathrm{m}$ \\
\hline Colombia & $\mathrm{m}$ & $\mathrm{m}$ & $\mathrm{m}$ & $\mathrm{m}$ & $\mathrm{m}$ & $\mathrm{m}$ & $\mathrm{m}$ \\
\hline Federación Rusa & $\mathrm{m}$ & $\mathrm{m}$ & $\mathrm{m}$ & $\mathrm{m}$ & $\mathrm{m}$ & $\mathrm{m}$ & $\mathrm{m}$ \\
\hline India & $\mathrm{m}$ & $\mathrm{m}$ & $\mathrm{m}$ & $\mathrm{m}$ & $\mathrm{m}$ & $\mathrm{m}$ & $\mathrm{m}$ \\
\hline Indonesia & $\mathrm{m}$ & $\mathrm{m}$ & $\mathrm{m}$ & $\mathrm{m}$ & $\mathrm{m}$ & $\mathrm{m}$ & $\mathrm{m}$ \\
\hline Letonia & 5,7 & 1,3 & 6,9 & 5,2 & 1,6 & 1,3 & 8,1 \\
\hline Sudáfrica & $\mathrm{m}$ & $\mathrm{m}$ & $\mathrm{m}$ & $\mathrm{m}$ & $\mathrm{m}$ & $\mathrm{m}$ & $\mathrm{m}$ \\
\hline
\end{tabular}

\section{Media G20}

1. Los estudiantes en programas de trabajo-estudio se consideran tanto en educación como empleados, con independencia de su situación en el mercado laboral según la definición de la OIT.

2. Año de referencia 2011.

3. Los datos se refieren a la población de 15 a 24 años.

Fuente: OCDE. Arabia Saudí, Argentina, China, Colombia, India, Indonesia y Sudáfrica: Instituto de Estadística de la UNESCO. Letonia: Eurostat. Para ver notas, consulte Anexo 3 (www.oecd.org/edu/eag.htm).

Para obtener más información acerca de los símbolos utilizados en lugar de los datos que faltan, consulte la Guía del lector.

StatLink 젝ㄴ http://dx.doi.org/10.1787/888933118922 
Tabla C5.2a. [1/6] Porcentaje de jóvenes de 15 a 29 años en educación y no en educación, por grupo de edad y situación laboral (2012)

\begin{tabular}{|c|c|c|c|c|c|c|c|c|c|c|c|c|}
\hline & \multirow[b]{4}{*}{$\begin{array}{c}\text { Grupo } \\
\text { de edad }\end{array}$} & \multicolumn{11}{|c|}{ En educación } \\
\hline & & \multirow[b]{2}{*}{ 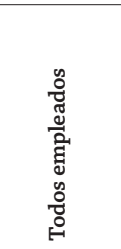 } & \multicolumn{2}{|c|}{ Empleados } & \multicolumn{3}{|c|}{ Tipo de empleo } & \multirow[b]{2}{*}{ 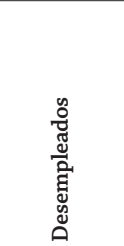 } & \multicolumn{2}{|c|}{$\begin{array}{c}\text { Duración } \\
\text { del desempleo }\end{array}$} & \multirow[b]{2}{*}{ 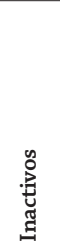 } & \multirow[b]{2}{*}{ 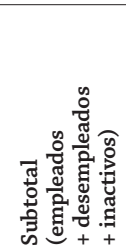 } \\
\hline & & & 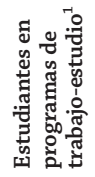 & 总 & 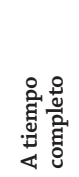 & 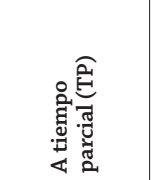 & 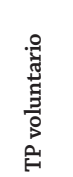 & & 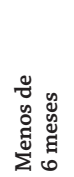 & 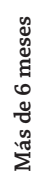 & & \\
\hline & & $\begin{array}{c}(1) \\
=(2)+(3) \\
y / 0(4)+(5) \\
+ \text { desconocidos }\end{array}$ & (2) & (3) & (4) & $\begin{array}{c}(5) \\
=(6) \\
+ \text { TP involuntario }\end{array}$ & (6) & $\begin{aligned} &(7) \\
&=(8)+(9) \\
&+ \text { desconocidos }\end{aligned}$ & (8) & (9) & (10) & $\begin{array}{c}(11) \\
=(1)+(7)+(10)\end{array}$ \\
\hline \multirow[t]{4}{*}{ Alemania } & $15-19$ & 22,9 & 15,3 & 7,6 & 16,9 & 6,0 & c & 1,2 & 0,8 & 0,4 & 70,0 & 94,1 \\
\hline & $20-24$ & 25,1 & 13,7 & 11,4 & 17,2 & 7,9 & c & 0,6 & 0,5 & 0,1 & 25,2 & 51,0 \\
\hline & $25-29$ & 10,5 & 2,2 & 8,4 & 4,8 & 5,8 & c & 0,4 & 0,3 & 0,1 & 8,0 & 18,9 \\
\hline & $15-29$ & 19,4 & 10,2 & 9,2 & 12,8 & 6,6 & 0,1 & 0,7 & 0,5 & 0,2 & 32,5 & 52,5 \\
\hline \multirow{4}{*}{ Australia } & $15-19$ & 35,9 & 6,1 & 29,8 & 1,6 & 28,1 & 21,7 & 6,0 & 4,8 & 1,2 & 39,3 & 81,1 \\
\hline & $20-24$ & 26,9 & 4,7 & 22,2 & 5,6 & 16,6 & 13,8 & 2,4 & 2,0 & 0,4 & 12,4 & 41,7 \\
\hline & $25-29$ & 11,7 & 1,3 & 10,4 & 6,0 & 4,4 & 3,2 & 0,9 & 0,6 & 0,3 & 4,6 & 17,3 \\
\hline & $15-29$ & 24,3 & 3,9 & 20,4 & 4,6 & 15,8 & 12,5 & 3,0 & 2,4 & 0,6 & 17,8 & 45,1 \\
\hline \multirow[t]{4}{*}{ Austria } & 15-19 & 29,7 & 24,6 & 5,1 & c & 4,3 & $\mathrm{~m}$ & 1,2 & 0,9 & c & 56,8 & 87,6 \\
\hline & $20-24$ & 15,8 & 3,0 & 12,8 & 4,1 & 8,7 & $\mathrm{~m}$ & 1,4 & 1,3 & c & 20,3 & 37,5 \\
\hline & $25-29$ & 10,6 & c & 10,5 & 5,0 & 5,5 & $\mathrm{~m}$ & 0,8 & 0,7 & c & 5,3 & 16,8 \\
\hline & $15-29$ & 18,2 & 8,6 & 9,6 & 3,4 & 6,2 & $\mathrm{~m}$ & 1,1 & 1,0 & c & 26,2 & 45,5 \\
\hline Bélgica & 15-19 & 3,2 & 1,5 & 1,7 & c & 1,5 & 1,5 & c & c & c & 85,4 & 88,7 \\
\hline & $20-24$ & 4,2 & 0,8 & 3,4 & 1,4 & 2,0 & 1,8 & 0,9 & 0,6 & c & 37,8 & 42,9 \\
\hline & $25-29$ & 4,1 & c & 3,8 & 2,6 & 1,2 & 0,9 & 0,5 & c & c & 4,2 & 8,8 \\
\hline & $15-29$ & 3,8 & 0,8 & 3,0 & 1,5 & 1,6 & 1,4 & 0,5 & 0,3 & 0,2 & 41,3 & 45,6 \\
\hline Canadá & $15-19$ & 24,9 & a & 24,9 & 1,3 & 23,7 & 23,0 & 5,9 & 5,3 & 0,5 & 50,7 & 81,6 \\
\hline & $20-24$ & 21,2 & a & 21,2 & 3,6 & 17,6 & 16,8 & 2,0 & 1,8 & 0,1 & 18,9 & 42,1 \\
\hline & $25-29$ & 7,1 & a & 7,1 & 3,4 & 3,7 & 3,4 & 0,6 & 0,5 & 0,1 & 5,8 & 13,5 \\
\hline & $15-29$ & 17,4 & a & 17,4 & 2,8 & 14,7 & 14,1 & 2,7 & 2,4 & 0,2 & 24,2 & 44,4 \\
\hline Chile $^{3}$ & $15-19$ & 4,2 & a & 4,2 & 2,6 & 1,6 & 0,8 & 2,2 & 2,1 & 0,0 & 68,3 & 74,7 \\
\hline & $20-24$ & 8,8 & a & 8,8 & 5,2 & 3,6 & 1,7 & 2,3 & 2,2 & 0,1 & 28,9 & 40,0 \\
\hline & $25-29$ & 7,5 & a & 7,5 & 5,2 & 2,3 & 0,8 & 0,7 & 0,6 & 0,0 & 7,7 & 15,9 \\
\hline & $15-29$ & 6,8 & a & 6,8 & 4,3 & 2,5 & 1,1 & 1,8 & 1,7 & 0,0 & 36,6 & 45,2 \\
\hline Corea & $15-19$ & 4,5 & a & 4,5 & 1,3 & 3,2 & 3,2 & 0,3 & 0,3 & 0,0 & 84,1 & 89,0 \\
\hline & $20-24$ & 9,4 & a & 9,4 & 3,4 & 6,0 & 5,9 & 0,7 & 0,7 & 0,0 & 32,3 & 42,4 \\
\hline & $25-29$ & 2,8 & a & 2,8 & 1,9 & 0,9 & 0,9 & 0,3 & 0,3 & 0,0 & 5,7 & 8,8 \\
\hline & $15-29$ & 5,3 & a & 5,3 & 2,2 & 3,2 & 3,1 & 0,4 & 0,4 & 0,0 & 40,7 & 46,5 \\
\hline Dinamarca & $15-19$ & 39,9 & a & 39,9 & 3,9 & 36,1 & $\mathrm{~m}$ & 8,3 & 6,2 & 1,8 & 41,0 & 89,2 \\
\hline & $20-24$ & 34,0 & a & 34,0 & 9,9 & 24,1 & $\mathrm{~m}$ & 4,3 & 3,2 & 1,1 & 18,5 & 56,9 \\
\hline & $25-29$ & 17,1 & a & 17,1 & 4,2 & 13,0 & $\mathrm{~m}$ & 1,5 & 1,1 & c & 8,4 & 27,0 \\
\hline & $15-29$ & 30,8 & a & 30,8 & 6,0 & 24,8 & $\mathrm{~m}$ & 4,8 & 3,6 & 1,1 & 23,1 & 58,7 \\
\hline Eslovenia & $15-19$ & 7,0 & a & 7,0 & 1,6 & 5,4 & $\mathrm{~m}$ & c & c & c & 87,9 & 95,3 \\
\hline & $20-24$ & 24,1 & a & 24,1 & 8,9 & 15,2 & $\mathrm{~m}$ & 3,2 & 2,3 & 0,9 & 41,5 & 68,8 \\
\hline & $25-29$ & 18,1 & a & 18,1 & 12,6 & 5,5 & $\mathrm{~m}$ & 2,2 & 1,3 & 0,9 & 7,0 & 27,3 \\
\hline & $15-29$ & 17,1 & a & 17,1 & 8,3 & 8,8 & $\mathrm{~m}$ & 2,1 & 1,3 & 0,8 & 41,2 & 60,4 \\
\hline España & $15-19$ & 1,1 & a & 1,1 & c & 0,9 & 0,8 & 2,7 & 1,2 & 1,4 & 82,2 & 86,0 \\
\hline & $20-24$ & 6,0 & a & 6,0 & 1,6 & 4,4 & 3,4 & 6,0 & 1,7 & 4,1 & 31,9 & 43,9 \\
\hline & $25-29$ & 5,2 & a & 5,2 & 3,2 & 2,0 & 1,3 & 3,1 & 1,0 & 2,0 & 5,0 & 13,2 \\
\hline & $15-29$ & 4,3 & a & 4,3 & 1,8 & 2,4 & 1,8 & 3,9 & 1,3 & 2,5 & 36,1 & 44,3 \\
\hline Estados Unidos & $15-19$ & 15,6 & $\mathrm{a}$ & 15,6 & 1,7 & 13,4 & 13,0 & 3,8 & 2,8 & 1,0 & 66,1 & 85,5 \\
\hline & $20-24$ & 20,0 & a & 20,0 & 6,3 & 13,4 & 12,7 & 2,1 & 1,5 & 0,6 & 18,1 & 40,2 \\
\hline & $25-29$ & 8,7 & a & 8,7 & 5,8 & 2,9 & 2,6 & 0,9 & 0,6 & c & 4,3 & 14,0 \\
\hline & $15-29$ & 14,9 & a & 14,9 & 4,6 & 10,0 & 9,5 & 2,3 & 1,6 & 0,6 & 29,5 & 46,6 \\
\hline Estonia & $15-19$ & 3,9 & a & 3,9 & c & 1,7 & c & c & c & c & 83,9 & 89,1 \\
\hline & $20-24$ & 18,9 & a & 18,9 & 14,0 & 4,9 & 4,8 & 2,4 & c & c & 28,4 & 49,6 \\
\hline & $25-29$ & 12,0 & a & 12,0 & 9,6 & 2,4 & 2,3 & c & c & c & 4,8 & 17,8 \\
\hline & $15-29$ & 12,5 & a & 12,5 & 9,4 & 3,1 & 3,1 & 1,6 & 1,0 & c & 33,5 & 47,5 \\
\hline Finlandia & $15-19$ & 11,0 & a & 11,0 & 1,4 & 9,6 & $\mathrm{~m}$ & 6,7 & 5,9 & c & 73,3 & 91,0 \\
\hline & $20-24$ & 20,6 & $\mathrm{a}$ & 20,6 & 4,9 & 15,7 & $\mathrm{~m}$ & 3,9 & 3,5 & c & 25,7 & 50,2 \\
\hline & $25-29$ & 18,5 & a & 18,5 & 11,8 & 6,6 & $\mathrm{~m}$ & 1,9 & 1,8 & c & 8,4 & 28,7 \\
\hline & $15-29$ & 16,8 & $\mathrm{a}$ & 16,8 & 6,2 & 10,6 & $\mathrm{~m}$ & 4,1 & 3,6 & 0,2 & 34,8 & 55,6 \\
\hline Francia & $15-19$ & 6,8 & & 6,8 & 5,1 & 1,7 & $\mathrm{~m}$ & 0,5 & 0,4 & 0,1 & 83,3 & 90,6 \\
\hline & $20-24$ & 9,7 & a & 9,7 & 5,8 & 3,9 & $\mathrm{~m}$ & 0,7 & 0,5 & 0,2 & 32,9 & 43,3 \\
\hline & $25-29$ & 2,4 & a & 2,4 & 1,6 & 0,8 & $\mathrm{~m}$ & 0,3 & 0,2 & 0,1 & 2,6 & 5,3 \\
\hline & $15-29$ & 6,3 & a & 6,3 & 4,2 & 2,1 & $\mathrm{~m}$ & 0,5 & 0,4 & 0,1 & 39,0 & 45,8 \\
\hline
\end{tabular}

1. Los estudiantes en programas de trabajo-estudio se consideran tanto en educación como empleados, con independencia de su situación en el mercado laboral según la definición de la OIT.

2. Jóvenes ni empleados ni en educación o formación.

3. Año de referencia 2011.

Fuente: OCDE. Arabia Saudí, Argentina, China, Colombia, India, Indonesia y Sudáfrica: Instituto de Estadística de la UNESCO. Letonia: Eurostat. Para ver notas, consulte Anexo 3 (www.oecd.org/edu/eag.htm).

Para obtener más información acerca de los símbolos utilizados en lugar de los datos que faltan, consulte la Guía del lector.

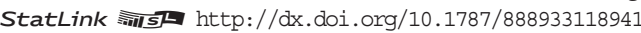


Tabla C5.2a. [2/6] Porcentaje de jóvenes de 15 a 29 años en educación y no en educación, por grupo de edad y situación laboral (2012)

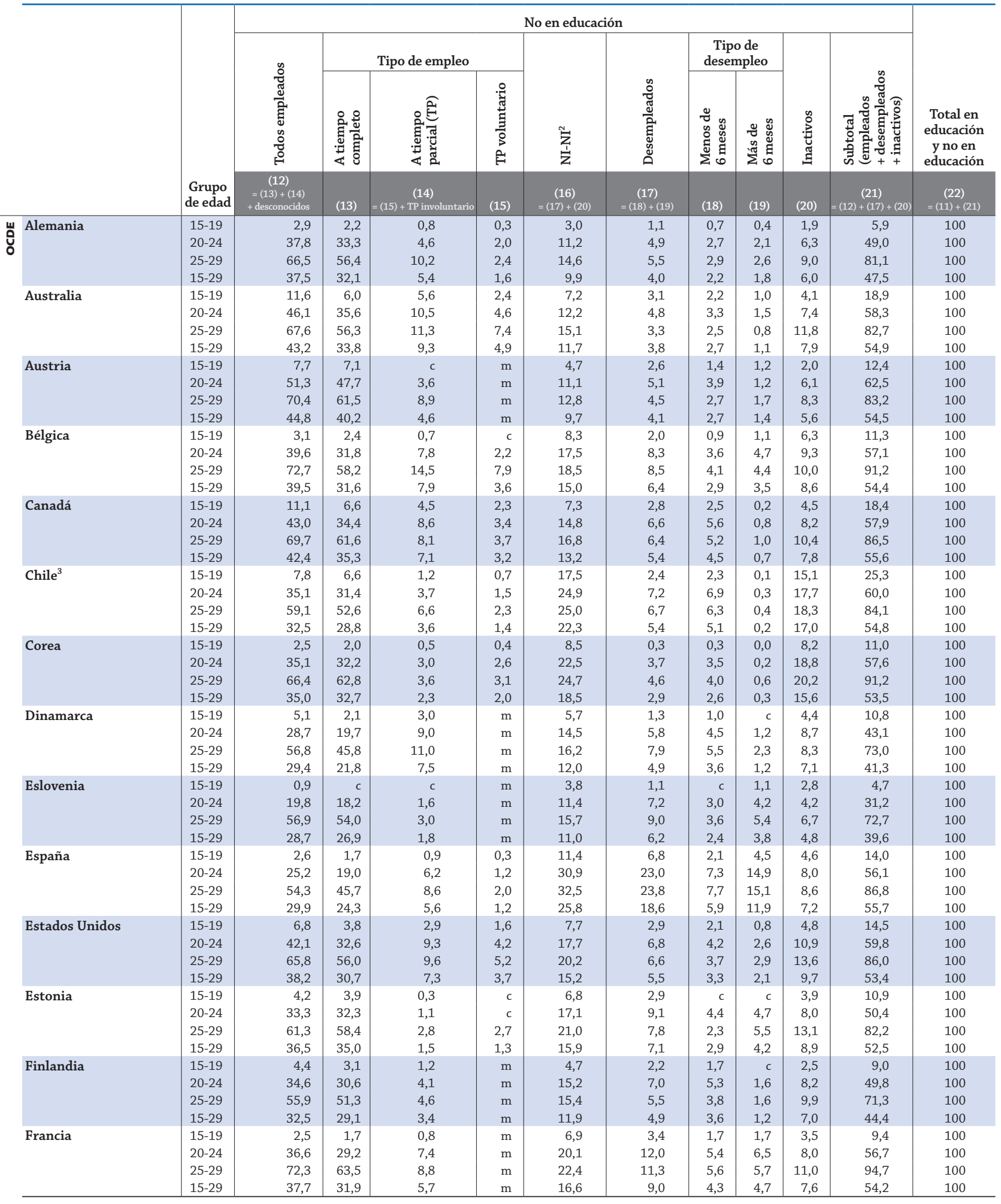

1. Los estudiantes en programas de trabajo-estudio se consideran tanto en educación como empleados, con independencia de su situación en el mercado laboral según la definición de la OIT.

2. Jóvenes ni empleados ni en educación o formación.

3. Año de referencia 2011.

Fuente: OCDE. Arabia Saudí, Argentina, China, Colombia, India, Indonesia y Sudáfrica: Instituto de Estadística de la UNESCO. Letonia: Eurostat. Para ver notas, consulte Anexo 3 (www.oecd.org/edu/eag.htm).

Para obtener más información acerca de los símbolos utilizados en lugar de los datos que faltan, consulte la Guía del lector.

StatLink 제매 http://dx.doi.org/10.1787/888933118941 
Tabla C5.2a. [3/6] Porcentaje de jóvenes de 15 a 29 años en educación y no en educación, por grupo de edad y situación laboral (2012)

\begin{tabular}{|c|c|c|c|c|c|c|c|c|c|c|c|c|}
\hline & & \multicolumn{11}{|c|}{ En educación } \\
\hline & & \multirow[b]{2}{*}{ 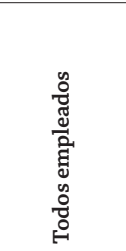 } & \multicolumn{2}{|c|}{ Empleados } & \multicolumn{3}{|c|}{ Tipo de empleo } & \multirow[b]{2}{*}{ 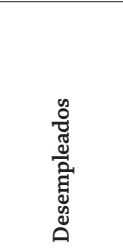 } & \multicolumn{2}{|c|}{$\begin{array}{c}\text { Duración } \\
\text { del desempleo }\end{array}$} & \multirow[b]{2}{*}{ 总 } & \multirow[b]{2}{*}{ 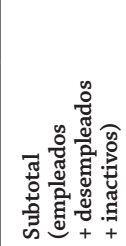 } \\
\hline & & & 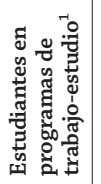 & 总 & 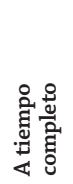 & 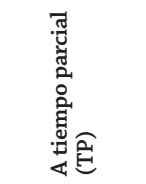 & 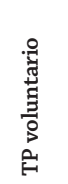 & & 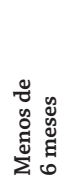 & 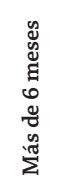 & & \\
\hline & $\begin{array}{c}\text { Grupo } \\
\text { de edad }\end{array}$ & $\begin{array}{c}(1) \\
=(2)+(3) \\
y / 0(4)+(5) \\
+ \text { desconocidos }\end{array}$ & (2) & (3) & (4) & $\begin{array}{c}(5) \\
=(6) \\
+ \text { TP involuntario }\end{array}$ & (6) & $\begin{aligned} &(7) \\
&=(8)+(9) \\
&+ \text { desconocidos }\end{aligned}$ & (8) & (9) & (10) & $\begin{array}{c}\quad(11) \\
=(1)+(7)+(10)\end{array}$ \\
\hline \multirow{4}{*}{ Grecia } & $15-19$ & 2,0 & $\mathrm{a}$ & 2,0 & 1,1 & 0,9 & c & 3,1 & 1,4 & 1,7 & 88,6 & 93,7 \\
\hline & $20-24$ & 13,9 & a & 13,9 & 11,3 & 2,6 & c & 14,5 & 4,8 & 9,7 & 44,8 & 73,3 \\
\hline & $25-29$ & 28,3 & a & 28,3 & 25,1 & 3,2 & 0,9 & 16,1 & 4,0 & 12,1 & 10,6 & 55,0 \\
\hline & $15-29$ & 15,8 & a & 15,8 & 13,5 & 2,3 & 0,8 & 11,6 & 3,4 & 8,1 & 45,1 & 72,5 \\
\hline \multirow[t]{4}{*}{ Hungría } & $15-19$ & c & a & c & c & 0,1 & c & c & c & c & 93,8 & 93,9 \\
\hline & $20-24$ & 2,5 & a & 2,5 & 1,5 & 1,0 & 0,9 & c & c & c & 45,0 & 48,2 \\
\hline & $25-29$ & 3,5 & a & 3,5 & 3,1 & 0,4 & c & c & c & c & 6,2 & 9,9 \\
\hline & $15-29$ & 2,1 & $\mathrm{a}$ & 2,1 & 1,6 & 0,5 & 0,5 & 0,3 & c & c & 45,7 & 48,1 \\
\hline \multirow{4}{*}{ Irlanda } & $15-19$ & 6,1 & $\mathrm{a}$ & 6,1 & 0,4 & 5,6 & $\mathrm{~m}$ & 1,4 & 0,5 & 0,8 & 79,7 & 87,1 \\
\hline & $20-24$ & 12,0 & a & 12,0 & 2,8 & 9,2 & $\mathrm{~m}$ & 1,3 & 0,6 & 0,7 & 28,6 & 41,8 \\
\hline & $25-29$ & 5,4 & a & 5,4 & 3,7 & 1,6 & $\mathrm{~m}$ & 0,8 & c & 0,6 & 5,6 & 11,8 \\
\hline & $15-29$ & 7,6 & a & 7,6 & 2,4 & 5,2 & $\mathrm{~m}$ & 1,1 & 0,4 & 0,7 & 35,4 & 44,2 \\
\hline \multirow[t]{4}{*}{ Islandia } & $15-19$ & 37,7 & a & 37,7 & c & 35,6 & $\mathrm{~m}$ & 9,0 & 8,3 & c & 38,6 & 85,3 \\
\hline & $20-24$ & 36,5 & a & 36,5 & 7,4 & 29,2 & $\mathrm{~m}$ & 6,0 & 5,1 & c & 20,4 & 62,9 \\
\hline & $25-29$ & 15,9 & a & 15,9 & 7,1 & 8,8 & $\mathrm{~m}$ & c & c & c & 14,3 & 31,5 \\
\hline & $15-29$ & 29,9 & a & 29,9 & 5,7 & 24,2 & $\mathrm{~m}$ & 5,3 & 4,6 & c & 23,7 & 59,0 \\
\hline \multirow[t]{4}{*}{ Israel } & $15-19$ & 5,3 & a & 5,3 & 0,5 & 4,8 & 4,5 & 1,3 & 1,0 & c & 62,0 & 68,6 \\
\hline & $20-24$ & 13,5 & a & 13,5 & 4,9 & 8,6 & 8,1 & 1,4 & 1,2 & c & 14,8 & 29,7 \\
\hline & $25-29$ & 20,4 & a & 20,4 & 9,1 & 11,4 & 10,7 & 1,6 & 1,4 & c & 8,7 & 30,7 \\
\hline & $15-29$ & 13,0 & a & 13,0 & 4,8 & 8,2 & 7,8 & 1,4 & 1,2 & 0,1 & 28,9 & 43,3 \\
\hline \multirow[t]{4}{*}{ Italia } & $15-19$ & 0,7 & 0,2 & 0,6 & 0,1 & 0,4 & 0,3 & 0,4 & 0,3 & c & 83,9 & 85,1 \\
\hline & $20-24$ & 2,9 & 0,2 & 2,6 & 0,8 & 1,9 & 1,3 & 1,2 & 0,6 & 0,6 & 34,8 & 38,9 \\
\hline & $25-29$ & 3,6 & 0,2 & 3,4 & 1,7 & 1,7 & 0,8 & 1,0 & 0,3 & 0,8 & 10,9 & 15,6 \\
\hline & $15-29$ & 2,5 & 0,2 & 2,3 & 0,9 & 1,4 & 0,8 & 0,9 & 0,4 & 0,5 & 41,3 & 44,7 \\
\hline Japón & $15-24$ & 8,8 & a & 8,8 & 0,3 & 8,5 & $\mathrm{~m}$ & 0,2 & $\mathrm{~m}$ & $\mathrm{~m}$ & 55,6 & 64,5 \\
\hline Luxemburgo & $15-19$ & 2,8 & a & 2,8 & c & c & $\mathrm{m}$ & 0,3 & c & c & 92,6 & 95,7 \\
\hline & $20-24$ & 10,5 & a & 10,5 & 4,3 & 6,0 & $\mathrm{~m}$ & 3,8 & c & 3,1 & 51,5 & 65,9 \\
\hline & $25-29$ & 5,7 & a & 5,7 & 3,7 & 2,0 & $\mathrm{~m}$ & c & c & c & 13,2 & 20,0 \\
\hline & $15-29$ & 6,3 & a & 6,3 & 3,1 & 3,1 & $\mathrm{~m}$ & 1,7 & 0,6 & 1,1 & 50,4 & 58,4 \\
\hline México & $15-19$ & 14,2 & $\mathrm{a}$ & 14,2 & 3,1 & 11,0 & 4,0 & 0,6 & 0,5 & 0,0 & 46,8 & 61,6 \\
\hline & $20-24$ & 10,9 & a & 10,9 & 4,8 & 6,1 & 2,4 & 0,8 & 0,7 & 0,0 & 16,8 & 28,5 \\
\hline & $25-29$ & 4,9 & a & 4,9 & 3,1 & 1,7 & 0,7 & 0,3 & 0,2 & 0,0 & 2,6 & 7,8 \\
\hline & $15-29$ & 10,4 & a & 10,4 & 3,7 & 6,7 & 2,5 & 0,6 & 0,5 & 0,0 & 24,2 & 35,3 \\
\hline Noruega & $15-19$ & 23,2 & a & 23,2 & c & 22,8 & $\mathrm{~m}$ & 3,7 & 3,1 & c & 55,5 & 82,4 \\
\hline & $20-24$ & 18,3 & a & 18,3 & c & 17,5 & $\mathrm{~m}$ & c & c & c & 20,9 & 40,6 \\
\hline & $25-29$ & 6,1 & $\mathrm{a}$ & 6,1 & c & 6,0 & $\mathrm{~m}$ & c & c & c & 7,8 & 14,6 \\
\hline & $15-29$ & 15,9 & a & 15,9 & c & 15,4 & $\mathrm{~m}$ & 1,9 & 1,6 & c & 28,0 & 45,8 \\
\hline Nueva Zelanda & $15-19$ & 20,8 & a & 20,8 & 2,5 & 18,2 & 16,2 & 6,9 & 4,9 & 1,3 & 50,8 & 78,5 \\
\hline & $20-24$ & 18,6 & a & 18,6 & 6,9 & 11,8 & 10,0 & 2,8 & 1,7 & 0,5 & 15,1 & 36,5 \\
\hline & $25-29$ & 11,0 & a & 11,0 & 7,5 & 3,5 & 2,8 & 1,3 & 0,7 & c & 5,6 & 17,9 \\
\hline & $15-29$ & 16,9 & $\mathrm{a}$ & 16,9 & 5,6 & 11,3 & 9,8 & 3,7 & 2,5 & 0,7 & 24,0 & 44,6 \\
\hline Países Bajos & $15-19$ & 47,8 & a & 47,8 & 1,7 & 46,1 & $\mathrm{~m}$ & 7,1 & 5,0 & 1,8 & 38,5 & 93,4 \\
\hline & $20-24$ & 37,8 & a & 37,8 & 5,6 & 32,2 & $\mathrm{~m}$ & 3,2 & 2,1 & 1,0 & 17,3 & 58,3 \\
\hline & $25-29$ & 17,2 & $\mathrm{a}$ & 17,2 & 7,9 & 9,3 & $\mathrm{~m}$ & 0,9 & 0,6 & 0,3 & 4,1 & 22,2 \\
\hline & $15-29$ & 34,2 & a & 34,2 & 5,1 & 29,2 & $\mathrm{~m}$ & 3,7 & 2,6 & 1,0 & 19,9 & 57,9 \\
\hline Polonia & $15-19$ & 2,9 & a & 2,9 & 0,8 & 2,1 & c & 1,0 & 0,7 & 0,3 & 90,6 & 94,5 \\
\hline & $20-24$ & 12,8 & a & 12,8 & 9,5 & 3,3 & 0,4 & 3,6 & 1,8 & 1,8 & 35,5 & 52,0 \\
\hline & $25-29$ & 7,0 & a & 7,0 & 6,0 & 0,9 & c & 1,0 & 0,5 & 0,6 & 3,4 & 11,4 \\
\hline & $15-29$ & 7,8 & a & 7,8 & 5,7 & 2,1 & 0,2 & 1,9 & 1,0 & 0,9 & 39,0 & 48,6 \\
\hline Portugal & $15-19$ & 1,9 & a & 1,9 & $\mathrm{~m}$ & $\mathrm{~m}$ & $\mathrm{~m}$ & 1,6 & 0,9 & c & 84,9 & 88,4 \\
\hline & $20-24$ & 5,1 & a & 5,1 & $\mathrm{~m}$ & $\mathrm{~m}$ & $\mathrm{~m}$ & 3,5 & 1,6 & 1,9 & 33,0 & 41,6 \\
\hline & $25-29$ & 6,9 & $\mathrm{a}$ & 6,9 & $\mathrm{~m}$ & $\mathrm{~m}$ & $\mathrm{~m}$ & 2,8 & 0,8 & 2,0 & 5,6 & 15,3 \\
\hline & $15-29$ & 4,8 & a & 4,8 & $\mathrm{~m}$ & $\mathrm{~m}$ & $\mathrm{~m}$ & 2,6 & 1,1 & 1,6 & 38,3 & 45,7 \\
\hline
\end{tabular}

1. Los estudiantes en programas de trabajo-estudio se consideran tanto en educación como empleados, con independencia de su situación en el mercado laboral según la definición de la OIT.

2. Jóvenes ni empleados ni en educación o formación.

3. Año de referencia 2011

Fuente: OCDE. Arabia Saudí, Argentina, China, Colombia, India, Indonesia y Sudáfrica: Instituto de Estadística de la UNESCO. Letonia: Eurostat. Para ver notas, consulte Anexo 3 (www.oecd.org/edu/eag.htm).

Para obtener más información acerca de los símbolos utilizados en lugar de los datos que faltan, consulte la Guía del lector.

StatLink 제이 http://dx.doi.org/10.1787/888933118941 
Tabla C5.2a. [4/6] Porcentaje de jóvenes de 15 a 29 años en educación y no en educación, por grupo de edad y situación laboral (2012)

\begin{tabular}{|c|c|c|c|c|c|c|c|c|c|c|c|c|}
\hline & & \multicolumn{10}{|c|}{ No en educación } & \multirow[b]{3}{*}{$\begin{array}{c}\text { Total en } \\
\text { educación } \\
\text { y no en } \\
\text { educación }\end{array}$} \\
\hline & & \multirow[b]{2}{*}{ 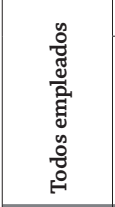 } & \multicolumn{3}{|c|}{ Tipo de empleo } & \multirow[b]{2}{*}{ 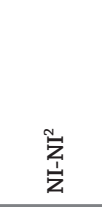 } & \multirow[b]{2}{*}{ 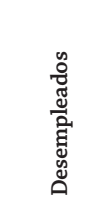 } & \multicolumn{2}{|c|}{ Tipo de desempleo } & \multirow[b]{2}{*}{ 总 } & \multirow[b]{2}{*}{ 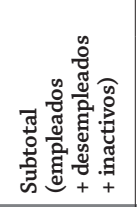 } & \\
\hline & & & 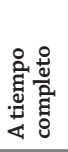 & 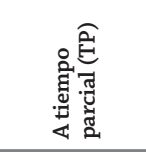 & 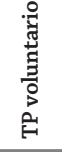 & & & 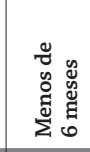 & 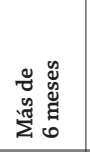 & & & \\
\hline & $\begin{array}{c}\text { Grupo } \\
\text { de edad }\end{array}$ & $\begin{array}{c}(12) \\
=(13)+(14) \\
+ \text { desconocidos }\end{array}$ & (13) & $\begin{aligned} & (14) \\
& =(15) \\
+ & \text { TP involuntario }\end{aligned}$ & (15) & $\begin{array}{c}(16) \\
=(17)+(20)\end{array}$ & $\begin{aligned} & (17) \\
= & (18)+(19)\end{aligned}$ & (18) & (19) & (20) & 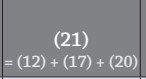 & $\begin{aligned} & (22) \\
= & (11)+(21)\end{aligned}$ \\
\hline \multirow{4}{*}{ ü Grecia } & $15-19$ & 1,0 & 0,8 & 0,2 & c & 5,3 & 2,1 & 0,9 & 1,3 & 3,2 & 6,3 & 100 \\
\hline & $20-24$ & 11,4 & 9,7 & 1,6 & c & 15,4 & 11,7 & 3,5 & 8,2 & 3,7 & 26,7 & 100 \\
\hline & $25-29$ & 26,4 & 23,6 & 2,9 & 0,7 & 18,5 & 14,3 & 3,6 & 10,7 & 4,2 & 45,0 & 100 \\
\hline & $15-29$ & 14,0 & 12,3 & 1,7 & 0,4 & 13,5 & 9,7 & 2,7 & 7,0 & 3,7 & 27,5 & 100 \\
\hline \multirow{4}{*}{ Hungría } & $15-19$ & 1,3 & 1,2 & 0,1 & c & 4,8 & 1,4 & c & c & 3,3 & 6,1 & 100 \\
\hline & $20-24$ & 29,4 & 27,3 & 2,0 & c & 22,5 & 10,9 & 3,9 & 7,0 & 11,6 & 51,8 & 100 \\
\hline & $25-29$ & 62,8 & 59,9 & 2,9 & 1,1 & 27,3 & 10,8 & 4,1 & 6,7 & 16,5 & 90,1 & 100 \\
\hline & $15-29$ & 33,0 & 31,2 & 1,8 & 0,6 & 18,9 & 8,0 & 3,0 & 5,0 & 10,9 & 51,9 & 100 \\
\hline \multirow[t]{4}{*}{ Irlanda } & $15-19$ & 3,3 & 1,6 & 1,7 & $\mathrm{~m}$ & 9,6 & 4,1 & 1,0 & 3,0 & 5,6 & 12,9 & 100 \\
\hline & $20-24$ & 32,5 & 23,8 & 8,6 & $\mathrm{~m}$ & 25,7 & 16,0 & 4,3 & 11,6 & 9,7 & 58,2 & 100 \\
\hline & $25-29$ & 61,7 & 51,6 & 10,1 & $\mathrm{~m}$ & 26,5 & 14,1 & 3,0 & 11,0 & 12,3 & 88,2 & 100 \\
\hline & $15-29$ & 34,7 & 27,7 & 7,1 & $\mathrm{~m}$ & 21,1 & 11,7 & 2,8 & 8,7 & 9,4 & 55,8 & 100 \\
\hline \multirow[t]{4}{*}{ Islandia } & $15-19$ & 9,9 & 8,2 & c & $\mathrm{m}$ & 4,8 & c & c & c & c & 14,7 & 100 \\
\hline & $20-24$ & 28,1 & 21,6 & 6,3 & $\mathrm{~m}$ & 9,0 & 5,9 & 4,7 & c & c & 37,1 & 100 \\
\hline & $25-29$ & 56,2 & 50,6 & 5,6 & $\mathrm{~m}$ & 12,4 & 6,2 & 4,9 & c & 6,1 & 68,5 & 100 \\
\hline & $15-29$ & 32,2 & 27,4 & 4,7 & $\mathrm{~m}$ & 8,9 & 5,1 & 4,0 & c & 3,8 & 41,0 & 100 \\
\hline \multirow[t]{4}{*}{ Israel } & $15-19$ & 20,6 & 18,1 & 2,5 & 1,5 & 10,7 & 2,7 & 2,1 & 0,6 & 8,0 & 31,4 & 100 \\
\hline & $20-24$ & 51,5 & 42,7 & 8,7 & 5,4 & 18,7 & 6,5 & 4,6 & 1,5 & 12,3 & 70,3 & 100 \\
\hline & $25-29$ & 51,6 & 41,5 & 10,1 & 6,8 & 17,7 & 6,2 & 4,0 & 1,7 & 11,5 & 69,3 & 100 \\
\hline & $15-29$ & 41,0 & 33,9 & 7,1 & 4,5 & 15,7 & 5,1 & 3,5 & 1,2 & 10,6 & 56,7 & 100 \\
\hline Italia & $15-19$ & 3,0 & 2,2 & 0,8 & c & 12,0 & 4,3 & 1,3 & 3,0 & 7,7 & 14,9 & 100 \\
\hline & $20-24$ & 29,5 & 23,0 & 6,5 & 0,8 & 31,5 & 14,6 & 5,4 & 9,1 & 17,0 & 61,1 & 100 \\
\hline & $25-29$ & 55,4 & 44,0 & 11,3 & 2,4 & 29,0 & 11,2 & 4,2 & 7,1 & 17,8 & 84,4 & 100 \\
\hline & $15-29$ & 30,7 & 24,2 & 6,5 & 1,1 & 24,6 & 10,2 & 3,7 & 6,5 & 14,4 & 55,3 & 100 \\
\hline Japón & $15-24$ & 26,1 & 17,4 & 8,6 & $\mathrm{~m}$ & 9,4 & 3,5 & $\mathrm{~m}$ & $\mathrm{~m}$ & 5,9 & 35,5 & 100 \\
\hline Luxemburgo & $15-19$ & c & c & c & $\mathrm{m}$ & 2,9 & c & c & c & 1,9 & 4,3 & 100 \\
\hline & $20-24$ & 23,8 & 21,2 & 2,7 & $\mathrm{~m}$ & 10,3 & 6,2 & 3,3 & 2,9 & 4,1 & 34,1 & 100 \\
\hline & $25-29$ & 69,1 & 64,8 & 4,3 & $\mathrm{~m}$ & 10,9 & 4,2 & 2,8 & c & 6,7 & 80,0 & 100 \\
\hline & $15-29$ & 33,4 & 30,9 & 2,6 & $\mathrm{~m}$ & 8,2 & 3,8 & 2,2 & 1,6 & 4,4 & 41,6 & 100 \\
\hline México & $15-19$ & 21,5 & 14,7 & 6,7 & 1,9 & 17,0 & 2,6 & 2,3 & 0,1 & 14,4 & 38,4 & 100 \\
\hline & $20-24$ & 48,0 & 37,1 & 10,6 & 3,2 & 23,6 & 4,3 & 3,8 & 0,3 & 19,3 & 71,5 & 100 \\
\hline & $25-29$ & 65,1 & 49,6 & 15,1 & 4,8 & 27,1 & 4,2 & 3,7 & 0,3 & 22,9 & 92,2 & 100 \\
\hline & $15-29$ & 42,7 & 32,1 & 10,4 & 3,1 & 22,0 & 3,6 & 3,2 & 0,2 & 18,5 & 64,7 & 100 \\
\hline Noruega & $15-19$ & 14,6 & 10,1 & 2,7 & $\mathrm{~m}$ & 3,0 & c & c & c & 2,3 & 17,6 & 100 \\
\hline & $20-24$ & 48,8 & 38,2 & 9,3 & $\mathrm{~m}$ & 10,7 & 3,9 & 2,9 & c & 6,7 & 59,4 & 100 \\
\hline & $25-29$ & 74,0 & 64,4 & 8,8 & $\mathrm{~m}$ & 11,4 & 3,0 & 2,2 & c & 8,4 & 85,4 & 100 \\
\hline & $15-29$ & 45,8 & 37,6 & 7,0 & $\mathrm{~m}$ & 8,4 & 2,6 & 1,9 & 0,5 & 5,8 & 54,2 & 100 \\
\hline Nueva Zelanda & $15-19$ & 12,8 & 7,5 & 5,3 & 3,1 & 8,7 & 3,6 & 2,4 & 0,7 & 5,1 & 21,5 & 100 \\
\hline & $20-24$ & 46,6 & 37,6 & 9,0 & 5,9 & 16,9 & 6,2 & 3,9 & 1,7 & 10,7 & 63,5 & 100 \\
\hline & $25-29$ & 63,2 & 54,2 & 9,0 & 5,7 & 18,9 & 4,3 & 2,6 & 1,0 & 14,6 & 82,1 & 100 \\
\hline & $15-29$ & 40,6 & 32,8 & 7,7 & 4,9 & 14,8 & 4,7 & 3,0 & 1,1 & 10,1 & 55,4 & 100 \\
\hline Países Bajos & $15-19$ & 4,2 & 1,6 & 2,7 & $\mathrm{~m}$ & 2,4 & 0,6 & 0,4 & 0,2 & 1,8 & 6,6 & 100 \\
\hline & $20-24$ & 34,5 & 19,8 & 14,7 & $\mathrm{~m}$ & 7,1 & 2,8 & 1,8 & 0,9 & 4,3 & 41,7 & 100 \\
\hline & $25-29$ & 67,3 & 43,3 & 23,9 & $\mathrm{~m}$ & 10,6 & 3,6 & 2,1 & 1,4 & 7,0 & 77,8 & 100 \\
\hline & $15-29$ & 35,4 & 21,6 & 13,8 & $\mathrm{~m}$ & 6,7 & 2,3 & 1,5 & 0,8 & 4,4 & 42,1 & 100 \\
\hline Polonia & $15-19$ & 1,6 & 1,3 & 0,3 & c & 3,9 & 1,8 & 1,1 & 0,7 & 2,2 & 5,5 & 100 \\
\hline & $20-24$ & 29,1 & 26,8 & 2,3 & 0,6 & 18,9 & 10,5 & 4,4 & 6,1 & 8,4 & 48,0 & 100 \\
\hline & $25-29$ & 66,2 & 62,8 & 3,3 & 0,9 & 22,4 & 10,0 & 4,1 & 5,9 & 12,4 & 88,6 & 100 \\
\hline & $15-29$ & 35,4 & 33,3 & 2,1 & 0,6 & 16,0 & 7,8 & 3,3 & 4,5 & 8,2 & 51,4 & 100 \\
\hline Portugal & $15-19$ & 3,8 & $\mathrm{~m}$ & $\mathrm{~m}$ & $\mathrm{~m}$ & 7,9 & 5,2 & 3,2 & 2,0 & 2,6 & 11,6 & 100 \\
\hline & $20-24$ & 35,7 & $\mathrm{~m}$ & $\mathrm{~m}$ & $\mathrm{~m}$ & 22,7 & 16,4 & 6,3 & 10,1 & 6,3 & 58,4 & 100 \\
\hline & $25-29$ & 66,4 & $\mathrm{~m}$ & $\mathrm{~m}$ & $\mathrm{~m}$ & 18,3 & 13,0 & 4,3 & 8,7 & 5,3 & 84,7 & 100 \\
\hline & $15-29$ & 37,6 & $\mathrm{~m}$ & $\mathrm{~m}$ & $\mathrm{~m}$ & 16,6 & 11,8 & 4,6 & 7,2 & 4,8 & 54,3 & 100 \\
\hline
\end{tabular}

1. Los estudiantes en programas de trabajo-estudio se consideran tanto en educación como empleados, con independencia de su situación en el mercado laboral según la definición de la OIT.

2. Jóvenes ni empleados ni en educación o formación.

3. Año de referencia 2011.

Fuente: OCDE. Arabia Saudí, Argentina, China, Colombia, India, Indonesia y Sudáfrica: Instituto de Estadística de la UNESCO. Letonia: Eurostat. Para ver notas, consulte Anexo 3 (www.oecd.org/edu/eag.htm).

Para obtener más información acerca de los símbolos utilizados en lugar de los datos que faltan, consulte la Guía del lector.

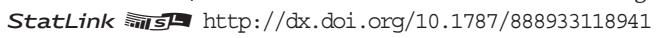


Tabla C5.2a. [5/6] Porcentaje de jóvenes de 15 a 29 años en educación y no en educación, por grupo de edad y situación laboral (2012)

\begin{tabular}{|c|c|c|c|c|c|c|c|c|c|c|c|c|}
\hline & \multirow[b]{4}{*}{$\begin{array}{c}\text { Grupo } \\
\text { de edad }\end{array}$} & \multicolumn{11}{|c|}{ En educación } \\
\hline & & \multirow[b]{2}{*}{ 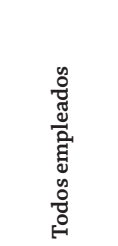 } & \multicolumn{2}{|c|}{ Empleados } & \multicolumn{3}{|c|}{ Tipo de empleo } & \multirow[b]{2}{*}{ 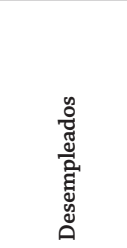 } & \multicolumn{2}{|c|}{$\begin{array}{c}\text { Duración } \\
\text { del desempleo }\end{array}$} & \multirow[b]{2}{*}{ : } & \multirow[b]{2}{*}{ 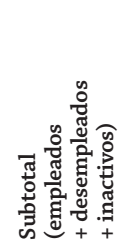 } \\
\hline & & & 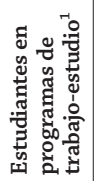 & 串 & 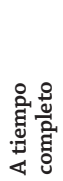 & 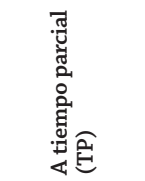 & 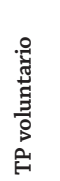 & & 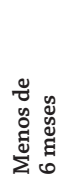 & 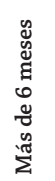 & & \\
\hline & & $\begin{array}{c}(1) \\
=(2)+(3) \\
y / o(4)+(5) \\
+ \text { desconocidos }\end{array}$ & (2) & (3) & (4) & $\begin{aligned} & (5) \\
& =(6) \\
+ & \mathrm{TP} \text { involuntario }\end{aligned}$ & (6) & $\begin{aligned} & (7) \\
= & (8)+(9) \\
+ & \text { desconocidos }\end{aligned}$ & (8) & (9) & (10) & $\begin{aligned} & (11) \\
= & (1)+(7)+(10)\end{aligned}$ \\
\hline \multirow[t]{4}{*}{ Reino Unido } & $15-19$ & 18,2 & 3,8 & 14,3 & 0,5 & 13,3 & 13,1 & 6,0 & 3,3 & 2,6 & 58,1 & 82,3 \\
\hline & $20-24$ & 13,7 & 2,6 & 11,1 & 3,8 & 6,9 & 6,6 & 2,0 & 1,3 & 0,7 & 17,9 & 33,6 \\
\hline & $25-29$ & 8,9 & 0,9 & 8,0 & 5,7 & 2,0 & 1,8 & 0,7 & c & 0,4 & 4,4 & 14,0 \\
\hline & $15-29$ & 13,5 & 2,4 & 11,1 & 3,5 & 7,2 & 6,9 & 2,8 & 1,5 & 1,2 & 25,4 & 41,6 \\
\hline \multirow[t]{4}{*}{ República Checa } & $15-19$ & 20,2 & 19,5 & 0,7 & c & 0,4 & c & c & c & c & 73,0 & 93,4 \\
\hline & $20-24$ & 7,1 & 1,5 & 5,6 & 3,1 & 2,5 & 2,4 & 0,6 & 0,5 & c & 42,4 & 50,1 \\
\hline & $25-29$ & 4,9 & c & 4,8 & 3,8 & 1,0 & 1,0 & 0,4 & c & c & 6,9 & 12,2 \\
\hline & $15-29$ & 9,9 & 5,9 & 4,0 & 2,6 & 1,4 & 1,3 & 0,4 & 0,4 & c & 37,5 & 47,8 \\
\hline \multirow[t]{4}{*}{ República Eslovaca } & $15-19$ & 11,0 & 10,8 & 0,1 & c & c & $\mathrm{m}$ & c & c & c & 81,3 & 92,4 \\
\hline & $20-24$ & 2,3 & c & 1,9 & 1,4 & c & $\mathrm{m}$ & c & c & c & 44,1 & 46,7 \\
\hline & $25-29$ & 2,3 & c & 2,2 & 2,0 & c & $\mathrm{m}$ & c & c & c & 4,9 & 7,6 \\
\hline & $15-29$ & 4,8 & 3,3 & 1,5 & 1,2 & 0,3 & $\mathrm{~m}$ & 0,3 & c & 0,2 & 40,1 & 45,1 \\
\hline \multirow[t]{4}{*}{ Suecia } & $15-19$ & 10,6 & a & 10,6 & c & 10,0 & 8,6 & 7,6 & 6,4 & c & 72,1 & 90,3 \\
\hline & $20-24$ & 13,1 & a & 13,1 & 3,0 & 10,0 & 8,5 & 6,5 & 4,5 & 1,2 & 25,5 & 45,0 \\
\hline & $25-29$ & 10,9 & a & 10,9 & 4,9 & 5,9 & 5,0 & 2,9 & 1,6 & 1,0 & 10,3 & 24,1 \\
\hline & $15-29$ & 11,6 & $\mathrm{a}$ & 11,6 & 2,8 & 8,6 & 7,4 & 5,7 & 4,2 & 0,9 & 35,4 & 52,7 \\
\hline \multirow[t]{4}{*}{ Suiza } & $15-19$ & 44,4 & 36,8 & 7,6 & 1,5 & 6,1 & 5,9 & 1,5 & c & c & 42,7 & 88,6 \\
\hline & $20-24$ & 26,6 & 11,3 & 15,3 & 5,6 & 9,7 & 9,6 & 1,6 & c & c & 15,4 & 43,7 \\
\hline & $25-29$ & 12,4 & 1,3 & 11,1 & 5,0 & 6,1 & 6,1 & c & c & c & 4,5 & 17,4 \\
\hline & $15-29$ & 26,9 & 15,5 & 11,4 & 4,1 & 7,3 & 7,2 & 1,2 & 0,8 & 0,4 & 19,8 & 48,0 \\
\hline \multirow[t]{4}{*}{ Turquía } & $15-19$ & 5,6 & a & 5,6 & 3,2 & 2,4 & $\mathrm{~m}$ & 1,0 & 0,5 & 0,5 & 57,8 & 64,4 \\
\hline & $20-24$ & 11,2 & a & 11,2 & 9,8 & 1,4 & $\mathrm{~m}$ & 2,2 & 1,3 & 1,0 & 25,0 & 38,4 \\
\hline & $25-29$ & 8,2 & a & 8,2 & 7,6 & 0,6 & $\mathrm{~m}$ & 0,9 & 0,4 & 0,5 & 8,0 & 17,1 \\
\hline & $15-29$ & 8,2 & a & 8,2 & 6,7 & 1,5 & $\mathrm{~m}$ & 1,3 & 0,7 & 0,7 & 30,5 & 40,1 \\
\hline \multirow{4}{*}{$\begin{array}{l}\text { Media OCDE } \\
\text { (excluyendo Chile y Japón) }\end{array}$} & $15-19$ & 15,5 & & 11,7 & 2,5 & 10,9 & 8,9 & 3,4 & 2,7 & 1,0 & 68,6 & 86,5 \\
\hline & $20-24$ & 15,8 & & 14,6 & 5,8 & 10,0 & 6,4 & 3,0 & 1,8 & 1,4 & 27,9 & 46,4 \\
\hline & $25-29$ & 9,8 & & 9,6 & 6,0 & 4,0 & 2,8 & 1,8 & 0,9 & 1,3 & 6,6 & 17,9 \\
\hline & $15-29$ & 13,5 & & 12,0 & 4,7 & 7,9 & 4,8 & 2,4 & 1,6 & 1,0 & 32,9 & 48,8 \\
\hline \multirow[t]{4}{*}{ Media UE21 } & $15-19$ & 12,5 & & 8,7 & 3,1 & 8,1 & 4,9 & 3,3 & 2,4 & 1,2 & 76,2 & 90,6 \\
\hline & $20-24$ & 13,9 & & 12,9 & 5,7 & 8,5 & 3,3 & 3,3 & 1,8 & 1,9 & 32,5 & 49,5 \\
\hline & $25-29$ & 9,7 & & 9,5 & 6,1 & 3,7 & 1,8 & 2,2 & 1,1 & 1,7 & 6,7 & 18,2 \\
\hline & $15-29$ & 11,9 & & 10,4 & 4,8 & 6,4 & 2,2 & 2,5 & 1,5 & 1,3 & 36,2 & 50,6 \\
\hline
\end{tabular}

\begin{tabular}{|c|c|c|c|c|c|c|c|c|c|c|c|c|}
\hline Arabia Saudí & & $\mathrm{m}$ & $\mathrm{m}$ & $\mathrm{m}$ & $\mathrm{m}$ & $\mathrm{m}$ & $\mathrm{m}$ & $\mathrm{m}$ & $\mathrm{m}$ & $\mathrm{m}$ & $\mathrm{m}$ & $\mathrm{m}$ \\
\hline Argentina & & $\mathrm{m}$ & $\mathrm{m}$ & $\mathrm{m}$ & $\mathrm{m}$ & $\mathrm{m}$ & $\mathrm{m}$ & $\mathrm{m}$ & $\mathrm{m}$ & $\mathrm{m}$ & $\mathrm{m}$ & $\mathrm{m}$ \\
\hline \multirow[t]{3}{*}{ Brasil } & $15-19$ & 18,4 & $\mathrm{a}$ & 18,4 & 10,5 & 7,9 & $\mathrm{~m}$ & 5,2 & 5,1 & 0,1 & 44,6 & 68,3 \\
\hline & $20-24$ & 13,4 & a & 13,4 & 10,8 & 2,6 & $\mathrm{~m}$ & 1,9 & 1,8 & 0,1 & 7,7 & 23,0 \\
\hline & $15-29$ & 13,4 & $\mathrm{a}$ & 13,4 & 9,4 & 4,0 & $\mathrm{~m}$ & 2,7 & 2,6 & 0,1 & 18,8 & 35,0 \\
\hline China & & $\mathrm{m}$ & $\mathrm{m}$ & $\mathrm{m}$ & $\mathrm{m}$ & $\mathrm{m}$ & $\mathrm{m}$ & $\mathrm{m}$ & $\mathrm{m}$ & $\mathrm{m}$ & $\mathrm{m}$ & $\mathrm{m}$ \\
\hline Colombia & & $\mathrm{m}$ & $\mathrm{m}$ & $\mathrm{m}$ & $\mathrm{m}$ & $\mathrm{m}$ & $\mathrm{m}$ & $\mathrm{m}$ & $\mathrm{m}$ & $\mathrm{m}$ & $\mathrm{m}$ & $\mathrm{m}$ \\
\hline Federación Rusa & & $\mathrm{m}$ & $\mathrm{m}$ & $\mathrm{m}$ & $\mathrm{m}$ & $\mathrm{m}$ & $\mathrm{m}$ & $\mathrm{m}$ & $\mathrm{m}$ & $\mathrm{m}$ & $\mathrm{m}$ & $\mathrm{m}$ \\
\hline India & & $\mathrm{m}$ & $\mathrm{m}$ & $\mathrm{m}$ & $\mathrm{m}$ & $\mathrm{m}$ & $\mathrm{m}$ & $\mathrm{m}$ & $\mathrm{m}$ & $\mathrm{m}$ & $\mathrm{m}$ & $\mathrm{m}$ \\
\hline Indonesia & & $\mathrm{m}$ & $\mathrm{m}$ & $\mathrm{m}$ & $\mathrm{m}$ & $\mathrm{m}$ & $\mathrm{m}$ & $\mathrm{m}$ & $\mathrm{m}$ & $\mathrm{m}$ & $\mathrm{m}$ & $\mathrm{m}$ \\
\hline \multirow[t]{4}{*}{ Letonia } & $15-19$ & 1,0 & a & 1,0 & 0,9 & 0,1 & $\mathrm{~m}$ & 1,0 & 0,6 & 0,4 & 89,1 & 91,0 \\
\hline & $20-24$ & 11,9 & a & 11,9 & 7,6 & 4,3 & $\mathrm{~m}$ & 4,0 & 1,5 & 2,5 & 30,1 & 46,0 \\
\hline & $25-29$ & 10,9 & $\mathrm{a}$ & 10,9 & 10,3 & 0,6 & $\mathrm{~m}$ & 0,9 & 0,6 & 0,3 & 1,7 & 13,5 \\
\hline & $15-29$ & 8,5 & $\mathrm{a}$ & 8,5 & 6,8 & 1,8 & $\mathrm{~m}$ & 2,0 & 0,9 & 1,1 & 35,7 & 46,3 \\
\hline Sudáfrica & & $\mathrm{m}$ & $\mathrm{m}$ & $\mathrm{m}$ & $\mathrm{m}$ & $\mathrm{m}$ & $\mathrm{m}$ & $\mathrm{m}$ & $\mathrm{m}$ & $\mathrm{m}$ & $\mathrm{m}$ & $\mathrm{m}$ \\
\hline
\end{tabular}

\section{Media G20}

1. Los estudiantes en programas de trabajo-estudio se consideran tanto en educación como empleados, con independencia de su situación en el mercado laboral según la definición de la OIT.

2. Jóvenes ni empleados ni en educación o formación.

3. Año de referencia 2011.

Fuente: OCDE. Arabia Saudí, Argentina, China, Colombia, India, Indonesia y Sudáfrica: Instituto de Estadística de la UNESCO. Letonia: Eurostat. Para ver notas, consulte Anexo 3 (www.oecd.org/edu/eag.htm)

Para obtener más información acerca de los símbolos utilizados en lugar de los datos que faltan, consulte la Guía del lector.

StatLink 제개 http://dx.doi.org/10.1787/888933118941 
Tabla C5.2a. [6/6] Porcentaje de jóvenes de 15 a 29 años en educación y no en educación, por grupo de edad y situación laboral (2012)

\begin{tabular}{|c|c|c|c|c|c|c|c|c|c|c|c|c|}
\hline & & \multicolumn{10}{|c|}{ No en educación } & \multirow[b]{3}{*}{$\begin{array}{c}\text { Total en } \\
\text { educación } \\
\text { y no en } \\
\text { educación }\end{array}$} \\
\hline & & \multirow[b]{2}{*}{ 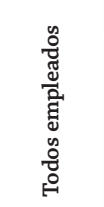 } & \multicolumn{3}{|c|}{ Tipo de empleo } & \multirow[b]{2}{*}{$\begin{array}{l}\sum_{z}^{n} \\
\text { 亗 }\end{array}$} & \multirow[b]{2}{*}{ 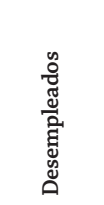 } & \multicolumn{2}{|c|}{ Tipo de desempleo } & \multirow[b]{2}{*}{ 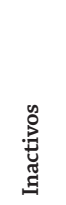 } & \multirow[b]{2}{*}{ 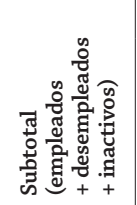 } & \\
\hline & & & 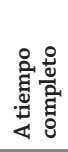 & 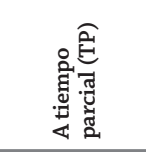 & 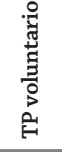 & & & 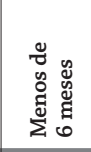 & 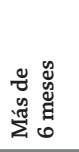 & & & \\
\hline & $\begin{array}{l}\text { Grupo } \\
\text { de edad }\end{array}$ & $\begin{aligned} & (12) \\
= & (13)+(14) \\
+ & \text { desconocidos }\end{aligned}$ & (13) & $\begin{aligned} &(14) \\
&=(15) \\
&+(15 \text { involuntario } \\
&\end{aligned}$ & (15) & $\begin{aligned} & (16) \\
= & (17)+(20)\end{aligned}$ & $\begin{aligned} & (17) \\
= & (18)+(19)\end{aligned}$ & (18) & (19) & (20) & $\begin{array}{c}(21) \\
=(12)+(17)+(20)\end{array}$ & $\begin{aligned} & (22) \\
= & (11)+(21)\end{aligned}$ \\
\hline \multirow{4}{*}{ 亗 Reino Unido } & $15-19$ & 8,2 & 4,6 & 3,3 & 1,2 & 9,5 & 5,1 & 2,5 & 2,6 & 4,3 & 17,7 & 100 \\
\hline & $20-24$ & 46,1 & 34,7 & 10,4 & 4,9 & 20,2 & 10,2 & 4,6 & 5,6 & 10,0 & 66,4 & 100 \\
\hline & $25-29$ & 67,7 & 55,1 & 10,9 & 7,6 & 18,3 & 7,0 & 3,3 & 3,7 & 11,2 & 86,0 & 100 \\
\hline & $15-29$ & 42,1 & 32,7 & 8,4 & 4,7 & 16,3 & 7,6 & 3,5 & 4,0 & 8,7 & 58,4 & 100 \\
\hline \multirow[t]{4}{*}{ República Checa } & $15-19$ & 2,7 & 2,5 & 0,2 & c & 4,0 & 2,8 & 1,5 & 1,3 & 1,2 & 6,6 & 100 \\
\hline & $20-24$ & 36,5 & 35,6 & 0,9 & 0,7 & 13,4 & 7,8 & 3,2 & 4,6 & 5,6 & 49,9 & 100 \\
\hline & $25-29$ & 67,4 & 65,7 & 1,7 & 1,4 & 20,4 & 6,6 & 2,7 & 3,9 & 13,7 & 87,8 & 100 \\
\hline & $15-29$ & 38,8 & 37,8 & 1,0 & 0,8 & 13,4 & 6,0 & 2,6 & 3,4 & 7,4 & 52,2 & 100 \\
\hline \multirow[t]{4}{*}{ República Eslovaca } & $15-19$ & 1,9 & 1,5 & c & $\mathrm{m}$ & 5,6 & 4,4 & 0,8 & 3,6 & 1,2 & 7,6 & 100 \\
\hline & $20-24$ & 33,1 & 31,4 & 1,7 & $\mathrm{~m}$ & 20,2 & 14,6 & 2,8 & 11,9 & 5,6 & 53,3 & 100 \\
\hline & $25-29$ & 64,9 & 61,7 & 3,1 & $\mathrm{~m}$ & 27,5 & 14,8 & 2,2 & 12,7 & 12,7 & 92,4 & 100 \\
\hline & $15-29$ & 36,1 & 34,2 & 1,9 & $\mathrm{~m}$ & 18,8 & 11,8 & 2,0 & 9,8 & 7,0 & 54,9 & 100 \\
\hline \multirow[t]{4}{*}{ Suecia } & $15-19$ & 5,6 & 3,6 & 2,0 & c & 4,1 & 2,3 & 1,7 & c & 1,8 & 9,7 & 100 \\
\hline & $20-24$ & 41,5 & 33,2 & 8,2 & 3,3 & 13,5 & 7,5 & 5,2 & 1,9 & 5,9 & 55,0 & 100 \\
\hline & $25-29$ & 64,8 & 58,5 & 6,2 & 3,1 & 11,1 & 5,4 & 3,8 & 1,5 & 5,6 & 75,9 & 100 \\
\hline & $15-29$ & 37,6 & 32,0 & 5,6 & 2,4 & 9,7 & 5,2 & 3,6 & 1,3 & 4,5 & 47,3 & 100 \\
\hline \multirow[t]{4}{*}{ Suiza } & $15-19$ & 6,7 & 5,5 & 1,2 & 1,2 & 4,7 & 1,7 & c & c & 3,0 & 11,4 & 100 \\
\hline & $20-24$ & 44,2 & 38,6 & 5,6 & 5,5 & 12,1 & 6,0 & 4,0 & 1,9 & 6,1 & 56,3 & 100 \\
\hline & $25-29$ & 71,3 & 60,5 & 10,8 & 10,7 & 11,3 & 4,7 & 2,7 & 1,9 & 6,6 & 82,6 & 100 \\
\hline & $15-29$ & 42,5 & 36,4 & 6,1 & 6,1 & 9,6 & 4,2 & 2,6 & 1,5 & 5,3 & 52,0 & 100 \\
\hline \multirow[t]{4}{*}{ Turquía } & $15-19$ & 12,8 & 10,8 & 1,9 & $\mathrm{~m}$ & 22,8 & 3,1 & 2,1 & 1,0 & 19,7 & 35,6 & 100 \\
\hline & $20-24$ & 30,6 & 27,7 & 3,0 & $\mathrm{~m}$ & 30,9 & 7,2 & 4,2 & 3,0 & 23,7 & 61,6 & 100 \\
\hline & 25-29 & 48,8 & 45,1 & 3,7 & $\mathrm{~m}$ & 34,1 & 7,8 & 4,4 & 3,4 & 26,3 & 82,9 & 100 \\
\hline & $15-29$ & 30,7 & 27,8 & 2,9 & $\mathrm{~m}$ & 29,2 & 6,0 & 3,6 & 2,4 & 23,2 & 59,9 & 100 \\
\hline \multirow{4}{*}{$\begin{array}{l}\text { Media OCDE } \\
\text { (excluyendo Chile y Japón) }\end{array}$} & $\mid 15-19$ & 6,5 & 4,8 & 2,0 & 1,5 & 7,2 & 2,8 & 1,6 & 1,5 & 4,6 & 13,5 & 100 \\
\hline & $20-24$ & 36,1 & 29,9 & 6,1 & 3,1 & 17,5 & 8,5 & 4,2 & 4,5 & 9,1 & 53,6 & 100 \\
\hline & $25-29$ & 62,7 & 54,5 & 8,0 & 4,2 & 19,4 & 8,0 & 3,7 & 4,5 & 11,3 & 82,1 & 100 \\
\hline & $15-29$ & 36,2 & 30,7 & 5,4 & 2,7 & 15,0 & 6,6 & 3,2 & 3,4 & 8,4 & 51,2 & 100 \\
\hline \multirow[t]{4}{*}{ Media UE21 } & $15-19$ & 3,5 & 2,5 & 1,2 & 0,6 & 6,1 & 2,9 & 1,3 & 1,9 & 3,3 & 9,4 & 100 \\
\hline & $20-24$ & 32,9 & 27,4 & 5,3 & 2,0 & 17,6 & 10,1 & 4,2 & 5,8 & 7,6 & 50,5 & 100 \\
\hline & $25-29$ & 62,2 & 54,3 & 7,7 & 2,9 & 19,5 & 9,5 & 3,7 & 5,9 & 10,0 & 81,8 & 100 \\
\hline & $15-29$ & 34,5 & 29,5 & 4,8 & 1,7 & 14,8 & 7,7 & 3,1 & 4,5 & 7,2 & 49,4 & 100 \\
\hline
\end{tabular}

\begin{tabular}{|c|c|c|c|c|c|c|c|c|c|c|c|c|}
\hline Arabia Saudí & & $\mathrm{m}$ & $\mathrm{m}$ & $\mathrm{m}$ & $\mathrm{m}$ & $\mathrm{m}$ & $\mathrm{m}$ & $\mathrm{m}$ & $\mathrm{m}$ & $\mathrm{m}$ & $\mathrm{m}$ & $\mathrm{m}$ \\
\hline Argentina & & $\mathrm{m}$ & $\mathrm{m}$ & $\mathrm{m}$ & $\mathrm{m}$ & $\mathrm{m}$ & $\mathrm{m}$ & $\mathrm{m}$ & $\mathrm{m}$ & $\mathrm{m}$ & $\mathrm{m}$ & $\mathrm{m}$ \\
\hline \multirow[t]{3}{*}{ Brasil } & $15-19$ & 16,5 & 13,9 & 2,5 & $\mathrm{~m}$ & 15,2 & 3,3 & 3,2 & 0,1 & 11,9 & 31,7 & 100 \\
\hline & $20-24$ & 53,3 & 47,7 & 5,6 & $\mathrm{~m}$ & 23,7 & 6,8 & 6,4 & 0,4 & 16,9 & 77,0 & 100 \\
\hline & $15-29$ & 45,1 & 40,0 & 5,1 & $\mathrm{~m}$ & 20,0 & 5,0 & 4,7 & 0,3 & 14,9 & 65,0 & 100 \\
\hline China & & $\mathrm{m}$ & $\mathrm{m}$ & $\mathrm{m}$ & $\mathrm{m}$ & $\mathrm{m}$ & $\mathrm{m}$ & $\mathrm{m}$ & $\mathrm{m}$ & $\mathrm{m}$ & $\mathrm{m}$ & $\mathrm{m}$ \\
\hline Colombia & & $\mathrm{m}$ & $\mathrm{m}$ & $\mathrm{m}$ & $\mathrm{m}$ & $\mathrm{m}$ & $\mathrm{m}$ & $\mathrm{m}$ & $\mathrm{m}$ & $\mathrm{m}$ & $\mathrm{m}$ & $\mathrm{m}$ \\
\hline Federación Rusa & & $\mathrm{m}$ & $\mathrm{m}$ & $\mathrm{m}$ & $\mathrm{m}$ & $\mathrm{m}$ & $\mathrm{m}$ & $\mathrm{m}$ & $\mathrm{m}$ & $\mathrm{m}$ & $\mathrm{m}$ & $\mathrm{m}$ \\
\hline India & & $\mathrm{m}$ & $\mathrm{m}$ & $\mathrm{m}$ & $\mathrm{m}$ & $\mathrm{m}$ & $\mathrm{m}$ & $\mathrm{m}$ & $\mathrm{m}$ & $\mathrm{m}$ & $\mathrm{m}$ & $\mathrm{m}$ \\
\hline Indonesia & & $\mathrm{m}$ & $\mathrm{m}$ & $\mathrm{m}$ & $\mathrm{m}$ & $\mathrm{m}$ & $\mathrm{m}$ & $\mathrm{m}$ & $\mathrm{m}$ & $\mathrm{m}$ & $\mathrm{m}$ & $\mathrm{m}$ \\
\hline \multirow[t]{4}{*}{ Letonia } & $15-19$ & 1,8 & 1,5 & 0,3 & $\mathrm{~m}$ & 7,2 & 4,0 & 2,4 & 1,6 & 3,1 & 9,0 & 100 \\
\hline & $20-24$ & 33,7 & 30,8 & 2,9 & $\mathrm{~m}$ & 20,3 & 12,5 & 4,4 & 8,1 & 7,8 & 54,0 & 100 \\
\hline & $25-29$ & 59,9 & 55,6 & 4,3 & $\mathrm{~m}$ & 26,7 & 13,9 & 5,7 & 8,2 & 12,8 & 86,5 & 100 \\
\hline & $15-29$ & 34,6 & 31,9 & 2,7 & $\mathrm{~m}$ & 19,1 & 10,7 & 4,3 & 6,4 & 8,4 & 53,7 & 100 \\
\hline Sudáfrica & & $\mathrm{m}$ & $\mathrm{m}$ & $\mathrm{m}$ & $\mathrm{m}$ & $\mathrm{m}$ & $\mathrm{m}$ & $\mathrm{m}$ & $\mathrm{m}$ & $\mathrm{m}$ & $\mathrm{m}$ & $\mathrm{m}$ \\
\hline
\end{tabular}

\section{Media G20}

\begin{tabular}{l|l|l}
$\mathrm{m}$ & $\mathrm{m}$ & $\mathrm{m}$
\end{tabular}

\section{$\mathrm{m}$}

\begin{tabular}{l|l}
$\mathrm{m}$ & $\mathrm{m}$ \\
\hline
\end{tabular}

\begin{tabular}{l|l|l|}
$\mathrm{m}$ & $\mathrm{m}$ & $\mathrm{m}$
\end{tabular}

1. Los estudiantes en programas de trabajo-estudio se consideran tanto en educación como empleados, con independencia de su situación en el mercado laboral según la definición de la OIT.

2. Jóvenes ni empleados ni en educación o formación.

3. Año de referencia 2011.

Fuente: OCDE. Arabia Saudí, Argentina, China, Colombia, India, Indonesia y Sudáfrica: Instituto de Estadística de la UNESCO. Letonia: Eurostat. Para ver notas, consulte Anexo 3 (www.oecd.org/edu/eag.htm).

Para obtener más información acerca de los símbolos utilizados en lugar de los datos que faltan, consulte la Guía del lector.

StatLink 제내 http://dx.doi.org/10.1787/888933118941 
Tabla C5.3a. [1/3] Tendencias del porcentaje de jóvenes de 15 a 29 años en educación y no en educación, empleados o no, por grupo de edad (1997-2012)

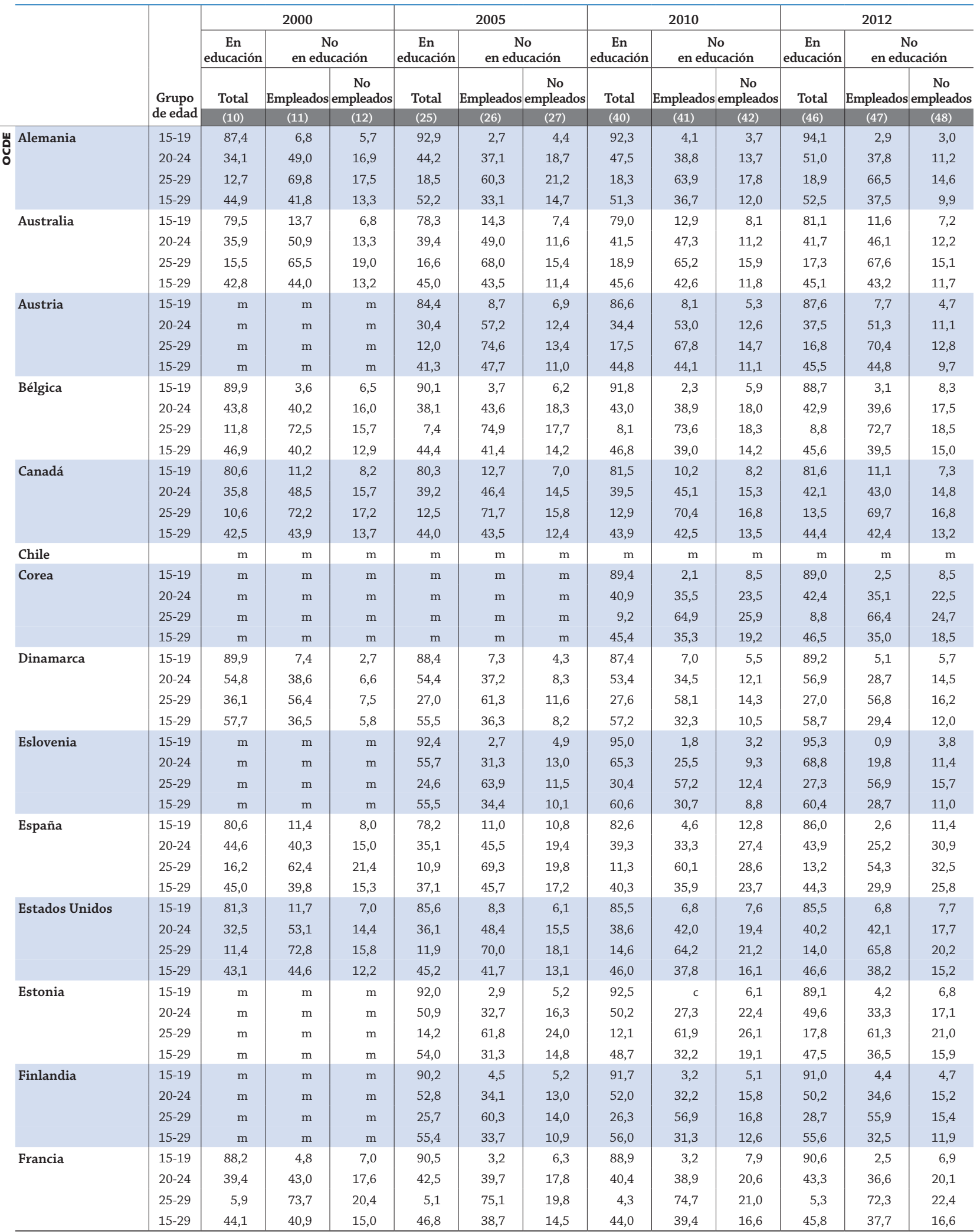

Nota: Las columnas que muestran más años están disponibles en Internet (véase StatLink más abajo).

Fuente: OCDE. Arabia Saudí, Argentina, China, Colombia, India, Indonesia y Sudáfrica: Instituto de Estadística de la UNESCO. Letonia: Eurostat. Para ver notas, consulte Anexo 3 (www.oecd.org/edu/eag.htm).

Para obtener más información acerca de los símbolos utilizados en lugar de los datos que faltan, consulte la Guía del lector.

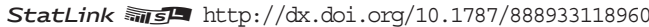


Tabla C5.3a. [2/3] Tendencias del porcentaje de jóvenes de 15 a 29 años en educación y no en educación, empleados o no, por grupo de edad (1997-2012)

\begin{tabular}{|c|c|c|c|c|c|c|c|c|c|c|c|c|c|}
\hline & \multirow{4}{*}{$\begin{array}{c}\text { Grupo } \\
\text { de edad }\end{array}$} & \multicolumn{3}{|c|}{2000} & \multicolumn{3}{|c|}{2005} & \multicolumn{3}{|c|}{2010} & \multicolumn{3}{|c|}{2012} \\
\hline & & \multirow{2}{*}{\begin{tabular}{|c|}
$\begin{array}{c}\text { En } \\
\text { educación }\end{array}$ \\
Total \\
\end{tabular}} & \multicolumn{2}{|c|}{$\begin{array}{c}\text { No } \\
\text { en educación }\end{array}$} & \multirow{2}{*}{\begin{tabular}{|c|}
$\begin{array}{c}\text { En } \\
\text { educación }\end{array}$ \\
Total \\
\end{tabular}} & \multicolumn{2}{|c|}{$\begin{array}{c}\text { No } \\
\text { en educación }\end{array}$} & \multirow{2}{*}{\begin{tabular}{|c|}
$\begin{array}{c}\text { En } \\
\text { educación }\end{array}$ \\
Total \\
\end{tabular}} & \multicolumn{2}{|c|}{$\begin{array}{c}\text { No } \\
\text { en educación }\end{array}$} & \multirow{2}{*}{\begin{tabular}{|c|}
$\begin{array}{c}\text { En } \\
\text { educación }\end{array}$ \\
$s$ \\
Total \\
\end{tabular}} & \multicolumn{2}{|c|}{$\begin{array}{c}\text { No } \\
\text { en educación }\end{array}$} \\
\hline & & & Empleados & $\begin{array}{c}\text { No } \\
\text { empleados }\end{array}$ & & Empleados & \begin{tabular}{|c|} 
No \\
s empleados
\end{tabular} & & Empleados & \begin{tabular}{|c|c|} 
No \\
s empleados
\end{tabular} & & Empleados & $\begin{array}{c}\text { No } \\
\text { empleados }\end{array}$ \\
\hline & & (10) & (11) & (12) & (25) & (26) & (27) & (40) & (41) & (42) & (46) & (47) & (48) \\
\hline \multirow{4}{*}{ 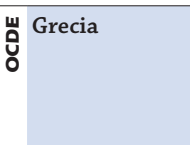 } & $15-19$ & 82,6 & 8,1 & 9,3 & 82,2 & 6,1 & 11,7 & 88,8 & 3,7 & 7,5 & 93,7 & 1,0 & 5,3 \\
\hline & $20-24$ & 30,7 & 43,4 & 25,9 & 40,4 & 38,0 & 21,6 & 46,6 & 31,8 & 21,6 & 73,3 & 11,4 & 15,4 \\
\hline & $25-29$ & 5,1 & 65,8 & 29,2 & 6,4 & 69,8 & 23,7 & 9,2 & 67,2 & 23,6 & 55,0 & 26,4 & 18,5 \\
\hline & $15-29$ & 39,0 & 39,4 & 21,5 & 38,6 & 41,7 & 19,7 & 43,9 & 37,8 & 18,3 & 72,5 & 14,0 & 13,5 \\
\hline Hungría & $15-19$ & 83,7 & 7,7 & 8,6 & 90,6 & 3,0 & 6,4 & 94,0 & 1,4 & 4,6 & 93,9 & 1,3 & 4,8 \\
\hline & $20-24$ & 32,3 & 45,7 & 22,0 & 46,6 & 34,5 & 18,9 & 48,1 & 30,4 & 21,5 & 48,2 & 29,4 & 22,5 \\
\hline & $25-29$ & 9,4 & 61,4 & 29,2 & 13,1 & 63,0 & 24,0 & 9,8 & 61,5 & 28,6 & 9,9 & 62,8 & 27,3 \\
\hline & $15-29$ & 40,7 & 39,1 & 20,2 & 46,3 & 36,5 & 17,2 & 48,3 & 32,8 & 18,9 & 48,1 & 33,0 & 18,9 \\
\hline Irlanda & $15-19$ & 80,0 & 15,6 & 4,4 & 82,4 & 13,1 & 4,5 & 85,7 & 4,2 & 10,1 & 87,1 & 3,3 & 9,6 \\
\hline & $20-24$ & 26,7 & 63,6 & 9,7 & 27,7 & 60,0 & 12,3 & 36,9 & 37,0 & 26,1 & 41,8 & 32,5 & 25,7 \\
\hline & $25-29$ & 3,3 & 83,4 & 13,3 & 5,3 & 80,9 & 13,8 & 11,1 & 64,6 & 24,2 & 11,8 & 61,7 & 26,5 \\
\hline & $15-29$ & 37,9 & 53,2 & 9,0 & 36,2 & 53,4 & 10,5 & 41,1 & 38,1 & 20,8 & 44,2 & 34,7 & 21,1 \\
\hline Islandia & $15-19$ & 83,1 & 14,8 & c & 86,4 & 10,7 & c & 85,0 & 8,2 & 6,8 & 85,3 & 9,9 & 4,8 \\
\hline & $20-24$ & 48,0 & 47,7 & c & 53,0 & 37,1 & 10,0 & 55,3 & 34,1 & 10,5 & 62,9 & 28,1 & 9,0 \\
\hline & $25-29$ & 34,9 & 59,2 & 5,9 & 30,9 & 61,5 & 7,6 & 32,9 & 54,3 & 12,8 & 31,5 & 56,2 & 12,4 \\
\hline & $15-29$ & 56,0 & 39,9 & 4,1 & 57,0 & 36,2 & 6,8 & 55,8 & 33,9 & 10,3 & 59,0 & 32,2 & 8,9 \\
\hline Israel & $15-19$ & $\mathrm{~m}$ & $\mathrm{~m}$ & $\mathrm{~m}$ & 68,9 & 6,3 & 24,7 & 72,0 & 5,5 & 22,5 & 68,6 & 20,6 & 10,7 \\
\hline & $20-24$ & $\mathrm{~m}$ & $\mathrm{~m}$ & $\mathrm{~m}$ & 28,3 & 31,4 & 40,3 & 30,9 & 32,1 & 36,9 & 29,7 & 51,5 & 18,7 \\
\hline & $25-29$ & $\mathrm{~m}$ & $\mathrm{~m}$ & $\mathrm{~m}$ & 21,4 & 54,3 & 24,2 & 27,0 & 50,1 & 22,9 & 30,7 & 51,6 & 17,7 \\
\hline & $15-29$ & $\mathrm{~m}$ & $\mathrm{~m}$ & $\mathrm{~m}$ & 40,2 & 30,2 & 29,6 & 44,0 & 28,6 & 27,4 & 43,3 & 41,0 & 15,7 \\
\hline Italia & $15-19$ & 77,1 & 9,8 & 13,1 & 81,8 & 7,0 & 11,2 & 83,6 & 4,0 & 12,5 & 85,1 & 3,0 & 12,0 \\
\hline & $20-24$ & 36,0 & 36,5 & 27,5 & 38,6 & 37,3 & 24,1 & 40,8 & 32,1 & 27,1 & 38,9 & 29,5 & 31,5 \\
\hline & $25-29$ & 17,0 & 56,1 & 26,9 & 14,4 & 59,8 & 25,8 & 16,9 & 54,9 & 28,2 & 15,6 & 55,4 & 29,0 \\
\hline & $15-29$ & 39,9 & 36,8 & 23,3 & 41,5 & 37,5 & 21,1 & 45,3 & 31,7 & 23,0 & 44,7 & 30,7 & 24,6 \\
\hline Japón & $15-24$ & 62,1 & 29,2 & 8,8 & 59,7 & 31,5 & 8,8 & 61,7 & 28,4 & 9,9 & 64,5 & 26,1 & 9,4 \\
\hline Luxemburgo & $15-19$ & 92,2 & 6,1 & c & 93,4 & 4,4 & 2,2 & 92,1 & c & 6,3 & 95,7 & c & 2,9 \\
\hline & $20-24$ & 42,8 & 48,9 & 8,2 & 47,4 & 43,3 & 9,3 & 63,1 & 29,4 & 7,5 & 65,9 & 23,8 & 10,3 \\
\hline & $25-29$ & 11,6 & 75,5 & 12,9 & 8,6 & 81,2 & 10,3 & 15,5 & 76,9 & 7,6 & 20,0 & 69,1 & 10,9 \\
\hline & $15-29$ & 45,3 & 46,6 & 8,1 & 48,5 & 44,2 & 7,3 & 54,7 & 38,1 & 7,1 & 58,4 & 33,4 & 8,2 \\
\hline México & $15-19$ & 47,9 & 33,8 & 18,3 & 57,6 & 24,2 & 18,2 & 60,7 & 22,3 & 17,1 & 61,6 & 21,5 & 17,0 \\
\hline & $20-24$ & 17,7 & 55,2 & 27,1 & 24,3 & 48,7 & 27,0 & 26,1 & 49,2 & 24,6 & 28,5 & 48,0 & 23,6 \\
\hline & $25-29$ & 4,0 & 65,8 & 30,2 & 5,7 & 62,8 & 31,5 & 6,6 & 65,8 & 27,6 & 7,8 & 65,1 & 27,1 \\
\hline & $15-29$ & 25,4 & 50,0 & 24,6 & 31,9 & 43,2 & 24,9 & 34,1 & 43,3 & 22,5 & 35,3 & 42,7 & 22,0 \\
\hline Noruega & $15-19$ & 92,4 & 5,9 & c & 87,4 & 10,1 & 2,5 & 81,4 & 15,1 & 3,5 & 82,4 & 14,6 & 3,0 \\
\hline & $20-24$ & 41,7 & 50,3 & 8,0 & 41,5 & 48,9 & 9,6 & 42,2 & 48,8 & 9,0 & 40,6 & 48,8 & 10,7 \\
\hline & $25-29$ & 17,5 & 72,1 & 10,4 & 15,7 & 72,0 & 12,3 & 13,5 & 73,5 & 13,0 & 14,6 & 74,0 & 11,4 \\
\hline & $15-29$ & 48,4 & 44,6 & 7,0 & 48,6 & 43,4 & 8,1 & 46,2 & 45,3 & 8,5 & 45,8 & 45,8 & 8,4 \\
\hline Nueva Zelanda & $15-19$ & $\mathrm{~m}$ & $\mathrm{~m}$ & $\mathrm{~m}$ & 75,6 & 17,2 & 7,2 & 78,3 & 13,1 & 8,6 & 78,5 & 12,8 & 8,7 \\
\hline & $20-24$ & $\mathrm{~m}$ & $\mathrm{~m}$ & $\mathrm{~m}$ & 39,2 & 46,7 & 14,0 & 38,9 & 43,3 & 17,8 & 36,5 & 46,6 & 16,9 \\
\hline & $25-29$ & $\mathrm{~m}$ & $\mathrm{~m}$ & $\mathrm{~m}$ & 19,1 & 65,5 & 15,4 & 17,7 & 62,3 & 20,1 & 17,9 & 63,2 & 18,9 \\
\hline & $15-29$ & $\mathrm{~m}$ & $\mathrm{~m}$ & $\mathrm{~m}$ & 46,3 & 41,7 & 12,0 & 46,1 & 38,6 & 15,3 & 44,6 & 40,6 & 14,8 \\
\hline Países Bajos & $15-19$ & 80,6 & 15,7 & 3,7 & 89,2 & 7,0 & 3,9 & 90,3 & 6,6 & 3,1 & 93,4 & 4,2 & 2,4 \\
\hline & $20-24$ & 36,5 & 55,2 & 8,2 & 49,1 & 41,8 & 9,1 & 55,3 & 37,3 & 7,4 & 58,3 & 34,5 & 7,1 \\
\hline & $25-29$ & 5,0 & 83,0 & 12,1 & 18,2 & 70,2 & 11,6 & 19,5 & 70,6 & 9,9 & 22,2 & 67,3 & 10,6 \\
\hline & $15-29$ & 38,1 & 53,6 & 8,3 & 52,1 & 39,7 & 8,2 & 55,4 & 37,9 & 6,8 & 57,9 & 35,4 & 6,7 \\
\hline Polonia & $15-19$ & 92,8 & 2,6 & 4,5 & 97,9 & 0,4 & 1,7 & 94,2 & 2,2 & 3,6 & 94,5 & 1,6 & 3,9 \\
\hline & $20-24$ & 34,9 & 34,3 & 30,8 & 62,7 & 17,2 & 20,1 & 52,9 & 29,5 & 17,6 & 52,0 & 29,1 & 18,9 \\
\hline & $25-29$ & 8,0 & 62,9 & 29,1 & 16,4 & 54,3 & 29,3 & 12,3 & 65,8 & 21,9 & 11,4 & 66,2 & 22,4 \\
\hline & $15-29$ & 43,8 & 34,1 & 22,1 & 55,7 & 26,0 & 18,4 & 50,2 & 34,8 & 15,0 & 48,6 & 35,4 & 16,0 \\
\hline Portugal & $15-19$ & 72,6 & 19,7 & 7,7 & 79,3 & 12,2 & 8,4 & 85,2 & 7,4 & 7,4 & 88,4 & 3,8 & 7,9 \\
\hline & $20-24$ & 36,5 & 52,6 & 11,0 & 37,4 & 48,4 & 14,1 & 39,6 & 44,1 & 16,4 & 41,6 & 35,7 & 22,7 \\
\hline & $25-29$ & 11,0 & 76,6 & 12,5 & 11,5 & 73,6 & 14,9 & 13,8 & 70,5 & 15,7 & 15,3 & 66,4 & 18,3 \\
\hline & $15-29$ & 38,2 & 51,2 & 10,5 & 38,9 & 48,2 & 12,9 & 43,1 & 43,5 & 13,5 & 45,7 & 37,6 & 16,6 \\
\hline
\end{tabular}

Nota: Las columnas que muestran más años están disponibles en Internet (véase StatLink más abajo).

Fuente: OCDE. Arabia Saudí, Argentina, China, Colombia, India, Indonesia y Sudáfrica: Instituto de Estadística de la UNESCO. Letonia: Eurostat. Para ver notas, consulte Anexo 3 (www.oecd.org/edu/eag.htm).

Para obtener más información acerca de los símbolos utilizados en lugar de los datos que faltan, consulte la Guía del lector.

StatLink 제요 http://dx.doi.org/10.1787/888933118960 
Tabla C5.3a. [3/3] Tendencias del porcentaje de jóvenes de 15 a 29 años en educación y no en educación, empleados o no, por grupo de edad (1997-2012)

\begin{tabular}{|c|c|c|c|c|c|c|c|c|c|c|c|c|c|}
\hline & \multirow{4}{*}{$\begin{array}{l}\text { Grupo } \\
\text { de edad }\end{array}$} & \multicolumn{3}{|c|}{2000} & \multicolumn{3}{|c|}{2005} & \multicolumn{3}{|c|}{2010} & \multicolumn{3}{|c|}{2012} \\
\hline & & \multirow{3}{*}{\begin{tabular}{|c|}
$\begin{array}{c}\text { En } \\
\text { educación }\end{array}$ \\
Total \\
$(10)$
\end{tabular}} & \multicolumn{2}{|c|}{$\begin{array}{c}\text { No } \\
\text { en educación }\end{array}$} & \multirow{3}{*}{\begin{tabular}{|c|}
$\begin{array}{c}\text { En } \\
\text { educación }\end{array}$ \\
Total \\
$(25)$
\end{tabular}} & \multicolumn{2}{|c|}{$\begin{array}{c}\text { No } \\
\text { en educación }\end{array}$} & \multirow{3}{*}{\begin{tabular}{|c|}
$\begin{array}{c}\text { En } \\
\text { educación }\end{array}$ \\
Total \\
$(40)$
\end{tabular}} & \multicolumn{2}{|c|}{$\begin{array}{c}\text { No } \\
\text { en educación }\end{array}$} & \multirow{3}{*}{\begin{tabular}{|c|}
$\begin{array}{c}\text { En } \\
\text { educación }\end{array}$ \\
Total \\
$(46)$ \\
\end{tabular}} & \multicolumn{2}{|c|}{$\begin{array}{c}\text { No } \\
\text { en educación }\end{array}$} \\
\hline & & & Empleados & $\begin{array}{c}\text { No } \\
\text { empleados }\end{array}$ & & Empleado & $\begin{array}{c}\text { No } \\
\text { empleados }\end{array}$ & & Empleado & $\begin{array}{c}\text { No } \\
\text { empleados }\end{array}$ & & Empleados & $\begin{array}{c}\text { No } \\
\text { s empleados }\end{array}$ \\
\hline & & & (11) & (12) & & (26) & (27) & & (41) & $(42)$ & & (47) & (48) \\
\hline \multirow{4}{*}{ uू̆ Reino Unido } & $15-19$ & 77,0 & 15,0 & 8,0 & 76,0 & 14,6 & 9,3 & 80,6 & 9,4 & 10,0 & 82,3 & 8,2 & 9,5 \\
\hline & $20-24$ & 32,4 & 52,2 & 15,4 & 32,1 & 51,0 & 16,8 & 33,7 & 46,9 & 19,3 & 33,6 & 46,1 & 20,2 \\
\hline & $25-29$ & 13,3 & 70,3 & 16,3 & 13,3 & 70,1 & 16,6 & 14,3 & 67,6 & 18,1 & 14,0 & 67,7 & 18,3 \\
\hline & $15-29$ & 40,0 & 46,6 & 13,3 & 41,2 & 44,6 & 14,2 & 42,1 & 42,0 & 15,9 & 41,6 & 42,1 & 16,3 \\
\hline \multirow[t]{4}{*}{ República Checa } & $15-19$ & 82,1 & 10,0 & 7,9 & 90,3 & 4,4 & 5,3 & 93,2 & 3,0 & 3,8 & 93,4 & 2,7 & 4,0 \\
\hline & $20-24$ & 19,7 & 60,0 & 20,3 & 35,9 & 47,5 & 16,6 & 48,4 & 38,1 & 13,6 & 50,1 & 36,5 & 13,4 \\
\hline & $25-29$ & 2,4 & 72,1 & 25,6 & 4,4 & 72,4 & 23,2 & 12,0 & 67,6 & 20,4 & 12,2 & 67,4 & 20,4 \\
\hline & $15-29$ & 31,7 & 49,7 & 18,5 & 39,5 & 44,6 & 15,9 & 48,1 & 38,7 & 13,2 & 47,8 & 38,8 & 13,4 \\
\hline \multirow[t]{4}{*}{ República Eslovaca } & $15-19$ & 67,3 & 6,4 & 26,3 & 90,4 & 3,3 & 6,3 & 93,8 & 1,7 & 4,6 & 92,4 & 1,9 & 5,6 \\
\hline & $20-24$ & 18,1 & 48,8 & 33,1 & 31,0 & 43,8 & 25,2 & 44,8 & 33,0 & 22,1 & 46,7 & 33,1 & 20,2 \\
\hline & $25-29$ & 1,3 & 66,9 & 31,8 & 6,1 & 64,9 & 29,0 & 7,3 & 65,1 & 27,5 & 7,6 & 64,9 & 27,5 \\
\hline & $15-29$ & 29,3 & 40,3 & 30,4 & 41,1 & 38,3 & 20,5 & 45,9 & 35,2 & 18,8 & 45,1 & 36,1 & 18,8 \\
\hline \multirow[t]{4}{*}{ Suecia } & $15-19$ & 90,6 & 5,8 & 3,6 & 89,6 & 5,8 & 4,7 & 89,5 & 5,2 & 5,3 & 90,3 & 5,6 & 4,1 \\
\hline & $20-24$ & 42,1 & 47,2 & 10,7 & 42,5 & 44,1 & 13,4 & 46,0 & 39,8 & 14,2 & 45,0 & 41,5 & 13,5 \\
\hline & $25-29$ & 21,9 & 68,9 & 9,2 & 23,6 & 66,5 & 10,0 & 24,8 & 63,6 & 11,6 & 24,1 & 64,8 & 11,1 \\
\hline & $15-29$ & 50,2 & 41,9 & 7,9 & 52,9 & 38,0 & 9,2 & 54,5 & 35,2 & 10,3 & 52,7 & 37,6 & 9,7 \\
\hline \multirow[t]{4}{*}{ Suiza } & $15-19$ & 84,6 & 7,5 & 7,9 & 85,3 & 7,2 & 7,5 & 88,5 & 6,7 & 4,8 & 88,6 & 6,7 & 4,7 \\
\hline & $20-24$ & 37,4 & 56,7 & 5,9 & 37,9 & 50,3 & 11,9 & 45,8 & 43,1 & 11,1 & 43,7 & 44,2 & 12,1 \\
\hline & $25-29$ & 15,1 & 73,9 & 11,0 & 12,3 & 75,9 & 11,8 & 17,2 & 70,0 & 12,8 & 17,4 & 71,3 & 11,3 \\
\hline & $15-29$ & 45,1 & 46,6 & 8,3 & 44,4 & 45,2 & 10,4 & 49,3 & 41,1 & 9,7 & 48,0 & 42,5 & 9,6 \\
\hline \multirow[t]{4}{*}{ Turquía } & $15-19$ & 39,2 & 29,6 & 31,2 & 45,8 & 18,1 & 36,1 & 59,7 & 14,7 & 25,6 & 64,4 & 12,8 & 22,8 \\
\hline & $20-24$ & 12,7 & 43,1 & 44,2 & 15,4 & 34,9 & 49,7 & 25,2 & 31,1 & 43,7 & 38,4 & 30,6 & 30,9 \\
\hline & $25-29$ & 2,9 & 58,8 & 38,3 & 4,0 & 50,2 & 45,8 & 8,1 & 50,1 & 41,8 & 17,1 & 48,8 & 34,1 \\
\hline & $15-29$ & 18,5 & 43,7 & 37,8 & 22,4 & 34,0 & 43,6 & 31,4 & 32,0 & 36,6 & 40,1 & 30,7 & 29,2 \\
\hline \multirow{4}{*}{$\begin{array}{l}\text { Media OCDE } \\
\text { (excluyendo Japón) }\end{array}$} & $15-19$ & 80,1 & 11,4 & 9,4 & 83,7 & 8,3 & 8,2 & 85,6 & 6,7 & 8,0 & 86,5 & 6,5 & 7,2 \\
\hline & $20-24$ & 34,7 & 48,2 & 17,7 & 40,3 & 42,2 & 17,5 & 44,0 & 37,6 & 18,4 & 46,4 & 36,1 & 17,5 \\
\hline & 25-29 & 12,2 & 68,7 & 19,1 & 14,1 & 67,1 & 18,8 & 15,7 & 64,4 & 19,9 & 17,9 & 62,7 & 19,4 \\
\hline & $15-29$ & 41,4 & 43,6 & 15,1 & 45,1 & 39,9 & 14,9 & 47,2 & 37,1 & 15,7 & 48,8 & 36,2 & 15,0 \\
\hline \multirow[t]{4}{*}{ Media UE21 } & $15-19$ & 83,2 & 9,2 & 7,9 & 87,7 & 6,1 & 6,2 & 89,5 & 4,4 & 6,4 & 90,6 & 3,5 & 6,1 \\
\hline & 20-24 & 35,6 & 47,0 & 17,3 & 42,6 & 41,2 & 16,1 & 46,8 & 35,8 & 17,4 & 49,5 & 32,9 & 17,6 \\
\hline & $25-29$ & 11,3 & 69,3 & 19,4 & 13,7 & 68,0 & 18,3 & 15,4 & 65,2 & 19,4 & 18,2 & 62,2 & 19,5 \\
\hline & $15-29$ & 41,9 & 43,0 & 15,0 & 46,4 & 39,8 & 13,8 & 48,7 & 36,5 & 14,8 & 50,6 & 34,5 & 14,8 \\
\hline
\end{tabular}

\begin{tabular}{|c|c|c|c|c|c|c|c|c|c|c|c|c|c|}
\hline Arabia Saudí & & $\mathrm{m}$ & $\mathrm{m}$ & $\mathrm{m}$ & $\mathrm{m}$ & $\mathrm{m}$ & $\mathrm{m}$ & $\mathrm{m}$ & $\mathrm{m}$ & $\mathrm{m}$ & $\mathrm{m}$ & $\mathrm{m}$ & $\mathrm{m}$ \\
\hline Argentina & & $\mathrm{m}$ & $\mathrm{m}$ & $\mathrm{m}$ & $\mathrm{m}$ & $\mathrm{m}$ & $\mathrm{m}$ & $\mathrm{m}$ & $\mathrm{m}$ & $\mathrm{m}$ & $\mathrm{m}$ & $\mathrm{m}$ & $\mathrm{m}$ \\
\hline \multirow[t]{4}{*}{ Brasil } & $15-19$ & $\mathrm{~m}$ & $\mathrm{~m}$ & $\mathrm{~m}$ & $\mathrm{~m}$ & $\mathrm{~m}$ & $\mathrm{~m}$ & $\mathrm{~m}$ & $\mathrm{~m}$ & $\mathrm{~m}$ & 68,3 & 16,5 & 15,2 \\
\hline & $20-24$ & $\mathrm{~m}$ & $\mathrm{~m}$ & $\mathrm{~m}$ & $\mathrm{~m}$ & $\mathrm{~m}$ & $\mathrm{~m}$ & $\mathrm{~m}$ & $\mathrm{~m}$ & $\mathrm{~m}$ & 23,0 & 53,3 & 23,7 \\
\hline & $25-29$ & $\mathrm{~m}$ & $\mathrm{~m}$ & $\mathrm{~m}$ & $\mathrm{~m}$ & $\mathrm{~m}$ & $\mathrm{~m}$ & $\mathrm{~m}$ & $\mathrm{~m}$ & $\mathrm{~m}$ & 11,1 & 67,6 & 21,3 \\
\hline & $15-29$ & $\mathrm{~m}$ & $\mathrm{~m}$ & $\mathrm{~m}$ & $\mathrm{~m}$ & $\mathrm{~m}$ & $\mathrm{~m}$ & $\mathrm{~m}$ & $\mathrm{~m}$ & $\mathrm{~m}$ & 35,0 & 45,1 & 20,0 \\
\hline China & & $\mathrm{m}$ & $\mathrm{m}$ & $\mathrm{m}$ & $\mathrm{m}$ & $\mathrm{m}$ & $\mathrm{m}$ & $\mathrm{m}$ & $\mathrm{m}$ & $\mathrm{m}$ & $\mathrm{m}$ & $\mathrm{m}$ & $\mathrm{m}$ \\
\hline Colombia & & $\mathrm{m}$ & $\mathrm{m}$ & $\mathrm{m}$ & $\mathrm{m}$ & $\mathrm{m}$ & $\mathrm{m}$ & $\mathrm{m}$ & $\mathrm{m}$ & $\mathrm{m}$ & $\mathrm{m}$ & $\mathrm{m}$ & $\mathrm{m}$ \\
\hline Federación Rusa & & $\mathrm{m}$ & $\mathrm{m}$ & $\mathrm{m}$ & $\mathrm{m}$ & $\mathrm{m}$ & $\mathrm{m}$ & $\mathrm{m}$ & $\mathrm{m}$ & $\mathrm{m}$ & $\mathrm{m}$ & $\mathrm{m}$ & $\mathrm{m}$ \\
\hline India & & $\mathrm{m}$ & $\mathrm{m}$ & $\mathrm{m}$ & $\mathrm{m}$ & $\mathrm{m}$ & $\mathrm{m}$ & $\mathrm{m}$ & $\mathrm{m}$ & $\mathrm{m}$ & $\mathrm{m}$ & $\mathrm{m}$ & $\mathrm{m}$ \\
\hline Indonesia & & $\mathrm{m}$ & $\mathrm{m}$ & $\mathrm{m}$ & $\mathrm{m}$ & $\mathrm{m}$ & $\mathrm{m}$ & $\mathrm{m}$ & $\mathrm{m}$ & $\mathrm{m}$ & $\mathrm{m}$ & $\mathrm{m}$ & $\mathrm{m}$ \\
\hline \multirow[t]{4}{*}{ Letonia } & $15-19$ & $\mathrm{~m}$ & $\mathrm{~m}$ & $\mathrm{~m}$ & $\mathrm{~m}$ & $\mathrm{~m}$ & $\mathrm{~m}$ & 91,8 & 1,8 & 6,4 & 91,0 & 1,8 & 7,2 \\
\hline & $20-24$ & $\mathrm{~m}$ & $\mathrm{~m}$ & $\mathrm{~m}$ & $\mathrm{~m}$ & $\mathrm{~m}$ & $\mathrm{~m}$ & 39,8 & 30,3 & 29,9 & 46,0 & 33,7 & 20,3 \\
\hline & $25-29$ & $\mathrm{~m}$ & $\mathrm{~m}$ & $\mathrm{~m}$ & $\mathrm{~m}$ & $\mathrm{~m}$ & $\mathrm{~m}$ & 10,0 & 60,9 & 29,2 & 13,5 & 59,9 & 26,7 \\
\hline & $15-29$ & $\mathrm{~m}$ & $\mathrm{~m}$ & $\mathrm{~m}$ & $\mathrm{~m}$ & $\mathrm{~m}$ & $\mathrm{~m}$ & 44,5 & 32,7 & 22,9 & 46,3 & 34,6 & 19,1 \\
\hline Sudáfrica & & $\mathrm{m}$ & $\mathrm{m}$ & $\mathrm{m}$ & $\mathrm{m}$ & $\mathrm{m}$ & $\mathrm{m}$ & $\mathrm{m}$ & $\mathrm{m}$ & $\mathrm{m}$ & $\mathrm{m}$ & $\mathrm{m}$ & $\mathrm{m}$ \\
\hline
\end{tabular}

Nota: Las columnas que muestran más años están disponibles en Internet (véase StatLink más abajo).

Fuente: OCDE. Arabia Saudí, Argentina, China, Colombia, India, Indonesia y Sudáfrica: Instituto de Estadística de la UNESCO. Letonia: Eurostat. Para ver notas, consulte Anexo 3 (www.oecd.org/edu/eag.htm).

Para obtener más información acerca de los símbolos utilizados en lugar de los datos que faltan, consulte la Guía del lector.

StatLink त्ञाI 5 htp: //dx.doi.org/10.1787/888933118960 
Tabla C5.4. [1/6] Porcentaje de jóvenes de 15 a 29 años en educación y no en educación, por nivel educativo alcanzado y situación laboral (2012)

\begin{tabular}{|c|c|c|c|c|c|c|c|c|c|c|c|c|}
\hline & \multirow{4}{*}{ 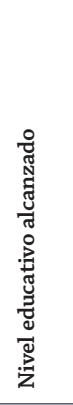 } & \multicolumn{11}{|c|}{ En educación } \\
\hline & & \multirow[b]{2}{*}{ 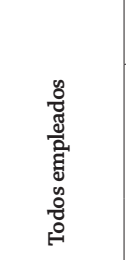 } & \multicolumn{2}{|c|}{ Empleados } & \multicolumn{3}{|c|}{$\begin{array}{c}\text { Tipo } \\
\text { de empleo }\end{array}$} & \multirow[b]{2}{*}{ 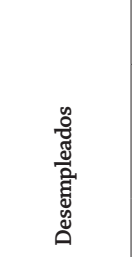 } & \multicolumn{2}{|c|}{$\begin{array}{c}\text { Duración } \\
\text { del desempleo }\end{array}$} & \multirow[b]{2}{*}{ 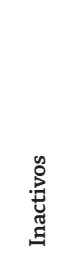 } & \multirow[b]{2}{*}{ 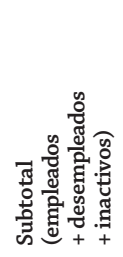 } \\
\hline & & & 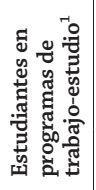 & 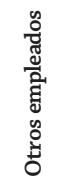 & 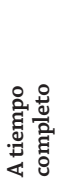 & 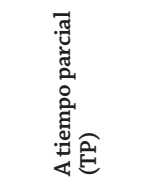 & 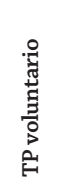 & & 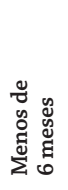 & 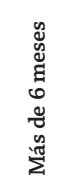 & & \\
\hline & & $\begin{array}{c}(1) \\
=(2)+(3) \\
y / 0(4)+(5) \\
+ \text { desconocidos }\end{array}$ & (2) & (3) & (4) & $\begin{array}{r}(5) \\
=(6) \\
+ \text { TP involuntario } \\
\end{array}$ & (6) & $\begin{aligned} &(7) \\
&=(8)+(9) \\
&+ \text { desconocidos }\end{aligned}$ & (8) & (9) & (10) & $\begin{array}{c}(11) \\
=(1)+(7)+(10)\end{array}$ \\
\hline \multirow[t]{3}{*}{ Alemania } & $0 / 1 / 2$ & 24,1 & 17,5 & 6,6 & 19,3 & 4,8 & c & 1,0 & 0,6 & 0,3 & 52,9 & 78,0 \\
\hline & $3 / 4$ & 16,8 & 6,0 & 10,9 & 8,8 & 8,0 & c & 0,5 & 0,4 & 0,1 & 20,6 & 37,9 \\
\hline & $5 / 6$ & 12,6 & 0,9 & 11,7 & 5,6 & 6,9 & c & 0,8 & 0,6 & c & 7,8 & 21,1 \\
\hline \multirow[t]{3}{*}{ Australia } & $0 / 1 / 2$ & 25,0 & 4,7 & 20,3 & 1,2 & 19,1 & 15,3 & 4,8 & 3,7 & 1,2 & 34,1 & 63,9 \\
\hline & $3 / 4$ & 28,1 & 5,1 & 23,0 & 5,4 & 17,6 & 13,7 & 2,6 & 2,3 & 0,4 & 12,9 & 43,6 \\
\hline & $5 / 6$ & 16,5 & 0,9 & 15,6 & 7,1 & 8,4 & 6,7 & 1,4 & 1,0 & 0,4 & 7,5 & 25,3 \\
\hline \multirow[t]{3}{*}{ Austria } & $0 / 1 / 2$ & 26,4 & 22,3 & 4,1 & c & 3,4 & $\mathrm{~m}$ & 1,0 & 0,8 & c & 47,5 & 74,9 \\
\hline & $3 / 4$ & 13,0 & 1,6 & 11,4 & 3,8 & 7,5 & $\mathrm{~m}$ & 1,3 & 1,1 & c & 15,5 & 29,7 \\
\hline & $5 / 6$ & 19,7 & a & 19,7 & 11,0 & 8,7 & $\mathrm{~m}$ & c & c & c & 10,6 & 31,1 \\
\hline \multirow[t]{3}{*}{ Bélgica } & $0 / 1 / 2$ & 2,9 & 1,3 & 1,7 & c & 1,5 & 1,3 & 0,5 & c & c & 61,5 & 64,9 \\
\hline & $3 / 4$ & 3,8 & 0,5 & 3,2 & 1,8 & 1,4 & 1,3 & 0,5 & c & c & 37,4 & 41,7 \\
\hline & $5 / 6$ & 5,4 & 0,7 & 4,7 & 2,8 & 1,9 & 1,5 & c & c & c & 16,7 & 22,6 \\
\hline \multirow[t]{3}{*}{ Canadá } & $0 / 1 / 2$ & 19,0 & a & 19,0 & 0,8 & 18,2 & 17,6 & 5,6 & 4,9 & 0,6 & 46,3 & 71,0 \\
\hline & $3 / 4$ & 18,3 & a & 18,3 & 2,7 & 15,6 & 14,9 & 2,3 & 2,0 & 0,1 & 20,8 & 41,4 \\
\hline & $5 / 6$ & 15,1 & a & 15,1 & 4,4 & 10,6 & 10,1 & 1,1 & 1,0 & 0,1 & 11,4 & 27,6 \\
\hline \multirow[t]{3}{*}{ Chile $^{3}$} & $0 / 1 / 2$ & 3,7 & a & 3,7 & 2,6 & 1,1 & 0,6 & 1,8 & 1,8 & 0,0 & 54,6 & 60,1 \\
\hline & $3 / 4$ & 10,1 & a & 10,1 & 6,2 & 3,9 & 1,7 & 2,1 & 2,0 & 0,1 & 28,8 & 41,0 \\
\hline & $5 / 6$ & 1,1 & $\mathrm{a}$ & 1,1 & 0,7 & 0,4 & 0,1 & 0,0 & 0,0 & 0,0 & 0,9 & 2,1 \\
\hline \multirow[t]{3}{*}{ Corea } & $0 / 1 / 2$ & 1,6 & $\mathrm{a}$ & 1,6 & 0,6 & 0,9 & 0,9 & 0,2 & 0,2 & $\mathrm{n}$ & 90,5 & 92,3 \\
\hline & $3 / 4$ & 10,8 & $\mathrm{a}$ & 10,8 & 4,1 & 6,7 & 6,6 & 0,9 & 0,9 & $\mathrm{n}$ & 36,8 & 48,5 \\
\hline & $5 / 6$ & 1,4 & a & 1,4 & 0,9 & 0,5 & 0,5 & 0,1 & 0,1 & $\mathrm{n}$ & 1,8 & 3,3 \\
\hline \multirow[t]{3}{*}{ Dinamarca } & $0 / 1 / 2$ & 35,2 & a & 35,2 & 6,7 & 28,5 & $\mathrm{~m}$ & 7,2 & 5,2 & 1,8 & 34,2 & 76,6 \\
\hline & $3 / 4$ & 29,2 & a & 29,2 & 5,5 & 23,8 & $\mathrm{~m}$ & 3,0 & 2,4 & 0,5 & 14,7 & 46,8 \\
\hline & $5 / 6$ & 24,8 & a & 24,8 & 5,9 & 18,8 & $\mathrm{~m}$ & 2,4 & 1,8 & c & 9,9 & 37,1 \\
\hline \multirow[t]{3}{*}{ Eslovenia } & $0 / 1 / 2$ & 7,5 & a & 7,5 & 2,3 & 5,3 & $\mathrm{~m}$ & 1,2 & c & 0,8 & 75,7 & 84,4 \\
\hline & $3 / 4$ & 21,9 & a & 21,9 & 10,9 & 11,0 & $\mathrm{~m}$ & 2,3 & 1,4 & 0,9 & 31,7 & 55,9 \\
\hline & $5 / 6$ & 17,5 & a & 17,5 & 10,3 & 7,2 & $\mathrm{~m}$ & 3,1 & 3,0 & c & 7,1 & 27,7 \\
\hline España & $0 / 1 / 2$ & 1,3 & a & 1,3 & 0,6 & 0,7 & 0,5 & 3,1 & 0,9 & 2,1 & 42,4 & 46,9 \\
\hline & $3 / 4$ & 5,9 & a & 5,9 & 1,6 & 4,3 & 3,4 & 5,0 & 2,0 & 2,8 & 41,8 & 52,6 \\
\hline & $5 / 6$ & 9,0 & $\mathrm{a}$ & 9,0 & 4,9 & 4,1 & 2,8 & 4,3 & 1,3 & 2,9 & 14,2 & 27,5 \\
\hline Estados Unidos & $0 / 1 / 2$ & 10,2 & $\mathrm{a}$ & 10,2 & 0,7 & 9,0 & 8,8 & 3,3 & 2,3 & 1,0 & 61,8 & 75,2 \\
\hline & $3 / 4$ & 18,2 & a & 18,2 & 5,4 & 12,5 & 11,8 & 2,4 & 1,7 & 0,6 & 19,5 & 40,0 \\
\hline & $5 / 6$ & 13,8 & a & 13,8 & 8,0 & 5,6 & 5,2 & 0,8 & c & c & 8,7 & 23,3 \\
\hline Estonia & $0 / 1 / 2$ & 4,3 & a & 4,3 & 2,8 & 1,4 & c & c & c & c & 62,9 & 68,5 \\
\hline & $3 / 4$ & 16,3 & $\mathrm{a}$ & 16,3 & 12,5 & 3,8 & 3,6 & 1,9 & c & c & 22,3 & 40,5 \\
\hline & $5 / 6$ & 17,3 & $\mathrm{a}$ & 17,3 & 12,9 & 4,5 & 4,5 & c & c & c & 10,7 & 29,2 \\
\hline Finlandia & $0 / 1 / 2$ & 10,7 & a & 10,7 & 2,2 & 8,4 & $\mathrm{~m}$ & 5,9 & 5,1 & c & 64,3 & 80,8 \\
\hline & $3 / 4$ & 19,9 & a & 19,9 & 6,5 & 13,4 & $\mathrm{~m}$ & 3,4 & 3,2 & c & 20,6 & 44,0 \\
\hline & $5 / 6$ & 22,0 & a & 22,0 & 15,4 & 6,6 & $\mathrm{~m}$ & c & c & c & 6,4 & 29,7 \\
\hline Francia & $0 / 1 / 2$ & 4,2 & $\mathrm{a}$ & 4,2 & 3,4 & 0,8 & $\mathrm{~m}$ & 0,2 & 0,1 & 0,1 & 60,6 & 65,0 \\
\hline & $3 / 4$ & 7,7 & a & 7,7 & 4,6 & 3,1 & $\mathrm{~m}$ & 0,8 & 0,6 & 0,2 & 32,4 & 40,9 \\
\hline & $5 / 6$ & 6,7 & $\mathrm{a}$ & 6,7 & 4,4 & 2,3 & $\mathrm{~m}$ & 0,5 & 0,4 & 0,1 & 18,7 & 26,0 \\
\hline Grecia & $0 / 1 / 2$ & 13,4 & a & 13,4 & 11,5 & 1,9 & c & 9,3 & 2,6 & 6,7 & 49,7 & 72,3 \\
\hline & $3 / 4$ & 18,7 & $\mathrm{a}$ & 18,7 & 15,9 & 2,8 & 0,9 & 14,2 & 4,4 & 9,8 & 32,3 & 65,2 \\
\hline & $5 / 6$ & 28,6 & $\mathrm{a}$ & 28,6 & 25,5 & 3,1 & c & 19,2 & 5,1 & 14,1 & 4,4 & 52,2 \\
\hline
\end{tabular}

Nota: Las filas que muestran los datos de todos los niveles de educación combinados están disponibles en Internet (véase Statlink más abajo).

1. Los estudiantes en programas de trabajo-estudio se consideran tanto en educación como empleados, con independencia de su situación en el mercado laboral según la definición de la OIT.

2. Jóvenes de 15 a 29 años ni empleados ni en educación o formación.

3. Año de referencia 2011.

4. Los datos se refieren a la población de 15 a 24 años.

Fuente: OCDE. Arabia Saudí, Argentina, China, Colombia, India, Indonesia y Sudáfrica: Instituto de Estadística de la UNESCO. Letonia: Eurostat. Para ver notas, consulte Anexo 3 (www.oecd.org/edu/eag.htm).

Para obtener más información acerca de los símbolos utilizados en lugar de los datos que faltan, consulte la Guía del lector.

StatLink 제개 http://dx.doi.org/10.1787/888933118979 
Tabla C5.4. [2/6] Porcentaje de jóvenes de 15 a 29 años en educación y no en educación, por nivel educativo alcanzado y situación laboral (2012)

No en educación

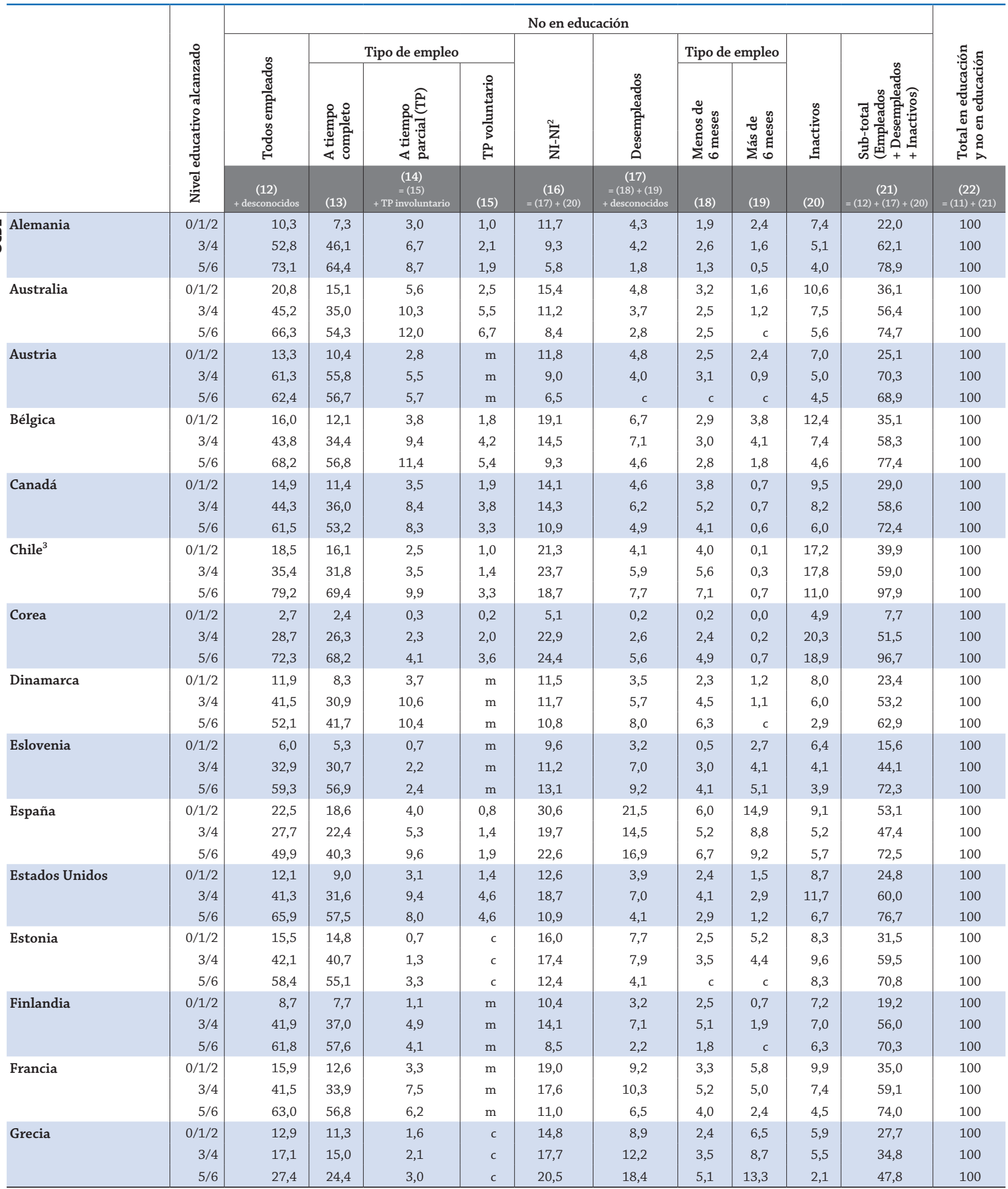

Nota: Las filas que muestran los datos de todos los niveles de educación combinados están disponibles en Internet (véase Statlink más abajo).

1. Los estudiantes en programas de trabajo-estudio se consideran tanto en educación como empleados, con independencia de su situación en el mercado laboral según la definición de la OIT.

2. Jóvenes de 15 a 29 años ni empleados ni en educación o formación.

3. Año de referencia 2011.

4. Los datos se refieren a la población de 15 a 24 años.

Fuente: OCDE. Arabia Saudí, Argentina, China, Colombia, India, Indonesia y Sudáfrica: Instituto de Estadística de la UNESCO. Letonia: Eurostat. Para ver notas, consulte Anexo 3 (www.oecd.org/edu/eag.htm).

Para obtener más información acerca de los símbolos utilizados en lugar de los datos que faltan, consulte la Guía del lector.

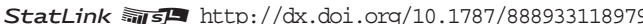


Tabla C5.4. [3/6] Porcentaje de jóvenes de 15 a 29 años en educación y no en educación, por nivel educativo alcanzado y situación laboral (2012)

\begin{tabular}{|c|c|c|c|c|c|c|c|c|c|c|c|c|}
\hline & \multirow{4}{*}{ 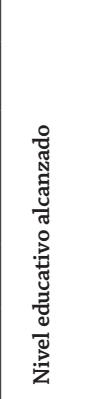 } & \multicolumn{11}{|c|}{ En educación } \\
\hline & & \multirow{3}{*}{ 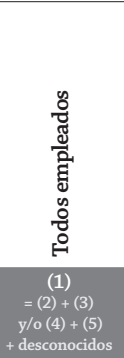 } & \multicolumn{2}{|c|}{ Empleados } & \multicolumn{3}{|c|}{$\begin{array}{c}\text { Tipo } \\
\text { de empleo }\end{array}$} & \multirow[b]{2}{*}{ 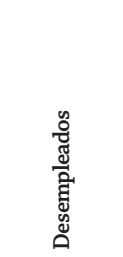 } & \multicolumn{2}{|c|}{$\begin{array}{c}\text { Duración } \\
\text { del desempleo }\end{array}$} & \multirow[b]{2}{*}{ 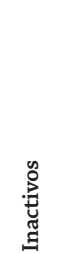 } & \multirow[b]{2}{*}{ 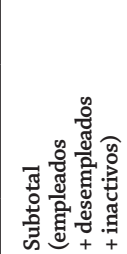 } \\
\hline & & & 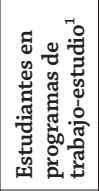 & 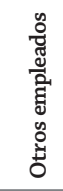 & 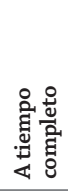 & 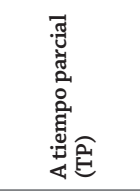 & 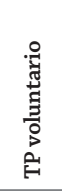 & & 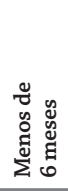 & 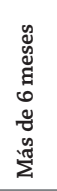 & & \\
\hline & & & (2) & (3) & (4) & $\begin{aligned} & (5) \\
& (6) \\
+ & (6) \\
+ & \text { TP Pinvoluntario }\end{aligned}$ & (6) & $\begin{aligned} &(7) \\
&=(8)+(9) \\
&+ \text { desconocidos }\end{aligned}$ & (8) & (9) & (10) & 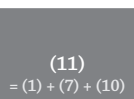 \\
\hline \multirow[t]{3}{*}{ ư Hungría } & $0 / 1 / 2$ & c & $\mathrm{a}$ & c & c & 0,0 & c & c & c & c & 73,2 & 73,3 \\
\hline & $3 / 4$ & 2,4 & $\mathrm{a}$ & 2,4 & 1,8 & 0,6 & 0,6 & c & c & c & 36,0 & 38,8 \\
\hline & $5 / 6$ & 6,6 & a & 6,6 & 5,1 & 1,4 & c & c & c & c & 9,5 & 16,4 \\
\hline \multirow[t]{3}{*}{ Irlanda } & $0 / 1 / 2$ & 2,6 & a & 2,6 & 0,3 & 2,2 & $\mathrm{~m}$ & 0,9 & c & 0,6 & 64,1 & 67,5 \\
\hline & $3 / 4$ & 10,6 & $\mathrm{a}$ & 10,6 & 2,2 & 8,4 & $\mathrm{~m}$ & 1,6 & 0,6 & 1,0 & 29,1 & 41,3 \\
\hline & $5 / 6$ & 9,6 & a & 9,6 & 5,6 & 4,0 & $\mathrm{~m}$ & 0,8 & c & 0,5 & 10,8 & 21,2 \\
\hline \multirow[t]{3}{*}{ Islandia } & $0 / 1 / 2$ & 31,5 & a & 31,5 & 4,1 & 27,4 & $\mathrm{~m}$ & 7,4 & 6,3 & c & 27,6 & 66,5 \\
\hline & $3 / 4$ & 32,4 & a & 32,4 & 7,1 & 25,4 & $\mathrm{~m}$ & c & c & c & 22,8 & 58,6 \\
\hline & $5 / 6$ & 14,4 & a & 14,4 & c & c & $\mathrm{m}$ & c & c & c & c & 24,5 \\
\hline \multirow[t]{3}{*}{ Israel } & $0 / 1 / 2$ & 5,2 & a & 5,2 & 0,5 & 4,7 & 4,4 & 1,4 & 1,1 & c & 68,1 & 74,7 \\
\hline & $3 / 4$ & 15,7 & a & 15,7 & 5,7 & 10,0 & 9,5 & 1,4 & 1,2 & c & 15,2 & 32,3 \\
\hline & $5 / 6$ & 18,1 & a & 18,1 & 9,4 & 8,7 & 7,9 & 1,7 & 1,4 & c & 4,7 & 24,5 \\
\hline \multirow[t]{3}{*}{ Italia } & $0 / 1 / 2$ & 0,7 & 0,1 & 0,6 & 0,3 & 0,4 & 0,3 & 0,3 & 0,1 & 0,1 & 56,0 & 57,0 \\
\hline & $3 / 4$ & 3,3 & 0,3 & 3,0 & 1,2 & 1,8 & 1,2 & 1,1 & 0,6 & 0,6 & 30,8 & 35,2 \\
\hline & $5 / 6$ & 6,4 & 0,4 & 6,0 & 2,5 & 3,4 & 1,7 & 2,6 & 0,7 & 1,9 & 26,5 & 35,5 \\
\hline \multirow[t]{3}{*}{ Japón ${ }^{4}$} & $0 / 1 / 2 / 3$ & 14,9 & a & 14,9 & 0,7 & 14,3 & $\mathrm{~m}$ & 0,3 & $\mathrm{~m}$ & $\mathrm{~m}$ & 40,6 & 55,9 \\
\hline & $3 / 4$ & $\mathrm{~m}$ & a & $\mathrm{m}$ & $\mathrm{m}$ & $\mathrm{m}$ & $\mathrm{m}$ & $\mathrm{m}$ & $\mathrm{m}$ & $\mathrm{m}$ & $\mathrm{m}$ & $\mathrm{m}$ \\
\hline & $5 / 6$ & $\mathrm{~m}$ & a & $\mathrm{m}$ & $\mathrm{m}$ & $\mathrm{m}$ & $\mathrm{m}$ & $\mathrm{m}$ & $\mathrm{m}$ & $\mathrm{m}$ & $\mathrm{m}$ & $\mathrm{m}$ \\
\hline \multirow[t]{3}{*}{ Luxemburgo } & $0 / 1 / 2$ & 5,6 & a & 5,6 & 3,3 & 2,3 & $\mathrm{~m}$ & 0,4 & c & c & 73,2 & 79,1 \\
\hline & $3 / 4$ & 7,3 & a & 7,3 & 2,9 & 4,4 & $\mathrm{~m}$ & 3,0 & c & 2,4 & 44,1 & 54,4 \\
\hline & $5 / 6$ & 5,7 & a & 5,7 & c & c & $\mathrm{m}$ & c & c & c & 11,1 & 18,9 \\
\hline \multirow[t]{3}{*}{ México } & $0 / 1 / 2$ & 8,3 & a & 8,3 & 2,2 & 6,1 & 2,2 & 0,4 & 0,3 & $\mathrm{n}$ & 25,0 & 33,7 \\
\hline & $3 / 4$ & 16,5 & a & 16,5 & 6,7 & 9,7 & 3,8 & 1,0 & 0,9 & $\mathrm{n}$ & 27,4 & 44,9 \\
\hline & $5 / 6$ & 9,9 & a & 9,9 & 6,0 & 3,7 & 1,5 & 0,8 & 0,6 & 0,1 & 9,7 & 20,4 \\
\hline \multirow[t]{3}{*}{ Noruega } & $0 / 1 / 2$ & 17,5 & a & 17,5 & c & 17,1 & $\mathrm{~m}$ & 2,8 & 2,3 & c & 41,7 & 62,0 \\
\hline & $3 / 4$ & 16,5 & a & 16,5 & c & 16,0 & $\mathrm{~m}$ & c & $c$ & c & 19,2 & 36,8 \\
\hline & $5 / 6$ & 11,0 & a & 11,0 & c & 10,5 & $\mathrm{~m}$ & c & c & c & 11,2 & 23,4 \\
\hline Nueva Zelanda & $0 / 1 / 2$ & 11,5 & a & 11,5 & 2,2 & 9,3 & 8,4 & 4,7 & 3,5 & 0,9 & 37,9 & 54,2 \\
\hline & $3 / 4$ & 23,2 & a & 23,2 & 7,7 & 15,6 & 13,7 & 4,0 & 2,6 & 0,7 & 23,3 & 50,5 \\
\hline & $5 / 6$ & 13,4 & a & 13,4 & 6,9 & 6,4 & 4,6 & 1,9 & 1,1 & c & 6,4 & 21,7 \\
\hline Países Bajos & $0 / 1 / 2$ & 38,3 & a & 38,3 & 3,1 & 35,2 & $\mathrm{~m}$ & 5,9 & 4,0 & 1,7 & 30,6 & 74,7 \\
\hline & $3 / 4$ & 35,4 & a & 35,4 & 5,5 & 29,8 & $\mathrm{~m}$ & 3,0 & 2,0 & 0,9 & 15,5 & 53,9 \\
\hline & $5 / 6$ & 25,7 & a & 25,7 & 8,4 & 17,3 & $\mathrm{~m}$ & 1,2 & 1,0 & c & 8,5 & 35,4 \\
\hline Polonia & $0 / 1 / 2$ & 3,2 & a & 3,2 & 0,9 & 2,3 & c & 0,8 & 0,4 & 0,4 & 76,1 & 80,0 \\
\hline & $3 / 4$ & 9,0 & a & 9,0 & 6,9 & 2,0 & 0,2 & 2,5 & 1,3 & 1,2 & 24,8 & 36,2 \\
\hline & $5 / 6$ & 12,4 & a & 12,4 & 10,0 & 2,4 & 0,4 & 2,3 & 1,2 & 1,0 & 11,8 & 26,5 \\
\hline Portugal & $0 / 1 / 2$ & 2,5 & a & 2,5 & $\mathrm{~m}$ & $\mathrm{~m}$ & $\mathrm{~m}$ & 2,7 & 1,0 & 1,7 & 47,3 & 52,5 \\
\hline & $3 / 4$ & 6,0 & a & 6,0 & $\mathrm{~m}$ & $\mathrm{~m}$ & $\mathrm{~m}$ & 2,1 & 1,1 & 1,0 & 36,3 & 44,4 \\
\hline & $5 / 6$ & 9,5 & a & 9,5 & $\mathrm{~m}$ & $\mathrm{~m}$ & $\mathrm{~m}$ & 3,7 & $c$ & 2,5 & 13,8 & 26,9 \\
\hline Reino Unido & $0 / 1 / 2$ & 4,5 & 2,1 & 2,4 & 0,9 & 1,5 & 1,3 & 1,5 & 0,7 & 0,7 & 46,4 & 52,4 \\
\hline & $3 / 4$ & 17,6 & 3,3 & 14,2 & 2,6 & 11,1 & 10,7 & 4,1 & 2,3 & 1,8 & 25,3 & 46,9 \\
\hline & $5 / 6$ & 13,2 & 0,7 & 12,5 & 7,9 & 4,3 & 4,2 & 1,2 & 0,8 & 0,5 & 10,0 & 24,4 \\
\hline República Checa & $0 / 1 / 2$ & 19,2 & 18,4 & 0,8 & c & 0,3 & c & c & c & c & 63,4 & 82,7 \\
\hline & $3 / 4$ & 4,9 & 0,9 & 4,0 & 2,6 & 1,4 & 1,3 & 0,5 & 0,4 & c & 27,8 & 33,2 \\
\hline & $5 / 6$ & 10,3 & $a$ & 10,3 & 6,9 & 3,4 & 3,4 & c & $c$ & $c$ & 22,6 & 33,8 \\
\hline
\end{tabular}

Nota: Las filas que muestran los datos de todos los niveles de educación combinados están disponibles en Internet (véase Statlink más abajo).

1. Los estudiantes en programas de trabajo-estudio se consideran tanto en educación como empleados, con independencia de su situación en el mercado laboral según la definición de la OIT.

2. Jóvenes de 15 a 29 años ni empleados ni en educación o formación.

3. Año de referencia 2011.

4. Los datos se refieren a la población de 15 a 24 años.

Fuente: OCDE. Arabia Saudí, Argentina, China, Colombia, India, Indonesia y Sudáfrica: Instituto de Estadística de la UNESCO. Letonia: Eurostat. Para ver notas, consulte Anexo 3 (www.oecd.org/edu/eag.htm).

Para obtener más información acerca de los símbolos utilizados en lugar de los datos que faltan, consulte la Guía del lector. 
Tabla C5.4. [4/6] Porcentaje de jóvenes de 15 a 29 años en educación y no en educación, por nivel educativo alcanzado y situación laboral (2012)

No en educación

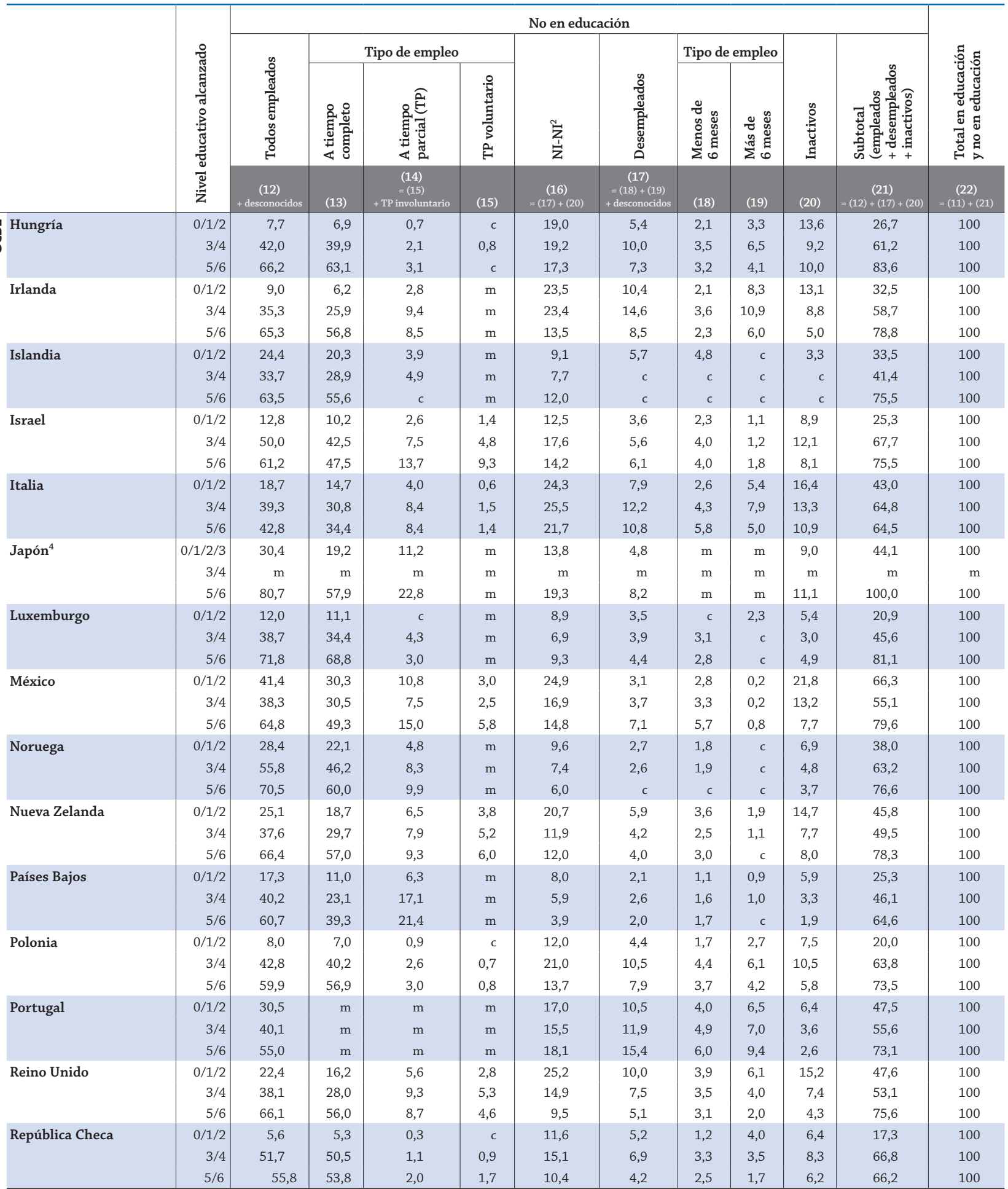

Nota: Las filas que muestran los datos de todos los niveles de educación combinados están disponibles en Internet (véase Statlink más abajo).

1. Los estudiantes en programas de trabajo-estudio se consideran tanto en educación como empleados, con independencia de su situación en el mercado laboral según la definición de la OIT.

2. Jóvenes de 15 a 29 años ni empleados ni en educación o formación.

3. Año de referencia 2011

4. Los datos se refieren a la población de 15 a 24 años.

Fuente: OCDE. Arabia Saudí, Argentina, China, Colombia, India, Indonesia y Sudáfrica: Instituto de Estadística de la UNESCO. Letonia: Eurostat. Para ver notas, consulte Anexo 3 (www.oecd.org/edu/eag.htm).

Para obtener más información acerca de los símbolos utilizados en lugar de los datos que faltan, consulte la Guía del lector.

StatLink 젶ㄴ http://dx.doi.org/10.1787/888933118979 
Tabla C5.4. [5/6] Porcentaje de jóvenes de 15 a 29 años en educación y no en educación, por nivel educativo alcanzado y situación laboral (2012)

\begin{tabular}{|c|c|c|c|c|c|c|c|c|c|c|c|c|}
\hline & \multirow{4}{*}{ 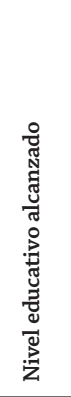 } & \multicolumn{11}{|c|}{ En educación } \\
\hline & & \multirow{3}{*}{ 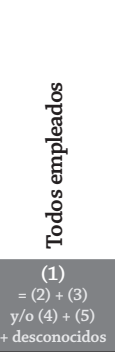 } & \multicolumn{2}{|c|}{ Empleados } & \multicolumn{3}{|c|}{$\begin{array}{c}\text { Tipo } \\
\text { de empleo }\end{array}$} & \multirow[b]{2}{*}{ 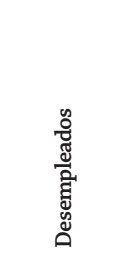 } & \multicolumn{2}{|c|}{$\begin{array}{c}\text { Duración del } \\
\text { desempleo }\end{array}$} & \multirow[b]{2}{*}{ 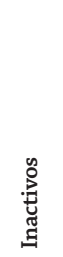 } & \multirow[b]{2}{*}{ 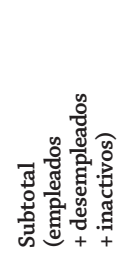 } \\
\hline & & & 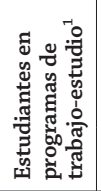 & 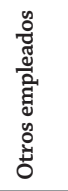 & 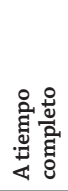 & 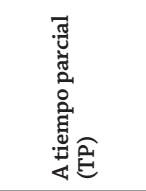 & 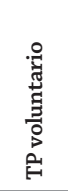 & & 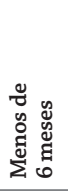 & 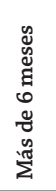 & & \\
\hline & & & (2) & (3) & (4) & $\begin{aligned} &(5) \\
&=(6) \\
&+ \text { TP involuntario }\end{aligned}$ & (6) & $\begin{aligned} &(7) \\
&=(8)+(9) \\
&+ \text { desconocidos }\end{aligned}$ & (8) & (9) & (10) & $\begin{array}{c}(11) \\
=(1)+(7)+(10)\end{array}$ \\
\hline \multirow{3}{*}{ República Eslovaca } & $0 / 1 / 2$ & 10,3 & 10,3 & $\mathrm{n}$ & c & c & $\mathrm{m}$ & c & c & c & 73,2 & 83,6 \\
\hline & $3 / 4$ & 1,7 & c & 1,5 & 1,2 & c & $\mathrm{m}$ & 0,5 & c & c & 24,6 & 26,8 \\
\hline & $5 / 6$ & 4,6 & c & 4,6 & 3,9 & c & $\mathrm{m}$ & c & c & c & 27,9 & 32,7 \\
\hline \multirow[t]{3}{*}{ Suecia } & $0 / 1 / 2$ & 9,7 & a & 9,7 & c & 8,9 & 7,6 & 7,8 & 6,3 & 0,8 & 66,3 & 83,9 \\
\hline & $3 / 4$ & 8,2 & a & 8,2 & 2,6 & 5,6 & 4,6 & 4,7 & 2,9 & 1,3 & 13,8 & 26,7 \\
\hline & $5 / 6$ & 19,1 & a & 19,1 & 6,0 & 12,9 & 11,4 & 4,3 & 3,3 & c & 26,0 & 49,4 \\
\hline \multirow[t]{3}{*}{ Suiza } & $0 / 1 / 2$ & 43,2 & 37,0 & 6,2 & 1,2 & 5,0 & 4,9 & 1,2 & c & c & 34,7 & 79,1 \\
\hline & $3 / 4$ & 18,9 & 4,3 & 14,6 & 5,8 & 8,8 & 8,8 & 1,1 & 0,8 & c & 12,8 & 32,8 \\
\hline & $5 / 6$ & 14,7 & c & 14,0 & 6,0 & 8,0 & 8,0 & c & c & c & 7,3 & 23,6 \\
\hline \multirow[t]{3}{*}{ Turquía } & $0 / 1 / 2$ & 7,5 & a & 7,5 & 5,7 & 1,8 & $\mathrm{~m}$ & 0,8 & 0,4 & 0,4 & 37,4 & 45,7 \\
\hline & $3 / 4$ & 8,1 & a & 8,1 & 7,1 & 1,1 & $\mathrm{~m}$ & 2,0 & 1,3 & 0,7 & 25,8 & 35,9 \\
\hline & $5 / 6$ & 12,0 & a & 12,0 & 11,2 & 0,8 & $\mathrm{~m}$ & 2,7 & 1,0 & 1,7 & 6,0 & 20,7 \\
\hline \multirow{3}{*}{$\begin{array}{l}\text { Media OCDE } \\
\text { (excluyendo Chile y Japón) }\end{array}$} & $0 / 1 / 2$ & 13,1 & & 9,5 & 3,2 & 7,6 & 5,7 & 2,9 & 2,3 & 1,1 & 54,0 & 69,3 \\
\hline & $3 / 4$ & 14,4 & & 13,8 & 5,3 & 9,3 & 5,9 & 2,5 & 1,6 & 1,2 & 25,5 & 42,4 \\
\hline & $5 / 6$ & 13,0 & & 12,8 & 7,4 & 6,1 & 4,4 & 2,6 & 1,3 & 1,8 & 11,3 & 26,2 \\
\hline \multirow[t]{3}{*}{ Media UE21 } & $0 / 1 / 2$ & 11,3 & & 7,7 & 4,1 & 5,8 & 2,2 & 2,9 & 2,1 & 1,4 & 58,2 & 71,4 \\
\hline & $3 / 4$ & 12,4 & & 11,8 & 5,1 & 7,6 & 2,8 & 2,8 & 1,7 & 1,7 & 27,5 & 42,5 \\
\hline & $5 / 6$ & 13,6 & & 13,5 & 8,2 & 6,3 & 3,7 & 3,6 & 1,8 & 2,9 & 13,6 & 29,8 \\
\hline \multirow{5}{*}{ 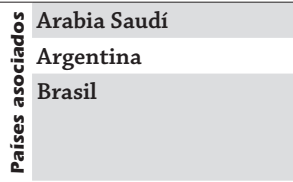 } & & $\mathrm{m}$ & $\mathrm{m}$ & $\mathrm{m}$ & $\mathrm{m}$ & $\mathrm{m}$ & $\mathrm{m}$ & $\mathrm{m}$ & $\mathrm{m}$ & $\mathrm{m}$ & $\mathrm{m}$ & $\mathrm{m}$ \\
\hline & & $\mathrm{m}$ & $\mathrm{m}$ & $\mathrm{m}$ & $\mathrm{m}$ & $\mathrm{m}$ & $\mathrm{m}$ & $\mathrm{m}$ & $\mathrm{m}$ & $\mathrm{m}$ & $\mathrm{m}$ & $\mathrm{m}$ \\
\hline & $0 / 1 / 2$ & 13,2 & a & 13,2 & 7,9 & 5,3 & $\mathrm{~m}$ & 3,6 & 3,6 & 0,1 & 28,9 & 45,7 \\
\hline & $3 / 4$ & 14,6 & a & 14,6 & 12,0 & 2,6 & $\mathrm{~m}$ & 1,6 & 1,6 & 0,1 & 7,1 & 23,4 \\
\hline & $5 / 6$ & 8,6 & a & 8,6 & 6,7 & 1,9 & $\mathrm{~m}$ & 1,0 & 0,9 & 0,1 & 4,7 & 14,3 \\
\hline China & & $\mathrm{m}$ & $\mathrm{m}$ & $\mathrm{m}$ & $\mathrm{m}$ & $\mathrm{m}$ & $\mathrm{m}$ & $\mathrm{m}$ & $\mathrm{m}$ & $\mathrm{m}$ & $\mathrm{m}$ & $\mathrm{m}$ \\
\hline Colombia & & $\mathrm{m}$ & $\mathrm{m}$ & $\mathrm{m}$ & $\mathrm{m}$ & $\mathrm{m}$ & $\mathrm{m}$ & $\mathrm{m}$ & $\mathrm{m}$ & $\mathrm{m}$ & $\mathrm{m}$ & $\mathrm{m}$ \\
\hline Federación Rusa & & $\mathrm{m}$ & $\mathrm{m}$ & $\mathrm{m}$ & $\mathrm{m}$ & $\mathrm{m}$ & $\mathrm{m}$ & $\mathrm{m}$ & $\mathrm{m}$ & $\mathrm{m}$ & $\mathrm{m}$ & $\mathrm{m}$ \\
\hline India & & $\mathrm{m}$ & $\mathrm{m}$ & $\mathrm{m}$ & $\mathrm{m}$ & $\mathrm{m}$ & $\mathrm{m}$ & $\mathrm{m}$ & $\mathrm{m}$ & $\mathrm{m}$ & $\mathrm{m}$ & $\mathrm{m}$ \\
\hline Indonesia & & $\mathrm{m}$ & $\mathrm{m}$ & $\mathrm{m}$ & $\mathrm{m}$ & $\mathrm{m}$ & $\mathrm{m}$ & $\mathrm{m}$ & $\mathrm{m}$ & $\mathrm{m}$ & $\mathrm{m}$ & $\mathrm{m}$ \\
\hline \multirow[t]{3}{*}{ Letonia } & $0 / 1 / 2$ & 1,3 & a & 1,3 & 1,2 & 0,1 & $\mathrm{~m}$ & 0,9 & 0,4 & 0,5 & 66,0 & 68,2 \\
\hline & $3 / 4$ & 12,3 & a & 12,3 & 9,7 & 2,7 & $\mathrm{~m}$ & 3,7 & 1,6 & 2,1 & 25,7 & 41,7 \\
\hline & $5 / 6$ & 12,9 & a & 12,9 & 10,0 & 2,9 & $\mathrm{~m}$ & 0,2 & 0,2 & $\mathrm{n}$ & 4,9 & 18,0 \\
\hline Sudáfrica & & $\mathrm{m}$ & $\mathrm{m}$ & $\mathrm{m}$ & $\mathrm{m}$ & $\mathrm{m}$ & $\mathrm{m}$ & $\mathrm{m}$ & $\mathrm{m}$ & $\mathrm{m}$ & $\mathrm{m}$ & $\mathrm{m}$ \\
\hline Media G20 & & $\mathrm{m}$ & $\mathrm{m}$ & $\mathrm{m}$ & $\mathrm{m}$ & $\mathrm{m}$ & $\mathrm{m}$ & $\mathrm{m}$ & $\mathrm{m}$ & $\mathrm{m}$ & $\mathrm{m}$ & $\mathrm{m}$ \\
\hline
\end{tabular}

Nota: Las filas que muestran los datos de todos los niveles de educación combinados están disponibles en Internet (véase Statlink más abajo).

1. Los estudiantes en programas de trabajo-estudio se consideran tanto en educación como empleados, con independencia de su situación en el mercado laboral según la definición de la OIT.

2. Jóvenes de 15 a 29 años ni empleados ni en educación o formación.

3. Año de referencia 2011.

4. Los datos se refieren a la población de 15 a 24 años.

Fuente: OCDE. Arabia Saudí, Argentina, China, Colombia, India, Indonesia y Sudáfrica: Instituto de Estadística de la UNESCO. Letonia: Eurostat. Para ver notas, consulte Anexo 3 (www.oecd.org/edu/eag.htm).

Para obtener más información acerca de los símbolos utilizados en lugar de los datos que faltan, consulte la Guía del lector.

StatLink 제느 http://dx.doi.org/10.1787/888933118979 
Tabla C5.4. [6/6] Porcentaje de jóvenes de 15 a 29 años en educación y no en educación, por nivel educativo alcanzado y situación laboral (2012)

\begin{tabular}{|c|c|c|c|c|c|c|c|c|c|c|c|c|}
\hline & \multirow{3}{*}{ 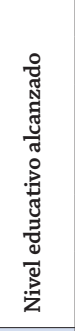 } & \multicolumn{10}{|c|}{ No en educación } & \multirow{3}{*}{ 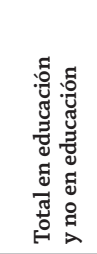 } \\
\hline & & \multirow[b]{2}{*}{ 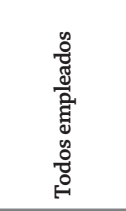 } & \multicolumn{3}{|c|}{ Tipo de empleo } & \multirow[b]{2}{*}{ 艺 } & \multirow[b]{2}{*}{ 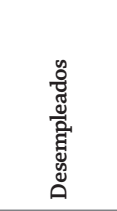 } & \multicolumn{2}{|c|}{ Tipo de empleo } & \multirow[b]{2}{*}{ 节 } & \multirow[b]{2}{*}{ 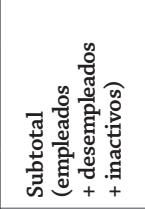 } & \\
\hline & & & 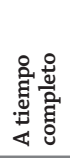 & 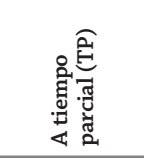 & 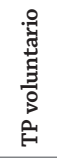 & & & 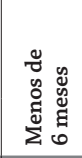 & 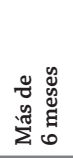 & & & \\
\hline \multirow[t]{3}{*}{ República Eslovaca } & $0 / 1 / 2$ & 3,6 & 1,6 & 2,0 & $\mathrm{~m}$ & 12,9 & 6,8 & 0,7 & 6,0 & 6,1 & 16,4 & 100 \\
\hline & $3 / 4$ & 49,8 & 47,9 & 1,9 & $\mathrm{~m}$ & 23,4 & 15,5 & 2,7 & 12,8 & 7,9 & 73,2 & 100 \\
\hline & $5 / 6$ & 52,8 & 51,1 & 1,7 & $\mathrm{~m}$ & 14,5 & 8,7 & 1,7 & 7,0 & 5,8 & 67,3 & 100 \\
\hline \multirow[t]{3}{*}{ Suecia } & $0 / 1 / 2$ & 8,6 & 6,8 & 1,7 & c & 7,5 & 3,3 & 2,2 & 0,9 & 4,3 & 16,1 & 100 \\
\hline & $3 / 4$ & 59,0 & 48,5 & 10,3 & 4,5 & 14,3 & 8,5 & 5,8 & 2,0 & 5,8 & 73,3 & 100 \\
\hline & $5 / 6$ & 45,4 & 41,4 & 3,8 & 1,8 & 5,2 & 2,9 & 2,2 & c & 2,4 & 50,6 & 100 \\
\hline \multirow{2}{*}{ Suiza } & $3 / 4$ & 56,5 & 48,9 & 7,6 & 7,5 & 10,7 & 4,8 & 3,0 & 1,7 & 5,9 & 67,2 & 100 \\
\hline & $5 / 6$ & 68,4 & 58,6 & 9,7 & 9,7 & 8,0 & 4,5 & 3,9 & c & 3,5 & 76,4 & 100 \\
\hline \multirow[t]{3}{*}{ Turquía } & $0 / 1 / 2$ & 25,0 & 21,6 & 3,4 & $\mathrm{~m}$ & 29,2 & 5,0 & 3,5 & 1,5 & 24,3 & 54,3 & 100 \\
\hline & $3 / 4$ & 32,8 & 31,3 & 1,5 & $\mathrm{~m}$ & 31,3 & 6,3 & 3,8 & 2,5 & 25,0 & 64,1 & 100 \\
\hline & $5 / 6$ & 54,8 & 52,1 & 2,8 & $\mathrm{~m}$ & 24,5 & 10,6 & 3,5 & 7,0 & 13,9 & 79,3 & 100 \\
\hline \multirow{3}{*}{$\begin{array}{l}\text { Media OCDE } \\
\text { (excluyendo Chile y Japón) }\end{array}$} & $0 / 1 / 2$ & 15,5 & 11,8 & 3,2 & 1,8 & 15,2 & 5,8 & 2,5 & 3,4 & 9,4 & 30,7 & 100 \\
\hline & $3 / 4$ & 41,8 & 35,5 & 6,3 & 3,3 & 15,8 & 7,4 & 3,7 & 3,8 & 8,7 & 57,6 & 100 \\
\hline & $5 / 6$ & 61,6 & 53,7 & 7,9 & 4,2 & 13,0 & 6,9 & 3,8 & 4,0 & 6,4 & 74,5 & 100 \\
\hline \multirow[t]{3}{*}{ Media UE21 } & $0 / 1 / 2$ & 13,2 & 9,8 & 2,6 & 1,4 & 15,5 & 6,8 & 2,4 & 4,4 & 8,7 & 28,6 & 100 \\
\hline & $3 / 4$ & 41,9 & 35,8 & 6,1 & 2,4 & 15,6 & 8,8 & 3,8 & 5,1 & 6,8 & 57,5 & 100 \\
\hline & $5 / 6$ & 58,0 & 51,6 & 6,4 & 2,4 & 12,3 & 7,4 & 3,5 & 5,1 & 5,1 & 70,2 & 100 \\
\hline
\end{tabular}

\begin{tabular}{|c|c|c|c|c|c|c|c|c|c|c|c|c|}
\hline Arabia Saudí & & $\mathrm{m}$ & $\mathrm{m}$ & $\mathrm{m}$ & $\mathrm{m}$ & $\mathrm{m}$ & $\mathrm{m}$ & $\mathrm{m}$ & $\mathrm{m}$ & $\mathrm{m}$ & $\mathrm{m}$ & $\mathrm{m}$ \\
\hline Argentina & & $\mathrm{m}$ & $\mathrm{m}$ & $\mathrm{m}$ & $\mathrm{m}$ & $\mathrm{m}$ & $\mathrm{m}$ & $\mathrm{m}$ & $\mathrm{m}$ & $\mathrm{m}$ & $\mathrm{m}$ & $\mathrm{m}$ \\
\hline \multirow[t]{3}{*}{ Brasil } & $0 / 1 / 2$ & 34,1 & 29,2 & 4,9 & $\mathrm{~m}$ & 20,2 & 4,0 & 3,8 & 0,2 & 16,3 & 54,3 & 100 \\
\hline & $3 / 4$ & 55,7 & 50,7 & 5,0 & $\mathrm{~m}$ & 20,9 & 6,6 & 6,2 & 0,4 & 14,3 & 76,6 & 100 \\
\hline & $5 / 6$ & 74,1 & 66,4 & 7,7 & $\mathrm{~m}$ & 11,6 & 4,5 & 4,2 & 0,4 & 7,1 & 85,7 & 100 \\
\hline China & & $\mathrm{m}$ & $\mathrm{m}$ & $\mathrm{m}$ & $\mathrm{m}$ & $\mathrm{m}$ & $\mathrm{m}$ & $\mathrm{m}$ & $\mathrm{m}$ & $\mathrm{m}$ & $\mathrm{m}$ & $\mathrm{m}$ \\
\hline Colombia & & $\mathrm{m}$ & $\mathrm{m}$ & $\mathrm{m}$ & $\mathrm{m}$ & $\mathrm{m}$ & $\mathrm{m}$ & $\mathrm{m}$ & $\mathrm{m}$ & $\mathrm{m}$ & $\mathrm{m}$ & $\mathrm{m}$ \\
\hline Federación Rusa & & $\mathrm{m}$ & $\mathrm{m}$ & $\mathrm{m}$ & $\mathrm{m}$ & $\mathrm{m}$ & $\mathrm{m}$ & $\mathrm{m}$ & $\mathrm{m}$ & $\mathrm{m}$ & $\mathrm{m}$ & $\mathrm{m}$ \\
\hline Indonesia & & $\mathrm{m}$ & $\mathrm{m}$ & $\mathrm{m}$ & $\mathrm{m}$ & $\mathrm{m}$ & $\mathrm{m}$ & $\mathrm{m}$ & $\mathrm{m}$ & $\mathrm{m}$ & $\mathrm{m}$ & $\mathrm{m}$ \\
\hline \multirow[t]{3}{*}{ Letonia } & $0 / 1 / 2$ & 14,9 & 13,0 & 1,9 & $\mathrm{~m}$ & 16,9 & 7,6 & 3,6 & 4,0 & 9,3 & 31,8 & 100 \\
\hline & $3 / 4$ & 36,3 & 34,0 & 2,3 & $\mathrm{~m}$ & 22,0 & 13,7 & 4,9 & 8,7 & 8,3 & 58,3 & 100 \\
\hline & $5 / 6$ & 65,7 & 60,7 & 5,1 & $\mathrm{~m}$ & 16,3 & 9,5 & 4,4 & 5,1 & 6,8 & 82,0 & 100 \\
\hline Sudáfrica & & $\mathrm{m}$ & $\mathrm{m}$ & $\mathrm{m}$ & $\mathrm{m}$ & $\mathrm{m}$ & $\mathrm{m}$ & $\mathrm{m}$ & $\mathrm{m}$ & $\mathrm{m}$ & $\mathrm{m}$ & $\mathrm{m}$ \\
\hline Media G20 & & $\mathrm{m}$ & $\mathrm{m}$ & $\mathrm{m}$ & $\mathrm{m}$ & $\mathrm{m}$ & $\mathrm{m}$ & $\mathrm{m}$ & $\mathrm{m}$ & $\mathrm{m}$ & $\mathrm{m}$ & $\mathrm{m}$ \\
\hline
\end{tabular}

Nota: Las filas que muestran los datos de todos los niveles de educación combinados están disponibles en Internet (véase Statlink más abajo)

1. Los estudiantes en programas de trabajo-estudio se consideran tanto en educación como empleados, con independencia de su situación en el mercado laboral según la definición de la OIT.

2. Jóvenes de 15 a 29 años ni empleados ni en educación o formación.

3. Año de referencia 2011.

4. Los datos se refieren a la población de 15 a 24 años.

Fuente: OCDE. Arabia Saudí, Argentina, China, Colombia, India, Indonesia y Sudáfrica: Instituto de Estadística de la UNESCO. Letonia: Eurostat. Para ver notas, consulte Anexo 3 (www.oecd.org/edu/eag.htm).

Para obtener más información acerca de los símbolos utilizados en lugar de los datos que faltan, consulte la Guía del lector.

StatLink 제개 http://dx.doi.org/10.1787/888933118979 
Tabla C5.5. [1/2] Tendencias del porcentaje de trabajadores de 15 a 29 años a tiempo parcial y a tiempo completo en educación y no en educación (2006-2012)

\begin{tabular}{|c|c|c|c|c|c|c|c|c|c|c|}
\hline & \multicolumn{5}{|c|}{2006} & \multicolumn{5}{|c|}{2010} \\
\hline & \multicolumn{2}{|c|}{$\begin{array}{c}\text { Empleados a TP } \\
\text { como \% de los jóvenes } \\
\text { de } 15 \text { a } 29 \text { años }\end{array}$} & \multicolumn{2}{|c|}{$\begin{array}{c}\text { Empleados a TC } \\
\text { como \% de los jóvenes } \\
\text { de } 15 \text { a } 29 \text { años }\end{array}$} & \multirow{2}{*}{$\begin{array}{c}\text { A TP } \\
\text { como \% de } \\
\text { los empleados }\end{array}$} & \multicolumn{2}{|c|}{$\begin{array}{c}\text { Empleados a TP } \\
\text { como \% de los jóvenes } \\
\text { de } 15 \text { a } 29 \text { años }\end{array}$} & \multicolumn{2}{|c|}{$\begin{array}{c}\text { Empleados a TC } \\
\text { como \% de los jóvenes } \\
\text { de } 15 \text { a } 29 \text { años }\end{array}$} & \multirow{2}{*}{$\begin{array}{c}\text { A TP } \\
\text { como \% de } \\
\text { los empleados }\end{array}$} \\
\hline & $\begin{array}{c}\text { En } \\
\text { educación }\end{array}$ & $\begin{array}{c}\text { No en } \\
\text { educación }\end{array}$ & $\begin{array}{c}\text { En } \\
\text { educación }\end{array}$ & $\begin{array}{c}\text { No en } \\
\text { educación }\end{array}$ & & $\begin{array}{c}\text { En } \\
\text { educación }\end{array}$ & $\begin{array}{c}\text { No en } \\
\text { educación }\end{array}$ & $\begin{array}{c}\text { En } \\
\text { educación }\end{array}$ & $\begin{array}{c}\text { No en } \\
\text { educación }\end{array}$ & \\
\hline & (1) & (2) & (3) & (4) & (5) & (21) & $(22)$ & (23) & (24) & (25) \\
\hline 㟔 Alemania & 5,4 & 5,7 & 12,9 & 28,4 & 21,2 & 5,4 & 5,7 & 13,2 & 31,0 & 20,1 \\
\hline ○ Australia & 16,2 & 8,0 & 9,3 & 35,6 & 35,0 & 15,9 & 8,6 & 8,6 & 34,0 & 36,5 \\
\hline Austria & 4,0 & 3,9 & 11,3 & 41,7 & 12,9 & 5,9 & 4,3 & 11,7 & 39,8 & 16,5 \\
\hline Bélgica & 1,3 & 6,8 & 1,6 & 36,1 & 17,6 & 1,3 & 6,3 & 1,8 & 32,7 & 18,1 \\
\hline Canadá & 15,7 & 6,4 & 2,9 & 37,5 & 35,4 & 15,0 & 7,0 & 2,8 & 35,5 & 36,5 \\
\hline Chile & $\mathrm{m}$ & $\mathrm{m}$ & $\mathrm{m}$ & $\mathrm{m}$ & $\mathrm{m}$ & $\mathrm{m}$ & $\mathrm{m}$ & $\mathrm{m}$ & $\mathrm{m}$ & $\mathrm{m}$ \\
\hline Corea & $\mathrm{m}$ & $\mathrm{m}$ & $\mathrm{m}$ & $\mathrm{m}$ & $\mathrm{m}$ & 2,7 & 2,6 & 2,3 & 32,7 & 13,0 \\
\hline Dinamarca & 24,2 & 5,9 & 8,1 & 29,8 & 44,1 & 23,1 & 4,8 & 7,6 & 27,4 & 44,2 \\
\hline España & 3,5 & 5,3 & 2,3 & 41,7 & 16,5 & 2,8 & 5,4 & 2,0 & 30,6 & 20,1 \\
\hline Estados Unidos & $\mathrm{m}$ & $\mathrm{m}$ & $\mathrm{m}$ & $\mathrm{m}$ & $\mathrm{m}$ & $\mathrm{m}$ & $\mathrm{m}$ & $\mathrm{m}$ & $\mathrm{m}$ & $\mathrm{m}$ \\
\hline Estonia & 3,2 & 1,3 & 5,0 & 36,6 & 9,8 & 3,2 & 1,2 & 5,7 & 31,0 & 10,6 \\
\hline Finlandia & 10,4 & 4,3 & 5,4 & 29,7 & 29,5 & 10,1 & 3,7 & 5,5 & 27,6 & 29,5 \\
\hline Francia & 2,7 & 5,2 & 3,3 & 33,5 & 17,6 & 2,0 & 5,9 & 4,2 & 33,5 & 17,3 \\
\hline Grecia & 0,9 & 2,9 & 1,4 & 38,7 & 8,7 & 1,0 & 3,1 & 1,9 & 34,7 & 10,2 \\
\hline Hungría & 0,3 & 0,6 & 3,8 & 32,5 & 2,1 & 0,3 & 0,8 & 1,5 & 30,0 & 3,4 \\
\hline Irlanda & $\mathrm{m}$ & $\mathrm{m}$ & $\mathrm{m}$ & $\mathrm{m}$ & $\mathrm{m}$ & 5,3 & 6,8 & 2,7 & 31,3 & 26,2 \\
\hline Islandia & 21,2 & 5,4 & 6,2 & 32,5 & 40,6 & 23,3 & 7,9 & 5,2 & 25,9 & 50,0 \\
\hline Israel & 7,7 & 7,8 & 3,5 & 21,3 & 38,5 & 6,9 & 7,2 & 3,6 & 21,3 & 36,0 \\
\hline Italia & 1,8 & 4,5 & 1,6 & 32,7 & 15,6 & 1,5 & 5,2 & 1,4 & 26,6 & 19,4 \\
\hline Japón ${ }^{1}$ & 7,0 & 11,3 & 0,2 & 22,9 & 44,2 & 7,7 & 8,8 & 0,2 & 19,6 & 45,5 \\
\hline Luxemburgo & 0,6 & 2,9 & 1,2 & 38,9 & 8,2 & 1,6 & 3,5 & 3,3 & 34,5 & 11,9 \\
\hline México & 3,5 & 5,0 & 3,9 & 37,9 & 16,8 & 6,6 & 10,5 & 3,3 & 32,6 & 32,0 \\
\hline Países Bajos & 22,8 & 6,9 & 7,9 & 32,9 & 41,9 & 24,6 & 7,6 & 7,9 & 30,3 & 45,5 \\
\hline Polonia & 2,2 & 2,8 & 5,8 & 26,9 & 13,3 & 2,1 & 2,0 & 6,9 & 32,8 & 9,5 \\
\hline Portugal & $\mathrm{m}$ & $\mathrm{m}$ & $\mathrm{m}$ & $\mathrm{m}$ & $\mathrm{m}$ & $\mathrm{m}$ & $\mathrm{m}$ & $\mathrm{m}$ & $\mathrm{m}$ & $\mathrm{m}$ \\
\hline Reino Unido & 9,8 & 7,4 & 6,0 & 36,8 & 26,8 & 8,0 & 7,0 & 4,8 & 33,7 & 26,9 \\
\hline República Checa & 0,6 & 0,6 & 1,7 & 42,5 & 2,6 & 1,3 & 0,7 & 2,6 & 37,9 & 4,7 \\
\hline República Eslovaca & 0,3 & 0,8 & 1,7 & 38,3 & 2,7 & 0,3 & 1,2 & 2,1 & 34,0 & 4,1 \\
\hline Suecia & 7,9 & 5,3 & 2,4 & 32,2 & 27,5 & 8,2 & 5,3 & 2,6 & 29,7 & 29,3 \\
\hline Suiza & 6,7 & 6,4 & 18,7 & 38,9 & 18,4 & 8,0 & 5,3 & 19,4 & 35,8 & 19,3 \\
\hline Turquía & 0,4 & 2,0 & 2,8 & 31,2 & 6,5 & 1,0 & 3,2 & 4,0 & 28,8 & 11,5 \\
\hline $\begin{array}{l}\text { Media OCDE } \\
\text { (excluyendo Chile, Corea, } \\
\text { Estados Unidos, Irlanda, } \\
\text { Japón y Portugal) }\end{array}$ & 7,4 & 4,8 & 5,1 & 34,3 & 22,0 & 7,7 & 5,1 & 5,1 & 31,3 & 24,3 \\
\hline Media UE21 & 5,7 & 3,9 & 4,9 & 34,8 & 17,7 & 5,9 & 4,1 & 4,9 & 31,9 & 19,5 \\
\hline ¿ Arabia Saudí & $\mathrm{m}$ & $\mathrm{m}$ & $\mathrm{m}$ & $\mathrm{m}$ & $\mathrm{m}$ & $\mathrm{m}$ & $\mathrm{m}$ & $\mathrm{m}$ & $\mathrm{m}$ & $\mathrm{m}$ \\
\hline Argentina & $\mathrm{m}$ & $\mathrm{m}$ & $\mathrm{m}$ & $\mathrm{m}$ & $\mathrm{m}$ & $\mathrm{m}$ & $\mathrm{m}$ & $\mathrm{m}$ & $\mathrm{m}$ & $\mathrm{m}$ \\
\hline ڤ̊ํ Brasil & $\mathrm{m}$ & $\mathrm{m}$ & $\mathrm{m}$ & $\mathrm{m}$ & $\mathrm{m}$ & $\mathrm{m}$ & $\mathrm{m}$ & $\mathrm{m}$ & $\mathrm{m}$ & $\mathrm{m}$ \\
\hline y China & $\mathrm{m}$ & $\mathrm{m}$ & $\mathrm{m}$ & $\mathrm{m}$ & $\mathrm{m}$ & $\mathrm{m}$ & $\mathrm{m}$ & $\mathrm{m}$ & $\mathrm{m}$ & $\mathrm{m}$ \\
\hline Colombia & $\mathrm{m}$ & $\mathrm{m}$ & $\mathrm{m}$ & $\mathrm{m}$ & $\mathrm{m}$ & $\mathrm{m}$ & $\mathrm{m}$ & $\mathrm{m}$ & $\mathrm{m}$ & $\mathrm{m}$ \\
\hline Federación Rusa & $\mathrm{m}$ & $\mathrm{m}$ & $\mathrm{m}$ & $\mathrm{m}$ & $\mathrm{m}$ & $\mathrm{m}$ & $\mathrm{m}$ & $\mathrm{m}$ & $\mathrm{m}$ & $\mathrm{m}$ \\
\hline India & $\mathrm{m}$ & $\mathrm{m}$ & $\mathrm{m}$ & $\mathrm{m}$ & $\mathrm{m}$ & $\mathrm{m}$ & $\mathrm{m}$ & $\mathrm{m}$ & $\mathrm{m}$ & $\mathrm{m}$ \\
\hline Indonesia & $\mathrm{m}$ & $\mathrm{m}$ & $\mathrm{m}$ & $\mathrm{m}$ & $\mathrm{m}$ & $\mathrm{m}$ & $\mathrm{m}$ & $\mathrm{m}$ & $\mathrm{m}$ & $\mathrm{m}$ \\
\hline Letonia & $\mathrm{m}$ & $\mathrm{m}$ & $\mathrm{m}$ & $\mathrm{m}$ & $\mathrm{m}$ & 1,9 & 2,9 & 5,2 & 29,7 & 12,2 \\
\hline Sudáfrica & $\mathrm{m}$ & $\mathrm{m}$ & $\mathrm{m}$ & $\mathrm{m}$ & $\mathrm{m}$ & $\mathrm{m}$ & $\mathrm{m}$ & $\mathrm{m}$ & $\mathrm{m}$ & $\mathrm{m}$ \\
\hline Media G20 & $\mathrm{m}$ & $\mathrm{m}$ & $\mathrm{m}$ & $\mathrm{m}$ & $\mathrm{m}$ & $\mathrm{m}$ & $\mathrm{m}$ & $\mathrm{m}$ & $\mathrm{m}$ & $\mathrm{m}$ \\
\hline
\end{tabular}

Nota: Las columnas que muestran más años están disponibles en Internet (véase StatLink más abajo).

1. Los datos se refieren a la población de 15 a 24 años.

Fuente: OCDE. Arabia Saudí, Argentina, China, Colombia, India, Indonesia y Sudáfrica: Instituto de Estadística de la UNESCO. Letonia: Eurostat. Para ver notas, consulte Anexo 3 (www.oecd.org/edu/eag.htm).

Para obtener más información acerca de los símbolos utilizados en lugar de los datos que faltan, consulte la Guía del lector.

StatLink 제내 http://dx.doi.org/10.1787/888933118998 
Tabla C5.5. [2/2] Tendencias del porcentaje de trabajadores de 15 a 29 años a tiempo parcial y a tiempo completo en educación y no en educación (2006-2012)

\begin{tabular}{|c|c|c|c|c|c|}
\hline \multicolumn{6}{|c|}{2012} \\
\hline \multicolumn{2}{|c|}{$\begin{array}{c}\text { Empleados a TP como \% } \\
\text { de los jóvenes de } 15 \text { a } 29 \text { años }\end{array}$} & \multicolumn{2}{|c|}{$\begin{array}{c}\text { Empleados a TC como \% } \\
\text { de los jóvenes de } 15 \text { a } 29 \text { años }\end{array}$} & \multirow{2}{*}{$\begin{array}{c}\text { A TP como \% } \\
\text { de los empleados }\end{array}$} & \multirow{2}{*}{$\begin{array}{c}\text { Tiempo parcial } \\
\text { involuntario / tiempo } \\
\text { parcial total }\end{array}$} \\
\hline En educación & No en educación & En educación & No en educación & & \\
\hline (32) & (33) & (34) & (35) & (36) & (37) \\
\hline 6,6 & 5,4 & 12,8 & 32,1 & 21,1 & 86,1 \\
\hline 16,3 & 9,3 & 8,1 & 33,8 & 37,9 & 30,7 \\
\hline 6,2 & 4,6 & 12,0 & 40,2 & 17,2 & $\mathrm{~m}$ \\
\hline 1,8 & 7,9 & 1,6 & 31,6 & 22,6 & 46,9 \\
\hline 14,7 & 7,1 & 2,8 & 35,3 & 36,5 & 21,1 \\
\hline $\mathrm{m}$ & $\mathrm{m}$ & $\mathrm{m}$ & $\mathrm{m}$ & $\mathrm{m}$ & $\mathrm{m}$ \\
\hline 3,2 & 2,3 & 2,2 & 32,7 & 13,6 & 6,5 \\
\hline 24,8 & 7,5 & 6,0 & 21,8 & 53,7 & $\mathrm{~m}$ \\
\hline 8,8 & 1,8 & 8,3 & 26,9 & 23,3 & $\mathrm{~m}$ \\
\hline 2,4 & 5,6 & 1,8 & 24,3 & 23,5 & 62,0 \\
\hline 10,3 & 7,5 & 4,6 & 30,7 & 33,5 & 23,0 \\
\hline 3,1 & 1,5 & 9,4 & 35,0 & 9,5 & c \\
\hline 10,6 & 3,4 & 6,2 & 29,1 & 28,3 & $\mathrm{~m}$ \\
\hline 2,1 & 5,7 & 4,2 & 31,9 & 17,9 & $\mathrm{~m}$ \\
\hline 2,3 & 1,7 & 13,5 & 12,3 & 13,3 & 71,3 \\
\hline 0,5 & 1,8 & 1,6 & 31,2 & 6,5 & 51,2 \\
\hline 5,2 & 7,1 & 2,4 & 27,7 & 29,0 & $\mathrm{~m}$ \\
\hline 24,2 & 4,7 & 5,7 & 27,4 & 46,5 & $\mathrm{~m}$ \\
\hline 8,2 & 7,1 & 4,8 & 33,9 & 28,3 & 19,4 \\
\hline 1,5 & 6,5 & 1,0 & 24,2 & 24,0 & 75,1 \\
\hline 8,5 & 8,6 & 0,3 & 17,4 & 49,1 & $\mathrm{~m}$ \\
\hline 3,1 & 2,6 & 3,1 & 30,9 & 14,3 & $\mathrm{~m}$ \\
\hline 6,7 & 10,4 & 3,7 & 32,1 & 32,2 & 16,7 \\
\hline 15,4 & 7,0 & 0,4 & 37,6 & 36,3 & $\mathrm{~m}$ \\
\hline 11,3 & 7,7 & 5,6 & 32,8 & 33,2 & 23,1 \\
\hline 29,2 & 13,8 & 5,1 & 21,6 & 61,7 & $\mathrm{~m}$ \\
\hline 2,1 & 2,1 & 5,7 & 33,3 & 9,7 & 81,5 \\
\hline $\mathrm{m}$ & $\mathrm{m}$ & $\mathrm{m}$ & $\mathrm{m}$ & $\mathrm{m}$ & $\mathrm{m}$ \\
\hline 7,2 & 8,1 & 4,7 & 31,3 & 28,6 & 25,4 \\
\hline 1,4 & 1,0 & 2,7 & 37,8 & 5,6 & 8,6 \\
\hline 0,3 & 1,9 & 1,2 & 34,2 & 5,7 & $\mathrm{~m}$ \\
\hline 8,6 & 5,6 & 2,8 & 32,0 & 28,9 & 30,9 \\
\hline 7,5 & 6,1 & 19,5 & 36,4 & 19,6 & c \\
\hline 1,5 & 2,9 & 6,7 & 27,8 & 11,2 & $\mathrm{~m}$ \\
\hline
\end{tabular}

\begin{tabular}{|c|c|c|c|c|c|c|}
\hline $\begin{array}{l}\text { Media OCDE } \\
\text { (excluyendo Chile, Corea, } \\
\text { Estados Unidos, Irlanda, } \\
\text { Japón y Portugal) }\end{array}$ & 8,2 & 5,5 & 5,6 & 30,2 & 25,7 & 43,3 \\
\hline Media UE21 & 6,4 & 4,8 & 5,3 & 29,5 & 22,2 & 53,9 \\
\hline
\end{tabular}

\begin{tabular}{|c|c|c|c|c|c|c|}
\hline $\begin{array}{l}\text { Arabia Saudí } \\
\text { ¿ } \\
\text { Argentina }\end{array}$ & $\begin{array}{l}\mathrm{m} \\
\mathrm{m}\end{array}$ & $\begin{array}{l}\mathrm{m} \\
\mathrm{m}\end{array}$ & $\begin{array}{l}\mathrm{m} \\
\mathrm{m}\end{array}$ & $\begin{array}{l}\mathrm{m} \\
\mathrm{m}\end{array}$ & $\begin{array}{l}\mathrm{m} \\
\mathrm{m}\end{array}$ & $\begin{array}{l}\mathrm{m} \\
\mathrm{m}\end{array}$ \\
\hline $\begin{array}{l}\text { ֻั Brasil } \\
\text { y̆ China }\end{array}$ & $\begin{array}{r}4,0 \\
\mathrm{~m}\end{array}$ & $\begin{array}{r}5,1 \\
\mathrm{~m}\end{array}$ & $\begin{array}{r}9,4 \\
\mathrm{~m}\end{array}$ & $\begin{array}{r}40,0 \\
\mathrm{~m}\end{array}$ & $\begin{array}{r}15,6 \\
\mathrm{~m}\end{array}$ & $\begin{array}{l}\mathrm{m} \\
\mathrm{m}\end{array}$ \\
\hline $\begin{array}{l}\text { Colombia } \\
\text { Federación Rusa }\end{array}$ & $\begin{array}{l}\mathrm{m} \\
\mathrm{m}\end{array}$ & $\begin{array}{l}\mathrm{m} \\
\mathrm{m}\end{array}$ & $\begin{array}{l}\mathrm{m} \\
\mathrm{m}\end{array}$ & $\begin{array}{l}\mathrm{m} \\
\mathrm{m}\end{array}$ & $\begin{array}{l}\mathrm{m} \\
\mathrm{m}\end{array}$ & $\begin{array}{l}\mathrm{m} \\
\mathrm{m}\end{array}$ \\
\hline $\begin{array}{l}\text { India } \\
\text { Indonesia }\end{array}$ & $\begin{array}{l}\mathrm{m} \\
\mathrm{m}\end{array}$ & $\begin{array}{l}\mathrm{m} \\
\mathrm{m}\end{array}$ & $\begin{array}{l}\mathrm{m} \\
\mathrm{m}\end{array}$ & $\begin{array}{l}\mathrm{m} \\
\mathrm{m}\end{array}$ & $\begin{array}{l}\mathrm{m} \\
\mathrm{m}\end{array}$ & $\begin{array}{l}\mathrm{m} \\
\mathrm{m}\end{array}$ \\
\hline $\begin{array}{l}\text { Letonia } \\
\text { Sudáfrica }\end{array}$ & $\begin{array}{r}1,8 \\
\mathrm{~m}\end{array}$ & $\begin{array}{r}2,7 \\
\mathrm{~m}\end{array}$ & $\begin{array}{r}6,8 \\
\mathrm{~m}\end{array}$ & $\begin{array}{r}31,9 \\
\mathrm{~m}\end{array}$ & $\begin{array}{r}10,5 \\
\mathrm{~m}\end{array}$ & $\begin{array}{l}\mathrm{m} \\
\mathrm{m}\end{array}$ \\
\hline
\end{tabular}

\section{Media G20}

1. Los datos se refieren a la población de 15 a 24 años.

Fuente: OCDE. Arabia Saudí, Argentina, China, Colombia, India, Indonesia y Sudáfrica: Instituto de Estadística de la UNESCO. Letonia: Eurostat. Para ver notas, consulte Anexo 3 (www.oecd.org/edu/eag.htm).

Para obtener más información acerca de los símbolos utilizados en lugar de los datos que faltan, consulte la Guía del lector.

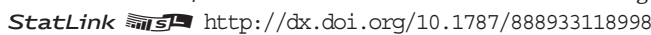





\section{¿CUÁNTOS ADULTOS PARTICIPAN EN LA EDUCACIÓN Y EL APRENDIZANE?}

- Más del 50\% de los adultos de todos los países participa en educación formal y/o no formal en un año determinado. La proporción oscila entre más de dos de cada tres personas en Dinamarca, Finlandia y Suecia, una de cada tres en República Eslovaca, una de cada cuatro en Italia y una de cada cinco en Federación Rusa.

- La participación en educación formal y/o no formal está fuertemente relacionada con los niveles de comprensión lectora, el nivel educativo alcanzado, el grupo de edad, el estatus en la población activa y el nivel educativo de los padres.

- En conjunto, el $25 \%$ de los adultos de los países de la OCDE deseaban participar en actividades de aprendizaje en los 12 meses anteriores a la Encuesta sobre las Competencias de los Adultos (PIAAC), pero no habían comenzado a hacerlo. Aproximadamente el $45 \%$ de estos participantes potenciales citaban la carga de trabajo o las responsabilidades familiares como motivo para no comenzar la actividad.

- Como media en el conjunto de los países, el $10 \%$ de las personas de 25 a 64 años participa en actividades de aprendizaje organizadas por el sistema educativo formal. Esta proporción varía desde el $2 \%$ en Japón hasta el $17 \%$ en Australia.

\section{Gráfico C6.1. Participación en educación formal y/o no formal, 2012 Personas de 25 a 64 años}

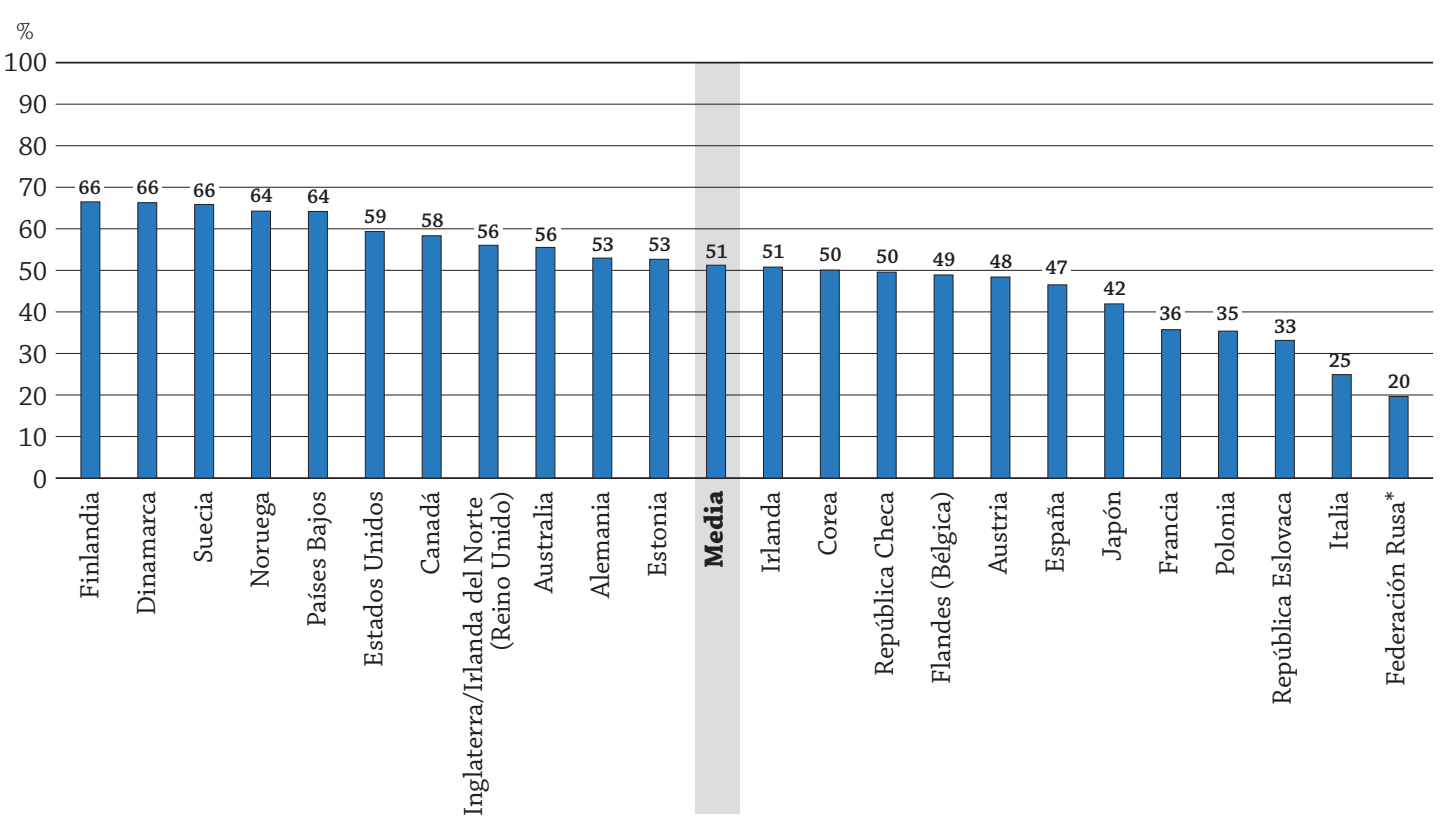

* Para los datos de Federación Rusa, véase nota en la sección de Metodología.

Los países están clasificados en orden descendente del porcentaje de personas de 25 a 64 años que participan en educación formal y/o no formal.

Fuente: OCDE. Tabla C6.4. Para ver notas, consulte Anexo 3 (www.oecd.org/edu/eag.htm).

StatLink 젠 http://dx.doi.org/10.1787/888933119207

\section{Contexto}

La educación para adultos puede jugar un papel importante a la hora de ayudar a la población adulta a desarrollar y mantener competencias clave de procesamiento de la información, así como a adquirir otros conocimientos y competencias a lo largo de sus vidas. Es crucial proporcionar y garantizar el acceso a oportunidades de aprendizaje organizadas para adultos más allá de la educación formal inicial, especialmente para aquellos trabajadores que necesitan adaptarse a cambios a lo largo de sus carreras. La relevancia de las oportunidades de formación continua se extiende hoy día tanto a los trabajadores en puestos que requieren altas cualificaciones como a los que requieren bajas cualificaciones. En los secto- 
res de alta tecnología, los trabajadores han de actualizar sus competencias y mantenerse al día en técnicas que cambian con mucha rapidez. Los trabajadores de sectores de bajo nivel y aquellos que realizan labores que exigen una cualificación baja deben aprender a adaptarse, ya que corren un mayor riesgo de perder su empleo debido a que las labores rutinarias son realizadas por máquinas cada vez con más frecuencia y las empresas pueden trasladarse a países con costes laborales inferiores (OECD, 2013).

El aprendizaje a lo largo de la vida también puede contribuir a objetivos no económicos como la satisfacción personal, mejoras en la salud, la participación cívica y la inclusión social (ver Indicador «¿Cuáles son los resultados sociales de la educación?» en ediciones previas de Panorama de la educación). La gran variación en la participación y las actividades de aprendizaje para adultos entre los países de la OCDE en niveles similares de desarrollo económico sugiere que hay diferencias significativas en cuanto a las culturas de aprendizaje, las oportunidades de formación en el trabajo y las estructuras educativas para adultos. Los resultados de la Encuesta sobre las Competencias de los Adultos, producto del Programa para la Evaluación Internacional de las Competencias de los Adultos (PIAAC, por sus siglas en inglés) de la OCDE, muestran una clara relación entre el grado de participación en actividades organizadas de aprendizaje para adultos y el nivel medio en competencias clave de procesamiento de la información en un país determinado.

\section{Otros resultados}

- La participación en educación formal y/o no formal en todos los países está fuertemente relacionada con los niveles en competencias clave y con el nivel educativo alcanzado. Estos factores se combinan y producen un círculo virtuoso para las personas que tienen niveles altos de competencias y un alto nivel educativo, ya que tienden a adquirir aún más competencias asistiendo a actividades de educación para adultos. Los factores también se combinan para establecer un círculo vicioso en las personas con bajo nivel educativo, niveles bajos de competencias y ningún acceso a la formación institucional que pudiera enmendar estas deficiencias en las competencias.

- La participación en educación formal y/o no formal es más común en los adultos jóvenes (de 25 a 34 años) y se reduce de forma constante en los adultos de más edad. Esta pauta se cumple en cada nivel de comprensión lectora. En los países con una participación global alta en educación formal y/o no formal, la edad y las competencias lectoras tienen menos influencia en la participación en actividades de aprendizaje para adultos.

- Los adultos que han crecido en familias desfavorecidas (definidos aquí como aquellos cuyos dos progenitores tienen un nivel educativo inferior a la educación secundaria superior) participan menos en actividades educativas formales y/o no formales para adultos. Esto se cumple incluso en aquellos que han alcanzado niveles altos de comprensión lectora según la Encuesta sobre las Competencias de los Adultos.

- En general, los países con tasas altas de participación de la población adulta en educación formal también tienden a tener tasas altas de participación de adultos en educación no formal. Dos de cada tres adultos que participan en educación formal participan también en educación no formal. 


\section{Análisis}

\section{Grandes diferencias entre paises}

Como media en el conjunto de los países, el $51 \%$ de las personas de 25 a 64 años participaron al menos en una actividad de aprendizaje en educación formal y/o no formal en el año anterior. Los países que han realizado la encuesta se pueden dividir en seis grupos, según diferencias significativas en sus tasas de participación.

- El Grupo 1, con tasas de participación superiores al 60\%, incluye a Dinamarca, Finlandia, Noruega, Países Bajos y Suecia.

- El Grupo 2, con tasas de participación entre el 55\% y el 59\%, incluye a Australia, Canadá, Estados Unidos e Inglaterra/Irlanda del Norte (Reino Unido).

- El Grupo 3, con tasas de participación cercanas a la media de la OCDE del 48\% al 53\%, incluye a Alemania, Austria, Corea, Estonia, Flandes (Bélgica), Irlanda y República Checa.

- El Grupo 4 está formado por dos países con tasas de participación entre el 38\% y el 47\%: España y Japón.

- El Grupo 5, con tasas de participación entre el 33\% y el 36 \%, incluye a Francia, Polonia y República Eslovaca.

- El Grupo 6, con tasas de participación inferiores al 25\%, está formado por Federación Rusa e Italia.

\section{La educación conduce a más educación}

Tanto los niveles de competencias como el nivel educativo alcanzado afectan al aprendizaje de la población adulta. Como media en el conjunto de los países, el $30 \%$ de quienes tienen niveles bajos de comprensión lectora (Nivel 1 o inferior en la Encuesta sobre las Competencias de los Adultos) participaron en educación formal y/o no formal durante los 12 meses anteriores a la encuesta, mientras que de los adultos con un nivel alto de comprensión lectora (Niveles 4 o 5) lo hicieron el 74\%. Una persona con un nivel de comprensión alto tenía, por tanto, casi 2,5 veces más probabilidades de participar en educación formal y/o no formal que una persona con un nivel bajo de comprensión lectora. Aproximadamente el $27 \%$ de los adultos que no tienen educación secundaria superior participaron en educación formal y/o no formal, mientras que de los adultos con educación terciaria lo hicieron el $71 \%$. Los adultos con educación terciaria tenían, pues, 2,5 veces más probabilidades de participar en educación formal y/o no formal que los adultos sin educación secundaria superior. La fuerte relación positiva entre la participación en educación formal y/o no formal, la compresión lectora y el nivel educativo alcanzado es constante en todos los países (Tabla C6.1 [L]).

Los niveles de comprensión lectora y el nivel educativo alcanzado parecen tener un efecto de refuerzo mutuo en la participación en educación formal y/o no formal. Alrededor del 79\% de las personas con altos niveles de competen-

\section{Gráfico C6.2. Participación de los adultos en educación formal y/o no formal, por nivel de comprensión lectora y nivel educativo alcanzado (2012) \\ Encuesta sobre las Competencias de los Adultos, de 25 a 64 años, promedio}

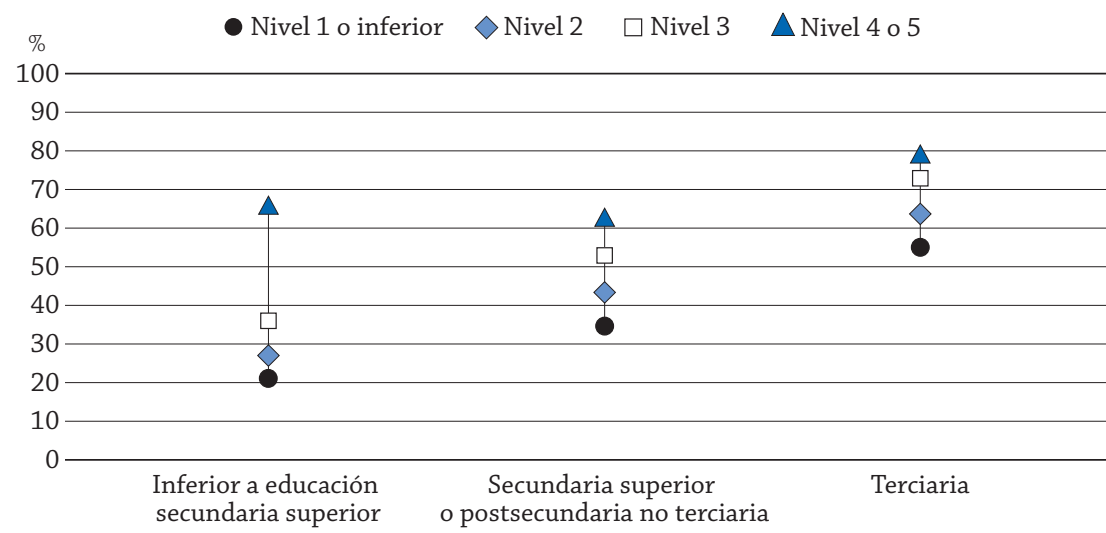

Nota: La participación de los adultos en educación formal y/o no formal, por nivel de comprensión lectora, por nivel educativo alcanzado y por países está disponible en Internet.

Fuente: OCDE. Tabla C6.2a (L). Para ver notas, consulte Anexo 3 (www.oecd.org/edu/eag.htm).

StatLink त्ताजा http://dx.doi.org/10.1787/888933119226 
cia en lectura y un nivel educativo alto participaron en educación formal y/o no formal. Tenían casi cuatro veces más probabilidades de participar en esta que las personas con niveles bajos de comprensión lectora y que no habían alcanzado la educación secundaria superior.

Solo el $21 \%$ de este último grupo participó en educación. Estos aspectos que se refuerzan mutuamente crean un ciclo virtuoso para los adultos que poseen altas competencias y un ciclo vicioso para aquellos con bajos niveles de competencias. Al contrario que los adultos con menores niveles de competencias, aquellos con mayores niveles tienen más probabilidades de participar en actividades de aprendizaje que las mejoren, lo que a su vez proporciona a estos adultos más probabilidades de continuar beneficiándose de oportunidades de aprendizaje (Gráfico C6.2).

Dinamarca, Noruega, Países Bajos y Suecia son los países más exitosos en proporcionar oportunidades de participar en educación formal y/o no formal a los adultos que puntuaron en el Nivel 1 o inferior de la Encuesta sobre las Competencias de los Adultos y que tienen un nivel educativo inferior a la secundaria superior: en cada uno de esos países, más del 30\% de este grupo de adultos participan en educación (Tabla C6.2a [L]).

\section{Diferencias de la participación en educación entre grupos sociales}

Hay diferencias considerables entre países en el nivel de participación de la población adulta en actividades de aprendizaje institucionalizadas. Diversos factores influyen en la tasa de participación en el aprendizaje para adultos de forma similar en todas las entidades nacionales que fueron encuestadas. Estos factores incluyen la situación en la población activa, la edad, el nivel educativo de los padres y, en menor medida, el sexo.

En los países de la OCDE, los adultos empleados participan con más frecuencia en educación formal y/o no formal (59\%) que los adultos desempleados (44\%) y que los adultos que se encuentran fuera de la población activa (22\%) (Gráfico C6.3). En los adultos empleados, aquellos con una alta comprensión lectora (Nivel 4 o 5) tienen casi el doble de probabilidades de participar en educación que aquellos con niveles bajos de comprensión (en el Nivel 1 o inferior). La mayoría de los países muestran esta pauta, mientras que las diferencias de las tasas de participación relacionadas

\section{Gráfico C6.3. Participación en educación formal y/o no formal, por situación en el mercado laboral (2012)}

Personas de 25 a 64 años

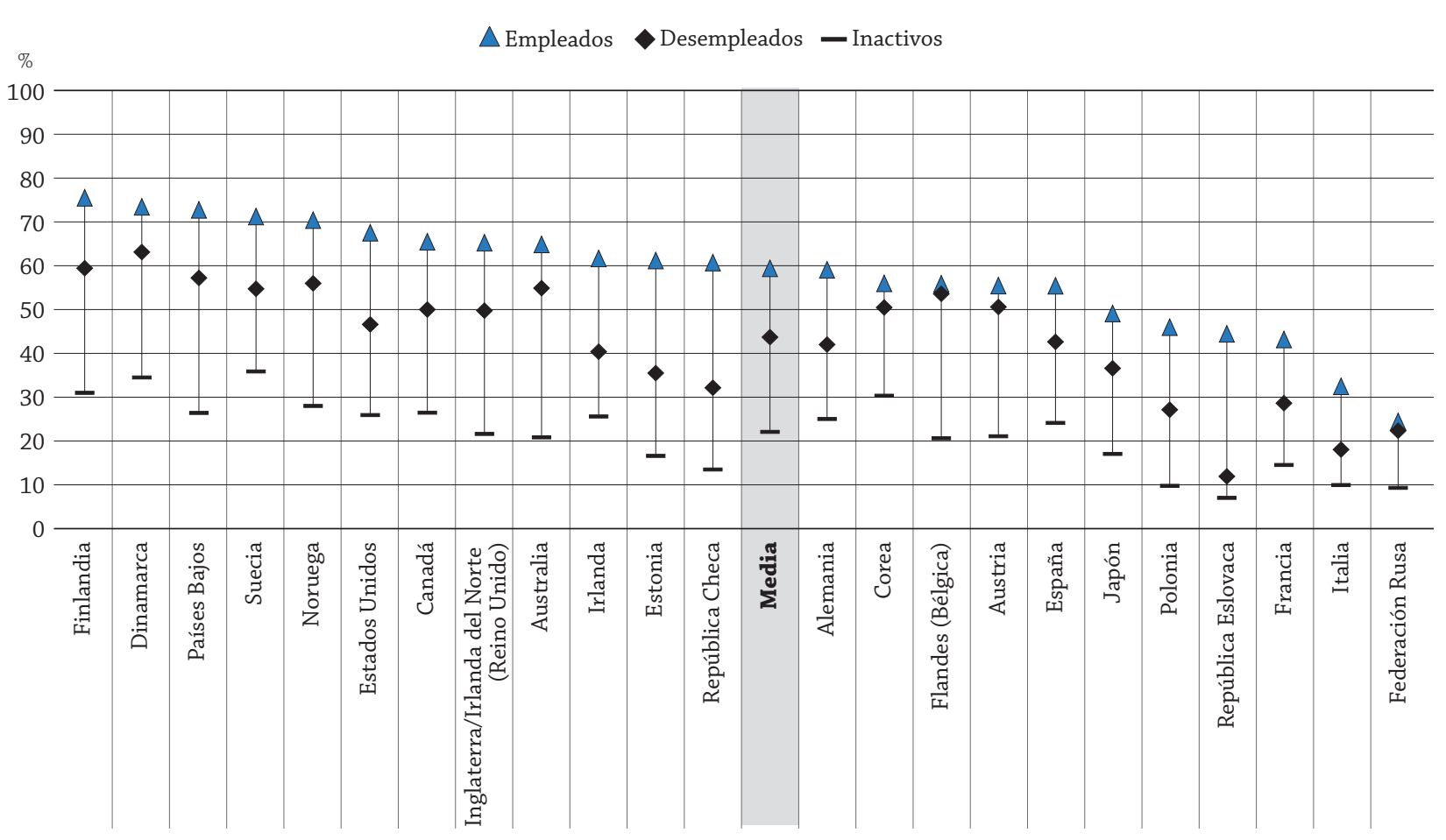

* Para los datos de Federación Rusa, véase nota en la sección de Metodología.

Los países están clasificados en orden descendente del porcentaje de personas empleadas de 25 y a 64 años que participan en educación formal y/o no formal. Fuente: OCDE. Tabla C6.2d (L), disponible en Internet. Para ver notas, consulte Anexo 3 (www.oecd.org/edu/eag.htm).

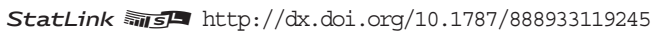


con el nivel de comprensión lectora tienden a ser mayores en los países con tasas de participación globalmente bajas (correlación = -0,54) (Tabla C6.2d [L], disponible en Internet).

En muchos países, la participación en diferentes tipos de aprendizaje para adultos -formal, no formal e informaltiende a reducirse en las personas de mayor edad (OECD, 2011 y Statistics Canada, 2011). Como media en los países encuestados, el grupo de edad más joven (de 25 a 34 años) participa más en educación formal y/o no formal (tasa de participación del $62 \%$ ), mientras que el grupo de mayor edad (de 55 a 64 años) es el que menos participa (tasa de participación del $34 \%$ ). Los grupos de edad que se encuentran entre estos dos extremos muestran niveles de participación moderados ( $56 \%$ para las personas de 35 a 44 años, $51 \%$ para personas de 45 a 54 años) (Tabla C6.2b [L], disponible en Internet).

La disminución constante de la participación en educación formal y/o no formal por grupo de edad se mantiene en cada nivel de comprensión lectora. Por tanto, los adultos de menos edad con altas competencias lectoras (Nivel 4 o 5 ) son los que más participan (79\%), mientras que los adultos de más edad con bajas competencias lectoras (Nivel 1 o inferior) muestran la participación más baja (21\%). Los adultos más jóvenes con mayores niveles de competencia tienen, pues, 3,8 veces más probabilidades de participar en educación formal y/o no formal que los adultos de mayor edad con menores niveles de competencia (Tabla C6.2b [L], disponible en Internet).

La edad y la comprensión lectora parecen reforzar mutuamente el aprendizaje en la edad adulta. Esta relación se verifica en cada país encuestado, aunque hay algunas diferencias en cuanto a la fuerza de la misma. En Estados Unidos, por ejemplo, la diferencia por grupo de edad y comprensión lectora es más pequeña: las personas jóvenes con niveles altos de comprensión lectora tienen 2,6 veces más probabilidades de participar en educación formal y/o no formal que los adultos de más edad con niveles bajos de competencia. La mayor diferencia se registra en Polonia,

\section{Gráfico C6.4. Participación en educación formal y/o no formal de adultos con puntuación en los Niveles 4/5 de comprensión lectora, por nivel educativo de los padres (2012)} Encuesta sobre las Competencias de los Adultos, de 25 a 64 años

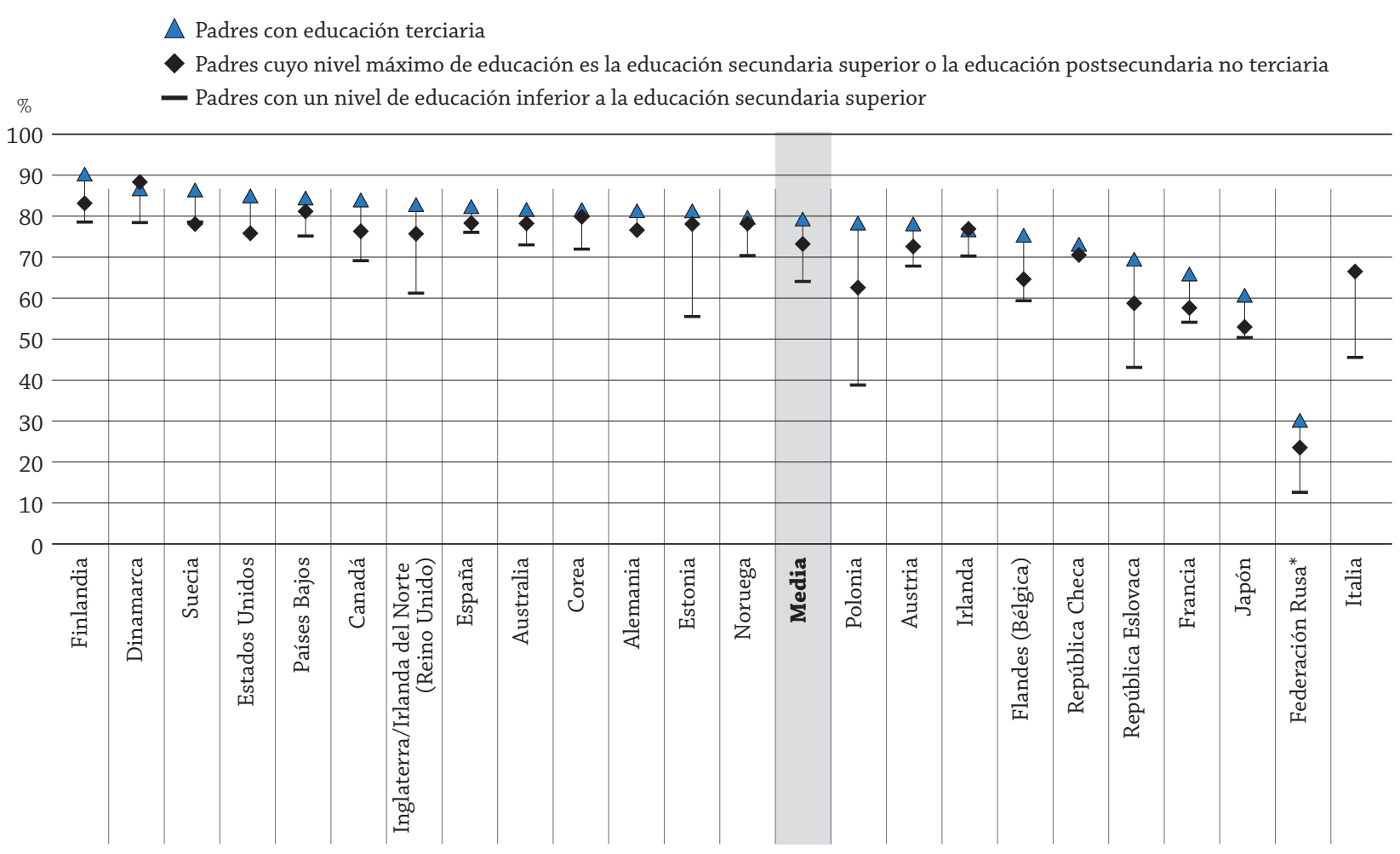

* Para los datos de Federación Rusa, véase nota en la sección de Metodología.

Los países están clasificados en orden descendente del porcentaje de personas de 25 a 64 años que participan en educación formal y/o no formal, que puntúan en los niveles 4 o 5 de comprensión lectora y cuyos padres han alcanzado la educación terciaria.

Fuente: OCDE. Tabla C6.2e (L), disponible en Internet. Para ver notas, consulte Anexo 3 (www.oecd.org/edu/eag.htm).

StatLink 젶ㄴ http://dx.doi.org/10.1787/888933119264 
donde las personas jóvenes con mayores competencias tienen más de nueve veces más probabilidades de participar que los adultos con más edad y menos competencias. Cuanto más alta es la tasa de participación global de un país, menor es la ventaja relativa de estos adultos jóvenes; cuanto menor es la tasa global de participación, mayor es su ventaja relativa (correlación $=-0,86$ ) (Tabla C6.2b [L], disponible en Internet).

Hay varias posibles razones para las tasas más bajas de participación en los adultos mayores. Entre ellas está el elevado número de inactivos en las personas de más edad (véase Indicador A5), la baja inversión de los empleadores en las competencias de sus empleados de más edad y la menor cantidad de incentivos para mejorar las capacidades de los trabajadores de más edad.

El nivel educativo de los padres puede verse como un indicativo del estatus socioeconómico (OECD, 2013). La educación de los padres está relacionada con el nivel educativo alcanzado por una persona (véase Indicador A4) y con sus niveles de competencia (OECD, 2013). La participación de los adultos en educación formal y/o no formal puede contribuir a compensar los efectos negativos de la desventaja en etapas anteriores de la vida.

Como media en el conjunto de los países, el $68 \%$ de los adultos que tenían al menos un progenitor con educación terciaria participaron en educación formal y/o no formal. De los adultos que tenían al menos un progenitor con educación secundaria superior participaron alrededor del $56 \%$, mientras que de la población adulta cuyos padres, en ninguno de los dos casos, había alcanzado la educación secundaria superior participaron el $40 \%$. Los adultos cuyos padres han alcanzado la educación terciaria tienen 1,7 veces más probabilidades de participar en educación para adultos que aquellos cuyos padres no han alcanzado la educación secundaria superior (Tabla C6.2e [L], disponible en Internet). El Gráfico C6.4 muestra que, de los adultos que puntúan en los Niveles 4 o 5 de comprensión lectora en la Encuesta sobre las Competencias de los Adultos, el 79 \% de los que tienen al menos un progenitor que alcanzó la educación terciaria participan en educación formal y/o no formal, el $73 \%$ de los que tienen al menos un progenitor con educación secundaria superior también participan, y de aquellos cuyos padres no tienen educación secundaria superior participan el $64 \%$.

Los países que tienen una tasa global alta de participación en educación formal y/o no formal muestran diferencias menores en la participación relacionadas con el nivel educativo de los padres (correlación = -0,74). Los países que más han logrado reducir la influencia del nivel educativo de los padres en la participación de los adultos con niveles altos de competencia son Australia, Corea, Dinamarca, España, Irlanda, Noruega, Países Bajos y Suecia; la mayor influencia se observa en Alemania, Estonia, Federación Rusa, Italia, Polonia y República Eslovaca.

\section{Barreras a la participación en actividades de aprendizaje}

Se preguntó a todos los adultos (de 25 a 64 años) si habían querido participar en (más) actividades de aprendizaje formal y/o no formal durante los 12 meses anteriores, pero no habían comenzado una actividad. El Gráfico C6.5 muestra que el $25 \%$ de la población adulta de todos los países tenía interés en participar, pero no pudo hacerlo. De los adultos interesados en una mayor participación, tres de cada cuatro habían participado en otras actividades de educación formal y/o no formal durante los 12 meses anteriores (el 18\% de todas las personas adultas). Solo una pequeña minoría (7\%) de todos los adultos estaba interesada en participar, pero no lo había hecho durante los 12 meses anteriores, por lo que estas personas podrían ser consideradas potenciales nuevos participantes. La proporción de adultos que habían querido participar en actividades de aprendizaje, pero que no lo habían hecho, oscila entre más del 33\% en Corea, Dinamarca y Estados Unidos y menos del $15 \%$ en Federación Rusa, Polonia y República Eslovaca. En todos los países encuestados, eran más los participantes que los no participantes los que querían tomar parte en (más) actividades de aprendizaje. La diferencia es pequeña en Federación Rusa, Francia e Italia. En general, los países con las mayores tasas de participación en educación formal y/o no formal también tienen mayores proporciones de personas que quieren comenzar actividades de aprendizaje (correlación = 0,76) (Tabla C6.4).

Se pidió a aquellas personas que deseaban comenzar una actividad de aprendizaje que indicaran por qué no la habían empezado. Se sugerían siete posibles respuestas y la categoría «otros». En los países de la OCDE, el $30 \%$ de los encuestados citaron el motivo «Estaba demasiado ocupado en el trabajo». Un 15\% citaron el motivo «No tuve tiempo debido al cuidado de los hijos o a responsabilidades familiares». Por lo tanto, para el $45 \%$ de las personas que respondieron, la carga del trabajo o la familia parece que no les dejaban tiempo para realizar (más) actividades de aprendizaje. Los factores relacionados con cómo estaban organizadas las actividades de aprendizaje también impedían a algunas personas participar en ellas: «El curso o programa se ofrecía en un horario o lugar que no me convenía» $(12 \%)$. «El curso o formación era demasiado caro/No me lo podía permitir» (14\%) y «No cumplía con los prerrequisitos» (3\%) fueron motivos citados por un total del 29\% de los encuestados. Alrededor del $8 \%$ citaron la «Falta de apoyo del empleador» como la razón por la cual no habían podido realizar una actividad de aprendizaje que deseaban, 


\title{
Gráfico C6.5. Participación en educación formal y/o no formal y deseo de participar en actividades de aprendizaje (2012) \\ Personas de 25 a 64 años
}

\begin{abstract}
$\square$ Participante, desea realizar actividades de aprendizaje
$\square$ No participante, desea realizar actividades de aprendizaje

$\llbracket$ Participante, no desea realizar actividades de aprendizaje

$\square$ No participante, no desea realizar actividades de aprendizaje
\end{abstract}

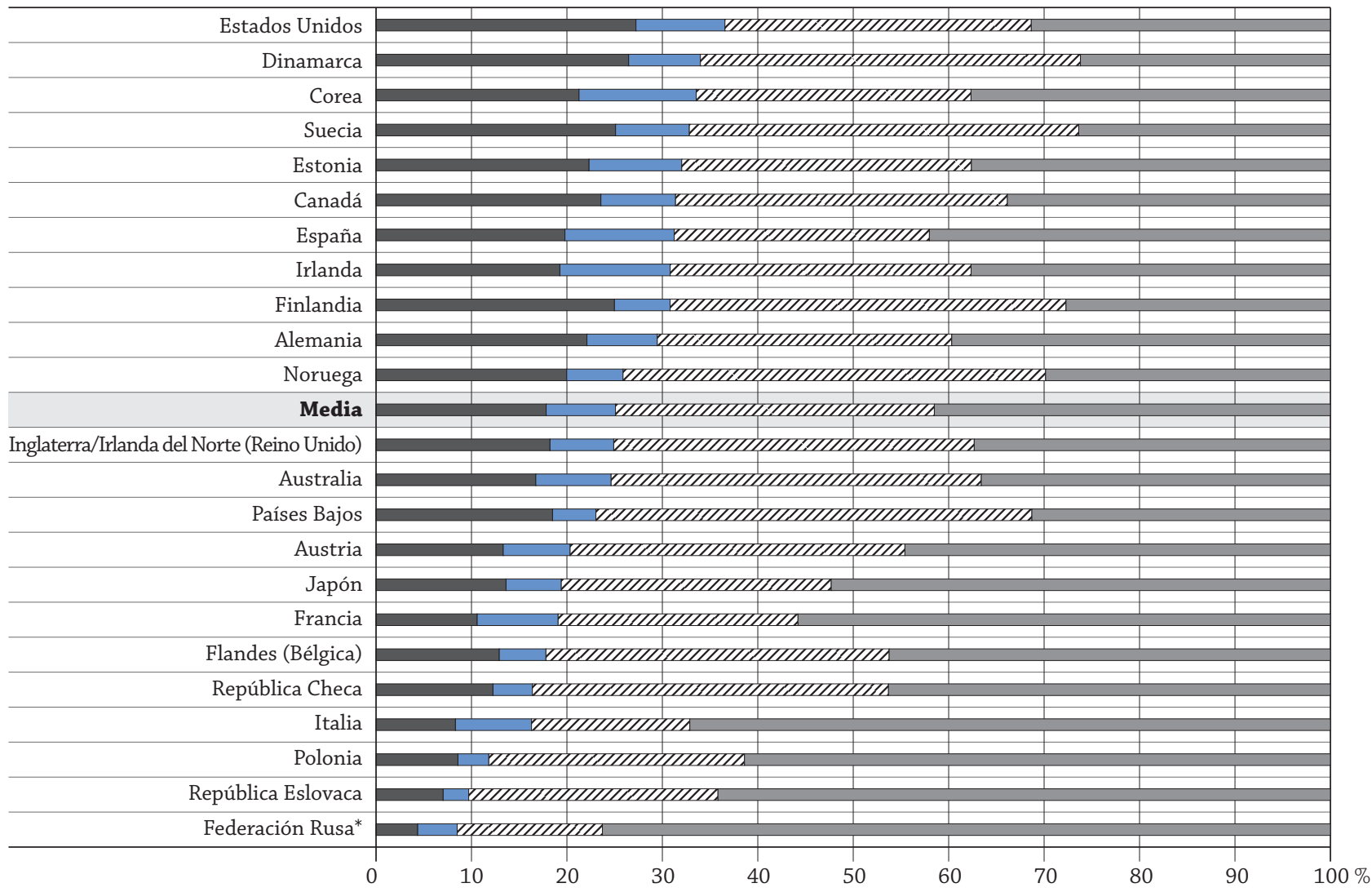

* Para los datos de Federación Rusa, véase nota en la sección de Metodología.

Los países están clasificados en orden descendente de la suma de los participantes que desean realizar actividades de aprendizaje y los no participantes que desean realizar actividades de aprendizaje.

Fuente: OCDE. Tabla C6.4. Para ver notas, consulte Anexo 3 (www.oecd.org/edu/eag.htm).

StatLink : InIs http://dx.doi.org/10.1787/888933119283

y aproximadamente el $4 \%$ indicaron que «Surgió un imprevisto que me impidió participar en el curso o formación» (Tabla C6.5).

El motivo «Estaba demasiado ocupado en el trabajo» fue indicado por más del $35 \%$ de los encuestados en Corea, Italia, Japón y República Checa, y por menos del $25 \%$ en Francia, Irlanda y Portugal. «No tuve tiempo debido al cuidado de los hijos o a responsabilidades familiares» fue indicado por el $20 \%$ o más en Australia, España, Flandes (Bélgica) e Irlanda; y por el $10 \%$ o menos en Dinamarca, Estonia, Finlandia, Francia y República Eslovaca. «El curso o programa se ofrecía en un horario o lugar que no me convenía» fue el motivo citado por más del $17 \%$ de los encuestados en Finlandia, Flandes (Bélgica) y Japón, y por menos del 7\% en Francia, Italia y República Checa. «El curso o formación era demasiado caro/No me lo podía permitir» fue indicado por el $20 \%$ o más de los encuestados en Estados Unidos, Federación Rusa, Irlanda y Polonia, y por el $9 \%$ o menos en Finlandia, Flandes (Bélgica), Japón y Noruega (Tabla C6.5).

Los motivos citados para no participar también diferían si los adultos eran participantes o no en educación formal y/o no formal. Como media en el conjunto de los países, el $34 \%$ de los participantes y el $22 \%$ de los no participantes citaron el motivo «Estaba demasiado ocupado en el trabajo». En todos los países, los participantes citaron la carga de trabajo más que los no participantes. Alrededor del $21 \%$ de los no participantes se sentían impedidos por el cuidado 
de los hijos y las responsabilidades familiares, con más frecuencia que los participantes (12\%). «El curso o programa se ofrecía en un horario o lugar que no me convenía» fue indicado por el $13 \%$ de los participantes y por el $8 \%$ de los no participantes. En todos los países encuestados, los participantes citaron este motivo con más frecuencia que los no participantes (Tabla C6.5).

\section{Participación en educación formal frente a participación en educación no formal}

Los países difieren en el nivel de acceso de la población adulta al sistema educativo formal para cubrir sus necesidades de educación y formación. En el conjunto de los países, una media del $10 \%$ de las personas de 25 a 64 años participan en educación formal. Las proporciones varían desde el 17\% en Australia al $2 \%$ en Japón. Canadá, todos los países anglosajones (es decir, Australia, Estados Unidos, Inglaterra/Irlanda del Norte [Reino Unido] e Irlanda) y todos los países nórdicos (es decir, Dinamarca, Finlandia, Noruega y Suecia) muestran una proporción superior a la media de adultos que participan en instituciones formales. Aparte de estos dos grupos, solo España y Países Bajos muestran tasas de participación superiores a la media. En cambio, menos del $5 \%$ de la población adulta de Corea, Francia y Japón participa en educación formal (Tabla C6.3).

En general, los países con tasas altas de participación de la población adulta en educación formal también tienen tasas altas de participación de adultos en educación no formal. No obstante, la relación (correlación $=0,66$ ) no es perfecta: Corea y República Checa combinan tasas bajas de participación en educación formal con tasas medias de participación en educación no formal.

Como media, dos de cada tres adultos que participan en educación formal también participan en educación no formal, lo que indica que estas personas aprovechan una variedad de oportunidades de aprendizaje. El Gráfico C6.6 muestra que aproximadamente la mitad de la población adulta no participa en ningún tipo de educación formal o no formal.

\section{Gráfico C6.6. Participación en educación formal y/o no formal (2012)}

Personas de 25 a 64 años

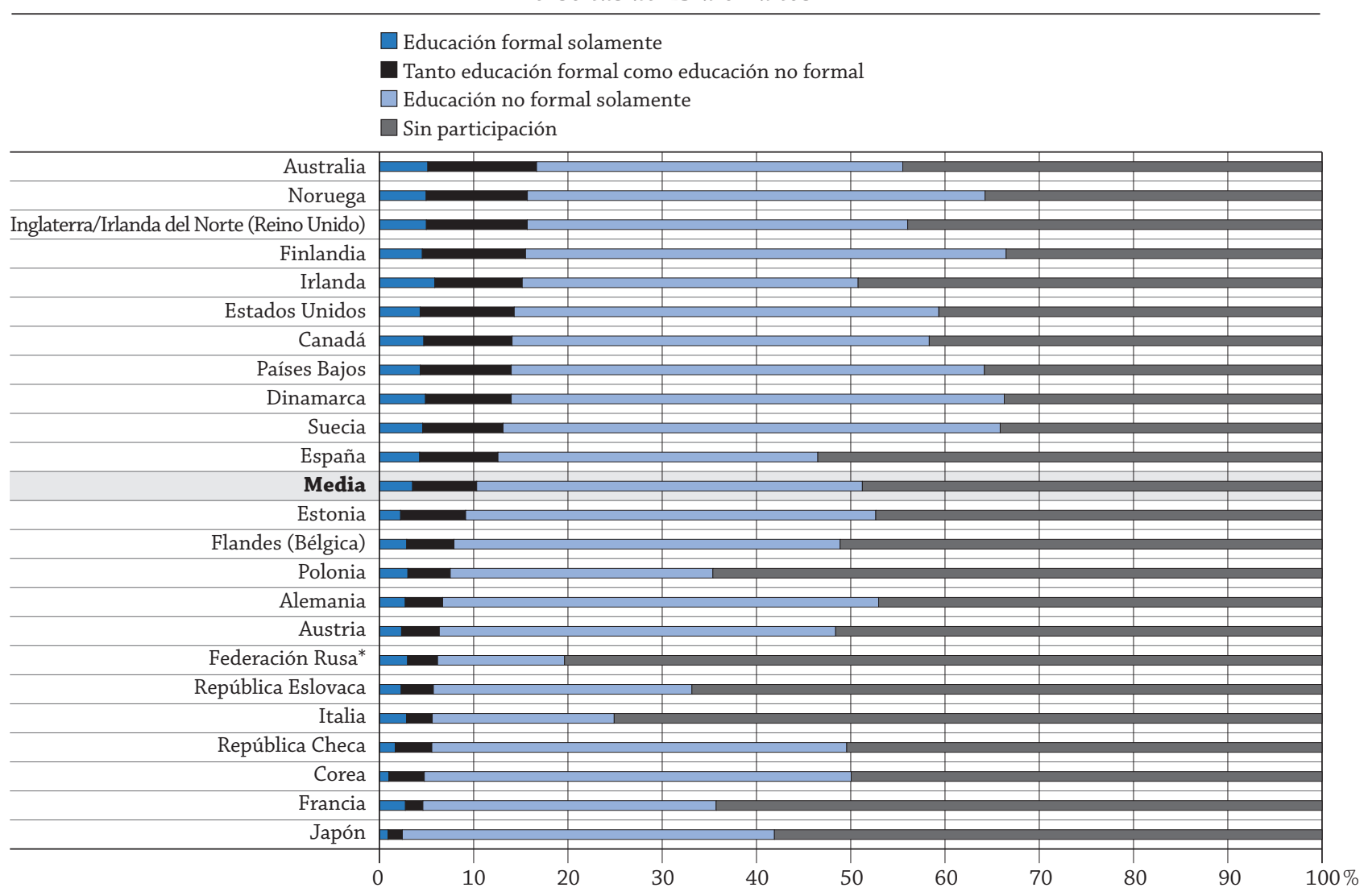

* Para los datos de Federación Rusa, véase nota en la sección de Metodología.

Los países están clasificados en orden descendente de la suma de los participantes en educación formal solamente y en educación formal y no formal.

Fuente: OCDE. Tabla C6.3. Para ver notas, consulte Anexo 3 (www.oecd.org/edu/eag.htm).

StatLink 部 


\section{Definiciones}

Grupos de edad: adultos se refiere a las personas de 25 a 64 años de edad; adultos jóvenes se refiere a personas de 25 a 34 años; adultos mayores se refiere a personas de 55 a 64 años.

Educación y formación formal se define como una educación institucionalizada y planificada, proporcionada en el sistema de centros escolares, centros de educación superior, universidades y demás instituciones educativas formales y que normalmente constituyen una «escala» continua de educación a tiempo completo para niños y jóvenes. Los centros que la proporcionan pueden ser públicos o privados.

Niveles educativos: inferior a la secundaria superior corresponde a los niveles CINE 0, 1, 2 y 3 C cortos; secundaria superior o postsecundaria no terciaria corresponde a los niveles CINE 3A, 3B y 3C largos y al nivel CINE 4; y la terciaria corresponde a los niveles CINE 5A, 5B y 6. Para una presentación de todos los niveles CINE, consulte la Guía del lector al principio de este libro.

Educación y formación no formal se define como una actividad educativa sostenida que no corresponde exactamente a la definición anterior de la educación formal. Por consiguiente, la educación no formal puede tener lugar tanto dentro como fuera de las instituciones educativas y estar dirigida a personas de cualquier edad. Dependiendo del contexto del país, puede abarcar programas educativos de alfabetización de adultos, educación básica para niños fuera del centro escolar, competencias para la vida, competencias para el trabajo y cultura general. La Encuesta sobre las Competencias de los Adulos utiliza una lista de posibles actividades educativas no formales que incluye cursos de aprendizaje abiertos o a distancia, clases particulares, sesiones organizadas para la formación en el trabajo y talleres o seminarios, con la finalidad de inducir a los encuestados a enumerar todas sus actividades de aprendizaje en los últimos 12 meses. Algunas de estas actividades de aprendizaje pueden ser de corta duración.

Nivel educativo de los padres: por debajo de la educación secundaria superior significa que ambos padres han alcanzado el nivel CINE 0, 1, 2 o 3C programas cortos; secundaria superior o postsecundaria no terciaria indica que al menos uno de los padres (la madre o el padre) ha alcanzado niveles 3A, 3B, 3C programas largos, o el nivel CINE 4; y terciaria significa que al menos uno de los padres (la madre o el padre) ha alcanzado el nivel CINE 5A, 5B o 6. Para una presentación de todos los niveles CINE, consulte la Guía del lector al principio de este libro.

\section{Metodología}

Todos los datos se han basado en la Encuesta sobre las Competencias de los Adultos (PIAAC, por sus siglas en inglés) (2012). PIAAC es el Programa para la Evaluación Internacional de las Competencias de los Adultos. Consulte Acerca de la Encuesta sobre las Competencias de los Adultos al comienzo de esta publicación, y para más detalles consulte el Anexo 3 (www.oecd.org/edu/eag.htm).

Nota sobre los datos de Federación Rusa en la Encuesta sobre las Competencias de los Adultos (PIAAC)

Los lectores deben tener en cuenta que la muestra de Federación Rusa no incluye a la población del área municipal de Moscú. Por tanto, los datos publicados no representan a toda la población de 16 a 65 años residente en Rusia, sino a la población de Rusia excluyendo la población que reside en el área municipal de Moscú. Se puede encontrar información más detallada sobre los datos de la Federación Rusa así como de otros países en el Technical Report of the Survey of Adult Skills (OECD, de próxima publicación).

\section{Referencias}

OECD (2013), OECD Skills Outlook 2013: First Results from the Survey of Adult Skills, OECD Publishing, París, http://dx.doi. org/10.1787/9789264204256-en.

OECD (2011), Education at a Glance 2011: OECD Indicators, OECD Publishing, París, http://dx.doi.org/10.1787/eag-2011-en.

Versión española: Panorama de la educación 2011: Indicadores de la OCDE, Ministerio de Educación, Cultura y Deporte, Santillana, Madrid.

OECD/Statistics Canada (2011), Literacy for Life: Further Results from the Adult Literacy and Life Skills Survey, OECD Publishing, París. 
Tablas del Indicador C6

StatLink त्नाज http://dx.doi.org/10.1787/888933119093

Tabla C6.1 (L) Participación en educación formal y/o no formal, por nivel de comprensión lectora (2012)

WEB Tabla C6.1 (N) Participación en educación formal y/o no formal, por nivel de competencia matemática (2012)

Tabla C6.2a (L) Participación en educación formal y/o no formal, por nivel de comprensión lectora y nivel educativo alcanzado (2012)

WEB Tabla C6.2a (N) Participación en educación formal y/o no formal, por nivel de competencia matemática y nivel educativo alcanzado (2012)

WEB Tabla C6.2b (L) Participación en educación formal y/o no formal, por nivel de comprensión lectora y grupo de edad (2012)

WEB Tabla C6.2b (N) Participación en educación formal y/o no formal, por nivel de competencia matemática y grupo de edad (2012)

WEB Tabla C6.2c (L) Participación en educación formal y/o no formal, por nivel de comprensión lectora y sexo (2102)

WEB Tabla C6.2c (N) Participación en educación formal y/o no formal, por nivel de competencia matemática y sexo (2012)

WEB Tabla C6.2d (L) Participación en educación formal y/o no formal, por nivel de comprensión lectora y por situación en la población activa (2012)

WEB Tabla C6.2d (N) Participación en educación formal y/o no formal, por nivel de competencia matemática y situación en el mercado laboral (2012)

WEB Tabla C6.2e (L) Participación en educación formal y/o no formal, por nivel de comprensión lectora y nivel educativo de los padres (2012)

WEB Tabla C6.2e (N) Participación en educación formal y/o no formal, por nivel de competencia matemática y nivel educativo de los padres (2012)

Tabla C6.3 Participación en educación formal y/o no formal, por sexo (2012)

Tabla C6.4 Participación en educación formal y/o no formal y deseo de participar en actividades de aprendizaje (2012)

Tabla C6.5 Motivos dados para no haber participado en más actividades de aprendizaje o en alguna, por situación de participación en actividades de educación formal y/o no formal (2012) 
Tabla C6.1 (L). Participación en educación formal y/o no formal, por nivel de comprensión lectora (2012) Encuesta sobre las Competencias de los Adultos, de 25 a 64 años

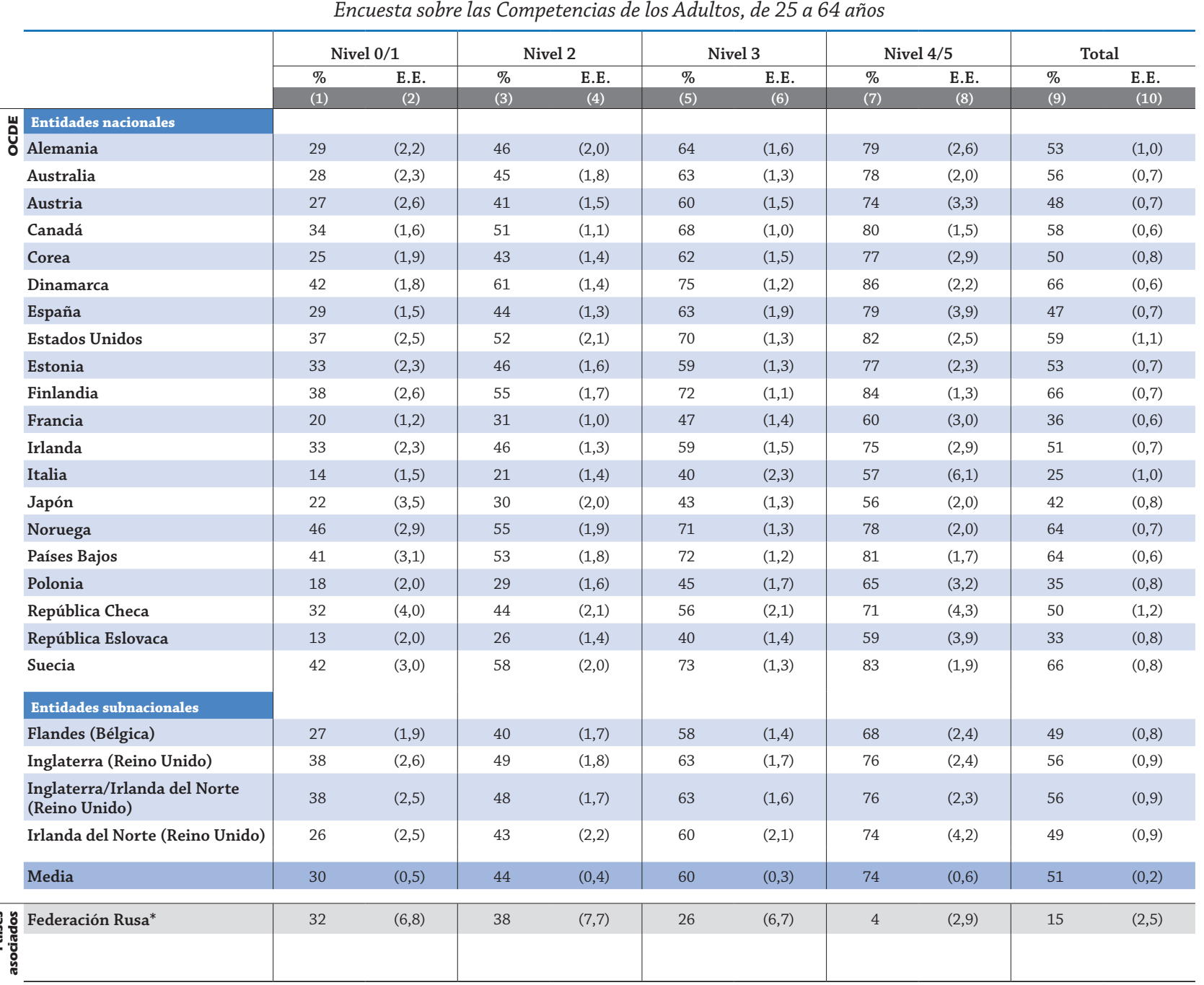

* Para los datos de Federación Rusa, véase nota en la sección de Metodología.

Fuente: OCDE. Encuesta sobre las Competencias de los Adultos (PIAAC) (2012). PIAAC se refiere al Programa para la Evaluación Internacional de las Competencias de los Adultos de la OCDE. Para ver notas, consulte Anexo 3 (www.oecd.org/edu/eag.htm).

Para obtener más información acerca de los símbolos utilizados en lugar de los datos que faltan, consulte la Guía del lector.

StatLink 제개 http://dx.doi.org/10.1787/888933119112 
Tabla C6.2a (L). [1/2] Participación en educación formal y/o no formal, por nivel de comprensión lectora y nivel educativo alcanzado (2012)

Encuesta sobre las Competencias de los Adultos, de 25 a 64 años

\begin{tabular}{|c|c|c|c|c|c|c|c|c|c|c|c|}
\hline & \multirow[b]{3}{*}{ Nivel educativo alcanzado } & \multicolumn{2}{|c|}{ Nivel 0/1 } & \multicolumn{2}{|c|}{ Nivel 2} & \multicolumn{2}{|c|}{ Nivel 3} & \multicolumn{2}{|c|}{ Nivel 4/5 } & \multicolumn{2}{|c|}{ Total } \\
\hline & & $\%$ & E.E. & $\%$ & E.E. & $\%$ & E.E. & $\%$ & E.E. & $\%$ & E.E. \\
\hline & & $(1)$ & $(2)$ & $(3)$ & $(4)$ & $(5)$ & $(6)$ & $(7)$ & $(8)$ & $(9)$ & (10) \\
\hline \multirow{4}{*}{$\begin{array}{l}\text { Entidades nacionales } \\
\text { Оั Alemania }\end{array}$} & & & & & & & & & & & \\
\hline & Inferior a educación secundaria superior & 17 & $(3,6)$ & 24 & $(5,0)$ & 40 & $(10,1)$ & c & c & 22 & $(2,7)$ \\
\hline & Secundaria superior o postsecundaria no terciaria & 31 & $(3,1)$ & 44 & $(2,6)$ & 57 & $(2,5)$ & 73 & $(4,3)$ & 47 & $(1,4)$ \\
\hline & Terciaria & 47 & $(7,2)$ & 62 & $(3,4)$ & 73 & $(2,1)$ & 82 & $(2,8)$ & 71 & $(1,3)$ \\
\hline \multirow[t]{2}{*}{ Australia } & Inferior a educación secundaria superior & 19 & $(2,9)$ & 31 & $(2,6)$ & 44 & $(3,3)$ & 60 & $(8,9)$ & 32 & $(1,5)$ \\
\hline & Terciaria & 59 & $(6,1)$ & 66 & $(3,3)$ & 77 & $(1,8)$ & 84 & $(1,9)$ & 76 & $(1,1)$ \\
\hline \multirow[t]{3}{*}{ Austria } & Inferior a educación secundaria superior & 20 & $(3,2)$ & 23 & $(2,9)$ & 37 & $(5,4)$ & c & c & 25 & $(1,8)$ \\
\hline & Secundaria superior o postsecundaria no terciaria & 31 & $(3,6)$ & 44 & $(1,7)$ & 57 & $(1,9)$ & 67 & $(5,0)$ & 48 & $(0,9)$ \\
\hline & Terciaria & 53 & $(10,3)$ & 58 & $(4,0)$ & 74 & $(2,3)$ & 80 & $(3,7)$ & 71 & $(1,5)$ \\
\hline \multirow[t]{3}{*}{ Canadá } & Inferior a educación secundaria superior & 22 & $(2,0)$ & 29 & $(3,0)$ & 35 & $(5,0)$ & c & c & 26 & $(1,3)$ \\
\hline & Secundaria superior o postsecundaria no terciaria & 33 & $(2,5)$ & 47 & $(1,7)$ & 59 & $(1,7)$ & 71 & $(3,7)$ & 50 & $(1,0)$ \\
\hline & Terciaria & 50 & $(3,4)$ & 61 & $(1,7)$ & 75 & $(1,3)$ & 82 & $(1,7)$ & 70 & $(0,8)$ \\
\hline \multirow[t]{2}{*}{ Corea } & Inferior a educación secundaria superior & 15 & $(2,0)$ & 24 & $(2,5)$ & 31 & $(6,1)$ & c & c & 21 & $(1,3)$ \\
\hline & Terciaria & 65 & $(8,0)$ & 62 & $(2,4)$ & 73 & $(1,7)$ & 82 & $(3,6)$ & 71 & $(1,1)$ \\
\hline Dinamarca & Inferior a educación secundaria superior & 33 & $(2,8)$ & 46 & $(3,5)$ & 59 & $(5,4)$ & c & c & 44 & $(1,9)$ \\
\hline & Secundaria superior o postsecundaria no terciaria & 45 & $(3,2)$ & 60 & $(2,0)$ & 68 & $(1,9)$ & 83 & $(5,5)$ & 62 & $(1,0)$ \\
\hline & Terciaria & 64 & $(4,3)$ & 77 & $(2,0)$ & 83 & $(1,3)$ & 88 & $(2,0)$ & 82 & $(0,7)$ \\
\hline España & Inferior a educación secundaria superior & 22 & $(1,4)$ & 32 & $(1,7)$ & 41 & $(3,4)$ & c & c & 28 & $(1,0)$ \\
\hline & Secundaria superior o postsecundaria no terciaria & 43 & $(4,8)$ & 46 & $(2,8)$ & 54 & $(4,2)$ & 72 & $(11,9)$ & 49 & $(2,0)$ \\
\hline & Terciaria & 56 & $(5,4)$ & 65 & $(2,5)$ & 75 & $(2,0)$ & 82 & $(3,5)$ & 71 & $(1,2)$ \\
\hline Estados Unidos & Inferior a educación secundaria superior & 25 & $(3,0)$ & 29 & $(5,7)$ & 44 & $(11,9)$ & c & c & 28 & $(2,2)$ \\
\hline & Secundaria superior o postsecundaria no terciaria & 40 & $(3,6)$ & 48 & $(2,6)$ & 58 & $(2,5)$ & 68 & $(6,4)$ & 50 & $(1,6)$ \\
\hline & Terciaria & 63 & $(6,0)$ & 71 & $(3,3)$ & 80 & $(1,4)$ & 85 & $(2,1)$ & 79 & $(1,2)$ \\
\hline Estonia & Inferior a educación secundaria superior & 23 & $(2,8)$ & 28 & $(3,0)$ & 34 & $(4,3)$ & c & c & 28 & $(1,4)$ \\
\hline & Secundaria superior o postsecundaria no terciaria & 31 & $(3,1)$ & 39 & $(2,0)$ & 48 & $(1,8)$ & 64 & $(4,2)$ & 43 & $(0,9)$ \\
\hline & Terciaria & 51 & $(4,4)$ & 64 & $(2,3)$ & 72 & $(1,6)$ & 83 & $(2,5)$ & 70 & $(1,0)$ \\
\hline Finlandia & Inferior a educación secundaria superior & 24 & $(4,1)$ & 34 & $(3,6)$ & 44 & $(4,8)$ & c & c & 34 & $(2,2)$ \\
\hline & Secundaria superior o postsecundaria no terciaria & 40 & $(3,8)$ & 56 & $(2,2)$ & 68 & $(1,9)$ & 77 & $(3,6)$ & 62 & $(1,0)$ \\
\hline & Terciaria & 71 & $(6,7)$ & 71 & $(2,6)$ & 81 & $(1,5)$ & 88 & $(1,3)$ & 81 & $(0,9)$ \\
\hline & Terciaria & 33 & $(5,1)$ & 47 & $(2,6)$ & 60 & $(1,8)$ & 65 & $(3,3)$ & 56 & $(1,1)$ \\
\hline Irlanda & Inferior a educación secundaria superior & 27 & $(2,6)$ & 30 & $(2,7)$ & 32 & $(5,3)$ & c & c & 29 & $(1,5)$ \\
\hline & Secundaria superior o postsecundaria no terciaria & 35 & $(3,6)$ & 46 & $(1,9)$ & 50 & $(2,2)$ & 60 & $(7,4)$ & 47 & $(1,2)$ \\
\hline & Terciaria & 59 & $(7,1)$ & 66 & $(2,8)$ & 74 & $(1,8)$ & 82 & $(2,8)$ & 72 & $(1,1)$ \\
\hline Italia & Inferior a educación secundaria superior & 11 & $(1,8)$ & 12 & $(1,8)$ & 16 & $(3,9)$ & c & c & 12 & $(1,2)$ \\
\hline & Secundaria superior o postsecundaria no terciaria & 19 & $(3,1)$ & 26 & $(2,2)$ & 40 & $(2,8)$ & 46 & $(9,5)$ & 31 & $(1,4)$ \\
\hline & Terciaria & 36 & $(6,7)$ & 51 & $(4,8)$ & 65 & $(3,8)$ & 70 & $(8,1)$ & 59 & $(2,1)$ \\
\hline Japón & Inferior a educación secundaria superior & 16 & $(4,7)$ & 21 & $(4,0)$ & 25 & $(4,0)$ & c & c & 22 & $(2,2)$ \\
\hline & Secundaria superior o postsecundaria no terciaria & 24 & $(6,2)$ & 27 & $(3,2)$ & 35 & $(2,4)$ & 40 & $(3,8)$ & 32 & $(1,2)$ \\
\hline & Terciaria & c & c & 46 & $(3,3)$ & 54 & $(2,0)$ & 62 & $(2,2)$ & 56 & $(1,1)$ \\
\hline Noruega & Inferior a educación secundaria superior & 37 & $(4,3)$ & 38 & $(3,5)$ & 49 & $(3,7)$ & c & c & 42 & $(1,9)$ \\
\hline & Secundaria superior o postsecundaria no terciaria & 51 & $(4,4)$ & 57 & $(2,7)$ & 67 & $(2,3)$ & 70 & $(5,9)$ & 62 & $(1,4)$ \\
\hline & Terciaria & 61 & $(6,8)$ & 71 & $(3,6)$ & 80 & $(1,4)$ & 82 & $(2,0)$ & 78 & $(0,9)$ \\
\hline Países Bajos & Inferior a educación secundaria superior & 36 & $(3,4)$ & 38 & $(2,7)$ & 51 & $(3,3)$ & 70 & $(11,2)$ & 42 & $(1,3)$ \\
\hline & Secundaria superior o postsecundaria no terciaria & 50 & $(6,0)$ & 59 & $(2,6)$ & 70 & $(1,9)$ & 70 & $(3,8)$ & 65 & $(1,3)$ \\
\hline & Terciaria & 63 & $(11,0)$ & 75 & $(3,7)$ & 82 & $(1,6)$ & 86 & $(1,9)$ & 82 & $(0,9)$ \\
\hline Polonia & Inferior a educación secundaria superior & 10 & $(2,9)$ & 17 & $(3,6)$ & 18 & $(5,9)$ & c & c & 14 & $(1,9)$ \\
\hline & Secundaria superior o postsecundaria no terciaria & 17 & $(2,1)$ & 23 & $(1,6)$ & 30 & $(2,2)$ & 39 & $(7,3)$ & 24 & $(1,0)$ \\
\hline & Terciaria & 53 & $(8,4)$ & 60 & $(4,1)$ & 68 & $(2,4)$ & 75 & $(3,1)$ & 67 & $(1,5)$ \\
\hline República Checa & Inferior a educación secundaria superior & 14 & $(4,7)$ & 18 & $(5,0)$ & 27 & $(10,0)$ & c & c & 19 & $(2,6)$ \\
\hline & Secundaria superior o postsecundaria no terciaria & 38 & $(5,0)$ & 45 & $(2,4)$ & 52 & $(2,2)$ & 60 & $(8,3)$ & 48 & $(1,4)$ \\
\hline & Terciaria & c & c & 65 & $(6,4)$ & 70 & $(3,7)$ & 78 & $(4,7)$ & 71 & $(2,6)$ \\
\hline República Eslovaca & Inferior a educación secundaria superior & 3 & $(1,3)$ & 6 & $(1,6)$ & 14 & $(3,3)$ & c & c & 6 & $(0,9)$ \\
\hline & Secundaria superior o postsecundaria no terciaria & 19 & $(3,2)$ & 26 & $(1,8)$ & 33 & $(1,5)$ & 52 & $(5,8)$ & 30 & $(1,1)$ \\
\hline & Terciaria & c & c & 55 & $(4,7)$ & 62 & $(2,6)$ & 69 & $(5,3)$ & 62 & $(1,5)$ \\
\hline Suecia & Inferior a educación secundaria superior & 34 & $(4,1)$ & 43 & $(4,5)$ & 55 & $(6,4)$ & c & c & 43 & $(2,2)$ \\
\hline & Secundaria superior o postsecundaria no terciaria & 45 & $(4,6)$ & 60 & $(2,9)$ & 69 & $(2,2)$ & 78 & $(4,3)$ & 64 & $(1,1)$ \\
\hline & Terciaria & 61 & $(6,6)$ & 76 & $(3,6)$ & 82 & $(1,9)$ & 86 & $(1,9)$ & 81 & $(1,1)$ \\
\hline
\end{tabular}

* Para los datos de Federación Rusa, véase nota en la sección de Metodología.

Fuente: OCDE. Encuesta sobre las Competencias de lois Adultos (PIAAC) (2012). PIAAC se refiere al Programa para la Evaluación Internacional de las Competencias de los Adultos de la OCDE. Para ver notas, consulte Anexo 3 (www.oecd.org/edu/eag.htm).

Para obtener más información acerca de los símbolos utilizados en lugar de los datos que faltan, consulte la Guía del lector.

StatLink 제표 http://dx.doi.org/10.1787/888933119131 
Tabla C6.2a (L). [2/2] Participación en educación formal y/o no formal, por nivel de comprensión lectora y nivel educativo alcanzado (2012)

Encuesta sobre las Competencias de los Adultos, de 25 a 64 años

\begin{tabular}{|c|c|c|c|c|c|c|c|c|c|c|c|}
\hline & \multirow[b]{3}{*}{ Nivel educativo alcanzado } & \multicolumn{2}{|c|}{ Nivel 0/1 } & \multicolumn{2}{|c|}{ Nivel 2} & \multicolumn{2}{|c|}{ Nivel 3} & \multicolumn{2}{|c|}{ Nivel 4/5 } & \multicolumn{2}{|c|}{ Total } \\
\hline & & $\%$ & E.E. & $\%$ & E.E. & $\%$ & E.E. & $\%$ & E.E. & $\%$ & E.E. \\
\hline & & $(1)$ & (2) & (3) & $(4)$ & $(5)$ & $(6)$ & $(7)$ & $(8)$ & (9) & $(10)$ \\
\hline \multirow{4}{*}{$\begin{array}{l}\text { Uू } \\
\text { Entidades subnacionales } \\
\text { Olandes (Bélgica) }\end{array}$} & & & & & & & & & & & \\
\hline & Inferior a educación secundaria superior & 17 & $(2,4)$ & 20 & $(2,7)$ & 29 & $(5,7)$ & c & c & 20 & $(1,8)$ \\
\hline & Secundaria superior o postsecundaria no terciaria & 33 & $(3,4)$ & 39 & $(2,3)$ & 46 & $(2,4)$ & 52 & $(6,1)$ & 41 & $(1,3)$ \\
\hline & Terciaria & 47 & $(7,3)$ & 64 & $(3,6)$ & 71 & $(1,9)$ & 73 & $(2,7)$ & 69 & $(1,2)$ \\
\hline \multirow[t]{3}{*}{ Inglaterra (Reino Unido) } & Inferior a educación secundaria superior & 26 & $(3,2)$ & 33 & $(3,0)$ & 42 & $(4,9)$ & c & c & 33 & $(1,7)$ \\
\hline & Secundaria superior o postsecundaria no terciaria & 47 & $(4,7)$ & 48 & $(3,0)$ & 59 & $(2,7)$ & 67 & $(5,4)$ & 54 & $(1,4)$ \\
\hline & Terciaria & 54 & $(7,3)$ & 67 & $(3,5)$ & 72 & $(2,2)$ & 81 & $(2,4)$ & 72 & $(1,3)$ \\
\hline \multirow{3}{*}{$\begin{array}{l}\text { Inglaterra/Irlanda del Norte } \\
\text { (Reino Unido) }\end{array}$} & Inferior a educación secundaria superior & 26 & $(3,0)$ & 32 & $(2,8)$ & 41 & $(4,7)$ & 67 & $(13,5)$ & 33 & $(1,6)$ \\
\hline & Secundaria superior o postsecundaria no terciaria & 47 & $(4,6)$ & 48 & $(2,9)$ & 59 & $(2,6)$ & 67 & $(5,3)$ & 54 & $(1,4)$ \\
\hline & Terciaria & 54 & $(7,1)$ & 67 & $(3,3)$ & 72 & $(2,1)$ & 81 & $(2,3)$ & 72 & $(1,2)$ \\
\hline \multirow{3}{*}{$\begin{array}{l}\text { Irlanda del Norte } \\
\text { (Reino Unido) }\end{array}$} & Inferior a educación secundaria superior & 17 & $(2,4)$ & 25 & $(2,8)$ & 31 & $(4,9)$ & c & c & 23 & $(1,5)$ \\
\hline & Secundaria superior o postsecundaria no terciaria & 39 & $(5,3)$ & 48 & $(3,3)$ & 55 & $(3,7)$ & 68 & $(8,2)$ & 51 & $(1,9)$ \\
\hline & Terciaria & 55 & $(10,0)$ & 68 & $(4,1)$ & 73 & $(2,7)$ & 77 & $(4,4)$ & 72 & $(1,5)$ \\
\hline \multirow[t]{3}{*}{ Media } & Inferior a educación secundaria superior & 21 & $(0,7)$ & 27 & $(0,7)$ & 36 & $(1,3)$ & 66 & $(6,5)$ & 27 & $(0,4)$ \\
\hline & Secundaria superior o postsecundaria no terciaria & 35 & $(0,9)$ & 43 & $(0,5)$ & 53 & $(0,5)$ & 63 & $(1,4)$ & 47 & $(0,3)$ \\
\hline & Terciaria & 55 & $(1,6)$ & 64 & $(0,7)$ & 73 & $(0,4)$ & 79 & $(0,7)$ & 71 & $(0,3)$ \\
\hline
\end{tabular}

\begin{tabular}{|c|c|c|c|c|c|c|c|c|c|c|c|}
\hline \multirow[t]{3}{*}{ y̆ Federación Rusa* } & Inferior a educación secundaria superior & 4 & $(4,5)$ & c & c & c & c & c & c & 6 & $(3,0)$ \\
\hline & Secundaria superior o postsecundaria no terciaria & 9 & $(3,1)$ & 12 & $(3,5)$ & 12 & $(3,1)$ & 7 & $(4,8)$ & 11 & $(2,1)$ \\
\hline & Terciaria & 24 & $(3,2)$ & 22 & $(3,0)$ & 26 & $(2,2)$ & 29 & $(4,6)$ & 24 & $(1,8)$ \\
\hline
\end{tabular}

* Para los datos de Federación Rusa, véase nota en la sección de Metodología.

Fuente: OCDE. Encuesta sobre las Competencias de lois Adultos (PIAAC) (2012). PIAAC se refiere al Programa para la Evaluación Internacional de las Competencias de los Adultos de la OCDE. Para ver notas, consulte Anexo 3 (www.oecd.org/edu/eag.htm).

Para obtener más información acerca de los símbolos utilizados en lugar de los datos que faltan, consulte la Guía del lector.

StatLink 제내 http://dx.doi.org/10.1787/888933119131 
Tabla C6.3. Participación en educación formal y/o no formal, por sexo (2012)

Personas de 25 a 64 años

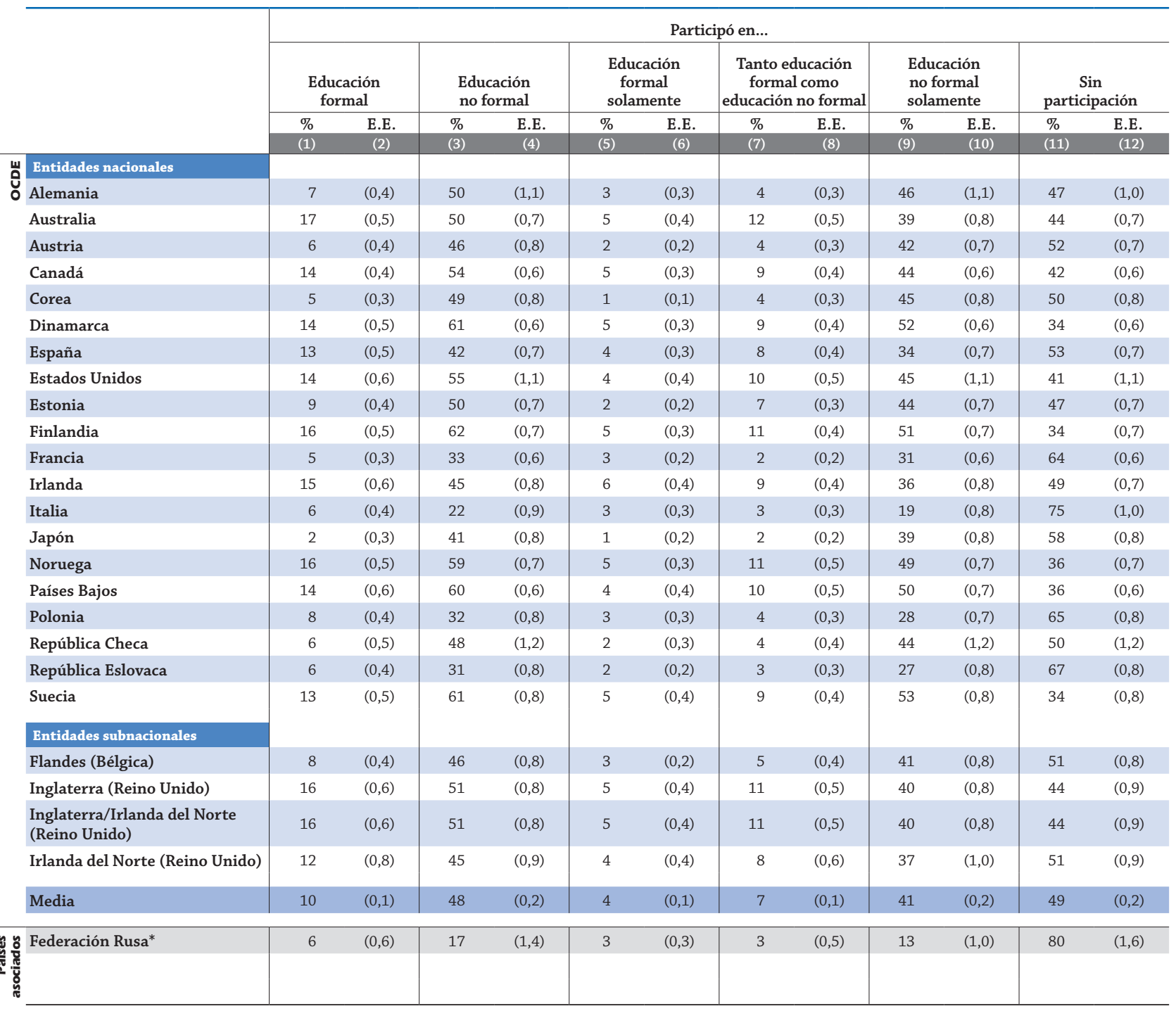

* Para los datos de Federación Rusa, véase nota en la sección de Metodología.

Nota: Las filas que muestran los datos de hombres y mujeres por separado están disponibles en Internet (véase StatLink más abajo)

Fuente: OCDE. Encuesta sobre las Competencias de los Adultos (PIAAC) (2012). PIAAC se refiere al Programa para la Evaluación Internacional de las Competencias de los Adultos de la OCDE. Para ver notas, consulte Anexo 3 (www.oecd.org/edu/eag.htm).

Para obtener más información acerca de los símbolos utilizados en lugar de los datos que faltan, consulte la Guía del lector.

StatLink त्तारा http://dx.doi.org/10.1787/888933119150 
Tabla C6.4. Participación en educación formal y/o no formal y deseo de participar en actividades de aprendizaje (2012)

Personas de 25 a 64 años

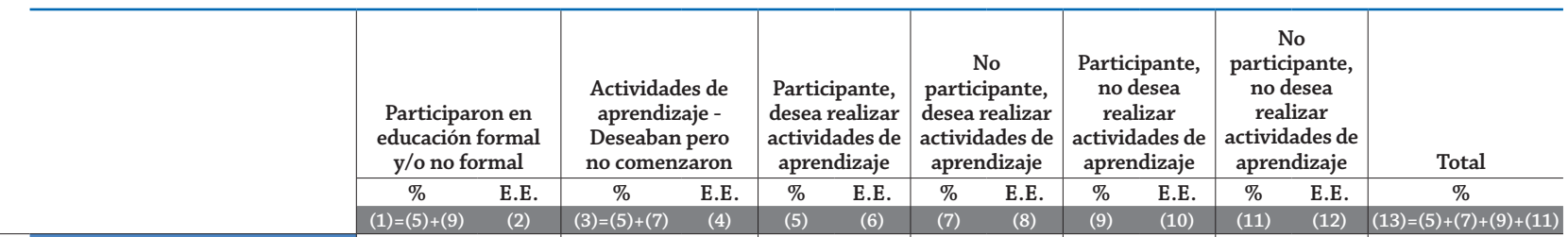

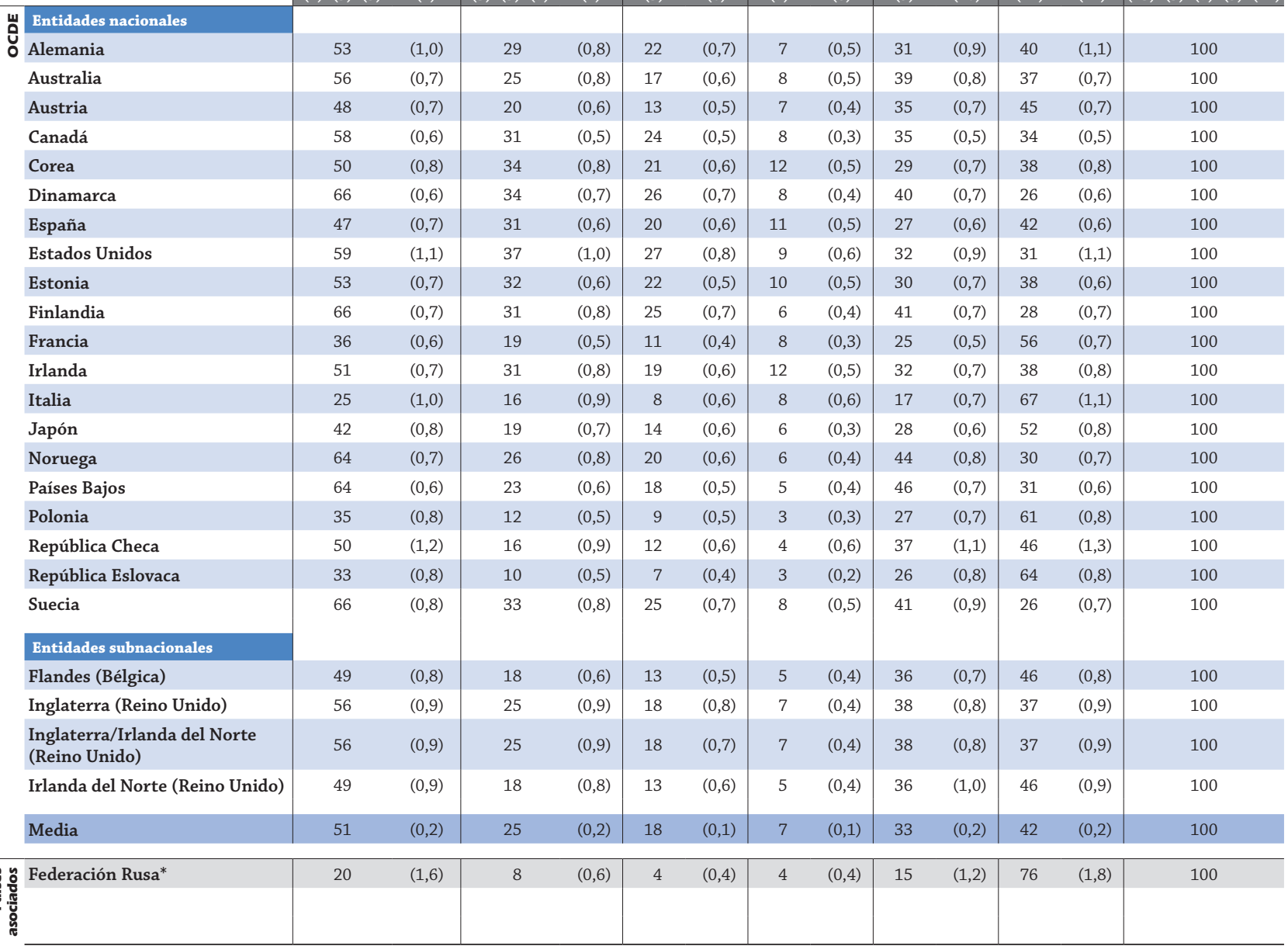

* Para los datos de Federación Rusa, véase nota en la sección de Metodología.

Fuente: OCDE. Encuesta sobre las Competencias de los Adultos (PIAAC) (2012). PIAAC se refiere al Programa para la Evaluación Internacional de las Competencias de los Adultos de la OCDE. Para ver notas, consulte Anexo 3 (www.oecd.org/edu/eag.htm).

Para obtener más información acerca de los símbolos utilizados en lugar de los datos que faltan, consulte la Guía del lector.

StatLink 제이 http://dx.doi.org/10.1787/888933119169 
Tabla C6.5. [1/2] Motivos dados para no haber participado en más actividades de aprendizaje o en alguna, por situación de participación en actividades de educación formal y/o no formal (2012)

Personas de 25 a 64 años

\begin{tabular}{|c|c|c|c|c|c|c|c|c|c|c|c|c|c|c|c|c|c|}
\hline & \multirow{4}{*}{$\begin{array}{l}\text { Situación de } \\
\text { participación }\end{array}$} & \multicolumn{16}{|c|}{ Motivo para no haber comenzado más actividades de aprendizaje o alguna } \\
\hline & & $\begin{array}{r}\text { Es } \\
\text { dem } \\
\text { ocup } \\
\text { el t }\end{array}$ & $\begin{array}{l}\text { aba } \\
\text { siado } \\
\text { do en } \\
\text { bajo }\end{array}$ & \multicolumn{2}{|c|}{$\begin{array}{c}\text { El curso o } \\
\text { programa } \\
\text { se ofrecía } \\
\text { en un } \\
\text { horario o } \\
\text { lugar que } \\
\text { no me } \\
\text { convenía }\end{array}$} & \multicolumn{2}{|c|}{$\begin{array}{c}\text { El curso o } \\
\text { formación } \\
\text { era } \\
\text { demasiado } \\
\text { caro/No } \\
\text { me lo podía } \\
\text { permitir }\end{array}$} & \multicolumn{2}{|c|}{$\begin{array}{l}\text { No tuve } \\
\text { tiempo debido } \\
\text { al cuidado } \\
\text { de los hijos o } \\
\text { a respon- } \\
\text { sabilidades } \\
\text { familiares }\end{array}$} & \multicolumn{2}{|c|}{$\begin{array}{l}\text { Falta de } \\
\text { apoyo del } \\
\text { empleador }\end{array}$} & \multicolumn{2}{|c|}{$\begin{array}{c}\text { Surgió un } \\
\text { imprevisto } \\
\text { que me } \\
\text { impidió } \\
\text { tomar } \\
\text { parte en } \\
\text { el curso o } \\
\text { formación }\end{array}$} & \multicolumn{2}{|c|}{$\begin{array}{l}\text { No cumplía } \\
\text { con los } \\
\text { prerrequi- } \\
\text { sitos }\end{array}$} & & $\cos$ \\
\hline & & $\%$ & E.E. & $\%$ & E.E. & $\%$ & E.E. & $\%$ & E.E. & $\%$ & E.E. & $\%$ & E.E. & $\%$ & E.E. & $\%$ & E.E. \\
\hline & & (1) & (2) & (3) & (4) & (5) & (6) & (7) & (8) & (9) & (10) & (11) & (12) & (13) & (14) & (15) & (16) \\
\hline Entidades nacionales & & & & & & & & & & & & & & & & & \\
\hline Alemania & Participante & 36 & $(1,7)$ & 17 & $(1,2)$ & 9 & $(0,9)$ & 11 & $(1,1)$ & 10 & $(1,2)$ & 2 & $(0,5)$ & 1 & $(0,3)$ & 14 & $(1,3)$ \\
\hline & No participante & 22 & $(2,9)$ & 6 & $(1,7)$ & 11 & $(2,0)$ & 26 & $(2,8)$ & 8 & $(1,6)$ & 3 & $(1,3)$ & 2 & $(0,8)$ & 21 & $(2,8)$ \\
\hline & Total & 33 & $(1,5)$ & 14 & $(1,0)$ & 9 & $(0,9)$ & 15 & $(1,2)$ & 10 & $(1,0)$ & 3 & $(0,5)$ & 1 & $(0,3)$ & 15 & $(1,2)$ \\
\hline Australia & Participante & 30 & $(1,4)$ & 13 & $(1,3)$ & 18 & $(1,5)$ & 18 & $(1,5)$ & 7 & $(1,1)$ & 2 & $(0,5)$ & 1 & $(0,4)$ & 10 & $(1,0)$ \\
\hline & No participante & 20 & $(2,5)$ & 7 & $(1,7)$ & 19 & $(2,5)$ & 27 & $(2,2)$ & 4 & $(1,1)$ & 4 & $(1,1)$ & 3 & $(0,8)$ & 17 & $(1,9)$ \\
\hline & Total & 27 & $(1,2)$ & 11 & $(1,0)$ & 18 & $(1,5)$ & 21 & $(1,3)$ & 6 & $(0,9)$ & 3 & $(0,5)$ & 2 & $(0,3)$ & 12 & $(0,9)$ \\
\hline Austria & Participante & 38 & $(1,8)$ & 16 & $(1,7)$ & 13 & $(1,8)$ & 13 & $(1,3)$ & 3 & $(0,7)$ & 6 & $(1,0)$ & 1 & $(0,5)$ & 10 & $(1,5)$ \\
\hline & No participante & 29 & $(3,0)$ & 11 & $(2,1)$ & 8 & $(1,8)$ & 19 & $(2,4)$ & 1 & $(0,7)$ & 9 & $(1,6)$ & 2 & $(0,9)$ & 20 & $(2,7)$ \\
\hline & Total & 35 & $(1,6)$ & 14 & $(1,3)$ & 11 & $(1,3)$ & 15 & $(1,2)$ & 2 & $(0,5)$ & 7 & $(0,9)$ & 1 & $(0,5)$ & 13 & $(1,3)$ \\
\hline Canadá & Participante & 33 & $(1,1)$ & 13 & $(0,9)$ & 17 & $(1,0)$ & 15 & $(1,0)$ & 7 & $(0,6)$ & 3 & $(0,4)$ & 2 & $(0,3)$ & 11 & $(0,7)$ \\
\hline & No participante & 22 & $(1,7)$ & 7 & $(0,9)$ & 23 & $(2,0)$ & 21 & $(1,9)$ & 4 & $(1,0)$ & 4 & $(0,7)$ & 2 & $(0,7)$ & 16 & $(1,4)$ \\
\hline & Total & 30 & $(0,9)$ & 12 & $(0,7)$ & 19 & $(0,9)$ & 17 & $(1,0)$ & 6 & $(0,5)$ & 3 & $(0,4)$ & 2 & $(0,3)$ & 12 & $(0,6)$ \\
\hline Corea & Participante & 49 & $(1,6)$ & 19 & $(1,2)$ & 11 & $(1,0)$ & 11 & $(0,8)$ & 1 & $(0,3)$ & 3 & $(0,5)$ & 2 & $(0,4)$ & 5 & $(0,6)$ \\
\hline & No participante & 40 & $(2,0)$ & 10 & $(1,2)$ & 10 & $(1,3)$ & 27 & $(1,8)$ & 0 & $(0,2)$ & 2 & $(0,5)$ & 2 & $(0,6)$ & 7 & $(0,9)$ \\
\hline & Total & 46 & $(1,3)$ & 16 & $(0,9)$ & 11 & $(0,9)$ & 17 & $(0,8)$ & 1 & $(0,2)$ & 2 & $(0,4)$ & 2 & $(0,4)$ & 6 & $(0,5)$ \\
\hline Dinamarca & Participante & 29 & $(1,3)$ & 10 & $(0,9)$ & 13 & $(1,0)$ & 5 & $(0,7)$ & 17 & $(1,1)$ & 4 & $(0,6)$ & 2 & $(0,4)$ & 20 & $(1,1)$ \\
\hline & No participante & 20 & $(2,7)$ & 6 & $(1,4)$ & 19 & $(2,3)$ & 7 & $(1,3)$ & 10 & $(1,6)$ & 6 & $(1,4)$ & 4 & $(1,2)$ & 27 & $(2,5)$ \\
\hline & Total & 27 & $(1,2)$ & 9 & $(0,8)$ & 14 & $(0,9)$ & 5 & $(0,6)$ & 15 & $(1,0)$ & 5 & $(0,5)$ & 2 & $(0,4)$ & 22 & $(1,0)$ \\
\hline España & Participante & 30 & $(1,8)$ & 9 & $(1,0)$ & 11 & $(1,1)$ & 19 & $(1,2)$ & 3 & $(0,6)$ & 2 & $(0,6)$ & 5 & $(0,6)$ & 21 & $(1,5)$ \\
\hline & No participante & 28 & $(1,8)$ & 7 & $(1,2)$ & 9 & $(1,2)$ & 28 & $(2,0)$ & 2 & $(0,6)$ & 2 & $(0,7)$ & 4 & $(0,9)$ & 20 & $(1,5)$ \\
\hline & Total & 29 & $(1,3)$ & 8 & $(0,8)$ & 10 & $(0,9)$ & 22 & $(1,0)$ & 3 & $(0,4)$ & 2 & $(0,4)$ & 5 & $(0,5)$ & 20 & $(1,0)$ \\
\hline Estados Unidos & Participante & 31 & $(1,7)$ & 12 & $(1,1)$ & 22 & $(1,3)$ & 17 & $(1,4)$ & 5 & $(0,6)$ & 4 & $(0,8)$ & 2 & $(0,4)$ & 7 & $(0,8)$ \\
\hline & No participante & 19 & $(2,3)$ & 7 & $(1,3)$ & 27 & $(3,1)$ & 18 & $(2,0)$ & 2 & $(0,8)$ & 9 & $(1,8)$ & 3 & $(0,8)$ & 16 & $(1,9)$ \\
\hline & Total & 28 & $(1,5)$ & 11 & $(0,9)$ & 23 & $(1,3)$ & 17 & $(1,1)$ & 4 & $(0,5)$ & 6 & $(0,8)$ & 2 & $(0,3)$ & 9 & $(0,9)$ \\
\hline Estonia & Participante & 32 & $(1,1)$ & 17 & $(1,1)$ & 18 & $(1,0)$ & 9 & $(0,8)$ & 8 & $(0,8)$ & 3 & $(0,4)$ & 3 & $(0,5)$ & 11 & $(0,9)$ \\
\hline & No participante & 24 & $(1,7)$ & 12 & $(1,2)$ & 21 & $(1,5)$ & 13 & $(1,5)$ & 5 & $(1,2)$ & 4 & $(0,8)$ & 5 & $(1,0)$ & 16 & $(1,4)$ \\
\hline & Total & 29 & $(0,9)$ & 15 & $(0,8)$ & 19 & $(0,9)$ & 10 & $(0,6)$ & 7 & $(0,7)$ & 3 & $(0,4)$ & 4 & $(0,5)$ & 13 & $(0,8)$ \\
\hline Finlandia & Participante & 33 & $(1,6)$ & 21 & $(1,2)$ & 7 & $(0,8)$ & 8 & $(0,7)$ & 11 & $(1,0)$ & 3 & $(0,4)$ & 2 & $(0,5)$ & 15 & $(1,2)$ \\
\hline & No participante & 14 & $(2,1)$ & 18 & $(2,4)$ & 7 & $(1,8)$ & 16 & $(2,3)$ & 5 & $(1,5)$ & 3 & $(1,1)$ & 4 & $(1,2)$ & 33 & $(2,6)$ \\
\hline & Total & 29 & $(1,4)$ & 21 & $(1,1)$ & 7 & $(0,7)$ & 9 & $(0,8)$ & 10 & $(0,8)$ & 3 & $(0,4)$ & 3 & $(0,5)$ & 18 & $(1,2)$ \\
\hline Francia & Participante & 26 & $(1,7)$ & 5 & $(0,7)$ & 16 & $(1,3)$ & 6 & $(0,9)$ & 21 & $(1,3)$ & 4 & $(0,7)$ & 1 & $(0,4)$ & 22 & $(1,3)$ \\
\hline & No participante & 18 & $(1,8)$ & 3 & $(0,7)$ & 19 & $(1,7)$ & 10 & $(1,3)$ & 14 & $(1,5)$ & 3 & $(0,6)$ & 4 & $(0,9)$ & 28 & $(1,9)$ \\
\hline & Total & 23 & $(1,3)$ & 4 & $(0,5)$ & 17 & $(1,1)$ & 8 & $(0,7)$ & 18 & $(1,0)$ & 4 & $(0,4)$ & 3 & $(0,5)$ & 24 & $(1,1)$ \\
\hline Irlanda & Participante & 26 & $(1,6)$ & 10 & $(0,9)$ & 23 & $(1,5)$ & 17 & $(1,2)$ & 6 & $(0,9)$ & 3 & $(0,5)$ & 2 & $(0,5)$ & 13 & $(1,4)$ \\
\hline & No participante & 14 & $(1,6)$ & 8 & $(1,3)$ & 19 & $(1,7)$ & 24 & $(1,9)$ & 3 & $(0,8)$ & 6 & $(1,1)$ & 3 & $(0,8)$ & 23 & $(2,0)$ \\
\hline & Total & 22 & $(1,1)$ & 10 & $(0,8)$ & 21 & $(1,1)$ & 20 & $(1,1)$ & 5 & $(0,7)$ & 4 & $(0,5)$ & 3 & $(0,4)$ & 17 & $(1,2)$ \\
\hline Italia & Participante & 47 & $(3,4)$ & 6 & $(1,4)$ & 15 & $(2,4)$ & 12 & $(1,5)$ & 5 & $(1,4)$ & 2 & $(0,9)$ & 1 & $(1,0)$ & 12 & $(2,0)$ \\
\hline & No participante & 32 & $(3,1)$ & 4 & $(1,5)$ & 14 & $(2,8)$ & 26 & $(3,4)$ & 2 & $(0,8)$ & 5 & $(1,6)$ & 5 & $(1,8)$ & 12 & $(2,4)$ \\
\hline & Total & 40 & $(2,3)$ & 5 & $(1,0)$ & 15 & $(1,6)$ & 19 & $(1,8)$ & 3 & $(0,8)$ & 4 & $(0,8)$ & 3 & $(1,0)$ & 12 & $(1,4)$ \\
\hline Japón & Participante & 42 & $(2,3)$ & 25 & $(1,7)$ & 8 & $(1,3)$ & 15 & $(1,3)$ & 1 & $(0,4)$ & 1 & $(0,5)$ & 4 & $(0,8)$ & 5 & $(0,9)$ \\
\hline & No participante & 30 & $(3,1)$ & 16 & $(2,2)$ & 7 & $(1,6)$ & 27 & $(3,2)$ & $\mathrm{n}$ & $\mathrm{n}$ & 1 & $(0,9)$ & 5 & $(1,6)$ & 14 & $(2,3)$ \\
\hline & Total & 38 & $(1,9)$ & 22 & $(1,5)$ & 8 & $(1,0)$ & 19 & $(1,4)$ & 1 & $(0,3)$ & 1 & $(0,4)$ & 4 & $(0,7)$ & 7 & $(0,9)$ \\
\hline Noruega & Participante & 36 & $(1,7)$ & 10 & $(1,2)$ & 8 & $(1,1)$ & 10 & $(1,2)$ & 13 & $(1,1)$ & 5 & $(0,7)$ & 2 & $(0,6)$ & 15 & $(1,1)$ \\
\hline & No participante & 19 & $(2,3)$ & 8 & $(1,7)$ & 13 & $(2,2)$ & 16 & $(2,7)$ & 8 & $(1,8)$ & 11 & $(2,3)$ & 3 & $(1,3)$ & 22 & $(2,8)$ \\
\hline & Total & 33 & $(1,3)$ & 9 & $(1,0)$ & 9 & $(0,9)$ & 12 & $(1,0)$ & 12 & $(0,9)$ & 6 & $(0,7)$ & 3 & $(0,6)$ & 17 & $(1,1)$ \\
\hline Países Bajos & Participante & 34 & $(2,0)$ & 9 & $(1,0)$ & 13 & $(1,3)$ & 10 & $(1,0)$ & 9 & $(1,0)$ & 7 & $(0,9)$ & 1 & $(0,4)$ & 17 & $(1,4)$ \\
\hline & No participante & 14 & $(2,8)$ & 6 & $(1,8)$ & 19 & $(3,3)$ & 17 & $(2,7)$ & 10 & $(2,4)$ & 8 & $(2,1)$ & 1 & $(0,8)$ & 24 & $(3,5)$ \\
\hline & Total & 30 & $(1,7)$ & 8 & $(0,9)$ & 14 & $(1,3)$ & 12 & $(1,0)$ & 9 & $(0,9)$ & 7 & $(0,9)$ & 1 & $(0,4)$ & 18 & $(1,4)$ \\
\hline Polonia & Participante & 18 & $(2,1)$ & 15 & $(1,7)$ & 23 & $(2,6)$ & 10 & $(2,0)$ & 11 & $(2,0)$ & 4 & $(1,0)$ & 4 & $(1,1)$ & 15 & $(2,5)$ \\
\hline & No participante & 9 & $(2,7)$ & 8 & $(2,2)$ & 14 & $(3,7)$ & 25 & $(3,8)$ & 3 & $(1,8)$ & 13 & $(2,9)$ & 9 & $(2,4)$ & 19 & $(3,7)$ \\
\hline & Total & 16 & $(1,7)$ & 13 & $(1,5)$ & 20 & $(2,2)$ & 14 & $(2,1)$ & 9 & $(1,5)$ & 7 & $(1,2)$ & 5 & $(1,1)$ & 16 & $(2,3)$ \\
\hline República Checa & Participante & 36 & $(3,7)$ & 8 & $(1,9)$ & 15 & $(2,2)$ & 11 & $(2,4)$ & 12 & $(2,7)$ & 5 & $(1,1)$ & 3 & $(1,2)$ & 9 & $(1,7)$ \\
\hline & No participante & 33 & $(6,6)$ & 3 & $(1,7)$ & 11 & $(3,0)$ & 17 & $(3,8)$ & 3 & $(1,3)$ & 8 & $(3,0)$ & 3 & $(1,3)$ & 21 & $(6,0)$ \\
\hline & Total & 36 & $(3,5)$ & 7 & $(1,4)$ & 14 & $(1,7)$ & 13 & $(2,0)$ & 10 & $(2,1)$ & 6 & $(1,1)$ & 3 & $(0,9)$ & 12 & $(2,2)$ \\
\hline República Eslovaca & Participante & 35 & $(3,0)$ & 9 & $(1,7)$ & 13 & $(2,2)$ & 6 & $(1,6)$ & 18 & $(3,2)$ & 3 & $(1,0)$ & 1 & $(0,9)$ & 14 & $(2,4)$ \\
\hline & No participante & 27 & $(4,9)$ & 6 & $(2,1)$ & 16 & $(4,0)$ & 20 & $(3,8)$ & 5 & $(3,2)$ & 6 & $(2,2)$ & 6 & $(2,1)$ & 15 & $(3,3)$ \\
\hline & Total & 33 & $(2,6)$ & 8 & $(1,4)$ & 14 & $(1,9)$ & 10 & $(1,7)$ & 14 & $(2,4)$ & 4 & $(1,0)$ & 2 & $(0,9)$ & 14 & $(2,0)$ \\
\hline Suecia & Participante & 29 & $(1,6)$ & 12 & $(1,0)$ & 11 & $(1,1)$ & 12 & $(1,1)$ & 8 & $(0,8)$ & 4 & $(0,7)$ & 3 & $(0,7)$ & 20 & $(1,5)$ \\
\hline & No participante & 16 & $(2,7)$ & 7 & $(1,7)$ & 17 & $(2,5)$ & 16 & $(2,5)$ & 8 & $(1,6)$ & 6 & $(1,2)$ & 5 & $(1,6)$ & 25 & $(3,2)$ \\
\hline & Total & 26 & $(1,3)$ & 11 & $(0,9)$ & 12 & $(1,0)$ & 13 & $(0,9)$ & 8 & $(0,7)$ & 4 & $(0,6)$ & 4 & $(0,6)$ & 21 & $(1,4)$ \\
\hline
\end{tabular}

* Para los datos de Federación Rusa, véase nota en la sección de Metodología.

Fuente: OCDE. Encuesta sobre las Competencias de los Adultos (PIAAC) (2012). PIAAC se refiere al Programa para la Evaluación Internacional de las Competencias de los Adultos de la OCDE. Para ver notas, consulte Anexo 3 (www.oecd.org/edu/eag.htm).

Para obtener más información acerca de los símbolos utilizados en lugar de los datos que faltan, consulte la Guía del lector.

StatLink 게개 http://dx.doi.org/10.1787/888933119188 
Tabla C6.5. [2/2] Motivos dados para no haber participado en más actividades de aprendizaje o en alguna, por situación de participación en actividades de educación formal y/o no formal (2012)

Personas de 25 a 64 años

\begin{tabular}{|c|c|c|c|c|c|c|c|c|c|c|c|c|c|c|c|c|c|}
\hline & \multirow{3}{*}{$\begin{array}{l}\text { Situación de } \\
\text { participación }\end{array}$} & \multicolumn{16}{|c|}{ Motivo para no haber comenzado más actividades de aprendizaje o alguna } \\
\hline & & \multicolumn{2}{|c|}{$\begin{array}{c}\text { Estaba } \\
\text { demasiado } \\
\text { ocupado } \\
\text { en el } \\
\text { trabajo }\end{array}$} & \multicolumn{2}{|c|}{$\begin{array}{c}\text { El curso o } \\
\text { programa se } \\
\text { ofrecía en } \\
\text { un horario } \\
\text { o lugar } \\
\text { que no me } \\
\text { convenía }\end{array}$} & \multicolumn{2}{|c|}{$\begin{array}{c}\text { El curso o } \\
\text { formación } \\
\text { era } \\
\text { demasiado } \\
\text { caro/No } \\
\text { me lo podía } \\
\text { permitir }\end{array}$} & \multicolumn{2}{|c|}{$\begin{array}{c}\text { No tuve tiem- } \\
\text { po debido al } \\
\text { cuidado de los } \\
\text { hijos o a res- } \\
\text { ponsabilidades } \\
\text { familiares }\end{array}$} & \multicolumn{2}{|c|}{$\begin{array}{l}\text { Falta de } \\
\text { apoyo del } \\
\text { emplea- } \\
\text { dor }\end{array}$} & \multicolumn{2}{|c|}{$\begin{array}{l}\text { Surgió un im- } \\
\text { previsto que } \\
\text { me impidió } \\
\text { tomar parte } \\
\text { en el curso o } \\
\text { formación }\end{array}$} & \multicolumn{2}{|c|}{$\begin{array}{l}\text { No cumplía } \\
\text { con los pre- } \\
\text { rrequisitos }\end{array}$} & \multicolumn{2}{|c|}{ Otros } \\
\hline & & & & (3) & $(4)$ & $(5)$ & $(6)$ & $(7)$ & $(8)$ & (9) & (10) & $(11)$ & (12) & $(13)$ & $(14)$ & $(15)$ & (16) \\
\hline \multicolumn{18}{|l|}{ Entidades subnacionales } \\
\hline \multirow{3}{*}{ Flandes (Bélgica) } & Participante & 37 & $(2,6)$ & 19 & $(1,9)$ & 5 & $(1,0)$ & 16 & $(1,7)$ & 7 & $(1,2)$ & 3 & $(0,7)$ & 1 & $(0,5)$ & 12 & $(1,4)$ \\
\hline & No participante & 20 & $(3,1)$ & 14 & $(2,5)$ & 5 & $(1,7)$ & 31 & $(3,2)$ & 3 & $(1,3)$ & 6 & $(1,5)$ & 3 & $(1,2)$ & 18 & $(2,8)$ \\
\hline & Total & 32 & $(1,8)$ & 18 & $(1,5)$ & 5 & $(0,8)$ & 20 & $(1,4)$ & 6 & $(1,0)$ & 4 & $(0,7)$ & 2 & $(0,5)$ & 14 & $(1,4)$ \\
\hline \multirow[t]{3}{*}{ Inglaterra (Reino Unido) } & Participante & 34 & $(1,8)$ & 10 & $(1,1)$ & 19 & $(1,5)$ & 12 & $(1,0)$ & 10 & $(1,2)$ & 3 & $(0,7)$ & 1 & $(0,5)$ & 10 & $(1,2)$ \\
\hline & No participante & 19 & $(2,7)$ & 5 & $(1,2)$ & 21 & $(3,0)$ & 19 & $(2,2)$ & 3 & $(1,2)$ & 6 & $(1,6)$ & 1 & $(0,7)$ & 25 & $(3,0)$ \\
\hline & Total & 30 & $(1,6)$ & 9 & $(0,9)$ & 20 & $(1,4)$ & 14 & $(0,9)$ & 8 & $(1,0)$ & 4 & $(0,7)$ & 1 & $(0,4)$ & 14 & $(1,1)$ \\
\hline \multirow{2}{*}{$\begin{array}{l}\text { Inglaterra/Irlanda } \\
\text { del Norte (Reino Unido) }\end{array}$} & No participante & 19 & $(2,6)$ & 6 & $(1,2)$ & 21 & $(2,9)$ & 19 & $(2,2)$ & 3 & $(1,2)$ & 6 & $(1,5)$ & 1 & $(0,7)$ & 25 & $(2,9)$ \\
\hline & Total & 30 & $(1,6)$ & 9 & $(0,9)$ & 19 & $(1,4)$ & 14 & $(0,9)$ & 8 & $(1,0)$ & 4 & $(0,7)$ & 1 & $(0,4)$ & 14 & $(1,1)$ \\
\hline \multirow[t]{3}{*}{$\begin{array}{l}\text { Irlanda del Norte } \\
\text { (Reino Unido) }\end{array}$} & Participante & 32 & $(2,8)$ & 14 & $(1,8)$ & 16 & $(2,1)$ & 14 & $(1,6)$ & 8 & $(1,5)$ & 1 & $(0,6)$ & 1 & $(0,7)$ & 13 & $(1,9)$ \\
\hline & No participante & 11 & $(2,4)$ & 14 & $(2,8)$ & 18 & $(3,9)$ & 23 & $(2,9)$ & 4 & $(1,3)$ & 7 & $(2,2)$ & 3 & $(1,6)$ & 21 & $(3,4)$ \\
\hline & Total & 26 & $(2,2)$ & 14 & $(1,7)$ & 17 & $(1,8)$ & 16 & $(1,5)$ & 7 & $(1,1)$ & 3 & $(0,8)$ & 2 & $(0,7)$ & 15 & $(1,7)$ \\
\hline \multirow[t]{3}{*}{ Media } & Participante & 34 & $(0,4)$ & 13 & $(0,3)$ & 14 & $(0,3)$ & 12 & $(0,3)$ & 9 & $(0,3)$ & 3 & $(0,2)$ & 2 & $(0,1)$ & 13 & $(0,3)$ \\
\hline & No participante & 22 & $(0,6)$ & 8 & $(0,4)$ & 15 & $(0,5)$ & 21 & $(0,6)$ & 5 & $(0,3)$ & 6 & $(0,3)$ & 4 & $(0,3)$ & 20 & $(0,6)$ \\
\hline & Total & 30 & $(0,4)$ & 12 & $(0,2)$ & 14 & $(0,3)$ & 15 & $(0,3)$ & 8 & $(0,2)$ & 4 & $(0,1)$ & 3 & $(0,1)$ & 15 & $(0,3)$ \\
\hline \multirow[t]{3}{*}{ Federación Rusa* } & Participante & 31 & $(3,2)$ & 22 & $(4,5)$ & 18 & $(4,4)$ & 7 & $(2,3)$ & 8 & $(2,5)$ & 7 & $(2,3)$ & 2 & $(1,2)$ & 6 & $(2,0)$ \\
\hline & No participante & 23 & $(5,1)$ & 8 & $(2,1)$ & 30 & $(4,1)$ & 20 & $(4,2)$ & 2 & $(0,8)$ & 7 & $(4,8)$ & 3 & $(1,4)$ & 7 & $(4,0)$ \\
\hline & Total & 27 & $(2,6)$ & 15 & $(2,8)$ & 24 & $(2,8)$ & 13 & $(2,8)$ & 5 & $(1,2)$ & 7 & $(2,4)$ & 2 & $(0,7)$ & 7 & $(2,1)$ \\
\hline
\end{tabular}

* Para los datos de Federación Rusa, véase nota en la sección de Metodología.

Fuente: OCDE. Encuesta sobre las Competencias de los Adultos (PIAAC) (2012). PIAAC se refiere al Programa para la Evaluación Internacional de las Competencias de los Adultos de la OCDE. Para ver notas, consulte Anexo 3 (www.oecd.org/edu/eag.htm).

Para obtener más información acerca de los símbolos utilizados en lugar de los datos que faltan, consulte la Guía del lector.

StatLink ज्ञात http://dx.doi.org/10.1787/888933119188 



\section{¿EN QUÉ SE DIFERENCIAN INSTITUCIONES Y CENTROS ESCOLARES PÜBUICOS DE INSTITUCIONES Y CENTROS PRIVADOS?}

- En la mayor parte de los países, los centros escolares privados proporcionan educación a una minoría de estudiantes, desde la educación primaria hasta los niveles de educación secundaria superior. Solo alrededor del $3 \%$ de todos los estudiantes de educación primaria y secundaria asistieron a centros escolares privados independientes en 2012. Las proporciones de alumnos matriculados en centros escolares privados de educación infantil son considerablemente mayores, alrededor de un $11 \%$.

- Los estudiantes que asisten a centros escolares privados, sean estos dependientes del gobierno o independientes, tienden a conseguir resultados significativamente mejores en las pruebas del Programa para la Evaluación Internacional de Alumnos (PISA) de la OCDE que los estudiantes que asisten a centros escolares públicos. Sin embargo, los estudiantes de centros escolares públicos cuyo entorno socioeconómico es similar al de los centros escolares privados tienden a obtener resultados similares.

- Como media en los países de la OCDE, el tamaño de la clase en la educación primaria y secundaria es aproximadamente igual en los centros escolares públicos y privados. Esto sugiere que, en países en los que una proporción importante de estudiantes y familias optan por los centros escolares privados, el tamaño de la clase no es un factor que determine su elección.

\section{Gráfico C7.1. Porcentaje de estudiantes de 15 años de edad matriculados en centros escolares públicos $(2003,2012)$}

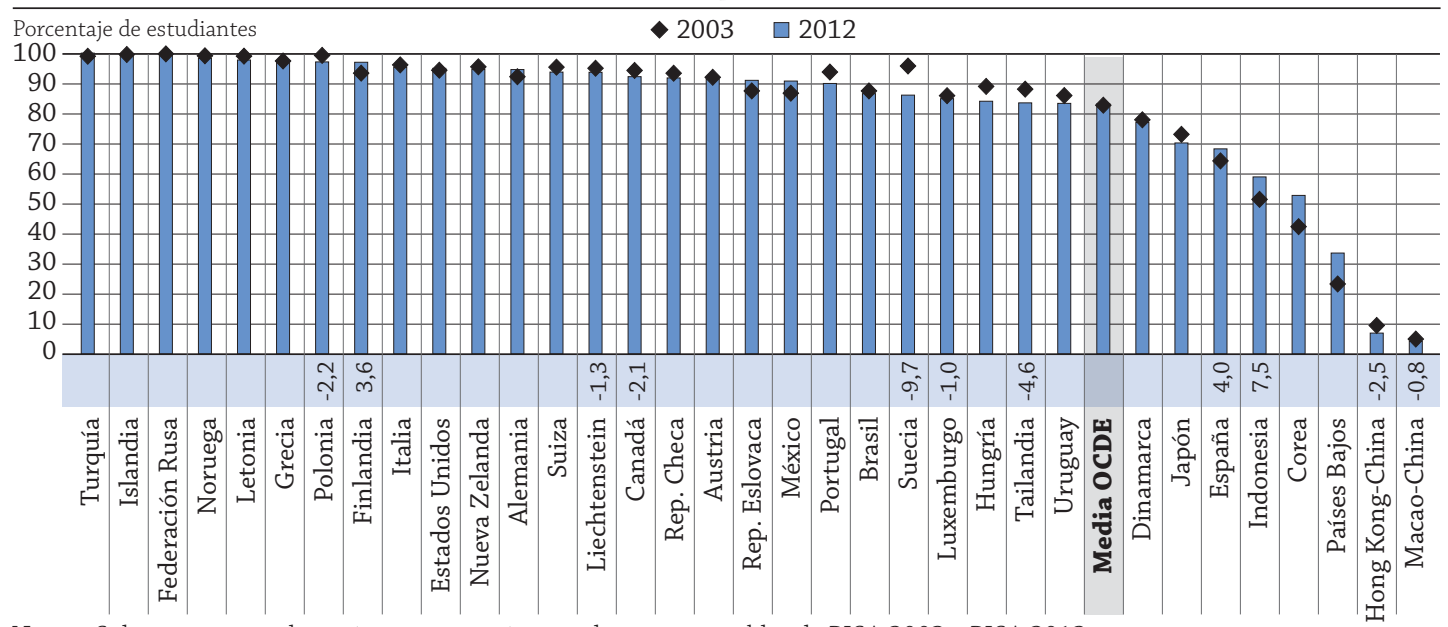

Notas: Solo se muestran los países y economías con datos comparables de PISA 2003 y PISA 2012

La diferencia en puntos porcentuales entre la proporción de estudiantes que asistieron a centros escolares públicos en 2012 y 2003 (2012-2003) se muestra encima del nombre del país o economía. Solo se muestran diferencias estadísticamente significativas.

La media 2003 de la OCDE solo compara países de la OCDE con datos disponibles desde 2003.

1. Aproximadamente un $99 \%$ de los estudiantes de 15 años de edad en Países Bajos asisten a centros escolares con financiación pública: $1 / 3$ de estos centros escolares están gobernados de manera pública y $2 / 3$ están gobernados de manera privada.

Los países y las economías están clasificados en orden descendente de la proporción de estudiantes matriculados en centros escolares públicos en 2012.

Fuente: OCDE. Tablas C7.2 y C7.3. Para ver notas, consulte Anexo 3 (www.oecd.org/edu/eag.htm).

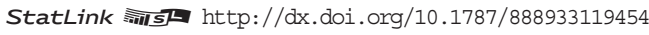

\section{Contexto}

En algún momento de la educación de su hijo, muchos padres han considerado si valdría la pena afrontar el gasto de matricular a su hijo en un centro escolar privado. De manera similar, un número cada vez mayor de estudiantes deciden estudiar en universidades privadas. En algunos casos, los centros escolares privados pueden ofrecer a padres y estudiantes un tipo particular de enseñanza. Algunos sistemas educativos también promueven los centros escolares privados bajo el supuesto de que, con la flexibilidad que acompaña a la autonomía en el diseño del currículo y la asignación de recursos, los centros privados pueden ser considerados como un estímulo de innovación en el sistema escolar. Sin embargo, los centros escolares privados pueden también segregar a los estudiantes e intensificar las desigualdades con respecto a las oportunidades educativas, particularmente si estos centros escolares cobran tasas a los padres. Con mayores recursos económicos, estos centros escolares pueden permitirse atraer y reclutar a los mejores estudiantes y profesores. 
Sin embargo, hasta el momento no existen datos que demuestren con claridad que existe una relación entre la prevalencia de los centros escolares privados y el rendimiento académico de los sistemas educativos. Por ejemplo, estudios realizados en Chile (Lara, Mizala y Repetto, 2009), Estados Unidos (Couch, Shugart y Williams, 1993; Peterson et al., 2003), Reino Unido (Green et al., 2011) República Checa (Filer y Munich, 2003) y Suecia (Sandstrom y Bergstrom, 2005) muestran que existe relación entre una proporción mayor de matriculaciones en centros escolares privados y un mejor rendimiento, de acuerdo con datos transversales o longitudinales. Sin embargo, el debate sobre el rendimiento no es para nada concluyente, ya que otros estudios encuentran efectos escasos, negativos o insignificantes, o muestran que los resultados a menudo dependen de las opciones metodológicas utilizadas.

Por ejemplo, algunos estudios basados en datos recogidos por diferentes estados de Estados Unidos concluyeron que un nivel más alto de matriculación en centros escolares privados no guarda relación significativa con el rendimiento (Wrinkle et al., 1999; Sander, 1999; Geller, Sjoquist y Walker, 2006). Unos pocos estudios muestran ligeros efectos negativos (Smith y Meier, 1995), efectos negativos en distritos de rentas bajas (Maranto, Milliman y Scott, 2000), o muestran que la relación depende del resultado educativo que se mida (Greene y Kang, 2004). En todos los países de la OCDE y en todos los países y las economías que participaron en PISA 2012, el porcentaje de estudiantes matriculados en centros escolares privados no guarda relación con el rendimiento general del sistema (véase el Volumen IV de PISA 2012). Al analizar los centros escolares privados, se hace una distinción entre los que dependen del gobierno y los que son independientes, en función del grado de dependencia de la financiación recibida del gobierno. De hecho, no todos los centros escolares gestionados de manera privada se sustentan con financiación privada, tal y como se suele asumir.

\section{Otros resultados}

- En la mayoría de los países y economías que participan en PISA, los estudiantes que asisten a centros escolares privados dependientes del gobierno o independientes suelen proceder de un entorno socioeconómico medio más favorecido que los estudiantes que asisten a centros escolares públicos.

- Los centros escolares privados tienden a disfrutar de mayor autonomía para «asignar recursos» o «tomar decisiones sobre el currículo y las evaluaciones» que los centros escolares públicos. Sin embargo, el grado de autonomía de los centros escolares privados varía de manera significativa entre países y entre centros escolares privados dependientes del gobierno e independientes.

- Los directores de centros escolares públicos declararon experimentar una mayor escasez de profesores que los de centros escolares privados en 34 de 47 países y economías.

- Como media en los países de la OCDE, los estudiantes matriculados en centros escolares privados dedican una hora más a hacer deberes u otros estudios establecidos por el profesor que los estudiantes matriculados en centros escolares públicos (5,6 y 4,7 horas respectivamente). El tiempo adicional excede 1,5 horas en Australia, Austria, Canadá, Catar, Colombia, Emiratos Árabes Unidos, Estados Unidos, Nueva Zelanda y Portugal.

- En 2012, un $\mathbf{7 2 \%}$ de los estudiantes de educación terciaria de tipo A asistieron a instituciones públicas, un $14 \%$ asistieron a instituciones privadas dependientes del gobierno y un $14 \%$ asistieron a instituciones privadas independientes. La matriculación en una institución privada implica un coste adicional para los estudiantes, ya que en la mayor parte de los países las tasas de matriculación son más altas en las instituciones privadas que en las públicas.

\section{Tendencias}

La proporción de jóvenes de 15 años de edad matriculados en centros escolares privados, como media, no aumentó entre 2003 y 2012, pero algunos países experimentaron movimientos significativos de estudiantes entre centros escolares públicos y privados durante este periodo.

En cambio, en 21 de los 29 países de la OCDE con datos disponibles para los años 2003 y 2012, la proporción de estudiantes matriculados en instituciones privadas en el nivel de educación terciaria aumentó de manera significativa entre 2003 y 2012. De manera similar, las matriculaciones en las instituciones privadas de educación terciaria de tipo A (de orientación académica) aumentaron dos puntos porcentuales, desde un $23 \%$ a un $25 \%$ como media en los países con datos disponibles para los años 2003 y 2012, mientras que las matriculaciones en instituciones privadas de educación terciaria de tipo B (de orientación vocacional) aumentaron cuatro puntos porcentuales, desde un $33 \%$ a un $37 \%$ durante ese periodo. 


\section{Análisis}

\section{Matriculación en centros escolares públicos y privados}

En la mayor parte del mundo, la escolarización tiene lugar principalmente en centros escolares públicos, definidos como aquellos que son gestionados de manera directa o indirecta por una autoridad de educación pública, un órgano gubernamental o un consejo directivo designado por el gobierno o elegido por concesión pública. Como media en los países de la OCDE, en 2012 casi un 89\% de los estudiantes de educación primaria, un $86 \%$ de los estudiantes de educación secundaria inferior y un $81 \%$ de los estudiantes de educación secundaria superior estaban matriculados en centros escolares públicos.

Al analizar los centros escolares privados, se hace una distinción entre los dependientes del gobierno y los independientes, de acuerdo con la proporción de financiación que reciben del gobierno. De hecho, no todos los centros escolares gestionados de manera privada se sustentan con financiación privada, tal como se suele asumir (véase la sección Definiciones y metodología). Por tanto, en Australia, Bélgica, Chile y España, y en menor grado en Argentina, Dinamarca, Francia e Israel, proporciones significativas de estudiantes (un $14 \%$ o más) asisten a centros escolares de educación primaria y secundaria inferior controlados por una organización no gubernamental, pero financiados en gran parte con dinero público (Tabla C7.1).

En cambio, como media en los países de la OCDE, solo aproximadamente un $3 \%$ de todos los estudiantes asisten a centros escolares privados independientes durante la educación primaria y secundaria (por ejemplo, centros escolares que son gestionados de manera directa o indirecta por una organización no gubernamental y reciben menos del $50 \%$ de su financiación de órganos gubernamentales). Sin embargo, según asciende el nivel de educación, aumenta también la matriculación en centros escolares independientes. Por ejemplo, un $2 \%$ de estudiantes de educación primaria están matriculados en centros escolares privados independientes, mientras que en educación secundaria inferior esta proporción es del $3 \%$ y en educación secundaria superior del 5\% (Tabla C7.1). En Brasil, Colombia, Indonesia, Japón, México, Polonia y Portugal, más del $10 \%$ de los estudiantes de educación secundaria superior asisten a centros escolares privados independientes.

Las proporciones de estudiantes matriculados en centros escolares privados de educación infantil son considerablemente mayores que la proporción de estudiantes matriculados en centros escolares privados de educación primaria y secundaria. Aproximadamente un $11 \%$ de los estudiantes de educación infantil están matriculados en centros escolares privados independientes. Si se consideran de manera conjunta los centros escolares de educación infantil privados independientes y los dependientes del gobierno, un $31 \%$ de los estudiantes están matriculados en estos programas. Esta proporción excede el 50 \% en Alemania, Australia, Bélgica, Chile, Corea, Indonesia, Irlanda, Japón y Nueva Zelanda (Tabla C7.1).

\section{Cambios de las tasas de matriculación en centros escolares privados entre 2003 y 2012}

En 2003, como media en los países de la OCDE, un $83 \%$ de los estudiantes de 15 años de edad asistieron a centros escolares públicos, un $14 \%$ a centros escolares privados dependientes del gobierno y un $4 \%$ a centros escolares privados independientes. Estas proporciones medias se han mantenido estables desde entonces, pero con algunas variaciones entre países. En 2012, más del 98\% de los estudiantes de 15 años de edad en Bulgaria, Croacia, Federación Rusa, Islandia, Israel, Lituania, Montenegro, Noruega, Rumanía, Serbia, Túnez y Turquía asistieron a centros escolares públicos. En cambio, menos de uno de cada dos estudiantes de 15 años de edad en Chile, Hong Kong-China, Macao-China y Países Bajos asiste a centros públicos; la mayoría de los estudiantes de 15 años de estos países asisten a centros escolares privados dependientes del gobierno (Tablas C7.2 y C7.3).

Los datos sobre tendencias muestran patrones diferentes en los distintos países. Entre 2003 y 2012, algunos países y economías experimentaron un aumento del número de matriculaciones en centros escolares públicos (por ejemplo, Corea, Finlandia, Indonesia, México y República Eslovaca), mientras que otros como Canadá, Hong Kong-China, Hungría, Japón, Polonia, Portugal, Suecia, Tailandia y Uruguay, experimentaron un movimiento hacia los centros escolares privados. Como uno de los cambios más significativos, en España, Finlandia, Indonesia y México asistieron a centros escolares públicos en 2012 una proporción mayor de estudiantes de 15 años que en 2003. En Indonesia, la proporción de estudiantes que asistieron a centros escolares privados independientes experimentó una reducción de 21 puntos porcentuales, con el consiguiente aumento de matriculaciones en centros escolares privados dependientes del gobierno de 13 puntos porcentuales y aumento de matriculaciones en centros escolares públicos de 7 puntos porcentuales. En España, Finlandia y México, la proporción de estudiantes que asistieron a centros escolares públicos experimentó un aumento de cuatro puntos porcentuales. En Suecia, la proporción de estudiantes matriculados en 


\section{Gráfico C7.2. Tipo de centro escolar y rendimiento en matemáticas (2012)}

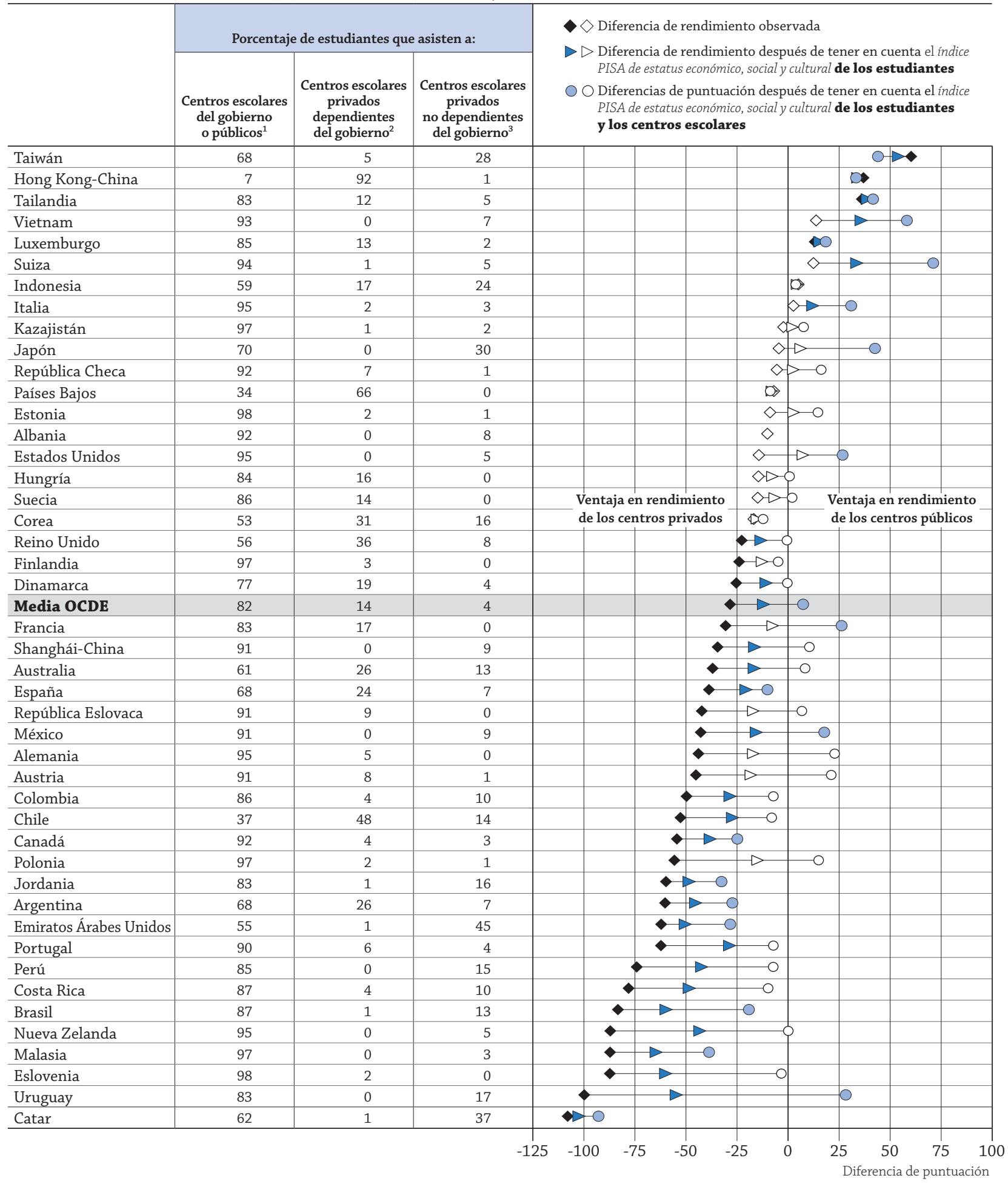

Nota: Los símbolos blancos representan diferencias que no son estadísticamente significativas.

1. Centros escolares que están directamente controlados o gestionados por: una autoridad educativa o agencia pública, o de manera directa por una agencia del gobierno o un órgano de gobierno, cuyos miembros son mayoritariamente designados por una autoridad pública o elegidos por concesión pública.

2. Centros escolares que reciben un $50 \%$ o más de su financiación básica (es decir, una financiación que apoya los servicios educativos básicos de la institución) de agencias gubernamentales.

3. Centros escolares que reciben menos de un 50\% de su financiación básica (es decir, financiación que apoya los servicios educativos básicos de la institución) de agencias gubernamentales.

Los países y las economías están clasificados en orden descendente de la diferencia de puntuación en el rendimiento en matemáticas entre centros escolares públicos y privados (dependientes del gobierno e independientes del gobierno de manera conjunta).

Fuente: OCDE. Tabla C7.2. Para ver notas, consulte Anexo 3 (www.oecd.org/edu/eag.htm).

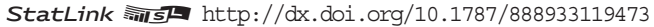


centros escolares públicos disminuyó diez puntos porcentuales, con el consiguiente aumento de la proporción de estudiantes que asistieron a centros escolares privados dependientes del gobierno. En Tailandia, y en menor medida en Polonia, se observó un movimiento similar de las tasas de matriculación hacia centros escolares dependientes del gobierno (Tablas C7.2, C7.3 y Gráfico C7.1).

\section{Tipo de centro escolar y rendimiento de los estudiantes}

Al comparar el rendimiento medio en matemáticas de los estudiantes de 15 años de edad de centros escolares públicos y privados, sin tener en cuenta las diferencias de estatus socioeconómico entre estudiantes, los centros escolares privados (sean centros escolares dependientes del gobierno o independientes) tienden a mostrar un mejor rendimiento que es estadísticamente significativo en 27 de los 45 países y economías con datos disponibles (Gráfico C7.2 y Tabla C7.2). Las diferencias de puntuación oscilan entre 23 puntos en Reino Unido y 108 puntos -o el equivalente de casi tres años de escolarización- en Catar.

La situación contraria (un rendimiento mejor estadísticamente significativo en centros escolares públicos) solo se da en 4 de estos 45 países y economías: en Hong Kong-China, Luxemburgo, Tailandia y Taiwán, los centros escolares públicos alcanzan un rendimiento que está entre 13 y 60 puntos por encima del rendimiento de los centros escolares privados. Entre 2003 y 2012, la diferencia global en el rendimiento en matemáticas entre los estudiantes de escuelas públicas y privadas de países de la OCDE se amplió en nueve puntos (y un máximo de 28 puntos a favor de los estudiantes de centros escolares privados) (Tabla C7.3).

Al comparar los centros escolares públicos con los centros escolares privados dependientes del gobierno, se observa un patrón similar. En estos casos, los centros escolares privados dependientes del gobierno muestran un mejor rendimiento estadísticamente significativo en 16 de los 30 países y economías con datos disponibles (Tabla C7.2). La diferencia de puntuación está entre 21 puntos en Australia y 112 puntos Taiwán. Solo Italia y Suiza presentan patrones atípicos. En Suiza, los estudiantes de 15 años de edad matriculados en centros escolares privados dependientes del gobierno alcanzan rendimientos que superan de manera estadísticamente significativa los de sus coetáneos matriculados en centros escolares públicos o privados independientes, mientras que en Italia sucede lo contrario.

Sin embargo, el estatus socioeconómico de los estudiantes de 15 años desempeña un papel muy importante en estos resultados. En 37 de los países y las economías que participaron, los estudiantes que asisten a centros escolares privados (sean centros escolares privados dependientes del gobierno o independientes) tienden a proceder de un entorno socioeconómicamente más favorecido que los estudiantes que asisten a centros escolares públicos. En 2012, la diferencia entre centros escolares públicos y privados en cuanto al estatus socioeconómico medio de sus estudiantes era particularmente grande en Brasil, Costa Rica, México, Perú, Polonia y Uruguay. Solo en Taiwán el estatus socioeconómico medio de los estudiantes que asisten a centros escolares públicos es más favorecido que el de los estudiantes que asisten a centros escolares privados. Como media, el estatus socioeconómico de los estudiantes matriculados en centros escolares públicos está aproximadamente 0,5 puntos por debajo del de los estudiantes que asisten a centros escolares privados, de acuerdo con el índice PISA de estatus económico, social y cultural. Se observa un patrón similar al comparar los centros escolares públicos con los centros escolares privados dependientes del gobierno, aunque la diferencia es menor. Como media, el estatus socioeconómico de los estudiantes matriculados en centros escolares públicos está aproximadamente 0,3 puntos por debajo del de los estudiantes que asisten a centros escolares privados dependientes del gobierno, de acuerdo con el índice PISA de estatus económico, social y cultural (Tabla C7.2).

Sin embargo, la ventaja en rendimiento de los centros escolares privados en comparación con los centros escolares públicos desaparece en la mayor parte de los países y economías cuando se tiene en cuenta el estatus socioeconómico de los estudiantes y los centros escolares. Si se tiene en cuenta el estatus socioeconómico de los estudiantes y los centros escolares, los centros escolares privados consiguen mejores resultados que los centros escolares públicos solo en 8 países y economías, y los centros escolares públicos consiguen mejores resultados que los centros escolares privados en 12 países y economías. Por tanto, asistir a centros escolares privados -y centros escolares públicos con estudiantes de entornos económicamente favorecidos- es beneficioso para los estudiantes individuales; pero no hay pruebas que indiquen que los centros escolares privados contribuyan a elevar el nivel de rendimiento del sistema escolar en general (Tabla C7.2 y Gráfico C7.2).

\section{El entorno de aprendizaje en los centros escolares públicos y privados}

\section{Escasez de profesores}

Los profesores constituyen un recurso esencial para el aprendizaje: la calidad de un sistema escolar no puede superar la calidad de sus profesores. De acuerdo con los resultados de PISA, los centros escolares que sufren fuerte escasez de profesores tienden a obtener puntuaciones más bajas en PISA. Por tanto, atraer y conservar a profesores eficien- 
tes constituye una prioridad para la política pública, y el desafío es aún mayor en los centros escolares públicos (aunque también de manera más global en centros escolares desfavorecidos), que informan de una mayor escasez de profesores que los centros escolares privados.

La escasez de profesores se mide en PISA utilizando la desviación estándar del índice de escasez de profesores. Los valores más altos de este índice indican que los directores consideran que existen más problemas con la enseñanza debido a la escasez de profesores. El valor general observado (en todos los centros escolares) es comparativamente elevado en Colombia, Israel, Jordania, Luxemburgo, Shanghái-China, Tailandia y Turquía, y comparativamente reducido en Bulgaria, Eslovenia, España, Lituania, Polonia, Portugal y Serbia (Tabla C7.4).

La Tabla C7.4 muestra también que los centros escolares públicos sufren la escasez de profesores más a menudo que los centros escolares privados dependientes del gobierno o independientes. En 33 de 47 países y economías, los directores de centros escolares públicos declararon una mayor escasez de profesores que los de centros escolares privados. Se observan brechas particularmente amplias entre centros escolares públicos y privados en la escasez de profesores en Australia, Brasil, Catar, Emiratos Árabes Unidos, Italia, Jordania, Luxemburgo, México, Nueva Zelanda, Perú, Uruguay y Vietnam, donde la diferencia supera en el índice los 0,5 puntos (es decir, la mitad de la desviación estándar de este índice). La brecha se estrecha ligeramente cuando los centros escolares públicos se comparan solo con los centros escolares privados dependientes del gobierno, pero los centros escolares públicos siguen declarando una mayor escasez de profesores que estos centros escolares privados en 20 de los 33 países de la OCDE con datos disponibles (Tabla C7.4).

\section{Tiempo dedicado a hacer los deberes u otros estudios establecidos por el profesor}

Los estudiantes que asisten a centros escolares privados también dedican más tiempo a hacer los deberes o a estudiar lo indicado por el profesor que sus compañeros matriculados en centros escolares públicos. Para medir este factor, PISA pidió a los estudiantes de 15 años de edad que indicaran el tiempo medio que dedicaban cada semana después del horario escolar a diversos tipos de actividades relacionadas con el estudio, teniendo en cuenta todas las asignaturas de manera conjunta.

En todos los países de la OCDE, los estudiantes declararon dedicar 4,9 horas a la semana a hacer los deberes o a estudiar lo que su profesor hubiera indicado. Los estudiantes de China-Shanghái, Federación Rusa, Italia, Kazajistán, Rumanía y Singapur declararon dedicar por lo menos siete horas a la semana a hacer los deberes o a estudiar lo que el profesor hubiera indicado. En cambio, en Argentina, Brasil, Chile, Costa Rica, Eslovenia, Japón, Liechtenstein, Portugal, República Checa, República Eslovaca, Suecia, Suiza y Túnez, los estudiantes dedican menos de cuatro horas a la semana a estas tareas (Tabla C7.4).

También se observan diferencias en esta medida entre estudiantes de centros escolares públicos y privados. Como media en los países de la OCDE, los estudiantes matriculados en centros escolares privados dedican una hora más a la semana a hacer los deberes o a estudiar lo que indique el profesor que los estudiantes matriculados en centros escolares públicos (5,6 y 4,7 horas, respectivamente). En 38 de los 47 países y economías con datos disponibles, los estudiantes matriculados en centros escolares privados dedican más tiempo a hacer los deberes que los estudiantes de centros escolares públicos; solo en 9 países o economías sucede lo contrario. El tiempo adicional que los estudiantes matriculados en centros escolares privados dedican a hacer los deberes supera las 1,5 horas en Australia, Austria, Canadá, Catar, Colombia, Emiratos Árabes Unidos, Estados Unidos, Nueva Zelanda y Portugal (Tabla C7.4). Las diferencias también son significativas al comparar los centros escolares dependientes del gobierno con los centros escolares privados independientes. Como media, los estudiantes de centros escolares privados independientes dedican respectivamente 0,4 horas más y 2 horas más que sus coetáneos matriculados en centros escolares privados dependientes del gobierno y centros escolares públicos a hacer los deberes o a estudiar lo indicado por el profesor (Tabla C7.4).

\section{Tamaño de la clase}

El tamaño de la clase es uno de los factores que los padres pueden tener en cuenta al escoger un centro escolar para sus hijos y que puede tener impacto sobre el entorno de aprendizaje. En los países de la OCDE y países del G20 que disponen de datos, el tamaño medio de la clase en los países de la OCDE generalmente no difiere entre centros escolares públicos y privados en más de dos estudiantes por clase tanto en educación primaria como en secundaria (Gráfico C7.3 y véase Indicador D2).

Sin embargo, existen diferencias importantes entre países. Por ejemplo, en Brasil, Estados Unidos, Federación Rusa, Islandia, Israel, Letonia, Polonia, Reino Unido, República Checa y Turquía, el tamaño medio de una clase de educación 


\section{Gráfico C7.3. Tamaño medio de la clase en instituciones públicas y privadas, por nivel de educación (2012)}

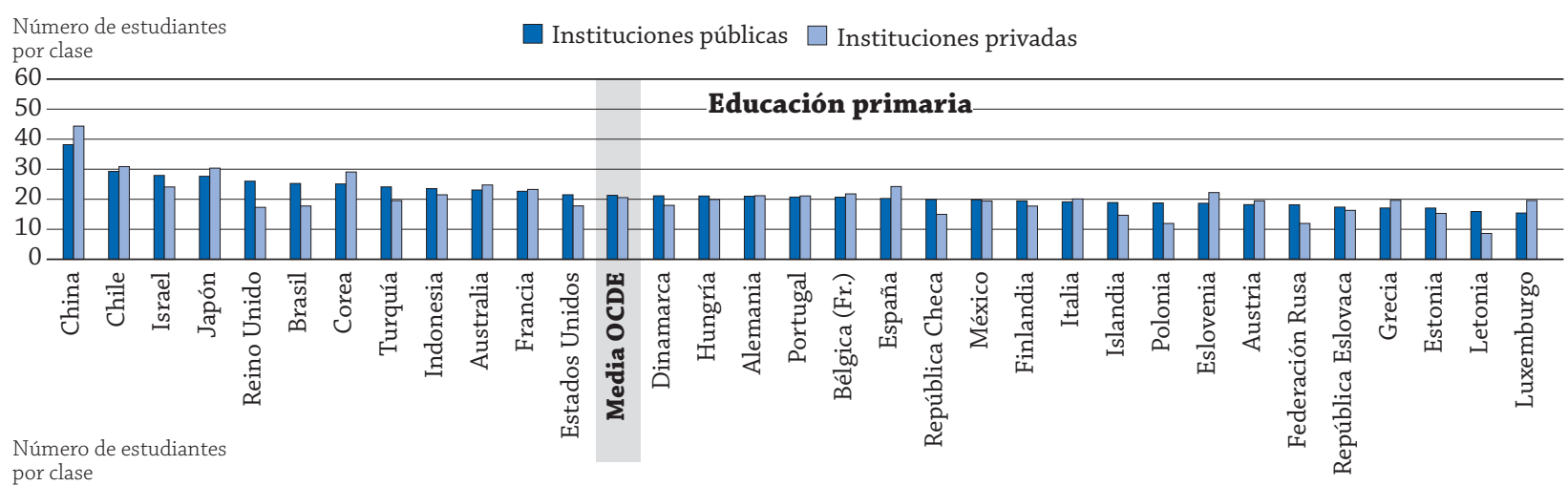

por clase

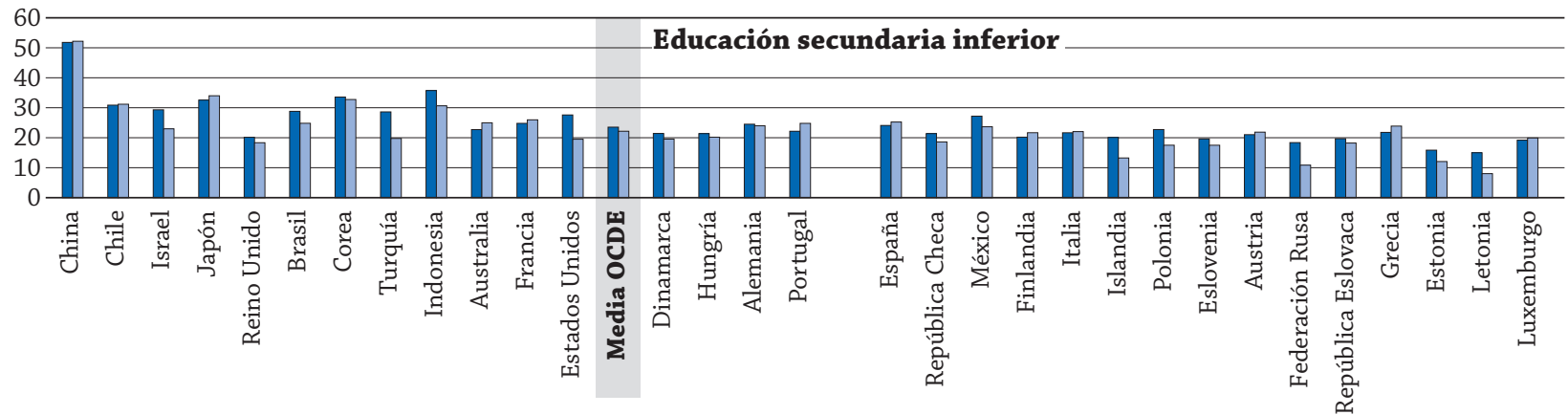

Los países están clasificados en orden descendente del tamaño medio de la clase en instituciones públicas de educación primaria.

Fuente: OCDE. Tabla D2.1 Para ver notas, consulte Anexo 3 (www.oecd.org/edu/eag.htm).

StatLink 제은 http://dx.doi.org/10.1787/888933119492

primaria en un centro escolar público supera en cuatro o más estudiantes el de una clase en un centro escolar privado. Sin embargo, con la excepción de Brasil e Israel, el sector privado de la educación es relativamente pequeño en todos estos países (Tabla C7.1) y representa como mucho un 5\% de los estudiantes de educación primaria. En cambio, en España, donde un $32 \%$ de los estudiantes de educación primaria están matriculados en centros escolares privados, el tamaño medio de la clase de educación primaria en los centros escolares privados supera en cuatro estudiantes el de la clase de los centros escolares públicos (Gráfico C7.3 y véase Indicador D2).

Al comparar el tamaño de las clases de los centros públicos y privados se obtienen resultados más diversos en educación secundaria inferior, donde los centros escolares privados son más comunes. En 12 países, el tamaño medio de la clase en los centros de educación secundaria inferior es mayor en los centros escolares privados que en los centros escolares públicos, aunque las diferencias tienden a ser menores que en educación primaria. En países en los que los centros escolares privados son más comunes en los niveles de educación primaria y secundaria inferior (es decir, en países en los que más del $10 \%$ de los estudiantes de estos niveles están matriculados en centros escolares privados), pueden darse grandes diferencias en el tamaño de las clases entre centros escolares públicos y privados (Tabla C7.1 y véase Indicador D2).

De manera similar, los datos de PISA 2012 muestran que en la OCDE no existen diferencias en el tamaño de la clase entre los centros escolares públicos y privados en los que están matriculados los estudiantes de 15 años de edad. Sin embargo, se observan algunas diferencias entre países: en 21 países y economías, las clases de matemáticas tienden a ser mayores en los centros escolares públicos, mientras que en otros 26 países y economías las clases de matemáticas tienden a ser mayores en los centros escolares privados (Tabla C7.4). Esto sugiere que en países en los que una proporción sustancial de estudiantes y familias eligen centros escolares privados, el tamaño de la clase no es un factor que determine su decisión.

\section{Grado de autonomía en la asignación de recursos y en el establecimiento de currículos y evaluaciones}

Entre las muchas decisiones que tienen que tomar los sistemas escolares y los centros escolares, las relativas al currículo y al modo en el que se asignan y gestionan los recursos tienen un impacto directo sobre la enseñanza y 
el aprendizaje. Desde principios de los años ochenta, muchos sistemas escolares han delegado cada vez mayor autoridad en los centros escolares, permitiéndoles tomar decisiones de manera autónoma sobre los currículos y la asignación de recursos, basándose en la premisa de que cada centro escolar puede evaluar de manera correcta cuáles son las necesidades de aprendizaje de sus estudiantes y cómo hacer uso de sus recursos de la manera más efectiva. El propósito era mejorar los niveles de rendimiento fomentando a nivel local la sensibilidad y capacidad de respuesta a las necesidades de los estudiantes y los centros escolares (Whitty, 1997; Carnoy, 2000; Clark; 2009; Machin y Vernoit, 2011). Esto ha implicado mayor capacidad de los directores para tomar decisiones y rendir cuentas, y en algunos casos mayores responsabilidades de los profesores o jefes de departamento relacionadas con la gestión.

PISA 2012 pidió a los directores de centros escolares que indicaran si los profesores, el director, el consejo escolar del centro, las autoridades educativas regionales o locales o la autoridad nacional de educación tenían una responsabilidad importante dentro del centro escolar en la asignación de recursos (nombramiento y despido de profesores, fijación del salario inicial y de los aumentos salariales de los profesores, y elaboración y asignación de los presupuestos), y respecto al currículo y a la evaluación académica (decisión de políticas para la evaluación de los estudiantes, elección de los libros de texto y elaboración de los cursos ofrecidos y del contenido de los mismos). Esta información se combinó para crear dos índices compuestos: un índice de responsabilidad del centro escolar en la asignación de recursos y un índice de responsabilidad del centro escolar respecto al currículo y la evaluación, de manera que ambos índices tuvieran una media de cero y una desviación estándar de uno en los países de la OCDE. Un valor más elevado indica que los directores y los profesores de los centros escolares tienen un nivel más elevado de autonomía (Tabla C7.5).

Los resultados muestran que los centros escolares privados generalmente tienen un mayor grado de autonomía que los centros escolares públicos en los dos índices. Sin embargo, esta diferencia es particularmente pronunciada en el índice de responsabilidad del centro escolar en la asignación de recursos. De acuerdo con este índice, prácticamente en todos los países y economías participantes, los centros escolares privados tanto dependientes del gobierno como independientes tienen mayor autonomía que los centros escolares públicos en la asignación de recursos. Se observa una jerarquía similar al comparar los dos tipos de centros escolares privados: en la mayor parte de los países, los centros escolares privados independientes tienen un mayor grado de autonomía en la asignación de recursos que los centros escolares dependientes del gobierno. La diferencia en el grado de autonomía entre centros escolares públicos y privados es mayor en Brasil, Colombia, Finlandia, Luxemburgo, Malasia, México y Perú.

La diferencia entre centros escolares públicos y privados es menos acusada en el índice que muestra la autonomía de los centros escolares en la toma de decisiones sobre el currículo y las evaluaciones, especialmente cuando se comparan los centros escolares dependientes del gobierno con los centros escolares públicos. En 26 países y economías, los centros escolares privados tienen una mayor autonomía en este índice, pero en Austria, Eslovenia, Estonia, Nueva Zelanda, Países Bajos, República Eslovaca y Taiwán se observa lo contrario (Tabla C7.5).

Los sistemas escolares también difieren en el grado de autonomía que se concede a los centros escolares privados. Por ejemplo, los centros escolares privados de los países de la OCDE muestran diversos grados de autonomía en la asignación de recursos. Los directores de los centros escolares en Alemania, Austria, Bélgica, Corea, España y Francia indicaron tener niveles relativamente bajos de autonomía (valores inferiores a 2 en el índice), mientras que los directores de Finlandia, Países Bajos, Reino Unido, República Checa y Suecia indicaron lo contrario (valores por encima de 1,68 en el índice) (Tabla C7.5).

\section{Matriculación y financiación de las instituciones terciarias públicas y privadas}

La proporción de estudiantes matriculados en instituciones privadas independientes es mayor en el nivel de educación terciaria. Aproximadamente un $17 \%$ de los estudiantes de educación terciaria de tipo B y un $14 \%$ de los estudiantes de educación terciaria de tipo A y programas de investigación avanzada están matriculados en instituciones privadas independientes. Si se consideran conjuntamente las instituciones privadas de educación terciaria independientes y dependientes del gobierno, un $41 \%$ de los estudiantes están matriculados en educación terciaria de tipo B y al menos un $28 \%$ de los estudiantes están matriculados en educación terciaria de tipo A y programas de investigación avanzada (Tabla C7.6).

En 2003, como media en los países de la OCDE, un 77\% de los estudiantes de educación terciaria de tipo A asistieron a instituciones públicas, un $11 \%$ a instituciones privadas dependientes del gobierno y un $12 \%$ a instituciones privadas independientes. La proporción de estudiantes matriculados en instituciones privadas en el nivel de educación terciaria ha aumentado en 21 de los 29 países de la OCDE con datos disponibles entre 2003 y 2012. De 


\section{Gráfico C7.4. Estudiantes matriculados en educación terciaria de tipo A y programas de investigación avanzada, por tipo de instituciones privadas $(2003,2012)$}

$\square$ Instituciones privadas dependientes del gobierno $\quad \square$ Instituciones privadas independientes

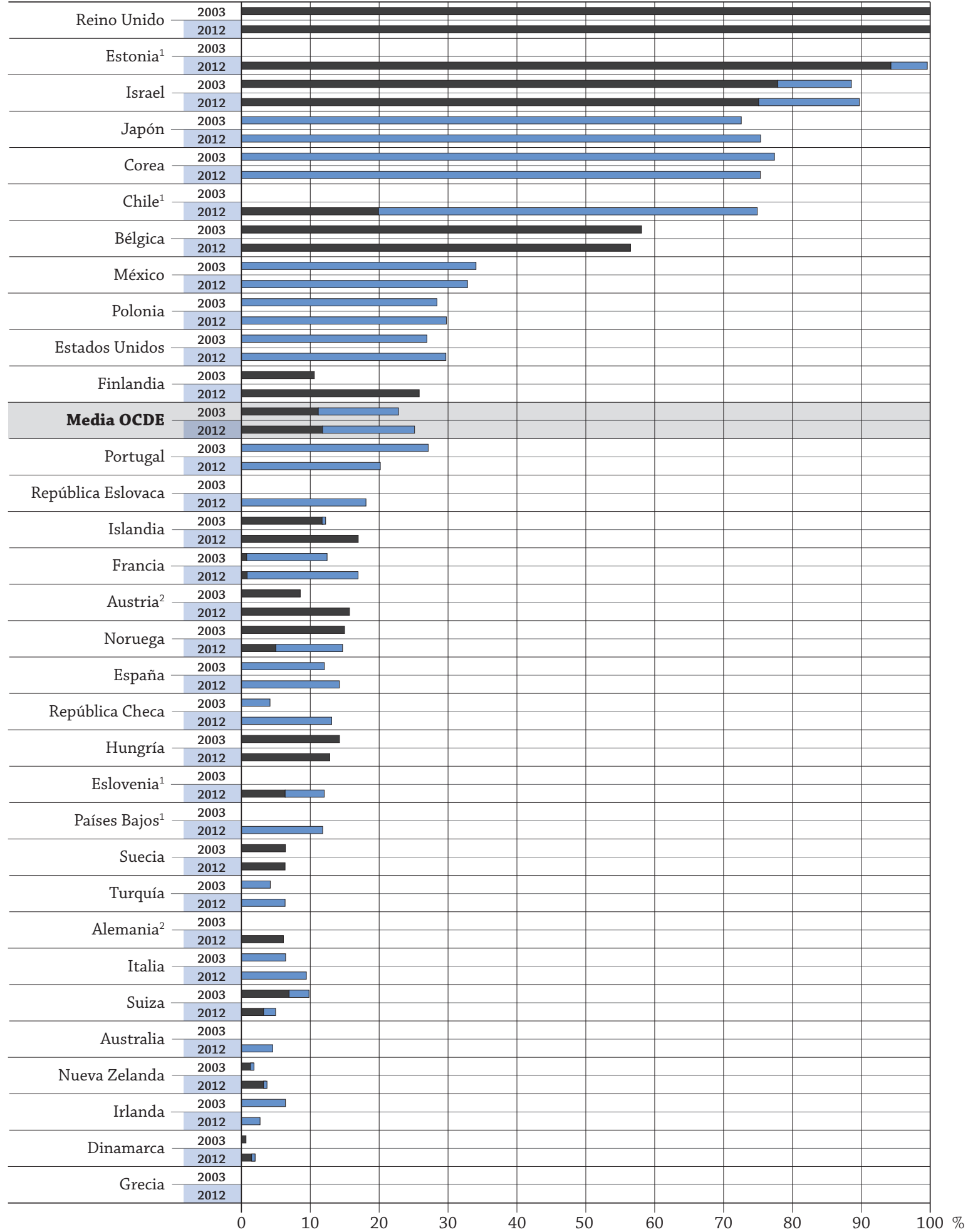

1. Faltan datos de 2003 .

2. Incluye instituciones privadas independientes.

Los países están clasificados en orden descendente de la proporción de estudiantes de nivel 5A/6 matriculados en instituciones privadas en 2012.

Fuente: OCDE. Tabla C7.6. Para ver notas, consulte Anexo 3 (www.oecd.org/edu/eag.htm).

StatLink 部吉 http://dx.doi.org/10.1787/888933119511 
manera similar, las matriculaciones en instituciones privadas de educación terciaria de tipo A en los países de la OCDE aumentaron una media de dos puntos porcentuales, de un $23 \%$ a un $25 \%$, entre 2003 y 2012, mientras que las matriculaciones en educación terciaria de tipo B aumentaron cuatro puntos porcentuales, de un $33 \%$ a un $37 \%$, durante este periodo. Los países que muestran el mayor aumento del número de matriculaciones en instituciones privadas de educación terciaria de tipo A durante este periodo son Alemania, Austria, Finlandia, República Checa y República Eslovaca, que experimentaron aumentos por encima de los 6 puntos porcentuales (Tabla C7.6 y Gráfico C7.4).

La expansión de las instituciones privadas en el nivel de educación terciaria refleja una respuesta al aumento significativo de la demanda de educación terciaria observada en las últimas décadas. Sin embargo, en la mayor parte de los países, la matriculación en instituciones privadas implica costes adicionales para los estudiantes. Los países de la OCDE y del G20 difieren de manera significativa en el importe de las tasas de matriculación de las instituciones de educación terciaria. En ocho países de la OCDE, las instituciones públicas no cobran tasas de matriculación, pero en un tercio de los 26 países de la OCDE con datos disponibles las instituciones públicas cobran tasas de matriculación anuales que superan los 1.500 dólares estadounidenses para estudiantes que son ciudadanos del país. En la mayor parte de los países, las instituciones privadas cobran tasas de matriculación más elevadas que las instituciones públicas. Finlandia y Suecia son los únicos países en los que no existen tasas de matriculación ni en las instituciones públicas ni en las privadas. Las variaciones dentro de cada país tienden a ser mayores en aquellos países en los que la mayor parte de los estudiantes están matriculados en instituciones de educación terciaria de tipo A privadas independientes. En cambio, en la mayor parte de los países, las tasas de matriculación que cobran las instituciones difieren menos entre instituciones públicas e instituciones privadas dependientes del gobierno que entre instituciones públicas e instituciones privadas independientes. En Austria no existe diferencia entre las tasas de matriculación que cobran estos dos tipos de instituciones (véase Indicador B5).

Según aumenta la variedad de oportunidades educativas, de programas y proveedores, los gobiernos establecen nuevas asociaciones para movilizar y dirigir recursos hacia la educación terciaria y para diseñar nuevas políticas que permitan a las diversas partes interesadas participar de manera más activa y compartir costes y beneficios de manera más equitativa. Por tanto, las empresas también están participando más en la financiación de las instituciones públicas de educación terciaria. En Australia, Austria, Canadá, Corea, Estados Unidos, Israel, Japón, Países Bajos, Reino Unido, República Checa, República Eslovaca y Suecia, un $9 \%$ o más del gasto destinado a instituciones de educación terciaria está cubierto por entidades privadas y no por los hogares particulares. En Suecia, estas contribuciones están dirigidas principalmente a patrocinar la investigación y el desarrollo (véase Indicador B3).

\section{Definiciones y metodología}

Tipo de centro escolar: Dado que el indicador está basado principalmente en la recopilación de datos realizada por UOE y PISA, las definiciones de los tipos de centros escolares son iguales en ambos sondeos. Los centros escolares se clasifican como públicos o privados, dependiendo de si es una agencia pública o una entidad privada la que tiene el poder final en la toma de decisiones a nivel interno. Esta información está combinada con datos sobre el porcentaje de financiación total que cubre el gobierno. Los indicadores incluyen tres categorías: centros escolares privados independientes, controlados por una organización no gubernamental o por medio de un consejo directivo no elegido por una agencia gubernamental y que reciben menos del $50 \%$ de su financiación principal de agencias gubernamentales; centros escolares privados dependientes del gobierno, controlados por una organización no gubernamental o por medio de un consejo directivo no elegido por una agencia gubernamental y que reciben más del $50 \%$ de su financiación principal de agencias gubernamentales; y centros escolares públicos, controlados y gestionados por una autoridad o agencia pública de educación.

Escasez de profesores: Para evaluar la percepción que tienen los directores de los centros sobre la oferta de profesores, PISA 2012 preguntó hasta qué punto pensaban que la enseñanza en sus centros escolares se veía dificultada por una escasez de profesores y personal cualificado en áreas clave. Esta información se combinó para crear un índice compuesto de escasez de profesores, de manera que el índice tuviera una media de 0 y una desviación estándar de 1 para los países de la OCDE. En este índice, los valores más elevados indican que los directores consideran que existen mayores problemas en la enseñanza debido a una escasez de profesores. Es necesario interpretar estos resultados con prudencia: los directores de centros escolares de diferentes países y economías, e incluso dentro de los mismos países y economías, pueden tener expectativas y parámetros distintos para determinar si existe una escasez de profesores cualificados. Sin embargo, estos informes proporcionan información valiosa que puede resultar útil para evaluar si los centros escolares y los sistemas escolares están poniendo suficientes recursos humanos a disposición de sus estudiantes. 


\section{Nota sobre los datos de Israel}

Los datos estadísticos para Israel fueron proporcionados por las autoridades israelíes competentes bajo su responsabilidad. El uso de estos datos por parte de la OCDE se hace sin prejuzgar la situación de los Altos del Golán, Jerusalén Este y los asentamientos israelíes en Cisjordania de acuerdo con los términos del derecho internacional.

\section{Referencias}

Couch, J., W. Shugart y A. Williams (1993), «Private school enrolment and public school performance», Public Choice, Vol. 76, pp. 301-312.

Filer, R.K. y D. Munich (2003), «Public support for private schools in post-communist Europe: Czech and Hungarian experiences», in D.N. Plank and G. Sykes (eds.), Choosing Choice: School Choice in International Perspective, Teachers College Press, Nueva York.

Geller, C.R., D.L. Sjoquist y M.B. Walker (2006), «The effect of private school competition on public school performance in Georgia», Public Finance Review, Vol. 34, No. 1, pp. 4-32.

Green, F., et al. (2011), «The changing economic advantage from private schools», Economica, Vol. 79, No. 316, pp. 658-678.

Greene, K.V. y B.G. Kang (2004), «The effect of public and private competition on high school outputs in New York State», Economics of Education Review, No. 23, pp. 497-506.

Lara, B., A. Mizala y A. Repetto (2009), «The effectiveness of private voucher education: Evidence from structural school switches», Working Paper No. 263, CEA, Universidad de Chile.

Maranto, R., S. Milliman y S. Scott (2000), «Does private school competition harm public schools? Revisiting Smith and Meier's The Case Against School Choice, Political Research Quarterly, Vol. 53, No. 1, pp. 177-192.

Peterson, P., et al. (2003), «School vouchers: Results from randomized experiments», in C. Hoxby (ed.), The Economics of School Choice, University of Chicago Press, Chicago, pp. 107-144.

Sander W. (1999), «Private schools and public school achievement», Journal of Human Resources, Vol. 34, No. 4, pp. 697-709.

Sandström, M. y F. Bergström (2005), «School vouchers in practice: Competition will not hurt you», Journal of Public Economics, Vol. 89, No. 2-3, pp. 351-380.

Wrinkle, R., et al. (1999), «Public school quality, private schools, and race», American Journal of Political Science, Vol. 43, No. 4, pp. 1248-1253.

\section{Tablas del Indicador C7}

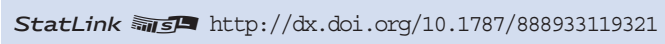

Tabla C7.1 Estudiantes en educación infantil, primaria y secundaria, por tipo de centro escolar (2012)

Tabla C7.2 Tipo de centro escolar y rendimiento en matemáticas (2012)

Tabla C7.3 Tipo de centro escolar y rendimiento en matemáticas (2003)

Tabla C7.4 Entorno de aprendizaje, por tipo de centro escolar (2012)

Tabla C7.5 Responsabilidad del centro escolar en la asignación de recursos, currículo y evaluación, por tipo de centro escolar y nivel de educación (2012)

Tabla C7.6 Estudiantes en educación terciaria, por tipo de institución $(2003,2012)$ 
Tabla C7.1. Estudiantes en educación infantil, primaria y secundaria, por tipo de centro escolar (2012) Distribución de los estudiantes, por tipo de centro escolar

\begin{tabular}{|c|c|c|c|c|c|c|c|c|c|c|c|c|}
\hline & \multicolumn{3}{|c|}{ Educación infantil } & \multicolumn{3}{|c|}{ Primaria } & \multicolumn{3}{|c|}{ Secundaria inferior } & \multicolumn{3}{|c|}{ Secundaria superior } \\
\hline & $\begin{array}{l}\stackrel{8}{0} \\
\bar{Z} \\
\text { : }\end{array}$ & 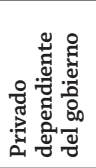 & 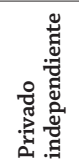 & 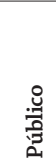 & 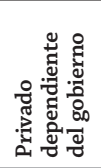 & 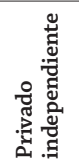 & $\begin{array}{l}\stackrel{8}{3} \\
\text { 咅 }\end{array}$ & 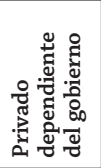 & 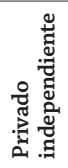 & 总咅 & 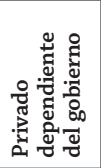 & 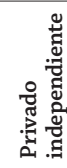 \\
\hline & (1) & (2) & (3) & (4) & (5) & (6) & (7) & (8) & (9) & (10) & (11) & (12) \\
\hline Alemania & 35 & 65 & $x(2)$ & 96 & 4 & $\mathrm{x}(5)$ & 91 & 9 & $x(8)$ & 92 & 8 & $\mathrm{x}(11)$ \\
\hline Australia ${ }^{1}$ & 22 & 78 & $\mathrm{~m}$ & 69 & 31 & a & 64 & 36 & $\mathrm{~m}$ & 63 & 36 & $\mathrm{~m}$ \\
\hline Austria & 70 & 30 & $\mathrm{x}(2)$ & 94 & 6 & $\mathrm{x}(5)$ & 91 & 9 & $x(8)$ & 90 & 10 & $\mathrm{x}(11)$ \\
\hline Bélgica $^{1}$ & 47 & 53 & $\mathrm{~m}$ & 46 & 54 & $\mathrm{~m}$ & 39 & 61 & $\mathrm{~m}$ & 43 & 57 & $\mathrm{~m}$ \\
\hline Canadá $^{2}$ & $\mathrm{~m}$ & $\mathrm{~m}$ & $\mathrm{~m}$ & 94 & 6 & $\mathrm{x}(5)$ & 91 & 9 & $x(8)$ & 94 & 6 & $\mathrm{x}(11)$ \\
\hline Chile & 34 & 60 & 6 & 40 & 53 & 7 & 45 & 48 & 7 & 38 & 55 & 7 \\
\hline Corea & 16 & 84 & a & 98 & a & 2 & 82 & 18 & a & 56 & 44 & $\mathrm{a}$ \\
\hline Dinamarca & 81 & 19 & $\mathrm{n}$ & 85 & 15 & $\mathrm{n}$ & 73 & 26 & 1 & 98 & 2 & $\mathrm{n}$ \\
\hline Eslovenia & 97 & 2 & $\mathrm{n}$ & 99 & 1 & $\mathrm{n}$ & 100 & $\mathrm{n}$ & a & 96 & 2 & 2 \\
\hline España & 65 & 24 & 11 & 68 & 28 & 4 & 69 & 28 & 3 & 79 & 12 & 9 \\
\hline Estados Unidos & 60 & $\mathrm{a}$ & 40 & 92 & $\mathrm{a}$ & 8 & 92 & $\mathrm{a}$ & 8 & 92 & $\mathrm{a}$ & 8 \\
\hline Estonia & 97 & a & 3 & 96 & a & 4 & 96 & a & 4 & 97 & a & 3 \\
\hline Finlandia & 92 & 8 & a & 98 & 2 & a & 95 & 5 & a & 81 & 19 & a \\
\hline Francia & 87 & 12 & $\mathrm{n}$ & 85 & 14 & $\mathrm{n}$ & 78 & 22 & $\mathrm{n}$ & 69 & 31 & 1 \\
\hline Grecia & 93 & $\mathrm{a}$ & 7 & 93 & $\mathrm{a}$ & 7 & 95 & a & 5 & 96 & a & 4 \\
\hline Hungría & 93 & 7 & a & 89 & 11 & $\mathrm{a}$ & 88 & 12 & a & 76 & 24 & a \\
\hline Irlanda & 2 & a & 98 & 99 & a & 1 & 100 & a & a & 99 & a & 1 \\
\hline Islandia & 88 & 12 & $\mathrm{n}$ & 97 & 3 & $\mathrm{n}$ & 99 & 1 & $\mathrm{n}$ & 79 & 20 & 1 \\
\hline Israel & 91 & a & 9 & 77 & 23 & a & 84 & 16 & $\mathrm{a}$ & 94 & 6 & a \\
\hline Italia & 70 & $\mathrm{a}$ & 30 & 93 & a & 7 & 96 & a & 4 & 91 & 4 & 5 \\
\hline Japón & 29 & a & 71 & 99 & a & 1 & 93 & a & 7 & 69 & a & 31 \\
\hline Luxemburgo & 91 & $\mathrm{n}$ & 9 & 91 & $\mathrm{n}$ & 9 & 81 & 10 & 9 & 84 & 7 & 9 \\
\hline México & 86 & a & 14 & 92 & a & 8 & 89 & a & 11 & 83 & a & 17 \\
\hline Noruega & 54 & 46 & $\mathrm{x}(2)$ & 98 & 2 & $\mathrm{x}(5)$ & 97 & 3 & $x(8)$ & 90 & 10 & $\mathrm{x}(11)$ \\
\hline Nueva Zelanda & 1 & 99 & $\mathrm{n}$ & 98 & $\mathrm{a}$ & 2 & 95 & $\mathrm{a}$ & 5 & 85 & 8 & 7 \\
\hline Países Bajos & 70 & a & 30 & 100 & a & $\mathrm{n}$ & 97 & a & 3 & 91 & a & 9 \\
\hline Polonia & 84 & 1 & 14 & 97 & 1 & 3 & 95 & 1 & 4 & 85 & 1 & 14 \\
\hline Portugal & 53 & 30 & 16 & 88 & 4 & 8 & 85 & 7 & 8 & 78 & 5 & 17 \\
\hline Reino Unido & 63 & 31 & 6 & 93 & 3 & 5 & 55 & 40 & 5 & 33 & 62 & 5 \\
\hline República Checa & 98 & 2 & a & 98 & 2 & a & 97 & 3 & a & 86 & 14 & a \\
\hline República Eslovaca & 96 & 4 & $\mathrm{n}$ & 94 & 6 & $\mathrm{n}$ & 93 & 7 & $\mathrm{n}$ & 85 & 15 & $\mathrm{n}$ \\
\hline Suecia & 83 & 17 & $\mathrm{n}$ & 91 & 9 & $\mathrm{n}$ & 86 & 14 & $\mathrm{n}$ & 83 & 17 & $\mathrm{n}$ \\
\hline Suiza & 96 & $\mathrm{n}$ & 4 & 95 & 2 & 3 & 92 & 3 & 5 & 87 & 9 & 4 \\
\hline Turquía & 91 & a & 9 & 97 & a & 3 & 97 & a & 3 & 97 & a & 3 \\
\hline Media OCDE & 68 & 20 & 11 & 89 & 8 & 3 & 86 & 11 & 3 & 81 & 14 & 5 \\
\hline Media UE21 & 75 & 15 & 11 & 90 & 8 & 2 & 86 & 12 & 2 & 82 & 14 & 4 \\
\hline 气 Arabia Saudí & 59 & 41 & $\mathrm{x}(2)$ & 90 & 10 & $\mathrm{x}(5)$ & 92 & 8 & $\mathrm{x}(8)$ & 83 & 17 & $\mathrm{x}(11)$ \\
\hline Argentina ${ }^{2}$ & 68 & 25 & 7 & 76 & 20 & 4 & 77 & 19 & 3 & 71 & 24 & 5 \\
\hline Brasil & 71 & a & 29 & 85 & a & 15 & 88 & a & 12 & 84 & a & 16 \\
\hline China & 51 & 49 & $x(2)$ & 94 & 6 & $\mathrm{x}(5)$ & 91 & 9 & $\mathrm{x}(8)$ & 89 & 11 & $\mathrm{x}(11)$ \\
\hline Colombia & 64 & a & 36 & 81 & a & 19 & 81 & a & 19 & 77 & a & 23 \\
\hline Federación Rusa & 99 & a & 1 & 99 & a & 1 & 99 & a & 1 & 98 & a & 2 \\
\hline India & $\mathrm{m}$ & $\mathrm{m}$ & $\mathrm{m}$ & $\mathrm{m}$ & $\mathrm{m}$ & $\mathrm{m}$ & $\mathrm{m}$ & $\mathrm{m}$ & $\mathrm{m}$ & $\mathrm{m}$ & $\mathrm{m}$ & $\mathrm{m}$ \\
\hline Indonesia & 3 & a & 97 & 83 & a & 17 & 64 & a & 36 & 50 & a & 50 \\
\hline Letonia & 95 & a & 5 & 99 & a & 1 & 99 & a & 1 & 98 & a & 2 \\
\hline Sudáfrica $^{2}$ & 94 & 6 & $x(2)$ & 96 & 4 & $\mathrm{x}(5)$ & 96 & 4 & $x(8)$ & 96 & 4 & $\mathrm{x}(11)$ \\
\hline Media G20 & 59 & 23 & 18 & 91 & 5 & 4 & 85 & 10 & 5 & 78 & 14 & 8 \\
\hline
\end{tabular}

1. Excluyendo instituciones privadas independientes.

2. Año de referencia 2011.

Fuentes: OCDE. Argentina, China, Colombia, Indonesia: Instituto de Estadística de la UNESCO (Programa Mundial de Indicadores de Educación).

Para ver notas, consulte Anexo 3 (www.oecd.org/edu/eag.htm).

Para obtener más información acerca de los símbolos utilizados en lugar de los datos que faltan, consulte la Guía del lector.

StatLink 젝ㄴ http://dx.doi.org/10.1787/888933119340 
Tabla C7.2. [1/2] Tipo de centro escolar y rendimiento en matemáticas (2012) Resultados basados en los informes de los directores de centros escolares

\begin{tabular}{|c|c|c|c|c|c|c|c|c|c|c|c|c|}
\hline & \multicolumn{4}{|c|}{ Centros escolares públicos } & \multicolumn{4}{|c|}{ Centros escolares dependientes del gobierno } & \multicolumn{4}{|c|}{ Centros escolares privados independientes } \\
\hline & \multicolumn{2}{|c|}{$\begin{array}{l}\text { Porcentaje de } \\
\text { estudiantes }\end{array}$} & \multicolumn{2}{|c|}{$\begin{array}{c}\text { Rendimiento en la } \\
\text { escala de matemáticas }\end{array}$} & \multicolumn{2}{|c|}{$\begin{array}{l}\text { Porcentaje de } \\
\text { estudiantes }\end{array}$} & \multicolumn{2}{|c|}{$\begin{array}{c}\text { Rendimiento en la } \\
\text { escala de matemáticas }\end{array}$} & \multicolumn{2}{|c|}{$\begin{array}{l}\text { Porcentaje de } \\
\text { estudiantes }\end{array}$} & $\begin{array}{r}\text { Rendimi } \\
\text { escala de } n\end{array}$ & $\begin{array}{l}\text { nto en la } \\
\text { temáticas }\end{array}$ \\
\hline & $\%$ & E.E. & $\begin{array}{l}\text { tuación } \\
\text { media }\end{array}$ & E.E. & $\%$ & E.E. & $\begin{array}{l}\text { tuación } \\
\text { media }\end{array}$ & E.E. & $\%$ & E.E. & $\begin{array}{l}\text { tuación } \\
\text { media }\end{array}$ & E.E. \\
\hline & (1) & (2) & (3) & (4) & (5) & (6) & (7) & (8) & (9) & (10) & (11) & (12) \\
\hline Alemania & 94,5 & $(1,6)$ & 511 & $(3,5)$ & 5,0 & $(1,6)$ & 549 & $(19,4)$ & 0,5 & $(0,4)$ & c & c \\
\hline Austria & 91,4 & $(2,3)$ & 502 & $(3,2)$ & 7,5 & $(2,1)$ & 546 & $(15,9)$ & 1,1 & $(0,9)$ & 559 & $(14,5)$ \\
\hline Bélgica & w & w & w & w & $\mathrm{w}$ & w & w & w & w & w & w & w \\
\hline Canadá & 92,2 & $(0,8)$ & 514 & $(2,0)$ & 4,3 & $(0,6)$ & 570 & $(8,1)$ & 3,5 & $(0,8)$ & 566 & $(10,1)$ \\
\hline Chile & 37,5 & $(1,6)$ & 390 & $(5,0)$ & 48,1 & $(2,7)$ & 424 & $(4,9)$ & 14,5 & $(2,2)$ & 503 & $(6,6)$ \\
\hline Corea & 52,7 & $(4,1)$ & 546 & $(7,1)$ & 31,4 & $(3,8)$ & 539 & $(7,2)$ & 15,9 & $(3,1)$ & 609 & $(10,5)$ \\
\hline Dinamarca & 77,0 & $(1,8)$ & 494 & $(2,5)$ & 18,9 & $(2,0)$ & 517 & $(6,2)$ & 4,2 & $(1,5)$ & 527 & $(13,0)$ \\
\hline Eslovenia & 97,6 & $(0,1)$ & 501 & $(1,3)$ & 2,4 & $(0,1)$ & 589 & $(6,9)$ & 0,0 & c & c & c \\
\hline España & 68,2 & $(0,8)$ & 471 & $(2,5)$ & 24,4 & $(1,1)$ & 506 & $(3,6)$ & 7,4 & $(1,0)$ & 523 & $(4,8)$ \\
\hline Estados Unidos & 94,9 & $(0,9)$ & 482 & $(4,0)$ & 0,0 & c & c & c & 5,1 & $(0,9)$ & 496 & $(10,0)$ \\
\hline Francia & 82,8 & $(1,4)$ & 490 & $(3,2)$ & 17,2 & $(1,4)$ & 521 & $(6,6)$ & 0,0 & c & c & c \\
\hline Grecia & 97,7 & $(0,7)$ & 450 & $(2,7)$ & 0,0 & c & c & c & 2,3 & $(0,7)$ & c & c \\
\hline Hungría & 84,0 & $(2,9)$ & 475 & $(3,4)$ & 16,0 & $(2,9)$ & 489 & $(14,1)$ & 0,0 & c & c & c \\
\hline Irlanda & w & w & w & w & w & w & w & w & w & w & w & w \\
\hline Islandia & 99,5 & $(0,1)$ & 493 & $(1,7)$ & 0,5 & $(0,1)$ & c & $c$ & 0,0 & c & c & c \\
\hline Israel & 100,0 & c & 466 & $(4,7)$ & 0,0 & c & c & c & 0,0 & c & c & c \\
\hline Italia & 95,3 & $(0,7)$ & 487 & $(2,3)$ & 1,8 & $(0,4)$ & 437 & $(7,1)$ & 2,9 & $(0,5)$ & 515 & $(8,9)$ \\
\hline Japón & 70,1 & $(1,2)$ & 535 & $(3,3)$ & 0,0 & $c$ & c & c & 29,9 & $(1,2)$ & 540 & $(9,6)$ \\
\hline Luxemburgo & 84,9 & $(0,1)$ & 492 & $(1,3)$ & 13,4 & $(0,0)$ & 464 & $(2,4)$ & 1,8 & $(0,0)$ & c & c \\
\hline México & 90,7 & $(0,9)$ & 408 & $(1,5)$ & 0,1 & $(0,1)$ & c & c & 9,2 & $(0,8)$ & 452 & $(6,0)$ \\
\hline Noruega & 98,3 & $(1,0)$ & 489 & $(2,8)$ & 1,7 & $(1,0)$ & c & c & 0,0 & c & c & c \\
\hline Nueva Zelanda & 94,7 & $(1,4)$ & 496 & $(2,5)$ & 0,0 & c & c & c & 5,3 & $(1,4)$ & 583 & $(6,8)$ \\
\hline Países Bajos ${ }^{1}$ & 33,6 & $(4,4)$ & 516 & $(10,0)$ & 66,4 & $(4,4)$ & 523 & $(5,6)$ & 0,0 & $\mathrm{C}$ & c & c \\
\hline Polonia & 97,1 & $(0,4)$ & 516 & $(3,6)$ & 1,9 & $(0,4)$ & 566 & $(22,1)$ & 1,0 & $(0,2)$ & 581 & $(14,9)$ \\
\hline Portugal & 89,9 & $(2,0)$ & 481 & $(3,8)$ & 5,8 & $(1,9)$ & 516 & $(7,3)$ & 4,2 & $(1,4)$ & 581 & $(5,2)$ \\
\hline Reino Unido & 56,2 & $(3,1)$ & 485 & $(3,6)$ & 36,0 & $(3,2)$ & 494 & $(7,6)$ & 7,8 & $(0,7)$ & 569 & $(12,7)$ \\
\hline República Checa & 91,8 & $(1,9)$ & 498 & $(3,8)$ & 6,9 & $(1,6)$ & 493 & $(17,3)$ & 1,3 & $(0,9)$ & c & $\mathrm{c}$ \\
\hline República Eslovaca & 91,0 & $(2,4)$ & 478 & $(4,1)$ & 8,6 & $(2,5)$ & 520 & $(20,2)$ & 0,5 & $(0,3)$ & c & c \\
\hline Turquía & 100.0 & c & 447 & (4.9) & 0.0 & c & c & c & 0.0 & c & c & c \\
\hline Media OCDE & 81,7 & $(0,3)$ & 489 & $(0,7)$ & 14,2 & $(0,4)$ & 517 & $(2,6)$ & 4,1 & $(0,2)$ & 542 & $(2,5)$ \\
\hline Albania & 91,7 & $(2,1)$ & 393 & $(2,2)$ & 0,0 & c & c & c & 8,3 & $(2,1)$ & 403 & $(6,4)$ \\
\hline Argentina & 67,7 & $(2,3)$ & 368 & $(4,1)$ & 25,6 & $(2,9)$ & 428 & $(5,7)$ & 6,7 & $(2,2)$ & 428 & $(14,3)$ \\
\hline Brasil & 86,5 & $(1,3)$ & 376 & $(2,0)$ & 0,6 & $(0,4)$ & C & $\mathrm{C}$ & 12,8 & $(1,3)$ & 461 & $(6,9)$ \\
\hline Bulgaria & 98,8 & $(0,9)$ & 438 & $(4,1)$ & 0,0 & c & c & c & 1,2 & $(0,9)$ & c & c \\
\hline Catar & 61,9 & $(0,1)$ & 335 & $(1,0)$ & 0,9 & $(0,0)$ & c & c & 37,2 & $(0,1)$ & 442 & $(1,3)$ \\
\hline Colombia & 85,9 & $(1,4)$ & 369 & $(2,8)$ & 4,0 & $(0,8)$ & 362 & $(8,0)$ & 10,1 & $(1,4)$ & 441 & $(12,7)$ \\
\hline Costa Rica & 86,9 & $(1,4)$ & 396 & $(3,3)$ & 3,6 & $(0,9)$ & 465 & $(17,1)$ & 9,5 & $(1,5)$ & 478 & $(9,5)$ \\
\hline Croacia & 98,2 & $(1,1)$ & 471 & $(3,6)$ & 0,8 & $(0,8)$ & c & C & 0,9 & $(0,7)$ & c & c \\
\hline Emiratos Árabes Unidos & 54,5 & $(1,7)$ & 399 & $(2,6)$ & 0,6 & $(0,4)$ & c & c & 44,9 & $(1,7)$ & 461 & $(4,3)$ \\
\hline Federación Rusa & 99,4 & $(0,6)$ & 482 & $(3,0)$ & 0,0 & c & c & c & 0,6 & $(0,6)$ & c & c \\
\hline Hong Kong-China & 7,0 & $(0,2)$ & 597 & $(9,5)$ & 91,9 & $(0,8)$ & 560 & $(3,5)$ & 1,2 & $(0,7)$ & c & c \\
\hline Indonesia & 58,9 & $(2,6)$ & 377 & $(5,0)$ & 17,5 & $(2,3)$ & 342 & $(5,6)$ & 23,7 & $(2,7)$ & 395 & $(10,7)$ \\
\hline Jordania & 83,3 & $(1,5)$ & 376 & $(3,1)$ & 0,9 & $(0,6)$ & c & c & 15,8 & $(1,2)$ & 440 & $(10,8)$ \\
\hline Kazajistán & 97,2 & $(1,0)$ & 432 & $(3,0)$ & 0,7 & $(0,5)$ & c & c & 2,1 & $(0,9)$ & 436 & $(14,7)$ \\
\hline Letonia & 97,7 & $(1,5)$ & 490 & $(2,9)$ & 0,4 & $(0,4)$ & c & c & 1,9 & $(1,3)$ & c & c \\
\hline Liechtenstein & 93,6 & $(0,4)$ & 541 & $(3,9)$ & 0,0 & $\mathrm{C}$ & c & c & 6,4 & $(0,4)$ & c & c \\
\hline Lituania & 98,6 & $(0,7)$ & 478 & $(2,7)$ & 1,1 & $(0,6)$ & c & c & 0,4 & $(0,4)$ & c & c \\
\hline Macao-China & 4,2 & $(0,0)$ & C & $\mathrm{C}$ & 81,3 & $(0,0)$ & 537 & $(1,1)$ & 14,5 & $(0,0)$ & 559 & $(2,9)$ \\
\hline Malasia & 96,6 & $(0,7)$ & 418 & $(3,2)$ & 0,0 & c & c & c & 3,4 & $(0,7)$ & 505 & $(27,3)$ \\
\hline Montenegro & 99,6 & $(0,0)$ & 410 & $(1,1)$ & 0,0 & c & c & c & 0,4 & $(0,0)$ & c & $\mathrm{c}$ \\
\hline Perú & 85,3 & $(1,8)$ & 350 & $(3,2)$ & 0,0 & c & c & c & 14,7 & $(1,8)$ & 424 & $(11,3)$ \\
\hline Rumanía & 99,4 & $(0,6)$ & 444 & $(3,7)$ & 0,0 & c & c & c & 0,6 & $(0,6)$ & c & C \\
\hline Serbia & 99,6 & $(0,4)$ & 448 & $(3,9)$ & 0,0 & c & c & c & 0,4 & $(0,4)$ & c & c \\
\hline Shanghái-China & 90,7 & $(1,8)$ & 609 & $(3,4)$ & 0,0 & c & c & c & 9,3 & $(1,8)$ & 644 & $(9,3)$ \\
\hline Singapur & 97,6 & $(0,7)$ & 574 & $(1,2)$ & 0,0 & c & c & c & 2,4 & $(0,7)$ & c & C \\
\hline Tailandia & 83,5 & $(0,6)$ & 433 & $(3,8)$ & 11,6 & $(1,5)$ & 396 & $(5,1)$ & 4,9 & $(1,3)$ & 398 & $(23,2)$ \\
\hline Taiwán & 67,6 & $(1,4)$ & 581 & $(3,7)$ & 4,6 & $(1,3)$ & 469 & $(9,5)$ & 27,9 & $(1,9)$ & 529 & $(7,9)$ \\
\hline Túnez & 99,4 & $(0,4)$ & 389 & $(3,9)$ & 0,0 & c & c & c & 0,6 & $(0,4)$ & c & $\mathrm{c}$ \\
\hline Uruguay & 83,3 & $(1,2)$ & 393 & $(2,6)$ & 0,0 & c & c & c & 16,7 & $(1,2)$ & 492 & $(6,6)$ \\
\hline Vietnam & 92,6 & $(1,1)$ & 513 & $(5,1)$ & 0,0 & c & c & c & 7,4 & $(1,1)$ & 499 & $(11,6)$ \\
\hline
\end{tabular}

Nota: Los valores estadísticamente significativos se indican en negrita (véase Anexo A3).

1. En Países Bajos, los centros escolares privados dependientes del gobierno están financiados públicamente, difieren de los centros escolares públicos en convicción religiosa y/o orientación pedagógica.

Fuente: OCDE, Base de datos PISA 2012. Para ver notas, consulte Anexo 3 (www.oecd.org/edu/eag.htm).

Para obtener más información acerca de los símbolos utilizados en lugar de los datos que faltan, consulte la Guía del lector

StatLink 젶ㄴ http://dx.doi.org/10.1787/888933119359 
Tabla C7.2. [2/2] Tipo de centro escolar y rendimiento en matemáticas (2012) Resultados basados en los informes de los directores de centros escolares

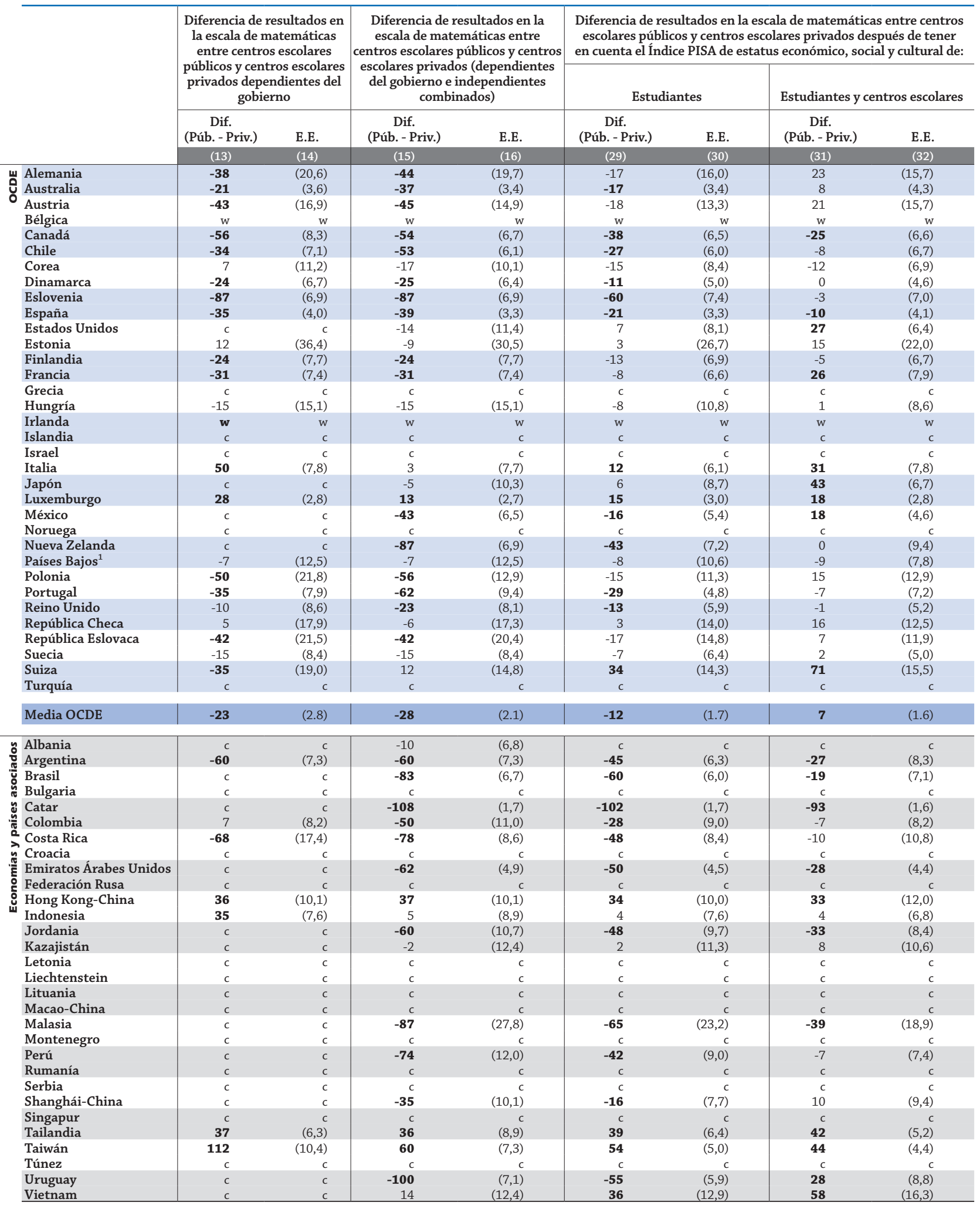

Nota: Los valores estadísticamente significativos se indican en negrita (véase Anexo A3).

1. En Países Bajos, los centros escolares privados dependientes del gobierno están financiados públicamente, difieren de los centros escolares públicos en convicción religiosa y/o orientación pedagógica.

Fuente: OCDE, Base de datos PISA 2012. Para ver notas, consulte Anexo 3 (www.oecd.org/edu/eag.htm).

Para obtener más información acerca de los símbolos utilizados en lugar de los datos que faltan, consulte la Guía del lector.

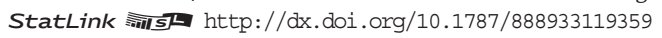


Tabla C7.3. [1/2] Tipo de centro escolar y rendimiento en matemáticas (2003) Resultados basados en los informes de los directores de centros escolares

\begin{tabular}{|c|c|c|c|c|c|c|c|c|c|c|c|c|}
\hline & \multicolumn{4}{|c|}{ Centros escolares públicos } & \multicolumn{4}{|c|}{$\begin{array}{l}\text { Centros escolares privados dependientes } \\
\text { del gobierno }\end{array}$} & \multicolumn{4}{|c|}{ Centros escolares privados independientes } \\
\hline & \multicolumn{2}{|c|}{$\begin{array}{l}\text { Porcentaje de } \\
\text { estudiantes }\end{array}$} & \multicolumn{2}{|c|}{$\begin{array}{l}\text { Rendimiento en la } \\
\text { escala de matemáticas }\end{array}$} & \multicolumn{2}{|c|}{$\begin{array}{l}\text { Porcentaje de } \\
\text { estudiantes }\end{array}$} & \multicolumn{2}{|c|}{$\begin{array}{c}\text { Rendimiento en la } \\
\text { escala de matemáticas }\end{array}$} & \multicolumn{2}{|c|}{$\begin{array}{l}\text { Porcentaje de } \\
\text { estudiantes }\end{array}$} & \multicolumn{2}{|c|}{$\begin{array}{l}\text { Rendimiento en la } \\
\text { escala de matemáticas }\end{array}$} \\
\hline & $\%$ & E.E. & $\begin{array}{l}\text { tuacion } \\
\text { media }\end{array}$ & E.E. & $\%$ & E.E. & $\begin{array}{l}\text { tuacion } \\
\text { media }\end{array}$ & E.E. & $\%$ & E.E. & $\begin{array}{l}\text { tuación } \\
\text { media }\end{array}$ & E.E. \\
\hline & (1) & (2) & (3) & (4) & (5) & (6) & (7) & (8) & (9) & (10) & (11) & (12) \\
\hline Alemania & 92,2 & $(1,7)$ & 497 & $(3,7)$ & 7,5 & $(1,8)$ & 566 & $(12,7)$ & 0,4 & $(0,4)$ & c & c \\
\hline Australia & $\mathrm{w}$ & $\mathrm{w}$ & $\mathrm{w}$ & $\mathrm{w}$ & $\mathrm{w}$ & $\mathrm{w}$ & $\mathrm{w}$ & $\mathrm{w}$ & w & $\mathrm{w}$ & $\mathrm{w}$ & $\mathrm{w}$ \\
\hline Austria & 92,0 & $(1,9)$ & 504 & $(3,4)$ & 6,7 & $(1,6)$ & 518 & $(12,6)$ & 1,3 & $(0,6)$ & c & c \\
\hline Bélgica & $\mathrm{w}$ & $\mathrm{w}$ & $\mathrm{w}$ & $\mathrm{w}$ & $\mathrm{w}$ & $\mathrm{w}$ & $\mathrm{w}$ & $\mathrm{w}$ & $\mathrm{w}$ & $\mathrm{w}$ & $\mathrm{w}$ & $\mathrm{w}$ \\
\hline Canadá & 94,2 & $(0,7)$ & 529 & $(1,8)$ & 3,8 & $(0,6)$ & 573 & $(10,8)$ & 1,9 & $(0,3)$ & 563 & $(11,1)$ \\
\hline Corea & 42,3 & $(3,7)$ & 527 & $(6,1)$ & 36,0 & $(4,1)$ & 532 & $(7,5)$ & 21,7 & $(3,4)$ & 593 & $(9,6)$ \\
\hline Dinamarca & 77,8 & $(2,5)$ & 515 & $(3,1)$ & 21,7 & $(2,6)$ & 511 & $(6,3)$ & 0,5 & $(0,5)$ & c & c \\
\hline España & 64,2 & $(1,5)$ & 472 & $(3,4)$ & 28,1 & $(2,1)$ & 505 & $(4,2)$ & 7,7 & $(1,7)$ & 520 & $(9,7)$ \\
\hline Estados Unidos & 94,3 & $(1,0)$ & 483 & $(3,6)$ & 0,0 & c & c & c & 5,7 & $(1,0)$ & 507 & $(9,1)$ \\
\hline Finlandia & 93,3 & $(1,6)$ & 545 & $(1,8)$ & 6,7 & $(1,6)$ & 539 & $(12,2)$ & 0,0 & c & c & c \\
\hline Francia & $\mathrm{w}$ & $\mathrm{w}$ & $\mathrm{w}$ & $\mathrm{w}$ & $\mathrm{w}$ & $\mathrm{w}$ & $\mathrm{w}$ & $\mathrm{w}$ & w & $\mathrm{w}$ & $\mathrm{w}$ & $\mathrm{w}$ \\
\hline Grecia & 97,4 & $(1,9)$ & 442 & $(3,6)$ & 0,0 & c & c & c & 2,6 & $(1,9)$ & 507 & $(30,1)$ \\
\hline Hungría & 88,9 & $(2,5)$ & 489 & $(3,6)$ & 9,8 & $(2,3)$ & 504 & $(16,8)$ & 1,2 & $(0,8)$ & c & c \\
\hline Irlanda & $\mathrm{w}$ & $\mathrm{w}$ & $\mathrm{w}$ & $\mathrm{w}$ & $\mathrm{w}$ & $\mathrm{w}$ & $\mathrm{w}$ & $\mathrm{w}$ & $\mathrm{w}$ & $\mathrm{w}$ & $\mathrm{w}$ & $\mathrm{w}$ \\
\hline Islandia & 99,5 & $(0,1)$ & 515 & $(1,6)$ & 0,0 & c & c & c & 0,5 & $(0,1)$ & c & c \\
\hline Italia & 96,1 & $(1,2)$ & 468 & $(3,1)$ & 0,4 & $(0,2)$ & 392 & $(61,4)$ & 3,5 & $(1,3)$ & 452 & $(35,4)$ \\
\hline Japón & 73,0 & $(1,7)$ & 544 & $(4,7)$ & 0,6 & $(0,6)$ & c & c & 26,4 & $(1,8)$ & 513 & $(7,5)$ \\
\hline Luxemburgo & 85,9 & $(0,1)$ & 498 & $(1,1)$ & 14,1 & $(0,1)$ & 463 & $(2,9)$ & 0,0 & c & c & c \\
\hline México & 86,7 & $(1,9)$ & 375 & $(3,5)$ & 0,1 & $(0,1)$ & c & c & 13,2 & $(1,9)$ & 430 & $(8,9)$ \\
\hline Noruega & 99,1 & $(0,7)$ & 494 & $(2,4)$ & 0,9 & $(0,7)$ & c & c & 0,0 & c & c & c \\
\hline Nueva Zelanda & 95,4 & $(0,5)$ & 522 & $(2,3)$ & 0,0 & c & c & c & 4,6 & $(0,5)$ & 579 & $(17,1)$ \\
\hline Países Bajos $^{1}$ & 23,3 & $(4,2)$ & 516 & $(14,0)$ & 76,7 & $(4,2)$ & 541 & $(4,5)$ & 0,0 & c & c & c \\
\hline Polonia & 99,2 & $(0,4)$ & 489 & $(2,5)$ & 0,4 & $(0,4)$ & c & c & 0,4 & $(0,3)$ & c & c \\
\hline Portugal & 93,7 & $(1,3)$ & 465 & $(3,6)$ & 4,2 & $(1,2)$ & 459 & $(8,5)$ & 2,1 & $(1,2)$ & c & c \\
\hline República Checa & 93,3 & $(1,7)$ & 517 & $(3,8)$ & 5,8 & $(1,6)$ & 505 & $(13,5)$ & 0,9 & $(0,5)$ & c & c \\
\hline República Eslovaca & 87,4 & $(2,7)$ & 495 & $(3,7)$ & 12,6 & $(2,7)$ & 523 & $(9,3)$ & 0,0 & c & c & c \\
\hline Suecia & 95,7 & $(0,5)$ & 509 & $(2,6)$ & 4,3 & $(0,5)$ & 516 & $(11,0)$ & 0,0 & c & c & c \\
\hline Suiza & 95,3 & $(1,0)$ & 528 & $(3,8)$ & 0,9 & $(0,7)$ & 546 & $(34,2)$ & 3,8 & $(0,7)$ & 497 & $(23,2)$ \\
\hline Turquía & 99,0 & $(1,0)$ & 420 & $(6,6)$ & 0,0 & c & c & c & 1,0 & $(1,0)$ & c & c \\
\hline
\end{tabular}

\begin{tabular}{|c|c|c|c|c|c|c|c|c|c|c|c|c|}
\hline $\begin{array}{l}\text { Media OCDE } \\
\text { (de los países con datos } \\
\text { para 2003 y 2012) }\end{array}$ & 82,7 & $(0,3)$ & 494 & $(0,9)$ & 13,6 & $(0,4)$ & 514 & $(4,5)$ & 3,7 & $(0,3)$ & 516 & $(5,9)$ \\
\hline Brasil & 87,4 & $(2,3)$ & 342 & $(6,2)$ & 0,0 & c & c & c & 12,6 & $(2,3)$ & 454 & $(11,3)$ \\
\hline Federación Rusa & 99,7 & $(0,2)$ & 468 & $(4,3)$ & 0,0 & c & c & c & 0,3 & $(0,2)$ & c & c \\
\hline Hong Kong-China & 9,5 & $(0,4)$ & 571 & $(11,4)$ & 90,1 & $(0,5)$ & 548 & $(4,8)$ & 0,4 & $(0,3)$ & c & c \\
\hline Indonesia & 51,4 & $(2,3)$ & 373 & $(4,9)$ & 4,1 & $(1,5)$ & 326 & $(19,3)$ & 44,5 & $(2,6)$ & 345 & $(7,0)$ \\
\hline Letonia & 99,0 & $(0,7)$ & 485 & $(3,7)$ & 0,0 & c & c & c & 1,0 & $(0,7)$ & c & c \\
\hline Liechtenstein & 95,0 & $(0,3)$ & 539 & $(4,1)$ & 0,0 & c & c & c & 5,0 & $(0,3)$ & c & c \\
\hline Macao-China & 5,0 & $(0,1)$ & c & c & 49,3 & $(0,2)$ & 528 & $(3,5)$ & 45,8 & $(0,2)$ & 529 & $(5,2)$ \\
\hline Tailandia & 88,0 & $(1,2)$ & 416 & $(3,0)$ & 6,0 & $(1,1)$ & 419 & $(18,8)$ & 6,0 & $(1,6)$ & 428 & $(13,7)$ \\
\hline Túnez & $\mathrm{m}$ & $\mathrm{m}$ & $\mathrm{m}$ & $\mathrm{m}$ & $\mathrm{m}$ & $\mathrm{m}$ & $\mathrm{m}$ & $\mathrm{m}$ & $\mathrm{m}$ & $\mathrm{m}$ & $\mathrm{m}$ & $\mathrm{m}$ \\
\hline Uruguay & 85,9 & $(0,8)$ & 409 & $(3,7)$ & 0,0 & c & c & c & 14,1 & $(0,8)$ & 501 & $(6,1)$ \\
\hline
\end{tabular}

Notas: Los valores estadísticamente significativos se indican en negrita (véase Anexo A3).

Solo se muestran los países y economías con datos comparables de PISA 2003 y PISA 2012.

1. En Países Bajos, los centros escolares privados dependientes del gobierno están financiados públicamente, difieren de los centros escolares públicos en convicción religiosa y/o orientación pedagógica.

Fuente: OCDE, Base de datos PISA 2003. Para ver notas, consulte Anexo 3 (www.oecd.org/edu/eag.htm).

Para obtener más información acerca de los símbolos utilizados en lugar de los datos que faltan, consulte la Guía del lector.

StatLink त्नाls http://dx.doi.org/10.1787/888933119378 
Tabla C7.3. [2/2] Tipo de centro escolar y rendimiento en matemáticas (2003) Resultados basados en los informes de los directores de centros escolares

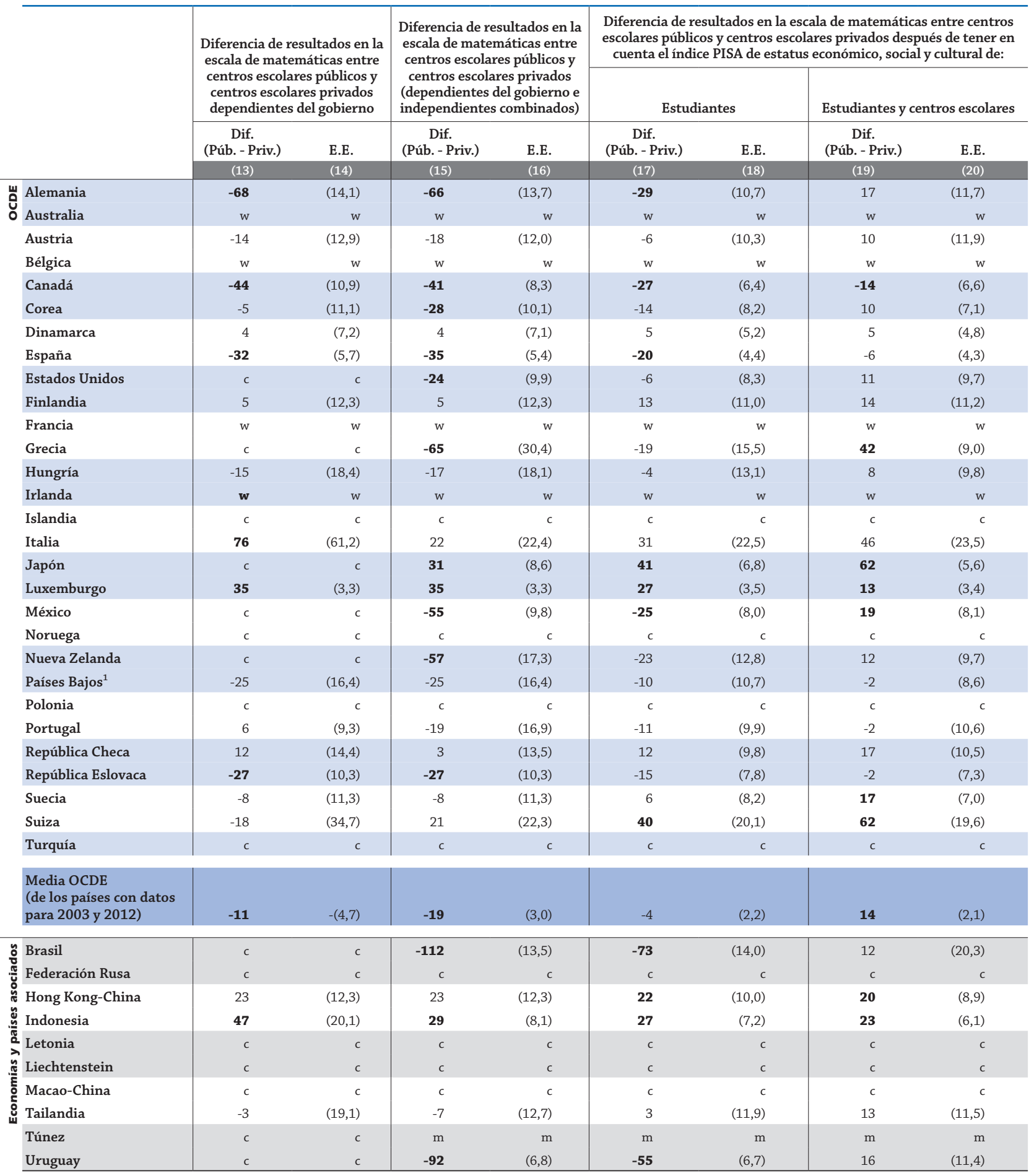

Notas: Los valores estadísticamente significativos se indican en negrita (véase Anexo A3).

Solo se muestran los países y economías con datos comparables de PISA 2003 y PISA 2012

1. En Países Bajos, los centros escolares privados dependientes del gobierno están financiados públicamente, difieren de los centros escolares públicos en convicción religiosa y/o orientación pedagógica.

Fuente: OCDE, Base de datos PISA 2003. Para ver notas, consulte Anexo 3 (www.oecd.org/edu/eag.htm).

Para obtener más información acerca de los símbolos utilizados en lugar de los datos que faltan, consulte la Guía del lector.

StatLink 규느 http://dx.doi.org/10.1787/888933119378 
Tabla C7.4. [1/2] Entorno de aprendizaje, por tipo de centro escolar (2012)

Resultados basados en los informes de los directores de centros escolares y los informes de los estudiantes sobre ellos mismos

\begin{tabular}{|c|c|c|c|c|c|c|c|c|c|c|c|c|c|c|c|c|}
\hline & \multicolumn{10}{|c|}{$\begin{array}{l}\text { Tamaño de la clase en la que están matriculados los estudiantes de } 15 \text { años de edad } \\
\text { (resultados de PISA basados en los informes de los estudiantes sobre ellos mismos) }\end{array}$} & \multicolumn{6}{|c|}{$\begin{array}{l}\text { Índice de escasez de profesores (resultados } \\
\text { de PISA basados en los informes de los directore } \\
\text { de los centros escolares) }\end{array}$} \\
\hline & \multicolumn{2}{|c|}{$\begin{array}{l}\text { Todos los } \\
\text { centros } \\
\text { escolares }\end{array}$} & \multicolumn{2}{|c|}{$\begin{array}{l}\text { Centros } \\
\text { escolares } \\
\text { públicos }\end{array}$} & \multicolumn{2}{|c|}{$\begin{array}{c}\text { Centros } \\
\text { escolares } \\
\text { dependientes } \\
\text { del gobierno }\end{array}$} & \multicolumn{2}{|c|}{$\begin{array}{c}\text { Centros } \\
\text { escolares } \\
\text { privados } \\
\text { independientes }\end{array}$} & $\begin{array}{l}\text { Cer } \\
\text { escc } \\
\text { priv }\end{array}$ & $\begin{array}{l}\text { ros } \\
\text { ares } \\
\text { dos }\end{array}$ & $\begin{array}{l}\text { Todo } \\
\text { cen } \\
\text { esco }\end{array}$ & $\begin{array}{l}\text { slos } \\
\text { ros } \\
\text { ares }\end{array}$ & $\begin{array}{l}\text { Cen } \\
\text { esco } \\
\text { púb }\end{array}$ & & $\begin{array}{r}\text { Cent } \\
\text { escol } \\
\text { depend } \\
\text { del gol }\end{array}$ & $\begin{array}{l}\text { ros } \\
\text { ares } \\
\text { ientes } \\
\text { ierno }\end{array}$ \\
\hline & Media & E.E. & Media & E.E. & Media & E.E. & Media & E.E. & Media & E.E. & Media & E.E. & Media & E.E. & Media & E.E. \\
\hline & (1) & (2) & (3) & (4) & (5) & (6) & (7) & $(8)$ & (9) & (10) & (11) & (12) & (13) & (14) & (15) & (16) \\
\hline Alemania & 24,1 & $(0,2)$ & 23,8 & $(0,2)$ & 25,9 & $(0,5)$ & c & c & 25,7 & $(0,5)$ & 0,4 & $(0,1)$ & 0,4 & $(0,1)$ & 0,0 & $(0,2)$ \\
\hline Australia & 22,6 & $(0,1)$ & 22,4 & $(0,2)$ & 23,4 & $(0,2)$ & 21,6 & $(0,3)$ & 22,8 & $(0,2)$ & 0,2 & $(0,0)$ & 0,4 & $(0,0)$ & 0,1 & $(0,1)$ \\
\hline Austria & 20,7 & $(0,2)$ & 20,7 & $(0,2)$ & 21,4 & $(1,0)$ & 21,4 & $(1,0)$ & 21,4 & $(0,9)$ & $-0,1$ & $(0,1)$ & $-0,1$ & $(0,1)$ & $-0,3$ & $(0,3)$ \\
\hline Bélgica & 18,8 & $(0,2)$ & 18,1 & $(0,3)$ & 18,9 & $(0,2)$ & c & c & 18,9 & $(0,2)$ & 0,3 & $(0,1)$ & 0,3 & $(0,1)$ & 0,2 & $(0,1)$ \\
\hline Canadá & 24,3 & $(0,1)$ & 24,0 & $(0,1)$ & 29,3 & $(0,7)$ & 24,3 & $(1,6)$ & 27,1 & $(0,8)$ & $-0,3$ & $(0,0)$ & $-0,3$ & $(0,0)$ & $-0,2$ & $(0,2)$ \\
\hline Chile & 34,3 & $(0,4)$ & 33,7 & $(0,7)$ & 36,0 & $(0,7)$ & 30,2 & $(1,1)$ & 34,6 & $(0,6)$ & 0,6 & $(0,1)$ & 0,9 & $(0,2)$ & 0,5 & $(0,1)$ \\
\hline Corea & 30,5 & $(0,4)$ & 30,8 & $(0,6)$ & 28,5 & $(0,6)$ & 33,6 & $(0,7)$ & 30,2 & $(0,5)$ & 0,1 & $(0,1)$ & 0,0 & $(0,1)$ & 0,3 & $(0,1)$ \\
\hline Dinamarca & 19,7 & $(0,2)$ & 19,8 & $(0,2)$ & 19,4 & $(0,7)$ & 19,9 & $(0,7)$ & 19,5 & $(0,6)$ & $-0,2$ & $(0,1)$ & $-0,1$ & $(0,1)$ & $-0,4$ & $(0,1)$ \\
\hline Eslovenia & 24,8 & $(0,2)$ & 24,8 & $(0,2)$ & 29,0 & $(0,3)$ & c & c & 29,0 & $(0,3)$ & $-0,7$ & $(0,0)$ & $-0,7$ & $(0,0)$ & $-0,4$ & $(0,0)$ \\
\hline España & 22,2 & $(0,1)$ & 21,8 & $(0,2)$ & 22,8 & $(0,3)$ & 23,3 & $(0,6)$ & 22,9 & $(0,3)$ & $-0,7$ & $(0,0)$ & $-0,7$ & $(0,0)$ & $-0,8$ & $(0,0)$ \\
\hline Estados Unidos & 24,5 & $(0,4)$ & 24,8 & $(0,4)$ & c & $\mathrm{c}$ & 19,8 & $(1,2)$ & 19,8 & $(1,2)$ & $-0,4$ & $(0,1)$ & $-0,4$ & $(0,1)$ & c & c \\
\hline Estonia & 20,6 & $(0,2)$ & 20,6 & $(0,2)$ & 18,8 & $(4,3)$ & c & c & 19,7 & $(3,3)$ & 0,0 & $(0,0)$ & 0,0 & $(0,0)$ & $-0,6$ & $(0,3)$ \\
\hline Finlandia & 18,3 & $(0,2)$ & 18,2 & $(0,2)$ & 20,9 & $(1,0)$ & c & c & 20,9 & $(1,0)$ & $-0,4$ & $(0,0)$ & $-0,4$ & $(0,0)$ & $-0,3$ & $(0,2)$ \\
\hline Francia & 27,1 & $(0,2)$ & 27,1 & $(0,3)$ & 27,8 & $(0,6)$ & c & c & 27,8 & $(0,6)$ & $-0,2$ & $(0,1)$ & $-0,2$ & $(0,1)$ & 0,0 & $(0,2)$ \\
\hline Grecia & 22,9 & $(0,2)$ & 22,9 & $(0,2)$ & c & $\mathrm{c}$ & c & c & c & c & $-0,4$ & $(0,1)$ & $-0,4$ & $(0,1)$ & c & c \\
\hline Hungría & 27,0 & $(0,3)$ & 27,0 & $(0,3)$ & 26,9 & $(1,1)$ & c & c & 26,9 & $(1,1)$ & $-0,6$ & $(0,1)$ & $-0,7$ & $(0,1)$ & $-0,5$ & $(0,1)$ \\
\hline Irlanda & w & w & w & $\mathrm{w}$ & $\mathrm{w}$ & w & $\mathrm{w}$ & $\mathrm{w}$ & w & w & w & w & $\mathrm{w}$ & w & w & w \\
\hline Islandia & 19,2 & $(0,1)$ & 19,3 & $(0,1)$ & c & c & c & c & c & c & 0,2 & $(0,0)$ & 0,2 & $(0,0)$ & c & c \\
\hline Israel & 27,1 & $(0,4)$ & 27,1 & $(0,4)$ & c & c & c & c & c & c & 0,7 & $(0,1)$ & 0,7 & $(0,1)$ & c & c \\
\hline Italia & 21,3 & $(0,1)$ & 21,5 & $(0,1)$ & 19,9 & $(0,4)$ & 19,0 & $(1,1)$ & 19,4 & $(0,7)$ & 0,2 & $(0,0)$ & 0,3 & $(0,0)$ & 0,0 & $(0,4)$ \\
\hline Japón & 37,2 & $(0,3)$ & 37,3 & $(0,4)$ & c & c & 37,0 & $(0,6)$ & 37,0 & $(0,6)$ & $-0,3$ & $(0,1)$ & $-0,3$ & $(0,1)$ & c & c \\
\hline Luxemburgo & 20,9 & $(0,1)$ & 21,0 & $(0,1)$ & 20,7 & $(0,2)$ & c & c & 20,3 & $(0,1)$ & 1,1 & $(0,0)$ & 1,3 & $(0,0)$ & 0,0 & $(0,0)$ \\
\hline México & 33,8 & $(0,3)$ & 34,6 & $(0,3)$ & c & c & 28,9 & $(0,9)$ & 28,6 & $(0,8)$ & 0,5 & $(0,0)$ & 0,6 & $(0,0)$ & c & c \\
\hline Noruega & 23,4 & $(0,2)$ & 23,4 & $(0,3)$ & c & c & c & c & c & $c$ & 0,3 & $(0,1)$ & 0,3 & $(0,1)$ & c & c \\
\hline Nueva Zelanda & 23,9 & $(0,2)$ & 24,1 & $(0,2)$ & c & c & 21,3 & $(0,9)$ & 21,3 & $(0,9)$ & 0,1 & $(0,1)$ & 0,1 & $(0,1)$ & c & c \\
\hline Países Bajos & 24,4 & $(0,2)$ & 24,1 & $(0,5)$ & 24,4 & $(0,3)$ & c & c & 24,4 & $(0,3)$ & 0,6 & $(0,1)$ & 0,6 & $(0,1)$ & 0,6 & $(0,1)$ \\
\hline Polonia & 22,8 & $(0,2)$ & 23,0 & $(0,3)$ & 19,1 & $(1,4)$ & 15,7 & $(1,1)$ & 17,8 & $(1,1)$ & $-1,0$ & $(0,0)$ & $-1,0$ & $(0,0)$ & $-1,1$ & $(0,0)$ \\
\hline Portugal & 21,7 & $(0,3)$ & 21,5 & $(0,3)$ & 23,7 & $(0,6)$ & 24,1 & $(0,8)$ & 23,9 & $(0,5)$ & $-0,8$ & $(0,1)$ & $-0,8$ & $(0,1)$ & $-0,8$ & $(0,1)$ \\
\hline Reino Unido & 24,2 & $(0,1)$ & 25,0 & $(0,2)$ & 24,8 & $(0,3)$ & 16,7 & $(0,7)$ & 23,3 & $(0,3)$ & $-0,2$ & $(0,1)$ & $-0,1$ & $(0,1)$ & $-0,2$ & $(0,1)$ \\
\hline República Checa & 22,1 & $(0,3)$ & 22,2 & $(0,3)$ & 23,0 & $(1,1)$ & c & c & 22,6 & $(1,0)$ & $-0,4$ & $(0,0)$ & $-0,4$ & $(0,1)$ & $-0,8$ & $(0,1)$ \\
\hline República Eslovaca & 21,4 & $(0,3)$ & 21,4 & $(0,3)$ & 21,7 & $(1,3)$ & c & c & 21,5 & $(1,3)$ & $-0,3$ & $(0,0)$ & $-0,3$ & $(0,1)$ & $-0,5$ & $(0,2)$ \\
\hline Suecia & 21,1 & $(0,3)$ & 21,1 & $(0,3)$ & 21,1 & $(1,0)$ & c & c & 21,1 & $(1,0)$ & $-0,1$ & $(0,1)$ & $-0,1$ & $(0,1)$ & $-0,1$ & $(0,2)$ \\
\hline Suiza & 19,0 & $(0,2)$ & 18,9 & $(0,2)$ & 20,6 & $(2,0)$ & 19,0 & $(0,9)$ & 19,4 & $(0,8)$ & 0,1 & $(0,1)$ & 0,1 & $(0,1)$ & $-0,1$ & $(0,8)$ \\
\hline Turquía & 23,2 & $(0,3)$ & 23,3 & $(0,3)$ & c & c & c & c & c & c & 0,9 & $(0,1)$ & 0,9 & $(0,1)$ & c & c \\
\hline Media OCDE & 23,9 & $(0,0)$ & 23,9 & $(0,1)$ & 23,7 & $(0,2)$ & 23,5 & $(0,2)$ & 23,8 & $(0,2)$ & 0,0 & $(0,0)$ & 0,0 & $(0,0)$ & $-0,2$ & $(0,0)$ \\
\hline Albania & 26,0 & $(0,3)$ & 26,0 & $(0,3)$ & c & c & 24,5 & $(1,8)$ & 24,5 & $(1,8)$ & $-0,2$ & $(0,1)$ & $-0,2$ & $(0$, & c & c \\
\hline Argentina & 28,5 & $(0,4)$ & 27,0 & $(0,4)$ & 31,3 & $(0,7)$ & 29,6 & $(1,6)$ & 31,0 & $(0,8)$ & $-0,1$ & $(0,1)$ & 0,0 & $(0,1)$ & $-0,3$ & $(0,2)$ \\
\hline Brasil & 32,8 & $(0,3)$ & 32,6 & $(0,2)$ & 32,6 & $(2,8)$ & 32,8 & $(1,5)$ & 32,9 & $(1,5)$ & 0,2 & $(0,1)$ & 0,3 & $(0,1)$ & 0,9 & $(0,5)$ \\
\hline Bulgaria & 22,0 & $(0,3)$ & 22,0 & $(0,3)$ & c & c & c & c & c & c & $-0,8$ & $(0,0)$ & $-0,8$ & $(0,0)$ & c & c \\
\hline Catar & 27,4 & $(0,1)$ & 26,7 & $(0,1)$ & c & c & 28,5 & $(0,1)$ & 28,3 & $(0,1)$ & $-0,1$ & $(0,0)$ & 0,2 & $(0,0)$ & c & c \\
\hline Colombia & 33,5 & $(0,4)$ & 33,7 & $(0,4)$ & 34,7 & $(2,1)$ & 33,9 & $(2,4)$ & 34,1 & $(1,8)$ & 0,7 & $(0,1)$ & 0,7 & $(0,1)$ & $-0,6$ & $(0,2)$ \\
\hline Costa Rica & 25,6 & $(0,4)$ & 25,6 & $(0,4)$ & 31,2 & $(2,1)$ & 23,2 & $(1,2)$ & 25,6 & $(1,2)$ & 0,0 & $(0,1)$ & 0,0 & $(0,1)$ & $-0,5$ & $(0,4)$ \\
\hline Croacia & 26,9 & $(0,2)$ & 27,0 & $(0,2)$ & c & c c & c & c & c & c & $-0,4$ & $(0,1)$ & $-0,4$ & $(0,1)$ & c & c \\
\hline Emiratos Árabes Unidos & 24,5 & $(0,2)$ & 24,1 & $(0,3)$ & c & c & 24,4 & $(0,4)$ & 24,3 & $(0,4)$ & 0,1 & $(0,1)$ & 0,5 & $(0,1)$ & c & c \\
\hline Federación Rusa & 20,0 & $(0,2)$ & 20,1 & $(0,2)$ & c & c & c & c & c & c & 0,4 & $(0,1)$ & 0,4 & $(0,1)$ & c & c \\
\hline Hong Kong-China & 33,2 & $(0,3)$ & 36,1 & $(0,9)$ & 33,1 & $(0,3)$ & c & c & 32,9 & $(0,3)$ & $-0,2$ & $(0,1)$ & $-0,3$ & $(0,4)$ & $-0,2$ & $(0,1)$ \\
\hline Indonesia & 31,8 & $(0,4)$ & 32,8 & $(0,4)$ & 28,9 & $(1,0)$ & 31,8 & $(1,5)$ & 30,6 & $(0,9)$ & 0,3 & $(0,1)$ & 0,2 & $(0,1)$ & 0,9 & $(0,1)$ \\
\hline Jordania & 30,8 & $(0,4)$ & 31,7 & $(0,5)$ & c & c & 26,8 & $(0,6)$ & 26,8 & $(0,6)$ & 1,0 & $(0,1)$ & 1,1 & $(0,1)$ & c & c \\
\hline Kazajistán & 19,5 & $(0,3$ & 19,6 & $(0,3)$ & c & c & 17,7 & $(1,3)$ & 16,1 & $(1,4)$ & 0,3 & $(0,1)$ & 0,3 & $(0,1)$ & c & c \\
\hline Letonia & 18,7 & $(0,3)$ & 18,8 & $(0,3)$ & c & c & c & c & c & c & $-0,4$ & $(0,1)$ & $-0,4$ & $(0,1)$ & c & c \\
\hline Liechtenstein & 17,6 & $(0,7)$ & 17,8 & $(0,7)$ & c & c & c & c & c & c & 0,1 & $(0,0)$ & 0,0 & $(0,0)$ & c & c \\
\hline Lituania & 23,8 & $(0,2)$ & 23,9 & $(0,2)$ & c & c & c & c & c & c & $-0,7$ & $(0,0)$ & $-0,7$ & $(0,0)$ & c & c \\
\hline Macao-China & 35,7 & $(0,1)$ & c & c & 35,7 & $(0,1)$ & 39,5 & $(0,4)$ & 36,3 & $(0,1)$ & 0,0 & $(0,0)$ & c & c & 0,1 & $(0,0)$ \\
\hline Malasia & 30,3 & $(0,4)$ & 29,9 & $(0,3)$ & c & c & 39,6 & $(4,6)$ & 39,6 & $(4,6)$ & 0,2 & $(0,1)$ & 0,2 & $(0,1)$ & c & c \\
\hline Montenegro & 29,1 & $(0,2)$ & 29,2 & $(0,2)$ & c & c & c & c & c & c & $-0,5$ & $(0,0)$ & $-0,5$ & $(0,0)$ & c & c \\
\hline Perú & 26,9 & $(0,5)$ & 26,8 & $(0,5)$ & c & c & 26,9 & $(0,7)$ & 26,9 & $(0,7)$ & 0,6 & $(0,1)$ & 0,8 & $(0,1)$ & c & c \\
\hline Rumanía & 27,5 & $(0,2)$ & 27,5 & $(0,2)$ & c & c & c & c & c & $\mathrm{c}$ & $-0,5$ & $(0,1)$ & $-0,5$ & $(0,1)$ & c & c \\
\hline Serbia & 26,4 & $(0,3)$ & 26,4 & $(0,3)$ & c & c & c & 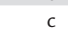 & c & 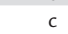 & $-0,7$ & $(0,1)$ & $-0,7$ & $(0,1)$ & c & c \\
\hline Shanghái-China & 35,9 & $(0,4)$ & 35,4 & $(0,4)$ & c & c & 40,1 & $(1,3)$ & 40,1 & $(1,3)$ & 0,8 & $(0,1)$ & 0,7 & $(0,1)$ & c & c \\
\hline Singapur & 33,0 & $(0,1)$ & 33,5 & $(0,1)$ & c & c & c & c & c & & 0,1 & $(0,0)$ & 0,2 & $(0,0)$ & c & c \\
\hline Tailandia & 36,7 & $(0,4)$ & 36,8 & $(0,5)$ & 35,0 & $(1,6)$ & 39,1 & $(2,0)$ & 36,2 & $(1,3)$ & 0,9 & $(0,1)$ & 1,0 & $(0,1)$ & 0,7 & $(0,3)$ \\
\hline Taiwán & 39,0 & $(0,3)$ & 35,5 & $(0,2)$ & 45,2 & $(1,9)$ & 45,3 & $(0,7)$ & 45,3 & $(0,6)$ & $-0,2$ & $(0,1)$ & $-0,2$ & $(0,1)$ & 0,1 & $(0,3)$ \\
\hline Túnez & 25,5 & $(0,3)$ & 25,6 & $(0,3)$ & c & c & c & c & c & c & $-0,1$ & $(0,1)$ & $-0,1$ & $(0,1)$ & c & c \\
\hline Uruguay & 24,8 & $(0,3)$ & 24,7 & $(0,3)$ & c & c & 25,6 & $(0,7)$ & 25,6 & $(0,7)$ & 0,3 & $(0,1)$ & 0,5 & $(0,1)$ & c & c \\
\hline Vietnam & 41,0 & $(0,3)$ & 41,0 & $(0,3)$ & c & c & 40,2 & $(1,1)$ & 40,2 & $(1,1)$ & 0,4 & $(0,1)$ & 0,5 & $(0,1)$ & c & c \\
\hline
\end{tabular}

1. PISA 2012 preguntó en qué medida se ve obstaculizada la enseñanza por una escasez de profesores y de personal cualificado en áreas clave. Esta información se combinó para crear un índice compuesto de escasez de profesores, de tal manera que el índice tenga una media de 0 y una desviación estándar de 1 para los países de la OCDE. Los valores más elevados del índice indican que los directores no perciben ningún problema en la enseñanza a causa de la escasez de profesores.

Fuente: OCDE, Base de datos PISA 2012. Para ver notas, consulte Anexo 3 (www.oecd.org/edu/eag.htm).

Para obtener más información acerca de los símbolos utilizados en lugar de los datos que faltan, consulte la Guía del lector.

StatLink त्नाजम http://dx.doi.org/10.1787/888933119397 
Tabla C7.4. [2/2] Entorno de aprendizaje, por tipo de centro escolar (2012)

Resultados basados en los informes de los directores de centros escolares y los informes de los estudiantes sobre ellos mismos

\begin{tabular}{|c|c|c|c|c|c|c|c|c|c|c|c|c|c|c|}
\hline & \multicolumn{4}{|c|}{$\begin{array}{c}\text { Índice de escasez de profesores } \\
\text { (resultados de PISA basados } \\
\text { en los informes de los directores } \\
\text { de centros escolares) }{ }^{1}\end{array}$} & \multicolumn{10}{|c|}{$\begin{array}{l}\text { Tiempo dedicado (a la semana, en horas) a hacer en casa los deberes o a estudiar } \\
\text { lo que el profesor hubiera indicado (resultados de PISA basados en los informes } \\
\text { de los estudiantes sobre ellos mismos) }\end{array}$} \\
\hline & \multicolumn{2}{|c|}{$\begin{array}{l}\text { Centros escolares } \\
\text { privados } \\
\text { independientes }\end{array}$} & \multicolumn{2}{|c|}{$\begin{array}{c}\text { Centros escolares } \\
\text { privados }\end{array}$} & \multicolumn{2}{|c|}{$\begin{array}{c}\text { Todos los centros } \\
\text { escolares }\end{array}$} & \multicolumn{2}{|c|}{$\begin{array}{c}\text { Centros escolares } \\
\text { públicos }\end{array}$} & \multicolumn{2}{|c|}{$\begin{array}{c}\text { Centros escolares } \\
\text { dependientes } \\
\text { del gobierno }\end{array}$} & $\begin{array}{r}\text { Centros } \\
\text { priv } \\
\text { indeper }\end{array}$ & $\begin{array}{l}\text { scolares } \\
\text { dos } \\
\text { lientes }\end{array}$ & $\begin{array}{r}\text { Centros } \\
\text { priv }\end{array}$ & $\begin{array}{l}\text { scolares } \\
\text { dos }\end{array}$ \\
\hline & Media & E.E. & Media & E.E. & Media & E.E. & Media & E.E. & Media & E.E. & Media & E.E. & Media & E.E. \\
\hline Alemania & c & c & 0,0 & $(0,2)$ & 4,7 & $(0,1)$ & 4,6 & $(0,1)$ & 5,5 & $(0,3)$ & c & c & 5,0 & $(0,5)$ \\
\hline Australia & $-0,4$ & $(0,1)$ & $-0,1$ & $(0,1)$ & 6,0 & $(0,1)$ & 5,1 & $(0,1)$ & 6,6 & $(0,2)$ & 9,0 & $(0,3)$ & 7,4 & $(0,2)$ \\
\hline Austria & $-0,9$ & $(0,2)$ & $-0,4$ & $(0,2)$ & 4,5 & $(0,1)$ & 4,4 & $(0,1)$ & 6,0 & $(0,5)$ & 8,5 & $(0,4)$ & 6,3 & $(0,5)$ \\
\hline Bélgica & c & c & 0,2 & $(0,1)$ & 5,5 & $(0,1)$ & 4,7 & $(0,2)$ & 5,7 & $(0,1)$ & c & c & 5,8 & $(0,1)$ \\
\hline Canadá & $-0,6$ & $(0,3)$ & $-0,4$ & $(0,1)$ & 5,5 & $(0,1)$ & 5,3 & $(0,1)$ & 6,4 & $(0,4)$ & 7,8 & $(0,7)$ & 7,0 & $(0,4)$ \\
\hline Chile & 0,2 & $(0,2)$ & 0,4 & $(0,1)$ & 3,5 & $(0,1)$ & 3,2 & $(0,1)$ & 3,4 & $(0,1)$ & 4,4 & $(0,2)$ & 3,7 & $(0,1)$ \\
\hline Corea & $-0,2$ & $(0,3)$ & 0,1 & $(0,1)$ & 2,9 & $(0,1)$ & 2,7 & $(0,2)$ & 2,6 & $(0,1)$ & 3,9 & $(0,4)$ & 3,1 & $(0,2)$ \\
\hline Dinamarca & $-0,3$ & $(0,2)$ & $-0,4$ & $(0,1)$ & 4,3 & $(0,1)$ & 4,2 & $(0,1)$ & 4,4 & $(0,2)$ & 4,6 & $(0,7)$ & 4,4 & $(0,2)$ \\
\hline Eslovenia & c & c & $-0,4$ & $(0,0)$ & 3,7 & $(0,1)$ & 3,7 & $(0,1)$ & 4,4 & $(0,4)$ & c & c & 4,4 & $(0,4)$ \\
\hline Estonia & c & c & $-0,4$ & $(0,3)$ & 6,9 & $(0,1)$ & 7,0 & $(0,1)$ & 4,8 & $(0,3)$ & c & c & 5,3 & $(0,3)$ \\
\hline Finlandia & c & c & $-0,3$ & $(0,2)$ & 2,8 & $(0,1)$ & 2,8 & $(0,1)$ & 3,4 & $(0,3)$ & c & c & 3,4 & $(0,3)$ \\
\hline Francia & c & c & 0,0 & $(0,2)$ & 5,1 & $(0,1)$ & 4,8 & $(0,1)$ & 6,1 & $(0,3)$ & c & c & 6,1 & $(0,3)$ \\
\hline Grecia & c & c & c & c & 5,3 & $(0,1)$ & 5,1 & $(0,1)$ & c & c & c & c & c & c \\
\hline Hungría & c & c & $-0,5$ & $(0,1)$ & 6,2 & $(0,1)$ & 6,0 & $(0,1)$ & 7,4 & $(0,5)$ & c & c & 7,4 & $(0,5)$ \\
\hline Irlanda & w & w & w & w & w & w & w & w & w & w & w & w & w & w \\
\hline Islandia & c & c & c & c & 4,1 & $(0,1)$ & 4,1 & $(0,1)$ & c & c & c & c & c & c \\
\hline Israel & c & c & c & c & 4,6 & $(0,1)$ & 4,6 & $(0,1)$ & c & c & c & c & c & c \\
\hline Italia & $-0,4$ & $(0,2)$ & $-0,3$ & $(0,2)$ & 8,7 & $(0,1)$ & 8,9 & $(0,1)$ & 3,6 & $(0,5)$ & 9,8 & $(0,5)$ & 7,4 & $(0,6)$ \\
\hline Japón & $-0,3$ & $(0,1)$ & $-0,3$ & $(0,1)$ & 3,8 & $(0,1)$ & 3,8 & $(0,1)$ & c & c & 3,9 & $(0,3)$ & 3,9 & $(0,3)$ \\
\hline Luxemburgo & c & c & $-0,1$ & $(0,0)$ & 4,6 & $(0,1)$ & 4,4 & $(0,1)$ & 5,1 & $(0,2)$ & c & c & 5,4 & $(0,2)$ \\
\hline México & $-0,1$ & $(0,1)$ & $-0,1$ & $(0,1)$ & 5,2 & $(0,1)$ & 5,2 & $(0,1)$ & c & c & 5,6 & $(0,2)$ & 5,6 & $(0,2)$ \\
\hline Noruega & c & c & c & c & 4,7 & $(0,1)$ & 4,7 & $(0,1)$ & c & c & c & c & c & c \\
\hline Nueva Zelanda & $-0,4$ & $(0,3)$ & $-0,4$ & $(0,3)$ & 4,2 & $(0,1)$ & 4,1 & $(0,1)$ & c & c & 7,2 & $(0,6)$ & 7,2 & $(0,6)$ \\
\hline Países Bajos & c & c & 0,6 & $(0,1)$ & 5,8 & $(0,1)$ & 5,7 & $(0,3)$ & 6,0 & $(0,2)$ & c & c & 6,0 & $(0,2)$ \\
\hline Polonia & $-1,0$ & $(0,1)$ & $-1,1$ & $(0,0)$ & 6,6 & $(0,1)$ & 6,6 & $(0,1)$ & 6,7 & $(0,7)$ & 7,4 & $(0,7)$ & 6,9 & $(0,5)$ \\
\hline Portugal & $-1,1$ & $(0,0)$ & $-0,9$ & $(0,1)$ & 3,8 & $(0,1)$ & 3,7 & $(0,1)$ & 4,7 & $(0,4)$ & 6,1 & $(0,6)$ & 5,3 & $(0,5)$ \\
\hline Reino Unido & $-1,0$ & $(0,1)$ & $-0,3$ & $(0,1)$ & 4,9 & $(0,1)$ & 4,5 & $(0,1)$ & 4,7 & $(0,3)$ & 9,1 & $(0,6)$ & 5,4 & $(0,3)$ \\
\hline República Checa & c & c & $-0,8$ & $(0,1)$ & 3,1 & $(0,1)$ & 3,1 & $(0,1)$ & 3,1 & $(0,3)$ & c & c & 3,2 & $(0,3)$ \\
\hline Turquía & c & c & c & c & 4,2 & $(0,1)$ & 4,3 & $(0,1)$ & c & c & c & c & c & c \\
\hline Media OCDE & -0.5 & $(0.0)$ & -0.3 & $(0.0)$ & 4.9 & $(0.0)$ & 4.7 & $(0.0)$ & 5.1 & $(0.1)$ & 6.8 & $(0.1)$ & 5.6 & $(0.1)$ \\
\hline Albania & $-0,4$ & $(0,3)$ & $-0,4$ & $(0,3)$ & 5,1 & $(0,1)$ & 5,1 & $(0,1)$ & c & c & 4,9 & $(0,3)$ & 4,9 & $(0,3)$ \\
\hline ¿ Argentina & 0,0 & $(0,3)$ & $-0,2$ & $(0,1)$ & 3,7 & $(0,1)$ & 3,4 & $(0,1)$ & 4,3 & $(0,2)$ & 4,1 & $(0,3)$ & 4,3 & $(0,2)$ \\
\hline Brasil & $-0,5$ & $(0,1)$ & $-0,4$ & $(0,2)$ & 3,3 & $(0,1)$ & 3,1 & $(0,1)$ & 4,0 & $(0,2)$ & 4,2 & $(0,2)$ & 4,2 & $(0,2)$ \\
\hline Bulgaria & c & c & c & c & 5,6 & $(0,2)$ & 5,6 & $(0,2)$ & c & c & c & c & c & c \\
\hline Catar & $-0,7$ & $(0,0)$ & $-0,7$ & $(0,0)$ & 4,3 & $(0,0)$ & 3,5 & $(0,1)$ & c & c & 5,4 & $(0,1)$ & 5,5 & $(0,1)$ \\
\hline Colombia & 0,7 & $(0,7)$ & 0,4 & $(0,5)$ & 5,3 & $(0,1)$ & 5,1 & $(0,1)$ & 5,8 & $(0,5)$ & 7,0 & $(0,9)$ & 6,7 & $(0,6)$ \\
\hline Costa Rica & $-0,2$ & $(0,2)$ & $-0,3$ & $(0,2)$ & 3,5 & $(0,2)$ & 3,3 & $(0,2)$ & 4,6 & $(0,4)$ & 4,8 & $(0,7)$ & 4,8 & $(0,5)$ \\
\hline Croacia & c & c & c & c & 5,9 & $(0,1)$ & 5,9 & $(0,1)$ & c & c & c & c & c & c \\
\hline $\begin{array}{l}\text { Emiratos Árabes } \\
\text { Unidos }\end{array}$ & $-0,3$ & $(0,1)$ & $-0,3$ & $(0,1)$ & 6,2 & $(0,1)$ & 4,9 & $(0,1)$ & c & c & 7,1 & $(0,2)$ & 7,0 & $(0,2)$ \\
\hline Federación Rusa & c & c & c & c & 9,7 & $(0,2)$ & 9,7 & $(0,2)$ & c & c & c & c & c & c \\
\hline Hong Kong-China & c & c & $-0,2$ & $(0,1)$ & 6,0 & $(0,2)$ & 6,0 & $(1,0)$ & 6,0 & $(0,2)$ & c & c & 6,1 & $(0,2)$ \\
\hline Indonesia & 0,1 & $(0,2)$ & 0,4 & $(0,1)$ & 4,9 & $(0,2)$ & 5,2 & $(0,2)$ & 3,7 & $(0,2)$ & 5,1 & $(0,3)$ & 4,5 & $(0,2)$ \\
\hline Jordania & 0,4 & $(0,3)$ & 0,5 & $(0,3)$ & 4,2 & $(0,1)$ & 4,1 & $(0,1)$ & c & c & 4,8 & $(0,4)$ & 4,9 & $(0,4)$ \\
\hline Kazajistán & 0,5 & $(0,3)$ & 0,6 & $(0,2)$ & 8,8 & $(0,2)$ & 8,9 & $(0,2)$ & c & c & 6,5 & $(0,6)$ & 6,9 & $(0,6)$ \\
\hline Letonia & c & c & c & c & 6,2 & $(0,1)$ & 6,1 & $(0,2)$ & c & c & c & c & c & c \\
\hline Liechtenstein & c & c & c & c & 3,3 & $(0,2)$ & 3,2 & $(0,2)$ & c & c & c & c & c & c \\
\hline Lituania & c & c & c & c & 6,7 & $(0,1)$ & 6,7 & $(0,1)$ & c & c & c & c & c & c \\
\hline Macao-China & $-0,3$ & $(0,0)$ & 0,0 & $(0,0)$ & 5,9 & $(0,1)$ & c & c & 5,7 & $(0,1)$ & 7,8 & $(0,3)$ & 6,0 & $(0,1)$ \\
\hline Malasia & 0,8 & $(0,4)$ & 0,8 & $(0,4)$ & 4,8 & $(0,1)$ & 4,8 & $(0,1)$ & c & c & 5,6 & $(0,7)$ & 5,6 & $(0,7)$ \\
\hline Montenegro & c & c & c & c & 4,3 & $(0,1)$ & 4,3 & $(0,1)$ & c & c & c & c & c & c \\
\hline Perú & $-0,2$ & $(0,2)$ & $-0,2$ & $(0,2)$ & 5,5 & $(0,1)$ & 5,4 & $(0,1)$ & c & c & 5,2 & $(0,3)$ & 5,2 & $(0,3)$ \\
\hline Rumanía & c & c & c & c & 7,3 & $(0,2)$ & 7,3 & $(0,2)$ & c & c & c & c & c & c \\
\hline Serbia & c & c & c & c & 4,4 & $(0,1)$ & 4,4 & $(0,1)$ & c & c & c & c & c & c \\
\hline Shanghái-China & 0,9 & $(0,4)$ & 0,9 & $(0,4)$ & 13,8 & $(0,3)$ & 13,7 & $(0,3)$ & c & c & 14,9 & $(0,9)$ & 14,9 & $(0,9)$ \\
\hline Singapur & c & c & c & c & 9,4 & $(0,2)$ & 9,4 & $(0,1)$ & c & c & c & c & c & c \\
\hline Tailandia & 0,8 & $(0,3)$ & 0,7 & $(0,3)$ & 5,6 & $(0,1)$ & 5,8 & $(0,2)$ & 4,3 & $(0,2)$ & 4,2 & $(0,8)$ & 4,3 & $(0,3)$ \\
\hline Taiwán & 0,0 & $(0,2)$ & 0,0 & $(0,2)$ & 5,3 & $(0,1)$ & 5,9 & $(0,2)$ & 3,4 & $(0,3)$ & 4,6 & $(0,3)$ & 4,4 & $(0,3)$ \\
\hline Túnez & c & c & c & c & 3,5 & $(0,1)$ & 3,6 & $(0,1)$ & c & c & c & c & c & c \\
\hline Uruguay & $-0,3$ & $(0,2)$ & $-0,3$ & $(0,2)$ & 4,7 & $(0,1)$ & 4,5 & $(0,1)$ & c & c & 5,4 & $(0,2)$ & 5,4 & $(0,2)$ \\
\hline Vietnam & $-0,7$ & $(0,2)$ & $-0,7$ & $(0,2)$ & 5,8 & $(0,2)$ & 5,9 & $(0,2)$ & c & c & 5,6 & $(0,7)$ & 5,6 & $(0,7)$ \\
\hline
\end{tabular}


Tabla C7.5. [1/2] Responsabilidad del centro escolar en la asignación de recursos, currículo y evaluación, por tipo de centro escolar y nivel de educación (2012)

Resultados basados en los informes de los directores de centros escolares

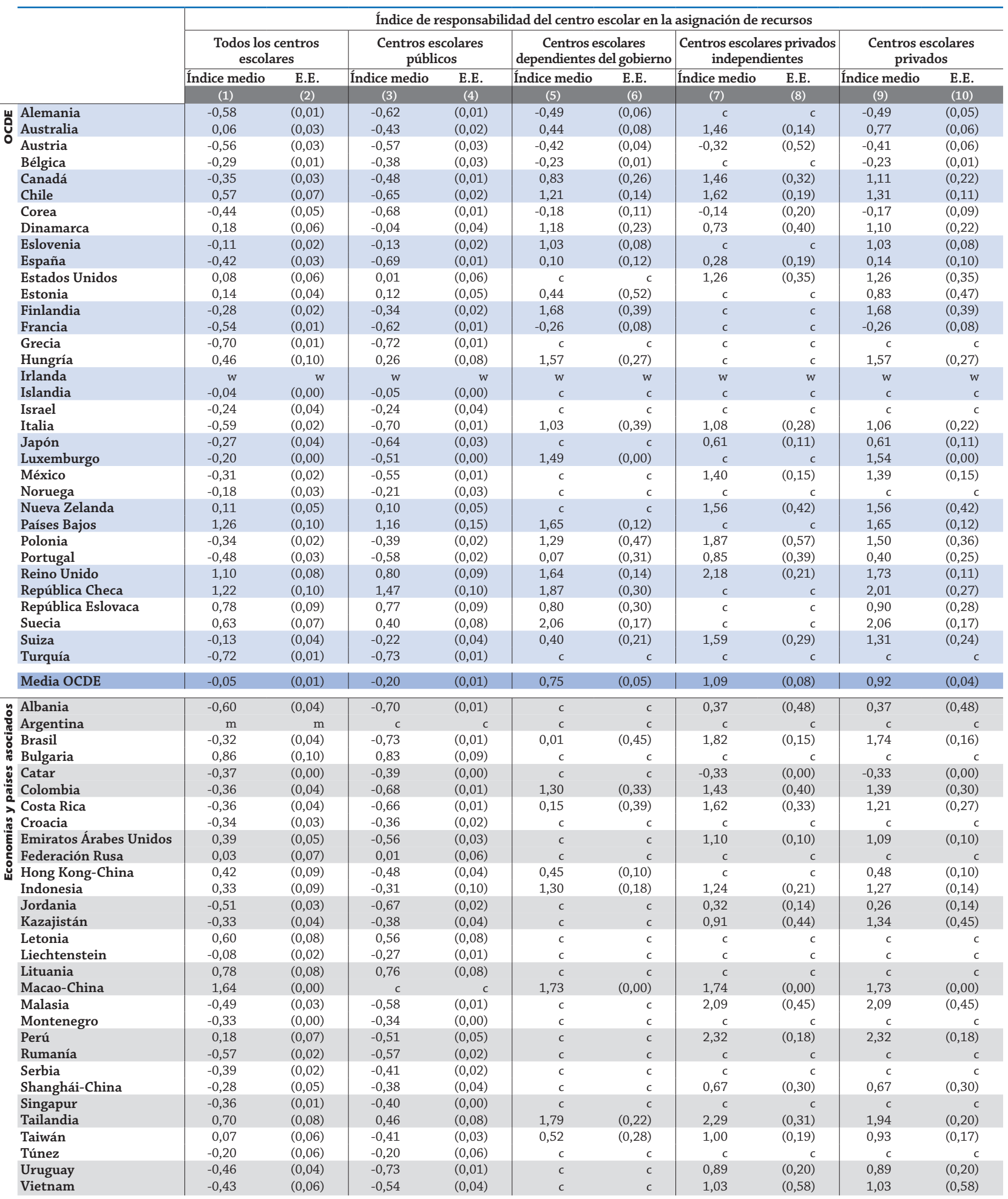

Nota: PISA 2012 pidió a los directores de los centros escolares que declararan si los profesores, el director, el consejo directivo del centro escolar, las delegaciones regionales o locales o la delegación nacional de educación tienen una responsabilidad considerable en la asignación de recursos a los centros escolares, el currículo y la evaluación de la enseñanza dentro del centro escolar. Esta información se combinó para crear dos índices compuestos: un índice de responsabilidad del centro escolar en la asignación de recursos y un índice de responsabilidad del centro escolar en el currículo y la evaluación, de manera que ambos índices tengan una media de cero y una desviación estándar de uno para los países de la OCDE. Los valores más elevados indican una mayor autonomía para los directores y los profesores de los centros escolares. Fuente: OCDE, Base de datos PISA 2012. Para ver notas, consulte Anexo 3 (www.oecd.org/edu/eag.htm).

Para obtener más información acerca de los símbolos utilizados en lugar de los datos que faltan, consulte la Guía del lector.

StatLink 제개 http://dx.doi.org/10.1787/888933119416 
Tabla C7.5. [2/2] Responsabilidad del centro escolar en la asignación de recursos, currículo y evaluación, por tipo de centro escolar y nivel de educación (2012)

Resultados basados en los informes de los directores de centros escolares

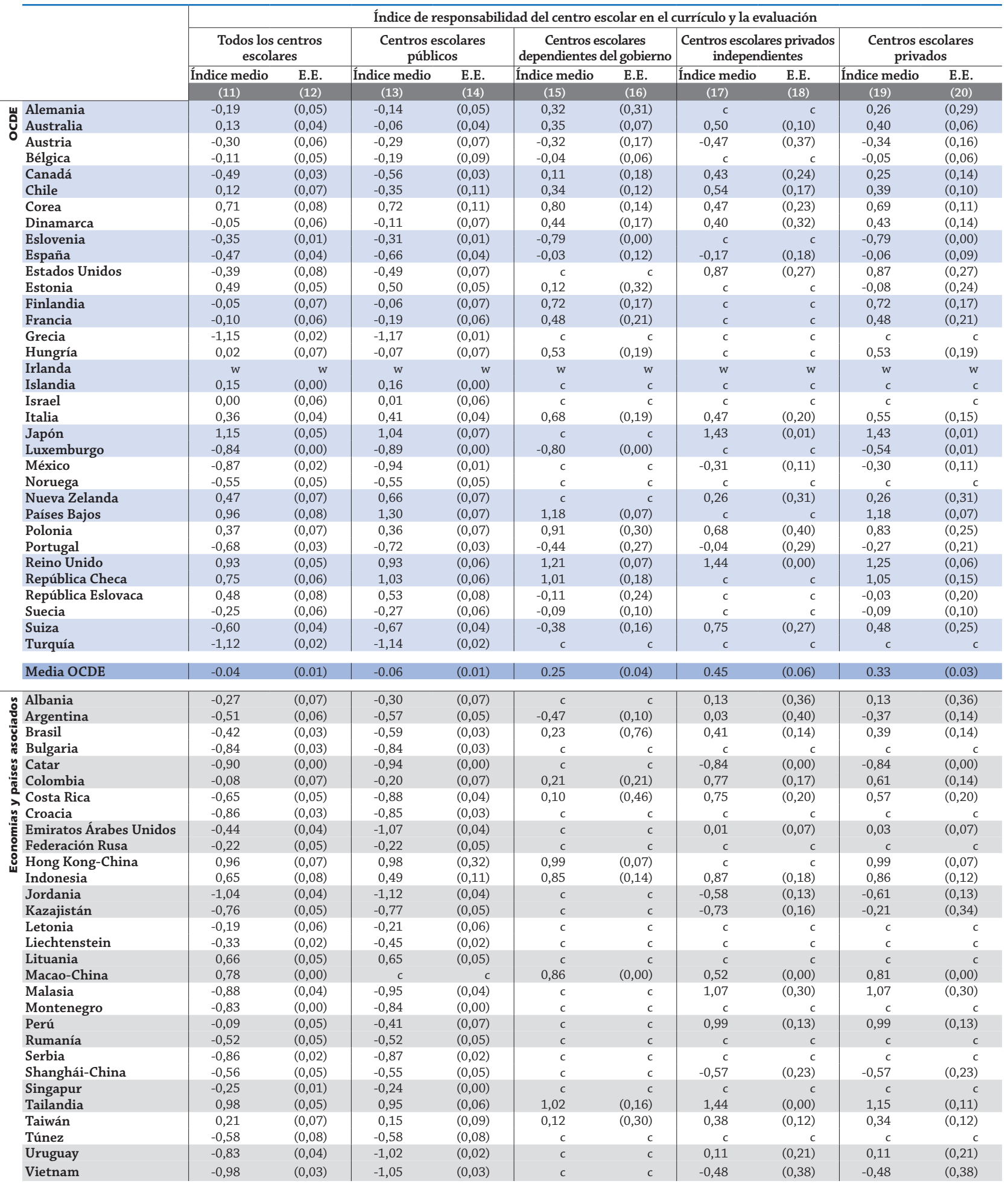

Nota: PISA 2012 pidió a los directores de los centros escolares que declararan si los profesores, el director, el consejo directivo del centro escolar, las delegaciones regionales o locales o la delegación nacional de educación tienen una responsabilidad considerable en la asignación de recursos a los centros escolares, el currículo y la evaluación de la enseñanza dentro del centro escolar. Esta información se combinó para crear dos índices compuestos: un índice de responsabilidad del centro escolar en la asignación de recursos y un índice de responsabilidad del centro escolar en el currículo y la evaluación, de manera que ambos índices tengan una media de cero y una desviación estándar de uno para los países de la OCDE. Los valores más elevados indican una mayor autonomía para los directores y los profesores de los centros escolares. Fuente: OCDE, Base de datos PISA 2012. Para ver notas, consulte Anexo 3 (www.oecd.org/edu/eag.htm).

Para obtener más información acerca de los símbolos utilizados en lugar de los datos que faltan, consulte la Guía del lector.

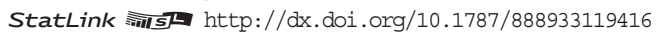


Tabla C7.6. Estudiantes en educación terciaria, por tipo de institución $(2003,2012)$

Distribución de los estudiantes, por tipo de institución y destino del programa

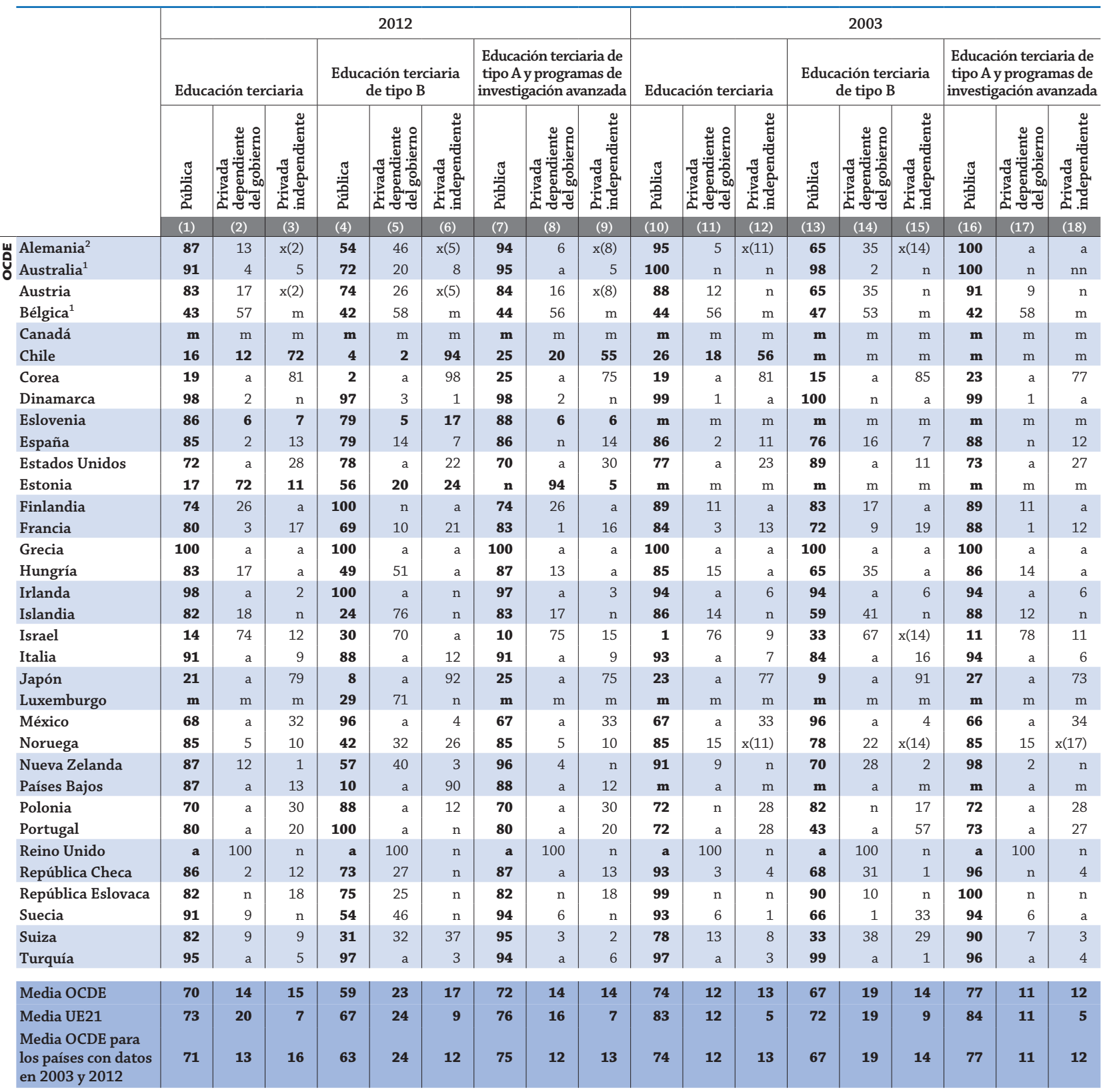

\begin{tabular}{|c|c|c|c|c|c|c|c|c|c|c|c|c|c|c|c|c|c|c|}
\hline $\begin{array}{l}\text { Arabia Saudí } \\
\text { Argentina }^{3}\end{array}$ & $\begin{array}{l}95 \\
74\end{array}$ & $\begin{array}{l}5 \\
5\end{array}$ & $\begin{array}{r}\mathbf{a} \\
20\end{array}$ & $\begin{array}{r}100 \\
64\end{array}$ & $\begin{array}{r}n \\
17\end{array}$ & $\begin{array}{r}n \\
20\end{array}$ & $\begin{array}{l}95 \\
79\end{array}$ & $\begin{array}{l}\mathbf{5} \\
\mathbf{a}\end{array}$ & $\begin{array}{r}\text { a } \\
21\end{array}$ & $\begin{array}{r}\mathrm{m} \\
78\end{array}$ & $\begin{array}{r}\mathbf{m} \\
\mathbf{8}\end{array}$ & $\begin{array}{r}\mathrm{m} \\
13\end{array}$ & $\begin{array}{l}\mathbf{m} \\
\mathbf{m}\end{array}$ & $\begin{array}{l}\mathbf{m} \\
\mathbf{m}\end{array}$ & $\begin{array}{l}\mathbf{m} \\
\mathbf{m}\end{array}$ & $\begin{array}{l}\mathbf{m} \\
\mathbf{m}\end{array}$ & $\begin{array}{l}\mathbf{m} \\
\mathbf{m}\end{array}$ & $\begin{array}{l}\mathbf{m} \\
\mathbf{m}\end{array}$ \\
\hline Brasil & 29 & $\mathbf{a}$ & 71 & 15 & $\mathbf{a}$ & 85 & 31 & $\mathbf{a}$ & 69 & 32 & $\mathbf{a}$ & 68 & $\mathbf{m}$ & $\mathbf{m}$ & $\mathbf{m}$ & $\mathbf{m}$ & $\mathbf{m}$ & $\mathbf{m}$ \\
\hline yू China & $\mathbf{m}$ & $\mathbf{m}$ & $\mathbf{m}$ & $\mathbf{m}$ & $\mathbf{m}$ & $\mathbf{m}$ & $\mathbf{m}$ & $\mathbf{m}$ & $\mathbf{m}$ & $\mathbf{m}$ & $\mathbf{m}$ & $\mathbf{m}$ & $\mathbf{m}$ & $\mathbf{m}$ & $\mathbf{m}$ & $\mathbf{m}$ & $\mathbf{m}$ & $\mathbf{m}$ \\
\hline$\frac{\pi}{\pi}$ Colombia & 53 & $\mathbf{a}$ & 47 & $\mathbf{m}$ & $\mathbf{a}$ & m & $\mathbf{m}$ & $\mathbf{a}$ & $\mathbf{m}$ & $\mathbf{m}$ & $\mathbf{m}$ & $\mathbf{m}$ & $\mathbf{m}$ & $\mathbf{m}$ & $\mathbf{m}$ & $\mathbf{m}$ & $\mathbf{m}$ & $\mathbf{m}$ \\
\hline Federación Rusa ${ }^{2}$ & 86 & a & 14 & 95 & a & 5 & 84 & a & 16 & 91 & a & 9 & $\mathbf{m}$ & $\mathbf{m}$ & $\mathbf{m}$ & $\mathbf{m}$ & $\mathbf{m}$ & $\mathbf{m}$ \\
\hline India & $\mathbf{m}$ & $\mathbf{m}$ & $\mathbf{m}$ & $\mathbf{m}$ & $\mathbf{m}$ & $\mathbf{m}$ & $\mathbf{m}$ & $\mathbf{m}$ & $\mathbf{m}$ & $\mathbf{m}$ & $\mathbf{m}$ & $\mathbf{m}$ & $\mathbf{m}$ & $\mathbf{m}$ & $\mathbf{m}$ & $\mathbf{m}$ & $\mathbf{m}$ & $\mathbf{m}$ \\
\hline Indonesia & 34 & $\mathbf{a}$ & 66 & 43 & $\mathbf{a}$ & 57 & 32 & $\mathbf{a}$ & 68 & 39 & $\mathbf{a}$ & 61 & $\mathbf{m}$ & $\mathbf{m}$ & $\mathbf{m}$ & $\mathbf{m}$ & $\mathbf{m}$ & $\mathbf{m}$ \\
\hline Letonia & 7 & 64 & 29 & 42 & 17 & 41 & $\mathbf{a}$ & 74 & 26 & $\mathbf{m}$ & $\mathbf{m}$ & $\mathbf{m}$ & $\mathbf{m}$ & $\mathbf{m}$ & $\mathbf{m}$ & $\mathbf{m}$ & $\mathbf{m}$ & $\mathbf{m}$ \\
\hline Sudáfrica & $\mathbf{m}$ & $\mathbf{m}$ & $\mathbf{m}$ & $\mathbf{m}$ & $\mathbf{m}$ & $\mathbf{m}$ & $\mathbf{m}$ & $\mathbf{m}$ & $\mathbf{m}$ & $\mathbf{m}$ & $\mathbf{m}$ & $\mathbf{m}$ & $\mathbf{m}$ & $\mathbf{m}$ & $\mathbf{m}$ & $\mathbf{m}$ & $\mathbf{m}$ & $\mathbf{m}$ \\
\hline
\end{tabular}

\begin{tabular}{|l|c|c|c|c|c|c|c|c|c|c|c|c|c|c|c|c|c|c|}
\hline Media G20 & $\mathbf{m}$ & $\mathbf{m}$ & $\mathbf{m}$ & $\mathbf{m}$ & $\mathbf{m}$ & $\mathbf{m}$ & $\mathbf{m}$ & $\mathbf{m}$ & $\mathbf{m}$ & $\mathbf{m}$ & $\mathbf{m}$ & $\mathbf{m}$ & $\mathbf{m}$ & $\mathbf{m}$ & $\mathbf{m}$ & $\mathbf{m}$ & $\mathbf{m}$ & $\mathbf{m}$ \\
\hline
\end{tabular}

1. Excluyendo instituciones privadas independientes.

2. Excluye programas de investigación avanzada.

3. Año de referencia 2011 en lugar de 2012.

Fuente: OCDE. Argentina, China, India, Indonesia: Instituto de Estadística de la UNESCO (Programa Mundial de Indicadores de Educación). Para ver notas, consulte Anexo 3 (www.oecd.org/edu/eag.htm).

Para obtener más información acerca de los símbolos utilizados en lugar de los datos que faltan, consulte la Guía del lector.

StatLink 젠 http://dx.doi.org/10.1787/888933119435 


\section{Capítulo}

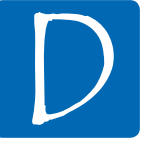

\section{El ENTORNO dE AprendizAJe Y LA ORGANIZACIÓN de los Centros Escolares}

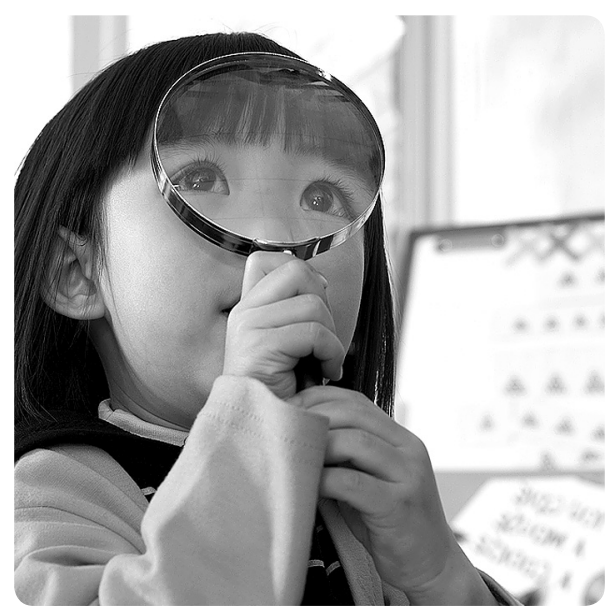

Indicador D1 ¿Cuánto tiempo pasan los estudiantes en clase?

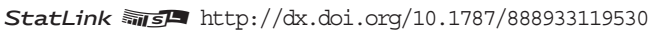

Indicador D2 ¿Cuál es la ratio alumnos-profesor y cómo es el tamaño de las clases? StatLink ज्ञाइ http://dx.doi.org/10.1787/888933119682

Indicador D3 ¿Cuál es el salario de los profesores? StatLink 部可 http://dx.doi.org/10.1787/888933119815

Indicador D4 ¿Cuánto tiempo dedican los profesores a enseñar?

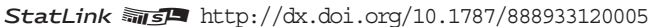

Indicador D5 ¿Quiénes componen el profesorado? StatLink 게제 http://dx.doi.org/10.1787/888933120138

Indicador D6 ¿Qué requisitos son necesarios para ser profesor?

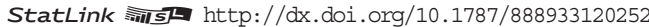

Indicador D7 ¿Qué implantación tienen las actividades de desarrollo profesional para los profesores?

StatLink Ails http://dx.doi.org/10.1787/888933120461 


\section{¿CUÁNTO TIEMPO PASAN LOS ESTUDIANTES EN CLASE?}

- En los países de la OCDE, los estudiantes reciben una media de 7.475 horas de enseñanza obligatorias durante la educación primaria y secundaria inferior.

- El tiempo medio dedicado a la enseñanza de la lectura, escritura y literatura, matemáticas y artes en los países de la OCDE representa el $45 \%$ de las horas de enseñanza obligatorias para los estudiantes de primaria. La enseñanza de la lectura, escritura y literatura, primera lengua y otras lenguas extranjeras y matemáticas ocupa el $39 \%$ del tiempo de enseñanza obligatorio para los estudiantes de secundaria inferior.

INDICADOR $\mathrm{D}_{1}$

\section{Gráfico D1.1. Horas de enseñanza obligatorias en educación general (2014)}

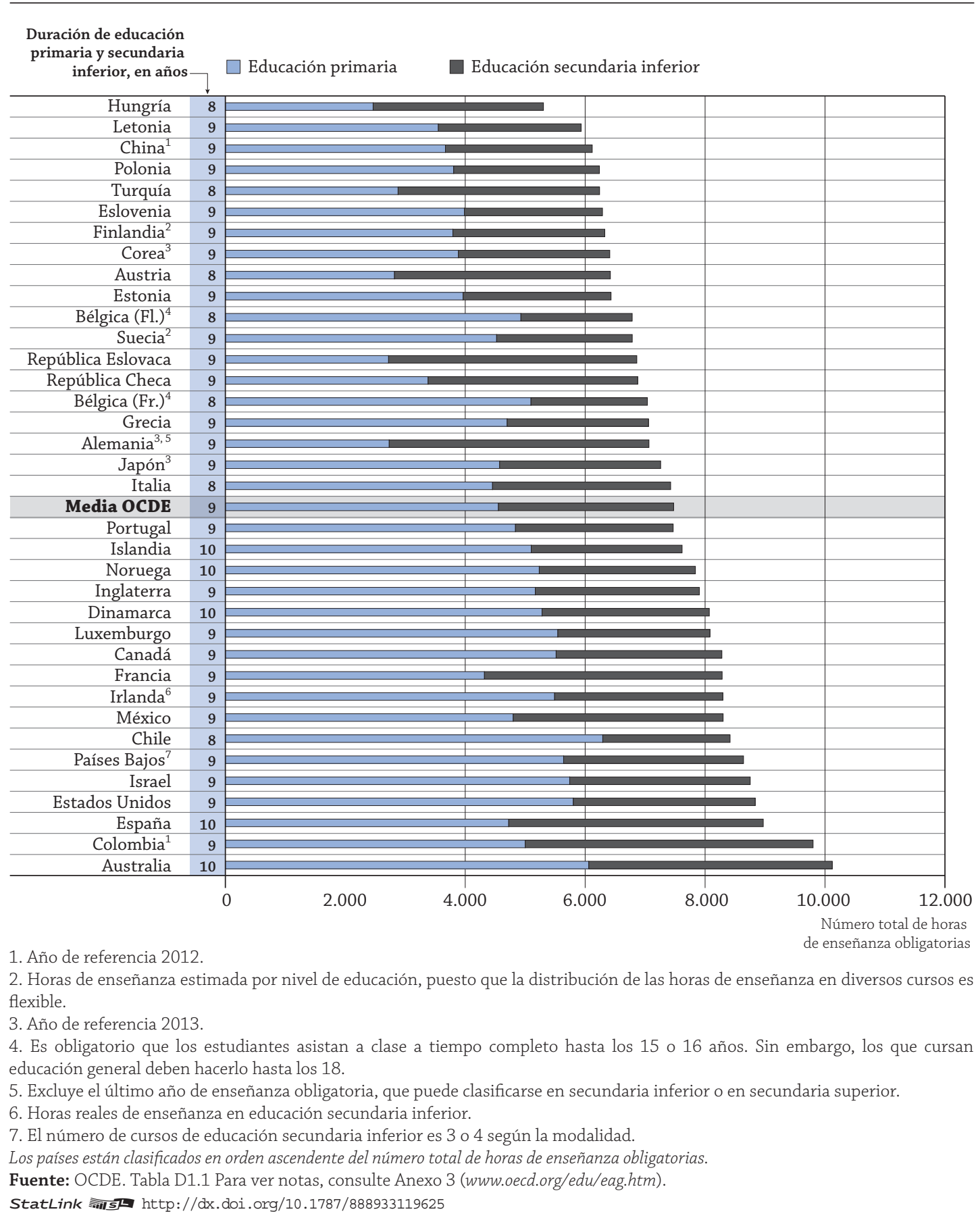




\section{Contexto}

El tiempo dedicado a la enseñanza en el marco escolar institucional representa una gran parte de la inversión pública destinada a la educación. Los países deciden cuánto tiempo se dedica a la enseñanza y qué asignaturas son obligatorias. Estas decisiones reflejan las prioridades y preferencias nacionales y/o regionales en lo que se refiere a los contenidos que enseñar y la edad a la que deben enseñarse. La mayoría de los países cuentan con requisitos legales o reglamentarios respecto a las horas de enseñanza, que generalmente están estipuladas como el número mínimo de horas de enseñanza que debe ofrecer un centro educativo y se basan en la idea de que la provisión de un tiempo suficiente de enseñanza es necesaria para conseguir buenos resultados en el aprendizaje. Adaptar los recursos a las necesidades de los estudiantes y utilizar el tiempo de manera óptima son retos básicos para la política educativa. El coste de la educación incluye principalmente los salarios de los profesores, el mantenimiento de las infraestructuras escolares y otros recursos educativos. Por tanto, el tiempo durante el que estos recursos están a disposición de los estudiantes, tal como pone de relieve en parte este indicador, es un factor importante para la distribución de los fondos existentes (véase Indicador B7, que muestra los factores que influyen en el coste salarial de profesores por estudiante).

\section{Otros resultados}

- En los países de la OCDE, los estudiantes de primaria reciben una media de $\mathbf{7 9 4}$ horas de enseñanza obligatorias al año. Los estudiantes de secundaria inferior reciben, por término medio, unas 111 horas de enseñanza obligatorias más al año que los de primaria.

- La proporción del currículo obligatorio para los estudiantes de primaria dedicada a la lectura, escritura y literatura varía desde el $18 \%$ en Polonia al $37 \%$ en Francia. Para los estudiantes de secundaria inferior, oscila entre el 12 \% de Finlandia, Irlanda, Japón y República Checa y el $33 \%$ de Italia.

- En los países de la OCDE, una media de un $14 \%$ (para los estudiantes de primaria) y de un $6 \%$ (para los de secundaria inferior) del tiempo de enseñanza obligatorio se dedica a asignaturas del currículo obligatorio con horario flexible. Una media de un $4 \%$ del tiempo de enseñanza obligatoria para ambos grupos de estudiantes se dedica a materias obligatorias flexibles elegidas por los centros escolares.

- Aproximadamente en un tercio de los países de los que se dispone de datos, la asignación de las horas de enseñanza en los distintos cursos es flexible. Es decir, el tiempo de enseñanza que debe dedicarse a una asignatura específica se define para varios cursos, o incluso para el conjunto de la enseñanza obligatoria, sin especificar qué tiempo se ha de impartir en cada curso. 


\section{Análisis}

\section{Educación general obligatoria}

Las horas de enseñanza anuales deben analizarse conjuntamente con la duración de la educación obligatoria. En algunos países, la franja de edad de la educación obligatoria es más reducida y la carga de trabajo de los estudiantes es mayor. En otros, en cambio, la distribución más uniforme del aprendizaje durante más años suele generar una cifra más elevada de horas de enseñanza para todos.

Aproximadamente en tres de cada cuatro países con datos disponibles, los estudiantes comienzan la educación primaria a los 6 años. Sin embargo, en Estonia, Finlandia, Letonia, Polonia y Suecia no empiezan hasta los 7 años. Solo en Australia, Inglaterra y Escocia la educación primaria comienza a los 5 años. Se observan además diferencias sustanciales en la duración de la educación primaria. Como media, la educación primaria dura seis años, pero varía desde cuatro años en Alemania, Austria, Hungría, República Eslovaca y Turquía a siete en Dinamarca, Escocia, Islandia y Noruega. La duración media de la educación secundaria inferior es de tres años, pero varía desde dos años en Bélgica (Comunidades flamenca y francófona) y Chile a cinco años en República Eslovaca. En poco más de la mitad de los países de los que se dispone de datos, al menos un año de la educación secundaria superior forma parte de la educación obligatoria a tiempo completo (Tabla D1.2).

Por otra parte, los países distribuyen de forma diferente a lo largo del año el tiempo de enseñanza. Como media en los países de la OCDE, los estudiantes de primaria y secundaria inferior tienen 185 y 183 días de enseñanza al año, respectivamente. Sin embargo, en China (primaria y secundaria inferior), Francia (primaria), Grecia (secundaria inferior), Irlanda (secundaria inferior), Islandia (primaria y secundaria inferior) y Luxemburgo (secundaria inferior), los estudiantes reciben 170 días o menos de enseñanza al año. Por el contrario, los estudiantes de primaria y secundaria inferior en Brasil, Colombia, Israel, Italia, Japón y México reciben al menos 200 días de enseñanza al año (Tabla D1.2).

\section{Horas de enseñanza obligatorias}

El tiempo de enseñanza obligatorio se refiere al número y distribución de horas de enseñanza que deben impartirse en casi todos los centros escolares públicos y a las que tienen obligación de asistir casi todos los estudiantes del sector público, de acuerdo con una normativa establecida.

En los países de la OCDE, los estudiantes reciben una media de 4.553 horas de enseñanza durante la educación primaria y una media de 2.922 durante la secundaria inferior. Mientras que la media del total de horas de enseñanza para estudiantes de primaria y secundaria inferior de los países de la OCDE es de 7.475 horas, las horas de enseñanza formal requeridas varían de las 5.034 horas de Hungría a las 10.120 horas de Australia (Tabla D1.1).

El tiempo de enseñanza obligatorio puede no coincidir con el número de horas reales de enseñanza, dado que se consideran únicamente las horas de enseñanza formal en el aula y son solo una parte del tiempo total que los estudiantes pasan recibiendo enseñanza, sin considerar la enseñanza recibida fuera del aula y/o del centro escolar. En algunos países se anima a los estudiantes de educación secundaria a que asistan a clases extraescolares de asignaturas que ya estudian en los centros educativos para mejorar su rendimiento. Los estudiantes pueden asistir a clases extraescolares de recuperación o refuerzo, o como ampliación o profundización de los programas escolares, ya sean impartidas por profesores particulares, por profesores de centros escolares en grupo o en cursos independientes. Estas clases pueden pagarse con fondos públicos o por los estudiantes y sus familias (véase Cuadro D1.1, OECD, 2011).

\section{Horas de enseñanza previstas}

El número total de horas de enseñanza previstas es el número de horas durante las que los centros escolares están obligados a ofrecer la enseñanza de las asignaturas obligatorias y, si procede, de las no obligatorias.

El tiempo de enseñanza previsto es totalmente obligatorio, es decir, las horas de enseñanza previstas y las horas de enseñanza obligatorias tienen la misma duración, tanto en primaria como en secundaria inferior, en unos tres cuartos de los países con datos disponibles. Sin embargo, en Eslovenia, Finlandia, Grecia, Polonia y Portugal, el total de horas de enseñanza previstas en educación primaria y secundaria inferior es al menos un $5 \%$ superior a las horas de enseñanza obligatorias.

\section{Horas de enseñanza por materia}

Los estudiantes de primaria pasan una media del $45 \%$ del currículo obligatorio con tres materias básicas: lectura, escritura y literatura (22\%), matemáticas (15\%) y artes (9\%). Junto a la educación física y para la salud (8\%), las 
Gráfico D1.2a. Horas de enseñanza por materia en educación primaria (2014) Como porcentaje del total de horas de enseñanza obligatorias

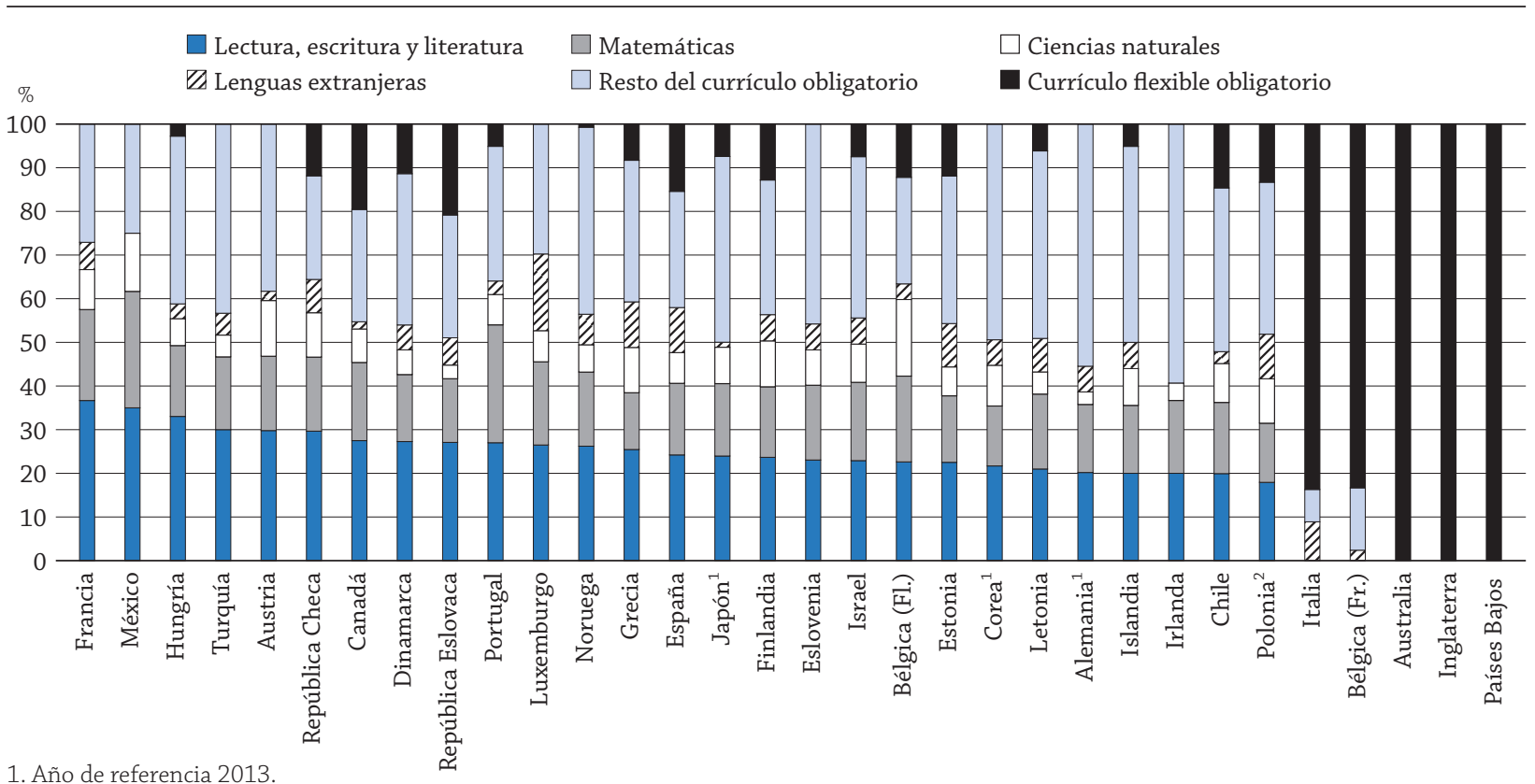

2. Excluye los tres primeros años de educación primaria en los cuales una proporción importante del tiempo dedicado a asignaturas obligatorias es flexible.

Los países están clasificados en orden descendente de la proporción del número de horas de enseñanza dedicadas a la lectura, escritura y literatura. Fuente: OCDE. Tabla D1.3a. Para ver notas, consulte Anexo 3 (www.oecd.org/edu/eag.htm).

StatLink : ints $\mathrm{http}: / / \mathrm{dx}$.doi.org/10.1787/888933119644

ciencias naturales (7\%) y las ciencias sociales (6\%), estas seis áreas de estudio conforman la parte principal del currículo para este grupo de edad en todos los países de la OCDE de los que hay datos de horas de enseñanza por asignatura. Las lenguas extranjeras, la educación religiosa, ética y moral, las tecnologías de la información y la comunicación (TIC), tecnología, materias prácticas y de iniciación profesional, y otras asignaturas completan el 16\% restante del currículo obligatorio total para estudiantes de primaria (Tabla D1.3a y Gráfico D1.2a).

Como media, la mayor proporción del currículo de los estudiantes de primaria se dedica a la lectura, escritura y literatura, pero las diferencias entre países son importantes. Por ejemplo, en Alemania, Chile, Irlanda, Islandia y Polonia, la lectura, escritura y literatura representan como mucho el $20 \%$ de las horas de enseñanza obligatorias, mientras que en Francia y México suponen al menos el $35 \%$ de las horas de enseñanza obligatorias. Las variaciones entre países en el tiempo dedicado al aprendizaje de matemáticas y artes son también muy importantes. En Corea, Grecia y Polonia, la formación en matemáticas representa no más de un $14 \%$ de las horas de enseñanza, frente al $27 \%$ en México y Portugal. En Israel y México, la formación en artes supone el $5 \%$ de las horas de enseñanza, mientras que en Alemania, Eslovenia, Estonia, Islandia y Noruega, representan al menos el $15 \%$ de las horas de enseñanza obligatorias. En Finlandia, las artes suponen como mínimo el 13\% de las horas de enseñanza obligatorias, pero los centros escolares deben programar además horas flexibles adicionales para artes, música o manualidades.

Para los estudiantes de secundaria inferior, una media del $39 \%$ del currículo obligatorio se compone de tres materias básicas: lectura, escritura y literatura (14\%), primera y otras lenguas extranjeras (13\%) y matemáticas (12\%). Como media, dedican a las ciencias naturales otro $11 \%$ del currículo obligatorio y un $10 \%$ a las ciencias sociales. Junto a la educación física y para la salud (7\%) y las artes (7\%), estas siete áreas de estudio conforman la parte principal del currículo para este grupo de edad en toda la OCDE y países asociados de los que se dispone de datos. La educación religiosa, ética y moral, las tecnologías de la información y la comunicación (TIC), la tecnología, las asignaturas prácticas y de iniciación profesional, y otras asignaturas completan el $12 \%$ restante del currículo obligatorio no flexible para los estudiantes de este nivel educativo (Tabla D1.3b y Gráfico D1.2b).

Se observan variaciones sustanciales en la asignación de horas de enseñanza para estudiantes de primaria. El porcentaje de horas de enseñanza obligatorias dedicadas a la lectura, escritura y literatura disminuye de un $22 \%$ a un $14 \%$. Las horas de enseñanza en matemáticas disminuyen de un $15 \%$ a un $12 \%$ de las horas de enseñanza obligato- 
Gráfico D1.2b. Horas de enseñanza por materia en educación secundaria inferior (2014) Como porcentaje del total de horas de enseñanza obligatorias

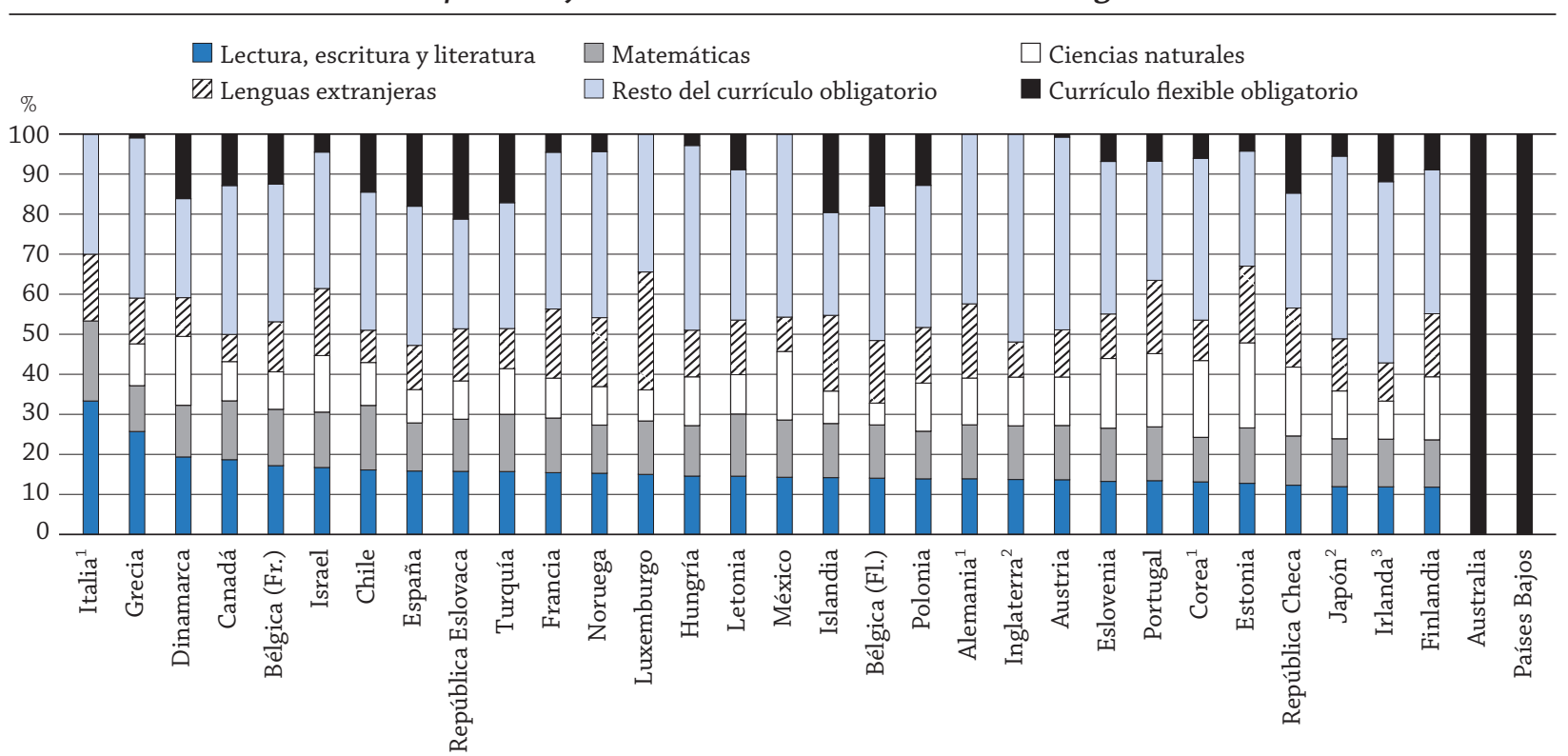

1. Ciencias naturales incluidas en matemáticas.

2. Año de referencia 2013.

3. Horas de enseñanza reales.

Los países están clasificados en orden descendente de la proporción del número de horas de enseñanza dedicadas a la lectura, escritura y literatura.

Fuente: OCDE. Tabla D1.3b. Para ver notas, consulte Anexo 3 (www.oecd.org/edu/eag.htm).

StatLink 需西 http://dx.doi.org/10.1787/888933119663

rias. Por el contrario, las horas de enseñanza dedicadas tanto a las ciencias naturales como a las ciencias sociales ascienden de un $7 \%$ y un $6 \%$ del currículo obligatorio a un $11 \%$ y un $10 \%$ respectivamente, mientras que la enseñanza de lenguas extranjeras (primera y otras) sube de un $5 \%$ a un $13 \%$. La enseñanza de lenguas extranjeras representa la mayor proporción del currículo obligatorio en secundaria inferior en Alemania, Bélgica (Comunidad flamenca), Finlandia (junto con las ciencias naturales), Alemania, Francia, Islandia e Israel, (junto con la lectura, escritura y literatura), Japón, Luxemburgo, Noruega, Polonia (junto con la lectura, escritura y literatura) y Portugal (junto con las ciencias naturales) (Tablas D1.3a y D1.3b).

En educación secundaria inferior, se observa una variación sustancial en la distribución de las diferentes materias del currículo obligatorio. Por ejemplo, la lectura, escritura y literatura representan el $12 \%$ del currículo obligatorio en Finlandia, Irlanda, Japón y República Checa, mientras que en Grecia e Italia suponen más del $25 \%$ de las horas de enseñanza obligatorias. En Canadá, Grecia e Inglaterra, las horas de enseñanza de la primera lengua extranjera representa el $7 \%$ o menos de las horas de enseñanza obligatorias, mientras que dicho porcentaje se eleva al $17 \%$ en Luxemburgo. Además, en algo menos de la mitad de los países con datos disponibles, el estudio de una segunda lengua extranjera es obligatorio para los estudiantes de secundaria inferior.

Como ocurría en educación primaria y secundaria inferior, se observan notables diferencias en la distribución de las diferentes asignaturas para estudiantes de cursos posteriores. Como media en los países de la OCDE, el 25\% de las horas de enseñanza para estudiantes de 7 años se dedica a lectura, escritura y literatura, mientras que estas asignaturas ocupan un $17 \%$ del tiempo de enseñanza para los estudiantes de 11 años y un $12 \%$ para los de 15 años. En cambio, mientras que los de 7 años dedican una media de un $2 \%$ de las horas de enseñanza a las lenguas extranjeras, los de 11 años pasan un $9 \%$ de las horas de enseñanza aprendiendo una primera lengua extranjera y un $2 \%$ aprendiendo otras lenguas, y los estudiantes de 15 años dedican un $10 \%$ y un $4 \%$ de las horas de enseñanza a la primera y otras lenguas extranjeras, respectivamente (Tablas D1.5b, $\mathrm{f} \mathrm{y} \mathrm{j,} \mathrm{disponibles} \mathrm{en} \mathrm{Internet).}$

\section{Flexibilidad del currículo}

En la mayoría de los países, las autoridades centrales y estatales establecen normas o recomendaciones sobre las horas de enseñanza y el currículo. Sin embargo, también las autoridades locales, los centros escolares, los profesores 
y los estudiantes participan en diversos grados en la organización de las horas de enseñanza o en la elección de las materias.

Aproximadamente en un tercio de los países con datos disponibles, la distribución de las horas de enseñanza en los distintos cursos es flexible, es decir, las horas de enseñanza de cada asignatura se definen para diversos cursos, o incluso para el conjunto de la educación obligatoria, sin especificar las horas que han de impartirse en cada curso. En estos casos, los centros escolares o las autoridades locales tienen libertad para decidir cuántas horas se imparten en cada curso (Tabla D1.2).

La distribución de materias obligatorias dentro de un horario flexible es más común en educación primaria donde, como media en los países de la OCDE, representa el $14 \%$ de las horas de enseñanza obligatorias. En este caso, las normas definen las materias obligatorias y el total de horas de enseñanza, pero no las horas dedicadas a cada materia. Las autoridades locales, los centros escolares y los profesores tienen libertad para decidir cuánto tiempo se dedica a cada materia obligatoria. En Bélgica (Comunidad francófona) e Italia, la distribución de asignaturas obligatorias en un horario flexible supone en torno al $85 \%$ de las horas de enseñanza en educación primaria y hasta el $100 \%$ en Australia, Inglaterra y Países Bajos. Esto ocurre también en Dinamarca en el primer año de educación primaria. En cuanto a la educación secundaria inferior, Australia y Países Bajos permiten también total flexibilidad en la distribución de las horas de enseñanza de las asignaturas obligatorias. En Escocia, tanto en primaria como secundaria inferior, se especifican algunas asignaturas obligatorias, pero no se establece el total de horas de enseñanza, que es responsabilidad de las autoridades locales.

En los países de la OCDE, la flexibilidad en la elección de materias es menos común que la flexibilidad en la distribución de las horas de enseñanza entre las materias obligatorias. Como media, un $4 \%$ de las horas de enseñanza obligatorias en educación primaria se distribuyen entre materias elegidas por el centro escolar. En educación secundaria inferior, un $4 \%$ de las horas de enseñanza obligatorias se dedican a materias elegidas por los centros y otro $4 \%$ a las elegidas por los estudiantes. Sin embargo, algunos países destinan una parte sustancial de las horas de enseñanza obligatoria a materias flexibles. Por ejemplo, en Bélgica (Comunidad flamenca, educación primaria), Chile, Estonia (educación primaria), Irlanda (educación secundaria inferior), Polonia y República Checa, al menos el $10 \%$ de las horas de enseñanza obligatoria se destinan a asignaturas elegidas por el centro escolar, y el porcentaje alcanza un $21 \%$ en República Eslovaca. En España, Islandia y Turquía, al menos el 17\% de las horas de enseñanza obligatorias se destinan a materias elegidas por los estudiantes de secundaria inferior (Tablas D1.3a y b).

\section{Horas de enseñanza no obligatorias}

En los países de la OCDE, la parte no obligatoria del currículo representa una media del $4 \%$ del total de horas de enseñanza previstas para estudiantes de primaria y del $2 \%$ del total de horas de enseñanza previstas para estudiantes de secundaria inferior. Sin embargo, en algunos casos se imparte un número considerablemente mayor de horas de enseñanza no obligatorias. Para los estudiantes de primaria, el tiempo de enseñanza no obligatorio adicional asciende a un $36 \%$ del total de horas de enseñanza en Grecia y a un $23 \%$ en Portugal. Para los estudiantes de secundaria inferior, las horas de enseñanza no obligatorias suponen un $13 \%$ del total de las horas de enseñanza obligatorias en Eslovenia y un $10 \%$ en Francia (Tablas D1.3a y b).

\section{Cuadro D1.1. Actividades extraescolares en el centro escolar}

Las horas de enseñanza previstas se refieren solo a las horas que los estudiantes pasan en un marco escolar formal. Sin embargo, los estudiantes pueden participar además en actividades extraescolares antes o después de la jornada escolar o durante las vacaciones escolares, en las instalaciones del centro escolar.

En los países de la OCDE y países asociados, las actividades extraescolares se ofrecen de manera más habitual durante el curso escolar (antes o después de las clases) que durante las vacaciones. Aunque los centros suelen tener autonomía para decidir si ofrecen o no estas actividades, en algunos casos la oferta de actividades extraescolares es obligatoria. Así ocurre, por ejemplo, en educación primaria y/o secundaria inferior, en Eslovenia, Francia y Polonia. En Hungría, no solo es obligatorio que los centros escolares organicen actividades para estos niveles educativos hasta las 16:00 horas, sino que estas actividades son obligatorias también para los estudiantes. 
Estas actividades pueden ser organizadas por los centros escolares, como en Brasil y Hungría, por los ayuntamientos, como en Israel, o por personal escolar voluntario, como en Irlanda. En otros casos, estas actividades pueden estar gestionadas por organizaciones externas públicas e incluso privadas, aunque esto es menos frecuente. Por ejemplo, las asociaciones de padres y organizaciones no gubernamentales suelen ocuparse de estas actividades en Portugal. En 16 de los 36 países con datos disponibles, se ofrece a los profesores un pago adicional por tomar parte en estas actividades extraescolares (véase el Indicador D3).

Las actividades extraescolares antes o después del horario escolar suelen incluir atención educativa (en educación primaria), clases particulares o de refuerzo, actividades deportivas, artísticas y culturales. En Hungría y Turquía, estas actividades incluyen también servicios a la comunidad. En España, se ofrecen clases de lengua extranjera, TIC y talleres de lectura y escritura.

\section{Definiciones}

Currículo obligatorio se refiere a la cantidad y distribución de las horas de enseñanza que casi todos los centros escolares públicos deben ofrecer y a las que casi todos los estudiantes del sector público deben asistir. El currículo obligatorio puede ser flexible, ya que las autoridades locales, los centros escolares, los profesores y los estudiantes pueden tener diferentes grados de libertad para elegir las asignaturas y la distribución de las horas de enseñanza obligatorias.

Materias obligatorias flexibles elegidas por los centros escolares se refieren al número total de horas de enseñanza obligatorias indicado por las autoridades centrales, que las autoridades regionales y locales, los centros escolares y los profesores destinan a materias de su elección (o materias que ellos eligen de una lista definida por las autoridades educativas centrales). Es obligatorio que los centros escolares ofrezcan una de estas materias y que los estudiantes asistan a ella.

Materias obligatorias flexibles elegidas por los estudiantes se refieren al número total de horas de enseñanza obligatorias de una o varias materias que los estudiantes deben elegir (de una serie de materias que el centro tiene obligación de ofrecer) para cubrir parte de sus horas de enseñanza obligatorias.

Materias obligatorias con horario flexible se refieren al número total de horas de enseñanza obligatorias indicado por las autoridades centrales para un determinado grupo de materias, que las autoridades regionales y locales, los centros escolares y los profesores destinan a materias concretas. El tiempo invertido en cada materia es flexible, pero no las materias que impartir.

Distribución flexible de las horas de enseñanza obligatorias a lo largo de varios cursos se refiere a los casos en que el currículo solo indica las horas totales de enseñanza de una materia concreta durante un determinado número de cursos, o incluso durante el conjunto de la educación obligatoria, sin especificar el tiempo que impartir en cada curso. En estos casos, los centros escolares o las autoridades locales tienen libertad para decidir cuántas horas de enseñanza deben destinarse a cada curso.

Horas de enseñanza se refieren al número de periodos de 60 minutos por curso escolar que los centros escolares públicos han de dedicar a la enseñanza de todas las materias incluidas en el currículo obligatorio y no obligatorio, en las instalaciones del centro escolar o en actividades anteriores o posteriores al horario escolar que formen parte del programa obligatorio. Las horas de enseñanza excluyen las pausas entre clases y otro tipo de interrupciones, las horas no obligatorias fuera del horario escolar, el tiempo dedicado al trabajo en casa y a clases particulares o estudio individual.

Horas de enseñanza previstas se refieren al número anual de horas de enseñanza obligatoria y no obligatoria del currículo que los estudiantes tienen derecho a recibir en los centros públicos. El currículo previsto puede basarse en normas o referencias de las autoridades educativas centrales (o de alto nivel) o puede establecerse como una serie de recomendaciones dictadas por las autoridades regionales.

Parte no obligatoria del currículo se refiere al número total de horas de enseñanza a que tienen derecho los estudiantes aparte de las horas de clase obligatorias y que se espera que casi todos los centros públicos ofrezcan. Las materias pueden variar entre centros y en cada región, y pueden ser optativas. No se exige que los estudiantes cursen estas materias optativas, pero todos los centros escolares públicos deben ofrecer esta posibilidad. 


\section{Metodología}

Los datos sobre horas de enseñanza proceden de la recogida de datos sobre horas de enseñanza realizada conjuntamente por la OCDE y la red Eurydice en 2013, y se refieren a las horas de enseñanza durante la educación primaria obligatoria y la educación secundaria obligatoria (inferior y superior) a tiempo completo para el curso escolar 2013-2014.

En anteriores ediciones de Panorama de la educación, los datos sobre horas de enseñanza solían recogerse mediante una encuesta distinta y con diferente alcance, metodología y definiciones que los utilizados en la recogida de datos sobre horas de enseñanza realizada conjuntamente por la OCDE y la red Eurydice en 2013. Como consecuencia de ello, los datos sobre horas de enseñanza no son comparables con las cifras publicadas en ediciones anteriores de Panorama de la educación.

Este indicador refleja las horas de enseñanza previstas, según se establece en la normativa educativa como medida del aprendizaje en el entorno formal del aula. El indicador no muestra el número real de horas de clase recibidas por los estudiantes y no cubre el aprendizaje que tiene lugar fuera del entorno formal del aula. Pueden existir diferencias según países entre las horas mínimas de clase establecidas y las horas de clase realmente recibidas por los estudiantes. Un estudio realizado por Regioplan Beleidsonderzoek en Países Bajos mostró que, debido a factores tales como decisiones sobre el horario escolar, cancelación de clases y absentismo docente, los centros escolares pueden no llegar a alcanzar adecuadamente las horas mínimas de clase establecidas (véase Cuadro D1.1 en OECD, 2007).

El indicador también ilustra cómo se distribuye el mínimo de horas de enseñanza entre las diversas áreas curriculares y muestra las horas de clase netas previstas para los cursos que conforman la educación obligatoria general a tiempo completo. Aunque es difícil la comparación entre países dadas las diferentes políticas curriculares, estos datos nos orientan sobre el número de horas de enseñanza formal que se consideran necesarias para que los estudiantes alcancen el objetivo educativo deseado.

Cuando la distribución de horas de enseñanza a lo largo de los distintos cursos es flexible, es decir, cuando se definen las horas de enseñanza de una determinada materia para una serie de cursos, o incluso para toda la enseñanza obligatoria, sin especificar cuántas horas deben impartirse en cada curso, las horas de enseñanza por edad o nivel educativo se estimaron dividiendo el número de horas de enseñanza totales por el número de cursos.

Las notas específicas sobre definiciones y metodología de este indicador para cada país están disponibles en el Anexo 3 en www.oecd.org/edu/eag.htm.

\section{Nota sobre los datos de Israel}

Los datos estadísticos para Israel fueron proporcionados por las autoridades israelíes competentes bajo su responsabilidad. El uso de estos datos por parte de la OCDE se hace sin prejuzgar la situación de los Altos del Golán, Jerusalén Este y los asentamientos israelíes en Cisjordania de acuerdo con los términos del derecho internacional.

\section{Referencias}

OECD (2011), Education at a Glance 2011: OECD Indicators, OECD Publishing, París, http://dx.doi.org/10.1787/eag-2011-en. Versión española: Panorama de la educación 2011: Indicadores de la OCDE, Ministerio de Educación, Cultura y Deporte, Santillana, Madrid.

OECD (2007), Education at a Glance 2007: OECD Indicators, OECD Publishing, Paris, http://dx.doi.org/10.1787/eag-2007-en. Versión española: Panorama de la educación 2007: Indicadores de la OCDE, Ministerio de Educación y Ciencia, Santillana, Madrid. 


\section{Tablas del Indicador D1}

StatLink त्नाड़ http://dx.doi.org/10.1787/888933119530

Tabla D1.1 Horas de enseñanza en educación general obligatoria (2014)

Tabla D1.2 Organización de la educación general obligatoria (2014)

Tabla D1.3a Horas de enseñanza por materia en educación primaria (2014)

Tabla D1.3b Horas de enseñanza por materia en educación secundaria inferior (2014)

WEB Tabla D1.4 Horas de enseñanza en educación general obligatoria, por edad (2014)

WEB Tabla D1.5a Horas de enseñanza por materia para estudiantes de 6 años (2014)

WEB Tabla D1.5b Horas de enseñanza por materia para estudiantes de 7 años (2014)

WEB Tabla D1.5c Horas de enseñanza por materia para estudiantes de 8 años (2014)

WEB Tabla D1.5d Horas de enseñanza por materia para estudiantes de 9 años (2014)

WEB Tabla D1.5e Horas de enseñanza por materia para estudiantes de 10 años (2014)

WEB Tabla D1.5f Horas de enseñanza por materia para estudiantes de 11 años (2014)

WEB Tabla D1.5g Horas de enseñanza por materia para estudiantes de 12 años (2014)

WEB Tabla D1.5h Horas de enseñanza por materia para estudiantes de 13 años (2014)

WEB Tabla D1.5i Horas de enseñanza por materia para estudiantes de 14 años (2014)

WEB Tabla D1.5j Horas de enseñanza por materia para estudiantes de 15 años (2014)

WEB Tabla D1.5k Horas de enseñanza por materia para estudiantes de 16 años (2014)

WEB Tabla D1.51 Horas de enseñanza por materia para estudiantes de 17 años (2014) 
Tabla D1.1. [1/2] Horas de enseñanza en educación general obligatoria ${ }^{1}$ (2014)

Por nivel de educación en instituciones públicas

\begin{tabular}{|c|c|c|c|c|c|c|c|c|c|c|c|}
\hline & \multicolumn{7}{|c|}{ Educación primaria } & \multicolumn{4}{|c|}{ Educación secundaria inferior } \\
\hline & \multirow[b]{2}{*}{ 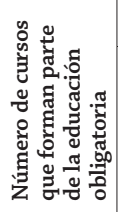 } & \multicolumn{3}{|c|}{ Media anual de horas } & \multicolumn{3}{|c|}{ Total de horas } & \multirow[b]{2}{*}{ 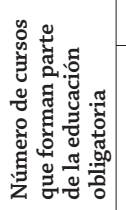 } & \multicolumn{3}{|c|}{ Media anual de horas } \\
\hline & & 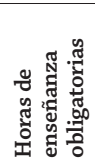 & 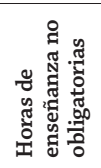 & 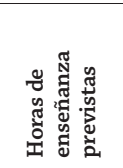 & 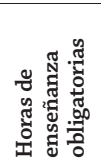 & 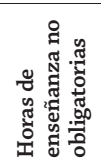 & 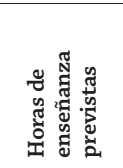 & & 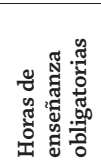 & 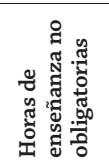 & 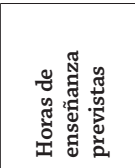 \\
\hline & (1) & (2) & (3) & $(4)=(2)+(3)$ & (5) & (6) & $(7)=(5)+(6)$ & (8) & (9) & (10) & $(11)=(9)+(10)$ \\
\hline Alemania ${ }^{4,5}$ & 4 & 683 & $a$ & 683 & 2.732 & $a$ & 2.732 & 5 & 866 & $a$ & 866 \\
\hline Australia & 6 & 1.010 & $\mathrm{~m}$ & $\mathrm{~m}$ & 6.060 & $\mathrm{~m}$ & $\mathrm{~m}$ & 4 & 1.015 & $\mathrm{~m}$ & $\mathrm{~m}$ \\
\hline Austria & 4 & 705 & $\mathrm{~m}$ & $\mathrm{~m}$ & 2.820 & $\mathrm{~m}$ & $\mathrm{~m}$ & 4 & 900 & $\mathrm{~m}$ & $\mathrm{~m}$ \\
\hline Bélgica $(\mathrm{Fl})^{2}$ & 6 & 821 & $\mathrm{n}$ & 821 & 4.928 & $\mathrm{n}$ & 4.928 & 2 & 928 & $\mathrm{n}$ & 928 \\
\hline Bélgica $(\mathrm{Fr} .)^{2}$ & 6 & 849 & $\mathrm{~m}$ & $\mathrm{~m}$ & 5.096 & $\mathrm{~m}$ & $\mathrm{~m}$ & 2 & 971 & $\mathrm{~m}$ & $\mathrm{~m}$ \\
\hline Canadá & 6 & 919 & $\mathrm{n}$ & 919 & 5.515 & $\mathrm{n}$ & 5.515 & 3 & 921 & 3 & 924 \\
\hline Chile & 6 & 1.049 & a & 1.049 & 6.293 & $\mathrm{a}$ & 6.293 & 2 & 1.062 & a & 1.062 \\
\hline Corea $^{4}$ & 6 & 648 & a & 648 & 3.885 & $\mathrm{a}$ & 3.885 & 3 & 842 & $\mathrm{a}$ & 842 \\
\hline Dinamarca & 7 & 754 & a & 754 & 5.280 & a & 5.280 & 3 & 930 & $\mathrm{a}$ & 930 \\
\hline Escocia $^{8}$ & 7 & $a$ & $\mathrm{a}$ & $a$ & $a$ & a & $\mathrm{a}$ & 3 & $\mathrm{a}$ & a & $\mathrm{a}$ \\
\hline Eslovenia & 6 & 664 & 79 & 743 & 3.986 & 473 & 4.459 & 3 & 767 & 102 & 869 \\
\hline España & 6 & 787 & $a$ & 787 & 4.725 & $\mathrm{a}$ & 4.725 & 4 & 1.061 & $\mathrm{a}$ & 1.061 \\
\hline Estados Unidos ${ }^{9}$ & 6 & 967 & $\mathrm{~m}$ & $\mathrm{~m}$ & 5.802 & $\mathrm{~m}$ & $\mathrm{~m}$ & 3 & 1.011 & $\mathrm{~m}$ & $\mathrm{~m}$ \\
\hline Estonia & 6 & 661 & a & 661 & 3.964 & $\mathrm{a}$ & 3.964 & 3 & 823 & $\mathrm{a}$ & 823 \\
\hline Finlandia $^{3}$ & 6 & 632 & 29 & 661 & 3.794 & 171 & 3.965 & 3 & 844 & 57 & 901 \\
\hline Francia & 5 & 864 & $\mathrm{n}$ & 864 & 4.320 & $\mathrm{n}$ & 4.320 & 4 & 991 & 99 & 1.090 \\
\hline Grecia & 6 & 783 & 282 & 1.065 & 4.699 & 1.690 & 6.390 & 3 & 785 & $\mathrm{n}$ & 785 \\
\hline Hungría & 4 & 616 & $\mathrm{a}$ & 616 & 2.464 & a & 2.464 & 4 & 710 & a & 710 \\
\hline Inglaterra & 6 & 861 & $\mathrm{~m}$ & $\mathrm{~m}$ & 5.168 & $\mathrm{~m}$ & $\mathrm{~m}$ & 3 & 912 & $\mathrm{n}$ & 912 \\
\hline Irlanda $^{6}$ & 6 & 915 & $\mathrm{a}$ & 915 & 5.490 & $\mathrm{a}$ & 5.490 & 3 & 935 & $\mathrm{a}$ & 935 \\
\hline Islandia & 7 & 729 & a & 729 & 5.100 & a & 5.100 & 3 & 839 & a & 839 \\
\hline Israel & 6 & 957 & $\mathrm{n}$ & 957 & 5.741 & $\mathrm{n}$ & 5.741 & 3 & 1.004 & $\mathrm{n}$ & 1.004 \\
\hline Italia & 5 & 891 & $\mathrm{a}$ & 891 & 4.455 & a & 4.455 & 3 & 990 & a & 990 \\
\hline Japón ${ }^{4}$ & 6 & 762 & $\mathrm{~m}$ & $\mathrm{~m}$ & 4.573 & $\mathrm{~m}$ & $\mathrm{~m}$ & 3 & 895 & $\mathrm{~m}$ & $\mathrm{~m}$ \\
\hline Luxemburgo & 6 & 924 & $\mathrm{a}$ & 924 & 5.544 & $\mathrm{a}$ & 5.544 & 3 & 845 & $\mathrm{a}$ & 845 \\
\hline México & 6 & 800 & $\mathrm{a}$ & 800 & 4.800 & $\mathrm{a}$ & 4.800 & 3 & 1.167 & a & 1.167 \\
\hline Noruega & 7 & 748 & a & 748 & 5.234 & $\mathrm{a}$ & 5.234 & 3 & 868 & a & 868 \\
\hline Nueva Zelanda & $\mathrm{m}$ & $\mathrm{m}$ & $\mathrm{m}$ & $\mathrm{m}$ & $\mathrm{m}$ & $\mathrm{m}$ & $\mathrm{m}$ & $\mathrm{m}$ & $\mathrm{m}$ & $\mathrm{m}$ & $\mathrm{m}$ \\
\hline Países Bajos ${ }^{7}$ & 6 & 940 & $\mathrm{~m}$ & $\mathrm{~m}$ & 5.640 & $\mathrm{~m}$ & $\mathrm{~m}$ & 3 & 1.000 & $\mathrm{~m}$ & $\mathrm{~m}$ \\
\hline Polonia & 6 & 635 & 58 & 693 & 3.807 & 348 & 4.155 & 3 & 810 & 64 & 874 \\
\hline Portugal & 6 & 806 & 189 & 995 & 4.838 & 1.133 & 5.971 & 3 & 877 & 27 & 903 \\
\hline República Checa & 5 & 676 & $\mathrm{~m}$ & $\mathrm{~m}$ & 3.381 & $\mathrm{~m}$ & $\mathrm{~m}$ & 4 & 874 & $\mathrm{~m}$ & $\mathrm{~m}$ \\
\hline República Eslovaca & 4 & 680 & $\mathrm{a}$ & 680 & 2.722 & $\mathrm{a}$ & 2.722 & 5 & 828 & $\mathrm{a}$ & 828 \\
\hline Suecia $^{3}$ & 6 & 754 & $\mathrm{~m}$ & $\mathrm{~m}$ & 4.523 & $\mathrm{~m}$ & $\mathrm{~m}$ & 3 & 754 & $\mathrm{~m}$ & $\mathrm{~m}$ \\
\hline Suiza & $\mathrm{m}$ & $\mathrm{m}$ & $\mathrm{m}$ & $\mathrm{m}$ & $\mathrm{m}$ & $\mathrm{m}$ & $\mathrm{m}$ & $\mathrm{m}$ & $\mathrm{m}$ & $\mathrm{m}$ & $\mathrm{m}$ \\
\hline Turquía & 4 & 720 & a & 720 & 2.880 & a & 2.880 & 4 & 840 & a & 840 \\
\hline Media $O C D E^{8}$ & 6 & 794 & 26 & $\sim$ & 4.553 & 159 & $\sim$ & 3 & 905 & 14 & $\sim$ \\
\hline Media UE218 & 6 & 768 & 40 & & 4.290 & 238 & $\sim$ & 3 & 882 & 21 & \\
\hline
\end{tabular}

\begin{tabular}{|c|c|c|c|c|c|c|c|c|c|c|c|}
\hline $\begin{array}{l}\text { ¿̊ Arabia Saudí } \\
\underset{\tau}{\tau} \text { Argentina }\end{array}$ & $\begin{array}{l}\mathrm{m} \\
\mathrm{m}\end{array}$ & $\begin{array}{l}\mathrm{m} \\
\mathrm{m}\end{array}$ & $\begin{array}{l}\mathrm{m} \\
\mathrm{m}\end{array}$ & $\begin{array}{l}\mathrm{m} \\
\mathrm{m}\end{array}$ & $\begin{array}{l}\mathrm{m} \\
\mathrm{m}\end{array}$ & $\begin{array}{l}\mathrm{m} \\
\mathrm{m}\end{array}$ & $\begin{array}{l}\mathrm{m} \\
\mathrm{m}\end{array}$ & $\begin{array}{l}\mathrm{m} \\
\mathrm{m}\end{array}$ & $\begin{array}{l}\mathrm{m} \\
\mathrm{m}\end{array}$ & $\begin{array}{l}\mathrm{m} \\
\mathrm{m}\end{array}$ & $\begin{array}{l}\mathrm{m} \\
\mathrm{m}\end{array}$ \\
\hline : Brasil ${ }^{8}$ & 5 & $\mathrm{~m}$ & $\mathrm{~m}$ & $\mathrm{~m}$ & $\mathrm{~m}$ & $\mathrm{~m}$ & $\mathrm{~m}$ & 4 & $\mathrm{~m}$ & $\mathrm{~m}$ & $\mathrm{~m}$ \\
\hline China ${ }^{9}$ & 6 & 612 & $\mathrm{~m}$ & $\mathrm{~m}$ & 3.669 & $\mathrm{~m}$ & $\mathrm{~m}$ & 3 & 816 & $\mathrm{~m}$ & $\mathrm{~m}$ \\
\hline ֻू Colombia ${ }^{9}$ & 5 & 1.000 & $\mathrm{~m}$ & $\mathrm{~m}$ & 5.000 & $\mathrm{~m}$ & $\mathrm{~m}$ & 4 & 1.200 & $\mathrm{~m}$ & $\mathrm{~m}$ \\
\hline Federación Rusa & $\mathrm{m}$ & $\mathrm{m}$ & $\mathrm{m}$ & $\mathrm{m}$ & $\mathrm{m}$ & $\mathrm{m}$ & $\mathrm{m}$ & $\mathrm{m}$ & $\mathrm{m}$ & $\mathrm{m}$ & $\mathrm{m}$ \\
\hline India & $\mathrm{m}$ & $\mathrm{m}$ & $\mathrm{m}$ & $\mathrm{m}$ & $\mathrm{m}$ & $\mathrm{m}$ & $\mathrm{m}$ & $\mathrm{m}$ & $\mathrm{m}$ & $\mathrm{m}$ & $\mathrm{m}$ \\
\hline Indonesia & $\mathrm{m}$ & $\mathrm{m}$ & $\mathrm{m}$ & $\mathrm{m}$ & $\mathrm{m}$ & $\mathrm{m}$ & $\mathrm{m}$ & $\mathrm{m}$ & $\mathrm{m}$ & $\mathrm{m}$ & $\mathrm{m}$ \\
\hline Letonia & 6 & 592 & $\mathrm{~m}$ & $\mathrm{~m}$ & 3.551 & $\mathrm{~m}$ & $\mathrm{~m}$ & 3 & 794 & $\mathrm{~m}$ & $\mathrm{~m}$ \\
\hline Sudáfrica & $\mathrm{m}$ & $\mathrm{m}$ & $\mathrm{m}$ & $\mathrm{m}$ & $\mathrm{m}$ & $\mathrm{m}$ & $\mathrm{m}$ & $\mathrm{m}$ & $\mathrm{m}$ & $\mathrm{m}$ & $\mathrm{m}$ \\
\hline
\end{tabular}

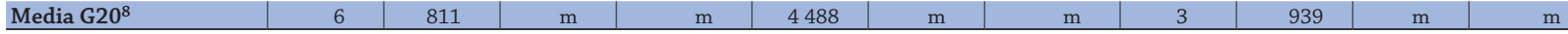

Notas: Las columnas que muestran las horas de enseñanza en educación secundaria superior están disponibles en Internet (véase StatLink más abajo).

1. Se refiere a la educación obligatoria a tiempo completo y excluye la educación infantil, aunque sea obligatoria.

2. Es obligatorio que los estudiantes asistan a clase a tiempo completo hasta los 15 o 16 años. Sin embargo, los que cursan educación general deben hacerlo hasta los 18.

3. Horas de enseñanza estimadas por nivel de educación, puesto que la distribución de las horas de enseñanza en diversos cursos es flexible.

4. Año de referencia 2013.

5. Excluye el último año de enseñanza obligatoria, que puede clasificarse en secundaria inferior o en secundaria superior.

6. Horas reales de enseñanza en educación secundaria inferior y superior.

7. El número de cursos de educación secundaria inferior es 3 o 4 según la modalidad. El cuarto curso de educación secundaria preprofesional (VMBO) se ha excluido del cálculo.

8. Brasil y Escocia no están incluidos en las medias.

9. Año de referencia 2012.

Fuentes: OCDE. Arabia Saudí, Argentina, China, Colombia, India, Indonesia, Sudáfrica: Instituto de Estadística de la UNESCO. Letonia: Eurydice. Para ver notas, consulte Anexo 3 (www.oecd.org/edu/eag.htm).

Para obtener más información acerca de los símbolos utilizados en lugar de los datos que faltan, consulte la Guía del lector.

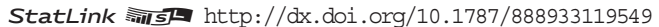


Tabla D1.1. [2/2] Horas de enseñanza en educación general obligatoria ${ }^{1}$ (2014)

Por nivel de educación en instituciones públicas

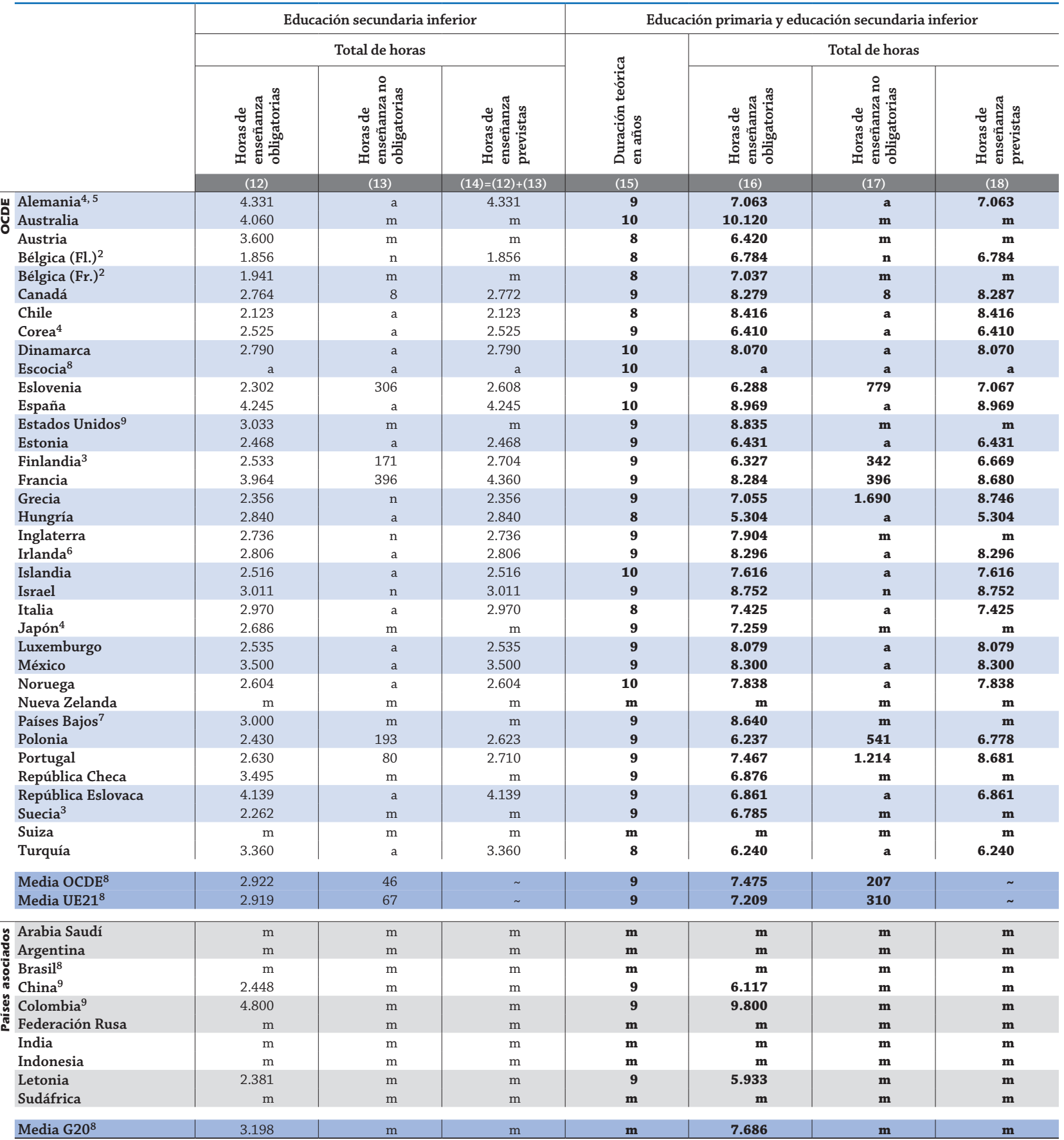

Notas: Las columnas que muestran las horas de enseñanza en educación secundaria superior están disponibles en Internet (véase StatLink más abajo).

1. Se refiere a la educación obligatoria a tiempo completo y excluye la educación infantil, aunque sea obligatoria.

2. Es obligatorio que los estudiantes asistan a clase a tiempo completo hasta los 15 o 16 años. Sin embargo, los que cursan educación general deben hacerlo hasta los 18.

3. Horas de enseñanza estimadas por nivel de educación, puesto que la distribución de las horas de enseñanza en diversos cursos es flexible.

4. Año de referencia 2013

5. Excluye el último año de enseñanza obligatoria, que puede clasificarse en secundaria inferior o en secundaria superior.

6. Horas reales de enseñanza en educación secundaria inferior y superior

7. El número de cursos de educación secundaria inferior es 3 o 4 según la modalidad. El cuarto curso de educación secundaria pre-profesional (VMBO) se ha excluido del cálculo.

8. Brasil y Escocia no están incluidos en las medias.

9. Año de referencia 2012.

Fuentes: OCDE. Arabia Saudí, Argentina, China, Colombia, India, Indonesia, Sudáfrica: Instituto de Estadística de la UNESCO. Letonia: Eurydice. Para ver notas, consulte Anexo 3 (www.oecd.org/edu/eag.htm).(www.oecd.org/edu/eag.htm).

Para obtener más información acerca de los símbolos utilizados en lugar de los datos que faltan, consulte la Guía del lector.

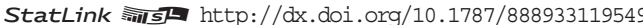


Tabla D1.2. Organización de la educación general obligatoria ${ }^{\mathbf{1}}$ (2014)

Por nivel de educación en instituciones públicas

\begin{tabular}{|c|c|c|c|c|c|c|c|c|c|c|}
\hline & \multicolumn{5}{|c|}{ Educación primaria } & \multicolumn{5}{|c|}{ Educación secundaria inferior } \\
\hline & $\begin{array}{c}\text { Número } \\
\text { de cursos } \\
\text { que forman } \\
\text { parte de la } \\
\text { educación } \\
\text { obligatoria }\end{array}$ & $\begin{array}{l}\text { Edad teórica } \\
\text { de comienzo }\end{array}$ & $\begin{array}{c}\text { Numero } \\
\text { medio } \\
\text { de días de } \\
\text { enseñanza } \\
\text { por año }\end{array}$ & $\begin{array}{c}\text { Numero } \\
\text { medio } \\
\text { de días de } \\
\text { enseñanza } \\
\text { por semana } \\
\text { escolar }\end{array}$ & $\begin{array}{c}\text { Distribución } \\
\text { flexible } \\
\text { de las horas } \\
\text { de enseñanza } \\
\text { en varios } \\
\text { cursos }\end{array}$ & \begin{tabular}{|c} 
Número \\
de cursos \\
que forman \\
parte de la \\
educación \\
obligatoria
\end{tabular} & $\begin{array}{l}\text { Edad teórica } \\
\text { de comienzo }\end{array}$ & $\begin{array}{c}\text { Numero } \\
\text { medio } \\
\text { de días de } \\
\text { enseñanza } \\
\text { por año }\end{array}$ & $\begin{array}{c}\text { Numero } \\
\text { medio } \\
\text { de días de } \\
\text { enseñanza } \\
\text { por semana } \\
\text { escolar }\end{array}$ & $\begin{array}{c}\text { Distribución } \\
\text { flexible } \\
\text { de las horas } \\
\text { de enseñanza } \\
\text { en varios } \\
\text { cursos }\end{array}$ \\
\hline & (1) & (2) & (3) & (4) & (5) & (6) & (7) & (8) & (9) & (10) \\
\hline Alemania $^{3,4}$ & 4 & 6 & 180 & 5 & No & 5 & 10 & 180 & 5 & No \\
\hline Australia & 6 & 5 & 197 & 5 & No & 4 & 11 & 197 & 5 & No \\
\hline Austria & 4 & 6 & 180 & 5 & No & 4 & 10 & 180 & 5 & No \\
\hline Bélgica $(\mathrm{Fl} .)^{2}$ & 6 & 6 & 176 & 5 & No & 2 & 12 & 174 & 5 & No \\
\hline Bélgica $(\mathrm{Fr} .)^{2}$ & 6 & 6 & 182 & 5 & No & 2 & 12 & 182 & 5 & No \\
\hline Canadá & 6 & 6 & 183 & 5 & No & 3 & 12 & 183 & 5 & No \\
\hline Chile & 6 & 6 & 190 & 5 & No & 2 & 12 & 190 & 5 & No \\
\hline Corea $^{3}$ & 6 & 6 & 190 & 5 & Sí & 3 & 12 & 190 & 5 & Sí \\
\hline Dinamarca & 7 & 6 & a & 5 & No & 3 & 13 & a & 5 & No \\
\hline Escocia & 7 & 5 & 190 & 5 & Sí & 3 & 12 & 190 & 5 & Sí \\
\hline Eslovenia & 6 & 6 & 190 & 5 & No & 3 & 12 & 185 & 5 & No \\
\hline España & 6 & 6 & 175 & 5 & No & 4 & 12 & 175 & 5 & No \\
\hline Estados Unidos & 6 & 6 & 180 & 5 & $\mathrm{~m}$ & 3 & 12 & 180 & 5 & $\mathrm{~m}$ \\
\hline Estonia & 6 & 7 & 175 & 5 & Sí & 3 & 13 & 175 & 5 & Sí \\
\hline Finlandia & 6 & 7 & 187 & 5 & Sí & 3 & 13 & 187 & 5 & Sí \\
\hline Francia & 5 & 6 & 162 & 4,5 & No & 4 & 11 & 180 & 5 & No \\
\hline Grecia & 6 & 6 & 171 & 5 & No & 3 & 12 & 152 & 5 & No \\
\hline Hungría & 4 & 6 & 180 & 5 & No & 4 & 10 & 180 & 5 & No \\
\hline Inglaterra & 6 & 5 & 190 & 5 & No & 3 & 11 & 190 & 5 & No \\
\hline Irlanda & 6 & 6 & 183 & 5 & No & 3 & 12 & 167 & 5 & No \\
\hline Islandia & 7 & 6 & 170 & 5 & Sí & 3 & 13 & 170 & 5 & Sí \\
\hline Israel & 6 & 6 & 219 & 6 & No & 3 & 12 & 210 & 6 & Sí \\
\hline Italia & 5 & 6 & 200 & 5 & No & 3 & 11 & 200 & 6 & No \\
\hline Japón ${ }^{3}$ & 6 & 6 & 200 & 5 & No & 3 & 12 & 200 & 5 & No \\
\hline Luxemburgo & 6 & 6 & 180 & 5 & Sí & 3 & 12 & 169 & 5 & No \\
\hline México & 6 & 6 & 200 & 5 & No & 3 & 12 & 200 & 5 & No \\
\hline Noruega & 7 & 6 & 190 & 5 & Sí & 3 & 13 & 190 & 5 & Sí \\
\hline Nueva Zelanda & $\mathrm{m}$ & $\mathrm{m}$ & $\mathrm{m}$ & $\mathrm{m}$ & $\mathrm{m}$ & $\mathrm{m}$ & $\mathrm{m}$ & $\mathrm{m}$ & $\mathrm{m}$ & $\mathrm{m}$ \\
\hline Países Bajos ${ }^{5}$ & 6 & 6 & $\mathrm{~m}$ & 5 & Sí & 3 & 12 & $\mathrm{~m}$ & 5 & Sí \\
\hline Polonia & 6 & 7 & 181 & 5 & Sí & 3 & 13 & 179 & 5 & Sí \\
\hline Portugal & 6 & 6 & 179 & 5 & No & 3 & 12 & 178 & 5 & No \\
\hline República Checa & 5 & 6 & 191 & 5 & Sí & 4 & 11 & 191 & 5 & Sí \\
\hline República Eslovaca & 4 & 6 & 189 & 5 & Sí & 5 & 10 & 189 & 5 & Sí \\
\hline Suecia & 6 & 7 & 178 & 5 & Sí & 3 & 13 & 178 & 5 & Sí \\
\hline Suiza & $\mathrm{m}$ & $\mathrm{m}$ & $\mathrm{m}$ & $\mathrm{m}$ & $\mathrm{m}$ & $\mathrm{m}$ & $\mathrm{m}$ & $\mathrm{m}$ & $\mathrm{m}$ & $\mathrm{m}$ \\
\hline Turquía & 4 & 6 & 180 & 5 & No & 4 & 10 & 180 & 5 & No \\
\hline Media OCDE & 6 & 6 & 185 & 5 & - & 3 & 12 & 183 & 5 & - \\
\hline Media UE21 & 6 & 6 & 182 & 5 & - & 3 & 12 & 180 & 5 & - \\
\hline
\end{tabular}

\begin{tabular}{|c|c|c|c|c|c|c|c|c|c|c|}
\hline $\begin{array}{l}\text { Arabia Saudí } \\
\text { ¿े Argentina }\end{array}$ & $\begin{array}{l}\mathrm{m} \\
\mathrm{m}\end{array}$ & $\begin{array}{l}\mathrm{m} \\
\mathrm{m}\end{array}$ & $\begin{array}{l}\mathrm{m} \\
\mathrm{m}\end{array}$ & $\begin{array}{l}\mathrm{m} \\
\mathrm{m}\end{array}$ & $\begin{array}{l}\mathrm{m} \\
\mathrm{m}\end{array}$ & $\begin{array}{l}\mathrm{m} \\
\mathrm{m}\end{array}$ & $\begin{array}{l}\mathrm{m} \\
\mathrm{m}\end{array}$ & $\begin{array}{l}\mathrm{m} \\
\mathrm{m}\end{array}$ & $\begin{array}{l}\mathrm{m} \\
\mathrm{m}\end{array}$ & $\begin{array}{l}\mathrm{m} \\
\mathrm{m}\end{array}$ \\
\hline Brasil & 5 & 6 & 200 & 5 & $\mathrm{~m}$ & 4 & 11 & 200 & 5 & $\mathrm{~m}$ \\
\hline " China ${ }^{6}$ & 6 & 6 & 160 & 5 & $\mathrm{~m}$ & 3 & 12 & 160 & 5 & $\mathrm{~m}$ \\
\hline Colombia $^{6}$ & 5 & 6 & 200 & 5 & $\mathrm{~m}$ & 4 & 11 & 200 & 5 & $\mathrm{~m}$ \\
\hline c Federación Rusa & $\mathrm{m}$ & $\mathrm{m}$ & $\mathrm{m}$ & $\mathrm{m}$ & $\mathrm{m}$ & $\mathrm{m}$ & $\mathrm{m}$ & $\mathrm{m}$ & $\mathrm{m}$ & $\mathrm{m}$ \\
\hline India & $\mathrm{m}$ & $\mathrm{m}$ & $\mathrm{m}$ & $\mathrm{m}$ & $\mathrm{m}$ & $\mathrm{m}$ & $\mathrm{m}$ & $\mathrm{m}$ & $\mathrm{m}$ & $\mathrm{m}$ \\
\hline Indonesia & $\mathrm{m}$ & $\mathrm{m}$ & $\mathrm{m}$ & $\mathrm{m}$ & $\mathrm{m}$ & $\mathrm{m}$ & $\mathrm{m}$ & $\mathrm{m}$ & $\mathrm{m}$ & $\mathrm{m}$ \\
\hline Letonia & 6 & 7 & 169 & 5 & No & 3 & 13 & 173 & 5 & No \\
\hline Sudáfrica & $\mathrm{m}$ & $\mathrm{m}$ & $\mathrm{m}$ & $\mathrm{m}$ & $\mathrm{m}$ & $\mathrm{m}$ & $\mathrm{m}$ & $\mathrm{m}$ & $\mathrm{m}$ & $\mathrm{m}$ \\
\hline
\end{tabular}

\begin{tabular}{l|l|l|l|l|l|l|l|l|} 
Media G20 & 6 & 6 & 187 & 5 & - & 3 & 11 & 188 \\
\hline
\end{tabular}

Notas: Las columnas que muestran las horas de enseñanza en educación secundaria superior (columnas 11-15) están disponibles en Internet (véase StatLink más abajo).

1. Se refiere a la educación obligatoria a tiempo completo y excluye la educación infantil, aunque sea obligatoria.

2. Es obligatorio que los estudiantes asistan a clase a tiempo completo hasta los 15 o 16 años. Sin embargo, los que cursan educación general deben hacerlo hasta los 18.

3. Año de referencia 2013.

4. Excluye el último año de enseñanza obligatoria, que puede clasificarse en secundaria inferior o en secundaria superior.

5. El número de cursos de educación secundaria inferior es 3 o 4 según la modalidad. El cuarto curso de educación secundaria preprofesional (VMBO) se ha excluido del cálculo.

6. Año de referencia 2012.

Fuentes: OCDE. Arabia Saudí, Argentina, China, Colombia, India, Indonesia, Sudáfrica: Instituto de Estadística de la UNESCO. Letonia: Eurydice. Para ver notas, consulte Anexo 3 (www.oecd.org/edu/eag.htm).(www.oecd.org/edu/eag.htm).

Para obtener más información acerca de los símbolos utilizados en lugar de los datos que faltan, consulte la Guía del lector.

StatLink 젝ㄴ http://dx.doi.org/10.1787/888933119568 
Tabla D1.3a. Horas de enseñanza por materia en educación primaria (2014)

Como porcentaje del total de las horas de enseñanza obligatorias

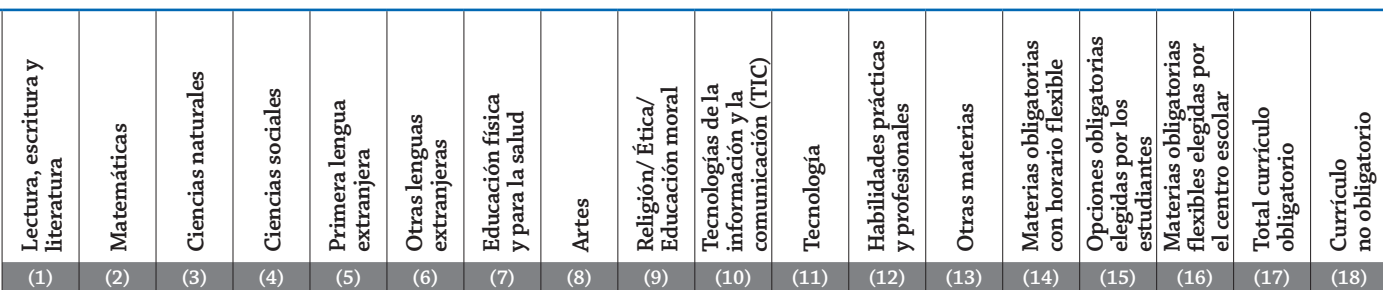

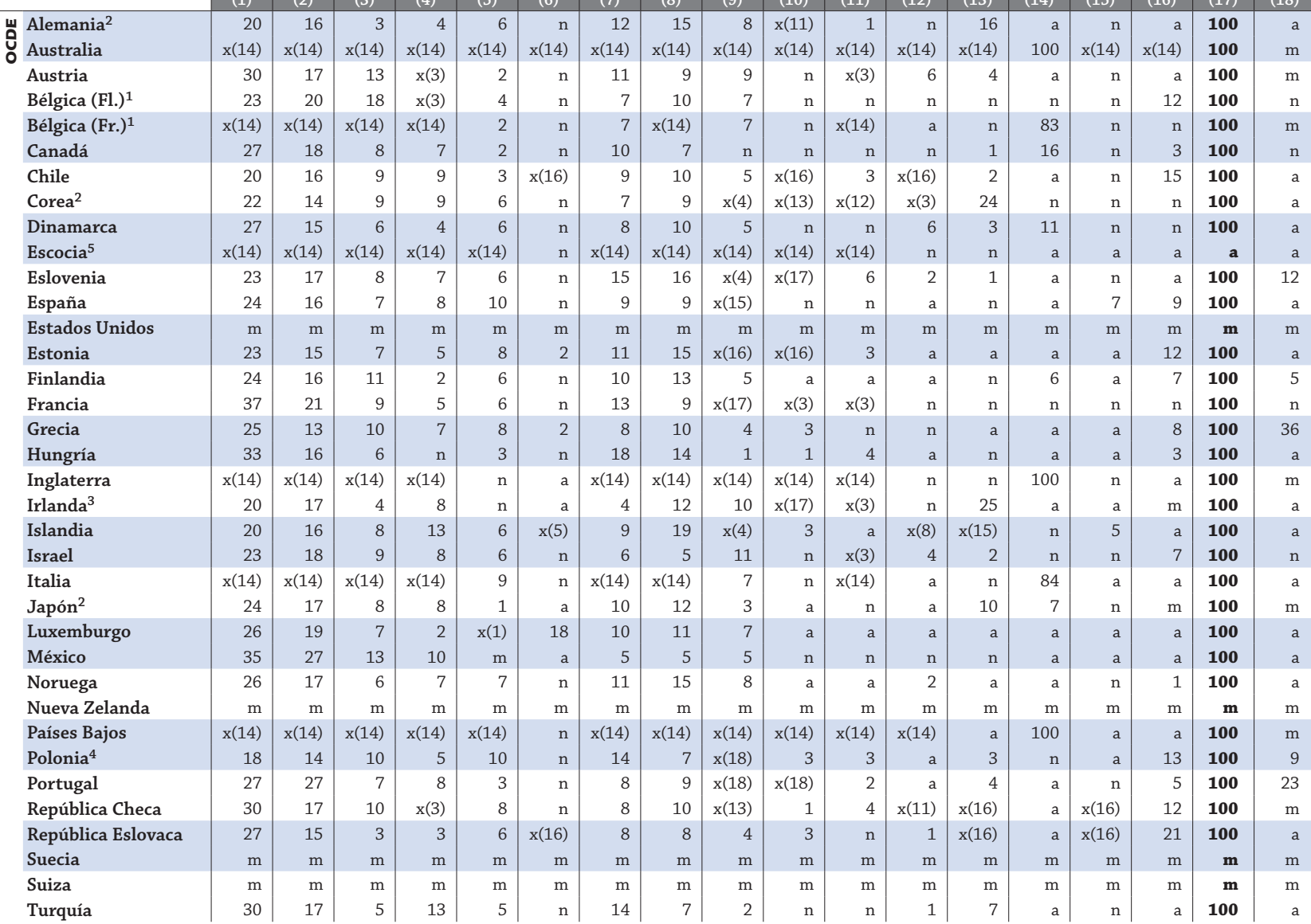

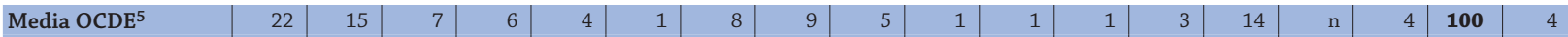

\begin{tabular}{|c|c|c|c|}
\hline Media UE215 & 21 & 14 & 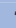 \\
\hline
\end{tabular}

\begin{tabular}{|c|c|c|c|c|c|c|c|c|c|c|c|c|c|c|c|c|c|c|}
\hline $\begin{array}{l}\text { Arabia Saudí } \\
\text { ¿্ّ Argentina }\end{array}$ & $\begin{array}{l}\mathrm{m} \\
\mathrm{m}\end{array}$ & $\begin{array}{l}\mathrm{m} \\
\mathrm{m}\end{array}$ & $\begin{array}{l}\mathrm{m} \\
\mathrm{m}\end{array}$ & $\begin{array}{l}\mathrm{m} \\
\mathrm{m}\end{array}$ & $\begin{array}{l}\mathrm{m} \\
\mathrm{m}\end{array}$ & $\begin{array}{l}\mathrm{m} \\
\mathrm{m}\end{array}$ & $\begin{array}{l}\mathrm{m} \\
\mathrm{m}\end{array}$ & $\begin{array}{l}\mathrm{m} \\
\mathrm{m}\end{array}$ & $\begin{array}{l}\mathrm{m} \\
\mathrm{m}\end{array}$ & $\begin{array}{l}\mathrm{m} \\
\mathrm{m}\end{array}$ & $\begin{array}{l}\mathrm{m} \\
\mathrm{m}\end{array}$ & $\begin{array}{l}\mathrm{m} \\
\mathrm{m}\end{array}$ & $\begin{array}{l}\mathrm{m} \\
\mathrm{m}\end{array}$ & $\begin{array}{l}\mathrm{m} \\
\mathrm{m}\end{array}$ & $\begin{array}{l}\mathrm{m} \\
\mathrm{m}\end{array}$ & $\begin{array}{l}\mathrm{m} \\
\mathrm{m}\end{array}$ & $\begin{array}{l}\mathbf{m} \\
\mathbf{m}\end{array}$ & $\begin{array}{l}\mathrm{m} \\
\mathrm{m}\end{array}$ \\
\hline ¿ Brasil & $\mathrm{m}$ & $\mathrm{m}$ & $\mathrm{m}$ & $\mathrm{m}$ & $\mathrm{m}$ & $\mathrm{n}$ & $\mathrm{m}$ & $\mathrm{m}$ & $\mathrm{m}$ & $\mathrm{m}$ & a & a & $\mathrm{m}$ & $\mathrm{m}$ & $\mathrm{m}$ & $\mathrm{m}$ & $\mathbf{m}$ & $\mathrm{m}$ \\
\hline in China & $\mathrm{m}$ & $\mathrm{m}$ & $\mathrm{m}$ & $\mathrm{m}$ & $\mathrm{m}$ & $\mathrm{m}$ & $\mathrm{m}$ & $\mathrm{m}$ & $\mathrm{m}$ & $\mathrm{m}$ & $\mathrm{m}$ & $\mathrm{m}$ & $\mathrm{m}$ & $\mathrm{m}$ & $\mathrm{m}$ & $\mathrm{m}$ & $\mathbf{m}$ & $\mathrm{m}$ \\
\hline Colombia & $\mathrm{m}$ & $\mathrm{m}$ & $\mathrm{m}$ & $\mathrm{m}$ & $\mathrm{m}$ & $\mathrm{m}$ & $\mathrm{m}$ & $\mathrm{m}$ & $\mathrm{m}$ & $\mathrm{m}$ & $\mathrm{m}$ & $\mathrm{m}$ & $\mathrm{m}$ & $\mathrm{m}$ & $\mathrm{m}$ & $\mathrm{m}$ & m & $\mathrm{m}$ \\
\hline Federación Rusa & $\mathrm{m}$ & $\mathrm{m}$ & $\mathrm{m}$ & $\mathrm{m}$ & $\mathrm{m}$ & $\mathrm{m}$ & $\mathrm{m}$ & $\mathrm{m}$ & $\mathrm{m}$ & $\mathrm{m}$ & $\mathrm{m}$ & $\mathrm{m}$ & $\mathrm{m}$ & $\mathrm{m}$ & $\mathrm{m}$ & $\mathrm{m}$ & $\mathbf{m}$ & $\mathrm{m}$ \\
\hline India & $\mathrm{m}$ & $\mathrm{m}$ & $\mathrm{m}$ & $\mathrm{m}$ & $\mathrm{m}$ & $\mathrm{m}$ & $\mathrm{m}$ & $\mathrm{m}$ & $\mathrm{m}$ & $\mathrm{m}$ & $\mathrm{m}$ & $\mathrm{m}$ & $\mathrm{m}$ & $\mathrm{m}$ & $\mathrm{m}$ & $\mathrm{m}$ & $\mathbf{m}$ & $\mathrm{m}$ \\
\hline Indonesia & $\mathrm{m}$ & $\mathrm{m}$ & $\mathrm{m}$ & $\mathrm{m}$ & $\mathrm{m}$ & $\mathrm{m}$ & $\mathrm{m}$ & $\mathrm{m}$ & $\mathrm{m}$ & $\mathrm{m}$ & $\mathrm{m}$ & $\mathrm{m}$ & $\mathrm{m}$ & $\mathrm{m}$ & $\mathrm{m}$ & $\mathrm{m}$ & $\mathbf{m}$ & $\mathrm{m}$ \\
\hline Letonia & 21 & 17 & 5 & 6 & 7 & 1 & 8 & 12 & 2 & 1 & a & 4 & 11 & a & a & 6 & 100 & $\mathrm{~m}$ \\
\hline
\end{tabular}

\section{Media G20}

Notas: En las Tablas D1.5a a D1.5l, disponibles en Internet, se especifican las horas de enseñanza por materia para cada edad (véase StatLink más abajo).

Las medias se han ajustado al $100 \%$ y no se corresponden con exactitud con la media de cada columna.

1. Es obligatorio que los estudiantes asistan a clase a tiempo completo hasta los 15 o 16 años. Sin embargo, los que cursan educación general deben hacerlor hasta los 18.

2. Año de referencia 2013.

3. La segunda lengua del centro escolar (ya sea Irlandés o Inglés) se incluye en «Otros»

4. Excluye los tres primeros años de educación primaria para los cuales una proporción importante del tiempo dedicado a materias obligatorias es flexible.

5. Escocia no está incluida en las medias.

Fuentes: OCDE. Arabia Saudí, Argentina, China, Colombia, India, Indonesia, Sudáfrica: Instituto de Estadística de la UNESCO. Letonia: Eurydice. Para ver notas, consulte Anexo 3 (www.oecd.org/edu/eag.htm).(www.oecd.org/edu/eag.htm).

Para obtener más información acerca de los símbolos utilizados en lugar de los datos que faltan, consulte la Guía del lector.

StatLink 젶ㄴ http://dx.doi.org/10.1787/888933119587 
Tabla D1.3b. Horas de enseñanza por materia en educación secundaria inferior (2014)

Como porcentaje del total de horas de enseñanza obligatorias

\begin{tabular}{|c|c|c|c|c|c|c|c|c|c|c|c|c|c|c|c|c|c|c|}
\hline & 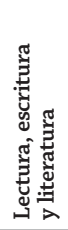 & 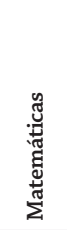 & 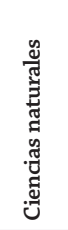 & 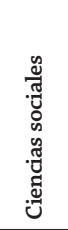 & 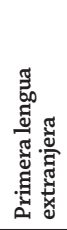 & 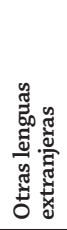 & 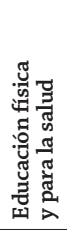 & 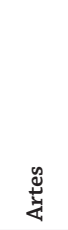 & 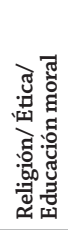 & 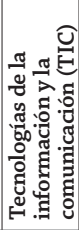 & 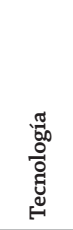 & 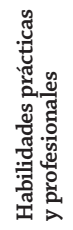 & 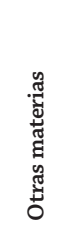 & 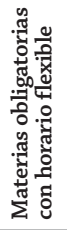 & 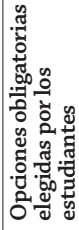 & 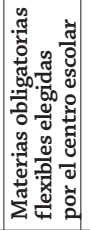 & 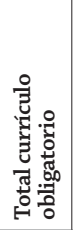 & 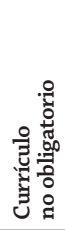 \\
\hline & (1) & (2) & (3) & (4) & (5) & (6) & (7) & (8) & (9) & (10) & (11) & (12) & (13) & (14) & (15) & (16) & (17) & (18) \\
\hline Alemania $^{3}$ & 14 & 13 & 12 & 11 & 19 & $\mathrm{x}(5)$ & 9 & 10 & 6 & $\mathrm{x}(11)$ & 3 & 2 & 1 & $\mathrm{a}$ & $\mathrm{n}$ & a & 100 & $\mathrm{a}$ \\
\hline ठ Australia & $x(14)$ & $\mathrm{x}(14)$ & $\mathrm{x}(14)$ & $\mathrm{x}(14)$ & $\mathrm{x}(14)$ & $\mathrm{x}(14)$ & $\mathrm{x}(14)$ & $\mathrm{x}(14)$ & $\mathrm{x}(14)$ & $\mathrm{x}(14)$ & $\mathrm{x}(14)$ & $\mathrm{x}(14)$ & $\mathrm{x}(14)$ & 100 & $\mathrm{x}(14)$ & $\mathrm{x}(14)$ & 100 & $\mathrm{~m}$ \\
\hline Austria & 14 & 14 & 12 & 11 & 12 & $\mathrm{n}$ & 11 & 12 & 7 & $\mathrm{n}$ & $\mathrm{n}$ & 7 & $\mathrm{n}$ & $\mathrm{a}$ & 1 & a & 100 & $\mathrm{~m}$ \\
\hline Bélgica (Fl.) ${ }^{1}$ & 14 & 13 & 5 & 9 & 9 & 6 & 6 & 5 & 6 & $\mathrm{x}(15)$ & 6 & $\mathrm{x}(15)$ & $\mathrm{x}(15)$ & $\mathrm{n}$ & 9 & 9 & 100 & $\mathrm{n}$ \\
\hline Bélgica $(\mathrm{Fr} .)^{1}$ & 17 & 14 & 9 & 13 & 13 & $\mathrm{n}$ & 9 & 3 & 6 & $\mathrm{~m}$ & 3 & $\mathrm{a}$ & $\mathrm{x}(15)$ & $\mathrm{n}$ & 13 & $\mathrm{n}$ & 100 & $\mathrm{~m}$ \\
\hline Canadá & 19 & 15 & 10 & 13 & 7 & $\mathrm{n}$ & 10 & 8 & 1 & $\mathrm{n}$ & 3 & 1 & 2 & 4 & 1 & 8 & 100 & $\mathrm{n}$ \\
\hline Chile & 16 & 16 & 11 & 11 & 8 & $\mathrm{x}(16)$ & 5 & 8 & 5 & $\mathrm{x}(16)$ & 3 & $\mathrm{x}(16)$ & 3 & $\mathrm{a}$ & $\mathrm{n}$ & 14 & 100 & $\mathrm{a}$ \\
\hline Corea $^{3}$ & 13 & 11 & 19 & 15 & 10 & $\mathrm{n}$ & 8 & 8 & $\mathrm{x}(4)$ & $\mathrm{x}(12)$ & $\mathrm{x}(12)$ & $x(3)$ & 9 & $\mathrm{n}$ & $x(16)$ & 6 & 100 & $\mathrm{a}$ \\
\hline Dinamarca & 19 & 13 & 17 & 10 & 10 & $\mathrm{x}(15)$ & 6 & $\mathrm{x}(15)$ & 2 & $\mathrm{x}(15)$ & $\mathrm{x}(15)$ & 3 & 3 & $\mathrm{n}$ & 12 & 4 & 100 & a \\
\hline Escocia $^{4}$ & $\mathrm{x}(14)$ & $\mathrm{x}(14)$ & $\mathrm{x}(14)$ & $\mathrm{x}(14)$ & $\mathrm{x}(14)$ & $\mathrm{n}$ & $\mathrm{x}(14)$ & $\mathrm{x}(14)$ & $\mathrm{x}(14)$ & $\mathrm{x}(14)$ & $\mathrm{x}(14)$ & $\mathrm{n}$ & $\mathrm{n}$ & a & a & a & a & a \\
\hline Eslovenia & 13 & 13 & 17 & 15 & 11 & $\mathrm{x}(15)$ & 9 & 8 & $\mathrm{x}(4)$ & $x(17)$ & 4 & $\mathrm{n}$ & 2 & $\mathrm{a}$ & 7 & $\mathrm{a}$ & 100 & 13 \\
\hline España & 16 & 12 & 8 & 12 & 11 & $\mathrm{n}$ & 7 & 7 & 1 & $\mathrm{x}(11)$ & 5 & a & 3 & a & 18 & $\mathrm{n}$ & 100 & a \\
\hline Estados Unidos & $\mathrm{m}$ & $\mathrm{m}$ & $\mathrm{m}$ & $\mathrm{m}$ & $\mathrm{m}$ & $\mathrm{m}$ & $\mathrm{m}$ & $\mathrm{m}$ & $\mathrm{m}$ & $\mathrm{m}$ & $\mathrm{m}$ & $\mathrm{m}$ & $\mathrm{m}$ & $\mathrm{m}$ & $\mathrm{m}$ & $\mathrm{m}$ & $\mathbf{m}$ & $\mathrm{m}$ \\
\hline Estonia & 13 & 14 & 21 & 11 & 10 & 10 & 6 & 6 & $\mathrm{x}(16)$ & $\mathrm{x}(16)$ & 5 & a & a & a & a & 4 & 100 & a \\
\hline Finlandia & 12 & 12 & 16 & 8 & 9 & 7 & 9 & 9 & 4 & $\mathrm{a}$ & a & $\mathrm{a}$ & 6 & 4 & $\mathrm{a}$ & 5 & 100 & 7 \\
\hline Francia & 15 & 14 & 10 & 11 & 12 & 5 & 12 & 7 & $\mathrm{x}(4)$ & $\mathrm{x}(11)$ & 6 & $\mathrm{x}(15)$ & 3 & $\mathrm{n}$ & 4 & 1 & 100 & 10 \\
\hline Grecia & 26 & 11 & 10 & 12 & 6 & 6 & 7 & 6 & 6 & 3 & 2 & 5 & a & a & a & 1 & 100 & $\mathrm{n}$ \\
\hline Hungría & 15 & 13 & 12 & 13 & 12 & $\mathrm{n}$ & 15 & 8 & 2 & 3 & 3 & $\mathrm{a}$ & 2 & a & $\mathrm{a}$ & 3 & 100 & a \\
\hline Inglaterra $^{2}$ & 14 & 13 & 12 & 14 & 5 & 4 & 9 & 11 & 4 & 4 & 8 & $\mathrm{n}$ & 3 & $\mathrm{a}$ & $\mathrm{a}$ & a & 100 & $\mathrm{n}$ \\
\hline Irlanda $^{2}$ & 12 & 12 & 10 & 17 & 10 & $\mathrm{~m}$ & 7 & $\mathrm{~m}$ & 7 & 5 & $\mathrm{~m}$ & $\mathrm{~m}$ & 10 & $\mathrm{~m}$ & $\mathrm{~m}$ & 12 & 100 & $\mathrm{a}$ \\
\hline Islandia & 14 & 14 & 8 & 8 & 19 & $\mathrm{x}(5)$ & 8 & 8 & $\mathrm{x}(4)$ & 2 & a & $\mathrm{x}(8)$ & $\mathrm{x}(15)$ & $\mathrm{n}$ & 20 & a & 100 & a \\
\hline Israel & 17 & 14 & 14 & 15 & 11 & 6 & 5 & $\mathrm{x}(16)$ & 9 & $\mathrm{x}(3)$ & $\mathrm{x}(3)$ & 1 & 4 & 3 & $\mathrm{n}$ & 2 & 100 & $\mathrm{n}$ \\
\hline Italia & 33 & 20 & $\mathrm{x}(2)$ & $\mathrm{x}(1)$ & 10 & 7 & 7 & 13 & 3 & $\mathrm{n}$ & 7 & $\mathrm{a}$ & $\mathrm{n}$ & $\mathrm{n}$ & a & a & 100 & $\mathrm{a}$ \\
\hline Japón ${ }^{3}$ & 12 & 12 & 12 & 11 & 13 & $\mathrm{a}$ & 10 & 7 & 3 & $\mathrm{a}$ & 3 & $\mathrm{a}$ & 12 & 6 & $\mathrm{n}$ & $\mathrm{m}$ & 100 & $\mathrm{~m}$ \\
\hline Luxemburgo & 15 & 13 & 8 & 11 & 17 & 13 & 8 & 9 & 7 & a & a & a & a & a & a & a & 100 & a \\
\hline México & 14 & 14 & 17 & 12 & 9 & a & 6 & 6 & 8 & $\mathrm{n}$ & 9 & $\mathrm{n}$ & 6 & a & a & a & 100 & a \\
\hline Noruega & 15 & 12 & 10 & 11 & 9 & 9 & 9 & 9 & 6 & $\mathrm{a}$ & a & 7 & a & a & 4 & $\mathrm{n}$ & 100 & a \\
\hline Nueva Zelanda & $\mathrm{m}$ & $\mathrm{m}$ & $\mathrm{m}$ & $\mathrm{m}$ & $\mathrm{m}$ & $\mathrm{m}$ & $\mathrm{m}$ & $\mathrm{m}$ & $\mathrm{m}$ & $\mathrm{m}$ & $\mathrm{m}$ & $\mathrm{m}$ & $\mathrm{m}$ & $\mathrm{m}$ & $\mathrm{m}$ & $\mathrm{m}$ & $\mathbf{m}$ & $\mathrm{m}$ \\
\hline Países Bajos & $\mathrm{x}(14)$ & $\mathrm{x}(14)$ & $\mathrm{x}(14)$ & $\mathrm{x}(14)$ & $\mathrm{x}(14)$ & $\mathrm{x}(14)$ & $\mathrm{x}(14)$ & $\mathrm{x}(14)$ & $\mathrm{x}(14)$ & $\mathrm{x}(14)$ & $\mathrm{x}(14)$ & $x(14)$ & a & 100 & $\mathrm{a}$ & $\mathrm{a}$ & 100 & $\mathrm{~m}$ \\
\hline Polonia & 14 & 12 & 12 & 12 & 14 & $\mathrm{x}(5)$ & 12 & 4 & $\mathrm{x}(18)$ & 2 & 2 & $\mathrm{a}$ & 4 & $\mathrm{n}$ & $\mathrm{a}$ & 13 & 100 & 8 \\
\hline Portugal & 13 & 13 & 18 & 15 & 9 & 9 & 7 & 6 & $\mathrm{x}(18)$ & 2 & $\mathrm{n}$ & a & $\mathrm{n}$ & a & $\mathrm{n}$ & 7 & 100 & 3 \\
\hline República Checa & 12 & 12 & 17 & 9 & 10 & 5 & 8 & 8 & $\mathrm{x}(13)$ & 1 & 2 & $\mathrm{x}(11)$ & $\mathrm{x}(16)$ & $\mathrm{a}$ & $x(16)$ & 15 & 100 & $\mathrm{~m}$ \\
\hline República Eslovaca & 16 & 13 & 10 & 10 & 10 & 3 & 7 & 5 & 3 & 1 & $\mathrm{x}(16)$ & 1 & $\mathrm{x}(16)$ & $\mathrm{a}$ & $\mathrm{x}(16)$ & 21 & 100 & a \\
\hline Suecia & $\mathrm{m}$ & $\mathrm{m}$ & $\mathrm{m}$ & $\mathrm{m}$ & $\mathrm{m}$ & $\mathrm{m}$ & $\mathrm{m}$ & $\mathrm{m}$ & $\mathrm{m}$ & $\mathrm{m}$ & $\mathrm{m}$ & $\mathrm{m}$ & $\mathrm{m}$ & $\mathrm{m}$ & $\mathrm{m}$ & $\mathrm{m}$ & $\mathbf{m}$ & $\mathrm{m}$ \\
\hline Suiza & $\mathrm{m}$ & $\mathrm{m}$ & $\mathrm{m}$ & $\mathrm{m}$ & $\mathrm{m}$ & $\mathrm{m}$ & $\mathrm{m}$ & $\mathrm{m}$ & $\mathrm{m}$ & $\mathrm{m}$ & $\mathrm{m}$ & $\mathrm{m}$ & $\mathrm{m}$ & $\mathrm{m}$ & $\mathrm{m}$ & $\mathrm{m}$ & $\mathbf{m}$ & $\mathrm{m}$ \\
\hline Turquía & 16 & 14 & 11 & 8 & 10 & $\mathrm{n}$ & 6 & 6 & 6 & 3 & 3 & 1 & $\mathrm{n}$ & a & 17 & a & 100 & a \\
\hline Media OCDE ${ }^{4}$ & 14 & 12 & 11 & 10 & 10 & 4 & 7 & 7 & 4 & 1 & 3 & 1 & 3 & 6 & 4 & 4 & 100 & 2 \\
\hline Media UE21 $^{4}$ & 14 & 12 & 11 & 11 & 10 & 4 & 8 & 7 & 4 & 2 & 3 & 1 & 2 & 5 & 3 & 4 & 100 & 2 \\
\hline 气̆ Arabia Saudí & $\mathrm{m}$ & $\mathrm{m}$ & $\mathrm{m}$ & $\mathrm{m}$ & $\mathrm{m}$ & $\mathrm{m}$ & $\mathrm{m}$ & $\mathrm{m}$ & $\mathrm{m}$ & $\mathrm{m}$ & $\mathrm{m}$ & $\mathrm{m}$ & $\mathrm{m}$ & $\mathrm{m}$ & $\mathrm{m}$ & $\mathrm{m}$ & m & $\mathrm{m}$ \\
\hline 苞 Argentina & $\mathrm{m}$ & $\mathrm{m}$ & $\mathrm{m}$ & $\mathrm{m}$ & $\mathrm{m}$ & $\mathrm{m}$ & $\mathrm{m}$ & $\mathrm{m}$ & $\mathrm{m}$ & $\mathrm{m}$ & $\mathrm{m}$ & $\mathrm{m}$ & $\mathrm{m}$ & $\mathrm{m}$ & $\mathrm{m}$ & $\mathrm{m}$ & m & $\mathrm{m}$ \\
\hline ¿ Brasil & $\mathrm{m}$ & $\mathrm{m}$ & $\mathrm{m}$ & $\mathrm{m}$ & $\mathrm{m}$ & $\mathrm{n}$ & $\mathrm{m}$ & $\mathrm{m}$ & $\mathrm{m}$ & $\mathrm{m}$ & a & $\mathrm{m}$ & $\mathrm{m}$ & $\mathrm{m}$ & $\mathrm{m}$ & $\mathrm{m}$ & $\mathbf{m}$ & $\mathrm{m}$ \\
\hline ¿ China & $\mathrm{m}$ & $\mathrm{m}$ & $\mathrm{m}$ & $\mathrm{m}$ & $\mathrm{m}$ & $\mathrm{m}$ & $\mathrm{m}$ & $\mathrm{m}$ & $\mathrm{m}$ & $\mathrm{m}$ & $\mathrm{m}$ & $\mathrm{m}$ & $\mathrm{m}$ & $\mathrm{m}$ & $\mathrm{m}$ & $\mathrm{m}$ & $\mathbf{m}$ & $\mathrm{m}$ \\
\hline Colombia & $\mathrm{m}$ & $\mathrm{m}$ & $\mathrm{m}$ & $\mathrm{m}$ & $\mathrm{m}$ & $\mathrm{m}$ & $\mathrm{m}$ & $\mathrm{m}$ & $\mathrm{m}$ & $\mathrm{m}$ & $\mathrm{m}$ & $\mathrm{m}$ & $\mathrm{m}$ & $\mathrm{m}$ & $\mathrm{m}$ & $\mathrm{m}$ & $\mathbf{m}$ & $\mathrm{m}$ \\
\hline Federación Rusa & $\mathrm{m}$ & $\mathrm{m}$ & $\mathrm{m}$ & $\mathrm{m}$ & $\mathrm{m}$ & $\mathrm{m}$ & $\mathrm{m}$ & $\mathrm{m}$ & $\mathrm{m}$ & $\mathrm{m}$ & $\mathrm{m}$ & $\mathrm{m}$ & $\mathrm{m}$ & $\mathrm{m}$ & $\mathrm{m}$ & $\mathrm{m}$ & m & $\mathrm{m}$ \\
\hline India & $\mathrm{m}$ & $\mathrm{m}$ & $\mathrm{m}$ & $\mathrm{m}$ & $\mathrm{m}$ & $\mathrm{m}$ & $\mathrm{m}$ & $\mathrm{m}$ & $\mathrm{m}$ & $\mathrm{m}$ & $\mathrm{m}$ & $\mathrm{m}$ & $\mathrm{m}$ & $\mathrm{m}$ & $\mathrm{m}$ & $\mathrm{m}$ & $\mathbf{m}$ & $\mathrm{m}$ \\
\hline Indonesia & $\mathrm{m}$ & $\mathrm{m}$ & $\mathrm{m}$ & $\mathrm{m}$ & $\mathrm{m}$ & $\mathrm{m}$ & $\mathrm{m}$ & $\mathrm{m}$ & $\mathrm{m}$ & $\mathrm{m}$ & $\mathrm{m}$ & $\mathrm{m}$ & $\mathrm{m}$ & $\mathrm{m}$ & $\mathrm{m}$ & $\mathrm{m}$ & $\mathbf{m}$ & $\mathrm{m}$ \\
\hline Letonia & 15 & 16 & 10 & 14 & 8 & 6 & 6 & 6 & $\mathrm{n}$ & 1 & a & 4 & 8 & a & a & 9 & 100 & $\mathrm{~m}$ \\
\hline Sudáfrica & $\mathrm{m}$ & $\mathrm{m}$ & $\mathrm{m}$ & $\mathrm{m}$ & $\mathrm{m}$ & $\mathrm{m}$ & $\mathrm{m}$ & $\mathrm{m}$ & $\mathrm{m}$ & $\mathrm{m}$ & $\mathrm{m}$ & $\mathrm{m}$ & $\mathrm{m}$ & $\mathrm{m}$ & $\mathrm{m}$ & $\mathrm{m}$ & $\mathbf{m}$ & $\mathrm{m}$ \\
\hline
\end{tabular}

Notas: En lasTablas D1.5a a D1.5l, disponibles en Internet, se especifican las horas de enseñanza por materia para cada edad (véase StatLink más abajo).

Las medias se han ajustado al $100 \%$ y no se corresponden con exactitud con la media de cada columna.

1. Es obligatorio que los estudiantes asistan a clase a tiempo completo hasta los 15 o 16 años. Sin embargo, los que cursan educación general deben hacerlo hasta los 18 .

2. Horas de enseñanza reales.

3. Año de referencia 2013

4. Escocia no está incluida en las medias.

Fuentes: OCDE. Arabia Saudí, Argentina, China, Colombia, India, Indonesia, Sudáfrica: Instituto de Estadística de la UNESCO. Letonia: Eurydice. Para ver notas, consulte Anexo 3 (www.oecd.org/edu/eag.htm).(www.oecd.org/edu/eag.htm).

Para obtener más información acerca de los símbolos utilizados en lugar de los datos que faltan, consulte la Guía del lector.

StatLink 세대 http://dx.doi.org/10.1787/888933119606 


\section{¿CUÁL ES LA RATIO ALUMNOS-PROFESOR Y CÓMO ES EL TAMAÑO DE LAS CLASES?}

- En educación primaria, el tamaño medio de la clase en los países de la OCDE es superior a 21 estudiantes por clase, sin embargo, el tamaño de las clases en los países asociados es mayor.

- El tamaño de las clases ha tendido a reducirse en educación primaria entre 2000 y 2012, especialmente en países que tenían clases relativamente grandes, como Corea y Turquía.

INDICADOR D2 - Como media en los países de la OCDE, el número de estudiantes por clase aumenta en dos estudiantes entre la educación primaria y la educación secundaria inferior.

- Aunque la satisfacción laboral de los profesores se relaciona ligeramente con el tamaño de las clases, disminuye de forma evidente cuando la proporción de estudiantes con problemas de comportamiento en una clase supera el 30\%, según los resultados de TALIS 2013 (Estudio Internacional sobre Enseñanza y Aprendizaje).

\section{Gráfico D2.1. Tamaño medio de la clase en educación primaria $(2000,2012)$}

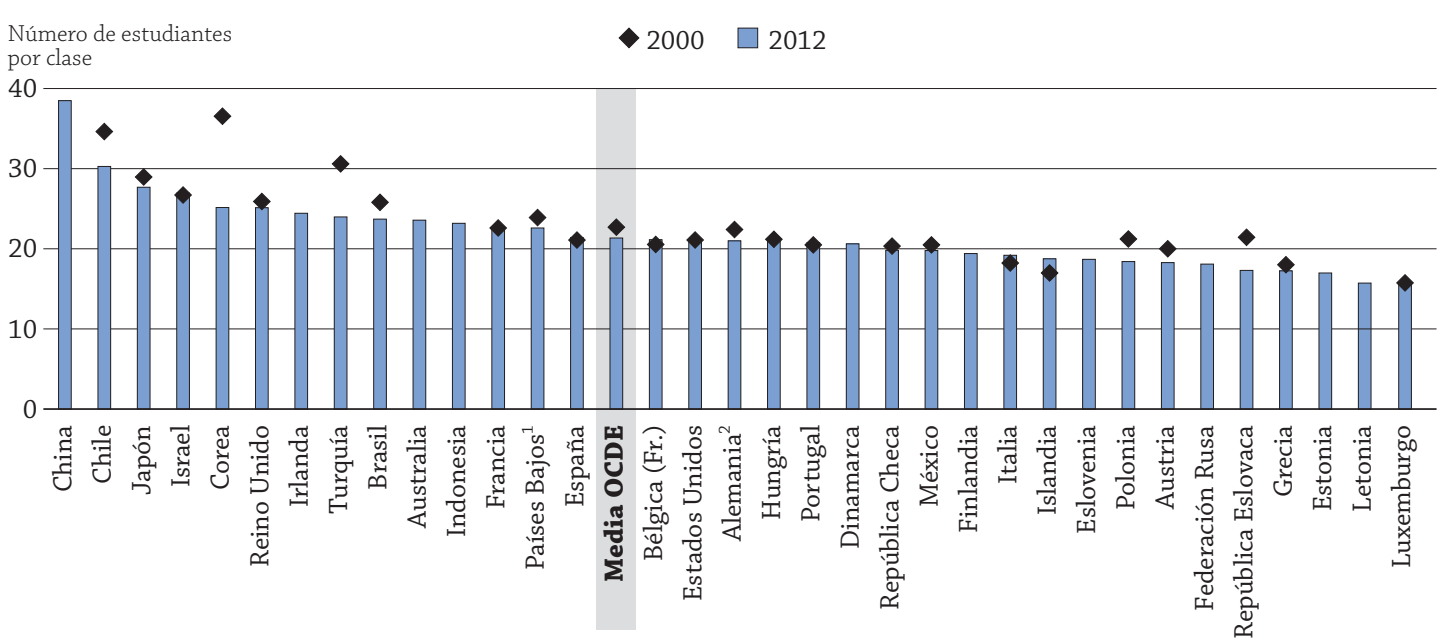

1. Solo instituciones públicas.

2. Año de referencia 2001 en lugar de 2000.

Los países están clasificados en orden descendente del tamaño medio de la clase en educación primaria en 2012.

Fuente: OCDE. Datos de 2011: Tabla D2.1 Datos de 2000: Tabla D2.4, disponible en Internet. Para ver notas, consulte Anexo 3 (www.oecd.org/edu/eag.htm).

StatLink 제매 http://dx.doi.org/10.1787/888933119758

\section{Contexto}

El tamaño de la clase y la ratio alumnos-profesor son aspectos muy discutidos en el ámbito educativo y, junto con las horas de enseñanza que reciben los estudiantes (véase Indicador D1), las horas de trabajo de los profesores (véase Indicador D4) y el reparto de su jornada laboral entre la enseñanza propiamente dicha y otras obligaciones, son algunos de los factores determinantes en la dotación de personal docente en los distintos países. El tamaño de la clase y la ratio alumnos-profesor, junto con los salarios de los profesores (véase Indicador D3) y su distribución por edad (véase Indicador D5), tienen también un impacto considerable en el nivel actual de gasto en educación (véanse Indicadores B6 y B7).

Se suele pensar que las clases más pequeñas son beneficiosas, ya que permiten a los profesores centrarse más en las necesidades individuales de los alumnos y reducir el tiempo de clase que dedican a mantener el orden. Sin embargo, aunque existen estudios que demuestran que un número menor de estudiantes por clase puede beneficiar a grupos específicos de estudiantes, como los que proceden de ámbitos desfavorecidos (Finn, 1998; Krueger, 2002 y Piketty, T. y M. Valdenaire, 2006), en conjunto, no hay pruebas determinantes acerca del tamaño del aula y su repercusión en el rendimiento estudiantil. Según conclusiones recientes del Estudio Internacional sobre Enseñanza y Aprendizaje (TALIS 2013) de la OCDE, contar con clases más reducidas no está relacionado necesariamente con una mayor satisfac- 
ción laboral de los profesores, excepto en algunos casos (véase Cuadro D2.1). Sin embargo, hay estudios que indican que las clases más pequeñas favorecen el desarrollo de métodos de enseñanza más innovadores (Hattie, 2009; OECD, 2014).

La ratio alumnos-profesor permite ver cómo se distribuyen los recursos destinados a la educación. A menudo se tiene que sopesar si es más conveniente reducir la ratio alumnos-profesor o mejorar los salarios de los profesores, invertir en su desarrollo profesional, en tecnología educativa, o en ampliar la participación de profesores de apoyo y otros profesionales, cuya retribución suele ser considerablemente menor que la de un profesor cualificado. Puesto que hay más alumnos con necesidades educativas especiales integrados en las clases comunes, una mayor participación de personal especializado y de apoyo puede limitar los recursos disponibles para reducir la ratio alumnos-profesor.

\section{Otros resultados}

- Con la excepción de Chile, Islandia, México y Noruega, la ratio alumnos-profesor disminuye entre educación primaria y secundaria inferior en todos los países con datos disponibles, aunque hay un aumento general del tamaño de las clases entre estos niveles.

- Como media en los países de la OCDE, la ratio alumnos-profesor en educación secundaria es ligeramente más favorable en institucioiones escolares privadas que en las públicas. El ejemplo más llamativo es el de México, donde en educación secundaria hay al menos 15 estudiantes más por profesor en los centros públicos que en los privados.

- El tamaño de las clases varía de forma significativa según países. Las clases más numerosas en educación primaria se encuentran en Chile y China con 30 estudiantes o más por clase, mientras que en Estonia, Letonia y Luxemburgo las clases tienen como media menos de 17 estudiantes.

\section{Tendencias}

Entre 2000 y 2012, el tamaño medio de la clase en los países con datos disponibles para ambos años disminuyó tanto en educación primaria como en educación secundaria inferior, y las diferencias en el tamaño de las clases entre los países de la OCDE se redujeron. Por ejemplo, en secundaria inferior, el tamaño de las clases osciló entre 17 estudiantes (Islandia) y 38 (Corea) en 2000 y entre 16 estudiantes (Estonia) y 33 (Corea) en 2012. Sin embargo, el tamaño de las clases ha tendido a aumentar en algunos países que tenían clases relativamente reducidas en 2000, entre los que destacan Dinamarca e Islandia. 


\section{Análisis}

\section{El tamaño medio de la clase en educación primaria y secundaria inferior}

La clase típica en primaria en los países de la OCDE supera los 21 estudiantes en 2012, pero esta cifra varía mucho entre todos los países con datos disponibles: desde menos de 16 estudiantes en Letonia y Luxemburgo hasta más de 30 en Chile y China. En casi la mitad de países con datos disponibles hay menos de 20 estudiantes por clase en primaria: así en Austria, Eslovenia, Estonia, Federación Rusa, Finlandia, Grecia, Islandia, Italia, México, Polonia, República Checa y República Eslovaca.

En secundaria inferior, en programas generales, el tamaño medio de la clase en los países de la OCDE es de casi 24 estudiantes. En los países con datos disponibles para ese nivel educativo, ese número varía desde 20 estudiantes o menos en Eslovenia, Estonia, Federación Rusa, Finlandia, Islandia, Letonia, Luxemburgo, Reino Unido y República Eslovaca hasta 33 estudiantes por clase en Corea, Japón e Indonesia y casi 52 en China (Tabla D2.1).

El número de estudiantes por clase tiende a aumentar entre la educación primaria y la secundaria inferior. En Corea, China, Indonesia y México, el aumento del tamaño medio de la clase es superior a siete estudiantes. Mientras que en Reino Unido y, en menor grado, Estonia y Letonia, el número de estudiantes por clase se reduce entre estos dos niveles (Gráfico D2.2).

El tamaño medio de la clase de educación primaria ha decrecido ligeramente entre 2000 y 2012 en los países de la OCDE con datos disponibles para esos dos años (21 estudiantes por clase en 2012 comparados con 23 en 2000). Es más probable que el tamaño de las clases se haya reducido en países en los que ha disminuido el número de estudiantes matriculados. No obstante, la reducción es también resultado de las reformas relativas al tamaño de las clases que algunos países han llevado a cabo durante ese periodo (véase Indicador B7). En los países con datos comparables, el tamaño de la clase disminuyó, y de forma notable (más de cuatro estudiantes) en los países con clases más numerosas en el año 2000, como Corea y Turquía, mientras que aumentó o no varió en los países con clases menos numerosas en el año 2000, como Dinamarca, Islandia, Italia y Luxemburgo (Gráfico D2.1). En educación secundaria inferior, las variaciones del tamaño de la clase se redujeron en el periodo 2000-2012: en los países con datos comparables para esos dos años, el tamaño de las clases varió de 17 estudiantes (Islandia) a 38 (Corea) en 2000 y de 16 estudiantes (Estonia) a 33 (Corea) en 2012 (Tabla D2.1 y Tabla D2.4 disponible en Internet).

El indicador del tamaño de la clase se limita a educación primaria y secundaria inferior, dado que el tamaño de las clases es difícil de definir y comparar en los niveles superiores, donde los estudiantes asisten a menudo a clases diferentes según las asignaturas.

\section{Gráfico D2.2. Tamaño medio de la clase en instituciones educativas, por nivel de educación (2012)}

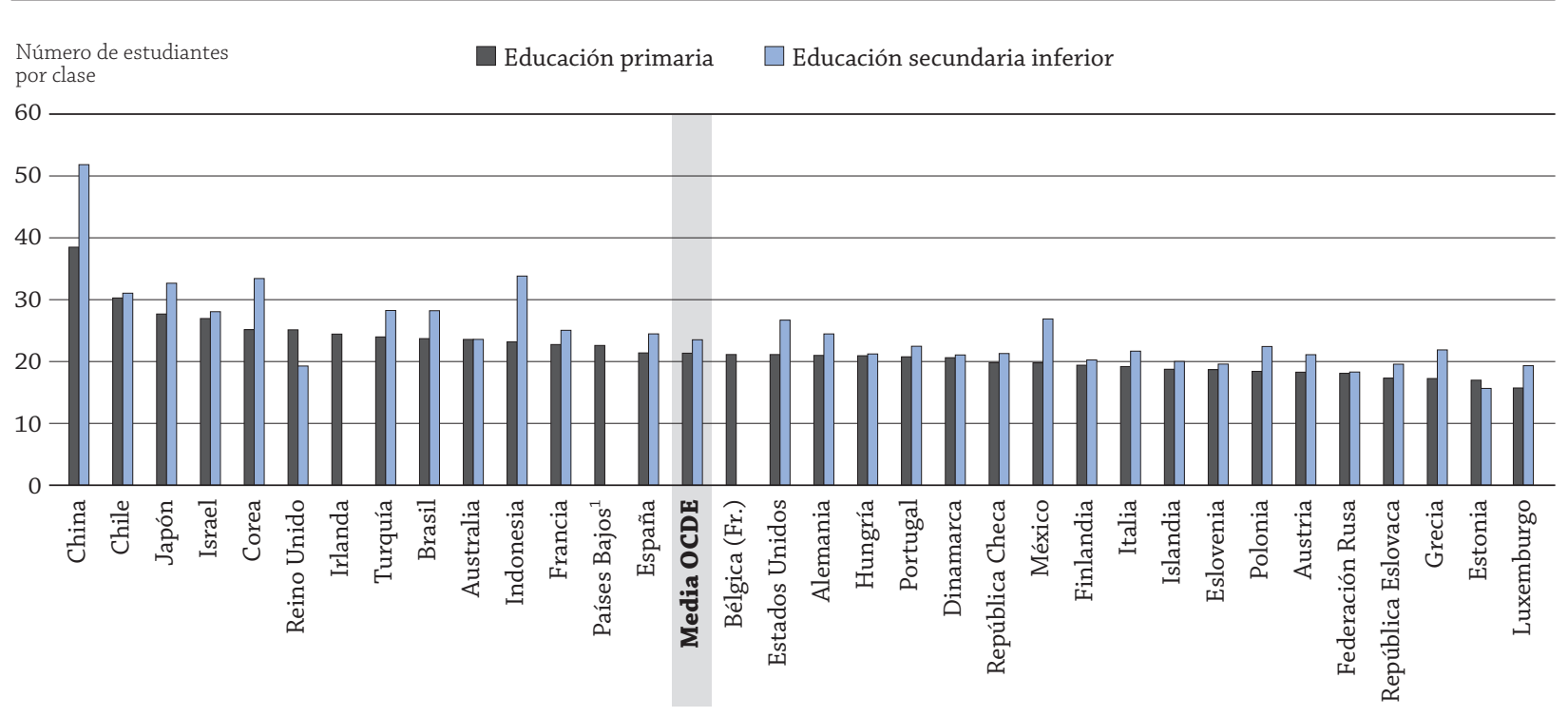

1. Solo instituciones públicas.

Los países están clasificados en orden descendente del tamaño medio de la clase en educación secundaria inferior en 2012.

Fuente: OCDE. Tabla D2.1 Para ver notas, consulte Anexo 3 (www.oecd.org/edu/eag.htm).

StatLink 젝ㄴ http://dx.doi.org/10.1787/888933119777 


\section{Cuadro D2.1. Relación entre el tamaño de las clases y la satisfacción laboral de los profesores}

En muchos países se debate sobre el tamaño óptimo de las clases para que la enseñanza y el aprendizaje sean eficaces. El tamaño de las clases tiende a variar según países y parece tener solo un pequeño impacto sobre la satisfacción laboral de los profesores. Los datos del Estudio Internacional sobre Enseñanza y Aprendizaje (TALIS 2013) de la OCDE muestran que no es tanto el número, sino el tipo de estudiantes de una clase, lo que está conectado más directamente con la eficacia personal y la satisfacción laboral de los profesores. Un ejemplo de ello se facilita en el Gráfico D2.a, donde se contrasta el efecto mínimo del tamaño de las clases sobre la satisfacción laboral de los profesores con el impacto de enseñar a estudiantes con problemas de comportamiento, ejerciendo una mayor influencia este último.

Estos dos gráficos demuestran que los profesores de educación secundaria inferior declararon una menor satisfacción laboral cuando aumentaba la proporción de estudiantes con problemas de comportamiento. Los profesores dijeron estar muy satisfechos con su trabajo cuando no tenían estudiantes con problemas de comportamiento en sus clases y poco satisfechos cuando la proporción de estudiantes con problemas de comportamiento en sus clases superaba el $30 \%$. Los resultados de TALIS muestran que en todos los países participantes, excepto Islandia, Noruega y Países Bajos, esta relación inversa es estadísticamente significativa y alcanza mayor relevancia en Abu Dhabi (Emiratos Árabes Unidos), Croacia, Dinamarca, España, Francia, Inglaterrra (Reino Unido) y Rumania.

Cuando las clases son más numerosas, no se observa una reducción similar de la satisfacción laboral. Como muestra el Gráfico D2.a, el nivel medio de satisfacción laboral se mantiene relativamente constante al variar el tamaño de las clases. Los únicos países donde el tamaño de las clases muestra una relación inversa significativa con la satisfacción laboral son Estonia, Inglaterra y Malasia. En el resto de países, esta relación no es significativa, excepto en Letonia, donde los resultados muestran una relación positiva.

En cambio, se recomienda dar prioridad a que los profesores estén bien preparados para dar clase a grupos de estudiantes complicados y diversos. Esto tiene especial importancia si se considera que más de uno de cada cinco profesores de secundaria inferior, por término medio, declararon que necesitaban desarrollo profesional para poder dar clase a estudiantes con necesidades especiales y otro $13 \%$ declararon que necesitaban desarrollo profesional en las áreas de comportamiento de los estudiantes y gestión de las clases.

\section{Gráfico D2.a. Satisfacción laboral de los profesores y composición de las clases (2013) \\ Nivel de satisfacción laboral de los profesores en educación secundaria inferior según el número de estudiantes por clase y el porcentaje de estudiantes con problemas de comportamiento ${ }^{1}$}

Satisfacción laboral de los profesores (nivel)

13,0

12,5

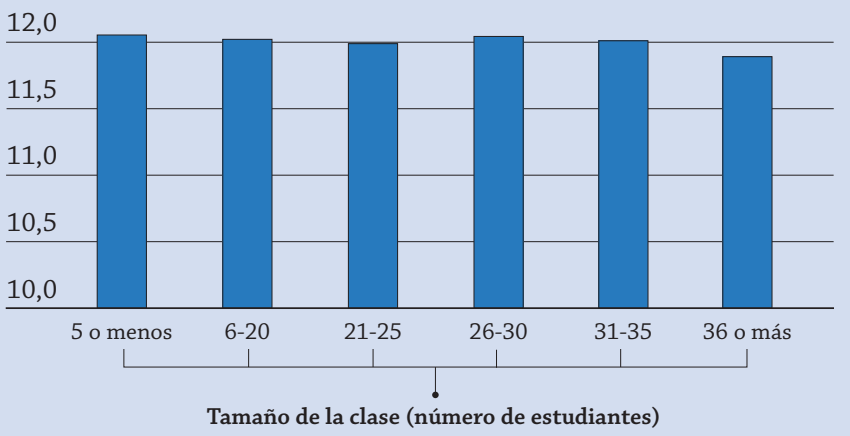

Satisfacción laboral de los profesores (nivel) 13,0

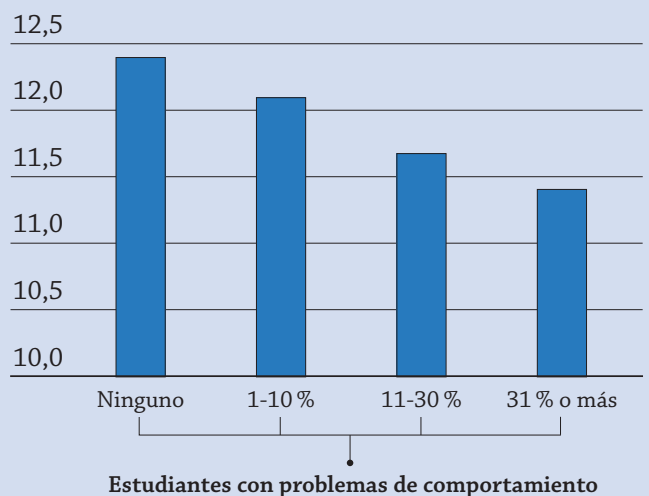

1. Los datos sobre el tamaño de la clase y sobre los estudiantes con problemas de comportamiento son aportados por los profesores y se refieren a una clase elegida al azar de las que componen su horario semanal.

Fuente: OECD (2014), TALIS 2013 Results: An International Perspective on Teaching and Learning, TALIS, OECD Publishing.

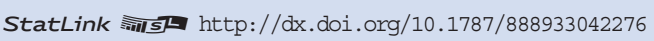




\section{Ratios alumnos-profesor}

La ratio alumnos-profesor compara el número de estudiantes (en equivalentes a tiempo completo) con el número de profesores (en equivalentes a tiempo completo) en un determinado nivel de educación y en centros escolares del mismo tipo. Sin embargo, esta ratio no tiene en cuenta el número de horas de enseñanza a los estudiantes en relación con la duración del día de trabajo del profesor, ni las horas que el profesor pasa enseñando. Por tanto, no puede interpretarse en términos de tamaño de las clases (Cuadro D2.2).

Como media en los países de la OCDE, hay menos de 16 estudiantes por cada profesor en educación primaria. La ratio alumnos-profesor oscila desde más de 28 estudiantes por profesor en México y más de 22 en Chile hasta 11 estudiantes por profesor o menos en Arabia Saudí, Hungría, Indonesia, Islandia, Luxemburgo, Noruega y Polonia (Gráfico D2.3).

\section{Gráfico D2.3. Ratio alumnos-profesor en instituciones educativas, por nivel de educación (2012)}
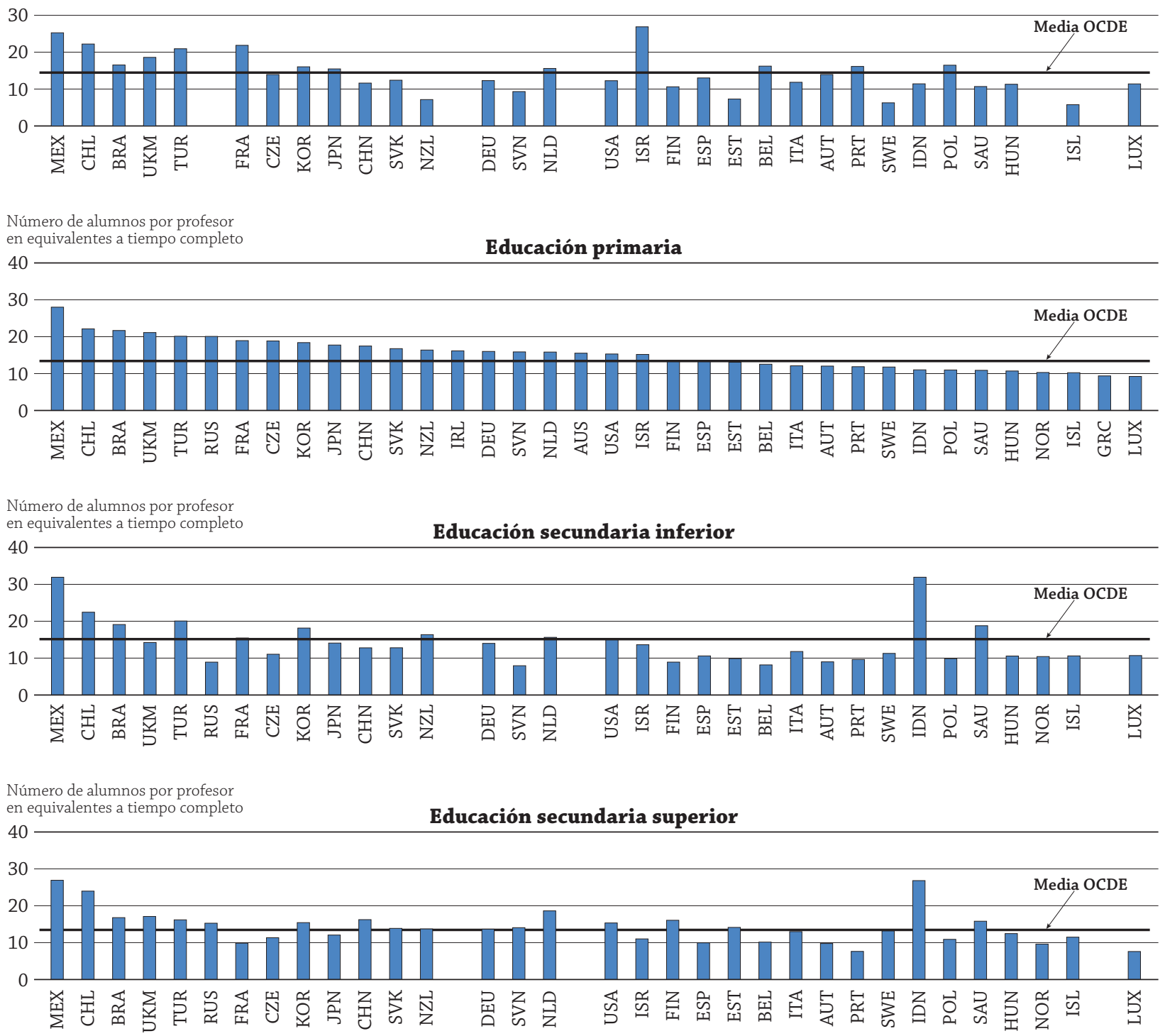

Los países están clasificados en orden descendente de la ratio alumnos-profesor en educación primaria.

Fuente: OCDE. Tabla D2.2. Para ver notas, consulte Anexo 3 (www.oecd.org/edu/eag.htm).

Para información sobre los códigos de los países utilizados en este gráfico, consulte la Guía del lector.

StatLink 젶ㄴ http://dx.doi.org/10.1787/888933119796 
En educación secundaria, la ratio alumnos-profesor también varía, incluso más que en primaria: de 30 estudiantes por profesor en equivalentes a tiempo completo en México a menos de 10 en Austria, Bélgica, Indonesia, Luxemburgo y Portugal. Como media en los países de la OCDE, la ratio alumnos-profesor en educación secundaria es de unos 13 estudiantes (Tabla D2.2).

Las diferencias entre las ratios alumnos-profesor ponen de relieve que hay menos estudiantes por profesor en equivalentes a tiempo completo en educación secundaria que en primaria. En la mayoría de los países, la ratio alumnosprofesor disminuye entre los niveles de educación primaria y secundaria, a pesar de que los tamaños de las clases tienden a aumentar. Esto sucede en todos los países de la OCDE, excepto en cuatro: Chile, Islandia, Luxemburgo y México.

Esta reducción de la ratio alumnos-profesor refleja las diferencias en las horas de enseñanza anuales, que tienden a aumentar en los niveles educativos superiores (véase Indicador D1). También puede deberse al periodo necesario para ajustar el número de profesores a los cambios demográficos o a la diferencia entre el número de horas lectivas de los profesores en los distintos niveles educativos, que tienden a reducirse a medida que aumenta el nivel educativo, al aumentar la especialización de los profesores. La tendencia general es uniforme entre países, pero diferentes estudios apuntan en sentido opuesto cuando se trata de decidir si, desde el punto de vista pedagógico, es más conveniente una ratio alumnos-profesor más reducida en niveles educativos superiores.

Las ratios alumnos-profesor en educación infantil se muestran en la Tabla D2.2 (véase también Indicador C2). La información sobre este nivel educativo también incluye la ratio alumnos-personal de contacto (profesores y asistentes educativos). Algunos países emplean a un gran número de asistentes educativos en el nivel de educación infantil. En doce países de la OCDE (y tres países asociados), la ratio alumnos-personal de contacto es menor que la ratio alumnos-profesor. Sin embargo, pocos países cuentan con un gran número de asistentes educativos. Ello implica que la ratio alumnos-personal de contacto es sustancialmente menor que la de alumnos-profesor (al menos en dos estudiantes) en Alemania, Austria, Brasil, Estados Unidos, Francia, Indonesia, Países Bajos y Reino Unido. Esta diferencia es especialmente importante en Chile e Israel, donde hay al menos 10 estudiantes menos entre la ratio alumnospersonal de contacto y la ratio alumnos-profesor.

\section{Cuadro D2.2. ¿Cuál es la relación entre el tamaño de la clase y la ratio alumnos-profesor?}

El número de alumnos por clase se calcula a partir de una serie de elementos: la ratio de alumnos-profesor, el número de clases o estudiantes de los cuales un profesor es responsable, las horas de enseñanza impartidas en relación con las horas totales de la jornada de trabajo de los profesores, la proporción de tiempo que los profesores pasan dando clases, la forma de agrupar a los estudiantes en clases y la organización de la enseñanza en equipo.

Por ejemplo, en un centro educativo que tenga 48 estudiantes a tiempo completo y 8 profesores a tiempo completo, la ratio alumnos-profesor es 6 a 1. Si los profesores trabajan 35 horas a la semana, incluidas 10 horas lectivas, y si el tiempo de enseñanza de los estudiantes es de 40 horas por semana, entonces, cualquiera que sea el modo de agrupación de los estudiantes en este centro educativo, el tamaño medio de la clase puede calcularse de la siguiente manera:

Estimación del tamaño de la clase $=6$ alumnos por profesor $\times(40$ horas de enseñanza por estudiante $/ 10$ horas lectivas por profesor) $=24$ alumnos.

En contraste con esta estimación, el tamaño de la clase que figura en la Tabla D2.1 se define como el número de estudiantes que siguen un programa general, sobre la base del número más alto de asignaturas comunes (generalmente se trata de asignaturas obligatorias), pero prescindiendo de las clases de grupos pequeños de estudiantes. Así pues, las estimaciones del tamaño de la clase se aproximarán más a los tamaños medios que figuran en la Tabla D2.1 en los casos en que sean menos frecuentes las clases de grupos pequeños (como en educación primaria y en secundaria inferior).

Estas definiciones explican por qué ratios similares alumnos-profesor en distintos países pueden traducirse en diferentes tamaños de clase. Por ejemplo, en educación primaria, Estados Unidos e Israel tienen ratios alumnos-profesor similares (15 estudiantes por profesor; Tabla D2.2), pero el tamaño medio de la clase varía substancialmente: 21 estudiantes en Estados Unidos, comparados con 27 en Israel (Tabla D2.1). 
En educación terciaria, la ratio alumnos-profesor varía desde 20 o más estudiantes por profesor en Arabia Saudí, Bélgica, Brasil, Federación Rusa, Reino Unido, República Checa y Turquía, hasta menos de 10 en Noruega (Tabla D2.2). En todo caso, es preciso interpretar estas cifras con prudencia, debido a la dificultad de calcular cifras de estudiantes y profesores en equivalentes a tiempo completo que sean comparables en el nivel de la educación terciaria. En 8 de los 14 países de la OCDE de los que hay datos comparables, la ratio alumnos-profesor es menor en los programas terciarios de tipo $\mathrm{B}$, más orientados a una formación profesional específica, que en los de tipo A, programas académicos, y de investigación avanzada. Turquía es el único país en los que la ratio alumnos-profesor es significativamente mayor en programas de formación profesional a ese nivel (53 a 1) que en programas de tipo A y de investigación avanzada (16 a 1) (Tabla D2.2).

\section{Tamaño de la clase en centros escolares públicos y privados}

El tamaño de la clase es uno de los factores que los padres suelen tener en cuenta al elegir un centro escolar para sus hijos y la diferencia del tamaño medio de la clase entre los centros privados y públicos (y entre los diversos tipos de centros privados) puede influir en los niveles de matriculación.

En los países de la OCDE y países asociados de los que se dispone de datos, los tamaños medios de la clase no difieren entre centros escolares públicos y privados en más de un estudiante por clase en educación primaria y secundaria inferior (Tabla D2.1). Sin embargo, existen importantes variaciones entre países. Por ejemplo, en educación primaria, en Brasil, Estados Unidos, Federación Rusa, Islandia, Israel, Polonia, Reino Unido, República Checa y Turquía, el tamaño medio de la clase en centros escolares públicos es mayor en cuatro estudiantes o más por clase que en centros privados. No obstante, con la excepción de Brasil e Israel, el sector privado es relativamente pequeño en todos esos países, escolarizando como mucho al $5 \%$ de los estudiantes de educación primaria (véase Tabla C1.5, disponible en Internet). Por el contrario, el tamaño medio de la clase en centros escolares privados es mayor que en los centros públicos en cuatro o más estudiantes en España (donde más del $30 \%$ de los estudiantes están matriculados en centros privados).

La comparación de tamaños de clase entre centros escolares públicos y privados muestra también un panorama heterogéneo en secundaria inferior, en la que se da una mayor presencia de la educación privada. El tamaño medio de la clase en secundaria inferior es mayor en las instituciones privadas que en las públicas en 12 países, aunque las diferencias tienden a ser menores que en educación primaria.

En los países donde los centros privados (incluidos tanto los independientes como los dependientes del gobierno) tienen mayor presencia en educación primaria y secundaria inferior (es decir, países donde más del $10 \%$ de los estudiantes de estos niveles están matriculados en instituciones privadas), tales como Argentina, Australia, Bélgica (Comunidad francófona), Brasil, Chile, Dinamarca, España, Francia, Indonesia y Portugal, puede haber grandes diferencias en el tamaño de las clases entre centros escolares públicos y privados. Estas diferencias son mayores en España (cuatro estudiantes o más en primaria), y en Brasil (en ambos niveles), donde los centros escolares privados suelen tener más estudiantes por clase que los centros públicos (véanse Tablas C1.4 y D2.1). Esto indica que los países en que una proporción considerable de estudiantes y familias eligen centros privados, el tamaño de las clases no es un factor determinante en su elección.

Al comparar el número de estudiantes con relación al de profesores, el resultado es similar. Como media para los países de los que se dispone de datos, las ratios alumnos-profesor son ligeramente inferiores en los centros privados que en los públicos en secundaria inferior y superior (Tabla D2.3). Las mayores diferencias entre centros escolares públicos y privados se encuentran en Brasil, México y Turquía, donde en secundaria inferior hay al menos ocho estudiantes más por profesor en los centros públicos que en los privados. En secundaria superior en México, la diferencia entre las ratios alumnos-profesor en los centros públicos y privados (una diferencia de más de 17 alumnos por profesor) es aún mayor que en el nivel de secundaria inferior (15 alumnos por profesor).

Por el contrario, en algunos países, las ratios alumnos-profesor son más reducidas en los centros escolares públicos que en los privados. Reino Unido presenta este patrón de manera más acusada en secundaria inferior, donde hay alrededor de 22 alumnos por profesor en los centros privados y menos de 11 en los centros públicos.

\section{Definiciones}

El personal de enseñanza (personal docente) incluye dos categorías:

- La categoría de asistentes educativos y de investigación incluye al personal no profesional o a los estudiantes que ayudan a los profesores a dar clase. 
- El personal docente es el personal cualificado implicado directamente en la enseñanza de los estudiantes. Incluye a los profesores, a los profesores de educación especial y a otros profesores que se hacen cargo en un aula de estudiantes que constituyen una clase entera, de estudiantes reunidos en grupos pequeños en un aula especializada o que dan clases particulares dentro o fuera de la clase habitual. El personal docente también incluye a los jefes de departamento cuyas obligaciones incluyen algunas horas de clase, pero excluye al personal no profesional que ayuda a los profesores en sus tareas de enseñanza, como los asistentes educativos y otros tipos de personal auxiliar.

\section{Metodología}

Los datos se refieren al año escolar 2011-2012 y se basan en la recopilación de estadísticas educativas UOE realizada por la OCDE en 2012 (para más información véase Anexo 3 en www.oecd.org/ edu/eag.htm).

El tamaño de las clases se ha obtenido dividiendo el número de estudiantes matriculados entre el número de clases. Se han excluido los programas de educación especial a fin de garantizar la posibilidad de comparación internacional de los datos. Este indicador comprende únicamente los programas habituales impartidos en educación primaria y secundaria inferior y excluye los subgrupos de estudiantes constituidos fuera de las clases normales.

La ratio alumnos-profesor se ha calculado dividiendo el número de estudiantes en equivalentes a tiempo completo en un nivel educativo determinado entre el número de profesores igualmente en equivalentes a tiempo completo en ese mismo nivel y en el mismo tipo de institución educativa.

\section{Nota sobre los datos de Israel}

Los datos estadísticos para Israel fueron proporcionados por las autoridades israelíes competentes bajo su responsabilidad. El uso de estos datos por parte de la OCDE se hace sin prejuzgar la situación de los Altos del Golán, Jerusalén Este y los asentamientos israelíes en Cisjordania de acuerdo con los términos del derecho internacional.

\section{Referencias}

Finn, J. (1998), Class Size and Students at Risk: What is Known? What is Next?, US Department of Education, Office of Educational Research and Improvement, National Institute on the Education of At-Risk Students, Washington, DC.

Hattie, J. (2009), Visible Learning: A Synthesis of over 800 Meta-Analyses Relating to Achievement, Routledge, Londres.

Krueger, A.B. (2002), «Economic considerations and class size», National Bureau of Economic Research Working Paper, No. 8875.

OECD (2014), TALIS 2013 Results: An International Perspective on Teaching and Learning, TALIS, OECD Publishing, París, http:// dx.doi.org/10.1787/9789264196261-en.

Piketty, T. y M. Valdenaire (2006), L'Impact de la taille des classes sur la réussite scolaire dans les écoles, collèges et lycées français : Estimations à partir du panel primaire 1997 et du panel secondaire 1995, Ministère de l'Éducation nationale, de l'Enseignement supérieur et de la Recherche, Direction de l'évaluation et de la prospective, París.

\section{Tablas del Indicador D2}

\section{StatLink 霜}

Tabla D2.1 Tamaño medio de la clase, por tipo de institución y nivel de educación (2012)

Tabla D2.2 Ratio alumnos-profesor en instituciones educativas (2012)

Tabla D2.3 Ratio alumnos-profesor por tipo de institución (2012)

WEB Tabla D2.4 Tamaño medio de la clase, por tipo de institución y nivel de educación (2000) 
Tabla D2.1. Tamaño medio de la clase, por tipo de institución y nivel de educación Cálculos basados en número de estudiantes y número de aulas

\begin{tabular}{|c|c|c|c|c|c|c|c|c|c|c|}
\hline & \multicolumn{5}{|c|}{ Educación primaria } & \multicolumn{5}{|c|}{$\begin{array}{l}\text { Educación secundaria inferior } \\
\text { (programas generales) }\end{array}$} \\
\hline & \multirow[b]{2}{*}{ 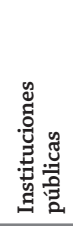 } & \multicolumn{3}{|c|}{ Instituciones privadas } & \multirow[b]{2}{*}{ 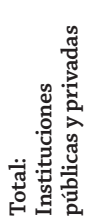 } & \multirow[b]{2}{*}{ 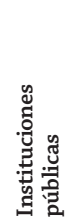 } & \multicolumn{3}{|c|}{ Instituciones privadas } & \multirow[b]{2}{*}{ 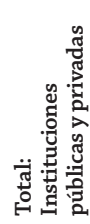 } \\
\hline & & 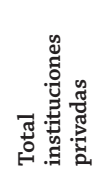 & 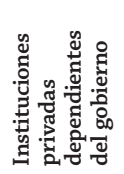 & 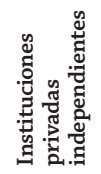 & & & 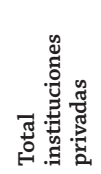 & 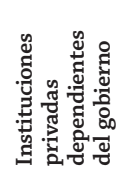 & 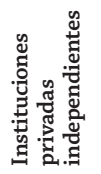 & \\
\hline & (1) & (2) & (3) & (4) & (5) & (6) & (7) & (8) & (9) & (10) \\
\hline Alemania & 21 & 21 & 21 & $\mathrm{x}(3)$ & 21 & 25 & 24 & 24 & $\mathrm{x}(8)$ & 24 \\
\hline Australia & 23 & 25 & 25 & $a$ & 24 & 23 & 25 & 25 & $\mathrm{a}$ & 24 \\
\hline Austria & 18 & 19 & 19 & $\mathrm{x}(3)$ & 18 & 21 & 22 & 22 & $\mathrm{x}(7)$ & 21 \\
\hline Bélgica & $\mathrm{m}$ & $\mathrm{m}$ & $\mathrm{m}$ & $\mathrm{m}$ & $\mathbf{m}$ & $\mathrm{m}$ & $\mathrm{m}$ & $\mathrm{m}$ & $\mathrm{m}$ & $\mathbf{m}$ \\
\hline Bélgica (Fr.) & 21 & 22 & 22 & $\mathrm{a}$ & 21 & $\mathrm{~m}$ & $\mathrm{~m}$ & $\mathrm{~m}$ & a & $\mathbf{m}$ \\
\hline Canadá & $\mathrm{m}$ & $\mathrm{m}$ & $\mathrm{m}$ & $\mathrm{m}$ & $\mathbf{m}$ & $\mathrm{m}$ & $\mathrm{m}$ & $\mathrm{m}$ & $\mathrm{m}$ & $\mathbf{m}$ \\
\hline Chile & 29 & 31 & 32 & 24 & 30 & 31 & 31 & 33 & 25 & 31 \\
\hline Corea & 25 & 29 & $\mathrm{a}$ & 29 & 25 & 34 & 33 & 33 & $\mathrm{a}$ & 33 \\
\hline Dinamarca & 21 & 18 & 18 & $\mathrm{x}(3)$ & 21 & 21 & 20 & 20 & $\mathrm{x}(8)$ & 21 \\
\hline Eslovenia & 19 & 22 & 22 & a & 19 & 20 & 18 & 18 & a & 20 \\
\hline España & 20 & 24 & 24 & 22 & 21 & 24 & 25 & 26 & 22 & 24 \\
\hline Estados Unidos & 22 & 18 & $\mathrm{a}$ & 18 & 21 & 28 & 20 & $\mathrm{a}$ & 20 & 27 \\
\hline Estonia & 17 & 15 & $\mathrm{a}$ & 15 & 17 & 16 & 12 & $\mathrm{a}$ & 12 & 16 \\
\hline Finlandia & 19 & 18 & 18 & $\mathrm{a}$ & 19 & 20 & 22 & 22 & a & 20 \\
\hline Francia & 23 & 23 & $\mathrm{x}(2)$ & $\mathrm{x}(2)$ & 23 & 25 & 26 & 26 & 14 & 25 \\
\hline Grecia & 17 & 20 & a & 20 & 17 & 22 & 24 & a & 24 & 22 \\
\hline Hungría & 21 & 20 & 20 & $\mathrm{a}$ & 21 & 21 & 20 & 20 & $\mathrm{a}$ & 21 \\
\hline Irlanda & 24 & $\mathrm{~m}$ & a & $\mathrm{m}$ & 24 & $\mathrm{~m}$ & $\mathrm{~m}$ & $\mathrm{~m}$ & $\mathrm{~m}$ & $\mathbf{m}$ \\
\hline Islandia & 19 & 15 & 15 & $\mathrm{a}$ & 19 & 20 & 13 & 13 & a & 20 \\
\hline Israel & 28 & 24 & 24 & a & 27 & 29 & 23 & 23 & a & 28 \\
\hline Italia & 19 & 20 & $\mathrm{a}$ & 20 & 19 & 22 & 22 & $\mathrm{a}$ & 22 & 22 \\
\hline Japón & 28 & 30 & a & 30 & 28 & 33 & 34 & a & 34 & 33 \\
\hline Luxemburgo & 15 & 20 & 17 & 20 & 16 & 19 & 20 & 20 & 20 & 19 \\
\hline México & 20 & 19 & a & 19 & 20 & 27 & 24 & $\mathrm{a}$ & 24 & 27 \\
\hline Noruega & $\mathrm{a}$ & $a$ & a & $\mathrm{a}$ & $\mathbf{a}$ & a & a & $a$ & $\mathrm{a}$ & $\mathbf{a}$ \\
\hline Nueva Zelanda & $\mathrm{m}$ & $\mathrm{m}$ & $\mathrm{m}$ & $\mathrm{m}$ & $\mathbf{m}$ & $\mathrm{m}$ & $\mathrm{m}$ & $\mathrm{m}$ & $\mathrm{m}$ & $\mathbf{m}$ \\
\hline Países Bajos ${ }^{1}$ & $\mathrm{x}(5)$ & $\mathrm{x}(5)$ & $\mathrm{x}(5)$ & $\mathrm{x}(5)$ & 23 & $\mathrm{~m}$ & $\mathrm{~m}$ & $\mathrm{~m}$ & $\mathrm{~m}$ & $\mathbf{m}$ \\
\hline Polonia & 19 & 12 & 11 & 12 & 18 & 23 & 18 & 23 & 16 & 22 \\
\hline Portugal & 21 & 21 & 23 & 20 & 21 & 22 & 25 & 24 & 26 & 22 \\
\hline Reino Unido & 26 & 17 & 26 & 15 & 25 & 20 & 18 & 20 & 11 & 19 \\
\hline República Checa & 20 & 15 & 15 & a & 20 & 21 & 19 & 19 & a & 21 \\
\hline República Eslovaca & 17 & 16 & 16 & $\mathrm{a}$ & 17 & 20 & 18 & 18 & a & 20 \\
\hline Suecia & $\mathrm{m}$ & $\mathrm{m}$ & $\mathrm{m}$ & $\mathrm{m}$ & $\mathbf{m}$ & $\mathrm{m}$ & $\mathrm{m}$ & $\mathrm{m}$ & $\mathrm{m}$ & $\mathbf{m}$ \\
\hline Suiza & $\mathrm{m}$ & $\mathrm{m}$ & $\mathrm{m}$ & $\mathrm{m}$ & $\mathbf{m}$ & $\mathrm{m}$ & $\mathrm{m}$ & $\mathrm{m}$ & $\mathrm{m}$ & $\mathbf{m}$ \\
\hline Turquía & 24 & 20 & $\mathrm{a}$ & 20 & 24 & 29 & 20 & $\mathrm{a}$ & 20 & 28 \\
\hline
\end{tabular}

\begin{tabular}{|l|l|l|l|l|l|l|l|l|l|l|l|} 
Media OCDE & 21 & 21 & 21 & 20 & $\mathbf{2 1}$ & 24 & 22 & 22 & 21 & $\mathbf{2 4}$ \\
Media UE21 & 20 & 19 & 19 & 18 & $\mathbf{2 0}$ & 21 & 21 & 21 & 18 & $\mathbf{2 1}$ \\
\hline
\end{tabular}

\begin{tabular}{|c|c|c|c|c|c|c|c|c|c|c|}
\hline $\begin{array}{l}\text { Arabia Saudí } \\
\text { Argentina }\end{array}$ & $\begin{array}{l}\mathrm{m} \\
\mathrm{m}\end{array}$ & $\begin{array}{l}\mathrm{m} \\
\mathrm{m}\end{array}$ & $\begin{array}{l}\mathrm{m} \\
\mathrm{m}\end{array}$ & $\begin{array}{l}\mathrm{m} \\
\mathrm{m}\end{array}$ & $\begin{array}{l}\mathbf{m} \\
\mathbf{m}\end{array}$ & $\begin{array}{l}\mathrm{m} \\
\mathrm{m}\end{array}$ & $\begin{array}{l}\mathrm{m} \\
\mathrm{m}\end{array}$ & $\begin{array}{l}\mathrm{m} \\
\mathrm{m}\end{array}$ & $\begin{array}{l}\mathrm{m} \\
\mathrm{m}\end{array}$ & $\begin{array}{l}\text { m } \\
\text { m }\end{array}$ \\
\hline Bù Brasil & 25 & 18 & $\mathrm{a}$ & 18 & 24 & 29 & 25 & $\mathrm{a}$ & 25 & 28 \\
\hline 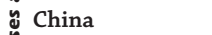 & 38 & 44 & $x(2)$ & $x(2)$ & 38 & 52 & 52 & $x(7)$ & $x(7)$ & 52 \\
\hline Colombia & $\mathrm{m}$ & $\mathrm{m}$ & $\mathrm{m}$ & $\mathrm{m}$ & $\mathbf{m}$ & $\mathrm{m}$ & $\mathrm{m}$ & $\mathrm{m}$ & $\mathrm{m}$ & m \\
\hline Federación Rusa & 18 & 12 & $\mathrm{a}$ & 12 & 18 & 18 & 11 & $\mathrm{a}$ & 11 & 18 \\
\hline India & $\mathrm{m}$ & $\mathrm{m}$ & $\mathrm{m}$ & $\mathrm{m}$ & $\mathbf{m}$ & $\mathrm{m}$ & $\mathrm{m}$ & $\mathrm{m}$ & $\mathrm{m}$ & $\mathbf{m}$ \\
\hline Indonesia & 24 & 21 & $\mathrm{a}$ & 21 & 23 & 36 & 31 & a & 31 & 34 \\
\hline Letonia & 16 & 9 & $\mathrm{a}$ & 9 & 16 & 15 & 8 & $\mathrm{a}$ & 8 & 15 \\
\hline Sudáfrica & $\mathrm{m}$ & $\mathrm{m}$ & $\mathrm{m}$ & $\mathrm{m}$ & $\mathbf{m}$ & $\mathrm{m}$ & $\mathrm{m}$ & $\mathrm{m}$ & $\mathrm{m}$ & m \\
\hline Media G20 & 24 & 23 & $\sim$ & $\sim$ & 24 & 28 & 26 & $\sim$ & $\sim$ & 28 \\
\hline
\end{tabular}

1. Excluidos los programas para estudiantes con necesidades educativas especiales e incluido en parte CINE 0.

Fuentes: OCDE. Arabia Saudí, Argentina, China, Colombia, India, Indonesia, Sudáfrica: Instituto de Estadística de la UNESCO. Letonia: Eurostat. Para ver notas, consulte Anexo 3 (www.oecd.org/edu/eag.htm).

Para obtener más información acerca de los símbolos utilizados en lugar de los datos que faltan, consulte la Guía del lector.

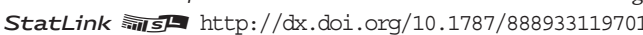


Tabla D2.2. Ratio alumnos-profesor en instituciones educativas (2012)

Por nivel educativo, cálculos basados en equivalentes a tiempo completo

\begin{tabular}{|c|c|c|c|c|c|c|c|c|c|c|}
\hline & \multicolumn{2}{|c|}{ Educación infantil } & \multirow[b]{2}{*}{ 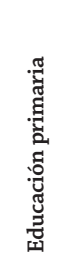 } & \multicolumn{3}{|c|}{ Educación secundaria } & \multirow[b]{2}{*}{ 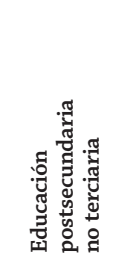 } & \multicolumn{3}{|c|}{ Educación terciaria } \\
\hline & 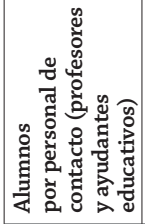 & 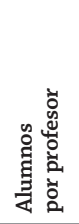 & & 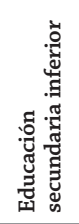 & 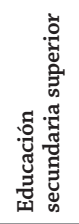 & 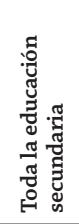 & & 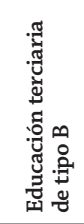 & 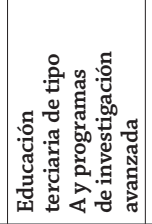 & 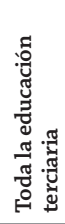 \\
\hline & (1) & (2) & (3) & (4) & (5) & (6) & (7) & (8) & (9) & (10) \\
\hline Alemania & 10 & 12 & 16 & 14 & 14 & 14 & 13 & 14 & 11 & 12 \\
\hline Australia ${ }^{1,2}$ & $\mathrm{~m}$ & $\mathrm{~m}$ & 16 & $\mathrm{x}(6)$ & $x(6)$ & 12 & $\mathrm{~m}$ & $\mathrm{~m}$ & 14 & $\mathrm{~m}$ \\
\hline Austria & 10 & 14 & 12 & 9 & 10 & 9 & 10 & $\mathrm{n}$ & 17 & 17 \\
\hline Bélgica $^{3}$ & 16 & 16 & 13 & 8 & 10 & 9 & $\mathrm{x}(5)$ & $\mathrm{x}(10)$ & $\mathrm{x}(10)$ & 21 \\
\hline Canadá 2,4 & $\mathrm{~m}$ & $\mathrm{x}(4)$ & $\mathrm{x}(4)$ & 16 & 14 & 14 & $\mathrm{~m}$ & $\mathrm{~m}$ & 14 & $\mathrm{~m}$ \\
\hline Chile & 11 & 22 & 22 & 22 & 24 & 23 & $\mathrm{a}$ & $\mathrm{m}$ & $\mathrm{m}$ & $\mathrm{m}$ \\
\hline Corea & 16 & 16 & 18 & 18 & 15 & 17 & $\mathrm{a}$ & $\mathrm{m}$ & $\mathrm{m}$ & $\mathrm{m}$ \\
\hline Dinamarca & $\mathrm{m}$ & $\mathrm{m}$ & $\mathrm{x}(4)$ & 12 & $\mathrm{~m}$ & $\mathrm{~m}$ & $\mathrm{~m}$ & $\mathrm{~m}$ & $\mathrm{~m}$ & $\mathrm{~m}$ \\
\hline Eslovenia & 9 & 9 & 16 & 8 & 14 & 11 & $\mathrm{x}(5)$ & $\mathrm{x}(10)$ & 16 & 18 \\
\hline España & $\mathrm{m}$ & 13 & 13 & 11 & 10 & 10 & a & 10 & 12 & 12 \\
\hline Estados Unidos & 10 & 12 & 15 & 15 & 15 & 15 & 16 & $\mathrm{x}(10)$ & $\mathrm{x}(10)$ & 16 \\
\hline Estonia & $\mathrm{m}$ & 7 & 13 & 10 & 14 & 12 & $\mathrm{x}(5)$ & $\mathrm{m}$ & $\mathrm{m}$ & $\mathrm{m}$ \\
\hline Finlandia & $\mathrm{m}$ & 11 & 14 & 9 & 16 & 13 & $\mathrm{x}(5)$ & $\mathrm{n}$ & 14 & 14 \\
\hline Francia $^{3}$ & 14 & 22 & 19 & 15 & 10 & 13 & $\mathrm{x}(8)$ & 17 & 15 & 16 \\
\hline Grecia & $\mathrm{m}$ & $\mathrm{m}$ & 9 & $\mathrm{~m}$ & $\mathrm{~m}$ & $\mathrm{~m}$ & $\mathrm{~m}$ & $\mathrm{~m}$ & $\mathrm{~m}$ & $\mathrm{~m}$ \\
\hline Hungría & $\mathrm{m}$ & 11 & 11 & 11 & 12 & 12 & 14 & 21 & 15 & 15 \\
\hline Irlanda ${ }^{2}$ & $\mathrm{~m}$ & $\mathrm{~m}$ & 16 & $\mathrm{x}(6)$ & $\mathrm{x}(6)$ & 15 & $\mathrm{x}(6)$ & $\mathrm{x}(10)$ & $\mathrm{x}(10)$ & 19 \\
\hline Islandia & 6 & 6 & 10 & 11 & 11 & 11 & $x(5,10)$ & $\mathrm{x}(10)$ & $\mathrm{x}(10)$ & 11 \\
\hline Israel & 13 & 27 & 15 & 14 & 11 & 12 & $\mathrm{~m}$ & $\mathrm{~m}$ & $\mathrm{~m}$ & $\mathrm{~m}$ \\
\hline Italia $^{2}$ & $\mathrm{~m}$ & 12 & 12 & 12 & 13 & 12 & $\mathrm{~m}$ & 10 & 19 & 19 \\
\hline Japón & 15 & 15 & 18 & 14 & 12 & 13 & $\mathrm{x}(5,10)$ & $\mathrm{m}$ & $\mathrm{m}$ & $\mathrm{m}$ \\
\hline Luxemburgo & $\mathrm{m}$ & 11 & 9 & 11 & 8 & 9 & $\mathrm{~m}$ & $\mathrm{~m}$ & $\mathrm{~m}$ & $\mathrm{~m}$ \\
\hline México & 25 & 25 & 28 & 32 & 27 & 30 & $\mathrm{a}$ & 16 & 15 & 15 \\
\hline Noruega & $\mathrm{m}$ & $\mathrm{m}$ & 10 & 10 & 10 & 10 & $\mathrm{x}(5)$ & $\mathrm{x}(10)$ & $\mathrm{x}(10)$ & 9 \\
\hline Nueva Zelanda & $\mathrm{m}$ & 7 & 16 & 16 & 14 & 15 & 22 & 17 & 18 & 18 \\
\hline Países Bajos & 14 & 16 & 16 & 16 & 19 & 17 & 21 & 15 & 15 & 15 \\
\hline Polonia & $\mathrm{m}$ & 16 & 11 & 10 & 11 & 10 & 16 & 8 & 15 & 15 \\
\hline Portugal & $\mathrm{m}$ & 16 & 12 & 10 & 8 & 9 & $\mathrm{x}(5,10)$ & $\mathrm{x}(10)$ & $\mathrm{x}(10)$ & 15 \\
\hline Reino Unido & 12 & 19 & 21 & 14 & 17 & 16 & a & $\mathrm{x}(10)$ & $\mathrm{x}(10)$ & 20 \\
\hline República Checa & 14 & 14 & 19 & 11 & 11 & 11 & 18 & 17 & 22 & 21 \\
\hline República Eslovaca & 12 & 12 & 17 & 13 & 14 & 13 & 11 & 9 & 14 & 14 \\
\hline Suecia & 6 & 6 & 12 & 11 & 13 & 12 & 30 & $\mathrm{x}(10)$ & 11 & 11 \\
\hline Suiza & $\mathrm{m}$ & $\mathrm{m}$ & $\mathrm{m}$ & $\mathrm{m}$ & $\mathrm{m}$ & $\mathrm{m}$ & $\mathrm{m}$ & $\mathrm{m}$ & $\mathrm{m}$ & $\mathrm{m}$ \\
\hline Turquía & $\mathrm{m}$ & 21 & 20 & 20 & 16 & 18 & a & 53 & 16 & 20 \\
\hline Media OCDE & 13 & 14 & 15 & 14 & 14 & 13 & 17 & 15 & 15 & 14 \\
\hline Media UE21 & 11 & 13 & 14 & 11 & 13 & 12 & 17 & 13 & 15 & 16 \\
\hline Arabia Saudí & $\mathrm{m}$ & 11 & 11 & 10 & 11 & 10 & $\mathrm{a}$ & $x(10)$ & $\mathrm{x}(10)$ & 21 \\
\hline Argentina & $\mathrm{m}$ & $\mathrm{m}$ & $\mathrm{m}$ & $\mathrm{m}$ & $\mathrm{m}$ & $\mathrm{m}$ & a & $\mathrm{m}$ & $\mathrm{m}$ & $\mathrm{m}$ \\
\hline Brasil & 12 & 17 & 22 & 19 & 17 & 18 & $\mathrm{a}$ & $\mathrm{x}(10)$ & $\mathrm{x}(10)$ & 27 \\
\hline China & $\mathrm{m}$ & $\mathrm{m}$ & 17 & 13 & 16 & 14 & $\mathrm{~m}$ & $\mathrm{~m}$ & $\mathrm{~m}$ & $\mathrm{~m}$ \\
\hline Colombia & $\mathrm{m}$ & $\mathrm{m}$ & $\mathrm{m}$ & $\mathrm{m}$ & $\mathrm{m}$ & $\mathrm{m}$ & $\mathrm{m}$ & $\mathrm{m}$ & $\mathrm{m}$ & $\mathrm{m}$ \\
\hline Federación Rusa² & $\mathrm{m}$ & $\mathrm{m}$ & 20 & 9 & 15 & 10 & $\mathrm{x}(6)$ & 11 & 13 & 12 \\
\hline India & $\mathrm{m}$ & $\mathrm{m}$ & $\mathrm{m}$ & $\mathrm{m}$ & $\mathrm{m}$ & $\mathrm{m}$ & $\mathrm{m}$ & $\mathrm{m}$ & $\mathrm{m}$ & $\mathrm{m}$ \\
\hline Indonesia & $\mathrm{m}$ & 11 & 11 & 8 & 11 & 9 & 17 & 20 & 20 & 20 \\
\hline Letonia & 23 & 26 & 25 & 22 & 23 & 22 & a & $\mathrm{x}(10)$ & $\mathrm{x}(10)$ & 31 \\
\hline Sudáfrica & $\mathrm{m}$ & $\mathrm{m}$ & $\mathrm{m}$ & $\mathrm{m}$ & $\mathrm{m}$ & $\mathrm{m}$ & a & $\mathrm{m}$ & $\mathrm{m}$ & $\mathrm{m}$ \\
\hline Media G20 & 15 & 17 & 19 & 16 & 16 & 15 & $\sim$ & $\sim$ & $\sim$ & $\sim$ \\
\hline
\end{tabular}

1. Incluye solo programas generales en educación secundaria superior.

2. Solo instituciones públicas (Australia, en educación terciaria de tipo A y programas de investigación avanzada; Canadá, solo en educación terciaria; Irlanda, solo en educación terciaria; Italia, de educación infantil a secundaria; Federación Rusa, solo en primaria y secundaria).

3. Excluye instituciones privadas independientes.

4. Año de referencia 2011.

Fuentes: OCDE. Arabia Saudí, Argentina, China, Colombia, India, Indonesia, Sudáfrica: Instituto de Estadística de la UNESCO. Letonia: Eurostat. Para ver notas, consulte Anexo 3 (www.oecd.org/edu/eag.htm).

Para obtener más información acerca de los símbolos utilizados en lugar de los datos que faltan, consulte la Guía del lector.

StatLink 젝ㄴ http://dx.doi.org/10.1787/888933119720 
Tabla D2.3. Ratio alumnos-profesor por tipo de institución (2012)

Por nivel educativo, cálculos basados en equivalentes a tiempo completo

\begin{tabular}{|c|c|c|c|c|c|c|c|c|c|c|c|c|}
\hline & \multicolumn{4}{|c|}{ Educación secundaria inferior } & \multicolumn{4}{|c|}{ Educación secundaria superior } & \multicolumn{4}{|c|}{ Toda la educación secundaria } \\
\hline & \multirow[b]{2}{*}{ Públicas } & \multicolumn{3}{|c|}{ Privadas } & \multirow[b]{2}{*}{ Públicas } & \multicolumn{3}{|c|}{ Privadas } & \multirow[b]{2}{*}{ Públicas } & \multicolumn{3}{|c|}{ Privadas } \\
\hline & & 总 & 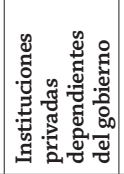 & 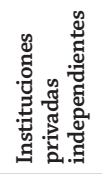 & & 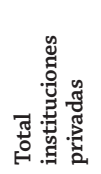 & 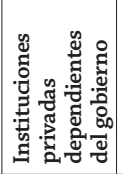 & 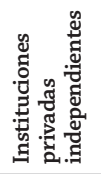 & & 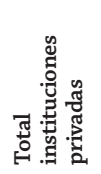 & 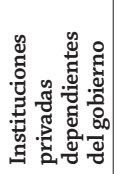 & 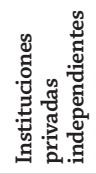 \\
\hline & (1) & (2) & (3) & (4) & (5) & (6) & (7) & (8) & (9) & (10) & (11) & (12) \\
\hline Alemania & 14 & 13 & 13 & $\mathrm{x}(3)$ & 14 & 13 & 13 & $x(7)$ & 14 & 13 & 13 & $\mathrm{x}(11)$ \\
\hline Australia $^{1}$ & $\mathrm{x}(9)$ & $\mathrm{x}(10)$ & $\mathrm{x}(11)$ & a & $\mathrm{x}(9)$ & $\mathrm{x}(10)$ & $\mathrm{x}(11)$ & $\mathrm{a}$ & 12 & 12 & 12 & a \\
\hline Austria & 9 & 10 & 10 & $\mathrm{x}(2)$ & 10 & 8 & 8 & $\mathrm{x}(6)$ & 9 & 9 & 9 & $\mathrm{x}(9)$ \\
\hline Bélgica $^{2}$ & 8 & 9 & 9 & $\mathrm{~m}$ & 11 & 10 & 10 & $\mathrm{~m}$ & 10 & 9 & 9 & $\mathrm{~m}$ \\
\hline Canadá $^{3,4,5}$ & $\mathrm{~m}$ & $\mathrm{~m}$ & $\mathrm{~m}$ & $\mathrm{~m}$ & 14 & 12 & $\mathrm{x}(6)$ & $\mathrm{x}(6)$ & 14 & 12 & $\mathrm{x}(10)$ & $\mathrm{x}(10)$ \\
\hline Chile & 21 & 24 & 25 & 17 & 23 & 24 & 26 & 15 & 22 & 24 & 26 & 16 \\
\hline Corea & 18 & 19 & 19 & $\mathrm{a}$ & 15 & 16 & 16 & a & 16 & 17 & 17 & a \\
\hline Dinamarca $^{4}$ & 12 & 12 & 12 & $\mathrm{~m}$ & $\mathrm{~m}$ & $\mathrm{~m}$ & $\mathrm{~m}$ & $\mathrm{~m}$ & $\mathrm{~m}$ & $\mathrm{~m}$ & $\mathrm{~m}$ & $\mathrm{~m}$ \\
\hline Eslovenia $^{2}$ & 8 & 4 & 4 & $\mathrm{n}$ & 14 & 14 & 11 & 28 & 11 & 13 & 10 & 28 \\
\hline España & 9 & 15 & 15 & 16 & 9 & 14 & 15 & 13 & 9 & 15 & 15 & 14 \\
\hline Estados Unidos & 16 & 11 & a & 11 & 16 & 11 & a & 11 & 16 & 11 & $\mathrm{a}$ & 11 \\
\hline Estonia & 10 & 9 & a & 9 & 14 & 13 & $\mathrm{a}$ & 13 & 12 & 11 & $\mathrm{a}$ & 11 \\
\hline Finlandia $^{6}$ & 9 & 9 & 9 & $\mathrm{a}$ & 16 & 18 & 18 & a & 12 & 17 & 17 & a \\
\hline Francia & 15 & 17 & 17 & $\mathrm{~m}$ & 9 & 12 & 12 & $\mathrm{~m}$ & 12 & 14 & 14 & $\mathrm{~m}$ \\
\hline Grecia & $\mathrm{m}$ & $\mathrm{m}$ & $\mathrm{m}$ & $\mathrm{m}$ & $\mathrm{m}$ & $\mathrm{m}$ & $\mathrm{m}$ & $\mathrm{m}$ & $\mathrm{m}$ & $\mathrm{m}$ & $\mathrm{m}$ & $\mathrm{m}$ \\
\hline Hungría & 11 & 10 & 10 & $\mathrm{a}$ & 12 & 13 & 13 & a & 12 & 12 & 12 & $\mathrm{a}$ \\
\hline Irlanda $^{2}$ & $\mathrm{x}(9)$ & $\mathrm{m}$ & a & $\mathrm{m}$ & $\mathrm{x}(9)$ & $\mathrm{m}$ & a & $\mathrm{m}$ & 15 & $\mathrm{~m}$ & a & $\mathrm{m}$ \\
\hline Islandia $^{6}$ & 11 & 4 & 4 & $\mathrm{n}$ & 11 & 12 & 12 & $\mathrm{n}$ & 11 & 11 & 11 & $\mathrm{n}$ \\
\hline Israel & 14 & 7 & 7 & a & 11 & a & a & a & 12 & 7 & 7 & $\mathrm{a}$ \\
\hline Italia & 12 & $\mathrm{~m}$ & $\mathrm{a}$ & $\mathrm{m}$ & 13 & $\mathrm{~m}$ & a & $\mathrm{m}$ & 12 & $\mathrm{~m}$ & $\mathrm{a}$ & $\mathrm{m}$ \\
\hline Japón $^{6}$ & 14 & 12 & a & 12 & 11 & 14 & $\mathrm{a}$ & 14 & 13 & 14 & $\mathrm{a}$ & 14 \\
\hline Luxemburgo & 10 & 18 & 10 & $\mathrm{x}(12)$ & 9 & 4 & 7 & 3 & 9 & 7 & 8 & 6 \\
\hline México & 35 & 19 & a & 19 & 32 & 15 & a & 15 & 34 & 17 & $\mathrm{a}$ & 17 \\
\hline Noruega & 10 & $\mathrm{~m}$ & $\mathrm{~m}$ & $\mathrm{~m}$ & 10 & $\mathrm{~m}$ & $\mathrm{~m}$ & $\mathrm{~m}$ & 10 & $\mathrm{~m}$ & $\mathrm{~m}$ & $\mathrm{~m}$ \\
\hline Nueva Zelanda & 17 & 13 & a & 13 & 14 & 12 & 16 & 10 & 15 & 12 & 16 & 11 \\
\hline Países Bajos & 16 & 15 & a & 15 & 19 & 19 & a & 19 & 17 & 18 & a & 18 \\
\hline Polonia & 10 & 9 & 11 & 8 & 11 & 11 & 12 & 11 & 10 & 10 & 12 & 10 \\
\hline Portugal $^{7}$ & 9 & 13 & 13 & 13 & 8 & 7 & 11 & 6 & 9 & 9 & 12 & 7 \\
\hline Reino Unido & 11 & 22 & 47 & 5 & 10 & 28 & 38 & 7 & 11 & 26 & 40 & 6 \\
\hline República Checa & 11 & 9 & 9 & a & 11 & 13 & 13 & a & 11 & 12 & 12 & a \\
\hline República Eslovaca & 13 & 12 & 12 & $\mathrm{n}$ & 14 & 12 & 12 & $\mathrm{n}$ & 13 & 12 & 12 & $\mathrm{n}$ \\
\hline Suecia & 11 & 12 & 12 & $\mathrm{n}$ & 13 & 15 & 15 & $\mathrm{n}$ & 12 & 14 & 14 & $\mathrm{n}$ \\
\hline Suiza & $\mathrm{m}$ & $\mathrm{m}$ & $\mathrm{m}$ & $\mathrm{m}$ & $\mathrm{m}$ & $\mathrm{m}$ & $\mathrm{m}$ & $\mathrm{m}$ & $\mathrm{m}$ & $\mathrm{m}$ & $\mathrm{m}$ & $\mathrm{m}$ \\
\hline Turquía & 21 & 9 & a & 9 & 17 & 7 & $\mathrm{a}$ & 7 & 19 & 8 & $\mathrm{a}$ & 8 \\
\hline
\end{tabular}

\begin{tabular}{|c|c|c|c|c|c|c|c|c|c|c|c|c|}
\hline $\begin{array}{l}\text { Media OCDE } \\
\text { Media UE21 }\end{array}$ & $\begin{array}{l}13 \\
11\end{array}$ & $\begin{array}{l}13 \\
12\end{array}$ & $\begin{array}{l}14 \\
14\end{array}$ & $\begin{array}{r}9 \\
11\end{array}$ & $\begin{array}{l}13 \\
12\end{array}$ & $\begin{array}{l}13 \\
13\end{array}$ & $\begin{array}{l}15 \\
14\end{array}$ & $\begin{array}{l}10 \\
12\end{array}$ & $\begin{array}{l}13 \\
12\end{array}$ & $\begin{array}{l}13 \\
13\end{array}$ & $\begin{array}{l}14 \\
14\end{array}$ & $\begin{array}{l}10 \\
12\end{array}$ \\
\hline Arabia Saudí & 10 & 11 & $\mathrm{x}(2)$ & $\mathrm{x}(2)$ & 10 & 15 & $\mathrm{x}(6)$ & $\mathrm{x}(6)$ & 10 & 13 & $\mathrm{x}(10)$ & $\mathrm{x}(10)$ \\
\hline Argentina & $\mathrm{m}$ & $\mathrm{m}$ & $\mathrm{m}$ & $\mathrm{m}$ & $\mathrm{m}$ & $\mathrm{m}$ & $\mathrm{m}$ & $\mathrm{m}$ & $\mathrm{m}$ & $\mathrm{m}$ & $\mathrm{m}$ & $\mathrm{m}$ \\
\hline Brasil & 21 & 13 & a & 13 & 18 & 12 & a & 12 & 19 & 12 & a & 12 \\
\hline China & $\mathrm{m}$ & 13 & $\mathrm{x}(2)$ & $x(2)$ & $\mathrm{m}$ & 15 & $\mathrm{x}(6)$ & $\mathrm{x}(6)$ & $\mathrm{m}$ & 14 & $\mathrm{x}(10)$ & $x(10)$ \\
\hline Colombia & $\mathrm{m}$ & $\mathrm{m}$ & $\mathrm{m}$ & $\mathrm{m}$ & $\mathrm{m}$ & $\mathrm{m}$ & $\mathrm{m}$ & $\mathrm{m}$ & $\mathrm{m}$ & $\mathrm{m}$ & $\mathrm{m}$ & $\mathrm{m}$ \\
\hline Federación Rusa & 9 & 4 & a & 4 & 15 & 20 & $\mathrm{a}$ & 20 & 10 & 6 & a & 6 \\
\hline India & $\mathrm{m}$ & $\mathrm{m}$ & $\mathrm{m}$ & $\mathrm{m}$ & $\mathrm{m}$ & $\mathrm{m}$ & $\mathrm{m}$ & $\mathrm{m}$ & $\mathrm{m}$ & $\mathrm{m}$ & $\mathrm{m}$ & $\mathrm{m}$ \\
\hline Indonesia & 21 & 23 & a & 23 & 19 & 28 & a & 28 & 20 & 25 & a & 25 \\
\hline Letonia & $\mathrm{m}$ & $\mathrm{m}$ & $\mathrm{m}$ & $\mathrm{m}$ & $\mathrm{m}$ & $\mathrm{m}$ & $\mathrm{m}$ & $\mathrm{m}$ & $\mathrm{m}$ & $\mathrm{m}$ & $\mathrm{m}$ & $\mathrm{m}$ \\
\hline Sudáfrica & $\mathrm{m}$ & $\mathrm{m}$ & $\mathrm{m}$ & $\mathrm{m}$ & $\mathrm{m}$ & $\mathrm{m}$ & $\mathrm{m}$ & $\mathrm{m}$ & $\mathrm{m}$ & $\mathrm{m}$ & $\mathrm{m}$ & $\mathrm{m}$ \\
\hline Media G20 & 13 & 15 & $\sim$ & $\sim$ & 13 & 15 & $\sim$ & $\sim$ & 13 & 15 & $\sim$ & $\sim$ \\
\hline
\end{tabular}

1. Incluye solo programas generales de educación secundaria inferior y superior.

2. La educación secundaria superior incluye la educación postsecundaria no terciaria.

3. Año de referencia 2011.

4. La educación secundaria inferior incluye educación primaria.

5. La educación secundaria inferior incluye educación infantil.

6. La educación secundaria superior incluye programas de educación postsecundaria.

7. Los datos se refieren a profesores (número de personas) en primaria, secundaria y postsecundaria no terciaria.

Fuentes: OCDE. Arabia Saudí, Argentina, China, Colombia, India, Indonesia, Sudáfrica: Instituto de Estadística de la UNESCO. Letonia: Eurostat. Para ver notas, consulte Anexo 3 (www.oecd.org/edu/eag.htm).

Para obtener más información acerca de los símbolos utilizados en lugar de los datos que faltan, consulte la Guía del lector.

StatLink 제에 $\mathrm{http}: / /$ dx.doi.org/10.1787/888933119739 



\section{¿CUÁL ES EL SALARIO DE LOS PROFESORES?}

- Como media en los países de la OCDE, un profesor de educación infantil gana un $80 \%$ del salario de un trabajador de 25 a 64 años de edad con educación terciaria empleado durante todo el año a tiempo completo. El sueldo de un profesor de educación primaria supone un $85 \%$ de ese punto de referencia salarial, porcentaje que asciende a un $88 \%$ para un profesor de educación secundaria inferior, y a un $92 \%$ para un profesor de educación secundaria superior.

- Los salarios reglamentarios de los profesores con 15 años de experiencia alcanzan una media de 37.350 dólares estadounidenses en educación infantil, de 39.024 dólares estadounidenses en educación primaria, de 40.570 dólares estadounidenses en secundaria inferior y de 42.861 dólares estadounidenses en secundaria superior.

\section{Gráfico D3.1. Salarios de los profesores en relación con los ingresos de los trabajadores con educación terciaria de 25 a 64 años de edad (2012) \\ Salarios de los profesores de educación secundaria inferior, en instituciones públicas}

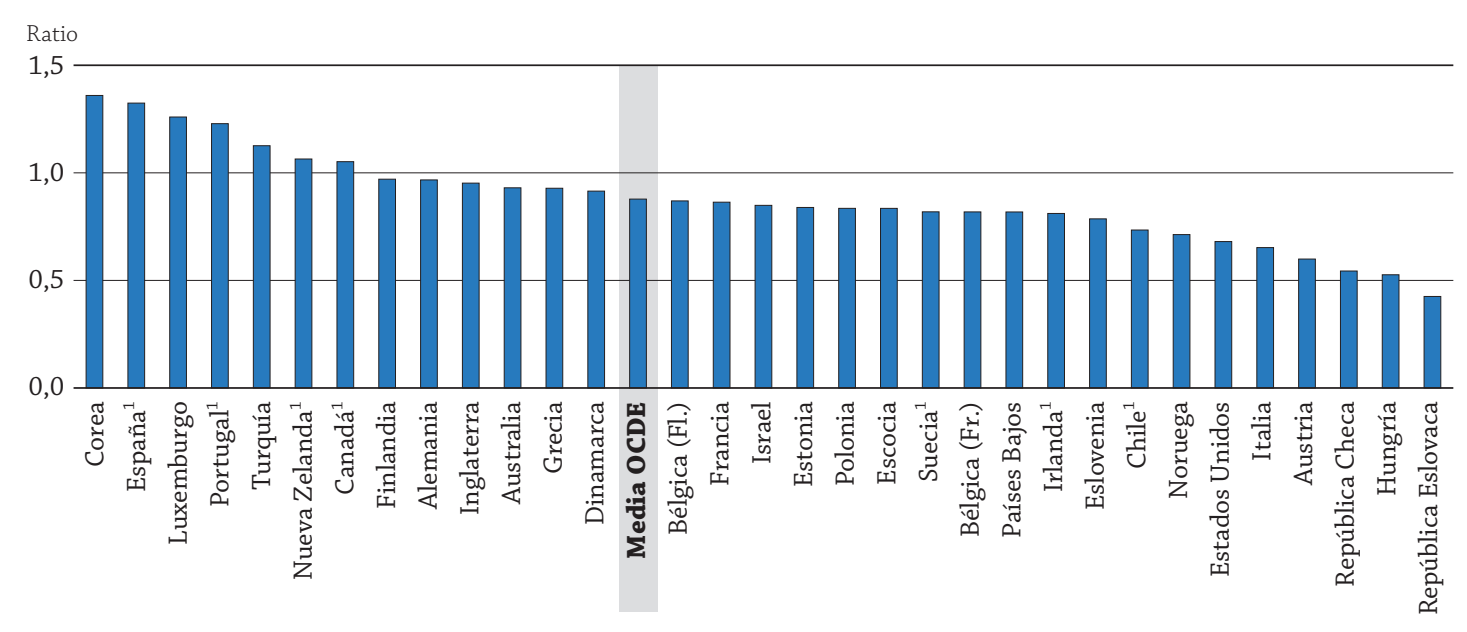

Notas: Los salarios de los profesores se refieren al salario real, incluyendo las primas y las bonificaciones, de los profesores de 25 a 64 años, o a la retribución reglamentaria después de 15 años de experiencia y con formación mínima. Consúltese la Tabla D3.2. para más detalles sobre la metodología.

1. Año de referencia 2011.

Los países están clasificados en orden descendente de la ratio entre los salarios de los profesores y los ingresos de los trabajadores con educación terciaria, a tiempo completo, todo el año, de 25 a 64 años de edad.

Fuente: OCDE. Tabla D3.2. Para ver notas, consulte Anexo 3 (www.oecd.org/edu/eag.htm).

StatLink 젶ㄴ $h$ htp://dx.doi.org/10.1787/888933119929

\section{Contexto}

Los salarios de los profesores representan el capítulo principal del presupuesto de la educación formal y repercuten directamente en el atractivo de la profesión docente. Estos aspectos influyen en la decisión de acceder a la formación como profesor, dedicarse a la docencia tras la graduación (ya que las decisiones que los graduados toman sobre su carrera profesional se asocian a los ingresos relativos que se obtienen en la docencia y en otras profesiones, y a sus probabilidades de crecimiento a largo plazo), volver a la profesión docente después de una interrupción en la carrera profesional, y continuar o no siendo profesor (puesto que, por regla general, cuanto más altos son los salarios, menos personas abandonan la profesión) (OECD, 2005). La creciente deuda nacional, estimulada por las respuestas de los gobiernos a la crisis económica de finales de 2008, ha ejercido presión sobre los responsables de las políticas para que reduzcan los gastos gubernamentales, sobre todo en nóminas públicas. Los salarios y las condiciones laborales son importantes para atraer, desarrollar y conservar profesores altamente cualificados. Por consiguiente, dichas retribuciones constituyen un elemento clave en manos de los responsables políticos que traten de mantener tanto una enseñanza de calidad como un presupuesto de educación sostenible (véanse Indicadores B6 y B7). 


\section{Otros resultados}

- En la mayoría de los países de la OCDE, los salarios de los profesores aumentan con el nivel educativo que imparten. Por ejemplo, en Bélgica, Dinamarca, Finlandia, Indonesia y Polonia, el salario de un profesor de secundaria superior, con un mínimo de 15 años de experiencia, y en Suiza (con un mínimo de 11 años de experiencia), es al menos un $25 \%$ mayor que el de un profesor de educación infantil con la misma experiencia.

- Los salarios máximos de la escala son, como media, un $58 \%$, un $61 \%$, un $61 \%$ y un $62 \%$ más altos que los iniciales en educación infantil, primaria y secundaria inferior y superior, respectivamente. La diferencia tiende a incrementarse cuando hacen falta muchos años de experiencia para avanzar en la escala retributiva. En los países en los que alcanzar el extremo superior de la escala requiere 30 años o más, las retribuciones a ese nivel son por término medio un $80 \%$ superiores que al inicio.

- El salario máximo percibido por los profesores con las máximas cualificaciones en el extremo más alto de la escala retributiva es por término medio de 48.937 dólares estadounidenses en el nivel de educación infantil, de 50.984 dólares estadounidenses en el nivel de educación primaria, de 53.686 dólares estadounidenses en el nivel de educación secundaria inferior y de 55.119 dólares estadounidenses en el nivel de educación secundaria superior. No obstante, la prima salarial para un nivel más alto de cualificación varía de unos países a otros. Los profesores de primaria con la máxima cualificación en Eslovenia, Israel, México y Polonia, por ejemplo, ganan al menos un $30 \%$ más que los profesores de un centro de educación primaria con cualificación mínima y similar experiencia. No obstante, aproximadamente en un tercio de los países con datos disponibles no hay diferencias.

- En 10 de los 24 países con datos disponibles, el salario anual medio de los profesores de educación secundaria superior, incluyendo bonificaciones y complementos, es al menos un $10 \%$ superior a los salarios reglamentarios de los profesores de educación secundaria superior con 15 años de experiencia.

\section{Tendencias}

Los salarios de los profesores en términos reales han aumentado entre 2000 y 2012 en casi todos los países con datos disponibles, con la excepción de Francia, Grecia y Japón.

No obstante, en la mayoría de los países, dichos salarios aumentaron menos desde 2005 que durante el periodo de 2000 a 2005. La crisis económica de 2008 ha influido de manera directa sobre los salarios de los profesores, que fueron recortados o congelados en algunos países. Como consecuencia, el número de países que han registrado un aumento en los salarios de los profesores en términos reales entre 2008 y 2012 se ha reducido a menos de la mitad de los países de la OCDE. 


\section{Análisis}

\section{Salarios reglamentarios de los profesores}

Los salarios de los profesores son uno de los componentes del total de su salario. Otros incentivos económicos, como bonificaciones regionales si los puestos de trabajo se encuentran en zonas apartadas, asignaciones familiares, tarifas reducidas en el transporte público y reducciones fiscales en la compra de bienes culturales, también pueden formar parte de el salario total de los profesores. Además, los sistemas fiscales y de prestaciones sociales varían notablemente entre los países de la OCDE. Es obligada, por tanto, la cautela a la hora de comparar los salarios de los profesores.

Los salarios de los profesores registran grandes variaciones entre los países. El salario de los profesores de enseñanza secundaria inferior con 15 años de experiencia profesional varía desde menos de 15.000 dólares estadounidenses en Estonia, Hungría, Indonesia y República Eslovaca hasta más de 60.000 dólares estadounidenses en Alemania, Países Bajos y Suiza (para profesores al menos con 11 años de experiencia) y supera los 100.000 dólares estadounidenses en Luxemburgo (Tabla D3.1 y Gráfico D3.2).

En la mayoría de los países, el salario de los profesores aumenta con el nivel educativo que imparten. En Bélgica, Dinamarca, Hungría, Indonesia, Países Bajos, Polonia y República Checa, el salario de un profesor de secundaria superior al menos con 15 años de experiencia es entre un $20 \%$ y un $30 \%$ mayor que el de un profesor de educación infantil con la misma experiencia. Esta diferencia alcanza el $50 \%$ en Finlandia y Suiza (para profesores al menos con 11 años de experiencia). En Finlandia y en República Eslovaca, dicha diferencia se debe principalmente a la marcada disparidad entre los salarios en educación infantil y educación primaria. En Países Bajos, la principal diferencia de salarios se da entre los profesores de educación primaria y los de secundaria inferior, mientras que en Bélgica los salarios de los profesores de educación secundaria superior son significativamente más elevados que los de profesores en otros niveles educativos. En Dinamarca y Hungría, las principales diferencias se encuentran entre los profesores de educación secundaria inferior y superior, mientras que no existe diferencia entre los de educación primaria y secundaria inferior. Como contrapunto, los salarios de los profesores en Suiza aumentan de manera constante desde educación infantil hasta educación secundaria superior. Al interpretar las diferencias entre los salarios de los profesores de distintos niveles educativos, se han de tener en cuenta cuáles son los requisitos para acceder a la profesión docente (véase indicador D6).

En Australia, Canadá, Corea y Turquía hay una diferencia de menos del $5 \%$ entre los salarios de los profesores de educación secundaria superior y de educación infantil con 15 años de experiencia; en Escocia, Eslovenia, Grecia, Inglaterra y Portugal, los profesores perciben el mismo salario, con independencia del nivel de educación que impartan. Esto ocurre también en Estonia, Irlanda y Japón en la educación primaria y secundaria inferior y superior. En Israel, hay una diferencia del $13 \%$ entre el salario de un profesor de educación secundaria superior y el de un profesor de educación infantil, a favor de este último. Esta diferencia se debe a la reforma «New Horizon», que se ha ido aplicando gradualmente desde 2008. Dicha reforma ha aumentado los salarios de los profesores de educación infantil, primaria y secundaria inferior. No obstante, otra reforma que se implantó en 2012 tiene como objetivo aumentar los salarios de los profesores de enseñanza secundaria superior. En Luxemburgo, los profesores de los centros escolares de educación primaria con 15 años de experiencia ganaban alrededor del $50 \%$ menos que los profesores de secundaria con los mismos años de experiencia antes de la reforma de 2009. Ahora, sin embargo, la diferencia entre los salarios de los profesores de educación primaria y de secundaria es inferior al $10 \%$.

Las diferencias de los salarios de los profesores de diferentes niveles educativos pueden influir en la forma en que los centros escolares y sistemas educativos atraen y conservan a los profesores, y también en el grado de movilidad que tienen los profesores entre diferentes niveles educativos.

\section{Salarios mínimos y máximos de los profesores}

Los sistemas educativos se enfrentan al reto de contratar graduados altamente cualificados como profesores. Las investigaciones demuestran que tanto los salarios como las oportunidades alternativas de empleo influyen de manera crucial en el atractivo de la profesión docente (Santiago, 2004). El salario inicial de un profesor en comparación con el de otros trabajos, y la probabilidad de que dichos ingresos vayan aumentando, influyen de forma decisiva en que los graduados opten por la docencia. Los países que buscan incrementar el número de profesores, especialmente aquellos cuyo profesorado va envejeciendo y/o cuyo alumnado escolar va en aumento, pueden aplicar unas retribuciones iniciales más atractivas y mejores perspectivas profesionales de desarrollo. No obstante, para garantizar una formación adecuada del profesorado, no se han de ahorrar esfuerzos, no solo contratando y seleccionando a los profesores más competentes y cualificados, sino también conservando a aquellos que son competentes. 


\section{Cuadro D3.1. Relación entre los salarios de los profesores y el rendimiento escolar}

Los resultados del Programa para la Evaluación Internacional de Alumnos (PISA 2012) sugieren que los sistemas educativos con un alto rendimiento suelen dar prioridad a unos salarios de los profesores más elevados, especialmente en países con rentas altas. En aquellos países y economías donde el PIB por habitante es superior a 20.000 dólares estadounidenses, incluyendo a la mayoría de los países de la OCDE, los sistemas educativos que pagan más a los profesores (es decir, que cuentan con mayores salarios en relación con la renta nacional per cápita) tienden a obtener mejores resultados en matemáticas. La correlación entre estos dos factores en 33 países y economías con altos ingresos es de 0,30 y en 32 países y economías con altos ingresos, excluyendo a Catar, es de 0,40 . Por el contrario, en los países y las economías cuyo PIB es inferior a 20.000 dólares estadounidenses, los resultados del sistema educativo no están relacionados con los salarios de sus profesores, lo que tal vez indique que una gran cantidad de sus recursos (infraestructuras materiales, materiales de instrucción, transporte, etc.) también deben mejorarse hasta que alcancen un cierto nivel a partir del cual ya no tengan un efecto positivo en los resultados de los alumnos, sino que lo tengan las mejoras en recursos humanos (por ejemplo, aumentando los salarios de los profesores).

\section{Gráfico D3.a. Salarios de los profesores y rendimiento en matemáticas}

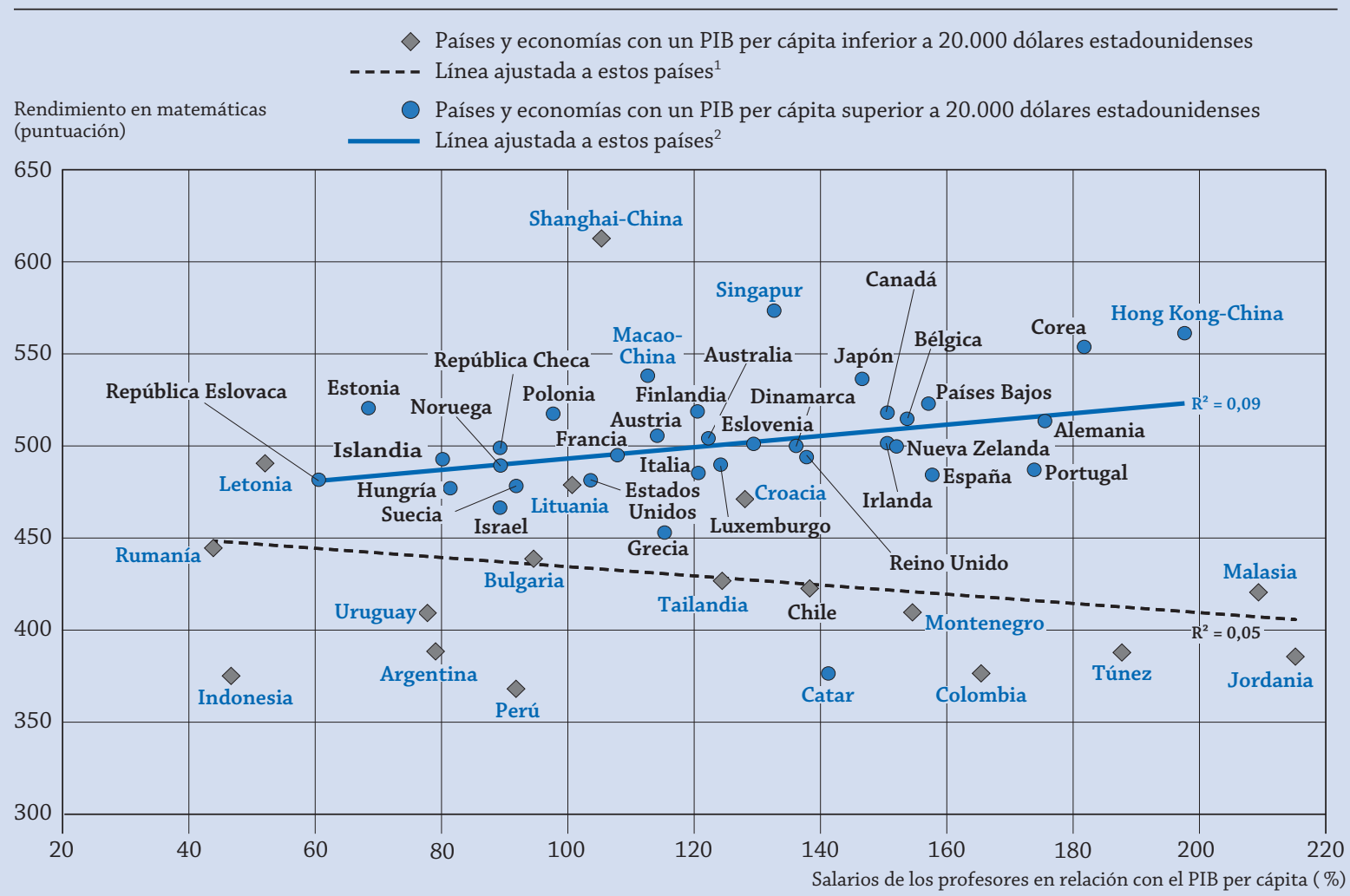

Notas: Los salarios de los profesores en relación con el PIB per cápita se refieren a la media ponderada de los profesores de educación secundaria superior e inferior. La media se calcula ponderando los salarios de los profesores de centros escolares de secundaria superior e inferior de acuerdo con las respectivas matrículas de estudiantes de 15 años de edad (para países y economías de los que se dispone de información sobre los dos niveles de secundaria).

Solo se muestran países y economías con datos disponibles.

1. Una relación no significativa $(p>0,10)$ se muestra con línea de puntos.

2. Una relación significativa $(\mathrm{p}<0,10)$ se muestra con línea continua.

Fuente: OECD (2013), PISA 2012 Results: What Makes Schools Successful? (Volume IV): Resources, Policies and Practices, PISA, OECD Publishing.

StatLink 제에 $h$ htp://dx.doi.org/10.1787/888932957403

En el nivel educativo de secundaria inferior, los profesores que acaban de acceder a la profesión con las cualificaciones mínimas ganan por término medio 30.735 dólares estadounidenses. Este salario mínimo oscila desde cantidades inferiores a los 15.000 dólares estadounidenses en Brasil, Estonia, Hungría, Indonesia, Polonia y República Eslovaca hasta más de 40.000 dólares estadounidenses en Alemania, Dinamarca, Luxemburgo y Suiza. La media salarial de los profesores que están en el nivel más alto de la escala retributiva y tienen las máximas cualificaciones 
es de 53.686 dólares estadounidenses. Este salario máximo oscila desde cantidades inferiores a los 20.000 dólares estadounidenses en Estonia, Indonesia y República Eslovaca, a los 75.000 dólares estadounidenses o más en Austria, Corea y Suiza, y hasta 130.000 dólares estadounidenses en Luxemburgo.

La mayoría de los países con salarios iniciales por debajo de la media de la OCDE también muestran menores salarios máximos. En educación secundaria inferior, hay excepciones como Corea, Francia, Japón y México, cuyos salarios iniciales son un $5 \%$ inferiores a la media de la OCDE, pero los máximos son bastante mayores. En Escocia, sin embargo, el salario inicial es un $10 \%$ inferior a la media de la OCDE y los salarios máximos están dentro de la media de la OCDE. Ocurre lo contrario en Dinamarca y Finlandia, donde los salarios iniciales son por lo menos un $10 \%$ superiores a la media de la OCDE y los salarios máximos son un $5 \%$ inferiores a la media de la OCDE. En Australia y Noruega, los salarios iniciales están al menos un $10 \%$ por encima de la media de la OCDE y los salarios máximos están dentro de la media de la OCDE. En Suecia, los salarios iniciales están dentro de la media de la OCDE, pero los salarios máximos están un $25 \%$ por debajo de la media de la OCDE (Gráfico D3.2 y Tabla D3.6, disponible en Internet).

\section{Gráfico D3.2. Salarios de los profesores de educación secundaria inferior en diferentes momentos de su carrera (2012)}

Salarios reglamentarios anuales de los profesores en instituciones públicas, en equivalente a dólares estadounidenses convertidos mediante PPA

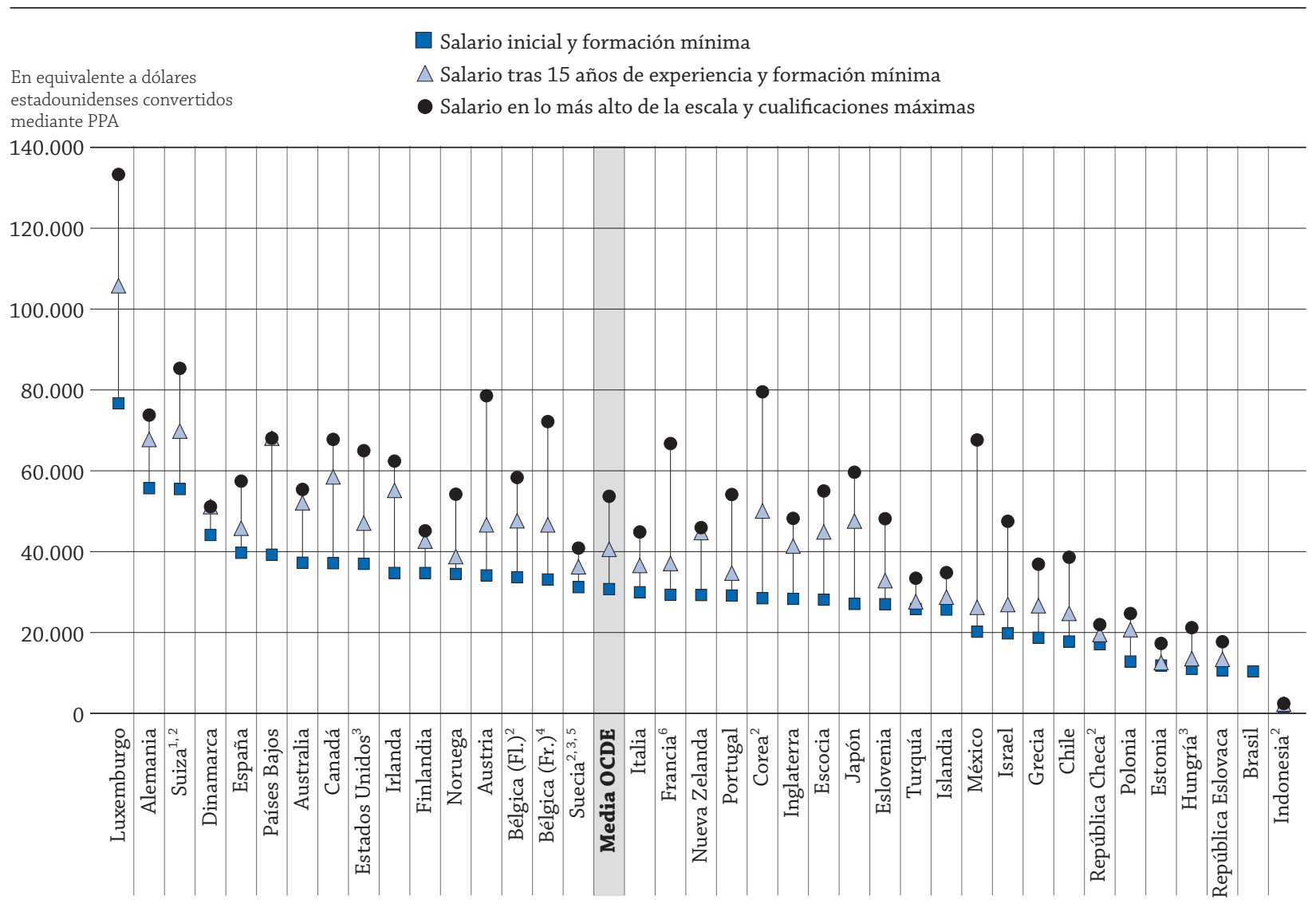

1. Salarios después de 11 años de experiencia en lugar de 15 años.

2. Salarios máximos de la escala y formación mínima en lugar de cualificaciones máximas.

3. Salarios base reales.

4. Salarios de los profesores con cualificaciones típicas en lugar de mínimas.

5. Año de referencia 2011.

6. Incluye la media de primas obtenidas por las horas extraordinarias.

Los países están clasificados en orden descendente del salario inicial para profesores de educación secundaria inferior con formación mínima.

Fuente: OCDE. Tablas D3.1 y D3.6, disponibles en Internet. Para ver notas, consulte Anexo 3 (www.oecd.org/edu/eag.htm).

StatLink त्राज http://dx.doi.org/10.1787/888933119948 
Hay varios países con unas escalas retributivas bastante planas. Por ejemplo, en República Checa la diferencia entre el salario mínimo y el salario máximo es inferior al 30\% en todos los niveles educativos, en Dinamarca en los niveles de educación infantil, educación primaria y secundaria inferior, en Turquía en la educación secundaria inferior y superior, y en Finlandia, Noruega y Suecia en educación infantil.

Unos débiles incentivos económicos pueden provocar que los países tengan algunas dificultades para conservar a los profesores cuando estos llegan al máximo de sus ingresos. No obstante, la compresión de las escalas retributivas podría tener algunos beneficios. A menudo se argumenta, por ejemplo, que las organizaciones con menores diferencias salariales entre los empleados disfrutan de un mayor nivel de confianza, un flujo más libre de información y un mayor compañerismo entre ellos.

Por el contrario, los salarios máximos duplican como mínimo los salarios iniciales en Austria, Chile, Corea e Israel en todos los niveles educativos, en Bélgica (Comunidad francófona) en educación infantil, primaria y secundaria inferior, en Francia en educación secundaria superior e inferior, en Hungría en educación secundaria superior, en Japón en educación primaria y secundaria, y en Polonia en educación infantil y primaria. Dichos salarios iniciales se triplican en México en educación infantil, educación primaria y secundaria inferior (Gráfico D3.2 y Tabla D3.6, disponible en Internet).

La bonificación salarial para un mayor nivel de cualificación en lo más alto de la escala retributiva también varía en los diferentes países. En el nivel de secundaria inferior, en 10 de 32 países con ambos datos, no hay diferencia entre los salarios en el extremo superior de la escala retributiva para los profesores con cualificaciones mínimas y los que tienen cualificaciones máximas. No ocurre lo mismo en Bélgica (Comunidad francófona), Eslovenia, Francia, Israel y Noruega, donde los profesores que están en el extremo superior de la escala y además tienen la máxima cualificación ganan al menos un $25 \%$ más que los profesores con la misma experiencia, pero con una formación mínima. Esta diferencia salarial asciende al $57 \%$ en México. En educación secundaria superior se observa un panorama similar (Tabla D3.1 y Tabla D3.6, disponible en Internet).

Es importante recordar que, cuando se tiene en cuenta la estructura salarial de los profesores, no todos ellos alcanzan el extremo superior de la escala retributiva y tan solo unos cuantos tienen la máxima cualificación. En Grecia e Italia, por ejemplo, menos de un $5 \%$ de todos los profesores la alcanzaron en 2012 y en Francia solo el $5 \%$ del profesorado posee la cualificación más alta en secundaria inferior.

\section{Experiencia docente y escalas salariales}

Las estructuras retributivas definen los incentivos salariales disponibles para los profesores en las diferentes etapas de su vida profesional. La compensación aplazada, que gratifica a los trabajadores por mantenerse en una organización o profesión y por satisfacer determinados criterios de rendimiento, también se utiliza en las estructuras salariales de los profesores. Los datos de la OCDE sobre el salario de los profesores se limitan a los salarios reglamentarios en cuatro puntos de la escala salarial: salario inicial, salario tras 10 años de servicio, salario tras 15 años de experiencia y salario máximo de la escala. Estos salarios corresponden a profesores con la formación mínima necesaria. Como se ha mencionado anteriormente, unas mayores cualificaciones pueden conducir a un aumento salarial en determinados países.

En los países de la OCDE, los salarios de los profesores durante su desarrollo profesional varían dependiendo de cada país. Los salarios reglamentarios de los profesores de educación secundaria inferior con 10 y 15 años de experiencia son, respectivamente, un $24 \%$ y un $35 \%$ superiores por término medio a sus salarios iniciales. Además, los salarios máximos de la escala, que se alcanzan tras 24 años de experiencia, son como media un $61 \%$ más altos que los iniciales. En Corea, España, Hungría, Israel e Italia, los profesores de enseñanza secundaria inferior alcanzan el máximo de la escala retributiva por término medio tras 35 años de docencia. Por el contrario, los profesores de educación secundaria inferior en Australia, Dinamarca, Escocia, Estonia y Nueva Zelanda alcanzan el nivel máximo de la escala retributiva después de seis a nueve años de docencia (Tablas D 3.1 y D3.3).

Mientras que los aumentos salariales son graduales en casi la mitad de los 31 países de la OCDE con datos relevantes, en el resto de los países las escalas retributivas abarcan tramos de desigual magnitud.

\section{Salarios reglamentarios por hora lectiva neta}

El salario reglamentario medio por hora lectiva tras 15 años de experiencia es de 50 dólares estadounidenses para los profesores de educación primaria, de 59 dólares estadounidenses para los profesores de educación secundaria inferior y de 68 dólares estadounidenses para los profesores de los programas de carácter general en educación secundaria superior. Los países que registran los menores salarios por hora lectiva, menos de 30 dólares estadounidenses, son 
Chile, Estonia, Hungría, Indonesia, México (en educación primaria y secundaria inferior), Polonia (en educación primaria), República Checa (en educación primaria) y República Eslovaca. En cambio, dichos salarios son superiores a los 90 dólares en Alemania, Bélgica, Corea, Dinamarca, Japón y Países Bajos en el nivel de educación secundaria superior y a los 120 dólares en Luxemburgo en todos los niveles educativos (Tabla D3.3).

Como los profesores de educación secundaria imparten menos horas lectivas que los de enseñanza primaria, sus salarios por hora lectiva suelen ser mayores que las de los profesores de niveles más bajos de educación, incluso en los países en que los salarios reglamentarios son similares (véase Indicador D4). Como media en los países de la OCDE, los salarios de los profesores de educación secundaria superior por hora lectiva son superiores en un $32 \%$ a las de los profesores de enseñanza primaria. En Escocia no existe esta diferencia, mientras que en Dinamarca los profesores de secundaria superior ganan el doble que los de educación primaria por hora lectiva (Tabla D3.3).

No obstante, esta diferencia retributiva por hora lectiva entre los profesores de educación primaria y de secundaria puede desaparecer cuando se comparan los salarios por hora de trabajo. Por ejemplo, en Portugal, existe una diferencia retributiva por hora lectiva del $23 \%$ entre los profesores de primaria y de secundaria superior, aun cuando sus salarios reglamentarios y el tiempo de trabajo requerido sean los mismos. Esta diferencia se explica porque los profesores de educación primaria pasan más tiempo realizando actividades de enseñanza que los profesores de educación secundaria superior (véase Tabla D 4.1).

\section{Tendencias desde 2000}

Entre 2000 y 2012, los salarios de los profesores aumentaron en términos reales en casi todos los países con datos disponibles. Son notables excepciones Francia, Grecia y Japón, donde ha habido una disminución del 10\% en los salarios de los profesores durante ese periodo. En Estonia, República Checa y Turquía (en educación primaria y secundaria superior), los salarios de los profesores aumentaron un $50 \%$ durante el mismo periodo (Tabla D3.5).

No obstante, entre 2005 y 2012, solo en algo más de la mitad de los países de la OCDE con datos disponibles se han incrementado los salarios de los profesores y, en la mayoría de los países, los salarios han aumentado menos desde 2005 que entre 2000 y 2005. Las excepciones a este modelo son Bélgica (Comunidad francófona, en enseñanza secundaria), Dinamarca, Estonia, Israel y México (en educación primaria y secundaria inferior) y Nueva Zelanda, donde la mayor parte del incremento se produjo después de 2005. En Polonia, los salarios también aumentaron después de 2005 un mínimo del $20 \%$ en todos los niveles educativos como resultado de un programa educativo implantado desde 2007 que pretendía incrementar en un $50 \%$ los salarios de los profesores de manera gradual entre 2008 y 2012. La reforma gubernamental se llevó a cabo para mejorar la calidad de la educación mediante incentivos económicos que atrajeran a profesores altamente cualificados.

Por el contrario, en Grecia y Hungría los salarios económicas disminuyeron por lo menos un 20\% desde 2005 (Gráfico D3.3), aunque dicha disminución tuvo lugar principalmente entre 2008 y 2012. Esto refleja el impacto económico sufrido en los salarios de los profesores tras la crisis económica de 2008, cuando en esos países se congelaron o recortaron los salarios entre 2008 y 2012 (Cuadro 3.2). El número de países que han aumentado los salarios en términos reales entre 2008 y 2012 ha disminuido hasta algo más de la mitad de los países de la OCDE. En Escocia, España, Estonia e Inglaterra, los salarios disminuyeron por lo menos un $5 \%$ entre el 2008 y 2012 y no menos de un $10 \%$ en República Checa en el mismo periodo.

El análisis de las tendencias de los salarios se basa en profesores con 15 años de experiencia (aproximadamente la mitad de su carrera profesional); no obstante, los profesores en determinadas etapas de su carrera pueden experimentar un incremento más rápido que en otras. Por ejemplo, algunos países que han tenido escasez de docentes pueden poner en práctica políticas específicas para mejorar el atractivo de la profesión mediante el aumento de los salarios iniciales (OECD, 2005). En Francia, por ejemplo, los profesores que accedieron a la educación recibieron un aumento de salario en 2010 y 2011.

En la mayoría de los países, los aumentos y descensos en los salarios de los profesores fueron similares para los niveles educativos de primaria, secundaria inferior y secundaria superior. No obstante, en Israel y Luxemburgo aumentaron significativamente más en los niveles de primaria que en los niveles de secundaria en el mismo periodo de tiempo. En estos países, la diferencia del índice de cambio en el salario entre los profesores de educación primaria y los de secundaria se debe a las reformas que tenían como objetivo aumentar los salarios de los profesores de primaria. En Israel, esta diferencia se debe principalmente a la reforma «New Horizon», que se ha ido aplicando gradualmente desde 2008 en los centros de educación primaria y secundaria inferior tras un acuerdo entre las autoridades educativas y el sindicato de profesores de Israel (de educación primaria y secundaria inferior). Esta reforma incluye una salario superior a cambio de más horas de trabajo (véase Indicador D4). En 2012 se incluyó en la reforma al 


\section{Gráfico D3.3. Cambio en los salarios de los profesores de educación secundaria inferior (2000, 2005 y 2012) \\ Índice de cambio entre 2000 y 2012 (2005 = 100, precios constantes), para profesores con 15 años de experiencia y formación mínima}

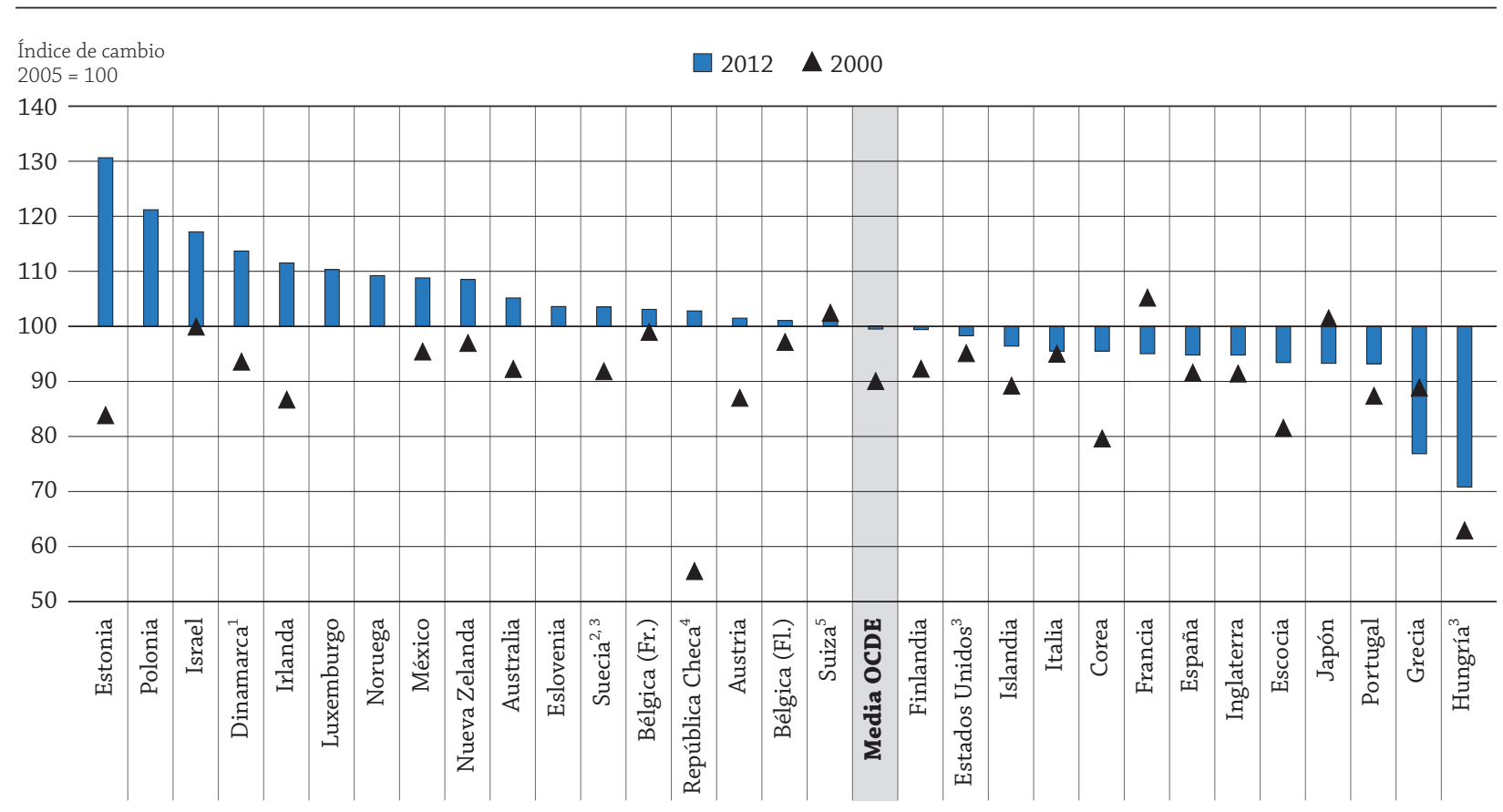

1. Ruptura de la serie temporal tras cambios en la metodología en 2009.

2. Año de referencia 2011 en lugar de 2012.

3. Salarios base reales.

4. Ruptura de la serie temporal tras cambios en la metodología en 2012.

5. Salarios tras 11 años de experiencia.

Los países están clasificados en orden descendente del índice de cambio entre 2000 y 2012 en los salarios de los profesores de educación secundaria inferior con 15 años de experiencia.

Fuente: OCDE. Tabla D3.5. Para ver notas, consulte Anexo 3 (www.oecd.org/edu/eag.htm).

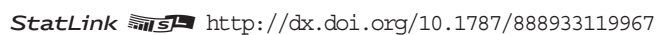

\section{Cuadro D3.2. Efectos de la crisis económica}

La crisis financiera y económica que golpeó a la economía mundial en los últimos meses del año 2008 ha afectado significativamente a los salarios de los funcionarios públicos y de los trabajadores del sector público en general. La presión de los gobiernos para reducir la deuda nacional ha provocado recortes en los salarios de profesores y funcionarios en un número cada vez mayor de países. Como media en los países de la OCDE con datos disponibles, los salarios de los profesores disminuyeron por primera vez desde el año 2000 un $5 \%$ aproximadamente en todos los niveles educativos entre 2009 y 2012.

Los salarios de los profesores se vieron significativamente afectados, por ejemplo, en Escocia, España, Estonia, Grecia, Hungría, Inglaterra, Irlanda, Italia y Portugal. En Estonia, los salarios mínimos de los profesores se recortaron a niveles de 2008 en 2010 y quedaron congelados en ese punto. En Grecia, los ingresos de los profesores se vieron afectados por sucesivas reducciones de las bonificaciones y complementos retributivos en 2010, 2011 y 2012. Como resultado, los ingresos brutos disminuyeron aproximadamente un $25 \%$ en términos reales entre 2009 y 2012. Además, los profesores griegos vieron como sus salarios netos disminuían debido a la creación de un impuesto de solidaridad. Este impuesto incrementó el nivel impositivo de los profesores cuyo salario bruto ya había sido reducido; además, la cobertura de la asistencia sanitaria pagada por los profesores todavía se calcula sobre la base de las últimas nóminas, más elevadas. En Hungría se 
suspendió en 2009 el decimotercer mes de salario, una bonificación adicional que se pagaba a todos los empleados y, aunque a todos los empleados del sector público cuyas retribuciones estaban por debajo de un determinado umbral se les pagó una bonificación compensatoria, el salario base de los profesores se vio afectado considerablemente. En 2012, el descenso continuado de los salarios de los profesores se debió a una reducción de los complementos salariales, tales como clases extra. Estos pagos adicionales eran un factor importante en el salario total de los profesores, ya que se pagaban por encima del salario base. En 2012, estos pagos se redujeron en menor medida en el nivel secundario inferior y en mayor medida en el nivel secundario superior.

\section{Gráfico D3.b. Cambios en los salarios de los profesores en países de la OCDE (2005-2012)}

Media de la OCDE, para los países de los que se dispone de datos para todos los años de referencia, del índice de cambio para profesores con 15 años de experiencia y formación mínima (2005 =100, precios constantes)

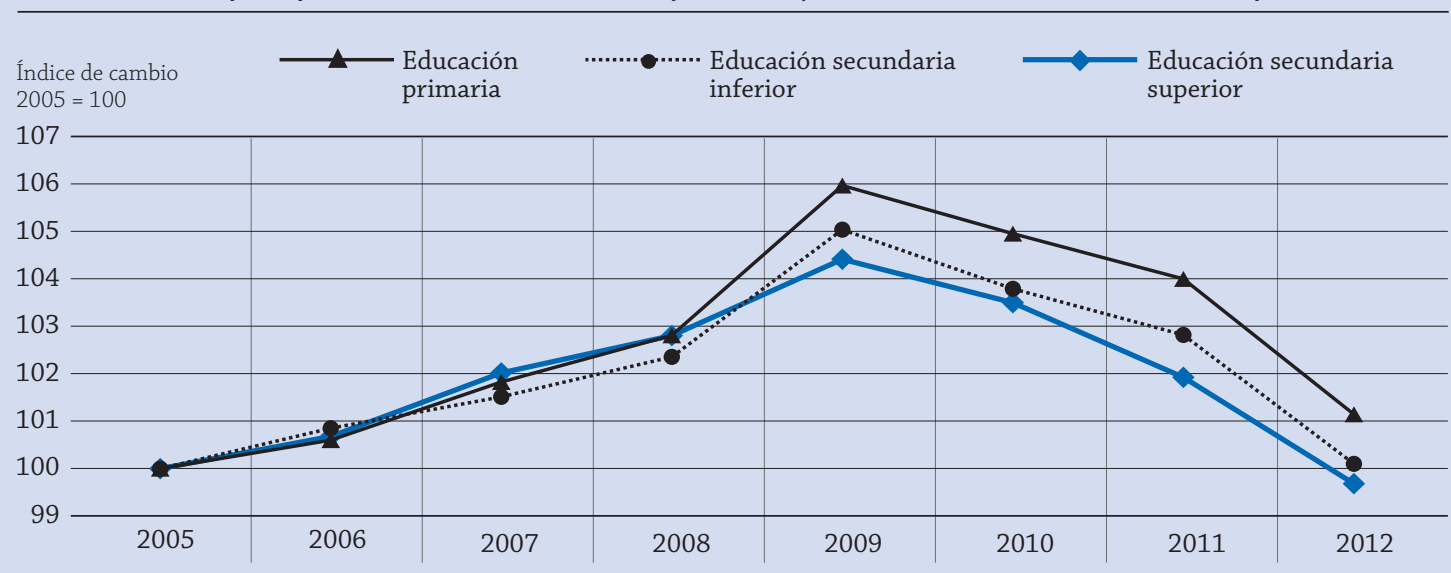

Fuente: OCDE. Tabla D3.5. Para ver notas, consulte Anexo 3 (www.oecd.org/edu/eag.htm).

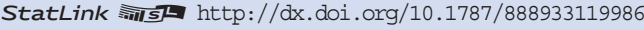

En España, todos los funcionarios vieron sus salarios reducidos en julio de 2010. Esta reducción está relacionada directamente con la cantidad anual percibida y afectó tanto a la base salarial como a las bonificaciones. En Irlanda, los salarios de los profesores se redujeron el 1 de enero de 2010 como parte de la reducción salarial de los funcionarios públicos. Además, el salario de los profesores que comenzaron su trayectoria después del 1 de enero de 2011 se calcula sobre la base de una nueva escala salarial que es un $10 \%$ inferior a la de sus colegas que accedieron a la profesión con anterioridad. En Portugal, en 2011, los salarios superiores a 1.500 euros se redujeron usando un método recogido en un paquete de reformas incluidas en una nueva ley. Estos salarios volvieron a bajar en 2012 cuando los funcionarios cobraron 12 pagas en vez de las 14 pagas que solían percibir. En Inglaterra, debido a la crisis financiera, los salarios de los profesores se congelaron entre 2011 y 2012 en todos los niveles educativos. Además el año siguiente se produjo un aumento del $1 \%$, por debajo de la subida de la inflación, para el sector público. Como los profesores tenían un acuerdo salarial a tres años, la congelación salarial se aplicó más tarde para los profesores que para otros trabajadores del sector público. Del mismo modo, la Comisión Negociadora Escocesa para Profesores (SNCT) acordó congelar los salarios de los profesores en Escocia desde abril de 2011 hasta marzo de 2013. Aunque los profesores en Escocia no son funcionarios públicos, mediante este acuerdo sufrieron la misma congelación salarial que afectó a otros empleados funcionarios públicos. En Italia, los salarios de los profesores se congelaron desde 2011. Esta medida afectó a todos los funcionarios públicos, incluyendo profesores, y se introdujo como respuesta a la situación económica internacional para lograr los objetivos de financiación pública marcados a nivel de la UE.

La crisis económica también puede haber influido en la oferta de profesores. En general, cuando la economía está debilitada y hay un alto nivel de desempleo y salarios bajos para los graduados, la enseñanza podría parecerles una opción laboral más atractiva que otras ocupaciones (OECD, 2005). 


\section{Cuadro D3.3. Pagos adicionales: incentivos y complementos}

Además de las escalas retributivas básicas, cada vez más sistemas educativos aplican esquemas que ofrecen a los profesores retribuciones adicionales u otras gratificaciones. Junto al salario inicial, estos pagos adicionales pueden ser determinantes para elegir la docencia como profesión o continuar en ella. No se han recogido datos sobre los importes de los pagos, sino sobre si existen o no pagos adicionales y el nivel en el que se toma la decisión para realizar dichos pagos (Tablas D3.7a, b, c y d disponibles en Internet, y Anexo 3 en www.oecd.org/edu/eag.htm).

Los pagos adicionales se suelen adjudicar por responsabilidades o condiciones laborales especiales como, por ejemplo, enseñar en centros escolares más desfavorecidos, sobre todo los que se encuentran en barrios muy pobres o los que tienen una gran proporción de estudiantes cuya lengua materna no es la lengua de enseñanza. Estos centros suelen tener dificultades para atraer a los profesores y, por tanto, es más probable que tengan profesores con menos experiencia (OECD, 2005). La mayor parte de los países ofrecen pagos adicionales por aceptar responsabilidades directivas añadidas a las de enseñanza, y aproximadamente dos de cada tres países de la OCDE ofrecen este tipo de suplementos, que se pagan anualmente. Aproximadamente dos de cada tres países ofrecen además pagos adicionales por enseñar en zonas desfavorecidas. La mitad de los países de la OCDE ofrecen también pagos adicionales por actividades extraescolares, como deportes, clubs teatrales y enseñanza especial al alumnado con necesidades especiales en centros escolares ordinarios.

Los pagos adicionales basados en la cualificación de los profesores, su formación y rendimiento también son comunes en los países de la OCDE. Los tipos de pagos más comunes se realizan para una cualificación educativa inicial y/o un nivel de certificación o formación superior a los requisitos mínimos requeridos para el ejercicio de la profesión. Cerca del $80 \%$ de los países ofrecen este tipo de pagos y alrededor de dos tercios de ellos ofrecen ambos tipos de pagos. Además, 21 de los países de la OCDE con datos disponibles ofrecen pagos adicionales a los profesores que han destacado en su labor profesional. En 17 de estos países, la decisión de otorgar estos incentivos es responsabilidad del director del centro escolar.

La mitad de los países de la OCDE ofrecen incentivos adicionales basándose en características demográficas de los profesores (condiciones familiares o edad), y la mayoría se pagan anualmente.

$88 \%$ de los profesores a tiempo completo de educación primaria, así como al 33\% de educación secundaria y al $71 \%$ de educación infantil. Ese mismo año, el gobierno israelí negoció un programa de reformas similar para los centros de secundaria superior con los sindicatos de educación secundaria superior. A medida que se vaya aplicando la reforma se espera que los salarios en educación secundaria inferior y superior aumenten considerablemente.

\section{Salarios medios reales}

Los salarios reglamentarios facilitados por la mayoría de los países en este indicador deben diferenciarse de los gastos reales de los gobiernos en retribuciones y de los salarios medios reales de los profesores, los cuales se ven influidos por factores tales como los niveles de experiencia de los profesores y la prevalencia de las bonificaciones y complementos en el sistema de retribuciones.

Las bonificaciones y complementos pueden significar un suplemento importante de los salarios base. En República Eslovaca, por ejemplo, la mayoría de los profesores reciben bonificaciones mensuales, como las derivadas de evaluaciones personales. En función de los recursos financieros del centro y la evaluación individual de los profesores, sus salarios medios, incluyendo las bonificaciones, pueden llegar a ser el doble del salario base reglamentario.

La comparación entre los salarios anuales reales de todos los profesores entre 25 y 64 años y los salarios reglamentarios de los profesores con 15 años de experiencia muestra que, en Chile, Estonia (educación primaria y secundaria), Francia (educación secundaria superior), Hungría (educación primaria y secundaria), Islandia (educación secundaria superior), Israel (nivel secundario), Noruega (educación primaria y secundaria inferior) y Polonia (educación infantil, primaria y secundaria inferior), la media salarial, incluyendo incentivos y complementos, es al menos un $20 \%$ superior al salario reglamentario de los profesores con 15 años de experiencia. Como contrapunto, en Bélgica (comunidad francófona, educación secundaria superior), Escocia, Grecia, Luxemburgo (educación infantil y primaria) y Países Bajos, la media salarial de los profesores entre 25 y 64 años es al menos un $5 \%$ inferior al salario reglamentario de los profesores con 15 años de experiencia (Tabla D3.1 y D3.4). 
En algunos países, la media actual de los salarios de los profesores varía más entre los diferentes niveles educativos que los salarios reglamentarios para profesores con 15 años de experiencia. En Inglaterra, Finlandia, Noruega y República Checa, la diferencia entre los salarios reales obtenidos en educación secundaria superior y educación infantil es al menos 10 puntos porcentuales mayor que la diferencia en sus salarios reglamentarios. En Francia existe una diferencia del $30 \%$ en los salarios salariales obtenidas entre educación infantil y secundaria superior, pero solo un $10 \%$ de diferencia entre los salarios reglamentarios de ambos niveles educativos. En Israel, los salarios reglamentarios de los profesores de educación secundaria superior son un $10 \%$ inferiores a los salarios reglamentarios de los profesores de educación infantil, pero ocurre lo contrario cuando se miran los salarios medios reales: los profesores de secundaria superior ganan por término medio casi un $10 \%$ más que los de educación infantil. En Noruega y Polonia, existe una diferencia del $15 \%$ entre los niveles de educación infantil y primaria en los salarios medios reales, a pesar de que los salarios reglamentarios son similares en estos niveles. Lo contrario ocurre en Polonia, donde el salario real es similar entre los profesores de educación primaria y secundaria superior, pero existe una diferencia de casi el $15 \%$ con respecto a los salarios reglamentarios. La variedad de bonificaciones posibles en los distintos niveles de educación explica en parte estas diferencias (véase Anexo 3 disponible en www.oecd.org/edu/eag.htm).

\section{Salarios de los profesores en relación con los ingresos de trabajadores con educación terciaria}

La tendencia de los jóvenes a formarse como profesores, así como la de los graduados a comenzar programas de formación docente o permanecer en la profesión, se verán influidas por los salarios de los profesores en relación con los de otras ocupaciones que requieren similares cualificaciones y por potenciales aumentos salariales. En todos los

\section{Cuadro D3.4. Salarios medios reales, por grupo de edad y sexo}

En general, los salarios medios reales de los profesores de edades comprendidas entre 25 y 64 son de 38.253 dólares estadounidenses en el nivel de educación infantil, de 41.300 dólares estadounidenses en el de educación primaria, de 43. 374 dólares estadounidenses en el de educación secundaria inferior y de 47.165 dólares estadounidenses en el de educación secundaria superior. El modelo de incremento salarial en cada nivel educativo es similar para los distintos grupos de edad dentro del rango de 25 a 64 años de edad y tanto para hombres como para mujeres.

Los salarios reales de los profesores mayores (de 55 a 64 años) son como media un $31 \%$ (en educación infantil), un $33 \%$ (en educación primaria), un $35 \%$ (en educación secundaria) y un 38\% (en educación secundaria superior) más altos que los salarios reales de los profesores más jóvenes (de 25 a 34 años).

Cuando los salarios de los profesores, comparados con los de los trabajadores de 25 a 64 años con educación terciaria empleados a tiempo completo durante todo el año, se separan por grupos de edad, la ratio entre dichos grupos difiere. Los salarios relativas de los profesores son más altas en el grupo más joven (25-34 años) y menores para los grupos de mayor edad. La ratio en los profesores de 25 a 34 años es al menos cuatro puntos porcentuales superior (en secundaria superior) y alcanza los 8 puntos porcentuales de diferencia (en educación infantil) respecto a la ratio en los profesores de 55 a 64 años. La ratio más elevada en el grupo más joven, comparado con otros grupos de edad, indica el atractivo de entrar en la profesión docente. Sin embargo, esta ratio disminuye con la edad de los profesores, lo que indica que los salarios de otros profesionales con educación similar son más atractivos con la edad.

La comparación de los salarios reales por sexo muestra que las profesoras ganan como media ligeramente más que los profesores en educación infantil y ligeramente menos en educación primaria, educación secundaria inferior y superior. No obstante, esta diferencia de los salarios es inferior al 3\%.

Se dan mayores diferencias entre sexos en la ratio de los salarios de los profesores con respecto a los ingresos de los trabajadores con titulación de educación terciaria de 25 a 64 años de edad. Por término medio, en todos los niveles educativos, los profesores de sexo masculino entre 25 a 64 años ganan menos del $85 \%$ del salario de un trabajador a tiempo completo y durante todo el año con educación terciaria de 25 a 64 años de edad. Las profesoras de 25 a 64 años de edad perciben un salario superior en un $85 \%$ (educación infantil) y hasta un $103 \%$ en secundaria superior con respecto al salario de referencia. Esta ratio más elevada en las profesoras refleja las diferencias entre sexos aún existentes en los salarios en el mercado laboral. Esto no ocurre en la docencia, lo que hace que esta profesión resulte particularmente atractiva para las mujeres en comparación con otras profesiones (Tablas D3.2 y D3.4). 
países de la OCDE es necesario obtener una cualificación terciaria para ser profesor (véase Indicador D6), de modo que la alternativa más probable a la formación del profesorado es otro programa de educación terciaria. Por tanto, para interpretar los niveles salariales en diferentes países y reflejar las condiciones comparativas del mercado de trabajo, se comparan los salarios de los profesores con los de otros profesionales con un nivel educativo equivalente: trabajadores a tiempo completo, de edades comprendidas entre 25-64 años de edad y con educación terciaria.

Los salarios de los profesores de educación infantil ascienden por término medio a un $80 \%$ de los ingresos anuales a tiempo completo de los trabajadores de 25 a 64 años con educación terciaria, a un $85 \%$ de ese salario de referencia en el nivel de educación primaria, a un $88 \%$ en educación secundaria inferior y a un $92 \%$ para los profesores de educación secundaria superior. En este último nivel, los profesores pueden ganar mucho más que los trabajadores con educación terciaria en 12 de los 32 países con datos disponibles. Los salarios relativos más altos de los profesores se registran en Corea, España, Luxemburgo (en educación secundaria inferior y superior) y Portugal, donde los salarios de los profesores son al menos un $20 \%$ más altos que los de los trabajadores con una formación equiparable. Los menores salarios relativos de los profesores en comparación con los salarios de otros profesionales con una formación similar se registran en Hungría y República Checa en educación infantil y en todos los niveles educativos en República Eslovaca, donde los salarios reglamentarios de los profesores con 15 años de experiencia son por término medio inferiores al $50 \%$ de lo que percibe anualmente un trabajador a tiempo completo con un nivel de educación terciaria (Tabla D3.2 y Gráfico D3.1).

\section{Definiciones}

Los salarios reales de los profesores de 25 a 64 años hacen referencia a sus ingresos medios anuales antes de impuestos. Incluyen tanto los pagos relacionados con su trabajo como las primas anuales, las bonificaciones relacionadas con resultados, la paga extra para las vacaciones y la baja por enfermedad. No se incluyen los ingresos de otras fuentes, como por ejemplo las prestaciones sociales gubernamentales, los ingresos por inversiones y cualesquiera otros ingresos no relacionados de forma directa con la profesión docente.

Un ajuste del salario base se define como toda diferencia de salario entre lo que percibe un profesor determinado por el trabajo realizado en un centro y lo que debería percibir en virtud de su experiencia (es decir, el número de años dedicados a la enseñanza). Los ajustes pueden ser temporales o permanentes y pueden favorecer la promoción de un profesor haciéndole cambiar de escala o avanzar dentro de la misma.

Los ingresos de los trabajadores con educación terciaria son los ingresos medios anuales de los trabajadores a tiempo completo de 25 a 64 años con un nivel de educación CINE 5A/5B/6. El indicador salarial relativo se calcula a partir de los datos sobre los ingresos del último año con datos disponibles. En los países que no tienen datos disponibles para ese mismo año sobre el salario de los profesores y los ingresos de los trabajadores (por ejemplo, Bélgica, Francia, Italia, Noruega, Países Bajos, República Checa y Suecia), se ajusta el indicador teniendo en cuenta la inflación, utilizando los deflactores del consumo privado. En el Anexo 3 se aportan estadísticas de referencia sobre los ingresos de los trabajadores con educación terciaria.

El salario tras 15 años de experiencia es el que corresponde anualmente a un profesor a tiempo completo con la formación mínima requerida para estar plenamente cualificado después de 15 años de ejercicio profesional.

El salario inicial es el salario anual medio bruto de un profesor a tiempo completo con la formación mínima requerida para estar plenamente cualificado al comienzo de su carrera docente, mientras que el salario máximo corresponde al máximo anual previsto (extremo superior de la escala retributiva) para un profesor a tiempo completo con las cualificaciones máximas reconocidas para su salario.

Los salarios reglamentarios son los establecidos en las escalas salariales oficiales. Las cantidades indicadas son brutas y corresponden a la suma total del dinero abonado por el empleador, una vez deducidas las cotizaciones patronales a la seguridad social y sistemas de pensiones (de acuerdo con las escalas salariales en vigor). Los salarios se consideran «antes de impuestos», es decir, antes de practicar la deducción correspondiente al impuesto sobre la renta. En la Tabla D3.3, el salario por hora neta de contacto es el resultado de dividir el salario anual reglamentario de un profesor por el número de horas lectivas netas anuales (véase Tabla D4.1).

\section{Metodología}

Los datos sobre salarios reglamentarios de los profesores y bonificaciones complementarias proceden de la Encuesta OCDE-INES 2013 sobre Profesores y Currículo. Estos datos se refieren al año escolar 2011-2012 y están de acuerdo con las políticas oficiales que se aplican en los centros públicos. 
Los datos suministrados sobre los salarios de los profesores en el nivel educativo secundario superior se refieren únicamente a los programas generales.

Medir el salario reglamentario de un profesor a tiempo completo en relación con el número de horas al año que ha de pasar enseñando no ajusta los salarios al tiempo que los profesores pasan en diversas actividades relacionadas con la enseñanza. Se han de interpretar con cautela los datos sobre los salarios reglamentarios por hora lectiva neta (véase Indicador D4), ya que la proporción del tiempo de trabajo que los profesores pasan enseñando es variable en los distintos países de la OCDE. No obstante, esta puede dar una idea aproximada del coste del tiempo real que los profesores pasan en el aula.

El salario bruto de los profesores se ha convertido usando PPA para el consumo privado de la base de datos de las Cuentas Nacionales de la OCDE. En las ediciones anteriores a 2012 del Panorama de la educación solían convertirse los salarios utilizando PPA para el PIB. Por tanto, los salarios de los profesores en dólares estadounidenses (Tabla D3.1) no se pueden comparar directamente con las cifras publicadas en ediciones previas a la edición de de Panorama de la educación 2012. En la Tabla D3.5 se puede encontrar información sobre las tendencias de los salarios de los profesores. Se ha añadido al Anexo 2 una tabla con los salarios de los profesores en moneda nacional, como complemento a la Tabla D3.1, que presenta la equivalencia en dólares estadounidenses de dichos salarios, convertidos mediante PPA. El periodo de referencia para los salarios de los profesores es del 1 de julio de 2011 al 30 de junio de 2012. La fecha de referencia de las PPA es 2011-2012.

Para calcular los cambios de los salarios de los profesores (Tabla D3.5) se usa el deflactor del consumo privado para convertir los salarios a precios de 2005.

La ratio de los salarios de los profesores y los ingresos de los trabajadores con educación terciaria de 25 a 64 años a tiempo completo durante todo el año se ha calculado usando los salarios medios anuales (incluyendo bonificaciones y complementos) de los profesores de edades entre los 25 y 64 años, en países con datos disponibles (Tabla D3.4). Para otros países se han tomado como referencia los salarios reglamentarios de los profesores con 15 años de experiencia y la formación mínima requerida. La metodología usada en cada país se proporciona en la Tabla D3.2.

Notas sobre definiciones y metodologías para cada país se proporcionan en Anexo 3 (www.oecd.org/edu/eag.htm).

Nota sobre los datos de Israel

Los datos estadísticos para Israel fueron proporcionados por las autoridades israelíes competentes bajo su responsabilidad. El uso de estos datos por parte de la OCDE se hace sin prejuzgar la situación de los Altos del Golán, Jerusalén Este y los asentamientos israelíes en Cisjordania de acuerdo con los términos del derecho internacional.

\section{Referencias}

OECD (2013), PISA 2013 Results: What Makes Schools Successful? (Volume IV): Resources, Policies and Practices, PISA, OECD Publishing, París, http://dx.doi.org/10.1787/9789264201156-en.

OECD (2012), Education at a Glance 2012: OCDE Indicators, OECD Publishing, París, http://dx.doi.org/10.1787/eag-2012-en. Versión española: Panorama de la educación 2012: Indicadores de la OCDE, Ministerio de Educación, Cultura y Deporte, Santillana, Madrid.

OECD (2005), Teachers Matter: Attracting, Developing and Retaining Effective Teachers, OECD Publishing, París, http://dx.doi. org/10.1787/9789264018044-en.

Santiago, P. (2004), «The Labour Market for Teachers», en G. Jones y J. Jones (eds), International Handbook on the Economics of Education, Edward Elgar, Cheltenham.

\section{Tablas del Indicador D3}

\section{StatLink न्ता st http://dx.doi.org/10.1787/888933119815}

Tabla D3.1 Salarios reglamentarios de los profesores en diferentes momentos de su carrera (2012)

Tabla D3.2 Salarios de los profesores en relación con los ingresos de los trabajadores con educación terciaria de 25 a 64 años de edad a tiempo completo, todo el año (2012)

Tabla D3.3 Comparación de los salarios reglamentarios de los profesores (2012) 
Tabla D3.4 Salarios medios reales de los profesores (2012)

Tabla D3.5 Tendencias de los salarios de los profesores entre 2000 y 2012

WEB Tabla D3.6 Salarios reglamentarios mínimos y máximos de los profesores (2012)

WEB Tabla D3.7a Decisiones sobre los pagos a los profesores en instituciones públicas (2012)

WEB Tabla D3.7b Decisiones tomadas por el director del centro escolar sobre los pagos a los profesores en instituciones públicas (2012)

WEB Tabla D3.7c Decisiones tomadas por la autoridad local o regional sobre los pagos a los profesores en instituciones públicas (2012)

WEB Tabla D3.7d Decisiones tomadas por la autoridad nacional sobre los pagos a los profesores en instituciones públicas (2012) 
Tabla D3.1. [1/2] Salarios reglamentarios de los profesores en diferentes momentos de su carrera (2012) Salarios anuales en instituciones públicas, en equivalente a dólares estadounidenses convertidos mediante PPA para el consumo privado

\begin{tabular}{|c|c|c|c|c|c|c|c|c|}
\hline & \multicolumn{4}{|c|}{ Educación infantil } & \multicolumn{4}{|c|}{ Educación primaria } \\
\hline & $\begin{array}{c}\text { Salario } \\
\text { inicial, } \\
\text { formación } \\
\text { mínima }\end{array}$ & $\begin{array}{c}\text { Salario tras } \\
10 \text { años de } \\
\text { experiencia, } \\
\text { formación } \\
\text { mínima }\end{array}$ & $\begin{array}{c}\text { Salario tras } \\
15 \text { años de } \\
\text { experiencia, } \\
\text { formación } \\
\text { mínima }\end{array}$ & $\begin{array}{c}\text { Salario } \\
\text { máximo } \\
\text { de la escala, } \\
\text { formación } \\
\text { mínima }\end{array}$ & $\begin{array}{c}\text { Salario } \\
\text { inicial, } \\
\text { formación } \\
\text { mínima }\end{array}$ & $\begin{array}{c}\text { Salario tras } \\
10 \text { años de } \\
\text { experiencia, } \\
\text { formación } \\
\text { mínima }\end{array}$ & $\begin{array}{c}\text { Salario tras } \\
15 \text { años de } \\
\text { experiencia, } \\
\text { formación } \\
\text { mínima }\end{array}$ & $\begin{array}{c}\text { Salario } \\
\text { máximo } \\
\text { de la escala, } \\
\text { formación } \\
\text { mínima }\end{array}$ \\
\hline & (1) & (2) & (3) & (4) & (5) & (6) & (7) & (8) \\
\hline Alemania & $\mathrm{m}$ & $\mathrm{m}$ & $\mathrm{m}$ & $\mathrm{m}$ & 50.007 & 59.795 & 62.195 & 66.396 \\
\hline Australia & 36.768 & 51.163 & 50.947 & 51.320 & 37.221 & 51.504 & 51.289 & 51.662 \\
\hline Austria & 32.587 & 38.353 & 42.994 & 64.057 & 32.587 & 38.353 & 42.994 & 64.057 \\
\hline Bélgica (Fl.) & 33.667 & 42.283 & 47.635 & 58.340 & 33.667 & 42.283 & 47.635 & 58.340 \\
\hline Bélgica $(\mathrm{Fr} .)^{1}$ & 33.109 & 41.403 & 46.616 & 57.042 & 33.109 & 41.403 & 46.616 & 57.042 \\
\hline Canadá & 37.145 & 55.765 & 58.495 & 58.495 & 37.145 & 55.765 & 58.495 & 58.495 \\
\hline Chile & 17.770 & 22.742 & 24.725 & 32.656 & 17.770 & 22.742 & 24.725 & 32.656 \\
\hline Corea & 28.012 & 41.700 & 48.738 & 79.631 & 28.591 & 42.972 & 50.145 & 79.631 \\
\hline Dinamarca & 42.230 & 44.797 & 46.037 & 46.037 & 44.131 & 49.353 & 51.122 & 51.122 \\
\hline Escocia & 28.124 & 44.867 & 44.867 & 44.867 & 28.124 & 44.867 & 44.867 & 44.867 \\
\hline Eslovenia & 27.006 & 29.958 & 32.819 & 33.819 & 27.006 & 29.958 & 32.819 & 34.476 \\
\hline España & 36.268 & 39.437 & 41.862 & 51.341 & 36.268 & 39.437 & 41.862 & 51.341 \\
\hline Estados Unidos ${ }^{4}$ & 35.952 & 46.116 & 45.300 & 60.984 & 36.333 & 44.995 & 45.998 & 58.793 \\
\hline Estonia & $\mathrm{m}$ & $\mathrm{m}$ & $\mathrm{m}$ & $\mathrm{m}$ & 11.828 & 12.525 & 12.525 & 17.288 \\
\hline Finlandia $^{2}$ & 27.443 & 29.638 & 29.638 & 29.638 & 32.148 & 37.212 & 39.445 & 41.811 \\
\hline Francia $^{3}$ & 26.247 & 31.689 & 33.994 & 50.127 & 26.247 & 31.689 & 33.994 & 50.127 \\
\hline Grecia & 18.718 & 23.320 & 26.617 & 35.503 & 18.718 & 23.320 & 26.617 & 35.503 \\
\hline Hungría $^{4}$ & 10.627 & 11.969 & 12.717 & 16.771 & 10.992 & 12.562 & 13.520 & 18.020 \\
\hline Inglaterra & 28.321 & 41.393 & 41.393 & 41.393 & 28.321 & 41.393 & 41.393 & 41.393 \\
\hline Irlanda & $\mathrm{m}$ & $\mathrm{m}$ & $\mathrm{m}$ & $\mathrm{m}$ & 33.602 & 49.233 & 55.148 & 62.386 \\
\hline Islandia & 23.763 & 26.429 & 26.429 & 30.240 & 25.672 & 28.046 & 28.742 & 29.938 \\
\hline Israel & 22.215 & 26.780 & 29.628 & 46.539 & 19.680 & 26.181 & 29.413 & 41.318 \\
\hline Italia & 27.786 & 30.567 & 33.570 & 40.851 & 27.786 & 30.567 & 33.570 & 40.851 \\
\hline Japón & $\mathrm{m}$ & $\mathrm{m}$ & $\mathrm{m}$ & $\mathrm{m}$ & 27.067 & 40.204 & 47.561 & 59.643 \\
\hline Luxemburgo & 66.085 & 87.511 & 98.788 & 118.412 & 66.085 & 87.511 & 98.788 & 118.412 \\
\hline México & 15.556 & 15.648 & 20.296 & 33.319 & 15.556 & 15.648 & 20.296 & 33.319 \\
\hline Noruega & 33.816 & 39.235 & 39.235 & 39.235 & 34.484 & 38.773 & 38.773 & 43.318 \\
\hline Nueva Zelanda & $\mathrm{m}$ & $\mathrm{m}$ & $\mathrm{m}$ & $\mathrm{m}$ & 28.961 & 43.050 & 43.050 & 43.050 \\
\hline Países Bajos & 37.104 & 45.950 & 54.865 & 54.865 & 37.104 & 45.950 & 54.865 & 54.865 \\
\hline Polonia & 11.388 & 14.966 & 18.160 & 18.925 & 11.388 & 14.966 & 18.160 & 18.925 \\
\hline Portugal & 29.151 & 31.928 & 34.694 & 48.321 & 29.151 & 31.928 & 34.694 & 48.321 \\
\hline República Checa & 15.807 & 16.669 & 17.224 & 18.728 & 16.986 & 18.508 & 19.363 & 21.835 \\
\hline República Eslovaca & 9.513 & 10.468 & 10.946 & 11.806 & 10.644 & 12.778 & 13.365 & 14.411 \\
\hline Suecia $^{4,5}$ & 30.695 & 32.785 & 34.614 & 36.443 & 30.695 & 34.070 & 35.115 & 40.709 \\
\hline Suiza ${ }^{6}$ & 43.758 & 54.812 & $\mathrm{~m}$ & 67.289 & 48.904 & 61.279 & $\mathrm{~m}$ & 75.575 \\
\hline Turquía & 24.834 & 25.632 & 26.653 & 28.818 & 24.834 & 25.632 & 26.678 & 28.818 \\
\hline Media OCDE & 28.757 & 35.354 & 37.350 & 45.349 & 29.411 & 36.846 & 39.024 & 46.909 \\
\hline Media UE21 & 28.594 & 34.498 & 37.502 & 43.864 & 29.417 & 36.072 & 39.160 & 45.761 \\
\hline Arabia Saudí & $\mathrm{m}$ & $\mathrm{m}$ & $\mathrm{m}$ & $\mathrm{m}$ & $\mathrm{m}$ & $\mathrm{m}$ & $\mathrm{m}$ & $\mathrm{m}$ \\
\hline Argentina & $\mathrm{m}$ & $\mathrm{m}$ & $\mathrm{m}$ & $\mathrm{m}$ & $\mathrm{m}$ & $\mathrm{m}$ & $\mathrm{m}$ & $\mathrm{m}$ \\
\hline Brasil & 10.375 & $\mathrm{~m}$ & $\mathrm{~m}$ & $\mathrm{~m}$ & 10.375 & $\mathrm{~m}$ & $\mathrm{~m}$ & $\mathrm{~m}$ \\
\hline China & $\mathrm{m}$ & $\mathrm{m}$ & $\mathrm{m}$ & $\mathrm{m}$ & $\mathrm{m}$ & $\mathrm{m}$ & $\mathrm{m}$ & $\mathrm{m}$ \\
\hline Colombia & $\mathrm{m}$ & $\mathrm{m}$ & $\mathrm{m}$ & $\mathrm{m}$ & $\mathrm{m}$ & $\mathrm{m}$ & $\mathrm{m}$ & $\mathrm{m}$ \\
\hline Federación Rusa & $\mathrm{m}$ & $\mathrm{m}$ & $\mathrm{m}$ & $\mathrm{m}$ & $\mathrm{m}$ & $\mathrm{m}$ & $\mathrm{m}$ & $\mathrm{m}$ \\
\hline India & $\mathrm{m}$ & $\mathrm{m}$ & $\mathrm{m}$ & $\mathrm{m}$ & $\mathrm{m}$ & $\mathrm{m}$ & $\mathrm{m}$ & $\mathrm{m}$ \\
\hline Indonesia & 1.560 & $\mathrm{~m}$ & 1.974 & 2.249 & 1.560 & $\mathrm{~m}$ & 1.974 & 2.249 \\
\hline Letonia & $\mathrm{m}$ & $\mathrm{m}$ & $\mathrm{m}$ & $\mathrm{m}$ & $\mathrm{m}$ & $\mathrm{m}$ & $\mathrm{m}$ & $\mathrm{m}$ \\
\hline Sudáfrica & $\mathrm{m}$ & $\mathrm{m}$ & $\mathrm{m}$ & $\mathrm{m}$ & $\mathrm{m}$ & $\mathrm{m}$ & $\mathrm{m}$ & $\mathrm{m}$ \\
\hline Media G20 & $\mathrm{m}$ & $\mathrm{m}$ & $\mathrm{m}$ & $\mathrm{m}$ & $\mathrm{m}$ & $\mathrm{m}$ & $\mathrm{m}$ & $\mathrm{m}$ \\
\hline
\end{tabular}

1. Salarios de los profesores con cualificaciones típicas en lugar de mínimas. Para más información sobre el salario de los profesores con cualificaciones mínimas, consulte Anexo 3.

2. Incluye profesores de jardín de infancia solo para la educación infantil.

3. Incluye la media de bonificaciones obtenidas por horas extraordinarias para los profesores de secundaria inferior y superior.

4. Salarios base reales.

5. Año de referencia 2011.

6. Salarios tras 11 años de experiencia para las columnas 2, 6, 10 y 14 .

Fuentes: OCDE. Arabia Saudí, Argentina, China, Colombia, India, Indonesia, Sudáfrica: Instituto de Estadística de la UNESCO. Para ver notas, consulte Anexo 3 (www.oecd.org/edu/eag.htm).

Para obtener más información acerca de los símbolos utilizados en lugar de los datos que faltan, consulte la Guía del lector.

StatLink 젶ㄴ http://dx.doi.org/10.1787/888933119834 
Tabla D3.1. [2/2] Salarios reglamentarios de los profesores en diferentes momentos de su carrera (2012) Salarios anuales en instituciones públicas, en equivalente a dólares estadounidenses convertidos mediante PPA para el consumo privado

\begin{tabular}{|c|c|c|c|c|c|c|c|c|}
\hline & \multicolumn{4}{|c|}{ Educación secundaria inferior } & \multicolumn{4}{|c|}{ Educación secundaria superior } \\
\hline & $\begin{array}{c}\text { Salario } \\
\text { inicial, } \\
\text { formación } \\
\text { mínima }\end{array}$ & $\begin{array}{c}\text { Salario tras } \\
10 \text { años de } \\
\text { experiencia, } \\
\text { formación } \\
\text { mínima }\end{array}$ & $\begin{array}{c}\text { Salario tras } \\
15 \text { años de } \\
\text { experiencia, } \\
\text { formación } \\
\text { mínima }\end{array}$ & $\begin{array}{c}\text { Salario } \\
\text { máximo } \\
\text { de la escala, } \\
\text { formación } \\
\text { mínima }\end{array}$ & $\begin{array}{c}\text { Salario } \\
\text { inicial, } \\
\text { formación } \\
\text { mínima }\end{array}$ & $\begin{array}{l}\text { Salario tras } \\
10 \text { años de } \\
\text { experiencia, } \\
\text { formación } \\
\text { mínima }\end{array}$ & $\begin{array}{c}\text { Salario tras } \\
15 \text { años de } \\
\text { experiencia, } \\
\text { formación } \\
\text { mínima }\end{array}$ & $\begin{array}{c}\text { Salario } \\
\text { máximo } \\
\text { de la escala, } \\
\text { formación } \\
\text { mínima }\end{array}$ \\
\hline & (9) & (10) & (11) & (12) & (13) & (14) & (15) & (16) \\
\hline Alemania & 55.700 & 64.964 & 67.736 & 73.778 & 60.528 & 69.512 & 72.633 & 82.911 \\
\hline Australia & 37.259 & 52.082 & 52.082 & 52.214 & 37.259 & 52.082 & 52.082 & 52.214 \\
\hline Austria & 34.126 & 41.499 & 46.625 & 66.465 & 34.551 & 37.199 & 47.841 & 69.414 \\
\hline Bélgica (Fl.) & 33.667 & 42.283 & 47.635 & 58.340 & 42.065 & 53.684 & 61.256 & 73.875 \\
\hline Bélgica $(\mathrm{Fr} .)^{1}$ & 33.109 & 41.403 & 46.616 & 57.042 & 41.191 & 52.507 & 59.882 & 72.172 \\
\hline Canadá & 37.145 & 55.765 & 58.495 & 58.495 & 37.294 & 56.021 & 58.728 & 58.728 \\
\hline Chile & 17.770 & 22.742 & 24.725 & 32.656 & 18.876 & 24.108 & 26.195 & 34.541 \\
\hline Corea & 28.485 & 42.867 & 50.040 & 79.526 & 28.485 & 42.867 & 50.040 & 79.526 \\
\hline Dinamarca & 44.131 & 49.353 & 51.122 & 51.122 & 45.504 & 59.368 & 59.368 & 59.368 \\
\hline Escocia & 28.124 & 44.867 & 44.867 & 44.867 & 28.124 & 44.867 & 44.867 & 44.867 \\
\hline Eslovenia & 27.006 & 29.958 & 32.819 & 34.476 & 27.006 & 29.958 & 32.819 & 34.476 \\
\hline España & 39.726 & 43.173 & 45.783 & 55.989 & 40.767 & 44.334 & 47.026 & 57.580 \\
\hline Estados Unidos ${ }^{4}$ & 36.993 & 43.762 & 47.046 & 56.938 & 38.433 & 44.819 & 49.822 & 56.937 \\
\hline Estonia & 11.828 & 12.525 & 12.525 & 17.288 & 11.828 & 12.525 & 12.525 & 17.288 \\
\hline Finlandia $^{2}$ & 34.720 & 40.189 & 42.601 & 45.157 & 36.817 & 44.217 & 45.986 & 48.745 \\
\hline Francia $^{3}$ & 29.320 & 34.761 & 37.065 & 53.368 & 29.320 & 35.051 & 37.355 & 53.688 \\
\hline Grecia & 18.718 & 23.320 & 26.617 & 35.503 & 18.718 & 23.320 & 26.617 & 35.503 \\
\hline Hungría $^{4}$ & 10.992 & 12.562 & 13.520 & 18.020 & 11.736 & 14.118 & 15.626 & 22.098 \\
\hline Inglaterra & 28.321 & 41.393 & 41.393 & 41.393 & 28.321 & 41.393 & 41.393 & 41.393 \\
\hline Irlanda & 34.726 & 50.658 & 55.148 & 62.386 & 34.726 & 50.658 & 55.148 & 62.386 \\
\hline Islandia & 25.672 & 28.046 & 28.742 & 29.938 & 25.035 & 28.127 & 30.501 & 31.899 \\
\hline Israel & 19.790 & 24.136 & 26.912 & 37.676 & 18.973 & 22.995 & 25.634 & 37.266 \\
\hline Italia & 29.954 & 33.182 & 36.577 & 44.862 & 29.954 & 33.989 & 37.602 & 46.900 \\
\hline Japón & 27.067 & 40.204 & 47.561 & 59.643 & 27.067 & 40.204 & 47.561 & 61.274 \\
\hline Luxemburgo & 76.685 & 95.856 & 105.780 & 133.297 & 76.685 & 95.856 & 105.780 & 133.297 \\
\hline México & 20.206 & 20.759 & 26.229 & 43.003 & $\mathrm{~m}$ & $\mathrm{~m}$ & $\mathrm{~m}$ & $\mathrm{~m}$ \\
\hline Noruega & 34.484 & 38.773 & 38.773 & 43.318 & 37.888 & 41.652 & 41.652 & 45.931 \\
\hline Nueva Zelanda & 29.279 & 44.710 & 44.710 & 44.710 & 29.160 & 45.469 & 45.469 & 45.469 \\
\hline Países Bajos & 39.249 & 55.522 & 68.064 & 68.064 & 39.249 & 55.522 & 68.064 & 68.064 \\
\hline Polonia & 12.824 & 16.975 & 20.700 & 21.576 & 14.497 & 19.397 & 23.688 & 24.693 \\
\hline Portugal & 29.151 & 31.928 & 34.694 & 48.321 & 29.151 & 31.928 & 34.694 & 48.321 \\
\hline República Checa & 17.104 & 18.683 & 19.515 & 21.951 & 17.541 & 19.236 & 20.063 & 22.748 \\
\hline República Eslovaca & 10.644 & 12.778 & 13.365 & 14.411 & 10.644 & 12.778 & 13.365 & 14.411 \\
\hline Suecia $^{4,5}$ & 31.218 & 35.006 & 36.247 & 40.873 & 32.655 & 36.704 & 38.380 & 43.681 \\
\hline Suiza $^{6}$ & 55.485 & 69.816 & $\mathrm{~m}$ & 85.336 & 63.086 & 80.956 & $\mathrm{~m}$ & 96.593 \\
\hline Turquía & 25.790 & 26.588 & 27.607 & 29.773 & 25.790 & 26.588 & 27.607 & 29.773 \\
\hline Media OCDE & 30.735 & 38.419 & 40.570 & 48.938 & 32.255 & 40.686 & 42.861 & 51.658 \\
\hline Media UE21 & 30.915 & 37.949 & 41.174 & 48.198 & 32.243 & 39.918 & 43.564 & 51.212 \\
\hline Arabia Saudí & $\mathrm{m}$ & $\mathrm{m}$ & $\mathrm{m}$ & $\mathrm{m}$ & $\mathrm{m}$ & $\mathrm{m}$ & $\mathrm{m}$ & $\mathrm{m}$ \\
\hline Argentina & $\mathrm{m}$ & $\mathrm{m}$ & $\mathrm{m}$ & $\mathrm{m}$ & $\mathrm{m}$ & $\mathrm{m}$ & $\mathrm{m}$ & $\mathrm{m}$ \\
\hline Brasil & 10.375 & $\mathrm{~m}$ & $\mathrm{~m}$ & $\mathrm{~m}$ & 10.375 & $\mathrm{~m}$ & $\mathrm{~m}$ & $\mathrm{~m}$ \\
\hline China & $\mathrm{m}$ & $\mathrm{m}$ & $\mathrm{m}$ & $\mathrm{m}$ & $\mathrm{m}$ & $\mathrm{m}$ & $\mathrm{m}$ & $\mathrm{m}$ \\
\hline Colombia & $\mathrm{m}$ & $\mathrm{m}$ & $\mathrm{m}$ & $\mathrm{m}$ & $\mathrm{m}$ & $\mathrm{m}$ & $\mathrm{m}$ & $\mathrm{m}$ \\
\hline Federación Rusa & $\mathrm{m}$ & $\mathrm{m}$ & $\mathrm{m}$ & $\mathrm{m}$ & $\mathrm{m}$ & $\mathrm{m}$ & $\mathrm{m}$ & $\mathrm{m}$ \\
\hline India & $\mathrm{m}$ & $\mathrm{m}$ & $\mathrm{m}$ & $\mathrm{m}$ & $\mathrm{m}$ & $\mathrm{m}$ & $\mathrm{m}$ & $\mathrm{m}$ \\
\hline Indonesia & 1.663 & $\mathrm{~m}$ & 2.249 & 2.443 & 1.925 & $\mathrm{~m}$ & 2.491 & 2.714 \\
\hline Letonia & $\mathrm{m}$ & $\mathrm{m}$ & $\mathrm{m}$ & $\mathrm{m}$ & $\mathrm{m}$ & $\mathrm{m}$ & $\mathrm{m}$ & $\mathrm{m}$ \\
\hline Sudáfrica & $\mathrm{m}$ & $\mathrm{m}$ & $\mathrm{m}$ & $\mathrm{m}$ & $\mathrm{m}$ & $\mathrm{m}$ & $\mathrm{m}$ & $\mathrm{m}$ \\
\hline Media G20 & $\mathrm{m}$ & $\mathrm{m}$ & $\mathrm{m}$ & $\mathrm{m}$ & $\mathrm{m}$ & $\mathrm{m}$ & $\mathrm{m}$ & $\mathrm{m}$ \\
\hline
\end{tabular}

1. Salarios de los profesores con cualificaciones típicas en lugar de mínimas. Para más información sobre el salario de los profesores con cualificaciones mínimas, consulte Anexo 3.

2. Incluye profesores de jardín de infancia solo para la educación infantil.

3. Incluye la media de bonificaciones obtenidas por horas extraordinarias para los profesores de secundaria inferior y superior.

4. Salarios base reales.

5. Año de referencia 2011.

6. Salarios tras 11 años de experiencia para las columnas 2, 6, 10 y 14.

Fuentes: OCDE. Arabia Saudí, Argentina, China, Colombia, India, Indonesia, Sudáfrica: Instituto de Estadística de la UNESCO. Para ver notas, consulte Anexo 3 (www.oecd.org/edu/eag.htm).

Para obtener más información acerca de los símbolos utilizados en lugar de los datos que faltan, consulte la Guía del lector.

StatLink 제그 http://dx.doi.org/10.1787/888933119834 
Tabla D3.2. Salarios de los profesores en relación con los ingresos de los trabajadores con educación terciaria de 25 a 64 años de edad a tiempo completo, todo el año (2012)

Ratio de los salarios, por grupo de edad y sexo

\begin{tabular}{|c|c|c|c|c|c|c|}
\hline & & & & & años & \\
\hline & Método $^{1}$ & Año de referencia & $\begin{array}{c}\text { Educación } \\
\text { infantil }\end{array}$ & $\begin{array}{c}\text { Educación } \\
\text { primaria }\end{array}$ & $\begin{array}{c}\text { Educación } \\
\text { secundaria inferior }\end{array}$ & $\begin{array}{c}\text { Educación } \\
\text { secundaria superior }\end{array}$ \\
\hline & (1) & (2) & (3) & (4) & (5) & (6) \\
\hline ulemania & Reales & 2012 & $\mathrm{~m}$ & 0,88 & 0,97 & 1,05 \\
\hline Australia & Reales & 2012 & 0,89 & 0,93 & 0,93 & 0,93 \\
\hline Austria & Reglamentarios & 2012 & 0,55 & 0,55 & 0,60 & 0,61 \\
\hline Bélgica $(\mathrm{Fl} .)^{2}$ & Reales & 2012 & 0,88 & 0,89 & 0,87 & 1,13 \\
\hline Bélgica $(\mathrm{Fr} .)^{2}$ & Reales & 2012 & 0,82 & 0,82 & 0,82 & 1,01 \\
\hline Canadá & Reglamentarios & 2011 & 1,05 & 1,05 & 1,05 & 1,06 \\
\hline Chile & Reales & 2011 & 0,73 & 0,73 & 0,73 & 0,77 \\
\hline Corea & Reglamentarios & 2012 & 1,32 & 1,36 & 1,36 & 1,36 \\
\hline Dinamarca & Reales & 2012 & 0,83 & 0,92 & 0,92 & 1,06 \\
\hline Escocia $^{3,5}$ & Reales & 2012 & 0,83 & 0,83 & 0,83 & 0,83 \\
\hline Eslovenia & Reglamentarios & 2012 & 0,79 & 0,79 & 0,79 & 0,79 \\
\hline España & Reglamentarios & 2011 & 1,20 & 1,20 & 1,32 & 1,35 \\
\hline Estados Unidos & Reales & 2012 & 0,65 & 0,67 & 0,68 & 0,70 \\
\hline Estonia & Reales & 2012 & 0,61 & 0,84 & 0,84 & 0,84 \\
\hline Finlandia ${ }^{4}$ & Reales & 2012 & 0,65 & 0,89 & 0,97 & 1,09 \\
\hline Francia & Reales & 2012 & 0,73 & 0,72 & 0,86 & 0,95 \\
\hline Grecia & Reales & 2012 & 0,89 & 0,89 & 0,93 & 0,93 \\
\hline Hungría & Reales & 2012 & 0,47 & 0,53 & 0,53 & 0,59 \\
\hline Inglaterra $^{3}$ & Reales & 2012 & 0,86 & 0,86 & 0,95 & 0,95 \\
\hline Irlanda & Reglamentarios & 2011 & $\mathrm{~m}$ & 0,81 & 0,81 & 0,81 \\
\hline Islandia & $\mathrm{m}$ & $\mathrm{m}$ & $\mathrm{m}$ & $\mathrm{m}$ & $\mathrm{m}$ & $\mathrm{m}$ \\
\hline Israel & Reales & 2012 & 0,80 & 0,87 & 0,85 & 0,88 \\
\hline Italia & Reales & 2012 & 0,60 & 0,60 & 0,65 & 0,69 \\
\hline Japón & $\mathrm{m}$ & $\mathrm{m}$ & $\mathrm{m}$ & $\mathrm{m}$ & $\mathrm{m}$ & $\mathrm{m}$ \\
\hline Luxemburgo & Reales & 2012 & 1,11 & 1,11 & 1,26 & 1,26 \\
\hline México & $\mathrm{m}$ & $\mathrm{m}$ & $\mathrm{m}$ & $\mathrm{m}$ & $\mathrm{m}$ & $\mathrm{m}$ \\
\hline Noruega & Reales & 2012 & 0,63 & 0,71 & 0,71 & 0,76 \\
\hline Nueva Zelanda & Reales & 2011 & $\mathrm{~m}$ & 1,04 & 1,06 & 1,09 \\
\hline Países Bajos & Reales & 2012 & 0,69 & 0,69 & 0,82 & 0,82 \\
\hline Polonia & Reales & 2012 & 0,71 & 0,82 & 0,83 & 0,82 \\
\hline Portugal & Reglamentarios & 2011 & 1,23 & 1,23 & 1,23 & 1,23 \\
\hline República Checa & Reales & 2012 & 0,46 & 0,54 & 0,54 & 0,58 \\
\hline República Eslovaca & Reglamentarios & 2012 & 0,35 & 0,43 & 0,43 & 0,43 \\
\hline Suecia ${ }^{6}$ & Reales & 2011 & 0,75 & 0,82 & 0,82 & 0,87 \\
\hline Suiza & $\mathrm{m}$ & $\mathrm{m}$ & $\mathrm{m}$ & $\mathrm{m}$ & $\mathrm{m}$ & $\mathrm{m}$ \\
\hline Turquía & Reglamentarios & 2012 & 1,09 & 1,09 & 1,13 & 1,13 \\
\hline Media OCDE & & & 0,80 & 0,85 & 0,88 & 0,92 \\
\hline Media UE21 & & & 0,76 & 0,81 & 0,85 & 0,90 \\
\hline 气 Arabia Saudí & $\mathrm{m}$ & $\mathrm{m}$ & $\mathrm{m}$ & $\mathrm{m}$ & $\mathrm{m}$ & $\mathrm{m}$ \\
\hline Argentina & $\mathrm{m}$ & $\mathrm{m}$ & $\mathrm{m}$ & $\mathrm{m}$ & $\mathrm{m}$ & $\mathrm{m}$ \\
\hline Brasil & $\mathrm{m}$ & $\mathrm{m}$ & $\mathrm{m}$ & $\mathrm{m}$ & $\mathrm{m}$ & $\mathrm{m}$ \\
\hline ¿ China & $\mathrm{m}$ & $\mathrm{m}$ & $\mathrm{m}$ & $\mathrm{m}$ & $\mathrm{m}$ & $\mathrm{m}$ \\
\hline$\frac{\breve{n}}{\bar{c}}$ Colombia & $\mathrm{m}$ & $\mathrm{m}$ & $\mathrm{m}$ & $\mathrm{m}$ & $\mathrm{m}$ & $\mathrm{m}$ \\
\hline Federación Rusa & $\mathrm{m}$ & $\mathrm{m}$ & $\mathrm{m}$ & $\mathrm{m}$ & $\mathrm{m}$ & $\mathrm{m}$ \\
\hline India & $\mathrm{m}$ & $\mathrm{m}$ & $\mathrm{m}$ & $\mathrm{m}$ & $\mathrm{m}$ & $\mathrm{m}$ \\
\hline Indonesia & $\mathrm{m}$ & $\mathrm{m}$ & $\mathrm{m}$ & $\mathrm{m}$ & $\mathrm{m}$ & $\mathrm{m}$ \\
\hline Letonia & $\mathrm{m}$ & $\mathrm{m}$ & $\mathrm{m}$ & $\mathrm{m}$ & $\mathrm{m}$ & $\mathrm{m}$ \\
\hline Sudáfrica & $\mathrm{m}$ & $\mathrm{m}$ & $\mathrm{m}$ & $\mathrm{m}$ & $\mathrm{m}$ & $\mathrm{m}$ \\
\hline Media G20 & & & $\mathrm{m}$ & $\mathrm{m}$ & $\mathrm{m}$ & $\mathrm{m}$ \\
\hline
\end{tabular}

Notas: Las columnas que muestran los salarios de los profesores en relación con los ingresos de los trabajadores a tiempo completo durante todo el año con educación terciaria, separados por grupos de edad y sexo (es decir, de la columna 7 a la 30), están disponibles en Internet (véase StatLink más abajo).

1. El método «Reales» hace referencia a la ratio entre la media del salario real, incluyendo primas y bonificaciones, de los profesores de 25 a 64 años de edad y los ingresos de los trabajadores a tiempo completo durante todo el año con educación terciaria de 25 a 64 años de edad. El método «Reglamentarios» hace referencia a la ratio entre los salarios reglamentarios de los profesores tras 15 años de experiencia y formación mínima (independientemente de la edad) y los ingresos de los trabajadores a tiempo completo y todo el año con educación terciaria de 25 a 64 años de edad.

2. Los datos sobre los ingresos de los trabajadores a tiempo completo, todo el año, con educación terciaria se refieren a Bélgica.

3. Datos sobre los ingresos de los trabajadores a tiempo completo durante todo el año con educación terciaria en Reino Unido.

4. Incluye profesores de jardín de infancia solo para la educación infantil.

5. Incluye a todos los profesores, independientemente de su edad.

6. Salarios medios reales de los profesores, sin incluir las primas y las bonificaciones.

Fuentes: OCDE. Arabia Saudí, Argentina, China, Colombia, India, Indonesia, Sudáfrica: Instituto de Estadística de la UNESCO. Para ver notas, consulte Anexo 3 (www.oecd.org/edu/eag.htm)

Para obtener más información acerca de los símbolos utilizados en lugar de los datos que faltan, consulte la Guía del lector.

StatLink 젶ㄴ http://dx.doi.org/10.1787/888933119853 
Tabla D3.3. Comparación de los salarios reglamentarios de los profesores (2012)

Ratio de los salarios en diferentes puntos de la experiencia docente, con formación mínima y salario por hora en equivalente a dólares estadounidenses convertidos mediante PPA para el consumo privado

\begin{tabular}{|c|c|c|c|c|c|c|c|c|c|}
\hline & \multicolumn{4}{|c|}{$\begin{array}{c}\text { Ratio entre el salario máximo de la escala } \\
\text { y el salario inicial }\end{array}$} & \multirow{2}{*}{\begin{tabular}{|c|} 
Años \\
transcurridos \\
desde el salario \\
inicial al máximo \\
de la escala \\
(educación \\
secundaria \\
inferior)
\end{tabular}} & \multicolumn{3}{|c|}{$\begin{array}{l}\text { Salario por hora de contacto neto } \\
\text { (enseñanza) tras } 15 \text { años de experiencia }\end{array}$} & \multirow{2}{*}{$\begin{array}{l}\text { Ratio de los salarios } \\
\text { por hora lectiva } \\
\text { de los profesores } \\
\text { de educación } \\
\text { secundaria superior } \\
\text { y los profesores de } \\
\text { educación primaria } \\
\text { (tras } 15 \text { años } \\
\text { de experiencia) }\end{array}$} \\
\hline & $\begin{array}{c}\text { Educación } \\
\text { infantil }\end{array}$ & $\begin{array}{l}\text { Educación } \\
\text { primaria }\end{array}$ & $\begin{array}{l}\text { Educación } \\
\text { secundaria } \\
\text { inferior }\end{array}$ & $\begin{array}{c}\text { Educación } \\
\text { secundaria } \\
\text { superior }\end{array}$ & & $\begin{array}{l}\text { Educación } \\
\text { primaria }\end{array}$ & $\begin{array}{l}\text { Educación } \\
\text { secundaria } \\
\text { inferior }\end{array}$ & $\begin{array}{l}\text { Educación } \\
\text { secundaria } \\
\text { superior }\end{array}$ & \\
\hline & (1) & (2) & (3) & (4) & (5) & (6) & (7) & (8) & (9) \\
\hline Alemania & $\mathrm{m}$ & 1,33 & 1,32 & 1,37 & 28 & 77 & 90 & 101 & 1,31 \\
\hline Australia & 1,40 & 1,39 & 1,40 & 1,40 & 9 & 59 & 64 & 65 & 1,10 \\
\hline Austria & 1,97 & 1,97 & 1,95 & 2,01 & 34 & 55 & 77 & 81 & 1,47 \\
\hline Bélgica (Fl.) & 1,73 & 1,73 & 1,73 & 1,76 & 27 & 64 & 73 & 101 & 1,58 \\
\hline Bélgica (Fr.) & 1,72 & 1,72 & 1,72 & 1,75 & 27 & 65 & 71 & 100 & 1,54 \\
\hline Canadá & 1,57 & 1,57 & 1,57 & 1,57 & 11 & 73 & 78 & 78 & 1,07 \\
\hline Chile & 1,84 & 1,84 & 1,84 & 1,83 & 30 & 22 & 22 & 24 & 1,06 \\
\hline Corea & 2,84 & 2,79 & 2,79 & 2,79 & 37 & 72 & 88 & 91 & 1,26 \\
\hline Dinamarca & 1,09 & 1,16 & 1,16 & 1,30 & 8 & 78 & 78 & 161 & 2,07 \\
\hline Escocia & 1,60 & 1,60 & 1,60 & 1,60 & 6 & 52 & 52 & 52 & 1,00 \\
\hline Eslovenia & 1,25 & 1,28 & 1,28 & 1,28 & 13 & 52 & 52 & 58 & 1,10 \\
\hline España & 1,42 & 1,42 & 1,41 & 1,41 & 38 & 48 & 64 & 68 & 1,43 \\
\hline Estados Unidos ${ }^{2}$ & 1,70 & 1,62 & 1,54 & 1,48 & $\mathrm{~m}$ & 41 & 43 & 46 & 1,14 \\
\hline Estonia & $\mathrm{m}$ & 1,46 & 1,46 & 1,46 & 7 & 20 & 20 & 22 & 1,09 \\
\hline Finlandia ${ }^{1}$ & 1,08 & 1,30 & 1,30 & 1,32 & 20 & 59 & 72 & 84 & 1,43 \\
\hline Francia & 1,91 & 1,91 & 1,82 & 1,83 & 29 & 37 & 57 & 58 & 1,57 \\
\hline Grecia & 1,90 & 1,90 & 1,90 & 1,90 & 45 & 47 & 64 & 64 & 1,37 \\
\hline Hungría $^{2}$ & 1,58 & 1,64 & 1,64 & 1,88 & 40 & 22 & 22 & 26 & 1,16 \\
\hline Inglaterra & 1,46 & 1,46 & 1,46 & 1,46 & 12 & 61 & 60 & 60 & 0,98 \\
\hline Irlanda & $\mathrm{m}$ & 1,86 & 1,80 & 1,80 & 22 & 60 & 75 & 75 & 1,25 \\
\hline Islandia & 1,27 & 1,17 & 1,17 & 1,27 & 18 & 46 & 46 & 56 & 1,22 \\
\hline Israel & 2,09 & 2,10 & 1,90 & 1,96 & 36 & 35 & 43 & 46 & 1,31 \\
\hline Italia & 1,47 & 1,47 & 1,50 & 1,57 & 35 & 45 & 59 & 61 & 1,37 \\
\hline Japón & $\mathrm{m}$ & 2,20 & 2,20 & 2,26 & 34 & 65 & 79 & 93 & 1,43 \\
\hline Luxemburgo & 1,79 & 1,79 & 1,74 & 1,74 & 30 & 122 & 143 & 143 & 1,17 \\
\hline México & 2,14 & 2,14 & 2,13 & $\mathrm{~m}$ & 14 & 25 & 25 & $\mathrm{~m}$ & $\mathrm{~m}$ \\
\hline Noruega & 1,16 & 1,26 & 1,26 & 1,21 & 16 & 52 & 58 & 80 & 1,52 \\
\hline Nueva Zelanda & $\mathrm{m}$ & 1,49 & 1,53 & 1,56 & 8 & 46 & 53 & 60 & 1,30 \\
\hline Países Bajos & 1,48 & 1,48 & 1,73 & 1,73 & 14 & 59 & 91 & 91 & 1,54 \\
\hline Polonia & 1,66 & 1,66 & 1,68 & 1,70 & 20 & 29 & 37 & 42 & 1,48 \\
\hline Portugal & 1,66 & 1,66 & 1,66 & 1,66 & 34 & 46 & 56 & 56 & 1,23 \\
\hline República Checa & 1,18 & 1,29 & 1,28 & 1,30 & 27 & 23 & 31 & 34 & 1,45 \\
\hline República Eslovaca & 1,24 & 1,35 & 1,35 & 1,35 & 32 & 16 & 21 & 22 & 1,35 \\
\hline Suecia $^{2,3}$ & 1,19 & 1,33 & 1,31 & 1,34 & a & $\mathrm{m}$ & $\mathrm{m}$ & $\mathrm{m}$ & $\mathrm{m}$ \\
\hline Suiza & 1,54 & 1,55 & 1,54 & 1,53 & 27 & $\mathrm{~m}$ & $\mathrm{~m}$ & $\mathrm{~m}$ & $\mathrm{~m}$ \\
\hline Turquía & 1,16 & 1,16 & 1,15 & 1,15 & 27 & 37 & 55 & 49 & 1,31 \\
\hline Media OCDE & 1,58 & 1,61 & 1,61 & 1,62 & 24 & 50 & 59 & 68 & 1,32 \\
\hline Media UE21 & 1,52 & 1,55 & 1,56 & 1,59 & 25 & 52 & 62 & 71 & 1,36 \\
\hline $\begin{array}{l}\text { Arabia Saudí } \\
\text { Argentina }^{3}\end{array}$ & $\begin{array}{l}\mathrm{m} \\
\mathrm{m}\end{array}$ & $\begin{array}{l}\mathrm{m} \\
\mathrm{m}\end{array}$ & $\begin{array}{l}\mathrm{m} \\
\mathrm{m}\end{array}$ & $\begin{array}{l}\mathrm{m} \\
\mathrm{m}\end{array}$ & $\begin{array}{l}\mathrm{m} \\
25\end{array}$ & $\begin{array}{l}\mathrm{m} \\
\mathrm{m}\end{array}$ & $\begin{array}{l}\mathrm{m} \\
\mathrm{m}\end{array}$ & $\begin{array}{l}\mathrm{m} \\
\mathrm{m}\end{array}$ & $\begin{array}{l}\mathrm{m} \\
\mathrm{m}\end{array}$ \\
\hline Brasil & $\mathrm{m}$ & $\mathrm{m}$ & $\mathrm{m}$ & $\mathrm{m}$ & $\mathrm{m}$ & $\mathrm{m}$ & $\mathrm{m}$ & $\mathrm{m}$ & $\mathrm{m}$ \\
\hline China & $\mathrm{m}$ & $\mathrm{m}$ & $\mathrm{m}$ & $\mathrm{m}$ & $\mathrm{m}$ & $\mathrm{m}$ & $\mathrm{m}$ & $\mathrm{m}$ & $\mathrm{m}$ \\
\hline Colombia & $\mathrm{m}$ & $\mathrm{m}$ & $\mathrm{m}$ & $\mathrm{m}$ & $\mathrm{m}$ & $\mathrm{m}$ & $\mathrm{m}$ & $\mathrm{m}$ & $\mathrm{m}$ \\
\hline Federación Rusa & $\mathrm{m}$ & $\mathrm{m}$ & $\mathrm{m}$ & $\mathrm{m}$ & $\mathrm{m}$ & $\mathrm{m}$ & $\mathrm{m}$ & $\mathrm{m}$ & $\mathrm{m}$ \\
\hline India & $\mathrm{m}$ & $\mathrm{m}$ & $\mathrm{m}$ & $\mathrm{m}$ & $\mathrm{m}$ & $\mathrm{m}$ & $\mathrm{m}$ & $\mathrm{m}$ & $\mathrm{m}$ \\
\hline Indonesia & 1,44 & 1,44 & 1,47 & 1,41 & 32 & 2 & 3 & 3 & 2,16 \\
\hline Letonia & $\mathrm{m}$ & $\mathrm{m}$ & $\mathrm{m}$ & $\mathrm{m}$ & $\mathrm{m}$ & $\mathrm{m}$ & $\mathrm{m}$ & $\mathrm{m}$ & $\mathrm{m}$ \\
\hline Sudáfrica & $\mathrm{m}$ & $\mathrm{m}$ & $\mathrm{m}$ & $\mathrm{m}$ & $\mathrm{m}$ & $\mathrm{m}$ & $\mathrm{m}$ & $\mathrm{m}$ & $\mathrm{m}$ \\
\hline Media G20 & $\mathrm{m}$ & $\mathrm{m}$ & $\mathrm{m}$ & $\mathrm{m}$ & $\mathrm{m}$ & $\mathrm{m}$ & $\mathrm{m}$ & $\mathrm{m}$ & $\mathrm{m}$ \\
\hline
\end{tabular}

1. Incluye profesores de jardín de infancia solo para la educación infantil.

2. Salarios base reales.

3. Año de referencia 2011.

Fuentes: OCDE. Arabia Saudí, Argentina, China, Colombia, India, Indonesia, Sudáfrica: Instituto de Estadística de la UNESCO. Para ver notas, consulte Anexo 3 (www.oecd.org/edu/eag.htm).

Para obtener más información acerca de los símbolos utilizados en lugar de los datos que faltan, consulte la Guía del lector.

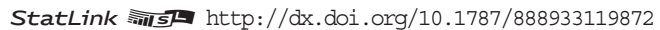


Tabla D3.4. Salarios medios reales de los profesores (2012)

Salarios medios anuales (incluidas primas y bonificaciones) de los profesores de instituciones públicas, en equivalente a dólares estadounidenses convertidos mediante PPA para el consumo privado, por grupos de edad y sexo

\begin{tabular}{|c|c|c|c|}
\hline \multicolumn{4}{|c|}{ De 25 a 64 años } \\
\hline Educación infantil & Educación primaria & Educación secundaria inferior & Educación secundaria superior \\
\hline (1) & (2) & (3) & (4) \\
\hline $\mathrm{m}$ & 59.598 & 65.545 & 71.396 \\
\hline 50.767 & 52.659 & 52.928 & 52.961 \\
\hline $\mathrm{m}$ & $\mathrm{m}$ & $\mathrm{m}$ & $\mathrm{m}$ \\
\hline 48.998 & 49.439 & 48.255 & 62.528 \\
\hline 45.608 & 45.513 & 45.418 & 56.270 \\
\hline $\mathrm{m}$ & $\mathrm{m}$ & $\mathrm{m}$ & $\mathrm{m}$ \\
\hline 32.728 & 32.728 & 32.728 & 34.480 \\
\hline $\mathrm{m}$ & $\mathrm{m}$ & $\mathrm{m}$ & $\mathrm{m}$ \\
\hline 50.477 & 55.330 & 55.330 & 64.384 \\
\hline 42.444 & 42.444 & 42.444 & 42.444 \\
\hline $\mathrm{m}$ & $\mathrm{m}$ & $\mathrm{m}$ & $\mathrm{m}$ \\
\hline $\mathrm{m}$ & $\mathrm{m}$ & $\mathrm{m}$ & $\mathrm{m}$ \\
\hline 48.985 & 50.494 & 51.487 & 53.198 \\
\hline 11.456 & 15.803 & 15.803 & 15.803 \\
\hline 31.531 & 42.910 & 46.968 & 52.606 \\
\hline 35.716 & 35.432 & 42.217 & 46.247 \\
\hline 22.992 & 22.992 & 23.941 & 23.941 \\
\hline 15.031 & 16.731 & 16.731 & 18.716 \\
\hline 43.949 & 43.949 & 48.409 & 48.409 \\
\hline $\mathrm{m}$ & $\mathrm{m}$ & $\mathrm{m}$ & $\mathrm{m}$ \\
\hline $\mathrm{m}$ & $\mathrm{m}$ & $\mathrm{m}$ & 38.751 \\
\hline 30.544 & 33.181 & 32.228 & 33.386 \\
\hline 34.162 & 34.162 & 36.947 & 39.233 \\
\hline $\mathrm{m}$ & $\mathrm{m}$ & $\mathrm{m}$ & $\mathrm{m}$ \\
\hline 92.248 & 92.248 & 104.991 & 104.991 \\
\hline $\mathrm{m}$ & $\mathrm{m}$ & $\mathrm{m}$ & $\mathrm{m}$ \\
\hline 40.988 & 46.722 & 46.722 & 49.665 \\
\hline $\mathrm{m}$ & 43.102 & 43.999 & 44.897 \\
\hline 49.924 & 49.924 & 59.469 & 59.469 \\
\hline 24.317 & 27.986 & 28.409 & 27.769 \\
\hline $\mathrm{m}$ & $\mathrm{m}$ & $\mathrm{m}$ & $\mathrm{m}$ \\
\hline 17.411 & 20.743 & 20.724 & 21.985 \\
\hline $\mathrm{m}$ & $\mathrm{m}$ & $\mathrm{m}$ & $\mathrm{m}$ \\
\hline 33.036 & 35.822 & 35.909 & 38.347 \\
\hline $\mathrm{m}$ & $\mathrm{m}$ & $\mathrm{m}$ & 77.250 \\
\hline $\mathrm{m}$ & $\mathrm{m}$ & $\mathrm{m}$ & $\mathrm{m}$ \\
\hline 38.253 & 41.300 & 43.374 & 47.165 \\
\hline
\end{tabular}

\begin{tabular}{|c|c|c|c|c|}
\hline Media & 38.253 & 41.300 & 43.374 & 47.165 \\
\hline 气 Arabia Saudí & $\mathrm{m}$ & $\mathrm{m}$ & $\mathrm{m}$ & $\mathrm{m}$ \\
\hline Argentina & $\mathrm{m}$ & $\mathrm{m}$ & $\mathrm{m}$ & $\mathrm{m}$ \\
\hline : Brasil & $\mathrm{m}$ & $\mathrm{m}$ & $\mathrm{m}$ & $\mathrm{m}$ \\
\hline y China & $\mathrm{m}$ & $\mathrm{m}$ & $\mathrm{m}$ & $\mathrm{m}$ \\
\hline Colombia & $\mathrm{m}$ & $\mathrm{m}$ & $\mathrm{m}$ & $\mathrm{m}$ \\
\hline Federación Rusa $a^{2,5}$ & 18.445 & 18.445 & 18.445 & 18.445 \\
\hline India & $\mathrm{m}$ & $\mathrm{m}$ & $\mathrm{m}$ & $\mathrm{m}$ \\
\hline Indonesia & $\mathrm{m}$ & $\mathrm{m}$ & $\mathrm{m}$ & $\mathrm{m}$ \\
\hline Letonia & $\mathrm{m}$ & $\mathrm{m}$ & $\mathrm{m}$ & $\mathrm{m}$ \\
\hline Sudáfrica & $\mathrm{m}$ & $\mathrm{m}$ & $\mathrm{m}$ & $\mathrm{m}$ \\
\hline
\end{tabular}

Notas: Las columnas que muestran los salarios medios de los profesores separados por grupos de edad y sexo (es decir, de la columna 5 a la 28 ) están disponibles en Internet (véase StatLink más abajo)

1. Incluye profesores de jardín de infancia solo para la educación infantil.

2. Año de referencia 2011.

3. Incluye a todos los profesores, independientemente de su edad.

4. Salarios medios reales de los profesores, sin incluir las primas y las bonificaciones.

5. Salarios medios reales de los profesores, independientemente del nivel de educación que imparten.

Fuentes: OCDE. Arabia Saudí, Argentina, China, Colombia, India, Indonesia, Sudáfrica: Instituto de Estadística de la UNESCO. Para ver notas, consulte Anexo 3 (www.oecd.org/edu/eag.htm).

Para obtener más información acerca de los símbolos utilizados en lugar de los datos que faltan, consulte la Guía del lector.

StatLink 제개 http://dx.doi.org/10.1787/888933119891 
Tabla D3.5. Tendencias de los salarios de los profesores entre 2000 y 2012

Índice de cambio entre 2000 y 2012 en los salarios reglamentarios de los profesores tras 15 años de experiencia y con formación mínima (2005 = 100), por nivel de educación, convertidos a precios constantes utilizando deflactores para el consumo privado

\begin{tabular}{|c|c|c|c|c|c|c|c|c|c|c|c|c|c|c|c|c|}
\hline & & \multicolumn{5}{|c|}{ Educación primaria } & \multicolumn{5}{|c|}{ Educación secundaria inferior } & \multicolumn{5}{|c|}{ Educación secundaria superior } \\
\hline & & 2000 & 2005 & 2010 & 2011 & 2012 & 2000 & 2005 & 2010 & 2011 & 2012 & 2000 & 2005 & 2010 & 2011 & 2012 \\
\hline & & $(1)$ & $(2)$ & $(7)$ & $(8)$ & $(9)$ & $(10)$ & $(11)$ & (16) & $(17)$ & (18) & (19) & $(20)$ & (25) & (26) & (27) \\
\hline \multirow{34}{*}{ Ü } & Alemania & $\mathrm{m}$ & $\mathrm{m}$ & $\mathrm{m}$ & $\mathrm{m}$ & $\mathrm{m}$ & $\mathrm{m}$ & $\mathrm{m}$ & $\mathrm{m}$ & $\mathrm{m}$ & $\mathrm{m}$ & $\mathrm{m}$ & $\mathrm{m}$ & $\mathrm{m}$ & $\mathrm{m}$ & $\mathrm{m}$ \\
\hline & Australia & 92 & 100 & 102 & 104 & 104 & 92 & 100 & 102 & 105 & 105 & 92 & 100 & 102 & 105 & 105 \\
\hline & Austria & 90 & 100 & 104 & 102 & 101 & 87 & 100 & 104 & 102 & 102 & 94 & 100 & 105 & 103 & 102 \\
\hline & Bélgica (Fl.) & 92 & 100 & 102 & 102 & 101 & 97 & 100 & 102 & 102 & 101 & 97 & 100 & 102 & 102 & 102 \\
\hline & Bélgica (Fr.) & 94 & 100 & 104 & 105 & 104 & 99 & 100 & 103 & 104 & 103 & 99 & 100 & 103 & 104 & 103 \\
\hline & Chile & $\mathrm{m}$ & $\mathrm{m}$ & $\mathrm{m}$ & $\mathrm{m}$ & $\mathrm{m}$ & $\mathrm{m}$ & $\mathrm{m}$ & $\mathrm{m}$ & $\mathrm{m}$ & $\mathrm{m}$ & $\mathrm{m}$ & $\mathrm{m}$ & $\mathrm{m}$ & $\mathrm{m}$ & $\mathrm{m}$ \\
\hline & Corea & 80 & 100 & 93 & 95 & 95 & 80 & 100 & 93 & 95 & 96 & 80 & 100 & 93 & 95 & 96 \\
\hline & Dinamarca $^{2}$ & 94 & 100 & 119 & 116 & 114 & 94 & 100 & 119 & 116 & 114 & 90 & 100 & 114 & 111 & 108 \\
\hline & Escocia & 82 & 100 & 99 & 97 & 93 & 82 & 100 & 99 & 97 & 93 & 82 & 100 & 99 & 97 & 93 \\
\hline & Eslovenia & $\mathrm{m}$ & 100 & 108 & 107 & 104 & $\mathrm{~m}$ & 100 & 108 & 107 & 104 & $\mathrm{~m}$ & 100 & 108 & 107 & 104 \\
\hline & España & 95 & 100 & 107 & 101 & 97 & 92 & 100 & 106 & 99 & 95 & 96 & 100 & 106 & 99 & 95 \\
\hline & Estados Unidos ${ }^{3}$ & 96 & 100 & 99 & 99 & 97 & 95 & 100 & 98 & 98 & 98 & 102 & 100 & 106 & 106 & 104 \\
\hline & Estonia & 84 & 100 & 141 & 136 & 131 & 84 & 100 & 141 & 136 & 131 & 84 & 100 & 141 & 136 & 131 \\
\hline & Francia & 105 & 100 & 97 & 96 & 94 & 105 & 100 & 97 & 97 & 95 & 104 & 100 & 97 & 97 & 95 \\
\hline & Grecia & 89 & 100 & 92 & 86 & 77 & 89 & 100 & 92 & 86 & 77 & 89 & 100 & 92 & 86 & 77 \\
\hline & Hungría $^{3}$ & 63 & 100 & 78 & 75 & 71 & 63 & 100 & 78 & 75 & 71 & 63 & 100 & 74 & 71 & 65 \\
\hline & Inglaterra & 91 & 100 & 100 & 98 & 95 & 91 & 100 & 100 & 98 & 95 & 91 & 100 & 100 & 98 & 95 \\
\hline & Irlanda & 86 & 100 & 115 & 113 & 112 & 87 & 100 & 115 & 113 & 112 & 87 & 100 & 115 & 113 & 112 \\
\hline & Islandia & 89 & 100 & 103 & 100 & 96 & 89 & 100 & 103 & 100 & 96 & 90 & 100 & 89 & 86 & 87 \\
\hline & Israel & 100 & 100 & 135 & 142 & 143 & 100 & 100 & 110 & 117 & 117 & 101 & 100 & 103 & 102 & 114 \\
\hline & Italia & 94 & 100 & 100 & 98 & 95 & 95 & 100 & 100 & 98 & 96 & 95 & 100 & 100 & 98 & 96 \\
\hline & Japón & 101 & 100 & 93 & 93 & 93 & 101 & 100 & 93 & 93 & 93 & 101 & 100 & 93 & 93 & 93 \\
\hline & Luxemburgo & $\mathrm{m}$ & 100 & 134 & 131 & 135 & $\mathrm{~m}$ & 100 & 110 & 108 & 110 & $\mathrm{~m}$ & 100 & 110 & 108 & 110 \\
\hline & México & 96 & 100 & 103 & 107 & 107 & 95 & 100 & 104 & 107 & 109 & $\mathrm{~m}$ & $\mathrm{~m}$ & $\mathrm{~m}$ & $\mathrm{~m}$ & $\mathrm{~m}$ \\
\hline & Noruega & $\mathrm{m}$ & 100 & 104 & 108 & 109 & $\mathrm{~m}$ & 100 & 104 & 108 & 109 & $\mathrm{~m}$ & 100 & 106 & 110 & 110 \\
\hline & Nueva Zelanda & 97 & 100 & 105 & 106 & 104 & 97 & 100 & 108 & 107 & 109 & 97 & 100 & 111 & 108 & 110 \\
\hline & Países Bajos & $\mathrm{m}$ & $\mathrm{m}$ & $\mathrm{m}$ & $\mathrm{m}$ & $\mathrm{m}$ & $\mathrm{m}$ & $\mathrm{m}$ & $\mathrm{m}$ & $\mathrm{m}$ & $\mathrm{m}$ & $\mathrm{m}$ & $\mathrm{m}$ & $\mathrm{m}$ & $\mathrm{m}$ & $\mathrm{m}$ \\
\hline & Polonia & $\mathrm{m}$ & 100 & 116 & 120 & 123 & $\mathrm{~m}$ & 100 & 115 & 118 & 121 & $\mathrm{~m}$ & 100 & 113 & 117 & 120 \\
\hline & Suecia $^{3}$ & 94 & 100 & $\mathrm{~m}$ & 103 & $\mathrm{~m}$ & 92 & 100 & $\mathrm{~m}$ & 104 & $\mathrm{~m}$ & 91 & 100 & $\mathrm{~m}$ & 102 & $\mathrm{~m}$ \\
\hline & Suiza $^{4}$ & 97 & 100 & 100 & 100 & 101 & 102 & 100 & 100 & 101 & 101 & 104 & 100 & 100 & 100 & 100 \\
\hline & Turquía & 55 & 100 & 111 & 108 & 107 & $\mathrm{~m}$ & $\mathrm{~m}$ & $\mathrm{~m}$ & $\mathrm{~m}$ & $\mathrm{~m}$ & 50 & 100 & 113 & 109 & 110 \\
\hline & Media OCDE & 88 & 100 & 106 & 106 & 103 & 90 & 100 & 105 & 104 & 102 & 89 & 100 & 104 & 103 & 101 \\
\hline & $\begin{array}{l}\text { Media OCDE para } \\
\text { países con datos } \\
\text { de todos los años de } \\
\text { referencia }\end{array}$ & 88 & 100 & 105 & 104 & 101 & 90 & 100 & 104 & 103 & 100 & 89 & 100 & 103 & 102 & 100 \\
\hline & $\begin{array}{l}\text { Media EU21 para } \\
\text { países con datos } \\
\text { de todos los años de } \\
\text { referencia }\end{array}$ & 87 & 100 & 105 & 103 & 99 & 87 & 100 & 105 & 103 & 99 & 89 & 100 & 105 & 103 & 98 \\
\hline \multirow{10}{*}{ 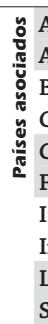 } & Arabia Saudí & $\mathrm{m}$ & $\mathrm{m}$ & $\mathrm{m}$ & $\mathrm{m}$ & $\mathrm{m}$ & $\mathrm{m}$ & $\mathrm{m}$ & $\mathrm{m}$ & $\mathrm{m}$ & $\mathrm{m}$ & $\mathrm{m}$ & $\mathrm{m}$ & $\mathrm{m}$ & $\mathrm{m}$ & $\mathrm{m}$ \\
\hline & Argentina & $\mathrm{m}$ & $\mathrm{m}$ & $\mathrm{m}$ & $\mathrm{m}$ & $\mathrm{m}$ & $\mathrm{m}$ & $\mathrm{m}$ & $\mathrm{m}$ & $\mathrm{m}$ & $\mathrm{m}$ & $\mathrm{m}$ & $\mathrm{m}$ & $\mathrm{m}$ & $\mathrm{m}$ & $\mathrm{m}$ \\
\hline & Brasil & $\mathrm{m}$ & $\mathrm{m}$ & $\mathrm{m}$ & $\mathrm{m}$ & $\mathrm{m}$ & $\mathrm{m}$ & $\mathrm{m}$ & $\mathrm{m}$ & $\mathrm{m}$ & $\mathrm{m}$ & $\mathrm{m}$ & $\mathrm{m}$ & $\mathrm{m}$ & $\mathrm{m}$ & $\mathrm{m}$ \\
\hline & China & $\mathrm{m}$ & $\mathrm{m}$ & $\mathrm{m}$ & $\mathrm{m}$ & $\mathrm{m}$ & $\mathrm{m}$ & $\mathrm{m}$ & $\mathrm{m}$ & $\mathrm{m}$ & $\mathrm{m}$ & $\mathrm{m}$ & $\mathrm{m}$ & $\mathrm{m}$ & $\mathrm{m}$ & $\mathrm{m}$ \\
\hline & Colombia & $\mathrm{m}$ & $\mathrm{m}$ & $\mathrm{m}$ & $\mathrm{m}$ & $\mathrm{m}$ & $\mathrm{m}$ & $\mathrm{m}$ & $\mathrm{m}$ & $\mathrm{m}$ & $\mathrm{m}$ & $\mathrm{m}$ & $\mathrm{m}$ & $\mathrm{m}$ & $\mathrm{m}$ & $\mathrm{m}$ \\
\hline & Federación Rusa & $\mathrm{m}$ & $\mathrm{m}$ & $\mathrm{m}$ & $\mathrm{m}$ & $\mathrm{m}$ & $\mathrm{m}$ & $\mathrm{m}$ & $\mathrm{m}$ & $\mathrm{m}$ & $\mathrm{m}$ & $\mathrm{m}$ & $\mathrm{m}$ & $\mathrm{m}$ & $\mathrm{m}$ & $\mathrm{m}$ \\
\hline & India & $\mathrm{m}$ & $\mathrm{m}$ & $\mathrm{m}$ & $\mathrm{m}$ & $\mathrm{m}$ & $\mathrm{m}$ & $\mathrm{m}$ & $\mathrm{m}$ & $\mathrm{m}$ & $\mathrm{m}$ & $\mathrm{m}$ & $\mathrm{m}$ & $\mathrm{m}$ & $\mathrm{m}$ & $\mathrm{m}$ \\
\hline & Indonesia & $\mathrm{m}$ & $\mathrm{m}$ & $\mathrm{m}$ & $\mathrm{m}$ & $\mathrm{m}$ & $\mathrm{m}$ & $\mathrm{m}$ & $\mathrm{m}$ & $\mathrm{m}$ & $\mathrm{m}$ & $\mathrm{m}$ & $\mathrm{m}$ & $\mathrm{m}$ & $\mathrm{m}$ & $\mathrm{m}$ \\
\hline & Letonia & $\mathrm{m}$ & $\mathrm{m}$ & $\mathrm{m}$ & $\mathrm{m}$ & $\mathrm{m}$ & $\mathrm{m}$ & $\mathrm{m}$ & $\mathrm{m}$ & $\mathrm{m}$ & $\mathrm{m}$ & $\mathrm{m}$ & $\mathrm{m}$ & $\mathrm{m}$ & $\mathrm{m}$ & $\mathrm{m}$ \\
\hline & Sudáfrica & $\mathrm{m}$ & $\mathrm{m}$ & $\mathrm{m}$ & $\mathrm{m}$ & $\mathrm{m}$ & $\mathrm{m}$ & $\mathrm{m}$ & $\mathrm{m}$ & $\mathrm{m}$ & $\mathrm{m}$ & $\mathrm{m}$ & $\mathrm{m}$ & $\mathrm{m}$ & $\mathrm{m}$ & $\mathrm{m}$ \\
\hline
\end{tabular}

\begin{tabular}{l|l|l|l|l|l|l|l|l|l|l|l|l|l|l|l|} 
Media G20 & $\mathrm{m}$ & $\mathrm{m}$ & $\mathrm{m}$ & $\mathrm{m}$ & $\mathrm{m}$ & $\mathrm{m}$ & $\mathrm{m}$ & $\mathrm{m}$ & $\mathrm{m}$ & $\mathrm{m}$ & $\mathrm{m}$ & $\mathrm{m}$ & $\mathrm{m}$ & $\mathrm{m}$ & $\mathrm{m}$
\end{tabular}

Notas: Los años 2006, 2007, 2008, 2009 (columnas 3-6, 12-15, 21-24) están disponibles en Internet (véase StatLink más abajo).

1. Ruptura de la serie temporal tras cambios en la metodología en 2012.

2. Ruptura de la serie temporal tras cambios en la metodología en 2009.

3. Salarios base reales.

4. Salarios tras 11 años de experiencia.

Fuentes: OCDE. Arabia Saudí, Argentina, China, Colombia, India, Indonesia, Sudáfrica: Instituto de Estadística de la UNESCO. Para ver notas, consulte Anexo 3 (www.oecd.org/edu/eag.htm).

Para obtener más información acerca de los símbolos utilizados en lugar de los datos que faltan, consulte la Guía del lector.

StatLink 게그 http://dx.doi.org/10.1787/888933119910 


\section{¿CUÁNTO TIEMPO DEDICAN LOS PROFESORES A ENSEÑAR?}

- Los profesores de centros escolares públicos dedican a enseñar una media de 1.001 horas al año en educación infantil, 782 horas en primaria, 694 horas en educación secundaria inferior y 655 horas en secundaria superior.

- Aproximadamente en un tercio de los países con datos disponibles, la cantidad de horas lectivas aumentó o disminuyó al menos un 10\% entre 2000 y 2012 en educación primaria, secundaria inferior y/o secundaria superior.

\section{Gráfico D4.1. Número de horas de enseñanza al año en educación secundaria inferior (2000, 2005 y 2012) \\ Tiempo de contacto neto reglamentario en instituciones públicas}

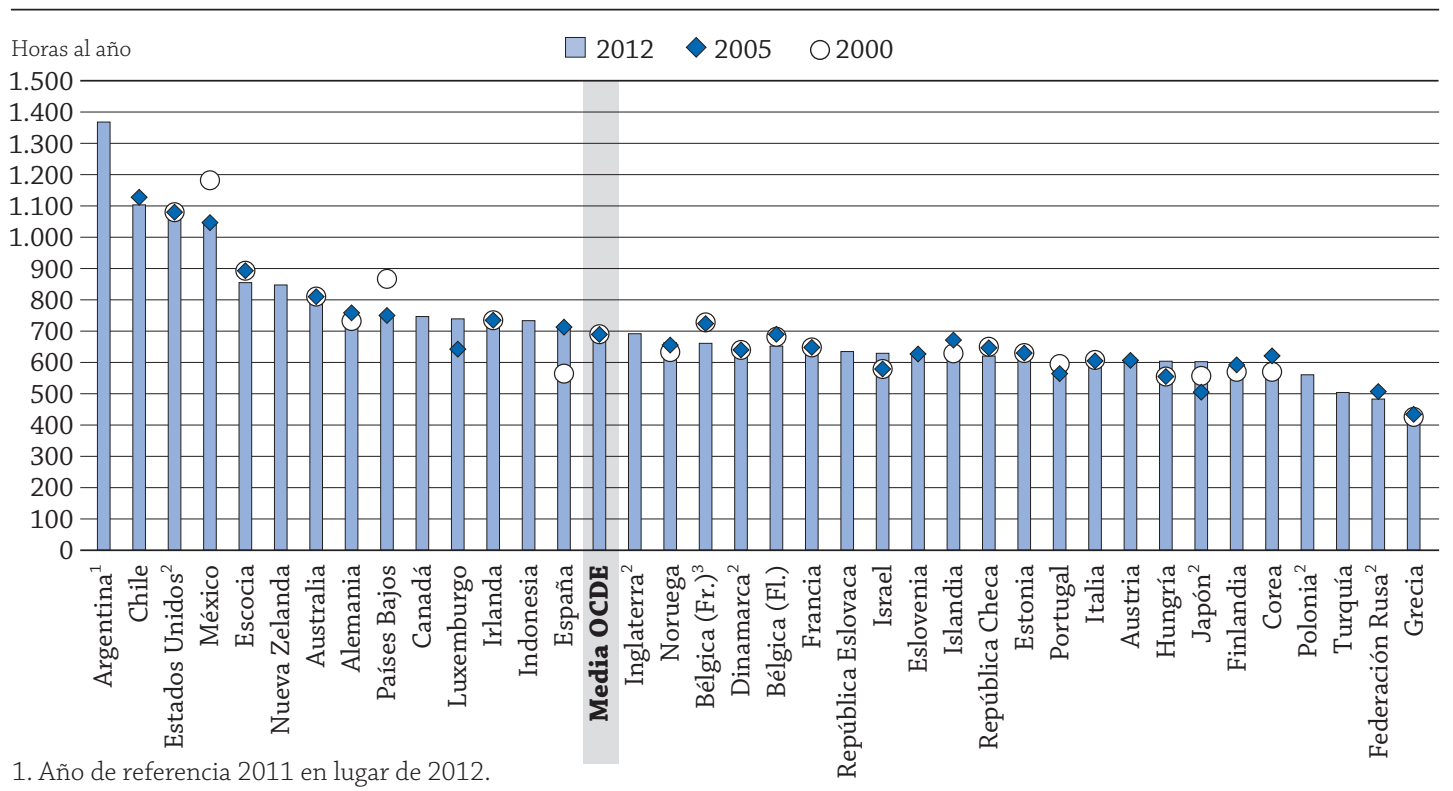

1. Año de referencia 2011 en lugar de 2012

2. Horas lectivas reales.

3. Ruptura de la serie temporal tras cambios en la metodología en 2006.

Los países están clasificados en orden descendente del número de horas de enseñanza al año en educación secundaria inferior en 2012

Fuente: OCDE. Tabla D4.2. Para ver notas, consulte Anexo 3 (www.oecd.org/edu/eag.htm).

StatLink 겐 http://dx.doi.org/10.1787/888933120062

\section{Contexto}

A pesar de que el horario laboral y las horas lectivas reglamentarias determinan solo en parte la carga de trabajo real de los profesores, sí ofrecen información valiosa sobre lo que se exige a los profesores en los diversos países. El número de horas lectivas y el alcance de otras obligaciones no docentes pueden influir también en el grado de atracción de la profesión docente. Junto con los salarios de los profesores (véase Indicador D3) y el tamaño medio de la clase (véase Indicador D2), este indicador presenta algunos aspectos esenciales de las condiciones de trabajo de los profesores.

La parte del horario laboral que el profesor dedica a la enseñanza aporta información acerca del tiempo que se puede dedicar a otras actividades, como preparación de clases, corrección, formación continua y reuniones de personal. Una elevada proporción del horario laboral dedicado a la enseñanza puede indicar que se concede menos tiempo a otras tareas, como la evaluación de los estudiantes y la preparación de las clases.

Además de factores como el tamaño de la clase y la ratio alumnos-profesor (véase Indicador D2), las horas de enseñanza previstas para los estudiantes (véase Indicador D1) y los salarios de los profesores (véase Indicador D3), el tiempo que los profesores dedican a enseñar también influye en los recursos económicos que los países necesitan destinar a la educación (véase Indicador B7). 


\section{Otros resultados}

- El número medio de horas lectivas en los centros públicos de educación infantil es de 1.001 al año, pero oscila de 532 horas en México a más de 1.500 horas en Islandia, Noruega y Suecia.

- Los profesores de centros públicos de primaria dedican a la enseñanza una media de $\mathbf{7 8 2}$ horas al año, pero las horas lectivas oscilan entre menos de 570 horas en Federación Rusa y Grecia a más de 1.000 horas en Chile, Estados Unidos e Indonesia.

- La media del número de horas lectivas en los centros públicos de educación secundaria inferior es de 694 horas al año, pero oscila de 415 horas en Grecia a más de 1.000 horas en Argentina, Chile, Estados Unidos y México.

- Los profesores de los centros públicos de educación secundaria superior enseñan una media de 655 horas al año, pero varía desde 369 horas en Dinamarca a más de 1.000 horas en Argentina, Chile y Estados Unidos.

- Como media, los profesores de educación infantil deben enseñar casi un $25 \%$ más de horas que los de primaria, pero el tiempo que los profesores deben trabajar en el centro escolar, del total de su horario laboral, suele ser equivalente en estos dos niveles de educación.

- La regulación del horario laboral obligatorio de los profesores varía considerablemente. En la mayoría de los países, se exige formalmente a los profesores que trabajen un número específico de horas al año. En algunos, el tiempo de enseñanza se especifica solo por el número de clases a la semana y se pueden establecer supuestos sobre la cantidad de tiempo no dedicado a la docencia necesario por clase, en el centro escolar o en otros lugares.

\section{Tendencias}

En torno a un tercio de los países con datos disponibles refirió un incremento o una disminución del $10 \%$ o más de las horas lectivas de 2000 a 2012 en educación primaria, secundaria inferior y/o secundaria superior. El número de horas lectivas cambió drásticamente en unos pocos países: aumentó un $26 \%$ en España en educación secundaria, y disminuyó casi un $20 \%$ en Corea en primaria. 


\section{Análisis}

\section{Tiempo de enseñanza}

En todos los niveles educativos, los países varían en el número de horas lectivas al año exigidas al profesor medio de enseñanza pública.

En educación infantil, las horas de enseñanza requeridas en un centro público varían más de un país a otro que en cualquier otro nivel. El número de días lectivos oscila entre 144 días en Francia y 251 en Indonesia; las horas lectivas anuales oscilan entre menos de 700 horas en Argentina, Corea, Grecia, Indonesia, Inglaterra y México y más de 1.500 en Islandia, Noruega y Suecia. Como media en los países de la OCDE, los profesores de este nivel educativo deben enseñar 1.001 horas al año repartidas a lo largo de 40 semanas o 191 días lectivos.

Los profesores de los centros de primaria deben enseñar una media de 782 horas al año. En la mayoría de los países con datos disponibles, los profesores deben enseñar entre 3 y 6 horas al día. Las excepciones son Chile, Estados Unidos y Francia, donde los profesores enseñan algo más de 6 horas al día. No existe ninguna regla fija sobre la distribución del tiempo de enseñanza a lo largo del año. En España, por ejemplo, los profesores de educación primaria deben enseñar 880 horas al año, unas 100 horas más que la media de la OCDE. Sin embargo, esas horas lectivas se reparten en menos días de enseñanza que la media de la OCDE, porque los profesores de primaria en España enseñan una media de cinco horas al día en comparación con la media de la OCDE de 4,3 horas.

Los profesores de educación secundaria inferior enseñan una media de 694 horas al año. El tiempo de enseñanza en educación secundaria inferior oscila entre menos de 600 horas en Corea, Federación Rusa, Finlandia, Grecia, Polonia y Turquía y más de 1.000 horas en Argentina, Chile, Estados Unidos y México.

Un profesor de materias generales en educación secundaria superior tiene una carga lectiva media de 655 horas al año. Las horas lectivas superan las 800 horas en solo seis países: Argentina, Australia, Chile, Escocia, Estados Unidos y México. Sin embargo, en el caso de Chile y Escocia, las horas reportadas se refieren al tiempo máximo que los profesores tienen que dedicar a enseñar y no a su carga docente típica. En cambio, los profesores deben enseñar menos de 500 horas al año en Dinamarca, Federación Rusa y Grecia. Los profesores en Corea, Eslovenia, Federación Rusa, Finlandia, Grecia, Japón y Noruega enseñan tres horas o menos al día como media, en comparación con más de cinco horas en Chile y Estados Unidos y hasta ocho horas en Argentina. Algunas de estas diferencias pueden deberse a la inclusión de los descansos entre las clases en el tiempo de enseñanza en algunos países, pero no en otros (Tabla D4.1 y Gráfico D4.2).

\section{Gráfico D4.2. Número de horas de enseñanza al año, por nivel de educación (2012) Tiempo de contacto neto reglamentario en instituciones públicas}

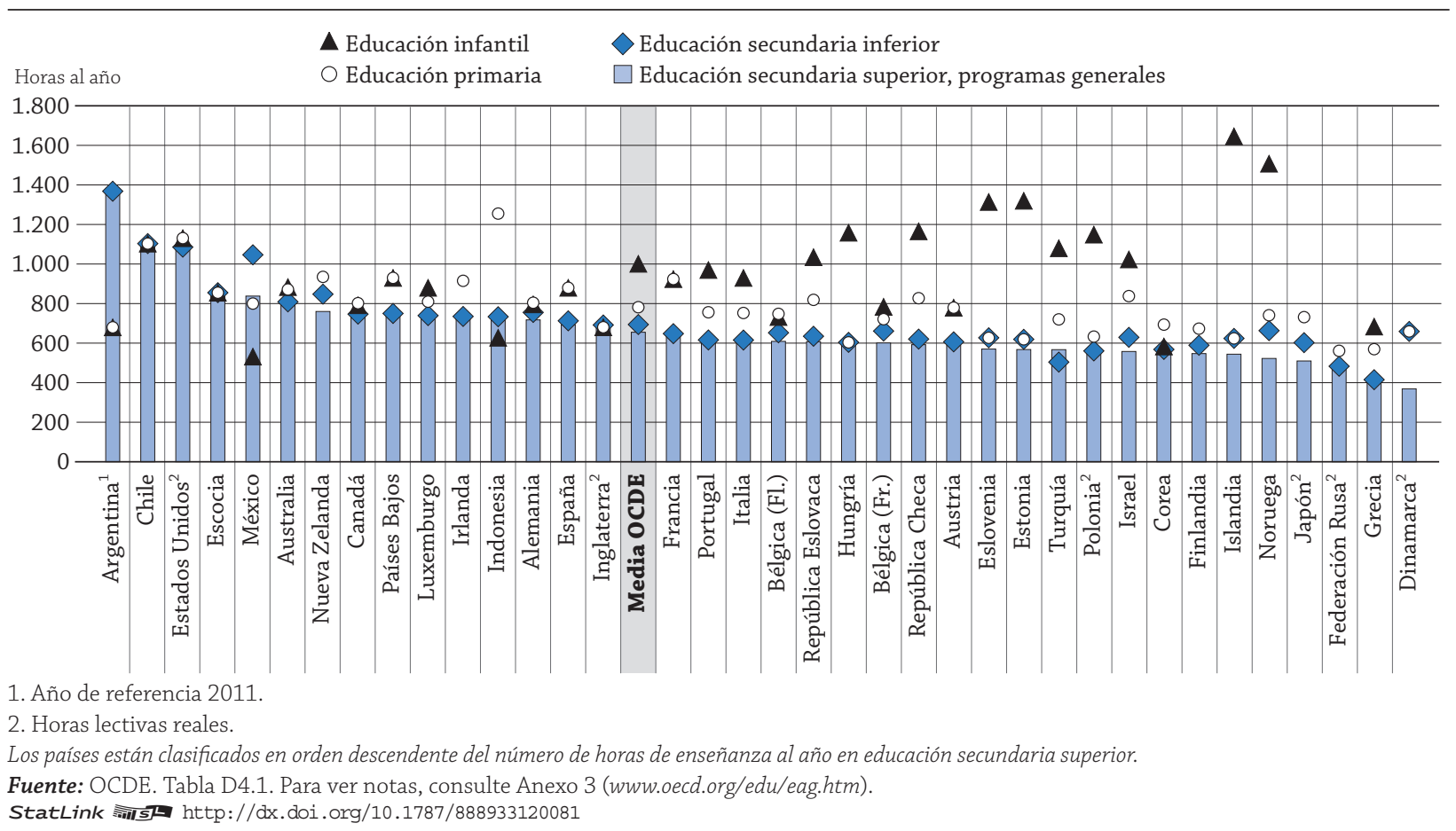




\section{Diferencias en el tiempo de enseñanza entre niveles de educación}

En la mayoría de los países, el tiempo de enseñanza en educación secundaria superior es menor que en educación infantil. Las excepciones son Chile y Escocia, donde los profesores deben enseñar el mismo número de horas independientemente del nivel educativo impartido, y Argentina, Indonesia, Inglaterra y México, donde los profesores de educación secundaria deben enseñar más horas que los profesores de educación infantil (Tabla D4.1 y Gráfico D4.2).

Las horas lectivas obligatorias varían más entre los niveles de educación infantil y primaria. Como media en los países de la OCDE, los profesores de educación infantil deben dedicar casi un $25 \%$ más de tiempo a las aulas que los profesores de primaria. En Eslovenia, Estonia y Noruega, los profesores de educación infantil deben enseñar al menos el doble de horas que los profesores de primaria. Aunque las obligaciones de los profesores suelen ser diferentes en estos dos niveles educativos, unas diferencias considerables de las condiciones laborales entre la educación infantil y otros niveles de educación podrían afectar el atractivo de la profesión docente en el nivel de educación infantil.

En Francia, Grecia, Indonesia, Israel, República Checa y Turquía, los profesores de educación primaria tienen al menos un $30 \%$ más de horas lectivas que los profesores de educación secundaria inferior. En cambio, la diferencia no supera el $5 \%$ en Estados Unidos, y no hay ninguna diferencia en Chile, Dinamarca, Escocia, Eslovenia, Estonia, Hungría e Islandia. Argentina, Inglaterra y México son los únicos países en los que la carga lectiva de los profesores de primaria es menor que la de los profesores de educación secundaria inferior.

El tiempo dedicado a la enseñanza en los niveles de educación secundaria inferior y superior es similar en la mayoría de los países. Sin embargo, en México y Noruega, las horas lectivas anuales exigidas en educación secundaria inferior son al menos un $20 \%$ más que en educación secundaria superior. Esta diferencia es de más del $75 \%$ en Dinamarca.

\section{Tiempo de enseñanza real}

El tiempo de enseñanza obligatorio, según refieren la mayoría de los países en este indicador, debe diferenciarse del número de horas de enseñanza reales. El tiempo de enseñanza real es la media anual del número de horas que los profesores a tiempo completo enseñan a un grupo o clase de estudiantes, incluyendo las horas extra, y se basa en los registros administrativos, bases de datos estadísticas, estudios de muestras representativas y otras fuentes representativas.

Solo unos pocos países registran tanto el tiempo de enseñanza obligatorio como el real, pero estos datos indican que el tiempo de enseñanza real a veces difiere significativamente del obligatorio. En Australia, por ejemplo, un profesor de educación secundaria inferior trabaja alrededor de un $5 \%$ más que el tiempo obligatorio de referencia, mientras que en Polonia el tiempo lectivo real es hasta un $14 \%$ más que lo exigido. En cambio, en Estonia, el tiempo lectivo real es un $5 \%$ menor que el obligatorio en educación secundaria inferior (Tabla D4.3 y Gráfico D4.4, disponibles en Internet).

\section{Tendencias del tiempo de enseñanza}

Aproximadamente en un tercio de los países con datos disponibles, el tiempo de enseñanza varió al menos un $10 \%$ en uno o varios niveles educativos entre 2000 y 2012 (Tabla D4.2 y Gráfico D4.1).

En Israel y Japón, ha habido un incremento del 15\% en el tiempo de enseñanza en primaria entre 2000 y 2012, y el tiempo de enseñanza aumentó también un $13 \%$ en Turquía en este nivel de educación. En Israel, este incremento de las horas docentes y laborales forma parte de la reforma «Nuevo Horizonte» que se ha ido implantando progresivamente desde 2008. Una de las medidas clave de esta reforma fue prolongar la semana laboral de los profesores para dar cabida a una enseñanza en pequeños grupos a cambio de una retribución más generosa. El horario de los profesores ha crecido de 30 a 36 horas a la semana y ahora incluye cinco horas de enseñanza en pequeños grupos en centros escolares de primaria. Como compensación, se han subido los salarios sustancialmente (véase Indicador D3).

Los profesores de educación secundaria en España debían enseñar un 26\% más en 2012 que en 2000; en Luxemburgo, los profesores de secundaria debían enseñar un 15\% más de horas en 2012 que en 2005. Las horas de enseñanza también aumentaron en torno a un $20 \%$ en Portugal, un $17 \%$ en Islandia y un $13 \%$ en Turquía en educación secundaria superior, entre 2000 y 2012.

En cambio, el tiempo lectivo neto disminuyó alrededor del 20\% de 2000 a 2012 en Corea en primaria y alrededor del $10 \%$ en Escocia (primaria), en México (educación secundaria inferior) y en Países Bajos (educación secundaria inferior y superior). En Escocia, la disminución formó parte del Convenio de los Profesores, «Una profesión docente para el siglo XXI», que introdujo una semana laboral de 35 horas para todos los profesores y una reducción gradual del tiempo de enseñanza máximo a 22,5 horas a la semana para los profesores de primaria, secundaria y educación especial en 2001. Sin embargo, incluso con esta disminución del tiempo de contacto neto, los profesores de estos niveles en Escocia siguen obligados a enseñar más horas que la media de los países de la OCDE. 


\section{Cuadro D4.1. ¿Cómo distribuyen los profesores de educación secundaria inferior su tiempo lectivo?}

Según el Estudio Internacional sobre Enseñanza y Aprendizaje (TALIS, por sus siglas en inglés), de los tres tipos de actividades -actividades de enseñanza y aprendizaje, tareas administrativas y mantener el orden (o gestionar la conducta de estudiantes individuales o de toda la clase)-, los profesores de educación secundaria inferior en los países y economías participantes refieren dedicar la mayor parte de sus horas de clase (79\%) a actividades de enseñanza y aprendizaje. Sin embargo, esta proporción varía entre los países, del $87 \%$ en Bulgaria al $67 \%$ en Brasil. Mantener el orden en la clase, generalmente la mayor preocupación de los profesores nuevos, ocupa una media del $13 \%$ del tiempo de los profesores en todos los países, aunque dicha proporción también varía entre los países, del $8 \%$ en Polonia al $20 \%$ en Brasil. Las tareas administrativas requieren el menor tiempo de los profesores ( $8 \%$ ) en comparación con las otras dos categorías más amplias. Los profesores en Bulgaria y Estonia dicen dedicar un $5 \%$ de su tiempo de clase a tareas administrativas, mientras que los profesores en Brasil dicen que el $12 \%$ de su tiempo de clase se dedica a dichas tareas. No hay duda de que la enseñanza y el aprendizaje deberían comprender la mayor parte del tiempo de enseñanza diario de los profesores. No obstante, no está claro si las otras dos tareas interfieren con la docencia de alta calidad o si los profesores, y en definitiva los estudiantes, se beneficiarían de una reducción del tiempo lectivo dedicado a tareas administrativas y a mantenimiento del orden para que profesores y estudiantes pudieran dedicar más tiempo a la enseñanza y el aprendizaje.

\section{Gráfico D4.a. Distribución del tiempo durante una clase habitual (2013) \\ Proporción media de tiempo que los profesores de educación secundaria inferior declaran dedicar a cada una de estas actividades en una clase habitual ${ }^{1}$}

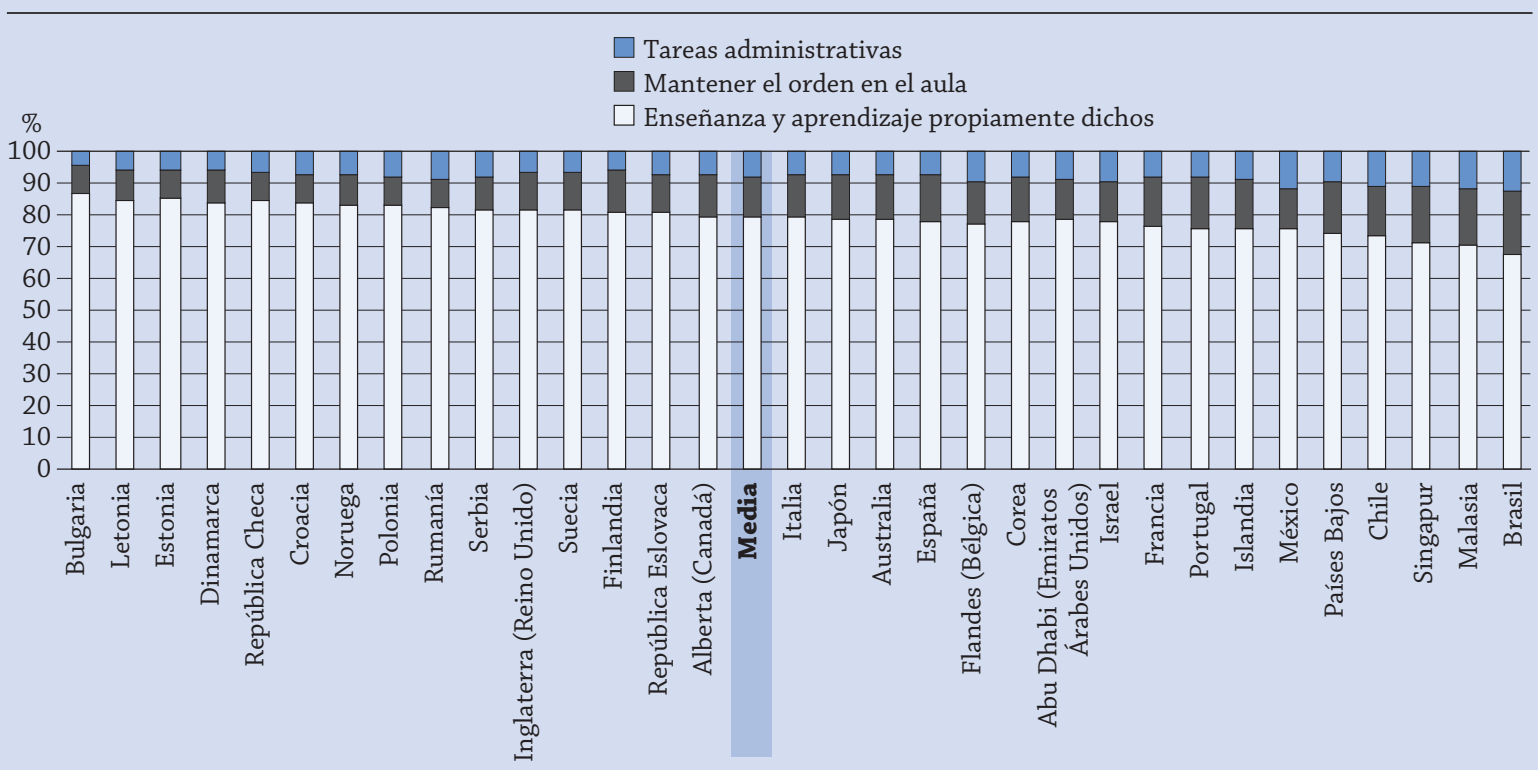

1. Estos datos son aportados por los profesores y se refieren a una clase elegida al azar de las que componen su horario semanal. Los países están clasificados en orden descendente de la proporción media de tiempo que los profesores de educación secundaria inferior declaran dedicar a la enseñanza y el aprendizaje propiamente dichos.

Fuente: OECD (2014), TALIS 2013 Results: An International Perspective on Teaching and Learning, TALIS, OECD Publishing.

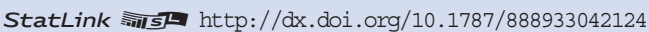

\section{Horario laboral de los profesores}

En la mayoría de los países, los profesores deben trabajar un número determinado de horas a la semana, para percibir el salario correspondiente a un contrato a tiempo completo, lo que incluye tanto la docencia como las actividades no docentes. Algunos países también regulan las horas que un profesor debe estar presente en el centro. Sin embargo, dentro de este contexto, los países difieren en la distribución del tiempo asignado a cada actividad (Gráfico D4.3).

Más de la mitad de los países de la OCDE especifican el número de horas que los profesores deben estar disponibles en el centro escolar, sea para dedicarlo a la enseñanza o a otras actividades, en uno o varios niveles de educación. En algo más de la mitad de estos países, la diferencia entre las horas que los profesores de educación secundaria superior y educación infantil deben estar disponibles en el centro escolar es inferior al 10\%. En Israel, Noruega y Suecia, los 
profesores de educación infantil deben estar disponibles en el centro escolar al menos un $30 \%$ más de horas que los profesores de educación secundaria superior (Tabla D4.1).

En Alemania, Austria (educación infantil, primaria y secundaria inferior), Dinamarca, Francia (educación secundaria inferior y superior), Japón, Países Bajos y República Checa, se especifica el horario laboral total anual de los profesores, ya sea en el centro escolar o fuera, pero no así la distribución del tiempo en el centro escolar y otro sitio.

En Suecia, aunque el horario laboral total anual se decide mediante convenios colectivos, el director del centro decide el número de horas laborales semanales y el uso del tiempo de los profesores (en actividades docentes y no docentes) tras consultar con los sindicatos locales de profesores.

Además, la carga de trabajo y la carga lectiva pueden evolucionar a lo largo de la vida profesional. Mientras que algunos profesores nuevos pueden tener una carga lectiva menor como parte de los programas de orientación, algunos países también animan a los profesores mayores a permanecer en la profesión diversificando sus tareas y reduciendo sus horas lectivas.

\section{Cuadro D4.2. ¿Cuánto tiempo dedican los profesores a diversas tareas laborales a la semana?}

Los resultados del estudio TALIS 2013 sugieren que el trabajo de los profesores de educación secundaria inferior se compone de múltiples responsabilidades, a menudo en conflicto. Como es de esperar, los profesores, a tiempo completo o parcial, refieren dedicar más tiempo a la enseñanza que a cualquier otra tarea. La media global es de 19 horas a la semana, oscilando entre 15 horas en Noruega y 27 horas en Chile. Los profesores japoneses refieren que dedican solo 18 horas a la enseñanza de una media de 54 totales, lo que significa que dedican sustancialmente más tiempo a otras tareas relacionadas con su trabajo que a la docencia. La media de tiempo dedicado a la planificación o preparación de las clases es de 7 horas, que oscila entre 5 horas en Finlandia, Israel, Italia, Países Bajos y Polonia, y 10 horas en Croacia. El tiempo medio que declaran que se dedica a corregir las tareas de los estudiantes es de 5 horas, pero es alrededor del doble en Portugal (10 horas) y Singapur (9 horas).

Gráfico D4.b. Horas de trabajo de los profesores (2013)

Número medio de horas de 60 minutos que los profesores de educación secundaria inferior declaran haber dedicado a las siguientes actividades durante la semana natural completa más reciente ${ }^{1}$

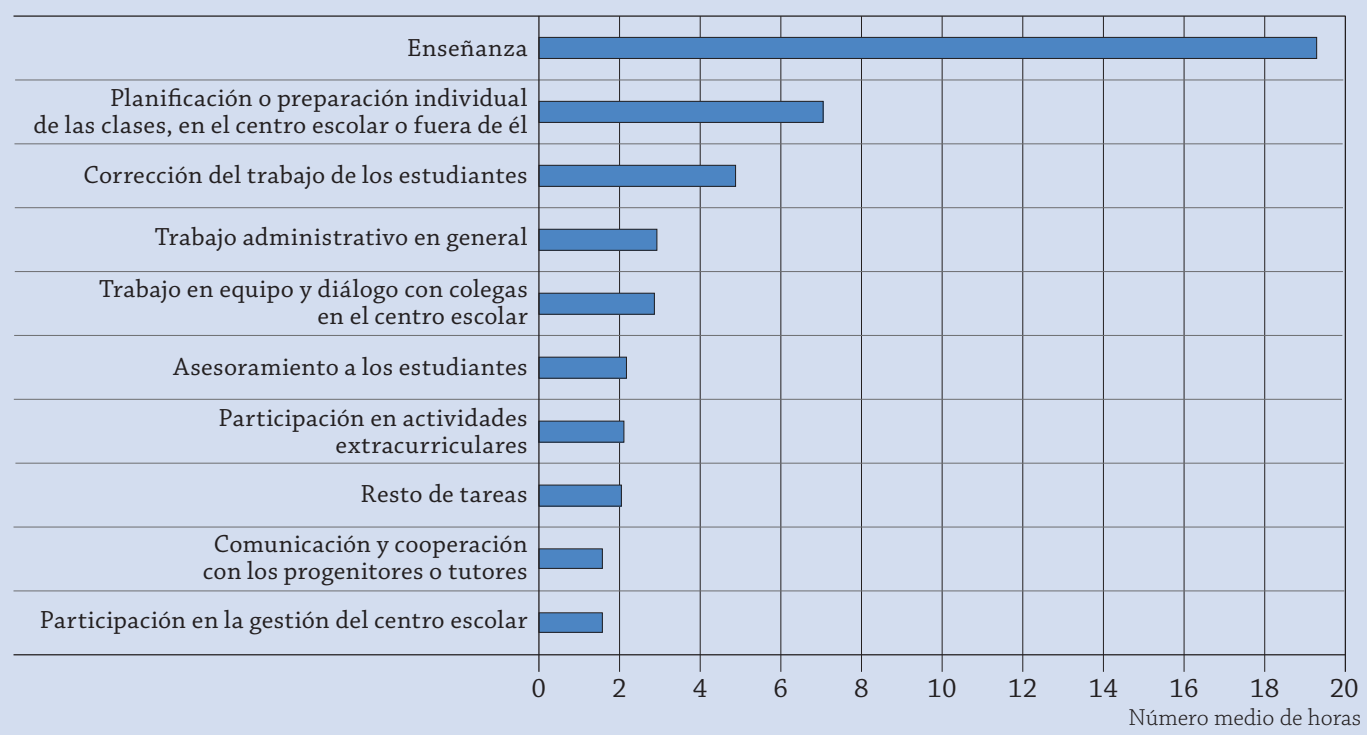

1. Una semana natural «completa» es aquella que no se ha visto reducida por días festivos públicos, vacaciones, baja por enfermedad, etc. También incluye las tareas que se llevaron a cabo durante el fin de semana, las tardes y otras horas aparte de las docentes.

Los elementos están clasificados en orden descendente del número medio de horas de 60 minutos dedicados a las siguientes actividades durante la semana natural completa más reciente.

Fuente: OECD (2014), TALIS 2013 Results: An International Perspective on Teaching and Learning, TALIS, OECD Publishing. StatLink त्नाजा http://dx.doi.org/10.1787/888933042029 
Otras tareas, como la gestión del centro escolar, el trabajo con los padres y las actividades extracurriculares, ocupan una media de solo 2 horas a la semana. Los profesores en Corea y Malasia dicen dedicar el doble (6 horas) que la media de TALIS a tareas administrativas generales. Las actividades extracurriculares son una parte importante del trabajo de los profesores en Japón, donde refieren dedicarles 8 horas, muy por encima de la media de TALIS de 2 horas.

Estos resultados pretenden dar una imagen de la semana laboral típica de los profesores de educación secundaria inferior en cada país $y$, por tanto, incluyen respuestas tanto de profesores a tiempo completo como a tiempo parcial. Puesto que pueden existir solapamientos en algunas actividades, no deben sumarse al número total de horas laborales.

Por ejemplo, Grecia reduce las horas según la antigüedad del profesor. En el nivel de secundaria, los profesores deben enseñar 21 sesiones de clase a la semana. Tras 6 años, estas se reducen a 19 y, después de 12 años, a 18 sesiones. Después de 20 años de ejercicio, los profesores deben impartir 16 sesiones de clase semanales, más del $25 \%$ menos que un profesor al inicio de su carrera docente. Sin embargo, el profesor debe pasar el resto de las horas de su horario laboral en el centro.

\section{Horario no dedicado a la enseñanza}

Aunque las horas de enseñanza son un componente sustancial de la carga de trabajo de los profesores, evaluar a los estudiantes, preparar las clases, corregir las tareas de los estudiantes, la formación en el trabajo y las reuniones de personal también deben tenerse en cuenta al analizar lo que se exige a los profesores en distintos países. La cantidad de tiempo disponible para estas actividades no docentes varía de un país a otro, y una gran proporción del horario laboral obligatorio dedicado a la enseñanza podría indicar que se dedica menos tiempo a evaluar a los estudiantes y preparar las clases.

En los 21 países que especifican tanto el tiempo de enseñanza como el horario laboral total de los profesores de educación secundaria inferior, el porcentaje del horario laboral de los profesores dedicado a la enseñanza oscila entre menos del 35\% en Austria, Hungría, Islandia, Japón, República Checa y Turquía, y el 63 \% en Escocia (Gráfico D4.3).

\section{Gráfico D4.3. Porcentaje del horario laboral de los profesores de educación secundaria inferior dedicado a la enseñanza (2012) \\ Horas lectivas netas como porcentaje del horario laboral reglamentario total y el horario laboral exigido en el centro escolar}

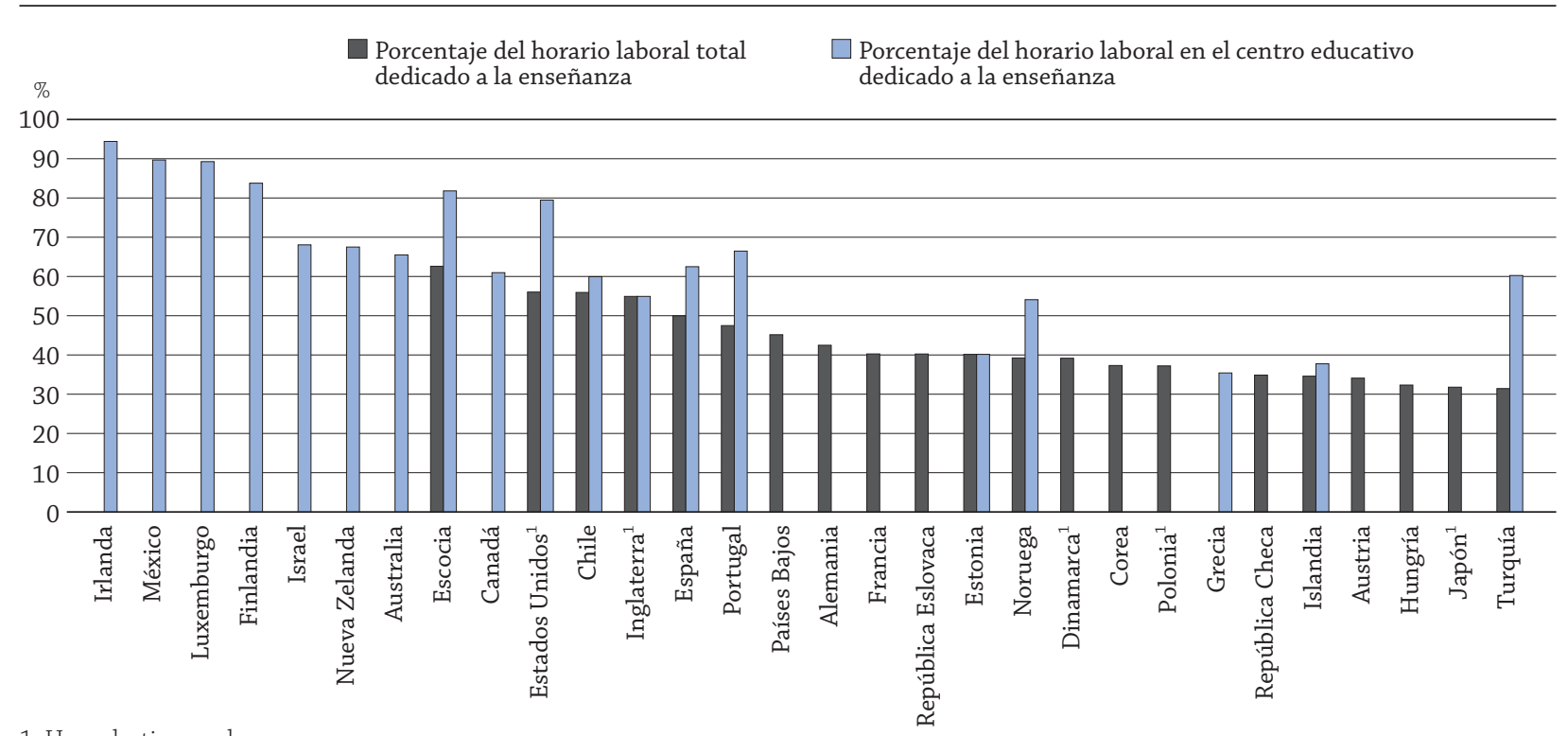

1. Horas lectivas reales.

Los países están clasificados en orden descendente del porcentaje del horario laboral de los profesores de educación secundaria inferior dedicado a la enseñanza. Fuente: OCDE. Tabla D4.1 Para ver notas, consulte Anexo 3 (www.oecd.org/edu/eag.htm).

StatLink 제요 http://dx.doi.org/10.1787/888933120100 


\section{Cuadro D4.3. Tareas no docentes exigidas a los profesores en educación secundaria inferior}

Tareas exigidas por las normativas o convenios dentro del horario laboral reglamentario en el centro escolar y/o horario laboral total reglamentario

\begin{tabular}{|c|c|c|}
\hline Tareas de los profesores & Tarea exigida & A discreción del centro escolar \\
\hline $\begin{array}{l}\text { Planificación y preparación } \\
\text { individual de clases }\end{array}$ & $\begin{array}{l}\text { AUS, BFR, BFL, CHL, DNK, ENG, EST, GRC, ISL, ISR, } \\
\text { ITA, NOR, POL, PRT, SCO, SVK¹ ESP, SWE, TUR, USA }\end{array}$ & $\begin{array}{l}\text { BRA, CZE, HUN, KOR, NLD, NZL, } \\
\text { SVK² , SVN, USA }\end{array}$ \\
\hline $\begin{array}{l}\text { Trabajo en equipo y diálogo } \\
\text { con los compañeros }\end{array}$ & $\begin{array}{l}\text { AUS, BFR, CHL, DNK, ENG, EST, FIN, FRA, GRC, ISR, } \\
\text { ITA, LUX, NOR, POL, PRT, SCO, SVK, ESP, SWE, TUR }\end{array}$ & $\begin{array}{l}\text { BFL, BRA, CZE, HUN, ISL, KOR, NLD, } \\
\text { NZL, SVN, USA }\end{array}$ \\
\hline $\begin{array}{l}\text { Corrección de trabajos } \\
\text { de los estudiantes }\end{array}$ & $\begin{array}{l}\text { AUS, CHL, DNK, ENG, EST, FRA, GRC, ISL, ISR, NOR, } \\
\text { POL, PRT, SCO, SVK }{ }^{1} \text { ESP, SWE, TUR, USA }\end{array}$ & $\begin{array}{l}\text { BFL, BRA, CZE, HUN, KOR, NLD, } \\
\text { NZL, SVK², SVN, USA }\end{array}$ \\
\hline $\begin{array}{l}\text { Supervisión de estudiantes } \\
\text { durante los recreos }\end{array}$ & AUS, CHL, DNK, EST, GRC, ISR, LUX, POL, SVK, TUR & $\begin{array}{l}\text { BFL, BRA, CZE, ENG, HUN, IRL, KOR, } \\
\text { NLD, NZL, SCO, SVN, SWE, USA }\end{array}$ \\
\hline $\begin{array}{l}\text { Proporcionar orientación y } \\
\text { asesoramiento a los estudiantes }\end{array}$ & $\begin{array}{l}\text { CHL, DNK, EST, FRA, GRC, ISR, LUX, PRT, ESP, SVK, } \\
\text { SWE, TUR }\end{array}$ & $\begin{array}{l}\text { AUS, BFL, BRA, CZE, HUN, ISL, KOR, } \\
\text { NLD, NZL, SCO, SVN, USA }\end{array}$ \\
\hline $\begin{array}{l}\text { Participación en la gestión } \\
\text { del centro escolar }\end{array}$ & $\begin{array}{l}\text { CHL, DNK, EST, FRA, GRC, ISL, ISR, PRT, ESP, SVK, } \\
\text { TUR }\end{array}$ & $\begin{array}{l}\text { AUS, BFL, BRA, CZE, HUN, KOR, } \\
\text { NLD, NZL, SCO, SVN, SWE, USA }\end{array}$ \\
\hline $\begin{array}{l}\text { Comunicaciones y trámites } \\
\text { administrativos generales }\end{array}$ & $\begin{array}{l}\text { AUS, BFR, CHL, DNK, ENG, EST, FRA, GRC, ISL, ISR, } \\
\text { NOR, POL, PRT, SVK }{ }^{1} \text {, SWE, TUR }\end{array}$ & $\begin{array}{l}\text { BFL, BRA, CZE, HUN, KOR, NLD, } \\
\text { SCO, SVN, SVK }{ }^{2} \text {, USA }\end{array}$ \\
\hline $\begin{array}{l}\text { Comunicación y cooperación } \\
\text { con padres o tutores }\end{array}$ & $\begin{array}{l}\text { AUS, BFR, CHL, DNK, ENG, EST, FIN, FRA, GRC, ISL, } \\
\text { ISR, ITA, LUX, NOR, POL, PRT, SVK, SWE, ESP, TUR }\end{array}$ & $\begin{array}{l}\text { BFL, BRA, CZE, HUN, KOR, NLD, } \\
\text { NZL, SCO, SVN, USA }\end{array}$ \\
\hline $\begin{array}{l}\text { Participación en actividades } \\
\text { extracurriculares después } \\
\text { de la escuela }\end{array}$ & CHL, DNK, EST, ISR, POL, PRT, ESP, TUR & $\begin{array}{l}\text { AUS, BFL, BRA, CZE, ENG, GRC, } \\
\text { HUN, KOR, NLD, NZL, SVN, USA }\end{array}$ \\
\hline $\begin{array}{l}\text { Actividades de desarrollo } \\
\text { profesional }\end{array}$ & $\begin{array}{l}\text { BFR, DNK, ENG, EST, FIN, GRC, HUN, ISR, NOR, POL, } \\
\text { PRT, SCO } \text { SVK }^{1} \text {, SWE, TUR }\end{array}$ & $\begin{array}{l}\text { AUS, BFL, BRA, CHL, CZE, ISL, KOR, } \\
\text { NLD, NZL, SCO }{ }^{2}, \text { SVK}^{2}, \text { SVN, USA }\end{array}$ \\
\hline Otras & CHL, DNK, FIN, FRA, GRC, IRL, PRT, SWE & $\begin{array}{l}\text { BFR, BFL, CZE, EST, HUN, KOR, NLD, } \\
\text { NZL, SCO, SVN, POL, USA }\end{array}$ \\
\hline
\end{tabular}

1. Dentro del tiempo total de trabajo.

2. Dentro del tiempo de trabajo en el centro escolar.

Fuente: OCDE. Tabla D4.4c, disponible en Internet. Para ver notas, consulte Anexo 3 (www.oecd.org/edu/eag.htm).

Para información sobre los códigos de los países utilizados en este cuadro, consulte la Guía del lector.

StatLink 제

Las tareas no docentes forman parte de la carga de trabajo y de las condiciones laborales de los profesores. Las actividades no docentes requeridas por la legislación, normativa o convenios entre los partícipes (por ejemplo, sindicatos de profesores, autoridades locales, consejos escolares, etc.) no reflejan necesariamente la participación real de los profesores en las actividades no docentes, pero ofrecen una idea sobre la amplitud y complejidad de la función docente.

La planificación individual o preparación de clases, el trabajo en equipo y diálogo con los compañeros, y la comunicación y cooperación con los padres son las tareas no docentes más frecuentes exigidas a los profesores de educación secundaria inferior durante su horario laboral en el centro escolar o el total reglamentario. Estas tareas se exigen al menos en 20 de los 34 países con datos disponibles. Corregir trabajos de los estudiantes, comunicaciones y trámites administrativos generales y actividades de desarrollo profesional son tareas obligatorias también en alrededor de la mitad de los países de los que se dispone de datos. Los profesores de educación secundaria inferior deben supervisar a los estudiantes durante los recreos, ofrecer orientación y asesoramiento a los estudiantes y/o participar en la gestión del centro en alrededor de un tercio de los países, y solo 8 países exigen que los profesores de educación secundaria inferior participen en actividades extracurriculares después de las clases. En la mayoría de los países que registran las tareas no docentes exigidas a los profesores, no se especiica el número concreto de horas asignadas a cada tarea. En Brasil, Corea, Eslovenia, Hungría, Nueva Zelanda, Países Bajos y República Checa, se puede exigir cualquiera de estas tareas no docentes a los profesores, pero la decisión se toma en el centro escolar. 
En los 19 países que especifican tanto el tiempo de enseñanza como la cantidad de tiempo que los profesores de educación secundaria inferior deben estar disponibles en el centro escolar, el porcentaje de horas laborales que los profesores dedican a la enseñanza en el centro escolar oscila entre $40 \%$ o menos en Grecia e Islandia, y más del $90 \%$ en Irlanda.

En Austria (secundaria superior), Bélgica (Comunidad flamenca, nivel secundario), Bélgica (Comunidad francófona), Italia y Japón (educación infantil), no existe regulación oficial del tiempo que deben dedicar los profesores de educación primaria y secundaria a actividades no lectivas. Sin embargo, ello no significa que tengan plena libertad para realizar otras tareas. En la Comunidad flamenca de Bélgica, aunque no se regula el tiempo que ha de dedicarse a la preparación de las clases, corrección de ejercicios y exámenes de los estudiantes, etc., las horas no lectivas en el centro escolar se fijan en el centro escolar. En Italia, se exigen al año hasta 80 horas de trabajo no lectivo programado en el centro escolar. De estas 80 horas, hasta 40 horas de trabajo obligatorio al año se dedican a reuniones de las asambleas de profesores, reuniones de planificación de personal y reuniones con padres; las 40 horas obligatorias restantes se dedican a las tutorías.

\section{Definiciones}

Tiempo de enseñanza real es el número medio anual de horas que los profesores a tiempo completo enseñan a un grupo o clase de estudiantes, incluyendo todas las horas adicionales como horas extras. Los datos pueden ser de los registros administrativos, bases de datos estadísticos, encuestas por muestreo de representación u otras fuentes representativas.

El número de días de enseñanza es el número de semanas de enseñanza multiplicadas por el número de días semanales que enseña un profesor, menos el número de días que el centro escolar cierra por vacaciones.

El número de semanas de enseñanza se refiere al número de semanas lectivas excluyendo las semanas de vacaciones.

El tiempo de enseñanza reglamentario se refiere al número de horas de 60 minutos programadas al año que un profesor a tiempo completo enseña a un grupo o a una clase de estudiantes según las normas oficiales en vigor. Normalmente se calcula multiplicando el número de días lectivos al año por el número de horas de clase que un profesor imparte al día (excluyendo los periodos de tiempo reglamentariamente destinados a los descansos entre clases o conjuntos de clases). Algunos países aportan estimaciones del número de horas lectivas basadas en datos procedentes de encuestas. En educación primaria se incluyen los breves descansos entre clases si el profesor es responsable de su clase durante ese tiempo.

El horario laboral se refiere al número normal de horas de trabajo de un profesor a tiempo completo. No incluye las horas extras remuneradas. Según la política oficial vigente en cada país, el horario laboral puede comprender:

- El tiempo directamente dedicado a la enseñanza y a otras actividades escolares dirigidas a los estudiantes, tales como la asignación de deberes y controles.

- El tiempo directamente dedicado a la enseñanza y las horas dedicadas a otras actividades relacionadas con la enseñanza, como preparación de clases, orientación de estudiantes, corrección de deberes y controles, actividades de perfeccionamiento profesional, reuniones con los padres, reuniones de personal y tareas generales de carácter escolar.

Horario laboral en el centro escolar se refiere al tiempo que los profesores deben permanecer en el mismo, sea para la enseñanza o para otras actividades.

\section{Metodología}

Los datos proceden de la Encuesta OCDE-INES 2013 sobre Profesores y Currículo y se refieren al año escolar 2011-2012.

$\mathrm{Al}$ interpretar las diferencias de las horas de enseñanza entre los diversos países, el tiempo de contacto neto, tal como se utiliza aquí, no corresponde necesariamente a la carga lectiva. El tiempo de contacto es un componente sustancial, pero la preparación de clases y el seguimiento necesario, incluyendo la corrección de los trabajos de los estudiantes, también deben incluirse al comparar las cargas de trabajo de los profesores. Otros elementos relevantes, como el número de asignaturas impartidas, el número de estudiantes a los que se enseña y el número de años que un profesor enseña a los mismos estudiantes, también deben tenerse en cuenta.

Véase el Anexo 3 en www.oecd.org/edu/eag.htm para notas sobre las definiciones y metodología de cada país. 


\section{Nota sobre los datos de Israel}

Los datos estadísticos para Israel fueron proporcionados por las autoridades israelíes competentes bajo su responsabilidad. El uso de estos datos por parte de la OCDE se hace sin prejuzgar la situación de los Altos del Golán, Jerusalén Este y los asentamientos israelíes en Cisjordania de acuerdo con los términos del derecho internacional.

\section{Referencia}

OECD (2014), Talis 2013 Results: An International Perspective on Teaching and Learning, OECD Publishing, París, http://dx.doi.org/10.1787/9789264196261-en

\section{Tablas del Indicador D4}

StatLink 需西 http://dx.doi.org/10.1787/888933120005

Tabla D4.1 Organización del horario laboral de los profesores (2012)

Tabla D4.2 Número de horas de enseñanza al año (2000, 2005, 2010 y 2012)

WEB Tabla D4.3 Tiempo de enseñanza real (2012)

WEB Tabla D4.4a Tareas exigidas a los profesores según normativa o acuerdos, en educación infantil (2012)

WEB Tabla D4.4b Tareas exigidas a los profesores según normativa o acuerdos, en educación primaria (2012)

WEB Tabla D4.4c Tareas exigidas a los profesores según normativa o acuerdos, en educación secundaria inferior (2012)

WEB Tabla D4.4d Tareas exigidas a los profesores según normativa o acuerdos, en educación secundaria superior (2012) 
Tabla D4.1. Organización del horario laboral de los profesores (2012)

Número de semanas de enseñanza, días de enseñanza, horas de enseñanza netas y horario laboral de los profesores en instituciones públicas a lo largo del año escolar

\begin{tabular}{|c|c|c|c|c|c|c|c|c|c|c|c|c|c|c|c|c|c|c|c|}
\hline \multicolumn{4}{|c|}{$\begin{array}{c}\text { Número de semanas } \\
\text { de enseñanza }\end{array}$} & \multicolumn{4}{|c|}{$\begin{array}{l}\text { Número de días } \\
\text { de enseñanza }\end{array}$} & \multicolumn{4}{|c|}{$\begin{array}{c}\text { Tiempo de enseñanza neto, } \\
\text { en horas }\end{array}$} & \multicolumn{4}{|c|}{$\begin{array}{l}\text { Horario laboral exigido en } \\
\text { el centro escolar, en horas }\end{array}$} & \multicolumn{4}{|c|}{$\begin{array}{c}\text { Horario laboral } \\
\text { reglamentario total, en horas }\end{array}$} \\
\hline 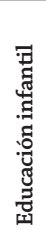 & 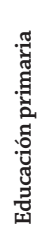 & 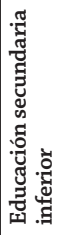 & 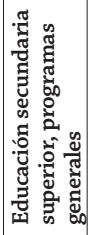 & 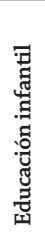 & 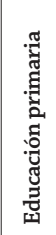 & 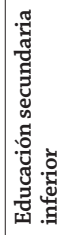 & 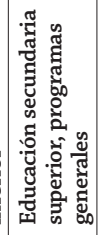 & 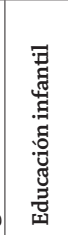 & 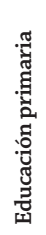 & 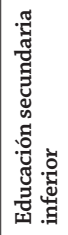 & 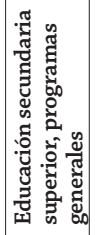 & 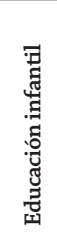 & 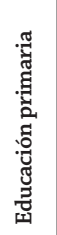 & 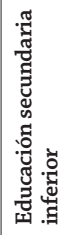 & 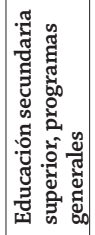 & 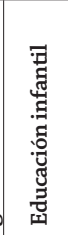 & 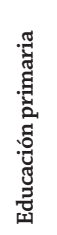 & 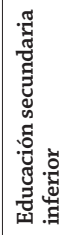 & 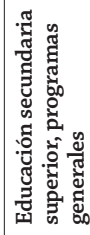 \\
\hline
\end{tabular}

\begin{tabular}{|c|c|c|c|c|c|c|c|c|c|c|c|c|c|c|c|c|c|c|c|c|}
\hline Alemania $^{1}$ & 40 & 40 & 40 & 40 & 193 & 193 & 193 & 193 & 796 & 804 & 755 & 718 & a & $\mathrm{a}$ & $\mathrm{a}$ & a & 1.776 & 1.776 & 1.776 & 1.776 \\
\hline Austr & 40 & 40 & 40 & 40 & 197 & 197 & 197 & 195 & 884 & 871 & 809 & 801 & 1.172 & 1.211 & 1.234 & 1.234 & & $\mathrm{a}$ & $\mathrm{a}$ & a \\
\hline Austria $^{1}$ & 38 & 38 & 38 & 38 & 180 & 180 & 180 & 180 & 779 & 779 & 607 & 589 & a & $\mathrm{a}$ & a & a & 1.776 & 1.776 & 1.776 & a \\
\hline Bélgica (Fl.) ${ }^{1}$ & 37 & 37 & 37 & 37 & 176 & 176 & 174 & 174 & 732 & 748 & 652 & 609 & 915 & 915 & $\mathrm{a}$ & $\mathrm{a}$ & $\mathrm{a}$ & $\mathrm{a}$ & $\mathrm{a}$ & $\mathrm{a}$ \\
\hline Bélgica (Fr.) ${ }^{1}$ & 37 & 37 & 37 & 37 & 181 & 181 & 181 & 181 & 784 & 721 & 661 & 601 & a & $\mathrm{a}$ & $\mathrm{a}$ & a & $\mathrm{a}$ & $\mathrm{a}$ & $\mathrm{a}$ & a \\
\hline Canadá $^{1}$ & 37 & 37 & 37 & 37 & 183 & 183 & 183 & 183 & 792 & 802 & 747 & 751 & 1.213 & 1.223 & 1.224 & 1.229 & | & $\mathrm{a}$ & $\mathrm{a}$ & a \\
\hline Chile $^{2}$ & 38 & 38 & 38 & 38 & 179 & 179 & 179 & 179 & 1.103 & 1.103 & 1.103 & 1.103 & 1.839 & 1.839 & 1.839 & 1.839 & 1.971 & 1.971 & 1.971 & 1.971 \\
\hline Corea $^{4}$ & 36 & 38 & 38 & 38 & 180 & 190 & 190 & 190 & 583 & 694 & 568 & 549 & a & $\mathrm{a}$ & $\mathrm{a}$ & a & 1.520 & 1.520 & 1.520 & 1.520 \\
\hline Dinamarca $^{3}$ & a & $\mathrm{a}$ & $\mathrm{a}$ & $\mathrm{a}$ & & $\mathrm{a}$ & $\mathrm{a}$ & $\mathrm{a}$ & $\mathrm{a}$ & 659 & 659 & 369 & a & $\mathrm{a}$ & $\mathrm{a}$ & a & 1.680 & 1.680 & 1.680 & 1.680 \\
\hline Escocia & 38 & 38 & 38 & 38 & 190 & 190 & 190 & 190 & 855 & 855 & 855 & 855 & 1.045 & 1.045 & 1.045 & 1.045 & 365 & 1.365 & 1.365 & 1.365 \\
\hline Eslovenia $^{1}$ & 46 & 40 & 40 & 40 & 219 & 190 & 190 & 190 & 1.314 & 627 & 627 & 570 & $\mathrm{a}$ & $\mathrm{a}$ & $\mathrm{a}$ & $\mathrm{a}$ & $\mathrm{m}$ & $\mathrm{m}$ & $\mathrm{m}$ & $\mathrm{m}$ \\
\hline España $^{1}$ & 37 & 37 & 37 & 36 & 176 & 176 & 176 & 171 & 880 & 880 & 713 & 693 & 1.140 & 1.140 & 1.140 & 1.140 & 1.425 & 1.425 & 1.425 & 1.425 \\
\hline Estados Unidos ${ }^{3}$ & 36 & 36 & 36 & 36 & 180 & 180 & 180 & 180 & 1.131 & 1.131 & 1.085 & 1.076 & 1.365 & 1.362 & 1.366 & 1.365 & 1.890 & 1.922 & 1.936 & 1.960 \\
\hline Estonia $^{2}$ & 46 & 35 & 35 & 35 & 220 & 172 & 172 & 172 & 1.320 & 619 & 619 & 568 & 1.610 & 1.540 & 1.540 & 1.540 & 1.610 & 1.540 & 1.540 & 1.540 \\
\hline Finlandia $^{4}$ & $\mathrm{~m}$ & 38 & 38 & 38 & $\mathrm{~m}$ & 187 & 187 & 187 & $\mathrm{~m}$ & 673 & 589 & 547 & $\mathrm{~m}$ & 787 & 703 & 642 & $\mathrm{a}$ & $\mathrm{a}$ & $\mathrm{a}$ & a \\
\hline Francia $^{1}$ & 36 & 36 & 36 & 36 & 144 & 144 & $\mathrm{a}$ & a & 924 & 924 & 648 & 648 & 972 & 972 & $\mathrm{a}$ & a & 1.607 & 1.607 & 1.607 & 1.607 \\
\hline Grecia $^{1}$ & 35 & 35 & 31 & 31 & 171 & 171 & 152 & 152 & 684 & 569 & 415 & 415 & 1.140 & 1.140 & 1.170 & 1.170 & $\mathrm{a}$ & $\mathrm{a}$ & $\mathrm{a}$ & $\mathrm{a}$ \\
\hline Hungría $^{4}$ & 37 & 37 & 37 & 37 & 181 & 183 & 183 & 183 & 1.158 & 604 & 604 & 604 & $\mathrm{~m}$ & $\mathrm{~m}$ & $\mathrm{~m}$ & $\mathrm{~m}$ & 1.864 & 1.864 & 1.864 & 1.864 \\
\hline Inglaterra $^{3}$ & 38 & 38 & 38 & 38 & 189 & 189 & 189 & 189 & 680 & 680 & 692 & 692 & 1.259 & 1.259 & 1.259 & 1.259 & 1.259 & 1.259 & 1.259 & 1.259 \\
\hline Irlanda $^{1}$ & $\mathrm{~m}$ & 37 & 33 & 33 & $\mathrm{~m}$ & 183 & 167 & 167 & $\mathrm{~m}$ & 915 & 735 & 735 & $\mathrm{~m}$ & 1.079 & 778 & 778 & $\mathrm{a}$ & $\mathrm{a}$ & $\mathrm{a}$ & $\mathrm{a}$ \\
\hline Islandia $^{1}$ & 48 & 37 & 37 & 35 & 227 & 180 & 180 & 170 & 1.646 & 624 & 624 & 544 & 1.800 & 1.650 & 1.650 & 1.720 & 1.800 & 1.800 & 1.800 & 1.800 \\
\hline Israel $^{1}$ & 38 & 38 & 37 & 37 & 182 & 182 & 175 & 175 & 1.023 & 838 & 629 & 558 & 1.023 & 1.219 & 924 & 781 & $\mathrm{a}$ & $\mathrm{a}$ & $\mathrm{a}$ & a \\
\hline Italia $^{1}$ & 42 & 39 & 39 & 39 & 186 & 171 & 171 & 171 & 930 & 752 & 616 & 616 & a & $\mathrm{a}$ & a & a & $\mathrm{a}$ & $\mathrm{a}$ & $\mathrm{a}$ & a \\
\hline Japón $^{3}$ & 39 & 40 & 40 & 39 & $\mathrm{~m}$ & 200 & 200 & 196 & $\mathrm{~m}$ & 731 & 602 & 510 & a & $\mathrm{a}$ & $\mathrm{a}$ & $\mathrm{a}$ & $\mathrm{a}$ & 1.891 & 1.891 & 1.891 \\
\hline Luxemburgo $^{1}$ & 36 & 36 & 36 & 36 & 176 & 176 & 176 & 176 & 880 & 810 & 739 & 739 & 1.060 & 990 & 828 & 828 & a & $\mathrm{a}$ & $\mathrm{a}$ & a \\
\hline México $^{1}$ & 42 & 42 & 42 & 36 & 200 & 200 & 200 & 171 & 532 & 800 & 1.047 & 838 & 772 & 800 & 1.167 & 971 & $\mathrm{a}$ & $\mathrm{a}$ & $\mathrm{a}$ & a \\
\hline Noruega $^{1}$ & 45 & 38 & 38 & 38 & 225 & 190 & 190 & 190 & 1.508 & 741 & 663 & 523 & 1.508 & 1.300 & 1.225 & 1.150 & 1.688 & 1.688 & 1.688 & 1.688 \\
\hline Nueva Zelanda $^{1}$ & $\mathrm{~m}$ & 39 & 39 & 38 & $\mathrm{~m}$ & 195 & 193 & 190 & $\mathrm{~m}$ & 935 & 848 & 760 & $\mathrm{~m}$ & 1.560 & 1.255 & 950 & $\mathrm{a}$ & $\mathrm{a}$ & $\mathrm{a}$ & $\mathrm{a}$ \\
\hline Países Bajos² & 40 & 40 & $\mathrm{~m}$ & $\mathrm{~m}$ & 195 & 195 & $\mathrm{~m}$ & $\mathrm{~m}$ & 930 & 930 & 750 & 750 & a & $\mathrm{a}$ & $\mathrm{a}$ & a & 1.659 & 1.659 & 1.659 & 1.659 \\
\hline Polonia $^{3}$ & 45 & 38 & 38 & 37 & 218 & 184 & 182 & 180 & 1.149 & 633 & 561 & 558 & $\mathrm{~m}$ & $\mathrm{~m}$ & $\mathrm{~m}$ & $\mathrm{~m}$ & 1.816 & 1.520 & 1.504 & 1.488 \\
\hline Portugal $^{2}$ & 42 & 37 & 37 & 37 & 194 & 168 & 168 & 168 & 970 & 756 & 616 & 616 & 1.116 & 1.027 & 926 & 926 & 1.426 & 1.296 & 1.296 & 1.296 \\
\hline República Checa ${ }^{1}$ & 39 & 39 & 39 & 39 & 188 & 188 & 188 & 188 & 1.166 & 827 & 620 & 592 & a & $\mathrm{a}$ & $\mathrm{a}$ & $\mathrm{a}$ & 1.776 & 1.776 & 1.776 & 1.776 \\
\hline República Eslovaca ${ }^{1}$ & 42 & 38 & 38 & 38 & 199 & 184 & 184 & 184 & 1.035 & 819 & 635 & 607 & $\mathrm{~m}$ & $\mathrm{~m}$ & $\mathrm{~m}$ & $\mathrm{~m}$ & 1.575 & 1.575 & 1.575 & 1.575 \\
\hline Suecia $^{1}$ & 47 & a & a & a & 224 & $\mathrm{a}$ & $\mathrm{a}$ & a & 1.792 & $\mathrm{~m}$ & $\mathrm{~m}$ & $\mathrm{~m}$ & 1.792 & 1.360 & 1.360 & 1.360 & a & 1.767 & 1.767 & 1.767 \\
\hline $\begin{array}{l}\text { Suiza } \\
\text { Turquía }^{1}\end{array}$ & $\begin{array}{r}\mathrm{m} \\
38\end{array}$ & $\begin{array}{r}\mathrm{m} \\
38\end{array}$ & $\begin{array}{r}\mathrm{m} \\
38\end{array}$ & $\begin{array}{r}\mathrm{m} \\
38\end{array}$ & $\begin{array}{r}\mathrm{m} \\
180\end{array}$ & $\begin{array}{r}\mathrm{m} \\
180\end{array}$ & $\begin{array}{r}\mathrm{m} \\
180\end{array}$ & $\begin{array}{r}\mathrm{m} \\
180\end{array}$ & $\begin{array}{r}\mathrm{m} \\
1.080\end{array}$ & $\begin{array}{r}m \\
720\end{array}$ & $\begin{array}{r}\mathrm{m} \\
504\end{array}$ & $\begin{array}{r}\mathrm{m} \\
567\end{array}$ & $\begin{array}{r}\mathrm{m} \\
1.160\end{array}$ & $\begin{array}{r}\mathrm{m} \\
980\end{array}$ & $\begin{array}{r}m \\
836\end{array}$ & $\begin{array}{r}\mathrm{m} \\
921\end{array}$ & $\begin{array}{r}\mathrm{m} \\
1.600\end{array}$ & $\begin{array}{r}\mathrm{m} \\
1.600\end{array}$ & $\begin{array}{r}\mathrm{m} \\
1.600\end{array}$ & $\begin{array}{r}\mathrm{m} \\
1.600\end{array}$ \\
\hline Media O & 40 & 38 & 38 & 37 & 191 & 183 & 182 & 180 & 1.001 & 782 & 694 & 655 & 1.258 & 1.200 & 1.173 & 1.142 & 1.654 & 1.649 & 1.649 & 1.643 \\
\hline Media UE21 & 40 & 38 & 37 & 37 & 190 & 180 & 179 & 179 & 988 & 754 & 653 & 622 & 1.205 & $\mid 1.104$ & 1.075 & 1.069 & 1.615 & 1.592 & $\mid 1.591$ & 1.577 \\
\hline Arabia S & $\mathrm{m}$ & $\mathrm{m}$ & $\mathrm{m}$ & $\mathrm{m}$ & $\mathrm{m}$ & ${ }^{4}$ & 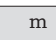 & $\mathrm{m}$ & 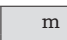 & $\mathrm{m}$ & $\mathrm{m}$ & 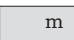 & $\mathrm{m}$ & $\mathrm{m}$ & $\mathrm{m}$ & $\mathrm{m}$ & $\mathrm{m}$ & $\mathrm{m}$ & $\mathrm{m}$ & $\mathrm{m}$ \\
\hline & 36 & 36 & 36 & 3 & 1 & 17 & 17 & & 80 & 680 & 368 & 368 & $\mathrm{~m}$ & $\mathrm{~m}$ & $\mathrm{~m}$ & $\mathrm{~m}$ & $\mathrm{~m}$ & $\mathrm{~m}$ & $\mathrm{~m}$ & $\mathrm{~m}$ \\
\hline Brasil & 42 & 42 & 42 & 42 & 203 & 203 & 203 & 203 & $\mathrm{~m}$ & $\mathrm{~m}$ & $\mathrm{~m}$ & $\mathrm{~m}$ & a & $\mathrm{a}$ & $\mathrm{a}$ & $\mathrm{a}$ & $\mathrm{a}$ & $\mathrm{a}$ & $\mathrm{a}$ & a \\
\hline Chir & $\mathrm{m}$ & $\mathrm{m}$ & $\mathrm{m}$ & $\mathrm{m}$ & $\mathrm{m}$ & $\mathrm{m}$ & $\mathrm{m}$ & $\mathrm{m}$ & $\mathrm{m}$ & $\mathrm{m}$ & $\mathrm{m}$ & $\mathrm{m}$ & $\mathrm{m}$ & $\mathrm{m}$ & $\mathrm{m}$ & $\mathrm{m}$ & $\mathrm{m}$ & $\mathrm{m}$ & $\mathrm{m}$ & $\mathrm{m}$ \\
\hline Col & $\mathrm{m}$ & $\mathrm{m}$ & $\mathrm{m}$ & $\mathrm{m}$ & $\mathrm{m}$ & $\mathrm{m}$ & & & $\mathrm{m}$ & $\mathrm{m}$ & $\mathrm{m}$ & & $\mathrm{m}$ & $\mathrm{m}$ & $\mathrm{m}$ & $\mathrm{m}$ & $\mathrm{m}$ & $\mathrm{m}$ & $\mathrm{m}$ & $\mathrm{m}$ \\
\hline Fed & $\mathrm{m}$ & 34 & 35 & 35 & $\mathrm{~m}$ & 170 & 210 & 210 & $\mathrm{~m}$ & 561 & 483 & 483 & a & $\mathrm{a}$ & a & a & 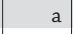 & $\mathrm{a}$ & $\mathrm{a}$ & a \\
\hline Ind & $\mathrm{m}$ & $\mathrm{m}$ & $\mathrm{m}$ & $\mathrm{m}$ & & $\mathrm{m}$ & $\mathrm{m}$ & 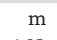 & $\mathrm{m}$ & & $\mathrm{m}$ & & m & $\mathrm{m}$ & $\mathrm{m}$ & $\mathrm{m}$ & $\mathrm{m}$ & $\mathrm{m}$ & $\mathrm{m}$ & $\mathrm{m}$ \\
\hline Indonesi & 44 & 44 & 44 & 44 & 251 & 251 & 163 & 163 & 628 & 1.255 & 734 & 734 & $\mathrm{~m}$ & $\mathrm{~m}$ & $\mathrm{~m}$ & $\mathrm{~m}$ & $\mathrm{~m}$ & $\mathrm{~m}$ & $\mathrm{~m}$ & $\mathrm{~m}$ \\
\hline Leto & $\mathrm{m}$ & $\mathrm{m}$ & $\mathrm{m}$ & $\mathrm{m}$ & $\mathrm{m}$ & $\mathrm{m}$ & $\mathrm{m}$ & $\mathrm{m}$ & $\mathrm{m}$ & $\mathrm{m}$ & $\mathrm{m}$ & $\mathrm{m}$ & $\mathrm{m}$ & $\mathrm{m}$ & $\mathrm{m}$ & $\mathrm{m}$ & $\mathrm{m}$ & $\mathrm{m}$ & $\mathrm{m}$ & $\mathrm{m}$ \\
\hline Sudáfrica & $\mathrm{m}$ & $\mathrm{m}$ & $\mathrm{m}$ & $\mathrm{m}$ & $\mathrm{m}$ & $\mathrm{m}$ & $\mathrm{m}$ & $\mathrm{m}$ & $\mathrm{m}$ & $\mathrm{m}$ & $\mathrm{m}$ & $\mathrm{m}$ & $\mathrm{m}$ & $\mathrm{m}$ & $\mathrm{m}$ & $\mathrm{m}$ & $\mathrm{m}$ & $\mathrm{m}$ & $\mathrm{m}$ & $\mathrm{m}$ \\
\hline Media G20 & $\mathrm{m}$ & $\mathrm{m}$ & $\mathrm{m}$ & $\mathrm{m}$ & $\mathrm{m}$ & $\mathrm{m}$ & $\mathrm{m}$ & $\mathrm{m}$ & $\mathrm{m}$ & $\mathrm{m}$ & $\mathrm{m}$ & $\mathrm{m}$ & $\mathrm{m}$ & $\mathrm{m}$ & $\mathrm{m}$ & $\mathrm{m}$ & $\mathrm{m}$ & $\mathrm{m}$ & $\mathrm{m}$ & $\mathrm{m}$ \\
\hline
\end{tabular}

1. Horas lectivas habituales.

2. Horas máximas de enseñanza.

3. Horas lectivas reales.

4. Horas mínimas de enseñanza.

5. Año de referencia 2011.

Fuentes: OCDE. Arabia Saudí, Argentina, China, Colombia, India, Indonesia, Sudáfrica: Instituto de Estadística de la UNESCO. Para ver notas, consulte Anexo 3 (www.oecd.org/edu/eag.htm).

Para obtener más información acerca de los símbolos utilizados en lugar de los datos que faltan, consulte la Guía del lector.

StatLink त्ञाI $\mathrm{Tl}$ http://dx.doi.org/10.1787/888933120024 
Tabla D4.2. Número de horas de enseñanza al año (2000, 2005, 2010 y 2012)

Tiempo de contacto neto reglamentario en instituciones públicas, por nivel de educación

\begin{tabular}{|c|c|c|c|c|c|c|c|c|c|c|c|c|}
\hline & \multicolumn{4}{|c|}{ Educación primaria } & \multicolumn{4}{|c|}{ Educación secundaria inferior } & \multicolumn{4}{|c|}{ Educación secundaria superior } \\
\hline & 2000 & 2005 & 2010 & 2012 & 2000 & 2005 & 2010 & 2012 & 2000 & 2005 & 2010 & 2012 \\
\hline & (1) & (2) & (7) & (9) & (10) & (11) & (16) & (18) & (19) & (20) & (25) & (27) \\
\hline Alemania & 783 & 808 & 805 & 804 & 732 & 758 & 756 & 755 & 690 & 714 & 713 & 718 \\
\hline Australia & 882 & 888 & 868 & 871 & 811 & 810 & 819 & 809 & 803 & 810 & 803 & 801 \\
\hline Austria & $\mathrm{m}$ & 774 & 779 & 779 & $\mathrm{~m}$ & 607 & 607 & 607 & $\mathrm{~m}$ & 589 & 589 & 589 \\
\hline Bélgica (Fl.) & 767 & 761 & 761 & 748 & 682 & 690 & 675 & 652 & 638 & 645 & 630 & 609 \\
\hline Bélgica (Fr.) $)^{1}$ & 804 & 722 & 732 & 721 & 728 & 724 & 671 & 661 & 668 & 664 & 610 & 601 \\
\hline Canadá & $\mathrm{m}$ & $\mathrm{m}$ & 799 & 802 & $\mathrm{~m}$ & $\mathrm{~m}$ & 740 & 747 & $\mathrm{~m}$ & $\mathrm{~m}$ & 744 & 751 \\
\hline Chile & $\mathrm{m}$ & 1.128 & 1.105 & 1.103 & $\mathrm{~m}$ & 1.128 & 1.105 & 1.103 & $\mathrm{~m}$ & 1.128 & 1.105 & 1.103 \\
\hline Corea & 865 & 883 & 807 & 694 & 570 & 621 & 627 & 568 & 530 & 605 & 616 & 549 \\
\hline Dinamarca $^{2}$ & 640 & 640 & 650 & 659 & 640 & 640 & 650 & 659 & $\mathrm{~m}$ & $\mathrm{~m}$ & 377 & 369 \\
\hline Escocia & 950 & 893 & 855 & 855 & 893 & 893 & 855 & 855 & 893 & 893 & 855 & 855 \\
\hline Eslovenia & $\mathrm{m}$ & 627 & 627 & 627 & $\mathrm{~m}$ & 627 & 627 & 627 & $\mathrm{~m}$ & 570 & 570 & 570 \\
\hline España & 880 & 880 & 880 & 880 & 564 & 713 & 713 & 713 & 548 & 693 & 693 & 693 \\
\hline Estados Unidos ${ }^{2}$ & 1.080 & 1.080 & 1.097 & 1.131 & 1.080 & 1.080 & 1.068 & 1.085 & 1.080 & 1.080 & 1.051 & 1.076 \\
\hline Estonia & 630 & 630 & 630 & 619 & 630 & 630 & 630 & 619 & 578 & 578 & 578 & 568 \\
\hline Finlandia & 656 & 677 & 680 & 673 & 570 & 592 & 595 & 589 & 527 & 550 & 553 & 547 \\
\hline Francia & 936 & 936 & 936 & 924 & 648 & 648 & 648 & 648 & 648 & 648 & 648 & 648 \\
\hline Grecia & 609 & 604 & 589 & 569 & 426 & 434 & 415 & 415 & 429 & 430 & 415 & 415 \\
\hline Hungría & 583 & 583 & 604 & 604 & 555 & 555 & 604 & 604 & 555 & 555 & 604 & 604 \\
\hline Inglaterra $^{2}$ & $\mathrm{~m}$ & $\mathrm{~m}$ & 684 & 680 & $\mathrm{~m}$ & $\mathrm{~m}$ & 703 & 692 & $\mathrm{~m}$ & $\mathrm{~m}$ & 703 & 692 \\
\hline Irlanda & 915 & 915 & 915 & 915 & 735 & 735 & 735 & 735 & 735 & 735 & 735 & 735 \\
\hline Islandia & 629 & 671 & 624 & 624 & 629 & 671 & 624 & 624 & 464 & 560 & 544 & 544 \\
\hline Israel & 731 & 731 & 820 & 838 & 579 & 579 & 598 & 629 & 524 & 524 & 521 & 558 \\
\hline Italia & 744 & 739 & 770 & 752 & 608 & 605 & 630 & 616 & 608 & 605 & 630 & 616 \\
\hline Japón ${ }^{2}$ & 635 & 578 & 707 & 731 & 557 & 505 & 602 & 602 & 478 & 429 & 500 & 510 \\
\hline Luxemburgo & $\mathrm{m}$ & 774 & 739 & 810 & $\mathrm{~m}$ & 642 & 634 & 739 & $\mathrm{~m}$ & 642 & 634 & 739 \\
\hline México & 800 & 800 & 800 & 800 & 1.182 & 1.047 & 1.047 & 1.047 & $\mathrm{~m}$ & 848 & 843 & 838 \\
\hline Noruega & 713 & 741 & 741 & 741 & 633 & 656 & 654 & 663 & 505 & 524 & 523 & 523 \\
\hline Nueva Zelanda & $\mathrm{m}$ & $\mathrm{m}$ & 930 & 935 & $\mathrm{~m}$ & $\mathrm{~m}$ & 845 & 848 & $\mathrm{~m}$ & $\mathrm{~m}$ & 760 & 760 \\
\hline Países Bajos & 930 & 930 & 930 & 930 & 867 & 750 & 750 & 750 & 867 & 750 & 750 & 750 \\
\hline Polonia $^{2}$ & $\mathrm{~m}$ & $\mathrm{~m}$ & 644 & 633 & $\mathrm{~m}$ & $\mathrm{~m}$ & 572 & 561 & $\mathrm{~m}$ & $\mathrm{~m}$ & 571 & 558 \\
\hline Portugal & 815 & 855 & 779 & 756 & 595 & 564 & 634 & 616 & 515 & 513 & 634 & 616 \\
\hline República Checa & $\mathrm{m}$ & 813 & 862 & 827 & 650 & 647 & 647 & 620 & 621 & 617 & 617 & 592 \\
\hline República Eslovaca & $\mathrm{m}$ & $\mathrm{m}$ & 841 & 819 & $\mathrm{~m}$ & $\mathrm{~m}$ & 652 & 635 & $\mathrm{~m}$ & $\mathrm{~m}$ & 624 & 607 \\
\hline Suecia & $\mathrm{m}$ & $\mathrm{m}$ & $\mathrm{m}$ & $\mathrm{m}$ & $\mathrm{m}$ & $\mathrm{m}$ & $\mathrm{m}$ & $\mathrm{m}$ & $\mathrm{m}$ & $\mathrm{m}$ & $\mathrm{m}$ & $\mathrm{m}$ \\
\hline Suiza & 884 & $\mathrm{~m}$ & $\mathrm{~m}$ & $\mathrm{~m}$ & 859 & $\mathrm{~m}$ & $\mathrm{~m}$ & $\mathrm{~m}$ & 674 & $\mathrm{~m}$ & $\mathrm{~m}$ & $\mathrm{~m}$ \\
\hline Turquía & 639 & 639 & 621 & 720 & $\mathrm{a}$ & a & a & 504 & 504 & 567 & 551 & 567 \\
\hline Media OCDE & 780 & 783 & 783 & 782 & 697 & 698 & 701 & 694 & 628 & 659 & 656 & 655 \\
\hline $\begin{array}{l}\text { Media de la OCDE } \\
\text { para los países con } \\
\text { datos de } 2000,2005, \\
2010 \text { y } 2012\end{array}$ & 776 & 774 & 775 & 773 & 690 & 689 & 694 & 689 & 626 & 639 & 642 & 639 \\
\hline $\begin{array}{l}\text { Media EU21 para } \\
\text { los países con datos } \\
\text { de } 2000,2005,2010 \\
\text { y } 2012\end{array}$ & 776 & 771 & 768 & 761 & 658 & 661 & 663 & 657 & 635 & 639 & 644 & 638 \\
\hline Arabia Saudí & $\mathrm{m}$ & $\mathrm{m}$ & $\mathrm{m}$ & $\mathrm{m}$ & $\mathrm{m}$ & $\mathrm{m}$ & $\mathrm{m}$ & $\mathrm{m}$ & $\mathrm{m}$ & $\mathrm{m}$ & $\mathrm{m}$ & $\mathrm{m}$ \\
\hline Argentina $^{3}$ & $\mathrm{~m}$ & $\mathrm{~m}$ & 720 & 680 & $\mathrm{~m}$ & $\mathrm{~m}$ & 1.448 & 1.368 & $\mathrm{~m}$ & $\mathrm{~m}$ & 1.448 & 1.368 \\
\hline Brasil & $\mathrm{m}$ & $\mathrm{m}$ & $\mathrm{m}$ & $\mathrm{m}$ & $\mathrm{m}$ & $\mathrm{m}$ & $\mathrm{m}$ & $\mathrm{m}$ & $\mathrm{m}$ & $\mathrm{m}$ & $\mathrm{m}$ & $\mathrm{m}$ \\
\hline China & $\mathrm{m}$ & $\mathrm{m}$ & $\mathrm{m}$ & $\mathrm{m}$ & $\mathrm{m}$ & $\mathrm{m}$ & $\mathrm{m}$ & $\mathrm{m}$ & $\mathrm{m}$ & $\mathrm{m}$ & $\mathrm{m}$ & $\mathrm{m}$ \\
\hline Colombia & $\mathrm{m}$ & $\mathrm{m}$ & $\mathrm{m}$ & $\mathrm{m}$ & $\mathrm{m}$ & $\mathrm{m}$ & $\mathrm{m}$ & $\mathrm{m}$ & $\mathrm{m}$ & $\mathrm{m}$ & $\mathrm{m}$ & $\mathrm{m}$ \\
\hline Federación Rusa ${ }^{2}$ & $\mathrm{~m}$ & 615 & 615 & 561 & $\mathrm{~m}$ & 507 & 507 & 483 & $\mathrm{~m}$ & 507 & 507 & 483 \\
\hline India & $\mathrm{m}$ & $\mathrm{m}$ & $\mathrm{m}$ & $\mathrm{m}$ & $\mathrm{m}$ & $\mathrm{m}$ & $\mathrm{m}$ & $\mathrm{m}$ & $\mathrm{m}$ & $\mathrm{m}$ & $\mathrm{m}$ & $\mathrm{m}$ \\
\hline Indonesia & $\mathrm{m}$ & $\mathrm{m}$ & $\mathrm{m}$ & 1.255 & $\mathrm{~m}$ & $\mathrm{~m}$ & $\mathrm{~m}$ & 734 & $\mathrm{~m}$ & $\mathrm{~m}$ & $\mathrm{~m}$ & 734 \\
\hline Letonia & $\mathrm{m}$ & $\mathrm{m}$ & $\mathrm{m}$ & $\mathrm{m}$ & $\mathrm{m}$ & $\mathrm{m}$ & $\mathrm{m}$ & $\mathrm{m}$ & $\mathrm{m}$ & $\mathrm{m}$ & $\mathrm{m}$ & $\mathrm{m}$ \\
\hline Sudáfrica & $\mathrm{m}$ & $\mathrm{m}$ & $\mathrm{m}$ & $\mathrm{m}$ & $\mathrm{m}$ & $\mathrm{m}$ & $\mathrm{m}$ & $\mathrm{m}$ & $\mathrm{m}$ & $\mathrm{m}$ & $\mathrm{m}$ & $\mathrm{m}$ \\
\hline Media G20 & $\mathrm{m}$ & $\mathrm{m}$ & $\mathrm{m}$ & $\mathrm{m}$ & $\mathrm{m}$ & $\mathrm{m}$ & $\mathrm{m}$ & $\mathrm{m}$ & $\mathrm{m}$ & $\mathrm{m}$ & $\mathrm{m}$ & $\mathrm{m}$ \\
\hline
\end{tabular}

Notas: Los años 2006, 2007, 2008, 2009 y 2011 (columnas 3-6, 8, 12-15, 17, 21-24, 26) están disponibles en Internet (véase StatLink más abajo).

1. Ruptura de la serie temporal tras cambios en la metodología en 2006.

2. Horas lectivas reales.

3. Año de referencia 2011 en lugar de 2012

Fuentes: OCDE. Arabia Saudí, Argentina, China, Colombia, India, Indonesia, Sudáfrica: Instituto de Estadística de la UNESCO. Para ver notas, consulte Anexo 3 (www.oecd.org/edu/eag.htm).

Para obtener más información acerca de los símbolos utilizados en lugar de los datos que faltan, consulte la Guía del lector.

StatLink त्ञाज http://dx.doi.org/10.1787/888933120043 


\section{¿QUIÉNES COMPONEN EL PROFESORADO?}

- Como media en los países de la OCDE, un 36\% de los profesores de educación secundaria tenían 50 años de edad o más en 2012; desde un $25 \%$ o menos en Brasil, Corea, Indonesia, Luxemburgo y Polonia hasta más de un $60 \%$ en Italia.

- Entre 2002 y 2012, la proporción de los profesores de educación secundaria de 50 años de edad o más aumentó de acuerdo con una tasa media de crecimiento anual de un 1,3\% en los países con datos comparables.

- Como media en los países de la OCDE, dos tercios del profesorado y del personal académico están compuestos por mujeres; sin embargo, la proporción de profesoras desciende según asciende el nivel educativo: un $97 \%$ en educación infantil, un $82 \%$ en educación primaria, un $67 \%$ en educación secundaria inferior, un $57 \%$ en educación secundaria superior y un $42 \%$ en educación terciaria.

\section{Gráfico D5.1. Porcentaje de profesores de educación secundaria de 50 años de edad o más y su tasa media de crecimiento anual (2002-2012)}

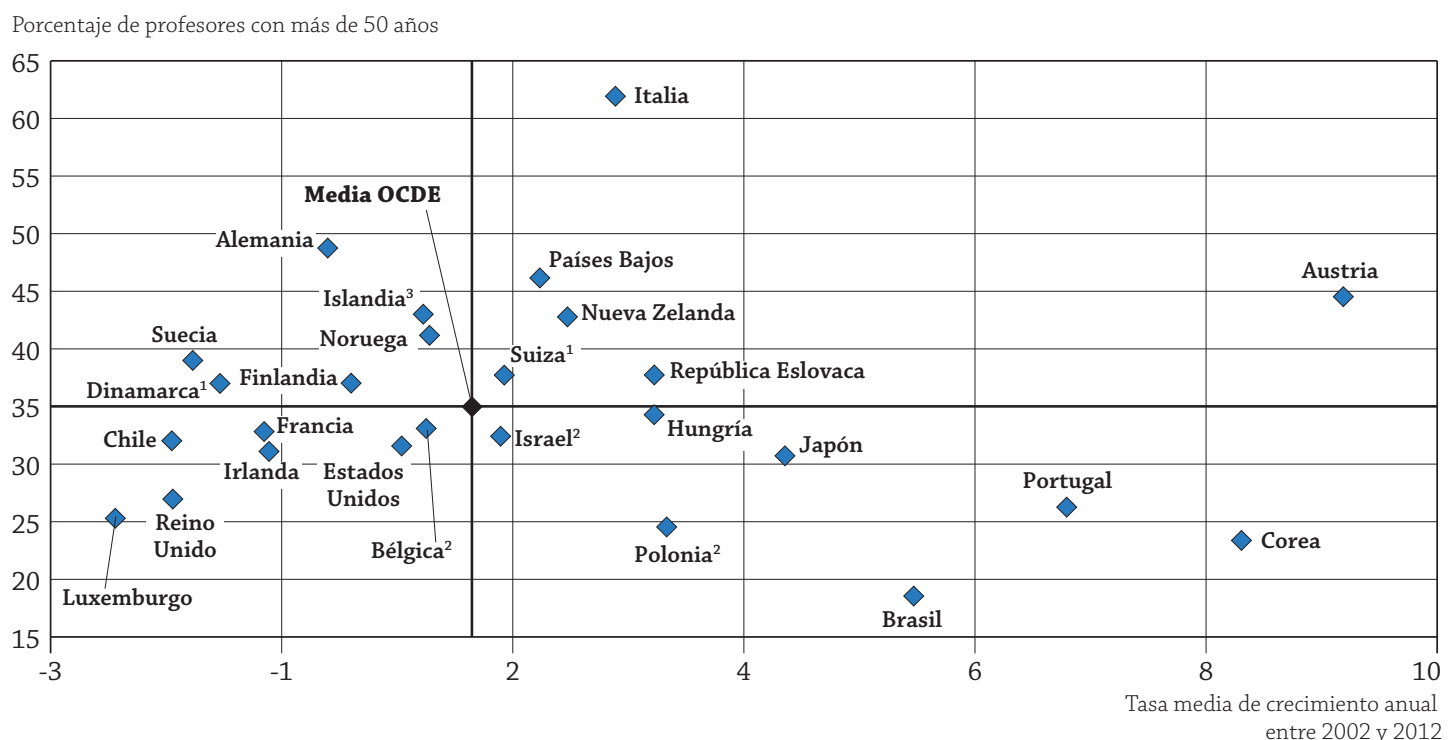

1. Año de referencia 2003 en lugar de 2002.

2. Año de referencia 2004 en lugar de 2002

3. Año de referencia 2011 en lugar de 2012

Fuente: OCDE. Tabla D5.2. Para ver notas, consulte Anexo 3 (www.oecd.org/edu/eag.htm).

StatLink 갠 http://dx.doi.org/10.1787/888933120214

\section{Contexto}

La demanda de profesores depende de factores como la distribución por edades de la población en edad escolar, el tamaño medio de la clase, la carga docente de los profesores, las horas de enseñanza obligatorias para los alumnos, el uso que hacen los centros escolares de asistentes educativos y de personal externo al aula, las tasas de matriculación en los distintos niveles educativos, las tasas de repetición de cada curso y las edades de comienzo y finalización de la educación obligatoria. La alta proporción de profesores que alcanzarán la edad de jubilación durante la próxima década en varios países de la OCDE y/o el incremento previsto del tamaño de la población en edad escolar ejercerán presión sobre los gobiernos, que tendrán que contratar y formar a nuevos profesores. Dada las irrefutables pruebas que demuestran que la calidad del profesorado es el factor que determina de manera más significativa el rendimiento de los alumnos en los centros escolares, es necesario aunar esfuerzos para atraer al mejor talento académico a la profesión docente y proporcionar una formación de alta calidad (Hiebert y Stigler, 1999; OECD, 2005). 
La política educativa docente debe garantizar un entorno de trabajo que fomente la permanencia en la profesión de los profesores eficaces. Además, la enseñanza en educación infantil, primaria y secundaria inferior sigue estando dominada por mujeres, y este desequilibrio de sexo en la profesión docente y su impacto sobre el aprendizaje de los alumnos merecen ser estudiados en detalle.

\section{Otros resultados}

- La mayor parte del profesorado de educación terciaria está compuesto por hombres en casi todos los países, exceptuando Federación Rusa y Finlandia.

\section{INDICADOR D5}

- Como media en los países de la OCDE, un $31 \%$ de los profesores de educación primaria tienen 50 años de edad o más. Sin embargo, en siete países de la OCDE y países asociados -Bélgica, Brasil, Corea, Irlanda, Israel, Luxemburgo y Reino Unido-, más de uno de cada dos profesores de educación primaria tienen menos de 40 años de edad.

- Los profesores de educación secundaria inferior cuentan con una experiencia media en enseñanza de 16 años (incluyendo casi 10 años en su centro escolar actual), 3 años de experiencia en otros roles dentro de la educación y 4 años de experiencia en otro tipo de trabajos.

\section{Tendencias}

Entre 2002 y 2012, la proporción de profesores de educación secundaria de 50 años de edad o más aumentó 4 puntos porcentuales como media en los países que disponen de datos comparables. Este aumento es de 10 puntos porcentuales o más en Corea, Italia, Japón y Portugal, y es especialmente llamativo en Austria, con un incremento de 26 puntos porcentuales durante este periodo. En los países que están abocados a perder un número significativo de profesores que alcanzan la edad de jubilación y cuya población en edad escolar se mantiene igual o aumenta, los gobiernos tendrán que hacer más atractiva la enseñanza a los estudiantes de educación secundaria superior y educación terciaria, expandir los programas de formación del profesorado y, en caso necesario, proporcionar rutas alternativas para que los profesionales que quieran reorientar su carrera profesional hacia la enseñanza puedan obtener la cualificación necesaria. Las limitaciones fiscales -particularmente las derivadas de la obligación de pagar pensiones y de cubrir los gastos sanitarios de las personas jubiladas- probablemente aumentarán la presión sobre los gobiernos llevándoles a reducir la oferta académica, aumentar el tamaño de las clases, integrar más aprendizaje de autoformación y por Internet o a implementar una combinación de algunas de estas medidas (Abrams, 2011; Peterson, 2010). 


\section{Análisis}

\section{Perfil del profesorado por sexo}

Como media en los países de la OCDE, dos tercios del profesorado y del personal académico en todos los niveles educativos (es decir, desde la educación infantil hasta la educación terciaria) son mujeres. Desde la educación infantil hasta los niveles de educación secundaria superior, la mayor parte del profesorado de los países de la OCDE son mujeres, aunque la proporción descienda según asciende el nivel educativo. En la educación terciaria, la mayor parte del profesorado y del personal académico en los países de la OCDE son hombres. Como media en los países de la OCDE, las mujeres representan solo un $42 \%$ del personal docente en este nivel. A pesar de este patrón general, existen amplias diferencias de un país a otro en cada uno de los niveles educativos.

Como media en los países de la OCDE, las mujeres ocupan un 97\% de los puestos docentes en educación infantil y un $82 \%$ de los puestos docentes en educación primaria. En todos los países con datos disponibles, excepto Francia, al menos un $93 \%$ del profesorado en educación infantil está compuesto por mujeres; en Francia, esta cifra es de un $83 \%$. En 37 países que disponen de datos relativos al personal docente, exceptuando Arabia Saudí, Canadá, China, Indonesia, Japón, México y Turquía, al menos 3 de cada 4 profesores de educación primaria son mujeres (Gráfico D5.2).

\section{Gráfico D5.2. Distribución por sexo del profesorado (2012)}

\section{Porcentaje de mujeres en el profesorado de instituciones públicas y privadas, por nivel de educación}

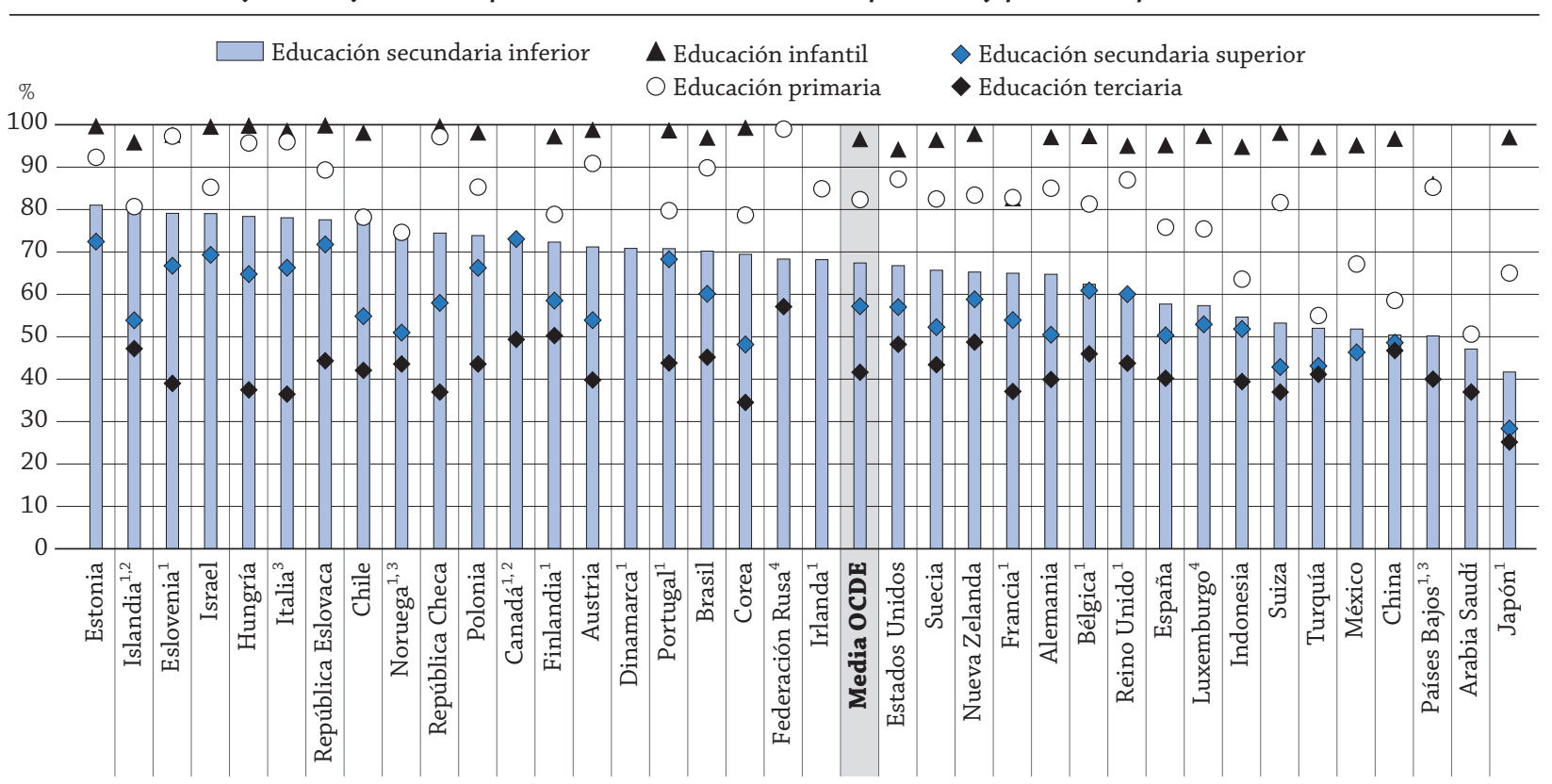

1. Algunos niveles educativos están incluidos junto con otros. Véase el código «X» en la Tabla D5.3 para obtener más detalles.

2. Año de referencia 2011.

3. Solo instituciones publicas (para Italia, desde educación infantil hasta niveles de educación secundaria).

4. Instituciones privadas de educación secundaria inferior incluidas con las instituciones de educación secundaria superior

Los países están clasificados en orden descendente del porcentaje de profesoras en el nivel de educación secundaria inferior.

Fuente: OCDE. Tabla D5.3. Para ver notas, consulte Anexo 3 (www.oecd.org/edu/eag.htm).

StatLink 제내 http://dx.doi.org/10.1787/888933120233

Aunque en educación secundaria inferior la mayor parte del profesorado (67\%) está compuesto por mujeres en los países de la OCDE, la proporción de hombres en ese nivel es mayor que en educación primaria. En los países de la OCDE, la proporción de profesoras varía considerablemente, desde menos de la mitad del profesorado en Japón hasta más del $80 \%$ en Estonia, Federación Rusa e Islandia. En educación secundaria superior, el porcentaje medio de profesoras en los países de la OCDE desciende a un 57\% y varía entre un $28 \%$ en Japón y un $73 \%$ en Canadá.

Como media en los países de la OCDE, la mayor parte del profesorado de educación terciaria es masculino. No obstante, la proporción de profesoras varía considerablemente de un país a otro, entre aproximadamente una de cada 4 en Japón y una de cada 2 o más en Federación Rusa y Finlandia. 


\section{Distribución de los profesores por edad}

Las variaciones del tamaño y de la distribución por edad de la población, la duración de la educación terciaria, los salarios del profesorado y las condiciones de trabajo afectan a la distribución por edad de los profesores. Así, el descenso de la tasa de natalidad hace disminuir la demanda de nuevos docentes y la educación terciaria se completa más tarde en unos países que en otros. A pesar de que en algunos países los salarios competitivos y las buenas condiciones laborales atraen a los jóvenes hacia la enseñanza, también disuaden a los profesores de dejar la profesión, de manera que limitan el número de vacantes (véase el Cuadro D.5.2 para más información sobre la situación laboral del profesorado).

Como media en los países de la OCDE, aproximadamente un $31 \%$ de los profesores de educación secundaria tienen 50 años de edad o más. Esta proporción supera el $40 \%$ en Alemania, Italia y Suecia. La proporción de los profesores de menos de 30 años de edad solo iguala o supera el $20 \%$ en Bélgica, Chile, Corea, Irlanda, Luxemburgo y Reino Unido (Gráfico D5.3, disponible en Internet).

En educación secundaria, la distribución por edad del profesorado es similar. Como media en los países de la OCDE, el 36\% de los profesores tienen como mínimo 50 años de edad. En Alemania, Austria, Estonia, Islandia, Italia, Noruega, Nueva Zelanda y Países Bajos, un mínimo del $40 \%$ de los profesores de educación secundaria tienen como mínimo 50 años de edad. Solo en Brasil e Indonesia hay más profesores de secundaria ( $51 \%$ y $62 \%$, respectivamente) menores de 40 años. La proporción de profesores que tienen 50 o más años en educación secundaria superior supera la proporción equivalente en la educación primaria en un mínimo de 10 puntos porcentuales en Estonia, Francia, Israel, Italia y República Eslovaca (Tablas D5.1 y D5.2).

Además de fomentar iniciativas de contratación y apoyo a la formación para reemplazar al profesorado que se jubila, el envejecimiento de los trabajadores docentes también tiene implicaciones presupuestarias. En la mayor parte de los sistemas escolares, los salarios del profesorado están relacionados con los años de experiencia en la docencia. El envejecimiento del profesorado incrementa los costes escolares, lo cual a su vez limita los recursos disponibles para implementar otras iniciativas a nivel escolar (Indicador D3).

A pesar de que las proporciones de los profesores que alcanzan o superan los 50 años de edad en educación secundaria sean mayores que en educación primaria, los profesores jóvenes siguen representando una parte significativa del personal docente (como media en los países de la OCDE, en educación primaria y secundaria un $13 \%$ y un $10 \%$ de los profesores, respectivamente, tienen 30 años de edad o menos). Solo en Alemania, Eslovenia, Estonia, Finlandia, Hungría, Islandia, Italia, Portugal, República Checa y Suecia los profesores de primaria y secundaria que no alcanzan los 30 años de edad representan un $10 \%$ o menos. Esto puede deberse en parte a la edad relativamente tardía a la que los estudiantes completan la educación terciaria en estos países (véase Anexo 1).

\section{Cuadro D5.1. Experiencia profesional de los profesores}

Los resultados del Estudio Internacional sobre Enseñanza y Aprendizaje (TALIS 2013) proporcionan un perfil de la experiencia profesional de los profesores. Se preguntó a los profesores acerca de su experiencia profesional como docentes en su centro escolar, como docentes a lo largo de su carrera profesional, en otros roles dentro de la educación (exceptuando el docente) y en otros trabajos. Como muestra la figura que aparece a continuación, los profesores de educación secundaria inferior cuentan como media con 16 años de experiencia en la docencia (que incluyen casi 10 años en su centro escolar actual), 3 años de experiencia en otros roles educativos y 4 años de experiencia en otro tipo de trabajos. Los profesores de Bulgaria, Estonia y Letonia son los que cuentan con más años de experiencia en la profesión, más de 20 años como docentes y aproximadamente 15 años en su centro escolar actual. En el extremo opuesto, los profesores de Singapur declaran que su experiencia en la docencia se encuentra ligeramente por debajo de los 10 años como media. Resulta interesante que la gran proporción de profesores con experiencia parece no guardar relación con una mayor participación en programas de orientación a profesores noveles. De hecho, el porcentaje de profesores que declaran tener un mentor o hacer de mentor no supera el $10 \%$ en Bulgaria, Estonia y Letonia, mientras que en Singapur casi el $40 \%$ de los profesores declaran participar en este tipo de programas.

La figura que aparece a continuación también muestra que los profesores de Corea y Japón cuentan con menos experiencia en su centro escolar actual en comparación con otros países que participaron en TALIS, poniendo 
de manifiesto una mayor movilidad entre centros escolares en estos dos países. Aunque los profesores de Corea y Japón se encuentran por encima de la media de TALIS en cuanto a su experiencia total en la docencia, también es cierto que se encuentran muy por debajo de la media en lo que se refiere a su experiencia en su centro escolar actual. De hecho declaran que la experiencia profesional adquirida en su centro escolar actual ni siquiera alcanza un tercio de su experiencia total. La experiencia profesional de estos profesores también difiere de la de sus compañeros de otros países en cuanto al número de años dedicados a otros roles dentro de la educación o a otros trabajos. Los profesores de Corea y Japón declaran que su experiencia profesional se centra casi exclusivamente en su trayectoria como docentes, mientras que, como media en los países participantes en TALIS, los profesores dicen haber dedicado más de 5 años a otros roles en el ámbito de la educación o a otros trabajos.

Estos resultados son significativos teniendo en cuenta que la experiencia profesional de los profesores contribuye a mejorar sus competencias. La antigüedad de un docente también puede afectar a su disposición para implementar prácticas o reformas innovadoras (Goodson, Moore y Hargreaves, 2006). Los años de experiencia pueden ser de particular importancia al principio de la carrera docente. Existen estudios que muestran que cada año de experiencia adicional produce mejores resultados en los alumnos, particularmente durante los primeros cinco años de la carrera profesional como docente (Rockoff, 2004; Rivkin, Hanushek y Kain, 2005; Harris y Sass, 2011).

\section{Gráfico D5.a. Experiencia laboral de los profesores (2013)}

\section{Número medio de años de experiencia laboral de los profesores de educación secundaria inferior}

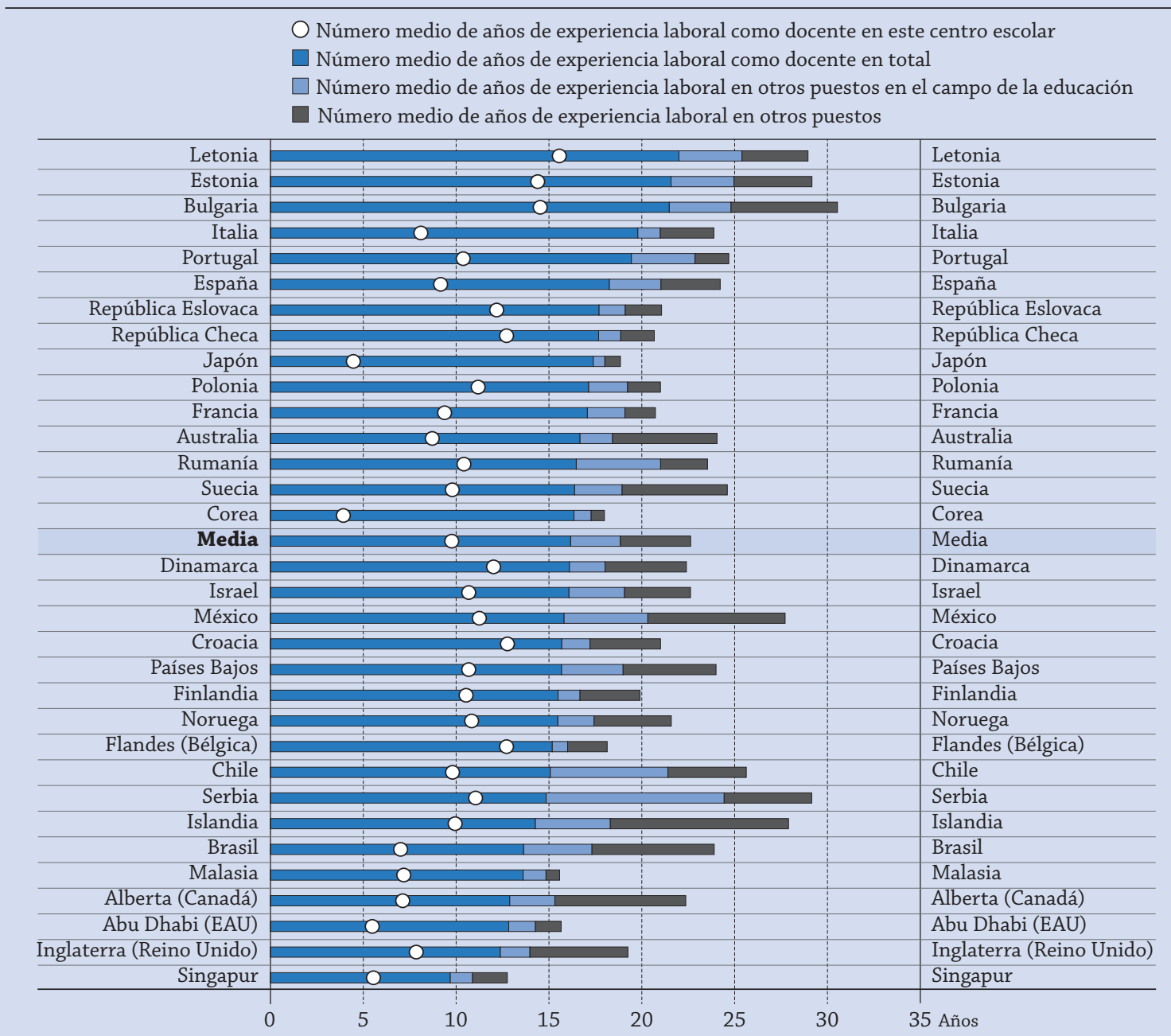

Los países están clasificados en orden descendente del número medio de años de experiencia laboral como docente en total.

Fuente: OECD (2014), TALIS 2013 Results: An International Perspective on Teaching and Learning, TALIS, OECD Publishing StatLink 제대 http://dx.doi.org/10.1787/888933041155 


\section{Cuadro D5.2. Situación laboral de los profesores}

Los resultados del Estudio internacional sobre Enseñanza y Aprendizaje (TALIS 2013) muestran que, como media en los países, excluidos los docentes sustitutos, un $83 \%$ de los profesores de educación secundaria inferior cuentan con un contrato indefinido y un $82 \%$ están contratados a tiempo completo. Como muestra la figura que aparece a continuación, los profesores de Malasia son los que declaran disfrutar de un mayor nivel de seguridad laboral. Todos los profesores declaran tener un puesto docente indefinido y casi todos declaran trabajar a tiempo completo.

Dado que la situación laboral puede ser un factor importante para atraer y mantener a los profesores en la profesión, se debería promover una mayor seguridad laboral (por medio de contratos indefinidos o de larga duración) y mayor flexibilidad (ofreciendo la posibilidad de trabajar a tiempo parcial) (OECD, 2005).

\section{Gráfico D5.b. Tipo de contrato laboral de los profesores de educación secundaria inferior Porcentaje de profesores permanentes en educación secundaria inferior}

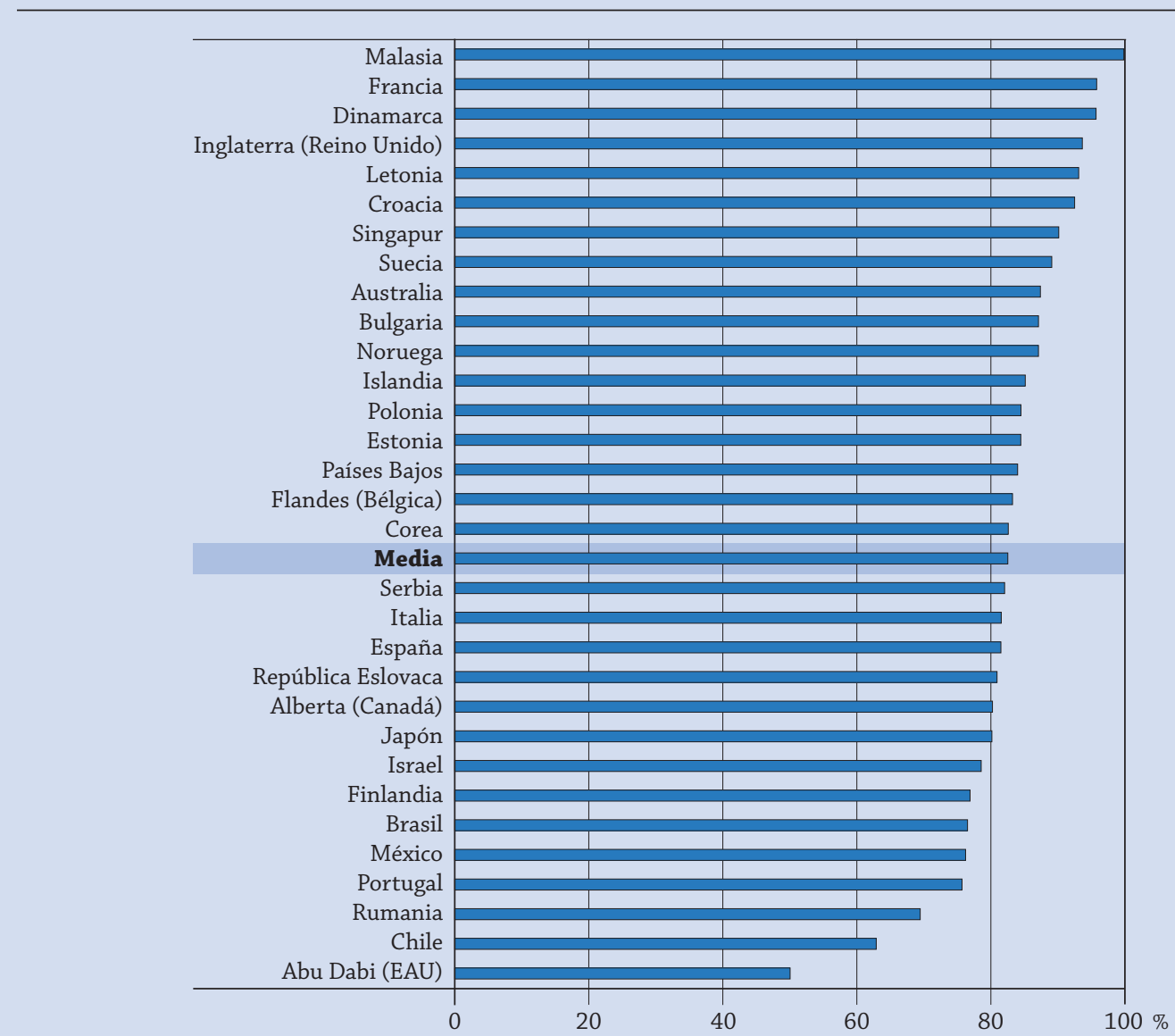

Fuente: OECD (2014), TALIS 2013 Results: An International Perspective on Teaching and Learning, TALIS, OECD Publishing.

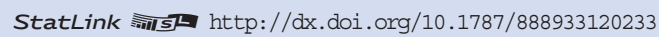

\section{Cambio de la distribución por edad de los profesores entre 2002 y 2012}

En los países que cuentan con datos de tendencias comparables para los años 2002 y 2012, la proporción media de profesores de educación secundaria de 50 años o más aumentó de acuerdo con una tasa de crecimiento anual del 1,3\% entre 2002 y 2012. Sin embargo, la variación entre países es amplia. En Brasil, Corea, Japón y Portugal, la tasa media de crecimiento anual aumentó más de un $4 \%$. La proporción de profesores de educación secundaria que alcanzaban o superaban los 50 años de edad experimentó el mayor aumento en Austria, con un $9 \%$ anual. En Chile, Dinamarca, Luxemburgo, Suecia y Reino Unido, la tasa media de crecimiento anual descendió a un $1 \%$ o más (Tabla D5.2). 
En todos los países, los cambios del número de profesores se deberían contrastar con los cambios de la población en edad escolar. En países que experimentan un aumento de la población en edad escolar durante ese periodo (véase Indicador $\mathrm{C} 1$ ), serán necesarios nuevos profesores para compensar la cantidad significativa de personal contratado durante las décadas de 1960 y 1970 que alcanzará la edad de jubilación en la próxima década. Los programas de formación para el profesorado probablemente tendrán que ampliarse y es posible que haya que aumentar los incentivos para que los estudiantes opten por la profesión docente (véase Indicador D6). En cambio, dado que la inversión sustancial de recursos en educación para el profesorado puede generar altos costes personales y colectivos, los países en los que la población en edad escolar decrece, tales como Alemania, Austria, Corea, Chile, Japón y Polonia, necesitan garantizar que la calidad de la formación para el profesorado no disminuya debido a la gran cantidad de candidatos y/o graduados de programas de formación para el profesorado que no encuentran trabajo como docentes (OECD, 2005).

\section{Definiciones}

La clasificación CINE de cualificaciones finales se refiere al tipo de cualificación educativa (por ejemplo, CINE 3, 5B, $5 \mathrm{~A})$ que un nuevo docente necesitaría obtener para enseñar en educación primaria, secundaria inferior y secundaria superior (programas generales) en el sector público.

\section{Metodologia}

Los datos se refieren al año académico 2011-2012 y se basan en los datos UOE sobre estadísticas educativas recopilados por la OCDE en 2012 (para más información, consulte Anexo 3 en www.oecd.org/edu/eag.htm). Los datos sobre los profesores por edad referentes al año 2002 pueden haber sido revisados en 2013 para garantizar la coherencia con los datos de 2011.

\section{Nota sobre los datos de Israel}

Los datos estadísticos para Israel fueron proporcionados por las autoridades israelíes competentes bajo su responsabilidad. El uso de estos datos por parte de la OCDE se hace sin prejuzgar la situación de los Altos del Golán, Jerusalén Este y los asentamientos israelíes en Cisjordania de acuerdo con los términos del derecho internacional.

\section{Referencias}

Abrams, S.E. (2011), «Technology in Moderation», The Teachers College Record, disponible en www.tcrecord.org/content. asp?contentid $=16584$.

Goodson, I., S. Moore y A. Hargreaves (2006), «Teacher nostalgia and the sustainability of reform: The generation and degeneration of teachers' missions, memory and meaning», Educational Administrative Quarterly, Vol. 42, pp. $42-61$.

Harris, D.N. y T.R. Sass (2011), «Teacher training, teacher quality and student achievement», Journal of Public Economics, Vol. 95, pp. 798-812.

Hanushek, E., S. Machin y L. Woessmann (2011), «The Economics of International Differences in Educational Achievement», Handbook of the Economics of Education, Vol. 3, pp. 89-200.

Hiebert, J. y J. Stigler (1999), The Teaching Gap: Best Ideas from the World's Teachers for Improving Education in the Classroom, Free Press, Nueva York.

OECD (2014), TALIS 2013 Results: An International Perspective on Teaching and Learning, OECD Publishing. http://dx.doi. org/10.1787/9789264196261-en

OECD (2005), Teachers Matter: Attracting, Developing and Retaining Effective Teachers, OECD Publishing, París.

Peterson, P. (2010), Saving Schools: From Horace Mann to Virtual Learning, Harvard University Press, Cambridge.

Rivkin, S., E. Hanushek y J. Kain (2005), «Teachers, schools, and academic achievement», Econometrica, Vol. 73/2, pp. 417-458.

Rockoff, J.E. (2004), «The impact of individual teachers on students' achievement: Evidence from panel data», American Economic Review, Vol. 94/2, pp. 247-252.

\section{Tablas del Indicador D5}

StatLink न्माI $\mathrm{http}: / / \mathrm{dx}$.doi.org/10.1787/888933120138

Tabla D5.1 Distribución por edad del profesorado (2012)

Tabla D5.2 Distribución por edad del profesorado (2012, 2002)

Tabla D5.3 Distribución por sexo del profesorado (2012) 
Tabla D5.1. Distribución por edad del profesorado (2012)

Porcentaje de profesores en instituciones públicas y privadas, por nivel de educación y grupo de edad, basado en recuentos

\begin{tabular}{|c|c|c|c|c|c|c|c|c|c|c|c|c|c|c|c|}
\hline & \multicolumn{5}{|c|}{ Educación primaria } & \multicolumn{5}{|c|}{ Educación secundaria inferior } & \multicolumn{5}{|c|}{ Educación secundaria superior } \\
\hline & $\begin{array}{l}<30 \\
\text { años }\end{array}$ & $\begin{array}{l}\text { 30-39 } \\
\text { años }\end{array}$ & $\begin{array}{l}40-49 \\
\text { años }\end{array}$ & $\begin{array}{l}50-59 \\
\text { años }\end{array}$ & $\begin{array}{l}>=60 \\
\text { años }\end{array}$ & $\begin{array}{l}<30 \\
\text { años }\end{array}$ & $\begin{array}{c}\text { 30-39 } \\
\text { años }\end{array}$ & $\begin{array}{l}40-49 \\
\text { años }\end{array}$ & $\begin{array}{c}50-59 \\
\text { años }\end{array}$ & $\begin{array}{l}>=60 \\
\text { años }\end{array}$ & $\begin{array}{l}<30 \\
\text { años }\end{array}$ & $\begin{array}{c}\text { 30-39 } \\
\text { años }\end{array}$ & $\begin{array}{l}40-49 \\
\text { años }\end{array}$ & $\begin{array}{c}50-59 \\
\text { años }\end{array}$ & $\begin{array}{l}>=60 \\
\text { años }\end{array}$ \\
\hline & (1) & $(2)$ & (3) & (4) & $(5)$ & (6) & (7) & $(8)$ & (9) & $(10)$ & $(11)$ & (12) & (13) & $(14)$ & (15) \\
\hline Alemania & 7 & 22 & 25 & 33 & 13 & 6 & 20 & 24 & 36 & 14 & 4 & 21 & 29 & 33 & 12 \\
\hline Australia & $\mathrm{m}$ & $\mathrm{m}$ & $\mathrm{m}$ & $\mathrm{m}$ & $\mathrm{m}$ & $\mathrm{m}$ & $\mathrm{m}$ & $\mathrm{m}$ & $\mathrm{m}$ & $\mathrm{m}$ & $\mathrm{m}$ & $\mathrm{m}$ & $\mathrm{m}$ & $\mathrm{m}$ & $\mathrm{m}$ \\
\hline Bélgica $^{1}$ & 21 & 31 & 25 & 22 & 1 & 17 & 27 & 24 & 28 & 4 & 14 & 27 & 26 & 30 & 4 \\
\hline Canadá ${ }^{2,3}$ & 14 & 32 & 29 & 21 & 4 & $\mathrm{x}(1)$ & $x(2)$ & $x(3)$ & $\mathrm{x}(4)$ & $\mathrm{x}(5)$ & 14 & 32 & 29 & 21 & 4 \\
\hline Chile & 20 & 28 & 20 & 22 & 9 & 20 & 27 & 20 & 22 & 10 & 18 & 28 & 21 & 23 & 9 \\
\hline Corea & 22 & 38 & 24 & 14 & 2 & 13 & 32 & 34 & 20 & 1 & 13 & 31 & 30 & 25 & 1 \\
\hline Dinamarca & $\mathrm{x}(6)$ & $x(7)$ & $\mathrm{x}(8)$ & $\mathrm{x}(9)$ & $\mathrm{x}(10)$ & 6 & 31 & 26 & 27 & 10 & $\mathrm{~m}$ & $\mathrm{~m}$ & $\mathrm{~m}$ & $\mathrm{~m}$ & $\mathrm{~m}$ \\
\hline Eslovenia $^{1}$ & 7 & 32 & 36 & 24 & 1 & 7 & 33 & 28 & 29 & 3 & 5 & 27 & 36 & 27 & 5 \\
\hline España & 13 & 31 & 24 & 27 & 4 & 8 & 29 & 31 & 28 & 4 & 4 & 28 & 36 & 28 & 4 \\
\hline Estonia & 9 & 21 & 33 & 26 & 10 & 8 & 16 & 27 & 31 & 17 & 8 & 17 & 25 & 31 & 19 \\
\hline Finlandia $^{1}$ & 9 & 30 & 33 & 26 & 3 & 10 & 30 & 30 & 26 & 5 & 5 & 21 & 31 & 31 & 12 \\
\hline Francia & 13 & 37 & 30 & 20 & 1 & 10 & 34 & 27 & 25 & 4 & 4 & 24 & 35 & 29 & 8 \\
\hline Grecia & $\mathrm{m}$ & $\mathrm{m}$ & $\mathrm{m}$ & $\mathrm{m}$ & $\mathrm{m}$ & $\mathrm{m}$ & $\mathrm{m}$ & $\mathrm{m}$ & $\mathrm{m}$ & $\mathrm{m}$ & $\mathrm{m}$ & $\mathrm{m}$ & $\mathrm{m}$ & $\mathrm{m}$ & $\mathrm{m}$ \\
\hline Hungría & 7 & 23 & 37 & 32 & 1 & 6 & 23 & 33 & 35 & 2 & 8 & 31 & 29 & 28 & 4 \\
\hline Irlanda ${ }^{1}$ & 21 & 34 & 18 & 22 & 4 & $\mathrm{x}(11)$ & $x(12)$ & $\mathrm{x}(13)$ & $\mathrm{x}(14)$ & $\mathrm{x}(15)$ & 9 & 36 & 27 & 24 & 4 \\
\hline Islandia $^{1,3}$ & 8 & 29 & 29 & 24 & 10 & 8 & 29 & 29 & 24 & 10 & 5 & 19 & 27 & 32 & 17 \\
\hline Israel & 16 & 36 & 26 & 18 & 3 & 11 & 31 & 30 & 23 & 5 & 10 & 28 & 26 & 24 & 12 \\
\hline Italia $^{4}$ & $\mathrm{n}$ & 12 & 36 & 41 & 11 & $\mathrm{n}$ & 13 & 29 & 43 & 15 & $\mathrm{n}$ & 8 & 27 & 52 & 13 \\
\hline Japón & 15 & 23 & 30 & 30 & 1 & 13 & 25 & 34 & 26 & 1 & 9 & 24 & 33 & 30 & 4 \\
\hline Luxemburgo $^{5}$ & 24 & 32 & 23 & 20 & 2 & 22 & 36 & 24 & 17 & 2 & 12 & 28 & 31 & 25 & 4 \\
\hline México & $\mathrm{m}$ & $\mathrm{m}$ & $\mathrm{m}$ & $\mathrm{m}$ & $\mathrm{m}$ & $\mathrm{m}$ & $\mathrm{m}$ & $\mathrm{m}$ & $\mathrm{m}$ & $\mathrm{m}$ & $\mathrm{m}$ & $\mathrm{m}$ & $\mathrm{m}$ & $\mathrm{m}$ & $\mathrm{m}$ \\
\hline Noruega $^{1,4}$ & 13 & 28 & 25 & 22 & 12 & 13 & 28 & 25 & 22 & 12 & 5 & 20 & 27 & 29 & 18 \\
\hline Nueva Zelanda & 12 & 23 & 26 & 27 & 13 & 11 & 23 & 24 & 28 & 14 & 10 & 22 & 25 & 29 & 15 \\
\hline Portugal $^{1}$ & 4 & 35 & 30 & 28 & 2 & 3 & 31 & 37 & 25 & 3 & 6 & 34 & 35 & 22 & 3 \\
\hline Reino Unido & 31 & 29 & 20 & 19 & 2 & 23 & 31 & 22 & 22 & 3 & 20 & 28 & 24 & 24 & 5 \\
\hline República Checa & 9 & 22 & 38 & 27 & 4 & 12 & 27 & 28 & 27 & 6 & 7 & 20 & 28 & 33 & 11 \\
\hline República Eslovaca & 11 & 32 & 31 & 23 & 3 & 15 & 26 & 22 & 31 & 6 & 12 & 24 & 25 & 31 & 8 \\
\hline Suecia & 5 & 23 & 27 & 27 & 17 & 7 & 31 & 29 & 21 & 12 & 6 & 23 & 27 & 27 & 17 \\
\hline Suiza & 17 & 25 & 24 & 29 & 6 & 12 & 28 & 25 & 28 & 7 & 6 & 23 & 31 & 31 & 9 \\
\hline Turquía & $\mathrm{m}$ & $\mathrm{m}$ & $\mathrm{m}$ & $\mathrm{m}$ & $\mathrm{m}$ & $\mathrm{m}$ & $\mathrm{m}$ & $\mathrm{m}$ & $\mathrm{m}$ & $\mathrm{m}$ & $\mathrm{m}$ & $\mathrm{m}$ & $\mathrm{m}$ & $\mathrm{m}$ & $\mathrm{m}$ \\
\hline
\end{tabular}

\begin{tabular}{|c|c|c|c|c|c|c|c|c|c|c|c|c|c|c|c|}
\hline Media OCDE & 13 & 28 & 28 & 25 & 5 & 11 & 27 & 28 & 27 & 7 & 9 & 25 & 29 & 29 & 9 \\
\hline Media UE21 & 12 & 27 & 29 & 26 & 5 & 10 & 27 & 28 & 29 & 7 & 8 & 25 & 29 & 30 & 8 \\
\hline
\end{tabular}

\begin{tabular}{|c|c|c|c|c|c|c|c|c|c|c|c|c|c|c|c|}
\hline $\begin{array}{l}\text { Arabia Saudí } \\
\frac{\pi}{0} \text { Argentina }\end{array}$ & $\begin{array}{l}\mathrm{m} \\
\mathrm{m}\end{array}$ & $\begin{array}{l}\mathrm{m} \\
\mathrm{m}\end{array}$ & $\begin{array}{l}\mathrm{m} \\
\mathrm{m}\end{array}$ & $\begin{array}{l}\mathrm{m} \\
\mathrm{m}\end{array}$ & $\begin{array}{l}\mathrm{m} \\
\mathrm{m}\end{array}$ & $\begin{array}{l}\mathrm{m} \\
\mathrm{m}\end{array}$ & $\begin{array}{l}\mathrm{m} \\
\mathrm{m}\end{array}$ & $\begin{array}{l}\mathrm{m} \\
\mathrm{m}\end{array}$ & $\begin{array}{l}\mathrm{m} \\
\mathrm{m}\end{array}$ & $\begin{array}{l}\mathrm{m} \\
\mathrm{m}\end{array}$ & $\begin{array}{l}\mathrm{m} \\
\mathrm{m}\end{array}$ & $\begin{array}{l}\mathrm{m} \\
\mathrm{m}\end{array}$ & $\begin{array}{l}\mathrm{m} \\
\mathrm{m}\end{array}$ & $\begin{array}{l}\mathrm{m} \\
\mathrm{m}\end{array}$ & $\begin{array}{l}\mathrm{m} \\
\mathrm{m}\end{array}$ \\
\hline प्र Brasil & 16 & 36 & 33 & 13 & 2 & 17 & 35 & 30 & 15 & 3 & 16 & 34 & 30 & 16 & 3 \\
\hline$\underline{y}$ China & $\mathrm{m}$ & $\mathrm{m}$ & $\mathrm{m}$ & $\mathrm{m}$ & $\mathrm{m}$ & $\mathrm{m}$ & $\mathrm{m}$ & $\mathrm{m}$ & $\mathrm{m}$ & $\mathrm{m}$ & $\mathrm{m}$ & $\mathrm{m}$ & $\mathrm{m}$ & $\mathrm{m}$ & $\mathrm{m}$ \\
\hline Colombia & $\mathrm{m}$ & $\mathrm{m}$ & $\mathrm{m}$ & $\mathrm{m}$ & $\mathrm{m}$ & $\mathrm{m}$ & $\mathrm{m}$ & $\mathrm{m}$ & $\mathrm{m}$ & $\mathrm{m}$ & $\mathrm{m}$ & $\mathrm{m}$ & $\mathrm{m}$ & $\mathrm{m}$ & $\mathrm{m}$ \\
\hline Federación Rusa & $\mathrm{m}$ & $\mathrm{m}$ & $\mathrm{m}$ & $\mathrm{m}$ & $\mathrm{m}$ & $\mathrm{m}$ & $\mathrm{m}$ & $\mathrm{m}$ & $\mathrm{m}$ & $\mathrm{m}$ & $\mathrm{m}$ & $\mathrm{m}$ & $\mathrm{m}$ & $\mathrm{m}$ & $\mathrm{m}$ \\
\hline India & $\mathrm{m}$ & $\mathrm{m}$ & $\mathrm{m}$ & $\mathrm{m}$ & $\mathrm{m}$ & $\mathrm{m}$ & $\mathrm{m}$ & $\mathrm{m}$ & $\mathrm{m}$ & $\mathrm{m}$ & $\mathrm{m}$ & $\mathrm{m}$ & $\mathrm{m}$ & $\mathrm{m}$ & $\mathrm{m}$ \\
\hline Letonia & $\mathrm{m}$ & $\mathrm{m}$ & $\mathrm{m}$ & $\mathrm{m}$ & $\mathrm{m}$ & $\mathrm{m}$ & $\mathrm{m}$ & $\mathrm{m}$ & $\mathrm{m}$ & $\mathrm{m}$ & $\mathrm{m}$ & $\mathrm{m}$ & $\mathrm{m}$ & $\mathrm{m}$ & $\mathrm{m}$ \\
\hline Sudáfrica & $\mathrm{m}$ & $\mathrm{m}$ & $\mathrm{m}$ & $\mathrm{m}$ & $\mathrm{m}$ & $\mathrm{m}$ & $\mathrm{m}$ & $\mathrm{m}$ & $\mathrm{m}$ & $\mathrm{m}$ & $\mathrm{m}$ & $\mathrm{m}$ & $\mathrm{m}$ & $\mathrm{m}$ & $\mathrm{m}$ \\
\hline
\end{tabular}

\section{Media G20}

1. La educación secundaria superior incluye la educación postsecundaria no terciaria (o parte de la educación postsecundaria no terciaria en Islandia y Portugal y la educación secundaria inferior y postsecundaria no terciaria en Irlanda).

2. La educación primaria incluye la educación infantil.

3. Año de referencia 2011.

4. Solo instituciones públicas.

5. Instituciones privadas de educación secundaria inferior incluidas con las instituciones de educación secundaria superior.

Fuentes: OCDE. Arabia Saudí, Argentina, China, Colombia, India, Indonesia, Sudáfrica: Instituto de Estadística de la UNESCO. Letonia: Eurostat. Para ver notas, consulte Anexo 3 (www.oecd.org/edu/eag.htm).

Para obtener más información acerca de los símbolos utilizados en lugar de los datos que faltan, consulte la Guía del lector.

StatLink 제이 http://dx.doi.org/10.1787/888933120157 
Tabla D5.2. Distribución por edad del profesorado $(2012,2002)$

Porcentaje de profesores en instituciones públicas y privadas de educación secundaria, basado en recuentos

\begin{tabular}{|c|c|c|c|c|c|c|c|c|c|c|c|c|c|}
\hline & \multicolumn{5}{|c|}{ Educación secundaria (2012) } & \multicolumn{5}{|c|}{ Educación secundaria (2002) } & \multicolumn{3}{|c|}{$\begin{array}{l}\text { Porcentaje de profesores } \\
\text { de educación secundaria } \\
\text { de } 50 \text { años de edad o más }\end{array}$} \\
\hline & $\begin{array}{l}<30 \\
\text { años }\end{array}$ & $\begin{array}{c}\text { 30-39 } \\
\text { años }\end{array}$ & $\begin{array}{c}40-49 \\
\text { años }\end{array}$ & $\begin{array}{c}50-59 \\
\text { años }\end{array}$ & $\begin{array}{l}>=60 \\
\text { años }\end{array}$ & $\begin{array}{l}<30 \\
\text { años }\end{array}$ & $\begin{array}{c}30-39 \\
\text { años }\end{array}$ & $\begin{array}{c}40-49 \\
\text { años }\end{array}$ & $\begin{array}{c}50-59 \\
\text { años }\end{array}$ & $\begin{array}{l}>=60 \\
\text { años }\end{array}$ & 2012 & 2002 & $\begin{array}{l}\text { Tasa media de } \\
\text { crecimiento } \\
\text { anual } \\
(2002-2012)\end{array}$ \\
\hline & (1) & (2) & (3) & (4) & (5) & (6) & (7) & (8) & (9) & (10) & (11) & $(12)$ & (13) \\
\hline Alemania & 5 & 21 & 26 & 35 & 13 & 4 & 15 & 33 & 42 & 7 & 49 & 49 & 0,0 \\
\hline Australia & $\mathrm{m}$ & $\mathrm{m}$ & $\mathrm{m}$ & $\mathrm{m}$ & $\mathrm{m}$ & $\mathrm{m}$ & $\mathrm{m}$ & $\mathrm{m}$ & $\mathrm{m}$ & $\mathrm{m}$ & $\mathrm{m}$ & $\mathrm{m}$ & $\mathrm{m}$ \\
\hline Austria & 7 & 18 & 31 & 41 & 4 & 10 & 29 & 43 & 18 & 1 & 45 & 19 & 9,2 \\
\hline Bélgica $^{1,2}$ & 15 & 27 & 25 & 29 & 4 & 14 & 23 & 33 & 28 & 3 & 33 & 30 & 0,9 \\
\hline Canadá $^{3}$ & 14 & 32 & 29 & 21 & 4 & $\mathrm{~m}$ & $\mathrm{~m}$ & $\mathrm{~m}$ & $\mathrm{~m}$ & $\mathrm{~m}$ & 26 & $\mathrm{~m}$ & $\mathrm{~m}$ \\
\hline Chile & 19 & 28 & 21 & 23 & 9 & 7 & 23 & 33 & 27 & 10 & 32 & 37 & $-1,4$ \\
\hline Corea & 13 & 32 & 32 & 22 & 1 & 17 & 37 & 35 & 10 & 1 & 23 & 11 & 8,2 \\
\hline Dinamarca $^{4}$ & 6 & 31 & 26 & 27 & 10 & 12 & 24 & 24 & 35 & 6 & 37 & 41 & $-1,0$ \\
\hline Eslovenia $^{1}$ & 6 & 30 & 32 & 28 & 4 & $\mathrm{~m}$ & $\mathrm{~m}$ & $\mathrm{~m}$ & $\mathrm{~m}$ & $\mathrm{~m}$ & 32 & $\mathrm{~m}$ & $\mathrm{~m}$ \\
\hline España & 6 & 29 & 33 & 28 & 4 & $\mathrm{~m}$ & $\mathrm{~m}$ & $\mathrm{~m}$ & $\mathrm{~m}$ & $\mathrm{~m}$ & 32 & $\mathrm{~m}$ & $\mathrm{~m}$ \\
\hline Estados Unidos & 16 & 28 & 25 & 23 & 9 & 17 & 22 & 32 & 26 & 3 & 32 & 30 & 0,7 \\
\hline Estonia & 8 & 17 & 26 & 31 & 18 & $\mathrm{~m}$ & $\mathrm{~m}$ & $\mathrm{~m}$ & $\mathrm{~m}$ & $\mathrm{~m}$ & 49 & $\mathrm{~m}$ & $\mathrm{~m}$ \\
\hline Finlandia $^{1}$ & 7 & 25 & 30 & 28 & 9 & 8 & 26 & 30 & 32 & 4 & 37 & 36 & 0,2 \\
\hline Francia & 7 & 29 & 31 & 27 & 6 & 13 & 27 & 25 & 34 & 1 & 33 & 35 & $-0,6$ \\
\hline Grecia & $\mathrm{m}$ & $\mathrm{m}$ & $\mathrm{m}$ & $\mathrm{m}$ & $\mathrm{m}$ & $\mathrm{m}$ & $\mathrm{m}$ & $\mathrm{m}$ & $\mathrm{m}$ & $\mathrm{m}$ & $\mathrm{m}$ & $\mathrm{m}$ & $\mathrm{m}$ \\
\hline Hungría & 7 & 28 & 31 & 31 & 3 & 15 & 26 & 33 & 22 & 3 & 34 & 26 & 2,9 \\
\hline Irlanda $^{1}$ & 9 & 33 & 26 & 26 & 6 & 11 & 26 & 30 & 27 & 6 & 31 & 33 & $-0,5$ \\
\hline Islandia $^{1,3}$ & 6 & 23 & 28 & 29 & 14 & 7 & 21 & 32 & 28 & 12 & 43 & 39 & 0,9 \\
\hline Israel $^{2}$ & 10 & 30 & 28 & 23 & 9 & 12 & 30 & 31 & 24 & 4 & 32 & 28 & 1,6 \\
\hline Italia $^{5}$ & $\mathrm{n}$ & 10 & 28 & 48 & 14 & 1 & 11 & 40 & 44 & 4 & 62 & 48 & 2,6 \\
\hline Japón & 11 & 24 & 34 & 28 & 3 & 11 & 32 & 36 & 19 & 2 & 31 & 21 & 4,1 \\
\hline Luxemburgo & 15 & 31 & 28 & 22 & 3 & 8 & 27 & 29 & 29 & 2 & 25 & 31 & $-1,9$ \\
\hline México & $\mathrm{m}$ & $\mathrm{m}$ & $\mathrm{m}$ & $\mathrm{m}$ & $\mathrm{m}$ & $\mathrm{m}$ & $\mathrm{m}$ & $\mathrm{m}$ & $\mathrm{m}$ & $\mathrm{m}$ & $\mathrm{m}$ & $\mathrm{m}$ & $\mathrm{m}$ \\
\hline Noruega $^{1,5}$ & 9 & 24 & 26 & 26 & 15 & 12 & 23 & 27 & 30 & 7 & 41 & 38 & 0,9 \\
\hline Nueva Zelanda & 10 & 22 & 25 & 28 & 15 & 14 & 20 & 32 & 28 & 7 & 43 & 35 & 2,2 \\
\hline Países Bajos ${ }^{5}$ & 12 & 20 & 22 & 34 & 12 & 9 & 17 & 36 & 35 & 3 & 46 & 38 & 1,9 \\
\hline Polonia $^{2}$ & 11 & 35 & 30 & 20 & 4 & 22 & 31 & 28 & 16 & 3 & 25 & 18 & 3,1 \\
\hline Portugal $^{1}$ & 5 & 33 & 36 & 24 & 3 & 22 & 37 & 27 & 12 & 2 & 26 & 14 & 6,7 \\
\hline Reino Unido & 21 & 29 & 23 & 23 & 4 & 13 & 22 & 33 & 30 & 1 & 27 & 31 & $-1,4$ \\
\hline República Checa & 9 & 23 & 28 & 30 & 9 & $\mathrm{~m}$ & $\mathrm{~m}$ & $\mathrm{~m}$ & $\mathrm{~m}$ & $\mathrm{~m}$ & 39 & $\mathrm{~m}$ & $\mathrm{~m}$ \\
\hline República Eslovaca & 14 & 25 & 23 & 31 & 7 & 19 & 24 & 29 & 23 & 6 & 38 & 28 & 2,9 \\
\hline Suecia & 7 & 27 & 28 & 24 & 15 & 11 & 20 & 24 & 35 & 9 & 39 & 44 & $-1,2$ \\
\hline Suiza $a^{4,5}$ & 9 & 26 & 28 & 30 & 8 & 13 & 24 & 31 & 28 & 5 & 38 & 32 & 1,6 \\
\hline Turquía & $\mathrm{m}$ & $\mathrm{m}$ & $\mathrm{m}$ & $\mathrm{m}$ & $\mathrm{m}$ & $\mathrm{m}$ & $\mathrm{m}$ & $\mathrm{m}$ & $\mathrm{m}$ & $\mathrm{m}$ & $\mathrm{m}$ & $\mathrm{m}$ & $\mathrm{m}$ \\
\hline
\end{tabular}

\begin{tabular}{|c|c|c|c|c|c|c|c|c|c|c|c|c|c|}
\hline Media OCDE & 10 & 26 & 28 & 28 & 8 & 12 & 25 & 31 & 27 & 4 & 36 & 32 & $\sim$ \\
\hline $\begin{array}{l}\text { Media de los países } \\
\text { con datos de ambos } \\
\text { años de referencia }\end{array}$ & 10 & 27 & 28 & 27 & 8 & 13 & 25 & 31 & 26 & 4 & 35 & 31 & 1,3 \\
\hline Media UE21 & 9 & 26 & 28 & 29 & 8 & 12 & 24 & 31 & 29 & 4 & 37 & 33 & $\sim$ \\
\hline
\end{tabular}

\begin{tabular}{|c|c|c|c|c|c|c|c|c|c|c|c|c|c|}
\hline $\begin{array}{l}\text { ¿ Arabia Saudí } \\
\text { Argentina }\end{array}$ & $\begin{array}{l}\mathrm{m} \\
\mathrm{m}\end{array}$ & $\begin{array}{l}\mathrm{m} \\
\mathrm{m}\end{array}$ & $\begin{array}{l}\mathrm{m} \\
\mathrm{m}\end{array}$ & $\begin{array}{l}\mathrm{m} \\
\mathrm{m}\end{array}$ & $\begin{array}{l}\mathrm{m} \\
\mathrm{m}\end{array}$ & $\begin{array}{l}\mathrm{m} \\
\mathrm{m}\end{array}$ & $\begin{array}{l}\mathrm{m} \\
\mathrm{m}\end{array}$ & $\begin{array}{l}\mathrm{m} \\
\mathrm{m}\end{array}$ & $\begin{array}{l}\mathrm{m} \\
\mathrm{m}\end{array}$ & $\begin{array}{l}\mathrm{m} \\
\mathrm{m}\end{array}$ & $\begin{array}{l}\mathrm{m} \\
\mathrm{m}\end{array}$ & $\begin{array}{l}\mathrm{m} \\
\mathrm{m}\end{array}$ & $\begin{array}{l}\mathrm{m} \\
\mathrm{m}\end{array}$ \\
\hline Brasil & 17 & 35 & 30 & 16 & 3 & 26 & 35 & 26 & 11 & 2 & 19 & 13 & 5,3 \\
\hline y China & $\mathrm{m}$ & $\mathrm{m}$ & $\mathrm{m}$ & $\mathrm{m}$ & $\mathrm{m}$ & $\mathrm{m}$ & $\mathrm{m}$ & $\mathrm{m}$ & $\mathrm{m}$ & $\mathrm{m}$ & $\mathrm{m}$ & $\mathrm{m}$ & $\mathrm{m}$ \\
\hline Colombia & $\mathrm{m}$ & $\mathrm{m}$ & $\mathrm{m}$ & $\mathrm{m}$ & $\mathrm{m}$ & $\mathrm{m}$ & $\mathrm{m}$ & $\mathrm{m}$ & $\mathrm{m}$ & $\mathrm{m}$ & $\mathrm{m}$ & $\mathrm{m}$ & $\mathrm{m}$ \\
\hline Federación Rusa & $\mathrm{m}$ & $\mathrm{m}$ & $\mathrm{m}$ & $\mathrm{m}$ & $\mathrm{m}$ & $\mathrm{m}$ & $\mathrm{m}$ & $\mathrm{m}$ & $\mathrm{m}$ & $\mathrm{m}$ & $\mathrm{m}$ & $\mathrm{m}$ & $\mathrm{m}$ \\
\hline India & $\mathrm{m}$ & $\mathrm{m}$ & $\mathrm{m}$ & $\mathrm{m}$ & $\mathrm{m}$ & $\mathrm{m}$ & $\mathrm{m}$ & $\mathrm{m}$ & $\mathrm{m}$ & $\mathrm{m}$ & $\mathrm{m}$ & $\mathrm{m}$ & $\mathrm{m}$ \\
\hline Indonesia & 29 & 33 & 29 & 8 & 1 & $\mathrm{~m}$ & $\mathrm{~m}$ & $\mathrm{~m}$ & $\mathrm{~m}$ & $\mathrm{~m}$ & 10 & $\mathrm{~m}$ & $\mathrm{~m}$ \\
\hline Sudáfrica & $\mathrm{m}$ & $\mathrm{m}$ & $\mathrm{m}$ & $\mathrm{m}$ & $\mathrm{m}$ & $\mathrm{m}$ & $\mathrm{m}$ & $\mathrm{m}$ & $\mathrm{m}$ & $\mathrm{m}$ & $\mathrm{m}$ & $\mathrm{m}$ & $\mathrm{m}$ \\
\hline
\end{tabular}

\begin{tabular}{|l|l|l|l|l|l|l|l|l|l|l|l|l|l|} 
Media G20 & $\mathrm{m}$ & $\mathrm{m}$ & $\mathrm{m}$ & $\mathrm{m}$ & $\mathrm{m}$ & $\mathrm{m}$ & $\mathrm{m}$ & $\mathrm{m}$ & $\mathrm{m}$ & $\mathrm{m}$ & $\mathrm{m}$ & $\mathrm{m}$ & $\mathrm{m}$ \\
\hline
\end{tabular}

1. Incluyendo la educación postsecundaria no terciaria (parte de la educación postsecundaria no terciaria en Islandia y Portugal).

2. Año de referencia 2003 en lugar de 2002.

3. Año de referencia 2011 en lugar de 2012

4. Año de referencia 2004 en lugar de 2002.

5. Instituciones públicas exclusivamente (en el caso de Suiza solo del año 2002).

Fuentes: OCDE. Arabia Saudí, Argentina, China, Colombia, India, Indonesia, Sudáfrica: Instituto de Estadística de la UNESCO. Letonia: Eurostat. Para ver notas, consulte Anexo 3 (www.oecd.org/edu/eag.htm).

Para obtener más información acerca de los símbolos utilizados en lugar de los datos que faltan, consulte la Guía del lector.

StatLink 제내 http://dx.doi.org/10.1787/888933120176 
Tabla D5.3. Distribución por sexo del profesorado (2012)

Porcentaje de mujeres en el personal docente de instituciones públicas y privadas por nivel de educación, basado en recuentos

\begin{tabular}{|c|c|c|c|c|c|c|c|c|c|c|c|}
\hline & \multirow[b]{2}{*}{ 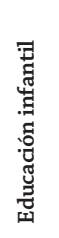 } & \multirow[b]{2}{*}{ 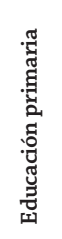 } & \multirow[b]{2}{*}{ 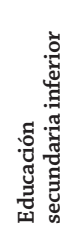 } & \multicolumn{3}{|c|}{ Educación secundaria superior } & \multirow[b]{2}{*}{ 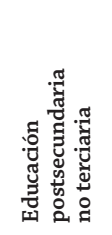 } & \multicolumn{3}{|c|}{ Educación terciaria } & \multirow[b]{2}{*}{ 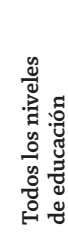 } \\
\hline & & & & 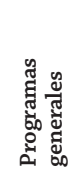 & 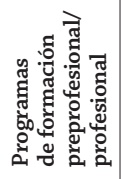 & 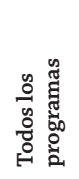 & & $\begin{array}{c}\infty \\
\stackrel{2}{2} \\
\stackrel{2}{2}\end{array}$ & 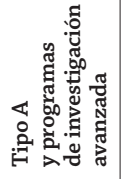 & 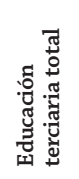 & \\
\hline & (1) & (2) & (3) & (4) & (5) & (6) & (7) & (8) & (9) & $(10)$ & (11) \\
\hline Alemania & 97 & 85 & 65 & 54 & 43 & 50 & 53 & 55 & 37 & 40 & 65 \\
\hline Australia & $\mathrm{m}$ & $\mathrm{m}$ & $\mathrm{m}$ & $\mathrm{m}$ & $\mathrm{m}$ & $\mathrm{m}$ & $\mathrm{m}$ & $\mathrm{m}$ & 44 & $\mathrm{~m}$ & $\mathrm{~m}$ \\
\hline Austria & 99 & 91 & 71 & 63 & 50 & 54 & 53 & $x(10)$ & $\mathrm{x}(10)$ & 40 & 65 \\
\hline Bélgica & 97 & 81 & 62 & 61 & $\mathrm{x}(6)$ & 61 & $\mathrm{x}(6)$ & $\mathrm{x}(10)$ & $\mathrm{x}(10)$ & 46 & 70 \\
\hline Canadá ${ }^{1}$ & $\mathrm{x}(2)$ & 73 & $\mathrm{x}(2)$ & $\mathrm{x}(6)$ & $\mathrm{x}(6)$ & 73 & $\mathrm{~m}$ & 54 & 43 & 49 & $\mathrm{~m}$ \\
\hline Chile & 98 & 78 & 77 & 57 & 49 & 55 & a & 43 & 42 & 42 & 64 \\
\hline Corea & 99 & 79 & 69 & 50 & 43 & 48 & a & 43 & 32 & 35 & 60 \\
\hline Dinamarca & $\mathrm{x}(3)$ & $\mathrm{x}(3)$ & 71 & $\mathrm{~m}$ & $\mathrm{~m}$ & $\mathrm{~m}$ & $\mathrm{~m}$ & $\mathrm{~m}$ & $\mathrm{~m}$ & $\mathrm{~m}$ & $\mathrm{~m}$ \\
\hline Eslovenia & 98 & 97 & 79 & 71 & 64 & 67 & $\mathrm{x}(4,5)$ & $\mathrm{x}(10)$ & 39 & 39 & 75 \\
\hline España & 95 & 76 & 58 & $\mathrm{x}(6)$ & $\mathrm{x}(6)$ & 50 & a & 45 & 39 & 40 & 65 \\
\hline Estados Unidos & 94 & 87 & 67 & $\mathrm{x}(6)$ & $\mathrm{x}(6)$ & 57 & 63 & $\mathrm{x}(10)$ & $\mathrm{x}(10)$ & 48 & 70 \\
\hline Estonia & 100 & 92 & 81 & 78 & 64 & 72 & $\mathrm{x}(5)$ & $\mathrm{m}$ & $\mathrm{m}$ & $\mathrm{m}$ & 88 \\
\hline Finlandia & 97 & 79 & 72 & 70 & 54 & 59 & $\mathrm{x}(6)$ & $\mathrm{n}$ & 50 & 50 & 71 \\
\hline Francia & 83 & 83 & 65 & 55 & 51 & 54 & $\mathrm{x}(8)$ & 38 & 37 & 37 & 66 \\
\hline Grecia & $\mathrm{m}$ & $\mathrm{m}$ & $\mathrm{m}$ & $\mathrm{m}$ & $\mathrm{m}$ & $\mathrm{m}$ & $\mathrm{m}$ & $\mathrm{m}$ & $\mathrm{m}$ & $\mathrm{m}$ & $\mathrm{m}$ \\
\hline Hungría & 100 & 96 & 78 & 68 & 54 & 65 & 52 & 48 & 36 & 37 & 76 \\
\hline Irlanda & $\mathrm{m}$ & 85 & $\mathrm{x}(6)$ & 69 & 53 & 68 & $\mathrm{x}(6)$ & $\mathrm{m}$ & $\mathrm{m}$ & $\mathrm{m}$ & $\mathrm{m}$ \\
\hline Islandia $^{1}$ & 96 & 81 & 81 & $x(6)$ & $\mathrm{x}(6)$ & 54 & $\mathrm{x}(6,10)$ & $\mathrm{x}(10)$ & $\mathrm{x}(10)$ & 47 & 73 \\
\hline Israel & 99 & 85 & 79 & $x(6)$ & $\mathrm{x}(6)$ & 69 & $\mathrm{~m}$ & $\mathrm{~m}$ & $\mathrm{~m}$ & $\mathrm{~m}$ & $\mathrm{~m}$ \\
\hline Italia $^{2}$ & 99 & 96 & 78 & 75 & 61 & 66 & $\mathrm{~m}$ & 33 & 36 & 36 & 77 \\
\hline Japón & 97 & 65 & 42 & 28 & 63 & 28 & $x(4,8,9)$ & 47 & 19 & 25 & 48 \\
\hline Luxemburgo $^{3}$ & 97 & 75 & 57 & 62 & 43 & 53 & $\mathrm{~m}$ & $\mathrm{~m}$ & 45 & 45 & $\mathrm{~m}$ \\
\hline México & 95 & 67 & 52 & 46 & 48 & 46 & $\mathrm{a}$ & $\mathrm{m}$ & $\mathrm{m}$ & $\mathrm{m}$ & $\mathrm{m}$ \\
\hline Noruega $^{2}$ & $\mathrm{~m}$ & 75 & 75 & $x(6)$ & $\mathrm{x}(6)$ & 51 & $\mathrm{x}(6)$ & $\mathrm{x}(10)$ & $\mathrm{x}(10)$ & 44 & 63 \\
\hline Nueva Zelanda & 98 & 83 & 65 & 60 & 54 & 59 & 55 & 49 & 49 & 49 & 70 \\
\hline Países Bajos ${ }^{2}$ & 86 & 85 & 50 & 50 & 50 & 50 & 51 & 41 & 40 & 40 & 64 \\
\hline Polonia & 98 & 85 & 74 & 71 & 62 & 66 & 65 & 69 & 43 & 44 & 74 \\
\hline Portugal & 99 & 80 & 71 & $x(6)$ & $\mathrm{x}(6)$ & 68 & $\mathrm{x}(6,10)$ & $\mathrm{x}(10)$ & $\mathrm{x}(10)$ & 44 & 70 \\
\hline Reino Unido & 95 & 87 & 60 & 60 & 60 & 60 & $\mathrm{a}$ & $\mathrm{x}(10)$ & $\mathrm{x}(10)$ & 44 & 68 \\
\hline República Checa & 100 & 97 & 74 & $x(6)$ & $x(6)$ & 58 & 56 & 61 & 34 & 37 & $\mathrm{~m}$ \\
\hline República Eslovaca & 100 & 89 & 78 & 74 & 71 & 72 & 55 & 62 & 44 & 44 & 76 \\
\hline Suecia & 96 & 82 & 66 & 50 & 54 & 52 & 51 & $\mathrm{n}$ & 43 & 43 & 74 \\
\hline Suiza & 98 & 82 & 53 & 45 & 42 & 43 & $\mathrm{~m}$ & 33 & 37 & 37 & 58 \\
\hline Turquía & 95 & 55 & 52 & 44 & 42 & 43 & $\mathrm{a}$ & 33 & 42 & 41 & 52 \\
\hline Media OCDE & 97 & 82 & 67 & 59 & 53 & 57 & 55 & 47 & 40 & 42 & 68 \\
\hline Media UE21 & 96 & 86 & 69 & 64 & 56 & 60 & 54 & 50 & 40 & 42 & 71 \\
\hline Arabia Saudí & $\mathrm{m}$ & 51 & 52 & $\mathrm{x}(6)$ & $\mathrm{x}(6)$ & 56 & $\mathrm{a}$ & $\mathrm{x}(10)$ & $\mathrm{x}(10)$ & 37 & 51 \\
\hline Argentina & $\mathrm{m}$ & $\mathrm{m}$ & $\mathrm{m}$ & $\mathrm{m}$ & $\mathrm{m}$ & $\mathrm{m}$ & $\mathrm{m}$ & $\mathrm{m}$ & $\mathrm{m}$ & $\mathrm{m}$ & $\mathrm{m}$ \\
\hline Brasil & 97 & 90 & 70 & 62 & 52 & 60 & a & $\mathrm{x}(10)$ & $\mathrm{x}(10)$ & 45 & 74 \\
\hline China & 97 & 59 & 50 & 48 & 49 & 49 & $\mathrm{~m}$ & 49 & 28 & 47 & 57 \\
\hline Colombia & 93 & 77 & 54 & $x(6)$ & $\mathrm{x}(6)$ & 46 & $\mathrm{a}$ & $\mathrm{m}$ & $\mathrm{m}$ & $\mathrm{m}$ & 68 \\
\hline Federación Rusa & 100 & 99 & 84 & $x(6)$ & 68 & 68 & $\mathrm{x}(8)$ & 75 & 53 & 57 & 83 \\
\hline India & $\mathrm{m}$ & $\mathrm{m}$ & $\mathrm{m}$ & $\mathrm{m}$ & $\mathrm{m}$ & $\mathrm{m}$ & $\mathrm{m}$ & $\mathrm{m}$ & $\mathrm{m}$ & $\mathrm{m}$ & $\mathrm{m}$ \\
\hline Indonesia & 95 & 64 & 55 & 53 & 49 & 52 & $\mathrm{~m}$ & 39 & $\mathrm{x}(10)$ & 39 & 61 \\
\hline Letonia & $\mathrm{m}$ & $\mathrm{m}$ & $\mathrm{m}$ & $\mathrm{m}$ & $\mathrm{m}$ & $\mathrm{m}$ & $\mathrm{m}$ & $\mathrm{m}$ & $\mathrm{m}$ & $\mathrm{m}$ & $\mathrm{m}$ \\
\hline Sudáfrica & $\mathrm{m}$ & $\mathrm{m}$ & $\mathrm{m}$ & $\mathrm{m}$ & $\mathrm{m}$ & $\mathrm{m}$ & $\mathrm{m}$ & $\mathrm{m}$ & $\mathrm{m}$ & $\mathrm{m}$ & $\mathrm{m}$ \\
\hline Media G20 & $\mathrm{m}$ & $\mathrm{m}$ & $\mathrm{m}$ & $\mathrm{m}$ & $\mathrm{m}$ & $\mathrm{m}$ & $\mathrm{m}$ & $\mathrm{m}$ & $\mathrm{m}$ & $\mathrm{m}$ & $\mathrm{m}$ \\
\hline
\end{tabular}

1. Año de referencia 2011.

2. Solo instituciones publicas (para Italia, desde educación infantil hasta niveles de educación secundaria).

3. Instituciones privadas de educación secundaria inferior incluidas con las instituciones de educación secundaria superior.

Fuentes: OCDE. Arabia Saudí, Argentina, China, Colombia, India, Indonesia, Sudáfrica: Instituto de Estadística de la UNESCO. Letonia: Eurostat. Para ver notas, consulte Anexo 3 (www.oecd.org/edu/eag.htm).

Para obtener más información acerca de los símbolos utilizados en lugar de los datos que faltan, consulte la Guía del lector.

StatLink 需可 http://dx.doi.org/10.1787/888933120195 


\section{¿QUÉ REQUISITOS SON NECESARIOS PARA SER PROFESOR?}

- Solo en cuatro de los 35 países de la OCDE con datos disponibles se exige que los profesores de educación infantil tengan un máster, mientras que en educación secundaria superior se requiere esa misma titulación en 22 de los 36 países con datos dsiponibles.

- En 27 de los 36 países de la OCDE y países asociados existen criterios de selección para ingresar o progresar en la formación inicial docente al menos en un nivel educativo; en 20 países, además de la formación inicial docente, se piden requisitos adicionales para adquirir la capacitación necesaria que permita comenzar a enseñar y/o convertirse en un profesor cualificado.

Gráfico D6.1. Selección de profesores (2013)

Para profesores que imparten materias generales en instituciones públicas

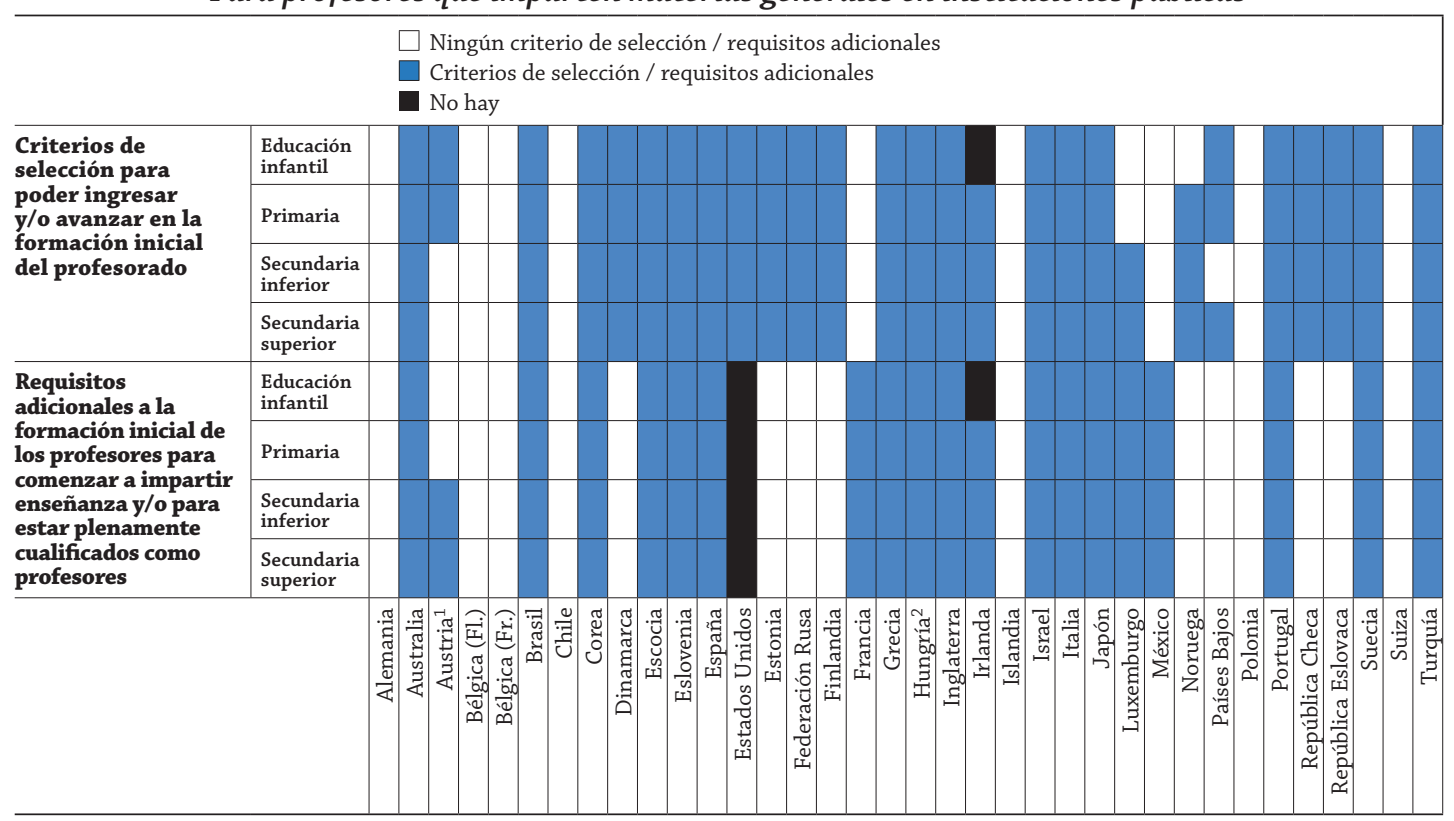

1. Se refiere únicamente a los profesores de los centros académicos de secundaria, en educación secundaria inferior.

2. Año de referencia 2014.

Fuente: OCDE. Tablas D6.1a, b, c y d. Para ver notas, consulte Anexo 3 (www.oecd.org/edu/eag.htm).

StatLink 제개 http://dx.doi.org/10.1787/888933120404

\section{Contexto}

El profundo calado de los cambios económicos y sociales acaecidos en los últimos años ha provocado que la educación de calidad sea más importante que nunca. Los países ya no se conforman simplemente con contar con el número adecuado de profesores, sino que cada vez dan más importancia a mejorar la calidad de la educación para todos. Esto último solo puede lograrse si todos los estudiantes reciben una formación de calidad. Los profesores desempeñan un papel esencial para realizar mejoras en los centros educativos: una mayor eficiencia en los centros escolares depende en gran medida de conseguir que personas competentes y motivadas quieran ser profesores y de que sean eficaces en su trabajo (OECD, 2005).

Para atraer a los mejores candidatos a la profesión docente, los países no solo deben ofrecer sueldos adecuados, factor que evidencia el reconocimiento social, también se les ha de proporcionar un entorno profesional que les permita trabajar con autonomía y concederles un papel fundamental en la mejora del centro escolar.

Además, los futuros profesores deben recibir una formación inicial de calidad. Factores como los tipos de cualificaciones, la duración de su formación y el contenido del programa pueden influir en el grado de formación inicial que prepara a los profesores para el papel que deberán desarrollar como docentes. 
Incluso si la formación inicial que reciben es de excelente calidad, no se puede esperar que les prepare para todos los desafíos a los que tendrán que enfrentarse durante el desempeño de su carrera profesional. Este tipo de formación se ha de contemplar únicamente como punto de partida para la formación continua del profesorado, pues se han de tener en cuenta aspectos tales como los cambios demográficos de los estudiantes, la duración de sus carreras profesionales y la necesidad de reciclarse periódicamente en conocimientos y competencias. Dado que muchas competencias pedagógicas se desarrollan con la práctica, los docentes deberían recibir apoyo durante las primeras etapas de sus carreras mediante programas de orientación y tutoría para nuevos profesores en el centro y, más adelante, a través de incentivos y recursos que les permita participar en actividades que fomenten su desarrollo profesional continuo (véase Indicador D7).

\section{Otros resultados}

- Aproximadamente la mitad de los países con datos disponibles limitan las plazas mediante un sistema de numerus clausus en los programas de formación para profesores, independientemente del nivel educativo.

- La duración de los programas de formación inicial destinados a los docentes de educación infantil varía más que en cualquier otro nivel de educación: oscila entre los dos años de certificación básica en Corea y Japón y los cinco años en Austria, Chile, Francia, Islandia e Italia.

- Los programas de formación destinados a los profesores de educación infantil y primaria siguen el método simultáneo, en el que la formación pedagógica y la formación práctica se imparten a la vez que las materias específicas, mientras que en los programas de formación de los profesores de educación secundaria inferior y superior está más extendido el método consecutivo, en el que primero se imparten las materias y posteriormente se recibe formación pedagógica y práctica.

- En torno al $80 \%$ de los países con datos disponibles, los futuros profesores de educación secundaria de materias generales deben hacer un practicum y asistir a cursos de pedagogía y didáctica, además de formarse en materias académicas y en estudios de ciencias de la educación. Asimismo, aproximadamente dos tercios de los países exigen a los profesores una formación específica sobre el desarrollo de niños y adolescentes, y la mitad de los países requieren el desarrollo de competencias en investigación.

- En torno al $70 \%$ de los países con datos disponibles, los graduados de los programas de formación inicial del profesorado de cualquier nivel educativo pueden comenzar a enseñar de forma inmediata. En 20 países se considera que están plenamente preparados para la docencia sin requerir más cualificaciones.

- Los programas formales de orientación son obligatorios aproximadamente en la mitad de los países con datos disponibles; en la mayoría de los países, es el personal docente de los centros educativos el que ha de impartir dichos programas.

- Aproximadamente la mitad de los países con datos disponibles ofrecen vías alternativas para acceder a la profesión docente. A menudo son programas de formación específica impartidos por instituciones tradicionalmente dedicadas a la formación de profesores. 


\section{Análisis}

\section{La formación inicial del profesorado}

La formación inicial de los profesores, junto con otros factores tales como la imagen y el estatus del profesor en la sociedad, así como las condiciones de trabajo en los centros educativos y los requisitos de acceso a esta formación inicial, influyen de manera determinante en la cantidad y calidad de los futuros profesores. Además, el tipo de requisitos repercute en el atractivo de la profesión docente para candidatos de diferentes entornos.

\section{La selección de profesores para ingresar y progresar en la formación inicial}

Los requisitos educativos necesarios para poder ingresar en los programas de formación inicial de profesores no difieren mucho en los países de la OCDE y países asociados. El requisito mínimo suele ser la obtención de una titulación en educación secundaria superior. Solamante en Austria y República Eslovaca un diploma en educación secundaria inferior es suficiente para entrar en programas formativos, aunque solo para dar clase en educación infantil (Tabla D6.2c y Tablas D6.2a, b y d, disponibles en Internet).

Sin embargo, los países difieren considerablemente en los requisitos adicionales que aplican para ingresar en la formación inicial docente. Así, aproximadamente en la mitad de los países con datos disponibles, las plazas se limitan por un sistema de numerus clausus. En la mayoría de los países, estas políticas se aplican a programas de preparación de profesores para todos los niveles educativos (tanto para acceder a la primera etapa como a una etapa posterior de formación inicial como profesor). Sin embargo, solo las aplican para algunos niveles educativos: en Austria (solo para educación infantil), en Dinamarca (para todos los niveles excepto para educación secundaria superior), en España (para educación infantil y primaria solo); en Alemania e Irlanda (para educación primaria y secundaria) y en Luxemburgo (solo para acceder a una etapa posterior de formación docente en educación secundaria).

En alrededor de dos tercios de los países con datos disponibles se utilizan determinados criterios de selección, además de la titulación requerida, para ingresar en la formación inicial para todos los niveles educativos. En la mayoría de los casos, los candidatos son seleccionados sobre la base de la media obtenida en educación secundaria. Así ocurre en 19 de los 32 países con datos disponibles para futuros profesores de secundaria inferior. En nueve países, la selección para programas de este nivel educativo se basa en una entrevista personal, mientras que en otros nueve países se selecciona mediante oposiciones. En cinco países, los candidatos deben hacer una prueba estandarizada para verificar que cumplen con ciertos requisitos mínimos. En la gran mayoría de los países que utilizan criterios selectivos para ingresar en programas educativos de educación secundaria, los candidatos son seleccionados siguiendo diversos criterios. En 18 de los 23 países que afirmaron utilizar criterios de selección para ingresar en los programas para profesores de secundaria inferior dijeron que utilizaban más de un criterio.

El modelo de selección de futuros profesores para ingresar en programas iniciales de formación es similar para todos los niveles de educación. Sin embargo, los criterios de selección empleados para avanzar en la formación inicial tienen más puntos en común en los programas para futuros profesores de educación secundaria superior: en 9 de 35 países con datos disponibles se utilizan dichos criterios para futuros profesores de educación primaria, mientras que en la formación de profesores de educación secundaria general ocurre esto en 12 de 36 países.

\section{Duración de la formación inicial del profesorado}

La duración de los programas de formación inicial del profesorado para educación infantil varía considerablemente en los 35 países con datos relevantes: oscila desde los dos años de certificación básica en Japón hasta cinco años en Austria, Chile, Francia, Islandia e Italia. En los países que disponen de datos referentes a educación infantil y educación primaria, la duración de los programas iniciales de formación es similar en 22 países, aunque su duración es entre medio año y un año mayor en educación primaria en cinco países y dos años superior en otros cuatro países. En Alemania hay una diferencia de 3 años y medio entre estos dos niveles educativos. Solo en Austria la formación inicial de los profesores de primaria es más corta ( 3 años) que la de los profesores de educación infantil (5 años) (Tablas D6.1a, b, c y d).

Para los profesores de educación secundaria inferior, la duración de la formación inicial va desde los 3 años en Austria (para la nueva educación secundaria y la educación secundaria inferior) y Bélgica hasta los 6 años y 6,5 años en Alemania, Italia y Luxemburgo. De los 36 países con datos para formación inicial de profesores de secundaria inferior y superior, la duración de los programas formativos es similar en 25 países, aunque existen algunas variaciones en el resto de los países. En Chile, Hungría, Suecia, Suiza y Turquía, los programas para educación secundaria superior son entre medio año y un año más extensos que los programas para educación secundaria inferior; en Bélgica, Dinamar- 


\section{Gráfico D6.2. Duración de la formación inicial del profesorado (2013)}

Para profesores que imparten materias generales en instituciones públicas

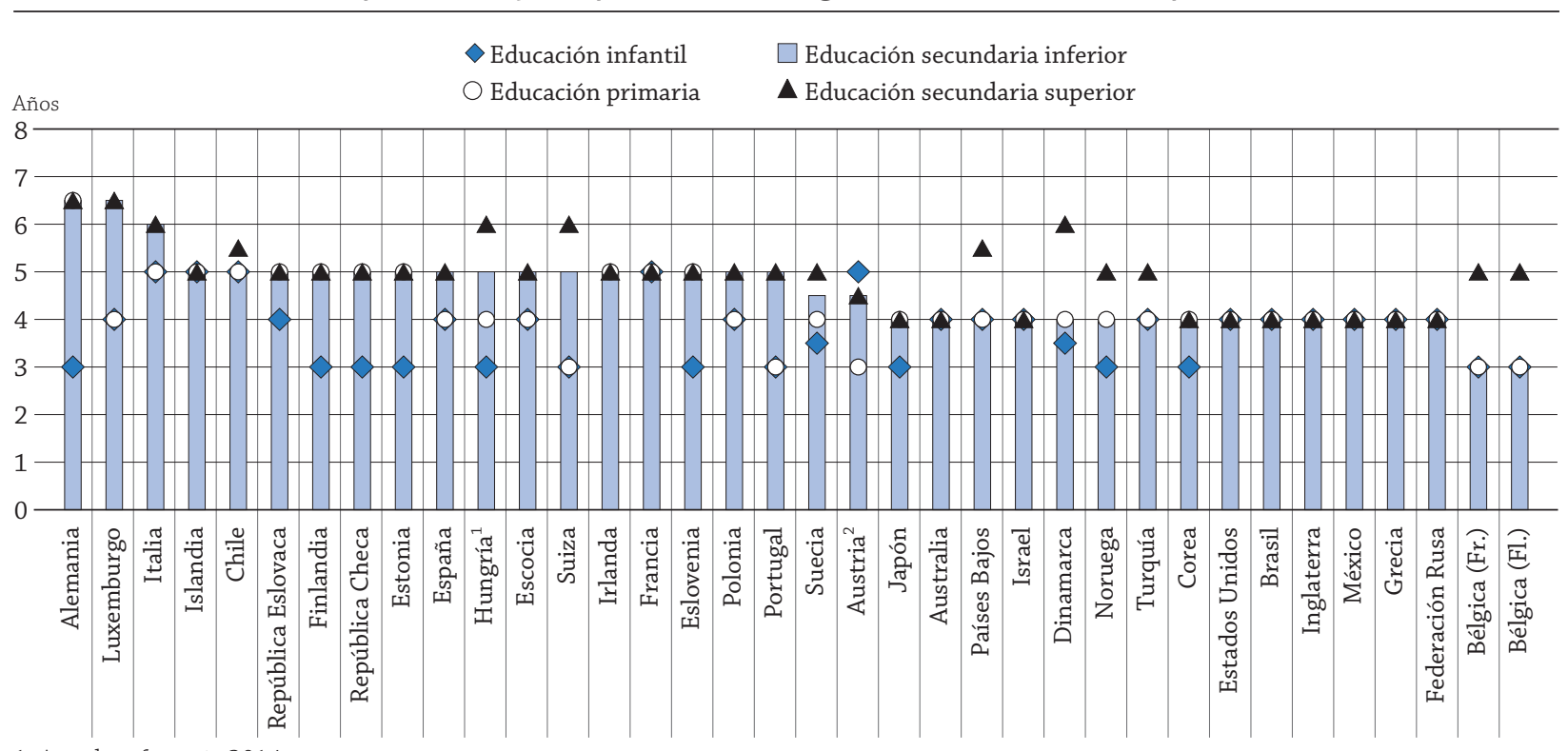

1. Año de referencia 2014.

2. Se refiere únicamente a los profesores de los centros académicos de secundaria, en educación secundaria inferior.

Los países están clasificados en orden descendente de la duración de la formación inicial del profesorado para educación secundaria inferior.

Fuente: OCDE. Tablas D6.1a, D6.1b, D6.1c y D6.1d. Para ver notas, consulte Anexo 3 (www.oecd.org/edu/eag.htm).

StatLink 部 SL http://dx.doi.org/10.1787/888933120423

ca y los Países Bajos duran entre 1,5 años y 2 años más. La formación inicial del profesorado de secundaria superior general oscila desde los 4 años en 10 países a 6 años y medio en Alemania y Luxemburgo (Cuadro D6.2).

\section{Organización de la educación inicial del profesorado}

En términos generales, existen dos métodos de enseñanza para los profesores: el método simultáneo y el método consecutivo. Los países de la OCDE y los países asociados suelen elegir el método de enseñanza simultáneo para los programas de formación de profesores de educación infantil y primaria, donde la formación pedagógica y la formación práctica se imparten a la vez que las materias específicas. Esto ocurre en 23 de los 35 países con datos disponibles para futuros profesores de educación infantil y en 22 de los 36 países con datos disponibles para futuros profesores de educación primaria. Solo se utiliza el método consecutivo tanto para profesores de infantil como de primaria en Brasil, Francia e Inglaterra, es decir, se imparten las materias específicas y posteriormente se recibe la formación pedagógica y la formación práctica relacionadas con esa materia. Sin embargo, el patrón cambia en los programas de educación secundaria general inferior y superior. En formación de profesores de secundaria inferior (en materias generales), en 13 de los 36 países con datos disponibles se utiliza el método simultáneo, mientras que en otros 13 países se alternan ambos métodos. Para los programas de formación de profesores de educación secundaria superior (en materias generales), solo Federación Rusa, Finlandia, Grecia, Japón, Polonia y República Eslovaca ofrecen principalmente métodos simultáneos. En 16 de los 36 países con datos disponibles se ofrecen ambos métodos, mientras que en 13 países los futuros profesores deben obtener primero su titulación terciaria en una o varias materias antes de estudiar la formación pedagógica y la formación práctica (método consecutivo) (Tablas D6.1a, b, c y d).

En los 12 países de la OCDE con datos disponibles sobre los requisitos para los profesores de formación profesional y secundaria general superior, la mitad organizan la formación inicial del profesorado de formación profesional de manera diferente a la formación de profesores de materias generales. En Austria, Bélgica (Comunidad francófona) y Países Bajos, los futuros profesores de formación profesional realizan la formación pedagógica y práctica al mismo tiempo que la formación en la asignatura específica (es decir, método simultáneo), mientras que ambos métodos, se emplean indistintamente en los programas formativos de las asignaturas generales (Tabla D6.1d). 


\section{La elección del contenido de los programas de formación inicial del profesorado}

Las instituciones educativas de educación superior suelen ser las responsables de diseñar el plan de estudios de los programas de formación inicial de los profesores. En Australia, Chile, Escocia, Grecia, Islandia, México, República Checa y Turquía, desempeñan además un papel determinante en la creación de un marco de contenidos. Aproximadamente en dos tercios de los países con datos disponibles, el gobierno central o las autoridades educativas regionales establecen el marco de contenidos de los programas de formación inicial del profesorado. En alrededor de un tercio de los países, estas autoridades son también responsables de acreditar los programas de educación inicial para profesores. Aproximadamente la mitad de los países cuentan con un organismo independiente que trabaja en representación de las instituciones públicas y cuya misión es establecer los contenidos de estos programas formativos, además de evaluar y acreditar dichos programas. Asimismo, la mitad de los países cuenta con el asesoramiento de asociaciones de profesores o sindicatos que aportan recomendaciones y asesoran sobre los contenidos de los programas formativos. En menos de un tercio de los países, los centros educativos y la inspección participan en la decisión de contenidos de la formación inicial del profesorado. Únicamente en Brasil, Corea, Dinamarca, Federación Rusa, Finlandia (en la organización de la práctica de la enseñanza) y Noruega, son las autoridades educativas locales, municipales, subregionales y regionales las que participan en la decisión de los contenidos de la formación inicial del profesorado (Tablas D6.4 a, b, c y d, disponibles en Internet).

\section{Contenido del programa de formación inicial del profesorado}

En la mayoría de los países de la OCDE y países asociados, los futuros profesores de educación secundaria inferior y materias generales deben realizar cursos en pedagogía, didáctica y en ciencias educativas, además de recibir formación académica y realizar prácticas. Estos cursos son obligatorios en alrededor del $80 \%$ de los países con datos disponibles. Aproximadamente dos tercios de los países con datos disponibles exigen además estudios sobre el desarrollo de los niños y adolescentes, mientras que la mitad de los países piden a los profesores desarrollar sus competencias en investigación. En 14 de 32 países, las instituciones que forman a los profesores son las que deciden si incluyen o no el desarrollo de las competencias en investigación en la formación docente (Gráfico D6.3 y Tabla D6.3c). La situación es similar para los futuros profesores de educación secundaria superior de programas generales (Tabla D6.3d, disponible en Internet).

\section{Gráfico D6.3. Contenidos requeridos para la formación inicial del profesorado (2013)}

Para profesores que imparten materias generales en instituciones públicas de educación secundaria inferior

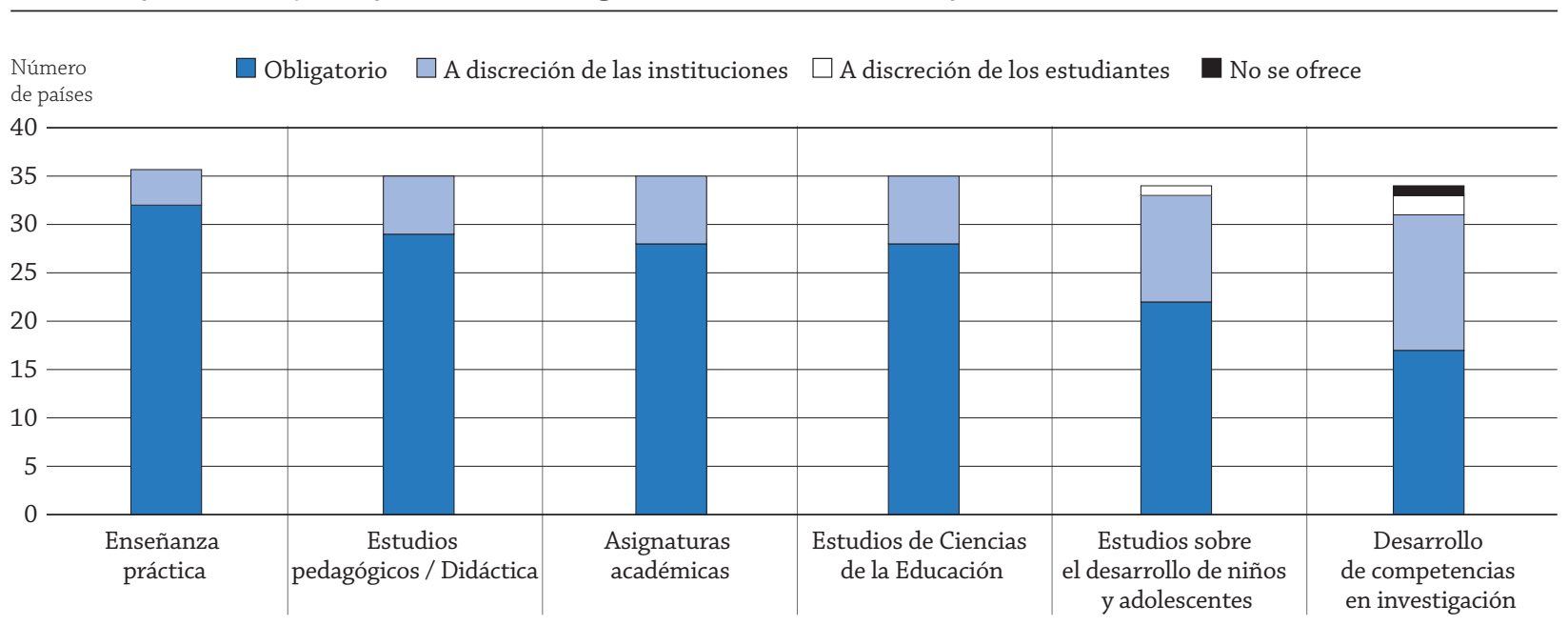

Las áreas de contenido están clasificadas en orden descendente del número de países que informan que estas áreas son obligatorias.

Fuente: OCDE. Tabla D6.3c. Para ver notas, consulte Anexo 3 (www.oecd.org/edu/eag.htm).

StatLink 제에 $h$ http://dx.doi.org/10.1787/888933120442

Las áreas de contenido de la formación inicial del profesorado difieren poco entre los programas dirigidos a profesores que imparten materias generales o de formación profesional, y entre los diferentes niveles de educación, excepto en lo que respecta a las materias objeto de estudio. Para los profesores de educación infantil, estas materias académicas son obligatorias en 20 de los 33 países con datos disponibles. Sin embargo, como sería de esperar, estas son más comunes para futuros profesores de asignaturas generales en educación secundaria superior (en 28 de 34 países). 


\section{Cuadro D6.1. ¿Reciben los profesores formación pedagógica, formación práctica y el contenido formal para algunas o para todas las materias que imparten? ¿Se consideran bien preparados para el desempeño de su trabajo?}

La estructura, el contenido y la importancia de la formación inicial de los profesores varían mucho de unos países a otros. Sin embargo, los programas de formación de los docentes suelen dar la oportunidad de compaginar la formación práctica, la académica y la pedagógica. Según el Estudio Internacional sobre Enseñanza y Aprendizaje (TALIS, por sus siglas en inglés) llevada a cabo por la OCDE en 2013, la mayoría de los profesores de educación secundaria inferior han recibido formación pedagógica, teórica y práctica en algunas o en todas las materias que imparten. Un promedio del $72 \%$ de los profesores afirman haber recibido contenidos de to-

Gráfico D6.a. Percepción de los profesores sobre su preparación para la enseñanza (2013)

Porcentaje de profesores de educación secundaria inferior que se sienten «muy bien preparados», «bien preparados», «algo preparados» 0 «no preparados en absoluto» con respecto al contenido y a la pedagogía de la(s) materia(s) que imparten, y si estos formaron parte de su formación y capacitación formal

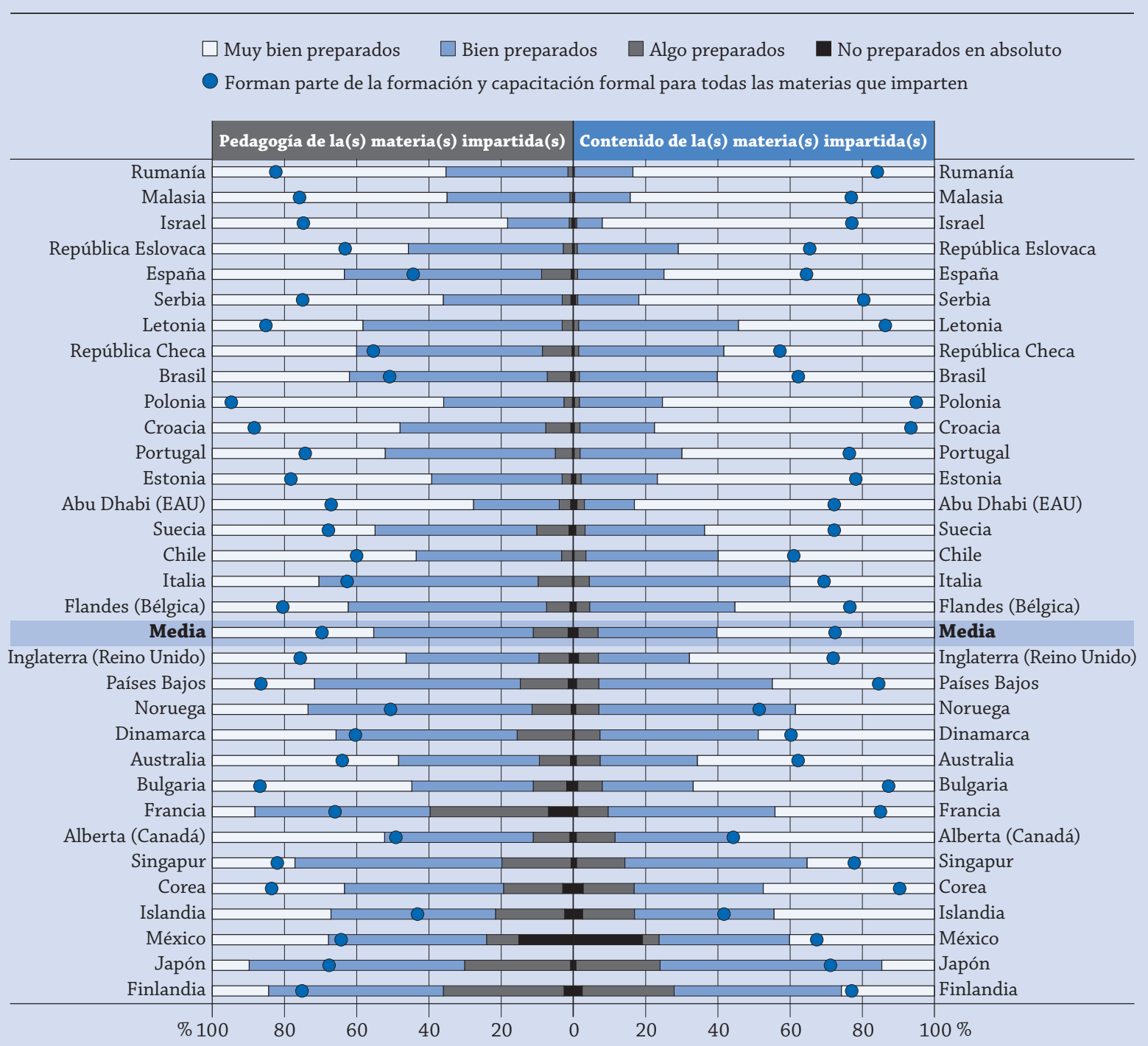

Los países están clasificados en orden ascendente del porcentaje de profesores que se sienten «no preparados en absoluto» o «algo preparados» con respecto al contenido de la(s) materia(s) que imparten.

Fuente: OECD (2014), TALIS 2013 Results: An International Perspective on Teaching and Learning, TALIS, OECD Publishing.

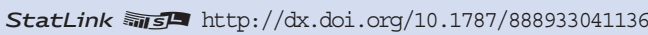


das las asignaturas que enseñan. Un $23 \%$ de ellos indican que han recibido formación previa al menos en algunas de las materias que imparten.

En Islandia y Alberta (Canadá), menos de la mitad de los profesores (el $42 \%$ y el $44 \%$, respectivamente) declararon que su educación formal incluía contenidos de todas las materias que enseñan, lo que indica que una proporción considerable de profesores imparten materias para las que no se han preparado específicamente durante su educación formal. Alrededor del $70 \%$ de los docentes de educación secundaria inferior afirmaron que su educación formal incluía el contenido pedagógico de todas las asignaturas que imparten y el $23 \%$ dijeron haber recibido formación pedagógica solo de algunas. Las proporciones son similares en las prácticas: el $67 \%$ de los profesores informaron de que su educación formal incluía prácticas en el aula de todas las asignaturas que imparten, mientras que el $22 \%$ aseguraron que su formación incluía prácticas solo para algunas de estas.

En general, los profesores opinan que la formación que recibieron les prepara bien para el desempeño de su profesión. Un promedio del $93 \%$ de los profesores afirmaron sentirse bien preparados o muy bien preparados para enseñar el contenido de las asignaturas que imparten y el $89 \%$ se sienten bien preparados o muy bien preparados en la pedagogía y en la práctica de dichas asignaturas. Sin embargo, llama la atención que en Finlandia, Japón y México aproximadamente uno de cada cuatro profesores no se sienta preparado o se sienta solo parcialmente preparado para enseñar el contenido y los componentes pedagógicos y prácticos de las asignaturas que imparten.

Además, aproximadamente en dos tercios de los países hay cursos en asignaturas específicas para los futuros profesores de educación infantil y en tres cuartas partes de los países los hay para educación primaria, pero solo en un tercio de los países existen cursos en asignaturas específicas para educación secundaria superior. Aproximadamente en dos de cada tres países hay asignaturas generales para todos los futuros docentes independientemente del nivel educativo que van a enseñar, lo que facilita la movilidad entre los diferentes niveles de educación (Tabla D6.3c y Tablas D6.3a, b y d, disponibles en Internet).

En Chile, Estados Unidos y Francia, las instituciones de formación docente son las responsables del plan de estudios de los futuros profesores. No obstante, Francia ha puesto en marcha una reforma para el año académico 2013-2014 que afecta a las materias obligatorias en la formación inicial de los profesores.

Las prácticas son obligatorias para todos los niveles educativos en la mayoría de los países de la OCDE y países asociados con datos disponibles. Sin embargo, su duración y organización difieren de manera significativa. En 32 de los 36 países con datos disponibles, los futuros profesores de educación secundaria inferior (materias generales) han de realizar prácticas de enseñanza. Aproximadamente en la mitad de los países de los que se dispone de datos, la duración de las prácticas oscila entre 70 y 120 días. Sin embargo, en Corea, España, Federación Rusa, Japón y Turquía son necesarios 40 días o menos de prácticas y en Alemania al menos 282 días. Cuando las prácticas son obligatorias en la formación académica de los profesores, la responsabilidad recae en tutores que forman parte del profesorado de los centros académicos. En 27 de los 35 países con datos disponibles, el personal de la institución que imparte la formación docente también se involucra en el proceso y, en 20 países, lo hace la dirección del centro escolar. Por el contario, solo en Estados Unidos y México la autoridad educativa local es la responsable de dar apoyo a los profesores en prácticas. Únicamente en México la Inspección de Enseñanza forma parte del proceso (Tabla D6.3c).

\section{El nivel de preparación de los profesores}

La cualificación obtenida al finalizar con éxito la formación docente no solo indica el grado de conocimientos y competencias que ha adquirido un nuevo profesor, también puede indicar el estatus social de los profesores (OECD, 2005).

En la mayoría de los países encuestados, la cualificación obtenida tras completar un programa de formación docente supone una cualificación en educación terciaria. Sin embargo, se da más variación cuando se trata de futuros profesores de educación infantil. En República Eslovaca, los profesores de educación infantil pueden enseñar con una titulación de educación secundaria superior; en Austria, pueden comenzar a trabajar con una titulación de educación postsecundaria no terciaria (CINE 4). En 25 de los 35 países con datos disponibles pueden impartir clases las personas que logran una titulación terciaria de tipo A al finalizar los estudios de formación inicial para docentes; en 6 paí- 
ses, los futuros profesores tienen una titulación terciaria de tipo B. Por el contrario, en 35 de los 36 países con datos disponibles, los profesores deben tener una titulación terciaria de tipo A para poder impartir materias generales de educación secundaria superior (Tabla D6.1a, b, c y d).

Solo en Francia, Inglaterra, Islandia e Italia es necesario tener un máster para dar clase en educación infantil, mientras que en 11 de los 35 países con datos disponibles se necesita un máster para dar clases en educación primaria, y en 17 países y 22 países, respectivamente, se requiere la misma titulación para enseñar materias generales en educación secundaria inferior y educación secundaria superior.

Cuando los requisitos para enseñar asignaturas de formación profesional son diferentes de los que se necesitan para enseñar asignaturas generales, suele deberse a que la formación inicial del profesor es más corta y se obtiene una cualificación inferior. En ocho países, en educación secundaria superior la formación inicial para materias de formación profesional es más corta; en seis países, los futuros profesores necesitan obtener una titulación de grado en vez de un máster para impartir asignaturas generales (Tabla D6.1d).

\section{Requisitos para ingresar en la profesión docente}

Los requisitos para ingresar en la profesión docente son prácticamente iguales para todos los niveles educativos y para las materias de formación profesional y secundaria general. En 25 de los 35 países con datos disponibles, los graduados en programas de formación inicial del profesorado pueden comenzar directamente a dar clase en educación primaria, educación secundaria inferior y educación secundaria superior, y en 24 de 34 países pueden hacerlo en educación infantil. En 20 países se considera que los nuevos profesores tienen la cualificación necesaria para impartir cualquier nivel educativo sin exigir más requisitos (Tabla D6.5c y Tablas D6.5a, b ay d, disponibles en Internet).

Por el contrario, los futuros profesores de Brasil, Corea, España, Francia, México y Turquía deben realizar unas oposiciones para poder ejercer la profesión docente. En Japón, deben realizar unas oposiciones y obtener una licencia, algo que también ocurre en Grecia, donde los candidatos deben pasar una prueba estandarizada. En Luxemburgo (en educación infantil y en primaria), los futuros profesores deben realizar unas oposiciones y una prueba estandarizada de idiomas en las tres lenguas nacionales. En Australia y Austria (en los centros educativos de educación secundaria superior e inferior), los candidatos deben obtener una licencia para poder ejercer la profesión.

En 14 de los 35 países con datos disponibles, los profesores de educación secundaria inferior (materias generales) han de pasar un periodo de prueba antes de adquirir la cualificación necesaria. En Escocia, Grecia, Inglaterra, Israel y Suecia, los nuevos profesores deben obtener una licencia y pasar un periodo de prueba para estar plenamente cualificados.

\section{Programas formales de orientación}

La calidad de la experiencia profesional en los primeros años de enseñanza es crucial para decidir si se continúa ejerciendo o no la profesión docente. Los programas de orientación y apoyo bien diseñados pueden mejorar la satisfacción y efectividad de los nuevos profesores y las tasas de retención del profesorado (OECD, 2005).

Los programas formales de orientación son obligatorios en la mitad de los países que aportan datos y son similares en todos los niveles educativos. Por ejemplo, para los profesores que imparten educación secundaria inferior, los programas de orientación formales son obligatorios en 18 de los 33 países con datos disponibles y, en otros ocho países, dependen de los centros educativos. En la mayor parte de los países donde estos programas orientativos son obligatorios (en 13 de 18 países), se obtiene la cualificación necesaria para ser profesor una vez que se finalizan con éxito estos programas. Únicamente en Corea, Estonia, Japón y México, los programas de orientación son obligatorios, aunque no están vinculados a la total certificación para educación secundaria inferior. En 20 países con datos disponibles, la duración de los programas de orientación va desde un mes o menos en Corea, Grecia y México hasta 24 meses en Hungría (el promedio es de 10,6 meses) (Tabla D6.5c y Tablas D6.5a, b y d, disponibles en Internet).

En la mayoría de los países (23 de los 25 con datos dsiponibles y que cuentan con programas de orientación para profesores de educación secundaria inferior), son otros profesores del centro escolar los que actúan como tutores; y en 21 de esos 25 países la dirección del centro escolar es también responsable del apoyo a los profesores principiantes. Es menos común encontrar personal externo participando en programas de apoyo a los nuevos docentes: por ejemplo, el personal de las instituciones educativas solo se involucra aproximadamente en una tercera parte de los países, y la inspección de enseñanza y autoridades de educación locales, solo en 4 países. No obstante, en la mitad de los países con programas de orientación y datos disponibles, la orientación se organiza en colaboración con los centros escolares y las instituciones de formación del profesorado o el ministerio. 


\section{Cuadro D6.2. ¿Profesores con poca experiencia tienen la oportunidad de participar en programas formales de orientación?}

Para poder examinar el vínculo entre la disponibilidad de programas de orientación y la participación en ellos, es necesario tener en cuenta la tasa de participación de los profesores con acceso a programas de orientación cuando son elegibles para entrar en dichos programas (por ejemplo, al principio de sus carreras o cuando se incorporan a un nuevo centro escolar). Lamentablemente, el estudio TALIS no recoge esos datos. Por ello el siguiente análisis se centra en profesores con menos de tres años de experiencia o que trabajan en su actual centro educativo desde hace menos de tres años. Al restringir la muestra a estos profesores poco experimentados se reduce el lapso de tiempo transcurrido desde su incorporación a programas de orientación y aumentan las posibilidades de que estos profesores continúen en su primer centro educativo (y sobre los cuales los directores de los centros escolares aportan datos acerca de la disponibilidad de programas de iniciación).

Según el estudio TALIS 2013, alrededor del $70 \%$ de los profesores inexpertos en educación secundaria inferior trabajan en centros que, según información de los directores, disponen de programas de orientación, pero solo algo más de la mitad de ellos confirmaron su participación en los mismos. Esto significa que algunos profesores con acceso a estos programas de orientación pueden no estar aprovechándolos. En Inglaterra (Reino Unido), Malasia, República Checa, Rumanía y Singapur, el porcentaje de participación obtenido de la encuesta realizada a los profesores sobre su participación en dichos programas de orientación parece coincidir con el obtenido de la encuesta a los directores de los centros, lo que indica que la mayoría de los profesores se aprovechan de los programas de orientación disponibles.

\section{Gráfico D6.b. Acceso de los nuevos docentes a programas formales de orientación y su participación en los mismos (2013)}

Porcentaje de profesores de educación secundaria inferior con menos de tres años de experiencia en su centro escolar y menos de tres años de experiencia como docentes que están trabajando en centros escolares en los que el director declara el acceso indicado a programas formales de iniciación y porcentaje de profesores de las mismas características que declaran haber participado en programas formales de iniciación ${ }^{1,2}$

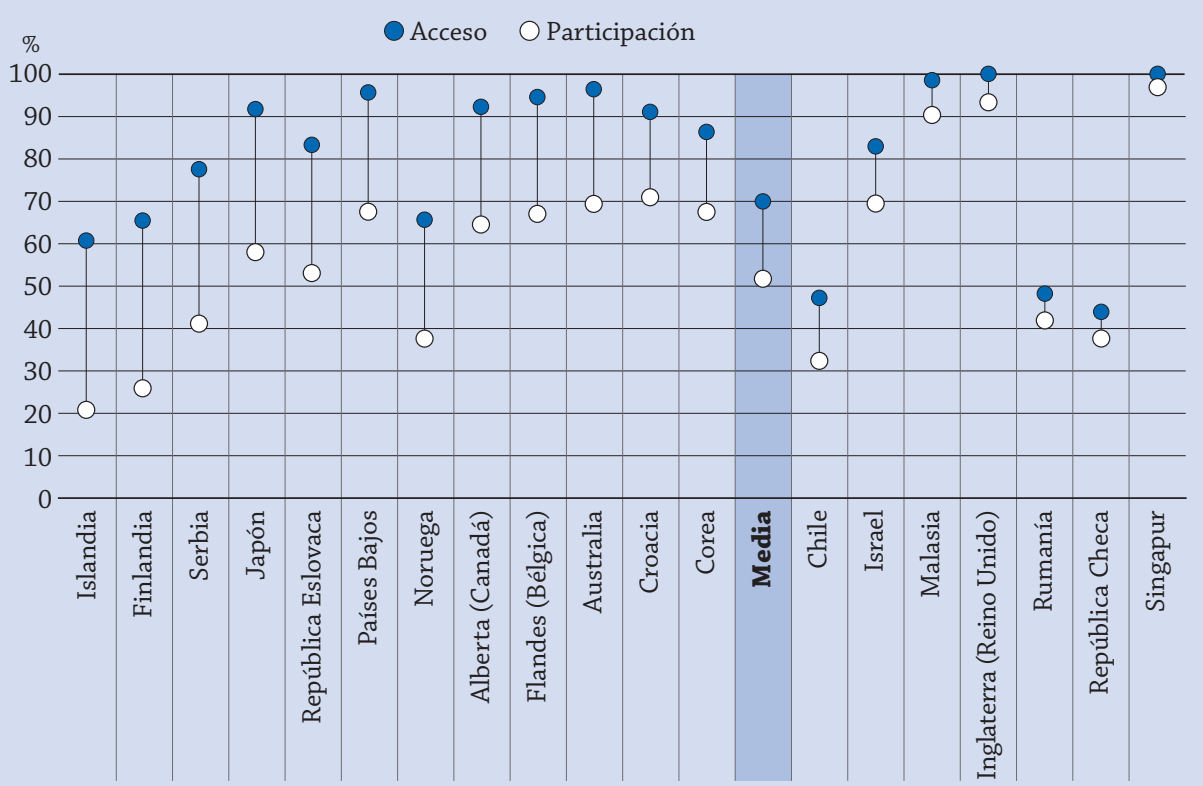

1. Los datos sobre el acceso a programas de iniciación se han extraído del cuestionario para directores, mientras que los datos sobre participación se han extraído del cuestionario para docentes. A los docentes se les preguntó sobre su participación en un programa de iniciación en su primer empleo regular como docentes.

2. Los datos que se presentan en este gráfico son solo para programas formales de iniciación y no incluyen la participación o el acceso a actividades informales de iniciación que no formen parte de un programa de inducción ni una introducción general y/o administrativa al centro escolar.

Los países están clasificados en orden descendente de la diferencia entre el acceso a programas de iniciación y la participación en los mismos. Este gráfico no incluye aquellos países en los que el porcentaje de profesores con menos de tres años de experiencia en su centro escolar y menos de tres años de experiencia como docentes sea inferior al $5 \%$.

Fuente: OECD (2014), TALIS 2013 Results: An International Perspective on Teaching and Learning, TALIS, OECD Publishing.

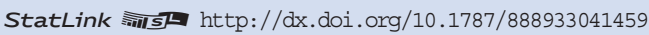


En dos de cada tres países no se pide un requisito específico formativo a aquellas personas que dan apoyo a los profesores nuevos en educación secundaria inferior, pero en algunos países reciben algún tipo de compensación. En 8 de los 21 países con programas de orientación, estas personas reciben un salario compensatorio y en 3 países obtienen horas libres.

\section{Vías alternativas para ingresar en la profesión docente}

Muchos países ofrecen vías alternativas para incorporarse a la profesión docente a personas con experiencia profesional fuera del mundo educativo y sin titulación relacionada con la enseñanza. Estas opciones se dan como respuesta a la escasez de profesores o con el objetivo de ampliar las posibilidades de contratación.

Estas vías alternativas existen en alrededor de la mitad de los países con datos disponibles. Solo algunos países pudieron informar sobre la proporción de profesores que entraron en la profesión gracias a esas vías alternativas, pero en Israel (en educación infantil y educación secundaria superior) y en Inglaterra (en educación primaria y secundaria) al menos el $10 \%$ de los nuevos profesores utilizaron estas vías. En Bélgica (Comunidad francófona), el porcentaje de los actuales profesores que ingresaron por este medio en la profesión docente representa el $12 \%$ en educación secundaria inferior y el $20 \%$ en educación secundaria superior (Tablas D6.6a, b, c y d, disponibles en internet).

La mayoría de los países que cuentan con estas vías alternativas informaron que los profesores que las utilizaron se tuvieron que formar en instituciones tradicionales de formación para el profesorado, aunque a veces, en circunstancias especiales, también se puede acceder sin la necesidad de dicha formación específica. Otras vías alternativas se basan en programas en el centro escolar y programas de educación a distancia. En Países Bajos, los solicitantes pueden pasar un examen de acceso e impartir clases de forma inmediata y, en el plazo de dos años, reciben una enseñanza tutorizada y apoyo para obtener la completa cualificación como profesores.

\section{Definiciones}

Las vías alternativas son mecanismos que permiten el acceso a la enseñanza a personas con experiencia laboral fuera del mundo docente y que no tienen cualificación como profesores. A las personas que se incorporan a la profesión educativa por medio de vías alternativas se les denomina profesores solicitantes.

El término oposición se refiere a un examen convocado por las autoridades locales, regionales o nacionales para seleccionar a los candidatos con los mejores resultados que optan a un número limitado de plazas para los estudiantes y/o los profesores en el sistema educativo público.

El método simultáneo es un modelo organizativo de la formación inicial de los profesores en donde la formación pedagógica y la formación práctica se realizan al mismo tiempo que el estudio de las materias específicas.

El método consecutivo es un modelo organizativo de la formación inicial de los profesores en donde, tras el estudio de las asignaturas específicas, se realizan la formación pedagógica y la formación práctica. Si se sigue este modelo, primero se obtiene titulación terciaria (de tipo A o B) en una o más asignaturas antes de estudiar teoría y práctica de la educación.

Una credencial o una licencia se refieren a la certificación, licencia o documento similar otorgado por una agencia gubernamental o institución que atestigua que el profesor está cualificado y alcanza los conocimientos necesarios para enseñar en el sistema educativo público. Estos requisitos de credenciales y licencias son superiores al diploma educativo.

Un programa de orientación se define como un conjunto de actividades repetitivas y estructuradas enfocadas a facilitar el acceso a la profesión docente, como por ejemplo tutorías realizadas por profesores experimentados, revisión de trabajos con otros profesores nuevos, etc. Los programas de orientación se deben diferenciar de los programas de prácticas, que forman parte de la formación inicial como profesor.

La formación inicial del profesorado se refiere a la educación formal y a los programas de prácticas que los individuos deben completar para obtener el diploma o el grado necesario para convertirse en profesores del sistema educativo público (sin considerar las vías alternativas). La formación inicial docente incluye tanto el estudio de uno o varios ámbitos específicos, la formación pedagógica y la formación en prácticas, incluso si están organizadas con el método consecutivo.

El sistema de numerus clausus se refiere al número limitado de plazas para acceder a la formación inicial del profesorado. 
El periodo de prueba se refiere a la situación laboral de los nuevos profesores que obtienen una plaza dependiendo de si su rendimiento es satisfactorio durante un determinado periodo de tiempo. Esta experiencia laboral obligatoria es necesaria en algunos países para lograr la licencia como profesor.

Las prácticas de enseñanza aportan a los futuros docentes una experiencia educativa donde se pueden beneficiar de los consejos e instrucciones de profesores experimentados.

\section{Metodología}

Los datos proceden de la Encuesta sobre el desarrollo de conocimientos y competencias docentes, OCDE 2013 (OECD-INES Survey on Developing Teachers' Knowledge and Skills) y se refieren al año escolar 2012-2013.

Las notas sobre las definiciones y metodologías para cada país en relación con este indicador figuran en el Anexo 3 , disponible en www.oecd.org/edu/eag.htm.

\section{Nota sobre los datos de Israel}

Los datos estadísticos para Israel fueron proporcionados por las autoridades israelíes competentes bajo su responsabilidad. El uso de estos datos por parte de la OCDE se hace sin prejuzgar la situación de los Altos del Golán, Jerusalén Este y los asentamientos israelíes en Cisjordania de acuerdo con los términos del derecho internacional.

\section{Referencias}

OECD (2005), Teachers Matter: Attracting, Developing and Retaining Effective Teachers, OECD Publishing, París, http://dx.doi. org/10.1787/9789264018044-en

OECD (2014), TALIS 2013 Results: An International Perspective on Teaching and Learning, OECD Publishing, París, http://dx.doi. org/10.1787/9789264196261-en

\section{Tablas de Indicador D6}

StatLink 需s http://dx.doi.org/10.1787/888933120252

Tabla D6.1a Formación inicial del profesorado e ingreso en la profesión docente, en educación infantil (2013)

Tabla D6.1b Formación inicial del profesorado e ingreso en la profesión docente, en educación primaria (2013)

Tabla D6.1c Formación inicial del profesorado e ingreso en la profesión docente, en educación secundaria inferior (2013)

Tabla D6.1d Formación inicial del profesorado e ingreso en la profesión docente, en educación secundaria superior (2013)

WEB Tabla D6.2a Requisitos para ingresar y avanzar en la formación inicial del profesorado, en educación infantil (2013)

WEB Tabla D6.2b Requisitos para ingresar y avanzar en la formación inicial del profesorado, en educación primaria (2013)

Tabla D6.2c Requisitos para ingresar y avanzar en la formación inicial del profesorado, en educación secundaria inferior (2013)

WEB Tabla D6.2d Requisitos para ingresar y avanzar en la formación inicial del profesorado, en educación secundaria superior (2013)

WEB Tabla D6.3a Contenidos de la formación inicial del profesorado, en educación infantil (2013)

WEB Tabla D6.3b Contenidos de la formación inicial del profesorado, en educación primaria (2013)

Tabla D6.3c Contenidos de la formación inicial del profesorado, en educación secundaria inferior (2013)

WEB Tabla D6.3d Contenidos de la formación inicial del profesorado, en educación secundaria superior (2013)

WEB Tabla D6.4a Papel de las entidades y niveles de gobierno para decidir el contenido de los programas de formación inicial del profesorado, en educación infantil (2013)

WEB Tabla D6.4b Papel de las entidades y niveles de gobierno para decidir el contenido de los programas de formación inicial del profesorado, en educación primaria (2013)

WEB Tabla D6.4c Papel de las entidades y niveles de gobierno para decidir el contenido de los programas de formación inicial del profesorado, en educación secundaria inferior (2013) 
WEB Tabla D6.4d Papel de las entidades y niveles de gobierno para decidir el contenido de los programas de formación inicial del profesorado, en educación secundaria superior (2013)

WEB Tabla D6.5a Ingreso en la profesión docente, en educación infantil (2013)

WEB Tabla D6.5b Ingreso en la profesión docente, en educación primaria (2013)

Tabla D6.5c Ingreso en la profesión docente, en educación secundaria inferior (2013)

WEB Tabla D6.5d Ingreso en la profesión docente, en educación secundaria superior (2013)

WEB Tabla D6.6a Vías alternativas para ingresar en la profesión docente, en educación infantil (2013)

WEB Tabla D6.6b Vías alternativas para ingresar en la profesión docente, en educación primaria (2013)

WEB Tabla D6.6c Vías alternativas para ingresar en la profesión docente, en educación secundaria inferior (2013)

WEB Tabla D6.6d Vías alternativas para ingresar en la profesión docente, en ducación secundaria superior (2013) 


\section{Tabla D6.1a. Formación inicial del profesorado e ingreso en la profesión docente, en educación infantil (2013)}

En instituciones públicas

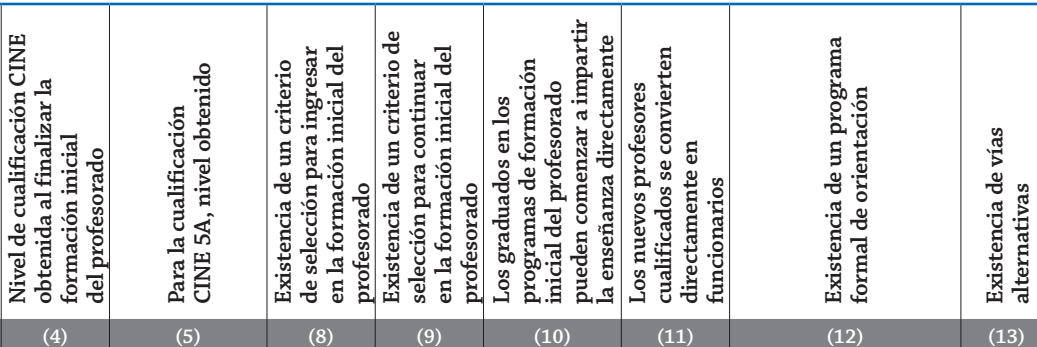

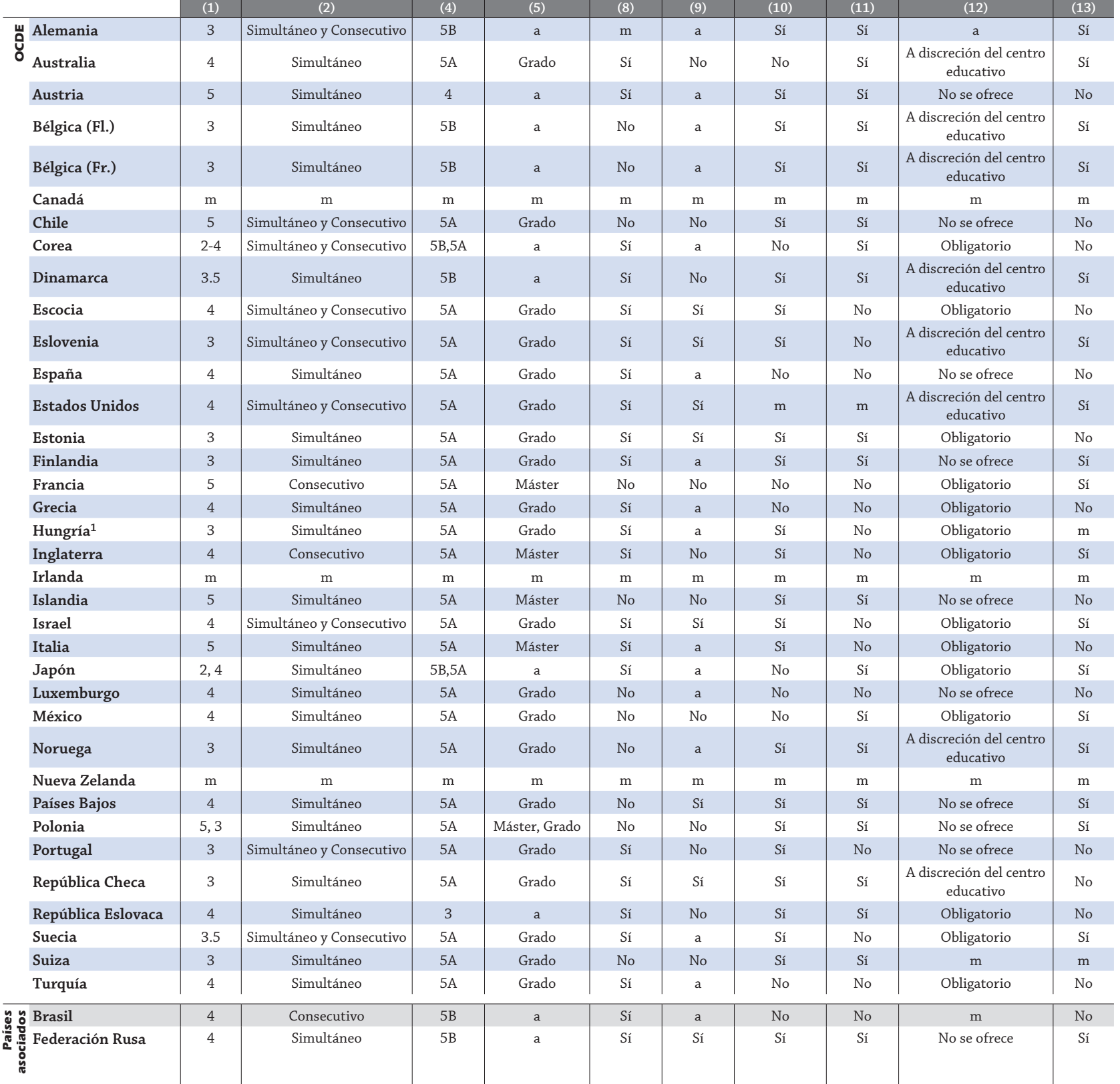

Notas: Las columnas que muestran la duración de la formación para los modelos consecutivos (columna 3) y los porcentajes de los nuevos profesores y los profesores en activo que completaron la formación inicial del profesorado (columnas 6 y 7) están disponibles en Internet (véase StatLink más abajo).

Los estados federales o países con sistemas educativos altamente descentralizados pueden tener distintas normativas en cada estado, provincia o región. Para obtener más información, consulte Anexo 3.

1. Año de referencia 2014.

Fuente: OCDE. Para ver notas, consulte Anexo 3 (www.oecd.org/edu/eag.htm).

Para obtener más información acerca de los símbolos utilizados en lugar de los datos que faltan, consulte la Guía del lector.

StatLink 제프 http://dx.doi.org/10.1787/888933120271 
Tabla D6.1b. Formación inicial del profesorado e ingreso en la profesión docente, en educación primaria (2013)

En instituciones públicas

\begin{tabular}{|c|c|c|c|c|c|c|c|c|c|c|}
\hline & 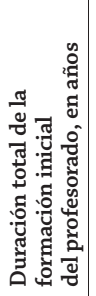 & 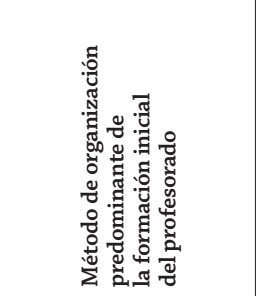 & 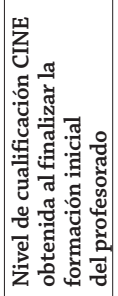 & 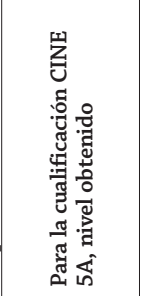 & 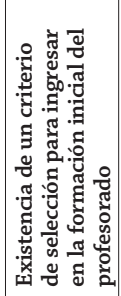 & 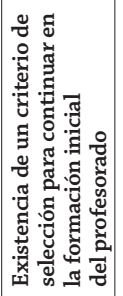 & 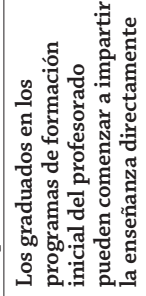 & 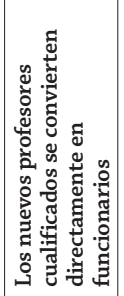 & 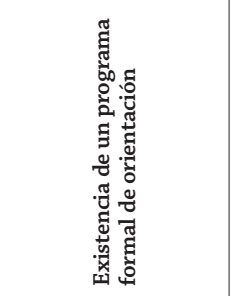 & 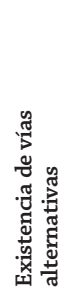 \\
\hline & (1) & (2) & (4) & (5) & (8) & (9) & (10) & (11) & (12) & (13) \\
\hline Alemania & 6.5 & Consecutivo & $5 \mathrm{~A}$ & Máster & No & No & Sí & Sí & $\mathrm{m}$ & Sí \\
\hline Australia & 4 & Simultáneo y Consecutivo & $5 \mathrm{~A}$ & Grado, Otro & Sí & No & No & Sí & $\begin{array}{c}\text { A discreción del centro } \\
\text { educativo }\end{array}$ & $\mathrm{m}$ \\
\hline Austria & 3 & Simultáneo & $5 \mathrm{~A}$ & Grado & Sí & a & Sí & Sí & No se ofrece & No \\
\hline Bélgica (Fl.) & 3 & Simultáneo & $5 \mathrm{~B}$ & a & No & a & Sí & Sí & $\begin{array}{c}\text { A discreción del centro } \\
\text { educativo }\end{array}$ & Sí \\
\hline Bélgica (Fr.) & 3 & Simultáneo & $5 \mathrm{~B}$ & a & No & a & Sí & Sí & $\begin{array}{l}\text { A discreción del centro } \\
\text { educativo }\end{array}$ & Sí \\
\hline Canadá & $\mathrm{m}$ & $\mathrm{m}$ & $\mathrm{m}$ & $\mathrm{m}$ & $\mathrm{m}$ & $\mathrm{m}$ & $\mathrm{m}$ & $\mathrm{m}$ & $\mathrm{m}$ & $\mathrm{m}$ \\
\hline Chile & 5 & Simultáneo y Consecutivo & $5 \mathrm{~A}$ & Grado & No & No & Sí & Sí & No se ofrece & No \\
\hline Corea & 4 & Simultáneo y Consecutivo & $5 \mathrm{~A}$ & Grado & Sí & $\mathrm{a}$ & No & Sí & Obligatorio & No \\
\hline Dinamarca & 4 & Simultáneo & $5 \mathrm{~B}$ & a & Sí & No & Sí & Sí & $\begin{array}{c}\text { A discreción del centro } \\
\text { educativo }\end{array}$ & Sí \\
\hline Escocia & 4 & Simultáneo y Consecutivo & $5 \mathrm{~A}$ & Grado & Sí & Sí & Sí & No & Obligatorio & No \\
\hline Eslovenia & 5 & Simultáneo y Consecutivo & $5 \mathrm{~A}$ & Máster & Sí & Sí & Sí & No & $\begin{array}{l}\text { A discreción del centro } \\
\text { educativo }\end{array}$ & Sí \\
\hline España & 4 & Simultáneo & $5 \mathrm{~A}$ & Grado & Sí & a & No & No & No se ofrece & No \\
\hline Estados Unidos & 4 & Simultáneo y Consecutivo & $5 \mathrm{~A}$ & Grado & Sí & Sí & $\mathrm{m}$ & $\mathrm{m}$ & $\begin{array}{c}\text { A discreción del centro } \\
\text { educativo }\end{array}$ & Sí \\
\hline Estonia & 5 & Simultáneo y Consecutivo & $5 \mathrm{~A}$ & Máster & Sí & Sí & Sí & Sí & Obligatorio & No \\
\hline Finlandia & 5 & Simultáneo & $5 \mathrm{~A}$ & Máster & Sí & $\mathrm{a}$ & Sí & Sí & No se ofrece & Sí \\
\hline Francia & 5 & Consecutivo & $5 \mathrm{~A}$ & Máster & No & No & No & No & Obligatorio & Sí \\
\hline Grecia & 4 & Simultáneo & $5 \mathrm{~A}$ & Grado & Sí & a & No & No & Obligatorio & No \\
\hline Hungriáa $^{1}$ & 4 & Simultáneo & $5 \mathrm{~A}$ & Grado & Sí & a & Sí & No & Obligatorio & $\mathrm{m}$ \\
\hline Inglaterra & 4 & Consecutivo & $5 \mathrm{~A}$ & Máster & Sí & No & Sí & No & Obligatorio & Sí \\
\hline Irlanda & 4,6 & Simultáneo y Consecutivo & $5 \mathrm{~A}$ & Grado & Sí & Sí & Sí & No & Obligatorio & No \\
\hline Islandia & 5 & Simultáneo & $5 \mathrm{~A}$ & Máster & No & No & Sí & Sí & No se ofrece & No \\
\hline Israel & 4 & Simultáneo y Consecutivo & $5 \mathrm{~A}$ & Grado & Sí & Sí & Sí & No & Obligatorio & Sí \\
\hline Italia & 5 & Simultáneo & $5 \mathrm{~A}$ & Máster & Sí & a & Sí & No & Obligatorio & No \\
\hline Japón & 4 & Simultáneo & $5 \mathrm{~A}$ & Grado & Sí & a & No & Sí & Obligatorio & Sí \\
\hline Luxemburgo & 4 & Simultáneo & $5 \mathrm{~A}$ & Grado & No & a & No & No & No se ofrece & No \\
\hline México & 4 & Simultáneo & $5 \mathrm{~A}$ & Grado & No & No & No & Sí & Obligatorio & Sí \\
\hline Noruega & 4 & Simultáneo & $5 \mathrm{~A}$ & Grado & Sí & a & Sí & Sí & $\begin{array}{c}\text { A discreción del centro } \\
\text { educativo }\end{array}$ & $\mathrm{m}$ \\
\hline Nueva Zelanda & $\mathrm{m}$ & $\mathrm{m}$ & $\mathrm{m}$ & $\mathrm{m}$ & $\mathrm{m}$ & $\mathrm{m}$ & $\mathrm{m}$ & $\mathrm{m}$ & $\mathrm{m}$ & $\mathrm{m}$ \\
\hline Países Bajos & 4 & Simultáneo & $5 \mathrm{~A}$ & Grado & No & Sí & Sí & Sí & No se ofrece & Sí \\
\hline Polonia & 5,3 & Simultáneo & $5 \mathrm{~A}$ & Máster, Grado & No & No & Sí & Sí & No se ofrece & Sí \\
\hline Portugal & 3 & Simultáneo y Consecutivo & $5 \mathrm{~A}$ & Grado & Sí & No & Sí & No & No se ofrece & No \\
\hline República Checa & 5 & Simultáneo & $5 \mathrm{~A}$ & Máster & Sí & Sí & Sí & Sí & $\begin{array}{c}\text { A discreción del centro } \\
\text { educativo }\end{array}$ & Sí \\
\hline República Eslovaca & 5 & Simultáneo & $5 \mathrm{~A}$ & Máster & Sí & No & Sí & Sí & Obligatorio & No \\
\hline Suecia & 4 & Simultáneo y Consecutivo & $5 \mathrm{~A}$ & Máster & Sí & a & Sí & No & Obligatorio & Sí \\
\hline Suiza & 3 & Simultáneo & $5 \mathrm{~A}$ & Grado & No & No & Sí & Sí & $\mathrm{m}$ & $\mathrm{m}$ \\
\hline Turquía & 4 & Simultáneo & $5 \mathrm{~A}$ & Grado & Sí & a & No & No & Obligatorio & No \\
\hline Brasil & 4 & Consecutivo & $5 B$ & $\mathrm{a}$ & Sí & a & No & No & $\mathrm{m}$ & No \\
\hline Federación Rusa & 4 & Simultáneo & $5 \mathrm{~A}$ & Grado & Sí & Sí & Sí & Sí & No se ofrece & Sí \\
\hline
\end{tabular}

Notas: Las columnas que muestran la duración de la formación para los modelos consecutivos (columna 3 ) y los porcentajes de los nuevos profesores y los profesores en activo que completaron la formación inicial del profesorado (columnas 6 y 7) están disponibles en Internet (véase StatLink más abajo).

Los estados federales o países con sistemas educativos altamente descentralizados pueden tener distintas normativas en cada estado, provincia o región. Para obtener más información, consulte Anexo 3.

1. Año de referencia 2014.

Fuente: OCDE. Para ver notas, consulte Anexo 3 (www.oecd.org/edu/eag.htm)

Para obtener más información acerca de los símbolos utilizados en lugar de los datos que faltan, consulte la Guía del lector.

StatLink 제피 http://dx.doi.org/10.1787/888933120290 
Tabla D6.1c. Formación inicial del profesorado e ingreso en la profesión docente, en educación secundaria inferior (2013)

En instituciones públicas

\begin{tabular}{|c|c|c|c|c|c|c|c|c|c|c|c|}
\hline & & 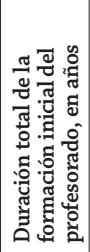 & 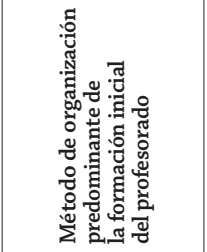 & 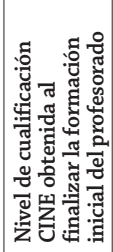 & 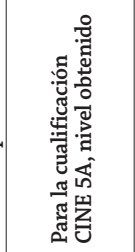 & 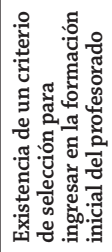 & 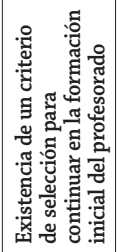 & 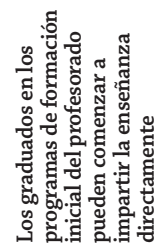 & 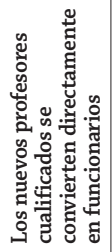 & 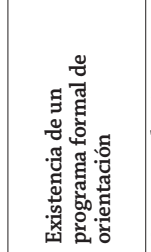 & 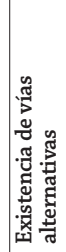 \\
\hline & Tipo de materia & (1) & (2) & (4) & (5) & (8) & (9) & (10) & (11) & (12) & (13) \\
\hline Alemania & Todos & 6,5 & Consecutivo & $5 \mathrm{~A}$ & Máster & No & No & Sí & Sí & $\mathrm{m}$ & Sí \\
\hline Australia & $\begin{array}{c}\text { General } \\
\text { Formación profesional }\end{array}$ & $\begin{array}{l}4 \\
\mathrm{~m}\end{array}$ & $\begin{array}{c}\text { Simultáneo } \\
\text { y Consecutivo } \\
\mathrm{m}\end{array}$ & $\begin{array}{l}5 \mathrm{~A} \\
\mathrm{~m}\end{array}$ & $\begin{array}{c}\text { Grado, Otro } \\
\mathrm{m}\end{array}$ & $\begin{array}{l}\text { Sí } \\
\mathrm{m}\end{array}$ & $\begin{array}{l}\text { No } \\
\mathrm{m}\end{array}$ & $\begin{array}{l}\text { No } \\
\mathrm{m}\end{array}$ & $\begin{array}{l}\text { Sí } \\
\mathrm{m}\end{array}$ & $\begin{array}{c}\text { A discreción del } \\
\text { centro educativo } \\
\mathrm{m}\end{array}$ & $\begin{array}{l}\mathrm{m} \\
\mathrm{m}\end{array}$ \\
\hline Austria & $\begin{array}{c}\text { Todos (Académico) }{ }^{1} \\
\text { Todo }(\text { Nuevo e Inferior) }\end{array}$ & $\begin{array}{c}4,5 \\
3\end{array}$ & $\begin{array}{c}\text { Simultáneo y Consecutivo } \\
\text { Simultáneo }\end{array}$ & $\begin{array}{l}5 \mathrm{~A} \\
5 \mathrm{~A}\end{array}$ & $\begin{array}{l}\text { Máster } \\
\text { Grado }\end{array}$ & $\begin{array}{l}\text { No } \\
\text { Sí }\end{array}$ & $\begin{array}{c}\text { No } \\
\mathrm{a}\end{array}$ & $\begin{array}{l}\text { No } \\
\text { Sí }\end{array}$ & $\begin{array}{l}\text { Sí } \\
\text { Sí }\end{array}$ & $\begin{array}{l}\text { Obligatorio } \\
\text { No se ofrece }\end{array}$ & $\begin{array}{l}\text { No } \\
\text { No }\end{array}$ \\
\hline Bélgica (Fl.) & $\begin{array}{c}\text { General } \\
\text { Formación profesional }\end{array}$ & $\begin{array}{l}3 \\
\mathrm{~m}\end{array}$ & $\begin{array}{c}\text { Simultáneo } \\
\text { Simultáneo y Consecutivo }\end{array}$ & $\begin{array}{l}5 \mathrm{~B} \\
\mathrm{~m}\end{array}$ & a & $\begin{array}{l}\text { No } \\
\text { No }\end{array}$ & $\begin{array}{l}\text { a } \\
\text { No }\end{array}$ & $\begin{array}{l}\text { Sí } \\
\text { Sí }\end{array}$ & $\begin{array}{l}\text { Sí } \\
\text { Sí }\end{array}$ & $\begin{array}{l}\text { A discreción del } \\
\text { centro educativo } \\
\text { A discreción del } \\
\text { centro educativo }\end{array}$ & \begin{tabular}{|l|l} 
& Sí \\
& Sí
\end{tabular} \\
\hline Bélgica (Fr.) & Todos & 3 & Simultáneo & $5 B$ & $\mathrm{a}$ & No & a & Sí & Sí & $\begin{array}{l}\text { A discreción del } \\
\text { centro educativo }\end{array}$ & ó \\
\hline Canadá & $\mathrm{m}$ & $\mathrm{m}$ & $\mathrm{m}$ & $\mathrm{m}$ & $\mathrm{m}$ & $\mathrm{m}$ & $\mathrm{m}$ & $\mathrm{m}$ & $\mathrm{m}$ & $\mathrm{m}$ & $\mathrm{m}$ \\
\hline Chile & Todos & 5 & Simultáneo y Consecutivo & $5 \mathrm{~A}$ & Grado & No & No & Sí & Sí & No se ofrece & No \\
\hline Corea & Todos & 4 & Simultáneo y Consecutivo & $5 \mathrm{~A}$ & Grado & Sí & $\mathrm{a}$ & No & Sí & Obligatorio & No \\
\hline Dinamarca & Todos & 4 & Simultáneo & $5 B$ & $\mathrm{a}$ & Sí & No & Sí & Sí & $\begin{array}{l}\text { A discreción del } \\
\text { centro educativo }\end{array}$ & Sí \\
\hline Escocia & Todos & 5 & Simultáneo y Consecutivo & $5 \mathrm{~A}$ & Grado & Sí & Sí & Sí & No & Obligatorio & No \\
\hline Eslovenia & Todos & 5 & Simultáneo y Consecutivo & $5 \mathrm{~A}$ & Máster & Sí & Sí & Sí & No & \begin{tabular}{|} 
A discreción del \\
centro educativo
\end{tabular} & o Sí \\
\hline España & Todos & 5 & Consecutivo & $5 \mathrm{~A}$ & Máster & Sí & No & No & No & No se ofrece & No \\
\hline $\begin{array}{l}\text { Estados } \\
\text { Unidos }\end{array}$ & Todos & 4 & Simultáneo y Consecutivo & $5 \mathrm{~A}$ & Grado & Sí & Sí & $\mathrm{m}$ & $\mathrm{m}$ & $\begin{array}{l}\text { A discreción del } \\
\text { centro educativo }\end{array}$ & Sí \\
\hline Estonia & Todos & 5 & Consecutivo & $5 \mathrm{~A}$ & Máster & Sí & Sí & Sí & Sí & Obligatorio & No \\
\hline Finlandia & Todos & 5 & Simultáneo & $5 \mathrm{~A}$ & Máster & Sí & $\mathrm{a}$ & Sí & Sí & No se ofrece & Sí \\
\hline Francia & Todos & 5 & Consecutivo & $5 \mathrm{~A}$ & Máster & No & No & No & No & Obligatorio & Sí \\
\hline Grecia & Todos & 4 & Simultáneo & $5 \mathrm{~A}$ & Grado & Sí & $\mathrm{a}$ & No & No & Obligatorio & No \\
\hline Hungría $^{3}$ & Todos & 5 & Simultáneo y Consecutivo & $5 \mathrm{~A}$ & Máster & Sí & Sí & Sí & No & Obligatorio & $\mathrm{m}$ \\
\hline Inglaterra & Todos & 4 & Consecutivo & $5 \mathrm{~A}$ & Máster & Sí & No & Sí & No & Obligatorio & Sí \\
\hline Irlanda & Todos & 5 & Consecutivo & $5 \mathrm{~A}$ & Grado & Sí & No & Sí & No & Obligatorio & No \\
\hline Islandia & Todos & 5 & Simultáneo & $5 \mathrm{~A}$ & Máster & No & No & Sí & Sí & No se ofrece & No \\
\hline Israel & Todos & 4 & Simultáneo y Consecutivo & $5 \mathrm{~A}$ & Grado & Sí & Sí & Sí & No & Obligatorio & Sí \\
\hline Italia & Todos & 6 & Consecutivo & $5 \mathrm{~A}$ & Máster & $\mathrm{m}$ & Sí & Sí & No & Obligatorio & No \\
\hline Japón & Todos & 4 & Simultáneo & $5 \mathrm{~A}$ & Grado & Sí & $\mathrm{a}$ & No & Sí & Obligatorio & Sí \\
\hline Luxemburgo & $\begin{array}{c}\text { General } \\
\text { Formación profesional }\end{array}$ & $\begin{array}{l}6,5 \\
6,5\end{array}$ & $\begin{array}{l}\text { Consecutivo } \\
\text { Consecutivo }\end{array}$ & $\begin{array}{l}5 \mathrm{~A} \\
5 \mathrm{~A}\end{array}$ & $\begin{array}{l}\text { Máster } \\
\text { Máster }\end{array}$ & $\begin{array}{l}\text { No } \\
\text { No }\end{array}$ & $\begin{array}{l}\text { Sí } \\
\text { Sí }\end{array}$ & $\begin{array}{l}\text { Sí } \\
\text { Sí }\end{array}$ & $\begin{array}{l}\text { No } \\
\text { No }\end{array}$ & $\begin{array}{l}\text { Obligatorio } \\
\text { Obligatorio }\end{array}$ & $\begin{array}{l}\text { No } \\
\text { Sí }\end{array}$ \\
\hline México & $\begin{array}{c}\text { General } \\
\text { Formación profesional }\end{array}$ & $\begin{array}{l}4 \\
\mathrm{~m}\end{array}$ & $\begin{array}{c}\text { Simultáneo } \\
\mathrm{m}\end{array}$ & $\begin{array}{l}5 \mathrm{~A} \\
\mathrm{~m}\end{array}$ & $\begin{array}{c}\text { Grado } \\
\mathrm{m}\end{array}$ & $\begin{array}{l}\text { No } \\
\mathrm{m}\end{array}$ & $\begin{array}{l}\text { No } \\
m\end{array}$ & $\begin{array}{l}\text { No } \\
\mathrm{m}\end{array}$ & $\begin{array}{l}\text { Sí } \\
\mathrm{m}\end{array}$ & $\begin{array}{l}\text { Obligatorio } \\
\mathrm{m}\end{array}$ & $\begin{array}{c}\text { No } \\
\mathrm{m}\end{array}$ \\
\hline Noruega & Todos & 4 & Simultáneo y Consecutivo & $5 \mathrm{~A}$ & Grado & Sí & $\mathrm{a}$ & Sí & Sí & $\begin{array}{l}\text { A discreción del } \\
\text { centro educativo }\end{array}$ & $\mathrm{m}$ \\
\hline Nueva Zelanda & $\mathrm{m}$ & $\mathrm{m}$ & $\mathrm{m}$ & $\mathrm{m}$ & $\mathrm{m}$ & $\mathrm{m}$ & $\mathrm{m}$ & $\mathrm{m}$ & $\mathrm{m}$ & $\mathrm{m}$ & $\mathrm{m}$ \\
\hline Países Bajos & Todos & 4 & Simultáneo & $5 \mathrm{~A}$ & Grado & No & No & Sí & Sí & No se ofrece & Sí \\
\hline Polonia & Todos & 5 & Simultáneo & $5 \mathrm{~A}$ & Máster, Grado & No & No & Sí & Sí & No se ofrece & Sí \\
\hline Portugal & Todos & 5 & Simultáneo y Consecutivo & $5 \mathrm{~A}$ & Máster & Sí & No & Sí & No & No se ofrece & No \\
\hline $\begin{array}{l}\text { República } \\
\text { Checa }\end{array}$ & Todos & 5 & Simultáneo y Consecutivo & $5 \mathrm{~A}$ & Máster & Sí & Sí & Sí & Sí & $\begin{array}{l}\text { A discreción del } \\
\text { centro educativo }\end{array}$ & ó \\
\hline $\begin{array}{l}\text { República } \\
\text { Eslovaca }\end{array}$ & Todos & 5 & Simultáneo & $5 \mathrm{~A}$ & Máster & Sí & No & Sí & Sí & Obligatorio & Sí \\
\hline Suecia & Todos & 4,5 & Simultáneo y Consecutivo & $5 \mathrm{~A}$ & Máster & Sí & $\mathrm{a}$ & Sí & No & Obligatorio & Sí \\
\hline Suiza & Todos & 5 & Simultáneo y Consecutivo & $5 \mathrm{~A}$ & Máster & No & No & Sí & Sí & $\mathrm{m}$ & $\mathrm{m}$ \\
\hline Turquía & Todos & 4 & Simultáneo & $5 \mathrm{~A}$ & Grado & Sí & $\mathrm{a}$ & No & No & Obligatorio & No \\
\hline Brasil & Todos & 4 & Consecutivo & $5 B$ & $\mathrm{a}$ & Sí & $\mathrm{a}$ & No & No & $\mathrm{m}$ & No \\
\hline $\begin{array}{l}\text { Federación } \\
\text { Rusa }\end{array}$ & Todos & 4 & Simultáneo & $5 \mathrm{~A}$ & Grado & Sí & Sí & Sí & Sí & No se ofrece & Sí \\
\hline
\end{tabular}

Notas: Las columnas que muestran la duración de la formación para los modelos consecutivos (columna 3 ) y los porcentajes de los nuevos profesores y los profesores en activo que completaron la formación inicial del profesorado (columnas 6 y 7) están disponibles en Internet (véase StatLink más abajo).

Los estados federales o países con sistemas educativos altamente descentralizados pueden tener distintas normativas en cada estado, provincia o región. Para obtener más información, consulte Anexo 3.

1. «Todos (Académico)» se refiere a «Centro de educación secundaria inferior».

2. «Todos (Nuevo e Inferior)» se refiere a «Nuevo centro escolar de educación secundaria y a centro escolar de educación secundaria inferior».

3. Año de referencia 2014.

Fuente: OCDE. Para ver notas, consulte Anexo 3 (www.oecd.org/edu/eag.htm).

Para obtener más información acerca de los símbolos utilizados en lugar de los datos que faltan, consulte la Guía del lector.

StatLink הत्गाड http://dx.doi.org/10.1787/888933120309 
Tabla D6.1d. Formación inicial del profesorado e ingreso en la profesión docente, educación secundaria superior (2013)

En instituciones públicas

\begin{tabular}{|c|c|c|c|c|c|c|c|c|c|c|c|}
\hline & & 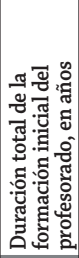 & 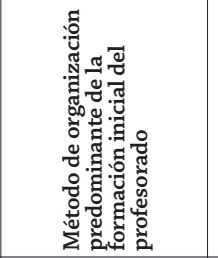 & 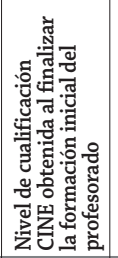 & 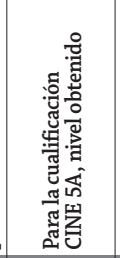 & 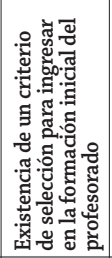 & 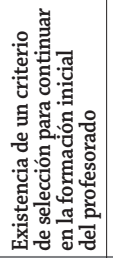 & 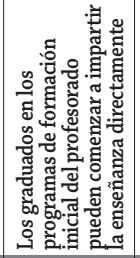 & 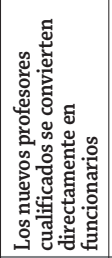 & 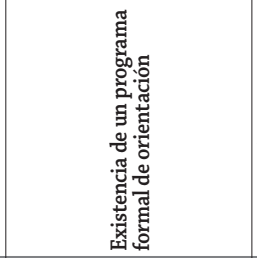 & 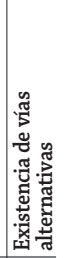 \\
\hline & Tipo de materia & (1) & (2) & (4) & (5) & (8) & (9) & (10) & (11) & (12) & (13) \\
\hline 㟔 Alemania & Todos & 6,5 & Consecutivo & $5 \mathrm{~A}$ & Máster & No & No & Sí & Sí & $\mathrm{m}$ & Sí \\
\hline$\widetilde{\Xi}$ Australia & \begin{tabular}{c|} 
General \\
Formación profesional
\end{tabular} & $\begin{array}{l}4 \\
\mathrm{~m}\end{array}$ & $\begin{array}{c}\text { Simultáneo y Consecutivo } \\
\mathrm{m}\end{array}$ & $\begin{array}{l}5 \mathrm{~A} \\
\mathrm{~m}\end{array}$ & $\begin{array}{c}\text { Grado, Otro } \\
\mathrm{m}\end{array}$ & $\begin{array}{l}\text { Sí } \\
\mathrm{m}\end{array}$ & $\begin{array}{l}\text { No } \\
\mathrm{m}\end{array}$ & $\begin{array}{l}\text { No } \\
\mathrm{m}\end{array}$ & $\begin{array}{l}\text { Sí } \\
\mathrm{m}\end{array}$ & $\begin{array}{c}\text { A discreción del centro educativo } \\
\mathrm{m}\end{array}$ & $\begin{array}{l}\mathrm{m} \\
\mathrm{m}\end{array}$ \\
\hline Austria & $\begin{array}{c}\text { General } \\
\text { Formación profesional }\end{array}$ & $\begin{array}{c}4,5 \\
4\end{array}$ & $\begin{array}{c}\text { Simultáneo y Consecutivo } \\
\text { Simultáneo }\end{array}$ & $\begin{array}{l}5 \mathrm{~A} \\
5 \mathrm{~A}\end{array}$ & $\begin{array}{l}\text { Máster } \\
\text { Grado }\end{array}$ & $\begin{array}{l}\text { No } \\
\text { Sí }\end{array}$ & $\begin{array}{c}\text { No } \\
\text { a }\end{array}$ & $\begin{array}{l}\text { No } \\
\text { Sí }\end{array}$ & $\begin{array}{l}\text { Sí } \\
\text { Sí }\end{array}$ & $\begin{array}{l}\text { Obligatorio } \\
\text { No se ofrece }\end{array}$ & $\begin{array}{l}\text { No } \\
\text { No }\end{array}$ \\
\hline Bélgica (Fl.) & \begin{tabular}{c|} 
General \\
Formación profesional
\end{tabular} & $\begin{array}{l}5 \\
\mathrm{~m}\end{array}$ & \begin{tabular}{|c|} 
Consecutivo \\
Simultáneo y Consecutivo
\end{tabular} & $\begin{array}{l}5 \mathrm{~A} \\
\mathrm{~m}\end{array}$ & $\begin{array}{c}\text { Otros } \\
\text { a }\end{array}$ & $\begin{array}{l}\text { No } \\
\text { No }\end{array}$ & $\begin{array}{l}\text { No } \\
\text { No }\end{array}$ & $\begin{array}{l}\text { Sí } \\
\text { Sí }\end{array}$ & $\begin{array}{l}\text { Sí } \\
\text { Sí }\end{array}$ & $\begin{array}{l}\text { A discreción del centro educativo } \\
\text { A discreción del centro educativo }\end{array}$ & $\begin{array}{l}\text { Sí } \\
\text { Sí }\end{array}$ \\
\hline Bélgica (Fr.) & $\begin{array}{c}\text { General } \\
\text { Formación profesional }\end{array}$ & $\begin{array}{l}5 \\
3\end{array}$ & $\begin{array}{c}\text { Simultáneo y Consecutivo } \\
\text { Simultáneo }\end{array}$ & $\begin{array}{l}5 \mathrm{~A} \\
5 \mathrm{~B}\end{array}$ & $\begin{array}{c}\text { Máster } \\
\text { a }\end{array}$ & $\begin{array}{l}\text { No } \\
\text { No }\end{array}$ & $\begin{array}{l}\text { No } \\
\text { No }\end{array}$ & $\begin{array}{l}\text { Sí } \\
\text { Sí }\end{array}$ & $\begin{array}{l}\text { Sí } \\
\text { Sí }\end{array}$ & $\begin{array}{l}\text { A discreción del centro educativo } \\
\text { A discreción del centro educativo }\end{array}$ & $\begin{array}{l}\text { Sí } \\
\text { Sí }\end{array}$ \\
\hline Canadá & $\mathrm{m}$ & $\mathrm{m}$ & $\mathrm{m}$ & $\mathrm{m}$ & $\mathrm{m}$ & $\mathrm{m}$ & $\mathrm{m}$ & $\mathrm{m}$ & $\mathrm{m}$ & $\mathrm{m}$ & $\mathrm{m}$ \\
\hline Chile & Todos & 5,5 & Simultáneo y Consecutivo & $5 \mathrm{~A}$ & Grado & No & No & Sí & Sí & No se ofrece & Sí \\
\hline Corea & Todos & 4 & Simultáneo y Consecutivo & $5 \mathrm{~A}$ & Grado & Sí & a & No & Sí & Obligatorio & No \\
\hline Dinamarca & $\begin{array}{c}\text { General } \\
\text { Formación profesional }\end{array}$ & $\begin{array}{l}6 \\
\mathrm{~m}\end{array}$ & $\begin{array}{l}\text { Consecutivo } \\
\text { Consecutivo }\end{array}$ & $\begin{array}{l}5 \mathrm{~A} \\
5 \mathrm{~B}\end{array}$ & $\begin{array}{c}\text { Máster } \\
\text { a }\end{array}$ & $\begin{array}{l}\text { Sí } \\
\text { No }\end{array}$ & $\begin{array}{l}\text { No } \\
\text { No }\end{array}$ & $\begin{array}{l}\text { Sí } \\
\text { Sí }\end{array}$ & $\begin{array}{l}\text { Sí } \\
\text { Sí }\end{array}$ & $\begin{array}{l}\text { A discreción del centro educativo } \\
\text { A discreción del centro educativo }\end{array}$ & $\begin{array}{l}\text { No } \\
\text { No }\end{array}$ \\
\hline Escocia & Todos & 5 & Simultáneo y Consecutivo & $5 \mathrm{~A}$ & Grado & Sí & Sí & Sí & No & Obligatorio & No \\
\hline Eslovenia & Todos & 5 & Simultáneo y Consecutivo & $5 \mathrm{~A}$ & Máster & Sí & Sí & Sí & No & A discreción del centro educativo & Sí \\
\hline España & Todos & 5 & Consecutivo & $5 \mathrm{~A}$ & Máster & Sí & No & No & No & No se ofrece & No \\
\hline Estados Unidos & Todos & 4 & Simultáneo y Consecutivo & $5 \mathrm{~A}$ & Grado & Sí & Sí & $\mathrm{m}$ & $\mathrm{m}$ & A discreción del centro educativo & Sí \\
\hline Estonia & $\begin{array}{c}\text { General } \\
\text { Formación profesional }\end{array}$ & $\begin{array}{l}5 \\
3\end{array}$ & $\begin{array}{l}\text { Consecutivo } \\
\text { Consecutivo }\end{array}$ & $\begin{array}{l}5 \mathrm{~A} \\
5 \mathrm{~A}\end{array}$ & $\begin{array}{l}\text { Máster } \\
\text { Grado }\end{array}$ & $\begin{array}{l}\text { Sí } \\
\text { Sí }\end{array}$ & $\begin{array}{l}\text { Sí } \\
\text { Sí }\end{array}$ & $\begin{array}{l}\text { Sí } \\
\text { Sí }\end{array}$ & $\begin{array}{l}\text { Sí } \\
\text { Sí }\end{array}$ & $\begin{array}{l}\text { Obligatorio } \\
\text { Obligatorio }\end{array}$ & $\begin{array}{l}\text { No } \\
\text { No }\end{array}$ \\
\hline Finlandia & $\begin{array}{c}\text { General } \\
\text { Formación profesional }\end{array}$ & $\begin{array}{l}5 \\
4\end{array}$ & $\begin{array}{l}\text { Simultáneo } \\
\text { Consecutivo }\end{array}$ & $\begin{array}{l}5 \mathrm{~A} \\
5 \mathrm{~A}\end{array}$ & $\begin{array}{l}\text { Máster } \\
\text { Grado }\end{array}$ & $\begin{array}{l}\text { Sí } \\
\text { Sí }\end{array}$ & $\begin{array}{l}\mathrm{a} \\
\mathrm{a}\end{array}$ & $\begin{array}{l}\text { Sí } \\
\text { Sí }\end{array}$ & $\begin{array}{l}\text { Sí } \\
\text { Sí }\end{array}$ & $\begin{array}{l}\text { No se ofrece } \\
\text { No se ofrece }\end{array}$ & $\begin{array}{l}\text { Sí } \\
\mathrm{m}\end{array}$ \\
\hline Francia & Todos & 5 & Consecutivo & $5 \mathrm{~A}$ & Máster & No & No & No & No & Obligatorio & Sí \\
\hline Grecia & Todos & 4 & Simultáneo & $5 \mathrm{~A}$ & Grado & Sí & a & No & No & Obligatorio & Sí \\
\hline Hungría $^{1}$ & Todos & 6 & Simultáneo y Consecutivo & $5 \mathrm{~A}$ & Máster & Sí & Sí & Sí & No & Obligatorio & $\mathrm{m}$ \\
\hline Inglaterra & Todos & 4 & Consecutivo & $5 \mathrm{~A}$ & Máster & Sí & No & Sí & No & Obligatorio & Sí \\
\hline Irlanda & Todos & 5 & Consecutivo & $5 \mathrm{~A}$ & Grado & Sí & No & Sí & No & Obligatorio & No \\
\hline Islandia & $\begin{array}{c}\text { General } \\
\text { Formación profesional }\end{array}$ & $\begin{array}{l}5 \\
4\end{array}$ & $\begin{array}{l}\text { Consecutivo } \\
\text { Consecutivo }\end{array}$ & $\begin{array}{l}5 \mathrm{~A} \\
5 \mathrm{~A}\end{array}$ & $\begin{array}{l}\text { Máster } \\
\text { Máster }\end{array}$ & $\begin{array}{l}\text { No } \\
\text { No }\end{array}$ & $\begin{array}{l}\text { No } \\
\text { No }\end{array}$ & $\begin{array}{l}\text { Sí } \\
\text { Sí }\end{array}$ & $\begin{array}{l}\text { Sí } \\
\text { Sí }\end{array}$ & $\begin{array}{l}\text { No se ofrece } \\
\text { No se ofrece }\end{array}$ & $\begin{array}{l}\text { No } \\
\text { No }\end{array}$ \\
\hline Israel & Todos & 4 & $\begin{array}{l}\text { Simultáneo y } \\
\text { Consecutivo }\end{array}$ & $5 \mathrm{~A}$ & Grado & Sí & Sí & Sí & No & Obligatorio & Sí \\
\hline Italia & Todos & 6 & Consecutivo & $5 \mathrm{~A}$ & Máster & $\mathrm{m}$ & Sí & Sí & No & Obligatorio & No \\
\hline Japón & Todos & 4 & Simultáneo & $5 \mathrm{~A}$ & Grado & Sí & $\mathrm{a}$ & No & Sí & Obligatorio & Sí \\
\hline Luxemburgo & $\begin{array}{c}\text { General } \\
\text { Formación profesional }\end{array}$ & $\begin{array}{l}6,5 \\
6,5\end{array}$ & $\begin{array}{l}\text { Consecutivo } \\
\text { Consecutivo }\end{array}$ & $\begin{array}{l}5 \mathrm{~A} \\
5 \mathrm{~A}\end{array}$ & $\begin{array}{l}\text { Máster } \\
\text { Máster }\end{array}$ & $\begin{array}{l}\text { No } \\
\text { No }\end{array}$ & $\begin{array}{l}\text { Sí } \\
\text { Sí }\end{array}$ & $\begin{array}{l}\text { Sí } \\
\text { Sí }\end{array}$ & $\begin{array}{l}\text { No } \\
\text { No }\end{array}$ & $\begin{array}{l}\text { Obligatorio } \\
\text { Obligatorio }\end{array}$ & $\begin{array}{l}\text { No } \\
\text { Sí }\end{array}$ \\
\hline México & Todos & 4 & $\mathrm{a}$ & $5 \mathrm{~A}$ & Grado & No & No & No & Sí & No se ofrece & No \\
\hline Noruega & $\begin{array}{c}\text { General } \\
\text { Formación profesional }\end{array}$ & $\begin{array}{c}4-6 \\
3\end{array}$ & $\begin{array}{l}\text { Consecutivo } \\
\text { Consecutivo }\end{array}$ & $\begin{array}{l}5 \mathrm{~A} \\
5 \mathrm{~A}\end{array}$ & $\begin{array}{l}\text { Máster } \\
\text { Grado }\end{array}$ & $\begin{array}{l}\text { Sí } \\
\text { Sí }\end{array}$ & $\begin{array}{l}\text { No } \\
\text { No }\end{array}$ & $\begin{array}{l}\text { Sí } \\
\text { Sí }\end{array}$ & $\begin{array}{l}\text { Sí } \\
\text { Sí }\end{array}$ & $\begin{array}{l}\text { A discreción del centro educativo } \\
\text { A discreción del centro educativo }\end{array}$ & $\begin{array}{l}\mathrm{m} \\
\mathrm{m}\end{array}$ \\
\hline Nueva Zelanda & $\mathrm{m}$ & $\mathrm{m}$ & $\mathrm{m}$ & $\mathrm{m}$ & $\mathrm{m}$ & $\mathrm{m}$ & $\mathrm{m}$ & $\mathrm{m}$ & $\mathrm{m}$ & $\mathrm{m}$ & $\mathrm{m}$ \\
\hline Países Bajos & $\begin{array}{c}\text { General } \\
\text { Formación profesional }\end{array}$ & $\begin{array}{c}5,5 \\
4\end{array}$ & \begin{tabular}{|c|} 
Simultáneo y Consecutivo \\
Simultáneo
\end{tabular} & $\begin{array}{l}5 \mathrm{~A} \\
5 \mathrm{~A}\end{array}$ & $\begin{array}{l}\text { Máster } \\
\text { Grado }\end{array}$ & $\begin{array}{l}\text { No } \\
\text { No }\end{array}$ & $\begin{array}{l}\text { Sí } \\
\text { No }\end{array}$ & $\begin{array}{l}\text { Sí } \\
\text { Sí }\end{array}$ & $\begin{array}{l}\text { Sí } \\
\text { Sí }\end{array}$ & $\begin{array}{l}\text { No se ofrece } \\
\text { No se ofrece }\end{array}$ & $\begin{array}{l}\text { Sí } \\
\text { Sí }\end{array}$ \\
\hline Polonia & Todos & 5 & Simultáneo & $5 \mathrm{~A}$ & Máster & No & No & Sí & Sí & No se ofrece & Sí \\
\hline Portugal & Todos & 5 & Simultáneo y Consecutivo & $5 \mathrm{~A}$ & Máster & Sí & No & Sí & No & No se ofrece & No \\
\hline República Checa & $\begin{array}{c}\text { General } \\
\text { Formación profesional }\end{array}$ & $\begin{array}{l}5 \\
\mathrm{~m}\end{array}$ & $\begin{array}{c}\text { Simultáneo y Consecutivo } \\
\text { Consecutivo }\end{array}$ & $\begin{array}{l}5 \mathrm{~A} \\
5 \mathrm{~A}\end{array}$ & $\begin{array}{l}\text { Máster } \\
\text { Grado }\end{array}$ & $\begin{array}{l}\text { Sí } \\
\text { Sí }\end{array}$ & $\begin{array}{c}\text { Sí } \\
\text { a }\end{array}$ & $\begin{array}{l}\text { Sí } \\
\text { Sí }\end{array}$ & $\begin{array}{l}\text { Sí } \\
\text { Sí }\end{array}$ & $\begin{array}{l}\text { A discreción del centro educativo } \\
\text { A discreción del centro educativo }\end{array}$ & $\begin{array}{l}\text { Sí } \\
\text { Sí }\end{array}$ \\
\hline República Eslovaca & Todos & 5 & Simultáneo & $5 \mathrm{~A}$ & Máster & Sí & No & Sí & Sí & Obligatorio & Sí \\
\hline Suecia & \begin{tabular}{c|} 
General \\
Formación profesional
\end{tabular} & \begin{tabular}{|c|}
5 \\
1,5
\end{tabular} & \begin{tabular}{|} 
Simultáneo y Consecutivo \\
Simultáneo y Consecutivo
\end{tabular} & $\begin{array}{l}5 \mathrm{~A} \\
5 \mathrm{~B}\end{array}$ & $\begin{array}{c}\text { Máster } \\
\text { a }\end{array}$ & $\begin{array}{l}\text { Sí } \\
\text { Sí }\end{array}$ & $\begin{array}{l}\mathrm{a} \\
\mathrm{a}\end{array}$ & $\begin{array}{l}\text { Sí } \\
\text { Sí }\end{array}$ & $\begin{array}{l}\text { No } \\
\text { No }\end{array}$ & $\begin{array}{l}\text { Obligatorio } \\
\text { Obligatorio }\end{array}$ & $\begin{array}{l}\text { Sí } \\
\text { Sí }\end{array}$ \\
\hline Suiza & $\begin{array}{c}\text { General } \\
\text { Formación profesional }\end{array}$ & $\begin{array}{l}6 \\
\mathrm{~m}\end{array}$ & $\begin{array}{c}\text { Simultáneo y Consecutivo } \\
\mathrm{m}\end{array}$ & $\begin{array}{l}5 \mathrm{~A} \\
5 \mathrm{~A}\end{array}$ & $\begin{array}{l}\text { Máster } \\
\text { Máster }\end{array}$ & $\begin{array}{l}\text { No } \\
\text { No }\end{array}$ & $\begin{array}{l}\text { No } \\
\text { No }\end{array}$ & $\begin{array}{l}\text { Sí } \\
\mathrm{m}\end{array}$ & $\begin{array}{l}\text { Sí } \\
\text { Sí }\end{array}$ & $\begin{array}{l}\mathrm{m} \\
\mathrm{m}\end{array}$ & $\begin{array}{l}\mathrm{m} \\
\mathrm{m}\end{array}$ \\
\hline Turquía & Todos & 5 & Simultáneo y Consecutivo & $5 \mathrm{~A}$ & Grado & Sí & a & No & No & Obligatorio & No \\
\hline Brasil & Todos & 4 & Consecutivo & $5 \mathrm{~B}$ & a & Sí & a & No & No & $\mathrm{m}$ & No \\
\hline 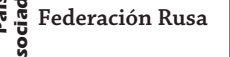 & Todos & 4 & Simultáneo & $5 \mathrm{~A}$ & Grado & Sí & Sí & Sí & Sí & No se ofrece & Sí \\
\hline
\end{tabular}


Tabla D6.2c. Requisitos para ingresar y avanzar en la formación inicial del profesorado, en educación secundaria inferior (2013)

En instituciones públicas

\begin{tabular}{|c|c|c|c|c|c|c|c|c|c|c|}
\hline \multirow{2}{*}{ 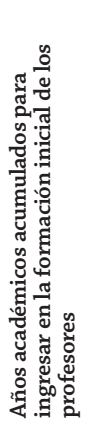 } & \multirow{2}{*}{ 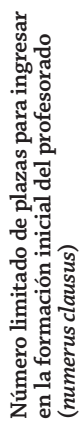 } & \multicolumn{6}{|c|}{$\begin{array}{l}\text { Criterios de selección para ingresar } \\
\text { en la formación inicial del profesorado }\end{array}$} & \multirow{2}{*}{ 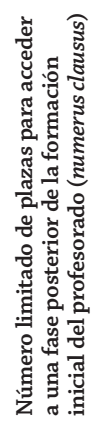 } & \multicolumn{2}{|c|}{$\begin{array}{l}\text { Criterios de selección en } \\
\text { una etapa posterior (para } \\
\text { avanzar en la formación } \\
\text { inicial del profesorado) }\end{array}$} \\
\hline & & 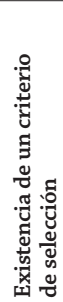 & 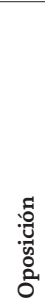 & 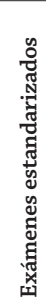 & 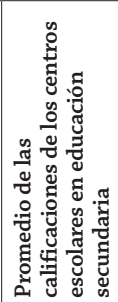 & 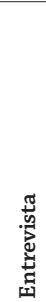 & O⿱艹 & & 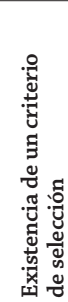 & 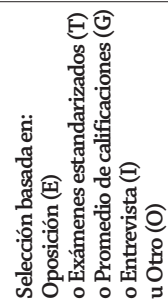 \\
\hline & (3) & (4) & (5) & (6) & (7) & (8) & (9) & (10) & (11) & (12) \\
\hline
\end{tabular}

\begin{tabular}{|c|c|c|c|c|c|c|c|c|c|c|c|c|}
\hline \multirow{4}{*}{$\begin{array}{l}\text { Alemania } \\
\text { ه̆ Australia }\end{array}$} & & & & & & & & & & & & \\
\hline & Todos & 12 & $\mathrm{~m}$ & No & $\mathrm{a}$ & $\mathrm{a}$ & $\mathrm{a}$ & $\mathrm{a}$ & $\mathrm{a}$ & Sí & No & $\mathrm{a}$ \\
\hline & General & 13 & No & Sí & No & No & Sí & No & Sí & No & No & $\mathrm{a}$ \\
\hline & Formación profesional & $\mathrm{m}$ & $\mathrm{m}$ & $\mathrm{m}$ & $\mathrm{m}$ & $\mathrm{m}$ & $\mathrm{m}$ & $\mathrm{m}$ & $\mathrm{m}$ & $\mathrm{m}$ & $\mathrm{m}$ & $\mathrm{m}$ \\
\hline \multirow[t]{2}{*}{ Austria } & Todos $(\text { Académico })^{1}$ & 12 & No & No & a & a & a & a & a & No & No & a \\
\hline & Todos (Nuevo e Inferior) $)^{2}$ & 12 & No & Sí & No & Sí & No & Sí & No & a & a & a \\
\hline \multirow[t]{2}{*}{ Bélgica (Fl.) } & General & 12 & No & No & $\mathrm{a}$ & a & $\mathrm{a}$ & a & $\mathrm{a}$ & a & a & a \\
\hline & Formación profesional & 12 & No & No & a & $\mathrm{a}$ & $\mathrm{a}$ & $\mathrm{a}$ & $\mathrm{a}$ & No & No & $\mathrm{a}$ \\
\hline Bélgica (Fr.) & Todos & 12 & No & No & a & a & a & a & a & a & $\mathrm{a}$ & a \\
\hline Canadá & $\mathrm{m}$ & $\mathrm{m}$ & $\mathrm{m}$ & $\mathrm{m}$ & $\mathrm{m}$ & $\mathrm{m}$ & $\mathrm{m}$ & $\mathrm{m}$ & $\mathrm{m}$ & $\mathrm{m}$ & $\mathrm{m}$ & $\mathrm{m}$ \\
\hline Chile & Todos & 12 & No & No & a & a & a & a & a & No & No & a \\
\hline Corea & Todos & 12 & Sí & Sí & Sí & Sí & Sí & Sí & No & a & $\mathrm{a}$ & a \\
\hline Dinamarca & Todos & 13 & Sí & Sí & No & No & Sí & Sí & No & No & No & a \\
\hline Escocia & Todos & 13 & No & Sí & $\mathrm{m}$ & No & Sí & Sí & No & Sí & Sí & I \\
\hline Eslovenia & Todos & 13 & Sí & Sí & No & No & Sí & No & No & Sí & Sí & G \\
\hline España & Todos & 12 & No & Sí & No & Sí & Sí & No & No & No & No & a \\
\hline Estados Unidos & Todos & 12 & No & Sí & $\mathrm{m}$ & $\mathrm{m}$ & $\mathrm{m}$ & $\mathrm{m}$ & $\mathrm{m}$ & No & Sí & $\mathrm{m}$ \\
\hline Estonia & Todos & 12 & No & Sí & No & No & No & Sí & No & No & Sí & I \\
\hline Finlandia & Todos & 12 & Sí & Sí & Sí & No & Sí & $\mathrm{m}$ & Sí & a & a & a \\
\hline Francia & Todos & 12 & No & No & a & $\mathrm{a}$ & a & $\mathrm{a}$ & a & No & No & $\mathrm{a}$ \\
\hline Grecia & Todos & 12 & Sí & Sí & Sí & No & Sí & No & No & a & a & a \\
\hline Hungría $^{3}$ & Todos & 12 & Sí & Sí & No & No & Sí & Sí & No & No & Sí & G, I \\
\hline Inglaterra & Todos & 13 & Sí & Sí & No & No & Sí & No & Sí & No & No & a \\
\hline Irlanda & Todos & 13 & Sí & Sí & No & No & Sí & Sí & Sí & Sí & No & a \\
\hline Islandia & Todos & 14 & No & No & a & a & a & a & a & No & No & a \\
\hline Israel & Todos & 12 & Sí & Sí & Sí & Sí & Sí & Sí & No & No & Sí & G, I \\
\hline Italia & Todos & 13 & $\mathrm{~m}$ & $\mathrm{~m}$ & $\mathrm{~m}$ & $\mathrm{~m}$ & $\mathrm{~m}$ & $\mathrm{~m}$ & $\mathrm{~m}$ & Sí & Sí & $\mathrm{m}$ \\
\hline Japón & Todos & 12 & Sí & Sí & $\mathrm{m}$ & $\mathrm{m}$ & $\mathrm{m}$ & $\mathrm{m}$ & $\mathrm{m}$ & a & a & a \\
\hline Luxemburgo & Todos & 13 & No & No & a & a & a & $\mathrm{a}$ & a & Sí & Sí & $\mathrm{E}, \mathrm{T}$ \\
\hline México & General & 12 & No & No & a & a & a & a & a & No & No & a \\
\hline & Formación profesional & $\mathrm{m}$ & $\mathrm{m}$ & $\mathrm{m}$ & $\mathrm{m}$ & $\mathrm{m}$ & $\mathrm{m}$ & $\mathrm{m}$ & $\mathrm{m}$ & $\mathrm{m}$ & $\mathrm{m}$ & $\mathrm{m}$ \\
\hline Noruega & Todos & 13 & Sí & Sí & No & No & Sí & No & Sí & a & a & a \\
\hline Nueva Zelanda & $\mathrm{m}$ & $\mathrm{m}$ & $\mathrm{m}$ & $\mathrm{m}$ & $\mathrm{m}$ & $\mathrm{m}$ & $\mathrm{m}$ & $\mathrm{m}$ & $\mathrm{m}$ & $\mathrm{m}$ & $\mathrm{m}$ & $\mathrm{m}$ \\
\hline Países Bajos & Todos & 11 & No & No & a & a & a & a & a & a & No & a \\
\hline Polonia & Todos & 12 & No & No & $\mathrm{a}$ & $\mathrm{a}$ & $\mathrm{a}$ & a & a & No & No & $\mathrm{a}$ \\
\hline Portugal & Todos & 12 & Sí & Sí & Sí & Sí & Sí & No & No & Sí & Sí & G, I, O \\
\hline República Checa & Todos & 13 & No & Sí & Sí & No & Sí & Sí & No & No & Sí & E, G, I \\
\hline República Eslovaca & Todos & 13 & No & Sí & No & Sí & Sí & Sí & No & No & No & a \\
\hline Suecia & Todos & 12 & Sí & Sí & No & No & Sí & No & Sí & a & $\mathrm{a}$ & $\mathrm{a}$ \\
\hline Suiza & Todos & 13 & No & No & a & a & a & a & a & No & No & a \\
\hline Turquía & Todos & 12 & Sí & Sí & Sí & No & Sí & No & No & a & a & a \\
\hline Brasil & Todos & 12 & No & Sí & Sí & $\mathrm{m}$ & $\mathrm{m}$ & $\mathrm{m}$ & $\mathrm{m}$ & No & $\mathrm{a}$ & $\mathrm{a}$ \\
\hline Federación Rusa & Todos & 11 & Sí & Sí & Sí & No & Sí & No & No & Sí & Sí & E \\
\hline
\end{tabular}

Notas: Las columnas que muestran el nivel mínimo CINE necesario para ingresar en la formación inicial del profesorado (columna 2) y las columnas individuales con el criterio de selección para continuar dicha formación inicial (columnas 13 a 17) están disponibles en Internet (véase StatLink más abajo).

Los estados federales o países con sistemas educativos altamente descentralizados pueden tener distintas normativas en cada estado, provincia o región. Para obtener más información, consulte Anexo 3.

1. «Todos (Académico)» se refiere a "Centro de educación secundaria inferior».

2. «Todos (Nuevo e Inferior)» se refiere a «Nuevo centro escolar de educación secundaria y a centro escolar de educación secundaria inferior».

3. Año de referencia 2014.

Fuente: OCDE. Para ver notas, consulte Anexo 3 (www.oecd.org/edu/eag.htm).

Para obtener más información acerca de los símbolos utilizados en lugar de los datos que faltan, consulte la Guía del lector.

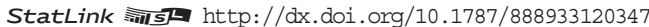


Tabla D6.3c. [1/2] Contenidos de la formación inicial del profesorado, en educación secundaria inferior (2013) En instituciones públicas

\begin{tabular}{|c|c|c|c|c|c|c|c|c|}
\hline & & \multirow{3}{*}{$\begin{array}{c}\text { Tipo } \\
\text { de materia }\end{array}$} & \multicolumn{2}{|l|}{$\begin{array}{l}\text { Asignaturas } \\
\text { académicas }\end{array}$} & \multirow{2}{*}{ 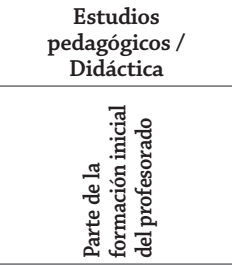 } & \multirow{2}{*}{ 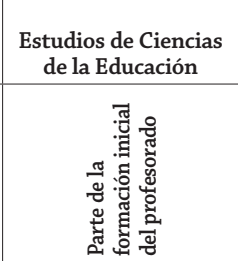 } & \multirow{2}{*}{ 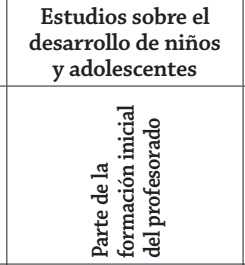 } & \multirow{2}{*}{ 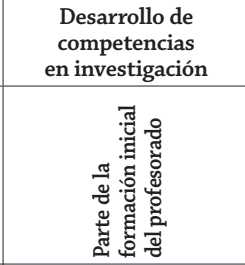 } \\
\hline & & & 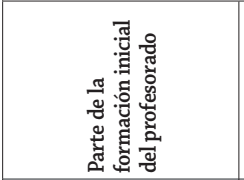 & 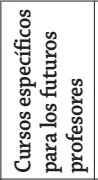 & & & & \\
\hline & & & (1) & (3) & (4) & (5) & (6) & (7) \\
\hline \multirow{3}{*}{\multicolumn{2}{|c|}{$\begin{array}{l}\text { Ŭ } \text { Alemania }^{1} \\
\text { Australia }\end{array}$}} & Todos & Obligatorio & No & Obligatorio & Obligatorio & Obligatorio & A discreción de las instituciones \\
\hline & & $\begin{array}{c}\text { General } \\
\text { Formación } \\
\text { profesional }\end{array}$ & $\begin{array}{l}\text { Obligatorio } \\
\mathrm{m}\end{array}$ & $\begin{array}{l}\text { No } \\
\mathrm{m}\end{array}$ & $\begin{array}{l}\text { Obligatorio } \\
\mathrm{m}\end{array}$ & $\begin{array}{l}\text { Obligatorio } \\
\mathrm{m}\end{array}$ & $\begin{array}{l}\text { Obligatorio } \\
\mathrm{m}\end{array}$ & $\begin{array}{l}\text { A discreción de las instituciones } \\
\qquad \mathrm{m}\end{array}$ \\
\hline & & $\begin{array}{c}\text { Todos } \\
\text { (Académico) }^{1,2} \\
\text { Todos }\left(\text { Nuevo }^{1}\right. \\
\text { e Inferior) }^{1,3}\end{array}$ & $\begin{array}{l}\text { Obligatorio } \\
\text { Obligatorio }\end{array}$ & $\begin{array}{l}\text { No } \\
\text { Sí }\end{array}$ & $\begin{array}{l}\text { Obligatorio } \\
\text { Obligatorio }\end{array}$ & $\begin{array}{l}\text { Obligatorio } \\
\text { Obligatorio }\end{array}$ & $\begin{array}{l}\text { Obligatorio } \\
\text { Obligatorio }\end{array}$ & $\begin{array}{l}\text { Obligatorio } \\
\text { Obligatorio }\end{array}$ \\
\hline \multicolumn{2}{|r|}{ Bélgica (Fl.) } & \begin{tabular}{|c|} 
General \\
Formación \\
profesional
\end{tabular} & $\begin{array}{l}\text { Obligatorio } \\
\mathrm{m}\end{array}$ & $\begin{array}{l}\text { Sí } \\
\mathrm{m}\end{array}$ & $\begin{array}{l}\text { A discreción de las instituciones } \\
\text { A discreción de las instituciones }\end{array}$ & $\begin{array}{l}\text { A discreción de las instituciones } \\
\text { A discreción de las instituciones }\end{array}$ & $\begin{array}{l}\text { A discreción de las instituciones } \\
\text { A discreción de las instituciones }\end{array}$ & $\begin{array}{l}\text { A discreción de las instituciones } \\
\text { A discreción de las instituciones }\end{array}$ \\
\hline & Bélgica $(\mathrm{Fr} .)^{1}$ & Todos & Obligatorio & Sí & Obligatorio & Obligatorio & Obligatorio & Obligatorio \\
\hline & Canadá & $\mathrm{m}$ & $\mathrm{m}$ & $\mathrm{m}$ & $\mathrm{m}$ & $\mathrm{m}$ & $\mathrm{m}$ & $\mathrm{m}$ \\
\hline & Chile & Todos & A discreción de las instituciones & No & A discreción de las instituciones & A discreción de las instituciones & A discreción de las instituciones & A discreción de las instituciones \\
\hline & Corea & Todos & Obligatorio & Sí & Obligatorio & Obligatorio & A discreción de las instituciones & A discreción de las instituciones \\
\hline & Dinamarca $^{1}$ & Todos & Obligatorio & Sí & Obligatorio & Obligatorio & Obligatorio & No se ofrece \\
\hline & Escocia & Todos & $\mathrm{m}$ & $\mathrm{m}$ & Obligatorio & Obligatorio & Obligatorio & $\mathrm{m}$ \\
\hline & Eslovenia $^{1}$ & Todos & Obligatorio & Sí & Obligatorio & Obligatorio & Obligatorio & Obligatorio \\
\hline & España $^{1}$ & Todos & Obligatorio & No & Obligatorio & Obligatorio & Obligatorio & Obligatorio \\
\hline & Estados Unidos & Todos & A discreción de las instituciones & $\mathrm{m}$ & A discreción de las instituciones & A discreción de las instituciones & A discreción de las instituciones & A discreción de las instituciones \\
\hline & Estonia & Todos & A discreción de las instituciones & No & Obligatorio & Obligatorio & A discreción de las instituciones & Obligatorio \\
\hline & Finlandia & Todos & Obligatorio & No & Obligatorio & Obligatorio & A discreción de las instituciones & Obligatorio \\
\hline & Francia & Todos & A discreción de las instituciones & No & A discreción de las instituciones & A discreción de las instituciones & A discreción de las instituciones & A discreción de las instituciones \\
\hline & Grecia & Todos & Obligatorio & Sí & Obligatorio & Obligatorio & A discreción de las instituciones & A discreción de las instituciones \\
\hline & Hungría $^{1,4}$ & Todos & Obligatorio & Sí & Obligatorio & Obligatorio & Obligatorio & Obligatorio \\
\hline & Inglaterra & Todos & Obligatorio & Sí & Obligatorio & A discreción de las instituciones & A discreción de las instituciones & A discreción de las instituciones \\
\hline & Irlanda $^{1}$ & Todos & Obligatorio & No & Obligatorio & Obligatorio & Obligatorio & Obligatorio \\
\hline & Islandia & Todos & A discreción de las instituciones & $\mathrm{m}$ & A discreción de las instituciones & A discreción de las instituciones & A discreción de las instituciones & A discreción de las instituciones \\
\hline & Israel $^{1}$ & Todos & Obligatorio & Sí & Obligatorio & Obligatorio & Obligatorio & Obligatorio \\
\hline & Italia & Todos & Obligatorio & $\mathrm{m}$ & $\mathrm{m}$ & $\mathrm{m}$ & $\mathrm{m}$ & $\mathrm{m}$ \\
\hline & Japón ${ }^{1}$ & Todos & Obligatorio & Sí & Obligatorio & Obligatorio & Obligatorio & A discreción de los estudiantes \\
\hline & Luxemburgo & Todos & Obligatorio & No & Obligatorio & Obligatorio & Obligatorio & Obligatorio \\
\hline \multicolumn{2}{|r|}{ México $^{1}$} & \begin{tabular}{|c|} 
General \\
Formación \\
profesional
\end{tabular} & $\begin{array}{l}\text { Obligatorio } \\
\text { No se ofrece }\end{array}$ & $\begin{array}{l}\text { Sí } \\
\text { a }\end{array}$ & $\begin{array}{l}\text { Obligatorio } \\
\text { No se ofrece }\end{array}$ & $\begin{array}{l}\text { Obligatorio } \\
\text { No se ofrece }\end{array}$ & $\begin{array}{l}\text { Obligatorio } \\
\text { No se ofrece }\end{array}$ & $\begin{array}{c}\text { A discreción de los estudiantes } \\
\text { No se ofrece }\end{array}$ \\
\hline & Noruega & Todos & Obligatorio & Sí & Obligatorio & Obligatorio & Obligatorio & Obligatorio \\
\hline & Nueva Zelanda & $\mathrm{m}$ & $\mathrm{m}$ & $\mathrm{m}$ & $\mathrm{m}$ & $\mathrm{m}$ & $\mathrm{m}$ & $\mathrm{m}$ \\
\hline & Países Bajos & Todos & A discreción de las instituciones & Sí & A discreción de las instituciones & A discreción de las instituciones & A discreción de las instituciones & A discreción de las instituciones \\
\hline & Polonia & Todos & Obligatorio & No & Obligatorio & Obligatorio & Obligatorio & Obligatorio \\
\hline & Portugal & Todos & Obligatorio & Sí & Obligatorio & Obligatorio & Obligatorio & Obligatorio \\
\hline & República Checa & Todos & A discreción de las instituciones & $\mathrm{m}$ & Obligatorio & Obligatorio & Obligatorio & A discreción de las instituciones \\
\hline & República Eslovaca & Todos & Obligatorio & Sí & Obligatorio & Obligatorio & Obligatorio & A discreción de las instituciones \\
\hline & Suecia $^{1}$ & Todos & Obligatorio & No & Obligatorio & Obligatorio & Obligatorio & Obligatorio \\
\hline & Suiza & Todos & Obligatorio & No & Obligatorio & Obligatorio & $\mathrm{m}$ & Obligatorio \\
\hline & Turquía & Todos & Obligatorio & Sí & Obligatorio & Obligatorio & Obligatorio & Obligatorio \\
\hline \multirow{2}{*}{ 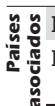 } & Brasil $^{1}$ & Todos & Obligatorio & No & Obligatorio & Obligatorio & A discreción de los estudiantes & A discreción de las instituciones \\
\hline & Federación Rusa & Todos & Obligatorio & Sí & Obligatorio & Obligatorio & Obligatorio & Obligatorio \\
\hline
\end{tabular}

Notas: Las columnas que muestran el número mínimo de asignaturas que se deben estudiar (columna 2), los requisitos para presentar una tésis basada en la investigación llevada a cabo por los estudiantes (columna 8) y si existen cursos comunes para todos los futuros profesores (columna 17) están disponibles en Internet (véase StatLink más abajo).

Los estados federales o países con sistemas educativos altamente descentralizados pueden tener distintas normativas en cada estado, provincia o región. Para obtener más información, consulte Anexo 3.

1. En la columna 10, la duración total típica en días se estima sobre la base de los requisitos en una unidad diferente, a saber, el número de horas, de semanas, de años o de créditos. Para ver notas, consulte Anexo 3.

2. «Todos (Académico)» se refiere a «Centro de educación secundaria inferior».

3. «Todos (Nuevo e Inferior)» se refiere a «Nuevo centro escolar de educación secundaria y a centro escolar de educación secundaria inferior».

4. Año de referencia 2014.

Fuente: OCDE. Para ver notas, consulte Anexo 3 (www.oecd.org/edu/eag.htm).

Para obtener más información acerca de los símbolos utilizados en lugar de los datos que faltan, consulte la Guía del lector.

StatLink 제피 $\mathrm{http}: / / \mathrm{dx}$.doi.org/10.1787/888933120366 
Tabla D6.3c. [2/2] Contenidos de la formación inicial del profesorado, en educación secundaria inferior (2013) En instituciones públicas

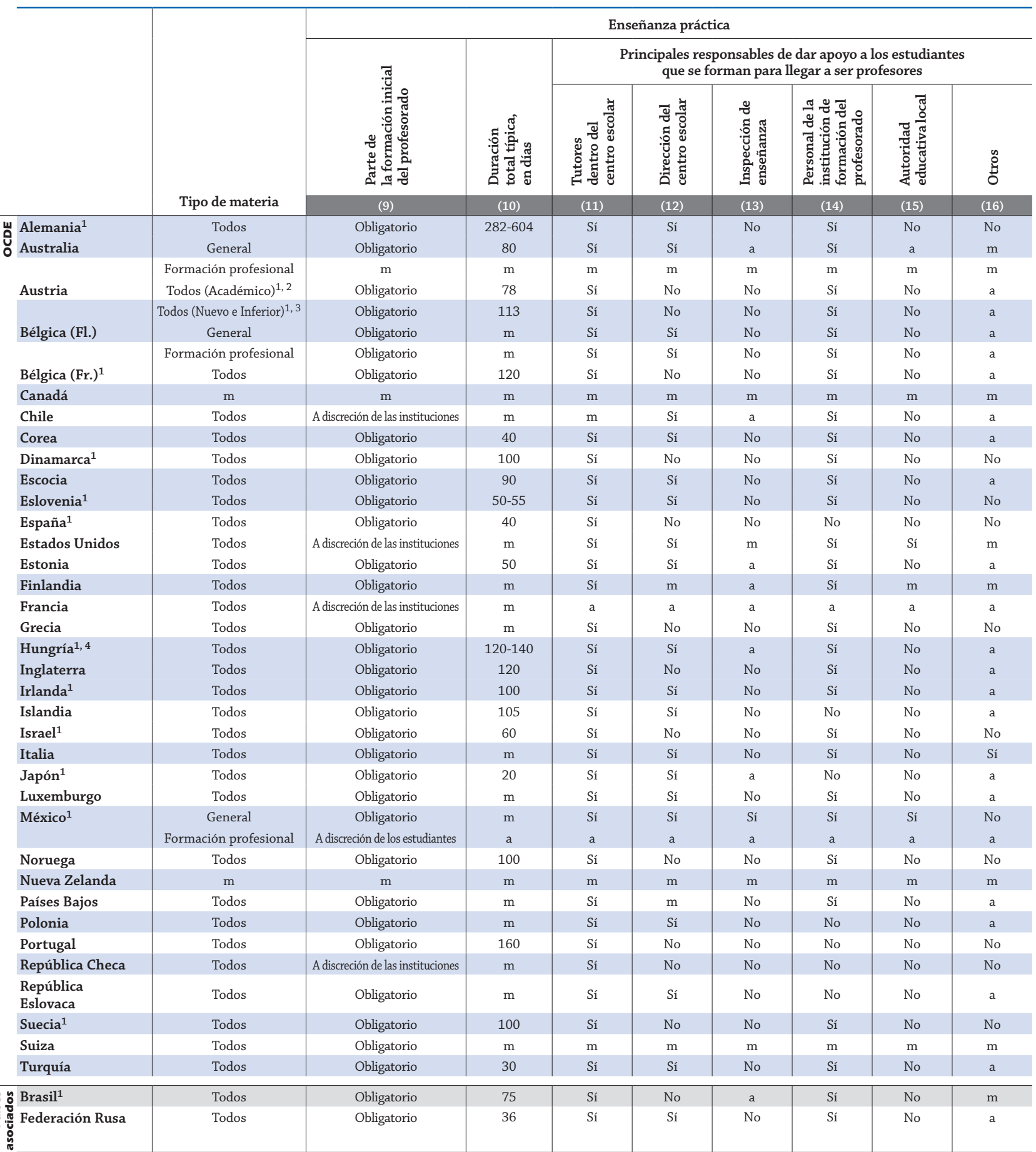

Notas: Las columnas que muestran el número mínimo de asignaturas que se deben estudiar (columna 2), los requisitos para presentar una tésis basada en la investigación llevada a cabo por los estudiantes (columna 8) y si existen cursos comunes para todos los futuros profesores (columna 17) están disponibles en Internet (véase StatLink más abajo).

Los estados federales o países con sistemas educativos altamente descentralizados pueden tener distintas normativas en cada estado, provincia o región. Para obtener más información, consulte Anexo 3.

1. En la columna 10, la duración total típica en días se estima sobre la base de los requisitos en una unidad diferente, a saber, el número de horas, de semanas, de años o de créditos. Para ver notas, consulte Anexo 3.

2. «Todos (Académico)» se refiere a "Centro de educación secundaria inferior».

3. «Todos (Nuevo e Inferior)» se refiere a "Nuevo centro escolar de educación secundaria y a centro escolar de educación secundaria inferior».

4. Año de referencia 2014.

Fuente: OCDE. Para ver notas, consulte Anexo 3 (www.oecd.org/edu/eag.htm).

Para obtener más información acerca de los símbolos utilizados en lugar de los datos que faltan, consulte la Guía del lector.

StatLink 제이 http://dx.doi.org/10.1787/888933120366 
Tabla D6.5c. Ingreso en la profesión docente, en educación secundaria inferior (2013)

En instituciones públicas

\begin{tabular}{|c|c|c|c|c|c|c|c|c|c|}
\hline & \multirow[b]{3}{*}{ Tipo de materia } & \multirow[b]{2}{*}{ 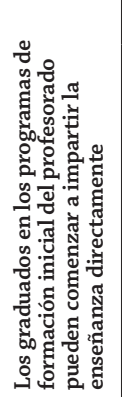 } & \multirow[b]{2}{*}{ 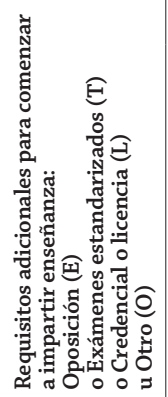 } & \multirow[b]{2}{*}{ 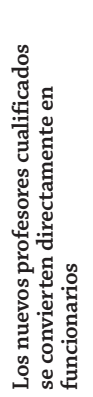 } & \multirow[b]{2}{*}{ 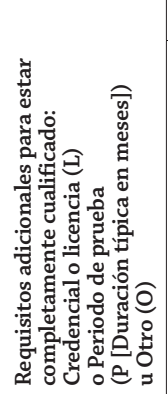 } & \multicolumn{4}{|c|}{ Programa de orientación formal } \\
\hline & & & & & & 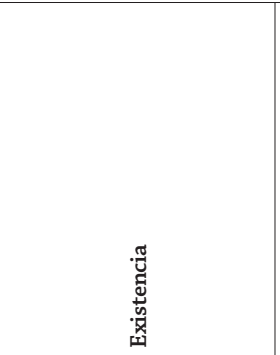 & 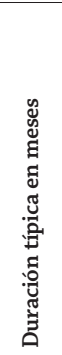 & 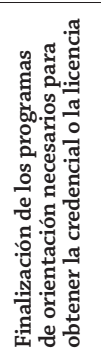 & 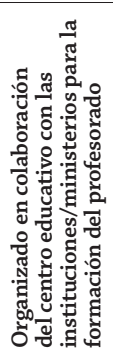 \\
\hline & & (1) & (2) & (7) & (8) & (13) & (14) & (15) & (16) \\
\hline $\begin{array}{l}\text { Alemania } \\
\text { Australia }\end{array}$ & $\begin{array}{l}\text { Todos } \\
\text { General }\end{array}$ & $\begin{array}{l}\text { Sí } \\
\text { No }\end{array}$ & $\begin{array}{l}\mathrm{a} \\
\mathrm{L}\end{array}$ & $\begin{array}{l}\text { Sí } \\
\text { Sí }\end{array}$ & $\begin{array}{l}\mathrm{a} \\
\mathrm{a}\end{array}$ & $\begin{array}{c}\mathrm{m} \\
\text { A discreción del centro educativo }\end{array}$ & $\begin{array}{l}\mathrm{m} \\
\mathrm{m}\end{array}$ & $\begin{array}{l}\mathrm{m} \\
\text { No }\end{array}$ & $\begin{array}{l}\mathrm{m} \\
\mathrm{m}\end{array}$ \\
\hline Austria & $\begin{array}{c}\text { Formación profesional } \\
\text { Todos (Académico) }{ }^{1}\end{array}$ & $\begin{array}{l}\mathrm{m} \\
\text { No }\end{array}$ & $\begin{array}{c}\mathrm{m} \\
\mathrm{L}, \mathrm{O}\end{array}$ & $\begin{array}{l}\text { m } \\
\text { Sí }\end{array}$ & $\begin{array}{c}\mathrm{m} \\
\mathrm{a}\end{array}$ & $\begin{array}{c}\mathrm{m} \\
\text { Obligatorio }\end{array}$ & $\begin{array}{l}\mathrm{m} \\
12\end{array}$ & $\begin{array}{l}\text { m } \\
\text { Sí }\end{array}$ & $\begin{array}{l}\mathrm{m} \\
\text { Sí }\end{array}$ \\
\hline Bélgica (Fl.) & $\begin{array}{c}\text { Todos (Nuevo e Inferior) })^{2} \\
\text { General }\end{array}$ & $\begin{array}{l}\text { Sí } \\
\text { Sí }\end{array}$ & $\begin{array}{l}\mathrm{a} \\
\mathrm{a}\end{array}$ & $\begin{array}{l}\text { Sí } \\
\text { Sí }\end{array}$ & $\begin{array}{l}\mathrm{a} \\
\mathrm{a}\end{array}$ & $\begin{array}{c}\text { No se ofrece } \\
\text { A discreción del centro educativo }\end{array}$ & $\mathrm{a}$ & $\begin{array}{l}\text { a } \\
\text { No }\end{array}$ & $\begin{array}{l}\text { a } \\
\text { No }\end{array}$ \\
\hline Bélgica (Fr.) & $\begin{array}{c}\text { Formación profesional } \\
\text { Todos }\end{array}$ & $\begin{array}{l}\text { Sí } \\
\text { Sí }\end{array}$ & $\begin{array}{l}\mathrm{a} \\
\mathrm{a}\end{array}$ & $\begin{array}{l}\text { Sí } \\
\text { Sí }\end{array}$ & $\begin{array}{l}\mathrm{a} \\
\mathrm{a}\end{array}$ & $\begin{array}{l}\text { A discreción del centro educativo } \\
\text { A discreción del centro educativo }\end{array}$ & $\begin{array}{l}\mathrm{m} \\
\mathrm{m}\end{array}$ & $\begin{array}{l}\text { No } \\
\text { No }\end{array}$ & $\begin{array}{c}\text { No } \\
m\end{array}$ \\
\hline Canadá & $\mathrm{m}$ & $\mathrm{m}$ & $\mathrm{m}$ & $\mathrm{m}$ & $\mathrm{m}$ & $\mathrm{m}$ & $\mathrm{m}$ & $\mathrm{m}$ & $\mathrm{m}$ \\
\hline Chile & Todos & Sí & a & Sí & a & No se ofrece & a & a & a \\
\hline Corea $^{4}$ & Todos & No & E & Sí & a & Obligatorio & 0.25 & No & No \\
\hline Dinamarca & Todos & Sí & a & Sí & a & A discreción del centro educativo & $\mathrm{m}$ & No & No \\
\hline Escocia & Todos & Sí & a & No & L, P[10] & Obligatorio & 10 & Sí & Sí \\
\hline Eslovenia & Todos & Sí & a & No & $\mathrm{L}$ & A discreción del centro educativo & 10 & No & Sí \\
\hline España & Todos & No & $\mathrm{E}$ & No & $\mathrm{P}[3-12]$ & No se ofrece & a & a & a \\
\hline Estados Unidos & Todos & $\mathrm{m}$ & $\mathrm{m}$ & $\mathrm{m}$ & $\mathrm{m}$ & A discreción del centro educativo & $\mathrm{m}$ & $\mathrm{m}$ & $\mathrm{m}$ \\
\hline Estonia & Todos & Sí & $\mathrm{a}$ & Sí & a & Obligatorio & 12 & No & Sí \\
\hline Finlandia & Todos & Sí & a & Sí & a & No se ofrece & a & a & a \\
\hline Francia & Todos & No & $\mathrm{E}$ & No & $\mathrm{P}[12]$ & Obligatorio & 12 & Sí & Sí \\
\hline Grecia & Todos & No & $E, T, L$ & No & $\mathrm{L}, \mathrm{P}[24]$ & Obligatorio & 1 & Sí & Sí \\
\hline Hungría $^{3}$ & Todos & Sí & $\mathrm{a}$ & No & $\mathrm{P}[24], \mathrm{O}$ & Obligatorio & 24 & Sí & No \\
\hline Inglaterra & Todos & Sí & $\mathrm{a}$ & No & L, P[12] & Obligatorio & 12 & Sí & No \\
\hline Irlanda ${ }^{4}$ & Todos & Sí & $\mathrm{a}$ & No & $\mathrm{P}[4.8], \mathrm{O}$ & Obligatorio & 12 & Sí & No \\
\hline Islandia & Todos & Sí & a & Sí & a & No se ofrece & a & a & a \\
\hline Israel & Todos & Sí & a & No & L, P[10], O & Obligatorio & 10 & Sí & Sí \\
\hline Italia $^{4}$ & Todos & Sí & $\mathrm{a}$ & No & $\mathrm{P}[12], \mathrm{O}$ & Obligatorio & 12 & Sí & Sí \\
\hline Japón $^{4}$ & Todos & No & E, L & Sí & a & Obligatorio & 12 & No & Sí \\
\hline Luxemburgo & Todos & Sí & a & No & $P[24], O$ & Obligatorio & 18 & Sí & Sí \\
\hline México $^{4}$ & $\begin{array}{c}\text { General } \\
\text { Formación profesional }\end{array}$ & $\begin{array}{c}\text { No } \\
m\end{array}$ & $\begin{array}{l}\mathrm{E} \\
\mathrm{m}\end{array}$ & $\begin{array}{l}\text { Sí } \\
\mathrm{m}\end{array}$ & $\mathrm{a}$ & $\begin{array}{l}\text { Obligatorio } \\
\mathrm{m}\end{array}$ & $\begin{array}{c}0.5 \\
\mathrm{~m}\end{array}$ & $\begin{array}{c}\text { No } \\
m\end{array}$ & $\begin{array}{l}\text { Sí } \\
\text { m }\end{array}$ \\
\hline Noruega & Todos & Sí & $\mathrm{a}$ & Sí & $\mathrm{a}$ & A discreción del centro educativo & 12 & No & No \\
\hline Nueva Zelanda & $\mathrm{m}$ & $\mathrm{m}$ & $\mathrm{m}$ & $\mathrm{m}$ & $\mathrm{m}$ & $\mathrm{m}$ & $\mathrm{m}$ & $\mathrm{m}$ & $\mathrm{m}$ \\
\hline Países Bajos & Todos & Sí & a & Sí & a & No se ofrece & a & a & a \\
\hline Polonia & Todos & Sí & $\mathrm{a}$ & Sí & $\mathrm{a}$ & Obligatorio & 9 & No & No \\
\hline Portugal & Todos & Sí & a & No & $P[12], O$ & No se ofrece & a & a & a \\
\hline República Checa & Todos & Sí & a & Sí & a & A discreción del centro educativo & $\mathrm{m}$ & No & $\mathrm{m}$ \\
\hline República Eslovaca & Todos & Sí & a & Sí & a & Obligatorio & 10 & Sí & No \\
\hline Suecia $^{4}$ & Todos & Sí & a & No & $\mathrm{L}, \mathrm{P}[11]$ & Obligatorio & 11 & Sí & No \\
\hline Suiza & Todos & Sí & a & Sí & a & $\mathrm{m}$ & $\mathrm{m}$ & $\mathrm{m}$ & $\mathrm{m}$ \\
\hline Turquía & Todos & No & E & No & $\mathrm{P}[12]$ & Obligatorio & 12 & Sí & Sí \\
\hline ŏ Brasil ${ }^{4}$ & Todos & No & E & No & $\mathrm{P}[36], \mathrm{O}$ & $\mathrm{m}$ & $\mathrm{m}$ & $\mathrm{m}$ & $\mathrm{m}$ \\
\hline 胥 Federación Rusa & Todos & Sí & a & Sí & a & No se ofrece & $\mathrm{a}$ & a & a \\
\hline
\end{tabular}

Notas: Las columnas individuales que muestran los requisitos adicionales para comenzar a impartir enseñanza (columnas 3 a 6 ) y estar plenamente cualificado (columnas 9 a 12), así como los principales responsables de dar apoyo a los nuevos profesores (columnas 17 a 22), la formación requerida y su compensación (columnas 23 y 24 ) y el porcentaje de profesores que abandonan la profesión en los primeros 5 años (columna 25) están disponibles en Internet (véase StatLink más abajo).

Los estados federales o países con sistemas educativos altamente descentralizados pueden tener distintas normativas en cada estado, provincia o región. Para obtener más información, consulte Anexo 3.

1. «Todos (Académico)» se refiere a «Centro de educación secundaria inferior».

2. «Todos (Nuevo e Inferior)» se refiere a «Nuevo centro escolar de educación secundaria y a centro escolar de educación secundaria inferior».

3. Año de referencia 2014.

4. La duración total típica en meses para las columnas 8, 11 y/o 14 se estima sobre la base de los requisitos en una unidad diferente, a saber, número de horas, de semanas, de años o de créditos. Para ver notas, consulte Anexo 3.

Fuente: OCDE. Para ver notas, consulte Anexo 3 (www.oecd.org/edu/eag.htm).

Para obtener más información acerca de los símbolos utilizados en lugar de los datos que faltan, consulte la Guía del lector.

StatLink 제개 http://dx.doi.org/10.1787/888933120385 


\section{¿QUÉ IMPLANTACIÓN TIENEN LAS ACTIVIDADES DE DESARROLLO PROFESIONAL PARA LOS PROFESORES?}

- Aproximadamente en tres cuartas partes de los países de la OCDE y países asociados con datos disponibles, el desarrollo profesional es obligatorio para los profesores en todos los niveles educativos. Aunque el desarrollo profesional es obligatorio en 17 países para educación secundaria inferior y en 8 países para optar a la promoción o la mejora salarial, en 6 países no es necesario.

- En la mayoría de los países, las decisiones acerca de las actividades de desarrollo profesional obligatorio de los profesores las adoptan los propios profesores y la dirección del centro escolar.

\section{Gráfico D7.1. Requisitos para el desarrollo profesional de los profesores (2013) Para profesores que imparten materias generales en instituciones públicas de educación secundaria inferior}

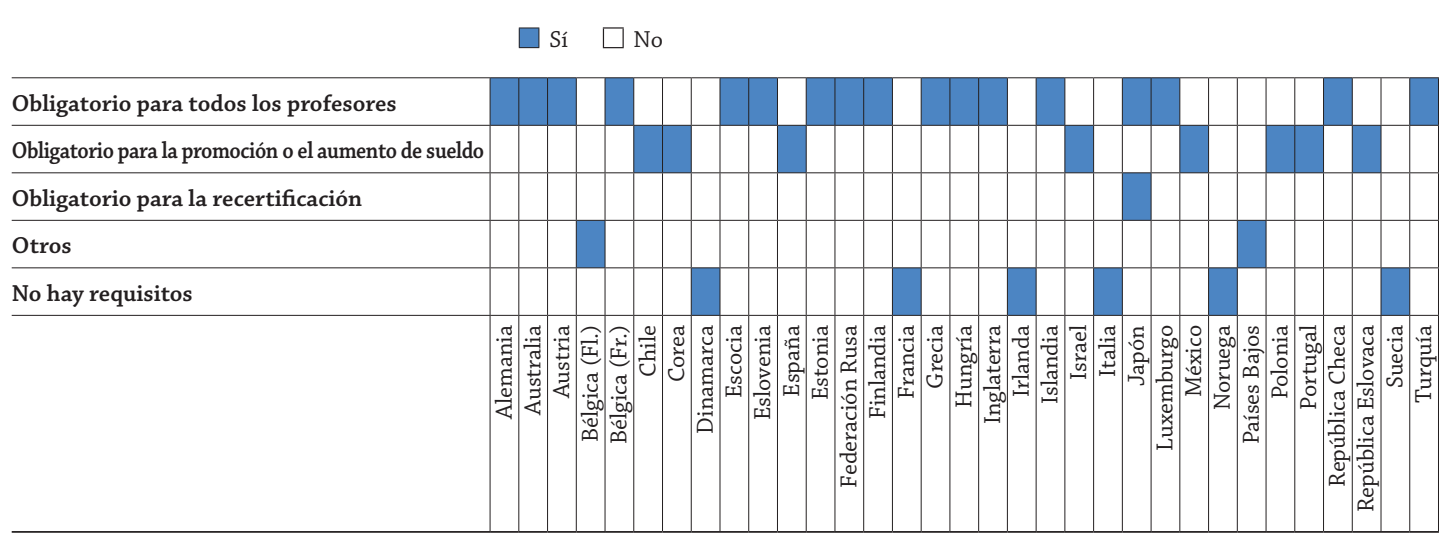

Fuente: OCDE. Tablas D7.1c. Para ver notas, consulte Anexo 3 (www.oecd.org/edu/eag.htm). StatLink 제이 http://dx.doi.org/10.1787/888933120537

\section{Contexto}

La formación de los profesores se considera cada vez más un proceso de aprendizaje permanente. Aunque la formación inicial sienta las bases, el desarrollo profesional continuo proporciona un medio para mejorar la calidad de los profesores y para retener por más tiempo al profesorado eficaz. Este tipo de acciones permiten a los profesores actualizar, desarrollar y ampliar sus conocimientos y comprensión de la enseñanza, además de mejorar sus competencias y prácticas docentes. También ayuda a la integración de los nuevos docentes y compensa las deficiencias de la formación inicial. El aprendizaje permanente para el desarrollo de los profesores es esencial si se tiene en cuenta que las expectativas del profesor pueden evolucionar con el tiempo. Las nuevas demandas, como por ejemplo la creciente diversidad de los estudiantes, la mayor integración de los niños y estudiantes con necesidades especiales y el uso creciente de las nuevas tecnologías de la información y de la comunicación, exigen que los profesores actualicen continuamente sus competencias. En formación profesional, los docentes y formadores necesitan un continuo reciclaje para afrontar las necesidades cambiantes de los modernos entornos de trabajo (OECD, 2005).

Diversos estudios sostienen que el desarrollo profesional continuo de los profesores mejora significativamente el aprendizaje de los alumnos (Yoon et al., 2007). Con una mayor incorporación de profesores que acceden a la profesión docente a través de vías alternativas, ya sean profesionales que deciden realizar un movimiento lateral a mitad de carrera o recién graduados universitarios que deciden suplir por vía rápida las vacantes en áreas de gran demanda, la necesidad de un desarrollo profesional pertinente y accesible es cada vez más imperativa (Clotfelter et al, 2007; Mueller, 2012; Headden, 2014). Los estudios muestran que, además de los talleres formales, las tutorías de los profesores experimentados pueden mejorar significativamente la calidad de la enseñanza y ser especialmente útiles para los profesores que ingresan en la profesión a través de vías alternativas (Rockoff, 2008). 
El desarrollo profesional de calidad influye en gran medida en la decisión de continuar en la profesión docente (Allensworth, Ponisciak y Mazzeo, 2009). Debido al serio problema de rotación de los profesores, el desarrollo profesional, especialmente en centros escolares de comunidades marginales (Ewing y Smith, 2003; OECD, 2005; Headden, 2014), debe convertirse en un asunto de alta prioridad.

\section{Otros resultados}

- En la mayoría de los países, las actividades de desarrollo profesional se consideran prioritarias para el desarrollo del centro educativo. En educación secundaria inferior, en 20 países se planifican dichas actividades de desarrollo profesional siguiendo este criterio, de manera exclusiva o no exclusiva. No ocurre así en otros 4 países.

- Los países cuentan con estrategias de apoyo y financiación destinadas al desarrollo profesional obligatorio. En 14 países de la OCDE y países asociados, el coste de ese desarrollo en educación secundaria inferior está totalmente subvencionado o compartido por el gobierno y en 8 países está parcialmente subvencionado.

- Además del desarrollo profesional obligatorio, todos los países afirmaron que los profesores podían realizar actividades de desarrollo profesional no obligatorias. Sin embargo, la financiación de estas actividades rara vez está totalmente subvencionada por el gobierno.

- Las actividades de desarrollo profesional para profesores de educación secundaria inferior se suelen impartir en las instituciones de educación superior (34 países), en instituciones de formación inicial del profesorado (30 países), en centros educativos (31 países) y en empresas privadas (30 países). Otros proveedores que participan en actividades para el desarrollo profesional son los organismos públicos dedicados al desarrollo profesional de los profesores y las organizaciones profesionales de profesores (22 países), los sindicatos de profesores (20 países) y las autoridades educativas locales (18 países). La inspección de enseñanza proporciona estas actividades solo en 6 países.

- La dirección de centro escolar es la principal fuente de información sobre actividades de desarrollo profesional. Aproximadamente en dos tercios de los países de la OCDE, las autoridades educativas centrales o estatales son también responsables de facilitar información sobre estas actividades. 


\section{Análisis}

\section{Requisitos para el desarrollo profesional obligatorio de los profesores}

El aprendizaje permanente en lo referente a la formación de profesores requiere oportunidades e incentivos para el desarrollo profesional a lo largo de su carrera docente. El desarrollo profesional puede abarcar toda una serie de actividades, como cursos formales, seminarios, conferencias y talleres, así como formación a distancia, tutorías y supervisión. Sin embargo, los beneficios que aporta el desarrollo profesional dependen de la calidad de los programas y de su evaluación y seguimiento posterior.

El desarrollo profesional como requisito abarca todos los niveles educativos. En 25 de los 33 países con datos disponibles, el desarrollo profesional es obligatorio para los profesores en todos los niveles. Aunque en 16 de 25 países indicaron que es obligatorio para todos los docentes, el desarrollo profesional es necesario para promocionar o conseguir un aumento salarial en Corea, Chile, Israel, México (para los profesores de educación infantil, primaria y secundaria inferior de programas generales), España, Polonia, Portugal y República Eslovaca. En Islandia es una obligación contractual incluida en un acuerdo salarial entre los sindicatos de profesores y los contratantes que afecta a los profesores de educación infantil y educación secundaria superior. En Japón se exige el desarrollo profesional a todos los profesores durante su décimo año de carrera docente y también para obtener su recertificación. En Bélgica (Comunidad flamenca) y Países Bajos, aunque el desarrollo profesional es habitual en los profesores y puede ser impuesto por el centro escolar o la entidad organizadora (dependiendo del centro escolar), no existe una ley que indique que es obligatorio. En Austria (en formación profesional superior), Francia, Irlanda (en educación primaria y secundaria) y México (formación profesional inferior y educación secundaria superior) no se requieren actividades de desarrollo profesional. En Dinamarca, Noruega y Suecia, aunque no son obligatorias, las autoridades educativas u organizadores escolares son responsables de organizar y permitir que los profesores puedan participar en dichas actividades. En Italia, el Contrato Nacional de Profesores obliga a los centros escolares y a las autoridades educativas a promover actividades de desarrollo profesional como un derecho de los profesores (Tabla D7.1c y Tablas D7.1a, b y d, disponibles en Internet).

\section{Duración mínima del desarrollo profesional requerido}

La duración de los programas de desarrollo profesional obligatorio varía mucho entre los diferentes países. Mientras que algunos países (por ejemplo, Alemania, Federación Rusa e Inglaterra) no establecen un requisito mínimo para que los profesores se involucren en el desarrollo profesional, otros países sí lo hacen. En los países que imponen un requisito mínimo anual para todos los profesores, este oscila entre las 8 horas al año en Luxemburgo y las 150 horas anuales en Islandia (para profesores de educación primaria y secundaria inferior). En Estonia, los profesores deben realizar un mínimo de 160 horas de desarrollo profesional durante 5 años, mientras que en Hungría el mínimo es de 120 horas a lo largo de 7 años. En Japón, todos los profesores con diez años de experiencia deben completar un programa de desarrollo profesional. Esto incluye un promedio de 123 horas de actividades de desarrollo profesional para los profesores de educación infantil y 231 horas para los profesores de educación primaria y educación secundaria. Además, los profesores japoneses deben realizar 30 horas de desarrollo profesional cada 10 años para obtener su recertificación (Tabla D7.1c y Tablas D7.1a, b y d, disponibles en Internet).

En España, los profesores deben realizar entre 250 y 300 horas de actividades de desarrollo profesional cada 6 años para conseguir un ascenso o un aumento de sueldo, mientras que en México se exigen 78 horas anuales a los profesores de educación infantil, educación primaria y secundaria inferior. En Israel, los profesores de educación infantil, primaria y secundaria inferior deben dedicar a su desarrollo profesional entre 180 y 210 horas cada tres años, mientras que los profesores de educación secundaria superior deben completar 112 horas de formación anuales. En Corea, los profesores deben emplear 90 horas en actividades de desarrollo profesional para conseguir un ascenso o un incremento salarial. En República Eslovaca, los profesores han de completar un programa de desarrollo profesional de 300 horas para obtener un aumento de sueldo. No obstante, estos créditos solo son válidos durante siete años a partir de su obtención, lo que implica una continua renovación de créditos en actividades de desarrollo profesional y mantener la cantidad mínima de créditos requerida para conservar dichos aumentos salariales.

\section{Planificación del desarrollo profesional}

De los 23 países que exigen llevar a cabo actividades de desarrollo profesional a sus profesores y con datos disponibles sobre su planificación, solo 10 exigen al profesorado y al centro educativo una programación previa de dichas actividades. Solamente en Federación Rusa, Grecia, Hungría, Islandia y República Checa se exige dicha planificación al centro educativo, mientras que en Escocia, Estonia (en educación primaria y secundaria) y Turquía, son los profesores los encargados de presentar esta programación. Por el contrario, no se requiere ningún tipo de planificación en 
Alemania, Austria, Estonia (en educación infantil), España, Finlandia y Luxemburgo (Tabla D7.2c y Tablas D7.2a, b y d, disponibles en Internet).

En 20 de los 24 países con datos disponibles, las actividades de desarrollo profesional obligatorio para los profesores se planifican como actividades prioritarias para el desarrollo de los centros educativos en educación secundaria inferior. Estas actividades se planifican exclusivamente en el contexto de las prioridades de desarollo de cada centro escolar en Federación Rusa, Japón, República Checa y República Eslovaca, pero no ocurre de forma exclusiva en 16 de estos 20 países. Por el contrario, este tipo de actividades no se planifican como actividades prioritarias para el desarrollo de los centros educativos en Corea, España, Luxemburgo y México.

Entre los 32 países de la OCDE y países asociados con datos disponibles, en 24 países las actividades de desarrollo profesional no obligatorio para profesores de educación secundaria inferior se planifican en el contexto de las prioridades de desarrollo de cada centro educativo, aunque no es así en 8 países. Por otro lado, 22 de los 24 países afirmaron que estas actividades no se han planificado en exclusiva en el contexto de las prioridades de desarrollo del centro, con la excepción de República Checa y Japón, que sí las planificaron exclusivamente en este contexto. Los requisitos de planificación de desarrollo profesional son similares para los profesores de educación infantil, primaria y secundaria superior (Tabla D7.3c y Tablas D7.3a, b y d, disponibles en Internet).

\section{Contenido de las actividades de desarrollo profesional}

El contenido de las actividades de desarrollo profesional obligatorio para profesores de secundaria inferior no está estipulado en 17 de los 24 países de la OCDE y países asociados con datos disponibles. Sin embargo, aunque no se especifica su contenido, estas actividades deben ajustarse a las normas establecidas en 6 de estos 17 países. Estas normas las establecen exclusivamente las autoridades centrales educativas en Bélgica (Comunidad francófona) e Inglaterra, mientras que en Corea lo hacen tanto las autoridades educativas centrales como las autoridades regionales. En Grecia, las autoridades educativas centrales y las autoridades regionales, además de la Inspección de Enseñanza y el Instituto de Política Educativa, fijan dichas normas. En Federación Rusa, esta tarea recae en las autoridades educativas centrales y regionales junto con las universidades y los centros escolares.

En cambio, el contenido de las actividades de desarrollo profesional obligatorio está previamente estipulado en Eslovenia, España, Israel, México, República Eslovaca y Turquía. Además, en España, México y República Eslovaca, el contenido lo fija exclusivamente la autoridad educativa central y, en Eslovenia, las autoridades centrales de educación, las universidades y los centros escolares. En Portugal, el contenido lo especifican en conjunto las autoridades educativas, las organizaciones de profesionales, los sindicatos de docentes, las universidades y los centros escolares, y en Turquía, dicho contenido lo establecen las autoridades educativas centrales y las regionales junto con las universidades y la Inspección de Enseñanza. En Israel lo especifican las autoridades centrales de educación, la Inspección de Enseñanza, las organizaciones profesionales, los sindicatos de los profesores, las universidades, los centros escolares y otros proveedores de educación. Un panorama similar se observa en educación infantil, educación primaria y educación secundaria superior (Tabla D7.2c y Tablas D7.2a, b y d, disponibles en Internet).

\section{Cuadro D7.1. ¿En qué áreas consideran los profesores que tienen mayor necesidad de desarrollo profesional?}

Según el Estudio Internacional sobre Enseñanza y Aprendizaje de la OCDE (TALIS, por sus siglas en inglés, 2013), todos los países participantes afirmaron que el aspecto que necesita un mayor desarrollo profesional es la enseñanza de los alumnos con necesidades especiales. Por término medio, alrededor del $22 \%$ de los profesores informaron de la necesidad de desarrollo profesional en este aspecto de la enseñanza, llegando al $60 \%$ de los profesores en Brasil y al $47 \%$ en México. Según los profesores encuestados, el segundo y tercer aspecto donde se necesita un mayor desarrollo profesional son las tecnologías de la información y la comunicación (un $19 \%$ de los profesores) y el uso de las nuevas tecnologías en el lugar de trabajo (el 18\%). Los profesores de todos los países participantes en el estudio identificaron estas áreas como importantes puntos de desarrollo, en particular los profesores de Brasil (en un $27 \%$ y un $37 \%$, respectivamente), Italia ( $36 \%$ y $32 \%$, respectivamente) y Malasia (38\% y $31 \%$, respectivamente). Esto sugiere que los profesores no se sienten preparados para un buen uso de estas tecnologías tanto en la enseñanza como en el aprendizaje.

En algunos países, los profesores identifican otras áreas de mejora. Por ejemplo, en Corea y Japón, más del $40 \%$ de los profesores piden un mayor desarrollo profesional en la orientación profesional y en el asesoramiento a 
los estudiantes. Los profesores japoneses tienen necesidades específicas en áreas tales como la formación en el conocimiento y la comprensión de la asignatura ( $51 \%)$, las competencias pedagógicas (57\%), el comportamiento de los alumnos y la gestión del aula (43\%), la evaluación de los alumnos (40\%) y la forma de abordar el aprendizaje individualizado (40\%). La enseñanza en un entorno multicultural y multilingüe no parece ser un asunto de interés para la mayoría de los países europeos, pero sí una gran preocupación en los países de América Latina y en Italia: el $46 \%$ de los profesores brasileños, el $24 \%$ de los profesores chilenos, el $27 \%$ de los docentes italianos y el $33 \%$ de los mexicanos mencionan la necesidad de desarrollarse profesionalmente en esta área.

\section{Gráfico D7.a. Necesidades de desarrollo profesional de los profesores (2013) Porcentaje de profesores de educación secundaria inferior que declaran tener una gran necesidad de desarrollo profesional en las siguientes áreas}

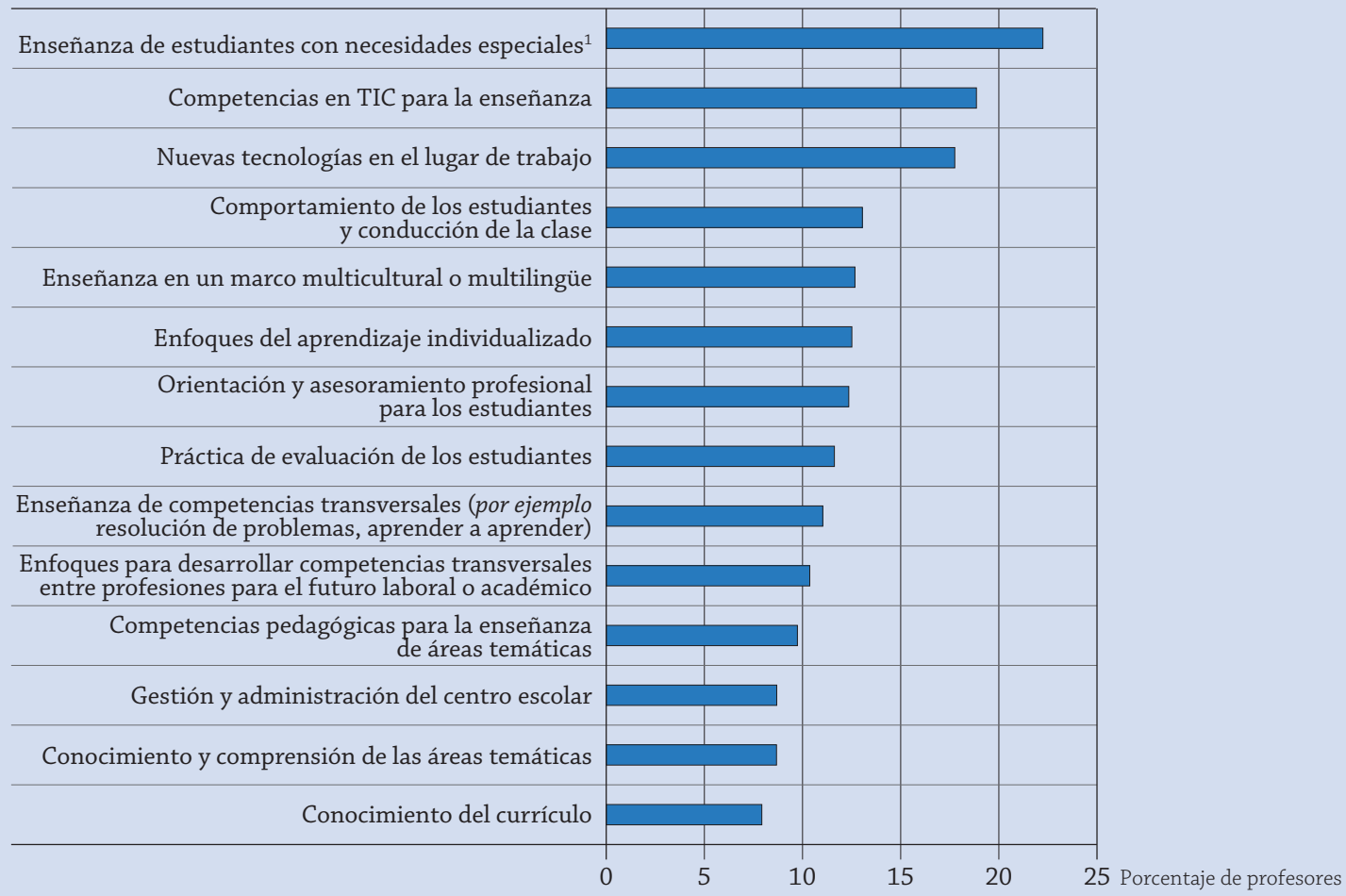

1. El concepto de estudiantes con necesidades especiales no está bien definido a nivel internacional, pero generalmente incluye a aquellos estudiantes para los cuales se ha identificado de manera formal una necesidad de aprendizaje especial por tener una desventaja mental, física o emocional. A menudo, los estudiantes con necesidades especiales son aquellos a los que se han destinado recursos públicos o privados adicionales (humanos, materiales o económicos) para apoyar su educación. No se considera que los «estudiantes superdotados» tengan necesidades especiales de acuerdo con la definición que se utiliza aquí o en otros trabajos de la OCDE. Algunos docentes consideran que todos los estudiantes tienen un modo de aprender único y, por tanto, tienen alguna necesidad especial en el aprendizaje. Teniendo en cuenta el propósito de esta encuesta, es importante aplicar un criterio más objetivo para determinar cuáles son los estudiantes con necesidades especiales y cuáles no. Por este motivo se hace hincapié arriba en la necesidad de una identificación formal.

Los elementos están clasificados en orden descendente del porcentaje de profesores que declaran tener una gran necesidad de desarrollo profesional.

Fuente: OECD (2014) TALIS 2013 Results: An International Perspective on Teaching and Learning, TALIS, OECD Publishing.

StatLink 섹ㄴ http://dx.doi.org/10.1787/888933041668

\section{Decisiones sobre la elección de actividades de desarrollo profesional de profesores individuales}

Los profesores y los administradores del centro escolar desempeñan el papel más importante al decidir qué actividades de desarrollo profesional obligatorio ha de realizar cada profesor. Dos tercios de los países que cuentan con programas de desarrollo profesional obligatorio afirmaron que, en educación secundaria inferior, los profesores proponen las actividades en las que participan, mientras que en siete países son los profesores los que deciden qué tipo de actividades realizan. En Bélgica (Comunidad francófona), Eslovenia, Estonia, Finlandia, Israel, Polonia y Turquía, aunque los profesores proponen las actividades, es la dirección del centro escolar la que valida la elección de sus actividades de desarrollo profesional. La dirección del centro escolar propone las actividades que han de realizar 
los profesores aproximadamente en un tercio de los países: solo en Austria, Federación Rusa, Hungría y República Checa, la dirección del centro escolar decide qué actividades se llevarán a cabo.

En Japón, tanto los profesores como la dirección del centro escolar proponen las actividades de desarrollo profesional, pero son las autoridades educativas las que las validan. En Corea, los profesores proponen las actividades, pero la decisión la toman las autoridades educativas. En Chile, tanto la dirección del centro escolar como las autoridades educativas proponen las actividades, pero es el profesor quien decide si las realiza o no. Del mismo modo, en España son las autoridades regionales de educación las que proponen las actividades y el profesor el que toma la decisión final. En Turquía, los profesores, la Inspección de Enseñanza y las autoridades educativas locales proponen estas actividades, que son validadas por la dirección del centro, y la decisión final se hace conjuntamente con las autoridades educativas regionales y centrales (Gráfico D7.2a y Tabla D7.1c).

\section{Gráfico D7.2a. ¿Quién decide las actividades de desarrollo profesional obligatorio que han de realizar los profesores? (2013)}

Para los profesores que imparten materias generales en instituciones públicas de educación secundaria inferior

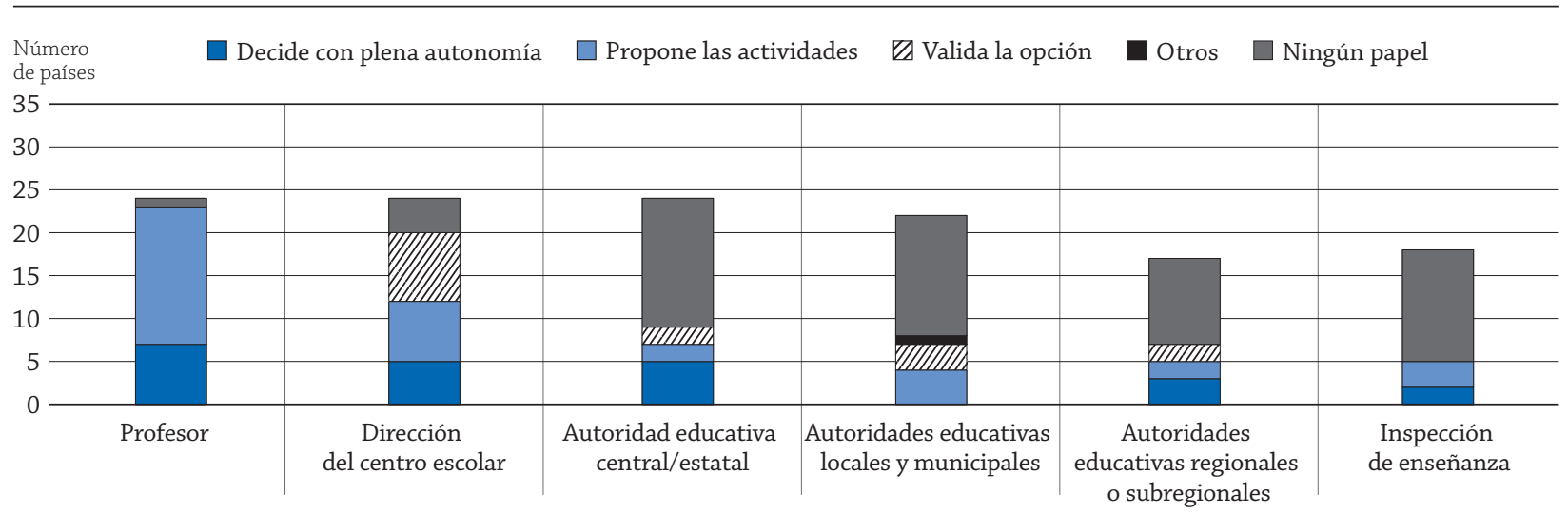

Las instituciones están clasificadas en orden descendente del número de países que refieren que estas instituciones desempeñan un papel en la decisión sobre las actividades de desarrollo profesional obligatorio que han de realizar los profesores.

Fuente: OCDE. Tabla D7.1c. Para ver notas, consulte Anexo 3 (www.oecd.org/edu/eag.htm).

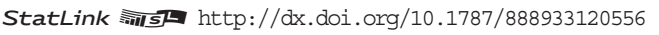

Se observa un panorama similar en educación infantil, educación primaria y secundaria superior. Sin embargo, en Austria, aunque tanto la dirección del centro escolar como la Inspección de Enseñanza proponen las actividades de desarrollo profesional obligatorio para los profesores de educación infantil, son los docentes los que tienen la potestad de llevar a cabo esas actividades. En educación primaria y educación secundaria ocurre lo contrario: los profesores proponen las actividades y la dirección del centro escolar y la Inspección de Enseñanza deciden si los profesores deben realizarlas (Tablas D7.2a, b y d, disponibles en Internet).

En la mitad de los países, los profesores deciden el tipo de actividades de desarrollo profesional no obligatorio en las que van a participar; en la otra mitad de los países solo pueden proponer esas actividades. Sin embargo, en un tercio de estos países, las decisiones o propuestas de los docentes deben ser validadas por la dirección del centro escolar; y en la mitad de países la dirección del centro escolar es la que las propone (Gráfico D7.2b). En Suecia, los docentes y la dirección del centro escolar pueden intervenir de manera extraoficial en su propio desarrollo profesional, pero son las autoridades educativas locales y regionales las responsables de ofrecer actividades para el desarrollo profesional de los profesores. En Dinamarca, solo la dirección del centro escolar determina las actividades de desarrollo profesional de los docentes.

Solo en ocho países, la inspección de enseñanza desempeña un papel decisivo en las actividades de desarrollo profesional no obligatorio de los profesores. En seis de estos países, la inspección de enseñanza puede proponer dichas actividades, en Austria es la que decide qué actividades van a realizar los profesores de educación primaria y secundaria, y en Israel las valida. Del mismo modo, en un tercio de los países con datos disponibles, el papel de las autoridades educativas centrales, regionales y locales es principalmente proponer o validar estas actividades de desarrollo profesional. Solo en Turquía la autoridad educativa central es la encargada de determinar qué actividad profesional no obligatoria realiza el profesorado (Tabla D7.3c y Tablas D7.3a, b y d, disponibles en Internet). 


\section{Gráfico D7.2b. ¿Quién decide las actividades de desarrollo profesional no obligatorio que deben realizar los profesores? (2013)}

Para profesores que imparten materias generales en instituciones públicas de educación secundaria inferior

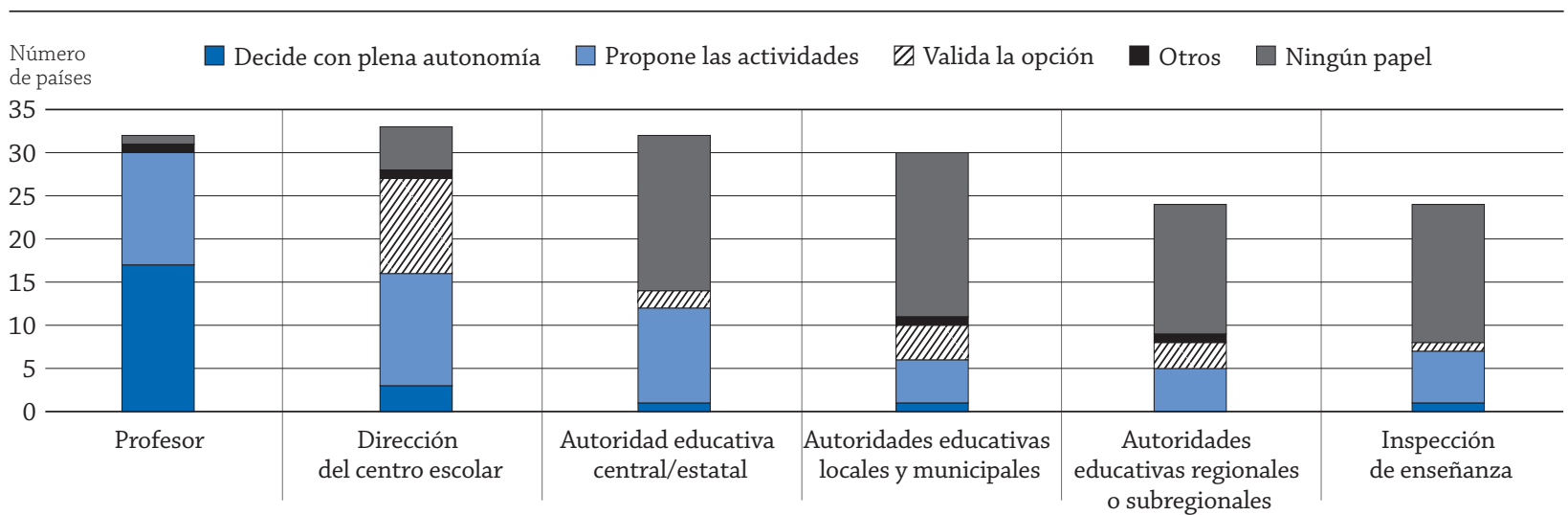

Las instituciones están clasificadas en orden descendente del número de países que refieren que estas instituciones desempeñan un papel en la decisión sobre las actividades de desarrollo profesional no obligatorio que han de realizar los profesores.

Fuente: OCDE. Tabla D7.3c. Para ver notas, consulte Anexo 3 (www.oecd.org/edu/eag.htm).

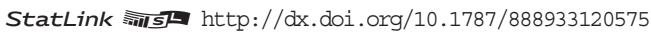

\section{Financiación y estrategias de apoyo para el desarrollo profesional}

El desarrollo profesional puede estar financiado por gobiernos, empresas y personas, o mediante acuerdos de cofinanciación. Los gobiernos pueden proporcionar estrategias de apoyo y financiación cuando los costes de las actividades de desarrollo profesional están subvencionados o compartidos por el gobierno para incentivar a los profesores a participar en su desarrollo profesional. Estas estrategias incluyen la provisión de fondos para cubrir los costes de formación, la pérdida de ingresos (es decir, permiso con sueldo durante la formación) y el coste de sustitución de profesores.

Todos los países de la OCDE con planes de desarrollo profesional obligatorio cuentan con estrategias de apoyo y de financiación. La mitad de los países con datos disponibles sufragan totalmente los planes de desarrollo profesional obligatorio. En 11 países, el coste de los planes para profesores de educación infantil se cubre totalmente y en otros 10 países está parcialmente cubierto. En 14 países, el coste de estos planes para los profesores de educación primaria y de educación secundaria inferior está totalmente cubierto, y en 8 países, parcialmente financiado. En 12 países, el coste para los profesores de educación secundaria superior está totalmente cubierto y en 9 países está parcialmente financiado (Gráfico D7.3a y Tablas D7.1a, b y d, disponibles en Internet).

\section{Gráfico D7.3a. Financiación y estrategias de apoyo \\ para el desarrollo profesional obligatorio (2013)}

Para profesores que imparten materias generales en instituciones públicas de educación secundaria inferior

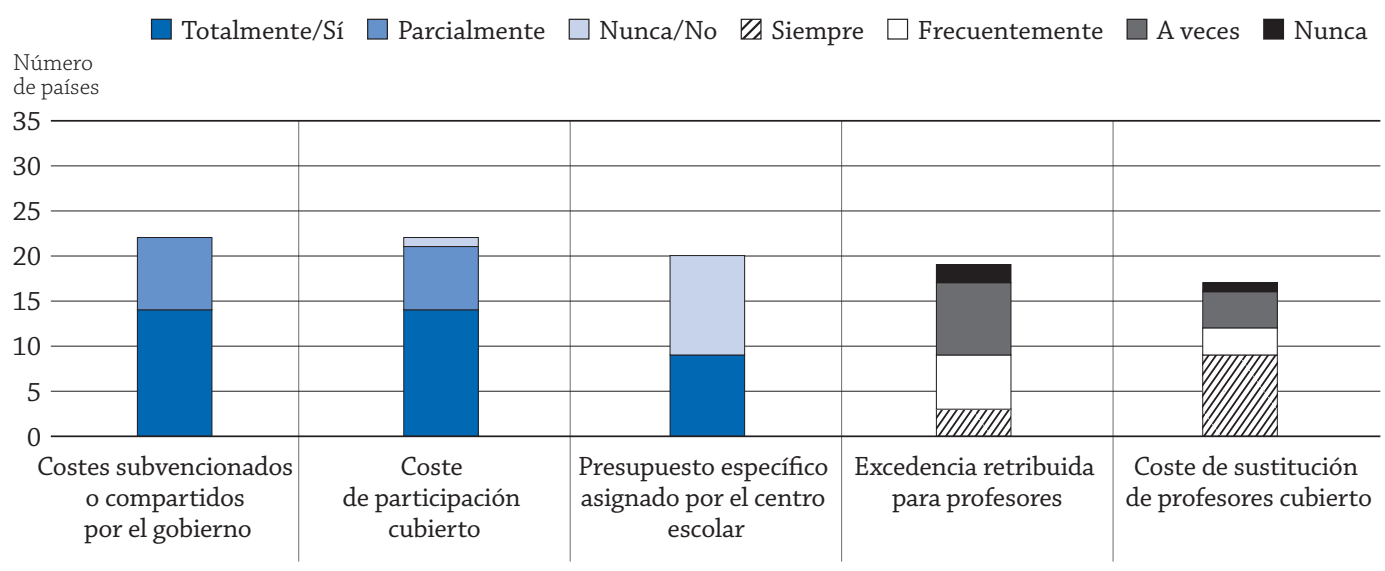

Fuente: OCDE. Tabla D7.1c. Para ver notas, consulte Anexo 3 (www.oecd.org/edu/eag.htm).

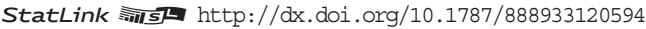


En general, las tasas de participación en los cursos de desarrollo profesional obligatorio están total o parcialmente financiadas en todos los países que requieren actividades obligatorias, a excepción de Chile y Japón (cuando es para la recertificación), donde los costes de participación nunca se cubren. En Alemania, Eslovenia y Federación Rusa, la pérdida de ingresos de los profesores (mientras están formándose) y el coste de los profesores sustitutos están siempre sufragados. En cambio, estos costes nunca se cubren en Japón (si dicho desarrollo profesional es para la recertificación) ni en España. No obstante, en aproximadamente la mitad de los países, el coste de los profesores sustitutos sí queda cubierto. En el resto de países, la pérdida de ingresos de los profesores y el coste de los profesores sustitutos no siempre están cubiertos. En la mitad de los países, los centros educativos incluso contemplan un presupuesto adicional para las actividades de desarrollo profesional obligatorio para los profesores (Tabla D7.1c y Tablas D7.1a, b y d, disponibles en Internet).

Por otro lado, el coste de los planes de desarrollo profesional no obligatorio rara vez están sufragados en su totalidad en los países de la OCDE y países asociados con datos disponibles. Para los profesores de educación secundaria inferior de Alemania, Bélgica (Comunidad flamenca), Grecia, Israel y México, el coste de estos planes está totalmente cubierto, y parcialmente cubierto en 21 países, pero no así en Bélgica (Comunidad francófona), Estonia y República Eslovaca. Tres cuartas partes de los países que disponen de datos afirmaron que las tasas de participación en estas actividades están parcialmente costeadas, y en el resto de países las tasas se financian totalmente. Además, en algunos países de la OCDE, a los profesores de educación secundaria inferior se les abona un permiso de ausencia por asistir a estos cursos a veces (11 países), a menudo (4 países) o siempre (3 países). Sin embargo, esto no ocurre en España, Israel, Japón y Luxemburgo en el caso de los profesores de educación secundaria inferior. El coste de sustitución de profesores está financiado en 7 países y a menudo financiado en otros 10 países. Sin embargo, estos costes no se sufragan en España. En 9 países, los centros educativos asignan un presupuesto adicional para actividades de desarrollo profesional no obligatorio para profesores (Gráfico D7.3b y Tabla D7.3c) y cuentan con estrategias similares de apoyo y de financiación para profesores de educación infantil, primaria y secundaria superior (Tablas D7.3a, b y d, disponibles en Internet).

\section{Gráfico D7.3b. Financiación y estrategias de apoyo para el desarrollo profesional no obligatorio (2013)}

Para profesores que imparten materias generales en instituciones públicas de educación secundaria inferior

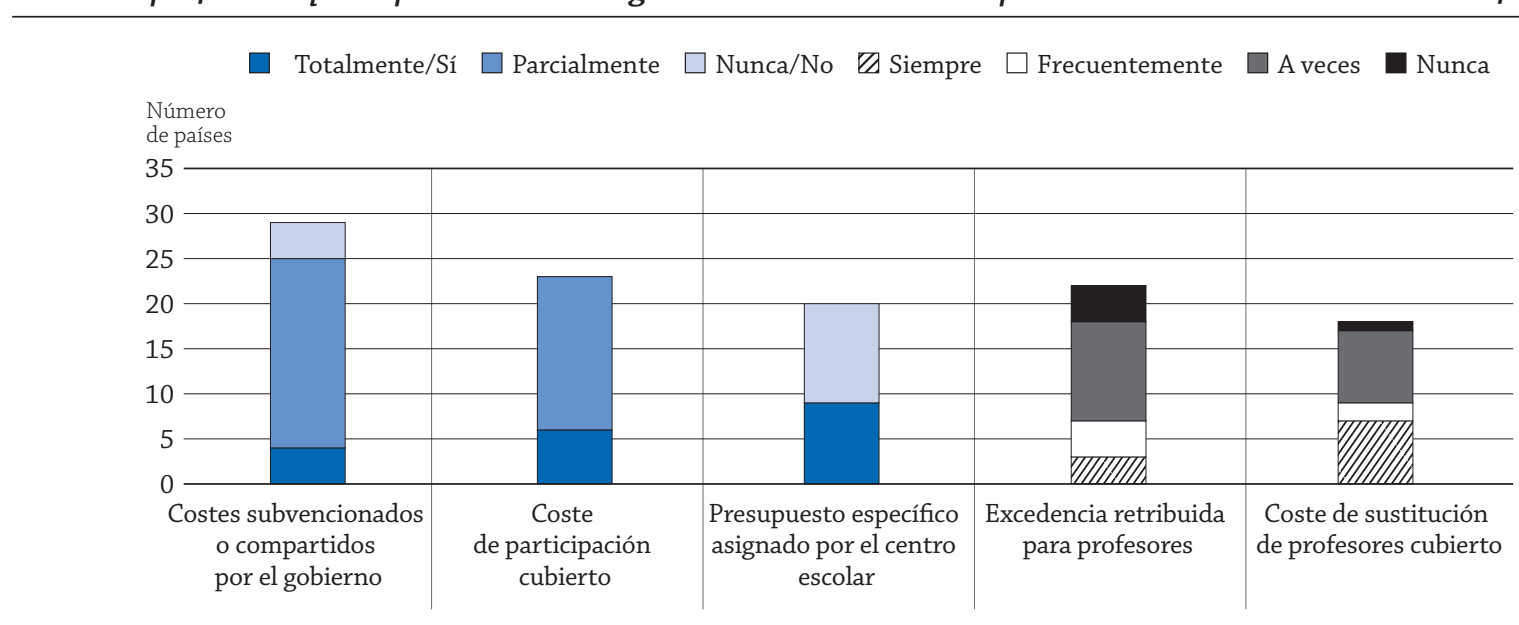

Fuente: OCDE. Tabla D7.3c. Para ver notas, consulte Anexo 3 (www.oecd.org/edu/eag.htm).

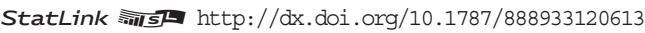

\section{Proveedores de las actividades de desarrollo profesional}

En algunos países, el uso de fondos públicos destinados a actividades de desarrollo profesional queda circunscrito a programas ofrecidos por un determinado grupo de organizaciones (instituciones educativas para profesores o agencias especializadas en desarrollo profesional). Esto puede reducir los incentivos de innovación y calidad, especialmente en aquellos países donde el desarrollo profesional es obligatorio. Por tanto, es importante tener varios proveedores para asegurar la calidad y las buenas prácticas (OECD, 2005).

El desarrollo profesional se promueve desde diferentes marcos institucionales y puede ofrecerse en las instituciones o a través de proveedores externos tales como institutos de formación y universidades. En todos los países de la 


\section{Cuadro D7.2. ¿Deben pagar los profesores por asistir a actividades de desarrollo profesional?}

Cada actividad de desarrollo profesional requiere un tipo de gasto diferente. Según el Estudio Internacional sobre Enseñanza y Aprendizaje TALIS 2013, más de la mitad de los profesores que participaron en actividades de desarrollo profesional afirmaron que no asumieron ningún coste, independientemente del tipo de programa (excepto los programas de cualificación), y el $10 \%$ o menos de los profesores tuvieron que asumir el coste total. Los programas de cualificación suelen exigir más compromiso (tanto en tiempo como en dinero) y suelen organizarse fuera de los centros escolares (es decir, en una universidad o centro universitario). Por ello no sorprende que sea en estos programas en los que con más probabilidad los profesores tengan que pagar total o parcialmente el coste.

\section{Gráfico D7.b. Nivel de contribución personal de los profesores para la participación en su desarrollo profesional (2013)}

Porcentaje de profesores de educación secundaria inferior que declaran haber participado en las siguientes actividades de desarrollo profesional y que "no pagó ningún coste», "pagó parte del coste» $\boldsymbol{o}$ "pagó todo el coste» de las actividades en las que participó ${ }^{1}$

No pagó ningún coste $\square$ Pagó parte del coste $\square$ Pagó todo el coste

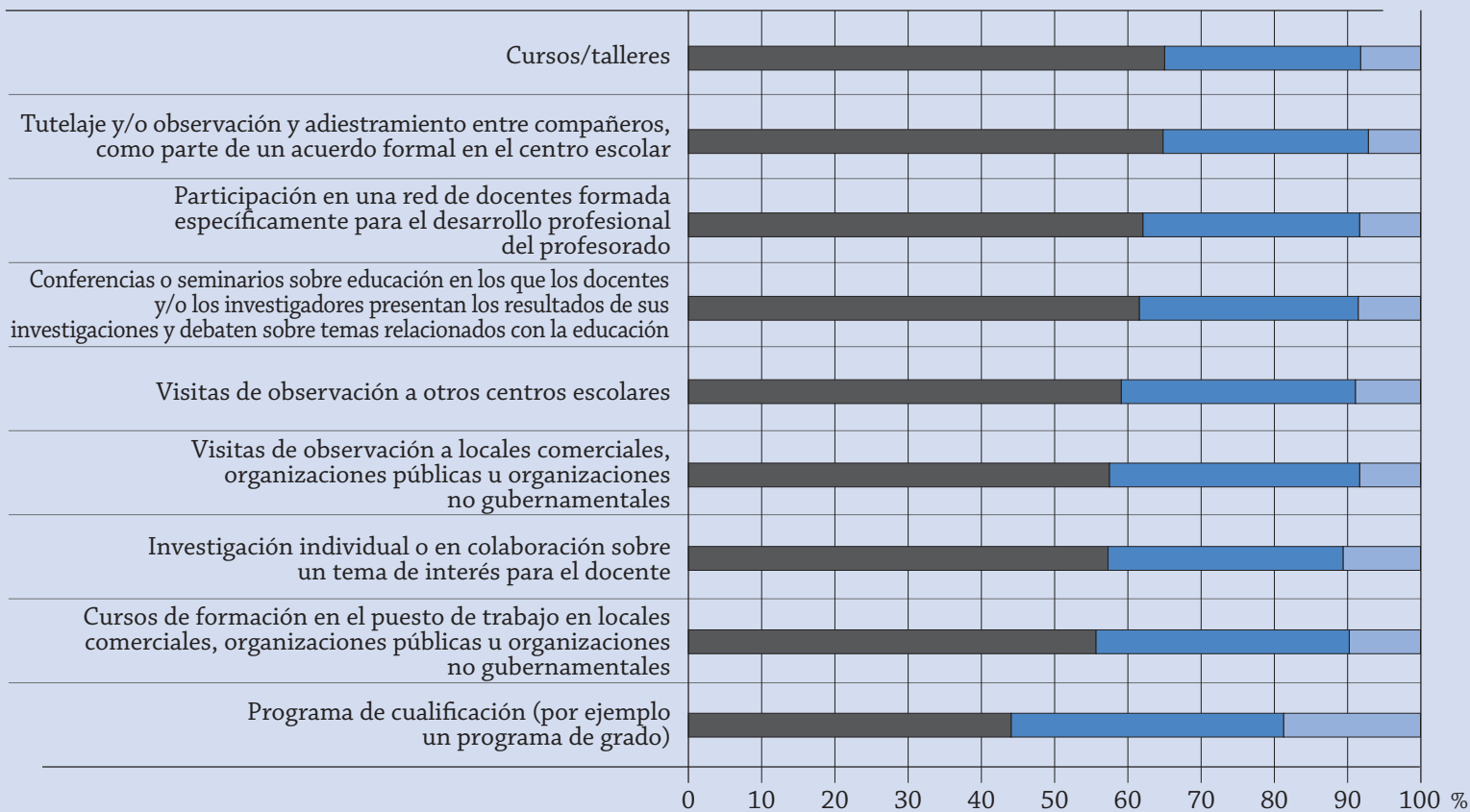

1. El profesorado puede participar en más de una actividad de desarrollo profesional al mismo tiempo. A los docentes no se les preguntó sobre su contribución al pago de cada actividad, sino sobre el nivel general de contribución personal al pago de todas las actividades de desarrollo profesional en las que participaron. Por lo tanto, los porcentajes que aparecen en este gráfico deberían interpretarse como el nivel de contribución personal al pago declarado por los docentes que participaron en cada tipo de actividad de desarrollo profesional.

Las actividades de desarrollo profesional están clasificadas en orden descendente del porcentajes medio de profesores que declararon no pagar ningún coste. Fuente: OECD (2014), TALIS 2013 Results: An International Perspective on Teaching and Learning, TALIS, OECD Publishing.

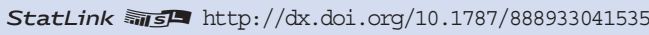

OCDE y países asociados excepto en Japón, las instituciones de educación superior imparten los programas de desarrollo profesional en todos los niveles educativos. Estas actividades también pueden cursarse en las instituciones de formación inicial del profesorado, excepto en Austria (en educación infantil y secundaria inferior y superior), Bélgica (Comunidad francófona), Islandia, Japón y Luxemburgo (en educación infantil y educación primaria). Asimismo, los centros escolares desempeñan un papel relevante organizando actividades de desarrollo profesional en todos los países menos en Austria (en educación primaria y educación secundaria inferior y superior), Federación Rusa, Islandia y República Checa. 
Además de las diferentes instituciones educativas, empresas privadas son los proveedores más habituales de actividades de desarrollo profesional: esto ocurre en cuatro de cada cinco países, excepto en Austria, España, Israel, Japón, Luxemburgo (en educación infantil, primaria y secundaria superior) y República Checa.

Dos tercios de los países también afirmaron que las instituciones que organizan estas actividades son agencias públicas de desarrollo profesional para profesores y/o organizaciones profesionales de profesores. Aproximadamente en la mitad de los países, dichas actividades las ofertan los sindicatos de profesores y las autoridades locales de educación. Solo en Austria (en formación profesional superior), Escocia, Francia, Grecia, Israel (en educación infantil), Italia, Luxemburgo (en educación infantil y primaria), Polonia y Turquía estas actividades para profesores son responsabilidad de la Inspección de Enseñanza (Tablas D7.4a, b, c y d, disponibles en Internet).

\section{Cuadro D7.3. ¿En qué tipo de actividades de desarrollo profesional participan los profesores?}

Los resultados del estudio TALIS 2013 sugieren que las actividades de desarrollo profesional donde más participan los profesores son los cursos y los talleres, con una media de participación del $71 \%$ de los profesores de secundaria inferior durante el periodo del estudio. De hecho, prácticamente en todos los países y economías participantes, la participación más frecuente se da en talleres y cursos, con un $80 \%$ de participación en algunos países y más de un $90 \%$ en Malasia, México y Singapur.

Las actividades más citadas después de los cursos y los talleres son las conferencias o los seminarios (un 44\%) y la participación en una red de profesores (un 37\%). Las actividades menos comunes de desarrollo profesional son las visitas de observación a empresas u otras organizaciones $(13 \%)$ y los cursos de prácticas en estas organizaciones $(14 \%)$.

\section{Gráfico D7.c. Desarrollo profesional reciente del profesorado, por tipo e intensidad (2013) Tasas de participación y número medio de días de cada tipo de actividad de desarrollo profesional que los profesores de educación secundaria inferior declararon haber realizado en los 12 meses anteriores al estudio}

\begin{tabular}{|c|c|c|}
\hline & $\begin{array}{c}\text { Porcentaje de profesores que } \\
\text { participaron en las siguientes actividades } \\
\text { de desarrollo profesional en los } 12 \text { meses } \\
\text { anteriores al estudio }\end{array}$ & $\begin{array}{l}\text { Número medio } \\
\text { de dias de } \\
\text { participación de } \\
\text { los participantes }\end{array}$ \\
\hline Cursos/Talleres & $71 \%$ & 8 \\
\hline $\begin{array}{r}\text { Conferencias o seminarios sobre educación en los que los docentes } \\
\text { y/o los investigadores presentan los resultados de sus investigaciones } \\
\text { y debaten sobre temas relacionados con la educación }\end{array}$ & $44 \%$ & 4 \\
\hline Visitas de observación a otros centros escolares & $\square 19 \%$ & 3 \\
\hline $\begin{array}{r}\text { Cursos de formación en el puesto de trabajo en locales comerciales, } \\
\text { organizaciones públicas u organizaciones no gubernamentales }\end{array}$ & $14 \%$ & 7 \\
\hline $\begin{array}{r}\text { Visitas de observación a locales comerciales, organizaciones públicas } \\
\text { u organizaciones no gubernamentales }\end{array}$ & $13 \%$ & 3 \\
\hline $\begin{array}{r}\text { Participación en una red de docentes formada específicamente } \\
\text { para el desarrollo profesional del profesorado }\end{array}$ & $37 \%$ & \\
\hline $\begin{array}{r}\text { Investigación individual o en colaboración sobre un tema } \\
\text { de interés para el docente }\end{array}$ & $31 \%$ & \\
\hline $\begin{array}{r}\text { Tutelaje y/o observación y adiestramiento entre compañeros, } \\
\text { como parte de un acuerdo formal en el centro escolar }\end{array}$ & $29 \%$ & \\
\hline Programa de cualificación (por ejemplo, un programa de grado) & $18 \%$ & \\
\hline
\end{tabular}

En cada bloque los elementos están clasificados en orden descendente del porcentaje de profesores que declararon haber participado en actividades de desarrollo. profesional en los 12 meses anteriores al estudio.

Fuente: OECD (2014), TALIS 2013 Results: An International Perspective on Teaching and Learning, TALIS, OECD Publishing.

StatLink 젝ㄴ http://dx.doi.org/10.1787/888933041554 


\section{Difusión de las actividades de desarrollo profesional de los profesores}

En todos los niveles educativos, la dirección del centro escolar desempeña un papel clave al facilitar información sobre actividades de desarrollo profesional. De los 34 países de la OCDE y países asociados, solo en Finlandia y en Suecia la dirección de los centros educativos no es formalmente responsable de la difusión de este tipo de información. Aproximadamente en dos tercios de los países, las autoridades estatales y/o centrales de educación son también responsables de informar sobre las actividades de desarrollo profesional. Algo más de la mitad de los países afirmaron que las autoridades regionales o locales de educación desempeñan un papel importante en esa difusión. La inspección de enseñanza además proporciona esta información a los profesores en Austria (en educación infantil y formación profesional superior), Escocia, Francia, Grecia, Israel, Italia, Luxemburgo (en educación infantil, primaria y secundaria inferior) y Polonia (Tablas D7.4a, b, c, y d, disponibles en Internet).

\section{Participación en actividades de desarrollo profesional}

El porcentaje de profesores que participan en actividades de desarrollo profesional varía mucho entre países. En los 14 países con datos disponibles, oscila desde la totalidad de los profesores en Austria (en educación primaria), Bélgica (Comunidad francófona), Escocia, Luxemburgo y Turquía (en educación infantil y primaria) y el $90 \%$ o más de los profesores de educación secundaria en Estados Unidos (en educación primaria y secundaria), Estonia (en educación primaria y secundaria), Israel (en educación infantil, primaria y secundaria inferior) y los Países Bajos hasta el $24 \%$ de los profesores de educación secundaria superior en Brasil. (Tablas D7.4a, b, c, y d, disponibles en Internet).

\section{Definiciones}

Actividades de desarrollo profesional son aquellas actividades diseñadas para desarrollar las competencias, los conocimientos y la experiencia de los profesores como docentes (o, más en general, como profesionales). Estas actividades son formales y pueden referirse a actividades como talleres y cursos, pero también a redes profesionales de colaboración y participación de los profesores. Por tanto, estas actividades de desarrollo profesional no se refieren a las prácticas diarias que también desarrollan profesionalmente a los profesores.

\section{Metodología}

Los datos provienen de la Encuesta sobre el desarrollo de conocimientos y competencias de los profesores OCDE-INES 2013 y corresponden al año escolar 2012-2013.

Notas sobre definiciones y metodologías para cada país se proporcionan en Anexo 3 (www.oecd.org/edu/eag.htm).

Nota sobre los datos de Israel

Los datos estadísticos para Israel fueron proporcionados por las autoridades israelíes competentes bajo su responsabilidad. El uso de estos datos por parte de la OCDE se hace sin prejuzgar la situación de los Altos del Golán, Jerusalén Este y los asentamientos israelíes en Cisjordania de acuerdo con los términos del derecho internacional.

\section{Referencias}

Allensworth, E., S. Ponisciak, y C. Mazzeo (2009), The Schools Teachers Leave: Teacher Mobility in Chicago Public Schools, Consortium on Chicago School Research, University of Chicago, Chicago.

Clotfelter, C.T., H.F. Ladd, y J.L. Vigdor, «How and Why Do Teacher Credentials Matter for Student Achievement?», National Bureau of Economic Research, Working Paper 12828, enero de 2007, disponible en http://www.nber.org/papers/w12828.

Ewing, R. A., y D.L. Smith, «Retaining Quality Beginning Teachers in the Profession», English Teaching: Practice and Critique, mayo de 2003, Vol. 2, No. 1, 15-32, disponible en http://education.waikato.ac.nz/research/files/etpc/2003v2n1art2.pdf.

Headden, S., Beginners in the Classroom: What the Changing Demographics of Teaching Mean for Schools, Students, and Society, Carnegie Foundation for the Advancement of Teaching, marzo de 2014, disponible en http://www.carnegiefoundation.org/sites/default/files/new_teachers_carnegie_report.pdf.

Mueller, C.M. (2012), The Impact of Teacher Certification Programmes on Teacher Efficacy, Job Satisfaction, and Teacher Performance: A Comparison of Traditional and Alternative Certification, disponible en http://digitalcommons.wku.edu/diss/28.

OECD (2014), TALIS 2013 Results: An International Perspective on Teaching and Learning, OECD Publishing, París, disponible en http://dx.doi.org/10.1787/9789264196261-en

OECD (2005), Teachers Matter: Attracting, Developing and Retaining Effective Teachers, Education and Training Policy, OECD Publishing, París, disponible en http://dx.doi.org/10.1787/9789264018044-en. 
Rockoff, J. (2008), «Does Mentoring Reduce Turnover and Improve Skills of New Employees? Evidence from Teachers in New York City", National Bureau of Economic Research, Working Paper 13868, marzo de 2008, disponible en http://www.nber.org/papers/ w13868.

Yoon, K. S., T. Duncan, S. W.-Y. Lee, B. Scarloss y K. Shapley (2007), «Reviewing the evidence on how teacher professional development affects student achievement» (Issues \& Answers Report, REL 2007-No. 033), Washington, DC: U.S. Department of Education, Institute of Education Sciences, National Center for Education Evaluation and Regional Assistance, Regional Educational Laboratory Southwest, disponible en http://ies.ed.gov/ncee/edlabs/regions/southwest/pdf/REL_2007033.pdf.

\section{Tablas del Indicador D7}

StatLink त्नाजा http://dx.doi.org/10.1787/888933120461

WEB Tabla D7.1a Requisitos para el desarrollo profesional de los profesores, en educación infantil (2013)

WEB Tabla D7.1b Requisitos para el desarrollo profesional de los profesores, en educación primaria (2013)

Tabla D7.1c Requisitos para el desarrollo profesional de los profesores, en educación secundaria inferior (2013)

WEB Tabla D7.1d Requisitos para el desarrollo profesional de los profesores, en educación secundaria superior (2013)

WEB Tabla D7.2a Contenido de las actividades de desarrollo profesional obligatorio de los profesores, en educación infantil (2013)

WEB Tabla D7.2b Contenido de las actividades de desarrollo profesional obligatorio de los profesores, en educación primaria (2013)

Tabla D7.2c Contenido de las actividades de desarrollo profesional obligatorio de los profesores, en educación secundaria inferior (2013)

WEB Tabla D7.2d Contenido de las actividades de desarrollo profesional obligatorio de los profesores, en educación secundaria superior (2013)

WEB Tabla D7.3a Desarrollo profesional no obligatorio de los profesores, en educación infantil (2013)

WEB Tabla D7.3b Desarrollo profesional no obligatorio de los profesores, en educación primaria (2013)

Tabla D7.3c Desarrollo profesional no obligatorio de los profesores, en educación secundaria inferior (2013)

WEB Tabla D7.3d Desarrollo profesional no obligatorio de los profesores, en educación secundaria superior (2013)

WEB Tabla D7.4a Difusión de las actividades de desarrollo profesional de los profesores, en educación infantil (2013)

WEB Tabla D7.4b Difusión de las actividades de desarrollo profesional de los profesores, en educación primaria (2013)

WEB Tabla D7.4c Difusión de las actividades de desarrollo profesional de los profesores, en educación secundaria inferior (2013)

WEB Tabla D7.4d Difusión de las actividades de desarrollo profesional de los profesores, en educación secundaria superior (2013) 
Tabla D7.1c. [1/2] Requisitos para el desarrollo profesional de los profesores, en educación secundaria inferior (2013)

En instituciones públicas

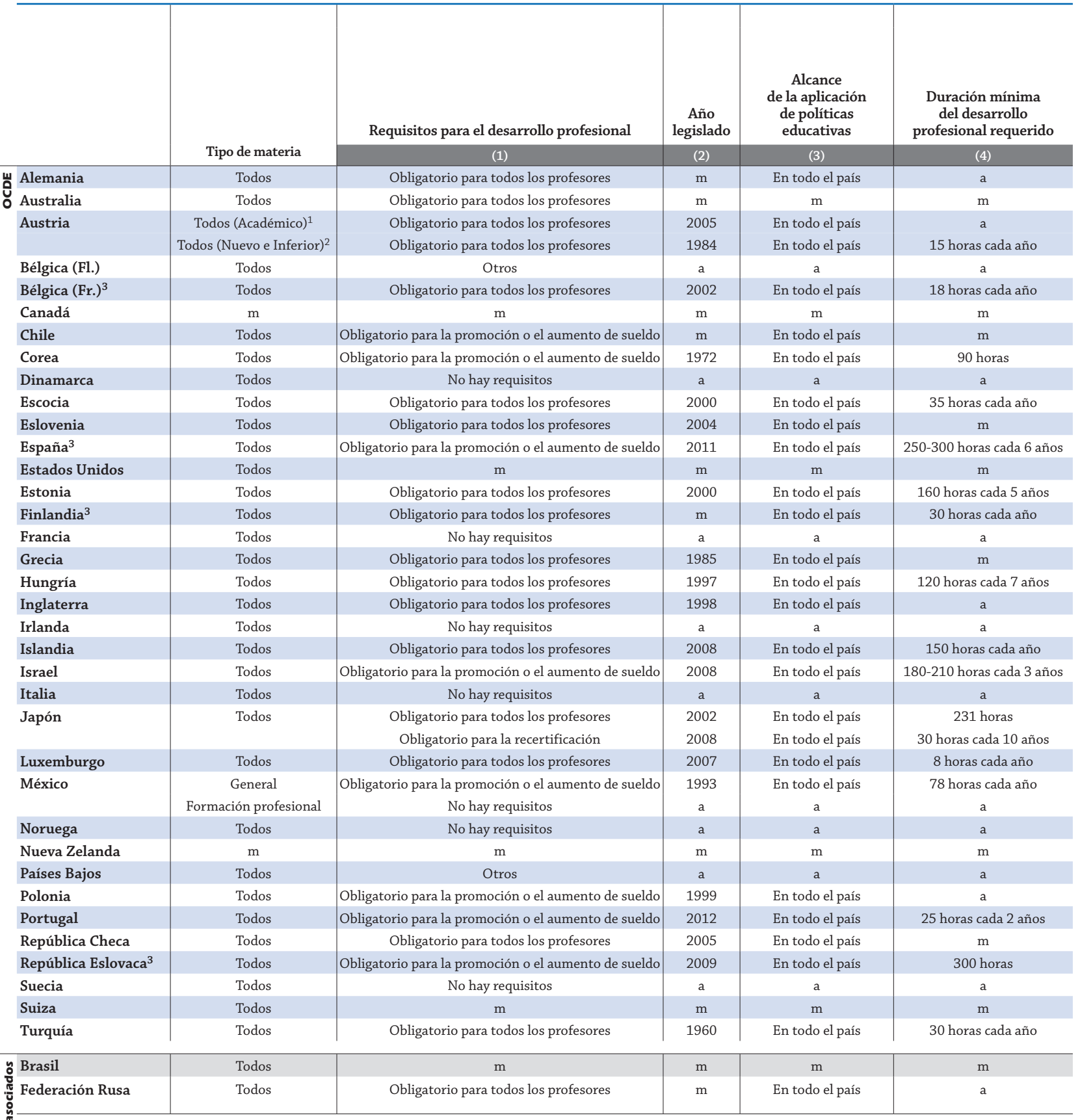

Papel al decidir las actividades de desarrollo profesional

DA: Decide con plena autonomía

PA: Propone las actividades

VO: Valida la opción

OT: Otros

NP: Ningún papel

Notas: Los estados federales o países con sistemas educativos altamente descentralizados pueden tener distintas normativas en cada estado, provincia o región. Para obtener más información, consulte Anexo 3.

1. «Todos (Académico)» se refiere a «Centro de educación secundaria inferior».

2. «Todos (Nuevo e Inferior)» se refiere a «Nuevo centro escolar de educación secundaria y a centro escolar de educación secundaria inferior».

3. Para la columna 4, la duración mínima de horas se estima sobre la base de los requisitos en una unidad diferente, a saber, el número de días, de semanas o de créditos. Para ver notas, consulte Anexo 3.

Fuente: OCDE. Para ver notas, consulte Anexo 3 (www.oecd.org/edu/eag.htm).

Para obtener más información acerca de los símbolos utilizados en lugar de los datos que faltan, consulte la Guía del lector.

StatLink त्ताज् http://dx.doi.org/10.1787/888933120480 
Tabla D7.1c. [2/2] Requisitos para el desarrollo profesional de los profesores, en educación secundaria inferior (2013)

En instituciones públicas

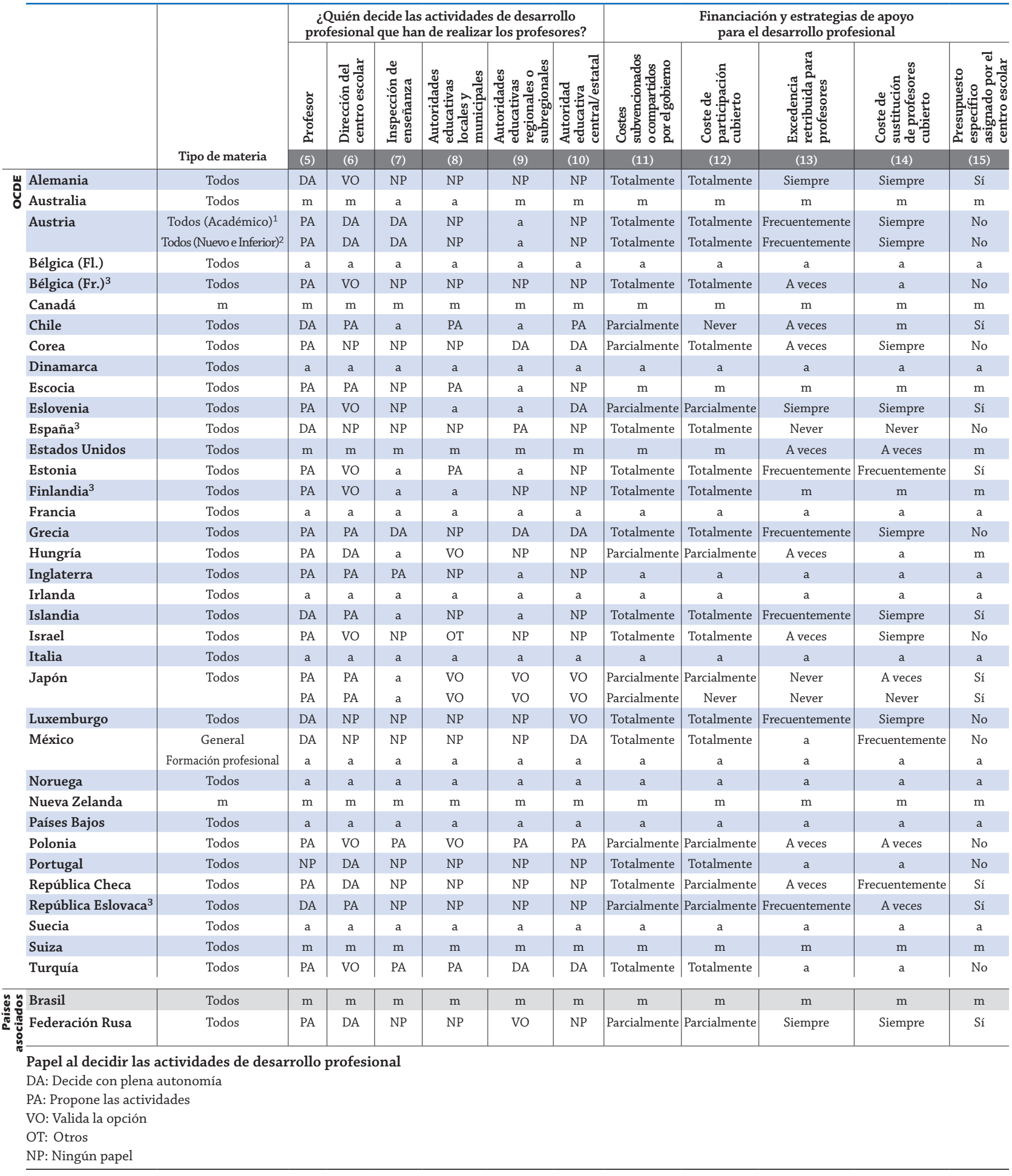

Notas: Los estados federales o países con sistemas educativos altamente descentralizados pueden tener distintas normativas en cada estado, provincia o región. Para obtener más información, consulte Anexo 3.

1. «Todos (Académico)» se refiere a «Centro de educación secundaria inferior».

2. «Todos (Nuevo e Inferior)» se refiere a «Nuevo centro escolar de educación secundaria y a centro escolar de educación secundaria inferior».

3. Para la columna 4, la duración mínima de horas se estima sobre la base de los requisitos en una unidad diferente, a saber, el número de días, de semanas o de créditos. Para ver notas, consulte Anexo 3.

Fuente: OCDE. Para ver notas, consulte Anexo 3 (www.oecd.org/edu/eag.htm).

Para obtener más información acerca de los símbolos utilizados en lugar de los datos que faltan, consulte la Guía del lector.

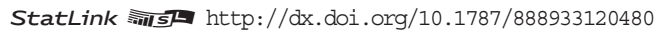


Tabla D7.2c. [1/2] Contenido de las actividades de desarrollo profesional obligatorio de los profesores, en educación secundaria inferior (2013)

En instituciones públicas

\begin{tabular}{|c|c|c|c|c|}
\hline & & $\begin{array}{c}\text { Requisitos } \\
\text { para el desarrollo profesional }\end{array}$ & $\begin{array}{c}\text { Requisitos } \\
\text { para la planificación } \\
\text { del desarrollo profesional }\end{array}$ & $\begin{array}{c}\text { Actividades de desarrollo } \\
\text { profesional planificadas } \\
\text { como actividades } \\
\text { prioritarias para } \\
\text { el desarrollo del centro } \\
\text { educativo }\end{array}$ \\
\hline & Tipo de materia & (1) & (2) & (3) \\
\hline Alemania & Todos & Obligatorio para todos los profesores & No existe plan & Sí, pero no exclusivamente \\
\hline Australia & Todos & Obligatorio para todos los profesores & $\mathrm{m}$ & $\mathrm{m}$ \\
\hline Austria & $\begin{array}{c}\text { Todos (Académico) })^{1} \\
\text { Todos (Nuevo e Inferior) }{ }^{2}\end{array}$ & $\begin{array}{l}\text { Obligatorio para todos los profesores } \\
\text { Obligatorio para todos los profesores }\end{array}$ & $\begin{array}{l}\text { No existe plan } \\
\text { No existe plan }\end{array}$ & $\begin{array}{l}\text { Sí, pero no exclusivamente } \\
\text { Sí, pero no exclusivamente }\end{array}$ \\
\hline Bélgica (Fl.) & Todos & Otros & a & a \\
\hline Bélgica (Fr.) & Todos & Obligatorio para todos los profesores & Plan del profesor y del centro escolar & Sí, pero no exclusivamente \\
\hline Canadá & $\mathrm{m}$ & $\mathrm{m}$ & $\mathrm{m}$ & $\mathrm{m}$ \\
\hline Chile & Todos & Obligatorio para la promoción o el aumento de sueldo & $\mathrm{m}$ & Sí, pero no exclusivamente \\
\hline Corea & Todos & Obligatorio para la promoción o el aumento de sueldo & Plan del profesor y del centro escolar & No \\
\hline Escocia & Todos & Obligatorio para todos los profesores & Plan del profesor & Sí, pero no exclusivamente \\
\hline Eslovenia & Todos & Obligatorio para todos los profesores & Plan del profesor y del centro escolar & Sí, pero no exclusivamente \\
\hline España & Todos & Obligatorio para la promoción o el aumento de sueldo & No existe plan & No \\
\hline Estados Unidos & Todos & $\mathrm{m}$ & $\mathrm{m}$ & Sí, pero no exclusivamente \\
\hline Estonia & Todos & Obligatorio para todos los profesores & Plan del profesor & Sí, pero no exclusivamente \\
\hline Finlandia & Todos & Obligatorio para todos los profesores & No existe plan & $\mathrm{m}$ \\
\hline Francia & Todos & No hay requisitos & a & $\mathrm{a}$ \\
\hline Grecia & Todos & Obligatorio para todos los profesores & Plan del centro escolar & Sí, pero no exclusivamente \\
\hline Hungría & Todos & Obligatorio para todos los profesores & Plan del centro escolar & Sí, pero no exclusivamente \\
\hline Inglaterra & Todos & Obligatorio para todos los profesores & Plan del profesor y del centro escolar & Sí, pero no exclusivamente \\
\hline Irlanda & Todos & No hay requisitos & a & a \\
\hline Islandia & Todos & Obligatorio para todos los profesores & Plan del centro escolar & Sí, pero no exclusivamente \\
\hline Israel & Todos & Obligatorio para la promoción o el aumento de sueldo & Plan del profesor y del centro escolar & Sí, pero no exclusivamente \\
\hline Italia & Todos & No hay requisitos & a & a \\
\hline Japón & Todos & $\begin{array}{l}\text { Obligatorio para todos los profesores } \\
\text { Obligatorio para la recertificación }\end{array}$ & $\begin{array}{l}\text { Plan del profesor y del centro escolar } \\
\text { Plan del profesor y del centro escolar }\end{array}$ & $\begin{array}{l}\text { Sí, exclusivamente } \\
\text { Sí, exclusivamente }\end{array}$ \\
\hline Luxemburgo & Todos & Obligatorio para todos los profesores & No existe plan & No \\
\hline México & $\begin{array}{l}\text { General } \\
\text { Formación profesional }\end{array}$ & $\begin{array}{l}\text { Obligatorio para la promoción o el aumento de sueldo } \\
\text { No hay requisitos }\end{array}$ & $\begin{array}{c}\text { Plan del profesor y del centro escolar } \\
\text { a }\end{array}$ & $\begin{array}{c}\text { No } \\
\text { a }\end{array}$ \\
\hline Noruega & Todos & No hay requisitos & a & a \\
\hline Nueva Zelanda & $\mathrm{m}$ & $\mathrm{m}$ & $\mathrm{m}$ & $\mathrm{m}$ \\
\hline Países Bajos & Todos & Otros & a & a \\
\hline Polonia & Todos & Obligatorio para la promoción o el aumento de sueldo & Plan del profesor y del centro escolar & Sí, pero no exclusivamente \\
\hline Portugal & Todos & Obligatorio para la promoción o el aumento de sueldo & Plan del profesor y del centro escolar & Sí, pero no exclusivamente \\
\hline República Checa & Todos & Obligatorio para todos los profesores & Plan del centro escolar & Sí, exclusivamente \\
\hline República Eslovaca & Todos & Obligatorio para la promoción o el aumento de sueldo & Plan del profesor y del centro escolar & Sí, exclusivamente \\
\hline Suecia & Todos & No hay requisitos & a & a \\
\hline Suiza & Todos & $\mathrm{m}$ & $\mathrm{m}$ & $\mathrm{m}$ \\
\hline Turquía & Todos & Obligatorio para todos los profesores & Plan del profesor & Sí, pero no exclusivamente \\
\hline Brasil & Todos & $\mathrm{m}$ & $\mathrm{m}$ & $\mathrm{m}$ \\
\hline Federación Rusa & Todos & Obligatorio para todos los profesores & Plan del centro escolar & Sí, exclusivamente \\
\hline
\end{tabular}

Notas: Las columnas individuales que muestran quién establece los estándares y las áreas de contenido para el desarrollo profesional, es decir, universidades, centros escolares, otros proveedores de educación (columnas 6 a 8), organizaciones profesionales de profesores y sindicatos de profesores (columnas 10 a 11 ), autoridades educativas locales, municipales, regionales, subregionales o autoridades educativas centrales y estatales (columnas 13 a 15), inspección de enseñanza u otros (columnas 17 a 18) están disponibles en Internet (véase StatLink más abajo).

Los estados federales o países con sistemas educativos altamente descentralizados pueden tener distintas normativas en cada estado, provincia o región. Para obtener más información, consulte Anexo 3.

1. «Todos (Académico)» se refiere a «Centro de educación secundaria inferior».

2. «Todos (Nuevo e Inferior)» se refiere a «Nuevo centro escolar de educación secundaria y a centro escolar de educación secundaria inferior».

Fuente: OCDE. Para ver notas, consulte Anexo 3 (www.oecd.org/edu/eag.htm).

Para obtener más información acerca de los símbolos utilizados en lugar de los datos que faltan, consulte la Guía del lector.

StatLink 제개 http://dx.doi.org/10.1787/888933120499 
Tabla D7.2c. [2/2] Contenido de las actividades de desarrollo profesional obligatorio de los profesores, en educación secundaria inferior (2013)

En instituciones públicas

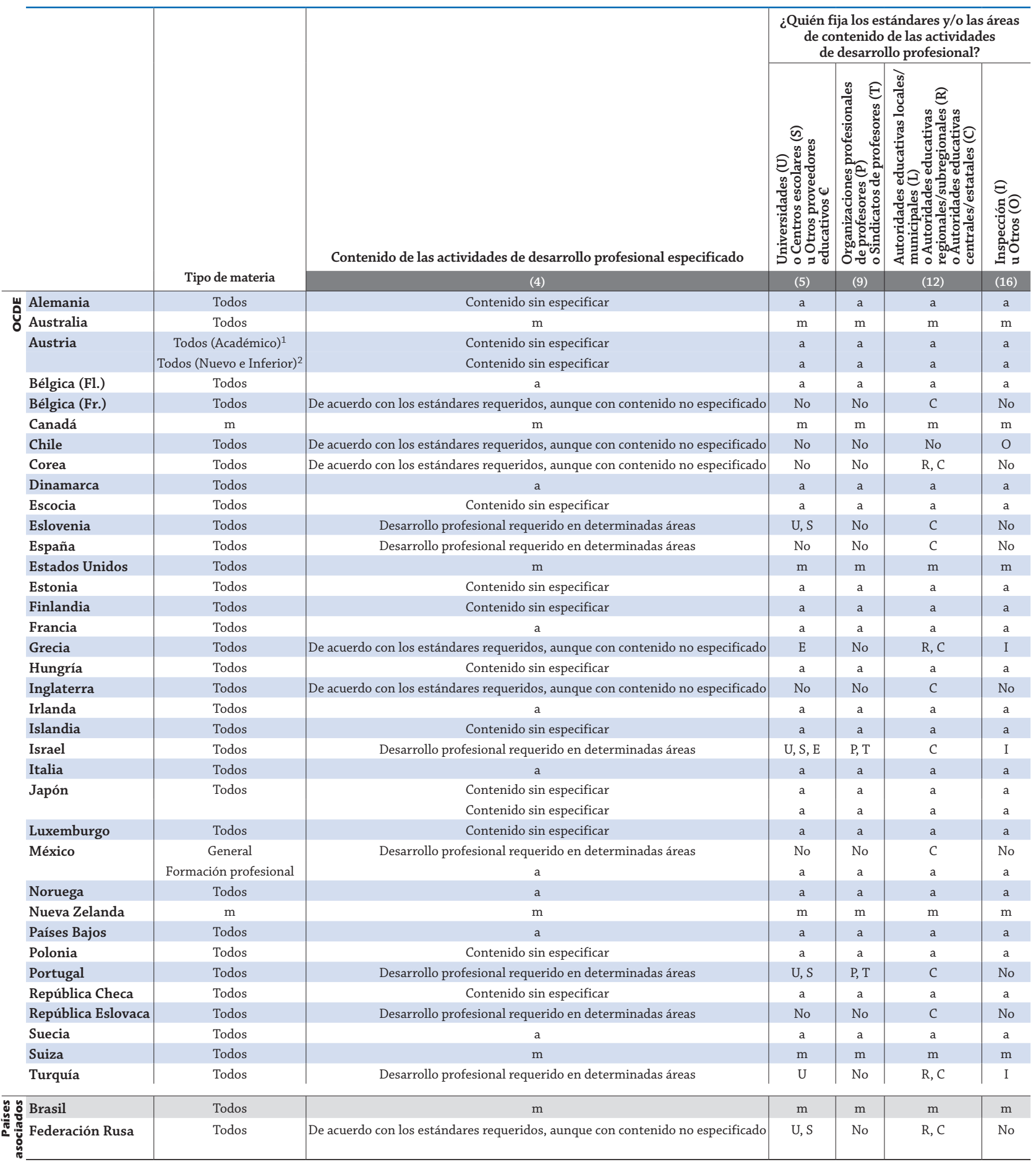

Notas: Las columnas individuales que muestran quién establece los estándares y las áreas de contenido para el desarrollo profesional, es decir, universidades, centros escolares, otros proveedores de educación (columnas 6 a 8), organizaciones profesionales de profesores y sindicatos de profesores (columnas 10 a 11 ), autoridades educativas locales, municipales, regionales, subregionales o autoridades educativas centrales y estatales (columnas 13 a 15), inspección de enseñanza u otros (columnas 17 a 18) están disponibles en Internet (véase StatLink más abajo).

Los estados federales o países con sistemas educativos altamente descentralizados pueden tener distintas normativas en cada estado, provincia o región. Para obtener más información, consulte Anexo 3.

1. «Todos (Académico)» se refiere a «Centro de educación secundaria inferior».

2. «Todos (Nuevo e Inferior)» se refiere a «Nuevo centro escolar de educación secundaria y a centro escolar de educación secundaria inferior».

Fuente: OCDE. Para ver notas, consulte Anexo 3 (www.oecd.org/edu/eag.htm).

Para obtener más información acerca de los símbolos utilizados en lugar de los datos que faltan, consulte la Guía del lector.

StatLink 제개 http://dx.doi.org/10.1787/888933120499 
Tabla D7.3c [1/2] Desarrollo profesional no obligatorio de los profesores, en educación secundaria inferior (2013)

En instituciones públicas

\begin{tabular}{|c|c|c|c|c|c|c|c|c|}
\hline & \multirow[b]{3}{*}{ Tipo de materia } & \multicolumn{7}{|c|}{ ¿Quién decide las actividades de desarrollo profesional que han de realizar los profesores? } \\
\hline & & Profesor & $\begin{array}{l}\text { Dirección del } \\
\text { centro escolar }\end{array}$ & $\begin{array}{c}\text { Inspección } \\
\text { de enseñanza }\end{array}$ & $\begin{array}{c}\text { Autoridades } \\
\text { educativas locales } \\
\text { y municipales }\end{array}$ & $\begin{array}{l}\text { Autoridades } \\
\text { educativas } \\
\text { regionales o } \\
\text { subregionales }\end{array}$ & \begin{tabular}{|c|} 
Autoridad \\
educativa \\
central/estatal
\end{tabular} & Otros \\
\hline & & (1) & $(2)$ & (3) & (4) & $(5)$ & (6) & (7) \\
\hline Alemania & Todos & DA & VO & NP & NP & NP & NP & a \\
\hline Australia & Todos & $\mathrm{m}$ & $\mathrm{m}$ & a & $\mathrm{a}$ & $\mathrm{m}$ & $\mathrm{m}$ & $\mathrm{m}$ \\
\hline Austria & Todos (Académico) ${ }^{1}$ & $\mathrm{PA}$ & DA & DA & NP & a & NP & a \\
\hline & Todos (Nuevo e Inferior) ${ }^{2}$ & $\mathrm{PA}$ & DA & DA & NP & a & NP & a \\
\hline Bélgica (Fl.) & Todos & PA & $\mathrm{PA}$ & NP & NP & NP & $\mathrm{PA}$ & $\mathrm{a}$ \\
\hline Bélgica (Fr.) & Todos & DA & VO & NP & NP & NP & PA & a \\
\hline Canadá & $\mathrm{m}$ & $\mathrm{m}$ & $\mathrm{m}$ & $\mathrm{m}$ & $\mathrm{m}$ & $\mathrm{m}$ & $\mathrm{m}$ & $\mathrm{m}$ \\
\hline Chile & Todos & DA & VO & $\mathrm{a}$ & NP & $\mathrm{a}$ & $\mathrm{PA}$ & a \\
\hline Corea & Todos & DA & $\mathrm{PA}$ & $\mathrm{PA}$ & $\mathrm{PA}$ & $\mathrm{PA}$ & $\mathrm{PA}$ & a \\
\hline Escocia & Todos & PA & $\mathrm{PA}$ & NP & PA & $\mathrm{a}$ & NP & $\mathrm{m}$ \\
\hline Eslovenia & Todos & DA & VO & a & a & a & $\mathrm{PA}$ & $\mathrm{a}$ \\
\hline España & Todos & DA & NP & NP & NP & NP & VO & $\mathrm{a}$ \\
\hline Estados Unidos & Todos & $\mathrm{m}$ & $\mathrm{m}$ & $\mathrm{m}$ & $\mathrm{m}$ & $\mathrm{m}$ & $\mathrm{m}$ & $\mathrm{m}$ \\
\hline Estonia & Todos & DA & $\mathrm{PA}$ & $\mathrm{a}$ & $\mathrm{PA}$ & a & NP & $\mathrm{a}$ \\
\hline Finlandia & Todos & $\mathrm{PA}$ & vo & $\mathrm{a}$ & $\mathrm{a}$ & NP & NP & a \\
\hline Francia & Todos & PA & VO & $\mathrm{PA}$ & NP & NP & VO & PA \\
\hline Grecia & Todos & DA & $\mathrm{PA}$ & $\mathrm{PA}$ & NP & $\mathrm{PA}$ & $\mathrm{PA}$ & a \\
\hline Hungría & Todos & $\mathrm{PA}$ & NP & $\mathrm{NP}$ & NP & NP & NP & a \\
\hline Inglaterra & Todos & DA & $\mathrm{PA}$ & NP & NP & $\mathrm{a}$ & NP & a \\
\hline Irlanda & Todos & PA & PA & NP & $\mathrm{a}$ & $\mathrm{a}$ & PA & a \\
\hline Islandia & Todos & PA & $\mathrm{PA}$ & a & NP & a & NP & a \\
\hline Israel & Todos & DA & VO & VO & OT & OT & NP & a \\
\hline Luxemburgo & Todos & DA & $\mathrm{PA}$ & NP & NP & NP & NP & NP \\
\hline México & $\begin{array}{l}\text { General } \\
\text { Formación profesional }\end{array}$ & $\begin{array}{c}\text { DA } \\
\mathrm{a}\end{array}$ & $\begin{array}{c}\text { NP } \\
\text { a }\end{array}$ & $\begin{array}{c}\mathrm{NP} \\
\mathrm{a}\end{array}$ & $\begin{array}{c}\text { NP } \\
\mathrm{a}\end{array}$ & $\begin{array}{c}\mathrm{PA} \\
\mathrm{a}\end{array}$ & $\begin{array}{c}\mathrm{PA} \\
\mathrm{a}\end{array}$ & $\begin{array}{l}\mathrm{a} \\
\mathrm{a}\end{array}$ \\
\hline Nueva Zelanda & $\mathrm{m}$ & $\mathrm{m}$ & $\mathrm{m}$ & $\mathrm{m}$ & $\mathrm{m}$ & $\mathrm{m}$ & $\mathrm{m}$ & $\mathrm{m}$ \\
\hline Noruega & Todos & $\mathrm{m}$ & VO & $\mathrm{m}$ & VO & $\mathrm{m}$ & $\mathrm{m}$ & $\mathrm{a}$ \\
\hline Países Bajos & Todos & PA & $\mathrm{PA}$ & NP & NP & NP & NP & NP \\
\hline Polonia & Todos & DA & $\mathrm{PA}$ & $\mathrm{PA}$ & $\mathrm{PA}$ & $\mathrm{PA}$ & $\mathrm{PA}$ & a \\
\hline Portugal & Todos & DA & NP & NP & NP & NP & NP & NP \\
\hline República Checa & Todos & $\mathrm{PA}$ & DA & NP & NP & NP & NP & $\mathrm{a}$ \\
\hline República Eslovaca & Todos & DA & NP & NP & NP & NP & NP & NP \\
\hline Suecia & Todos & OT & OT & NP & DA & NP & NP & $\mathrm{a}$ \\
\hline Suiza & Todos & $\mathrm{m}$ & $\mathrm{m}$ & $\mathrm{m}$ & $\mathrm{m}$ & $\mathrm{m}$ & $\mathrm{m}$ & $\mathrm{m}$ \\
\hline Turquía & Todos & $\mathrm{PA}$ & $\mathrm{VO}$ & $\mathrm{PA}$ & VO & vo & DA & $\mathrm{a}$ \\
\hline Brasil & Todos & DA & VO & a & VO & VO & NP & $\mathrm{m}$ \\
\hline Federación Rusa & Todos & PA & VO & NP & NP & NP & NP & a \\
\hline
\end{tabular}

Papel al decidir las actividades de desarrollo profesional

DA: Decide con plena autonomía

PA: Propone las actividades

VO: Valida la opción

OT: Otros

NP: Ningún papel

Notas: Los estados federales o países con sistemas educativos altamente descentralizados pueden tener distintas normativas en cada estado, provincia o región. Para obtener más información, consulte Anexo 3.

1. «Todos (Académico)» se refiere a «Centro de educación secundaria inferior».

2. «Todos (Nuevo e Inferior)» se refiere a «Nuevo centro escolar de educación secundaria y a centro escolar de educación secundaria inferior».

Fuente: OCDE. See Annex 3 for notes (www.oecd.org/edu/eag.htm).

Para obtener más información acerca de los símbolos utilizados en lugar de los datos que DAltan, consulte la Guía del lector.

StatLink 제 जी http://dx.doi.org/10.1787/888933120518 
Tabla D7.3c [2/2] Desarrollo profesional no obligatorio de los profesores, en educación secundaria inferior (2013)

En instituciones públicas

\begin{tabular}{|c|c|c|c|c|c|c|c|c|}
\hline & & \multirow[b]{3}{*}{ Tipo de materia } & \multirow[b]{2}{*}{$\begin{array}{c}\text { Actividades de desarrollo } \\
\text { profesional planificadas } \\
\text { como actividades prioritarias } \\
\text { para el desarrollo del centro } \\
\text { educativo }\end{array}$} & \multicolumn{5}{|c|}{ Financiación y estrategias de apoyo para el desarrollo profesional } \\
\hline & & & & \begin{tabular}{|c} 
Costes \\
subvencionados \\
o compartidos \\
el gobierno
\end{tabular} & $\begin{array}{c}\text { Coste de } \\
\text { participación } \\
\text { cubierto }\end{array}$ & $\begin{array}{l}\text { Excedencia } \\
\text { retribuida } \\
\text { para } \\
\text { profesores }\end{array}$ & $\begin{array}{c}\text { Coste de } \\
\text { sustitución } \\
\text { de profesores } \\
\text { cubierto }\end{array}$ & $\begin{array}{l}\text { Presupuesto } \\
\text { específico } \\
\text { asignado por el } \\
\text { centro escolar }\end{array}$ \\
\hline & & & $(8)$ & (9) & $(10)$ & (11) & (12) & (13) \\
\hline \multirow{37}{*}{ :ّ } & Alemania & Todos & Sí, pero no exclusivamente & Totalmente & Totalmente & Siempre & Siempre & Sí \\
\hline & Australia & Todos & $\mathrm{m}$ & $\mathrm{m}$ & $\mathrm{m}$ & $\mathrm{m}$ & $\mathrm{m}$ & $\mathrm{m}$ \\
\hline & Austria & Todos $(\text { Academic) })^{1}$ & Sí, pero no exclusivamente & Parcialmente & Parcialmente & Frecuentemente & Siempre & No \\
\hline & & Todos ((Nuevo e Inferior $)^{2}$ & Sí, pero no exclusivamente & Parcialmente & Parcialmente & Frecuentemente & Siempre & No \\
\hline & Bélgica (Fl.) & Todos & Sí, pero no exclusivamente & Parcialmente & Parcialmente & Frecuentemente & a & Sí \\
\hline & Bélgica (Fr.) & Todos & No & Nunca & a & a & a & a \\
\hline & Canadá & $\mathrm{m}$ & $\mathrm{m}$ & $\mathrm{m}$ & $\mathrm{m}$ & $\mathrm{m}$ & $\mathrm{m}$ & $\mathrm{m}$ \\
\hline & Chile & Todos & Sí, pero no exclusivamente & Parcialmente & $\mathrm{m}$ & $\mathrm{m}$ & $\mathrm{m}$ & $\mathrm{m}$ \\
\hline & Corea & Todos & Sí, pero no exclusivamente & Parcialmente & Parcialmente & A veces & A veces & Sí \\
\hline & Dinamarca & Todos & Sí, pero no exclusivamente & Parcialmente & $\mathrm{m}$ & $\mathrm{m}$ & $\mathrm{m}$ & $\mathrm{m}$ \\
\hline & Escocia & Todos & Sí, pero no exclusivamente & $\mathrm{m}$ & $\mathrm{m}$ & $\mathrm{m}$ & $\mathrm{m}$ & $\mathrm{m}$ \\
\hline & Eslovenia & Todos & Sí, pero no exclusivamente & Parcialmente & Parcialmente & Siempre & Siempre & Sí \\
\hline & España & Todos & No & Parcialmente & Parcialmente & Nunca & Nunca & No \\
\hline & Estados Unidos & Todos & Sí, pero no exclusivamente & $\mathrm{m}$ & $\mathrm{m}$ & $\mathrm{m}$ & $\mathrm{m}$ & $\mathrm{m}$ \\
\hline & Estonia & Todos & No & Nunca & a & a & a & a \\
\hline & Finlandia & Todos & $\mathrm{m}$ & $\mathrm{m}$ & $\mathrm{m}$ & $\mathrm{m}$ & $\mathrm{m}$ & $\mathrm{m}$ \\
\hline & Francia & Todos & Sí, pero no exclusivamente & Parcialmente & Parcialmente & Siempre & A veces & No \\
\hline & Grecia & Todos & Sí, pero no exclusivamente & Totalmente & Totalmente & A veces & A veces & No \\
\hline & Hungría & Todos & Sí, pero no exclusivamente & $\mathrm{m}$ & $\mathrm{m}$ & $\mathrm{m}$ & $\mathrm{m}$ & $\mathrm{m}$ \\
\hline & Inglaterra & Todos & Sí, pero no exclusivamente & Parcialmente & Parcialmente & A veces & A veces & No \\
\hline & Irlanda & Todos & Sí, pero no exclusivamente & Parcialmente & Parcialmente & Frecuentemente & Frecuentemente & No \\
\hline & Islandia & Todos & Sí, pero no exclusivamente & Parcialmente & Totalmente & A veces & Siempre & $\mathrm{m}$ \\
\hline & Israel & Todos & Sí, pero no exclusivamente & Totalmente & Totalmente & Nunca & Siempre & Sí \\
\hline & Italia & Todos & Sí, pero no exclusivamente & Parcialmente & Totalmente & A veces & $A$ veces & Sí \\
\hline & Japón & Todos & Sí, exclusively & Parcialmente & Parcialmente & Nunca & $\mathrm{m}$ & Sí \\
\hline & Luxemburgo & Todos & Sí, pero no exclusivamente & Parcialmente & Parcialmente & Nunca & Siempre & No \\
\hline & México & $\begin{array}{l}\text { General } \\
\text { Formación profesional }\end{array}$ & $\begin{array}{c}\text { No } \\
\text { a }\end{array}$ & $\begin{array}{c}\text { Totalmente } \\
\text { a }\end{array}$ & $\begin{array}{c}\text { Totalmente } \\
\text { a }\end{array}$ & $\begin{array}{l}\mathrm{a} \\
\mathrm{a}\end{array}$ & $\begin{array}{l}\mathrm{a} \\
\mathrm{a}\end{array}$ & $\begin{array}{c}\text { No } \\
\text { a }\end{array}$ \\
\hline & Noruega & Todos & Sí, pero no exclusivamente & Parcialmente & Parcialmente & Frecuentemente & A veces & $\mathrm{m}$ \\
\hline & Nueva Zelanda & $\mathrm{m}$ & $\mathrm{m}$ & $\mathrm{m}$ & $\mathrm{m}$ & $\mathrm{m}$ & $\mathrm{m}$ & $\mathrm{m}$ \\
\hline & Países Bajos & Todos & $\mathrm{m}$ & Parcialmente & Parcialmente & A veces & A veces & Sí \\
\hline & Polonia & Todos & No & Parcialmente & Parcialmente & A veces & A veces & No \\
\hline & Portugal & Todos & Sí, pero no exclusivamente & Nunca & $\mathrm{a}$ & a & $\mathrm{a}$ & a \\
\hline & República Checa & Todos & Sí, exclusively & Parcialmente & Parcialmente & A veces & Frecuentemente & Sí \\
\hline & República Eslovaca & Todos & No & Nunca & a & a & a & a \\
\hline & Suecia & Todos & Sí, pero no exclusivamente & Parcialmente & Parcialmente & A veces & $\mathrm{m}$ & No \\
\hline & Suiza & Todos & $\mathrm{m}$ & $\mathrm{m}$ & $\mathrm{m}$ & $\mathrm{m}$ & $\mathrm{m}$ & $\mathrm{m}$ \\
\hline & Turquía & Todos & Sí, pero no exclusivamente & Parcialmente & Parcialmente & A veces & a & No \\
\hline \multirow{2}{*}{ 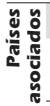 } & Brasil & Todos & No & Parcialmente & Parcialmente & A veces & Siempre & $\mathrm{m}$ \\
\hline & Federación Rusa & Todos & No & $\mathrm{m}$ & $\mathrm{m}$ & $\mathrm{m}$ & $\mathrm{m}$ & $\mathrm{m}$ \\
\hline
\end{tabular}

Papel al decidir las actividades de desarrollo profesional

DA: Decide con plena autonomía

PA: Propone las actividades

VO: Valida la opción

OT: Otros

NP: Ningún papel

Notas: Los estados federales o países con sistemas educativos altamente descentralizados pueden tener distintas normativas en cada estado, provincia o región. Para obtener más información, consulte Anexo 3.

1. «Todos (Académico)» se refiere a «Centro de educación secundaria inferior».

2. «Todos (Nuevo e Inferior)» se refiere a «Nuevo centro escolar de educación secundaria y a centro escolar de educación secundaria inferior».

Fuente: OCDE. See Annex 3 (www.oecd.org/edu/eag.htm).

Para obtener más información acerca de los símbolos utilizados en lugar de los datos que faltan, consulte la Guía del lector.

StatLink 게그 http://dx.doi.org/10.1787/888933120518 



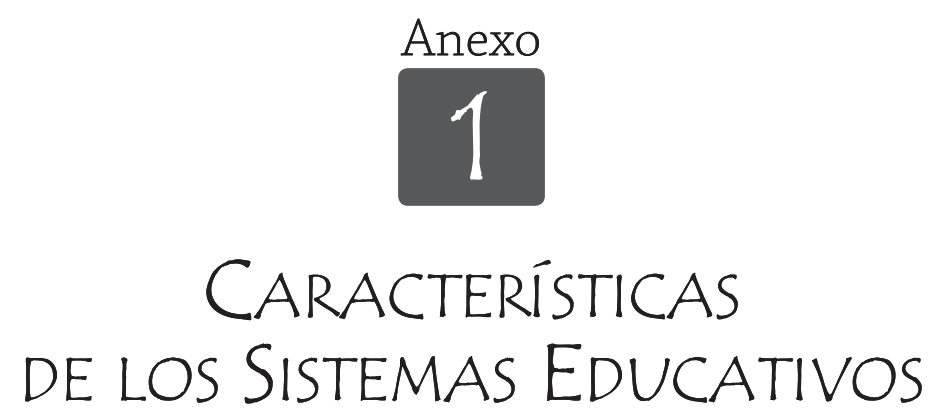

Todas las tablas del Anexo 1 están disponibles en Internet en:

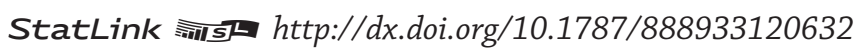


Tabla X1.1a. [1/2] Tasa de graduación en educación secundaria superior: edades típicas de graduación y método utilizado para calcular las tasas de graduación (2012)

La edad típica de graduación se refiere a la edad de los estudiantes al principio del año escolar; los estudiantes, por norma general, serán un año mayores que la edad indicada cuando consigan la graduación al final del año escolar. La edad típica se utiliza para el cálculo de las tasas brutas de graduación

\begin{tabular}{|c|c|c|c|c|c|c|c|}
\hline & \multicolumn{7}{|c|}{ Edades típicas de graduación } \\
\hline & \multirow[b]{2}{*}{$\begin{array}{c}\text { Graduados } \\
\text { por primera vez }\end{array}$} & \multicolumn{2}{|c|}{ Orientación del programa } & \multicolumn{4}{|c|}{ Destino al sistema educativo o al mercado laboral } \\
\hline & & $\begin{array}{c}\text { Programas } \\
\text { generales }\end{array}$ & $\begin{array}{c}\text { Programas } \\
\text { de formación } \\
\text { preprofesional } \\
\text { o profesional }\end{array}$ & $\begin{array}{l}\text { Programas } \\
\text { CINE 3A }\end{array}$ & $\begin{array}{l}\text { Programas } \\
\text { CINE 3B }\end{array}$ & $\begin{array}{c}\text { Programas } \\
\text { cortos CINE } 3 C^{1}\end{array}$ & $\begin{array}{c}\text { Programas } \\
\text { largos CINE } 3 C^{1}\end{array}$ \\
\hline Alemania & $19-20$ & $19-20$ & $19-20$ & $19-20$ & $19-20$ & $19-20$ & a \\
\hline Australia & 17 & 17 & 17 & 17 & a & 17 & 17 \\
\hline Austria & $17-18$ & $17-18$ & $17-19$ & $17-18$ & $17-19$ & $14-15$ & $16-17$ \\
\hline Bélgica & 18 & 18 & 18 & 18 & $\mathrm{a}$ & 18 & 18 \\
\hline Canadá & $17-18$ & $17-18$ & $17-18$ & $17-18$ & a & a & $17-18$ \\
\hline Chile & 17 & 17 & 17 & 17 & a & a & a \\
\hline Corea & 18 & 18 & 18 & 18 & a & a & 18 \\
\hline Dinamarca & $18-19$ & $18-19$ & $20-21$ & $18-19$ & a & 27 & $20-21$ \\
\hline Eslovenia & 18 & 18 & $16-18$ & 18 & 18 & 16 & 17 \\
\hline España & 17 & 17 & 17 & 17 & 17 & 17 & 17 \\
\hline Estados Unidos & 17 & 17 & $\mathrm{~m}$ & 17 & $\mathrm{~m}$ & $\mathrm{~m}$ & $\mathrm{~m}$ \\
\hline Estonia & 19 & 19 & 19 & 19 & 19 & a & 19 \\
\hline Finlandia & 19 & 19 & 19 & 19 & $\mathrm{a}$ & a & a \\
\hline Francia & $17-19$ & $17-18$ & $16-19$ & $17-18$ & $18-20$ & $16-18$ & $18-20$ \\
\hline Grecia & 18 & 18 & 18 & 18 & $\mathrm{a}$ & 18 & 18 \\
\hline Hungría & 18 & 18 & $18-19$ & 18 & $\mathrm{a}$ & 18 & $18-19$ \\
\hline Irlanda & $18-19$ & 18 & 19 & 18 & a & 19 & 18 \\
\hline Islandia & 19 & 19 & 17 & 19 & 20 & 19 & 19 \\
\hline Israel & 17 & 17 & 17 & 17 & a & a & 17 \\
\hline Italia & 19 & 19 & 18 & 19 & 18 & 17 & a \\
\hline Japón & 17 & 17 & 17 & 17 & 17 & 15 & 17 \\
\hline Luxemburgo & $17-20$ & $17-18$ & $17-20$ & $17-19$ & $18-20$ & $16-18$ & $17-19$ \\
\hline México & $17-18$ & $17-18$ & $17-18$ & $17-18$ & $\mathrm{a}$ & $\mathrm{a}$ & $17-18$ \\
\hline Noruega & $18-20$ & 18 & $19-20$ & 18 & $\mathrm{a}$ & $\mathrm{m}$ & $19-20$ \\
\hline Nueva Zelanda & $17-18$ & $17-18$ & $17-18$ & 18 & 17 & 16 & 17 \\
\hline Países Bajos & $17-19$ & 17 & 19 & 17 & a & a & 18 \\
\hline Polonia & $18-19$ & 19 & 20 & 19 & $\mathrm{a}$ & a & 19 \\
\hline Portugal & 17 & 17 & 18 & $\mathrm{~m}$ & $\mathrm{~m}$ & $\mathrm{~m}$ & $\mathrm{~m}$ \\
\hline Reino Unido & 16 & 16 & 16 & 18 & 18 & 16 & 16 \\
\hline República Checa & $18-19$ & $18-19$ & $17-19$ & $18-19$ & $18-19$ & a & $17-18$ \\
\hline República Eslovaca & $18-19$ & 19 & 19 & $19-20$ & $\mathrm{a}$ & 17 & $18-19$ \\
\hline Suecia & 18 & 18 & 18 & 18 & 18 & 18 & 18 \\
\hline Suiza & $18-20$ & $18-20$ & $18-20$ & $18-20$ & $18-20$ & $17-19$ & $18-20$ \\
\hline Turquía & 17 & 17 & 17 & 17 & $\mathrm{a}$ & $\mathrm{m}$ & a \\
\hline Arabia Saudí & $\mathrm{m}$ & $\mathrm{m}$ & $\mathrm{m}$ & $\mathrm{m}$ & $\mathrm{m}$ & $\mathrm{m}$ & $\mathrm{m}$ \\
\hline Argentina & 17 & 17 & 17 & 17 & a & a & a \\
\hline Brasil & $17-18$ & $17-18$ & $18-19$ & $17-18$ & $18-19$ & $\mathrm{a}$ & $\mathrm{a}$ \\
\hline China & 17 & 17 & 17 & 17 & $\mathrm{~m}$ & 17 & 17 \\
\hline Colombia & $\mathrm{m}$ & $\mathrm{m}$ & $\mathrm{m}$ & $\mathrm{m}$ & $\mathrm{m}$ & $\mathrm{m}$ & $\mathrm{m}$ \\
\hline Federación Rusa & 17 & 17 & 17 & 17 & 17 & 16 & 17 \\
\hline India & $\mathrm{m}$ & $\mathrm{m}$ & $\mathrm{m}$ & $\mathrm{m}$ & $\mathrm{m}$ & $\mathrm{m}$ & $\mathrm{m}$ \\
\hline Indonesia & 17 & 17 & 17 & 17 & 17 & $\mathrm{a}$ & $\mathrm{a}$ \\
\hline Letonia & 19 & 19 & 19 & 19 & $\mathrm{a}$ & $\mathrm{a}$ & 19 \\
\hline Sudáfrica & $\mathrm{m}$ & $\mathrm{m}$ & $\mathrm{m}$ & $\mathrm{m}$ & $\mathrm{m}$ & $\mathrm{m}$ & $\mathrm{m}$ \\
\hline
\end{tabular}

1. Duración para las categorías de programas CINE 3C: cortos, por lo menos un año más breves que los programas CINE 3A/3B; largos, de duración similar a los programas CINE 3A o 3B.

Fuentes: OCDE. Arabia Saudí, Argentina, China, Colombia, India, Indonesia, Sudáfrica: Instituto de Estadística de la UNESCO. Letonia: Eurostat. Para ver notas, consulte Anexo 3 (www.oecd.org/edu/eag.htm).

Para obtener más información acerca de los símbolos utilizados en lugar de los datos que faltan, consulte la Guía del lector.

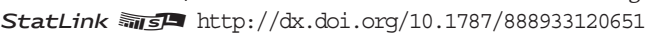


Tabla X1.1a. [2/2] Tasa de graduación en educación secundaria superior: edades típicas de graduación y método utilizado para calcular las tasas de graduación (2012)

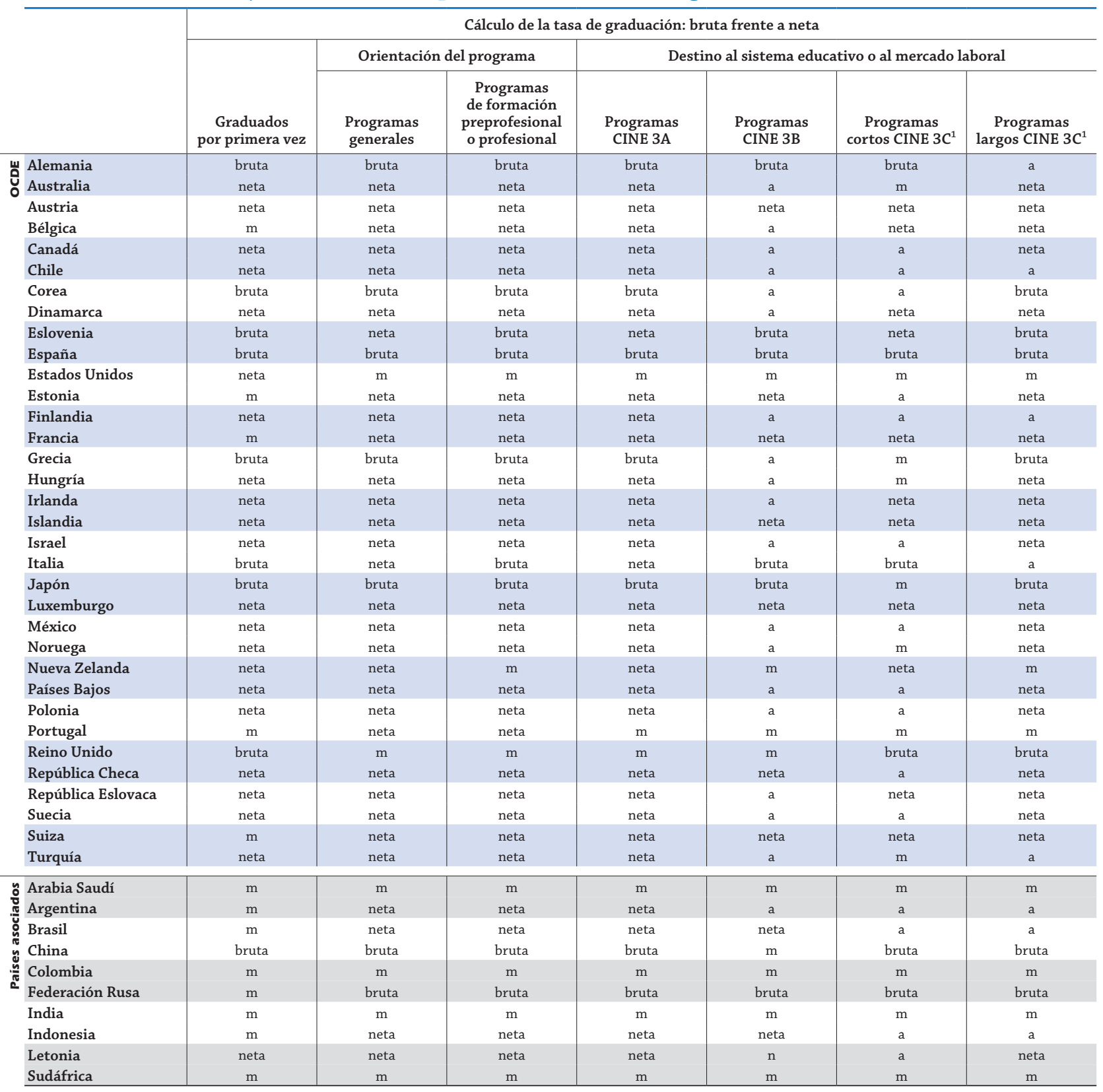

1. Duración para las categorías de programas CINE 3C: cortos, por lo menos un año más breves que los programas CINE 3A/3B; largos, de duración similar a los programas CINE 3A o 3B.

Fuentes: OCDE. Arabia Saudí, Argentina, China, Colombia, India, Indonesia, Sudáfrica: Instituto de Estadística de la UNESCO. Letonia: Eurostat. Para ver notas, consulte Anexo 3 (www.oecd.org/edu/eag.htm).

Para obtener más información acerca de los símbolos utilizados en lugar de los datos que faltan, consulte la Guía del lector.

StatLink 제 SL http://dx.doi.org/10.1787/888933120651 
Tabla X1.1b. Tasa de graduación en educación postsecundaria no terciaria: edades típicas de graduación y método utilizado para calcular las tasas de graduación (2012)

La edad típica de graduación se refiere a la edad de los estudiantes al principio del año escolar; los estudiantes, por norma general, serán un año mayores que la edad indicada cuando consigan la graduación al final del año escolar. La edad típica se utiliza para el cálculo de las tasas brutas de graduación

\begin{tabular}{|c|c|c|c|c|c|c|c|c|}
\hline & \multicolumn{4}{|c|}{ Edades típicas de graduación } & \multirow{2}{*}{\multicolumn{4}{|c|}{$\begin{array}{l}\text { Cálculo de la tasa de graduación: bruta frente a neta } \\
\text { Destino al sistema educativo o al mercado laboral }\end{array}$}} \\
\hline & \multirow[b]{2}{*}{$\begin{array}{l}\text { Graduados por } \\
\text { primera vez }\end{array}$} & \multicolumn{3}{|c|}{ Destino al sistema educativo o al mercado laboral } & & & & \\
\hline & & $\begin{array}{l}\text { Programas } \\
\text { CINE 4A }\end{array}$ & $\begin{array}{l}\text { Programas } \\
\text { CINE 4B }\end{array}$ & $\begin{array}{l}\text { Programas } \\
\text { CINE 4C }\end{array}$ & $\begin{array}{c}\text { Graduados por } \\
\text { primera vez }\end{array}$ & $\begin{array}{l}\text { Programas } \\
\text { CINE 4A }\end{array}$ & $\begin{array}{l}\text { Programas } \\
\text { CINE 4B }\end{array}$ & $\begin{array}{c}\text { Programas } \\
\text { CINE 4C }\end{array}$ \\
\hline $\begin{array}{l}\text { Alemania } \\
\text { Australia }\end{array}$ & $\begin{array}{c}22 \\
18-20\end{array}$ & $\begin{array}{c}22 \\
a\end{array}$ & $\begin{array}{c}22 \\
a\end{array}$ & $\begin{array}{c}a \\
18-20\end{array}$ & $\begin{array}{l}\text { bruta } \\
\text { neta }\end{array}$ & $\begin{array}{c}\text { bruta } \\
\text { a }\end{array}$ & $\begin{array}{c}\text { bruta } \\
\text { a }\end{array}$ & $\begin{array}{c}\mathrm{a} \\
\text { neta }\end{array}$ \\
\hline Austria & 18-19 & 18-19 & $19-20$ & $23-24$ & neta & neta & neta & neta \\
\hline Bélgica & $19-21$ & 19 & $19-21$ & $19-21$ & $\mathrm{~m}$ & neta & neta & neta \\
\hline Canadá & $\mathrm{m}$ & $\mathrm{m}$ & $\mathrm{m}$ & $30-34$ & $\mathrm{~m}$ & $\mathrm{~m}$ & $\mathrm{~m}$ & $\mathrm{~m}$ \\
\hline Chile & a & a & a & a & a & a & a & a \\
\hline Corea & a & a & a & a & a & $\mathrm{a}$ & a & a \\
\hline Dinamarca & 21 & 21 & a & $\mathrm{a}$ & neta & neta & $\mathrm{a}$ & a \\
\hline Eslovenia & $19-20$ & $19-20$ & $19-20$ & a & neta & neta & neta & a \\
\hline España & a & a & a & a & a & a & a & a \\
\hline Estados Unidos & $\mathrm{m}$ & $\mathrm{m}$ & $\mathrm{m}$ & $\mathrm{m}$ & $\mathrm{m}$ & $\mathrm{m}$ & $\mathrm{m}$ & $\mathrm{m}$ \\
\hline Estonia & 21 & a & 21 & a & $\mathrm{m}$ & a & neta & $\mathrm{a}$ \\
\hline Finlandia & 35-39 & a & a & 35-39 & neta & a & a & neta \\
\hline Francia & $\mathrm{m}$ & $\mathrm{m}$ & $\mathrm{m}$ & $\mathrm{m}$ & $\mathrm{m}$ & bruta & a & bruta \\
\hline Grecia & 20 & $\mathrm{a}$ & $\mathrm{a}$ & 20 & $\mathrm{~m}$ & $\mathrm{a}$ & a & neta \\
\hline Hungría & a & a & a & $19-20$ & neta & a & a & neta \\
\hline Irlanda & 23 & a & $\mathrm{a}$ & 23 & neta & a & a & neta \\
\hline Islandia & a & a & a & 26 & neta & a & a & neta \\
\hline Israel & $\mathrm{m}$ & $\mathrm{m}$ & $\mathrm{m}$ & a & $\mathrm{m}$ & $\mathrm{m}$ & $\mathrm{m}$ & $\mathrm{a}$ \\
\hline Italia & 20 & a & $\mathrm{a}$ & 20 & bruta & $\mathrm{a}$ & $\mathrm{a}$ & bruta \\
\hline Japón & 18 & 18 & 18 & 18 & $\mathrm{~m}$ & $\mathrm{~m}$ & $\mathrm{~m}$ & $\mathrm{~m}$ \\
\hline Luxemburgo & $21-25$ & $\mathrm{a}$ & $\mathrm{a}$ & $21-25$ & neta & a & a & neta \\
\hline México & $\mathrm{a}$ & a & a & a & $\mathrm{a}$ & a & a & $\mathrm{a}$ \\
\hline Noruega & $20-22$ & $20-22$ & a & $21-22$ & neta & neta & a & neta \\
\hline Nueva Zelanda & 18 & 18 & 18 & 18 & neta & neta & neta & neta \\
\hline Países Bajos & 20 & a & a & 20 & neta & $\mathrm{a}$ & $\mathrm{a}$ & neta \\
\hline Polonia & 21 & a & $\mathrm{a}$ & 21 & neta & a & a & neta \\
\hline Portugal & 21 & $\mathrm{a}$ & a & $\mathrm{a}$ & neta & a & a & $\mathrm{a}$ \\
\hline Reino Unido & $\mathrm{a}$ & a & a & $\mathrm{a}$ & $\mathrm{a}$ & $\mathrm{a}$ & a & a \\
\hline República Checa & $19-20$ & $19-20$ & a & $19-20$ & neta & neta & a & neta \\
\hline República Eslovaca & 21 & $21-22$ & a & a & neta & neta & a & a \\
\hline Suecia & $19-22$ & $\mathrm{~m}$ & $\mathrm{~m}$ & $19-22$ & $\mathrm{~m}$ & $\mathrm{~m}$ & $\mathrm{~m}$ & neta \\
\hline Suiza & $21-23$ & $21-23$ & $21-23$ & a & $\mathrm{m}$ & neta & neta & a \\
\hline Turquía & a & a & a & a & a & a & a & a \\
\hline Arabia Saudí & $\mathrm{m}$ & $\mathrm{m}$ & $\mathrm{m}$ & $\mathrm{m}$ & $\mathrm{m}$ & $\mathrm{m}$ & $\mathrm{m}$ & $\mathrm{m}$ \\
\hline Argentina & a & a & a & a & $\mathrm{a}$ & a & a & a \\
\hline Brasil & a & a & a & $\mathrm{a}$ & a & $\mathrm{a}$ & $\mathrm{a}$ & a \\
\hline China & a & $\mathrm{m}$ & $\mathrm{m}$ & $\mathrm{m}$ & $\mathrm{m}$ & $\mathrm{m}$ & neta & $\mathrm{m}$ \\
\hline Colombia & 18 & 18 & 18 & 18 & $\mathrm{~m}$ & bruta & bruta & bruta \\
\hline Federación Rusa & 18 & a & a & 18 & $\mathrm{~m}$ & $\mathrm{a}$ & $\mathrm{a}$ & $\mathrm{m}$ \\
\hline India & $\mathrm{m}$ & $\mathrm{m}$ & $\mathrm{m}$ & $\mathrm{m}$ & $\mathrm{m}$ & $\mathrm{m}$ & $\mathrm{m}$ & $\mathrm{m}$ \\
\hline Indonesia & $\mathrm{m}$ & $\mathrm{m}$ & $\mathrm{m}$ & $\mathrm{m}$ & $\mathrm{m}$ & $\mathrm{m}$ & $\mathrm{m}$ & $\mathrm{m}$ \\
\hline Letonia & $\mathrm{a}$ & a & $\mathrm{a}$ & $\mathrm{a}$ & $\mathrm{a}$ & a & $\mathrm{a}$ & $\mathrm{a}$ \\
\hline Sudáfrica & $\mathrm{m}$ & $\mathrm{m}$ & $\mathrm{m}$ & $\mathrm{m}$ & $\mathrm{m}$ & $\mathrm{m}$ & $\mathrm{m}$ & $\mathrm{m}$ \\
\hline
\end{tabular}

Fuentes: OCDE. Arabia Saudí, Argentina, China, Colombia, India, Indonesia, Sudáfrica: Instituto de Estadística de la UNESCO. Letonia: Eurostat. Para ver notas, consulte Anexo 3 (www.oecd.org/edu/eag.htm).

Para obtener más información acerca de los símbolos utilizados en lugar de los datos que faltan, consulte la Guía del lector.

StatLink 젠 http://dx.doi.org/10.1787/888933120670 
Tabla X1.1c. [1/2] Tasa de graduación en educación terciaria: edades típicas de graduación y método utilizado para calcular las tasas de graduación (2012)

La edad típica de graduación se refiere a la edad de los estudiantes al principio del año escolar; los estudiantes, por norma general, serán un año mayores que la edad indicada cuando consigan la graduación al final del año escolar. La edad típica se utiliza para el cálculo de las tasas brutas de graduación

\begin{tabular}{|c|c|c|c|c|c|c|c|}
\hline & \multicolumn{7}{|c|}{ Edades típicas de graduación } \\
\hline & \multirow{2}{*}{$\begin{array}{c}\text { Graduados por } \\
\text { primera vez } \\
\text { en educación } \\
\text { terciaria } \\
\text { de tipo } B\end{array}$} & \multirow[b]{2}{*}{$\begin{array}{c}\text { Educación } \\
\text { terciaria de tipo B } \\
\text { (primer grado) }\end{array}$} & \multirow{2}{*}{$\begin{array}{c}\text { Graduados } \\
\text { por primera vez } \\
\text { en educación } \\
\text { terciaria de tipo A }\end{array}$} & \multicolumn{3}{|c|}{ Educación terciaria de tipo A (primer y segundo grado) } & \multirow[b]{2}{*}{$\begin{array}{c}\text { Programas } \\
\text { de investigación } \\
\text { avanzada }\end{array}$} \\
\hline & & & & $\begin{array}{c}\text { De } 3 \text { a menos } \\
\text { de } 5 \text { años }\end{array}$ & De 5 a 6 años & $\begin{array}{l}\text { De más } \\
\text { de } 6 \text { años }\end{array}$ & \\
\hline $\begin{array}{l}\text { Alemania } \\
\text { Australia }\end{array}$ & $\begin{array}{c}21-23 \\
21\end{array}$ & $\begin{array}{c}21-23 \\
21\end{array}$ & $\begin{array}{c}24-27 \\
23\end{array}$ & $\begin{array}{c}24-26 \\
23\end{array}$ & $\begin{array}{c}25-27 \\
23\end{array}$ & $\begin{array}{c}\mathrm{a} \\
23\end{array}$ & $\begin{array}{c}28-29 \\
\mathrm{~m}\end{array}$ \\
\hline Austria & $21-23$ & $21-23$ & $23-25$ & $22-24$ & $24-26$ & a & $27-29$ \\
\hline Bélgica & $21-22$ & $21-22$ & 21 & $\mathrm{~m}$ & $\mathrm{~m}$ & $\mathrm{~m}$ & $27-29$ \\
\hline Canadá & $21-24$ & $21-24$ & $22-24$ & 22 & $23-24$ & 25 & $27-29$ \\
\hline Chile & $21-25$ & $21-25$ & $24-26$ & $23-26$ & $24-26$ & $25-26$ & $30-34$ \\
\hline Corea & 20 & 20 & $22-24$ & $22-26$ & $24-25$ & a & $30-34$ \\
\hline Dinamarca & $23-25$ & $23-25$ & 24 & 24 & 26 & $25-29$ & $30-34$ \\
\hline Eslovenia & $23-25$ & $23-25$ & $23-26$ & $23-24$ & $25-26$ & a & 28 \\
\hline España & 19 & 19 & $20-22$ & 20 & 22 & $\mathrm{a}$ & $26-28$ \\
\hline Estados Unidos & 19 & 19 & 21 & 21 & 23 & 24 & 26 \\
\hline Estonia & 22 & 22 & $22-24$ & 22 & 24 & $\mathrm{a}$ & $30-34$ \\
\hline Finlandia & $30-34$ & $30-34$ & $25-29$ & 24 & $\mathrm{a}$ & $\mathrm{a}$ & $30-34$ \\
\hline Francia & $19-23$ & $19-23$ & $19-24$ & $19-22$ & $21-24$ & $27-29$ & $26-28$ \\
\hline Grecia & $24-25$ & $24-25$ & $23-24$ & $23-24$ & $23-24$ & $\mathrm{a}$ & $30-34$ \\
\hline Hungría & 20 & 20 & $22-24$ & $21-23$ & $23-24$ & a & $30-34$ \\
\hline Irlanda & $20-21$ & $20-21$ & 21 & 21 & 23 & 25 & 27 \\
\hline Islandia & 25 & 25 & 23 & 23 & 25 & a & 29 \\
\hline Israel & $\mathrm{m}$ & $\mathrm{m}$ & $26-27$ & $26-27$ & $27-29$ & $\mathrm{a}$ & $30-34$ \\
\hline Italia & $22-23$ & $22-23$ & 23 & 23 & 25 & a & $30-34$ \\
\hline Japón & 19 & 19 & $21-23$ & 21 & 23 & a & 26 \\
\hline Luxemburgo & $20-25$ & $20-25$ & $21-25$ & $21-22$ & $23-24$ & $24-25$ & $26-28$ \\
\hline México & 20 & 20 & 23 & 23 & $23-26$ & $\mathrm{~m}$ & $24-28$ \\
\hline Noruega & 24 & 24 & $22-27$ & $22-23$ & $24-25$ & $26-27$ & $29-34$ \\
\hline Nueva Zelanda & $19-21$ & $19-21$ & $21-23$ & $21-23$ & 23 & 24 & $27-28$ \\
\hline Países Bajos & 27 & 27 & 23 & 23 & a & a & $\mathrm{m}$ \\
\hline Polonia & 22 & 22 & $23-25$ & 23 & 25 & a & $25-29$ \\
\hline Portugal & $35-39$ & $35-39$ & 22 & 22 & $>40$ & $\mathrm{a}$ & $>40$ \\
\hline Reino Unido & $19-24$ & $19-24$ & $20-25$ & $20-22$ & $22-24$ & $23-25$ & $25-29$ \\
\hline República Checa & $21-22$ & $21-22$ & $22-24$ & $22-24$ & $25-26$ & a & $30-34$ \\
\hline República Eslovaca & $21-22$ & $21-22$ & $21-22$ & $21-22$ & 23 & a & $26-27$ \\
\hline Suecia & $21-23$ & $21-23$ & 25 & 25 & 25 & $\mathrm{n}$ & $30-34$ \\
\hline Suiza & $23-29$ & $23-29$ & $24-26$ & $24-26$ & $25-27$ & $25-27$ & $30-34$ \\
\hline Turquía & 21 & 21 & $22-24$ & 23-24 & $25-26$ & a & $30-34$ \\
\hline ¿ Arabia Saudí & 20 & 20 & 21 & 21 & 21 & 21 & 27 \\
\hline Argentina & $20-24$ & $20-24$ & $21-24$ & $21-22$ & $22-23$ & $23-24$ & $25-29$ \\
\hline ఏ Brasil & $21-23$ & $21-23$ & $22-24$ & $22-24$ & $\mathrm{~m}$ & $\mathrm{~m}$ & $30-34$ \\
\hline ¿ّ China & 20 & 20 & 21 & 21 & 22 & 22 & 27 \\
\hline Colombia & $\mathrm{m}$ & $\mathrm{m}$ & $\mathrm{m}$ & $\mathrm{m}$ & $\mathrm{m}$ & $\mathrm{m}$ & $\mathrm{m}$ \\
\hline Federación Rusa & 20 & 20 & 22 & 21 & 22 & 23 & $\mathrm{~m}$ \\
\hline India & $\mathrm{m}$ & $\mathrm{m}$ & $\mathrm{m}$ & $\mathrm{m}$ & $\mathrm{m}$ & $\mathrm{m}$ & $\mathrm{m}$ \\
\hline Indonesia & 24 & 24 & 22 & 22 & 24 & 26 & 27 \\
\hline Letonia & $21-23$ & $21-23$ & $23-25$ & $22-25$ & $\mathrm{a}$ & $\mathrm{a}$ & $30-34$ \\
\hline Sudáfrica & 20 & 20 & 21 & 21 & 22 & 22 & 25 \\
\hline
\end{tabular}

Nota: Cuando se dispone de datos de educación terciaria de tipo A por duración del programa, la tasa de graduación de todos los programas es la suma de las tasas de graduación por duración del programa.

Fuentes: OCDE. Arabia Saudí, Argentina, China, Colombia, India, Indonesia, Sudáfrica: Instituto de Estadística de la UNESCO. Letonia: Eurostat. Para ver notas, consulte Anexo 3 (www.oecd.org/edu/eag.htm).

Para obtener más información acerca de los símbolos utilizados en lugar de los datos que faltan, consulte la Guía del lector.

StatLink 세에 $\mathrm{http}: / / \mathrm{dx}$.doi.org/10.1787/888933120689 
Tabla X1.1c. [2/2] Tasa de graduación en educación terciaria: edades típicas de graduación y método utilizado para calcular las tasas de graduación (2012)

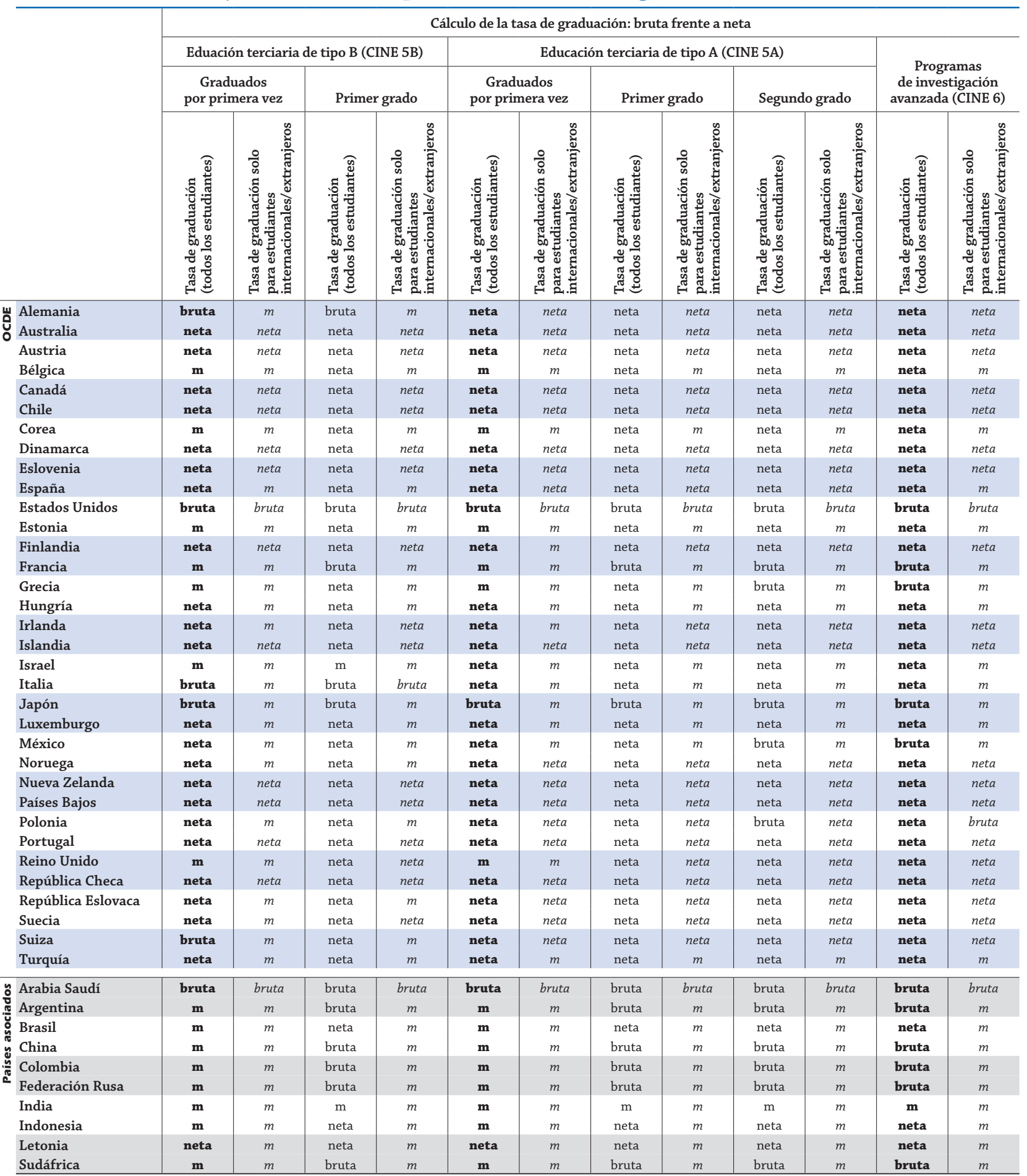

Nota: Cuando se dispone de datos de educación terciaria de tipo A por duración del programa, la tasa de graduación de todos los programas es la suma de las tasas de graduación por duración del programa.

Fuentes: OCDE. Arabia Saudí, Argentina, China, Colombia, India, Indonesia, Sudáfrica: Instituto de Estadística de la UNESCO. Letonia: Eurostat. Para ver notas, consulte Anexo 3 (www.oecd.org/edu/eag.htm).

Para obtener más información acerca de los símbolos utilizados en lugar de los datos que faltan, consulte la Guía del lector.

StatLink sils http://dx.doi.org/10.1787/888933120689 
Tabla X1.1d. Tasa de ingreso en educación terciaria: edades típicas de ingreso y método utilizado para calcular las tasas de ingreso (2012)

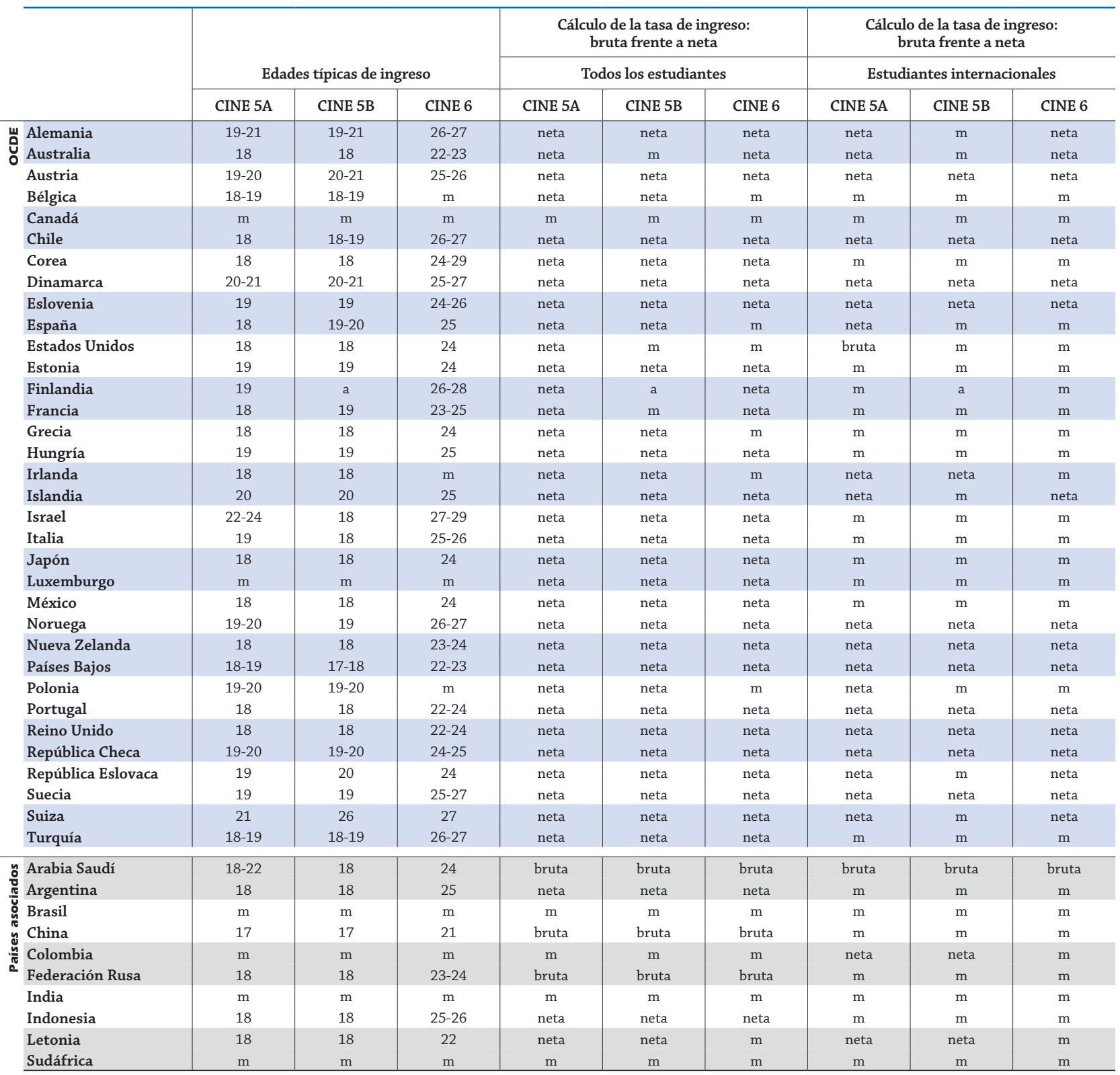

Fuentes: OCDE. Arabia Saudí, Argentina, China, Colombia, India, Indonesia, Sudáfrica: Instituto de Estadística de la UNESCO. Letonia: Eurostat. Para ver notas, consulte Anexo 3 (www.oecd.org/edu/eag.htm).

Para obtener más información acerca de los símbolos utilizados en lugar de los datos que faltan, consulte la Guía del lector.

StatLink त्राजा http://dx.doi.org/10.1787/888933120708 
Tabla X1.2a. Año escolar y año presupuestario utilizados en los cálculos de los indicadores para los países de la OCDE

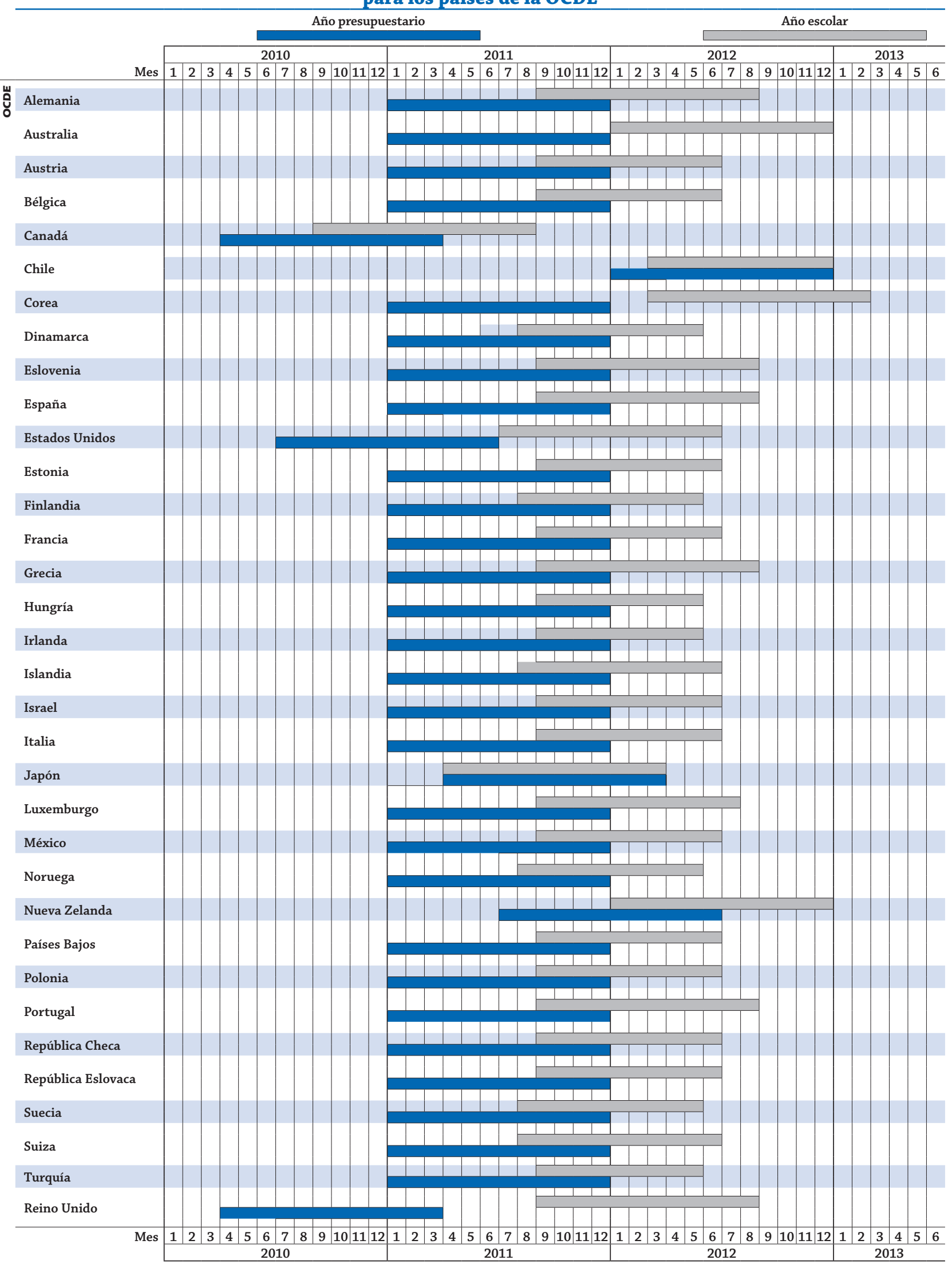

Fuente: OCDE. Para ver notas, consulte Anexo 3 (www.oecd.org/edu/eag.htm).

StatLink त्नाजम http://dx.doi.org/10.1787/888933120727 
Tabla X1.2b. Año escolar y año presupuestario utilizados en los cálculos de los indicadores para los países asociados

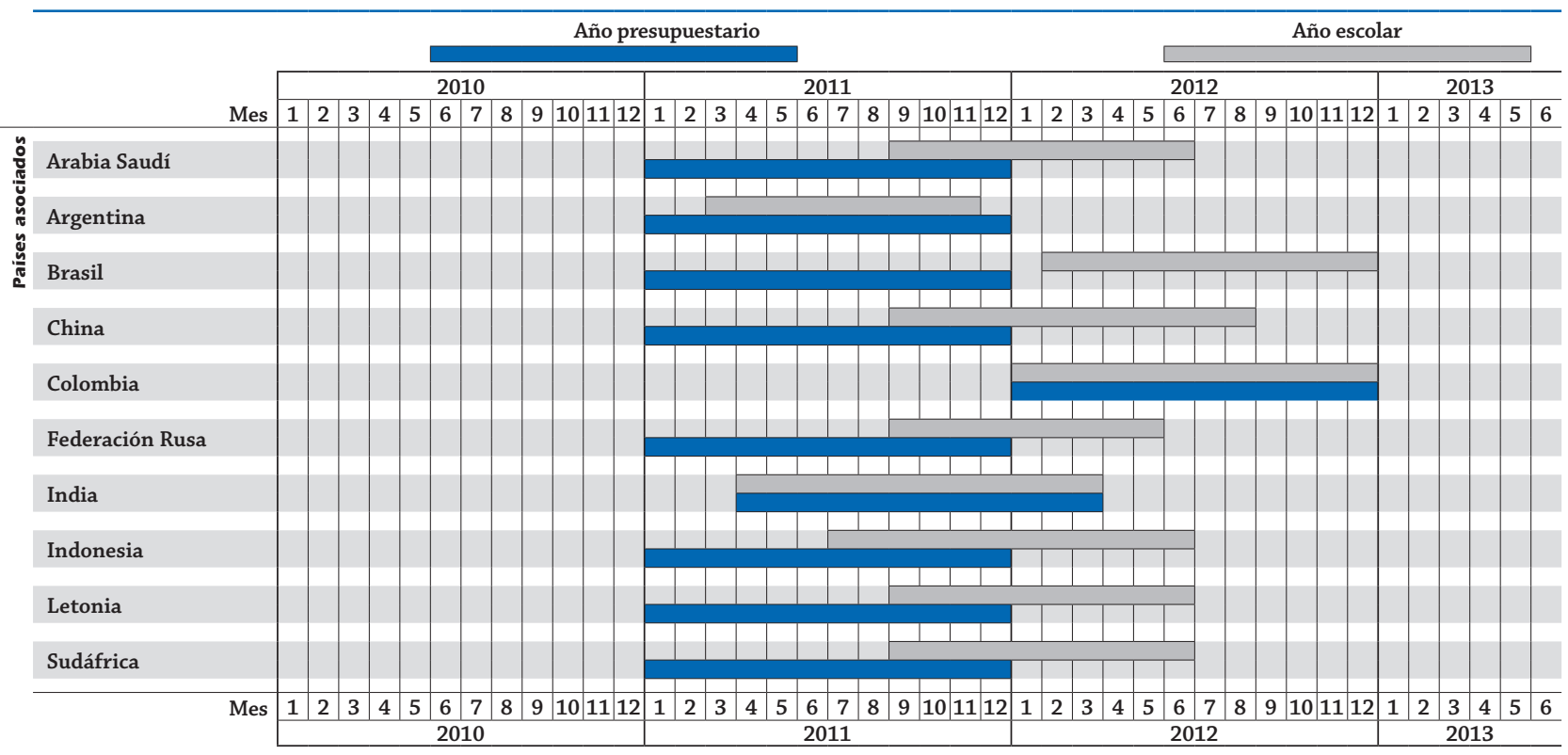

Fuentes: OCDE. Arabia Saudí, Argentina, China, Colombia, India, Indonesia, Sudáfrica: Instituto de Estadística de la UNESCO. Letonia: Eurostat. Para ver notas, consulte Anexo 3 (www.oecd.org/edu/eag.htm).

StatLink 需政 http://dx.doi.org/10.1787/888933120746

Nota sobre los datos de Israel

Los datos estadísticos para Israel fueron proporcionados por las autoridades israelíes competentes bajo su responsabilidad. El uso de estos datos por parte de la OCDE se hace sin prejuzgar la situación de los Altos del Golán, Jerusalén Este y los asentamientos israelíes en Cisjordania de acuerdo con los términos del derecho internacional. 



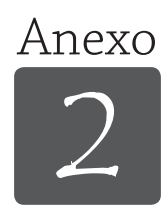

\section{ESTADISTICAS DE REFERENCIA}

Todas las tablas del Anexo 2 están disponibles en Internet en:

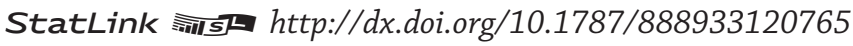


Tabla X2.1. Visión general del contexto económico mediante las variables básicas (periodo de referencia: año natural 2011, precios corrientes de 2011)

\begin{tabular}{|c|c|c|c|}
\hline $\begin{array}{l}\text { Gasto público total como } \\
\text { porcentaje del PIB }\end{array}$ & $\begin{array}{c}\text { PIB per cápita } \\
\text { (en equivalente a dólares } \\
\text { estadounidenses convertidos } \\
\text { mediante PPA) }\end{array}$ & $\begin{array}{l}\text { Deflactor del PIB } \\
\quad(2005=100)\end{array}$ & $\begin{array}{l}\text { Deflactor del PIB } \\
\quad(2000=100)\end{array}$ \\
\hline (1) & (2) & (3) & (4) \\
\hline 45,2 & 40.990 & 106,3 & 112,1 \\
\hline 33,5 & 43.208 & 125,9 & 150,3 \\
\hline 50,8 & 42.978 & 111,2 & 120,3 \\
\hline 53,5 & 40.093 & 112,7 & 125,1 \\
\hline 41,8 & 37.480 & 115,0 & 129,4 \\
\hline $\mathrm{m}$ & 21.486 & 125,3 & 177,3 \\
\hline 30,2 & 29.035 & 114,2 & 131,4 \\
\hline 57,7 & 41.843 & 115,1 & 129,1 \\
\hline 50,8 & 28.156 & 114,5 & 148,3 \\
\hline 45,9 & 32.157 & 110,3 & 135,6 \\
\hline 37,4 & 49.321 & 112,2 & 126,0 \\
\hline 37,7 & 23.088 & 132,5 & 170,2 \\
\hline 55,3 & 38.611 & 111,9 & 117,0 \\
\hline 55,9 & 36.391 & 110,7 & 122,0 \\
\hline $\mathrm{m}$ & 26.622 & 115,9 & 135,9 \\
\hline 50,1 & 22.413 & 125,0 & 171,5 \\
\hline 47,1 & 42.943 & 97,4 & 118,3 \\
\hline 47,4 & 38.224 & 153,7 & 187,0 \\
\hline 39,6 & 30.168 & 112,2 & 119,4 \\
\hline 49,9 & 33.870 & 110,9 & 126,6 \\
\hline 42,2 & 34.576 & 92,4 & 86,0 \\
\hline 42,9 & 88.668 & 125,1 & 144,5 \\
\hline 25,5 & 17.125 & 137,6 & 192,0 \\
\hline 58,2 & 46.696 & 123,2 & 141,7 \\
\hline 34,2 & 31.487 & 119,0 & 133,8 \\
\hline 49,9 & 43.150 & 108,0 & 124,3 \\
\hline 43,4 & 21.753 & 118,1 & 134,0 \\
\hline 49,3 & 25.672 & 109,3 & 127,1 \\
\hline 49,6 & 33.886 & 117,1 & 130,9 \\
\hline 43,2 & 27.046 & 105,6 & 118,6 \\
\hline 38,2 & 25.130 & 108,1 & 134,5 \\
\hline 51,5 & 41.761 & 112,7 & 120,6 \\
\hline 33,7 & 51.582 & 108,0 & 112,1 \\
\hline 37,4 & 17.781 & 157,1 & 489,7 \\
\hline $\mathrm{m}$ & $\mathrm{m}$ & $\mathrm{m}$ & $\mathrm{m}$ \\
\hline $\mathrm{m}$ & 10.805 & $\mathrm{~m}$ & $\mathrm{~m}$ \\
\hline 31,6 & 11.735 & 151,1 & 239,7 \\
\hline $\mathrm{m}$ & 8.397 & $\mathrm{~m}$ & $\mathrm{~m}$ \\
\hline $\mathrm{m}$ & 10.303 & $\mathrm{~m}$ & $\mathrm{~m}$ \\
\hline $\mathrm{m}$ & 22.502 & 208,0 & 457,4 \\
\hline $\mathrm{m}$ & $\mathrm{m}$ & $\mathrm{m}$ & $\mathrm{m}$ \\
\hline $\mathrm{m}$ & $\mathrm{m}$ & $\mathrm{m}$ & $\mathrm{m}$ \\
\hline $\mathrm{m}$ & 19.984 & $\mathrm{~m}$ & $\mathrm{~m}$ \\
\hline $\mathrm{m}$ & 10.052 & $\mathrm{~m}$ & $\mathrm{~m}$ \\
\hline
\end{tabular}

1. Año de referencia 2010

2. Año de referencia 2012 en lugar de 2010. Los deflactores del PIB se refieren a 2001-2012 en lugar de 2000-2011 y a 2006-2012 en lugar de 2005-2011.

3. El valor de mercado del PIB peninsular se utiliza para Noruega.

Fuente: OCDE. Para ver notas, consulte Anexo 3 (www.oecd.org/edu/eag.htm).

Para obtener más información acerca de los símbolos utilizados en lugar de los datos que faltan, consulte la Guía del lector.

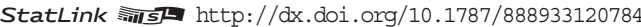


Tabla X2.2. Estadísticas de referencia básicas (periodo de referencia: año natural 2011, precios corrientes de 2011) ${ }^{1}$

\begin{tabular}{|c|c|c|c|c|c|c|c|}
\hline & $\begin{array}{c}\text { PIB (en millones } \\
\text { de la moneda } \\
\text { nacional) }\end{array}$ & $\begin{array}{c}\text { PIB (ajustado } \\
\quad \text { al año } \\
\text { presupuestario) }\end{array}$ & $\begin{array}{c}\text { Gasto público } \\
\text { total (en millones } \\
\text { de la moneda } \\
\text { nacional) }\end{array}$ & $\begin{array}{c}\text { Población } \\
\text { total en miles } \\
\text { (estimaciones } \\
\text { a mitad de año) }\end{array}$ & $\begin{array}{c}\text { Paridad de poder } \\
\text { adquisitivo para } \\
\text { el PIB (PPA) } \\
\text { (dólar } \\
\text { estadounidense = 1) }\end{array}$ & $\begin{array}{c}\text { Paridad de poder } \\
\text { adquisitivo para } \\
\text { el PIB }(\text { PPA }) \\
(\text { zona euro }=1)\end{array}$ & $\begin{array}{c}\text { Paridad de poder } \\
\text { adquisitivo para el } \\
\text { consumo privado } \\
\text { (PPA) (dólar } \\
\text { estadounidense = 1) }\end{array}$ \\
\hline & (1) & (2) & (3) & (4) & (5) & (6) & (7) \\
\hline Alemania & 2.609 .900 & & 1.178 .650 & 81.779 & 0,7786 & 0,9982 & 0,8503 \\
\hline Australia & 1.486 .071 & & 498.406 & 22.761 & 1,5111 & 1,9372 & 1,5805 \\
\hline Austria & 299.240 & & 151.994 & 8.389 & 0,8300 & 1,0641 & 0,8574 \\
\hline Bélgica & 369.259 & & 197.422 & 10.978 & 0,8390 & 1,0756 & 0,9056 \\
\hline Canadá ${ }^{4}$ & 1.719 .631 & 1.576 .759 & 658.901 & 34.483 & 1,2200 & 1,5641 & 1,2999 \\
\hline Chile $^{5}$ & 130.526 .894 & & $\mathrm{~m}$ & 17.450 & 348,1310 & 446,3218 & 370,1642 \\
\hline Corea & 1.235 .160 .500 & & 373.227 .400 & 49.779 & 854,5857 & 1095,6227 & 910,4712 \\
\hline Dinamarca & 1.791 .773 & & 1.034 .208 & 5.569 & 7,6893 & 9,8581 & 8,5705 \\
\hline Eslovenia & 36.150 & & 18.350 & 2.053 & 0,6254 & 0,8018 & 0,7078 \\
\hline España & 1.046 .327 & & 480.111 & 46.125 & 0,7054 & 0,9044 & 0,7898 \\
\hline Estados Unidos & 15.533 .800 & 15.389 .925 & 5.754 .000 & 312.036 & 1 & 1,2821 & 1 \\
\hline Estonia & 16.216 & & 6.109 & 1.340 & 0,5241 & 0,6719 & 0,6214 \\
\hline Finlandia & 188.679 & & 104.259 & 5.387 & 0,9071 & 1,1629 & 1,0019 \\
\hline Francia & 2.001 .398 & & 1.118 .728 & 65.115 & 0,8446 & 1,0828 & 0,9019 \\
\hline Grecia & 208.532 & & 108.003 & 11.300 & 0,6932 & 0,8887 & 0,7793 \\
\hline Hungría & 27.635 .435 & & 13.834 .811 & 9.972 & 123,6501 & 158,5258 & 145,0074 \\
\hline Irlanda & 162.600 & & 76.536 & 4.577 & 0,8273 & 1,0606 & 0,9621 \\
\hline Islandia & 1.628 .677 & & 771.800 & 319 & 133,5633 & 171,2350 & 145,9209 \\
\hline Israel & 923.900 & & 365.561 & 7.763 & 3,9450 & 5,0577 & 4,47 \\
\hline Italia & 1.580 .410 & & 788.137 & 60.724 & 0,7684 & 0,9852 & 0,8385 \\
\hline Japón $^{6}$ & 470.623 .200 & 471.876 .500 & 199.103 .100 & 127.831 & 106,7619 & 136,8742 & 121,3658 \\
\hline Luxemburgo & 41.730 & & 17.882 & 519 & 0,9061 & 1,1617 & 0,9938 \\
\hline México & 14.351 .494 & & 3.655 .757 & 109.220 & 7,6730 & 9,8372 & 8,9529 \\
\hline Noruega $^{7}$ & 2.075 .197 & & 1.207 .768 & 4.953 & 8,9725 & 11,5032 & 9,8063 \\
\hline Nueva Zelanda & 206.546 & & 70.669 & 4.415 & 1,4859 & 1,9050 & 1,6071 \\
\hline Países Bajos & 599.047 & & 298.715 & 16.693 & 0,8317 & 1,0663 & 0,8822 \\
\hline Polonia & 1.528.127 & & 663.757 & 38.526 & 1,8234 & 2,3377 & 1,9923 \\
\hline Portugal & 171.126 & & 84.423 & 10.622 & 0,6276 & 0,8046 & 0,7147 \\
\hline Reino Unido & 1.536 .937 & 1.484 .161 & 736.445 & 62.735 & 0,6982 & 0,8951 & 0,7046 \\
\hline República Checa & 3.823 .401 & & 1.653 .244 & 10.497 & 13,4680 & 17,2667 & 15,565 \\
\hline República Eslovaca & 68.974 & & 26.381 & 5.398 & 0,5085 & 0,6519 & 0,58 \\
\hline Suecia & 3.480 .543 & & 1.792 .006 & 9.450 & 8,8199 & 11,3075 & 9,4636 \\
\hline Suiza & 585.102 & & 196.889 & 7.869 & 1,4414 & 1,8480 & 1,6538 \\
\hline Turquía & 1.297 .713 & & 485.001 & 73.950 & 0,9869 & 1,2653 & 1,1474 \\
\hline Zona Euro & & & & & 0,7800 & & \\
\hline Arabia Saudí & $\mathrm{m}$ & & $\mathrm{m}$ & $\mathrm{m}$ & $\mathrm{m}$ & $\mathrm{m}$ & $\mathrm{m}$ \\
\hline Argentina & 1.842 .022 & & $\mathrm{~m}$ & 41.282 & 4,1297 & 5,2945 & $\mathrm{~m}$ \\
\hline Brasil & 4.143 .013 & & 1.308 .035 & 195.243 & 1,8083 & 2,3183 & $\mathrm{~m}$ \\
\hline China & 47.310 .405 & & $\mathrm{~m}$ & 1.347 .350 & 4,1819 & 5,3614 & $\mathrm{~m}$ \\
\hline Colombia & 621.615 .000 & & $\mathrm{~m}$ & 46.045 & 1310,3673 & 1679,9581 & $\mathrm{~m}$ \\
\hline Federación Rusa & 55.799 .573 & & $\mathrm{~m}$ & 142.961 & 17,3456 & 22,2379 & 17,4149 \\
\hline India & $\mathrm{m}$ & & $\mathrm{m}$ & 1.221 .156 & 19,7865 & 25,3673 & $\mathrm{~m}$ \\
\hline Indonesia $^{5}$ & $\mathrm{~m}$ & & 1.435 .406 .700 & $\mathrm{~m}$ & 6737,7456 & 8638,1354 & $\mathrm{~m}$ \\
\hline Letonia & 14.275 & & $\mathrm{~m}$ & 2.058 & 0,3471 & 0,4450 & $\mathrm{~m}$ \\
\hline Sudáfrica & 2.659 .366 & & $\mathrm{~m}$ & 50.587 & 5,2297 & 6,7047 & $\mathrm{~m}$ \\
\hline
\end{tabular}

1. Para los países de la zona euro, los datos sobre PIB, PPA y gasto público total se presentan en euros.

2. El PIB de Australia y el PIB y el gasto público total de Nueva Zelanda se calculan para el año fiscal.

3. En los países en los cuales el PIB no tiene el mismo periodo de referencia que los datos sobre presupuesto educativo, el PIB se calcula como sigue: wt-1 (GDPt - 1) + wt (GDPt), donde wt y wt-1 representan el peso relativo de los dos periodos de referencia del PIB que coinciden con el año presupuestario educativo. En el Capítulo B se han aplicado los ajustes necesarios en los casos de Canadá, Estados Unidos, Japón y Reino Unido.

4. Año de referencia 2010.

5. Año de referencia 2012.

6. Gasto público total ajustado al año presupuestario.

7. El valor de mercado del PIB peninsular se utiliza para Noruega.

Fuente: OCDE. Para ver notas, consulte Anexo 3 (www.oecd.org/edu/eag.htm).

Para obtener más información acerca de los símbolos utilizados en lugar de los datos que faltan, consulte la Guía del lector.

StatLink 需s http://dx.doi.org/10.1787/888933120803 
Tabla X2.3. [1/3] Estadísticas de referencia básicas (periodo de referencia: año natural 1995, 2000, 2005, 2008, 2009, 2010) ${ }^{1}$

\begin{tabular}{|c|c|c|c|c|c|c|}
\hline & \multicolumn{6}{|c|}{$\begin{array}{c}\text { PIB } \\
\text { (en millones de la moneda nacional, precios corrientes) }\end{array}$} \\
\hline & 1995 & 2000 & 2005 & 2008 & 2009 & 2010 \\
\hline & (1) & (2) & (3) & (4) & (5) & (6) \\
\hline Alemania & 1.848 .500 & 2.047 .500 & 2.224 .400 & 2.473 .800 & 2.374 .200 & 2.495 .000 \\
\hline Australia & 529.282 & 705.562 & 998.312 & 1.258 .654 & 1.296 .324 & 1.406 .671 \\
\hline Austria & 174.794 & 208.474 & 245.243 & 282.744 & 276.228 & 285.165 \\
\hline Bélgica & 207.927 & 252.543 & 303.435 & 346.375 & 340.669 & 355.740 \\
\hline Canadá & 810.426 & 1.076 .577 & 1.373 .845 & 1.603 .418 & 1.528 .985 & 1.624 .608 \\
\hline Chile $^{2}$ & 29.336 .967 & 42.094 .989 & 82.018 .171 & 96.443 .761 & 111.007 .886 & 121.492 .697 \\
\hline Corea & 409.653 .600 & 603.236 .000 & 865.240 .900 & 1.026 .451 .800 & 1.065 .036 .800 & 1.173.274.900 \\
\hline Dinamarca & 1.019 .545 & 1.293 .963 & 1.545 .257 & 1.753 .152 & 1.664 .790 & 1.760 .051 \\
\hline Eslovenia & 10.357 & 18.566 & 28.722 & 37.244 & 35.420 & 35.485 \\
\hline España & 446.795 & 629.907 & 909.298 & 1.087 .788 & 1.046 .894 & 1.045 .620 \\
\hline Estados Unidos ${ }^{4}$ & 7.664 .000 & 10.289 .700 & 13.095 .400 & 14.720 .300 & 14.417 .900 & 14.958 .300 \\
\hline Estonia & 2.767 & 6.160 & 11.182 & 16.235 & 13.970 & 14.371 \\
\hline Finlandia & 96.064 & 132.195 & 157.429 & 185.670 & 172.318 & 178.724 \\
\hline Francia & 1.196.181 & 1.439 .603 & 1.718 .047 & 1.933 .195 & 1.885 .763 & 1.936 .720 \\
\hline Grecia & 88.742 & 135.043 & 193.050 & 233.198 & 231.081 & 222.152 \\
\hline Hungría & 5.727 .829 & 13.089 .047 & 22.018 .283 & 26.543 .305 & 25.626 .480 & 26.513 .032 \\
\hline Irlanda & 53.775 & 105.644 & 162.897 & 180.249 & 162.284 & 158.097 \\
\hline Islandia & 454.013 & 683.747 & 1.025 .740 & 1.480 .346 & 1.497 .934 & 1.535 .932 \\
\hline Israel & 289.555 & 506.173 & 600.011 & 764.697 & 809.230 & 866.231 \\
\hline Italia & 952.158 & 1.198 .292 & 1.436 .379 & 1.575 .144 & 1.519 .695 & 1.551 .886 \\
\hline Japón & 501.706 .900 & 509.860 .000 & 503.903 .000 & 501.209 .300 & 471.138 .700 & 482.384 .400 \\
\hline Luxemburgo & 15.108 & 21.998 & 30.270 & 37.372 & 35.575 & 39.303 \\
\hline México & 2.013 .954 & 6.020 .649 & 9.220 .649 & 12.153 .436 & 11.893 .247 & 13.029 .103 \\
\hline Noruega $^{3}$ & 806.858 & 1.113 .894 & 1.464 .974 & 1.862 .873 & 1.875 .850 & 1.987 .362 \\
\hline Nueva Zelanda & 95.368 & 118.377 & 161.645 & 185.555 & 189.718 & 199.113 \\
\hline Países Bajos & 305.261 & 417.960 & 513.407 & 594.481 & 573.235 & 586.789 \\
\hline Polonia & 337.222 & 744.378 & 983.302 & 1.275 .508 & 1.344 .505 & 1.416 .585 \\
\hline Portugal & 87.841 & 127.317 & 154.269 & 171.983 & 168.529 & 172.860 \\
\hline Reino Unido & 748.200 & 987.139 & 1.276 .743 & 1.462 .070 & 1.417.359 & 1.485 .615 \\
\hline República Checa & 1.533 .676 & 2.269 .695 & 3.116 .056 & 3.848 .411 & 3.758 .979 & 3.790 .880 \\
\hline República Eslovaca & 19.319 & 31.177 & 49.314 & 66.842 & 62.794 & 65.897 \\
\hline Suecia & 1.809 .575 & 2.265 .447 & 2.769 .375 & 3.204 .320 & 3.105 .790 & 3.337.531 \\
\hline Suiza & 383.096 & 432.405 & 479.088 & 567.852 & 554.372 & 574.314 \\
\hline Turquía & 10.435 & 166.658 & 648.932 & 950.534 & 952.559 & 1.098 .799 \\
\hline Brasil & 705.641 & 1.179 .482 & 2.147 .240 & 3.032 .204 & 3.239 .404 & 3.770 .085 \\
\hline Federación Rusa & 1.427 .029 & 7.298 .009 & 21.609 .766 & 41.276 .849 & 38.807 .219 & 46.308 .541 \\
\hline
\end{tabular}

1. Para los países de la zona euro, los datos sobre PIB y gasto público total se presentan en euros.

2. Años de referencia 1996, 2001, 2006, 2009, 2010 y 2011 en lugar de 1995, 2000, 2005, 2008, 2009 y 2010.

3. El valor de mercado del PIB peninsular se utiliza para Noruega.

4. Estados Unidos revisó toda su serie de PIB en los últimos 6 meses. Los datos presentados en dólares corrientes no coinciden con los presentados en X2.3 de Panorama de la educación 2013.

Fuente: OCDE. Para ver notas, consulte Anexo 3 (www.oecd.org/edu/eag.htm).

Para obtener más información acerca de los símbolos utilizados en lugar de los datos que faltan, consulte la Guía del lector.

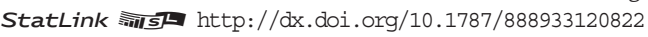


Table X2.3. [2/3] Estadísticas de referencia básicas (periodo de referencia: año natural 1995, 2000, 2005, 2008, 2009, 2010) ${ }^{1}$

\begin{tabular}{|c|c|c|c|c|c|c|}
\hline & \multicolumn{6}{|c|}{$\begin{array}{l}\text { Gasto público total } \\
\text { (en millones de la moneda nacional, precios corrientes) }\end{array}$} \\
\hline & 1995 & 2000 & 2005 & 2008 & 2009 & 2010 \\
\hline & (7) & (8) & (9) & (10) & (11) & (12) \\
\hline Цّ Alemania & 1.014 .050 & 923.360 & 1.043 .450 & 1.090 .460 & 1.146 .270 & 1.194 .130 \\
\hline Australia & 184.270 & 225.913 & 309.431 & 405.784 & 450.682 & 473.579 \\
\hline Austria & 98.428 & 108.287 & 122.585 & 139.494 & 145.333 & 150.593 \\
\hline Bélgica & 108.336 & 123.943 & 157.399 & 172.484 & 183.071 & 187.026 \\
\hline Canadá & 392.886 & 442.560 & 539.234 & 612.322 & 619.880 & 638.212 \\
\hline Chile $^{2}$ & 6.705 .897 & 10.559 .689 & 15.327 .440 & 23.797 .395 & 24.273.284 & 27.847 .954 \\
\hline Corea & 83.399 .300 & 135.324 .800 & 230.062 .600 & 312.548 .300 & 352.323 .300 & 353.006 .600 \\
\hline Dinamarca & 604.404 & 694.479 & 815.717 & 903.263 & 967.096 & 1.016 .158 \\
\hline Eslovenia & $\mathrm{m}$ & 8.636 & 13.011 & 16.511 & 17.456 & 17.894 \\
\hline España & 198.730 & 246.890 & 349.501 & 450.948 & 484.759 & 485.467 \\
\hline Estados Unidos ${ }^{4}$ & 2.732 .629 & 3.353 .547 & 4.563 .353 & 5.567 .081 & 5.913 .918 & 6.153 .839 \\
\hline Estonia & 1.142 & 2.225 & 3.757 & 6.441 & 6.259 & 5.828 \\
\hline Finlandia & 59.103 & 63.903 & 79.262 & 91.372 & 96.708 & 99.707 \\
\hline Francia & 650.606 & 744.119 & 920.351 & 1.030 .025 & 1.070 .585 & 1.095 .602 \\
\hline Grecia & 40.783 & 63.693 & 86.097 & 117.992 & 124.669 & 114.302 \\
\hline Hungría & 3.197 .916 & 6.251 .647 & 11.032 .047 & 13.070 .489 & 13.179 .236 & 13.252 .926 \\
\hline Irlanda & 22.093 & 33.010 & 55.177 & 77.009 & 78.500 & 103.427 \\
\hline Islandia & $\mathrm{m}$ & 286.259 & 433.346 & 853.725 & 763.327 & 791.880 \\
\hline Israel & 152.248 & 261.087 & 296.289 & 332.256 & 350.569 & 367.301 \\
\hline Italia & 497.257 & 549.577 & 688.251 & 765.537 & 788.361 & 782.101 \\
\hline Japón & 181.284 .700 & 193.917 .400 & 183.640 .900 & 188.561 .300 & 197.216 .300 & 195.879 .800 \\
\hline Luxemburgo & 5.996 & 8.270 & 12.573 & 14.624 & 16.084 & 17.098 \\
\hline México & 384.960 & 1.139 .998 & 1.979 .808 & 2.894 .807 & 3.114 .065 & 3.355 .288 \\
\hline Noruega $^{3}$ & 480.575 & 626.569 & 818.805 & 1.018.107 & 1.101 .034 & 1.149 .163 \\
\hline Nueva Zelanda & 31.743 & $\mathrm{~m}$ & 62.645 & 64.002 & 64.013 & 70.450 \\
\hline Países Bajos & 172.305 & 184.612 & 229.965 & 274.781 & 294.782 & 301.284 \\
\hline Polonia & 147.561 & 294.012 & 427.147 & 551.403 & 599.837 & 643.465 \\
\hline Portugal & 36.787 & 52.983 & 71.830 & 77.055 & 83.842 & 88.987 \\
\hline Reino Unido & 322.956 & 358.902 & 553.033 & 686.738 & 719.127 & 738.598 \\
\hline República Checa & 813.015 & 945.255 & 1.340 .123 & 1.583 .527 & 1.679 .551 & 1.661 .774 \\
\hline República Eslovaca & 9.392 & 16.255 & 18.730 & 23.340 & 26.079 & 26.329 \\
\hline Suecia & 1.175 .297 & 1.248 .029 & 1.491 .382 & 1.657 .889 & 1.706 .362 & 1.746 .603 \\
\hline Suiza & 139.873 & 151.837 & 176.236 & 187.914 & 185.629 & 189.561 \\
\hline Turquía & $\mathrm{m}$ & $\mathrm{m}$ & $\mathrm{m}$ & 345.392 & 410.658 & 442.178 \\
\hline Brasil & 224.283 & 394.349 & 670.514 & 939.831 & 1.082 .430 & 1.211 .373 \\
\hline Federación Rusa & $\mathrm{m}$ & 2.016 .630 & 7.380 .575 & $\mathrm{~m}$ & $\mathrm{~m}$ & $\mathrm{~m}$ \\
\hline
\end{tabular}

1. Para los países de la zona euro, los datos sobre PIB y gasto público total se presentan en euros.

2. Años de referencia 1996, 2001, 2006, 2009, 2010 y 2011 en lugar de 1995, 2000, 2005, 2008, 2009 y 2010.

3. El valor de mercado del PIB peninsular se utiliza para Noruega.

4. Estados Unidos revisó toda su serie de PIB en los últimos 6 meses. Los datos presentados en dólares corrientes no coinciden con los presentados en X2.3 de Panorama de la educación 2013.

Fuente: OCDE. Para ver notas, consulte Anexo 3 (www.oecd.org/edu/eag.htm).

Para obtener más información acerca de los símbolos utilizados en lugar de los datos que faltan, consulte la Guía del lector.

StatLink הins $\mathrm{http}: / / \mathrm{dx}$.doi.org/10.1787/888933120822 
Tabla X2.3. [3/3] Estadísticas de referencia básicas (periodo de referencia: año natural 1995, 2000, 2005, 2008, 2009, 2010) ${ }^{1}$

\begin{tabular}{|c|c|c|c|c|c|c|}
\hline & \multicolumn{3}{|c|}{$\begin{array}{l}\text { PIB (en millones de la moneda nacional, } \\
\text { precios constantes 2011) }\end{array}$} & \multicolumn{3}{|c|}{$\begin{array}{l}\text { Gasto público total (en millones de la moneda nacional, } \\
\text { precios constantes 2011) }\end{array}$} \\
\hline & 2008 & 2009 & 2010 & 2008 & 2009 & 2010 \\
\hline & (13) & (14) & (15) & (16) & (17) & (18) \\
\hline Alemania & 2.560 .001 & 2.428 .276 & 2.525 .710 & 1.128 .458 & 1.170 .839 & 1.205 .713 \\
\hline Australia & 1.375 .819 & 1.402 .865 & 1.434 .244 & 443.558 & 487.722 & 482.862 \\
\hline Austria & 297.293 & 285.925 & 291.003 & 146.672 & 150.435 & 153.676 \\
\hline Bélgica & 364.791 & 354.574 & 362.822 & 181.655 & 190.543 & 190.749 \\
\hline Canadá & 1.671 .305 & 1.624 .953 & 1.677 .274 & 638.247 & 658.787 & 658.901 \\
\hline Chile $^{2}$ & 110.452 .877 & 116.818 .603 & 123.656 .889 & 27.254.129 & 25.543.871 & 28.344 .020 \\
\hline Corea & 1.116.963.517 & 1.120.497.242 & 1.191 .330 .100 & 340.108 .565 & 370.670 .089 & 358.438 .920 \\
\hline Dinamarca & 1.853 .636 & 1.748 .645 & 1.772 .834 & 955.034 & 1.015 .808 & 1.023 .538 \\
\hline Eslovenia & 38.509 & 35.448 & 35.895 & 17.071 & 17.470 & 18.101 \\
\hline España & 1.089 .665 & 1.047 .939 & 1.045 .810 & 451.726 & 485.243 & 485.555 \\
\hline Estados Unidos ${ }^{4}$ & 15.307 .038 & 14.878 .116 & 15.251 .973 & 5.788 .980 & 6.102 .689 & 6.274 .656 \\
\hline Estonia & 16.799 & 14.432 & 14.801 & 6.665 & 6.466 & 6.002 \\
\hline Finlandia & 194.283 & 177.686 & 183.665 & 95.611 & 99.721 & 102.464 \\
\hline Francia & 1.990 .948 & 1.928 .281 & 1.961 .536 & 1.060 .796 & 1.094 .723 & 1.109 .640 \\
\hline Grecia & 243.803 & 236.157 & 224.476 & 123.358 & 127.407 & 115.498 \\
\hline Hungría & 28.879 .245 & 26.925.469 & 27.209.655 & 14.220 .756 & 13.847.282 & 13.601.143 \\
\hline Irlanda & 171.830 & 160.862 & 159.143 & 73.412 & 77.813 & 104.111 \\
\hline Islandia & 1.770 .149 & 1.653 .991 & 1.586 .198 & 1.020 .856 & 842.852 & 817.795 \\
\hline Israel & 825.824 & 836.130 & 883.492 & 360.815 & 363.329 & 376.084 \\
\hline Italia & 1.636 .078 & 1.546 .188 & 1.572 .878 & 795.152 & 802.104 & 792.681 \\
\hline Japón & 478.719 .139 & 452.242 .239 & 473.315 .676 & 180.100 .216 & 189.306.336 & 192.197.301 \\
\hline Luxemburgo & 42.053 & 39.717 & 40.949 & 16.456 & 17.957 & 17.814 \\
\hline México & 13.948 .277 & 13.111.724 & 13.809 .745 & 3.322.317 & 3.433 .105 & 3.556 .321 \\
\hline Noruega $^{3}$ & 2.022 .838 & 1.989 .836 & 2.023 .518 & 1.105 .532 & 1.167 .938 & 1.170 .070 \\
\hline Nueva Zelanda & 198.840 & 201.811 & 202.120 & 68.584 & 68.093 & 71.514 \\
\hline Países Bajos & 606.723 & 584.488 & 593.435 & 280.440 & 300.569 & 304.625 \\
\hline Polonia & 1.384 .908 & 1.407 .547 & 1.462 .014 & 598.697 & 627.963 & 664.100 \\
\hline Portugal & 175.091 & 169.991 & 173.288 & 78.447 & 84.569 & 89.207 \\
\hline Reino Unido & 1.576 .650 & 1.495 .115 & 1.520 .013 & 740.556 & 758.578 & 755.700 \\
\hline República Checa & 3.837 .505 & 3.664 .553 & 3.754 .953 & 1.579 .039 & 1.637 .361 & 1.646 .025 \\
\hline República Eslovaca & 67.467 & 64.142 & 66.975 & 23.558 & 26.639 & 26.760 \\
\hline Suecia & 3.341 .343 & 3.173 .393 & 3.381 .351 & 1.728 .784 & 1.743 .504 & 1.769 .535 \\
\hline Suiza & 569.329 & 558.302 & 576.450 & 188.403 & 186.945 & 190.266 \\
\hline Turquía & 1.148 .373 & 1.092 .921 & 1.193 .023 & 417.280 & 471.170 & 480.096 \\
\hline Brasil & 3.762 .637 & 3.750 .286 & 4.121 .383 & 1.166 .228 & 1.253 .138 & 1.324 .250 \\
\hline Federación Rusa & 55.541 .270 & 51.198 .261 & 53.504 .548 & $\mathrm{~m}$ & $\mathrm{~m}$ & $\mathrm{~m}$ \\
\hline
\end{tabular}

1. Para los países de la zona euro, los datos sobre PIB y gasto público total se presentan en euros.

2. Años de referencia 1996, 2001, 2006, 2009, 2010 y 2011 en lugar de 1995, 2000, 2005, 2008, 2009 y 2010

3. El valor de mercado del PIB peninsular se utiliza para Noruega.

4. Estados Unidos revisó toda su serie de PIB en los últimos 6 meses. Los datos presentados en dólares corrientes no coinciden con los presentados en X2.3 de Panorama de la educación 2013

Fuente: OCDE. Para ver notas, consulte Anexo 3 (www.oecd.org/edu/eag.htm).

Para obtener más información acerca de los símbolos utilizados en lugar de los datos que faltan, consulte la Guía del lector.

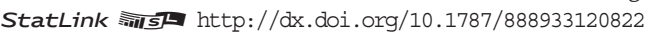


Tabla X2.4a. [1/2] Salarios reglamentarios de los profesores en varios momentos de su carrera (2012) Salarios anuales en instituciones públicas, en moneda nacional

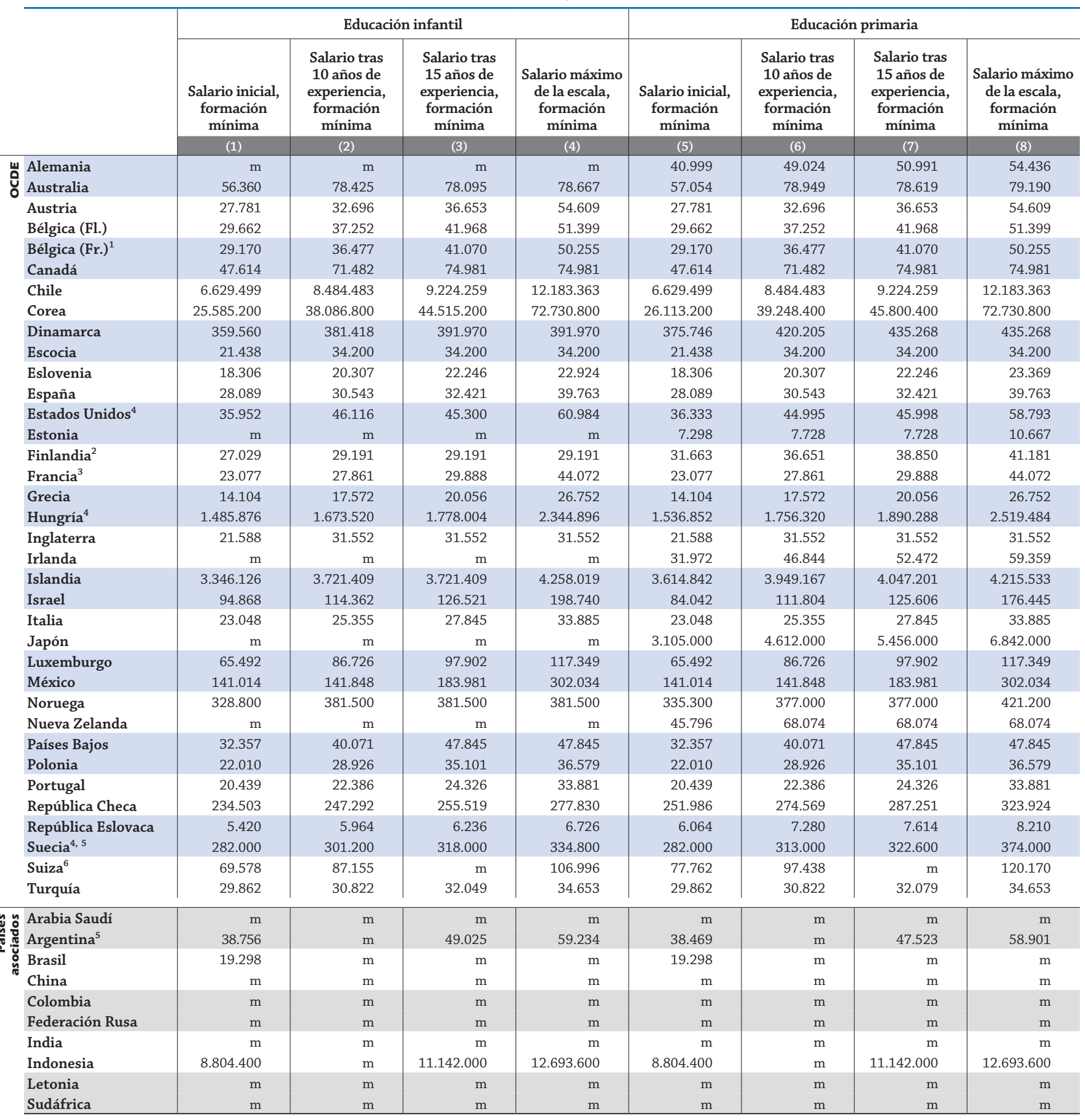

1. Salarios de los profesores con cualificaciones típicas en lugar de mínimas. Para más información sobre el salario de los profesores con cualificaciones mínimas, consulte Anexo 3.

2. Incluye solo profesores de jardín de infancia para la enseñanza infantil.

3. Incluye la media de bonificaciones obtenidas por horas extraordinarias para los profesores de secundaria inferior y superior.

4. Salarios base reales.

5. Año de referencia 2011.

6. Salarios tras 11 años de experiencia para las columnas 2, 6, 10 y 14 .

Fuente: OCDE. Argentina: Instituto de Estadística de la UNESCO (Programa Mundial de Indicadores de Educación). Para ver notas, consulte Anexo 3 (www.oecd.org/ edu/eag.htm).

Para obtener más información acerca de los símbolos utilizados en lugar de los datos que faltan, consulte la Guía del lector.

StatLink 젠 http://dx.doi.org/10.1787/888933120860 
Tabla X2.4a. [2/2] Salarios reglamentarios de los profesores en varios momentos de su carrera (2012) Salarios anuales en instituciones públicas, en moneda nacional

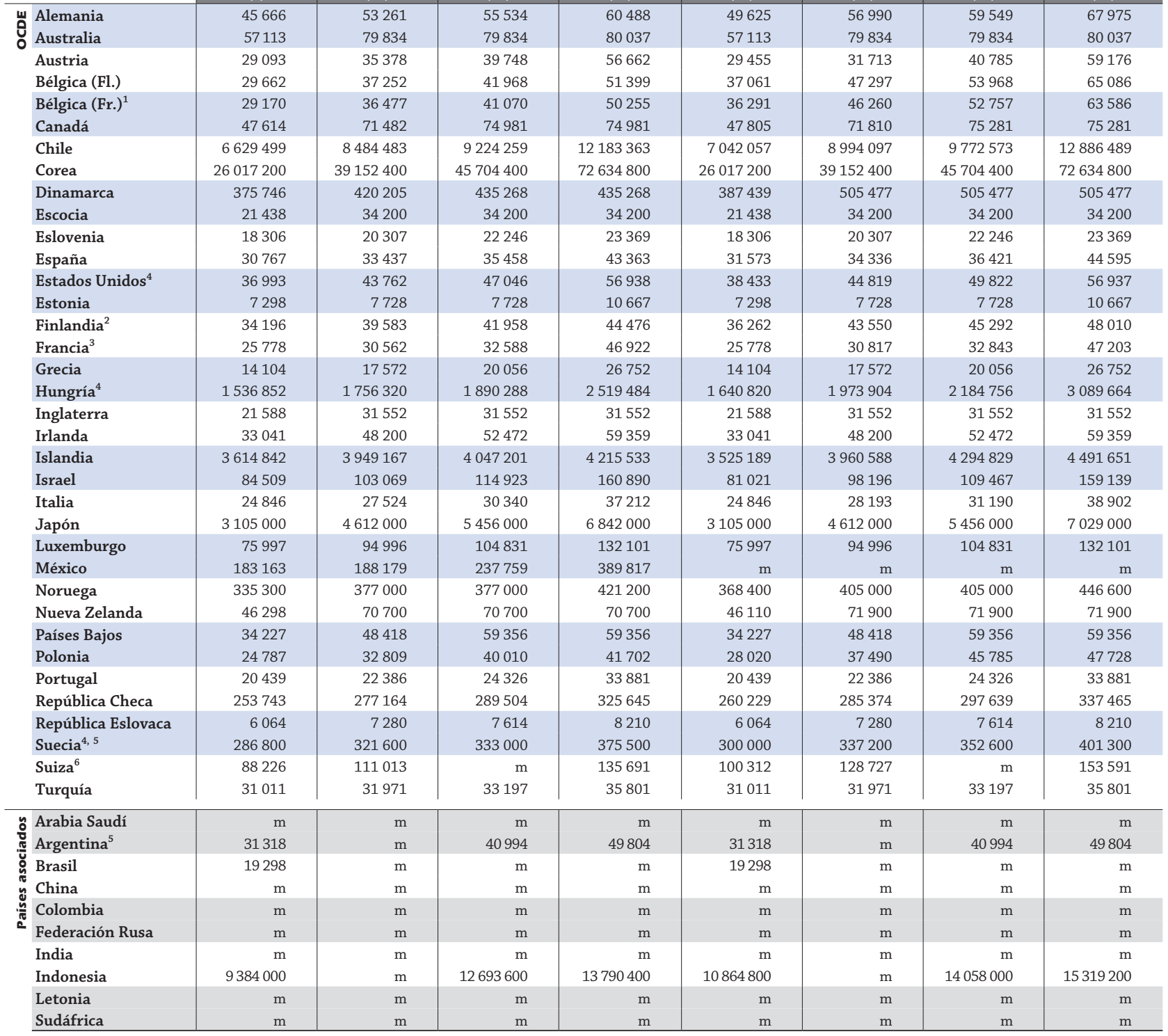

1. Salarios de los profesores con cualificaciones típicas en lugar de mínimas. Para más información sobre el salario de los profesores con cualificaciones mínimas, consulte Anexo 3.

2. Incluye solo profesores de jardín de infancia para la enseñanza infantil.

3. Incluye la media de bonificaciones obtenidas por horas extraordinarias para los profesores de secundaria inferior y superior.

4. Salarios base reales.

5. Año de referencia 2011

6. Salarios tras 11 años de experiencia para las columnas 2, 6, 10 y 14

Fuente: OCDE. Argentina: Instituto de Estadística de la UNESCO (Programa Mundial de Indicadores de Educación). Para ver notas, consulte Anexo 3 (www.oecd.org/ edu/eag.htm).

Para obtener más información acerca de los símbolos utilizados en lugar de los datos que faltan, consulte la Guía del lector.

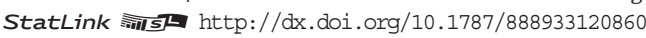


Tabla X2.4b. [1/2] Tendencias en los salarios de los profesores entre 2000 y $2012^{1}$

Salario anual reglamentario de los profesores en instituciones públicas tras 15 años de experiencia y formación mínima, por nivel de educación, en moneda nacional

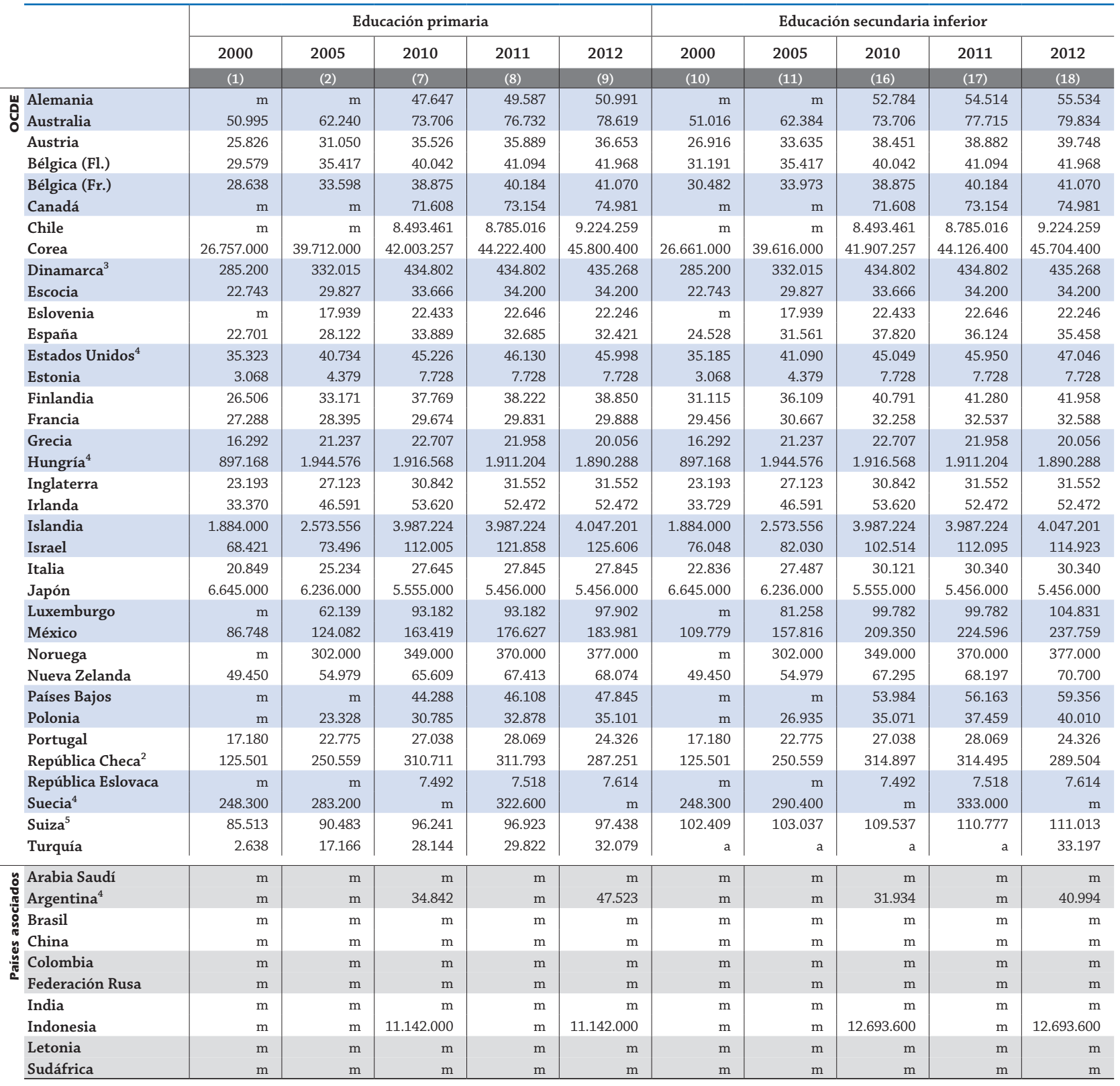

Notas: Los años 2006, 2007, 2008, 2009 (columnas 3-6; 12-15; 21-24) están disponibles en Internet (véase StatLink más abajo).

1. Los datos de salarios de los países que ahora están en la zona euro se muestran en euros.

2. Ruptura de la serie temporal tras cambios en la metodología en 2012.

3. Ruptura de la serie temporal tras cambios en la metodología en 2009.

4. Salarios base reales.

5. Salario tras 11 años de experiencia.

Fuente: OCDE. Argentina: Instituto de Estadística de la UNESCO (Programa Mundial de Indicadores de Educación). Para ver notas, consulte Anexo 3 (www.oecd.org/ edu/eag.htm).

Para obtener más información acerca de los símbolos utilizados en lugar de los datos que faltan, consulte la Guía del lector.

StatLink 제그 http://dx.doi.org/10.1787/888933120879 
Tabla X2.4b. [2/2] Tendencias en los salarios de los profesores entre 2000 y $2012^{1}$

Salario anual reglamentario de los profesores en instituciones públicas tras 15 años de experiencia y formación mínima, por nivel de educación, en moneda nacional

\begin{tabular}{|c|c|c|c|c|c|}
\hline & \multicolumn{5}{|c|}{ Educación secundaria superior } \\
\hline & 2000 & 2005 & 2010 & 2011 & 2012 \\
\hline & (19) & $(20)$ & $(25)$ & $(26)$ & $(27)$ \\
\hline Alemania & $\mathrm{m}$ & $\mathrm{m}$ & 57.150 & 58.930 & 59.549 \\
\hline Australia & 51.016 & 62.384 & 73.706 & 77.715 & 79.834 \\
\hline Austria & 29.728 & 34.265 & 39.535 & 39.927 & 40.785 \\
\hline Bélgica (Fl.) & 39.886 & 45.301 & 51.454 & 52.844 & 53.968 \\
\hline Bélgica (Fr.) & 39.207 & 43.704 & 50.108 & 51.643 & 52.757 \\
\hline Canadá & $\mathrm{m}$ & $\mathrm{m}$ & 71.886 & 73.440 & 75.281 \\
\hline Chile & $\mathrm{m}$ & $\mathrm{m}$ & 9.004 .818 & 9.307 .217 & 9.772 .573 \\
\hline Corea & 26.661 .000 & 39.616 .000 & 41.907 .257 & 44.126 .400 & 45.704 .400 \\
\hline Dinamarca $^{3}$ & 335.000 & 404.229 & 504.046 & 504.046 & 505.477 \\
\hline Escocia & 22.743 & 29.827 & 33.666 & 34.200 & 34.200 \\
\hline Eslovenia & $\mathrm{m}$ & 17.939 & 22.433 & 22.646 & 22.246 \\
\hline España & 26.366 & 32.293 & 38.613 & 36.749 & 36.421 \\
\hline Estados Unidos ${ }^{4}$ & 37.838 & 41.044 & 48.446 & 49.414 & 49.822 \\
\hline Estonia & 3.068 & 4.379 & 7.728 & 7.728 & 7.728 \\
\hline Finlandia & 32.681 & 38.263 & 43.168 & 43.686 & 45.292 \\
\hline Francia & 29.456 & 30.895 & 32.472 & 32.752 & 32.843 \\
\hline Grecia & 16.292 & 21.237 & 22.707 & 21.958 & 20.056 \\
\hline Hungría $^{4}$ & 1.128 .996 & 2.432 .388 & 2.262 .636 & 2.260 .944 & 2.184 .756 \\
\hline Inglaterra & 23.193 & 27.123 & 30.842 & 31.552 & 31.552 \\
\hline Irlanda & 33.729 & 46.591 & 53.620 & 52.472 & 52.472 \\
\hline Islandia & 2.220 .000 & 3.014 .000 & 4.012 .000 & 4.012 .000 & 4.294 .829 \\
\hline Israel & 75.097 & 80.052 & 93.450 & 95.590 & 109.467 \\
\hline Italia & 23.518 & 28.259 & 30.966 & 31.190 & 31.190 \\
\hline Japón & 6.649 .000 & 6.237 .000 & 5.555 .000 & 5.456 .000 & 5.456 .000 \\
\hline Luxemburgo & $\mathrm{m}$ & 81.258 & 99.782 & 99.782 & 104.831 \\
\hline México & $\mathrm{m}$ & $\mathrm{m}$ & $\mathrm{m}$ & $\mathrm{m}$ & $\mathrm{m}$ \\
\hline Noruega & $\mathrm{m}$ & 321.000 & 376.400 & 398.000 & 405.000 \\
\hline Nueva Zelanda & 49.450 & 54.979 & 68.980 & 68.980 & 71.900 \\
\hline Países Bajos & $\mathrm{m}$ & $\mathrm{m}$ & 53.984 & 56.163 & 59.356 \\
\hline Polonia & $\mathrm{m}$ & 31.216 & 40.120 & 42.860 & 45.785 \\
\hline Portugal & 17.180 & 22.775 & 27.038 & 28.069 & 24.326 \\
\hline República Checa ${ }^{2}$ & 152.941 & 255.125 & 334.084 & 335.696 & 297.639 \\
\hline República Eslovaca & $\mathrm{m}$ & $\mathrm{m}$ & 7.498 & 7.518 & 7.614 \\
\hline Suecia $^{4}$ & 264.700 & 313.600 & $\mathrm{~m}$ & 352.600 & $\mathrm{~m}$ \\
\hline Suiza $^{5}$ & 121.629 & 120.602 & 127.839 & 128.860 & 128.727 \\
\hline Turquía & 2.441 & 17.403 & 28.883 & 30.483 & 33.197 \\
\hline Arabia Saudí & $\mathrm{m}$ & $\mathrm{m}$ & $\mathrm{m}$ & $\mathrm{m}$ & $\mathrm{m}$ \\
\hline Argentina $^{4}$ & $\mathrm{~m}$ & $\mathrm{~m}$ & 31.934 & $\mathrm{~m}$ & 40.994 \\
\hline Brasil & $\mathrm{m}$ & $\mathrm{m}$ & $\mathrm{m}$ & $\mathrm{m}$ & $\mathrm{m}$ \\
\hline China & $\mathrm{m}$ & $\mathrm{m}$ & $\mathrm{m}$ & $\mathrm{m}$ & $\mathrm{m}$ \\
\hline Colombia & $\mathrm{m}$ & $\mathrm{m}$ & $\mathrm{m}$ & $\mathrm{m}$ & $\mathrm{m}$ \\
\hline Federación Rusa & $\mathrm{m}$ & $\mathrm{m}$ & $\mathrm{m}$ & $\mathrm{m}$ & $\mathrm{m}$ \\
\hline India & $\mathrm{m}$ & $\mathrm{m}$ & $\mathrm{m}$ & $\mathrm{m}$ & $\mathrm{m}$ \\
\hline Indonesia & $\mathrm{m}$ & $\mathrm{m}$ & 14.058 .000 & $\mathrm{~m}$ & 14.058 .000 \\
\hline Letonia & $\mathrm{m}$ & $\mathrm{m}$ & $\mathrm{m}$ & $\mathrm{m}$ & $\mathrm{m}$ \\
\hline Sudáfrica & $\mathrm{m}$ & $\mathrm{m}$ & $\mathrm{m}$ & $\mathrm{m}$ & $\mathrm{m}$ \\
\hline
\end{tabular}

Notas: Los años 2006, 2007, 2008, 2009 (columnas 3-6; 12-15; 21-24) están disponibles en Internet (véase StatLink más abajo).

1. Los datos de salarios de los países que ahora están en la zona euro se muestran en euros.

2. Ruptura de la serie temporal tras cambios en la metodología en 2012.

3. Ruptura de la serie temporal tras cambios en la metodología en 2009.

4. Salarios base reales.

5. Salario tras 11 años de experiencia.

Fuente: OCDE. Argentina: Instituto de Estadística de la UNESCO (Programa Mundial de Indicadores de Educación). Para ver notas, consulte Anexo 3 (www.oecd.org/ edu/eag.htm).

Para obtener más información acerca de los símbolos utilizados en lugar de los datos que faltan, consulte la Guía del lector.

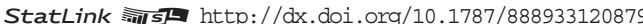


Tabla X2.4c. Estadísticas de referencia para el cálculo de los salarios de los profesores (2000, 2005-2012)

\begin{tabular}{|c|c|c|c|c|c|c|c|c|c|c|c|c|c|c|}
\hline & & \multicolumn{3}{|c|}{$\begin{array}{c}\text { Paridad de poder adquisitivo } \\
\text { para el consumo privado }(\mathrm{PPA})^{1}\end{array}$} & \multicolumn{9}{|c|}{ Deflactores para el consumo privado $(2005=100)$} & \multirow{2}{*}{$\begin{array}{c}\text { Año de } \\
\text { referencia } \\
\text { para los datos } \\
\text { sobre salarios } \\
\text { de } 2012\end{array}$} \\
\hline & & 2011 & 2012 & $\begin{array}{c}\text { Enero } \\
2012\end{array}$ & $\begin{array}{c}\text { Enero } \\
2000\end{array}$ & $\begin{array}{c}\text { Enero } \\
2005\end{array}$ & $\begin{array}{c}\text { Enero } \\
2006\end{array}$ & $\begin{array}{c}\text { Enero } \\
2007\end{array}$ & $\begin{array}{c}\text { Enero } \\
2008\end{array}$ & $\begin{array}{c}\text { Enero } \\
2009\end{array}$ & $\begin{array}{c}\text { Enero } \\
2010\end{array}$ & $\begin{array}{c}\text { Enero } \\
2011\end{array}$ & $\begin{array}{c}\text { Enero } \\
2012\end{array}$ & \\
\hline & & $(1)$ & (2) & (3) & $(4)$ & (5) & $(6)$ & $(7)$ & (8) & (9) & $(10)$ & $(11)$ & $(12)$ & (13) \\
\hline \multirow{32}{*}{ 岂 } & Alemania & 0,82 & 0,82 & 0,82 & 93 & 100 & 101 & 103 & 104 & 105 & 106 & 108 & 110 & $2011 / 2012$ \\
\hline & Australia & 1,53 & 1,54 & 1,53 & 89 & 100 & 103 & 106 & 110 & 113 & 116 & 119 & 122 & 2012 \\
\hline & Austria & 0,85 & 0,86 & 0,85 & 92 & 100 & 102 & 105 & 107 & 109 & 110 & 113 & 116 & 2011/2012 \\
\hline & Bélgica (Fr.) ${ }^{2}$ & 0,88 & 0,88 & 0,88 & 91 & 100 & 103 & 106 & 109 & 110 & 111 & 114 & 117 & Enero 2012 \\
\hline & Canadá & 1,28 & 1,28 & 1,28 & 91 & 100 & 102 & 103 & 105 & 106 & 107 & 109 & 110 & 2011/2012 \\
\hline & Chile & 370,20 & 375,95 & 373,08 & 86 & 100 & 104 & 107 & 113 & 118 & 121 & 125 & 130 & 2012 \\
\hline & Corea & 912,02 & 914,68 & 913,35 & 85 & 100 & 102 & 104 & 107 & 111 & 114 & 117 & 121 & 2012 \\
\hline & Dinamarca & 8,52 & 8,50 & 8,51 & 92 & 100 & 102 & 103 & 105 & 108 & 110 & 113 & 115 & 2011/2012 \\
\hline & Escocia $^{3}$ & 0,76 & 0,77 & 0,76 & 94 & 100 & 103 & 105 & 108 & 111 & 114 & 119 & 123 & $2011 / 2012$ \\
\hline & Eslovenia & 0,68 & 0,67 & 0,68 & 76 & 100 & 102 & 106 & 111 & 114 & 116 & 118 & 120 & 2011/2012 \\
\hline & España & 0,78 & 0,77 & 0,77 & 85 & 100 & 104 & 107 & 111 & 112 & 113 & 115 & 119 & $2011 / 2012$ \\
\hline & Estonia & 0,61 & 0,63 & 0,62 & 84 & 100 & 105 & 112 & 120 & 124 & 125 & 130 & 135 & $2011 / 2012$ \\
\hline & Finlandia & 0,98 & 0,99 & 0,98 & 93 & 100 & 101 & 103 & 106 & 108 & 110 & 113 & 117 & Enero 2012 \\
\hline & Francia & 0,88 & 0,88 & 0,88 & 91 & 100 & 102 & 104 & 107 & 108 & 108 & 110 & 112 & $2011 / 2012$ \\
\hline & Grecia & 0,76 & 0,75 & 0,75 & 86 & 100 & 103 & 107 & 111 & 113 & 116 & 120 & 123 & 2012 \\
\hline & Hungría & 137,88 & 141,75 & 139,82 & 73 & 100 & 104 & 109 & 116 & 121 & 126 & 131 & 137 & 2011/2012 \\
\hline & Inglaterra $^{3}$ & 0,76 & 0,77 & 0,76 & 94 & 100 & 103 & 105 & 108 & 111 & 114 & 119 & 123 & $2011 / 2012$ \\
\hline & Irlanda & 0,95 & 0,95 & 0,95 & 84 & 100 & 102 & 105 & 107 & 104 & 100 & 99 & 101 & $2011 / 2012$ \\
\hline & Islandia & 138,89 & 142,72 & 140,81 & 82 & 100 & 105 & 111 & 122 & 139 & 150 & 156 & 163 & $2011 / 2012$ \\
\hline & Israel & 4,27 & 4,27 & 4,27 & 93 & 100 & 102 & 103 & 106 & 110 & 113 & 117 & 120 & $2011 / 2012$ \\
\hline & Italia & 0,83 & 0,83 & 0,83 & 87 & 100 & 102 & 105 & 108 & 109 & 110 & 112 & 116 & $2011 / 2012$ \\
\hline & Japón & 116,10 & 113,33 & 114,72 & 105 & 100 & 100 & 99 & 99 & 98 & 96 & 94 & 94 & $2011 / 2012$ \\
\hline & Luxemburgo & 0,99 & 0,99 & 0,99 & 90 & 100 & 103 & 105 & 108 & 110 & 112 & 114 & 117 & $2011 / 2012$ \\
\hline & México & 8,94 & 9,19 & 9,06 & 73 & 100 & 103 & 108 & 113 & 121 & 128 & 133 & 138 & $2011 / 2012$ \\
\hline & Noruega & 9,80 & 9,65 & 9,72 & 91 & 100 & 101 & 103 & 105 & 109 & 111 & 113 & 114 & $2011 / 2012$ \\
\hline & Nueva Zelanda & 1,59 & 1,57 & 1,58 & 93 & 100 & 102 & 105 & 107 & 111 & 114 & 116 & 118 & $2011 / 2012$ \\
\hline & Países Bajos & 0,87 & 0,87 & 0,87 & 87 & 100 & 102 & 104 & 106 & 106 & 106 & 108 & 111 & $2011 / 2012$ \\
\hline & República Checa & 14,90 & 14,77 & 14,84 & 90 & 100 & 101 & 103 & 107 & 110 & 111 & 111 & 112 & $2011 / 2012$ \\
\hline & República Eslovaca & 0,57 & 0,57 & 0,57 & 76 & 100 & 104 & 108 & 111 & 114 & 115 & 117 & 122 & $2011 / 2012$ \\
\hline & Suecia & 9,27 & 9,11 & 9,19 & 93 & 100 & 101 & 102 & 105 & 107 & 109 & 111 & 112 & 2011 \\
\hline & Suiza & 1,61 & 1,57 & 1,59 & 97 & 100 & 101 & 103 & 105 & 106 & 106 & 107 & 107 & 2011/2012 \\
\hline & Turquía & 1,16 & 1,24 & 1,20 & 28 & 100 & 109 & 118 & 128 & 138 & 147 & 160 & 174 & 2012 \\
\hline \multirow{10}{*}{ 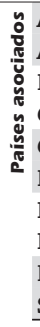 } & Arabia Saudí & $\mathrm{m}$ & $\mathrm{m}$ & $\mathrm{m}$ & $\mathrm{m}$ & $\mathrm{m}$ & $\mathrm{m}$ & $\mathrm{m}$ & $\mathrm{m}$ & $\mathrm{m}$ & $\mathrm{m}$ & $\mathrm{m}$ & $\mathrm{m}$ & $\mathrm{m}$ \\
\hline & Argentina & $\mathrm{m}$ & $\mathrm{m}$ & $\mathrm{m}$ & $\mathrm{m}$ & $\mathrm{m}$ & $\mathrm{m}$ & $\mathrm{m}$ & $\mathrm{m}$ & $\mathrm{m}$ & $\mathrm{m}$ & $\mathrm{m}$ & $\mathrm{m}$ & 2011 \\
\hline & Brasil & 1,83 & 1,89 & 1,86 & 65 & 100 & 106 & 111 & 117 & 125 & 132 & 141 & 150 & 2012 \\
\hline & China & $\mathrm{m}$ & $\mathrm{m}$ & $\mathrm{m}$ & $\mathrm{m}$ & $\mathrm{m}$ & $\mathrm{m}$ & $\mathrm{m}$ & $\mathrm{m}$ & $\mathrm{m}$ & $\mathrm{m}$ & $\mathrm{m}$ & $\mathrm{m}$ & $\mathrm{m}$ \\
\hline & Colombia & $\mathrm{m}$ & $\mathrm{m}$ & $\mathrm{m}$ & $\mathrm{m}$ & $\mathrm{m}$ & $\mathrm{m}$ & $\mathrm{m}$ & $\mathrm{m}$ & $\mathrm{m}$ & $\mathrm{m}$ & $\mathrm{m}$ & $\mathrm{m}$ & $\mathrm{m}$ \\
\hline & Federación Rusa & 17,08 & 17,69 & 17,39 & $\mathrm{~m}$ & $\mathrm{~m}$ & $\mathrm{~m}$ & $\mathrm{~m}$ & $\mathrm{~m}$ & $\mathrm{~m}$ & $\mathrm{~m}$ & $\mathrm{~m}$ & $\mathrm{~m}$ & 2011 \\
\hline & India & $\mathrm{m}$ & $\mathrm{m}$ & $\mathrm{m}$ & $\mathrm{m}$ & $\mathrm{m}$ & $\mathrm{m}$ & $\mathrm{m}$ & $\mathrm{m}$ & $\mathrm{m}$ & $\mathrm{m}$ & $\mathrm{m}$ & $\mathrm{m}$ & $\mathrm{m}$ \\
\hline & Indonesia & $5.583,76$ & $5.704,67$ & $5.644,22$ & 61 & 100 & 113 & 129 & 146 & 159 & 167 & 177 & 188 & $2011 / 2012$ \\
\hline & Letonia & $\mathrm{m}$ & $\mathrm{m}$ & $\mathrm{m}$ & $\mathrm{m}$ & $\mathrm{m}$ & $\mathrm{m}$ & $\mathrm{m}$ & $\mathrm{m}$ & $\mathrm{m}$ & $\mathrm{m}$ & $\mathrm{m}$ & $\mathrm{m}$ & $\mathrm{m}$ \\
\hline & Sudáfrica & $\mathrm{m}$ & $\mathrm{m}$ & $\mathrm{m}$ & $\mathrm{m}$ & $\mathrm{m}$ & $\mathrm{m}$ & $\mathrm{m}$ & $\mathrm{m}$ & $\mathrm{m}$ & $\mathrm{m}$ & $\mathrm{m}$ & $\mathrm{m}$ & $\mathrm{m}$ \\
\hline
\end{tabular}

1. Los datos de PPA y PIB de los países que ahora están en la zona euro se muestran en euros.

2. Los datos de PPA y deflactores se refieren a Bélgica.

3. Los datos de PPA y deflactores se refieren a Reino Unido.

Fuente: OCDE. Argentina: Instituto de Estadística de la UNESCO (Programa Mundial de Indicadores de Educación). Para ver notas, consulte Anexo 3 (www.oecd.org/ edu/eag.htm).

Para obtener más información acerca de los símbolos utilizados en lugar de los datos que faltan, consulte la Guía del lector.

StatLink 게그 http://dx.doi.org/10.1787/888933120898 


\section{Notas generales}

\section{Definiciones}

Producto interior bruto (PIB) es el valor de mercado de la producción bruta de los productores residentes, incluyendo el transporte y la comercialización, restando el valor del consumo intermedio de los compradores y el valor de las tasas de importación. El PIB se expresa en millones de divisas nacionales. En aquellos países cuyo año de referencia del PIB sea diferente al año natural (como Australia y Nueva Zelanda), la ponderación lineal del PIB entre dos años de referencia consecutivos se hace de manera que se corresponda con el año natural.

El deflactor del PIB se obtiene dividiendo el PIB expresado en precios corrientes por el PIB expresado en precios constantes, lo que indica el nivel de precios relativos de un país.

El PIB per cápita es el producto interior bruto (en equivalente a dólares estadounidenses convertidos mediante PPA) dividido por la población.

Tasas de paridad de poder adquisitivo (PPA) son tipos de cambio que igualan el poder adquisitivo de las diferentes monedas. Lo que significa que, si se convierte una determinada suma de dinero a diferentes monedas nacionales utilizando las tasas de PPA, se puede adquirir la misma cesta de bienes y servicios en los países en cuestión. En otros términos, las tasas de PPA son tipos de cambio monetario que eliminan las diferencias de niveles de precios entre países. De esta manera, si se convierten los gastos relativos al PIB a una moneda común utilizando las tasas de PPA, tales gastos se refieren a un mismo conjunto de precios internacionales, aunque las comparaciones entre países van a reflejar únicamente las diferencias en cuanto al volumen de productos y servicios adquiridos.

Gasto público total, utilizado para el cálculo de los indicadores educativos, corresponde a la suma de gastos corrientes y de capital no reembolsables de todos los niveles de la administración. Los gastos corrientes incluyen el consumo final (por ejemplo, la remuneración de los empleados, los bienes y servicios consumidos, el consumo de capital fijo y los gastos militares), los pagos de las rentas de propiedades, subsidios y otros pagos de transferencias corrientes (por ejemplo, seguridad social, prestaciones sociales, pensiones y otros beneficios sociales). Los gastos de capital se destinan a adquirir o mejorar bienes de capital fijo, terrenos, activos intangibles, reservas de la administración y activos no militares y no financieros, y a financiar las transferencias netas de capital.

\section{Fuentes}

Edición 2014 de National Accounts of OECD countries: Detailed Tables, Volume II.

Desde hace años, el marco teórico utilizado para las cuentas nacionales procede de la publicación de Naciones Unidas A System of National Accounts, editada en 1968. Existe una versión actualizada en 1993 (más conocida como SNA93).

Base de Datos Analítica de la OCDE, enero de 2014.

\section{Nota sobre los datos de Israel}

Los datos estadísticos para Israel fueron proporcionados por las autoridades israelíes competentes bajo su responsabilidad. El uso de estos datos por parte de la OCDE se hace sin prejuzgar la situación de los Altos del Golán, Jerusalén Este y los asentamientos israelíes en Cisjordania de acuerdo con los términos del derecho internacional. 


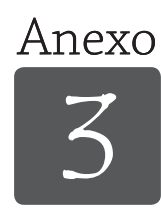

\section{FUENTES, MÉTODOS Y NOTAS TÉCNICAS}

El Anexo 3 sobre fuentes y métodos tan solo está disponible en formato electrónico y se puede encontrar en Internet en la siguiente dirección:

www.oecd.org/edu/eag.htm

Anexo 3: Capítulo A

www.oecd.org/edu/eag/annex3-ChapterA.pdf

Anexo 3: Capítulo B

www.oecd.org/edu/eag/annex3-ChapterB.pdf

Anexo 3: Capítulo C

www.oecd.org/edu/eag/annex3-ChapterC.pdf

Anexo 3: Indicador D1

www.oecd.org/edu/eag/annex3-IndicatorD1.pdf

Anexo 3: Indicadores D2-D5

www.oecd.org/edu/eag/annex3-IndicatorD2-D5.pdf

Anexo 3: Indicador D6

www.oecd.org/edu/eag/annex3-IndicatorD6.pdf

Anexo 3: Indicador D7

www.oecd.org/edu/eag/annex3-IndicatorD7.pdf 



\title{
Personas qUE haN PARTICIPAdo EN ESTA PUblicación
}

\author{
Muchas personas han contribuido a realizar esta publicación. La lista que sigue incluye \\ los nombres de los representantes nacionales que han tomado parte en las reunions de INES \\ y en los trabajos preparatorios de esta edición de Panorama de la educación 2014: Indicadores de la OCDE.
}

La OCDE desea agradecerles sus valiosas aportaciones.

\section{Grupo de trabajo INES}

Hans-Werner FREITAG (Alemania)

Heinz-Werner HETMEIER (Alemania)

Christiane KRUGER-HEMMER (Alemania)

Marco MUNDELIUS (Alemania)

Martin SCHULZE (Alemania)

Eveline VON GAESSLER (Alemania)

Katrin WERY (Alemania)

Heinrich WIRTZ (Alemania)

Ahmed F. HAYAJNEH (Arabia Saudí)

Maria Laura ALONSO (Argentina)

Julián FALCONE (Argentina)

Marcela JÁUREGUI (Argentina)

Stephanie BOWLES (Australia)

Paul CMIEL (Australia)

Stuart FAUNT (Australia)

Cheryl HOPKINS (Australia)

Joanna KORDIS (Australia)

Scott MATHESON (Presidente Grupo de trabajo INES, Australia)

Margaret PEARCE (Australia)

Mary-Anne SAKKARA (Australia)

Mark UNWIN (Australia)

Shelagh WHITTLESTON (Australia)

Sabine MARTINSCHITZ (Austria)

Mark NÉMET (Austria)

Wolfgang PAULI (Austria)

Helga POSSET (Austria)

Natascha RIHA (Austria)

Philippe DIEU (Bélgica)

Isabelle ERAUW (Bélgica)

Nathalie JAUNIAUX (Bélgica)

Guy STOFFELEN (Bélgica)

Raymond VAN DE SIJPE (Bélgica)

Ann VAN DRIESSCHE (Bélgica)

Daniel Jaime CAPISTRANO DE OLIVEIRA (Brasil)

Carla D'Lourdes DO NASCIMENTO (Brasil)

Juliana MARQUES DA SILVA (Brasil)

Ana Carolina SILVA CIROTTO (Brasil)

Patric BLOUIN (Canadá)

Shannon DELBRIDGE (Canadá)

Tomasz GLUSZYNSKI (Canadá)

Amanda HODGKINSON (Canadá)

Michael MARTIN (Canadá)

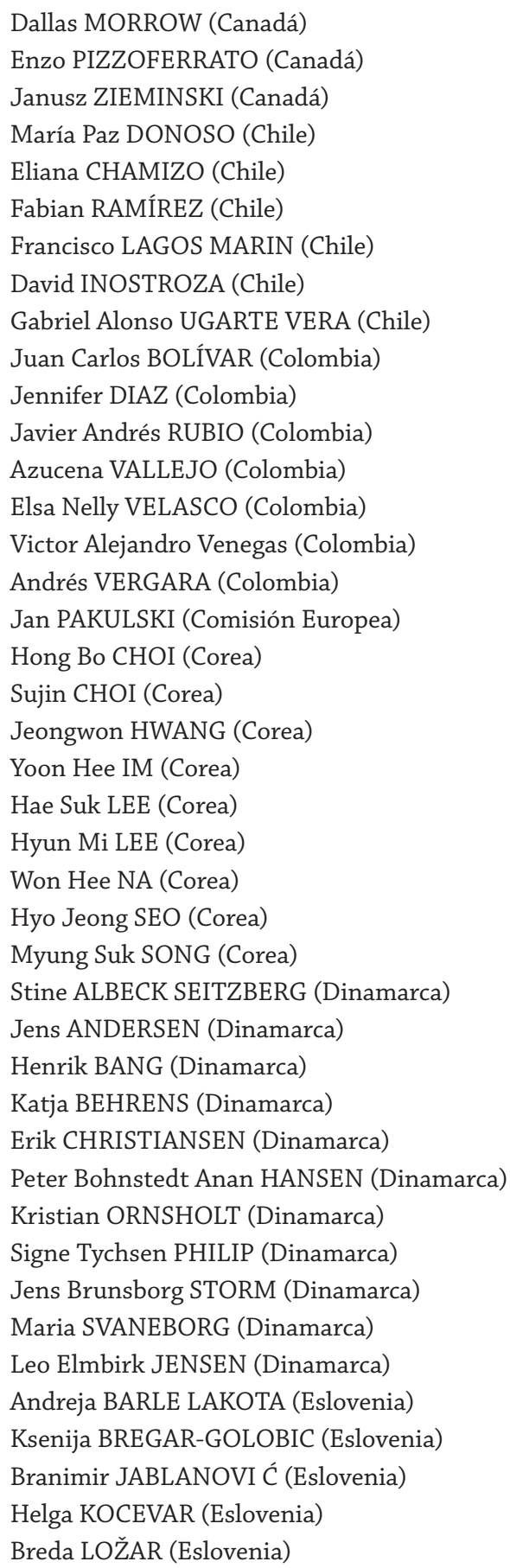


Dusa MARJETIC (Eslovenia)

Mitja SARDOC (Eslovenia)

Tatjana SKRBEC (Eslovenia)

Irena SVETIN (Eslovenia)

Tanja TAŠTANOSKA (Eslovenia)

Jadranka TUŠ (Eslovenia)

Laura ALONSO CARMONA (España)

Eduardo DE LA FUENTE FUENTE (España)

Jesús IBAÑEZ MILLA (España)

Joaquín MARTÍN MUÑOZ (España)

Cristina MONEO OCAÑA (España)

Ismael SANZ LABRADOR (España)

Carmen UREÑA UREÑA (España)

Rachel DINKES (Estados Unidos)

Jennifer HARWOOD (Estados Unidos)

Jana KEMP (Estados Unidos)

Ashley ROBERTS (Estados Unidos)

Mr.Thomas SNYDER (Estados Unidos)

Tiina ANNUS (Estonia)

Christine COIN (Eurostat, Comisión Europea)

Jacques LANNELUC (Eurostat, Comisión Europea)

Mark AGRANOVICH (Federación Rusa)

Evgeny BUTKO (Federación Rusa)

Anna FATEEVA (Federación Rusa)

Irina SELIVERSTOVA (Federación Rusa)

Timo ERTOLA (Finlandia)

Ville HEINONEN (Finlandia)

Matti KYRÖ (Finlandia)

Mika TUONONEN (Finlandia)

Cedric AFSA (Francia)

Pierrette BRIANT (Francia)

Mireille DUBOIS (Francia)

Nadine ESQUIEU (Francia)

Ms Bénédicte GALTIER (Francia)

Florence LEFRESNE (Francia)

Stéphanie LEMERLE (Francia)

Valérie LIOGIER (Francia)

Hélène MICHAUDON (Francia)

Pascale POULET-COULIBANDO (Francia)

Robert RAKOCEVIC (Francia)

Marguerite RUDOLF (Francia)

Dimitra FARMAKIOUTOU (Grecia)

Maria FASSARI (Grecia)

Konstantinos KAMPANAKIS (Grecia)

Akrivi NIKOLAKOPOULOU (Grecia)

Athena PLESSA-PAPADAKI (Grecia)

Tünde HAGYMÁSY (Hungría)

Tibor KÖNYVESI (Hungría)

László LIMBACHER (Hungría)

Kristián SZÉLL (Hungría)

Ida KINTAMANI (Indonesia)

Yul Yunazwin NAZARUDDIN (Indonesia)

Siti SOFIA (Indonesia)

Gary Ó DONNCHADHA (Irlanda)
Diarmuid REIDY (Irlanda)

Nicola TICKNER (Irlanda)

Gunnar J. ÁRNASON (Islandia)

Julius BJORNSSON (Islandia)

Asta URBANCIC (Islandia)

Sophie ARTSEV (Israel)

Yael ATIYAH (Israel)

Yoav AZULAY (Israel)

Yonatan BAR ON (Israel)

Nava BRENNER (Israel)

Livnat GAVRIELOV (Israel)

Yosef GIDANIAN (Israel)

Pinhas KLEIN (Israel)

Aviel KRENTZLER (Israel)

Daniel LEVI-MAZLOUM (Israel)

Haim PORTNOY (Israel)

Naama STEINBERG (Israel)

Gianna BARBIERI (Italia)

Massimiliano CICCIA (Italia)

Daniela DI ASCENZO (Italia)

Paola DI GIROLAMO (Italia)

Maria Teresa MORANA (Italia)

Claudia PIZZELLA (Italia)

Paolo SESTITO (Italia)

Paolo TURCHETTI (Italia)

Hiroe HINO (Japón)

Nami JINDA (Japón)

Yu KAMEOKA (Japón)

Takashi MURAO (Japón)

Naoki OYAKE (Japón)

Natsue SAITO (Japón)

Hiromi SASAI (Japón)

Kumiko TANSHO-HIRABAYASHI (Japón)

Koji YANAGISAWA (Japón)

Ennata KIVRINA (Letonia)

Reinis MARKVARTS (Letonia)

Jérôme LEVY (Luxemburgo)

Charlotte MAHON (Luxemburgo)

Elisa MAZZUCATO (Luxemburgo)

Claude SCHABER (Luxemburgo)

Antonio ÁVILA DÍAZ (México)

Cynthia CABRERA CARDENAS (México)

Agustin CASO-RAPHAEL (México)

René GÓMORA CASTILLO (México)

Juan Manuel HERNÁNDEZ VÁZQUEZ (México)

Tomás RAMÍREZ REYNOSO (México)

Héctor Virgilio ROBLES VASQUEZ (México)

Annette SANTOS (México)

Lorenzo VERGARA LÓPEZ (México)

Marie ARNEBERG (Noruega)

Sadiq Kwesi BOATENG (Noruega)

Kjetil DIGRE (Noruega)

Anne Katrine MORTENSEN (Noruega)

Geir NYGÅRD (Noruega) 


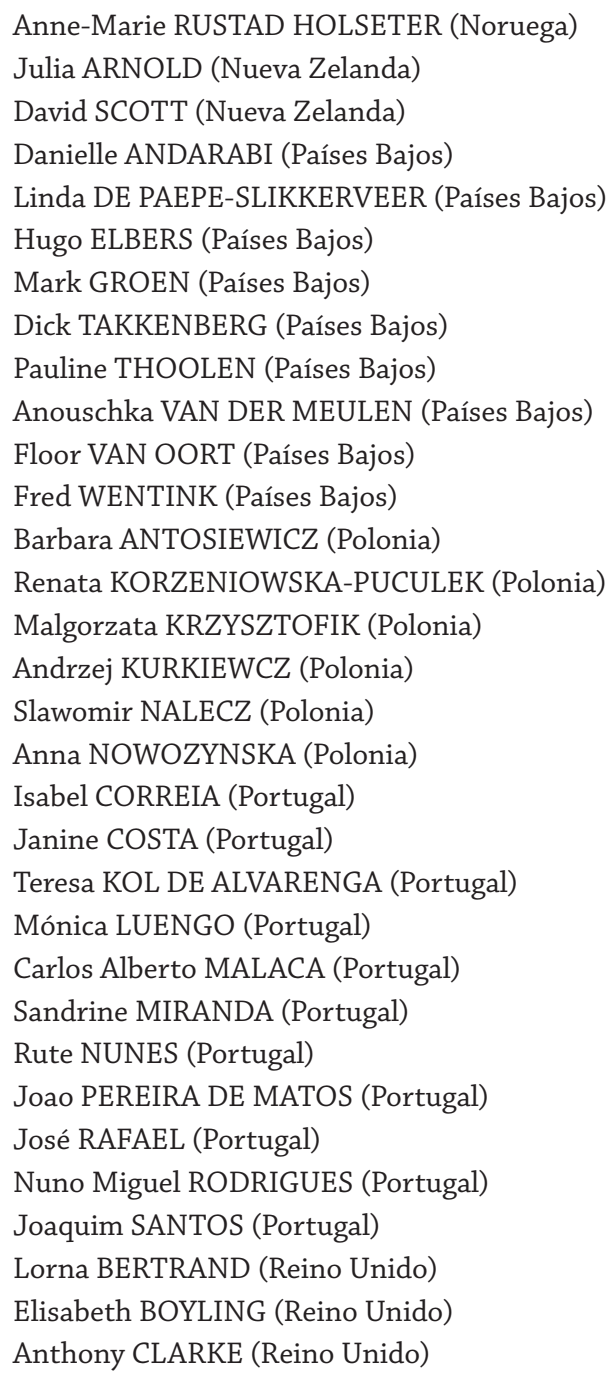

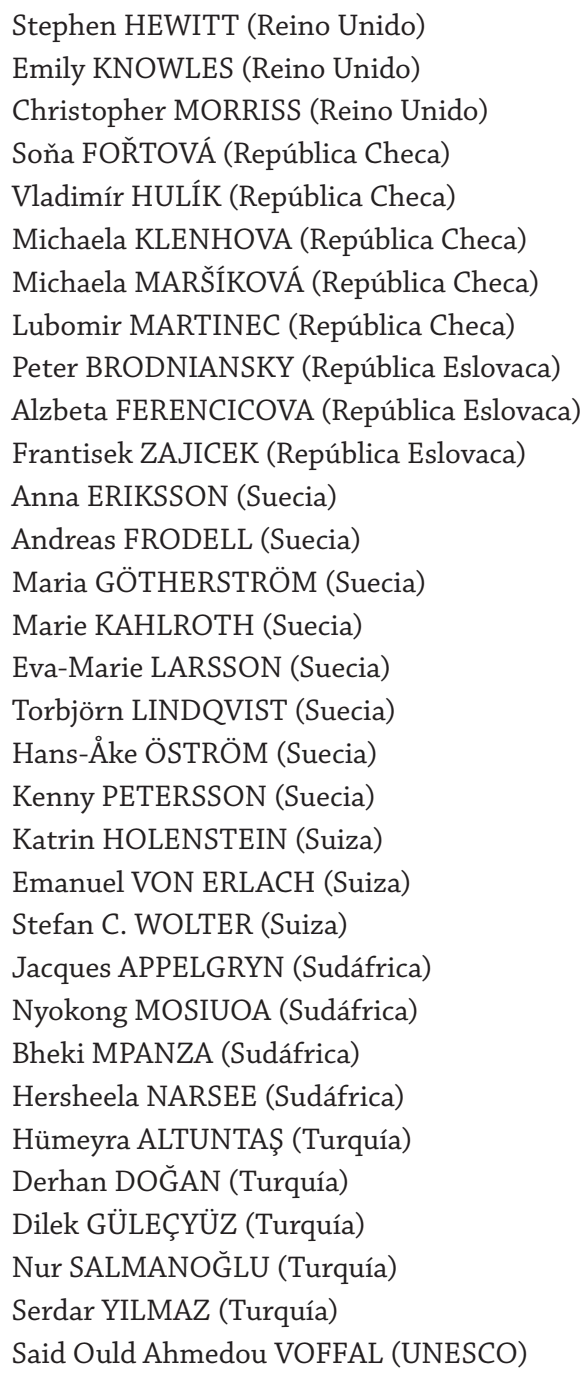

Red sobre el mercado laboral y los resultados económicos y sociales del aprendizaje (LSO)

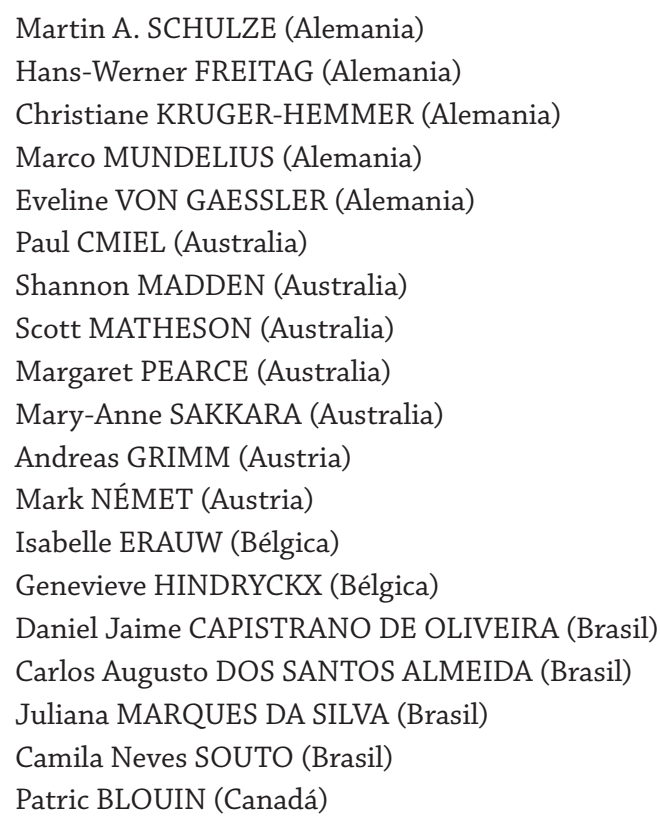

Patrick BUSSIERE (Canadá)

Patrice DE BROUCKER (Presidente, Red LSO, Canadá)

Amanda HODGKINSON (Canadá)

Dallas MORROW (Canadá)

Nicolas RAHAL (Canadá)

Mircea BADESCU (CEDEFOP)

Marco SERAFINI (CEDEFOP)

Fabián GREDIG (Chile)

Paulina HUAIQUIMIL (Chile)

David INOSTROZA (Chile)

Fabián RAMIREZ (Chile)

Alexandra RUEDA (Chile)

Gabriel UGARTE (Chile)

Jens FISHER-KOTTENSTEDE (Comisión Europea)

Jihee CHOI (Corea)

Jeongwon HWANG (Corea)

Eunhye LEE (Corea)

Cheonsoo PARK (Corea)

Young Sun RA (Corea) 
Ji Young RYU (Corea)

Jung-seung Thomas YANG (Corea)

Jens ANDERSEN (Dinamarca)

RHelga KOCEVAR (Eslovenia)

Tatjana SKRBEC (Eslovenia)

Raquel ÁLVAREZ-ESTEBAN (España)

Carmen UREÑA UREÑA (España)

Rachel DINKES (Estados Unidos)

Ashley ROBERTS (Estados Unidos)

Thomas SNYDER (Estados Unidos)

Tiina ANNUS (Estonia)

Ingrid JAGGO (Estonia)

Priit LAANOJA (Estonia)

Katrin REIN (Estonia)

Eve TÕNISSON (Estonia)

Aune VALK (Estonia)

Marta BECK-DOMZALSKA (Eurostat, Comisión Europea)

Sabine GAGEL (Eurostat, Comisión Europea)

Mark AGRANOVICH (Federación Rusa)

Anna FATEEVA (Federación Rusa)

Natalia KOVALEVA (Federación Rusa)

Irja BLOMQVIST (Finlandia)

Aila REPO (Finlandia)

Mika WITTING (Finlandia)

Cédric AFSA (Francia)

Pascale POULET-COULIBANDO (Francia)

Vasileios KARAVITIS (Grecia)

Athena PLESSA-PAPADAKI (Grecia)

Georgios VAFIAS (Grecia)

László LIMBACHER (Hungría)

Kristián SZÉLL (Hungría)

Eva TOT (Hungría)

Gillian GOLDEN (Irlanda)

Nicola TICKNER (Irlanda)

Ásta M. URBANCIC (Islandia)

Yosef GIDANIAN (Israel)

David MAAGAN (Israel)

Haim PORTNOY (Israel)

Raffaella CASCIOLI (Italia)

Gaetano PROTO (Italia)

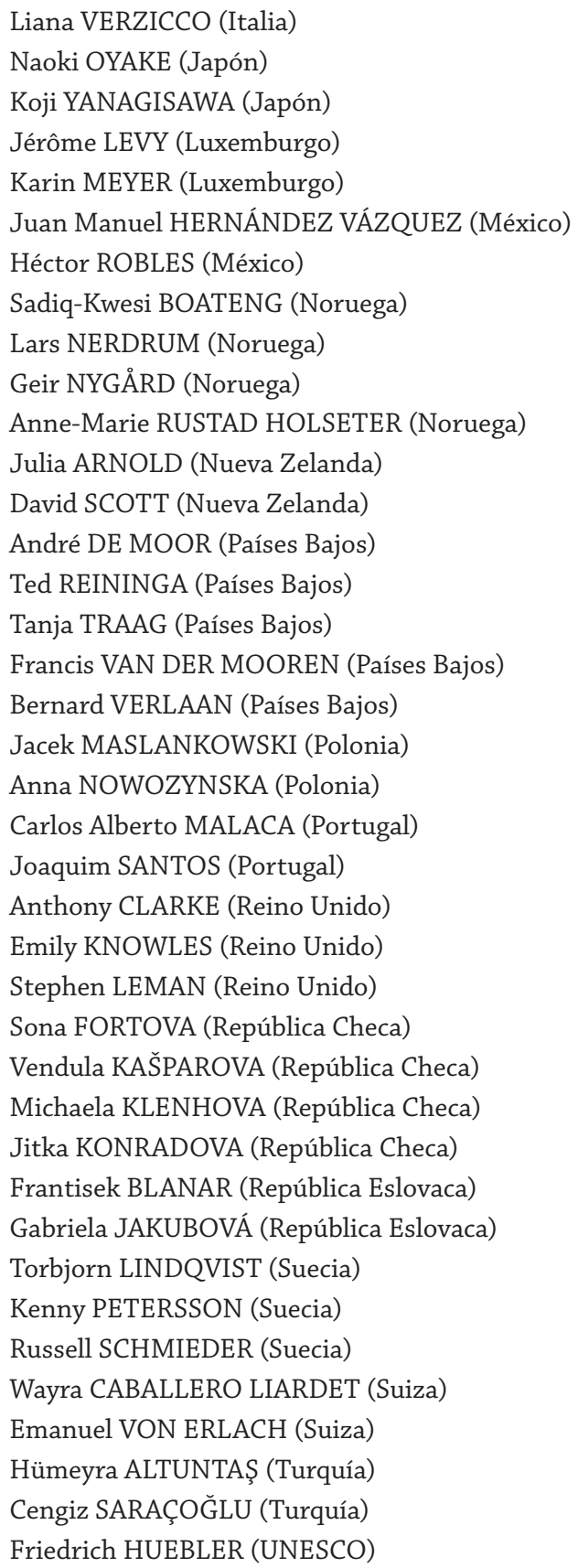

\section{Red para la recopilación de información descriptiva sobre el nivel del sistema de estructuras,} políticas y prácticas educativas (NESLI)

Pia BRUGGER (Alemania)

Heinz-Werner HETMEIER (Alemania)

Christiane KRÜGER-HEMMER (Alemania)

Marco MUNDELIUS (Alemania)

Stephanie BOWLES (Australia)

Paul CMIEL (Australia)

Shannon MADDEN (Australia)

Scott MATHESON (Australia)

Andreas GRIMM (Austria)

Christian KRENTHALLER (Austria)

Philippe DIEU (Bélgica)

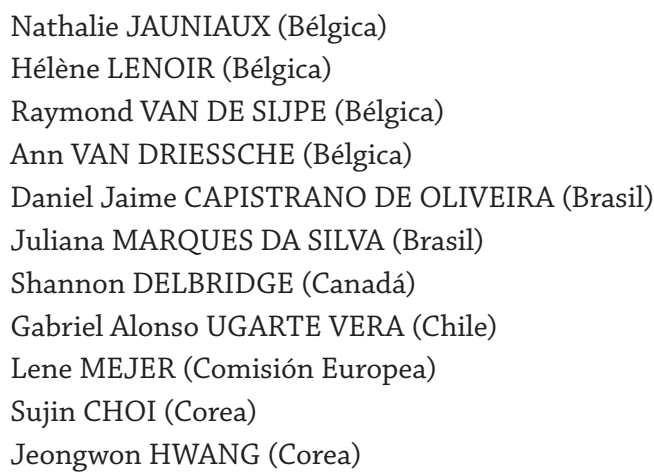


Jorgen Balling RASMUSSEN (Dinamarca)

Amalie SCHMIDT (Dinamarca)

Andreja BARLE LAKOTA (Eslovenia)

Ksenija BREGAR GOLOBIC (Eslovenia)

Mitja SARDOC (Eslovenia)

Matija VILFAN (Eslovenia)

Laura ALONSO CARMONA (España)

Antonio DEL SASTRE (España)

Joaquin MARTIN (España)

Valentín RAMOS SALVADOR (España)

Ismael SANZ LABRADOR (España)

Noelia VALLE BENITO (España)

Rachel DINKES (Estados Unidos)

Jana KEMP (Estados Unidos)

Tom SNYDER (Presidente Red NESLI, Estados Unidos)

Tiina ANNUS (Estonia)

Nathalie BAIDAK (Eurydice)

Arlette DELHAXHE (Eurydice)

Mark AGRANOVICH (Federación Rusa)

Anna FATEEVA (Federación Rusa)

Timo KUMPULAINEN (Finlandia)

Petra PACKALEN (Finlandia)

Mika VÄISÄNEN (Finlandia)

Kristiina VOLMARI (Finlandia)

Florence LEFRESNE (Francia)

Robert RAKOCEVIC (Francia)

Dimitra FARMAKIOTOU (Grecia)

Maria FASSARI (Grecia)

Eudokia KARDAMITSI (Grecia)

Georgios MALLIOS (Grecia)

Stylianos MERKOURIS (Grecia)

Konstantinos PAPACHRISTOS (Grecia)

Athena PLESSA-PAPADAKI (Grecia)

Anna IMRE (Hungría)

Gary Ó DONNCHADHA (Irlanda)

Nicola TICKNER (Irlanda)

Gunnar J. ÁRNASON (Islandia)

Asta URBANCIC (Islandia)

Yoav AZULAY (Israel)

Livnat GAVRIELOV (Israel)

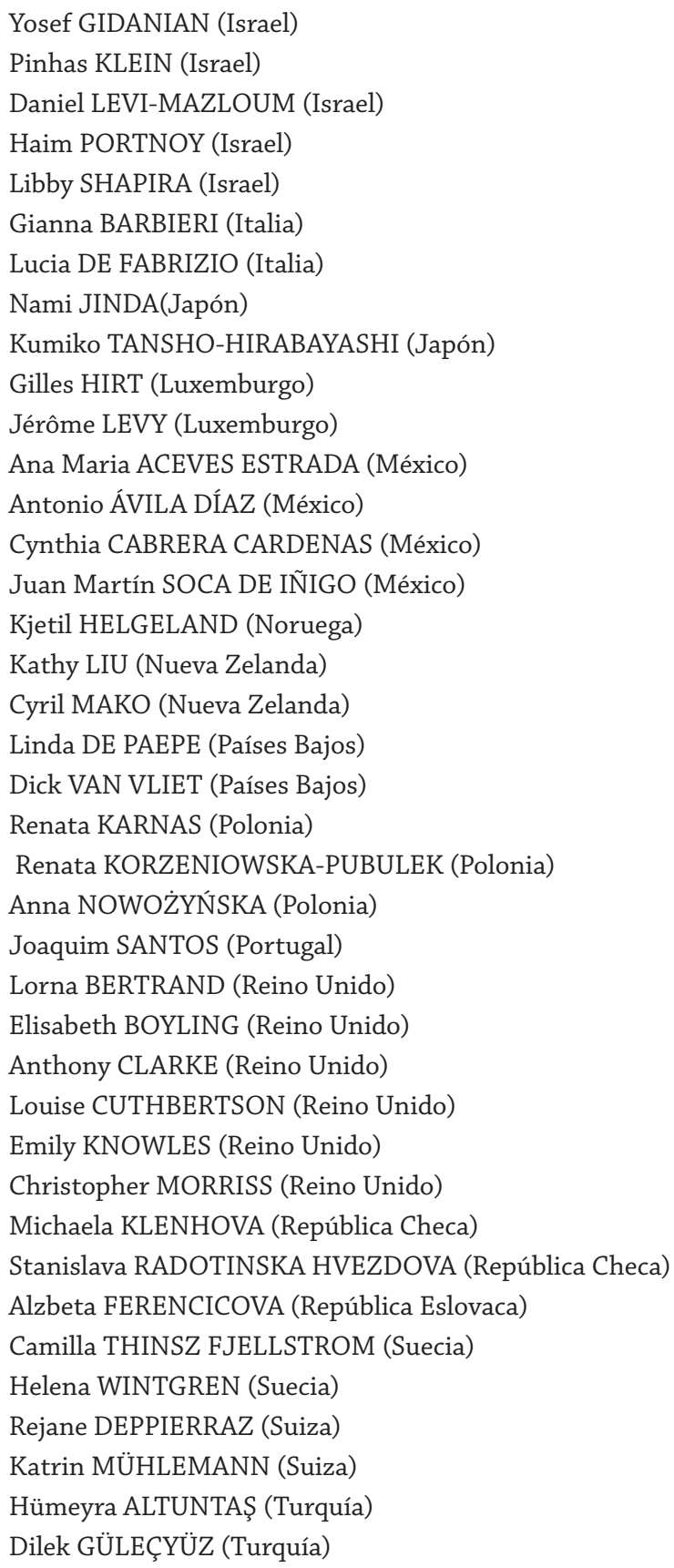

Otras personas que han participado en esta publicación

Samuel E. ABRAMS (consultor NESLI)

Sam STERN (consultor NESLI)

Anna BORKOWSKY (consultor LSO)

BRANTRA SPRL (traducción)
Sally Caroline HINCHCLIFFE (edición)

Dan SHERMAN (consultor LSO)

Fung-Kwan TAM (maquetación) 



\section{PublicaCiones RelaCiOnAdAs de LA OCDE}

Equity, Excellence and Inclusiveness in Education: Policy Lessons from Around the World, International Summit on the Teaching Profession (2014)

http://dx.doi.org/10.1787/9789264214033-en

Teachers for the 21st Century: Using Evaluation to Improve Teaching, International Summit on the Teaching Profession (2013) http://dx.doi.org/10.1787/9789264193864-en

PISA 2012 Results: What Students Know and Can Do (Volume I, edición revisada, febrero de 2014): Student Performance in Mathematics, Reading and Science (2014)

http://dx.doi.org/10.1787/9789264208780-en

PISA 2012 Results: Excellence through Equity (Volume II): Giving Every Student the Chance to Succeed (2013) http://dx.doi.org/10.1787/9789264201132-en

PISA 2012 Results: Ready to Learn (Volume III): Students' Engagement, Drive and Self-Beliefs (2013)

http://dx.doi.org/10.1787/9789264201170-en

PISA 2012 Results: What Makes Schools Successful (Volume IV): Resources, Policies and Practices (2013)

http://dx.doi.org/10.1787/9789264201156-en

PISA 2012 Results: Creative Problem Solving (Volume V): Students' Skills in Tackling Real-Life Problems (2014)

http://dx.doi.org/10.1787/9789264208070-en

PISA 2012 Results: Students and Money (Volume VI): Financial Literacy Skills for the 21st Century (2014)

http://dx.doi.org/10.1787/9789264208094-en

TALIS 2013 Results: An International Perspective on Teaching and Learning (2014)

http://dx.doi.org/10.1787/9789264196261-en

OECD Skills Outlook 2013: First Results from the Survey of Adult Skills (2013)

http://dx.doi.org/10.1787/9789264204256-en

The Survey of Adult Skills: Reader's Companion (2013)

http://dx.doi.org/10.1787/9789264204027-en

Innovative Learning Environments, Educational Research and Innovation (2013)

http://dx.doi.org/10.1787/9789264203488-en

Synergies for Better Learning: An International Perspective on Evaluation and Assessment (2013)

http://dx.doi.org/10.1787/9789264190658-en

Trends Shaping Education 2013 (2013)

http://dx.doi.org/10.1787/trends_edu-2013-en

How's Life? 2013: Measuring Well-being (2013)

http://dx.doi.org/10.1787/9789264201392-en

International Migration Outlook 2013 (2013)

http://dx.doi.org/migr_outlook-2013-en

Better Skills, Better Jobs, Better Lives: A Strategic Approach to Skills Policies (2012)

http://dx.doi.org/10.1787/9789264177338-en

Equity and Quality in Education: Supporting Disadvantaged Students and Schools (2012)

http://dx.doi.org/10.1787/9789264130852-en

Closing the Gender Gap: Act Now (2012)

http://dx.doi.org/10.1787/9789264179370-en

Starting Strong III: A Quality Toolbox for Early Childhood Education and Care (2011)

http://dx.doi.org/10.1787/9789264123564-en 
Health at a Glance: OECD Indicators (2011)

http://dx.doi.org/10.1787/health_glance-2011-en

Learning for Jobs: OECD Reviews of Vocational Education and Training (2010)

http://dx.doi.org/10.1787/9789264087460-en

OECD Information Technology Outlook 2010 (2010)

http://dx.doi.org/10.1787/it_outlook-2010-en

Improving Health and Social Cohesion through Education (2010)

http://dx.doi.org/10.1787/9789264086319-en

Tertiary Education for the Knowledge Society: Volume 1 and Volume 2 (2008)

http://dx.doi.org/10.1787/9789264046535-en

Starting Strong II: Early Childhood Education and Care (2006)

http://dx.doi.org/ 10.1787/9789264035461-en

Teachers Matter: Attracting, Developing and Retaining Effective Teachers, Education and Training Policy (2005)

http://dx.doi.org/ 10.1787/9789264018044-en

Se pueden consultar o adquirir estas publicaciones en la librería de la OCDE en Internet (www.oecd-ilibrary.org). 


\section{ORGANIZACIÓN PARA LA COOPERACIÓN Y EL DESARROLLO ECONÓMICO}

La OCDE constituye un foro único en su género, en el que los gobiernos trabajan conjuntamente para afrontar los retos económicos, sociales y medioambientales que plantea la globalización. La OCDE está a la vanguardia de los esfuerzos emprendidos para entender los cambios y preocupaciones del mundo actual, como la gobernanza corporativa, la economía de la información y los desafíos que genera el envejecimiento de la población, y para ayudar a los gobiernos a responder a tales cambios. La Organización proporciona a los gobiernos un marco en el que pueden comparar sus experiencias políticas, buscar respuestas a problemas comunes, identificar buenas prácticas y trabajar en la coordinación de políticas nacionales e internacionales.

Los países miembros de la OCDE son: Alemania, Australia, Austria, Bélgica, Canadá, Chile, Corea, Dinamarca, Eslovenia, España, Estados Unidos, Estonia, Finlandia, Francia, Grecia, Hungría, Irlanda, Islandia, Israel, Italia, Japón, Luxemburgo, México, Noruega, Nueva Zelanda, Países Bajos, Polonia, Portugal, Reino Unido, República Checa, República Eslovaca, Suecia, Suiza y Turquía. La Comisión Europea participa en el trabajo de la OCDE.

Las publicaciones de la OCDE aseguran una amplia difusión de los resultados obtenidos por la Organización en la compilación de estadísticas y en la investigación sobre cuestiones económicas, sociales y medioambientales, así como de las convenciones, las directrices y los estándares desarrollados por los países miembros. 
Panorama de la educación. Indicadores de la OCDE es la fuente autorizada de información precisa y relevante sobre el estado de la educación en todo el mundo. Proporciona datos sobre las estructuras, la situación económica y el rendimiento de los sistemas educativos en los 34 países miembros de la OCDE, así como en otros países asociados.

Panorama de la educación incluye más de 150 gráficos, 300 tablas y más de 100.000 cifras, y ofrece información clave sobre los resultados de las instituciones educativas; el impacto del aprendizaje en los distintos países; los recursos económicos y humanos invertidos en educación; el acceso, la participación y la progresión en la educación; y el entorno de aprendizaje y la organización de los centros escolares.

En la edición de 2014, nuevos indicadores se centran en los siguientes temas:

- Nuevos indicadores sobre instituciones privadas, sobre qué es necesario para convertirse en docente y sobre la disponibilidad de actividades para el desarrollo profesional de los profesores y su participación en las mismas.

- Datos procedentes de la Encuesta sobre las Competencias de los Adultos, un producto del Programa para la Evaluación Internacional de las Competencias de los Adultos (PIAAC 2012) de la OCDE, sobre niveles de educación, empleo, movilidad educativa intergeneracional, ingresos y resultados sociales relacionados con el nivel de competencias.

- Datos procedentes del Estudio Internacional sobre Enseñanza y Aprendizaje de la OCDE (TALIS 2013) y del Programa para la Evaluación Internacional de Alumnos (PISA 2012) incluidos en varios indicadores.

- Análisis del impacto de la reciente crisis económica sobre la interacción entre nivel educativo, empleo, ingresos y financiación pública.

- Información más detallada sobre las tasas de graduación en educación secundaria superior y los tipos de préstamos para estudiantes y su utilización.

- Por primera vez se incluyen datos de Colombia y Letonia.

Las hojas de cálculo Excel ${ }^{\circledR}$ utilizadas para crear los gráficos y las tablas de este libro están disponibles en Internet mediante los StatLinks incluidos en la parte inferior izquierda de los mismos. Se pueden consultar gratuitamente dichos gráficos y tablas, así como la base completa de datos de la OCDE sobre educación, en la siguiente página de Internet: www.oecd.org/edu/eag.htm.

\section{Contenidos}

Capítulo A. Resultados de las instituciones educativas e impacto del aprendizaje

Capítulo B. Recursos económicos y humanos invertidos en educación

Capítulo C. Acceso a la educación, participación y progresión

Capítulo D. El entorno de aprendizaje y la organización de los centros escolares

La presente obra ha sido publicada en inglés con el título Education at a Glance 2014: OECD Indicators, OECD Publishing, y está disponible en Internet en la dirección siguiente:

http://dx.doi.org/10.1787/eag-2014-en

Esta obra está publicada asimismo en la OECD iLibrary, que reúne todos los libros, publicaciones periódicas y bases de datos estadísticos de la OCDE.

Visite el sitio www.oecd-ilibrary.org y no dude en contactar con sus gestores para obtener más información. 